\title{
The Savannah River Site's Groundwater Monitoring Program - 34025 Second Quarter 1998 (April through June 1998)
}

by

J. B. Hutchison

Westinghouse Savannah River Company

Savannah River Site

Aiken, South Carolina 29808

This paper was prepared in connection with work done under the above contract number with the U.S. Department of Energy. By acceptance of this paper, the publisher and/or recipient acknowledges the U. S. Government's right to retain a nonexclusive, royalty-free license in and to any copyright covering this paper. along with the right to reproduce and to authorize others to reproduce all or part of the copyrighted paper. 


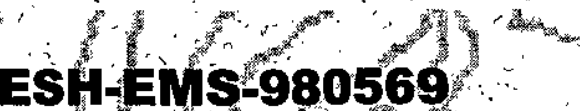
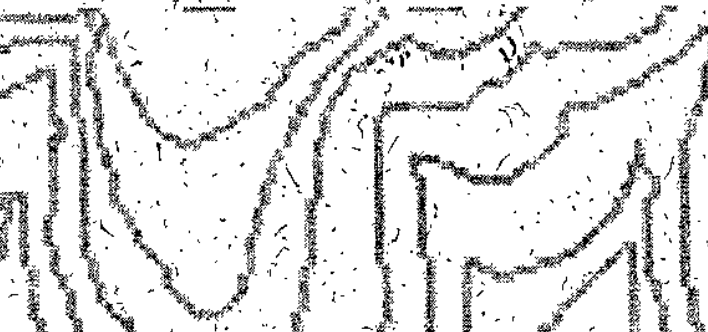

THE ENVIRONMENAAL PROTECTIONDDEPARMTENT TI

ENTIRONMENTAL MONITORING SECTION.

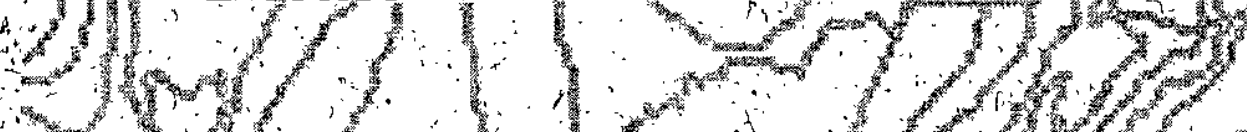

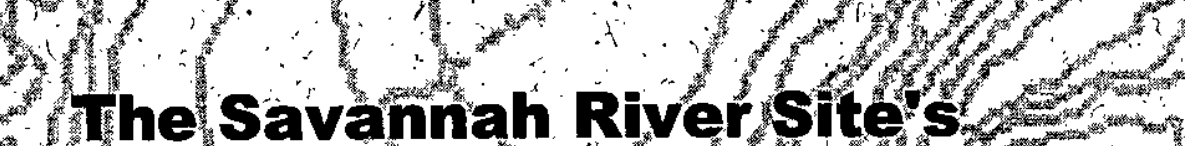

\section{Croundwater Monitóng $\mathrm{p}$ yogram}

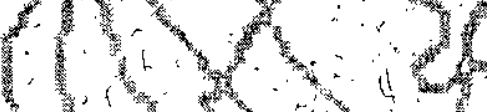

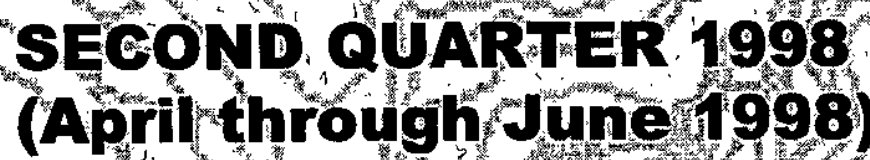
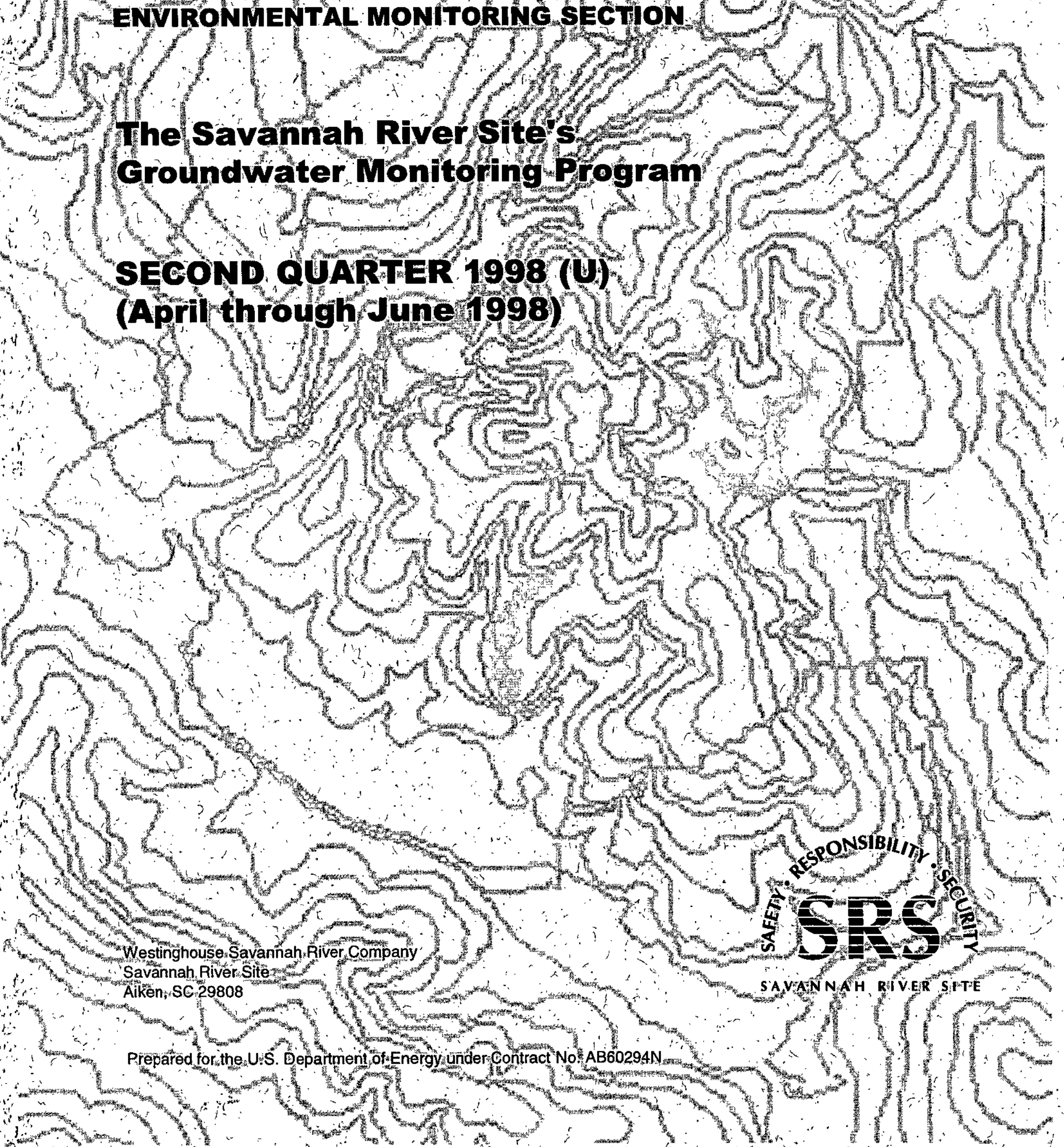


\section{'This Quarter at a Glance .}

Executive Summary táble of all analytes detected â or above Flag. 2 criteria

Flagging Criteria standards for flagging results

Sample Scheduling-description of the sampling schedule

Field Notès - comments from the field-data books

- Analytical Data Review - discrepancies in each laboratory's analytical datá; laboratory-specific methods:and estimated quantitation limits

Quality Control'Samples-discussion of the quality of the analytical data in terms of precision, accuracy,

representativeness, comparability, and completeness

Site Index table of the well series and their site locations; also discusses the history of the sites

Appendices:

A. Water-Level Data-tables listing field data obtained for hydrogeologic studies

$B$. Analytical Results - tables listing the quarter's analytical resuits and field data

C. Sampling Blanks Results tables listing all analyticâl results for sampling blanks tor the quarter

The following is a key to the numbered areas of the Savannah River Site.

site

100 Areas Réactörs

200.Areas - Separations

300 Areas - Reactor Materials

400 Area - Heavy Water

600 Areas-General

700 Area Administrátion

Function

To operate and support the reactors

To separate and purify, the product from fuel and target assemblies; to process waste

Tô fabricate new fuel and target assemblies from raw materials

To produce steam and electrical power; to process heavy wàter

Other (ǵeneral)

To provide administrative and support sévices

\section{DISCLAIMER}

This report was prepared as an account of work sponsored by an agency of the United States Government. Neither the United States Government nor any agency thereof, nor any of their employees, makes any warranty, express or implied, or assumes any legal liability or responsibility for the accuracy, completeness, or usefulness of any information, apparatus, product, or process disclosed, or represents that its use would not infringe privately owned rights. Reference herein to any specific commercial product, process, or service by trade name, trademark, manufacturer, or otherwise does not necessarily constitute or imply its endorsement, recommendation, or favoring by the United States Government or any agency thereof. The views and opinions of authors expressed herein do not necessarily state or reflect those of the United States Government or any agency thereof.

This report has been reproduced directly from the best available copy.

Available to DOE and DOE contractors from the Office of Scientific and Technical Information, P.O. Box 62, Oak Ridge, TN 37831; prices available from (615) 576-8401.

Available to the public from the National Technical Information Service, U.S. Department of Commerce, 5285 Port Royal Road, Springfield, VA 22161. 


\title{
THE ENVIRONMENTAL PROTECTION DEPARTMENT ENVIRONMENTAL MONITORING SECTION
}

\author{
The Savannah River Site's \\ Groundwater Monitoring Program
}

\section{SECOND QUARTER 1998 (U) \\ (April through July 1998)}

Environmental Protection Department

Westinghouse Savannah River Company

Aiken, SC

and

Exploration Resources, Inc.

Athens, GA

Reviewed and approved by

Jay Hutchison

EPD/EMS Groundwater Coordinator

Cover graphics supplied by R.A. Hiergesell

Savannah River Technology Center

Environmental Sciences Section

Publication Date: November 1998

Westinghouse Savannah River Company

Savannah River Site

Aiken, SC 29808

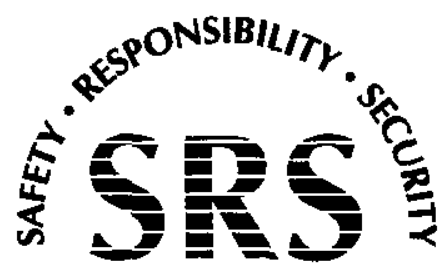

SAVANNAH RIVER SITE 


\section{Contents}

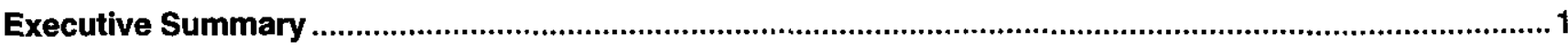

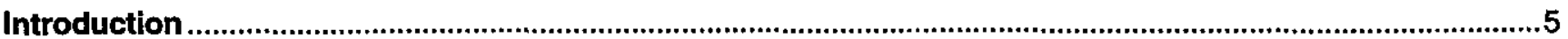

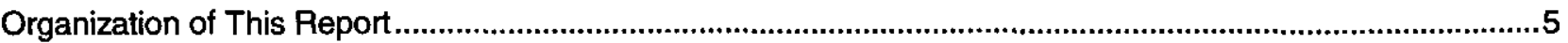

Flagging Criteria

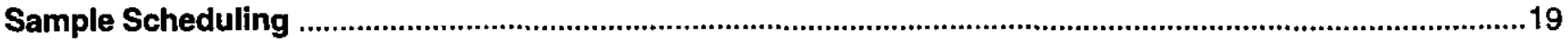

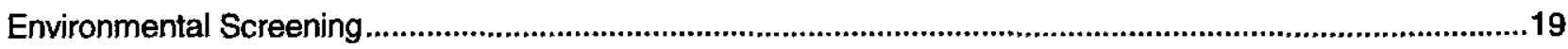

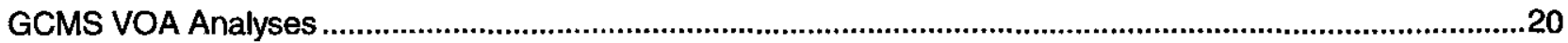

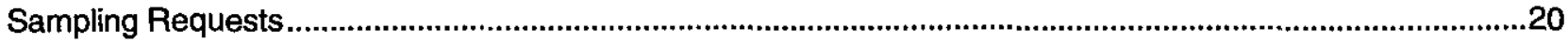

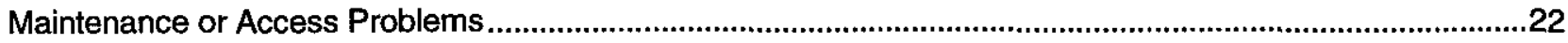

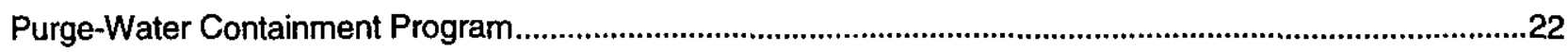

Field Notes

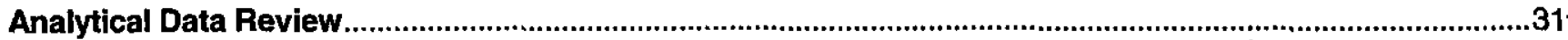

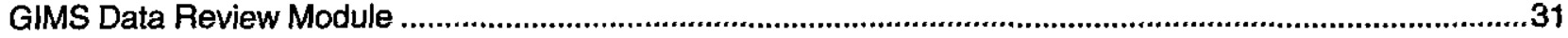

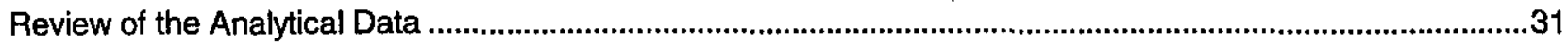

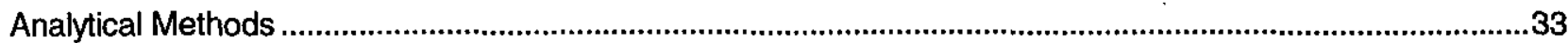

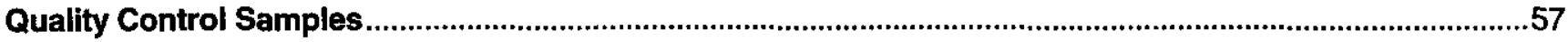

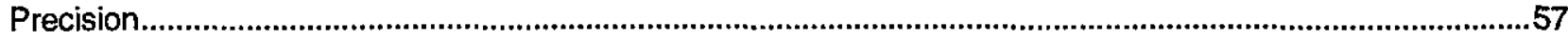

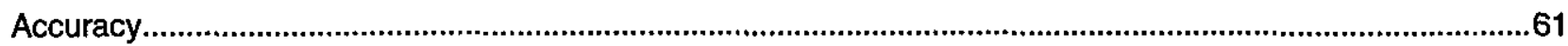

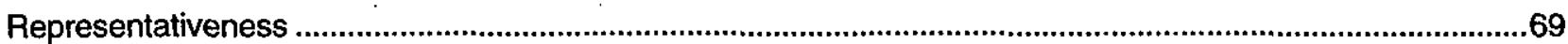

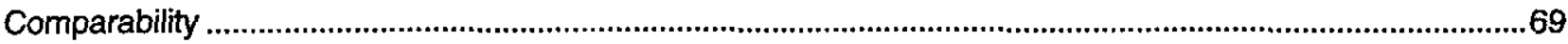

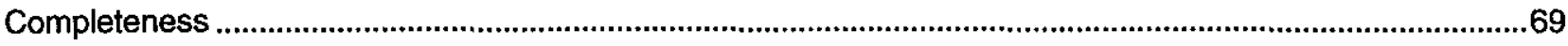

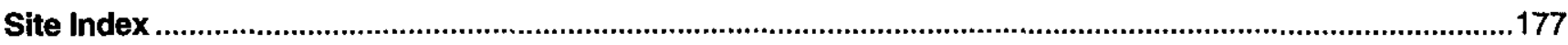

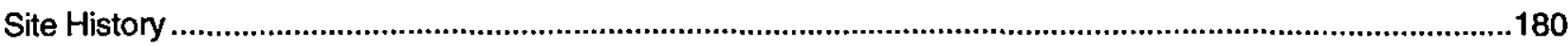

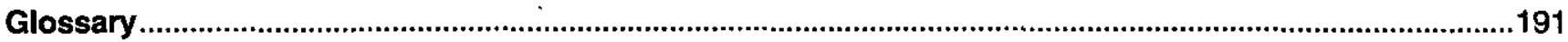

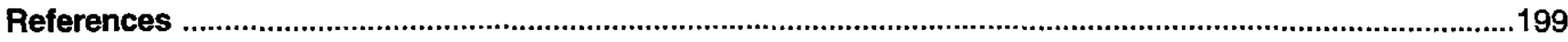




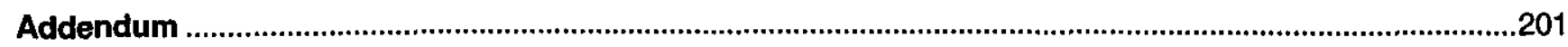

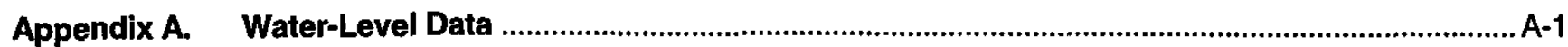

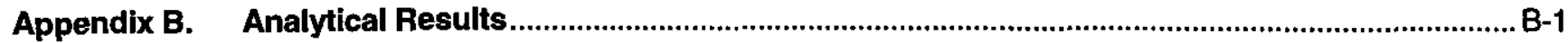

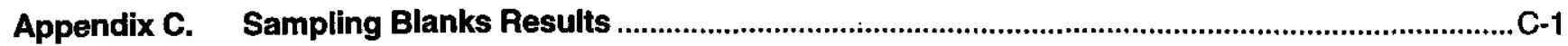




\section{LIST OF FIGURES}

Figure 1. Areas and Locations Monitored for Groundwater Quality .................................................

Figure 2. Separations and Waste Management Areas Monitored for Groundwater Quality ...................8

Figure 3. Three Types of Groundwater Monitoring Wellheads ..........................................................23

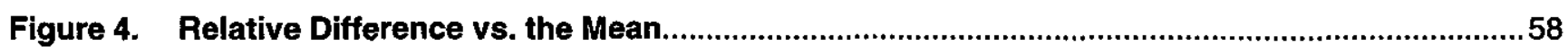

Figure 5. Relationship between $w_{i}$ and Analyte Concentration .......................................................55

Figure 6. Effect of a Linear-Weight Function on the MRDadj........................................................59 


\section{LIST OF TABLES}

Table 1. Analytes above Flag 2 Criteria 1

Table 2. Flagging Criteria 10

Table 3. Comments from the Field Data .24

Table 4. ES Samples with High Analytical Results as Compared to Historical Data .33

Table 5. ES Samples with Low Analytical Results as Compared to Historical Data .34

Table 6. GE Samples with High Analytical Results as Compared to Historical Data .34

Table 7. GE Samples with Low Analytical Results as Compared to Historical Data............................34

Table 8. GP Samples with High Analytical Results as Compared to Historical Data ..........................34

Table 9. WA Samples with High Analytical Results as Compared to Historical Data ..........................34

Table 10. WA Samples with Low Analytical Results as Compared to Historical Data ...........................35

Table 11. TM Samples with High Analytical Results as Compared to Historical Data ..........................35

Table 12. TM Samples with Low Analytical Results as Compared to Historical Data...........................35

Table 13. Methods and Estimated Quantitation Limits Used by ES ...............................................35

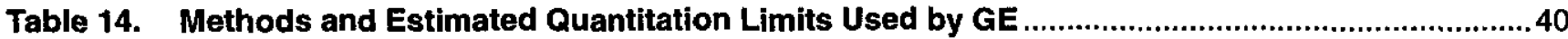

Table 15. Methods and Estimated Quantitation Limits Used by WA .................................................4 46

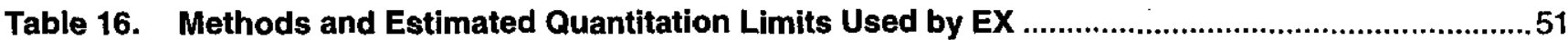

Table 17. Methods and Estimated Quantitation Limits Used by GP ................................................55

Table 18. Methods and Estimated Quantitation Limits Used by TM ..................................................56

Table 19. Quality Control Limits for Selected Laboratory Control Samples and Blank Spikes .............64

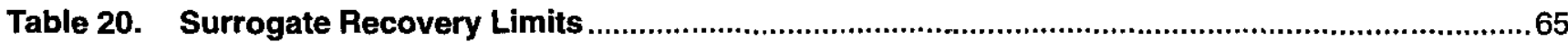

Table 21. Quality Control Limits for Selected Matrix Spike Samples ..................................................66

Table 22. Wells Providing Blind Replicate Samples and Associated Blanks ....................................70

Table 23. Analytes Not Showing Measurable Concentrations above Estimated Quantitation Limits in Any Replicated or Duplicated Samples for GE, WA, ES, and EX.

Table 24. Analytes Not Showing Measurable Concentrations above Estimated Quantitation Limits in Any Replicated or Duplicated Samples for GP, TM, and ES

Table 25. Intralaboratory MRD Indices for ES

\section{Contents}


Table 26. Intralaboratory MRD Indices for EX

Table 27. Intralaboratory MRD indices for GE. .78

Table 28. Intralaboratory MRD Matrix Spike Indices for GE . 81

Table 29. Intralaboratory MRD indices for WA 82

Table 30. Intralaboratory MRD Indices for GP. .85

Table 31. Intralaboratory MRD Indices for TM 86

Table 32. Interlaboratory MRD and t-test Results for Analytes with at Least One Pair of Results above the RDL for GE and WA

Table 33. Interlaboratory MRD and t-test Results for Analytes with at Least One Pair of Results above the RDL for ES and EX.

Table 34. Interlaboratory MRD and t-test Results for Analytes with at Least One Pair of Results above the RDL for ES and WA.

Table 35. Interlaboratory MRD and t-test Results for Analytes with at Least One Pair of Results above the RDL for EX and WA.

Table 36. Interlaboratory MRD and t-test Results for Analytes with at Least One Pair of Results above the RDL for ES and TM

Table 37. Interlaboratory MRD and t-test Results for Analytes with at Least One Pair of Results above the RDL for EX and TM.

Table 38. Interlaboratory MRD and t-test Results for Analytes with at Least One Pair of Results above the RDL for GP and TM.

Table 39. ES Samples and Blind Replicates Yielding Results Where One Is More Than Twice Another.

Table 40. ES Samples and Laboratory Duplicates Yielding Results Where One is More Than Twice Another.

Table 41. GE Samples and Blind Replicates Yielding Results Where One Is More Than Twice Another.

Table 42. GE Samples and Laboratory Duplicates Yielding Results Where One Is More Than Twice Another.

Table 43. GP Samples and Blind Replicates Yielding Results Where One Is More Than Twice Another.

Table 44. GP Samples and Laboratory Duplicates Yielding Results Where One Is More Than Twice Another.

Table 45. TM Samples and Blind Replicates Yielding Results Where One Is More Than Twice Another...

\section{Contents}


Table 46. TM Samples and Laboratory Duplicates Yielding Results Where One is More Than Twice Another.

Table 47. WA Samples and Blind Replicates Yielding Results Where One Is More Than Twice Another.

Table 48. WA Samples and Laboratory Duplicates Yielding Results Where One Is More Than Twice Another

Table 49. Analytes with One Laboratory's Result Greater Than Twice the Result from the Other Laboratory between ES and EX.

Table 50. Analytes with One Laboratory's Result Greater Than Twice the Result from the Other Laboratory between EX and WA.

Table 51. Analytes with One Laboratory's Result Greater Than Twice the Result from the Other Laboratory between GE and WA

Table 52. Analytes with One Laboratory's Result Greater Than Twice the Result from the Other Laboratory between ES and TM

Table 53. Analytes with One Laboratory's Result Greater Than Twice the Result from the Other Laboratory between GP and TM

Table 54. Quality Control Standards for Selected Analyses for GE....................................................96

Table 55. Quality Control Standards for Selected Analyses for WA ..................................................99

Table 56. Quality Control Standards for Selected Analyses for EX ...............................................101

Table 57. ES, EX, and WA Performance Evaluation, Water Pollution Study WP038...........................104

Table 58. WA Performance Evaluation, Water Pollution Study WP039................................................106

Table 59. WA Performance Evaluation, Water Supply Study WS040 ..............................................107

Table 60. Laboratory Control Sample and Blank Spike Recoveries for ES...................................... 110

Table 61. Laboratory Control Sample and Blank Spike Recoveries for EX.......................................113

Table 62. Laboratory Control Sample and Blank Spike Recoveries for GE .................................... 115

Table 63. Laboratory Control Sample and Blank Spike Recoveries for WA ...................................... 117

Table 64. Laboratory Control Sample and Blank Spike Recoveries for GP ......................................120

Table 65. Laboratory Control Sample and Blank Spike Recoveries for TM ......................................121

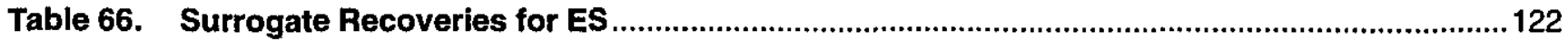

Table 67. Surrogate Recoveries for EX

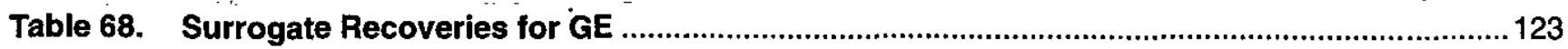


Table 69. Surrogate Recoveries for WA 124

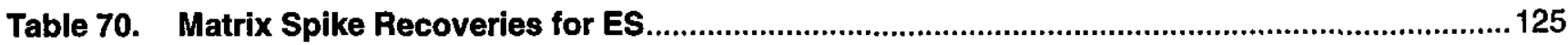

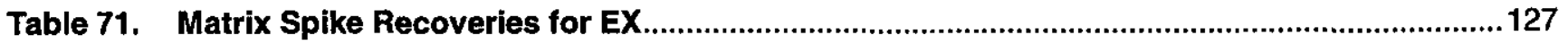

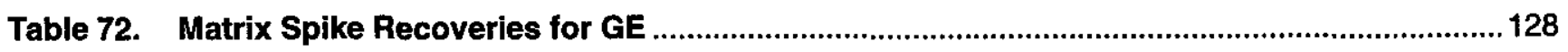

Table 73. Matrix Spike Recoveries for WA

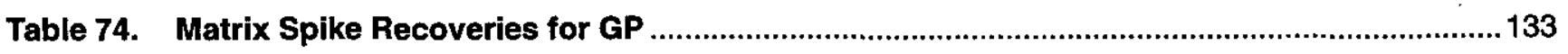

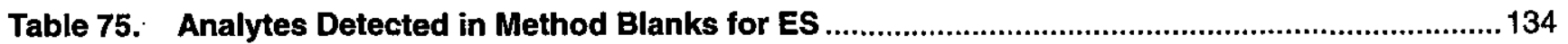

Table 76. Analytes Detected in Method Blanks for EX .................................................................. 140

Table 77. Analytes Detected in Method Blanks for GE................................................................ 144

Table 78. Analytes Detected in Method Blanks for WA ...............................................................148

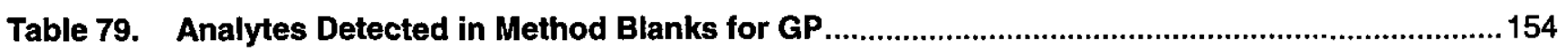

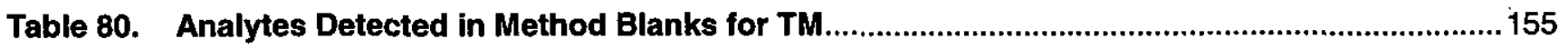

Table 81. Analytes Detected in Field Blanks for ES .....................................................................156

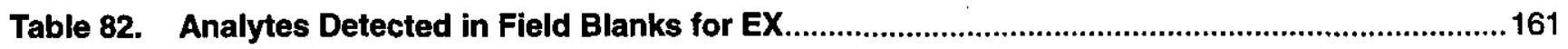

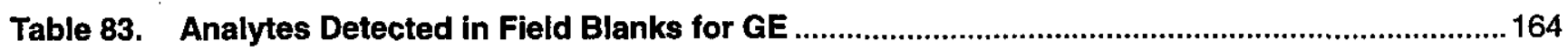

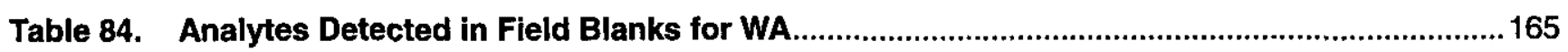

Table 85. Analytes Detected in Field Blanks for GP .....................................................................169

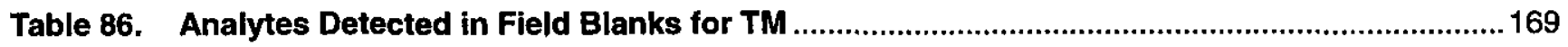

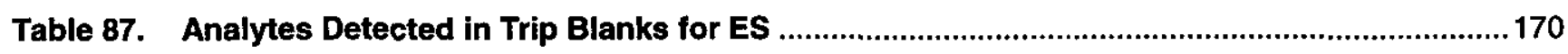

Table 88. Analytes Detected in Trip Blanks for EX ........................................................................171

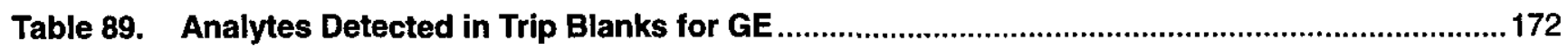

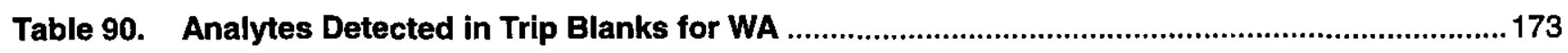

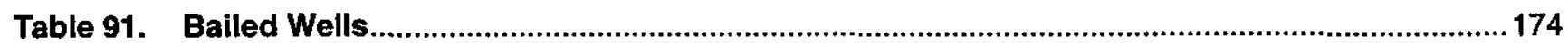

Table 92. Sampled Wells with Metal Casings................................................................................ 174

Table 93. Wells That Had Turbidity Greater Than 15 NTU..............................................................174

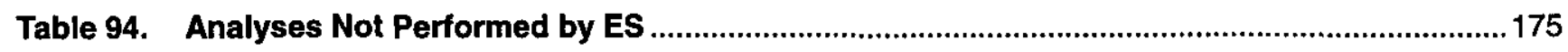

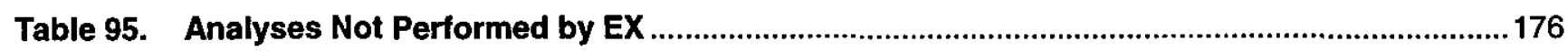

\section{Contents}


Table 96. Analyses Not Performed by GE.

Table 97. Analyses Not Performed by WA

176

Table 98. Sites and Locations by Well Series 


\section{Executive Summary}

The Environmental Protection Department/Environmental Monitoring Section (EPD/EMS) administers the Savannah River Site's (SRS) Groundwater Monitoring Program. During second quarter 1998, EPD/EMS conducted extensive sampling of monitoring wells.

EPD/EMS has established two sets of flagging criteria to assist in managing sample results. The flagging criteria do not define contamination levels; instead, they aid personnel in sample scheduling, data interpretation, and trend identification. Since 1991, the flagging criteria have been based on the U.S. Environmental Protection Agency (EPA) drinking water standards and on method detection limits. A detailed explanation of the flagging criteria is presented in the Flagging Criteria section of this document. Analytical results from second quarter 1998 are included in this report, which is distributed to all site custodians.

One or more analytes exceeded Flag 2 criteria during second quarter 1998 in 41 monitoring well series. Analytes exceeded the current Flag 2 criteria for the first time since 1984 in 11 of those 41 monitoring well series.

Table 1, organized alphabetically by well series, lists those well series with analytical results above Flag 2 criteria during second quarter 1998. Results from all laboratory analyses are used to generate this table. Specific conductance and $\mathrm{pH}$ data from field measurements also are included in this table.

\section{Table 1. Analytes above Flag 2 Criteria}

\begin{tabular}{|c|c|c|}
\hline Site & $\begin{array}{l}\text { Well } \\
\text { Series }\end{array}$ & Analytes above Flag 2 Criteria \\
\hline A-Area Burning/Rubble Pits & ARP & $\begin{array}{l}\text { Aluminum, gross alpha, iron, manganese, specific } \\
\text { conductance, tetrachloroethylene, trichloroethylene }\end{array}$ \\
\hline $\begin{array}{l}\text { Mixed Waste Management Facility (Site } \\
643-28 E \text { ) and Low-Level Radioactive } \\
\text { Waste Disposal Facility (643-7E) }\end{array}$ & BGO & $\begin{array}{l}\text { Aluminum, antimony, bromomethane, carbon-14, iron, lead, } \\
\text { manganese, mercury, nickel, pH, specific conductance, } \\
\text { strontium-90, tetrachloroethylene, thallium, total organic } \\
\text { halogens, trichloroethylene, trichlorofluoromethane, tritium }\end{array}$ \\
\hline C-Area Burning/Rubble Pit & CRP & Total organic halogens, trichloroethylene \\
\hline C-Area Reactor Seepage Basins & CSB & Aluminum, iron, manganese, trichloroethylene, tritium \\
\hline $\begin{array}{l}\text { N-Area (Central Shops) Burning/Rubble } \\
\text { Pits }\end{array}$ & CSR & $\begin{array}{l}\text { Aluminum, antimony, benzo[a]pyrene, } \\
\text { benzo[b]fluoranthene, benzo[ } k] \text { fluoranthene, beryllium, } \\
\text { bis }(2-e t h y l h e x y l) \text { phthalate, dibenz }[a, h] \text { anthracene, } \\
\text { indeno[1,2,3-c,d]pyrene, iron, manganese, specific } \\
\text { conductance, tetrachloroethylene, trichloroethylene }\end{array}$ \\
\hline D-Area Burning/Rubble Pits & DBP & Bis(2-ethylhexyl) phthalate, manganese \\
\hline $\begin{array}{l}\text { D-Area Coal Pile Runoff Containment } \\
\text { Basin and Ash Basin }\end{array}$ & DCB & $\begin{array}{l}\text { Aluminum, iron, manganese, specific conductance, sulfate, } \\
\text { tetrachloroethylene, trichloroethylene }\end{array}$ \\
\hline D-Area Oil Seepage Basin & DOB & Aluminum, iron, manganese, tetrachloroethylene, thallium \\
\hline F-Area Burning/Rubble Pits & FBP & $\begin{array}{l}\text { Iron, nitrate as nitrogen, } \mathbf{p H} \text {, specific conductance, } \\
\text { tetrachloroethylene, trichloroethylene, } \\
\text { trichlorofluoromethane, tritium }\end{array}$ \\
\hline
\end{tabular}




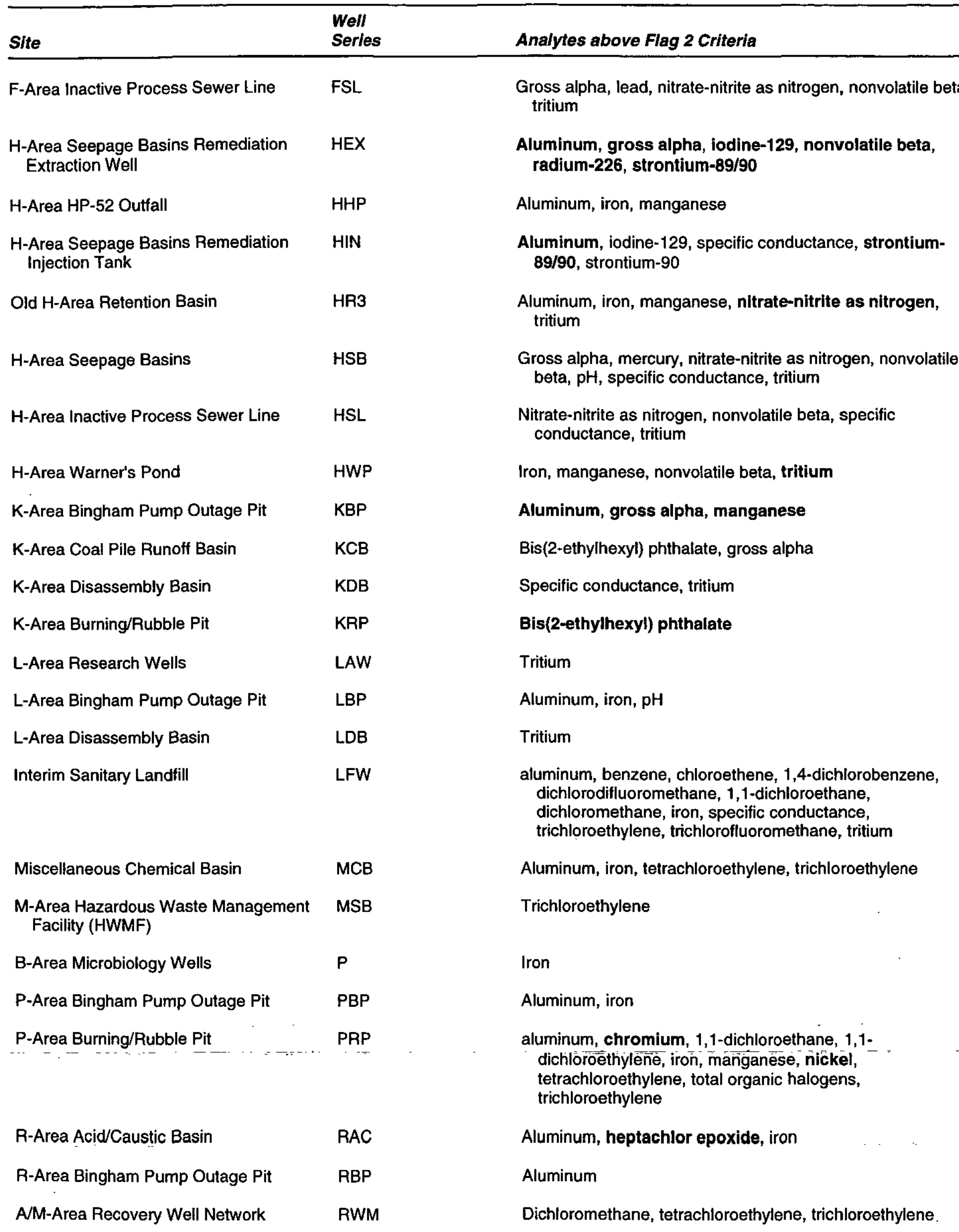

\section{Executive Summary}




\begin{tabular}{|c|c|c|}
\hline Site & $\begin{array}{l}\text { Well } \\
\text { Series }\end{array}$ & Analytes above Flag 2 Criteria \\
\hline TNX Burying Ground & TBG & $\begin{array}{l}\text { Aluminum, carbon tetrachloride, gross alpha, iron, nitrate as } \\
\text { nitrogen, tetrachloroethylene, trichloroethylene }\end{array}$ \\
\hline TNX-Area Operable Unit & TCM & Carbon tetrachloride, trichloroethylene \\
\hline TNX-Area Operable Unit & TIR & Carbon tetrachloride, trichloroethylene \\
\hline TNX-Area Assessment Wells & TNX & $\begin{array}{l}\text { Aluminum, carbon tetrachloride, gross alpha, iron, } \\
\text { manganese, nitrate as nitrogen, tetrachloroethylene, } \\
\text { trichloroethylene }\end{array}$ \\
\hline TNX-Area Recovery Wells & TRW & $\begin{array}{l}\text { Aluminum, carbon tetrachloride, nitrate as nitrogen, } \\
\text { trichloroethylene }\end{array}$ \\
\hline Old TNX Seepage Basin & XSB & $\begin{array}{l}\text { Aluminum, carbon tetrachloride, gross alpha, iron, mercury, } \\
\text { nitrate as nitrogen, specific conductance, trichloroethylene }\end{array}$ \\
\hline
\end{tabular}

Note: The groundwater samples are unfiltered. Therefore, the results for metals are for total recoverable metals. Analytes in bold were detected at levels above the current Flag 2 criteria for the first time since 1984. 


\section{NOTES}




\section{Introduction}

This report summarizes the Groundwater Monitoring Program conducted by SRS during second quarter 1998. It includes the analytical data, field data, data review, quality control, and other documentation for this program; provides a record of the program's activities; and serves as an official record of the analytical results.

EPD/EMS is responsible for providing drilling, sampling, and analytical and data management support for the SRS Groundwater Monitoring Program at approximately 135 waste sites in 17 areas at SRS (see figures 1 and 2 at the end of this section). The majority of this monitoring is required by U.S. Department of Energy (DOE) orders and by federal and state regulations administered by the EPA and the South Carolina Department of Health and Environmental Control (SCDHEC). The Groundwater Monitoring Program includes the following activities:

- installation, maintenance, and abandonment of monitoring wells

- environmental soil borings

- development of sampling and analytical schedules

- collection and analysis of groundwater samples

- review of analytical and other data

- maintenance of the databases containing groundwater monitoring data

- quality assurance (QA) evaluations of laboratory performance

- reports of results to waste-site facility custodians and the Environmental Protection Department

The custodian of each waste site is responsible for informing EPD/EMS of sampling and analytical requirements and special requests for the sampling schedule, assisting in review of the data, and making any decisions regarding groundwater monitoring at the waste site.

Each custodian receives a copy of this report. Each custodian also receives site-specific data on request, including the following:

- a computer printout of the analytical data for the current quarter and for the previous seven quarters, designed to assist in identifying trends

- a computer printout of analytical results at or above Flag 1 and Flag 2 criteria for the quarter, designed to assist in identifying elevated constituents

\section{ORGANIZATION OF THIS REPORT}

This report is divided into sections that focus on specific aspects of the SRS Groundwater Monitoring Program. The Executive Summary section presents a listing by waste site and well series of all analytes detected at or above Flag 2 criteria during the quarter. Analytes detected at or above Flag 2 criteria for the second time since 1984 are indicated in bold type.

The Flagging Criteria section lists flagging criteria for analytes and provides a short description of how the criteria were derived. The Sample Scheduling section discusses the preparation of the sampling schedule and the criteria for analyte selection. 
During sample collection, samplers write comments in the field logbooks that may be pertinent to the analysis of samples. Many of the comments concern wells that went dry during sampling or water that appeared colored, turbid, or aerated. These comments are included in the Field Notes section.

Samples are analyzed by one or more off-site laboratories. During second quarter 1998, EMAX Laboratories, Inc. (EX), of Torrance, CA; General Engineering Laboratories (GE), of Charleston, SC; QST Environmental Inc. (ES), formerly Environmental Science and Engineering, Inc., of Gainesville, FL; and Recra LabNet Philadelphia (WA), of Lionville, PA, were the primary off-site laboratories. Radionuclide analyses were conducted by Environmental Physics, Inc. (GP), a subcontractor for GE, and Thermo NUtech (TM), a subcontractor for WA and ES. The Analytical Data Review section contains three subsections. The GIMS Data Review Module subsection discusses automated data management activities at EPD/EMS. The Review of the Analytical Data subsection includes a discussion of discrepancies in each laboratory's analytical data, including results that were considerably higher or lower than previous results. This subsection also includes information about the analytical narratives that were used as reference materials throughout the data validation process. The Analytical Methods subsection lists the methods the laboratories used for measuring concentrations of each analyte.

The Quality Control Samples section contains five subsections and discusses the analytical data in terms of the following indicators of data quality: precision, accuracy, representativeness, comparability, and completeness. The Precision subsection explains the replicate analysis program, gives the statistical methods used for comparison, and lists the results of the comparisons between the replicate and duplicate analyses. The Accuracy subsection examines the relationship between an observed value and an accepted reference value and/or the measure of the over- or underestimation of reported concentrations. The Representativeness subsection describes how groundwater samples can be affected to produce results that may be biased positively or negatively. The Comparability subsection discusses whether the laboratories use the same standardized procedures for sample preparation and analysis, whether the reporting units are the same, and whether similar quantitation limits were obtained. The Completeness section evaluates the amount of useable data that resulted from the data collection.

The Site Index section lists and gives a description of the sites associated with each well series, as well as historical information for the sites. A list of terms, abbreviations, and acronyms used in this report can be found in the Glossary section. References cited are included in the References section.

The Water-Level Data section (Appendix A) includes concurrent water elevations obtained in AM and other areas; these data are used by SRS personnel in hydrogeologic studies. The Analytical Results section (Appendix B) includes tables listing the analytical results from all laboratories and field data for all wells sampled during the quarter. The tables appear in aiphabetical order by well name. The Sampling Blanks Results section (Appendix C) contains tables listing the analytical results of laboratory tests on sampling blanks.

\section{Introduction}




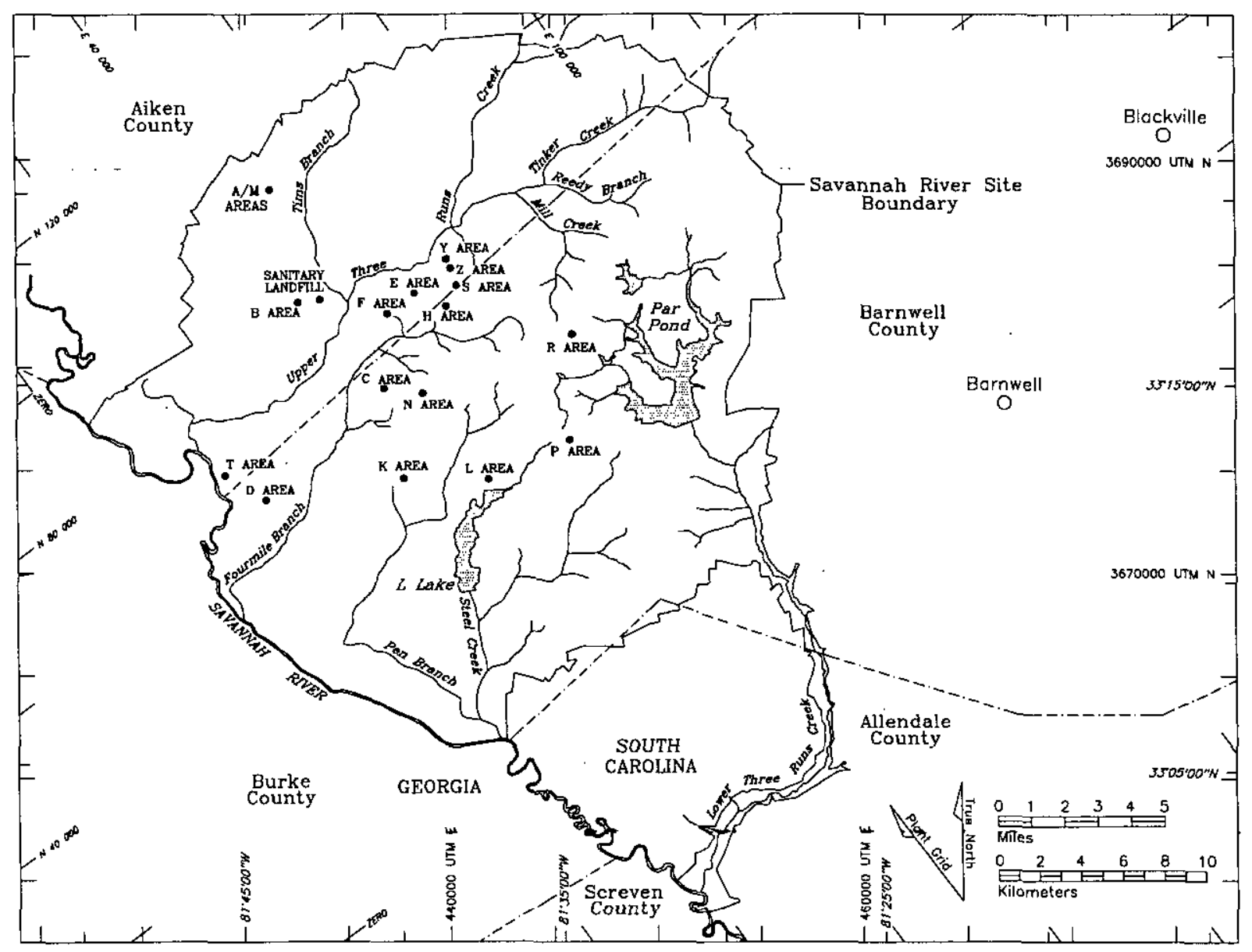

Figure 1. Areas and Locations Monitored for Groundwater Quality 


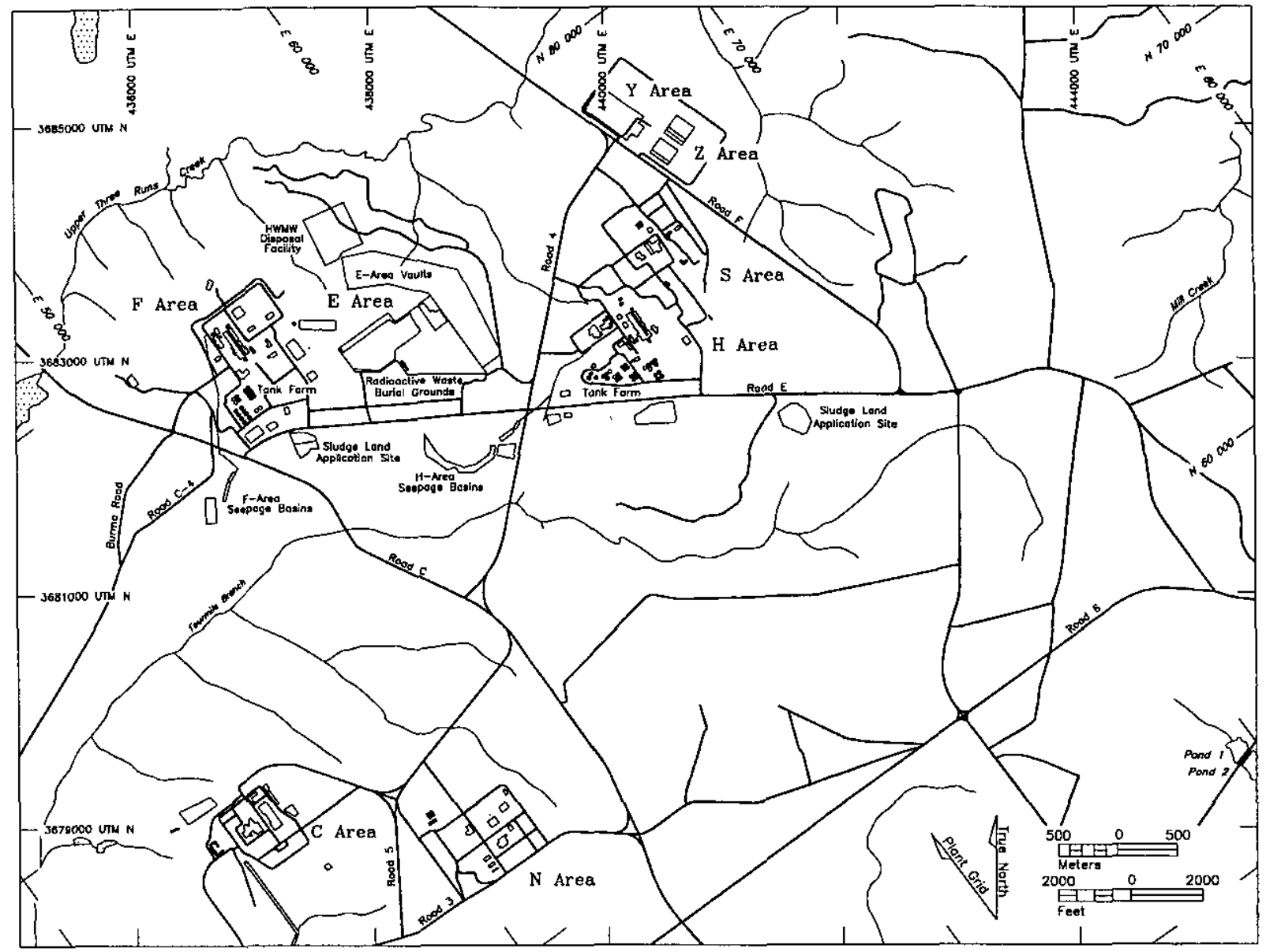

Figure 2. Separations and Waste Management Areas Monitored for Groundwater Quality 


\section{Flagging Criteria}

Analytes in the data tables are assigned flagging levels $(0,1$, or 2$)$ depending on their concentrations in a groundwater sample. The flagging levels dictate the scheduling and frequency of groundwater sampling. Beginning first quarter 1992, flagging criteria were established for all of the constituents currently being analyzed as part of the EPD/EMS Groundwater Monitoring Program, except for certain aesthetic constituents, indicator parameters, major cations, and common laboratory contaminants and cleaners, which can be analyzed by special request. The flagging criteria in table 2 were determined as follows:

Flag 0: Analytical results below Flag 1 and constituents having no flagging criteria were classified as Flag 0.

Flag 1: The Flag 1 criterion for a constituent was set as one-half of the EPA final primary drinking water standard, the EPA proposed primary drinking water standard, or the EPA secondary drinking water standard for that constituent. If a constituent did not have an EPA drinking water standard, the Flag 1 criterion was set as five times a recently published 90 th percentile detection limit obtained by one of the primary laboratories.

Flag 2: The Flag 2 criterion for a constituent was set as the EPA final primary drinking water standard, the EPA proposed primary drinking water standard, or the EPA secondary drinking water standard for that constituent. If a constituent did not have a drinking water standard, the Flag 2 criterion was set as 10 times a recently published 90 th percentile detection limit obtained by one of the primary laboratories.

The following acronyms are used as abbreviated sources in the flagging criteria table. Complete information concerning documents cited can be found in the References section of this report.

APHA - American Public Health Association.

APHA Method - A specific analytical method for testing constituent levels in a sample as established by the APHA, American Water Works Association, and Water Pollution Control Federation. See American Public Health Association et al. in References.

EPA - U.S. Environmental Protection Agency.

EPA Method - A specific analytical method for testing constituent levels. Descriptions of these methods can be found in the EPA publications Methods for Chemical Analysis of Water and Wastes (1983) and Test Methods for Evaluating Solid Waste (1986b) and in the 1991 Code of Federal Regulations, Title 40, Part 136. See Environmental Protection Agency in References.

EPD/EMS - The Environmental Protection Department/Environmental Monitoring Section at the Savannah River Site.

PDWS — Primary Drinking Water Standards.

SCDHEC — South Carolina Department of Health and Environmental Control.

SDWS - Secondary Drinking Water Standards. 
Table 2. Flagging Criteria

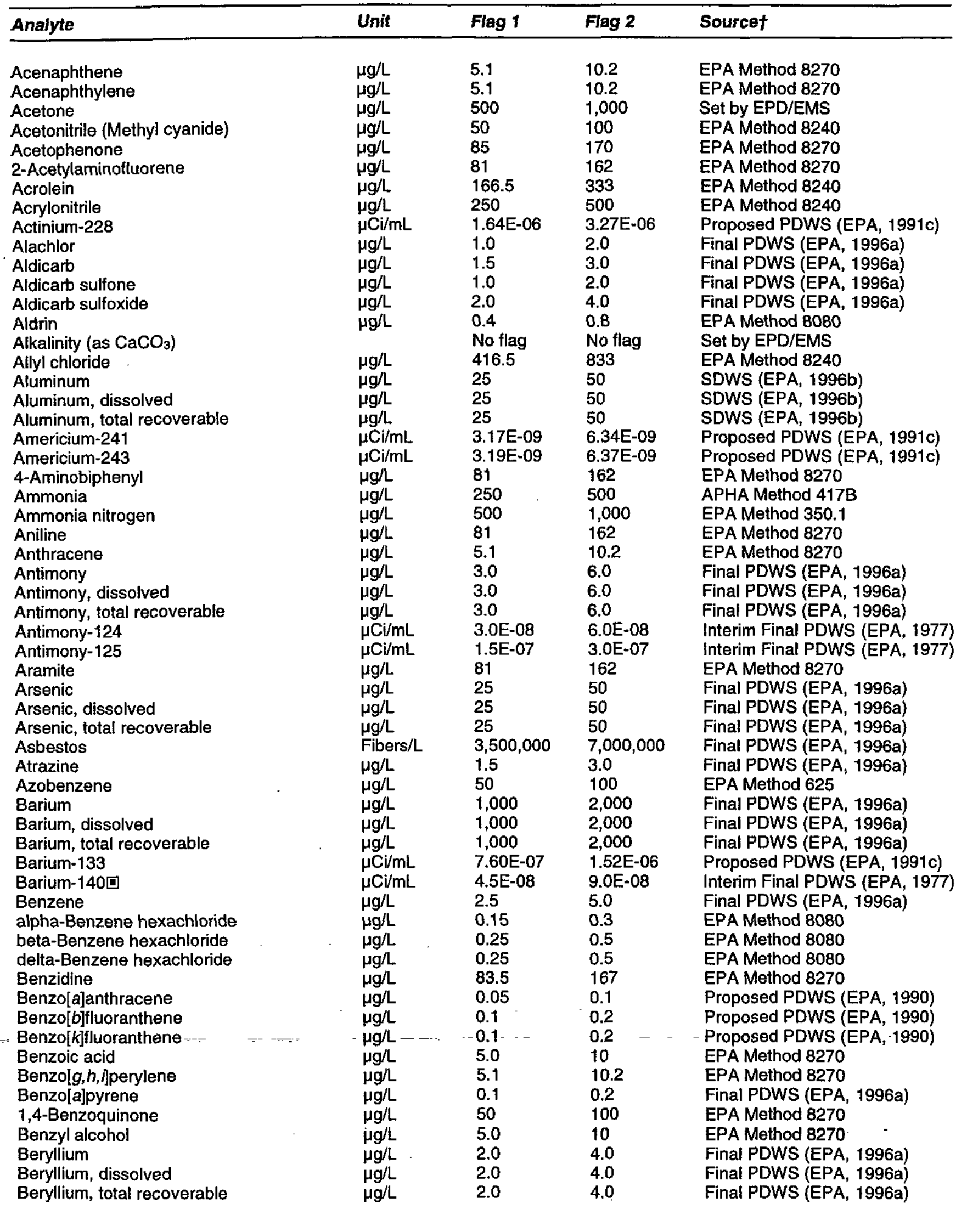




\begin{tabular}{|c|c|c|c|c|}
\hline Analyte & Unit & Flag 1 & Flag 2 & Sourcet \\
\hline 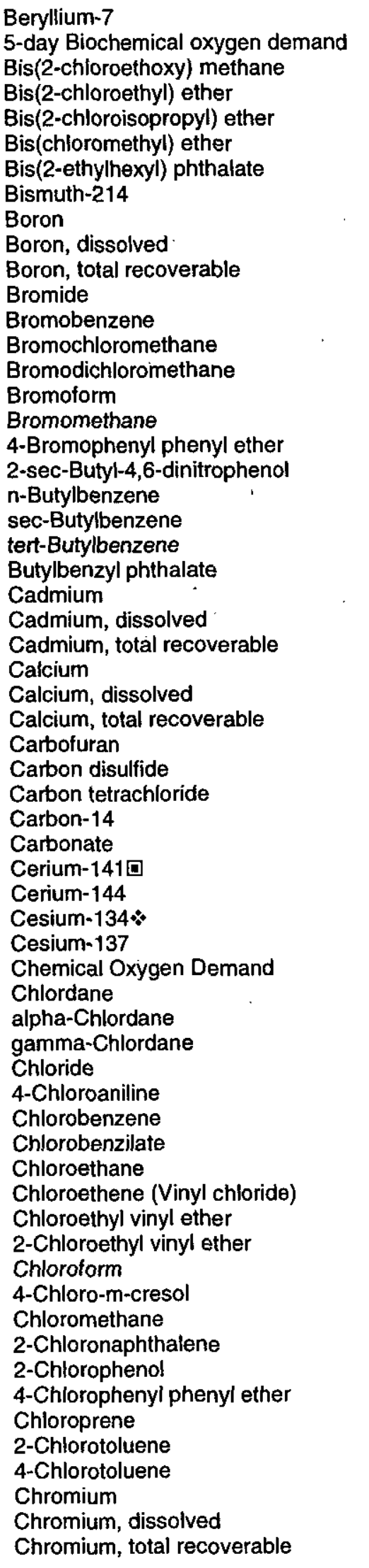 & $\begin{array}{l}\mu g / L \\
\mu g / L \\
\mu g / L \\
\mu C i / m L \\
\mu C i / m L \\
\mu C i / m L \\
\mu C i / m L \\
\mu C i / m L \\
\mu g / L \\
\mu g / L \\
\mu g / L \\
\mu g / L \\
\mu g / L \\
\mu g / L \\
\mu g / L \\
\mu g / L \\
\mu g / L \\
\mu g / L \\
\mu g / L \\
\mu g / L \\
\mu g / L \\
\mu g / L \\
\mu g / L \\
\mu g / L \\
\mu g / L \\
\mu g / L \\
\mu g / L \\
\mu g / L \\
\mu g / L \\
\mu g / L \\
\mu g / L\end{array}$ & 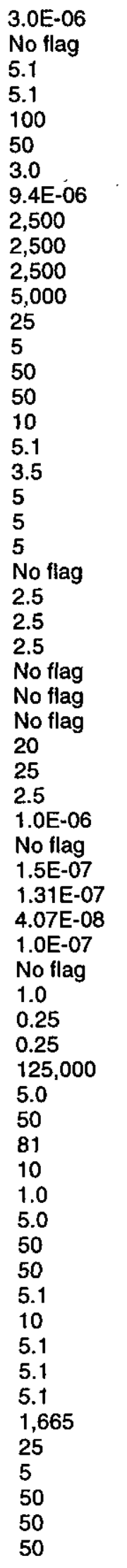 & 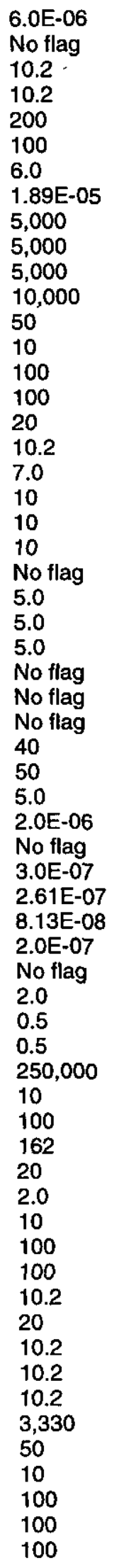 & 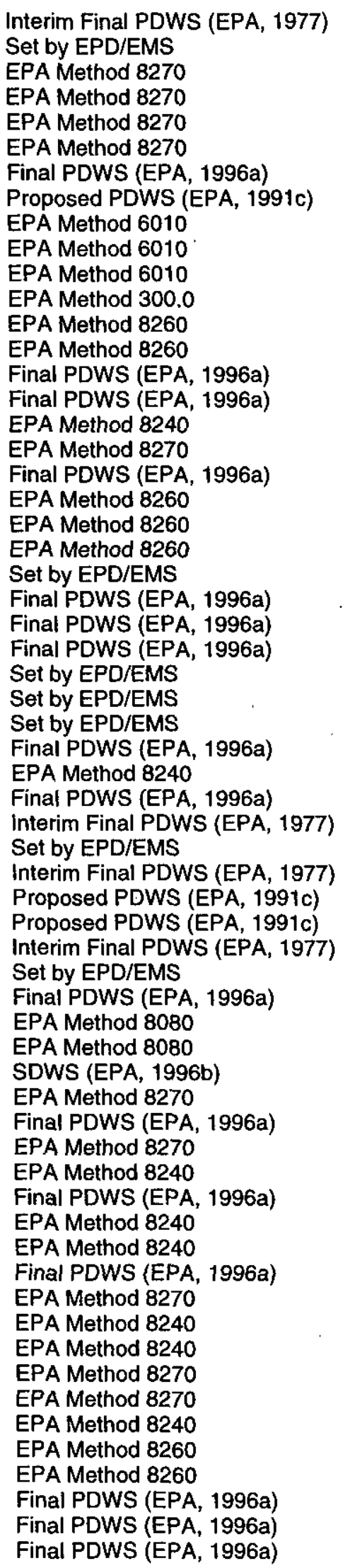 \\
\hline
\end{tabular}




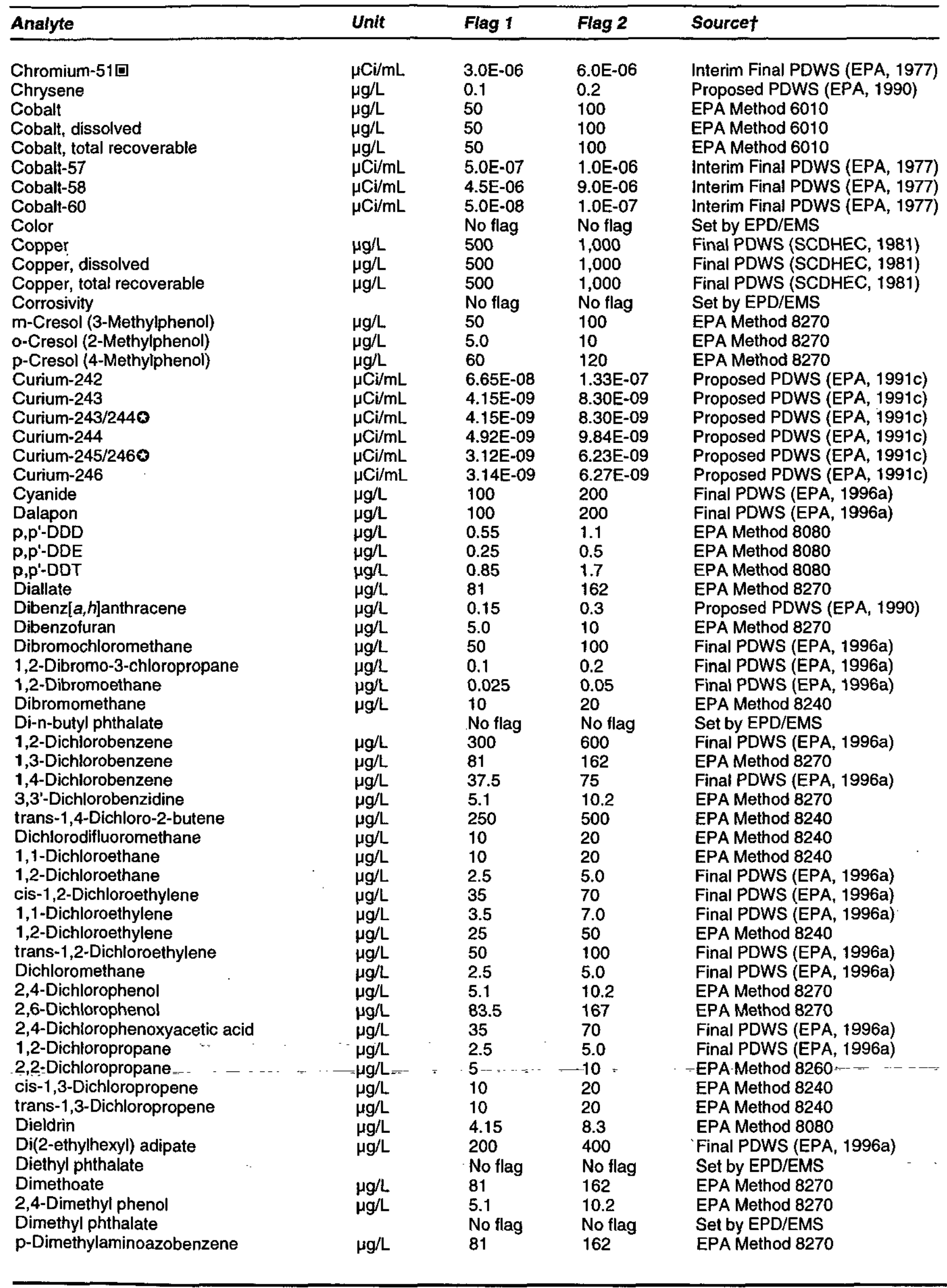




\begin{tabular}{|c|c|c|c|c|}
\hline Analyte & Unit & Flag 1 & Flag 2 & Sourcet \\
\hline p-(Dimethylamino)ethylbenzene & $\mu g / L$ & 50 & 100 & EPA Method 8270 \\
\hline 7,12-Dimethylbenz [a]anthracene & $\mu g / L$ & 81 & 162 & EPA Method 8270 \\
\hline 3,3'-Dimethylbenzidine & $\mu g / L$ & 81 & 162 & EPA Method 8270 \\
\hline a,a-Dimethylphenethylamine & $\mu g / L$ & 81 & 162 & EPA Method 8270 \\
\hline 1,3-Dinitrobenzene & $\mu g / L$ & 81 & 162 & EPA Method 8270 \\
\hline 2,4-Dinitrophenol & $\mu g / L$ & 51 & 102 & EPA Method 8270 \\
\hline 2,4-Dinitrotoluene & $\mu g / L$ & 0.5 & 1.0 & EPA Method 8270 \\
\hline 2,6-Dinitrotoluene & $\mu g / L$ & 0.5 & 1.0 & EPA Method 8270 \\
\hline Di-n-octyl phthalate & & No flag & No flag & Set by EPD/EMS \\
\hline 1,4-Dioxane & $\mu g / L$ & 500 & 1000 & EPA Method 8270 \\
\hline Diphenylamine & $\mu g / L$ & 81 & 162 & EPA Method 8270 \\
\hline 1,2-Diphenylhydrazine & $\mu g / L$ & 83.5 & 167 & EPA Method 8270 \\
\hline Diquat dibromide & $\mu g / L$ & 10 & 20 & Final PDWS (EPA, 1996a) \\
\hline Dissolved organic carbon & $\mu g / L$ & $10,500,000$ & $21,000,000$ & EPA Method 9060 \\
\hline Disulfoton & $\mu g / L$ & 81 & 162 & EPA Method 8270 \\
\hline Endosulfan I & $\mu g / L$ & 0.25 & 0.5 & EPA Method 8080 \\
\hline Endosulfan II & $\mu g / L$ & 0.55 & 1.1 & EPA Method 8080 \\
\hline Endosulfan sulfate & $\mu g / L$ & 0.55 & 1.1 & EPA Method 8080 \\
\hline Endothall & $\mu g / L$ & 50 & 100 & Final PDWS (EPA, 1996a) \\
\hline Endrin & $\mu g / L$ & 1.0 & 2.0 & Final PDWS (EPA, 1996a) \\
\hline Endrin aldehyde & $\mu g / L$ & 0.85 & 1.7 & EPA Method 8080 \\
\hline Endrin ketone & & No flag & No flag & Set by EPD/EMS \\
\hline Ethyl ether & $\mu g / L$ & 50 & 100 & EPA Method 8260 \\
\hline Ethyl methacrylate & $\mu g / L$ & 2.5 & 5.0 & EPA Method 8270 \\
\hline Ethyl methanesulfonate & $\mu g / L$ & 81 & 162 & EPA Method 8270 \\
\hline Ethylbenzene & $\mu \mathrm{g} / \mathrm{L}$ & 350 & 700 & Final PDWS (EPA, 1996a) \\
\hline Europium-152 & $\mu \mathrm{Ci} / \mathrm{mL}$ & 3.0E-08 & $6.0 \mathrm{E}-08$ & interim Final PDWS (EPA, 1977) \\
\hline Europium-154 & $\mu \mathrm{Ci} / \mathrm{mL}$ & 1.0E-07 & 2.0E-07 & Interim Final PDWS (EPA, 1977) \\
\hline Europium-155 & $\mu \mathrm{Ci} / \mathrm{mL}$ & 3.0E-07 & 6.0E-07 & Interim Final PDWS (EPA, 1977) \\
\hline Famphur & $\mu g / L$ & 81 & 162 & EPA Method 8270 \\
\hline Fluoranthene & $\mu g / L$ & 5.1 & 10.2 & EPA Method 8270 \\
\hline Fluorene & $\mu g / L$ & 5.1 & 10.2 & EPA Method 8270 \\
\hline Fluoride & $\mu \mathrm{g} / \mathrm{L}$ & 2,000 & 4,000 & Final PDWS (EPA, 1996a) \\
\hline Glyphosate & $\mu g / L$ & 350 & 700 & Final PDWS (EPA, 1996a) \\
\hline Gross alpha & $\mu \mathrm{Ci} / \mathrm{mL}$ & 7.5E-09 & $1.5 E-08$ & Final PDWS (EPA, 1996a) \\
\hline Heptachlor & $\mu g / L$ & 0.2 & 0.4 & Final PDWS (EPA, 1996a) \\
\hline Heptachlor epoxide & $\mu g / L$ & 0.1 & 0.2 & Final PDWS (EPA, 1996a) \\
\hline Heptachlorodibenzo-p-dioxins & $\mu g / L$ & 0.007 & 0.014 & EPA Method 8280 \\
\hline $1,2,3,4,6,7,8-H P C D D$ & $\mu g / L$ & 0.007 & 0.014 & EPA Method 8280 \\
\hline Heptachlorodibenzo-p-furans & $\mu g / L$ & 0.008 & 0.016 & EPA Method 8280 \\
\hline $1,2,3,4,6,7,8-\mathrm{HPCDF}$ & $\mu g / L$ & 0.008 & 0.016 & EPA Method 8280 \\
\hline Hexachlorobenzene & $\mu g / L$ & 0.5 & 1.0 & Final PDWS (EPA, 1996a) \\
\hline Hexachlorobutadiene & $\mu g / L$ & 5.0 & 10 & EPA Method 8270 \\
\hline Hexachlorocyclopentadiene - & $\mu g / L$ & 25 & 50 & Final PDWS (EPA, 1996a) \\
\hline Hexachlorodibenzo-p-dioxins & $\mu g / L$ & 0.008 & 0.016 & EPA Method 8280 \\
\hline $1,2,3,4,7,8-H \times C D D$ & $\mu g / L$ & 0.0105 & 0.021 & EPA Method 8280 \\
\hline Hexachlorodibenzo-p-furans & $\mu g / L$ & 0.006 & 0.012 & EPA Method 8280 \\
\hline $1,2,3,4,7,8-\mathrm{HXCDF}$ & $\mu g / L$ & 0.0085 & 0.017 & EPA Method 8280 \\
\hline Hexachloroethane & $\mu g / L$ & 0.5 & 1.0 & EPA Method 8270 \\
\hline Hexachlorophene & $\mu g / L$ & 83.5 & 167 & EPA Method 8270 \\
\hline Hexachloropropene & $\mu g / L$ & 81 & 162 & EPA Method 8270 \\
\hline 2-Hexanone & $\mu g / L$ & 50 & 100 & EPA Method 8240 \\
\hline Indeno $[1,2,3-c, d]$ pyrene & $\mu g / L$ & 0.5 & 1.0 & EPA Method 8270 \\
\hline lodine & $\mu g / L$ & 250 & 500 & APHA Method $415 \mathrm{~A}$ \\
\hline lodine-129 & $\mu \mathrm{Ci} / \mathrm{mL}$ & 5.0E-10 & 1.0E-09 & Interim Final PDWS (EPA, 1977) \\
\hline lodine-131! & $\mu \mathrm{Ci} / \mathrm{mL}$ & $1.5 \mathrm{E}-09$ & 3.0E-09 & Interim Final PDWS (EPA, 1977) \\
\hline lodomethane (Methyl iodide) & $\mu g / L$ & 125 & 250 & EPA Method 8240 \\
\hline Iron & $\mu g / L$ & 150 & 300 & SDWS (EPA, 1996b) \\
\hline Iron, dissolved & $\mu g / L$ & 150 & 300 & SDWS (EPA, 1996b) \\
\hline Iron, total recoverable & $\mu \mathrm{g} / \mathrm{L}$ & 150 & 300 & SDWS (EPA, 1996b) \\
\hline Iron-55口 & $\mu \mathrm{Ci} / \mathrm{mL}$ & 1.0E-06 & $2.0 \mathrm{E}-06$ & Interim Final PDWS (EPA, 1977) \\
\hline Iron-59ם & $\mu \mathrm{Ci} / \mathrm{mL}$ & 1.0E-07 & 2.0E-07 & Interim Final PDWS (EPA, 1977) \\
\hline
\end{tabular}




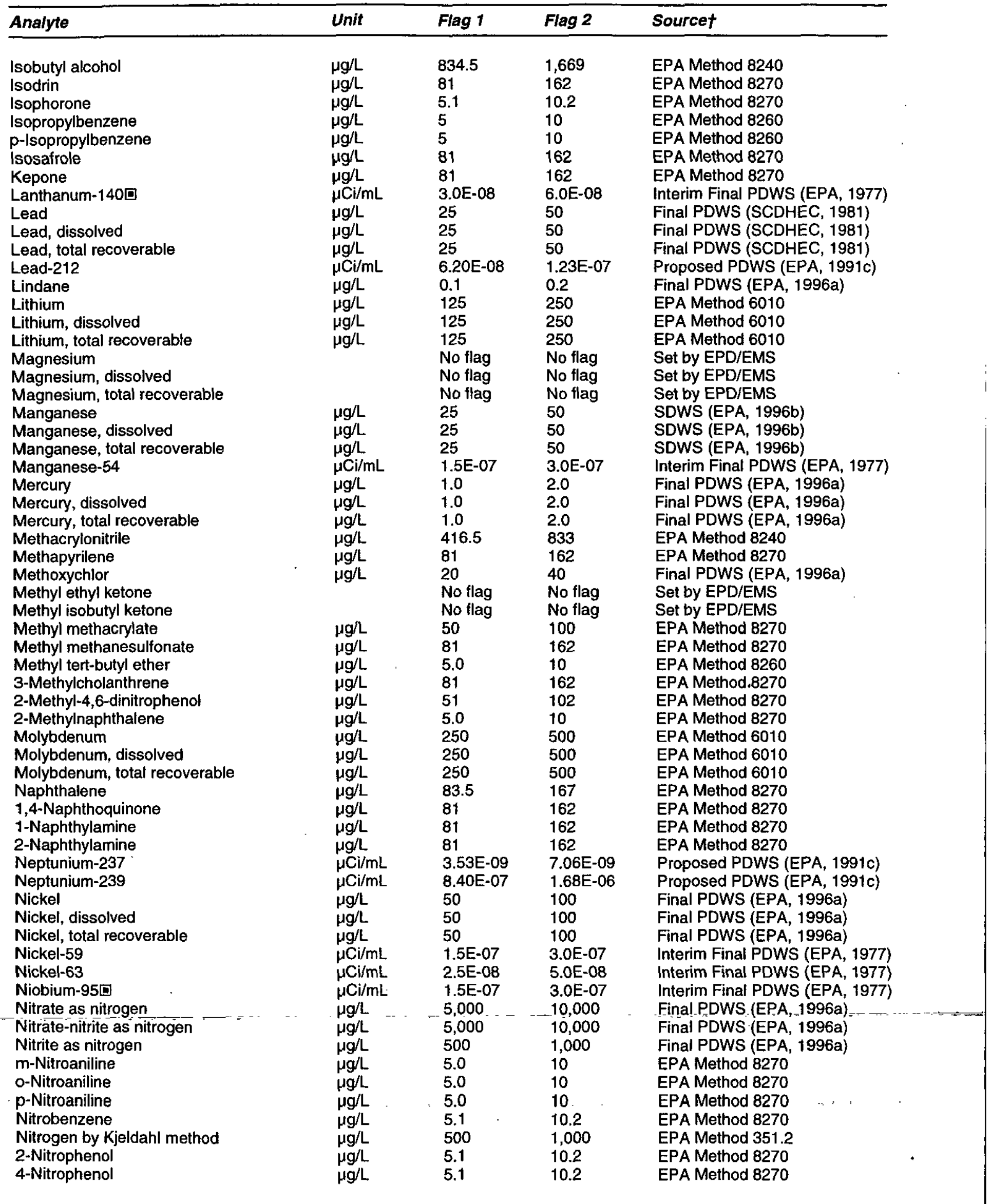




\begin{tabular}{|c|c|c|c|c|}
\hline Analyte & Unit & Flag 1 & Flag 2 & Sourcet \\
\hline 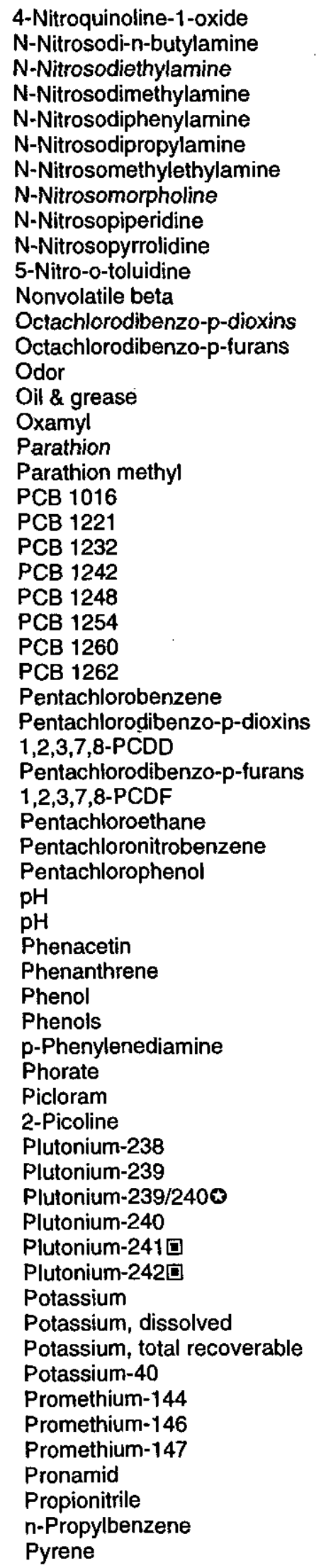 & $\begin{array}{l}\mu g / L \\
\mu g / L \\
\mu g / L \\
\mu g / L \\
\mu g / L \\
\mu g / L \\
\mu g / L \\
\mu g / L \\
\mu g / L \\
\mu g / L \\
\mu C i / m L \\
\mu g / L \\
\mu g / L \\
\mu g / L \\
\mu g / L \\
\mu g / L \\
\mu g / L \\
\mu g / L \\
\mu g / L \\
\mu g / L \\
\mu g / L\end{array}$ & $\begin{array}{l}81 \\
81 \\
81 \\
83.5 \\
5.1 \\
5.1 \\
81 \\
81 \\
81 \\
81 \\
81 \\
2.5 \mathrm{E}-08 \\
0.0085 \\
0.0065 \\
\text { No flag } \\
8,350 \\
100 \\
0.4 \\
0.4 \\
0.25 \\
0.25 \\
0.25 \\
0.25 \\
0.25 \\
0.25 \\
0.25 \\
0.25 \\
81 \\
0.008 \\
0.0075 \\
0.0085 \\
0.0085 \\
81 \\
81 \\
0.5 \\
8.0 \\
4.0 \\
81 \\
5.1 \\
83.5 \\
50 \\
81 \\
0.85 \\
250 \\
81 \\
3.51 \mathrm{E}-09 \\
3.11 \mathrm{E}-08 \\
3.11 \mathrm{E}-08 \\
3.11 \mathrm{E}-08 \\
3.13 \mathrm{E}-08 \\
3.27 \mathrm{E}-08 \\
\text { No flag } \\
\text { No flag } \\
\text { No flag } \\
1.5 \mathrm{E}-07 \\
5.0 \mathrm{E}-08 \\
5.0 \mathrm{E}-08 \\
2.62 \mathrm{E}-06 \\
81 \\
1,665 \\
5 \\
5.1 \\
\\
5 \\
\end{array}$ & $\begin{array}{l}162 \\
162 \\
162 \\
167 \\
10.2 \\
10.2 \\
162 \\
162 \\
162 \\
162 \\
162 \\
5.0 \mathrm{E}-08 \\
0.017 \\
0.013 \\
\text { No flag } \\
16,700 \\
200 \\
0.8 \\
0.8 \\
0.5 \\
0.5 \\
0.5 \\
0.5 \\
0.5 \\
0.5 \\
0.5 \\
0.5 \\
162 \\
0.016 \\
0.015 \\
0.017 \\
0.017 \\
162 \\
162 \\
1.0 \\
10 \\
3.0 \\
162 \\
10.2 \\
167 \\
100 \\
162 \\
1.7 \\
500 \\
162 \\
7.02 \mathrm{E}-09 \\
6.21 \mathrm{E}-08 \\
6.21 \mathrm{E}-08 \\
6.22 \mathrm{E}-08 \\
6.26 \mathrm{E}-08 \\
6.54 \mathrm{E}-08 \\
\text { No flag } \\
\text { No flag } \\
\text { No flag } \\
3.0 \mathrm{E}-07 \\
1.0 \mathrm{E}-07 \\
1.0 \mathrm{E}-07 \\
5.24 \mathrm{E}-06 \\
162 \\
3,330 \\
10 \\
10.2 \\
\\
100 \\
100 \\
100\end{array}$ & $\begin{array}{l}\text { EPA Method 8270 } \\
\text { EPA Method 8270 } \\
\text { EPA Method 8270 } \\
\text { EPA Method 8270 } \\
\text { EPA Method 8270 } \\
\text { EPA Method 8270 } \\
\text { EPA Method 8270 } \\
\text { EPA Method 8270 } \\
\text { EPA Method 8270 } \\
\text { EPA Method 8270 } \\
\text { EPA Method 8270 } \\
\text { Interim Final PDWS (EPA, 1977) } \\
\text { EPA Method 8280 } \\
\text { EPA Method 8280 } \\
\text { Set by EPD/EMS } \\
\text { EPA Method 413.1 } \\
\text { Final PDWS (EPA, 1996a) } \\
\text { EPA Method 8080 } \\
\text { EPA Method 8080 } \\
\text { Final PDWS (EPA, 1996a) } \\
\text { Final PDWS (EPA, 1996a) } \\
\text { Final PDWS (EPA, 1996a) } \\
\text { Final PDWS (EPA, 1996a) } \\
\text { Final PDWS (EPA, 1996a) } \\
\text { Final PDWS (EPA, 1996a) } \\
\text { Final PDWS (EPA, 1996a) } \\
\text { Final PDWS (EPA, 1996a) } \\
\text { EPA Method 8270 } \\
\text { EPA Method 8280 } \\
\text { EPA Method 8280 } \\
\text { EPA Method 8280 } \\
\text { EPA Method 8280 } \\
\text { EPA Method 8270 } \\
\text { EPA Method 8270 } \\
\text { Final PDWS (EPA, 1996a) } \\
\text { Set by EPD/EMS } \\
\text { Set by EPD/EMS } \\
\text { EPA Method 8270 } \\
\text { EPA Method 8270 } \\
\text { EPA Method 8270 } \\
\text { EPA Method 420.1 } \\
\text { EPA Method 8270 } \\
\text { EPA Method 8080 } \\
\text { Final PDWS (EPA, 1996a) } \\
\text { EPA Method 8270 } \\
\text { Proposed PDWS (EPA, 1991c) } \\
\text { Proposed PDWS (EPA, 1991c) } \\
\text { Proposed PDWS (EPA, 1991c) } \\
\text { Proposed PDWS (EPA, 1991c) } \\
\text { Proposed PDWS (EPA, 1991c) } \\
\text { Proposed PDWS (EPA, 1991c) } \\
\text { Set by EPD/EMS } \\
\text { Set by EPD/EMS } \\
\text { Set by EPD/EMS } \\
\text { Proposed PDWS (EPA, 1986a) } \\
\text { EPA Method 901.1 } \\
\text { EPA Method } 901.1 \\
\text { Proposed PDWS (EPA, 1991c) } \\
\text { EPA Method 8270 } \\
\text { EPA Method 8240 } \\
\text { EPA Method 8260 } \\
\text { EPA Method 8270 }\end{array}$ \\
\hline
\end{tabular}




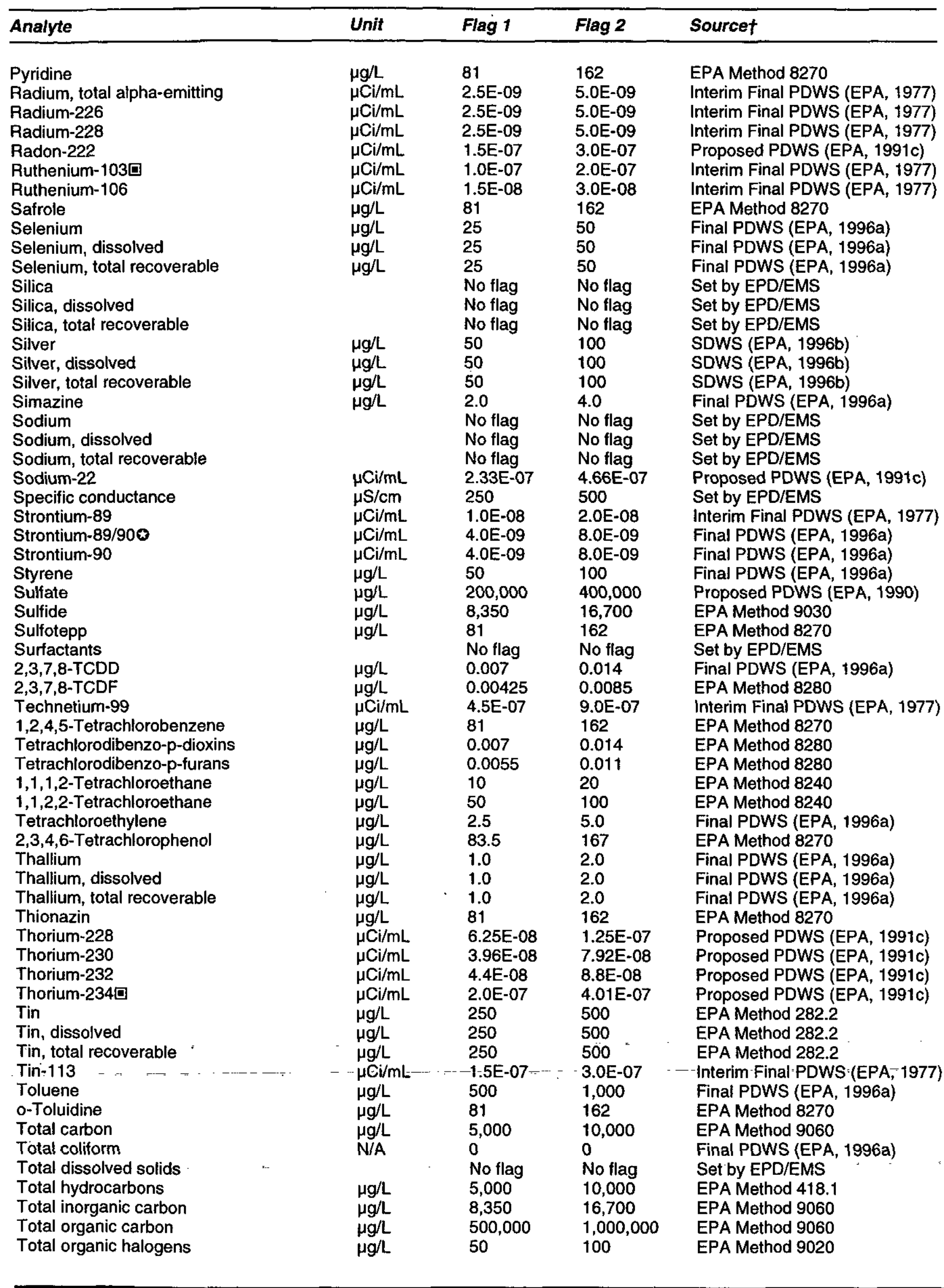




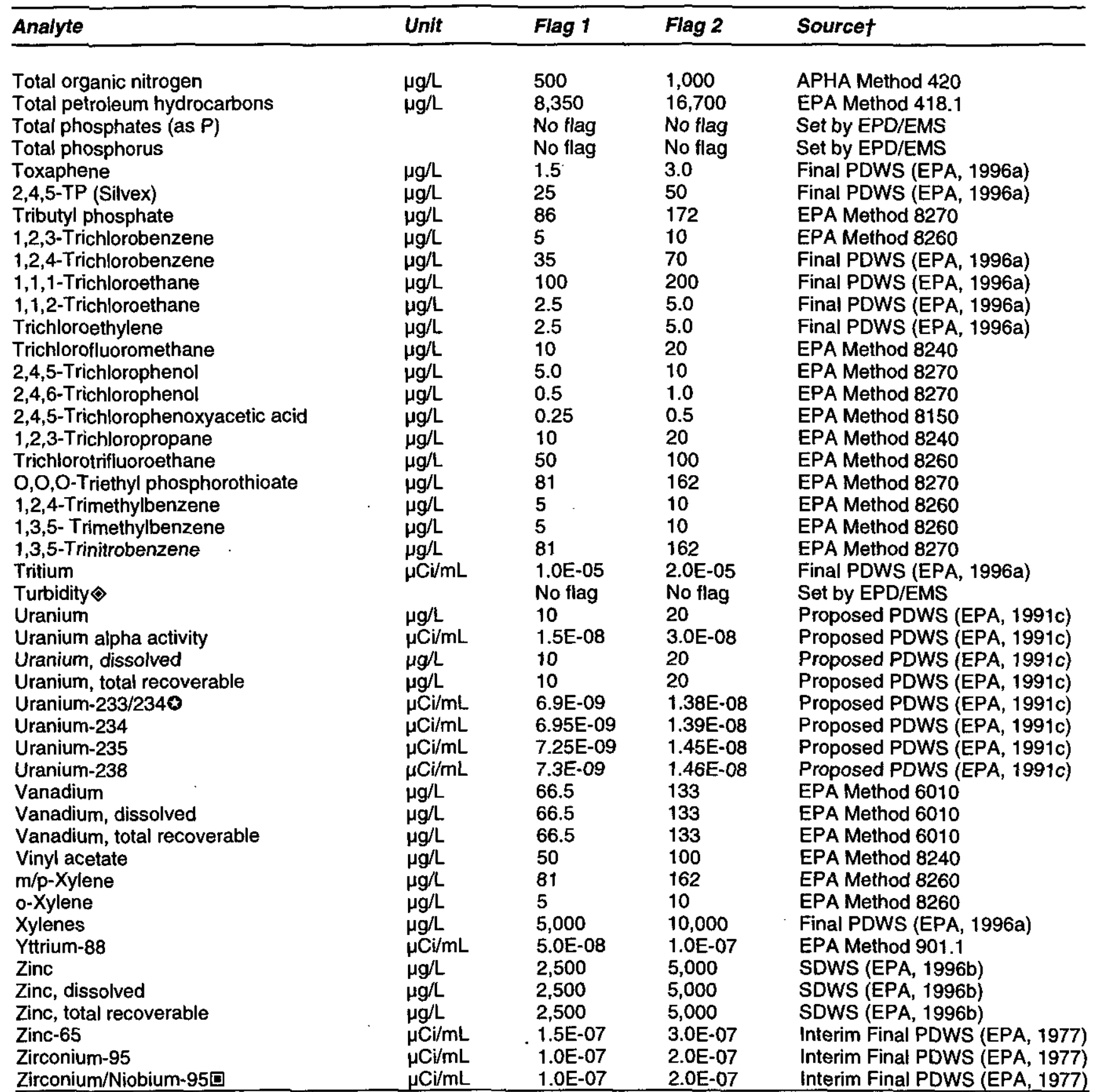

$\uparrow$ Analytical methods are discussed in the Analytical Data Review section of this document; references for dated sources are in the References section.

口EMS discontinued monitoring this radionuclide because it is inappropriate for the SRS Groundwater Monitoring Program. * EPD/EMS set this flagging criterion using the 1991 proposed PDWS because the final PDWS in 1977 may have been in error.

When radionuclide analyses are combined, the lower DWS of the two isotopes is used for flagging.

$\checkmark$ The primary maximum contaminant level range for turbidity is 1-5 NTU, which is inappropriate for the SRS Groundwater Monitoring Program.

Note: Beginning fourth quarter 1992, samples were no longer filtered at the wells. Therefore, the methods for analyzing metals now include a digestion step. Beginning fourth quarter 1993, the laboratories were required to report all metals as total recoverable metals. Flagging criteria remain unchanged. 
NOTES 


\section{Sample Scheduling}

Scheduling of sampling and analyses for the SRS Groundwater Monitoring Program conducted by EPD/EMS is based on several factors. Environmental screening is scheduled on a regular basis. Additional scheduling is based on previous flagging levels, regulatory requirements, and special requests that fall within the scope of the Groundwater Monitoring Program. This information is used to generate The Savannah River Site's Groundwater Monitoring Program 1998 Sampling Schedule.

A breakdown by laboratory of the total number of analyses performed during second quarter 1998 follows:

\author{
Laboratory \\ EMAX Laboratories, Inc. \\ Environmental Physics \\ General Engineering Laboratories \\ QST Environmental, Inc. \\ Recra LabNet Philadelphia \\ Thermo NUtech
}

Number of Analyses
17,186
1,764
4,752
16,398
15,897
1,672

\section{ENVIRONMENTAL SCREENING}

New wells designated as screening program wells are scheduled initially for four quarters of environmental screening. Environmental-screening constituents, which include indicator parameters, groundwater quality characteristics, and some drinking water characteristics, are listed below. After the initial four quarters of analyses for new wells, environmental screening is scheduled once every three years for wells identified as environmental-screening program wells. The wells are sampled only for the environmental screening that has not been analyzed within the past three years.

Beginning in 1996, EPD/EMS changed its policy concerning quarterly field measurements. Only wells scheduled by request or wells identified for environmental screening receive field measurements.

\section{Environmental-Screening Constituents}

$\begin{array}{llll}\text { Aluminum } & \mathrm{pH} & \text { Well condition } & \text { Mercury } \\ \text { Arsenic } & \text { Phenolphthalein alkalinity } & \text { Fluoride } & \text { Nitrate-nitrite as nitrogen } \\ \text { Barium } & \text { Program } & \text { Gross alpha } & \text { Nonvolatile beta } \\ \text { Boron } & \text { Sampling method } & \text { Iron } & \text { Selenium } \\ \text { Cadmium } & \text { Site code } & \text { Lead } & \text { Silver } \\ \text { Chloride } & \text { Specific conductance } & \text { Lithium } & \text { Sodium } \\ \text { Chromium } & \text { Stabilized (Yes or No) } & \text { Major ions } & \text { Sulfate } \\ \text { Field measurements } & \text { Time } & \text { Calcium } & \text { Total dissolved solids } \\ \text { Air temperature } & \text { Total alkalinity } & \text { Magnesium } & \text { Total organic carbon } \\ \text { Date } & \text { Turbidity } & \text { Potassium } & \text { Total organic halogens } \\ \text { Depth to water } & \text { Volume purged } & \text { Silica } & \text { Total phosphates (as P) } \\ \text { Flow rate } & \text { Water temperature } & \text { Manganese } & \text { Tritium }\end{array}$

\section{Scheduling Based on Flagging Levels}

Only the flagging criteria for environmental screening and GC VOA (see Glossary) are used to trigger scheduling. Wells are grouped for scheduling by monitoring site or by the investigation for which they are sampled. Specific criteria for Flag 1 and Flag 2 designations are found in the Flagging Criteria section of this report. 
Beginning in 1996, only wells in the environmental-screening program were scheduled by flagging criteria once a year. Constituents classified as Flag 0 in each well series are scheduled for analyses only by custodian request or as part of the triennial environmental-screening program. If an analytical result for an environmentalscreening or GC VOA analysis in any well exceeds Flag 2 or Flag 1, the environmental-screening wells in the same monitoring series are sampled and analyzed for that constituent once a year. If a constituent falls below Flag 2 for three consecutive sampling events, the individual well's flag is reduced from Flag 2 status to Flag 1 or Flag 0 status, depending on the results, and the well is scheduled according to the lower flag. If a constituent falls below Flag 1 for three consecutive sampling events, the individual well's flag is reduced from Flag 1 status to Flag 0 status, and the flagging-based sampling ceases.

If an environmental-screening or GC VOA constituent has ever been flagged in a well series, it automatically is flagged for all new wells of that series that are designated as environmental-screening wells. The rules previously referred to also apply to removal of a flag from a new well.

When one or more of the five constituents in the GC VOA suite are flagged, the entire suite is scheduled for analysis. The GC VOA suite includes the following: carbon tetrachloride, chloroform, tetrachloroethylene, 1,1,1-trichloroethane, and trichloroethylene.

The following constituents are exceptions to the flagging rules but still receive analyses by custodian request or during triennial environmental-screening analyses:

- Specific conductance and $\mathrm{pH}$, two indicator constituents, have flagging criteria but do not trigger the scheduling mechanism.

- No flags are set for the following indicator parameters and major cations: alkalinity, 5-day biochemical oxygen demand, calcium, carbonate, chemical oxygen demand, magnesium, potassium, silica, sodium, total dissolved solids, total phosphates (as P), and total phosphorus.

- Aesthetic analyses such as color, odor, corrosivity, Eh, turbidity, and surfactants will not be assigned flagging criteria but may be analyzed by special request.

- Common laboratory contaminants and cleaners including phthalates, dichloromethane (methylene chloride), ketones, and toluene are not assigned flagging criteria unless they have primary drinking water standards. These constituents may be analyzed by special request.

\section{GCMS VOA ANALYSES}

All wells are reviewed for total organic halogens (TOH) results twice a year. GCMS VOA (see Glossary) is scheduled once for individual wells that are designated as environmental-screening wells, have had two results for TOH greater than $10 \mu \mathrm{g} / \mathrm{L}$ (excluding the first TOH analysis), and have never received GCMS VOA analysis.

\section{SAMPLING REQUESTS}

Many analyses are scheduled at the request of various SRS groups. The person or group requesting an analysis must submit a formal sampling request form to EPD/EMS. If the request is within the scope of the Groundwater Monitoring Program, and if provision for the analysis has been made in the current laboratory contract, the analysis is added to the sampling schedule. Likewise, if a sampling request should be deleted, the originator of the request must submit a deletion form.

\section{Regulatory Requirements}

All regulatory sampling requirements, such as those mandated by the Resource Conservation and Recovery Act (RCRA), are scheduled by request.

\section{Changes in Sampling}

For changes in sampling for second quarter 1998, please refer to the The Savannah River Site's Groundwater Monitoring Program 1998 Sampling Schedule. 


\section{RFI/RI Projects}

The following RCRA Facility Investigation/Remedial Investigation (RFI/RI) projects were either in process or new during second quarter 1998:

- A/M Area and MetLab

- $\mathrm{F} / \mathrm{H}$ Area

- Mixed Waste Management Facility

- Sanitary Landfill

\section{CERCLA Projects}

The following Comprehensive Environmental Response, Compensation, and Liability Act (CERCLA) projects were either in process or new during second quarter 1998:

- C-Area Reactor Seepage Basin

- D-Area Burning/Rubble Pits

- D-Area Oil Seepage Basin

- F-Area Burning/Rubble Pits

- K-Area Burning/Rubble Pit

- K-Area Coal Pile Runoff Basin

- Miscellaneous Chemical Basin

- N-Area (Central Shops) Burning/Rubble Pits

- P-Area Burning/Rubble Pit

- R-Area Acid/Caustic Basin

- R-Area Reactor Seepage Basins

- TNX Area

\section{Special Studies}

The Diesel Project and monthly testing of the disassembly basins were special studies during second quarter 1998.

\section{New Wells Scheduled for Sampling}

The following new wells were scheduled for sampling for the first time during second quarter 1998: MCB 23B, MCB 25B, MCB 27B, and PRP 5.

New extraction tanks FEX 1TK and HEX500TK were scheduled for sampling for the first time during second quarter 1998. 


\section{MAINTENANCE OR ACCESS PROBLEMS}

The following wells had flowmeter problems during second quarter 1998: DOB 2, FBP 44D, FRB 3, FSB 77 , FSB 78, HSB 65A, LDB 1, P 26A, P 26B, P 26D, and TNX 10D.

The following wells were scheduled for sampling during second quarter 1998, but sampling was incomplete: CDS 1P, CSR 7DL, CSR 10DU, CSR 11DL, FSB106D, FSB115D, FSB116D, FSB119D, FSB120D, HSB141D, KCB 5, MCB 23B, MCB 25B, and QA 71B.

Wells LWF 60D and 62D were resampled for volatiles in April because the volatile vials for the March sampling event were broken.

Wells BGO 3C, BGO 6A, FRB 2, HSB111D, MCB 19B, and MCB 20B were not sampled because of mechanical problems.

Injection tank FIN 2TK was not sampled monthly because the injection system was not operating. Injection tank HIN600TK was not sampled in May because the system was not operating.

Well RWM 10 was not in operation for the April and May sampling events; and wells TRW 1, TRW 2, TRW 3 , and TRW 4 were not in operation for the April event.

In April, wells FBP 44D, FBP 45D, FBP 46D, FBP 47D, FBP 48D, TCM 2, TIR 3B, TNX 16D, and TNX 26D, and, in May, wells TNX 10D and TNX 26D were sampled using hand-held pumps.

Well BGO 2D was inaccessible because of construction.

Well FBP 43DU was not sampled twice because there was not enough water to collect a sample.

The following wells had purging problems during second quarter 1998: BGO 33C, CSR 9DL, CSR 9DU, FRB 2, FSB113C, FSB121DR, FSL 3D, FSL 4D, HSB116, LFW 62D, and TNX $27 D$.

\section{PURGE-WATER CONTAINMENT PROGRAM}

Beginning in 1991, a purge-water containment program was partially implemented to dispose properly of the water purged from certain wells before sampling. According to the Investigation-Derived Waste Management Plan (WSRC, 1995), additional wells were identified for purge-water treatment at the M-1 Air Stripper and Fand H-Area Effluent Treatment Facility. The program has been implemented, and no well that was scheduled for analysis as part of the Groundwater Monitoring Program during second quarter 1998 was not sampled. 
A sampler may visit a well to collect field data, collect samples, and/or measure depth to water. A well may be visited multiple times during a quarter for any combination of these reasons. Field measurements generally include air temperature, depth to water prior to pumping, dissolved oxygen, Eh (REDOX potential), flow rate, $\mathrm{pH}$, phenolphthalein alkalinity, specific conductance, total alkalinity, turbidity, volume of water purged prior to sampling, and water temperature.

EPD/EMS personnel and RCS Corporation of Aiken, SC, performed well visitations during second quarter 1998. Each sampler maintained a field notebook. These notebooks are in the second quarter 1998 section of the EPD/EMS Groundwater Monitoring Library. All well visitations were routine during second quarter 1998, except as indicated in table 3. The table includes samplers' comments on conditions that may affect the samples or the data-collection process. The majority of wells sampled during second quarter 1998 were pumped. Bailed wells are listed in table 91 in the Quality Control Samples section.

Among $Z$ series wells, only six of the 15 wells have casings large enough to allow sampling $(Z 4,7,9,19,20$, and $20 \mathrm{~B})$. All other $Z$ wells have very narrow casings ( .75 in.), making bailing impractical. A bailer is stuck in well $Z 3$. $Z$ wells are scheduled generally for water-jevel measurements only.

If a well pumps or is bailed dry during purging and is revisited and sampled within 24 hours, this is considered one sampling event yielding a single set of field and analytical data. For such wells, table 3 lists the volume purged before the well went dry during the first visitation. The Analytical Results section gives the total amount of water purged from each well in one sampling event.

Comments about dry wells and continuously pumping wells are in the Analytical Results section.
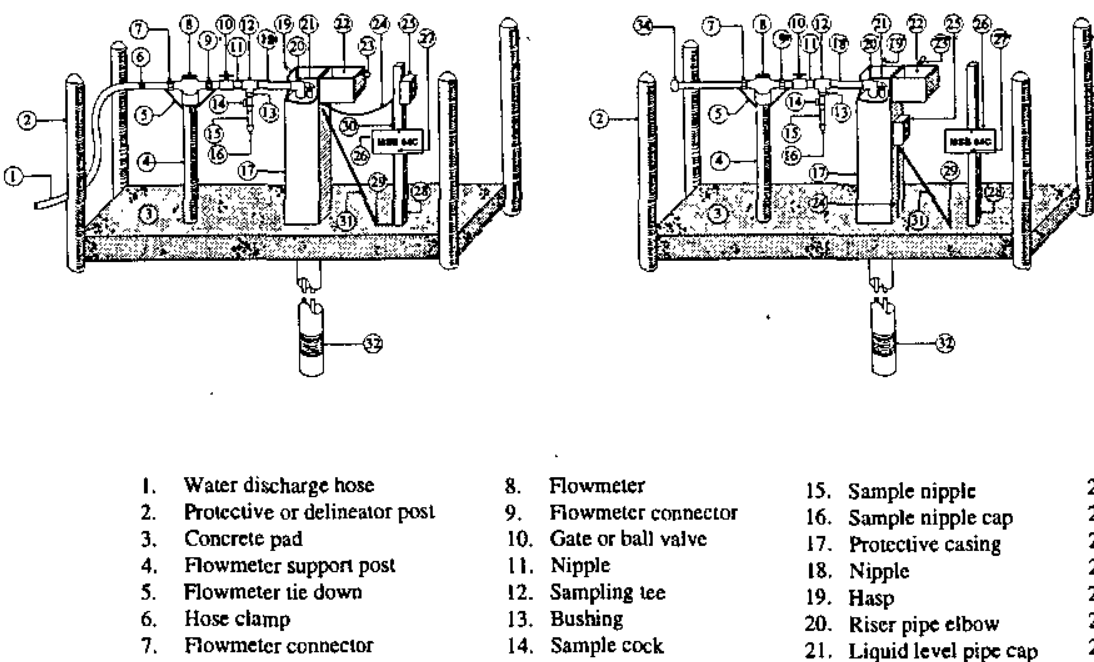

8. Flowmeter
9. Fowmeter connector
10. Gate or ball valve
11. Nipple
12. Sampling tee
13. Bushing
14. Sample cock

16. Sample nipple cap

17. Potective casing

18. Nipple

19. Hasp

20. Riser pipe elbow

21. Liquid level pipe cap
15. Sample nipple

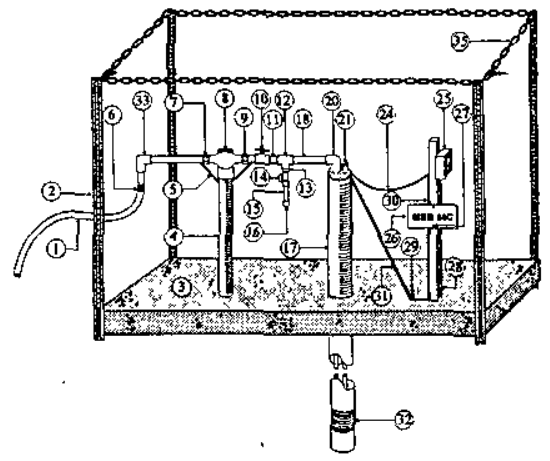

22. Protective casing lid

23. Lock

24. Electrical conduit

25. Electrical box

26. Well identification sign

27. Sign bolt

28. Mounting post
29. Grounding rod

30. Grounding wire

31. Security cable

32. Pump

33. Elbow

34. Quick disconnect

35. Yellow chain

Figure 3. Three Types of Groundwater Monitoring Wellheads 


\begin{tabular}{lll}
\hline Well & Date & Comments \\
\hline
\end{tabular}

\section{ARP Series}

ARP 5D

$06 / 08 / 98$

\section{BGO Series}

$\begin{array}{ll}\text { BGO 1D } & 04 / 28 / 98 \\ & 05 / 05 / 98 \\ \text { BGO 2D } & 04 / 28 / 98 \\ \text { BGO 3C } & 05 / 05 / 98 \\ \text { BGO 4D } & 04 / 28 / 98 \\ & 06 / 09 / 98 \\ \text { BGO 5D } & 05 / 05 / 98 \\ \text { BGO 6A } & 05 / 04 / 98 \\ \text { BGO 6B } & 05 / 04 / 98 \\ \text { BGO 6D } & 05 / 04 / 98 \\ \text { BGO 10C } & 04 / 30 / 98 \\ \text { BGO 10DR } & 05 / 01 / 98 \\ \text { BGO 12DR } & 04 / 30 / 98 \\ & \\ \text { BGO 13DR } & 05 / 04 / 98 \\ \text { BGO 14CR } & 05 / 05 / 98 \\ \text { BGO 16B } & 05 / 04 / 98 \\ \text { BGO 16D } & 05 / 05 / 98 \\ \text { BGO 17DR } & 05 / 04 / 98 \\ \text { BGO 20D } & 05 / 06 / 98 \\ \text { BGO 21D } & 05 / 07 / 98 \\ \text { BGO 24D } & 05 / 11 / 98 \\ \text { BGO 33C } & 06 / 11 / 98\end{array}$

CDS Series

CDS $1 \mathrm{P}$

$04 / 02 / 98$

$04 / 03 / 98$

CSR Series

CSR BDL

$04 / 29 / 98$

$06 / 01 / 98$

CSR 8DU 04/29/98

CSR 9DL 06/01/98

$06 / 01 / 98$

CSR 9DU

CSR 10DU

CSR 11DL

$06 / 01 / 98$

$06 / 01 / 98$

$04 / 29 / 98$

$04 / 29 / 98$

$04 / 29 / 98$

DBP Series

DBP 1

$04 / 16 / 98$

DBP 2

$04 / 16 / 98$

DOB Series

DOB 2

06/03/98

FBP Series

FBP 42C

FBP 43DU
$04 / 23 / 98$

$04 / 08 / 98$

$04 / 09 / 98$
Dry after $6 \mathrm{gal}$

Dry after $17 \mathrm{gal}$

Dry after $17 \mathrm{gal}$

Inaccessible because of construction

Variable box does not work

Inaccessible because of construction

Dry after 1 gal; no water in standpipe

Dry after $4 \mathrm{gal}$

Valve gate broken

Dry after 75 gal

Dry after $5 \mathrm{gal}$

Dry after $38 \mathrm{gal}$

Dry after 3 gal

Appeared to be a film on the water, may be evidence of an oily substance

Dry after 6 gal

Dry after $19 \mathrm{gal}$

Dry after $44 \mathrm{gal}$

Dry after 4 gal

Dry after $8 \mathrm{gal}$

Dry after $18 \mathrm{gal}$

Dry after $6 \mathrm{gal}$

Dry after 13 gal

Well maintenance needed, had to discontinue sampling

Dry after $<1$ gal

Orange, muddy

Dry after 5 gal

Dry after $5 \mathrm{gal}$

Variable box showed overload

Dry after 5 gal

Purged 4 gal through sample port to lower turbidity

Dry atter $1 \mathrm{gal}$

Purged 1 gal through sample port to lower turbidity

Metals not collected

Dry after $30 \mathrm{gal}$

Metals not collected

Pump broken

Pump did not work

Flowmeter broken, estimated volume purged

Dry after 12 gal

Dry after $1 \mathrm{gal}$

Pumped dry; not sampled because of insufficient water 


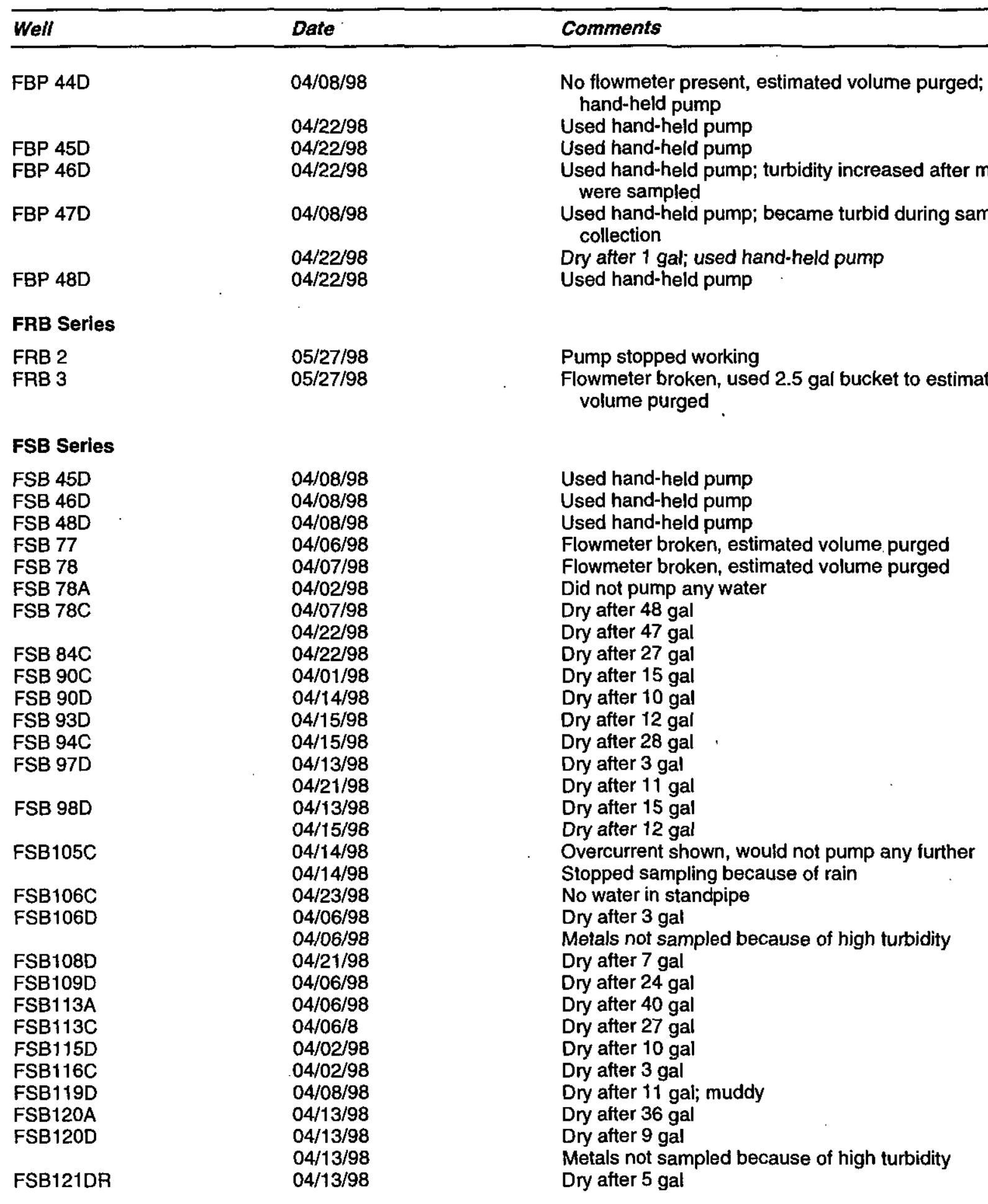

FSL Series

FSL 1D

$04 / 20 / 98$

FSL 2D 04/20/98

FSL 3D $\quad 04 / 15 / 98$

FSL 4D 04/15/98

$04 / 16 / 98$

Dry after $1 \mathrm{gal}$

Dry after $5 \mathrm{gal}$

Dry after $5 \mathrm{gal}$

Dry after $1 \mathrm{gal}$

Dry after $1 \mathrm{gal}$ 


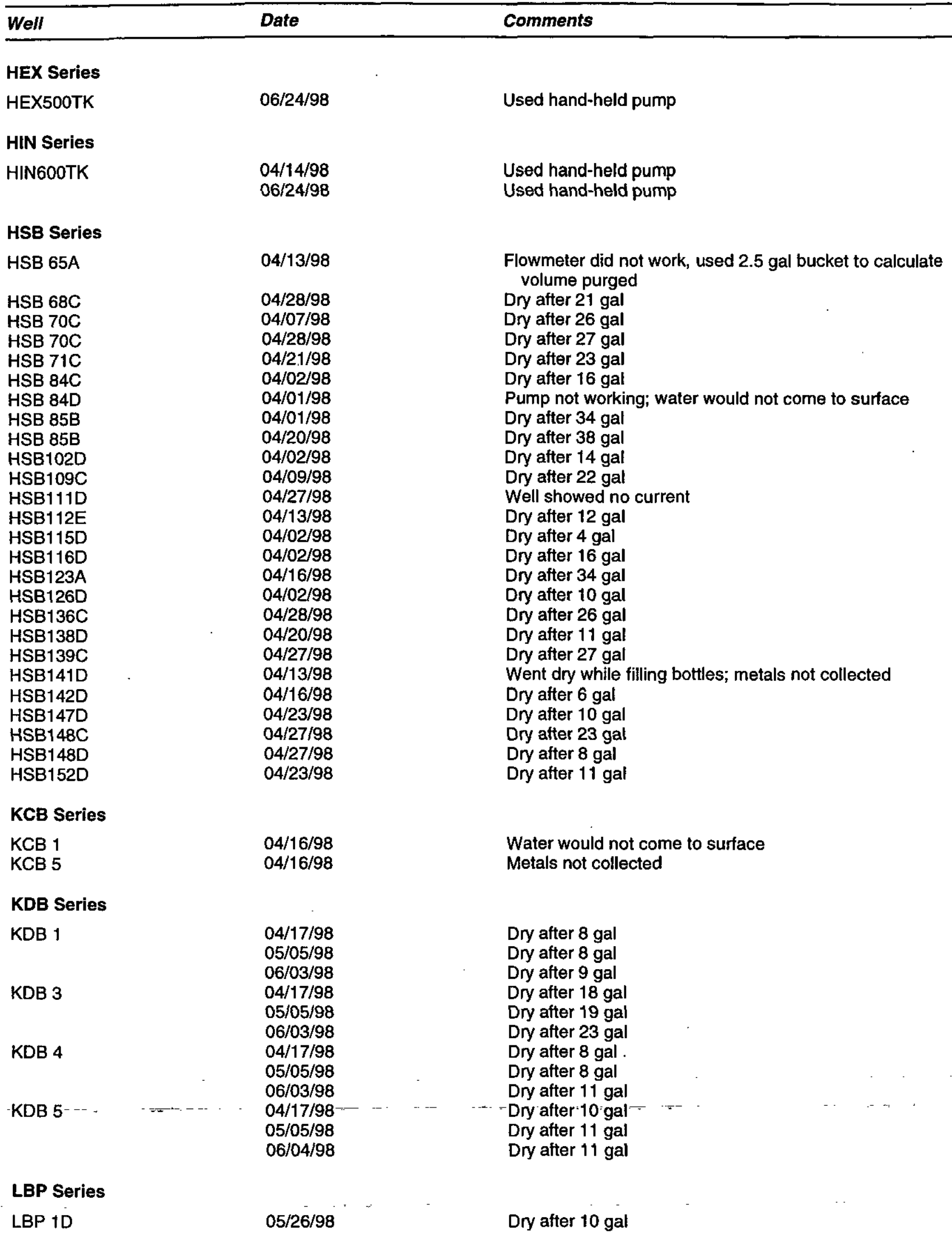




\section{LDB Series}

LDB 1

$04 / 17 / 98$

$05 / 05 / 98$

$06 / 04 / 98$

LDB 10

$04 / 17 / 98$

LDB 2

$04 / 17 / 98$

$05 / 05 / 98$

$06 / 04 / 98$

LDB 4

04/17/98

$05 / 05 / 98$

$06 / 04 / 98$

LFW Series

LFW 60D

$04 / 03 / 98$

$06 / 09 / 98$

$04 / 06 / 98$

$06 / 12 / 98$

MCB Series

MCB 19B

MCB 20B

MCB 27B

MSB Series

MSB 74C

P Series

P 26A

$P 26 B$

$P 26 D$

PRP Series

PRP 3

$06 / 02 / 98$

\section{RWM Series}

RWM 1

$04 / 17 / 98$

$05 / 08 / 98$

$06 / 08 / 98$

RWM 2

$04 / 17 / 98$

$05 / 08 / 98$

$06 / 08 / 98$

RWM $3 \quad 04 / 17 / 98$

$05 / 08 / 98$

$06 / 08 / 98$

RWM $4 \quad 04 / 17 / 98$

$05 / 07 / 98$

$06 / 08 / 98$

RWM $5 \quad 04 / 17 / 98$

$05 / 08 / 98$

$06 / 08 / 98$

RWM $6 \quad 04 / 17 / 98$

$05 / 07 / 98$

$06 / 08 / 98$

RWM 7
$04 / 17 / 98$

$05 / 07 / 98$

$06 / 08 / 98$
Flowmeter broken, estimated volume purged

Flowmeter broken, estimated volume purged

Flowmeter broken, estimated volume purged

Dry after $15 \mathrm{gal}$; flowmeter broken, estimated volume purged

Dry after $26 \mathrm{gal}$

Dry after $27 \mathrm{gal}$

Dry after $19 \mathrm{gal}$

Dry after $14 \mathrm{gal}$

Dry after $16 \mathrm{gal}$

Dry after $18 \mathrm{gal}$

Resampled for volatiles

Dry after $9 \mathrm{gal}$

Dry after $10 \mathrm{gal}$

Dry after $10 \mathrm{gal}$

High/low voltage on variable box

Overloads variable box

Pump inoperable, variable box shows overload

Dry after $21 \mathrm{gal}$

No flowmeter, estimated volume purged

No flowmeter present, estimated volume purged

No flowmeter present, estimated volume purged

Dry after $57 \mathrm{gal}$

No water in standpipe; used hand-held pump Continuous pumping well; used hand-held pump No water in standpipe, used hand-held pump No water in standpipe; used hand-held pump Used hand-held pump

No water in standpipe; used hand-held pump No water in standpipe; used hand-held pump Used hand-held pump

No water in standpipe; used hand-held pump Used hand-held pump

Used hand-held pump

Used hand-held pump

Used hand-held pump

Used hand-held pump

Used hand-held pump

Used hand-held pump

Used hand-held pump

Used hand-held pump

Used hand-held pump

Used hand-held pump

Used hand-held pump 


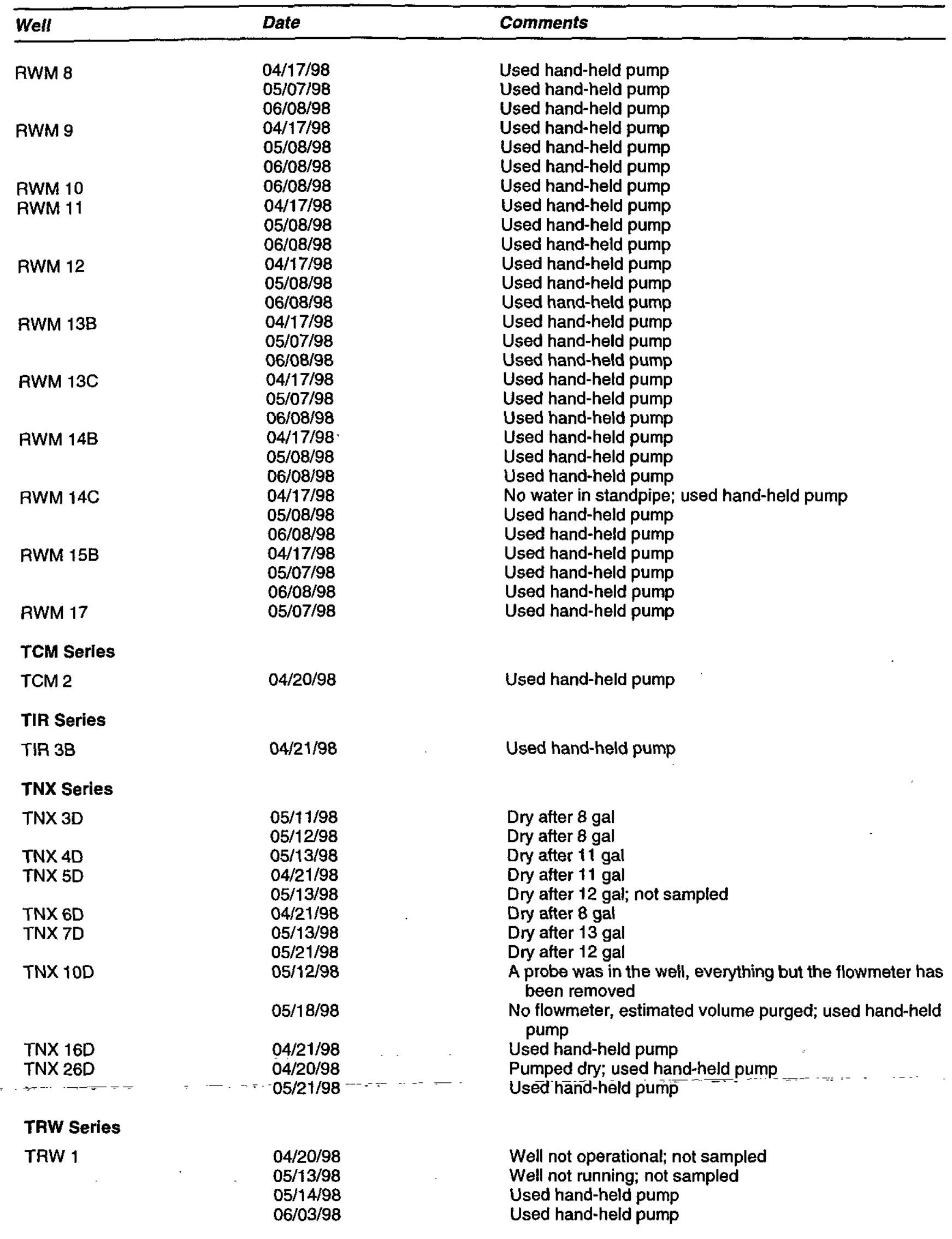

\section{Field Notes}


Well

TRW 2

Date

$04 / 20 / 98$

$05 / 13 / 98$

$05 / 14 / 98$

$06 / 03 / 98$

TRW 3

$04 / 20 / 98$

$05 / 13 / 98$

$05 / 29 / 98$

$06 / 03 / 98$

TRW 4

$05 / 13 / 98$

$05 / 29 / 98$

$06 / 03 / 98$
Comments

Used hand-held pump

Well not running; not sampled

Used hand-held pump

No water in standpipe; used hand-held pump

Well not operational; not sampled

Well not running; not sampled

Used hand-held pump

Used hand-held pump

Well not operational; not sampled

Well not running; not sampled

Used hand-held pump

Used hand-held pump 
NOTES 


\section{Analytical Data Review}

The SRS Groundwater Monitoring Program evaluates all data systematically to provide high-quality data for reporting on the environmental monitoring and cleanup efforts at SRS. Data verification and validation are continuous, interactive processes, usually completed within 60 days after the last data are received for a quarter.

ES, EX, GE, and WA, the primary contracting laboratories for sample analyses, performed all analyses with the following exceptions:

- GE subcontracted radionuclide analyses to GP, and WA and ES subcontracted radionuclide analyses to TM. GP and TM conducted gross alpha, nonvolatile beta, tritium, and selected radionuclide analyses.

\section{GIMS DATA REVIEW MODULE}

The Geochemical Information Management System (GIMS) is a combination of hardware, software, data, and procedures that supports EPD/EMS' data management activities. The GIMS Data Review Module provides automated data loading, validation and verification functions, data editing, determination of data review status, report generation, and data review QA. The data editing program allows users to correct errors in loaded analytical, field, and shipping data. When the review process is complete, data are loaded into the permanent production database tables in GIMS and are available sitewide.

\section{REVIEW OF THE ANALYTICAL DATA}

EPD/EMS reviews analytical data from the laboratories for errors and unusual results before releasing the data for use. The laboratories are asked to review and comment on suspect data.

Typical errors identified during data loading into GIMS include incorrect sample dates, run dates, and sample identifications; incorrectly entered analytical units, methods, and corresponding detection limits; and incorrect dilution factor calculations.

Analytical results that appear different from historical data collected since 1991 are brought to the attention of the appropriate laboratory. Thus, the laboratory is able to identify problems with some of the analyses, including incorrect dilution factor calculations and data entry errors. EPD/EMS corrects data files after receiving written notification from the laboratory. Specific details concerning the corrections are entered in the EMS Groundwater Monitoring Program Changes to the Database Logbook.

Samples that exceeded holding times are indicated by an analysis qualifier of $Q$ in the analytical results tables (see Appendix $\mathbf{B}$ for further information). The analysis qualifier $V$ is used to indicate sample results associated with method laboratory blanks at the preparation step that are elevated above the instrument detection limit. Samples that were preserved incorrectly are marked with a $Y$ analysis qualifier in the analytical results tables (see Appendix B). Usually, the $Y$ indicates that the sample coolers were not cold enough. An / analysis qualifier indicates that a sample's matrix spike recovery was not within control limits.

To determine if a new analytical result for a sampling site is similar to or relatively higher or lower than historical results, new results for each well are compared to its historical results using the following procedure:

- GIMS calculates the mean of the historical results and the mean of the historical results above detection for all analytes in the wells being compared. The historical results that are below their detection limit value are considered at their detection limits for the purpose of the calculation. The process eliminates any false high values due to diluted samples.

- GIMS factors in trends in the data calculated from the previous eight sampling events. If no previous data are available for a particular weil/analyte combination, the program includes previous results from other wells in the same vicinity. 
- Results greater than $\mathbf{1 0}$ times the calculated mean of the previous results are marked as "high." Results (or their detection limits if the results are below detection) less than 10 percent of the calculated mean of the previous results are marked as "low."

GIMS flags the potentially anomalous results for review. The data reviewer examines the results and takes into account individual historical values, variations of certain values, general trends in the data, and data in the prep batch associated with the current result. The data reviewer eliminates results if anomalous historical results have skewed the calculated mean. Another data reviewer inspects and confirms that the results marked as anomalous are properly identified. Anomalous results are presented to the lab for review and comment. Results significantly high or low compared with historical data are rerun by the lab.

\section{Review of the Analytical Narratives}

EPD/EMS reviews the analytical narratives received from the laboratories, which are used as reference materials throughout the data validation process. Any discrepancies between the narratives and the analytical or chain-of-custody $(\mathrm{COC})$ data must be resolved by the laboratories. The narratives include the following types of problems: QA samples that do not meet the criteria specified by the analytical method, problems with matrix interference, sample-specific adjustments to the method caused by high concentrations of some analytes, problems with sample preservation and holding time, instrument calibration problems, and contaminated blanks. The narratives also include additional information about $\mathrm{COC}$ and analytical data.

The four primary laboratories (ES, EX, GE, and WA) differ in their analytical suite assignments for certain constituents. Thus, some analytes may not be analyzed by all laboratories. See the Sample Scheduling, Field Notes, Quality Control Samples, and Analytical Results sections of this report for more information on wells scheduled but not sampled this quarter.

\section{Review of ES's Arialytical Data}

A technical review of the quarter's analytical data identified at least one reported result for each of the analyses in table 4 as high compared with historical data. A review of the laboratory records did not reveal any problems with the analyses.

A technical review of the quarter's analytical data identified at least one reported result for each of the analyses in table 5 as low compared with historical data. A review of the laboratory records did not reveal any problems with the analyses.

\section{Review of EX's Analytical Data}

A technical review of the quarter's analytical data identified no reported results as high or low compared with historical data.

\section{Review of GE's Analytical Data}

A technical review of the quarter's analytical data identified at least one reported result for each of the analyses in table 6 as high compared with historical data. A review of the laboratory records did not reveal any problems with the analyses.

A technical review of the quarter's analytical data identified at least one reported result for each of the analyses in table 7 as low compared with historical data. A review of the laboratory records did not reveal any problems with the analyses.

\section{Review of GP's Analytical Data}

A technical review of the quarter's analytical data identified at least one reported result for each of the GP analyses in table 8 as being high compared with historical data. The review identified no results as being low compared with historical data.

HEX500TK did not meet the minimum detectable activity for thorium-228 because of low yield. 


\section{Review of WA's Analytical Data}

A technical review of the quarter's analytical data identified at least one reported result for each of the analyses in table 9 as high as compared with historical data. A review of the laboratory records did not reveal any problems.

Acidifying volatiles samples to a pH level of less than or equal to 2 eliminates the presence of 2-chloroethyl vinyl ether.

A technical review of the quarter's analytical data identified at least one reported result for each of the analyses in table 10 as low as compared with historical data. A review of the laboratory records did not reveal any problems.

\section{Review of TM's Analytical Data}

A technical review of the quarter's analytical data identified at least one reported result for each of the analyses in table 11 as high as compared with historical data. A review of the laboratory records did not reveal any problems.

A technical review of the quarter's analytical data identified at least one reported result for each of the analyses in table 12 as low as compared with historical data. A review of the laboratory records did not reveal any problems.

\section{ANALYTICAL METHODS}

Sample analyses performed for EPD/EMS during second quarter 1998 were conducted using EPA and other methods as noted in tables 13-18 at the end of this section. ES, EX, GE, and WA performed most of the analyses conducted during the quarter. Their methods and estimated quantitation limits (EQLS) are listed in table 13 for ES, table 14 for GE, table 15 for WA, and table 16 for EX.

GP and TM performed the radionuclide analyses during second quarter 1998. Radionuclide methods generally are modified by the laboratories performing the analyses. Their methods and EQLs are listed in table 17 for GP and table 18 for TM.

If the laboratories used more than one analytical method for an analyte, the methods are listed in the tables in descending order according to frequency of use. Generally, the method listed first was used for at least half of the analyses.

\section{Table 4. ES Samples with High Analytical Results as Compared to Historical Data}

\begin{tabular}{ll}
\hline Analyte & Well(s) \\
\hline & LFW 56D, LFW 58D, LFW 63B, LFW 64C, LFW 69D, PRP 3 \\
Aluminum & LFW 58Dt \\
Benzene & KBP 1D \\
Chloride & LFW 58D \\
1,4-Dichlorobenzene & LFW 58Dt, PRP 2, PRP 3 \\
Iron & XSB 1D \\
Nitrate & LBP 3D \\
Total dissolved solids & DBP 3 \\
Total radium & TBG 3, XSB 4Dt \\
Trichloroethylene & DBP 3 \\
\hline Tritium & \\
\hline
\end{tabular}

† The questioned value was at least 10 times higher than historical data. Lab confirmation was unavailable for the result. 
Table 5. ES Samples with Low Analytical Results as Compared to Historical Data

\begin{tabular}{ll}
\hline Analyte & Well(s) \\
\hline & HWP 2D \\
Aluminum & LFW 62D \\
1,4-Dichlorobenzene & HWP 2D \\
Iron & \\
\hline
\end{tabular}

Table 6. GE Samples with High Analytical Results as Compared to Historical Data

\begin{tabular}{ll}
\hline Analyte & Well(s) \\
\hline & \\
Copper & BGO 33C \\
Toluene & BGO 33Ct \\
\hline
\end{tabular}

† The questioned value was at least 10 times higher than historical data. Because holding time had been exceeded, the laboratory was not asked to reanalyze the sample.

Table 7. GE Samples with Low Analytical Results as Compared to Historical Date

\begin{tabular}{ll}
\hline Analyte & Well(s) \\
\hline Cadmium & PRP 4 \\
Chromium & PRP 4 \\
Copper & PRP 4 \\
Mercury & PRP 4 \\
p',p'-DDD & PRP 4 \\
Selenium & PRP 4† \\
Vanadium & PRP 4 \\
\hline
\end{tabular}

$\dagger$ The questioned value was at least 10 times lower than historical data. Because holding time had not been exceeded, the laboratory was asked to reanalyze the sample.

Table 8. GP Samples with High Analytical Results as Compared to Historical Data

Analyte Well(s)

Carbon-14

Gross alpha

Nonvolatile beta

Tritium
FSB $78 C$, FSB 79

FSB115Dt, FSB120D, RAC 3†

FSB 90C, RAC $3 \dagger$

FSB 77

$\dagger$ The questioned value was at least 10 times higher than historical data. Because holding time had not been exceeded, the laboratory was asked to reanalyze the sample.

Table 9. WA Samples with High Analytical Results as Compared to Historical Data

\begin{tabular}{ll}
\hline Analyte & Well(s) \\
\hline Bis(2-ethylhexyl) phthalate & KCB 1†, KCB 3† \\
Copper & BGO 18D \\
Lithium & BGO 10C
\end{tabular}

Lithium

BGO 10C 
Analyte Well(s)

Nickel

BGO 1D, BGO 4D†, BGO 5C†, BGO 8AR, BGO 9D†, BGO 14ARt, BGO 15D, BGO 16AR, BGO 16B, BGO 16D†, BGO 17DR, BGO 18A BGO 18D, BGO 21D†, BGO 22DX, BGO 23D

Total organic carbon BGO 15D, BGO 16AR

Trichlorofluoromethane BGO 18D

$\dagger$ The questioned value was at least 10 times higher than historical data. Lab confirmation was unavailable for the result.

Table 10. WA Samples with Low Analytical Results as Compared to Historical Data

\begin{tabular}{ll}
\hline Analyte & Well(s) \\
\hline Chromium & DBP 4 \\
\hline
\end{tabular}

Table 11. TM Samples with High Analytical Results as Compared to Historical Data

Analyte Well(s)

Carbon-14

Gross alpha

Nonvolatile beta

Total radium

Tritium
BGO 6C†, BGO 6D†, BGO 15D†, BGO 16D†

PRP 3†, XSB 4D

PRP 1A, PRP 2, PRP 3

BGO 23D, BGO 16AR

KDB 5t

t The questioned value was at least 10 times higher than historical data. Lab confirmation was unavailable for the result.

Table 12. TM Samples with Low Analytical Results as Compared to Historical Data

\begin{tabular}{ll}
\hline Analyte & Well(s) \\
\hline Tritium & BGO 14CR \\
\hline
\end{tabular}

Table 13. Methods and Estimated Quantitation Limits Used by ES

\begin{tabular}{llll}
\hline Analyte & Unit & Method & Minimum/Maximum EQLs \\
\hline & & & $10.0 / 11.0$ \\
Acenaphthene & $\mu g / \mathrm{L}$ & EPA8270 & $10.0 / 11.0$ \\
Acenaphthylene & $\mu g / \mathrm{L}$ & EPA8270 & $10.0 / 50.0$ \\
Acetone & $\mu g / \mathrm{L}$ & EPA8260 & $20.0 / 100$ \\
Acetonitrile & $\mu g / \mathrm{L}$ & EPA8260 & 10.0 \\
Acetophenone & $\mu g / \mathrm{L}$ & EPA8270 & 10.0 \\
2-Acetylaminofluorene & $\mu \mathrm{g} / \mathrm{L}$ & EPA8270 & $10.0 / 50.0$ \\
Acrolein & $\mu \mathrm{g} / \mathrm{L}$ & EPA8260 & $5.0 / 25.0$ \\
Acrylonitrile & $\mu \mathrm{g} / \mathrm{L}$ & EPA8260 & $1.06 \mathrm{E}-08 / 1.58 \mathrm{E}-08$ \\
Actinium-228 & $\mu \mathrm{Ci} / \mathrm{mL}$ & ESESOPM008 & 0.015 \\
Aldrin & $\mu \mathrm{g} / \mathrm{L}$ & EPA8081 & $10.0 / 50.0$ \\
Allyl chloride & $\mu \mathrm{g} / \mathrm{L}$ & EPA8260 & 20.0 \\
Aluminum & $\mu \mathrm{g} / \mathrm{L}$ & EPA6010 & $7.0 \mathrm{E}-11 / 1.7 \mathrm{E}-10$ \\
Americium-241 & $\mu \mathrm{C} / \mathrm{mL}$ & ESESOPM032 & 10.0 \\
4-Aminobiphenyl & $\mu \mathrm{g} / \mathrm{L}$ & EPA8270 & 50.0 \\
Ammonia nitrogen & $\mu \mathrm{g} / \mathrm{L}$ & EPA350.1 & 10.0
\end{tabular}




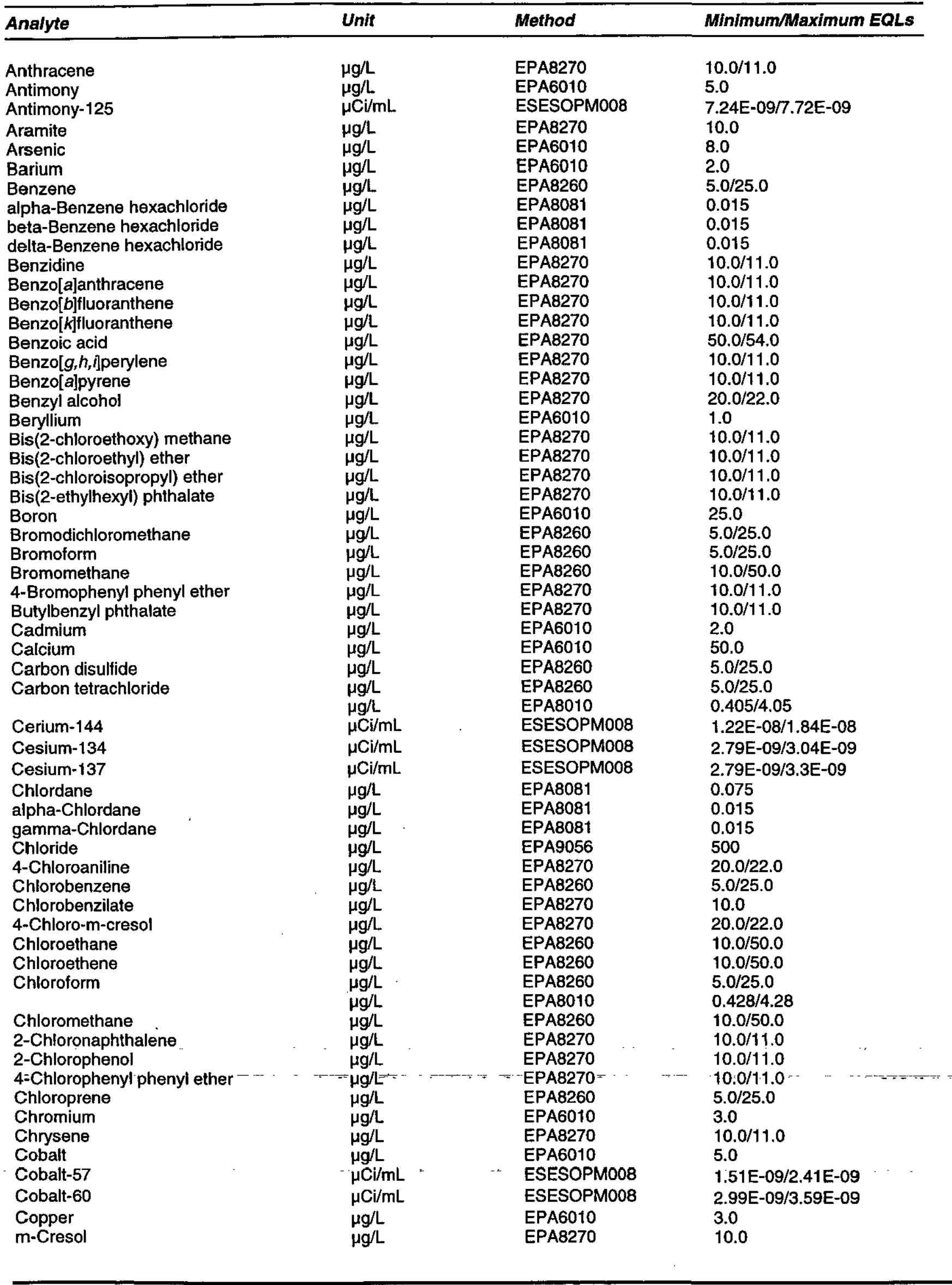




\begin{tabular}{|c|c|c|c|c|}
\hline Analyte & Unit & & Method & Minimum/Maximum EQLs \\
\hline $\begin{array}{l}\mathrm{m} / \mathrm{p} \text {-Cresol } \\
\text { o-Cresol } \\
\text { Curium-242 }\end{array}$ & $\begin{array}{l}\mu g / L \\
\mu g / L \\
\mu \mathrm{Ci} / \mathrm{mL}\end{array}$ & & $\begin{array}{l}\text { EPA8270 } \\
\text { EPA8270 } \\
\text { ESESOPM032 }\end{array}$ & $\begin{array}{l}10.0 / 11.0 \\
10.0 / 11.0 \\
5.0 \mathrm{E}-11 / 1.6 \mathrm{E}-10\end{array}$ \\
\hline Curium-243/244 & $\mu \mathrm{Ci} / \mathrm{mL}$ & . & ESESOPM032 & 1.2E-10/2.7E-10 \\
\hline Curium-245/246 & $\mu \mathrm{Ci} / \mathrm{mL}$ & & ESESOPM032 & 7.0E-11/1.7E-10 \\
\hline Cyanide & $\mu g / L$ & & EPA9010A & 5.0 \\
\hline$p, p^{\prime}-D D D$ & $\mu g / L$ & & EPA8081 & 0.015 \\
\hline$p, p^{\prime}-D D E$ & $\mu g / L$ & & EPA8081 & 0.015 \\
\hline$p, p^{\prime}-D D T$ & $\mu g / L$ & & EPA8081 & 0.015 \\
\hline Diallate & $\mu g / L$ & & EPA8270 & 10.0 \\
\hline Dibenz $[a, h]$ anthracene & $\mu g / L$ & & EPA8270 & $10.0 / 11.0$ \\
\hline Dibenzofuran & $\mu g / L$ & & EPA8270 & $10.0 / 11.0$ \\
\hline Dibromochloromethane & $\mu g / L$ & & EPA8260 & $5.0 / 25.0$ \\
\hline 1,2-Dibromo-3-chloropropane & $\mu g / L$ & & EPA8260 & $5.0 / 25.0$ \\
\hline 1,2-Dibromoethane & $\mu \mathrm{g} / \mathrm{L}$ & & EPA8260 & $5.0 / 25.0$ \\
\hline Dibromomethane & $\mu g / L$ & & EPA8260 & $5.0 / 25.0$ \\
\hline Di-n-butyl phthalate & $\mu g / L$ & & EPA8270 & $10.0 / 11.0$ \\
\hline 1,2-Dichlorobenzene & $\mu g / L$ & & EPA8270 & $10.0 / 11.0$ \\
\hline 1,3-Dichlorobenzene & $\mu g / L$ & & EPA8270 & $10.0 / 11.0$ \\
\hline 1,4-Dichlorobenzene & $\mu g / L$ & & $\begin{array}{l}\text { EPA8260 } \\
\text { FPA8270 }\end{array}$ & $5.0 / 25.0$ \\
\hline 3,3'-Dichlorobenzidine & $\begin{array}{l}\mu g / L \\
\mu \sigma^{\prime} L\end{array}$ & & $\begin{array}{l}\text { EPA8270 } \\
\text { EPA8270 }\end{array}$ & $\begin{array}{l}10.0 / 11.0 \\
20.0 / 22.0\end{array}$ \\
\hline trans-1,4-Dichloro-2-butene & $\mu g / L$ & & EPA8260 & $5.0 / 25.0$ \\
\hline Dichlorodifluoromethane & $\mu \mathrm{g} / \mathrm{L}$ & & EPA8260 & $5.0 / 25.0$ \\
\hline 1,1-Dichloroethane & $\mu g / L$ & & EPA8260 & $5.0 / 25.0$ \\
\hline 1,2-Dichloroethane & $\mu g / L$ & & EPA8260 & $5.0 / 25.0$ \\
\hline 1,1-Dichloroethylene & $\mu g / L$ & & EPA8260 & $5.0 / 25.0$ \\
\hline cis-1,2-Dichloroethylene & $\mu g / L$ & & EPA8260 & 5.0 \\
\hline trans-1,2-Dichloroethylene & $\mu g / L$ & & EPA8260 & 5.0 \\
\hline Dichloromethane & $\mu g / L$ & & EPA8260 & $5.0 / 25.0$ \\
\hline 2,4-Dichlorophenol & $\mu g / L$ & & EPA8270 & $10.0 / 11.0$ \\
\hline 2,6-Dichlorophenol & $\mu g / L$ & & EPA8270 & 10.0 \\
\hline 1,2-Dichloropropane & $\mu g / L$ & & EPA8260 & $5.0 / 25.0$ \\
\hline cis-1,3-Dichloropropene & $\mu g / L$ & & EPA8260 & $5.0 / 25.0$ \\
\hline trans-1,3-Dichloropropene & $\mu g / L$ & & EPA8260 & $5.0 / 25.0$ \\
\hline Dieldrin & $\mu g / L$ & & EPA8081 & 0.015 \\
\hline Diethyl phthalate & $\mu g / L$ & & EPA8270 & $10.0 / 11.0$ \\
\hline Dimethoate & $\mu g / L$ & & EPA8270 & 10.0 \\
\hline 2,4-Dimethyl phenol & $\mu g / L$ & & EPA8270 & $10.0 / 11.0$ \\
\hline Dimethyl phthalate & $\mu g / L$ & & EPA8270 & $10.0 / 11.0$ \\
\hline p-Dimethylaminoazobenzene & $\mu g / L$ & & EPA8270 & 10.0 \\
\hline 7,12-Dimethylbenz[a]anthracene & $\mu g / L$ & $\cdot$ & EPA8270 & 10.0 \\
\hline 3,3'-Dimethylbenzidine & $\mu g / L$ & & EPA8270 & 10.0 \\
\hline a,a-Dimethylphenethylamine & $\mu g / L$ & & EPA8270 & 10.0 \\
\hline 1,3-Dinitrobenzene & $\mu g / L$ & & EPA8270 & 10.0 \\
\hline 2,4-Dinitrophenol & $\mu g / L$ & & EPA8270 & $50.0 / 54.0$ \\
\hline 2,4-Dinitrotoluene & $\mu g / L$ & & EPA8270 & $10.0 / 11.0$ \\
\hline 2,6-Dinitrotoluene & $\mu g / L$ & & EPA8270 & $10.0 / 11.0$ \\
\hline Di-n-octyl phthalate & $\mathrm{Hg} / \mathrm{L}$ & & EPA8270 & $10.0 / 11.0$ \\
\hline Diphenylamine & $\mu g / L$ & & EPA8270 & 10.0 \\
\hline Disulfoton & $\mu g / L$ & & EPA8270 & 10.0 \\
\hline Endosulfan sulfate & $\mu \mathrm{g} / \mathrm{L}$ & & EPA8081 & 0.015 \\
\hline Endosulfan I & $\mu g / L$ & & EPA8081 & 0.015 \\
\hline Endosulfan II & $\mu g / L$ & & EPA8081 & 0.015 \\
\hline Endrin & $\mu g / L$ & & EPA8081 & 0.015 \\
\hline Endrin aldehyde & $\mu g / L$ & & EPA8081 & 0.015 \\
\hline Endrin ketone & $\mu g / L$ & & EPA8081 & 0.015 \\
\hline Ethyl methanesulfonate & $\mu g / L$ & & EPA8270 & 10.0 \\
\hline Ethylbenzene & $\mu g / L$ & & EPA8260 & $5.0 / 25.0$ \\
\hline Europium-152 & $\mu \mathrm{Ci} / \mathrm{mL}$ & & ESESOPM008 & 1.47E-08/1.66E-08 \\
\hline Europium-154 & $\mu \mathrm{Ci} / \mathrm{mL}$ & & ESESOPM008 & 8.23E-09/9.77E-09 \\
\hline
\end{tabular}




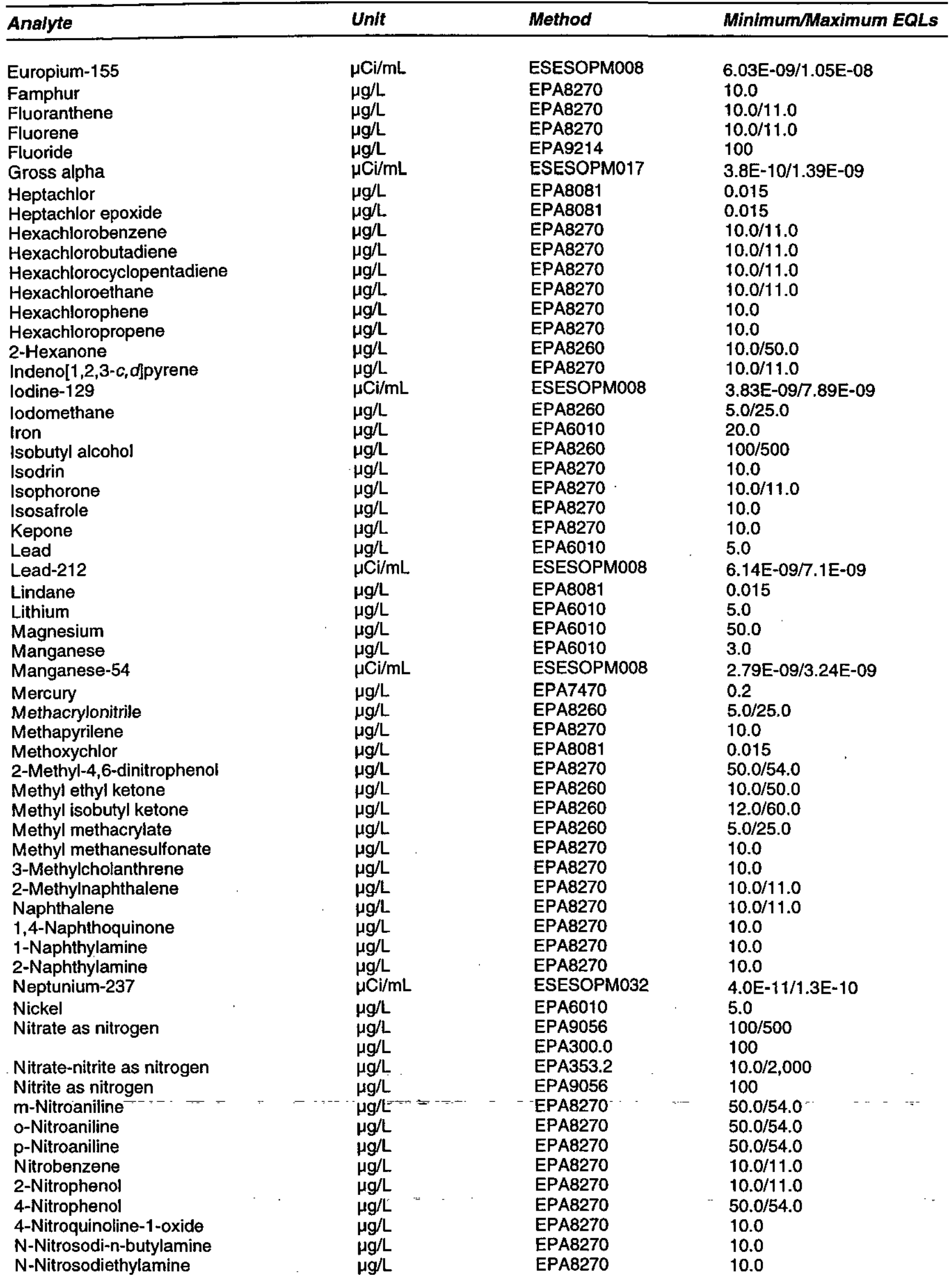




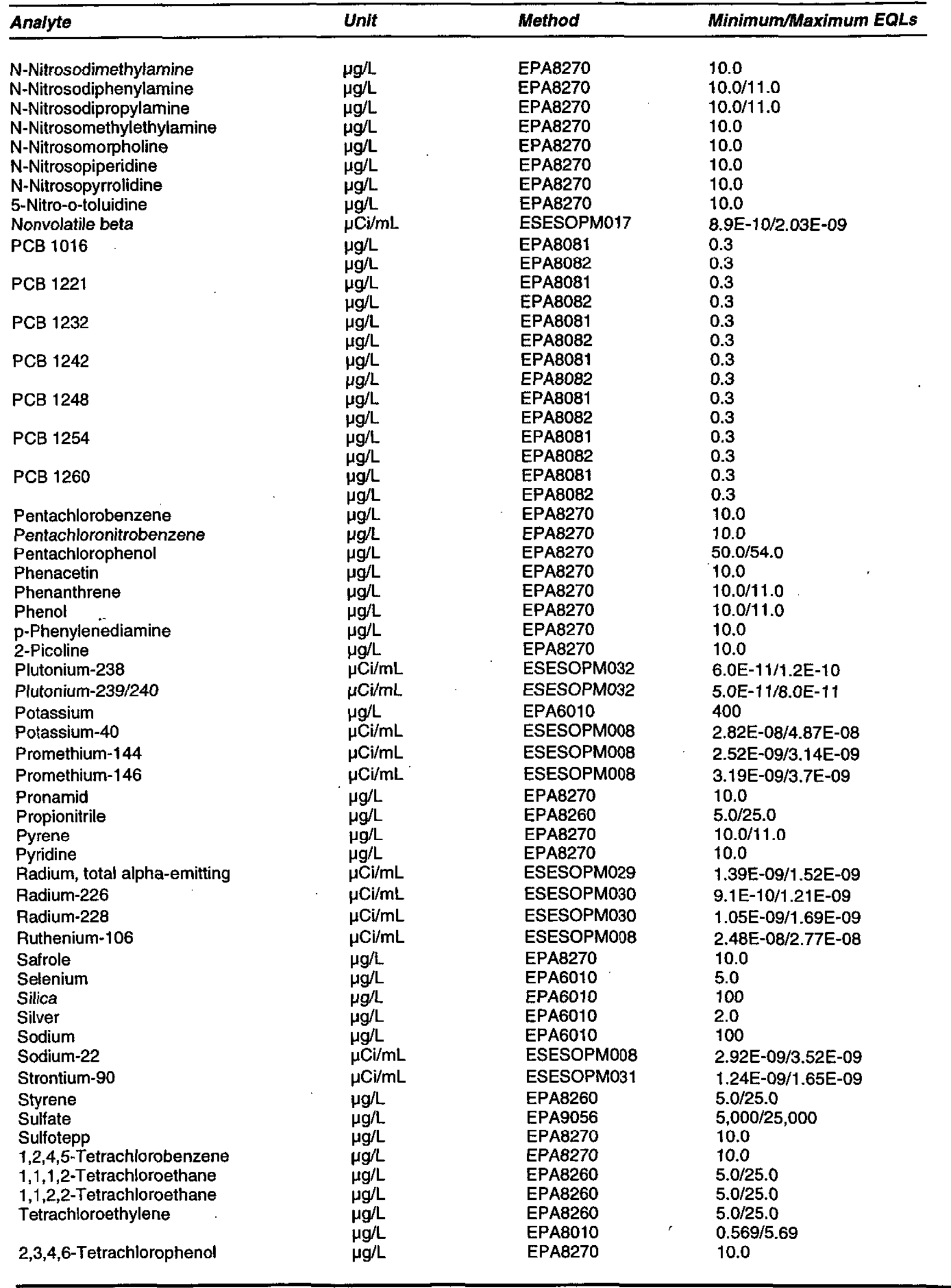




\begin{tabular}{|c|c|c|c|}
\hline Analyte & Unit & Method & Minimum/Maximum EQLs \\
\hline Thallium & $\mu g / L$ & EPA6010 & 5.0 \\
\hline Thionazin & $\mu g / L$ & EPA8270 & 10.0 \\
\hline Thorium-228 & $\mu \mathrm{Ci} / \mathrm{mL}$ & ESESOPM032 & $1.2 \mathrm{E}-10 / 1.8 \mathrm{E}-10$ \\
\hline Thorium-230 & $\mu \mathrm{Ci} / \mathrm{mL}$ & ESESOPM032 & 1.5E-10/2.3E-10 \\
\hline Thorium-232 & $\mu \mathrm{Ci} / \mathrm{mL}$ & ESESOPM032 & 7.0E-11/1.0E-10 \\
\hline Thorium-234 & $\mu \mathrm{Ci} / \mathrm{mL}$ & ESESOPMOOB & 4.59E-08/2.15E-07 \\
\hline Toluene & $\mu g / L$ & EPA8260 & $5.0 / 25.0$ \\
\hline o-Toluidine & $\mu g / L$ & EPA8270 & 10.0 \\
\hline Total dissolved solids & $\mu g / L$ & EPA160.1 & 1,000 \\
\hline Total organic carbon & $\mu g / L$ & EPA9060M & 1,000 \\
\hline Total phosphates (as P) & $\mu g / L$ & EPA365.1 & 10.0 \\
\hline Toxaphene & $\mu g / L$ & EPA8081 & 1.5 \\
\hline 1,2,4-Trichlorobenzene & $\mu g / L$ & EPA8270 & $10.0 / 11.0$ \\
\hline 1,1,1-Trichloroethane & $\mu g / L$ & EPA8260 & $5.0 / 25.0$ \\
\hline 1,1,2-Trichloroethane & $\begin{array}{l}\mu g / L \\
\mu q / L\end{array}$ & $\begin{array}{l}\text { EPA8010 } \\
\text { EPA8260 }\end{array}$ & $\begin{array}{l}0.462 \\
5.0 / 25.0\end{array}$ \\
\hline Trichloroethylene & $\mu g / L$ & EPA8260 & $5.0 / 25.0$ \\
\hline & $\mu g / L$ & EPA8010 & $0.39 / 390$ \\
\hline Trichlorofluoromethane & $\mu g / L$ & EPA8260 & $5.0 / 25.0$ \\
\hline 2,4,5-Trichlorophenol & $\mu g / L$ & EPA8270 & $10.0 / 11.0$ \\
\hline 2,4,6-Trichlorophenol & $\mu g / L$ & EPA8270 & $10.0 / 11.0$ \\
\hline $1,2,3$-Trichloropropane & $\mu g / L$ & EPA8260 & $5.0 / 25.0$ \\
\hline $0,0,0-$ Triethyl phosphorothioate & $\mu g / L$ & EPA8270 & 10.0 \\
\hline Tritium & $\mu \mathrm{Ci} / \mathrm{mL}$ & ESESOPM020 & 5.9E-07/7.36E-07 \\
\hline Uranium-233/234 & $\mu \mathrm{Ci} / \mathrm{mL}$ & ESESOPM032 & $9.0 \mathrm{E}-11 / 1.5 \mathrm{E}-10$ \\
\hline Uranium-235 & $\mu \mathrm{Ci} / \mathrm{mL}$ & ESESOPM032 & $8.0 \mathrm{E}-11 / 1.0 \mathrm{E}-10$ \\
\hline Uranium-238 & $\mu \mathrm{Ci} / \mathrm{mL}$ & ESESOPM032 & $3.0 \mathrm{E}-11 / 1.3 \mathrm{E}-10$ \\
\hline Vanadium & $\mu g / L$ & EPA6010 & 2.0 \\
\hline Vinyl acetate & $\mu g / L$ & EPA8260 & $5.0 / 25.0$ \\
\hline Xylenes & $\mu g / L$ & EPA8260 & $5.0 / 25.0$ \\
\hline Yttrium-88 & $\mu \mathrm{Ci} / \mathrm{mL}$ & ESESOPM008 & 3.03E-09/4.09E-09 \\
\hline Zinc & $\mu g / L$ & EPA6010 & 10.0 \\
\hline Zinc-65 & $\mu \mathrm{Ci} / \mathrm{mL}$ & ESESOPM008 & 6.71E-09/8.44E-09 \\
\hline
\end{tabular}

Note: The groundwater samples are unfiltered; thus, the methods for metals are for total recoverable metals. Method 6010 is an inductively coupled plasma atomic emission spectroscopy method for metals determination and is published for RCRA determinations.

Tablo 14. Mothods and Estimated Quantitation Limits Used by GE

\begin{tabular}{llll}
\hline Analyte & Unit & Method & Minimum/Maximum EQLS \\
\hline & & & \\
Acenaphthene & $\mu \mathrm{g} / \mathrm{L}$ & EPA8270C & $9.9 / 10.0$ \\
& $\mu \mathrm{g} / \mathrm{L}$ & EPA8270B & $9.8 / 10.0$ \\
Acenaphthylene & $\mu \mathrm{g} / \mathrm{L}$ & EPA8270C & $9.9 / 10.0$ \\
& $\mu \mathrm{g} / \mathrm{L}$ & EPA82708 & $9.8 / 10.0$ \\
Acetone & $\mu \mathrm{g} / \mathrm{L}$ & EPA8260A & $5.0 / 25.0$ \\
Aldrin & $\mu \mathrm{g} / \mathrm{L}$ & EPA8081A & $0.0196 / 0.0211$ \\
& $\mu \mathrm{g} / \mathrm{L}$ & EPA8081 & $0.0199 / 0.02$ \\
Alkalinity (as CaCOB) & $\mathrm{meq} / \mathrm{L}$ & EPA310.1 & 1,000 \\
Aluminum & $\mu \mathrm{g} / \mathrm{L}$ & EPA6010A & 50.0 \\
& $\mu \mathrm{g} / \mathrm{L}$ & EPA6010B & 50.0 \\
Anthracene & $\mu \mathrm{g} / \mathrm{L}$ & EPA6020 & 15.0 \\
$\cdots$ & $\mu \mathrm{g} / \mathrm{L}$ & EPA8270C & $9.9 / 10.0$ \\
Antimony & $\mu \mathrm{g} / \mathrm{L}$ & EPA8270B & $9.8 / 10.0$ \\
& $\mu \mathrm{g} / \mathrm{L}$ & EPA6010A & 10.0
\end{tabular}




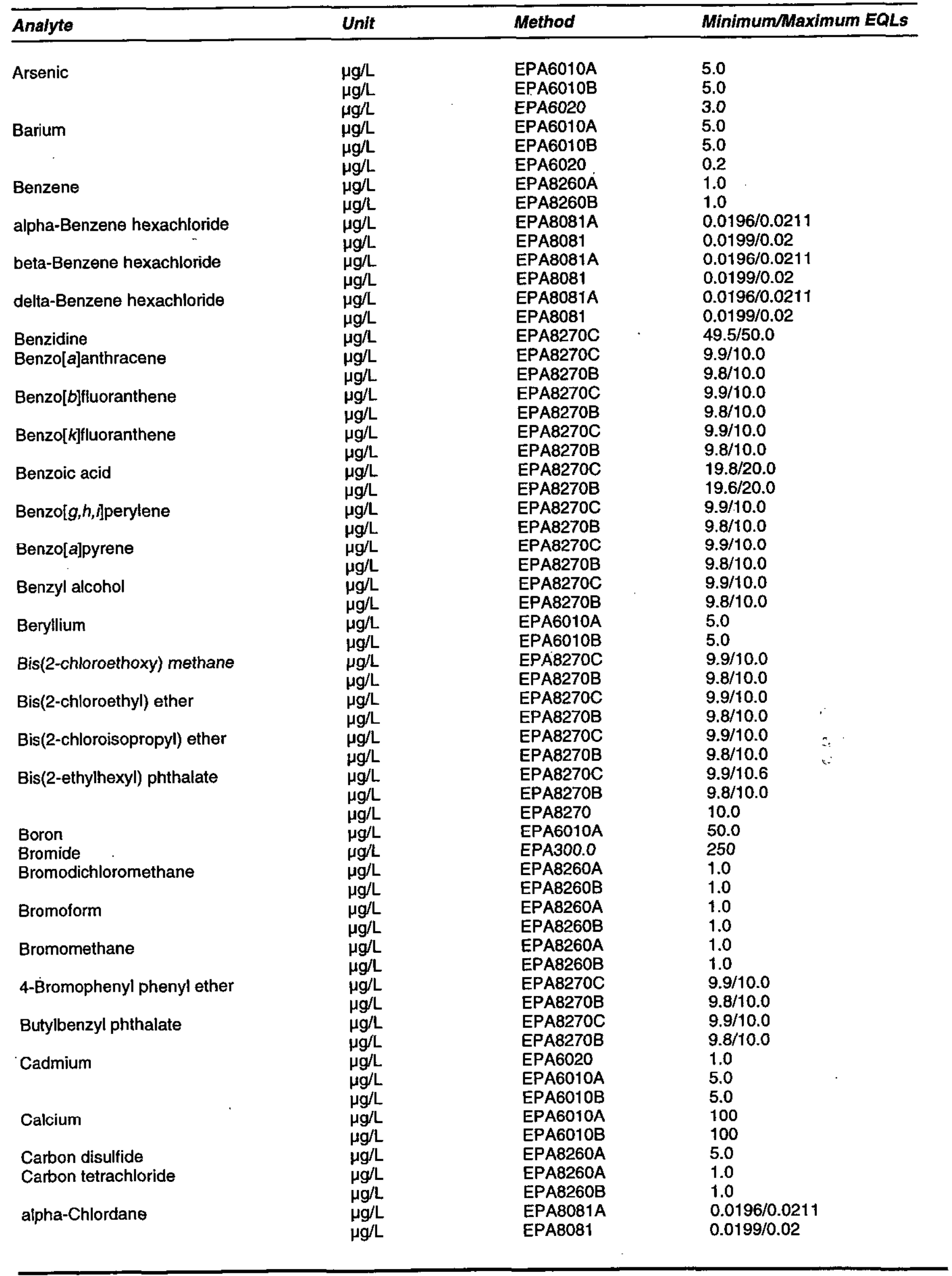




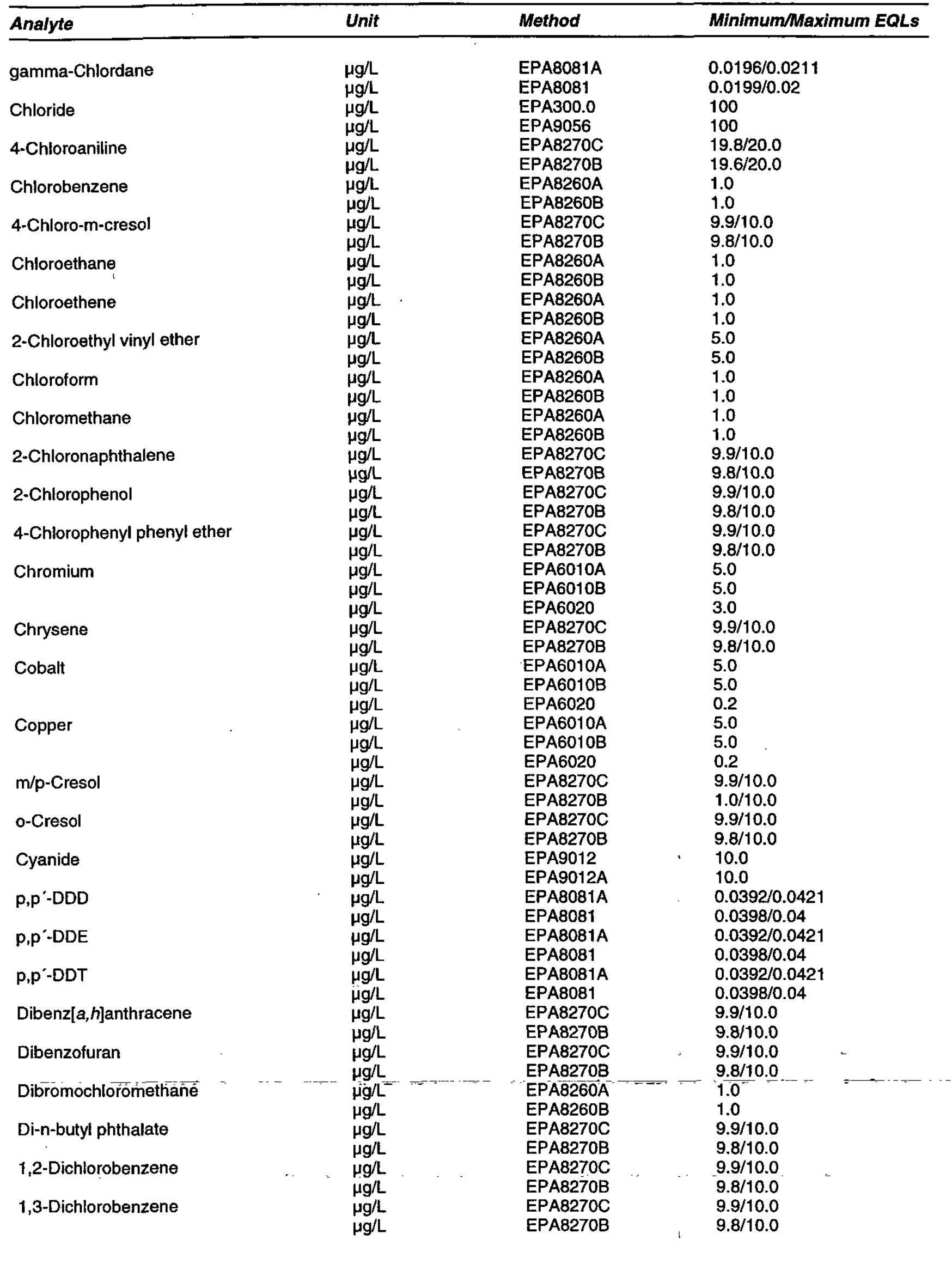




\begin{tabular}{|c|c|c|c|}
\hline \multirow{2}{*}{ Analyte } & \multirow{2}{*}{$\begin{array}{l}\text { Unit } \\
\substack{\mu g / L \\
\mu g / L}\end{array}$} & \multirow{2}{*}{$\begin{array}{l}\text { Method } \\
\text { EPA8270C } \\
\text { EPA8270B }\end{array}$} & Minimum/Maximum EQLs \\
\hline & & & $\begin{array}{l}9.9 / 10.0 \\
9.8 / 10.0\end{array}$ \\
\hline 3,3'-Dichlorobenzidine & $\mu g / L$ & EPA8270C & $49.5 / 50.0$ \\
\hline & $\mu g / L$ & EPA8270B & $49.0 / 50.0$ \\
\hline 1,1-Dichloroethane & $\mu g / L$ & EPA8260A & 1.0 \\
\hline & $\mu g / L$ & EPA8260B & 1.0 \\
\hline 1,2-Dichloroethane & $\mu g / L$ & EPA8260A & 1.0 \\
\hline & $\mu g / L$ & EPA8260B & 1.0 \\
\hline 1,1-Dichloroethylene & $\mu g / L$ & EPA8260A & 1.0 \\
\hline & $\mu g / L$ & EPA8260B & 1.0 \\
\hline 1,2-Dichloroethylene & $\mu g / L$ & EPA8260A & 1.0 \\
\hline trans-1,2-Dichloroethylene & $\mu g / L$ & EPA8260A & 1.0 \\
\hline & $\mu g / L$ & EPA8260B & 1.0 \\
\hline Dichloromethane & $\mu g / L$ & EPA8260A & 1.0 \\
\hline 2,4-Dichlorophenol & $\mu g / L$ & EPA8260B & 1.0 \\
\hline 2,4-Dichlorophenol & $\begin{array}{l}\mu g / L \\
\mu g / L\end{array}$ & $\begin{array}{l}\text { EPA8270C } \\
\text { EPA8270B }\end{array}$ & $9.9 / 10.0$ \\
\hline 2,4-Dichlorophenoxyacetic acid & $\mu g / L$ & EPA8151 & $\begin{array}{l}9.8 / 10.0 \\
0.1\end{array}$ \\
\hline 1,2-Dichloropropane & $\mu g / L$ & EPA8260A & 1.0 \\
\hline & $\mu g / L$ & EPA8260B & 1.0 \\
\hline cis-1,3-Dichloropropene & $\mu g / L$ & EPA8260A & 1.0 \\
\hline & $\mu g / L$ & EPA8260B & 1.0 \\
\hline trans-1,3-Dichloropropene & $\mu g / L$ & EPA8260A & 1.0 \\
\hline & $\mu g / L$ & EPA8260B & 1.0 \\
\hline Dieldrin & $\mu g / L$ & EPA8081A & $0.0392 / 0.0421$ \\
\hline & $\mu g / L$ & EPA8081 & $0.0398 / 0.04$ \\
\hline Diethyl phthalate & $\begin{array}{l}\mu g / L \\
\mu g / L\end{array}$ & $\begin{array}{l}\text { EPA8270C } \\
\text { EPA8270B }\end{array}$ & $\begin{array}{l}9.9 / 10.0 \\
9.8 / 10.0\end{array}$ \\
\hline 2,4-Dimethyl phenol & $\mu g / L$ & EPA8270C & $9.9 / 10.0$ \\
\hline & $\mu g / L$ & EPA8270B & $9.8 / 10.0$ \\
\hline Dimethyl phthalate & $\mu g / L$ & EPA8270C & $9.9 / 10.0$ \\
\hline & $\mu g / L$ & EPA8270B & $9.8 / 10.0$ \\
\hline 2,4-Dinitrophenol & $\mu g / L$ & $\begin{array}{l}\text { EPA8270C } \\
\text { EPA8270B }\end{array}$ & $\begin{array}{l}19.8 / 20.0 \\
19.6 / 20.0\end{array}$ \\
\hline 2,4-Dinitrotoluene & $\begin{array}{l}\mu g / L \\
\mu g / L\end{array}$ & $\begin{array}{l}\text { EPA8270B } \\
\text { EPA8270C }\end{array}$ & $\begin{array}{l}19.6 / 20.0 \\
9.9 / 10.0\end{array}$ \\
\hline 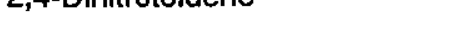 & $\begin{array}{l}\mu g / L \\
\mu g / L\end{array}$ & EPA8270B & $\begin{array}{l}9.9 / 10.0 \\
9.8 / 10.0\end{array}$ \\
\hline 2,6-Dinitrotoluene & $\mu g / L$ & EPA8270C & $9.9 / 10.0$ \\
\hline & $\mu g / L$ & EPA8270B & $9.8 / 10.0$ \\
\hline Di-n-octyl phthalate & $\mu g / L$ & EPA8270C & $9.9 / 10.0$ \\
\hline & $\mu g / L$ & EPA8270B & $9.8 / 10.0$ \\
\hline Endosulfan sulfate & $\mu g / L$ & EPA8081A & $0.0392 / 0.0421$ \\
\hline & $\mu \mathrm{g} / \mathrm{L}$ & EPA8081 & $0.0398 / 0.04$ \\
\hline Endosulfan I & $\mu g / L$ & EPA8081A & $0.0196 / 0.0211$ \\
\hline & $\mu g / L$ & EPA8081 & $0.0199 / 0.02$ \\
\hline Endosulfan II & $\mu g / L$ & EPA8081A & $0.0392 / 0.0421$ \\
\hline & $\mu g / L$ & EPA8081 & $0.0398 / 0.04$ \\
\hline Endrin & $\mu g / L$ & EPA8081A & $0.0392 / 0.0421$ \\
\hline & $\mu g / L$ & EPA8081 & $0.0398 / 0.04$ \\
\hline Endrin aldehyde & $\mu g / L$ & EPA8081A & $0.0392 / 0.0421$ \\
\hline Endrin ketone & $\mu g / L$ & EPA8081 & $0.0398 / 0.04$ \\
\hline Ethylbenzene & $\mu g / L$ & EPA8260A & 1.0 \\
\hline & $\mu g / L$ & EPA8260B & 1.0 \\
\hline Fluoranthene & $\mu g / L$ & EPA8270C & $9.9 / 10.0$ \\
\hline & $\mu g / L$ & EPA8270B & $9.8 / 10.0$ \\
\hline Fluorene & $\begin{array}{l}\mu g / L \\
\mu g / L\end{array}$ & $\begin{array}{l}\text { EPA8270C } \\
\text { FPA8270B }\end{array}$ & $\begin{array}{l}9.9 / 10.0 \\
9.8 / 10.0\end{array}$ \\
\hline Fluoride & $\mu g / L$ & EPA9056 & 50.0 \\
\hline Heptachlor & $\begin{array}{l}\mu g / L \\
\mu g / L\end{array}$ & $\begin{array}{l}\text { EPA8081A } \\
\text { EPA8081 }\end{array}$ & $\begin{array}{l}0.0196 / 0.0211 \\
0.0199 / 0.02\end{array}$ \\
\hline Heptachlor epoxide & $\mu \mathrm{g} / \mathrm{L}$ & $\begin{array}{l}\text { EPA8081A } \\
\text { EPA8081 }\end{array}$ & $\begin{array}{l}0.0196 / 0.0211 \\
0.0199 / 0.02\end{array}$ \\
\hline
\end{tabular}




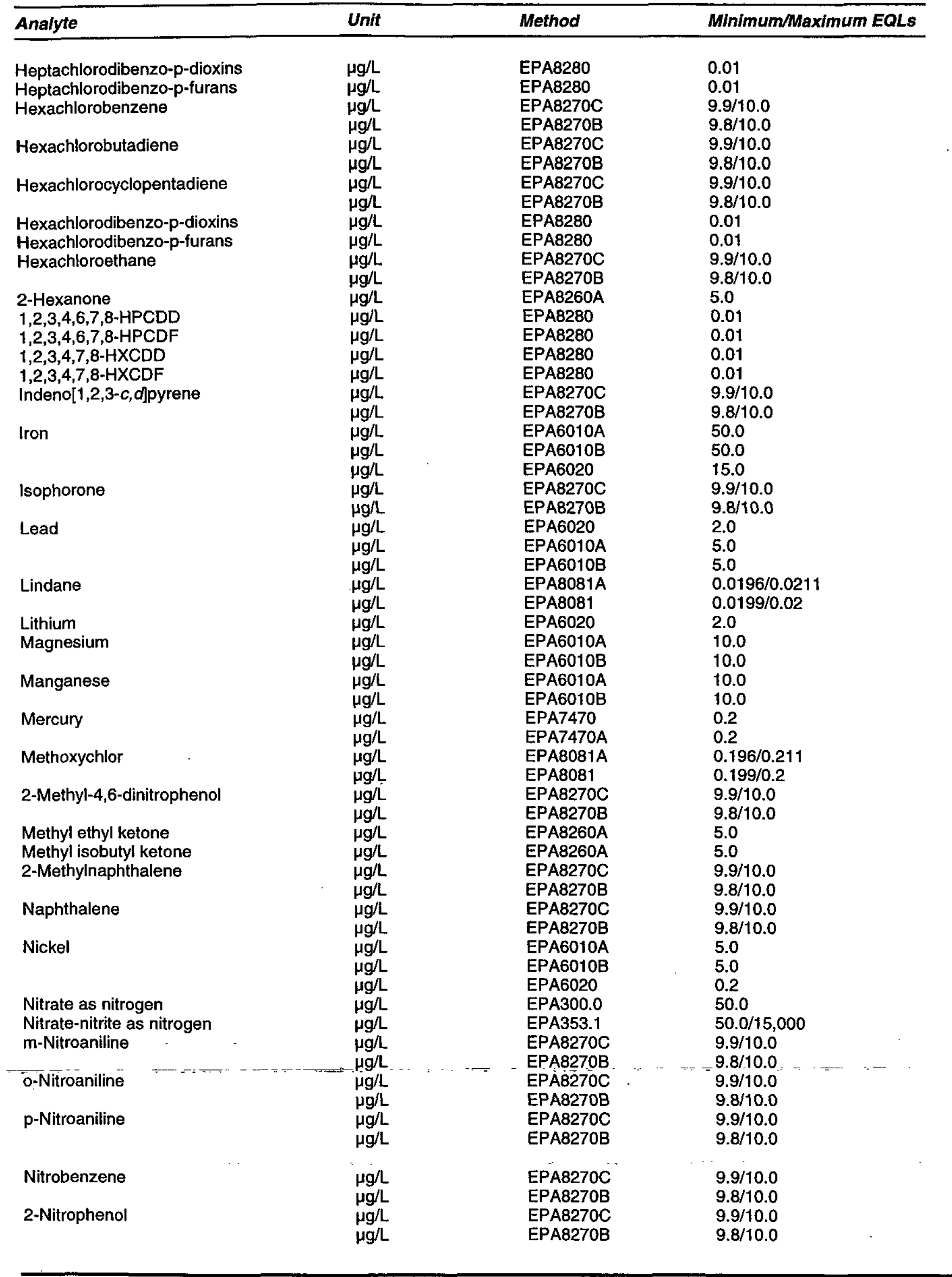




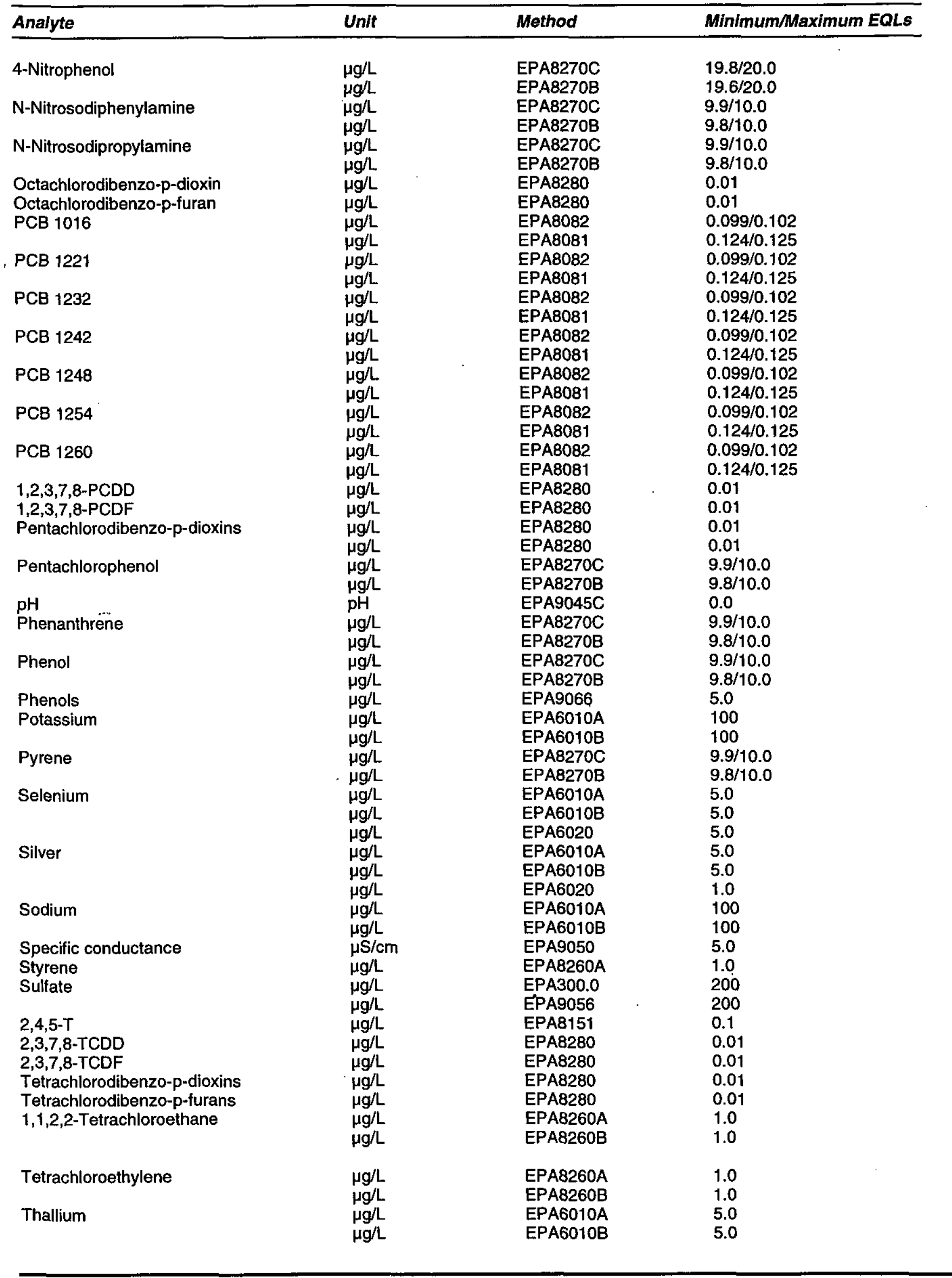




\begin{tabular}{|c|c|c|c|}
\hline Analyte & Unit & Method & Minimum/Maximum EQLs \\
\hline Tin & $\begin{array}{l}\mu g / L \\
\mu g / L\end{array}$ & $\begin{array}{l}\text { EPA6010A } \\
\text { EPA6020 }\end{array}$ & $\begin{array}{l}10.0 \\
2.0\end{array}$ \\
\hline Toluene & $\mu g / L$ & $\begin{array}{l}\text { EPA8260A } \\
\text { EPA8260B }\end{array}$ & $\begin{array}{l}1.0 / 10.0 \\
1.0\end{array}$ \\
\hline Total dissolved solids & $\mu q / L$ & EPA160.† & $\begin{array}{l}1.0 \\
10,000\end{array}$ \\
\hline Total organic carbon & $\mu g / L$ & EPA9060 & 5,000 \\
\hline Total organic halogens & $\mu g / L$ & EPA9020B & $10.0 / 50.0$ \\
\hline Total phosphates (as P) & $\mu g / L$ & EPA365.4 & 50.0 \\
\hline \multirow[t]{2}{*}{ Toxaphene } & $\mu g / L$ & EPA8081A & $0.98 / 1.05$ \\
\hline & $\mu g / L$ & EPA8081 & $0.995 / 1.0$ \\
\hline \multirow{2}{*}{$\begin{array}{l}\text { 2,4,5-TP (Silvex) } \\
\text { 1,2,4-Trichlorobenzene }\end{array}$} & $\mu g / L$ & EPA8151 & 0.1 \\
\hline & $\begin{array}{l}\mu g / L \\
\mu g / L\end{array}$ & $\begin{array}{l}\text { EPA8270C } \\
\text { EPA8270B }\end{array}$ & $\begin{array}{l}9.9 / 10.0 \\
9.8 / 10.0\end{array}$ \\
\hline \multirow[t]{2}{*}{ 1,1,1-Trichloroethane } & $\mu g / L$ & EPA8260A & 1.0 \\
\hline & $\mu g / L$ & EPA8260B & 1.0 \\
\hline \multirow[t]{2}{*}{$1,1,2-$ Trichloroethane } & $\mu g / L$ & EPA8260A & 1.0 \\
\hline & $\mu g / L$ & EPA8260B & 1.0 \\
\hline \multirow[t]{2}{*}{ Trichloroethylene } & $\mu g / L$ & EPA8260A & 1.0 \\
\hline & $\mu g / L$ & EPA8260B & 1.0 \\
\hline \multirow[t]{2}{*}{ Trichlorofluoromethane } & $\mu g / L$ & EPA8260A & 1.0 \\
\hline & $\mu g / L$ & EPA8260B & 1.0 \\
\hline \multirow[t]{2}{*}{ 2,4,5-Trichlorophenol } & $\mu g / L$ & EPAB270C & $9.9 / 10.0$ \\
\hline & $\mu g / L$ & EPA8270B & $9.8 / 10.0$ \\
\hline \multirow[t]{2}{*}{ 2,4,6-Trichlorophenol } & $\mu g / L$ & EPA8270C & $9.9 / 10.0$ \\
\hline & $\mu g / L$ & EPA8270B & $9.8 / 10.0$ \\
\hline \multirow[t]{3}{*}{ Vanadium } & $\mu g / L$ & EPA6010A & 5.0 \\
\hline & $\mu g / L$ & EPA6010B & 5.0 \\
\hline & $\mu g / L$ & EPA6020 & 2.0 \\
\hline \multirow{4}{*}{$\begin{array}{l}\text { Vinyl acetate } \\
\mathrm{m} / \mathrm{p} \text {-Xylene } \\
\text { Xylenes }\end{array}$} & $\mu g / L$ & EPA8260A & 5.0 \\
\hline & $\mu g / L$ & EPA8260A & 1.0 \\
\hline & $\mu g / L$ & EPA8260A & 1.0 \\
\hline & $\mu g / L$ & EPA8260 & 1.0 \\
\hline \multirow[t]{3}{*}{ Zinc } & $\mu g / L$ & EPA6010A & 5.0 \\
\hline & $\mu g / L$ & EPA6010B & 5.0 \\
\hline & $\mu \mathrm{g} / \mathrm{L}$ & EPA6020 & 5.0 \\
\hline
\end{tabular}

Note: The groundwater samples are unfiltered; thus, the methods for metals are for total recoverable metals. Method 6010 is an inductively coupled plasma atomic emission spectroscopy method for metals determination and is published for RCRA determinations.

Table 15. Methods and Estimated Quantitation Limits Used by WA

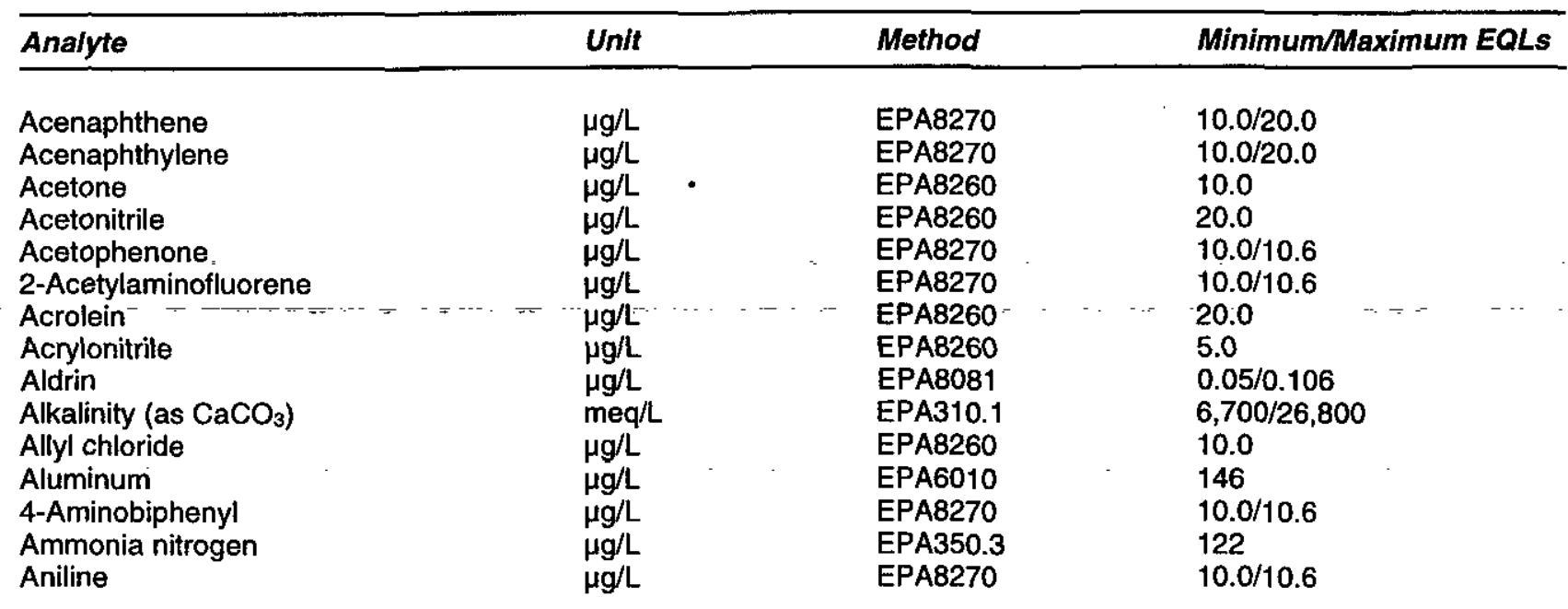




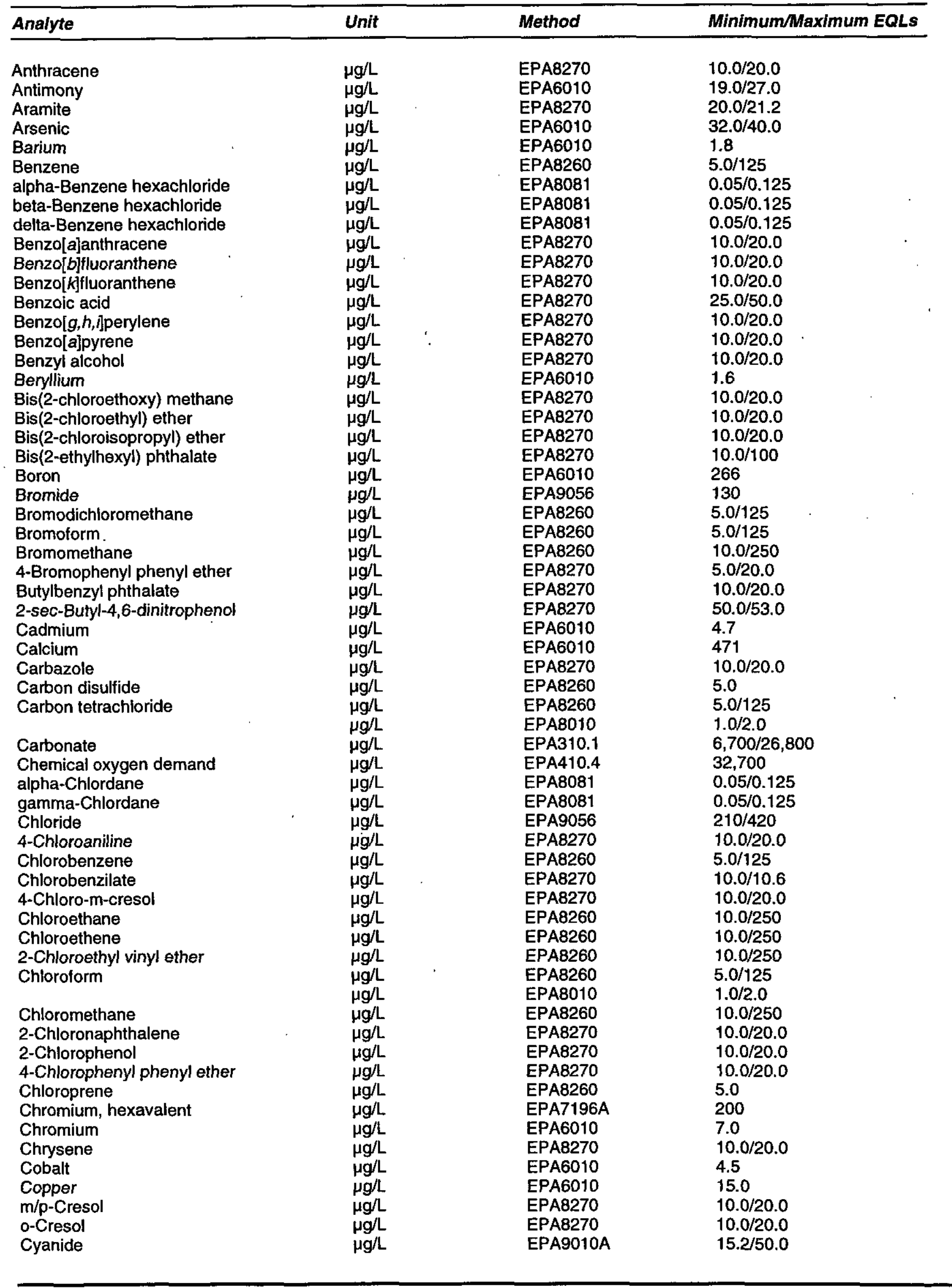




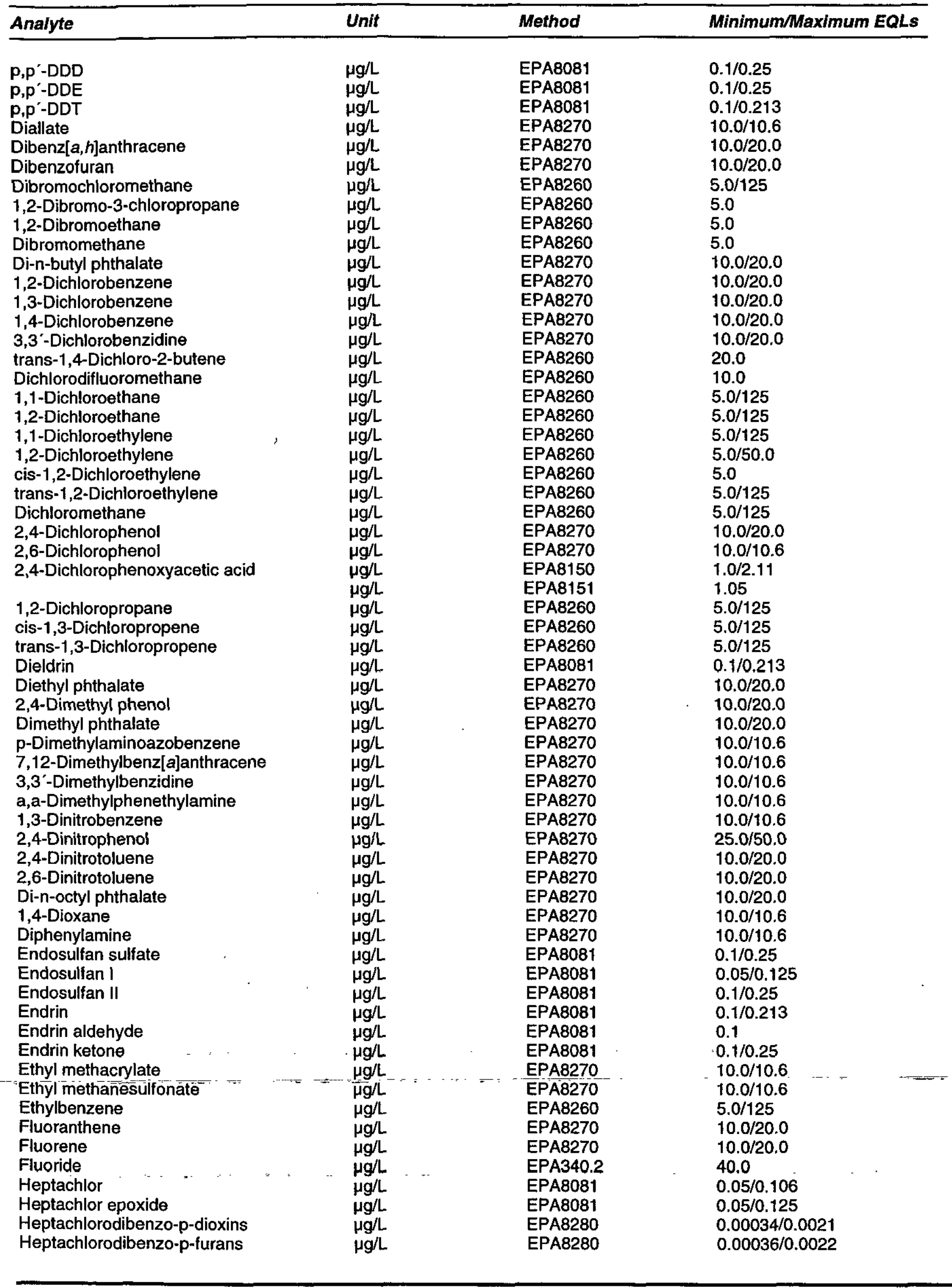




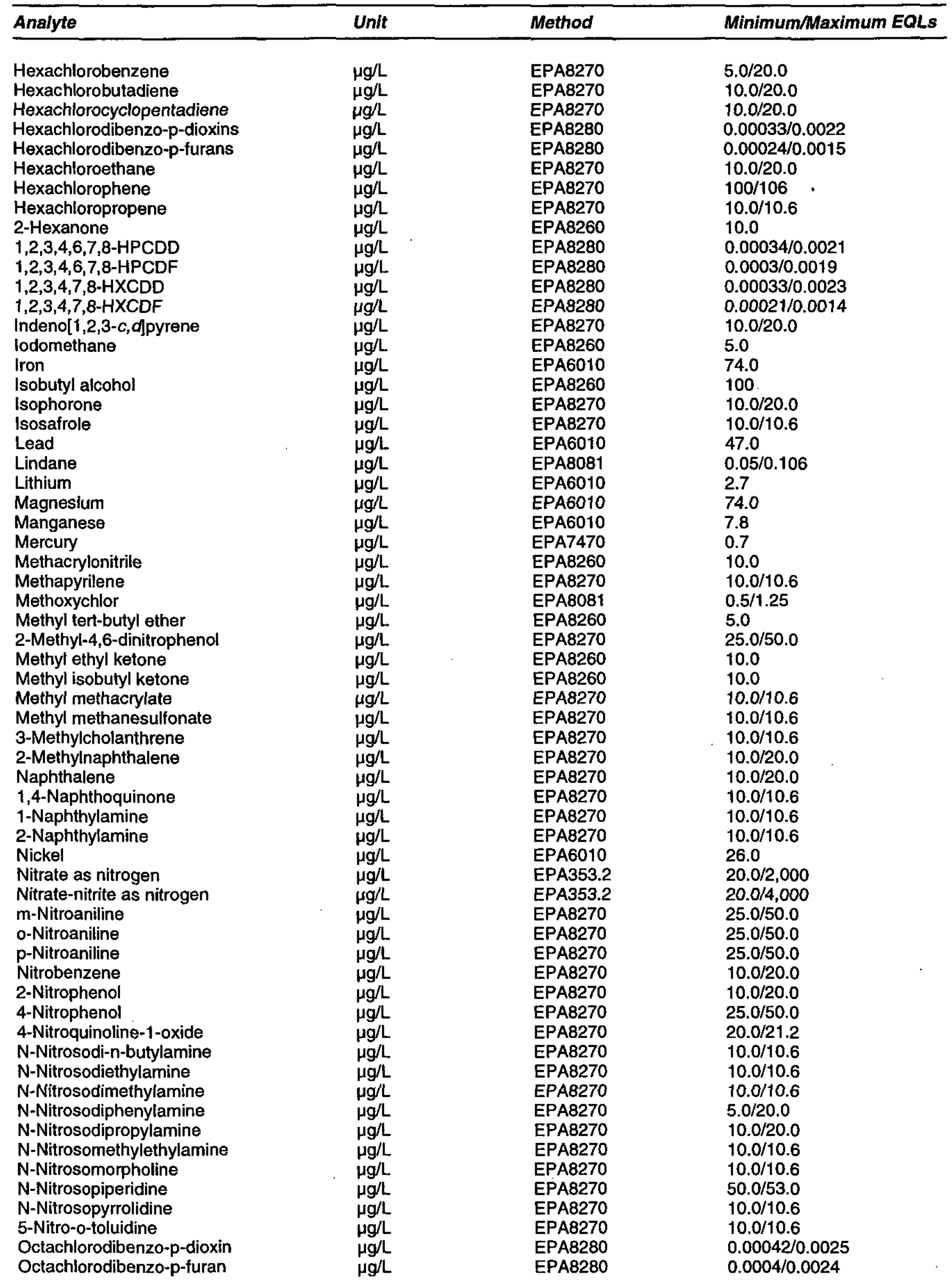




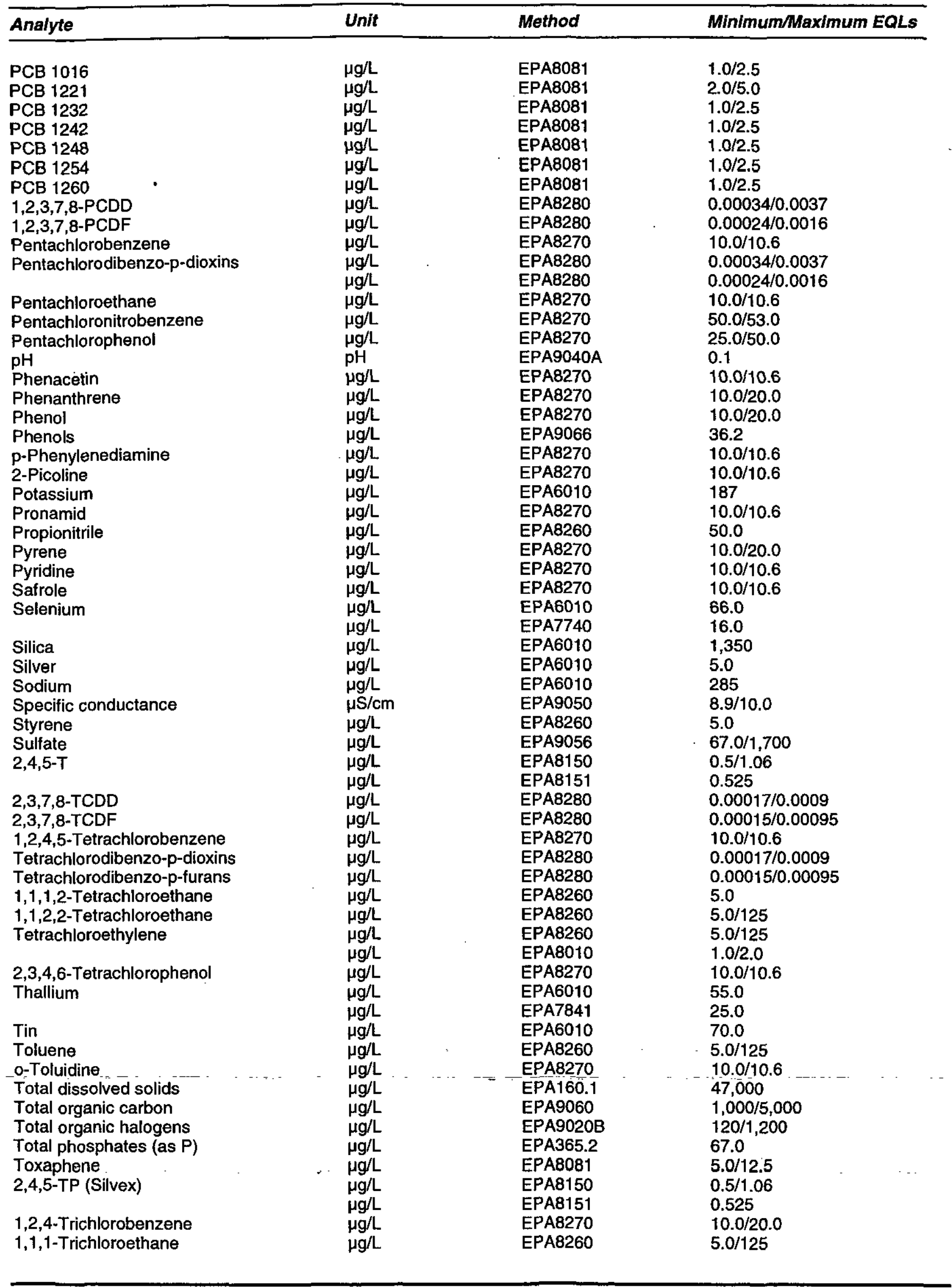




\begin{tabular}{|c|c|c|c|}
\hline Analyte & Unit & Method & Minimum/Maximum EQLs \\
\hline $\begin{array}{l}\text { 1,1,2-Trichloroethane } \\
\text { Trichloroethylene } \\
\text { Trichlorofluoromethane } \\
\text { 2,4,5-Trichlorophenol } \\
\text { 2,4,6-Trichlorophenol } \\
\text { 1,2,3-Trichloropropane } \\
\text { 1,3,5-Trinitrobenzene } \\
\text { Vanadium } \\
\text { Vinyl acetate } \\
\text { Xylenes } \\
\text { Zinc }\end{array}$ & $\begin{array}{l}\mu g / L \\
\mu g / L \\
\mu g / L \\
\mu g / L \\
\mu g / L \\
\mu g / L \\
\mu g / L \\
\mu g / L \\
\mu g / L \\
\mu g / L \\
\mu g / L \\
\mu g / L \\
\mu g / L\end{array}$ & $\begin{array}{l}\text { EPA8010 } \\
\text { EPA8260 } \\
\text { EPA8260 } \\
\text { EPA8010 } \\
\text { EPA8260 } \\
\text { EPA8270 } \\
\text { EPA8270 } \\
\text { EPA8260 } \\
\text { EPA8270 } \\
\text { EPA6010 } \\
\text { EPA8260 } \\
\text { EPA8260 } \\
\text { EPA6010 }\end{array}$ & $\begin{array}{l}1.0 / 2.0 \\
5.0 / 125 \\
5.0 / 125 \\
1.0 / 2.0 \\
5.0 / 125 \\
25.0 / 50.0 \\
10.0 / 20.0 \\
5.0 \\
10.0 / 10.6 \\
6.9 \\
10.0 \\
5.0 / 125 \\
53.0 \\
\end{array}$ \\
\hline
\end{tabular}

Note: The groundwater samples are unfiltered; thus, the methods for metals are for total recoverable metals. Method 6010 is an inductively coupled plasma atomic emission spectroscopy method for metals determination and is published for RCRA determinations.

Table 16. Methods and Estimated Quantitation Limits Used by EX

\begin{tabular}{|c|c|c|c|}
\hline Analyte & Unit & Method & Minimum/Maximum EQLs \\
\hline $\begin{array}{l}\text { Acenaphthene } \\
\text { Acenaphthylene } \\
\text { Acetone } \\
\text { Acetonitrile } \\
\text { Acrolein } \\
\text { Acrylonitrile } \\
\text { Aldrin } \\
\text { Allyl chloride } \\
\text { Aluminum } \\
\text { Anthracene } \\
\text { Antimony } \\
\text { Arsenic } \\
\text { Barium } \\
\text { Benzene } \\
\text { alpha-Benzene hexachloride } \\
\text { beta-Benzene hexachloride } \\
\text { delta-Benzene hexachloride } \\
\text { Benzidine } \\
\text { Benzo[a]anthracene } \\
\text { Benzo[b]fluoranthene } \\
\text { Benzo[k]fluoranthene } \\
\text { Benzoic acid } \\
\text { Benzo[g,h,i]perylene } \\
\text { Benzo[a]pyrene } \\
\text { Benzyl alcohol } \\
\text { Beryllium } \\
\text { Bis(2-chloroethoxy) methane } \\
\text { Bis(2-chloroethyl) ether } \\
\text { Bis(2-chloroisopropyl) ether } \\
\text { Bis(2-ethylhexyl) phthalate } \\
\text { Boron } \\
\text { Bromodichloromethane } \\
\text { Bromoform } \\
\text { Bromomethane } \\
\text { 4-Bromophenyl phenyl ether } \\
\text { Butylbenzyl phthalate } \\
\text { 2-sec-Butyl-4,6-dinitrophenol }\end{array}$ & $\begin{array}{l}\mu g / L \\
\mu g / L \\
\mu g / L \\
\mu g / L \\
\mu g / L \\
\mu g / L \\
\mu g / L \\
\mu g / L \\
\mu g / L \\
\mu g / L \\
\mu g / L \\
\mu g / L \\
\mu g / L \\
\mu g / L \\
\mu g / L \\
\mu g / L \\
\mu g / L \\
\mu g / L \\
\mu g / L \\
\mu g / L \\
\mu g / L \\
\mu g / L \\
\mu g / L \\
\mu g / L \\
\mu g / L \\
\mu g / L \\
\mu g / L \\
\mu g / L \\
\mu g / L \\
\mu g / L \\
\mu g / L \\
\mu g / L \\
\mu g / L \\
\mu g / L \\
\mu g / L \\
\mu g / L\end{array}$ & $\begin{array}{l}\text { EPA8270B } \\
\text { EPA8270B } \\
\text { EPA8260A } \\
\text { EPA8260A } \\
\text { EPA8260A } \\
\text { EPA8260A } \\
\text { EPA8081 } \\
\text { EPA8260A } \\
\text { EPA6010A } \\
\text { EPA8270B } \\
\text { EPA6010A } \\
\text { EPA6010A } \\
\text { EPA6010A } \\
\text { EPA8260A } \\
\text { EPA8081 } \\
\text { EPA8081 } \\
\text { EPA8081 } \\
\text { EPA8270B } \\
\text { EPA8270B } \\
\text { EPA8270B } \\
\text { EPA8270B } \\
\text { EPA8270B } \\
\text { EPA8270B } \\
\text { EPA8270B } \\
\text { EPA8270B } \\
\text { EPA6010A } \\
\text { EPA8270B } \\
\text { EPA8270B } \\
\text { EPA8270B } \\
\text { EPA8270B } \\
\text { EPA6010A } \\
\text { EPA8260A } \\
\text { EPA8260A } \\
\text { EPA8270B } \\
\text { EPA8270B } \\
\text { EPA8151 }\end{array}$ & $\begin{array}{l}10.0 \\
10.0 \\
10.0 / 5,000 \\
200 / 100,000 \\
10.0 / 5,000 \\
10.0 / 5,000 \\
0.05 \\
20.0 / 10,000 \\
100 \\
10.0 \\
100 \\
10.0 \\
5.0 / 10.0 \\
5.0 / 2,500 \\
0.05 \\
0.05 \\
0.05 \\
50.0 \\
10.0 \\
10.0 \\
10.0 \\
10.0 / 50.0 \\
10.0 \\
10.0 \\
20.0 \\
5.0 \\
10.0 \\
10.0 \\
10.0 \\
10.0 \\
50.0 \\
5.0 / 2,500 \\
5.0 / 2,500 \\
5.0 / 2,500 \\
10.0 \\
10.0 \\
0.5 \\
10 \\
10 \\
10 \\
10 \\
10 \\
10 \\
10\end{array}$ \\
\hline
\end{tabular}




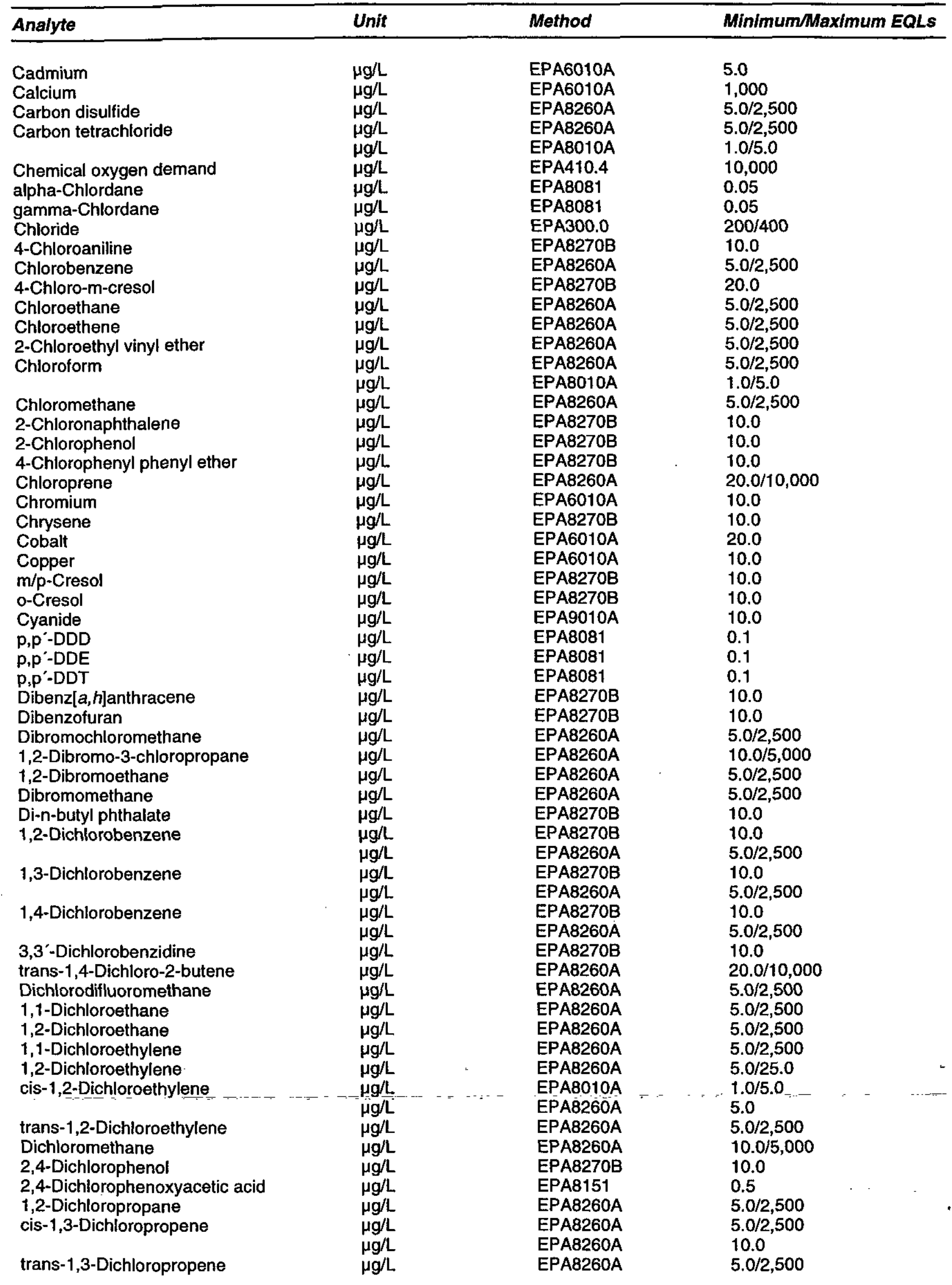




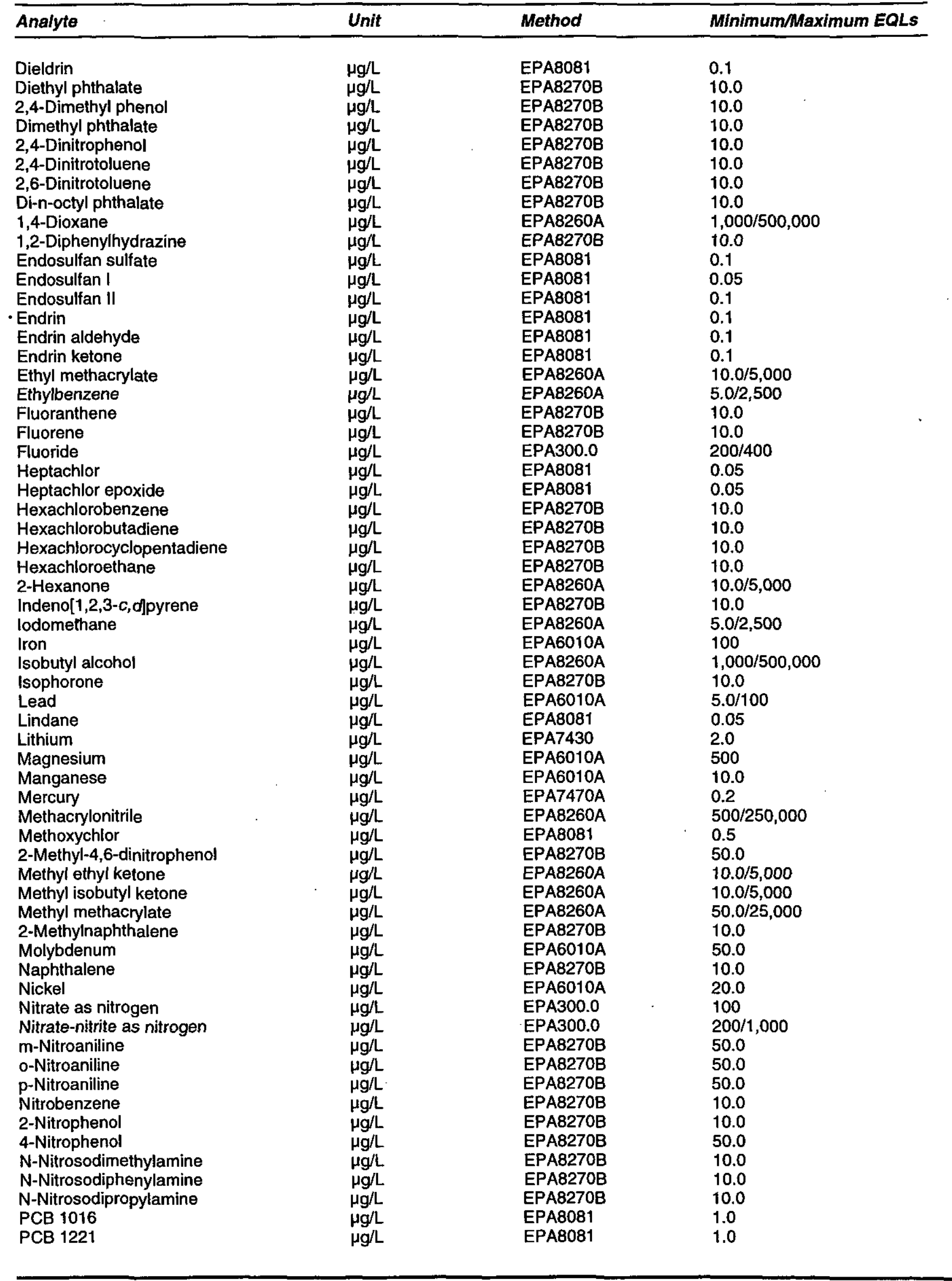




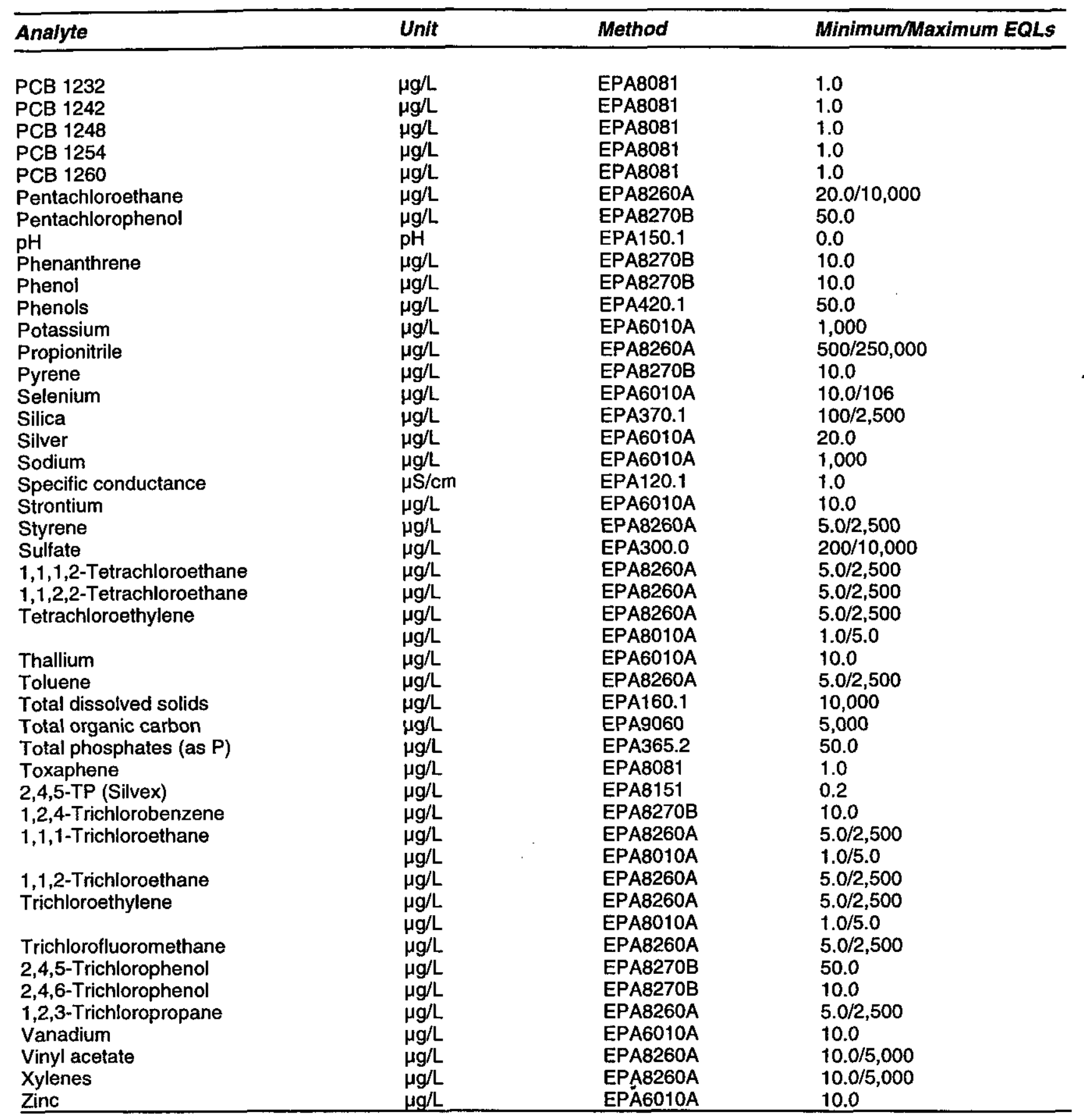

Note: The groundwater samples are unfiltered; thus, the methods for metals are for total recoverable metals. Method 6010 is an inductively coupled plasma atomic emission spectroscopy method for metals determination and is published for RCRA determinations. 
Table 17. Mothods and Estimated Quantitation Limits Used by GP

\begin{tabular}{|c|c|c|c|}
\hline Analyte & Unit & Method & Minimum/Maximum EQLs \\
\hline Actinium-228 & $\mu \mathrm{Ci} / \mathrm{mL}$ & EPIA-013 & 1.17E-08/1.71E-08 \\
\hline Americium-241 & $\mu \mathrm{Ci} / \mathrm{mL}$ & EPIA-011 & 4.9E-11/6.03E-10 \\
\hline Antimony-125 & $\mu \mathrm{Ci} / \mathrm{mL}$ & EPIA-013 & 7.57E-09/1.13E-08 \\
\hline Carbon-14 & $\mu \mathrm{Ci} / \mathrm{mL}$ & EPIA-003 & 5.21E-09/1.55E-08 \\
\hline Cerium-144 & $\mu \mathrm{Ci} / \mathrm{mL}$ & EPIA-013 & 1.82E-08/2.9E-08 \\
\hline Cesium-134 & $\mu \mathrm{Ci} / \mathrm{mL}$ & EPIA-013 & 2.79E-09/3.71E-09 \\
\hline Cesium-137 & $\mu \mathrm{Ci} / \mathrm{mL}$ & EPIA-013 & 3.24E-09/5.23E-09 \\
\hline Cobalt-57 & $\mu \mathrm{Ci} / \mathrm{mL}$ & EPIA-013 & 2.18E-09/3.67E-09 \\
\hline Cobalt-60 & $\mu \mathrm{Cl} / \mathrm{mL}$ & EPIA-013 & 2.58E-09/4.06E-09 \\
\hline Curium-242 & $\mu \mathrm{Ci} / \mathrm{mL}$ & EPIA-011 & 4.2E-11/4.51E-10 \\
\hline Curium-243/244 & $\mu \mathrm{Ci} / \mathrm{mL}$ & EPIA-011 & 7.3E-11/6.5E-10 \\
\hline Curium-245/246 & $\mu \mathrm{Ci} / \mathrm{mL}$ & EPIA-011 & 4.1E-11/2.5E-10 \\
\hline Europium-152 & $\mu \mathrm{Ci} / \mathrm{mL}$ & EPIA-013 & 7.54E-09/1.23E-08 \\
\hline Europium-154 & $\mu \mathrm{Ci} / \mathrm{mL}$ & EPIA-013 & 7.57E-09/1.16E-08 \\
\hline Europium-155 & $\mu \mathrm{Ci} / \mathrm{mL}$ & EPIA-013 & 8.58E-09/1.61E-08 \\
\hline Gross alpha & $\mu \mathrm{Ci} / \mathrm{mL}$ & EPIA-001 & 5.7E-11/6.53E-09 \\
\hline lodine-129 & $\mu \mathrm{Ci} / \mathrm{mL}$ & EPIA-006 & $3.18 \mathrm{E}-10 / 1.33 \mathrm{E}-09$ \\
\hline Lead-212 & $\mu \mathrm{Ci} / \mathrm{mL}$ & EPIA-013 & 5.22E-09/7.39E-09 \\
\hline Manganese-54 & $\mu \mathrm{Ci} / \mathrm{mL}$ & EPIA-013 & 2.61E-09/3.95E-09 \\
\hline Neptunium-237 & $\mu \mathrm{Ci} / \mathrm{mL}$ & EPIA-032 & 4.4E-11/2.51E-10 \\
\hline Nickel-63 & $\mu \mathrm{Ci} / \mathrm{mL}$ & EPIA-022 & 2.37E-08/2.45E-07 \\
\hline Nonvolatile beta & $\mu \mathrm{Ci} / \mathrm{mL}$ & EPIA-001 & $1.11 \mathrm{E}-10 / 7.13 \mathrm{E}-09$ \\
\hline Plutonium-238 & $\mu \mathrm{Ci} / \mathrm{mL}$ & EPIA-011 & 5.7E-11/5.74E-10 \\
\hline Plutonium-239/240 & $\mu \mathrm{Ci} / \mathrm{mL}$ & EPIA-011 & $3.9 E-11 / 5.93 E-10$ \\
\hline Potassium-40 & $\mu \mathrm{Ci} / \mathrm{mL}$ & EPIA-013 & 2.59E-08/5.34E-08 \\
\hline Promethium-144 & $\mu \mathrm{Ci} / \mathrm{mL}$ & EPIA-013 & 2.41E-09/3.66E-09 \\
\hline Promethium-146 & $\mu \mathrm{Ci} / \mathrm{mL}$ & EPIA-013 & 3.67E-09/5.19E-09 \\
\hline Promethium-147 & $\mu \mathrm{Ci} / \mathrm{mL}$ & EPIA-020 & $9.98 \mathrm{E}-10 / 1.44 \mathrm{E}-09$ \\
\hline Radium, total alpha-emitting & $\mu \mathrm{Ci} / \mathrm{mL}$ & EPIA-010 & 2.25E-10/5.62E-10 \\
\hline Radium-226 & $\mu \mathrm{Ci} / \mathrm{mL}$ & EPIA-008 & 4.32E-10/1.03E-09 \\
\hline Radium-228 & $\mu \mathrm{Ci} / \mathrm{mL}$ & EPIA-009 & $6.62 \mathrm{E}-10 / 1.42 \mathrm{E}-09$ \\
\hline Ruthenium-106 & $\mu \mathrm{Ci} / \mathrm{mL}$ & EPIA-013 & 2.43E-08/3.47E-08 \\
\hline Sodium-22 & $\mu \mathrm{Ci} / \mathrm{mL}$ & EPIA-013 & 2.69E-09/4.13E-09 \\
\hline Strontium-89/90 & $\mu \mathrm{Ci} / \mathrm{mL}$ & EPIA-004 & 1.22E-09/1.71E-09 \\
\hline Strontium-90 & $\mu \mathrm{Ci} / \mathrm{mL}$ & EPIA-004 & 8.51E-10/2.57E-09 \\
\hline Technetium-99 & $\mu \mathrm{Ci} / \mathrm{mL}$ & EPIA-005 & 3.11E-09/3.17E-08 \\
\hline Thorium-228 & $\mu \mathrm{Ci} / \mathrm{mL}$ & EPIA-012 & 8.9E-11/1.6E-09 \\
\hline Thorium-230 & $\mu \mathrm{Ci} / \mathrm{mL}$ & EPIA-012 & $5.6 \mathrm{E}-11 / 7.92 \mathrm{E}-10$ \\
\hline Thorium-232 & $\mu \mathrm{Ci} / \mathrm{mL}$ & EPIA-012 & 4.7E-11/6.72E-10 \\
\hline Tritium & $\mu \mathrm{Ci} / \mathrm{mL}$ & EPIA-002 & 5.27E-07/1.08E-05 \\
\hline Uranium-233/234 & $\mu \mathrm{Ci} / \mathrm{mL}$ & EPIA-011 & $1.8 E-11 / 3.39 E-10$ \\
\hline Uranium-235 & $\mu \mathrm{Cl} / \mathrm{mL}$ & EPIA-011 & $2.2 E-11 / 2.95 E-10$ \\
\hline Uranium-238 & $\mu \mathrm{Ci} / \mathrm{mL}$ & EPIA-011 & 1.8E-11/3.02E-10 \\
\hline Yttrium-88 & $\mu \mathrm{Ci} / \mathrm{mL}$ & EPIA-013 & 3.04E-09/5.49E-09 \\
\hline Zinc-65 & $\mu \mathrm{Ci} / \mathrm{mL}$ & EPIA-013 & 4.62E-09/8.07E-09 \\
\hline
\end{tabular}


Table 18. Methods and Estimated Quantitation Limits Used by TM

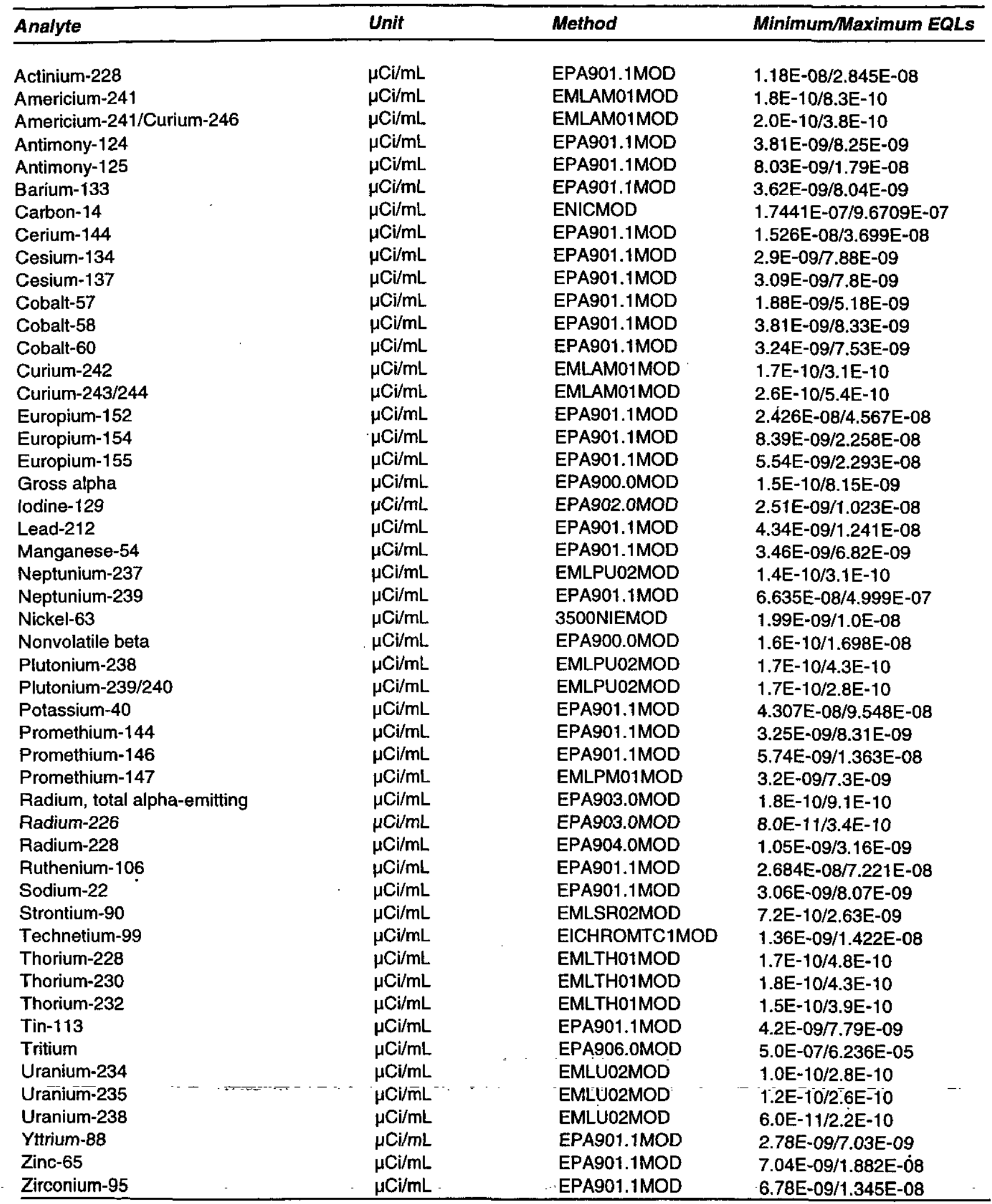




\section{Quality Control Samples}

This section discusses the analytical data in terms of the following indicators of data quality: precision, accuracy, representativeness, comparability, and completeness. Precision is determined from the field and laboratory duplicate or replicate analyses and indicates the consistency of field and laboratory techniques. Accuracy is determined from the quality control standards, laboratory control samples or blank spikes, surrogates, matrix spikes, and the results of method, field, and trip blanks and indicates the ability of the laboratory to generate correct results. (Equipment blanks are used to evaluate the effectiveness of the cleaning procedures used in the field.) Representativeness is the determination of how well the sample reflects the site's characteristics. Comparability expresses the confidence with which data from different laboratories are considered to be equivalent. Completeness measures the amount of useable data resulting from the data collection activity.

\section{PRECISION}

Precision is a measure of the repeatability of a measurement and is evaluated from the results of duplicate samples and splits. Blind replicates, or field replicates, measure the repeatability of the sampling and analytical techniques, and laboratory duplicates measure the ability of the laboratory to reproduce a result. Split samples measure whether two laboratories using comparable procedures obtain equivalent results. Low precision can be caused by poor instrument performance, poor operator technique, inconsistent application of method protocols, laboratory environment, time between analyses, or by a difficult, heterogeneous sample matrix.

\section{Replicate and Duplicate Analyses of Samples}

Blind replicate and duplicate samples are analyzed to establish the precision of scheduled analyses. The replicate and duplicate analytical results are used to generate Mean Relative Difference (MRD) indices, which are used to evaluate the laboratories' performances.

The primary laboratories, ES, EX, GE, and WA, performed all analyses with the following exceptions: GP and TM performed radionuclide analyses for ES, EX, GE, and WA.

For intralaboratory comparisons, generally $10 \%$ of the samples are analyzed in duplicate. In addition, EPD/EMS sends blind replicates of approximately $5 \%$ of the total samples to the laboratories for analysis. The results of the blind replicate analyses are used for both intralaboratory and interlaboratory comparisons.

All these results are included in the Analytical Results section (Appendix B) of this report. Results from duplicate samples are included in the main table for a given well and sample date. Results from analyses of replicate samples and duplicate analyses of the replicates are reported in a second table for the same well and sample date.

Table 22 lists the weil names, sample dates, and associated blanks for wells used as blind replicates for ES, $E X, G E$, and WA.

Certain analytes were not present in concentrations above estimated quantitation limits in any well samples having replicates or duplicates. These analytes are not considered in further evaluation of replicate and duplicate analyses and are listed in tables 23 and 24. See tables 13-18 for the estimated quantitation limits that are applicable this quarter.

\section{Intralaboratory Comparisons}

Intralaboratory comparisons are of two types: in-house duplicates and blind replicates. The MRD was developed by R.C. Tuckfield of the Applied Statistics Group at the Savannah River Technology Center, in conjunction with M.M. Khalil of EPD/EMS, to assess the reproducibility of identical chemical analyses. For both intralaboratory comparisons, the MRD is defined as the average absolute difference between an original sample and its duplicate or blind replicate, expressed as a percentage of the mean of those two values. It is calculated as 


$$
\mathrm{MRD}=\left\{\frac{\sum_{i=1}^{n}\left(\left|x_{i}-y_{i}\right| /\left[\left(x_{i}+y_{i}\right) / 2\right]\right)}{n}\right\} \times 100
$$

where

$$
\begin{aligned}
& x_{i}=\text { an analyte's mean concentration } \\
& \text { in a water sample for the } i^{\text {th }} \text { well, } \\
& y_{i}=\text { the analyte's mean concentration } \\
& \text { in the replicate or duplicate, and } \\
& n=\text { the number of pairs of observations. }
\end{aligned}
$$

For the in-house duplicate comparisons, the quantities $x_{i}$ and $y_{i}$ represent the results for the original sample and the in-house duplicate, respectively. For the blind replicate comparisons, $x_{i}$ and $y_{i}$ represent the results for the known sample and the EPD blind replicate, respectively. Generally, the closer the original results and their replicate or duplicate results are to each other, the lower the MRD.

\section{An Adjusted Mean Relative Difference}

A drawback to the MRD statistic occurs when $x_{i}$ and $y_{i}$ are close to zero. This drawback can be illustrated by determining the relative difference (RD) for the ith well or sample as follows:

$$
\begin{gathered}
\mathrm{RD}_{i}=\frac{\left|x_{i}-y_{i}\right|}{z_{i}} \\
\text { where } z_{i}=\left(\frac{x_{i}+y_{i}}{2}\right)
\end{gathered}
$$

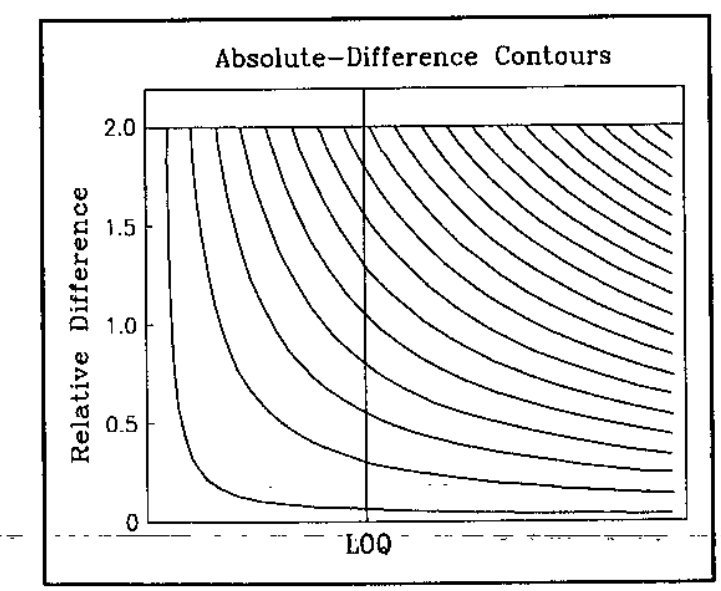

Figure 4. Relative Difforence vs. the Moan

The $\mathrm{RD}_{i}$ is an individual term in the MRD calculation for the $i$ th replicated sample. For example, if $x_{i}=99$ and $y_{i}$ $=101$, then $\mathrm{RD}_{i}=2 \%$. However, if $x_{i}=3$ and $y_{i}=1$, then $\mathrm{RD}_{i}=100 \%$. Both situations have the same absolute difference, but the latter situation has a much larger relative difference. The effect can be shown by graphing the relative difference vs. the mean $\left(z_{i}\right)$ and marking contours for constant levels of absolute difference 
(figure 4). The first contour, in the lower left corner of the figure, represents the smallest absolute difference. The last contour, in the upper right corner of the figure, represents the largest absolute difference.

The inordinate inflation of the MRD when $x_{i}$ and $y_{i}$ are near zero is of particular concern when the results are below the limit of quantitation (LOQ). Briefly, the LOQ is defined by L.H. Keith (1991) as 10 times the instrument signal standard deviation $(\sigma)$ for blank samples. For perspective, the limit of detection is defined as $3 \sigma$.

The reproducibility of analytical results less than the LOQ is considered by environmental chemists to be questionable. In this situation, the $\mathrm{RD}_{\text {; }}$ may reflect variation more in the measuring device itself than in the measuring process. However, the MRD can be a useful statistic if adjusted so that results below the LOQ have less influence than more reproducible results above the LOQ.

The simplest adjustment to the MRD to reduce the influence of analyte concentrations near zero is to weight each $\mathrm{RD}_{i}$ in the calculation by an amount, $w_{i}$, that reflects its proximity to the LOQ value. Figure 5 shows the relationship between $w_{i}$ and analyte concentration. This relationship is a linear-weight function.

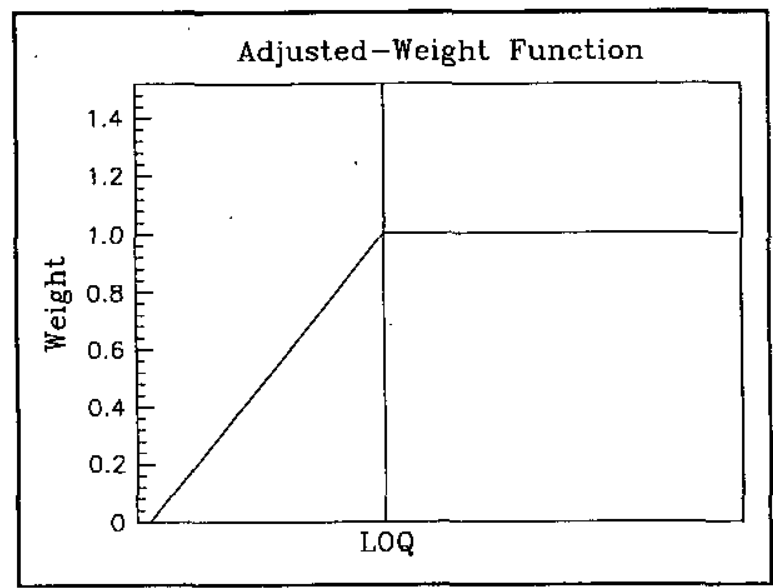

Figure 5. Relationship between $w_{1}$ and Analyte Concentration

Figure 6 shows the computer simulation results for the effect of a linear-weight function on the now-adjusted MRD (MRDadj), developed by Tuckfield and Khalil, again by determining constant contours of absolute difference. Below the LOQ, all samples with the same absolute difference are given the same adjusted RD value. Above the LOQ, the unadjusted RD is preserved because the weight function is unity when $z_{i}$ is greater than the LOQ.

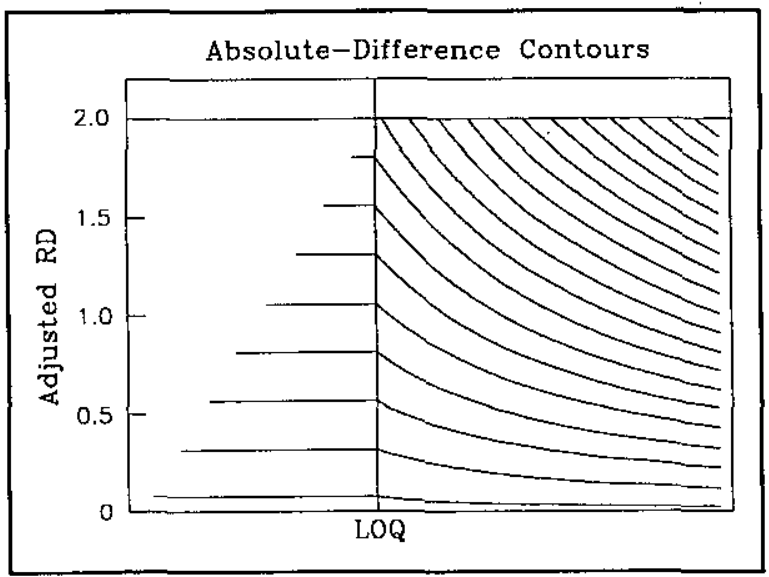

Figure 6. Effect of a Linear-Weight Function on the MRDadj 
The MRDadj, then, has the following form:

$$
\begin{gathered}
\text { MRDadj }=\frac{\sum_{i=1}^{n} \mathrm{w}_{i} \mathrm{RD}_{i}}{n}, \\
\text { where } \mathrm{w}_{i}= \begin{cases}\frac{z_{i}}{\mathrm{LOQ}} & ; \text { if } z_{i}<\mathrm{LOQ} \\
1 & ; \text { otherwise. }\end{cases}
\end{gathered}
$$

This adjustment has several advantages. For example, the weight function reflects the chemist's view of the reliability of the measurement. If analyses are conducted on different equipment (i.e., with different LOQs), the precision of the equipment is included automatically in the MRD. Data from more precise equipment are given more influence. Also, no data are removed from the computation completely, so the sample size $(n)$ is not affected.

\section{Normalizing Data to the Reference Detection Limit}

Because some detection limits may be anomalously high (because of dilution or other effects, for example), it is necessary to use a reference detection limit (RDL) in the MRD calculations. This is set as the 90th percentile value of the detection limits of the not-detected samples. All the results less than the RDL are adjusted up to that value. Results that are detection limit values above the RDL are eliminated from the MRD index calculations. By definition, fewer than $10 \%$ of the detection limit values are above the RDL. The intralaboratory MRD indices are listed in tables 25-31.

\section{Interlaboratory Comparisons}

For interlaboratory comparisons, the MRD is calculated as the average absolute difference between the laboratories for the $i$ th well expressed as a percentage of the mean of both laboratories. For these comparisons, $x_{i}$ and $y_{i}$ represent the mean analyte concentrations for the $i$ th well; $x_{i}$ represents the mean from one laboratory, and $y_{i}$ represents the mean from the other. The means are calculated from the known sample results and the EPD blind replicate results.

\section{Choosing an RDL.}

For interlaboratory comparisons, a new RDL must be established for calculation of the MRD. The interlaboratory RDL is chosen as the 90th percentile value from the combined array of non-detected sample results from both laboratories.

\section{Normalizing Data to the RDL.}

All results less than the RDL are adjusted to the new RDL value. Detection limit values above the RDL are eliminated from the MRD index comparison and from the $t$-tests. By definition, fewer than $10 \%$ of the detection limit values are above the RDL. In addition to the interlaboratory MRD calculations, paired $t$-tests are performed to see if the difference between the mean concentrations of an analyte from the same well reported by each laboratory is significant. The $t$-test tests the null hypothesis that there is no significant difference in the concentrations reported by the two laboratories. The MRD and the $t$-test results for analytes with at least one pair of results above the interlaboratory RDL are listed in tables 32-38. No result pairs were above the RDL for ES and GE.

Analytes with significance-of-probability values less than .050 (tables 32-38) indicate a probability of less than $5 \%$ that the results for that analyte are the same from both laboratories.

\section{Presentation of the Replicate and Duplicate Analyses}

In tables 32-38, high MRDs (greater than or equal to 20) appear in bold type. Low MRDs (less than or equal to $.050)$ appear in bold italic type. 
Table 39 lists analytes and wells for which samples and blind replicates analyzed by ES yielded results where one was more than twice another.

Table 40 lists analytes and wells for which samples and laboratory duplicates analyzed by ES yielded results where one was more than twice another.

Table 41 lists analytes and wells for which samples and blind replicates analyzed by GE yielded results where one was more than twice another.

Table 42 lists analytes and wells for which samples and laboratory duplicates analyzed by GE yielded results where one was more than twice another.

Table 43 lists analytes and wells for which samples and blind replicates analyzed by GP yielded results where one was more than twice another.

Table 44 lists analytes and wells for which samples and laboratory duplicates analyzed by GP yielded results where one was more than twice another.

Table 45 lists analytes and wells for which samples and blind replicates analyzed by TM yielded results where one was more than twice another.

Table 46 lists analytes and wells for which samples and laboratory duplicates analyzed by TM yielded results where one was more than twice another.

Table 47 lists analytes and wells for which samples and blind replicates analyzed by WA yielded results where one was more than twice another.

Table 48 lists analytes and wells for which samples and laboratory duplicates analyzed by WA yielded results where one was more than twice another.

Tables 49-53 list analytes and wells where a result from one laboratory was more than twice the corresponding result from the other laboratory.

See the Analytical Methods subsection of the Analytical Data Review section of this report for more information.

\section{ACCURACY}

Accuracy is defined as the closeness of agreement between an observed value and an accepted reference value or as a measure of the over- or underestimation of reported concentrations. Accuracy is especially important when the concentration of concern approaches the detection limit and/or the action limit. When the concentration is underestimated near the detection limit, the analyte may be present but reported as not detected; near the action limit, the analyte may be at a concentration that would require remediation, but the remediation would not be performed. When the concentration is overestimated near the detection limit, the analyte may not be present but reported as detected; near the action limit, the analyte may not be at a concentration that would require remediation, but the remediation would be performed. Quality control standards, performance evaluation studies, laboratory data records reviews, laboratory control samples and blank spikes, surrogate and matrix spikes, and method blanks are used to evaluate accuracy.

\section{Quality Control Standards}

During second quarter 1998, EPD/EMS conducted quality assessments of GE, WA, EX, ES laboratories. Each laboratory received a set of certified environmental quality control standards from Environmental Resource Associates (ERA) of Arvada, CO (lot numbers 435, 582, 3224, 3424, 8913, and 9982). Each laboratory's results were compared with the ERA-certified values and performance acceptance limits (PALs). The PALs are listed as guidelines for acceptable analytical results given the limitations of the EPA methods used to determine these parameters. The PALs closely approximate the $95 \%$ confidence interval. GE, WA, and 
EX returned results for second quarter 1998 quality control assessments. ES results were not available for this publication. The laboratories' results and the certified values and limits are listed in tables 54-56.

EX, GE, and WA analyzed total petroleum hydrocarbons by the infrared method.

Of 103 analyses reported by GE, 100 , or $97 \%$, were within the PALs. Of 101 analyses reported by WA, 93 , or $92 \%$, were within the PALs. Of the 104 analyses reported by EX, 99, or 95.2\%, were within the PALs.

\section{Performance Evaluation Studies}

ES, EX, and WA participated in EPA's Laboratory Performance Evaluation Water Pollution Study WP038, for which results were reported in November 1997; WA participated in WP039, reported in May 1998. WA participated in Water Supply Study WS040, for which results were reported in March 1998. EPA conducts the studies biannually to certify laboratories for specific analyses. EPA's Environmental Monitoring Systems Laboratory (EMSL) of Cincinnati, OH, prepares water samples spiked with known concentrations of constituents found in polluted waters and submits them to all laboratories seeking certification to analyze wastewater. EMSL evaluates the results, using limits statistically based on the performance of approximately 100 top-rated laboratories that analyze each constituent by the same procedure as the laboratory being evaluated.

Table 57 contains results for WP038. In study WP038, the ES results for aldrin, chloroform, PCB 1232, specific conductance, and total organic carbon were acceptable but near the acceptance limits; ES was instructed to check for error. The EX results for aluminum, chloride, fluoride, and total phenolics were outside the acceptance limits. The results for antimony, mercury, and 1,1,1-trichloroethane were acceptable but near the acceptance limits; EX was instructed to check for error. The WA results for nitrate as nitrogen, nonfilterable residue, and sulfate were outside the acceptance limits. The results for arsenic, chlordane, molybdenum, and selenium were acceptable but near the acceptance limits; WA was instructed to check for error.

Table 58 contains results for WP039. In study WP039, the WA results were all acceptable, but results for chemical oxygen demand and methylene chloride were near the acceptance limits; WA was instructed to check for error.

Table 59 contains results for WS040. In study WS040, the WA results were all acceptable.

\section{Laboratory Data Records Review}

Reviewers visited ES, EX, GE, GP, TM, and WA during September 1998 to determine if the laboratories' practices and recordkeeping conformed with the standards of SW-846 for definitive data (EPA, 1986b). The reviewers examined SRS Groundwater Monitoring Program records for samples collected during second quarter 1998. Reviews were not conducted for the other off-site laboratories.

The purpose of the reviews was to investigate technical validation issues that are not adequately addressed by computer review of electronic data deliverables, review of analytical narratives, or review of COC forms. These technical issues included instrument calibration and performance, analyte identification, and analyte quantitation. The issues were addressed by comparing the instrument printouts associated with particular analyses to validation checklists. These method-specific checklists consisted of approximately 9 to 20 questions and were compiled from discussions with laboratory personnel and both laboratory-specific and standard operating procedures.

\section{Second Quarter 1998 Rocords Roviow of ES}

During September 1998, laboratory data records were reviewed for inorganic and organic anālyses conducted by ES during second quarter 1998. A percentage of the samples analyzed for each analytical method were chosen for review.

\section{Major lssues}

No technical issues of concern were identified during the review. 


\section{Second Quarter 1998 Records Review of EX}

During September 1998, laboratory data records were reviewed for inorganic and organic analyses conducted by EX during second quarter 1998. Approximately $3 \%$ of the samples analyzed for each analytical method were chosen for review.

\section{Major Issues}

No technical issues of concern were identified during the review.

\section{Second Quarter 1998 Records Review of GE}

During September 1998, laboratory data records were reviewed for inorganic and organic analyses conducted by GE during second quarter 1998. A representative cross section of the preparation batches and samples analyzed for each analytical method was chosen for review.

\section{Major Issues}

No technical issues of concern were identified during the review.

\section{Second Quarter 1998 Records Review of GP}

During September 1998, laboratory data records were reviewed for radiochemical analyses conducted by GP during second quarter 1998. A representative cross section of the samples analyzed for each analytical method was chosen for review.

\section{Major Issues}

No technical issues of concern were identified during the review.

\section{Second Quarter 1998 Records Review of TM}

During September 1998, laboratory data records were reviewed for radiochemical analyses conducted by TM during second quarter 1998. A representative cross section (approximately $1 \%$ ) of the preparation batches and samples analyzed for each analytical method was chosen for review.

\section{Major Issues}

No technical issues of concern were identified during the review.

\section{Second Quarter 1998 Records Review of WA}

During September 1998, laboratory data records were reviewed for inorganic and organic analyses conducted by WA during second quarter 1998. A representative cross section of the preparation batches and samples analyzed for each analytical method was chosen for review.

\section{Major Issues}

No technical issues of concern were identified during the review.

\section{Laboratory Control Samples and Blank Spikes}

Laboratory control samples and blank spikes are used to monitor the performance of all steps in the analysis process, inciuding sample preparation, and are used to identify problems with the analytical procedure. Laboratory control samples are deionized water that is spiked with the target analyte, digested, and analyzed with the regular samples for inorganic parameters. Blank spikes are organic-free water that is spiked with selected target analytes, extracted, and analyzed with the regular samples for organic parameters. The spiking solutions for laboratory control samples and blank spikes are obtained from the EPA or a third party supplier, or they are prepared in the laboratory with chemicals from a different source than the calibration standards. Table 19 lists the quality control limits for each analyte type. 
The percent recovery $(\% \mathrm{R})$ for laboratory control samples or blank spikes is calculated as

$$
\% R=\frac{\text { Observed concentration }}{\text { Known concentration }} \times 100 \text {. }
$$

Table 19. Quality Control Limits for Solected Laboratory Control Samples and Blank Spikes

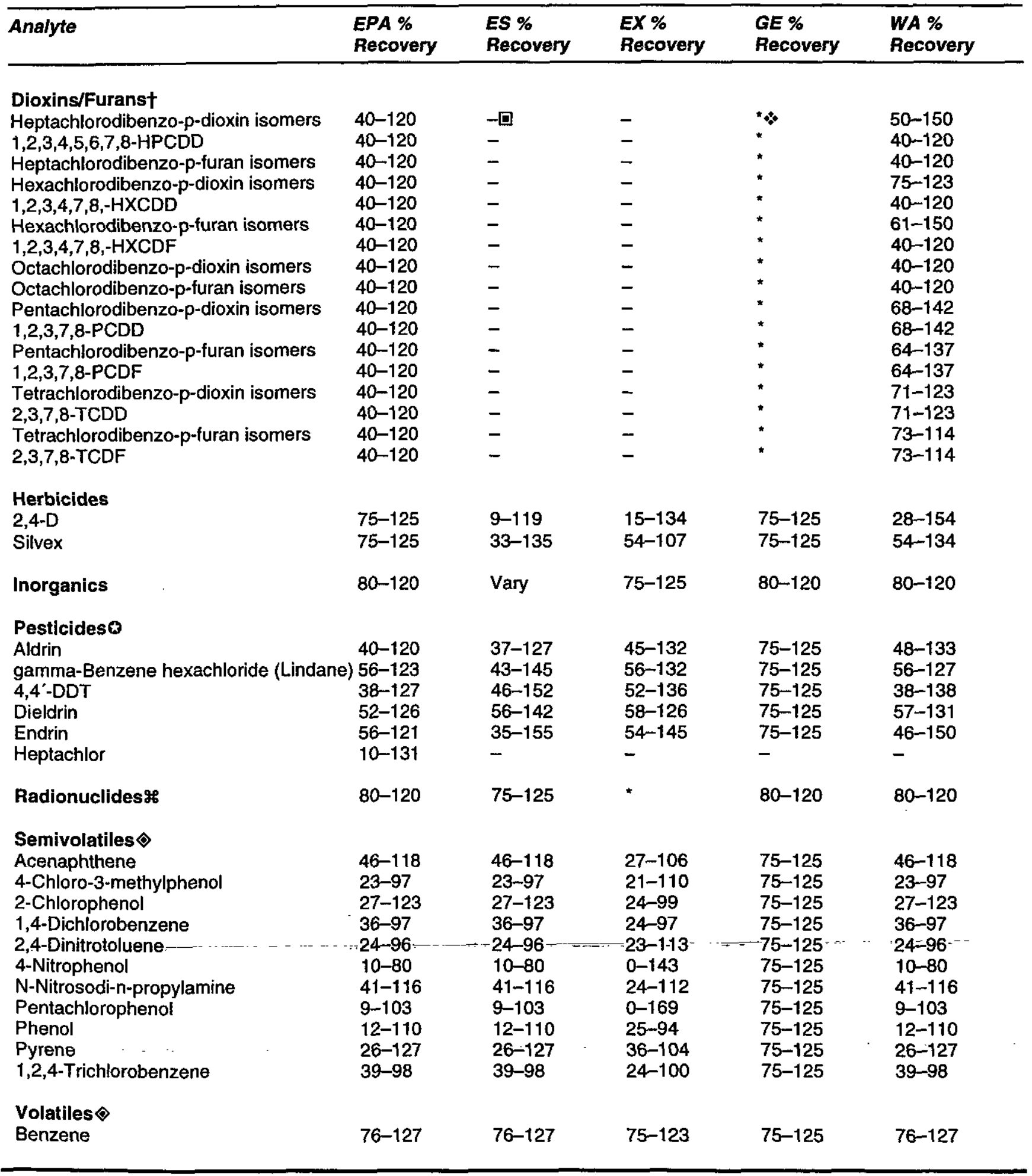




\begin{tabular}{|c|c|c|c|c|c|}
\hline Analyte & $\begin{array}{l}\text { EPA \% } \\
\text { Recovery }\end{array}$ & $\begin{array}{l}\text { ES \% } \\
\text { Recovery }\end{array}$ & $\begin{array}{l}\text { EX \% } \\
\text { Recovery }\end{array}$ & $\begin{array}{l}\text { GE \% } \\
\text { Recovery }\end{array}$ & $\begin{array}{l}\text { WA \% } \\
\text { Recovery }\end{array}$ \\
\hline $\begin{array}{l}\text { Chlorobenzene } \\
\text { 1,1-Dichloroethylene } \\
\text { Toluene } \\
\text { Trichloroethylene }\end{array}$ & $\begin{array}{l}75-130 \\
61-145 \\
76-125 \\
71-120\end{array}$ & $\begin{array}{l}75-130 \\
61-145 \\
76-125 \\
71-120\end{array}$ & $\begin{array}{l}76-122 \\
68-133 \\
77-123 \\
75-122\end{array}$ & $\begin{array}{l}75-125 \\
- \\
75-125 \\
75-125\end{array}$ & $\begin{array}{l}75-130 \\
- \\
76-125 \\
71-120\end{array}$ \\
\hline
\end{tabular}

$\dagger$ These limits are from SW-846 method EPA8280 for EPA and GE; WA uses laboratory-determined limits.

口- Not available.

* Not analyzed.

- GE and WA use laboratory-determined limits.

He GE and WA develop their own methods based on EPA, DOE, and other methods.

$\diamond$ GE uses laboratory-determined limits.

Note: TM analyzes WA's radionuclides; GP analyzes GE's radionuclides.

Tables 60-65 list the statistical information for the percent recovery for laboratory control samples and blank spikes by analyte for ES, EX, GE, WA, GP, and TM. The Qualified Out of Range column provides the number of laboratory control samples or blank spikes that had percent recoveries outside the acceptance limits compared to the total number analyzed; the other columns provide the mean recovery, standard deviation, and the minimum and maximum recoveries.

\section{Surrogates}

Surrogates are analytes not normally found in environmental samples that are used to spike all samples, QC samples, and calibration standards for organic analyses. Surrogates are added prior to analysis for VOAs (volatile organic analyses) and prior to extraction for semivolatiles, pesticides, and herbicides. Low surrogate recovery is a measure of the effect of the sample matrix, high analyte concentration, or laboratory error. High surrogate recovery usually indicates instrument or sample preparation errors. Table 20 lists the recovery limits for each surrogate.

Table 20. Surrogate Recovery Limits

\begin{tabular}{|c|c|c|c|c|c|}
\hline Analyte & $\begin{array}{l}\text { EPA \% } \\
\text { Recovery }\end{array}$ & $\begin{array}{l}\text { ES \% } \\
\text { Recovery }\end{array}$ & $\begin{array}{l}\text { EX \% } \\
\text { Recovery }\end{array}$ & $\begin{array}{l}\text { GE \% } \\
\text { Recovery }\end{array}$ & $\begin{array}{l}\text { WA \% } \\
\text { Recovery }\end{array}$ \\
\hline $\begin{array}{l}\text { Herbicides } \\
\text { 4-(2,4-Dichlorophenoxy)butyric acid } \\
\text { 2,4-Dichlorophenylacetic acid }\end{array}$ & $\begin{array}{l}75-125 \\
75-125\end{array}$ & $\begin{array}{l}-\square \\
28-112\end{array}$ & - & $\begin{array}{l}50-150 \\
50-150\end{array}$ & $\overline{40-150}$ \\
\hline $\begin{array}{l}\text { Pesticides } \\
\text { Decachlorobiphenyl } \\
\text { Dibutylchlorendate } \\
\text { Tetrachloro-m-xylene }\end{array}$ & $\begin{array}{l}30-150 \\
30-150 \\
30-150\end{array}$ & $\begin{array}{l}31-145 \\
- \\
23-109\end{array}$ & $\begin{array}{l}- \\
-\end{array}$ & $\begin{array}{l}- \\
40-127 \\
40-156\end{array}$ & $\begin{array}{l}22-126 \\
- \\
27-129\end{array}$ \\
\hline $\begin{array}{l}\text { Semivolatiles } \\
\text { 2-Fluorobiphenyl } \\
\text { 2-Fluorophenol } \\
\text { Nitrobenzene-d5 } \\
\text { Phenol-d5 (used by ES, EX, and WA) } \\
\text { Phenol-d6 (used by GE) } \\
\text { Terphenyl-d14 } \\
\text { 2,4,6-Tribromophenol }\end{array}$ & $\begin{array}{l}43-116 \\
24-100 \\
35-114 \\
10-94 \\
10-94 \\
33-141 \\
10-123\end{array}$ & $\begin{array}{l}43-116 \\
21-100 \\
35-114 \\
10-94 \\
- \\
33-141 \\
10-123\end{array}$ & $\begin{array}{l}43-116 \\
27-89 \\
35-114 \\
28-91 \\
- \\
33-141 \\
36-103\end{array}$ & $\begin{array}{l}43-108.3 \\
21-100 \\
35-114 \\
- \\
18.9-94 \\
33-125.5 \\
26.9-123\end{array}$ & $\begin{array}{l}43-116 \\
21-100 \\
35-114 \\
10-94 \\
- \\
33-141 \\
10-123\end{array}$ \\
\hline $\begin{array}{l}\text { Volatiles } \% \\
\text { p-Bromofluorobenzene } \\
\text { Dibromochloromethane }\end{array}$ & $\begin{array}{l}86-115 \\
86-118\end{array}$ & $\begin{array}{l}86-115 \\
-\end{array}$ & $\begin{array}{l}86-115 \\
-\end{array}$ & $\begin{array}{l}80-128 \\
-\end{array}$ & $\begin{array}{l}86-115 \\
-\end{array}$ \\
\hline
\end{tabular}




\begin{tabular}{llllll}
\hline Analyte & EPA \% & ES \% & EX \% & GE \% & WA \% \\
& Recovery & Recovery & Recovery & $\begin{array}{l}\text { Recovery } \\
\text { Recovery }\end{array}$ \\
\hline & & & & & \\
Dibromofluoromethane-d4 & $86-118$ & $86-118$ & $86-118$ & $67.7-135$ & $86-118$ \\
1,2-Dichloroethane-d4 & $76-114$ & $80-120$ & $76-114$ & $86-118$ & $76-114$ \\
Toluene-d8 & $88-110$ & $88-110$ & $88-110$ & $76.8-121.9$ & $88-110$ \\
\hline
\end{tabular}

† There are no established limits for herbicide surrogate recoveries.

$\square-$ Not available.

* GE uses laboratory-determined limits.

Tables 66-69 list the statistical information for the percent recovery for the surrogates by analyte for ES, EX, $\mathrm{GE}$, and WA. The Qualified Out of Range column gives the number of surrogates that had percent recoveries outside the acceptance limits compared to the total number analyzed; the other columns provide the mean recovery, standard deviation, and the minimum and maximum recoveries.

\section{Matrix Spikes}

Matrix spikes are used to evaluate the effect of the sample matrix on the analytical procedure. Matrix spikes are prepared by adding a known quantity of the target analyte to at least $5 \%$ of the samples prior to sample preparation. For the inorganic analyses, all target analytes are spiked. For the organic analyses, selected target analytes are used in the spiking solution. Results from the matrix spike are used to evaluate the extent of matrix interference and to determine the bias of the procedure for the sample matrix. Table 21 lists the quality control limits for each analyte type.

The percent recovery for matrix spikes is calculated as

$$
\% R=\frac{S S R-S R}{S A} \times 100
$$

where

$$
\begin{aligned}
& \% \mathrm{R}=\text { percent recovery } \\
& \text { SSR }=\text { spiked sample result } \\
& \text { SR }=\text { sample result } \\
& \text { SA }=\text { spike added }
\end{aligned}
$$

Table 21. Quality Control Limits for Selected Matrix Spike Samples

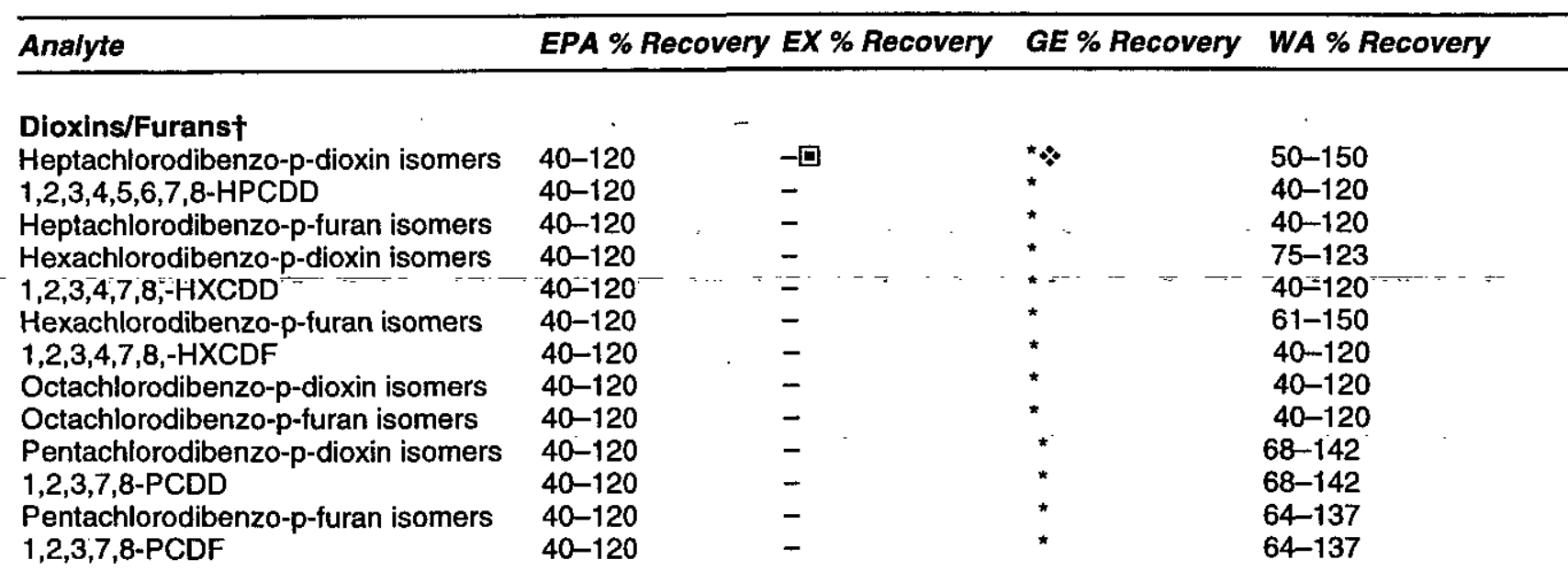

\section{Quality Control Samples}




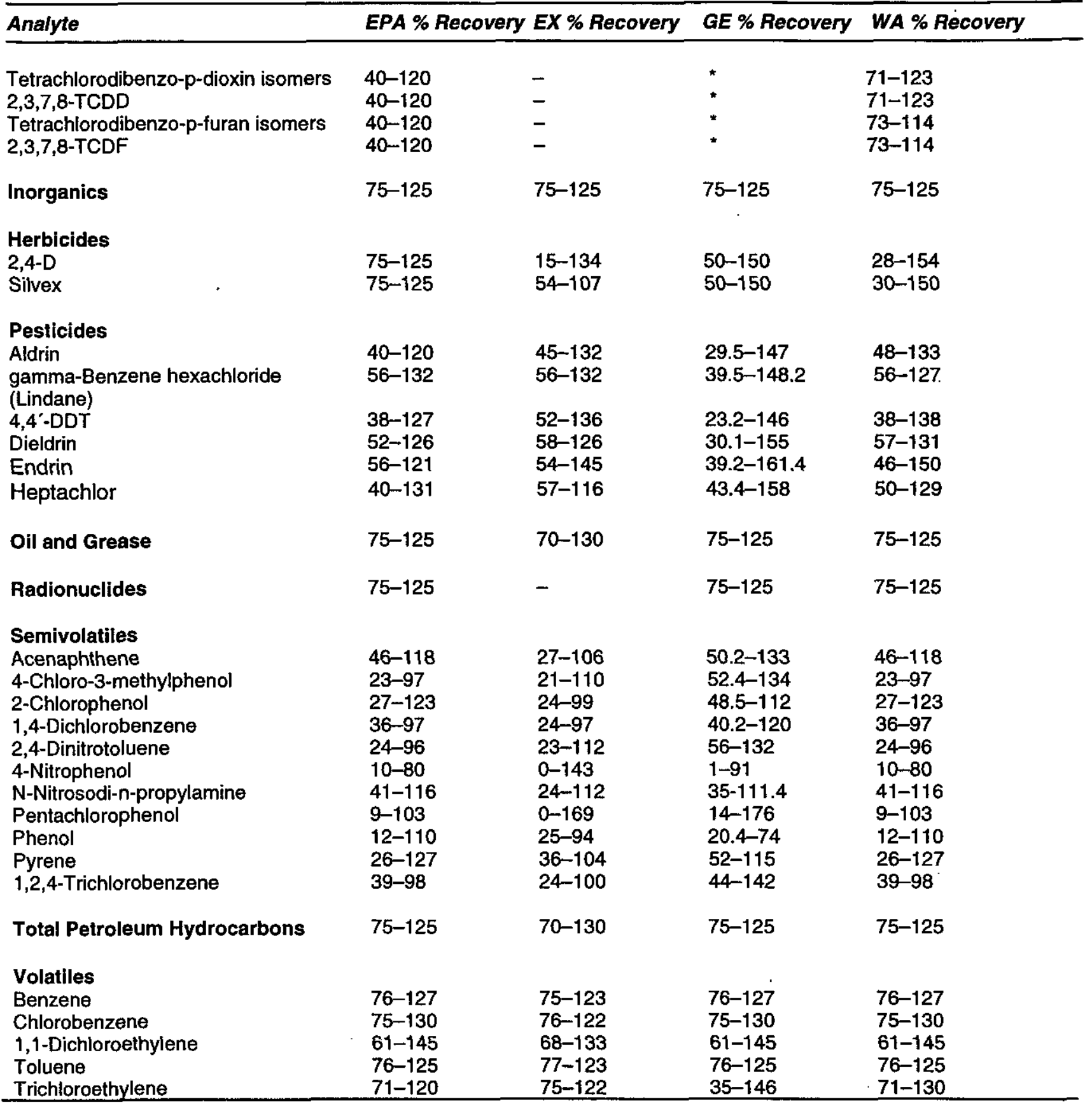

$\dagger-$ Not available.

$\square$ * Not analyzed.

Note: TM analyzes WA's radionuclides; GP analyzes GE's radionuclides.

Percent bias in tables $70-74$ is the difference between $100 \%$ and the mean recovery; a negative value indicates that the mean recovery was below $100 \%$. If the bias is consistently positive, the laboratory may be overestimating the concentration of the analyte, and if the bias is consistently negative, the laboratory may be underestimating the concentration of the analyte. Results close to the quantitation and action limits should be closely examined, and their use in decision-making should be carefully considered.

Matrix spikes are rejected if the concentration of the analyte in the sample is more than four times the amount of the spike. Results for matrix spikes are provided in tables 70-74 for ES, EX, GE, WA, and GP. The Qualified 
Out of Range column provides the number of matrix spikes that had percent recoveries outside the acceptance limits compared to the total number analyzed; the other columns provide the mean recovery, standard deviation, percent bias, and the minimum and maximum recoveries.

\section{Method Blanks}

Method blanks, or laboratory blanks, are used to determine the existence and magnitude of contamination problems resulting from the analytical process. Method blanks are deionized water to which all reagents are added in the same proportions used in sample processing. When method blanks have detectable concentrations of the analytes, the laboratory must determine the cause and take corrective action to eliminate the contamination.

Tables 75-80 list the statistical information for analytes detected in method blanks for ES, EX, GE, WA, GP, and TM. The Frequency of Detection column provides the number of method blanks analyzed for each analyte during the quarter that had detectable concentrations compared to the total number that were analyzed. The other columns list the mean result, standard deviation, and minimum and maximum results.

\section{Field Blanks}

Field blanks (called QA blanks in the tables) are used to identify possible sources of contamination from the processing and shipping of samples. Field blanks are sample bottles filled with deionized water prior to well sampling; the bottles are not opened at the sampling site. The field blanks are sent along with, and analyzed in the same manner as, the samples. Positive results from field blanks can result from analytical bias, contaminated sample bottles, contaminated deionized water, or contamination during shipping or analysis. The results from all samples in the sample delivery group are evaluated by the laboratory and data validators to determine the cause of the contamination and the corrective action to be taken.

Tables 81-86 list the statistical information for the field blanks by analyte for ES, EX, GE, WA, GP, and TM. The Frequency of Detection column gives the number of field blanks analyzed for each analyte during the quarter that had detectable concentrations compared to the total number analyzed. The other columns list the mean result, standard deviation, and minimum and maximum results.

\section{Trip Blanks}

Trip blanks are vials of deionized water sent to the laboratory for volatiles analysis with each shipping cooler containing volatiles samples. Trip blanks are used to check for contamination resulting from shipping, primarily due to the breaking of the vial's seal because of depressurization during air transport. Trip blanks are used also to test the laboratories' reliability. The blanks are prepared by adding preservative to a $40 \mathrm{~mL}$ vial, filling it completely with deionized water, and sealing the top with a teflon-lined septum cap. The results from all samples in the sample delivery group are evaluated by the laboratory and data validators to determine the cause of the contamination and the corrective action to be taken.

Tables 87-90 list the statistical information for the analytes detected in trip blanks by ES, EX, GE, and WA. The Frequency of Detection column gives the number of trip blanks analyzed for each analyte during the quarter that had detectable concentrations compared to the total number analyzed. The other columns list the mean result, standard deviation, and minimum and maximum results. 


\section{Equipment Blanks or Rinsates}

Equipment blanks (called EPT blanks in the tables) or rinsates are used to determine if sampling equipment that has been cleaned in the field is contaminated. Prior to sampling, deionized water is poured over or pumped through portions of the sampling equipment that come in contact with the sample. If the equipment blank is contaminated, the field cleaning procedure must be evaluated to determine the cause of the contamination. Results for all samples collected with equipment cleaned in the field must be evaluated to determine whether the contamination is isolated or generalized.

No information about equipment blanks was provided for second quarter 1998.

\section{Blanks Results}

The blanks results tables in Appendix $\mathbf{C}$ list the dates, field measurements, and analytical results for the sampling blanks. See Appendix B for a key to the abbreviations used in the tables.

\section{REPRESENTATIVENESS}

A representative sample is a sample that can be expected to exhibit the average properties of the population being sampled. Representativeness for groundwater samples can be affected by using a bailer to collect the sample from the well, metal casings in the well, and turbidity (suspended particulates) in the sample. The results may be biased positively or negatively.

If a well is bailed, VOAs are biased negatively due to aeration of the sample in the sampling process. Table 91 lists the well that was bailed during second quarter 1998.

For metal casings, the bias for metals can be positive or negative depending on whether the casing is releasing or absorbing metals. Table 92 lists the wells with metal casings that were sampled during second quarter 1998.

If turbidity is greater than $15 \mathrm{NTU}$, the metals can be biased positively or negatively, and the radionuclidesparticularly those that are determined by gamma spectroscopy-can be masked due to self-absorption. Table 93 lists the wells that had turbidity results greater than 15 NTU during second quarter 1998.

\section{COMPARABILITY}

Comparability is evaluated by confirming that the laboratories used the same standardized procedures for sample preparation and analysis, that the reporting units are the same, and that similar quantitation limits were obtained. The analytical methods, reporting units, and estimated quantitation limits (EQLs) reported by each laboratory are given in tables 13-18 in the Analytical Data Review section. Tables 49-53 list the analytes and wells where a result from one laboratory was more than twice the corresponding result from the other laboratory.

\section{COMPLETENESS}

Completeness is evaluated by comparing the wells scheduled for sampling with the wells sampled and comparing the requested analyses with the analytical data received. The number of wells sampled and the requested analyses are determined from the chains of custody. Tables 94-97 list the reasons the laboratories did not perform certain analyses on samples from wells that could be sampled. See the Sample Scheduling, Field Notes, and Analytical Results sections of this report for more information on wells scheduled but not sampled this quarter. 
Table 22. Wolls Providing Blind Replicate Samples and Associated Blanks

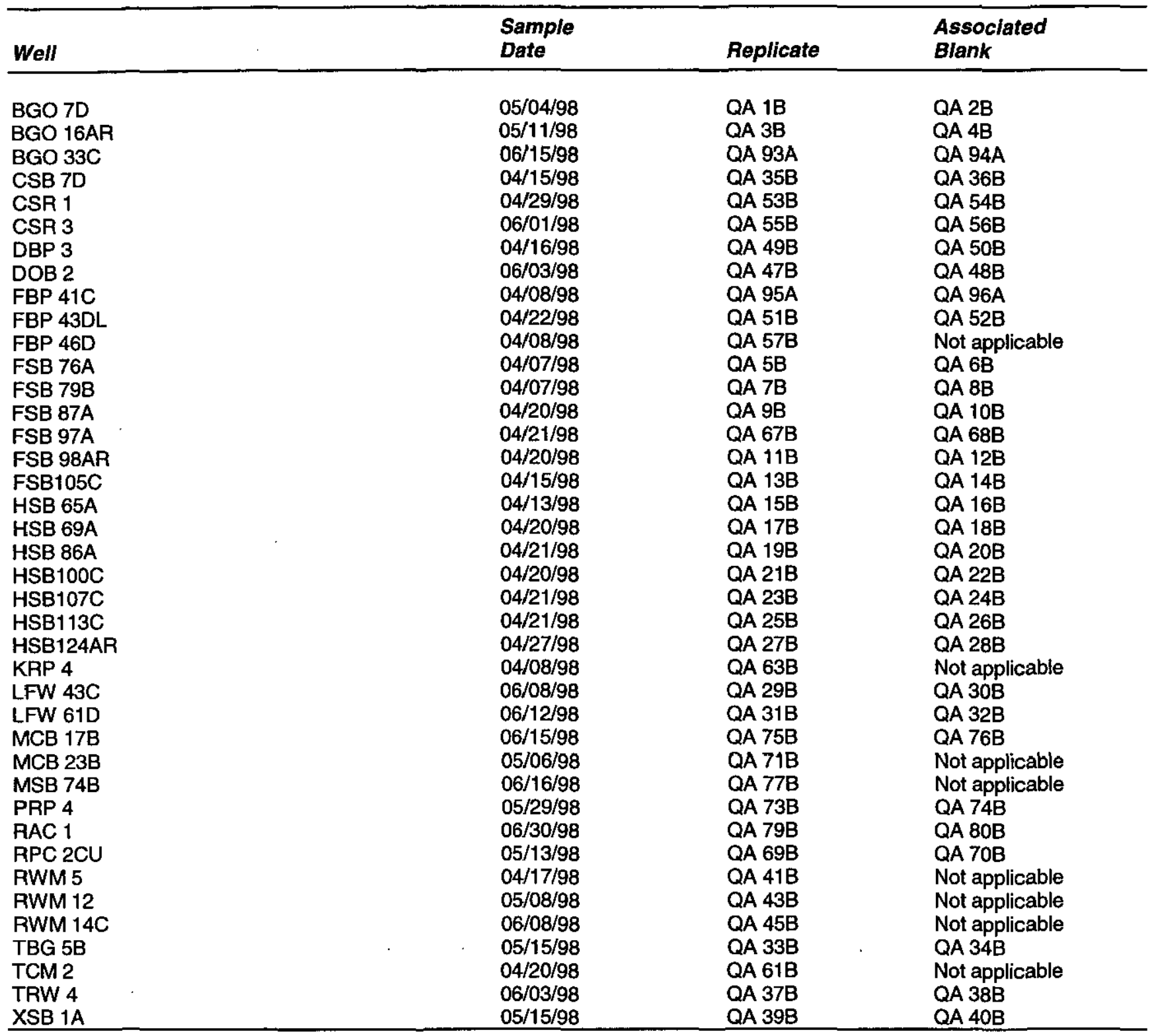


Table 23. Analytes Not Showing Measurable Concentrations above Estimated Quantitation Limits in Any Replicated or Duplicated Samples for GE, WA, ES, and EX

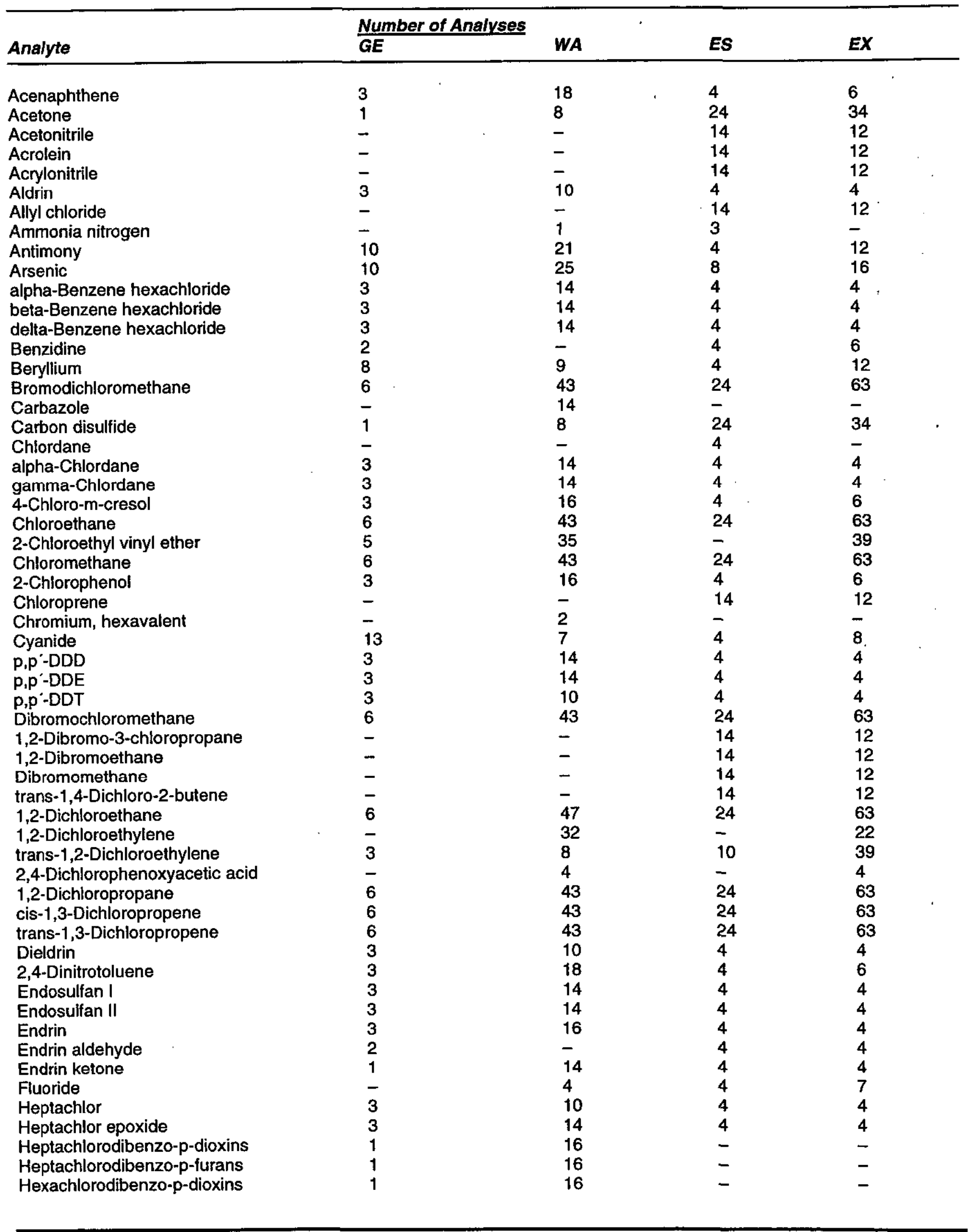




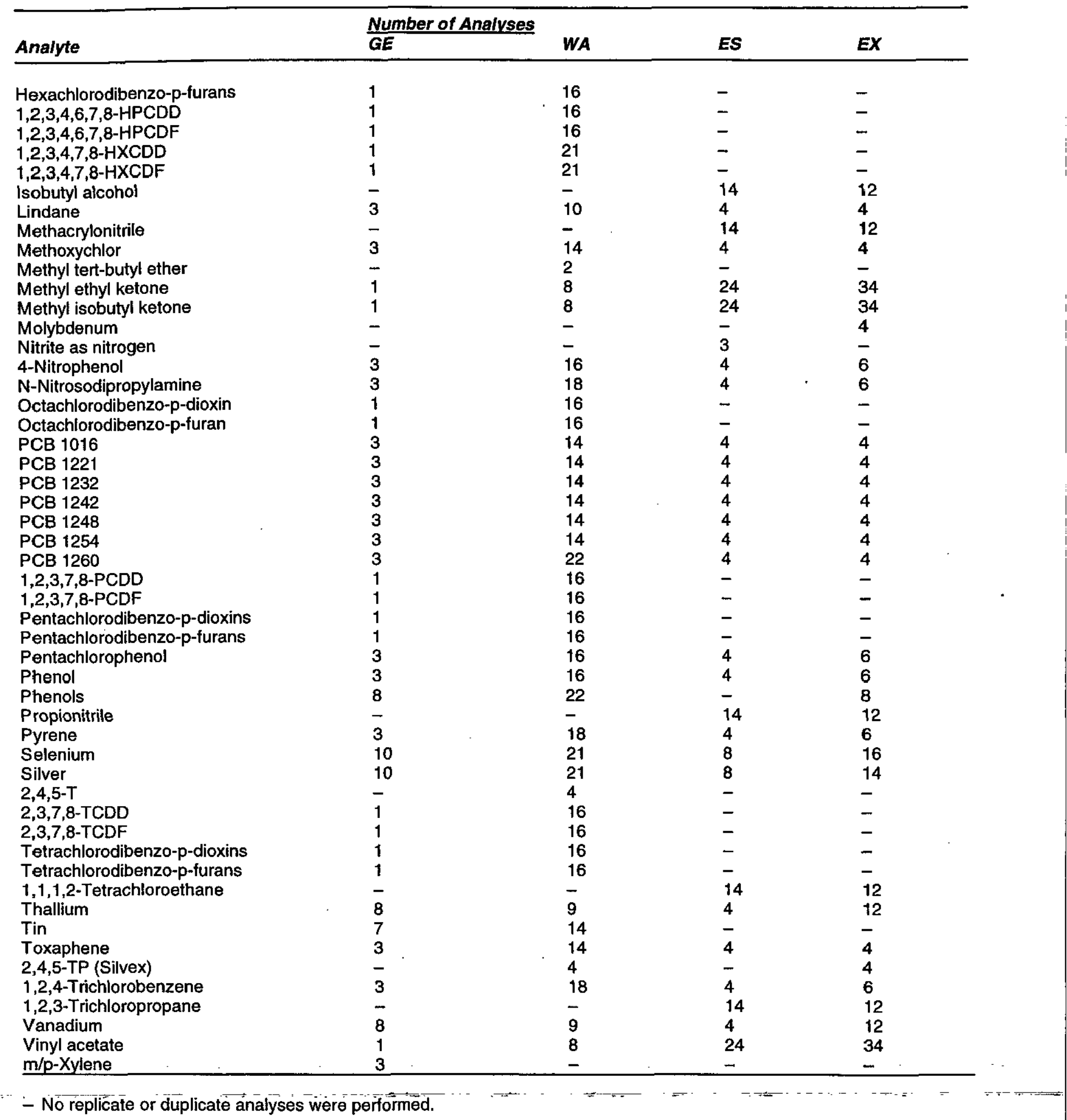

- No replicate or duplicate analyses were performed. 
Table 24. Analytes Not Showing Measurable Concentrations above Estimated Quantitation Limits in Any Replicated or Duplicated Samples for GP, TM, and ES

\begin{tabular}{|c|c|c|c|c|}
\hline Analyte & $\frac{\text { Num }}{\text { GP }}$ & $T M$ & ES & \\
\hline Americium-241/Curium-246 & - & 2 & - & \\
\hline Antimony-124 & - & 11 & - & \\
\hline Antimony-125 & 8 & 11 & 4 & \\
\hline Barium-133 & - & 11 & - & \\
\hline Cerium-144 & 8 & 11 & 4 & \\
\hline Cesium-134 & 8 & 11 & 4 & \\
\hline Cesium-137 & 8 & 11 & 4 & \\
\hline Cobalt-57 & 8 & 11 & 4 & \\
\hline Cobalt-58 & - & 11 & - & \\
\hline Cobalt-60 & 8 & 11 & 4 & \\
\hline Curium-242 & 4 & 2 & 5 & \\
\hline Curium-243/244 & 4 & 2 & 5 & \\
\hline Curium-245/246 & 4 & - & 5 & \\
\hline Europium-152 & 8 & 11 & 4 & \\
\hline Europium-154 & 8 & 11 & 4 & \\
\hline Europium-155 & 8 & 11 & 4 & \\
\hline Lead-212 & 8 & 11 & 4 & \\
\hline Manganese-54 & 8 & 11 & 4 & \\
\hline Neptunium-239 & - & 9 & - & \\
\hline Nickel-63 & 9 & 2 & - & \\
\hline Plutonium-238 & 4 & 2 & 3 & \\
\hline Plutonium-239/240 & 4 & 2 & 3 & \\
\hline Potassium-40 & 8 & 11 & 4 & \\
\hline Promethium-144 & 8 & 11 & 4 & \\
\hline Promethium-146 & 8 & 11 & 4 & \\
\hline Ruthenium-106 & 8 & 11 & 4 & \\
\hline Sodium-22 & 8 & 11 & 4 & \\
\hline Thorium-228 & 6 & 2 & 4 & \\
\hline Thorium-232 & 6 & 2 & 4 & \\
\hline Tin-113 & - & 11 & - & \\
\hline Uranium-234 & - & 2 & - & \\
\hline Uranium-235 & 6 & 2 & 3 & . \\
\hline Yttrium-88 & 8 & 11 & 4 & \\
\hline Zinc-65 & 8 & 11 & 4 & \\
\hline Zirconium-95 & $\therefore$ & 11 & - & \\
\hline
\end{tabular}

- No replicate or duplicate analyses were performed.

Table 25. Intralaboratory MRD Indices for ES

\begin{tabular}{|c|c|c|c|c|c|c|c|}
\hline Analyte & RDL & $\begin{array}{l}\text { In-house D } \\
\text { Number of } \\
\text { Dup. Pairs }\end{array}$ & $\begin{array}{l}\text { licates } \\
\text { MAD }\end{array}$ & MRDadj & $\begin{array}{l}\text { Blind Replli } \\
\text { Number of } \\
\text { Dup. Pairs }\end{array}$ & MAD & MRDadj \\
\hline Acenaphthylene & $1.0 \mathrm{E}+01 \mu \mathrm{g} / \mathrm{L}$ & 0 & - & - & 2 & 0.00 & 0.00 \\
\hline Actinium-228 & $\begin{array}{c}1.53 \mathrm{E}-08 \\
\mu \mathrm{Ci} / \mathrm{mL}\end{array}$ & 1 & 0.00 & 0.00 & 1 & 0.00 & 0.00 \\
\hline Aluminum & $3.28 \mathrm{E}+01 \mu \mathrm{g} / \mathrm{L}$ & 0 & - & - & 7 & 17.35 & 15.56 \\
\hline Americium-241 & $\begin{array}{l}1.7 \mathrm{E}-10 \\
\mu \mathrm{Ci} / \mathrm{mL}\end{array}$ & 2 & 0.00 & 0.00 & 1 & 0.00 & 0.00 \\
\hline Anthracene & $1.0 \mathrm{E}+01 \mu \mathrm{g} / \mathrm{L}$ & 0 & - & - & 2 & 0.00 & 0.00 \\
\hline Barium & $6.8 \mathrm{E}+00 \mu \mathrm{g} / \mathrm{L}$ & 0 & - & - & 4 & 3.34 & 1.43 \\
\hline Benzene & $5.0 \mathrm{E}+00 \mu \mathrm{g} / \mathrm{L}$ & 8 & 0.51 & 0.51 & 4 & 0.00 & 0.00 \\
\hline Benzo[a]anthracene & $1.0 \mathrm{E}+01 \mu \mathrm{g} / \mathrm{L}$ & 0 & - & - & 2 & 0.00 & 0.00 \\
\hline
\end{tabular}




\begin{tabular}{|c|c|c|c|c|c|c|c|}
\hline \multirow{2}{*}{ Analyte } & \multirow{2}{*}{$\frac{R D L}{1.0 \mathrm{E}+01 \mu \mathrm{g} / \mathrm{L}}$} & \multicolumn{2}{|c|}{$\frac{\text { In-house Duplicates }}{\text { Number of }}$} & MRDadj & $\begin{array}{l}\text { Blind Repli } \\
\text { Number of } \\
\text { Dup. Pairs }\end{array}$ & MRD & MRDadj \\
\hline & & 0 & - & - & 2 & 0.00 & 0.00 \\
\hline Benzo[k]fluoranthene & $1.0 \mathrm{E}+01 \mu \mathrm{g} / \mathrm{L}$ & 0 & - & - & 2 & 0.00 & 0.00 \\
\hline Benzoic acid & $5.0 \mathrm{E}+01 \mu \mathrm{g} / \mathrm{L}$ & 0 & . & - & 2 & 0.00 & 0.00 \\
\hline Benzo[g,h,]perylene & $1.0 \mathrm{E}+01 \mu \mathrm{g} / \mathrm{L}$ & 0 & - & - & 2 & 0.00 & 0.00 \\
\hline Benzo[a]pyrene & $1.0 \mathrm{E}+01 \mu \mathrm{g} / \mathrm{L}$ & 0 & - & - & 2 & 0.00 & 0.00 \\
\hline Benzyl alcohol & $2.0 \mathrm{E}+01 \mu \mathrm{g} / \mathrm{L}$ & 0 & - & - & 2 & 0.00 & 0.00 \\
\hline Bis(2-chloroethoxy) methane & $1.0 \mathrm{E}+01 \mu \mathrm{g} / \mathrm{L}$ & 0 & - & - & 2 & 0.00 & 0.00 \\
\hline Bis(2-chloroethyl) ether & $1.0 E+01 \mu g / L$ & 0 & - & - & 2 & 0.00 & 0.00 \\
\hline Bis(2-chloroisopropyl) ether & $1.0 \mathrm{E}+01 \mu \mathrm{g} / \mathrm{L}$ & 0 & - & - & 2 & 0.00 & 0.00 \\
\hline Bis(2-ethylhexyl) phthalate & $1.0 \mathrm{E}+01 \mu \mathrm{g} / \mathrm{L}$ & 0 & - & - & 2 & 84.62 & 84.62 \\
\hline Boron & $2.5 \mathrm{E}+01 \mu \mathrm{g} / \mathrm{L}$ & 0 & - & - & 1 & 29.64 & 10.44 \\
\hline $\begin{array}{l}\text { Bromoform } \\
\text { Bromomethane }\end{array}$ & $\begin{array}{l}5.0 \mathrm{E}+00 \mu \mathrm{g} / \mathrm{L} \\
1.0 \mathrm{E}+01 \mu \mathrm{g} / \mathrm{L}\end{array}$ & $\begin{array}{l}8 \\
8\end{array}$ & $\begin{array}{l}0.00 \\
0.00\end{array}$ & $\begin{array}{l}0.00 \\
0.00\end{array}$ & $\begin{array}{l}4 \\
4\end{array}$ & $\begin{array}{l}0.00 \\
0.00\end{array}$ & $\begin{array}{l}0.00 \\
0.00\end{array}$ \\
\hline 4-Bromophenyl phenyl ether & $1.0 \mathrm{E}+01 \mu \mathrm{g} / \mathrm{L}$ & 0 & $\cdot$ & - & 2 & 0.00 & 0.00 \\
\hline Butylbenzyl phthalate & $1.0 \mathrm{E}+01 \mu \mathrm{g} / \mathrm{L}$ & 0 & - & - & 2 & 0.00 & 0.00 \\
\hline Cadmium & $2.0 \mathrm{E}+00 \mu \mathrm{g} / \mathrm{L}$ & 0 & - & - & 4 & 0.00 & 0.00 \\
\hline Calcium & $\dagger$ & 0 & - & - & 2 & 5.97 & 5.97 \\
\hline Carbon tetrachloride & $5.0 \mathrm{E}+00 \mu \mathrm{g} / \mathrm{L}$ & 8 & 0.00 & 0.00 & 8 & 2.56 & 2.18 \\
\hline Chloride & & 4 & 2.55 & 2.55 & 1 & 0.71 & 0.71 \\
\hline 4-Chloroaniline & $2.0 \mathrm{E}+01 \mu \mathrm{g} / \mathrm{L}$ & 0 & - & - & 2 & 0.00 & 0.00 \\
\hline Chlorobenzene & $5.0 \mathrm{E}+00 \mu \mathrm{g} / \mathrm{L}$ & 8 & 0.00 & 0.00 & 4 & 0.00 & 0.00 \\
\hline Chloroethene & $1.0 \mathrm{E}+01 \mu \mathrm{g} / \mathrm{L}$ & 8 & 0.61 & 0.61 & 4 & 0.00 & 0.00 \\
\hline Chloroform & $5.0 \mathrm{E}+00 \mu \mathrm{g} / \mathrm{L}$ & 8 & 0.00 & 0.00 & 8 & 0.00 & 0.00 \\
\hline 2-Chloronaphthalene & $1.0 \mathrm{E}+01 \mu \mathrm{g} / \mathrm{L}$ & 0 & - & - & 2 & 0.00 & 0.00 \\
\hline 4-Chlorophenyl phenyl ether & $1.0 \mathrm{E}+01 \mu \mathrm{g} / \mathrm{L}$ & 0 & - & - & 2 & 0.00 & 0.00 \\
\hline Chromium & $3.0 \mathrm{E}+00 \mu \mathrm{g} / \mathrm{L}$ & 0 & - & - & 4 & 0.00 & 0.00 \\
\hline Chrysene & $1.0 \mathrm{E}+01 \mu \mathrm{g} / \mathrm{L}$ & 0 & - & - & 2 & 0.00 & 0.00 \\
\hline Cobalt & $5.0 \mathrm{E}+00 \mu \mathrm{g} / \mathrm{L}$ & 0 & - & - & 2 & 0.00 & 0.00 \\
\hline Copper & $3.0 \mathrm{E}+00 \mu \mathrm{g} / \mathrm{L}$ & 0 & - & - & 2 & 22.89 & 9.50 \\
\hline $\mathrm{m} / \mathrm{p}$-Cresol & $1.0 E+01 \mu g / L$ & 0 & - & - & 2 & 0.00 & 0.00 \\
\hline o-Cresol & $1.0 \mathrm{E}+01 \mu \mathrm{g} / \mathrm{L}$ & 0 & - & - & 2 & 0.00 & 0.00 \\
\hline Dibenz $[a, h]$ anthracene & $1.0 \mathrm{E}+01 \mu \mathrm{g} / \mathrm{L}$ & 0 & - & - & 2 & 0.00 & 0.00 \\
\hline Dibenzofuran & $1.0 \mathrm{E}+01 \mu \mathrm{g} / \mathrm{L}$ & 0 & - & - & 2 & 0.00 & 0.00 \\
\hline Di-n-butyl phthalate & $1.0 E+01 \mu g / L$ & 0 & - & - & 2 & 0.00 & 0.00 \\
\hline 1,2-Dichlorobenzene & $1.0 \mathrm{E}+01 \mu \mathrm{g} / \mathrm{L}$ & 0 & - & - & 2 & 0.00 & 0.00 \\
\hline 1,3-Dichlorobenzene & $1.0 \mathrm{E}+01 \mu \mathrm{g} / \mathrm{L}$ & 0 & - & - & 2 & 0.00 & 0.00 \\
\hline $\begin{array}{l}\text { 1,4-Dichlorobenzene } \\
\text { 3,3'-Dichlorobenzidine }\end{array}$ & $\begin{array}{l}1.0 \mathrm{E}+01 \mu \mathrm{g} / \mathrm{L} \\
2.0 \mathrm{E}+01 \mu \mathrm{g} / \mathrm{L}\end{array}$ & $\begin{array}{l}5 \\
0\end{array}$ & 0.00 & 0.00 & $\begin{array}{l}4 \\
2\end{array}$ & $\begin{array}{l}0.00 \\
0.00\end{array}$ & $\begin{array}{l}0.00 \\
0.00\end{array}$ \\
\hline Dichlorodifluoromethane & $5.0 \mathrm{E}+00 \mu \mathrm{g} / \mathrm{L}$ & 5 & 1.29 & 1.20 & 2 & 0.00 & 0.00 \\
\hline 1,1-Dichloroethane & $5.0 \mathrm{E}+00 \mu g / \mathrm{L}$ & 8 & 2.13 & 2.13 & 4 & 2.69 & 2.69 \\
\hline 1,1-Dichloroethylene & $5.0 \mathrm{E}+00 \mu \mathrm{g} / \mathrm{L}$ & 8 & 1.16 & 1.16 & 4 & 0.00 & 0.00 \\
\hline cis-1,2-Dichloroethylene & $5.0 \mathrm{E}+00 \mu \mathrm{g} / \mathrm{L}$ & 3 & 3.51 & 2.20 & 3 & 2.78 & 2.78 \\
\hline Dichloromethane & $5.0 \mathrm{E}+00 \mu \mathrm{g} / \mathrm{L}$ & 7 & 0.00 & 0.00 & 4 & 0.00 & 0.00 \\
\hline 2,4-Dichlorophenol & $1.0 \mathrm{E}+01 \mu \mathrm{g} / \mathrm{L}$ & 0 & 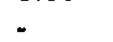 & - & 2 & 0.00 & 0.00 \\
\hline Diethyl phthalate & $1.0 \mathrm{E}+01 \mu \mathrm{g} / \mathrm{L}$ & 0 & - & - & 2 & 0.00 & 0.00 \\
\hline 2,4-Dimethyl phenol & $1.0 \mathrm{E}+01 \mu \mathrm{g} / \mathrm{L}$ & 0 & - & - & 2 & 0.00 & 0.00 \\
\hline Dimethyl.phthalate & $1.0 \mathrm{E}+01 \mu \mathrm{g} / \mathrm{L}$ & 0 & - & - & 2 & 0.00 & 0.00 \\
\hline 2,4-Dinitrophenol & $5.0 \mathrm{E}+01 \mu \mathrm{g} / \mathrm{L}$ & 0 & - & - & 2 & 0.00 & 0.00 \\
\hline 2,6-Dinitrotoluene & $1.0 \mathrm{E}+01 \mu \mathrm{g} / \mathrm{L}$ & 0 & - & - & 2 & 0.00 & 0.00 \\
\hline Di-n-octyl phthalate & $1.0 \mathrm{E}+01 \mu \mathrm{g} / \mathrm{L}$ & 0 & - & - & 2 & 0.00 & 0.00 \\
\hline Endosulfan sulfate & $1.5 \mathrm{E}-02 \mu \mathrm{g} / \mathrm{L}$ & 0 & - & - & 2 & 0.00 & 0.00 \\
\hline $\begin{array}{l}\text { Ethylbenzene } \\
\text { Fluoranthene }\end{array}$ & $5.0 \mathrm{E}+00 \mu \mathrm{g} / \mathrm{L}$ & 8 & 0.00 & 0.00 & 4 & 0.00 & 0.00 \\
\hline Fluoranthene & $1.0 \mathrm{E}+01 \mu \mathrm{g} / \mathrm{L}$ & 0 & - & - & 2 & 0.00 & 0.00 \\
\hline Fluorene & $1.0 \mathrm{E}+01 \mu \mathrm{g} / \mathrm{L}$ & 0 & - & - & 2 & 0.00 & 0.00 \\
\hline
\end{tabular}




\begin{tabular}{|c|c|c|c|c|c|c|c|}
\hline Analyte & $R D L$ & $\begin{array}{l}\text { In-house Du } \\
\text { Number of } \\
\text { Dup. Pairs }\end{array}$ & icates & MRDadj & $\begin{array}{l}\text { Blind Replic } \\
\text { Number of } \\
\text { Dup. Pairs }\end{array}$ & MRD & MRDadj \\
\hline Gross alpha & $\begin{array}{r}1.39 \mathrm{E}-09 \\
\mu \mathrm{Ci} / \mathrm{mL}\end{array}$ & 1 & 0.00 & 0.00 & 1 & 0.00 & 0.00 \\
\hline Hexachlorobenzene & $1.0 \mathrm{E}+01 \mu \mathrm{g} / \mathrm{L}$ & 0 & - & - & 2 & 0.00 & 0.00 \\
\hline Hexachlorobutadiene & $1.0 \mathrm{E}+01 \mu \mathrm{g} / \mathrm{L}$ & 0 & - & - & 2 & 0.00 & 0.00 \\
\hline Hexachlorocyclopentadiene & $1.0 \mathrm{E}+01 \mu \mathrm{g} / \mathrm{L}$ & 0 & - & - & 2 & 0.00 & 0.00 \\
\hline Hexachloroethane & $1.0 \mathrm{E}+01 \mu \mathrm{g} / \mathrm{L}$ & 0 & - & - & 2 & 0.00 & 0.00 \\
\hline $\begin{array}{l}\text { 2-Hexanone } \\
\text { Indeno[1,2,3-c, c]pyrene }\end{array}$ & $\begin{array}{l}1.0 \mathrm{E}+01 \mu \mathrm{g} / \mathrm{L} \\
1.0 \mathrm{E}+01 \mu \mathrm{g} / \mathrm{L}\end{array}$ & $\begin{array}{l}8 \\
0\end{array}$ & 0.00 & 0.00 & $\begin{array}{l}4 \\
2\end{array}$ & $\begin{array}{l}0.00 \\
0.00\end{array}$ & $\begin{array}{l}0.00 \\
0.00\end{array}$ \\
\hline lodine-129 & $\begin{array}{l}\text { 7.89E-09 } \\
\mu \mathrm{Ci} / \mathrm{mL}\end{array}$ & 1 & 0.00 & 0.00 & 0 & - & - \\
\hline $\begin{array}{l}\text { lodomethane } \\
\text { Iron }\end{array}$ & $\begin{array}{l}5.0 \mathrm{E}+00 \mu \mathrm{g} / \mathrm{L} \\
6.13 \mathrm{E}+01 \mu \mathrm{g} / \mathrm{L}\end{array}$ & $\begin{array}{l}5 \\
0\end{array}$ & $\begin{array}{l}15.00 \\
-\end{array}$ & $\begin{array}{l}7.20 \\
-\end{array}$ & $\begin{array}{l}2 \\
7\end{array}$ & $\begin{array}{l}0.00 \\
2.57\end{array}$ & $\begin{array}{l}0.00 \\
2.57\end{array}$ \\
\hline Isophorone & $1.0 \mathrm{E}+01 \mu \mathrm{g} / \mathrm{L}$ & 0 & - & - & 2 & 0.00 & 0.00 \\
\hline Lead & $5.0 \mathrm{E}+00 \mu \mathrm{g} / \mathrm{L}$ & 0 & - & - & 6 & 3.57 & 1.20 \\
\hline Magnesium & $t$ & 0 & - & - & 2 & 3.13 & 3.13 \\
\hline Manganese & $t$ & 0 & - & - & 2 & 5.22 & 5.22 \\
\hline Mercury & 2.0E-01 $\mu \mathrm{g} / \mathrm{L}$ & 0 & - & - & 7 & 1.62 & 0.64 \\
\hline 2-Methyl-4,6-dinitrophenol & $5.0 \mathrm{E}+01 \mu \mathrm{g} / \mathrm{L}$ & 0 & - & - & 2 & 0.00 & 0.00 \\
\hline Methyl methacrylate & $5.0 \mathrm{E}+00 \mu \mathrm{g} / \mathrm{L}$ & 5 & 0.00 & 0.00 & 2 & 0.00 & 0.00 \\
\hline 2-Methylnaphthalene & $1.0 \mathrm{E}+01 \mu \mathrm{g} / \mathrm{L}$ & 0 & - & - & 2 & 0.00 & 0.00 \\
\hline Naphthalene & $1.0 \mathrm{E}+01 \mu \mathrm{g} / \mathrm{L}$ & 0 & - & - & 2 & 0.00 & 0.00 \\
\hline Neptunium-237 & $\begin{array}{l}1.2 \mathrm{E}-10 \\
\mu \mathrm{Ci} / \mathrm{mL}\end{array}$ & 0 & - & - & 1 & 0.00 & 0.00 \\
\hline Nickel & $5.0 \mathrm{E}+00 \mu \mathrm{g} / \mathrm{L}$ & 0 & - & - & 2 & 0.00 & 0.00 \\
\hline Nitrate as nitrogen & $1.0 \mathrm{E}+02 \mu \mathrm{g} / \mathrm{L}$ & 10 & 0.80 & 0.80 & 4 & 1.98 & 1.98 \\
\hline Nitrate-nitrite as nitrogen & $\dagger$ & 2 & 2.20 & 2.20 & 0 & - & - \\
\hline m-Nitroaniline & $5.0 \mathrm{E}+01 \mu \mathrm{g} / \mathrm{L}$ & 0 & - & - & 2 & 0.00 & 0.00 \\
\hline o-Nitroaniline & $5.0 \mathrm{E}+01 \mu \mathrm{g} / \mathrm{L}$ & 0 & - & - & 2 & 0.00 & 0.00 \\
\hline p-Nitroaniline & $5.0 \mathrm{E}+01 \mu \mathrm{g} / \mathrm{L}$ & 0 & - & - & 2 & 0.00 & 0.00 \\
\hline Nitrobenzene & $1.0 \mathrm{E}+01 \mu \mathrm{g} / \mathrm{L}$ & 0 & - & $:$ & 2 & 0.00 & 0.00 \\
\hline 2-Nitrophenol & $1.0 \mathrm{E}+01 \mu \mathrm{g} / \mathrm{L}$ & 0 & - & - & 2 & 0.00 & 0.00 \\
\hline N-Nitrosodiphenylamine & $1.0 \mathrm{E}+01 \mu \mathrm{g} / \mathrm{L}$ & 0 & - & - & 2 & 0.00 & 0.00 \\
\hline Nonvolatile beta & $\begin{array}{c}2.03 \mathrm{E}-09 \\
\mu \mathrm{Ci} / \mathrm{mL}\end{array}$ & 1 & 0.00 & 0.00 & 1 & 0.00 & 0.00 \\
\hline Phenanthrene & $1.0 \mathrm{E}+01 \mu \mathrm{g} / \mathrm{L}$ & 0 & - & - & 2 & 0.00 & 0.00 \\
\hline Potassium & $4.0 \mathrm{E}+02 \mu \mathrm{g} / \mathrm{L}$ & 0 & - & - & 2 & 6.10 & 1.95 \\
\hline Radium, total alpha-emitting & $\begin{array}{c}1.45 \mathrm{E}-09 \\
\mu \mathrm{Ci} / \mathrm{mL}\end{array}$ & 1 & 47.77 & 18.83 & 0 & - & - \\
\hline Radium-226 & $\begin{array}{r}1.21 \mathrm{E}-09 \\
\mu \mathrm{Ci} / \mathrm{mL}\end{array}$ & 1 & 0.00 & 0.00 & 1 & 0.00 & 0.00 \\
\hline Radium-228 & $\begin{array}{r}1.69 \mathrm{E}-09 \\
\mu \mathrm{Ci} / \mathrm{mL}\end{array}$ & 1 & 0.00 & 0.00 & 1 & 0.00 & 0.00 \\
\hline Sodium & $1.34 \mathrm{E}+03 \mu \mathrm{g} / \mathrm{L}$ & $\angle 0$ & - & - & 2 & 2.82 & 2.82 \\
\hline Strontium-90 & $\begin{array}{c}1.65 \mathrm{E}-09 \\
\mu \mathrm{Ci} / \mathrm{mL}\end{array}$ & 1 & 0.00 & 0.00 & 1 & 0.00 & 0.00 \\
\hline Styrene & $5.0 \mathrm{E}+00 \mu \mathrm{g} / \mathrm{L}$ & 8 & 0.00 & 0.00 & 4 & 0.00 & 0.00 \\
\hline Sulfate & $5.0 \mathrm{E}+03 \mu \mathrm{g} / \mathrm{L}$ & 4 & 0.29 & 0.29 & 1 & 0.00 & 0.00 \\
\hline $1,1,2,2$-Tetrachloroethane & $5.0 \mathrm{E}+00 \mu \mathrm{g} / \mathrm{L}$ & 8 & 0.00 & 0.00 & 4 & 0.00 & 0.00 \\
\hline Tetrachloroethylene & $5.0 \mathrm{E}+00 \mu \mathrm{g} / \mathrm{L}$ & 8 & 0.79 & 0.38 & 8 & 0.00 & 0.00 \\
\hline Thorium-230 & $\begin{array}{c}1.8 \mathrm{E}-10 \\
\mu \mathrm{Ci} / \mathrm{mL}\end{array}$ & 1 & 0.00 & 0.00 & 1 & 0.00 & 0.00 \\
\hline Thorium-234 & $\begin{array}{r}2.15 \mathrm{E}-07 \\
\mu \mathrm{Ci} / \mathrm{mL}\end{array}$ & 1 & 37.43 & 13.81 & 1 & 0.00 & 0.00 \\
\hline
\end{tabular}




\begin{tabular}{|c|c|c|c|c|c|c|c|}
\hline Analyte & $R D L$ & $\begin{array}{l}\text { In-house Du } \\
\text { Number of } \\
\text { Dup. Pairs }\end{array}$ & $\frac{\text { lcates }}{\text { MRD }}$ & MRDadj & $\begin{array}{l}\text { Blind Repli } \\
\text { Number of } \\
\text { Dup. Pairs }\end{array}$ & MRD & MRDadj \\
\hline $\begin{array}{l}\text { Toluene } \\
\text { Total dissolved solids }\end{array}$ & $\begin{array}{l}5.0 \mathrm{E}+00 \mu \mathrm{g} / \mathrm{L} \\
\dagger\end{array}$ & $\begin{array}{l}8 \\
5\end{array}$ & $\begin{array}{l}0.00 \\
5.08\end{array}$ & $\begin{array}{l}0.00 \\
5.08\end{array}$ & $\begin{array}{l}4 \\
0\end{array}$ & 0.00 & $\begin{array}{l}0.00 \\
-\end{array}$ \\
\hline $\begin{array}{l}\text { Total organic carbon } \\
\text { Total phosphates (as P) }\end{array}$ & $\begin{array}{l}2.4 \mathrm{E}+03 \mu \mathrm{g} / \mathrm{L} \\
1.0 \mathrm{E}+01 \mu \mathrm{g} / \mathrm{L}\end{array}$ & $\begin{array}{l}2 \\
4\end{array}$ & $\begin{array}{l}0.00 \\
22.97\end{array}$ & $\begin{array}{l}0.00 \\
10.63\end{array}$ & $\begin{array}{l}1 \\
1\end{array}$ & $\begin{array}{l}0.00 \\
0.00\end{array}$ & $\begin{array}{l}0.00 \\
0.00\end{array}$ \\
\hline 1,1,1-Trichloroethane & $\begin{array}{l}5.0 \mathrm{E}+00 \mu \mathrm{g} / \mathrm{L} \\
5.0 \mathrm{E}+00 \mu \mathrm{g} / \mathrm{L}\end{array}$ & $\begin{array}{l}8 \\
8\end{array}$ & $\begin{array}{l}0.81 \\
0.00\end{array}$ & $\begin{array}{l}0.81 \\
0.00\end{array}$ & $\begin{array}{l}8 \\
4\end{array}$ & $\begin{array}{l}1.67 \\
0.00\end{array}$ & $\begin{array}{l}0.75 \\
0.00\end{array}$ \\
\hline Trichloroethylene & $5.0 \mathrm{E}+00 \mu \mathrm{g} / \mathrm{L}$ & 8 & 1.31 & 1.31 & 8 & 1.63 & 1.63 \\
\hline Trichlorofluoromethane & $5.0 \mathrm{E}+00 \mu \mathrm{g} / \mathrm{L}$ & 5 & 1.87 & 1.87 & 2 & 0.70 & 0.30 \\
\hline 2,4,5-Trichlorophenol & $1.0 \mathrm{E}+01 \mu \mathrm{g} / \mathrm{L}$ & 0 & 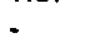 & - & 2 & 0.00 & 0.00 \\
\hline 2,4,6-Trichlorophenol & $1.0 \mathrm{E}+01 \mu \mathrm{g} / \mathrm{L}$ & 0 & - & - & 2 & 0.00 & 0.00 \\
\hline Tritium & $\begin{array}{c}7.36 \mathrm{E}-07 \\
\mu \mathrm{Ci} / \mathrm{mL}\end{array}$ & 2 & 8.48 & 3.12 & 1 & 0.00 & 0.00 \\
\hline Uranium-233/234 & $\begin{array}{c}1.5 \mathrm{E}-10 \\
\mu \mathrm{Ci} / \mathrm{mL}\end{array}$ & 1 & 0.00 & 0.00 & 1 & 0.00 & 0.00 \\
\hline Uranium-238. & $\begin{array}{l}1.3 \mathrm{E}-10 \\
\mu \mathrm{Ci} / \mathrm{mL}\end{array}$ & 1 & 0.00 & 0.00 & 1 & 0.00 & 0.00 \\
\hline Xylenes & 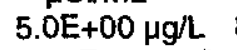 & 8 & 0.00 & 0.00 & 4 & 3.57 & 3.00 \\
\hline Zinc & $1.66 \mathrm{E}+01 \mu \mathrm{g} / \mathrm{L}$ & 0 & - & - & 2 & 11.93 & 6.14 \\
\hline
\end{tabular}

$\dagger$ No detection limit, or no replicate or duplicate results below detection limit.

- No replicate or duplicate analyses could be calculated.

Note: An MRD of 0.00 indicates no difference between any of the pairs of results used in calculating the MRD. MRD results greater than or equal to 20 appear in bold.

Table 26. Intralaboratory MRD Indices for EX

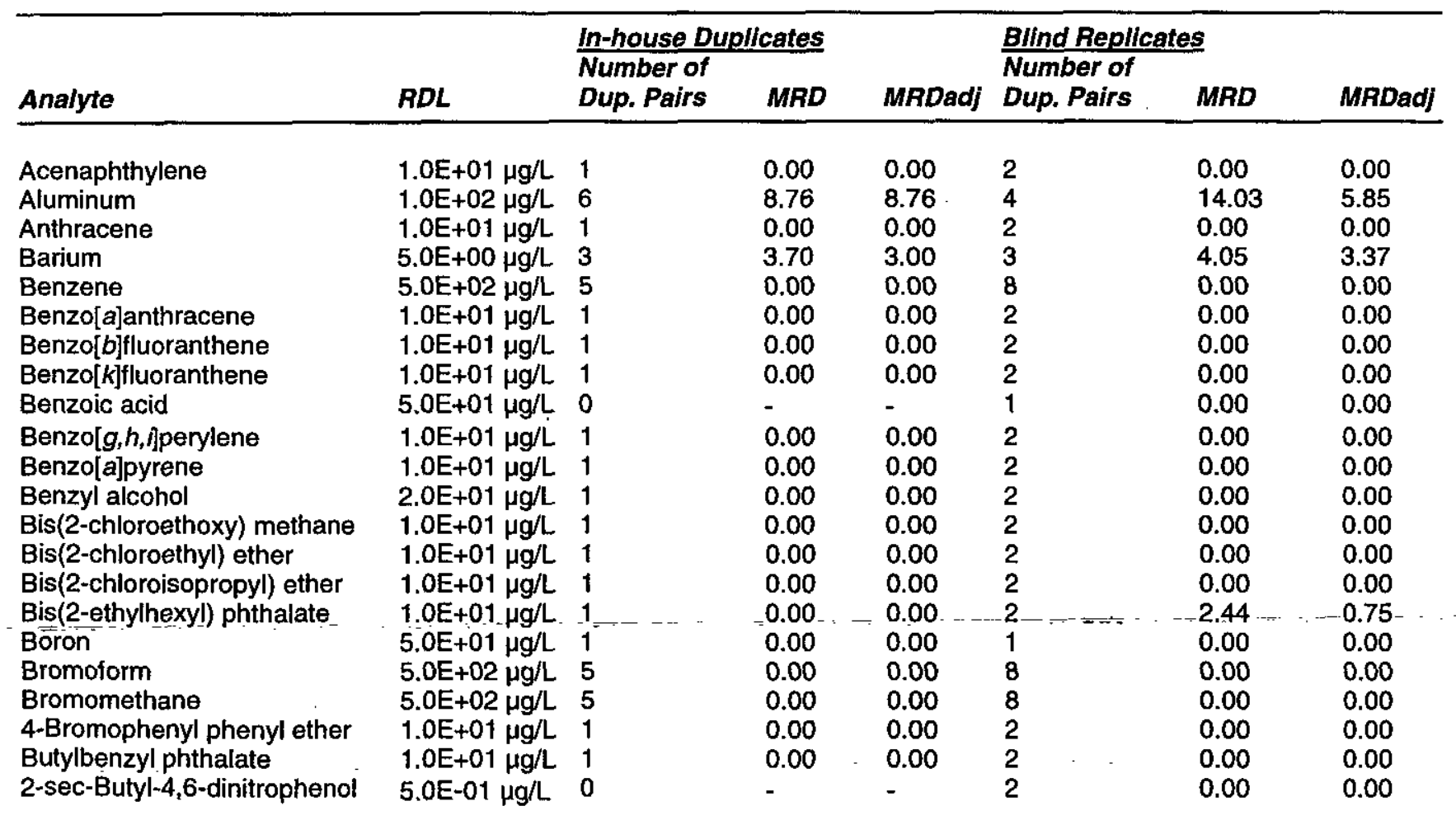




\begin{tabular}{|c|c|c|c|c|c|c|c|}
\hline Analyte & $R D L$ & $\begin{array}{l}\text { In-house Du } \\
\text { Number of } \\
\text { Dup. Pairs }\end{array}$ & $M R D$ & MRDadf & $\begin{array}{l}\text { Blind Replic } \\
\text { Number of } \\
\text { Dup. Pairs }\end{array}$ & $M R D$ & MRDadj \\
\hline $\begin{array}{l}\text { Cadmium } \\
\text { Calcium } \\
\text { Carbon tetrachloride } \\
\text { Chemical oxygen demand } \\
\text { Chloride } \\
\text { 4-Chloroaniline } \\
\text { Chlorobenzene } \\
\text { Chloroethene } \\
\text { Chloroform } \\
\text { 2-Chloronaphthalene } \\
\text { 4-Chlorophenyl phenyl ether } \\
\text { Chromium } \\
\text { Chrysene } \\
\text { Cobalt } \\
\text { Copper } \\
\text { m/p-Cresol } \\
\text { o-Cresol } \\
\text { Dibenz[a, h]anthracene } \\
\text { Dibenzofuran } \\
\text { Di-n-butyl phthalate } \\
\text { 1,2-Dichlorobenzene } \\
\text { 1,3-Dichlorobenzene } \\
\text { 1,4-Dichlorobenzene } \\
\text { 3,3'-Dichlorobenzidine } \\
\text { Dichlorodifluoromethane }\end{array}$ & $\begin{array}{l}5.0 \mathrm{E}+00 \mu \mathrm{g} / \mathrm{L} \\
1.0 \mathrm{E}+03 \mu \mathrm{g} / \mathrm{L} \\
5.0 \mathrm{E}+02 \mu \mathrm{g} / \mathrm{L} \\
\dagger \\
\dagger \\
1.0 \mathrm{E}+01 \mu \mathrm{g} / \mathrm{L} \\
5.0 \mathrm{E}+02 \mu \mathrm{g} / \mathrm{L} \\
5.0 \mathrm{E}+02 \mu \mathrm{g} / \mathrm{L} \\
5.0 \mathrm{E}+02 \mu \mathrm{g} / \mathrm{L} \\
1.0 \mathrm{E}+01 \mu \mathrm{g} / \mathrm{L} \\
1.0 \mathrm{E}+01 \mu \mathrm{g} / \mathrm{L} \\
1.0 \mathrm{E}+01 \mu \mathrm{g} / \mathrm{L} \\
1.0 \mathrm{E}+01 \mu \mathrm{g} / \mathrm{L} \\
2.0 \mathrm{E}+01 \mu \mathrm{g} / \mathrm{L} \\
1.0 \mathrm{E}+01 \mu \mathrm{g} / \mathrm{L} \\
1.0 \mathrm{E}+01 \mu \mathrm{g} / \mathrm{L} \\
1.0 \mathrm{E}+01 \mu \mathrm{g} / \mathrm{L} \\
1.0 \mathrm{E}+01 \mu \mathrm{g} / \mathrm{L} \\
1.0 \mathrm{E}+01 \mu \mathrm{g} / \mathrm{L} \\
1.0 \mathrm{E}+01 \mu \mathrm{g} / \mathrm{L} \\
1.0 \mathrm{E}+03 \mu \mathrm{g} / \mathrm{L} \\
1.0 \mathrm{E}+03 \mu \mathrm{g} / \mathrm{L} \\
1.0 \mathrm{E}+03 \mu \mathrm{g} / \mathrm{L} \\
1.0 \mathrm{E}+01 \mu \mathrm{g} / \mathrm{L} \\
1.0 \mathrm{E}+03 \mu \mathrm{g} / \mathrm{L}\end{array}$ & $\begin{array}{l}3 \\
3 \\
7 \\
1 \\
3 \\
1 \\
5 \\
5 \\
7 \\
1 \\
1 \\
3 \\
1 \\
3 \\
3 \\
1 \\
1 \\
1 \\
1 \\
1 \\
1 \\
1 \\
1 \\
1 \\
0\end{array}$ & $\begin{array}{l}0.00 \\
9.72 \\
0.00 \\
0.00 \\
1.61 \\
0.00 \\
0.00 \\
0.00 \\
0.00 \\
0.00 \\
0.00 \\
0.00 \\
0.00 \\
0.00 \\
0.00 \\
0.00 \\
0.00 \\
0.00 \\
0.00 \\
0.00 \\
0.00 \\
0.00 \\
0.00 \\
0.00 \\
-\end{array}$ & $\begin{array}{l}0.00 \\
4.80 \\
0.00 \\
0.00 \\
1.61 \\
0.00 \\
0.00 \\
0.00 \\
0.00 \\
0.00 \\
0.00 \\
0.00 \\
0.00 \\
0.00 \\
0.00 \\
0.00 \\
0.00 \\
0.00 \\
0.00 \\
0.00 \\
0.00 \\
0.00 \\
0.00 \\
0.00 \\
-\end{array}$ & $\begin{array}{l}3 \\
3 \\
9 \\
1 \\
3 \\
2 \\
8 \\
8 \\
9 \\
2 \\
2 \\
3 \\
2 \\
3 \\
3 \\
2 \\
2 \\
2 \\
2 \\
2 \\
3 \\
3 \\
3 \\
2 \\
1\end{array}$ & $\begin{array}{l}0.00 \\
4.23 \\
0.00 \\
16.56 \\
2.13 \\
0.00 \\
0.00 \\
0.00 \\
0.00 \\
0.00 \\
0.00 \\
0.00 \\
0.00 \\
0.00 \\
2.88 \\
0.00 \\
0.00 \\
0.00 \\
0.00 \\
0.00 \\
0.00 \\
0.00 \\
0.00 \\
0.00 \\
0.00\end{array}$ & $\begin{array}{l}0.00 \\
3.65 \\
0.00 \\
16.56 \\
2.13 \\
0.00 \\
0.00 \\
0.00 \\
0.00 \\
0.00 \\
0.00 \\
0.00 \\
0.00 \\
0.00 \\
1.20 \\
0.00 \\
0.00 \\
0.00 \\
0.00 \\
0.00 \\
0.00 \\
0.00 \\
0.00 \\
0.00 \\
0.00\end{array}$ \\
\hline $\begin{array}{l}\text { 1,1-Dichloroethane } \\
\text { 1,1-Dichloroethylene } \\
\text { cis-1,2-Dichloroethylene }\end{array}$ & $\begin{array}{l}5.0 \mathrm{E}+02 \mu \mathrm{g} / \mathrm{L} \\
5.0 \mathrm{E}+02 \mu \mathrm{g} / \mathrm{L} \\
5.0 \mathrm{E}+00 \mu \mathrm{g} / \mathrm{L}\end{array}$ & $\begin{array}{l}5 \\
5 \\
0\end{array}$ & $\begin{array}{l}0.00 \\
0.00 \\
-\end{array}$ & $\begin{array}{l}0.00 \\
0.00 \\
-\end{array}$ & $\begin{array}{l}8 \\
8 \\
0\end{array}$ & $\begin{array}{l}0.00 \\
0.00 \\
-\end{array}$ & $\begin{array}{l}0.00 \\
0.00 \\
-\end{array}$ \\
\hline $\begin{array}{l}\text { Dichloromethane } \\
\text { 2,4-Dichlorophenol } \\
\text { Diethyl phthalate } \\
\text { 2,4-Dimethyl phenol } \\
\text { Dimethyl phthalate } \\
\text { 2,4-Dinitrophenol } \\
\text { 2,6-Dinitrotoluene } \\
\text { Di-n-octyl phthalate } \\
\text { 1,4-Dioxane }\end{array}$ & $\begin{array}{l}1.0 \mathrm{E}+03 \mu \mathrm{g} / \mathrm{L} \\
1.0 \mathrm{E}+01 \mu \mathrm{g} / \mathrm{L} \\
1.0 \mathrm{E}+01 \mu \mathrm{g} / \mathrm{L} \\
1.0 \mathrm{E}+01 \mu \mathrm{g} / \mathrm{L} \\
1.0 \mathrm{E}+01 \mu \mathrm{g} / \mathrm{L} \\
1.0 \mathrm{E}+01 \mu \mathrm{g} / \mathrm{L} \\
1.0 \mathrm{E}+01 \mu \mathrm{g} / \mathrm{L} \\
1.0 \mathrm{E}+01 \mu \mathrm{g} / \mathrm{L} \\
2.0 \mathrm{E}+05 \mu \mathrm{g} / \mathrm{L}\end{array}$ & $\begin{array}{l}5 \\
1 \\
1 \\
1 \\
1 \\
1 \\
1 \\
1 \\
0\end{array}$ & $\begin{array}{l}0.00 \\
0.00 \\
0.00 \\
0.00 \\
0.00 \\
0.00 \\
0.00 \\
0.00 \\
-\end{array}$ & $\begin{array}{l}0.00 \\
0.00 \\
0.00 \\
0.00 \\
0.00 \\
0.00 \\
0.00 \\
0.00 \\
-\end{array}$ & $\begin{array}{l}8 \\
2 \\
2 \\
2 \\
2 \\
2 \\
2 \\
2 \\
1\end{array}$ & $\begin{array}{l}0.00 \\
0.00 \\
0.00 \\
0.00 \\
0.00 \\
0.00 \\
0.00 \\
0.00 \\
0.00\end{array}$ & $\begin{array}{l}0.00 \\
0.00 \\
0.00 \\
0.00 \\
0.00 \\
0.00 \\
0.00 \\
0.00 \\
0.00\end{array}$ \\
\hline Endosulfan sulfate & $1.0 \mathrm{E}-01 \mu \mathrm{g} / \mathrm{L}$ & 0 & - & - & 2 & 0.00 & 0.00 \\
\hline Ethy! methacrylate & $2.0 \mathrm{E}+03 \mu \mathrm{g} / \mathrm{L}$ & 0 & - & - & 1 & 0.00 & 0.00 \\
\hline $\begin{array}{l}\text { Ethylbenzene } \\
\text { Fluoranthene } \\
\text { Fluorene } \\
\text { Hexachlorobenzene } \\
\text { Hexachlorobutadiene } \\
\text { Hexachlorocyclopentadiene } \\
\text { Hexachloroethane } \\
\text { 2-Hexanone } \\
\text { Indeno[1,2,3-c,d]pyrene } \\
\text { lodomethane }\end{array}$ & $\begin{array}{l}5.0 \mathrm{E}+02 \mu \mathrm{g} / \mathrm{L} \\
1.0 \mathrm{E}+01 \mu \mathrm{g} / \mathrm{L} \\
1.0 \mathrm{E}+01 \mu \mathrm{g} / \mathrm{L} \\
1.0 \mathrm{E}+01 \mu \mathrm{g} / \mathrm{L} \\
1.0 \mathrm{E}+01 \mu \mathrm{g} / \mathrm{L} \\
1.0 \mathrm{E}+01 \mu \mathrm{g} / \mathrm{L} \\
1.0 \mathrm{E}+01 \mu \mathrm{g} / \mathrm{L} \\
5.0 \mathrm{E}+02 \mu \mathrm{g} / \mathrm{L} \\
1.0 \mathrm{E}+01 \mu \mathrm{g} / \mathrm{L} \\
1.0 \mathrm{E}+03 \mu \mathrm{g} / \mathrm{L}\end{array}$ & $\begin{array}{l}5 \\
1 \\
1 \\
1 \\
1 \\
1 \\
1 \\
3 \\
1 \\
0\end{array}$ & $\begin{array}{l}0.00 \\
0.00 \\
0.00 \\
0.00 \\
0.00 \\
0.00 \\
0.00 \\
0.00 \\
0.00 \\
-\end{array}$ & $\begin{array}{l}0.00 \\
0.00 \\
0.00 \\
0.00 \\
0.00 \\
0.00 \\
0.00 \\
0.00 \\
0.00 \\
-\end{array}$ & $\begin{array}{l}8 \\
2 \\
2 \\
2 \\
2 \\
2 \\
2 \\
2 \\
6 \\
2 \\
1\end{array}$ & $\begin{array}{l}0.00 \\
0.00 \\
0.00 \\
0.00 \\
0.00 \\
0.00 \\
0.00 \\
0.00 \\
0.00 \\
0.00\end{array}$ & $\begin{array}{l}0.00 \\
0.00 \\
0.00 \\
0.00 \\
0.00 \\
0.00 \\
0.00 \\
0.00 \\
0.00 \\
0.00\end{array}$ \\
\hline $\begin{array}{l}\text { Iron } \\
\text { Isophorone } \\
\text { Lead } \\
\text { Lithium } \\
\text { Magnesium } \\
\text { Manganese } \\
\text { Mercury }\end{array}$ & $\begin{array}{l}1.0 \mathrm{E}+02 \mu \mathrm{g} / \mathrm{L} \\
1.0 \mathrm{E}+01 \mu \mathrm{g} / \mathrm{L} \\
1.0 \mathrm{E}+02 \mu \mathrm{g} / \mathrm{L} \\
2.0 \mathrm{E}+00 \mu \mathrm{g} / \mathrm{L} \\
5.0 \mathrm{E}+02 \mu \mathrm{g} / \mathrm{L} \\
1.0 \mathrm{E}+01 \mu \mathrm{g} / \mathrm{L} \\
2.0 \mathrm{E}-01 \mu \mathrm{g} / \mathrm{L}\end{array}$ & $\begin{array}{l}6 \\
1 \\
6 \\
2 \\
3 \\
3 \\
4\end{array}$ & $\begin{array}{l}6.03 \\
0.00 \\
0.00 \\
0.00 \\
8.64 \\
8.53 \\
0.00\end{array}$ & $\begin{array}{l}5.85 \\
0.00 \\
0.00 \\
0.00 \\
5.14 \\
3.20 \\
0.00\end{array}$ & $\begin{array}{l}4 \\
2 \\
4 \\
2 \\
3 \\
3 \\
3\end{array}$ & $\begin{array}{l}8.38 \\
0.00 \\
0.00 \\
0.00 \\
3.87 \\
2.54 \\
0.00\end{array}$ & $\begin{array}{l}4.80 \\
0.00 \\
0.00 \\
0.00 \\
3.58 \\
1.00 \\
0.00\end{array}$ \\
\hline
\end{tabular}




\begin{tabular}{|c|c|c|c|c|c|c|c|}
\hline Analyte & $R D L$ & $\begin{array}{l}\text { In-house Du } \\
\text { Number of } \\
\text { Dup. Pairs }\end{array}$ & $\frac{\text { licates }}{\text { MRD }}$ & MRDadj & $\begin{array}{l}\text { Blind Replic } \\
\text { Number of } \\
\text { Dup. Pairs }\end{array}$ & MRD & MRDad] \\
\hline $\begin{array}{l}\text { 2-Methyl-4,6-dinitrophenol } \\
\text { Methyl methacrylate }\end{array}$ & $\begin{array}{l}5.0 \mathrm{E}+01 \mu \mathrm{g} / \mathrm{L} \\
1.0 \mathrm{E}+04 \mu \mathrm{g} / \mathrm{L}\end{array}$ & $\begin{array}{l}1 \\
0\end{array}$ & $\begin{array}{l}0.00 \\
-\end{array}$ & $\begin{array}{l}0.00 \\
-\end{array}$ & $\begin{array}{l}2 \\
1\end{array}$ & $\begin{array}{l}0.00 \\
0.00\end{array}$ & $\begin{array}{l}0.00 \\
0.00\end{array}$ \\
\hline $\begin{array}{l}\text { 2-Methylnaphthalene } \\
\text { Naphthalene } \\
\text { Nickel } \\
\text { Nitrate as nitrogen }\end{array}$ & $\begin{array}{l}1.0 \mathrm{E}+01 \mu \mathrm{g} / \mathrm{L} \\
1.0 \mathrm{E}+01 \mu \mathrm{g} / \mathrm{L} \\
2.0 \mathrm{E}+01 \mu \mathrm{g} / \mathrm{L} \\
1.0 \mathrm{E}+02 \mu \mathrm{g} / \mathrm{L}\end{array}$ & $\begin{array}{l}1 \\
1 \\
3 \\
2\end{array}$ & $\begin{array}{l}0.00 \\
0.00 \\
0.00 \\
0.42\end{array}$ & $\begin{array}{l}0.00 \\
0.00 \\
0.00 \\
0.42\end{array}$ & $\begin{array}{l}2 \\
2 \\
3 \\
0\end{array}$ & $\begin{array}{l}0.00 \\
0.00 \\
9.79 \\
-\end{array}$ & $\begin{array}{l}0.00 \\
0.00 \\
3.65 \\
-\end{array}$ \\
\hline Nitrate-nitrite as nitrogen & $1.0 \mathrm{E}+03 \mu \mathrm{g} / \mathrm{L}$ & 5 & 0.32 & 0.12 & 3 & 0.00 & 0.00 \\
\hline m-Nitroanitine & $5.0 \mathrm{E}+01 \mu \mathrm{g} / \mathrm{L}$ & 1 & 0.00 & 0.00 & 2 & 0.00 & 0.00 \\
\hline o-Nitroaniline & $5.0 \mathrm{E}+01 \mu \mathrm{g} / \mathrm{L}$ & 1 & 0.00 & 0.00 & 2 & 0.00 & 0.00 \\
\hline p-Nitroaniline & $5.0 \mathrm{E}+01 \mu \mathrm{g} / \mathrm{L}$ & 1 & 0.00 & 0.00 & 2 & 0.00 & 0.00 \\
\hline Nitrobenzene & $1.0 \mathrm{E}+01 \mu \mathrm{g} / \mathrm{L}$ & 1 & 0.00 & 0.00 & 2 & 0.00 & 0.00 \\
\hline 2-Nitrophenol & $1.0 \mathrm{E}+01 \mu \mathrm{g} / \mathrm{L}$ & 1 & 0.00 & 0.00 & 2 & 0.00 & 0.00 \\
\hline $\mathrm{N}$-Nitrosodimethylamine & $1.0 \mathrm{E}+01 \mu \mathrm{g} / \mathrm{L}$ & 1 & 0.00 & 0.00 & 2 & 0.00 & 0.00 \\
\hline N-Nitrosodiphenylamine & $1.0 \mathrm{E}+01 \mu \mathrm{g} / \mathrm{L}$ & 1 & 0.00 & 0.00 & 2 & 0.00 & 0.00 \\
\hline Pentachloroethane & $4.0 \mathrm{E}+03 \mu \mathrm{g} / \mathrm{L}$ & 0 & - & - & $\overline{1}$ & 0.00 & 0.00 \\
\hline $\mathrm{pH}$ & $\dagger$ & 5 & 1.11 & 1.11 & 3 & 3.67 & 3.67 \\
\hline Phenanthrene & $1.0 \mathrm{E}+01 \mu \mathrm{g} / \mathrm{L}$ & 1 & 0.00 & 0.00 & 2 & 0.00 & 0.00 \\
\hline Potassium & $1.89 \mathrm{E}+03 \mu \mathrm{g} / \mathrm{L}$ & 2 & 0.00 & 0.00 & 3 & 0.00 & 0.00 \\
\hline Silica & $1.0 \mathrm{E}+02 \mu \mathrm{g} / \mathrm{L}$ & 2 & 5.52 & 5.52 & 2 & 20.49 & 20.49 \\
\hline Sodium & $1.0 \mathrm{E}+03 \mu \mathrm{g} / \mathrm{L}$ & 3 & 7.47 & 7.47 & 3 & 5.17 & 3.80 \\
\hline Specific conductance & $\dagger$ & 3 & 0.00 & 0.00 & 3 & 0.78 & 0.78 \\
\hline Strontium & $t$ & 1 & 22.22 & 22.22 & 1 & 7.96 & 7.96 \\
\hline Styrene & $2.5 \mathrm{E}+02 \mu \mathrm{g} / \mathrm{L}$ & 3 & 0.00 & 0.00 & 6 & 0.00 & 0.00 \\
\hline Sulfate & $2.0 \mathrm{E}+02 \mu \mathrm{g} / \mathrm{L}$ & 3 & 1.94 & 1.94 & 3 & 1.90 & 1.90 \\
\hline $1,1,2,2$-Tetrachloroethane & $5.0 \mathrm{E}+02 \mu \mathrm{g} / \mathrm{L}$ & 5 & 0.00 & 0.00 & 8 & 0.00 & 0.00 \\
\hline Tetrachloroethylene & $5.0 \mathrm{E}+01 \mu \mathrm{g} / \mathrm{L}$ & 7 & 2.23 & 2.23 & 8 & 0.23 & 0.23 \\
\hline Toluene & $5.0 \mathrm{E}+02 \mu \mathrm{g} / \mathrm{L}$ & 5 & 0.00 & 0.00 & 8 & 0.00 & 0.00 \\
\hline Total dissolved solids & $\dagger$ & 2 & 4.76 & 4.76 & 2 & 40.00 & 40.00 \\
\hline Total organic carbon & $5.0 \mathrm{E}+03 \mu \mathrm{g} / \mathrm{L}$ & 2 & 0.00 & 0.00 & 3 & 13.03 & 10.00 \\
\hline Total phosphates (as P) & $5.0 \mathrm{E}+01 \mu \mathrm{g} / \mathrm{L}$ & 2 & 0.00 & 0.00 & 2 & 0.00 & 0.00 \\
\hline 1,1,1-Trichloroethane & $5.0 \mathrm{E}+02 \mu \mathrm{g} / \mathrm{L}$ & 7 & 0.00 & 0.00 & 9 & 0.00 & 0.00 \\
\hline $1,1,2$-Trichloroethane & $5.0 \mathrm{E}+02 \mu \mathrm{g} / \mathrm{L}$ & 5 & 0.00 & 0.00 & 8 & 0.00 & 0.00 \\
\hline Trichloroethylene & $5.0 \mathrm{E}+00 \mu \mathrm{g} / \mathrm{L}$ & 7 & 5.30 & 5.30 & 9 & 4.67 & 4.67 \\
\hline Trichlorofluoromethane & $1.0 \mathrm{E}+03 \mu \mathrm{g} / \mathrm{L}$ & 2 & 0.00 & 0.00 & 3 & 0.00 & 0.00 \\
\hline 2,4,5-Trichlorophenol & $5.0 \mathrm{E}+01 \mu \mathrm{g} / \mathrm{L}$ & 1 & 0.00 & 0.00 & 2 & 0.00 & 0.00 \\
\hline 2,4,6-Trichlorophenol & $1.0 \mathrm{E}+01 \mu \mathrm{g} / \mathrm{L}$ & 1 & 0.00 & 0.00 & 2 & 0.00 & 0.00 \\
\hline Xylenes & $5.0 \mathrm{E}+02 \mu \mathrm{g} / \mathrm{L}$ & 3 & 0.00 & 0.00 & $\overline{6}$ & 0.00 & 0.00 \\
\hline Zinc & $1.0 \mathrm{E}+01 \mu \mathrm{g} / \mathrm{L}$ & 2 & 0.00 & 0.00 & 3 & 5.32 & 2.50 \\
\hline
\end{tabular}

† No detection limit, or no replicate or duplicate results below detection limit.

- No replicate or duplicate analyses coutd be calculated.

Note: An MRD of 0.00 indicates no difference between any of the pairs of results used in calculating the MRD. MRD results greater than or equal to 20 appear in bold.

Table 27. Intralaboratory MRD Indices for $G E$

\begin{tabular}{|c|c|c|c|c|c|c|c|}
\hline Analyte & $R D L$ & $\begin{array}{l}\text { In-house Du } \\
\text { Number of } \\
\text { Dup. Pairs }\end{array}$ & $\begin{array}{l}\text { licates } \\
\text { MRD }\end{array}$ & MRDadj & $\begin{array}{l}\text { Blind Repllo } \\
\text { Nümber of } \\
\text { Dup. Pairs }\end{array}$ & $\begin{array}{l}\text { es } \\
\text { MRD }\end{array}$ & MRDadj \\
\hline Acenaphthylene & $10.0 \mu \mathrm{g} / \mathrm{L}$ & 0 & - & - & 1 & 0.00 & 0.00 \\
\hline Alkalinity (as $\mathrm{CaCO}_{3}$ ) & $1,000 \mu \mathrm{g} / \mathrm{L}$ & 2 & -4.51 & 3.27 & 1 & 3.98 & 2.40 \\
\hline Aluminum & $50.0 \mu \mathrm{g} / \mathrm{L}$ & 1 & 0.00 & 0.00 & 2 & 43.82 & 39.51 \\
\hline Anthracene & $10.0 \mu \mathrm{g} / \mathrm{L}$ & 0 & - & - & 1 & 0.00 & 0.00 \\
\hline Barium & $5.0 \mu \mathrm{g} / \mathrm{L}$ & 1 & 0.00 & 0.00 & 2 & 4.60 & 4.00 \\
\hline
\end{tabular}




\begin{tabular}{|c|c|c|c|c|c|c|c|}
\hline Analyte & $R D L$ & $\begin{array}{l}\text { In-house Du } \\
\text { Number of } \\
\text { Dup. Pairs }\end{array}$ & $\frac{\text { licates }}{\text { MRD }}$ & MRDadJ & $\begin{array}{l}\text { Blind Replic } \\
\text { Number of } \\
\text { Dup. Pairs }\end{array}$ & MRD & MRDadj \\
\hline Benzene & $1.0 \mu \mathrm{g} / \mathrm{L}$ & 0 & - & - & 1 & 5.11 & 2.85 \\
\hline Benzo[a]anthracene & $10.0 \mu \mathrm{g} / \mathrm{L}$ & 0 & - & - & 1 & 0.00 & 0.00 \\
\hline Benzo[b]fluoranthene & $10.0 \mu \mathrm{g} / \mathrm{L}$ & 0 & - & - & 1 & 0.00 & 0.00 \\
\hline Benzo[k]fluoranthene & $10.0 \mu \mathrm{g} / \mathrm{L}$ & 0 & - & - & 1 & 0.00 & 0.00 \\
\hline Benzoic acid & $20.0 \mu \mathrm{g} / \mathrm{L}$ & 0 & - & - & 1 & 0.00 & 0.00 \\
\hline Benzo[g,h,i]perylene & $10.0 \mu \mathrm{g} / \mathrm{L}$ & 0 & - & - & 1 & 0.00 & 0.00 \\
\hline Benzo[a]pyrene & $10.0 \mu \mathrm{g} / \mathrm{L}$ & 0 & - & - & 1 & 0.00 & 0.00 \\
\hline Benzyl alcohol & $10.0 \mu \mathrm{g} / \mathrm{L}$ & 0 & - & - & 1 & 0.00 & 0.00 \\
\hline Bis(2-chloroethoxy) methane & $10.0 \mu \mathrm{g} / \mathrm{L}$ & 0 & - & - & 1 & 0.00 & 0.00 \\
\hline Bis(2-chloroethyl) ether & $10.0 \mu \mathrm{g} / \mathrm{L}$ & 0 & - & - & 1 & 0.00 & 0.00 \\
\hline Bis(2-chloroisopropyl) ether & $10.0 \mu \mathrm{g} / \mathrm{L}$ & 0 & - & - & 1 & 0.00 & 0.00 \\
\hline Bis(2-ethylhexyl) phthalate & $10.0 \mu \mathrm{g} / \mathrm{L}$ & 0 & - & - & 1 & 0.00 & 0.00 \\
\hline $\begin{array}{l}\text { Boron } \\
\text { Bromide }\end{array}$ & $\begin{array}{l}50.0 \mu \mathrm{g} / \mathrm{L} \\
250 \mu \mathrm{g} / \mathrm{L}\end{array}$ & $\begin{array}{l}1 \\
1\end{array}$ & $\begin{array}{l}0.00 \\
149.11\end{array}$ & $\begin{array}{l}0.00 \\
149.11\end{array}$ & $\begin{array}{l}1 \\
1\end{array}$ & $\begin{array}{l}0.00 \\
64.56\end{array}$ & $\begin{array}{l}0.00 \\
64.56\end{array}$ \\
\hline Bromoform & $1.0 \mu \mathrm{g} / \mathrm{L}$ & 0 & - & - & 1 & 0.00 & 0.00 \\
\hline Bromomethane & $1.0 \mu \mathrm{g} / \mathrm{L}$ & 0 & - & - & 1 & 0.00 & 0.00 \\
\hline 4-Bromophenyl phenyl ether & $10.0 \mu \mathrm{g} / \mathrm{L}$ & 0 & - & - & 1 & 0.00 & 0.00 \\
\hline Butylbenzyl phthalate & $10.0 \mu \mathrm{g} / \mathrm{L}$ & 0 & - & - & 1 & 0.00 & 0.00 \\
\hline Cadmium & $5.0 \mu \mathrm{g} / \mathrm{L}$ & 1 & 145.50 & 145.50 & 7 & 0.11 & 0.09 \\
\hline Calcium & $100 \mu \mathrm{g} / \mathrm{L}$ & 1 & 0.00 & 0.00 & 2 & 7.49 & 7.49 \\
\hline Carbon tetrachloride & $1.0 \mu \mathrm{g} / \mathrm{L}$ & 0 & - & - & 1 & 5.35 & 1.65 \\
\hline Chloride & $\dagger$ & 1 & 3.71 & 3.71 & 1 & 0.00 & 0.00 \\
\hline 4-Chloroaniline & $20.0 \mu \mathrm{g} / \mathrm{L}$ & 0 & - & - & 1 & 0.00 & 0.00 \\
\hline Chlorobenzene & $1.0 \mu \mathrm{g} / \mathrm{L}$ & 0 & - & - & 1 & 0.00 & 0.00 \\
\hline Chloroethene & $1.0 \mu \mathrm{g} / \mathrm{L}$ & 0 & - & - & 1 & 0.00 & 0.00 \\
\hline Chloroform & $1.0 \mu \mathrm{g} / \mathrm{L}$ & 0 & - & - & 1 & 11.68 & 11.68 \\
\hline 2-Chloronaphthalene & $10.0 \mu \mathrm{g} / \mathrm{L}$ & 0 & - & - & 1 & 0.00 & 0.00 \\
\hline 4-Chlorophenyl phenyl ether & $10.0 \mu \mathrm{g} / \mathrm{L}$ & 0 & - & - & 1 & 0.00 & 0.00 \\
\hline $\begin{array}{l}\text { Chromium } \\
\text { Chrysene }\end{array}$ & $\begin{array}{l}5.0 \mu \mathrm{g} / \mathrm{L} \\
10.0 \mu \mathrm{g} / \mathrm{L}\end{array}$ & $\begin{array}{l}1 \\
0\end{array}$ & $\begin{array}{l}0.00 \\
-\end{array}$ & $\begin{array}{l}0.00 \\
-\end{array}$ & $\begin{array}{l}2 \\
1\end{array}$ & $\begin{array}{l}16.23 \\
0.00\end{array}$ & $\begin{array}{l}6.30 \\
0.00\end{array}$ \\
\hline Cobalt & $5.0 \mu \mathrm{g} / \mathrm{L}$ & 1 & 0.00 & 0.00 & 2 & 0.00 & 0.00 \\
\hline Copper & $5.0 \mu \mathrm{g} / \mathrm{L}$ & 1 & 0.00 & 0.00 & 2 & 16.08 & 14.74 \\
\hline $\mathrm{m} / \mathrm{p}$-Cresol & $10.0 \mu \mathrm{g} / \mathrm{L}$ & 0 & - & - & 1 & 0.00 & 0.00 \\
\hline 0 -Cresol & $10.0 \mu \mathrm{g} / \mathrm{L}$ & 0 & - & - & 1 & 0.00 & 0.00 \\
\hline Dibenz $[a, h]$ anthracene & $10.0 \mu \mathrm{g} / \mathrm{L}$ & 0 & - & - & 1 & 0.00 & 0.00 \\
\hline Dibenzofuran & $10.0 \mu \mathrm{g} / \mathrm{L}$ & 0 & - & - & 1 & 0.00 & 0.00 \\
\hline Di-n-butyl phthalate & $10.0 \mu g / L$ & 0 & - & - & 1 & 0.00 & 0.00 \\
\hline 1,2-Dichlorobenzene & $10.0 \mu \mathrm{g} / \mathrm{L}$ & 0 & - & - & 1 & 0.00 & 0.00 \\
\hline 1,3-Dichlorobenzene & $10.0 \mu \mathrm{g} / \mathrm{L}$ & 0 & - & - & 1 & 0.00 & 0.00 \\
\hline 1,4-Dichlorobenzene & $10.0 \mu \mathrm{g} / \mathrm{L}$ & 0 & - & - & 1 & 0.00 & 0.00 \\
\hline 3,3'-Dichlorobenzidine & $50.0 \mu \mathrm{g} / \mathrm{L}$ & 0 & - & - & 1 & 0.00 & 0.00 \\
\hline 1,1-Dichloroethane & $1.0 \mu \mathrm{g} / \mathrm{L}$ & 0 & - & - & 1 & 0.00 & 0.00 \\
\hline 1,1-Dichloroethylene & $1.0 \mu \mathrm{g} / \mathrm{L}$ & 0 & - & - & 1 & 0.00 & 0.00 \\
\hline Dichloromethane & $5.17 \mu \mathrm{g} / \mathrm{L}$ & 0 & - & - & 1 & 0.00 & 0.00 \\
\hline 2,4-Dichlorophenol & $10.0 \mu \mathrm{g} / \mathrm{L}$ & 0 & - & - & 1 & 0.00 & 0.00 \\
\hline Diethyl phthalate & $10.0 \mu \mathrm{g} / \mathrm{L}$ & 0 & - & - & 1 & 0.00 & 0.00 \\
\hline 2,4-Dimethyl phenol & $10.0 \mu \mathrm{g} / \mathrm{L}$ & 0 & - & $\cdot$ & 1 & 0.00 & 0.00 \\
\hline Dimethyl phthalate & $10.0 \mu \mathrm{g} / \mathrm{L}$ & 0 & - & - & 1 & 0.00 & 0.00 \\
\hline 2,4-Dinitrophenol & $20.0 \mu \mathrm{g} / \mathrm{L}$ & 0 & - & - & 1 & 0.00 & 0.00 \\
\hline 2,6-Dinitrotoluene & to.0 $\mu \mathrm{g} / \mathrm{L}$ & 0 & - & - & 1 & 0.00 & 0.00 \\
\hline Di-n-octyl phthalate & $10.0 \mu \mathrm{g} / \mathrm{L}$ & 0 & - & - & 1 & 0.00 & 0.00 \\
\hline
\end{tabular}




\begin{tabular}{|c|c|c|c|c|c|c|c|}
\hline Analyte & $R D L$ & $\begin{array}{l}\text { In-house Du } \\
\text { Number of } \\
\text { Dup. Pairs }\end{array}$ & $\frac{\text { licates }}{\text { MRD }}$ & MRDadj & $\begin{array}{l}\text { Blind Replic } \\
\text { Number of } \\
\text { Dup. Pairs }\end{array}$ & MRD & MRDadf \\
\hline Endosulfan sulfate & $0.0398 \mu \mathrm{g} / \mathrm{L}$ & 0 & - & - & 1 & 76.61 & 42.59 \\
\hline Ethylbenzene & $1.0 \mu \mathrm{g} / \mathrm{L}$ & 0 & - & - & 1 & 0.00 & 0.00 \\
\hline Fluoranthene & $10.0 \mu \mathrm{g} / \mathrm{L}$ & 0 & - & - & 1 & 0.00 & 0.00 \\
\hline Fluorene & $10.0 \mu \mathrm{g} / \mathrm{L}$ & 0 & - & - & 1 & 0.00 & 0.00 \\
\hline Hexachlorobenzene & $10.0 \mu \mathrm{g} / \mathrm{L}$ & 0 & - & - & 1 & 0.00 & 0.00 \\
\hline Hexachlorobutadiene & $10.0 \mu \mathrm{g} / \mathrm{L}$ & 0 & - & $\cdot$ & 1 & 0.00 & 0.00 \\
\hline Hexachlorocyclopentadiene & $10.0 \mu \mathrm{g} / \mathrm{L}$ & 0 & - & - & 1 & 0.00 & 0.00 \\
\hline Hexachloroethane & $10.0 \mu \mathrm{g} / \mathrm{L}$ & 0 & - & - & 1 & 0.00 & 0.00 \\
\hline 2-Hexanone & $t$ & 0 & - & - & 0 & - & - \\
\hline Indeno[1,2,3-c,d]pyrene & $10.0 \mu \mathrm{g} / \mathrm{L}$ & 0 & - & - & 1 & 0.00 & 0.00 \\
\hline Iron & $50.0 \mu \mathrm{g} / \mathrm{L}$ & 1 & 0.00 & 0.00 & 2 & 23.16 & 18.77 \\
\hline Isophorone & $10.0 \mu \mathrm{g} / \mathrm{L}$ & 0 & - & - & 1 & 0.00 & 0.00 \\
\hline Lead & $5.0 \mu \mathrm{g} / \mathrm{L}$ & 1 & 0.00 & 0.00 & 6 & 3.50 & 1.90 \\
\hline Lithium & $2.0 \mu \mathrm{g} / \mathrm{L}$ & 0 & - & - & 1 & 9.20 & 3.08 \\
\hline Magnesium & $10.0 \mu \mathrm{g} / \mathrm{L}$ & 1 & 0.00 & 0.00 & 2 & 5.01 & 5.01 \\
\hline Manganese & $10.0 \mu \mathrm{g} / \mathrm{L}$ & 1 & 0.00 & 0.00 & 2 & 9.25 & 6.14 \\
\hline Mercury & $0.2 \mu \mathrm{g} / \mathrm{L}$ & 3 & 11.88 & 8.27 & 9 & 2.63 & 2.63 \\
\hline 2-Methyl-4,6-dinitrophenol & $10.0 \mu \mathrm{g} / \mathrm{L}$ & 0 & - & - & 1 & 0.00 & 0.00 \\
\hline 2-Methylnaphthalene & $10.0 \mu \mathrm{g} / \mathrm{L}$ & 0 & - & - & 1 & 0.00 & 0.00 \\
\hline Naphthalene & $10.0 \mu \mathrm{g} / \mathrm{L}$ & 0 & - & - & 1 & 0.00 & 0.00 \\
\hline Nickel & $5.0 \mu \mathrm{g} / \mathrm{L}$ & 1 & 0.00 & 0.00 & 2 & 10.13 & 10.13 \\
\hline Nitrate as nitrogen & $t$ & 1 & 1.68 & 1.68 & 1 & 15.53 & 15.53 \\
\hline Nitrate-nitrite as nitrogen & $90.0 \mu \mathrm{g} / \mathrm{L}$ & 27 & 1.17 & 1.17 & 12 & 18.49 & 15.92 \\
\hline m-Nitroaniline & $10.0 \mu \mathrm{g} / \mathrm{L}$ & 0 & - & - & 1 & 0.00 & 0.00 \\
\hline o-Nitroaniline & $10.0 \mu \mathrm{g} / \mathrm{L}$ & 0 & - & - & 1 & 0.00 & 0.00 \\
\hline p-Nitroaniline & $10.0 \mu \mathrm{g} / \mathrm{L}$ & 0 & - & - & 1 & 0.00 & 0.00 \\
\hline Nitrobenzene & $10.0 \mu \mathrm{g} / \mathrm{L}$ & 0 & - & - & 1 & 0.00 & 0.00 \\
\hline 2-Nitrophenol & $10.0 \mu \mathrm{g} / \mathrm{L}$ & 0 & - & - & 1 & 0.00 & 0.00 \\
\hline N-Nitrosodiphenylamine & $10.0 \mu \mathrm{g} / \mathrm{L}$ & 0 & - & - & 1 & 0.00 & 0.00 \\
\hline $\mathrm{pH}$ & $t$ & 35 & 0.59 & 0.59 & 12 & 1.05 & 1.05 \\
\hline Phenanthrene & $10.0 \mu \mathrm{g} / \mathrm{L}$ & 0 & - & - & 1 & 0.00 & 0.00 \\
\hline Potassium & $100 \mu \mathrm{g} / \mathrm{L}$ & 1 & 0.00 & 0.00 & 2 & 25.93 & 25.93 \\
\hline Sodium & $100 \mu \mathrm{g} / \mathrm{L}$ & 1 & 0.00 & 0.00 & 2 & 6.74 & 6.74 \\
\hline Specific conductance & $5.0 \mu \mathrm{S} / \mathrm{cm}$ & 27 & 0.41 & 0.41 & 12 & 19.66 & 19.66 \\
\hline Styrene & $t$ & 0 & - & - & 0 & - & - \\
\hline Sulfate & $384 \mu \mathrm{g} / \mathrm{L}$ & 2 & 3.17 & 1.72 & 1 & 23.04 & 7.81 \\
\hline 1,1,2,2-Tetrachloroethane & $1.0 \mu \mathrm{g} / \mathrm{L}$ & 0 & - & - & 1 & 0.00 & 0.00 \\
\hline Tetrachloroethylene & $1.26 \mu \mathrm{g} / \mathrm{L}$ & 0 & - & - & 1 & 39.68 & 39.68 \\
\hline Toluene & $1.0 \mu \mathrm{g} / \mathrm{L}$ & 0 & - & $\cdot$ & 1 & 122.00 & 122.00 \\
\hline Total dissolved solids & $28,000 \mu \mathrm{g} / \mathrm{L}$ & 3 & 0.29 & 0.29 & 1 & 23.11 & 15.54 \\
\hline Total organic carbon & $5,000 \mu \mathrm{g} / \mathrm{L}$ & 2 & 0.00 & 0.00 & 1 & 0.00 & 0.00 \\
\hline Total organic halogens & $10.0 \mu \mathrm{g} / \mathrm{L}$ & 2 & 0.00 & 0.00 & 1 & $\mathbf{3 3 . 7 7}$ & 33.77 \\
\hline 1,1,1-Trichloroethane & $1.0 \mu \mathrm{g} / \mathrm{L}$ & 0 & - & - & 1 & 0.00 & 0.00 \\
\hline 1,1,2-Trichloroethane & $1.0 \mu \mathrm{g} / \mathrm{L}$ & 0 & - & - & 1 & 0.00 & 0.00 \\
\hline Trichloroethylene & $1.0 \mu \mathrm{g} / \mathrm{L}$ & 0 & - & - & 1 & 24.44 & 24.44 \\
\hline Trichlorofluoromethane & $1.0 \mu \mathrm{g} / \mathrm{L}$ & 0 & - & - & 1 & 0.00 & 0.00 \\
\hline
\end{tabular}




\begin{tabular}{|c|c|c|c|c|c|c|c|}
\hline Analyte & $R D L$ & $\begin{array}{l}\text { In-house Du } \\
\text { Number of } \\
\text { Dup. Pairs }\end{array}$ & $\frac{\text { icates }}{\text { MRD }}$ & MRDadj & $\begin{array}{l}\text { Blind Replic } \\
\text { Number of } \\
\text { Dup. Pairs }\end{array}$ & MRD & MRDadj \\
\hline 2,4,5-Trichlorophenol & $10.0 \mu \mathrm{g} / \mathrm{L}$ & 0 & - & - & 1 & 0.00 & 0.00 \\
\hline 2,4,6-Trichlorophenol & $10.0 \mu \mathrm{g} / \mathrm{L}$ & 0 & - & - & 1 & 0.00 & 0.00 \\
\hline Xylenes & $1.0 \mu \mathrm{g} / \mathrm{L}$ & 0 & - & - & 1 & 0.00 & .0 .00 \\
\hline Zinc & $6.83 \mu \mathrm{g} / \mathrm{L}$ & 1 & 0.00 & 0.00 & 2 & 9.09 & 9.09 \\
\hline
\end{tabular}

$\dagger$ No detection limit, or no replicate or duplicate results below detection limit.

- No replicate or duplicate analyses could be calculated.

Note: An MRD of 0.00 indicates no difference between any of the pairs of results used in calculating the MRD. MRD results greater than or equal to 20 appear in bold.

Table 28. Intralaboratory MRD Matrix Spike Indices for GE

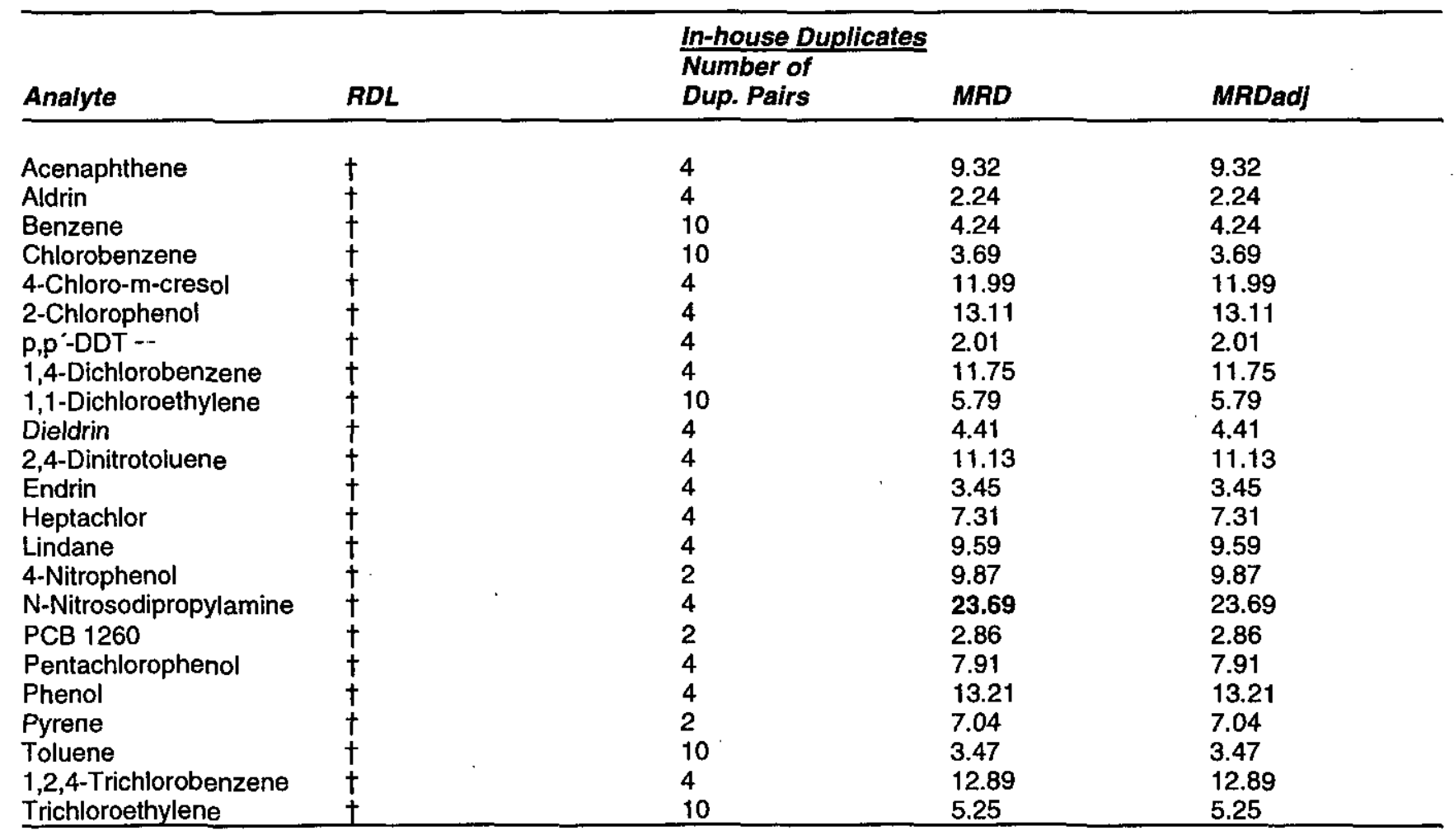

† No detection limit, or no replicate or duplicate results below detection limit.

Note: An MRD of 0.00 indicates no difference between any of the pairs of results used in calculating the MRD. MRD results greater than or equal to 20 appear in bold. 


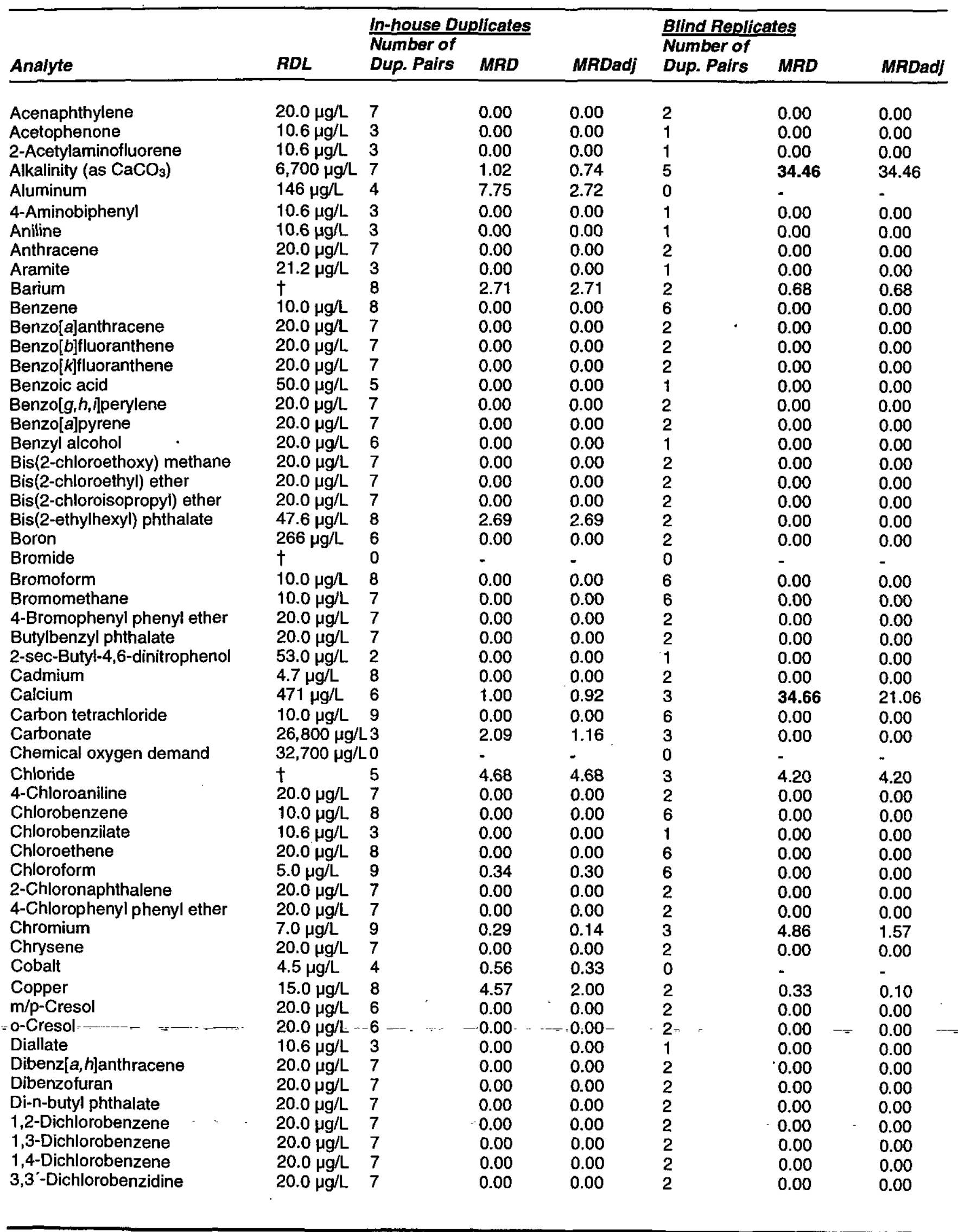




\begin{tabular}{|c|c|c|c|c|c|c|c|}
\hline Analyte & $R D L$ & $\begin{array}{l}\text { In-house Du } \\
\text { Number of } \\
\text { Dup. Pairs }\end{array}$ & $\begin{array}{l}\text { olicates } \\
\text { MRD }\end{array}$ & MRDadj & $\begin{array}{l}\text { Blind Replic } \\
\text { Number of } \\
\text { Dup. Pairs }\end{array}$ & $\frac{\text { tes }}{M R D}$ & MRDadj \\
\hline 1,1-Dichloroethane & $10.0 \mu \mathrm{g} / \mathrm{L}$ & 7 & 0.00 & 0.00 & 6 & 0.00 & 0.00 \\
\hline 1,1-Dichloroethylene & $10.0 \mu \mathrm{g} / \mathrm{L}$ & 8 & 0.00 & 0.00 & 6 & 0.00 & 0.00 \\
\hline Dichloromethane & $10.5 \mu \mathrm{g} / \mathrm{L}$ & 7 & 0.00 & 0.00 & 6 & 0.00 & 0.00 \\
\hline 2,4-Dichlorophenol & $20.0 \mu \mathrm{g} / \mathrm{L}$ & 6 & 0.00 & 0.00 & 2 & 0.00 & 0.00 \\
\hline 2,6-Dichlorophenol & $10.6 \mu g / L$ & 2 & 0.00 & 0.00 & 1 & 0.00 & 0.00 \\
\hline Diethyl phthalate & $20.0 \mu \mathrm{g} / \mathrm{L}$ & 7 & 0.00 & 0.00 & 2 & 0.00 & 0.00 \\
\hline 2,4-Dimethyl phenol & $20.0 \mu \mathrm{g} / \mathrm{L}$ & 6 & 0.00 & 0.00 & 2 & 0.00 & 0.00 \\
\hline Dimethyl phthalate & $20.0 \mu \mathrm{g} / \mathrm{L}$ & 7 & 0.00 & 0.00 & 2 & 0.00 & 0.00 \\
\hline p-Dimethylaminoazobenzene & $10.6 \mu \mathrm{g} / \mathrm{L}$ & 3 & 0.00 & 0.00 & $\overline{1}$ & 0.00 & 0.00 \\
\hline 7,12-Dimethylbenz[a]anthracene & $10.6 \mu \mathrm{g} / \mathrm{L}$ & 3 & 0.00 & 0.00 & 1 & 0.00 & 0.00 \\
\hline 3,3'-Dimethylbenzidine & $10.6 \mu \mathrm{g} / \mathrm{L}$ & 3 & 0.00 & 0.00 & 1 & 0.00 & 0.00 \\
\hline a,a-Dimethylphenethylamine & $10.6 \mu \mathrm{g} / \mathrm{L}$ & 3 & 0.00 & 0.00 & 1 & 0.00 & 0.00 \\
\hline 1,3-Dinitrobenzene & $10.6 \mu \mathrm{g} / \mathrm{L}$ & 3 & 0.00 & 0.00 & 1 & 0.00 & 0.00 \\
\hline 2,4-Dinitrophenol & $50.0 \mu \mathrm{g} / \mathrm{L}$ & 6 & 0.00 & 0.00 & 2 & 0.00 & 0.00 \\
\hline 2,6-Dinitrotoluene & $20.0 \mu \mathrm{g} / \mathrm{L}$ & 7 & 0.00 & 0.00 & 2 & 0.00 & 0.00 \\
\hline Di-n-octyl phthalate & $20.0 \mu \mathrm{g} / \mathrm{L}$ & 7 & 0.00 & 0.00 & 2 & 0.00 & 0.00 \\
\hline 1,4-Dioxane & $10.6 \mu \mathrm{g} / \mathrm{L}$ & 3 & 0.00 & 0.00 & 1 & 0.00 & 0.00 \\
\hline Diphenylamine & $10.6 \mu \mathrm{g} / \mathrm{L}$ & 3 & 0.00 & 0.00 & 1 & 0.00 & 0.00 \\
\hline Endosulfan sulfate & $0.213 \mu g / L$ & 4 & 0.00 & 0.00 & 1 & 0.00 & 0.00 \\
\hline Ethyl methacrylate & $10.6 \mu \mathrm{g} / \mathrm{L}$ & 3 & 0.00 & 0.00 & 1 & 0.00 & 0.00 \\
\hline Ethyl methanesulfonate & $10.6 \mu \mathrm{g} / \mathrm{L}$ & 3 & 0.00 & 0.00 & 1 & 0.00 & 0.00 \\
\hline Ethylbenzene & $10.0 \mu \mathrm{g} / \mathrm{L}$ & 9 & 0.00 & 0.00 & 6 & 0.00 & 0.00 \\
\hline Fluoranthene & $20.0 \mu \mathrm{g} / \mathrm{L}$ & 7 & 0.00 & 0.00 & 2 & 0.00 & 0.00 \\
\hline Fluorene & $20.0 \mu \mathrm{g} / \mathrm{L}$ & 7 & 0.00 & 0.00 & 2 & 0.00 & 0.00 \\
\hline Hexachlorobenzene & $20.0 \mu \mathrm{g} / \mathrm{L}$ & 7 & 0.00 & 0.00 & 2 & 0.00 & 0.00 \\
\hline Hexachlorobutadiene & $20.0 \mu \mathrm{g} / \mathrm{L}$ & 7 & 0.00 & 0.00 & 2 & 0.00 & 0.00 \\
\hline Hexachlorocyclopentadiene & $20.0 \mu \mathrm{g} / \mathrm{L}$ & 7 & 0.00 & 0.00 & 2 & 0.00 & 0.00 \\
\hline Hexachloroethane & $20.0 \mu \mathrm{g} / \mathrm{L}$ & 7 & 0.00 & 0.00 & 2 & 0.00 & 0.00 \\
\hline Hexachlorophene & $106 \mu \mathrm{g} / \mathrm{L}$ & 3 & 0.00 & 0.00 & 1 & 0.00 & 0.00 \\
\hline Hexachloropropene & $10.6 \mu \mathrm{g} / \mathrm{L}$ & 3 & 0.00 & 0.00 & 1 & 0.00 & 0.00 \\
\hline 2-Hexanone & $10.0 \mu \mathrm{g} / \mathrm{L}$ & 2 & 0.00 & 0.00 & 0 & - & - \\
\hline Indeno[1,2,3-c, d]pyrene & $20.0 \mu \mathrm{g} / \mathrm{L}$ & 7 & 0.00 & 0.00 & 2 & 0.00 & 0.00 \\
\hline Iron & $74.0 \mu \mathrm{g} / \mathrm{L}$ & 6 & 2.18 & 2.17 & 3 & 37.26 & 37.26 \\
\hline Isophorone & $20.0 \mu \mathrm{g} / \mathrm{L}$ & 7 & 0.00 & 0.00 & 2 & 0.00 & 0.00 \\
\hline Isosafrole & $10.6 \mu \mathrm{g} / \mathrm{L}$ & 3 & 0.00 & 0.00 & 1 & 0.00 & 0.00 \\
\hline Lead & $47.0 \mu \mathrm{g} / \mathrm{L}$ & 8 & 0.00 & 0.00 & 2 & 0.00 & 0.00 \\
\hline Lithium & $12.6 \mu \mathrm{g} / \mathrm{L}$ & 6 & 0.37 & 0.16 & 2 & 0.00 & 0.00 \\
\hline Magnesium & $t$ & 6 & 1.69 & 1.69 & 3 & 3.67 & 3.67 \\
\hline Manganese & $7.8 \mu \mathrm{g} / \mathrm{L}$ & 5 & 1.37 & 1.07 & 1 & 0.69 & 0.69 \\
\hline Mercury & $0.7 \mu \mathrm{g} / \mathrm{L}$ & 8 & 0.13 & 0.13 & 2 & 0.00 & 0.00 \\
\hline Methapyrilene & $10.6 \mu \mathrm{g} / \mathrm{L}$ & 3 & 0.00 & 0.00 & $\overline{1}$ & 0.00 & 0.00 \\
\hline 2-Methyl-4,6-dinitrophenol & $50.0 \mu \mathrm{g} / \mathrm{L}$ & 6 & 0.00 & 0.00 & 2 & 0.00 & 0.00 \\
\hline Methyl methacrylate & $10.6 \mu \mathrm{g} / \mathrm{L}$ & 3 & 0.00 & 0.00 & 1 & 0.00 & 0.00 \\
\hline Methyl methanesulfonate & $10.6 \mu \mathrm{g} / \mathrm{L}$ & 3 & 0.00 & 0.00 & 1 & 0.00 & 0.00 \\
\hline 3-Methylcholanthrene & $10.6 \mu \mathrm{g} / \mathrm{L}$ & 3 & 0.00 & 0.00 & 1 & 0.00 & 0.00 \\
\hline 2-Methylnaphthalene & $20.0 \mu \mathrm{g} / \mathrm{L}$ & 7 & 0.00 & 0.00 & 2 & 0.00 & 0.00 \\
\hline Naphthalene & $20.0 \mu \mathrm{g} / \mathrm{L}$ & 7 & 0.00 & 0.00 & 2 & 0.00 & 0.00 \\
\hline 1,4-Naphthoquinone & $10.6 \mu \mathrm{g} / \mathrm{L}$ & 3 & 0.00 & 0.00 & $\overline{1}$ & 0.00 & 0.00 \\
\hline 1-Naphthylamine & $10.6 \mu \mathrm{g} / \mathrm{L}$ & 3 & 0.00 & 0.00 & 1 & 0.00 & 0.00 \\
\hline 2-Naphthylamine & $10.6 \mu \mathrm{g} / \mathrm{L}$ & 3 & 0.00 & 0.00 & 1 & 0.00 & 0.00 \\
\hline Nickel & $85.8 \mu \mathrm{g} / \mathrm{L}$ & 8 & 0.50 & 0.19 & 1 & 0.00 & 0.00 \\
\hline Nitrate as nitrogen & $\dagger$ & 4 & 21.38 & 21.38 & 3 & 5.91 & 5.91 \\
\hline Nitrate-nitrite as nitrogen & $20.0 \mu \mathrm{g} / \mathrm{L}$ & 5 & 2.86 & 1.92 & 0 & - & - \\
\hline m-Nitroaniline & $50.0 \mu \mathrm{g} / \mathrm{L}$ & 7 & 0.00 & 0.00 & 2 & 0.00 & 0.00 \\
\hline o-Nitroaniline & $50.0 \mu \mathrm{g} / \mathrm{L}$ & 7 & 0.00 & 0.00 & 2 & 0.00 & 0.00 \\
\hline p-Nitroaniline & $50.0 \mu \mathrm{g} / \mathrm{L}$ & 7 & 0.00 & 0.00 & 2 & 0.00 & 0.00 \\
\hline Nitrobenzene & $20.0 \mu \mathrm{g} / \mathrm{L}$ & 7 & 0.00 & 0.00 & 2 & 0.00 & 0.00 \\
\hline 2-Nitrophenol & $20.0 \mu \mathrm{g} / \mathrm{L}$ & 6 & 0.00 & 0.00 & 2 & 0.00 & 0.00 \\
\hline 4-Nitroquinoline-1-oxide & $21.2 \mu \mathrm{g} / \mathrm{L}$ & 3 & 0.00 & 0.00 & 1 & 0.00 & 0.00 \\
\hline N-Nitrosodi- $n$-butylamine & $10.6 \mu \mathrm{g} / \mathrm{L}$ & 3 & 0.00 & 0.00 & 1 & 0.00 & 0.00 \\
\hline
\end{tabular}




\begin{tabular}{|c|c|c|c|c|c|c|c|}
\hline Analyte & $R D L$ & \multicolumn{3}{|c|}{$\begin{array}{l}\text { In-house Duplicates } \\
\text { Number of }\end{array}$} & \multicolumn{2}{|c|}{ Blind Replicates } & MRDadf \\
\hline N-Nitrosodiethylamine & $10.6 \mu \mathrm{g} / \mathrm{L}$ & 3 & 0.00 & 0.00 & 1 & 0.00 & 0.00 \\
\hline $\mathrm{N}$-Nitrosodimethylamine & $10.6 \mu \mathrm{g} / \mathrm{L}$ & 3 & 0.00 & 0.00 & 1 & 0.00 & 0.00 \\
\hline N-Nitrosodiphenylamine & $20.0 \mu \mathrm{g} / \mathrm{L}$ & 7 & 0.00 & 0.00 & 2 & 0.00 & 0.00 \\
\hline $\mathrm{N}$-Nitrosomethylethylamine & $10.6 \mu g / L$ & 3 & 0.00 & 0.00 & 1 & 0.00 & 0.00 \\
\hline $\mathrm{N}$-Nitrosomorpholine & $10.6 \mu \mathrm{g} / \mathrm{L}$ & 3 & 0.00 & 0.00 & 1 & 0.00 & 0.00 \\
\hline N-Nitrosopiperidine & $53.0 \mu \mathrm{g} / \mathrm{L}$ & 3 & 0.00 & 0.00 & 1 & 0.00 & 0.00 \\
\hline N-Nitrosopyrrolidine & $10.6 \mu \mathrm{g} / \mathrm{L}$ & 3 & 0.00 & 0.00 & 1 & 0.00 & 0.00 \\
\hline 5-Nitro-o-toluidine & $10.6 \mu \mathrm{g} / \mathrm{L}$ & 3 & 0.00 & 0.00 & 1 & 0.00 & 0.00 \\
\hline Pentachlorobenzene & $10.6 \mu \mathrm{g} / \mathrm{L}$ & 3 & 0.00 & 0.00 & 1 & 0.00 & 0.00 \\
\hline Pentachloroethane & $10.6 \mu \mathrm{g} / \mathrm{L}$ & 3 & 0.00 & 0.00 & 1 & 0.00 & 0.00 \\
\hline Pentachloronitrobenzene & $53.0 \mu \mathrm{g} / \mathrm{L}$ & 3 & 0.00 & 0.00 & 1 & 0.00 & 0.00 \\
\hline $\mathrm{pH}$ & $t$ & 6 & 0.37 & 0.37 & 0 & - & - \\
\hline Phenacetin & $10.6 \mu \mathrm{g} / \mathrm{L}$ & 3 & 0.00 & 0.00 & 1 & 0.00 & 0.00 \\
\hline Phenanthrene & $20.0 \mu \mathrm{g} / \mathrm{L}$ & 7 & 0.00 & 0.00 & 2 & 0.00 & 0.00 \\
\hline p-Phenylenediamine & $10.6 \mu \mathrm{g} / \mathrm{L}$ & 3 & 0.00 & 0.00 & 1 & 0.00 & 0.00 \\
\hline 2-Picoline & $10.6 \mu \mathrm{g} / \mathrm{L}$ & 3 & 0.00 & 0.00 & 1 & 0.00 & 0.00 \\
\hline Potassium & $253 \mu g / L$ & 4 & 2.14 & 1.54 & 0 & - & - \\
\hline Pronamid & $10.6 \mu \mathrm{g} / \mathrm{L}$ & 3 & 0.00 & 0.00 & 1 & 0.00 & 0.00 \\
\hline Pyridine & $10.6 \mu \mathrm{g} / \mathrm{L}$ & 3 & 0.00 & 0.00 & 1 & 0.00 & 0.00 \\
\hline Safrole & $10.6 \mu \mathrm{g} / \mathrm{L}$ & 3 & 0.00 & 0.00 & 1 & 0.00 & 0.00 \\
\hline Silica & $\dagger$ & 4 & 1.10 & 1.10 & 3 & 10.45 & 10.45 \\
\hline Sodium & $\dot{t}$ & 6 & 3.40 & 3.40 & 3 & 13.77 & 13.77 \\
\hline Specific conductance & $t$ & 4 & 1.17 & 1.17 & 0 & - & - \\
\hline Styrene & $5.0 \mu \mathrm{g} / \mathrm{L}$ & 2 & 0.00 & 0.00 & 0 & - & - \\
\hline Sulfate & $t$ & 9 & 9.58 & 9.58 & 5 & 24.90 & 24.90 \\
\hline t,2,4,5-Tetrachlorobenzen $\theta$ & $10.6 \mu \mathrm{g} / \mathrm{L}$ & 3 & 0.00 & 0.00 & 1 & 0.00 & 0.00 \\
\hline $1,1,2,2$-Tetrachloroethane & $10.0 \mu \mathrm{g} / \mathrm{L}$ & 8 & 0.00 & 0.00 & 6 & 0.00 & 0.00 \\
\hline $\begin{array}{l}\text { Tetrachloroethylene } \\
\text { Then }\end{array}$ & $10.0 \mu \mathrm{g} / \mathrm{L}$ & 9 & 0.00 & 0.00 & 6 & 0.00 & 0.00 \\
\hline $2,3,4,6$-Tetrachlorophenol & $10.6 \mu \mathrm{g} / \mathrm{L}$ & 2 & 0.00 & 0.00 & 1 & 0.00 & 0.00 \\
\hline Toluene & $5.0 \mu \mathrm{g} / \mathrm{L}$ & 9 & 0.00 & 0.00 & 6 & 0.00 & 0.00 \\
\hline o-Toluidine & $10.6 \mu \mathrm{g} / \mathrm{L}$ & 3 & 0.00 & 0.00 & 1 & 0.00 & 0.00 \\
\hline Total dissolved solids & $47,000 \mu \mathrm{g} /$ & $L 9$ & 2.13 & 1.13 & 5 & 21.70 & 12.13 \\
\hline Total organic carbon & $1,110 \mu \mathrm{g} / \mathrm{L}$ & 7 & 6.77 & 6.77 & 5 & 4.16 & 1.55 \\
\hline Total organic halogens & $120 \mu \mathrm{g} / \mathrm{L}$ & 10 & 0.00 & 0.00 & 8 & 0.00 & 0.00 \\
\hline Total phosphates (as P) & $67.0 \mu \mathrm{g} / \mathrm{L}$ & 3 & 0.00 & 0.00 & 3 & 109.76 & 104.43 \\
\hline 1,1,1-Trichloroethane & $10.0 \mu \mathrm{g} / \mathrm{L}$ & 9 & 0.00 & 0.00 & 6 & 0.00 & 0.00 \\
\hline 1,1,2-Trichloroethane & $10.0 \mu \mathrm{g} / \mathrm{L}$ & 8 & 0.00 & 0.00 & 6 & 0.00 & 0.00 \\
\hline Trichloroethylene & $5.0 \mu \mathrm{g} / \mathrm{L}$ & 9 & 0.75 & 0.75 & 6 & 5.55 & 1.98 \\
\hline Trichlorofluoromethane & $50.0 \mu \mathrm{g} / \mathrm{L}$ & 6 & 0.00 & 0.00 & 6 & 0.00 & 0.00 \\
\hline $2,4,5$-Trichlorophenol & $50.0 \mu \mathrm{g} / \mathrm{L}$ & 6 & 0.00 & 0.00 & 2 & 0.00 & 0.00 \\
\hline 2,4,6-Trichlorophenol & $20.0 \mu \mathrm{g} / \mathrm{L}$ & 6 & 0.00 & 0.00 & 2 & 0.00 & 0.00 \\
\hline 1,3,5-Trinitrobenzene & $10.6 \mu \mathrm{g} / \mathrm{L}$ & 3 & 0.00 & 0.00 & 1 & 0.00 & 0.00 \\
\hline Xylenes & $5.0 \mu \mathrm{g} / \mathrm{L}$ & 8 & 0.00 & 0.00 & 6 & 0.00 & 0.00 \\
\hline Zinc & $53.0 \mu \mathrm{g} / \mathrm{L}$ & 8 & 0.12 & 0.04 & 2 & 0.00 & 0.00 \\
\hline
\end{tabular}

† No detection limit, or no replicate or duplicate results below detection limit.

- No replicate or duplicate analyses could be calculated.

Note: An MRD of $0: 00$ indicates no difference between any of the pairs of results used in calculating the MRD. MRD results - $=$ greater than or equal to 20 appear in bold. 
Table 30. Intralaboratory MRD Indices for GP

\begin{tabular}{|c|c|c|c|c|c|c|c|}
\hline Analyte & $R D L$ & $\begin{array}{l}\text { In-house Du } \\
\text { Number of } \\
\text { Dup. Pairs }\end{array}$ & MRD & MRDadj & $\begin{array}{l}\text { Blind Replic } \\
\text { Number of } \\
\text { Dup. Palrs }\end{array}$ & MRD & MRDadj \\
\hline Actinium-228 & $\begin{array}{r}1.57 \mathrm{E}-08 \\
\mu \mathrm{Ci} / \mathrm{mL}\end{array}$ & 4 & 0.00 & 0.00 & 0 & - & - \\
\hline Americium-241 & $\begin{array}{r}6.03 \mathrm{E}-10 \\
\mu \mathrm{Ci} / \mathrm{mL}\end{array}$ & 3 & 0.00 & 0.00 & 1 & 0.00 & 0.00 \\
\hline Carbon-14 & $\begin{array}{r}1.55 \mathrm{E}-08 \\
\mu \mathrm{Ci} / \mathrm{mL}\end{array}$ & 7 & 17.62 & 11.22 & 2 & 30.96 & 13.45 \\
\hline Gross alpha & $\begin{array}{r}1.25 \mathrm{E}-09 \\
\mu \mathrm{Ci} / \mathrm{mL}\end{array}$ & 28 & 11.29 & 7.64 & 15 & 5.21 & 2.09 \\
\hline lodine-129 & $t$ & 2 & 16.16 & 16.16 & 0 & - & - \\
\hline Neptunium-237 & $\begin{array}{r}2.51 \mathrm{E}-10 \\
\mu \mathrm{Ci} / \mathrm{mL}\end{array}$ & 1 & 0.00 & 0.00 & 0 & - & - \\
\hline Nonvolatile beta & $\begin{array}{l}1.6 \mathrm{E}-09 \\
\mu \mathrm{Ci} / \mathrm{mL}\end{array}$ & 27 & 11.23 & 7.89 & 15 & 10.83 & 8.89 \\
\hline Promethium-147 & $\begin{array}{r}1.42 \mathrm{E}-09 \\
\mu \mathrm{Ci} / \mathrm{mL}\end{array}$ & 1 & 0.00 & 0.00 & 1 & 0.00 & 0.00 \\
\hline $\begin{array}{l}\text { Radium, total alpha- } \\
\text { emitting }\end{array}$ & $\begin{array}{r}5.09 \mathrm{E}-10 \\
\mu \mathrm{Ci} / \mathrm{mL}\end{array}$ & 4 & 17.98 & 7.10 & 1 & 17.15 & 5.63 \\
\hline Radium-226 & $\begin{array}{r}6.69 \mathrm{E}-10 \\
\mu \mathrm{Ci} / \mathrm{mL}\end{array}$ & 2 & 2.23 & 2.23 & 0 & - & - \\
\hline Radium-228 & $\begin{array}{r}1.42 \mathrm{E}-09 \\
\mu \mathrm{Ci} / \mathrm{mL}\end{array}$ & 2 & 7.69 & 3.91 & 0 & - & - \\
\hline Strontium-89/90 & $t$ & 1 & 5.53 & 5.53 & 0 & - & - \\
\hline Strontium-90 & $\begin{array}{r}1.35 \mathrm{E}-09 \\
\mu \mathrm{Ci} / \mathrm{mL}\end{array}$ & 4 & 1.80 & 1.80 & 2 & 0.00 & 0.00 \\
\hline Technetium-99 & $\begin{array}{r}\text { 2.42E-08 } \\
\mu \mathrm{Ci} / \mathrm{mL}\end{array}$ & 3 & 8.86 & 4.55 & 1 & 0.00 & 0.00 \\
\hline Thorium-230 & $\begin{array}{r}3.01 \mathrm{E}-10 \\
\mu \mathrm{Ci} / \mathrm{mL}\end{array}$ & 2 & 52.15 & 32.69 & 0 & - & - \\
\hline Tritium & $\begin{array}{r}7.12 \mathrm{E}-07 \\
\mu \mathrm{Ci} / \mathrm{mL}\end{array}$ & 21 & 3.56 & 3.45 & 14 & 18.60 & 11.32 \\
\hline Uranium-233/234 & $\begin{array}{r}3.39 \mathrm{E}-10 \\
\mu \mathrm{Ci} / \mathrm{mL}\end{array}$ & 3 & 26.25 & 15.76 & 0 & - & - \\
\hline Uranium-238 & $\begin{array}{r}3.02 \mathrm{E}-10 \\
\mu \mathrm{Ci} / \mathrm{mL}\end{array}$ & 3 & 2.99 & 0.96 & 0 & - & - \\
\hline
\end{tabular}

† No detection limit, or no replicate or duplicate results below detection limit.

- No replicate or duplicate analyses could be calculated.

Note: An MRD of 0.00 indicates no difference between any of the pairs of results used in calculating the MRD. MRD results greater than or equal to 20 appear in bold. 
Table 31. Intralaboratory MRD Indices for $T M$

\begin{tabular}{|c|c|c|c|c|c|c|c|}
\hline Analyte & $R D L$ & $\begin{array}{l}\text { In-house } D_{L} \\
\text { Number of } \\
\text { Dup. Pairs }\end{array}$ & $\begin{array}{l}\text { Mates } \\
\text { MRD }\end{array}$ & MRDadj & $\begin{array}{l}\text { Blind Replic } \\
\text { Number of } \\
\text { Dup. Pairs }\end{array}$ & MRD & MRDadj \\
\hline Actinium-228 & $\begin{array}{c}2.819 \mathrm{E}-08 \\
\mu \mathrm{Ci} / \mathrm{mL}\end{array}$ & 4 & 1.94 & 0.61 & 1 & 0.00 & 0.00 \\
\hline Americium-241 & $\begin{array}{l}\text { 8.3E-10 } \\
\mu \mathrm{Ci} / \mathrm{mL}\end{array}$ & 1 & 0.00 & 0.00 & 0 & - & - \\
\hline Carbon-14 & $\begin{array}{l}9.1895 \mathrm{E}-07 \\
\mu \mathrm{Ci} / \mathrm{mL}\end{array}$ & 12 & 0.08 & 0.08 & 2 & 0.00 & 0.00 \\
\hline Gross alpha & $\begin{array}{r}1.63 \mathrm{E}-09 \\
\mu \mathrm{Ci} / \mathrm{mL}\end{array}$ & 47 & 10.89 & 7.48 & 6 & 17.23 & 7.82 \\
\hline lodine-129 & $\begin{array}{c}1.023 \mathrm{E}-08 \\
\mu \mathrm{Ci} / \mathrm{mL}\end{array}$ & 1 & 0.00 & 0.00 & 0 & - & - \\
\hline Neptunium-237 & $\begin{array}{l}\text { 3.1E-10 } \\
\mu \mathrm{Ci} / \mathrm{mL}\end{array}$ & 1 & 0.00 & 0.00 & 0 & - & $\cdot$ \\
\hline Nonvolatile beta & $\begin{array}{l}2.9 \mathrm{E}-09 \\
\mu \mathrm{Ci} / \mathrm{mL}\end{array}$ & 33 & 24.08 & 16.73 & 2 & 0.00 & 0.00 \\
\hline Promethium-147 & $\begin{array}{c}\text { 7.3E-09 } \\
\mu \mathrm{Ci} / \mathrm{mL}\end{array}$ & 1 & 0.00 & 0.00 & 0 & - & - \\
\hline $\begin{array}{l}\text { Radium, total alpha- } \\
\text { emitting }\end{array}$ & $\begin{array}{l}7.5 \mathrm{E}-10 \\
\mu \mathrm{Ci} / \mathrm{mL}\end{array}$ & 14 & 3.76 & 2.14 & 3 & 2.15 & 0.67 \\
\hline Radium-226 & $\begin{array}{l}2.7 \mathrm{E}-10 \\
\mu \mathrm{Ci} / \mathrm{mL}\end{array}$ & 3 & 24.60 & 12.22 & 0 & - & - \\
\hline Radium-228 & $\begin{array}{l}\text { 3.0E-09 } \\
\mu \mathrm{Ci} / \mathrm{mL}\end{array}$ & 3 & 4.37 & 1.53 & 0 & - & - \\
\hline Strontium-90 & $\begin{array}{r}2.47 \mathrm{E}-09 \\
\mu \mathrm{Ci} / \mathrm{mL}\end{array}$ & 12 & 0.00 & 0.00 & 2 & 0.00 & 0.00 \\
\hline Technetium-99 & $\begin{array}{c}1.422 \mathrm{E}-08 \\
\mu \mathrm{Ci} / \mathrm{mL}\end{array}$ & 1 & 0.00 & 0.00 & 0 & - & - \\
\hline Thorium-230 & $\begin{array}{l}\text { 4.3E-10 } \\
\mu \mathrm{Ci} / \mathrm{mL}\end{array}$ & 1 & 0.00 & 0.00 & 0 & - & - \\
\hline Tritium & $\begin{array}{r}1.45 \mathrm{E}-06 \\
\mu \mathrm{Ci} / \mathrm{mL}\end{array}$ & 48 & 6.95 & 4.92 & 8 & 36.15 & 35.90 \\
\hline Uranium-238 & $\begin{array}{c}2.2 \mathrm{E}-10 \\
\mathrm{\mu C \textrm {Ci }} / \mathrm{mL} \\
\end{array}$ & 1 & 0.00 & 0.00 & 0 & - & - \\
\hline
\end{tabular}

- No replicate or duplicate analyses could be calculated.

Note: An MRD of 0.00 indicates no difference between any of the pairs of results used in calculating the MRD. MRD results greater than or equal to 20 appear in bold.

Table 32. Interlaboratory MRD and t-test Results for Analytes with at Least One Pair of Results above the RDL for GE and WA

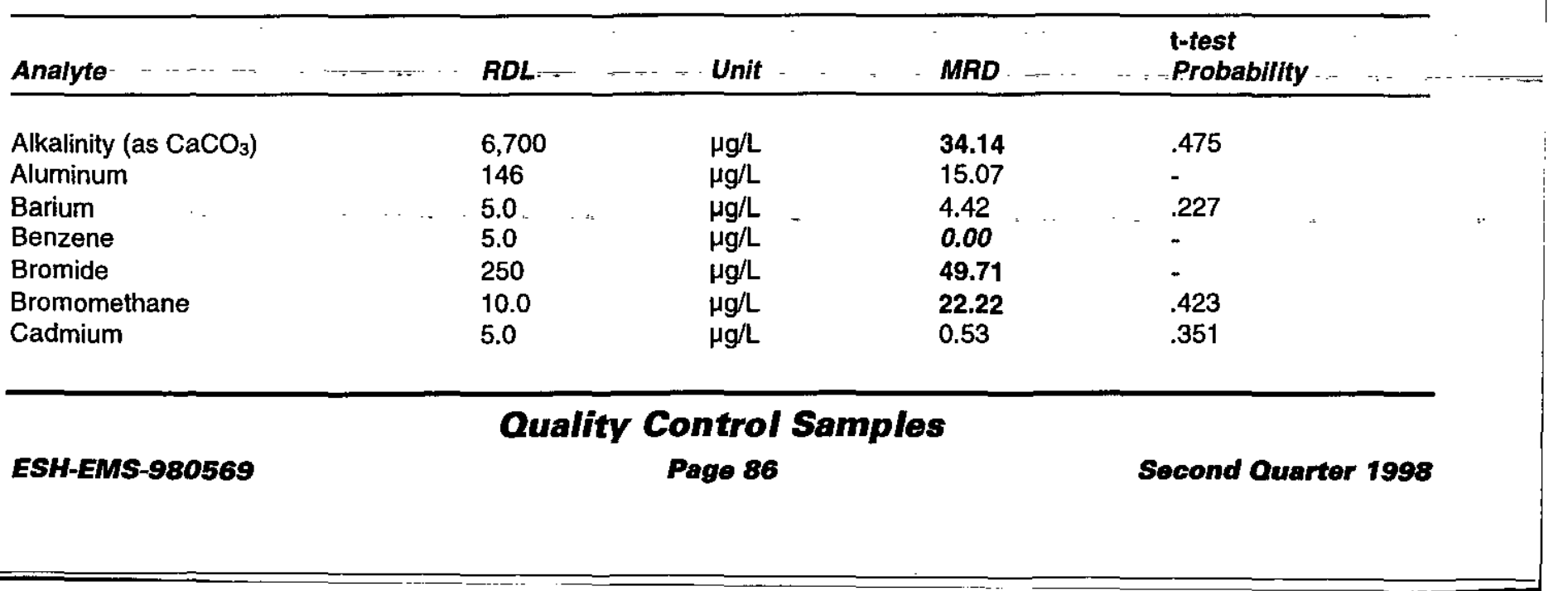




\begin{tabular}{|c|c|c|c|c|}
\hline Analyte & RDL & Unit & $M R D$ & $\begin{array}{l}\text { t-test } \\
\text { Probability }\end{array}$ \\
\hline Calcium & 471 & $\mu g / L$ & 0.78 & - \\
\hline Carbon tetrachloride & 5.0 & $\mu g / L$ & 0.00 & - \\
\hline Chloroform & 5.0 & $\mu g / L$ & 0.76 & .423 \\
\hline Chromium & 7.0 & $\mu g / L$ & 0.00 & - \\
\hline Cobalt & 5.0 & $\mu g / L$ & 0.00 & - \\
\hline Copper & 15.0 & $\mu g / L$ & 10.46 & .419 \\
\hline Iron & 74.0 & $\mu g / L$ & 113.39 & - \\
\hline Lead & 47.0 & $\mu g / L$ & 0.00 & - \\
\hline Lithium & 12.6 & $\mu g / L$ & 0.00 & - \\
\hline Magnesium & 10.0 & $\mu g / L$ & 4.73 & - \\
\hline Manganese & 10.0 & $\mu g / L$ & 1.16 & - \\
\hline Mercury & 0.7 & $\mu g / L$ & 16.70 & .858 \\
\hline Nickel & 85.8 & $\mu g / L$ & 0.00 & - \\
\hline Nitrate-nitrite as nitrogen & 90.0 & $\mu g / L$ & 13.57 & .802 \\
\hline Potassium & 253 & $\mu g / L$ & 19.32 & - \\
\hline Sodium & 100 & $\mu g / L$ & 14.40 & - \\
\hline Specific conductance & 5.0 & $\mu \mathrm{S} / \mathrm{cm}$ & 24.99 & .336 \\
\hline Sulfate & 384 & $\mu g / L$ & 21.39 & .159 \\
\hline Tetrachloroethylene & 5.0 & $\mu g / L$ & 0.00 & - \\
\hline Toluene & 5.0 & $\mu g / L$ & 22.96 & .423 \\
\hline Total dissolved solids & 47,000 & $\mu g / L$ & 63.13 & .460 \\
\hline Total organic carbon & 5,000 & $\mu g / L$ & 34.62 & .423 \\
\hline Total organic halogens & 120 & $\mu g / L$ & 12.80 & .423 \\
\hline Trichloroethylene & 5.0 & $\mu g / L$. & 8.14 & .640 \\
\hline Trichlorofluoromethane & 5.0 & $\mu g / L$ & 0.00 & - \\
\hline Zinc $\quad \ldots$ & 53.0 & $\mu g / L$ & 0.00 & - \\
\hline
\end{tabular}

- Could not calculate because there are no differences between pairs.'

Note: Values less than .050 indicate a probability of less than 1 in 20 that the results for that analyte are the same from both laboratories. MRD results less than or equal to .050 appear in bold italic. MRD results greater than or equal to 20 appear in bold.

Table 33. Interlaboratory MRD and t-test Results for Analytes with at Least One Pair of Results above the RDL for ES and EX

\begin{tabular}{|c|c|c|c|c|}
\hline Analyte & $R D L$ & Unit & $M R D$ & $\begin{array}{l}\text { t-test } \\
\text { Probability }\end{array}$ \\
\hline Aluminum & 100 & $\mu g / L$ & 27.88 & .374 \\
\hline Barium & 6.8 & $\mu g / L$ & 11.73 & .500 \\
\hline Benzene & 250 & $\mu g / L$ & 0.00 & - \\
\hline Carbon tetrachloride & 250 & $\mu g / L$ & 0.00 & - \\
\hline Chlorobenzene & 250 & $\mu g / L$ & 0.00 & - \\
\hline Chloroethene & 250 & $\mu \mathrm{g} / \mathrm{L}$ & 0.00 & - \\
\hline Chloroform & 250 & $\mu g / L$ & 0.00 & - \\
\hline 1,4-Dichlorobenzene & 250 & $\mu g / L$ & 0.00 & - \\
\hline Dichlorodifluoromethane & 250 & $\mu g / L$ & 0.00 & - \\
\hline 1,1-Dichloroethane & 250 & $\mu g / L$ & 0.00 & - \\
\hline 1,1-Dichloroethylene & 250 & $\mu g / L$ & 0.00 & - \\
\hline cis-1,2-Dichloroethylene & 5.0 & $\mu g / L$ & 5.35 & - \\
\hline lodomethane & 250 & $\mu g / L$ & 0.00 & - \\
\hline Iron & 100 & $\mu g / L$ & 7.86 & .366 \\
\hline Lead & 100 & $\mu g / L$ & 0.00 & - \\
\hline
\end{tabular}




\begin{tabular}{|c|c|c|c|c|}
\hline Analyte & $R D L$ & Unit & $M R D$ & $\begin{array}{l}\text { t-test } \\
\text { Probabllity }\end{array}$ \\
\hline Mercury & 0.2 & $\mu g / L$ & 0.00 & - \\
\hline Nitrate as nitrogen & $\begin{array}{l}100 \\
500\end{array}$ & $\mu g / L$ & $\begin{array}{l}0.54 \\
0.00\end{array}$ & .185 \\
\hline Tetrachloroethylene & 50.0 & $\mu g / L$ & 0.00 & - \\
\hline 1,1,1-Trichloroethane & 250 & $\mu g / L$ & 0.00 & - \\
\hline Trichloroethylene & 5.0 & $\mu g / L$ & 33.38 & .252 \\
\hline Trichlorofluoromethane & 1,000 & $\mu g / L$ & 0.00 & - \\
\hline Xylenes & 100 & $\mu g / L$ & 0.00 & - \\
\hline
\end{tabular}

- Could not calculate because there are no differences between pairs.

Note: Values less than .050 indicate a probability of less than 1 in 20 that the results for that analyte are the same from both laboratories. MRD results less than or equal to .050 appear in bold italic. MRD results greater than or equal to 20 appear in bold.

Table 34. Interlaboratory MRD and t-test Results for Analytes with at Least One Pair of Results above the RDL for ES and WA

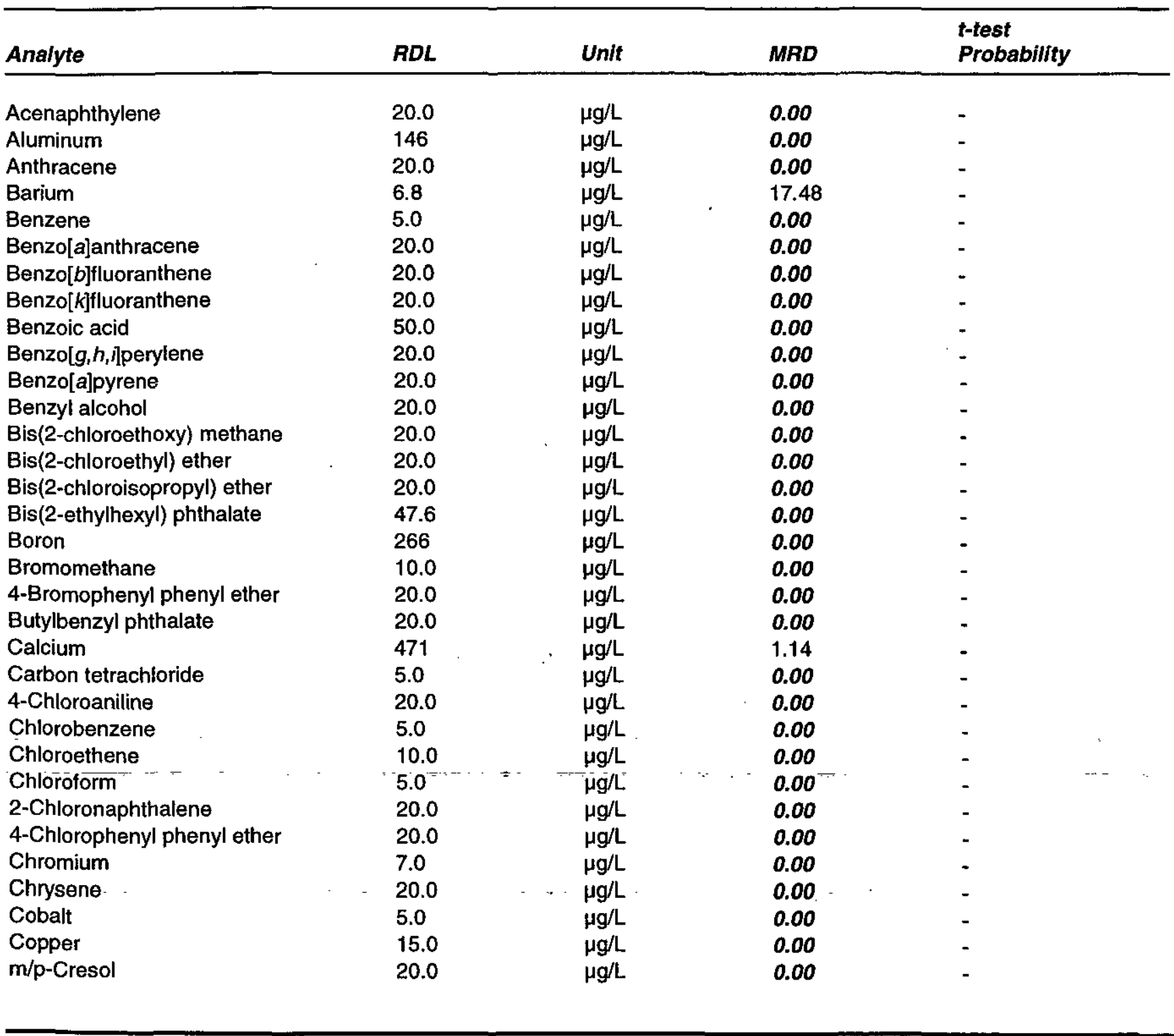




\begin{tabular}{|c|c|c|c|c|}
\hline Analyte & $R D L$ & Unit & $M R D$ & $\begin{array}{l}\text { t-test } \\
\text { Probabillty }\end{array}$ \\
\hline o-Cresol & 20.0 & $\mu g / L$ & 0.00 & - \\
\hline Dibenz $[a, h]$ anthracene & 20.0 & $\mu g / L$ & 0.00 & - \\
\hline Dibenzofuran & 20.0 & $\mu g / L$ & 0.00 & - \\
\hline Di-n-butyl phthalate & 20.0 & $\mu g / L$ & 0.00 & - \\
\hline 1,2-Dichlorobenzene & 20.0 & $\mu g / L$ & 0.00 & - \\
\hline 1,3-Dichlorobenzene & 20.0 & $\mu g / L$ & 0.00 & - \\
\hline 1,4-Dichlorobenzene & 10.6 & $\mu g / L$ & 0.00 & - \\
\hline 3,3'-Dichlorobenzidine & 20.0 & $\mu g / L$ & 0.00 & - \\
\hline 1,1-Dichloroethane & 5.0 & $\mu g / L$ & 0.00 & - \\
\hline 1,1-Dichloroethylene & 5.0 & $\mu g / L$ & 0.00 & - \\
\hline 2,4-Dichlorophenol & 20.0 & $\mu g / L$ & 0.00 & - \\
\hline Diethyl phthalate & 20.0 & $\mu g / L$ & 0.00 & - \\
\hline 2,4-Dimethyl phenol & 20.0 & $\mu g / L$ & 0.00 & - \\
\hline Dimethyl phthalate & 20.0 & $\mu g / L$ & 0.00 & - \\
\hline 2,4-Dinitrophenol & 50.0 & $\mu g / L$ & 0.00 & - \\
\hline 2,6-Dinitrotoluene & 20.0 & $\mu g / L$ & 0.00 & - \\
\hline Di-n-octyl phthalate & 20.0 & $\mu \mathrm{g} / \mathrm{L}$ & 0.00 & - \\
\hline Fluoranthene & 20.0 & $\mu g / L$ & 0.00 & - \\
\hline Fluorene & 20.0 & $\mu g / L$ & 0.00 & - \\
\hline Hexachlorobenzene & 20.0 & $\mu g / L$ & 0.00 & - \\
\hline Hexachlorobutadiene & 20.0 & $\mu g / L$ & 0.00 & - \\
\hline Hexachlorocyclopentadiene & 20.0 & $\mu \mathrm{g} / \mathrm{L}$ & 0.00 & - \\
\hline Hexachloroethane & 20.0 & $\mu g / L$ & 0.00 & - \\
\hline Indeno $[1,2,3-c, d]$ pyrene & 20.0 & $\mu g / L$ & 0.00 & - \\
\hline Iron & 74.0 & $\mu g / L$ & 0.00 & - \\
\hline Isophorone & 20.0 & $\mu g / L$ & 0.00 & - \\
\hline Lead & 47.0 & $\mu g / L$ & 0.00 & - \\
\hline Manganese & 7.8 & $\mu g / L$ & 15.86 & - \\
\hline Mercury & 0.7 & $\mu g / L$ & 0.00 & - \\
\hline 2-Methyl-4,6-dinitrophenol & 50.0 & $\mu g / L$ & 0.00 & - \\
\hline 2-Methylnaphthalene & 20.0 & $\mu g / L$ & 0.00 & - \\
\hline Naphthalene & 20.0 & $\mu g / L$ & 0.00 & - \\
\hline Nickel & 85.8 & $\mu g / L$ & 0.00 & - \\
\hline m-Nitroaniline & 50.0 & $\mu g / L$ & 0.00 & - \\
\hline o-Nitroaniline & 50.0 & $\mu g / L$ & 0.00 & - \\
\hline p-Nitroaniline & 50.0 & $\mu g / L$ & 0.00 & - \\
\hline Nitrobenzene & 20.0 & $\mu g / L$ & 0.00 & - \\
\hline 2-Nitrophenol & 20.0 & $\mu g / L$ & 0.00 & - \\
\hline N-Nitrosodiphenylamine & 20.0 & $\mu g / L$ & 0.00 & - \\
\hline Phenanthrene & 20.0 & $\mu g / L$ & 0.00 & - \\
\hline Potassium & 400 & $\mu g / L$ & 2.50 & $\therefore$ \\
\hline Sodium & 1,340 & $\mu g / L$ & 10.69 & - \\
\hline Sulfate & 5,000 & $\mu g / L$ & 0.00 & - \\
\hline Tetrachloroethylene & 5.0 & $\mu g / L$ & 0.00 & - \\
\hline Toluene & 5.0 & $\mu g / L$ & 0.00 & - \\
\hline Total organic carbon & 1,110 & $\mu g / L$ & 0.00 & - \\
\hline Total phosphates (as P) & 67.0 & $\mu g / L$ & 0.00 & - \\
\hline 1,1,1-Trichloroethane & 5.0 & $\mu g / L$ & 0.00 & - \\
\hline Trichloroethylene & 5.0 & $\mu g / L$ & 0.00 & - \\
\hline 2,4,5-Trichlorophenol & 50.0 & $\mu g / L$ & 0.00 & - \\
\hline 2,4,6-Trichlorophenol & 20.0 & $\mu g / L$ & 0.00 & - \\
\hline
\end{tabular}




\begin{tabular}{lllll}
\hline Analyte & RDL & Unit & MRD & $\begin{array}{l}\text { t-test } \\
\text { Probability }\end{array}$ \\
\hline Xylenes & & & & \\
Zinc & 5.0 & $\mu g / L$ & 0.00 & - \\
\hline
\end{tabular}

- Could not calculate because there are no differences between pairs.

Note: Values less than .050 indicate a probability of less than 1 in 20 that the results for that analyte are the same from both laboratories. MRD results less than or equal to .050 appear in bold italic. MRD results greater than or equal to 20 appear in bold.

Table 35. Interlaboratory MRD and t-test Results for Analytes with at Least One Pair of Results above the RDL for EX and WA

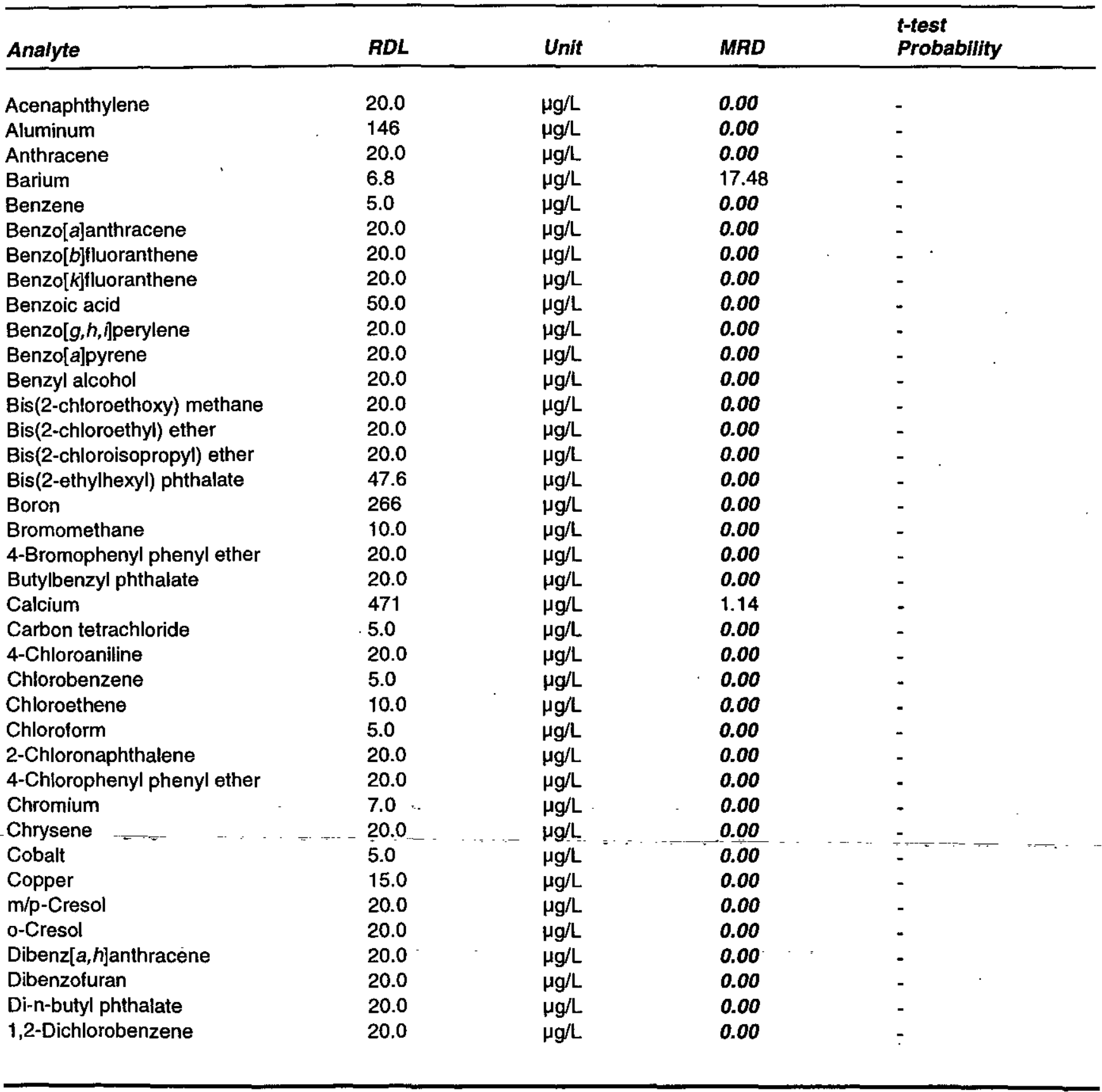




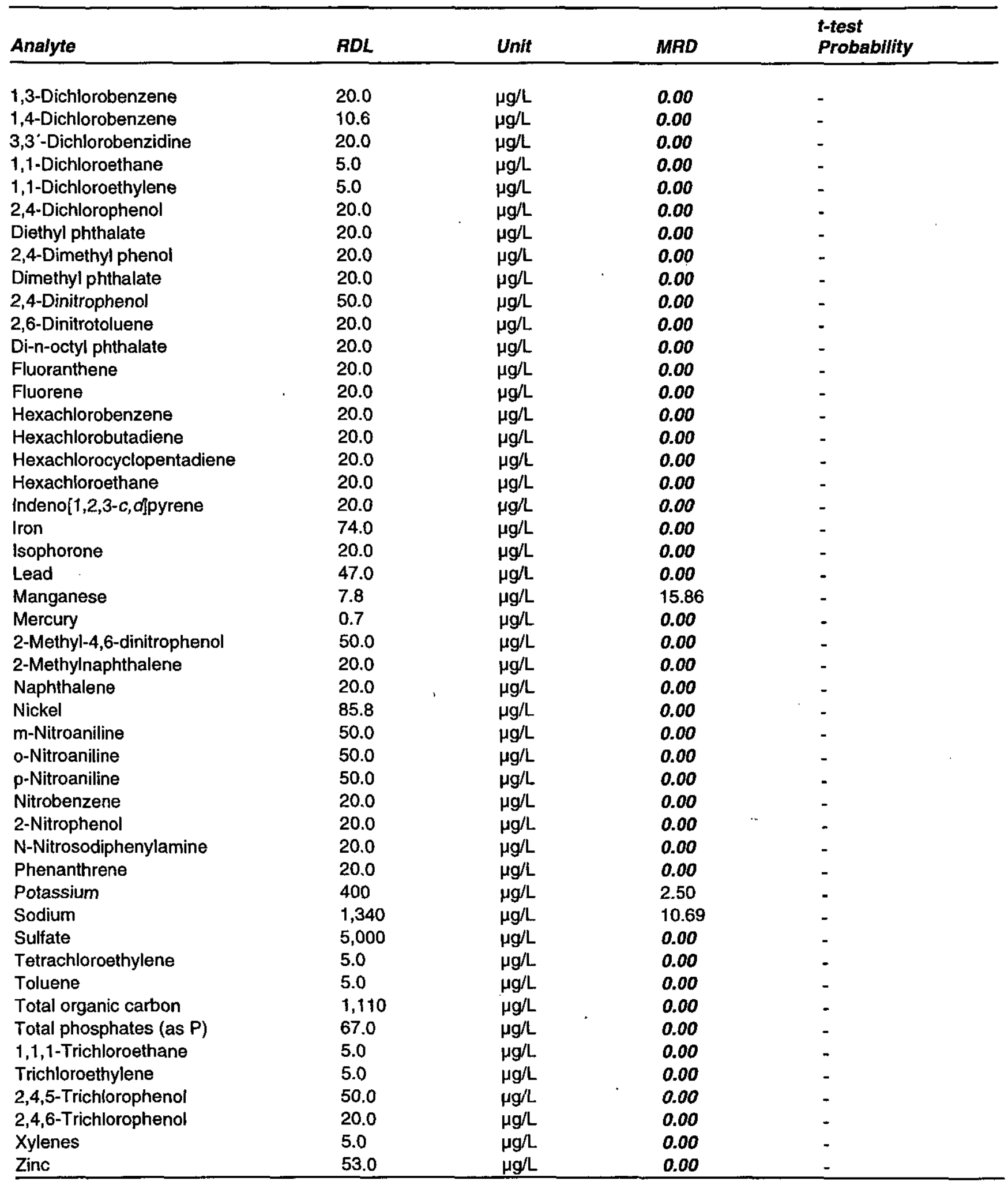

- Could not calculate because there are no differences between pairs.

Note: Values less than .050 indicate a probability of less than 1 in 20 that the results for that analyte are the same from both laboratories. MRD results less than or equal to .050 appear in bold italic. MRD results greater than or equal to 20 appear in bold. 
Table 36. Interlaboratory MRD and t-test Results for Analytes with at Least One Pair of Results above the RDL for ES and TM

\begin{tabular}{lllll}
\hline Analyte & RDL & Unit & MRD & $\begin{array}{l}\text { t-test } \\
\text { Probability }\end{array}$ \\
\hline Chloride & & & & - \\
Magnesium & $\dagger$ & & 1.27 & - \\
Actinium-228 & $\dagger$ & 6.41 & - \\
Gross alpha & $2.819 \mathrm{E}-08$ & $\mu \mathrm{Ci} / \mathrm{mL}$ & 0.00 & - \\
Neptunium-237 & $1.63 \mathrm{E}-09$ & $\mu \mathrm{Ci} / \mathrm{mL}$ & 0.00 & - \\
Nonvolatile beta & $3.1 \mathrm{E}-10$ & $\mu \mathrm{Ci} / \mathrm{mL}$ & 0.00 & - \\
Radium, total alpha-emitting & $2.86 \mathrm{E}-09$ & $\mu \mathrm{Ci} / \mathrm{mL}$ & 0.00 & - \\
Radium-226 & $9.1 \mathrm{E}-10$ & $\mu \mathrm{Ci} / \mathrm{mL}$ & $\mathbf{8 8 . 6 9}$ & - \\
Radium-228 & $1.21 \mathrm{E}-09$ & $\mu \mathrm{Ci} / \mathrm{mL}$ & 0.00 & - \\
Strontium-90 & $3.0 \mathrm{E}-09$ & $\mu \mathrm{Ci} / \mathrm{mL}$ & 0.00 & - \\
Tritium & $2.47 \mathrm{E}-09$ & $\mu \mathrm{Ci} / \mathrm{mL}$ & 0.00 & .500 \\
\hline
\end{tabular}

† No detection limit, or no replicate or duplicate results below detection limit.

- Could not calculate because there are no differences between pairs.

Note: Values less than .050 indicate a probability of less than 1 in 20 that the results for that analyte are the same from both laboratories. MRD results less than or equal to .050 appear in bold italic. MRD results greater than or equal to 20 appear in bold.

Table 37. Interlaboratory MRD and t-test Results for Analytes with at Least One Pair of Results above the RDL for EX and TMA

\begin{tabular}{lcccc}
\hline Analyte & RDL & Unit & MRD & t-test \\
Probability
\end{tabular}

† No detection limit, or no replicate or duplicate results below detection limit.

Note: Values less than .050 indicate a probability of less than 1 in 20 that the results for that analyte are the same from both laboratories.

Table 38. Interlaboratory MRD and t-test Results for Analytes with at Least One Pair of Results above the RDL for GP and TM

\begin{tabular}{lllll}
\hline Analyte & RDL. & Unit & MRD & $\begin{array}{l}\text { t-test } \\
\text { Probability }\end{array}$ \\
\hline Chloride & & & & \\
Nitrate as nitrogen & $\dagger$ & & 7.91 & - \\
$\mathrm{pH}$ & $\dagger$ & 1.10 & .004 \\
Actinium-228 & $2.819 \mathrm{E}-08$ & $\mu \mathrm{Ci} / \mathrm{mL}$ & 0.00 & - \\
Americium-241 & $8.3 \mathrm{E}-10$ & $\mu \mathrm{Ci} / \mathrm{mL}$ & 0.00 & - \\
Carbon-14 & $9.1379 \mathrm{E}-07$ & $\mu \mathrm{Ci} / \mathrm{mL}$ & 0.00 & .487 \\
Gross alpha & $1.63 \mathrm{E}-09$ & $\mu \mathrm{Ci} / \mathrm{mL}$ & 17.63 & .252 \\
Nonvolatile beta & $2.45 \mathrm{E}-09$ & $\mu \mathrm{Ci} / \mathrm{mL}$ & $\mathbf{3 1 . 5 4}$ & - \\
Promethium-147 & $7.3 \mathrm{E}-09$ & $\mu \mathrm{Ci} / \mathrm{mL}$ & $\mathbf{0 . 0 0}$ & -
\end{tabular}

\section{Quality Control Samples}




\begin{tabular}{lllll}
\hline Analyte & RDL & Unit & MRD & $\begin{array}{l}\text { t-test } \\
\text { Probability }\end{array}$ \\
\hline Radium, total alpha-emitting & & & & \\
Strontium-90 & $7.5 \mathrm{E}-10$ & $\mu \mathrm{Ci} / \mathrm{mL}$ & 15.46 & .390 \\
Technetium-99 & $1.93 \mathrm{E}-09$ & $\mu \mathrm{Ci} / \mathrm{mL}$ & 0.00 & - \\
Tritium & $2.24 \mathrm{E}-08$ & $\mu \mathrm{Ci} / \mathrm{mL}$ & 0.00 & - \\
\hline
\end{tabular}

† No detection limit, or no replicate or duplicate results below detection limit.

- Could not calculate because there are no differences between pairs.

Note: Values less than .050 indicate a probability of less than 1 in 20 that the results for that analyte are the same from both laboratories. MRD results less than or equal to .050 appear in bold italic. MRD results greater than or equal to 20 appear in bold.

Table 39. ES Samples and Blind Replicates Vielding Results Where One Is More Than Twice Another

Analyte Wells

Bis(2-ethylhexyl) phthalate

PRP 4

Table 40. ES Samples and Laboratory Duplicates Yiolding Results Whore One Is More Than Twice Another

\begin{tabular}{ll}
\hline Analyte & Wells \\
\hline lodomethane & LFW 58D \\
\hline
\end{tabular}

Table 41. GE Samples and Blind Replicates Vielding Results Where One Is More Than Twice Another

\begin{tabular}{ll}
\hline Analyte & Wells \\
\hline Endosulfan sulfate & RAC 1 \\
Nitrate-nitrite as nitrogen & FSB 76A \\
Toluene & BGO 33C \\
\hline
\end{tabular}

Table 42. GE Samples and Laboratory Duplicates Yielding Results Where One Is More Than Twice Another

\begin{tabular}{ll}
\hline Analyte & Wells \\
\hline Bromide & BGO 33C \\
Cadmium & QA 94A \\
\hline
\end{tabular}


Table 43. GP Samples and Blind Replicates Yielding Results Where One Is More Than Twice Another

Analyte Wells

Tritium

FSB 87A, HSB 86A

Table 44. GP Samples and Laboratory Duplicates Yiolding Results Where One Is More Than Twice Another

Analyte Wells

Gross alpha

Nonvolatile beta

Thorium-230
HSL 70

HSL 7D

HEX500TK

Table 45. TM Samples and Blind Replicates Yielding Results Where One Is More Than Twice Another

\begin{tabular}{ll}
\hline Analyte & Wells \\
\hline Tritium & FBP 43DL, PRP 4 \\
\hline
\end{tabular}

Table 46. TM Samples and Laboratory Duplicates Yielding Results Where One Is More Than Twice Another

\begin{tabular}{ll}
\hline Analyte & Wells \\
\hline Gross alpha & ARP 5D \\
Nonvolatile beta & BGO 14CR, BGO 33C, FSB 76A, HHP 1D, HSB 65A, HSB 85A, PRP 5 \\
Radium-226 & KCB 1 \\
\hline
\end{tabular}

Table 47. WA Samples and Blind Replicetes Yielding Results Where One Is More Than Twice Another

\begin{tabular}{ll}
\hline Analyte & Wells \\
\hline Alkalinity (as CaCO3) & BGO 16AR \\
Calcium & FBP 46D \\
Iron & FBP 46D \\
Sulfate & FBP 41C \\
Total dissolved solids & BGO 16AR \\
Total phosphates (as P) & FBP 43DL, FBP 46D \\
\hline
\end{tabular}


Table 48. WA Samples and Laboratory Duplicates Vielding Results Where One Is More Than Twice Another

Analyte Wells

Nitrate as nitrogen

FBP 42C

Table 49. Analytes with One Laboratory's Result Greater Than Twice the Result from the Other Laboratory between ES and EX

\begin{tabular}{ll}
\hline Analyte & Wells \\
\hline & LFW 61D \\
Aluminum & TRW 4 \\
\hline Trichloroethylene & TRW
\end{tabular}

Note: Results for blind blanks are given in Appendix $B$.

Table 50. Analytes with One Laboratory's Result Greater Than Twice the Result from the Other Laboratory betwoen EX and WA

\begin{tabular}{ll}
\hline Analyte & Wells \\
\hline Bis(2-ethylhexyl) phthalate & CSR 3 \\
Iron & CSR 1 \\
Nickel & CSR 1 \\
Sulfate & CSR 3 \\
Total organic carbon & CSR 1 \\
\hline
\end{tabular}

Note: Results for blind blanks are given in Appendix B.

Table 51. Analytes with One Laboratory's Result Greater Than Twice the Result from the Other Laboratory between GE and WA

\begin{tabular}{ll}
\hline Analyte & Wells \\
\hline Bromomethane & BGO 33C \\
Iron & BGO 33C \\
Mercury & BGO 7D \\
Nitrate-nitrite as nitrogen & FSB 76A \\
Specific conductance & HSB 69A \\
Toluene & BGO 33C \\
Total dissolved solids & BGO 33C \\
Total organic carbon & BGO 16AR \\
\hline
\end{tabular}

Note: Results for blind blanks are given in Appendix B. 
Table 52. Analytes with One Laboratory's Result Greater Than Twice the Result from the Other Laboratory between ES and TM

\begin{tabular}{ll}
\hline Analyte & Wells \\
\hline Radium, total alpha-emitting & DBP 3 \\
\hline
\end{tabular}

Note: Results for blind blanks are given in Appendix B.

Table 53. Analytes with One Laboratory's Result Greater Than Twice the Result from the Other Laboratory between GP and $M$

\begin{tabular}{ll}
\hline Analyte & Wells \\
\hline Gross alpha & BGO 33C, HSB 69A \\
Nonvolatile beta & BGO 33C, FSB 76A, FSB 98AR \\
Tritium & PRP 4 \\
\hline
\end{tabular}

Note: Results for blind blanks are given in Appendix B.

Table 54. Quality Control Standards for Selected Analyses for GE

\begin{tabular}{lllll}
\hline Analyte & $\begin{array}{l}\text { Certified } \\
\text { Value }\end{array}$ & $\begin{array}{l}\text { Performance } \\
\text { Acceptance Limits }\end{array}$ & $\begin{array}{l}\text { GE } \\
\text { Result }\end{array}$ & $\begin{array}{l}\text { Result } \\
\text { Qualifler }\end{array}$ \\
\hline
\end{tabular}

Acids (Lot 582)

4-Chloro-m-cresol $(\mu \mathrm{g} / \mathrm{L})$

2-Chlorophenol ( $\mu g / L)$

o-Cresol (2-methylphenol) ( $\mu \mathrm{g} / \mathrm{L})$

p-Cresol (4-methylphenol) $(\mu \mathrm{g} / \mathrm{L})$

Pentachlorophenol $(\mu \mathrm{g} / \mathrm{L})$

2,4,6-Trichlorophenol $(\mu g / L)$

91.4

15.3

51.3

31.9

29.9

26.7

Base/Neutrals (Lot 582)

Acenaphthene $(\mu g / L)$

Anthracene $(\mu g / L)$

Benzo[b]fluoranthene $(\mu g / L)$

Bis(2-ethylhexyl) phthalate $(\mu g / L)$

Butylbenzyl phthlate $(\mu \mathrm{g} / \mathrm{L})$

4-Chlorophenyl phenyl ether ( $\mu \mathrm{g} / \mathrm{L}$ )

Chrysene ( $\mu g / L)$

Dibenzofuran $(\mu \mathrm{g} / \mathrm{L})$

1,2-Dichlorobenzene $(\mu g / L)$

2,4-Dinitrotoluene $(\mu g / L)$

Di-n-octyl phthlate $(\mu g / L)$

Hexachlorobenzene $(\mu g / L)$

Naphthalene $(\mu g / L)$

- Phenanthrene $(\mu g / L)$

Pyrene $(\mu g / L)$

1,2,4-Trichlorobenzene $(\mu \mathrm{g} / \mathrm{L})$

Cations (Lot 435)

Calcium $(\mu \mathrm{g} / \mathrm{L})$

Magnesium $(\mu g / L)$

Potassium $(\mu \mathrm{g} / \mathrm{L}$ )

Sodium $(\mu g / L)$
71.6

24.9

19.1

111

40.2

124

23.0

35.3

49.0

31.3

121

39.6

150

$-99.1$

125

39.9

19,500

15,900

28,200

22,300
43.8-104

$6.29-17.2$

$16.3-59.3$

9.78-37.0

9.30-37.6

$11.5-30.6$

32.5-78.9

11.7-29.0

7.71-23.3

44.8-142

15.2-44.9

64.7-145

10.6-28.2

16.8-39.1

11.5-56.0

13.1-36.1

54.6-152

19.4-45.6

53.2-171

$-53.7-114=$

58.4-152

11.6-45.3

$17,600-21,500$

$14,200-17,600$

$25,700-30,700$

$19,600-25,000$
63.2

11.7

37.3

21.7

13.9

19.7

53.9

24.3

15.4

92.1

37.4

92.4

21.5

28.3

35.6

25.1

90.0

33.3

101

$-80: 9$

110

28.9

19,600

15,500

28,600

22,600

\section{Quality Control Samples}




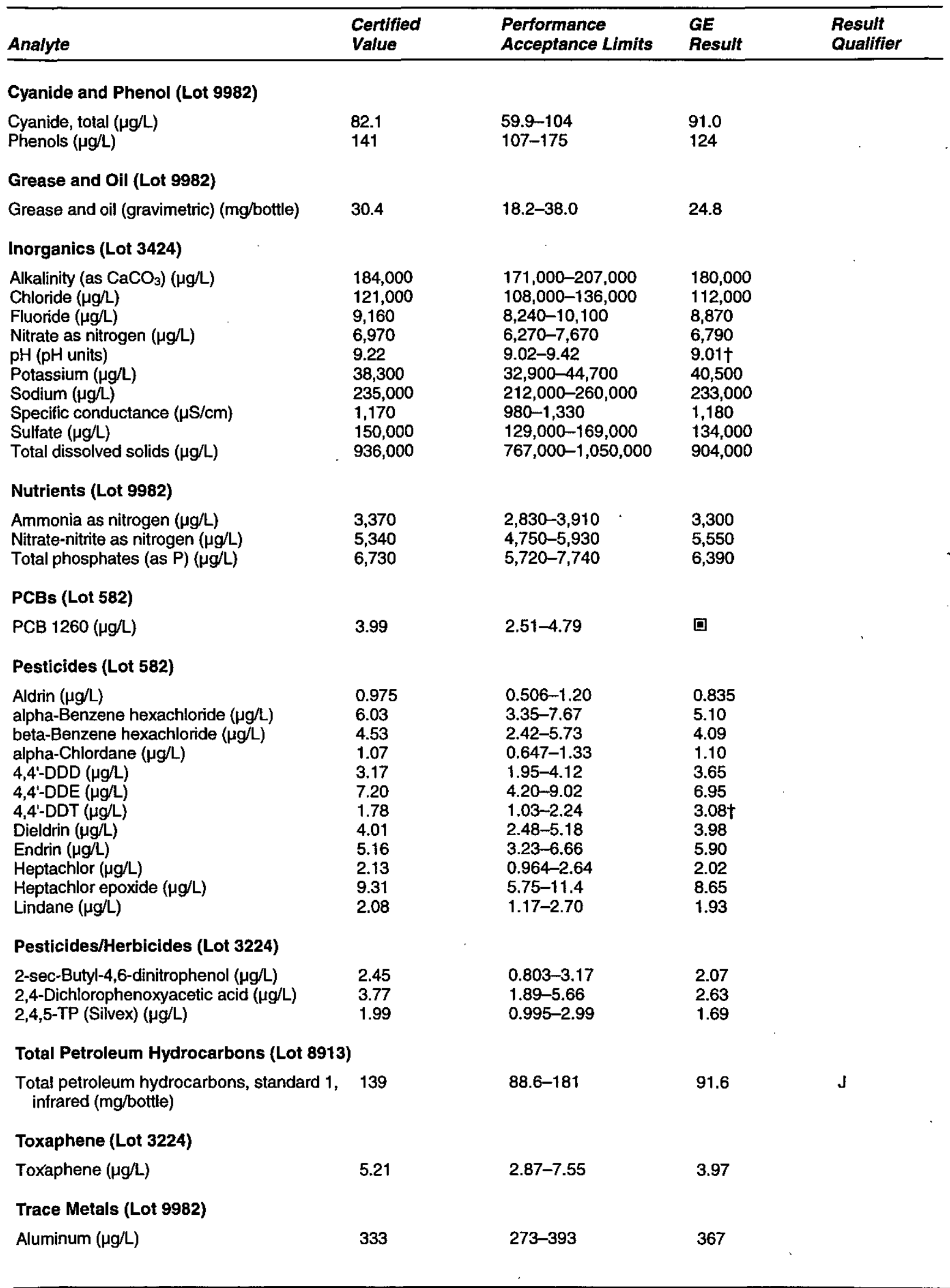




\begin{tabular}{|c|c|c|c|c|}
\hline Analyte & $\begin{array}{l}\text { Certified } \\
\text { Value }\end{array}$ & $\begin{array}{l}\text { Performance } \\
\text { Acceptance Limits }\end{array}$ & $\begin{array}{l}\text { GE } \\
\text { Result }\end{array}$ & $\begin{array}{l}\text { Result } \\
\text { Qualifier }\end{array}$ \\
\hline $\begin{array}{l}\text { Antimony }(\mu g / L) \\
\text { Arsenic }(\mu g / L) \\
\text { Barium }(\mu g / L) \\
\text { Beryllium }(\mu g / L) \\
\text { Boron }(\mu g / L) \\
\text { Cadmium }(\mu g / L) \\
\text { Chromium }(\mu g / L) \\
\text { Cobalt }(\mu g / L) \\
\text { Copper }(\mu g / L) \\
\text { Iron }(\mu g / L) \\
\text { Lead }(\mu g / L) \\
\text { Manganese }(\mu g / L) \\
\text { Mercury }(\mu g / L) \\
\text { Molybdenum }(\mu g / L) \\
\text { Nickel }(\mu g / L) \\
\text { Selenium }(\mu g / L) \\
\text { Silver }(\mu g / L) \\
\text { Strontium }(\mu g / L) \\
\text { Thallium }(\mu g / L) \\
\text { Vanadium }(\mu g / L) \\
\text { Zinc }(\mu g / L)\end{array}$ & $\begin{array}{l}122 \\
167 \\
311 \\
88.9 \\
235 \\
156 \\
389 \\
189 \\
172 \\
333 \\
144 \\
244 \\
8.89 \\
211 \\
194 \\
156 \\
161 \\
267 \\
139 \\
228 \\
378\end{array}$ & $\begin{array}{l}91.5-153 \\
125-197 \\
255-367 \\
72.9-105 \\
193-294 \\
128-184 \\
319-459 \\
155-223 \\
141-203 \\
273-393 \\
118-170 \\
200-288 \\
6.67-12.4 \\
173-249 \\
159-229 \\
117-184 \\
132-190 \\
219-315 \\
104-174 \\
187-269 \\
310-446\end{array}$ & $\begin{array}{l}128 \\
175 \\
304 \\
87.4 \\
288 \\
156 \\
388 \\
198 \\
168 \\
337 \\
145 \\
242 \\
8.07 \\
197 \\
199 \\
159 \\
145 \\
258 \\
144 \\
220 \\
378\end{array}$ & \\
\hline \multicolumn{5}{|l|}{ Turbidity (Lot 3424) } \\
\hline Turbidity (NTU) & 2.80 & $2.38-3.27$ & 2.75 & \\
\hline \multicolumn{5}{|l|}{ Volatiles (Lot 582) } \\
\hline $\begin{array}{l}\text { Benzene }(\mu g / L) \\
\text { Bromodichloromethane }(\mu g / L) \\
\text { Bromoform }(\mu g / L) \\
\text { Carbon tetrachloride }(\mu g / L) \\
\text { Chlorobenzene }(\mu g / L) \\
\text { Chloroform }(\mu g / L) \\
\text { Dibromochloromethane }(\mu g / L) \\
\text { 1,2-Dichlorobenzene }(\mu g / L) \\
\text { 1,3-Dichlorobenzene }(\mu g / L) \\
\text { 1,4-Dichlorobenzene }(\mu g / L) \\
\text { 1,2-Dichloroethane }(\mu g / L) \\
\text { Dichloromethane }(\operatorname{lmethylene~chloride)~}(\mu g / L) \\
\text { 1,2-Dichloropropane }(\mu g / L) \\
\text { Ethylbenzene }(\mu g / L) \\
\text { 2-Hexanone }(\mu g / L) \\
\text { Methyl isobutyl ketone }(\mu g / L) \\
\text { Tetrachloroethylene }(\mu g / L) \\
\text { Toluene }(\mu g / L) \\
\text { 1,1,1-Trichloroethane }(\mu g / L) \\
\text { Trichloroethylene }(\mu g / L) \\
\text { o-Xylene }(\mu g / L)\end{array}$ & $\begin{array}{l}18.0 \\
99.6 \\
98.4 \\
59.9 \\
72.9 \\
50.3 \\
44.5 \\
32.3 \\
20.1 \\
42.6 \\
53.2 \\
84.9 \\
50.3 \\
19.7 \\
83.4 \\
75.3 \\
26.5 \\
17.5 \\
15.0 \\
70.5 \\
63.7\end{array}$ & $\begin{array}{l}13.9-22.4 \\
76.6-124 \\
72.0-127 \\
44.0-74.6 \\
57.0-87.4 \\
38.6-61.5 \\
34.6-54.8 \\
24.5-39.7 \\
15.4-24.2 \\
32.0-51.9 \\
41.6-66.9 \\
60.1-111 \\
37.9-61.6 \\
14.7-23.0 \\
49.2-121 \\
43.5-103 \\
19.6-32.0 \\
13.5-21.1 \\
10.8-17.9 \\
52.3-85.3 \\
41.2-80.2\end{array}$ & $\begin{array}{l}21.3 \\
113 \\
104 \\
58.1 \\
79.8 \\
54.8 \\
47.8 \\
36.4 \\
24.8 t \\
48.8 \\
58.5 \\
101 \\
55.7 \\
21.1 \\
107 \\
94.4 \\
25.0 \\
18.9 \\
15.3 \\
68.0 \\
71.1\end{array}$ & . \\
\hline
\end{tabular}

$\uparrow$ Result is out of range.

$\square$ Result was not reported by lab.

- J-The analytical result is an estimated quantity..... 
Table 55. Quality Control Standards for Selected Analyses for WA

\begin{tabular}{|c|c|c|c|c|}
\hline Analyte & $\begin{array}{l}\text { Certified } \\
\text { Value }\end{array}$ & $\begin{array}{l}\text { Performance } \\
\text { Acceptance Limits }\end{array}$ & $\begin{array}{l}\text { WA } \\
\text { Result }\end{array}$ & $\begin{array}{l}\text { Result } \\
\text { Qualifier }\end{array}$ \\
\hline \multicolumn{5}{|l|}{ Acids (Lot 582) } \\
\hline $\begin{array}{l}\text { 4-Chloro-m-cresol }(\mu g / L) \\
\text { 2-Chlorophenol }(\mu g / L) \\
\text { o-Cresol (2-methylphenol) }(\mu g / L) \\
\text { p-Cresol (4-methylphenol) }(\mu g / L) \\
\text { Pentachlorophenol }(\mu g / L) \\
\text { 2,4,6-Trichlorophenol }(\mu g / L)\end{array}$ & $\begin{array}{l}91.4 \\
15.3 \\
51.3 \\
31.9 \\
29.9 \\
26.7\end{array}$ & $\begin{array}{l}43.8-104 \\
6.29-17.2 \\
16.3-59.3 \\
9.78-37.0 \\
9.30-37.6 \\
11.5-30.6\end{array}$ & $\begin{array}{l}76.4 \\
14.1 \\
45.4 \\
33.1 \\
37.2 \\
28.9\end{array}$ & \\
\hline \multicolumn{5}{|l|}{ Base/Neutrals (Lot 582) } \\
\hline $\begin{array}{l}\text { Acenaphthene }(\mu g / L) \\
\text { Anthracene }(\mu g / L) \\
\text { Benzo[b]fluoranthene }(\mu g / L) \\
\text { Bis(2-ethylhexyl) phthalate }(\mu g / L) \\
\text { Butylbenzyl phthlate }(\mu g / L) \\
\text { 4-Chlorophenyl phenyl ether }(\mu g / L) \\
\text { Chrysene }(\mu g / L) \\
\text { Dibenzofuran }(\mu g / L) \\
1,2 \text {-Dichlorobenzene }(\mu g / L) \\
2,4-\text { Dinitrotoluene }(\mu g / L) \\
\text { Di-n-octyl phthlate }(\mu g / L) \\
\text { Hexachlorobenzene }(\mu g / L) \\
\text { Naphthalene }(\mu g / L) \\
\text { Phenanthrene }(\mu g / L) \\
\text { Pyrene }(\mu g / L) \\
1,2,4-\text { Trichlorobenzene }(\mu g / L)\end{array}$ & $\begin{array}{l}71.6 \\
24.9 \\
19.1 \\
111 \\
40.2 \\
124 \\
23.0 \\
35.3 \\
49.0 \\
31.3 \\
121 \\
39.6 \\
150 \\
99.1 \\
125 \\
39.9\end{array}$ & $\begin{array}{l}32.5-78.9 \\
11.7-29.0 \\
7.71-23.3 \\
44.8-142 \\
15.2-44.9 \\
64.7-145 \\
10.6-28.2 \\
16.8-39.1 \\
11.5-56.0 \\
13.1-36.1 \\
54.6-152 \\
19.4-45.6 \\
53.2-171 \\
53.7-114 \\
58.4-152 \\
11.6-45.3\end{array}$ & $\begin{array}{l}56.1 \\
19.9 \\
23.3 \\
83.6 \\
27.0 \\
104 \\
18.5 \\
29.9 \\
9.6 \dagger \\
29.2 \\
125 \\
37.2 \\
62.2 \\
82.1 \\
89.6 \\
15.5\end{array}$ & $\cdot$ \\
\hline \multicolumn{5}{|l|}{ Cations (Lot 435) } \\
\hline $\begin{array}{l}\text { Calcium }(\mu g / L) \\
\text { Magnesium }(\mu g / L) \\
\text { Potassium }(\mu g / L) \\
\text { Sodium }(\mu g / L)\end{array}$ & $\begin{array}{l}19,500 \\
15,900 \\
28,200 \\
22,300\end{array}$ & $\begin{array}{l}17,600-21,500 \\
14,200-17,600 \\
25,700-30,700 \\
19,600-25,000\end{array}$ & $\begin{array}{l}20,500 \\
17,200 \\
30,200 \\
23,900\end{array}$ & \\
\hline \multicolumn{5}{|l|}{ Cyanide and Phenol (Lot 9982) } \\
\hline $\begin{array}{l}\text { Cyanide, total }(\mu g / L) \\
\text { Phenols }(\mu g / L)\end{array}$ & $\begin{array}{l}82.1 \\
141\end{array}$ & $\begin{array}{l}59.9-104 \\
107-175\end{array}$ & $\begin{array}{l}90.5 \\
137\end{array}$ & \\
\hline \multicolumn{5}{|l|}{ Grease and Oil (Lot 9982) } \\
\hline Grease and oil (gravimetric) (mg/bottle) & 30.4 & $18.2-38.0$ & $<17.9 \dagger$ & \\
\hline \multicolumn{5}{|l|}{ Inorganics (Lot 3424) } \\
\hline $\begin{array}{l}\left.\text { Alkalinity (as } \mathrm{CaCO}_{3}\right)(\mu \mathrm{g} / \mathrm{L}) \\
\text { Chloride }(\mu \mathrm{g} / \mathrm{L}) \\
\text { Fluoride }(\mu \mathrm{g} / \mathrm{L}) \\
\text { Nitrate as nitrogen }(\mu \mathrm{g} / \mathrm{L}) \\
\mathrm{pH}(\mathrm{pH} \text { units) } \\
\text { Potassium }(\mu \mathrm{g} / \mathrm{L}) \\
\text { Sodium }(\mu \mathrm{g} / \mathrm{L}) \\
\text { Specific conductance }(\mu \mathrm{S} / \mathrm{cm}) \\
\text { Sulfate }(\mu \mathrm{g} / \mathrm{L}) \\
\text { Total dissolved solids }(\mu \mathrm{g} / \mathrm{L})\end{array}$ & $\begin{array}{l}184,000 \\
121,000 \\
9,160 \\
6,970 \\
9.22 \\
38,300 \\
235,000 \\
1,170 \\
150,000 \\
936,000\end{array}$ & $\begin{array}{l}171,000-207,000 \\
108,000-136,000 \\
8,240-10,100 \\
6,270-7,670 \\
9.02-9.42 \\
32,900-44,700 \\
212,000-260,000 \\
980-1,330 \\
129,000-169,000 \\
767,000-1,050,000\end{array}$ & $\begin{array}{l}192,000 \\
117,000 \\
10,200 \dagger \\
\square \\
9.10 \\
39,900 \\
232,000 \\
1,180 \\
146,000 \\
904,000\end{array}$ & \\
\hline \multicolumn{5}{|l|}{ Nutrients (Lot 9982) } \\
\hline $\begin{array}{l}\text { Ammonia as nitrogen }(\mu g / L) \\
\text { Nitrate-nitrite as nitrogen }(\mu g / L)\end{array}$ & $\begin{array}{l}3,370 \\
5,340\end{array}$ & $\begin{array}{l}2,830-3,910 \\
4,750-5,930\end{array}$ & $\begin{array}{l}3,340 \\
5,420\end{array}$ & \\
\hline
\end{tabular}




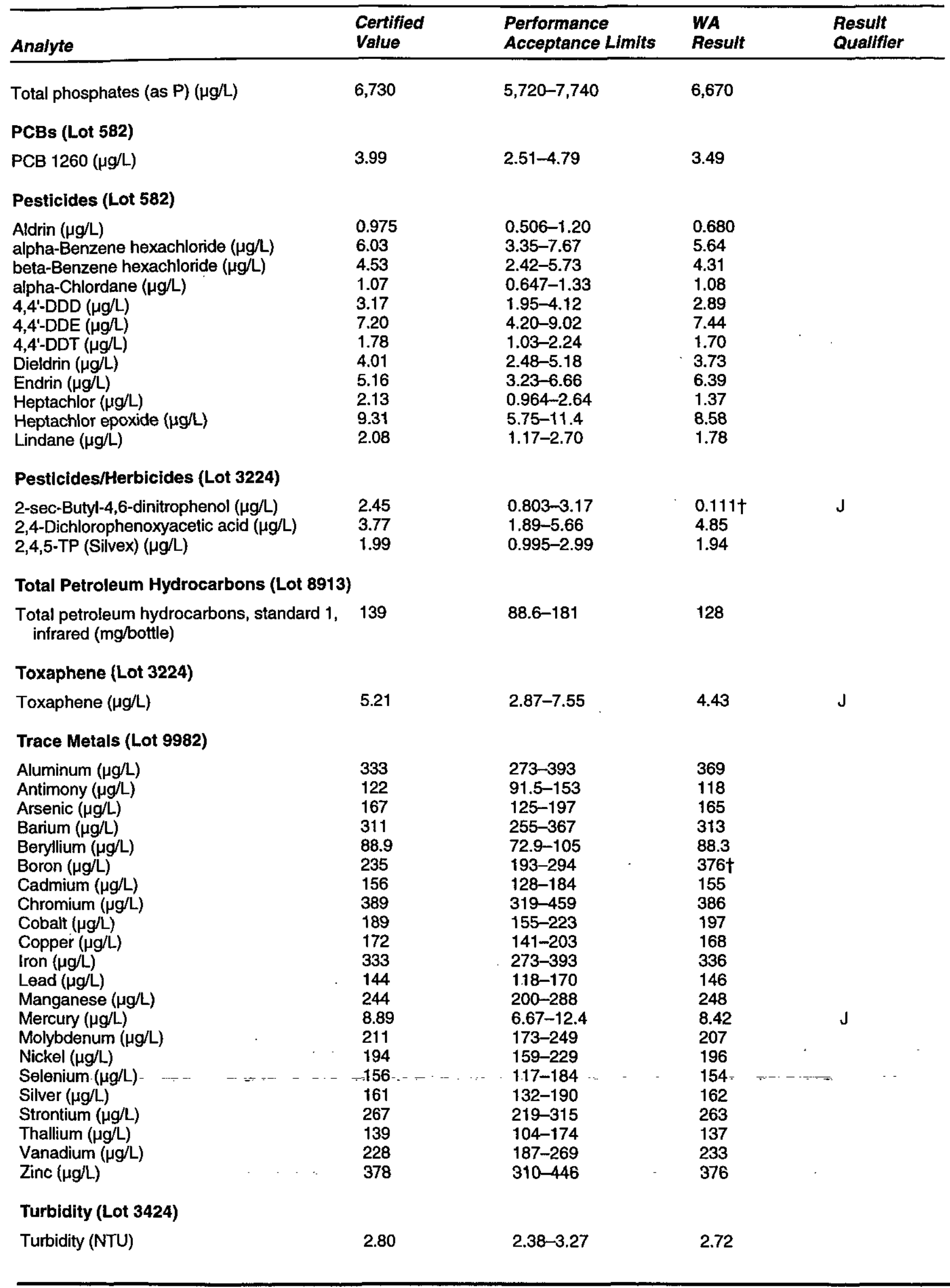




\begin{tabular}{|c|c|c|c|c|}
\hline Analyte & $\begin{array}{l}\text { Certified } \\
\text { Value }\end{array}$ & $\begin{array}{l}\text { Performance } \\
\text { Acceptance Limits }\end{array}$ & $\begin{array}{l}\text { WA } \\
\text { Result }\end{array}$ & $\begin{array}{l}\text { Result } \\
\text { Qualifier }\end{array}$ \\
\hline \multicolumn{5}{|l|}{ Volatiles (Lot 582) } \\
\hline $\begin{array}{l}\text { Benzene }(\mu g / L) \\
\text { Bromodichloromethane }(\mu g / L) \\
\text { Bromoform }(\mu g / L) \\
\text { Carbon tetrachloride }(\mu g / L) \\
\text { Chlorobenzene }(\mu g / L) \\
\text { Chloroform }(\mu g / L) \\
\text { Dibromochloromethane }(\mu g / L) \\
\text { 1,2-Dichlorobenzene }(\mu g / L) \\
\text { 1,3-Dichlorobenzene }(\mu g / L) \\
\text { 1,4-Dichlorobenzene }(\mu g / L) \\
\text { 1,2-Dichloroethane }(\mu g / L) \\
\text { Dichloromethane }(\text { methylene chloride) }(\mu g / L) \\
\text { 1,2-Dichloropropane }(\mu g / L) \\
\text { Ethylbenzene }(\mu g / L) \\
\text { 2-Hexanone }(\mu g / L) \\
\text { Methyl isobutyl ketone }(\mu g / L) \\
\text { Tetrachloroethylene }(\mu g / L) \\
\text { Toluene }(\mu g / L) \\
1,1,1-T r i c h l o r o e t h a n e(\mu g / L) \\
\text { Trichloroethylene }(\mu g / L) \\
\text { o-Xylene }(\mu g / L)\end{array}$ & $\begin{array}{l}18.0 \\
99.6 \\
98.4 \\
59.9 \\
72.9 \\
50.3 \\
44.5 \\
32.3 \\
20.1 \\
42.6 \\
53.2 \\
84.9 \\
50.3 \\
19.7 \\
83.4 \\
75.3 \\
26.5 \\
17.5 \\
15.0 \\
70.5 \\
63.7\end{array}$ & $\begin{array}{l}13.9-22.4 \\
76.6-124 \\
72.0-127 \\
44.0-74.6 \\
57.0-87.4 \\
38.6-61.5 \\
34.6-54.8 \\
24.5-39.7 \\
15.4-24.2 \\
32.0-51.9 \\
41.6-66.9 \\
60.1-111 \\
37.9-61.6 \\
14.7-23.0 \\
49.2-121 \\
43.5-103 \\
19.6-32.0 \\
13.5-21.1 \\
10.8-17.9 \\
52.3-85.3 \\
41.2-80.2\end{array}$ & $\begin{array}{l}16.3 \\
91.5 \\
86.8 \\
61.3 \\
62.9 \\
47.1 \\
39.9 \\
19.2 \dagger \\
45.4 \dagger \\
23.5 \dagger \\
49.6 \\
77.8 \\
\square \\
16.8 \\
\square \\
67.4 \\
22.4 \\
15.0 \\
13.8 \\
57.7 \\
<5.00 \\
\end{array}$ & $\cdot$ \\
\hline
\end{tabular}

$\uparrow$ Result is out of range.

口Result was not reported by laboratory.

$\mathrm{J}$ The analytical result is an estimated quantity.

Table 56. Quality Control Standards for Selected Analyses for EX

\begin{tabular}{lllll}
\hline & Certified & Performance & EX & \\
Analyte & Value & Acceptance Limits & Result & Qualt \\
\hline
\end{tabular}

Acids (Lot 582)

4-Chloro-m-cresol ( $\mu \mathrm{g} / \mathrm{L})$

2-Chlorophenol $(\mu g / L)$

o-Cresol (2-methylphenol) ( $\mu \mathrm{g} / \mathrm{L})$

p-Cresol (4-methylphenol) ( $\mu \mathrm{g} / \mathrm{L})$

Pentachlorophenol $(\mu g / L)$

2,4,6-Trichlorophenol ( $\mu g / L)$

\section{Base/Neutrals (Lot 582)}

Acenaphthene $(\mu g / L)$

Anthracene $(\mu g / L)$

Benzo[b]fluoranthene ( $\mu g / L)$

Bis(2-ethylhexyl) phthalate $(\mu g / L)$

Butylbenzyl phthlate $(\mu g / L)$

4-Chlorophenyl phenyl ether $(\mu g / L)$

Chrysene $(\mu g / L)$

Dibenzofuran $(\mu g / \mathrm{L})$

1,2-Dichlorobenzene ( $\mu g / L)$

2,4-Dinitrotoluene $(\mu \mathrm{g} / \mathrm{L})$

Di-n-octyl phthlate $(\mu \mathrm{g} / \mathrm{L})$

Hexachlorobenzene $(\mu g / L)$

Naphthalene $(\mu g / L)$

Phenanthrene $(\mu g / L)$

Pyrene ( $\mu g /$ L)

1,2,4-Trichlorobenzene $(\mu g / L)$
91.4

15.3

51.3

31.9

29.9

26.7

71.6

24.9

19.1

111

40.2

124

23.0

35.3

49.0

31.3

121

39.6

150

99.1

125

39.9
43.8-104

6.29-17.2

16.3-59.3

9.78-37.0

9.30-37.6

$11.5-30.6$

32.5-78.9

$11.7-29.0$

7.71-23.3

44.8-142

$15.2-44.9$

64.7-145

10.6-28.2

16.8-39.1

11.5-56.0

13.1-36.1

54.6-152

19.4-45.6

53.2-171

53.7-114

58.4-152

$11.6-45.3$
80.2

12.8

46.3

31.7

20.5

25.7

53.0

26.2

17.0

102

31.1

96.6

24.6

31.9

38.7

24.4

108

36.3

105

85.2

102

31.6 


\begin{tabular}{lllll}
\hline & $\begin{array}{l}\text { Certified } \\
\text { Analyte }\end{array}$ & $\begin{array}{l}\text { Performance } \\
\text { Acceptance Limits }\end{array}$ & $\begin{array}{l}\text { EX } \\
\text { Aesult }\end{array}$ & $\begin{array}{l}\text { Result } \\
\text { Quallfier }\end{array}$ \\
\hline
\end{tabular}

Cations (Lot 435)

Calcium ( $\mu g / L)$

Magnesium ( $\mu g / \mathrm{L})$

Potassium $(\mu \mathrm{g} / \mathrm{L})$

Sodium $(\mu g / L)$

Cyanide and Phenol (Lot 9982)

Cyanide, total $(\mu g / L)$

Phenols $(\mu g / L)$

\section{Grease and Oil (Lot 9982)}

Grease and oil (gravimetric) (mg/bottle)

Inorganics (Lot 3424)

Alkalinity (as $\mathrm{CaCO}_{3}$ ) ( $\left.\mu \mathrm{g} / \mathrm{L}\right)$

Chloride $(\mu g / L)$

Fluoride $(\mu \mathrm{g} / \mathrm{L})$

Nitrate as nitrogen $(\mu g / L)$

$\mathrm{pH}$ (pH units)

Potassium $(\mu g / L)$

Sodium $(\mu g / L)$

Specific conductance $(\mu \mathrm{S} / \mathrm{cm})$

Sulfate $(\mu g / L)$

Total dissolved solids ( $\mu \mathrm{g} / \mathrm{L}$ )

\section{Nutrients (Lot 9982)}

Ammonia as nitrogen $(\mu g / L)$

Nitrate-nitrite as nitrogen $(\mu \mathrm{g} / \mathrm{L})$

Total phosphates (as P) ( $\mu g / L)$

PCBs (Lot 582)

PCB $1260(\mu \mathrm{g} / \mathrm{L})$

Pesticides (Lot 582)

Aldrin $(\mu g / L)$

alpha-Benzene hexachloride $(\mu \mathrm{g} / \mathrm{L})$

beta-Benzene hexachloride $(\mu \mathrm{g} / \mathrm{L})$

alpha-Chlordane ( $\mu \mathrm{g} / \mathrm{L}$ )

4,4'-DDD ( $\mu g / L)$

4,4'-DDE $(\mu \mathrm{g} / \mathrm{L})$

4,4'-DDT $(\mu g / L)$

Dieldrin $(\mu g / L)$

Endrin $(\mu g / L)$

Heptachlor $(\mu g / L)$

Heptachlor epoxide $(\mu g / L)$

Lindane $(\mu g / L)$

Pesticides/Herbicides (Lot 3224)

2-sec-Butyl-4,6-dinitrophenol ( $\mu g / L)$

2,4-Dichlorophenoxyacetic acid $(\mu g / L)$

2,4,5-TP (Silvex) ( $\mu g / L$ )
19,500

15,900

28,200

22,300

82.1

141

30.4

$17,600-21,500$
$14,200-17,600$
$25,700-30,700$
$19,600-25,000$

18,800

15,100

26,800

21,200

59.9-104

107-175

80.0

128

$18.2-38.0$

22.5

184,000

121,000

9,160

6,970

9.22

38,300

235,000

1,170

150,000

936,000

3,370

5,340

6,730

3.99

$2.51-4.79$

4.19

0.975

6.03

4.53

1.07

3.17

7.20

1.78

4.01

5.16

2.13

9.31

2.08

$171,000-207,000$

$108,000-136,000$

$8,240-10,100$

$6,270-7,670$

9.02-9.42

$32,900-44,700$

$212,000-260,000$

980-1,330

$129,000-169,000$

$767,000-1,050,000$

$2,830-3,910$

$4,750-5,930$

$5,720-7,740$

3,560

5,010

6,670

0.506-1.20

3.35-7.67

2.42-5.73

$0.647-1.33$

$1.95-4.12$

$4.20-9.02$

$1.03-2.24$

$2.48-5.18$

$3.23-6.66$

$0.964-2.64$

$5.75-11.4$

$1.17-2.70$

$0.803-3.17$

1.89-5.66

$0.995-2.99$

1.68

3.66

2.24

Total Petroleum Hydrocarbons (Lot 8913)

Total petroleum hydrocarbons, standard 1, 139 infrared ( $\mathrm{mg} /$ bottle)

88.6-181

$184 \dagger$ 


\begin{tabular}{lllll}
\hline Analyte & $\begin{array}{l}\text { Certified } \\
\text { Value }\end{array}$ & $\begin{array}{l}\text { Performance } \\
\text { Acceptance Limits }\end{array}$ & $\begin{array}{l}\text { EX } \\
\text { Result }\end{array}$ & $\begin{array}{l}\text { Result } \\
\text { Qualifier }\end{array}$ \\
\hline
\end{tabular}

Toxaphene (Lot 3224)

Toxaphene $(\mu g / L)$

5.21

$2.87-7.55$

3.75

Trace Metals (Lot 9982)

Aluminum $(\mu g / L)$

Antimony ( $\mu g / L)$

333

122

Arsenic $(\mu g / L)$

167

Barium ( $\mu \mathrm{g} / \mathrm{L})$

Beryllium $(\mu g / L)$

Boron $(\mu g / L)$

Cadmium ( $\mu g / L)$

Chromium ( $\mu \mathrm{g} / \mathrm{L}$ )

Cobalt $(\mu g / L)$

Copper ( $\mu g /$ )

Iron $(\mu g / L)$

Lead $(\mu g / L)$

Manganese $(\mu \mathrm{g} / \mathrm{L})$

Mercury $(\mu g / L)$

Molybdenum $(\mu g / L)$

Nickel $(\mu g / L)$

Selenium ( $\mu g / L)$

Silver $(\mu \mathrm{g} / \mathrm{L})$

Strontium $(\mu g / L)$

Thallium $\left(\mu g^{\prime} L\right)$

Vanadium ( $\mu g / L)$

Zinc ( $\mu g / L)$

155-223

141-203

273-393

118-170

200-288

6.67-12.4

173-249

159-229

117-184

132-190

219-315

104-174

187-269

$310-446$

Turbidity (Lot 3424)

Turbidity (NTU)

\section{Volatiles (Lot 582)}

Benzene $(\mu g / L)$

18.0

Bromodichloromethane $(\mu g / L)$

\section{4}

Carbon tetrachloride $(\mu \mathrm{g} / \mathrm{L}) \quad 59.9$

Chlorobenzene $(\mu \mathrm{g} / \mathrm{L}) \quad 72.9$

Chloroform $(\mu \mathrm{g} / \mathrm{L})$

72.9
50.3

44.5

$\begin{array}{ll}\text { 1,2-Dichlorobenzene }(\mu g / L) & 32.3 \\ \text { 1,3-Dichlorobenzene }(\mu g / L) & 20.1\end{array}$

1,4-Dichlorobenzene $(\mu \mathrm{g} / \mathrm{L}) \quad 42.6$

1,2-Dichloroethane ( $\left.\mu g^{\prime} L\right)$

Dichloromethane (methylene chloride) ( $\mu \mathrm{g} / \mathrm{L}$ ) 50.3

1,2-Dichloropropane $(\mu g / L)$

Ethylbenzene $(\mu g / L)$

84.9

2-Hexanone $(\mu \mathrm{g} / \mathrm{L})$

19.7

83.4

75.3

26.5

Tetrachloroethylene $(\mu g / L)$

17.5

Toluene $(\mu \mathrm{g} / \mathrm{L})$

15.0
70.5

1,1,1-Trichloroethane $(\mu g / L)$

Trichloroethylene $(\mu g / L)$ 63.7
13.9-22.4

76.6-124

$72.0-127$

44.0-74.6

$57.0-87.4$

$38.6-61.5$

34.6-54.8

24.5-39.7

$15.4-24.2$

$32.0-51.9$

$41.6-66.9$

37.9-61.6

60.1-111

14.7-23.0

49.2-121

43.5-103

19.6-32.0

13.5-21.1

10.8-17.9

52.3-85.3

41.2-80.2
19.3
$128 \dagger$
$130 \dagger$
64.2
79.2
52.8
54.1
33.3
20.7
45.5
58.6
$79.1 \dagger$
$49.9 \dagger$
22.9
68.8
76.3
25.2
17.9
15.2
68.4
68.8

$\uparrow$ Result is out of range.

$\mathrm{J}$ The analytical result is an estimated quantity. 
Table 57. ES, EX, and WA Performance Evaluation, Water Pollution Study WP038

\begin{tabular}{|c|c|c|c|c|c|}
\hline Analyte & $\begin{array}{l}\text { ES } \\
\text { Result }\end{array}$ & $\begin{array}{l}\text { EX } \\
\text { Result }\end{array}$ & $\begin{array}{l}\text { WA } \\
\text { Result }\end{array}$ & $\begin{array}{l}\text { True } \\
\text { Value }\end{array}$ & $\begin{array}{l}\text { Performance } \\
\text { Acceptance Limits }\end{array}$ \\
\hline \multicolumn{6}{|l|}{ Trace Metals ( $\mu g / L)$} \\
\hline $\begin{array}{l}\text { Aluminum } \\
\text { Antimony } \\
\text { Arsenic } \\
\text { Beryllium } \\
\text { Cadmium } \\
\text { Chromium } \\
\text { Cobalt } \\
\text { Copper } \\
\text { Iron } \\
\text { Lead } \\
\text { Manganese } \\
\text { Mercury } \\
\text { Molybdenum } \\
\text { Nickel } \\
\text { Selenium } \\
\text { Silver } \\
\text { Strontium } \\
\text { Thallium } \\
\text { Titanium } \\
\text { Vanadium } \\
\text { Zinc }\end{array}$ & $\begin{array}{l}1920 \\
162 \\
408 \\
7.00 \\
69.0 \\
426 \\
402 \\
293 \\
2130 \\
427 \\
1120 \\
3.71 \\
57.1 \\
193 \\
1940 \\
55.5 \\
33.8 \\
201 \\
48.2 \\
7620 \\
1550\end{array}$ & $\begin{array}{l}1540 \\
111 \\
407 \\
7.45 \\
68.7 \\
431 \\
418 \\
292 \\
2150 \\
431 \\
1150 \\
4.25 \\
55.1 \\
198 \\
1900 \\
64.9 \\
32.6 \\
200 \\
48.7 \\
7770 \\
1560\end{array}$ & $\begin{array}{l}1920 \\
160 \\
466 \\
7.00 \\
65.6 \\
419 \\
406 \\
274 \\
2130 \\
442 \\
1140 \\
3.55 \\
65.1 \\
180 \\
2160 \\
63.6 \\
31.3 \\
220 \\
48.7 \\
7680 \\
1510\end{array}$ & $\begin{array}{l}1903 \\
170 \\
410 \\
8.25 \\
69.0 \\
420 \\
401 \\
277 \\
2100 \\
430 \\
1100 \\
3.85 \\
56.9 \\
188 \\
1951 \\
60.0 \\
32.1 \\
200 \\
48.9 \\
7604 \\
1551\end{array}$ & $\begin{array}{l}1690-2150 \\
108-206 \\
344-478 \\
4.87-11.2 \\
58.5-78.6 \\
371-473 \\
346-456 \\
252-305 \\
1890-2280 \\
379-480 \\
995-1240 \\
2.87-4.30 \\
45.8-65.4 \\
168-213 \\
1570-2220 \\
51.7-67.7 \\
27.4-36.9 \\
161-230 \\
40.9-56.0 \\
6890-8310 \\
1360-1760\end{array}$ \\
\hline \multicolumn{6}{|l|}{ Minerals (mg/L, except as noted) } \\
\hline $\begin{array}{l}\left.\text { Alkalinity (as } \mathrm{CaCO}_{3}\right) \text {, total } \\
\text { Calcium } \\
\text { Chloride } \\
\text { Fluoride } \\
\text { Hardness (as } \mathrm{CaCO}_{3} \text { ), total } \\
\text { Magnesium } \\
\text { Potassium } \\
\text { Sodium } \\
\text { Specific conductance ( } \mu \mathrm{S} / \mathrm{cm}) \\
\text { Sulfate } \\
\text { Total dissolved solids at } 180^{\circ} \mathrm{C}\end{array}$ & $\begin{array}{l}59.0 \\
82.9 \\
163 \\
1.86 \\
226 \\
5.28 \\
13.5 \\
69.3 \\
817 \\
95.7 \\
558\end{array}$ & $\begin{array}{l}59.0 \\
84.1 \\
248 \\
1.63 \\
231 \\
5.18 \\
11.5 \\
72.6 \\
870 \\
96.9 \\
540\end{array}$ & $\begin{array}{l}54.7 \\
83.7 \\
168 \\
1.81 \\
234 \\
5.44 \\
13.1 \\
72.0 \\
879 \\
77.5 \\
591\end{array}$ & $\begin{array}{l}58.1 \\
83.0 \\
163 \\
1.90 \\
229 \\
5.30 \\
12.5 \\
68.3 \\
887 \\
96.0 \\
512\end{array}$ & $\begin{array}{l}52.6-64.1 \\
74.6-92.9 \\
150-176 \\
1.65-2.12 \\
208-249 \\
4.51-5.86 \\
10.9-14.4 \\
61.3-76.1 \\
804-920 \\
81.7-109 \\
440-668\end{array}$ \\
\hline \multicolumn{6}{|l|}{ Nutrients $(\mathbf{m g} / \mathrm{L})$} \\
\hline $\begin{array}{l}\text { Ammonia nitrogen } \\
\text { Nitrate nitrogen } \\
\text { Nitrogen by Kjeldahl method } \\
\text { Orthophosphate } \\
\text { Total phosphorus }\end{array}$ & $\begin{array}{l}2.92 \\
31.6 \\
21.4 \\
1.51 \\
1.05\end{array}$ & $\begin{array}{l}2.72 \\
31.4 \\
27.4 \\
1.59 \\
1.16\end{array}$ & $\begin{array}{l}2.85 \\
36.8 \\
23.4 \\
1.49 \\
1.15\end{array}$ & $\begin{array}{l}2.80 \\
31.0 \\
24.0 \\
1.50 \\
1.10\end{array}$ & $\begin{array}{l}2.16-3.47 \\
25.4-35.7 \\
18.3-29.2 \\
1.29-1.72 \\
0.906-1.33\end{array}$ \\
\hline \multicolumn{6}{|l|}{ Demands (mg/L) } \\
\hline $\begin{array}{l}\text { 5-day Biochemical oxygen demand } \\
\text { Carbonaceous BOD } \\
\text { Chemical oxygen demand } \\
\text { Total organic carbon }\end{array}$ & $\begin{array}{l}56.1 \\
48.0 \\
72.0 \\
36.1\end{array}$ & $\begin{array}{l}53.3 \\
\dagger \\
76.3 \\
30.5\end{array}$ & $\begin{array}{l}56 \\
47 \\
81.5 \\
32.4\end{array}$ & $\begin{array}{l}50.3 \\
43.0 \\
81.0 \\
32.0\end{array}$ & $\begin{array}{r}26.0-74.6 \\
18.1-68.6 \\
-59.4-95.7 \\
26.7-37.2\end{array}$ \\
\hline \multicolumn{6}{|l|}{ PCBs ( $\mu g / L)$} \\
\hline $\begin{array}{l}\text { PCB } 1232 \\
\text { PCB } 1248\end{array}$ & $\begin{array}{c}0.821 \\
1.28\end{array}$ & $\begin{array}{l}2.00 \\
1.71\end{array}$ & $\begin{array}{l}1.52 \\
1.22\end{array}$ & $\begin{array}{l}1.61 \\
1.51\end{array}$ & $\begin{array}{l}0.682-2.37 \\
0.672-1.96\end{array}$ \\
\hline \multicolumn{6}{|l|}{ PCBs in Oil (mg/kg) } \\
\hline РCB 1254 & 35.0 & 30.0 & 25.1 & 32.7 & $0.983-46.2$ \\
\hline
\end{tabular}




\begin{tabular}{|c|c|c|c|c|c|}
\hline Analyte & $\begin{array}{l}\text { ES } \\
\text { Result }\end{array}$ & $\begin{array}{l}\text { EX } \\
\text { Result }\end{array}$ & $\begin{array}{l}\text { WA } \\
\text { Result }\end{array}$ & $\begin{array}{l}\text { True } \\
\text { Value }\end{array}$ & $\begin{array}{l}\text { Performance } \\
\text { Acceptance Limits }\end{array}$ \\
\hline PCB 1260 & 44.0 & 32.1 & 30.8 & 39.0 & $6.88-53.6$ \\
\hline \multicolumn{6}{|l|}{ Pesticides ( $\mu g / L)$} \\
\hline $\begin{array}{l}\text { Aldrin } \\
\text { Chlordane } \\
\text { p,p'-DDD } \\
\text { p,p-DDE } \\
\text { p,p'-DDT } \\
\text { Dieldrin } \\
\text { Heptachlor } \\
\text { Heptachlor epoxide }\end{array}$ & $\begin{array}{l}0.442 \\
6.85 \\
4.77 \\
1.75 \\
7.17 \\
2.16 \\
0.525 \\
0.242\end{array}$ & $\begin{array}{l}0.328 \\
6.74 \\
5.00 \\
1.86 \\
7.81 \\
2.25 \\
0.438 \\
0.229\end{array}$ & $\begin{array}{l}0.32 \\
3.25 \\
4.96 \\
1.95 \\
7.75 \\
2.08 \\
0.48 \\
0.24\end{array}$ & $\begin{array}{l}0.349 \\
6.46 \\
4.64 \\
1.86 \\
7.42 \\
2.22 \\
0.564 \\
0.244\end{array}$ & $\begin{array}{l}0.109-0.463 \\
2.94-9.13 \\
2.49-6.53 \\
0.959-2.45 \\
3.92-9.31 \\
1.25-2.99 \\
0.182-0.762 \\
0.135-0.319\end{array}$ \\
\hline \multicolumn{6}{|l|}{ Volatile Halocarbons ( $\mu \mathrm{g} / \mathrm{L})$} \\
\hline $\begin{array}{l}\text { Bromodichloromethane } \\
\text { Bromoform } \\
\text { Carbon tetrachloride } \\
\text { Chlorobenzene } \\
\text { Chloroform } \\
\text { Dibromochloromethane } \\
\text { 1,2-Dichloroethane } \\
\text { Methylene chloride } \\
\text { Tetrachloroethylene } \\
\text { 1,1,1-Trichloroethane } \\
\text { Trichloroethylene }\end{array}$ & $\begin{array}{l}53.3 \\
24.4 \\
44.7 \\
41.0 \\
49.0 \\
29.0 \\
31.2 \\
67.0 \\
45.0 \\
36.4 \\
33.0\end{array}$ & $\begin{array}{l}50.4 \\
24.9 \\
45.7 \\
39.0 \\
45.7 \\
26.0 \\
33.2 \\
61.2 \\
45.8 \\
41.5 \\
30.7\end{array}$ & $\begin{array}{l}41.8 \\
21.4 \\
36.0 \\
33.1 \\
41.2 \\
23.4 \\
31.0 \\
50.5 \\
38.0 \\
32.9 \\
26.7\end{array}$ & $\begin{array}{l}50.3 \\
26.4 \\
44.8 \\
37.7 \\
46.4 \\
27.3 \\
32.8 \\
64.2 \\
43.7 \\
38.7 \\
33.6\end{array}$ & $\begin{array}{l}33.5-62.1 \\
15.6-36.1 \\
27.9-53.5 \\
26.4-47.4 \\
30.6-51.5 \\
17.6-34.8 \\
21.2-42.3 \\
37.1-75.0 \\
26.1-55.0 \\
26.3-42.8 \\
20.4-40.3\end{array}$ \\
\hline \multicolumn{6}{|l|}{ Volatile Aromatics ( $\mu g / L)$} \\
\hline $\begin{array}{l}\text { Benzene } \\
\text { 1,2-Dichlorobenzene } \\
\text { 1,3-Dichlorobenzene } \\
\text { 1,4-Dichlorobenzene } \\
\text { Ethylbenzene } \\
\text { Toluene }\end{array}$ & $\begin{array}{l}14.0 \\
35.5 \\
17.9 \\
26.1 \\
8.10 \\
13.0\end{array}$ & $\begin{array}{l}13.6 \\
36.4 \\
19.5 \\
26.6 \\
9.00 \\
13.0\end{array}$ & $\begin{array}{l}12.1 \\
28.2 \\
14.3 \\
20.6 \\
7.10 \\
11.1\end{array}$ & $\begin{array}{l}13.3 \\
34.7 \\
18.3 \\
25.4 \\
8.60 \\
12.7\end{array}$ & $\begin{array}{l}9.69-17.1 \\
25.1-42.3 \\
13.0-21.9 \\
18.6-32.1 \\
6.02-10.5 \\
9.21-15.7\end{array}$ \\
\hline \multicolumn{6}{|l|}{ Miscellaneous Parameters (mg/L) } \\
\hline $\begin{array}{l}\text { Cyanide, total } \\
\text { Nonfilterable residue } \\
\text { Oil and grease (hexane extraction) } \\
\text { Oil and grease (Freon extraction) } \\
\text { pH (pH units) } \\
\text { Phenolics, total } \\
\text { Residual chlorine, total } \\
\end{array}$ & $\begin{array}{l}0.142 \\
41.0 \\
t \\
12.0 \\
6.58 \\
0.127 \\
+\end{array}$ & $\begin{array}{l}0.175 \\
36.0 \\
10.6 \\
\dagger \\
6.60 \\
0.267 \\
1.57 \\
\end{array}$ & $\begin{array}{l}0.168 \\
218 \\
\dagger \\
12.4 \\
6.62 \\
0.125 \\
1.47 \\
\end{array}$ & $\begin{array}{l}0.190 \\
46.0 \\
12.2 \\
12.2 \\
6.58 \\
0.113 \\
1.39 \\
\end{array}$ & $\begin{array}{l}0.119-0.259 \\
33.3-48.0 \\
5.10-17.6 \\
4.35-18.2 \\
6.44-6.74 \\
0.0402-0.180 \\
1.14-1.73 \\
\end{array}$ \\
\hline
\end{tabular}

† Result was not reported.

Note: The true value is based on gravimetric calculations or a reference value when necessary. Reported values that were out of range appear in bold. In cases where the laboratory was asked to check for error, the reported values appear in bold italic. 
Table 58. WA Performance Evaluation, Water Pollution Study WP039

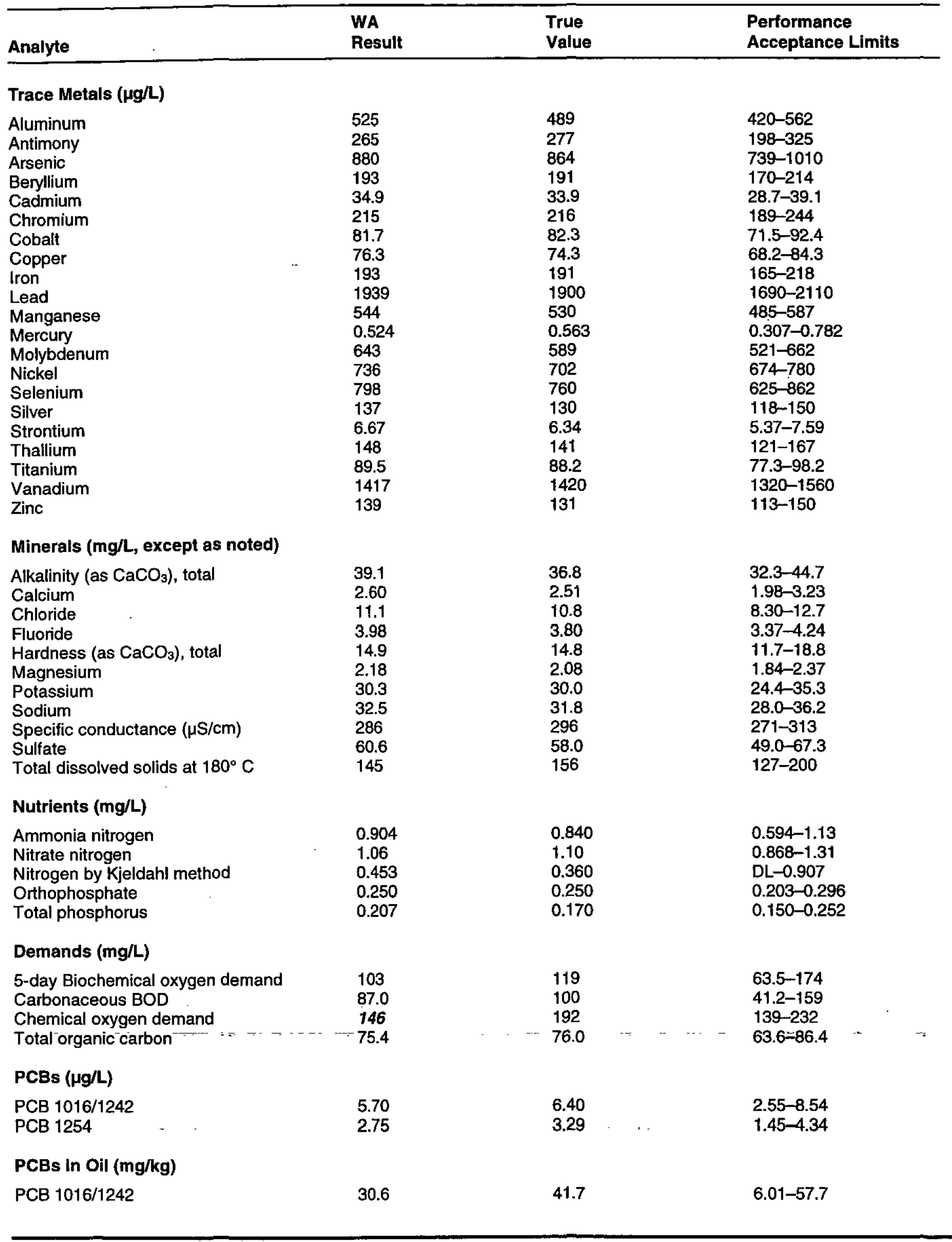




\begin{tabular}{|c|c|c|c|}
\hline Analyte & $\begin{array}{l}\text { WA } \\
\text { Result }\end{array}$ & $\begin{array}{l}\text { True } \\
\text { Value }\end{array}$ & $\begin{array}{l}\text { Performance } \\
\text { Acceptance Limits }\end{array}$ \\
\hline PCB 1260 & 13.9 & 16.6 & $2.93-23.7$ \\
\hline \multicolumn{4}{|l|}{ Pesticides ( $\mu g / L)$} \\
\hline $\begin{array}{l}\text { Aldrin } \\
\text { Chlordane } \\
\text { p,p'-DDD } \\
\text { p,p'-DDE } \\
\text { p,p'-DDT } \\
\text { Dieldrin } \\
\text { Heptachlor } \\
\text { Heptachlor epoxide }\end{array}$ & $\begin{array}{l}1.38 \\
11.6 \\
2.23 \\
1.55 \\
2.93 \\
1.72 \\
0.750 \\
0.480\end{array}$ & $\begin{array}{l}1.48 \\
12.7 \\
2.35 \\
1.47 \\
3.25 \\
1.72 \\
0.764 \\
0.586\end{array}$ & $\begin{array}{l}0.354-2.12 \\
5.86-18.9 \\
1.19-2.94 \\
0.791-2.56 \\
1.07-3.76 \\
0.949-2.14 \\
0.236-1.03 \\
0.317-0.693\end{array}$ \\
\hline \multicolumn{4}{|l|}{ Volatile Halocarbons ( $\mu g / L$ ) } \\
\hline $\begin{array}{l}\text { Bromodichloromethane } \\
\text { Bromoform } \\
\text { Carbon tetrachloride } \\
\text { Chlorobenzene } \\
\text { Chloroform } \\
\text { Dibromochloromethane } \\
\text { 1,2-Dichloroethane } \\
\text { Methylene chloride } \\
\text { Tetrachloroethylene } \\
\text { 1,1,1-Trichloroethane } \\
\text { Trichloroethylene }\end{array}$ & $\begin{array}{l}18.8 \\
32.2 \\
13.8 \\
14.3 \\
23.4 \\
18.1 \\
19.7 \\
23.7 \\
14.2 \\
15.5 \\
10.5\end{array}$ & $\begin{array}{l}21.6 \\
36.8 \\
15.2 \\
16.6 \\
27.2 \\
20.4 \\
22.8 \\
33.6 \\
17.5 \\
17.4 \\
12.7\end{array}$ & $\begin{array}{l}15.7-25.8 \\
21.7-47.5 \\
8.37-20.9 \\
11.8-20.6 \\
18.5-33.3 \\
13.7-25.0 \\
15.8-28.9 \\
21.8-41.8 \\
11.1-22.3 \\
11.3-23.3 \\
7.88-15.3\end{array}$ \\
\hline \multicolumn{4}{|l|}{ Volatile Aromatics ( $\mu g / L)$} \\
\hline $\begin{array}{l}\text { Benzene } \\
\text { 1,2-Dichlorobenzene } \\
\text { 1,3-Dichlorobenzene } \\
\text { 1,4-Dichlorobenzene } \\
\text { Ethylbenzene } \\
\text { Toluene }\end{array}$ & $\begin{array}{l}38.3 \\
11.0 \\
18.1 \\
16.0 \\
22.8 \\
51.7\end{array}$ & $\begin{array}{l}46.4 \\
13.8 \\
22.4 \\
18.8 \\
27.3 \\
62.6\end{array}$ & $\begin{array}{l}35.0-57.9 \\
9.42-16.2 \\
15.7-26.4 \\
13.6-23.9 \\
19.2-34.5 \\
46.5-76.5\end{array}$ \\
\hline \multicolumn{4}{|l|}{ Miscellaneous Parameters (mg/L) } \\
\hline $\begin{array}{l}\text { Cyanide, total } \\
\text { Nonfilterable residue } \\
\text { Oil and grease (Freon extraction) } \\
\mathrm{pH} \text { (pH units) } \\
\text { Phenolics, total } \\
\text { Residual chlorine, total }\end{array}$ & $\begin{array}{l}0.705 \\
76.3 \\
41.0 \\
5.01 \\
0.942 \\
0.350 \\
\end{array}$ & $\begin{array}{l}0.639 \\
96.0 \\
44.0 \\
5.03 \\
0.799 \\
0.280 \\
\end{array}$ & $\begin{array}{l}0.447-0.836 \\
36.8-109 \\
31.0-49.2 \\
4.93-5.14 \\
0.443-1.15 \\
0.229-0.439 \\
\end{array}$ \\
\hline
\end{tabular}

Note: The true value is based on gravimetric calculations or a reference value when necessary. Reported values that were out of range appear in bold. In cases where the laboratory was asked to check for error, the reported values appear in bold italic. "DL" stands for detection limit.

Table 59. WA Performance Evaluation, Water Supply Study WS040

\begin{tabular}{llll}
\hline Analyte & $\begin{array}{l}\text { WA } \\
\text { Result }\end{array}$ & $\begin{array}{l}\text { True } \\
\text { Value }\end{array}$ & $\begin{array}{l}\text { Performance } \\
\text { Acceptance Limits }\end{array}$ \\
\hline Trace Metals, $(\mu \mathrm{g} / \mathrm{L})$ & & & \\
Antimony & & & $9.1-16.9$ \\
Arsenic & 15.1 & 13.0 & $89.3-113$ \\
Barium & 108 & 102 & $2300-3110$ \\
Beryllium & 2724 & 2700 & $5.61-7.59$ \\
Boron & 6.62 & 6.60 & $1050-1290$ \\
\hline
\end{tabular}




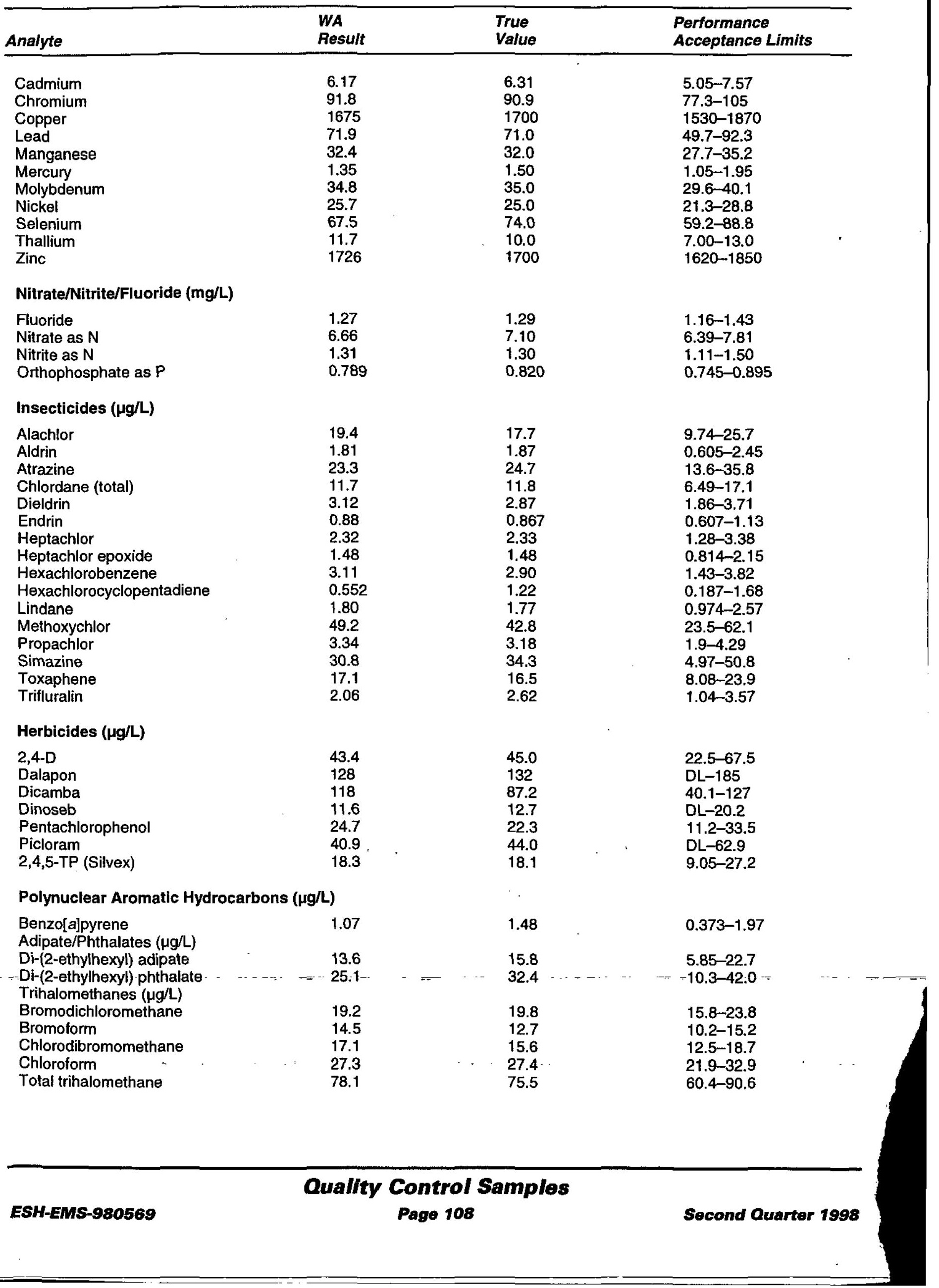




\begin{tabular}{|c|c|c|c|}
\hline Analyte & $\begin{array}{l}\text { WA } \\
\text { Result }\end{array}$ & $\begin{array}{l}\text { True } \\
\text { Value }\end{array}$ & $\begin{array}{l}\text { Performance } \\
\text { Acceptance Limits }\end{array}$ \\
\hline \multicolumn{4}{|l|}{ Volatile Organic Compounds ( $\mu g / L)$} \\
\hline $\begin{array}{l}\text { Benzene } \\
\text { Carbon tetrachloride } \\
\text { Chlorobenzene } \\
\text { 2-Chlorotoleune } \\
\text { 1,2-Dibromo-3-chloropropane } \\
\text { 1,2-Dichlorobenzene } \\
\text { 1,3-Dichlorobenzene } \\
\text { 1,4-Dichlorobenzene } \\
\text { 1,2-Dichloroethane } \\
\text { 1,1-Dichloroethylene } \\
\text { cis-1,2-Dichloroethylene } \\
\text { trans-1,2-Dichloroethylene } \\
\text { Dichloromethane } \\
\text { 1,2-Dichloropropane } \\
\text { cis-1,3-Dichloropropene } \\
\text { trans-1,3-Dichloropropene } \\
\text { Ethylbenzene } \\
\text { Ethylene dibromide } \\
\text { Hexachlorobutadiene } \\
\text { Styrene } \\
\text { 1,1,1,2-Tetrachloroethane } \\
\text { Tetrachloroethylene } \\
\text { Toluene } \\
\text { 1,2,4-Trichlorobenzene } \\
\text { 1,1,1-Trichloroethane } \\
1,1,2-\text { Trichloroethane } \\
\text { Trichloroethylene } \\
\text { 1,2,3-Trichloropropane } \\
\text { Vinyl chloride } \\
\text { Xylenes (total) }\end{array}$ & $\begin{array}{l}16.6 \\
9.44 \\
21.2 \\
11.0 \\
0.437 \\
16.7 \\
21.4 \\
10.9 \\
18.1 \\
20.2 \\
18.1 \\
24.6 \\
7.11 \\
19.0 \\
5.92 \\
6.97 \\
16.5 \\
0.603 \\
16.2 \\
18.6 \\
13.3 \\
13.4 \\
13.0 \\
11.6 \\
7.39 \\
15.6 \\
6.13 \\
17.9 \\
32.3 \\
30.1\end{array}$ & $\begin{array}{l}16.7 \\
8.90 \\
22.9 \\
10.2 \\
0.527 \\
18.4 \\
18.3 \\
11.6 \\
17.2 \\
18.3 \\
18.4 \\
26.8 \\
6.20 \\
19.0 \\
7.42 \\
8.60 \\
17.8 \\
0.638 \\
15.3 \\
18.9 \\
13.3 \\
14.7 \\
14.6 \\
12.3 \\
7.20 \\
17.2 \\
5.80 \\
18.7 \\
27.2 \\
30.3 \\
\end{array}$ & $\begin{array}{l}13.4-20.0 \\
5.34-12.5 \\
18.3-27.5 \\
7.28-12.5 \\
0.316-0.738 \\
14.7-22.1 \\
13.8-22.5 \\
9.28-13.9 \\
13.8-20.6 \\
14.6-22.0 \\
14.7-22.1 \\
21.4-32.2 \\
3.72-8.68 \\
15.2-22.8 \\
4.15-7.52 \\
4.49-8.92 \\
14.2-21.4 \\
0.383-0.893 \\
11.5-19.8 \\
15.1-22.7 \\
9.87-15.2 \\
11.8-17.6 \\
11.7-17.5 \\
9.84-14.8 \\
4.32-10.1 \\
13.8-20.6 \\
3.48-8.14 \\
12.0-22.8 \\
16.3-38.1 \\
24.2-36.4\end{array}$ \\
\hline \multicolumn{4}{|c|}{ Inorganic Disinfection By-products ( $\mu g / L)$} \\
\hline $\begin{array}{l}\text { Bromate } \\
\text { Bromide } \\
\text { Chlorate } \\
\text { Chlorite }\end{array}$ & $\begin{array}{l}43.0 \\
363 \\
114 \\
482\end{array}$ & $\begin{array}{l}36.0 \\
379 \\
110 \\
420\end{array}$ & $\begin{array}{l}15.0-57.6 \\
310-452 \\
85.5-134 \\
259-660\end{array}$ \\
\hline \multicolumn{4}{|c|}{ Miscellaneous Analytes (mg/L except as noted) } \\
\hline $\begin{array}{l}\text { Residual free chlorine } \\
\text { Turbidity (NTU) } \\
\text { Total filterable residue } \\
\text { Calcium hardness (mg CaCO} / \mathrm{L} \text { ) } \\
\text { pH (units) } \\
\text { Alkalinity (mg } \mathrm{CaCO}_{3} / \mathrm{L} \text { ) } \\
\text { Sodium } \\
\text { Sulfate } \\
\text { Cyanide (total) } \\
\text { Total organic carbon }\end{array}$ & $\begin{array}{l}0.27 \\
8.49 \\
215 \\
92.2 \\
9.15 \\
37.1 \\
16.0 \\
222 \\
0.506 \\
3.82 \\
\end{array}$ & $\begin{array}{l}0.240 \\
7.80 \\
232 \\
95.0 \\
9.13 \\
34.4 \\
15.8 \\
225 \\
0.554 \\
3.70 \\
\end{array}$ & $\begin{array}{l}0.0199-0.460 \\
7.00-9.67 \\
147-380 \\
88.0-104 \\
8.93-9.33 \\
32.8-39.6 \\
14.4-17.8 \\
202-247 \\
0.416-0.693 \\
3.27-4.54 \\
\end{array}$ \\
\hline
\end{tabular}

Note: The true value is based on gravimetric calculations or a reference value when necessary. Reported values that were out of range appear in bold. In cases where the laboratory was asked to check for error, the reported values appear in bold italic. "DL" stands for detection limit. 
Table 60. Laboratory Control Sample and Blank Spike Recoveries for ES

\begin{tabular}{|c|c|c|c|c|c|}
\hline Analyte & $\begin{array}{l}\text { Qualified } \\
\text { Out of Ranget }\end{array}$ & $\begin{array}{l}\text { Mean } \\
\text { Recovery (\%) }\end{array}$ & $\begin{array}{l}\text { Standard } \\
\text { Deviation }\end{array}$ & $\begin{array}{l}\text { Minimum } \\
\text { Recovery (\%) }\end{array}$ & $\begin{array}{l}\text { Maximum } \\
\text { Recovery (\%) }\end{array}$ \\
\hline \multicolumn{6}{|l|}{ EPA300.0 } \\
\hline Nitrate as nitrogen & $2 / 5$ & 100 & 2.65 & 98.1 & 103 \\
\hline \multicolumn{6}{|l|}{ EPA350.1 } \\
\hline Ammonia nitrogen & $1 / 2$ & 99.9 & 1.63 & 98.7 & 101 \\
\hline \multicolumn{6}{|l|}{ EPA353.2 } \\
\hline Nitrate-nitrite as nitrogen & $6 / 10$ & 99.6 & 4.97 & 90.0 & 106 \\
\hline \multicolumn{6}{|l|}{ EPA365.1 } \\
\hline Total phosphates (as P) & $0 / 4$ & 99.4 & 3.17 & 95.3 & 103 \\
\hline \multicolumn{6}{|l|}{ EPA6010 } \\
\hline Aluminum & $0 / 12$ & 98.6 & 1.65 & 95.5 & 100 \\
\hline Antimony & $0 / 4$ & 101 & 0.96 & 100 & 102 \\
\hline Arsenic & $0 / 12$ & 99.6 & 3.24 & 95.5 & 106 \\
\hline Barium & $0 / 11$ & 96.5 & 2.20 & 93.0 & 100 \\
\hline Beryllium & $0 / 4$ & 101 & 0.50 & 100 & 101 \\
\hline Boron & $0 / 3$ & 101 & 3.33 & 96.8 & 103 \\
\hline Cadmium & $0 / 11$ & 97.8 & 2.38 & 94.8 & 102 \\
\hline Calcium & $0 / 6$ & 101 & 1.72 & 98.2 & 103 \\
\hline Chromium & $0 / 12$ & 98.5 & 2.36 & 96.0 & 105 \\
\hline Cobalt & $0 / 4$ & 98.4 & 0.90 & 97.6 & 99.6 \\
\hline Copper & $0 / 4$ & 101 & 1.72 & 99.6 & 103 \\
\hline Iron & $0 / 12$ & 101 & 2.04 & 96.8 & 103 \\
\hline Lead & $0 / 14$ & 100 & 3.16 & 95.6 & 105 \\
\hline Lithium & $0 / 2$ & 101 & 2.62 & 99.3 & 103 \\
\hline Magnesium & $0 / 6$ & 103 & 2.0 & 100 & 106 \\
\hline Manganese & $0 / 7$ & 100 & 2.24 & 98.4 & 105 \\
\hline Nickel & $0 / 4$ & 97.2 & 0.83 & 96.2 & 98.2 \\
\hline Potassium & $0 / 6$ & 92.3 & 2.51 & 87.9 & 94.2 \\
\hline Selenium & $0 / 11$ & 99.1 & 5.72 & 90.3 & 108 \\
\hline Silica & $0 / 2$ & 104 & 0.71 & 103 & 104 \\
\hline Silver & $0 / 11$ & 99.6 & 4.0 & 92.8 & 105 \\
\hline Sodium & $0 / 6$ & 91.2 & 3.64 & 86.7 & 96.0 \\
\hline Thallium & $0 / 4$ & 95.4 & 2.01 & 92.6 & 96.9 \\
\hline Vanadium & $0 / 4$ & 101 & 0.50 & 100 & 101 \\
\hline Zinc & $0 / 4$ & 111 & 9.67 & 101 & 120 \\
\hline \multicolumn{6}{|l|}{ EPA7470 } \\
\hline Mercury. & $0 / 37$ & 101 & 6.34 & 85.4 & 117 \\
\hline \multicolumn{6}{|l|}{ EPA8010 } \\
\hline Carbon tetrachloride & $0 / 12$ & 96.1 & 3.43 & 89.6 & 99.6 \\
\hline Chloroform & $0 / 12$ & 96.1 & 2.98 & 92.0 & 100 \\
\hline Tetrachloroethylene & $0 / 12$ & 97.7 & 3.16 & 93.2 & 102 \\
\hline $1,1,1$-Trichloroethane & $0 / 12$ & 96.4 & 2.89 & 90.4 & 98.4 \\
\hline Trichloroethylene & $0 / 12$ & 100 & 4.66 & 94.4 & $109 \ldots$ \\
\hline \multicolumn{6}{|l|}{ EPA8081 } \\
\hline Aldrin & $0 / 5$ & 76.5 & 7.52 & 65.5 & 84.0 \\
\hline Dieldrin & $0 / 5$ & 105 & 10.7 & 87.7 & 117 \\
\hline Endrin & $0 / 6$ & 96.2 & 10.7 & 78.4 & 111 \\
\hline Heptachlor & $0 / 5$ & 92.5 & 7.88 & 79.2 & 99.0 \\
\hline Lindane & $0 / 5$ & 78.7 & 8.64 & 63.3 & 83.5 \\
\hline \multicolumn{6}{|l|}{ EPA8260 } \\
\hline Benzene & $0 / 25$ & 100 & 5.39 & 90.0 & 110 \\
\hline
\end{tabular}




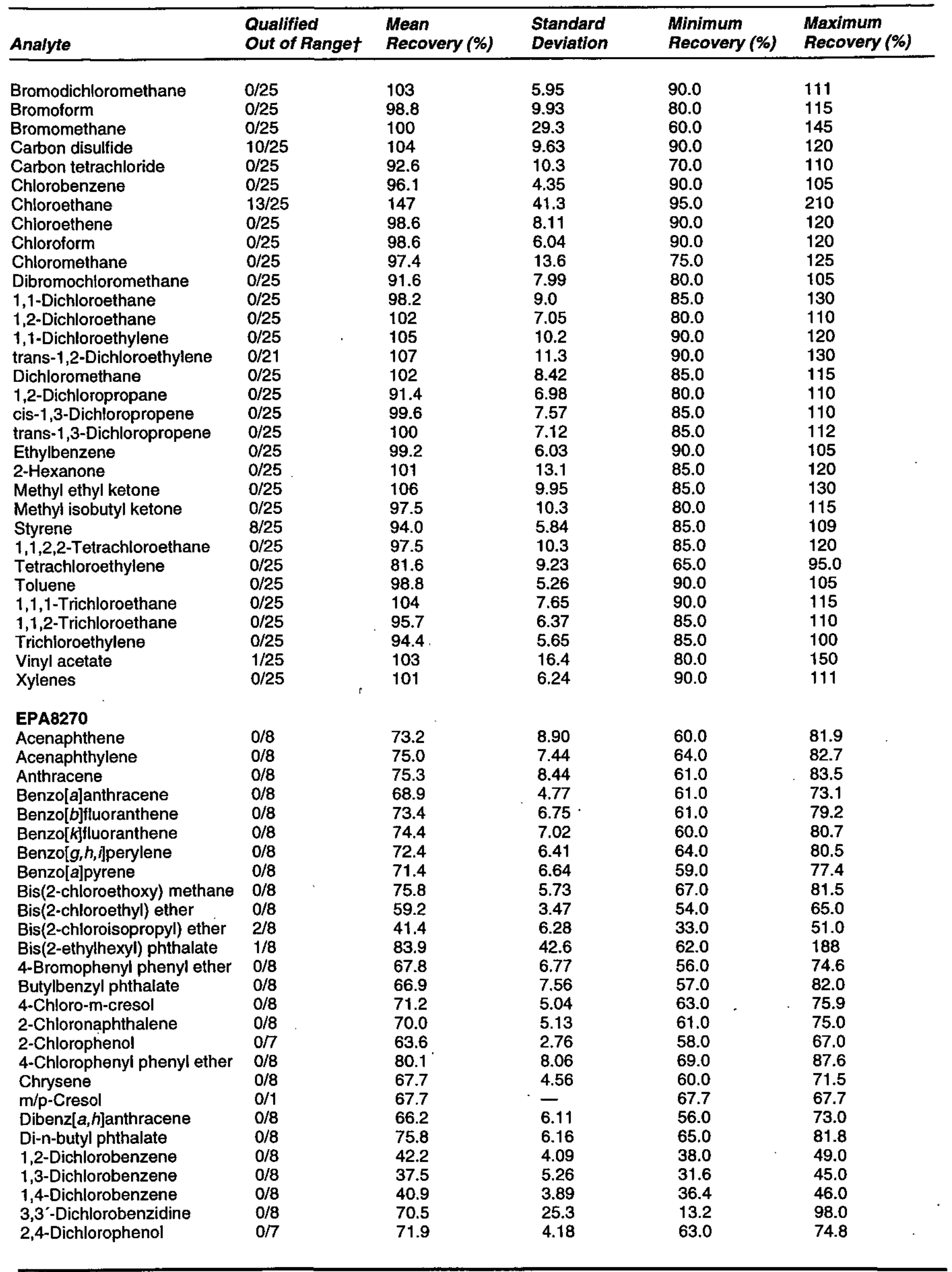




\begin{tabular}{|c|c|c|c|c|c|}
\hline Analyte & $\begin{array}{l}\text { Qualified } \\
\text { Out of Ranget }\end{array}$ & $\begin{array}{l}\text { Mean } \\
\text { Recovery (\%) }\end{array}$ & $\begin{array}{l}\text { Standard } \\
\text { Deviation }\end{array}$ & $\begin{array}{l}\text { Minimum } \\
\text { Recovery (\%) }\end{array}$ & $\begin{array}{l}\text { Maximum } \\
\text { Recovery (\%) }\end{array}$ \\
\hline $\begin{array}{l}\text { Diethyl phthalate } \\
\text { 2,4-Dimethyl phenol } \\
\text { Dimethyl phthalate } \\
\text { 2,4-Dinitrophenol } \\
\text { 2,4-Dinitrotoluene } \\
\text { 2,6-Dinitrotoluene } \\
\text { Di-n-octyl phthalate } \\
\text { Fluoranthene } \\
\text { Fluorene } \\
\text { Hexachlorobenzene } \\
\text { Hexachlorobutadiene } \\
\text { Hexachloroethane } \\
\text { Indeno[1,2,3-c,d]pyrene } \\
\text { Isophorone } \\
\text { 2-Methyl-4,6-dinitrophenol } \\
\text { Naphthalene } \\
\text { Nitrobenzene } \\
\text { 2-Nitrophenol } \\
\text { 4-Nitrophenol } \\
\text { N-Nitrosodipropylamine } \\
\text { Pentachlorophenol } \\
\text { Phenanthrene } \\
\text { Phenol } \\
\text { Pyrene } \\
\text { 1,2,4-Trichlorobenzene } \\
\text { 2,4,6-Trichlorophenol }\end{array}$ & $\begin{array}{l}0 / 8 \\
0 / 7 \\
0 / 8 \\
0 / 7 \\
3 / 8 \\
0 / 8 \\
0 / 8 \\
0 / 8 \\
0 / 8 \\
0 / 8 \\
0 / 8 \\
2 / 8 \\
0 / 8 \\
0 / 8 \\
0 / 7 \\
0 / 8 \\
0 / 8 \\
0 / 7 \\
3 / 7 \\
0 / 8 \\
0 / 7 \\
0 / 8 \\
0 / 7 \\
0 / 8 \\
0 / 8 \\
0 / 7\end{array}$ & $\begin{array}{l}78.5 \\
58.7 \\
75.8 \\
83.0 \\
90.2 \\
86.8 \\
77.0 \\
78.7 \\
77.0 \\
80.2 \\
52.0 \\
41.0 \\
76.9 \\
63.7 \\
84.8 \\
55.1 \\
65.5 \\
64.2 \\
74.5 \\
63.0 \\
73.6 \\
73.6 \\
65.9 \\
66.2 \\
51.5 \\
76.0\end{array}$ & $\begin{array}{l}8.28 \\
5.45 \\
7.66 \\
9.78 \\
11.3 \\
9.02 \\
7.27 \\
7.86 \\
9.68 \\
6.98 \\
3.33 \\
3.66 \\
6.73 \\
5.55 \\
4.29 \\
3.34 \\
5.88 \\
3.64 \\
6.32 \\
6.92 \\
4.01 \\
7.63 \\
3.14 \\
5.30 \\
3.32 \\
5.17\end{array}$ & $\begin{array}{l}66.0 \\
52.0 \\
64.0 \\
66.0 \\
66.0 \\
69.0 \\
62.0 \\
67.0 \\
61.0 \\
69.0 \\
48.0 \\
34.3 \\
66.0 \\
56.0 \\
78.0 \\
50.0 \\
56.0 \\
57.0 \\
67.0 \\
49.0 \\
65.0 \\
61.0 \\
61.0 \\
58.0 \\
46.0 \\
68.0\end{array}$ & $\begin{array}{l}86.8 \\
63.9 \\
83.6 \\
89.5 \\
99.1 \\
93.9 \\
85.0 \\
86.4 \\
86.3 \\
87.3 \\
58.0 \\
46.0 \\
84.8 \\
71.0 \\
88.5 \\
58.5 \\
72.0 \\
66.9 \\
80.3 \\
68.0 \\
76.1 \\
81.0 \\
68.8 \\
72.6 \\
56.1 \\
81.0\end{array}$ \\
\hline $\begin{array}{l}\text { EPA9010A } \\
\text { Cyanide }\end{array}$ & $0 / 3$ & 103 & 3.06 & 100 & 106 \\
\hline $\begin{array}{l}\text { EPA9056 } \\
\text { Chloride } \\
\text { Nitrate as nitrogen } \\
\text { Nitrite as nitrogen } \\
\text { Sulfate }\end{array}$ & $\begin{array}{l}4 / 8 \\
12 / 24 \\
0 / 4 \\
4 / 8\end{array}$ & $\begin{array}{l}99.1 \\
99.0 \\
97.9 \\
98.4\end{array}$ & $\begin{array}{l}1.95 \\
1.07 \\
1.05 \\
1.43\end{array}$ & $\begin{array}{l}96.9 \\
97.0 \\
96.7 \\
96.9\end{array}$ & $\begin{array}{l}103 \\
101 \\
99.1 \\
101\end{array}$ \\
\hline $\begin{array}{l}\text { EPA9060M } \\
\text { Total organic carbon }\end{array}$ & $0 / 7$ & 96.4 & 6.25 & 88.3 & 104 \\
\hline $\begin{array}{l}\text { EPA9214 } \\
\text { Fluoride }\end{array}$ & $0 / 2$ & 102 & 0.0 & 102 & 102 \\
\hline $\begin{array}{l}\text { ESESOPM008 } \\
\text { Cesium-137 } \\
\text { Cobalt-57 } \\
\text { Cobalt-60 } \\
\text { Yttrium-88 }\end{array}$ & $\begin{array}{l}0 / 2 \\
0 / 2 \\
0 / 2 \\
0 / 2\end{array}$ & $\begin{array}{l}106 \\
102 \\
100 \\
98.2\end{array}$ & $\begin{array}{l}0.0 \\
0.0 \\
0.0 \\
0.0\end{array}$ & $\begin{array}{l}106 \\
102 \\
100 \\
98.2\end{array}$ & $\begin{array}{l}106 \\
102 \\
100 \\
98.2\end{array}$ \\
\hline $\begin{array}{l}\text { ESESOPM017 } \\
\text { Gross alpha } \\
\text { Nonvolatile beta }\end{array}$ & $\begin{array}{l}0 / 9 \\
0 / 8\end{array}$ & $\begin{array}{l}98.8 \\
92.3\end{array}$ & $\begin{array}{l}3.23 \\
9.29\end{array}$ & $\begin{array}{l}93.8 \\
81.9\end{array}$ & $\begin{array}{l}102 \\
106\end{array}$ \\
\hline $\begin{array}{l}\text { ESESOPM020 } \\
\text { Tritium }\end{array}$ & $0 / 4$ & 89.9 & 2.25 & 87.9 & 91.8 \\
\hline $\begin{array}{l}\text { ESESOPMO29 } \\
\text { Radium, total alpha-emitting }\end{array}$ & $1 / 2$ & 69.5 & 43.2 & 38.9 & 100 \\
\hline $\begin{array}{l}\text { ESESOPM030 } \\
\text { Radium-226 }\end{array}$ & $0 / 2$ & 89.9 & 0.0 & 89.9 & 89.9 \\
\hline
\end{tabular}




\begin{tabular}{llllll}
\hline Analyte & $\begin{array}{l}\text { Qualified } \\
\text { Out of Ranget }\end{array}$ & $\begin{array}{l}\text { Mean } \\
\text { Recovery (\%) }\end{array}$ & $\begin{array}{l}\text { Standard } \\
\text { Deviation }\end{array}$ & $\begin{array}{l}\text { Minimum } \\
\text { Recovery (\%) }\end{array}$ & $\begin{array}{l}\text { Maximum } \\
\text { Recovery (\%) }\end{array}$ \\
\hline Radium-228 & $0 / 2$ & 115 & 0.0 & 115 & 115 \\
$\begin{array}{l}\text { ESESOPM031 } \\
\text { Strontium-90 }\end{array}$ & $0 / 2$ & 96.0 & 0.0 & 96.0 & 96.0 \\
ESESOPM032 & & & & & \\
Americium-241 & $0 / 1$ & 91.3 & - & 91.3 & 91.3 \\
Curium-245/246 & $0 / 1$ & 91.3 & - & 91.3 & 91.3 \\
Neptunium-237 & $1 / 1$ & 65.0 & - & 65.0 & 65.0 \\
Plutonium-238 & $0 / 2$ & 100 & 0.0 & 100 & 100 \\
Thorium-230 & $0 / 2$ & 112 & 0.0 & 112 & 112 \\
Uranium-233/234 & $0 / 2$ & 97.3 & 0.0 & 97.3 & 97.3 \\
Uranium-238 & $0 / 2$ & 99.0 & 0.0 & 99.0 & 99.0 \\
\hline
\end{tabular}

† Number of batches qualified that exhibit poor laboratory control sample and blank spike recovery due to interference compared to the total number of batches containing laboratory control samples and blank spikes.

- Standard deviation cannot be determined.

Note: A value of 0 is reported as 0.0 .

Table 61. Laboratory Control Sample and Blank Spike Recoveries for EX

\begin{tabular}{|c|c|c|c|c|c|}
\hline Analyte & $\begin{array}{l}\text { Qualified } \\
\text { Out of Ranget }\end{array}$ & $\begin{array}{l}\text { Mean } \\
\text { Recovery (\%) }\end{array}$ & $\begin{array}{l}\text { Standard } \\
\text { Deviation }\end{array}$ & $\begin{array}{l}\text { Minimum } \\
\text { Recovery (\%) }\end{array}$ & $\begin{array}{l}\text { Maximum } \\
\text { Recovery (\%) }\end{array}$ \\
\hline $\begin{array}{l}\text { EPA120.1 } \\
\text { Specific conductance }\end{array}$ & $0 / 3$ & 100 & 1.15 & 99.0 & 101 \\
\hline $\begin{array}{l}\text { EPA160.1 } \\
\text { Total dissolved solids }\end{array}$ & $0 / 4$ & 98.0 & 0.82 & 97.0 & 99.0 \\
\hline $\begin{array}{l}\text { EPA300.0 } \\
\text { Chloride } \\
\text { Fluoride } \\
\text { Nitrate as nitrogen } \\
\text { Nitrate-nitrite as nitrogen } \\
\text { Sulfate }\end{array}$ & $\begin{array}{l}0 / 8 \\
0 / 4 \\
0 / 4 \\
0 / 9 \\
0 / 10\end{array}$ & $\begin{array}{l}75.6 \\
102 \\
105 \\
104 \\
96.6\end{array}$ & $\begin{array}{l}46.7 \\
1.50 \\
1.50 \\
1.94 \\
1.35\end{array}$ & $\begin{array}{l}0.0 \\
101 \\
103 \\
103 \\
94.0\end{array}$ & $\begin{array}{l}102 \\
104 \\
106 \\
109 \\
99.0\end{array}$ \\
\hline $\begin{array}{l}\text { EPA365.2 } \\
\text { Total phosphates (as P) }\end{array}$ & $0 / 3$ & 100 & 0.0 & 100 & 100 \\
\hline $\begin{array}{l}\text { EPA370.1 } \\
\text { Silica }\end{array}$ & $0 / 5$ & 94.8 & 2.05 & 93.0 & 98.0 \\
\hline $\begin{array}{l}\text { EPA410.4 } \\
\text { Chemical oxygen demand }\end{array}$ & $0 / 4$ & 96.0 & 0.0 & 96.0 & 96.0 \\
\hline $\begin{array}{l}\text { EPA420.1 } \\
\text { Phenols }\end{array}$ & $0 / 4$ & 103 & 6.99 & 96.0 & 112 \\
\hline $\begin{array}{l}\text { EPA6010A } \\
\text { Aluminum } \\
\text { Antimony } \\
\text { Arsenic } \\
\text { Barium } \\
\text { Beryllium } \\
\text { Boron } \\
\text { Cadmium }\end{array}$ & $\begin{array}{l}0 / 18 \\
0 / 8 \\
0 / 18 \\
0 / 12 \\
0 / 8 \\
0 / 2 \\
0 / 14\end{array}$ & $\begin{array}{l}108 \\
109 \\
105 \\
105 \\
105 \\
105 \\
107\end{array}$ & $\begin{array}{l}4.51 \\
6.67 \\
5.58 \\
3.99 \\
1.83 \\
0.0 \\
3.70\end{array}$ & $\begin{array}{l}102 \\
103 \\
93.0 \\
97.0 \\
103 \\
105 \\
98.0\end{array}$ & $\begin{array}{l}115 \\
119 \\
112 \\
112 \\
108 \\
105 \\
113\end{array}$ \\
\hline
\end{tabular}




\begin{tabular}{|c|c|c|c|c|c|}
\hline Analyte & $\begin{array}{l}\text { Qualified } \\
\text { Out of Ranget }\end{array}$ & $\begin{array}{l}\text { Mean } \\
\text { Recovery (\%) }\end{array}$ & $\begin{array}{l}\text { Standard } \\
\text { Deviation }\end{array}$ & $\begin{array}{l}\text { Minimum } \\
\text { Recovery (\%) }\end{array}$ & $\begin{array}{l}\text { Maximum } \\
\text { Recovery (\%) }\end{array}$ \\
\hline $\begin{array}{l}\text { Calcium } \\
\text { Chromium } \\
\text { Cobalt } \\
\text { Copper } \\
\text { Iron } \\
\text { Lead } \\
\text { Magnesium } \\
\text { Manganese } \\
\text { Molybdenum } \\
\text { Nickel } \\
\text { Potassium } \\
\text { Selenium } \\
\text { Silver } \\
\text { Sodium } \\
\text { Strontium } \\
\text { Thallium } \\
\text { Vanadium } \\
\text { Zinc }\end{array}$ & $\begin{array}{l}0 / 6 \\
0 / 14 \\
0 / 6 \\
0 / 8 \\
0 / 18 \\
0 / 28 \\
0 / 6 \\
0 / 6 \\
0 / 2 \\
0 / 8 \\
0 / 6 \\
0 / 18 \\
0 / 14 \\
0 / 6 \\
0 / 2 \\
0 / 12 \\
0 / 6 \\
0 / 8\end{array}$ & $\begin{array}{l}107 \\
107 \\
109 \\
105 \\
108 \\
105 \\
107 \\
107 \\
104 \\
106 \\
102 \\
111 \\
107 \\
106 \\
104 \\
106 \\
105 \\
106\end{array}$ & $\begin{array}{l}2.58 \\
4.50 \\
2.32 \\
1.85 \\
4.39 \\
5.58 \\
3.20 \\
2.23 \\
4.95 \\
1.64 \\
3.13 \\
5.87 \\
4.09 \\
1.17 \\
0.0 \\
3.33 \\
1.26 \\
2.23\end{array}$ & $\begin{array}{l}104 \\
97.0 \\
106 \\
102 \\
102 \\
92.0 \\
103 \\
104 \\
100 \\
103 \\
96.0 \\
98.0 \\
98.0 \\
105 \\
104 \\
99.0 \\
103 \\
103\end{array}$ & $\begin{array}{l}111 \\
114 \\
112 \\
107 \\
114 \\
115 \\
111 \\
109 \\
107 \\
108 \\
104 \\
119 \\
114 \\
108 \\
104 \\
109 \\
106 \\
109\end{array}$ \\
\hline $\begin{array}{l}\text { EPA7430 } \\
\text { Lithium }\end{array}$ & $0 / 6$ & 99.0 & 1.67 & 96.0 & 100 \\
\hline $\begin{array}{l}\text { EPA7470A } \\
\text { Mercury }\end{array}$ & $1 / 14$ & 93.3 & 6.97 & 76.0 & 103 \\
\hline $\begin{array}{l}\text { EPA8010A } \\
\text { Carbon tetrachloride } \\
\text { Chloroform } \\
\text { cis-1,2-Dichloroethylene } \\
\text { Tetrachloroethylene } \\
\text { 1,1,1-Trichloroethane } \\
\text { Trichloroethylene }\end{array}$ & $\begin{array}{l}0 / 8 \\
2 / 8 \\
0 / 8 \\
2 / 8 \\
2 / 8 \\
2 / 8\end{array}$ & $\begin{array}{l}102 \\
108 \\
115 \\
111 \\
102 \\
107\end{array}$ & $\begin{array}{l}11.0 \\
15.0 \\
6.94 \\
13.2 \\
20.1 \\
15.4\end{array}$ & $\begin{array}{l}91.0 \\
91.0 \\
104 \\
98.0 \\
84.0 \\
95.0\end{array}$ & $\begin{array}{l}120 \\
133 \\
124 \\
133 \\
135 \\
133\end{array}$ \\
\hline $\begin{array}{l}\text { EPA8081 } \\
\text { Aldrin } \\
\text { p,p'-DDT } \\
\text { Dieldrin } \\
\text { Endrin } \\
\text { Heptachlor } \\
\text { Lindane } \\
\text { PCB } 1260\end{array}$ & $\begin{array}{l}0 / 6 \\
0 / 6 \\
0 / 6 \\
0 / 6 \\
1 / 6 \\
0 / 6 \\
0 / 4\end{array}$ & $\begin{array}{l}86.2 \\
107 \\
97.7 \\
101 \\
82.3 \\
86.0 \\
104\end{array}$ & $\begin{array}{l}19.2 \\
19.6 \\
10.8 \\
11.7 \\
21.5 \\
20.1 \\
0.82\end{array}$ & $\begin{array}{l}52.0 \\
80.0 \\
84.0 \\
86.0 \\
45.0 \\
49.0 \\
103\end{array}$ & $\begin{array}{l}106 \\
132 \\
112 \\
113 \\
103 \\
108 \\
105\end{array}$ \\
\hline $\begin{array}{l}\text { EPA8151 } \\
\text { 2-sec-Butyl-4,6-dinitrophenol } \\
\text { 2,4-Dichlorophenoxyacetic } \\
\text { acid } \\
\text { 2,4,5-TP (Silvex) }\end{array}$ & $\begin{array}{l}4 / 5 \\
0 / 5 \\
2 / 5\end{array}$ & $\begin{array}{l}60.4 \\
82.8 \\
102\end{array}$ & $\begin{array}{l}17.3 \\
5.17 \\
7.37\end{array}$ & $\begin{array}{l}48.0 \\
80.0 \\
90.0\end{array}$ & $\begin{array}{l}90.0 \\
92.0 \\
108\end{array}$ \\
\hline $\begin{array}{l}\text { EPA8260A } \\
\text { Benzene } \\
\text { Chlorobenzene } \\
\text { 1,1-Dichloroethylene } \\
\text { Toluene } \\
\text { Trichloroethylene }\end{array}$ & $\begin{array}{l}0 / 56 \\
0 / 56 \\
0 / 56 \\
0 / 56 \\
1 / 56\end{array}$ & $\begin{array}{l}95.7 \\
99.0 \\
-105- \\
94.9 \\
94.0\end{array}$ & $\begin{array}{l}8.60 \\
5.90 \\
-12.4 \\
8.59 \\
7.12\end{array}$ & $\begin{array}{r}80.0 \\
86.0 \\
-75.0 \\
79.0 \\
73.0\end{array}$ & $\begin{array}{r}113 \\
115 \\
124 \\
112 \\
112\end{array}$ \\
\hline $\begin{array}{l}\text { EPA8270B } \\
\text { Acenaphthene } \\
\text { 4-Chloro-m-cresol } \\
\text { 2-Chlorophenol } \\
\text { 1,4-Dichlorobenzene } \\
\text { 2,4-Dinitrotoluene }\end{array}$ & $\begin{array}{l}0 / 8 \\
0 / 8 \\
0 / 8 \\
0 / 8 \\
0 / 8\end{array}$ & $\begin{array}{l}74.3 \\
77.3 \\
69.4 \\
62.8 \\
87.0\end{array}$ & $\begin{array}{l}12.9 \\
16.1 \\
15.4 \\
7.89 \\
10.2\end{array}$ & $\begin{array}{l}62.0 \\
64.0 \\
54.0 \\
51.0 \\
78.0\end{array}$ & $\begin{array}{l}95.0 \\
104 \\
95.0 \\
74.0 \\
103\end{array}$ \\
\hline
\end{tabular}




\begin{tabular}{llllll}
\hline Analyte & $\begin{array}{l}\text { Qualified } \\
\text { Out of Ranget }\end{array}$ & $\begin{array}{l}\text { Mean } \\
\text { Recovery (\%) }\end{array}$ & $\begin{array}{l}\text { Standard } \\
\text { Deviation }\end{array}$ & $\begin{array}{l}\text { Minimum } \\
\text { Recovery (\%) }\end{array}$ & $\begin{array}{l}\text { Maximum } \\
\text { Recovery (\%) }\end{array}$ \\
\hline & & & & & \\
4-Nitrophenol & $0 / 8$ & 83.5 & 8.40 & 71.0 & 94.0 \\
N-Nitrosodipropylamine & $0 / 7$ & 81.0 & 7.42 & 73.0 & 91.0 \\
$\begin{array}{l}\text { Pentachlorophenol } \\
\text { Phenol }\end{array}$ & $0 / 8$ & 83.1 & 22.2 & 64.0 & 119 \\
$\begin{array}{l}\text { Pyrene } \\
\text { 1,2,4-Trichlorobenzene }\end{array}$ & $0 / 8$ & 688.8 & 15.4 & 54.0 & 94.0 \\
EPA9010A & $0 / 8$ & 73.4 & 15.7 & 61.0 & 100 \\
Cyanide & & 65.1 & 12.0 & 55.0 & 85.0 \\
EPA9060 & $0 / 12$ & 98.7 & & & \\
Total organic carbon & & 2.10 & 95.0 & 101 \\
\hline
\end{tabular}

† Number of batches qualified that exhibit poor laboratory control sample and blank spike recovery due to interference compared to the total number of batches containing laboratory control samples and blank spikes.

Note: A value of 0 is reported as 0.0 .

Table 62. Laboratory Control Sample and Blank Spike Recoveries for GE

\begin{tabular}{|c|c|c|c|c|c|}
\hline Analyte & $\begin{array}{l}\text { Qualified } \\
\text { Out of Ranget }\end{array}$ & $\begin{array}{l}\text { Mean } \\
\text { Recovery (\%) }\end{array}$ & $\begin{array}{l}\text { Standard } \\
\text { Deviation }\end{array}$ & $\begin{array}{l}\text { Minimum } \\
\text { Recovery (\%) }\end{array}$ & $\begin{array}{l}\text { Maximum } \\
\text { Recovery (\%) }\end{array}$ \\
\hline \multicolumn{6}{|l|}{ EPA160.1 } \\
\hline Total dissolved solids & $0 / 7$ & 102 & 1.57 & 99.7 & 104 \\
\hline \multicolumn{6}{|l|}{ EPA300.0 } \\
\hline Bromide & $0 / 1$ & 102 & - & 102 & 102 \\
\hline Chloride & $0 / 1$ & 98.5 & - & 98.5 & 98.5 \\
\hline Nitrate as nitrogen & $0 / 1$ & 101 & - & 101 & 101 \\
\hline Sulfate & $0 / 1$ & 100 & - & 100 & 100 \\
\hline \multicolumn{6}{|l|}{ EPA353.1 } \\
\hline Nitrate-nitrite as nitrogen & $0 / 17$ & 102 & 5.88 & 95.0 & 118. \\
\hline \multicolumn{6}{|l|}{ EPA365.4 } \\
\hline Total phosphates (as P) & $0 / 1$ & 86.0 & - & 86.0 & 86.0 \\
\hline \multicolumn{6}{|l|}{ EPA6010A } \\
\hline Aluminum & $0 / 4$ & 99.5 & 1.86 & 97.2 & 101 \\
\hline Antimony & $0 / 7$ & 97.0 & 4.93 & 91.0 & 102 \\
\hline Arsenic & $0 / 7$ & 98.0 & 4.24 & 92.2 & 103 \\
\hline Barium & $0 / 7$ & 99.5 & 2.51 & 96.6 & 102 \\
\hline Beryllium & $0 / 4$ & 96.7 & 3.39 & 93.6 & 99.9 \\
\hline Boron & $0 / 4$ & 98.0 & 4.10 & 91.8 & 100 \\
\hline Cadmium & $0 / 7$ & 102 & 2.66 & 98.9 & 106 \\
\hline Calcium & $0 / 4$ & 98.2 & 3.81 & 94.7 & 102 \\
\hline Chromium & $0 / 7$ & 99.4 & 3.98 & 94.8 & 103 \\
\hline Cobalt & $0 / 5$ & 99.6 & 4.61 & 94.2 & 103 \\
\hline Copper & $0 / 7$ & 98.5 & 4.26 & 93.8 & 104 \\
\hline Iron & $0 / 4$ & 98.9 & 5.33 & 94.0 & 104 \\
\hline Lead & $0 / 7$ & 100 & 3.35 & 96.0 & 104 \\
\hline Magnesium & $0 / 4$ & 95.3 & 3.58 & 92.1 & 98.5 \\
\hline Manganese & $0 / 4$ & 96.1 & 6.22 & 90.7 & 102 \\
\hline Nickel & $0 / 7$ & 102 & 2.11 & 99.1 & 105 \\
\hline Potassium & $0 / 4$ & 99.8 & 8.90 & 91.3 & 108 \\
\hline Selenium & $0 / 6$ & 94.9 & 5.21 & 89.2 & 100 \\
\hline Silver & $2 / 9$ & 78.4 & 42.0 & 4.24 & 104 \\
\hline
\end{tabular}




\begin{tabular}{|c|c|c|c|c|c|}
\hline Analyte & $\begin{array}{l}\text { Qualified } \\
\text { Out of Ranget }\end{array}$ & $\begin{array}{l}\text { Mean } \\
\text { Recovery (\%) }\end{array}$ & $\begin{array}{l}\text { Standard } \\
\text { Deviation }\end{array}$ & $\begin{array}{l}\text { Minimum } \\
\text { Recovery (\%) }\end{array}$ & $\begin{array}{l}\text { Maximum } \\
\text { Recovery (\%) }\end{array}$ \\
\hline $\begin{array}{l}\text { Sodium } \\
\text { Thallium } \\
\text { Tin } \\
\text { Vanadium } \\
\text { Zinc }\end{array}$ & $\begin{array}{l}0 / 4 \\
0 / 4 \\
0 / 5 \\
0 / 5 \\
0 / 9\end{array}$ & $\begin{array}{l}103 \\
102 \\
98.7 \\
98.5 \\
102\end{array}$ & $\begin{array}{l}4.12 \\
2.46 \\
3.73 \\
4.31 \\
2.13\end{array}$ & $\begin{array}{l}98.9 \\
99.5 \\
92.3 \\
93.4 \\
98.2\end{array}$ & $\begin{array}{l}107 \\
104 \\
102 \\
102 \\
105\end{array}$ \\
\hline $\begin{array}{l}\text { EPA6020 } \\
\text { Cadmium } \\
\text { Lead } \\
\text { Lithium }\end{array}$ & $\begin{array}{l}0 / 10 \\
0 / 11 \\
0 / 2\end{array}$ & $\begin{array}{l}100 \\
101 \\
105\end{array}$ & $\begin{array}{l}2.48 \\
2.48 \\
1.41\end{array}$ & $\begin{array}{l}96.6 \\
97.0 \\
104\end{array}$ & $\begin{array}{l}104 \\
107 \\
106\end{array}$ \\
\hline $\begin{array}{l}\text { EPA7470 } \\
\text { Mercury }\end{array}$ & $0 / 30$ & 100 & 7.78 & 81.5 & 113 \\
\hline $\begin{array}{l}\text { EPA8081 } \\
\text { Aldrin } \\
\text { p,p'-DDT } \\
\text { Dieldrin } \\
\text { Endrin } \\
\text { Heptachlor } \\
\text { Lindane }\end{array}$ & $\begin{array}{l}0 / 3 \\
0 / 3 \\
0 / 3 \\
0 / 3 \\
0 / 3 \\
0 / 3\end{array}$ & $\begin{array}{l}85.0 \\
83.7 \\
84.8 \\
96.0 \\
95.1 \\
93.8\end{array}$ & $\begin{array}{l}21.9 \\
12.4 \\
9.73 \\
6.93 \\
13.9 \\
14.2\end{array}$ & $\begin{array}{l}69.1 \\
71.2 \\
78.4 \\
92.0 \\
82.4 \\
83.4\end{array}$ & $\begin{array}{l}110 \\
96.0 \\
96.0 \\
104 \\
110 \\
110\end{array}$ \\
\hline $\begin{array}{l}\text { EPA8151 } \\
2,4-\text {-Dichlorophenoxyacetic } \\
\quad \text { acid } \\
2,4,5-T \\
2,4,5-T P \text { (Silvex) }\end{array}$ & $\begin{array}{l}1 / 2 \\
1 / 2 \\
0 / 2\end{array}$ & $\begin{array}{l}74.5 \\
85.0 \\
87.2\end{array}$ & $\begin{array}{l}12.0 \\
17.0 \\
12.5\end{array}$ & $\begin{array}{l}66.0 \\
73.0 \\
78.3\end{array}$ & $\begin{array}{l}83.0 \\
97.0 \\
96.0\end{array}$ \\
\hline $\begin{array}{l}\text { EPA8260A } \\
\text { Benzene } \\
\text { Chlorobenzene } \\
\text { 1,1-Dichloroethylene } \\
\text { Toluene } \\
\text { Trichloroethylene }\end{array}$ & $\begin{array}{l}0 / 14 \\
0 / 14 \\
1 / 14 \\
0 / 14 \\
0 / 14\end{array}$ & $\begin{array}{l}94.8 \\
93.0 \\
86.8 \\
94.1 \\
93.8\end{array}$ & $\begin{array}{l}9.23 \\
7.16 \\
9.92 \\
8.63 \\
9.45\end{array}$ & $\begin{array}{l}84.1 \\
84.1 \\
63.1 \\
83.1 \\
83.0\end{array}$ & $\begin{array}{l}111 \\
105 \\
102 \\
109 \\
118\end{array}$ \\
\hline $\begin{array}{l}\text { EPA8270B } \\
\text { Acenaphthene } \\
\text { 4-Chloro-m-cresol } \\
\text { 2-Chlorophenol } \\
\text { 1,4-Dichlorobenzene } \\
\text { 2,4-Dinitrotoluene } \\
\text { 4-Nitrophenol } \\
\text { N-Nitrosodipropylamine } \\
\text { Pentachlorophenol } \\
\text { Phenol } \\
\text { Pyrene } \\
\text { 1,2,4-Trichlorobenzene }\end{array}$ & $\begin{array}{l}1 / 3 \\
1 / 3 \\
1 / 3 \\
1 / 3 \\
3 / 3 \\
1 / 3 \\
1 / 3 \\
0 / 3 \\
1 / 3 \\
0 / 3 \\
2 / 3\end{array}$ & $\begin{array}{l}78.8 \\
74.9 \\
65.3 \\
65.7 \\
95.1 \\
27.8 \\
69.6 \\
91.1 \\
27.1 \\
81.9 \\
70.4\end{array}$ & $\begin{array}{l}6.06 \\
2.87 \\
2.31 \\
6.56 \\
20.3 \\
2.47 \\
3.25 \\
2.88 \\
1.75 \\
7.32 \\
6.48\end{array}$ & $\begin{array}{l}72.6 \\
72.8 \\
63.9 \\
58.6 \\
72.3 \\
25.1 \\
66.4 \\
88.0 \\
25.4 \\
73.9 \\
63.2\end{array}$ & $\begin{array}{l}84.7 \\
78.2 \\
68.0 \\
71.5 \\
111 \\
29.9 \\
72.9 \\
93.7 \\
28.9 \\
88.3 \\
75.7\end{array}$ \\
\hline $\begin{array}{l}\text { EPA9012 } \\
\text { Cyanide }\end{array}$ & $1 / 4$ & 107 & 12.0 & 94.2 & 123 \\
\hline $\begin{array}{l}\text { EPA9020B } \\
\text { Total organic halogens }\end{array}$ & $0 / 4$ & $-\cdots+\cdot$ & 7.08 & $\begin{array}{l}97.3 \\
97\end{array}$ & 114 \\
\hline $\begin{array}{l}\text { EPA9045C } \\
\mathrm{pH}\end{array}$ & $0 / 25$ & 99.8 & 0.65 & 98.7 & 102 \\
\hline $\begin{array}{l}\text { EPA9050 } \\
\text { Specific conductance } \\
\text { EPA9056 }\end{array}$ & $0 / 16$ & 100 & 0.77 & 98.7 & 102 \\
\hline \multicolumn{6}{|c|}{ Quality Control Samples } \\
\hline
\end{tabular}




\begin{tabular}{|c|c|c|c|c|c|}
\hline Analyte & $\begin{array}{l}\text { Qualified } \\
\text { Out of Ranget }\end{array}$ & $\begin{array}{l}\text { Mean } \\
\text { Recovery (\%) }\end{array}$ & $\begin{array}{l}\text { Standard } \\
\text { Deviation }\end{array}$ & $\begin{array}{l}\text { Minimum } \\
\text { Recovery (\%) }\end{array}$ & $\begin{array}{l}\text { Maximum } \\
\text { Recovery (\%) }\end{array}$ \\
\hline $\begin{array}{l}\text { Chloride } \\
\text { Fluoride } \\
\text { Sulfate }\end{array}$ & $\begin{array}{l}0 / 1 \\
0 / 1 \\
0 / 2\end{array}$ & $\begin{array}{l}100 \\
96.9 \\
102\end{array}$ & $\overline{\overline{1}}$ & $\begin{array}{l}100 \\
96.9 \\
101\end{array}$ & $\begin{array}{l}100 \\
96.9 \\
103\end{array}$ \\
\hline $\begin{array}{l}\text { EPA9060 } \\
\text { Total organic carbon }\end{array}$ & $0 / 5$ & 105 & 4.15 & 101 & 111 \\
\hline $\begin{array}{l}\text { EPA9066 } \\
\text { Phenols }\end{array}$ & $0 / 2$ & 88.1 & 1.84 & 86.8 & 89.4 \\
\hline
\end{tabular}

† Number of batches qualified that exhibit poor laboratory control sample and blank spike recovery due to interference compared to the total number of batches containing laboratory control samples and blank spikes.

- Standard deviation cannot be determined.

Table 63. Laboratory Control Sample and Blank Spike Recoveries for WA

\begin{tabular}{|c|c|c|c|c|c|}
\hline Analyte & $\begin{array}{l}\text { Qualified } \\
\text { Out of Ranget }\end{array}$ & $\begin{array}{l}\text { Mean } \\
\text { Recovery (\%) }\end{array}$ & $\begin{array}{l}\text { Standard } \\
\text { Deviation }\end{array}$ & $\begin{array}{l}\text { Minimum } \\
\text { Recovery (\%) }\end{array}$ & $\begin{array}{l}\text { Maximum } \\
\text { Recovery (\%) }\end{array}$ \\
\hline \multicolumn{6}{|l|}{ EPA160.1 } \\
\hline Total dissolved solids & $0 / 28$ & 104 & 3.56 & 96.0 & 115 \\
\hline \multicolumn{6}{|l|}{ EPA310.1 } \\
\hline Alkalinity $\left(2 \mathrm{CaCO}_{3}\right)$ & $0 / 18$ & 99.7 & 1.15 & 97.5 & 102 \\
\hline Carbonate & $0 / 10$ & 96.7 & 1.31 & 94.2 & 98.5 \\
\hline \multicolumn{6}{|l|}{ EPA340.2 } \\
\hline Fluoride & $0 / 6$ & 99.0 & 2.05 & 95.9 & 102 \\
\hline \multicolumn{6}{|l|}{ EPA350.3 } \\
\hline Ammonia & $0 / 1$ & 88.9 & - & 88.9 & 88.9 \\
\hline Ammonia nitrogen & $0 / 1$ & 92.6 & - & 92.6 & 92.6 \\
\hline \multicolumn{6}{|l|}{ EPA353.2 } \\
\hline Nitrate as nitrogen & $0 / 11$ & 105 & 3.18 & 98.4 & 108 \\
\hline Nitrate-nitrite as nitrogen & $0 / 22$ & 103 & 3.37 & 95.6 & 108 \\
\hline \multicolumn{6}{|l|}{ EPA365.2 } \\
\hline Total phosphates (as P) & $0 / 13$ & 100 & 2.34 & 95.9 & 104 \\
\hline \multicolumn{6}{|l|}{ EPA410.4 } \\
\hline Chemical oxygen demand & $0 / 2$ & 104 & 0.0 & 104 & 104 \\
\hline \multicolumn{6}{|l|}{ EPA6010 } \\
\hline Aluminum & $0 / 6$ & 102 & 2.22 & 98.6 & 105 \\
\hline Antimony & $0 / 10$ & 101 & 7.07 & 95.2 & 120 \\
\hline Arsenic & $0 / 11$ & 100 & 6.44 & 95.5 & 119 \\
\hline Barium & $0 / 18$ & 100 & 2.16 & 96.6 & 103 \\
\hline Beryllium & $0 / 7$ & 103 & 2.34 & 99.7 & 106 \\
\hline Boron & $0 / 5$ & 97.9 & 2.91 & 94.3 & 102 \\
\hline Cadmium & $0 / 10$ & 101 & 2.22 & 97.8 & 104 \\
\hline Calcium & $0 / 8$ & 102 & 1.15 & 99.7 & 103 \\
\hline Chromium & $0 / 12$ & 100 & 2.13 & 96.8 & 103 \\
\hline Cobalt & $0 / 7$ & 101 & 3.12 & 98.0 & 107 \\
\hline Copper & $0 / 10$ & 100 & 1.78 & 97.7 & 103 \\
\hline Iron & $0 / 12$ & 99.6 & 2.25 & 95.2 & 104 \\
\hline Lead & $0 / 17$ & 101 & 2.68 & 93.0 & 104 \\
\hline
\end{tabular}




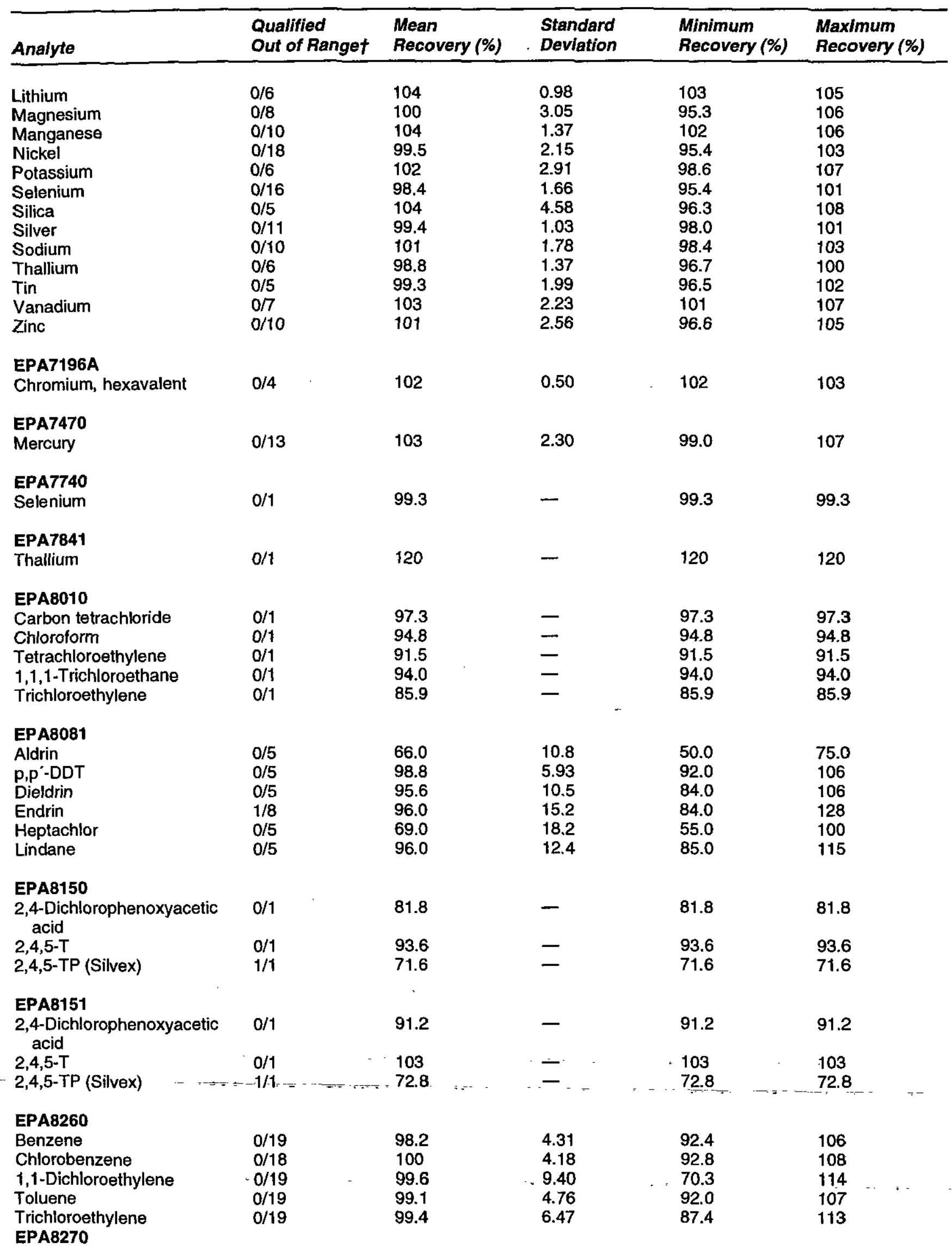




\begin{tabular}{|c|c|c|c|c|c|}
\hline Analyte & $\begin{array}{l}\text { Qualified } \\
\text { Out of Ranget }\end{array}$ & $\begin{array}{l}\text { Mean } \\
\text { Recovery (\%) }\end{array}$ & $\begin{array}{l}\text { Standard } \\
\text { Deviation }\end{array}$ & $\begin{array}{l}\text { Minimum } \\
\text { Recovery (\%) }\end{array}$ & $\begin{array}{l}\text { Maximum } \\
\text { Recovery (\%) }\end{array}$ \\
\hline $\begin{array}{l}\text { Acenaphthene } \\
\text { Bis(2-ethylhexyl) phthalate } \\
\text { 4-Chloro-m-cresol } \\
\text { 2-Chlorophenol } \\
\text { 1,4-Dichlorobenzene } \\
\text { 2,4-Dinitrotoluene } \\
\text { 4-Nitrophenol } \\
\text { N-Nitrosodipropylamine } \\
\text { Pentachlorophenol } \\
\text { Phenol } \\
\text { Pyrene } \\
\text { 1,2,4-Trichlorobenzene }\end{array}$ & $\begin{array}{l}0 / 9 \\
1 / 2 \\
0 / 9 \\
0 / 9 \\
0 / 9 \\
0 / 9 \\
0 / 9 \\
0 / 9 \\
0 / 9 \\
0 / 9 \\
0 / 9 \\
0 / 9\end{array}$ & $\begin{array}{l}76.3 \\
124 \\
70.2 \\
71.6 \\
63.4 \\
72.7 \\
50.0 \\
74.8 \\
68.4 \\
54.5 \\
84.2 \\
68.3\end{array}$ & $\begin{array}{l}12.3 \\
4.95 \\
10.1 \\
11.0 \\
15.2 \\
15.4 \\
26.5 \\
12.0 \\
25.1 \\
22.2 \\
17.9 \\
15.5\end{array}$ & $\begin{array}{l}51.3 \\
120 \\
51.5 \\
53.2 \\
44.4 \\
43.9 \\
14.8 \\
51.7 \\
19.7 \\
22.8 \\
49.9 \\
46.3\end{array}$ & $\begin{array}{l}88.5 \\
127 \\
85.7 \\
84.1 \\
87.2 \\
94.1 \\
91.7 \\
85.9 \\
97.0 \\
79.9 \\
105 \\
93.2\end{array}$ \\
\hline $\begin{array}{l}\text { EPA8280 } \\
\text { Heptachlorodibenzo-p-dioxins } \\
\text { Heptachlorodibenzo-p-furans } \\
\text { Hexachlorodibenzo-p-dioxins } \\
\text { Hexachlorodibenzo-p-furans } \\
1,2,3,4,6,7,8-H P C D D \\
1,2,3,4,6,7,8-H P C D F \\
\text { Octachlorodibenzo-p-dioxin } \\
\text { Octachlorodibenzo-p-furan } \\
1,2,3,7,8-P C D D \\
1,2,3,7,8-P C D F \\
\text { Pentachlorodibenzo-p-furans } \\
2,3,7,8-T C D D \\
2,3,7,8-T C D F \\
\text { Tetrachlorodibenzo-p-dioxins } \\
\text { Tetrachlorodibenzo-p-furans }\end{array}$ & $\begin{array}{l}0 / 7 \\
0 / 7 \\
0 / 7 \\
0 / 7 \\
0 / 7 \\
0 / 7 \\
0 / 7 \\
0 / 7 \\
0 / 7 \\
0 / 7 \\
0 / 14 \\
0 / 8 \\
0 / 7 \\
0 / 7 \\
0 / 7\end{array}$ & $\begin{array}{l}110 \\
112 \\
95.1 \\
100 \\
110 \\
112 \\
102 \\
107 \\
117 \\
111 \\
114 \\
109 \\
96.9 \\
109 \\
96.9\end{array}$ & $\begin{array}{l}7.61 \\
2.34 \\
4.81 \\
6.27 \\
7.61 \\
2.34 \\
2.88 \\
4.11 \\
6.65 \\
3.16 \\
5.97 \\
3.18 \\
2.34 \\
3.31 \\
2.34\end{array}$ & $\begin{array}{l}96.0 \\
110 \\
90.0 \\
93.0 \\
96.0 \\
110 \\
99.0 \\
101 \\
106 \\
107 \\
106 \\
105 \\
95.0 \\
105 \\
95.0\end{array}$ & $\begin{array}{l}119 \\
115 \\
102 \\
112 \\
119 \\
115 \\
107 \\
114 \\
124 \\
116 \\
124 \\
113 \\
101 \\
113 \\
101\end{array}$ \\
\hline $\begin{array}{l}\text { EPA9010A } \\
\text { Cyanide }\end{array}$ & $0 / 14$ & 94.4 & 3.03 & 88.8 & 99.9 \\
\hline $\begin{array}{l}\text { EPA9020B } \\
\text { Total organic halogens }\end{array}$ & $0 / 128$ & 99.4 & 4.34 & 90.3 & 110 \\
\hline $\begin{array}{l}\text { EPA9050 } \\
\text { Specific conductance }\end{array}$ & $0 / 10$ & 96.3 & 5.65 & 85.2 & 100 \\
\hline $\begin{array}{l}\text { EPA9056 } \\
\text { Chloride } \\
\text { Sulfate }\end{array}$ & $\begin{array}{l}0 / 8 \\
0 / 17\end{array}$ & $\begin{array}{l}94.8 \\
96.9\end{array}$ & $\begin{array}{l}3.14 \\
2.04\end{array}$ & $\begin{array}{l}87.6 \\
91.2\end{array}$ & $\begin{array}{l}97.1 \\
101\end{array}$ \\
\hline $\begin{array}{l}\text { EPA9060 } \\
\text { Total organic carbon }\end{array}$ & $0 / 35$ & 102 & 5.87 & 90.1 & 112 \\
\hline $\begin{array}{l}\text { EPA9066 } \\
\text { Phenols }\end{array}$ & $0 / 12$ & 101 & 4.22 & 94.4 & 109 \\
\hline
\end{tabular}

† Number of batches qualified that exhibit poor laboratory control sample and blank spike recovery due to interference compared to the total number of batches containing laboratory control samples and blank spikes.

- Standard deviation cannot be determined.

Note: A value of 0 is reported as 0.0 . 
Table 64. Laboratory Control Sample and Blank Spike Recoveries for GP

\begin{tabular}{|c|c|c|c|c|c|}
\hline Analyte & $\begin{array}{l}\text { Qualified } \\
\text { Out of Ranget }\end{array}$ & $\begin{array}{l}\text { Mean } \\
\text { Recovery (\%) }\end{array}$ & $\begin{array}{l}\text { Standard } \\
\text { Deviation }\end{array}$ & $\begin{array}{l}\text { Minimum } \\
\text { Recovery (\%) }\end{array}$ & $\begin{array}{l}\text { Maximum } \\
\text { Recovery (\%) }\end{array}$ \\
\hline $\begin{array}{l}\text { EPIA-001 } \\
\text { Gross alpha } \\
\text { Nonvolatile beta }\end{array}$ & $\begin{array}{l}3 / 28 \\
1 / 27\end{array}$ & $\begin{array}{l}104 \\
106\end{array}$ & $\begin{array}{l}12.1 \\
8.41\end{array}$ & $\begin{array}{l}79.8 \\
80.2\end{array}$ & $\begin{array}{l}123 \\
121\end{array}$ \\
\hline $\begin{array}{l}\text { EPIA-002 } \\
\text { Tritium }\end{array}$ & $1 / 22$ & 96.4 & 5.34 & 75.5 & 102 \\
\hline $\begin{array}{l}\text { EPIA-003 } \\
\text { Carbon-14 }\end{array}$ & $0 / 5$ & 99.7 & 2.51 & 96.0 & 102 \\
\hline $\begin{array}{l}\text { EPIA-004 } \\
\text { Strontium-90 }\end{array}$ & $2 / 6$ & 92.1 & 11.9 & 76.7 & 103 \\
\hline $\begin{array}{l}\text { EPIA-005 } \\
\text { Technetium-99 }\end{array}$ & $0 / 3$ & 100 & 1.39 & 98.6 & 101 \\
\hline $\begin{array}{l}\text { EPIA-006 } \\
\text { lodine-129 }\end{array}$ & $0 / 2$ & 106 & 17.0 & 93.9 & 118 \\
\hline $\begin{array}{l}\text { EPIA-008 } \\
\text { Radium-226 }\end{array}$ & $0 / 2$ & 97.4 & 10.8 & 89.7 & 105 \\
\hline $\begin{array}{l}\text { EPIA-009 } \\
\text { Radium-228 }\end{array}$ & $1 / 3$ & 109 & 15.8 & 91.1 & 121 \\
\hline $\begin{array}{l}\text { EPIA-010 } \\
\text { Radium, total alpha-emitting }\end{array}$ & $1 / 5$ & 84.4 & 7.98 & 74.9 & 95.5 \\
\hline $\begin{array}{l}\text { EPIA-011 } \\
\text { Americium-241 } \\
\text { Curium-243/244 } \\
\text { Plutonium-239/240 } \\
\text { Uranium-238 }\end{array}$ & $\begin{array}{l}0 / 3 \\
1 / 2 \\
0 / 2 \\
0 / 2\end{array}$ & $\begin{array}{l}105 \\
106 \\
95.6 \\
94.2\end{array}$ & $\begin{array}{l}12.9 \\
23.3 \\
4.45 \\
6.22\end{array}$ & $\begin{array}{l}93.3 \\
89.0 \\
92.4 \\
89.8\end{array}$ & $\begin{array}{l}119 \\
122 \\
98.7 \\
98.6\end{array}$ \\
\hline $\begin{array}{l}\text { EPIA-012 } \\
\text { Thorium-232 }\end{array}$ & $0 / 2$ & 109 & 8.49 & 103 & 115 \\
\hline $\begin{array}{l}\text { EPIA-013 } \\
\text { Cesium-137 }\end{array}$ & $0 / 3$ & 100 & 2.72 & 97.6 & 103 \\
\hline $\begin{array}{l}\text { EPIA-020 } \\
\text { Promethium-147 }\end{array}$ & $0 / 1$ & 97.6 & - & 97.6 & 97.6 \\
\hline $\begin{array}{l}\text { EPIA-022 } \\
\text { Nickel-63 }\end{array}$ & $0 / 2$ & 91.5 & 5.80 & 87.4 & 95.6 \\
\hline $\begin{array}{l}\text { EPIA-032 } \\
\text { Neptunium-237 }\end{array}$ & $0 / 1$ & 93.0 & - & 93.0 & 93.0 \\
\hline
\end{tabular}

† Number of batches qualified that exhibit poor laboratory control sample and blank spike recovery due to interference compared to the total number of batches containing laboratory control samples and blank spikes.

- Standard deviation cannot be determined. 
Table 65. Laboratory Control Sample and Blank Spike Recoveries for TM

\begin{tabular}{|c|c|c|c|c|c|}
\hline Analyte & $\begin{array}{l}\text { Qualified } \\
\text { Out of Ranget }\end{array}$ & $\begin{array}{l}\text { Mean } \\
\text { Recovery (\%) }\end{array}$ & $\begin{array}{l}\text { Standard } \\
\text { Deviation }\end{array}$ & $\begin{array}{l}\text { Minimum } \\
\text { Recovery (\%) }\end{array}$ & $\begin{array}{l}\text { Maximum } \\
\text { Recovery (\%) }\end{array}$ \\
\hline \multicolumn{6}{|l|}{ 3500NIEMOD } \\
\hline Nickel-63 & $0 / 1$ & 107 & - & 107 & 107 \\
\hline \multicolumn{6}{|l|}{ EICHROMTC1MOD } \\
\hline Technetium-99 & $0 / 1$ & 101 & - & 101 & 101 \\
\hline \multicolumn{6}{|l|}{ EMLAM01MOD } \\
\hline Americium-241 & $0 / 1$ & 96.8 & - & 96.8 & 96.8 \\
\hline Americium-241/Curium-246 & $0 / 1$ & 112 & - & 112 & 112 \\
\hline Curium-243/244 & $0 / 1$ & 102 & - & 102 & 102 \\
\hline \multicolumn{6}{|l|}{ EMLPM01MOD } \\
\hline Promethium-147 & $1 / 1$ & 136 & - & 136 & 136 \\
\hline \multicolumn{6}{|l|}{ EMLPU02MOD } \\
\hline Neptunium-237 & $1 / 1$ & 193 & - & 193 & 193 \\
\hline Plutonium-238 & $0 / 1$ & 96.8 & - & 96.8 & 96.8 \\
\hline Plutonium-239/240 & $0 / 1$ & 105 & - & 105 & 105 \\
\hline \multicolumn{6}{|l|}{ EMLSR02MOD } \\
\hline Strontium-90 & $2 / 14$ & 89.0 & 10.4 & 73.0 & 114 \\
\hline \multicolumn{6}{|l|}{ EMLTHO1MOD } \\
\hline Thorium-228 & $0 / 1$ & 104 & - & 104 & 104 \\
\hline Thorium-230 & $0 / 1$ & 99.1 & - & 99.1 & 99.1 \\
\hline Thorium-232 & $0 / 1$ & 105 & - & 105 & 105 \\
\hline \multicolumn{6}{|l|}{ EMLU02MOD } \\
\hline Uranium-234 & $0 / 2$ & 99.2 & 3.96 & 96.4 & 102 \\
\hline Uranium-235 & $0 / 2$ & 86.5 & 3.82 & 83.8 & 89.2 \\
\hline Uranium-238 & $0 / 2$ & 103 & 3.54 & 100 & 105 \\
\hline \multicolumn{6}{|l|}{ ENICMOD } \\
\hline Carbon-14 & $0 / 13$ & 101 & 2.91 & 97.2 & 106 \\
\hline \multicolumn{6}{|l|}{ EPA900.0MOD } \\
\hline $\begin{array}{l}\text { Gross alpha } \\
\text { Nonvolatile beta }\end{array}$ & $\begin{array}{l}1 / 49 \\
0 / 33\end{array}$ & $\begin{array}{l}92.2 \\
97.8\end{array}$ & $\begin{array}{l}9.78 \\
50\end{array}$ & $\begin{array}{l}79.0 \\
86.7\end{array}$ & 126 \\
\hline Nonvolatile beta & & & & 86.7 & 111 \\
\hline \multicolumn{6}{|l|}{ EPA901.1MOD } \\
\hline Cesium-137 & $0 / 5$ & 100 & 0.90 & 99.0 & 101 \\
\hline Cobalt-60 & $0 / 5$ & 98.7 & 1.48 & 96.9 & 101 \\
\hline \multicolumn{6}{|l|}{ EPA902.0MOD } \\
\hline \multicolumn{6}{|l|}{ EPA903.0MOD } \\
\hline Radium, total alpha-emitting & $0 / 15$ & 103 & 1.85 & 100 & 106 \\
\hline Radium-226 & $0 / 4$ & 96.2 & 3.56 & 92.4 & 101 \\
\hline \multicolumn{6}{|l|}{ EPA904.0MOD } \\
\hline Radium-228 & $2 / 4$ & 102 & 21.3 & 77.8 & 126 \\
\hline
\end{tabular}




\begin{tabular}{llllll}
\hline Analyte & $\begin{array}{l}\text { Qualified } \\
\text { Out of Ranget }\end{array}$ & $\begin{array}{l}\text { Mean } \\
\text { Recovery (\%) }\end{array}$ & $\begin{array}{l}\text { Standard } \\
\text { Deviation }\end{array}$ & $\begin{array}{l}\text { Minimum } \\
\text { Recovery (\%) }\end{array}$ & $\begin{array}{l}\text { Maximum } \\
\text { Recovery (\%) }\end{array}$ \\
\hline $\begin{array}{l}\text { EPA906.0MOD } \\
\text { Tritium }\end{array}$ & $2 / 55$ & 97.4 & 7.61 & 71.1 & 124 \\
\hline
\end{tabular}

† Number of batches qualified that exhibit poor laboratory control sample and blank spike recovery due to interference compared to the total number of batches containing laboratory control samples and blank spikes.

- Standard deviation cannot be determined.

Table 66. Surrogate Recoveries for ES

\begin{tabular}{|c|c|c|c|c|c|}
\hline Analyte & $\begin{array}{l}\text { Qualified } \\
\text { Out of Ranget }\end{array}$ & $\begin{array}{l}\text { Mean } \\
\text { Recovery (\%) }\end{array}$ & $\begin{array}{l}\text { Standard } \\
\text { Deviation }\end{array}$ & $\begin{array}{l}\text { Minimum } \\
\text { Recovery (\%) }\end{array}$ & $\begin{array}{l}\text { Maximum } \\
\text { Recovery (\%) }\end{array}$ \\
\hline EPA8010 & $=$ & & & & \\
\hline $\begin{array}{l}\text { Dibromofluoromethane } \\
\text { 1,3-Chlorofluorbenzene }\end{array}$ & $\begin{array}{l}13 / 108 \\
0 / 108\end{array}$ & $\begin{array}{l}95.6 \\
98.4\end{array}$ & $\begin{array}{l}9.38 \\
5.63\end{array}$ & $\begin{array}{l}78.0 \\
83.5\end{array}$ & $\begin{array}{l}115 \\
124\end{array}$ \\
\hline EPA8081 & & & & & $\cdot$ \\
\hline $\begin{array}{l}\text { Decachlorobiphenyl } \\
\text { Tetrachloro-m-xylene }\end{array}$ & $\begin{array}{l}0 / 35 \\
0 / 41\end{array}$ & $\begin{array}{l}88.1 \\
88.6\end{array}$ & $\begin{array}{l}15.3 \\
8.43\end{array}$ & $\begin{array}{l}39.7 \\
71.0\end{array}$ & $\begin{array}{l}126 \\
103\end{array}$ \\
\hline $\begin{array}{l}\text { EPA8082 } \\
\text { Decachlorobiphenyl }\end{array}$ & $0 / 6$ & 89.1 & 6.36 & 83.3 & 101 \\
\hline $\begin{array}{l}\text { EPA8260 } \\
\text { p-Bromofluorobenzene } \\
\text { Dibromofluoromethane } \\
\text { 1,2-Dichloroethane-d4 } \\
\text { Toluene-d8 }\end{array}$ & $\begin{array}{l}2 / 174 \\
1 / 174 \\
1 / 174 \\
6 / 174\end{array}$ & $\begin{array}{l}97.5 \\
99.0 \\
102 \\
98.3\end{array}$ & $\begin{array}{l}5.61 \\
4.38 \\
6.75 \\
5.38\end{array}$ & $\begin{array}{l}80.0 \\
84.0 \\
64.0 \\
86.0\end{array}$ & $\begin{array}{l}114 \\
112 \\
118 \\
112\end{array}$ \\
\hline $\begin{array}{l}\text { EPA8270 } \\
\text { 2-Fluorobiphenyl } \\
\text { 2-Fluorophenol } \\
\text { Nitrobenzene-d5 } \\
\text { Phenol-d5 } \\
\text { p-Terphenyl-d14 } \\
\text { 2,4,6-Tribromophenol (surr) }\end{array}$ & $\begin{array}{l}1 / 38 \\
0 / 38 \\
0 / 38 \\
0 / 38 \\
0 / 38 \\
0 / 38\end{array}$ & $\begin{array}{l}64.0 \\
60.5 \\
63.2 \\
63.6 \\
79.8 \\
81.4\end{array}$ & $\begin{array}{l}9.50 \\
8.31 \\
8.25 \\
7.88 \\
10.2 \\
13.7 \\
\end{array}$ & $\begin{array}{l}41.9 \\
40.4 \\
41.4 \\
42.3 \\
54.1 \\
56.1 \\
\end{array}$ & $\begin{array}{l}78.8 \\
72.0 \\
78.0 \\
75.0 \\
100 \\
110\end{array}$ \\
\hline
\end{tabular}

+ Number of batches qualified that exhibit poor surrogate recovery due to interference compared to the total number of batches containing surrogates.

Table 67. Surrogate Recoveries for EX

\begin{tabular}{|c|c|c|c|c|c|}
\hline Analyte & $\begin{array}{l}\text { Qualified } \\
\text { Out of Ranget }\end{array}$ & $\begin{array}{l}\text { Mean } \\
\text { Recovery (\%) }\end{array}$ & $\begin{array}{l}\text { Standard } \\
\text { Deviation }\end{array}$ & $\begin{array}{l}\text { Minimum } \\
\text { Recovery (\%) }\end{array}$ & $\begin{array}{l}\text { Maximum } \\
\text { Recovery (\%) }\end{array}$ \\
\hline $\begin{array}{l}\text { EPA8010A } \\
\text { p-Bromofluorobenzene }\end{array}$ & $0 / 24$ & $\overline{102}$ & $8.33^{-\cdots}$ & $88.0 \div-$ & $118=$ \\
\hline $\begin{array}{l}\text { EPA8081 } \\
\text { Decachlorobiphenyl } \\
\text { Tetrachloro-m-xylene }\end{array}$ & $\begin{array}{l}0 / 51 \\
0 / 51\end{array}$ & $\begin{array}{l}105 \\
74.1\end{array}$ & $\begin{array}{l}10.2 \\
16.9\end{array}$ & $\begin{array}{l}83.0 \\
33.0\end{array}$ & $\begin{array}{l}129 \\
111\end{array}$ \\
\hline
\end{tabular}




\begin{tabular}{llllll}
\hline Analyte & $\begin{array}{l}\text { Qualified } \\
\text { Out of Ranget }\end{array}$ & $\begin{array}{l}\text { Mean } \\
\text { Recovery (\%) }\end{array}$ & $\begin{array}{l}\text { Standard } \\
\text { Deviation }\end{array}$ & $\begin{array}{l}\text { Minimum } \\
\text { Recovery (\%) }\end{array}$ & $\begin{array}{l}\text { Maximum } \\
\text { Recovery (\%) }\end{array}$ \\
\hline EPA8151 & & & & & \\
2,4-Dichlorophenylacetic acid & $4 / 48$ & & & & 131 \\
& & 95.6 & 19.7 & 15.0 & \\
EPA8260A & & & & 124 \\
p-Bromofluorobenzene & $31 / 271$ & 96.0 & 8.98 & 58.0 & 125 \\
1,2-Dichloroethane-d4 & $10 / 271$ & 96.9 & 10.1 & 36.0 & \\
Toluene-d8 & $24 / 271$ & 98.1 & 7.51 & 78.0 & \\
EPA8270B & & & & & \\
2-Fluorobiphenyl & $4 / 49$ & 58.8 & 10.5 & 35.0 & 84.0 \\
2-Fluorophenol & $0 / 49$ & 56.8 & 11.8 & 31.0 & 73.0 \\
Nitrobenzene-d5 & $0 / 49$ & 66.0 & 13.8 & 35.0 & 85.0 \\
Phenol-d5 & $0 / 49$ & 58.8 & 11.3 & 33.0 & 74.0 \\
p-Terphenyl-d14 & $0 / 49$ & 55.6 & 9.35 & 39.0 & 87.0 \\
2,4,6-Tribromophenol (surr) & $2 / 49$ & 60.0 & 10.9 & 32.0 & 91.0 \\
\hline
\end{tabular}

† Number of batches qualified that exhibit poor surrogate recovery due to interference compared to the total number of batches containing surrogates.

Table 68. Surrogate Recoveries for GE

\begin{tabular}{|c|c|c|c|c|c|}
\hline Analyte & $\begin{array}{l}\text { Quallfied } \\
\text { Out of Ranget }\end{array}$ & $\begin{array}{l}\text { Mean } \\
\text { Recovery (\%) }\end{array}$ & $\begin{array}{l}\text { Standard } \\
\text { Dẹviation }\end{array}$ & $\begin{array}{l}\text { Minimum } \\
\text { Recovery (\%) }\end{array}$ & $\begin{array}{l}\text { Maximum } \\
\text { Recovery (\%) }\end{array}$ \\
\hline \multicolumn{6}{|l|}{ EPA8081 } \\
\hline Decachlorobiphenyl & $0 / 7$ & 81.1 & 12.2 & 73.0 & 107 \\
\hline Dibutylchlorendate & $0 / 2$ & 103 & 10.6 & 95.0 & 110 \\
\hline Tetrachloro-m-xylene & $1 / 9$ & 68.1 & 27.5 & 7.0 & 104 \\
\hline \multicolumn{6}{|l|}{ EPA8081A } \\
\hline Decachlorobiphenyl & $1 / 8$ & 79.1 & 5.71 & 72.0 & 88.3 \\
\hline Tetrachloro-m-xylene & $1 / 8$ & 107 & 9.33 & 98.0 & 127 \\
\hline \multicolumn{6}{|l|}{ EPA8082 } \\
\hline Decachlorobiphenyl & $0 / 8$ & 62.6 & 8.01 & 50.0 & 74.7 \\
\hline Tetrachloro-m-xylene & $0 / 8$ & 55.5 & 3.64 & 48.5 & 60.2 \\
\hline \multicolumn{6}{|c|}{ EPA8151 } \\
\hline 2,4-Dichlorophenylacetic acid & $0 / 4$ & 71.1 & 4.48 & 66.5 & 75.0 \\
\hline \multicolumn{6}{|l|}{ EPA8260 } \\
\hline p-Bromofluorobenzene & $0 / 5$ & 89.6 & 1.49 & 87.8 & 91.8 \\
\hline Dibromofluoromethane & $5 / 5$ & 82.6 & 1.69 & 80.2 & 84.4 \\
\hline Toluene-d8 & $4 / 5$ & 86.6 & 2.09 & 84.6 & 90.0 \\
\hline \multicolumn{6}{|l|}{ EPA8260A } \\
\hline p-Bromofluorobenzene & $28 / 43$ & 85.2 & 9.37 & 71.8 & 114 \\
\hline Dibromofluoromethane & $29 / 43$ & 87.9 & 14.5 & 65.9 & 121 \\
\hline Toluene-d8 & $19 / 43$ & 91.3 & 7.07 & 79.0 & 108 \\
\hline \multicolumn{6}{|l|}{ EPA8260B } \\
\hline p-Bromofluorobenzene & $4 / 4$ & 78.4 & 3.80 & 74.8 & 83.6 \\
\hline Dibromofluoromethane & $4 / 4$ & 76.2 & 3.10 & 72.6 & 80.0 \\
\hline Toluene-d8 & $1 / 4$ & 90.3 & 5.49 & 82.1 & 94.1 \\
\hline \multicolumn{6}{|l|}{ EPA8270 } \\
\hline 2-Fluorobiphenyl & $0 / 3$ & 86.8 & 3.26 & 83.2 & 89.5 \\
\hline Nitrobenzene-d5 & $0 / 3$ & 73.2 & 3.61 & 69.0 & 75.3 \\
\hline
\end{tabular}




\begin{tabular}{llllll}
\hline Analyte & $\begin{array}{l}\text { Qualified } \\
\text { Out of Ranget }\end{array}$ & $\begin{array}{l}\text { Mean } \\
\text { Recovery (\%) }\end{array}$ & $\begin{array}{l}\text { Standard } \\
\text { Deviation }\end{array}$ & $\begin{array}{l}\text { Minimum } \\
\text { Recovery (\%) }\end{array}$ & $\begin{array}{l}\text { Maximum } \\
\text { Recovery (\%) }\end{array}$ \\
\hline p-Terphenyl-d14 & & & & & \\
& $0 / 3$ & 77.6 & 12.0 & 63.8 & 85.8 \\
EPA8270B & & & & \\
2-Fluorobiphenyl & $0 / 8$ & 74.1 & 8.14 & 57.6 & .7 \\
2-Fluorophenol & $0 / 8$ & 42.1 & 2.16 & 39.1 & 46.1 \\
Nitrobenzene-d5 & $0 / 8$ & 69.8 & 7.53 & 53.8 & 77.2 \\
Phenol-d6 & $0 / 8$ & 29.1 & 3.65 & 26.4 & 37.4 \\
p-Terphenyl-d14 & $0 / 8$ & 79.2 & 6.20 & 71.8 & 90.4 \\
2,4,6-Tribromophenol (surr) & $0 / 8$ & 85.9 & 6.72 & 71.2 & 93.1 \\
& & & & & \\
EPA8270C & & & & & \\
2-Fluorobiphenyl & $0 / 10$ & 82.7 & 12.8 & 61.0 & 97.4 \\
2-Fluorophenol & $0 / 6$ & 48.2 & 3.63 & 42.3 & 51.7 \\
Nitrobenzene-d5 & $0 / 10$ & 78.1 & 12.7 & 58.9 & 93.2 \\
Phenol-d6 & $0 / 6$ & 33.4 & 3.46 & 28.6 & 37.4 \\
p-Terphenyl-d14 & $0 / 10$ & 63.2 & 15.4 & 42.9 & 86.8 \\
2,4,6-Tribromophenol (surr) & $0 / 6$ & 72.3 & 8.16 & 64.1 & 84.2 \\
\hline
\end{tabular}

† Number of batches qualified that exhibit poor surrogate recovery due to interference compared to the total number of batches containing surrogates.

Table 69. Surrogate Recoveries for WA

\begin{tabular}{|c|c|c|c|c|c|}
\hline Analyte & $\begin{array}{l}\text { Qualified } \\
\text { Out of Ranget }\end{array}$ & $\begin{array}{l}\text { Mean } \\
\text { Recovery (\%) }\end{array}$ & $\begin{array}{l}\text { Standard } \\
\text { Deviation }\end{array}$ & $\begin{array}{l}\text { Minimum } \\
\text { Recovery (\%) }\end{array}$ & $\begin{array}{l}\text { Maximum } \\
\text { Recovery (\%) }\end{array}$ \\
\hline \multicolumn{6}{|l|}{ EPA8010 } \\
\hline Bromochloromethane & $0 / 5$ & 102 & 9.50 & 95.5 & 117 \\
\hline \multicolumn{6}{|l|}{ EPA8081 } \\
\hline Decachlorobiphenyl & $0 / 43$ & $\begin{array}{l}85.8 \\
62.3\end{array}$ & $\begin{array}{l}12.3 \\
22.2\end{array}$ & $\begin{array}{l}44.0 \\
27.5\end{array}$ & $\begin{array}{l}112 \\
120\end{array}$ \\
\hline Tetrachloro-m-xylene & $2 / 43$ & & & & 120 \\
\hline \multicolumn{6}{|c|}{ EPA8150 } \\
\hline 2,4-Dichlorophenylacetic acid & $2 / 5$ & 74.3 & 10.9 & 58.6 & 86.1 \\
\hline \multicolumn{6}{|c|}{ EPA8151 } \\
\hline 2,4-Dichlorophenylacetic acid & $1 / 5$ & 78.5 & 8.84 & 63.9 & 87.0 \\
\hline \multicolumn{6}{|l|}{ EPA8260 } \\
\hline p-Bromofluorobenzene & $4 / 197$ & 95.6 & 6.74 & 83.0 & 120 \\
\hline 1,2-Dichloroethane-d4 & $3 / 197$ & 96.9 & 9.92 & 77.0 & 120 \\
\hline Toluene-d8 & $5 / 197$ & 99.3 & 5.10 & 84.0 & 113 \\
\hline \multicolumn{6}{|l|}{ EPA8270 } \\
\hline 2-Fluorobiphenyl & $0 / 63$ & 69.1 & 15.6 & 34.1 & 102 \\
\hline 2-Fluorophenol & $0 / 46$ & 56.1 & 15.4 & 30.2 & 84.9 \\
\hline Nitrobenzene-d5 & $0 / 63$ & 71.8 & 14.4 & 35.2 & 101 \\
\hline Phenol-d5 $=\ldots \ldots$ & $0 / 46-\cdots=\cdots$ & $-46.7--$ & $-18.5-\ldots-$ & $=-16.9 \ldots-\cdots+$ & $-78: 4 \ldots-\cdots$ \\
\hline p-Terphenyl-d14 & $1 / 63$ & 79.4 & 19.7 & 9.74 & 118 \\
\hline 2,4,6-Tribromophenol (surr) & $0 / 46$ & 64.9 & 21.3 & 23.8 & 102 \\
\hline \multicolumn{6}{|c|}{ EPA8280 } \\
\hline $\begin{array}{l}\text { Carbon 13-labeled 1,2,3,6,7,8- } \\
\text { HXCDD }\end{array}$ & $0 / 68$ & 82.6 & 7.66 & 62.0 & 98.0 \\
\hline $\begin{array}{l}\text { Carbon 13-labeled 2,3,7,8- } \\
\text { TCDD }\end{array}$ & $0 / 70$ & 79.5 & 8.71 & 60.0 & 99.0 \\
\hline
\end{tabular}




\begin{tabular}{|c|c|c|c|c|c|}
\hline Analyte & $\begin{array}{l}\text { Qualified } \\
\text { Out of Ranget }\end{array}$ & $\begin{array}{l}\text { Mean } \\
\text { Recovery (\%) }\end{array}$ & $\begin{array}{l}\text { Standard } \\
\text { Deviation }\end{array}$ & $\begin{array}{l}\text { Minimum } \\
\text { Recovery (\%) }\end{array}$ & $\begin{array}{l}\text { Maximum } \\
\text { Recovery (\%) }\end{array}$ \\
\hline $\begin{array}{l}\text { Carbon 13-labeled 2,3,7,8- } \\
\text { TCDF }\end{array}$ & $0 / 68$ & 75.5 & 8.33 & 56.0 & 97.0 \\
\hline $\begin{array}{l}\text { Carbon 13-labeled HPCDF } \\
\text { Carbon 13-labeled OCDD }\end{array}$ & $\begin{array}{l}0 / 68 \\
0 / 68\end{array}$ & $\begin{array}{l}83.3 \\
79.4\end{array}$ & $\begin{array}{l}8.40 \\
10.2\end{array}$ & $\begin{array}{l}64.0 \\
55.0\end{array}$ & $\begin{array}{l}101 \\
102\end{array}$ \\
\hline
\end{tabular}

$\uparrow$ Number of batches qualified that exhibit poor surrogate recovery due to interference compared to the total number of batches containing surrogates.

Table 70. Matrix Spike Recoveries for ES

\begin{tabular}{|c|c|c|c|c|c|c|}
\hline Analyte & $\begin{array}{l}\text { Qualified } \\
\text { Out of Ranget }\end{array}$ & $\begin{array}{l}\text { Mean } \\
\text { Recovery (\%) }\end{array}$ & $\begin{array}{l}\text { Standard } \\
\text { Deviation }\end{array}$ & Bias (\%) & $\begin{array}{l}\text { Minimum } \\
\text { Recovery (\%) }\end{array}$ & $\begin{array}{l}\text { Maximum } \\
\text { Recovery (\%) }\end{array}$ \\
\hline \multicolumn{7}{|l|}{ EPA300.0 } \\
\hline Nitrate as nitrogen & $0 / 2$ & 102 & 0.0 & 2.0 & 102 & 102 \\
\hline \multicolumn{7}{|l|}{ EPA350.1 } \\
\hline Ammonia nitrogen & $0 / 2$ & 99.8 & 1.77 & -0.20 & 98.5 & 101 \\
\hline \multicolumn{7}{|l|}{ EPA353.2 } \\
\hline Nitrate-nitrite as nitrogen & $0 / 2$ & $91: 7$ & 0.21 & -8.30 & 91.5 & 91.8 \\
\hline \multicolumn{7}{|l|}{ EPA365.1 } \\
\hline Total phosphates (as P) & $5 / 8$ & 96.8 & 11.7 & -3.20 & 82.0 & 113 \\
\hline \multicolumn{7}{|l|}{ EPA6010 } \\
\hline Aluminum & $2 / 22$ & 109 & 23.5 & 9.0 & 85.0 & 177 \\
\hline Antimony & $0 / 6$ & 100 & 2.06 & 0.0 & 96.2 & 102 \\
\hline Arsenic & $0 / 16$ & 101 & 2.88 & 1.0 & 96.7 & 107 \\
\hline Barium & $0 / 16$ & 96.3 & 1.49 & -3.70 & 94.0 & 99.0 \\
\hline Beryllium & $0 / 6$ & 99.2 & 2.20 & -0.80 & 94.8 & 101 \\
\hline Boron & $0 / 6$ & 99.2 & 2.20 & -0.80 & 97.2 & 103 \\
\hline Cadmium & $0 / 16$ & 98.1 & 2.01 & -1.90 & 94.6 & 102 \\
\hline Calcium & $0 / 10$ & 99.2 & 3.48 & -0.80 & 96.0 & 107 \\
\hline Chromium & $0 / 16$ & 98.6 & 4.47 & -1.40 & 89.5 & 105 \\
\hline Cobalt & $0 / 6$ & 96.5 & 1.62 & -3.50 & 94.0 & 98.8 \\
\hline Copper & $0 / 6$ & 95.9 & 7.88 & -4.10 & 84.4 & 103 \\
\hline Iron & $0 / 22$ & 22.2 & 122 & -77.8 & -241 & 112 \\
\hline Lead & $0 / 20$ & 99.8 & 4.12 & -0.20 & 92.8 & 110 \\
\hline Lithium & $0 / 4$ & 103 & 2.06 & 3.0 & 100 & 105 \\
\hline Magnesium & $0 / 10$ & 102 & 3.28 & 2.0 & 98.0 & 108 \\
\hline Manganese & $0 / 10$ & 98.8 & 3.91 & -1.20 & $94: 2$ & 105 \\
\hline Nickel & $0 / 6$ & 94.9 & 2.72 & -5.10 & 91.6 & 98.0 \\
\hline Potassium & $0 / 10$ & 91.8 & 2.99 & -8.20 & 88.0 & 95.9 \\
\hline Selenium & $0 / 16$ & 101 & 3.96 & 1.0 & 95.5 & 111 \\
\hline Silica & $0 / 4$ & 111 & 8.60 & 11.0 & 98.2 & 118 \\
\hline Silver & $0 / 16$ & 101 & 2.75 & 1.0 & 96.4 & 107 \\
\hline Sodium & $0 / 10$ & 95.6 & 8.43 & -4.40 & 87.8 & 118 \\
\hline Thallium & $0 / 6$ & 94.2 & 2.37 & -5.80 & 91.1 & 96.5 \\
\hline Vanadium & $0 / 6$ & 98.4 & 1.68 & .1 .60 & 95.0 & 99.4 \\
\hline Zinc & $1 / 6$ & 102 & 7.52 & 2.0 & 96.0 & 117 \\
\hline \multicolumn{7}{|l|}{ EPA7470 } \\
\hline Mercury & $1 / 18$ & 104 & 9.88 & 4.0 & 89.6 & 133 \\
\hline \multicolumn{7}{|l|}{ EPA8010 } \\
\hline Carbon tetrachloride & $0 / 12$ & 95.1 & 2.32 & -4.90 & 91.6 & 98.0 \\
\hline Chloroform & $0 / 12$ & 93.8 & 2.31 & -6.20 & 90.4 & 97.6 \\
\hline
\end{tabular}




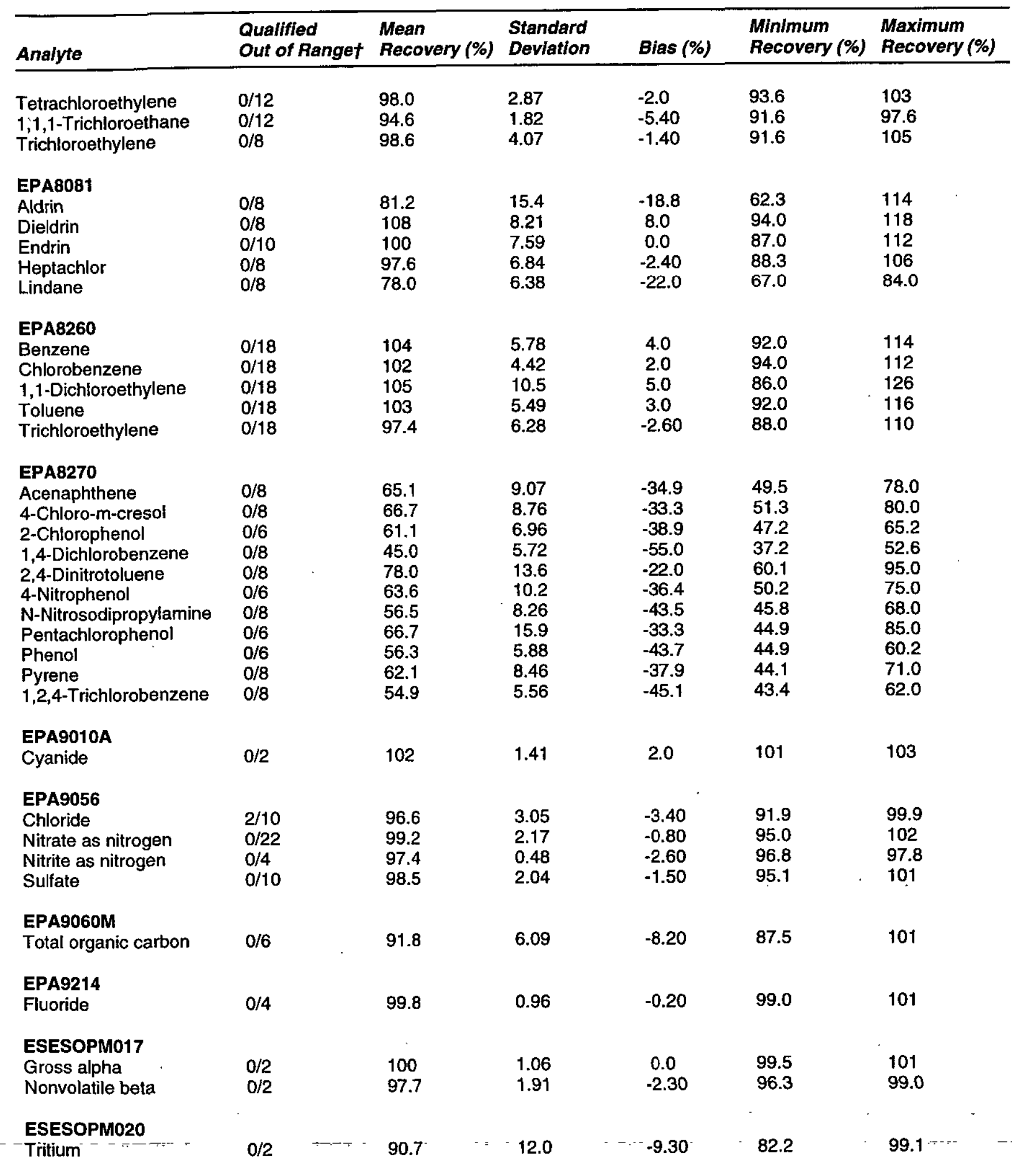




\begin{tabular}{|c|c|c|c|c|c|c|}
\hline Analyte & $\begin{array}{l}\text { Qualified } \\
\text { Out of Ranget }\end{array}$ & $\begin{array}{l}\text { Mean } \\
\text { Recovery (\%) }\end{array}$ & $\begin{array}{l}\text { Standard } \\
\text { Deviation }\end{array}$ & Bias (\%) & $\begin{array}{l}\text { Minimum } \\
\text { Recovery (\%) }\end{array}$ & $\begin{array}{l}\text { Maximum } \\
\text { Recovery (\%) }\end{array}$ \\
\hline \multicolumn{7}{|l|}{ ESESOPM029 } \\
\hline $\begin{array}{l}\text { Radium, total alpha- } \\
\text { emitting }\end{array}$ & $0 / 1$ & 113 & - & 13.0 & 113 & 113 \\
\hline
\end{tabular}

† Number of batches qualified that exhibit poor spike recovery due to interference compared to the total number of batches containing spikes.

- Standard deviation cannot be determined.

Note: A value of 0 is reported as 0.0 .

Table 71. Matrix Spike Recoveries for EX

\begin{tabular}{|c|c|c|c|c|c|c|}
\hline Analyte & $\begin{array}{l}\text { Qualified } \\
\text { Out of Panget }\end{array}$ & $\begin{array}{l}\text { Mean } \\
\text { Recovery (\%) }\end{array}$ & $\begin{array}{l}\text { Standard } \\
\text { Deviation }\end{array}$ & Blas (\%) & $\begin{array}{l}\text { Minimum } \\
\text { Recovery (\%) }\end{array}$ & $\begin{array}{l}\text { Maximum } \\
\text { Recovery (\%) }\end{array}$ \\
\hline \multicolumn{7}{|l|}{ EPA300.0 } \\
\hline Chloride & $0 / 3$ & 93.0 & 17.6 & -7.0 & 80.0 & 113 \\
\hline Fluoride & $0 / 2$ & 105 & 0.71 & 5.0 & 104 & 105 \\
\hline Nitrate as nitrogen & $0 / 2$ & 94.0 & 15.6 & -6.0 & 83.0 & 105 \\
\hline Nitrate-nitrite as nitrogen & $0 / 4$ & 109 & 7.53 & 9.0 & 102 & 116 \\
\hline Sulfate & $0 / 3$ & 96.3 & 7.77 & -3.70 & 90.0 & 105 \\
\hline \multicolumn{7}{|l|}{ EPA365.2 } \\
\hline Total phosphates (as P) & $0 / 2$ & 98.0 & 2.83 & -2.0 & 96.0 & 100 \\
\hline \multicolumn{7}{|l|}{ EPA370.1 } \\
\hline Silica & $0 / 2$ & 99.0 & 4.24 & -1.0 & 96.0 & 102 \\
\hline \multicolumn{7}{|c|}{ EPA410.4 } \\
\hline Chemical oxygen demand & $0 / 1$ & 115 & - & 15.0 & 115 & 115 \\
\hline \multicolumn{7}{|l|}{ EPA420.1 } \\
\hline Phenols & $0 / 2$ & 96.0 & 8.49 & -4.0 & 90.0 & 102 \\
\hline \multicolumn{7}{|l|}{ EPA6010A } \\
\hline Aluminum & $0 / 6$ & 108 & 6.80 & 8.0 & 95.0 & 113 \\
\hline Antimony & $0 / 3$ & 101 & 6.08 & 1.0 & 94.0 & 105 \\
\hline Arsenic & $0 / 3$ & 102 & 6.03 & 2.0 & 96.0 & 108 \\
\hline Barium & $0 / 3$ & 101 & 5.51 & 1.0 & 96.0 & 107 \\
\hline Beryllium & $0 / 3$ & 102 & 6.56 & 2.0 & 95.0 & 108 \\
\hline Boron & $0 / 1$ & 96.0 & - & -4.0 & 96.0 & 96.0 \\
\hline Cadmium & $0 / 3$ & 103 & 7.02 & 3.0 & 96.0 & 110 \\
\hline Calcium & $0 / 3$ & 104 & 7.21 & 4.0 & 96.0 & 110 \\
\hline Chromium & $0 / 3$ & 104 & 7.64 & 4.0 & 96.0 & 111 \\
\hline Cobalt & $0 / 3$ & 106 & 7.21 & 6.0 & 98.0 & 112 \\
\hline Copper & $0 / 3$ & 102 & 6.56 & 2.0 & 95.0 & 108 \\
\hline Iron & $0 / 6$ & 107 & 6.12 & 7.0 & 95.0 & 112 \\
\hline Lead & $0 / 8$ & 107 & 5.72 & 7.0 & 98.0 & 114 \\
\hline Magnesium & $0 / 3$ & 103 & 7.21 & 3.0 & 95.0 & 109 \\
\hline Manganese & $0 / 3$ & 104 & 7.09 & 4.0 & 96.0 & 110 \\
\hline Molybdenum & $0 / 1$ & 89.0 & - & -11.0 & 89.0 & 89.0 \\
\hline Nickel & $0 / 3$ & 103 & 6.51 & 3.0 & 96.0 & 109 \\
\hline Potassium & $0 / 3$ & 101 & 2.65 & 1.0 & 98.0 & 103 \\
\hline Selenium & $0 / 3$ & 104 & 5.0 & 4.0 & 99.0 & 109 \\
\hline Silver & $0 / 3$ & 103 & 5.51 & 3.0 & 97.0 & 108 \\
\hline Sodium & $0 / 3$ & 102 & 5.57 & 2.0 & 96.0 & 107 \\
\hline Strontium & $0 / 1$ & 95.0 & - & -5.0 & 95.0 & 95.0 \\
\hline Thallium & $0 / 3$ & 103 & 8.08 & 3.0 & 98.0 & 1.12 \\
\hline
\end{tabular}




\begin{tabular}{|c|c|c|c|c|c|c|}
\hline Analyte & $\begin{array}{l}\text { Qualified } \\
\text { Out of Ranget }\end{array}$ & $\begin{array}{l}\text { Mean } \\
\text { Recovery (\%) }\end{array}$ & $\begin{array}{l}\text { Standard } \\
\text { Deviation }\end{array}$ & Blas (\%) & $\begin{array}{l}\text { Minimum } \\
\text { Recovery (\%) }\end{array}$ & $\begin{array}{l}\text { Maximum } \\
\text { Recovery (\%) }\end{array}$ \\
\hline $\begin{array}{l}\text { Vanadium } \\
\text { Zinc }\end{array}$ & $\begin{array}{l}0 / 3 \\
0 / 3\end{array}$ & $\begin{array}{l}101 \\
103\end{array}$ & $\begin{array}{l}6.03 \\
7.55\end{array}$ & $\begin{array}{l}1.0 \\
3.0\end{array}$ & $\begin{array}{l}95.0 \\
95.0\end{array}$ & $\begin{array}{l}107 \\
110\end{array}$ \\
\hline $\begin{array}{l}\text { EPA7430 } \\
\text { Lithium }\end{array}$ & $0 / 2$ & 108 & 3.54 & 8.0 & 105 & 110 \\
\hline $\begin{array}{l}\text { EPA7470A } \\
\text { Mercury }\end{array}$ & $0 / 4$ & 95.8 & 4.86 & -4.20 & 91.0 & 102 \\
\hline $\begin{array}{l}\text { EPA8010A } \\
\text { Carbon tetrachloride } \\
\text { Chloroform } \\
\text { cis-1,2-Dichloroethylene } \\
\text { Tetrachloroethylene } \\
\text { 1,1,1-Trichloroethane } \\
\text { Trichloroethylene }\end{array}$ & $\begin{array}{l}0 / 6 \\
1 / 6 \\
0 / 6 \\
0 / 6 \\
2 / 6 \\
3 / 6\end{array}$ & $\begin{array}{l}103 \\
110 \\
109 \\
108 \\
106 \\
84.5\end{array}$ & $\begin{array}{l}6.09 \\
17.6 \\
4.72 \\
13.8 \\
22.9 \\
36.3\end{array}$ & $\begin{array}{l}3.0 \\
10.0 \\
9.0 \\
8.0 \\
6.0 \\
-15.5\end{array}$ & $\begin{array}{l}94.0 \\
88.0 \\
101 \\
90.0 \\
77.0 \\
37.0\end{array}$ & $\begin{array}{l}110 \\
128 \\
115 \\
124 \\
131 \\
124\end{array}$ \\
\hline $\begin{array}{l}\text { EPAB151 } \\
\text { 2-sec-Butyl-4,6- } \\
\text { dinitrophenol }\end{array}$ & $3 / 4$ & 72.3 & 9.29 & -27.7 & 63.0 & 85.0 \\
\hline $\begin{array}{l}\text { 2,4-Dichlorophenoxyacetic } \\
\text { acid } \\
\text { 2,4,5-TP (Silvex) }\end{array}$ & $0 / 4$ & $\begin{array}{l}98.0 \\
104\end{array}$ & $\begin{array}{l}22.2 \\
31.6\end{array}$ & 4.0 & 72.0 & $\begin{array}{l}124 \\
142\end{array}$ \\
\hline $\begin{array}{l}\text { EPA8260A } \\
\text { Benzene } \\
\text { Chlorobenzene } \\
\text { 1,t-Dichloroethylene } \\
\text { Toluene } \\
\text { Trichloroethylene }\end{array}$ & $\begin{array}{l}0 / 26 \\
0 / 26 \\
2 / 26 \\
0 / 26 \\
4 / 26\end{array}$ & $\begin{array}{l}95.3 \\
97.8 \\
102 \\
94.7 \\
85.7\end{array}$ & $\begin{array}{l}7.09 \\
3.98 \\
22.6 \\
7.51 \\
19.0\end{array}$ & $\begin{array}{c}-4.70 \\
-2.20 \\
2.0 \\
-5.30 \\
-14.3\end{array}$ & $\begin{array}{l}83.0 \\
88.0 \\
36.0 \\
82.0 \\
27.0\end{array}$ & $\begin{array}{l}109 \\
106 \\
133 \\
107 \\
118\end{array}$ \\
\hline $\begin{array}{l}\text { EPA9060 } \\
\text { Total organic carbon }\end{array}$ & $1 / 2$ & 111 & 15.6 & 11.0 & 100 & 122 \\
\hline
\end{tabular}

$\uparrow$ Number of batches qualified that exhibit poor spike recovery due to interference compared to the total number of batches containing spikes.

- Standard deviation cannot be determined.

Table 72. Matrix Spike Recoveries for GE

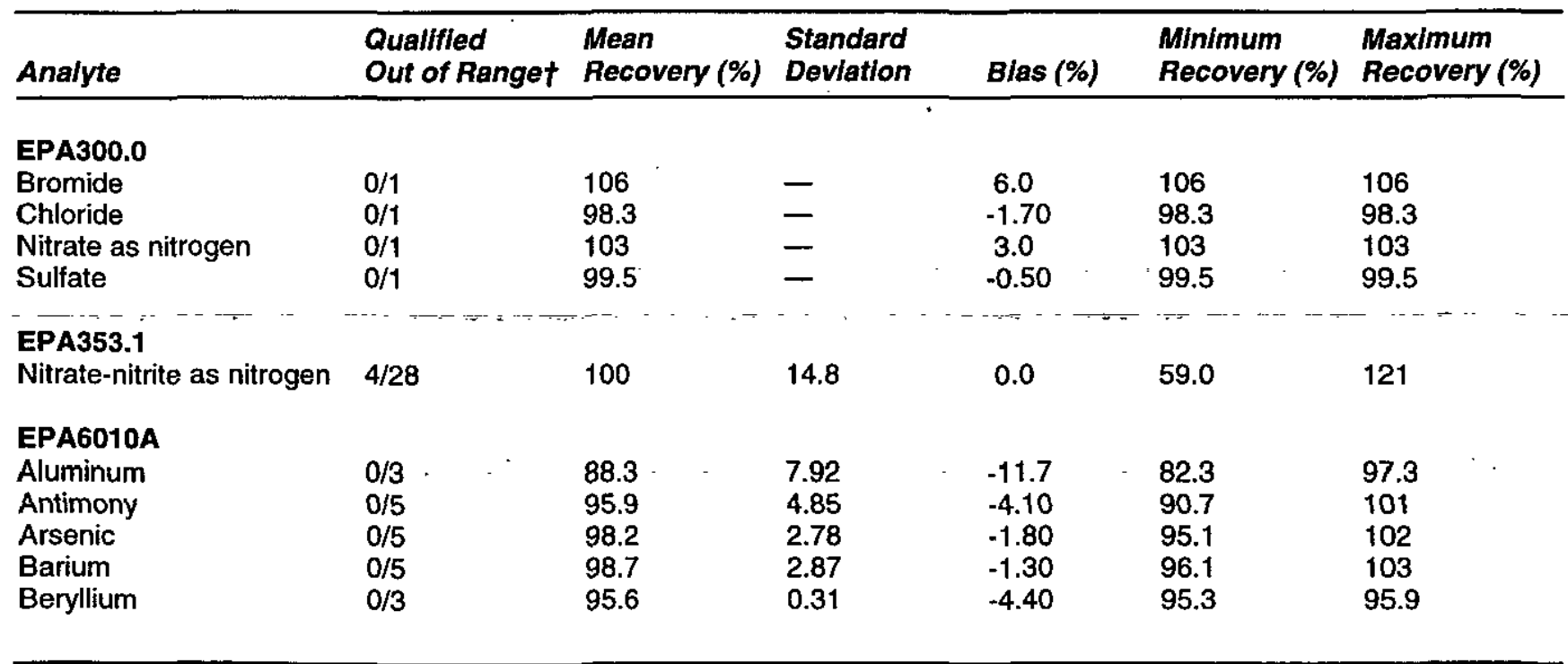




\begin{tabular}{|c|c|c|c|c|c|c|}
\hline Analyte & $\begin{array}{l}\text { Qualified } \\
\text { Out of Ranget }\end{array}$ & $\begin{array}{l}\text { Mean } \\
\text { Recovery (\%) }\end{array}$ & $\begin{array}{l}\text { Standard } \\
\text { Deviation }\end{array}$ & Bias (\%) & $\begin{array}{l}\text { Minimum } \\
\text { Recovery (\%) }\end{array}$ & $\begin{array}{l}\text { Maximum } \\
\text { Recovery (\%) }\end{array}$ \\
\hline $\begin{array}{l}\text { Boron } \\
\text { Cadmium } \\
\text { Calcium } \\
\text { Chromium } \\
\text { Cobalt } \\
\text { Copper } \\
\text { Iron } \\
\text { Lead } \\
\text { Magnesium } \\
\text { Manganese } \\
\text { Nicke! } \\
\text { Potassium } \\
\text { Selenium } \\
\text { Silver } \\
\text { Sodium } \\
\text { Thallium } \\
\text { Tin } \\
\text { Vanadium } \\
\text { Zinc }\end{array}$ & $\begin{array}{l}0 / 3 \\
0 / 5 \\
0 / 3 \\
0 / 5 \\
0 / 3 \\
0 / 5 \\
0 / 3 \\
0 / 5 \\
0 / 3 \\
0 / 3 \\
0 / 5 \\
0 / 3 \\
0 / 5 \\
1 / 7 \\
0 / 3 \\
0 / 3 \\
0 / 3 \\
0 / 3 \\
0 / 7\end{array}$ & $\begin{array}{l}99.4 \\
99.7 \\
95.1 \\
99.2 \\
96.9 \\
99.3 \\
94.3 \\
99.8 \\
87.0 \\
93.3 \\
100 \\
92.1 \\
96.2 \\
87.6 \\
99.7 \\
97.2 \\
100 \\
96.1 \\
101\end{array}$ & $\begin{array}{l}2.65 \\
3.69 \\
2.24 \\
2.43 \\
1.88 \\
3.24 \\
5.83 \\
2.93 \\
6.18 \\
4.39 \\
3.44 \\
9.41 \\
3.29 \\
35.9 \\
2.84 \\
3.34 \\
4.04 \\
2.08 \\
4.27\end{array}$ & $\begin{array}{l}-0.60 \\
-0.30 \\
-4.90 \\
-0.80 \\
-3.10 \\
-0.70 \\
-5.70 \\
-0.20 \\
-13.0 \\
-6.70 \\
0.0 \\
-7.90 \\
-3.80 \\
-12.4 \\
-0.30 \\
-2.80 \\
0.0 \\
-3.90 \\
1.0\end{array}$ & $\begin{array}{l}96.7 \\
96.6 \\
93.6 \\
97.0 \\
95.8 \\
96.4 \\
90.7 \\
96.9 \\
82.8 \\
90.8 \\
96.8 \\
86.7 \\
93.2 \\
6.50 \\
97.8 \\
94.9 \\
96.0 \\
94.8 \\
95.1\end{array}$ & $\begin{array}{l}102 \\
105 \\
97.7 \\
103 \\
99.1 \\
104 \\
101 \\
104 \\
94.1 \\
98.4 \\
105 \\
103 \\
101 \\
105 \\
103 \\
101 \\
104 \\
98.5 \\
106\end{array}$ \\
\hline $\begin{array}{l}\text { EPA6020 } \\
\text { Cadmium } \\
\text { Lead } \\
\text { Lithium }\end{array}$ & $\begin{array}{l}0 / 18 \\
0 / 20 \\
0 / 4\end{array}$ & $\begin{array}{l}100 \\
100 \\
114\end{array}$ & $\begin{array}{l}4.22 \\
4.21 \\
11.9\end{array}$ & $\begin{array}{l}0.0 \\
0.0 \\
14.0\end{array}$ & $\begin{array}{l}94.2 \\
93.4 \\
103\end{array}$ & $\begin{array}{l}107 \\
108 \\
125\end{array}$ \\
\hline $\begin{array}{l}\text { EPA7470 } \\
\text { Mercury }\end{array}$ & $0 / 13$ & 101 & 9.66 & 1.0 & 84.2 & 119 \\
\hline $\begin{array}{l}\text { EPA7470A } \\
\text { Mercury }\end{array}$ & $0 / 1$ & 78.5 & - & -21.5 & 78.5 & 78.5 \\
\hline $\begin{array}{l}\text { EPA8081 } \\
\text { Aldrin } \\
\text { p,p'-DDT } \\
\text { Dieldrin } \\
\text { Endrin } \\
\text { Heptachtor } \\
\text { Lindane }\end{array}$ & $\begin{array}{l}0 / 2 \\
0 / 2 \\
0 / 2 \\
0 / 2 \\
0 / 2 \\
0 / 2\end{array}$ & $\begin{array}{l}72.6 \\
68.1 \\
76.2 \\
88.0 \\
97.9 \\
85.0\end{array}$ & $\begin{array}{l}1.77 \\
0.99 \\
2.55 \\
1.13 \\
8.70 \\
4.45\end{array}$ & $\begin{array}{l}-27.4 \\
-31.9 \\
-23.8 \\
-12.0 \\
-2.10 \\
-15.0\end{array}$ & $\begin{array}{l}71.3 \\
67.4 \\
74.4 \\
87.2 \\
91.7 \\
81.8\end{array}$ & $\begin{array}{l}73.8 \\
68.8 \\
78.0 \\
88.8 \\
104 \\
88.1\end{array}$ \\
\hline $\begin{array}{l}\text { EPA8081A } \\
\text { Aldrin } \\
\text { p,p'-DDT } \\
\text { Dieldrin } \\
\text { Endrin } \\
\text { Heptachlor } \\
\text { Lindane }\end{array}$ & $\begin{array}{l}0 / 2 \\
0 / 2 \\
0 / 2 \\
0 / 2 \\
0 / 2 \\
0 / 2\end{array}$ & $\begin{array}{l}97.5 \\
71.8 \\
87.8 \\
111 \\
98.0 \\
93.5\end{array}$ & $\begin{array}{l}0.71 \\
0.85 \\
2.55 \\
3.54 \\
1.41 \\
7.78\end{array}$ & $\begin{array}{l}-2.50 \\
-28.2 \\
-12.2 \\
11.0 \\
-2.0 \\
-6.50\end{array}$ & $\begin{array}{l}97.0 \\
71.2 \\
86.0 \\
108 \\
97.0 \\
88.0\end{array}$ & $\begin{array}{l}98.0 \\
72.4 \\
89.6 \\
113 \\
99.0 \\
99.0\end{array}$ \\
\hline $\begin{array}{l}\text { EPA8082 } \\
\text { PCB } 1260\end{array}$ & $0 / 2$ & 70.0 & 1.41 & -30.0 & 69.0 & 71.0 \\
\hline $\begin{array}{l}\text { EPA8260A } \\
\text { Benzene } \\
\text { Chlorobenzene } \\
\text { 1,1-Dichloroethylene } \\
\text { Toluene } \\
\text { Trichloroethylene }\end{array}$ & $\begin{array}{l}0 / 4 \\
0 / 4 \\
0 / 4 \\
0 / 4 \\
0 / 4\end{array}$ & $\begin{array}{l}92.6 \\
89.5 \\
80.8 \\
86.2 \\
86.1\end{array}$ & $\begin{array}{l}10.5 \\
8.26 \\
3.30 \\
5.02 \\
3.11\end{array}$ & $\begin{array}{l}-7.40 \\
-10.5 \\
-19.2 \\
-13.8 \\
-13.9\end{array}$ & $\begin{array}{l}81.1 \\
80.1 \\
77.9 \\
80.0 \\
83.7\end{array}$ & $\begin{array}{l}102 \\
97.3 \\
85.3 \\
90.7 \\
90.6\end{array}$ \\
\hline
\end{tabular}




\begin{tabular}{|c|c|c|c|c|c|c|}
\hline Analyte & $\begin{array}{l}\text { Qualified } \\
\text { Out of Ranget }\end{array}$ & $\begin{array}{l}\text { Mean } \\
\text { Recovery (\%) }\end{array}$ & $\begin{array}{l}\text { Standard } \\
\text { Deviation }\end{array}$ & Bias (\%) & $\begin{array}{l}\text { Minimum } \\
\text { Recovery (\%) }\end{array}$ & $\begin{array}{l}\text { Maximum } \\
\text { Recovery (\%) }\end{array}$ \\
\hline \multicolumn{7}{|l|}{ EPA8260B } \\
\hline Benzene & $0 / 2$ & 104 & 0.71 & 4.0 & 103 & 104 \\
\hline Chlorobenzene & $0 / 2$ & 97.9 & 0.50 & -2.10 & 97.5 & 98.2 \\
\hline 1,1-Dichloroethylene & $0 / 2$ & 81.4 & 3.18 & -18.6 & 79.1 & 83.6 \\
\hline Toluene & $0 / 2$ & 93.1 & 0.78 & -6.90 & 92.5 & 93.6 \\
\hline Trichloroethylene & $0 / 2$ & 84.9 & 1.56 & -15.1 & 83.8 & 86.0 \\
\hline \multicolumn{7}{|l|}{ EPA8270B } \\
\hline Acenaphthene & $0 / 2$ & 65.0 & 7.14 & -35.0 & 59.9 & 70.0 \\
\hline 4-Chloro-m-cresol & $0 / 2$ & 63.4 & 7.50 & -36.6 & 58.1 & 68.7 \\
\hline 2-Chlorophenol & $0 / 2$ & 53.7 & 5.66 & -46.3 & 49.7 & 57.7 \\
\hline 1,4-Dichlorobenzene & $0 / 2$ & 52.7 & 8.13 & -47.3 & 46.9 & 58.4 \\
\hline 2,4-Dinitrotoluene & $0 / 2$ & 89.3 & 9.76 & -10.7 & 82.4 & 96.2 \\
\hline 4-Nitrophenol & $0 / 2$ & 43.6 & 3.04 & -56.4 & 41.4 & 45.7 \\
\hline N-Nitrosodipropylamine & $0 / 2$ & 54.8 & 7.71 & -45.2 & 49.3 & 60.2 \\
\hline Pentachlorophenol & $0 / 2$ & 84.9 & 7.57 & -15.1 & 79.5 & 90.2 \\
\hline Phenol & $0 / 2$ & 29.8 & 3.68 & -70.2 & 27.2 & 32.4 \\
\hline Pyrene & $0 / 2$ & 76.8 & 3.89 & -23.2 & 74.0 & 79.5 \\
\hline $1,2,4$-Trichlorobenzene & $0 / 2$ & 59.8 & 8.41 & -40.2 & 53.8 & 65.7 \\
\hline \multicolumn{7}{|l|}{ EPA9012 } \\
\hline Cyanide & $0 / 3$ & 106 & 5.57 & 6.0 & 100 & 111 \\
\hline \multicolumn{7}{|l|}{ EPA9012A } \\
\hline Cyanide & $0 / 1$ & 107 & - & 7.0 & 107 & 107 \\
\hline \multicolumn{7}{|l|}{ EPA9020B } \\
\hline Total organic halogens & $0 / 2$ & 101 & 3.61 & 1.0 & 98.9 & 104 \\
\hline \multicolumn{7}{|l|}{ EPA9056 } \\
\hline Sulfate & $0 / 1$ & 99.7 & - & -0.30 & 99.7 & 99.7 \\
\hline \multicolumn{7}{|l|}{ EPA9060 } \\
\hline Total organic carbon & $0 / 2$ & 112 & 2.12 & 12.0 & 110 & 113 \\
\hline \multicolumn{7}{|l|}{ EPA9066 } \\
\hline
\end{tabular}

$\dagger$ Number of batches qualified that exhibit poor spike recovery due to interference compared to the total number of batches containing spikes.

- Standard deviation cannot be determined.

Note: A value of 0 is reported as 0.0 .

Table 73. Matrix Spike Recoveries for WA

\begin{tabular}{|c|c|c|c|c|c|c|}
\hline Analyte & $\begin{array}{l}\text { Qualified } \\
\text { Out of Ranget }\end{array}$ & $\begin{array}{l}\text { Mean } \\
\text { Recovery (\%) }\end{array}$ & $\begin{array}{l}\text { Standard } \\
\text { Deviation }\end{array}$ & Bias (\%) & $\begin{array}{l}\text { Minimum } \\
\text { Recovery (\%) }\end{array}$ & $\begin{array}{l}\text { Maximum } \\
\text { Recovery (\%) }\end{array}$ \\
\hline $\begin{array}{l}\text { EP } \bar{A} \mathbf{A} 310.1 \\
\left.\text { Alkalinity (as } \mathrm{CaCO}_{3}\right)\end{array}$ & $0 / 8$ & $-\cdots$ & 4.45 & $\begin{array}{ll}-- & - \\
1.0 & \end{array}$ & 95.2 & 108 \\
\hline $\begin{array}{l}\text { EPA340.2 } \\
\text { Fluoride }\end{array}$ & $0 / 2$ & 100 & 6.72 & 0.0 & 95.5 & 105 \\
\hline $\begin{array}{l}\text { EPA353.2 } \\
\text { Nitrate as nitrogen } \\
\text { Nitrate-nitrite as nitrogen }\end{array}$ & $\begin{array}{l}0 / 3 \\
0 / 5\end{array}$ & $\begin{array}{l}108 \\
95.9\end{array}$ & $\begin{array}{l}1.53 \\
9.39\end{array}$ & $\begin{array}{c}8.0 \\
-4.10\end{array}$ & $\begin{array}{l}107 \\
83.9\end{array}$ & $\begin{array}{l}110 \\
104\end{array}$ \\
\hline
\end{tabular}




\begin{tabular}{|c|c|c|c|c|c|c|}
\hline Analyte & $\begin{array}{l}\text { Qualified } \\
\text { Out of Ranget }\end{array}$ & $\begin{array}{l}\text { Mean } \\
\text { Recovery (\%) }\end{array}$ & $\begin{array}{l}\text { Standard } \\
\text { Deviation }\end{array}$ & Blas (\%) & $\begin{array}{l}\text { Minimum } \\
\text { Recovery (\%) }\end{array}$ & $\begin{array}{l}\text { Maximum } \\
\text { Recovery (\%) }\end{array}$ \\
\hline $\begin{array}{l}\text { EPA365.2 } \\
\text { Total phosphates (as P) }\end{array}$ & $0 / 4$ & 98.8 & 3.31 & -1.20 & 94.2 & 102 \\
\hline $\begin{array}{l}\text { EPA6010 } \\
\text { Aluminum } \\
\text { Antimony } \\
\text { Arsenic } \\
\text { Barium } \\
\text { Beryllium } \\
\text { Boron } \\
\text { Cadmium } \\
\text { Calcium } \\
\text { Chromium } \\
\text { Cobalt } \\
\text { Copper } \\
\text { Iron } \\
\text { Lead } \\
\text { Lithium } \\
\text { Magnesium } \\
\text { Manganese } \\
\text { Nickel } \\
\text { Potassium } \\
\text { Selenium } \\
\text { Silica } \\
\text { Silver } \\
\text { Sodium } \\
\text { Thallium } \\
\text { Tin } \\
\text { Vanadium } \\
\text { Zinc }\end{array}$ & $\begin{array}{l}0 / 8 \\
0 / 16 \\
0 / 18 \\
0 / 16 \\
0 / 8 \\
0 / 12 \\
0 / 16 \\
0 / 12 \\
0 / 18 \\
0 / 8 \\
0 / 16 \\
0 / 12 \\
0 / 16 \\
0 / 14 \\
0 / 12 \\
0 / 10 \\
0 / 16 \\
0 / 8 \\
0 / 16 \\
0 / 6 \\
0 / 16 \\
0 / 12 \\
0 / 8 \\
0 / 10 \\
0 / 8 \\
0 / 16\end{array}$ & $\begin{array}{l}\cdot \\
102 \\
99.7 \\
101 \\
98.7 \\
99.0 \\
97.6 \\
100 \\
99.7 \\
99.7 \\
98.7 \\
99.2 \\
98.8 \\
101 \\
106 \\
98.8 \\
102 \\
99.0 \\
101 \\
100 \\
109 \\
99.1 \\
97.7 \\
101 \\
99.2 \\
100 \\
99.2\end{array}$ & $\begin{array}{l}3.56 \\
2.86 \\
2.43 \\
1.0 \\
2.74 \\
4.35 \\
3.67 \\
5.17 \\
1.98 \\
1.55 \\
2.88 \\
3.94 \\
2.23 \\
1.83 \\
2.15 \\
3.10 \\
3.29 \\
2.51 \\
2.24 \\
7.62 \\
1.91 \\
2.44 \\
1.40 \\
3.19 \\
2.43 \\
2.55\end{array}$ & $\begin{array}{c}2.0 \\
-0.30 \\
1.0 \\
-1.30 \\
-1.0 \\
-2.40 \\
0.0 \\
-0.30 \\
-0.30 \\
-1.30 \\
-0.80 \\
-1.20 \\
1.0 \\
6.0 \\
-1.20 \\
2.0 \\
-1.0 \\
1.0 \\
0.0 \\
9.0 \\
-0.90 \\
-2.30 \\
1.0 \\
-0.80 \\
0.0 \\
-0.80\end{array}$ & $\begin{array}{l}97.0 \\
93.6 \\
96.7 \\
96.8 \\
94.9 \\
87.5 \\
92.6 \\
89.0 \\
96.4 \\
97.3 \\
96.6 \\
93.5 \\
97.9 \\
103 \\
96.8 \\
96.4 \\
92.8 \\
97.7 \\
96.5 \\
99.6 \\
96.2 \\
94.5 \\
98.8 \\
94.8 \\
97.4 \\
95.8\end{array}$ & $\begin{array}{l}107 \\
103 \\
105 \\
101 \\
103 \\
104 \\
105 \\
106 \\
103 \\
102 \\
106 \\
107 \\
105 \\
109 \\
104 \\
106 \\
104 \\
103 \\
104 \\
117 \\
103 \\
102 \\
103 \\
103 \\
104 \\
104\end{array}$ \\
\hline $\begin{array}{l}\text { EPA7196A } \\
\text { Chromium, hexavalent }\end{array}$ & $0 / 1$ & 104 & - & 4.0 & 104 & 104 \\
\hline $\begin{array}{l}\text { EPA7470 } \\
\text { Mercury }\end{array}$ & $0 / 16$ & 97.8 & 9.69 & -2.20 & 81.9 & 123 \\
\hline $\begin{array}{l}\text { EPA8010 } \\
\text { Carbon tetrachloride } \\
\text { Chloroform } \\
\text { Tetrachloroethylene } \\
1,1,1 \text {-Trichloroethane } \\
\text { Trichloroethylene }\end{array}$ & $\begin{array}{l}0 / 1 \\
0 / 1 \\
0 / 1 \\
0 / 1 \\
0 / 1\end{array}$ & $\begin{array}{l}102 \\
100 \\
101 \\
99.2 \\
100\end{array}$ & $\begin{array}{l}- \\
- \\
-\end{array}$ & $\begin{array}{l}2.0 \\
0.0 \\
1.0 \\
-0.80 \\
0.0\end{array}$ & $\begin{array}{l}102 \\
100 \\
101 \\
99.2 \\
100\end{array}$ & $\begin{array}{l}102 \\
100 \\
101 \\
99.2 \\
100\end{array}$ \\
\hline $\begin{array}{l}\text { EPA8081 } \\
\text { Aldrin } \\
\text { p,p'-DDT } \\
\text { Dieldrin } \\
\text { Endrin } \\
\text { Heptachlor } \\
\text { Lindane }\end{array}$ & $\begin{array}{l}0 / 4 \\
0 / 4 \\
0 / 4 \\
0 / 6 \\
0 / 4 \\
0 / 4\end{array}$ & $\begin{array}{l}80.0 \\
93.5 \\
95.5 \\
95.0 \\
77.5 \\
93.8\end{array}$ & $\begin{array}{l}20.4 \\
2.52 \\
9.15 \\
13.8 \\
11.9 \\
8.54\end{array}$ & $\begin{array}{l}-20.0 \\
-6.50 \\
-4.50 \\
-5.0 \\
-22.5 \\
-6.20\end{array}$ & $\begin{array}{l}50.0 \\
90.0 \\
86.0 \\
80.0 \\
65.0 \\
85.0\end{array}$ & $\begin{array}{l}95.0 \\
96.0 \\
106 \\
120 \\
90.0 \\
105\end{array}$ \\
\hline $\begin{array}{l}\text { EPAB150 } \\
\text { 2,4-Dichlorophenoxyacetic } \\
\quad \text { acid } \\
2,4,5-T \\
2,4,5-T P \text { (Silvex) }\end{array}$ & $\begin{array}{l}0 / 1 \\
1 / 1\end{array}$ & $\begin{array}{l}90.4 \\
71.2\end{array}$ & $\begin{array}{l}- \\
- \\
-\end{array}$ & $\begin{array}{l}-9.60 \\
-28.8\end{array}$ & $\begin{array}{l}90.4 \\
71.2\end{array}$ & $\begin{array}{l}90.4 \\
71.2\end{array}$ \\
\hline
\end{tabular}




\begin{tabular}{|c|c|c|c|c|c|c|}
\hline Analyte & $\begin{array}{l}\text { Qualified } \\
\text { Out of Ranget }\end{array}$ & $\begin{array}{l}\text { Mean } \\
\text { Recovery (\%) }\end{array}$ & $\begin{array}{l}\text { Standard } \\
\text { Deviation }\end{array}$ & Bias (\%) & $\begin{array}{l}\text { Minimum } \\
\text { Recovery (\%) }\end{array}$ & $\begin{array}{l}\text { Maximum } \\
\text { Recovery (\%) }\end{array}$ \\
\hline \multicolumn{7}{|c|}{ EPA8151 } \\
\hline $\begin{array}{l}\text { 2,4-Dichlorophenoxyacetic } \\
\text { acid }\end{array}$ & $0 / 1$ & 89.6 & - & -10.4 & 89.6 & 89.6 \\
\hline $2,4,5-\mathrm{T}$ & $0 / 1$ & 101 & - & $\cdot 1.0$ & 101 & 101 \\
\hline $2,4,5 \cdot$ TP (Silvex) & $1 / 1$ & 70.8 & - & -29.2 & 70.8 & \\
\hline \multicolumn{7}{|l|}{ EPA8260 } \\
\hline Benzene & $0 / 8$ & 100 & 5.96 & 0.0 & 91.5 & 108 \\
\hline Chlorobenzene & $0 / 8$ & 99.4 & 3.43 & -0.60 & 93.7 & 104 \\
\hline 1,1-Dichloroethylene & $0 / 8$ & 99.0 & 7.71 & -1.0 & 88.6 & 107 \\
\hline Toluene & $0 / 8$ & 101 & 4.76 & 1.0 & 95.1 & 110 \\
\hline Trichloroethylene & $0 / 8$ & 97.6 & 7.87 & -2.40 & 87.8 & 113 \\
\hline \multicolumn{7}{|l|}{ EPAB270 } \\
\hline Acenaphthene & $2 / 7$ & 59.1 & 26.8 & -40.9 & 11.7 & 89.1 \\
\hline Bis(2-ethylhexyl) phthalate & $0 / 2$ & 108 & 22.6 & 8.0 & 92.1 & 124 \\
\hline 4-Chloro-m-cresol & $0 / 6$ & 60.3 & 20.8 & -39.7 & 32.0 & 78.0 \\
\hline 2-Chlorophenol & $0 / 6$ & 62.4 & 17.5 & -37.6 & 37.5 & 85.4 \\
\hline 1,4-Dichlorobenzene & $1 / 7$ & 53.1 & 15.8 & -46.9 & 27.5 & 74.4 \\
\hline 2,4-Dinitrotoluene & $0 / 7$ & 65.1 & 20.8 & -34.9 & 35.0 & 88.7 \\
\hline 4-Nitrophenol & $2 / 6$ & 60.2 & 22.8 & -39.8 & 33.1 & 81.4 \\
\hline N-Nitrosodipropylamine & $2 / 7$ & 62.4 & 22.3 & -37.6 & 30.2 & 89.9 \\
\hline Pentachlorophenol & $0 / 6$ & 64.5 & 27.9 & -35.5 & 25.1 & 90.1 \\
\hline Phenol & $0 / 6$ & 52.0 & 24.5 & -48.0 & 16.3 & 78.1 \\
\hline Pyrene & $1 / 7$ & 66.2 & 33.5 & -33.8 & 2.46 & 94.9 \\
\hline 1,2,4-Trichlorobenzene & $1 / 7$ & 57.0 & 17.2 & -43.0 & 30.3 & 80.1 \\
\hline \multicolumn{7}{|l|}{ EPA8280 } \\
\hline $\begin{array}{l}\text { Heptachlorodibenzo-p- } \\
\text { dioxins }\end{array}$ & $0 / 5$ & 114 & 5.13 & 14.0 & 108 & 122 \\
\hline $\begin{array}{l}\text { Heptachlorodibenzo-p- } \\
\text { furans }\end{array}$ & $0 / 5$ & 112 & 3.32 & 12.0 & 108 & 115 \\
\hline $\begin{array}{l}\text { Hexachlorodibenzo-p- } \\
\text { dioxins }\end{array}$ & $0 / 5$ & 94.8 & 4.87 & -5.20 & 90.0 & 101 \\
\hline $\begin{array}{l}\text { Hexachlorodibenzo-p- } \\
\text { furans }\end{array}$ & $0 / 5$ & 96.0 & 4.53 & -4.0 & 90.0 & 101 \\
\hline 1,2,3,4,6,7,8-HPCDD & $1 / 5$ & 114 & 5.13 & 14.0 & 108 & 122 \\
\hline $1,2,3,4,6,7,8-H P C D F$ & $0 / 5$ & 112 & 3.32 & 12.0 & 108 & 115 \\
\hline \multirow{2}{*}{\multicolumn{2}{|c|}{$\begin{array}{l}\text { Octachlorodibenzo-p-dioxin } 0 / 5 \\
\text { Octachlorodibenzo-p-furan } 0 / 5\end{array}$}} & 104 & 1.34 & 4.0 & 102 & 105 \\
\hline & & 104 & 4.16 & 4.0 & 99.0 & 110 \\
\hline $1,2,3,7,8-P C D D$ & $0 / 5$ & 115 & 9.23 & 15.0 & 104 & 126 \\
\hline $1,2,3,7,8-\mathrm{PCDF}$ & $0 / 5$ & 105 & 5.81 & 5.0 & 98.0 & 111 \\
\hline $\begin{array}{l}\text { Pentachlorodibenzo-p- } \\
\text { furans }\end{array}$ & $0 / 10$ & 110 & 8.86 & 10.0 & 98.0 & 126 \\
\hline $2,3,7,8-T C D D$ & $0 / 5$ & 109 & 2.77 & 9.0 & 105 & 112 \\
\hline $2,3,7,8-T C D F$ & $0 / 5$ & 95.8 & 2.59 & -4.20 & 93.0 & 98.0 \\
\hline $\begin{array}{l}\text { Tetrachlorodibenzo-p- } \\
\text { dioxins }\end{array}$ & $0 / 5$ & 109 & 2.77 & 9.0 & 105 & 112 \\
\hline $\begin{array}{l}\text { Tetrachlorodibenzo-p- } \\
\text { furans }\end{array}$ & $0 / 5$ & 95.8 & 2.59 & -4.20 & 93.0 & 98.0 \\
\hline EPA9010A & --- & . . ..... & - & -- & - & \\
\hline Cyanide & $0 / 3$ & 99.8 & 2.25 & -0.20 & 97.5 & 102 \\
\hline \multicolumn{7}{|l|}{ EPA9020B } \\
\hline Total organic halogens & $0 / 9$ & 103 & 8.21 & 3.0 & 92.6 & 121 \\
\hline \multicolumn{7}{|l|}{ EPA9056 } \\
\hline Chloride & $0 / 5$ & 95.4 & 5.40 & -4.60 & 89.9 & 102 \\
\hline Sulfate & $1 / 10$ & 99.5 & 10.5 & -0.50 & 88.4 & 121 \\
\hline
\end{tabular}




\begin{tabular}{|c|c|c|c|c|c|c|}
\hline Analyte & $\begin{array}{l}\text { Qualified } \\
\text { Out of Ranget }\end{array}$ & $\begin{array}{l}\text { Mean } \\
\text { Recovery (\%) }\end{array}$ & $\begin{array}{l}\text { Standard } \\
\text { Deviation }\end{array}$ & Bias (\%) & $\begin{array}{l}\text { Minimum } \\
\text { Recovery (\%) }\end{array}$ & $\begin{array}{l}\text { Maximum } \\
\text { Recovery (\%) }\end{array}$ \\
\hline $\begin{array}{l}\text { EPA9060 } \\
\text { Total organic carbon }\end{array}$ & $0 / 9$ & 96.5 & 11.6 & -3.50 & 80.5 & 119 \\
\hline $\begin{array}{l}\text { EPA9066 } \\
\text { Phenols }\end{array}$ & $0 / 10$ & 99.7 & 5.11 & -0.30 & 92.7 & 111 \\
\hline
\end{tabular}

$\dagger$ Number of batches qualified that exhibit poor spike recovery due to interference compared to the total number of batches containing spikes.

- Standard deviation cannot be determined.

Note: $A$ value of 0 is reported as 0.0

Table 74. Matrix Spike Recoveries for GP

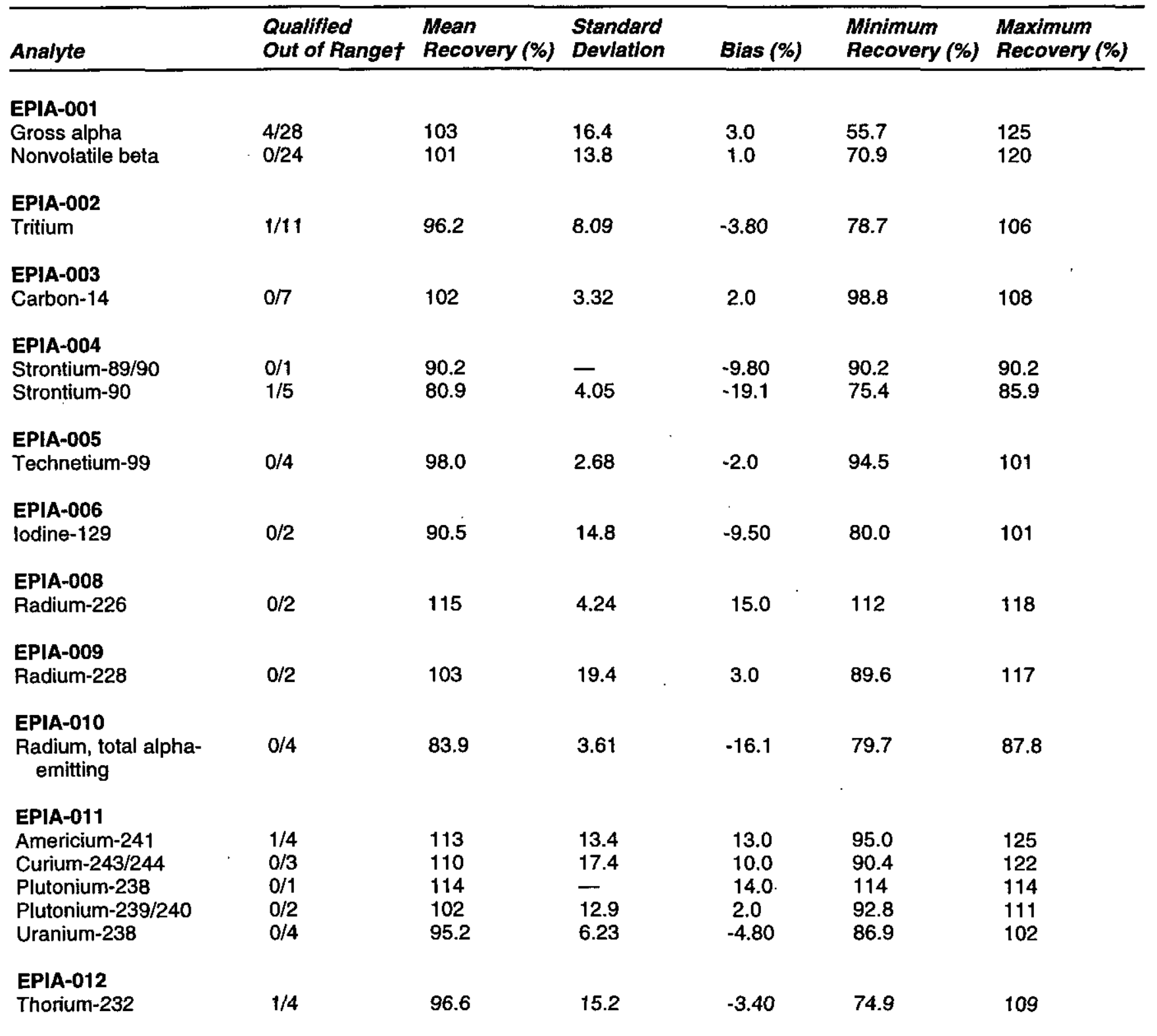




\begin{tabular}{|c|c|c|c|c|c|c|}
\hline Analyte & $\begin{array}{l}\text { Qualified } \\
\text { Out of Ranget }\end{array}$ & $\begin{array}{l}\text { Mean } \\
\text { Recovery (\%) }\end{array}$ & $\begin{array}{l}\text { Standard } \\
\text { Deviation }\end{array}$ & Blas (\%) & $\begin{array}{l}\text { Minimum } \\
\text { Recovery (\%) }\end{array}$ & $\begin{array}{l}\text { Maximum } \\
\text { Recovery (\%) }\end{array}$ \\
\hline \multicolumn{7}{|l|}{ EPIA-013 } \\
\hline Cesium-137 & $0 / 4$ & 101 & 4.49 & 1.0 & 95.7 & 105 \\
\hline \multicolumn{7}{|l|}{ EPIA-020 } \\
\hline Promethium-147 & $0 / 1$ & 89.3 & 一 & -10.7 & 89.3 & 89.3 \\
\hline \multicolumn{7}{|l|}{ EPIA-022 } \\
\hline Nickel-63 & $0 / 3$ & 90.9 & 2.64 & -9.10 & 89.1 & 93.9 \\
\hline \multicolumn{7}{|l|}{ EP|A-032 } \\
\hline Neptunium-237 & $0 / 1$ & 111 & - & 11.0 & 111 & 111 \\
\hline
\end{tabular}

$\dagger$ Number of batches qualified that exhibit poor spike recovery due to interference compared to the total number of batches containing spikes.

- Standard deviation cannot be determined.

Table 75. Analytes Detected in Mothod Blanks for ES

\begin{tabular}{|c|c|c|c|c|c|}
\hline Analyte & $\begin{array}{l}\text { Frequency } \\
\text { of Detectiont }\end{array}$ & Mean Result & $\begin{array}{l}\text { Standard } \\
\text { Deviation }\end{array}$ & Minimum/Maximum & Results \\
\hline \multicolumn{6}{|l|}{ EPA160.1 } \\
\hline Total dissolved solids & $1 / 6$ & 1,500 & 1,220 & $1,000 / 4,000 \mu g / L$ & \\
\hline \multicolumn{6}{|l|}{ EPA300.0 } \\
\hline Nitrate as nitrogen & $2 / 3$ & 76.7 & 20.2 & $65.0 / 100 \mu \mathrm{g} / \mathrm{L}$ & \\
\hline \multicolumn{6}{|l|}{ EPA350.1 } \\
\hline Ammonia nitrogen & $0 / 1$ & 50.0 & - & $50.0 / 50.0 \mu \mathrm{g} / \mathrm{L}$ & \\
\hline \multicolumn{6}{|l|}{ EPA353.2 } \\
\hline Nitrate-nitrite as nitrogen & $0 / 6$ & 10.0 & 0.0 & $10.0 / 10.0 \mu \mathrm{g} / \mathrm{L}$ & \\
\hline \multicolumn{6}{|l|}{ EPA365.1 } \\
\hline Total phosphates (as P) & $0 / 4$ & 10.0 & 0.0 & $10.0 / 10.0 \mu \mathrm{g} / \mathrm{L}$ & \\
\hline \multicolumn{6}{|l|}{ EPA6010 } \\
\hline Aluminum & $0 / 14$ & 20.0 & 0.0 & $20.0 / 20.0 \mu \mathrm{g} / \mathrm{L}$ & \\
\hline Antimony & $0 / 4$ & 5.0 & 0.0 & $5.0 / 5.0 \mu \mathrm{g} / \mathrm{L}$ & \\
\hline Arsenic & $0 / 12$ & 8.0 & 0.0 & $8.0 / 8.0 \mu \mathrm{g} / \mathrm{L}$ & \\
\hline Barium & $0 / 11$ & 2.0 & 0.0 & $2.0 / 2.0 \mu \mathrm{g} / \mathrm{L}$ & \\
\hline Beryllium & $0 / 4$ & 1.0 & 0.0 & $1.0 / 1.0 \mu g / L$ & \\
\hline Boron & $0 / 3$ & 25.0 & 0.0 & $25.0 / 25.0 \mu \mathrm{g} / \mathrm{L}$ & \\
\hline Cadmium & $0 / 11$ & 2.0 & 0.0 & $2.0 / 2.0 \mu \mathrm{g} / \mathrm{L}$ & \\
\hline Calcium & $0 / 6$ & 50.0 & 0.0 & $50.0 / 50.0 \mu \mathrm{g} / \mathrm{L}$ & \\
\hline Chromium & $0 / 12$ & 3.0 & 0.0 & $3.0 / 3.0 \mu \mathrm{g} / \mathrm{L}$ & \\
\hline Cobalt & $0 / 4$ & 5.0 & 0.0 & $5.0 / 5.0 \mu \mathrm{g} / \mathrm{L}$ & \\
\hline Copper & $0 / 4$ & 3.0 & 0.0 & $3.0 / 3.0 \mu \mathrm{g} / \mathrm{L}$ & - \\
\hline Iron $-\ldots-\ldots$ & $-0 / 14$ & 20.0 & 0.0 & $20: 0 / 20: 0 . \mu \mathrm{g} / \mathrm{L}$ & $=-----$ \\
\hline Lead & $0 / 16$ & 5.0 & 0.0 & $5.0 / 5.0 \mu \mathrm{g} / \mathrm{L}$ & \\
\hline Lithium & $0 / 2$ & 5.0 & 0.0 & $5.0 / 5.0 \mu g / \mathrm{L}$ & \\
\hline Magnesium & $0 / 6$ & 50.0 & 0.0 & $50.0 / 50.0 \mu \mathrm{g} / \mathrm{L}$ & \\
\hline Manganese & $0 / 7$ & 3.0 & 0.0 & $3.0 / 3.0 \mu \mathrm{g} / \mathrm{L}$ & \\
\hline Nickel & $0 / 4$ & 5.0 & $=0.0$ & $5.0 / 5.0 \mu \mathrm{g} / \mathrm{L}$ & $\cdot$ \\
\hline Potassium & $0 / 6$ & 400 & 0.0 & $400 / 400 \mu g / L$ & \\
\hline Selenium & $0 / 11$ & 5.0 & 0.0 & $5.0 / 5.0 \mu \mathrm{g} / \mathrm{L}$ & \\
\hline Silica & $0 / 2$ & 100 & 0.0 & $100 / 100 \mu \mathrm{g} / \mathrm{L}$ & \\
\hline Silver & $0 / 11$ & 2.0 & 0.0 & $2.0 / 2.0 \mu \mathrm{g} / \mathrm{L}$ & \\
\hline
\end{tabular}




\begin{tabular}{|c|c|c|c|c|}
\hline Analyte & $\begin{array}{l}\text { Frequency } \\
\text { of Detectiont }\end{array}$ & Mean Result & $\begin{array}{l}\text { Standard } \\
\text { Deviation }\end{array}$ & Minimum/Maximum Results \\
\hline $\begin{array}{l}\text { Sodium } \\
\text { Thallium } \\
\text { Vanadium } \\
\text { Zinc }\end{array}$ & $\begin{array}{l}0 / 6 \\
0 / 4 \\
0 / 4 \\
0 / 4\end{array}$ & $\begin{array}{l}100 \\
5.0 \\
2.0 \\
10.0\end{array}$ & $\begin{array}{l}0.0 \\
0.0 \\
0.0 \\
0.0\end{array}$ & $\begin{array}{l}100 / 100 \mu \mathrm{g} / \mathrm{L} \\
5.0 / 5.0 \mu \mathrm{g} / \mathrm{L} \\
2.0 / 2.0 \mu \mathrm{g} / \mathrm{L} \\
10.0 / 10.0 \mu \mathrm{g} / \mathrm{L}\end{array}$ \\
\hline $\begin{array}{l}\text { EPA7470 } \\
\text { Mercury }\end{array}$ & $1 / 28$ & 0.20 & 0.01 & $0.16 / 0.20 \mu \mathrm{g} / \mathrm{L}$ \\
\hline $\begin{array}{l}\text { EPA8010 } \\
\text { Carbon tetrachloride } \\
\text { Chloroform } \\
\text { Tetrachloroethylene } \\
1,1,1-\text { Trichloroethane } \\
\text { Trichloroethylene }\end{array}$ & $\begin{array}{l}0 / 15 \\
0 / 15 \\
0 / 15 \\
0 / 15 \\
0 / 15\end{array}$ & $\begin{array}{l}0.41 \\
0.43 \\
0.57 \\
0.46 \\
0.39\end{array}$ & $\begin{array}{l}0.0 \\
0.0 \\
0.0 \\
0.0 \\
0.0\end{array}$ & $\begin{array}{l}0.41 / 0.41 \mu \mathrm{g} / \mathrm{L} \\
0.43 / 0.43 \mu \mathrm{g} / \mathrm{L} \\
0.57 / 0.57 \mu \mathrm{g} / \mathrm{L} \\
0.46 / 0.46 \mu \mathrm{g} / \mathrm{L} \\
0.39 / 0.39 \mu \mathrm{g} / \mathrm{L}\end{array}$ \\
\hline $\begin{array}{l}\text { EPA8081 } \\
\text { Aldrin } \\
\text { alpha-Benzene hexachloride } \\
\text { beta-Benzene hexachloride } \\
\text { delta-Benzene hexachloride } \\
\text { Chlordane } \\
\text { alpha-Chlordane } \\
\text { gamma-Chlordane } \\
\text { p,p'-DDD } \\
\text { p,p'-DDE } \\
\text { p,p'-DDT } \\
\text { Dieldrin } \\
\text { Endosulfan sulfate } \\
\text { Endosulfan I } \\
\text { Endosulfan II } \\
\text { Endrin } \\
\text { Endrin aldehyde } \\
\text { Endrin ketone } \\
\text { Heptachlor } \\
\text { Heptachlor epoxide } \\
\text { Lindane } \\
\text { Methoxychlor } \\
\text { PCB } 1016 \\
\text { PCB } 1221 \\
\text { PCB } 1232 \\
\text { PCB } 1242 \\
\text { PCB } 1248 \\
\text { PCB } 1254 \\
\text { PCB } 1260 \\
\text { Toxaphene }\end{array}$ & $\begin{array}{l}0 / 5 \\
0 / 5 \\
0 / 5 \\
0 / 5 \\
0 / 5 \\
0 / 5 \\
0 / 5 \\
0 / 5 \\
0 / 5 \\
0 / 5 \\
0 / 5 \\
0 / 5 \\
0 / 5 \\
0 / 5 \\
0 / 6 \\
0 / 5 \\
0 / 5 \\
0 / 5 \\
0 / 5 \\
0 / 5 \\
0 / 5 \\
0 / 4 \\
0 / 4 \\
0 / 4 \\
0 / 4 \\
0 / 4 \\
0 / 4 \\
0 / 4 \\
0 / 5\end{array}$ & $\begin{array}{l}0.02 \\
0.02 \\
0.02 \\
0.02 \\
0.07 \\
0.02 \\
0.02 \\
0.02 \\
0.02 \\
0.02 \\
0.02 \\
0.02 \\
0.02 \\
0.02 \\
0.02 \\
0.02 \\
0.02 \\
0.02 \\
0.02 \\
0.02 \\
0.02 \\
0.30 \\
0.30 \\
0.30 \\
0.30 \\
0.30 \\
0.30 \\
0.30 \\
1.50\end{array}$ & $\begin{array}{l}0.0 \\
0.0 \\
0.0 \\
0.0 \\
0.0 \\
0.0 \\
0.0 \\
0.0 \\
0.0 \\
0.0 \\
0.0 \\
0.0 \\
0.0 \\
0.0 \\
0.0 \\
0.0 \\
0.0 \\
0.0 \\
0.0 \\
0.0 \\
0.0 \\
0.0 \\
0.0 \\
0.0 \\
0.0 \\
0.0 \\
0.0 \\
0.0 \\
0.0\end{array}$ & $\begin{array}{l}0.02 / 0.02 \mu \mathrm{g} / \mathrm{L} \\
0.02 / 0.02 \mu \mathrm{g} / \mathrm{L} \\
0.02 / 0.02 \mu \mathrm{g} / \mathrm{L} \\
0.02 / 0.02 \mu \mathrm{g} / \mathrm{L} \\
0.07 / 0.07 \mu \mathrm{g} / \mathrm{L} \\
0.02 / 0.02 \mu \mathrm{g} / \mathrm{L} \\
0.02 / 0.02 \mu \mathrm{g} / \mathrm{L} \\
0.02 / 0.02 \mu \mathrm{g} / \mathrm{L} \\
0.02 / 0.02 \mu \mathrm{g} / \mathrm{L} \\
0.02 / 0.02 \mu \mathrm{g} / \mathrm{L} \\
0.02 / 0.02 \mu \mathrm{g} / \mathrm{L} \\
0.02 / 0.02 \mu \mathrm{g} / \mathrm{L} \\
0.02 / 0.02 \mu \mathrm{g} / \mathrm{L} \\
0.02 / 0.02 \mu \mathrm{g} / \mathrm{L} \\
0.02 / 0.02 \mu \mathrm{g} / \mathrm{L} \\
0.02 / 0.02 \mu g / \mathrm{L} \\
0.02 / 0.02 \mu \mathrm{g} / \mathrm{L} \\
0.02 / 0.02 \mu \mathrm{g} / \mathrm{L} \\
0.02 / 0.02 \mu \mathrm{g} / \mathrm{L} \\
0.02 / 0.02 \mu \mathrm{g} / \mathrm{L} \\
0.02 / 0.02 \mu \mathrm{L} / \mathrm{L} \\
0.30 / 0.30 \mu \mathrm{L} / \mathrm{L} \\
0.30 / 0.30 \mu \mathrm{L} / \mathrm{L} \\
0.30 / 0.30 \mu \mathrm{L} / \mathrm{L} \\
0.30 / 0.30 \mu \mathrm{g} / \mathrm{L} \\
0.30 / 0.30 \mu \mathrm{g} / \mathrm{L} \\
0.30 / 0.30 \mu \mathrm{g} / \mathrm{L} \\
0.30 / 0.30 \mu \mathrm{g} / \mathrm{L} \\
1.50 / 1.50 \mu \mathrm{g} / \mathrm{L}\end{array}$ \\
\hline $\begin{array}{l}\text { EPA8082 } \\
\text { PCB } 1016 \\
\text { PCB } 1221 \\
\text { PCB } 1232 \\
\text { PCB } 1242 \\
\text { PCB } 1248 \\
\text { PCB } 1254 \\
\text { PCB } 1260\end{array}$ & $\begin{array}{l}0 / 1 \\
0 / 1 \\
0 / 1 \\
0 / 1 \\
0 / 1 \\
0 / 1 \\
0 / 2\end{array}$ & $\begin{array}{l}0.30 \\
0.30 \\
0.30 \\
0.30 \\
0.30 \\
0.30 \\
0.30\end{array}$ & $\begin{array}{l}= \\
= \\
= \\
\overline{0}\end{array}$ & $\begin{array}{l}0.30 / 0.30 \mu \mathrm{g} / \mathrm{L} \\
0.30 / 0.30 \mu \mathrm{g} / \mathrm{L} \\
0.30 / 0.30 \mu \mathrm{g} / \mathrm{L} \\
0.30 / 0.30 \mu \mathrm{g} / \mathrm{L} \\
0.30 / 0.30 \mu \mathrm{g} / \mathrm{L} \\
0.30 / 0.30 \mu \mathrm{g} / \mathrm{L} \\
0.30 / 0.30 \mu \mathrm{g} / \mathrm{L}\end{array}$ \\
\hline $\begin{array}{l}\text { EPA8260 } \\
\text { Acetone } \\
\text { Acetonitrile } \\
\text { Acrolein } \\
\text { Acrylonitrile } \\
\text { Allyl chloride }\end{array}$ & $\begin{array}{l}37 / 40 \\
0 / 11 \\
0 / 11 \\
0 / 11 \\
0 / 11\end{array}$ & $\begin{array}{l}6.05 \\
20.0 \\
10.0 \\
5.0 \\
10.0\end{array}$ & $\begin{array}{l}2.46 \\
0.0 \\
0.0 \\
0.0 \\
0.0\end{array}$ & $\begin{array}{l}3.10 / 15.0 \mu \mathrm{g} / \mathrm{L} \\
20.0 / 20.0 \mu \mathrm{g} / \mathrm{L} \\
10.0 / 10.0 \mu \mathrm{g} / \mathrm{L} \\
5.0 / 5.0 \mu \mathrm{g} / \mathrm{L} \\
10.0 / 10.0 \mu \mathrm{g} / \mathrm{L}\end{array}$ \\
\hline
\end{tabular}




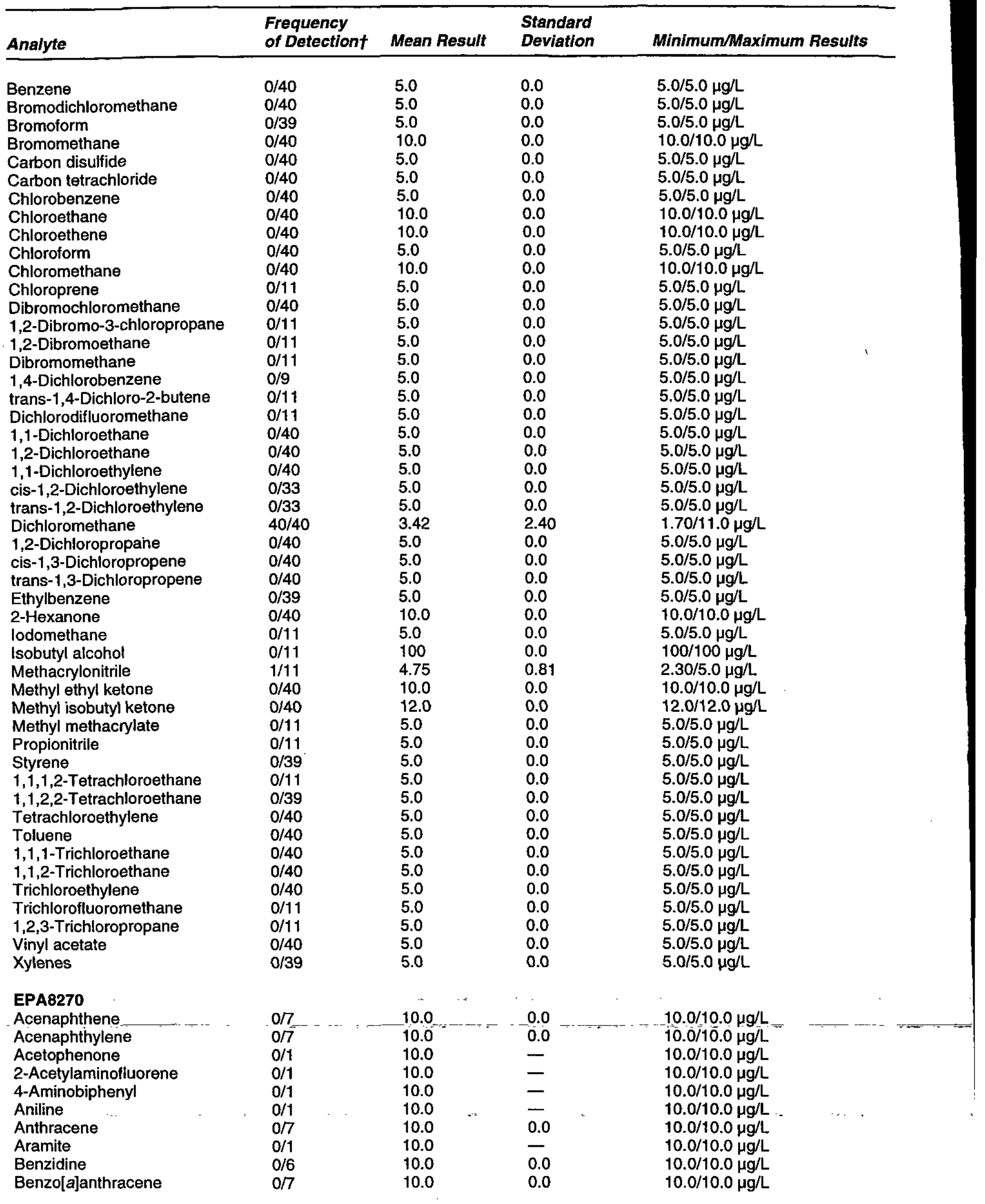




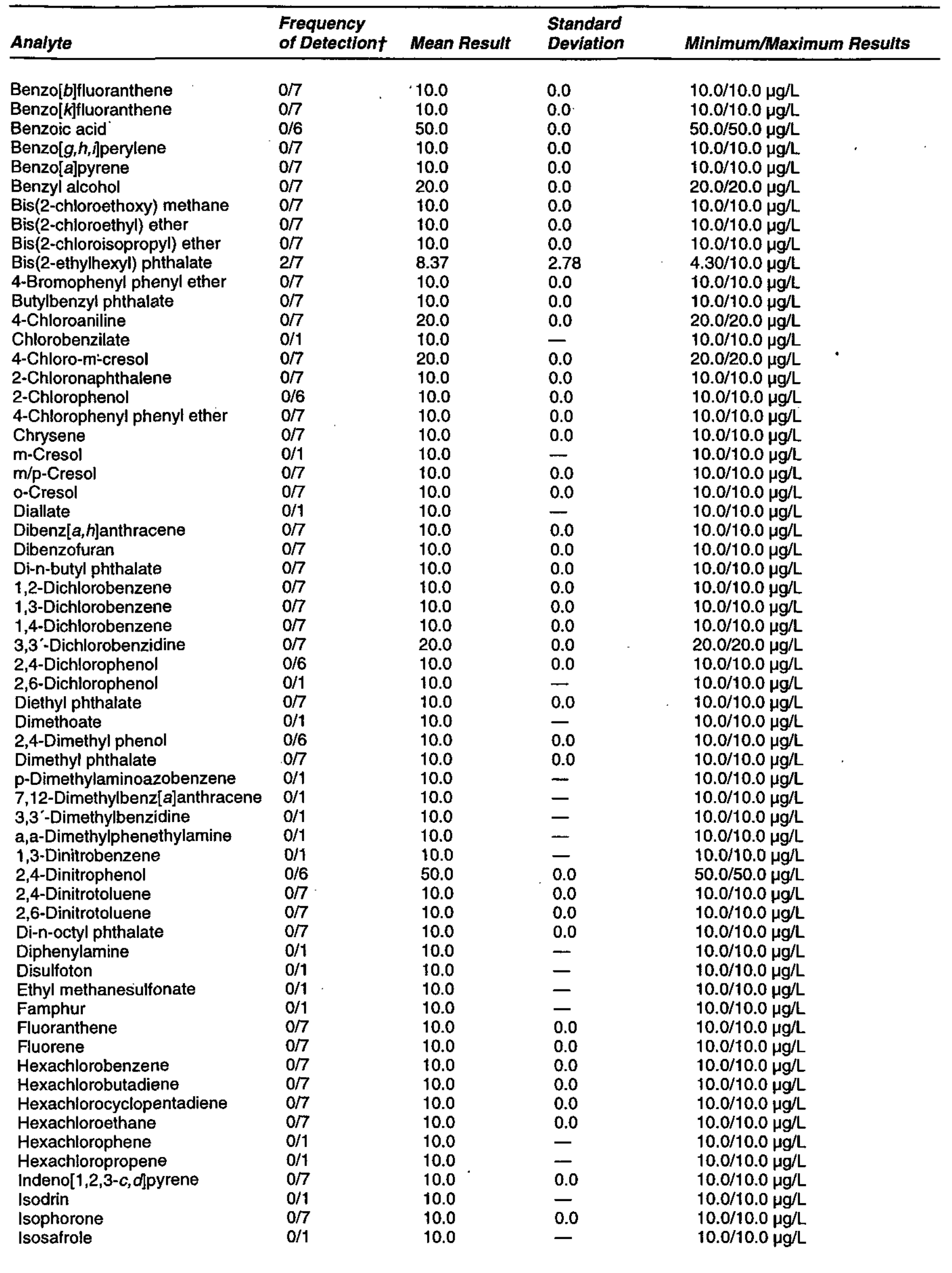




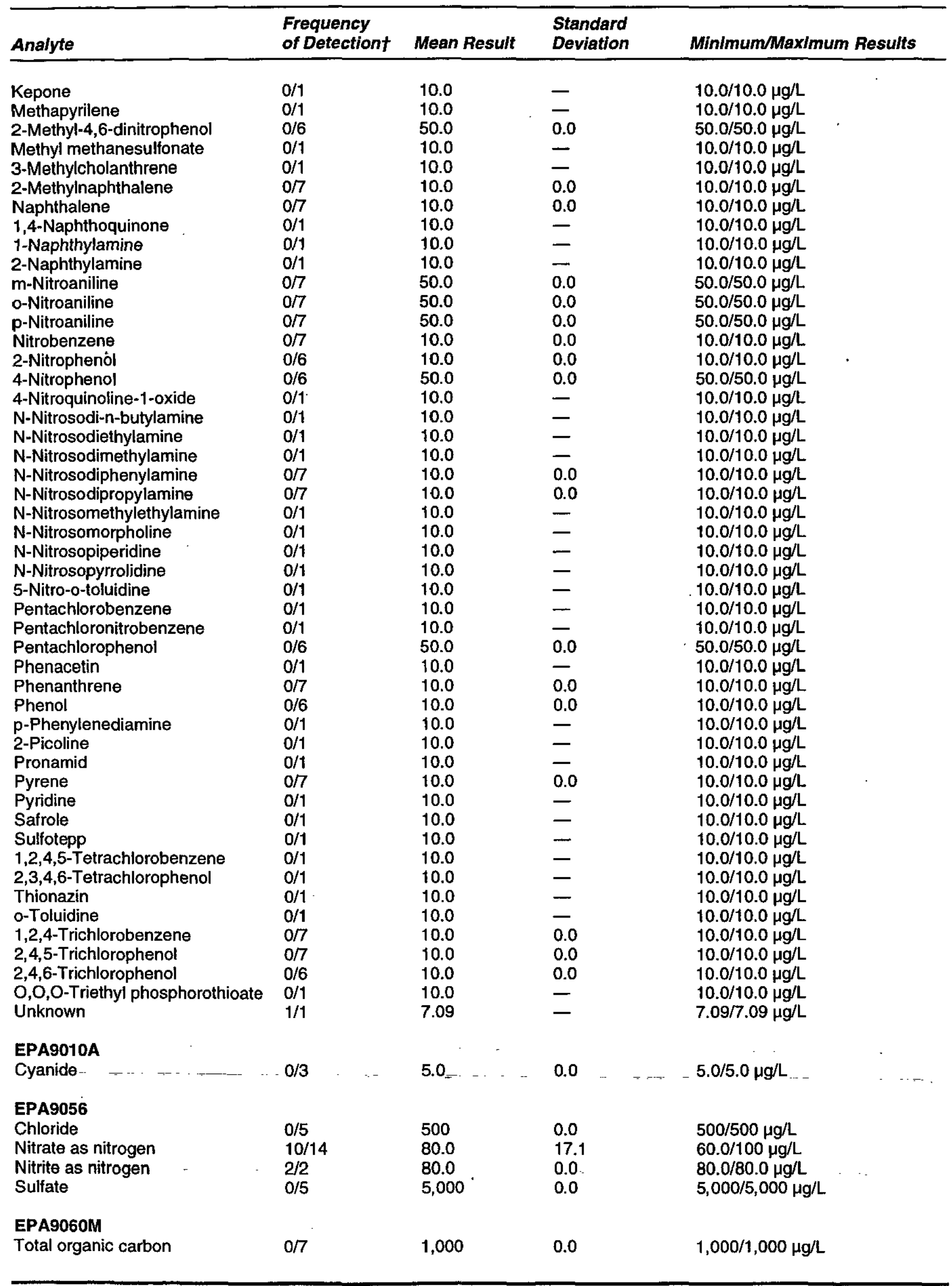




\begin{tabular}{|c|c|c|c|c|}
\hline Analyte & $\begin{array}{l}\text { Frequency } \\
\text { of Detectiont }\end{array}$ & Mean Result & $\begin{array}{l}\text { Standard } \\
\text { Deviation }\end{array}$ & Minimum/Maximum Results \\
\hline \multicolumn{5}{|l|}{ EPA9214 } \\
\hline Fluoride & $0 / 2$ & 100 & 0.0 & $100 / 100 \mu \mathrm{g} / \mathrm{L}$ \\
\hline \multicolumn{5}{|l|}{ ESESOPM008 } \\
\hline Actinium-228 & $1 / 1$ & $-3.30 \mathrm{E}-09$ & - & $-3.30 \mathrm{E}-09 /-3.30 \mathrm{E}-09 \mu \mathrm{Ci} / \mathrm{mL}$ \\
\hline Antimony-125 & $1 / 1$ & $-2.60 E-10$ & - & $-2.60 \mathrm{E}-10 /-2.60 \mathrm{E}-10 \mu \mathrm{Ci} / \mathrm{mL}$ \\
\hline Cerium-144 & $1 / 1$ & $3.26 \mathrm{E}-09$ & - & 3.26E-09/3.26E-09 $\mu \mathrm{Ci} / \mathrm{mL}$ \\
\hline Cesium-134 & $1 / 1$ & $-7.60 \mathrm{E}-10$ & - & $-7.60 \mathrm{E}-10 /-7.60 \mathrm{E}-10 \mu \mathrm{Ci} / \mathrm{mL}$ \\
\hline Cesium-137 & $1 / 1$ & $-4.80 E-10$ & - & $-4.80 \mathrm{E}-10 /-4.80 \mathrm{E}-10 \mu \mathrm{Ci} / \mathrm{mL}$ \\
\hline Cobalt-57 & $1 / 1$ & $9.30 \mathrm{E}-10$ & - & $9.30 \mathrm{E}-10 / 9.30 \mathrm{E}-10 \mu \mathrm{Ci} / \mathrm{mL}$ \\
\hline Cobalt-60 & $1 / 1$ & 5.50E-10 & - & $5.50 \mathrm{E}-10 / 5.50 \mathrm{E}-10 \mu \mathrm{Ci} / \mathrm{mL}$ \\
\hline Europium-152 & $1 / 1$ & $1.55 \mathrm{E}-08$ & - & 1.55E-08/1.55E-08 $\mu \mathrm{Ci} / \mathrm{mL}$ \\
\hline Europium-154 & $1 / 1$ & $-1.63 E-09$ & - & $-1.63 \mathrm{E}-09 /-1.63 \mathrm{E}-09 \mu \mathrm{Ci} / \mathrm{mL}$ \\
\hline Europium-155 & $1 / 1$ & $4.28 \mathrm{E}-09$ & - & 4.28E-09/4.28E-09 $\mu \mathrm{Ci} / \mathrm{mL}$ \\
\hline lodine-129 & $0 / 1$ & 3.61E-09 & - & 3.61E-09/3.61E-09 $\mu \mathrm{Ci} / \mathrm{mL}$ \\
\hline Lead-212 & $1 / 1$ & $2.00 \mathrm{E}-10$ & - & 2.00E-10/2.00E-10 $\mu \mathrm{Ci} / \mathrm{mL}$ \\
\hline Manganese-54 & $1 / 1$ & $-7.60 \mathrm{E}-10$ & - & $-7.60 \mathrm{E}-10 /-7.60 \mathrm{E}-10 \mu \mathrm{Ci} / \mathrm{mL}$ \\
\hline Potassium- 40 & $1 / 1$ & 4.36E-08 & - & 4.36E-08/4.36E- $08 \mu \mathrm{Ci} / \mathrm{mL}$ \\
\hline Promethium-144 & $1 / 1$ & $4.20 \mathrm{E}-10$ & - & 4.20E-10/4.20E-10 $\mu \mathrm{Ci} / \mathrm{mL}$ \\
\hline Promethium-146 & $1 / 1$ & $3.30 \mathrm{E}-10$ & - & 3.30E-10/3.30E-10 $\mu \mathrm{Ci} / \mathrm{mL}$ \\
\hline Ruthenium-106 & $1 / 1$ & $1.08 \mathrm{E}-08$ & - & $1.08 \mathrm{E}-08 / 1.08 \mathrm{E}-08 \mu \mathrm{Ci} / \mathrm{mL}$ \\
\hline Sodium-22 & $1 / 1$ & $-5.80 E-10$ & - & $-5.80 \mathrm{E}-10 /-5.80 \mathrm{E}-10 \mu \mathrm{Ci} / \mathrm{mL}$ \\
\hline Thorium-234 & $1 / 1$ & $1.36 \mathrm{E}-08$ & - & $1.36 \mathrm{E}-08 / 1.36 \mathrm{E}-08 \mu \mathrm{Ci} / \mathrm{mL}$ \\
\hline Yttrium-88 & $1 / 1$ & $5.20 \mathrm{E}-10$ & - & $5.20 \mathrm{E}-10 / 5.20 \mathrm{E}-10 \mu \mathrm{Ci} / \mathrm{mL}$ \\
\hline Zinc-65 & $1 / 1$ & $-1.04 \mathrm{E}-09$ & - & $-1.04 \mathrm{E}-09 /-1.04 \mathrm{E}-09 \mu \mathrm{Ci} / \mathrm{mL}$ \\
\hline \multicolumn{5}{|l|}{ ESESOPM017 } \\
\hline Gross alpha & $0 / 5$ & $-1.64 \mathrm{E}-10$ & $3.16 \mathrm{E}-10$ & $-4.50 \mathrm{E}-10 / 3.70 \mathrm{E}-10 \mu \mathrm{Ci} / \mathrm{mL}$ \\
\hline Nonvolatile beta & $0 / 4$ & $-1.75 \mathrm{E}-11$ & $7.38 \mathrm{E}-10$ & $-1.07 \mathrm{E}-09 / 6.10 \mathrm{E}-10 \mu \mathrm{Ci} / \mathrm{mL}$ \\
\hline \multicolumn{5}{|l|}{ ESESOPM020 } \\
\hline Tritium & $0 / 9$ & $1.71 E-09$ & $1.80 \mathrm{E}-07$ & $-1.96 \mathrm{E}-07 / 2.83 \mathrm{E}-07 \mu \mathrm{Ci} / \mathrm{mL}$ \\
\hline \multicolumn{5}{|l|}{ ESESOPM029 } \\
\hline Radium, total alpha-emitting & $0 / 1$ & $5.60 \mathrm{E}-10$ & - & $5.60 \mathrm{E}-10 / 5.60 \mathrm{E}-10 \mu \mathrm{Ci} / \mathrm{mL}$ \\
\hline \multicolumn{5}{|l|}{ ESESOPM030 } \\
\hline Radium-226 & $0 / 1$ & $4.90 \mathrm{E}-10$ & - & 4.90E-10/4.90E-10 $\mu \mathrm{Ci} / \mathrm{mL}$ \\
\hline Radium-228 & $0 / 1$ & $9.00 \mathrm{E}-11$ & - & 9.00E-11/9.00E-11 $\mu \mathrm{Ci} / \mathrm{mL}$ \\
\hline \multicolumn{5}{|l|}{ ESESOPM031 } \\
\hline Strontium-90 & $0 / 1$ & $-3.20 \mathrm{E}-10$ & - & $-3.20 \mathrm{E}-10 /-3.20 \mathrm{E}-10 \mu \mathrm{Ci} / \mathrm{mL}$ \\
\hline \multicolumn{5}{|l|}{ ESESOPM032 } \\
\hline Americium-241 & $0 / 1$ & $6.00 \mathrm{E}-11$ & - & $6.00 \mathrm{E}-11 / 6.00 \mathrm{E}-11 \mu \mathrm{Ci} / \mathrm{mL}$ \\
\hline Curium-242 & $0 / 1$ & $7.00 \mathrm{E}-11$ & - & 7.00E-11/7.00E-11 $\mu \mathrm{Ci} / \mathrm{mL}$ \\
\hline Curium-243/244 & $0 / 1$ & $8.00 \mathrm{E}-11$ & - & 8.00E-11/8.00E-11 $\mu \mathrm{Ci} / \mathrm{mL}$ \\
\hline Curium-245/246 & $0 / 1$ & $6.00 \mathrm{E}-11$ & - & 6.00E-11/6.00E-11 $\mu \mathrm{Ci} / \mathrm{mL}$ \\
\hline Neptunium-237 & $0 / 1$ & 0.0 & - & $0.0 / 0.0 \mu \mathrm{Ci} / \mathrm{mL}$ \\
\hline Plutonium-238 & $0 / 1$ & $1.00 \mathrm{E}-11$ & - & 1.00E-11/1.00E-11 $\mu \mathrm{Ci} / \mathrm{mL}$ \\
\hline Plutonium-239/240 & $0 / 1$ & 0.0 & - & $0.0 / 0.0 \mu \mathrm{Ci} / \mathrm{mL}$ \\
\hline Thorium-228 & $0 / 1$ & $1.00 \mathrm{E}-11$ & - & 1.00E-11/1.00E-11 $\mu \mathrm{Ci} / \mathrm{mL}$ \\
\hline Thorium-230 & $1 / 1$ & $2.90 \mathrm{E}-10$ & - & 2.90E-10/2.90E-10 $\mu \mathrm{Ci} / \mathrm{mL}$ \\
\hline Thorium-232 & $0 / 1$ & $4.00 \mathrm{E}-11$ & - & 4.00E-11/4.00E-11 $\mu \mathrm{Ci} / \mathrm{mL}$ \\
\hline Uranium-233/234 & $0 / 1$ & $1.00 \mathrm{E}-11$ & - & 1.00E-11/1.00E-11 $\mu \mathrm{Ci} / \mathrm{mL}$ \\
\hline
\end{tabular}




\begin{tabular}{lllll}
\hline Analyte & $\begin{array}{l}\text { Frequency } \\
\text { of Detectiont }\end{array}$ & Mean Result & $\begin{array}{l}\text { Standard } \\
\text { Deviation }\end{array}$ & Minimum/Maximum Results \\
\hline & $0 / 1$ & $1.00 \mathrm{E}-11$ & - & $1.00 \mathrm{E}-11 / 1.00 \mathrm{E}-11 \mu \mathrm{Ci} / \mathrm{mL}$ \\
Uranium-235 & $0 / 1$ & 0.0 & - & $0.0 / 0.0 \mu \mathrm{Ci} / \mathrm{mL}$ \\
\hline
\end{tabular}

$\dagger$ Number of times analyte was detected compared to the total number of method blanks for the analyte.

- Standard deviation cannot be determined.

Note: If the analyte was not detected in the method blank(s), detection limit information appears in the Mean Result and Minimum/Maximum Results columns.

Table 76. Analytes Detected in Method Blanks for EX

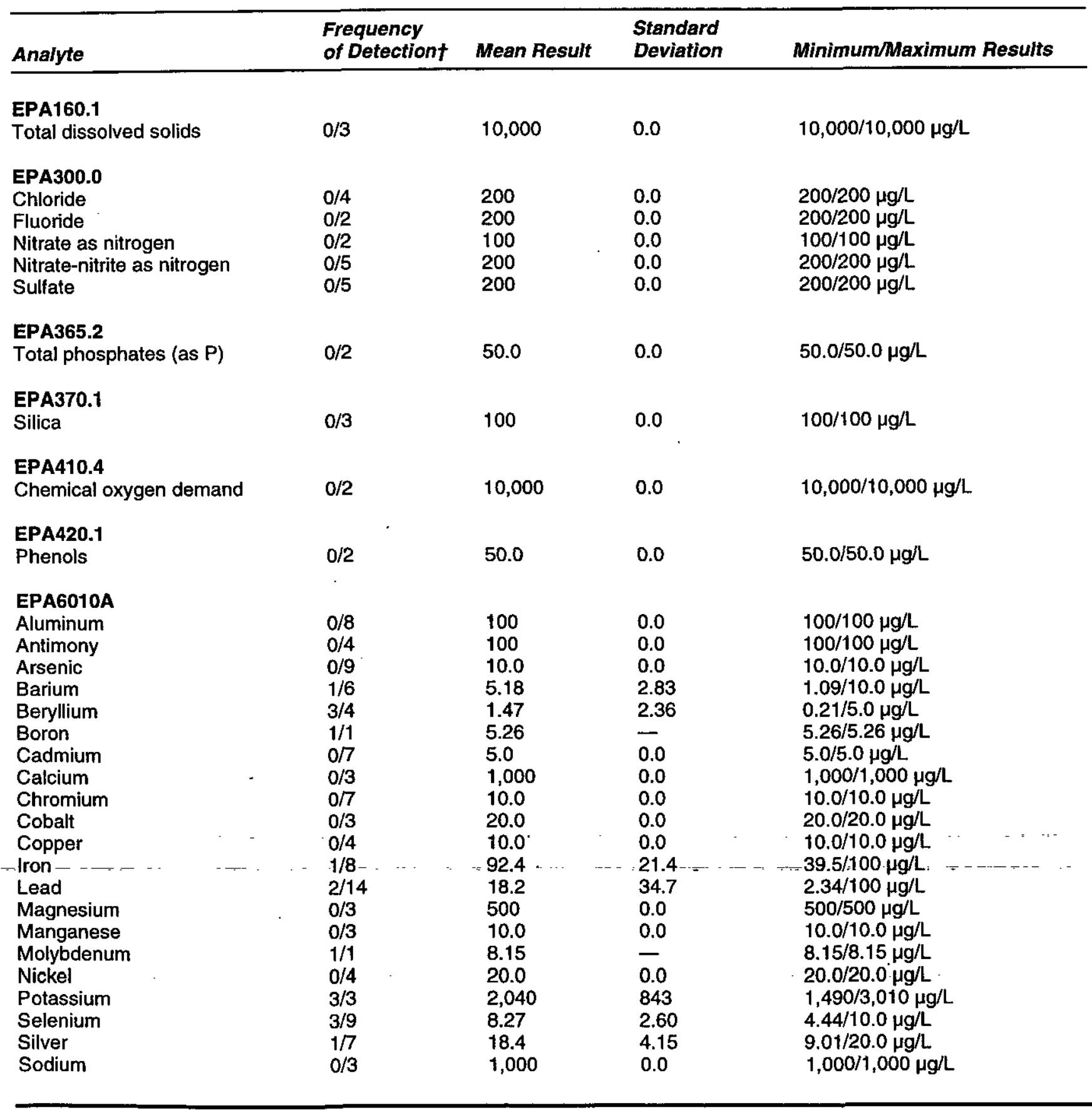




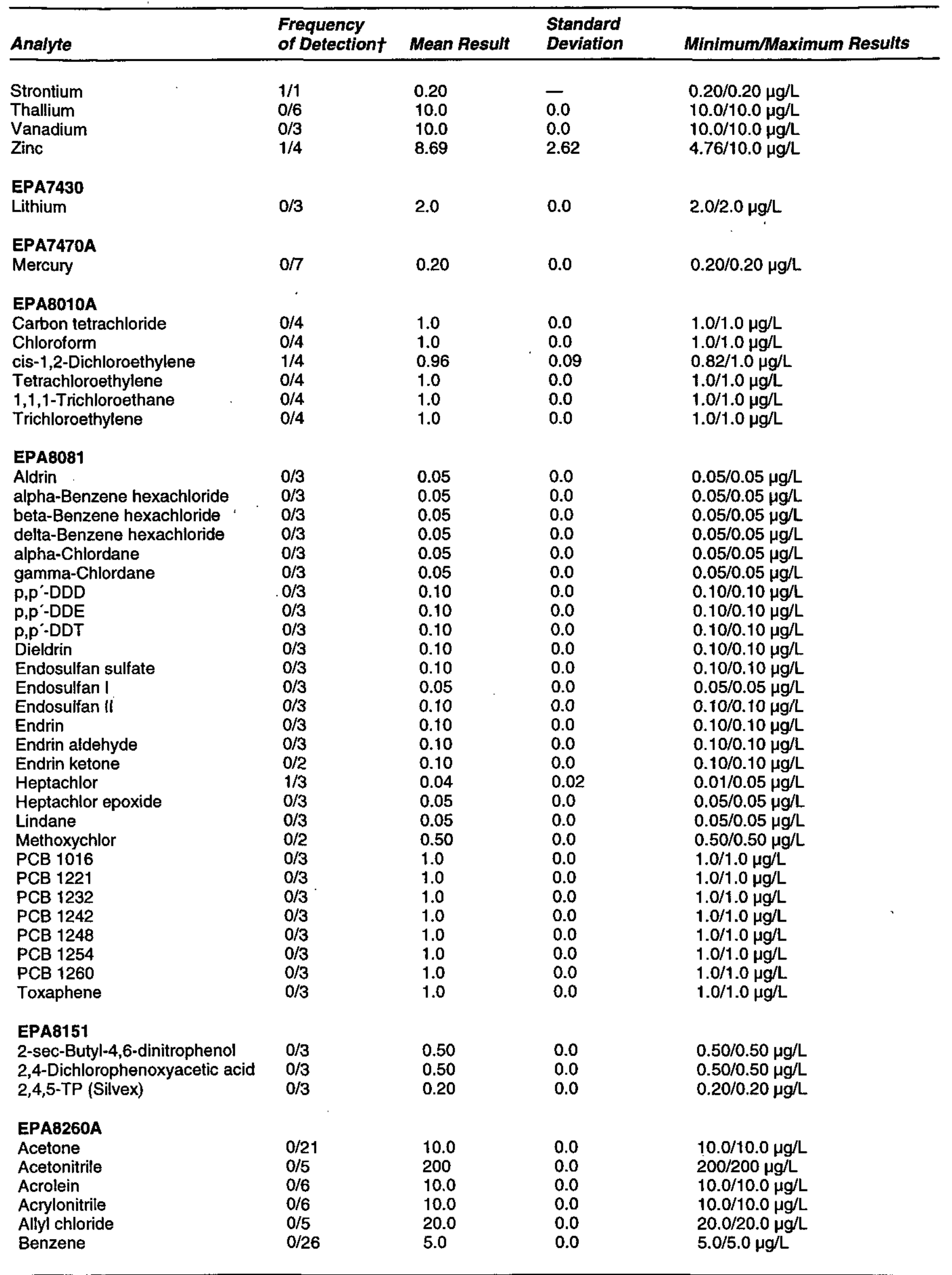




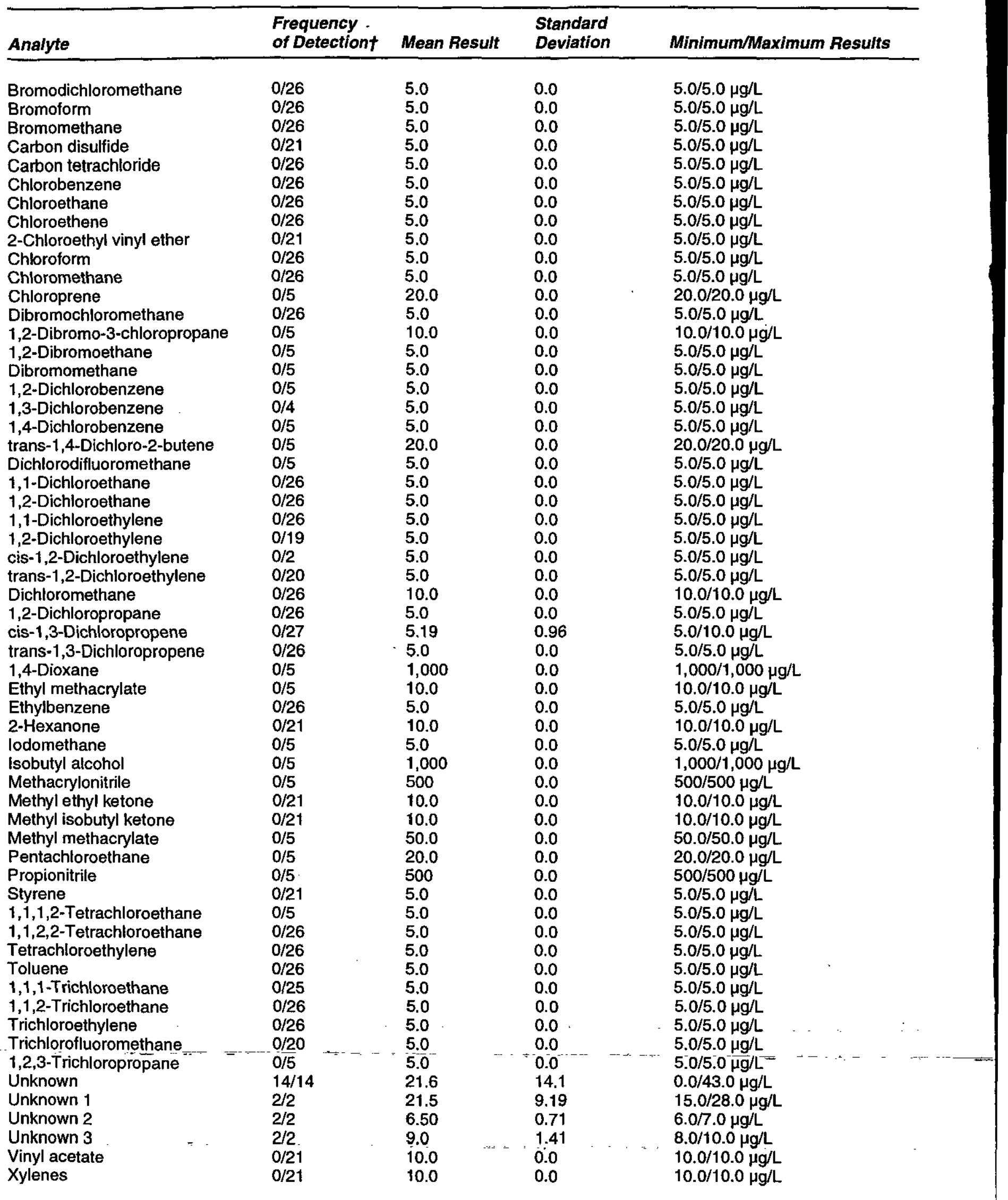




\begin{tabular}{|c|c|c|c|c|}
\hline Analyte & $\begin{array}{l}\text { Frequency } \\
\text { of Detectiont }\end{array}$ & Mean Result & $\begin{array}{l}\text { Standard } \\
\text { Deviation }\end{array}$ & Minimum/Maximum Results \\
\hline \multicolumn{5}{|l|}{ EPA8270B } \\
\hline Acenaphthene & $0 / 4$ & 10.0 & 0.0 & $10.0 / 10.0 \mu \mathrm{g} / \mathrm{L}$ \\
\hline Acenaphthylene & $0 / 4$ & 10.0 & 0.0 & $10.0 / 10.0 \mu \mathrm{g} / \mathrm{L}$ \\
\hline Anthracene & $0 / 4$ & 10.0 & 0.0 & $10.0 / 10.0 \mu \mathrm{g} / \mathrm{L}$ \\
\hline Benzidine & $0 / 4$ & 50.0 & 0.0 & $50.0 / 50.0 \mu \mathrm{g} / \mathrm{L}$ \\
\hline Benzo[a]anthracene & $0 / 4$ & 10.0 & 0.0 & $10.0 / 10.0 \mu \mathrm{g} / \mathrm{L}$ \\
\hline Benzo[b]fluoranthene & $0 / 4$ & 10.0 & 0.0 & $10.0 / 10.0 \mu \mathrm{g} / \mathrm{L}$ \\
\hline Benzo[ $[$ ffluoranthene & $0 / 4$ & 10.0 & 0.0 & $10.0 / 10.0 \mu g / L$ \\
\hline Benzoic acid & $0 / 1$ & 50.0 & - & $50.0 / 50.0 \mu \mathrm{g} / \mathrm{L}$ \\
\hline Benzo[g,h,i]perylene & $0 / 4$ & 10.0 & 0.0 & $10.0 / 10.0 \mu \mathrm{g} / \mathrm{L}$ \\
\hline Benzo[a]pyrene & $0 / 4$ & 10.0 & 0.0 & $10.0 / 10.0 \mu g / L$ \\
\hline Benzyl alcohol & $0 / 3$ & 20.0 & 0.0 & $20.0 / 20.0 \mu \mathrm{g} / \mathrm{L}$ \\
\hline Bis(2-chloroethoxy) methane & $0 / 4$ & 10.0 & 0.0 & 10.0/10.0 $\mu \mathrm{g} / \mathrm{L}$ \\
\hline Bis(2-chloroethyl) ether & $0 / 4$ & 10.0 & 0.0 & $10.0 / 10.0 \mu g / L$ \\
\hline Bis(2-chloroisopropyl) ether & $0 / 4$ & 10.0 & 0.0 & $10.0 / 10.0 \mu \mathrm{g} / \mathrm{L}$ \\
\hline Bis(2-ethylhexyl) phthalate & $0 / 4$ & 10.0 & 0.0 & $10.0 / 10.0 \mu \mathrm{g} / \mathrm{L}$ \\
\hline 4-Bromophenyl phenyl ether & $0 / 4$ & 10.0 & 0.0 & $10.0 / 10.0 \mu \mathrm{g} / \mathrm{L}$ \\
\hline Butylbenzyl phthalate & $0 / 4$ & 10.0 & 0.0 & $10.0 / 10.0 \mu g / L$ \\
\hline 4-Chloroaniline & $0 / 3$ & 10.0 & 0.0 & $10.0 / 10.0 \mu \mathrm{g} / \mathrm{L}$ \\
\hline 4-Chloro-m-cresol & $0 / 4$ & 20.0 & 0.0 & $20.0 / 20.0 \mu \mathrm{g} / \mathrm{L}$ \\
\hline 2-Chloronaphthalene & $0 / 4$ & 10.0 & 0.0 & $10.0 / 10.0 \mu g / L$ \\
\hline 2-Chtorophenol & $0 / 4$ & 10.0 & 0.0 & $10.0 / 10.0 \mu \mathrm{g} / \mathrm{L}$ \\
\hline 4-Chlorophenyl phenyl ether & $0 / 4$ & 10.0 & 0.0 & $10.0 / 10.0 \mu \mathrm{g} / \mathrm{L}$ \\
\hline Chrysene & $0 / 4$ & 10.0 & 0.0 & $10.0 / 10.0 \mu \mathrm{g} / \mathrm{L}$ \\
\hline $\mathrm{m} / \mathrm{p}$-Cresol & $0 / 3$ & 10.0 & 0.0 & $10.0 / 10.0 \mu g / L$ \\
\hline o-Cresol & $0 / 3$ & 10.0 & 0.0 & $10.0 / 10.0 \mu \mathrm{g} / \mathrm{L}$ \\
\hline Dibenz $[a, h]$ anthracene & $0 / 4$ & 10.0 & 0.0 & $10.0 / 10.0 \mu \mathrm{g} / \mathrm{L}$ \\
\hline Dibenzofuran & $0 / 3$ & 10.0 & 0.0 & $10.0 / 10.0 \mu g / L$ \\
\hline Di-n-butyl phthalate & $0 / 4$ & 10.0 & 0.0 & $10.0 / 10.0 \mu \mathrm{g} / \mathrm{L}$ \\
\hline 1,2-Dichlorobenzene & $0 / 4$ & 10.0 & 0.0 & $10.0 / 10.0 \mu \mathrm{g} / \mathrm{L}$ \\
\hline 1,3-Dichlorobenzene & $0 / 4$ & 10.0 & 0.0 & 10.0/10.0 $\mu \mathrm{g} / \mathrm{L}$ \\
\hline 1,4-Dichlorobenzene & $0 / 4$ & 10.0 & 0.0 & $10.0 / 10.0 \mu \mathrm{g} / \mathrm{L}$ \\
\hline 3,3'-Dichlorobenzidine & $0 / 4$ & 10.0 & 0.0 & $10.0 / 10.0 \mu \mathrm{g} / \mathrm{L}$ \\
\hline 2,4-Dichlorophenol & $0 / 4$ & 10.0 & 0.0 & 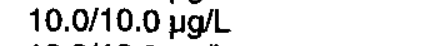 \\
\hline Diethyl phthalate & $0 / 4$ & 10.0 & 0.0 & $10.0 / 10.0 \mu \mathrm{g} / \mathrm{L}$ \\
\hline 2,4-Dimethyl phenol & $0 / 4$ & 10.0 & 0.0 & $10.0 / 10.0 \mu \mathrm{g} / \mathrm{L}$ \\
\hline Dimethyl phthalate & $0 / 4$ & 10.0 & 0.0 & $10.0 / 10.0 \mu \mathrm{g} / \mathrm{L}$ \\
\hline 2,4-Dinitrophenol & $0 / 4$ & 10.0 & 0.0 & $10.0 / 10.0 \mu \mathrm{g} / \mathrm{L}$ \\
\hline 2,4-Dinitrotoluene & $0 / 4$ & 10.0 & 0.0 & $10.0 / 10.0 \mu \mathrm{g} / \mathrm{L}$ \\
\hline 2,6-Dinitrotoluene & $0 / 4$ & 10.0 & 0.0 & $10.0 / 10.0 \mu \mathrm{g} / \mathrm{L}$ \\
\hline Di-n-octyl phthalate & $0 / 4$ & 10.0 & 0.0 & $10.0 / 10.0 \mu g / L$ \\
\hline 1,2-Diphenylhydrazine & $0 / 1$ & 10.0 & - & $10.0 / 10.0 \mu \mathrm{g} / \mathrm{L}$ \\
\hline Fluoranthene & $0 / 4$ & 10.0 & 0.0 & $10.0 / 10.0 \mu \mathrm{g} / \mathrm{L}$ \\
\hline Fluorene & $0 / 4$ & 10.0 & 0.0 & $10.0 / 10.0 \mu \mathrm{g} / \mathrm{L}$ \\
\hline Hexachlorobenzene & $0 / 4$ & 10.0 & 0.0 & $10.0 / 10.0 \mu \mathrm{g} / \mathrm{L}$ \\
\hline Hexachlorobutadiene & $0 / 4$ & 10.0 & 0.0 & $10.0 / 10.0 \mu \mathrm{g} / \mathrm{L}$ \\
\hline Hexachlorocyclopentadiene & $0 / 4$ & 10.0 & 0.0 & $10.0 / 10.0 \mu \mathrm{g} / \mathrm{L}$ \\
\hline Hexachloroethane & $0 / 4$ & 10.0 & 0.0 & $10.0 / 10.0 \mu \mathrm{g} / \mathrm{L}$ \\
\hline Indeno $[1,2,3-c$, d]pyrene & $0 / 4$ & 10.0 & 0.0 & $10.0 / 10.0 \mu \mathrm{g} / \mathrm{L}$ \\
\hline Isophorone & $0 / 4$ & 10.0 & 0.0 & $10.0 / 10.0 \mu \mathrm{g} / \mathrm{L}$ \\
\hline 2-Methyl-4,6-dinitrophenol & $0 / 4$ & 50.0 & 0.0 & $50.0 / 50.0 \mu g / L$ \\
\hline 2-Methyinaphthalene & $0 / 3$ & 10.0 & 0.0 & $10.0 / 10.0 \mu \mathrm{g} / \mathrm{L}$ \\
\hline Naphthalene & $0 / 4$ & 10.0 & 0.0 & $10.0 / 10,0 \mu \mathrm{g} / \mathrm{L}$ \\
\hline m-Nitroaniline & $0 / 3$ & 50.0 & 0.0 & $50.0 / 50.0 \mu g / L$ \\
\hline o-Nitroaniline & $0 / 3$ & 50.0 & 0.0 & $50.0 / 50.0 \mu \mathrm{g} / \mathrm{L}$ \\
\hline p-Nitroaniline & $0 / 3$ & 50.0 & 0.0 & $50.0 / 50.0 \mu \mathrm{g} / \mathrm{L}$ \\
\hline Nitrobenzene & $0 / 4$ & 10.0 & 0.0 & $10.0 / 10.0 \mu \mathrm{g} / \mathrm{L}$ \\
\hline 2-Nitrophenol & $0 / 4$ & 10.0 & 0.0 & $10.0 / 10.0 \mu \mathrm{g} / \mathrm{L}$ \\
\hline 4-Nitrophenol & $0 / 4$ & 50.0 & 0.0 & $50.0 / 50.0 \mu \mathrm{g} / \mathrm{L}$ \\
\hline N-Nitrosodimethylamine & $0 / 4$ & 10.0 & 0.0 & $10.0 / 10.0 \mu \mathrm{g} / \mathrm{L}$ \\
\hline N-Nitrosodiphenylamine & $0 / 4$ & 10.0 & 0.0 & $10.0 / 10.0 \mu \mathrm{g} / \mathrm{L}$ \\
\hline
\end{tabular}




\begin{tabular}{|c|c|c|c|c|}
\hline Analyte & $\begin{array}{l}\text { Frequency } \\
\text { of Detectiont }\end{array}$ & Mean Result & $\begin{array}{l}\text { Standard } \\
\text { Deviation }\end{array}$ & Minimum/Maximum Results \\
\hline $\begin{array}{l}\text { N-Nitrosodipropylamine } \\
\text { Pentachlorophenol } \\
\text { Phenanthrene } \\
\text { Phenol } \\
\text { Pyrene } \\
\text { 1,2,4-Trichlorobenzene } \\
\text { 2,4,5-Trichlorophenol } \\
\text { 2,4,6-Trichlorophenol }\end{array}$ & $\begin{array}{l}0 / 4 \\
0 / 4 \\
0 / 4 \\
0 / 4 \\
0 / 4 \\
0 / 4 \\
0 / 3 \\
0 / 4\end{array}$ & $\begin{array}{l}10.0 \\
50.0 \\
10.0 \\
10.0 \\
10.0 \\
10.0 \\
50.0 \\
10.0\end{array}$ & $\begin{array}{l}0.0 \\
0.0 \\
0.0 \\
0.0 \\
0.0 \\
0.0 \\
0.0 \\
0.0\end{array}$ & $\begin{array}{l}10.0 / 10.0 \mu \mathrm{g} / \mathrm{L} \\
50.0 / 50.0 \mu \mathrm{g} / \mathrm{L} \\
10.0 / 10.0 \mu \mathrm{g} / \mathrm{L} \\
10.0 / 10.0 \mu \mathrm{g} / \mathrm{L} \\
10.0 / 10.0 \mu \mathrm{g} / \mathrm{L} \\
10.0 / 10.0 \mu \mathrm{g} / \mathrm{L} \\
50.0 / 50.0 \mu \mathrm{g} / \mathrm{L} \\
10.0 / 10.0 \mu \mathrm{g} / \mathrm{L}\end{array}$ \\
\hline $\begin{array}{l}\text { EPA9010A } \\
\text { Cyanide }\end{array}$ & $0 / 6$ & 10.0 & 0.0 & $10.0 / 10.0 \mu \mathrm{g} / \mathrm{L}$ \\
\hline $\begin{array}{l}\text { EPA9060 } \\
\text { Total organic carbon }\end{array}$ & $0 / 3$ & 5,000 & 0.0 & $5,000 / 5,000 \mu \mathrm{g} / \mathrm{L}$ \\
\hline
\end{tabular}

t Number of times analyte was detected compared to the total number of method blanks for the analyte.

- Standard deviation cannot be determined.

Notes: If the analyte was not detected in the method blank(s), detection limit information appears in the Mean Result and Minimum/Maximum Results columns.

Table 77. Analytes Dotected in Mothod Blanks for GE

\begin{tabular}{|c|c|c|c|c|}
\hline Analyte & $\begin{array}{l}\text { Frequency } \\
\text { of Detectiont }\end{array}$ & Mean Result & $\begin{array}{l}\text { Standard } \\
\text { Deviation }\end{array}$ & Minimum/Maximum Results \\
\hline \multicolumn{5}{|l|}{ EPA160.1 } \\
\hline Total dissolved solids & $0 / 5$ & 10,000 & 0.0 & $10,000 / 10,000 \mu \mathrm{g} / \mathrm{L}$ \\
\hline \multicolumn{5}{|l|}{ EPA300.0 } \\
\hline Bromide & $1 / 1$ & 42.0 & - & $42.0 / 42.0 \mu \mathrm{g} / \mathrm{L}$ \\
\hline Chloride & $1 / 1$ & 38.0 & - & $38.0 / 38.0 \mu \mathrm{g} / \mathrm{L}$ \\
\hline Nitrate as nitrogen & $1 / 1$ & 20.0 & - & $20.0 / 20.0 \mu \mathrm{g} / \mathrm{L}$ \\
\hline Sulfate & $1 / 1$ & 91.0 & - & $91.0 / 91.0 \mu \mathrm{g} / \mathrm{L}$ \\
\hline \multicolumn{5}{|l|}{ EPA353.1 } \\
\hline Nitrate-nitrite as nitrogen & $6 / 16$ & 36.3 & 18.9 & $10.0 / 50.0 \mu \mathrm{g} / \mathrm{L}$ \\
\hline \multicolumn{5}{|l|}{ EPA365.4 } \\
\hline Total phosphates (as P) & $0 / 1$ & 50.0 & - & $50.0 / 50.0 \mu \mathrm{g} / \mathrm{L}$ \\
\hline \multicolumn{5}{|l|}{ EPA6010A } \\
\hline Aluminum & $0 / 2$ & 50.0 & 0.0 & $50.0 / 50.0 \mu \mathrm{g} / \mathrm{L}$ \\
\hline Antimony & $0 / 5$ & 10.0 & 0.0 & $10.0 / 10.0 \mu \mathrm{g} / \mathrm{L}$ \\
\hline Arsenic & $0 / 5$ & 5.0 & 0.0 & $5.0 / 5.0 \mu \mathrm{g} / \mathrm{L}$ \\
\hline Barium & $2 / 5$ & 3.14 & 2.55 & $0.34 / 5.0 \mu \mathrm{g} / \mathrm{L}$ \\
\hline Beryllium & $0 / 2$ & 5.0 & 0.0 & $5.0 / 5.0 \mu \mathrm{g} / \mathrm{L}$ \\
\hline Boron & $0 / 3$ & 50.0 & 0.0 & $50.0 / 50.0 \mu \mathrm{g} / \mathrm{L}$ \\
\hline Cadmium $_{=\ldots \ldots}$ & $0 / 5$ & -5.0 & 0.0 & $=-5.0 / 5.0 . \mu \mathrm{g} / \mathrm{L}_{--}$ \\
\hline Calcium & $2 / 2$ & 26.0 & 2.83 & $24.0 / 28.0 \mu \mathrm{g} / \mathrm{L}$ \\
\hline Chromium & $0 / 5$ & 5.0 & 0.0 & $5.0 / 5.0 \mu \mathrm{g} / \mathrm{L}$ \\
\hline Cobalt & $0 / 3$ & 5.0 & 0.0 & $5.0 / 5.0 \mu \mathrm{g} / \mathrm{L}$ \\
\hline Copper & $0 / 5$ & 5.0 & 0.0 & $5.0 / 5.0 \mu \mathrm{g} / \mathrm{L}$ \\
\hline Iron - & $0 / 2$ & 50.0 & 0.0 & $50.0 / 50.0 \mu \mathrm{g} / \mathrm{L}$ \\
\hline Lead & $2 / 5$ & 3.61 & 1.93 & $1.09 / 5.0 \mu \mathrm{g} / \mathrm{L}$ \\
\hline Magnesium & $2 / 2$ & 4.67 & 1.67 & $3.49 / 5.85 \mu \mathrm{g} / \mathrm{L}$ \\
\hline Manganese & $0 / 2$ & 10.0 & 0.0 & $10.0 / 10.0 \mu g / L$ \\
\hline Nickel & $0 / 5$ & 5.0 & 0.0 & $5.0 / 5.0 \mu \mathrm{g} / \mathrm{L}$ \\
\hline
\end{tabular}




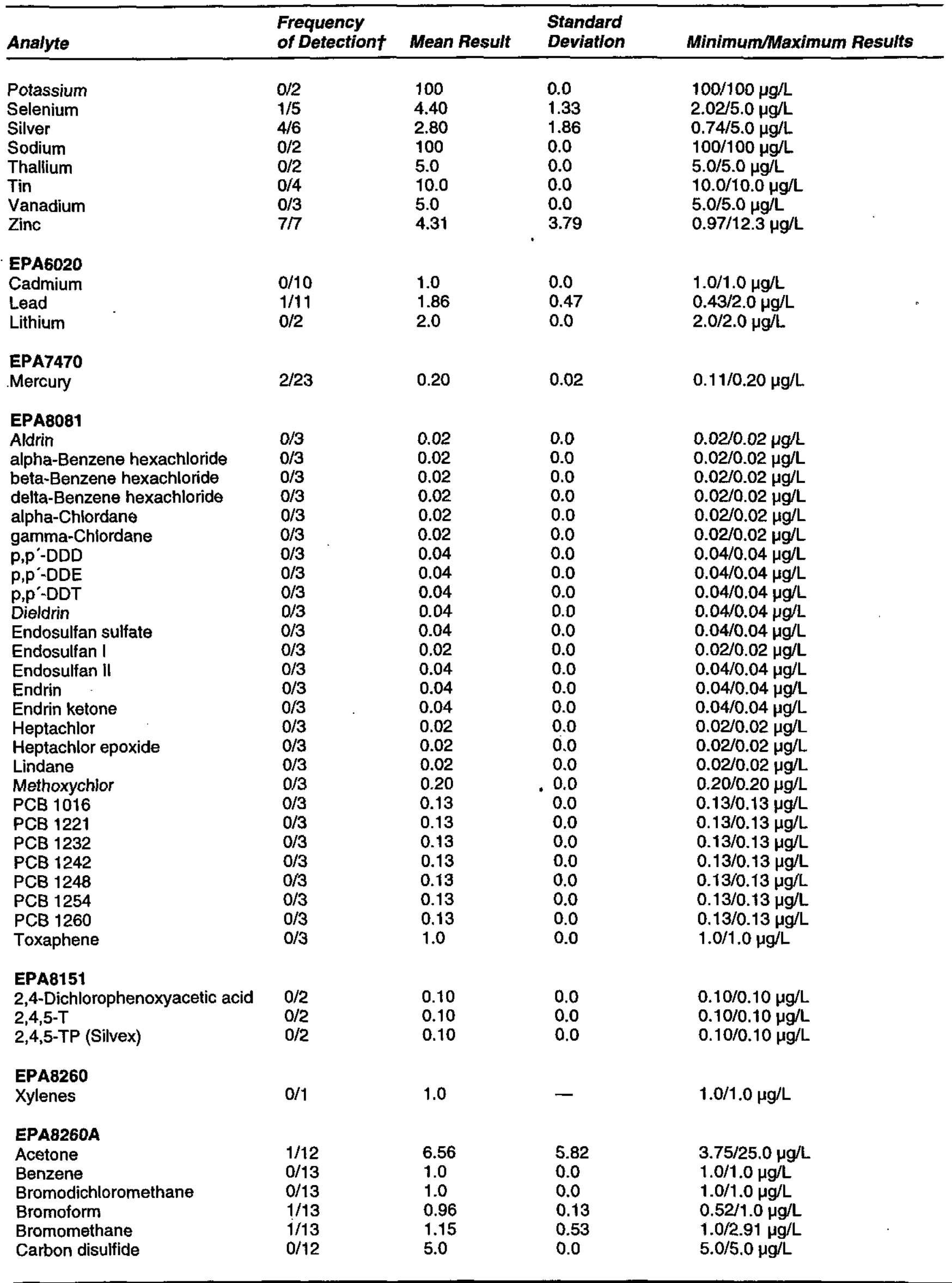




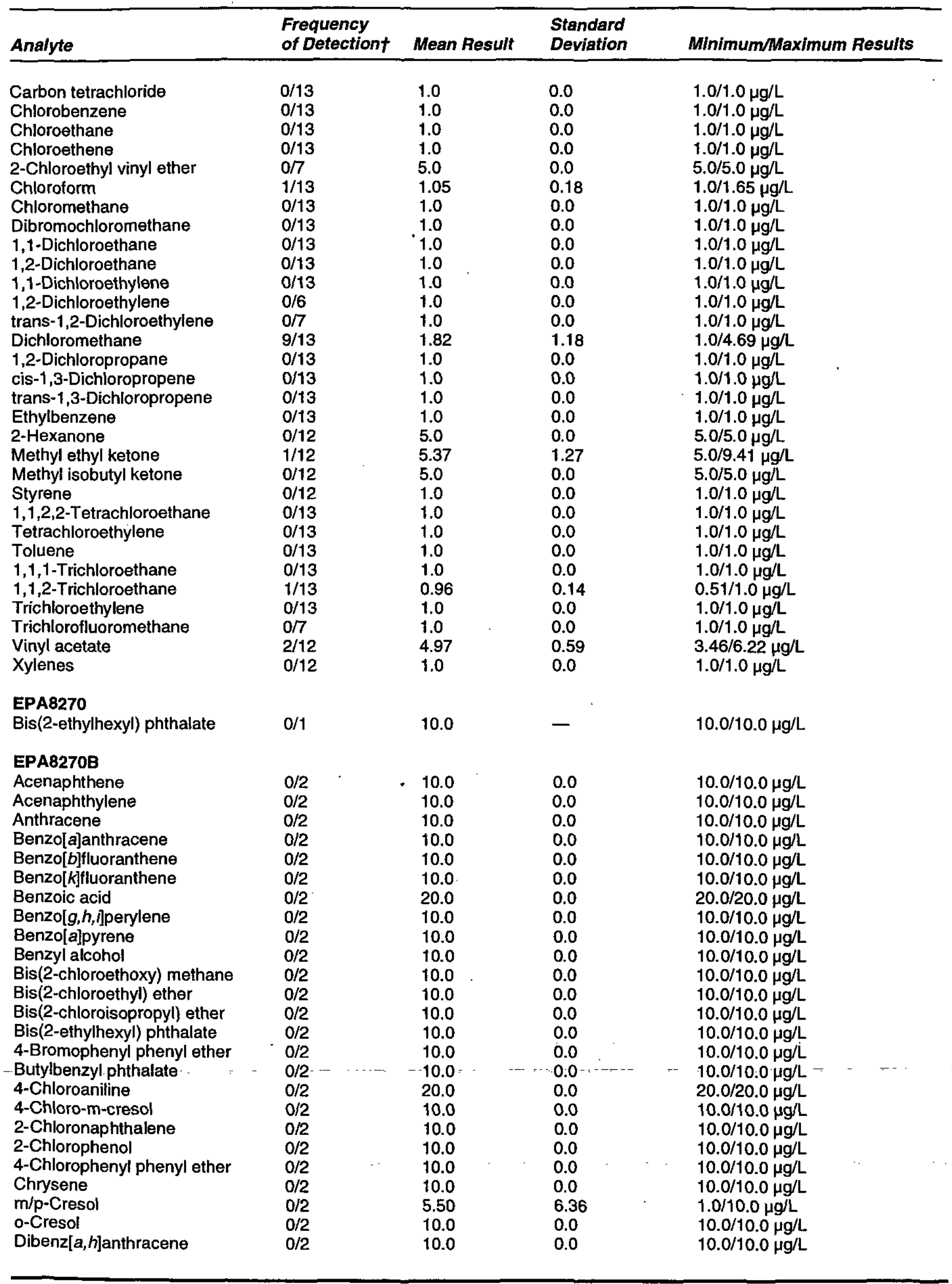




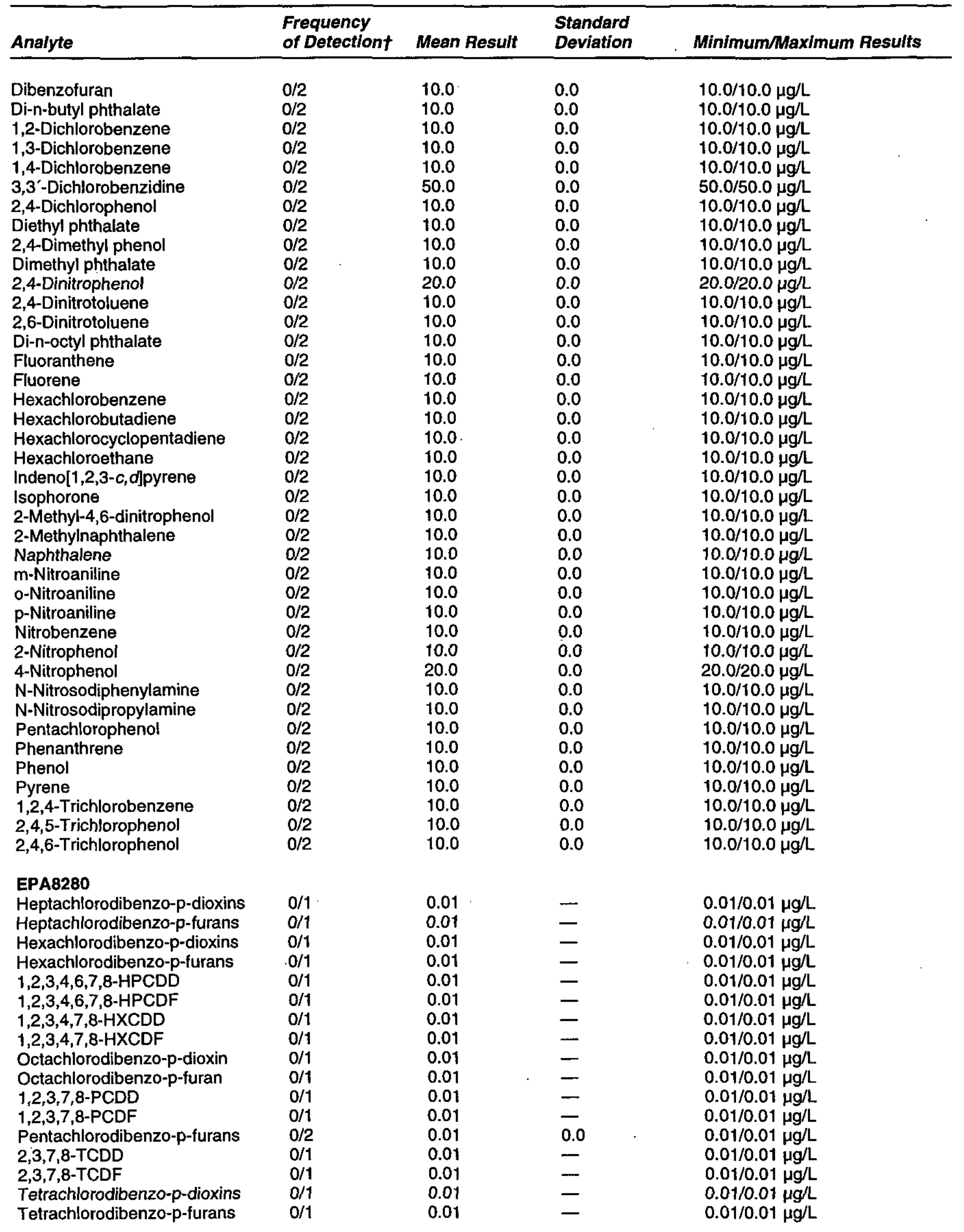




\begin{tabular}{|c|c|c|c|c|}
\hline Analyte & $\begin{array}{l}\text { Frequency } \\
\text { of Detectiont }\end{array}$ & Mean Result & $\begin{array}{l}\text { Standard } \\
\text { Deviation }\end{array}$ & Minimum/Maximum Results \\
\hline $\begin{array}{l}\text { EPA9012 } \\
\text { Cyanide }\end{array}$ & $0 / 4$ & 10.0 & 0.0 & $10.0 / 10.0 \mu \mathrm{g} / \mathrm{L}$ \\
\hline $\begin{array}{l}\text { EPA9020B } \\
\text { Total organic halogens }\end{array}$ & $1 / 4$ & 8.15 & 3.70 & $2.60 / 10.0 \mu \mathrm{g} / \mathrm{L}$ \\
\hline $\begin{array}{l}\text { EPA9056 } \\
\text { Chloride } \\
\text { Fluoride } \\
\text { Sulfate }\end{array}$ & $\begin{array}{l}1 / 1 \\
0 / 1 \\
1 / 2\end{array}$ & $\begin{array}{l}26.0 \\
50.0 \\
137\end{array}$ & $\overline{-}$ & $\begin{array}{l}26.0 / 26.0 \mu g / L \\
50.0 / 50.0 \mu g / L \\
74.0 / 200 \mu g / L\end{array}$ \\
\hline $\begin{array}{l}\text { EPA9060 } \\
\text { Total organic carbon }\end{array}$ & $0 / 7$ & 5,000 & 0.0 & $5,000 / 5,000 \mu \mathrm{g} / \mathrm{L}$ \\
\hline $\begin{array}{l}\text { EPA9066 } \\
\text { Phenols }\end{array}$ & $1 / 2$ & 4.44 & 0.79 & $3.88 / 5.0 \mu \mathrm{g} / \mathrm{L}$ \\
\hline
\end{tabular}

† Number of times analyte was detected compared to the total number of method blanks for the analyte.

- Standard deviation cannot be determined.

Note: If the analyte was not detected in the method blank(s), detection limit information appears in the Mean Result and Minimum/Maximum Results columns.

Table 78. Analytes Detected in Method Blanks for WA

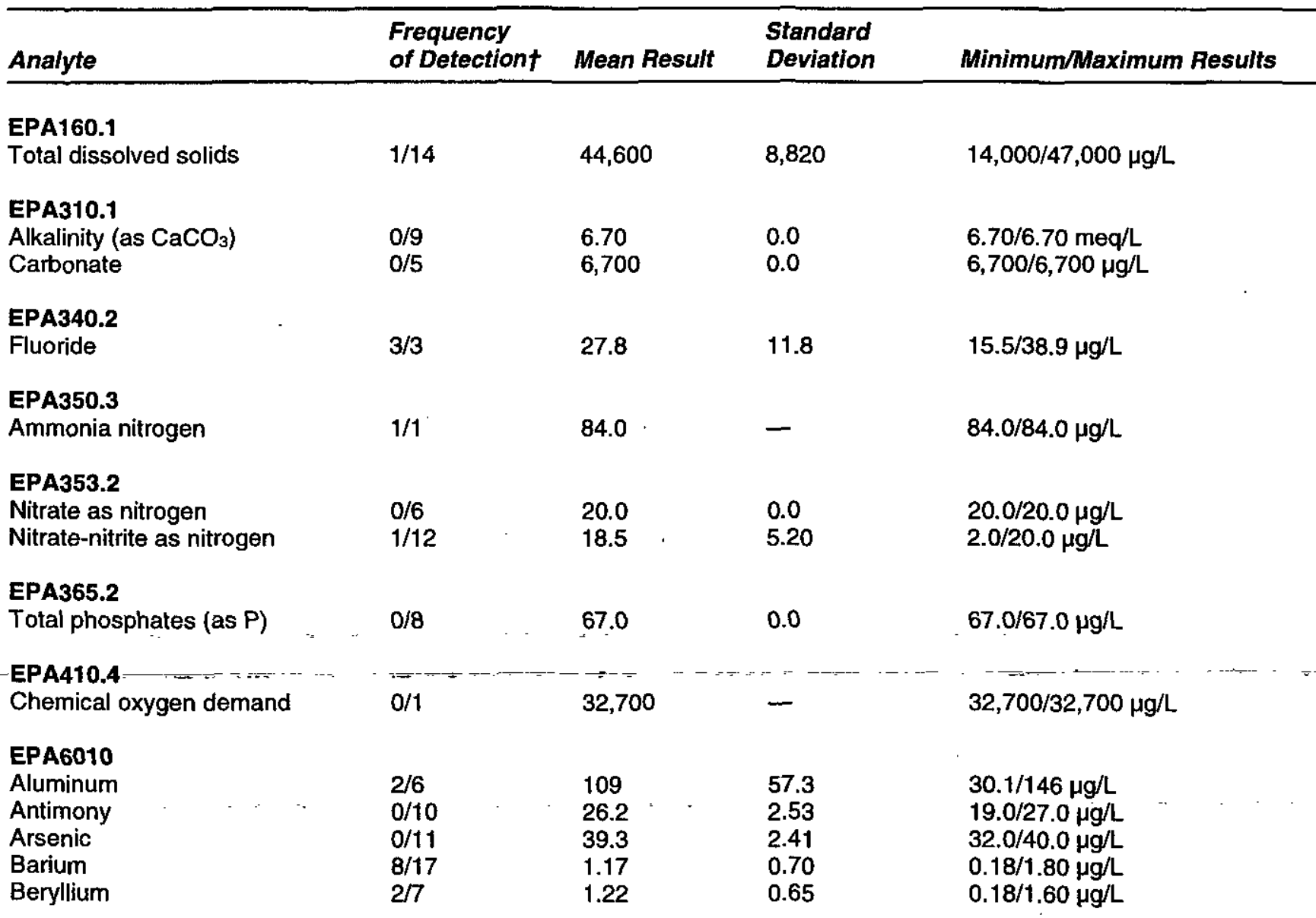




\begin{tabular}{|c|c|c|c|c|}
\hline Analyte & $\begin{array}{l}\text { Frequency } \\
\text { of Detectiont }\end{array}$ & Mean Result & $\begin{array}{l}\text { Standard } \\
\text { Deviation }\end{array}$ & Minimum/Maximum Results \\
\hline $\begin{array}{l}\text { Boron } \\
\text { Cadmium } \\
\text { Calcium } \\
\text { Chromium } \\
\text { Cobalt } \\
\text { Copper } \\
\text { Iron } \\
\text { Lead } \\
\text { Lithium } \\
\text { Magnesium } \\
\text { Manganese } \\
\text { Nickel } \\
\text { Potassium } \\
\text { Selenium } \\
\text { Silica } \\
\text { Silver } \\
\text { Sodium } \\
\text { Thallium } \\
\text { Tin } \\
\text { Vanadium } \\
\text { Zinc }\end{array}$ & $\begin{array}{l}2 / 5 \\
1 / 10 \\
2 / 8 \\
4 / 11 \\
1 / 7 \\
3 / 10 \\
8 / 14 \\
0 / 17 \\
7 / 8 \\
4 / 9 \\
0 / 9 \\
1 / 17 \\
1 / 6 \\
0 / 16 \\
5 / 5 \\
6 / 11 \\
10 / 10 \\
0 / 6 \\
0 / 5 \\
2 / 7 \\
0 / 10\end{array}$ & $\begin{array}{l}173 \\
4.29 \\
367 \\
4.93 \\
4.43 \\
11.0 \\
44.4 \\
47.0 \\
1.33 \\
46.8 \\
7.80 \\
24.8 \\
171 \\
66.0 \\
225 \\
2.87 \\
84.6 \\
55.0 \\
70.0 \\
5.48 \\
53.0\end{array}$ & $\begin{array}{l}128 \\
1.29 \\
193 \\
2.92 \\
0.19 \\
6.39 \\
32.1 \\
0.0 \\
1.34 \\
32.3 \\
0.0 \\
5.14 \\
38.7 \\
0.0 \\
63.1 \\
2.07 \\
67.4 \\
0.0 \\
0.0 \\
2.49 \\
0.0\end{array}$ & $\begin{array}{l}27.3 / 266 \mu g / \mathrm{L} \\
0.63 / 4.70 \mu \mathrm{g} / \mathrm{L} \\
51.2 / 471 \mu \mathrm{g} / \mathrm{L} \\
0.83 / 7.0 \mu \mathrm{g} / \mathrm{L} \\
4.0 / 4.50 \mu \mathrm{g} / \mathrm{L} \\
1.50 / 15.0 \mu \mathrm{g} / \mathrm{L} \\
9.10 / 79.1 \mu \mathrm{g} / \mathrm{L} \\
47.0 / 47.0 \mu \mathrm{g} / \mathrm{L} \\
0.39 / 4.10 \mu \mathrm{g} / \mathrm{L} \\
11.9 / 74.0 \mu \mathrm{g} / \mathrm{L} \\
7.80 / 7.80 \mu \mathrm{g} / \mathrm{L} \\
4.80 / 26.0 \mu \mathrm{g} / \mathrm{L} \\
92.3 / 187 \mu \mathrm{g} / \mathrm{L} \\
66.0 / 66.0 \mu \mathrm{g} / \mathrm{L} \\
191 / 337 \mu \mathrm{g} / \mathrm{L} \\
0.52 / 5.0 \mu \mathrm{g} / \mathrm{L} \\
33.5 / 247 \mu \mathrm{g} / \mathrm{L} \\
55.0 / 55.0 \mu \mathrm{g} / \mathrm{L} \\
70.0 / 70.0 \mu \mathrm{g} / \mathrm{L} \\
0.94 / 6.90 \mu \mathrm{g} / \mathrm{L} \\
53.0 / 53.0 \mu \mathrm{g} / \mathrm{L}\end{array}$ \\
\hline $\begin{array}{l}\text { EPA7196A } \\
\text { Chromium, hexavalent }\end{array}$ & $0 / 2$ & 200 & 0.0 & $200 / 200 \mu \mathrm{g} / \mathrm{L}$ \\
\hline $\begin{array}{l}\text { EPA7470 } \\
\text { Mercury }\end{array}$ & $0 / 18$ & 0.70 & 0.0 & $0.70 / 0.70 \mu \mathrm{g} / \mathrm{L}$ \\
\hline $\begin{array}{l}\text { EPA7740 } \\
\text { Selenium }\end{array}$ & $0 / 1$ & 16.0 & - & $16.0 / 16.0 \mu \mathrm{g} / \mathrm{L}$ \\
\hline $\begin{array}{l}\text { EPA7841 } \\
\text { Thallium }\end{array}$ & $0 / 1$ & 25.0 & - & $25.0 / 25.0 \mu \mathrm{g} / \mathrm{L}$ \\
\hline $\begin{array}{l}\text { EPA8010 } \\
\text { Carbon tetrachloride } \\
\text { Chloroform } \\
\text { Tetrachloroethylene } \\
1,1,1-\text { Trichloroethane } \\
\text { Trichloroethylene }\end{array}$ & $\begin{array}{l}0 / 1 \\
0 / 1 \\
0 / 1 \\
0 / 1 \\
0 / 1\end{array}$ & $\begin{array}{l}1.0 \\
1.0 \\
1.0 \\
1.0 \\
1.0\end{array}$ & $\begin{array}{l}- \\
- \\
-\end{array}$ & $\begin{array}{l}1.0 / 1.0 \mu \mathrm{g} / \mathrm{L} \\
1.0 / 1.0 \mu \mathrm{g} / \mathrm{L} \\
1.0 / 1.0 \mu \mathrm{g} / \mathrm{L} \\
1.0 / 1.0 \mu \mathrm{g} / \mathrm{L} \\
1.0 / 1.0 \mu \mathrm{g} / \mathrm{L}\end{array}$ \\
\hline $\begin{array}{l}\text { EPA8081 } \\
\text { Aldrin } \\
\text { alpha-Benzene hexachloride } \\
\text { beta-Benzene hexachloride } \\
\text { delta-Benzene hexachloride } \\
\text { alpha-Chlordane } \\
\text { gamma-Chlordane } \\
\text { p,p'-DDD } \\
\text { p,p'-DDE } \\
\text { p,p'-DDT } \\
\text { Dieldrin } \\
\text { Endosulfan sulfate } \\
\text { Endosulfan I } \\
\text { Endosulfan II } \\
\text { Endrin } \\
\text { Endrin aldehyde } \\
\text { Endrin ketone } \\
\text { Heptachlor } \\
\text { Heptachlor epoxide } \\
\text { Lindane }\end{array}$ & $\begin{array}{l}0 / 5 \\
0 / 5 \\
0 / 5 \\
0 / 5 \\
0 / 5 \\
0 / 5 \\
0 / 5 \\
0 / 5 \\
0 / 5 \\
0 / 5 \\
0 / 5 \\
0 / 5 \\
0 / 5 \\
0 / 8 \\
0 / 2 \\
0 / 5 \\
0 / 5 \\
0 / 5 \\
0 / 5\end{array}$ & $\begin{array}{l}0.05 \\
0.05 \\
0.05 \\
0.05 \\
0.05 \\
0.05 \\
0.10 \\
0.10 \\
0.10 \\
0.10 \\
0.10 \\
0.05 \\
0.10 \\
0.10 \\
0.10 \\
0.10 \\
0.05 \\
0.05 \\
0.05\end{array}$ & $\begin{array}{l}0.0 \\
0.0 \\
0.0 \\
0.0 \\
0.0 \\
0.0 \\
0.0 \\
0.0 \\
0.0 \\
0.0 \\
0.0 \\
0.0 \\
0.0 \\
0.0 \\
0.0 \\
0.0 \\
0.0 \\
0.0 \\
0.0\end{array}$ & $\begin{array}{l}0.05 / 0.05 \mu g / L \\
0.05 / 0.05 \mu g / L \\
0.05 / 0.05 \mu g / L \\
0.05 / 0.05 \mu g / L \\
0.05 / 0.05 \mu g / L \\
0.05 / 0.05 \mu g / L \\
0.10 / 0.10 \mu g / L \\
0.10 / 0.10 \mu g / L \\
0.10 / 0.10 \mu g / L \\
0.10 / 0.10 \mu g / L \\
0.10 / 0.10 \mu g / L \\
0.05 / 0.05 \mu g / L \\
0.10 / 0.10 \mu g / L \\
0.10 / 0.10 \mu g / L \\
0.10 / 0.10 \mu g / L \\
0.10 / 0.10 \mu g / L \\
0.05 / 0.05 \mu g / L \\
0.05 / 0.05 \mu g / L \\
0.05 / 0.05 \mu g / L\end{array}$ \\
\hline
\end{tabular}




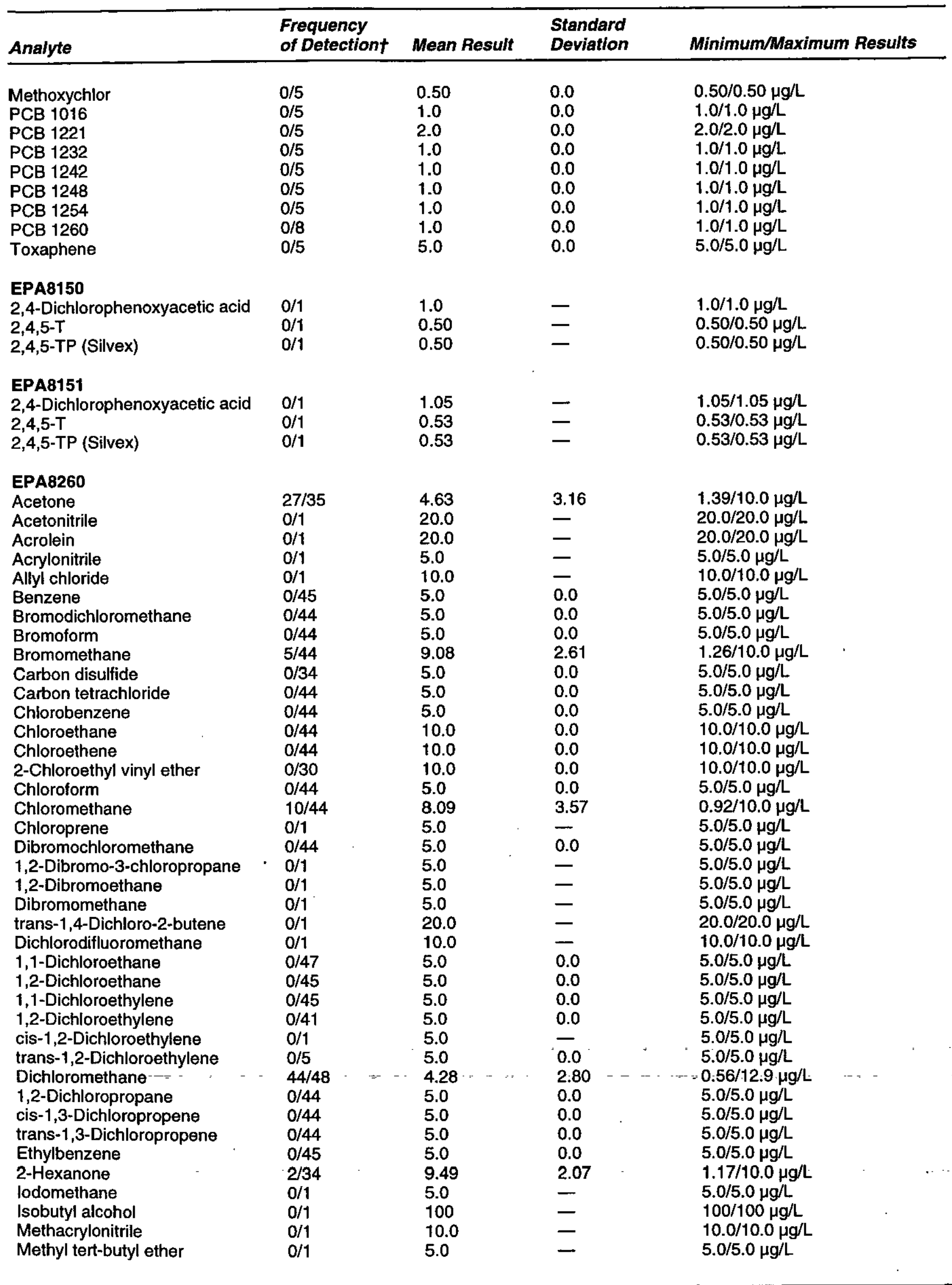




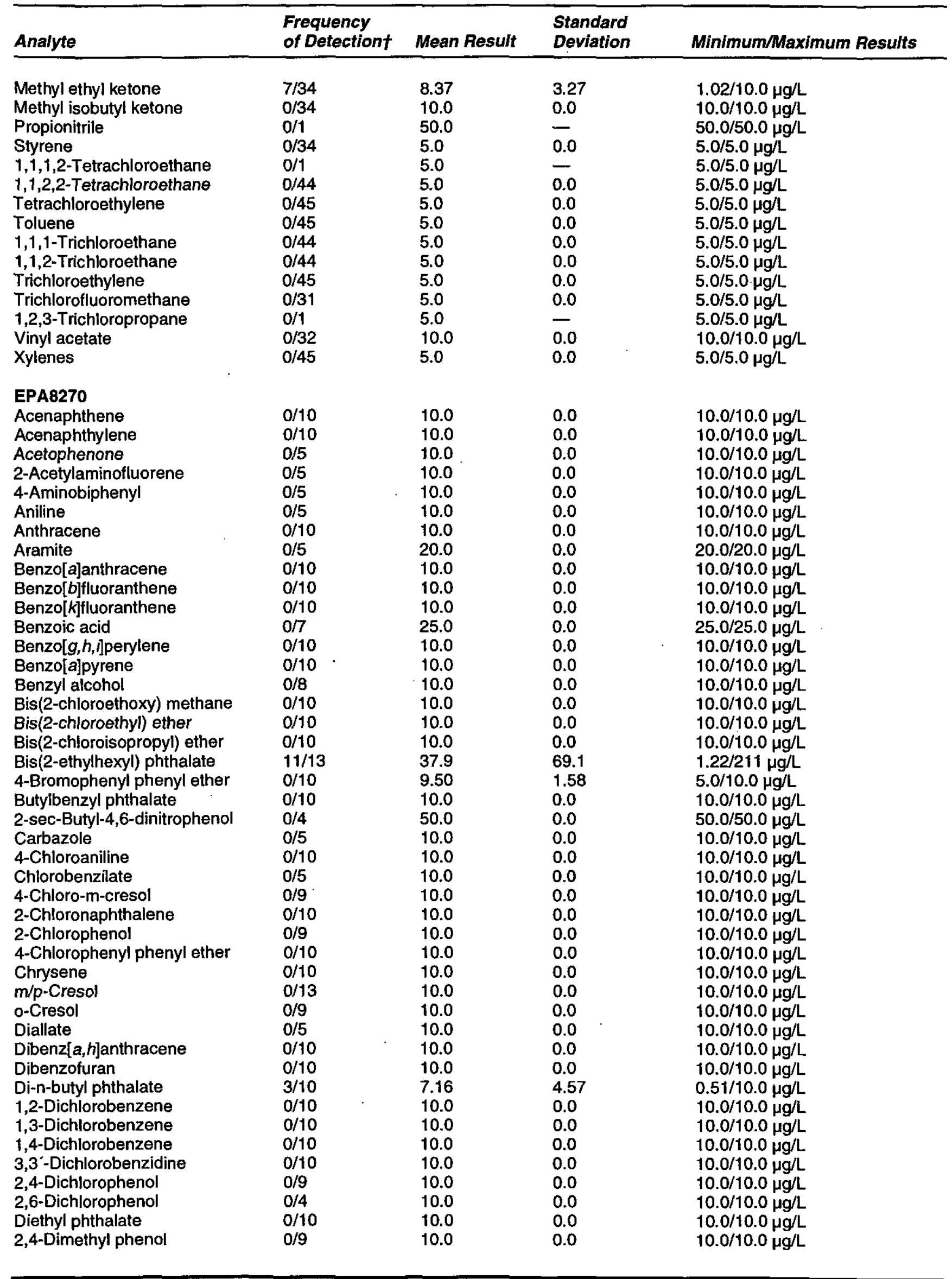




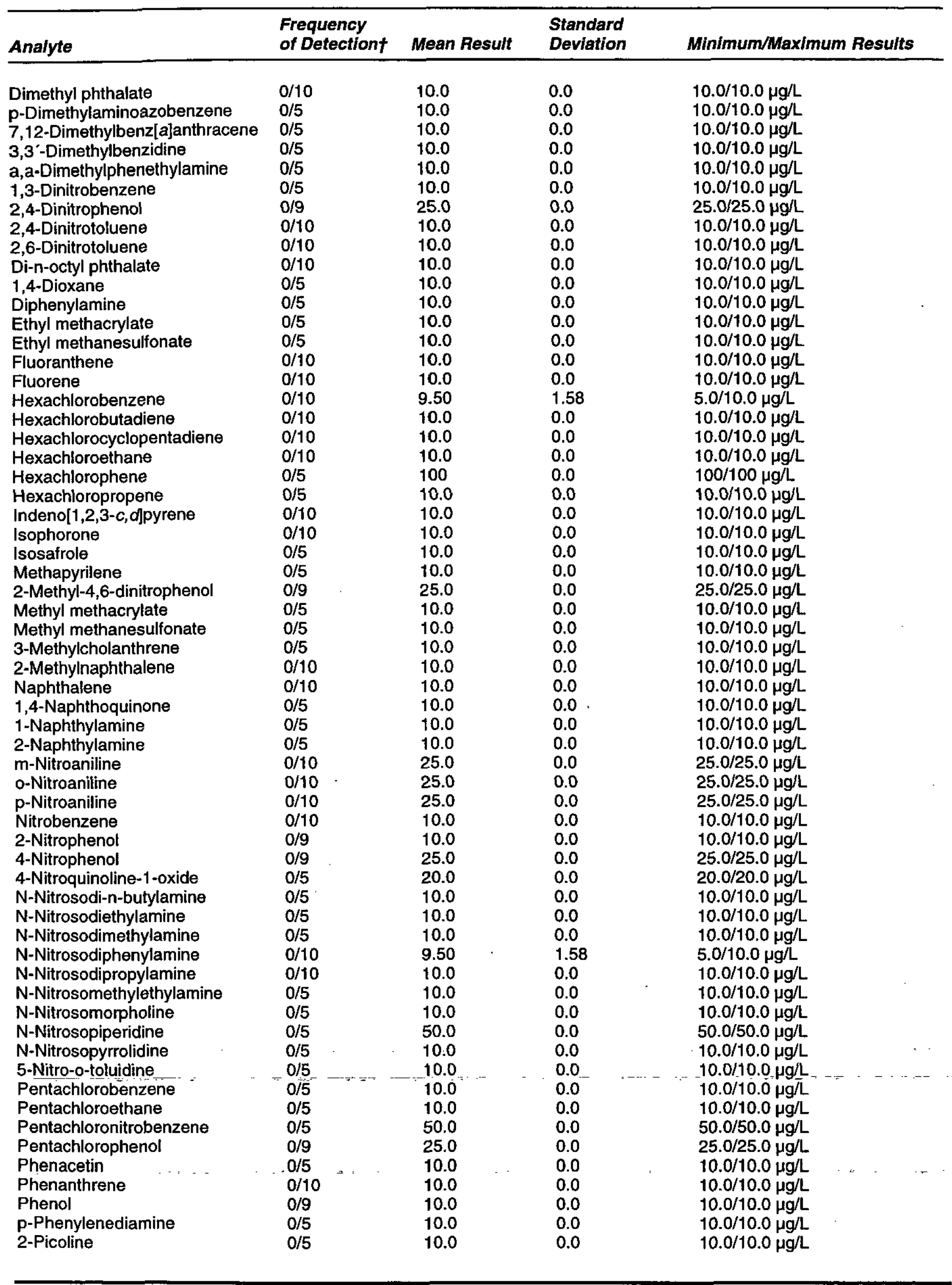




\begin{tabular}{|c|c|c|c|c|}
\hline Analyte & $\begin{array}{l}\text { Frequency } \\
\text { of Detectiont }\end{array}$ & Mean Result & $\begin{array}{l}\text { Standard } \\
\text { Deviation }\end{array}$ & Minimum/Maximum Results \\
\hline $\begin{array}{l}\text { Pronamid } \\
\text { Pyrene } \\
\text { Pyridine } \\
\text { Safrole } \\
\text { 1,2,4,5-Tetrachlorobenzene } \\
\text { 2,3,4,6-Tetrachlorophenol } \\
\text { o-Toluidine } \\
\text { 1,2,4-Trichlorobenzene } \\
\text { 2,4,5-Trichlorophenol } \\
\text { 2,4,6-Trichlorophenol } \\
\text { 1,3,5-Trinitrobenzene }\end{array}$ & $\begin{array}{l}0 / 5 \\
0 / 10 \\
0 / 5 \\
0 / 5 \\
0 / 5 \\
0 / 4 \\
0 / 5 \\
0 / 10 \\
0 / 9 \\
0 / 9 \\
0 / 5\end{array}$ & $\begin{array}{l}10.0 \\
10.0 \\
10.0 \\
10.0 \\
10.0 \\
10.0 \\
10.0 \\
10.0 \\
25.0 \\
10.0 \\
10.0\end{array}$ & $\begin{array}{l}0.0 \\
0.0 \\
0.0 \\
0.0 \\
0.0 \\
0.0 \\
0.0 \\
0.0 \\
0.0 \\
0.0 \\
0.0\end{array}$ & $\begin{array}{l}10.0 / 10.0 \mu \mathrm{g} / \mathrm{L} \\
10.0 / 10.0 \mu \mathrm{g} / \mathrm{L} \\
10.0 / 10.0 \mu \mathrm{g} / \mathrm{L} \\
10.0 / 10.0 \mu \mathrm{g} / \mathrm{L} \\
10.0 / 10.0 \mu \mathrm{g} / \mathrm{L} \\
10.0 / 10.0 \mu \mathrm{g} / \mathrm{L} \\
10.0 / 10.0 \mu \mathrm{g} / \mathrm{L} \\
10.0 / 10.0 \mu \mathrm{g} / \mathrm{L} \\
25.0 / 25.0 \mu \mathrm{g} / \mathrm{L} \\
10.0 / 10.0 \mu \mathrm{g} / \mathrm{L} \\
10.0 / 10.0 \mu \mathrm{g} / \mathrm{L}\end{array}$ \\
\hline $\begin{array}{l}\text { EPA8280 } \\
\text { Heptachlorodibenzo-p-dioxins } \\
\text { Heptachlorodibenzo-p-furans } \\
\text { Hexachlorodibenzo-p-dioxins } \\
\text { Hexachlorodibenzo-p-furans } \\
1,2,3,4,6,7,8-H P C D D \\
1,2,3,4,6,7,8-H P C D F \\
1,2,3,4,7,8-H X C D D \\
1,2,3,4,7,8-H X C D F \\
\text { Octachlorodibenzo-p-dioxin } \\
\text { Octachlorodibenzo-p-furan } \\
1,2,3,7,8-P C D D \\
1,2,3,7,8-P C D F \\
\text { Pentachlorodibenzo-p-furans } \\
2,3,7,8-T C D D \\
2,3,7,8-T C D F \\
\text { Tetrachlorodibenzo-p-dioxins } \\
\text { Tetrachlorodibenzo-p-furans }\end{array}$ & $\begin{array}{l}0 / 6 \\
0 / 6 \\
0 / 6 \\
0 / 6 \\
0 / 6 \\
0 / 6 \\
0 / 6 \\
0 / 6 \\
0 / 6 \\
0 / 6 \\
0 / 6 \\
0 / 6 \\
0 / 12 \\
0 / 7 \\
0 / 6 \\
0 / 6 \\
0 / 6\end{array}$ & $\begin{array}{l}0.00 \\
0.00 \\
0.00 \\
0.00 \\
0.00 \\
0.00 \\
0.00 \\
0.00 \\
0.00 \\
0.00 \\
0.00 \\
0.00 \\
0.00 \\
0.00 \\
0.00 \\
0.00 \\
0.00\end{array}$ & $\begin{array}{l}0.00 \\
0.00 \\
0.00 \\
0.00 \\
0.00 \\
0.00 \\
0.00 \\
0.00 \\
0.00 \\
0.00 \\
0.00 \\
0.00 \\
0.00 \\
0.00 \\
0.00 \\
0.00 \\
0.00\end{array}$ & $\begin{array}{l}0.00 / 0.00 \mu \mathrm{g} / \mathrm{L} \\
0.00 / 0.00 \mu \mathrm{g} / \mathrm{L} \\
0.00 / 0.00 \mu \mathrm{g} / \mathrm{L} \\
0.00 / 0.00 \mu \mathrm{g} / \mathrm{L} \\
0.00 / 0.00 \mu \mathrm{g} / \mathrm{L} \\
0.00 / 0.00 \mu \mathrm{g} / \mathrm{L} \\
0.00 / 0.00 \mu \mathrm{g} / \mathrm{L} \\
0.00 / 0.00 \mu \mathrm{g} / \mathrm{L} \\
0.00 / 0.00 \mu \mathrm{g} / \mathrm{L} \\
0.00 / 0.00 \mu \mathrm{g} / \mathrm{L} \\
0.00 / 0.00 \mu \mathrm{g} / \mathrm{L} \\
0.00 / 0.00 \mu \mathrm{g} / \mathrm{L} \\
0.00 / 0.00 \mu \mathrm{g} / \mathrm{L} \\
0.00 / 0.00 \mu \mathrm{g} / \mathrm{L} \\
0.00 / 0.00 \mu \mathrm{g} / \mathrm{L} \\
0.00 / 0.00 \mu \mathrm{L} / \mathrm{L} \\
0.00 / 0.00 \mu \mathrm{g} / \mathrm{L}\end{array}$ \\
\hline $\begin{array}{l}\text { EPA9010A } \\
\text { Cyanide }\end{array}$ & $1 / 7$ & 18.3 & 14.9 & $1.81 / 50.0 \mu \mathrm{g} / \mathrm{L}$ \\
\hline $\begin{array}{l}\text { EPA9020B } \\
\text { Total organic halogens }\end{array}$ & $0 / 64$ & 120 & 0.0 & $120 / 120 \mu \mathrm{g} / \mathrm{L}$ \\
\hline $\begin{array}{l}\text { EPA9050 } \\
\text { Specific conductance }\end{array}$ & $0 / 5$ & 9.12 & 0.49 & $8.90 / 10.0 \mu \mathrm{S} / \mathrm{cm}$ \\
\hline $\begin{array}{l}\text { EPA9056 } \\
\text { Chloride } \\
\text { Sulfate }\end{array}$ & $\begin{array}{l}2 / 8 \\
0 / 14\end{array}$ & $\begin{array}{l}190 \\
321\end{array}$ & $\begin{array}{l}43.4 \\
73.0\end{array}$ & $\begin{array}{l}88.0 / 210 \mu \mathrm{g} / \mathrm{L} \\
67.0 / 340 \mu \mathrm{g} / \mathrm{L}\end{array}$ \\
\hline $\begin{array}{l}\text { EPA9060 } \\
\text { Total organic carbon }\end{array}$ & $6 / 18$ & 730 & 394 & $122 / 1,000 \mu g / L$ \\
\hline $\begin{array}{l}\text { EPA9066 } \\
\text { Phenols }\end{array}$ & $0 / 6$ & 36.2 & 0.0 & $36.2 / 36.2 \mu g / L$ \\
\hline
\end{tabular}

† Number of times analyte was detected compared to the total number of method blanks for the analyte.

- Standard deviation cannot be determined.

Notes: $A$ value of 0 is reported as 0.0 .

Numbers less than 0.004 are reported as 0.00 .

If the analyte was not detected in the method blank(s), detection limit information appears in the Mean Result and Minimum/Maximum Results columns. 
Table 79. Analytes Detected in Method Blanks for GP

\begin{tabular}{|c|c|c|c|c|}
\hline Analyte & $\begin{array}{l}\text { Frequency } \\
\text { of Detectiont }\end{array}$ & Mean Result & $\begin{array}{l}\text { Standard } \\
\text { Deviation }\end{array}$ & Minimum/Maximum Results \\
\hline \multicolumn{5}{|l|}{ EPIA-001 } \\
\hline Gross alpha & $2 / 28$ & $1.43 \mathrm{E}-10$ & $2.70 \mathrm{E}-10$ & $-2.12 \mathrm{E}-10 / 9.44 \mathrm{E}-10 \mu \mathrm{Ci} / \mathrm{mL}$ \\
\hline Nonvolatile beta & $2 / 27$ & $2.40 E-10$ & $5.30 \mathrm{E}-10$ & $-5.75 \mathrm{E}-10 / 1.78 \mathrm{E}-09 \mu \mathrm{Ci} / \mathrm{mL}$ \\
\hline \multicolumn{5}{|l|}{ EPIA-002 } \\
\hline Tritium & $0 / 22$ & 2.48E-08 & $1.48 \mathrm{E}-07$ & $-1.34 \mathrm{E}-07 / 3.82 \mathrm{E}-07 \mu \mathrm{Ci} / \mathrm{mL}$ \\
\hline \multicolumn{5}{|l|}{ EPIA-003 } \\
\hline Carbon-14 & $0 / 6$ & $2.34 \mathrm{E}-09$ & $1.68 \mathrm{E}-09$ & $-3.76 \mathrm{E}-10 / 4.20 \mathrm{E}-09 \mu \mathrm{Ci} / \mathrm{mL}$ \\
\hline \multicolumn{5}{|l|}{ EPIA-004 } \\
\hline Strontium-90 & $0 / 6$ & $7.70 \mathrm{E}-11$ & $1.95 \mathrm{E}-10$ & $-1.49 \mathrm{E}-10 / 3.43 \mathrm{E}-10 \mu \mathrm{Ci} / \mathrm{mL}$ \\
\hline \multicolumn{5}{|l|}{ EPIA-005 } \\
\hline Technetium-99 & $0 / 5$ & $-9.32 E-10$ & $9.84 E-09$ & $-1.47 \mathrm{E}-08 / 1.31 \mathrm{E}-08 \mu \mathrm{Ci} / \mathrm{mL}$ \\
\hline \multicolumn{5}{|l|}{ EPIA-006 } \\
\hline lodine-129 & $1 / 2$ & $3.88 \mathrm{E}-10$ & $1.89 \mathrm{E}-10$ & $2.54 \mathrm{E}-10 / 5.21 \mathrm{E}-10 \mu \mathrm{Ci} / \mathrm{mL}$ \\
\hline \multicolumn{5}{|l|}{ EPIA-008 } \\
\hline Radium-226 & $0 / 2$ & $2.15 E-10$ & $3.46 \mathrm{E}-11$ & 1.90E-10/2.39E-10 $\mu \mathrm{Ci} / \mathrm{mL}$ \\
\hline \multicolumn{5}{|l|}{ EPIA-009 } \\
\hline Radium-228 & $0 / 3$ & $-6.70 \mathrm{E}-11$ & $4.65 \mathrm{E}-10$ & $-4.89 \mathrm{E}-10 / 4.32 \mathrm{E}-10 \mu \mathrm{Ci} / \mathrm{mL}$ \\
\hline \multicolumn{5}{|l|}{ EPIA-010 } \\
\hline Radium, total alpha-emitting & $0 / 5$ & $-2.00 E-11$ & $1.48 \mathrm{E}-10$ & $-2.00 \mathrm{E}-10 / 2.00 \mathrm{E}-10 \mu \mathrm{Ci} / \mathrm{mL}$ \\
\hline \multicolumn{5}{|l|}{ EPIA-011 } \\
\hline Americium-241 & $0 / 3$ & $2.23 \mathrm{E}-11$ & $2.18 \mathrm{E}-11$ & $3.00 \mathrm{E}-12 / 4.60 \mathrm{E}-11 \mu \mathrm{Ci} / \mathrm{mL}$ \\
\hline Curium-242 & $0 / 2$ & $1.05 \mathrm{E}-11$ & $1.62 \mathrm{E}-11$ & $0.0 / 2.20 \mathrm{E}-11 \mu \mathrm{Ci} / \mathrm{mL}$ \\
\hline Curium-243/244 & $0 / 2$ & $1.68 \mathrm{E}-11$ & $2.29 \mathrm{E}-11$ & $0.0 / 3.30 \mathrm{E}-11 \mu \mathrm{Ci} / \mathrm{mL}$ \\
\hline Curium-245/246 & $1 / 2$ & 3.60E- +1 & $2.26 \mathrm{E}-11$ & 2.00E-11/5.20E-11 $\mu \mathrm{Ci} / \mathrm{mL}$ \\
\hline Plutonium-238 & $2 / 2$ & $1.20 E-10$ & $7.78 \mathrm{E}-11$ & $6.50 \mathrm{E}-11 / 1.75 \mathrm{E}-10 \mu \mathrm{Ci} / \mathrm{mL}$ \\
\hline Plutonium-239/240 & $0 / 2$ & $-2.00 E-12$ & $1.41 \mathrm{E}-12$ & $-3.00 \mathrm{E}-12 / 0.0 \mu \mathrm{Ci} / \mathrm{mL}$ \\
\hline Uranium-233/234 & $0 / 2$ & $7.50 \mathrm{E}-12$ & $3.54 \mathrm{E}-12$ & $5.00 \mathrm{E}-12 / 1.00 \mathrm{E}-11 \mu \mathrm{Ci} / \mathrm{mL}$ \\
\hline Uranium-235 & $0 / 2$. & $4.00 \mathrm{E}-12$ & $2.83 \mathrm{E}-12$ & $2.00 \mathrm{E}-12 / 6.00 \mathrm{E}-12 \mu \mathrm{Ci} / \mathrm{mL}$ \\
\hline Uranium-238 & $0 / 2$ & $6.50 \mathrm{E}-12$ & $9.19 E-12$ & $0.0 / 1.30 \mathrm{E}-11 \mu \mathrm{Ci} / \mathrm{mL}$ \\
\hline \multicolumn{5}{|l|}{ EPIA-012 } \\
\hline Thorium-228 & $0 / 2$ & $-2.00 \mathrm{E}-12$ & $3.96 \mathrm{E}-11$ & $-3.00 \mathrm{E}-11 / 2.60 \mathrm{E}-11 \mu \mathrm{Ci} / \mathrm{mL}$ \\
\hline Thorium-230 & $0 / 2$ & $4.50 \mathrm{E}-12$ & $1.34 \mathrm{E}-11$ & $-5.00 \mathrm{E}-12 / 1.40 \mathrm{E}-11 \mu \mathrm{Ci} / \mathrm{mL}$ \\
\hline Thorium-232 & $0 / 2$ & $7.50 \mathrm{E}-12$ & $1.34 \mathrm{E}-11$ & $-2.00 \mathrm{E}-12 / 1.70 \mathrm{E}-11 \mu \mathrm{Ci} / \mathrm{mL}$ \\
\hline \multicolumn{5}{|l|}{ EPIA-013 } \\
\hline Actinium-228 & 0/3 & $-8.80 \mathrm{E}-09$ & $2.99 \mathrm{E}=09$ & $5.82 \mathrm{E}=09 / 1.18 \mathrm{E}-08 \mu \mathrm{Ci} / \mathrm{mL}$ \\
\hline Antimony-125 & $0 / 3$ & $-1.07 E-09$ & $3.64 \mathrm{E}-09$ & $-5.24 \mathrm{E}-09 / 1.44 \mathrm{E}-09 \mu \mathrm{Ci} / \mathrm{mL}$ \\
\hline Cerium-144 & $0 / 3$ & $1.10 E-08$ & $1.33 \mathrm{E}-08$ & $-3.96 \mathrm{E}-09 / 2.13 \mathrm{E}-08 \mu \mathrm{Ci} / \mathrm{mL}$ \\
\hline Cesium-134 & $0 / 3$ & $5.47 \mathrm{E}-10$ & $1.18 \mathrm{E}-09$ & $-2.80 \mathrm{E}-10 / 1.90 \mathrm{E}-09 \mu \mathrm{Ci} / \mathrm{mL}$ \\
\hline Cesium-137 & $0 / 3$ & $-3.34 \mathrm{E}-10$ & $3.90 E-10$ & $-7.03 \mathrm{E}-10 / 7.42 \mathrm{E}-11 \mu \mathrm{Ci} / \mathrm{mL}$ \\
\hline Cobalt-57 & $0 / 3$ & $-3.60 \mathrm{E}-11$ & $5.76 \mathrm{E}-10$ & $-6.06 \mathrm{E}-10 / 5.45 \mathrm{E}-10 \mu \mathrm{Ci} / \mathrm{mL}$ \\
\hline Cobalt -60 & $0 / 3$ & $1.50 E-11$ & 1.07E-09 & $-9.74 \mathrm{E}-10 / 1.15 \mathrm{E}-09 \mu \mathrm{Ci} / \mathrm{mL}$ \\
\hline Europium-152 & $0 / 3$ & $1.13 E-09$ & $3.11 \mathrm{E}-09$ & $-1.40 \mathrm{E}-09 / 4.60 \mathrm{E}-09 \mu \mathrm{Ci} / \mathrm{mL}$ \\
\hline Europium-154 & $0 / 3$ & $2.92 E-09$ & $2.26 \mathrm{E}-09$ & 5.20E-10/5.02E-09 $\mu \mathrm{Ci} / \mathrm{mL}$ \\
\hline
\end{tabular}




\begin{tabular}{lllll}
\hline Analyte & $\begin{array}{l}\text { Frequency } \\
\text { of Detectiont }\end{array}$ & Mean Result & $\begin{array}{c}\text { Standard } \\
\text { Deviation }\end{array}$ & Minimum/Maximum Results \\
\hline Europium-155 & $0 / 3$ & $3.36 \mathrm{E}-09$ & $4.10 \mathrm{E}-09$ & $-1.24 \mathrm{E}-09 / 6.61 \mathrm{E}-09 \mu \mathrm{Ci} / \mathrm{mL}$ \\
Lead-212 & $0 / 3$ & $3.76 \mathrm{E}-09$ & $1.31 \mathrm{E}-09$ & $2.35 \mathrm{E}-09 / 4.95 \mathrm{E}-09 \mu \mathrm{Ci} / \mathrm{mL}$ \\
Manganese-54 & $0 / 3$ & $1.07 \mathrm{E}-09$ & $4.53 \mathrm{E}-10$ & $6.93 \mathrm{E}-10 / 1.57 \mathrm{E}-09 \mu \mathrm{Ci} / \mathrm{mL}$ \\
Potassium-40 & $0 / 3$ & $2.14 \mathrm{E}-08$ & $6.48 \mathrm{E}-09$ & $1.46 \mathrm{E}-08 / 2.75 \mathrm{E}-08 \mu \mathrm{Ci} / \mathrm{mL}$ \\
Promethium-144 & $0 / 3$ & $3.21 \mathrm{E}-10$ & $1.40 \mathrm{E}-09$ & $-1.28 \mathrm{E}-09 / 1.33 \mathrm{E}-09 \mu \mathrm{Ci} / \mathrm{mL}$ \\
Promethium-146 & $0 / 3$ & $5.01 \mathrm{E}-10$ & $1.11 \mathrm{E}-09$ & $-2.68 \mathrm{E}-10 / 1.77 \mathrm{E}-09 \mu \mathrm{Ci} / \mathrm{mL}$ \\
Ruthenium-106 & $0 / 3$ & $8.87 \mathrm{E}-10$ & $1.36 \mathrm{E}-08$ & $-7.82 \mathrm{E}-09 / 1.65 \mathrm{E}-08 \mu \mathrm{Ci} / \mathrm{mL}$ \\
Sodium-22 & $0 / 3$ & $9.90 \mathrm{E}-10$ & $8.06 \mathrm{E}-10$ & $1.89 \mathrm{E}-10 / 1.80 \mathrm{E}-09 \mu \mathrm{Ci} / \mathrm{mL}$ \\
Yttrium-88 & $0 / 3$ & $-1.63 \mathrm{E}-11$ & $1.23 \mathrm{E}-09$ & $-9.11 \mathrm{E}-10 / 1.39 \mathrm{E}-09 \mu \mathrm{Ci} / \mathrm{mL}$ \\
Zinc-65 & $0 / 3$ & $-2.66 \mathrm{E}-09$ & $1.28 \mathrm{E}-09$ & $-3.98 \mathrm{E}-09 /-1.43 \mathrm{E}-09 \mu \mathrm{Ci} / \mathrm{mL}$ \\
EPIA-020 & & & & $7.80 \mathrm{E}-11 / 7.80 \mathrm{E}-11 \mu \mathrm{Ci} / \mathrm{mL}$ \\
Promethium-147 & $0 / 1$ & $7.80 \mathrm{E}-11$ & - & \\
EPIA-022 & & & & \\
Nickel-63 & $0 / 2$ & $2.29 \mathrm{E}-08$ & $5.18 \mathrm{E}-08$ & $-1.38 \mathrm{E}-08 / 5.95 \mathrm{E}-08 \mu \mathrm{Ci} / \mathrm{mL}$ \\
EPIA-032 & & & & \\
Neptunium-237 & $0 / 1$ & $1.60 \mathrm{E}-11$ & - & $1.60 \mathrm{E}-11 / 1.60 \mathrm{E}-11 \mu \mathrm{Ci} / \mathrm{mL}$ \\
\hline
\end{tabular}

$\dagger$ Number of times analyte was detected compared to the total number of method blanks for the analyte.

- Standard deviation cannot be determined.

Note: If the analyte was not detected in the method blank(s), detection limit information appears in the Mean Result and Minimum/Maximum Results columns.

Table 80. Analytes Detected in Method Blanks for TM

\begin{tabular}{|c|c|c|c|c|}
\hline Analyte & $\begin{array}{l}\text { Frequency } \\
\text { of Detectiont }\end{array}$ & Mean Result & $\begin{array}{l}\text { Standard } \\
\text { Deviation }\end{array}$ & Minimum/Maximum Results \\
\hline \multicolumn{5}{|l|}{ 3500NIEMOD } \\
\hline Nickel-63 & $1 / 1$ & 5.99E-09 & 一 & 5.99E-09/5.99E-09 $\mu \mathrm{Ci} / \mathrm{mL}$ \\
\hline \multicolumn{5}{|l|}{ EICHROMTC1MOD } \\
\hline Technetium-99 & $0 / 1$ & $-6.60 \mathrm{E}-10$ & 一 & $-6.60 \mathrm{E}-10 /-6.60 \mathrm{E}-10 \mu \mathrm{Ci} / \mathrm{mL}$ \\
\hline \multicolumn{5}{|l|}{ EMLAM01MOD } \\
\hline Americium-241 & $0 / 1$ & $4.00 \mathrm{E}-11$ & 一 & 4.00E-11/4.00E-11 $\mu \mathrm{Ci} / \mathrm{mL}$ \\
\hline Americium-241/Curium-246 & $0 / 1$ & $1.70 \mathrm{E}-10$ & 一 & 1.70E-10/1.70E-10 $\mu \mathrm{Ci} / \mathrm{mL}$ \\
\hline Curium-242 & $0 / 1$ & $1.00 \mathrm{E}-11$ & - & 1.00E-11/1.00E-11 $\mu \mathrm{Ci} / \mathrm{mL}$ \\
\hline Curium-243/244 & $0 / 1$ & $1.00 \mathrm{E}-11$ & - & $1.00 \mathrm{E}-11 / 1.00 \mathrm{E}-11 \mu \mathrm{Ci} / \mathrm{mL}$ \\
\hline \multicolumn{5}{|l|}{ EMLPM01MOD } \\
\hline Promethium-147 & $0 / 1$ & $1.69 \mathrm{E}-09$ & 一 & 1.69E-09/1.69E-09 $\mu \mathrm{Ci} / \mathrm{mL}$ \\
\hline \multicolumn{5}{|l|}{ EMLPU02MOD } \\
\hline Neptunium-237 & $0 / 1$ & $1.00 \mathrm{E}-10$ & - & 1.00E-10/1.00E-10 $\mu \mathrm{Ci} / \mathrm{mL}$ \\
\hline Plutonium-238 & $0 / 1$ & 0.0 & - & $0.0 / 0.0 \mu \mathrm{Ci} / \mathrm{mL}$ \\
\hline Plutonium-239/240 & $0 / 1$ & $1.20 \mathrm{E}-10$ & - & 1.20E-10/1.20E-10 $\mu \mathrm{Ci} / \mathrm{mL}$ \\
\hline \multicolumn{5}{|l|}{ EMLSR02MOD } \\
\hline Strontium-90 & $1 / 14$ & $1.99 \mathrm{E}-10$ & $4.72 E-10$ & 0.0/1.81E-09 $\mu \mathrm{Ci} / \mathrm{mL}$ \\
\hline
\end{tabular}




\begin{tabular}{|c|c|c|c|c|}
\hline Analyte & $\begin{array}{l}\text { Frequency } \\
\text { of Detectiont }\end{array}$ & Mean Result & $\begin{array}{l}\text { Standard } \\
\text { Deviation }\end{array}$ & Minimum/Maximum Results \\
\hline \multicolumn{5}{|l|}{ EMLTH01MOD } \\
\hline Thorium-228 & $0 / 1$ & 0.0 & - & $0.0 / 0.0 \mu \mathrm{Ci} / \mathrm{mL}$ \\
\hline Thorium-230 & $1 / 1$ & $1.80 \mathrm{E}-10$ & - & 1.80E-10/1.80E-10 $\mu \mathrm{Ci} / \mathrm{mL}$ \\
\hline Thorium-232 & $0 / 1$ & $9.00 \mathrm{E}-11$ & - & $9.00 \mathrm{E}-11 / 9.00 \mathrm{E}-11 \mu \mathrm{Ci} / \mathrm{mL}$ \\
\hline \multicolumn{5}{|l|}{ EMLU02MOD } \\
\hline Uranium-234 & $0 / 2$ & $5.00 \mathrm{E}-11$ & $1.41 \mathrm{E}-11$ & 4.00E-11/6.00E-11 $\mu \mathrm{Ci} / \mathrm{mL}$ \\
\hline Uranium-235 & $0 / 2$ & $4.00 E-11$ & $5.66 E-11$ & $0.0 / 8.00 \mathrm{E}-11 \mu \mathrm{Ci} / \mathrm{mL}$ \\
\hline Uranium-238 & $0 / 2$ & $5.00 \mathrm{E}-11$ & $4.24 \mathrm{E}-11$ & $2.00 \mathrm{E}-11 / 8.00 \mathrm{E}-11 \mu \mathrm{Ci} / \mathrm{mL}$ \\
\hline \multicolumn{5}{|l|}{ ENICMOD } \\
\hline Carbon-14 & $0 / 13$ & $-1.47 E-07$ & $1.02 \mathrm{E}-07$ & $-3.16 \mathrm{E}-07 / 1.84 \mathrm{E}-08 \mu \mathrm{Ci} / \mathrm{mL}$ \\
\hline \multicolumn{5}{|l|}{ EPA900.0MOD } \\
\hline Gross alpha & $1 / 49$ & $9.96 \mathrm{E}-11$ & $1.63 \mathrm{E}-10$ & $-2.50 \mathrm{E}-10 / 5.20 \mathrm{E}-10 \mu \mathrm{Ci} / \mathrm{mL}$ \\
\hline Nonvolatile beta & $0 / 33$ & $-2.73 E-11$ & $3.90 \mathrm{E}-10$ & $-8.70 \mathrm{E}-10 / 8.00 \mathrm{E}-10 \mu \mathrm{Ci} / \mathrm{mL}$ \\
\hline \multicolumn{5}{|l|}{ EPA901.1MOD } \\
\hline Cesium-137 & $0 / 5$ & $-8.14 \mathrm{E}-10$ & $3.25 \mathrm{E}-09$ & $-4.97 \mathrm{E}-09 / 1.85 \mathrm{E}-09 \mu \mathrm{Ci} / \mathrm{mL}$ \\
\hline Cobalt-60 & $0 / 5$ & $-1.03 E-09$ & $1.04 \mathrm{E}-09$ & $-2.10 \mathrm{E}-09 / 1.30 \mathrm{E}-10 \mu \mathrm{Ci} / \mathrm{mL}$ \\
\hline \multicolumn{5}{|l|}{ EPA902.0MOD } \\
\hline lodine-129 & $0 / 1$ & $8.40 \mathrm{E}-10$ & - & 8.40E-10/8.40E-10 $\mu \mathrm{Ci} / \mathrm{mL}$ \\
\hline \multicolumn{5}{|l|}{ EPA903.0MOD } \\
\hline Radium, total alpha-emitting & $5 / 15$ & $3.71 \mathrm{E}-10$ & $6.54 \mathrm{E}-10$ & $-1.00 \mathrm{E}-10 / 2.09 \mathrm{E}-09 \mu \mathrm{Ci} / \mathrm{mL}$ \\
\hline Radium-226 & $0 / 4$ & 4.75E-11 & $3.10 \mathrm{E}-11$ & $2.00 \mathrm{E}-11 / 9.00 \mathrm{E}-11 \mu \mathrm{Ci} / \mathrm{mL}$ \\
\hline \multicolumn{5}{|l|}{ EPA904.0MOD } \\
\hline Radium-228 & $1 / 4$ & $9.18 \mathrm{E}-10$ & $3.04 \mathrm{E}-10$ & $5.80 \mathrm{E}-10 / 1.28 \mathrm{E}-09 \mu \mathrm{Ci} / \mathrm{mL}$ \\
\hline \multicolumn{5}{|l|}{ EPA906.0MOD } \\
\hline Tritium & $3 / 55$ & $3.44 \mathrm{E}-08$ & $1.06 \mathrm{E}-06$ & $-1.23 \mathrm{E}-06 / 5.13 \mathrm{E}-06 \mu \mathrm{Ci} / \mathrm{mL}$ \\
\hline
\end{tabular}

† Number of times analyte was detected compared to the total number of method blanks for the analyte.

- Standard deviation cannot be determined.

Note: If the analyte was not detected in the method blank(s), detection limit information appears in the Mean Result and Minimum/Maximum Results columns.

Table 81. Analytes Detected in Field Blanks for Es

\begin{tabular}{lllll}
\hline Analyte & $\begin{array}{l}\text { Frequency } \\
\text { of Detectiont }\end{array}$ & Mean Result & $\begin{array}{l}\text { Standard } \\
\text { Deviation }\end{array}$ & Minimum/Maximum Results \\
\hline EPA350.1 & & & & \\
Ammonia nitrogen & $0 / 1$ & 50.0 & & $50.0 / 50.0 \mu \mathrm{gg} / \mathrm{L}$ \\
EPA365.1 & & & & \\
Total phosphates (as P) & $0 / 1$ & 10.0 & & $10.0 / 10.0 \mu \mathrm{g} / \mathrm{L}$ \\
EPA6010 & & & & \\
Aluminum & $5 / 7$ & 16.3 & 8.61 & $8.40 / 32.6 \mu \mathrm{g} / \mathrm{L}$ \\
Antimony & $0 / 2$ & 5.0 & 0.0 & $5.0 / 5.0 \mu \mathrm{g} / \mathrm{L}$ \\
Arsenic & $0 / 4$ & 8.0 & 0.0 & $8.0 / 8.0 \mu \mathrm{g} / \mathrm{L}$ \\
Barium & $1 / 4$ & 2.05 & 0.10 & $2.0 / 2.20 \mu \mathrm{g} / \mathrm{L}$ \\
& & & & \\
\hline
\end{tabular}




\begin{tabular}{|c|c|c|c|c|}
\hline Analyte & $\begin{array}{l}\text { Frequency } \\
\text { of Detectiont }\end{array}$ & Mean Result & $\begin{array}{l}\text { Standard } \\
\text { Deviation }\end{array}$ & Min/mum/Maximum Results \\
\hline $\begin{array}{l}\text { Beryllium } \\
\text { Boron } \\
\text { Cadmium } \\
\text { Calcium } \\
\text { Chromium } \\
\text { Cobalt } \\
\text { Copper } \\
\text { Iron } \\
\text { Lead } \\
\text { Magnesium } \\
\text { Manganese } \\
\text { Nickel } \\
\text { Potassium } \\
\text { Selenium } \\
\text { Silver } \\
\text { Sodium } \\
\text { Thallium } \\
\text { Vanadium } \\
\text { Zinc }\end{array}$ & $\begin{array}{l}0 / 2 \\
0 / 1 \\
1 / 4 \\
2 / 2 \\
2 / 4 \\
0 / 2 \\
0 / 2 \\
3 / 7 \\
2 / 7 \\
1 / 2 \\
0 / 2 \\
0 / 2 \\
0 / 2 \\
0 / 4 \\
1 / 4 \\
2 / 2 \\
0 / 2 \\
0 / 2 \\
2 / 2\end{array}$ & $\begin{array}{l}1.0 \\
25.0 \\
1.60 \\
74.5 \\
2.05 \\
5.0 \\
3.0 \\
16.9 \\
4.66 \\
39.0 \\
3.0 \\
5.0 \\
400 \\
5.0 \\
1.93 \\
245 \\
5.0 \\
2.0 \\
19.2\end{array}$ & $\begin{array}{l}0.0 \\
0.80 \\
33.2 \\
1.17 \\
0.0 \\
0.0 \\
4.93 \\
0.65 \\
15.6 \\
0.0 \\
0.0 \\
0.0 \\
0.0 \\
0.15 \\
73.5 \\
0.0 \\
0.0 \\
8.84\end{array}$ & $\begin{array}{l}1.0 / 1.0 \mu \mathrm{g} / \mathrm{L} \\
25.0 / 25.0 \mu \mathrm{g} / \mathrm{L} \\
0.40 / 2.0 \mu \mathrm{g} / \mathrm{L} \\
51.0 / 98.0 \mu g / \mathrm{L} \\
0.60 / 3.0 \mu \mathrm{g} / \mathrm{L} \\
5.0 / 5.0 \mu \mathrm{g} / \mathrm{L} \\
3.0 / 3.0 \mu \mathrm{g} / \mathrm{L} \\
8.40 / 20.0 \mu \mathrm{g} / \mathrm{L} \\
3.30 / 5.0 \mu \mathrm{g} / \mathrm{L} \\
28.0 / 50.0 \mu \mathrm{g} / \mathrm{L} \\
3.0 / 3.0 \mu \mathrm{g} / \mathrm{L} \\
5.0 / 5.0 \mu \mathrm{g} / \mathrm{L} \\
400 / 400 \mu \mathrm{g} / \mathrm{L} \\
5.0 / 5.0 \mu \mathrm{g} / \mathrm{L} \\
1.70 / 2.0 \mu \mathrm{g} / \mathrm{L} \\
193 / 297 \mu g / \mathrm{L} \\
5.0 / 5.0 \mu \mathrm{g} / \mathrm{L} \\
2.0 / 2.0 \mu \mathrm{g} / \mathrm{L} \\
12.9 / 25.4 \mu \mathrm{g} / \mathrm{L}\end{array}$ \\
\hline $\begin{array}{l}\text { EPA7470 } \\
\text { Mercury }\end{array}$ & $0 / 7$ & 0.20 & 0.0 & $0.20 / 0.20 \mu g / L$ \\
\hline $\begin{array}{l}\text { EPA8081 } \\
\text { Aldrin } \\
\text { alpha-Benzene hexachloride } \\
\text { beta-Benzene hexachloride } \\
\text { delta-Benzene hexachloride } \\
\text { Chlordane } \\
\text { alpha-Chlordane } \\
\text { gamma-Chlordane } \\
\text { p,p'-DDD } \\
\text { p,p'-DDE } \\
\text { p,p'-DDT } \\
\text { Dieldrin } \\
\text { Endosulfan sulfate } \\
\text { Endosulfan I } \\
\text { Endosulfan II } \\
\text { Endrin } \\
\text { Endrin aldehyde } \\
\text { Endrin ketone } \\
\text { Heptachlor } \\
\text { Heptachlor epoxide } \\
\text { Lindane } \\
\text { Methoxychlor } \\
\text { PCB } 1016 \\
\text { PCB } 1221 \\
\text { PCB } 1232 \\
\text { PCB } 1242 \\
\text { PCB } 1248 \\
\text { PCB } 1254 \\
\text { PCB } 1260 \\
\text { Toxaphene }\end{array}$ & $\begin{array}{l}0 / 2 \\
0 / 2 \\
0 / 2 \\
0 / 2 \\
1 / 2 \\
0 / 2 \\
0 / 2 \\
0 / 2 \\
0 / 2 \\
0 / 2 \\
0 / 2 \\
0 / 2 \\
0 / 2 \\
0 / 2 \\
0 / 2 \\
0 / 2 \\
0 / 2 \\
0 / 2 \\
0 / 2 \\
0 / 2 \\
0 / 2 \\
0 / 1 \\
0 / 1 \\
0 / 1 \\
0 / 1 \\
0 / 1 \\
0 / 1 \\
0 / 1 \\
0 / 2\end{array}$ & $\begin{array}{l}0.02 \\
0.02 \\
0.02 \\
0.02 \\
0.05 \\
0.02 \\
0.02 \\
0.02 \\
0.02 \\
0.02 \\
0.02 \\
0.02 \\
0.02 \\
0.02 \\
0.02 \\
0.02 \\
0.02 \\
0.02 \\
0.02 \\
0.02 \\
0.02 \\
0.30 \\
0.30 \\
0.30 \\
0.30 \\
0.30 \\
0.30 \\
0.30 \\
1.50\end{array}$ & $\begin{array}{l}0.0 \\
0.0 \\
0.0 \\
0.0 \\
0.04 \\
0.0 \\
0.0 \\
0.0 \\
0.0 \\
0.0 \\
0.0 \\
0.0 \\
0.0 \\
0.0 \\
0.0 \\
0.0 \\
0.0 \\
0.0 \\
0.0 \\
0.0 \\
0.0 \\
- \\
- \\
- \\
- \\
- \\
- \\
0.0\end{array}$ & $\begin{array}{l}0.02 / 0.02 \mu \mathrm{g} / \mathrm{L} \\
0.02 / 0.02 \mu \mathrm{g} / \mathrm{L} \\
0.02 / 0.02 \mu \mathrm{g} / \mathrm{L} \\
0.02 / 0.02 \mu \mathrm{g} / \mathrm{L} \\
0.02 / 0.07 \mu \mathrm{g} / \mathrm{L} \\
0.02 / 0.02 \mu \mathrm{g} / \mathrm{L} \\
0.02 / 0.02 \mu \mathrm{g} / \mathrm{L} \\
0.02 / 0.02 \mu \mathrm{g} / \mathrm{L} \\
0.02 / 0.02 \mu \mathrm{g} / \mathrm{L} \\
0.02 / 0.02 \mu \mathrm{g} / \mathrm{L} \\
0.02 / 0.02 \mu \mathrm{g} / \mathrm{L} \\
0.02 / 0.02 \mu \mathrm{g} / \mathrm{L} \\
0.02 / 0.02 \mu \mathrm{g} / \mathrm{L} \\
0.02 / 0.02 \mu \mathrm{g} / \mathrm{L} \\
0.02 / 0.02 \mu \mathrm{g} / \mathrm{L} \\
0.02 / 0.02 \mu \mathrm{g} / \mathrm{L} \\
0.02 / 0.02 \mu \mathrm{g} / \mathrm{L} \\
0.02 / 0.02 \mu \mathrm{g} / \mathrm{L} \\
0.02 / 0.02 \mu \mathrm{g} / \mathrm{L} \\
0.02 / 0.02 \mu \mathrm{g} / \mathrm{L} \\
0.02 / 0.02 \mu \mathrm{g} / \mathrm{L} \\
0.30 / 0.30 \mu \mathrm{g} / \mathrm{L} \\
0.30 / 0.30 \mu \mathrm{g} / \mathrm{L} \\
0.30 / 0.30 \mu \mathrm{g} / \mathrm{L} \\
0.30 / 0.30 \mu \mathrm{g} / \mathrm{L} \\
0.30 / 0.30 \mu \mathrm{g} / \mathrm{L} \\
0.30 / 0.30 \mu \mathrm{g} / \mathrm{L} \\
0.30 / 0.30 \mu \mathrm{L} / \mathrm{L} \\
1.50 / 1.50 \mu \mathrm{g} / \mathrm{L}\end{array}$ \\
\hline $\begin{array}{l}\text { EPA8082 } \\
\text { PCB } 1016 \\
\text { PCB } 1221 \\
\text { PCB } 1232 \\
\text { PCB } 1242 \\
\text { PCB } 1248 \\
\text { PCB } 1254\end{array}$ & $\begin{array}{l}0 / 1 \\
0 / 1 \\
0 / 1 \\
0 / 1 \\
0 / 1 \\
0 / 1\end{array}$ & $\begin{array}{l}0.30 \\
0.30 \\
0.30 \\
0.30 \\
0.30 \\
0.30\end{array}$ & $\begin{array}{l}- \\
- \\
- \\
-\end{array}$ & $\begin{array}{l}0.30 / 0.30 \mu g / L \\
0.30 / 0.30 \mu g / L \\
0.30 / 0.30 \mu g / L \\
0.30 / 0.30 \mu g / L \\
0.30 / 0.30 \mu g / L \\
0.30 / 0.30 \mu g / L\end{array}$ \\
\hline
\end{tabular}




\begin{tabular}{|c|c|c|c|c|}
\hline Analyte & $\begin{array}{l}\text { Frequency } \\
\text { of Detectionf }\end{array}$ & Mean Result & $\begin{array}{l}\text { Standard } \\
\text { Deviation }\end{array}$ & Minimum/Maximum Results \\
\hline РCB 1260 & $0 / 1$ & 0.30 & - & $0.30 / 0.30 \mu g / L$ \\
\hline $\begin{array}{l}\text { EPA8260 } \\
\text { Acetone } \\
\text { Benzene } \\
\text { Bromodichloromethane } \\
\text { Bromoform } \\
\text { Bromomethane } \\
\text { Carbon disulfide } \\
\text { Carbon tetrachloride } \\
\text { Chlorobenzene } \\
\text { Chloroethane } \\
\text { Chloroethene } \\
\text { Chloroform } \\
\text { Chloromethane } \\
\text { Dibromochloromethane } \\
\text { 1,1-Dichloroethane } \\
\text { 1,2-Dichloroethane } \\
\text { 1,1-Dichloroethylene } \\
\text { cis-1,2-Dichloroethylene } \\
\text { trans-1,2-Dichloroethylene } \\
\text { Dichloromethane } \\
\text { 1,2-Dichloropropane } \\
\text { cis-1,3-Dichloropropene } \\
\text { trans-1,3-Dichloropropene } \\
\text { Ethylbenzene } \\
\text { 2-Hexanone } \\
\text { Methyl ethyl ketone } \\
\text { Methyl isobutyl ketone } \\
\text { Styrene } \\
1,1,2,2-\text { Tetrachloroethane } \\
\text { Tetrachloroethylene } \\
\text { Toluene } \\
1,1,1-\text { Trichloroethane } \\
1,1,2-\text { Trichloroethane } \\
\text { Trichloroethylene } \\
\text { Vinyl acetate } \\
\text { Xylenes }\end{array}$ & $\begin{array}{l}1 / 1 \\
0 / 1 \\
0 / 1 \\
0 / 1 \\
0 / 1 \\
0 / 1 \\
0 / 1 \\
0 / 1 \\
0 / 1 \\
0 / 1 \\
0 / 1 \\
0 / 1 \\
0 / 1 \\
0 / 1 \\
0 / 1 \\
0 / 1 \\
0 / 1 \\
0 / 1 \\
0 / 1 \\
0 / 1 \\
0 / 1 \\
0 / 1 \\
0 / 1 \\
0 / 1 \\
0 / 1 \\
0 / 1 \\
0 / 1 \\
0 / 1 \\
0 / 1 \\
0 / 1 \\
0 / 1 \\
0 / 1 \\
0 / 1 \\
0 / 1 \\
0 / 1\end{array}$ & $\begin{array}{l}60.0 \\
5.0 \\
5.0 \\
5.0 \\
10.0 \\
5.0 \\
5.0 \\
5.0 \\
10.0 \\
10.0 \\
5.0 \\
10.0 \\
5.0 \\
5.0 \\
5.0 \\
5.0 \\
5.0 \\
5.0 \\
5.0 \\
5.0 \\
5.0 \\
5.0 \\
5.0 \\
10.0 \\
10.0 \\
12.0 \\
5.0 \\
5.0 \\
5.0 \\
5.0 \\
5.0 \\
5.0 \\
5.0 \\
5.0 \\
5.0\end{array}$ & $\begin{array}{l}= \\
= \\
= \\
= \\
= \\
= \\
= \\
= \\
= \\
= \\
= \\
= \\
= \\
= \\
= \\
= \\
= \\
=\end{array}$ & $\begin{array}{l}60.0 / 60.0 \mu \mathrm{g} / \mathrm{L} \\
5.0 / 5.0 \mu \mathrm{g} / \mathrm{L} \\
5.0 / 5.0 \mu \mathrm{g} / \mathrm{L} \\
5.0 / 5.0 \mu \mathrm{g} / \mathrm{L} \\
10.0 / 10.0 \mu \mathrm{g} / \mathrm{L} \\
5.0 / 5.0 \mu \mathrm{g} / \mathrm{L} \\
5.0 / 5.0 \mu \mathrm{g} / \mathrm{L} \\
5.0 / 5.0 \mu \mathrm{g} / \mathrm{L} \\
10.0 / 10.0 \mu \mathrm{g} / \mathrm{L} \\
10.0 / 10.0 \mu \mathrm{g} / \mathrm{L} \\
5.0 / 5.0 \mu \mathrm{g} / \mathrm{L} \\
10.0 / 10.0 \mu \mathrm{g} / \mathrm{L} \\
5.0 / 5.0 \mu \mathrm{g} / \mathrm{L} \\
5.0 / 5.0 \mu \mathrm{g} / \mathrm{L} \\
5.0 / 5.0 \mu \mathrm{g} / \mathrm{L} \\
5.0 / 5.0 \mu \mathrm{g} / \mathrm{L} \\
5.0 / 5.0 \mu \mathrm{g} / \mathrm{L} \\
5.0 / 5.0 \mu \mathrm{g} / \mathrm{L} \\
5.0 / 5.0 \mu \mathrm{L} / \mathrm{L} \\
5.0 / 5.0 \mu \mathrm{g} / \mathrm{L} \\
5.0 / 5.0 \mu \mathrm{L} / \mathrm{L} \\
5.0 / 5.0 \mu \mathrm{g} / \mathrm{L} \\
5.0 / 5.0 \mu \mathrm{g} / \mathrm{L} \\
10.0 / 10.0 \mu \mathrm{g} / \mathrm{L} \\
10.0 / 10.0 \mu \mathrm{L} / \mathrm{L} \\
12.0 / 12.0 \mu \mathrm{g} / \mathrm{L} \\
5.0 / 5.0 \mu \mathrm{g} / \mathrm{L} \\
5.0 / 5.0 \mu \mathrm{g} / \mathrm{L} \\
5.0 / 5.0 \mu \mathrm{g} / \mathrm{L} \\
5.0 / 5.0 \mu \mathrm{g} / \mathrm{L} \\
5.0 / 5.0 \mu \mathrm{g} / \mathrm{L} \\
5.0 / 5.0 \mu \mathrm{g} / \mathrm{L} \\
5.0 / 5.0 \mu \mathrm{g} / \mathrm{L} \\
5.0 / 5.0 \mu \mathrm{g} / \mathrm{L} \\
5.0 / 5.0 \mu \mathrm{g} / \mathrm{L}\end{array}$ \\
\hline $\begin{array}{l}\text { EPA8270 } \\
\text { Acenaphthene } \\
\text { Acenaphthylene } \\
\text { Anthracene } \\
\text { Benzidine } \\
\text { Benzo[a]anthracene } \\
\text { Benzo[b]fluoranthene } \\
\text { Benzo[kfluoranthene } \\
\text { Benzoic acid } \\
\text { Benzo[g,h,i]perylene } \\
\text { Benzo[a]pyrene } \\
\text { Benzyl alcohol } \\
\text { Bis(2-chloroethoxy) methane }{ }^{-} \cdot- \\
\text { Bis(2-chloroethyl) ether } \\
\text { Bis(2-chloroisopropyl) ether } \\
\text { Bis(2-ethylhexyl) phthalate } \\
\text { 4-Bromophenyl phenyl ether } \\
\text { Butylbenzyl phthalate } \\
\text { 4-Chloroaniline } \\
\text { 4-Chloro-m-cresol } \\
\text { 2-Chloronaphthalene } \\
\text { 2-Chlorophenol }\end{array}$ & $\begin{array}{l}0 / 2 \\
0 / 2 \\
0 / 2 \\
0 / 2 \\
0 / 2 \\
0 / 2 \\
0 / 2 \\
0 / 2 \\
0 / 2 \\
0 / 2 \\
0 / 2 \\
0 / 2 \\
0 / 2 \\
0 / 2 \\
2 / 2 \\
0 / 2 \\
0 / 2 \\
0 / 2 \\
0 / 2 \\
0 / 2 \\
0 / 2\end{array}$ & $\begin{array}{l}10.0 \\
10.0 \\
10.0 \\
10.0 \\
10.0 \\
10.0 \\
10.0 \\
50.0 \\
10.0 \\
10.0 \\
20.0 \\
10.0^{-}= \\
10.0 \\
10.0 \\
47.5 \\
10.0 \\
10.0 \\
20.0 \\
20.0 \\
10.0 \\
10.0\end{array}$ & $\begin{array}{l}0.0 \\
0.0 \\
0.0 \\
0.0 \\
0.0 \\
0.0 \\
0.0 \\
0.0 \\
0.0 \\
0.0 \\
0.0 \\
0.0 \\
0.0 \\
0.0 \\
43.1 \\
0.0 \\
0.0 \\
0.0 \\
0.0 \\
0.0 \\
0.0\end{array}$ & $\begin{array}{l}10.0 / 10.0 \mu \mathrm{g} / \mathrm{L} \\
10.0 / 10.0 \mu \mathrm{g} / \mathrm{L} \\
10.0 / 10.0 \mu \mathrm{g} / \mathrm{L} \\
10.0 / 10.0 \mu \mathrm{g} / \mathrm{L} \\
10.0 / 10.0 \mu \mathrm{g} / \mathrm{L} \\
10.0 / 10.0 \mu \mathrm{g} / \mathrm{L} \\
10.0 / 10.0 \mu \mathrm{g} / \mathrm{L} \\
50.0 / 50.0 \mu \mathrm{g} / \mathrm{L} \\
10.0 / 10.0 \mu \mathrm{g} / \mathrm{L} \\
10.0 / 10.0 \mu \mathrm{g} / \mathrm{L} \\
20.0 / 20.0 \mu \mathrm{g} / \mathrm{L} \\
10.0 / 10.0 \mu \mathrm{g} / \mathrm{L} \\
10.0 / 10.0 \mu \mathrm{g} / \mathrm{L} \\
10.0 / 10.0 \mu \mathrm{L} / \mathrm{L} \\
17.0 / 78.0 \mu \mathrm{g} / \mathrm{L} \\
10.0 / 10.0 \mu \mathrm{L} / \mathrm{L} \\
10.0 / 10.0 \mu \mathrm{g} / \mathrm{L} \\
20.0 / 20.0 \mu \mathrm{L} / \mathrm{L} \\
20.0 / 20.0 \mu \mathrm{g} / \mathrm{L} \\
10.0 / 10.0 \mu \mathrm{g} / \mathrm{L} \\
10.0 / 10.0 \mu \mathrm{g} / \mathrm{L}\end{array}$ \\
\hline
\end{tabular}




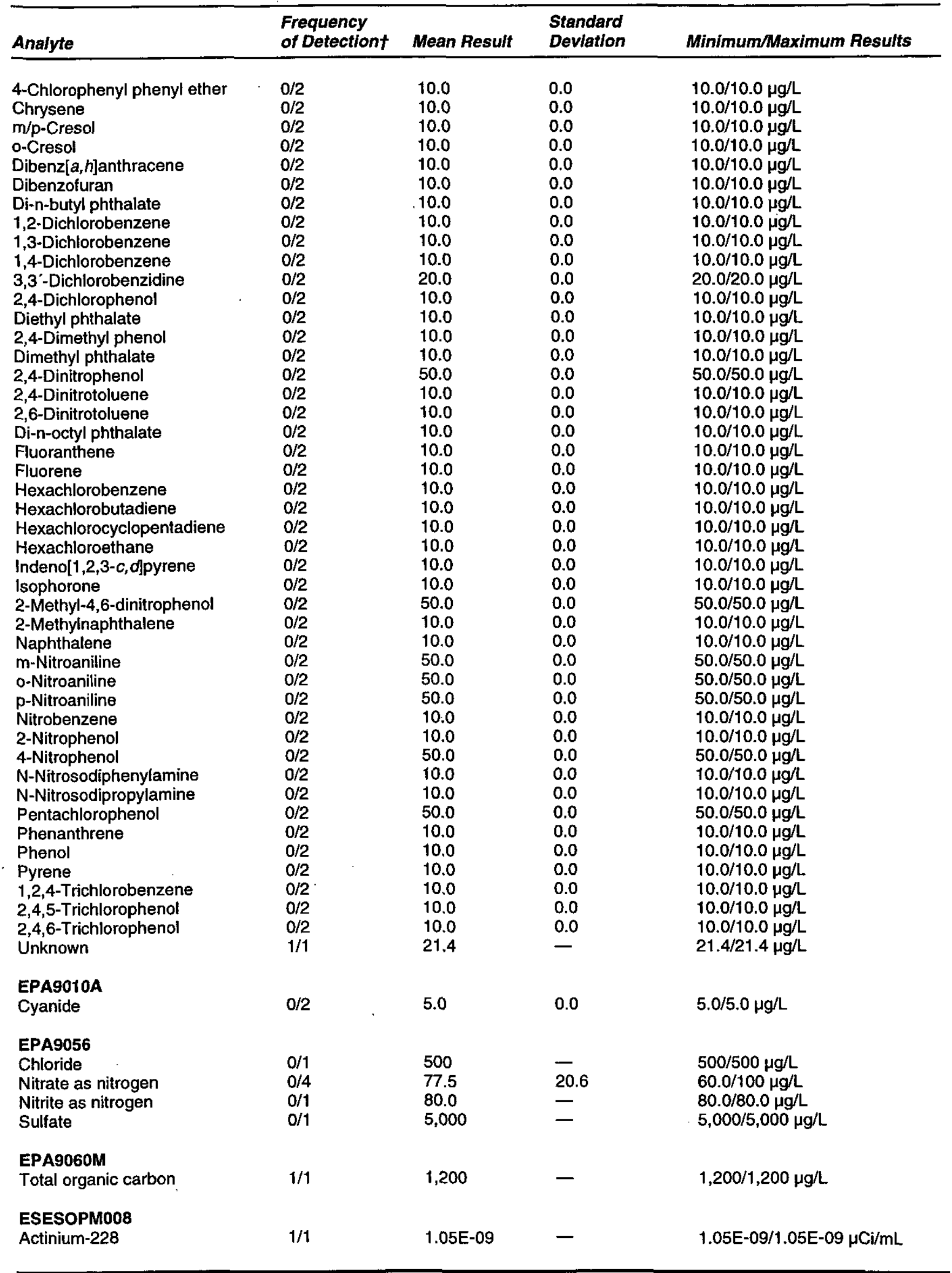




\begin{tabular}{|c|c|c|c|c|c|}
\hline Analyte & $\begin{array}{l}\text { Frequency } \\
\text { of Detectiont }\end{array}$ & Mean Result & $\begin{array}{l}\text { Standard } \\
\text { Deviation }\end{array}$ & Minimum/Maximum Results & \\
\hline Antimony-125 & $1 / 1$ & $4.80 \mathrm{E}-10$ & - & 4.80E-10/4.80E-10 $\mu \mathrm{Ci} / \mathrm{mL}$ & \\
\hline Cerium-144 & $1 / 1$ & 6.37E-09 & - & 6.37E-09/6.37E-09 $\mu \mathrm{Ci} / \mathrm{mL}$ & \\
\hline Cesium-134 & $1 / 1$ & $-2.35 E-09$ & - & $-2.35 \mathrm{E}-09 /-2.35 \mathrm{E}-09 \mu \mathrm{Ci} / \mathrm{mL}$ & \\
\hline Cesium-137 & $1 / 1$ & $3.80 \mathrm{E}-10$ & - & $3.80 \mathrm{E}-10 / 3.80 \mathrm{E}-10 \mu \mathrm{Ci} / \mathrm{mL}$ & \\
\hline Cobalt-57 & $1 / 1$ & $9.10 \mathrm{E}-10$ & 一 & $9.10 \mathrm{E}-10 / 9.10 \mathrm{E}-10 \mu \mathrm{Ci} / \mathrm{mL}$ & \\
\hline Cobalt-60 & $t / 1$ & $9.00 E-10$ & - & $9.00 \mathrm{E}-10 / 9.00 \mathrm{E}-10 \mu \mathrm{Ci} / \mathrm{mL}$ & \\
\hline Europium-152 & $1 / 1$ & 7.96E-09 & - & 7.96E-09/7.96E-09 $\mu \mathrm{Ci} / \mathrm{mL}$ & \\
\hline Europium-154 & $1 / 1$ & $-3.70 \mathrm{E}-10$ & - & $-3.70 \mathrm{E}-10 /-3.70 \mathrm{E}-10 \mu \mathrm{Ci} / \mathrm{mL}$ & \\
\hline Europium-155 & $1 / 1$ & $8.60 \mathrm{E}-10$ & - & 8.60E-10/8.60E-10 $\mu \mathrm{Ci} / \mathrm{mL}$ & \\
\hline lodine-129 & $0 / 1$ & $1.33 E-09$ & - & 1.33E-09/1.33E-09 $\mu \mathrm{Ci} / \mathrm{mL}$ & \\
\hline Lead-212 & $1 / 1$ & 4.10E-10 & - & 4.10E-10/4.10E-10 $\mathrm{\mu Ci} / \mathrm{mL}$ & \\
\hline Manganese-54 & $t / 1$ & $-3.00 E-11$ & - & $-3.00 \mathrm{E}-11 /-3.00 \mathrm{E}-11 \mu \mathrm{Ci} / \mathrm{mL}$ & \\
\hline Potassium-40 & $1 / 1$ & $-2.78 E-08$ & - & $-2.78 \mathrm{E}-08 /-2.78 \mathrm{E}-08 \mu \mathrm{Ci} / \mathrm{mL}$ & \\
\hline Promethium-144 & $1 / 1$ & 4.80E-10 & - & $4.80 \mathrm{E}-10 / 4.80 \mathrm{E}-10 \mu \mathrm{Ci} / \mathrm{mL}$ & \\
\hline Promethium-146 & $1 / 1$ & $-8.80 E-10$ & - & $-8.80 \mathrm{E}-10 /-8.80 \mathrm{E}-10 \mu \mathrm{Ci} / \mathrm{mL}$ & \\
\hline Ruthenium-106 & $1 / 1$ & $6.16 \mathrm{E}-09$ & - & 6.16E-09/6.16E-09 $\mu \mathrm{Ci} / \mathrm{mL}$ & \\
\hline Sodium-22 & $1 / 1$ & $-3.40 E-10$ & - & $-3.40 \mathrm{E}-10 /-3.40 \mathrm{E}-10 \mu \mathrm{Ci} / \mathrm{mL}$ & \\
\hline Thorium-234 & $1 / 1$ & $7.16 \mathrm{E}-10$ & - & 7.16E-10/7.16E-10 $\mu \mathrm{Ci} / \mathrm{mL}$ & \\
\hline Yttrium-88 & $1 / 1$ & $2.00 \mathrm{E}-11$ & - & 2.00E-11/2.00E-11 $\mu \mathrm{Ci} / \mathrm{mL}$ & \\
\hline Zinc-65 & $1 / 1$ & 5.32E-09 & 一 & 5.32E-09/5.32E-09 $\mu \mathrm{Ci} / \mathrm{mL}$ & \\
\hline \multicolumn{6}{|l|}{ ESESOPM017 } \\
\hline Gross alpha & $0 / 1$ & $-9.40 E-10$ & - & $-9.40 \mathrm{E}-10 /-9.40 \mathrm{E}-10 \mu \mathrm{Ci} / \mathrm{mL}$ & \\
\hline Nonvolatile beta & $0 / 1$ & $5.00 \mathrm{E}-11$ & - & $5.00 \mathrm{E}-11 / 5.00 \mathrm{E}-11 \mu \mathrm{Ci} / \mathrm{mL}$ & \\
\hline \multicolumn{6}{|l|}{ ESESOPM020 } \\
\hline Tritium & $0 / 1$ & $-1.49 E-07$ & - & -1.49E-07/-1.49E-07 $\mu \mathrm{Ci} / \mathrm{mL}$ & \\
\hline \multicolumn{6}{|l|}{ ESESOPM030 } \\
\hline Radium-226 & $0 / 1$ & $-2.22 E-09$ & - & -2.22E-09/-2.22E-09 $\mu \mathrm{Ci} / \mathrm{mL}$ & \\
\hline Radium-228 & $0 / 1$ & $-3.10 \mathrm{E}-10$ & - & $-3.10 \mathrm{E}-10 /-3.10 \mathrm{E}-10 \mu \mathrm{Ci} / \mathrm{mL}$ & \\
\hline ESESOPM031 & , & . & & & \\
\hline Strontium-90 & $0 / 1$ & $-1.13 E-09$ & - & -1.13E-09/-1.13E-09 $\mu \mathrm{Ci} / \mathrm{mL}$ & \\
\hline \multicolumn{6}{|l|}{ ESESOPM032 } \\
\hline Americium-241 & $0 / 2$ & $3.45 E-11$ & $3.61 \mathrm{E}-11$ & $9.00 \mathrm{E}-12 / 6.00 \mathrm{E}-11 \mu \mathrm{Ci} / \mathrm{mL}$ & \\
\hline Curium-242 & $0 / 2$ & $1.55 E-11$ & $3.46 \mathrm{E}-11$ & . $-9.00 \mathrm{E}-12 / 4.00 \mathrm{E}-11 \mu \mathrm{Ci} / \mathrm{mL}$ & . \\
\hline Curium-243/244 & $0 / 2$ & $1.00 \mathrm{E}-11$ & $1.41 E-11$ & $0.0 / 2.00 \mathrm{E}-1+\mu \mathrm{Ci} / \mathrm{mL}$ & \\
\hline Curium-245/246 & $0 / 2$ & $3.45 \mathrm{E}-11$ & $3.61 E-11$ & $9.00 \mathrm{E}-12 / 6.00 \mathrm{E}-11 \mu \mathrm{Ci} / \mathrm{mL}$ & \\
\hline Neptunium-237 & $0 / 1$ & 0.0 & - & $0.0 / 0.0 \mu \mathrm{Ci} / \mathrm{mL}$ & \\
\hline Plutonium-238 & $0 / 1$ & $-1.00 \mathrm{E}-11$ & - & $-1.00 \mathrm{E}-11 /-1.00 \mathrm{E}-11 \mu \mathrm{Ci} / \mathrm{mL}$ & \\
\hline Plutonium-239/240 & $0 / 1$ & $-1.00 \mathrm{E}-11$ & - & $=1.00 \mathrm{E}-11 /-1.00 \mathrm{E}-11 \mu \mathrm{Ci} / \mathrm{mL}$ & \\
\hline Thorium-228 & $0 / 1$ & $-5.00 E-11$ & - & $-5.00 \mathrm{E}-11 /-5.00 \mathrm{E}-11 \mu \mathrm{Ci} / \mathrm{mL}$ & \\
\hline Thorium-230 & $0 / 1$ & $2.80 \mathrm{E}-10$ & - & $2.80 \mathrm{E}-10 / 2.80 \mathrm{E}-10 \mu \mathrm{Ci} / \mathrm{mL}$ & \\
\hline Thorium-232 & $0 / 1$ & $7.00 \mathrm{E}-12$ & - & 7.00E-12/7.00E-12 $\mu \mathrm{Ci} / \mathrm{mL}$ & \\
\hline Uranium-233/234 & $0 / 1$ & $3.00 \mathrm{E}-11$ & - & 3.00E-11/3.00E-11 $\mu \mathrm{Ci} / \mathrm{mL}$ & \\
\hline
\end{tabular}




\begin{tabular}{lllll}
\hline Analyte & $\begin{array}{l}\text { Frequency } \\
\text { of Detectiont }\end{array}$ & Mean Result & $\begin{array}{l}\text { Standard } \\
\text { Deviation }\end{array}$ & Minimum/Maximum Results \\
\hline Uranium-235 & $0 / 1$ & $1.00 \mathrm{E}-11$ & - & $1.00 \mathrm{E}-11 / 1.00 \mathrm{E}-11 \mu \mathrm{Ci} / \mathrm{mL}$ \\
Uranium-238 & $0 / 1$ & $3.00 \mathrm{E}-11$ & - & $3.00 \mathrm{E}-11 / 3.00 \mathrm{E}-11 \mu \mathrm{Ci} / \mathrm{mL}$ \\
\hline
\end{tabular}

† Number of times analyte was detected compared to the total number of field blanks for the analyte.

- Standard deviation cannot be determined.

Note: If the analyte was not detected in the field blank(s), detection limit information appears in the Mean Result and Minimum/Maximum Results columns.

Table 82. Analytes Detected in Field Blanks for EX

\begin{tabular}{|c|c|c|c|c|}
\hline Analyte & $\begin{array}{l}\text { Frequency } \\
\text { of Detectiont }\end{array}$ & Mean Result & $\begin{array}{l}\text { Standard } \\
\text { Deviation }\end{array}$ & Minimum/Maximum Results \\
\hline $\begin{array}{l}\text { EPA120.1 } \\
\text { Specific conductance }\end{array}$ & $3 / 3$ & 1.59 & 0.57 & $0.94 / 2.0 \mu \mathrm{S} / \mathrm{cm}$ \\
\hline $\begin{array}{l}\text { EPA150.1 } \\
\text { pH }\end{array}$ & $5 / 5$ & 6.05 & 0.04 & $6.0 / 6.10 \mathrm{pH}$ \\
\hline $\begin{array}{l}\text { EPA160.1 } \\
\text { Total dissolved solids }\end{array}$ & $0 / 2$ & 10,000 & 0.0 & $10,000 / 10,000 \mu \mathrm{g} / \mathrm{L}$ \\
\hline $\begin{array}{l}\text { EPA300.0 } \\
\text { Chloride } \\
\text { Fluoride } \\
\text { Nitrate-nitrite as nitrogen } \\
\text { Sulfate }\end{array}$ & $\begin{array}{l}0 / 3 \\
0 / 2 \\
0 / 3 \\
0 / 3\end{array}$ & $\begin{array}{l}267 \\
400 \\
1,000 \\
267\end{array}$ & $\begin{array}{l}115 \\
0.0 \\
0.0 \\
115\end{array}$ & $\begin{array}{l}200 / 400 \mu g / \mathrm{L} \\
400 / 400 \mu g / \mathrm{L} \\
1,000 / 1,000 \mu \mathrm{g} / \mathrm{L} \\
200 / 400 \mu g / \mathrm{L}\end{array}$ \\
\hline $\begin{array}{l}\text { EPA365.2 } \\
\text { Total phosphates (as P) }\end{array}$ & $0 / 2$ & 50.0 & 0.0 & $50.0 / 50.0 \mu \mathrm{g} / \mathrm{L}$ \\
\hline $\begin{array}{l}\text { EPA370.1 } \\
\text { Silica }\end{array}$ & $0 / 1$ & 2,500 & - & $2,500 / 2,500 \mu g / L$ \\
\hline $\begin{array}{l}\text { EPA420.1 } \\
\text { Phenols }\end{array}$ & $0 / 1$ & 50.0 & - & $50.0 / 50.0 \mu \mathrm{g} / \mathrm{L}$ \\
\hline $\begin{array}{l}\text { EPA6010A } \\
\text { Aluminum } \\
\text { Antimony } \\
\text { Arsenic } \\
\text { Barium } \\
\text { Beryllium } \\
\text { Boron } \\
\text { Cadmium } \\
\text { Calcium } \\
\text { Chromium } \\
\text { Cobalt } \\
\text { Copper } \\
\text { Iron } \\
\text { Lead } \\
\text { Magnesium } \\
\text { Manganese } \\
\text { Molybdenum } \\
\text { Nickel } \\
\text { Potassium }\end{array}$ & $\begin{array}{l}0 / 5 \\
0 / 4 \\
0 / 5 \\
0 / 4 \\
0 / 4 \\
0 / 1 \\
0 / 4 \\
0 / 4 \\
0 / 4 \\
0 / 4 \\
0 / 4 \\
1 / 5 \\
1 / 5 \\
0 / 4 \\
0 / 4 \\
0 / 1 \\
0 / 4 \\
0 / 4\end{array}$ & $\begin{array}{l}100 \\
100 \\
10.0 \\
5.0 \\
3.80 \\
50.0 \\
5.0 \\
1,000 \\
10.0 \\
20.0 \\
10.0 \\
82.8 \\
4.33 \\
500 \\
10.0 \\
11.8 \\
20.0 \\
1,140\end{array}$ & $\begin{array}{l}0.0 \\
0.0 \\
0.0 \\
0.0 \\
2.40 \\
- \\
0.0 \\
0.0 \\
0.0 \\
0.0 \\
0.0 \\
38.5 \\
1.49 \\
0.0 \\
0.0 \\
0.0 \\
346\end{array}$ & $\begin{array}{l}100 / 100 \mu \mathrm{g} / \mathrm{L} \\
100 / 100 \mu \mathrm{g} / \mathrm{L} \\
10.0 / 10.0 \mu \mathrm{g} / \mathrm{L} \\
5.0 / 5.0 \mu \mathrm{g} / \mathrm{L} \\
0.20 / 5.0 \mu \mathrm{g} / \mathrm{L} \\
50.0 / 50.0 \mu \mathrm{g} / \mathrm{L} \\
5.0 / 5.0 \mu \mathrm{g} / \mathrm{L} \\
1,000 / 1,000 \mu \mathrm{g} / \mathrm{L} \\
10.0 / 10.0 \mu \mathrm{g} / \mathrm{L} \\
20.0 / 20.0 \mu \mathrm{g} / \mathrm{L} \\
10.0 / 10.0 \mu \mathrm{g} / \mathrm{L} \\
13.8 / 100 \mu \mathrm{g} / \mathrm{L} \\
1.66 / 5.0 \mu \mathrm{g} / \mathrm{L} \\
500 / 500 \mu \mathrm{L} / \mathrm{L} \\
10.0 / 10.0 \mu \mathrm{g} / \mathrm{L} \\
11.8 / 11.8 \mu \mathrm{g} / \mathrm{L} \\
20.0 / 20.0 \mu \mathrm{g} / \mathrm{L} \\
918 / 1,660 \mu \mathrm{g} / \mathrm{L}\end{array}$ \\
\hline
\end{tabular}




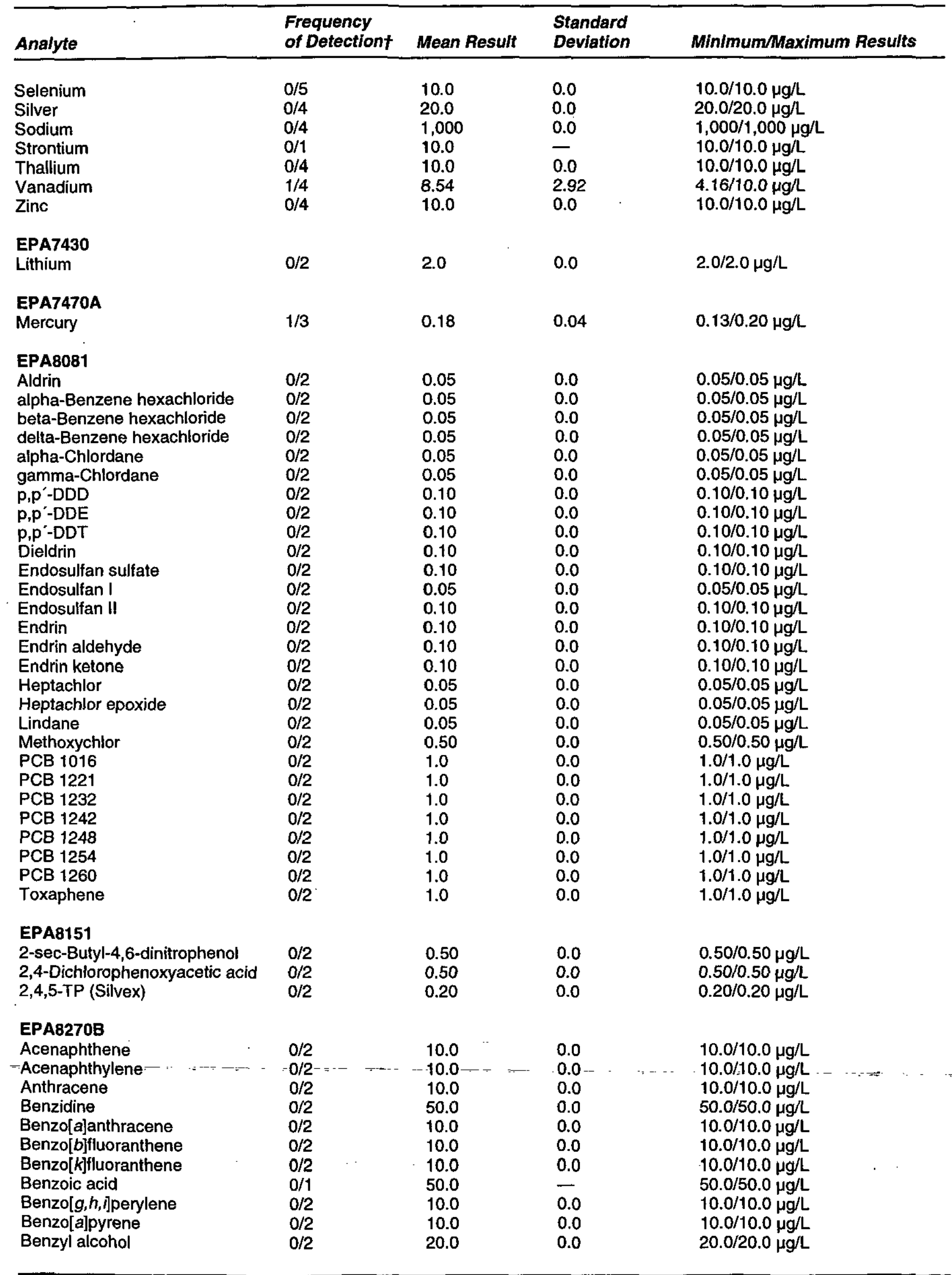




\begin{tabular}{|c|c|c|c|c|}
\hline Analyte & $\begin{array}{l}\text { Frequency } \\
\text { of Detectiont }\end{array}$ & Mean Result & $\begin{array}{l}\text { Standard } \\
\text { Deviation }\end{array}$ & Minimum/Maximum Results \\
\hline Bis(2-chloroethoxy) methane & $0 / 2$ & 10.0 & 0.0 & $10.0 / 10.0 \mu \mathrm{g} / \mathrm{L}$ \\
\hline Bis(2-chloroethyl) ether & $0 / 2$ & 10.0 & 0.0 & $10.0 / 10.0 \mu g / L$ \\
\hline Bis(2-chloroisopropyl) ether & $0 / 2$ & 10.0 & 0.0 & $10.0 / 10.0 \mu g / L$ \\
\hline Bis(2-ethylhexyl) phthalate & $2 / 2$ & 49.0 & 11.5 & $40.8 / 57.1 \mu \mathrm{g} / \mathrm{L}$ \\
\hline 4-Ḅromophenyl phenyl ether & $0 / 2$ & 10.0 & 0.0 & $10.0 / 10.0 \mu \mathrm{g} / \mathrm{L}$ \\
\hline Butylbenzyl phthalate & $0 / 2$ & 10.0 & 0.0 & $10.0 / 10.0 \mu \mathrm{g} / \mathrm{L}$ \\
\hline 4-Chloroaniline & $0 / 2$ & 10.0 & 0.0 & $10.0 / 10.0 \mu \mathrm{g} / \mathrm{L}$ \\
\hline 4-Chloro-m-cresol & $0 / 2$ & 20.0 & 0.0 & $20.0 / 20.0 \mu g / L$ \\
\hline 2-Chloronaphthalene & $0 / 2$ & 10.0 & 0.0 & $10.0 / 10.0 \mu \mathrm{g} / \mathrm{L}$ \\
\hline 2-Chlorophenol & $0 / 2$ & 10.0 & 0.0 & $10.0 / 10.0 \mu \mathrm{g} / \mathrm{L}$ \\
\hline 4-Chlorophenyl phenyl ether & $0 / 2$ & 10.0 & 0.0 & $10.0 / 10.0 \mu \mathrm{g} / \mathrm{L}$ \\
\hline Chrysene & $0 / 2$ & 10.0 & 0.0 & $10.0 / 10.0 \mu \mathrm{g} / \mathrm{L}$ \\
\hline $\mathrm{m} / \mathrm{p}$-Cresol & $0 / 2$ & 10.0 & 0.0 & $10.0 / 10.0 \mu \mathrm{g} / \mathrm{L}$ \\
\hline o-Cresol & $0 / 2$ & 10.0 & 0.0 & $10.0 / 10.0 \mu \mathrm{g} / \mathrm{L}$ \\
\hline Dibenz $[a, h]$ anthracene & $0 / 2$ & 10.0 & 0.0 & $10.0 / 10.0 \mu \mathrm{g} / \mathrm{L}$ \\
\hline Dibenzofuran & $0 / 2$ & 10.0 & 0.0 & $10.0 / 10.0 \mu \mathrm{g} / \mathrm{L}$ \\
\hline Di-n-butyl phthalate & $0 / 2$ & 10.0 & 0.0 & $10.0 / 10.0 \mu g / L$ \\
\hline 1,2-Dichlorobenzene & $0 / 2$ & 10.0 & 0.0 & $10.0 / 10.0 \mu \mathrm{g} / \mathrm{L}$ \\
\hline 1,3-Dichlorobenzene & $0 / 2$ & 10.0 & 0.0 & $10.0 / 10.0 \mu \mathrm{g} / \mathrm{L}$ \\
\hline 1,4-Dichlorobenzene & $0 / 2$ & 10.0 & 0.0 & $10.0 / 10.0 \mu g / L$ \\
\hline 3,3'-Dichlorobenzidine & $0 / 2$ & 10.0 & 0.0 & $10.0 / 10.0 \mu g / L$ \\
\hline 2,4-Dichlorophenol & $0 / 2$ & 10.0 & 0.0 & $10.0 / 10.0 \mu g / L$ \\
\hline Diethyl phthalate & $0 / 2$ & 10.0 & 0.0 & $10.0 / 10.0 \mu \mathrm{g} / \mathrm{L}$ \\
\hline 2,4-Dimethyl phenol & $0 / 2$. & 10.0 & 0.0 & $10.0 / 10.0 \mu \mathrm{g} / \mathrm{L}$ \\
\hline Dimethyl phthalate & $0 / 2$ & 10.0 & 0.0 & $10.0 / 10.0 \mu g / L$ \\
\hline 2,4-Dinitrophenol & $0 / 2$ & 10.0 & 0.0 & $10.0 / 10.0 \mu \mathrm{g} / \mathrm{L}$ \\
\hline 2,4-Dinitrotoluene & $0 / 2$ & 10.0 & 0.0 & $10.0 / 10.0 \mu g / L$ \\
\hline 2,6-Dinitrotoluene & $0 / 2$ & 10.0 & 0.0 & $10.0 / 10.0 \mu \mathrm{g} / \mathrm{L}$ \\
\hline Di-n-octyl phthalate & $0 / 2$ & 10.0 & 0.0 & $10.0 / 10.0 \mu \mathrm{g} / \mathrm{L}$ \\
\hline Fluoranthene & $0 / 2$ & 10.0 & 0.0 & $10.0 / 10.0 \mu \mathrm{g} / \mathrm{L}$ \\
\hline Fluorene - & $0 / 2$ & 10.0 & 0.0 & $10.0 / 10.0 \mu g / L$ \\
\hline Hexachlorobenzene & $0 / 2$ & 10.0 & 0.0 & $10.0 / 10.0 \mu g / L$ \\
\hline Hexachlorobutadiene & $0 / 2$ & 10.0 & 0.0 & $10.0 / 10.0 \mu \mathrm{g} / \mathrm{L}$ \\
\hline Hexachlorocyclopentadiene & $0 / 2$ & 10.0 & 0.0 & - $10.0 / 10.0 \mu g / L$ \\
\hline Hexachloroethane & $0 / 2$ & 10.0 & 0.0 & $10.0 / 10.0 \mu \mathrm{g} / \mathrm{L}$ \\
\hline Indeno $[1,2,3-c, d]$ pyrene & $0 / 2$ & 10.0 & 0.0 & $10.0 / 10.0 \mu \mathrm{g} / \mathrm{L}$ \\
\hline Isophorone & $0 / 2$ & 10.0 & 0.0 & $10.0 / 10.0 \mu \mathrm{g} / \mathrm{L}$ \\
\hline 2-Methyl-4,6-dinitrophenol & $0 / 2$ & 50.0 & 0.0 & $50.0 / 50.0 \mu \mathrm{g} / \mathrm{L}$ \\
\hline 2-Methylnaphthalene & $0 / 2$ & 10.0 & 0.0 & $10.0 / 10.0 \mu \mathrm{g} / \mathrm{L}$ \\
\hline Naphthalene & $0 / 2$ & 10.0 & 0.0 & $10.0 / 10.0 \mu \mathrm{g} / \mathrm{L}$ \\
\hline m-Nitroaniline & $0 / 2$ & 50.0 & 0.0 & $50.0 / 50.0 \mu \mathrm{g} / \mathrm{L}$ \\
\hline o-Nitroaniline & $0 / 2$ & 50.0 & 0.0 & $50.0 / 50.0 \mu \mathrm{g} / \mathrm{L}$ \\
\hline p-Nitroaniline & $0 / 2$ & 50.0 & 0.0 & $50.0 / 50.0 \mu g / L$ \\
\hline Nitrobenzene & $0 / 2$ & 10.0 & 0.0 & $10.0 / 10.0 \mu \mathrm{g} / \mathrm{L}$ \\
\hline 2-Nitrophenol & $0 / 2$ & 10.0 & 0.0 & $10.0 / 10.0 \mu g / L$ \\
\hline 4-Nitrophenol & $0 / 2$ & 50.0 & 0.0 & $50.0 / 50.0 \mu \mathrm{g} / \mathrm{L}$ \\
\hline $\mathrm{N}$-Nitrosodimethylamine & $0 / 2$ & 10.0 & 0.0 & $10.0 / 10.0 \mu \mathrm{g} / \mathrm{L}$ \\
\hline N-Nitrosodiphenylamine & $0 / 2$ & 10.0 & 0.0 & $10.0 / 10.0 \mu \mathrm{g} / \mathrm{L}$ \\
\hline N-Nitrosodipropylamine & $0 / 2$ & 10.0 & 0.0 & $10.0 / 10.0 \mu g / L$ \\
\hline Pentachlorophenol & $0 / 2$ & 50.0 & 0.0 & $50.0 / 50.0 \mu \mathrm{g} / \mathrm{L}$ \\
\hline Phenanthrene & $0 / 2$ & 10.0 & 0.0 & $10.0 / 10.0 \mu \mathrm{g} / \mathrm{L}$ \\
\hline Phenol & $0 / 2$ & 10.0 & 0.0 & $10.0 / 10.0 \mu \mathrm{g} / \mathrm{L}$ \\
\hline Pyrene & $0 / 2$ & 10.0 & 0.0 & $10.0 / 10.0 \mu \mathrm{g} / \mathrm{L}$ \\
\hline 1,2,4-Trichlorobenzene & $0 / 2$ & 10.0 & 0.0 & $10.0 / 10.0 \mu g / L$ \\
\hline $2,4,5$-Trichlorophenol & $0 / 2$ & 50.0 & 0.0 & $50.0 / 50.0 \mu \mathrm{g} / \mathrm{L}$ \\
\hline $2,4,6$-Trichlorophenol & $0 / 2$ & 10.0 & 0.0 & $10.0 / 10.0 \mu \mathrm{g} / \mathrm{L}$ \\
\hline \multicolumn{5}{|l|}{ EPA9010A } \\
\hline Cyanide & $0 / 3$ & 10.0 & 0.0 & $10.0 / 10.0 \mu \mathrm{g} / \mathrm{L}$ \\
\hline
\end{tabular}




\begin{tabular}{lllll}
\hline Analyte & $\begin{array}{l}\text { Frequency } \\
\text { of Detectiont }\end{array}$ & Mean Result & $\begin{array}{l}\text { Standard } \\
\text { Deviation }\end{array}$ & Minimum/Maximum Results \\
\hline $\begin{array}{l}\text { EPA9060 } \\
\text { Total organic carbon }\end{array}$ & $0 / 3$ & 5,000 & 0.0 & $5,000 / 5,000 \mu \mathrm{g} / \mathrm{L}$ \\
\hline
\end{tabular}

$†$ Number of times analyte was detected compared to the total number of field blanks for the analyte.

- Standard deviation cannot be determined.

Note: If the analyte was not detected in the field blank(s), detection limit information appears in the Mean Result and Minimum/Maximum Results columns.

Table 83. Analytes Detected in Fiold Blanks for GE

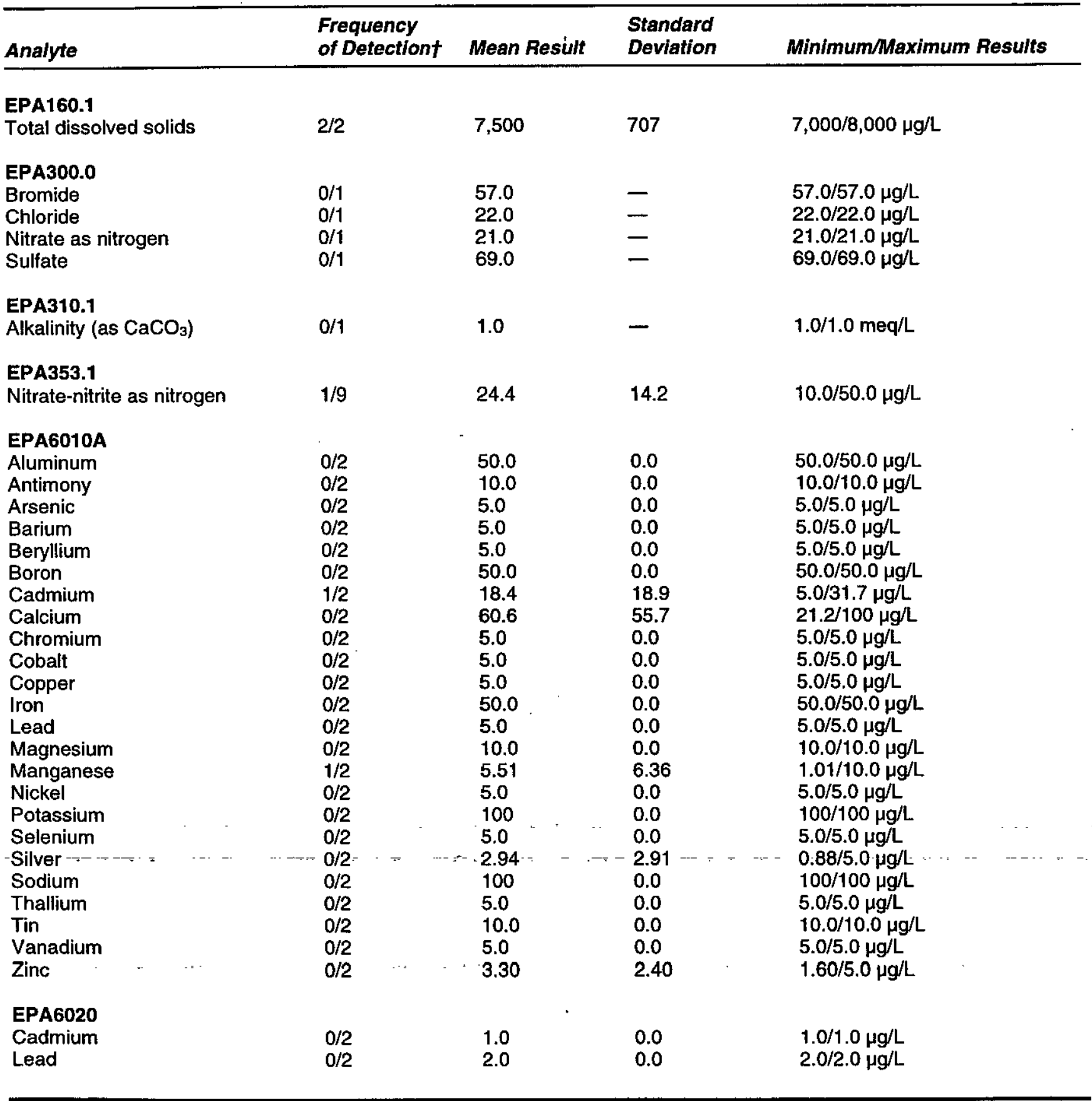




\begin{tabular}{lllll}
\hline Analyte & $\begin{array}{l}\text { Frequency } \\
\text { of Detectiont }\end{array}$ & Mean Result & $\begin{array}{l}\text { Standard } \\
\text { Deviation }\end{array}$ & Minimum/Maximum Results \\
\hline $\begin{array}{l}\text { Lithium } \\
\begin{array}{l}\text { EPA7470 } \\
\text { Mercury }\end{array}\end{array}$ & $0 / 1$ & 2.0 & - & $2.0 / 2.0 \mu \mathrm{g} / \mathrm{L}$ \\
$\begin{array}{l}\text { EPA9012 } \\
\text { Cyanide }\end{array}$ & $0 / 7$ & 0.20 & 0.0 & $0.20 / 0.20 \mu \mathrm{g} / \mathrm{L}$ \\
$\begin{array}{l}\text { EPA9020B } \\
\text { Total organic halogens }\end{array}$ & $0 / 2$ & 10.0 & 0.0 & $10.0 / 10.0 \mu \mathrm{g} / \mathrm{L}$ \\
$\begin{array}{l}\text { EPA9045C } \\
\text { pH }\end{array}$ & $0 / 2$ & 10.0 & 0.0 & $10.0 / 10.0 \mu \mathrm{g} / \mathrm{L}$ \\
$\begin{array}{l}\text { EPA9050 } \\
\text { Specific conductance }\end{array}$ & $12 / 12$ & 5.50 & 0.32 & $4.81 / 6.13 \mathrm{pH}$ \\
$\begin{array}{l}\text { EPA9060 } \\
\text { Total organic carbon }\end{array}$ & $11 / 11$ & 2.08 & 0.82 & $1.44 / 3.89 \mu \mathrm{S} / \mathrm{cm}$ \\
$\begin{array}{l}\text { EPA9066 } \\
\text { Phenols }\end{array}$ & $0 / 2$ & 5,000 & 0.0 & $5,000 / 5,000 \mu \mathrm{g} / \mathrm{L}$ \\
\hline
\end{tabular}

† Number of times analyte was detected compared to the total number of field blanks for the analyte.

- Standard deviation cannot be determined.

Note: If the analyte was not detected in the field blank(s), detection limit information appears in the Mean Result and Minimum/Maximum Results columns.

Table 84. Analytes Detected in Field Blanks for WA

\begin{tabular}{|c|c|c|c|c|}
\hline Analyte & $\begin{array}{l}\text { Frequency } \\
\text { of Detectiont }\end{array}$ & Mean Result & $\begin{array}{l}\text { Standard } \\
\text { Deviation }\end{array}$ & Minimum/Maximum Results \\
\hline $\begin{array}{l}\text { EPA160.1 } \\
\text { Total dissolved solids }\end{array}$ & $3 / 5$ & 22,600 & 22,300 & $6,000 / 47,000 \mu \mathrm{g} / \mathrm{L}$ \\
\hline $\begin{array}{l}\text { EPA310.1 } \\
\text { Alkalinity }\left(\text { as } \mathrm{CaCO}_{3}\right) \\
\text { Carbonate }\end{array}$ & $\begin{array}{l}0 / 4 \\
0 / 2\end{array}$ & $\begin{array}{l}6.70 \\
6,700\end{array}$ & $\begin{array}{l}0.0 \\
0.0\end{array}$ & $\begin{array}{l}6.70 / 6.70 \mathrm{meq} / \mathrm{L} \\
6,700 / 6,700 \mu \mathrm{g} / \mathrm{L}\end{array}$ \\
\hline $\begin{array}{l}\text { EPA353.2 } \\
\text { Nitrate as nitrogen }\end{array}$ & $0 / 2$ & 20.0 & 0.0 & $20.0 / 20.0 \mu g / L$ \\
\hline $\begin{array}{l}\text { EPA365.2 } \\
\text { Total phosphates (as P) }\end{array}$ & $0 / 2$ & 67.0 & 0.0 & $67.0 / 67.0 \mu \mathrm{g} / \mathrm{L}$ \\
\hline $\begin{array}{l}\text { EPA6010 } \\
\text { Antimony } \\
\text { Arsenic } \\
\text { Barium } \\
\text { Boron } \\
\text { Cadmium } \\
\text { Calcium } \\
\text { Chromium } \\
\text { Copper } \\
\text { iron }\end{array}$ & $\begin{array}{l}0 / 2 \\
0 / 3 \\
0 / 2 \\
0 / 2 \\
0 / 2 \\
1 / 2 \\
0 / 3 \\
1 / 2 \\
0 / 2\end{array}$ & $\begin{array}{l}27.0 \\
40.0 \\
0.73 \\
266 \\
4.70 \\
70.8 \\
7.0 \\
7.90 \\
42.3\end{array}$ & $\begin{array}{l}0.0 \\
0.0 \\
0.18 \\
0.0 \\
0.0 \\
3.11 \\
0.0 \\
8.34 \\
44.9\end{array}$ & $\begin{array}{l}27.0 / 27.0 \mu \mathrm{g} / \mathrm{L} \\
40.0 / 40.0 \mu \mathrm{g} / \mathrm{L} \\
0.60 / 0.85 \mu \mathrm{g} / \mathrm{L} \\
266 / 266 \mu \mathrm{g} / \mathrm{L} \\
4.70 / 4.70 \mu \mathrm{g} / \mathrm{L} \\
68.6 / 73.0 \mu \mathrm{g} / \mathrm{L} \\
7.0 / 7.0 \mu \mathrm{g} / \mathrm{L} \\
2.0 / 13.8 \mu \mathrm{g} / \mathrm{L} \\
10.5 / 74.0 \mu \mathrm{g} / \mathrm{L}\end{array}$ \\
\hline
\end{tabular}




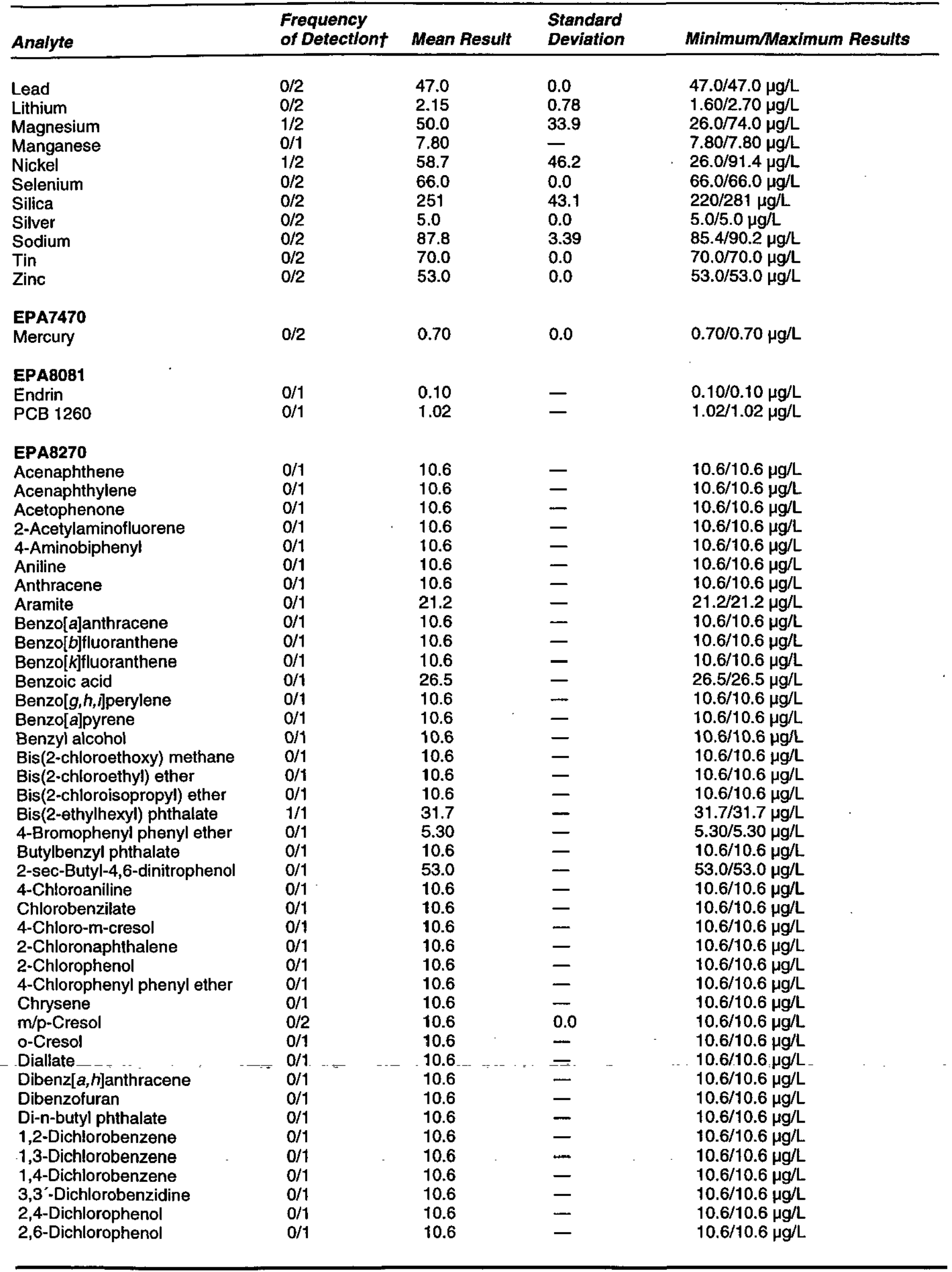




\begin{tabular}{|c|c|c|c|c|}
\hline Analyte & $\begin{array}{l}\text { Frequency } \\
\text { of Detectlont }\end{array}$ & Mean Result & $\begin{array}{l}\text { Standard } \\
\text { Deviation }\end{array}$ & Minimum/Maximum Results \\
\hline Diethyl phthalate & $0 / 1$ & 10.6 & - & $10.6 / 10.6 \mu g / L$ \\
\hline 2,4-Dimethyl phenol & $0 / 1$ & 10.6 & - & $10.6 / 10.6 \mu \mathrm{g} / \mathrm{L}$ \\
\hline Dimethyl phthalate & $0 / 1$ & 10.6 & 一 & $10.6 / 10.6 \mu g / L$ \\
\hline p-Dimethylaminoazobenzene & $0 / 1$ & 10.6 & - & $10.6 / 10.6 \mu g / L$ \\
\hline 7,12-Dimethyibenz[a]anthracene & $0 / 1$ & 10.6 & 一 & $10.6 / 10.6 \mu g / L$ \\
\hline $3,3^{\prime}$-Dimethylbenzidine & $0 / 1$ & 10.6 & - & $10.6 / 10.6 \mu \mathrm{g} / \mathrm{L}$ \\
\hline a,a-Dimethylphenethylamine & $0 / 1$ & 10.6 & - & $10.6 / 10.6 \mu \mathrm{g} / \mathrm{L}$ \\
\hline 1,3-Dinitrobenzene & $0 / 1$ & 10.6 & - & $10.6 / 10.6 \mu \mathrm{g} / \mathrm{L}$ \\
\hline 2,4-Dinitrophenol & $0 / 1$ & 26.5 & - & $26.5 / 26.5 \mu g / L$ \\
\hline 2,4-Dinitrotoluene & $0 / 1$ & 10.6 & - & $10.6 / 10.6 \mu g / L$ \\
\hline 2,6-Dinitrotoluene & $0 / 1$ & 10.6 & - & $10.6 / 10.6 \mu \mathrm{g} / \mathrm{L}$ \\
\hline Di-n-octyl phthalate & $0 / 1$ & 10.6 & - & $10.6 / 10.6 \mu \mathrm{g} / \mathrm{L}$ \\
\hline 1,4-Dioxane & $0 / 1$ & 10.6 & - & $10.6 / 10.6 \mu \mathrm{g} / \mathrm{L}$ \\
\hline Diphenylamine & $0 / 1$ & 10.6 & - & $10.6 / 10.6 \mu \mathrm{g} / \mathrm{L}$ \\
\hline Ethyl methacrylate & $0 / 1$ & 10.6 & - & $10.6 / 10.6 \mu \mathrm{g} / \mathrm{L}$ \\
\hline Ethyl methanesulfonate & $0 / 1$ & 10.6 & - & 10.6/10.6 $\mu g / L$ \\
\hline Fluoranthene & $0 / 1$ & 10.6 & - & $10.6 / 10.6 \mu \mathrm{g} / \mathrm{L}$ \\
\hline Fluorene & $0 / 1$ & 10.6 & - & $10.6 / 10.6 \mu \mathrm{g} / \mathrm{L}$ \\
\hline Hexachlorobenzene & $0 / 1$ & 5.30 & - & $5.30 / 5.30 \mu \mathrm{g} / \mathrm{L}$ \\
\hline Hexachlorobutadiene & $0 / 1$ & 10.6 & - & $10.6 / 10.6 \mu \mathrm{g} / \mathrm{L}$ \\
\hline Hexachlorocyclopentadiene & $0 / 1$ & 10.6 & - & $10.6 / 10.6 \mu \mathrm{g} / \mathrm{L}$ \\
\hline Hexachloroethane & $0 / 1$ & 10.6 & - & $10.6 / 10.6 \mu \mathrm{g} / \mathrm{L}$ \\
\hline Hexachlorophene & $0 / 1$ & 106 & - & $106 / 106 \mu g / L$ \\
\hline Hexachloropropene & $0 / 1$ & 10.6 & - & $10.6 / 10.6 \mu \mathrm{g} / \mathrm{L}$ \\
\hline Indeno $[1,2,3-c, d]$ pyrene & $0 / 1$ & 10.6 & 一 & $10.6 / 10.6 \mu \mathrm{g} / \mathrm{L}$ \\
\hline Isophorone & $0 / 1$ & 10.6 & - & $10.6 / 10.6 \mu g / L$ \\
\hline Isosafrole & $0 / 1$ & 10.6 & - & $10.6 / 10.6 \mu \mathrm{g} / \mathrm{L}$ \\
\hline Methapyrilene & $0 / 1$ & 10.6 & - & $10.6 / 10.6 \mu \mathrm{g} / \mathrm{L}$ \\
\hline 2-Methyl-4,6-dinitrophenol & $0 / 1$ & 26.5 & - & $26.5 / 26.5 \mu \mathrm{g} / \mathrm{L}$ \\
\hline Methyl methacrylate & $0 / 1$ & 10.6 & - & $10.6 / 10.6 \mu \mathrm{g} / \mathrm{L}$ \\
\hline Methyl methanesulfonate & $0 / 1$ & 10.6 & - & $10.6 / 10.6 \mu \mathrm{g} / \mathrm{L}$ \\
\hline 3-Methylcholanthrene & $0 / 1$ & 10.6 & 一 & $10.6 / 10.6 \mu \mathrm{g} / \mathrm{L}$ \\
\hline 2-Methylnaphthalene & $0 / 1$ & 10.6 & - & $10.6 / 10.6 \mu \mathrm{g} / \mathrm{L}$ \\
\hline Naphthalene & $0 / 1$ & 10.6 & - & $10.6 / 10.6 \mu \mathrm{g} / \mathrm{L}$ \\
\hline 1,4-Naphthoquinone & $0 / 1$ & 10.6 & - & $10.6 / 10.6 \mu \mathrm{g} / \mathrm{L}$ \\
\hline 1-Naphthylamine & $0 / 1$ & 10.6 & - & $10.6 / 10.6 \mu g / L$ \\
\hline 2-Naphthylamine & $0 / 1$ & 10.6 & - & $10.6 / 10.6 \mu \mathrm{g} / \mathrm{L}$ \\
\hline m-Nitroaniline & $0 / 1$ & 26.5 & - & $26.5 / 26.5 \mu g / L$ \\
\hline o-Nitroaniline & $0 / 1$ & 26.5 & - & $26.5 / 26.5 \mu g / L$ \\
\hline p-Nitroaniline & $0 / 1$ & 26.5 & - & $26.5 / 26.5 \mu g / L$ \\
\hline Nitrobenzene & $0 / 1$ & 10.6 & - & $10.6 / 10.6 \mu \mathrm{g} / \mathrm{L}$ \\
\hline 2-Nitrophenol & $0 / 1$ & 10.6 & - & $10.6 / 10.6 \mu \mathrm{g} / \mathrm{L}$ \\
\hline 4-Nitrophenol & $0 / 1$ & 26.5 & - & $26.5 / 26.5 \mu g / L$ \\
\hline 4-Nitroquinoline-1-oxide & $0 / 1$ & 21.2 & - & $21.2 / 21.2 \mu \mathrm{g} / \mathrm{L}$ \\
\hline N-Nitrosodi-n-butylamine & $0 / 1$ & 10.6 & - & $10.6 / 10.6 \mu \mathrm{g} / \mathrm{L}$ \\
\hline $\mathrm{N}$-Nitrosodiethylamine & $0 / 1$ & 10.6 & - & $10.6 / 10.6 \mu \mathrm{g} / \mathrm{L}$ \\
\hline N-Nitrosodimethylamine & $0 / 1$ & 10.6 & - & $10.6 / 10.6 \mu g / L$ \\
\hline N-Nitrosodiphenylamine & $0 / 1$ & 5.30 & - & $5.30 / 5.30 \mu \mathrm{g} / \mathrm{L}$ \\
\hline $\mathrm{N}$-Nitrosodipropylamine & $0 / 1$ & 10.6 & - & $10.6 / 10.6 \mu g / L$ \\
\hline N-Nitrosomethylethylamine & $0 / 1$ & 10.6 & - & $10.6 / 10.6 \mu g / L$ \\
\hline N-Nitrosomorpholine & $0 / 1$ & 10.6 & - & $10.6 / 10.6 \mu \mathrm{g} / \mathrm{L}$ \\
\hline N-Nitrosopiperidine & $0 / 1$ & 53.0 & - & $53.0 / 53.0 \mu \mathrm{g} / \mathrm{L}$ \\
\hline N-Nitrosopyrrolidine & $0 / 1$ & 10.6 & - & $10.6 / 10.6 \mu \mathrm{g} / \mathrm{L}$ \\
\hline 5-Nitro-o-toluidine & $0 / 1$ & 10.6 & - & $10.6 / 10.6 \mu g / L$ \\
\hline Pentachlorobenzene & $0 / 1$ & 10.6 & - & $10.6 / 10.6 \mu g / L$ \\
\hline Pentachloroethane & $0 / 1$ & 10.6 & - & $10.6 / 10.6 \mu \mathrm{g} / \mathrm{L}$ \\
\hline Pentachloronitrobenzene & $0 / 1$ & 53.0 & - & $53.0 / 53.0 \mu \mathrm{g} / \mathrm{L}$ \\
\hline Pentachlorophenol & $0 / 1$ & 26.5 & - & $26.5 / 26.5 \mu g / L$ \\
\hline Phenacetin & $0 / 1$ & 10.6 & - & $10.6 / 10.6 \mu \mathrm{g} / \mathrm{L}$ \\
\hline Phenanthrene & $0 / 1$ & 10.6 & - & $10.6 / 10.6 \mu \mathrm{g} / \mathrm{L}$ \\
\hline Phenol & $0 / 1$ & 10.6 & - & $10.6 / 10.6 \mu \mathrm{g} / \mathrm{L}$ \\
\hline
\end{tabular}




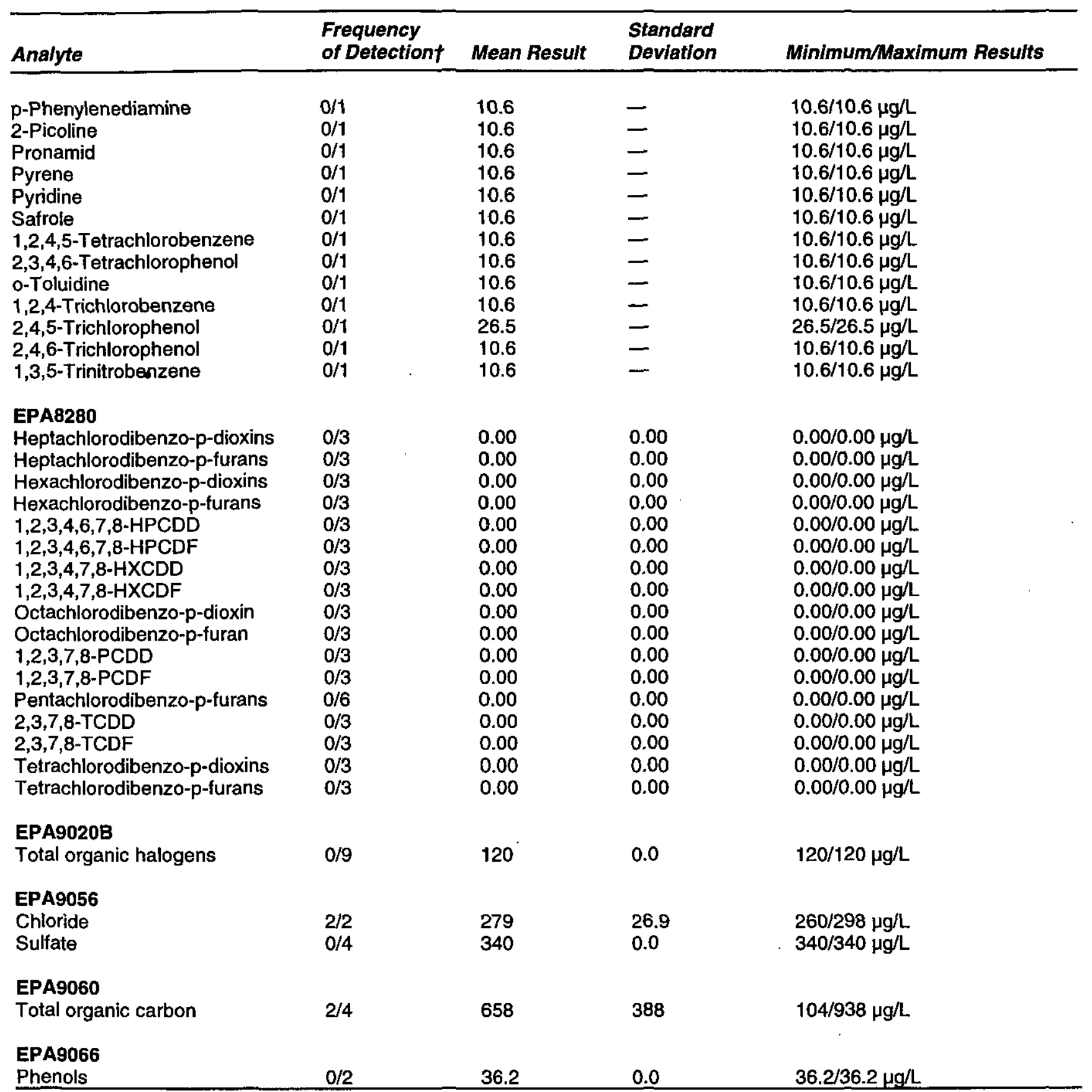

t Number of times analyte was detected compared to the total number of field blanks for the analyte.

- Standard deviation cannot be determined.

Notes: $A$ value of 0 is reported as 0.0 .

Numbers less than 0.004 are reported as 0.00 .

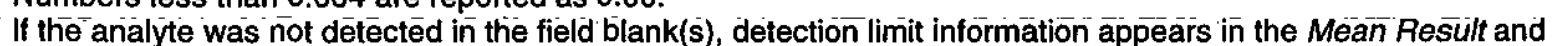
Minimum/Maximum Results columns. 
Table 85. Analytes Detected in Field Blanks for GP

\begin{tabular}{lllll}
\hline Analyte & $\begin{array}{l}\text { Frequency } \\
\text { of Detectiont }\end{array}$ & Mean Result & $\begin{array}{l}\text { Standard } \\
\text { Deviation }\end{array}$ & Minimum/Maximum Results \\
\hline $\begin{array}{l}\text { EPIA-001 } \\
\text { Gross alpha } \\
\text { Nonvolatile beta }\end{array}$ & $1 / 12$ & $1.63 \mathrm{E}-10$ & $1.61 \mathrm{E}-10$ & $-2.44 \mathrm{E}-10 / 3.59 \mathrm{E}-10 \mu \mathrm{Ci} / \mathrm{mL}$ \\
$\begin{array}{l}\text { EPIA-002 } \\
\text { Tritium }\end{array}$ & $1 / 12$ & $5.24 \mathrm{E}-10$ & $8.64 \mathrm{E}-10$ & $-1.68 \mathrm{E}-10 / 3.06 \mathrm{E}-09 \mu \mathrm{Ci} / \mathrm{mL}$ \\
$\begin{array}{l}\text { EPIA-003 } \\
\text { Carbon-14 }\end{array}$ & $0 / 11$ & $-1.11 \mathrm{E}-07$ & $1.26 \mathrm{E}-07$ & $-3.08 \mathrm{E}-07 / 6.50 \mathrm{E}-08 \mu \mathrm{Ci} / \mathrm{mL}$ \\
$\begin{array}{l}\text { EPIA-004 } \\
\text { Strontium-90 }\end{array}$ & $0 / 4$ & & \\
$\begin{array}{l}\text { EPIA-010 } \\
\text { Radium, total alpha-emitting }\end{array}$ & $0 / 2$ & $1.39 \mathrm{E}-09$ & $6.71 \mathrm{E}-09$ & $-3.89 \mathrm{E}-09 / 1.12 \mathrm{E}-08 \mu \mathrm{Ci} / \mathrm{mL}$ \\
$\begin{array}{l}\text { EPIA-011 } \\
\text { Americium-241 }\end{array}$ & $0 / 3$ & & \\
\hline
\end{tabular}

$\dagger$ Number of times analyte was detected compared to the total number of field blanks for the analyte.

- Standard deviation cannot be determined.

Note: If the analyte was not detected in the field blank(s), detection limit information appears in the Mean Result and Minimum/Maximum Results columns.

Table 86. Anälytes Detected in Field Blanks for TM

\begin{tabular}{|c|c|c|c|c|}
\hline Analyte & $\begin{array}{l}\text { Frequency } \\
\text { of Detectiont }\end{array}$ & Mean Result & $\begin{array}{l}\text { Standard } \\
\text { Deviation }\end{array}$ & Minimum/Maximum Results \\
\hline \multicolumn{5}{|l|}{ EMLSR02MOD } \\
\hline Strontium-90 & $0 / 4$ & $5.50 \mathrm{E}-11$ & $1.10 \mathrm{E}-10$ & $0.0 / 2.20 \mathrm{E}-10 \mu \mathrm{Ci} / \mathrm{mL}$ \\
\hline \multicolumn{5}{|l|}{ ENICMOD } \\
\hline Carbon-14 & $0 / 4$ & $-1.32 \mathrm{E}-07$ & $5.29 E-08$ & $-1.66 \mathrm{E}-07 /-5.45 \mathrm{E}-08 \mu \mathrm{Ci} / \mathrm{mL}$ \\
\hline \multicolumn{5}{|l|}{ EPA900.0MOD } \\
\hline Gross alpha & $1 / 10$ & $3.50 E-10$ & $4.20 \mathrm{E}-10$ & $-1.20 \mathrm{E}-10 / 1.42 \mathrm{E}-09 \mu \mathrm{Ci} / \mathrm{mL}$ \\
\hline Nonvolatile beta & $1 / 5$ & 4.02E-10 & 1.57E-09 & $-1.24 \mathrm{E}-09 / 2.86 \mathrm{E}-09 \mu \mathrm{Ci} / \mathrm{mL}$ \\
\hline \multicolumn{5}{|l|}{ EPA901.1MOD } \\
\hline Actinium-228 & $0 / 1$ & $-1.88 E-09$ & - & $-1.88 \mathrm{E}-09 /-1.88 \mathrm{E}-09 \mu \mathrm{Ci} / \mathrm{mL}$ \\
\hline Antimony-124 & $0 / 1$ & $-2.67 \mathrm{E}-09$ & - & $-2.67 \mathrm{E}-09 /-2.67 \mathrm{E}-09 \mu \mathrm{Ci} / \mathrm{mL}$ \\
\hline Antimony-125 & $0 / 1$ & $1.14 \mathrm{E}-09$ & - & 1.14E-09/1.14E-09 $\mu \mathrm{Ci} / \mathrm{mL}$ \\
\hline Barium-133 & $0 / 1$ & $1.66 \mathrm{E}-09$ & - & 1.66E-09/1.66E-09 $\mu \mathrm{Ci} / \mathrm{mL}$ \\
\hline Cerium-144 & $0 / 1$ & $-3.46 \mathrm{E}-09$ & - & $-3.46 \mathrm{E}-09 /-3.46 \mathrm{E}-09 \mu \mathrm{Ci} / \mathrm{mL}$ \\
\hline Cesium-134 & $0 / 1$ & $-1.44 \mathrm{E}-09$ & - & $-1.44 \mathrm{E}-09 /-1.44 \mathrm{E}-09 \mu \mathrm{Ci} / \mathrm{mL}$ \\
\hline Cesium-137 & $1 / 1$ & $5.85 \mathrm{E}-09$ & - & 5.85E-09/5.85E-09 $\mu \mathrm{Ci} / \mathrm{mL}$ \\
\hline Cobalt-57 & $0 / 1$ & $2.60 \mathrm{E}-10$ & - & $2.60 \mathrm{E}-10 / 2.60 \mathrm{E}-10 \mu \mathrm{Ci} / \mathrm{mL}$ \\
\hline Cobalt-58 & $0 / 1$ & $5.10 \mathrm{E}-10$ & - & $5.10 \mathrm{E}-10 / 5.10 \mathrm{E}-10 \mu \mathrm{Ci} / \mathrm{mL}$ \\
\hline Cobalt-60 & $0 / 1$ & $-1.45 \mathrm{E}-09$ & - & $-1.45 \mathrm{E}-09 /-1.45 \mathrm{E}-09 \mu \mathrm{Ci} / \mathrm{mL}$ \\
\hline Europium-152 & $0 / 1$ & $1.67 E-09$ & - & 1.67E-09/1.67E-09 $\mu \mathrm{Ci} / \mathrm{mL}$ \\
\hline
\end{tabular}




\begin{tabular}{lllll}
\hline Analyte & $\begin{array}{l}\text { Frequency } \\
\text { of Detectiont }\end{array}$ & Mean Result & $\begin{array}{l}\text { Standard } \\
\text { Deviation }\end{array}$ & Minimum/Maximum Results \\
\hline Europium-154 & $0 / 1$ & $-3.28 \mathrm{E}-09$ & - & $-3.28 \mathrm{E}-09 /-3.28 \mathrm{E}-09 \mu \mathrm{Ci} / \mathrm{mL}$ \\
Europium-155 & $0 / 1$ & $-1.23 \mathrm{E}-09$ & - & $-1.23 \mathrm{E}-09 /-1.23 \mathrm{E}-09 \mu \mathrm{Ci} / \mathrm{mL}$ \\
Lead-212 & $0 / 1$ & $2.32 \mathrm{E}-09$ & - & $2.32 \mathrm{E}-09 / 2.32 \mathrm{E}-09 \mu \mathrm{Ci} / \mathrm{mL}$ \\
Manganese-54 & $0 / 1$ & $-5.10 \mathrm{E}-10$ & - & $-5.10 \mathrm{E}-10 /-5.10 \mathrm{E}-10 \mu \mathrm{Ci} / \mathrm{mL}$ \\
Neptunium-239 & $0 / 1$ & $9.56 \mathrm{E}-08$ & - & $9.56 \mathrm{E}-08 / 9.56 \mathrm{E}-08 \mu \mathrm{Ci} / \mathrm{mL}$ \\
Potassium-40 & $0 / 1$ & $2.34 \mathrm{E}-08$ & - & $2.34 \mathrm{E}-08 / 2.34 \mathrm{E}-08 \mu \mathrm{Ci} / \mathrm{mL}$ \\
Promethium-144 & $0 / 1$ & $-2.40 \mathrm{E}-10$ & - & $-2.40 \mathrm{E}-10 /-2.40 \mathrm{E}-10 \mu \mathrm{Ci} / \mathrm{mL}$ \\
Promethium-146 & $0 / 1$ & $6.87 \mathrm{E}-09$ & - & $6.87 \mathrm{E}-09 / 6.87 \mathrm{E}-09 \mu \mathrm{Ci} / \mathrm{mL}$ \\
Ruthenium-106 & $0 / 1$ & $6.75 \mathrm{E}-09$ & - & $6.75 \mathrm{E}-09 / 6.75 \mathrm{E}-09 \mu \mathrm{Ci} / \mathrm{mL}$ \\
Sodium-22 & $0 / 1$ & $-1.19 \mathrm{E}-09$ & - & $-1.19 \mathrm{E}-09 /-1.19 \mathrm{E}-09 \mu \mathrm{Ci} / \mathrm{mL}$ \\
Tin-113 & $0 / 1$ & $-2.20 \mathrm{E}-10$ & - & $-2.20 \mathrm{E}-10 /-2.20 \mathrm{E}-10 \mu \mathrm{Ci} / \mathrm{mL}$ \\
Yttrium-88 & $0 / 1$ & $9.30 \mathrm{E}-10$ & - & $9.30 \mathrm{E}-10 / 9.30 \mathrm{E}-10 \mu \mathrm{Ci} / \mathrm{mL}$ \\
Zinc-65 & $0 / 1$ & $-7.10 \mathrm{E}-10$ & - & $-7.10 \mathrm{E}-10 /-7.10 \mathrm{E}-10 \mu \mathrm{Ci} / \mathrm{mL}$ \\
Zirconium-95 & $3.99 \mathrm{E}-09$ & - & $3.99 \mathrm{E}-09 / 3.99 \mathrm{E}-09 \mu \mathrm{Ci} / \mathrm{mL}$ \\
& $0 / 1$ & & & \\
EPA903.0MOD & & & & \\
Radium, total alpha-emitting & $0 / 5$ & $2.88 \mathrm{E}-09$ & $4.01 \mathrm{E}-09$ & $-1.80 \mathrm{E}-10 / 7.66 \mathrm{E}-09 \mu \mathrm{Ci} / \mathrm{mL}$ \\
EPA906.0MOD & & & & \\
Tritium & & & & \\
\hline
\end{tabular}

† Number of times analyte was detected compared to the total number of field blanks for the analyte.

- Standard deviation cannot be determined.

Note: If the analyte was not detected in the field blank(s), detection limit information appears in the Mean Result and Minimum/Maximum Results columns.

Table 87. Analytes Detected in Trip Blanks for ES

\begin{tabular}{|c|c|c|c|c|}
\hline Analyte & $\begin{array}{l}\text { Frequency } \\
\text { of Detectiont }\end{array}$ & Mean Result & $\begin{array}{l}\text { Standard } \\
\text { Deviation }\end{array}$ & Minimum/Maximum Results \\
\hline \multicolumn{5}{|l|}{ EPA8260 } \\
\hline Acetone & $0 / 23$ & 7.55 & 2.72 & $3.50 / 10.0 \mu \mathrm{g} / \mathrm{L}$ \\
\hline Acetonitrile & $0 / 1$ & 20.0 & - & $20.0 / 20.0 \mu \mathrm{g} / \mathrm{L}$ \\
\hline Acrolein & $0 / 1$ & 10.0 & - & $10.0 / 10.0 \mu \mathrm{g} / \mathrm{L}$ \\
\hline Acrylonitrile & $0 / 1$ & 5.0 & - & $5.0 / 5.0 \mu \mathrm{g} / \mathrm{L}$ \\
\hline Allyi chloride & $0 / 1$. & 10.0 & - & $10.0 / 10.0 \mu \mathrm{g} / \mathrm{L}$ \\
\hline Benzene & $0 / 23$ & 5.0 & 0.0 & $5.0 / 5.0 \mu \mathrm{g} / \mathrm{L}$ \\
\hline Bromodichloromethane & $0 / 23$ & 5.0 & 0.0 & $5.0 / 5.0 \mu \mathrm{g} / \mathrm{L}$ \\
\hline Bromoform & $0 / 23$ & 5.0 & 0.0 & $5.0 / 5.0 \mu \mathrm{g} / \mathrm{L}$ \\
\hline Bromomethane & $0 / 23$ & 10.0 & 0.0 & $10.0 / 10.0 \mu \mathrm{g} / \mathrm{L}$ \\
\hline Carbon disulfide & $0 / 23$ & 5.0 & 0.0 & $5.0 / 5.0 \mu \mathrm{g} / \mathrm{L}$ \\
\hline Carbon tetrachloride & $0 / 23$ & 5.0 & 0.0 & $5.0 / 5.0 \mu \mathrm{g} / \mathrm{L}$ \\
\hline Chlorobenzene & $0 / 23$ & 5.0 & 0.0 & $5.0 / 5.0 \mu \mathrm{g} / \mathrm{L}$ \\
\hline Chloroethane & $0 / 23$ & 10.0 & 0.0 & $10.0 / 10.0 \mu \mathrm{g} / \mathrm{L}$ \\
\hline Chloroethene & $0 / 23$ & 10.0 & 0.0 & $10.0 / 10.0 \mu \mathrm{g} / \mathrm{L}$ \\
\hline Chloroform & $1 / 23$ & $4.86^{-}$ & $0: 67$ & $180 / 5.0 \mu \mathrm{g} / \mathrm{L}^{-}$ \\
\hline Chloromethane & $0 / 23$ & 10.0 & 0.0 & $10.0 / 10.0 \mu \mathrm{g} / \mathrm{L}$ \\
\hline Chloroprene & $0 / 1$ & 5.0 & - & $5.0 / 5.0 \mu \mathrm{g} / \mathrm{L}$ \\
\hline Dibromochloromethane & $0 / 23$ & 5.0 & 0.0 & $5.0 / 5.0 \mu \mathrm{g} / \mathrm{L}$ \\
\hline 1,2-Dibromo-3-chloropropane & $0 / 1$ & 5.0 & - & $5.0 / 5.0 \mu \mathrm{g} / \mathrm{L}$ \\
\hline 1,2-Dibromoethane & $0 / 1$ & 5.0 & - & $5.0 / 5.0 \mu \mathrm{g} / \mathrm{L}$ \\
\hline Dibromomethane & $0 / 1$ & 5.0 & - & $5.0 / 5.0 \mu \mathrm{g} / \mathrm{L}$ \\
\hline trans-1,4-Dichloro-2-butene & $0 / 1$ & 5.0 & - & $5.0 / 5.0 \mu \mathrm{g} / \mathrm{L}$ \\
\hline Dichlorodifluoromethane & $0 / 1$ & 5.0 & - & $5.0 / 5.0 \mu \mathrm{g} / \mathrm{L}$ \\
\hline
\end{tabular}




\begin{tabular}{|c|c|c|c|c|}
\hline Analyte & $\begin{array}{l}\text { Frequency } \\
\text { of Detectiont }\end{array}$ & Mean Result & $\begin{array}{l}\text { Standard } \\
\text { Deviation }\end{array}$ & Minimum/Maximum Results \\
\hline 1,1-Dichloroethane & $0 / 23$ & 5.0 & 0.0 & $5.0 / 5.0 \mu \mathrm{g} / \mathrm{L}$ \\
\hline 1,2-Dichloroethane & $0 / 23$ & 5.0 & 0.0 & $5.0 / 5.0 \mu \mathrm{g} / \mathrm{L}$ \\
\hline 1,1-Dichloroethylene & $0 / 23$ & 5.0 & 0.0 & $5.0 / 5.0 \mu \mathrm{g} / \mathrm{L}$ \\
\hline cis-1,2-Dichloroethylene & $0 / 23$ & 5.0 & 0.0 & $5.0 / 5.0 \mu g / L$ \\
\hline trans-1,2-Dichloroethylene & $0 / 23$ & 5.0 & 0.0 & $5.0 / 5.0 \mu \mathrm{g} / \mathrm{L}$ \\
\hline Dichloromethane & $0 / 23$ & 3.62 & 1.26 & $2.10 / 5.0 \mu \mathrm{g} / \mathrm{L}$ \\
\hline 1,2-Dichloropropane & $0 / 23$ & 5.0 & 0.0 & $5.0 / 5.0 \mu \mathrm{g} / \mathrm{L}$ \\
\hline cis-1,3-Dichloropropene & $0 / 23$ & 5.0 & 0.0 & $5.0 / 5.0 \mu \mathrm{g} / \mathrm{L}$ \\
\hline trans-1,3-Dichloropropene & $0 / 23$ & 5.0 & 0.0 & $5.0 / 5.0 \mu g / L$ \\
\hline Ethylbenzene & $0 / 23$ & 5.0 & 0.0 & $5.0 / 5.0 \mu \mathrm{g} / \mathrm{L}$ \\
\hline 2-Hexanone & $0 / 23$ & 10.0 & 0.0 & $10.0 / 10.0 \mu \mathrm{g} / \mathrm{L}$ \\
\hline lodomethane & $0 / 1$ & 5.0 & - & $5.0 / 5.0 \mu \mathrm{g} / \mathrm{L}$ \\
\hline Isobutyl alcohol & $0 / 1$ & 100 & - & $100 / 100 \mu \mathrm{g} / \mathrm{L}$ \\
\hline Methacrylonitrile & $0 / 1$ & 5.0 & - & $5.0 / 5.0 \mu \mathrm{g} / \mathrm{L}$ \\
\hline Methyl ethyl ketone & $0 / 23$ & 10.0 & 0.0 & $10.0 / 10.0 \mu \mathrm{g} / \mathrm{L}$ \\
\hline Methyl isobutyl ketone & $0 / 23$ & 12.0 & 0.0 & $12.0 / 12.0 \mu \mathrm{g} / \mathrm{L}$ \\
\hline Methyl methacrylate & $0 / 1$ & 5.0 & - & $5.0 / 5.0 \mu g / L$ \\
\hline Propionitrile & $0 / 1$ & 5.0 & - & $5.0 / 5.0 \mu \mathrm{g} / \mathrm{L}$ \\
\hline Styrene & $0 / 23$ & 5.0 & 0.0 & $5.0 / 5.0 \mu \mathrm{g} / \mathrm{L}$ \\
\hline $1,1,1,2$-Tetrachloroethane & $0 / 1$ & 5.0 & - & $5.0 / 5.0 \mu \mathrm{g} / \mathrm{L}$ \\
\hline $1,1,2,2$-Tetrachloroethane & $0 / 23$ & 5.0 & 0.0 & $5.0 / 5.0 \mu \mathrm{g} / \mathrm{L}$ \\
\hline Tetrachloroethylene & $0 / 23$ & 5.0 & 0.0 & $5.0 / 5.0 \mu \mathrm{g} / \mathrm{L}$ \\
\hline Toluene & $0 / 23$ & 5.0 & 0.0 & $5.0 / 5.0 \mu \mathrm{g} / \mathrm{L}$ \\
\hline $1,1,1-$ Trichloroethane & $0 / 23$ & 5.0 & 0.0 & $5.0 / 5.0 \mu \mathrm{g} / \mathrm{L}$ \\
\hline $1,1,2-$ Trichloroethane & $0 / 23$ & 5.0 & 0.0 & $5.0 / 5.0 \mu \mathrm{g} / \mathrm{L}$ \\
\hline Trichloroethylene & $0 / 23$ & 5.0 & 0.0 & $5.0 / 5.0 \mu \mathrm{g} / \mathrm{L}$ \\
\hline Trichlorofluoromethane & $0 / 1$ & 5.0 & - & $5.0 / 5.0 \mu \mathrm{g} / \mathrm{L}$ \\
\hline 1,2,3-Trichloropropane & $0 / 1$ & 5.0 & - & $5.0 / 5.0 \mu \mathrm{g} / \mathrm{L}$ \\
\hline Unknown & $1 / 1$ & 5.79 & - & $5.79 / 5.79 \mu \mathrm{g} / \mathrm{L}$ \\
\hline Vinyl acetate & $0 / 23$ & 5.0 & 0.0 & $5.0 / 5.0 \mu g^{\prime} / L$ \\
\hline Xylenes & $0 / 23$ & 5.0 & 0.0 & $5.0 / 5.0 \mu \mathrm{g} / \mathrm{L}$ \\
\hline
\end{tabular}

$\dagger$ Number of times analyte was detected compared to the total number of trip blanks for the analyte.

- Standard deviation cannot be determined.

Note: If the analyte was not detected in the trip blank(s), detection limit information appears in the Mean Result and Minimum/Maximum Results columns.

Table 88. Analytes Detected in Trip Blanks for EX

\begin{tabular}{lllll}
\hline Analyte & $\begin{array}{l}\text { Frequency } \\
\text { of Detectiont }\end{array}$ & Mean Result & $\begin{array}{l}\text { Standard } \\
\text { Deviation }\end{array}$ & Minimum/Maximum Results \\
\hline EPA8260A & & & & \\
Acetone & $0 / 25$ & 10.0 & 0.0 & $10.0 / 10.0 \mu \mathrm{g} / \mathrm{L}$ \\
Benzene & $0 / 25$ & 5.0 & 0.0 & $5.0 / 5.0 \mu \mathrm{g} / \mathrm{L}$ \\
Bromodichloromethane & $0 / 25$ & 5.0 & 0.0 & $5.0 / 5.0 \mu \mathrm{g} / \mathrm{L}$ \\
Bromoform & $0 / 25$ & 5.0 & $5.0 / 5.0 \mu \mathrm{g} / \mathrm{L}$ \\
Bromomethane & $0 / 25$ & 5.0 & 0.0 & $5.0 / 5.0 \mu \mathrm{g} / \mathrm{L}$ \\
Carbon disulfide & $0 / 25$ & 5.0 & 0.0 & $5.0 / 5.0 \mu \mathrm{gg} / \mathrm{L}$ \\
Carbon tetrachloride & $0 / 25$ & 5.0 & 0.0 & $5.0 / 5.0 \mu \mathrm{L} / \mathrm{L}$ \\
Chlorobenzene & $0 / 25$ & 5.0 & 0.0 & $5.0 / 5.0 \mu \mathrm{g} / \mathrm{L}$ \\
Chloroethane & $0 / 25$ & 5.0 & 0.0 & $5.0 / 5.0 \mu \mathrm{g} / \mathrm{L}$ \\
Chloroethene & $0 / 25$ & 5.0 & 0.0 & $5.0 / 5.0 \mu \mathrm{g} / \mathrm{L}$ \\
Chloroform & $0 / 25$ & 5.0 & 0.0 & $5.0 / 5.0 \mu \mathrm{g} / \mathrm{L}$ \\
Chloromethane & $0 / 25$ & 5.0 & 0.0 & $5.0 / 5.0 \mu \mathrm{g} / \mathrm{L}$ \\
Dibromochloromethane & $0 / 25$ & 5.0 & 0.0 & $5.0 / 5.0 \mu \mathrm{g} / \mathrm{L}$ \\
1,1-Dichloroethane & $0 / 25$ & 5.0 & 0.0 & \\
& & & &
\end{tabular}




\begin{tabular}{|c|c|c|c|c|}
\hline Analyte & $\begin{array}{l}\text { Frequency } \\
\text { of Detectiont }\end{array}$ & Mean Result & $\begin{array}{l}\text { Standard } \\
\text { Devlation }\end{array}$ & Minimum/Maximum Results \\
\hline $\begin{array}{l}\text { 1,2-Dichloroethane } \\
\text { 1,1-Dichloroethylene } \\
\text { 1,2-Dichloroethylene } \\
\text { Dichloromethane } \\
\text { 1,2-Dichloropropane } \\
\text { cis-1,3-Dichloropropene } \\
\text { trans-1,3-Dichloropropene } \\
\text { Ethylbenzene } \\
\text { 2-Hexanone } \\
\text { Methyl ethyl ketone } \\
\text { Methyl isobutyl ketone } \\
\text { Styrene } \\
\text { 1,1,2,2-Tetrachloroethane } \\
\text { Tetrachloroethylene } \\
\text { Toluene } \\
\text { 1,1,1-Trichloroethane } \\
\text { 1,1,2-Trichloroethane } \\
\text { Trichloroethylene } \\
\text { Unknown } \\
\text { Unknown } 1 \\
\text { Unknown } 2 \\
\text { Unknown } 3 \\
\text { Unknown } 4 \\
\text { Vinyl acetate } \\
\text { Xylenes }\end{array}$ & $\begin{array}{l}0 / 25 \\
0 / 25 \\
0 / 25 \\
0 / 25 \\
0 / 25 \\
0 / 25 \\
0 / 25 \\
0 / 25 \\
0 / 25 \\
0 / 25 \\
0 / 25 \\
0 / 25 \\
0 / 25 \\
0 / 25 \\
0 / 25 \\
0 / 25 \\
0 / 25 \\
0 / 25 \\
9 / 9 \\
13 / 13 \\
13 / 13 \\
3 / 3 \\
2 / 2 \\
0 / 25 \\
0 / 25 \\
\end{array}$ & $\begin{array}{l}5.0 \\
5.0 \\
5.0 \\
10.0 \\
5.0 \\
5.0 \\
5.0 \\
5.0 \\
10.0 \\
10.0 \\
10.0 \\
5.0 \\
5.0 \\
5.0 \\
5.0 \\
5.0 \\
5.0 \\
5.0 \\
12.2 \\
12.8 \\
9.46 \\
12.7 \\
9.0 \\
10.0 \\
10.0 \\
\end{array}$ & $\begin{array}{l}0.0 \\
0.0 \\
0.0 \\
0.0 \\
0.0 \\
0.0 \\
0.0 \\
0.0 \\
0.0 \\
0.0 \\
0.0 \\
0.0 \\
0.0 \\
0.0 \\
0.0 \\
0.0 \\
0.0 \\
0.0 \\
7.71 \\
6.68 \\
4.14 \\
2.89 \\
0.0 \\
0.0 \\
0.0 \\
\end{array}$ & $\begin{array}{l}5.0 / 5.0 \mu \mathrm{g} / \mathrm{L} \\
5.0 / 5.0 \mu \mathrm{g} / \mathrm{L} \\
5.0 / 5.0 \mu \mathrm{g} / \mathrm{L} \\
10.0 / 10.0 \mu \mathrm{g} / \mathrm{L} \\
5.0 / 5.0 \mu \mathrm{g} / \mathrm{L} \\
5.0 / 5.0 \mu \mathrm{g} / \mathrm{L} \\
5.0 / 5.0 \mu \mathrm{g} / \mathrm{L} \\
5.0 / 5.0 \mu \mathrm{g} / \mathrm{L} \\
10.0 / 10.0 \mu \mathrm{g} / \mathrm{L} \\
10.0 / 10.0 \mu \mathrm{g} / \mathrm{L} \\
10.0 / 10.0 \mu \mathrm{g} / \mathrm{L} \\
5.0 / 5.0 \mu \mathrm{g} / \mathrm{L} \\
5.0 / 5.0 \mu \mathrm{g} / \mathrm{L} \\
5.0 / 5.0 \mu \mathrm{g} / \mathrm{L} \\
5.0 / 5.0 \mu \mathrm{g} / \mathrm{L} \\
5.0 / 5.0 \mu \mathrm{g} / \mathrm{L} \\
5.0 / 5.0 \mu \mathrm{g} / \mathrm{L} \\
5.0 / 5.0 \mu \mathrm{g} / \mathrm{L} \\
5.0 / 28.0 \mu \mathrm{g} / \mathrm{L} \\
7.0 / 27.0 \mu \mathrm{g} / \mathrm{L} \\
6.0 / 18.0 \mu \mathrm{g} / \mathrm{L} \\
11.0 / 16.0 \mu \mathrm{g} / \mathrm{L} \\
9.0 / 9.0 \mu \mathrm{g} / \mathrm{L} \\
10.0 / 10.0 \mu \mathrm{g} / \mathrm{L} \\
10.0 / 10.0 \mu \mathrm{g} / \mathrm{L}\end{array}$ \\
\hline
\end{tabular}

† Number of times analyte was detected compared to the total number of trip blanks for the analyte.

Note: If the analyte was not detected in the trip blank(s), detection limit information appears in the Mean Result and Minimum/Maximum Results columns.

Table 89. Analytes Detected in Trip Blanks for GE

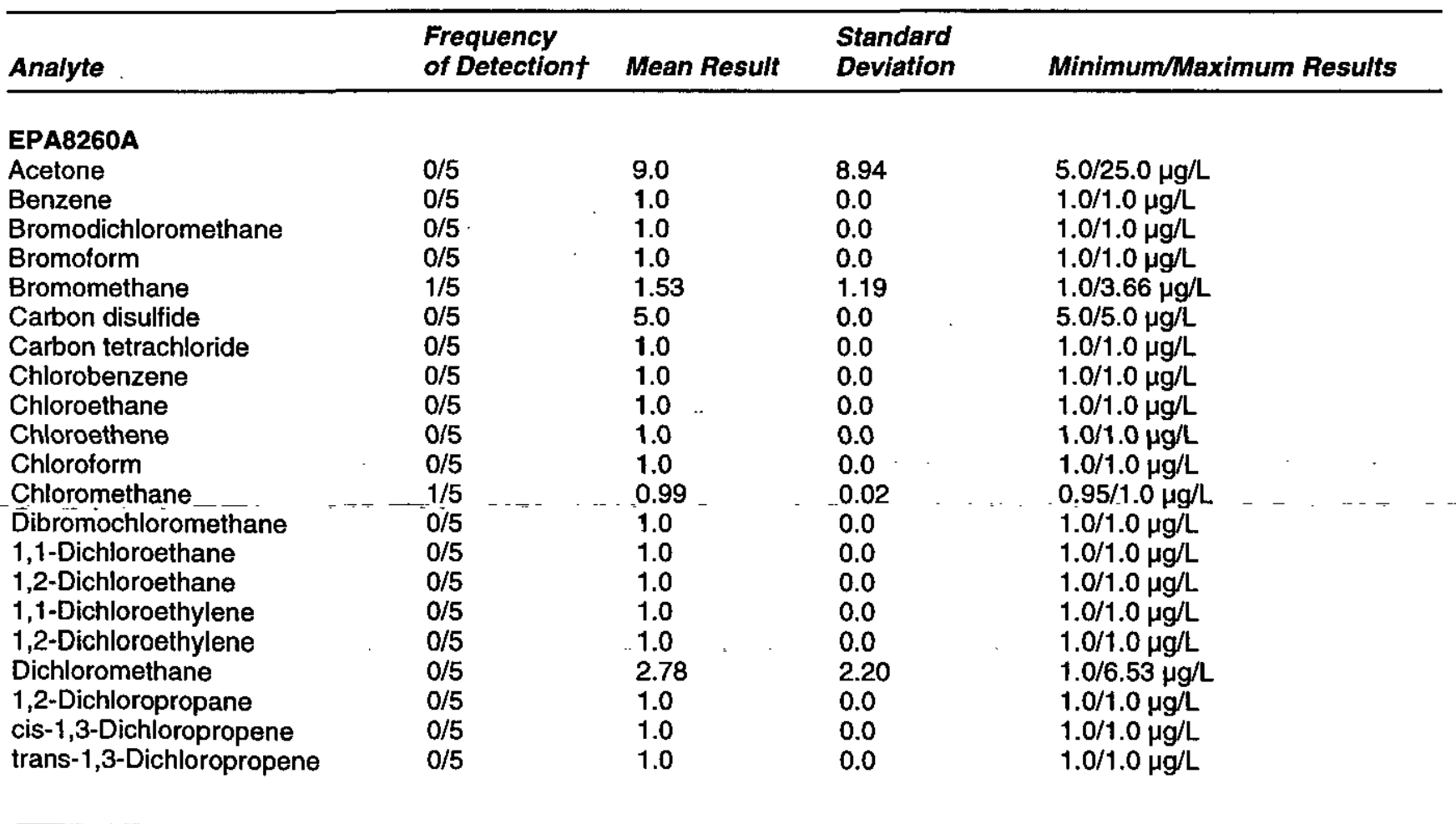




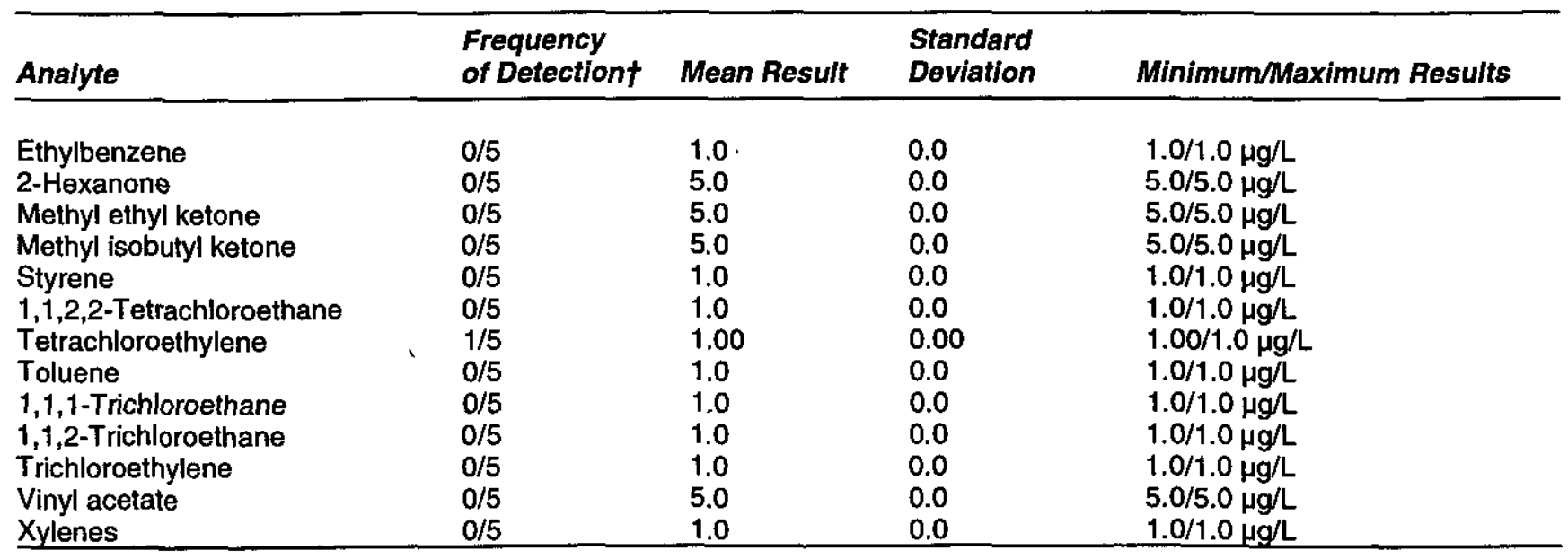

$\dagger$ Number of times analyte was detected compared to the total number of trip blanks for the analyte.

Notes: A value of 0 is reported as 0.0 .

Numbers less than 0.004 are reported as 0.00 .

If the analyte was not detected in the trip blank(s), detection limit information appears in the Mean Result and Minimum/Maximum Results columns.

Table 90. Analytes Detected in Trip Blanks for WA

\begin{tabular}{|c|c|c|c|c|}
\hline Analyte & $\begin{array}{l}\text { Frequency } \\
\text { of Detectiont }\end{array}$ & Mean Result & $\begin{array}{l}\text { Standard } \\
\text { Deviation }\end{array}$ & Minimum/Maximum Results \\
\hline \multicolumn{5}{|l|}{ EPA8260 } \\
\hline Acetone & $0 / 30$ & 7.77 & 2.56 & 2.38/10.0 Hg/L \\
\hline Benzene & $0 / 29$ & 5.0 & 0.0 & $5.0 / 5.0 \mu g / L$ \\
\hline Bromodichloromethane & $0 / 29$ & 5.0 & 0.0 & $5.0 / 5.0 \mu \mathrm{g} / \mathrm{L}$ \\
\hline Bromoform & $0 / 29$ & 5.0 & 0.0 & $5.0 / 5.0 \mu g / L$ \\
\hline Bromomethane & $0 / 30$ & 10.0 & 0.0 & $10.0 / 10.0 \mu \mathrm{g} / \mathrm{L}$ \\
\hline Carbon disulfide & $1 / 30$ & 4.87 & 0.71 & $1.13 / 5.0 \mu g / L$ \\
\hline Carbon tetrachloride & $0 / 29$ & 5.0 & 0.0 & $5.0 / 5.0 \mu \mathrm{g} / \mathrm{L}$ \\
\hline Chlorobenzene & $0 / 29$ & 5.0 & 0.0 & $5.0 / 5.0 \mu \mathrm{g} / \mathrm{L}$ \\
\hline Chioroethane & $0 / 30$ & 10.0 & 0.0 & $10.0 / 10.0 \mu \mathrm{g} / \mathrm{L}$ \\
\hline Chloroethene & $0 / 30$ & 10.0 & 0.0 & $10.0 / 10.0 \mu \mathrm{g} / \mathrm{L}$ \\
\hline Chloroform & $0 / 29$ & 5.0 & 0.0 & $5.0 / 5.0 \mu \mathrm{g} / \mathrm{L}$ \\
\hline Chloromethane & $0 / 30$ & 9.45 & 2.10 & $1.66 / 10.0 \mu \mathrm{g} / \mathrm{L}$ \\
\hline Dibromochloromethane & $0 / 29$ & 5.0 & 0.0 & $5.0 / 5.0 \mu \mathrm{g} / \mathrm{L}$ \\
\hline 1,1-Dichloroethane & $0 / 29$ & 5.0 & 0.0 & $5.0 / 5.0 \mu g / L$ \\
\hline 1,2-Dichloroethane & $0 / 29$ & 5.0 & 0.0 & $5.0 / 5.0 \mu \mathrm{g} / \mathrm{L}$ \\
\hline 1,1-Dichloroethylene & $0 / 29$ & 5.0 & 0.0 & $5.0 / 5.0 \mu \mathrm{g} / \mathrm{L}$ \\
\hline 1,2-Dichloroethylene & $0 / 29$ & 5.0 & 0.0 & $5.0 / 5.0 \mu \mathrm{g} / \mathrm{L}$ \\
\hline Dichloromethane & $2 / 30$ & 4.41 & 2.03 & $1.17 / 10.1 \mu \mathrm{g} / \mathrm{L}$ \\
\hline 1,2-Dichloropropane & $0 / 29$ & 5.0 & 0.0 & $5.0 / 5.0 \mu g / L$ \\
\hline cis-1,3-Dichloropropene & $0 / 29$ & 5.0 & 0.0 & $5.0 / 5.0 \mu \mathrm{g} / \mathrm{L}$ \\
\hline trans-1,3-Dichloropropene & $0 / 29$ & 5.0 & 0.0 & $5.0 / 5.0 \mu \mathrm{g} / \mathrm{L}$ \\
\hline Ethylbenzene & $0 / 29$ & 5.0 & 0.0 & $5.0 / 5.0 \mu \mathrm{g} / \mathrm{L}$ \\
\hline 2-Hexanone & $0 / 29$ & 10.0 & 0.0 & 10.0/10.0 Hg/L \\
\hline Methyl ethyl ketone & $0 / 29$ & 10.0 & 0.0 & $10.0 / 10.0 \mu \mathrm{g} / \mathrm{L}$ \\
\hline Methyl isobutyl ketone & $0 / 29$ & 10.0 & 0.0 & $10.0 / 10.0 \mu \mathrm{g} / \mathrm{L}$ \\
\hline Styrene & $0 / 29$ & 5.0 & 0.0 & $5.0 / 5.0 \mu \mathrm{g} / \mathrm{L}$ \\
\hline $1,1,2,2$-Tetrachloroethane & $0 / 29$ & 5.0 & 0.0 & $5.0 / 5.0 \mu \mathrm{g} / \mathrm{L}$ \\
\hline Tetrachloroethylene & $1 / 29$ & 4.89 & 0.57 & $1.92 / 5.0 \mu \mathrm{g} / \mathrm{L}$ \\
\hline Toluene & $0 / 29$ & 5.0 & 0.0 & $5.0 / 5.0 \mu \mathrm{g} / \mathrm{L}$ \\
\hline $1,1,1$-Trichloroethane & $0 / 29$ & 5.0 & 0.0 & $5.0 / 5.0 \mu \mathrm{g} / \mathrm{L}$ \\
\hline $1,1,2$-Trichloroethane & $0 / 29$ & 5.0 & 0.0 & $5.0 / 5.0 \mu \mathrm{g} / \mathrm{L}$ \\
\hline
\end{tabular}




\begin{tabular}{|c|c|c|c|c|}
\hline Analyte & $\begin{array}{l}\text { Frequency } \\
\text { of Detectiont }\end{array}$ & Mean Result & $\begin{array}{l}\text { Standard } \\
\text { Deviation }\end{array}$ & Minimum/Maximum Results \\
\hline $\begin{array}{l}\text { Trichloroethylene } \\
\text { Vinyl acetate } \\
\text { Xylenes }\end{array}$ & $\begin{array}{l}0 / 29 \\
0 / 29 \\
0 / 29 \\
\end{array}$ & $\begin{array}{l}5.0 \\
10.0 \\
5.0 \\
\end{array}$ & $\begin{array}{l}0.0 \\
0.0 \\
0.0\end{array}$ & $\begin{array}{l}5.0 / 5.0 \mu g / L \\
10.0 / 10.0 \mu g / L \\
5.0 / 5.0 \mu g / L\end{array}$ \\
\hline
\end{tabular}

† Number of times analyte was detected compared to the total number of trip blanks for the analyte.

Note: If the analyte was not detected in the trip blank(s), detection limit information appears in the Mean Result and Minimum/Maximum Results columns.

Table 91. Bailed Wells

\begin{tabular}{ll}
\hline Well & Date \\
\hline CDS IP & $04 / 02 / 98$ \\
& $04 / 03 / 98$ \\
\hline
\end{tabular}

Table 92. Sampled Wells with Metal Casings

\begin{tabular}{llll}
\hline Well & Casing & Well & Casing \\
\hline RWM 1 & Carbon steel & RWM 11 & Carbon steel \\
RWM 3 & Carbon steel & RWM 13B & Carbon steel \\
RWM 4 & Carbon steel & RWM 13C & Carbon steel \\
RWM 5 & Carbon steel & RWM 14B & Carbon steel \\
RWM 6 & Carbon steel & RWM 14C & Carbon steel \\
RWM 7 & Carbon steel & RWM 15B & Carbon steel \\
RWM 8 & Carbon steel & TNX 16D & Stainless steel \\
RWM 9 & Carbon steel & TNX 26D & Stainless steel \\
RWM 10 & Carbon steel & & \\
\hline
\end{tabular}

Table 93. Wolls That Had Turbidity Greater Than 15 NTU

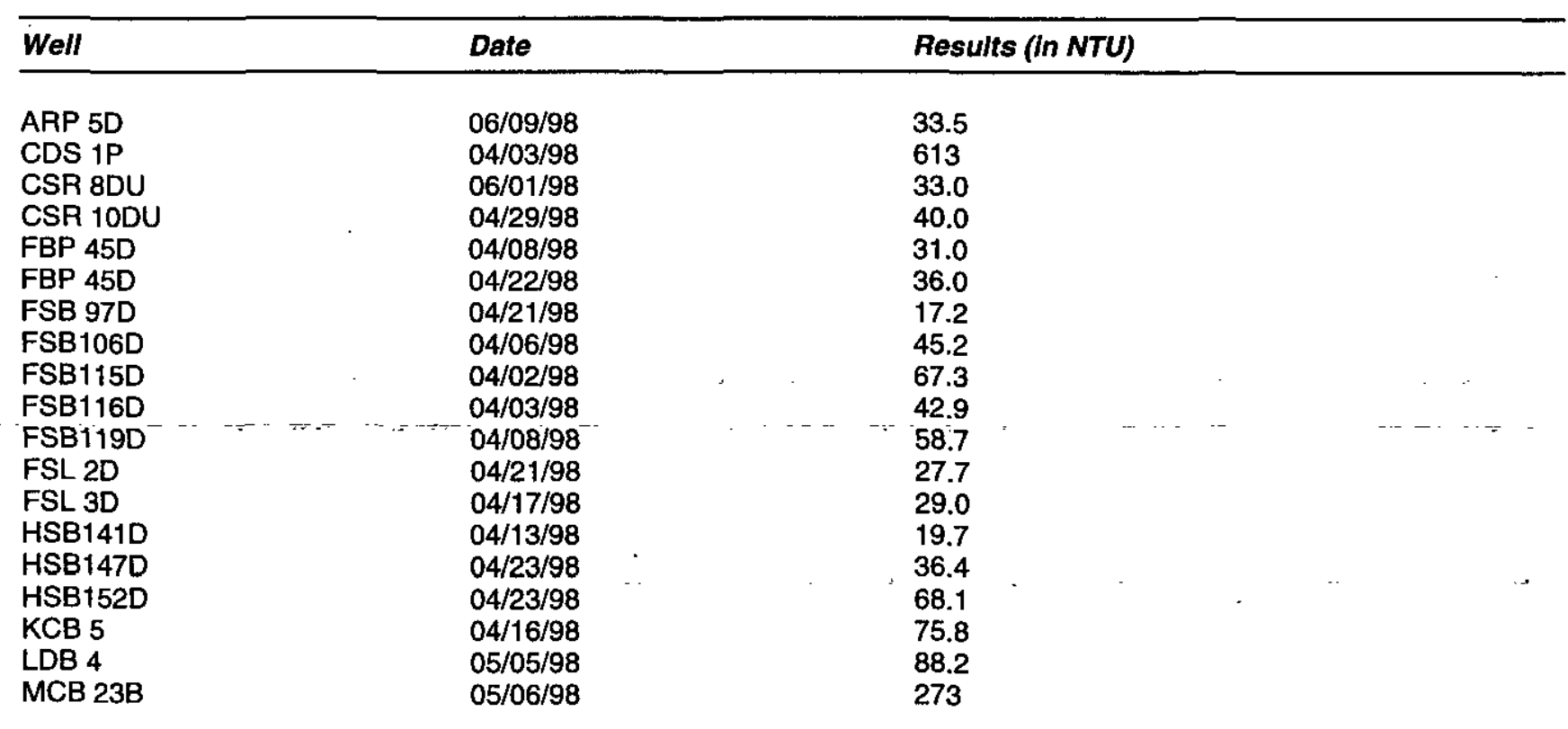




\begin{tabular}{lll}
\hline Well & Date & Results (in NTU) \\
\hline & & \\
MCB 23B & $05 / 20 / 98$ & 30.2 \\
MCB 25B & $05 / 07 / 98$ & 37.1 \\
MCB 25B & $05 / 20 / 98$ & 34.5 \\
PRP 3 & $06 / 02 / 98$ & 47.7 \\
RAC 1 & $06 / 30 / 98$ & 38.5 \\
RWM 14C & $06 / 08 / 98$ & 26.1 \\
TNX 26D & $04 / 20 / 98$ & 356 \\
\hline
\end{tabular}

Table 94. Analyses Not Performed by ES

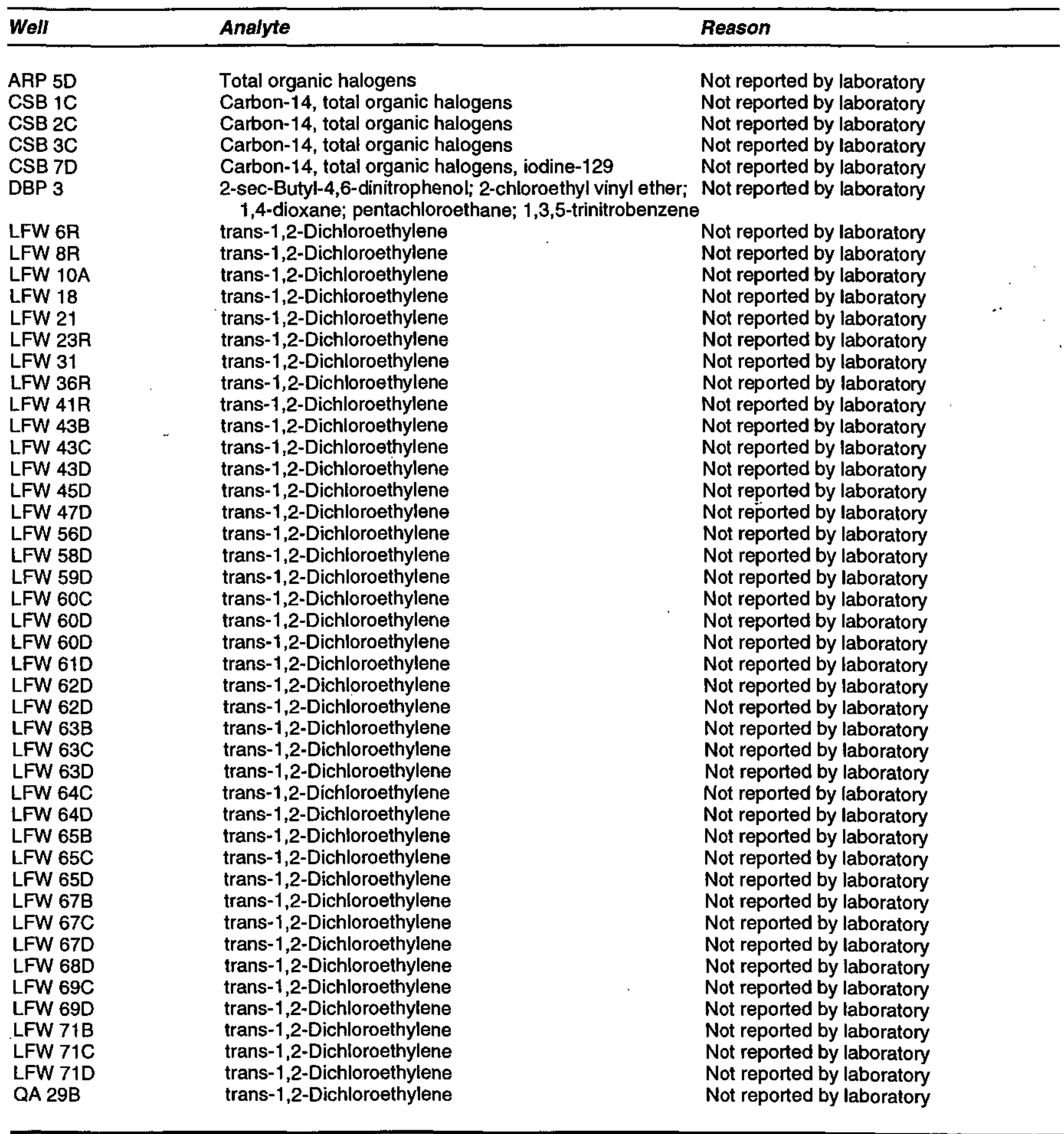




\begin{tabular}{lll}
\hline Well & Analyte & Reason \\
\hline QA 35B & Carbon-14, total organic halogens & Not reported by laboratory \\
QA 36B & Carbon-14, total organic halogens & Not reported by laboratory \\
QA 31B & trans-1,2-Dichloroethylene & Not reported by laboratory \\
TNX 27D & Chloride, fluoride, total phosphates & Not reported by laboratory \\
TRP171B & & Canceled \\
TRP174B & TCL volatiles & Not reported by laboratory \\
TRP191B & TCL volatiles & Not reported by laboratory \\
\hline
\end{tabular}

Table 95. Analyses Not Performed by EX

\begin{tabular}{lll}
\hline Well & Analyte & Reason \\
\hline CSR 1ODU & Metals & Canceled because of high turbidity \\
CSR 11DL & Metals & Canceled because of high turbidity \\
MCB 23B & Metals & Canceled because of high turbidity \\
MCB 25B & Metals & Canceled because of high turbidity \\
QA 71B & Metals & Canceled because of high turbidity \\
\hline
\end{tabular}

Table 96. Analyses Not Performed by GE

\begin{tabular}{lll}
\hline Well & Analyte & Reason \\
\hline FSB106D & Metals & Canceled because of high turbidity \\
QA 79B & Endrin ketone & TCL volatiles canceled \\
QA 80B & Endrin ketone & TCL volatiles canceled \\
RAC 1 & Endrin ketone & TCL volatiles canceled \\
RAC 2 & Endrin ketone & TCL volatiles canceled \\
RAC 3 & Endrin ketone & TCL volatiles canceled \\
RAC 4 & Endrin ketone & TCL volatiles canceled \\
\hline
\end{tabular}

Table 97. Analyses Not Performed by WA

\begin{tabular}{lll}
\hline Well & Analyte & Reason \\
\hline BGO 14CR & Alkalinity $\left(\mathrm{as} \mathrm{CaCO}_{3}\right)$ & Not reported by laboratory \\
HSB 85A & Alkalinity $\left(\mathrm{as} \mathrm{CaCO}_{3}\right)$ & Not reported by laboratory \\
HSB 85B & Alkalinity $\left(\mathrm{as} \mathrm{CaCO}_{3}\right)$ & Not reported by laboratory \\
HSB 85C & Alkalinity $\left(\mathrm{as} \mathrm{CaCO}_{3}\right)$ & Not reported by laboratory \\
KCB 5 & Metals & Canceled because of high turbidity \\
RAC 1 & Tritium & Not reported by laboratory \\
\hline
\end{tabular}




\section{Site Index}

Table 98 provides information about sites, locations, and well series. Some site names and locations were not available.

Table 98. Sites and Locations by Well Series

\begin{tabular}{|c|c|c|}
\hline Well Series & Site & Location \\
\hline $\begin{array}{l}\mathrm{ABP} \\
\mathrm{ABW} \\
\mathrm{AC}\end{array}$ & $\begin{array}{l}\text { A-Area Metals Buming Pit } \\
\text { A Area near Firing Range } \\
\text { A-Area Cluster Perimeter Wells and M-Area Plume Definition } \\
\text { Wells }\end{array}$ & $\begin{array}{l}\text { South of the burning/rubble pits } \\
\text { North of Road D-1 and east of Road 1-7 }\end{array}$ \\
\hline $\begin{array}{l}\mathrm{ACB} \\
\mathrm{AMB} \\
\mathrm{AOB}\end{array}$ & $\begin{array}{l}\text { A-Area Coal Pile Runoff Containment Basin } \\
\text { Metallurgical Laboratory Seepage Basin } \\
\text { Motor Shop Oil Basin }\end{array}$ & $\begin{array}{l}\text { Southeast of A Area } \\
\text { At the eastem edge of A Area } \\
\text { At the south edge of A Area near NPDES } \\
\text { Outfall A-14 }\end{array}$ \\
\hline $\begin{array}{l}\text { ARP } \\
\text { ASB }\end{array}$ & $\begin{array}{l}\text { A-Area Burning/Rubble Pits and A-Area Ash Pile } \\
\text { Savannah River Laboratory Seepage Basins }\end{array}$ & $\begin{array}{l}\text { West of Road D, south of A Area } \\
\text { Across the road from the Savannah River } \\
\text { Technology Center (formerly the Savannah } \\
\text { River Laboratory) }\end{array}$ \\
\hline $\begin{array}{l}\text { BGO } \\
\text { BGX } \\
\text { BRD } \\
\text { BRR }\end{array}$ & $\begin{array}{l}\text { Burial Grounds Perimeter } \\
\text { E-Area Vaults/Burial Ground Expansion } \\
\text { Road A Chemical Basin (Baxley Road) } \\
\text { Burma Road Rubble Pit }\end{array}$ & $\begin{array}{l}\text { Southern E Area } \\
\text { Northem E Area } \\
\text { East of D Area } \\
\text { Southwest of F Area }\end{array}$ \\
\hline CBR & $\begin{array}{l}\text { N-Area (Central Shops) Burning/Rubble Pit south of the Ford } \\
\text { Building Seepage Basin }\end{array}$ & Southeast of N Area \\
\hline $\begin{array}{l}\text { CCB } \\
\text { CDB }\end{array}$ & $\begin{array}{l}\text { C-Area Coal Pile Runoff Containment Basin } \\
\text { C-Area Disassembly Basin }\end{array}$ & Southeast of C Area \\
\hline CDS & 108-3C Bioremediation Facility & Near the C-Area reactor building \\
\hline CMP & Chemicals, Metals, and Pesticides Pits & $\begin{array}{l}\text { West of Road C, approximately two miles } \\
\text { southeast of N Area }\end{array}$ \\
\hline $\begin{array}{l}\text { CRP } \\
\text { CSB } \\
\text { CSR } \\
\text { CSO }\end{array}$ & $\begin{array}{l}\text { C-Area Burning/Rubble Pit } \\
\text { C-Area Reactor Seepage Basins } \\
\text { N-Area (Central Shops) Burning/Rubble Pits } \\
\text { Fire Department Training Facility }\end{array}$ & $\begin{array}{l}\text { Southeast of N Area } \\
\text { Southern C Area, west of the reactor building } \\
\text { North of N Area } \\
\text { Southeast portion of N Area }\end{array}$ \\
\hline $\begin{array}{l}\text { DBP } \\
\text { DCB }\end{array}$ & $\begin{array}{l}\text { D-Area Buming/Rubble Pits } \\
\text { D-Area Coal Pile Runoff Containment Basin and Ash Basins }\end{array}$ & $\begin{array}{l}\text { Western portion of D Area } \\
\text { South (containment basin) and southwest } \\
\text { (ash basins) of D Area }\end{array}$ \\
\hline DIW & D-Area Coal Pile Runoff Containment Basin and Ash Basins & $\begin{array}{l}\text { South (containment basin) and southwest } \\
\text { (ash basins) of D Area }\end{array}$ \\
\hline $\begin{array}{l}\text { DOB } \\
\text { DOL }\end{array}$ & $\begin{array}{l}\text { D-Area Oil Seepage Basin } \\
\text { D-Area Oil Seepage Basin }\end{array}$ & $\begin{array}{l}\text { North of D Area } \\
\text { North of D Area }\end{array}$ \\
\hline FAB & F-Area Ash Basin 288-1 Groundwater Quality Assessment & $\begin{array}{l}\text { East of F Area and south of the F-Area } \\
\text { acid/caustic basin }\end{array}$ \\
\hline $\begin{array}{l}\text { FAL } \\
\text { FBP } \\
\text { FCA } \\
\text { FCB } \\
\text { FET } \\
\text { FEX }\end{array}$ & $\begin{array}{l}\text { F-Area A Line } \\
\text { F-Area Buming/Rubble Pits } \\
\text { F-Area Canyon Building } \\
\text { F-Area Coal Pile Runoff Containment Basin } \\
\text { F-Area Effluent Treatment Cooling Water Basin } \\
\text { F-Area Seepage Basins Remediation Extraction Wells }\end{array}$ & $\begin{array}{l}\text { Adjacent to the F-Area canyon building } \\
\text { North of Road } C \text { and west of F Area } \\
\text { Central F Area } \\
\text { Southeast of F Area } \\
\text { South of F Area }\end{array}$ \\
\hline $\begin{array}{l}\text { FIN } \\
\text { FNB } \\
\text { FRB }\end{array}$ & $\begin{array}{l}\text { F-Area Seepage Basins Remediation Injection Wells } \\
\text { Old F-Area Seepage Basin } \\
\text { F-Area Retention Basin }\end{array}$ & $\begin{array}{l}\text { South of Road C } \\
\text { North of F Area }\end{array}$ \\
\hline $\begin{array}{l}\text { FSB } \\
\text { FSL } \\
\text { FSS }\end{array}$ & $\begin{array}{l}\text { F-Area Seepage Basins } \\
\text { F-Area Inactive Process Sewer Line } \\
\text { F-Area Sludge Land Application Site }\end{array}$ & $\begin{array}{l}\text { South of Road C; east of Road C-4 } \\
\text { South of Road C; east of Road C-4 }\end{array}$ \\
\hline
\end{tabular}




\begin{tabular}{ll}
\hline Well Series & Site \\
\hline FST & $\begin{array}{l}\text { Savannah River Ecology Laboratory Flowing Springs Site } \\
\text { FTF }\end{array}$ \\
F-Area Tank Farm \\
GBW & Background Well near Hawthorne Fire Tower \\
HAA & H-Area Tank Farm Groundwater Operable Unit \\
HAP & H-Area Auxiliary Pump Pit \\
HCA & H-Area Canyon Building \\
HCB & H-Area Coal Pile Runoff Containment Basin \\
HET & H-Area Effluent Treatment Cooling Water Basin \\
HEX & H-Area Seepage Basins Remediation Extraction Wells \\
HHP & HP-52 Outfall Area \\
HIN & H-Area Injection Tank \\
HWW & H-Area Injection Wells \\
HMD & Hazardous Waste/Mixed Waste Disposal Facility \\
HR3 & Old H-Area Retention Basin \\
HRB & H-Area Retention Basin \\
HSB & H-Area Seepage Basins \\
HSL & H-Area Inactive Process Sewer Line \\
HSS & H-Area Sludge Land Application Site \\
HTF & H-Area Tank Farm \\
HWP & Warner's Pond Outfall Area \\
HWS & Hazardous Waste Storage Facility \\
HXB & Ford Building Seepage Basin \\
&
\end{tabular}

IDB Interim Waste Technology Site Characterization Wells; Site B IDP Interim Waste Technology Site Characterization Wells, Site P IDQ Interim Waste Technology Site Characterization Wells, Site $Q$

$\mathrm{KAB}$

KBP

$\mathrm{KCB}$

KDB

KDT

KRB

KRP

KSB

KSM

KSS

LAC

LAW

LBP

LCO

LDB

LDS

$\overline{L F W}$

LRP

LSB

MCB

MSB
K-Area Ash Basin

K-Area Bingham Pump Outage Pit

K-Area Coal Pile Runoff Containment Basin

K-Area Disassembly Basin

K-Area Diesel Tank

K-Area Retention Basin

K-Area Burning/Rubble Pit

K-Area Reactor Seepage Basin

K-Area Tritium Sump

K-Area Sludge Land Application Site

L-Area Acid/Caustic Basin

L-Area Research Wells

L-Area Bingham Pump Outage Pit

L-Area Oil and Chemical Basin

L-Area Disassembly Basin

108-3L Bioremediation Facility

Sanitary Landfill

L-Area Burning/Rubble Pit

L-Area Reactor Seepage Basin

Miscellaneous Chemical Basin

M-Area Hazardous Waste Management Facility (HWMF) and MArea Plume Definition Wells
West of Road 2-1.1F

At the east end of H Area near the coal pile runoff containment basin

East of $\mathrm{H}$ Area

Southwest of $\mathrm{H}$ Area

East of Road 4

South of Road E

Near the H-Area seepage basins

Northwest of the burial ground expansion

Southeast of the intersection of Roads 4 and $E$

Southeast of the intersection of Roads 4 and $E$

Southwest of $\mathrm{H}$ Area and the intersection of Roads 4 and $E$

Extends from the southwest portion of $\mathrm{H}$ Area to north of the $\mathrm{H}$-Area seepage basins

Southeast of $\mathrm{H}$ Area

At the south end of $\mathrm{H}$ Area

Northwest of N Area

In the southeast portion of N Area

Two miles northeast of $\mathrm{H}$ Area

South of B Area

North of Highway 125

Southwest of K Area

West of K Area, between the K-Area ash basin and reactor seepage basin

Central K Area, north of the disassembly basin

Northwest of K Area

West of $\mathrm{K}$ Area

Near the K-Area process water storage tank Southeast of K Area

North of Road B and east of Road B-2.13

South of L Area

South of Road C

Northwest of $L$ Area

Southeast of $L$ Area, adjacent to the L-Area oil and chemical basin

West of Road D near the A-Area metals buming pit

South of A Area and M Area and west of Road D (HWMF). 


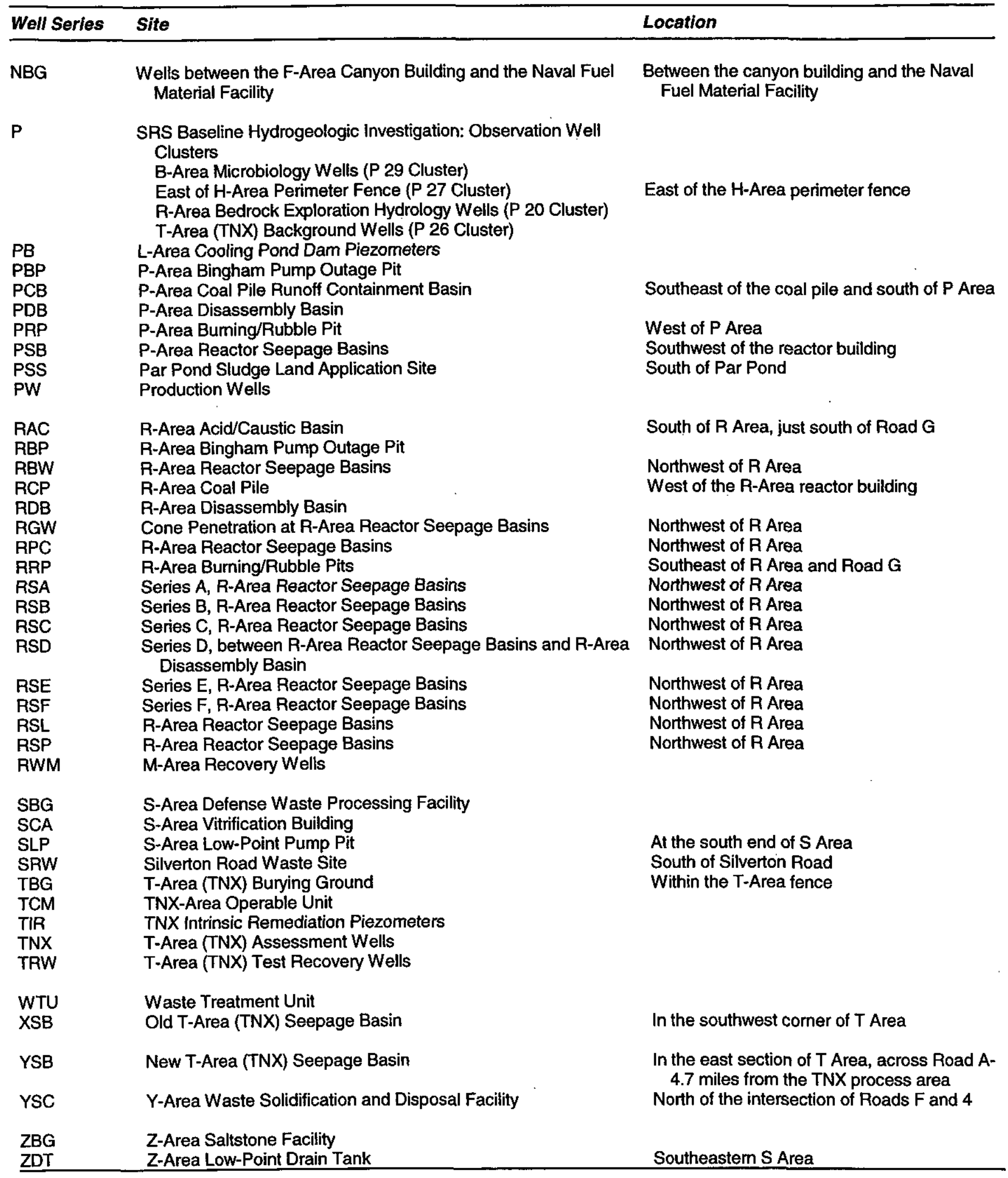




\section{SITE HISTORY}

Geographical descriptions in the text are based on true north rather than SRS grid coordinates.

The following sections describe facilities at approximately 100 locations within designated areas at SRS. The sections are arranged in the following order:

- acid/caustic basins

- burning/rubble, rubble, and metals burning pits

- coal pile runoff containment basins, ash basins, and coal piles

- disassembly basins

- seepage and retention basins

- operating buildings and facilities

- plume monitoring

- radioactive waste storage and disposal facilities

- sanitary landfill and interim sanitary landfill

- sludge application sites

- other sites

\section{Acid/Caustic Basins}

The acid/caustic basins in F Area, H Area, K Area, L Area, P Area, and R Area are unlined earthen pits (approximately 50 by 50 by 7 feet deep). These pits received dilute sulfuric acid and sodium hydroxide solutions used to regenerate ion-exchange units in power plant water purification processes at the reactor and separations areas in the center of SRS. The basins allowed mixing and neutralization of the dilute solutions before their discharge to nearby streams.

The basins were constructed between 1952 and 1955. They are uncovered, and most are dry except during periods of prolonged precipitation. The R-Area and L-Area basins were abandoned in 1964 and 1968, respectively. The other basins remained in service until 1982, when the water purification systems either were shut down or modernized. However, the $\mathrm{H}$-Area basin continued to receive steam condensate from a hose box and drainage from a chemical pad until the basin was abandoned in 1985. During July through September 1993, the F-, H-, K-, and P-Area basins were dewatered, vegetation was removed and disposed of, the basins were filled with compacted soil from the Burma Road clay pit, a grass cover was established, and the fences were reinstalled.

\section{Burning/Rubble, Rubble, and Metals Burning Pits}

From 1951 to 1973 , burnable wastes-such as paper, wood, plastics, rubber, oil, degreasers, and drummed solvents - were received and burned monthly in one or more of the burning/rubble pits in the following areas: $A$, C, D, F, K, L, N, P, and R. In 1973, waste no longer was burned at the pits, which were covered with a layer of soil. Rubble wastes-including paper, wood, cans, concrete, and empty galvanized-steel barrels and drumsthen were disposed of in the pits until they reached capacity and were covered with soil. All burning/rubble pits were inactive by 1981, and all are covered except the R-Area pit, which has not been backfilled. Lithiumaluminum alloy, aluminum pieces, metal drums, other metal scraps, and plastic pipe were deposited and burned periodically in the A-Area metals burning pit, beginning about 1952. In 1974, the solid materials remaining on the site were covered with soil, and the pit was regraded. The site is inactive. 
The Burma Road rubble pit consists of two excavated earthen pits that may contain paint cans, fluorescent light fixtures, metal, concrete, lumber, poles, and glass. Unknown quantities of refuse were deposited here from approximately 1973 through 1983 . The pit is inactive and has been covered with soil.

\section{Coal Pile Runoff Containment Basins, Ash Basins, and Coal Piles}

Electricity and steam at SRS are generated by burning coal. Coal piles originally existed in the following areas: $A, C, D, F, H, K, L, P$, and $R$. The facilities generally contained a 90-day reserve of coal that was not rotated. During long-term exposure to the environment, chemical and biological oxidation of sulfur compounds in coal resulted in the formation of sulfuric acid.

The R-Area coal pile was removed in 1964, and the L-Area coal pile was removed in 1968. To achieve compliance with the National Pollutant Discharge Elimination System (NPDES) permit issued in 1977, coal pile runoff containment basins in A Area and D Area were completed in October 1978, and basins in C Area, F Area, $\mathrm{H}$ Area, $\mathrm{K}$ Area, and $\mathrm{P}$ Area were completed in March 1981. The coal piles in C Area and $F$ Area were removed in 1985. In 1991, the K-Area coal pile was reduced to a 2-inch base, and 75 percent of the P-Area coal pile was removed.

Currently, rainwater runoff from the remaining coal piles in $A, D, H, K$, and $P$ Areas flows into the coal pile runoff containment basins via gravity flow ditches and sewers. The basins allow mixing of the runoff and its seepage into the subsurface, thus preventing the entry of large surges of low-pH runoff into surface streams. The basins in $C$ and $F$ Areas also still collect runoff, although no coal remains at either location. Ash sluice water from the D-Area and K-Area powerhouses has been discharged to the D-Area ash basins and the K-Area ash basin, respectively, since 1951.

\section{F-Area Ash Basin}

The F-Area ash basin was monitored for the first time during second quarter 1994.

\section{R-Area Coal Pile}

Two wells were installed in 1990 inside the boundaries of the former coal storage area, originally for groundwater assessment in relation to the R-Area coal pile.

\section{Disassembly Basins}

The disassembly basins, also called fuel and target storage basins, are concrete-lined, open tanks of water next to the reactor rooms inside the reactor buildings in C, K, L, P, and R Areas. Irradiated assemblies (reactor fuel and target rods) were rinsed and stored in the basins prior to their shipment to the separations areas. Some radioactivity was transferred to the basin water from leaks in porous components and as a liquid or oxide corrosion film on the irradiated components.

Sand filters were used to remove radioactive particulates from the disassembly basin water. The filtered water was circulated through deionizers to remove additional constituents and was purged periodically through regenerated deionizers to the reactor seepage basins.

\section{Seepage and Retention Basins}

Seepage, retention, and settling basins have been used at SRS to store or dispose of wastewater from various operations. Seepage and retention basins in the following areas are monitored: $A, C, F, H, K, L, M, N, P, R, T$, and the Savannah River Laboratory.

\section{C-Area Reactor Seepage Basins}

These basins have received low-level radioactive purge water from the disassembly basin since 1957. 


\section{F-Area Seepage Basins and Inactive Process Sewer Line}

Beginning in 1955, the F-Area seepage basins received F-Area wastewater containing low-level radioactivity and chemicals, including chromium, mercury, nitric acid, and sodium hydroxide. Clay caps were completed in 1991 when the basins were closed.

\section{Ford Building Seepage Basin}

The Ford Building seepage basin received low-level radioactive wastewater from Ford Building operations (repairing heat exchangers) from 1964 to January 1984.

\section{H-Area Retention Basins}

A small, unlined earthen retention basin (the old $\mathrm{H}$-Area retention basin) was used from 1955 to 1973 to provide temporary emergency storage for cooling water from the chemical separations process that contained radionuclides and possible trace quantities of chemicals.

A larger, rubber-lined retention basin replaced the original basin in 1973 and still is in use for receipt of diverted cooling water or tank farm stormwater runoff.

\section{H-Area Seepage Basins and Inactive Process Sewer Line}

Starting in 1955, the $\mathrm{H}$-Area seepage basins received wastewater from $\mathrm{H}$ Area containing low-level radioactivity and chemicals, including nitric acid, mercury, and sodium hydroxide. Basin 3 has been inactive since 1962. Basins 1,2, and 4 operated from 1980 until they were taken out of service in the fourth quarter of 1988. Clay caps were completed early in 1991 when the basins were closed.

\section{K-Area Reactor Seepage Basin}

This basin has received low-level radioactive purge water from the disassembly basin since 1957.

\section{L-Area Reactor Seepage Basin}

This basin has received low-level radioactive purge water from the disassembly basin since 1957.

\section{M-Area Hazardous Waste Management Facility}

The unlined M-Area settling basin, in operation from 1958 until 1985, received wastewater containing metalcleaning solvents, depleted uranium, and other chemicals and metals from fuel fabrication processes in $M$ Area. Because surface water flowed from this basin, it is classified as a settling basin rather than a seepage basin. Water from the basin flowed through an overflow ditch to Lost Lake, a shallow upland depression. A seepage area formed adjacent to the ditch and Lost Lake. The M-Area hazardous waste management facility comprises the settling basin, overflow ditch, seepage area, and Lost Lake. A closure cap was completed on the basin during 1989/1990.

Since the beginning of a full-scale recovery system for groundwater remediation in April 1985, groundwater flow has changed markedly near this facility, and changes over time in concentrations of analytes are difficult to interpret. See the Plume Monitoring section of this chapter for more information on remediation.

\section{Metallurgical Laboratory Seepage Basin}

The Metallurgical Laboratory seepage basin received wastewater effluent from the Metallurgical Laboratory building from 1956 until 1985. Wastewater released to the basin consisted of small quantities (5 to 10 gallons per day) of laboratory wastes-mostly rinse water-from metallographic sample preparation (degreasing, cleaning, etching) and corrosion testing of stainless steel and nickel-based alloys. Noncontact cooling water (approximately 900 gallons per day) also was discharged. The basin has been dewatered, backfilled, and capped with low-permeability clay.

\section{Now T-Area (TNX) Seepage Basin}

The new TNX seepage basin replaced the old TNX seepage basin and operated from 1980 to 1988 .

\section{Site Index}




\section{Old F-Area Seepage Basin}

The old F-Area seepage basin, the first seepage basin constructed in F Area, was used for disposal of wastewater from the canyon building from November 1954 until May 1955, when it was abandoned. During operation, the seepage basin received a variety of wastewaters, including evaporator overheads, laundry wastewater, and an unknown amount of chemicals. For three months in 1969, spent nitric acid solutions used to etch depleted uranium were discharged to the basin. In 1984, low-level contaminated water was released to the basin.

\section{Old T-Area (TNX) Seepage Basin}

The old TNX seepage basin received waste from pilot-scale tests conducted at TNX from 1958 to 1980 . In 1981, the basin wall was breached and the impounded water was drained into the adjacent wetlands. The basin then was backfilled with a sand and clay mixture, and the top was capped with clay.

\section{P-Area Reactor Seepage Basins}

These basins have received low-level radioactive purge water from the P-Area disassembly basin since 1957.

\section{R-Area Reactor Seepage Basins}

On November 8, 1957, an experimental fuel element failed during a calorimeter test in the emergency section of the R-Area disassembly basin. Following this incident, the original seepage basin received approximately $2,700 \mathrm{Ci}$ of nonvolatile beta activity, including strontium- 90 and cesium-137, each of which has a half-life of about 30 years. Much of the released radioactivity was contained in that basin, which was backfilled in December 1957. Five more basins were put into operation in 1957 and 1958 to assist in containing the radioactivity.

In 1960, Basins 2 through 5 were closed and backfilled. The ground surface above Basins 1 through 5 was treated with herbicide and covered with asphalt. In addition, a kaolinite cap and dike were constructed over and around Basin 1 and the northwest end of Basin 3 to minimize lateral movement of the radioactive contamination. Basin 6, which received water directly from the disassembly basin from 1960 until 1964, was backfilled in 1977.

\section{Savannah River Laboratory Seepage Basins}

The Savannah River Laboratory seepage basins received low-level radioactive laboratory wastewater through underground drains until they were taken out of service in October 1982. Two basins were put into operation in 1954; one more was added in 1958 and another in 1960 to provide additional holding capacity.

An exception to the practice of discharging only low-level alpha or beta-gamma wastewater was made in 1971, when $0.68 \mathrm{Ci}$ of curium from a leaking separator pit in the Savannah River Laboratory radioactive waste tanks was disposed of in the basins. Approximately 34 million gallons of wastewater were discharged to the basins during their operating life.

\section{Operating Buildings and Facilities}

\section{Defense Waste Processing Facility (S-Area Vitrification Building)}

The DWPF, also known as the S-Area vitrification building or S-Area canyon, contains the process and auxiliary equipment to incorporate high-level radioactive waste into leach-resistant glass. The facility began radioactive operations in 1996.

\section{F-Area Canyon Building and A-Line Uranium Recovery Facility}

At the canyon building, irradiated product from the reactors is dissolved using nitric acid, and the desired radionuclides are separated from fission products. At the A-Line uranium recovery facility, adjacent to the canyon building, uranium oxide is produced from uranyl nitrate. 


\section{F-Area Effluent Treatment Cooling Water Basin}

The F-Area effluent treatment cooling water basin receives diverted cooling water from the separations processes. The cooling water is sent from the basin to the F-Area and $\mathrm{H}$-Area effluent treatment facility (ETF) if contaminated or to a permitted outfall if uncontaminated. The ETF, on the south side of $H$ Area, was placed in service in 1988 to treat wastewater formerly sent to the F-Area and H-Area seepage basins. In addition to cooling water, it also receives separations area stormwater runoff and condensed overheads from the evaporators in the tank farms. The treatment facility removes hazardous and radioactive contaminants from these low-level liquid wastes and concentrates them for immobilization as saltstone.

\section{H-Area Auxiliary Pump Pit}

The $\mathrm{H}$-Area auxiliary pump pit facility will pump high-level radioactive sludge and precipitate from the $\mathrm{H}$-Area tank farm to the S-Area low-point pump pit en route to the vitrification facility. When the pumps are shut down, this facility will collect the solution in a temporary holding tank via gravity flow lines.

\section{H-Area Canyon Building}

As in F Area, materials from the reactors are dissolved at the canyon building, and the desired radionuclides are separated from waste products.

\section{H-Area Effluent Treatment Cooling Water Basin}

For more information, see the F-Area Effluent Treatment Cooling Water Basin section.

\section{K-Area Tritium Sump}

A single well, installed in 1992, monitors the water table just west of the K-Area reactor. The well was placed near the K-Area process water storage tank, which stores water collected in sumps within the K-Area reactor building. Tritium activity in this sump water has been reported at greater than $5 \mathrm{Ci} / \mathrm{mL}$.

\section{N-Area Hazardous Waste Storage Facility}

Building $645-\mathrm{N}$ of the hazardous waste storage facility has been in service since $1983,645-2 \mathrm{~N}$ since 1987 , and $645-4 \mathrm{~N}$ since 1984. Buildings $645-\mathrm{N}$ and $645-4 \mathrm{~N}$ contain hazardous waste, and building $645-2 \mathrm{~N}$ contains mixed waste (a mixture of low-level radioactive waste and hazardous waste). Wastes are stored inside the buildings in drums placed on diked concrete floors designed to contain liquid spills.

\section{Naval Fuel Material Facility}

The Naval Fuel Material Facility was used to produce HEU (highly enriched uranium) for naval reactors until shutdown in 1989. Monitoring wells in the NBG series are located between the canyon building and the Naval Fuel Material Facility.

\section{S-Area Facilities}

S-Area contains several facilities for processing high-level radioactive waste from the F-Area and H-Area tank farms into borosilicate glass solidified within stainless steel canisters. The glass is stored temporarily in specially designed storage buildings within S Area. Eventual permanent disposal is expected to be in an offsite federal geologic repository.

\section{S-Area Low-Point Pump Pit}

The S-Area low-point pump pit receives high-level radioactive sludge and precipitate from the $\mathrm{H}=\mathrm{Area}$ tank farm and pumps it to the defense waste processing facility (DWPF) vitrification building; it also receives waste being recycled from the vitrification building back to the tank farm. As at the $\mathrm{H}$-Area auxiliary pump pit, when the pumps are shut down, the sludge and precipitate remaining in the line drain back into a temporary holding tank via gravity flow lines. 


\section{Z-Area Low-Point Drain Tank}

The Z-Area low-point drain tank facility receives low-level radioactive salt solution from the H-Area tank farm and pumps it to the Z-Area salt solution holding tank. When the H-Area pump is shut down, the low-point drain tank can collect the solution remaining in the lines via gravity flow.

\section{Z-Area Saltstone Manufacturing and Disposal Facility}

The Z-Area saltstone manufacturing and disposal facility processes and permanently disposes of low-level radioactive salt solution supernatant from the underground storage tanks at $F$ Area and $H$ Area and from ETF concentrate.

The facility began radioactive operations in June 1990. In November 1992, a tank in the Z-Area saltstone manufacturing and disposal facility overflowed, and a portion of the liquid leaked from the building into a storm drain. Approximately 2 gallons of solution reached a drainage pipe that flows into a series of sedimentation basins and eventually into McQueen Branch. Sediment samples showed small amounts of cesium-137 exceeding those amounts observed in the Savannah River, but within the activity ranges in site streams.

\section{Plume Monitoring}

\section{A Area and M Area}

In addition to the groundwater monitoring conducted at specific locations in A Area and $M$ Area, numerous plume definition wells also monitor a 5-square-mile area to assess the extent of volatile organic contamination. The first plume definition wells were installed soon after discovery of the contamination in June 1981.

The plume definition well network extends from the region north of SRTC, between Road 1 and the SRS boundary, south to wells near the miscellaneous chemical basin and the metals burning pit, and from Tims Branch in the east toward the Silverton Road waste site in the west. The plume encompasses approximately three square miles and consists primarily of trichloroethylene, tetrachloroethylene, and 1,1,1-trichloroethane.

\section{Separations and Waste Management Areas}

A number of wells were installed in the separations areas in 1951 and 1952 . These wells, which range from approximately 15 to 90 feet in depth, are used to measure water table elevations and monitor for radioactive constituents (gross alpha, nonvolatile beta, and tritium) in the groundwater in and around F Area and H Area. They have steel casings that could affect the metal concentrations in the water.

\section{Radioactive Waste Storage and Disposal Facilities}

\section{Burial Grounds}

The burial grounds have been used for storage and disposal of radioactive solid waste produced at SRS or shipped from other facilities since 1952. The original area, known as the old burial ground, contains low-level alpha and beta-gamma trenches, intermediate-level beta-gamma trenches, and alpha waste trenches. As the trenches were filled, they were covered with soil. When the old burial ground was filled in 1974, operations moved to the adjacent low-level radioactive waste disposal facility (LLRWDF).

The sections of the LLRWDF currently being operated, known as the Solid Waste Disposal Facility (SWDF), contain trenches for only radioactive waste. Concrete vaults, known as the E-Area vaults, have been constructed east and north of the LLRWDF for disposal of solid radioactive waste. The first waste was placed there in September 1994.

Mixed waste storage building 643/29E, within the boundaries of the LLRWDF, has been in use since March 1987. The adjacent mixed waste storage building, 643/43E, was completed in July 1995 , and the facility began receiving waste later that same month.

Until 1965, transuranic (TRU) waste was placed in plastic bags and cardboard boxes and buried in earthen trenches. Between 1965 and 1974, lower level TRU waste was buried unencapsulated in trenches, and higher level TRU waste was buried in retrievable concrete containers or encapsulated in concrete. Since 1974, TRU 
wastes contaminated with greater than $0.01 \mathrm{Ci} / \mathrm{g}$ have been stored in watertight containers on concrete pads with monitoring sumps. TRU waste storage pads $1-19$ are on the FFA's list of RCRA-regulated units.

Since mid-1984, newly generated low-level beta-gamma waste has been placed in metal boxes or metal drums. Currently, it is disposed of in engineered trenches and covered with at least 4 feet of soil. Some wastes that do not have forms that are easily placed in containers are disposed of in shallow land-burial slit trenches.

Mixed wastes stored or disposed of within the old burial ground and portions of the LLRWDF include cadmium, lead, mercury, and tritiated pump oil. Some of the waste is contained in welded stainless steel containers or metal drums and stored within concrete cylinders. Degraded radioactive organic solvents and tritiated pump oil have been stored in 22 underground storage tanks in the old burial ground. In addition, two areas of the old burial ground were used for incineration of solvents.

The burial ground complex, comprising the old burial ground, solvent storage tanks S01-S22, and portions of the LLRWDF, is monitored by the following:

Burial Ground Expansion (E-Area Vaults)-This site is located in the northern section of E Area and is monitored by the BGX well series.

Hazardous Waste/Mixed Waste Disposal Facility-This site is northwest of the burial ground expansion and is monitored by the HMD well series.

Old Burial Ground-The old burial ground is in the southern portion of E Area and is monitored by wells in the $B G$ and $B G O$ well series.

Radioactive Waste Burial Ground-The LLRWDF, which includes the mixed waste management facility (MWMF), is monitored by wells in the BGO well series.

\section{Tank Farms}

Liquid radioactive wastes are stored and processed at the tank farms, which comprise subsurface tanks containing high-level aqueous radioactive wastes in the form of sludges, supernatant liquid of varying salt concentrations, and saltcake. Approximately 129 million liters of waste are stored in the tanks.

The high-level liquid waste volume is reduced in the tank farm evaporators. Certain tanks are used for pretreatment of the wastes before they are processed at the DWPF into saltstone (low-level waste) or a glass form (high-level waste). As described earlier, saltstone manufacturing and disposal is ongoing; vitrification was tested during 1995, and the DWPF began production operations in 1996. Pretreatment processes at the tank farms include in-tank precipitation and extended sludge processing.

More information about the function of the tank farms may be found in previous sections of this chapter, including the discussions of the F-Area effluent treatment cooling water basin, the H-Area auxiliary pump pit, $S$ Area, the S-Area low-point pump pit, the DWPF, the Z-Area low-point drain tank, and the Z-Area saltstone manufacturing and disposal facility.

Because of restrictions on the disposal of purge water, monitoring wells at the tank farms are bailed and not purged.

F-Area Tank Farm-The F-Area tank farm comprises 22 subsurface tanks. In 1961, Tank 8 was overfilled, causing soil and possible groundwater contamination.=

H-Area Tank Farm-The H-Area tank farm comprises 29 subsurface tanks. In 1960, Tank 16 leaked an unknown quantity (a few tens of gallons to a few hundred gallons) of waste into the soil. The tank's remaining waste was removed by 1972.

Several other releases of waste from $\mathrm{H}$-Area tanks have occurred, including a spill of approximately 100 gallons at Tank 13 in 1983. In 1989, approximately 500 pounds of volume-reduced waste leaked from a transfer line at 
Tank 37. The leak sites have been cleaned up or stabilized to prevent the spread of contamination. Both the FArea and $\mathrm{H}$-Area sites are being monitored for gross alpha, nonvolatile beta, and tritium.

\section{Sanitary Landfill and Interim Sanitary Landfill}

The sanitary landfill began receiving waste from office, cafeteria, and industrial activities during 1974. Materials such as paper, plastics, rubber, wood, cardboard, rags, metal debris, pesticide bags, empty cans, carcasses, asbestos in bags, and sludge from the site's wastewater treatment plant are placed in unlined trenches and covered daily with soil or a fabric substitute. The original section of the landfill and its southern expansion, with a total area of approximately 54 acres, have been filled. Operations at the portion of approximately 16 acres known as the northern expansion, or the interim sanitary landfill, were discontinued in November 1994.

Sanitary landfills are intended to receive only nonradioactive, nonhazardous waste. However, until October 1992, some hazardous wastes (specifically, solvent-laden rags and wipes used for cleaning, decontamination, and instrument calibration) were buried in portions of the original 32-acre landfill and its southern expansion.

\section{Sludge Application Sites}

These sites originally were the subject of a research program using domestic sewage sludge to reclaim borrow pits and to enhance forest productivity at SRS. In 1980, sludge was applied to the following application sites: K Area, Kato Road, Lower Kato Road, Orangeburg, PAR Pond, Road F, Sandy (Lucy), Second PAR Pond Borrow Pit, and 40-Acre Hardwood. After sludge was applied to the sites, hardwoods and pines were planted to quantify the effectiveness of the sludge as a fertilizer and soil conditioner.

Sludge from Aiken and Augusta municipal wastewater treatment plants was applied to the following sites: F Area, H Area, Kato Road, Lower Kato Road, Orangeburg, Road F, Sandy (Lucy), Second PAR Pond Borrow Pit, and 40-Acre Hardwood. Wastewater sludge was applied to the K Area and PAR Pond sites in 1981 and 1988. Revegetating of the sites is continuing.

In November 1993, groundwater monitoring was discontinued at the Kato Road, Lower Kato Road, Orangeburg, Road F, Sandy (Lucy), and 40-Acre Hardwood sites because they have not received applications of sewage sludge since 1981, and historical monitoring results show no impact from sludge applications. Monitoring was canceled after first quarter 1994.

\section{H-Area Sanitary Sludge Land Application Site}

Sewage sludge from SRS sanitary wastewater treatment plants was disposed of at this 13-acre site southeast of H Area from November 1990 to May 1992.

\section{K-Area and PAR Pond Sludge Land Application Sites (Formerly K-Area Borrow Pit and PAR Pond Borrow Pit Sites)}

In 1981, sludge from Aiken and Augusta municipal wastewater treatment plants was applied to the K-Area and PAR Pond borrow pits. In 1988, the N-Area sanitary sewage sludge lagoon was closed, and the lagoon sludge was applied to the K Area and PAR Pond borrow pits. In 1989, the K-Area location (now called the K-Area sludge land application site) was declared a RCRAVERCLA unit because of the presence of chlordane in the lagoon sludge applied to the site.

\section{Other Sites}

\section{B-Area Gas Station}

Elevated benzene, which could be the result of old underground gasoline or diesel storage tanks, has been detected near B Area. EMS has inspected the area and believes there may be two underground storage tanks southeast of B Area. The first suspected tank appears to be at an abandoned gas station between Kato Road and Road C-2. The second appears to be an old diesel tank in front of a storage and laboratory facility. 


\section{Baseline Hydrogeologic Investigation Observation Well Clusters}

Wells in the $P$ series that provide baseline hydrogeologic investigation data are located in numerous locations across SRS.

\section{Chemicals, Metals, and Pesticides Pits}

The chemicals, metals, and pesticides pits were used from 1971 to 1979 to dispose of oil in drums, organic solvents, and small amounts of pesticides and metals. In 1984, the pits were excavated to form two trenches, backfilled, and capped. During excavation, most of the contaminated material (liquid in original drums, free liquid placed in drums during excavation, and contaminated soil) was moved to the hazardous waste storage facility.

\section{D-Area Oil Disposal Basin}

The D-Area oil disposal basin was constructed in 1952 and received waste oil products from $D$ Area that were unacceptable for incineration in the powerhouse boilers. These waste oils may have contained hydrogen sulfide, chlorinated organics, or other chemicals. In 1975, the oil basin was removed from service and backfilled with soil.

\section{Interim Waste Technology Site Characterization Wells}

Characterization wells monitor interim waste technology sites $B, L, Q$, and $P$.

\section{K-Area Diesel Tank Spill}

Following the discovery in 1989 of a leaking buried diesel supply line, most of the diesel-contaminated soil was removed from this area except where continued excavation would have jeopardized the structural integrity of an underground storage tank.

\section{L-Area Acid/Caustic Basin and L-Area Oil and Chemical Basin}

From 1961 to 1979 , the L-Area oil and chemical basin received small quantities of radioactive oil and chemical waste that could not be discharged to effluent streams, regular seepage basins, or the 200 Areas' waste management systems. The waste came from throughout SRS, primarily from the reactor areas and the contaminated-equipment workshop through a pipeline known to have leaked. The basin has been inactive since 1979.

\section{M-Area Recovery Wells}

The RWM well series identifies the M-Area recovery wells. The first wells were installed in 1982 and 1983, with pumps added in 1985. Additional wells were installed in 1985, 1990, 1993, and 1996. The RWM wells pump contaminated groundwater to air strippers, which remove volatile organic compounds from the water before it is returned to the ground.

\section{Miscellaneous Chemical Basin}

The miscellaneous chemical basin, in operation by 1956, was closed and graded in 1974. No records document the materials disposed of at this location. However, soil gas investigations revealed volatile organics in the nearsurface soils at the basin. It is assumed that the site was used for disposal of waste solvents, liquid chemical wastes, and possibly waste oil. The basin is inactive.

\section{Motor Shop Oil Basin}

This unlined basin was placed in service in 1977 to receive liquid effluent from the Motor Shop, including trace quantities of engine oil, grease, kerosene, ethylene glycol, and soap. All waste passed through an oil skimmer prior to discharge into the basin. All discharges to the basin were terminated in August 1983. The basin is inactive but collects rainwater during periods of heavy precipitation.

\section{N-Area Diesel Spill Hazardous Waste Storage Facility}

The tanks have been filled with inert material, and the pipelines have been disconnected at this site. 


\section{N-Area Fire Department Training Facility}

The fire department training facility, also known as the $\mathrm{N}$-Area burnable-oil basin, is a shallow pit surrounded by an 18-inch-high asphalt dike. It was used from 1979 to 1982 by the SRS Fire Department to train personnel in the use of firefighting equipment. After this time, the area was excavated and backfilled.

\section{N-Area Hydrofluoric Acid Spill}

It is uncertain whether a spill occurred at the hydrofluoric acid spill area or if contaminated soil or containers were buried there. The spill or burial occurred prior to 1970 , and an identification sign is the only evidence that material was released.

\section{Production Wells}

The PW series wells are production wells scattered across SRS.

\section{Road A (Baxley Road) Chemical Basin}

The Road A chemical basin is reported to have received miscellaneous radioactive and chemical aqueous waste, but no records of the materials disposed of at the basin are available. The basin was closed and backfilled in 1973. The BRD well series is being monitored for environmental-screening constituents only.

\section{Silverton Road Waste Site}

The Silverton Road waste site, south of Silverton Road, was used for disposal of metal shavings, construction debris, tires, drums, tanks, and miscellaneous other items. The startup date is unknown, and no records of waste disposal activities were kept. Operations at this location ended in 1974, and the waste material is covered with soil and vegetation.

\section{TNX Burying Ground}

The TNX burying ground was created to dispose of debris from an experimental evaporator that exploded at T Area in 1953. The buried material included contaminated conduit, tin, drums, structural steel, and depleted uranium. Although most of this material was excavated and sent to the LLRWDF between 1980 and 1984, an estimated $27 \mathrm{~kg}$ of uranyl nitrate remains buried at this location. See the New TNX Seepage Basin section for more information on the unit. 
NOTES

Site Index 


\section{Glossary}

Also see p. B-1 for abbreviations and qualifiers used in the results tables in Appendix B.

2,4-D. 2,4-Dichlorophenoxyacetic acid.

absolute difference. The unsigned result of the subtraction of any two numbers.

accuracy. The degree of agreement between an observed value and an accepted reference value or a measure of the over- or underestimation of reported concentrations.

advisory range. A range of.acceptable analytical results established by the provider of known samples.

aerated sample. Groundwater sample supplied or charged with air. Aeration can occur naturally or during well pumping.

aliquot. A portion of a sample being used for analysis.

analysis qualifier. See qualifier.

analyte. Analyzed constituent.

analytical detection limit. The lowest reasonably accurate concentration of an analyte that can be detected. This value varies depending on the method, instrument, and dilution used.

APHA. American Public Health Association.

Appendix IX. A list of constituents specified by Appendix IX in the Code of Federal Regulations, Title 40, Part 264 (EPA, 1991d). Analysis for Appendix IX constituents is required by the Resource Conservation and Recovery Act (RCRA) under specified conditions.

associated samples. Samples analyzed by a laboratory in the same batch with field or laboratory blanks.

ASTM. American Society for Testing and Materials.

bail. To remove water from a well by lowering a container into the water, allowing it to fill with water, and removing it from the well.

bias qualifier. See qualifier.

blank. Aliquot of deionized water generated by laboratory or sampling personnel and analyzed like a groundwater sample. See equipment blank, field blank, laboratory blank, and trip blank.

blank spike. An organic-free water sample spiked with target analytes, extracted, and analyzed with the regular samples for organic parameters to monitor the performance of all steps in the analysis process.

blind replicate. A second sample taken from a well at the same time as the primary sample and sent to the laboratory for analysis as an unknown.

BNA. Base/neutral and acid extractables. Groups of organic compounds analyzed as part of the Appendix IX and Priority Pollutants suites; also, a group of compounds that can be analyzed by EPA Method 8270.

Bq/L. Becquerels per liter. A measurement of radioactivity. 
cation. Positively charged ion.

CERCLA. Comprehensive Environmental Response, Compensation, and Liability Act, commonly known as Superfund.

certified value. The known concentration of an analyte in a referenced sample.

CFR. Code of Federal Regulations. Sections of this annual document contain EPA standards and regulations for environmental monitoring.

chain-of-custody record. A form that documents the collection, transport, analysis, and disposal of well samples.

common analyses. Common parameters tested for, and generally found, in drinking water.

comparability. An evaluation made by confirming that the laboratories used the same standardized procedures for sample preparation and analysis, that the reporting units are the same, and that similar detection and quantitation limits were obtained.

completeness. An evaluation based on a comparison of the wells scheduled for sampling to the wells sampled, also a comparison of the requested analyses to the analytical data received.

deionized water. Water from which all charged species or ionizable organic and inorganic salts have been removed.

detection limit. See analytical detection limit.

dilution factor. The mathematical factor by which a sample is diluted to bring the concentration of an analyte in the sample within the analytical range of an instrument (e.g., $1 \mathrm{~mL}$ sample $+9 \mathrm{~mL}$ solvent $=1: 10$ dilution, or a dilution factor of 10 ).

DL. See analytical detection limit.

DNAPL. Dense nonaqueous phase liquid.

DOE. U.S. Department of Energy.

drinking water standards. Federal primary and secondary drinking water standards, as set forth by the EPA.

duplicate. Duplicate sample; an aliquot of a primary sample.

duplicate result. A result obtained from identical analyses performed on more than one aliquot of a primary sample.

DWS. See drinking water standards.

E. A code letter used in the analytical data tables that signifies exponential notation (e.g., $3.4 \mathrm{E}+03=3.4 \times 10^{3}=$ 3,400).

EM. EPD/EMS Laboratory at SRS.

EMAX Laboratories. EMAX Laboratories, Inc., of Torrance, CA.

EMS. The Environmental Monitoring Section of the Environmental Protection Department at SRS.

Environmental Physics. Environmental Physics, Inc., of Charleston, SC (subcontractor for General Engineering). 
environmental-screening analyses. A group of analyses that forms the core of the EPD/EMS Groundwater Monitoring Program each quarter. See the Sample Scheduling section of this report for a complete list of constituents.

EPA. U.S. Environmental Protection Agency.

EPD. Environmental Protection Department at SRS.

EPD/EMS. Environmental Protection Department's Environmental Monitoring Section at SRS.

EQL. See estimated quantitation limit.

equipment blank. A sample of deionized water that is opened at the sampling location and poured or pumped through the sampling device. Equipment blanks are used to identify possible contaminants in the sampling equipment.

\section{ES. See QST Environmental.}

estimated quantitation limit (EQL). The lowest concentration reliably achieved within specified limits of precision and accuracy during routine laboratory operating conditions. The EQL is generally $5 \times$ to $10 \times$ the method detection limit (MDL); however, it may be nominally chosen within these guidelines to simplify data reporting. For many analytes, the EQL analyte concentration is selected as the lowest nonzero standard in the calibration curve.

\section{EX. See EMAX Laboratories.}

Fibers/L. Fibers per liter. A unit of measurement for asbestos.

field blank. A sample container of deionized water sent to a laboratory under an alias as a quality control check.

field qualifier. See sample interference field qualifier. Due to space limitations, sample interference field qualifiers are referred to as field qualifiers in the analytical results tables in Appendix B.

flagging criteria. Criteria established to help determine the relative concentration and testing frequency for analytes. See the Flagging Criteria section of this report for further information.

gamma PHA. A group of analyses performed to determine activities of gamma-emitting radionuclides.

GC VOA. Gas chromatographic volatile organics analyses. Also used to refer to a group of volatile organic compounds that can be analyzed by gas chromatography.

GCMS VOA. Gas chromatograph/mass spectrometer volatile organics analyses. Also used to refer to a group of volatile organic compounds analyzed by gas chromatography and mass spectrometry methods.

\section{GE. See General Engineering.}

General Engineering. General Engineering Laboratories of Charleston, SC.

\section{GP. See Environmental Physics.}

halogen. Any of the elements of the halogen family, which consists of fluorine, chlorine, bromine, iodine, and astatine.

herbicides/pesticides. A suite of analyses. See the Sample Scheduling section of this report for further information. 
holding time. The length of time during which an analysis of a sample can be reliably performed. Holding times vary depending on which constituents are being analyzed.

interlaboratory comparisons. Comparisons conducted between two or more laboratories.

intralaboratory comparisons. Comparisons conducted within a single laboratory.

ion. An isolated electron or positron or an atom or molecule that has acquired a net electric charge by the loss or gain of one or more electrons.

laboratory blank. Deionized water or solvent sample generated by the laboratory. One blank is analyzed with each batch of samples as an in-house check of analytical procedures and equipment.

laboratory control sample. A deionized water sample that is spiked with the target analyte, digested, and analyzed with the regular samples for inorganic parameters to monitor the performance of all steps in the analysis process.

\section{MA. See Microanalytical Laboratories.}

major ions. A group of analyses performed in the EPD/EMS Groundwater Monitoring Program to determine the concentrations of calcium, magnesium, potassium, and silica ions and the alkalinity of a sample.

matrix spike. A known quantity of a target analyte added to at least $5 \%$ of the samples prior to sample preparation to evaluate the effect of the sample matrix on the analytical procedure.

MDL. See.method detection limit.

mean. The arithmetic mean; a single number that typifies a set of numbers.

method detection limit (MDL). A reproducible analyte- and method-specific detection limit: the minimum concentration of a substance that can be measured and reported with $99 \%$ confidence that the analyte concentration is greater than zero.

mg/L. Milligrams per liter.

$\mu \mathrm{Ci}$. Microcurie; unit of radioactivity equivalent to $3.7 \times 10^{4}$ disintegrations per second.

$\mu \mathrm{Ci} / \mathrm{mL}$. Microcuries per milliliter.

$\mu g / L$. Micrograms per liter.

$\boldsymbol{\mu S} / \mathrm{cm}$. Microsiemens per centimeter, equivalent to micromhos per centimeter. The unit of conductance across two points, used as the measure of specific conductance in analytical data tables.

Microanalytical Laboratories. Microanalytical Laboratories, Inc., of Gainesville, FL (subcontractor for QST Environmental).

modifier. See qualifier.

MRD. Mean relative difference. See the Quality Control Samples section of this report for further information.

msl. Mean sea level.

NTU. Nephelometric turbidity units. The standard unit of turbidity measurement. 
null hypothesis. A statement, which can be tested statistically, of no difference in a characteristic of a population or distribution.

organic. A chemical compound based on carbon chains or rings and containing hydrogen with or without oxygen, nitrogen, or other elements.

PCB. Polychlorinated biphenyl.

pCi. Picocurie; a unit of radioactivity equivalent to $3.7 \times 10^{-2}$ disintegrations per second.

pCi/L. Picocuries per liter.

pCi/mL. Picocuries per milliliter.

piezometer. An instrument used to measure the potentiometric surface of groundwater. Also, a well designed for this purpose.

plume. A volume of contaminated air or water originating at a point-source emission (e.g., a smokestack) or a waste source (e.g., a hazardous-waste disposal site).

potentiometric surface. The surface to which water in an aquifer would rise by hydrostatic pressure if unconfined.

precision. A measure of the repeatability of a measurement, evaluated from the results of duplicate samples and splits.

primary laboratory. A laboratory having a contract with EPD/EMS to perform a specific set of analyses; a primary laboratory may subcontract this work to other laboratories.

purge. To remove water from a well prior to sampling, generally by pumping or bailing. Under the EPD/EMS Groundwater Monitoring Program, two well volumes generally are purged before sampling.

QA. Quality assurance.

QC. Quality control.

QST Environmental. QST Environmental, of Gainesville, FL.

qualifier. A code used to convey additional information about an analytical result. Also called a modifier. Specific types include analysis, bias, and result qualifiers. See Appendix B for additional information.

radioisotopes. Radioactive isotopes.

radionuclide. A nuclide at an unstable, high-energy level that seeks a more stable, low-energy level by emitting particles of energy. Through these emissions, the nuclear configuration decays to simpler nuclides.

RCRA. See Resource Conservation and Recovery Act.

RCRA site. Solid-waste management unit under RCRA regulation.

RDL. See reference detection limit.

Recra LabNet Philadelphia. Recra LabNet Philadelphia, of Lionville, PA.

reference detection limit (RDL). The detection limit chosen to allow comparison of several analyses with different detection limits. For the purposes of this report, the individual detection limits of at least $90 \%$ of the analyses are 
less than the reference detection limit. See the Quality Control Samples section of this report for further information.

relative percent difference (RPD). A commonly used estimate of precision when only two samples are available. Precision is the agreement among a set of replicate measurements without assumption of the true value. Precision is estimated by means of duplicate analyses.

replicate. Replicate sample. Used in this report to mean only those duplicate samples sent to the laboratory as unknowns. See blind replicate.

representativeness. The quality of exhibiting the average properties of the population being sampled.

Resource Conservation and Recovery Act (RCRA). Federal legislation that regulates the transport, treatment, and disposal of solid and hazardous wastes.

result qualifier. See qualifier.

RFI Program. RCRA Facility Investigation Program. EPA-regulated investigation of a solid-waste management unit with regard to its potential impact on the environment.

RFI/RI Program. RCRA Facility Investigation/Remedial Investigation Program. At SRS, an expansion of the RFI Program that includes CERCLA and hazardous-substance regulations.

RPD. See relative percent difference.

run date. The calendar date denoting when an analysis is performed.

sample interference field qualifier. See also field qualifier. This describes interferences encountered during sample collection that could affect analytical resuits. It is used to qualify analytical data based on field condition.

sample quantitation limit (SQL). The sample-specific EQL, which is the EQL multiplied by factors of concentration, dilution, aliquot size, and percent solids.

sample-specific EQL (SSEQL). The EQL multiplied by factors of concentration, dilution, aliquot size, and percent solids. Also called the SQL.

sample-specific MDL (SSMDL). The MDL multiplied by factors of concentration, dilution, aliquot size, and percent solids. For radiological analyses it is known as the sample-specific minimum detectable concentration.

sampling device. Anything used in sampling, especially portable (nondedicated) pumps and bailers. Possible source of sample contamination if not cleaned thoroughly between uses.

SCDHEC. South Carolina Department of Health and Environmental Control.

seepage basin. An excavation that receives wastewater. Designed to prevent overflow or surface runoff.

settling basin. A temporary holding basin (excavation) that receives wastewater.

significance of probability. The probābility of observing a statistical value as significant as, or more significant than, the value actually observed.

site custodian. WSRC employee responsible for a site being monitored.

SQL. See sample quantitation limit.

SRL. Savannah River Laboratory at SRS; now Savannah River Technology Center (SRTC). 
SRP. Savannah River Plant; now Savannah River Site (SRS).

SRS. Savannah River Site.

SRTC. Savannah River Technology Center.

STORET. EPA national database for storage and retrieval of water quality information and monitoring data; some of the qualifiers listed in the Analytical Results section of this report (Appendix B) are based on STORET codes.

surrogate. An organic compound similar in composition and test performance to one of the analytes of interest; known quantities are used in an analysis as a quality assurance measure.

tank farm. An installation of interconnected underground tanks used for storage of high-level radioactive liquid wastes.

Thermo NUtech. Thermo NUtech, of Oak Ridge, TM (subcontractor for Recra LabNet Philadelphia and QST Environmental).

TL. See Triangle Laboratories.

TM. See Thermo NUtech.

TOC. Top of casing. The elevation of the casing at the top of a well; used as a reference for water-level measurements.

Triangle Laboratories. Triangle Laboratories, Inc., of Durham, NC (subcontractor for Environmental Science \& Engineering).

trip blank. A sample container of deionized water that is transported to the well sample location, treated as a well sample, and sent to the laboratory for analysis; trip blanks are used to check for contamination resulting from transport, shipping, and site conditions.

t-test. Statistical method used to determine if the means of groups of observations are equal.

turbidity. A measure of the concentration of sediment or suspended particles in solution.

U. Unclassified.

USDWS. U.S. Public Health Service drinking water standard.

volatile organic compounds. A broad range of organic compounds, commonly halogenated, that vaporize at ambient, or relatively low, temperatures (e.g., acetone, benzene, chloroform, and methyl alcohol).

\section{WA. See Recra LabNet Philadelphia.}

well volume. The volume of water between the well water surface and the bottom of the screen; the volume of water standing inside the well casing.

wellhead. The top of a well.

WSRC. Westinghouse Savannah River Company. 
NOTES 


\section{References}

American Public Health Association, American Water Works Association, and Water Pollution Control Federation. 1985. Standard Methods for the Examination of Water and Wastewater, 16th edition. Washington, DC.

American Society for Testing and Materials. 1992. Annual Book of ASTM Standards, Volume 11.02. Philadelphia, PA.

Environmental Protection Agency. 1977. National Interim Primary Drinking Water Regulations, EPA-570/9-76-003. Washington, DC.

Environmental Protection Agency. 1980. Prescribed Procedures for Measurement of Radioactivity in Drinking Water, EPA-600/4-80-032 (method 901.1). Cincinnati, OH.

Environmental Protection Agency. 1982. Methods for Organic Chemical Analysis of Municipal and Industrial Wastewater, PB83-201798 (method 625). Cincinnati, OH.

Environmental Protection Agency. 1983. Methods for Chemical Analysis of Water and Wastes, PB84-128677 (methods 200.7, 282.2, 310.1, 350.1, 351.2, 413.1, 418.1, and 420.1). Cincinnati, $\mathrm{OH}$.

Environmental Protection Agency. 1986a. RCRA Ground-Water Monitoring Technical Enforcement Guidance Document, OSWER-9950.1. Washington, DC: Office of Waste Programs Enforcement.

Environmental Protection Agency. 1986b. Test Methods for Evaluating Solid Waste, Volumes 1A, 1B, and 1C, third edition, SW-846 (methods 6010, 8080, 8150, 8240, 8270, 8280, 9020, 9030, and 9060). Washington, DC.

Environmental Protection Agency. 1988a. Laboratory Data Validation Functional Guidelines for Evaluating Organics Analyses. Washington, DC: Office of Solid Waste and Emergency Response.

Environmental Protection Agency. 1988b. Laboratory Data Validation Functional Guidelines for Inorganics Analyses, Draft. Washington, DC: Office of Solid Waste and Emergency Response.

Environmental Protection Agency. 1990. "National Primary and Secondary Drinking Water Regulations; Synthetic Organic Chemicals and Inorganic Chemicals; Proposed Rule" in Federal Register, July 25, 1990, pp. 3036930448. Washington, DC.

Environmental Protection Agency. 1991a. "Guidelines Establishing Test Procedures for the Analysis of Pollutants" in Code of Federal Regulations, Title 40, Part 136, pp. 293-575. Washington, DC.

Environmental Protection Agency. 1991b. National Functional Guidelines for Organic Data Review, Draft. Washington, DC: Office of Solid Waste and Emergency Response.

Environmental Protection Agency. 1991c. "National Primary Drinking Water Regulations; Radionuclides; Proposed Rule" in Federal Register, July 18, 1991, pp. 33052-33127. Washington, DC.

Environmental Protection Agency. 1991d. "Standards for Owners and Operators of Hazardous Waste Treatment, Storage, and Disposal Facilities" in Code of Federal Regulations, Title 40, Part 264, App. IX, pp. 310-316.

Washington, DC.

Environmental Protection Agency. 1991e. Test Method: The Determination of Inorganic Anions in Water by lon Chromatography Method 300.0, Revised August 1991. Cincinnati, OH.

Environmental Protection Agency. 1991f. USEPA Contract Laboratory Program, Statement of Work (CLP SOW) for Organics Analysis, Multi-Media, Multi-Concentration, ILM03.0. Washington, DC. 
Environmental Protection Agency. 1996a. "National Primary Drinking Water Regulations" in Code of Federal Regulations, Title 40, Part 141. Washington, DC.

Environmental Protection Agency. 1996b. "National Secondary Drinking Water Regulations" in Code of Federal Regulations, Title 40, Part 143. Washington, DC.

Keith, L.H. 1991. Environmental Sampling and Analysis: A Practical Guide. Chelsea, MI: Lewis Publishers.

South Carolina Department of Health and Environmental Control. 1981. State Primary Drinking Water Regulations, R.61-58.5. Columbia, SC.

U.S. Department of Energy. 1986. Savannah River Plant Environmental Report for 1985, Volumes I and II, DPSPU-86-30-1. Aiken, SC.

U.S. Department of Energy. 1987. Savannah River Plant Environmental Report for 1986, Volumes I and II, DPSPU-87-30-1. Aiken, SC.

U.S. Department of Energy. 1988a. Geohydrology Program Report. Aiken, SC: Environmental Division, Savannah River Operations Office.

U.S. Department of Energy. 1988b. Savannah River Plant Environmental Report for 1987, Volumes I and II, DPSPU-88-30-1. Aiken, SC.

U.S. Department of Energy. 1989a. Geoscience Implementation Plan. Aiken, SC: Environmental Division, Savannah River Operations Office.

U.S. Department of Energy. 1989b. Savannah River Site Environmental Report for 1988, Volumes I and II, WSRCRP-89-59-1. Aiken, SC. 


\section{Addendum}

The Analytical Data Review chapter in the first quarter 1998 report contained erroneous information about isotopes rejected by GP. The paragraph should have read, "The following isotopes were rejected for several wells because of matrix interference: cerium-144, cesium-137, curium-244, lead-212, manganese-54, potassium-40, thorium-228, thorium-230, yttrium-88, and zinc-65."

Appendix B: Analytical Results in the first quarter 1998 report contained erroneous information about well FSB 78A. Data reported for the well were actually FSB121DR blind duplicate data. FSB 78A was inoperable. 


\section{NOTES}




\section{Appendix A. Water-Level Data}

During second quarter 1998, water-level measurements were obtained for hydrogeologic projects. Most of the data presented on the following pages were obtained as concurrent data for hydrogeologic interpretation in the $A / M$ and $F / H$ areas. Only water levels were measured for this project; no field tests of water characteristics were conducted. RCS Corporation of Aiken, SC, collected the data. 
NOTES 
WELL ABP 1A

MEASUREMENTS CONDUCTED IN THE FIELD

Sample date: 06/23/98

Sample date: $06 / 23 \% 98$
Oepth to water: 13.31 (t $(42.16 \mathrm{~m})$ below TOC
Water elevation: $221.59 \mathrm{ft}(67.54 \mathrm{~m}) \mathrm{msl}$

\section{WELL ABP 1DD}

MEASUREMENTS CONDUCTED IN THE FIELD

Sample date: 06/23/98

Depth to water: $136.96 \mathrm{ft}(41.75 \mathrm{~m})$ below TOC

\section{WELL ABP 2A}

MEASUREMENTS CONDUCTED IN THE FIELD

Sample date: $06 / 23 / 98 \mathrm{f}(46.35 \mathrm{~m})$ below TOC

\section{WELL ABP 2DD}

MEASUREMENTS CONDUCTED IN THE FIELD

Sample date: 06/23/98

Depth to water: $150.85 \mathrm{ft}(45.98 \mathrm{~m})$ below TOC

.

WELL ABP 3

MEASUREMENTS CONDUCTED IN THE FIELD

Sample date: 06/23/98

$131.65 \mathrm{ft}(40.13 \mathrm{~m})$ below TOC

Water elevation: $222.05 \mathrm{ft}(67.68 \mathrm{~m}) \mathrm{msl}$

\section{WELL ABP 3C}

MEASUAEMENTS CONDUCTED IN THE FIELD

Sample date: $06 / 23 / 98$

Depth to water: $157.75 \mathrm{ft}$ (48.08m) below TOC

\section{WELL ABP 4}

MEASUPEMENTS CONDUCTED IN THE FIELD

Sample date: 06/23/98

Damplie date: $06 / 23 / 98 \mathrm{ft}(44.15 \mathrm{~m})$ below TOC

\section{WELL ABP 4DD}

MEASUREMENTS CONDUCTED IN THE FIELD

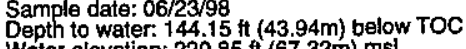

WELL ABP 6D

MEASUREMENTS CONDUCTED IN THE FIELD

Sample date: $06 / 23 / 98$

Wepth to water: $145.72 \mathrm{ft}(44.42 \mathrm{~m})$ below TOC

Time: 8:38

WELLL ABP 70

MEASUREMENTS CONDUCTED IN THE FIELD

Sample date: $06 / 23 / 98$

Depth to water: $143.48 \mathrm{Ht}(43.73 \mathrm{~m})$ below TOC

Time: 8:20

\section{WELL ABP 8C}

MEASUREMENTS CONDUCTED IN THE FIELD

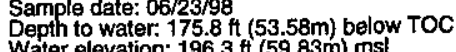

\section{WELL ABP 8D}

MEASUREMENTS CONDUCTED IN THE FIELD

Sample date: $06 / 23 / 98$ fop $(46.22 \mathrm{~m})$ below TOC

Time: 8:35

\section{WELL ABP 9B}

MEASUREMENTS CONDUCTED IN THE FIELD

Sample date: 06/23/98

Depth to water: $159.51 \mathrm{ft}(48.62 \mathrm{~m})$ below TOC
Water elevation: $192.69 \mathrm{ff}(58.73 \mathrm{~m}) \mathrm{ms}$

Time: 8:48

Time: 8:10

\section{WELL ABP 9C}

MEASUREMENTS CONDUCTED IN THE FIELD

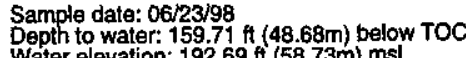

Time: 8:15 


\section{WELLL ABP 9D}

MEASUREMENTS CONDUCTED IN THE FIELD

Sample date: $06 / 23 / 98$

Water elevation: 220.18 if $(40.51 \mathrm{~m}$ ) below TOC

\section{WELL ABP 10D}

MEASUREMENTS CONDUCTED IN THE FIELD

Sample data: 06/23/98 $\mathrm{f}(4.42 \mathrm{~m})$ below Toc

We

\section{WELL ABW 1}

MEASUREMENTS CONDUCTED IN THE FIELD

Sample date: 06/22/98

Dopht to water $10.09 \mathrm{tt}(30.75 \mathrm{~m})$ below
Water elevation: $223.9 \mathrm{ft}(6825 \mathrm{~m}) \mathrm{ms}$

\section{WELL. AC 1A}

MEASUREMENTS CONDUCTED IN THE FIELD

Sample date: 06/22/98

Wepth to water. 48.9 it (1/4.90m) below TOC

\section{WELL AC 1B}

MEASUREMENTS CONDUCTED IN THE FIELD Sample date: $06 / 22198$
Depth to water: 48.65 fit $(14.83 \mathrm{~m})$ below ToC
Water elevation: $213.35 \mathrm{th}(65.03 \mathrm{~m}) \mathrm{msl}$

\section{WELL AC 2A}

MEASUREMENTS CONDUCTED IN THE FIELO

Sample date: 06/22/98

Wepth to water. $125.5 \mathrm{ft}(38.25 \mathrm{~m})$ below TOC

Water elevation: $219.2 \mathrm{ft}(6.86 \mathrm{~m}) \mathrm{ms} /$

\section{WELL AC 2B}

MEASUREMENTS CONDUCTED IN THE FIELD

Sample date: $06 / 22 / 98$ Depth to water: $119.8 \mathrm{ft}(36.52 \mathrm{~m})$ below TOC

Water elevation: $225 \mathrm{ft}(68.58 \mathrm{~m}) \mathrm{msl}$ )
WELL AC 3A

MEASUREMENTS CONDUCTED IN THE FIELD

Sample date: $06 / 22 / 98$

Water elovater: 94.6 tit (28.83m) below TOC

Time: $13: 25$

\section{WELL AC 3B}

MEASUREMENTS CONDUCTED IN THE FIELD

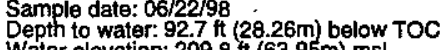

Time: 13:26

\section{WELL ACB 1A}

MEASUREMENTS CONDUCTED IN THE FIELD

Sample date: 06/24/98

Degth to water: $125.2 \mathrm{ft}(38.16 \mathrm{~m})$ below
Water elevation: $234.4 \mathrm{ft}(71.45 \mathrm{~m}) \mathrm{ms}$

Time: $14: 10$

\section{WELL ACB 2A}

MEASUREMENTS CONDUCTED IN THE FIELD

\section{Sample date: 06/24/98}

Wath to water: $115.18 \mathrm{ft}(35.11 \mathrm{~m})$ below TOC

Time: 14:08

\section{WELL ACB 3A}

MEASUREMENTS CONDUCTED IN THE FIELD

Sample date: $06 / 24 / 98$
Depth to water: $12.9 \mathrm{ft}(34.41 \mathrm{~m})$ below TOC
Water

Time: 14:14

\section{WELL ACB 4A}

MEASUREMENTS CONDUCTED IN THE FIELD

Sample date: 06/24/98

Depth to water. $24.15 \mathrm{ft}(37.84 \mathrm{~m})$ below TOC
Water elevation: $234.95 \mathrm{t}(71.61 \mathrm{~m}) \mathrm{msl}$

Time: 14:12

\section{WELL AMB 4A}

MEASUREMENTS CONDUCTED IN THE FIELD

Sample date: $06 / 25 / 98$
Depth to water: $163.9 \mathrm{At}(49.96 \mathrm{~m})$ below TOC

Time: 11:42 


\section{WELL AMB 4B}

MEASUREMENTS CONDUCTED IN THE FIELD

Sample date: 06/25/98

Wepth to water: $158.6 \mathrm{ft}(48.34 \mathrm{~m})$ below TOC

$8 \mathrm{ft}(67.61 \mathrm{~m}) \mathrm{msl}$

\section{WELL AMB 4D}

MEASUREMENTS CONDUCTED IN THE FIELD

Depth towater: $150.5 \mathrm{tt}(45.87 \mathrm{~m})$ below TOC

Water elevation: $229.8 \mathrm{ft}(70.04 \mathrm{~m}) \mathrm{msl}$

\section{WELL AMB 5}

MEASUREMENTS CONDUCTED IN THE FIELD

Sample date: $06 / 25 / 98$.

\section{WELL AMB 6}

MEASUREMENTS CONDUCTED IN THE FIELD

Sample date: $06 / 25 / 98$.

(

\section{WELL AMB 7}

MEASUREMENTS CONDUCTED IN THE FIELD

Sample date: $06 / 25 / 98$

Depht towater. $19.4 .4 \mathrm{ft}(42.4 \mathrm{~m})$ below toc
Water olevation: $230.5 \mathrm{tt}(70.26 \mathrm{~m}) \mathrm{msl}$

WELL AMB $7 A$

MEASUREMENTS CONDUCTED IN THE FIELD

Sample date: $06 / 25 / 98$

Depter to water. $156.78 \mathrm{ft}(47.79 \mathrm{~m})$ below toc

\section{WELL AMB 7B}

MEASUREMENTS CONDUCTED IN THE FIELD

Sample date: 06/25/98

Depht to water: $150.7 \mathrm{tt}(45.93 \mathrm{~m})$ below TOC

\section{WELL AMB 8D}

MEASUREMENTS CONDUCTED IN THE FIELD

Sample date: 06/25/98

Wepth to water. $139.5 \mathrm{ft}(42.52 \mathrm{~m})$ below TOC

Time: 10:12

\section{WELL AMB 9D}

MEASUREMENTS CONDUCTED IN THE FIELD

Sample date: $06 / 25 / 98$ (4) 0 (

Water elevation: $230.15 \mathrm{ft}(70.15 \mathrm{~m}) \mathrm{ms} \mid$

Time: 10:16

\section{WELL AMB 10A}

MEASUREMENTS CONDUCTED IN THE FIELD

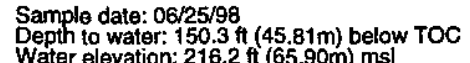

Time: 10:28

\section{WELL AMB 10B}

MEASUREMENTS CONDUCTED IN THE FIELD

Sample date: 06/25/98

Depth to water: $145.75 \mathrm{ft}(44.43 \mathrm{~m})$ below TOC

Time: 10:25

\section{WELL AMB 10D}

MEASUREMENTS CONDUCTED IN THE FIELD

Sample date: 06/25/98

Sample date: $06 / 25198$
Depth to water $134.2 \mathrm{ft}(40.90 \mathrm{~m})$ below
Water elevation: $231.3 \mathrm{ft}(70.50 \mathrm{~m}) \mathrm{msl}$

Time: 10:30

\section{WELL AMB 10DD}

MEASUREMENTS CONDUCTED IN THE FIELD

Sample date: 06/25/98

Water elevation: $35.5 \mathrm{tt}(3.81 \mathrm{~m})$ below TOC

Time: 10:32

\section{WELL AMB 11B}

MEASUREMENTS CONDUCTED IN THE FIELD Sample date: $06 / 25 / 98 \mathrm{ft}(43.82 \mathrm{~m})$ below TOC
Time: 9:34 


\section{WELL AMB 11D}

MEASUREMENTS CONDUCTED IN THE FIELD

Sample date: $06 / 25 / 98$.

\section{WELL AMB 12D}

MEASUREMENTS CONDUCTED IN THE FIELD

Sample date: $06 / 25 / 98$

Depth to water: $138.65 \mathrm{ft}(42.26 \mathrm{~m})$ below TOC

Water elevation: $231.15 \mathrm{ft}(70.46 \mathrm{~m}) \mathrm{msl}$

\section{WELL AMB 13AR}

MEASUREMENTS CONDUCTED IN THE FJELD

Sample date: 06/25/98

Depth to water: $148.14 \mathrm{At}(45.15 \mathrm{~m})$ below TOC

\section{WELL AMB 14D}

MEASUREMENTS CONDUCTED IN THE FIELD

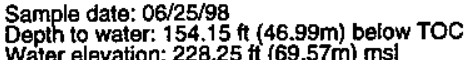

\section{WELL AMB 15D}

MEASUREMENTS CONDUCTED IN THE FIELD

Sample date: $06 / 25 / 98$ ft $(46.63 \mathrm{~m})$ below TOC

Weph to water. $152.98 \mathrm{H}(46.63 \mathrm{~m})$ below

\section{WELL AMB 16D}

MEASUREMENTS CONDUCTED IN THE FIELD

Depth to water: $50.4 \mathrm{ft}(45.84 \mathrm{~m})$ below TOC

Water elevation: $230 \mathrm{ft}(70.10 \mathrm{~m}) \mathrm{ms}$

\section{WELL AMB 17A}

MEASUREMENTS CONDUCTED IN THE FIELD

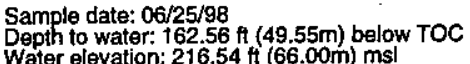

Time: 10:38

\section{WELLL AMB 18A}

MEASUREMENTS CONDUCTED IN THE FIELD

Time: 9:59

Depth to water: $16.0 .8 \mathrm{ft}(49.01 \mathrm{~m})$ below
Water elevation: $216.5 \mathrm{ft}(65.99 \mathrm{~m}) \mathrm{ms}$

\section{WELL AMB 18C}

MEASUREMENTS CONDUCTED IN THE FIELD

Sample date: $06 / 25 / 98$
Depth to water 146.2 f $(44.56 \mathrm{~m})$ below TOC

Time: 10:05

WELL AMB 19C

MEASUREMENTS CONDUCTED IN THE FIELD

Sample date: 06/25/98

Sample date: $06 / 25 / 98$
Depth to water $135.84 \mathrm{ft}(41.40 \mathrm{~m})$ below TOC
Water elevation: $227.86 \mathrm{ft}(69.4 \mathrm{~m})$ mst

WELL AOB 1

MEASUREMENTS CONDUCTED IN THE FIELD

Sample date: $06 / 24 / 98$
Depth to water. $106.9 \mathrm{ft}(32.58 \mathrm{~m})$ below TOC
Water elevation: $234.2 \mathrm{ft}(71.39 \mathrm{~m}) \mathrm{ms}$

Time: 14:32

\section{WELL AOB 2}

MEASUREMENTS CONDUCTED IN THE FIELD

Sample date: $06 / 24 / 98$.

Time: 14:30

\section{WELL AOB 3}

MEASUREMENTS CONDUCTED IN THE FIELD

Sample date: $06 / 24 / 98$.

\section{WELL ARP 1A}

MEASUREMENTS CONDUCTED IN THE FIELD

Sample date: 06/23/98

Time: 9:06
Time: 10:48 


\section{WELL ARP 2}

MEASUREMENTS CONDUCTED IN THE FIELD Sample date: $06 / 23 / 98 \mathrm{ft}(36.71 \mathrm{~m})$ below TOC

\section{WELL ARP 3}

MEASUREMENTS CONDUCTED IN THE FIELD

Sample data: $06 / 23 / 98$
Depht to water. $120.59 \mathrm{ft}(3.76 \mathrm{~m})$ below TOC
Water elevation: 219.21 (t) $(66.82 \mathrm{~m}) \mathrm{msl}$

\section{WELL ARP 4}

MEASUREMENTS CONDUCTED IN THE FIELD Sample date: 06/23/98 Wepth o water: $132.56 \mathrm{ft}(40.40 \mathrm{~m})$ below TOC

\section{WELL ASB 1A}

MEASUREMENTS CONDUCTED IN THE FIELD

Sample date: 06/25/98

Wepth to water. $13.6 \mathrm{ft}(34.63 \mathrm{~m})$ below TOC

\section{WELL ASB 2AR}

MEASUREMENTS CONDUCTED IN THE FIELD

Sample date: 06/25/98

Depth to water: $118.5 \mathrm{ft}(36.12 \mathrm{~m})$ below TOC

WELL ASB 2CR

MEASUREMENTS CONDUCTED IN THE FIELD . Sample data: $06 / 25 / 98$
Depth to water. $13.95 \mathrm{~h}(42.05 \mathrm{~m})$ below toc
Water elevation: $217.65 \mathrm{tt}(66.3 \mathrm{~m}) \mathrm{ms}$ )

\section{WELL ASB 3AR}

MEASUREMENTS CONDUCTED IN THE FIELD Sample date: $06 / 25 / 98$
Depth to water: $103.6 \mathrm{ft}(31.58 \mathrm{~m})$ below TOC
Time: 9:18

Time: 9:12

\section{WELL ASB 3CR}

MEASUREMENTS CONDUCTED IN THE FIELD Sample date: 06/25/98 Depth to water: $122.35 \mathrm{ft}(37.29 \mathrm{~m})$ bolow
Water glevation: $219.15 \mathrm{ft}(66.80 \mathrm{~m}) \mathrm{ms}$

\section{WELL ASB 4}

MEASUREMENTS CONDUCTED IN THE FIELD Sample date: $06 / 25 / 98$ Doph to water: 98.7 tt $30.08 \mathrm{~m})$ below TOC

\section{WELL ASB 5AR}

MEASUREMENTS CONDUCTED IN THE FIELD

Sample date: $06 / 25 / 98$

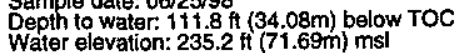

\section{WELL ASB 5C}

MEASUREMENTS CONDUCTED IN THE FIELD

Sample date: $06 / 25 / 98$ (39.01m) below TOC

Water elevation: $219.3 \mathrm{Ht}(66.8 \mathrm{~m}) \mathrm{msl}$

Time: 8:48

\section{WELL ASB 6A}

MEASUREMENTS CONDUCTED IN THE FIELD

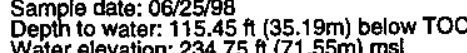

\section{WELL ASB 6AA}

MEASUREMENTS CONDUCTED IN THE FIELD

Sample date: 06/25/98

Depth to water: $138.95 \mathrm{ft}(42.35 \mathrm{~m})$ below TOC

\section{WELL ASB 6C}

MEASUREMENTS CONDUCTED IN THE FIELD

Sample date: 06/25/98

Water elevation: $220.6 \mathrm{ft}(67.24 \mathrm{~m}) \mathrm{msl}$ ) 


\section{WELL ASB 6TA}

MEASUAEMENTS CONDUCTED IN THE FIELD Sample date: $06 / 25 / 98$ Oopth to water: 142.15 th $(43.33 \mathrm{~m})$ below TOC

\section{WELL ASB 9}

MEASUREMENTS CONDUCTED IN THE FIELD

Sample date: $06 / 25 / 98$

Depth to water: 66.87 tt (20.38m) below TOC

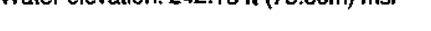

\section{WELL ASB 9B}

MEASUAEMENTS CONDUCTED IN THE FIELD

Sample date: 06/25/98

Sample data: $06 / 25 / 98$
Depth to water $90.8 \mathrm{Ht}(27.68 \mathrm{~m})$ below TOC
Water elevation: $218.2 \mathrm{Ht}(66.5 \mathrm{~m}) \mathrm{msl}$

\section{WELL ASB 9C}

MEASUREMENTS CONDUCTED IN THE FIELD

Sample date: 06/25/98

Dopth to water: $91.25 \mathrm{ft}(27.81 \mathrm{~m})$ below
Water elevation: $218.65 \mathrm{tt}(66.65 \mathrm{~m}) \mathrm{ms}$

\section{WELL ASB 10CR}

MEASUREMENTS CONDUCTED IN THE FIELD Sample date: $06 / 25 / 98$, $13.61 \mathrm{~m})$ below to

\section{WELL BGO 1D}

MEASUREMENTS CONDUCTED IN THE FIELD

Sample date: $06 / 29 / 98$

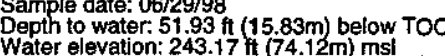

\section{WELL BGO 3A}

MEASUREMENTS CONDUCTED IN THE FIELD

Sample date: $06 / 30 / 98$

Sample date: $06 / 30 / 98$
Dept to water: $128.6 \mathrm{ft}(39.20 \mathrm{~m})$ below TOC
Water elevation: $163.3 \mathrm{ft}(49.7 \mathrm{~m}) \mathrm{ms}$ )

\section{WELL BGO 3C}

MEASUREMENTS CONDUCTED IN THE FIELD

Sample date: $06 / 30 / 98$.

Time: 8:38

\section{WELL BGO 3DR}

MEASUREMENTS CONDUCTED IN THE FIELD

Sample date: 06/30/98

Depth to water: $59.3 \mathrm{ft}(18.07 \mathrm{~m})$ below TOC

Time: 8:34

\section{WELL BGO 4D}

MEASUREMENTS CONDUCTED IN THE FIELD

Sample date: 06/30/98

Depth to water: Not available
Water elevation: Not available

Time: 8:42

\section{WELL BGO 5C}

MEASUREMENTS CONDUCTED IN THE FIELD

Sample date: 06/30/98

Depth to water. $78.6 \mathrm{ft}(23.96 \mathrm{~m})$ below
Water elevation: $217.5 \mathrm{t}(66.29 \mathrm{~m}) \mathrm{ms}$

Time: 8:46

\section{WELLL BGO 5D}

MEASUREMENTS CONDUCTED IN THE FIELD

Sample date: $06 / 30 / 98$

Wepth to water $6.1 \mathrm{it}(20.1 \mathrm{~m})$ below TOC

Time: 8:47

\section{WELL BGO 6A}

MEASUREMENTS CONDUCTED IN THE FIELD

Sample date: 06/29/98

Depth to water: $126.15 \mathrm{ft}(38.45 \mathrm{~m})$ below TOC

Time: 14:25

\section{WELL BGO 6B}

MEASUREMENTS CONDUCTED IN THE FIELD

Sample date: 06/29/98

Sample date: $06 / 29 / 98$
Depth to water: $66.7 \mathrm{ft}(20.33 \mathrm{~m})$ below TOC
Water elevation: $220.1 \mathrm{tt}(67.09 \mathrm{~m}) \mathrm{ms}$ !

Time: 14:29 


\section{WELL BGO 6C}

MEASUREMENTS CONDUCTED IN THE FIELD

Sample date: 06/29/98

Depth to water: $64.45 \mathrm{ft}(19.64 \mathrm{~m})$ below TOC

\section{WELL BGO 6D}

MEASUREMENTS CONDUCTED IN THE FIELD

Sample date: 06/29/98

Deptth to water: $55 \mathrm{ft}(16.76 \mathrm{~m})$ below TOC
Water elevation: $230.5 \mathrm{ft}(70.26 \mathrm{~m}) \mathrm{msl}$

\section{WELL BGO 7D}

MEASUREMENTS CONDUCTED IN THE FIELD

Sample date: 06/29/98

Depth to water: $55.9 \mathrm{~g}$ (t) $(17.04 \mathrm{~m})$ below TOC
Water elevation: $231.17(70.44 \mathrm{~m}) \mathrm{ms}$

\section{WELL BGO 8AR}

MEASUREMENTS CONDUCTED IN THE FIELD

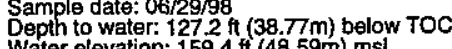

\section{WELL BGO 8C}

MEASUREMENTS CONDUCTED IN THE FIELD

Sample date: 0 \%/29/98

Depth to water: 63.65 A $(19.40 \mathrm{~m})$ below TOC

\section{WELL. BGO 8D}

MEASUREMENTS CONDUCTED IN THE FIELD

Sample date: 06/29/98

Depth to water $56.45 \mathrm{ft}(17.21 \mathrm{~m})$ below TOC
Water elivation
23135

\section{WELL BGO 9AA}

MEASUREMENTS CONDUCTED IN THE FIELD

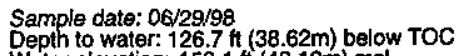

Time: 12:09

\section{WELL BGO 9D}

MEASUREMENTS CONDUCTED IN THE FIELD

Sample date: 06/29/98

Deph to water. 55.62 ft $(16.95 \mathrm{~m})$ below TOC
Water elevation: $229.48 \mathrm{tt}(69.95 \mathrm{~m}) \mathrm{msl}$

Time: 12:33

\section{WELL BGO 10AA}

MEASUREMENTS CONDUCTED IN THE FIELD Sample date: $06 / 29 / 98$
Depth to water: $142.8 \mathrm{ft}(43.53 \mathrm{~m})$ below TOC

\section{WELL BGO 10AR}

MEASUREMENTS CONDUCTED IN THE FIED

Sample date: 06/29/98

Depth to water: $141.87 \mathrm{ft}(43.24 \mathrm{~m})$ below TOC

\section{WELL BGO 10B}

MEASUREMENTS CONDUCTED IN THE FIELD

Sample date: 06/29/98

Depth to water: $20 \mathrm{ft}(24.38 \mathrm{~m})$ below TOC
Water elevation: $221 \mathrm{t}(67.36 \mathrm{~m}) \mathrm{ms}$

Time: 12:01

\section{WELL BGO $10 C$}

MEASUREMENTS CONDUCTED IN THE FIELD

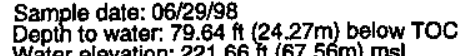

Time: 12:20

\section{WELL BGO 10DR}

MEASUREMENTS CONDUCTED IN THE FIELD

Sample date: $06 / 29 / 98$ (20.95m) below TOC

(aph

Time: 12:26

\section{WELL BGO 11DR}

MEASUREMENTS CONDUCTED IN THE FIELD

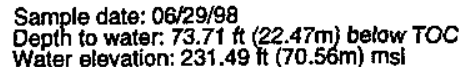

Time: 12:13 


\section{WELL BGO 12AX}

MEASUREMENTS CONDUCTED IN THE FIELD

Sample date: 06/29/98

Depth of watr: 55.2 ft $(47.31 \mathrm{~m})$ below TOC

me: 12:09

WELL BGO 12CX

MEASUREMENTS CONDUCTED IN THE FIELD

Sample date: 06/29/98

Depth to water: $81.76 \mathrm{ft}(24.92 \mathrm{~m})$ below TOC

Water elevation: $231.54 \mathrm{H}(70.57 \mathrm{~m}) \mathrm{msi}$

\section{WELL BGO 12DR}

MEASUREMENTS CONDUCTED IN THE FIELD

Sampla date: 06/29/98

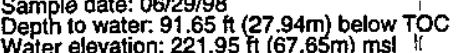

\section{WELL BGO 13D}

MEASUREMENTS CONDUCTED IN THE FIELD

Samplo date: 06/29/98

Depth to water: 86.76 ti $(26.44 \mathrm{~m}$ ) below ToC

\section{WELL. BGO 13DR}

MEASUREMENTS CONDUCTED IN THE FIELD

Sample date: $06 / 29 / 98$
Depth to water: $87.75 \mathrm{ft}(26.75 \mathrm{~m})$ below ToC
Water elevation: $231.55 \mathrm{tt}(70.58 \mathrm{~m}) \mathrm{msl}$

WELL BGO 14AR

MEASUREMENTS CONDUCTED IN THË"FIELD

Sample date: 06/29/98

Depth to water: $141.51 \mathrm{ft}(43.13 \mathrm{~m})$ below TOC

WELL BGO 14CR

MEASUREMENTS CONDUCTED IN THE FIELD

Sample date: 06/29/98

Depth to water 75.88 ft $(23.13 \mathrm{~m})$ below TOC
Water levation. $224.62 \mathrm{tt}(68.47 \mathrm{~m}) \mathrm{msl}$

Time: 11:43

Time: 12:04
WELL BGO 14DR

MEASUREMENTS CONDUCTED IN THE FIELD

Sample date: 06/29/98

Time: 11:41

Depth to water. $69.05 \mathrm{ft}(21.05 \mathrm{~m})$ bolow TOC
Water elevation: $231.25 \mathrm{tt}(70.49 \mathrm{~m}) \mathrm{ms}$

\section{WELL BGO 15D}

MEASUREMENTS CONDUCTED IN THE FIELD

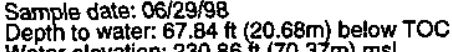

Time: 11:36

\section{WELL BGO 16AR}

MEASUREMENTS CONDUCTED IN THE FIELD

Sample date: $06 / 30 / 98$ ( $(43.36 \mathrm{~m})$ below TOC

Wepth to water: $142.25 \mathrm{f}(43.36 \mathrm{~m})$ below

\section{WELL BGO 16B}

MEASUREMENTS CONDUCTED IN THE FIELD

Sample date: $06 / 30 / 98$

Depth to water: $86.75 \mathrm{ft}(26.44 \mathrm{~m})$ below TOC

Water elevation: $218.35 \mathrm{ft}(66.55 \mathrm{~m}) \mathrm{ms}$ !

Time: 8:04

\section{WELL BGO 16D}

MEASUREMENTS CONDUCTED IN THE FIELD

Sample date: $06 / 30 / 98$

Wepth to water: $73.35 \mathrm{ft}(22.36 \mathrm{~m})$ below TOC

Time: 8:05

\section{WELL BGO 17DR}

MEASUREMENTS CONDUCTED IN THE FIELD

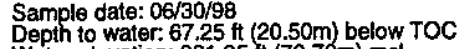

Time: 8:10

\section{WELL BGO 18A}

MEASUREMENTS CONDUCTED IN THE FIELD

Sample date: $06 / 30 / 98$

Depth to water: $133.25 \mathrm{ft}(40.62 \mathrm{~m})$ below TOC

Time: 8:16 


\section{WELL BGO 18D}

MEASUREMENTS CONDUCTED IN THE FIELD

Sample date: 06/30/98

Depth to water: Not available

\section{WELL BGO 19DR}

MEASUREMENTS CONDUCTED IN THE FIELD

Sample date: 06/30/98

Sample date: $06 / 30 / 98$
Depth to water $62 \mathrm{t}$ (18.90m) below TOC
Water elevation: $231.8 \mathrm{ft}(70.65 \mathrm{~m}) \mathrm{msl}$

\section{WELL BGO 20A}

MEASUREMENTS CONDUCTED IN THE FIELD

Sample date: $06 / 30 / 98$
Depth to water: $120.46 \mathrm{ft}(36.72 \mathrm{~m})$ below TOC
Water elevation: $163.44 \mathrm{ft}(49.82 \mathrm{~m}) \mathrm{msl}$

\section{WELL BGO 20AA}

MEASUREMENTS CONDUCTED IN THE FIELD

Sample date: $06 / 30 / 98$
Depth to water: $21.5 \mathrm{ft}(37.03 \mathrm{~m})$ below TOC

Time: 8:11

\section{WELL BGO 20B}

MEASUREMENTS CONDUCTED IN THE FIELD

Sample date: 06/30/98

Wath

WELL BGO 20C

MEASUREMENTS CONDUCTED IN THE FIELD

Sample date: 06/30/98

Depth to water: $52.71 \mathrm{ft}(16.07 \mathrm{~m})$ below TOC
Water elevation: $230.79 \mathrm{ft}(70.35 \mathrm{~m}) \mathrm{ms}$ l

\section{WELL BGO 20D}

MEASUREMENTS CONDUCTED IN THE FIELD

Sample date: 06/30/98

Depth to water: $49.57 \mathrm{ft}(15.11 \mathrm{~m})$ below TOC

Time: 8:04
WELL BGO 21D

MEASUREMENTS CONDUCTED IN THE FIELD

Sample date: 06/30/98

Depth to water: $50.47 \mathrm{H}(15.38 \mathrm{~m})$ below TOC

Time: 8:20

\section{WELL BGO 22DX}

MEASUREMENTS CONDUCTED IN THE FIELD

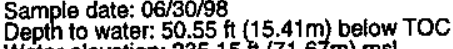

Time: 8:24

WELL BGO 23D

MEASUREMENTS CONDUCTED IN THE FIELD

Sample date: $06 / 30 / 98$

Depth to water. $52.35 \mathrm{ft}(15.96 \mathrm{~m})$ below TOC

WELL BGO 24D

MEASUREMENTS CONDUCTED IN THE FIELD

Sample date: $06 / 30 / 98$

Depth to water: 54.22 ft $(16.53 \mathrm{~m})$ below TOC
Water elevation: $238.98 \mathrm{ft}(72.84 \mathrm{~m}) \mathrm{ms}$

Time: 8:24

\section{WELL BGO 25A}

MEASUREMENTS CONDUCTED IN THE FIELD

Sample date: 06/29/98

Depth to water: $134.9 \mathrm{ft}(41.12 \mathrm{~m})$ below TOC

Time: 11:30

\section{WELL BGO 26A}

MEASUREMENTS CONDUCTED IN THE FIELD

Sample date: 06/29/98

Time: 9:49

\section{WELL BGO 26D}

MEASUREMENTS CONDUCTED IN THE FIELD

Sample date: 06/29/98

Depth to water: $56.63 \mathrm{ft}(17.26 \mathrm{~m})$ below TOC
Water elevation: $228.87 \mathrm{tt}(69.76 \mathrm{~m}) \mathrm{msl}$
Time: 9:51

Second Quarter 1998 


\section{WELL BGO 27C}

MEASUREMENTS CONDUCTED IN THE FIELD Sample date: $06 / 29 / 98$ (16.41m) below TOC Depth to water: $53.85 \mathrm{ft}(16.41 \mathrm{~m})$ below 100

\section{WELL BGO 27D}

MEASUREMENTS CONDUCTED IN THE FIELD

Sample date: 06/29/98

Depth to water: $47.37 \mathrm{ft}(14.44 \mathrm{~m})$ below TOC

Water elevation: $228.93 \mathrm{t} t(69.78 \mathrm{~m}) \mathrm{ms}$ )

\section{WELL BGO 28D}

MEASUREMENTS CONDUCTED IN THE FIELD

Sample date: 06/29/98

Water elevation: $228 \mathrm{ft}(15.06 \mathrm{~m})$ below TOC

\section{WELL BGO 29A}

MEASUREMENTS CONDUCTED IN THE FIELD

Sample date: 06/29/98

Depth to water: 103.74 ff (31.62m) below TOC

\section{WELL BGO 29C}

MEASUREMENTS CONDUCTED IN THE FIELD

Sample date: 06/29/98

Deph to water: $40.41 \mathrm{ft}(12.32 \mathrm{~m})$ below TOC

$39 \mathrm{Ht}(68.39 \mathrm{~m}) \mathrm{msl}$

\section{WELL BGO 29D}

MEASUREMENTS CONDUCTED IN THE FIELD

Sample date: 06/29/98

Depth to water. $37.52 \mathrm{ft}(11.44 \mathrm{~m})$ below TOC

Water elevation: $227.98 \mathrm{it}(69.49 \mathrm{~m}) \mathrm{msl}$

\section{WELL BGO 30C}

MEASUREMENTS CONDUCTED IN THE FIELD

Sample date: 06/29/98

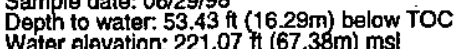

Time: 10:10
WELL BGO 30D

MEASUREMENTS CONDUCTED IN THE FIELD

Sample date: 06/29/98

Time: 10:13

Depth to water: $47.16 \mathrm{ft}(14.37 \mathrm{~m})$ below TOC

\section{WELL BGO 31C}

MEASUREMENTS CONDUCTED IN THE FIELD

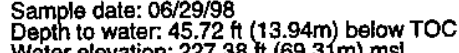

Time: 10:18

\section{WELL BGO 31D}

MEASUREMENTS CONDUCTED IN THE FIELD

Sample date: $06 / 29 / 98$

Sample date: $06 / 29 / 98$
Depth to water: $45.5 \mathrm{ft}(13.79 \mathrm{~m})$ below TOC
Water elevation: $228.45 \mathrm{ft}(69.63 \mathrm{~m}) \mathrm{msl}$

Time: 10:15

\section{WELL BGO 32D}

MEASUREMENTS CONDUCTED IN THE FIELD

Sarnple date: 06/29/98

Qepth to water: $52.33 \mathrm{ft}(15.95 \mathrm{~m})$ below TOC
Water elevation: $229.37 \mathrm{tt}(69.91 \mathrm{~m}) \mathrm{ms}$

Time: 10:22

\section{WELL BGO 33C}

MEASUREMENTS CONDUCTED IN THE FIELD

Sample date: $06 / 29 / 98$
Depth to water. $53.1 \mathrm{tt}(16.19 \mathrm{~m})$ below TOC
Water elevation: $226.3 \mathrm{Ht}(68.98 \mathrm{~m}) \mathrm{mst}$

Time: 10:26

\section{WELL BGO 33D}

MEASUREMENTS CONDUCTED IN THE FIELD

Sample date: 06/29/98

Dephth to water: $48.47 \mathrm{ft}(14.77 \mathrm{~m})$ below TOC

Time: 10:28

\section{WELL BGO 34D}

MEASUREMENTS CONDUCTED IN THE FIELD

Sample date: 06/29/98

Water to water: $40.82 \mathrm{ft}(12.44 \mathrm{~m})$ below TOC

Time: 10:34 
WELL BGO 35C

MEASUREMENTS CONDUCTED IN THE FIELD

Sample date: 06/29/98

Sample date: $06 / 29 / 98$
Depth to water: $42.67 \mathrm{tt}(13.01 \mathrm{~m})$ below TOC
Water elevation: $230.73 \mathrm{Ht}(70.33 \mathrm{~m}) \mathrm{msl}$

WELL BGO 35D

MEASUREMENTS CONDUCTED IN THE FIELD

Sample date: 06/29/98

Wepth to water 38.26 ft $(11.66 \mathrm{~m})$ below TOC

\section{WELL BGO 36D}

MEASUREMENTS CONDUCTED IN THE FIELD

Sample date: 06/29/98

Depth to water: $37.07 \mathrm{At}(11.30 \mathrm{~m})$ below TOC

\section{WELL BGO 37C}

MEASUREMENTS CONDUCTED IN THE FIELD

Sample date: 06/29/98

Sample date: 06/29/98
Depth to water: $53.2 \mathrm{ft}(16.22 \mathrm{~m})$ below TOC
Water elevation: $233.1 \mathrm{tt}(71.05 \mathrm{~m}) \mathrm{ms}$ l

WELL BGO 37D

MEASUREMENTS CONDUCTED IN THE FIELD

Sample date: $06 / 29 / 98$
Depth to water: $45.75 \mathrm{ft}(13.94 \mathrm{~m})$ below TOC
Water elevation: $241.55 \mathrm{ft}(73.63 \mathrm{~m}) \mathrm{ms}$

\section{WELL BGO 38D}

MEASUREMENTS CONDUCTED IN THE FIELD

Sample date: $06 / 29 / 98$

Depth to water: $51.59 \mathrm{ft}(15.72 \mathrm{~m})$ below TOC

\section{WELL BGO 39A}

MEASUREMENTS CONDUCTED IN THE FIELD

Sample date: $06 / 29 / 98$ A $(39.04 m)$ below TOC

Weph

ESH-EMS-980569

\section{WELL BGO 39C}

MEASUREMENTS CONDUCTED IN THE FIELD

Sample date: $06 / 29 / 98$.

WELL BGO 39D

MEASUREMENTS CONDUCTED IN THE FIELD

Sample date: 06/29/98

Depth to water. $58.48 \mathrm{ft}(17.82 \mathrm{~m})$ below TOC

WELL BGO 40D

MEASUREMENTS CONDUCTED IN THE FIELD

Sample date: 06/29/98

epth to water. 65.02 tt $(19.82 \mathrm{~m})$ below TOC

Time: 9:43

\section{WELL BGO 41A}

MEASUREMENTS CONDUCTED IN THE FIELD

Sample date: 06/29/98

Time: 11:34

\section{WELL BGO 42C}

MEASUREMENTS CONDUCTED IN THE FIELD

Sample date: 06/29/98

Depth to water: $73.65 \mathrm{ft}(22.45 \mathrm{~m})$ below TOC

Time: 11:42

\section{WELL BGO 43A}

MEASUREMENTS CONDUCTED IN THE FIELD

Depth to water: $157.7 \mathrm{ft}(48.07 \mathrm{~m})$ below TOC

Water elevation: $157.2 \mathrm{tt}(47.92 \mathrm{~m}) \mathrm{msl}$

Time: 11:50

\section{WELL BGO 43AA}

MEASUREMENTS CONDUCTED IN THE FIELD

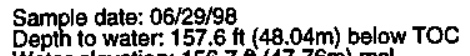

Time: 11:51 


\section{WELL BGO 43CR}

MEASUREMENTS CONDUCTED IN THE FIELD

Sample date: 06/29/98

Depth to water: $89.1 \mathrm{it}(27.16 \mathrm{~m})$ below TOC
Water elevation: $226.2 \mathrm{H}(68.95 \mathrm{~m}) \mathrm{mS})$

\section{WELL BGO 43D}

MEASUREMENTS CONDUCTED IN THE"FIELD

Sample date: $06 / 29 / 98$ (25.4m) below TOC

Depth to water: $83.4 \mathrm{tt}(25.42 \mathrm{~m})$ below TOC
Water elevation: $231.9 \mathrm{tt}(70.68 \mathrm{~m}) \mathrm{ms}$

\section{WELL BGO 44A}

MEASUREMENTS CONDUCTED IN THE FIELD

Sample date: 06/20/98

Depth to water: $12.6 .6 \mathrm{th}(38.59 \mathrm{~m})$ below TOC

\section{WELL BGO 44AA}

MEASUREMENTS CONDUCTED IN THE FIELD

Sample date: $06 / 29 / 98$

Depth to water: $126.45 \mathrm{tt}(38.54 \mathrm{~m})$ below TOC

\section{WELL BGO 44B}

MEASUREMENTS CONDUCTED IN THE FIELD Sample date: 06/29/98

Depth to water: 63.1. ft $19.23 \mathrm{~m}$ ) below TOC

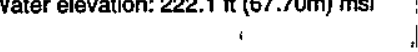

\section{WELL BGO 44C}

MEASUREMENTS CONDUCTEO IN THEFIELD

Sample date: $06 / 29 / 98$

Depth to water: $63.72 \mathrm{Ht}(19.42 \mathrm{~m})$ below TOC
Water elevation: $221.88 \mathrm{tt}(67.63 \mathrm{~m}) \mathrm{ms}$

\section{WELL BGO 44D}

MEASUREMENTS CONDUCTED IN THE FIELD

Sample data: $06 / 29198$
Depth to water: 53.65 . $116.35 \mathrm{~m}$ ) below Toc
Water elevation: $231.75 \mathrm{tt}(70.64 \mathrm{~m}) \mathrm{msl}$

\section{!}

ESH-EMS-980569
Time: 11:54

Time: 11:48

Time: 12:26

Time: 12:28
WELL BGO 45A

MEASUREMENTS CONDUCTED IN THE FIELD

Sample date: 06/29/98

Depth to water: $117.74 \mathrm{ft}(35.89 \mathrm{~m})$ below TOC
Water elevation: $161.16 \mathrm{ft}(49.12 \mathrm{~m}) \mathrm{msl}$

Time: 9:33

WELL BGO 45B

MEASUREMENTS CONDUCTED IN THE FIELD

Sample date: 06/29/98

Deph to water: 58.22 th $(17.75 \mathrm{~m})$ below TOC

Time: 9:35

\section{WELL BGO 45C}

MEASUREMENTS CONDUCTED IN THE FIELD

Sample date: $06 / 29 / 98$
Depth to water: 54.43 ft (16.59m) below TOC

Time: 9:37

WELL BGO 45D

MEASUREMENTS CONDUCTED IN THE FIELD

Sample date: 06/29/98 $20.61 \mathrm{~m})$ below TOC

Water elevation: $210.99 \mathrm{H}(64.3 \mathrm{~m})$ msl

Time: 9:39

\section{WELL BGO 46B}

MEASUREMENTS CONDUCTED IN THE FIELD

Sample date: 06/29/98

Depth to water 46.2 tt $(14.08 \mathrm{~m})$ below TOC

Time: 10:36

\section{WELL BGO 46C}

MEASUREMENTS CONDUCTED IN THE FIELD

Sample date: $06 / 29 / 98$ Depth to water: $44.2 \mathrm{ft}(13.47 \mathrm{~m})$ below TOC

Time: 10:38

\section{WELL BGO 46D}

MEASUREMENTS CONDUCTED IN THE FIELD

Sample date: 06/29/98

Depht to watere. $38 \mathrm{Ht}(1 \mathrm{~T}) .58 \mathrm{~m})$ below TOC
Water elevation: $227.1 \mathrm{tt}(69.22 \mathrm{~m}) \mathrm{ms}$
Time: 10:39 
WELL BGO 47A

MEASUREMENTS CONDUCTED IN THE FIELD

Sample date: 06/29/98

Depth to water: $104 \mathrm{ft}$ (31.70m) below TOC

\section{WELL BGO 47C}

MEASUREMENTS CONDUCTED IN THE FIELD

Sample date: 06/29/98 $(13.24 \mathrm{~m})$ below TOC
$\mathrm{ft}(68.32 \mathrm{~m}) \mathrm{ms}$

Water elevation: $224.15 \mathrm{Ht}(68.32 \mathrm{~m}) \mathrm{ms}$

\section{WELL BGO 47D}

MEASUAEMENTS CONDUCTED IN THE FIELD

Sample date: 06/29/98

\section{WELL BGO 48C}

MEASUREMENTS CONDUCTED IN THE FELD

Sample date: 06/29/98

Depth to water: $51.82 \mathrm{ft}(15.79 \mathrm{~m})$ below TOC

WELL BGO 48D

MEASUREMENTS CONDUCTED IN THE FIELD

Sample date: 06/29/98

Dopth to water: $48.8 \mathrm{ft}(14.87 \mathrm{~m})$ below TOC
Water elevation: $228.1 \mathrm{ft}(69.53 \mathrm{~m}) \mathrm{msl}$

\section{WELL BGO 49A}

MEASUREMENTS CONDUCTED IN THE FIELD

Sample date: $06 / 29 / 98$

Water elevation: Not available

\section{WELL BGO 49C}

MEASUREMENTS CONDUCTED IN THE FIELD

Sample date: 06/29/98

Time: 10:27

Wath

\section{WELL BGO 49D}

MEASUREMENTS CONDUCTED IN THE FIELD

Sample date: 06/29/98

Weph to waler: $36.3 \mathrm{ft}(11.06 \mathrm{~m})$ below TOC

\section{WELL BGO 50A}

MEASUREMENTS CONDUCTED IN THE FIELD Sample date: 06/29/98 Depth to water: $94.4 \mathrm{ft}(28.77 \mathrm{~m})$ below TOC

\section{WELL BGO 50C}

MEASUREMENTS CONDUCTED IN THE FIELD

Samplo date: 06/29/98 Deph to water. 50 tt $(15.24 \mathrm{~m})$ below
Water elevation: $205.5 \mathrm{tit}(62.64 \mathrm{~m}) \mathrm{ms}$

\section{WELL BGO 50D}

MEASUREMENTS CONDUCTED IN THE FIELD

Sample date: 06/29/98

Water to water: $29 \mathrm{H}(8.84 \mathrm{~m})$ below TOC

Time: 10:45

\section{WELL BGO 51A}

MEASUREMENTS CONDUCTED IN THE FIELD Sample date: 06/30/98

\section{WELL BGO 51AA}

MEASUREMENTS CONDUCTED IN THE FIELD

Sample date: 06/30/98

Depth to water: $120.55 \mathrm{ft}(36.74 \mathrm{~m})$ below TOC

Water elevation: $168.65 \mathrm{ft}(51.41 \mathrm{~m}) \mathrm{msl}$

Time: 9:33

WELL BGO 51B

MEASUREMENTS CONDUCTED IN THE FIELD

Sample date: 06/30/98

(17.31m) below TOC

Time: 9:37 


\section{WELL BGO 51C}

MEASUREMENTS CONDUCTED IN THE FIELD

Sample date: 06/30/98

Depth to water: $55.6 \mathrm{ft}(16.95 \mathrm{~m})$ below TOC

WELL BGO 51D

MEASUREMENTS CONDUCTED IN THE FIELD

Sample date: $06 / 30 / 98$

Depth to water. $52.55 \mathrm{ft}(16.02 \mathrm{~m})$ below TOC

Time: 9:34

WELL BGO 52A

MEASUREMENTS CONDUCTED IN THE FIELD

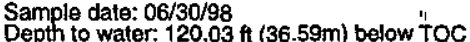

Water elevation: $164.37 \mathrm{ft}(50.10 \mathrm{~m}) \mathrm{ms}$

\section{WELL BGO 52AA}

MEASUREMENTS CONDUCTED IN THE FIELD

Sample date: $06 / 30 / 98$ ft $(36.84 \mathrm{~m})$ below toC

Depth to water: $120.85 \mathrm{ft}(36.84 \mathrm{~m})$ below
Water elevation: $163.65 \mathrm{ft}(49.88 \mathrm{~m}) \mathrm{msl}$

\section{WELL BGO 52B}

MEASUREMENTS CONDUCTED IN THE FIELD

Sample date: $06 / 30 / 98$
Depth to water: 54.03 th $(16.47 \mathrm{~m})$ below TOC
Water elevation: 230.37 t

\section{WELL BGO 52C}

MEASUREMENTS CONDUCTED IN THE FIELD Sample date: $06 / 30 / 98$ (16.09m) below TOC Depth to water: $52.8 \mathrm{ft}(16.09 \mathrm{~m})$ below TOC
Water elevation: $231.7 \mathrm{tt}(70.62 \mathrm{~m}) \mathrm{ms}$ if

\section{WELL BGO 52D}

MEASUREMENTS CONDUCTED IN THE.FIELD Sample date: $06 / 30 / 98$ (15.28m) below ToC

\section{WELL BGO 53A}

MEASUAEMENTS CONDUCTED IN THE FIELD

Sample date: 06/30/98

Depth to water: 131.85 ft $(40.19 \mathrm{~m})$ below TOC

Time: 7:50

\section{WELL BGO 53AA}

MEASUREMENTS CONDUCTED IN THE FIELD

Sample date: 06/30/98

Depth to water: $132.8 \mathrm{ft}(40.48 \mathrm{~m})$ below TOC

\section{WELL BGO 53B}

MEASUREMENTS CONDUCTED IN THE FIELD

Sample date: 06/30/98

Depth to water: $68.45 \mathrm{ft}(20.86 \mathrm{~m})$ below TOC

Water elevation: $222.65 \mathrm{ft}(67.86 \mathrm{~m}) \mathrm{ms} 1$

Time: 7:48

\section{WELL BGO 53C}

MEASUREMENTS CONDUCTED IN THE FIELD

Sample date: 06/30/98

Depth to water: $6.9 \mathrm{ft}(20.39 \mathrm{~m})$ below TOC
Water elevation: $224 \mathrm{tt}(68.28 \mathrm{~m}) \mathrm{ms}$ (

Time: 7:47

\section{WELL BGO 53D}

MEASUREMENTS CONDUCTED IN THE FIELD

Sample date: $06 / 30 / 98$
Depth to water: $60.9 \mathrm{At}(18.56 \mathrm{~m})$ below TOC

\section{WELL BGX 1A}

MEASUREMENTS CONDUCTED IN THE FIELD

Sample date: 06/29/98

Depth to water: $133 \mathrm{ft}$ (40.54m) below TOC

Water elevation: $158.2 \mathrm{ft}(48.22 \mathrm{~m}) \mathrm{msl}$

Time: 14:32

\section{WELL BGX $1 C$}

MEASUREMENTS CONDUCTED IN THE FIELD

Sample date: 06/29/98

Depth to water: $73.7 \mathrm{ft}(22.46 \mathrm{~m})$ below TOC
Water elevation: $217.6 \mathrm{ft}(66.33 \mathrm{~m}) \mathrm{msl}$

Time: 14:34 
WELL BGX 10

MEASUREMENTS CONDUCTED IN THE FIELD Sample date: 06/29/98 Depth to water: $61.98 \mathrm{ft}(18.89 \mathrm{~m})$ below $\mathrm{TOC}$
Water elevation: $229.32 \mathrm{ft}(69.90 \mathrm{~m}) \mathrm{msl}$

\section{WELL BGX 28}

MEASUREMENTS CONDUCTED IN THE FIELD

Sample date: 06/29/98

Depth to water: $76.99 \mathrm{ft}(23.47 \mathrm{~m})$ below TOC

Time: 14:25

\section{WELL BGX 2D}

MEASUREMENTS CONDUCTED IN THE FIELD

Sample date: $06 / 29 / 98$
Depth to water: $74.26 \mathrm{ft}(22.63 \mathrm{~m})$ below TOC
Weter

\section{WELL BGX 3D}

MEASUREMENTS CONDUCTED IN THE FIELD

Sample date: 06/29/98

Depth to water. $74.57 \mathrm{ft}(22.73 \mathrm{~m})$ below TOC
Water elevation: $216.63 \mathrm{Ht}(66.03 \mathrm{~m}) \mathrm{ms}$

\section{WELL BGX 4A}

MEASUREMENTS CONDUCTED IN THE FIELD

Sample date: 06/29/98

(4)

Water elevation: $155.41 \mathrm{ft}(47.37 \mathrm{~m}) \mathrm{msl}$

\section{WELL BGX 4C}

MEASUREMENTS CONDUCTED IN THE FIELD

Sample date: $06 / 29 / 98$
Oepth to water: $74.37 \mathrm{ft}(22.67 \mathrm{~m})$ below TOC
Water elevation: $216.43 \mathrm{ft}(65.97 \mathrm{~m}) \mathrm{msl}$

\section{WELL BGX 4D}

MEASUREMENTS CONDUCTED IN THE FIELD

Sample date: 06/29/98

Depth to water $73.46 \mathrm{Ht}(22.39 \mathrm{~m})$ below TOC

ESH-EMS-980569

\section{WELL BGX 5D}

MEASUREMENTS CONDUCTED IN THE FIELD

Sample date: $06 / 29 / 98$
Depth to water: 73.27 fi $(22.33 \mathrm{~m})$ below TOC

\section{WELL BGX 6D}

MEASUREMENTS CONDUCTED IN THE FIELD

Sample date: $06 / 30 / 98$

Sample date: 06/30/98
Depth to water: $67.97 \mathrm{ft}(20.72 \mathrm{~m})$ below TOC
Water elevation: $209.03 \mathrm{Ht}(63.71 \mathrm{~m}) \mathrm{msl}$

Time: 8:55

\section{WELL BGX 7D}

MEASUREMENTS CONDUCTED IN THE FIELD

Sample date: $06 / 30 / 98$
Depth to water: $70.72 \mathrm{ft}(21.56 \mathrm{~m})$ below TOC
Water elevation: $208.48 \mathrm{ft}(63.55 \mathrm{~m}) \mathrm{ms}$

Time: 8:50

\section{WELL BGX 8DR}

MEASUREMENTS CONDUCTED IN THE FIELD

Sample date: $06 / 30 / 9$

Depth to water: $69.9 \mathrm{ft}(21.31 \mathrm{~m})$ below TOC

Time: 8:45

\section{WELL BGX 9D}

MEASUAEMENTS CONDUCTED IN THE FIELD

Sample date: 06/30/98

Depth to water: 51.29 tt $(15.63 \mathrm{~m})$ below TOC

\section{WELL BGX 10D}

MEASUREMENTS CONDUCTED IN THE FIELD

Sample date: $06 / 30 / 98$

Depth to water: $50 \mathrm{t}(15.24 \mathrm{~m})$ below TOC
Water elevation: $226.9 \mathrm{ft}(69.16 \mathrm{~m}) \mathrm{msl}$

Time: 8:37

\section{WELL BGX 11D}

MEASUREMENTS CONDUCTED IN THE FIELD 


\section{WELL BGX 12C}

MEASUREMENTS CONDUCTED IN THE FIELD

Sample date: $06 / 30 / 98$

Depth to water: 37.82 f t (11.53m) below toc

\section{WELL BGX 12D}

MEASUREMENTS CONDUCTED IN THE FIELD

Sample date: 06/30/98

Depth to water: $33.14 \mathrm{ft}(10.10 \mathrm{~m})$ below TOC

$6 \mathrm{Ht}(73.78 \mathrm{~m}) \mathrm{msi}$

"

WELL CRP 1

MEASUREMENTS CONDUCTED IN THE FIELD

Sample date: 05/14/98
Depth to water: $64.6 \mathrm{ft}(19.39 \mathrm{~m})$ below TOC
Water elevation: $211 \mathrm{ft}(64.31 \mathrm{~m}) \mathrm{ms}$

\section{WELL CRP 2}

MEASUREMENTS CONDUCTED IN THE FIELD

Sample date: 05/14/98

Depth to water: $69 \mathrm{tt}(21.03 \mathrm{~m})$ below TOC
Water elevation: $209.7 \mathrm{tt}(63.92 \mathrm{~m}) \mathrm{ms}$

\section{WELL CRP 3C}

MEASUREMENTS CONDUCTED IN THE FIELD

Sample date: $05 / 14 / 98$
Depth to water: 70.55 th $(21.50 \mathrm{~m})$ below toc
What

\section{WELL CRP 3D}

MEASUREMENTS CONDUCTED IN THE FIELD

Sample date: 05/14/98

Wepth to water: Not available

\section{WELL CRP 5C}

MEASUREMENTS CONDUCTED IN THE FIELD

Sample date: $05 / 14 / 98$.

Wepth te waet: $7.55 \mathrm{ft}(23.64 \mathrm{~m})$ below
Water elevation: $199.35 \mathrm{H}(60.76 \mathrm{~m}) \mathrm{ms}$

\section{WELL CRP 5D}

MEASUREMENTS CONDUCTED IN THE FIELD

Sample date: 05/14/98

Water elevation: $62.59 \mathrm{ft}(19.19 \mathrm{~m})$ below TOC

TIme: 11:45

\section{WELL CRP 6DR}

MEASUREMENTS CONDUCTED IN THE FIELD

Sample date: 05/14/98

Wepth to water $53.4 \mathrm{ft}(16.28 \mathrm{~m}$ ) below TOC

Time: 10:25

\section{WELL CRP 7D}

MEASUREMENTS CONDUCTED IN THE FIELD

Sample date: 05/14/98

Water elevation: Not available

Time: 11:29

\section{WELL CRP 8D}

MEASUREMENTS CONDUCTED IN THE FIELD

Sample date: 05/14/98

Wather elevation: $210.9 \mathrm{ft}(11.43 \mathrm{~m})$ below
W
W.2.28m) $\mathrm{ms}$

Time: 10:34

\section{WELL CRP 9D}

MEASUREMENTS CONDUCTED IN THE FIELD

Sample date: 05/14/98

Depth to water: $61.4 \mathrm{At}(18.71 \mathrm{~m})$ below TOC

Time: 11:33

\section{WELL CRP 10D}

MEASUREMENTS CONDUCTED IN THE FIELD

Sample date: 05/14/98

Depth to water: 59 it (17.98m) below TOC

Time: 10:39

\section{WELL CRP 11D}

MEASUREMENTS CONDUCTED IN THE FIELD

Sample date: 05/14/98

Depth to water: $61.25 \mathrm{ft}(18.67 \mathrm{~m})$ below TOC

Time: 11:51 
WELL CSB 1A

MEASUREMENTS CONDUCTED IN THE FIELD

Sample date: 05/44/98

Depth to water: $77.95 \mathrm{ft}(23.76 \mathrm{~m})$ below TOC
Water elevation: $213.85 \mathrm{ht}(65.18 \mathrm{~m}) \mathrm{msl}$

\section{WELL CSB 1C}

MEASUREMENTS CONDUCTED IN THE FIELD

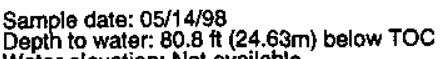

Water elevation: Not available

\section{WELL CSB 2A}

MEASUREMENTS CONDUCTED IN THE FIELD

Sample date: 05/14/98

Wopth to water: 70.8 $\mathrm{ft}(21.58 \mathrm{~m})$ below TOC

\section{WELL CSB 2C}

MEASUREMENTS CONDUCTED IN THE FIELD

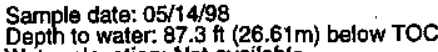

Weph to water. 7.3 .

\section{WELL CSB 3A}

MEASUREMENTS CONDUCTED IN THE FIELD

Sample date: 05/14/98

Depth to water: Not available
Water elevation: Not available

\section{WELLL CSB 3C}

MEASUREMENTS CONDUCTED IN THE FIELD

Sample date: $05 / 14 / 98$
Depth to water: $76.1 \mathrm{tt}(23.20 \mathrm{~m})$ below TOC
Water elevation: Not availablo

Time: 9:50

WELL CSB 4A

MEASUREMENTS CONDUCTED IN THE FIELD

Sample date: 05/14/98

Depth to water: $72.6 \mathrm{ft}(22.13 \mathrm{~m})$ below TOC

\section{WELL CSB 5A}

MEASUREMENTS CONDUCTED IN THE FIELD

Sample date: $05 / 14 / 98$

Depth to water. $7.3 \mathrm{H}(21.43 \mathrm{~m})$ below TOC

Time: 9:48

WELL CSB 6A

MEASUREMENTS CONDUCTED IN THE FIELO

Sample date: 05/14/98

Depth to water: Not available

Time: 9:56

WELL CSB 7D

MEASUREMENTS CONDUCTED IN THE FIELD

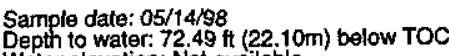

Time: 10:08

Water elevation: Not available

\section{WELL FIW 1ID}

MEASUREMENTS CONDUCTED IN THE FIELD

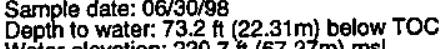

WELL FIW IMC

MEASUREMENTS CONDUCTED IN THE FIELD

Sample date: 06/30/98

Depth to water: $78.7 \mathrm{ft}$ (23.99m) below TOC

\section{WELL FIW 2IC}

MEASUREMENTS CONDUCTED IN THE FIELD

Sample date: 06/30/98

Depth to water. $76 \mathrm{ft}(23.17 \mathrm{~m})$ below TOC
Water elevation: $214.5 \mathrm{ft}(65.38 \mathrm{~m}) \mathrm{msl}$

Time: 11:25

\section{WELL. FIW 2MA}

MEASUREMENTS CONDUCTED IN THE FIELD

Sample date: $06 / 30 / 98$.

Time: 11:24 


\section{WELL FIW 2MC}

MEASUREMENTS CONDUCTED IN THE FIELD

Sample date: 06/30/98

Depth to water: $794(24.08 \mathrm{~m})$ below To
Water elevation: $206.8 \mathrm{ft}(63.03 \mathrm{~m}) \mathrm{ms}$

\section{WELL FIW 2MD}

Sample date: $06 / 30 / 98$

Sample date: $06 / 30198$.

\section{WELL FOB 1D}

MEASUREMENTS CONDUCTED IN THE FIELD

Sample date: 06/29/98

Depth tow water: $18.9 \mathrm{ft}(5.64 \mathrm{~m})$ below TOC
Water elevation: $206.9 \mathrm{Ht}(63.06 \mathrm{~m}) \mathrm{msl}$

\section{WELL FOB 2D}

MEASUREMENTS CONDUCTED IN THE FIELD

Sample date: $06 / 29 / 98$

Water elevation: $207 \mathrm{tt}(63.09 \mathrm{~m}) \mathrm{ms}$ ) TOC

\section{WELL FOB 3D}

MEASUREMENTS CONDUCTED IN THE FIELD Sample date: 06/29/198

\section{WELL FOB 4D}

MEASUREMENTS CONDUCTED IN THE FIELD Sample date: 06/29/98 Wepth to water: $42.52 \mathrm{ft}(12.96 \mathrm{~m})$ below TOC

\section{WELL FOB 5C}

MEASUREMENTS CONDUCTED IN THE FIELD Sample date: 06/30/98 Depth to water: $52.25 \mathrm{H}$ (15.93m) below Toc Water elevation: $206.25 \mathrm{H}(62.87 \mathrm{~m}) \mathrm{ms}$
MEASUREMENTS CONDUCTED IN THE FIELD

Deater to water: $19.15 \mathrm{ft}(5.84 \mathrm{~m})$ below TOC

Time: 11:33

\section{WELL FOB 7A}

MEASUREMENTS CONDUCTED IN THE FIELD

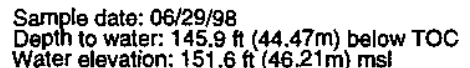

Time: 10:10

\section{WELL FOB 7C}

MEASUREMENTS CONDUCTED IN THE FIELD

Sample date: $06 / 29 / 98$ (26.17m) below TOC

Time: 10:09

\section{WELL FOB 7D}

MEASUREMENTS CONDUCTED IN THE FIELD

Sample date: 06/29/98

Depth to water. 81.08 itt $(24.71 \mathrm{~m})$ below TOC
Water elevation: $216.82 \mathrm{tt}(66.0 \mathrm{~m}) \mathrm{msl}$

Time: 10:08

\section{WELL FOB 8D}

MEASUREMENTS CONDUGTED IN THE FIELD

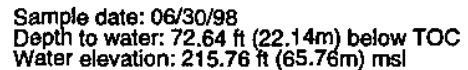

Time: 12:42

\section{WELL FOB 9C}

MEASUREMENTS CONDUCTED IN THE FIELD

Sample data: $01 / 30198$
Depth to
Water: 81.2 .
Watt $(24.75 \mathrm{~m})$ below

Time: 11:04

\section{WELL FOB 9D}

MEASUREMENTS CONDUCTED IN THE FIELD

$$
\begin{aligned}
& \text { Sample date: } 06 / 30 / 98 \\
& \text { Deptht to water. } 76.8 \text { tit } \\
& \text { Water elevatim) below TOC }
\end{aligned}
$$

Time: 11:03

\section{WELL FOB 10D}

MEASUREMENTS CONDUCTED IN THE FIELD

Sample date: $06 / 30 / 98$

Deph to water: $69.3 \mathrm{ft}(21.12 \mathrm{~m})$ below TOC

Water elevation: $218.4 \mathrm{ft}(66.5 \mathrm{~m}) \mathrm{ms}$

Time: 12:15 


\section{WELL FOB $11 \mathrm{C}$}

MEASUREMENTS CONDUCTED IN THE FIELD

Sample date: 06/29/98

Depth to water: $47.18 \mathrm{Ht}(14.38 \mathrm{~m})$ below TOC

Time: 9:00

\section{WELL FOB 110}

MEASUREMENTS CONDUCTED IN THE FIELD

Depth to water: $43.15 \mathrm{ft}(13.15 \mathrm{~m})$ below TOC

Water elevation: $220.25 \mathrm{tt}(67.13 \mathrm{~m}) \mathrm{ms}$ |

\section{WELL FOB 12D}

MEASUREMENTS CONDUCTED IN THE FIELD

Sample date: $06 / 30 / 98$

Depth to water: $63.5 \mathrm{ft}(19.36 \mathrm{~m})$ below TOC

\section{WELL. FSB 50PD}

MEASUREMENTS CONDUCTED IN THE FIELD

Sample date: 06/30/98

Depth to water: $47.13 \mathrm{ft}(14.37 \mathrm{~m})$ below TOC

\section{WELL FSB 76}

MEASUREMENTS CONDUCTED IN THE FIELD

Sample date: 06/29/98

Sample date: $06 / 29 / 98$
Depth to water: $73.8 \mathrm{ft}(22.49 \mathrm{~m})$ below TOC
Water elevation: $220.4 \mathrm{ft}(67.18 \mathrm{~m}) \mathrm{msl}$

\section{WELL FSB 76A}

MEASUREMENTS CONDUCTED IN THE FIELD

Sample date: 06/29/98

f $(41.97 \mathrm{~m})$ below TOC

Water elevation: $156.2 \mathrm{ft}(47.61 \mathrm{~m}) \mathrm{ms} \mid$

\section{WELL FSB 76B}

MEASUREMENTS CONDUCTED IN THE FIELD Sample date: $06 / 29 / 98$
Depth to water: $141.37 \mathrm{ft}(43.09 \mathrm{~m})$ below TOC
Water elevation: $152.43 \mathrm{ff}(46.46 \mathrm{~m}) \mathrm{ms}\}$

\section{WELL FSB 76C}

MEASUREMENTS CONDUCTED IN THE FIELD

Sample date: 06/29/98

Water elevation: $214.92 \mathrm{ft}(65.51 \mathrm{~m}) \mathrm{ms}$

Time: 8:49

\section{WELL FSB 77}

MEASUREMENTS CONDUCTED IN THE FIELD

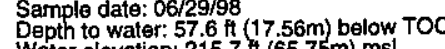

Time: 9:30

\section{WELL FSB 78}

MEASUREMENTS CONDUCTED IN THE FIELD

Sample date: $06 / 30 / 98$

Depth to water: $60.68 \mathrm{ft}(18.50 \mathrm{~m})$ below TOC

Water elevation: $211.92 \mathrm{Ht}(64.59 \mathrm{~m}) \mathrm{msl}$

Time: 12:20

WELLL FSB 78A

MEASUREMENTS CONDUCTED IN THE FIEL

Sample date: 06/30/98

Water elevation: $157.11 \mathrm{ft}(47.89 \mathrm{~m}) \mathrm{msl}$

Time: 12:25

\section{WELL FSB 78B}

MEASUREMENTS CONDUCTED IN THE FIELD

Sample date: 06/30/98

Time: $12 \cdot 30$

\section{WELLL FSB 78C}

MEASUREMENTS CONDUCTED IN THE FIELD

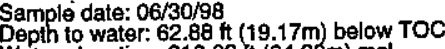

\section{WELL FSB 79}

MEASUREMENTS CONDUCTED IN THE FIELD Sample date: 06/29/98
Depth to water. $27.2 \mathrm{ft}(8.29 \mathrm{~m})$ below TOC
Water elevation: $190.6 \mathrm{tt}(58.10 \mathrm{~m}) \mathrm{ms}$ l 


\section{WELL FSB 79A}

MEASUREMENTS CONDUCTED IN THE FIELD

Sample date: 06/29/98

Depth to water: $59.1 \mathrm{ft}(18.01 \mathrm{~m})$ below TOC
Water elevation: $159 \mathrm{ft}(48.46 \mathrm{~m}) \mathrm{ms}$ I

\section{WELL FSB 79B}

MEASUREMENTS CONDUCTED IN THE FIELD

Sample date: $06 / 29 / 98$ Depth to water: $58.95 \mathrm{ft}$ (17.97m) below TOC

Depth to water: $58.95 \mathrm{ft}(17.97 \mathrm{~m})$ below TOC

\section{WELL FSB 79C}

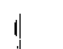

MEASUREMENTS CONDUCTED IN THE FIELD

Sample date: $06 / 29 / 98$
Depth to water: $20.9 \mathrm{ft}(6.37 \mathrm{~m})$ below roc
Water elevation: $197.5 \mathrm{tt}(60.20 \mathrm{~m}) \mathrm{ms}$

\section{WELL FSB 87A}

MEASUREMENTS CONDUCTED IN THE FIELD

Sample date: 06/30/98

Depth to water: $132.95 \mathrm{ft}(40.52 \mathrm{~m})$ below roc

Depth to water: $132.95 \mathrm{ft}(40.52 \mathrm{~m})$ below
Water olevation: $154.85 \mathrm{ft}(47.20 \mathrm{~m}) \mathrm{msl}$

\section{WELL FSB 87B}

MEASUREMENTS CONDUCTED IN THE FIELD

Samole date: $06 / 30 / 98$

Depth to water: $136.4 \mathrm{ft}(41.58 \mathrm{~m})$ below to

Water elevation: $151.1 \mathrm{ft}(46.06 \mathrm{~m}) \mathrm{msl}$

\section{WELL FSB 87C}

MEASUREMENTS CONDUCTED IN THE FIELD

Sample date: $06 / 30 / 98$

Wapter to water: 75.9 tt $(23.13 \mathrm{~m})$ below TOC

WELL FSB 87D

MEASUREMENTS CONDUCTED IN THE FIELD

Sample date: $06 / 30 / 98$

Wepth to water: Not available

Time: 12:49

Time: 9:44

Tirne: 9:43

Time: 9:42

Time: 12:55

Time: 12:53

Time: 12:5

ESH-EMS-980569
WELL FSB 88C

MEASUREMENTS CONDUCTED IN THE FIELD

Sample date: 06/29/98

Time: 9:09

Wath to water: $68.17 \mathrm{ft}(20.78 \mathrm{~m})$ below TOC

\section{WELL FSB 88D}

MEASUREMENTS CONDUCTED IN THE FIELD

Sample date: 06/29/98
Depth to water. 63.22 ft $(19.27 \mathrm{~m})$ below TOC

Time: 9:10

\section{WELL FSB $89 C$}

MEASUREMENTS CONDUCTED IN THE FIELD

Sample date: $06 / 29 / 98$

Depth to water: $67.05 \mathrm{ft}(20.44 \mathrm{~m})$ below TOC

Time: 9:19

WELL FSB 89D

MEASUREMENTS CONDUCTED IN THE FIELD

Sample date: 06/29/98

Depth to water $62.6 \mathrm{ft}(19.08 \mathrm{~m})$ below TOC
Water elevation: $218.6 \mathrm{ft}(66.63 \mathrm{~m}) \mathrm{ms}$

Time: 9:18

WELL FSB 90C

MEASUREMENTS CONDUCTED IN THE FIELD

Sample date: $06 / 30 / 98$

Water elovation: $65.47 .9 \mathrm{ft}(19.96 \mathrm{~m})$ below TOC

Time: 10:30

\section{WELL FSB 90D}

MEASUREMENTS CONDUCTED IN THE FIELD

Sample date: 06/30/98
Depth to water: 61.1
Wt $(18.62 \mathrm{~m})$ below TOC

Time: 10:33

\section{WELL FSB 91C}

MEASUREMENTS CONDUCTED IN THE FIELD

Sarmple date: 06/29/98 $(20.13 \mathrm{~m})$ below TOC

Wath to water: $66.05 \mathrm{ft}(20.13 \mathrm{~m})$ below $\mathrm{T}$ (O)
Time: 9:26 


\section{WELL FSB 91D}

MEASUREMENTS CONDUCTED IN THE FIELD

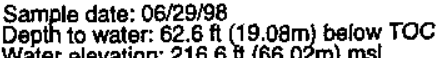

WELL FSB 92C

MEASUREMENTS CONDUCTED IN THE FEELD

Sample date: 06/29/98

Depth to water: $63.58 \mathrm{ft}(19.38 \mathrm{~m})$ below TOC
Water elevation: 212.12 \% $(64.65 \mathrm{~m}) \mathrm{msl}$

\section{WELL FSB 92D}

MEASUREMENTS CONDUCTED IN THE FIELD

Sample date: 06/29/9

Wepth to water. $60.75 \mathrm{ft}(12.52 \mathrm{~m})$ below TOC

\section{WELL FSB 93C}

MEASUREMENTS CONDUCTED IN THE FIELD

Sample date: 06/29/98

Weph to water. 65.05 th (19.83m) below TOC

\section{WELL FSB 93D}

MEASUREMENTS CONDUCTED IN THE FIELD

Sample date: 06/29/98

Depth to water: $62.35 \mathrm{ft}(19.00 \mathrm{~m})$ below TOC

\section{WELL FSB 94C}

MEASUREMENTS CONDUCTED IN THE FIELD

Sample date: 06/30/98

Depth to water: $70.57 \mathrm{ft}(21.51 \mathrm{~m})$ below TOC

\section{WELL FSB 94DR}

MEASUREMENTS CONDUCTED IN THE FIELD

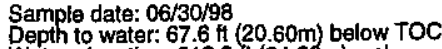

Depth to water: $67.6 \mathrm{Ht}(20.60 \mathrm{~m})$ below
WELL FSB 95CR

MEASUREMENTS CONDUCTED IN THE FIELD

Sample date: 06/30/9

Wath to water: $73.74 \mathrm{ft}(22.48 \mathrm{~m})$ below TOC

Time: 11:06

\section{WELL FSB 95DR}

MEASUREMENTS CONDUCTED IN THE FIELD

Sample date: $06 / 30 / 98$
Depth to water: $71.05 \mathrm{ft}(21.66 \mathrm{~m})$ below TOC

Time: 11:04

\section{WELL FSB 96AR}

MEASUREMENTS CONDUCTED IN THE FIELD

Sample date: 06/30/98

Depth to water: $127.27 \mathrm{ft}(38.79 \mathrm{~m})$ below TOC

\section{WELL FSB 97A}

MEASUREMENTS CONDUCTED IN THE FIELO

Sample date: 06/30/98

Depth to water: $133.74 \mathrm{ft}(40.76 \mathrm{~m})$ below TOC

Time: 11:17

\section{WELL FSB 97C}

MEASUREMENTS CONDUCTED IN THE FIELD

Sample date: $06 / 30 / 98$
Depth to water: $75.03 \mathrm{ft}(22.87 \mathrm{~m})$ below TOC

Time: 11:13

\section{WELL FSB 97D}

MEASUREMENTS CONDUCTED IN THE FIELD

Sample date: $06 / 30 / 98$

Depth to water. $71.91 \mathrm{ft}(21.92 \mathrm{~m})$ below TOC

\section{WELL FSB 98AR}

MEASUREMENTS CONDUCTED IN THE FIELD

Sample date: 06/30/98

Wepth to water: $131.76 \mathrm{ft}(40.16 \mathrm{~m})$ below TOC 
WELL FSB 98C

MEASUREMENTS CONDUCTED IN THE FIELD

Sample date: 06/30/98

Depth to water.72.88 tif (22.21 $\mathrm{m}$ below TOC

\section{WELL FSB 98D}

MEASUREMENTS CONDUCTED IN THE FIELD

Sample date: $06 / 30 / 98$
Depth to water: $69.28 \mathrm{H}(21.12 \mathrm{~m})$ below
Water elevation: $215.22 \mathrm{tt}(65.60 \mathrm{~m})$ msl

\section{WELL FSB 99A}

MEASUREMENTS CONDUCTED IN THE FIELD

Sample date: $06 / 30 / 98$

Depth to water: $136.3 \mathrm{ft}(41.54 \mathrm{~m})$ below TOC

Water elevation: $151.3 \mathrm{tt}(46.12 \mathrm{~m}) \mathrm{ms}$ |

\section{WELL FSB 99C}

MEASUREMENTS CONDUCTED IN THE FIELD

Sample date: 06/30/98

Depth to water. 75.42 t(22.99m) below TOC

Water elevation: $21228 \mathrm{Ht}(64.70 \mathrm{~m}) \mathrm{msl}$

\section{WELL FSB 99D}

MEASUREMENTS CONDUCTED IN THE FIELD

Sample date: 06/30/98

Depth to water. $71.3 \mathrm{~A}(21.7 \mathrm{~m})$ below TOC
Water elevation: $216.3 \mathrm{t}(65.93 \mathrm{~m}) \mathrm{ms}$

\section{WELL FSB100A}

MEASUREMENTS CONDUCTED IN THE FIELD

Sample date: $06 / 30 / 98$

Deph to waler. $33.73 \mathrm{ft}(40.76 \mathrm{~m})$ below ToC

$(46.41 \mathrm{~m}) \mathrm{ms}$

WELL FSB101A

MEASUREMENTS CONDUCTED IN THE FIELD

Sample date: 06/30/98

Depth to water: $132.66 \mathrm{ft}(40.44 \mathrm{~m})$ below TOC
Water elevation: $152.54 \mathrm{ft}(46.49 \mathrm{~m}) \mathrm{msl}$.

Time: 11:56

\section{WELL FSB102C}

MEASUREMENTS CONDUCTED IN THE FIELD

Sample date: 06/30/98

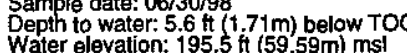

Time: 13:03

\section{WELL FSB103C}

MEASUREMENTS CONDUCTED IN THE FIELD

Sample date: 06/29/98

Weth to water.

Time: 12:47

\section{WELL FSB104C}

MEASUREMENTS CONDUCTED IN THE FIELD

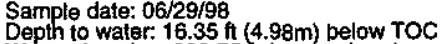

Wapter water: $16.35 \mathrm{H}$ (4.98m) pelow $\mathrm{roc}$

Time: 12:50

\section{WELL FSB104D}

MEASUREMENTS CONDUCTED IN THE FIELD

Sample date: 06/29/98

Wepth to water: $12.55 \mathrm{ft}(3.83 \mathrm{~m})$ below TOC

Time: 12:52

\section{WELL FSB105C}

MEASUREMENTS CONDUCTED IN THE FIELD

Sample date: $06 / 30 / 98$

Water olevation: $210.53 \mathrm{Ht}(64.17 \mathrm{~m}) \mathrm{ms}$ (

Time: 11:28

\section{WELL FSB105DR}

MEASUREMENTS CONDUCTED IN THE FIELD

Sample date: $06 / 30 / 98$
Depth to water: $71.63 \mathrm{ft}(21.83 \mathrm{~m})$ below TOC

Time: 11:23

\section{WELL FSB106C}

MEASUREMENTS CONDUCTED IN THE FIELD

Sample date: 06/29/98

Depth to water: 32.6 tt $(9.94 \mathrm{~m})$ below TOC

Time: 10:26 


\section{WELL. FSB106D}

MEASUREMENTS CONDUCTED IN THE FIELD

Sample date: 06/29/98

Depth to water: $27,1 \mathrm{tt}(8.26 \mathrm{~m})$ below TOC

\section{WELL FSB107C}

MEASUREMENTS CONDUCTED IN THE FIELD

Sample date: $06 / 29 / 98$
Depth to water: $58 \mathrm{ft}(17.68 \mathrm{~m})$ below TOC
Water elevation: $212.9 \mathrm{tt}(64.89 \mathrm{~m}) \mathrm{msl}$

\section{WELL FSB107D}

MEASUREMENTS CONDUCTED IN THE FIELLD

Sample date: 06/29/98

(16.46m) below TOC

Water elevation: $216.99 \mathrm{tr}(66.14 \mathrm{~m}) \mathrm{ms}$

\section{WELL FSB108D}

MEASUREMENTS CONDUCTED IN THE FIELD

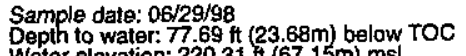

\section{WELL. FSB109D}

MEASUREMENTS CONDUCTED IN THE FIELD

Sample date: 06/30/98

Sample date: $06 / 30 / 98$
Depth to water: $76.2 \mathrm{Ht}(23.23 \mathrm{~m})$ below TOC
Water elevation: $216.9 \mathrm{tt}(66.1 \mathrm{~m}) \mathrm{ms}$

\section{WELL FSB110C}

MEASUREMENTS CONDUCTED IN THE FIELD

Sample date: 06/29/98

Depth to water: 31.95 tt $(9.74 \mathrm{~m})$ below TOC
Water elevation: $202.55 \mathrm{tt}(61.74 \mathrm{~m}) \mathrm{msl}$

\section{WELL FSB110D}

MEASUREMENTS CONDUCTED IN THE FIELD

Sample date: $06 / 29 / 98$

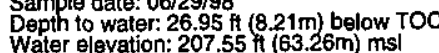

Time: 9:54

\section{WELL FSB111C}

MEASUREMENTS CONDUCTED IN THE FIELD

Sample date: 06/29/98

Depth to water: $61.98 \mathrm{ft}(18.89 \mathrm{~m})$ below TOC
Water elevation: $214.32 \mathrm{ft}(65.33 \mathrm{~m}) \mathrm{ms}$

Time: 9:15

\section{WELL FSB111D}

MEASUREMENTS CONDUCTED IN THE FIELD

Sample date: $06 / 29 / 98$
Depth to water: $58.25 \mathrm{ft}(17.75 \mathrm{~m})$ below TOC

Time: 9:14

\section{WELL FSB112A}

MEASUREMENTS CONDUCTED IN THE FIELD

Sample date: 06/29/98

Depth to water: $75.2 \mathrm{ft}(22.92 \mathrm{~m})$ below TOC
Water elevation: $153.9 \mathrm{ft}(46.91 \mathrm{~m}) \mathrm{ms}$

\section{WELL FSB112C}

MEASUREMENTS CONDUCTED IN THE FIELD

Sample date: 06/29/98
Depth to water: $25.3 \mathrm{ft}(7.71 \mathrm{~m})$ below TOC
Water elevation: $203.8 \mathrm{ft}(62.12 \mathrm{~m}) \mathrm{ms}$

Time: 10:05

Time: 13:12

\section{WELL FSB112D}

MEASUREMENTS CONDUCTED IN THE FIELD

Sample date: 06/29/98

Depth to water: $21.32 \mathrm{ft}(6.50 \mathrm{~m})$ below TOC
Water elevation: 208.28 t $(63.48 \mathrm{~m}) \mathrm{msl}$

Time: 13:14

\section{WELL FSB113A}

MEASUREMENTS CONDUCTED IN THE FIELL

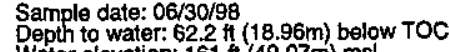

Time: 13:34

\section{WELL FSB113C}

MEASUREMENTS CONDUCTED IN THE FIELD

Sample date: $06 / 30 / 98$

Time: 13:35 


\section{WELL FSB113D}

MEASUREMENTS CONDUCTED IN THE FIELD Sample date: 06/30/98 Daph to water $13.75 \mathrm{ft}(4.19 \mathrm{~m})$ below foc
Water elevation: $208.75 \mathrm{tt}(63.63 \mathrm{~m}) \mathrm{ms}$

\section{WELL FSB114A}

Time: 13:37

MEASUREMENTS CONDUCTED IN THE FIELD

Sample date: 06/29/98

Deph to waler. $95.7 \mathrm{ft}(29.17 \mathrm{~m})$ below TOC

\section{WELL FSB114C}

MEASUREMENTS CONDUCTED IN THE FIELD

Sample date: 06/29/98

Dapth to water. $36.97 \mathrm{ft}(11.27 \mathrm{~m})$ below Toc
Water elevation: $215.23 \mathrm{th}(65.6 \mathrm{~m}) \mathrm{ms}$

\section{WELL FSB114D}

MEASUREMENTS CONDUCTED IN THE FIELD

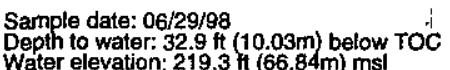

Time: 9:04

\section{WELL FSB115C}

MEASUREMENTS CONDUCTED IN THE FIELD

Sample date: $06 / 29 / 98$
Depth to water. $22.87 \mathrm{~A}(6.97 \mathrm{~m})$ below 700
Water elevation: $184.93 \mathrm{ft}(56.37 \mathrm{~m}) \mathrm{ms}$

\section{WELL FSB115D}

MEASUREMENTS CONDUCTED IN THE FIELD Sample date: 06/29/98

Sample date: $06 / 29 / 98$
Depth to water: $15.62 \mathrm{At}(4.76 \mathrm{~m})$ below TOC
Water elevation: 192.88 \&t $(58.79 \mathrm{~mm}) \mathrm{msl}$

\section{WELL FSB116C}

MEASUREMENTS CONDUCTED IN THE FIELD

Sample date: $06 / 30 / 98$

Weph to water: $12.058 \mathrm{ft}(3.67 \mathrm{~m})$ below TOC
Water elevation: $190.45 \mathrm{tt}(58.05 \mathrm{~m}) \mathrm{ms}$

ESH-EMS-980569

\section{WELL FSB116D}

MEASUREMENTS CONDUCTED IN THE FIELD

Sample date: 06/2.9/9

Time: 10:02

Water olevation: $19.53 .33(2.92 \mathrm{~m})$ below ToC

\section{WELL FSB117D}

MEASUREMENTS CONDUCTED IN THE FIELD

Sample date: $06 / 30 / 98$
Depph to water. $24.2 \mathrm{ft}(7.38 \mathrm{~m})$ below TOC

Time: 13:07

WELL FSB118D

MEASUREMENTS CONDUCTED IN THE FIELD

Sample date: 06/30/98

Depth to water: $29.45 \mathrm{ft}(8.98 \mathrm{~m})$ below TOC
Water elevation: $213.85 \mathrm{t}(65.18 \mathrm{~m}) \mathrm{msl}$

Time: 13:15

\section{WELL FSB119D}

MEASUREMENTS CONDUCTED IN THE FIELD

Sample date: 06/30/98

Water elevation: $23.5 \mathrm{H}(13.26 \mathrm{~m})$ below
TOC

Time: 13:10

\section{WELL FSB120A}

MEASUREMENTS CONDUCTED IN THE FIELD

Sample date: $06 / 29 / 98$ f $32.4 \mathrm{~m}$ ) below TOC

Time: 10:13

\section{WELL FSB120C}

MEASUREMENTS CONDUCTED IN THE FIELD

Sarnple date: $06 / 29 / 98$
Depth to watier.71.2 $\mathrm{A}(21.70 \mathrm{~m})$ below TOC
Water elevation: $208.5 \%(63.55 \mathrm{~m}) \mathrm{msl}$

Time: 10:14

\section{WELL FSB120D}

MEASUREMENTS CONDUCTED IN THE FIELD

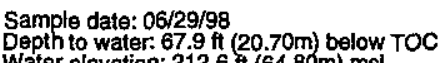

Time: 10:15 


\section{WELL FSB121C}

MEASUREMENTS CONDUCTED IN THE FIELD

Sample date: 06/29/98

Depth to water: $49.47 \mathrm{ft}(15.08 \mathrm{~m})$ below TOC

\section{WELL FSB121DR}

MEASUREMENTS CONDUCTED IN THE FIELD

Sample date: 06/29/98

Depth to water: $45.35 \mathrm{ft}(13.82 \mathrm{~m})$ below TOC

Water elevation: $210.15 \mathrm{H}(64.05 \mathrm{~m}) \mathrm{ms}$

\section{WELL FSB122C}

MEASUAEMENTS CONDUCTED IN THE FIELD

Sample date: 06/29/98

Wathr to water: $16.47 \mathrm{ft}(5.02 \mathrm{~m})$ below TOC

\section{WELL FSB122D}

MEASUREMENTS CONDUCTED IN THE FIELD

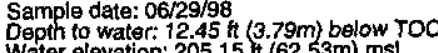

WELL FSB123C

MEASUREMENTS CONDUCTED IN THE FIELD

Sample data: $06 / 30 / 98$
Depth to water: 26.24 (t).99m) below To

\section{WELL FSB123D}

MEASUREMENTS CONOUCTED IN THE FIELD

Sample date: 06/30/98

Depth to water: $24.4 \mathrm{ft}(7.44 \mathrm{~m})$ below TOC
Water elevation: $213.7 \mathrm{ft}(65.14 \mathrm{~m}) \mathrm{msl}$

\section{WELL FSB150PC}

MEASUREMENTS CONDUCTED IN THE FIELD

Sample date: 06/29/98

Depth to water: $36.65 \mathrm{ft}(11.17 \mathrm{~m})$ below TOC

Time: $9: 51$
WELL FSB150PD

MEASUREMENTS CONDUCTED IN THE FIELD

Sample date: $06 / 30 / 98$

Wath to water: 48.54 A $(14.80 \mathrm{~m})$ balow TOC

Time: 13:00

\section{WELL FSL 1D}

MEASUREMENTS CONDUCTED IN THE FIELD

Sample date: $06 / 30 / 98$

Wepth to water: $85.9 \mathrm{ft}(26.18 \mathrm{~m})$ below TOC

Time: 10:14

\section{WELL FSL 2D}

MEASUREMENTS CONDUCTED IN THE FIELD

Sample date: $06 / 30 / 98$ (24.55m) below TOC

Water elevation: $225.25 \mathrm{Ht}(68.66 \mathrm{~m}) \mathrm{ms}$

Time: 10:21

\section{WELL FSL 3D}

MEASUREMENTS CONDUCTED IN THE FIELD

Sample date: $06 / 30 / 98$

Depth to water: $79.4 \mathrm{ft}(24.20 \mathrm{~m})$ below TOC
Water elevation: $222.6 \mathrm{Ht}(67.85 \mathrm{~m}) \mathrm{ms}$ )

Time: 10:25

\section{WELL FSL 4D}

MEASUREMENTS CONOUCTED IN THE FIELD

Sample date: 06/30/98

Depht to water $75.85 \mathrm{ft}(23.12 \mathrm{~m})$ below
Water elevation: $218.25 \mathrm{t}(66.52 \mathrm{~m}) \mathrm{ms}$

Time: 10:28

\section{WELL FSL 5D}

MEASUREMENTS CONDUCTED IN THE FIELD

Sample date: $06 / 30 / 98$ Depth to water: $70.25 \mathrm{ft}(21.41 \mathrm{~m})$ below TOC

Time: 10:32

\section{WELL FSL 6D}

MEASUREMENTS CONDUCTED IN THE FIELD

Sample date: $06 / 30 / 98$

Depth to water. $65 \mathrm{ft}(19.81 \mathrm{~m})$ below TOC
Water elevation: $221.2 \mathrm{ft}(67.42 \mathrm{~m})$ msl
Time: 10:36 
WELL FSL 7D

MEASUREMENTS CONDUCTED IN THE FIELD

Sample date: $06 / 29 / 98$. 40 below

Water elevation: $220.49 \mathrm{ft}(67.21 \mathrm{~m}) \mathrm{ms}$

\section{WELL FSL 8D}

MEASUREMENTS CONDUCTED IN THEFFELD

Sample date: 06/29/98

Time: 8:55

\section{WELL FSL 9D}

MEASUREMENTS CONDUCTED IN THE FIELD Sample date: $06 / 29 / 98$
Depth to water: $66.85 \mathrm{ft}(20.38 \mathrm{~m})$ below ToC
Water elevation: $219.05 \mathrm{H}(66.77 \mathrm{~m}) \mathrm{msl}$

Time: 8:57

WELL FSS 1D

MEASUREMENTS CONDUCTED IN THE.FIELD

Sample date: 06/30/98

Depth to water: $40.12 \mathrm{ft}(12.23 \mathrm{~m})$ below TOC
Water elevation: $225.88 \mathrm{ft}(68.85 \mathrm{~m}) \mathrm{ms}$

\section{WELL FSS 2D}

MEASUREMENTS CONDUCTED IN THE FIELD

Sample date: $06 / 30 / 98$
Depth to water: $36.26 \mathrm{ft}(11.05 \mathrm{~m})$ below TOC
Water elevation: $225.34 \mathrm{ft}(68.68 \mathrm{~m}) \mathrm{ms}$

\section{WELL FSS 3D}

MEASUREMENTS CONDUCTED IN THE FIELD

Sample date: 06/30/98

Depth to water: $34.95 \mathrm{ft}(10.65 \mathrm{~m})$ below TOC

$25 \mathrm{ft}(68.05 \mathrm{~m}) \mathrm{ms}$

\section{WELL FSS 4D}

MEASUREMENTS CONDUCTED IN THE FIELD

Sample date: 06/30/98 2 m below TOC

Water elevation: $221.36 \mathrm{ft}(67.47 \mathrm{~m})$ msl

Time: 10:04

Time: 9:48
WELL HIW 1MD

MEASUREMENTS CONDUCTED IN THE FIELD

Sample date: 06/22/98

Water elevation: $239.87+4(73.1 \mathrm{~m})$ below $\mathrm{mst}$

Time: 13:23

\section{WELL HIW 1PD}

MEASUREMENTS CONDUCTED IN THE FIELD

Sample date: 06/22/98

Weph to waitir. 37 t1 $11.28 \mathrm{~m}$ below TOC

Time: 13:20

\section{WELL HIW 2A}

MEASUREMENTS CONDUCTED IN THE FIELD

Sample date: 06/22/98

Depth to water: $109.7 \mathrm{ft}(33.44 \mathrm{~m})$ below TOC
Water elevation: $168.3 \mathrm{ft}(51.30 \mathrm{~m}) \mathrm{ms}$ !

Time: 13:38

\section{WELLL HIW 2D}

MEASUREMENTS CONDUCTED IN THE FIELD

Sample date: 06/22/98

Water elevation: $236.22 \mathrm{ft}$ (12.67m) below TOC

Time: 13:25

\section{WELL HIW 2MC}

MEASUREMENTS CONDUCTED IN THE FIELD

Sample date: 06/22/98
Depth to water: $39.17 \mathrm{ft}(11.94 \mathrm{~m})$ below TOC

Time: 13:40

\section{WELL HIW 3MC}

MEASUREMENTS CONDUCTED IN THE FIELD

Sample date: $06 / 22 / 98$
Depth to water. $42.31 \mathrm{ft}(12.90 \mathrm{~m})$ below TOC
Water elevation: $231.69 \mathrm{tt}(70.62 \mathrm{~m}) \mathrm{ms}$

Time: 13:10

\section{WELL HIW 5MC}

MEASUREMENTS CONDUCTED IN THE FIELD

Sample date: 06/22/98

Depth to water. $36.78 \mathrm{ft}(11.21 \mathrm{~m})$ below TOC

Time: $13: 50$ 


\section{WELL HMD 1D}

MEASUREMENTS CONDUCTED IN THE FIELD

Sample date: $06 / 22 / 98$

Sample date: $06 / 22 / 98$
Depth to water: $52.34 \mathrm{ft}(15.95 \mathrm{~m})$ below TOC
Water elevation: $212.16 \mathrm{ft}(64.67 \mathrm{~m}) \mathrm{msl}$

\section{WELL HMD 2D}

MEASUREMENTS CONDUCTED IN THE FIELD

Sample date: $06 / 22 / 98$
Depth to water: $56.65 \mathrm{ft}(17.27 \mathrm{~m})$ below TOC
Water elevation: $204.45 \mathrm{ft}(62.32 \mathrm{~m}) \mathrm{msl}$

\section{WELL HMD 3D}

MEASUREMENTS CONDUCTED IN THE FIELD

Sample date: 06/22/98

Depth to water: $55.6 \mathrm{ft}$ (16.95m) below TOC

\section{WELL HMD 4D}

MEASUREMENTS CONDUCTED IN THE FIELD

Sample date: $06 / 22 / 98$
Depth to water: $47.37 \mathrm{ft}(14.44 \mathrm{~m})$ below TOC
Water elevation: $203.53 \mathrm{ft}(62.04 \mathrm{~m}) \mathrm{ms}$

\section{WELL HOB 1D}

MEASUREMENTS CONDUCTED IN THE FIELD

Sample date: $06 / 22 / 98$

Depth to water: $48.3 \mathrm{ft}(14.72 \mathrm{~m})$ below TOC
Water elevation: $238 \mathrm{ft}(72.54 \mathrm{~m}) \mathrm{ms}$

\section{WELL HOB 2D}

MEASUREMENTS CONDUCTED IN THE FIELD

Sarnple date: 06/22/98
Depth to water: $54 \mathrm{At}(16.46 \mathrm{~m})$ below TOC
Water elevation: $233.8 \mathrm{ft}(71.26 \mathrm{~m}) \mathrm{msl}$

\section{WELL HOB 3D}

MEASUREMENTS CONDUCTED IN THE FIELD

Sample date: 06/22/98

Depth to water: $36.55 \mathrm{ft}(11.14 \mathrm{~m})$ below TOC

Water elevation: $233.25 \mathrm{ft}(\mathbf{7 1} .10 \mathrm{~m}) \mathrm{msl}$
Time: 14:39

Time: 13:13

Time: 13:54

Time: 13:30

\section{WELL HOB 4D}

MEASUREMENTS CONDUCTED IN THE FIELD

Sample date: 06/22/98

Depth to water: $31.86 \mathrm{ft}(9.71 \mathrm{~m})$ below TOC

Time: 13:28

\section{WELL HOB 5D}

MEASUREMENTS CONDUCTED IN THE FIELD

Depth to water: $30.28 \mathrm{ft}(9.23 \mathrm{~m})$ below TOC
Water elevation: $238.82 \mathrm{tt}(72.79 \mathrm{~m})$ msl

Time: 13:25

\section{WELL HOB 6D}

MEASUREMENTS CONDUCTED IN THE FIELD

Sample date: $06 / 22 / 98$
Depth to water: 7.6 ff (2.32m) below TOC

Time: 15:15

\section{WELL HOB $7 D$}

MEASUREMENTS CONDUCTED IN THE FIELD

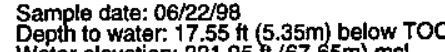

Time: 9:04

\section{WELL HR3 17P}

MEASUREMENTS CONDUCTED IN THE FIELD

Sample date: 06/22/98

Sample date: $06 / 22 / 98$
Depth to water: 16.9 t $(5.15 \mathrm{~m})$ below TOC
Water elevation: Not available

\section{WELL HR3 18P}

MEASUREMENTS CONDUCTED IN THE FELD

Sample date: $06 / 22 / 98$

Depth to water: $11.8 \mathrm{ft}(3.60 \mathrm{~m})$ below TOC
Water elevation: Not available

Time: 14:13

\section{WELL HR3 19P}

MEASUREMENTS CONDUCTED IN THE FIELD

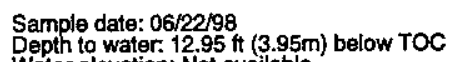

Time: 14:15 
WELL HR3 20P

MEASUREMENTS CONDUCTED IN THE'FIELD

Sample date: 06/22/98

Depth to water: $15.58 \mathrm{ft}(4.75 \mathrm{~m})$ below TOC

Water elevation: Not available

Time: 14:06

WELL HR8 11

MEASUREMENTS CONDUCTED IN THE.FIELD

Sample date: 06/22/98

Depth to water: $13 \mathrm{ft}(3.96 \mathrm{~m})$ below TOC
Water elevation: $246.2 \mathrm{ft}(75.04 \mathrm{~m}) \mathrm{ms}$

\section{WELL HSB 50PC}

MEASUREMENTS CONDUCTED IN THE FIELD

Sample date: $06 / 22 / 98$

Depth to water: $12.53 \mathrm{ft}(3.82 \mathrm{~m})$ below TOC

\section{WELL HSB 65}

MEASUREMENTS CONDUCTED IN THE FIELD

Sample date: 06/18/98

Depth to water: $49.15 \mathrm{ft}(14.98 \mathrm{~m})$ below TOC
Water elevation: $222.85 \mathrm{Ht}(67.93 \mathrm{~m}) \mathrm{ms|}$

Time: 7:40

WELL HSB 65A

MEASUREMENTS CONDUCTED IN THE FIELD

Sample date: 06/18/9

Depth to water: $101.2 \mathrm{ft}(30.85 \mathrm{~m})$ below TOC
Water elevation: $172.4 \mathrm{ft}(52.55 \mathrm{~m}) \mathrm{msl}$

\section{WELL HSB 65B}

MEASUREMENTS CONDUCTED IN THE FIELD

Sample date: 06/18/98

Depth to water: $46.7 \mathrm{ft}(14.23 \mathrm{~m})$ below TOC

\section{WELL HSB 65C}

Time: 9:29

MEASUREMENTS CONDUCTED IN THE FIELD

Sample date: 06/18/98

Depth to water: $36.15 \mathrm{H}(11.02 \mathrm{~m})$ below TOC
Water elevation: $237.45 \mathrm{Ht}(72.38 \mathrm{~m}) \mathrm{ms}$ !

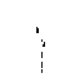

WELL HSB 66

MEASUREMENTS CONDUCTED IN THE FIELD

Sample date: 06/18/98

Time: 7:49

Depth to water. $57.1 \mathrm{ft}(17.40 \mathrm{~m})$ below TOC
Water elevation: $223.1 \mathrm{ft}(68.00 \mathrm{~m}) \mathrm{msl}$

\section{WELL HSB 67}

MEASUREMENTS CONDUCTED IN THE FIELD

Sample date: 06/18/98

Depth to water: $26.95 \mathrm{ft}(8.21 \mathrm{~m})$ below TOC
Water elevation: $210.85 \mathrm{tt}(64.27 \mathrm{~m}) \mathrm{msl}$

Time: 7:52

\section{WELL HSB 68}

MEASUREMENTS CONDUCTED IN THE FIELD

Sample date: 06/22/98

Depth to water: $27.15 \mathrm{ft}(8.28 \mathrm{~m})$ below TOC

Time: 8:45

\section{WELL HSB 68A}

MEASUREMENTS CONDUCTED IN THE FIELD

Sample date: 06/22/98

Weth to water: $76.5 \mathrm{ft}(23.32 \mathrm{~m})$ below TOC

\section{WELLL HSB 68B}

MEASUREMENTS CONDUCTED IN THE FIELD

Samplo date: 06/22/98

Depth to water: $31.7 \mathrm{ft}(9.66 \mathrm{~m})$ below TOC
Water glevation: $218.3 \mathrm{ft}(66.54 \mathrm{~m}) \mathrm{ms} \mid$

Time: 8:43

\section{WELL HSB 68C}

MEASUREMENTS CONDUCTED IN THE FIELD

Sample date: $06 / 22 / 98$

Water to water. $31 \mathrm{ft}(9.45 \mathrm{~m})$ below TOC

Time: 8:42

\section{WELL HSB 69}

MEASUREMENTS CONDUCTED IN THE FIELD

Sample date: 06/22/98 
WELL HSB 69A

MEASUREMENTS CONDUCTED IN THE FIELD

Sampla date: 06/22/98

Depth to water: $63.3 \mathrm{ft}(19.29 \mathrm{~m})$ below TOC
Water elevation: $173.3 \mathrm{Ht}(52.82 \mathrm{~m}) \mathrm{ms}$

\section{WELL HSB 70}

MEASUREMENTS CONDUCTED IN THE FIELD

ample date: 06/22/98

Depth to water: $17.65 \mathrm{ft}(5.38 \mathrm{~m})$ below TOC

\section{WELL HSB 70C}

MEASUREMENTS CONDUCTED IN THE FIELD

Sample date: $06 / 22 / 98$ (t) water: $19.15 \mathrm{ft}(5.84 \mathrm{~m})$ below TOC

\section{WELL HSB 71}

MEASUREMENTS CONDUCTED IN THE FIELD

Sample date: 06/22/98

Septh to water. $16.6 \mathrm{ft}(5.06 \mathrm{~m})$ below TOC
Water elevation: $224.8 \mathrm{ft}(68.52 \mathrm{~m}) \mathrm{msl}$

WELL HSB 71C

MEASUREMENTS CONDUCTED IN THE FIELD

Sample date: 06/22/98

Depth to water: $18.09 \mathrm{ft}(5.51 \mathrm{~m})$ below TOC
Water elevation: $223.51 \mathrm{ft}(68.13 \mathrm{~m}) \mathrm{msl}$

\section{WELL HSB 83A}

MEASUREMENTS CONDUCTED IN THE FIELD

Sample date: $06 / 18 / 9$

Depth to water: $62.8 \mathrm{ft}(19.14 \mathrm{~m})$ below TOC

\section{WELL HSB 83E}

MEASUAEMENTS CONDUCTED IN THE FIELD

Sample date: 06/18/98

Depth to water: $11.95 \mathrm{ft}(3.64 \mathrm{~m})$ below TOC

ESH-EMS-980569
Time: 7:59
WELL HSB 83C

MEASUAEMENTS CONDUCTED IN THE FIELD

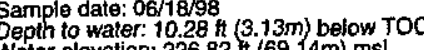

Time: 8:01

WELL HSB 83D

MEASUREMENTS CONDUCTED IN THE FIELD

Sample date: 06/18/98

Depth to water: $11.2 \mathrm{ft}(3.41 \mathrm{~m})$ below TOC

Time: 8:03

WELL HSB 84A

MEASUREMENTS CONDUCTED IN THE FIELD

Sample date: $06 / 22 / 98 / 16.98 \mathrm{~m})$ below TOC

Water elevation: $173 \mathrm{ft}(52.73 \mathrm{~m}) \mathrm{ms}$ !

Time: 8:59

\section{WELL HSB 84B}

MEASUREMENTS CONDUCTED IN THE FIELD

Sample date: $06 / 22 / 98$
Depth to water: $17.35 \mathrm{ft}(5.29 \mathrm{~m})$ below TOC
Water elevation: $211.55 \mathrm{ft}(64.48 \mathrm{~m}) \mathrm{msl}$

Time: $9: 00$

\section{WELLL HSB 84C}

MEASUREMENTS CONDUCTED IN THE FIELD

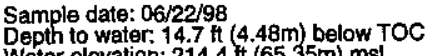

\section{WELL HSB 84D}

MEASUREMENTS CONDUCTED IN THE FIELD

Sample date: 06/22/98

Depth to water: $9.7 \mathrm{ft}(2.96 \mathrm{~m})$ below TOC
Water elevation: 219.1 if $(66.78 \mathrm{~m}) \mathrm{msl}$

Time: 9:02

\section{WELL HSB 85A}

MEASUREMENTS CONDUCTED IN THE FIELD

Sample date: $06 / 22 / 98$
Depth to water: $124.65 \mathrm{ft}(37.99 \mathrm{~m})$ below TOC
Water elevation: $169.75 \mathrm{ft}(51.74 \mathrm{~m}) \mathrm{msl}$

Time: $11: 15$ 


\section{WELL HSB 85B}

MEASUREMENTS CONDUCTED IN THÉ FIELD

Sample date: 06/22/98

Sample date: $06 / 22 / 98$
Depht to water: $58.56 \mathrm{ft}$ (17.85m) below Toc
Water elevation: $235.94 \mathrm{ft}(71.92 \mathrm{~m}) \mathrm{ms}$

\section{WELL HSB 85C}

MEASUREMENTS CONDUCTED IN THE FIELD

Sample date: 06/22/98

Depth to water: $50.96 \mathrm{ft}(15.53 \mathrm{~m})$ below ToC

\section{WELL HSB 86A}

MEASUREMENTS CONDUCTED IN THE FIELD

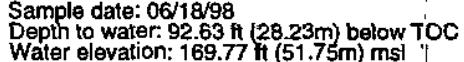

\section{WELL HSB 86B}

MEASUREMENTS CONDUCTED IN THE FIELD

Sample date: 06/18/98

Deph to water: 39.01 tt $(11.89 \mathrm{~m})$ below ToC

Wher $222.89 \mathrm{t}(67.94 \mathrm{~m}) \mathrm{msl}$

\section{WELL HSB 86C}

MEASUAEMENTS CONDUCTED IN THE FIELD Sample date: $06 / 18 / 98$
Depth to water. $38.29 \mathrm{ft}(11.67 \mathrm{~m})$ below TOC
Water elevation: $224.61 \mathrm{ft}(68.46 \mathrm{~m}) \mathrm{ms}$

\section{WELL HSB 86D}

MEASUREMENTS CONDUCTED IN THE FIELD

Sample date: 06/18/98

Deph to water. $38.38 \mathrm{H}(11.70 \mathrm{~m})$ below TOC
Water elevation: $224.62 \mathrm{t} t(68.47 \mathrm{~m}) \mathrm{msl}$

\section{WELL HSB100C}

MEASUREMENTS CONDUCTED IN THE FELD

Sample date: $06 / 18 / 98$

Deph to waler. $30.91 \mathrm{ft}(9.42 \mathrm{~m})$ below TO

(9)
Time: 11:10

WELL HSB100D

MEASUREMENTS CONDUCTED IN THE FIELD

Sample date: 06/18/98

Sample date: $06 / 18 / 98$
Depth to water: $22.55 \mathrm{ft}(6.87 \mathrm{~m})$ below TOC
Water elevation: $237.55 \mathrm{ft}(72.41 \mathrm{~m}) \mathrm{ms}$ |

Time: 8:17

\section{WELL HSB100PC}

MEASUREMENTS CONDUCTED IN THE FIELD

Sample date: $06 / 22 / 98$

Wath to water: $11.8 \mathrm{ft}(3.60 \mathrm{~m})$ below TOC

Time: 12:47

\section{WELL HSB100PD}

MEASUREMENTS CONDUCTED IN THE FIELD

Sample date: $06 / 22 / 98$

Wept to water. 8.18 it $(2.49$ m) below TOC

Time: 12:53

\section{WELL HSB101C}

MEASUREMENTS CONDUCTED IN THE FIELD

Sample date: 06/18/98

Depth to water: $30.5 \mathrm{ft}(9.30 \mathrm{~m})$ below TOC

Time: 8:20

\section{WELL HSB101D}

MEASUREMENTS CONDUCTED IN THE FIELD

Sample date: $06 / 18 / 98$
Depth to water: $24.65 \mathrm{ft}(7.51 \mathrm{~m})$ below TOC
Water elevation: $234.05 \mathrm{ft}(71.34 \mathrm{~m}) \mathrm{ms}$

Time: 8:10

Time: 8:22

\section{WELL HSB102C}

MEASUREMENTS CONDUCTED IN THE FIELD

Sample date: $06 / 18 / 98$

Wepth to water: $32.1 \mathrm{ft}(9.78 \mathrm{~m})$ below TOC

Time: 8:25

\section{WELL HSB102D}

MEASUREMENTS CONDUCTED IN THE FIELD

Sarmple date: $06 / 18 / 98$

Wepth to water: $27.25 \mathrm{ft}(8.31 \mathrm{~m})$ below TOC

Time: 8:27 
WELL HSB103C

MEASUREMENTS CONDUCTED IN THE FIELD

Sample date: $06 / 18 / 98$

Depth to water: $21.85 \mathrm{ft}(6.66 \mathrm{~m})$ below TOC

Time: $8: 30$

\section{WELL HSB103D}

MEASUREMENTS CONDUCTED IN THE FIELD

Sample date: 06/18/98

Depth to water: $20.2 \mathrm{tt}(6.16 \mathrm{~m})$ below TOC

\section{WELL HSB104C}

MEASUREMENTS CONDUCTED IN THE FIELD

Sample date: 06/18/98

Wepth to water: $25.5 \mathrm{ft}(7.77 \mathrm{~m})$ below TOC

\section{WELL HSB104D}

MEASUREMENTS CONDUCTED IN THE FIELD

Sample date: 06/18/98

Sample date: $06 / 18 / 98$
Depth to water: $20.85 \mathrm{ft}(6.36 \mathrm{~m})$ bolow TOC
Wat

\section{WELL. HSB105C}

MEASUREMENTS CONDUCTED IN THE FIELD

Sample date: 06/18/98
Depth to water: $28.3 \mathrm{Ht}(8.63 \mathrm{~m})$ below TOC
Water elevation: $221.2 \mathrm{tt}(67.42 \mathrm{~m}) \mathrm{ms}$

\section{WELL HSB105D}

MEASUREMENTS CONDUCTED IN THE FIELD

Sample date: 06/18/98

Depth to water: $22.1 \mathrm{ft}(6.74 \mathrm{~m})$ below TOC

\section{WELL HSB106C}

MEASUREMENTS CONDUCTED IN THE FIELD

Sample date: 06/18/98

Depth to water: $29.25 \mathrm{ft}(8.92 \mathrm{~m})$ below TOC

\section{WELL HSB106D}

MEASUREMENTS CONDUCTED IN THE FIELD

Sample date: 06/18/98

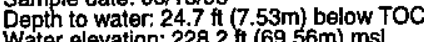

\section{WELL HSB107C}

MEASUREMENTS CONDUCTED IN THE FIELD

Sample date: 06/18/98

Depth to water. $40.7 \mathrm{ft}(12.41 \mathrm{~m})$ below TOC

Time: 8:50

\section{WELL HSB107D}

MEASUREMENTS CONDUCTED IN THE FIEL

Sample date: 06/18/98

Depth to water: $35.6 \mathrm{ft}(10.85 \mathrm{~m})$ below TOC

Time: 8:52

\section{WELL HSB108C}

MEASUREMENTS CONDUCTED IN THE FIELD

Sample date: $06 / 18 / 98$

Depth to water $46.95 \mathrm{ft}(14.07 \mathrm{~m})$ below TOC
Water elevation: $220.05 \mathrm{tt}(67.07 \mathrm{~m}) \mathrm{ms}$

Time: 8:55

\section{WELL HSB108D}

MEASUREMENTS CONDUCTED IN THE FIELD

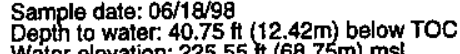

Time: 8:57

\section{WELL HSB109C}

MEASUREMENTS CONDUCTED IN THE FIELD

Sample date: 06/18/98

Depth to water: $41.12 \mathrm{ft}(12.53 \mathrm{~m})$ below TOC

Water elevation: $220.48 \mathrm{Ht}(67.20 \mathrm{~m}) \mathrm{msl}$

Time: 9:00

\section{WELL HSB109D}

MEASUREMENTS CONDUCTED IN THE FIELD

Sample date: 06/18/98

Wath to water. $36.83 \mathrm{ft}(11.23 \mathrm{~m})$ below TOC

Time: 9:02 


\section{WELL HSB110C}

MEASUREMENTS CONDUCTED IN THE FIELD Sample date: 06/18/98 Depth to water: $34.95 \mathrm{ft}(10.65 \mathrm{~m})$ below TOC Water elevation: $220.75 \mathrm{Ht}(67.29 \mathrm{~m}) \mathrm{msl}$ "

WELL HSB110D

MEASUREMENTS CONDUCTED IN THE FIELD Sample date: 06/18/98

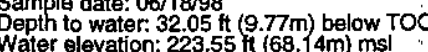

\section{WELL HSB111C}

MEASUREMENTS CONDUCTED IN THE FIELD Sample date: $06 / 18 / 98$. Wat

WELL HSB111D

\section{;}

MEASUREMENTS CONDUCTED IN THÉ FIELD

Sample date: 06/18/98

Sample date: $06 / 1898$
Depth to water. $32.9 \mathrm{At}(10.03 \mathrm{~m})$ below
Water elevation: $223.1 \mathrm{tt}(68.00 \mathrm{~m}) \mathrm{msl}$

\section{WELL HSB111E}

MEASUAEMENTS CONDUCTED IN THE FIELD

Samplo dete:06/18/98

Depth to water: $32.6 \mathrm{ft}(9.94 \mathrm{~m})$ below TOC
Water elevation: $223.3+t(68.06 \mathrm{~m}) \mathrm{ms}$

\section{WELL HSB112C}

MEASUREMENTS CONDUCTED IN THE FIELD

Sample date: $06 / 18 / 98$

Water elevation: 1.8 ft $(9.69 \mathrm{~m})$ below TOC

\section{WELL HSB112D}

MEASUREMENTS CONDUCTED IN THEFFELD

Sample date: 06/18/98

Depth to water $31 \mathrm{ft}(9.45 \mathrm{~m})$ bolow TOC
Water elevation: $224.1 \mathrm{tt}(68.31 \mathrm{~m}) \mathrm{msl}$

ESH-EMS-980569

\section{WELL HSB112E}

MEASUREMENTS CONDUCTED IN THE FIELD

Sample date: 06/18/98

Depth to water: $31.1 \mathrm{ft}(9.48 \mathrm{~m})$ below TOC

\section{WELL HSB113C}

MEASUREMENTS CONDUCTED IN THE FIELD

Sample date: $06 / 18 / 98$

Sepplo to water: $37.6 \mathrm{ft}(11.46 \mathrm{~m})$ below TOC

Water elevation: $223.4 \mathrm{tt}(68.09 \mathrm{~m}) \mathrm{msl}$

Time: 9:24

\section{WELL HSB113D}

MEASUREMENTS CONDUCTED IN THE FIELD

Sample date: 06/18/98

Wopte to water: $37.2 \pi$ t $(11.34 \mathrm{~m})$ below TOC

Time: 9:26

\section{WELL HSB114C}

MEASUREMENTS CONDUCTED IN THE FIELD

Sample date: $06 / 18 / 98$ (12.00m) below TOC

Time: 9:29

\section{WELL HSB114D}

MEASUREMENTS CONDUCTED IN THE FIELD

Sample date: 06/18/98

Sample date: $06 / 18.98$
Dopth to water: $39.6 \mathrm{ft}(12.07 \mathrm{~m})$ below TOC
Water elevation: $224.4 \mathrm{ft}(68.40 \mathrm{~m}) \mathrm{msl}$

Time: 9:31

\section{WELL HSB115C}

MEASUREMENTS CONDUCTED IN THE FIELD

Sample date: 06/18/98

Weph to water: $43.95 \mathrm{ft}(13.40 \mathrm{~m})$ below TOC

Time: 9:34

\section{WELL HSB115D}

MEASUREMENTS CONDUCTED IN THE FIELD

Sample date: 06/18/98
Depth to water: $43.75 \mathrm{ft}(13.34 \mathrm{~m})$ below TOC

Time: 9:36 


\section{WELL HSB116C}

MEASUREMENTS CONDUCTED IN THE FIELD

Sample date: $06 / 18 / 98$
Depth to water: $30.98 \mathrm{ft}(9.44 \mathrm{~m})$ below TOC
Water elevation: $226.52 \mathrm{ft}(69.04 \mathrm{~m}) \mathrm{msl}$

\section{WELL HSB116D}

MEASUREMENTS CONDUCTED IN THE FIELD

Sample date: 06/18/98

Depth to water: $29.9 \mathrm{At}(9.11 \mathrm{~m})$ below TOC

Time: 9:41

\section{WELL HSB117A}

MEASUREMENTS CONDUCTED IN THE FIELD

Sample date: $06 / 22 / 98$
Depth to water: $69.9 \mathrm{ft}(21.31 \mathrm{~m})$ below TOC
Water elevation: $167.4 \mathrm{tt}(51.02 \mathrm{~m}) \mathrm{ms}$

\section{WELL HSB117C}

MEASUREMENTS CONDUCTED IN THE FIELD

Sample date: $06 / 22 / 98$ (t)

We the

\section{WELL HSB117D}

MEASUREMENTS CONDUCTED IN THE FIELD

Sample date: 06/22/98

Depth to water: $14 \mathrm{ft}(4.27 \mathrm{~m})$ below TOC
Water elevation: $223.6 \mathrm{th}(68.15 \mathrm{~m}) \mathrm{msl}$

\section{WELL HSB118A}

MEASUREMENTS CONDUCTED IN THE FIELD

Sample date: 06/22/98

Depth to water: $78.68 \mathrm{ft}(23.98 \mathrm{~m})$ below TOC

\section{WELL HSB119A}

MEASUREMENTS CONDUCTED IN THE FIELD

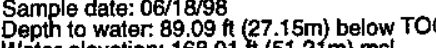

Time: 9:44
WELL HSB120A

MEASUREMENTS CONDUCTED IN THE FIELD

Sample date: $06 / 18 / 98$

Weph to water: $100.89 \mathrm{H}(30.75 \mathrm{~m})$ below TOC

\section{WELL HSB121A}

MEASUREMENTS CONDUCTED IN THE FIELD

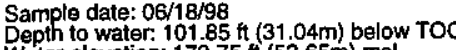

Time: 9:50

\section{WELL HSB122A}

MEASUREMENTS CONDUCTED IN THE FIELD

Sarmple date: $06 / 18 / 98$
Depth to water: $99.05 \mathrm{ft}(30.19 \mathrm{~m})$ below TOC
Water elevation: $172.55 \mathrm{Ht}(52.59 \mathrm{~m}) \mathrm{ms}$

Time: 9:53

\section{WELL HSB123A}

MEASUREMENTS CONDUCTED IN THE FIELD

Sample date: 06/18/98

Depth to water: $92.1 \mathrm{ft}(28.07 \mathrm{~m})$ below TOC

Time: 9:56

\section{WELL HSB124AR}

MEASUREMENTS CONDUCTED IN THE FIELD

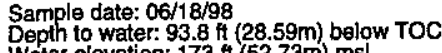

\section{WELL HSB125C}

MEASUREMENTS CONDUCTED IN THE FIELD

Sample date: 06/18/98

Depte to water: $6.45 \mathrm{ft}(1.97 \mathrm{~m})$ below TOC
Water elevation: $225.45 \mathrm{ft}(68.72 \mathrm{~m}) \mathrm{ms}$

Time: 10:01

\section{WELL HSB125D}

MEASUREMENTS CONDUCTED IN THE FIELD

Sample date: 06/18/98
Time: 10:03 


\section{WELL HSB126C}

MEASUREMENTS CONDUCTED IN THE FIELD Sample date: $06 / 22 / 98$

Depth to water: $8.07 \mathrm{At}(2.46 \mathrm{~m})$ below TOC

Water elevation: $204.53 \mathrm{ft}(62.34 \mathrm{~m}) \mathrm{msl}$

\section{WELL HSB126D}

MEASUREMENTS CONDUCTED IN THE FIELD Sample date: 06/22/98 Depth to water: $8.09 \mathrm{ft}(2.47 \mathrm{~m})$ below TOC
Water elevation: $204.61 \mathrm{ft}(62.37 \mathrm{~m}) \mathrm{ms}$ |

\section{WELL HSB127C}

MEASUREMENTS CONDUCTED IN THE FIELD Sample date: 06/22/98 Depth to water: $14.75 \mathrm{ft}(4.50 \mathrm{~m})$ below TOC

\section{WELL HSB127D}

MEASUREMENTS CONDUCTED IN THE FIELD

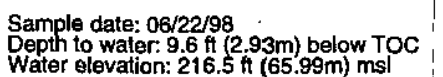

\section{WELL HSB129C}

MEASUREMENTS CONDUCTED IN THE FIELD

Sample date: 06/22/98 Depth to water: $9.23 \mathrm{ft}(2.81 \mathrm{~m})$ below TOC Water elevation: $205.87 \mathrm{ft}(62.75 \mathrm{~m}) \mathrm{ms}$ )

\section{WELL HSB129D}

MEASUREMENTS CONDUCTED IN THE FIELD

Sample date: 06/22/98

Depth to water: $6.8 \mathrm{ft}(2.07 \mathrm{~m})$ below TOC

\section{WELL HSB130C}

MEASUREMENTS CONDUCTED IN THÉ FIELD

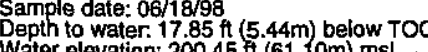
Water elevation: $200.45 \mathrm{t}(61,10 \mathrm{~m}) \mathrm{ms}$

\section{WELL HSB130D}

MEASUREMENTS CONDUCTED IN THE FIELD

Sample date: 06/18/98

Depth to water: $17.45 \mathrm{ft}(5.32 \mathrm{~m})$ below TOC

Water elevation: 201.15 t $(61.31 \mathrm{~m}) \mathrm{ms}$ !

Time: 10:09

\section{WELL. HSB131C}

MEASUREMENTS CONDUCTED IN THE FIELD

Depth to water: $7.4 \mathrm{ft}(2.26 \mathrm{~m})$ below TOC
Water elevation: $204.3 \mathrm{ft}(62.27 \mathrm{~m}) \mathrm{msl}$

Time: 7:41

\section{WELL HSB131D}

MEASUREMENTS CONDUCTED IN THE FIELD

Sample date: 06/22/98

Depth to water: 6.78 t $(2.07 m)$ below TOC

\section{WELL HSB132C}

MEASUREMENTS CONDUCTED IN THE FIELD

Sample date: 06/18/98

Depth to water: $19 \mathrm{ft}(5.79 \mathrm{~m})$ below TOC
Water elevation: $221.5 \mathrm{ft}(67.51 \mathrm{~m}) \mathrm{msl}$

Time: 10:12

\section{WELL HSB132D}

MEASUREMENTS CONDUCTED IN THE FIELD

Sampie date: 06/18/98

Depth to water: $19.89 \mathrm{ft}(6.06 \mathrm{~m})$ below TOC

Time: 10:14

\section{WELL HSB133C}

MEASUREMENTS CONDUCTED IN THE FIELD

Sample date: 06/22/98

Depht to water. $22.35 \mathrm{ft}(6.81 \mathrm{~m})$ below TOC
Water elevation: $233.25 \mathrm{tt}(71.30 \mathrm{~m}) \mathrm{msl}$

Time: 12:57

\section{WELL HSB133D}

MEASUREMENTS CONDUCTED IN THE FIELD

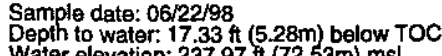

Time: 13:00 


\section{WELL HSB134C}

MEASUREMENTS CONDUCTED IN THE FIELD

Sample date: 06/22/98

Depth to water: $15.9 \mathrm{At}(4.85 \mathrm{~m})$ below TOC
Water elevation: $222.5 \mathrm{t}(67.82 \mathrm{~m}) \mathrm{msl}$

\section{WELL HSB134D}

MEASUREMENTS CONDUCTED IN THE FIELD

Sample date: 06/22/98

Depth to water: $15.53 \mathrm{ft}(4.73 \mathrm{~m})$ below TOC
Water elevation: $222.57 \mathrm{ft}(67.84 \mathrm{~m}) \mathrm{msl}$

\section{WELL HSB135C}

MEASUREMENTS CONDUCTED IN THE FIELD

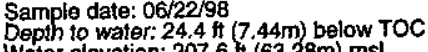

\section{WELL HSB135D}

MEASUREMENTS CONDUCTED IN THE FIELD

Sample date: 06/22/98

Semple date: 0622298
Depth to water $13.95 .4(4.25 \mathrm{~m})$ below TOC
Water elevation: $218.35 \mathrm{H}(66.55 \mathrm{~m}) \mathrm{ms}$ l

\section{WELL HSB136C}

MEASUREMENTS CONDUCTED IN THE FIELD

Sample date: 06/22/98

Depth to water: 10.18 望 $(3.10 \mathrm{~m})$ below TOC

\section{WELL HSB136D}

MEASUREMENTS CONDUCTED IN THE FIELD

Sample date: $06 / 22 / 98$

Wepth to wali. 7.23 (2) $2.20 \mathrm{~m})$ below TOC

\section{WELL HSB137C}

MEASUREMENTS CONDUCTED IN THE FIELD

Sample date: 06/22/98

Depth to water: $15.31 \mathrm{ft}(4.67 \mathrm{~m})$ below roC
Water elevation: $220.69 \mathrm{tt}(67.27 \mathrm{~m}) \mathrm{msl}$

Time: 9:48

Time: 9:32
WELL HSB137D

MEASUREMENTS CONDUCTED IN THE FIELD

Sample date: $06 / 22 / 98$

Time: 9:50

Depth to water: Not available

\section{WELL HSB138D}

MEASUREMENTS CONDUCTED IN THE FIELD

Sample date: $06 / 22 / 98$
Depth to water: $27.08 \mathrm{ft}(8.25 \mathrm{~m})$ below TOC
Water elevation: $225.32 \mathrm{th}(68.68 \mathrm{~m}) \mathrm{msl}$

Time: 10:12

\section{WELL HSB139A}

MEASUREMENTS CONDUCTED IN THE FIELD

Sample date: 06/22/98

Depth to water: $58.95 \mathrm{ft}(17.97 \mathrm{~m})$ below TOC

Time: 8:31

\section{WELL HSB139C}

MEASUREMENTS CONDUCTED IN THE FIELD

Sample date: $06 / 22 / 98$.

Time: $8: 30$

\section{WELL HSB139D}

MEASUREMENTS CONDUCTED IN THE FIELD

Sample date: 06/22/98

Sample date: $06 / 22 / 98$
Depth to water: $11.45 \mathrm{At}(3.49 \mathrm{~m})$ below TOC
Water elevation: $222.35 \mathrm{ft}(67.77 \mathrm{~m}) \mathrm{ms})$

Time: 8:29

\section{WELL HSB140A}

MEASUREMENTS CONDUCTED IN THE FIELD

Sample date: $06 / 22 / 98$ (18.04m) below TOC

Depth to water: $59.2 \mathrm{ft}(18.04 \mathrm{~m})$ below TOC

Time: 7:35

\section{WELL HSB140C}

MEASUREMENTS CONDUCTED IN THE FIELD

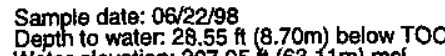

Time: 7:36 


\section{WELL HSB140D}

MEASUREMENTS CONDUCTED IN THE FIELD

Sample date: $06 / 22 / 98$
Depth to water: $18.75 \mathrm{ft}(5.72 \mathrm{~m})$ below TOC

Time: 7:37

\section{WELL HSB141A}

MEASUREMENTS CONDUCTED IN THE FIELD

Sample date: 06/18/98

(23.97m) below TOC

Water elevation: $175.95 \mathrm{tt}(53.63 \mathrm{~m}) \mathrm{ms}$ I

\section{WELL HSB141CR}

MEASUREMENTS CONDUCTED IN THE FIELD

Sample date: 06/18/98

Wepth to water 23.7 t $(7.22 \mathrm{~m})$ below TOC

WELL HSB141D

MEASUREMENTS CONDUCTED IN THE FIELD

Sample date: 06/18/98

Depth to water: $11.85 \mathrm{ft}(3.61 \mathrm{~m})$ below TOC

\section{WELL. HSB142C}

MEASUREMENTS CONDUCTED IN THE FIELD

Sample date: $06 / 17 / 98$
Depth to water: $6.06 \mathrm{ft}(1.85 \mathrm{~m})$ below TOC
Water elevation: $197.94 \mathrm{ft}(60.33 \mathrm{~m}) \mathrm{msl}$

\section{WELL HSB142D}

MEASUREMENTS CONDUCTED INTHE FIELD

Sample date: $06 / 17 / 98$

Water elevatifi: $772 \mathrm{At}(2.35 \mathrm{~m})$ below TOC

\section{WELL HSB143C}

MEASUREMENTS CONDUCTED IN THE FIELD

Sample date: 06/22/98

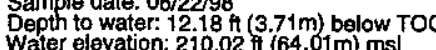

Time: 11:05

Time: 11:06
Time: 10:17
MEASUREMENTS CONDUCTED IN THE FIELD

Sample date: 06/18/98

Depth to water: $74.6 \mathrm{ft}(22.74 \mathrm{~m})$ below TOC
Water elevation: $177 \mathrm{ft}(53.95 \mathrm{~m}) \mathrm{msl}$

\section{WELL HSB146C}

MEASUREMENTS CONDUCTED IN THE FIELD

Sample date: 06/18/98

Depth to water: $41.7 \mathrm{t}(12.71 \mathrm{~m})$ below TOC

Time: 10:27

\section{WELLL HSB146D}

MEASUREMENTS CONDUCTED IN THE FIELD

Sample date: 06/18/98

Wepth to water: $27.2 \mathrm{tt}(8.29 \mathrm{~m})$ below TOC

Time: 10:29 


\section{WELL HSB147D}

MEASUREMENTS CONDUCTED IN THE FIELD

Sample date: 06/18/98

Time: 10:32

Depth to water: $34.12 \mathrm{ft}(10.40 \mathrm{~m})$ below TOC

\section{WELL HSB148C}

MEASUREMENTS CONDUCTED IN THE FIELD

Sample date: 06/18/98

Depth to water: $48.7 \mathrm{Ht}(14.84 \mathrm{~m})$ below TOC

Time: 10:35

\section{WELL HSB148D}

MEASUREMENTS CONDUCTED IN THE FIELD

Sample date: $06 / 18 / 98$

Depth to water: $35.8 \mathrm{ft}(10.91 \mathrm{~m})$ below TOC

\section{WELL HSB149D}

MEASUREMENTS CONDUCTED IN THE FIELD

Sample date: 06/22/98

Depin to water: 16.15 A $4.92 \mathrm{~m}$ below TOC

\section{WELL HSB150D}

MEASUREMENTS CONDUCTED IN THE FIELD

Sample date: 06/18/98

Depth to water: $12.98 \mathrm{ft}(3.96 \mathrm{~m})$ below TOC
Water elevation: $226.02 \mathrm{H}(68.89 \mathrm{~m}) \mathrm{msl}$

\section{WELL HSB150PC}

MEASUREMENTS CONDUCTED IN THE FIELD

Sample date: 06/22/98

Depth to water: $12.2 \mathrm{ft}(3.72 \mathrm{~m})$ below TOC
Water elevation: $219.5 \mathrm{tt}(66.90 \mathrm{~m}) \mathrm{ms}$

\section{WELL HSB151C}

MEASUREMENTS CONDUCTED IN THE FIELD

Sample date: 06/22/98

Depth to water: $6.5 \mathrm{ft}(1.98 \mathrm{~m})$ below TOC

Time: 10:15
WELLL HSB151D

MEASUREMENTS CONDUCTED IN THE FIELD

Sample date: 06/22/98

Depth to water: $7.6 \mathrm{tt}(2.32 \mathrm{~m})$ below TOC

Time: 10:18

\section{WELL HSB152C}

MEASUREMENTS CONDUCTED IN THE FIELD

Sample date: $06 / 22 / 9$

Depth to water $15.2 \mathrm{t}$ (4.63m) below TOC
Water elovation: $198.9 \mathrm{tt}(60.63 \mathrm{~m}) \mathrm{msl}$

Time: 10:44

\section{WELL HSB152D}

MEASUREMENTS CONDUCTED IN THE FIELD

Sample date: 06/22/98

Weph to water. No available

Time: 10:46

\section{WELL HSL 10}

MEASUREMENTS CONDUCTED IN THE FIELD

Sample date: $06 / 22 / 98$
Depth to water: 25.09 Ht $(7.65 \mathrm{~m})$ below TOC
Water elevation: $238.91+\pi(72.62 \mathrm{~m}) \mathrm{msl}$

Time: 11:53

\section{WELL HSL 2D}

MEASUREMENTS CONDUCTED IN THE FIELD

Sample date: 06/22/98

Depth to water: $20.96 \mathrm{ft}(6.39 \mathrm{~m})$ below TOC

Time: 11:50

\section{WELL HSL 3D}

MEASUREMENTS CONDUCTED IN THE FIELD

Sample date: 06/22/98

Water elevation: $252 \mathrm{tt}(76.8 \mathrm{~m})$ below TOC

Time: 11:47

WELL HSL 4D

MEASUREMENTS CONDUCTED IN THE FIELD

Sample date: 06/22/98

Depth to water: $9.4 \mathrm{ft}(2.87 \mathrm{~m})$ below TOC

Time: 11:40 


\section{WELL HSL 5D}

MEASUREMENTS CONDUCTED IN THE FIELD Sample date: 06/22/98

Demple to water: $8.74 \mathrm{tt}(2.66 \mathrm{~m})$ below TOC
Water elevation: $267.86 \mathrm{ft}(81.64 \mathrm{~m}) \mathrm{msl}$

\section{WELL HSL 6D}

MEASUREMENTS CONDUCTED IN THE FIELD

Sample date: 06/22/98

Depth to water: $21.85 \mathrm{ft}(6.66 \mathrm{~m})$ below TOC

Time: 11:30

\section{WELL HSL 7D}

MEASUREMENTS CONDUCTED IN THE FIELD

Sample date: 06/22/98

Wather

\section{WELL HSL 8D}

MEASUREMENTS CONDUCTED IN THE FIELD

Sample date: 06/22/98

Depth to water: $24.5 \mathrm{ft}(7.47 \mathrm{~m})$ below TOC

(80.53m) $\mathrm{ms}$

\section{WELL MCB 2}

MEASUREMENTS CONDUCTED IN THE FIELD

Sample date: 06/23/98

Sample date: $06 / 23 / 98$
Deptt to water: $133 \mathrm{ft}(31.39 \mathrm{~m})$ below TOC
Water elevation: $225.4 \mathrm{ft}(68.70 \mathrm{~m}) \mathrm{msl}$

\section{WELL MCB 4}

MEASUREMENTS CONDUCTED IN THE FIELD

Sample dato: 06/23/98

Depth to water: $127.69 \mathrm{ft}(38.92 \mathrm{~m})$ below TOC

Time: 10:12

\section{WELL MCB 5}

MEASUREMENTS CONDUCTED IN THE FIELD

Sample date: $06 / 23 / 98$

Weph to waler. $16 \mathrm{ft}$ (35.36m) below TOC

\section{WELL MCB 5C}

MEASUREMENTS CONDUCTED IN THE FIELD

Sample date: 06/23/98

epth to water: $144.4 \mathrm{ft}(44.01 \mathrm{~m})$ below TOC

\section{WELL MCB 6}

MEASUREMENTS CONDUCTED IN THE FIELL

Sample date: 06/23/98

epth to water $113.1 \mathrm{ft}(34.47 \mathrm{~m})$ below TOC
Water elevation: $219 \mathrm{ft}(66.75 \mathrm{~m})$ msl

Time: 10:17

\section{WELL MCB 6C}

MEASUREMENTS CONDUCTED IN THE FIELD

Sample date: 06/23/98

Wepth to water: $19.6 \pi(41.64 \mathrm{~m})$ below TOC

Time: 10:18

\section{WELL MCB 7C}

MEASUREMENTS CONDUCTED IN THE FIELD

Sample date: $06 / 23 / 98$ below TOC

Wepth to water: $143.65 \mathrm{ft}(43.79 \mathrm{~m})$ below TOC

\section{WELL MCB 8D}

MEASUREMENTS CONDUCTED IN THE FIELD

Sample date: 06/23/98

Deppt to water: $116.34 \mathrm{ft}(35.46 \mathrm{~m})$ below TOC
Water elevation: $224,36 \mathrm{ft}(68.39 \mathrm{~m}) \mathrm{msl}$

Time: 10:09

\section{WELL MCB 9D}

MEASUREMENTS CONDUCTED IN THE FIELO

Sample date: 06/23/98

Water elevation: $121.5 \mathrm{ft}(37.03 \mathrm{~m})$ below TOC

Time: 9:53

\section{WELL MCB 23B}

MEASUREMENTS CONDUCTED IN THE FIELD

Sample date: $06 / 22 / 98$
Depth to water: $167.1 \mathrm{ft}$ (50.93m) below TOC

Time: 7:07 


\section{WELL MCB 25B}

MEASUREMENTS CONDUCTED IN THE FIELD

Sample date: 06/22/98

Depth to water: $10.1 \mathrm{ft}(33.56 \mathrm{~m})$ below TOC

\section{WELL MCB 27B}

MEASUREMENTS CONDUCTED IN THE FIELO

Sample dato: 06 20

epth to water: $70.1 \mathrm{ft}(21.37 \mathrm{~m})$ below TOC

Water elevation: Not available

\section{WELL MSB 18}

MEASUREMENTS CONDUCTED IN THE FIELD Sample date: $06 / 24 / 98$

Wepth to water: $142.45 \mathrm{ft}(43.42 \mathrm{~m})$ below TOC

\section{WELL MSB 1C}

MEASUREMENTS CONDUCTED IN THE FIELD

Sample date: 06/24/98

Wepth to water. $37.7 \mathrm{ft}(41.97 \mathrm{~m})$ below TOC

\section{WELL MSB 1CC}

MEASUREMENTS CONDUCTED IN THE FIELD

Sample date: 06/24/98

Depth to water. $136.15 \mathrm{ft}(41.50 \mathrm{~m})$ below TOC

Water elevation: $218.75 \mathrm{ft}(66.68 \mathrm{~m}) \mathrm{msl}$

\section{WELL MSB 1D}

MEASUREMENTS CONDUCTED IN THE FIELD

Sample date: 06/24/98

Water elevation: $229.1 \mathrm{ft}(69.83 \mathrm{~m}) \mathrm{ms}$ ) TOC

\section{WELL MSB 2B}

MEASUREMENTS CONDUCTED IN THE FIELD

Sample date: $06 / 24 / 98$
Depth to water: $140.6 \mathrm{ft}(42.86 \mathrm{~m})$ below TOC
Weter
Time: 8:31

Time: 7:15

Time: 8:32
WELL MSB 2C

MEASUREMENTS CONDUCTED IN THE FIELD

Sample date: 06/24/98

epth to water: $136.25 \mathrm{ft}(41.53 \mathrm{~m})$ below TOC

Time: 7:32

\section{WELL MSB 2D}

MEASUREMENTS CONDUCTED IN THE FIELD

Sample date: 06/24/98

Water elevation: $229.7 \mathrm{ft}(70.01 \mathrm{~m}) \mathrm{ms}$ )

Time: 7:34

\section{WELL MSB 3B}

MEASUREMENTS CONDUCTED IN THE FIELD

Sample date: $06 / 24 / 98$

Water elevation: Not available

\section{WELL MSB 3C}

MEASUREMENTS CONDUCTED IN THE FIELD

Sample date: 06/24/98

Depth to water: $141 \mathrm{ft}(42.98 \mathrm{~m})$ below TOC

Time: 7:46

\section{WELL MSB 4B}

MEASUREMENTS CONDUCTED IN THE FIELD

Sample date: 06/24/98

Depth to water. $143.5 \mathrm{ft}(43.74 \mathrm{~m})$ below TOC

Water elevation: $211.8 \mathrm{ft}(64.56 \mathrm{~m}) \mathrm{ms}$ l

Time: 8:14

\section{WELL MSB 4C}

MEASUREMENTS CONDUCTED IN THE FIELD

Sample date: 06/24/98

Water elevation: $138.4 \mathrm{ft}(42.18 \mathrm{~m})$ below TOC
$216.8 \mathrm{ft}(66.08 \mathrm{~m}) \mathrm{ms}$

\section{WELL MSB 4D}

MEASUREMENTS CONDUCTED IN THE FIELD

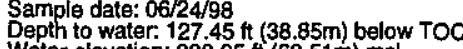

Time: 8:16 


\section{WELL MSB 5A}

MEASUREMENTS CONDUCTED IN THE FIELD

Sample date: 06/23/98

Depth to water: $119.2 \mathrm{ft}(36.33 \mathrm{~m})$ below TOC

\section{WELL MSB 5B}

MEASUREMENTS CONDUCTED IN THE FIELD

Sample date: $06 / 23 / 98$ ft $(41.27 \mathrm{~m})$ below TOC

Depth to water: $135.39 \mathrm{ft}(41.27 \mathrm{~m})$ below

\section{WELL MSB 5C}

MEASUREMENTS CONDUCTED IN THE, FIELD Sample date: $06 / 23 / 98$,

Depth to water: $123.7 \mathrm{ft}(37.70 \mathrm{~m})$ below TOC
Water elevation: $221.5 \mathrm{ft}(67.51 \mathrm{~m}) \mathrm{msl}$

\section{WELL MSB 6A}

MEASUREMENTS CONDUCTED IN THE FIELD

Sample date: $06 / 23 / 98$
Depth to water: $118.98 \mathrm{ft}(36.27 \mathrm{~m})$ below Tेoc
Water elevation: $224.82 \mathrm{ft}(68.53 \mathrm{~m}) \mathrm{ms}$

\section{WELL MSB 6B}

MEASUREMENTS CONDUCTED IN THE FIELD Sample date: 06/23/98

Depth to water: $137.6 \mathrm{ft}(41.94 \mathrm{~m})$ below TOC

\section{WELL MSB 6C}

MEASUREMENTS CONDUCTED IN THE FIELD Sample date: $06 / 23 / 98$ fit $(37.37 \mathrm{~m})$ below TOC

Wher elovation: $221.2 f(67.42 \mathrm{~m}) \mathrm{msl}$

\section{WELL MSB 7A}

MEASUREMENTS CONDUCTED IN THE FIELD

Sample date: $06 / 23 / 98$ (2) $(36.07 \mathrm{~m})$ below TOC

Water elevation: $225.95 \mathrm{ft}(68.87 \mathrm{~m}) \mathrm{ms}$
Time: 10:52

Time: 10:53

Time: 10:54

Time: 10:40

Time: 10:41

Time: 10:42

Time: 11:33
WELL MSB 78

MEASUREMENTS CONDUCTED IN THE FIELD

Sample date: $06 / 23 / 98$

Deph to water $137.38 \mathrm{ft}(41.87 \mathrm{~m})$ below TOC
Water elevation: $206.72 \mathrm{ft}(63.01 \mathrm{~m}) \mathrm{ms}$

\section{WELL MSB 7C}

MEASUREMENTS CONDUCTED IN THE FIELD

Sample date: $06 / 23 / 98$ ( $37.73 m$ ) below TOC

Water elevation: $220.7 \mathrm{ft}(67.27 \mathrm{~m}) \mathrm{ms}$ l

Time: 11:35

\section{WELL MSB 8A}

MEASUREMENTS CONDUCTED IN THE FIELD

Sample date: 06/23/98

epth to water. Not available

Time: 11:27

\section{WELL MSB 8B}

MEASUREMENTS CONDUCTED IN THE FIELD

Sample date: 06/23/98

Depth to water: $135.1 \mathrm{ft}(41.18 \mathrm{~m})$ below TOC

Time: 11:28

\section{WELL MSB 8C}

MEASUREMENTS CONDUCTED IN THE FIELD

Sample date: 06/23/98

Depth to water: $125.15 \mathrm{ft}(38.15 \mathrm{~m})$ below TOC

Water elevation: $218.85 \mathrm{ft}(66.71 \mathrm{~m}) \mathrm{msl}$

Time: 11:29

\section{WELL MSB 9A}

MEASUREMENTS CONDUCTED IN THE FIELD

Sample date: $06 / 24 / 98$ (t) $(44.61 \mathrm{~m})$ below TOC

Time: 8:05

\section{WELL MSB 9B}

MEASUREMENTS CONDUCTED IN THE FIELD

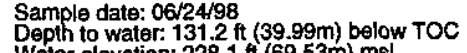

Time: 8:06 


\section{WELL MSB 9C}

MEASUREMENTS CONDUCTED IN THE FIELD

Sample date: 06/24/98

Depth to water: Not available
Water elevation: Not available

\section{WELL MSB 10A}

MEASUREMENTS CONDUCTED IN THE FIELD

Sample date: 06/24/98

Depth to water: $145.25 \mathrm{ft}(44.27 \mathrm{~m})$ below TOC

\section{WELL MSB 10B}

MEASUREMENTS CONDUCTED IN THE FIELD

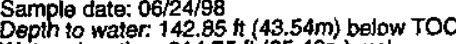

Demplow

\section{WELL MSB 10C}

MEASUREMENTS CONDUCTED IN THE FIELD

Sample date: 06/24/98

Depth to water: $129.95 \mathrm{ft}(39.61 \mathrm{~m})$ below TOC
Water elevation: $227.15 \mathrm{ft}(69.24 \mathrm{~m}) \mathrm{msl}$

\section{WELL MSB 10D}

MEASUREMENTS CONDUCTED IN THE FIELD

Sample date: 06/24/98

Water elevation: Not available

Time: 9:44

\section{WELL MSB 11A}

MEASUREMENTS CONDUCTED IN THE FIELD

Sample date: $06 / 24 / 98$
Depth to water: $151.65 \mathrm{ft}(46.22 \mathrm{~m})$ below TOC
Water elevation: $213.75 \mathrm{ft}(65.15 \mathrm{~m})$ msl

\section{WELL MSB 11B}

MEASUREMENTS CONDUCTED IN THE FIELD

Sample date: 06/24/98

Depth to water: $147.6 \mathrm{ft}(44.99 \mathrm{~m})$ below TOC
Water elevation: $217.8 \mathrm{ft}(66.39 \mathrm{~m}) \mathrm{msl}$

ESH-EMS-980569

\section{WELL MSB $11 C$}

MEASUREMENTS CONDUCTED IN THE FIELD

Sample date: 06/24/98

\section{WELL MSB 11D}

MEASUREMENTS CONDUCTED IN THE FIELD

Sample date: $06 / 24 / 98$
Depth to water: $137.92 \mathrm{ft}(42.04 \mathrm{~m})$ below TOC
Water elevation: $227.88 \mathrm{ft}(69.46 \mathrm{~m}) \mathrm{msl}$

Time: 8:44

\section{WELL MSB 11E}

MEASUREMENTS CONDUCTED IN THE FIELD

Sample date: 06/24/98

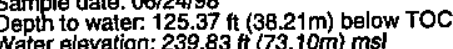

Time: 8:45

\section{WELL MSB 11F}

MEASUREMENTS CONDUCTED IN THE FIELD

Sample date: 06/24/98

Depth to water. Nor avalable

\section{WELL MSB 12A}

MEASUREMENTS CONDUCTED IN THE FIELD

Sample date: 06/24/98

Depth to water: $140.05 \mathrm{ft}(42.69 \mathrm{~m})$ below TOC

Time: 10:06

\section{WELL MSB 128}

MEASUREMENTS CONDUCTED IN THE FIELD

Sample date: 06/24/98

\section{WELL MSB $12 C$}

MEASUREMENTS CONDUCTED IN THE FIELD

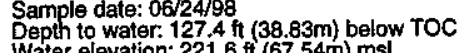

Time: 10:08 


\section{WELL MSB 12D}

MEASUREMENTS CONDUCTED IN THE FIELD

Sample date: 06/24/98

Depth to water: Not available
Water elevation: Not available

WELL MSB 12TA

MEASUREMENTS CONDUCTED IN THE FIELD

Sample date: 06/24/98

Water elevation: $191.25 \mathrm{tt}(58.29 \mathrm{~m}) \mathrm{msl}$

\section{WELL MSB 12TB}

MEASUREMENTS CONDUCTED IN THE FIELL

Sample date: $06 / 2498$
Depph to water: $157.85 \mathrm{ft}(48.11 \mathrm{~m})$ below Toc
Water elevation: $191.45 \mathrm{ft}(58.35 \mathrm{~m}) \mathrm{msl}$

\section{WELL MSB 13A}

MEASUAEMENTS CONDUCTED IN THE FIELD

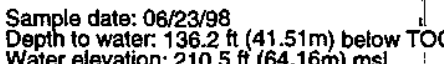

WELL MSB 13B

MEASUREMENTS CONDUCTED IN THE FIELD

Sample date: 06/23/98

Depth to water. $125.5 \mathrm{ft}(38.25 \mathrm{~m})$ below TOC
Water elevation: $221.6 \mathrm{ft}(67.54 \mathrm{~m}) \mathrm{msl}$

\section{WELL MSB 13C}

MEASUREMENTS CONDUCTED IN THE FIELD

Sample data: $06 / 23 / 98$
Depth to water. $120.7 \mathrm{ft}(36.79 \mathrm{~m})$ below toc
Water elevation: $226.6 \mathrm{tt}(69.07 \mathrm{~m}) \mathrm{msl}$

\section{WELL MSB 13CC}

MEASUREMENTS CONDUCTED IN THE FIELD

Sample date: $06 / 23 / 98$
Depph to water $123.5 \mathrm{ft}(37.64 \mathrm{~m})$ below TOC
Wat
Time: 10:10
WELL MSB 13D

MEASUREMENTS CONDUCTED IN THE FIELD

Sample date: 06/23/98

Depth to water: $120.95 \mathrm{ft}(36.87 \mathrm{~m})$ below TOC

Time: 11:05

\section{WELL MSB 14A}

MEASUREMENTS CONDUCTED IN THE FIELD

Sample date: 06/24/98

epth to water: $12.05 \mathrm{ft}(40.25 \mathrm{~m})$ below TOC

Time: 7:25

\section{WELL MSB 14B}

MEASUREMENTS CONDUCTED IN THE FIELD

Sample date: $06 / 24 / 98$
Depth to water: $130.9 \mathrm{ft}(39.90 \mathrm{~m})$ below TOC

Time: 7:24

\section{WELL MSB 14C}

MEASUREMENTS CONDUCTED IN THE FIELD

Sample date: 06/24/98

Depth to water: $116.9 \mathrm{ft}(35.63 \mathrm{~m})$ below TOC

\section{WELL MSB 15A}

MEASUREMENTS CONDUCTED IN THE FIELD

Sample date: 06/24/98

Depth to water: $147.5 \mathrm{ft}(44.96 \mathrm{~m})$ below TOC
Water elevation: $220.2 \mathrm{ft}(67.12 \mathrm{~m}) \mathrm{ms}$

Time: 8:56

\section{WELL MSB 15AA}

MEASUREMENTS CONDUCTED IN THE FIELD

Sample date: 06/24/98

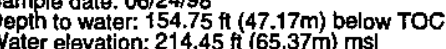

Time: 8:57

\section{WELL MSB 15C}

MEASUREMENTS CONDUCTED IN THE FIELD

Sample date: $06 / 24 / 98$
Depth to water. $122.6 \mathrm{ft}(37.37 \mathrm{~m})$ below TOC 
WELL MSB 15D

MEASUREMENTS CONDUCTED IN THE FIELD

Sample date: 06/24/98

Depth to water: Not available
Water elevation: Not available

\section{WELL MSB 16A}

MEASUREMENTS CONDUCTED IN THE FIELD

Sample date: 06/23/9

Water elevation: 222.2 ft (67.73m) below TOC

\section{WELL MSB 16C}

MEASUREMENTS CONDUCTED IN THE FIELD

Sample date: $06 / 23 / 98$
Depth to water: $139.29 \mathrm{ft}(42.46 \mathrm{~m})$ below TOC
Water elevation: $228.31 \mathrm{ft}(69.59 \mathrm{~m}) \mathrm{ms}$

\section{WELL MSB 17A}

MEASUREMENTS CONDUCTED IN THE FIELD

Sample date: 06/23/98

below TOC

(1)

\section{WELL MSB 17B}

MEASUREMENTS CONDUCTED IN THE FIELD

Sample date: 06/23/98

Depth to water: $136 \mathrm{ft}(41.45 \mathrm{~m})$ below TOC
Water elevation: $223.2 \mathrm{ft}(68.03 \mathrm{~m}) \mathrm{msl}$

\section{WELL MSB 17BB}

MEASUREMENTS CONDUCTED IN THE FIELD

Sample date: 06/23/98

Depth to water: 147.4 ft (44.93m) below TOC

\section{WELL MSB 17C}

MEASUREMENTS CONDUCTED IN THE FIELD

Sample date: 06/23/98

Depth to water: Nor available

Time: 11:55
WELL MSB 17D

MEASUREMENTS CONDUCTED IN THE FIELD

Sample date: $06 / 23 / 98$ (2)

Time: 11:40

\section{WELL MSB 18A}

MEASUREMENTS CONDUCTED IN THE FIELD

Sample date: $06 / 23 / 98$
Depth to water: $130.9 \mathrm{ft}(39.9 \mathrm{~m})$ below
Water lolevation: $210.93 \mathrm{ft}(64.29 \mathrm{~m}) \mathrm{msl}$

\section{WELL MSB 18B}

MEASUREMENTS CONDUCTED IN THE FIELD

Sample date: 06/23/98 $(37.25 \mathrm{~m})$ below TOC

Dapth to water: $122.22 \mathrm{t}(37.25 \mathrm{~m})$ below $\mathrm{TOC}$
Water elevation: $219.88 \mathrm{tt}(67.02 \mathrm{~m}) \mathrm{msl}$

Time: 10:35

\section{WELL MSB $18 C$}

MEASUREMENTS CONDUCTED IN THE FIELD

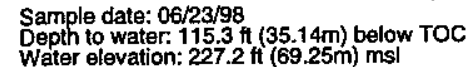

Time: 10:33

\section{WELL MSB 19A}

MEASUREMENTS CONDUCTED IN THE FIELD

Sample date: $06 / 24 / 98$ (26.35m) below TOC

Time: 13:48

WELL MSB 19B

MEASUREMENTS CONDUCTED IN THE FIELD

Sample date: 06/24/98

Depth to water: $84.1 \mathrm{ft}(25.63 \mathrm{~m})$ below TOC
Water elevation: $216.3 \mathrm{ft}(65.93 \mathrm{~m}) \mathrm{msl}$

Time: 13:49

WELL MSB 19C

MEASUREMENTS CONDUCTED IN THE FIELD

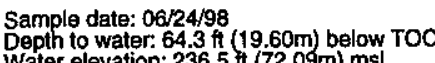

Time: $13: 50$ 
WELL MSB 20A

MEASUREMENTS CONDUCTED IN THE FIELD

Sample date: 06/23/98

Sepple date: $06 / 23798 \mathrm{ft}(42.05 \mathrm{~m})$ below toc
Water

\section{WELL MSB 20C}

MEASUREMENTS CONDUCTED IN THE FIELD

Sample date: $06 / 23 / 98$
Depth to water: $129.7 \mathrm{ft}(39.53 \mathrm{~m})$ below TOC
Water elevation: $225 \mathrm{ft}$ ( $(68.58 \mathrm{~m})$ msl

\section{WELL MSB 21A}

MEASUREMENTS CONDUCTED IN THE FIELD Sample date: $06 / 23 / 98 \mathrm{f}(41.05 \mathrm{~m})$ below ToC

(a)

\section{WELLL MSB 21B}

MEASUREMENTS CONDUCTED IN THE FIELD Sample date: 06/23/98 Depth to water: $135.4 \mathrm{ft}(41.27 \mathrm{~m})$ below TOC
Water elevation: $219.6 \mathrm{ft}(66.93 \mathrm{~m}) \mathrm{msl}$

\section{WELL. MSB 21C}

MEASUREMENTS CONDUCTED IN THË FIELD Sample date: $06 / 23 / 98$ (3) Water elevation: $226.48 \mathrm{ft}(69.03 \mathrm{~m}) \mathrm{msl}$

\section{WELL MSB 21TA}

MEASUREMENTS CONDUCTED IN THE FIELD Sample date: $06 / 23 / 98$ (49.41m) below TOC Water elevation: $192.5 \mathrm{ft}(58.67 \mathrm{~m}) \mathrm{msl}$

\section{WELL MSB 23}

MEASUREMENTS CONDUCTED IN THE FIELD

Sample date: 06/24/98

Depth to water. Nor available

Time: 12:20

\section{WELL MSB 23B}

MEASUREMENTS CONDUCTED IN THE FIELD

Sample date: 06/24/98

Depth to water: $151 \mathrm{ft}(46.03 \mathrm{~m})$ below TOC

Time: 14:36

\section{WELL MSB 23TA}

MEASUREMENTS CONDUCTED IN THE FIELD

Sample date: $06 / 24 / 98$
Depth to water: $174.75 \mathrm{ft}(53.26 \mathrm{~m})$ below TOC
Water elevation: $198.15 \mathrm{ft}(60.40 \mathrm{~m})$ msl

Time: 14:38

\section{WELL MSB 23TR}

MEASUREMENTS CONDUCTED IN THE FIELD

Sample date: 06/23/98

Wepth to water: $776.35 \mathrm{ft}(53.75 \mathrm{~m})$ below tOC

Time: 14:25

\section{WELL. MSB 24}

MEASUREMENTS CONDUCTED IN THE FIELD

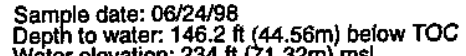

Time: 15:04

\section{WELL MSB 24A}

MEASUREMENTS CONDUCTED IN THE FIELD

Sample date: 06/24/98

Depth to water: $158.9 \mathrm{ft}(48.43 \mathrm{~m})$ below TOC

\section{WELL MSB 25}

MEASUREMENTS CONOUCTED IN THE FIELD

Sample date: 06/24/98

Depth to water. 129.8 it $(39.56 \mathrm{~m})$ below TOC

Time: 14:26

\section{WELL MSB 25A}

MEASUREMENTS CONDUCTED IN THE FIELD

Sample date: $06 / 24 / 98$
Depth to water $151.9 \mathrm{ft}$ (46.30m) below TOC

Time: 14:27 
WELL MSB 26

MEASUREMENTS CONDUCTED IN THE FIELD

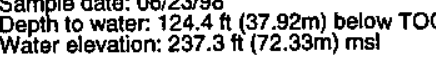

\section{WELL MSB 26A}

MEASUREMENTS CONDUCTED IN THE FIELD

Sample date: 06/23/98
Qepth to water: $137.7 \mathrm{ft}(41.97 \mathrm{~m})$ below TOC
Water elevation: $224.1 \mathrm{ff}(68.31 \mathrm{~m})$ msl

\section{WELL MSB 26B}

MEASUREMENTS CONDUCTED IN THE FIELD

Sample date: 06/23/98

Depth to water: $43.4 \mathrm{Ht}(43.71 \mathrm{~m})$ below TOC

\section{WELL MSB 27}

MEASUREMENTS CONDUCTED IN THE FIELD

Sample date: 06/24/98

Water to water $139.7 \mathrm{ft}(42.58 \mathrm{~m})$ below TOC

\section{WELL MSB 27A}

MEASUREMENTS CONDUCTED IN THE FIELD

Sample date: $06 / 24 / 98$

Depth to water: $148.7 \mathrm{ft}(45.32 \mathrm{~m})$ below TOC

\section{WELL MSB 27B}

MEASUREMENTS CONDUCTED IN THE FIELD

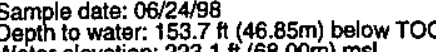

\section{WELL MSB 27TA}

MEASUREMENTS CONDUCTED IN THE FIELD

Sample date: 06/24/98

Depth to water: $179.3 \mathrm{ft}(54.65 \mathrm{~m})$ below TOC
Water elevation: $197.3 \mathrm{ft}(60.14 \mathrm{~m}) \mathrm{ms}$

\section{WELL MSB 28}

MEASUREMENTS CONDUCTED IN THE FIELD Sample date: $06 / 23 / 98$ fit $(38.60 \mathrm{~m})$ below TOC

WELL MSB 28A

MEASUREMENTS CONDUCTED IN THE FIELD

Sample date: 06/23/98

Depth to water: $131.8 \mathrm{ft}(40.17 \mathrm{~m})$ below TOC
Water elevation: $223.2 \mathrm{ft}(68.03 \mathrm{~m}) \mathrm{ms}$ l

Time: 13:40

WELL MSB 29A

MEASUREMENTS CONDUCTED IN THE FIELD

Sample date: 06/25/98 $(15.10 \mathrm{~m})$ below TOC

Water elevation: $217.25 \mathrm{ft}(66.22 \mathrm{~m}) \mathrm{msl}$

Time: 9:16

\section{WELL MSB $29 B$}

MEASUREMENTS CONDUCTED IN THE FIELD

Sample date: 06/25/98

Time: 9:14

\section{WELL MSB 29C}

MEASUREMENTS CONDUCTED IN THE FIELD

Sample date: 06/25/98

Depth to water: $136.95 \mathrm{ft}(41.74 \mathrm{~m})$ below TOC

WELL MSB 29D

MEASUREMENTS CONDUCTED IN THE FIELD

Sample date: 06/25/98

Depth to water $134.9 \mathrm{ft}(41.12 \mathrm{~m})$ below TOC

Water elevation: $230 \mathrm{ft}(70.10 \mathrm{~m}) \mathrm{msl}$

Time: 9:15

\section{WELL MSB 29DD}

MEASUREMENTS CONDUCTED IN THE FIELD

Sample date: $06 / 25 / 98 \mathrm{ft}(40.83 \mathrm{~m})$ below TOC

Time: 9:12 


\section{WELL MSB 29TA}

MEASUREMENTS CONDUCTED IN THE FIELD

Sample date: 06/25/98

Sample date: $06 / 25 / 98$
Depth to water $155.5 \mathrm{ft}(47.40 \mathrm{~m})$ below TOC
Water elevation: $209.5 \mathrm{ft}(63.86 \mathrm{~m}) \mathrm{msl}$

\section{WELL MSB 30A}

MEASUREMENTS CONDUCTED IN THE FIELD

Sample date: $06 / 23 / 98$
Depth to water: 159 ft $(48.46 \mathrm{~m})$ below TOC
Water elevation: $196 \mathrm{ft}(59.74 \mathrm{~m}) \mathrm{msl}$

\section{WELL MSB 30AA}

MEASUREMENTS CONDUCTED IN THE FIELD

Sample date: 06/23/98

Depth to water. $130.84 \mathrm{ft}(39.88 \mathrm{~m})$ below TOC

\section{WELL MSB 30B}

MEASUREMENTS CONDUCTED IN THE FIELD

Sample date: 06/23/98

Sample date: 06/23/98
Depth to water: $129.24 \mathrm{ft}(39.39 \mathrm{~m})$ below THOC
Water elevation: $224.26 \mathrm{ft}(68.36 \mathrm{~m})$ mst

\section{WELL MSB 30C}

MEASUREMENTS CONDUCTED IN THE FIELD

Sample date: 06/23/98

Pepth to water. $126.09 \mathrm{ft}(38.43 \mathrm{~m})$ below TOC

Water elevation: $228.51 \mathrm{ft}(69.65 \mathrm{~m}) \mathrm{ms}$ ।

\section{WELL MSB 30CC}

MEASUREMENTS CONDUCTED IN THE FIELD

Sample date: 06/23/98
Depth to water: $129.7 \mathrm{ft}(39.53 \mathrm{~m})$ below Tó
Water elevation: $224.3 \mathrm{ft}(68.37 \mathrm{~m}) \mathrm{msl}$

\section{WELL MSB 31A}

MEASUREMENTS CONDUCTED IN THE FIELD

Sample date: 06/24/98

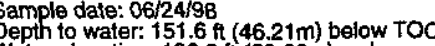

\section{WELLL MSB 31B}

MEASUREMENTS CONDUCTED IN THE FIELD

Sample date: $06 / 24 / 98$

Wepth to water. $134.9 \pi(41.12 m)$ below TOC

Time: 11:58

\section{WELL MSB 31C}

MEASUREMENTS CONDUCTED IN THE FIELD

Sample date: 06/24/98

Depth to water: $115.69 \mathrm{ft}(35.26 \mathrm{~m})$ below TOC

Time: 11:59

\section{WELL MSB 31CC}

MEASUREMENTS CONDUCTED IN THE FIELD Sample date: $06 / 24 / 98 \mathrm{ft}(41.22 \mathrm{~m})$ below TOC

\section{WELL MSB 32}

MEASUREMENTS CONDUCTED IN THE FIELD

Sample date: $06 / 24 / 98$

Depth to water: $32.1 \mathrm{ft}(9.78 \mathrm{~m})$ below TOC

Time: 13:07

\section{WELL MSB 32B}

MEASUREMENTS CONDUCTED IN THE FIELD

Sample date: 06/24/98

Depth to water: $44.4 \mathrm{ft}(13.53 \mathrm{~m})$ below TOC
Water elevation: $211 \mathrm{ft}(64.31 \mathrm{~m}) \mathrm{msl}$

\section{WELL MSB 32C}

MEASUREMENTS CONDUCTED IN THE FIELD

Sample date: 06/24/98

Water ele wateri: 39.8 th $(12.13 \mathrm{~m})$ below $\mathrm{TOC}$

Time: 13:09

\section{WELL MSB 33}

MEASUREMENTS CONDUCTED IN THE FIELD

Sample date: 06/24/98

Weth to water. $37.4 \mathrm{ft}(11.40 \mathrm{~m})$ below TOC

Time: 11:36 


\section{WELL MSB 33A}

MEASUREMENTS CONDUCTED IN THE FIELO Sample date: 06/24/98

Depth to water $50.15 \mathrm{ft}(15.29 \mathrm{~m})$ below TOC

\section{WELL MSB 33B}

MEASUREMENTS CONDUCTED IN THE FIELD

Sample date: 06/24/98

Depth to water: $47.05 \mathrm{ft}(14.34 \mathrm{~m})$ below TOC

Water elevation: $207.95 \mathrm{~h}(63.38 \mathrm{~m}) \mathrm{ms}$

\section{WELL MSB 33C}

MEASUREMENTS CONDUCTED IN THE FIELD

Sample date: 06/24/98

Water elevation: 210.83 th $(64.26 \mathrm{~m}) \mathrm{ms}$ |

\section{WELLL MSB 33TA}

MEASUREMENTS CONDUCTED IN THE FIELD

Sample date: 06/24/98

Depth to water: $60.7 \mathrm{ft}(18.50 \mathrm{~m})$ below TOC

\section{WELL MSB 34A}

MEASUREMENTS CONDUCTED IN THE FIELD

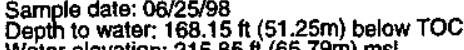

(1)

\section{WELL MSB 34B}

MEASUREMENTS CONDUCTED IN THE FIELD

Sample date: 06/25/98

Depth to water: $159.9 \mathrm{ft}(48.74 \mathrm{~m})$ below TOC
Water elevation: $224.1 \mathrm{ft}(68.31 \mathrm{~m}) \mathrm{msl}$

\section{WELL MSB 34C}

MEASUREMENTS CONDUCTED IN THE FIELD Sample date: 06/25/98

Depth to water: $155.05 \mathrm{ft}(47.26 \mathrm{~m})$ below TOC

Time: 11:40
WELL MSB 34TA

MEASUREMENTS CONDUCTED IN THE FIELD

Sample date: $06 / 25 / 98$

Depth to water. $192.55 \mathrm{ft}(58.69 \mathrm{~m})$ below TOC
Water elevation: $190.85 \mathrm{ft}(58.17 \mathrm{~m}) \mathrm{ms}$

Time: 9:44

\section{WELL MSB 34TB}

MEASUREMENTS CONDUCTED IN THE FIELD

Sample date: $06 / 25 / 98$
Depth to water: $186.25 \mathrm{ft}(56.77 \mathrm{~m})$ below TOC

Time: 9:43

\section{WELL MSB 35A}

MEASUREMENTS CONDUCTED IN THE FIELD

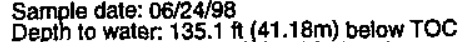

Water e vation: $215.8 \mathrm{ft}(65.78 \mathrm{~m}) \mathrm{msl}$

\section{WELL MSB 35B}

MEASUREMENTS CONDUCTED IN THE FIELD

Sample date: 06/24/98

Sample date: $06 / 24 / 98$
Depth to water: $132.95 \mathrm{ft}(40.52 \mathrm{~m})$ below TOC
Water elevation: $218.65 \mathrm{tt}(66.65 \mathrm{~m}) \mathrm{msl}$

Time: 14:24

\section{WELL MSB 35D}

MEASUAEMENTS CONDUCTED IN THE FIEL

Sample date: 06/24/98

Depth to water: Not available
Water elevation: Not availabi

Time: 14:23

\section{WELL MSB 35TA}

MEASUREMENTS CONDUCTED IN THE FIELD

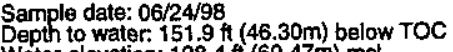

Time: 14:26

\section{WELL MSB 36A}

MEASUREMENTS CONDUCTED IN THE FIELD

Sample date: $06 / 22 / 98$

Sample date: 06/22/98
Depth to water $131.2 \mathrm{ft}(39.99 \mathrm{~m})$ below TOC
Water elevation: $209.4 \mathrm{ft}(63.83 \mathrm{~m}) \mathrm{msl}$

Time: 9:25 


\section{WELL MSB 36B}

MEASUREMENTS CONDUCTED IN THE FIELD Sampla date: 06/22/98 Depth to water $127.1 \mathrm{H}(38.74 \mathrm{~m})$ below toc

\section{WELL MSB 36C}

MEASUREMENTS CONDUCTED IN THE FIELD

Sample date: $06 / 22 / 98$

Depth to water: 127 tt $(38.71 \mathrm{~m})$ below TOC
Water elevation: $213.9 \mathrm{tt}(65.20 \mathrm{~m}) \mathrm{ms}$

\section{WELL MSB 36D}

MEASUREMENTS CONDUCTED IN THE FIED

Sample date: 06/22/98

Water of water: 108 tt $(32.92 \mathrm{~m})$ below TOC

War elevation: $233.6 \mathrm{ft}(71.20 \mathrm{~m}) \mathrm{msl}$

\section{WELL MSB 36TA}

MEASUREMENTS CONDUCTED IN THE FIELD

Sample date: 06/22/9

Deph to water. $14.7 .7 \mathrm{ft}(44.71 \mathrm{~m})$ below
Water elevation: $193.9 \mathrm{tt}(59.10 \mathrm{~m}) \mathrm{ms}$

\section{WELL MSB 38B}

MEASUREMENTS CONDUCTED IN THE FIELD

Sample date: $06 / 22 / 98$, $3(4.66 \mathrm{~m})$ below toc

Water elevation: 21575 ft(6570m) $\mathrm{ms}$ ।

\section{WELL MSB $38 C$}

MEASUREMENTS CONDUCTED IN THE FIELD

Sarmple date: $06 / 22 / 98$

Depth to water: $140.15 \mathrm{ft}(42.72 \mathrm{~m})$ below TOC
Water elevation: $218.65 \mathrm{ft}(66.65 \mathrm{~m}) \mathrm{msl}$

\section{WELL MSB 38D}

MEASUREMENTS CONDUCTED IN THE FIEL

Sample date: $06 / 22 / 98$

Demple tate: water. $1226.5 \mathrm{ft}(38.56 \mathrm{~m})$ below TOC
Water elevation: $232 \mathrm{ft}(70.71 \mathrm{~m}) \mathrm{ms}$ ।

\section{WELL MSB 38TA}

MEASUREMENTS CONDUCTED IN THE FIELD

Samiple date: 06/22/98

Depth to water: $163.1 \mathrm{ft}(49.71 \mathrm{~m})$ below TOC

\section{WELL MSB 39A}

MEASUREMENTS CONDUCTED IN THE FIELD

Sample date: $06 / 22 / 98$

Depth to water: $133 \mathrm{ft}(40.54 \mathrm{~m})$ below TOC

Time: 8:14

\section{WELL MSB 39B}

MEASUREMENTS CONDUCTED IN THE FIELD

Sample data: $06 / 22 / 98$
Depoth to water. $130.4 \mathrm{tt}(39.75 \mathrm{~m})$ below
Water elevation: $211.4 \mathrm{ft}(64.44 \mathrm{~m}) \mathrm{msl}$

Time: 8:16

\section{WELL MSB 39C}

MEASUREMENTS CONDUCTED IN THE FIEL

Sample date: 06/22/98

Dopth to water: $127 \mathrm{ft}(38.71 \mathrm{~m})$ below TOC
Water elevation: $214.5 \mathrm{ft}(65.38 \mathrm{~m})$ ms

Time: 8:17

\section{WELL MSB 39D}

MEASUREMENTS CONDUCTED IN THE FIELD

Depth to water: $111.35 \mathrm{ft}(33.94 \mathrm{~m})$ below TOC

Time: $8: 18$

\section{WELL MSB 39TA}

MEASUREMENTS CONDUCTED IN THE FIELD

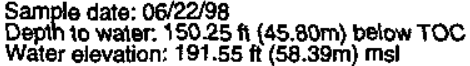

WELL. MSB 40A

MEASUREMENTS CONDUCTED IN THE FIELD

Sample date: $06 / 24 / 9$

Wellow TOC

Time: 10:56 


\section{WELL MSB 40B}

MEASUREMENTS CONDUCTED IN THE FIELD Sample date: $06 / 24 / 98 \mathrm{ft}(35.74 \mathrm{~m})$ below TOC

\section{WELL MSB 40C}

MEASUREMENTS CONDUCTED IN THE FIELD Sample date: $06 / 24 / 98 \mathrm{ft}(35.79 \mathrm{~m})$ below TOC

Water elevation: $204.58 \mathrm{ft}(62.36 \mathrm{~m}) \mathrm{msl}$

\section{WELL MSB 40D}

MEASUREMENTS CONDUCTED IN THE FIELD

Sample date: 06/24/98

Depth to water: $97.45 \mathrm{ft}(29.70 \mathrm{~m})$ below TOC

\section{WELL MSB 40TA}

MEASUREMENTS CONDUCTED IN THE FIELD

Sample date: $06 / 24 / 98$
Depth to water: $131.5 \mathrm{ft}(40.08 \mathrm{~m})$ below TOC
Water

\section{WELL MSB 41A}

MEASUREMENTS CONDUCTED IN THE FIELD

Sample date: $06 / 25 / 98$
Depth to water $107.6 \mathrm{ht}(32.80 \mathrm{~m})$ below TOC

\section{WELL MSB 41B}

MEASUREMENTS CONDUCTED IN THE FIELD

Sample date: 06/25/98

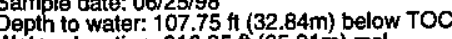

Depth to water: $107.75 \mathrm{ft}(32.84 \mathrm{~m})$ below
Water elevation: $216.25 \mathrm{ft}(65.91 \mathrm{~m}) \mathrm{ms}$ !

\section{WELL MSB 41C}

MEASUREMENTS CONDUCTED IN THE FIELD

Sample date: $06 / 25 / 98$ f $(32.85 \mathrm{~m})$ below TOC

Time: 8:17
WELL MSB 41D

MEASUREMENTS CONDUCTED IN THE FIELD

Sample date: 06/25/98

Depth to water: $84.05 \mathrm{ft}(25.62 \mathrm{~m})$ below TOC
Water elevation: $240.95 \mathrm{H}(73.44 \mathrm{~m}) \mathrm{ms}$ l

Time: $8: 11$

\section{WELL MSB 41TA}

MEASUREMENTS CONDUCTED IN THE FIELD

Sample date: 06/25/98

Depth to water: $18.52 \mathrm{ft}(36.13 \mathrm{~m})$ below TOC

Time: 8:20

\section{WELL MSB 42A}

MEASUREMENTS CONDUCTED IN THE FIELD

Sample date: $06 / 25 / 98$
Depth to water: $159.5 \mathrm{ft}(48.62 \mathrm{~m})$ below TOC
Water elavation: $217 \mathrm{ft}(66.14 \mathrm{~m}) \mathrm{ms}$

Time: 9:57

\section{WELL MSB 42B}

MEASUREMENTS CONDUCTED IN THE FIELD

Sample date: $06 / 25 / 98$ ( $(46.72 \mathrm{~m})$ below TOC

Water to wavation: $223.13 \mathrm{ft}(68.01 \mathrm{~m}) \mathrm{ms}$ l

Time: 9:58

\section{WELL MSB 42C}

MEASUREMENTS CONDUCTED IN THE FIELD

Sample date: $06 / 25 / 98$
Depth to water: $147.8 \mathrm{ft}(45.05 \mathrm{~m})$ below TOC
Water elevation: $228.6 \mathrm{ft}(69.68 \mathrm{~m}) \mathrm{ms}$ )

Time: 9:59

\section{WELL MSB 42D}

MEASUREMENTS CONDUCTED IN THE FIELD

Sample date: 06/25/98 $\mathrm{ft}(44.61 \mathrm{~m}$ ) below TOC

Time: 10:00

\section{WELL MSB 42TA}

MEASUREMENTS CONDUCTED IN THE FIELD

Sample date: $06 / 25 / 98$ ( $53.40 \mathrm{~m})$ below TOC

Depth to water: $175.2 \mathrm{tt}(53.40 \mathrm{~m})$ below
Time: 9:56 


\section{WELL MSB 43A}

MEASUREMENTS CONDUCTED IN THE FIELD Sample date: 06/25/98 Dephit to water $129.9 \mathrm{ft}(39.59 \mathrm{~m})$ below TOC
Water elevation: $227.8 \mathrm{ft}(9.43 \mathrm{~m}) \mathrm{ms}$

\section{WELL MSB 43B}

MEASUREMENTS CONDUCTED IN THE FIELD

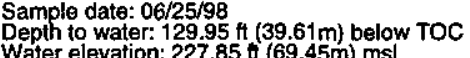

\section{WELL MSB 43D}

MEASUREMENTS CONDUCTED IN THE FIELD Sample date: $06 / 25 / 98$ (1) Water elevation: $230.11 \mathrm{ft}(70.14 \mathrm{~m}) \mathrm{msl}$

\section{WELL MSB 43DD}

MEASUREMENTS CONDUCTED IN THE FIELD Water elevation: $230.2 \mathrm{t}(70.17 \mathrm{~m}) \mathrm{msl}$

\section{WELL MSB 43TA}

MEASUREMENTS CONDUCTED IN THE FIELD Sample date: 06/25/98

Wapt

\section{WELL MSB 44A}

MEASUREMENTS CONDUCTED IN THE FIELD

Sample date: $06 / 25 / 98$

\section{WELL MSB 44B}

MEASUREMENTS CONDUCTED IN THE FIELD Sample date: $06 / 25 / 98$
Qepth to water: $154.78 \mathrm{ft}(47.18 \mathrm{~m})$ below toc
Water elevation: $222.22 \mathrm{tt}(67.73 \mathrm{~m}) \mathrm{msl}$ Sample date: $06 / 25 / 98$ (29)

Water tovation: 161.05 th $(49.09 \mathrm{~m})$ below TOC
WELL MSB 44C

MEASUREMENTS CONDUCTED IN THE FIELD

Sample date: 06/25/98

Depph to water. $145.5 \mathrm{ft}(44.35 \mathrm{~m})$ below TOC

Time: 10:10

\section{WELL MSB 45A}

MEASUREMENTS CONDUCTED IN THE FIELD

Sample date: $0625 / 98$
Depth to water $167.25 \mathrm{ft}(50.98 \mathrm{~m})$ below TOC

Time: 10:19

\section{WELL MSB 45B}

MEASUREMENTS CONDUCTED IN THE FELLD

Sample date: $06 / 25 / 98$

Depth to water: $157.95 \mathrm{ft}(48.14 \mathrm{~m})$ below TOC
Water elevation: $222.95 \mathrm{ft}(67.96 \mathrm{~m}) \mathrm{ms}$ )

Time: 10:18

WELL MSB 45C

MEASUAEMENTS CONDUCTED IN THE FIELD

Sample date: $06 / 25 / 98$

Water elevation: Not available

Time: 10:20

\section{WELL MSB 46A}

MEASUREMENTS CONDUCTED IN THE FIELD

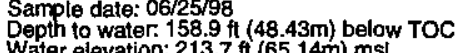

\section{WELL MSB 46B}

MEASUREMENTS CONDUCTED IN THE FIELO

Sample date: $06 / 25798$

Depth to water: $147.69 \mathrm{ft}(45.02 \mathrm{~m})$ below TOC

\section{WELL MSB 46C}

MEASUREMENTS CONDUCTED IN THE FIELD

Sample date: $06 / 25 / 98$ ft $(40.40 \mathrm{~m})$ below TOC

Time: 10:15 


\section{WELL MSB 47B}

MEASUREMENTS CONDUCTED IN THE FIELD

Sample date: 06/25/98

Water

\section{WELL MSB 47BB}

MEASUREMENTS CONDUCTED IN THE FIELD

Sample date: $06 / 25 / 98$

Sample date: $0625 / 98$
Depth to water $155.55 \mathrm{ft}(46.50 \mathrm{~m})$ below tOC
Waler elevation: $216.25 \mathrm{ft}(65.91 \mathrm{~m}) \mathrm{msl}$

\section{WELL MSB 47C}

MEASUAEMENTS CONDUCTED IN THE FIELD

Sample date: 06/25/98

Water elevation: $230 \mathrm{ft}(70.10 \mathrm{~m}) \mathrm{msl}$ )

\section{WELL MSB 47D}

MEASUREMENTS CONDUCTED IN THE FIELD Sample data: $06 / 25 / 98$
Depth to water: $137.9 \mathrm{ft}(42.03 \mathrm{~m})$ below TOC

Water elevation: $230.9 \mathrm{tt}(70.38 \mathrm{~m}) \mathrm{ms}$ !

\section{WELL MSB 47TA}

MEASUREMENTS CONDUCTED IN THE FIELD

Sample date: $06 / 25 / 98$

Depth to water: $155.15 \mathrm{ft}(47.29 \mathrm{~m})$ below $\mathrm{TOC}$

\section{WELL MSB 49A}

MEASUREMENTS CONDUCTED IN THE FIELD

Sample date: 06/25/98

Deph to water: $138.65 \mathrm{ft}(42.26 \mathrm{~m})$ below TOC
Water elevation: $196.05 \mathrm{ft}(59.76 \mathrm{~m}) \mathrm{msl}$

\section{WELL MSB 49B}

MEASUREMENTS CONDUCTED IN THE FIELD

Sample date: $06 / 25 / 98$

Depth to water $1.32 .45 \mathrm{ft}(40.37 \mathrm{~m}$ ) below TOC

\section{WELL MSB 49D}

MEASUREMENTS CONDUCTED IN THE FIELD

Sample date: $06 / 25 / 98$.

Time: 11:25

\section{WELL MSB 50B}

MEASUREMENTS CONDUCTED IN THE FIELD

Sample date: 06/22/98

Depth to water: $20.9 \mathrm{ft}(6.37 \mathrm{~m})$ bolow TOC

Time: 10:22

\section{WELL MSB 50D}

MEASUREMENTS CONDUCTED IN THE FIELD

Sample date: 06/22/98

Depth to water: $20.3 \mathrm{ft}(6.19 \mathrm{~m})$ below TOC

Water elevation: $202.9 \mathrm{tt}(61.84 \mathrm{~m}) \mathrm{msl}$

Time: 10:24

\section{WELL MSB 51B}

MEASUAEMENTS CONDUCTED IN THE FIELD

Sample date: $06 / 22 / 98$
Depth to water: $57.8 \mathrm{ft}(17.62 \mathrm{~m})$ below
Water elevation: $205.4 \mathrm{tt}(62.61 \mathrm{~m}) \mathrm{ms}$

Time: 10:48

\section{WELL MSB 51D}

MEASUREMENTS CONDUCTED IN THE FIELD

Sample date: 06/22/98

Depth to water: $50 \mathrm{ft}(15.24 \mathrm{~m})$ below TOC

Time: 10:49

\section{WELL MSB 51DD}

MEASUREMENTS CONDUCTED IN THE FIELD

Sample date: 06/22/98

Depth to water: $47 \mathrm{ft}$ (14.33m) below TOC
Water elevation: $216.2 \mathrm{ft}(65.90 \mathrm{~m}) \mathrm{msl}$

Time: 10:47

\section{WELL MSB 52B}

MEASUREMENTS CONDUCTED IN THE FIELD

Sample date: $06 / 25 / 98$

Depth to water $103.78 \mathrm{Ht}(31.63 \mathrm{~m})$ below TOC
Water relavation: $217.92 \mathrm{tt}(66.42 \mathrm{~m}) \mathrm{ms}$

Time: 7:11 


\section{WELL MSB 52D}

MEASUREMENTS CONDUCTED IN THE FIELD

Sample date: 06/25/98

Depth to water: Not available
Water elevation: Not availablo

Time: 7:14

\section{WELL MSB 53B}

MEASUREMENTS CONDUCTED IN THE FIELD

Sample date: 06/22/98

Sample date: $06 / 22298$
Depth to water: $124.6 \mathrm{ft}(37.98 \mathrm{~m})$ below TOC

\section{WELL MSB 53C}

MEASUREMENTS CONDUCTED IN THE' FIELD

Sample date: $06 / 20 / 98$

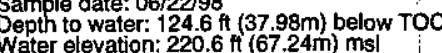

\section{WELL MSB 53D}

MEASUREMENTS CONDUCTED IN THE FIELD

Sample date: 06/22/98

Deph to water: $112.4 \mathrm{t}(34.2 \mathrm{~m})$ bolow $10 \mathrm{C}$

\section{WELL MSB 54B}

MEASUREMENTS CONDUCTED IN THE FIELD

Sample date: $06 / 23 / 98$

Sample date: $06 / 2398$
Depth to water: $153.4 \mathrm{ft}(46.76 \mathrm{~m})$ below TOC
Water elevation: $220 \mathrm{ft}(67.06 \mathrm{~m})$ ms

\section{WELL MSB 54C}

MEASUREMENTS CONDUCTED IN THE FIELD

Sample date: 06/23/98

Depth to water $148.8 \mathrm{ft}(45.35 \mathrm{~m})$ below TOC
Water elevation: $224.6 \mathrm{ft}(68.46 \mathrm{~m}) \mathrm{msl}$

\section{WELL. MSB 54D}

MEASUREMENTS CONDUCTED IN THE FIELD

Sample date: $06 / 23 / 98$ f

Wepth to water: $143.15 \mathrm{ft}(43.63 \mathrm{~m})$ below
Water elevation: $230.45 \mathrm{tt}(70.24 \mathrm{~m}) \mathrm{msl}$

$$
\text { ! }
$$

Time: 11:30

Time: $13: 52$

Time: 13:54
WELL MSB 54TA

MEASUREMENTS CONDUCTED IN THE FIELD

Sample date: 06/23/98

Depth to water. $156.1 \mathrm{ft}(47.58 \mathrm{~m})$ below TOC
Water elevation: $217.4 \mathrm{ft}(66.26 \mathrm{~m}) \mathrm{ms}$ l

Time: 13:50

\section{WELL MSB 55B}

MEASUREMENTS CONDUCTED IN THE FIELD

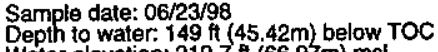

Time: 13:34

WELL MSB 55C

MEASUREMENTS CONDUCTED IN THE FIELD

Sample date: 06/23/98

Time: 13:38

\section{WELL MSB 55D}

MEASUREMENTS CONDUCTED IN THE FIELD

Sample date: 06/23/98

Sample date: $06 / 23 / 98$
Depth to water: $135 \mathrm{ft}(41.15 \mathrm{~m})$ below TOC
Water elevation: $232.7 \mathrm{ft}(70.93 \mathrm{~m}) \mathrm{msl}$

Time: 13:30

\section{WELL MSB 55HC}

MEASUREMENTS CONDUCTED IN THE FIELO

Sample date: $06 / 23 / 98$
Depth to water. $138.3 \mathrm{ft}(42.15 \mathrm{~m})$ below TOC

Time: 13:35

\section{WELL MSB 55TA}

MEASUREMENTS CONDUCTED IN THE FIELD

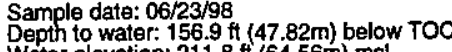

Time: 13:37

\section{WELL MSB 56D}

MEASUREMENTS CONDUCTED IN THE FIELD

Sample date: 06/22/98

Sample date: $06 / 22 / 98$
Wepth to water: $58 \mathrm{ft}(17.68 \mathrm{~m})$ below TOC
Water elevation: $221.5 \mathrm{ft}(67.51 \mathrm{~m}) \mathrm{msl}$ 


\section{WELL MSB 570}

MEASUREMENTS CONDUCTED IN THE FIELD

Sample date: 06/24/98

Depth to water: $126.3 \mathrm{ft}(38.50 \mathrm{~m})$ below TOC

\section{WELL MSB 58D}

MEASUREMENTS CONDUCTED IN THE FIELD

Sample date: $06 / 24 / 98$
Depth to water: $128.55 \mathrm{ht}(39.18 \mathrm{~m})$ below TOC
Water elevation: $229.35 \mathrm{ft}(69.91 \mathrm{~m}) \mathrm{msl}$

\section{WELL MSB 59D}

MEASUREMENTS CONDUCTED IN THE FIELD

Sample date: $06 / 24 / 98 \mathrm{ft}(39.92 \mathrm{~m})$ below TOC

\section{WELL MSB 60D}

MEASUREMENTS CONDUCTED IN THE FIELD

Sample date: 06/24/98

Weph

\section{WELL MSB 61C}

MEASUREMENTS CONDUCTED IN THE FIELD

Sample date: 06/2/98

Depth to water $95.65 \mathrm{ft}(29.15 \mathrm{~m})$ below TOC
Water elevation: $221.65 \mathrm{ft}(67.56 \mathrm{~m}) \mathrm{msl}$

\section{WELL MSB 61D}

MEASUREMENTS CONDUCTED IN THE FIELD

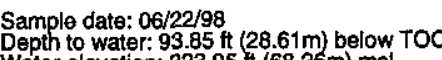

Water elevation: $223.95 \mathrm{Ht}(68.26 \mathrm{~m}) \mathrm{ms}$

\section{WELL MSB 62B}

MEASUREMENTS CONDUCTED IN THE FIELD

Sample date: 06/23/98

\section{WELL MSB 62C}

MEASUREMENTS CONDUCTED IN THE FIELD

Sample date: $06 / 23 / 98$
Depth to water: $126.55 \mathrm{ft}(38.57 \mathrm{~m})$ below TOC
Water elevation: $222.55 \mathrm{ff}(67.83 \mathrm{~m}) \mathrm{msl}$

Time: 11:16

\section{WELL MSB 62D}

MEASUREMENTS CONDUCTED IN THE FIELD

Sample date: 06/23/98

\section{WELL MSB 63B}

MEASUREMENTS CONDUCTED IN THE FIELD

Sample date: 06/23/98

Depth to water $136.7 \mathrm{ft}(41.67 \mathrm{~m})$ below TOC
Water elevation: $210.2 \mathrm{ft}(64.07 \mathrm{~m}) \mathrm{msl}$

\section{WELL MSB 63C}

MEASUREMENTS CONDUCTED IN THE FIELD

Sample date: $06 / 23 / 98$
Depth to water: $127.35 \mathrm{ft}(38.82 \mathrm{~m})$ below TOC
Water elevation: $219.65 \mathrm{ft}(66.95 \mathrm{~m}) \mathrm{msl}$

Time: 11:23

\section{WELL MSB 63D}

MEASUREMENTS CONDUCTED IN THE FIELD

Sample date: $06 / 23 / 98$ (t $(36.09 \mathrm{~m})$ below TOC

\section{WELL MSB 64B}

MEASUAEMENTS CONDUCTED IN THE FIELD

Sample date: 06/23/98

Depth to water: $139.95 \mathrm{ft}(42.66 \mathrm{~m})$ below TOC

WELL MSB 64C

MEASUREMENTS CONDUCTED IN THE FIELD

Sample date: $06 / 23 / 98$ (38 $89 \mathrm{~m})$ below TOC Water elevation: $220.8 \mathrm{ft}(67.30 \mathrm{~m}) \mathrm{ms} \mid$
Time: 10:48 
WELL MSB 64D

MEASUREMENTS CONDUCTED IN THE FIELD

Sample date: 06/23/98

Depth to water: $124 \mathrm{tt}(37.80 \mathrm{~m})$ below TOC
Water elevation: $224.6 \mathrm{Ht}(68.46 \mathrm{~m}) \mathrm{ms}$

Time: 10:47

\section{WELL MSB 65D}

MEASUREMENTS CONOUCTED IN THE FIELD

Sample data: $06 / 22198$
Depth to
Water. $117.35 \mathrm{ft}(35.77 \mathrm{~m})$ below TOC

\section{WELL MSB 66B}

MEASUREMENTS CONDUCTED IN THE FIELD

Sample date: 06/23/98

Depth to water. $16.6 \mathrm{ft}(50.72 \mathrm{~m})$ below TOC
Water elevation: $217 \mathrm{tt}(66.14 \mathrm{~m}) \mathrm{ms}$

WELL MSB 66C

MEASUREMENTS CONDUCTED IN THE FIELD

Sample date: $06 / 23 / 98$

Depth to water: $257.55 \mathrm{ft}(48.02 \mathrm{~m})$ below TOC
Water elevation: $225.85 \mathrm{ft}(68.84 \mathrm{~m}) \mathrm{ms}$

\section{WELL MSB 66D}

MEASUREMENTS CONDUCTED IN THE FIELD

Sample date: 06/23/9

Depth towater $1.55 \mathrm{th}(47.24 \mathrm{~m})$ below $\mathrm{TOC}$
Water elevation: $228.2 \mathrm{tit}(69.56 \mathrm{~m}) \mathrm{ms}$

\section{WELL MSB 66TA}

MEASUREMENTS CONOUCTED IN THE FIELD Sample date: $06 / 23 / 98$
Depch to water: $180.72 \mathrm{ft}\langle(55.08 \mathrm{~m})$ below TOC

Water elevation: $201.98 \mathrm{ft}(61.56 \mathrm{~m}) \mathrm{msl}$

\section{WELL MSB 67B}

MEASUREMENTS CONDUCTED IN THE FIELD Sample date: 06/24/98 Wopth to water. 149.1 1 (t) $(45.45 \mathrm{~m})$ below TOC
Water elevation: $216 \mathrm{ft}(65.84 \mathrm{~m}) \mathrm{ms}$
WELLL MSB 67C

MEASUREMENTS CONDUCTED IN THE FIELD

Sample date: $06 / 24 / 9$

Water elevation: $223.6 \mathrm{t} t(43.04 \mathrm{~m})$ below $T O C$

Time: 14:05

\section{WELL MSB 67D}

MEASUREMENTS CONDUCTED IN THE FIELD

Sample date: 06/24/98

Weit to water. 34.6 ( $41.03 \mathrm{~m})$ below TOC

\section{WELL MSB 68B}

MEASUREMENTS CONDUCTED IN THE FIELD Sample date: $06 / 24 / 98$
Depth to water: $140.6 \mathrm{ft}(42.86 \mathrm{~m})$ below
Water elevation: $216.3 \mathrm{ft}(65.93 \mathrm{~m}) \mathrm{ms}$

Time: 13:54

\section{WELL MSB 68C}

MEASUREMENTS CONDUCTED IN THE FIELD

Sample date: $06 / 24 / 98$
Deppth to water. $115.1 \mathrm{ft}(41.18 \mathrm{~m})$ below
Water elevation: $221.6 \mathrm{tt}(67.54 \mathrm{~m}) \mathrm{ms}$

Time: 13:56

\section{WELL MSB 68D}

MEASUREMENTS CONDUCTED IN THE FIELD

Sample date: 06/24/98

Deph to water. $125.55 \mathrm{ft}(38.36 \mathrm{~m})$ below TOC
Water elevation: $231.15 \mathrm{tt}(70.06 \mathrm{~m}) \mathrm{ms}$ -

\section{WELL MSB 69B}

MEASUREMENTS CONDUCTED IN THE FIELD

Sample date: 06/23/98

Depin to water.

Time: 14:22

\section{WELL MSB 69C}

MEASUREMENTS CONDUCTED IN THE FIELD

Sample date: 06/23/98

Depth to water: $156.8 \mathrm{ft}(47.79 \mathrm{~m})$ below TOC

Water elevation: $224.8 \mathrm{ft}(6 \mathrm{6} .5 \mathrm{~m} \mathrm{~m}) \mathrm{ms}$ )
Time: 14:20 


\section{WELL MSB 69D}

MEASUREMENTS CONDUCTED IN THE FIELD Sample date: 06/23/98

Depth to water: 151.4 ft $(46.15 \mathrm{~m})$ below TOC

WELL MSB 69TA

MEASUREMENTS CONDUCTED IN THE FIEL

Sample date: $06 / 23 / 98$
Depth to water: $168.7 \mathrm{ft}(51.42 \mathrm{~m})$ below $\mathrm{TOC}$
Water elevation: $212.7 \mathrm{ft}(64.83 \mathrm{~m}) \mathrm{msl}$

\section{WELL MSB 70C}

MEASUREMENTS CONDUCTED IN THE FIELD

Sample date: 06/24/98

Depth to water: $146.6 \mathrm{ft}(44.68 \mathrm{~m})$ below TOC

\section{WELL MSB 70D}

MEASUREMENTS CONDUCTED IN THE FIEL

Sample date: 06/24/98

Depth to water: $143.4 \mathrm{At}(43.71 \mathrm{~m})$ below $T O C$

\section{WELL MSB 71B}

MEASUREMENTS CONDUCTED IN THE FIELD

Sample date: $06 / 22 / 98$

Sample date: $06 / 229.9$
Depth to water: $129.6 \mathrm{tt}(39.50 \mathrm{~m})$ below TOC
Water elevation: $215.1 \mathrm{t}(65.56 \mathrm{~m}) \mathrm{msl}$

\section{WELLL MSB 72B}

MEASUREMENTS CONDUCTED IN THE FIELD

Sample date: 06/22/98

Water elevation: $19.3 \mathrm{ft}(39.11 \mathrm{~m})$ below TOC

\section{WELL MSB 73B}

MEASUREMENTS CONDUCTED IN THE FIELD

Sample date: 06/24/98

Weph to waier. 39 if (42.37m) below TOC

\section{WELLL MSB 74B}

MEASUREMENTS CONDUCTED IN THE FIELD

Sample date: $06 / 22 / 98$
Depth to water: 104.4
Wt (31.82m) below TOC

Time: 10:00

\section{WELL MSB 74C}

MEASUREMENTS CONDUCTED IN THE FIELD

Sample date: 06/22/98

Time: 9:58

\section{WELL MSB 74D}

MEASUREMENTS CONDUCTED IN THE FIELD

Depth to water: $81.75 \mathrm{ft}(24.92 \mathrm{~m})$ below TOC

Water elevation: $233.35 \mathrm{Ht}(71.13 \mathrm{~m}) \mathrm{msl}$

Time: 9:39

\section{WELL. MSB 75B}

MEASUREMENTS CONDUCTED IN THE FIELD

Sample date: 06/22/98 $3.80 \mathrm{~m})$ below TOC

Water elevation: $209.25 \mathrm{ft}(63.7 \mathrm{~mm}) \mathrm{msl}$

Time: 8:52

\section{WELL MSB 75C}

MEASUREMENTS CONDUCTED IN THE FIELD

Sample date: $06 / 22 / 98$
Depth to water: $118.5 \mathrm{ft}(36.12 \mathrm{~m})$ below TOC

Time: 8:50

\section{WELL MSB 76C}

MEASUREMENTS CONDUCTED IN THE FIELD

Sample date: $06 / 22 / 98$
Depth to water: $134.45 \mathrm{ft}(40.98 \mathrm{~m})$ betow TOC

\section{WELL MSB 77B}

MEASUREMENTS CONDUCTED IN THE FIELD

Sample date: 06/22/98

Wepth to water: $138.2 \mathrm{ht}(42.12 \mathrm{~m})$ below 
WELL MSB 77C

MEASUREMENTS CONDUCTED IN THE FIELD

Sample date: 06/22/98

Depth to water: $135.7 \mathrm{ft}(41.36 \mathrm{~m})$ below TOC

me: 11:09

WELL MSB 77D

MEASUREMENTS CONDUCTED IN THE FIELD

Sample date: $06 / 22 / 98$

Depth to water: $125.7 \mathrm{ft}$ (38.31m) below TOC

\section{WELLL MSB 77TA}

MEASUREMENTS CONDUCTED IN THE FIELD

Sample date: 06/22/98

Depth to water: $138 \mathrm{ft}(42.06 \mathrm{~m})$ below TOC

$8.9 \mathrm{ft}(66.72 \mathrm{~m}) \mathrm{ms}$

\section{WELL MSB 78DR}

MEASUREMENTS CONDUCTED IN THE FIELD

Sample date: 06/22/98

Depth to water: $142.9 \mathrm{ft}(43.56 \mathrm{~m})$ below TOC
Water elevation: $220.8 \mathrm{ft}(67.30 \mathrm{~m}) \mathrm{msl}$

\section{WELL MSB 79B}

MEASUREMENTS CONDUCTED IN THE FIELD

Sample date: 06/22/98

Water elevation: $206.5 \mathrm{ft}(62.94 \mathrm{~m}) \mathrm{ms}$ (O)

\section{WELL MSB 79C}

MEASUREMENTS CONDUCTED IN THE FIELD

Sample date: 06/22/98

Depth to water: 139 it $(42.37 \mathrm{~m})$ below TOC

il

\section{WELL MSB 81B}

MEASUREMENTS CONDUCTED IN THE FIELD

Sample date: $06 / 22 / 98$

Time: 11:47
WELL. MSB 82A

MEASUREMENTS CONDUCTED IN THE FIELD

Sample date: $06 / 23 / 98$

Wath to water: $155.25 \mathrm{ft}(47.32 \mathrm{~m})$ below TOC

Time: 14:36

\section{WELLL MSB 82B}

MEASUREMENTS CONDUCTED IN THE FIELD

Sample date: $06 / 23 / 98$
Depth to water: $157 \mathrm{ft}(47.85 \mathrm{~m})$ below TOC

Time: 14:39

\section{WELL MSB 82C}

MEASUREMENTS CONDUCTED IN THE FIELD

Sample date: 06/23/98

Depth to water: $148.55 \mathrm{ft}(45.28 \mathrm{~m})$ below TOC

WELLL MSB 82D

MEASUREMENTS CONDUCTED IN THE FIELD

Sample date: $06 / 23 / 98$

Depth to water $143.1 \mathrm{ft}(43.62 \mathrm{~m})$ below TOC
Water elevation: $230.5 \mathrm{ft}(70.26 \mathrm{~m}) \mathrm{msl}$

Time: 14:32

WELLL MSB 82TA

MEASUREMENTS CONDUCTED IN THE FIELD

Sample date: 06/23/98

Depth to water: $161.8 \mathrm{ft}(49.32 \mathrm{~m})$ below TOC
Water elevation: $211.9 \mathrm{ff}(64.59 \mathrm{~m}) \mathrm{ms}$

Time: 14:35

\section{WELL MSB 83B}

MEASUREMENTS CONDUCTED IN THE FIELD

Sample date: 06/23/98

Time: 14:10

\section{WELL MSB 83C}

MEASUREMENTS CONDUCTED IN THE FIELD

Sample date: 06/23/98

Depth to water: $145.9 \pi(44.47 \mathrm{~m})$ below TOC

Time: 14:03 


\section{WELL MSB 83D}

MEASUREMENTS CONDUCTED IN THE FIELD

Sample date: 06/23/98

Depth to water: $141 \mathrm{ft}(42.98 \mathrm{~m})$ below TOC

\section{WELL MSB 83TA}

MEASUREMENTS CONDUCTED IN THE FIELD

Sample date: $06 / 23 / 98$

Depth to water: $158.1 \mathrm{ft}(48.19 \mathrm{~m})$ below TOC
Water elevation: $213.6 \mathrm{ft}(65.11 \mathrm{~m}) \mathrm{msl}$

\section{WELL MSB 84A}

MEASUREMENTS CONDUCTED IN THE FIELD

Sample date: 06/23/98

Depth to water: $158.3 \mathrm{ft}(48.25 \mathrm{~m})$ below TOC

\section{WELL MSB 84C}

MEASUREMENTS CONDUCTED IN THE FIELD

Sample date: 06/23/98

Depth to water: $133.95 \mathrm{ft}(40.83 \mathrm{~m})$ below TOC

\section{WELL MSB 85B}

MEASUREMENTS CONDUCTED IN THE FIELD

Sample date: 06/23/98

Sample date: $06 / 23 / 98$
Depth to water $161.2 \mathrm{~h}(49.13 \mathrm{~m})$ below TOC
Water elevation: $219.1 \mathrm{ft}(66.78 \mathrm{~m}) \mathrm{msl}$

\section{WELL MSB 85C}

MEASUREMENTS CONDUCTED IN THE FIELD

Sample date: $06 / 23 / 98$ (4) $(48.39 \mathrm{~m})$ below TOC

Water elevation: $222.15 \mathrm{ft}(67.71 \mathrm{~m}) \mathrm{msl}$

\section{WELL MSB 85D}

MEASUREMENTS CONDUCTED IN THE FIELD Sample date: $06 / 23 / 98 \mathrm{ft}(45.10 \mathrm{~m})$ below TOC

\section{WELLL MSB 85TA}

MEASUREMENTS CONDUCTED IN THE FIELD

Sample date: 06/23/98

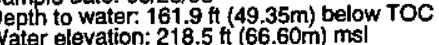

Time: 14:55

\section{WELL MSB 86C}

MEASUREMENTS CONDUCTEO IN THE FIELD

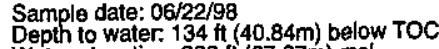

Time: 15:48

\section{WELL MSB 87B}

MEASUREMENTS CONDUCTED IN THE FIELD

Sample date: 06/24/98

Sample date: $06 / 24 / 98$
Depth to water: $118.45 \mathrm{ft}(36.10 \mathrm{~m})$ below TOC
Water elevation: $217.55 \mathrm{ft}(66.31 \mathrm{~m}) \mathrm{ms}$

Time: 13:56

\section{WELL MSB 87C}

MEASUREMENTS CONDUCTED IN THE FIELD

Sample date: $06 / 24 / 98$
Depth to water: $95.22 \mathrm{ft}(29.02 \mathrm{~m})$ below TOC
Water elevation: $241.38 \mathrm{ft}(73.57 \mathrm{~m}) \mathrm{msl}$

Time: 13:57

\section{WELL MSB 88B}

MEASUREMENTS CONDUCTEO IN THE FIELD

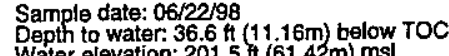

\section{WELL MSB 88C}

MEASUREMENTS CONDUCTED IN THE FIELD

Sample date: $06 / 22 / 98$

Depth to water: $33.1 \mathrm{At}(10.09 \mathrm{~m})$ below TOC

\section{WELL MSB 88D}

MEASUREMENTS CONDUCTED IN THE FIELD

Sample date: 06/22/98 $9.60 \mathrm{~m})$ below TOC
$(62.61 \mathrm{~m}) \mathrm{msl}$ 


\section{WELL MSB 89B}

MEASUREMENTS CONDUCTED IN THE FIELD

Sample date: $06 / 22 / 98$

below TOC

Water elevation: $206.2 \mathrm{ft}(62.85 \mathrm{~m}) \mathrm{msl}$

Time: 13:14

\section{WELL MSB 89C}

MEASUREMENTS CONDUCTED IN THE FIELD Sample date: $06 / 22 / 98$
Oepth to water: $113.1 \mathrm{ft}(34.47 \mathrm{~m})$ below TOC
Water elevation: $226.7 \mathrm{tt}(69.10 \mathrm{~m}) \mathrm{msl}$

\section{WELL SRW 1}

MEASUREMENTS CONDUCTED IN THE FIELD

Sample date: 06/26/98

Depth to water: Not available
Water elevation: Not available

Time: 11:45

WELL SRW 1BB

MEASUREMENTS CONDUCTED IN THE FIELD

Sample date: $06 / 26 / 98$

Semple date: 06/26/98
Wepth water: 100.7 $\mathrm{ft}(33.13 \mathrm{~m})$ below ToC
Water elevation: $207.6 \mathrm{ft}(63.28 \mathrm{~m}) \mathrm{ms}$ |

\section{WELL SRW 2}

MEASUREMENTS CONDUCTED IN THE FIELD

Sample date: 06/26/98

Depth to water: $107.85 \mathrm{ft}(32.87 \mathrm{~m})$ below ToC
Water elevation: $212.75(7.64 .85 \mathrm{~m}) \mathrm{ms}$

\section{WELL SRW 2A}

MEASUREMENTS CONDUCTED IN THE FIELD

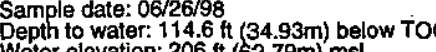

\section{WELL SRW 2B}

MEASUREMENTS CONDUCTED IN THE FIELD

Sample date: $06 / 26 / 98$

Depth to water: $133 \mathrm{ft}(40.54 \mathrm{~m})$ below TOC
Water elevation: $187.6 \mathrm{ft}(57.1 \mathrm{~m}) \mathrm{msl}$

\section{WELL SRW 3A}

MEASUREMENTS CONDUCTED IN THE FEELD

Sample date: 06/26/98

Time: 11:37

Water elevation: 211.2 ft $(64.37 \mathrm{~m}) \mathrm{ms}$ )

\section{WELL SRW 3BB}

MEASUREMENTS CONDUCTED IN THE FIELD

Sample date: $06 / 26 / 98$

epth to water: $123.95 \mathrm{ft}(37.78 \mathrm{~m})$ below TOC

Time: 11:38

\section{WELL SRW 4}

MEASUREMENTS CONDUCTED IN THE FIELD

Sample date: $06 / 26 / 98$ (33.32m) below TOC

Wept to water: $109.3 \mathrm{~A}(33.32 \mathrm{~m})$ below $7 \mathrm{CO}$

Time: 12:08

\section{WELL SRW 4BB}

MEASUREMENTS CONDUCTED IN THE FIELD

Sample date: 06/26/98

Depth to water: $113.3 \mathrm{ft}(34.53 \mathrm{~m})$ below TOC
Water elevation: $207.3 \mathrm{ft}(63.19 \mathrm{~m}) \mathrm{msl}$

Time: 12:09

\section{WELLL SRW 5}

MEASUREMENTS CONDUCTED IN THE FIELD

Sample date: 06/26/98

Water elevation: $209.55 \mathrm{ft}(63.8 \mathrm{~m})$ below TOC

Time: 12:03

\section{WELL SRW 6}

MEASUREMENTS CONDUCTED IN THE FIELD

Sample date: 06/26/98

Time: 11:49

\section{WELL SRW 7.}

MEASUREMENTS CONDUCTED IN THE FIELD

Sample date: 06/26/98

Depth to water: $88.9 \mathrm{ft}$ (27.10m) below TOC

Time: 11:52 
WELL SRW 8

MEASUREMENTS CONDUCTED IN THE FIELD Sample date: 06/25/98

Sample date: $06 / 25 / 98$
Depth to water: $82.4 \mathrm{ft}(25.12 \mathrm{~m})$ below TOC
Wat

\section{WELL SRW 8BB}

MEASUREMENTS CONDUCTED IN THE FIELD

Sample date: 06/25/98

Depth to water: $79.7 \mathrm{ft}(24.29 \mathrm{~m})$ below TOC
Water elevation: $209.8 \mathrm{ft}(63.95 \mathrm{~m}) \mathrm{msl}$

\section{WELL SRW 9A}

MEASUREMENTS CONDUCTED IN THE FIELD

Sample date: 06/26/9

Depth to water. $53.4 \mathrm{ft}(16.28 \mathrm{~m})$ below TOC
Water elevation: $199.94 t(60.93 \mathrm{~m})$ ms

\section{WELL SRW 9B}

MEASUREMENTS CONDUCTED IN THE FIELD

Sample date: $06 / 26 / 98$
Depth to water: $51.4 \mathrm{ft}(15.67 \mathrm{~m})$ below TOC

Depth to water: $51.44(15.67 \mathrm{~m})$ below

\section{WELL SRW 10}

MEASUREMENTS CONDUCTED IN THE FIELD

Sample date: 06/26/98

Depth to water: $90.1 \mathrm{ft}(27.46 \mathrm{~m})$ below TOC
Water elevation: $213.3 \mathrm{tt}(65.01 \mathrm{~m}) \mathrm{msl}$

\section{WELL SRW 10BB}

MEASUREMENTS CONDUCTED IN THE FIELD

Sample date: 06/26/98

Depth to water: $97 \mathrm{ft}(29.57 \mathrm{~m})$ below TOC

\section{WELL SRW 11}

MEASUREMENTS CONDUCTED IN THE FIELD

Sample date: $06 / 26 / 98$
Depth to water: $85.5 \mathrm{ft}(26.06 \mathrm{~m})$ below TOC
Water elovation: $210.3 \mathrm{tt}(64.10 \mathrm{~m}) \mathrm{ms}$

\section{WELL SRW 11BB}

MEASUREMENTS CONDUCTED IN THE FIELD

Sample date: 06/26/98

Wepth to waier: $90.35 \mathrm{ft}(27.54 \mathrm{~m})$ below TOC

\section{WELL SRW 12A}

MEASUREMENTS CONDUCTED IN THE FIELD

Sample date: $06 / 25 / 98$

Depth to water: $40.3 \mathrm{ft}(12.28 \mathrm{~m})$ below TOC

\section{WELL SRW 12B}

MEASUREMENTS CONDUCTED IN THE FIELD

Sample date: 06/25/98

Depth to water: $43.9 \mathrm{Ht}(13.38 \mathrm{~m})$ below TOC
Water elevation: $192.4 \mathrm{tt}(58.64 \mathrm{~m}) \mathrm{msl}$

Time: 10:34

\section{WELL SRW 12C}

MEASUREMENTS CONDUCTED IN THE FIELD

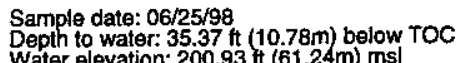

Time: 10:35

\section{WELL SRW 13A}

MEASUREMENTS CONDUCTED IN THE FIELD Sample date: 06/25/98
Depth to water: $95.7 \mathrm{ft}(29.17 \mathrm{~m})$ below TOC

\section{WELL SRW 13B}

MEASUREMENTS CONDUCTED IN THE FIELD

Sample date: 06/25/98

Depth to water: $93.75 \mathrm{ft}(28.58 \mathrm{~m})$ below TOC

\section{WELL SRW 13C}

MEASUREMENTS CONDUCTED IN THE FIELD

Sample date: $06 / 25 / 98$
Depth to water: 88.95 $\mathrm{ft}(27.11 \mathrm{~m})$ below TOC
Water

Time: 10:44 


\section{WELL SRW 14A}

MEASUREMENTS CONDUCTED IN THE FIELD Sample date: $06 / 25 / 98$ Depth to water. $123.35 \mathrm{t}(37.60 \mathrm{~m})$ below TOC Water elevation: $203.65 \mathrm{ft}(62.07 \mathrm{~m}) \mathrm{msl}$.

\section{WELL SRW 14B}

MEASUREMENTS CONDUCTED IN THE FIELD Sample date: $06 / 25 / 98$

Sample date: $06 / 25 / 98$
Depth to watior. $121.64(37.0 \mathrm{~m})$ below
Water

\section{WELL SRW 14C}

MEASUREMENTS CONDUCTED IN THE FIELD

Sample date: 06/25/98

Water to waler: $109.9 \mathrm{t}(33.50 \mathrm{~m})$ below TOC

(6)

\section{WELL SRW 15A}

MEASUREMENTS CONDUCTED IN THE FIELD

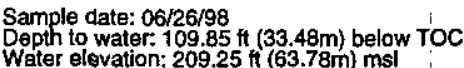

\section{WELL SRW 15B}

MEASUREMENTS CONDUCTED IN THE FIELD Sample data: $06 / 26 / 98$
Depph to water. $109.55 \mathrm{ft}(33.39 \mathrm{~m})$ below TOC
Water elevation: $209.55 \mathrm{ft}(63.87 \mathrm{~m}) \mathrm{msl}$

\section{WELL SRW 15C}

MEASUREMENTS CONDUCTED IN THE FIELD Sample date: 06/26/98 Depth to water: $107.6 \mathrm{ft}(32.80 \mathrm{~m})$ below TOC $\mathrm{ft}(64.47 \mathrm{~m}) \mathrm{msl}$

\section{WELL SRW 16A}

MEASUREMENTS CONDUCTED IN THE FIELD Sample date: 06/25/98

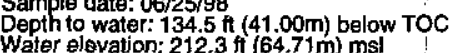

\section{WELL SRW 16B}

MEASUREMENTS CONDUCTED IN THE FIELD

Sample date: $06 / 25 / 98$ Water ter water: $133.95 \mathrm{ft}(40.83 \mathrm{~m})$ below TOC

Time: $10 \cdot 24$

\section{WELL SRW 16C}

MEASUREMENTS CONDUCTED IN THE FIELD

Sample date: 06/25/98

Weph to waler: $33.55 \mathrm{ft}(40.71 \mathrm{~m})$ below TOC

Time: 10:25

\section{WELL SRW 17BB}

MEASUREMENTS CONDUCTED IN THE FIELD

Sample date: 06/25/98

Depth to water: $122 \mathrm{ft}(37.19 \mathrm{~m})$ below TOC
Water elevation: $211.4 \mathrm{ft}(64.44 \mathrm{~m}) \mathrm{msl}$

Time: 10:30

WELL SRW 17C

MEASUREMENTS CONDUCTED IN THE FIELD

Sample date: 06/25/98

Water elovation: $211.48 \mathrm{ft}(37.22 \mathrm{~m})$ below TOC

Time: 10:29

\section{WELL SRW 170}

MEASUREMENTS CONDUCTED IN THE FIELD

Sample date: 06/25/98

Time: 10:28 


\section{Appendix B. Analytical Results}

This section presents the field and analytical results for samples collected during second quarter 1998. The results tables are presented in alphabetical order by well series and in numerical order within each series. The Site Index by Well Series section of this report contains the area name(s) for each series.

The tabular data contain all field and analytical results for well samples collected during this quarter. Results of laboratory analyses on sampling blanks are in Appendix $\mathbf{C}$ of this report.

Due to space limitations, the following abbreviations are used in the analytical and sampling blanks results tables.

\begin{tabular}{ll}
\hline Method or Analyte & Abbreviation \\
\hline EICHROMTC1M & EICHROM \\
MMES16009MOD & MMES16009 \\
ASTMD888-92B & ASTMD888 \\
EICHROMSRW01M & EICHROMS \\
5-day biochemical oxygen demand & 5 -day biochem oxygen demand \\
ESESOPM008 & ESOPM008 \\
ESESOPM017 & ESOPM017 \\
ESESOPM020 & ESOPM020 \\
ESESOPM022 & ESOPM022 \\
ESESOPM029 & ESOPM029 \\
ESESOPM030 & ESOPM030 \\
ESESOPM031 & ESOPM031 \\
ESESOPM032 & ESOPM032 \\
\hline
\end{tabular}

The Field Notes section of this report contains information about the inability to collect samples, unusual conditions during sample collection, and samplers' observations.

Properly defined and used qualifiers can be a key component in assessing data usability. Qualifiers designated by EPD/EMS and provided to the primary laboratories are defined below.

\section{Key to the Tables}

$\begin{array}{ll}\text { A } & \text { analytical qualifier } \\ \text { B } & \text { bias qualifier } \\ \text { E } & \left.\text { exponential notation (e.g., } 1.1 \mathrm{E}-09=1.1 \times 10^{-9}=0.0000000011\right) \\ \text { F } & \text { flag }\end{array}$

Fibers/L fibers per liter 


\begin{tabular}{cl}
$\mu \mathrm{Ci} / \mathrm{mL}$ & microcuries per mililiter \\
$\mu \mathrm{g} / \mathrm{L}$ & micrograms per liter \\
$\mu \mathrm{S} / \mathrm{cm}$ & microsiemens per centimeter \\
$\mathrm{mg} / \mathrm{L}$ & milligrams per liter \\
$\mathrm{msl}$ & mean sea level \\
$\mathrm{NTU}$ & nephelometric turbidity units \\
$\mathrm{R}$ & result qualifier \\
$\mathrm{SQL}$ & sample quantitation limit \\
TOC & top of casing \\
\hline
\end{tabular}

\begin{tabular}{|c|c|}
\hline Result Qualifler & Definition \\
\hline (Blank) & Data not remarked. Number should be interpreted exactly as reported. \\
\hline $\mathrm{C} \dagger$ & $\begin{array}{l}\text { Calculated. Analytical result reported is not measured directly but is calculated from other data } \\
\text { available. This does not apply to conversions nor does it apply to calculations made as part of } \\
\text { an analytical procedure. }\end{array}$ \\
\hline $\mathrm{D} \dagger$ & Field measurement. \\
\hline 1 & $\begin{array}{l}\text { The value in the result field is the instrument reading, not the sample quantification limit. Always } \\
\text { used with the result qualifier } U \text {. }\end{array}$ \\
\hline J日 & The analytical result is an estimated quantity. \\
\hline $\mathrm{L} \dagger$ & Off-scale high. The actual value is not known but is known to be greater than the value shown. \\
\hline M† & $\begin{array}{l}\text { Presence of material is verified but not quantified. The analytical result field should be blank. For } \\
\text { analyses yielding a presence/absence result, the analyte is present. }\end{array}$ \\
\hline Rt & $\begin{array}{l}\text { Rejected because performance requirements in the sample or associated quality control analyses } \\
\text { are not met. The analyte may or may not be present. }\end{array}$ \\
\hline T曰 & $\begin{array}{l}\text { The material is not present at the criterion of detection. The analytical result field should be blank. } \\
\text { For analyses yielding a presence/absence result, the analyte is considered to be absent. }\end{array}$ \\
\hline $\begin{array}{l}\text { U⿴囗十口 } \\
-\quad-=---\end{array}$ & $\begin{array}{l}\text { Material analyzed for but not detected. The analyte concentration is less than the sample-specific } \\
\text { estimated quantitation limit (ssEQL). Note: When both the result qualifier } U \text { and the result } \\
\text { qualifier } I \text { are reported, the numerical value in the result field is the instrument reading rather } \\
\text { than the ssEQL. }\end{array}$ \\
\hline V & $\begin{array}{l}\text { The analyte is detected in both the sample and the associated method blank. It indicates that the } \\
\text { sample's result falls within the } 5 x \text { and } 10 x \text { rule for organics or the } 5 \times \text { rule for pesticides. }\end{array}$ \\
\hline
\end{tabular}

$\dagger$ This code is based on the STORET codes from the EPA.

This code is based on the Contract Laboratory Procedure (CLP) Laboratory Data Qualifiers from the EPA.

Note: Bias qualifiers are used with result qualifiers of $J$ or $R$.

Analysis qualifiers provide the rationale for the assignment of result qualifiers. The following descriptions are based on the Laboratory Data Validation Functional Guidelines for Evaluating Organics Analyses (Volatiles and Semivolatiles, pp. 4-24; Pesticides, pp. 25-39) (EPA, 1988a) and the Laboratory Dafa Validation Functional Guidelines for 
Inorganics Analyses (EPA, 1988b). In the definitions following each qualifier, the category of QAQC requirement (in bold) is followed by the appropriate section from one of the Functional Guidelines.

\section{Analysis Qualifier Definition}

B

C

D

E

$\mathrm{F}$

G

$\mathrm{H}$

Target Compound List (TCL) Compound Identification (IX, Organics FG)

Relative retention time (RRT) or mass spectra criteria not met. Since this is a qualitative judgment, use ONLY with $U$ or $R$.

Compound Identification (VIII, Pesticides FG)

All anomalies. Use with $U, U J$, or $N$.

The result is below the sample quantitation limit and above or equal to the instrument detection limit. Use with $J$.

Laboratory Control Sample (V, Inorganics FG)

Criteria not met. Use with $J$. However, if laboratory control sample results are higher than the control limits and the sample result is less than the instrument detection limit, no qualifer other than $U$ is required.

ICP Serial Dilution (IX, Inorganics FG)

Criteria not met. Use with $J$ or $R$.

The detected result is between the ssEQL and the method detection limit. Report the actual result detected.

Pesticides Compound Identification (VIII, Pesticides FG)

Pesticide result has been confirmed by GCMS. If this code is ABSENT when a pesticide result exceeds $10 \mathrm{mg} / \mathrm{\mu L}$, the QAQC criterion has not been met.

Pesticides Instrument Performance (II, Pesticides FG)

Use for all conditions outside criteria other than those flagged $N J$ (see code $N$ below).

Internal Standards Performance (VIII, Organics FG)

Criteria not met. Use with $J, U J$, or $R$.

Matrix Spike/Matrix Spike Duplicate (VI, Organics FG; VI, Pesticides)

Matrix Spike Sample Analysis (VII, Inorganics FG)

Spike recovery not within control limits. Use alone or with $J$ or $R$.

Tentatively Identified Compounds (TICs) (IX, Organics FG)

A TIC is a suspected aldol-condensation product. Use with both $J$ and $N$.

Calibration Criteria Not Met (III, Organics FG; III, Pesticides FG; II, Inorganics FG)

Calibration criteria (initial or continuing) are not met. Use with $J$ or $R$. See also $Z$ for inorganics.

GCMS Tuning (Il, Organics FG)

Mass calibration in error. Use with $R$.

Ion abundance criteria are between criteria and expanded criteria. Use with $J$.

Ion abundance criteria are outside expanded criteria. Use with $R$.

Tentatively Identified Compounds (IX, Organics FG)

Use this code (with $\mathcal{J}$ ) for all TIC results.

Pesticides Instrument Performance (II, Pesticides FG)

Presumptive evidence of the presence of the material. For pesticides, where DDT/endrin degradation is out of control, use with $J$.

Compound Identification (VIII, Pesticides FG)

Use with $J$ for PCBs or multi-peak pesticides exhibiting marginal pattem-matching, if attributed to environmental "weathering."

Surrogate Recovery (V, Organics FG; V, Pesticides FG)

Surrogate spike recoveries are out of specification. Use with $J, U J$, or $R$. For pesticides, use for all surrogate recovery anomalies not covered by $E$ above. 
Fürnace Atomic Absorption QC (VIII,-'Inorganics FG)

Duplicate injection precision criteria are not met, or post-digestion spike recovery is not within control limits, but sample absorbance is greater than $50 \%$ of post-digestion spike absorbance. Use with $\mathrm{J}$, $U$ U, or $R$.

QD Holding Time (I, Organics FG; I, Pesticides FG; I, Inorganics FG)

Sample held beyond normal holding time. In addition, if the holding time is exceeded by less than 30 days, use a $f$, if the holding time is exceeded by 30 days or more, use an $R$.

R ICP Interference Check Sample (IV, Inorganics FG)

Criteria are not met. Use with $J, U J$, or $R$. However, if ICS recovery for an element is greater than or equal to $120 \%$ and the sample result is less than the instrument detection limit, no qualifier other than $U$ is required.

The reported value is determined by the method of standard additions.

Laboratory Blanks Contaminated (IV, Organics FG; IV, Pesticides FG; III, Inorganics FG)

Indicates the analyte detected in both the sample and associated method blank. Use with the resuit qualifier $V$ for organics or pesticides if the sample falls within the $5 \times$ and $10 \times$ rule for organics or the $5 \times$ rule for pesticides and inorganics. Report the actual result detected.

Furnace Atomic Absorption QC (VIII, Inorganics FG)

Post-digestion spike recovery for furnace atomic absorption analysis is out of control limits while sample absorbance is less than $50 \%$ of spike absorbance. Use with J or UJ.

$\mathrm{X}$

Matrix Spike/Matrix Spike Duplicates (VI, Organics FG; VI, Pesticides FG)

Laboratory Duplicate Sample Analysis (VI, Inorganics FG)

Duplicate analysis relative percent difference (RPD) was not within control limits.

Result obtained from unpreserved or improperly preserved sample. Data may not be accurate.

Z

Calibration (II, Inorganics FG)

Furnace Atomic Absorption QC (VIII, Inorganics FG)

Correlation coefficient was less than 0.995 .

Matrix interference. Value cannot be determined. Use with $R$.

The analytical value is four times higher than the standard concentration, and percent recovery cannot be determined. Use with $R$.

The analyte is detected in both the sample and associated field blank. Use with $R$ or $U$ for organics and with $U$ for pesticides. This will follow the $5 \%$ and $10 \%$ rule for organics and the $5 \%$ rule for pesticides and inorganics.

The analyte is detected in both the sample and associated rinsate or equipment blank. Use with $R$ or $U$ for organics and with $U$ for pesticides. This will follow the $5 \%$ and $10 \%$ rule for organics and the $5 \%$ rule for pesticides and inorganics.

The analyte is detected in both the sample and associated trip blank. Use with $R$ or $U$. This will follow the $5 \%$ and $10 \%$ rule.

t This code is based on the CLP Laboratory Data Qualifiers from the EPA.

This code is based on the STORET codes from the EPA. 
The following qualifiers are used to indicate bias, if known, when a $J$ or $R$ result qualifier has been used.

\section{Bias Qualifier Definition}

H Analytical factor causing bias. The associated result may overestimate the true value.

L Analytical factor causing bias. The associated result may underestimate the true value.

P Analytical factor causing poor precision. The associated result may be of high variability.

Sample interference field qualifiers were added to the field data in the analytical results tables beginning third quarter 1996. The qualifiers describe sampling interferences encountered during sample collection that could affect analytical results. They are used to qualify analytical data based on field condition. Due to space limitations, the sample interference field qualifiers are referred to as field qualifiers in the following table and in the field data section of the analytical results tables.

\section{Field Qualifiers Definition}

A

B

C

G

H

$\mathrm{N}$

S

U
The pump was surging excessively. Aeration could cause oxidation reactions and loss of volatiles (low results). Analytical results may be of poor precision (high variability) due to sampling bias. The sample qualifier shall include an $A$ if the site code is an $A$.

If the method code for a sample is $B$, then the sample qualifier shall include a $B$. This indicates that an open bucket bailer was used to collect the sample, which typically agitates the sample, increasing aeration and suspended solids. All analytical results may be of poor precision, volatile organic results may be biased low, and some metal and radionuclide results may be biased high.

Analytical results may be unrepresentative of true values due to reactions with metal well casing. This value will be automatically filled in if the casing type in the well inventory table is Al, CS, Iron, SS, or Steel. Analytical results for some metals and radionuclides may be higher or lower than actual groundwater concentrations.

If the method code for a sample is $G$, then the sample qualifier shall include a $G$. This indicates that an open bucket bailer was used to collect the sample without purging the well to attain stabilized field parameters. The grab sample method collects water that has undergone chemical reactions with the atmosphere and typically agitates the sample, increasing aeration and suspended solids. All analytical results may be of poor precision, volatile organic results may be biased low, and some metal and radionuclide results may be biased high. Analytical results may differ significantly for actual groundwater concentrations.

Analytical results may be unrepresentative of actual groundwater concentrations due to an elevated $\mathrm{pH}$, possibly due to well installation materials (drilling mud, grout). Results for some inorganic constituents (i.e., sodium, metals, radionuclides) may be affected. If the $\mathrm{pH}$ for a sample is greater than eight, then the sample qualifier shall include an $H$.

Analytical results may be unrepresentative of actual groundwater concentrations due to well installation or formation interferences causing elevated turbidity. Results for particle reactive constituents (i.e., metals, radionuclides) may be elevated. If the turbidity for a sample is greater than $15 \mathrm{NTU}$, then the sample qualifier shall include an $N$.

If the sample method is an $S$, then the sample qualifier shall include an $S$. Single-speed centrifugal submersible pump flow rates vary from 1 to $15 \mathrm{gpm}$, and agitation of the sample may occur at higher flow rates, causing poor precision, low volatile organic results, or elevated metal or radionuclide results.

One or more of the field parameters (i.e., $\mathrm{pH}$, conductivity, turbidity) did not stabilize prior to sample collection. The results may be of poor precision (high variability) due to sampling bias. The sample qualifier shall be a $U$ if the stabilized field is $N$ or the method code is $G$. 
If the method code is a $V$, then the sample qualifier shall include a $V$. Sample collection with variable-speed pumps indicates that flow rates were less than one-liter per minute. Sample collection at low flow rates provides the best estimates of actual groundwater concentrations due to reduced sampling bias.

$\mathrm{X}$

If the site code is an $X$, then the sample qualifier shall include an $X$. Analytical results may be of poor precision for many constituents, and volatile organic results may be biased low because the well went dry during purging.

Calculation of alkalinity relationships: The results obtained from the phenolphthalein and total alkalinity determinations offer a means for stoichiometric classification of the three principal forms of alkalinity present in many waters. The classification ascribes the entire alkalinity to bicarbonate, carbonate, and hydroxide, and assumes the absence of other (weak) inorganic or organic acids, such as silicic, phosphoric, and boric acids. It further presupposes the incompatibility of hydroxide and bicarbonate alkalinities. Because the calculations are made on a stoichiometric basis, ion concentrations in the strictest sense are not represented in the results, which may differ significantly from actual concentrations, especially at $\mathrm{pH}>10$. According to this scheme:

(1) Carbonate $\left(\mathrm{CO}_{3}{ }^{2-}\right)$ alkalinity is present when phenolphthalein alkalinity is not zero but is less than total alkalinity.

(2) Hydroxide $\left(\mathrm{OH}^{-}\right)$alkalinity is present if phenolphthalein alkalinity is more than half the total alkalinity.

(3) Bicarbonate $\left(\mathrm{HCO}_{3}\right)$ alkalinity is present if phenolphthalein alkalinity is less than half the total alkalinity. These relationships may be calculated by the following scheme, where $P$ is phenolphthalein alkalinity and $T$ is total alkalinity:

Select the smaller value of $P$ or $(T-P)$. Then, carbonate alkalinity equals twice the smaller value. When the smaller value is $P$, the balance $(T-2 P)$ is bicarbonate. When the smaller value is $(T-P)$, the balance $(2 P-T)$ is hydroxide. All results are expressed as $\mathrm{CaCO}_{3}$.

\begin{tabular}{llll}
\hline $\begin{array}{l}\text { If Phenolphthalein } \\
\text { Aklalinity Result }=\end{array}$ & $\begin{array}{l}\text { then Hydroxide } \\
\text { Alkalinity }=\end{array}$ & $\begin{array}{l}\text { then Carbonate } \\
\text { Alkalinity }=\end{array}$ & $\begin{array}{l}\text { then Bicarbonate } \\
\text { Alkalinity }=\end{array}$ \\
\hline 0 & 0 & 0 & Total Alk \\
$<1 / 2$ Total Alk & 0 & 2(Phen Alk) & Total Alk - 2(Phen Alk) \\
$=1 / 2$ Total Alk & 0 & 2(Phen Alk) & 0 \\
$>1 / 2$ Total Alk & 2(Phen Alk) - Total Alk & 2(Total Alk - Phen Alk) & 0 \\
Phen Alk = Total Alk & Total Alk & 0 & 0 \\
\hline
\end{tabular}


WELL ARP 5D

MEASUREMENTS CONDUCTED IN THE FIELD

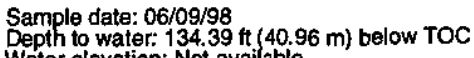
Water elevation: Not available Sp. conductance: $630 \mu \mathrm{S} / \mathrm{cm}$

Water evacuated from the well prior to sampling: $1 \mathrm{gal}$ ANALYSES

\begin{tabular}{|c|c|c|c|c|c|c|c|c|}
\hline Anslyte & Result & R & A & B & SOL & Unit & Lab & lethod \\
\hline 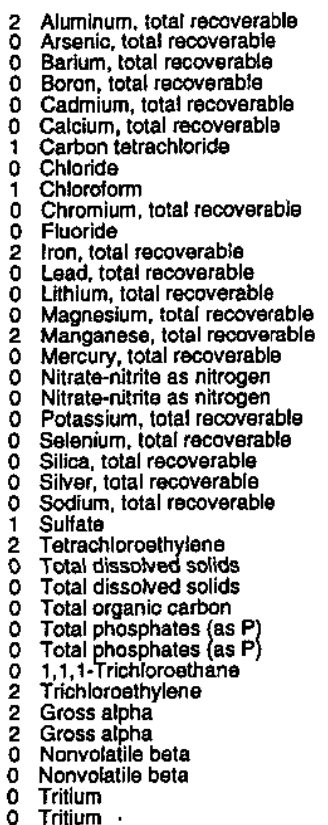 & 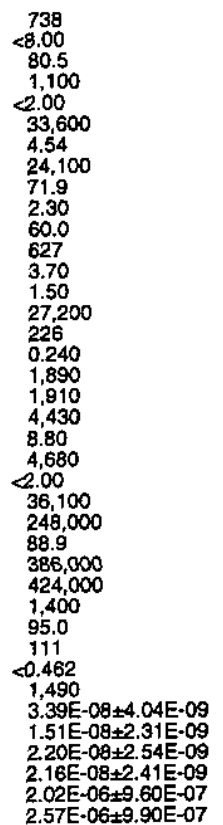 & $\vec{J}$ & $\underset{E}{E}$ & L & $\begin{array}{l}20.0 \\
8.00 \\
2.00 \\
25.0 \\
2.00 \\
50.0 \\
0.405 \\
500 \\
4.28 \\
3.00 \\
100 \\
200 \\
5.00 \\
5.00 \\
50.0 \\
3.00 \\
0.200 \\
200 \\
200 \\
400 \\
5.00 \\
100 \\
2.00 \\
100 \\
5.000 \\
5.69 \\
1,000 \\
1,000 \\
1.000 \\
10.0 \\
10.0 \\
0.462 \\
3390 \\
2.35 E-09 \\
1.63-09 \\
3.13-09 \\
2.94-09 \\
1.52-09 \\
1.52 E-06 \\
\end{array}$ & 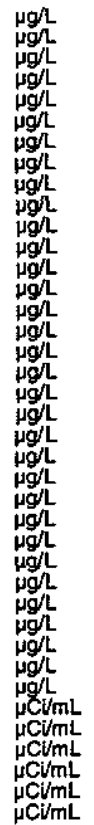 & $\begin{array}{l}\text { ES } \\
\text { ES } \\
\text { ES } \\
\text { ES } \\
\text { ES } \\
\text { ES } \\
\text { ES } \\
\text { ES } \\
\text { ES } \\
\text { ES } \\
\text { ES } \\
\text { ES } \\
\text { ES } \\
\text { ES } \\
\text { ES } \\
\text { ES } \\
\text { ES } \\
\text { ES } \\
\text { ES } \\
\text { ES } \\
\text { ES } \\
\text { ES } \\
\text { ES } \\
\text { TM } \\
T M \\
T M\end{array}$ & 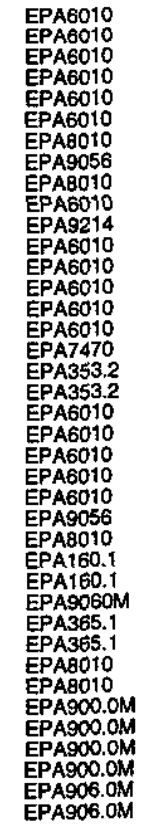 \\
\hline
\end{tabular}

\section{WELL BGO 1D}

MEASUREMENTS CONDUCTED IN THE FIELD

Sample date: $05 / 05 / 98$
Depth to water: $53.16 \mathrm{ft}(16.2 \mathrm{~m})$ below TOC
Water elevation: $241.94 \mathrm{ft}(73.74 \mathrm{~m}) \mathrm{msl}$
gH: 3.8
Sp. conductance: $45 \mu \mathrm{S} / \mathrm{cm}$

Sp. 3.8 conductance: $45 \mu \mathrm{S} / \mathrm{cm}$

Turbidity: 13 NTU
Water evacuated from the well prior to sampling: 3 gal ANALYSES

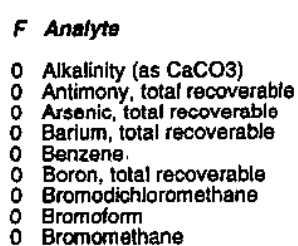

Resuft
$<6.70$
$<27.0$
$<40.0$
22.9
$<5.90$
$<266$
$<5.00$
$<5.00$
$<10.0$

ESH-EMS-980569

Well BGO 10 collected on 05/05/98 (cont.)

$F$ Analyto

Time: 11:36

Air temperature: $20.9^{\circ} \mathrm{C}$

Ar temperature: $29.8^{\circ} \mathrm{C}$ ) $9 \mathrm{mgh}$

Cadmium, total recoverable

Chlorobenzene

Chloroethane

Chlorpethene Ninyl chloride)

Chloroform

Chrornium, total recoverable

Copper, total recoverable

1,1-Dichloroethane
1,2-Dichloroethane

$\begin{array}{ll}0 & 1,1-\text { Dichloroethylene } \\ 0 & 1,2 \text {-Dichloroethylene }\end{array}$

Dichloromethane

1.2-Dichloroppopane
0
cis-1,3-Dichloropropene

Ethylbenzene

Liad, total recoverable

1 Mercury, total recoverable

o Phenols

- Selenium, total recoverable

o Silver, total recoverable

1,1,2,2-Totrachloroethan

Tin, total recoverable

Total dissolved solids

o Total organic carbon

o Total organic halogens

1,1,2-Trichloroethane

Trichlorothuoromethane

Xylenes

o Carbon-14

O Gross alphe

N Nonvolatile beta

: Radium, total alpha-emitting

Strontium-90

1 Tritium

WELL BGO 3A

MEASUREMENTS CONDUCTED IN THE FIELD

Sample date: $05 / 05 / 98$ (38.98 m) below TOC

Water elevation: $164 \mathrm{ft}(49.99 \mathrm{~m}) \mathrm{ms}$

Air temperature: $35.5^{\circ} \mathrm{C}$
Total alkalinity (as Caco3): $0 \mathrm{mgh}$
Phenolphthalein alkalinity: $0 \mathrm{mg} /$

Sp. conductance: $100 \mu \mathrm{S} / \mathrm{cm}$

Water evacuated from the well prior to sampling: $36 \mathrm{gal}$

ANALYSES

$\begin{array}{ll}6.700 & \mathrm{mgh} \\ 27.0 & \mu g h \\ 40.0 & \mu g h \\ 1.80 & \mu g / \\ 5.00 & \mu g h \\ 266 & \mu g h \\ 5.00 & \mu g h \\ 5.00 & \mu g h \\ 10.0 & \mu g h\end{array}$

WA
EPA310.1
WA
WAA6010
WA
WA6010
WA
WAA610
WA
WAA6010
WA EPA260
WA EPA260
WA EPAB260

Alkalinity (as $\mathrm{CaCO}$ )

Arsenic, total recoverable

Basium, total recoverab

Boron, total recoverable
Bromodichloromethane

0 Bromotorm

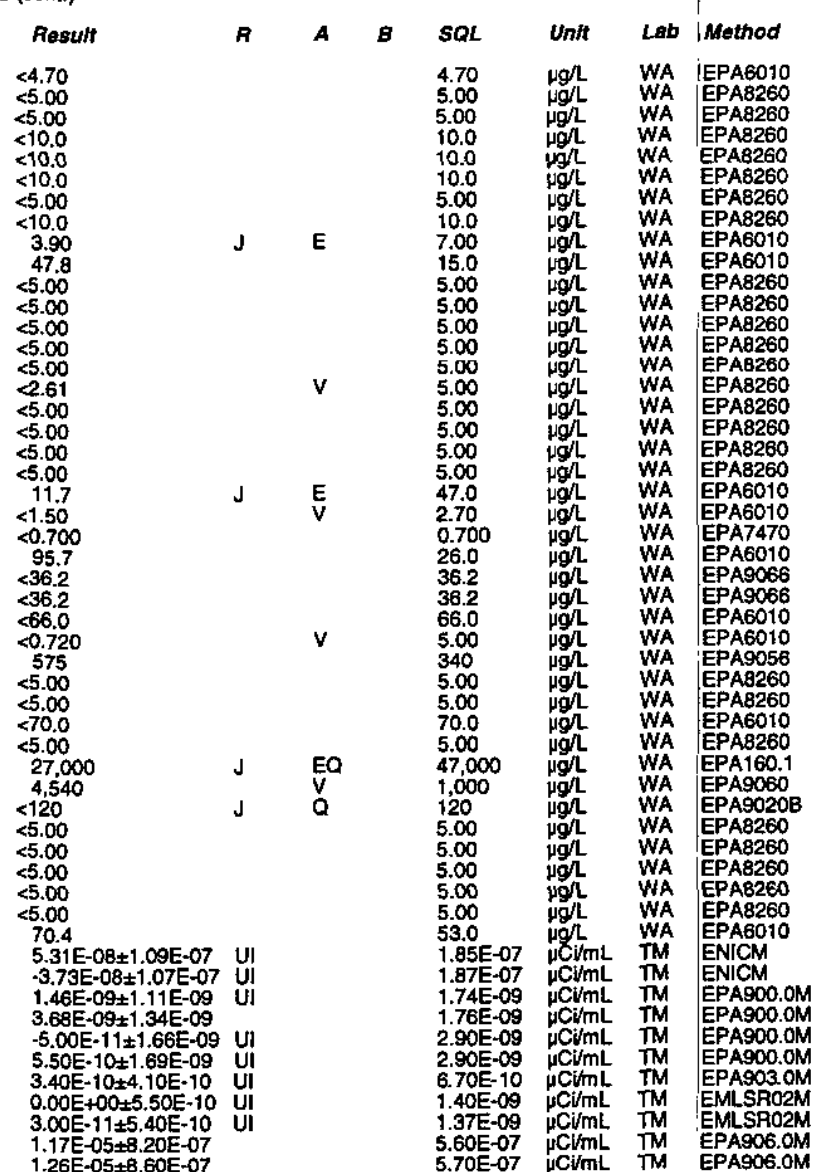


Well BGO $3 A$ collected on 05/05/98 (cont.)

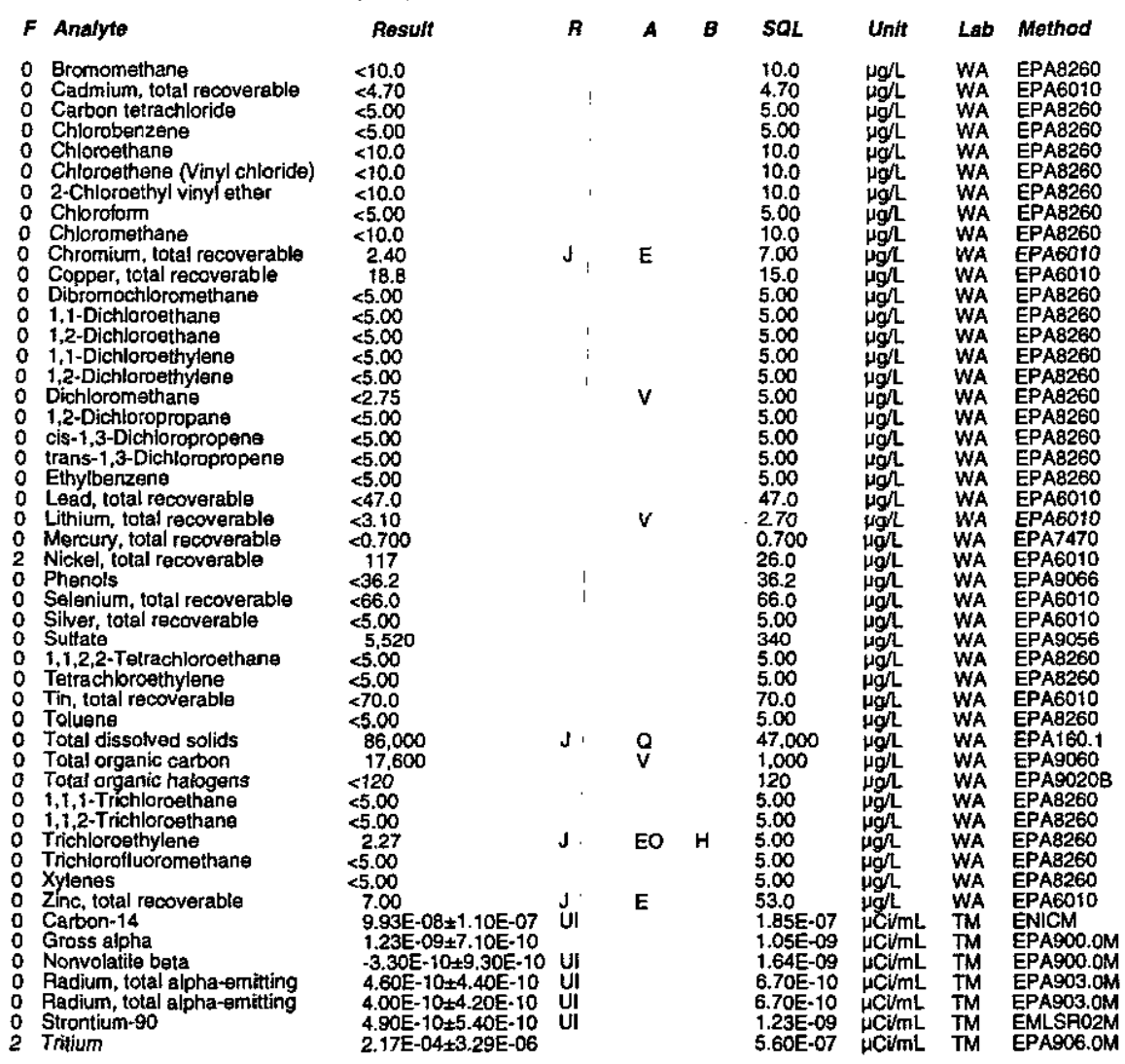

\section{WELL BGO 3DR}

MEASUREMENTS CONDUCTED IN THE FIELD Sample date: $05 / 05 / 98$
Depth to water: $59.75 \mathrm{ft}(18.21 \mathrm{~m})$ below TOC
Water elevation: $231.75 \mathrm{tt}(70.64 \mathrm{~m}) \mathrm{ms}$

$\mathrm{pH}: 4.2$ conductance: $32 \mu \mathrm{S} / \mathrm{cm}$

Water evacuated from the well prior to sampling: $39 \mathrm{gal}$ ANALYSES

F Analyte

- Alkalinity (as $\mathrm{CaCO}$ ) Antimony, total recoverable Arsenic, total recoverable
Barium, total recoverable Borzon, total recoverabla Bromodichloromethane

Bromomethan Cadmium, total recoverable Carbon tetrachloridor

ESH-EMS-980569

Time: 12:36

的

Total alkalinity (as CaCO3): $0 \mathrm{mg} /$

\begin{tabular}{|c|}
\hline $\begin{array}{l}6,700 \\
27.0 \\
40.0 \\
1.80 \\
10.0 \\
266 \\
10.0 \\
10.0 \\
20.0 \\
4.70 \\
10.0 \\
10.0\end{array}$ \\
\hline
\end{tabular}

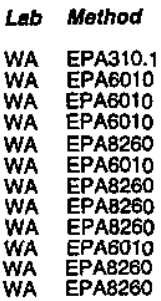

$<6.70$
$<27.0$
$<40.0$
16.1
$<10.0$
$<66$
$<10.0$
$<10.0$
$<20.0$
$<4.70$
$<10.0$
$<10.0$

Well BGO 3DR collected on 05/05/98 (cont.)

$F$ Analyte

OChloroethane
O Chloroethene (Vinyl chloride)
2-Chloroethyl vinyl ether

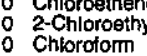

O Chloromethane

Chromium, total recoverable

Copper, total recoverab

1,1-Dichloroethane

1,1.Dichloroethylene

Dichloromethane

0
0
0
0
cis-1,3-Dichloropropen

trans-1,3-Dichloropropen

Lead, total recoverable

- Mercury, total recoverabable

Solgnium, total recoverable

O Sulfate Tetrachloroethan

Tetrachlorosthylene

Toluene

Total organic carbon

2 Total organic halogens

1,1, -Trichloroethane

Trichloroethylene

Xylenes

Cinc, total
Carbon-14
Carbon-14

Gross alpha

Nonvolatile beta

Radium, total alpha-emitting

Strontium-90

Tritium

WELL BGO 4D

\begin{tabular}{|c|c|c|c|c|c|c|c|}
\hline Result & $\boldsymbol{A}$ & A & 8 & SOL & Unit & Lab & Method \\
\hline 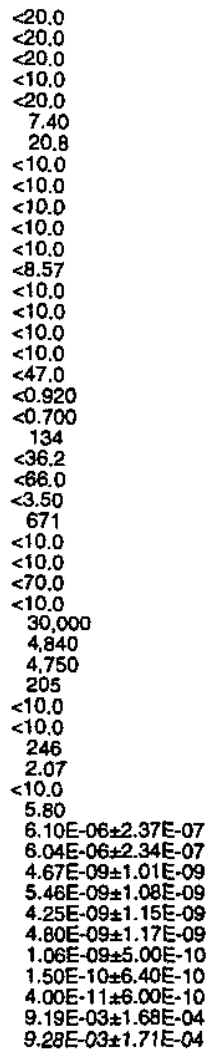 & Ju & $\begin{array}{l}E \\
\text { V } \\
\text { Q } \\
Q\end{array}$ & H & $\begin{array}{l}20.0 \\
20.0 \\
20.0 \\
10.0 \\
20.0 \\
7.00 \\
15.0 \\
10.0 \\
10.0 \\
10.0 \\
10.0 \\
10.0 \\
10.0 \\
10.0 \\
10.0 \\
10.0 \\
10.0 \\
47.0 \\
2.70 \\
0.700 \\
26.0 \\
36.2 \\
66.0 \\
5.00 \\
340 \\
10.0 \\
10.0 \\
70.0 \\
10.0 \\
47.000 \\
1,000 \\
1.000 \\
120 \\
10.0 \\
10.0 \\
10.0 \\
10.0 \\
10.0 \\
53.0 \\
2.05 E-07 \\
2.02 E-07 \\
1.50 E-10 \\
1.50 E-10 \\
1.61 E-09 \\
1.60 E-09 \\
5.20 E-10 \\
1.58 E-09 \\
1.53 E-09 \\
3.76 E-05 \\
3.82 E-05\end{array}$ & 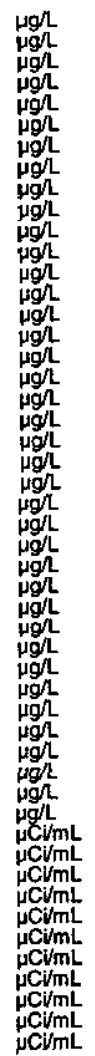 & $\begin{array}{l}\text { WA } \\
\text { WA } \\
\text { WA } \\
\text { WA } \\
\text { WA } \\
\text { WA } \\
\text { WA } \\
\text { WA } \\
\text { WA } \\
\text { WA } \\
\text { WA } \\
\text { WA } \\
\text { WA } \\
\text { WA } \\
\text { WA } \\
\text { WA } \\
\text { WA } \\
\text { WA } \\
\text { WA } \\
\text { WA } \\
\text { WA } \\
\text { WA } \\
\text { WA } \\
\text { WA } \\
\text { WA } \\
\text { WA } \\
\text { WA } \\
\text { WA } \\
\text { WA } \\
\text { WA } \\
\text { WA } \\
\text { WA } \\
\text { WA } \\
\text { WA } \\
\text { TM } \\
\text { TM } \\
\text { TM } \\
\text { TM } \\
\text { TM } \\
\text { TM } \\
\text { TM } \\
\text { TM } \\
\text { TM }\end{array}$ & 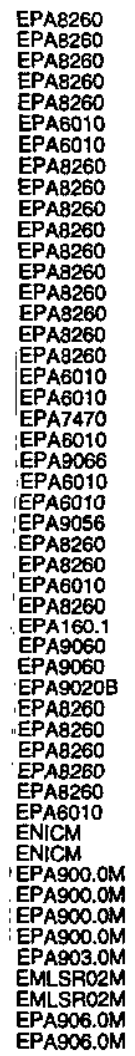 \\
\hline
\end{tabular}

MEASUREMENTS CONDUCTED IN THE FIELD

Sample date: 06/10/98

Depth to water. Not available

$\mathrm{PH}: 5.8$

p. conductance: $32 \mu \mathrm{S} / \mathrm{cm}$

Water evacuated from the well prior to sampling: $1 \mathrm{gal}$ ANALYSES

Alkalinity (as $\mathrm{CaCO}_{3}$ )

Antimony, total recoverable

Ansenic, total recoverablic

Arsenic, total recoverabl

Barium, total recoverable

Boron, total recoverable

Resuit
3.06
2.76
3.80
$<27.0$
$<40.0$
$<40.0$
6.30
5.90
$<5.00$
$<266$
$<266$

Time: 8:00

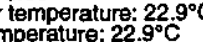

Total akalinity (as CaCO3): $5 \mathrm{mgh}$ 
Well BGO 4D collected on 06/10/98 (cont.)

\begin{tabular}{|c|c|c|c|c|c|c|c|}
\hline Analyto & Result & A & A & SOL & Unit & Lab & Method \\
\hline 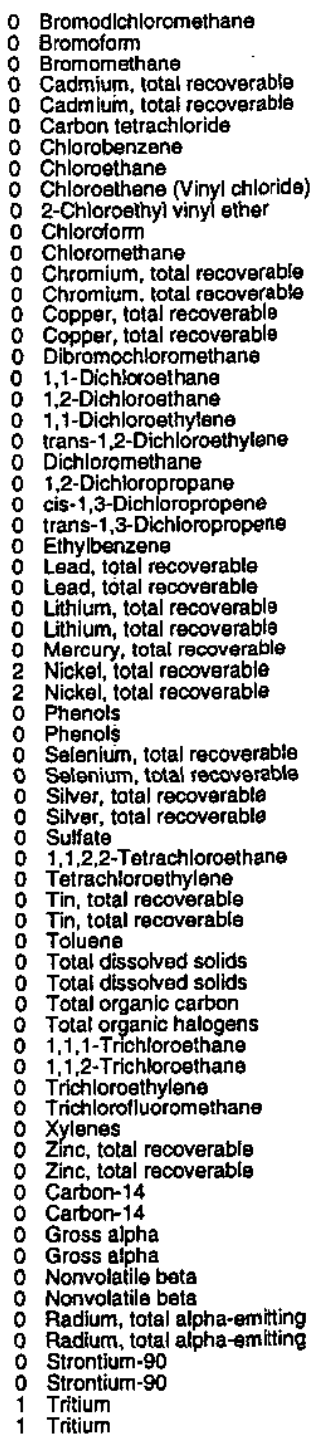 & 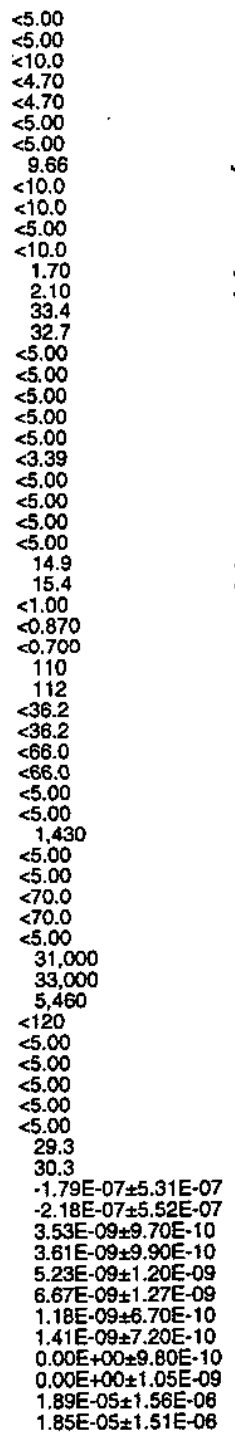 & 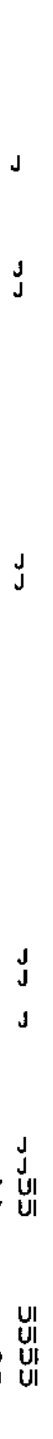 & $\begin{array}{l}\text { EQ } \\
\text { EQ } \\
\text { V } \\
Q\end{array}$ & $\begin{array}{l}5.00 \\
5.00 \\
10.0 \\
4.0 \\
4.70 \\
5.00 \\
5.00 \\
10.0 \\
10.0 \\
10.0 \\
5.00 \\
10.0 \\
7.00 \\
7.00 \\
15.0 \\
15.0 \\
5.00 \\
5.00 \\
5.00 \\
5.00 \\
5.00 \\
5.00 \\
5.00 \\
5.00 \\
5.00 \\
5.00 \\
47.0 \\
47.0 \\
2.70 \\
2.70 \\
0.700 \\
26.0 \\
26.0 \\
36.2 \\
36.2 \\
66.0 \\
66.0 \\
5.00 \\
5.00 \\
340 \\
5.00 \\
5.00 \\
70.0 \\
70.0 \\
5.00 \\
47.000 \\
47.000 \\
1.000 \\
120 \\
5.00 \\
5.00 \\
5.00 \\
5.00 \\
5.00 \\
53.0 \\
53.0 \\
9.29 E-07 \\
9.67 E-07 \\
8.20 E-10 \\
8.40 E-10 \\
1.59 E-09 \\
1.60 E-09 \\
7.50 E-10 \\
7.50 E-10 \\
2.47 E-09 \\
2.63 E-09 \\
1.52 E-06 \\
1.48 E-06 \\
\end{array}$ & 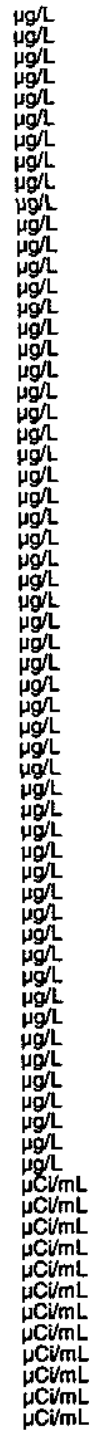 & $\begin{array}{l}\text { WA } \\
\text { WA } \\
\text { WA } \\
\text { WA } \\
\text { WA } \\
\text { WA } \\
\text { WA } \\
\text { WA } \\
\text { WA } \\
\text { WA } \\
\text { WA } \\
\text { WA } \\
\text { WA } \\
\text { WA } \\
\text { WA } \\
\text { WA } \\
\text { WA } \\
\text { WA } \\
\text { WA } \\
\text { WA } \\
\text { WA } \\
\text { WA } \\
\text { WA } \\
\text { WA } \\
\text { WA } \\
\text { WA } \\
\text { WA } \\
\text { WA } \\
\text { WA } \\
\text { WA } \\
\text { WA } \\
\text { WA } \\
\text { WA } \\
\text { WA } \\
\text { WA } \\
\text { WA } \\
\text { WA } \\
\text { WA } \\
\text { WA } \\
\text { WA } \\
\text { WA } \\
\text { WA } \\
\text { WA } \\
\text { WA } \\
\text { WA } \\
\text { WA } \\
\text { WA } \\
\text { WA } \\
\text { WA } \\
\text { WA } \\
\text { WA } \\
\text { WA } \\
\text { WA } \\
\text { WA } \\
\text { WA } \\
\text { TM } \\
\text { TM } \\
\text { TM } \\
\text { TM } \\
\text { TM } \\
\text { TM } \\
\text { TM } \\
\text { TM } \\
\text { TM } \\
\text { TM }\end{array}$ & 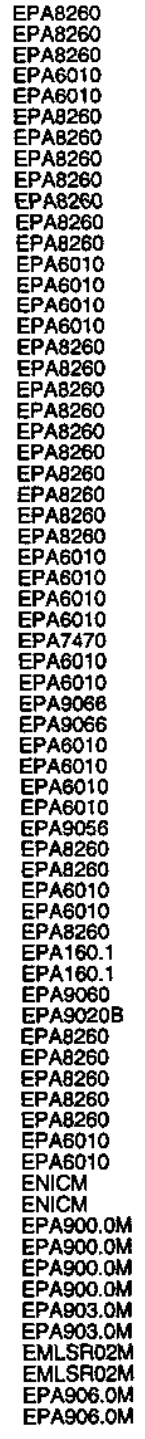 \\
\hline
\end{tabular}

\section{WELL BGO 5C}

MEASUREMENTS CONDUCTED IN THE FIELD Sample date: $05 / 05 / 98$
Depth to water: $78.5 \mathrm{ft}(23.93 \mathrm{~m})$ below TOC
Water elevation: $217.6 \mathrm{tt}(66.33 \mathrm{~m}) \mathrm{msl}$ $\mathrm{pH}: 5.8$ conductance: $43 \mu \mathrm{S} / \mathrm{cm}$ Water temperature: $23^{\circ} \mathrm{C}$ Water evacuated from the well prior to sampling: 51 gal ANALYSES

\begin{tabular}{|c|}
\hline 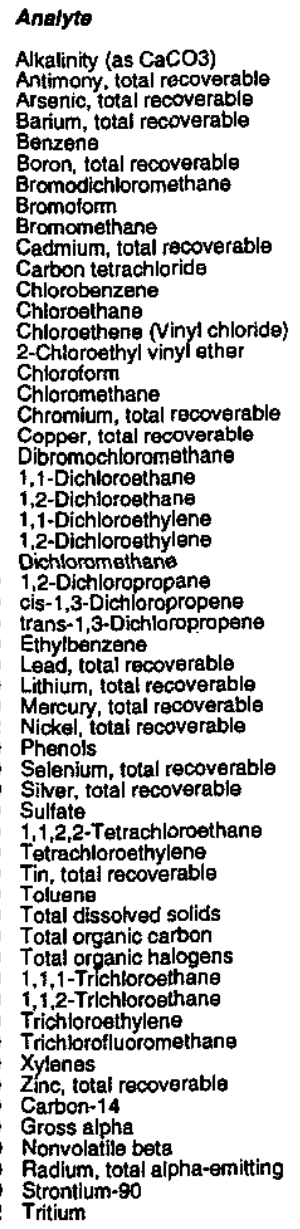 \\
\hline
\end{tabular}

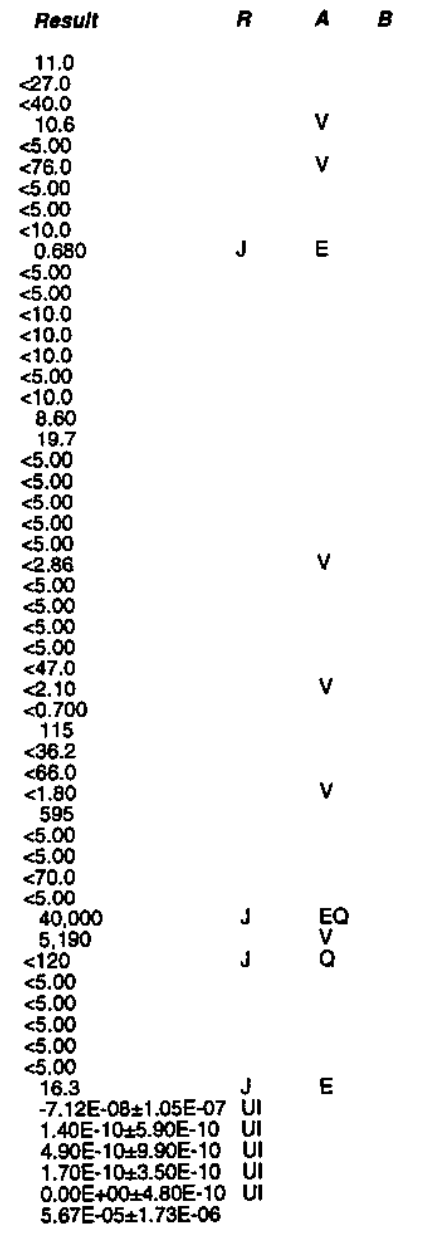

Lab Method

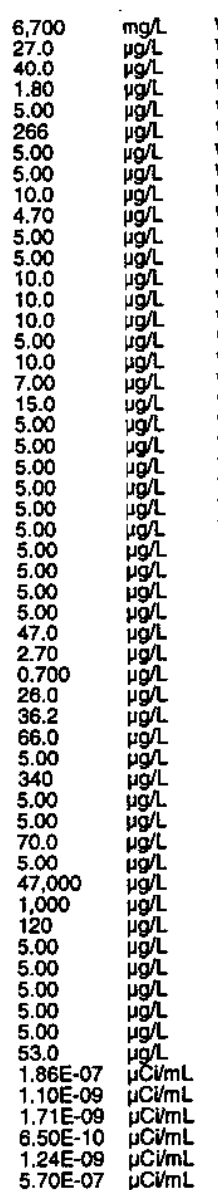

WA EPA310 WA EPAG010 EPAB260 EPA.260 \begin{tabular}{l:l} 
EPAB260 \\
\hline
\end{tabular} EPAB260 EPA6010 EPAG010 WA | EPA9066 EPA8260 WA ! EPA160.1 WA WA WA WA EPAB260 WA $\mid$ EPA8260 ENICM EPA900.0M EPA903.0M EPA906.0M 


\section{WELL BGO 5D}

MEASUREMENTS CONDUCTED IN THE FIELD

Sample date: $05 / 05 / 98$ Depth to water: $66.72 \mathrm{ft}(20.34 \mathrm{~m})$ below TOC Water elevation: $229.58 \mathrm{tt}(69.98 \mathrm{~m}) \mathrm{msl}$

$\mathrm{gH}: 3.9$ conductance: $38 \mu \mathrm{s} / \mathrm{cm}$ ANALYSES

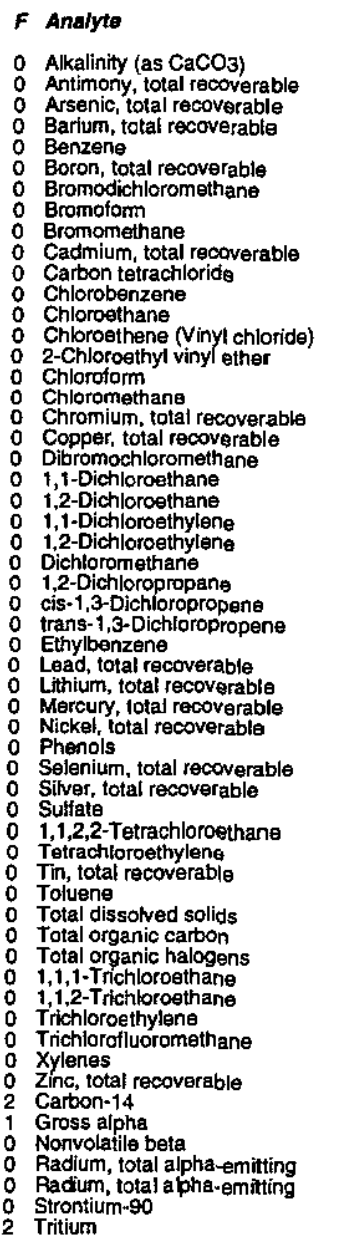

\begin{tabular}{|c|c|c|c|c|c|c|c|}
\hline Result & $\boldsymbol{B}$ & $A$ & $B$ & SOL & Unit & Lah & Mothod \\
\hline 1.15 & $\mathrm{j}^{1}$ & $E$ & & 6,700 & $\mathrm{mgh}$ & WA & EPA 10.1 \\
\hline $\begin{array}{l}<27.0 \\
<40.0\end{array}$ & & & & $\begin{array}{l}27.0 \\
40.0\end{array}$ & pgh & WA & EPACO10 \\
\hline 54.5 & & $v$ & & 1.80 & pgh & WA & EPA6010 \\
\hline $\begin{array}{l}<5.00 \\
<266\end{array}$ & ; & & & $\begin{array}{l}5.00 \\
266\end{array}$ & $\begin{array}{l}\mu g / L \\
\mu g / L\end{array}$ & $\begin{array}{l}\text { WA } \\
\text { WA }\end{array}$ & $\begin{array}{l}\text { EPA8260 } \\
\text { EPA6010 }\end{array}$ \\
\hline $\begin{array}{l}<5.00 \\
<5 . \infty\end{array}$ & & & & $\begin{array}{l}5.00 \\
5.00\end{array}$ & woll & $\begin{array}{l}\text { WA } \\
\text { WA }\end{array}$ & $\begin{array}{l}\text { EPA8260 } \\
\text { EPA8260 }\end{array}$ \\
\hline $\begin{array}{l}<10.0 \\
<40\end{array}$ & & & & 100 & $\mu g / 2$ & WA & EAB260 \\
\hline $\begin{array}{l}<4.00 \\
<5.00\end{array}$ & & & & $\begin{array}{l}4.70 \\
5.00\end{array}$ & $\underset{\mu g}{\mu g} \mathrm{~L}$ & $\begin{array}{l}\text { WA } \\
\text { WA }\end{array}$ & $\begin{array}{l}\text { EPA6010 } \\
\text { EPAB260 }\end{array}$ \\
\hline $\begin{array}{l}<5.00 \\
<10.0\end{array}$ & & & & $\begin{array}{r}5.00 \\
10.0\end{array}$ & pol & WA & $\begin{array}{l}E P A B 260 \\
\text { EAA260 }\end{array}$ \\
\hline$<10.0$ & . & & & 10.0 & $p g / 2$ & WA & EAAB260 \\
\hline $\begin{array}{l}<10.0 \\
<5.00\end{array}$ & : & & & $\begin{array}{l}10.0 \\
5.00\end{array}$ & 紧g & $\begin{array}{l}\text { WA } \\
\text { WA }\end{array}$ & $\begin{array}{l}\text { EPA8260 } \\
\text { EPA8260 }\end{array}$ \\
\hline $\begin{array}{r}<10.0 \\
10.7\end{array}$ & & $\mathrm{v}$ & & $\begin{array}{l}10.0 \\
7.00\end{array}$ & $\mu g / 2$ & $\begin{array}{l}\text { WA } \\
\text { WA }\end{array}$ & $\begin{array}{l}\text { EPAB260 } \\
\text { EPAG010 }\end{array}$ \\
\hline 20.1 & & 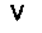 & & 15.0 & $\mu g$ & WA & EPAOD10 \\
\hline $\begin{array}{r}<5.00 \\
<5.00\end{array}$ & & & & $\begin{array}{l}5.00 \\
5.00\end{array}$ & 榬 & WA & $\begin{array}{l}\text { EPA260 } \\
\text { EPAB260 }\end{array}$ \\
\hline $\begin{array}{l}<.00 \\
<5.00\end{array}$ & & & & $\begin{array}{l}5.00 \\
5.00\end{array}$ & $\begin{array}{l}\mu g / L \\
\mu g h\end{array}$ & WA & $\begin{array}{l}\text { EPA2860 } \\
\text { EPA8260 }\end{array}$ \\
\hline $\begin{array}{l}<5.00 \\
<2.69\end{array}$ & & $v$ & & $\begin{array}{l}5.00 \\
500\end{array}$ & Hgl & WA & $\begin{array}{l}\text { EPAB260 } \\
\text { EPA260 }\end{array}$ \\
\hline $\begin{array}{l}<5.00 \\
<5.00\end{array}$ & & & & 5.00 & pgh & WA & EPAB260 \\
\hline $\begin{array}{l}<5.00 \\
<5.00\end{array}$ & ' & & & 5.00 & 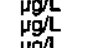 & WA & $\begin{array}{l}\text { EPA260 } \\
\text { EPAB260 }\end{array}$ \\
\hline $\begin{array}{r}<5.00 \\
6.00\end{array}$ & $\mathrm{~J}$ & E & & $\begin{array}{l}5.00 \\
47.0\end{array}$ & $\mu g h$ & $\begin{array}{l}\text { WA } \\
\text { WA }\end{array}$ & $\begin{array}{l}\text { EPA8260 } \\
\text { EPAG010 }\end{array}$ \\
\hline $\begin{array}{l}<1.30 \\
<0.700\end{array}$ & & & & $\begin{array}{l}2.70 \\
0.700\end{array}$ & $\underset{\mu g}{\mu g h}$ & WA & $\begin{array}{l}\text { EAA610 } \\
\text { EPA7470 }\end{array}$ \\
\hline $\begin{array}{r}6.70 \\
<36.2\end{array}$ & $J$ & $E$ & & $\begin{array}{l}26.0 \\
36.2\end{array}$ & wgh & $\begin{array}{l}\text { WA } \\
\text { WA }\end{array}$ & $\begin{array}{l}\text { EPA6010 } \\
\text { EPA9066 }\end{array}$ \\
\hline$<66.0$ & & $v$ & & $\begin{array}{l}66.0 \\
5.00\end{array}$ & $\underset{\mu g}{\mu g}$ & $\begin{array}{l}\text { WA } \\
\text { WA }\end{array}$ & $\begin{array}{l}\text { EPAG010 } \\
\text { EPAE010 }\end{array}$ \\
\hline $\begin{array}{r}246 \\
<5.00\end{array}$ & $J$ & iQ & $\mathrm{H}$ & $\begin{array}{l}340 \\
5.00\end{array}$ & igh & $\begin{array}{l}\text { WA } \\
\text { WA }\end{array}$ & $\begin{array}{l}\text { EPA9056 } \\
\text { EPAB260 }\end{array}$ \\
\hline $\begin{array}{r}<5.00 \\
8.60\end{array}$ & $J$ & E & & $\begin{array}{l}5.00 \\
70.0\end{array}$ & & $\begin{array}{l}\text { WA } \\
\text { WA }\end{array}$ & $\begin{array}{l}\text { EPA2600 } \\
\text { EPA6010 }\end{array}$ \\
\hline $\begin{array}{l}<5.00 \\
34,000\end{array}$ & J & E & & $\begin{array}{l}5.00 \\
47,000\end{array}$ & jgh & WA & $\begin{array}{l}\text { EPAB260 } \\
\text { EPA160.1 }\end{array}$ \\
\hline $\begin{array}{l}13,600 \\
22.4\end{array}$ & $\mathbf{J}$ & EQ & & $\begin{array}{l}1,000 \\
120\end{array}$ & $\underset{\mu g}{\mu g}$ & WA & $\begin{array}{l}\text { EPA9060 } \\
\text { EPA9020B }\end{array}$ \\
\hline $\begin{array}{l}<5.00 \\
<5.00\end{array}$ & & & & $\begin{array}{l}5.00 \\
5.00\end{array}$ & Hgh & $\begin{array}{l}\text { WA } \\
\text { WA }\end{array}$ & $\begin{array}{l}\text { EPAB260 } \\
\text { EPAB260 }\end{array}$ \\
\hline $\begin{array}{r}<5.00 \\
<5.00\end{array}$ & & & & $\begin{array}{l}5.00 \\
5.00\end{array}$ & Hgh & $\begin{array}{l}\text { WA } \\
\text { WA }\end{array}$ & 260 \\
\hline & $\mathbf{J}$ & $E$ & & & & WA & EPAB260 \\
\hline 3. $65 \mathrm{E}-06 \pm 1.98 \mathrm{E}-07$ & J & & & $2.05 E-07$ & & IM & ENICM \\
\hline $\begin{array}{l}9.53 \mathrm{E}-09+1.45 \mathrm{E}-09 \\
7.34 \mathrm{E}-09 \pm 1.30 \mathrm{E}-09\end{array}$ & & & & $\begin{array}{l}1.60 \mathrm{E}-10 \\
1.62 \mathrm{E}-09\end{array}$ & & $\mathrm{TM}$ & $\begin{array}{l}\text { EPA900.0M } \\
\text { EPA900.0M }\end{array}$ \\
\hline $\begin{array}{l}1.65 E-09 \pm 6.00 \\
1.59 E-09 \pm 5.908\end{array}$ & & & & $\begin{array}{l}5.20 \mathrm{E}-10 \\
5.20 \mathrm{E} 10\end{array}$ & & $T M$ & EPA903.0M \\
\hline $4.30 E-10 \pm 6$ & UH & & & $\begin{array}{l}1.50 E-09 \\
374 F-05\end{array}$ & ${ }_{\mu C \mathrm{C} / \mathrm{mL}}$ & TM & EMLSRO2M \\
\hline $4.93 E-03 \pm 1$ & & & & & ${ }_{\mu \mathrm{CV}} \mathrm{mL}$ & & EPA906.0M \\
\hline
\end{tabular}

\section{WELL BGO 6B}

MEASUREMENTS CONDUCTED IN THE FIELD

Sample data: $05 / 04 / 98$ (20.39 m) below TOC Water elevation: $219.92 \mathrm{ft}(67.03 \mathrm{~m}) \mathrm{ms}]$ Sp: 8.4 conductance: $130 \mu \mathrm{S} / \mathrm{cm}$

Time: 12:38 0 Water temperature: $25.6^{\circ} \mathrm{C}$

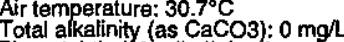
ANALYSES

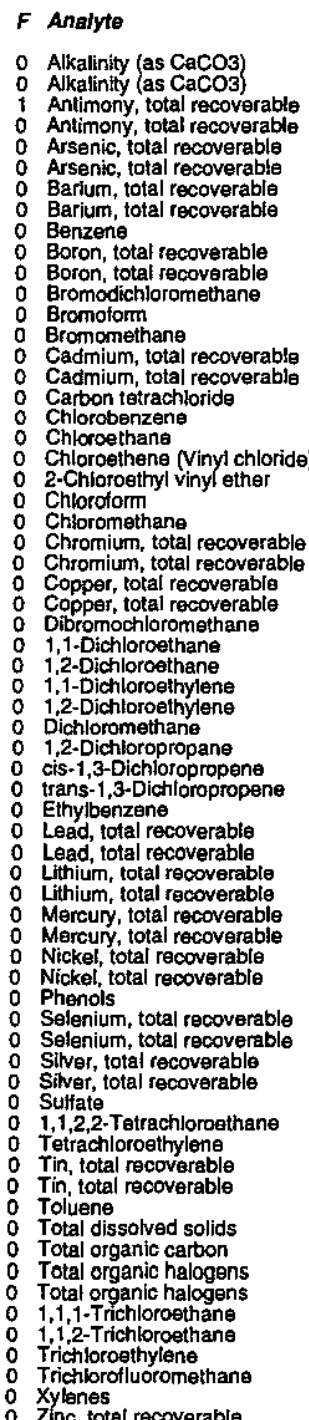

Time: 14:28 128 terature: $22^{\circ} \mathrm{C}$ Total alkalinity (as CaCO3): $66 \mathrm{mg} /$ alph 
Well BGO 6 B collected on 05/04/98 (cont.)

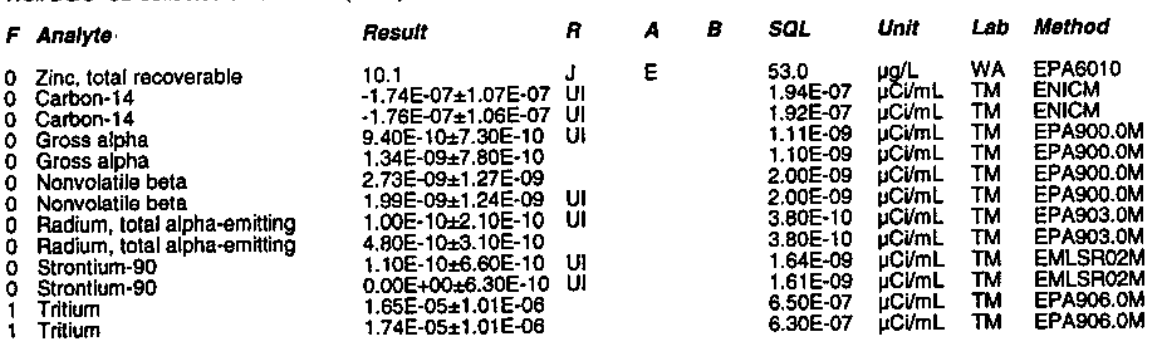

\section{WELL BGO 6C}

MEASUREMENTS CONDUCTED IN THE FIELD

Sampls date: $05 / 04 / 98$
Depth to water: $64.8 \mathrm{8t}(19.75 \mathrm{~m})$ below TOC
Weter

Water e

Sp. conductance: $100 \mu \mathrm{S} / \mathrm{cm}$

Water evacuated from the well prior to sampling: $134 \mathrm{gal}$

ANALYSES
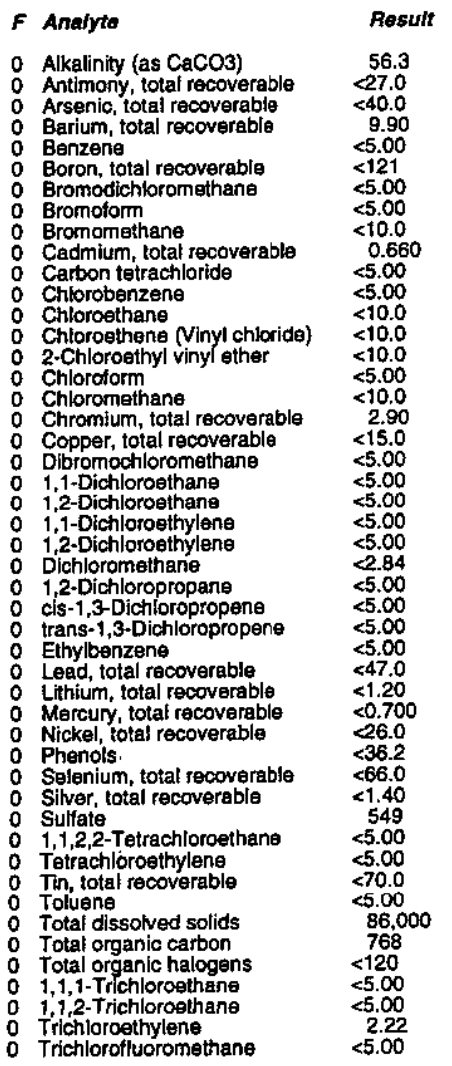

Time: 14:19

Water temperature: $17^{\circ} \mathrm{C}$

Total alkalinity (as CaCO3): $44 \mathrm{mg} /$

ESH-EMS-980569
Well BGO 6C collected on 05/04/98 (cont.)

$F$ Ansilyte

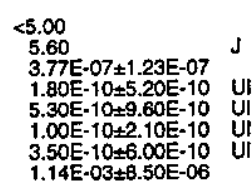

Xylenes
Zinc, total recoverable

Gross alpha

Radium, total alpha-emitting

Strontium-90

\section{WELL BGO 6D}

MEASUREMENTS CONDUCTED IN THE FIELD

Sample date: $05 / 04 / 98$
Depth to water: Not available
Water elevation: Not available

$\mathrm{gH}$. Nonductance: Not available

No water was evacuated from the well prior to sampling

ANALYSES

$F$ Anayte

- Alkalinity (as $\mathrm{CaCO}$ )

Arseric, total recoverab

Barium, total recoverable

Beron, total recoverable

Bromotorm

Cadmium, total recoverable

Carbon tetrachloride

Chloroethane
0. Chloroethene (Vinyl chloride)

Chloroform

Chloromethane

Copper, total recoverable

Dibromochloromethan

1,2-Dichloroethane

1, 1,-Dichloroethylen

Dichloromethane

cis-1,3-Dichloropropene
trans-1,3-Dichloropropene

Ethylbenzen re

Lithium, total recoverable

Nickel, total recoverable

Selenium, total recoverable
Siver, total recoverable

Silver, total recoverable

1,1,2,2-Tetrachloroeth

Tetrachloroethylene

Total dissolved sollids

Total dissolved solids

Total organic carbon

1,1,1. Trichloroethane

1,1,2-Trichloroethane

Trichlorofluoromethane

Zylenes

Garbon-14

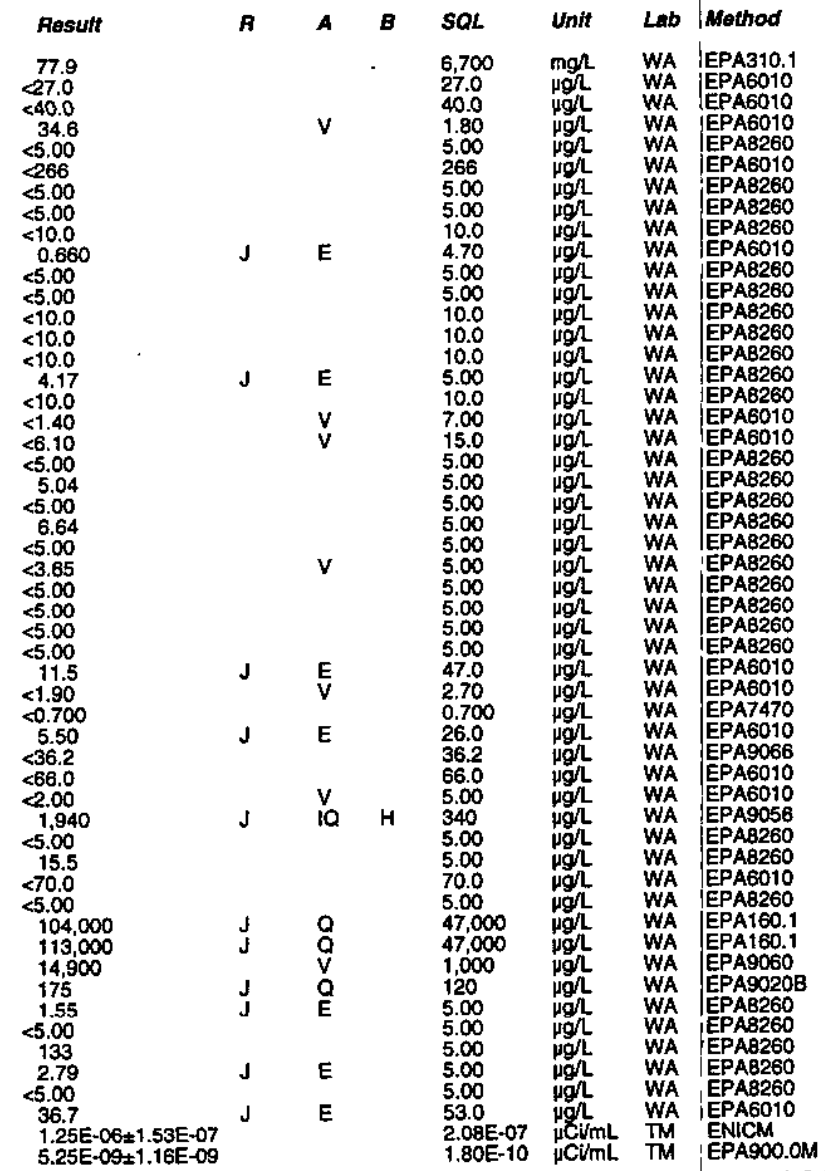

Second Quarter 1998
Time: Not available Water temperature: Not available Air temperature: Not available Total alkalinity (as CaCO3): Not available 
Well BGO 6D collected on 05/04/98 (cont.)

$F$ Analyte

Strontium 90 alpha-emitting Tritium

$8.20 \mathrm{E}-09 \pm 1.19 \mathrm{E}-09$ $1.80 E-10 \pm 6.10 E-10$

\section{WELL BGO 7D}

MEASUREMENTS CONDUCTED IN THE FIELD

Sample date: $05 / 04 / 98$

Wh: 4.6 . elevat

Sp. conductance: $22 \mu \mathrm{S} / \mathrm{cm}$

Watter evacuated from the well prior to sampling: $172 \mathrm{gal}$ ANALYSES

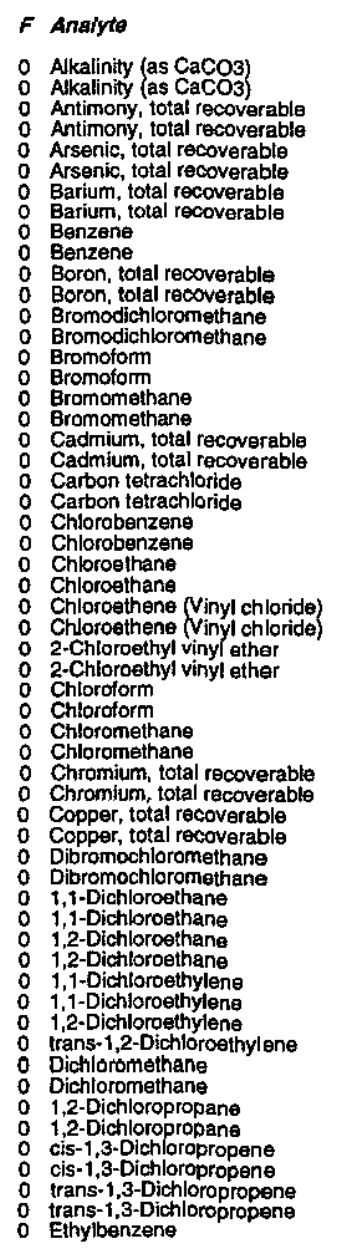

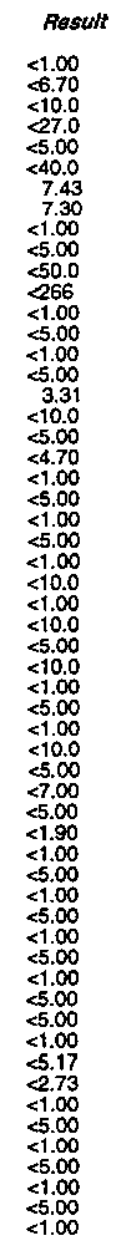

Depth to water: $56.25 \mathrm{ft}(17.15 \mathrm{~m})$ below TOC

Well BGO 7D collected on 05/04/98 (cont.)

$F$ Analyte

$1.67 E-09 \quad \mu C \mathrm{~V} / \mathrm{mL}$ TM EPA900.0M

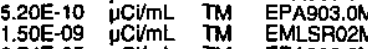
$3.74 \mathrm{E}-05 \mu \mathrm{CV} / \mathrm{mL}$ TM EPA906.

Ethylbenzene
Lead, total recover

Lead, total recoverable

Lithium, total recoverable

Mercury, total recoverable

Nickel, total recoverable

Phenols

Water temperature: $16^{\circ} \mathrm{C}$

Total akalinity ( (as CaCO3): $0 \mathrm{mg} / \mathrm{h}$
Phenolphthalein alkalinity $: 0 \mathrm{mg} / \mathrm{L}$

ESH-EMS-980569

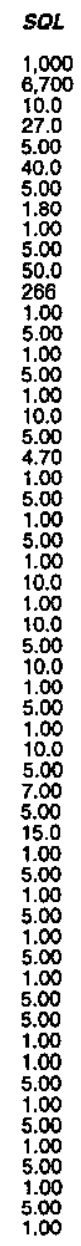

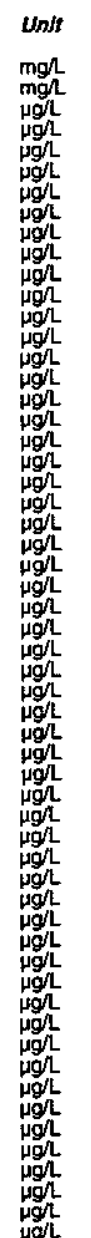

\section{Trtium}

MEASUREMENTS CONDUCTED IN THE FIELD

Sample date: $05 / 04 / 98$
Depth to water: $56.25 \mathrm{ft}(17.15 \mathrm{~m})$ below TOC

Water elevation: $230.75 \mathrm{ft}(70.33 \mathrm{~m}) \mathrm{ms}$

sp. conductance: $22 \mu \mathrm{S} / \mathrm{cm}$

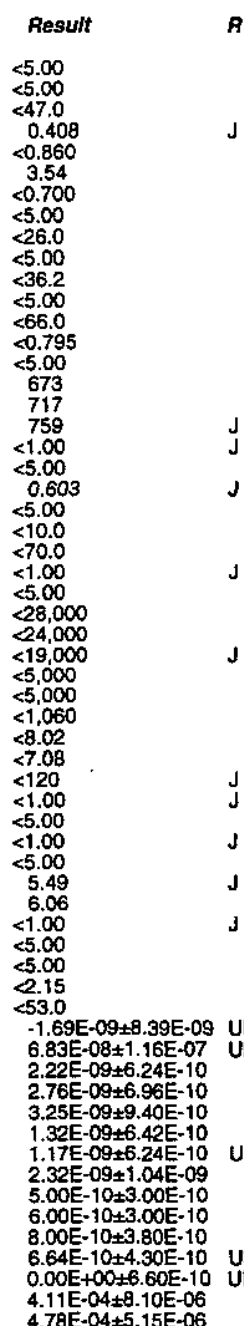

$4.11 \mathrm{E}-04 \pm 8.10 \mathrm{E}-06$

Water evacuated from the well prior to sampling: 172 gal

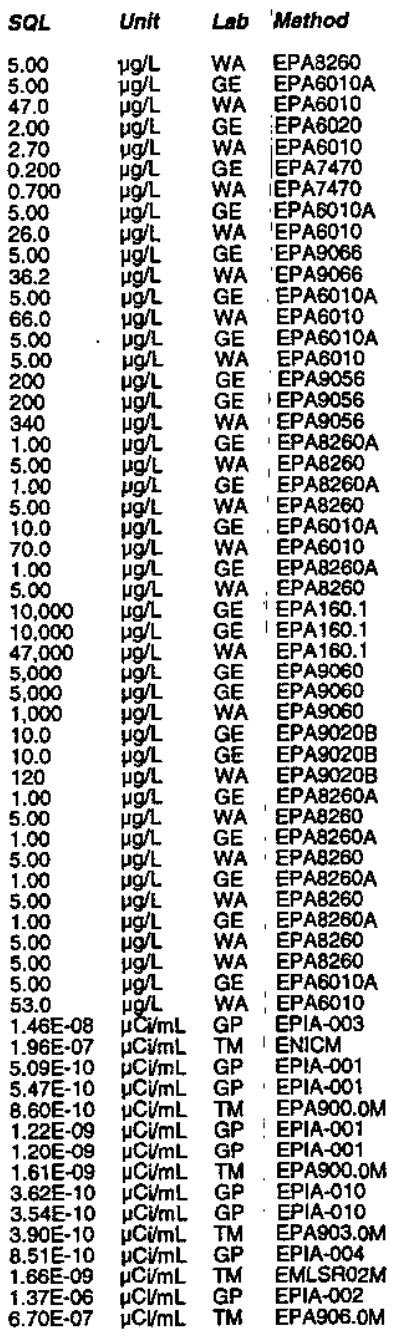

Time: 9:24

Water temperature: $16^{\circ} \mathrm{C}$

Phenol 
ANALYTICAL RESULTS

Well BGO 7D collected on 05/04/98 (cont.)

ANALYSES

$F$ Analyto

- Alkalinity (as $\mathrm{CaCO}$ )

: Antimony, total recoverable

o Benzene total recoverable

B Boron, lotal recoverable
0

o Bromoloim

- Cadmium, total recoverable

- Carbon tetrachlorido

C Chlorobesthane

Chloroetteane (Vinyl chloride)

o 2-Chloroethyl

Chromium, total recoverable

Copper, total recoverabla

1.1-Dichloroethane

i,1-Dichloroethyliten

1,2-Dichloroethyler
Dichloromethang

1,2-Dichloropropane
cis-1,3-Dichloropropen

trans-1,3-Dichloropropene

Elead, lotal recoverable

Lithium, total recoverable

Phenols

Siver, total recoverable

: $1,1,2,2$-Tetrachloroetha

o Tetrachloroethylene

Toluend

Total organic carbon

$\begin{aligned} & 0 \\ & 0 \\ & 0\end{aligned} 1,1,1$-Trichlorothane

Trichloroethylene

Xylenes
Zinc, total recoverable

G Carbon-14

Radium, total alpha-emitting

Strontium-so

\section{WELL BGO BAR}

MEASUREMENTS CONDUCTED IN THE FIELD

Sample date: $05 / 01 / 98 \mathrm{f}(38.34 \mathrm{~m})$ below TOC

Water elevet 7.5

Sp.conductance: $210 \mu \mathrm{S} / \mathrm{cm}$

Turbidity: ONTU:
Water evacuated from the well prior to sampling: 88 gal

ANALYSES

$F$ Anaiyto

Result

R

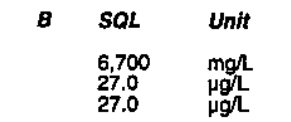

Well BGO 8AR collected on 05/01/98 (cont.)

$F$ Analyte Result

O Arsenic, total recoverable

Barium, total recoverable
Barium, total recoverable

Boron, total recoverable

Bromodichlor
0 Bromoform

Cadmium, total recoverable

Cadmium, total recoverab

Carbon tetrachloride

Chooroethane

Chlorosthene (Vinyl chloride)

2-Chloroethyl viny

Chromium, total recoverable

Copper, total recoscrab

Dibromochloromethan

1,1-Dichloroethane

1,1-Dichlorosthylene

Dichloromethane

cis-1,3-Dichloropropene
trans-1,3-Dichloropropene

Lead, total recoverable

Lithium, total recoverable

Mercury, total recoverable

Nickel, total recoverable
Nickel, total recoverable

O Selenlum, total recoverable

Silver, total recoverable

\section{Silver, total recoverable
Sulfate}

$1,1,2,2$-Tetrachloroethan

Tetrachloroethylene

Tin, total recoverable

Toluen dissolved solids

Total organic halogens

$1,1,1-$ Trichloroethane
$1,1,2-$ Trichloroethane

Trichloroethylene
Trichlorofluoromethane

Xylenes

Zince, total recoverable
Zinc, total recoverable

: Zinc, total recor

Carbon-14
Gross alpha

Nonvolatile beta

Nonvolatilie beta

Radium, total alpha-emitting

Strontium-90

o Tritium

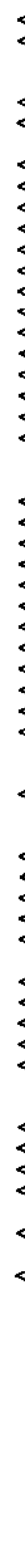

$<40.0$

15.6
14.9
$<5.00$
$<266$

34.3
35.00
$<5.00$

$<4.0$
$<4.70$

25.00
$<10$
$<10$

$<10.0$
$<10.0$
$<10.0$
$<5.00$

$<5.00$
$<10.0$
$<7.00$
$<7.00$

18.4
16.6
$<5.00$
$<5.00$
5

55.00

$<5.00$
$<6.79$
$<5.00$

$<5.00$

$<4.0$
$<47.0$
8.40

7.80
$<0.700$

113
111
$<36.2$
$<66.0$
5.00

$<66.0$
$<5.00$
$<5.00$
$<.00$

8,120
$<5.00$

$<5.00$
$>70.0$
$>70.0$
5

$<5.00,000$

$\quad 120$
$<5.00$
$<5.00$

45.00
3.01
45.00
7.50
530

$-7.725-08 \pm 1.00 E-07$ UI

$1.03 E-09+7.50 E-10$ UI

$2.09 E-09+1.09 E-09 \mathrm{~J}$

$3.00 E-11 \pm 3.60 E-10$ U

$-9.00 E-113.320 E-10$
$0.00 E+00+5.80 E-10$

$2.40 E-0654.70 E-07$
$239 E-06 \pm 400=-07$
A $A$ SOL Unit Lab Method

$40.0 \quad \mu g / \mathrm{h}$ WA EPA6010

40.0 pg/L WA EPAG010

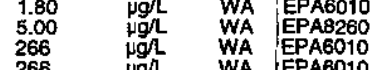

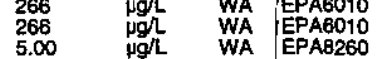

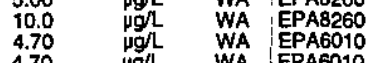

5.00 WA

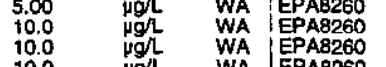

WA EPA310.1

$B-13$ 


\section{WELL BGO $8 \mathrm{C}$}

MEASUREMENTS CONDUCTED IN THE FIELD

Sample date: 05/01/98 Water elevation: $223.52 \mathrm{ft}(68.13 \mathrm{~m}) \mathrm{msl}$

pH: 6.8 conductance: $75 \mu \mathrm{S} / \mathrm{cm}$

Water evacuated from the well prior to sampling: $\mathbf{7 8}$ gal

ANALYSES

$F$ Analyto

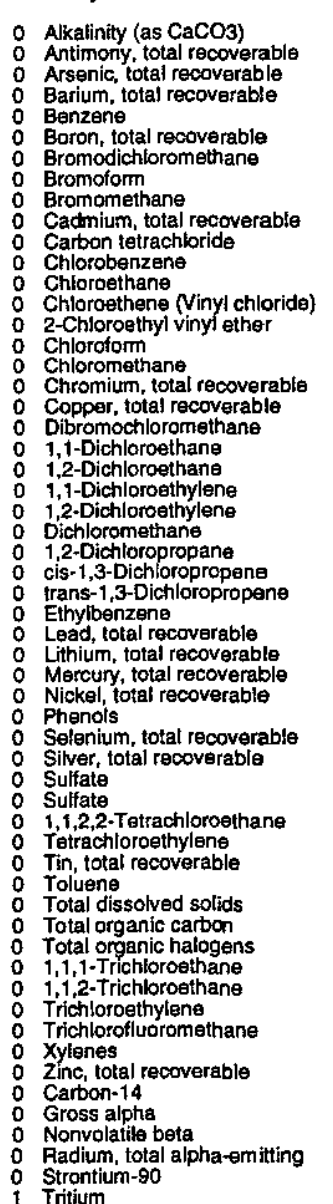

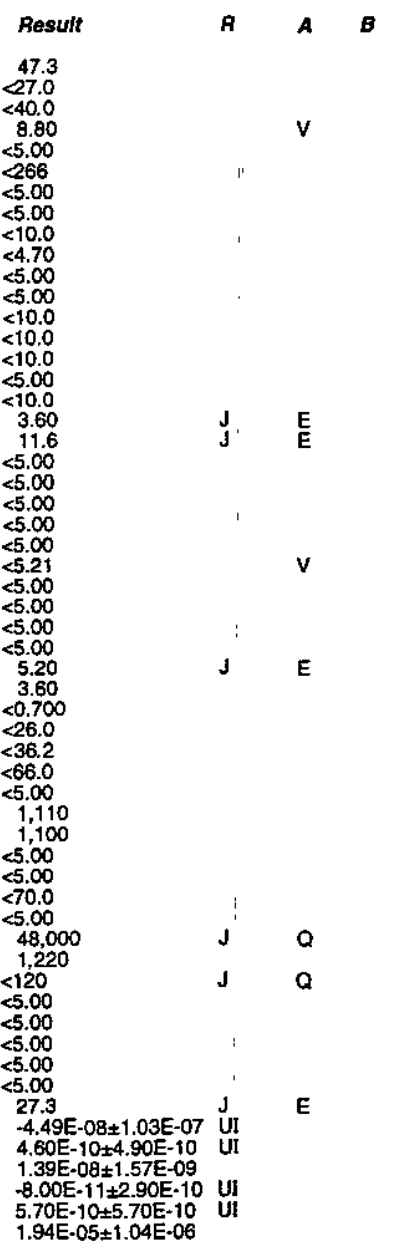

Time: 7:54

Total alkalinity (as CaCO3): $37 \mathrm{mg} / \mathrm{l}$

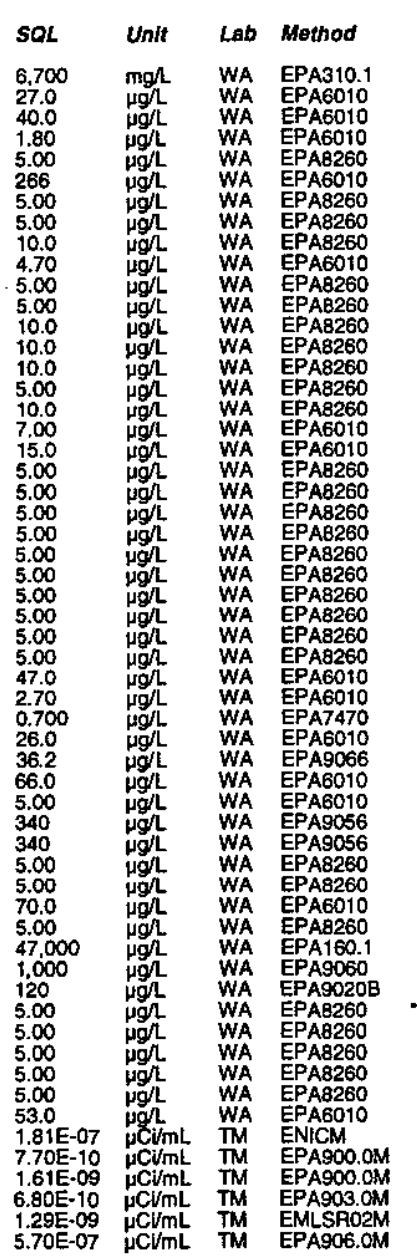

WELL BGO 8D

MEASUREMENTS CONDUCTED IN THE FIELD

Sample date: $05 / 01 / 98$
Depth to water: $56.64 \mathrm{ft}(17.26 \mathrm{~m})$ below TOC
Wete to

Water elevation: $231.16 \mathrm{ft}(70.46 \mathrm{~m}) \mathrm{msl}$

Sp: 4.4 conductance: $20 \mu \mathrm{s} / \mathrm{cm}$

Turbiditi: 1 NTU
Water evacuated from the well prior to sampling: $45 \mathrm{gat}$

ANALYSES

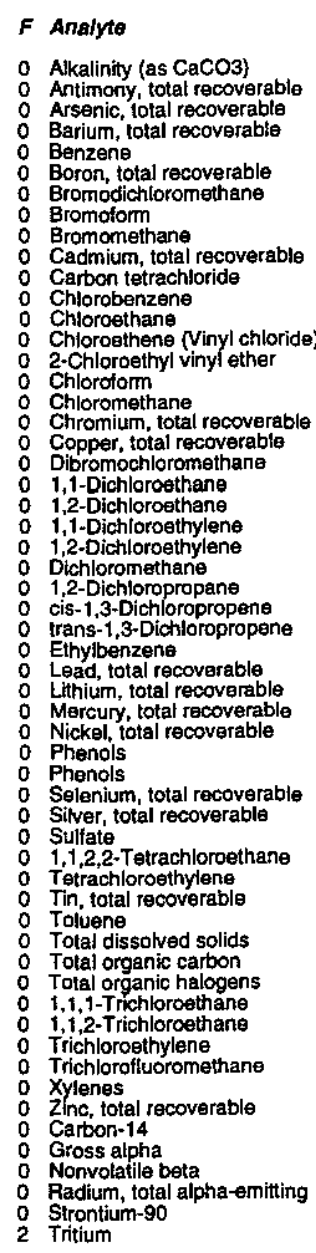

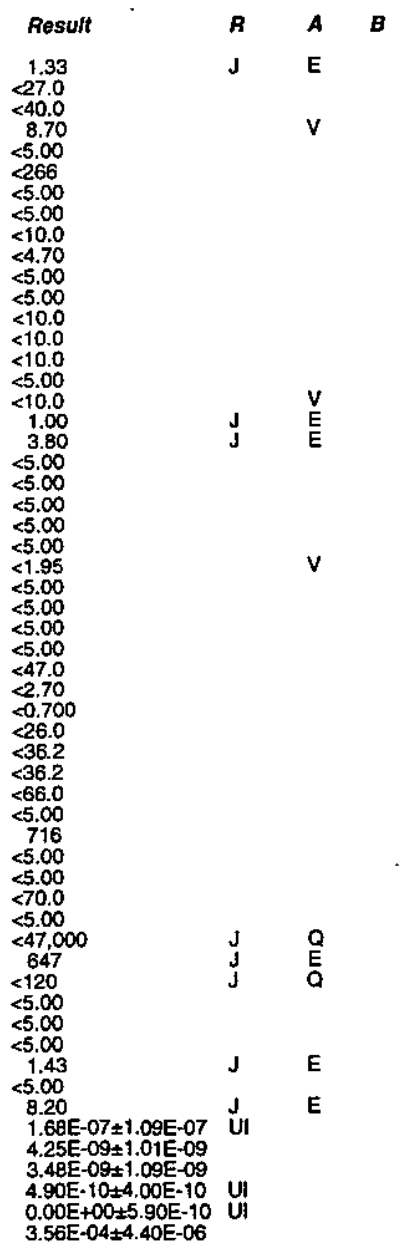

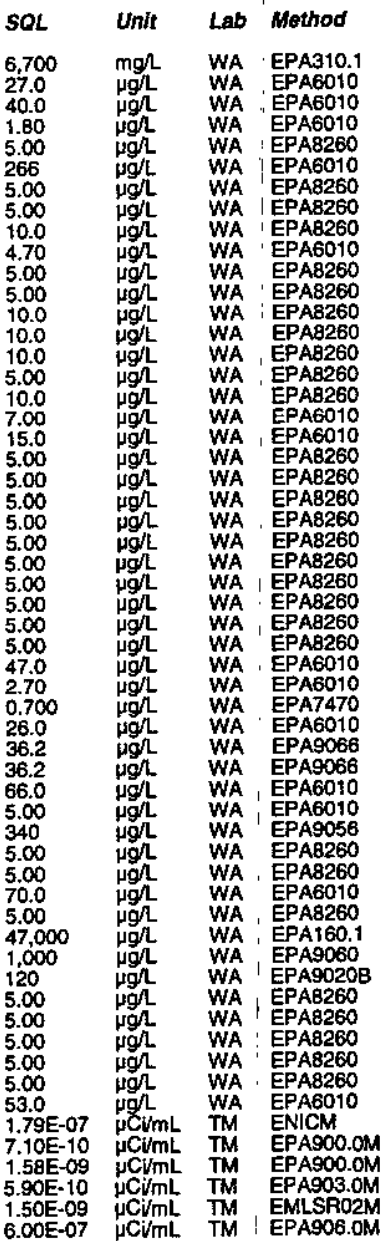




\section{WELL BGO $10 \mathrm{C}$}

MEASUREMENTS CONDUCTED IN THE FIELD

Sarmple date: $04 / 30 / 98$
Depth to water: $81.51 \mathrm{ft}(24.84 \mathrm{~m})$ below TOC

Water elevation:

pH: 10.4
Turbidituctance: 4 NTU $300 \mu \mathrm{S} / \mathrm{cm}$

ANALYSES

$F$ Analyte

Alkalinity (as $\mathrm{CaCO}$ )

- Arstimony, total recoverable

Boron, total recoverable
Bromodichloromethane

Bromodich

Bromomethane

Carbon tetrachloride

o Chloroethane

o Chloroethene (Vinyl chloride)

: Chloromethane

Dopper, total recoverabie

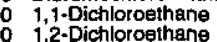

1.1.Dichloroethylene

1,2-Dichloreethylen
Dichloromethane

$\begin{array}{ll}0 & 1,2-D i c h l o r o p r o p a n e \\ 0 & \text { cis-1,3-Dichloropropene }\end{array}$

trans-1,3-Dichloropropen

Lead, total recoverable

- Mercury, total recoverabable

Phenols

Siver, total recoverable

: Sulfate Ti, Trachloroethane

Tetrachloroethylene

o Toluens

Total dissolved solids

Total organic halogens

1. $1,1,1$-Trichloroethane

Trichloroethylene

Zylenes

Carton-14

Nonvolatile beta

: Radium, total al

2 Stritium

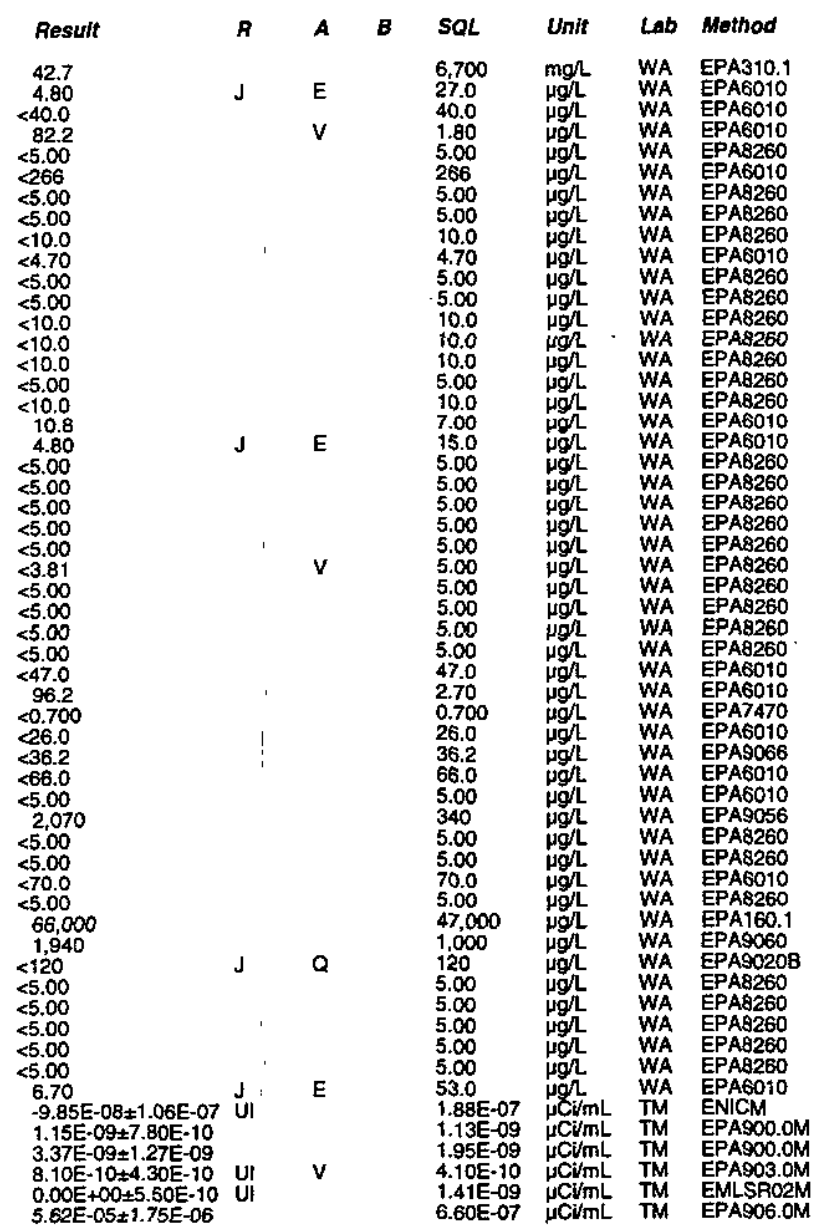

WELL BGO 10DR

MEASUREMENTS CONDUCTED IN THE FIELD

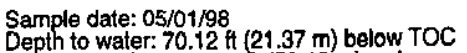
Water elevation: $230.28 \mathrm{ft}(70.19 \mathrm{~m}) \mathrm{msl}$

mperature: $21.5^{\circ} \mathrm{C}$ $\mathrm{pH}: 6.5$ conductance: $90 \mu \mathrm{S} / \mathrm{cm}$

Water temperature: $19.3^{\circ} \mathrm{C}$ Total alkalinity (as CaCO3): $84 \mathrm{mgh}$
Phenolphthalein alkalinity: $67 \mathrm{mgh}$

ANALYSES

$F$ Analyte

: Alkalinity (as $\mathrm{CaCO}$ )

- Artimonic, total recoverable

Benzeñ

Boron, total recoverable

Bromotom

Bromomethane
Cadmium, total recoverable

Chlorobenzene

Chloroethane

2-Chorothy Ninyl chloride

Chloroform

Chromium, total recoverable

Dibromochioromethane

1,2-Dichloroethane

1,2-Dichloroethylene

Dichloromethane

cis-1,3-Dichloropropene
trans $-1,3-$ Dichloropropene

Lead, total recoverable

Lithium, total recoverable

Nickel, total tecoverab?e

Selenium, total recoverable

Sulfate

Tetrachloroethylene

Total dissolved solids

Total organic carton

1,1,1-Trichloroethane

Trichlorofluoromethane

Zinc, total recoverable

Grorbon-14

Nonvolatile beta
Radium, total alpha-emitting

Radium, total

2 Stritium

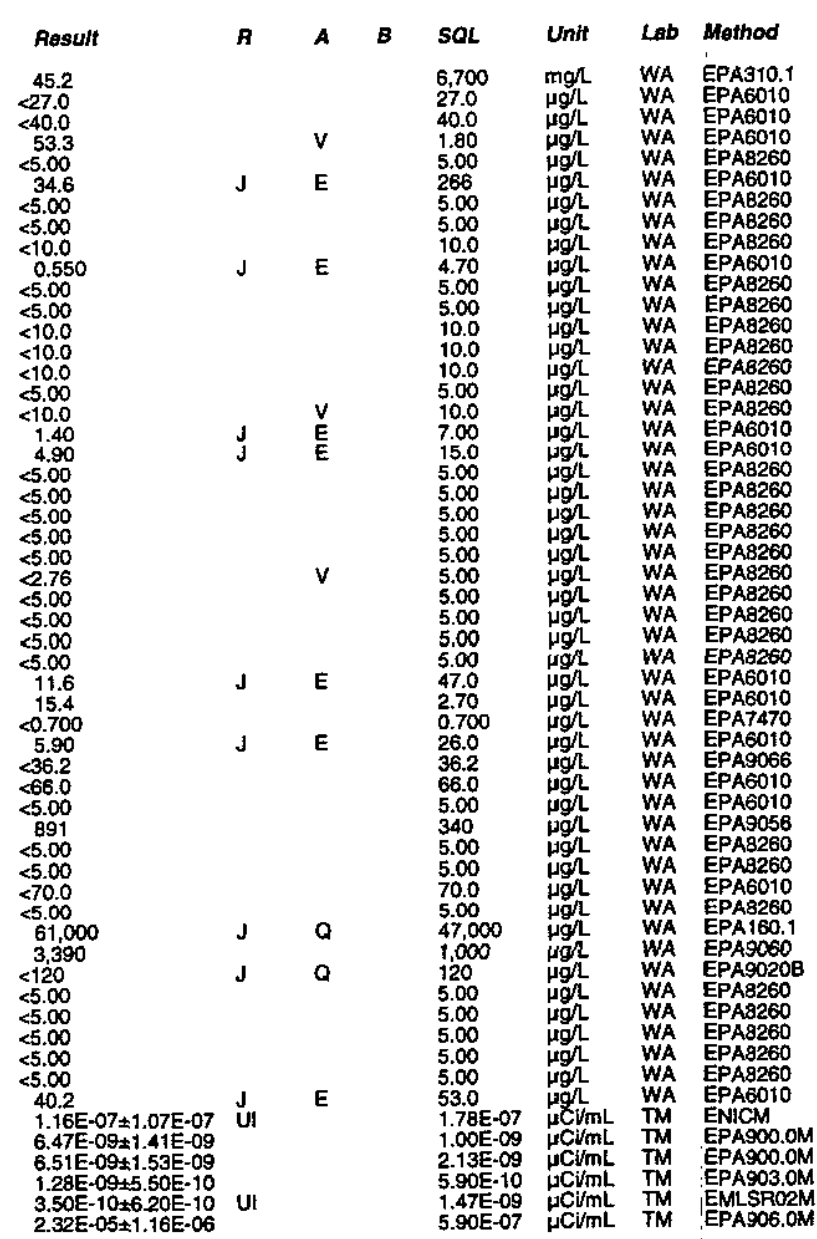




\section{WELL BGO 11DR}

MEASUREMENTS CONDUCTED IN THE FIELD

Sample date: $05 / 05 / 98$
Depth to water: $74.7 \mathrm{ft}(22.77 \mathrm{~m})$ below TOC
Water elevation: $230.5 \mathrm{ft}(70.26 \mathrm{~m}) \mathrm{msl}$

Water eleval

$\mathrm{SH}$. 4.7 conductance: $30 \mu \mathrm{s} / \mathrm{cm}$

Sp. conductance: $30 \mu \mathrm{S} / \mathrm{cm}$
Turbidity $1 \mathrm{NTU}$
Water evacuated from the well prior to sampling: 28 gal

ANALYSES

$F$ Analyte

- Alkalinity (as $\mathrm{CaCO}$ )

coverable

Arsenic, total recoverable
Barium, total recoverable

Benzene

Bromoform

Cadmium, total recoverable

Carbon totrachloride

Chlorobenzene

Chloroethene (Vinyl chloride)

2-Chloreothyl vinyl ether
Chloroform
Chloromethane

Chromium, total recoverable

Dibromochloromethan

1,2-Dichloreothane

1,1-Dichloroethylene

Dichloromathane

cis-1,3-Dichloropropene
trans-1,3-Dichloropropene

trans-1,3-Dichloropropen
Ethylbenzene

Lead, lotal recoverable

Mercury, total recoverable

Phenols

Selenium, rotal recoverable
Silver, total recoverable

Sulver, total recoverable

Tetrachiorcethylene

Toluene recoverable

Total organic carbon

Total organic halogens

$1,1,2$-Trichloroethane

Trichloroethylene

Xylenes

Carbon-14

Nons olatilia beta

Radium, total alpha-emitting

2 Tritium

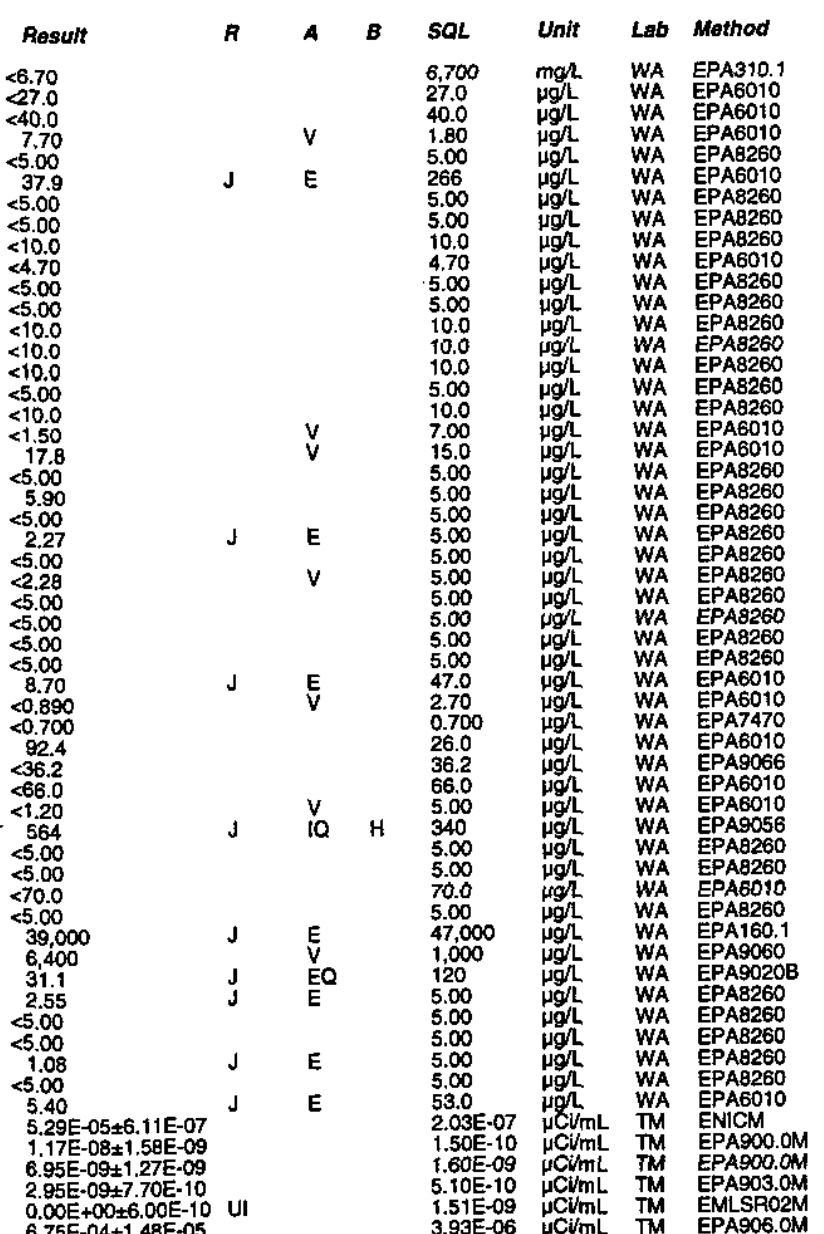

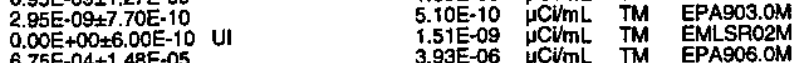

\section{WELL BGO 12AX}

MEASUREMENTS CONDUCTED IN THE FIELD

Sample date: $04 / 30 / 98$ (t) $(47.23 \mathrm{~m})$ below TOC

Water elation: $157.85 \mathrm{ft}(48.11 \mathrm{~m}) \mathrm{ms}$

$\mathrm{pH}: 8.2$

Pp. conductance: $160 \mu \mathrm{S} / \mathrm{cm}$

Water evacuated from the well prior to sampling: 102 gal

ANALYSES

$F$ Anatre

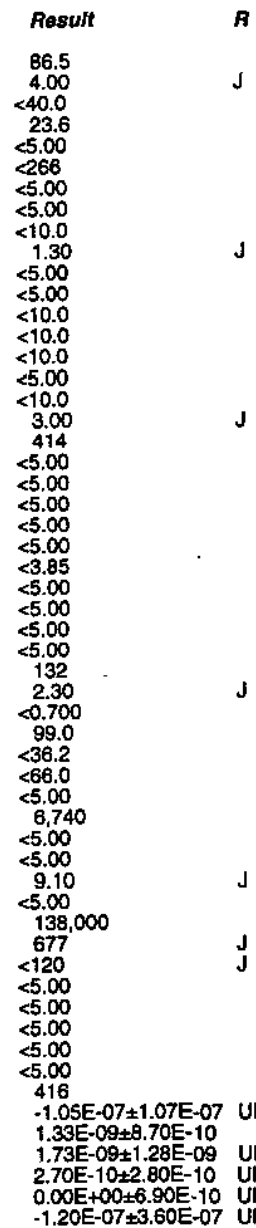

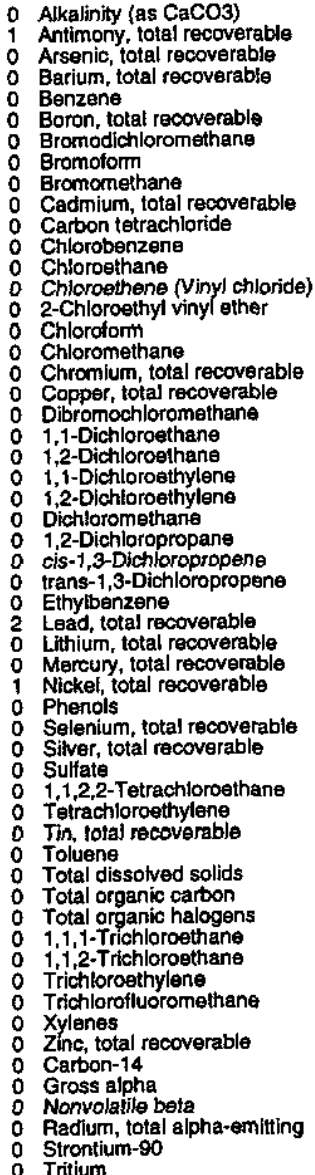

0 Tritium

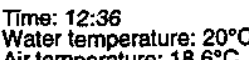

(as CaCO3): $178 \mathrm{mg}$

(

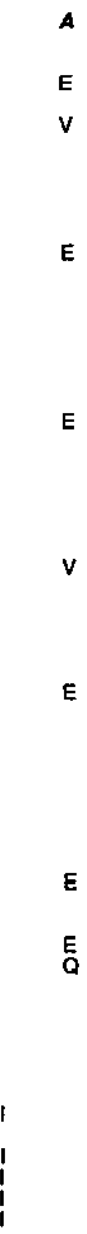

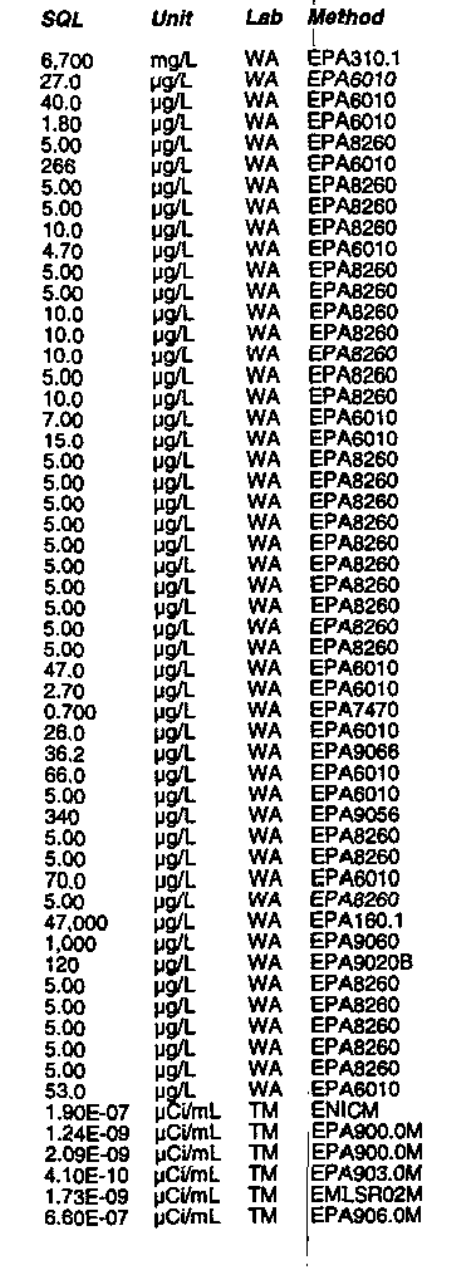




\section{WELL BGO 12CX}

MEASUREMENTS CONDUCTED IN THE FIELD

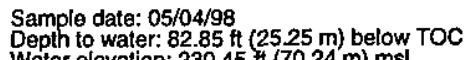

Water elevation: $232.85 .45+(25.25 \mathrm{~m})$ below

pH: 5.4

SP. conductance: $48 \mu \mathrm{S} / \mathrm{cm}$

Water evacuated from the well prior to sampling: 38 gal

ANALYSES

$F$ Anslyte

: Aikalinity (as CaCOO3) Arsenic, total recoverabable
Barium, total recoverable

Benzene

Bromodichloromethane

Bromelorm

Cadminum, total recoverable
Carbon tetrachloride

Chjorobenzente

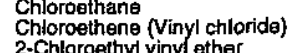

Chiloroform

Chromium, total recoverable
Copper, total recoverable

Dibromochloromethane

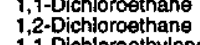

1,1-Dichloroesthylene

1.2-Dichloropropane

: cis-1, -Dichloropropene
trans-1,3-Dichlioropropene

o Lead, total recoverable Lithium, totat recovevarable
Mercury, total recoverable

Phenols Soltenium, total recoverable
Siver, total recoverable Sulfate

1.1,2,2.-Tetrachloroethan

Titrachloroethylene
Tin, lotal recoverable

Tolien
Total dissoved solids

Total organic catron

1,1,1-Trichloroethane

1,1,2-Trichlorosthane

Trichlorofluoromethane

Xylenes
Zinc, total recoverable

Carbon-14 14
Gross alpha
a

Nonvolatil beta
Radium, total alpha-emitting

2 Trtitum

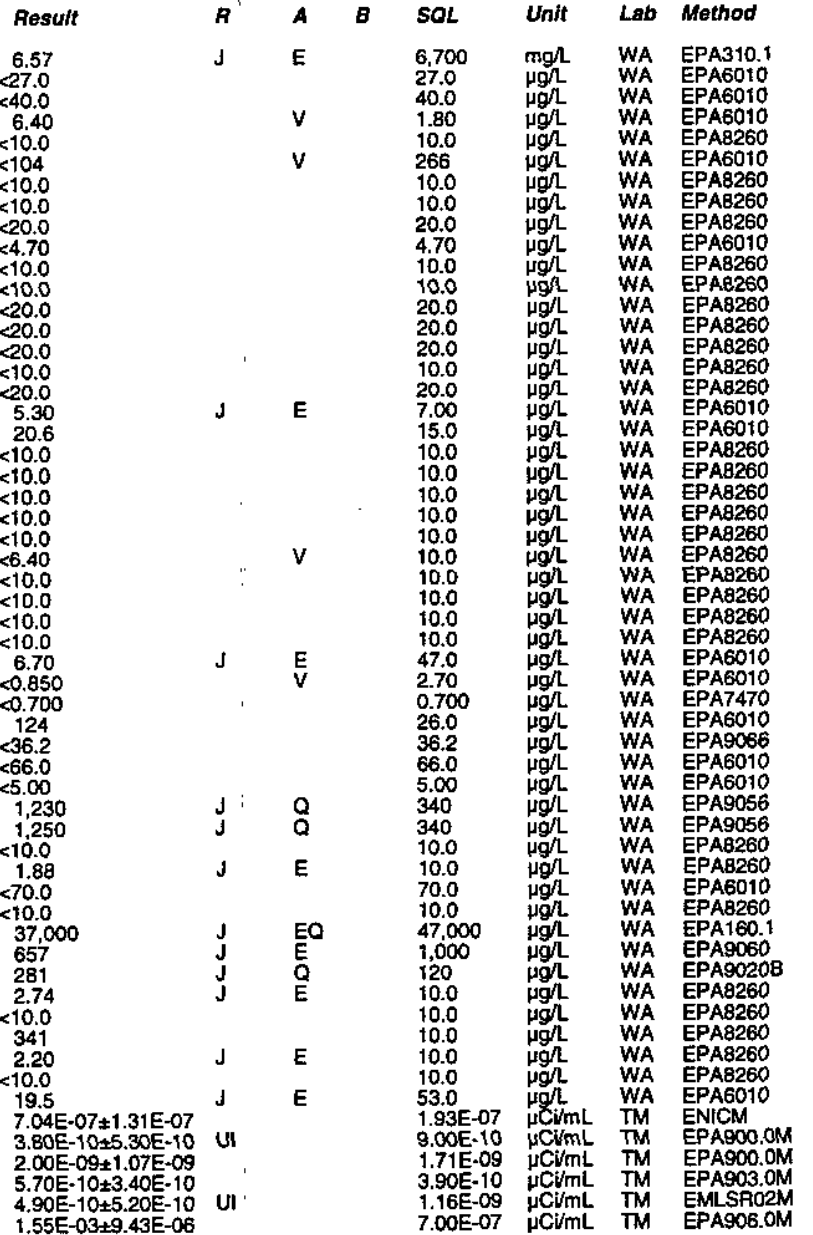

ESH-EMS-980569

Time: 12:07 Total alkalinity (as Caco3): $3 \mathrm{mg} / \mathrm{L}$

\section{WELL BGO 12DR}

MEASUREMENTS CONDUCTED IN THE FIELD Sample date: $04 / 30 / 98$
Dephth to water: $92.85 \mathrm{ft}(28.3 \mathrm{~m})$ below TOC
Water elevation: $220.75 \mathrm{ft}(67.29 \mathrm{~m}) \mathrm{msl}$
$\mathrm{pH}: 9.8$ Sp. conductance: $240 \mu \mathrm{S} / \mathrm{cm}$ Water evacuated from the well prior to sampling: 16 gal ANALYSES

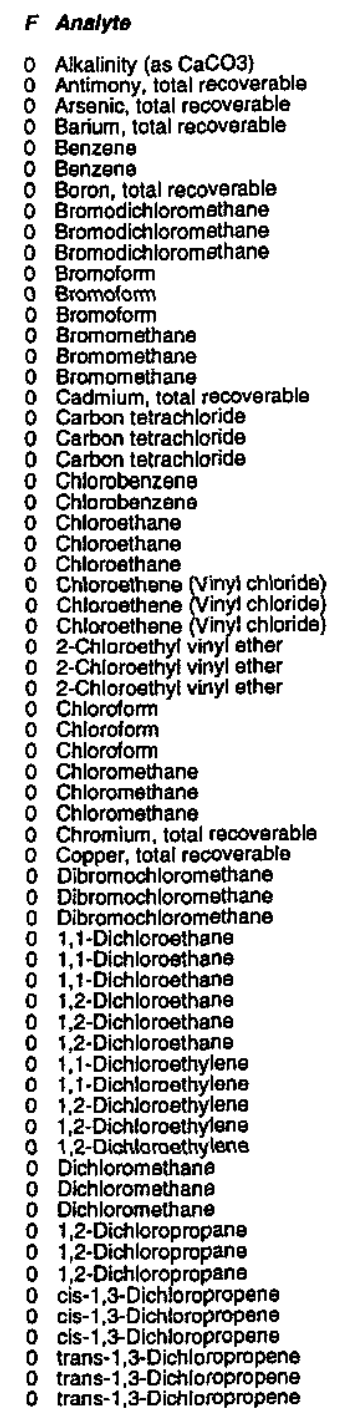

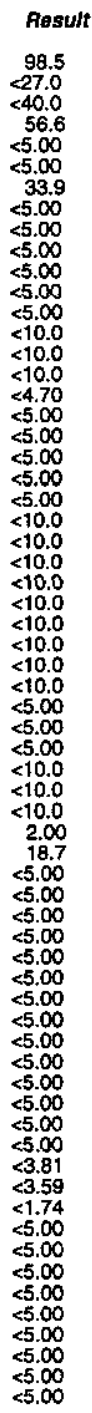

Water temperature: $21^{\circ} \mathrm{C}$

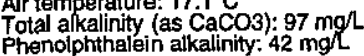

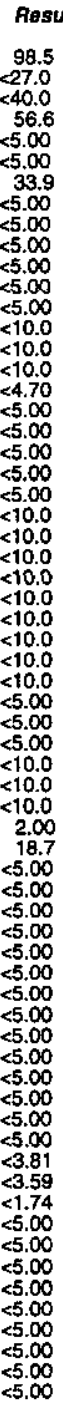

R

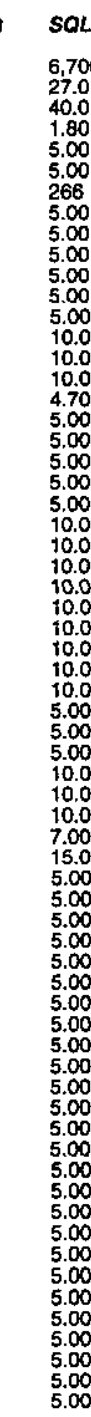

\begin{tabular}{l} 
SOL \\
6.700 \\
27.0 \\
40.0 \\
1.00 \\
5.00 \\
5.00 \\
266 \\
5.00 \\
5.00 \\
5.00 \\
5.00 \\
5.00 \\
5.00 \\
10.0 \\
10.0 \\
10.0 \\
4.70 \\
5.00 \\
5.00 \\
5.00 \\
5.00 \\
5.00 \\
10.0 \\
10.0 \\
10.0 \\
10.0 \\
10.0 \\
10.0 \\
10.0 \\
10.0 \\
10.0 \\
5.00 \\
5.00 \\
5.00 \\
10.0 \\
10.0 \\
10.0 \\
7.00 \\
15.0 \\
5.00 \\
5.00 \\
5.00 \\
5.00 \\
5.00 \\
5.00 \\
5.00 \\
5.00 \\
5.00 \\
5.00 \\
5.00 \\
5.00 \\
5.00 \\
5.00 \\
5.00 \\
5.00 \\
5.00 \\
5.00 \\
5.00 \\
5.00 \\
5.00 \\
5.00 \\
5.00 \\
5.00 \\
5.00 \\
100 \\
\hline
\end{tabular}

Unit Lab Method

WA EPA310.1

WA EPABO10

WA EPABO10

WA EPAB260

WA EPAG010

WA EPAB260

WA

WA

WA

WA

WA

WA

WA

WA

WA

WA EPA8260

WA

WA

EPA2260

WA EPA260

WA EPAA260

WA EPAGO10

WA EPAB260

WA

WA EPA8260

WA EPA3260

WA EPAB260

WA

WA

WA

WA EPAB260

WA

WA EPAB260

Second Quarter 1998 
Well BGO 12DR collected on 04/30/99 (cont.)

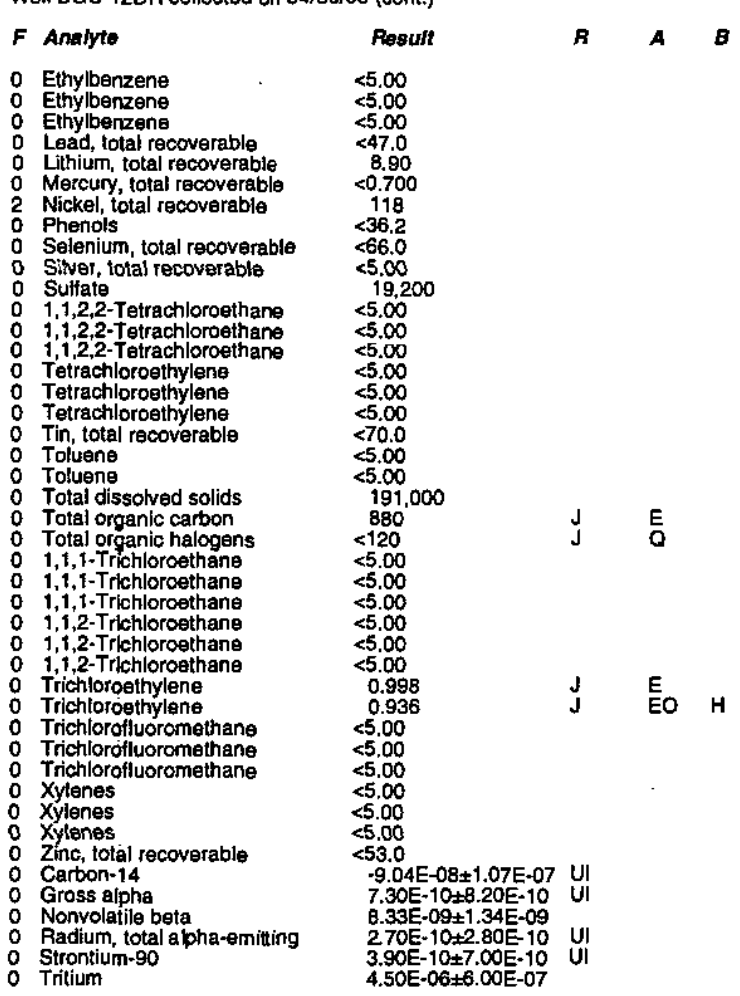

\section{WELL BGO 13DP}

MEASUREMENTS CONOUCTED IN THE FIELD

Sample date: 05/05/98

Depth to water: $88.8 \mathrm{ft}(27.07 \mathrm{~m})$ below TOC
Water elevation: $230.5 \mathrm{ht}(70.26 \mathrm{~m}) \mathrm{ms}$

$\mathrm{H:}: 11$

p. conductance: $740 \mu \mathrm{S} / \mathrm{cm}$

Water evacuated from the well prior to sampling: 1 ga

ANALYSES

$F$ Analyte.

- Alkalinity (as CaCO3)

Arsenic, total recoverabla
0 Barium, total recoverable

Boron, total recoverable

Bromodichlor

年

Carbon tetrachloride
Chlorobenzene

Chloreethane

Chloroethene (Vinyl chloride)
2-Chloroethyl viny/(ether

Chloromethane

ESH-EMS-980569
Well BGO 13DR collected on 05/05/98 (cont.)

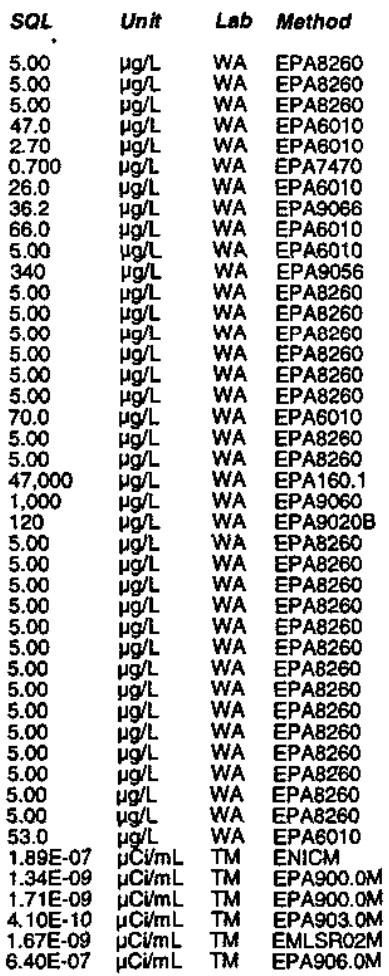

Anatyta

o Chromium, total recoverable

Dibpomochlorometha

o 1,1-Dichloroethylen

Dichloromethane

1,2-Dichloropropane

Ethylbenzene
Lead total recoverable

Lithium, total recoverable
Mercur, total recoverable

Phenols

Silver, total recoverable

1,1,2,2-Tetrachloroethane

Tetrachloroethylene

Total dissolved solids

Total dissolved solids

Total organic halogens

1, 1, 1-Trichloroettiane

: Trichloroethylerse

Zylents

Gross alpha

O Nanvolatile beta

2 Tritium

WELL BGO 14AR

MEASUREMENTS CONDUCTED IN THE FIELD

Sample date: $05 / 04 / 98$
Depth to water: $136.1 \mathrm{tt}(41.48 \mathrm{~m})$ below TOC

$\mathrm{pH}$ : 10.2 conductance: $200 \mu \mathrm{S} / \mathrm{cm}$

Time: 8:15

Total alkalinity (as CaCO3): $208 \mathrm{mg} / \mathrm{L}$

Water ovacuated from the well prior to sampling: $97 \mathrm{gal}$

ANALYSES

$F$ Anafyto

Alkalinity (as $\mathrm{CaCO}$ )

Arsenic, lotal recoverable
Barium, total recoverable

Benzen

Boron, total recoverable

Bromoform

Bromoform

Bromoform

Bromomethan

Bromomethane

Cadmium, total recoverab

Carbon tetractibride

Carbon tetrachloric

- 19
Resuft
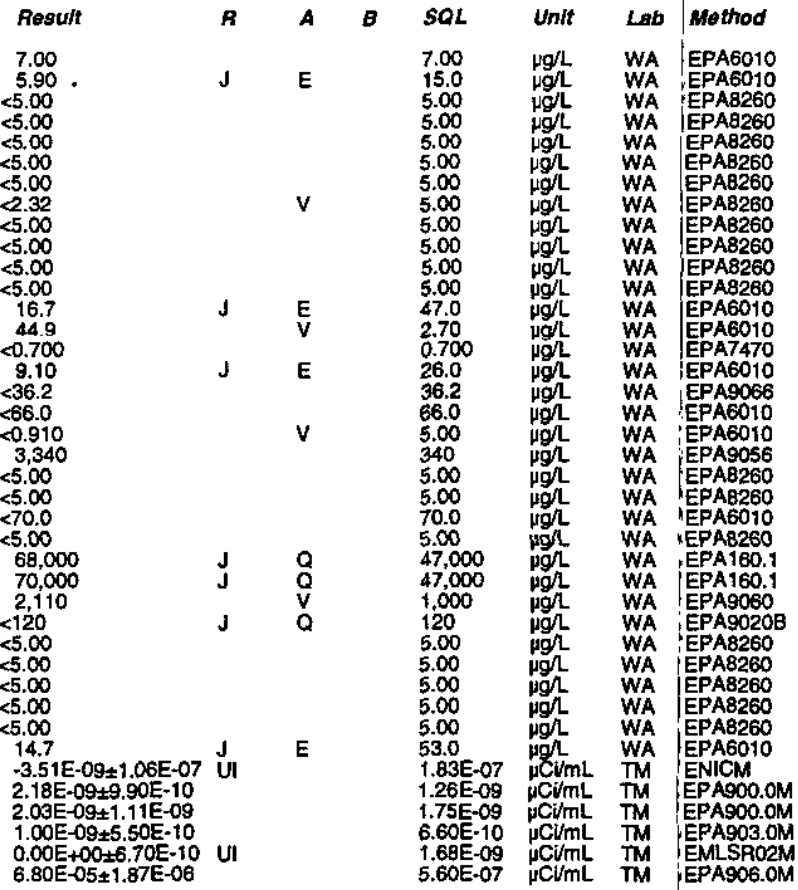

Time: 11:32

Air temperature: $21^{\circ} \mathrm{C}$

Total alkalinity (as CaCO3): $120 \mathrm{mgh}$ 
ANALYTICAL RESULTS

Well BGO 14AR collected on 05/04/98 (cont.)

$F$ Analyte

- Chlorobenzene

Chloroethane
Chloroethene
Choroethene

Chloresthane

Chloroethene (Vinyl chboride)

2-Chloroethyl vinyl ether

2-Chloroethyl vinyl ether

Chloroform

Chlorotom

Chloromethane

Chromium, total recoverab

Dibromochloromethane

Dibromochloromethane

1,1-Dichloroethane

1,1-Dichloroethane

1,2-Dichloroethane

1,1-Dichloroethylene

1,2 -Dichloroethylene

1,2 -Dictioroettylente

Dichloromethane

1,2-Dichloropropane

1.2-Dichloropropane

cis-1,3-Dichloropropen

cis-1,3-Dichloropropene

trans-1,3-Dichloropopopenen

ans-1,3-Dichloropropene

Ethylbenzen

Lead, total recoverable

Mercury, total recoverabable

Nickel, total recoverable

Selenjium, total recoverab!
Silver, solal recoverable Sulfate

: Sulfate

i, , , 2-Tetrachloreethane

Tetrachloroethylene

Tetrachloroethylene

Tin, total

Total dissolved solids

Total organic carbon

Total organic halogens

$1,1,1-$ Trichloroethane

1.1. Trichoroethan

1,1,2-Trichloroethane

Trichlorosthylene

ESH-EMS-980569

3,510
$<500$

Well BGO 14AR collected on 05/04/98 (cont)

$F$ Analyte

0 Trichlorofluoromethane

0
0
0

Xylenes
Zinc, total recoverable

Carbon-14

: Gross alpha

Radium, total alpha-ernitting
0 Strontium-90

\section{WELL BGO 14CR}

MEASUREMENTS CONDUCTED IN THE FIELD

Sample date: 05/06/98 Water $\mathrm{PH}: 6$. 6 ductionce: $88 \mu \mathrm{S} / \mathrm{cm}$

Result
55.00
55.00
5.00
5.50
55.00
$<53.0$
$-1.40 \mathrm{E}-07 \pm 1.07 \mathrm{E}-07 \mathrm{UI}$
$3.23 \mathrm{E}-09 \pm 9.00 \mathrm{E}-10$
$7.67 \mathrm{E}-09 \pm 1.10 \mathrm{E}-09$
$4.50 \mathrm{E}-10 \pm 3.10 \mathrm{E}-10$
$0.00 \mathrm{E}+00 \pm 6.50 \mathrm{E}-10 \mathrm{UI}$
$2.94 \mathrm{E}-06 \pm 5.10 \mathrm{E}-07$

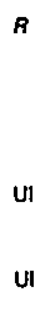

WA EPA8260

WA PAGO10

WA EPA8260

WA EPAB260

WA EPAB260

WA EPAB260

WA

WA EPA8260

WA

WA EPAE260

WA

WA

WA EPAB260

WA

WA EPAB260

WA EPA7470
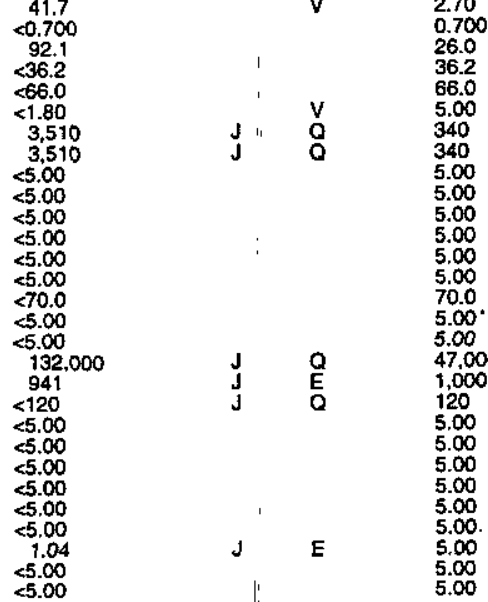

ANALYSES

$F$ Analyte

- Alkalinity (as $\mathrm{CaCO}$ )

Antimony, total recoverabible

Arsenic, total recoverable
Arsenic, total recoverabla

Barium, total recoverable
Barium, total recoverable

Boron, total recoverable

Boron, total recoverable

o Bromoform

Cadmium, total recoverable

benzene

Chloroethene (Vinyl chloride)

Chloroform

Chromium, total recoverable

Copper, total recoverab:

1.1-Dichlorcethane

1.1-Dichlorosthylen

1,2-Dichloroethylen

1.2-Dichloropropane

cis-1,3-Dichloropropene
trans-1,3-Dichloropropen

Ethybenzene

Lead, total recoverable

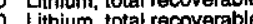

Mercury, total recoverab!

Nickel, total recoverable

Phenols

Selenium, total recoverable

- Silenium, total recolacorebera

$3-20$

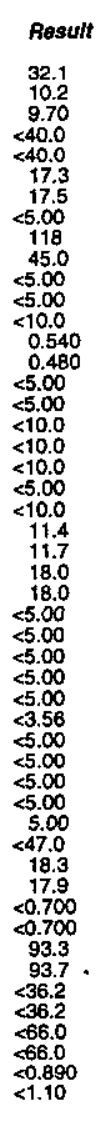

\begin{tabular}{|c|c|c|c|}
\hline & Unt & $L a b$ & Methoc \\
\hline $\begin{array}{l}.00 \\
.00 \\
5.00 \\
5.00 \\
53.0 \\
.93 E-07 \\
.10 E-10 \\
1.37 E-09\end{array}$ & 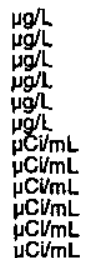 & $\begin{array}{l}\text { WA } \\
\text { WA } \\
\text { WA } \\
\text { WA } \\
\text { WA } \\
\text { WA } \\
\text { TM } \\
T M \\
T M \\
T M \\
\text { TM } \\
\text { TM }\end{array}$ & $\begin{array}{l}\text { EPA8260 } \\
\text { EPA8260 } \\
\text { EPA8260 } \\
\text { EPAB260 } \\
\text { EPA8260 } \\
\text { EPA6010 } \\
\text { ENICM } \\
\text { EPA900.0M } \\
\text { EPA900.0M } \\
\text { EPA903.0M } \\
\text { EMLSRO2M } \\
\text { EPA908.0M }\end{array}$ \\
\hline
\end{tabular}

Time: 7:45

Wature: $17^{\circ} \mathrm{C}$

Total alkalinity (as Caco3): $29 \mathrm{mgh}$ 
Well BGO 14CR collected on 05/06/98 (cont.)

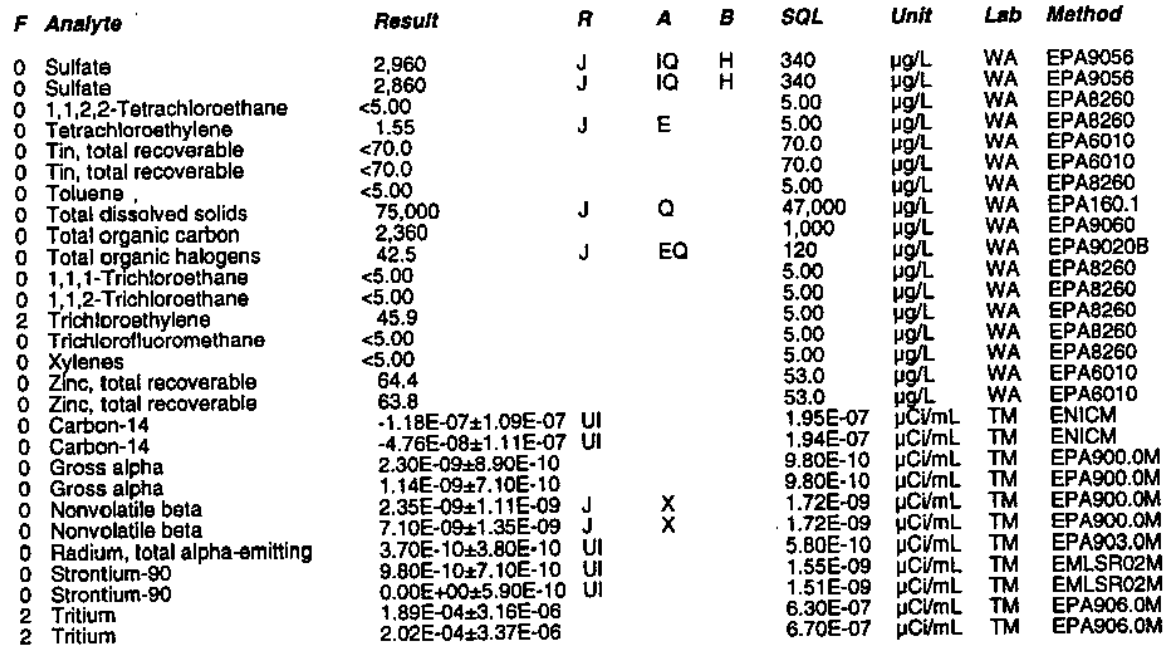

\section{WELL BGO 14DR}

MEASUREMENTS CONDUCTED IN THE FIELD

Sample date: $05 / 05 / 98$.

Water

Sp. conductance: $30 \mu \mathrm{S} / \mathrm{cm}$

Turbidity: $1 \mathrm{NTU}$ :

ANALYSES

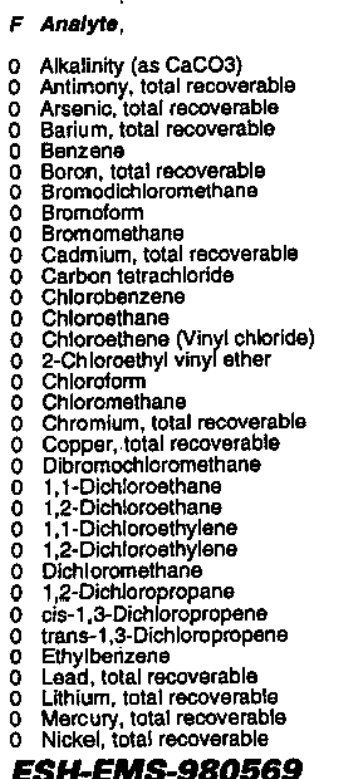

Result
0.672
527.0
$<40.0$
4.70
55.00
266
55.00
55.00
510.0
44.70
55.00
55.00
510.0
$<10.0$
510.0
5.00
510.0
1.20
30.6
55.00
55.00
55.00
5.00
55.00
53.82
55.00
5.00
55.00
5.00
7.40
$<.30$
50.700
26.0

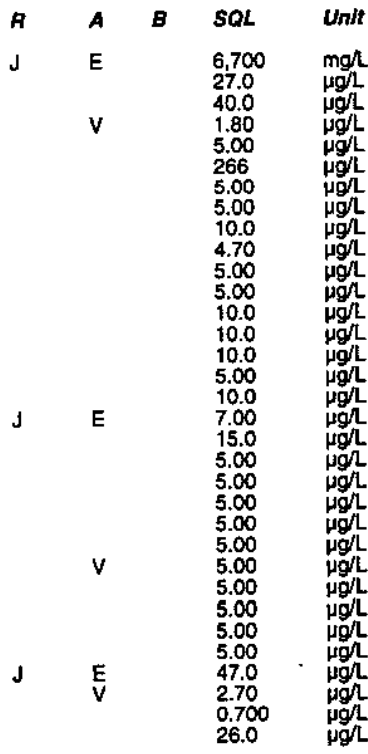

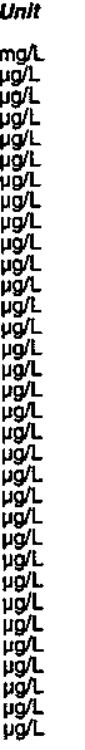

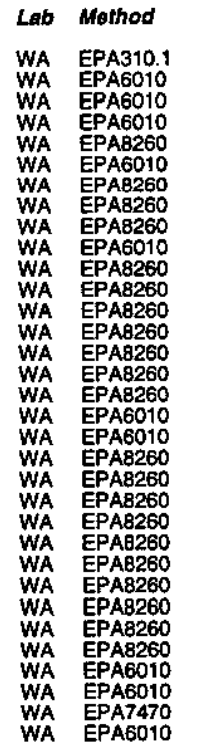

Well BGO 14DR collectod on 05/05/98 (cont)

F Aralyte

Phenols
0 Selenium, total recoverable
0 Siver, total recoverable

1,1,2,2-Tetrachloroethane

Tin, total recoverable

Toluene dissolved solids

Total organic carbon

1,1,1-Trichioroethane

2 Trichlorogthylene

Trichlorofluoromethan
Xylenes

Zinc, total recor

: Gross alpha

Radium, total alpha-emitting

2 Tritium

\section{WELL BGO 15D}

MEASUREMENTS CONDUCTED IN THE FIELD

\section{Sample date: 05/05/98 $20.97 \mathrm{~m}$ ) below TOC}

Water

Time: 9:36

Total alkalinity (as CaCO3): $1 \mathrm{mg} /$
Phenolphthalein alkalinity: $0 \mathrm{mgh}$

Sp: conductance: $30 \mu \mathrm{S} / \mathrm{cm}$

Water evacuated from the well prior to sampling: $100 \mathrm{gal}$ ANALYSES

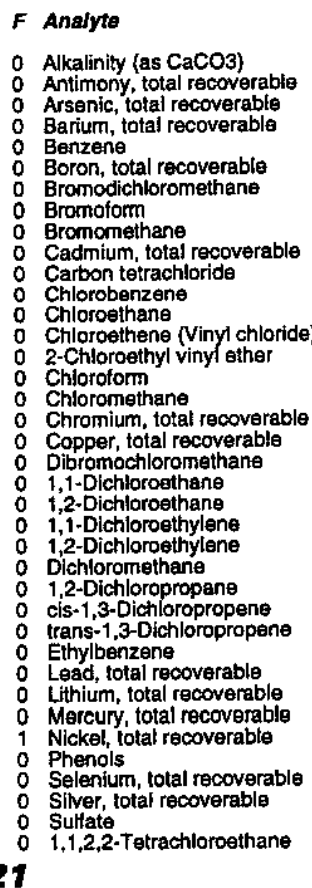

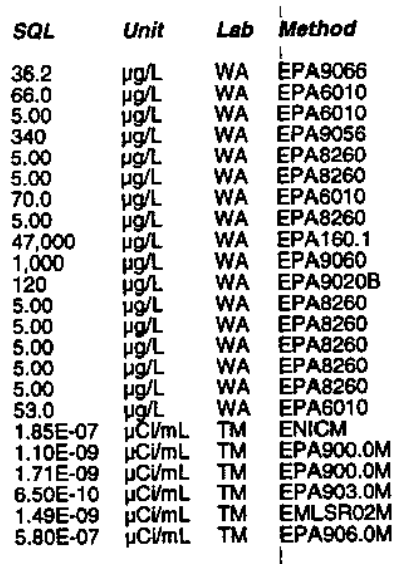

Time: 10:47

perature: $21^{\circ} \mathrm{C}$

Total alkalinite: $22.9^{\circ} \mathrm{C}$ ) 3 mol

alkalinity: $0 \mathrm{mg} /$

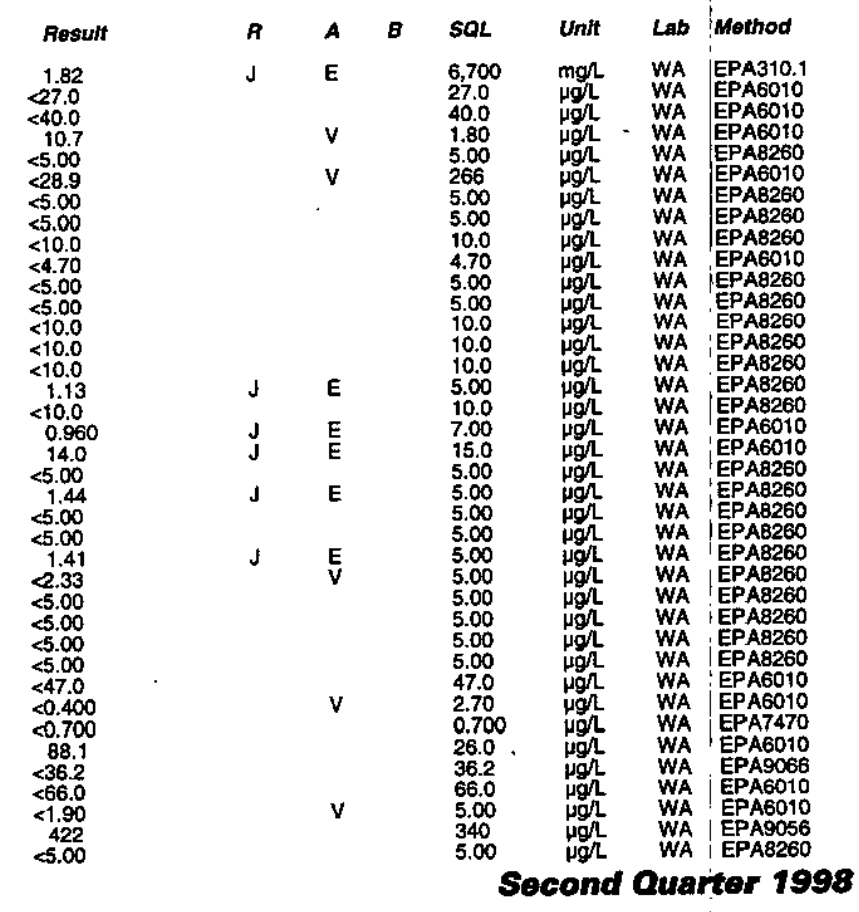


ANALYTICAL RESULTS

Well BGO 150 collected on 05/05/98 (cont.)

\section{$F$ Analyte}

2 Tetrachloroethylene

Th, total recoverable
Total dissolved solids 2 Total organic carbon $1,1,1$-Trichloroethane
$1,1,2$-Trichloroethane Tricthloroethylene

Zinc, total recoverable Carbon-14 Nonvolatile beta
Radium, total alpha-omitting
0 Strontium-90

\section{WELL BGO 16AR}

MEASUREMENTS CONDUCTED IN THE FIELD

Sample date: $05 / 11 / 38$
Depth to water: $141.67 \mathrm{ft}(43.18 \mathrm{~m})$ below TOC
Water

Water eleva

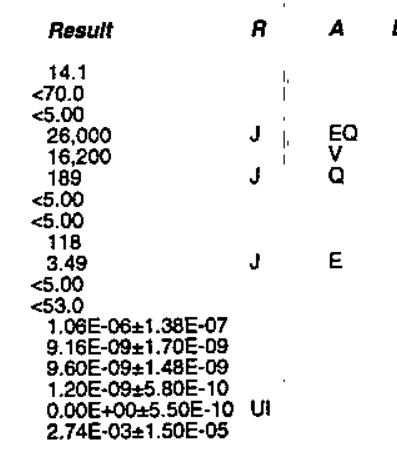

p. conductance: $160 \mu \mathrm{S} / \mathrm{cm}$

Water evacuated from the well prior to sampling: $116 \mathrm{gal}$

ANALYSES

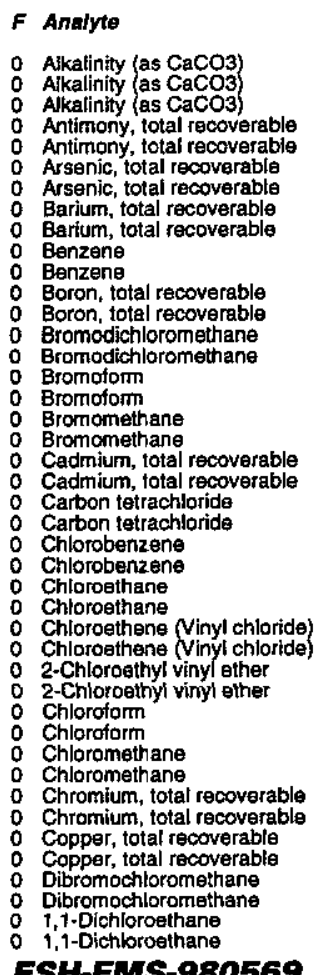

Well BGO 16AR collected on 05/11/98 (cont.)

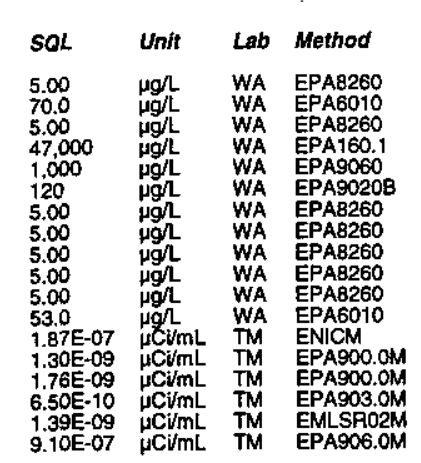

1,2-Dichloroethane

1,t-Dichloroethylene

trans-1,2-Dichloroethylene

D Dichloromethane

1,2-Dichloropropane

cis-1,3-Dichloropropen

trans-1,3-Dichloropropene

Elthylbenzena

Lead, total recoverable

Lead, total recoverable

Lithium, total recoverable

Mercury, total recoverable

Mickel, total recoverable

Phenols

O Phenols

Water temperature: $21.9^{\circ} \mathrm{C}$ Air temperature: $26.8 \mathrm{CO}$ ) $70 \mathrm{mgh}$
Total alkalinity (as CaCO3)
Phenolphthalein alkalinity: $0 \mathrm{mg} / \mathrm{h}$

\section{$F$ Analyte}

ESH-EMS-980569

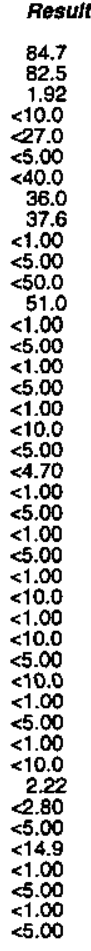

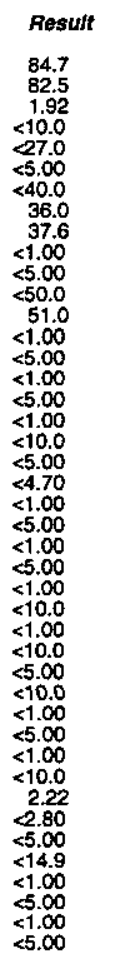

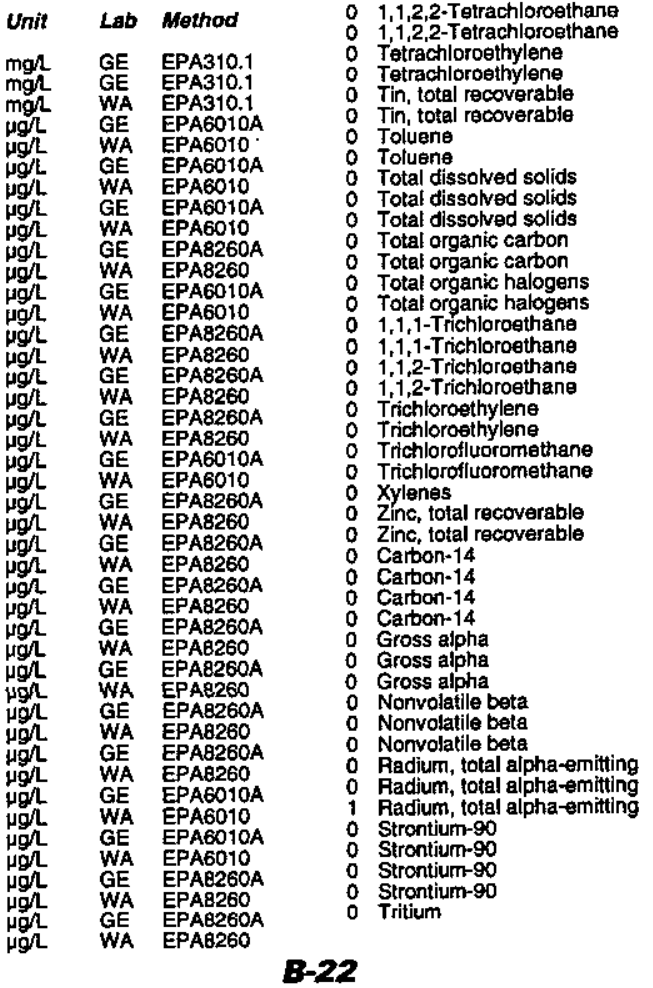

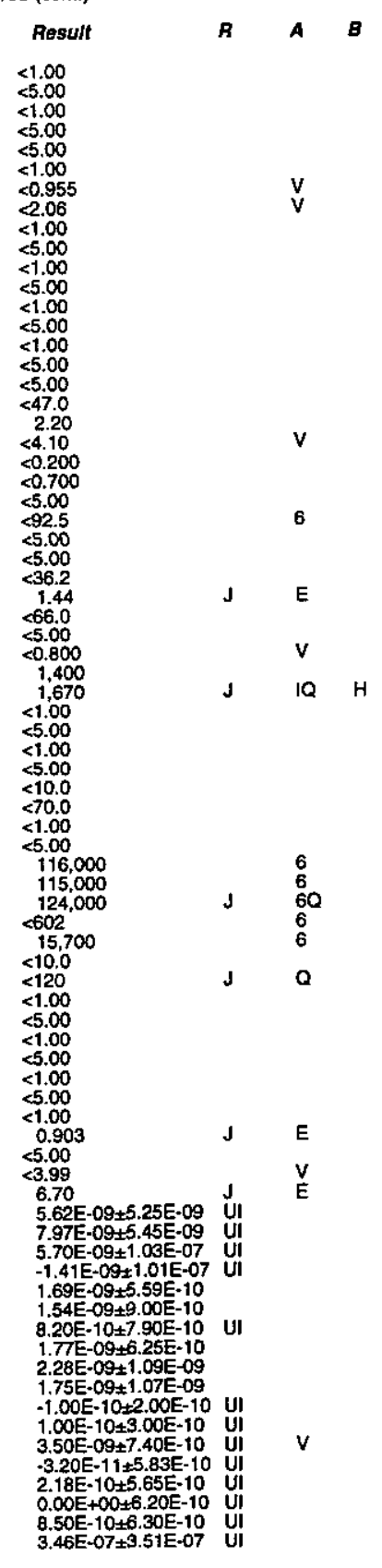

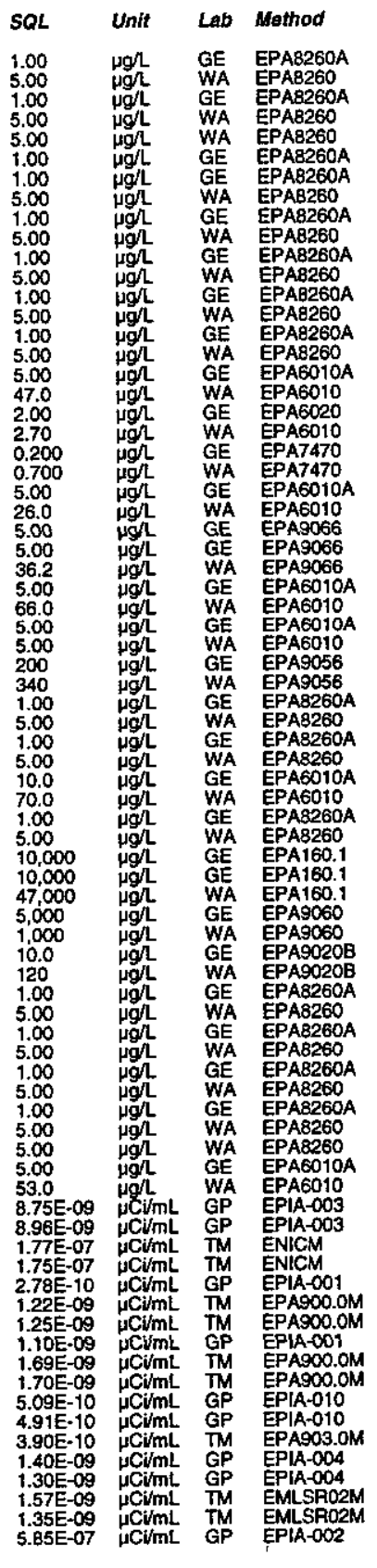

Second Quarter 1998 
Well BGO 16AR collected on 05/11/98 (cont.)

$F$ Analyte Result

$\begin{array}{ll}0 & \text { Tritium } \\ 0 & \text { Tritium } \\ 0 & \text { Tritium }\end{array}$

$3.21 \mathrm{E}-07 \pm 3.49 \mathrm{E}-07$ UI
$1.00 \mathrm{E}-07 \pm 3.70 \mathrm{E}-07$ UI
$2.00 \mathrm{E}-07 \pm 3.80 \mathrm{E}-07$

WELL BGO 16AR Replicate

MEASUREMENTS CONDUCTED IN THE FIELD

Sample date: $05 / 11 / 98 \mathrm{ft}(43.18 \mathrm{~m})$ below TOC

Water elevation: $162.03 \mathrm{ft}(49.39 \mathrm{~m}) \mathrm{ms}$

Sp. conductance: $160 \mu \mathrm{S} / \mathrm{cm}$

Water evacuated from the well prior to sampling: $116 \mathrm{ga}$

ANALYSES
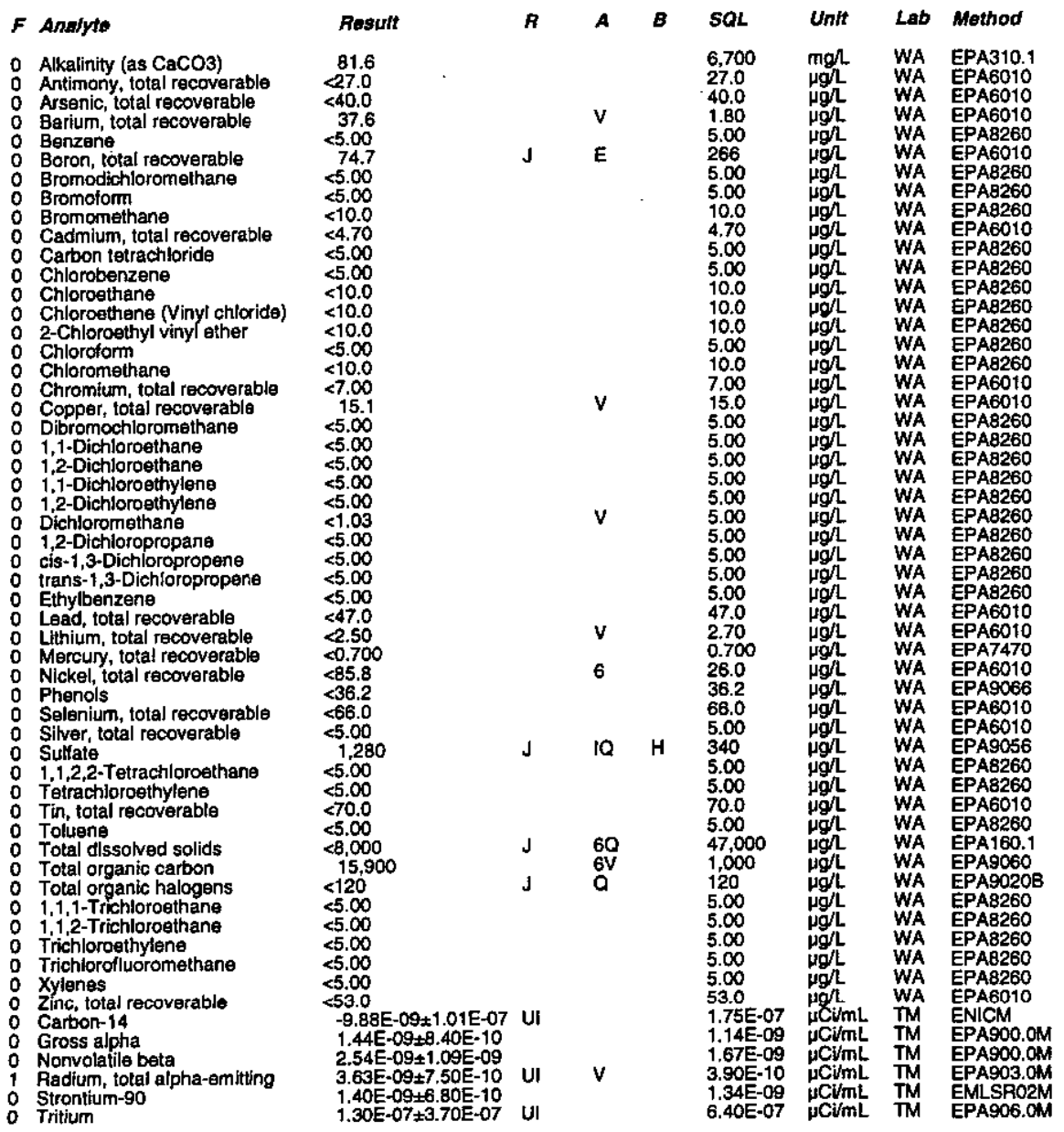

Time: 13:18

otal alkalinity (as CaCO3): $70 \mathrm{mg} /$

$5.84 E-07$
$6.50 \mathrm{C} / \mathrm{mL}$

WELL BGO 16B

MEASUREMENTS CONDUCTED IN THE FIELD

Sample date: 05/04/98

Depth to water. Not available

Water elevation: Not available
H: Not available
$\mathrm{Sp}$. conductance: Not available

Turbidity: Not available
No water was evacuated from the well prior to sampling

ANALYSES

ANAYSES

- Alkalinity (as $\mathrm{CaCO}$ )

Antimany, total recoverable

Brsenic, total recoverable

Boron, total recoverable

Bromodichlorome
Bromoform

Bromomethane
Cadmium, total recoverable

Carbon tetrachlorid

Chloroethene (Vinyl chlorid

2-Chloroethyl

Chroromethan

Copper, total recoverab

1,1-Dichloroethane

1,1 -Dichloroethylen

Dichloromethane

1,2-Dichloropropane

trans-1,3-Dichloropropen

Lead, total recoverable

Mercur, total recoverabable

Phenols

Selenium, total recoverab

S Sulfate -Tetrachloroethan

Tetrachloroethylenes

Toluene
Total dissolved solids

Total organic carbon

Total organic halogens

1,1,1-Trichloroethane

Trichloroethylene

Trichloroffluoromethane

Zyienes

Gross alph

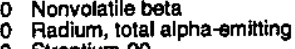

Tritium
Time: Not available

Total alkalinity (as $\mathrm{CaCO} 3$ ): Not available

Phenolphthalein alkalinity: Not available

ESH-EMS-980569

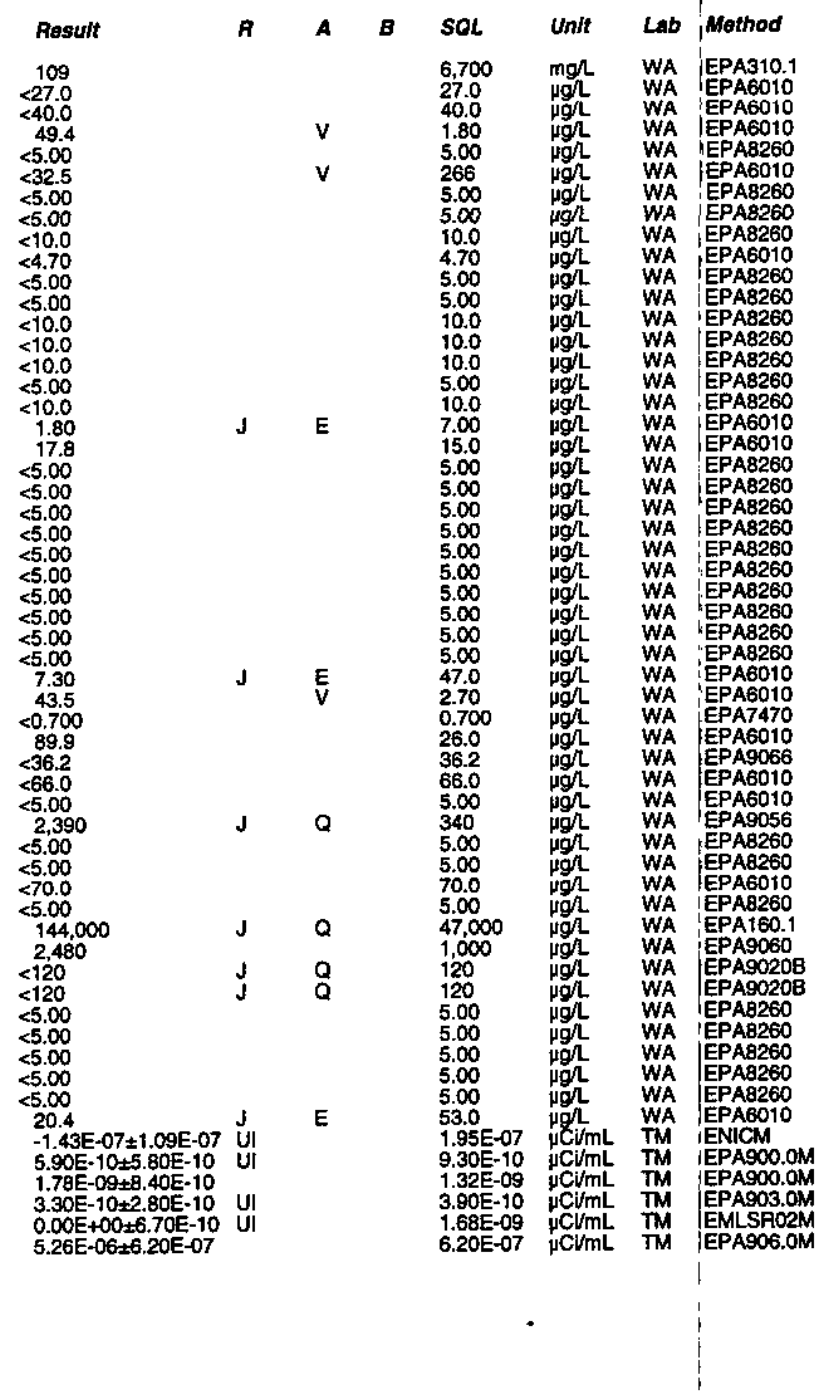

Second Quarter 1998 


\section{WELL BGO 16D}

MEASUREMENTS CONDUCTED IN THE FIELD

Sample date: $05 / 05 / 98$
Depth to water: Not available
Watter elevation: Not available

Water elevation: Not available
pH: Not available Sp. conductance: Not available

Tubidity: Not available
No water was evacuated from the well prior to sampling. ANALYSES

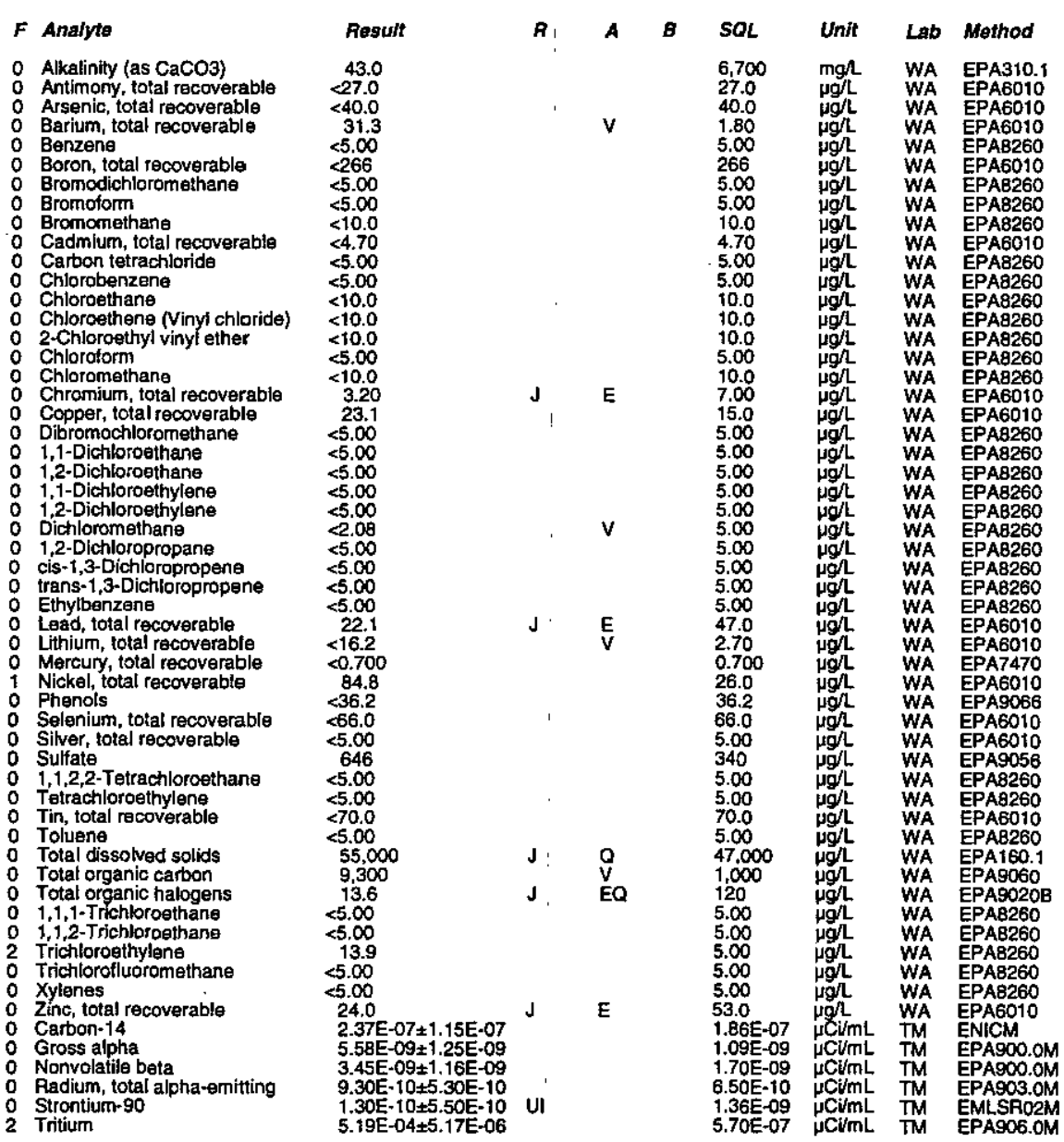

Time: Not available Water temperature: Not available

\section{WELL BGO 17DR}

MEASUREMENTS CONDUCTED IN THE FIELD

Depth to water: 67.99 ft $(20.72 \mathrm{~m})$ below TOC
Water elevation: $231.21 \mathrm{tt}(70.47 \mathrm{~m}) \mathrm{msl}$

gH: 5 conductance: $28 \mu \mathrm{S} / \mathrm{cm}$

Water evacuated from the well prior to sampling: $1 \mathrm{gal}$ ANALYSES
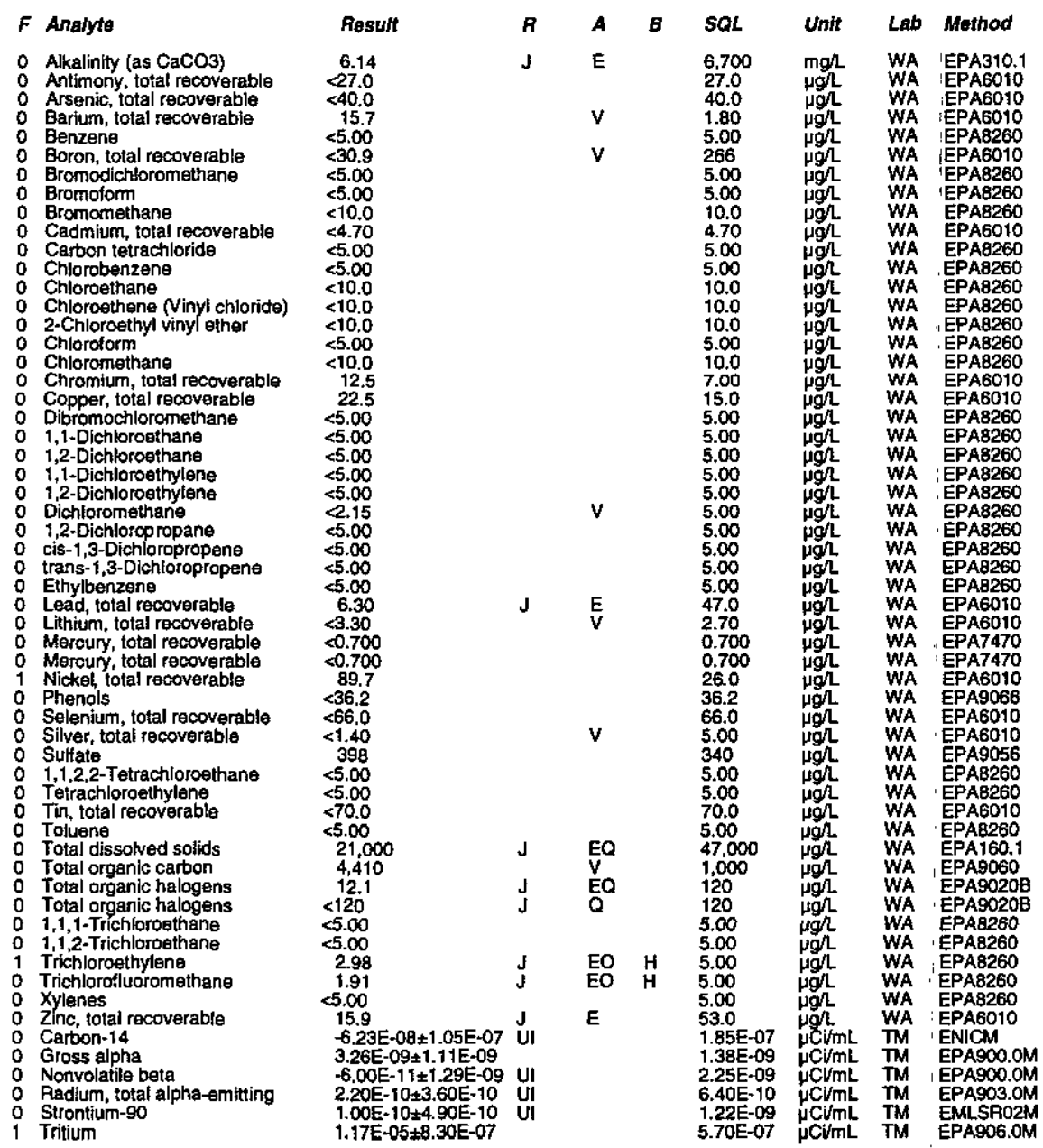

Time: 13:25

Wale remperature: $20^{\circ} \mathrm{C}$

Total alkalinity (as CaCO3): $5 \mathrm{mg} /$ 
ANALYTICAL RESULTS

\section{WELL BGO 18A}

MEASUREMENTS CONDUCTED IN THE FIELD

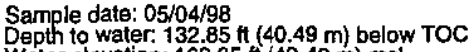
Wapth to water: $132.85 \mathrm{ft}(40.49 \mathrm{~m})$ below H: 7.2 Sp. conductance: $160 \mu \mathrm{S} / \mathrm{cm}$ Water evacuated from the well prior to sampling: $119 \mathrm{gal}$

ANALYSES

\begin{tabular}{|c|}
\hline 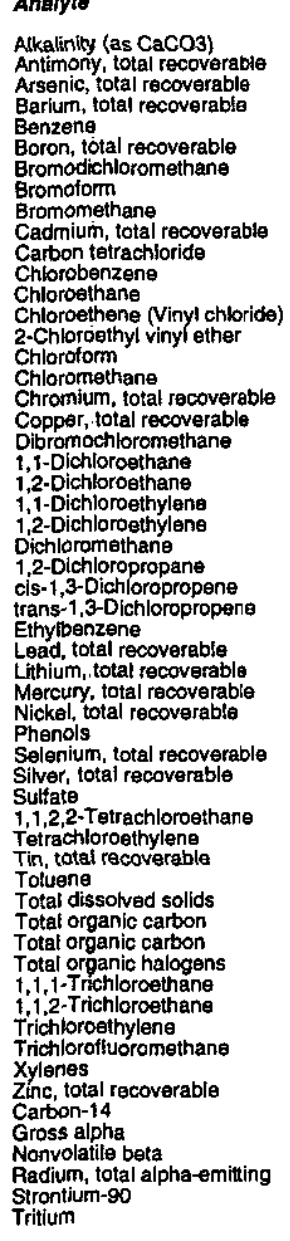 \\
\hline
\end{tabular}

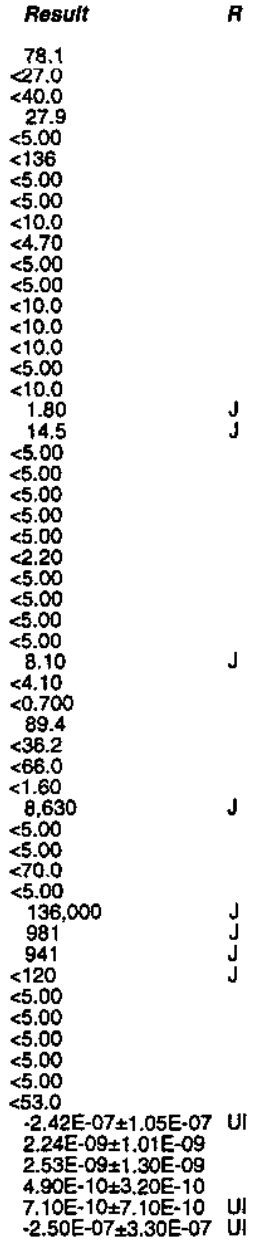

Time: 14:48

Warer temperature: $21{ }^{\circ} \mathrm{C}$ Total alkalinity (as CaCO3) $73 \mathrm{mgl}$

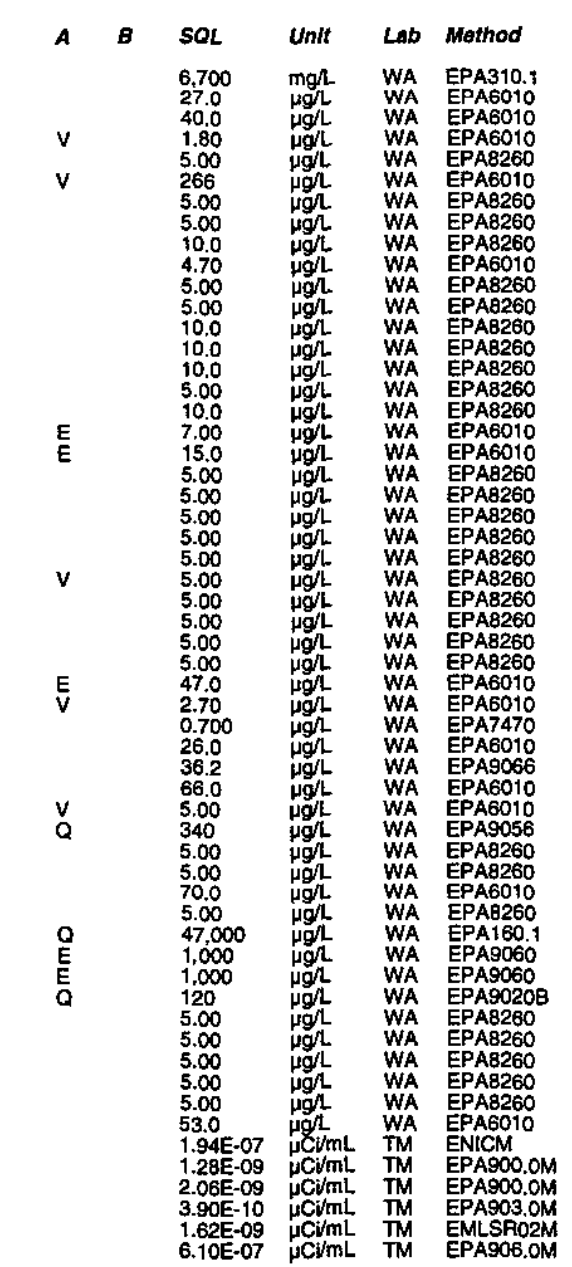

\section{WELL BGO 18D}

MEASUREMENTS CONDUCTED IN THE FIELD

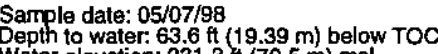
Water elevation: $231.3 \mathrm{Ht}(70.5 \mathrm{~m}) \mathrm{ms}$

$\mathrm{gH}$ : 4.2 conductance: $30 \mu \mathrm{S} / \mathrm{cm}$

Water evacuated from the well prior to sampling: $58 \mathrm{ga}$

ANALYSES

\begin{tabular}{|c|}
\hline 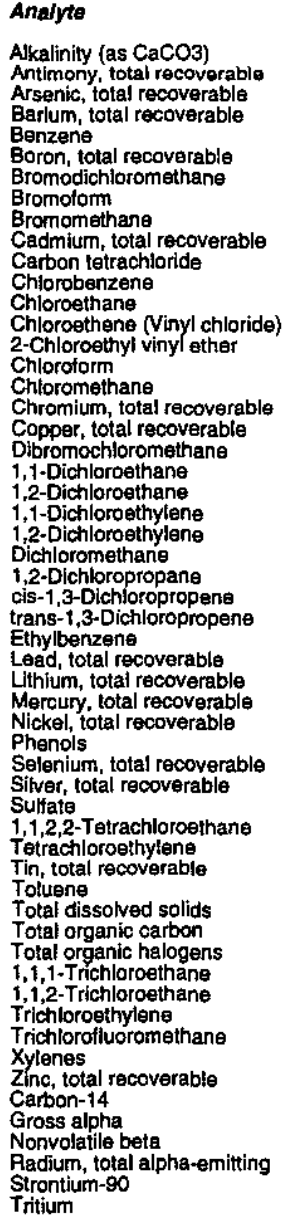 \\
\hline
\end{tabular}

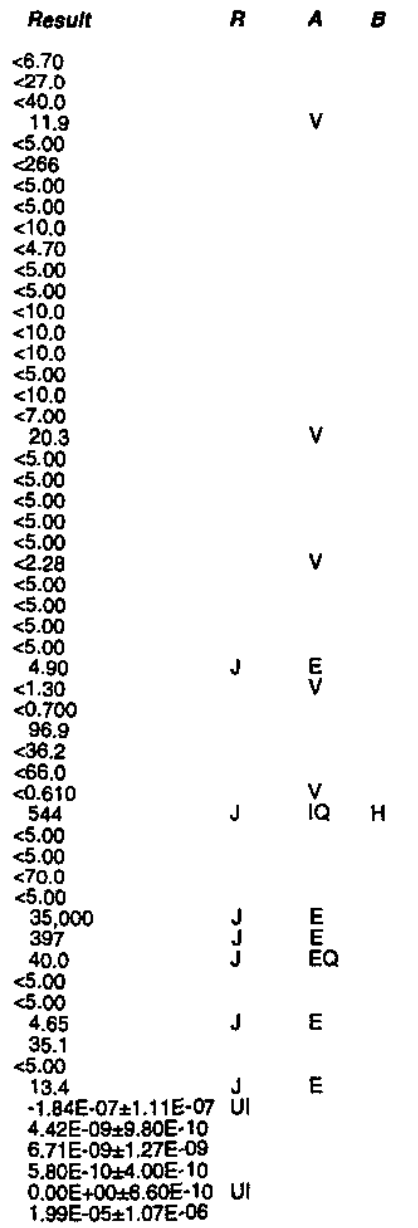

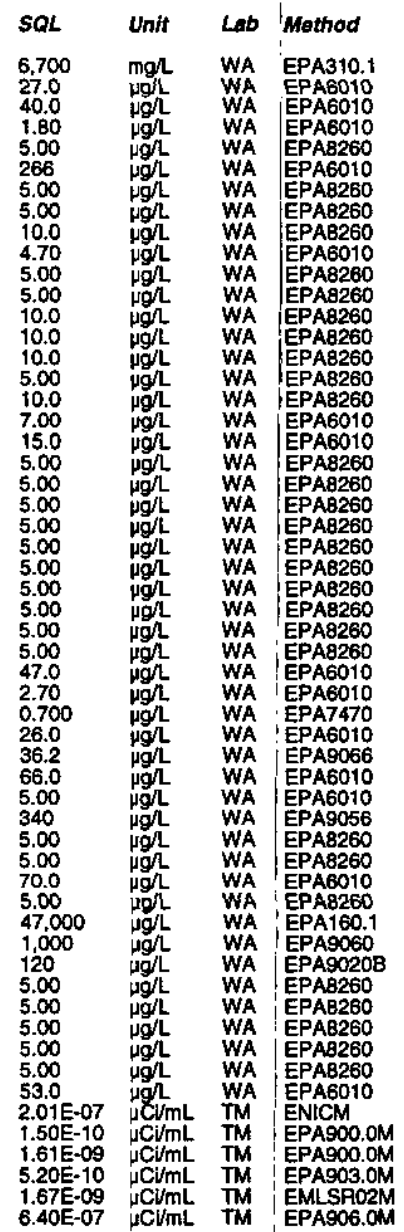

Time: 8.21 erature: $19^{\circ} \mathrm{C}$ Total alkalinity (as CaCO3): $0 \mathrm{mg} / \mathrm{L}$ 


\section{WELL BGO 19DR}

MEASUREMENTS CONDUCTED IN THE FIELD Sample date: $05 / 07 / 98$ (19.1 m) below TOC Water elevation: $231.15 \mathrm{t}(70.46 \mathrm{~m}) \mathrm{ms}$ ) SH: 4.8 conductance: $30 \mu \mathrm{S} / \mathrm{cm}$ Water evacuated from the well prior to sampling: $101 \mathrm{gal}$ ANALYSES

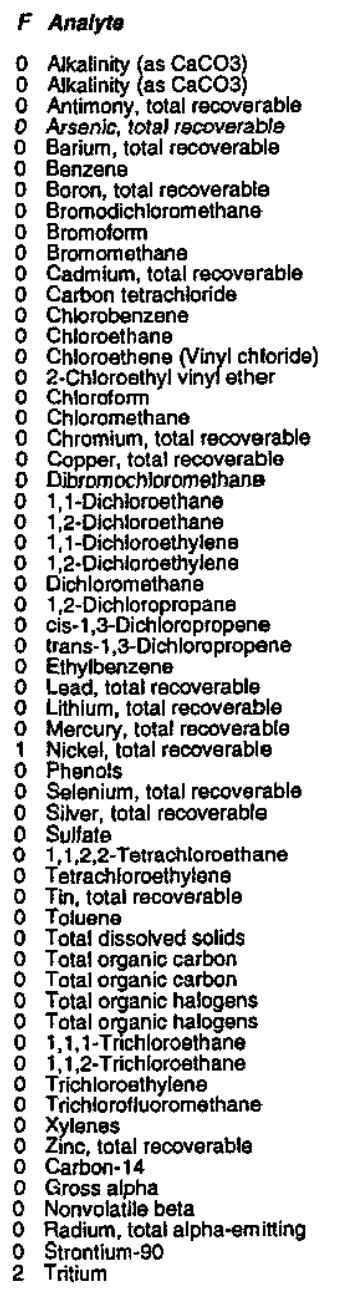

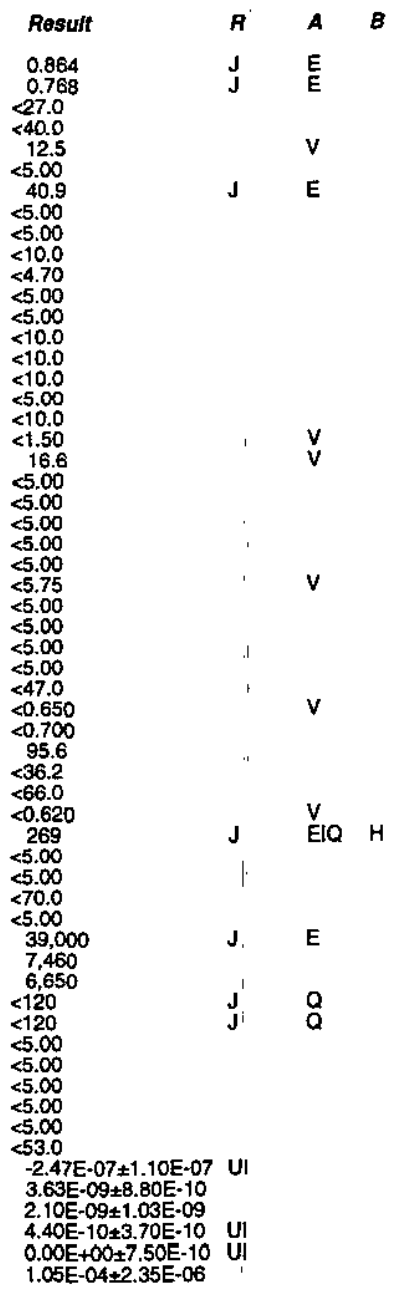

Time: $9: 41$

emperature: $20^{\circ} \mathrm{C}$ Total alkalinity (as CaCOO3): $0 \mathrm{mg} /$

\section{WELL. BGO 20A}

MEASUREMENTS CONDUCTED IN THE FIELD

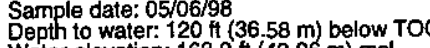
$\mathrm{pH}: 7.4$

P. conductance: $170 \mu \mathrm{S} / \mathrm{cm}$

Water evacuated from the well prior to sampling: $76 \mathrm{gal}$ ANALYSES

\begin{tabular}{|c|c|c|c|}
\hline & Unit & 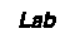 & Method \\
\hline $\begin{array}{l}6.700 \\
27.0 \\
40.0 \\
1.80 \\
5.00 \\
266 \\
5.00 \\
5.00 \\
10.0 \\
4.70 \\
5.00 \\
5.00 \\
10.0 \\
10.0 \\
10.0 \\
5.00 \\
10.0 \\
7.00 \\
15.0 \\
55.00 \\
5.00 \\
5.00 \\
5.00 \\
5.00 \\
5.00 \\
5.00 \\
5.00 \\
5.00 \\
5.00 \\
47.0 \\
2.70 \\
0.700 \\
26.0 \\
36.2 \\
66.0 \\
5.00 \\
340 \\
5.00 \\
5.00 \\
70.0 \\
5.00 \\
47,000 \\
1,000 \\
1,000 \\
120 \\
120 \\
5.00 \\
5.00 \\
5.00 \\
5.00 \\
5.00 \\
53.0 \\
2.03 E-07 \\
1.50-10 \\
1.600-09 \\
5.300-100 \\
\end{array}$ & 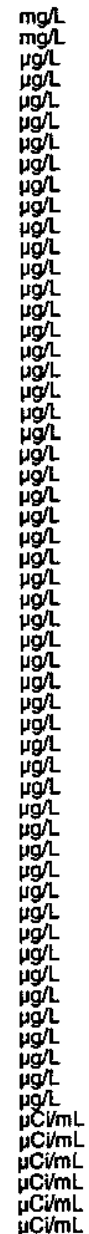 & $\begin{array}{l}\text { WA } \\
\text { WA } \\
\text { WA } \\
\text { WA } \\
\text { WA } \\
\text { WA } \\
\text { WA } \\
\text { WA } \\
\text { WA } \\
\text { WA } \\
\text { WA } \\
\text { WA } \\
\text { WA } \\
\text { WA } \\
\text { WA } \\
\text { WA } \\
\text { WA } \\
\text { WA } \\
\text { WA } \\
\text { WA } \\
\text { WA } \\
\text { WA } \\
\text { WA } \\
\text { WA } \\
\text { WA } \\
\text { WA } \\
\text { WA } \\
\text { WA } \\
\text { WA } \\
\text { WA } \\
\text { WA } \\
\text { WA } \\
\text { WA } \\
\text { WA } \\
\text { WA } \\
\text { WA } \\
\text { WA } \\
\text { WA } \\
\text { WA } \\
\text { WA } \\
\text { WA } \\
\text { WA } \\
\text { WA } \\
\text { WA } \\
\text { WA } \\
\text { WA } \\
\text { WA } \\
\text { WA } \\
\text { WA } \\
\text { TM } \\
\text { TM } \\
\text { TM } \\
\text { TM } \\
\text { TM }\end{array}$ & 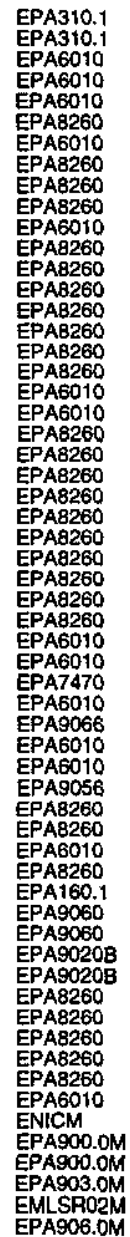 \\
\hline
\end{tabular}

Ansmony, total recoverable

Barium, total recoverable

Boron, total recoverable

Bromodichlorom

Cadmium, total racoverable

Carbon tetrachlorido

Chloroethane

Chloroethene (Vinyl chloride)

Chloroform

Chloromethane Copper, total recoverablo

1,1-Dichloroethane

1.2-Dichlorosthylene
Dichloromethane

1,2-Dichloropropane

trans-1,3-Dichloropropene

Lead, total recoverable

Methium, total recoverable

Nickel, total recoverable

Selenium, total recoverable

Sulfati Tetrachloroethane

Tetrachiforoethyliene

Toluene 0 Tolved solids

Total organic carbon

1,1,1-Trichloroethane

1,1,2-Trichloroethan

Trichlorofluoromethane

Zylenes

Gross alpha

Nonvolatile beta

Radium, total alpha-emittin

Strontium-90
Tritium
Alkalinity (as $\mathrm{CaCO}$ )

1,i-Dichloroethyletse
Time: 10:49

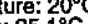
Total alkalinity (as CaCO3): $76 \mathrm{mg} / \mathrm{L}$

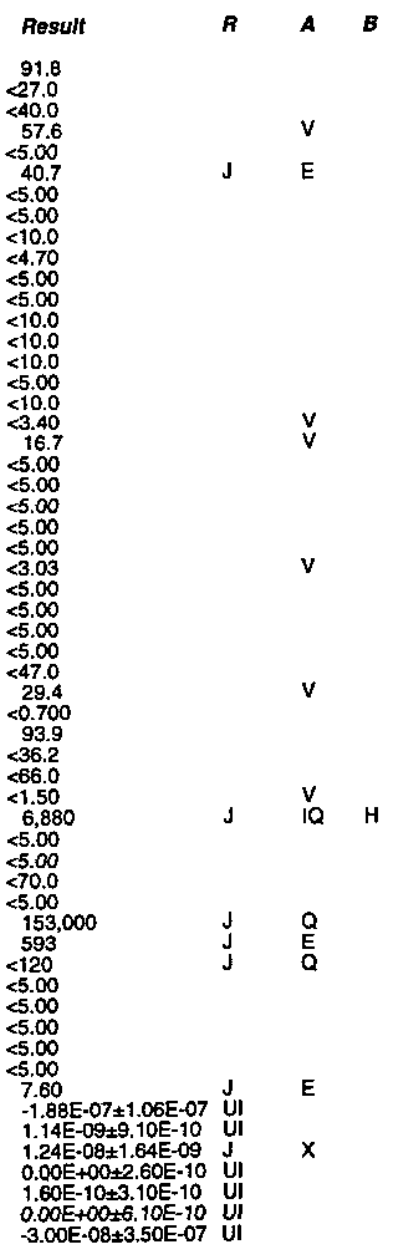

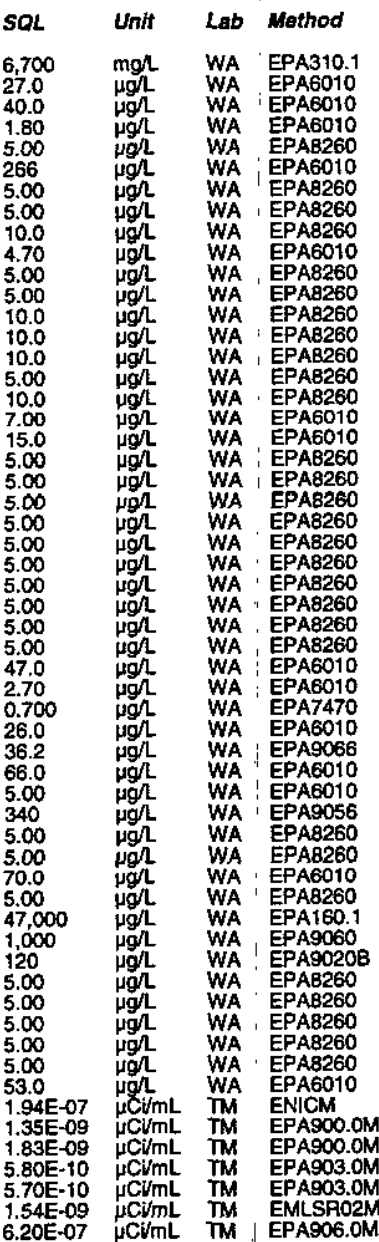




\section{WELL BGO 20AA}

MEASUREMENTS CONDUCTED IN THE FIELD

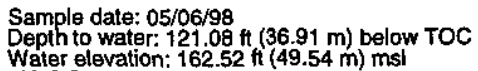

Water ril

Sp: 8.8 . conductance: $140 \mu \mathrm{s} / \mathrm{cm}$

Thibidity. 1 NTU
Water evacuated trom the well prior to sampling: $78 \mathrm{gal}$ ANALYSES

\section{$F$ Analyte}

- Alkalinity (as CaCO3) A Arsenic, total recoverable$$
\text { Berium, total recoverable }
$$

: Boron, total recoverable

0 Bromodlchlor

Bromomethane
0 Cadmilum, total recoverable

Carbon tetrachlorida

- Chloroethane

Chloroethene (Vinyl chlaride)

2-Chloroethy! vinyl ether

Chloromethan

- Chromium, total recoverable

Copper, total recoverab

0 1,1-Dichloroethane

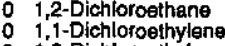

o t,2-Dichloroethylene

Dichloromethane

o cis-1,3-Dichloropropene

Ethylbenzene

Lithium, total recoverable

i Mickel, total recoverable

O Phenols

1,1,2,2-Tetrachloroethane

Tintrachloroethylens

${ }_{0}$ Toluene

Total organic carbon

1,1,1-Trichloroethane

1,1,2-Trichloroethan

Trichloroftuoronethane

Xylenes

Gross alphe

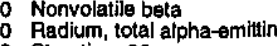

Strontium-9o
Tritium

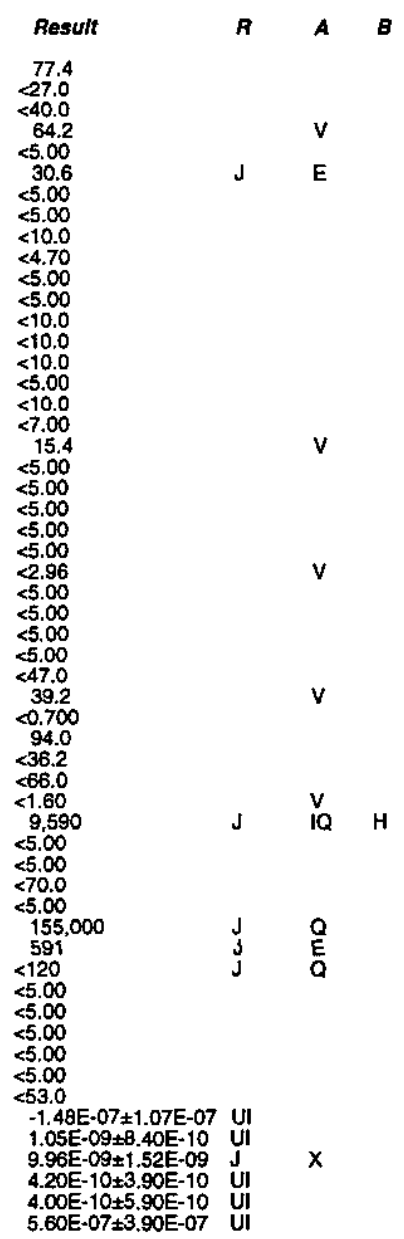

WELL BGO 20B

MEASUREMENTS CONDUCTED IN THE FIELD

Sample date: $05 / 06 / 98$
Depth to water: $54.8 \mathrm{ft}(16.7 \mathrm{~m})$ below TOC
Water totevation: $228.7 \mathrm{tt}(69.71 \mathrm{~m}) \mathrm{ms}$$$
\text { Water e }
$$

Water temperature: $21^{\circ} \mathrm{C}$

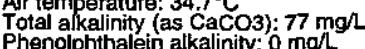

Sp. conductance: $96 \mu \mathrm{S} / \mathrm{cm}$

Water evacuated from the well prior to sampling: $39 \mathrm{gal}$ ANALYSES

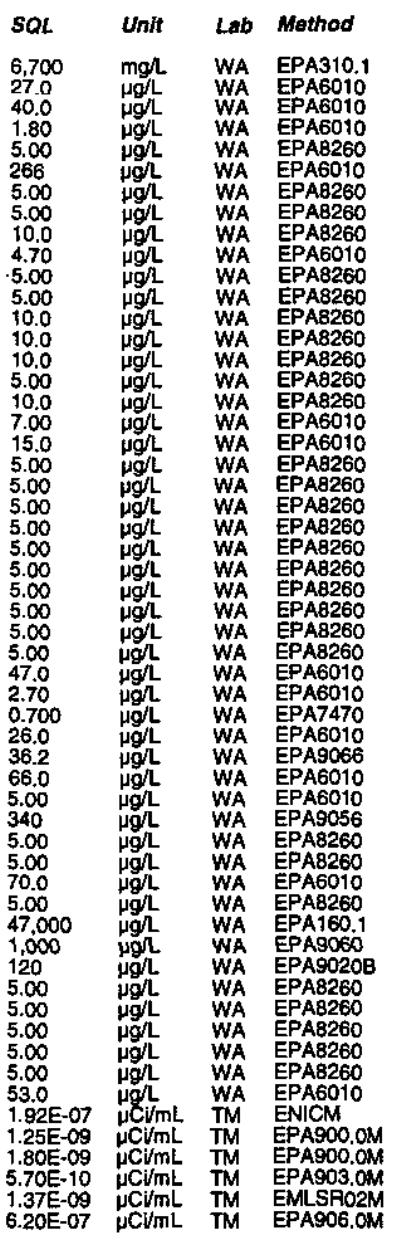

$F$ Anelyte

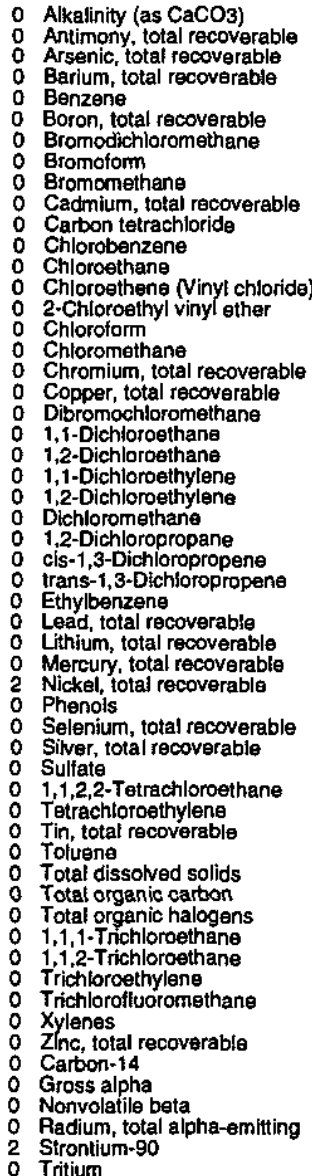

Time: 13:45

Water temperature: $21{ }^{\circ} \mathrm{C}$

Air temperature: $32.3^{\circ} \mathrm{C}$
Total alkalinity (as CaCO3) $40 \mathrm{mg} /$
Rosult

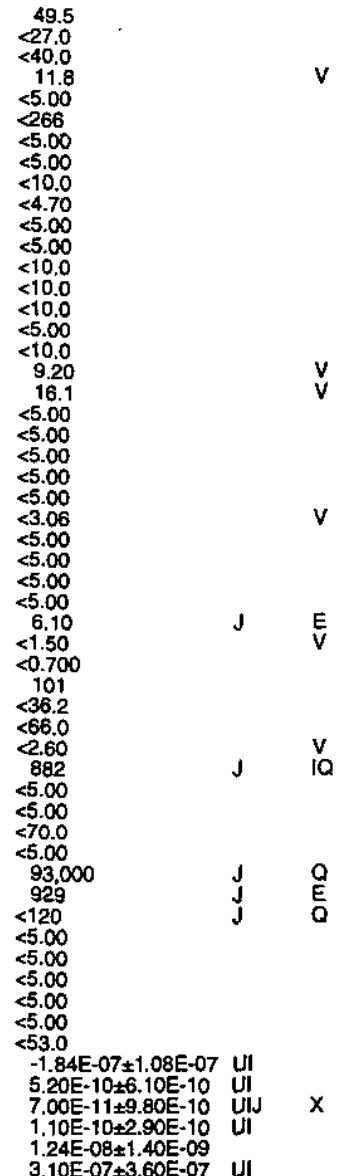




\section{WELL BGO 20C}

MEASUREMENTS CONDUCTED IN THE FIELD

Sample date: 05/06/98

Water elevation: $230.1 \mathrm{ft}(70.14 \mathrm{~m}) \mathrm{msl}$

pH: 5.4 conductance: $28 \mu \mathrm{S} / \mathrm{cm}$

Water evacuated from the well prior to sampling: $68 \mathrm{gal}$ ANALYSES

$F$ Analyte

0 Alkalinity (as $\mathrm{CaCO}$ )

Ansenic, total recoverable

Barium, total recoverable

Boron, total recoverable
Bromodichloromethane

Bromoform

Cadmium, total recoverable

Chloroethene (Vinyl chloride)

Chloroethene (Vinyl chloride)
2-Chloroethyl vinyl ether

Chlorometha

Chromium, total recoverable
Copper, total rocoverable

Copper, total recoverable

$\begin{array}{ll}\text { 1,1-Dichlorothane } \\ 0 & 1,2 \text {-Dichloroethane }\end{array}$

1,1-Dichloroethylen

Dichloromethane

1,2-Dichloropropane

trans-1,3-Dichlopropene

Ethylbenzene

Lithium, total recoverable

Nickel, total recoverable

Selenium, total recoverable

Sulfate 1,1,2-Tetrachloroethan

Tetrachloroethylene

Toluene

Total dissolved solids

Total organic halogens

1, 1,1-Trichloroethans

Trichloroethylene
Trichlorofluoromethane

Zilenes total recoverable

Gross alpha

Padium, total alpha-emitting

Strontium-90
Tritum

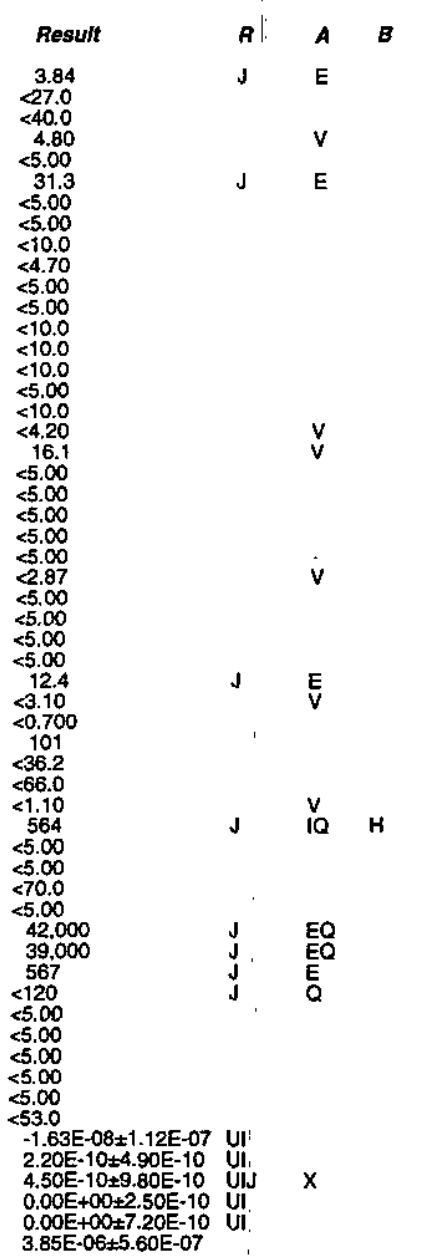

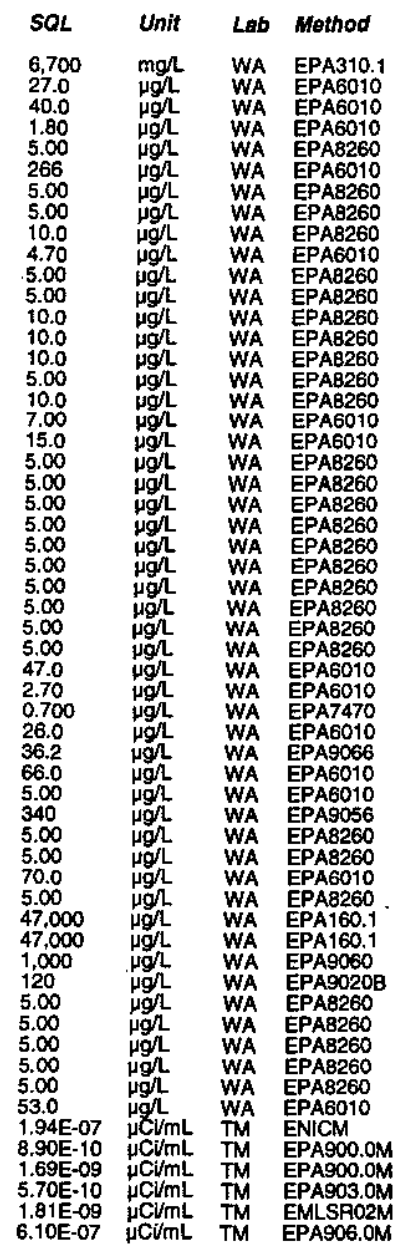

\section{WELL BGO 20D}

MEASUREMENTS CONDUCTED IN THE FIELD

Time: 12:05

remperature: $20^{\circ} \mathrm{C}$

Total alkalinity (as CaCOS): $4 \mathrm{mgl}$

Sample date: 05/06/98

Water elevation: Not available

$\mathrm{Sp}$ : Not avaductancle: Not available

No water was evacuated from the well prior to sampling.

ANALYSES

$F$ Analyte

- Alkalinity (as $\mathrm{CaCO}$ )

Antimony, total recoverable

Benzene recoverable

Boron, total recoverable

Oromotomethan

Cadmium, total recoverable

Carbon tetrachloride

Chloroethane

Chloroethene (Vinyl chloride)

2-Chlorosthy

Chloromethane

Copper, total recoverabl

1,1-Dichlorosthane

1,1-Dichloroethylen

Dichloromethane

1,2-Dichloropropane
cis-1,3-Dichloropropene

trans-1,3-Dichloroprope

Lead, total recoverable

Mercury, total recoverable
Nickel, total recoverable

Shenols Selenium, total recoverable

Siver, total recoverable

: Sulfate Titrachloroethane

Tetrachloroethylene

Total dissoved solids

Total organic carbon

$1,1,1-$ Trichloroethane
$1,1,2-$ Trichloroethane

Trichlorosthylene

Zylenes

Carbon-14

Nonvolatile beta
Radium, total alpha-emitting

Radium, tota
Strontium-90
Tritium
Time: Not available

Arempere: Not avaiabailab

Total alkalinity (as CaCO3): Not available

\begin{tabular}{|c|c|c|c|c|c|c|c|}
\hline Result & $\boldsymbol{B}$ & A & $B$ & $S Q L$ & Unit & $L a b$ & Mothod \\
\hline 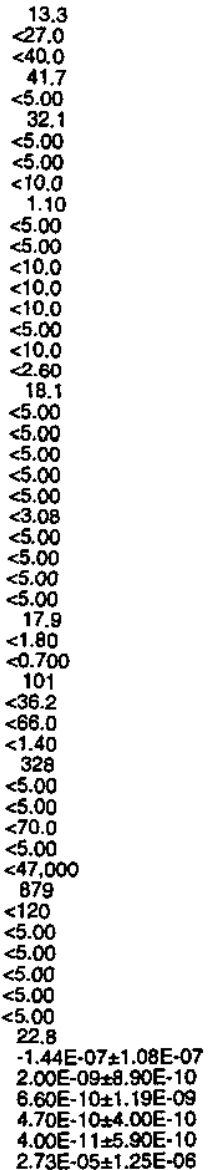 & $\begin{array}{l}J \\
J\end{array}$ & $\begin{array}{l}Q \\
\text { E } \\
Q\end{array}$ & $\mathrm{H}$ & $\begin{array}{l}6,700 \\
27.0 \\
40.0 \\
1.80 \\
5.00 \\
266 \\
5.00 \\
5.00 \\
10.0 \\
4.70 \\
5.00 \\
5.00 \\
10.0 \\
10.0 \\
10.0 \\
5.00 \\
10.0 \\
7.00 \\
15.0 \\
5.00 \\
5.00 \\
5.00 \\
5.00 \\
5.00 \\
5.00 \\
5.00 \\
5.00 \\
5.00 \\
5.00 \\
47.0 \\
2.70 \\
0.700 \\
26.0 \\
36.2 \\
66.0 \\
5.00 \\
340 \\
5.00 \\
5.00 \\
70.0 \\
5.00 \\
47.000 \\
1.000 \\
120 \\
5.00 \\
5.00 \\
5.00 \\
5.00 \\
5500 \\
53.0 \\
1.946-07 \\
1.05-09 \\
2.045-09 \\
5.600-10 \\
1.49-09 \\
6.300-07\end{array}$ & 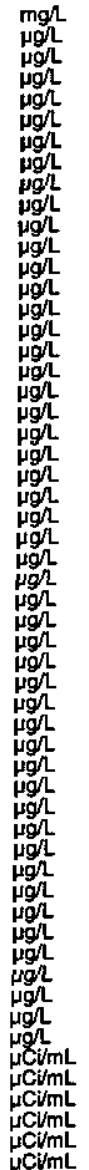 & $\begin{array}{l}\text { WA } \\
\text { WA } \\
\text { WA } \\
\text { WA } \\
\text { WA } \\
\text { WA } \\
\text { WA } \\
\text { WA } \\
\text { WA } \\
\text { WA } \\
\text { WA } \\
\text { WA } \\
\text { WA } \\
\text { WA } \\
\text { WA } \\
\text { WA } \\
\text { WA } \\
\text { WA } \\
\text { WA } \\
\text { WA } \\
\text { WA } \\
\text { WA } \\
\text { WA } \\
\text { WA } \\
\text { WA } \\
\text { WA } \\
\text { WA } \\
\text { WA } \\
\text { WA } \\
\text { WA } \\
\text { WA } \\
\text { WA } \\
\text { WA } \\
\text { WA } \\
\text { WA } \\
\text { WA } \\
\text { WA } \\
\text { WA } \\
\text { WA } \\
\text { WA } \\
\text { WA } \\
\text { WA } \\
\text { WA } \\
\text { WA } \\
\text { WA } \\
\text { TM } \\
\text { TM } \\
\text { TM } \\
\text { TM } \\
\text { TM }\end{array}$ & 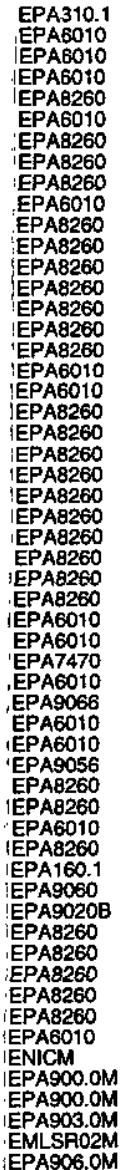 \\
\hline
\end{tabular}


AMALYTICAL RESULTS

\section{WELL BGO 210}

MEASUREMENTS CONDUCTED IN THE FIELD

Sample date: 05/07/98

Water alevat

Sp. conductance: $48 \mu \mathrm{S} / \mathrm{cm}$

Water evacuated from the well prior to sampling: $1 \mathrm{gal}$

ANALYSES

$F$ Aralyto

- Alkalinity (as $\mathrm{CaCO}$ )

Arsenic, total recoverable
Barium, total recoverable

Benzene

Boron, total recoverable
Bromodichloromethane

Bromotorm

Cadmium, total recoverable

Carbon tetrachlorid

Chloroethene (Vinyl chloride)
2-Chloroethyl vinylether

Chloroform

Chrormiuthane

Coppes, total recoverable

1,1-Dichloroetthane

1,1-Dichloroethylene

1,2-Dichloroethylen

1,2-Dichloropropan

Lead, total recoverable

Mercury, total recoverable

Nickel, total recoverable

Selenium, total racoverable

Sulfiat, to.

$1,1,2,2$-Tatrachloroethan

Tetrachtoroethylene

Toluene

Total organic carbon

1,1,1-Irfchloroethane

1.1,2-Trichloroethane

Trichlorofluoromethane

Zylenes

Canc, total reco
0 Gross alpha

Nonvolatile beta

Radium; total alpha-emitting

Trtrontium-
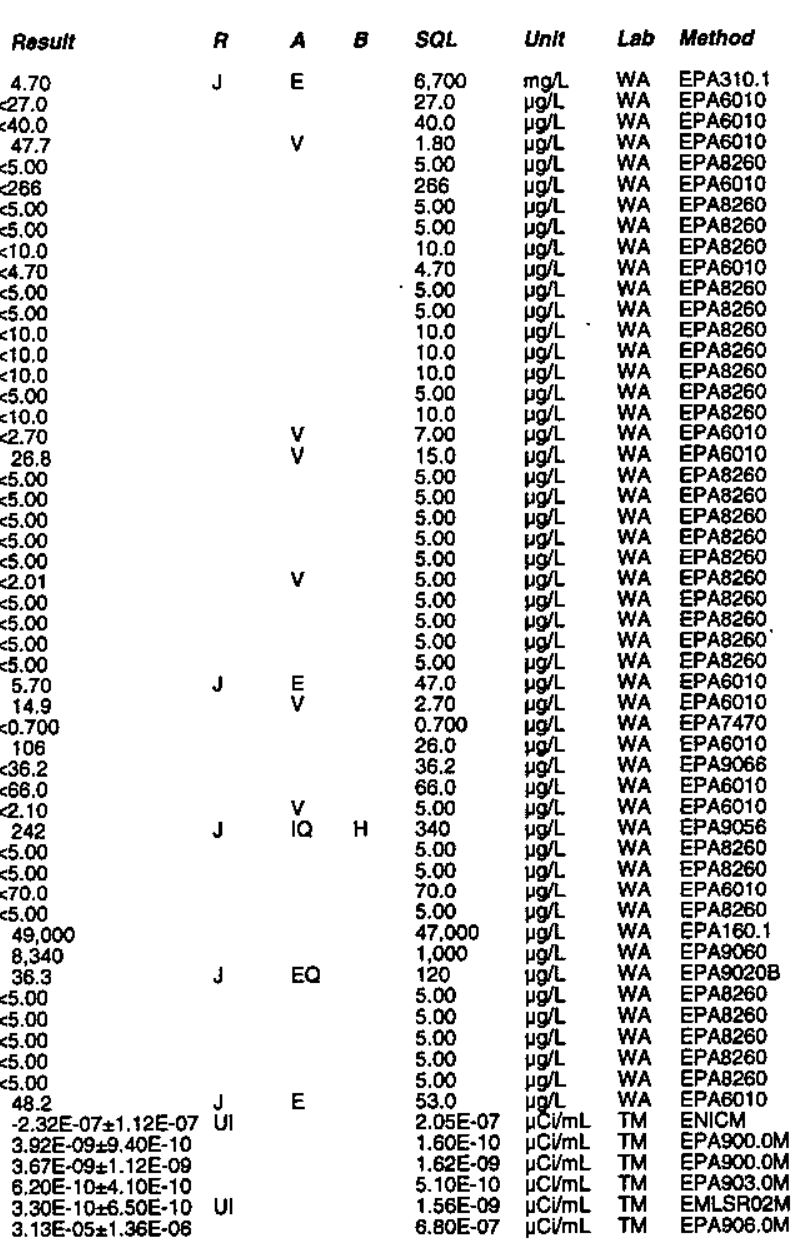

Time: 12:40

Total alkalinity (as CaCO3): $7 \mathrm{mgh}$
Depth to water: $51.05 \mathrm{ft}(15.56 \mathrm{~m})$ below TOC

cis-1,3-Dichloropropene

trans-1,3-Dichloropropene

\section{WELL BGO 22DX}

MEASUREMENTS CONDUCTED IN THE FIELD

Sample date: 05/07/98

Depth to water. $51 \mathrm{tt}(15.54 \mathrm{~m})$ below TOC

Water elevation: $234.7 \mathrm{tt}$ (71.54

Sp. conductance: $44 \mu \mathrm{S} / \mathrm{cm}$

Water evacuated from the well prior to sampling: $50 \mathrm{gal}$

ANALYSES

F Analyte

Result

Alkalinity (as CaCO3)

A Arsenic, total recoverable

$\begin{array}{ll}0 & \text { Barium, to } \\ 0 & \text { Benzens } \\ 0 & 0\end{array}$

Boron, total recoverable
Bromodichloromethane

Bromodichloromethane

Bromodich

Bromoform

Bromomethane
Bromomethane

Cadmium, total recoverable

Carbon tetrachloride

Carton tetrachlorid

Chlorobenzene

Chloroethane
Chloroetthane
Chlone

Chloroethene Vinyl chloride

Chloroes he vinyl chloride

2-Chloroettryl vinyl ether

2-Chloroethyl vinyl ether
2-Chloroethyl vinyl ether

Chloroform

Chloroform

Chloromethane

Chromium, total recoverable

Copper, total recoverable

Dibromochloromethane

1,1-Dichloroethane

1.1-Dichloroethane

1,2-Dichloroethane

1.2-Dichloroethane

i,1-Dichloroethylene

1,2-Dichloroethylene

Dichloromethene

Dichloromethane

1,2-Dlechloropropane

1,2-Dichloropropane

cis-1,3-Dichoropropen

cis-1,3-Dichloropropente

trans- $-1,3$-Dichloropropenen
0 trans 1 1,3-Dichloropropene

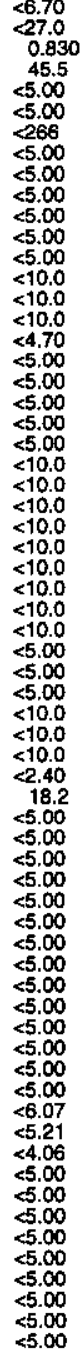

Wilter temperature: $20^{\circ} \mathrm{C}$

Total alkalinity (as CaCO3): $0 \mathrm{mg} /$

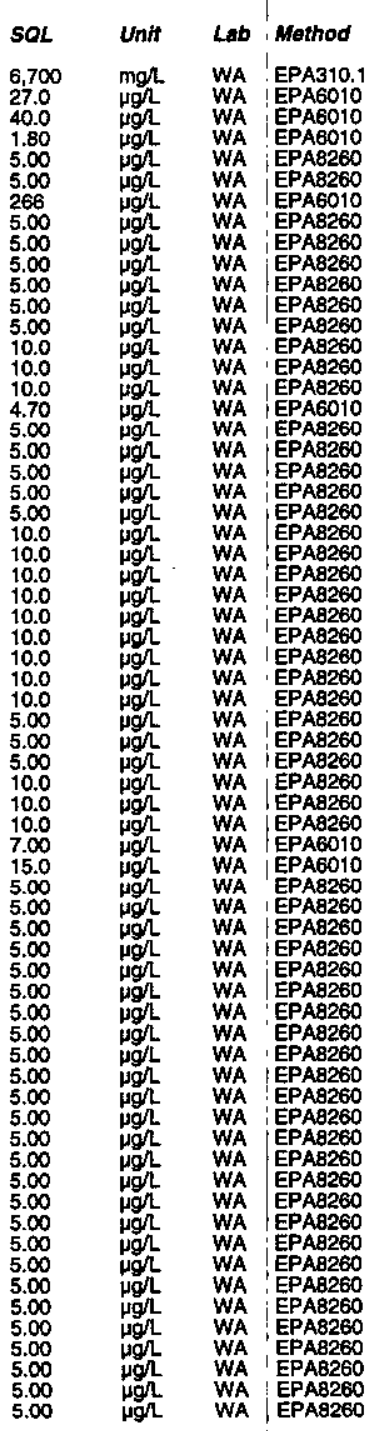

ESH-EMS-980569 
Well BGO 22DX collected on 05/07/98 (cont.)

\begin{tabular}{|c|c|c|c|c|c|c|c|c|}
\hline Analyte & Result & $\boldsymbol{R}$ & A & $B$ & SOL & Unit & Lab & Method \\
\hline 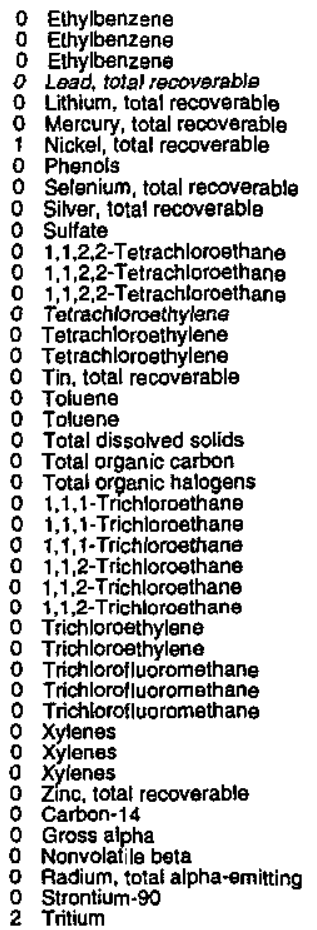 & 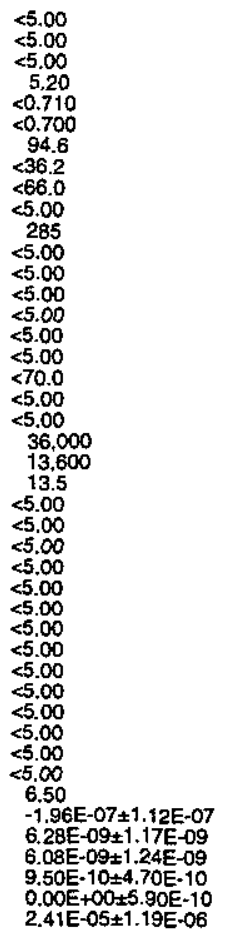 & $j$ & EIO & H & $\begin{array}{l}5.00 \\
5.00 \\
5.00 \\
47.0 \\
2.70 \\
0.700 \\
26.0 \\
36.2 \\
66.0 \\
5.00 \\
340 \\
5.00 \\
5.00 \\
5.00 \\
5.00 \\
5.00 \\
5.00 \\
70.0 \\
5.00 \\
5.00 \\
47.000 \\
1.000 \\
120 \\
5.00 \\
5.00 \\
5.00 \\
5.00 \\
5.00 \\
5.00 \\
5.00 \\
5.00 \\
5.00 \\
5.00 \\
5.00 \\
5.00 \\
5.00 \\
2.03 E-07 \\
1.50-10 \\
1.61--09 \\
5.10-10 \\
1.51-09 \\
6.60 E-07\end{array}$ & 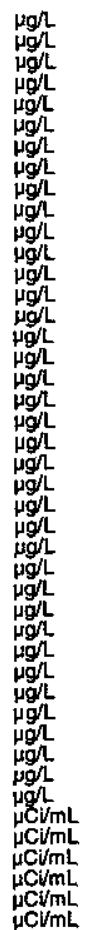 & $\begin{array}{l}\text { WA } \\
\text { WA } \\
\text { WA } \\
\text { WA } \\
\text { WA } \\
\text { WA } \\
\text { WA } \\
\text { WA } \\
\text { WA } \\
\text { WA } \\
\text { WA } \\
\text { WA } \\
\text { WA } \\
\text { WA } \\
\text { WA } \\
\text { WA } \\
\text { WA } \\
\text { WA } \\
\text { WA } \\
\text { WA } \\
\text { WA } \\
\text { WA } \\
\text { WA } \\
\text { WA } \\
\text { WA } \\
\text { WA } \\
\text { WA } \\
\text { WA } \\
\text { WA } \\
\text { WA } \\
\text { WA } \\
\text { WA } \\
\text { WA } \\
\text { WA } \\
\text { TM } \\
\text { TM } \\
\text { TM } \\
\text { TM } \\
\text { TM }\end{array}$ & 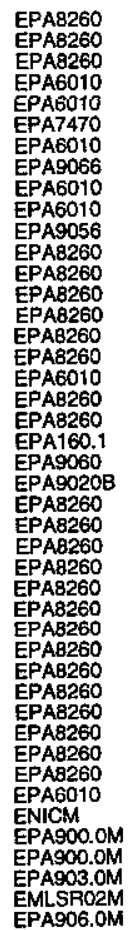 \\
\hline
\end{tabular}

\section{WELL BGO 23D}

MEASUREMENTS CONDUCTED IN THE FIELD

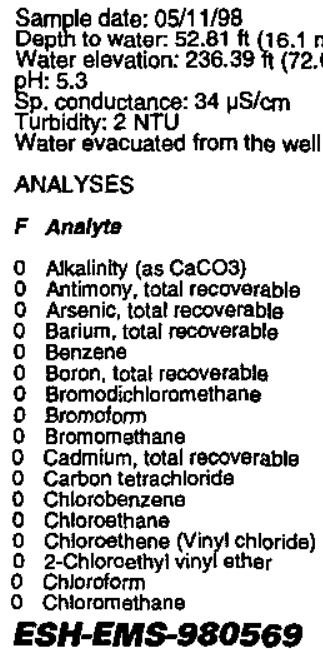

Total alkalinity (as CaCO3): $2 \mathrm{mgh}$
Phenolphthalein alkalinity: $0 \mathrm{mg} /$.

Resuft
82.6
$<27.0$
$<4.0$
12.6
$<5.00$
266
$<5.00$
55.00
$<10.0$
$<4.70$
$<5.00$
5.00
510.0
$<10.0$
$<10.0$
55.00
$<10.0$

WA EPAB260
Well BGO 23D collected on 05/1 1/98 (cont.)

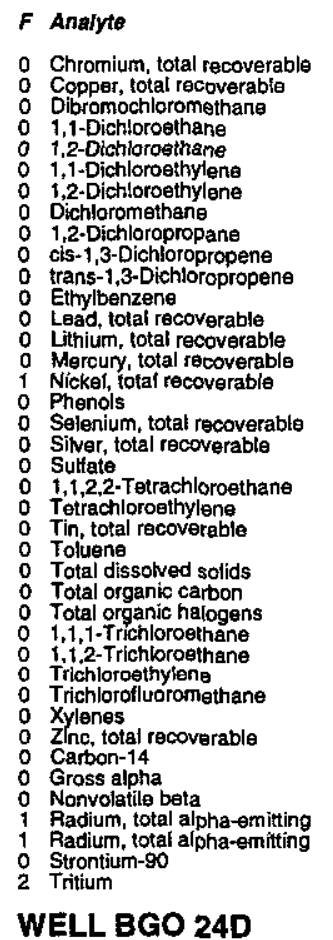

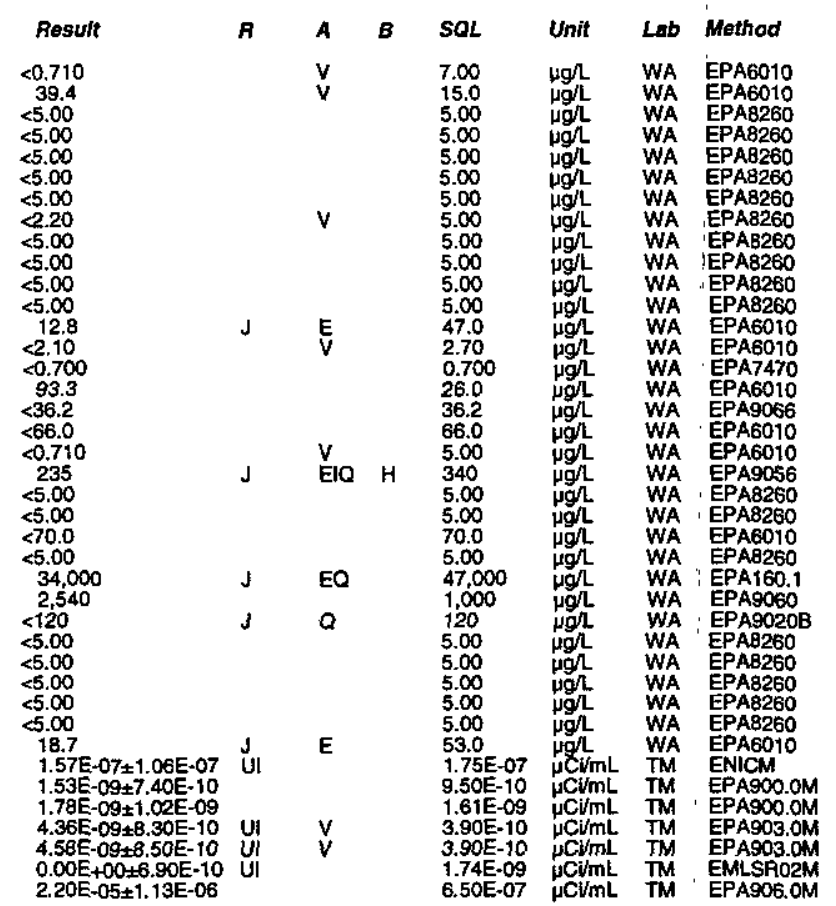

MEASUREMENTS CONDUCTED IN THE FIELD

\section{Sample date: $05 / 11 / 98$
Depth to water: $54.9 \mathrm{ft}$ (16.73 m) below TOC
Water}

Water et

Sp. conductance: $52 \mu \mathrm{S} / \mathrm{cm}$

Water evacuated from the well prior to sampling: $1 \mathrm{gal}$

ANALYSES

$F$ Anatyto

- Alkalinity (as $\mathrm{CaCO}$ )

- Artimony, total recoverable

Barium, total recoverable

Benzene
Boron, total recoverable

Bromotomn

Bromomethane
Cadmium, total recoverable

Carton tetrachloride

Chlorobenzene

Chloroethere (Vinyl chloride)

Chiloroform

Chloromethane

Copper total recocoverabla

Dibromochloromethane

$-30$

Result
15.7
27.0
$<40.0$
14.1
$<5.00$
$<266$
$<5.00$
$<5.00$
$<10.0$
54.70
$<5.00$
$<5.00$
$<10.0$
$<10.0$
$<10.0$
$<5.00$
$<10.0$
$<4.20$
$<5.80$
$<5.00$
$<5.00$

Time: 11:08

Water temperature: $22.3^{\circ} \mathrm{C}$ Total akealinity (as Caco3): $14 \mathrm{mg} /$
Phenolphthalein alkalinity: $0 \mathrm{mg} /$

(1)

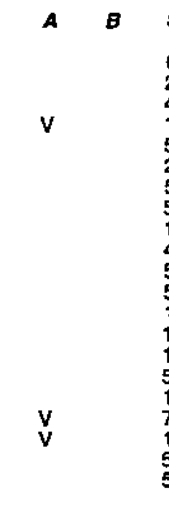


ANALYTICAL RESULTS

Well BGO 24D collected on 05/1 1/98 (cont.)

$F$ Analyte

o 1,2 -Dichloroethane 1,2-Dichloroethylene Dichlo:omethane cis-1,3-Dichloropropene trans-1,3-Dichloropropen Lead, total recoverable Lithium, 'total recoverable Nickel, total recoverable Phenols
Phenols

Silenium, total recoverable Sulfatio 1,1,2,2-Tatrachloroethan Tetrachlorosthylene Toluene Total organic carbon 1,1,1-Trichloroethane 1,1,2-Trichloroethan Trichlorofluoromethan Zinenes total recoverable Carbon-14

Nonvolatile beta
Radium, total alpha-emitting 1 Strontium-90

\section{WELL BGO 33C}

MEASUREMENTS CONDUCTED IN THE FIELD Sample date: $06 / 15 / 98$ Depth to water: 53.18 ft $(16.21 \mathrm{~m})$ below TOC

$\mathrm{HH}: 5.2$ p. conductance: $62 \mu \mathrm{S} / \mathrm{cm}$

Water evacuated from the well prior to sampling: 23 ga ANALYSES

ANALYSES

- Akkalinity (as $\mathrm{CaCO}$ ) Antimom, total recoverable Arsenic, total recoverable
Barium, total recoverable

Benzene
Beryllium, lotal recoverable Boron, total recoverable

Bromide

Bromodichloromethane

Bromotorm

Cad́mium, total recoverable

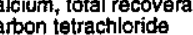

Chloride

(

Chloroethene (Vinyl chloride)

Chlorotorm

Chloromethane

5SH-EMS-980569

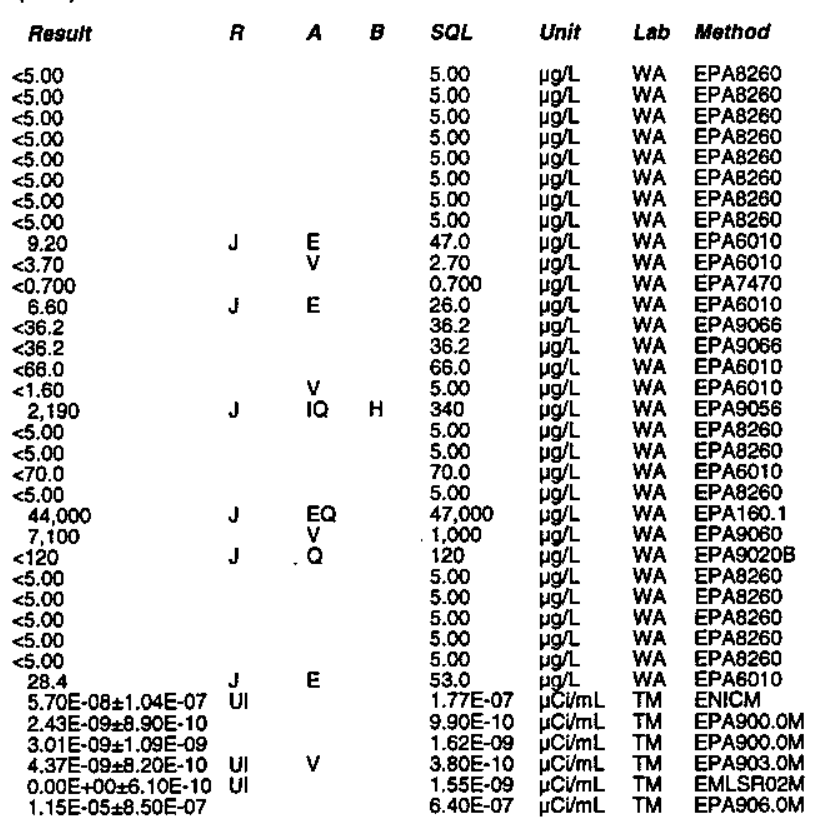

Time: 10:08

Wirter temperature: $20^{\circ} \mathrm{C}$

Total alkalinity (as CaCO3): $7 \mathrm{mg} /$
Phenolphthalein alkalinity: $0 \mathrm{mg} /$

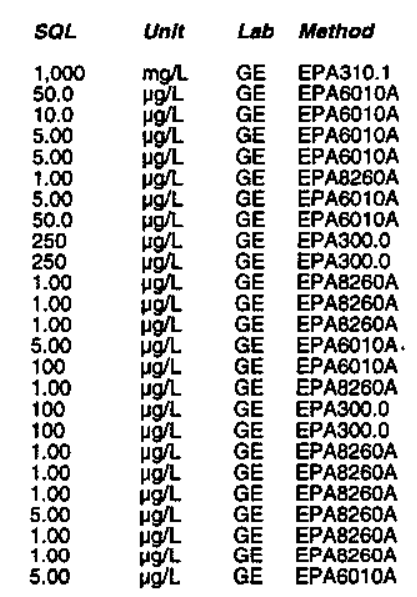

Well BGO 33C collected on 06/15/98 (cont.)

$F$ Analyte

Cobat, total recoverable

- Disromochloromethan

: 1,1-Dichloroethane

$1,1-D i c h$ loroethylene
trans $-1,2$-Dichloroethylene 1,2-Dichloropropan

cis-1,3-Dichloroprapene

Eron, total recoverable

Lead, total recoverab!e

Magnesium, total recoverable

Mercury, lotal recoverable

Nitrate as nitrogen
Nitrate as nitrogen

Potassium, total recoverable

Selenium, total recoverabie

Sodium, total recoverab

Suliate, Tetrachloroethane

Thallium, total recoverable

Tin, total recoverable

Total dissolved solids

Total organic halogens

1, 1, , - Trichloroethan

Trichloroethylene Vanadium, total recoverable

Xylenes
Zinc, total recoverable

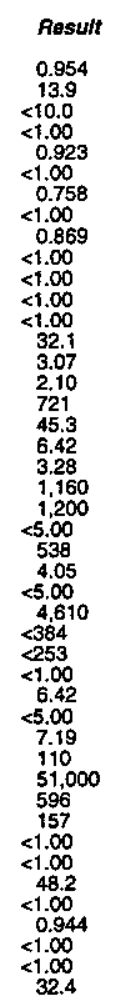

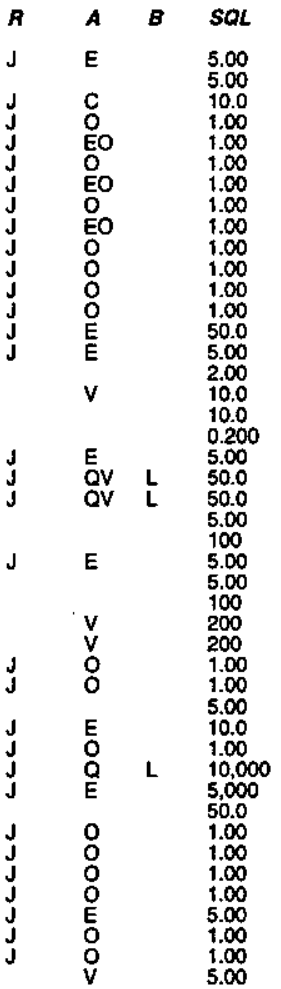

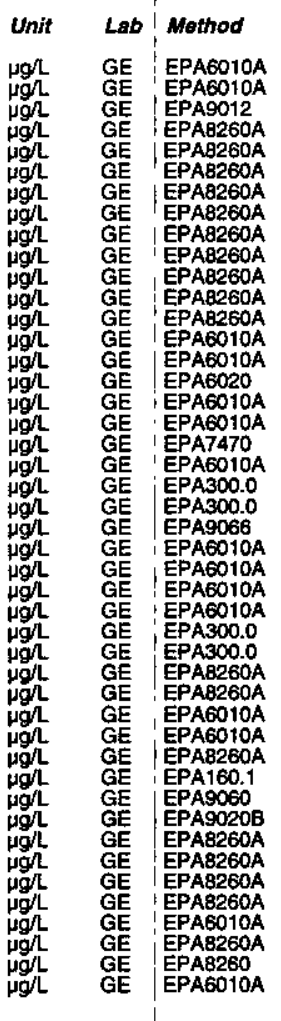

WELL BGO 33C

MEASUREMENTS CONDUCTED IN THE FIELD

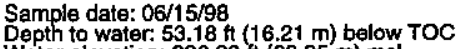

Water elevation: $226.22 \mathrm{ft}(68.95 \mathrm{~m}) \mathrm{m}$

$\mathrm{pH}: 5.2$ conductance: $60 \mu \mathrm{S} / \mathrm{cm}$

Water evacuated from the well prior to sampling: $20 \mathrm{ga}$

ANALYSES

$F$ Aralyto

A Alkalinity (as $\mathrm{CaCO}$

Alkalinity (as $\mathrm{CaCO} 3$ )

Aluminum, total recoverable

Aluminum, total recoverable

Antimony, total recoverable

Antimony, total recoverab

Arsenic, total recoverable

Arsenic, total recoverable

Barium, total recoverable

Barium, total recoverable
Barium, total recoverable

3-31

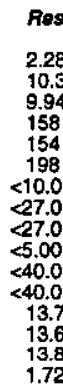

2.28
10.3
9.94
158
154
198
10.0
27.0
27.0
5.00
40.0
40.0
13.7
13.6
13.8
1.72
Time: 12:00

perature: $22.6^{\circ} \mathrm{C}$

Air temperature: $31.6 \mathrm{C}$
Total alkalinity (as CaCo3): $7 \mathrm{mgh}$
Phenolphthalein alkalinity: $0 \mathrm{mg} / \mathrm{L}$

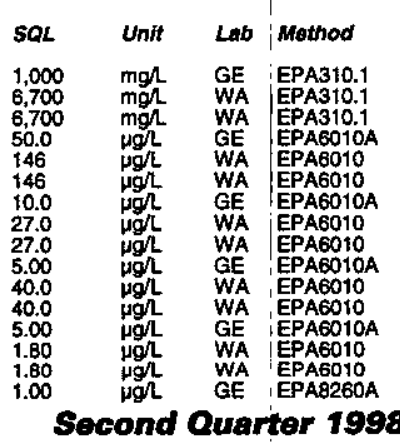


Well BGO $33 \mathrm{C}$ collacted on 06/15/98 (cont.)

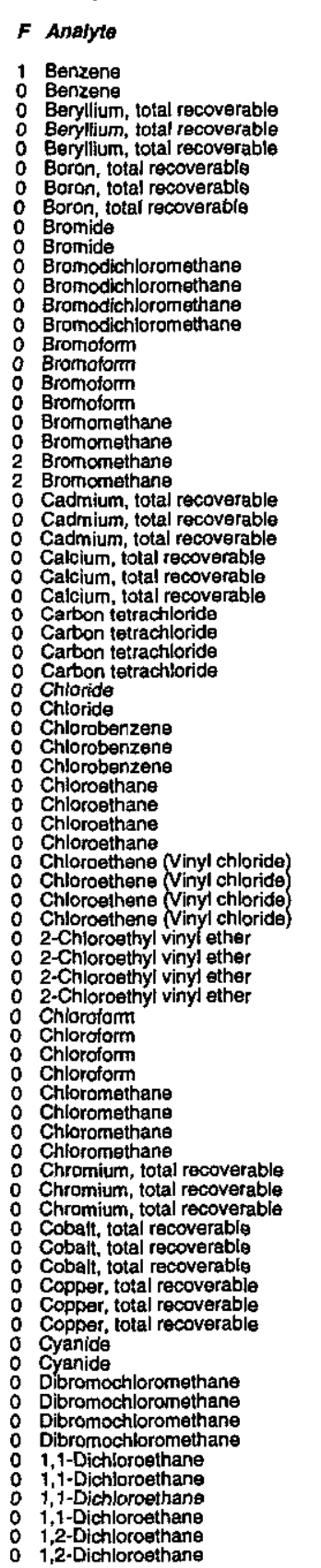

ESH-EMS-980569
Well BGO $33 \mathrm{C}$ collected on 06/15/98 (cont.)

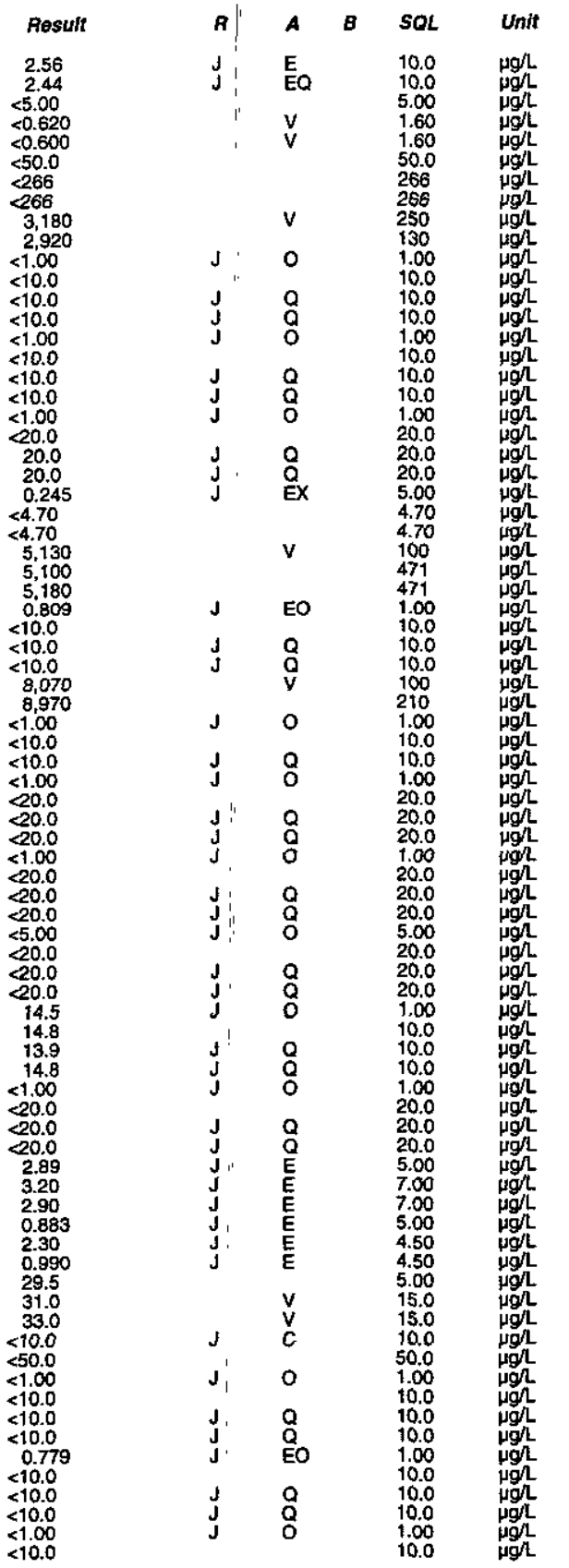

$F$ Analyte

$\begin{array}{ll}0 & \text { 1,2-Dichloroethane } \\ 0 & 1,2 \text {-Dichloroethane }\end{array}$

1.1-Dichloroethylene

1,1 -Dichloroethylene
0
trans-1,2-Dichloroethyler

0
0
trans-1,

0 trans-1,2-Dichloroethy

Dichloromethane

0 Dichloromethan

1,2-Dichloropropan

thoropropane

cis-1,3-Dichloropropen

cis-1.3-Dichoropropene

cis-1,3-Dichloropropene

trans-1,3-Dichloropropenen

trans-1,3-Dichloropropene

Ethylbenzene

Iron, total recoverable

Iron, total recoverable

Lithium, total recoverable

Magnesium, total recoverabje

Magnesium, total recoverabie

Manganese, total recoverab

Mercury, total recoverab!

Mercury, total recoverable

Nickel, total recoverable

Nitrate as nitrogen

o Phenols

Potassium, total recoverable

Potassium, total recoverabl

Selenium, total recoverable Selenium, total recoverable

Silver, total recoverable

Silver, total recoverable

Sodium, total recoverabt

Sulfate

o $1,1,2,2-$ Tetrachloroethane

1,1,2,2.Tetrachloroethane

$1,1,2,2$ Tatrachloroeth

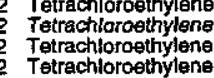

B-32
Lead, total recoverabibie

Mercury, total recoverabial

Sodium, total recoverable

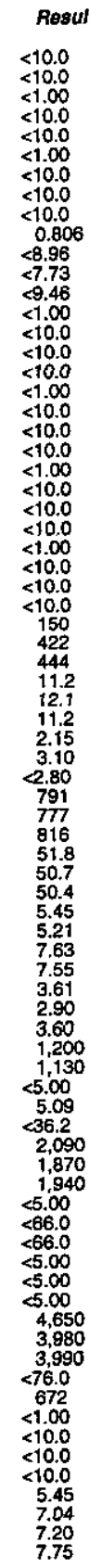

8 A soL

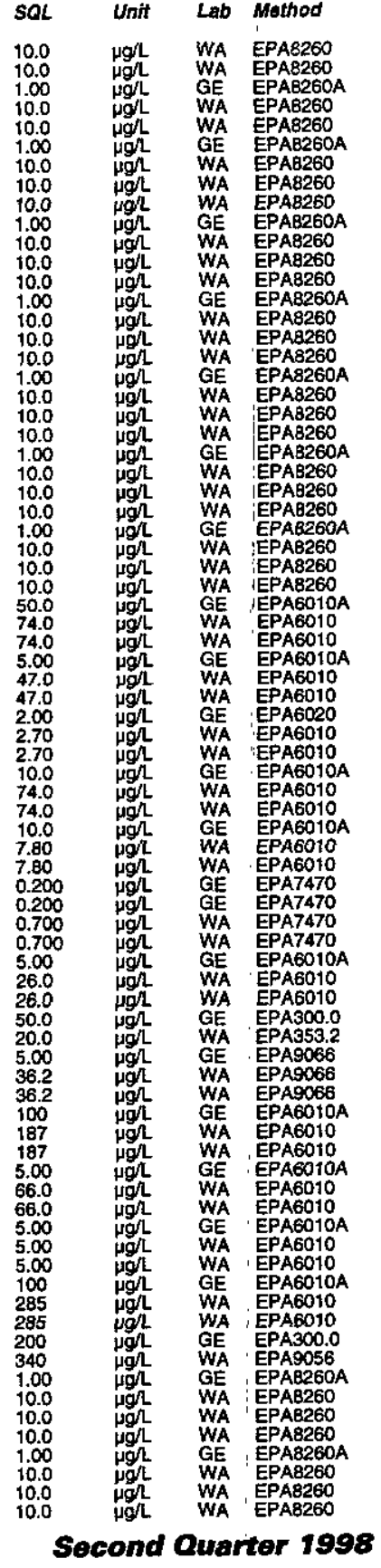


Well BGO 33C collected on 06/15/98 (cont.)

$F$ Analyte

Besuit

Thallium, total recoverable

Tin, total recoverab Tin, total recoverable 0 Toluene

Toluene
Total dissolved solids
Total dissolved solids Total organic carbon Total organic halogens Total organic hatogen $1,1,1$-Trichloroethan 1.1,1-Trichloroethan $1,1,2$-Trichloroethane 1,1,2-Trichlorosethane Trichloroethylene Trichloroethylene

Trichiorofiluoromethan Trichlorofluoromethan Vanadium, total recoverat Vanadium, total recoverable
Vanadium, total recoverable m/p-xylene Xylenes xylenos

\section{Zinc, total recoverable} Zinc, total recoverable Carbon-14

Gross alpha

Nonvolatile beta

O Radium, total alpha-mitting Strontium-90

2 Tritium

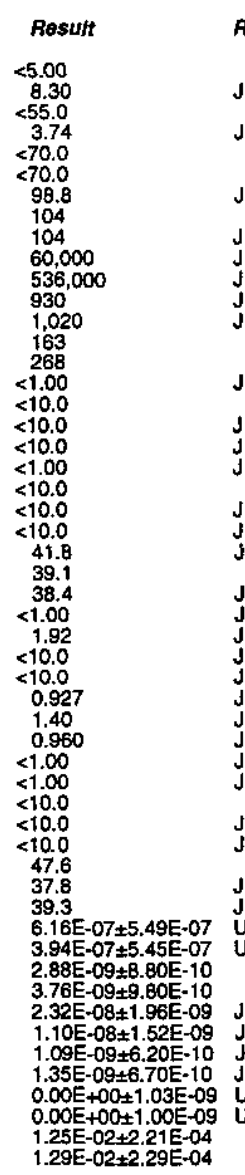

\section{WELL BGO 33C Replicate}

MEASUREMENTS CONDUCTED IN THE FIELD

\section{Sample date: $06 / 15 / 98$
Depth to water: $53.18 \mathrm{ft}(16.21 \mathrm{~m})$ below TOC \\ Water e \\ $\mathrm{Sp}$. conductance: $60 \mu \mathrm{S} / \mathrm{cm}$}

Water evacuated from the well prior to sampling: $20 \mathrm{gat}$

ANALYSES

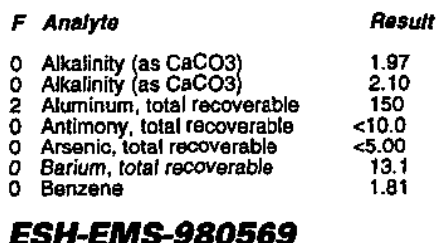

Well BGO $33 \mathrm{C}$ collected on 06/15/98 (cont.)

A

Analyte

Rosuft

$\begin{array}{ll}0 & \text { Beryllium, total recoverable } \\ 0 & \text { Boron, total recoverable } \\ 0 & \text { Bromide }\end{array}$

Bromidedichloromethan

Bromoform

Cadmium, total recoverable Calcium, total recoverablo

Chlorobenzene

Chiloroethenene (Vinyl chloride)

Chibromethane

Chromium, total recoverable

copper a la reverable

Dibromochloromethane

1.1-Dichloroethane

1,1-Dichlorosthylens
trans-1,2-Dletloreethylene

Dichloromethane

cis-1,3-Dichloropropene
trans-1,3-Dichloropropene

Iron, total recoverable

Lead, total recoverable

Magnesium, total recaborable Mercury, total recoverab

Nickel, total recoverablo

Phenols

Potassium, lotal recoverable

Silver, total recoverable

in, total recoverable

$1,1,2,2$-Tatrachloroethane

Thanlium, total recoverable
Tin, total recoverable

Toluene Total organic carbon Total organlc halogens 1,1,2. Trichloroethan Trichloroethylene
Vanadiutluoromethane
Votal recoverat Vanadium, to

Xylenes
Zlnc, total recoverable

Time: 12:00

Air temperature $316^{\circ} \mathrm{6} 6^{\circ} \mathrm{C}$

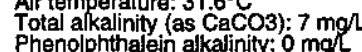

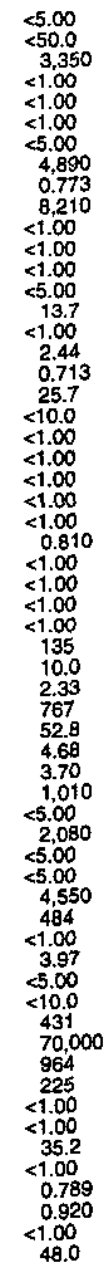




\section{WELL CDS 1P}

MEASUREMENTS CONDUCTED IN THE FIELD

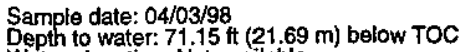
Water elevation: Not available

$\mathrm{pH}$ : 4.8 conductance: $54 \mu \mathrm{S} / \mathrm{cm}$

ANALYSES

\begin{tabular}{|c|c|c|c|c|c|c|c|c|}
\hline F Analyte & Resuft & $\boldsymbol{R}^{\prime}$ & $A$ & $B$ & SOL & Unit & Lab & Method \\
\hline $\begin{array}{ll}0 & \text { Benzene } \\
0 & \text { Ethylbenzene } \\
0 & \text { Methyl tert-butyl ether } \\
0 & \text { Tofturene } \\
0 & \text { Xylenes }\end{array}$ & $\begin{array}{l}<5.00 \\
<5.00 \\
55.00 \\
5.00 \\
<5.00\end{array}$ & 1 & & & $\begin{array}{l}5.00 \\
5500 \\
5.00 \\
5.00 \\
5.00\end{array}$ & $\begin{array}{l}\mu g / h \\
\mu g h \\
\mu g h \\
\mu g h \\
\mu g / L \\
\mu g\end{array}$ & $\begin{array}{l}\text { WA } \\
\text { WA } \\
\text { WA } \\
\text { WA } \\
\text { WA }\end{array}$ & $\begin{array}{l}\text { EPAB260 } \\
\text { EPAB260 } \\
\text { EPAB260 } \\
\text { EPAB260 } \\
\text { EPAB260 }\end{array}$ \\
\hline
\end{tabular}

WELL CRP 11D

MEASUREMENTS CONDUCTED IN THE FIELD

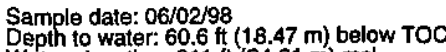

Water elevation: $211 \mathrm{ft}(64.31 \mathrm{~m}) \mathrm{ms}$

pH: 5.4

p. conductance: $88 \mu \mathrm{S} / \mathrm{cm}$

Water evacuated from the well prior to sampling: $22 \mathrm{gal}$

ANALYSES

\section{$F$ Analyte}

1 Aluminum, total recoverable Barium, total recovera

Cadmium, total recoverab Carbon, tetrachloride Chloride

Chrornium, total recoverable Fluoride

Iron, total recoverabie Lithium, total recoverable Magnesium, total recoverable Mercury, total recoverable Potassium, total recoverab? Selenium, total recoverable Siver, total recoverable Sultate Tetrachloroethylene Total organic carbon Total phosphates (as P) i,1,1-Trichloroethan Gross alpha

Time: 7:34

Water temperature: $16^{\circ} \mathrm{C}$ Total alkalinity (as CaCO3): $0 \mathrm{mg} /$.

Time: 10:56

(cinperature: $18^{\circ} \mathrm{C}$ Total alkalinity (as CaCo3): $8 \mathrm{mgl}$

1 Tritium

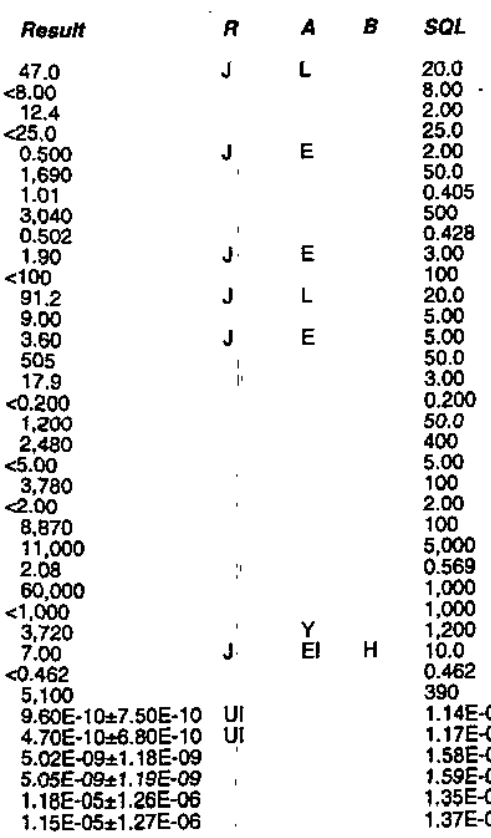

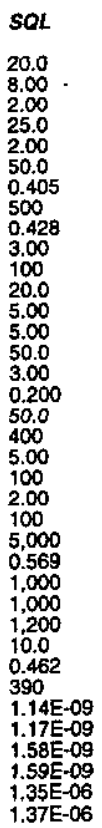

WELL CSB $1 C$

MEASUREMENTS CONDUCTED IN THE FIELD Sample date: 04/15/98 Depth to water: $81.9 \mathrm{ft}(24.96 \mathrm{~m})$ below TOC W: 6 (ovalion: Not aval $\mathrm{Sp}$. conductance: $34 \mu \mathrm{S} / \mathrm{cm}$ Wuthidity: 1 NTU ANALYSES

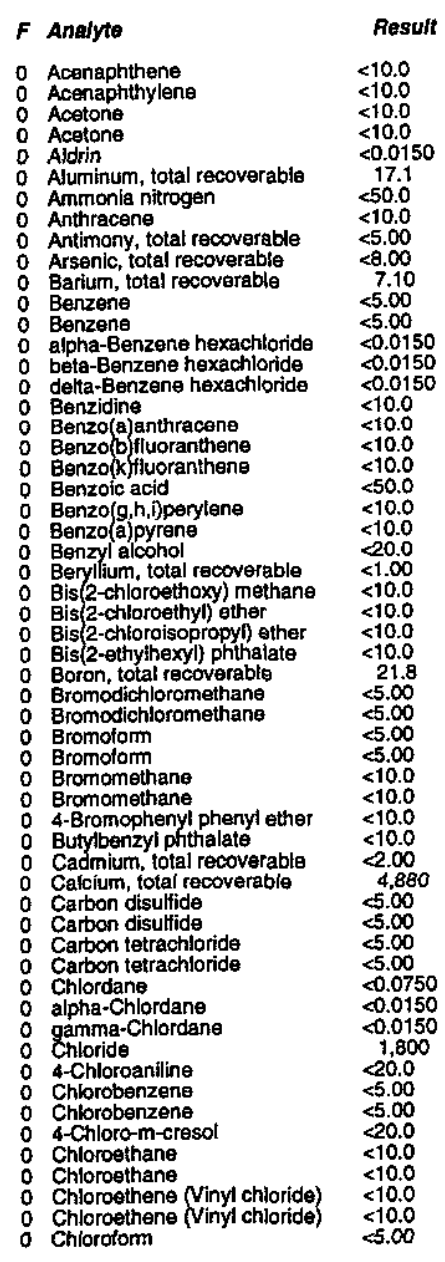
Time: 8:37 Air temperature: $20^{\circ} \mathrm{C}$ Total alkalinity (as CaCO3): $9 \mathrm{mg} /$
Phenolphthalein alkalinity: $0 \mathrm{mg} /$

ESH-EMS-980569 
Well CSB ic callected on 04/15/98 (cont.)

$F$ Analyte

O Chloroform

2-Chloronaphthalen
(n)

2-Chloronaphthat

4-Chlorophenyl phenyl ether

Chrysene

Cobalt, total recoverable

: m/p-Cresol

0 Cyanide

: p,p-DDE

Dibenz(a,h)anthracene

Dibenzofuran

Di-n-butyl phthalate

1,2-Dichlorobenzene

1,4-Dichlorobenzene

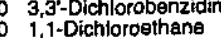

1,1-Dichlorogthane

1,2-Dichloroethane

$\begin{array}{ll}1,1-D i c h l o r o e t h y l e n e \\ 0 & \text { cis-1,2-Dichloroethyle }\end{array}$

o cis-1,2-Dichloroethylene

Irans- - , 2-Dichtoroethylene
trans-1,2-Dichtoroethylene

Dichloromethane

2,4-Dichlorophenol

1,2-Dichloropropane

cis-1,3-Dichloropropene

0 trans-1,3-Dichloropropen

Diethyl phthalate

2,4-Dimethyl pheno

2,4-Dínikrophenol

2,6-Dinitrotoluenen

Erdosulfien sulfate

Endosulfan I

Endrin aldehydo

Endrin ketone

Ethylbenzene

Fiuorene

Heptachlor
Heptachlor epoxide
Hexachlorobenzene

Hexachlorocyclopentadien

(a)

2-Hexanone
Indeno $(1,2,3-c, d)$ pyrene

Iron, totai recoverable

$<5$

Ros
$<5.00$
$<10.0$
$<10.0$
$<10.0$
$<10.0$
$<10.0$
$<3.00$
$<10.0$
$<5.00$
$<3.00$
$<10.0$
$<10.0$
$<5.00$
$<0.0150$
$<0.01$
$<0.01$
$<10.0$
$<10.0$
$<5.00$
$<5.00$
$<10.0$
$<10.0$
$<10.0$
$<10.0$
20.0
$<5.00$
$<5.00$
$<5.00$
$<5.00$
$<5.00$
$<5.00$
$<5.00$
$<5.00$
$<5.00$
$<5.00$
$<5.00$
$<5.00$
$<10.0$
$<5.00$
$<5.00$
$<5.00$
$<5.00$
$<5.00$
$<5.00$
$<0.015$
$<10.0$
$<10.0$
$<10.0$
$<50.0$
$<10.0$
$<10.0$
$<10.0$
$<0.01$
$<0.01$
$<0.01$
$<0.01$
$<0.01$
50.01
$<5.00$
$<5.00$
$<10.0$
$<10.0$
$<0.01$
$<0.01$
$<10.0$
$<10.0$
$<10.0$
$<10.0$
$<10.0$
$<10.0$
$<10.0$
19.2
$<10.0$

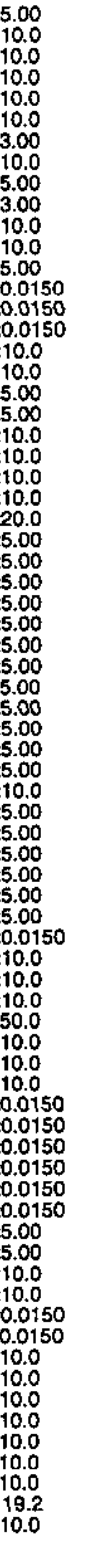

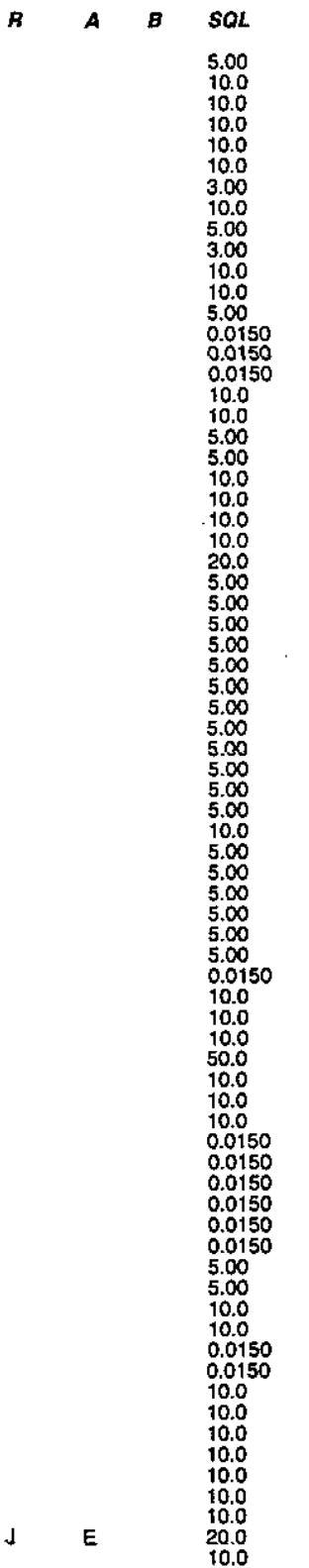

un
$\mu g /$
$\mu g$
$\mu g$
$\mu g$
$\mu g$
$\mu g$
$\mu g$
$\mu g$
$\mu g$
$\mu g$
$\mu g$
$\mu g$
$\mu g$
$\mu g$
$\mu g$
$\mu g$
$\mu g$
$\mu g$
$\mu g$
$\mu g$
$\mu g$
$\mu g$
$\mu g$
$\mu g$
$\mu g$
$\mu g$
$\mu g$
$\mu g$
$\mu g$
$\mu g$
$\mu g$
$\mu g$
$\mu g$
$\mu g$
$\mu g$
$\mu g$
$\mu g$
$\mu g$
$\mu g$
$\mu g$
$\mu g$
$\mu g$
$\mu g$
$\mu g$
$\mu g$
$\mu g$
$\mu g$
$\mu g$
$\mu g$
$\mu g$
$\mu g$
$\mu g$
$\mu g$
$\mu g$
$\mu g$
$\mu g$
$\mu g$
$\mu g$
$\mu g$
$\mu g$
$\mu g$
$\mu g$
$\mu g$
$\mu g$
$\mu g$
$\mu g$
$\mu g$
$\mu g$
$\mu g$
$g g$

Lab Mothod

ugh ES EPA8260

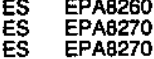

EPA8270

EPA6010

EPA8270

EPABO91

ES EPAB081

ES EPAB270

EPAB260
EPAB270
EPAB270

EPA8270

EPA8270

ES EPA8260

ES EPAB260

ES EPAB260

ES EPAB260

ES EPA8260

EPA8270

EPA8260

ES EPAB260

ES EPA8260

EPAB270

ES EPAB270

ES EPAB270

ES EPABOOI

EPABOA

ES EPABDA

ESS EPA82200

ES EPAB270

EPABOB1

EPA8270

EPAB270

EPAB260

EPAB270

EPA8270
Well CSB 1 C collected on 04/15/98 (cont.)

$F$ Analyte

0 Lead, total recoverable

Lindane
0 Magnesium, total recoverable
0

Mercury, total recoverable

2-Methyl-4,6-dinitrophen

Methyl ethyl ketone

. Methyl isobutyl ketone

Nachthalene

Nickel, total recoverab
Nitrate as nitrogen

Nitrite as nitrogen
m-Nitroaniling

o-Nitroaniling

2-Nitrophene

N-Nitrosodiphenylamine

P PCB 1016

PCB 1242

PCB 1254

Pentachlorophenol

Phenanthrene

otassium, total recoverable

Pyrene
Selenium, total recoverable

Sitver, total racoverable

Styrene

Sulfate

Tetrachloreethylene

Thallium, total recoverable

Toluene

Total organic carbon

1,2,4-Trichlorobenzene

1,1,1-Trichloroethane

1,1,2-Trlechloroetratiene

Trichloroethylene

2,4,5-Trictlorophenol

Vinyl acetate

Xylos

Zinc, total recoverable

Actinium-228

Antlmony-125

Cesium-137

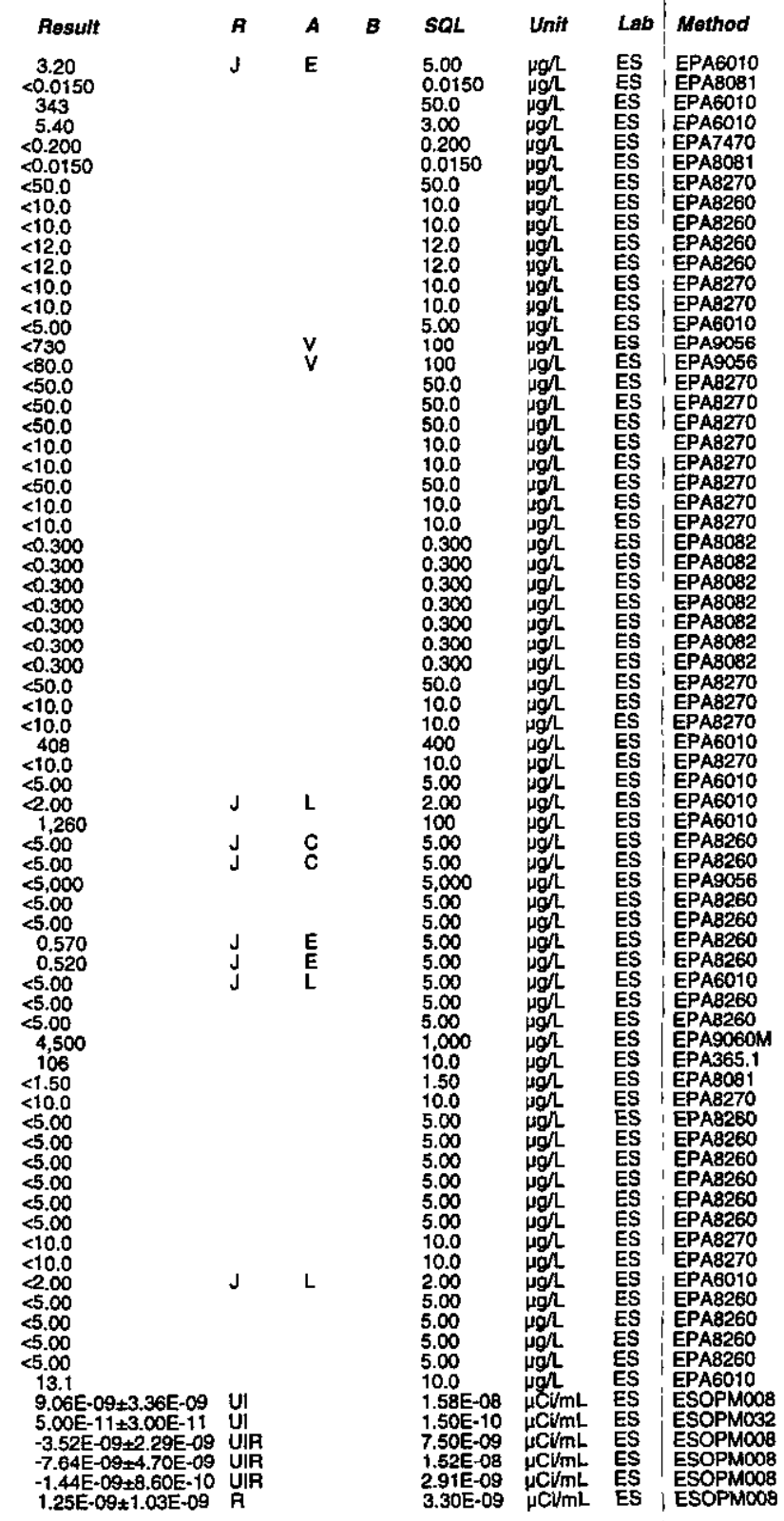

ESH-EMS-980569 
Well CSB 1C collected on 04/15/98 (cont.)

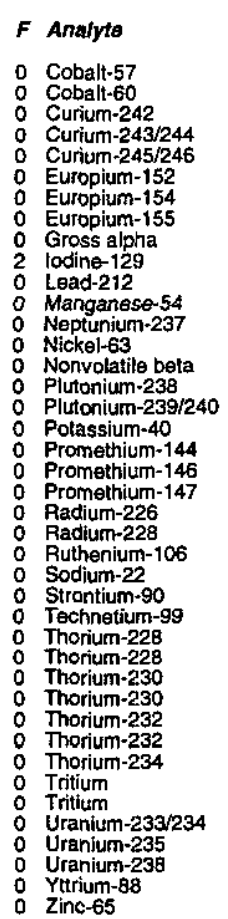

WELL CSB 2C

MEASUREMENTS CONDUCTED IN THE FIELD

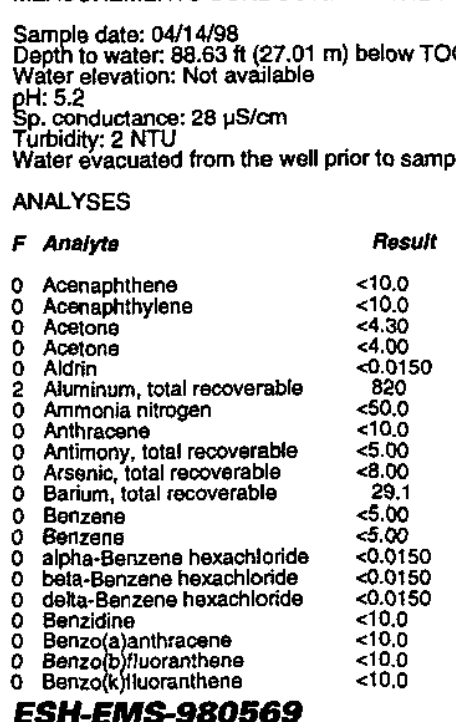

\begin{tabular}{|c|c|c|c|c|c|c|c|}
\hline Resuft & $\boldsymbol{R}_{1}$ & A & & SOL & Unit & Lab & Method \\
\hline 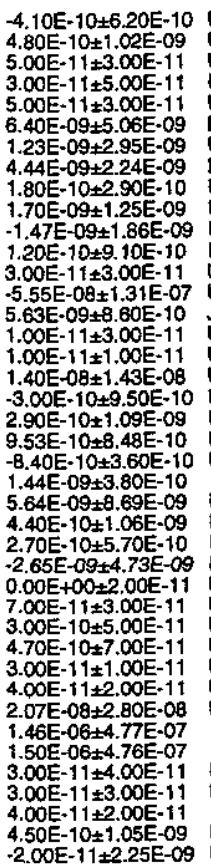 & 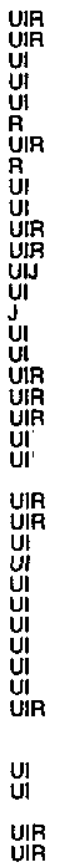 & $\stackrel{v}{v}$ & & 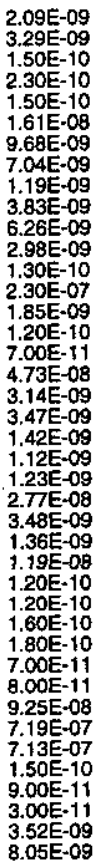 & 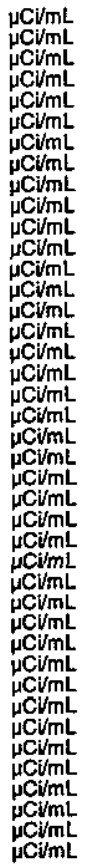 & $\begin{array}{l}\text { ES } \\
\text { ES } \\
\text { ES } \\
\text { ES } \\
\text { ES } \\
\text { ES } \\
\text { ES } \\
\text { ES } \\
\text { ES } \\
\text { GP } \\
\text { SS } \\
\text { ES } \\
\text { ES } \\
\text { ES } \\
\text { GP } \\
\text { ES } \\
\text { ES } \\
\text { ES } \\
\text { ES } \\
\text { GP } \\
\text { ES } \\
\text { ES } \\
\text { ES } \\
\text { ES } \\
\text { ES } \\
\text { SS } \\
\text { ES } \\
\text { ES } \\
\text { ES } \\
\text { ES }\end{array}$ & 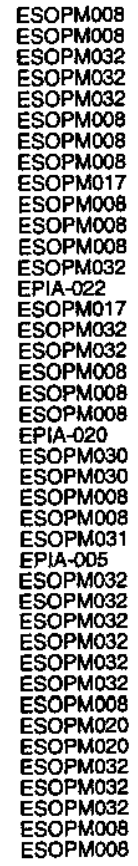 \\
\hline
\end{tabular}

Well CSB 2C collected on 04/14/98 (cont.)

0 Benzoic acid

$<50.0$

o Benzo(g,h,i)pery

Beryllium, total recoverable
Bis(2-chloroethoxy) mathane

Bis 2-chloroethoxy) meth ether

0 Bis(2-chloroisopropyl) ether
Bis(2-ethylhexyli) phthalate

Boron, total recoverable
0
0 Bromodichloromethane

Bromodichloromethane

o: Bromoform

Bromomethane

4.Bromophenyl phenyl ether

Cadmiunz, total recoverable

Calcium, total recoverable

O Carbon disulfide

Carbon tetrachloride

Chlordane

alpha-Chlordane

o chloride

4 Chloroaniline

- Chlorobenzenzene

o Chloroothane

Chloroethene (Vinyl chloride)

Chloroethene (Vinyl chloride)

Chloroform

- Chloromethane

2-Chloronaphthalene

4-Chlorophenyl phenyl ether

Cobalt, total recoverable

m/p-Cresol 2 -Cresol (2-Methyiphenol)

Cyanide

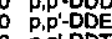

0
0
0

o Dibenz(a,h)anthracene

D Dibromochloromethane

Di-n-butyl phthalate

o 1,2-Dichlorobenzene

1,4-Dichlorobenzenze

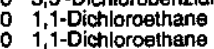

1,1-Dichloroethan

1,i-Dichlorotothanlen

1,1-Dichloroesthylene
cis-1,2-Dichloroethylene

cis-1,2-Dichloroethylene

trans-1,2-Dichloroesthylene
trans-1,2-Dichloroethylene

0 Dichloromethane

1,2-Dichlorophenor

1. -Dichloropropane

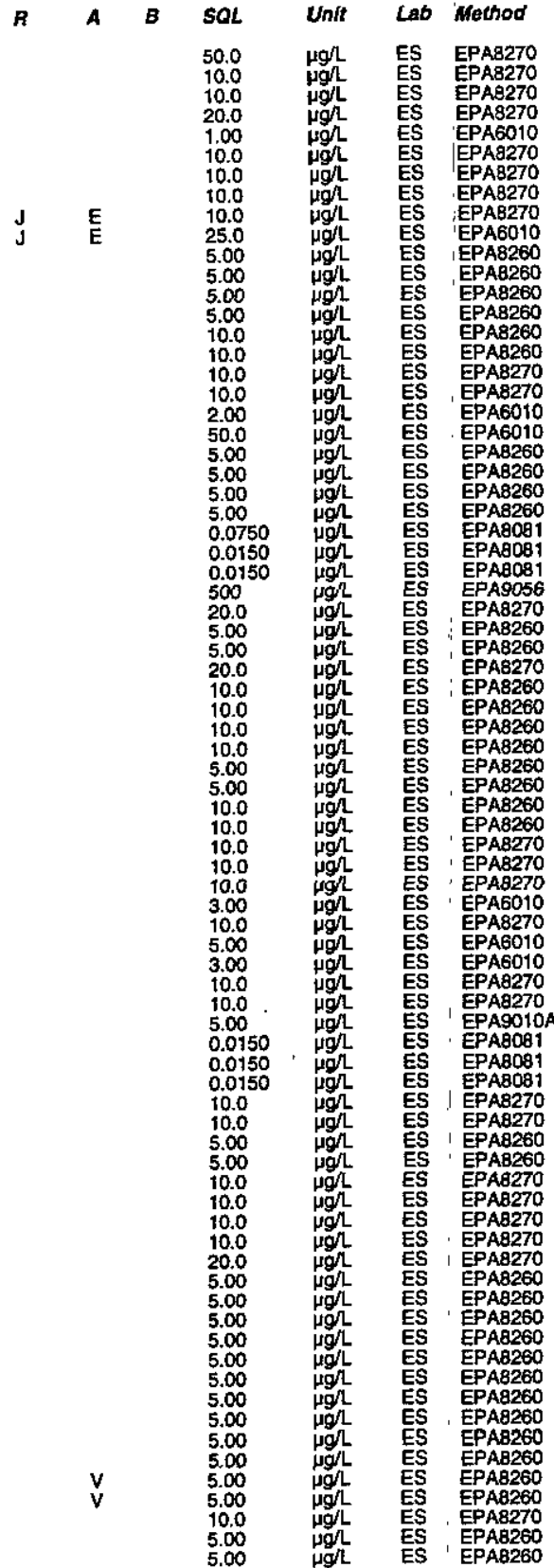

Second Quarter 1998 
Well CSB 2 C collected on 04/14/98 (cont.)

F Ansilyo

: cis-1,3-Dichloropropene

: trans-1,3-Dichloropropene
0 trans-1,3-Dichloropropena

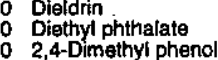

2,4-Dimethyy phenol

2,4-Dinitrophenol

2,6-Dinitrotoluene

Endosulfan sulfate

Endosulfian

Endrin aldehyde

Endrin ketone

Ehylbenzene

Fluorene

Heptachlor epoxide

Hexachlorobenzzene

Hexachlorocyclopentadiene

Hexachioroethan
2-Hexanone

Indeno $(1,2,3-c, d)$ pyrene

Iron, total recoverable

Isophorone total recoverable

Lindane

Magnesium, total recoverab

Mercury, total recoverable

Methoxychlor
2-Methyl-4,6-dinitropheno

Methyl ethyl ketone

Methyl isobutyl ketone

Methyl isobutyl ketone
2-Methylnaphthalene

Nickel, totai recoverable

Nitrite as nitrogen

m-Nitroaniline

P-Nitroaniline

2-Nitrophenol

N-Nitrosodjphenylamine

PCB 1016

0 PCB 1232

PCB 1248

PCB 1260

Phenol

Polassium, total recoverable

Sylentium, total recoverable

Sodium, total recoverable

Styrene

1.
0
$1,1,2,2,2$-Tetrachloroethane

Result

A

B 5

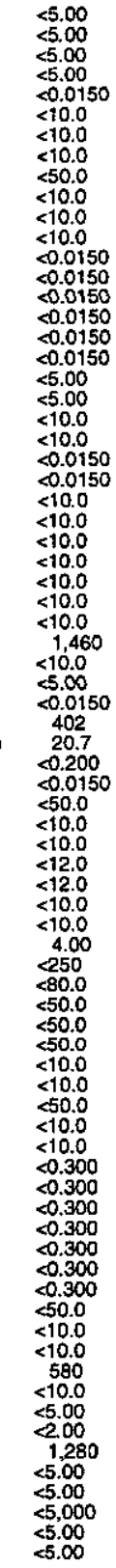

ESH-EMS-980569
Well CSB 2 C collected on 04/14/98 (cont.)

Result

$\because$ Tetrachloroethylene

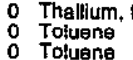

Total organic carbon
0 Total phosphates (as P)

- Toxaphene

o 1,2,4-Trichiorobenzen

1,1, Trichoroethan

o $1,1,2$-Trichloroethan

0 Trichiboroethylene

2,4,5-Trichlorophenol

Vanadium, total recoverable

o Vinyl acetate

a xyenes

- Zinc, total recoverable

- Americium-241

$\begin{array}{ll}0 & \text { Antimony-125 } \\ 0 & \text { Cerium- } 144\end{array}$

0 Cosium-134

o Cobalt-57

$\begin{array}{ll}\text { : Curium-242 } \\ 0 & \text { Curium-243/244 } \\ 0 & \text { Curium-245/246 }\end{array}$

O Eurium-245/24

Europium-152
0
0 Europlum-154

O Gross alpha

O Gross aiph

o Lead-212

O Neptunium-23

0 Nonvolatile beta

- Plutonjumr-238

Potassium-40

Promethium:-146

O Prodium-226

- Radium-228

S Sodtum-22

S Strontium-990

Technetium-99

: Thofium-230

0 Thorium-234

0 Uranium-233/234

: Uranium-235

0
0
0 Zinc- -65
$<5.00$
$<5.00$
$<5.00$
$<5.00$
$<5.00$
500
22.0
$-<1.50$
$<10.0$
$<5.00$
$<5.00$
$<5.00$
$<5.00$
$<5.00$
$<5.00$
$<10.0$
$<10.0$
3.10
$<5.00$
$<5.00$
$<5.00$
$<5.00$
17.9

7. $45 E-09+4.70 E-09 \quad R$

$4.00 E-11 \pm 3.00 E-11$
$1.10 E-09+2.32 E-09$

3.30E-10+9.20E-10 UIR

$1.10 \mathrm{E}-10 \pm 9.90 \mathrm{E}-10$
$4.50 \mathrm{E}-10 \pm 6.30 \mathrm{E}-10$

-5.20 E-101. $1.09 E-09$ UIP

$-9.00 \mathrm{E}-12+6.00 \mathrm{E}-11$
$4.00 \mathrm{E}-11 \pm 3.00 \mathrm{E}-11$

$-8.10 E-10 \pm 2.84 E-09$ UIR

$3.19 \mathrm{E}-09+2.25 \mathrm{E}-09$
$9.30 \mathrm{E}-10 \pm 4.00 \mathrm{E}-10$

1.03E-09+3.70E-10

$-4.30 E-10 \pm 1.26 E-09$
$-6.30 E-10 \pm 1.85 E-09$
UIR

.40E-10 UTR

$-1.26 \mathrm{E}-08 \pm 1.36 \mathrm{E}-07 \mathrm{JI}$
$2.00 \mathrm{E}-09 \pm 5.10 \mathrm{E}-10$
$\mathrm{~J}$

2.00 - $10+4.60 E-10$ UIJ $X$

$0.00 \mathrm{E}+00+1.00 \mathrm{E}-11$ UI
$5.10 \mathrm{E}-09+1.43 \mathrm{E}-0 \mathrm{OB}$

$5.10 \mathrm{E}-09+1.43 \mathrm{E}-\mathrm{OB}$ U.
$1.69 \mathrm{E}-09+9.40 \mathrm{E}-10 \mathrm{R}$

$6.00 E-11 \pm 1.08 E-09$ UI R

$9.00 E-10+2.70 E-10$ UI

$4.50 E-1024.10 E-10$
$5.92 E-09 \pm 8.67 E-09$

$-2.90 E-10+1.02 E-09$ UIP

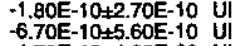

$2.90 E-10 \pm 6.00 E-11$
$5.50 E-10 \pm 0.00 E-11$

5. $15 \mathrm{E}-00 \pm 1.00 \mathrm{E}-11$ U

$3.00 \mathrm{E}-10+7.00 \mathrm{E}-11$
$3.0 \mathrm{U}-11+00 \mathrm{I}$

4.90E-10+9.00E-11 UI

$-1.30 E-09+1.13 E-09$
$1.56 E-09+2.41 E-09$

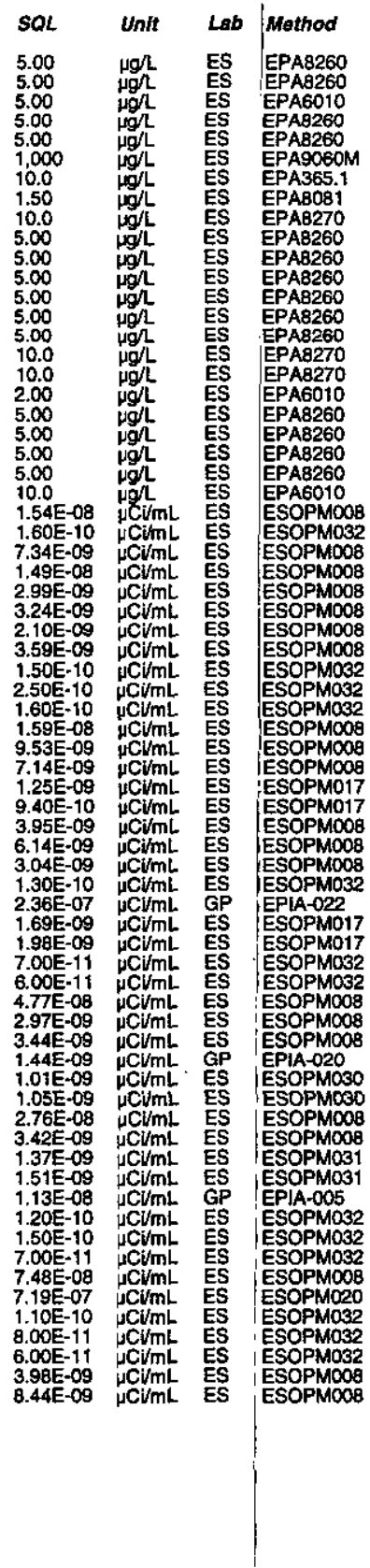

Second Quarter 1998 


\section{WELL CSB 3C}

MEASUREMENTS CONDUCTED IN THE FIELD

Sample date: $04 / 14 / 98$ (23.6 m) below TOC Water elevation: Not availiable

$\mathrm{pH}: 4.8$

Sp. conductance: $24 \mu \mathrm{S} / \mathrm{cm}$ Water evacuated from the well prior to sampling: 35 gal

ANALYSES

$F$ Analyte

O Acenaphthene

Acenaph
0 Actone
0 Aldrin

Aluminum, total recoverable

Anthracene

Antimony, total recoverable

Barium, total recoverable

alpha-Benzene hexachloride

beta-Benzene hexachloride

$\begin{array}{ll}0 & \text { Benzidine } \\ 0 & \text { Benzo(a)anthracene } \\ 0 & \text { Benzob) fluoranthene }\end{array}$

Berzo(k) fluoranthene

Benzoic acid
Benzo $($, hi, $)$ perylene

Benzo (g,h,i)pery

Beryllium, total recoverable

Bis (2-chloroethoxy) meth

Bis(2-chloroisopropyl) ether
Bis(2-ethy(hexyl) phithalate

Boron, total recoverable
Bromodichloromethane

Bromoform

4-Bromophentyl phenyl ether

Cadmium, total recoverablo

Calcium, total recoverable

Carbon tetrachloride

Chlordane

Chloride

4-Chloroaniline
Chlorobenzzene

4-Chloro-m-cresol

Chloroethane

Chlorotom

2-Chloronaphathalene
2-Chloroohenol

2-Chlorophenol
4-Chlorophenyl phenyl ethe

Chromium, total recoverable

Chrysene
Cobalt, total recoverable
Copper, total recoverable

mip-Cresol recoverabio

0 Cyanide

P,P -DDE

Dibenz (a,hjanthracene

Dibernzofuran
Dibromochloromethane
Di-n-butyl phthalate

ESH-EMS-980569
Well CSB 3C collected on 04/14/98 (cont.)

$F$ Anstyte

Result

Time: 8:53

ter temperature: $21^{\circ} \mathrm{C}$

Total alkalinity (as CaCO3): $1 \mathrm{mg} /$
Phenolphthalein alkalinity: $0 \mathrm{mg} / \mathrm{L}$

1,2-Dichlorobenzene

$<10.0$

1,3-Dichlorobenzenze

$\begin{array}{ll}0 & 3,3^{\prime} \text {-Dichlorobenzidine } \\ 0 & \text { 1,-Dichloroethane }\end{array}$

1,2 -Dichloroethane

0 cis-1,2-Dichloroethylene

0 trans-1,2-Dichlosoethyle

2,4-Dichlorophent

o cis-1,3-Dichloropropene

Diethyl phthalate

2.4-Dimethyl phenol

2.4-Dinitrophenol

2,4-Dinitrotoluen

Din-octyl phthalate

- Endosulfan II

O Endrin aldehyde

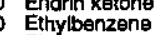

o Fluoranthen

Heptachlor

- Hexachlorobsenzene

Hexachlorocyclopentadien

Hexachloroethane

Indeno $(1,2,3-c, 0)$ pyrene

Iron, total recoverable

Lead, total recoverable Magnesium, total recoverable Manganese, total recoverab Methoxychlor Methyl ethyl ketone Methyl isobutyl ketone

Naphthalene

Nickel, total recoverable

Nitrite as nitrogen

0 m-Nitroaniline

o. -Nitroaniline

- Nitrobenzen

2-Nitropheno

N-Nitrosodidphenylamine

0 PCB 1016

0 PCB 1221

O PCB 1242

O PCB 1248

- Pentachloropheno

o Phenanthrene

Potassium, total recoverable

- Pyrene total racovera

S Selenlum, total recoverab

$-38$
$\boldsymbol{A}$

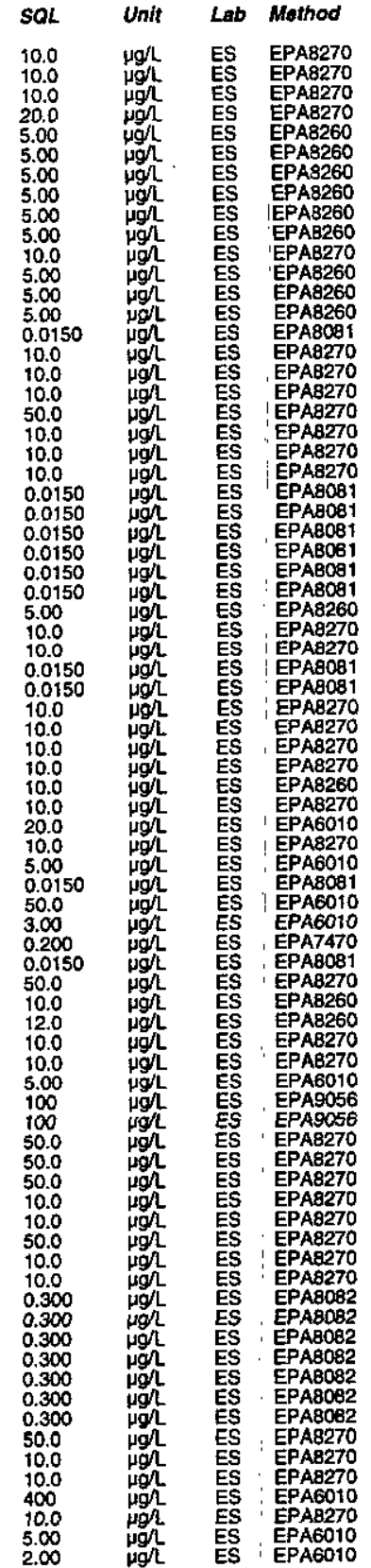

Second Quarter 1998 


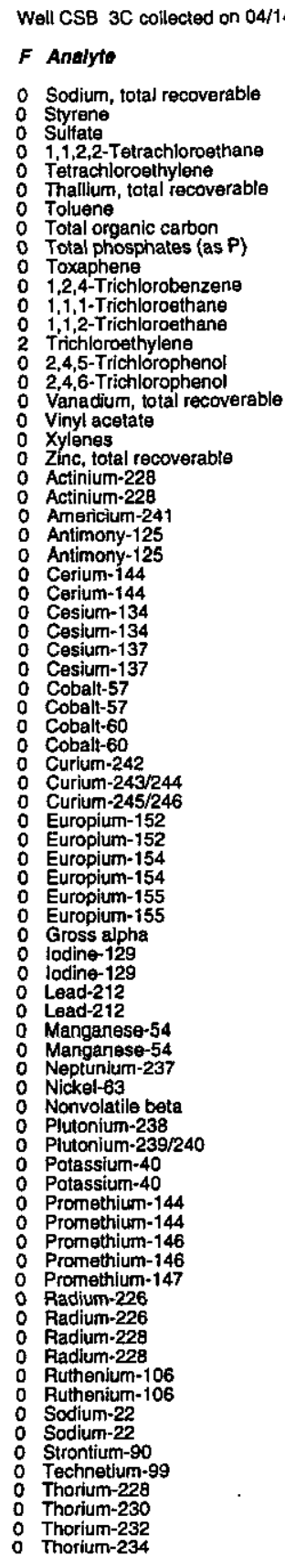

ESH-EMS-980569
Well CSB 3C collected on 04/14/98 (cont.)

\begin{tabular}{|c|c|c|c|c|c|c|c|c|}
\hline Result & R & $A$ & $B$ & $S Q L$ & Unit & Lab & Method & F Analyte \\
\hline $\begin{array}{c}1,420 \\
<5.00 \\
<5,000 \\
<5.00 \\
<5.00 \\
<5.00 \\
<5.00 \\
2,000 \\
19.0 \\
<1.50\end{array}$ & & & & $\begin{array}{l}100 \\
5.00 \\
5.000 \\
5.00 \\
5.00 \\
5.00 \\
5.00 \\
1.000 \\
10.0 \\
1.50\end{array}$ & 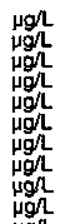 & $\begin{array}{l}\text { ES } \\
\text { ES } \\
\text { ES } \\
\text { ES } \\
\text { ES } \\
\text { ES } \\
\text { ES } \\
\text { ES } \\
\text { ES }\end{array}$ & $\begin{array}{l}\text { EPA6010 } \\
\text { EPAB260 } \\
\text { EPA9056 } \\
\text { EPAB260 } \\
\text { EPAB260 } \\
\text { EPA6010 } \\
\text { EPAB260 } \\
\text { EPA9060M } \\
\text { EPA365.1 } \\
\text { EPA8081 }\end{array}$ & $\begin{array}{ll}1 & \text { Thorium-234 } \\
2 & \text { Trutium } \\
0 & \text { Uranium-233/234 } \\
0 & \text { Uranium-235 } \\
0 & \text { Uranium-238 } \\
0 & \text { Ytrium-88 } \\
0 & \text { Ytrtuium-88 } \\
0 & \text { Zinc-65 } \\
0 & \text { Zirc-65 }\end{array}$ \\
\hline
\end{tabular}

\section{Result}

3.14E-07 $3.11 \mathrm{E}-06 \mathrm{E}-08 \mathrm{R}$

3. $11 \mathrm{E}-05 \pm 3.48 \mathrm{E}-06$

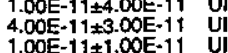

$2.13 \mathrm{E}-09 \pm 1.19 \mathrm{E}-09$
$1.92 \mathrm{E}-09+2.34 \mathrm{E}-09$
$-1.70 \mathrm{UIR}$
$-10 \pm 1.98 \mathrm{E}-09$ UIR
$1.00 E-11 \pm 1.00 E-11$
$-5.10 E-10 \pm 1.14 E-09$
UIR

\section{WELL CSB 7D}

MEASUREMENTS CONDUCTED IN THE FIELD

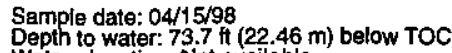
Water elevation: Not available

Wh: 5.4

c. conductance: $62 \mu \mathrm{S} / \mathrm{cm}$

Water evacuated from the well prior to sampling: 45 ol ANALYSES

$9.35 E-09 \pm 3.54 E-09$
$-1.17 E-08 \pm 4.37 E-09$
UIR $.00 \mathrm{E}-11 \pm 4.00 \mathrm{E}-11$ UI $1.25 \mathrm{E}-09.2 .40 \mathrm{E}-09$ UIR $-2.60 \mathrm{E}-10 \pm 5.16 \mathrm{E}-09$ UIR $-2.200-10 \pm 8.50 E-10$ UAP - $90.50 \mathrm{E}-10$ UIA $4.20 E-10 \pm 6.40 E-10$ UIR $4.70 \mathrm{E}-10 \pm 1.03 \mathrm{E}-09$
$8.40 \mathrm{E}-10 \pm 9.80 \mathrm{E}-10$ $2.00 \mathrm{E}-10 \pm 6.00 \mathrm{E}-11 \mathrm{UI}$ $6.00 \mathrm{E}-11 \pm 4.00 \mathrm{E}-11$
$1.34 \mathrm{E}-08 \pm 5.46 \mathrm{E}-09$ $4.40 \mathrm{E}-09+4.81 \mathrm{E}-99$ UIR $4.90 E-10+2.55 E-09$ UIR $-1.94 \mathrm{E}-09+2.49 \mathrm{E}-09$
$1.37 \mathrm{E}-09+2.26 \mathrm{E}-09$ $-4.00 E \cdot 10 \pm 2.50 E-10$ UI $3.01 E-09+2.43 E-09$ U $1.95 \mathrm{E}-09 \pm 2.14 \mathrm{E}-09$ UIP $-8.20 E-10 \pm 9.50 E-10$
$-6.10 E-10 \pm 8.40 E-10$
$U I R$ $0+1.99 E-09$
UIJ $1.48 E-09 \pm 4.90 E-10$ UIJ $X$ $5.00 \mathrm{E}-11+2.00 \mathrm{E}-11 \mathrm{U}$ $1.61 E-08 \pm 1.42 E-08$
$3.30 E-09 \pm 1.37 E-08$ $.00 E-10 \pm 9.00 E-10$ UIA $1.04 E-09 \pm 1.15 E-09$ UIR $1.12 \mathrm{E}-09+1.05 \mathrm{E}-09$ R $5.50 \mathrm{E}-10 \pm 4.40 \mathrm{E}-10 \mathrm{UI}$ E-09+8.03E-09 UPR $.00 E-10 \pm 1.01 E-09$ UIA 1.20E-10.9.20E-10 UH $3.41 \mathrm{E}-09 \pm 4.54 \mathrm{E}-09$ UI $6.70 \mathrm{E}-10 \pm 1.00 \mathrm{E}-10$ Ui $7.00 \mathrm{E}-11 \pm 3.00 \mathrm{E}-11$ UI
$4.01 \mathrm{E}-08 \pm 2.32 \mathrm{E}-08$

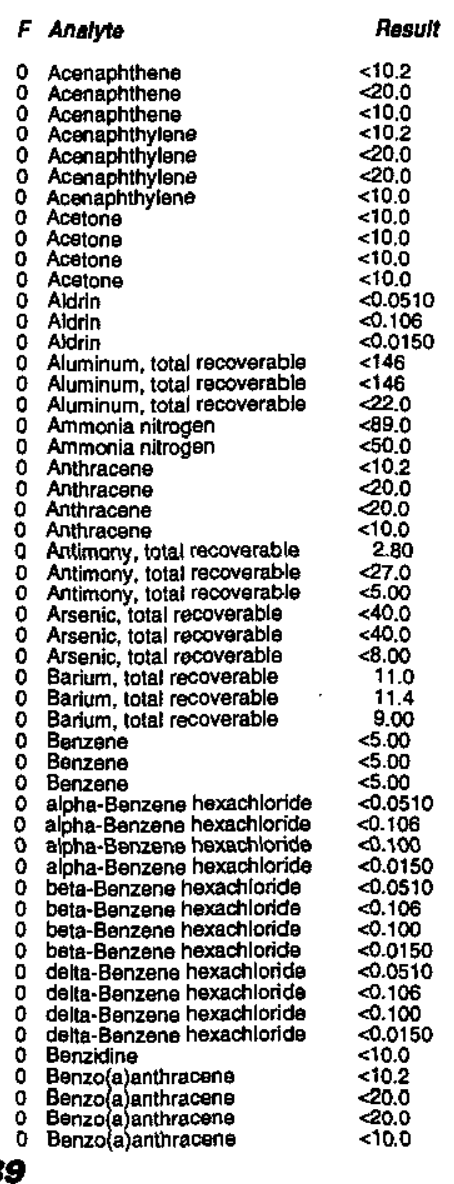

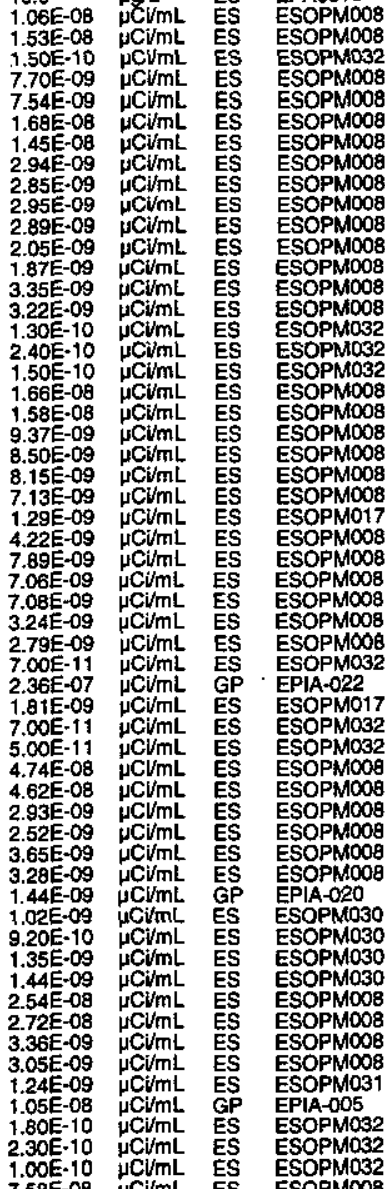

B-39
Time: 9:56

Total alkalinity (as CaCO3): $6 \mathrm{mg} /$
Phenolphthalein alkalinity: $0 \mathrm{mg} /$
A

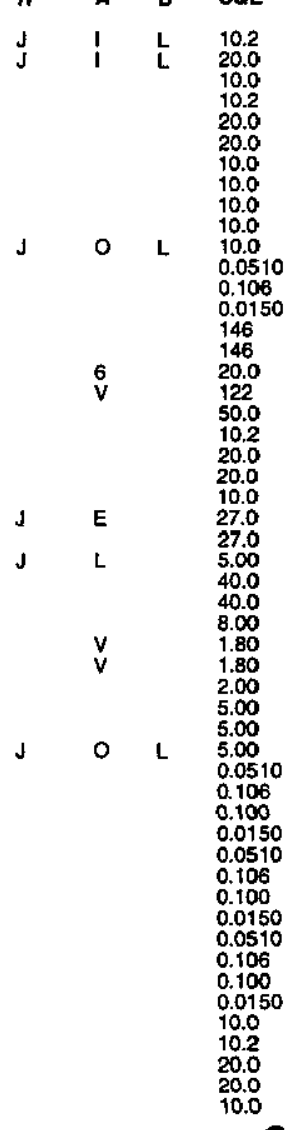

Unit

Lab | Method

WA EPA8270
WA EPAB270

WA EPAB270

WA EPAB270

WA $:$ EPAB270

WA

WS

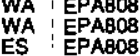

$\begin{array}{lll} & \text { ES } & \text { EPABD81 } \\ \text { WA } & \text { EPA6010 }\end{array}$

WA

SS

WA

WA

WA

WA EPA6010

WS EPA6010

WA I EPAG010

WA IEPA6010

WA

WA

WS IEPAB260

WA WPABOB

WA

WA WA EPABOB

WA EPABOB

WA : EPABOB

WA EPAB08

ES EPA808

WA

WA

Second Quarter 1998 
Well CSB 7D collected on 04/15/98 (cont.)

$F$ Analyte

O Benzo(b) fluoranthene

Benzobiffluoranthene

0 Benzo:k flluoranthene
0 Benzok kfluoranthene
0 Benzok kfluoranthene

- Benzo (k) fluoranthene

Benzoic acid
Benzoic acid

Benzoic acid

Benzo(g,h,i)perylene

Benzo (g,h,i)perylene

Benzo a) pyrene

Benzo a) pyrene

Benzyl accohol

Benzyl alcohol

Beryylium, total recoverable

- Beryllium, total recoverable

Bis (2-chloroetthoxy mexy methane
Bis 2-chloroethoxy methan

Bis(2-chloroethoxy) meth

Bis (2-chloroethy) ether

Bis (2-chlorosthy) ether

Bis (2-chloroisopropy) ether
Bis(2-chloroisopropy), ether

0 Bis(2-chloroisopropy) ether
Bis (2-chloroisopropyl) ether

Bis(2-ethythexyl) phthalato
Bis (2-ethylhexy) phthala

Bis(2-ethylhexyly phthalate
Bis(2-ethythexyl) phthalate

Boron, total recoverable

Boron, total recoverabl

Bromodichloromethan

Bromodichloromethan

Bromoform

Bromofom

Bromomethane

Bromomethane

Bromomethane
4-Bromophenyl phenyl ether 4. Bromophenyyl phenyl ether 4-Bromophenyl phenyl ether Butylbenzy! phttialate Butylbenzyl phthalate Cadrnium, total recoverable C Cadmium, total recovererable Cadmium, total recoverable Calcium, total recoverable - Carbazole Carbon disulfio

ESH-EMS-980569

$<10.0$
$<4.70$

$<4.70$
$<., 00$
1,300
1.300

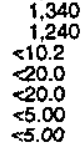

Well CSB 7D collected on 04/:5/98 (cont.)
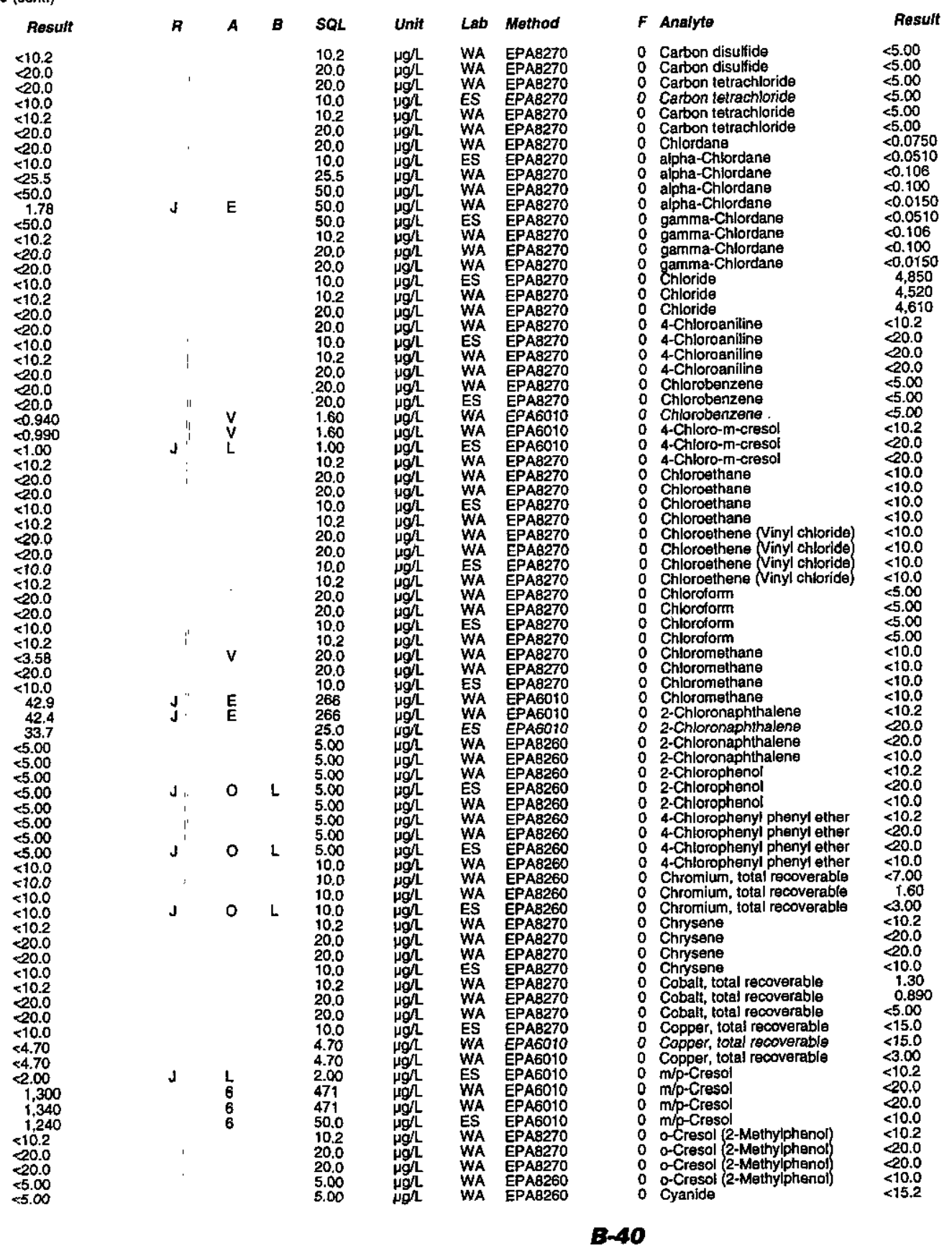

SQL

10.2
20.0
20.0
10.0
10.2
20.0
20.0
10.0
25.5
50.0
50.0
50.0
10.2
20.0
20.0
10.0
10.2
20.0
20.0
10.0
10.2
20.0
20.0
20.0
1.60
1.60
1.00
10.2
20.0
20.0
10.0
10.2
20.0
20.0
10.0
10.2
20.0
20.0
10.0
10.2
20.0
20.0
10.0
266
266
25.0
5.00
5.00
5.00
5.00
5.00
5.00
5.00
5.00
10.0
10.0
10.0
10.0
10.2
20.0
20.0
10.0
10.2
20.0
20.0
10.0
4.70
4.70
2.00
471
471
50.0
10.2
20.0
20.0
5.00
5.00

$<5.00$

Carbon tetrachloride

gamma-Chordane

Chloride

4-Chloroanitipe

Chloronaphthale

4-Chlorophenyl phenyl ether

Chrysene

Cobalt, total recovera

(n)

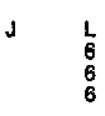

Second Querter 1998

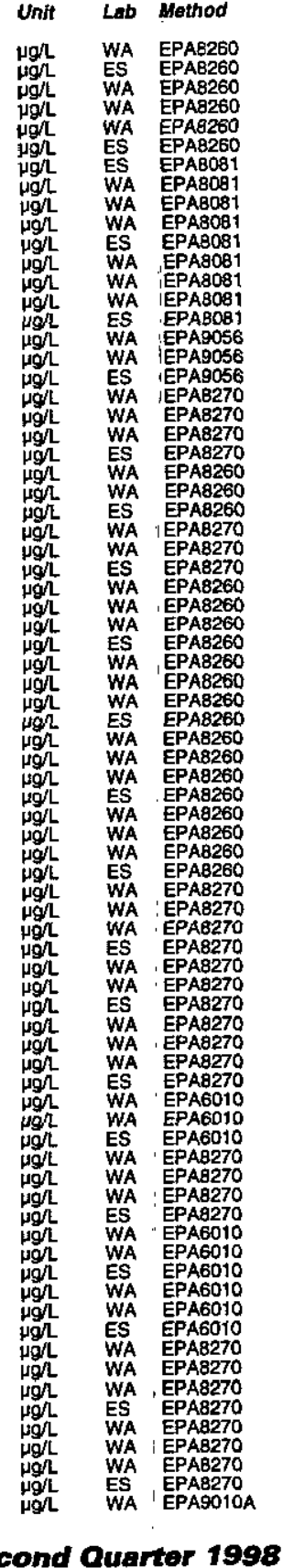


ANALYTICAL RESULTS

Well CSB $7 D$ collected on 04/15/98 (cont.)

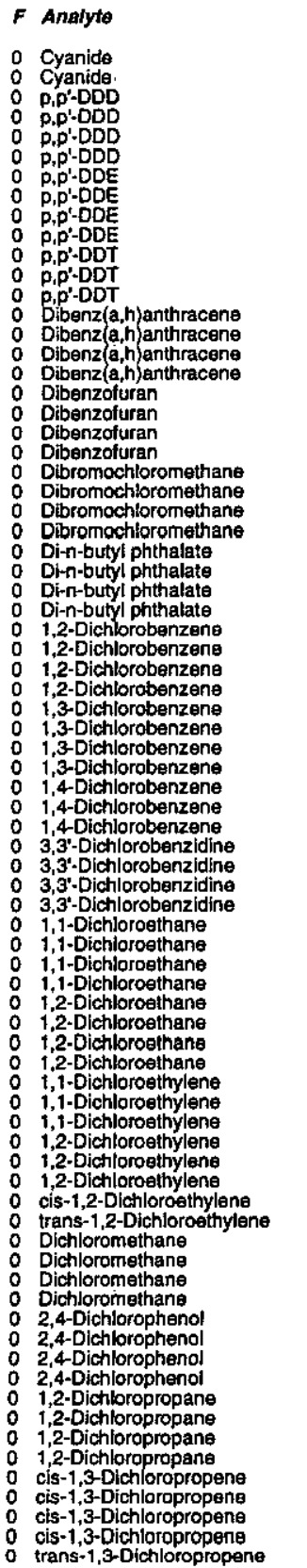

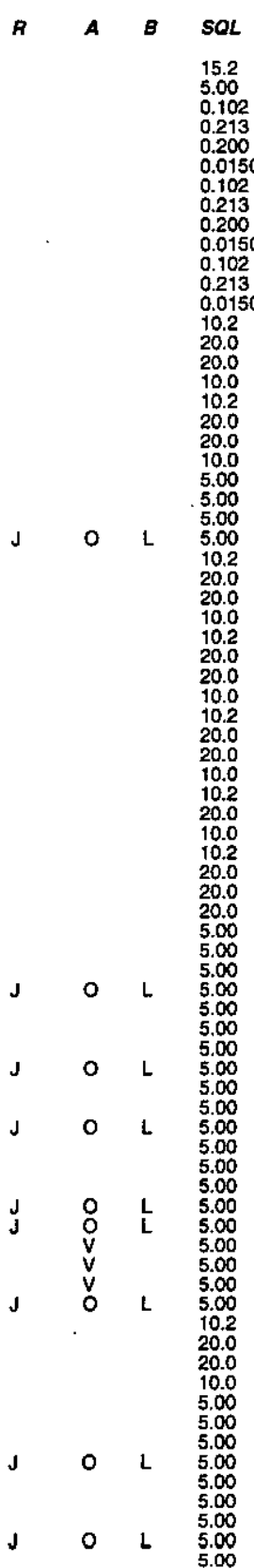

Well CSB 7D collected on 04/15/98 (cont.)

$F$ Analyte

0 trans-1,3-Dichloropropene

作

Dieldrin

\section{Diethyl phthalate}

Diethyl phthalate

Diethyl phthalate
2,4 -Dimethyl phenol

2,4-Dimethyl pheno

2,4-Dimethy pheno

Dimethyl phtthalate

Dimethyl phthalate

2,4-Dinitropheno

2,4-Dinitropheno

2,4-Dinitrotoluenol

2,4-Dininitrotololuen

2,6-Dinitrotoluene

2,6-Dinitrotoluene

Dil-n-octy| phthalate

Di-n-octy phthalate

Din-ocyl phinalate

Endosufian suliatat

Endosulfan sulfate

Endosulfan

Endosulfan

Endosulfan II

Endosulfan II

Endrin

Endrin aldehydo

Endrin ketone

Endrin ketone

Ethylbenzene

Ethylbenzzene

Ehyblbenzene

Fluoranthene

Fluoranthen

Fluorene

Fluorene

\section{: Fluorene}

\section{Heptachlor}

Heptachlor epoxido

Heptachlor epoxide

Heptactior epoxide

Hexachlorobenzene

Hexachlorobenzene

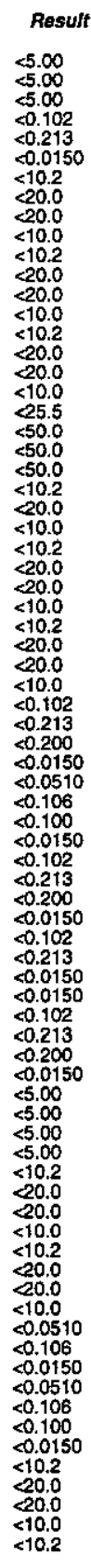

A A B SaL Unit Lab Mothod

$5.00 \mu$ Wh $\mathrm{L}$ WA EPA8260

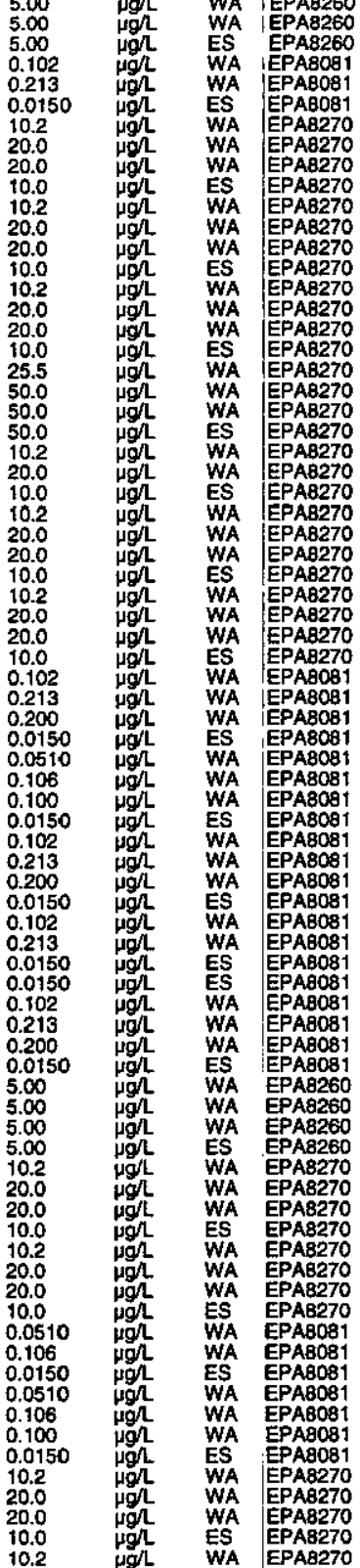


Weil CSB 7D collected on 04/15/98 (cont.)

F Analyte

- Hexachlorobutadiene

Hexachlorobutadiene

- Hexachlorocyclopentadiene

Hexachlorocyclopentadiene
Hexachlorocyclopentadiene

Hexachloroethane

Haxachloroesthane
Haxachloroethane

2-Hexanone

2-Hexanone

Indeno $(1,2,3-c, d)$ pyrene

Indeno $(1,2,3-c, d$ pyrene

Iron, total recoverable

Iron, total recoverabl

Isophorone

Isophorone

Lead, total recoverable

Lindane

Magnesium, total recoverable

Magnesium, total recoverable

Manganese, total recoverable

Manganese, total recoverab

Mercury, total recoverabla

Methoxychlor

Methoxychlor

2-Methyl-4.6-6initrophenol
2-Methyl-46-dinitrophenal

2-Methyli-4,6-6initrophenenol

Methyl etnyy ketone
Methyl ethyl ketone

Mothyy ethyl keton

Methyl isobutyl ketone

Methyl isobutyly keton

2-Methylnaphithalene
2-Methyinaphthalene

2-Methylnaphthaiene
2-Methylnaphthalene

Naphthalene
Naphthalene

Naphthalene

Nickel, total recoverable

Nickel, total recoverable

Nitrate as nitrogen
Nitrate-nitrite as nitrogen

Nitrite-nitinte as nitrog

m-Nitroaniling

m-Nitroanilin

O-Nitroaniline

ESH-EMS-980569
Well CSB 7D collected on 04/15/98 (cont.)

\section{$F$ Analyte}

$\begin{array}{ll}0 & \text { o-Nitroaniline } \\ 0 & \text { o-Nitroaniline } \\ 0 & \text { P-Ning }\end{array}$

o p-Nitroaniling

p-Nitroaniline

N Nitrobenzenene

Nitrobenzenen

2-Nitrophenol

2-Nitrophenol

4-Nitropheno

o N-Nitrosodiphenylamine

N-Nitrosodiphenylaminirise

N-Nitrosodiphenylamine

N-Nitrosodippopylamine

$\mathrm{N}-\mathrm{N}$ itos

PCB 1016

$\begin{array}{lll}0 & P C B & 1016 \\ 0 & P C B & 1016\end{array}$

- PCB 122

0 PCB 122

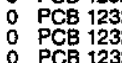

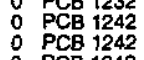

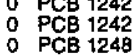

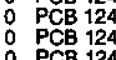

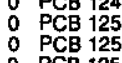

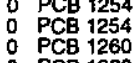

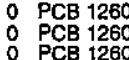

Pentachlorophen

Pentachlorophen

Phenanthrene

O Phenanthrene

Phenanthrene

Phenol

Potassium, total recoverable

: Pyrene

O Pyrene

Silver, total recoverable

Siver, total recoverable

Sodium, total recoverabite

of Sodium, total recoverable

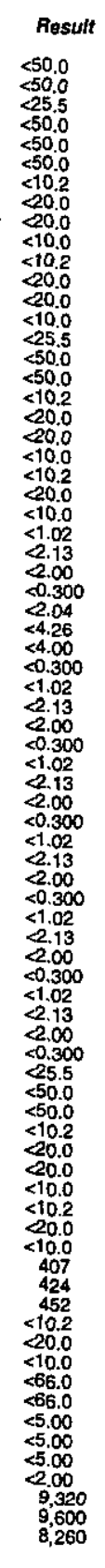

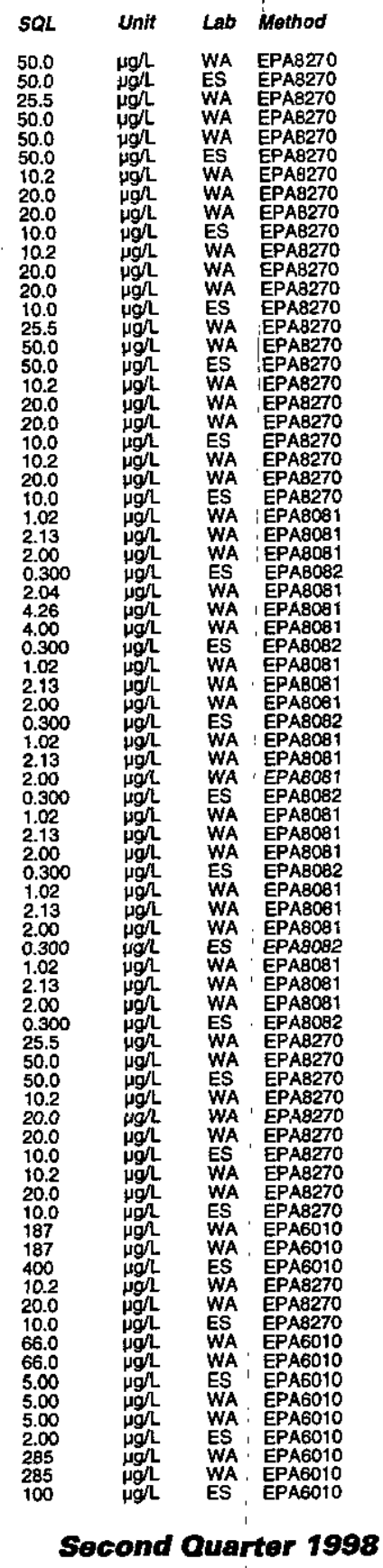


Well CSB 7D collected on 04/15/98 (cont.)

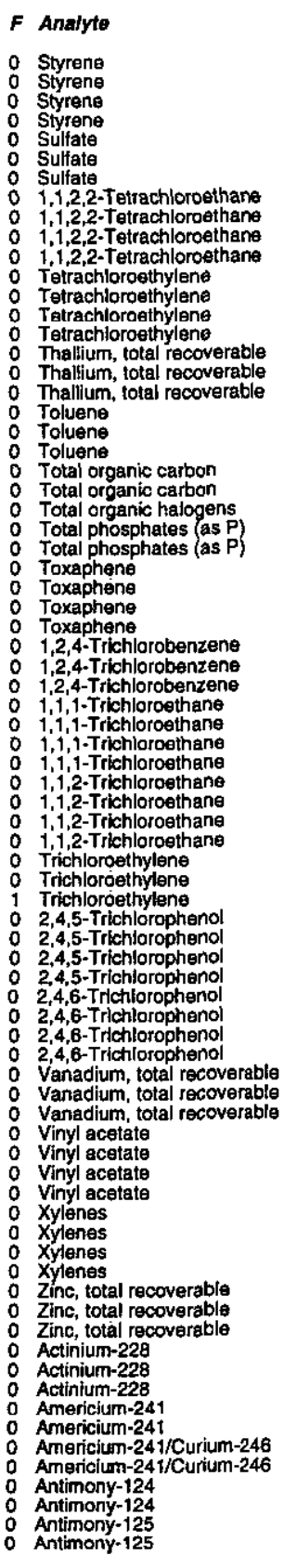

ESH-EMS-980569
Well CSB 7D collected on 04/15/98 (cont.)

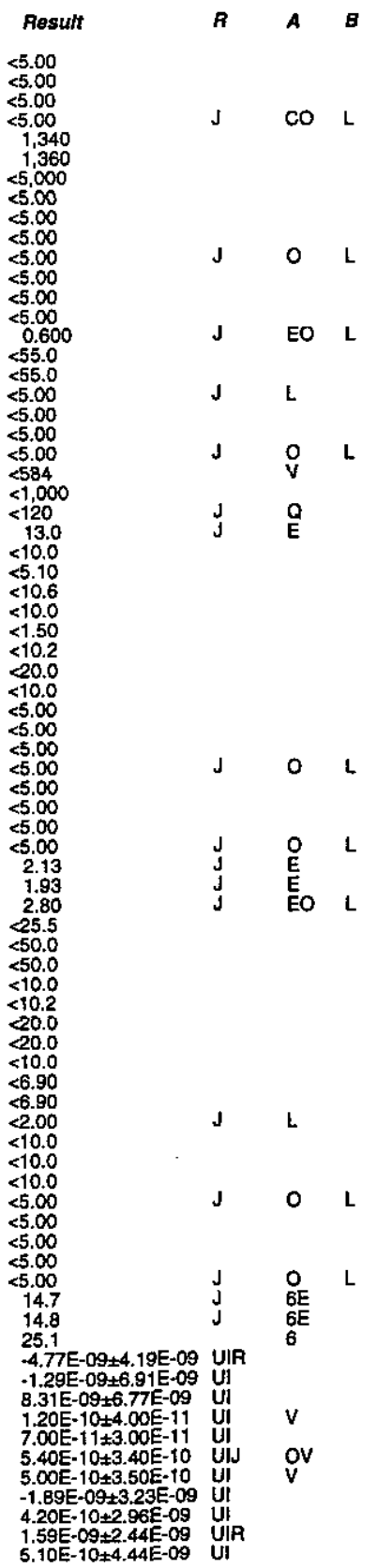

F Anatyte

0 Antimony-125

: Barium-133

0 Carbon-14

$\begin{array}{ll}0 & \text { Cerium-144 } \\ 0 & \text { Cerium-144 } \\ 0 & \text { Cerium- }-144\end{array}$

0 Cesium-134

Cesium-137
Cesium-137
Cesium-137

O Cobalt-57

0 Cobalt-57

Cobalt-58

- Cobalt-60

Curium-242
0 Curium-242
0

- Curium-242

o Curium-243/244

O Curium-243/244

$\begin{array}{ll}0 & \text { Curium-245/246 } \\ 0 & \text { Europlum-152 } \\ 0 & \text { Europium-152 }\end{array}$

Europium-152

Europium-154

Europium-155

Europium-155

Gross alpha

loding-129

0 Lead-212

0 Lead-212

Manganess-54
Manganese-54
Mengang-54

Neptunium-237

Nickel-63

Nickel-63

Nonvolatile beta

Nonvolatile beta

Plutonium-238

Plutonium-23:

Plutonium-239/240

Potassium-40

Potassium-40
Promethiump-144

Promethium-144
Promethium-144

Promethium-146

$\begin{array}{ll}0 & \text { Promethium-146 } \\ 0 & \text { Promethium-146 } \\ 0 & \text { Promgthium-147 }\end{array}$
Result

1.55E-09×4.78E-09 U

$-2.25 \mathrm{E}-07 \pm 1.09 \mathrm{E}-07$ UI
$-2.47 \mathrm{E}-07 \pm 1.09 \mathrm{E}-07$ UI

. $40 \mathrm{E}-10 \pm 1.21 \mathrm{E}-08$ UI

$3.16 \mathrm{E}-09 \pm 1.17 \mathrm{E}-08$ UI
$4.50 \mathrm{E}-10 \pm 0.60 \mathrm{E}-10 \mathrm{UIR}$

$-1.63 E-09+2.22 E-09$ UI

$8.00 \mathrm{E}-11 \pm 9.70 \mathrm{E}-10$
$-5.00 \mathrm{U}-10 \pm 1.79 \mathrm{UIR}$

. $80 \mathrm{E}-10 \pm 2.02 E-09$ U

$1.116-09+1.56 \mathrm{E}-09$
$9.100-101.49 \mathrm{E}-09$

$-1.60 \mathrm{E}-10+2.14 \mathrm{E}-09 \mathrm{UI}$

3. 30 E- $10 \pm 8.90 \mathrm{E}-10$ UIR

.

$.00 E-11+2.000-11$ U

$1.00 E-10 \pm 1.50 E-10$
$6.00 E-11 \pm 1.20 \mathrm{E}-10$

$-2.00 \mathrm{E}-11 \pm 4.00 \mathrm{E}-11$
$-1.30 \mathrm{E}-10 \pm 4.00 \mathrm{E}-11$

$1.00 \mathrm{E}-100 \pm 1.60 \mathrm{E}-10$

$1.20 E-10 \pm 4.00 E-11$

$1.33 \mathrm{E}-08 \pm 4.97 \mathrm{E}-09$
$3.92 \mathrm{E}-09+1.34 \mathrm{E}-08$ U

-6.19E-09+1.36E-08 UI

$-1.29 \mathrm{E}-09+4.45 \mathrm{E}-09 \mathrm{UT}$

$1.35 \mathrm{E}-09 \pm 3.22 \mathrm{E}-09$ UIR

$5.60 E-10 \pm 5.12 E-09$ U

$8.90 \mathrm{E}-10 \pm 4.50 \mathrm{E}-10$

$1.93 \mathrm{E}-09+6.11 \mathrm{E}-09$
$4.83 \mathrm{E}-09+5.22 \mathrm{E}-09$

$6.00 E-09+2.07 E-09$ UI

.20E-10+2.94E-09 UI

$2.90 \mathrm{E}-10+2.03 E-09$ U

$1.80 \mathrm{E}-10 \pm 2.10 \mathrm{E}-09$
$\mathrm{UUJ}$

$1.60 \mathrm{E}-10 \pm 1.70 \mathrm{E}-10$
$4.10 \mathrm{EI}-10 \pm 3.10 \mathrm{E}-10$ UIJ $\mathrm{CV}$

$7.66 \mathrm{E}-09 \pm 1.42 \mathrm{E}-07$ UI

$-7.29 \mathrm{E}-09 \pm 5.66 \mathrm{E}-09 \mathrm{U}$

$6.60 E-10 \pm 4.90 \mathrm{E}-10 \mathrm{UIJ}$

$-1.50 \mathrm{E}-10 \pm 9.40 \mathrm{E}-10 \mathrm{UI}$
$-2.10 \mathrm{E}-10 \pm 9.30 \mathrm{E}-10 \mathrm{UI}$

$2.00 E-11 \pm 2.00 E-11$ UI

$-1.50 E-10 \times 6.70 E-10$ UI

$4.00 E-11 \pm 0.00 E-11$ UI

$-3.211-09+1.41 \mathrm{E}-08$ UIR

$-8.00 \mathrm{E}-11 \pm 2.07 \mathrm{E}-08 \mathrm{UI}$

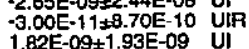

$1.82 \mathrm{E}-09+1.93 \mathrm{E}-09$ UI
$-4.00 \mathrm{E}-10 \pm 1.88 \mathrm{E}-09$
$\mathrm{UI}$

$8.90 E-10 \pm 1.10 E-09$
$-3.70-10 \pm 3.26-09$
UII

$-1.19 \mathrm{E}-09 \pm 3.35 \mathrm{E}-09$ UI
A B SOL Unit Lab Method

\begin{tabular}{lll|l}
$8.73 E-09$ & $\mu \mathrm{CV} / \mathrm{mL}$ & TM & EPA991.1M \\
$3.85 \mathrm{E}-09$ & $\mu \mathrm{C} V \mathrm{~mL}$ & TM & EPA901.1M
\end{tabular}

$3.62 E-09$ "

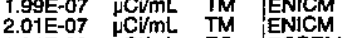

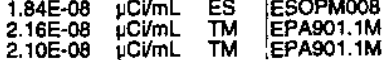

2.79E-09 $\mu \mathrm{CC} / \mathrm{mL}$ ES

$2.90 \mathrm{E}-09$ $1 \mathrm{CV \textrm {mL }}$ TM TEPA901.1M

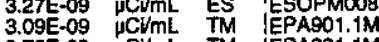

2.41E-09 $\mu \mathrm{CH} / \mathrm{mL}$ ES IESOPMOD8

2.86E-09 $\mathrm{WCVML}$ TM IEPA901.1M

3.83E-09 $\mathrm{NC} / \mathrm{mL}$ TM EPA901.1M

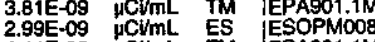

4.11E-09 $\mu \mathrm{C} / \mathrm{mL}$ TM EPA9O1.1M

7.00E-11 $\mu \mathrm{CWML}$ ES IESOPMO3

$3.00 E-10 \% \mathrm{CCmL}$ TM IEMLAMO1M

$1.20 E-10 \mu \mathrm{C} / \mathrm{mL}$ ES IESOPMO32

1.30E-10 $4 C \mathrm{CmL}$ ES IESOPMO32

$5.40 \mathrm{E}-10 \mathrm{HCV} / \mathrm{mL}$ TM EMLAMO1M

$8.000^{-11} \mu \mathrm{C} / \mathrm{mL}$ ES ESOPMO32

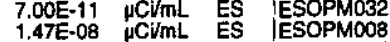

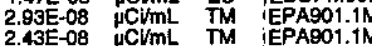

8.66E-09 $\mu \mathrm{C} / \mathrm{mL}$ ES IESOPMDO

8.39E-09 $\mu \mathrm{CVmL}$ TM EPA9O1.1M

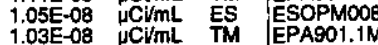

$1.03 E-08 \mu \mathrm{C} / \mathrm{mL}$ TM EPA901.1M

8.80E-10 $\mathrm{\mu CMmL}$ ES ESOPMO17

$1.60 \mathrm{E}-10 \mathrm{\mu C \textrm {CVm }}$ TM EPAM TMO0.OA

1.02E-08 $\mu \mathrm{C} / \mathrm{mL}$ TM EPA902.0N

6.57E-09 $\mu \mathrm{C} / \mathrm{mL}$ ES ES ESOPMOO8

$5.04 \mathrm{E}-09$ MCVML TM EPA901.1M

2.84E-O9 $\mathrm{HCVML}$ ES IESOPMOOO

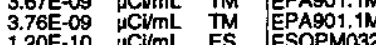

$2.20 \mathrm{E}-10$ MCUML TM EMLPUO2M

$3.10=-10 \mu \mathrm{CV} / \mathrm{mL}$ TM EMLPUO2M

1.00E-08 $\mu \mathrm{CV} / \mathrm{mL}$ TM $3500 \mathrm{NIEM}$

9.44E-09 $\mu \mathrm{CVMm}$ TM $3500 \mathrm{NIEM}$

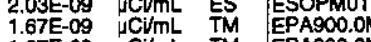

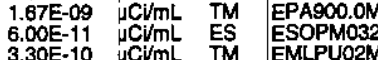

$3.30 \mathrm{E}-10$
$4.30 \mathrm{C}-10 \mathrm{~mL}$
$\mathrm{H} U \mathrm{~mL}$

$5.00 E-11$
$2.80 \mathrm{C} / \mathrm{mL}$

2.80E-10 $u$ C $V / m L$ TM EMLPU02M

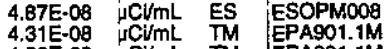

4.82E-OB $\mu \mathrm{CU} / \mathrm{mL}$ TM IEPAOPO1.1M

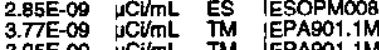

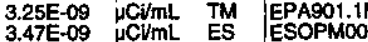

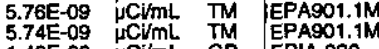


Well CSB 7D collected on 04/15/98 (cont.)

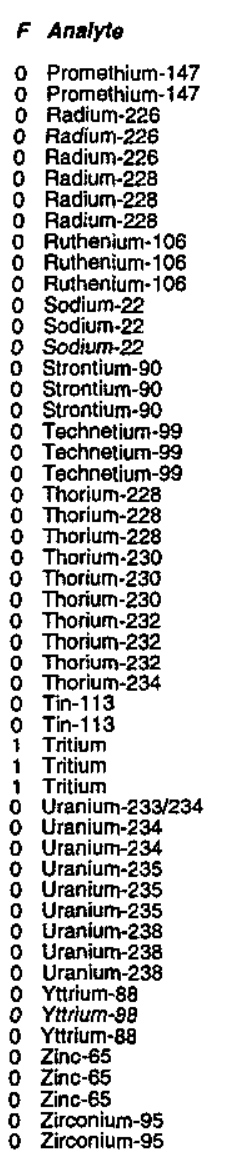$$
\text { resut }
$$

Result $R$

$4.10 \mathrm{E}-10 \pm 1.88 \mathrm{E}-09$ UI

$4.10 \mathrm{E}-10 \pm 1.88 \mathrm{E}-09$
$3.30 \mathrm{E}-10 \pm 4.25 \mathrm{E}-09$
$\mathrm{UI}$ $-2.71 \mathrm{E}-09 \pm 3.70 \mathrm{E}-10$
$6.00 \mathrm{U}-1 \pm 9.00 \mathrm{U}-11$ $1.20 \mathrm{E}-09 \pm 4.10 \mathrm{E}-10 \mathrm{U}$ $2.07 \mathrm{E}-09 \pm 1.08 \mathrm{E}-09$ U $\begin{array}{ll}1.10 \mathrm{E}-10 \pm 9.70 \mathrm{E}-10 & \mathrm{U} \\ 1.09 \mathrm{E}-08 \pm 7.92 \mathrm{E}-09 & \mathrm{~A}\end{array}$ $-2.62 \mathrm{E}-09 \pm 1.52 \mathrm{E}-08$ UI $1.50 \mathrm{E}-10 \pm 9.20 \mathrm{E}-10$
$-4.20 \mathrm{E}-10 \pm 1.61 \mathrm{U}$
-09 $-4.20 \mathrm{E}-10 \pm 1.61 \mathrm{E}-09$
$-6.40 \mathrm{E}-10 \pm 2.21 \mathrm{E}-09$
$\mathrm{UI}$ $2.40 \mathrm{E}-10+6.80 \mathrm{E}-10 \mathrm{UH}$
$0.00 \mathrm{E}+00 \pm 7.10 \mathrm{E}-10 \mathrm{UIJ}$ $3.51 \mathrm{E}-09 \pm 5.23 \mathrm{E}-09$ UI $-3.80 E-10 \pm 8.28 E-09$ UI $-3.00 \mathrm{E}-11+3.00 \mathrm{E}-11$ U $2.50 E-10+2.30 E-10$
$1.60 E-10+1.90 E-10$ $2.50 \mathrm{E}-10 \pm 5.00 \mathrm{E}-11$
$7.30 \mathrm{E}-10 \pm 4.00 \mathrm{E}-10$ $2.10 \mathrm{E}-10+2.20 \mathrm{E}-10 \mathrm{U}$ $0.00 E+00$
$2.70 E-10+2.40 E-10$
$\mathrm{UI}$ $-7.50 \mathrm{E}-10+2.52 \mathrm{E}-09 \mathrm{UI}$ $1.39 \mathrm{E}-05 \pm 1.65 \mathrm{E}-06$
$1.73 \mathrm{E}-05 \pm 9.90 \mathrm{E}-07$ $1.75 E-05 \pm 1.00 E-06$

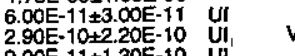
$9.00 E-11 \pm 1.30 E-10$
$0.000+00 \pm 3.00 E-11$ ..0OE-11ะ1.10E-10 $1.00 E-11 \pm 2.00 E-11$ U 1.80E-10+1.90E-10 U' $4.00 \mathrm{E}-10 \pm 1.10 \mathrm{E}-09$ UIP $8.80 E-10 \pm 2.57 E-09$ UI $1.39 \mathrm{E}-09+5.05 \mathrm{E}-09$ UI $1.20 \mathrm{E}-09 \pm 3.40 \mathrm{E}-09$
$2.07 \mathrm{E}-09 \pm 3.95 \mathrm{E}-09$

\section{WELL CSB 7D Replicate}

MEASUREMENTS CONDUCTED IN THE FIELD

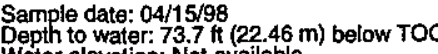

Water el

W. conductance: $62 \mu \mathrm{S} / \mathrm{cm}$

Turbidity: $0 \mathrm{NHU}$ (N)
Water evacuated from the well prior to sampling: $45 \mathrm{gal}$

ANALYSES

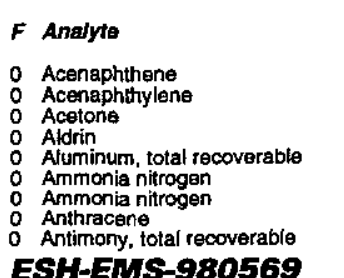

\begin{tabular}{|c|c|c|c|}
\hline Aesult & $\boldsymbol{F}^{\prime}$ & $\boldsymbol{A}$ & SOL \\
\hline $\begin{array}{l}<10.0 \\
<10.0 \\
<10.0 \\
<0.0150 \\
<16.7 \\
<50.0 \\
<50.0 \\
<10.0\end{array}$ & $\begin{array}{l}1 \\
1\end{array}$ & 6 & $\begin{array}{l}10.0 \\
10.0 \\
10.0 \\
0.0150 \\
20.0 \\
50.0 \\
50.0 \\
10.0 \\
5.00\end{array}$ \\
\hline
\end{tabular}

Time: 9:56

Ware: $21^{\circ} \mathrm{C}$

Phenolphthalein alkalinity: $0 \mathrm{mg} / \mathrm{L}$

\begin{tabular}{|c|c|c|c|}
\hline 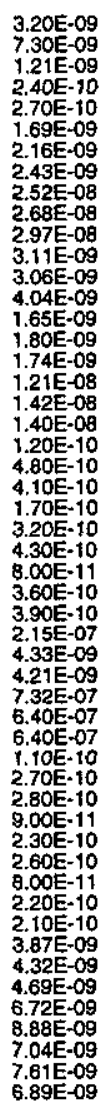 & 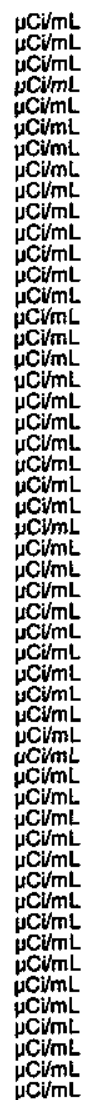 & & \\
\hline
\end{tabular}

Well CSB 7D collected on 04/15/98 (cont.)

$F$ Analyte

: Arsenic, total recoverable

alpha-Benzene hexachloride beta-Benzene hexachloride
delta-Benzene hexachloride

Benzidine

Benzo(b) fluoranthene
Benzo(k)fluoranthene

Benzorg, hi, j) perylene

Benzo(a)pyrent

Beyllium, tatal recoverable

Bis(2-chloroethyy) ther
Bis(2-chloroisopropyl) ether

Bis(2-ethythexyl) ph

Bromodichloromethan

Bromoform

4-Bromophenyl phenyl ether

Cadmium, total recoverab!e

Carcium, total recover disulfide

Chlordane

alpha-Chlordane

Chloride

4-Chloroaniline

4-Chloro-m-cresol

Chloroethane (Vinyl chloride)

Chlorotorm

C-Chloronaphthalene
2-Chonthe

4-Chlorophenyl phenyl ether

Chromium, total recoverable

Cobiti

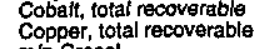

m/P-Cresol 2 -Cresol (2-Methylphenol)

P,P'-DDD

Bibenz(a,h)anthracen

Dibenzoturan

Di-n-butyl phthalate

1,3-Dichlorobenzen

3,3'-Dichlorobenzidine

1,2-Dichloroethane

1,1-Dichloroethylene
cis-1,2-Dichloroethylen

trans-1,2-Dichloroethylene

Dich-Dichmorthane

1,2-Dichloropropane
cis-1,3-Dichloropropene

trans-1,3-Dichloropropen

Diethyl phthalate

2,4-Dimethyl phen
Dimethyl phthalate
2,4-Dinitrophenol

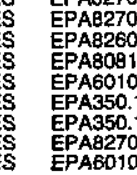

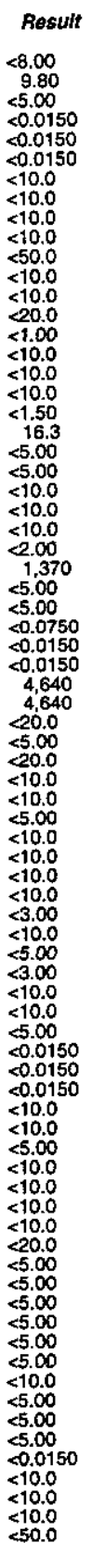

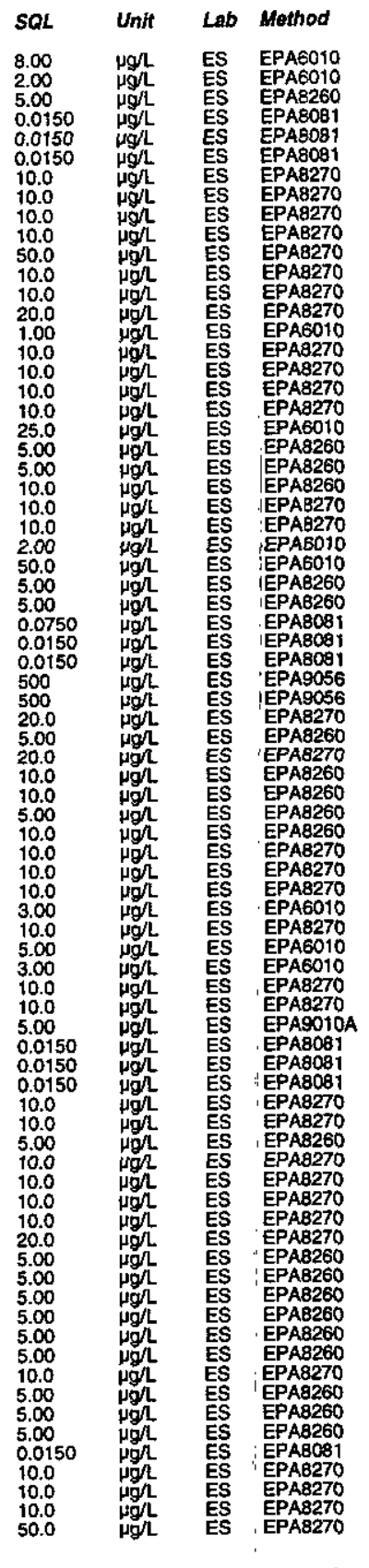

Second Quarter 1998 
Well CSB 7D collected on 04/15/98 (cont.)

$F$ Analyte.

0
0 2.4-Dinitrotoluene

Di-n-octyl phthalate

O Endosultan I

0 Endrin

Endrin kelone

Ethybbenzene
Fluoranthene

Fluorene

Heptachlor

Hexachlorobenzens

Hexachlorocyclopentadiene
Hexachloroethane

Indeno $(1,2,3-c, d)$ pyrene

Iron, total recoverable

L Lead, total recoverable

O Magnesium, total recoverable

Manganese, total recoverab

Mestoxy chlor recoverable

2-Methyy-4,6-dinitropheno
Methyl thyl ketone

Methyl isobutyl ketone

Naphthalene
Nickel, total recoverable

Nitrate as nitrogen
Nitrate as nitrogen

Nitrite as nitrogen
Nitrite as nitrogen

m-Nitroaniline

p-Nitroaniline

2-Nitrophenol

N-Nitrosodiphenylamin

N-Nitrosodipropylamin

PCB 1016
0 PCB 1221

PCB 1232

PCB 1248
0 PCB 1254
0.961260

Pentachlorophenol

Phenol

Potassium, total recoverable

Syrenienium, total recoverable

Silver, total recoverable
Sodium, total recoverable

Styrene

1.1,2,2-Tetrachloroethane

Tetrachloroethylene

- Toluene

Total organic carbon

Total phosphates (as P)
Total phosphates (as P)

Toxaphene

$1,1,1$-Trichloroethane

$1,1,2$-Trichloroetha
Trichloroethylene

ESH-ËMS-980569
Well CSB $7 D$ collected on 04/15/98 (cont.)

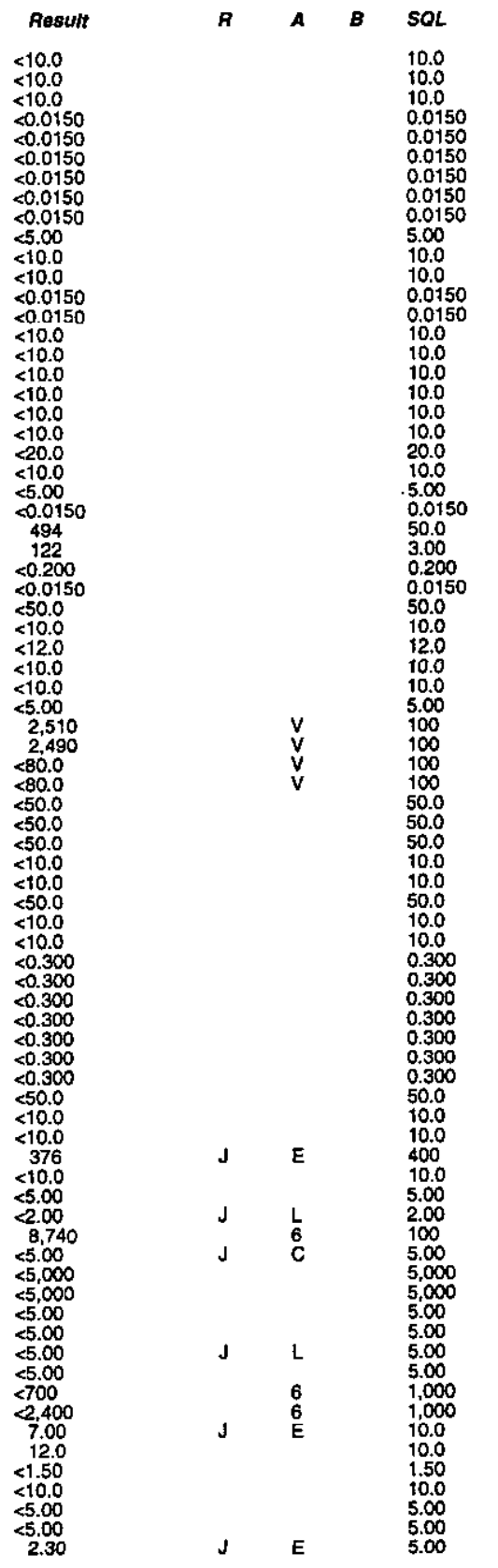

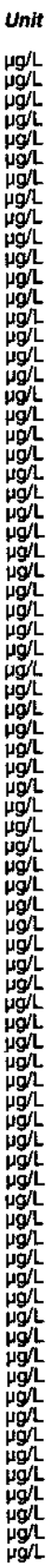

Lab Method

ES EPAB270

$F$ Analyte

Result

$\begin{array}{ll}0 & 2,4,5-\text { Trichlorophenol } \\ 0 & 2,4,6-\text { Trichlorophenol }\end{array}$

- Vanadium, total recoverabie

Z Zinc, total recoverable

- Americium-241

o Antimony-125

o Cosium-134

$\begin{array}{ll}0 & \text { Cobalt-57 } \\ 0 & \text { Cobalt-60 }\end{array}$

$\begin{array}{ll}0 & \text { Curium-242 } \\ 0 & \text { Curium-243/244 } \\ 0 & \text { Curium-245/246 }\end{array}$

0 Europium-152

Europium-155

0 Gross alpha

- Lead-212

N 2 Manganese-54

N Nonvolatile beta

: Phtonium-238

: Plutonium-239/240

- Potassium-40

Promethium-144

Radium-226

Radium-228

1 Sodium-22

Technetium-99

: Thorlum-228

o: Thorium-232

1 Trttium 2 Uranium-233/234

OUranium-233523

0 Uranilum-235

: Uranium-238

0 Zinc-65

WELL CSR 1

MEASUREMENTS CONDUCTED IN THE FIELD

Sample date: $04 / 29 / 98$
Depth to water: $12.83 \mathrm{ft}(3.91 \mathrm{~m})$ below TOC
Water elevation: $261.27 \mathrm{ft}(79.64 \mathrm{~m}) \mathrm{ms}$ l

Water el

pH: 4.5 conductance: $47 \mu \mathrm{S} / \mathrm{cm}$

$<10.0$
$<10.0$
$<2.00$
$<5.00$
$<5.00$

$\begin{array}{ll}31.9 & \end{array}$

$0.00 \mathrm{E}+00 \pm 2.00 \mathrm{E}-11$
$3.10 \mathrm{E}-09 \pm 2.38 \mathrm{E}-09 \mathrm{H}$

6.50E-104. $4.95 \mathrm{E}-09$ UIR

$7.10 \mathrm{E}-10 \pm 9.10 \mathrm{E}-10$
$4.10 \mathrm{E}-10 \pm 6.20 \mathrm{E}-10$
UIR

1.32E- $-99 \pm 9.70 E-10$ R

$-8.00 \mathrm{E}-11+5.00 \mathrm{E}-11 \mathrm{UI}$
$0.00 \mathrm{E}+00+2.00 \mathrm{E}-11 \mathrm{UI}$

$9.29 \mathrm{E}-09 \pm 4.94 \mathrm{E}-09$
$0.00 \mathrm{E}+00 \pm 1.00 \mathrm{E}-10$
$\mathrm{UIR}$

$3.07 E-09+2.46 E-09$ R
$-2.20 \mathrm{E}-10+2.90 \mathrm{E}-10 \mathrm{U}$

$-7.20 E-10+1.35 E-09$ UI
$-1.92 E-09+1.911 E-09$ UIR

$9.00 E-11 \pm 1.00 E-11 \mathrm{~J}$

$-1.23 \mathrm{E}-08+1.33 \mathrm{E}-07$ UIJ
$-6.20 \mathrm{E}-10 \pm 4.30 \mathrm{E}-10$
$\mathrm{UIJ}$

$-1.00 \mathrm{E}-11 \pm 3.00 \mathrm{E}-11 \mathrm{UI}$

$3.00 \mathrm{E}-11 \pm 2.00 \mathrm{E}-11$ U

$4.03 E-09 \pm 1.42 E-08$
$4.30 E-10 \pm 8.80 E-10$
UIR

$-9.60 E-10 \pm 11.12 E-09$ UP

$2.40 \mathrm{E}-10 \pm 3.30 \mathrm{E}-10$
$8.10 \mathrm{E}-10 \pm 3.30 \mathrm{E}-10$

$2.14 E-08 \pm 8.32 E-09$
$7.00 E-12 \pm 1.05 E-09$
UIR

$-2.80 \mathrm{E}-10 \pm 5.80 \mathrm{E}-10$ U

4. $15 \mathrm{E}-09+4.99 \mathrm{E}-09$ U

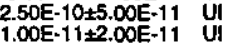

$1.39 E-09+2.47 E-08$ UIR

1.10E-10+4.00E-11

$6.00 E-11 \pm 4.00 E-11$
$-1.00 E-11 \pm 1.00 E-11$

$3.00 E-11 \pm 2.00 E-11$ UI

$-3.00 \mathrm{E}-11 \pm 3.00 \mathrm{E}-11$ UI
$-5.80 \mathrm{E}-10 \pm 1.19 \mathrm{E}-09$ UIA

$-5.80 E-10 \pm 1.19 E-09$
$-3.60 \mathrm{UIR}-10+2.1 \mathrm{E}-09$ UIR

Water evacuated from the well prior to sampling: $33 \mathrm{gal}$ ANALYSES

$F$ Analyte

O Acenaphthene

Acenaphthene

Acenaphthylene

Acenaphthylene

B-45

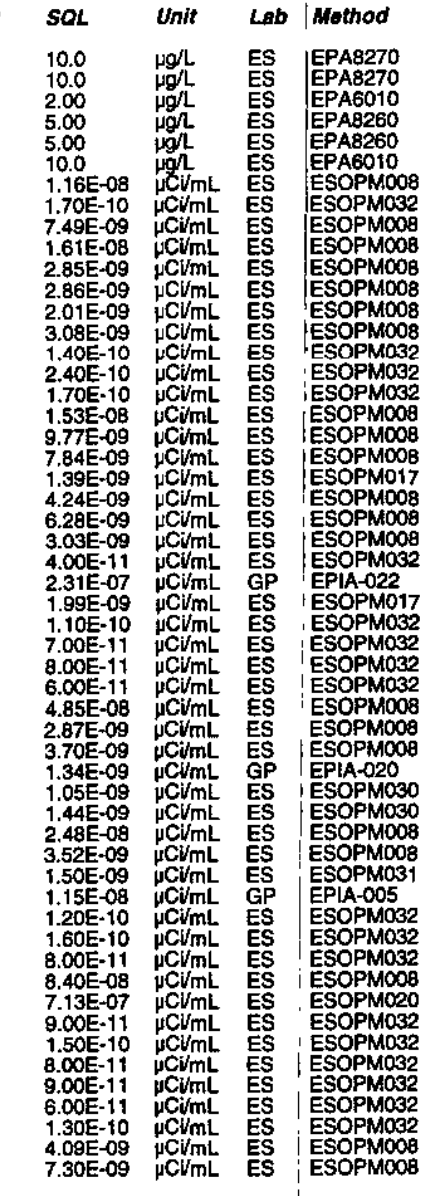

Time: 9:03

Water temperature: $17.4^{\circ} \mathrm{C}$

Air temperature: $17.3^{\circ} \mathrm{C}$
Total alkalinity (as Caco3) : $1 \mathrm{mg} / \mathrm{L}$
Phenolphthalein alkalinity: $0 \mathrm{mg} /$

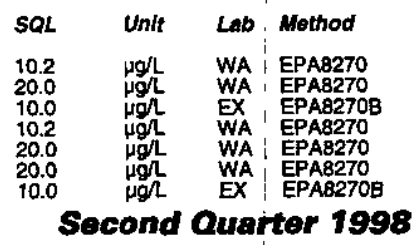


Well CSR 1 collected on 04/29/98 (cont.)
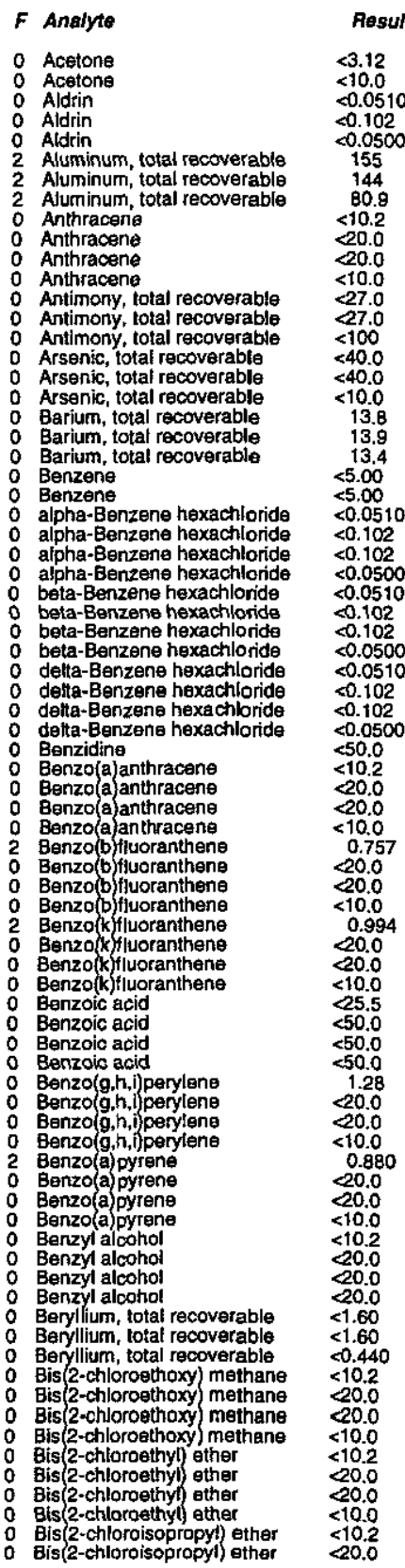

Well CSR 1 callected on 04/29/98 (cont.)

O Bis(2-chloroisopropyl ether
0 Bis 2-chloroisopropyl) ether
0 Bis 2-ethylhexy' phthalate

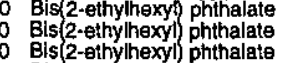

Bis(2-ethylhexyl) phthalate

Bromodichloromethane

Bromodich

Bromomethan

Bromomethane

4-Bromophenyl phenyl ether

4-Bromophenyl phenyl ether

Butylbenzyl phthalate
Butylbenzyl phthatate

Cadmium, total recoverable

C Cadmium, total recoverable

- Calcium, total recoverable

Carbazol

- Castazolo

Carbon disulfid

Carbon disulfide

0 Carbon tetrachloride

alpha-Chlordane

alpha-Chlordane
alpha-Chlordane

alpha-Chlordane

gamma-Chlordane

gamma-Chlordane

Chloride

Chloride

4-Chloroanlitine

4-Chloroaniline

Chlorobenzene

4-Chloro-m-cresol

Chloroethane

Chloroethane
0 Chloroethene Vinyl chtoride
0

Chloroororm

\section{Chloromethane}

2-Chloronaphthalene
2-Chloronaphthalene

2-Chloronaphthalene

2-Chlorophenol

2-Chlorophenol

4-Chlorophenyl phenyl ether

4-Chlorophenyl phenyl ether

4-Chlorophenyy phennyl ethe

4-Chlorophenyl phenyl ether
O Chromium, total recoverable
0 Chromium, totala recoverable
0 Chromium, total recoverable

5.00

$<20.0$
2-sec-Butyl-4,6-dinitropheno

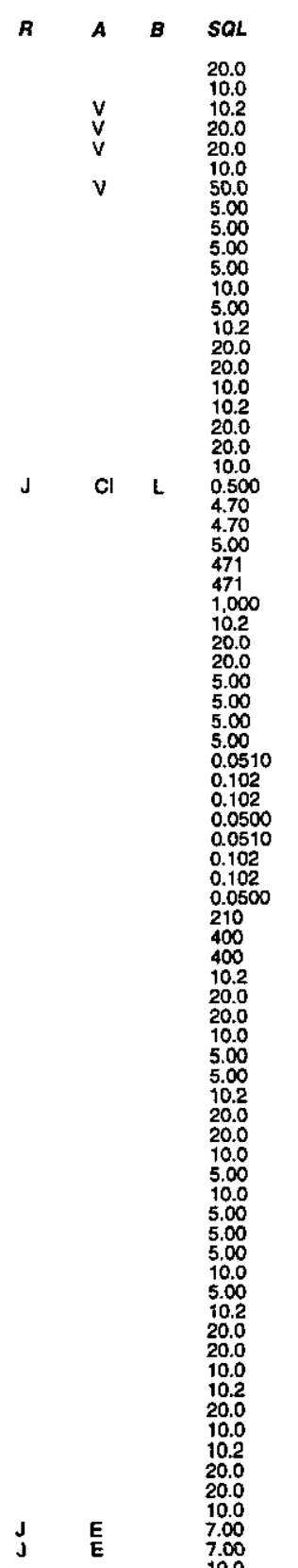

sQL
20.0
10.0
10.2
20.0
20.0
10.0
50.0
5.00
5.00
5.00
5.00
10.0
5.00
10.2
20.0
20.0
10.0
10.2
20.0
20.0
10.0
0.500
4.70
4.70
5.00
471
471
1.000
10.2
20.0
20.0
5.00
5.00
5.00
5.00
0.0510
0.102
0.102
0.0500
0.0510
0.102
0.102
0.0500
210
400
400
10.2
20.0
20.0
10.0
5.00
5.00
10.2
20.0
20.0
10.0
5.00
10.0
5500
5.00
5.00
100
5.00
10.2
20.0
20.0
10.0
10.2
20.0
10.0
10.2
20.0
20.0
10.0
7.00
7.00
10.0

Unit

$<20.0$

$<73.1$
$<84.7$
10.5
$<16.3$

$<5.00$
$<5.00$

$<10.0$
$<10.2$

$<1.500$
$<4.70$

$<.00$
2,750

$<20.00$

$<5.00$

$<0.0510$

$>0.0500$

$<0.102$

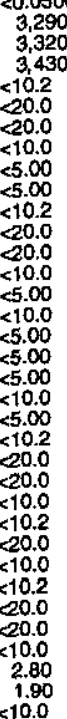

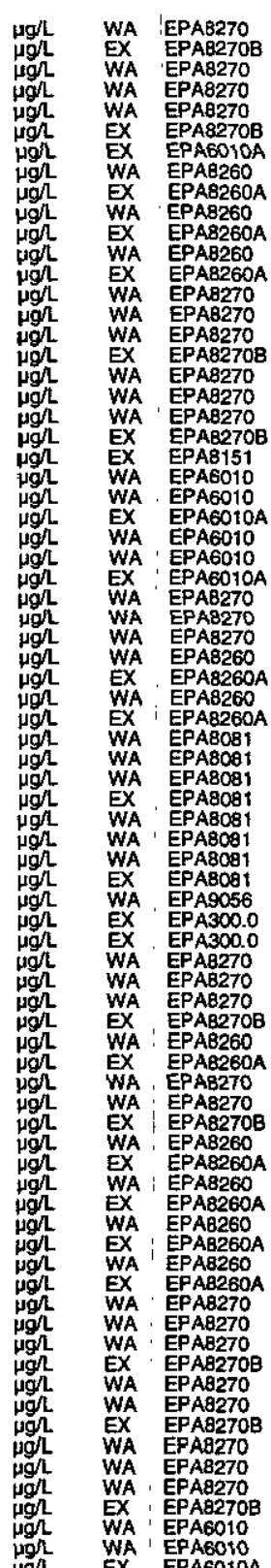

Socoind Quarter 1998 
Well CSR 1 collected on 04/29/98 (cont.)

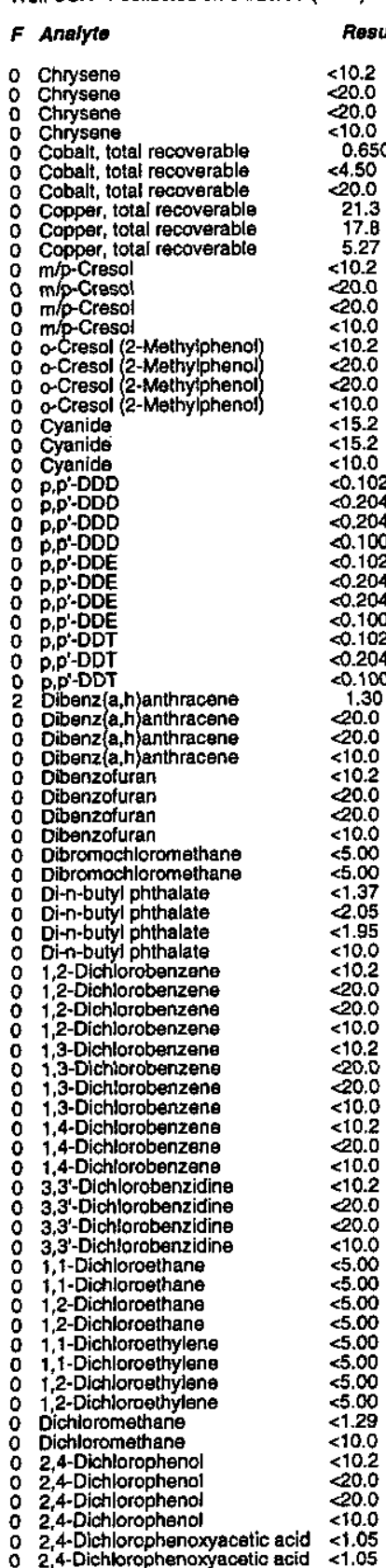

ESH-EMS-980569
Well CSR 1 collected on 04/29/98 (cont.)

Result

- 2.4-Dichlorophenoxya

0.500
55.00
5.00
5

cis-1,3-Dichloropropen

trans-1,3-Dichlorapropen

0 Dieldrin

D Diethyl phthalate

Diethyl phthalate

2,4-Dimethyl phenol

2.4-Dimethyl pheno

Dimethyl phthalate

Dimethyl phthalate

2,4-Dinitropheno

2,4-0initrophenol

2,4-Dinitophen

2,4-Dinitrotoluen

2,6-Dinitrotoluene

2,6-Dinitcotoluene

Di-n-octyy phthalate

Di-n-octyy phthalate

Endosulian suffate

Endosultan sulfate

Endosulfian I

Endosulfan

Endosulfan \#

Endosultan \|

Endrin

Endrin

o Endrin aldehyde

政 Endrin keton

Endrin ketone

Ethylbenzen:

Fluoranthene

Fluoranthene

o Fluorene

Fluorene

0 Fluorid

0 Fluoride

0 Fluoride

o Heptachlor

Heptachlor epoxide

Heptachlor epoxide

B-47
R

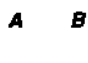

Lab Method

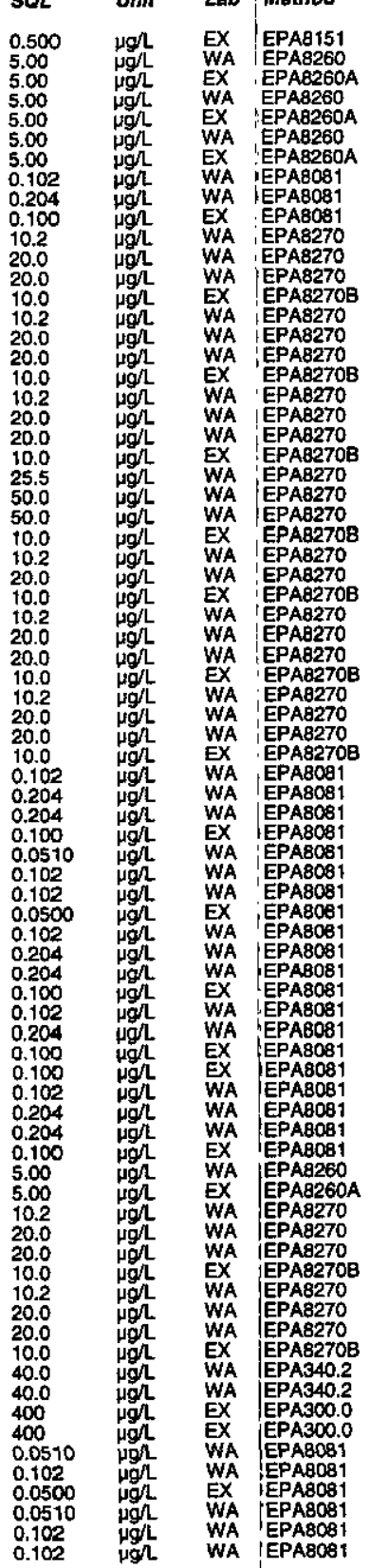

Second Quarter 1998 
Well CSR 1 collected on 04/29/98 (cont.)

F Analyte

- Heptachlor epoxide

Heptachlorodibenzo-p-dioxins

Heptachlorodibenzo-p-furans

Heptachlorodibenzo-p-turans

Hexachlorobenzene

Hexachlorobenzene

Hexachlorobutadien

Hexachlorobutadian

Hexachlorocyclopentadion

Hexachlorocyclopentadiente

Hexachlorocyclopentadiene
Hexachlosodibenzo-p-dioxins

Hexachlorodibenzo-p-dioxins

Hexachlorodibenzo-p-turans
Hexachlorodibenzzo-p turans

Hexachlorodibenzo-p-turans

Hexachloroethan
Hexachloroethan

Hexachloroethan

2-Hexanone

$1,2,3,4,6,7,8$-HPCDD

$1,2,3,4,6,7,8-H P C D D$
$1,2,3,4,6,7,8-H P C D D$

$1,2,3,4,6,7,8-\mathrm{HPCDPF}$
$1,2,3,4,6,7, \mathrm{HPCDDF}$
$1,2,3,6,7-\mathrm{HPCDF}$

$1,2,3,4,7,8-H X C D D$

$1,2,3,4,7,8-H X C D D$
$1,2,3,4,7,8-H X C D D$

$\begin{array}{ll}0 & 1,2,3,4,7,8-H X C D F \\ 0 & 1,2,3,4,7,8-H X C D F\end{array}$

$1,2,3,4,7,8-H \times C D F$

inderoo $1,2,3-c, 0$ pyrene

Indeno $(1,2,3-c, d)$ pyrene

Iron, total recoverable
Iron, total recoverable

Iron, total recoverable

Isophorone
isophorone
sophorone

Lead, total recoverabie

Lead, total recoverab:

o Lindane

0 Lithium, total recoverable

: Lithium, total recoverabie

Magnesium, lotal recoverab

Magnesium, total recoverable

Manganese, total recoverab:

Merculy, total recoverabie

Mercury, total recoverable

: Methoxychlor

ESH-EMS-980569

$<10$.
Well CSR 1 collected on 04/29/98 (cont.)

Resuit

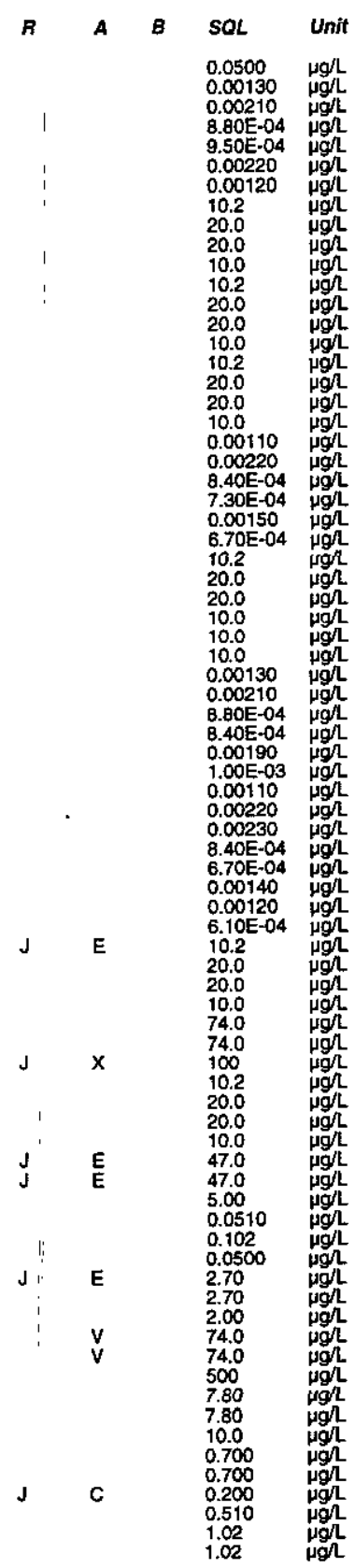

Lab Method

EX EPA8091

$<0.0500$
$<0.00130$
$<0.00210$ $<8.80 \mathrm{E}-04$
$<9.50 \mathrm{E}-04$
$<0.00220$

$<0.00120$

$<1.0$
40.2
20.0
20.0
$<10.0$
40.0
20.2
20.0
20.0
40.0

$<0.00220$

$<7.306-04$

$<6.70 \mathrm{E}-04$

$<0.2$
$<0.0$
$<0.0$
$<10.0$

$<<10.013$

$<0.00210$
$<.800-04$
5

$<8.8 .80 E^{-04}$

$<1.00 E-.03$

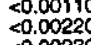

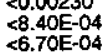

$<0.00140$
$<0.00120$
$<6.10 \mathrm{E}-04$

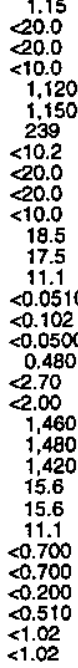

F Analyte

Result

\begin{tabular}{|c|c|}
\hline 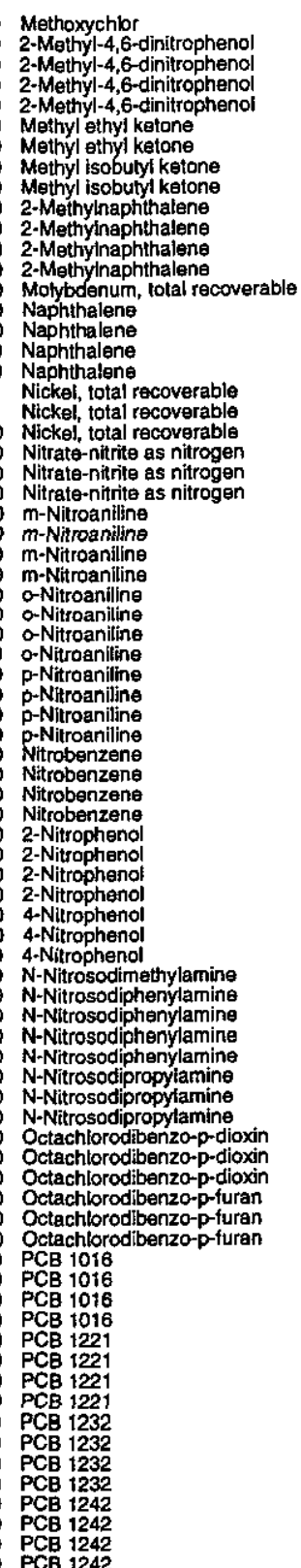 & 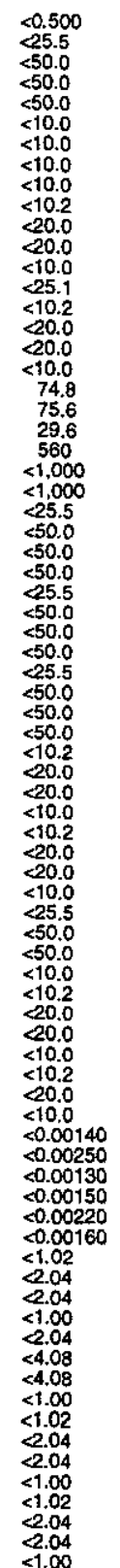 \\
\hline
\end{tabular}
$B$

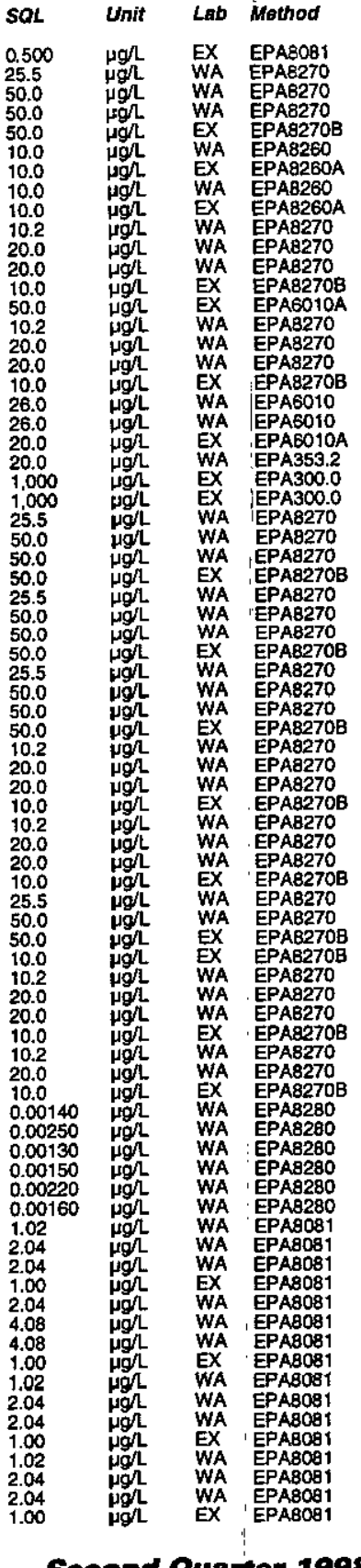


Well CSR 1 collected on 04/29/98 (cont)

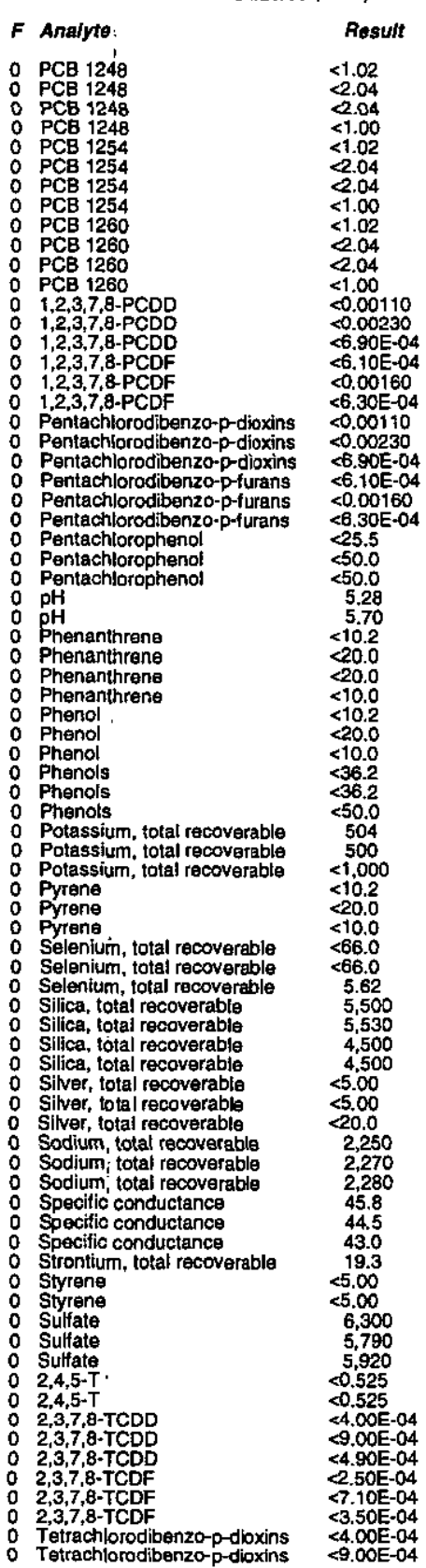

ESH-EMS-980569
Well CSR 1 collected on 04/29/98 (cont.)

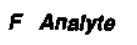
Result
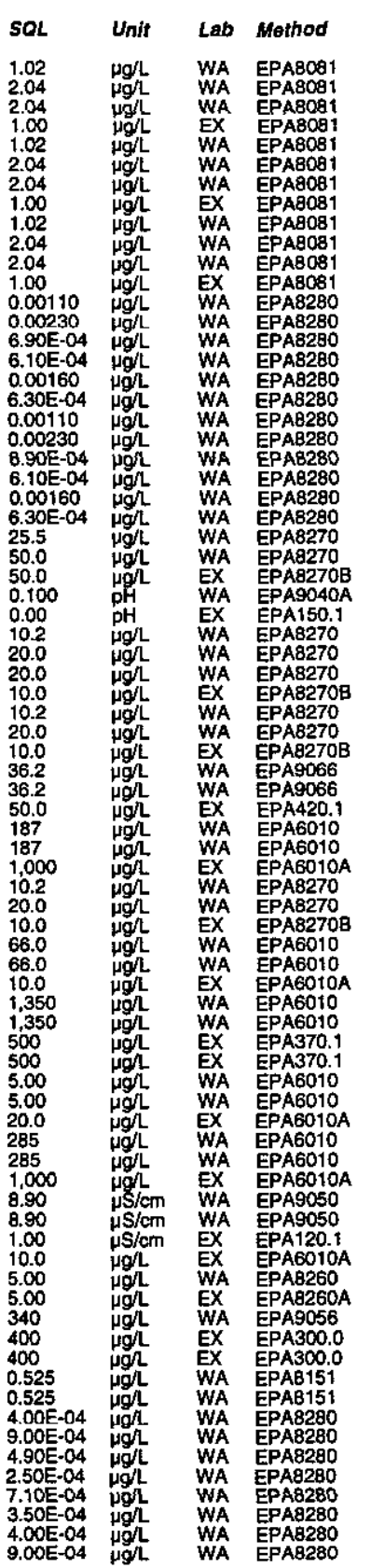

0 Tetrachlorodibenzo-p-dioxins

Tetrachlorodibenzo-p-furans
Tetrachlorodibenzo-p-furans
Tetrachlorodibenzo-p-furans

o $1,1,2,2$-Tetrachloroethane

Tetrachloroethylen

: Thallium, total recoverable

Thallium, total recoverabl

Toluene

0 Total dissolved solids

- Total organic cartoon

T Total organic carbon

- Total organic halogens

Total phosphates (es P)
0 Total phosphates (as P)

o Toxaphern

0 Toxaphene

2,4,5-TP (Silvex)

2,4,5-TP Silvex

: $\begin{aligned} & \text { t,2,4-Trichlorobenzene } \\ & 0\end{aligned}$

1,2,4-Trich orobenzen

o 1,i, i-Trichloroethan

1,1,2-Trichloroethane

Trichloroethylen

2,4,5-Trichlorophenol

2,4,5-Trichlorophenen

o $2,4,6$-Trichlorophenol

2,4,6-Trichlorophenol
o Vanadium, total recoverab

V vanadium, total recoverable

V Vanadium, total recoverable

Vinyl acetate

Xylense

o Zinc, total recoverable

o Zinc, total recoverable

WELL CSR 1 Replicate

$4.90 E-04$
$2.50 E-04$
$<7.10 E-04$
$3.50 E-04$

$<5.00$

$<5.00$

$<55.00$

$<5.00$
$<5.00$

MEASUREMENTS CONDUCTED IN THE FIELD

Sample date: 04/29/98

Wpiter to water: $12.83 \mathrm{H}(3.91 \mathrm{~m})$ below TOC

$\mathrm{pH}: 4.5$

Sp. conductance: $47 \mu \mathrm{S} / \mathrm{cm}$

Water evacuated trom the well prior to sampling: $33 \mathrm{gal}$

ANALYSES

F Anayte

Acenaphtinene
Acenaphthylane

: Acetont

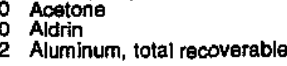

Resut

$<10.0$

B-49

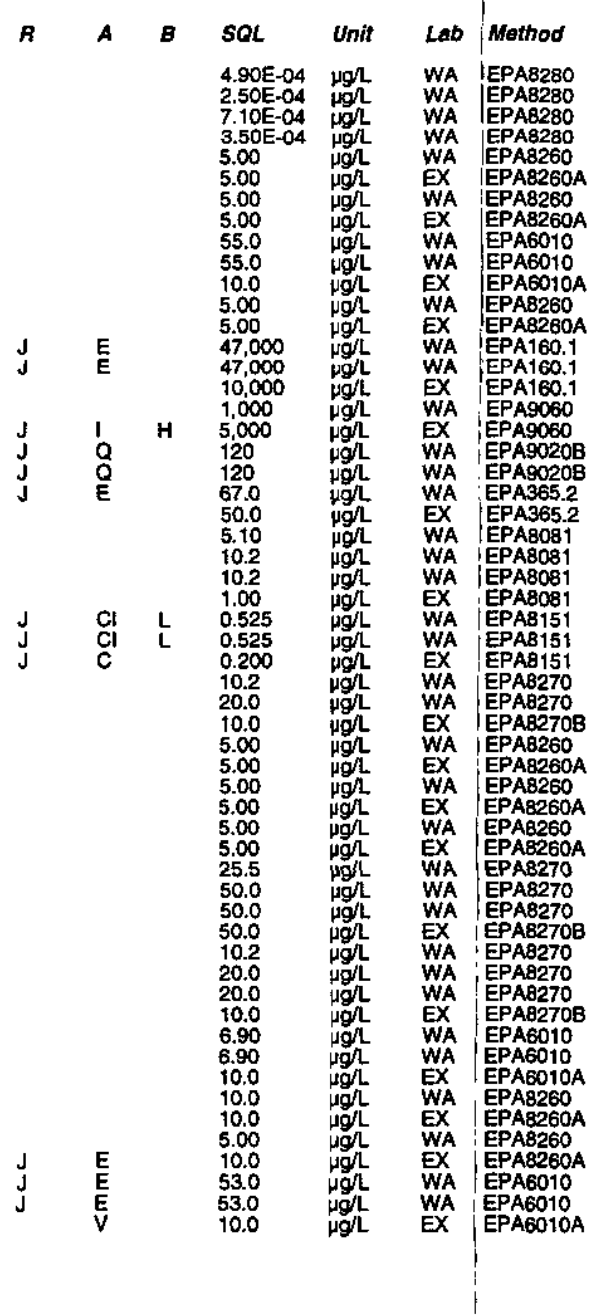

Time: 9:03

Air tomempere: $17.4^{\circ} \mathrm{C}$

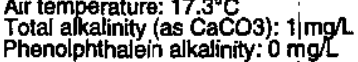

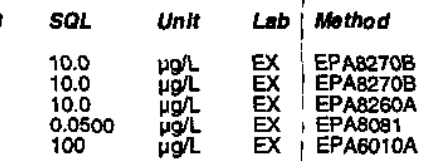

Second Quarter 1998 
Well CSR 1 collected on 04/29/98 (cont.)

$F$ Analyto

: Anthracene Arsenic, total recoverable
Barium, total recoverable alpha-Benzene hexachloride
beta-Benzene hexachloride detta-Benzene hexachloride Benzidine Benzoj blficuoractithene Benzo(k) fluoranthene Benzo(g,h,l)peryten Benzo(a)pyrene
Benzyl alcohol Beryllum, toat recoverabie
Bis(2-chloroethoxy) methan Bis(2-chloroethy) ether
Bis(2-chloroisopropyl) Bis(2-ethylhexy') phthalate Bromodichloromethane Bromomethan 4-Bromophenyl phenyl ether 2-58c-Butyl-4,6-dinitropheno Cadmium, total recoverable
Calcium, total recoverable Carbon disufficte alpha-Chlordane

4-Chboroanilin Chlorobenzene Chloroethene (Vinyl chloride) Chloroform 2-Chloronaphthalen 4-Chlorophenyl phenyl ether Cobalt, total recoverable mip-Cresol oresol (2-Methylphenol) P.p'-DDD

$p, P, D D E$

Dibenz $(a, h)$ anthracene Dibenzoturan Di-n-butyl phthalate 1,2-Dichlorobenzente 1.4-Dichlorobenzene 1.1-Dichtoroethane 1.1. Dichloroethylene Dichloromethane 2,4-Dichlorophenoxyacetic acid 1,2-Dichloropropane cis-1,3-Dichlioropropene
trans-1,3-Dichloropropene 2iethyl phthalate

Well CSR 1 collected on 04/29/98 (cont.)

Result
$<10.0$
$<100$
$<10.0$
13.8
$<5.00$
$<0.0500$
$<0.0500$
$<0.0500$
$<50.0$
$<10.0$
$<1.0$
$<10.0$
$<5.0$
$<10.0$
$<1.0$
$<20.0$
$<0.200$
$<10.0$
$<10.0$
$<10.0$
$<1.0$
$<1.5$
$<5.00$
$<5.00$
$<5.00$
$<10.0$
$<10.0$
$<0.500$
$<5.00$
2.810
$<5.00$
$<5.00$
$<0.0500$
$<0.0500$
3.270
$<10.0$
$<5.00$
$<20.0$
$<5.00$
$<500$
$<5.00$
$<5.00$
$<10.0$
$<10.0$
$<1.0$
$<10.0$
$<10.0$
$<20.0$
4.49
$<10.0$
$<10.0$
$<10.0$
$<0.100$
$<0.100$
$<0.100$
$<10.0$
$<10.0$
$<5.00$
$<10.0$
$<10.0$
$<10.0$
$<10.0$
$<10.0$
$<5.00$
$<5.00$
$<5.00$
$<5.00$
$<10.0$
$<10.0$
$<0.500$
$<5.00$
$<5.00$
$<5.00$
$<0.100$
$<10.0$
$<10.0$
$<10.0$

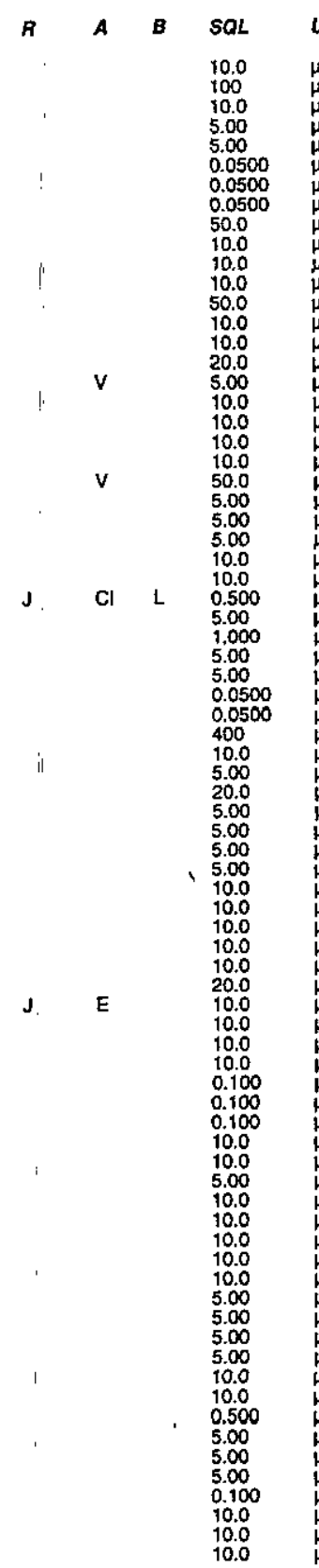

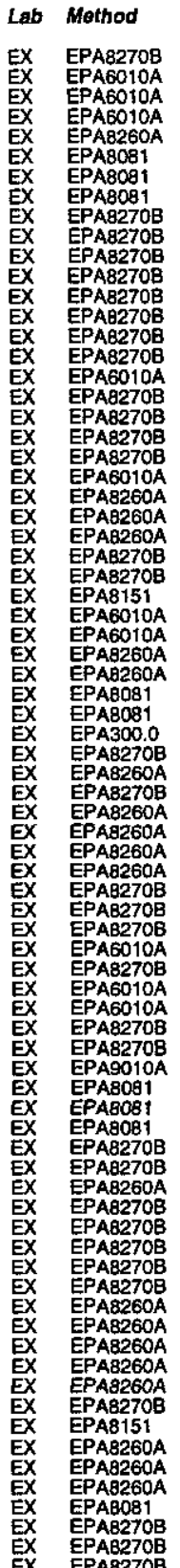

Analyte

2.4-Dinitrophenol
2.4-Dinitrotoluan

2,6-Dinitrotoluene

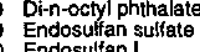

Endosultan I

Endrin aldehyde

Ethylbenzene

F Fluoranthene

o Fluorene

Heptachlor

Heptachlorodibenzo-p-dioxin

o Hexachlorobenzenzene

Hexachlorocyclopentadiene

Hexachlorodibenzo-p-dioxins
Hexachlorodibenzo-p-turans

o Hexachloroethane

of 2-Hexanon

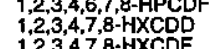

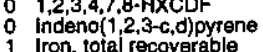

o Lophorone tocoverable

tithium, total recoverable Magnesium, total recoverable Manganese, total recovera

2-Methyl-4,6-dinitrophenal

Methyl ethyl ketone

2-Methylnaphthalane

Molybdenum, total recoverable

Nickel, total recoverable

Nitrate-nitrite as nitrogen

: m-Nitroaniline

P-Nitroaniline

2-Nitrophenol

$\begin{array}{ll}0 & \text { N-Nitrosodimethylamine } \\ 0 & \text { N-Nitrosodiphenylamine } \\ 0 & \text { N-Nitrosodipropylamine }\end{array}$

Octachlorodibenzzo-p-diloxin

- PCB 1016

PCB 1232

PCB 1248

$\begin{array}{ll}0 & 1,2,3,7,8-P C D D \\ 0 & 1,2,3,7,8-P C D F\end{array}$

benzo-p-dioxins

Pentachlorodibenzo-p-turan

Phenanthrene

o Phenols

Potassium, total recoverable

Dyrene tal recoverable
Resuft

$<10.0$
$<10.0$

$<10$.

$<0.100$

$<0.100$
$<0.100$
$<0.100$

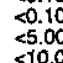

$<10.0$
$<400$
$<0.0500$

$\$ 0.0500-04$

10.0

$<10.0$

$<1.00 \mathrm{E}-03$

$<10.0$

$<9.40 \mathrm{E}-04$
$<0.00110$

$<\begin{aligned} & <1.00 \mathrm{E}-03 \\ & <7.90 \mathrm{E}-04\end{aligned}$

$<10$

$<10.0$
10.5
$<0.0500$

2.0 .500
2.00
1.530
5

$<0$

$<10.0$
$<10.0$
$<10.0$
$>>7.70$
$<10.0$

$<10.0$
24.7
$<1.000$
550.0

$<5$

$<55.0$
$<10.0$
$<10.0$
$\leq 50.0$
$<10.0$
$<10.0$

$<10.0$
$<0.00140$
$<0.0120$

$<1.00$

$<1.00$
$<1.00$
$<1.00$
$<1.00$

$<1.00$

$<1.00$
$<0.00110$
$<5.600-04$

$<0.00110$
$55.60 \mathrm{E}-04$

$<50.0$

$<10.0$
$<10.0$
$<50.0$

$<1.000$
$<100$
$<10.0$

s.

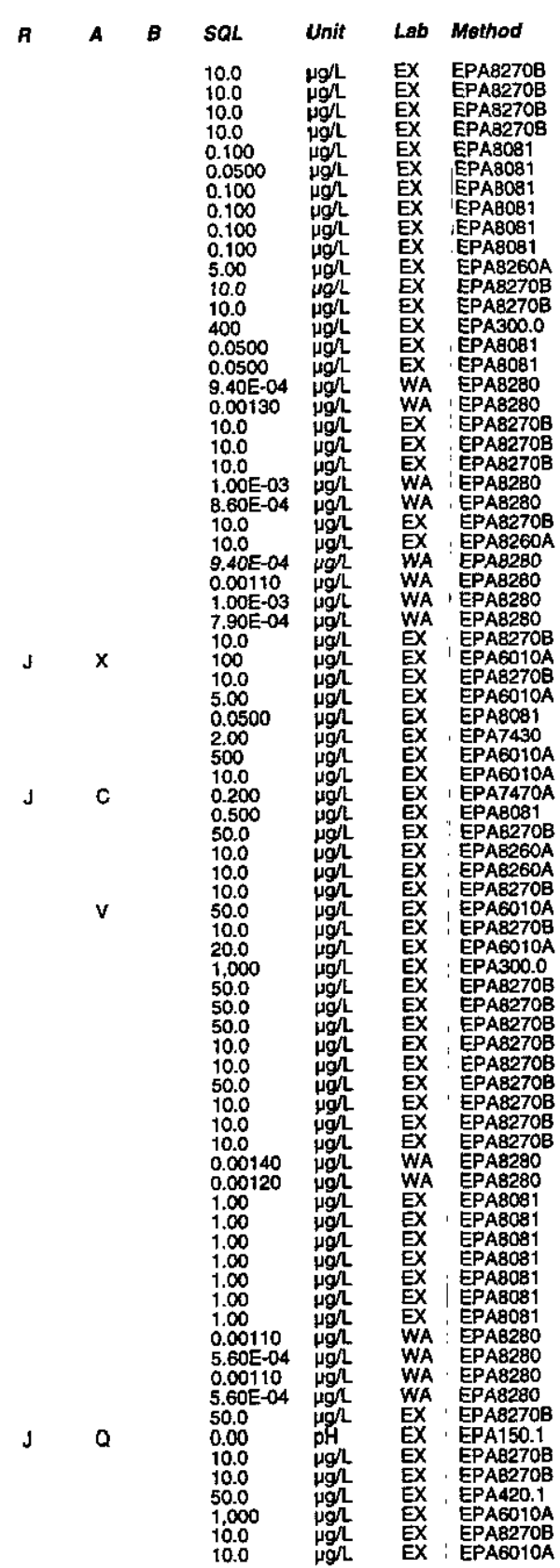

Second Quarter 1998 
Well CSR 1 coliected on 04/29/98 (cont.)

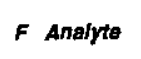

- Silica, total recoverable

Silica, total recoverable
silica, total recoverable

Silver, total recoverable

Specific conductance

: Styrene

2,3,7,8-TCDD

Tetrachlorodibenzo-p-dioxins

0 Tetrachlorodibenzo-p-turans

0 1,1,2,2-Tetrachtorosthane

Thallium, total recoverabie

Total dissolved sotids

Total organic caloogens

Toxaphene
2,4,5-TP (Silvex)

1,2,4-Trichlorobenzene

: $1,1,1$-Trichloroethane

Trichloroethylene

2,4,6-Trlchlorophenol

Vanadium, tot
Vinyl acotate

Zinc, total recoverable

\section{WELL CSR}

MEASUREMENTS CONDUCTED IN THE FIELD

Sample date: 06/01/98
Depth to water: $12.96 \mathrm{ft}(3.95 \mathrm{~m})$ below TOC
Water elevation: $261.14 \mathrm{ft}(79.6 \mathrm{~m}) \mathrm{ms}$

Water

Pp. conductance: $40 \mu \mathrm{S} / \mathrm{cm}$

Water evacuated from the well prior to sampling: $138 \mathrm{ga}$

ANALYSES

$F$ Analyto

: Acenaphthene

Acaton
Aldrin

Aluminum, total recoverable

Antimony, total recoverable

Arsenic, total recoverable

alpha-Benzene hexachloride

beta-Benzene hexachloride

Benzidine

Eenzo(:)anthracene

Benzo okf fluoranthene

Benzzog,h,i)pery

Eenzyl alcohol

Eerylium, lotal recoverable

Bis (2-chloroethyl) methan

Bis 2-chloroisopropyl) ether

Bis(2-ethylhoxyl) phthala
Bromodichloromethane

Bromoform

ESH-EMS-980569

Result
$<10.0$
$<10.0$
$<10.0$
$<0.0500$
114
$<10.0$
$<100$
$<10.0$
13.8
$<5.00$
$<0.0500$
$<0.050$
$<0.0500$
$<50.0$
$<10.0$
$<10.0$
$<10.0$
$<10.0$
$<10.0$
$<0.0$
$<0.530$
$<10.0$
$<10.0$
$<10.0$
$<10.0$
$<5.00$
$<5.00$
$<5.00$

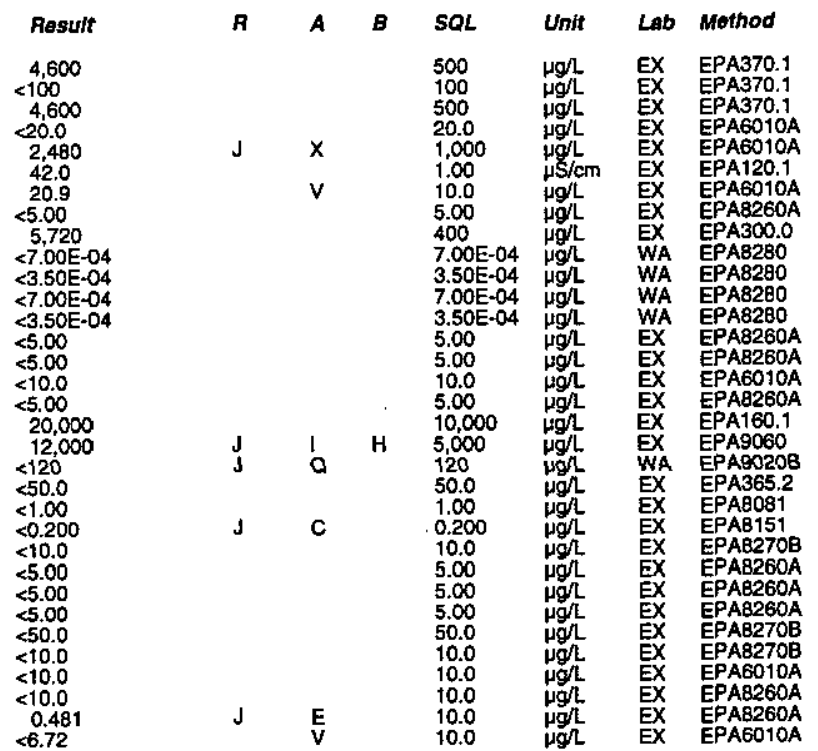

Well CSR 100

o 4-Bromophenyl phenyl ether

2-sec-Butyl-4,6-dinitropheno
Cadmmium, total recoverable

Caicium, total recoverable

Caboon tetrachioride
alpha-Chlordare

gamma-Chlordane

O Chlorida

4-Chloroaniline

4-Chloro-m-cresol

Chloroethene (Vinyl chloride)

2-Chlorenaphinthalene

4-Chlorophenyt phenyl ether

Coper total recoverabiable

m/p-Cresol

p,p'-DDD

P,P'-DDE

Dibenz(a,h)anthracene

1,2-Dichlorabenzen

1,4-Dichlorobenzenere

Time: 9:54

Water temperature: $15^{\circ} \mathrm{C}$

Total alkalinity (as CaCO3): $1 \mathrm{mg} / \mathrm{L}$
Phenolphthalein alkalinity: $0 \mathrm{mgL}$

1,1-Dichloroethane

1,i-Dichloroesthylen

1,2-Dichloroethylen

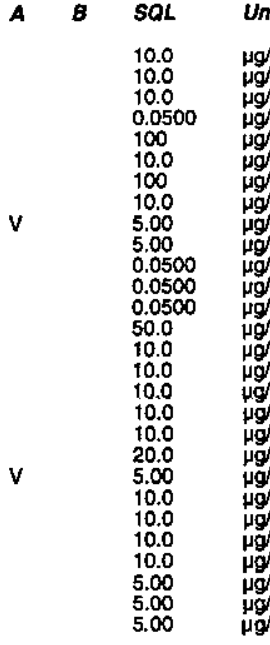

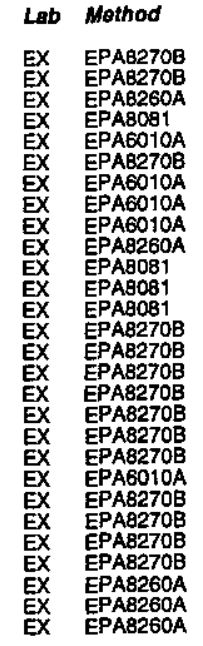

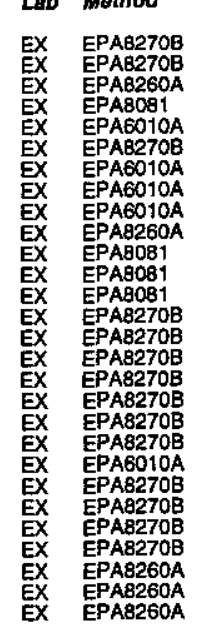

$<10.0$
$<10.0$

$<0.500$
$<5.00$
2.440

$<0.0500$

3.510

$<5.00$

$<5.00$

$<10.0$
$<10.0$

$<10.0$
$<10.0$

s.

$<10.0$
$<10.0$
$<0.100$
$<0.100$

$<0.100$
$<10.0$

$<10.0$
$<500$
$<10.0$

2,4-Dichlorophenol

1,2-Dichloropropane

o trans-1,3-Dichloropropene

Dieldrin

Dimethyl phthalate

2,4-Dintrophenol

Di-n-Dintrotoluene phthatate

Endosuffan sulfate

Endosulfan II

Endrin aldehyde

Endrin ketone

Fluoranthene

Fluoride

Fiuoride

Heptachlor epoxide
Heptachlorodibenzo-p-dioxin

Heptachlorodibenzo-p-dioxing

Heptachlorodibenzo-p-furans
Heptachlorodibenzo-p-furans

Hexachlorobenzene

Hexachlorobutadlene
Hexachlorocyclopentadiene

$3-51$

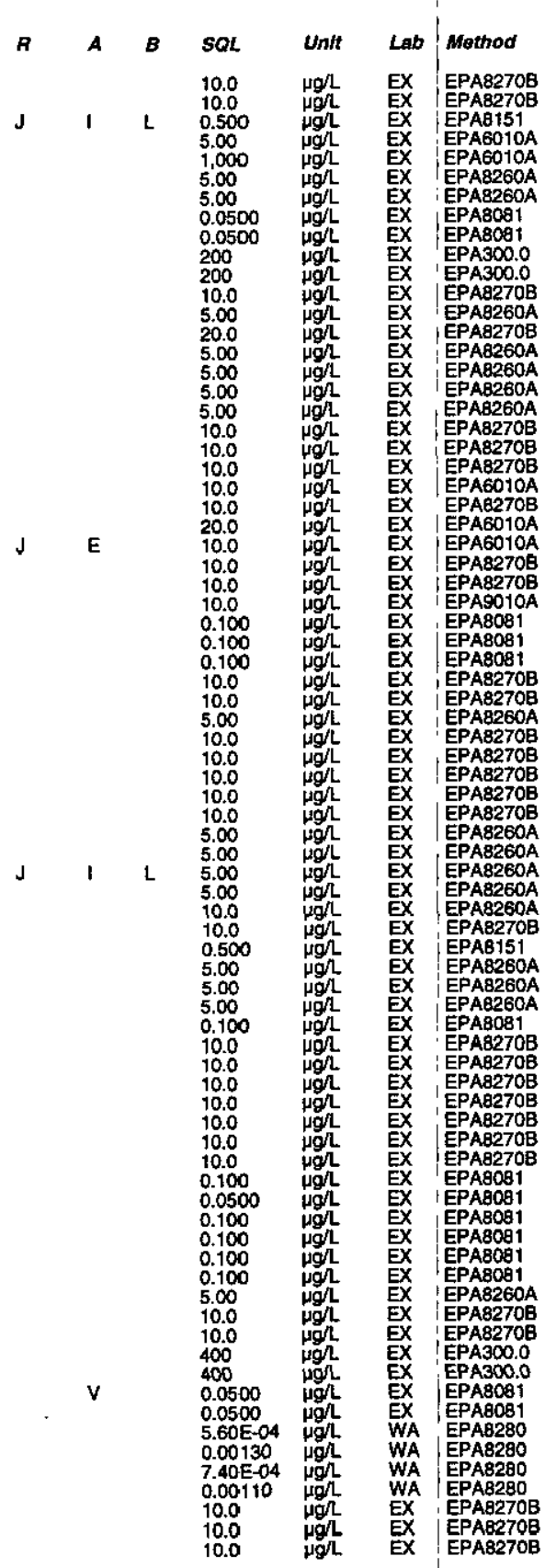

Second Quarter 1998 
Well CSA 1 collacted on 06/01/98 (cont),

$F$ Analyte

- Hexachlorodibenzo-p-dioxins Hexachlorodibenzo-p-dioxins
Hexachlorodibenzo-p-furans
Hexachlorodibenzo-p-furans Hexachlorothethanis 2-Hexanons $1,2,3,4,6,7,8-H P C D D$ $1,2,3,4,6,7,8$-HPCDF $1,2,3,4,7,8-4 X C D D$ $1,2,3,4,7,8-\mathrm{HXCDOD}$ $1,2,3,4,7,8-\mathrm{HXCD}$ Indeno( $1,2,3-c, d)$ pyrene
Iron, total recoverabiti Lead, total recoverable Lindane
Lithium, total recoverable Magnesium, total recoverab Mercury, total recoverable Methoxychlor
2-Methyl-4,6-dinitropheno Methyl ethyl ketone 2-Methylnaphinale Nickel, total recoverable Nitrati-nitinte as nitrogen
Nitrate-nitrite as nitrogen o-Nitroaniling p-Nitroanilin 2-Nitrophen N-Nitrosodimethylamine N-Nitrosodiphenylamine Octachlorodibenzo-p-dioxi Octachlorodibenzo-p-dioxin Octachlordibenzo-p-puran PCB 1016 $P C B 125$ $P C B, 3,7,8-P C D$
$1,2,7-P C D D$ $1,2,3,7,8-P C D D$
$1,2,3,8-P C D F$

Pentachlorodibenzo-p-dioxins Pentachlorodibenzo-p-dioxins Pentachlorodibenzo-p-jurans tachlorophen

0 Phenanthrene

Phenol

Potassium, total recoverable S Selenium, total recoverable - Silica, total recoverable - Sodium, total recoverab0
0
0

ESH-EMS-980569
Well CSR 1 collected on 06/01/98 (cont.)

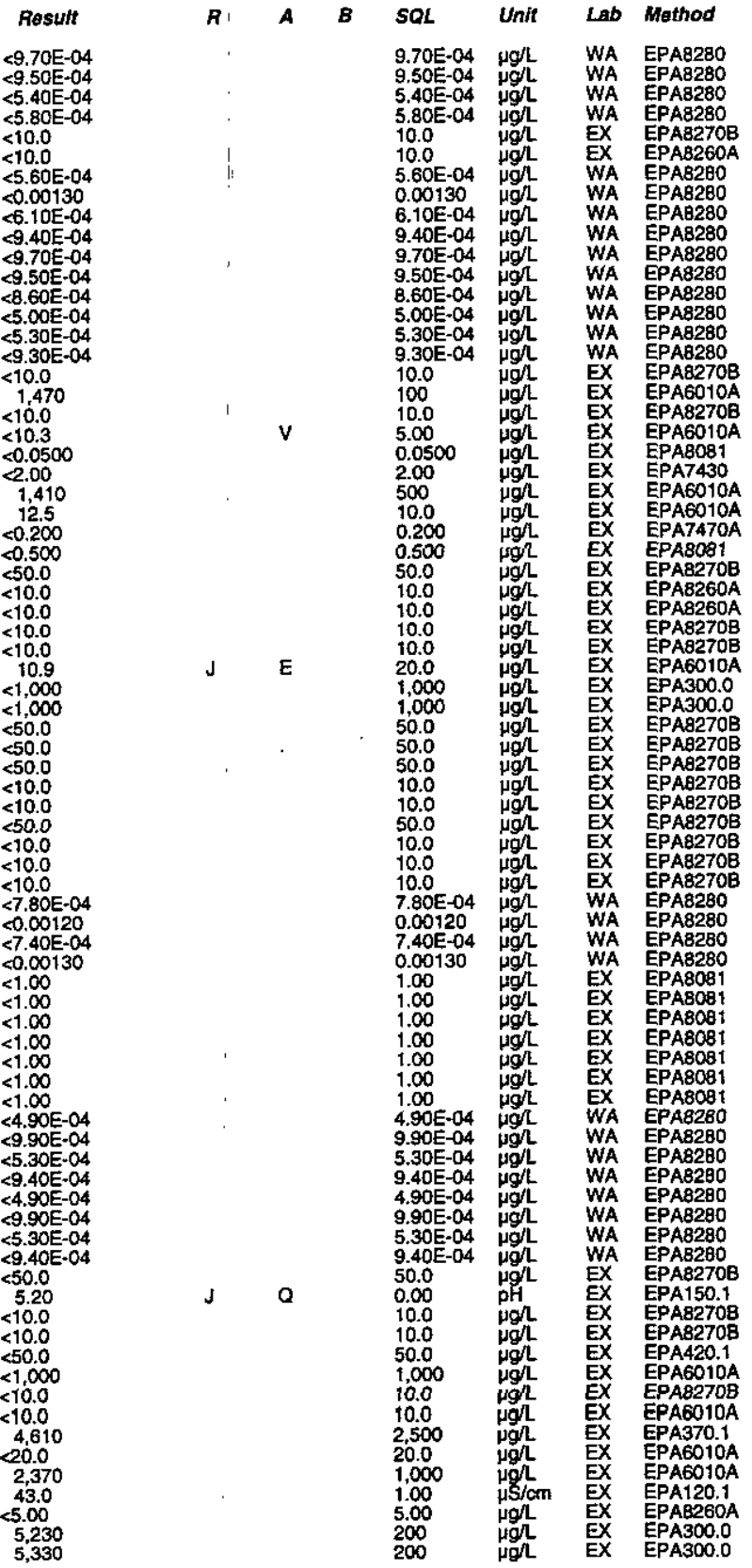

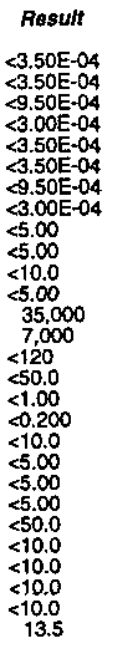

o $2,3,7,8-\mathrm{TCOD}$

2,3,7,6-TCDF

Tetrachlorodibenzo-p-dioxin

Tetrachlorodibenzo-p-purans

Tetrachlorodibenzo-p-turan
$0.1,2,2$-Tetrachloroethane

Thallium, total recoverable

0 Totuen 0

Total organic carbon
0 Total organic halogens
0

0 Toxaphene

1,2,4-Trichlorobenzene

$1,1,2$-Trichloroethan

2,4,5-Trichlorophenol

Vanadium, total recoverable

xylenes

O Zinc, total recoverable

\section{WELL CSR 2D}

MEASUREMENTS CONDUCTED IN THE FIELD

Sample date: 04/29/98 3 (11.96 m) below TOC Water elevation: Not available

D: 6.4

Sp. conductance: $65 \mu \mathrm{S} / \mathrm{cm}$

Water evacuated from the well prior to sampling: $17 \mathrm{gal}$

ANALYSES

\section{$F$ Analyto}

0 Acenaphthene

o Acetone

Aluminum, total recoverable

Anthracene

Arsenic, total recoverabis

Benzene

alpha-Benzene hexachloride

beta-Benzene hexachloride

delta-Benzene hexachlo

Benzo(a)anthracene

Benzolb)fluoranthene

Benzoic acid

- Benzo(a)pyrene

Benzyl atcohol

Bis thim, fotair recoverable

Bis (2-chloroethyl) ether

B Bis(2-chloroisopropyl) ether

Boron, total recoverable

Bromodichloromethane

Bromotom

B-52

Rosutt
$<10.0$
$<10.0$
$<10.0$
$<10.0$
$<0.0500$
311
$<10.0$
$<100$
$<10.0$
41.0
$<5.00$
$<5.00$
50.0500
$<0.0500$
50.0500
$<50.0$
$<10.0$
$<10.0$
$<10.0$
$<50.0$
$<10.0$
$<10.0$
20.0
$<0.250$
$<10.0$
$<10.0$
$<10.0$
$<10.0$
$<7.46$
$<5.00$
$<5.00$
$<5.00$
$<5.00$

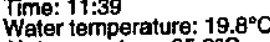

Ar temperature: $25.92 \mathrm{CO}$ ): $26 \mathrm{mg} /$
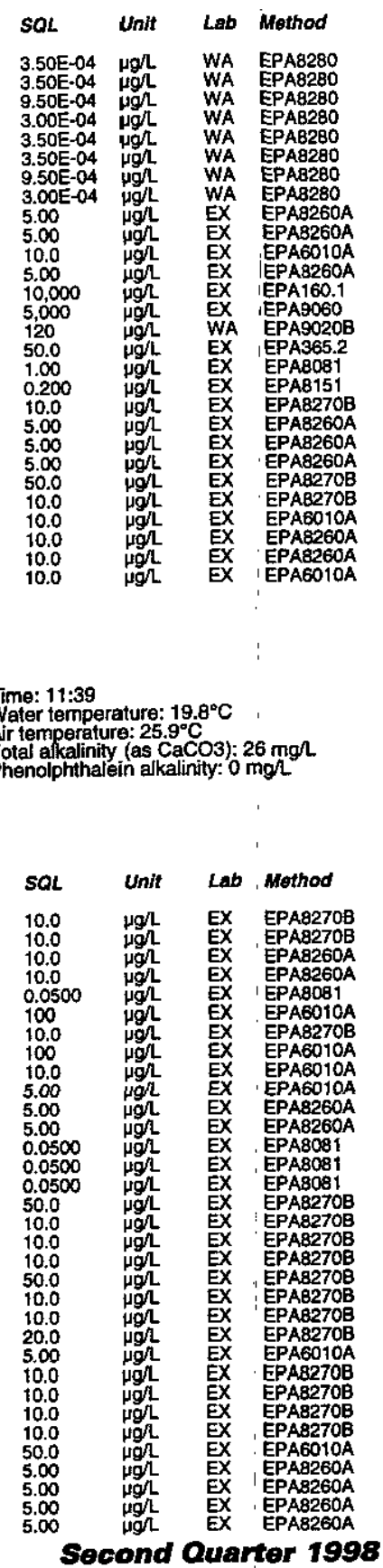
ANALYTICAL RESULTS

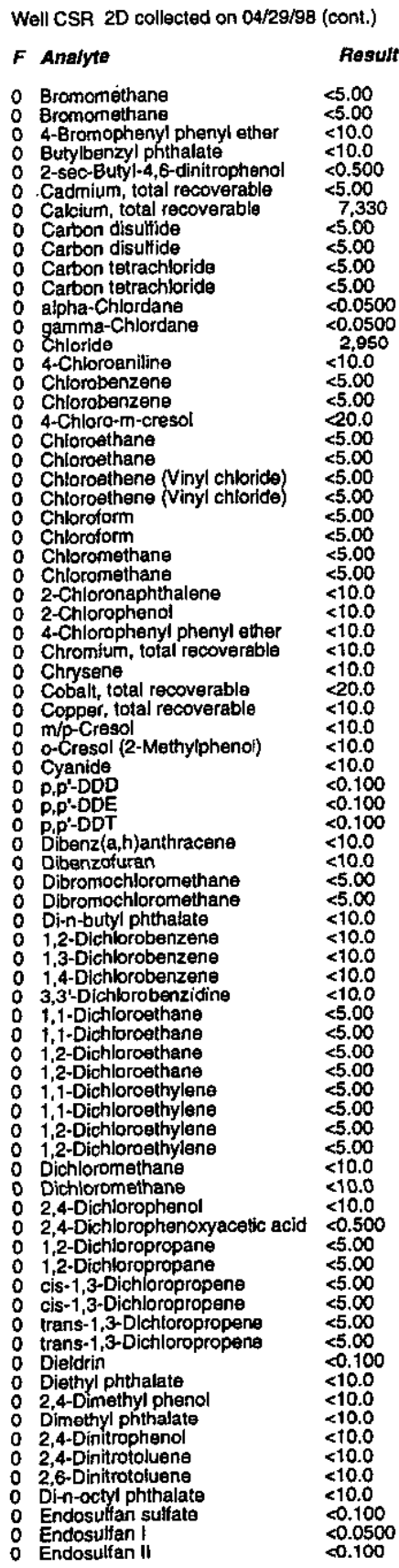

ESH-EMS-980569
Well CSR 20 collected on 04/29/98 (cont.)

\section{$F$ Analyto}

0 Endrin

O Endrin ketons

Fluoranthene

0 Fluorene

Heptachlor

Heptachlor epoxide

Heptachlorodibenzo-p-dioxins

Hexachlorobenzenze

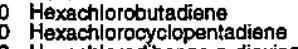

o Hexachlorodibenzo-p-dioxins

Hexachloroethan

2. 2-Hexanone

o $1,2,3,4,6,7,8$-HPCDD

1,2,3,7,7-HXCDD

o Indeno(1,2,3-c,d)pyrene

Isophorone

Lindani
Lithium, total recoverable

o. Lithium, total recoverable

- Manganese, total recoverable

O Mercury, total recoverable

2-Methyl-4,6-dinitropheno

Methyl ethyl ketone
Methyl ethyl ketone

Methyl ethyl ketone
Methyl isobutyl ketone

Methyl isobutyl ketong

Molythenum, total recoverab

Naphthalene
Nicksi, total recoverable

Nitrate-nititlte as nitrogen

m-Nitroaniline
o-Nitroannine

Nitrobenzene

2-Nitrophenol

N-Nitrosodimethylamine

N-Nitrosodiphenylamin

Octachlorodibenzo-p-dioxin

Octachlorodibenzo-p-turan

PCB 1221

PCB 1242

0 PCB 1248

0 1,2,3,7,-PCDD

Pentactibrodibenzo-p-dioxin

Pentachlorophenol

0 PH

O Phenol

Potassium, total recoverable

Sylenium, total recoverable

$\begin{array}{lll}0 & \text { Selenium, total recoverable } & 4.18 \\ 0 & \text { Silca, total recoverable } & 15,400 \\ 0 & \text { Silver, total recoverable } & 20.0\end{array}$

B-53

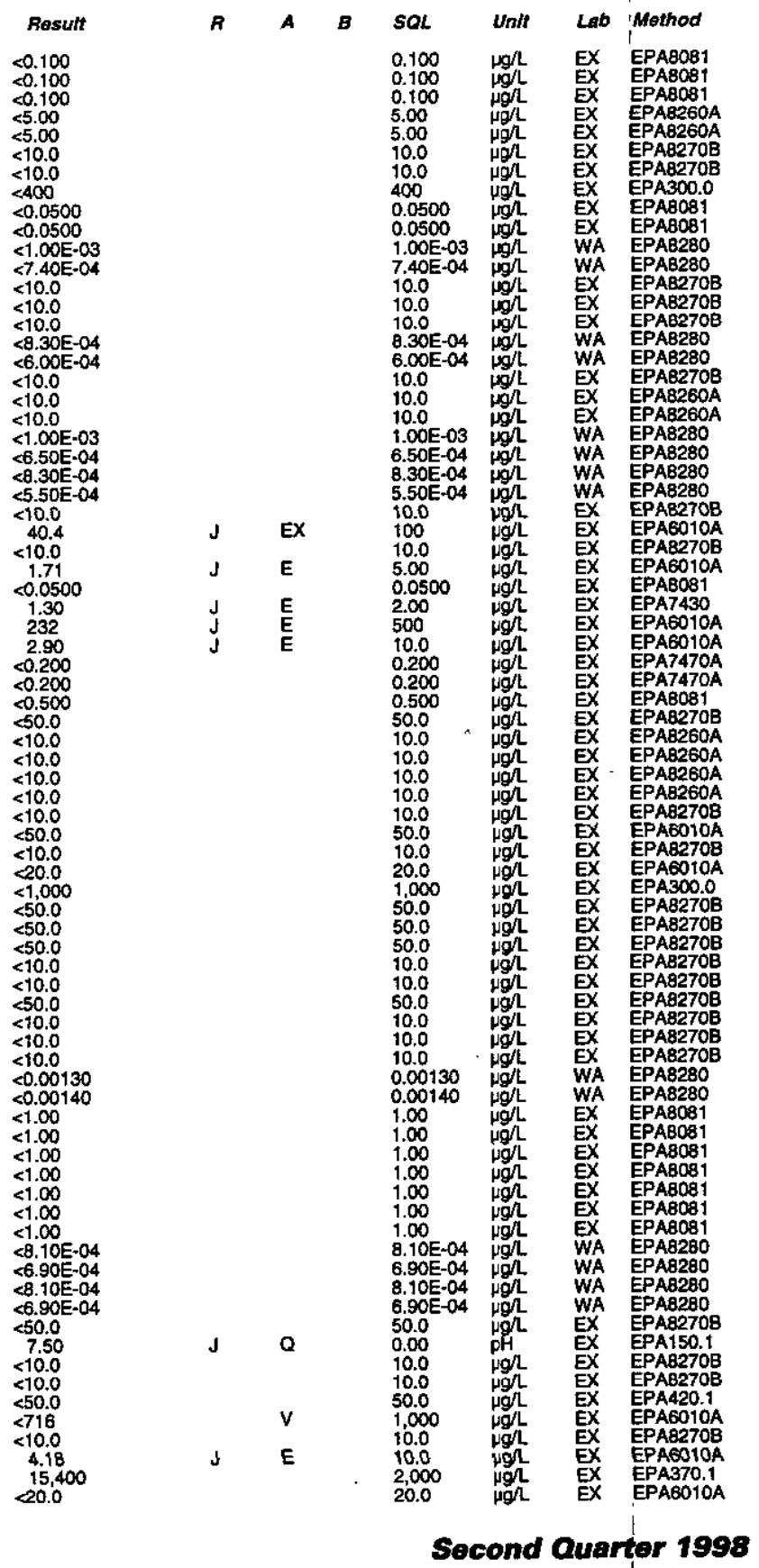


Well CSR 2D collected on 04/29/98 (cont.)

\begin{tabular}{|c|c|c|c|c|c|c|c|c|}
\hline Analyte & Result & $\boldsymbol{R}:$ & A & 8 & $S Q L$ & Unit & Lab & Mothod \\
\hline 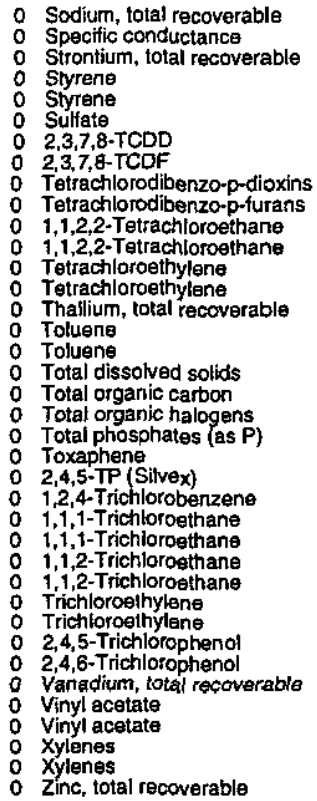 & 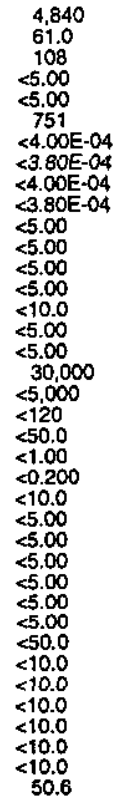 & J & 0 & & $\begin{array}{l}1,000 \\
1.00 \\
10.0 \\
5.00 \\
5.00 \\
400 \\
4.00 E-04 \\
3.80 E-04 \\
4.00 E-04 \\
3.80 \mathrm{E}-04 \\
5.00 \\
5.00 \\
5.00 \\
5.00 \\
10.0 \\
5.00 \\
5.00 \\
10,000 \\
5,000 \\
120 \\
50.0 \\
1.00 \\
0.200 \\
10.0 \\
5.00 \\
5.00 \\
5.00 \\
5.00 \\
5.00 \\
5.00 \\
50.0 \\
10.0 \\
10.0 \\
10.0 \\
10.0 \\
10.0 \\
10.0 \\
10.0\end{array}$ & 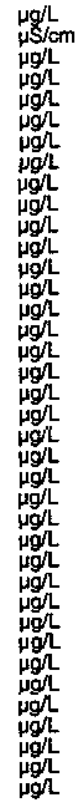 & $\begin{array}{l}\text { EX } \\
\text { EX } \\
\text { EX } \\
\text { EX } \\
\text { EX } \\
\text { EX } \\
\text { WA } \\
\text { WA } \\
\text { WA } \\
\text { WA } \\
\text { EX } \\
\text { EX } \\
\text { EX } \\
\text { EX } \\
\text { EX } \\
\text { EX } \\
\text { EX } \\
\text { EX } \\
\text { WA } \\
\text { EX } \\
\text { EX } \\
\text { EX } \\
\text { EX } \\
\text { EX } \\
\text { EX } \\
\text { EX } \\
\text { EX } \\
\text { EX } \\
\text { EX } \\
\text { EX } \\
\text { EX } \\
\text { EX } \\
\text { EX } \\
\text { EX }\end{array}$ & 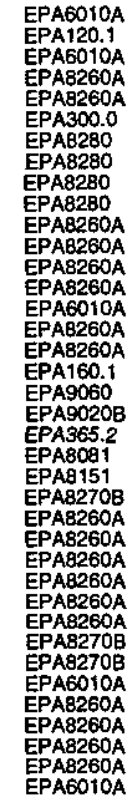 \\
\hline
\end{tabular}

\section{WELL CSR $2 D$}

MEASUREMENTS CONDUCTED IN THE FIELD

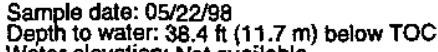
Water el pH: 5.8
Sp. conductance: $62 \mu \mathrm{S} / \mathrm{cm}$ Water evacuated from the well prior to sampling: $37 \mathrm{gal}$ ANALYSES

\begin{tabular}{|c|c|c|c|c|c|c|c|c|}
\hline Analyto & Result & $R$ & A & $B$ & SOL & Unit & Lab & Method \\
\hline $\begin{array}{l}\text { Boron, total recoverable } \\
\text { Gross alpha } \\
\text { Gross alpha } \\
\text { Nonvolatile beta } \\
\text { Nonvolatile beta } \\
\text { Tritium } \\
\text { Tritium }\end{array}$ & $\begin{array}{l}12.0 \\
3.01 E-09+8.30 \mathrm{E}-10 \\
2.10 \mathrm{E}-09+6.80 \mathrm{E}-10 \\
9.14 \mathrm{E}-09+1.65 \mathrm{E}-09 \\
1.75 \mathrm{E}-08+1.93 \mathrm{E}-09 \\
2.73 \mathrm{E}-06 \pm 9.40 \mathrm{E}-07 \\
2.23 \mathrm{E}-0.069 .20 \mathrm{O}-07\end{array}$ & $\frac{7}{j}$ & $\begin{array}{l}x \\
x\end{array}$ & b & $\begin{array}{l}25.0 \\
1.60 E-10 \\
1.60-10 \\
2.23 E-09 \\
2.22 E-09 \\
1.42 E-06 \\
1.43 E-06\end{array}$ & 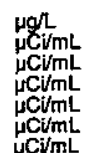 & $\begin{array}{l}\text { ES } \\
T M \\
T M \\
T M \\
T M \\
T M \\
T M\end{array}$ & $\begin{array}{l}\text { EPA6010 } \\
\text { EPA900.OM } \\
\text { EPA900.0M } \\
\text { EPA900.0M } \\
\text { EPA900.0M } \\
\text { EPA906.0M } \\
\text { EPA906.0M }\end{array}$ \\
\hline
\end{tabular}

\section{WELL CSR 2D}

MEASUREMENTS CONDUCTED IN THE FIELD

Sample date: $06 / 01 / 98$
Depth to water: $38.5 \mathrm{ft}$ (11.73 m) below TOC
Whtor elevation: Not ayailable Water elevatic H: 6.2 .

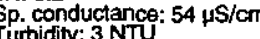

Water evacuated from the well prior to sampling: $20 \mathrm{gal}$

Time: 10:58

Water temperature: $16^{\circ} \mathrm{C}$

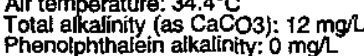

Well CSR 2D collected on 06/01/98 (cont.)

ANALYSES

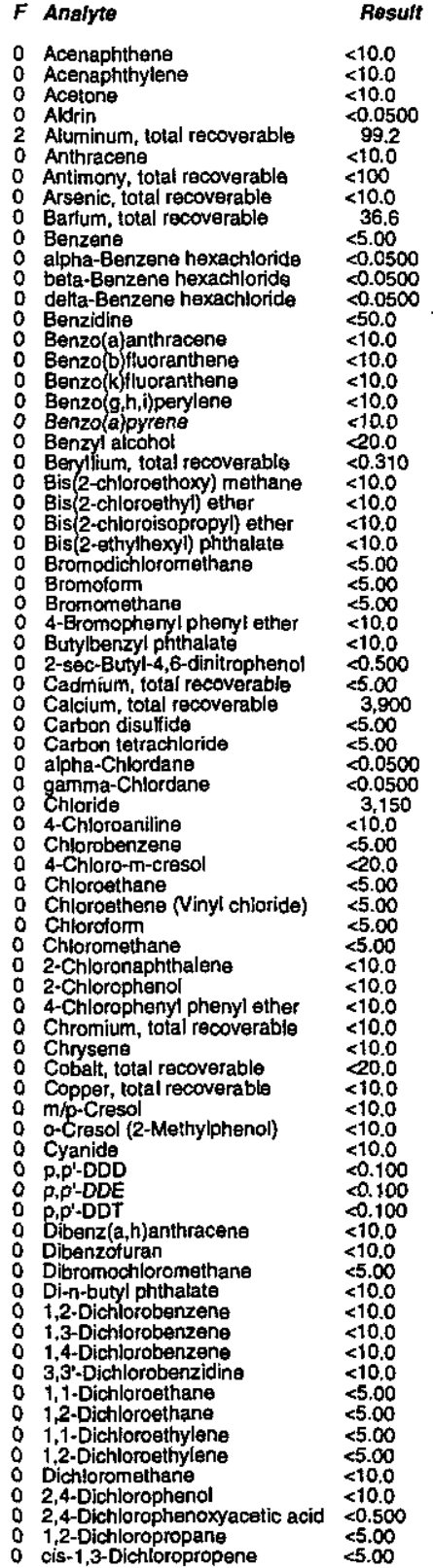

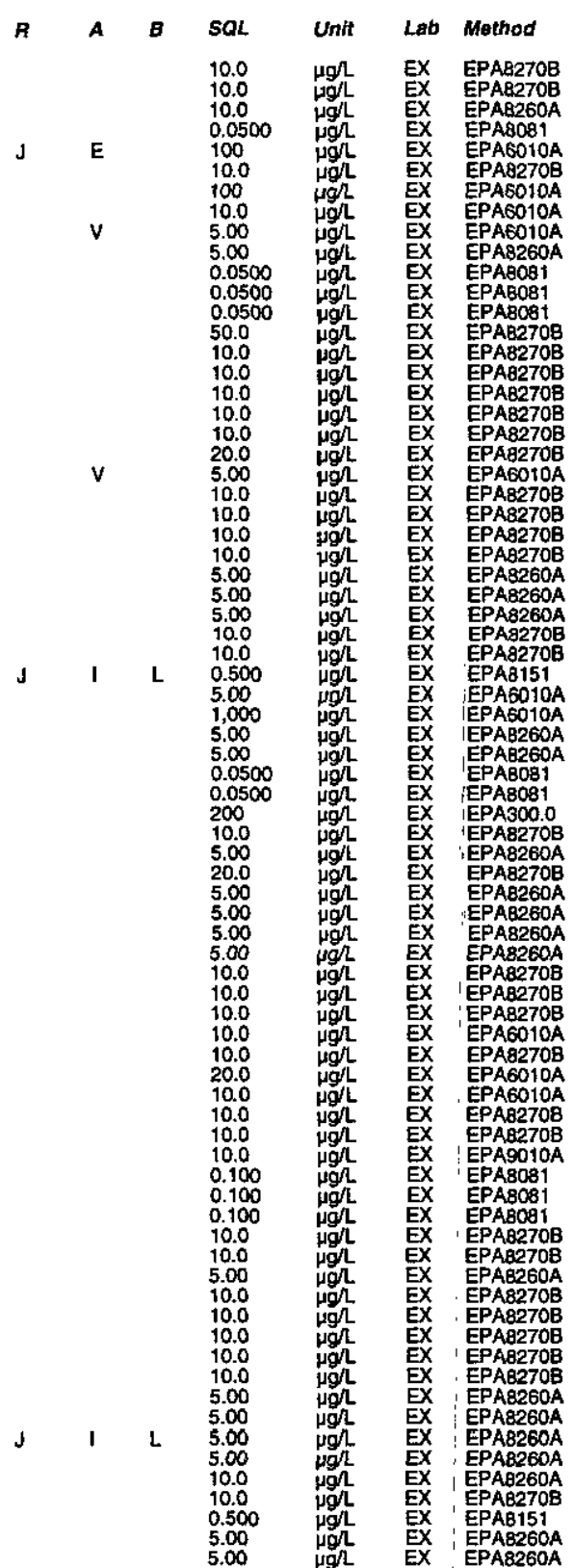

Second Quarter 1998 
Well CSR $2 D$ collected on 06/01/98 (cont.)

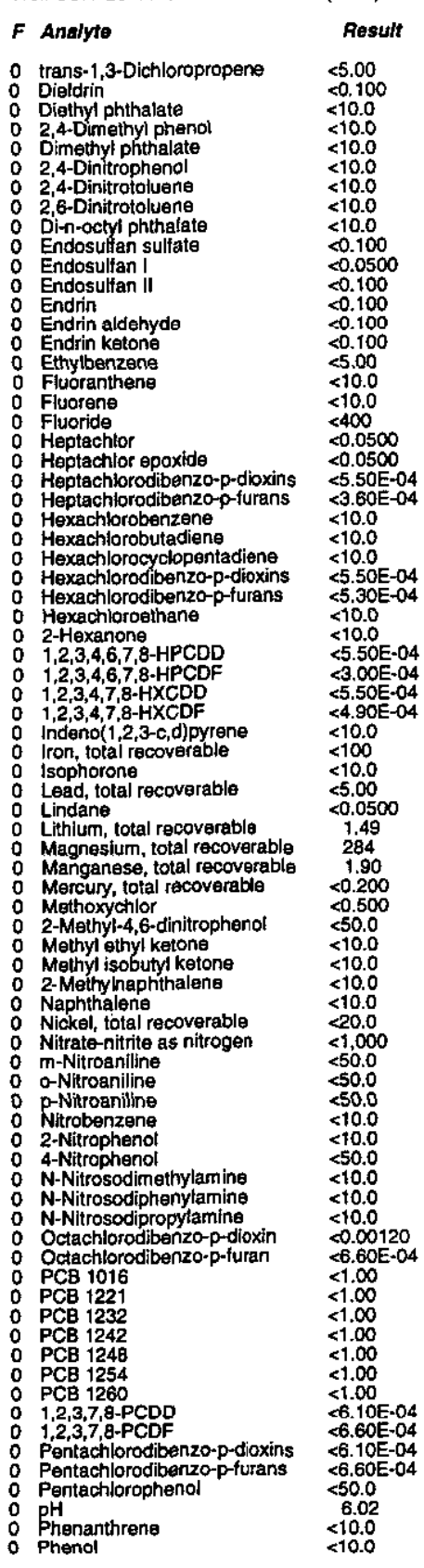

ESH-EMS-980569
Well CSF $2 \mathrm{D}$ collected on 06/01/98 (cont.)

$F$ Ansilyte

Result

88260

- Phenols

$<<<0.00$

Pyreng

Silica, total recoverabla

Sodium, total recoverable

Specific conductance

D.

$2,3,7,8-T C D D$
$2,3,7 C D F$

Tetrachiorodibenzo-p-dioxins

Tetrachlorodibenzo-p-turans

Tetrachloroethylene

Thallium, iotal recovera

Total dissolved solids

Total organic halogens

2,4,5-TP (Silvex)

1,2,4-Trichlorobenzene

1,1,2-Trichloroethane

2,4,5-Trichloropheno

Vanadium, total recoverable

- Zinc, total recoverable

WELL CSR 3

MEASUREMENTS CONDUCTED IN THE FIELD

Sample date: 04/29/98
Depth to water: $37.95 \mathrm{Ht}(11.57 \mathrm{~m})$ below TOC
Water elevation: $247.25 \mathrm{H}(75.36 \mathrm{~m}) \mathrm{msl}$

$\mathrm{gH}$. 5 conductance: $21 \mu \mathrm{S} / \mathrm{cm}$

Water evacuated from the well prior to sampling: $25 \mathrm{gal}$ ANALYSES

$F$ Aralyto

0 Acenaphthene

O Acetone

o Aluminum, total recoverable

0 Anthracene

Arsenic, total recoverabl

Benzene

beta-Benzene hexachloride

Benzidine

Benzo (a)anthracene
Benzoobffluoranthene

Benzo(k) fluoranthene
Benzole acid

Benzo(g., h.j)perylen

Benzyl alcohol

Beryllium, total recoverable

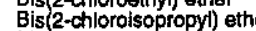

Bis(2-ethylhexyl) phthalal

$8-55$

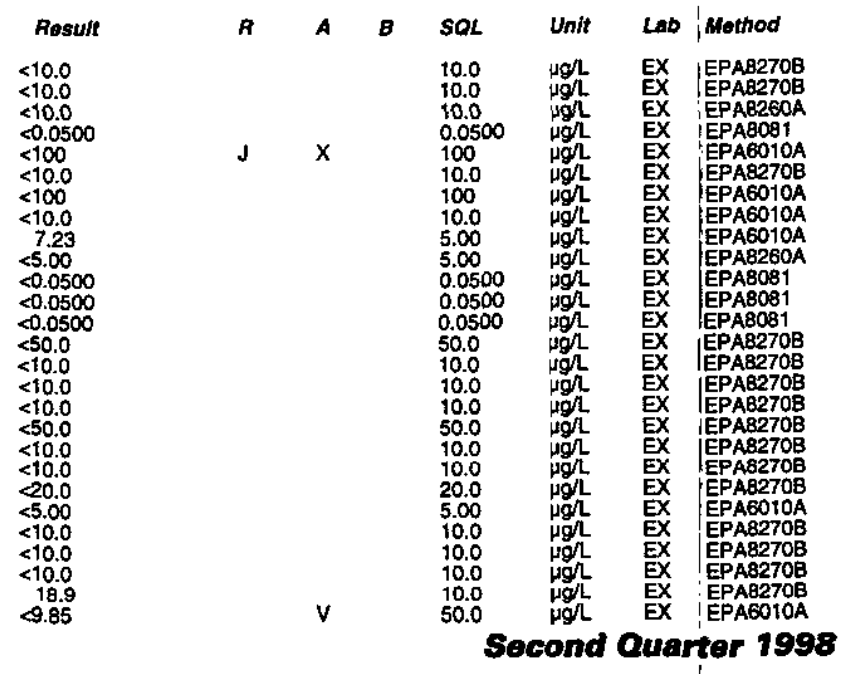

Time: 10:45

Water temperalure: $19.6^{\circ} \mathrm{C}$

Total alkalinity (as CaCO3): $1 \mathrm{mgl}$ 
Well CSR 3 collected on 04/29/98 (cont.)

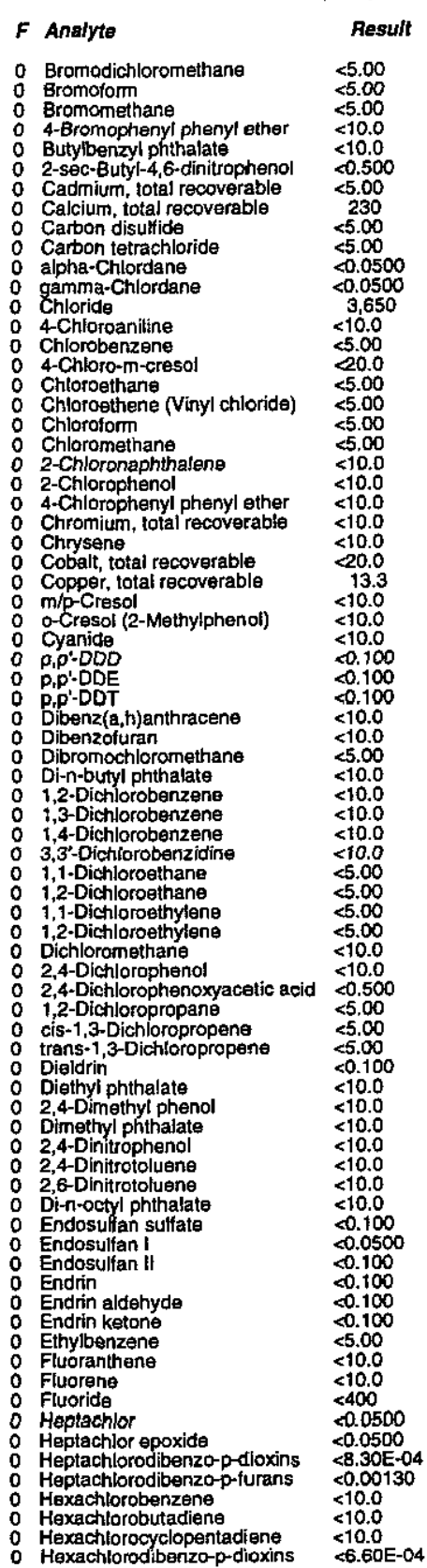

ESH-EMS-980569
Well CSR 3 collected on 04/29/98 (cont.)

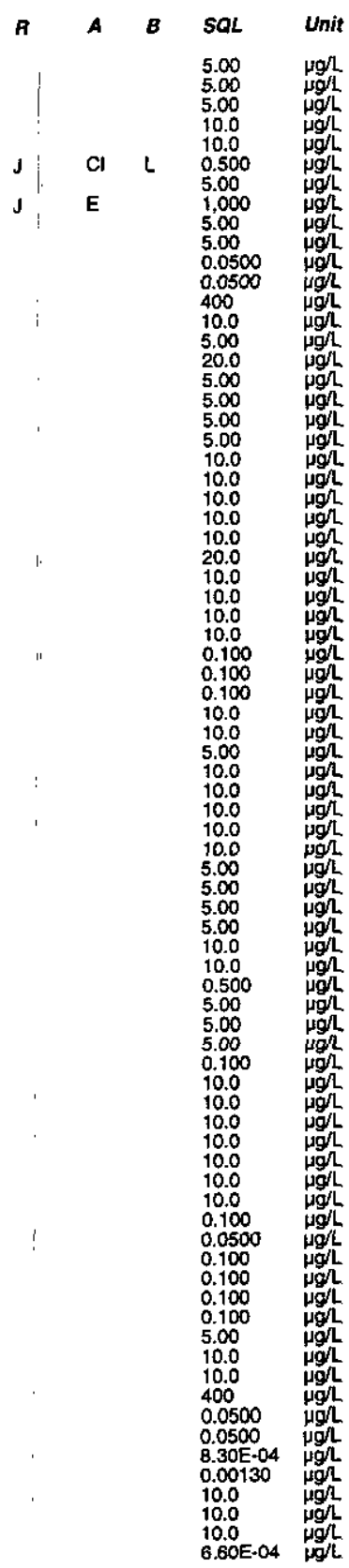

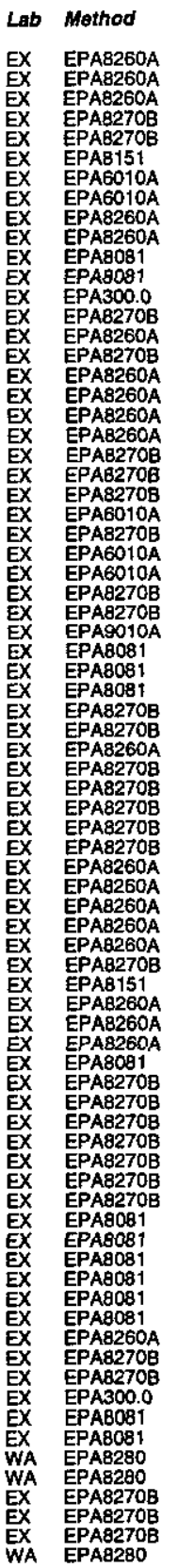
2-Hexanonethane

$1,2,3,4,6,7,8-H P C D D$
$1,2,3,4,6,7,8-H P C D F$ $1,2,3,4,7,8-\mathrm{HXCOD}$

Indeno $(1,2,3-c, d)$ pyrene

Isophorone

Lead, to

Lithium, total recoverable Magnesium, total recoverable

Mercury, total recoverable

2-Methyl-4,6-dinitrophenol

Methyl isobutyl keton

2-Methytnaphthalene

Nickel, total recoverable

Nitrate-nitrite as nitrog

Nitrobenzzene

2-Nitrophenol

N-Nitrosodimethylamine

N-Nitrosodipropylamine

Octachlorodibenzo-p-duran

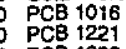

$P C B$

0 PCB 1248

$P C B, 260$
$1,2,3,7,8-P C D D$
$1,2,3,7,8-P C D F$

Pentachlorodibenzo-p-dioxins

Pentachloropheno

Phenanthrene

P Phanol

Potassium, total recoverable

Pyrene to recoverable

Silica, total recoverable

Sitver, total recoverable

Specific conductance
Strontium, total recoverable

Sirontium

\section{sultate}

Tetrachiorodibenzo-p-dioxins

Tetrachlorodibenzo-p-furans

$1,1,2,2$-Tetrachloroethane
Tetrachloroethylene

Thallium, total recoverable

Total dissolved solids

Total organle carbon

0
0
0
$2,4,5-T P$ (Silvex)
Hexachlorodibenzo-p-furans

o-Nitroaniline

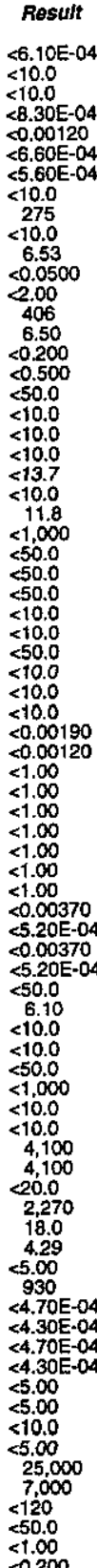

$<6.10 \mathrm{E}-04$

$<10.0$
$<0.001-04$
$<0.00120$

$<6.60 \mathrm{E}-04$

$<2.00$

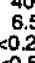

$\sum_{<100}^{50.0}$

$<10$.

11.8
$<1,000$

$<108$

$<0.0 .0190$

$<1.00$

$<1.00$

$5.20 \mathrm{E}-04$
40.00370

$<50.0$

$<1,000$

4,100
4,100

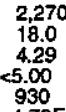

$<4.70 \mathrm{E}-04$

促

(1.00

7.000
4120
550.0
51.00
0.200

J

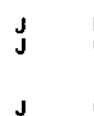

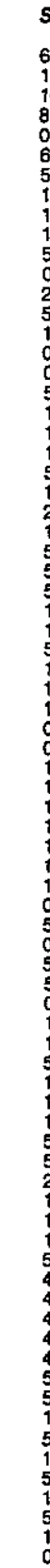

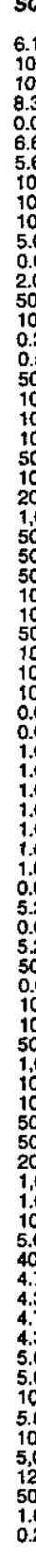

Lab Method

10E-04 $\mu \mathrm{gl}$ WA EPA8280

EX EPAB260A

WA EPAB280

WOE-04 WA EA828

$\begin{array}{lll}\text { EX EA9270B } & 0.0 \\ \text { EPA6010A }\end{array}$

$\begin{array}{lll}0.0 & \text { EX } & \text { EPAB270B } \\ 0.00 & \text { EX } & \text { EPAG010A }\end{array}$

$\begin{array}{llll}.0500 & \mu g h & \text { EX } & \text { EPABD81 } \\ 0 \mathrm{EX} & \text { EPA7430 }\end{array}$

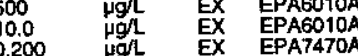

\begin{tabular}{lll}
$\mu g / L$ & EX & EPA8081 \\
\hline$\mu g$ & EX & EPAs270
\end{tabular}

$\begin{array}{llll} & & & \\ 10.0 & \mu g h & \text { EX } & \text { EPAB260A } \\ 10.0 & \mu g h & \text { EX } & \text { EPA8260A } \\ 0.0 & \mu g / L & \text { EX } & \text { EPA8270B }\end{array}$

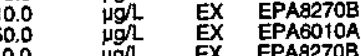

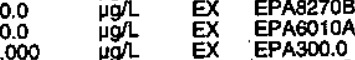

E.

$\begin{array}{llll} & \text { EX } & \text { EPAB270B } \\ 10.0 & \mu g h & \text { EX } & \text { EPAB270B } \\ & & \text { EX } & \text { EPA270 }\end{array}$

$\begin{array}{lll}\text { EX } & \text { EPA3270日 } \\ \text { EX IEPAB270B } & \text { EPAB270B }\end{array}$

0190

EX EPABOB

$\begin{array}{ll}\mathrm{Hg} / \mathrm{L} \\ 0.00 & \mathrm{pH} \\ 0.0 & \mathrm{Hg} / \mathrm{L}\end{array}$

WA EPAB280

EPAB280

EPA150.1
EPAB270B
EPA8270B

IEPA8270B

'EPA6010A

EPA6010A

'EPA370.1

EPAG010A

IEPA120.1

EX EPAE260A

70E-04 $\mu g$ WA EPA8280

.

Ex

Hgh EX EPA160.1

$\begin{array}{llll} & & \text { WA } & \text { EPA9020B } \\ .00 & \mu g h & \text { EX } & \text { EPA365.2 } \\ \text { EX } & \text { EPABO81 }\end{array}$

Second Ounter 1998 
ANALYTICAL RESULTS

Well CSR 3 collected on 04/29/98 (cont.)

$F$ Analyte.

- 1,2,4-Trichlorobenzene

$1,1,1$-Trichloroethane

Trichloroethylene

$2,4,6-$ Trichlorophenol
Vanadium, total recoverabl

Vinyl acetate

- Zinc, total recoverable

WELL CSR 3

MEASUREMENTS CONDUCTED IN THE FIELD

Sample date: $06 / 01 / 98$ (1) $11.56 \mathrm{~m}$ ) below TOC

Oepth to
Water ele
pH: 5.2

Water elevation: $247.27 \mathrm{Ht} / 55.37$
$\mathrm{HH}: 5.2$
$\mathrm{Sp}$. conductance: $24 \mu \mathrm{S} / \mathrm{cm}$

Watbidity: 3 NTU 24 from the well prior to sampling: 22 gal

ANALYSES

Anslyto

Acenaphthene-

Acenaphthene

Acenaphinhlene
Acenaphthylene

Acenaphthylene

O Acetone:

Acetone

Aldrin

Aluminum, total recoverable

Aluminum, total recoverable

Anthracente

Anthracene

Antimony, total recoverable

Antimony, total recoverable

Arsenic, total recoverable

Arsenic, total recoverable

Barium, total recoverable

Barium, total recoverabio

Benzene

alpha-Benzene hexachloride

alpha-Benzene hexachloride

appha-Benzene hexachloride

eta-Benzene hexachlorid

beta-Benzene hexachloride

beta-Benzene hexachlorid

detta-Benzene hexachiorida

delta-Benzene hexachlorido

Benzo (a) anthracinne

Benzo (a) anthracene

ESH-EMS-980569

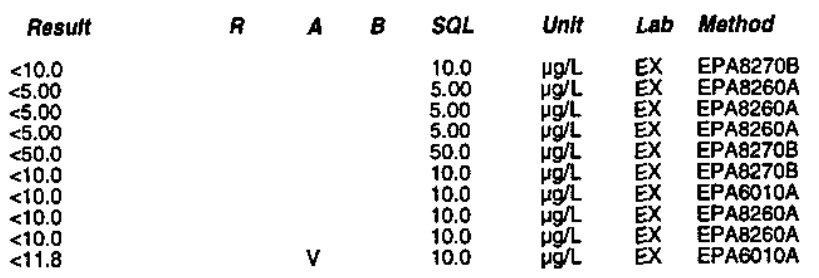

Time: 13:03

Air temperature: $36.6^{\circ} \mathrm{C}$

Total alkalinity (as CaCO3): $0 \mathrm{mg} / \mathrm{L}$
Well CSR 3 collected on 06/01/98 (cont.)

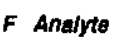

Result

0 Benzo(b)fiucranthene

Benzo (k) fluoranthene

Benzo (k) fluoranthene

Benzoic acid

Benzoic acid

Benzoic acid

Benzog, hi, perylene

Benzog, hilijperyle

Benzo(a) pyrene

Benzolappyrene

Benzyl alcoho

Benzyl alcoho

Benzyl alcohol

Beryllium, total recoverab

Beryllium, total recoverab

Bis 2-chloroethoxy) methano

Bis(2-chloroethoxy) methane

Bis (2-chioroethoxy) meth

Bis 2-chloroethyl) ether

Bis 2-chloroethyl) ather

Bis(2-chloroisopropyl) ether

Bis (2-chloroisopropyl) ethe

Bis 2-ethylhexyl) phithalai

Bis 2.ethylhexy| phithalate

Bis (2-ethyyhexyl) phthalat

Bromodichloromethan

Bromodichloromethane

Bromotorm

Bromoform

Bromoform

Bromomethane

4-Bromophenyl phenyl ether

4-Bromophenyl phenyl ether 4 4-Bromophenyl phenyl ether

Butylbenzyl phthalatis

Butylbenzyl phthalatate

Butylbenzyl phithalate

Cadmium, total recovererable

Calcium, total recoverable

Calcium, total recoverable

Carbazole

Carbon disulfide

Carton disulfidide

Carbon tetrachlorido

B-57

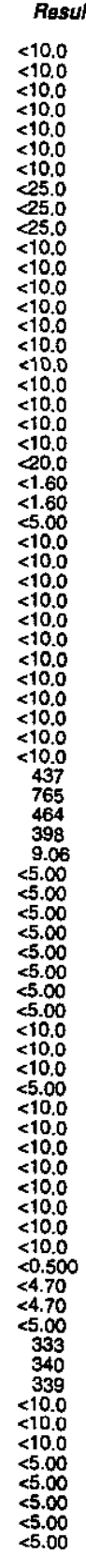

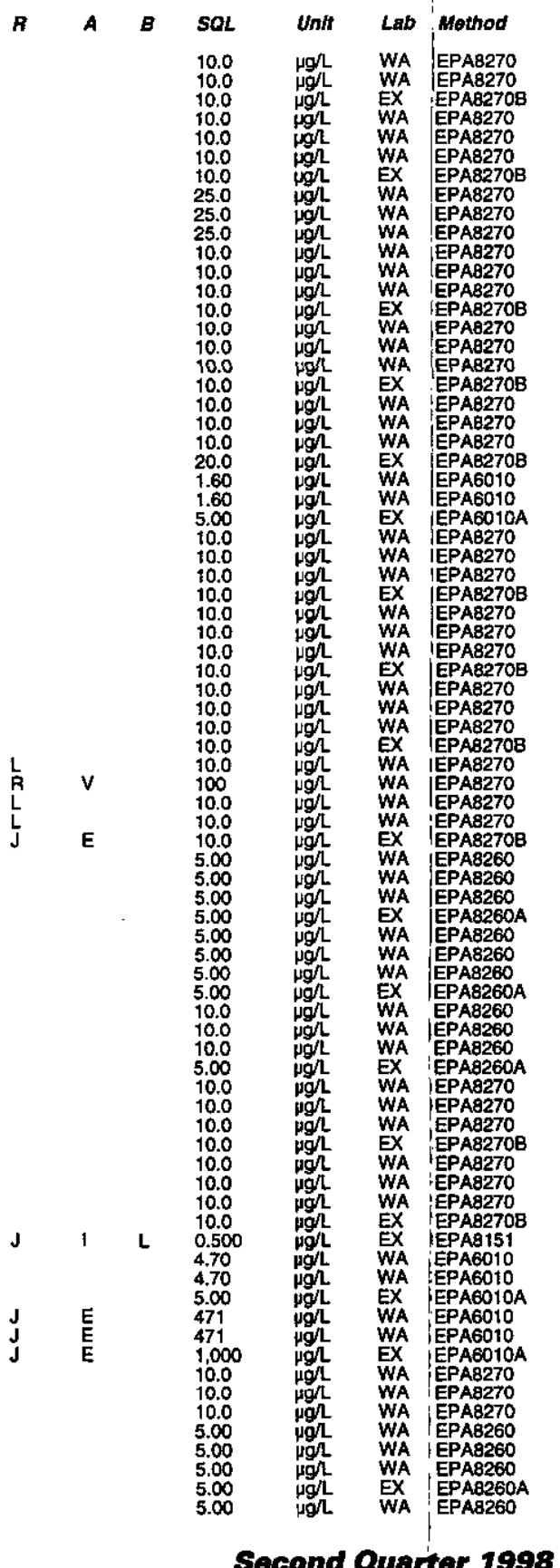


Well CSR 3 collected on 06/01/98 (cont.)

$F$ Analyte

: Carbon tetrachloride

Carbon

O alpha-Chlordane
o alpha.-CClordane

gamma-Chlordane

: gamma-Chlordane

Chloride

4-Chloroanilin

4.Chloroanilin

4-Chloroanitine

Chlorobenzene

4-Chloro-m-cresol

4-Chloro-m-crso

: Chloroethane

Chlorothane

Chloroethene Vinyl chloride
Chloroethene Vinyl chloride

Chloroethene

C Chlorofarm

C Chloroorm

Chloromethane
Chloromethane

Chloromelhane

2-Chloronaphthalene

2-Chloronaphthalen
2-Chloronaphthalene

2-Chloronaphthalen

2-Chloropheno

4-Chlorophenyl phenyl ether

4-Chlorophenyl phenyl ether

4-Chlorophenyl phenyl ether

Chromium, total recoverable

O Chrysene

Chrysene

Cobali, total recoverable

Cobalt, total recoverable

Cobalt, total recoverable

Copper, total recoverable

$0 \begin{array}{ll}0 \\ 0 \\ 0\end{array} / p$-Cresol

0.Cresol (2-Methylpheno:

o-Cresol (2-Methytpheno

Cyanide

0
0

0 P,P'DDD

ESH-EMS-980569
Well CSR 3 collected on 06/01/98 (cont.)

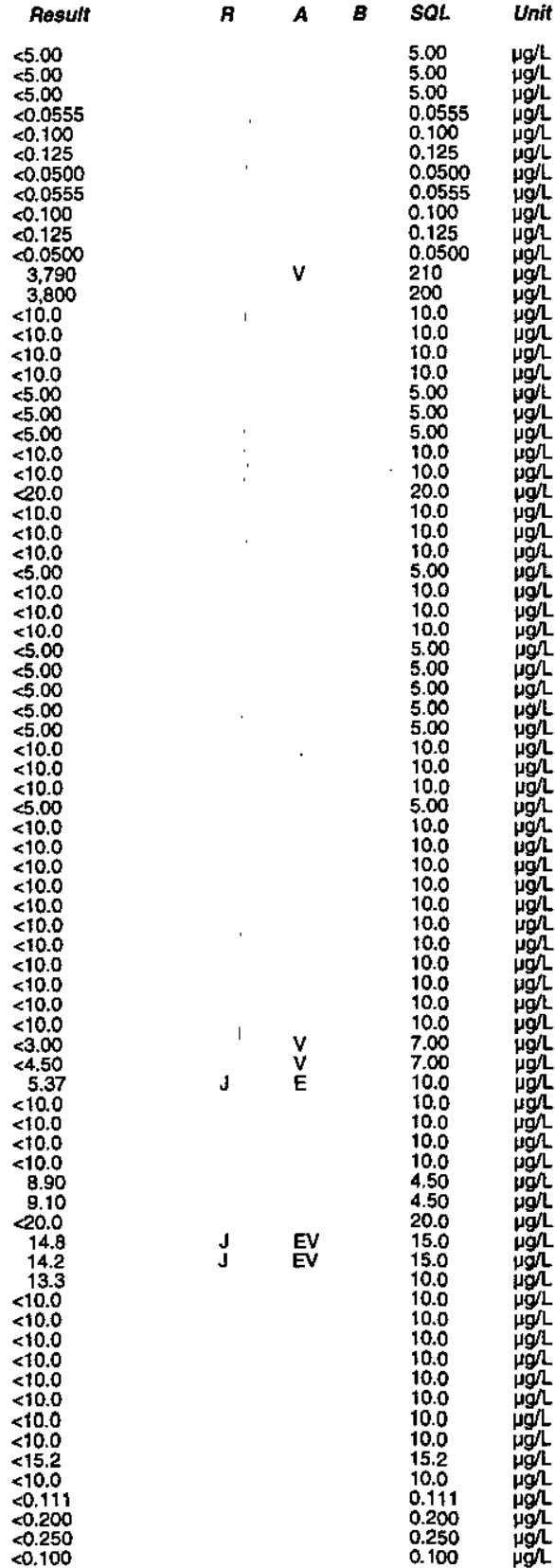

WA EPA8260

$\begin{array}{ll}\text { WA } & \text { EPA8260 } \\ \text { EX } & \text { EPAB260A } \\ \text { WA EPABO81 } \\ \text { WA EPABO81 }\end{array}$

WA EPAB011

WA EPABOB1

WA EPA9056

WA EPAB270

WA EPA8270

WA EPAB260

WA EPAB260A

EX EPA8270B

WA EPAB260

WA

WA EPA8260

EX EPAB260A

WA EPAA260

WA EPAA260

WA EPA8270

WA EPA8270

WA EPAB270

EX EPA8270B

A EPA8270

EPA8270B

WA EPAG010

WA EPADE10A

WA EPAB270

WA EPAG610

EPAGO10A

A EPA6010

A EPAB270

EPAB270

EPA8270
EA EPAB270
EPA8270

EPA8270B

E EPASO10A

WA EPABOB1
WA EPAOB1
WA EPABOB1

0 p,p'-DDE

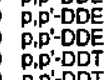

P.P'-DDT

Dibenz(a,h)anthracene

Dibenzza, hanthracen

Dibenzofuran
Dibenzofuran

Dibenzofuran

Dibromochboromethane

Dibromochloromethan

Di-n-butyl phthalate

Dii-n-butyy phthalate

1,2-Dichlorobenzene

1,2-Dichlorobenzen

1,3-Dichlorobenzen

1,3-Dichlorobenzen

1.4-Dichlorobenzenzen

3.4. - ichlorobenzer

3,3-Dichlorobenzidini

1.1.Dichloroethane

1,1-Dichloroethan

1.2-Dchloroethane

1,2-Dichloroethane

1.2-Dichloroethane

1,1-Dichloroethylene

1,2-Dichloroethylene

1,2-Dichloroethylene

Dichloromethane

Dichloromethane

2,4-Dichloropheno

2.4-Dichlorophenol

4-Dichloropenoxyacotic acid

2,4-Dichlorophenoxyacetic acic

1,2-Dichloropropane

cis-1,3-Dichloropropen

cis- 1,3 -Dichloropropen

cis-1,3-Dichloropropene

trans-13-Dlchloropen

trans-1,3-Dichloropropene
0
0
0
$F$ Analyte Result

WA EPAB260

1,2-Dichloropropane

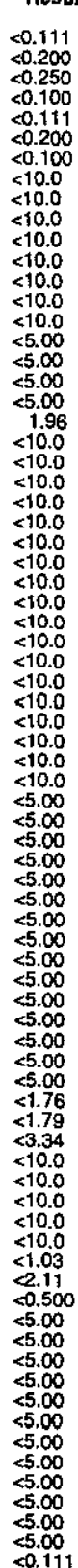

A

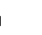

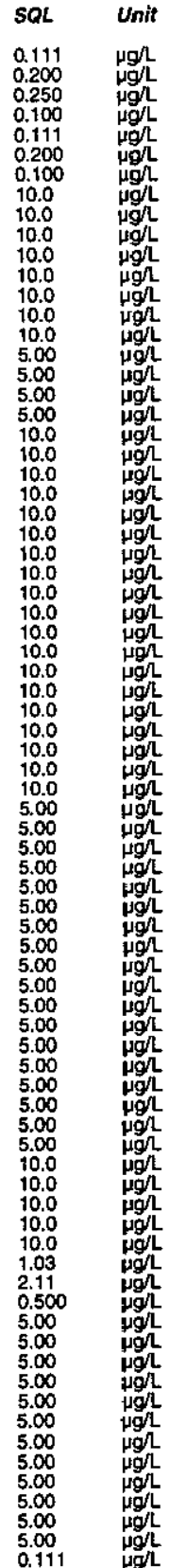

Lab Method

WA EPAB001

WA EPABOB1

WA

EX EPAB081

WA

NA EPAB270

WA EPAB270

WA

WA

WA

WA

WA EPAB270B

WA EPA8270

WA EPAB270

WA

WA

EX EPAB260A

WA

WA EPA260

WA IEPAB270

EX : EPAB270B

WA EPAB150

EX EPAB151

EX

EPA8260

WA 'EPAB260

WA EPAB260A

NA EPA260

EX ! EPAB260A

Second Quarter 1998 
ANALYTICAL RESULTS

Well CSA 3 collected on 06/01/98 (cont)

F Analyto

0 Dieldrin
0 Dieldrin
0 Diethyl

0 Diethyl phthalate

Diethyl phthalate

2,4-Dimethyl pheno

2,4-Dimethyl phene

Dimethyl phthalate

Dimethyl phithalate
Dimethyl phthalate
2,4-Dinitrophenol

2,4-Dinitropheno

2,4-Dinttrophenol
2,4-Dinitrotoluen

2,4-Dinititrotoluen

2,6-6initrotoluen

2,6-Dinitrotoluene

Di-n-octyl phthalate

Di-n-cotyy phthalat

Endosuran sulfate

Endosulfian suffate

: Endosultan I

Endosuftan I

Endosulfan II

Endosultan II

Endrin

Endrin

Endrin ketone

Endrin keton

Ethylbenzene

Ethylberzen

Fthylbenzene

Fluoranthene

Fluoranthe

Fluorene

OFluorene

Fluoride

0 Heptachlor

Heptachjor

Heptachlor epoxide

Heptachlor epoxide
Heptachlor epoxide

Heptachlorodibibenzo-p-dioxin

Heptachibrodibenzo-p-cioxins

Heptachlorodibenzo-p-furans
0 Heptachorodibenzonzo-purans
0

ESH-EMS-980569
Well CSR 3 collected on 06/01/98 (cont.)

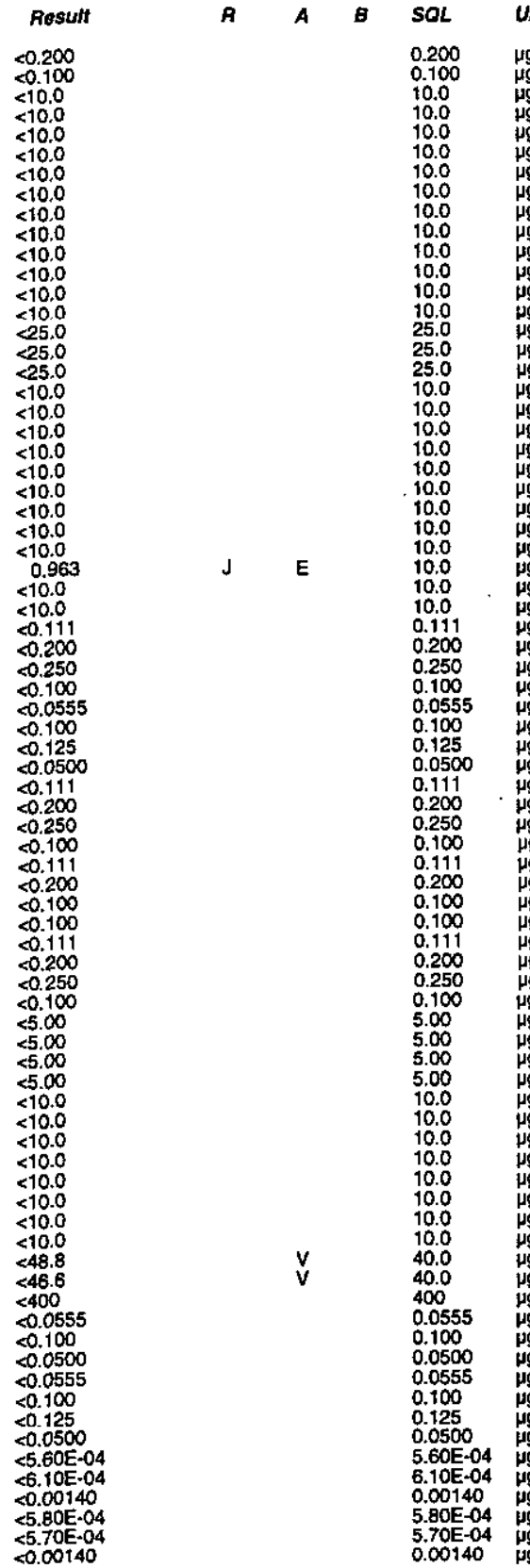

$F$ Analyte

WA EPA8081

WA EPA8270

WA EPAB270

WA EPA8270

WA EPA8270

WA EPA82

WA EPAB270

WA EPAB270

WA EPAB270

EPA82708

EPAB270

EPA2270B

WA EPAB270B

WA

WA EPABOB1

WA

WA EPABOS1

EX

WA EPABOA

XA

WA

EX EPA8260A

WA EPA8270

EX

WX EPA8270B

WA

WA

WA EPABOB

WX EPABOB1

WA EPAB28

WA
WA EPA8280
WA
EPAB2880

Hexachloroethane

Hexachloroethane

Hexachloroethan

2-Hexanone

$1,2,3,4,6,7,8-\mathrm{HPCD}$

$1,2,3,4,7,8-H X C D D$

0
0
0
$1,2,3,4,7,8-H X C D F$

$1,2,3,4,7,8-\mathrm{HXCDF}$
$1,2,3,4,7,8-\mathrm{HXCDF}$

Isophorone
isophorone

isophorone

Lindane

Methoxychlor

Methoxychior $\begin{array}{lll} & & \\ 0 & \text { Hexachlorabenzene } & <10.0 \\ 0 & \text { Hexachlorobenzenen } & <10.0\end{array}$

Hexachlorobenzene
Hexachlorobutadiens
Hexachlorobutadiene

Hexachlorobutadiene

Hexachicrocyclopentadiene

Hexachlorocyclopentadien

Hexachlorocyclopentadiene

Hexachlorodibenzo-p-dioxins $<8.10 E-04$
Hexachlorodibenzo-p-dioxins

Hexachlorodibenzo-p-furans

Hexachlorodibenzo-p-turans

2-Hexanone
$1,2,3,4,6,7,8-\mathrm{HPCDO}$

$1,2,3,4,6,7,8-\mathrm{HPCDD}$
0
$1,2,3,4,6,7, \mathrm{HPCDD}$
$1,2,3,4,6,7,8-\mathrm{HPCDD}$

$1,2,3,4,6,7,8-\mathrm{HPCDF}$
$1,2,3,4,6,7,8-\mathrm{HPCDF}$

indeno $\{1,2,3-c, d)$ pyrene

Indeno $1,2,3-c, d$, pyrene

Iron, totai recoverable
Iron, total recoverable

Iron, total recoverable

Lead, total recoverable

Lead, total recoverable recoverable

Lindinim, total recoverable

Lithium, total recoverable

Magnesium, total recoverable

Magnesium, total racoveraba

Manganese, total recoverable

Menganese, total recoverab

Mercury, total recoverab

2-Methyl-4,6-dinitrophenol

2-Methyl-4,6-6-dinitrophenol

$<4.70 E-04$
$<4.80 E-04$
$<0.00110$

$<100$

$<10.0$

$<10.0$
$<10.0$

$<10.0$
$<10.0$

$<5.60 \mathrm{E}-04$

$<.0 .0140$
$<4.80 E-04$

(1.906.04

$<8.00120$

$<4.30 E-04$
$<4.005-04$

$<9.50 \mathrm{E}-04$

$<10.0$

236
249
281
181

181
$<10.0$
$<10.0$

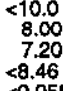

$<8.0555$
$<0.055$
$<0.0500$
$<0.0500$

$<0.890$

392
394
435
7.00
7.20
8.60
$<0.700$
$<0.700$
$<0.200$
$<0.555$
$<1.0$
$<1.25$
$<0.500$
25.0
25.0
$<5.0$
$<50.0$

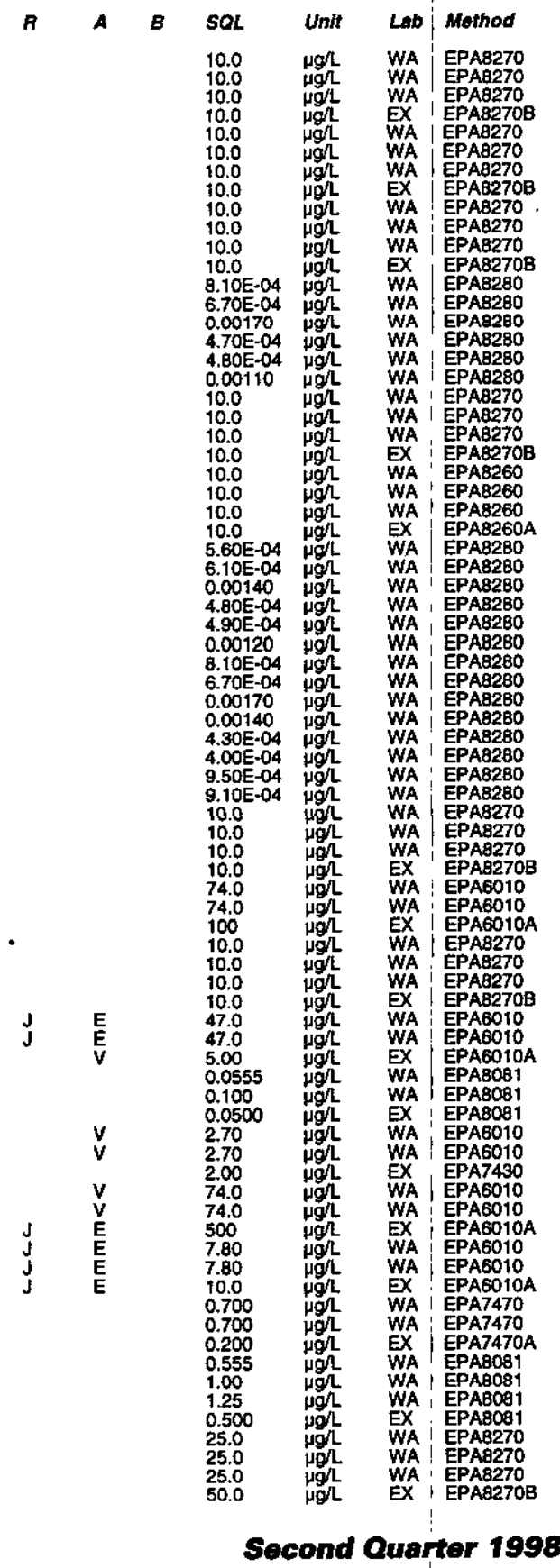


Well CSR 3 collected on 06/01/98 (cont.)

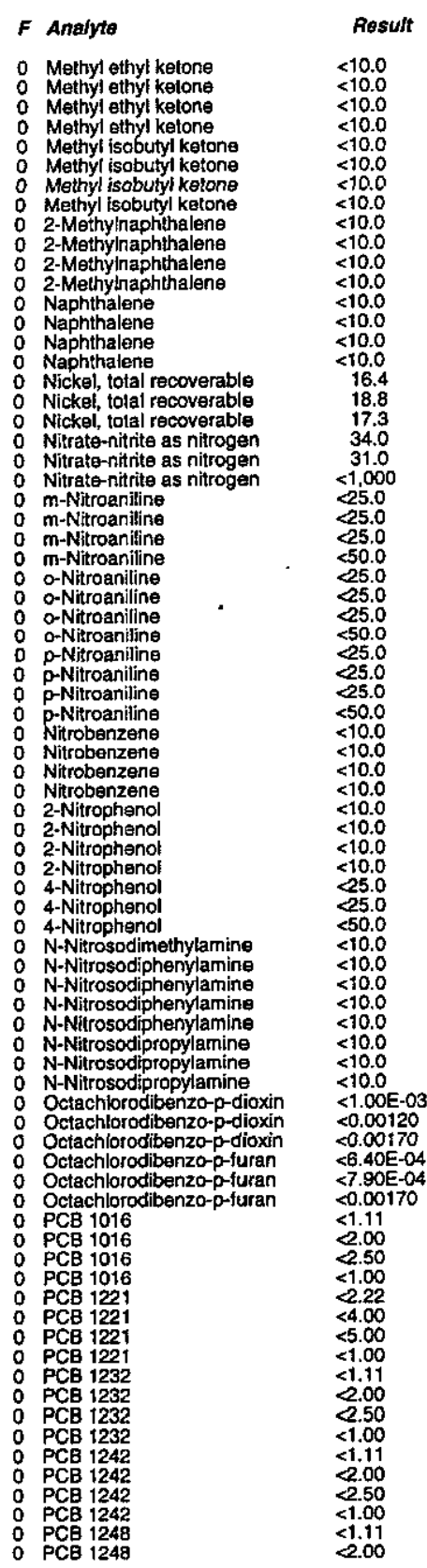

ESH-EMS-980569
Well CSA 3 collected on 06/01/98 (cont)

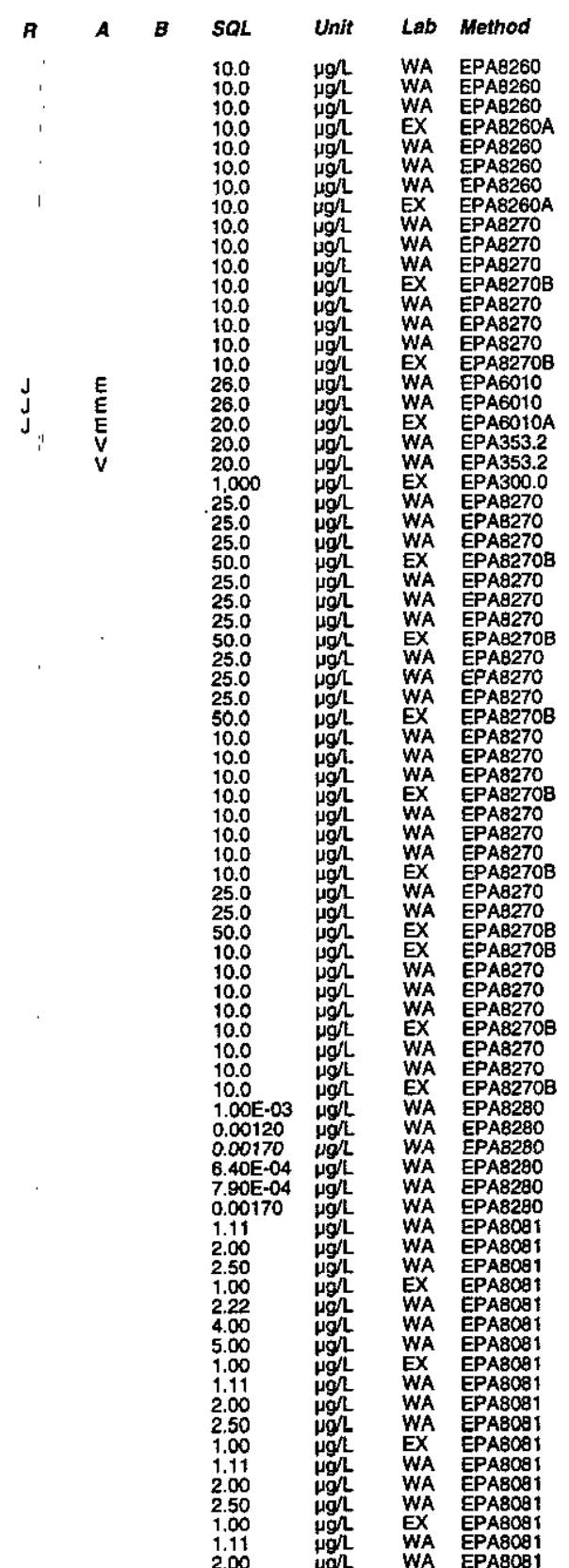

Analyte

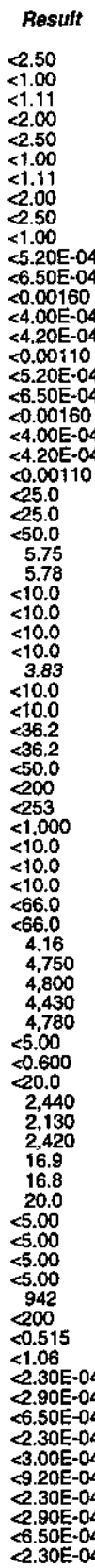

P PCB 1248
0

0
0
0

- PCB 1254

0
0

$\begin{array}{ll}0 & \text { PCB } 1260 \\ 0 & 1,2,3,7,8-P C D D \\ 0 & 1,2,3,7,8-P C D D\end{array}$

o $1,2,3,7, \mathrm{~B}-\mathrm{PCDD}$

o $1,2,3,7,7,8-\mathrm{PCDF}$

Pentachlorodibenzo-p-dioxins

Pentachlorodibenzo-p-dioxins

Pentachtorodibenzo-p-puran

Pentachloropheno

$\mathrm{PH}$

Phenanthrene

0 Phenanthrene

Phenanthrene
Phenanthrene

: Phenol

Phenots

Phenols

Potassium, total recoverabie

Potassium, total recoverabo

Potassium, total recoverab

Pyren

Selenium, total recoverable Selenium, total recove

Silica, total racove

- Silica, total recoverable

Silica, total recoverable

: Silver, total recoverable

Sodium, total recoverable

Sodium, total recoverab

Specificic conductance

Specific conductance

Styrene

Styrene

S Sultate

$2,4,5-T$
$2,4,5-T$
2

$\begin{array}{ll}0,3,7,8-T C D D \\ 0 & 2,3,7,8-T C D D\end{array}$

$2,3,7,8 . \mathrm{TCDO}$

$2,3,7,8-T C D F$

Tetrachlorodibenzo-p-dioxins

Tetracthiorodibenzo-po-dioxins

C. $30 \mathrm{E}-04$
R A B SOL Unit Lab 'Method

2.50 Hg L WA EPABOB

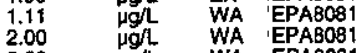

$1 . \infty$ Eg/L EX EPABO8

$\begin{array}{llll}1.11 & \mu g h & \text { WA } & \text { EPABO81 } \\ 2.00 & \mu g h & \text { WA } & \text { EPABOg1 }\end{array}$

$5.200-04$

0.00160

$4.00 \mathrm{E}-04$
$4.20 \mathrm{E}-04$

0.00110
$5.20 \mathrm{E}-04$

$6.50 \mathrm{E}-04$

$4.0 \mathrm{E}-04$
$4.20 \mathrm{E}-04$

.j $\quad \mathrm{a}$

WA

WA EPA8280

WA : EPAB280

WA

WA

EX EPA8270B

WA EPA9040.

WA, EPA8270

WA EPA8270

WA EPAB270

WA , EPAB270

WA ' EPA9066

WA EPA420

WA EPAG010

WA EPAB270

$\underset{\text { WX }}{\text { WA }}$

WA

WA:

WA W

WA WPAAB10

EX EPAGOYOA

WA EPAG010

Wa' EPASOSO

WA EPA950

WA EPAB260

WA,$E P A B 260$

EX EPA8260A

EX EPA300.0

WA EPAB150

WA EPA8280

WA EPA8280

WA EPA8280

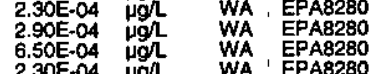

Second Quarter 1998 
Well CSR 3 collected on 06/01/98 (cont.)

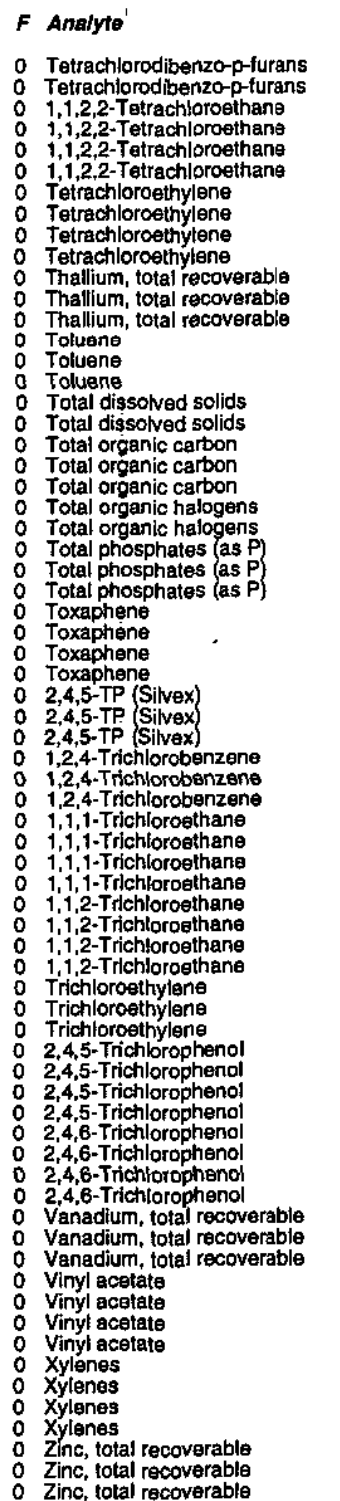

Rosut

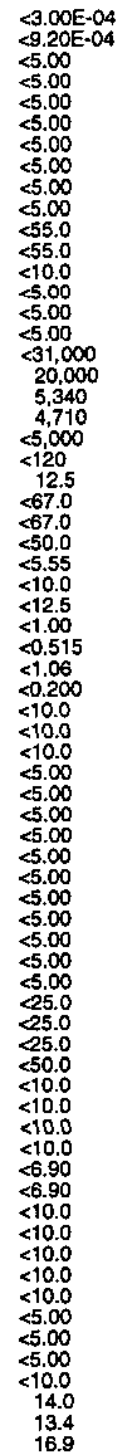

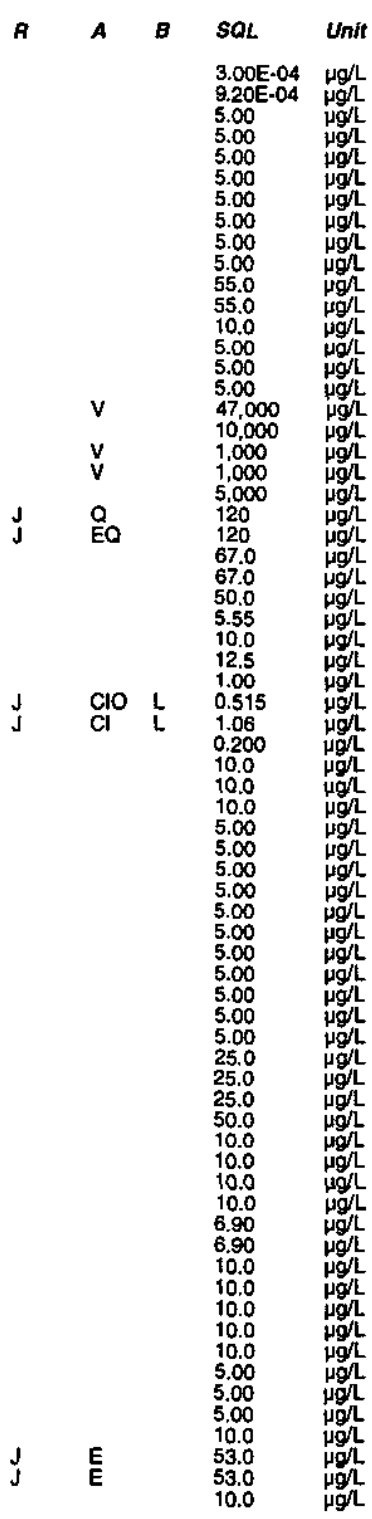

WELL CSR 3 Replicate

MEASUREMENTS CONDUCTED IN THE FIELD

Lab Method

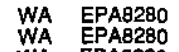

WA

WA EPAB260

WX EPAB260A

WA EPA8260

EX EPA260A

WA EPA6010

WA EPAB260

EPAB260A

EPA160.1

WA EPA9060

WA EPA9000

WA EPA365.2

EPA365.2

WA EPABOB

WA EPABOB1

EPAB150

WA EPAB270

EX EPAB270B

WA EPA826

EPA8260

WA EPA8260

E EPA2260

WA EPAB260

EPAB260A
WA
EPAB270
TPAB270

WA EPAB270

EPA8270

EPAB270

EPA270B

WA EPAG010

WA EPAB260

WA EPAB260

WA EPAB260

A EPAB260

EA EPAB010

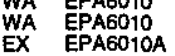

Anthracene , total recoverable

Berylium, total recoverable
Sample date: $06 / 01 / 98$
Depth to water: $37.93 \mathrm{ft}(11.56 \mathrm{~m})$ below TOC
Whter

Water elevation: 247.27 ft (75.3

Sp. conductance: $24 \mu \mathrm{S} / \mathrm{cm}$

Water evacuated from the well prior to sampling: 22 ga ANALYSES

F Analyte

0. Acenaphthene

0 Acetone

- Aluminum, total recoverablo

Arsenic, total recoverable
Barium, total recoverable

alpha-Benzene hexachloride

beta-Benzene hexachloride

Benzldine

Benzo(k) fluoranthene

Benzo(g, h,i)perylen

Bis(2-chloroethoxy) meth

Bis (2-chloroisopropyl) ether

Bis(2-ethyythexyly) phithalat
Bromodichloromethane

0 Bromoform

4-Bromophenyi phenyl ether
Butybenzyl phthalate

2-sec-Butyy-4,6-dinitrophen

Calcium, total recoverable

Carbon disulfide

alpha-Chlordane

Chloride

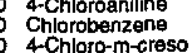

Chloroethane
Chloroethene (Vinyl chloride)

Chloroethene

2-Chloronaphthale

2-Chloronaphthal

4-Chlorophenyl phenyl ether

Chrysent

Cobalt, total recoverable

o o-Cresol (2-Methylphenol)

0 Cyanide

0 p,p'-DDE

Dibenz(a,h)anthracen

Dibenzofuran

Dibromochloromethane

1,2-Dichlorobenzen

1,4-Dichlorobenzene

B-61

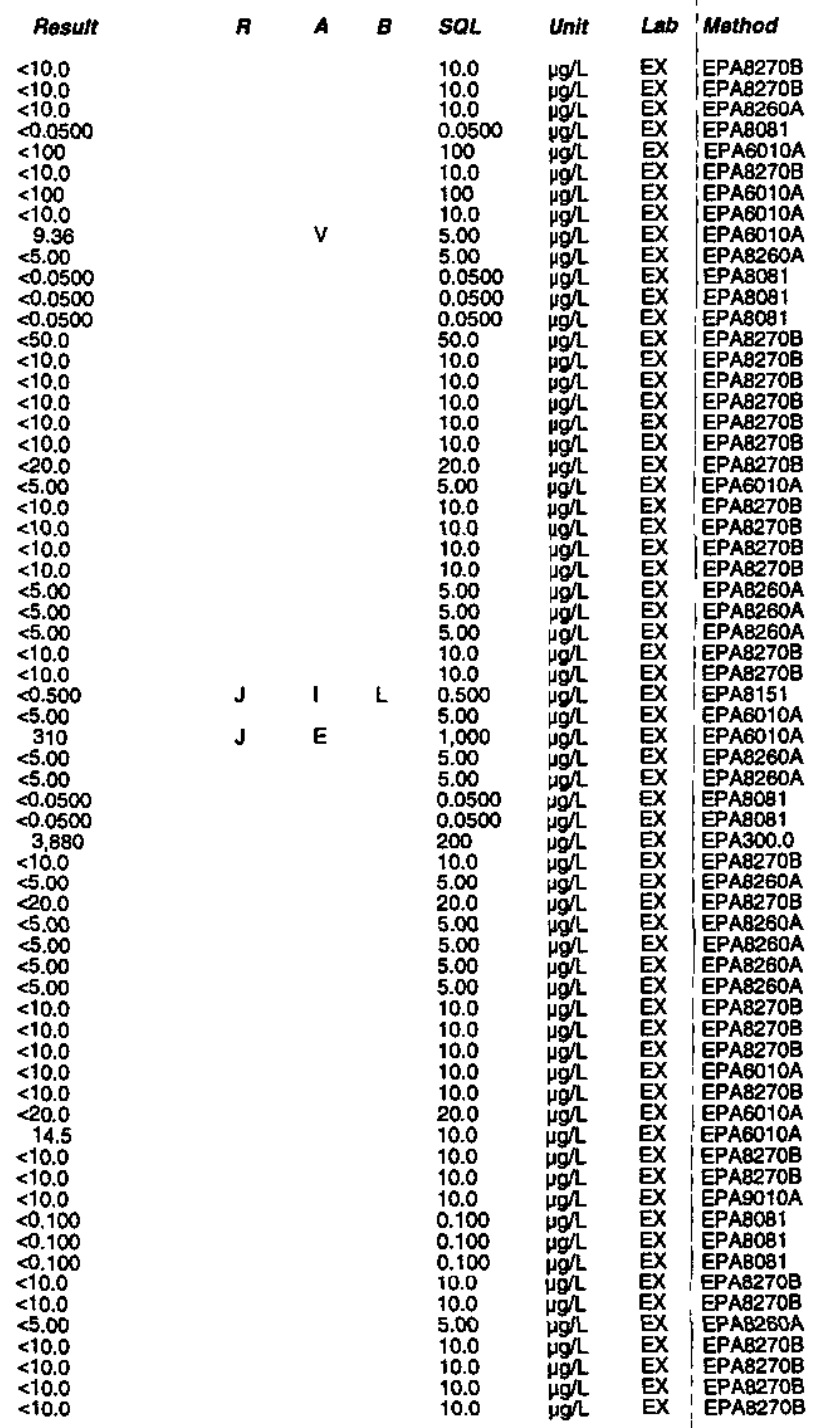

Second Quarter 1998
Time: 13:03

Air temperature: $36^{\circ} .6^{\circ} \mathrm{C}$

Total alkalinity (as CaCO3): $0 \mathrm{mgl}$

Lab 'Mathod

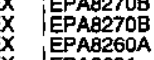

EPAG010A
EPA8270B
EPAG010A

EPABO1OA

EPABOS

FPAE27OB

EPA8270B

PA9010A

EABOB 


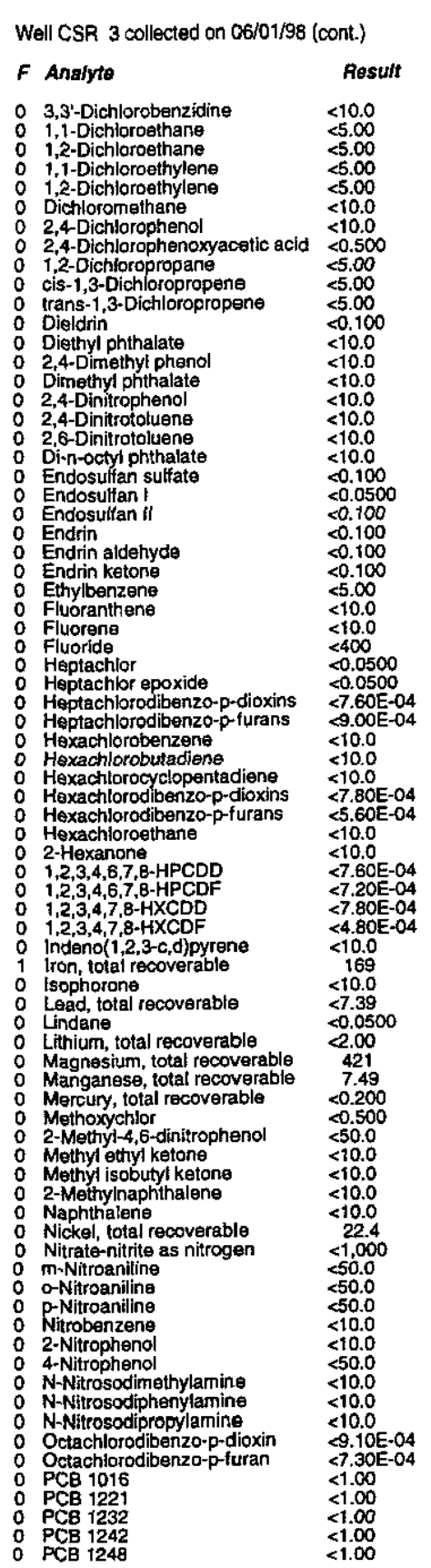

Well CSF 3 collected on 06/01/98 (cont.)

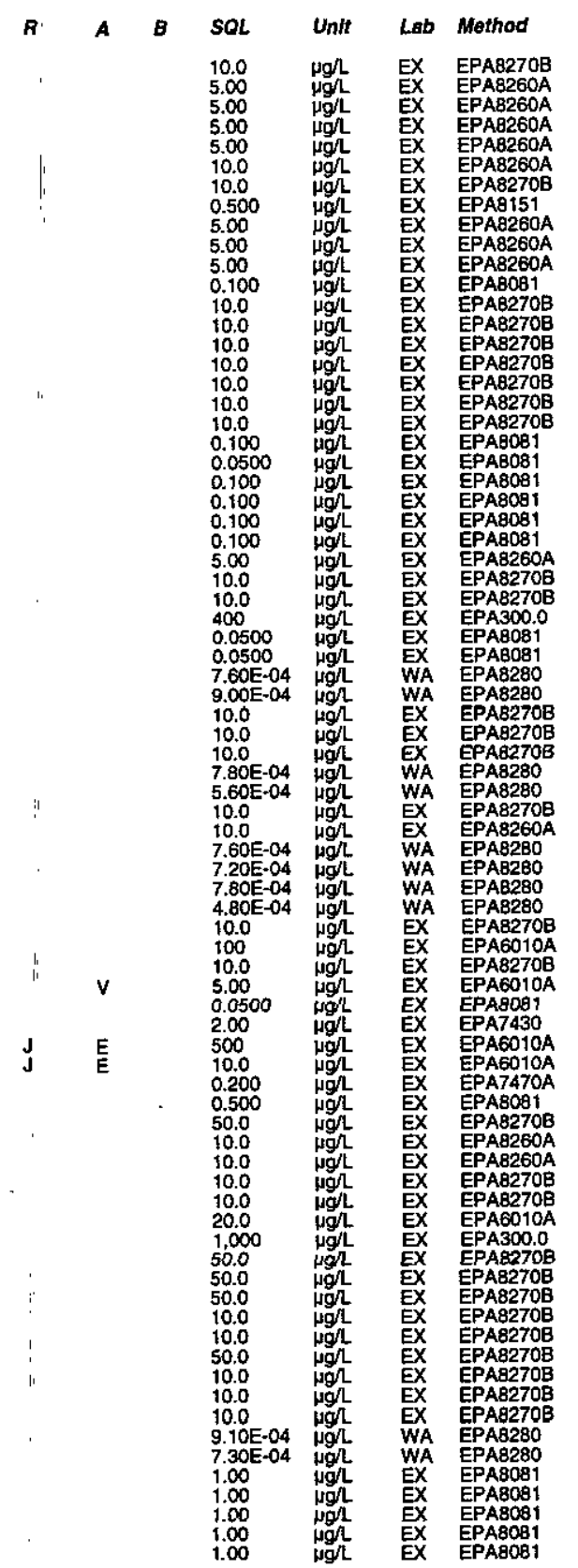

Pentachlorodibenzo-p-durans
ANALYSES

Analyte

: Acenaphthens

0 Acetone

Aluminum, total recoverable

Anthracene 1 tal recoverablo

Arsenic, total recoverable

- alpha-Benzene hexacthloride beta-Benzene hexachloride
detta-Benzerie hexachloride
$F$ Analyte Resut

0 PCB 1254

$\begin{array}{ll}1,2,3,7,8-P C D D \\ 0 & 1,2,3,7,8-P D F\end{array}$

Pentachlorodibenzo-

Phienanthrene

Phenol

lecoverable

Selenium, total recovera

Silica, total recoverable

Sodium, total recoverab

Specific conductanco

Specific conductanc

2,3,7,8-TCDD

Tetrachlorodibenzo-p-dioxins

1.12,2. Tetrachloroethane

Tetrachloroethylene

Thallum, total recovera

Total dissolved solids

Total organic carbon

Total phosphates (as P)

2,4,5-TP (Sivex)

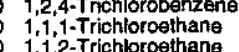

Trichloroethylens

2,4,6-Trichlorophenol

Vanadium, tote

0 Xylenes

WEL CSR 4

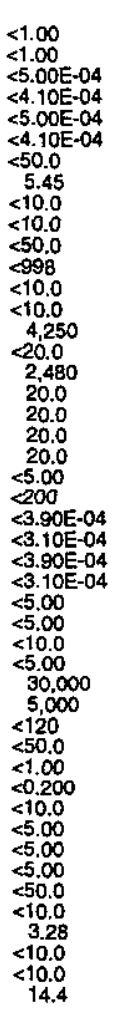

A A B SOL Unit

Lab Method

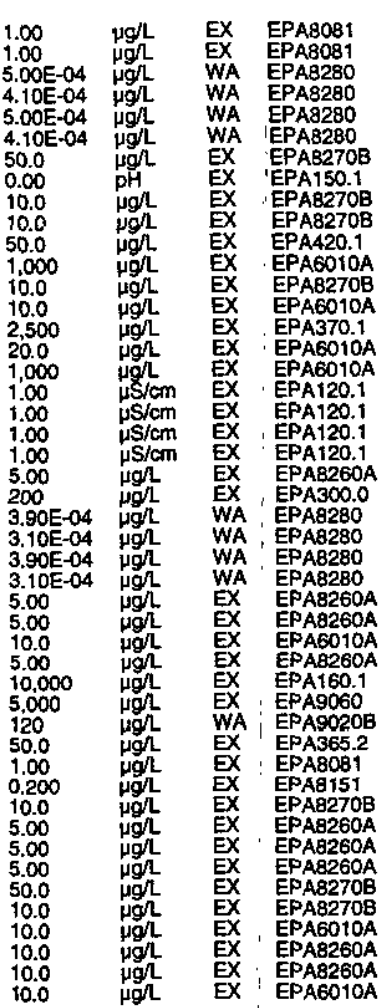

MEASUREMENTS CONDUCTED IN THE FIELD

\begin{tabular}{|c|c|}
\hline $\begin{array}{l}\text { Sample date: } 04 / 29 / 98 \\
\text { Depth to water: } 39.37 \mathrm{ft}(12 \mathrm{~m}) \text { below TOC } \\
\text { Water elevation: } 245.33 \mathrm{ft}(74.78 \mathrm{~m}) \mathrm{msl} \\
\text { cH: } 4.7 \\
\text { Sp. conductance: } 26 \mu \mathrm{S} / \mathrm{cm}\end{array}$ & $\begin{array}{l}\text { Time: } 12: 36 \\
\text { Water temperature: } 19^{\circ} \mathrm{C} \\
\text { Air termperature: } 24.9^{\circ} \mathrm{C} \\
\text { Total akealinity (as CaCo3): } 0 \text { mg/ } \\
\text { Phenolphthalein alkalinity: } 0 \mathrm{mgh}\end{array}$ \\
\hline
\end{tabular}

Fell prior to sampling: $44 \mathrm{gal}$

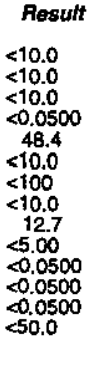

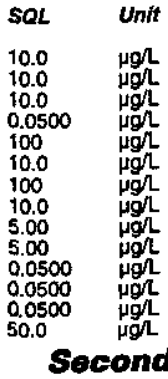

Lab Mathod

EX EPAB270B

EX EPAB270

EX EPABOB1

EX:

EPAG010A

EPAB260A

EX. EPAAO81

Quarter 1998 
Well CSA 4 collected on 04/29/98 (cont.)

\begin{tabular}{|c|c|c|}
\hline & Ansilyto & Result \\
\hline & 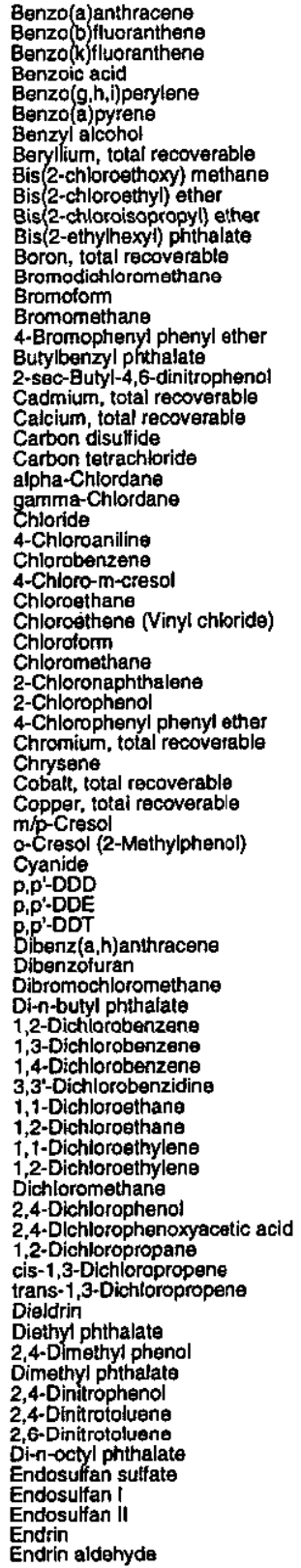 & 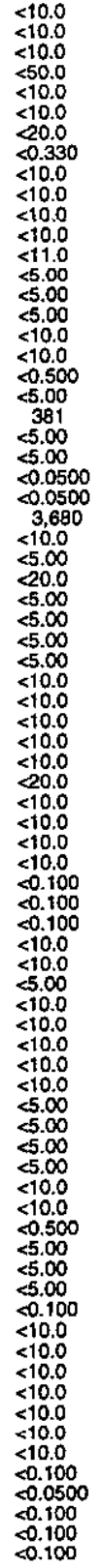 \\
\hline
\end{tabular}

Well CSR 4 collected on 04/29/98 (cont.)

A A B SOL

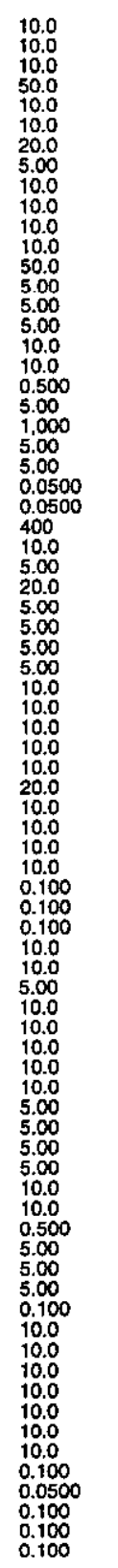

ESH-EMS-980569

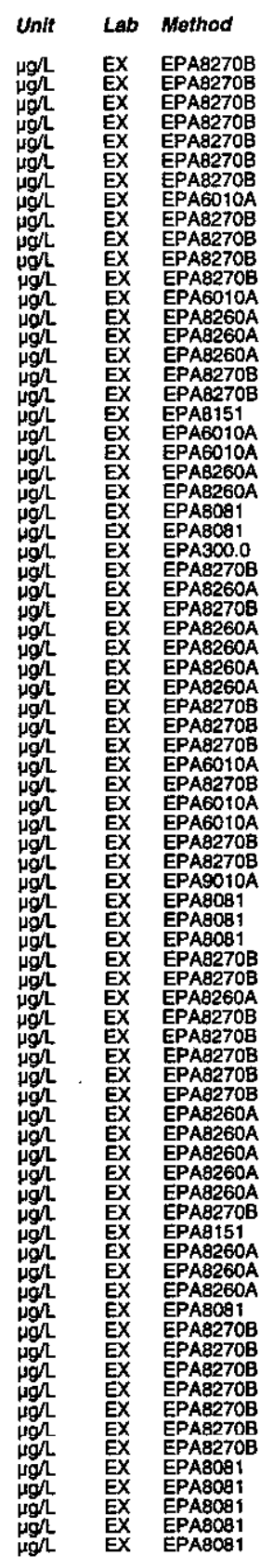

$F$ Analyte

0 Endrin ketone

o Ethylbenzene

o Fluoride

Heptachlor

Heptachloropocibenzo-p-dioxins
Heptachlorodibenzo-p-furans

Hextachlorocibenzo-p-fu

Hexachlorobutadiene

Hexachlorodibenzo-p-dioxins
Hexachlorodibenzo-p-furans

Hexachlorodibenze-pethane

2-Hexanone $1,2,3,4,6,7,8-\mathrm{HPCDD}$

$1,2,3,4,6,7,8-H P C D F$
0
$1,2,3,4,7,8-H \times C D D$
$1,2,3,4,7,8-H X C D F$

Indeno $(1,2,3-c$, cd)pyrene
0 Iron, total recoverable

o Lead, total recoverable

Lindane

O Manganese, total recoverable

Methry, total recoverable

O. Methyl ethyl katone

Molybdenum, total recoverable

Naphthalene
Nickel, total recoverable
Nitrate-nitrite as nitrogen

m-Nitroaniline
o-Nitroaniline
p-Nitroaniling

Nitrobenzent

2-Nitrophenol

N-Nitrosodimethylamine

\section{- N-Nitrosodipropylamine}

Octachlorodibenzo-p-dioxin

O PCB 1016

PCB 122

PCB 1242
0 PCB 1248
0.968

PCB 1260

$1,2,3,7,8-P C D D$
$1,2,3,7,8-P C D F$

- Pentachlorodibenzo-p-dioxin

Pentachlorodibenzo-p-furan

$\mathrm{pH}$.

o Phenanthrene

O Phenol

Potassium, total recoverable

Selenium, total recoverable

Silica, total recoverable

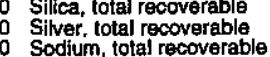

Sodium, total recoverabable

Strontium, total recoverable

$\begin{array}{ll}\text { o } & \text { Styrene } \\ \text { o } & \text { Sulfate } \\ 0 & 2,3,7,8-T C D D\end{array}$

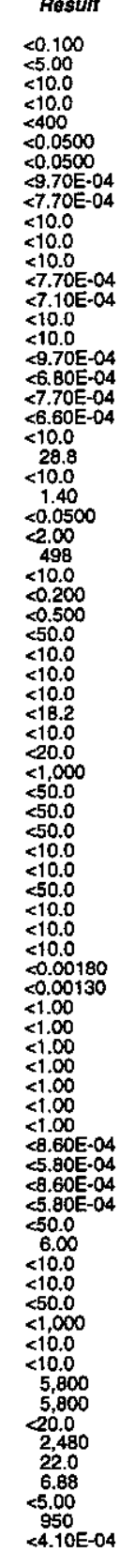

•
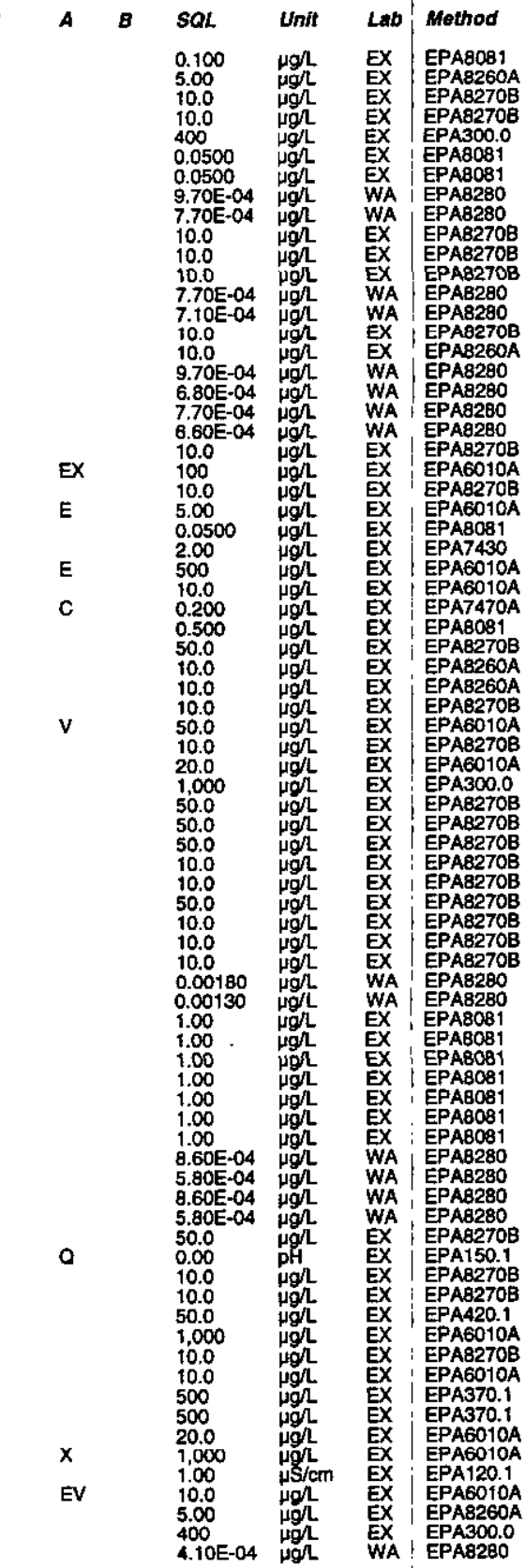

Second Quarter 1998 
Well CSA 4 collected on 04/29/98 (cont.)

$F$ Analyte

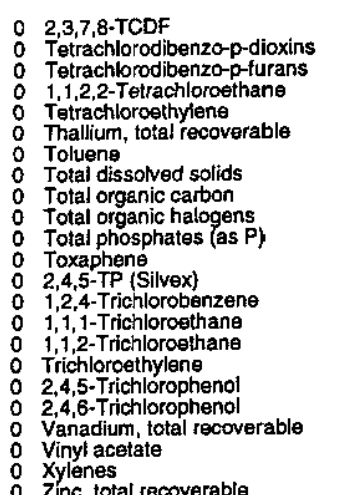
Resuit

\section{$<.70 E-04$
$<4.10 E-04$
$<3.70 E-04$}

$<5.00$

$<10.0$
5.00
25,000
6,000

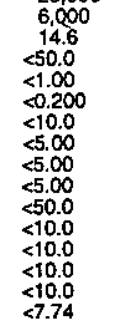

WELL CSR 4

MEASUREMENTS CONDUCTED IN THE FIELD

Sample date: $06 / 01 / 98$
Depth to water: $22.32 \mathrm{ft}(6.8 \mathrm{~m})$ below TOC
Water elevation: $262.38 \mathrm{ft}(79.97 \mathrm{~m}) \mathrm{msl}$
pH:

H. conductance: $29 \mu \mathrm{S} / \mathrm{cm}$

Turbidity: $2 \mathrm{NTT}$ frer evacuated from the well prior to sampling: $59 \mathrm{gal}$

ANALYSES
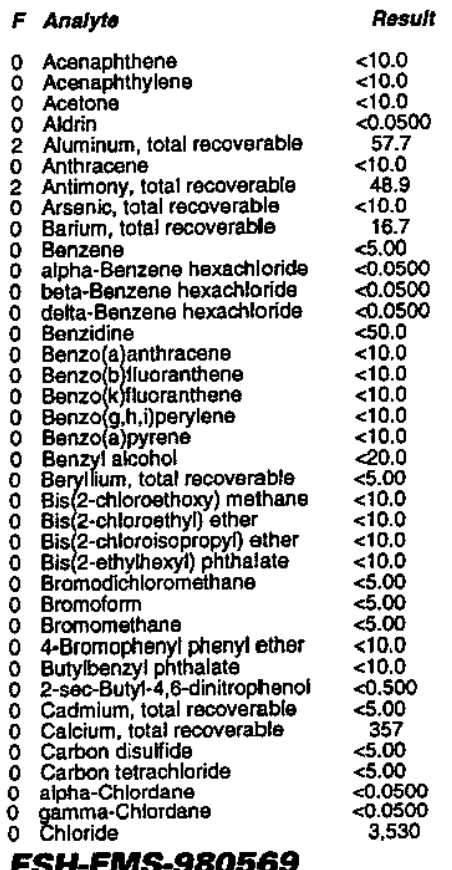

ESH-EMS-980569
Time: $11: 15$
Water temperature: $20.8^{\circ} \mathrm{C}$ Air temperature: $30.3^{\circ} \mathrm{C}$
Total alladinity (as CaCO3): $0 \mathrm{mg} /$
Phenolphthalein alkalinity: $0 \mathrm{mg} /$

Well CSA 4 collected on 06/01/98 (cont.)

$F$ Analyte

$\begin{array}{ll}0 & 4 \text {-Chloroaniline } \\ 0 & \text { Chlorobenzen } \\ 0 & 4 \text {-Chloro-m-creso }\end{array}$

Chloroethane

C Chlorotorm

Chloromethane
2-Choronaphthalen

o 4-Chlorophenyl phenyl ether

Cobsent total recoverab!e

Copper, lotal recoverable
m/p-Cresol
o-Cresol (2-Methylphenol)

O Cyanide

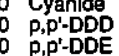

PD'-DDT

Dibromochloromethan

1,2-Dichlosobenzen

1,3-Dichlorobenzene

,1. Dichlorobenzidin

1,2-Dichloroethane

1,1-Dichloroethylene

Dichloromethans

2,4-Dichlorophenol

2,4-Dichlorophenoxyacetic acid

cis-1,3-Dichloropropopene

o Dieidrin - Dhthalate

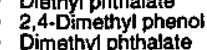

Dimathyl phthalate

2,4-Dinitrotoluene

Di-n-octyl phthalate

Endosultan I

Endosutan

Endrin aldehyde

Ethylbenzene

Fluorene

Heptachlor epoxide

Heptachlorodibenzo-p-dioxins

Hexachlorobenzene

Hexachlorobutadiene

Hexachlorodibenzo-p-dioxins Hexachlorodibenzo-p-furans

Hexachioroethane

\section{$1,2,3,4,6,7,8-\mathrm{HPCDO}$
$1,2,3,4,6,7,8-\mathrm{HPCDF}$}

$1,2,3,4,7,8-\mathrm{HXCDD}$

$1,2,3,4,7,8-H X C D F$
indeno $(1,2,3-c, d) p y r e n e$
tron total recoverable

Isophorone

Lindane total recoverable

- Lithium, total recoverable
Rosut

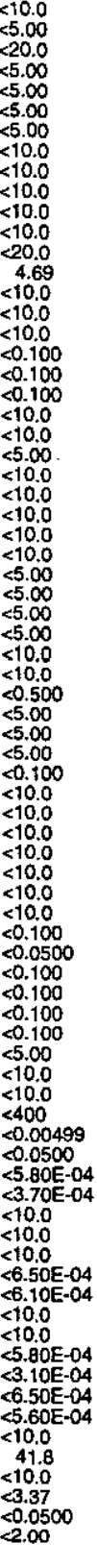

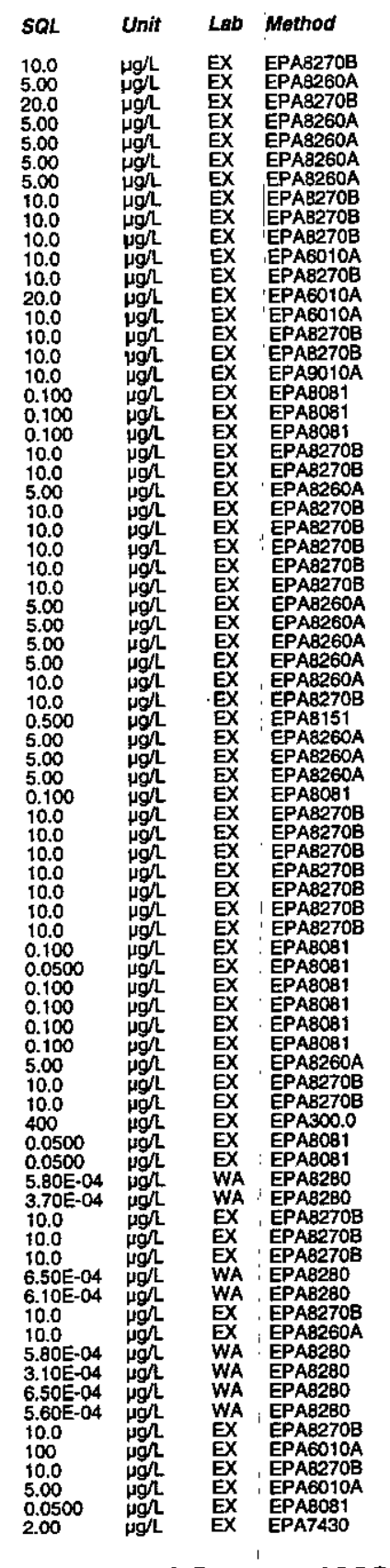


Well CSR 4 ' collected on 06/01/98 (cont.)

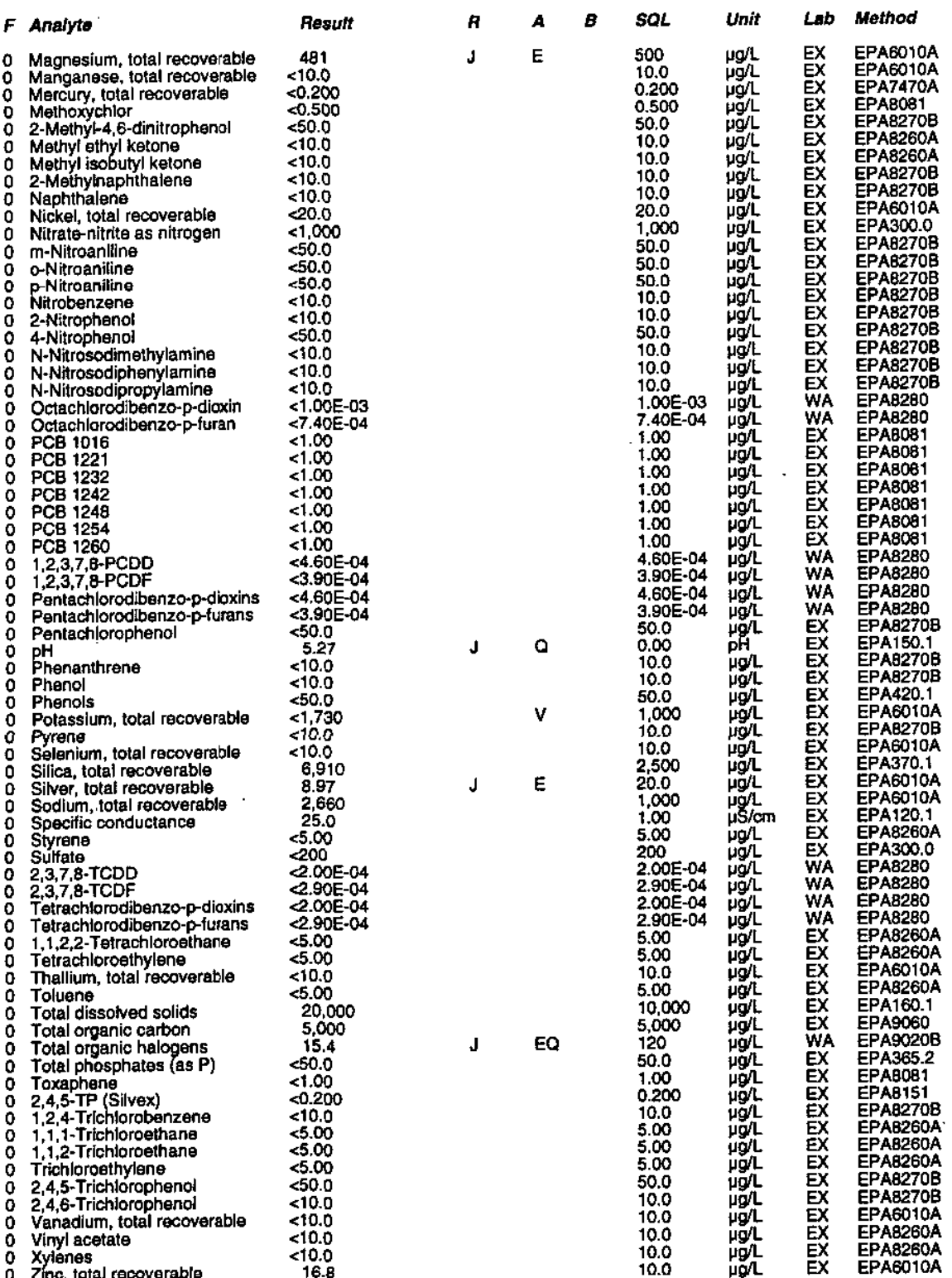

WELL CSR 5D

MEASUREMENTS CONDUCTED IN THE FIELD

Sample date: 04/29/98 $(3.98 \mathrm{~m})$ below TOC

Water

Water temperature: $18.6^{\circ} \mathrm{C}$

Sp. conductance: $650 \mu \mathrm{S} / \mathrm{cm}$

Turbidity: 1 NTU from the woll prior to sampling: 14 ga

Phenolphthalein alkalinity: $0 \mathrm{mg} /$
ANALYSES

$F$ Anaiyto

0 Acenaphthene

0 Aceton

Antimony, total recoverabte

Arsenic, total recoverable

aenzene

beta-Benzene hexachloride

Benzidine

Benzo (b) fluoranthene

Benzo(k)fluoranthen
Benzoic acid

Benzyl alcoho

Bisylium, total recoverable

Bis 2-chlorosthyl) ether

Bis 2-chloroisopropyl) ether

Boron, total recoverabla

Bromotichlor

4-Bromophenyl phenyl ether Butylbenzyl phthalate 2-sec-Butyl-4,6-dinitropheno

Calcium, total recoverable

Carbon disulfide

alpha-Chiordane

Chloride

Chlorobenzene

${ }_{0}$ Chloroethane

Chlorotom

2-Chloronaphthalene

2-Chlorophenol

4-Chlorophenyl phenyl ather

Cobalt, total recoverable

m/p-Cresol

Cyanida

p,p'-DDD

bibenz (a,h)anthracen

Dibenzofuran

Dibr-ntutuly phthalate
1,2-Dichlorobenzene
2 Aluminum, total recoverable

Benzo(g, h.j)peryler

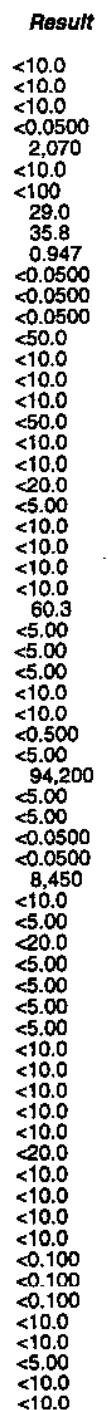

A soL

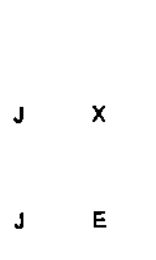

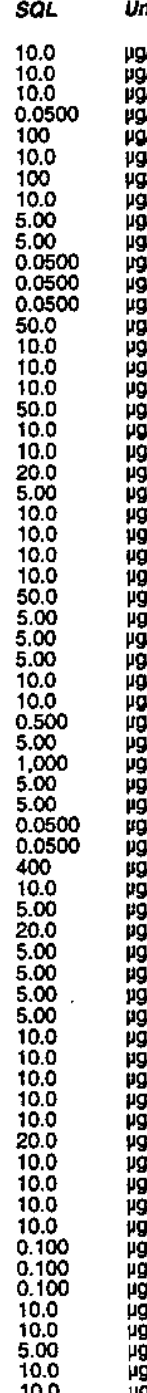

Unit

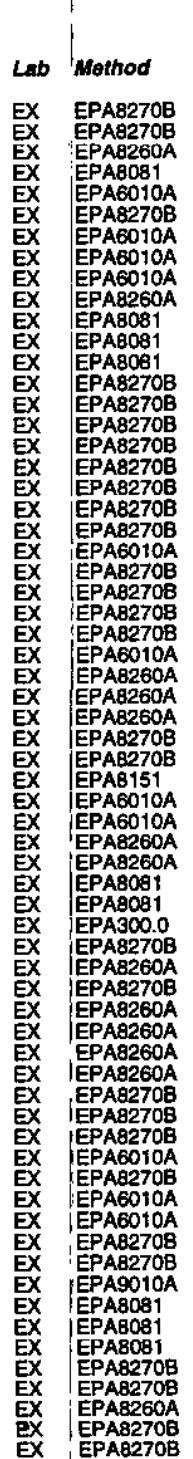

Second Quarter 1998 
Well CSR 5D collected on 04/29/98 (cont.)

\section{$F$ Analyte}

0 1,3-Dichlorobenzene

3,3'-Dichlorobenzidin

1.1.-Dichloroethane

1.1.Dichloroethylene

Dichloromethane

2,4-Dichlorophenoxyacetic acid

1,2-Dichiofopropane
cis-1,3-Dichloropropen

trans-1,3-Dichloropropene

2,4-Dimethyl pheno

Dimethyl phtthalate

2,4-Dinitrotoluene

Di-n-octyl phthalate

Endosultan !

Endrin

Endrin ketone

Fluoranthene

Fluorene

Heptachlor epoxide

Heptachlorodibenzo-p-dioxins

Heptachlorodibenzo-p-
Hexachlorobenzene

Hexachlorobutadiene

Hexachlorodibenenzo-p-dioxins

Hexachlorodibenzo-p-furans

Hexachloroethane

2-Hexanone

$1,2,3,4,6,7,8-H X C D D$
$1,2,3,4,7,8-H X C D F$

$1,2,3,4,7,8-H \times C D F$
Indeno (1,2,3-c,d)pyrene
lron, total recoverable

0 isophorone

Lead, total recoverable

Lithium, total recoverable

Magnesium, total recoverable

Marganese, total recoverable

2-Methyl-4,6-dinitropheno

Methyl ethyl ketore

2-Methyinaphthalene Molyoconum, total recoverable Nickel, total recoverable

o-Nitroaniling

P-Nitroaniline

2-Nitropheno

$\mathrm{N}$-Nitrosodimethylamine

N-Nitrosodipropylamine

Octachlorodibenzo-p-dioxin

0
0

ESH-EMS-980569
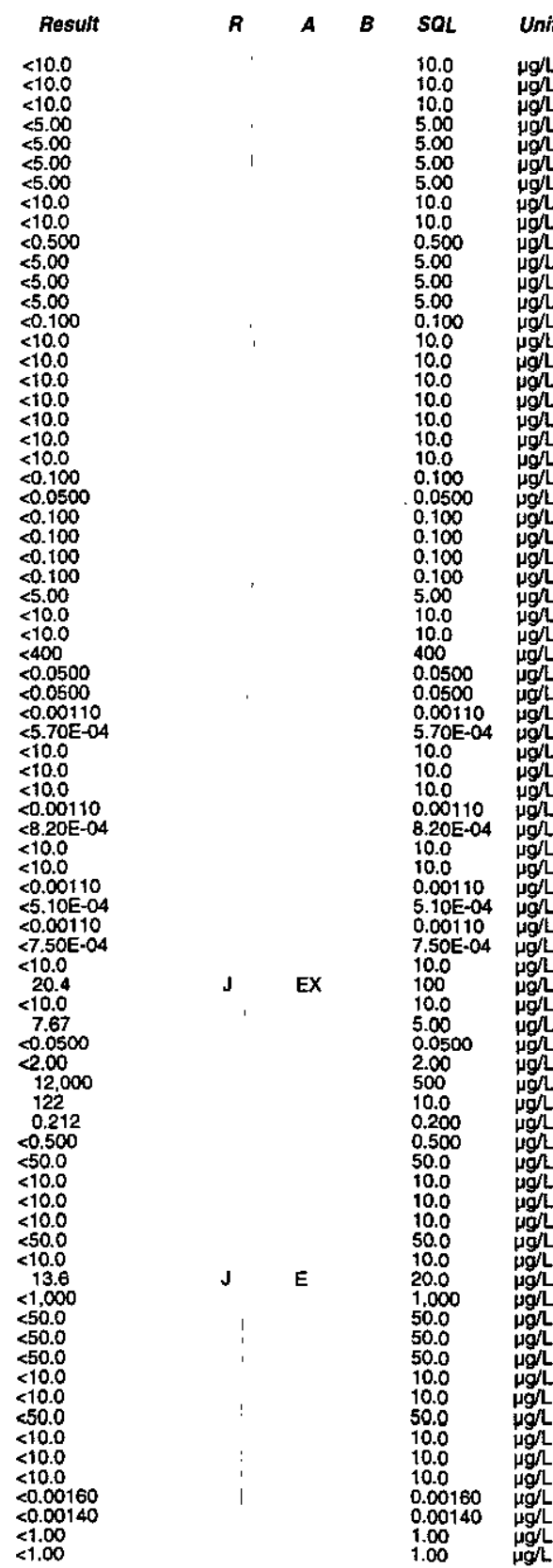

Lab Method

EX EPAB270B

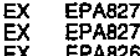

EX EPA260A

E EPAB260A

EPA8270

EPA8260A

EPAB2601

EPAB270B

EPAB270

EPA8270B

EPA8270

EPABO81

EPAB081

EPABOB1
EPAB260A

EPA8270B

EPABO81

EA EPAB280

EPA8270B

EPA8270B

EPA8280

EPA8270B

EPAB280

EPA8280

EPAG010A

EPA6010A

EPA7430

EPAG010A

EPA740A

EPAB270B

EPAB260A

EPAB270B

EPAED 10A
EPA300.0
EPAB270

EPAB270B

EPAB270B
EPAB270B

EPA8270B
EPA8270B

EPA8270B

WA EPA8280

EX EPABOB1
Well CSR SD collected on 04/29/98 (cont.)

$F$ Analyte Result

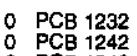

0 PCB 1254

1, $1,2,3,7,8-P C D D$

Pntachlorodibenzo-p-dioxins

Pentactlorophenol-p-furan

Phenanthrene

Phenols

Potassium, total recoverable

Selenium total recoverate

Silica, total recoverable

Solver, total recoverable

Strontium, total recoverabl

Sultate

2 $2,3,7,8$-TCDD

etrachlorodibenzo-p-dioxins

$1,1,2,2 \cdot$ Tetrachloroethane

Tetrachloroethylene

Total dissolved solids

Total organic carbon
Total organic halogens

Total phosphates (as P)

Toxaphene
2,4,5-TP (Silvex)

1,2,1.Trichlorobenzene

1, 1,2-Trichloroethan

2,4,5-Trichloropheno

Vanadium, total recoverable

Vinyl acetato

- Zinc, total recoverable
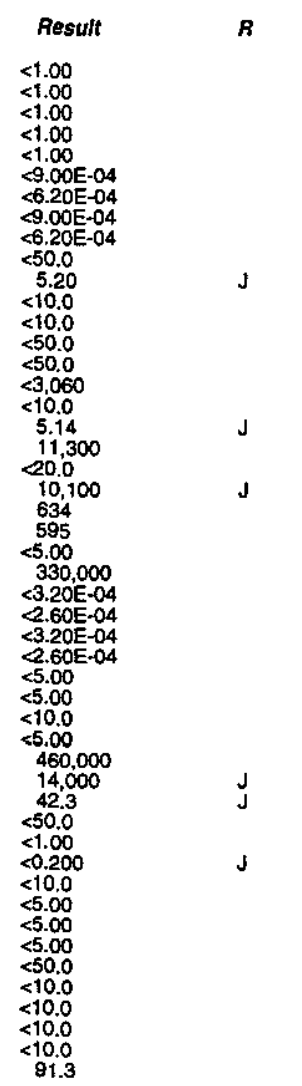

SQL Unit

Lab Method

\section{WELL CSR 5D}

MEASUREMENTS CONDUCTED IN THE FIELD

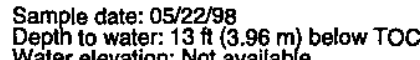

$\mathrm{gH}: 4.2$ conductance: $700 \mu \mathrm{S} / \mathrm{cm}$

Water evacuated from the well prior to sampling: $31 \mathrm{gal}$

ANALYSES

$F$ Ansiyte

Result

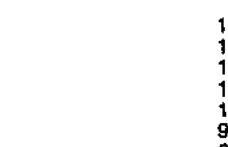

$\begin{array}{llll}.00 & \mu g^{\prime} L & \text { EX } & \text { EPABOB } 1\end{array}$

1 Grons, lotal recoverable

Nonvolatila beta
Trittium

1.14E- $08 \pm 2.45 E-09$ J $E$

$1.62 E-08 \pm 2.81 E-09$
$2.78 E-06 \pm 9.40 E-07$

Time: 12:34

Wir temperature: $19^{\circ} \mathrm{C}$

Total alkalinity (as CaCO3): $0 \mathrm{mgh}$
Phenolphthalein alkalinity: $0 \mathrm{mg} / \mathrm{L}$

SOL Unit Lab Mothod

$\begin{array}{llll}25.0 & \mu g / L & \text { ES } & \text { EPA6010 } \\ 3.70 E-10 & \mu \mathrm{C} / \mathrm{mL} & \mathrm{TM} & \mathrm{EPA900.0 \textrm {M }}\end{array}$

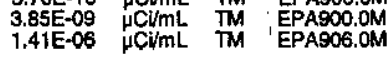


WELL CSR 5D

MEASUREMENTS CONDUCTED IN THE FIELD

Sample date: $06 / 01 / 98$
Depth to water: 13.25 ft (4.04 m) below TOC
Water Water elevation: Not available

Sp. conductance: $530 \mu \mathrm{S} / \mathrm{cm}$

Watter evacuated from the well prior to sampling: $17 \mathrm{gal}$ ANALYSES

$F$ Analyto

: Acenaphthene

O Aceton日

2 Aluminum, total recoverable

0 Anthracene

Antimony, total recoverable

Benzene

alpha-Benzene hexachloride beta-Benzene hexachloride
delta-Benzene hexachloride

Benzidine

- Benzofbifluoranthene

Benzo(i, hili)perylene

Benzyl alcohol

Beryllium, total recoverable
Bis(2-chloroethoxy) methane

Bis(2-chloroethyl) ether

Bis(2-chloroisopropyl) ether
Bis(2-ethylhexyl) phthalate

Bromodichloromethane
Bromodichloromethan

Bromoform
Bromoform

Bromomethane

4-Bromophenyl phenyl ether

2-sec-Butyl-4,6-dinitrophenol

Cadmium, total recoverable

Carbon disuffide

Carbon litrachloride
Carbon tetrachloride

alpha-Chlordane

o gamma-Chide

4-Chloroaniline

Chlorobenzene

Chloroethane

Chloroethene (Vinyl chloride)

Chloroform

Chloroform

Chloromiethane
2-Chloronaphthalene

4-Chlorophenyl phenyl ether

Chryseni

$\begin{array}{ll}0 & \text { Cobatit, total recoverable } \\ 0 & \text { Copper, total recoverable } \\ 0 & \text { mip-Cresol }\end{array}$
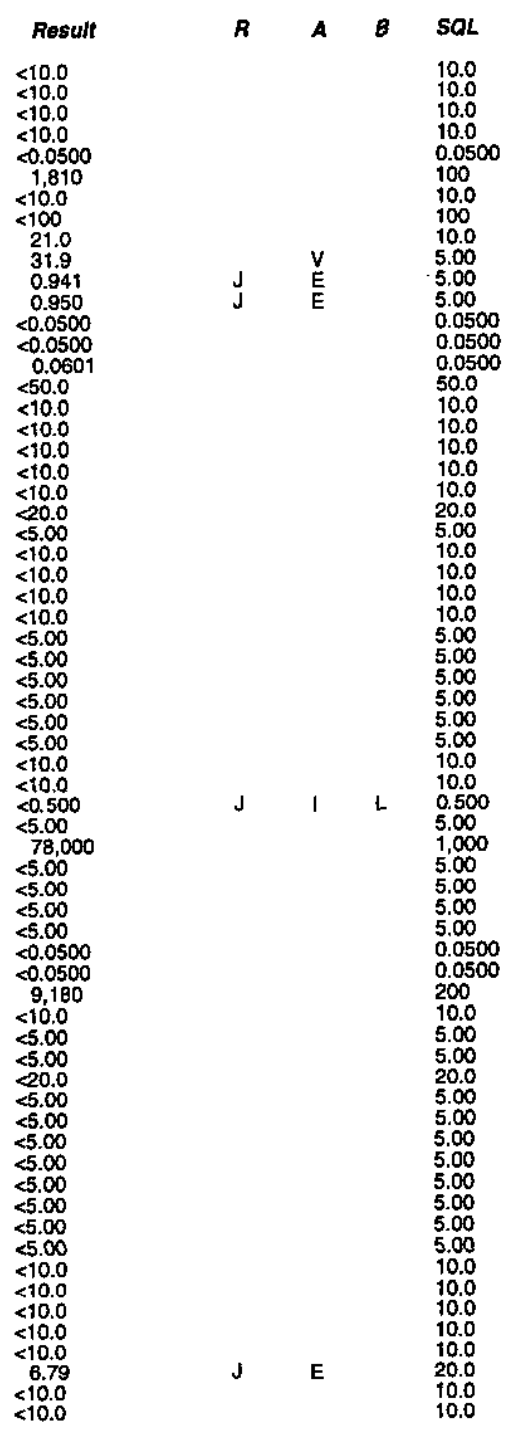

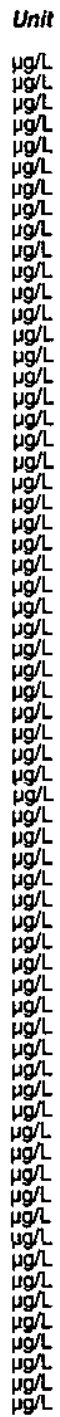

Lab Method

$\begin{array}{ll}\text { EX } & \text { EPAB270B } \\ \text { EX } & \text { EPAB270B } \\ \text { EX } & \text { EPAB260A }\end{array}$

$\begin{array}{ll}\text { EX } & \text { EPA8260A } \\ \text { EPAB260A } & \text { EPAB081 }\end{array}$

EX EPAG010A

EPAG010A
EX
EPAG010A
EPAG010A

EX EPAG010A

EX EPA8260A

EX EPABOB1

EX EPABOB1

EX EPAB270B

EX EPA8270B

EPA270B

EPAB270B

EPAB270B
EPA270B
$X$

EPAB26A

EPAB260A

EPAB151

EPAG010A

EPA260A
$X$ EPA260A

$X$
$X$
$X P A B 260 A$
EPAB081

EPABOB 1
EPA300.

EX EPAB270B

EX EPAB260A

EX EPAB260A

EPAB260A
EPAB260A

EPAB260A

EX EPA8260A

EX EPAB270B

EX EPABO10A

EX EPAB270B

EX EPAG010A
Well CSR 50 collected on 06/01/98 (cont.)

o O-Cresol (2-Methylphenol)

Resutt
$<10.0$

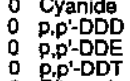

P.p'-DDT
Dibenza,h)anthracene
Dibenzofuran

Dibromochloromethane

Di-n-butyl phthalate

1,3-Dichlorobenzenene

1,4-Dichlorobenzene

1,1-Dichloroethane

1,2-Dictlorosthane

o i.1-Dichloroethylen

1,2-Dichloroethylene

Dichloromethane

2,4-Dichlorophenol

1,2-Dichloropropane

cis-1,3-Dichloropropene

trans-1,3-Dichloropropene

2.th-Dimethylat phen

Dimethyl phthatate

2,4-Dinitrophenol

Di-n-Dinitrotoluene

Endosuffan sulfate

Endosulfan II

Endrin aldahyde

Ethylbenzene

E Elyylbenzene

Fluorene

Heptachlor

Heptachlorodibenzo-p-furans

Hexactlorobenzene

Hexachlorocyclopentadiente

Mexachlorodibenzo-p-pturans

2-Hexanong

1,2,3,4,6,7,8-HPCOD

$1,2,3,4,6,7,8-H P C D F$
$1,2,3,4,7,6-H X C D D$

indeno $(1,2,3-c, 0)$ pyren

Isophorone

Lindane

Magnesium, total recoverable

2 Manganese, total recoverable
0 Mercury, total recoverable
o Methoxychlor
A A $B$ SOL Unit Lab Mothod

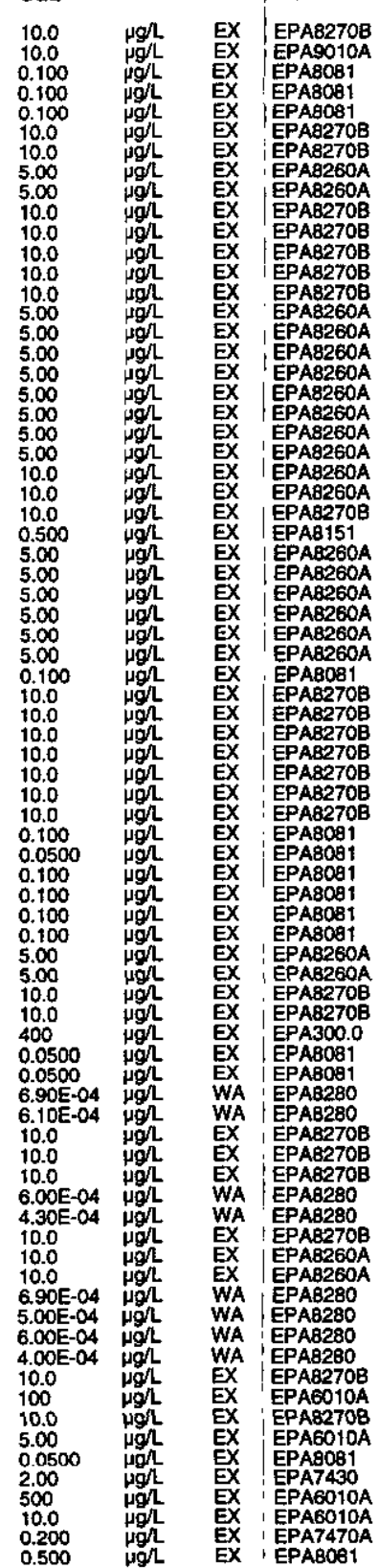

Second Quarter 1998

ESH-EMS-980569

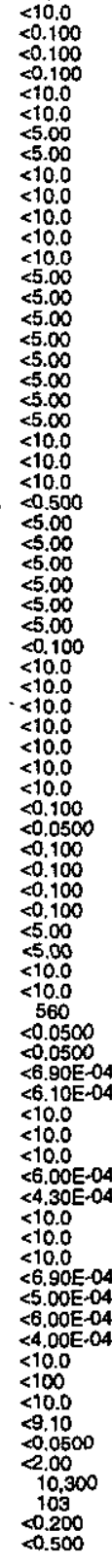

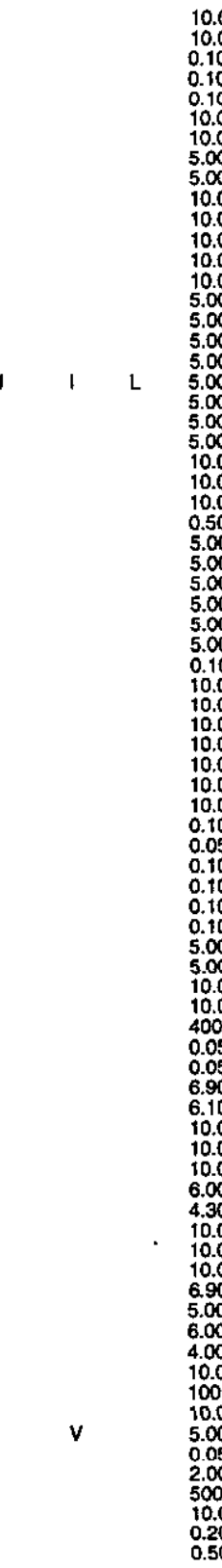


Well CSR 5D collected on 06/01/98 (cont.)

$F$ Analyte

2-Methyl-4,6-dinitrophenol

Methyl ethyl ketone

: Methyl isobutyy ketone

Naphthalene
0
0
0

O m-Nitroaniline

$\begin{array}{ll}0 & \text { Nitroaniline } \\ 0 & \text { p-Nitroaniling } \\ 0 & \end{array}$

2-Nitronzeneng

N-Nitrosodimethylamine

N-Nitrosodiphenylamine

Octachlorodibenzo-p-dioxin

PCB 1016

0 PCB 1242

PCB 1248

1,2,3,7,8-PCDD

Pentachlorodibenzo-p-dioxin

Pentachlorodibenzo-p-turans

$\mathrm{PH}^{\mathrm{H}}$

Phenol

Potassium, total recoverable

Pyrene

Selenium, total recoverabla

Silica, total recoverable

Sodium, total recoverable

Specific con

Sulfate

$2,3,7,8-\mathrm{TCDO}$

Tetrachloradibanzo-p-dioxins

Tetrachtorodibenzo-p-turans

1,1,2,2-Tetrachloroethane

Tetrachlorosthylene

Thallium, total recoverable

Toluene

Total dissolved solids

Total organic halogens

Toxaphene

1,2,4-Trichlorobenzene

1,1,1-Trichloroethane

1,1,2-Trichloroethane

Trichloroethylene

$2,4,5$-Trichlorophenol
$2,4,6-$ Trichloropheno

Vanadium, total recoverable

Vinyl acetate

Xylenes

ESH-EMS-980569
Well CSR 50 collected on 06/01/98 (cont.)
$F$ Analyte
Result
0 Zinc, total recoverable
22.7
R

$\begin{array}{llll}\text { SOL } & \text { Unit } & \text { Lab } & \text { Method } \\ 10.0 & \mu g / L & \text { EX } & \text { EPAGO10A }\end{array}$

\section{WELL CSR 6D}

MEASUREMENTS CONDUCTED IN THE FIELD

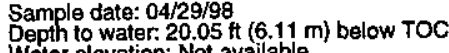

Time: $8: 18$

Water el

Sp. conductance: $26 \mu \mathrm{S} / \mathrm{cm}$

Turbidity: 0 NTU 26 from the well prior to sampling: 37 gal

Air temperature: $12.4^{\circ} \mathrm{C}$

Total alkalinity (as CaCO3): $4 \mathrm{mg} /$
Phenolphthalein alkalinity: $0 \mathrm{mg} L$

ANALYSES

$F$ Analyto

: Acenaphthene

Aceton

Aluminum, total recoverable

Anthracene

Arsenic, total recoverable

beta-Benzene hexachloride

tita-Benzene hexachlorida

Benzzo(a)anthracene

Benzo (k)fluoranthene

Benzo(g,h,i)perylen

Benzo(a)pyrene

Benzyl alcohol

Bis(2-chloroethoxy) methe

Bis (2-chloroethyl) ether

Bis(2-ethythexyl) phithala
Boron, total recoverable

Bromodichlorometh

Bromoform

4-Bromophenyi phenyl ether

2-sec-Butyl-4,6-dinitrophen

Calcium, total recoverablo

Carbon disulfide

alpha-Chhordane

Chloride
4-Chloroanilin

Chlorobenzene

Chloroethane (Vinyl chloride)

0 Chloroethe

Chloromethane

2-Chlorophenol

4-Chlorophentyl phenyl ether

Chrysene

Cobalt, total recoverable

$\mathrm{m} /$-Cresol
o-Cresol (2-Methylphenol)

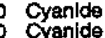

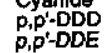

B-68

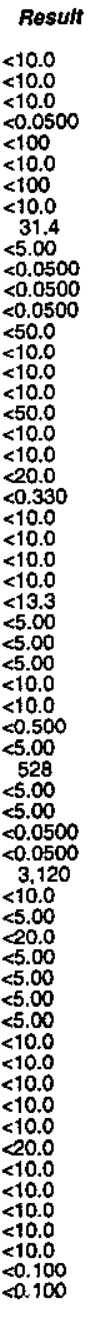

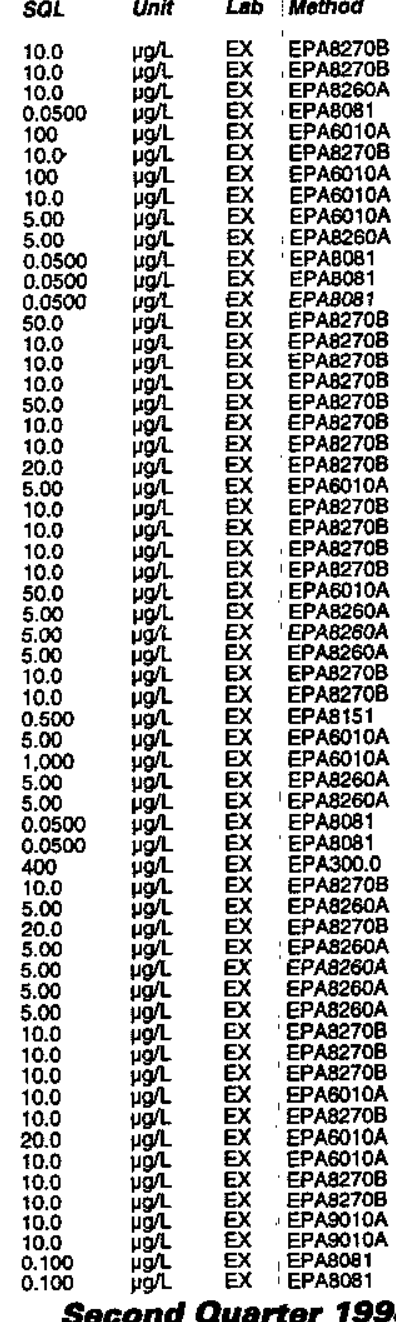


Well CSR 6D collected on 04/29/98 (cont.)

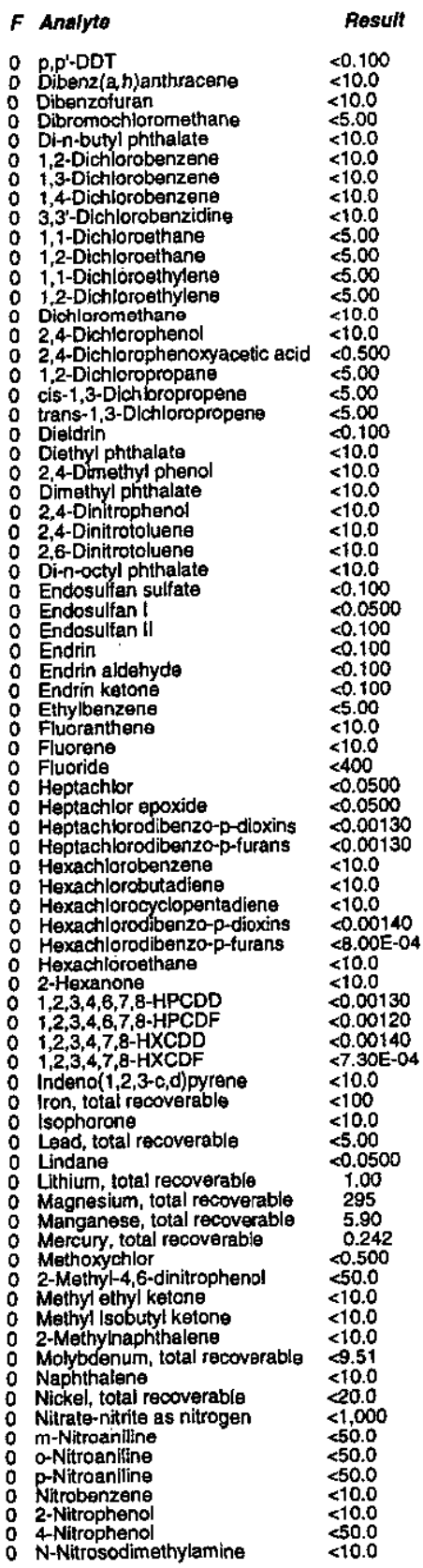

Well CSR 6D collected on 04/29/98 (cont.)

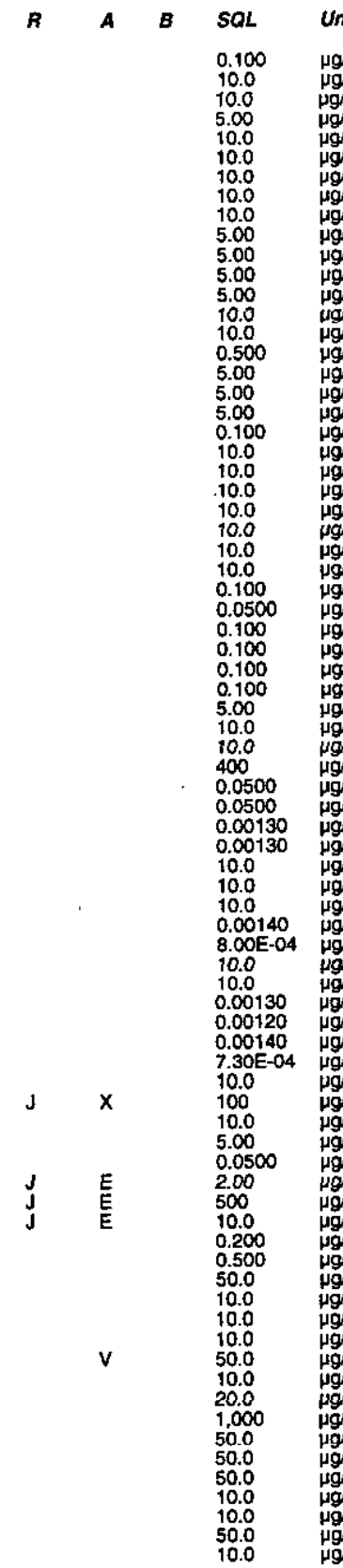

pr. 5.2 .
$F$ Analyte

N-Nitrosodiphenylamine

O N-Nitrosodipropylamine

0 PCB 1016

PCB 1232

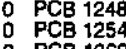

$\begin{array}{ll}1,2,3,7,8-P C D D \\ 0 & 1,2,3,7,8-P C D F\end{array}$

O Pentachlorodibenzo-p-dioxin

Pentachlorophenol

Phenanthrene

Phenol

Potassium, total recoverable

- Pyrene

Selenium, total recoverab

Situver, total recoverabo

Sodium, total recoverab

Specific conductance

(t)

$2,3,7,8-T C D$

Tor

Tetrachlorodibenzo-p-turans

1,1,2,2-Tetrachloroethane

Thallium, total recoverabte

Total dissolved solids

o Total organic carbon

Total phosphates (as P)

2,4,5-TP (Silvex)

o $1,2,4$ - Trichlorobenzene

0 1,1,2-Trichloroethan

$2,4,5-T r i c h l o r o p h e n$
0
0

- Vanadium, total recoverable

0 Vinyl acetate

o Zinc, total recoverable

WELL CSR 6D

MEASUREMENTS CONDUCTED IN THE FIELD

Sample date: 05/22/98

Water $\mathrm{e}$

Sp. conductance: $24 \mu \mathrm{S} / \mathrm{cm}$

Water evacuated from the well prior to sampling: $25 \mathrm{gal}$

ANALYSES

$F$ Analyte

Boron, total recoverable

O Goss alpha

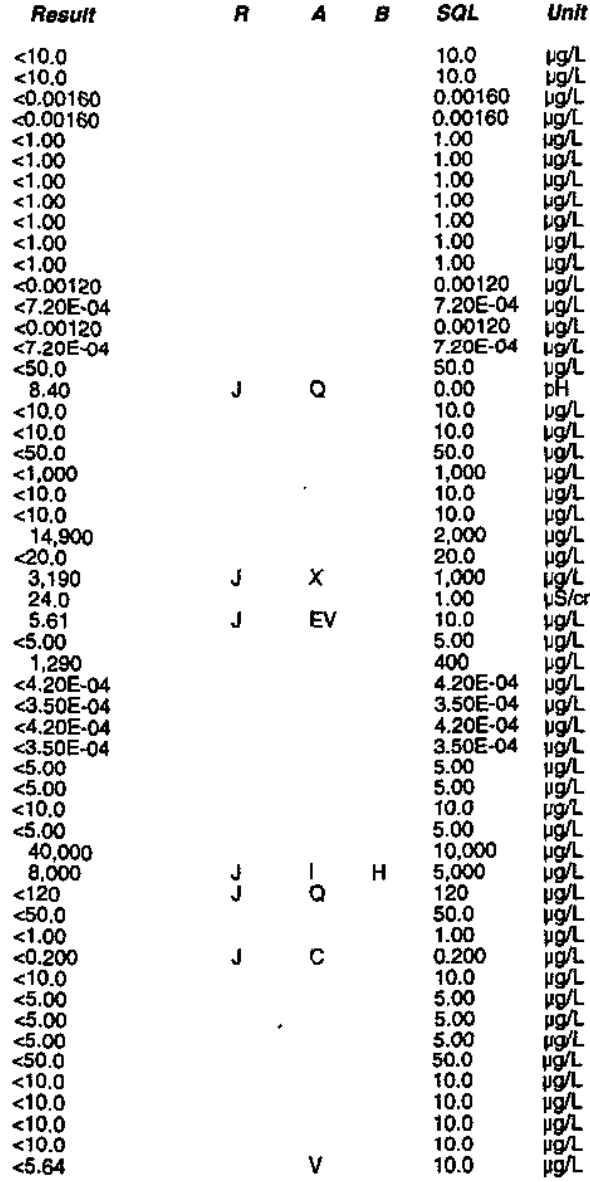

Lab Mathod

EX EPAB270B

WA EPAB280

EX EPABOB

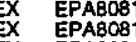

EPABOB

WA EPAB280

EPAB280

EPA150.1

EPAGO10A

EP EPA6010A

EX EPAG010A

EX EPA120,1

EPAB260A

WA EPA8280

WA

EPAA260A

EPAB260A

EPA9020B

EX EPABOB

EX EPAB270B

PPAB260A

EPAB270B

EX EPA6010A

EPA2260A 
ANALYTICAL RESULTS

\section{WELL CSR 6D}

MEASUREMENTS CONDUCTED IN THE FIELD

Sample date: $06 / 01 / 98$
Depth to water: $20.1 \mathrm{tt}(6.13 \mathrm{~m}$ ) below TOC

SH: 5 conductance: $24 \mu \mathrm{S} / \mathrm{cm}$

Water evacuated trom the well prior to sampling: $24 \mathrm{gal}$

ANALYSES

$F$ Analyts

: Acenaphthene

Acenaphithylene
Acenaphhthylene

A Acton

2 Aluminum, total recoverable Anthracene
0 Antracene
0

Antimony total recoverable : Arsenic, total recoverable

- alpha-Benzene hexachloride beta-Benzene hexachloride
delta-Benzent hexachloride : Benzidine

Benzoganthraceng

Benzoikffiuoranthene

Benzo(kffluoranthene

Benzogalpypena

Benzolapyrene
Benzyy alcohol

Benzyllaconol

Bis(2-chloroethroxy) methan

Bis 2 -chloroethy)
Bis 2 -chlther
2-chlorothyl) ether

Bas
Bis

Bis (2-ettyyhexyl phithalate

Bis(2-ethylhexyly phthala
Bromodichloromethane

Bromotom

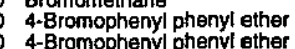
4 -Bromophenyl pheny
Butylbenzy' phthialate

Butyibenzy| phithalate

Cadcium, total recoverable

Carbon tisutitidio

alpha-Chlordane

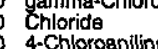

4 -Chloroaniline

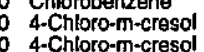

Chloroethene
Chloroesthene Ninyl chloride)

Chlorofom
Chloromethane

2.Chroronannthalene
0 2-Chloronaphithalene

ESH-EMS-980569

Well CSR $6 D$ collected on $06 / 01 / 98$ (cont.)

$F$ Analyte

Time: 11:44

re: $16^{\circ} \mathrm{C}$

Total alkalinity (as CaCo3): $1 \mathrm{mg} / \mathrm{L}$
2-Chlorophenol
0

4-Chlorophenyl phenyl ether

Chromium, total recoverable

Chrysene

Cobatt, total recoverable

$\mathrm{m} / \mathrm{p}$-Cresol
$\mathrm{m} / \mathrm{p}$-Cresol

$\begin{array}{ll}0 & \text { m/p-Cresol } \\ 0 & 0-\text { Cresol (2-Methylphenol) } \\ 0 & \text { o-Cresol (2-Methylphenol) }\end{array}$

0 Cyanide

p,p:DDE

Dibenz(a,h)anthracene

Dibenzofuran

Dibromochloromethane

Di-n-butyl phthalaters

o 1,2-Dichlorobenzene

1,2-Dichlorobenzene

1,3-Dichlorobenzene

1,4-Dichlorobonzenzene

o $3,3^{\prime}$-Dichlorobenzidine

1,1-Dichloroethane

o 1,1-Dichloroethylene

2,4-Dichlorophenol

henoxyacetic acid

0 1,2-Dichloropropane

to cis-1,3-Dichloropropene

0 Dieldrin

Diethyl phthalate
0
$2,4-D i m e t h y l$

2,4-Dimethy phenol

0 Dimethyl phthalate

Dimethy phinalate

2,4-Dinitreotoluene

2,4-Dinitrotoluene

2,6-Dinitrotoluene

o Di-n-octyl phthalate

Endosulfan sullate

Endosulfan II

E Endrin aldehyde

: Endrin ketong

$\begin{array}{ll}0 & \text { Ethylbenzene } \\ 0 & \text { Fluoranthene }\end{array}$

F Fuoranthene

0 Fluorene

$\therefore$ Fluoride

- Heptachlor epoxide

Heptachlorodibenzo-p-dioxins

作

: Hexachlorobonzenen

B-70

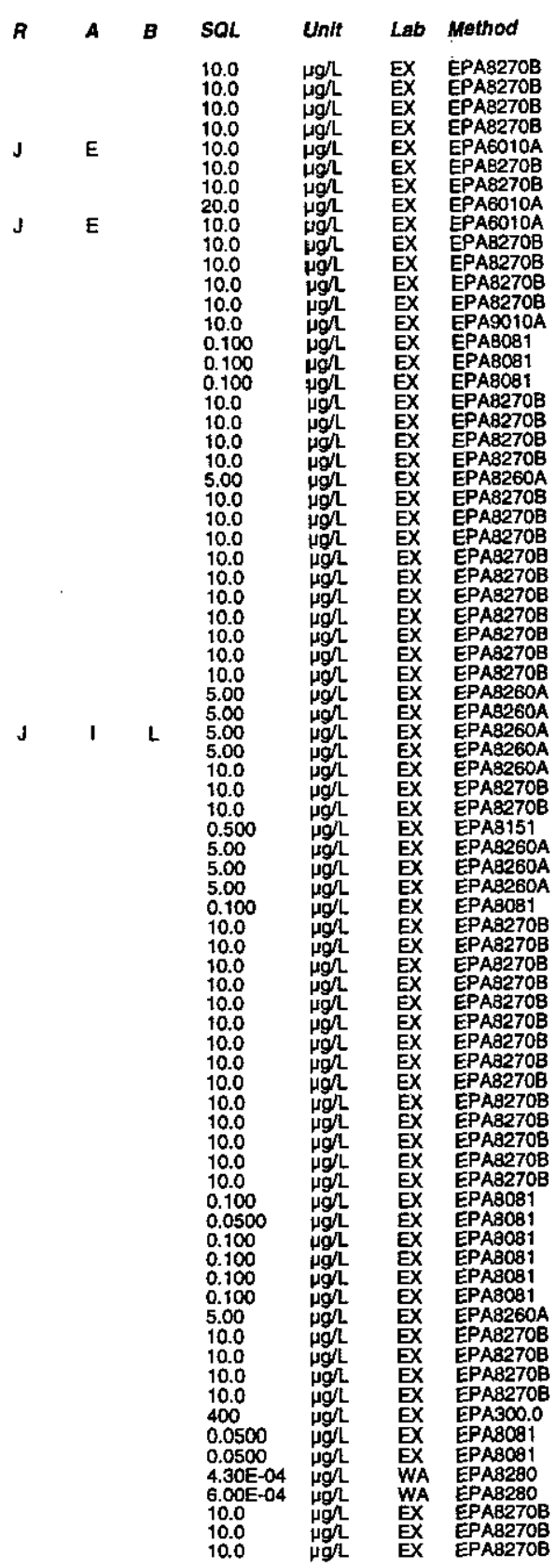

Second Quarter 1998 
Well CSR 60 collected on 06/01/98 (cont.)

$F$ Analyte

o Hexachlorobutadiene

Hexachlorocyclopentadiene

o Hexachlorodibenzo-p-durans

Hexachloroethan

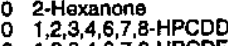

o $1,2,3,4,6,7,8-H P C D F$

indeno $(1,2,3-c, d)$ pyre

Indono $(1,2,3-c, d)$ pyrene

Iron, total reco
Isophorone

Lead, total recoverable

Lindane total recoverabl Magnesium, total recoverable Mercury, total recoverable 2-Methyl|-4,6-dinitrophenol Methyl ethyl ketone Methyl isooutyt ketone
2-Methyinaphthalene 2-Methylnaphtha

Naphthalene

Nickel, total recoverable
Nitrate-nitrite as nitrogen

m-Nitroaniline

o-Nitroaniline

o-Nitroaniline

p-Nitroaniline

Nitrobenzene

2-Nitropheno

4-Nitrophenol

N-Nitrosodimethylamine

N-Nitrosodimethylamine

N-Nitrosodiphenylamin

N-Nitrosodipropylamine

Octachlorodibenzo-p-puran

PCB 1016

0 PCB 1242

O $\mathrm{PCB} 1248$

: $1,2,3,7,8$-PCDO

Pentachlorodibenzo-p-dioxins

Pentachlorophenol

O Phenanthrene

Phenanth

Phenol

Potassium, total recoverable Pyrene

ESH-EMS-980569
Well CSR 6D collected on 06/01/98 (cont.)

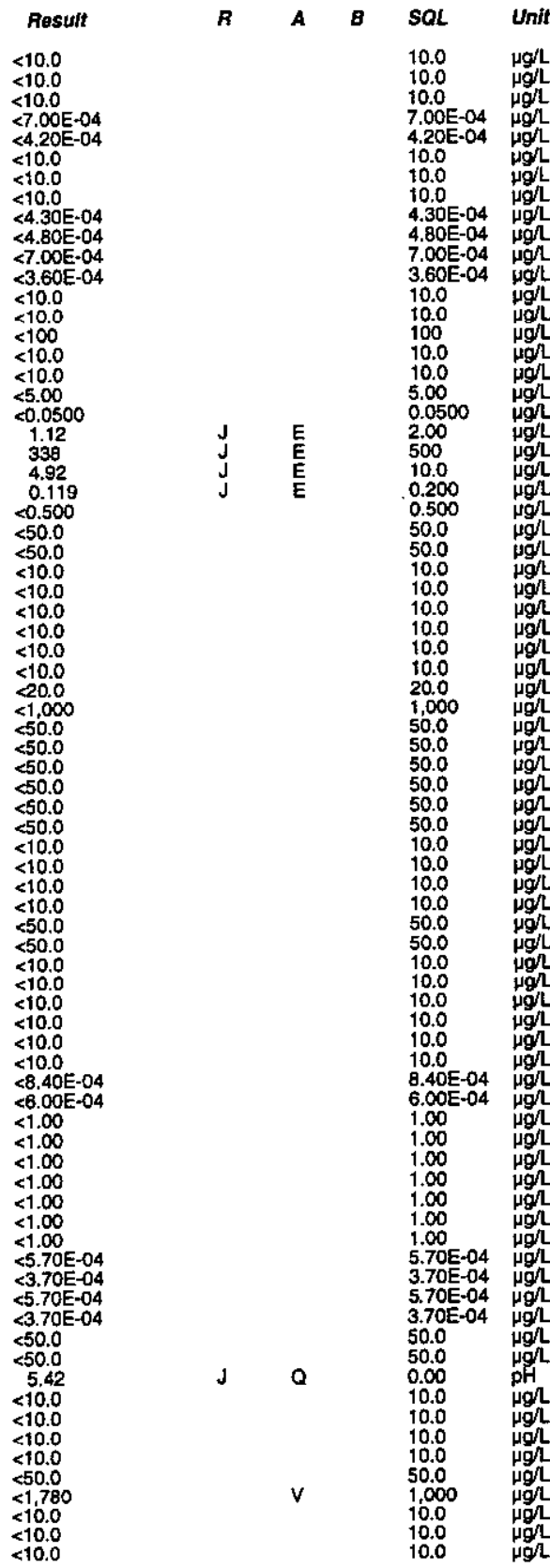

Lab Method

Analyte

Result

O Silica, total recoverable

- Sodium, total recoverab

: Syrene

$2,3,7,8-T C D D$
$2,3,7,8-T C D F$

Tetrachlorodibenzo-p-dioxin

1,1,2,2-Tetrachloroethane

Thentlium, total recoverable

Toluene
Total dissolved solids
Total organic carbon

Total organic halogens
Total phosphates (as P)

Toxaphene

1,2,4-Trichlorobenzene

o $1,1,1$-Trichloroethane

Trictiorosthylene

$2,4,5$-Trichlorophenol
$2,4,6$-Trichlorophenol

$2,4,6-$ Trichlorophenol
Van

Vinyl acetate

Xylenes
Zlnc, total recoverable

\section{WELL CSR 7DL}

MEASUREMENTS CONDUCTED IN THE FIELD

Sample date: $04 / 29 / 98$ ( $(6.82 \mathrm{~m})$ below TOC

Water e

: 5.4 .

Tutidity: 3 NTUU
Water evacuated from the

ANALYSES

$F$ Analyte

Acenaphthene

Acetone

Aluminum, total recoverable

Anthracene

Arsenic, total recoverable

aenzene

deta-Benzen hexachloride

Benzidine

Benzo(b) flunthracene

Benzoic acid
Benzo(o, hil)perylene

Benzo(g.h,i)peryle

Beryllium, total recoverable

Bis 2-chlorotrioxy) methan

Bis(2-chloroisopropyl) ether

Bis
0
0
0

$B-71$

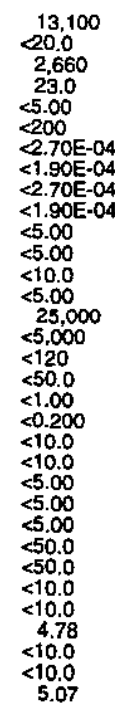

$\begin{array}{ll}\text { EX } & \text { EPA420.1 } \\ \text { EX } & \text { EPA6010A } \\ \text { EX } & \text { EPA8270B }\end{array}$

Resuft
$<10.0$
$<10.0$
$<10.0$
$<0.0500$
368
$<10.0$
$<100$
$<10.0$
21.8
$<5.00$
$<0.0500$
$<0.0500$
$<0.0500$
$<50.0$
$<10.0$
$<10.0$
$<10.0$
$<10.0$
$<10.0$
$<10.0$
20.0
20.350
210.0
510.0
$<10.0$
$<10.0$
$<13.4$
$<5.00$

A

SOL Unit Lab Method

\begin{tabular}{|c|c|c|c|}
\hline $\begin{array}{l}.000 \\
0.0 \\
.00 \\
.00 \\
.00 \\
.00 \\
70 E-04 \\
.00-04 \\
70 E-04 \\
.90 E-04 \\
.00 \\
.00 \\
0.0 \\
.00 \\
10.000 \\
.000 \\
120 \\
0.0 \\
.00 \\
200 \\
0.0 \\
10.0 \\
.00 \\
1.00 \\
.00 \\
50.0 \\
0.0 \\
10.0 \\
10.0 \\
10.0 \\
10.0 \\
10.0 \\
0.0\end{array}$ & 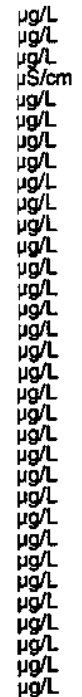 & $\begin{array}{l}\text { EX } \\
\text { EX } \\
\text { EX } \\
\text { EX } \\
\text { EX } \\
\text { EX } \\
\text { WA } \\
\text { WA } \\
\text { WA } \\
\text { WA } \\
\text { EX } \\
\text { EX } \\
\text { EX } \\
\text { EX } \\
\text { EX } \\
\text { WA } \\
\text { WX } \\
\text { EX } \\
\text { EX } \\
\text { EX } \\
\text { EX } \\
\text { EX } \\
\text { EX } \\
\text { EX } \\
\text { EX } \\
\text { EX } \\
\text { EX } \\
\text { EX } \\
\text { EX } \\
\text { EX }\end{array}$ & 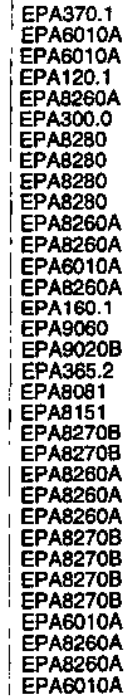 \\
\hline
\end{tabular}

me: 12:46

Air temperature: $26.5^{\circ} \mathrm{C}$

Total alkalinity (as CaCO3): $6 \mathrm{mgl}$

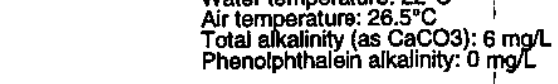

ค

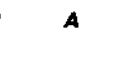

SOL
10.0
10.0
10.0
0.0500
100
10.0
100
10.0
5.00
5.00
0.0500
0.0500
0.0500
50.0
10.0
10.0
10.0
10.0
10.0
10.0
20.0
5.00
10.0
10.0
10.0
10.0
50.0
5.00

unt

Lab Method
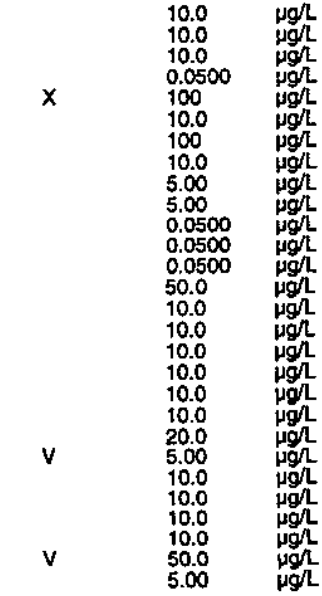

Ex

EX

EX
EX

E EPAB200A

XPA6010A

EPA8270B

EPAB270

EX EPAB270B

EPAGO10A

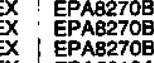

Second Quarter 1998 
ANALYTICAL RESULTS

Well CSR 7DL collected on 04/29/98 (cont.)

\begin{tabular}{|c|c|}
\hline Analyte & Result \\
\hline 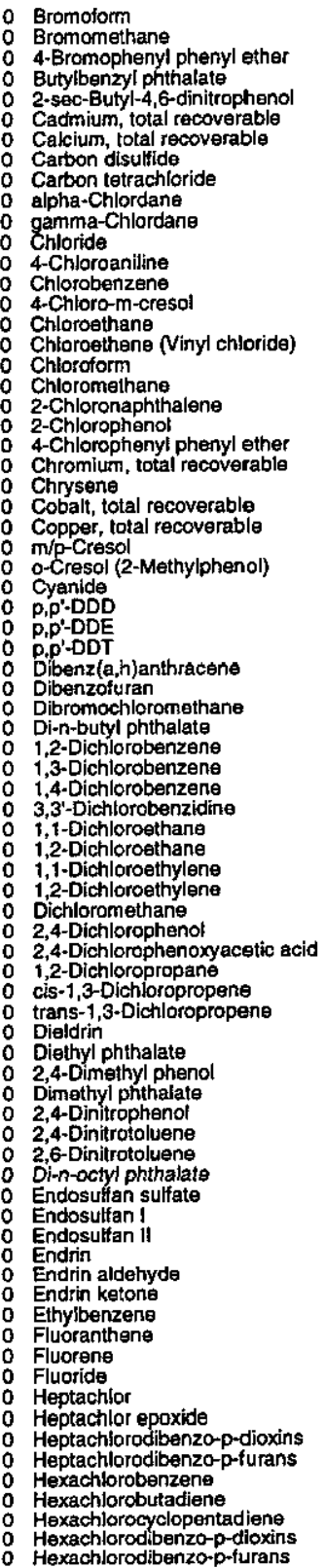 & 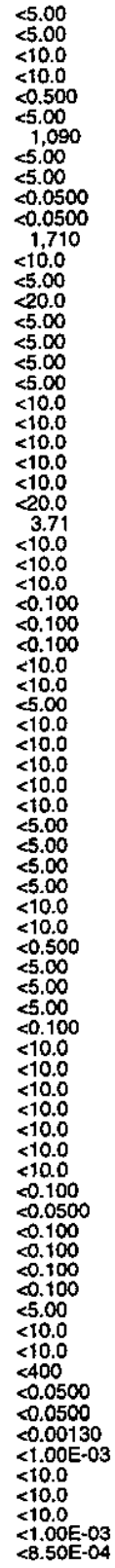 \\
\hline
\end{tabular}

ESH-EMS-980569
Well CSR 7DL collected on 04/29/98 (cont.)

\section{F Analyte}

Hexachloroethane

$\begin{array}{ll}2 \cdot H e x a n o n & \\ 0 & 1,2,3,4,6,7,8-H P C D D \\ 0 & 1,2,3,4,6,7,8-\mathrm{HPCDFF}\end{array}$

$\begin{array}{ll}0 & 1,2,3,4,6,7,8-\mathrm{ACD} \\ 0 & 1,2,3,4,8 \mathrm{HXCDD} \\ 0 & 1,2,3,4,7, \mathrm{~B}-\mathrm{HXCDF}\end{array}$

Indeno( $(1,2,3-c, d) p y r e n$ s.
Iron, total recoverable

Isophorone

Lindane

Magnesium, total recoverable

Manganese, total recoverab

Methoxychlor

Methyl ethyl ketone

2-Methylnaphthalene

Naphthalene
N Nickel, total recoverable
Nitrate-ritrite as nitrogen

o-Nitroaniline

Nitrobenzenene

4-Nitrophente

N-Nitrosodimethylamine

N-Nitrosodipropylamine

Octachlorodibenzo-p-dioxin

PCB 122

PCB 123

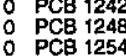

PCB 1260

Pentachlorodibenzo-p-dioxins
Pentachlorodibenzo-p-furans

PH

Phenol

Phenols
Potasslum, total recoverable

Pyrene
Selenium, total recoverabl

Silica, total racoverable

Sodium, total recoverab

Strontium, total recoverable

Styrene

o Sulfate

Tetrachlorodibenzo-p-dioxins

Tetrachlorodibenzo-p-furan

T Tetrachloroethylene

o Thallium, total recovera

Total dissolved solids

Total organic halogens
Total phosphates (as P)

2,4,5.TP (Silvex)

$\begin{array}{ll}0 & 2,4,5-\text { Trichlorobenzene } \\ 0 & 1,2,4 \text {-Trictions } \\ 0 & 1,1,1-\text { Trichloroethane }\end{array}$

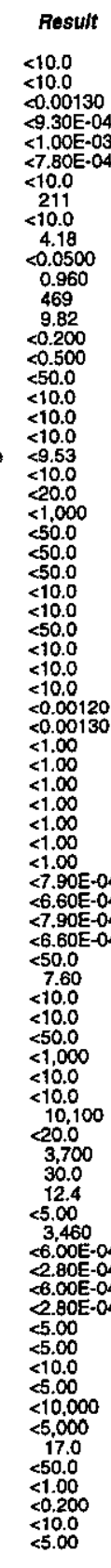

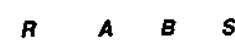

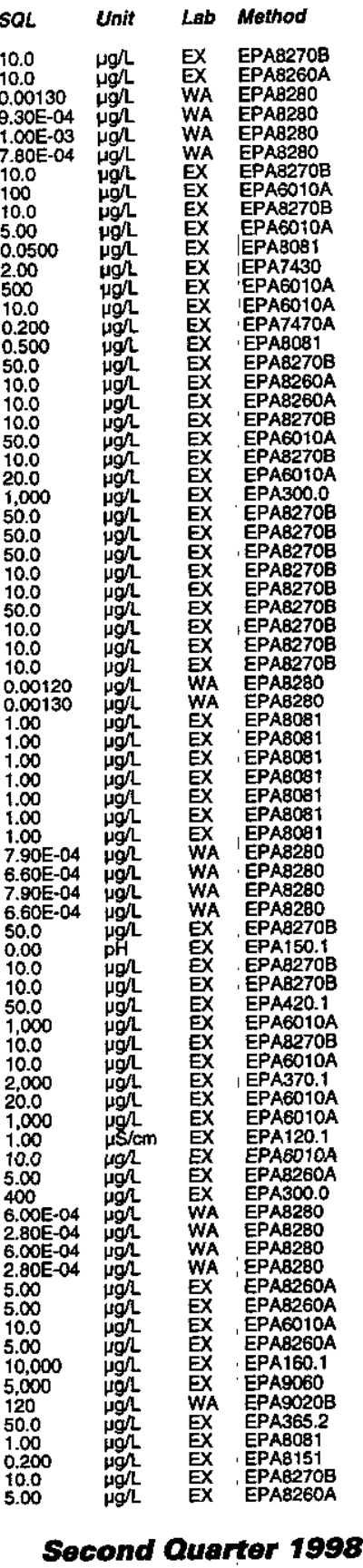


Well CSR 7DL collected on 04/29/98 (cont.)

$F$ Ansilyte

2 1,1,2-Trichloroethane

$2,4,5$-richloropheno
0

Vanadium, total recoverable

Vinyl acelate

0 Zinc, total recoverable

WELL CSR 7DL

MEASUREMENTS CONDUCTED IN THE FIELD

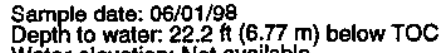

Water eil

Sp. conductance: $30 \mu \mathrm{S} / \mathrm{cm}$

Tubidity: 5 NTU
Water evacuated from the well prior to sampling: 10 gal

ANALYSES

$F$ Analyte

0 Acenaphthene

Acetone

- Aluminum, total recoverable

Antimaceny, total recoverable

: Arsenic, total recoverable

alpha-Benzene hexachioride beta-Benzene hexachloride Belta-Benzzen

- Benzo(a)anthracene

Benzo (k)fuuoranthene

Benzog,h,i)perylen

Benzllium, total recoverable

Bis(2-ctiloroethoxy) meth

Bis (2-chlorolisopropyl) ether

Bis(2-ethylhexyl) phinhalate
Bromodichloromethane

Bromoform

4romomethane
4-Bromophenyl phenyl ether

Butylbenzyl phthalate

Cadmium, total recoverable

Calcium, iotal recoverable

Carbon tetrachlorido

alpha-Chlordane

Chioride

Chlorobenzene
0 4-Chloro-m-cresol

Chloroethane (Vinyl chloride)

C Chlorotorm

2 Chloromethane

o 4-Chlorophenyl phenyl ether

: Chrysene

D Copper, total recoverable

ESH-EMS-980569

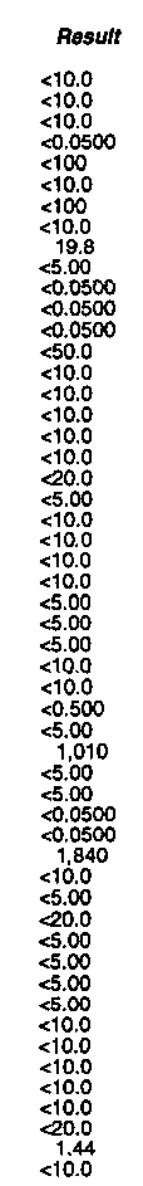

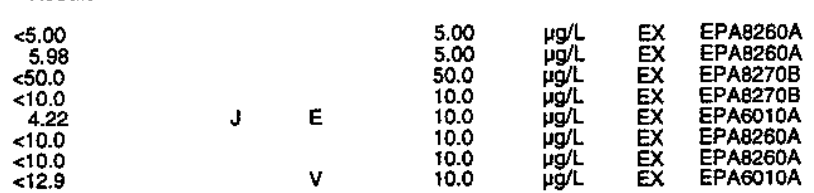

Time: 13:25

Wirter temperature: $18^{\circ} \mathrm{C}$ Total alkalinity, (as CaCO3); $4 \mathrm{mg} / \mathrm{L}$
Phenolphthalein alkalinity: $0 \mathrm{mg}$.

B
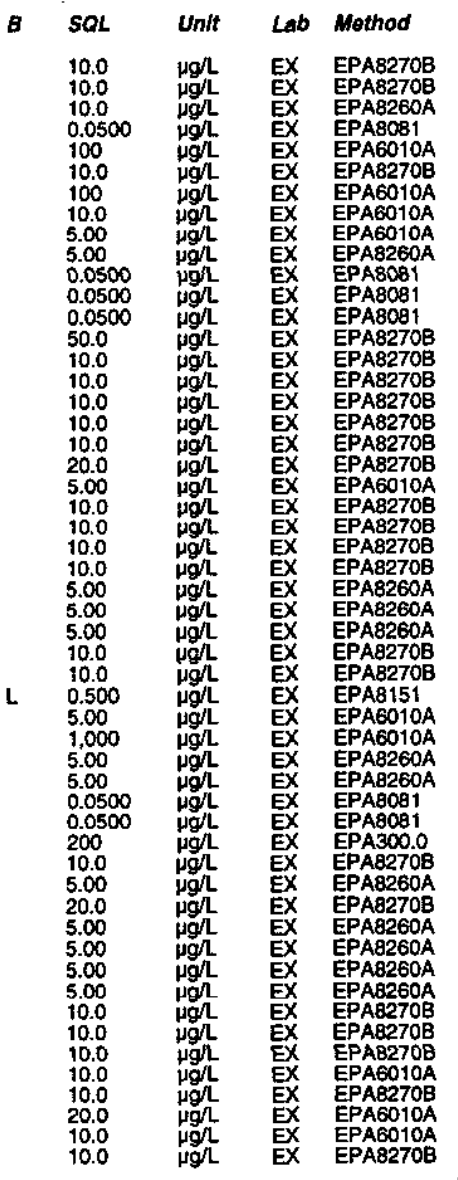

$F$ Analyte

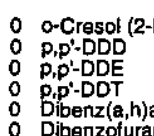

Dibenz(a,h)anthracene

D Dibromochloromethan

1,2-Dichlorobenzene

1,3 -Dichlorobenzene
0
0
0

1,1-Dichloroethane

o 1,1-Dlchtoroethylene

O Dichloromethane

2,4-Dichlorophenoxyacetic acid

1,2-Dichloropropane
cis-1,3-Dichloropropene

: trans-1,3-Dichloroprope

2,4-Dimethyl phenoi

Dimethyl phithalate

$\begin{array}{ll}2,4-D i n i t r o t o l u e n \\ 0 & 2,6-D i n i t r o t o l u e n \\ 0\end{array}$

Di-n-octyl phthalate

- Endosulfan I

: Endrin aldehyde

O Endrin ketone

O Flucranthen

o Fluoride

0 Heptachbor

- Heptachlorodibenzo-p-dioxins

o Heptachlorodibenzo-p-turans

0 Hexachiorobenzzene

Hexachlorocyclopentadiene

: Hexachlorodibenzo-p-dioxins

2-Hexanorothenan

$\begin{array}{ll}2-H \otimes x a n o n e \\ 0 & 1,2,3,4,7,8-H P C D D \\ 0 & 1,2,3,4,6,7,8-H P C D F\end{array}$

: $1,2,3,4,7,8-\mathrm{HXCD}$

0
0
0

o Lead tona recoverable

0 Lindane

- Lithium, total recoverable

Manganese, total recoverable

: Methoxychlor

- Methyl ethyl ketone

0 Methyl isobutyl keton

o Naphthalene

N Nickal, total recoverable

$\begin{array}{ll}0 & \text { m-Nitroaniline } \\ \text { o } & \text { o-Nitroaniline } \\ 0 & \text { P-Nroanline }\end{array}$

Notitrobenzene
$0.2-$ itrophenol
A A $B$ soL Unit Lab Mothod

$<<10.0$

$<0.100$
$<0.100$
$<10.0$

$<5.00$
$<100$
$<10.0$

$<10.0$
$<10.0$
$<10.0$
$<5.00$

$<5.00$
$<5.00$
5.00
$<10$.

$<10.0$
$<0.500$
$<5.00$

$<5.00$
$<5.00$
55.00
$<0.100$

$<.100$
$<10.0$
$<10.0$
$<10.0$

510.0

$<0.100$
$<0.500$

$<.100$
$<0.100$
$<0.100$

$<10.0$
$<1.0$
$<400$

$<0.0500$

$<4.70 \mathrm{E}-04$

$<7.80 \mathrm{E}-04$

$<10.0$

$<4.30 E-04$
$<3.80 E-04$

$<3.30 \mathrm{E}-04$

$<1.0$
79.9
$<10.0$
5.00
$<0.0500$
0.990
375
7.01
$<.200$
$<0.500$
$<50.0$
$<10.0$
$<10.0$
$<10.0$
$<10.0$
20.0
$<1.000$
$<50.0$
$<50.0$
$<50.0$
$<10.0$
$<10.0$

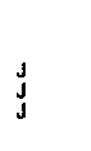

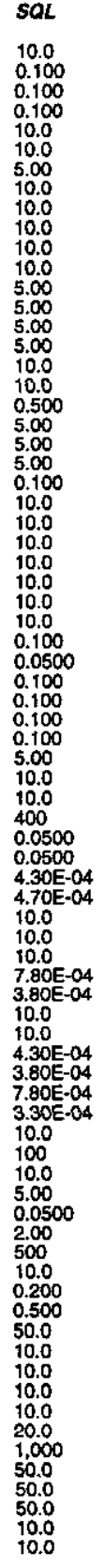

Second Quarter 1998 
Well CSR 7DL collected on 06/01/98 (cont.)

f Analyto

4-Nitrophenol

N-Nitrosodiphenylamine

Oetachlorodibenzom-p-dioxin

0 Octachlorodibenzo-p-furan
0 PCB 1016

PCB 123

PCB 1248

$\mathrm{PCB} 1260$
$1,2,3,7,8-\mathrm{PC}$

$1,2,3,7,8-P C D F$
Pentachlorodibenzo-p-dioxins

Pentachlorodibenzo-p-furans

Phenanthrene

Phenol

Potassium, total recoverable

Selenium, total recoverabte

Silica, total recoverable

Sodium, total recoverable

Styrena

Sulate
$2,3,8,8$-TCDD

Tetrachlorodibenzo-p-dioxins
Tetrachlorodibenzo-p-furans
1,1,2,2-Tetrachloroethane

Tetrachioroethylene

Total dissolved solids

Total organic cartoon

Total phosphates (as P)

2,4,5-TP (Silvex)

1,2,4-Trichlorobenzene

$1,1,2-$ Trichboroethat
Trichioroethylene

2,4,5-Trichlorophene

Vanadiurm, total recoverab

$\therefore$ Vinyl acetate

Zinc, total recoverable

\section{WELL CSR 7DU}

MEASUREMENTS CONDUCTED IN THE FIELD

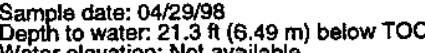

Water e

Sp. conductance: $24 \mu \mathrm{S} / \mathrm{cm}$

Furbidity: 1 NTU 24 Het

ANALYSES

F Analyts

: Acenaphthene

o Acetone

2 Aluminum, total recovarable

ESH-EMS-980569

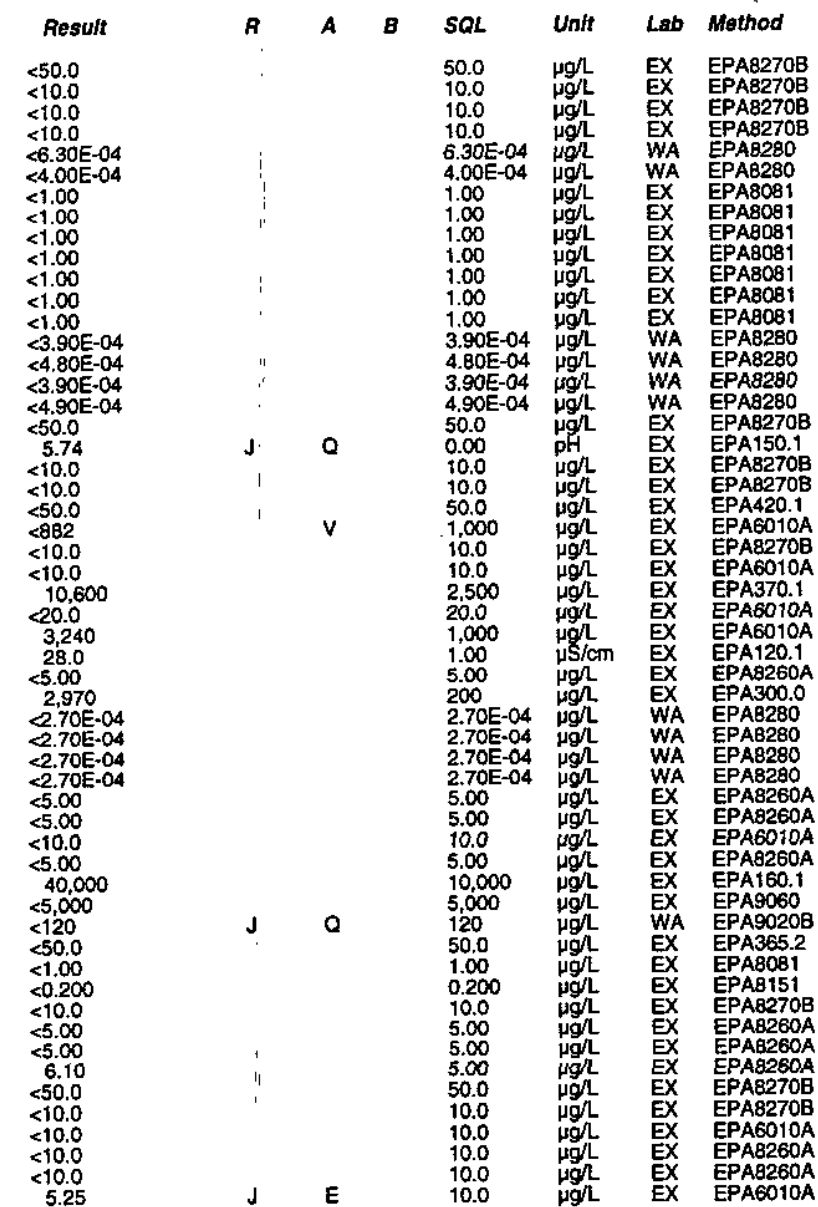

Time: 11:36

Wirter

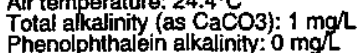

Well CSR 7DU coilected on 04/29/98 (cont)

Analyte Resuth

- Antimony, total recoverable

$<100$

Arenzm, total recoverabio

alpha-Benzene hexachloride
beta-Benzene hexachloride

deta-Benzene hexachloride

Benzidine

Benzo(b)fluoranthen
Benzo(kfluoranthen

Benzoic acid
Benzoo $(g, h, j)$ perylen

Benzo(a)pyren

Beryllium, total recoverable

Bis(2-chibroethoxy) methan

Bis 2-chloroisopropyl) ethe

Boron, total secoverable

Bromoform

Bromomemathane

2-sec-Buty-4,6-dinitrophenol

Cadmium, total recoverable

Calcium, total recove

Carbon tetrachloride

gamma-Chlordan

4-Chloroaniline

4-Chloro-m-creso

Chloroethene (Vinyl chloride)

Chloroform

2-Chloronaphthalen 4-Chlorophenyl phenyl ether

$$
\text { Chrysen }
$$

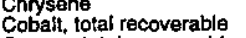

mpp-Cresol

$\begin{array}{ll}0 & \text { Cyanide } \\ 0 & \text { p, } \mathrm{p}^{\prime}-\mathrm{DDO} \\ 0 & \mathrm{P}, \mathrm{P}^{\prime}-\mathrm{DOE}\end{array}$

Dibenz $(a, h)$ anthracene

Dibenzofuran

Dibromochloromethane

1,2-Dichlorobenzen

1,3-Dichlorobenzens

3.3'-Dichlorobenzidin

1,1-Dichloroethane

1.1.-Dichloroethylen
1.2-Dichloroethylen

Dichloromethane

2,4-Dichlorophenol

1,2-Dichloropropane

trans-1,3-Dichloropropene

Dienthyl phthalate
24 -Dimethyl phenol

Dimethyl phithalate

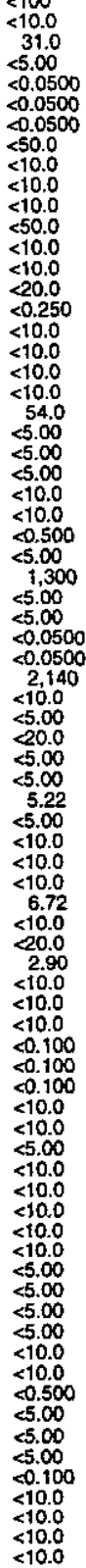

B-74

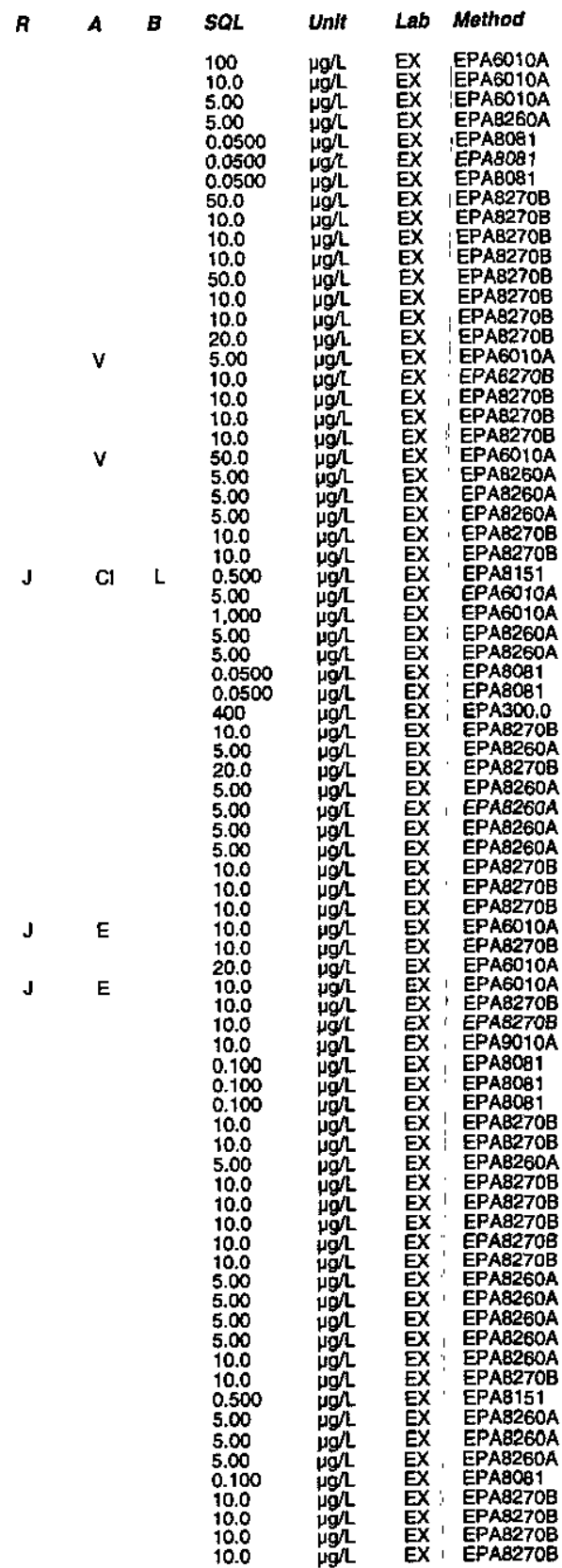

Second Quarter 1998 
Well CSR 7DU coilected on 04/29/98 (cont.)

$F$ Analyto

$2,4-$ Dinitrotoluene
2,6-Dinitrotoluene

Di-n-octyl phthalate

Endosuffan st

Endosutian II

Endrin aldehydo

Ethylbenzene

Fluorene

Fluoride

Heptachlor epoxide

Heptachlorodibenzo-p-dioxins
Heptachlorodibenzo-p-turans

Hexachlorobenzene

Hexachlorocyclopentadiene

Hexachlorodibenzo-p-dioxins
Hexachlorodibenzo-p-furans

Hexachloroethan

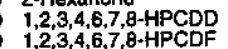

$1,2,3,4,7,8-H X C D D$

Irideno(1,2,3-c,d)pyrene

Lead, total recoverable
Lindane

Lithium, total recoveratile

Manganese, total recoverabable

Mercury, total recoverable

2-Methyl-4,6-dinitrophenol

Methyl isobutyl ketone

2-Methylnaphthalen
Molybodenum, total recoverable

N Nickel, total recoverable

m-Nitroaniline

Nitrobenzene

2-Nitropheno

N-Nitrosodimethylamine

N-Nitrosodiphenylamine

Octachlorodibenzo-p-dioxin

PCB 1016

PCB 1221

PCB 1242

PCB 1260

1,2,3,7,8-PCDD

Pentachlorodibenzo-p-dioxin

Pentachlorophenol

Phenanthrene

Phenol

Potassium, total recoverable

O. Selenium, total recoverable

ESH-EMS-980569

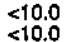

$<0$

$<0.0500$
$<0.100$
5

$<0.1100$
$<.100$
0.100

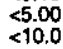

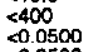

$<10.0$

$<10.0$

$<10.0$
1.83
$<0.0500$
$<2.00$

4.42
$<0.200$
0.500

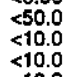

$<10.0$
$<11.8$
$<10.0$
20.0

$<1.000$
$<50.0$
$<50.0$

$<10.0$
$<10.0$
$<50.0$
$<10.0$

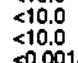

$<1.00$

$<<.00$
$<<.00$
$<<.00$
$<1.00$
$<1.00$

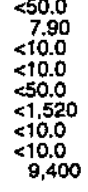

Well CSR 7DU collected on 04/29/98 (cont.)

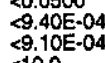

$<0.0 .0110$

$<9.40 E-04$
$88.00-0.04$

<0.0.0110

$<42.8$ J EX

$<0.0 .01350$

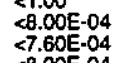

$<8.006-04$
$<7.605-04$
5

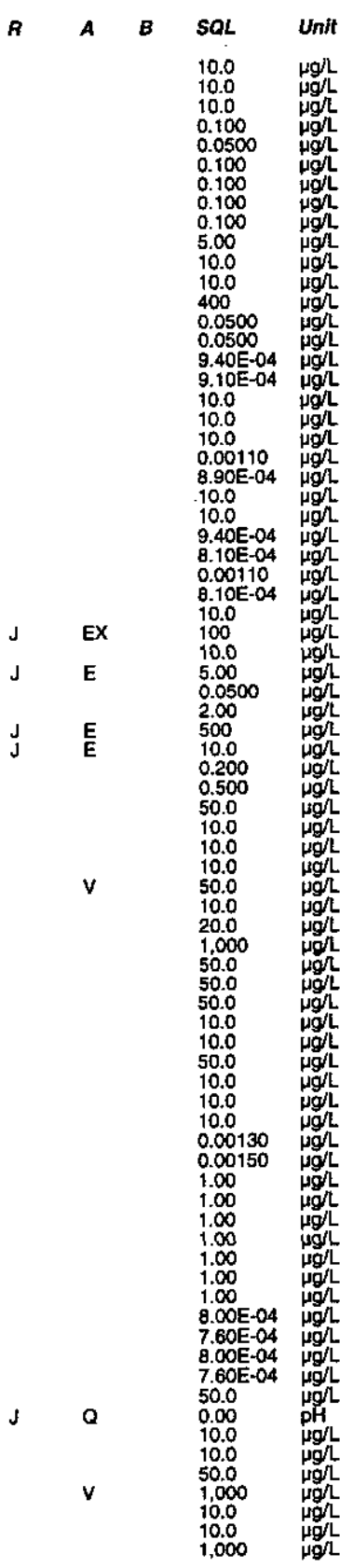

Method

EX EPAB270B

EX EPABO81

EX EPABD8

EX EPABOB1

EX EPAB270B

EPA300.0
EPABOB1

$X$ EPABOB

WA EPAB280

EPA8270B

WA EPA8280

EPA8270B
$X$ EPAB260A

WA EPAB280

WA EPAB280

EPAB270B

EPAB270B

EPABOB

EPABOB1

EPAB260A

\begin{tabular}{l} 
EPAB260A \\
EPAB270B \\
\hline
\end{tabular}

EPAB270B

EPA300.0

EPA8270B

EPAB270B

EPAB270B

EPAB270B

EPAB280

EPABOB

EPABOB1

EPABO1

WA EPAB28

WA EPAB280
WA EPAB280
EX EPAB270B
E

EPA8270B

\begin{tabular}{cc}
$E_{X}$ & $E P A 20.1$ \\
\hline & EPA6010A
\end{tabular}

EPAB2708
EPA370.1
Bis (2-ethylhoisopropyl) eth

4-Bromophenyl phenyl ether
$F$ Analyte

- Siver, total recoverable

Specific conductance

$2,3,7,8-T C D D$
$2,3,7-T C D F$

Tetrachlorodibenzo-p-durans

1,1,2,2-Tetrachloroethane

Thallium, total recoverable

Tolal dissolved solids

Total organic halogens
Total phosphates (as P)

2,4.5.TP (Silvex)

1,1,1-Trichloroethane

Trichloroethylene

$2,4,5$-Trichloropheno
$2,4,6$-Trichlorophenol

Vinyl acetate

WELL CSR 7DU

MEASUREMENTS CONDUCTED IN THE FIELD

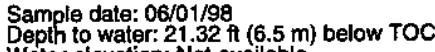

Water

H: 5 .

. conductance: $26 \mu \mathrm{S} / \mathrm{cm}$

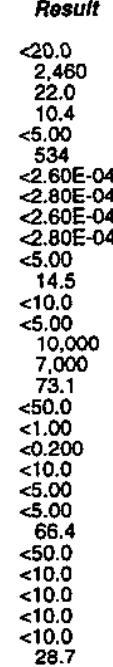

B A $B$ SQL Unit Lab Method

Water evacuated from the well prior to sampling: $17 \mathrm{gal}$

ANALYSES

$F$ Analyto

Acenaphthene
0 Accenaphthylene
0 Acetone

Aluminum, total recoverable

Antimony, total recoverabte

Arsentic, total recoverable

Benzene
alpha-Benzene hexachloride

delta-Benzene hexacthlorido

Benzidine Benzo(a)enthracene

Benzo b fluoranthen

Benzo $(g, h, i)$ perylen

Benzo(a)pyrene

Eeryllum, total recoverable

(2-chlorethy) ether

Bromodichloromethan

Bromornathan

B-75

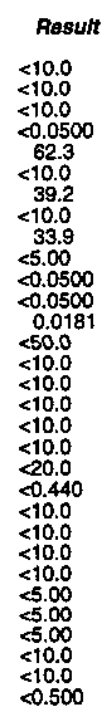

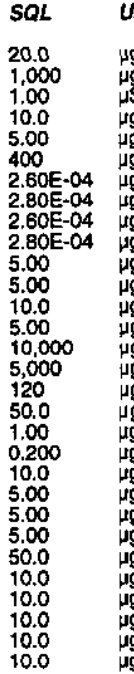

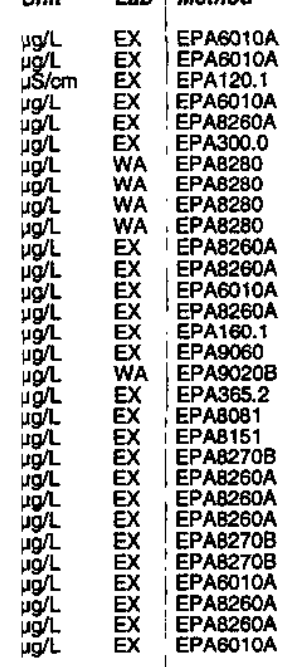

Time: 12:53

Wir tempmperature: $17^{\circ} \mathrm{C}$

Total akealinity. (as CaCO3): $11 \mathrm{mg} /$
Phenolphthalein alkalinity: $0 \mathrm{mg} L$ 
Well CSR 7DU collected on 06/01/98 (cont.)

$F$ Analyte

- Cadmium, total recoverable Calcium, total recoverable

- Carbon tetrachloride

o alpha-Chlordane

OChioride

4-Chloro-m-creso

o Chloroethane

Chlorotorm

2-ChJoronaphthalen

$\begin{array}{ll}\text { 2-Chlorophenol } & \text { 4-Chlorophenyl phenyl ether }\end{array}$

Cobalt, total recoverable

: m/p-Cresol 0 -Cresol (2-Methylphenol)

Cyanide

P,P'-DDE

O Dibenz(a,h)anthracene

Dibromochloromethan

Di-n-butyl phthalate

1,4-Dichlorobenzenene

0 3,3'-Dichlorobenzidine

0 1,2-Dichloroethane

1,2-Dichloroethylen

2,4-Dichlorophenoxyacatic acid

is

trans-1,3-Dichloropropen

Diethyl phthalate

Dimethyl phthalate

2,4-Dinitrophenol

Di-n-octy phthalate

Endosuffan sulfate

Endosultan I

Endrin aldahyde

Ethylbenzene

Fluorene

Heptachlor
Heptachlor epoxid

Heptachlorodibenzo-p-dioxin

Hexachlorobebenzene-p

Hexachlorocyctopentadiene

Mexachlorodibenzo-p-dioxins
Hexachlorodibenzo-p-furans

Hexachloroethane

1,2,3,4,6,7,8-HPCDD

$1,2,3,4,7,8-\mathrm{HXCDD}$

ESH-EMS-980569
Well CSR 7DU collected on 06/01/98 (cont.)

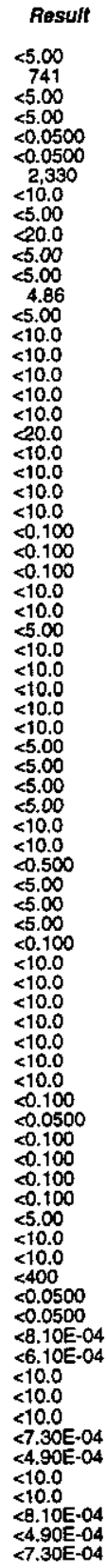

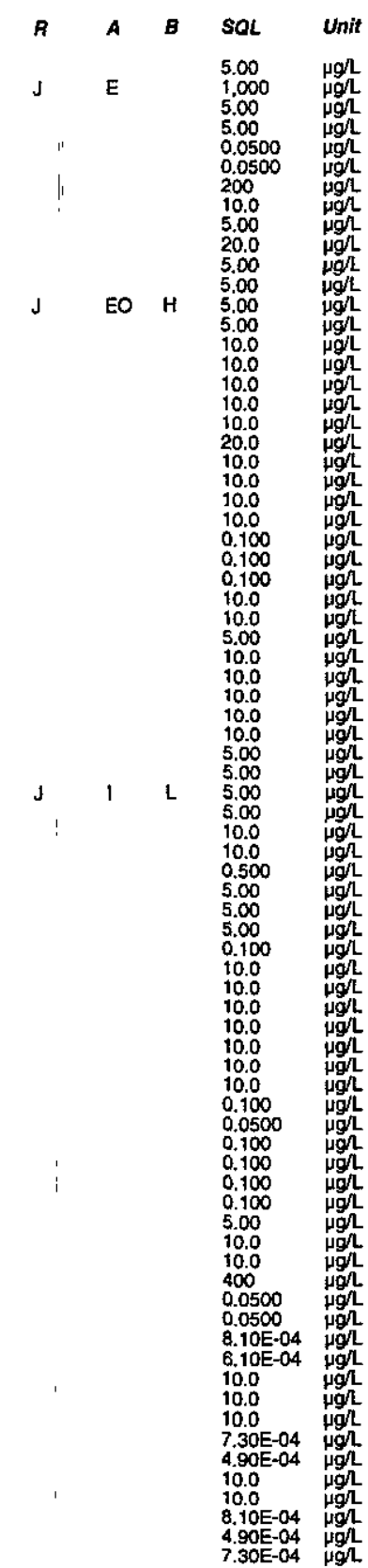

1,2,3,4,7,8-HXCDF

EX EPAG010A

EPAG010A

$\begin{array}{ll}\text { EX } & \text { EPA8260A } \\ \text { EX } & \text { EPA80B1 } \\ \text { EX } & \text { EPA8081 }\end{array}$

$\begin{array}{ll}\text { EX } & \text { EPA300.0 } \\ \text { EX } & \text { EPA8270B } \\ \text { EP } & \text { EPA8200A }\end{array}$

EX EPA8260A

EX EPAB260A

EX EPA8260A

EX

EX EPAGO10A

EX EPAG010A

EX EPA82708

E EPABOB1

EX EPABOB

\begin{tabular}{cc}
$X_{1}$ & EPAB270B \\
\hline EPAB270B
\end{tabular}

EPAB260

$\begin{array}{ll}E_{X} & E P A B 270 B \\ E X & \text { EPAB2708 }\end{array}$

EX

EX $\begin{gathered}\text { EPAB260A } \\ \text { EPAB260A }\end{gathered}$

EX EPAB260A

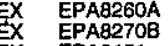

EX EPAB151

EX

EPAB270B

EX

$\mathrm{EP}$
$\mathrm{EPAB2270B}$

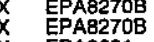

$\mathrm{EPABOB}$
$\times \mathrm{PABOOB}$

EPABOB

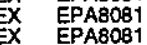

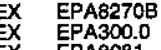

EPABOB1
EPABOB1

WA EPAB280

EPA82708

EPA8270B

WA EPA82B0

EX EPA8270B

WA EPAB2BO

o-Nitroanilin日

Nitrobenzene

PCB 1016

PCB 1242

PCB 125

$1,2,3,7,8-P C D D$

Pentachlorodíbenzo-p

Pentachlorophen

Phenanthrente

Styrene

Toxaphene

Trichloroethylene
EX EPAB220A

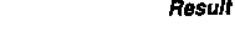

Lead, total secoverabie

Lithium, total recoverable

Manganese, total recoverable
Mercury, total recoverable

Methoxychlor

Methyl ethyl ketone

Nickel, total recoverable

N-Nitrosodimethylamine

Octactorine

Pentachlorodibenzo-p-dioxins

Potassium, total recoverable

Pyrenie

Silica, total recaverable

Sodium, total recovera

2,3,7,8-TCDF
Tetrachlorodibenzo-p-dioxins
Tetrachlorodibenzo-p-furans

Tetrachloroethylene

Thallium, total recovera

Total dissolved solids

1. Total organic halogens

1,2,4-Trichilorobenzene

i. 2 -Trichloroethane

Vanadiucm torophenol

Vinyl acetate

Zinc, total recoverable

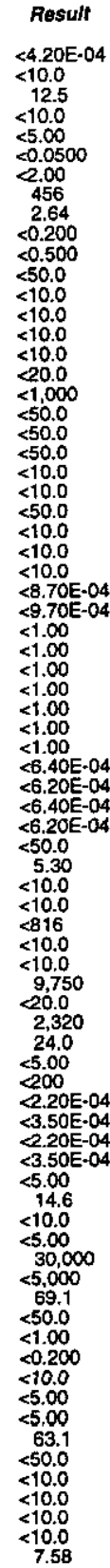

tron, totai recoverable

Octachlorodibenzo-p-furan

Sulfate

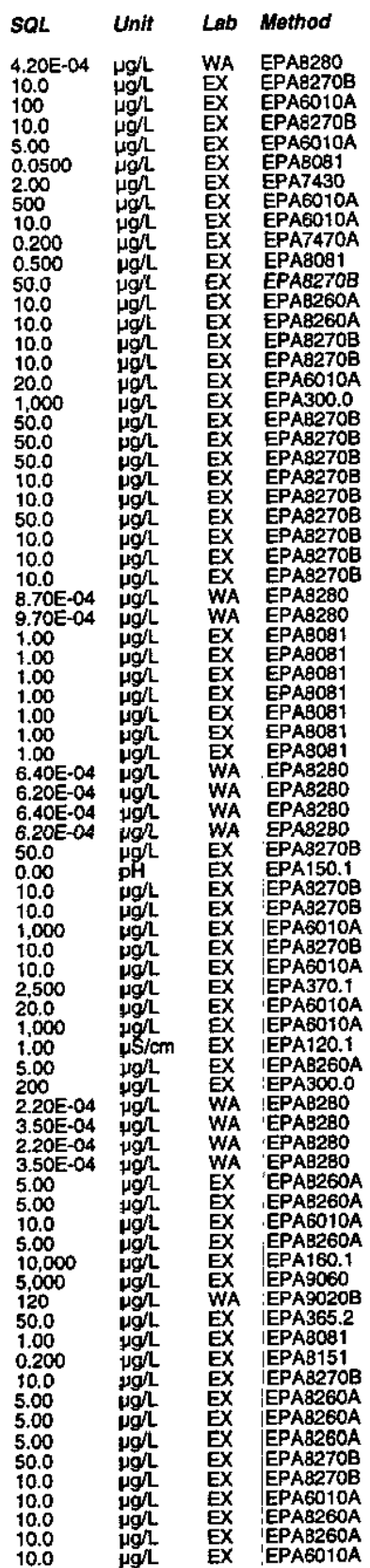

Second Quarter 1998 
WELL CSR 8DL

MEASUREMENTS CONDUCTED IN THE FIELD

Sample date: 04/29/98

Water to water: Not avaiian: Not available SH: Not available . conductance: Not available No water was evacuated from the well priar to sampling. ANALYSES

$F$ Analyto

: Acanaphthens

Acetone

Aluminum, total recoverable

: Antimony, total recoverable

alpha-Benzene hexachloride

beta-Benzene hexachloride

Benzo(a) anthracene

Benzoic acid

Benzo(g,hi) peryten
Benzo(a)pyrene

Beryllium, total recoverable

Bis(2-chloroethoxy) methane

Bis (2-chioroisopropyl) eth

Bis(2-ethylhexyl) phithalate

Boron, tolal recoverab-
Bromodichloromethane

Bromomethan

4-Bromophenyl phenyl ether

Butyibenzyl pithabate

Cadmium, total recoverable

Carbon disulfide

alpha-Chlordane

Chloride

Chlorobenzene

Chloroethene (Vinyl chloride)

$$
\text { Chlorotom }
$$

Chloromethane
2-Chloronaphthalen

4-Chlorophenyl phenyl ether

Chromium, total recoverabl

Chrysene

Cobper, total recoverable

m/p-Cresol 0 -Cresol (2-Methylphenol)

Cyanide

$p, p^{\prime}-D D E$

P.p-DDT

Dibromochioromethante

ESH-EMS-980569
Well CSR 8DL collected on 04/29/98 (cont.)

$F$ Ansily

$<10.0$

Wime: Not available

Air temperature: Not available
Total alkalinity (as CaCo3): Not available
Phenolphthalein alkalinity: Not available

(3,3'-Dichlorobenzididin

1,2-Dichloroethane

1.2-Dichiorothylen

Oichloromethane

.

1,2-Dichloropropane

trans-1,3-Dichloropropene

2,4-Dimethyl pheno

Dimethyl phthatate

2.4-Dinitrotoluene

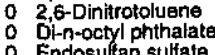

Endosulfan I

Endosulfan II

Endrin aldehydo

Endrin ketone

0 Filuoranthene

Fluorene

Heptachlor

Heptachlorodibenzo-p-dioxins

Heptachlorodibenzo-p-pturan

Hexachlorobenzenie

Hexachlorocyclopentadiene

Hexachlorodibenzo-p-dioxin

Hexachiorodibenzo-p-turans

Hexachloroeth

$1,2,3,4,6,7,8-H P C D D$

作, $1,3,4,7,4 X C D D$

indeno(1,2,3-c., d)pyren

Iron, total recoverable

Lead, total recoverable

Lindane

Magnesium, total recoverable

Manganese, total recoverable

Mercury, total recoverable

2-Methyl-4,6-dinitropheno

Methyl ethyl ketone

2-Menyinaph total recoverable

Naphthalene

Nitrate-nitrite as nitrogen

O Nitrate-nititite as

o- Ditroaniline

o Nitrobenzene

2-Nitrophenol

N-Nitrosodimethylamine

Nitrsodphomlamin

Octachlorodibenzo-p-dioxin
Octachlorodibenzo-p-turan
OCCB 1016

EPAB270B
$\times$
$\times$

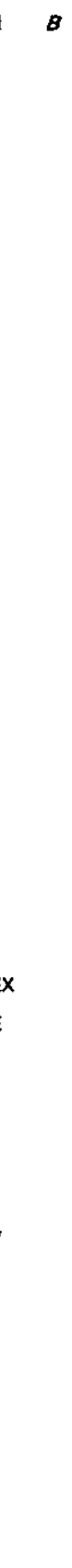

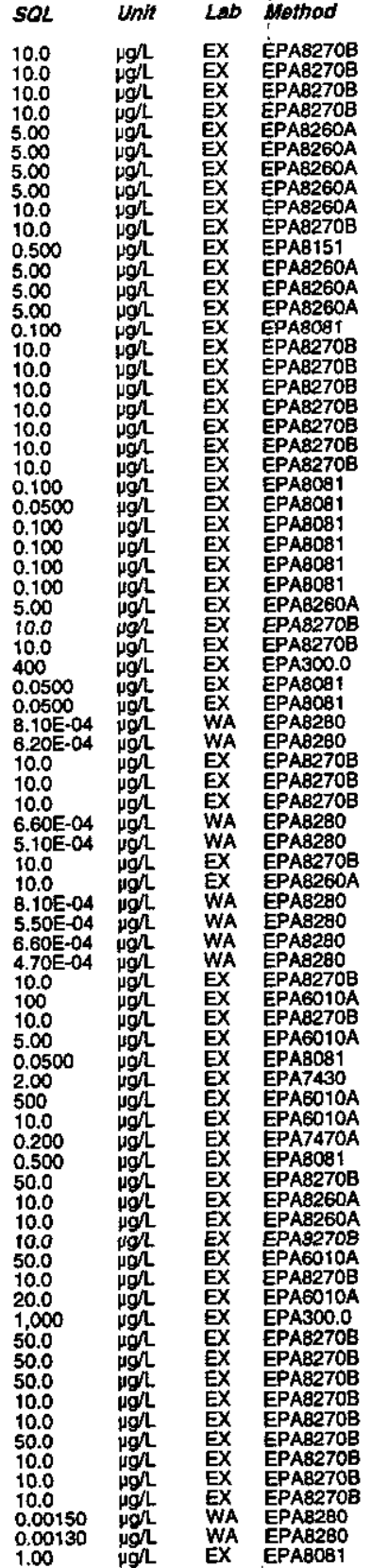

Second Quarter 1998 
ANALYTICAL RESULTS

Well CSA 8DL collected on 04/29/98 (cont.)

$F$ Analyte

0
0

0 PCB 1242

PCB 1254

$\begin{array}{ll}0 & 1,2,3,7,8 \cdot P C D D \\ 0 & 1,2,3,7,8-P C D F\end{array}$

Pentachlorodibenzo-p-dioxins

Pentachlorophenzo-p-turan

Phenanthrene

Phenol

Phenols

Silica, total recoverable

Sodium, total recoverable

Specitic concuctance

Syrene

$2,3,7,8-T C D D$

Tetrachlorodibenzo-p-dioxins

Tetrachlorodibenzo-p-furans

Tetrachlorosthylene

Toluene, total recovera

Total dissolved solids
Total organic carbon

Total organic halogens
Total phosphates (as P) Toxaphene

1,2,4-Trichlorobenzen

1,1,1-Trichloroethane

Trich

$2,4,6-$ Trichlorophenol
Vanadium, total recovera Vinylacotal

Zylenes

WELL CSR 8DL

MEASUREMENTS CONDUCTED IN THE FIELD

Sample date: $06 / 01 / 98$

Water elevation: Not available

PH: Not available Not available

Turbidity: Not available

No water was evacuated from the well prior to sampling.

ANALYSES

$F$ Analyto

- Acenaphthene

Acetone

Aluminum, total recoverable

Antimony, total recoverable

Arsenic, total recoverable
Barium, total recoverable

alpha-Benzene hexactloride

ESH-EMS-980569

$\quad$ Result
$<10.0$
$<1.0$
$<10.0$
$<0.0500$
$<100$
$<10.0$
41.3
$<10.0$
45.7
$<5.00$
$<0.0500$
$<0.0500$

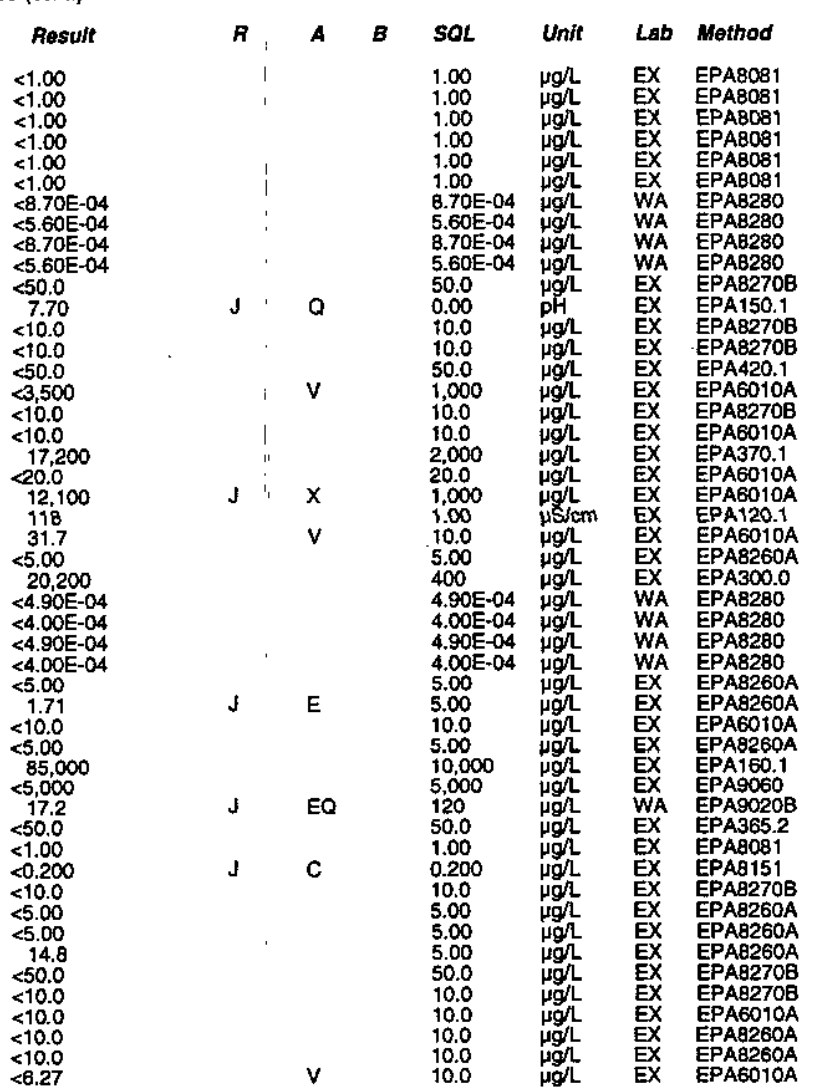

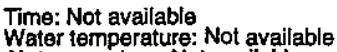
Air temperature: Not available
Total alkalinity, (as CacCos) Not available
Phenolphthalein alkalinity: Not available

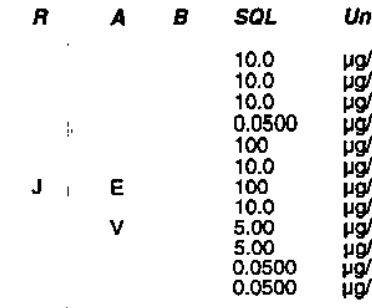

Well CSR BDL collected on 06/01/98 (cont.)

0 delta-Benzene hexachloride

Benzidine
Benzoja)anthracene
Benzo(j) fluoranthene

Benzo(k)fluoranthene
Benzofg,h,i)perylene

: Benzo(a)pyrene

Beryytium, total recoverable
Bis (2-chloroethoxy) methan

Bis(2-chloroisopropyl) eth

Bis(2-ethythexyl) phthalate

Bromodichlor

4.Bromophenyl phenyl ether

Butylbenzyl phithalate

2-sec-Buty-4,6-dinitrophenol

Caron disutidide.

alpha-Chlordane

Chloride

4-Chloro-m-creso

Chloroethane

Chloroethen

Chloromethane
2-Chloronaphthalen

4-Chlorophenyl phenyl ether

Cobalt, total recoverable

m/-Cresol 2 -Chethylphenoi)

Cyanide
$\mathrm{p}, \mathrm{p}^{\prime}-\mathrm{DDO}$

p,p'-DDE

P.P'-DDT
Dibenz(a,h)anthracene
Dibenzoturan

Dibromochloromethan

Di-n-butyl phthalate

1,3-Dichlorobenzene

3,3.-Dichlorobenzidi

1,2-Dichloroethane

1,1-Dichloroethylen

Dichloromethane

2,4-Dichlorophenoxyacetic acir

cis-1,3-Dichloroporopene

Dieldrin nthalate

2,4-Dimethyl phenol

Dimethyl phthalate
$0.4-$ Dinitrophenol

2,4-Dinitrophenol

Di-noctyl phthalate
Endosuftan sulfate

Endosuffan sulfit

Endrin

EX EPAB270B

EX EPAG010A

EX EPAB260A

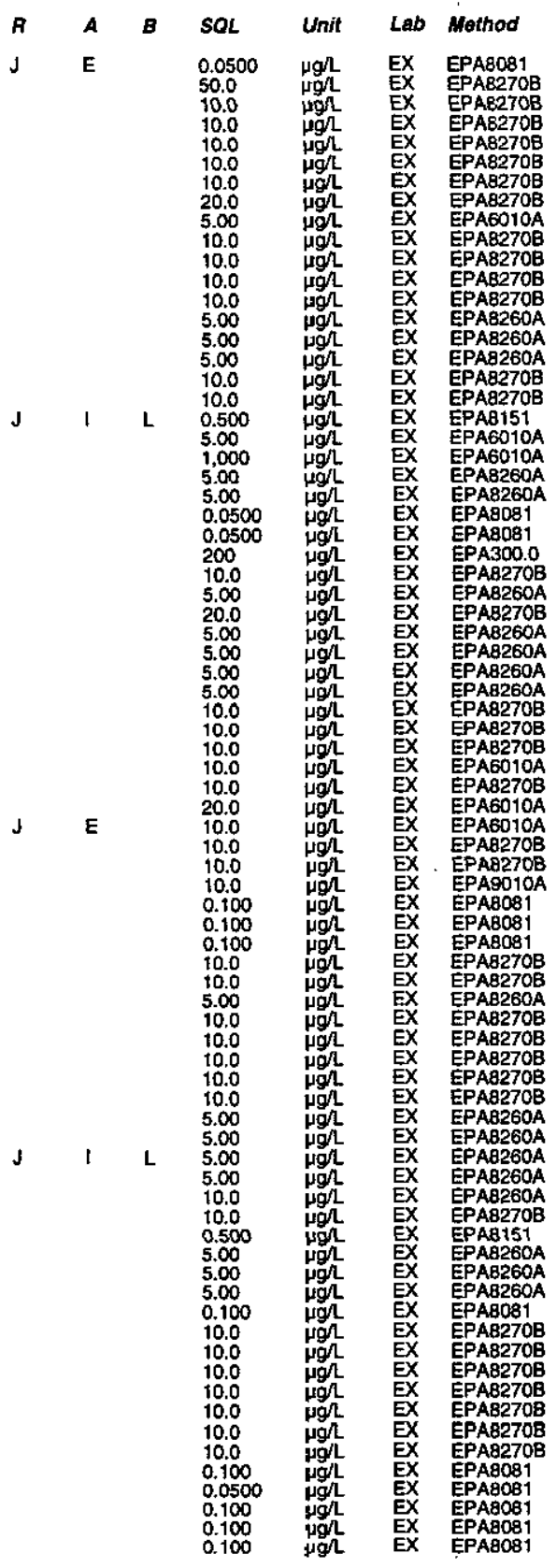

Second Quarter 1998 
ANALVTICAL RESULTS

Well CSR 8DL collected on 06/01/98 (cont.)

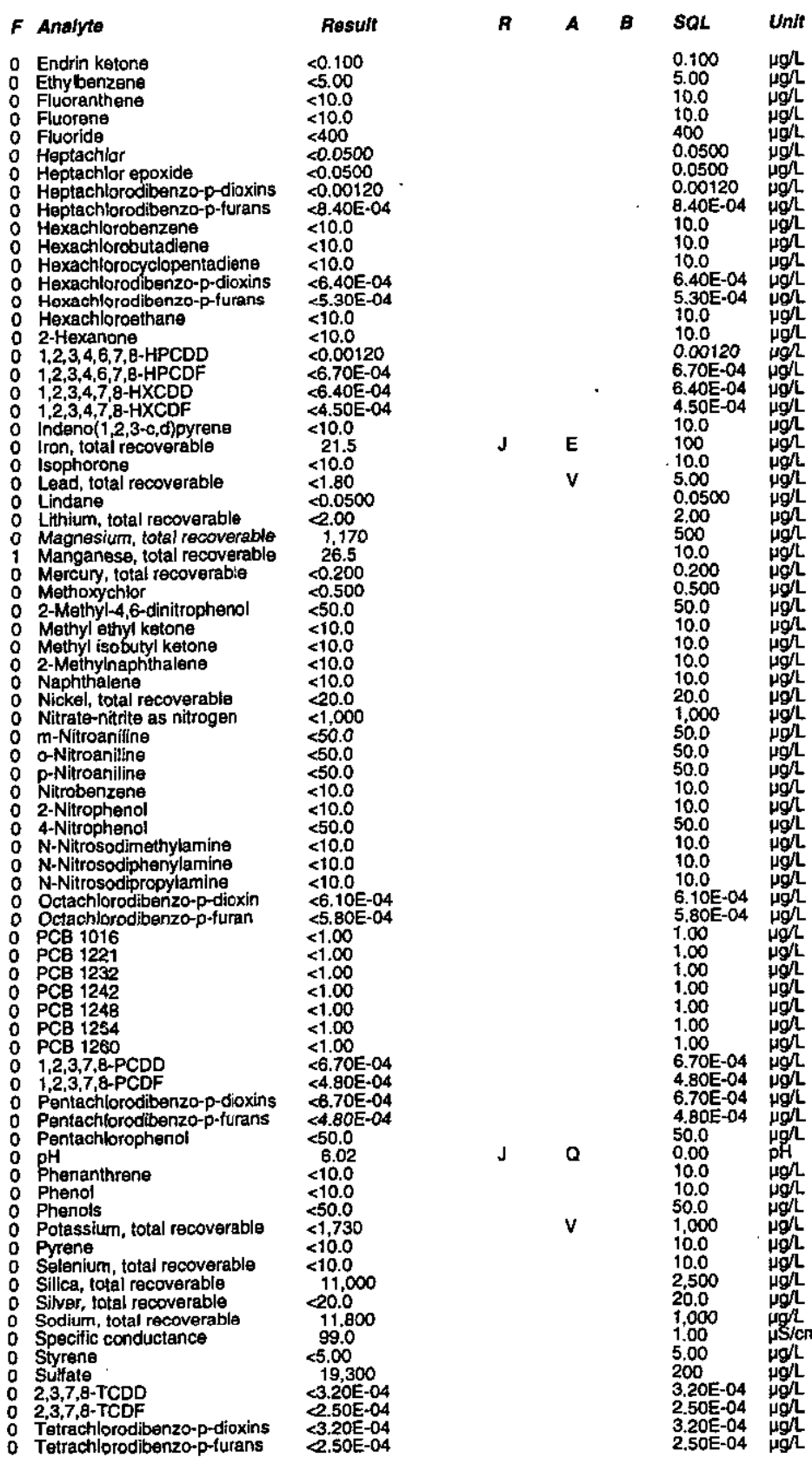

ESH-EMS-980569
Well CSA 8DL collected on 06/01/98 (cont.)

$F$ Analyte

Resuft
$<5.00$
11.11
10.0
$<5.00$
75,000
6.000
19.4
$<50.0$
$<1.00$
$<0.200$
$<10.0$
$<5.00$
$<5.00$
14.1
50.0
$<10.0$
$<10.0$
$<10.0$
$<10.0$
12.8

: Zinc, total recoverable

\section{WELL CSR 8DU}

MEASUREMENTS CONDUCTED IN THE FIELD

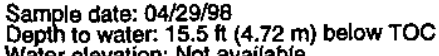

Water elevation: Not availabl

p. conductance: Not available

ANALYSES

F Analyte

: Heptachtorodibenzo-p-dioxins

o Hepfachlorodibenzo-p-durans

Hexachlorodibenzo-p-
$1,2,3,4,6,7,8-\mathrm{HPCDD}$
$1,2,3,4,6,7,8-\mathrm{HPCDF}$

$1,2,3,4,6,7,8-\mathrm{MCD}$
$1,2,3,4,7,8-\mathrm{HXCDD}$

Octactiorodibenzo-p-dioxin
Octachlorodibenzo-p-furan

$1,2,3,7,8-P C D D$

Pentachlorodibenzo-p-dioxins

2,3,7,8-TCDD

Tetrachlorodibenzo-p-dioxins

Tetrachlorodibenzo-p-furans

WELL CSR 8DU

MEASUREMENTS CONDUCTED IN THE FIELD

Sample date: $04 / 30 / 98$ Depth to water: $15.28 \mathrm{ft}(4.66 \mathrm{~m})$ below TOC

Water
$\mathrm{pH}: 5.2$

PH: 5.2 conductance: $48 \mu \mathrm{S} / \mathrm{cm}$

Water evacuated from the well prior to sampling: $30 \mathrm{gal}$

ANALYSES

F Analyte

: Acenaphthene

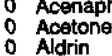

2 Aldrin

Result

\section{$<9.20 \mathrm{E}-04$}

$<9.30 \mathrm{E}-04$

$<8.30 \mathrm{E}-04$

$<0.00110$

$<0.00190$
$<1.00 E-03$
$<B .40 E-04$

$<\begin{aligned} & <1.00 \mathrm{E}-03 \\ & <8.40 \mathrm{E}-04\end{aligned}$

$<3.10 \mathrm{E}-04$

$<3.10 \mathrm{E}-04$

J

perature: Not availabte

Air temperature: $16.5^{\circ} \mathrm{C}$
Total alkalinity (as CaCO3) Not available

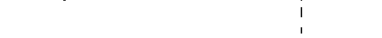

E-79

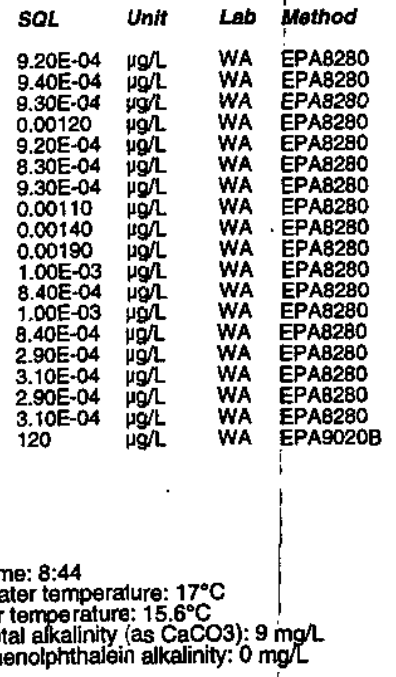

Total akalinity (as CaCO3) $9 \mathrm{mgh}$

\section{Result}

$<10.0$
$<10.0$
$<10.0$

$<10.0$
$<0.0500$
745
SOL
10.0
10.0
10.0
0.0500
100

Lab Mothod

$\begin{array}{ll}\text { EX } & \text { EPAB2708 } \\ \text { EX } & \text { EPAB2708 } \\ \text { EX } & \text { EPA8260A }\end{array}$

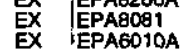


ANALYTICAL RESULTS

Well CSR 8DU collected on 04/30/98 (cont)

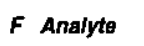

2 Aluminum, total recoverable Anthracene
0 Antimony, total recoverable
o Antimony, total recoverable
A Arsenic, total recoverable Arsenic, total recoverabble
Arsenic, total recoverable Barium, total recoverable

0 alpha-Benzeno hoxachlorido beta-Benzene hexachloride
delta-Benzene hexachloside Benzidine

Benzo (b)fluoranthene

o Benzoic acid

Benzo(a)pyyene
Benzyl alcohol

Beryllium, total recoverable Bis(2-chloroethoxy) methan Bis 2-chloroisopropy') ether Boron, total recoverable : Boron, total recoverable - Bromofich

4-Bromophenyl phenyl ether Butylbenzyl phthalate Cadmium, total recoverablo Cadcium, total recoverable Calcium, total recover
Carbon disulfide Carbon tetractiloride
alpha-Chlordane
gamma-chlordane Chloride 4-Chloroaniline
Chlorobenzene
4-Chloro-m-cresol Chloroethane Chlorotorm
Chloromethane 2.-Chloronaphthalen 4-Chlorophenyl phenyl ether Chromium, total recoverable Chrysene - Cobatt, total recoverable 作 (2-Methylphenol) $\begin{array}{ll}0 & 0 y a n i d e \\ 0 & p, p^{\prime}-D D D \\ 0 & 0 D 0\end{array}$ 0 P,P-DDE o Bibenz(a,h)anthracene 0 Dibromocthoromethane 1,3-Dichlorobenzen 3,3'-Dichlorobenzidi 1,1-Dichloroethylen

ESH-EMS-980569
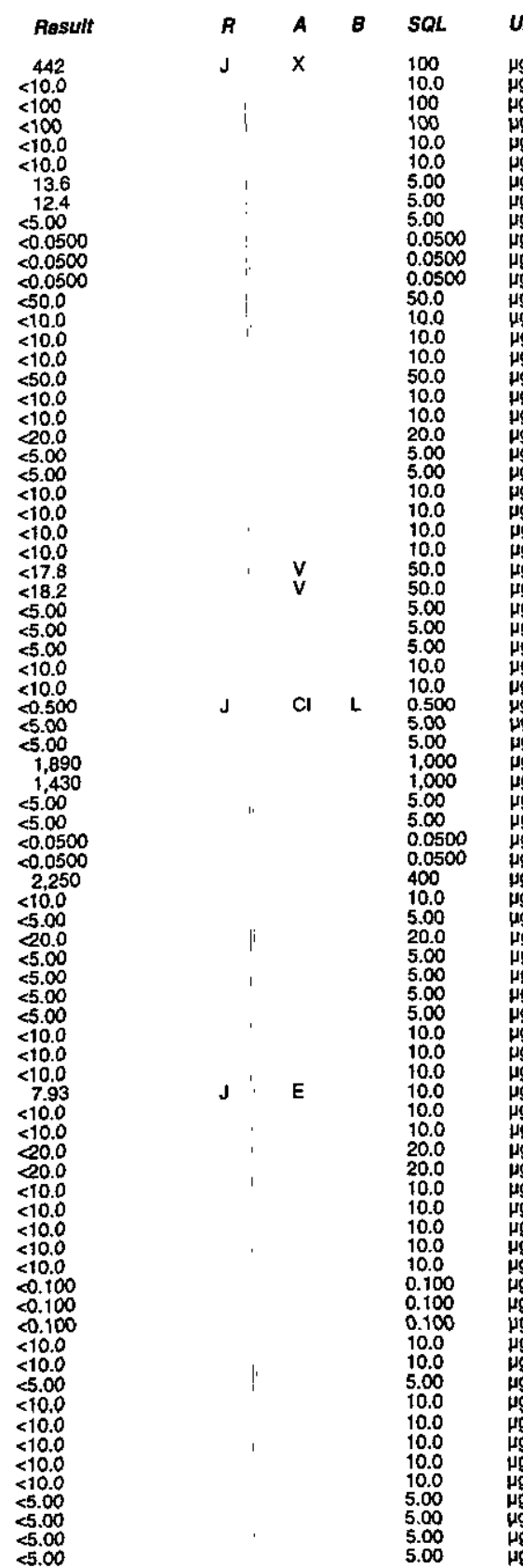

Well CSR BDU collected on 04/30/98 (cont.)

$\begin{array}{ll}\text { Dichloromethane } & <10.0 \\ 2,4 \text { - } & <10.0 \\ 2,4 \text {-Dichlorophenol } & <0.500\end{array}$

cis-1,3-Dichloosopropen

$\begin{array}{ll}\text { trans-7,3-Dichloropropene } & <5.00 \\ \text { Dieldrin } & <.100\end{array}$

2,4-Dimethyl phane

Dimethyl phithalate

2,4-Oinitrotoluene

Endosulfan sulfate

Endosulfan

Endrin

- Endryibenzens

o Fluoranthe

Fluoride

Heptachlor apoxide

Hexachlorobutadiene

Hexachlorocyclope

indeno(1,2,3-c,d)pyrene

Iron, total recoverable
iron, total recoverable

o Lead, total recoverable

Lithium, total recoverable

Magnesium, total recoverable

Manganese, total recoverable

Manganese, total recoverable

Methoyychlor

Methyl ethyl ketone
Methyl isobutyl keton

2-Merny halene

Molybdenum, total recoverabla Naphthalene

Nickel, total recoverable

Nitrate-nitrite as nitrogen

p-Nitroaniline

Nitrobenzene
2-Nitrophento
4Nitropheno

$\mathrm{N}$-Nitrosodimethylamine

N-Nitrosodiphenylamine

EX EPABOB1

EX EPAB270B

EPAB270B

EPA8270B
EPA8270B

$\begin{array}{cc}\text { EX } & \text { EPA8270B } \\ X & \text { EPA8270B } \\ & \text { EPA8270B }\end{array}$

\begin{tabular}{c}
$X P A B 270 B$ \\
$\times$ EPA260A \\
\hline
\end{tabular}

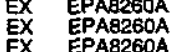

PCB 1016

PCB 123

PCB 1248

PCB 1260

- Phenanthrene

B-80

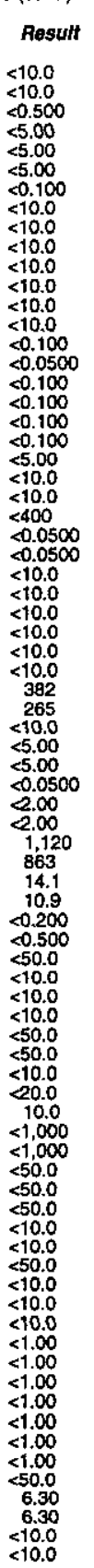

F

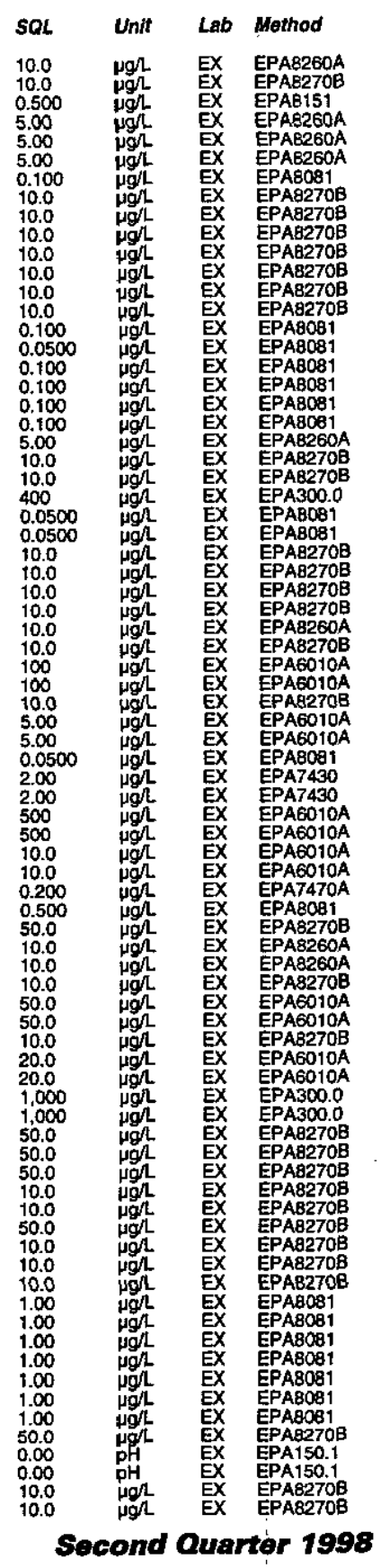


ANALYTICAL RESULTS

Well CSR BDU collected on 04/30/98 (cont.)

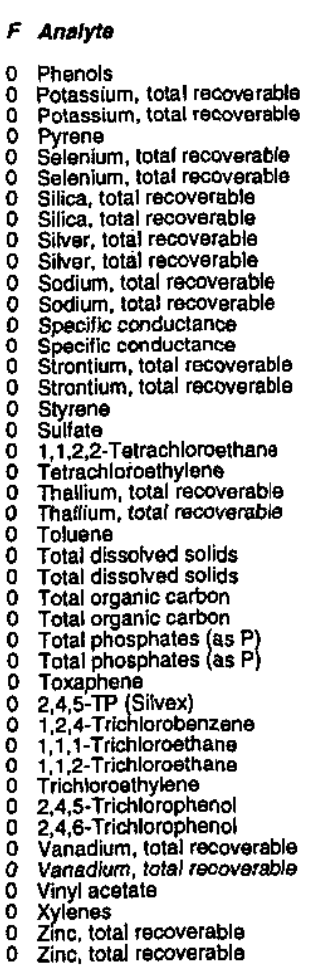

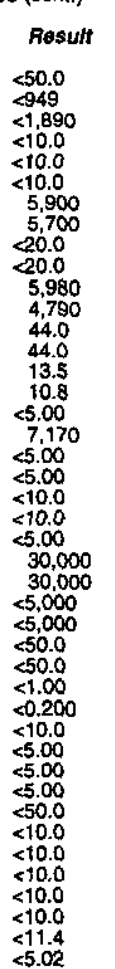

\section{WELL CSR 8DU}

MEASUREMENTS CONDUCTED IN THE FIELD Sample date: $06 / 01 / 98$
Depth to water: $15.6 \mathrm{ft}(4.75 \mathrm{~m})$ below TOC Wath re
pH: 4.8

: 4.8 elevation: Not availab

p. conductance: $42 \mu \mathrm{S} / \mathrm{cm}$

Turbidity: 33 NTU
Water evacuated from the well prior to sampling: $18 \mathrm{gal}$ ANALYSES

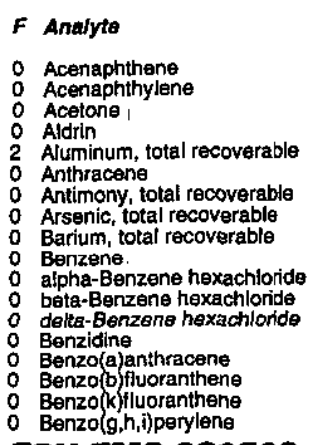

ESH-EMS-980569
Well CSR 8OU collectad on 06/01/98 (cont.)

$F$ Anatyte

: Benzo(a)pyrene

Bis(2-chloroethom) methan

Bis 2 chloroethyl) ether

1 Bis(2-ethythexyly) phthalate

Bromodichloromethan

Bromotomm

4-Bromophenyl phenyl ether

2-sec-Butyl-4,6-dinitropheno

Cadminn, rial recoverable

- Carbon ósulsulfide

- Carbon tetrachloride

o gamma-Chlordan

Chlorida

OChlorobenzena

4-Chloro-m-cresol

O Chloroethene (Ninyl chloride)

: Chlororomem

2-Choronaphthalen

2-Chlorophenol

4-Chlorophenyl phenyl ether

Chrysent
O Cobalt, total recoverabte
0 Copper, total recoverable

m/p-Cresol
$0-$ Cresol (2-Methylphenol)

0 Pyanide

O. P.

O Gibenz(a,h)anthracene

Dibenzofuran

Dibromochiloromethe

1,2-Dichlorobenazene
1,3-Dichlorobenzene

1,4-Dichlorobenzene

1,1-Dischloroethane

1,i-Dichloroesthylene

Dichloromethane

2,4-Dichorophenol

1,2-Dichloropropane

: cis-1,3-Dichloropropene

Dieldrin
0 Diethyl phthalate
2,4-Cimethyl phenol

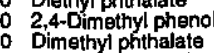

2.4-Dinitrophenol

$\begin{array}{ll}0 & 2,4-\text { Dinititotoluene } \\ 0 & 2,6-\text { Dinitrotoluene } \\ 0 & \end{array}$

Endosuffan sulfate

: Endosultian !

ildenydo

Endrin aldehyda

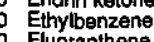

a Fuoranthen

: Fluoride

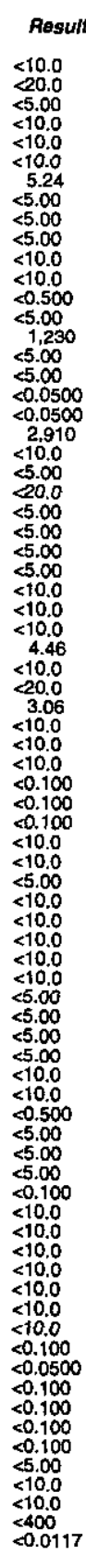

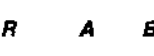

SOL Unit Lab Method

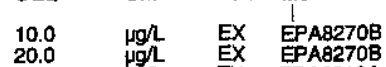

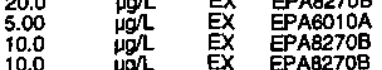

J E
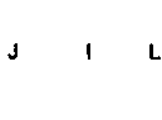

J E

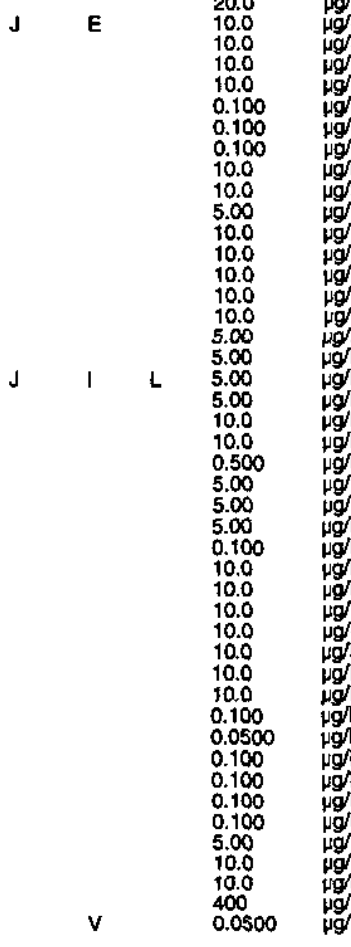

EX EPABO81

EX $\mathrm{EPAB081}$

EX EPAB270B

EX EPAB270B

EX EPA8270B

EX EPAB270

EX EPAB260A

EX EPA8270B

EX EPAB260A

EX EPAB260A

EX EPA8270B

EPAB270B
EPAB270B

EX EPAB270B

$X$ EPA808

EPABOB

$\begin{array}{ll} & \text { EPABOB-1 } \\ X & \text { EPABOB1 }\end{array}$

EPAB260A

EPA8270B
EPA300.0

Second Quarter 1998 
Well CSR 8DU collected on 06/01/98 (cont.)

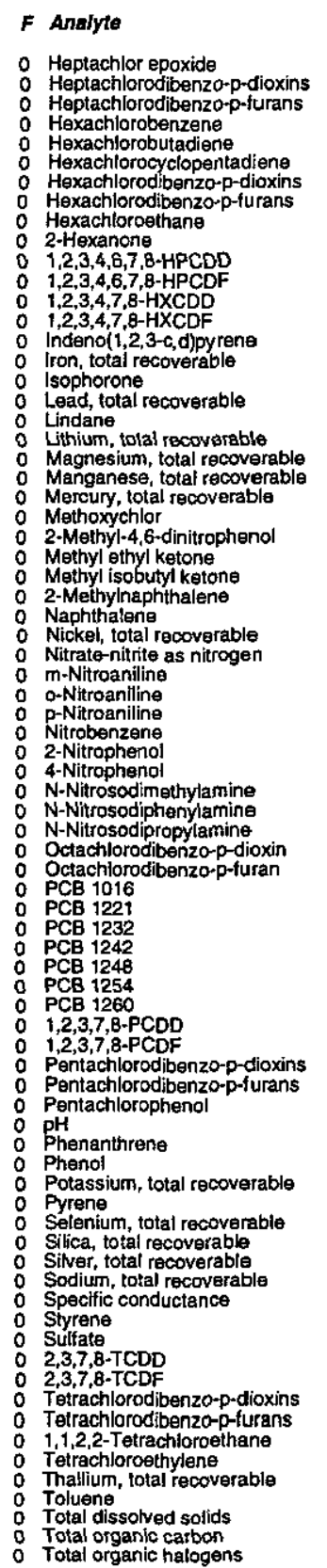

ESH-EMS-980569
Well CSR 8DU collected on 06/01/98 (cont)

F Analyto Res

O Total phosphates (as P)

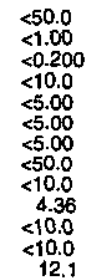

R

0.0500 ugh

$2,4,5-\mathrm{TP}$ (Silvex)
0

1,1,1-Trichloroethane

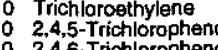

vanadium, total recoverab

- Vinyl acetate

O Zinc, total recoverable

WELL CSR 9DL

MEASUREMENTS CONDUCTED IN THE FIELD

Sample date: 04/29/98
Depth to water. 33.01 ft (10.06 m) below TOC

Water elevation: Not available

$\mathrm{SP}: 4.5$ conductance: $32 \mu \mathrm{S} / \mathrm{cm}$

Turbidity: 3 NTU
Water evacuated from the well prior to sampling: $7 \mathrm{gal}$

ANALYSES
F Ansiyte

Acenaphthene
Acenaphthylene

O Acetone

Aluminum, total recoverable

Anthracene

Arsenic, total recoverable

Benzene

delta-Benzene hexachloride

0 Benzidine

Benzo(k) fluoranthene

Benzo(g,hi)perytene

Benzo(a)pyrene

0 Benzyl alcoho

Brryllium, total recoverable

Bis (2-chloroesthoxy) methan
0 Bis(2-chloroethyl) ether

: Bis (2-chloroisopropyl) ether

Boron, tolas recoverable

o Bromoform

4-Bromophenyl phenyl ether

2-sec--Buty-4,6-dinitropheno

Calcium, total recoverable

- Carbon tetrachlorid

gamma-Chlorda

4-Chloroaniline

4-Chobro-m-cresol

Chlorosthane

Chloromethane
Carton disulfide

A.sun
$<10.0$
$<10.0$
$<10.0$
$<0.0500$
$<100$
$<100$
$<100$
$<10.0$
11.6
$<5.00$
$<0.0500$
$<0.0500$
$<0.0500$
$<50.0$
$<10.0$
$<10.0$
$<10.0$
$<50.0$
$<10.0$
$<10.0$
$<20.0$
$<0.270$
$<10.0$
$<10.0$
$<1.0$
$<10$.
$<9.86$
$<5.00$
$<5.00$
$<5.00$
$<10$.
$<10.0$
$<0.500$
$<5.00$
1.290
$<50$
$<5.00$
$<0.0500$
$<0.0500$
1,290
$<10.0$
$<5.00$
$<20$.
$<5.00$
$<5.00$
$<5.00$
$<5.00$

Time: 10:47

mperature: $22.3^{\circ} \mathrm{C}$

Total alkalinity (as CaCO3): $8 \mathrm{mgh}$
Phenolphthalein alkalinity: $0 \mathrm{mghL}$

\begin{tabular}{|c|c|c|c|}
\hline$S O L$ & Unit & Lab & Method \\
\hline $\begin{array}{l}50.0 \\
1.00 \\
0.200 \\
10.0 \\
5.00 \\
5.00 \\
5.00 \\
50.0 \\
10.0 \\
10.0 \\
10.0 \\
10.0 \\
10.0\end{array}$ & 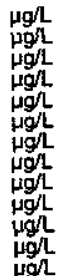 & $\begin{array}{l}\text { EX } \\
\text { EX } \\
\text { EX } \\
\text { EX } \\
\text { EX } \\
\text { EX } \\
\text { EX } \\
\text { EX } \\
\text { EX } \\
\text { EX } \\
\text { EX } \\
\text { EX } \\
\text { EX }\end{array}$ & 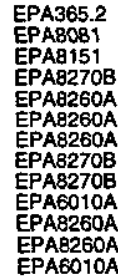 \\
\hline
\end{tabular}

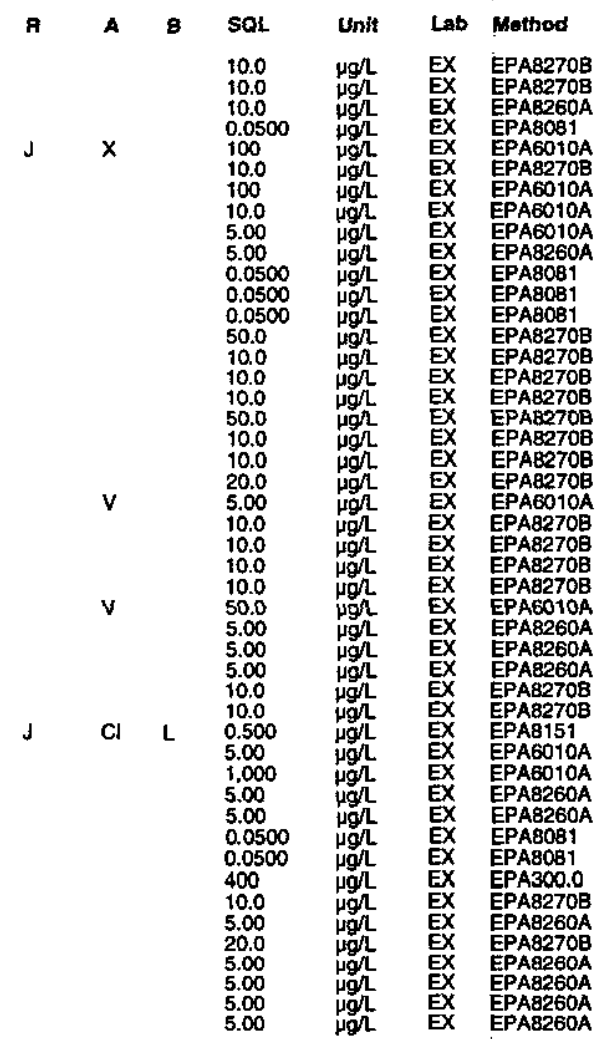

Second Quarter 1998 
Well CSA 9DL collected on 04/29/98 (cont.)

$F$ Analyte

: 2-Chloronaphthalene

4-Chlorophenyl phenyl ether

Chrysen

Cobalt, total recoverable

o m/p-Cresol

Pyanide

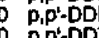

Dibenz(a,h)anthracene

Dibenzofuran

1,2-Dichlorobenzen

1,4-Dichlorobenzenene

1,1-Dichloroethane

1.2-Dichlorosthane

1,2-Dichloroethylen

Dichloromethane

2,4-Dichlorophenoxyacetic acid

cis-1,3-Dichloropropen

trans-1,3-Dichloropropene

Diethyl phthatate
2.4-Dimethyl pheno

Dimethyl phtitialate

2,4-Dinitrotoluene

Di-n-ocitrotolyent phenatate

Endosufian sut

Endosultan

Endrin alóehyde

Fthylbenzene

Fluorene

Heptachlor

Heptachlor epoxide

heptachlorodibenzo-p-dioxin

Hexachlorobenzene

Hexachlorocyclopentadiene

Haxachlorodibenzo-p-dioxins

Hexachlorodibenzo-p

$2-H e x a n o n$
$1,2,3,4,6,7,8-\mathrm{HPCDD}$
$1,2,3,4,6,7,8-\mathrm{HPCDDF}$

$1,2,3,4,7,8-\mathrm{HXCD}$

Indeno $(1,2,3-c, d)$ pyrene
Iron, totai recoverable

Isophorone

Lindane Lthium, total recoverabie

Magnesium, total recoverable

Mercury, total recoverable

Methoxychlor 2 - 2 initrophenol

0 Methyl isobutyl ketor

ESH-EMS-980569

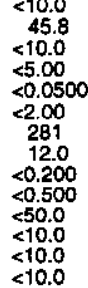

Well CSR 9DL collected on 04/29/98 (cont.)

F Analyto

Resuft

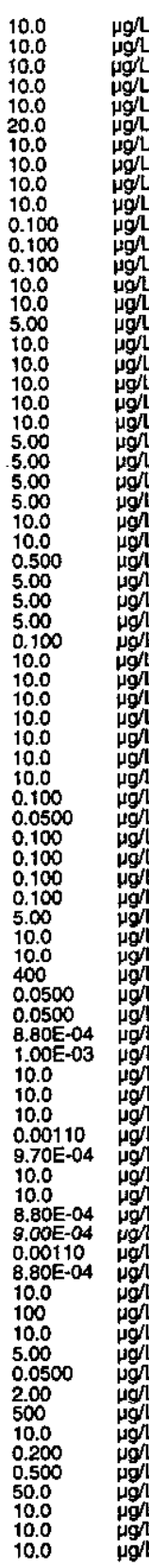

Lab Method

Molybcienum,

$<8.15$

Nickel, total recoverable

$\begin{array}{ll}0 & \text { m-Nitroaniline } \\ 0 & \text { o-Nitroaniline } \\ 0 & \text { Nitrobenzing }\end{array}$

p-Nitroaniline

2-Nitrophenol

o N-Nitrosodimethylamin

$\mathrm{N}$-Nitrosodiphenylamin

N-Nitrosodipropylamini

PCB 1016

PCB 1232

PCB 1248

PCB 1260

Pentachiorodibenzo-p-dioxins
Pentachtorodibenzo-p-furans

Phenanthrene

Phenol

Potasslum, total recoverable

Pyreno ral rocoverable

Silica, total recoverable

Silver, total recoverable

Spectic conductance

Styrene

Sulfate

Tetrachlorodibenzo-p-dioxins

Tetrachlorodibenzo-p-furans

Tetrachloroethylene

Thallitum,

Total dissolved solids

Total organic halogens

Total organic halogens
Total phosphates (as P)

Toxaphene

1,2,4-Trichlorobenzen

1,1,1-Trichloroethane

Trichloroethylene
$2,4,5$-Trichloropheno

Vis

Vinyl acetate

Xylenes

$<20.0$

$<50.0$
$<50.0$

$<10.0$
$<10.0$

$<<10.0$

$<10.0$
$<9.005-04$
$<0.0160$

$<1 . \infty$

$<1.00$

$<1.00$

$<8.200-04$
$<7.00 E-04$

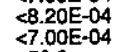

7.90
$<10.0$
$<10.0$
$<50.0$

$<2.370$

$<\begin{gathered}<1.0 \\ 8.600\end{gathered}$

8,600
$<20.0$
3,700
30.0

7.59
$<5.00$
2740

$3.905-04$
$<3.40-04$
$3.300-04$

$<3.40=-04$

$<5.00$

$>100$
51.00
10.000
55,000
5120
1,20

$<120$

$<0.00110$

$<10.0$
$<9.800-04$
$<.00$
-0.04

$<0.0110$
$<8.805-04$

EPA8280

EPAB270B

EPABDOB1

EPA7430

EX EPA6010A

$\begin{array}{ll}\text { EX } & \text { EPABOB1 } \\ \text { EX EPAB270B } \\ \text { EPAB260A }\end{array}$

EX EPAB260A
A A B SOL Unit LAb Method

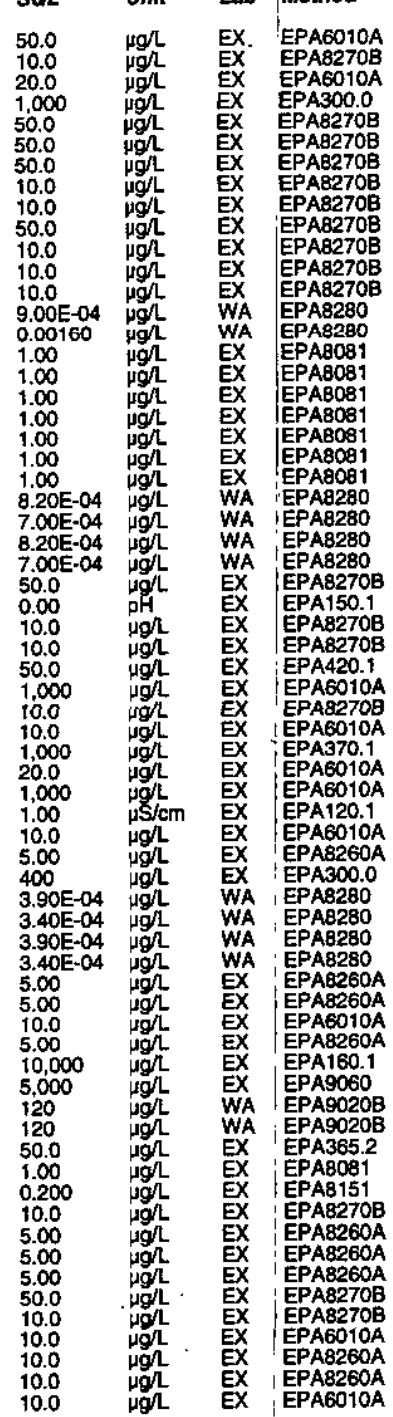

Second Quarter 1998 
WELL CSR 9DL

MEASUREMENTS CONDUCTED IN THE FIELD

Sample date: 06/01/98

Dephtowar: $32.3 \mathrm{ft}(9.85 \mathrm{~m})$ below TOC

Water eleverit

S. . conductance: $32 \mu \mathrm{S} / \mathrm{cm}$

Water evacuated trom the well prior to sampling: $4 \mathrm{gal}$

ANALYSES

$F$ Analyte

O Acenaphthiene

Acentone

Aldrin
Aluminum, total recoverable

Anthracene

2. Antimony, total recoverable

Arsenic, total recoverable

Barium, total recoverable

Garium total recoverable

alpha-Benzene hexachloride
beta-Benzene hexachloride

Benzo(a)anthracene

Benzo okjfluoranthene

Benzo (o hi)perylene

Beryllum, total recoverable

Bis (2-chiloroethoxy) methan

Bis 2-chloroisopropyl) eth

Bis(2-ethylhexyl) phthala

Bromofom

4-Bromophenyl phenyl ether

Eurybenzy phthalate

Cadmium, total recoverable

Cadmium, total recoverab

Caccicium, total recoverababl

Carbon disultide

alpha-Chlordane

Chlorido

4-Chloroaniline

4-Chlorom-cresol

Chloroethane

Chlorotom

2.Chloronaphthalene

4-Chlorophenenyl phenyl ether

Chromium, total recoverable

Chrysene

Copper, total recoverable

- Copper, total recoverable

Result
$<10.0$
$<10.0$
$<10.0$
$<0.0500$
77.3
78.7
$<10.0$
38.8
$<100$
$<10.0$
$<10.0$
16.3
16.0
$<5.00$
$<0.0500$
$<0.0500$
$<50500$
$<50.0$
$<10.0$
$<10.0$
$<10.0$
$<10.0$
$<10.0$
$<20.0$
$<5.00$
$<5.00$
$<10.0$
$<10.0$
$<10.0$
$<10.0$
$<5.00$
$<5.00$
$<5.00$
$<10.0$
$<10.0$
$<0.500$
$<5.00$
$<5.00$
1.390
1,370
$<5.00$
$<5.00$
$<0.0500$
$<0.0500$
1,380
$<10.0$
$<5.00$
$<20.0$
$<5.00$
$<5.00$
$<5.00$
$<5.00$
$<10.0$
$<10.0$
$<10.0$
$<10.0$
8.77
$<10.0$
$<20.0$
$<20.0$
2.13
5.39
$<10.0$

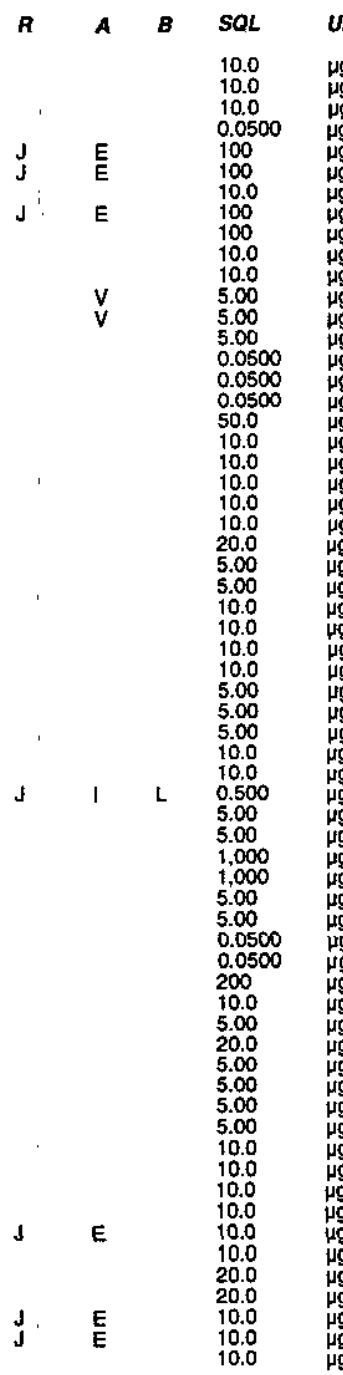

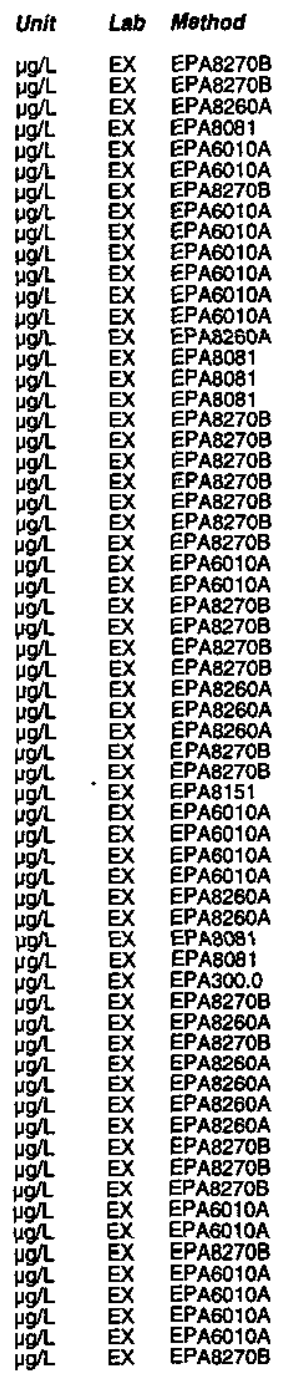

Well CSR SDL collected on 06/01/98 (cont.)

Time: $16: 33$

erature: $26.2^{\circ} \mathrm{C}$

Total alkalinity (as CaCO3): $4 \mathrm{mg} / \mathrm{L}$

0 O-Cresol

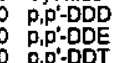

Bibenz(a.h)anthracene

Dibenzofuran

Di-n-butyl phthalate

1,3-Dichlorobenzen

1,4-Dichorobenzene

1, 1.-Dichloroethane

1,1-Dichloroethylen

Dichloromethans
2,4-Dichloropheno

2,4-Dichlorophenol

cis-1,3-Dichloropropene

trans-1,3-Dichloropropene

2,4-Dimethyl phenol

Dimethyl phithalate

2,4-Dinitrotoluene
2,6-Dinitrotoluene

Di-n-octyl phthalate

Endosutian I

Endrin

Endrin aldehyde

Fluoranthene

Fluorene

Heptachlor

Heptachlorodibenzo-p-dioxins

Heptachlorodibenzo-p-furans

Hexachlorobutadiene

Hexachlorocyclopentadiene

Hexachlorodifbenzo-p-dioxins
Hexachlorodibenzo-p-furans

Hexachioroethane

2-Hexano, $1,2,3,4,6,7$-HPCDD

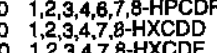

indenot $(1,2,3-c, d)$ pyrene
iron, otai recoverable
iron, total recoverable

Lead, total recoverable

Lindane

Lithium, total recoverable

Magnesium, total recoverab

Manganess, total recoverab

Mercury, total recoverable

2-Methyl-4,6-dinitropheno

Methyl ethyl ketone

Methyl isobutyly keton
Resuft

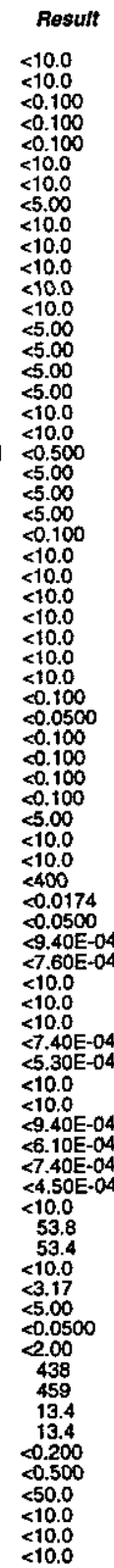

(1)

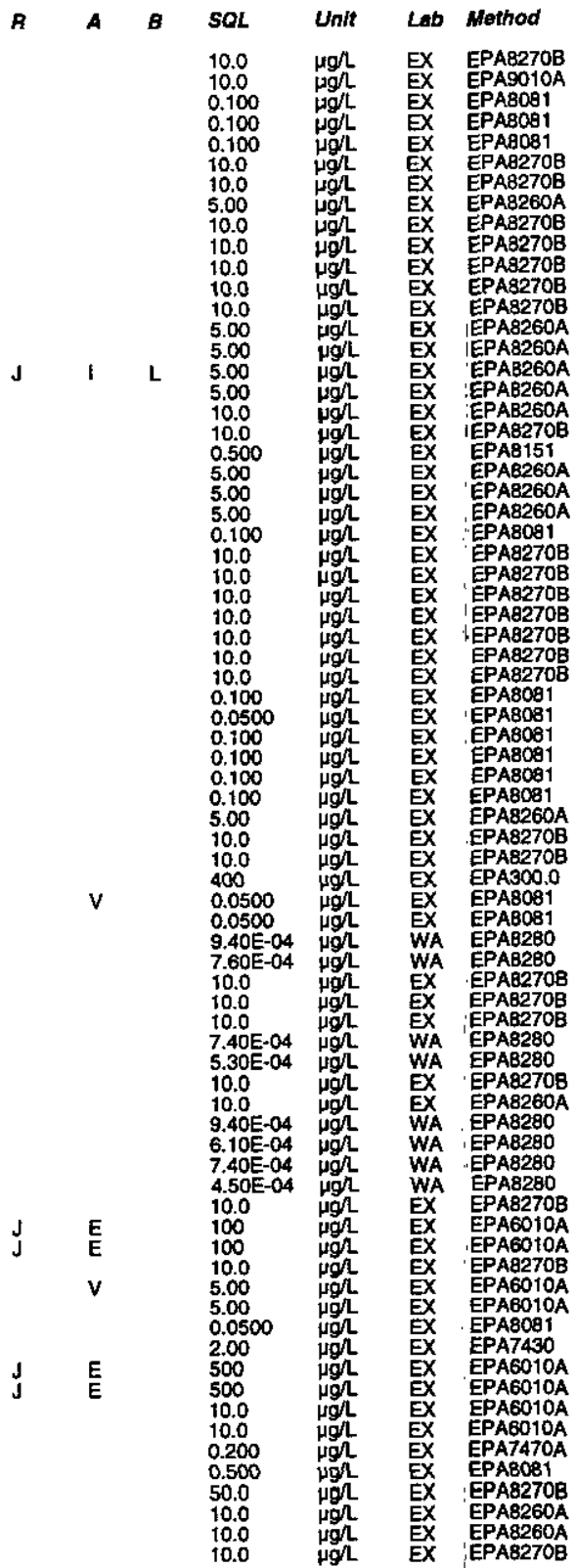

ESH-EMS-980569 
ANALYTICAL RESULTS

Well CSR 9DL collected on 06/01/98 (cont.)

$F$ Analyte

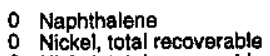
Nickel, total recoverable m-Nitroanilitine P-Nitroaniline 2-Nitrophenenol N-Nitrosodimethylamine
N-Nitrosodiphenylamine
N-Nitrosodipropylamine Octachlorodibenzo-p-dioxin PCB 1016 PCB 1242
0 1,2,3,7,8-PCDD

Pentachiorodibenzo-p-dioxins Pentachlorodibenzo-p-furans $\mathrm{pH}$ Phenanthr Phenois Potassium, total recoverable Pyreni , total recoverable Selenium, total recoverab Silver, total recoverable Sodium, total recoverable Specific conductance Styrene $2,3,7,8-T C D D$

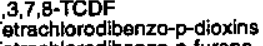
1,1,2,-Tertrachloroethane Thatrachioroethylene
Thallium, total recoverable
That recoverable Total dissolved solide Jotal organic carton Total organic halogens
Total phosphates (as P) Toxaphene

1.2.4-Trichlorobanzene 1,1.2-Trichichoroethan 2,4,5-Trichloropheno

Vanadium, total recoverable
Vanadium, total recoverable

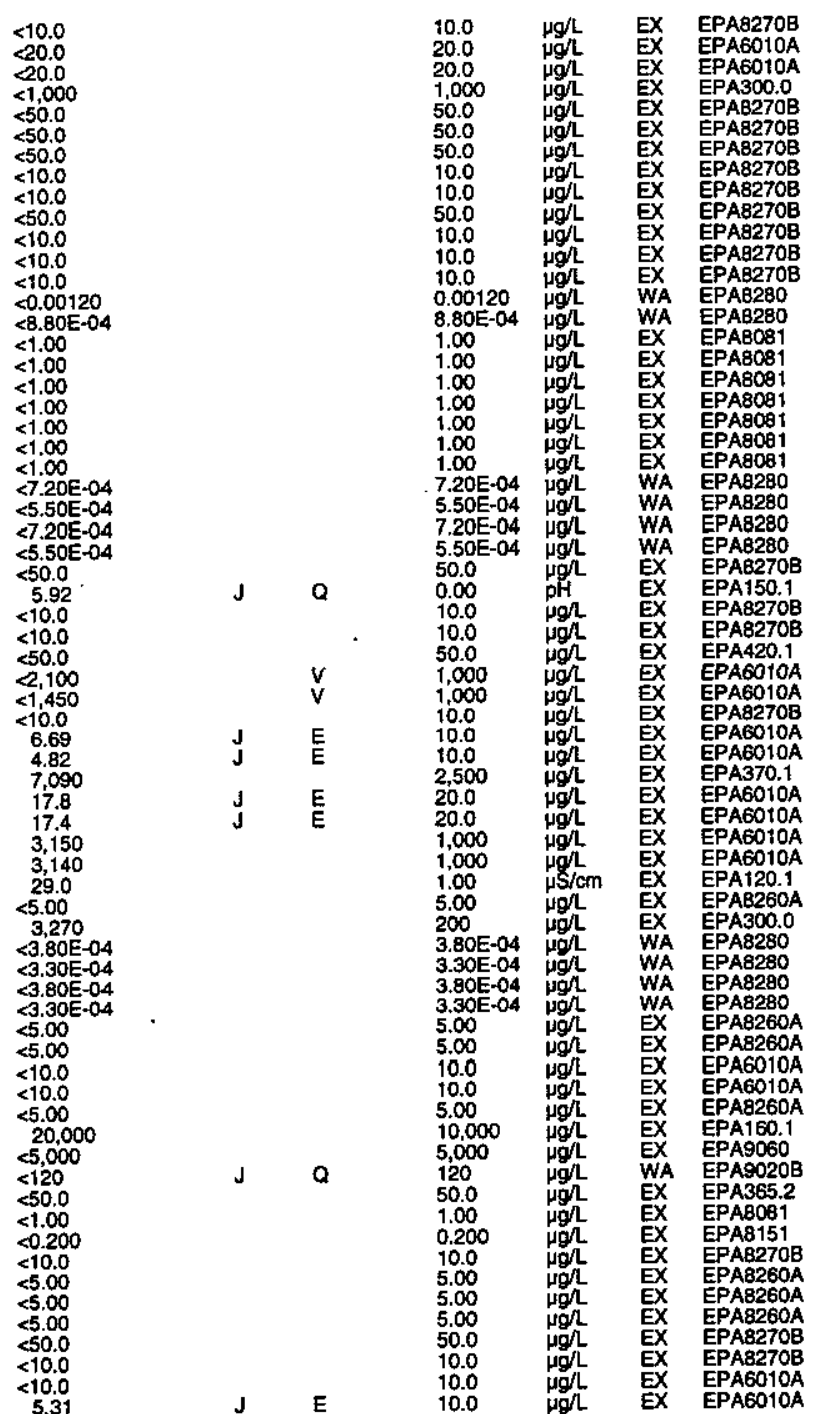

ESH-EMS-980569
Well CSR 9DL collected on 06/01/98 (cont.)

$F$ Analyte Result

0 Vinyl acetate

Resu

0 Zinc, total recoverable
0 Zinc, total recoverable

$<10.0$
$<10.0$
6.46
7.08

\section{WELL CSR 9DU}

MEASUREMENTS CONDUCTED IN THE FIELD

Sample date: 04/29/98 Water oleval

Pp: 6.6

Turbidity: $6 \mathrm{NTN}: 51 \mu \mathrm{S} / \mathrm{cm}$

ANALYSES

F Analyte

: Acenaphthene

Acaton

2 Aluminum, total recoverable

- Anthracene

: Arsenic, total recoverable

- alpha-Benzene hexachioride

detra-Benzene hexachloride

o Benzo(a)anthracene

B Benzo(b)fluoranthene

Benzo(k) fluoranthen

- Benzo(g,h,i)perylen

o Benzo(a)pyrene

Beryliuum, total recoverable

0 Bis (2-chloroethyl) ether

: Bis (2-chlorolsopropyl) ether

B Boron, total recoverable

0 Bromoform

4-Bromophent phenyl ather

2-sec-Butyl-4,6-dinitropheno

o cadmiutm, total recoverable

Calcium, total recovera

o Carbon tetrachlorida

o alpha-Chlordane

0 Chloride

o Chiorobenzenen

4 4-Chloro-m-creso

: Chloroethane (Vinyl chloride) o Chloroethene

2-Cromethane
0 2-Chlorophenol 4-Chlorophenyl phenyl ether Chrysene mip-Cresol recoverable
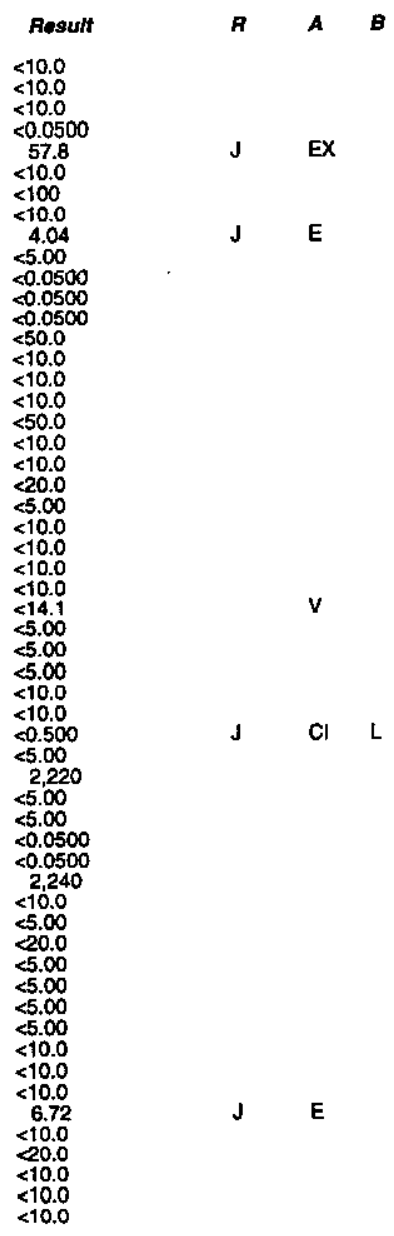

Time: 9:20

Water temperature: $32.1^{\circ} \mathrm{C}$

Total alkalinity (as CaCO3): $12 \mathrm{mg} /$
Phenolphthalein alkalinity: $0 \mathrm{mg} /$

SOL Unit Lab Method

$\begin{array}{llll}10.0 & \mu g h & \text { EX } & \text { EPAB260A } \\ 10.0 & \mu g h & \text { EX } & \text { EPAE260A }\end{array}$

$\begin{array}{llll}10.0 & \mu g h & \text { EX } & \text { EPAB260A } \\ 10.0 & \mu g h & \text { EX } & \text { EPA6010A } \\ 10.0 & \mu g h & \text { EX } & \text { EPAGO10A }\end{array}$

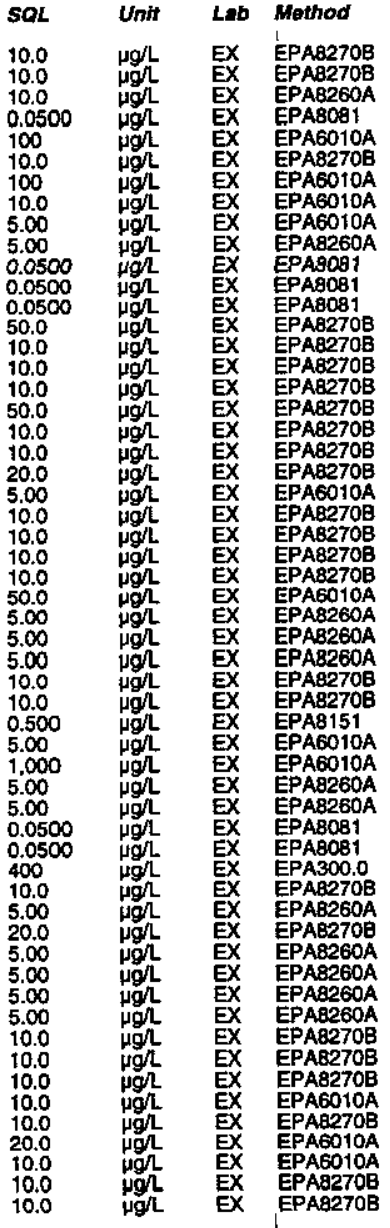

Second Quarter 1998 
Well CSR 9DU collected on 04/29/98 (cont.)

\begin{tabular}{|c|c|}
\hline Analyte & \\
\hline 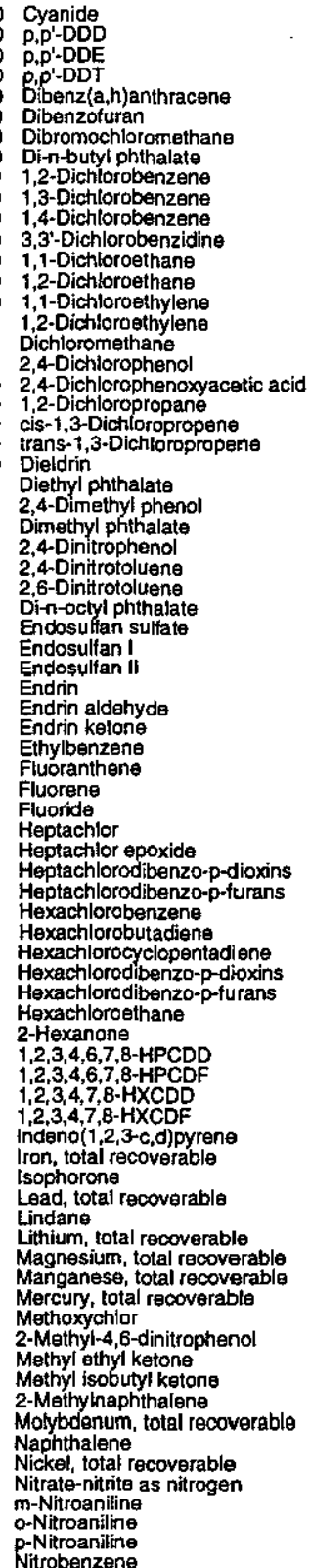 & 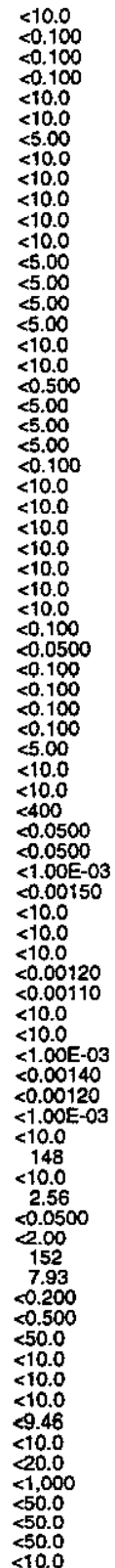 \\
\hline
\end{tabular}

Well CSR 9DU collected on 04/29/9B (cont.)

\section{$F$ Analyte}

2. 2-Nitrophenol

10.0 Hg/. EX EPA9010A

0.100 Hg/ EX EPAB081

$\begin{array}{ll}10.0 & \mu g h \\ 10.0 & \mu g \Omega\end{array}$

$\begin{array}{ll}5.00 & \mu g / \mathrm{L} \\ 10.0 & \mu g / \mathrm{L} \\ 10.0 & \mu g / \mathrm{L}\end{array}$

10.0
10.0
10.0

5.00
5.00
5.00

5.00
10.0
10.0

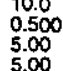

5.00
.0 .100
10.0

10.0

10.0
10.0
10.0
10.0

0.100

0.100
0.100
0.100

5.00
10.0
10.0
400

0.0500
0.0500

0.00150

10.0

10.0
0.00120
0.00110

10.0

$\begin{array}{ll}10.0 & \mu g \\ 1.00 \mathrm{E}-03 & \mu g \\ 0.00120 & \mu g h\end{array}$

0.00140 pg

0.00120
$1.00 \mathrm{E}-03$
$\mu g h / 2$

10.0

100
10.0
5.00
0.050

$\begin{array}{ll}5.00 & \mu g / \mathrm{h} \\ 2.050 & \mathrm{\mu gh} \\ \mathrm{\mu g} / \mathrm{h}\end{array}$

J E

$\checkmark$

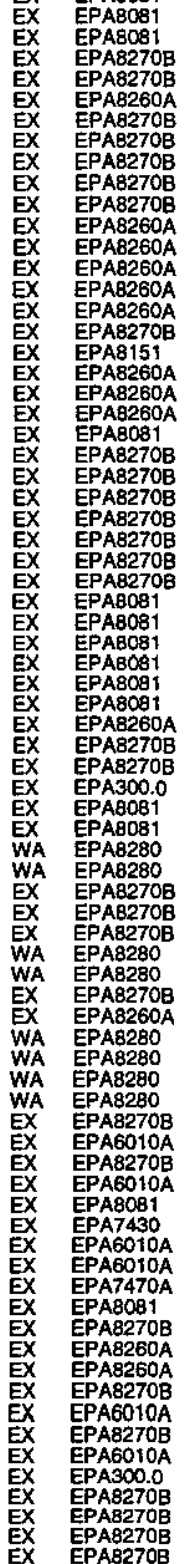

N-Nitrosodimethylamine

Octachlorodibenzzo:p-dioxin

PCB 1016 - $\quad<.00180$

PCB 1016

PCB 1242

PCB 1260

1,2,3,7,8-PCDD

Pentachlorodibenzo-p-dioxin

Pentachlorodibenzo-p-turans

pH

Phenol

Phenols

Selenium, total recoverable

Silica, total recoverable

Sodium, total recoverabl

Spentic conduclance

2,3,7,8-TCOD

Tetrachlorodibenzo-p-dioxins

Tetrachlorodibenzo-p-furan

Tetrachloroethylene

Thallium, total recoverab

Total dissoved solids

Total organic halogens
Total phosphates (as P)

$2,4,5-T P$ (Sivex)

1,1, 1-Trichlorobethane

1,1,2-Trichloroathe

2,4,5-Trichlorophenol

Vanadium, total recoverable

O Zinc, total recoverable

ESH-EMS-980569

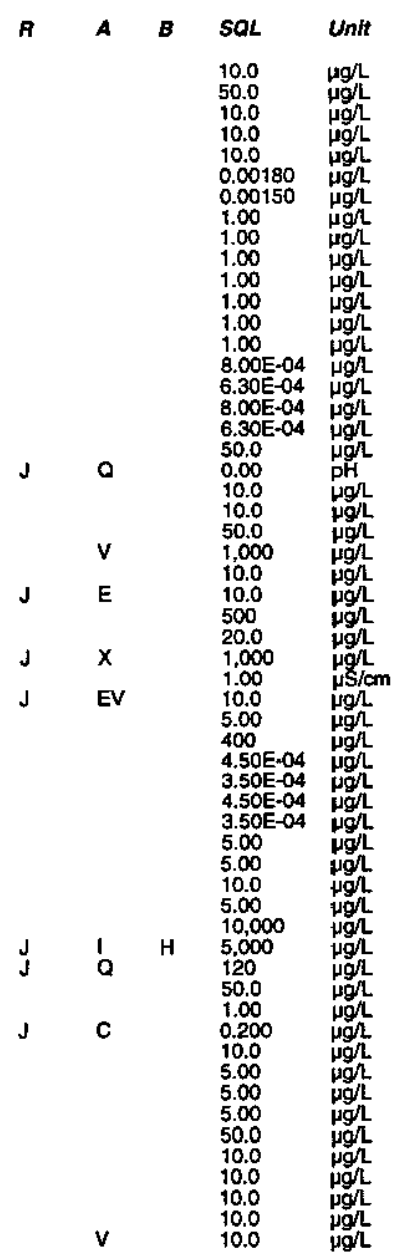

at Gethod

EX EPAB270B

EPAB270B

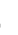

XX

XPA808

X

WA EPAB280

EPA8280

EPA8270B

EPA420.1

EPAB270B

EPA370.1
EPA6010A
EPA6010A

EPA6010A

EPAB260A
EPA300.0

EPA8280

EPA8260A

EPAG010A

EPA160.1

EPA9020B

EPABOB1

EPA8270B

EPA8260A

EPAB260A

EPAB270B

EPAG010A

EPAB260A 


\section{WELL CSR 9DU}

MEASUREMENTS CONDUCTED IN THE FIELD

Sample date: $06 / 01 / 98$. Water elevation: Not available

Sp. 6 conductance: $140 \mu \mathrm{S} / \mathrm{cm}$

Wuitidity: 11 NTU ANALYSES

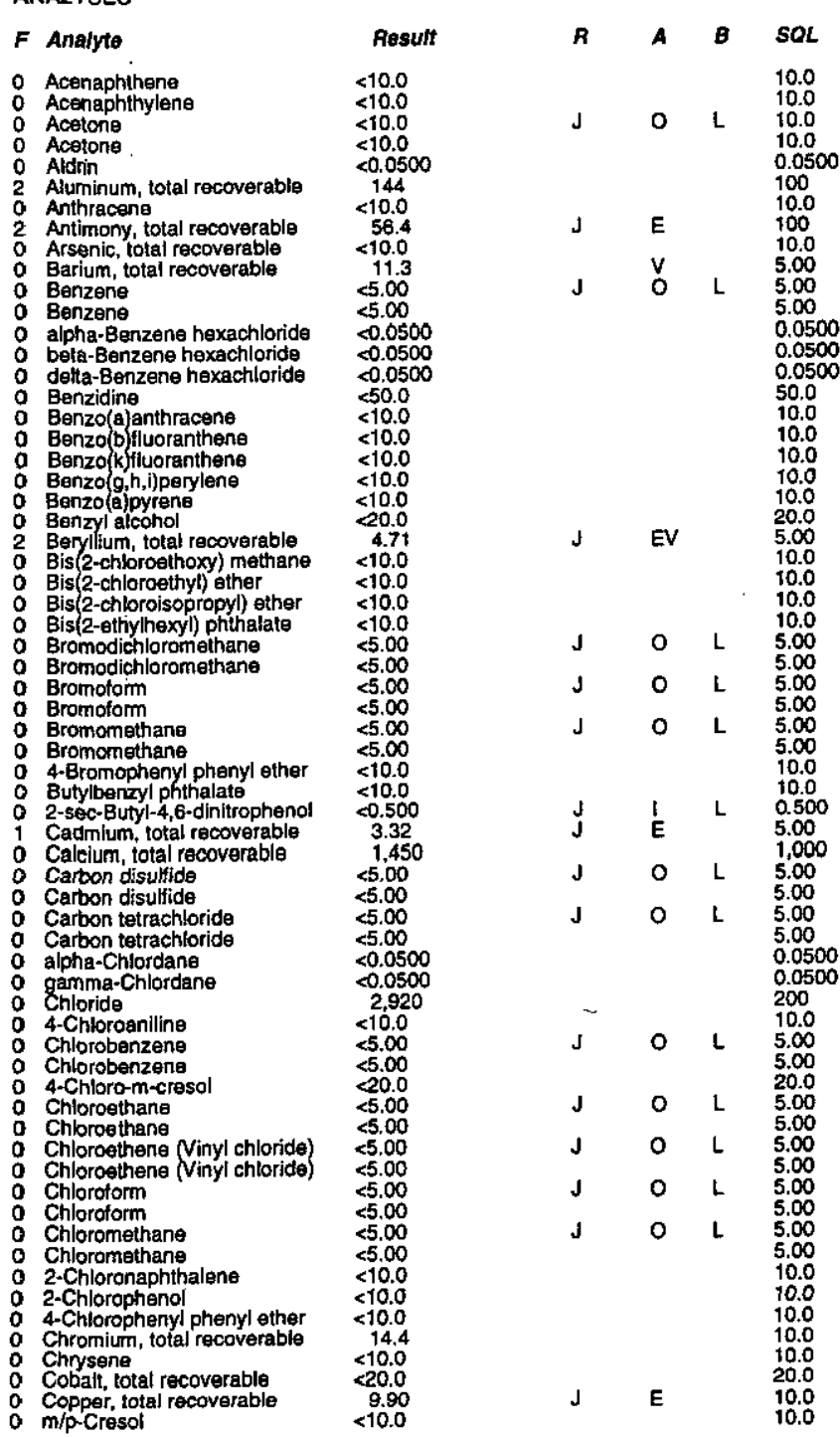

ESH-EMS-980569
Well CSR 9DU collected on 06/01/98 (cont.)

$F$ Anslyte

Time: 17:47

Water temperature: $24^{\circ} \mathrm{C}$

Air temperature: $36.1 \mathrm{C}$
Total alkalinity (as Cacos): $10 \mathrm{mg} / \mathrm{h}$
Phenolphthalein alkalinity: $0 \mathrm{mg} / \mathrm{L}$

0 o-Cresol (2-Methylphenol)

Result

$0_{0}^{0}$ p.p'-DDD

: Pibenz(a,h)anthracene

0. Dibenzofuran

: Dibromochloromethan

1,3-Dichiorobenzen

1,4-Dichlorobenzene

o 1,1-Dichloroethane

1,2-Dichloroethane

1,1-Dichloroethylen

1.2-Dichloroethylen

Dichloromethane

2, Dichloromethane

2,4-Dichlorophenoxyacotic acid

1.2-Dichloropropanane

cis-1,3-Dichioropropene
cis-1,3-Dichloropropene

trans-1,3-Dichloropropen

Dieldrin Dithatate

Dimethyl phthalate

2,4-Dinitropheno

2,6 -Dinitrotoluene

Endosuffian sulfiate

O Endosulfan I

Endrin aldehyde

Etryilbenzene

Ethylbenzene

Fluorene

Heptachlor

Heptachlor epoxide

Heptachlorodibenzo-p-dioxin

Hexachlorobenzene-p-t

Hexachlorobutadiene

Hexachlorodibenzo-p-dioxin

Hexactloroethane

2-Hexanon

$2,-1,3,4,6,7,8-H P C D D$
$1,2,3,4,7,8-H P C D F$

$1,2,3,4,6,7,8-\mathrm{HPCD}$

$1,2,3,4,7,8-\mathrm{HXCDF}$

Indeno(1,2,3-c,d)pyrene

isophorone

Lindane

Lithium, total recoverable Magnesium, total recoverab

Mercury, total recoverable

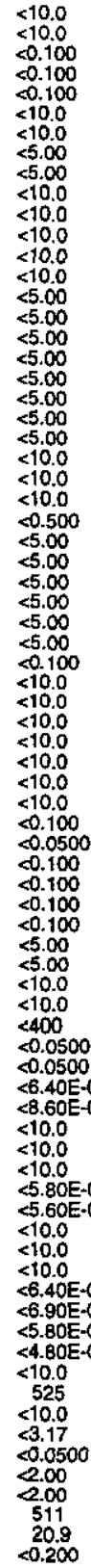

B-87
A A B SQL Unit Lab Method

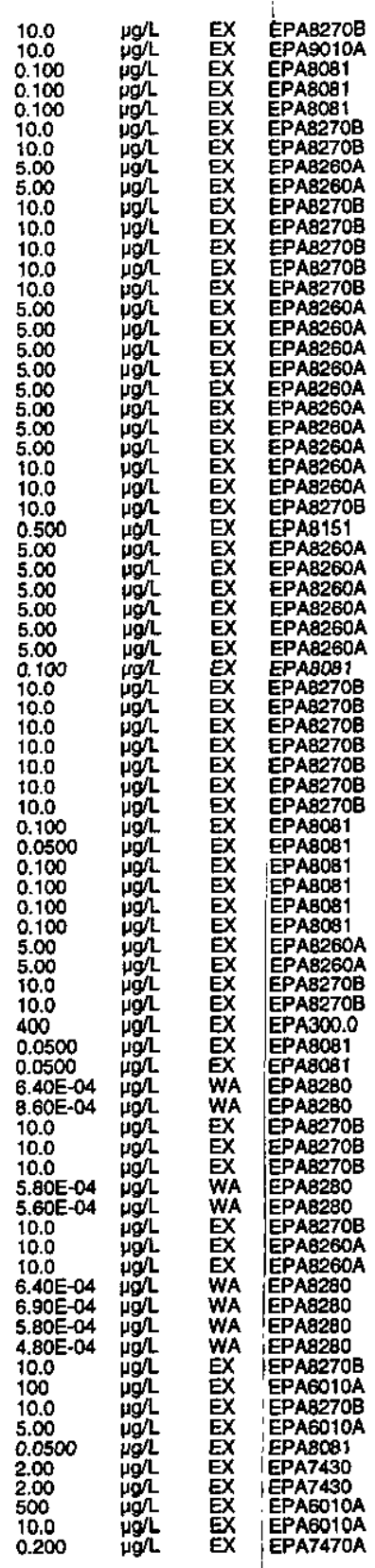

Second Quarter 1998 
ANALYTICAL RESULTS

Well CSR SDU collected on 06/01/98 (cont.)

$F$ Analyte

$\begin{array}{ll}0 & \text { Methoxychlot } \\ 0 & 2-\text { Methyl-4,6-dinitrophenol } \\ 0 & \text { Methyl thyl ketone }\end{array}$

: Methyl ethyl ketone

Methyl isobutyl ketone
2-Methylnaphithalene

Naphthalene
0
0 Nickel, total recoverable
Nitrate-nitrite as nitrogen

m-Nitroaniline
o-Nitroaniline

Nitrobenzenting

N
0

N-Nitrosodimethylamine

N-Nitrosodipropylamine
0
0 Octachlorodibenzo-p-dioxin
0
Octachlorodibenzo-p-furan

$\begin{array}{lll}0 & \text { PCB } 1016 \\ 0 & \text { PCB } 1221 \\ 0 & \text { PCB } 1232\end{array}$

PCB 1242

PCB 1254

$1,2,3,7,8-P C D D$
$1,2,3,7,8-P C D F$

Pentachiorodibenzo-p-dioxins

Pentachlorodibenzo-p-furan

Phenanthrene

Potassium, total recoverable Pyrene

Silica, total recoverable

Sodium, total recoverab

Syren

Sulfate Tetrachlorodibenzo-p-dioxins i, 1,2 - Tetrachloroethan Tetrachloroethylene

Thallium, total recoverable

Toluen dissolved solids
Total organic carbon

Total organic carbon
0 Total organic halogens
0

Toxaphene

1,2,4-Trichlorobenzene

1,1,1-Trichloroethane

1,1,2-Trichlorothane

Trichloroethylene

Trichloroethylene

Vanadium, total recoverable Vinyl acetate

Z Zinc, total recoverable

ESH-EMS-980569

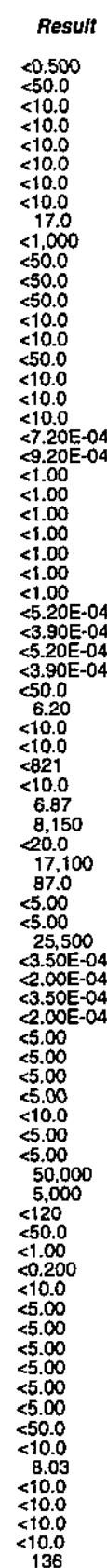

$<821$
$<10.0$
6.87
8.150

$<200$
17,100
87.00
$<5.00$
$<5.00$

$<.50 \mathrm{E}-04$
$<.00 \mathrm{E}-04$
$3.50 \mathrm{E}-04$

$<5.00$
$<10.0$
$<5.00$
$<5.00$

5,000
$<120$
$<50.0$
$<1.00$
$<0.200$
$<10.0$
$<5.00$
$<5.00$
$<5.00$
$<5.00$
$<5.00$
$<5.00$
$<50.0$
$<10.0$
8.03
$<10.0$
$<10.0$
$<10.0$
$<10.0$
136

A B SOL Untt

0.500

EX EPABOB1

EX EPA8260A

EPAB260A

EPA8270B

EPA300.0

EPAB270B

EPAB270B

EPAB270B

EPA82708

EPAB270B

$20 \mathrm{E}-04$

$1 . \infty$

$1 . \infty$

$\infty$

$5.20 \mathrm{E}-04$

$5.20 \mathrm{E}-04$

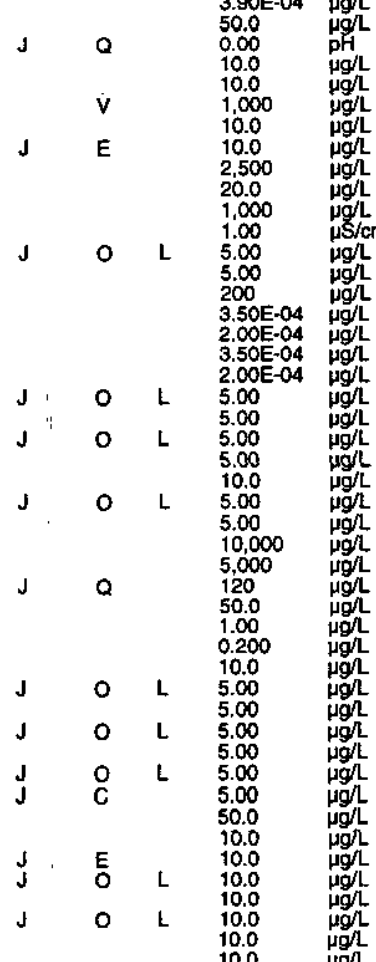

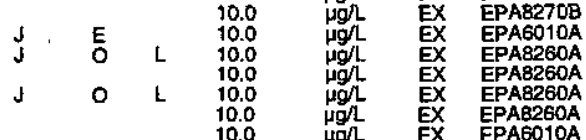

EX EPAB2GOA
WELL CSR 10DL

MEASUREMENTS CONDUCTED IN THE FIELD

Sarmpie date: $04 / 29 / 98,3$ m below TOC Water elevation: Not availab

Sp. 5.4 conductance: $35 \mu \mathrm{S} / \mathrm{cm}$

Water temperature: $21.6^{\circ} \mathrm{C}$

Turbidity: $1 \mathrm{NTU}$ U $35 \mu \mathrm{S} / \mathrm{cm}$
Water evacuated from the well prior to sampling: $25 \mathrm{gal}$

Total alkalinity (as CaCO3): $6 \mathrm{mg} /$
Phenolphthalein alkalinity: $\mathrm{mg}$ ANALYSES

: Acenaphthene

Acentoph
0 Aldrin

Aluminum, total recoverable

Antimony, total recoverabte

: Barium, total recoverable

alpha-Benzene hexachloride

delte Benzene hexachloride

Benzo(a)anthracene

Benzobyuoranthen

: Benzoic acid

- Benzil alcohol

Beyllium, total recoverab!e

Bis (2-chloroethoxy) moth
Bis 2-chloroethyl) ether

Bis(2-chloroisopropyl) ether
Bis(2-ethylhexyl) phthalate

Boron, total recoverable

O Bromoform

Bromomethane

2-sec-Butyl-4,6-dinitrophen

Cadmium, total recoverable

o Carton disulfide

: alpha-Chlordane

o gamma-Chloride

4-Chloroaniline

4-Chloro-m-creso

- Chloroethenene (Vinyl chloride)

Chlorotorm

2-Chloronaphanthalen
2-Chor

4-Chlorophenyl phenyl ether

Chrysene

Copper, total recoverable

o-Cresol (2-Methyiphenol)

0 P,p.ODD

P,

Dibenz $(a, h)$ anthracene

Dibromochloromethane

Result

$<10$

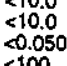

$<100$
$<10.0$

$<100$
$<10.0$

$<0.00$

$<0.0500$

$<50.0$
$<10.0$
$<10.0$
$<10.0$

$<10.0$

$<10.0$
$<10.0$
$<20.0$

$<5.00$

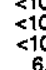

6.59
$<9.10$
$<5.00$
$<5.00$

$<5.00$
$<5.00$
$<10.0$

$<10.0$
$<0.50$

J ClO L

$<5.00$
$<5.00$
$<0.0500$

$<0.05000$

$<10.0$

$<5.00$
$<0.0$
$<5.00$

$<5.00$

$<5.00$
$<10.0$
$<10.0$
$<10.0$
$<10.0$

$<<<10.0$

$<10$

$<10.0$
$<10.0$
$<0.100$

$<0.100$
$0<.100$
$<100$
$<10.0$
$<5.00$

$<5$

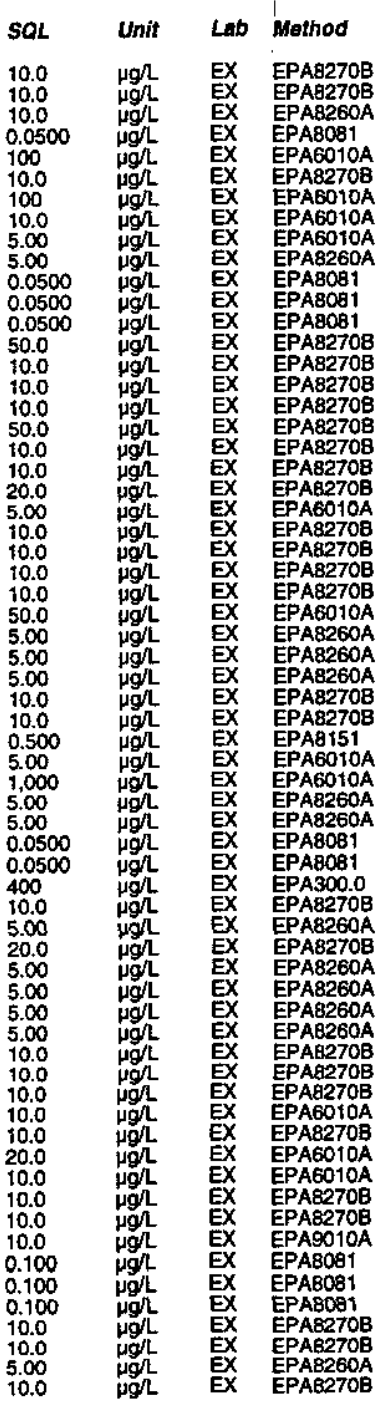

Second Quarter 1998 


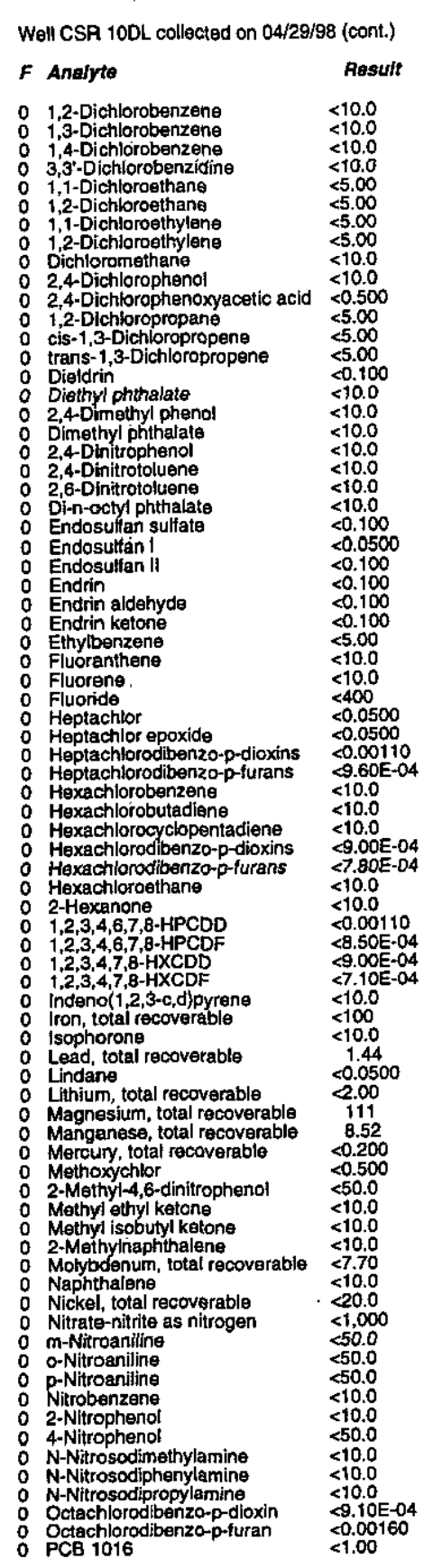

ESH-EMS-980569
Well CSR 10DL collected on 04/29/98 (cont.)

$F$ Anelyte

0
0 PCB 1221

$\begin{array}{ll}0 & \text { PCB } 1242 \\ 0 & \text { PCB } 1248 \\ 0 & \text { PCB } 1254\end{array}$

$\begin{array}{ll}0 & P C B \\ 0 & 1,2,3,7,8 \\ 0 & 1,2,3,7,6-P C D F\end{array}$

Pentachlorodibenzo-p-dioxin

Pentactiorodbenzo-pr

0 Phenanthrene

Phenol

Potassium, total recoverable

: Pyrene Selenium, total recoverable

Silica, total recoverable

o siver, total recoverable

: Specitic cond

0 Styrente

2,3,7,8-TCDD

- Tetrachlorodibenzo-p-dioxins

: Tetrachlorodibenzo-p-furans

T Tetrachloroethylene

Toluene

$\because$ Total dissolved solids

0
0 Total organic halogens
0

: Toxaphene

1 $1,2,4$-Trichlorobenzene

o 1,1,1-Trichloroethane

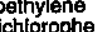

2,4,6-Trichlorophenol

Vanadium, total recoverab
0 Vinyl acetate

Zinnes

WELL CSR 10DL

MEASUREMENTS CONDUCTED IN THE FIELD

Sample date: 06/01/98

Water elevation: Not available

$\mathrm{HH}: 5.6$

p. conductance: $36 \mu \mathrm{S} / \mathrm{cm}$

Water evacuated from the well prior to sampling: $18 \mathrm{gal}$

ANALYSES

$F$ Analyte

O Acenaphthene

: Acetone

Aldrin

Antimony, total recoverab

Arsenic, total recoverable

Benzene

$3-89$
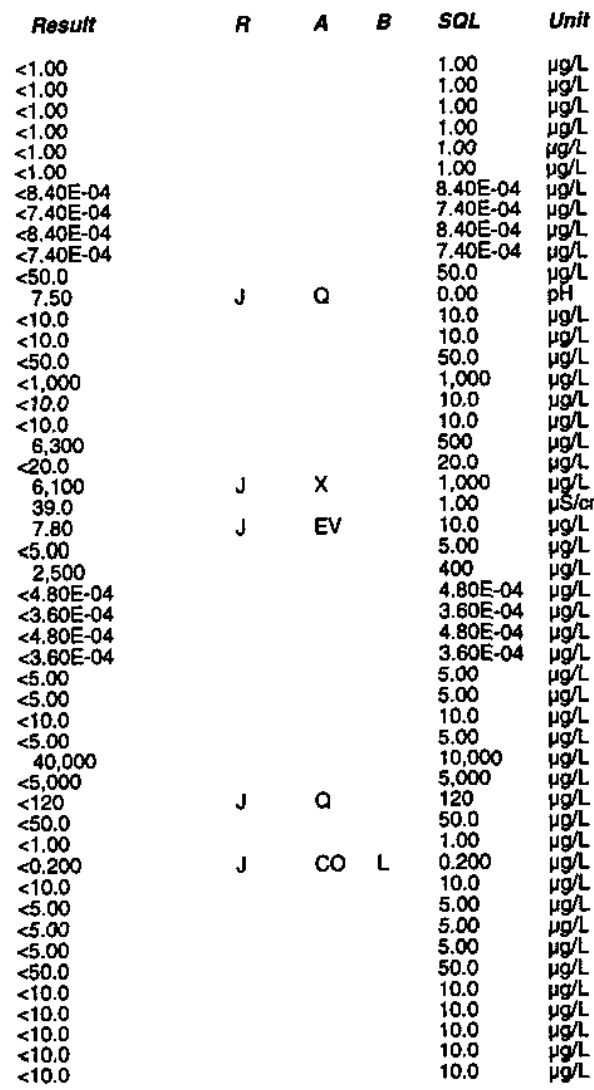

Unit Lab Wothod

$\begin{array}{ll}\text { EX } & \text { EPABOB1 } \\ \text { EX } & \text { EPABOB1 }\end{array}$

EX

WA EPAB280

WA

WA EPAE280

EX EPA150.1

EX EPA4270B

EX EPAB270B

EPABO10A

EX EPAGO10A

EX EPAEO10A

EPA300.

WA EPA8280

WA EPAB280

EPA6260A

EX EPAEO10A

EPA365.2

EPA8151

EX EPA8260A

EPA8260A

EPAB270B

EPAB260A

EPAG010A

ime: 15:54

Water temperature: $17^{\circ} \mathrm{C}$

Total alkalinity (as CaCO3): $5 \mathrm{mgh}$

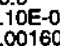

$9.10 E-04$
0.00160
1.00

WA EPAB280
EX EPAOB 1

Resutt
10.0
510.0
510.0
$<10.0$
10.0500
592
$<10.0$
39.3
30.0
17.0
5.00
55.00
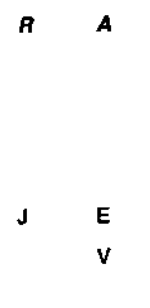

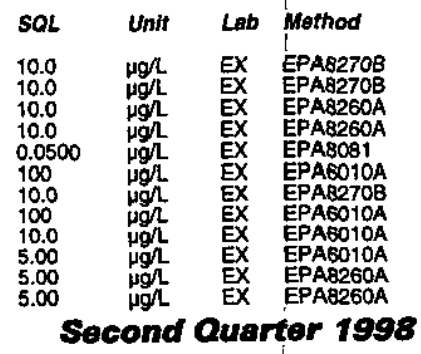


ANALYTICAL RESULTS

Well CSR 10DL collected on 06/01/98 (cont)

$F$ Analyte Result

0 alpha-Benzene hexachloride $<0.0500$
$<0.0500$
$<0.0500$ delta-Benzene hexachloride Benzo(a)anthracene Benzolkffluoranthene Benzo(g,h,i)perylen Benzyl alcohol Berylium, total recoverable
Bis(2-chloroethoxy) methane Bis (2-chloroethy) etther Bis (2-ethylhexyly) phithalate Bromodichloromethane Bromotorm Bromomethane 4-Bromophenyl phenyl ether Butyloenzyl phithalate O Cadmium, total recoverable - Carton disultide Carbon tistrachloride alpha-Chlordane o Chioride o Chlorobenzene 4-Chloro-m-cresol Chloroethane Chloroethane
Chloroesthene Vinyl chloride) Chloroform Chloromethane 2-Chloronaphthalen 4-Chlorophenyl phenyl ether Chrysene Cobatt, total recoverable : m/p-Cresol Cyanid P,P-DDD D.p-DDT
0 - Dibromochloromethane : Dibromochlorometh 1,2-Dichlorobenzene 1,4-Dichlorobenzenen 1,1-Dichlarobenzid 1,1-Dichloroethan 1,2 -Dichloroothane 1,1-Dichloroethylen 1,2-Dichloroethyiene : Dichloromethane

ESH-EMS-980569

Well CSR 10DL collected on 06/01/98 (cont)

$F$ Anaiyte

0 2,4-Dichtorophenol 1,2-Dichloropropane
1,2-Dichloropropane cis-1,3-Dichloropropen trans-1,3-2-Dichloropropene
trans-1,3-Dichloropropene 0
0 Diethyl phthalate
2,4-Dimethyl pheno 2,4-Dimethyl phene 2.4-Dinitrophenor Di-n-octyl phthalate Endosulian I Endrin Endrin aldehyde Echylbenzene Fluorene o Fluoride

Heptachlor epoxida Heptachlorodibenzo-p-dioxins Hexachlorobenzene Hexachlorobutadiens Hexachlorocyclopentadiene - Hexachlorodibenzo-p-p-flioxins Hexachloroethane 2. 2-Hexanone $1,2,3,4,6,7,8-\mathrm{HPCDO}$
$1,2,3,4,6,7,8-\mathrm{HPCDF}$ $1,2,4,7,8-H X C D D$ indeno(1,2,3-c,d)pyrene
iron, total recoverabie Isophorone Lindane Magnes Mercury, total recaverable 2-Methyl-4,6-dinitropheno : Methyl ethyl ketone Methyl isobutyl ketone 2-Methylnaphthalen Naphthalene mitrati-nitititie o-Nitroaniline

4 Nitropheno

$\mathrm{N}$-Nitrosodimethylamin N-Nitrosodipropyiamine Octachlorodibenzo-p-pioxin PCB 1016

$\begin{array}{lll}0 & P C B & 1221 \\ 0 & P C B & 1232\end{array}$
$\boldsymbol{R}$

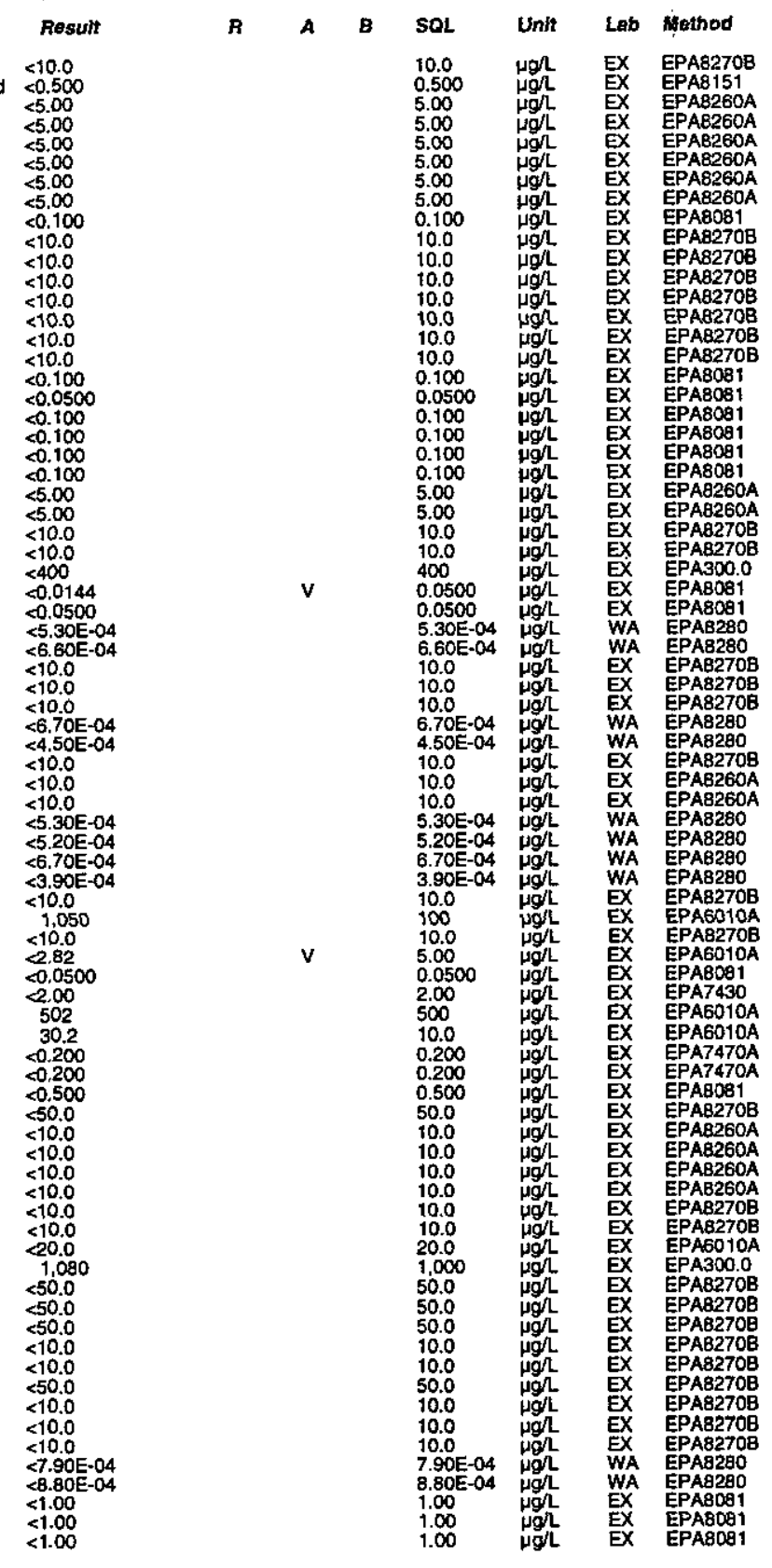

Second Quarter 1998 
Well CSR 10DL collected on 06/01/98 (cont.)

$F$ Ansiyte

0
0

PCB 1254

$1,2,3,7,8-P C D D$

Pentachlorodibenzo-p-dioxins

Pentachlorophen

Phenanthrene

Phenol

Polassium, total recoverable

Selenium; total recoverable

Silica, fotal recoverable

Sodium, total recoverab

Styrene

Sultate

$2,3,7,8-T C D D$

Tetrachiorodibenzo-p-dioxins

Tetrachlorodibenzo-p-turan

$1,1,2,2-$ Tetrachloroeth
Totrachloroethylene

Tetrachloroethylene

o. Toluenes

Total dissolved solids

Total organic halogens

2,4,5-TP (Sivex)

o 1,2,4-Trichlorobenzene

1.1.1-Trichloroethane

1,1,2-Trichloroethan

Tricthoroethylene

2,4,5-Trichloraphenol
$2,4,6$-Trichlorophenol

Vanadium, total recoverablo

o. Vinyl acotate

Zinc, total recoverable
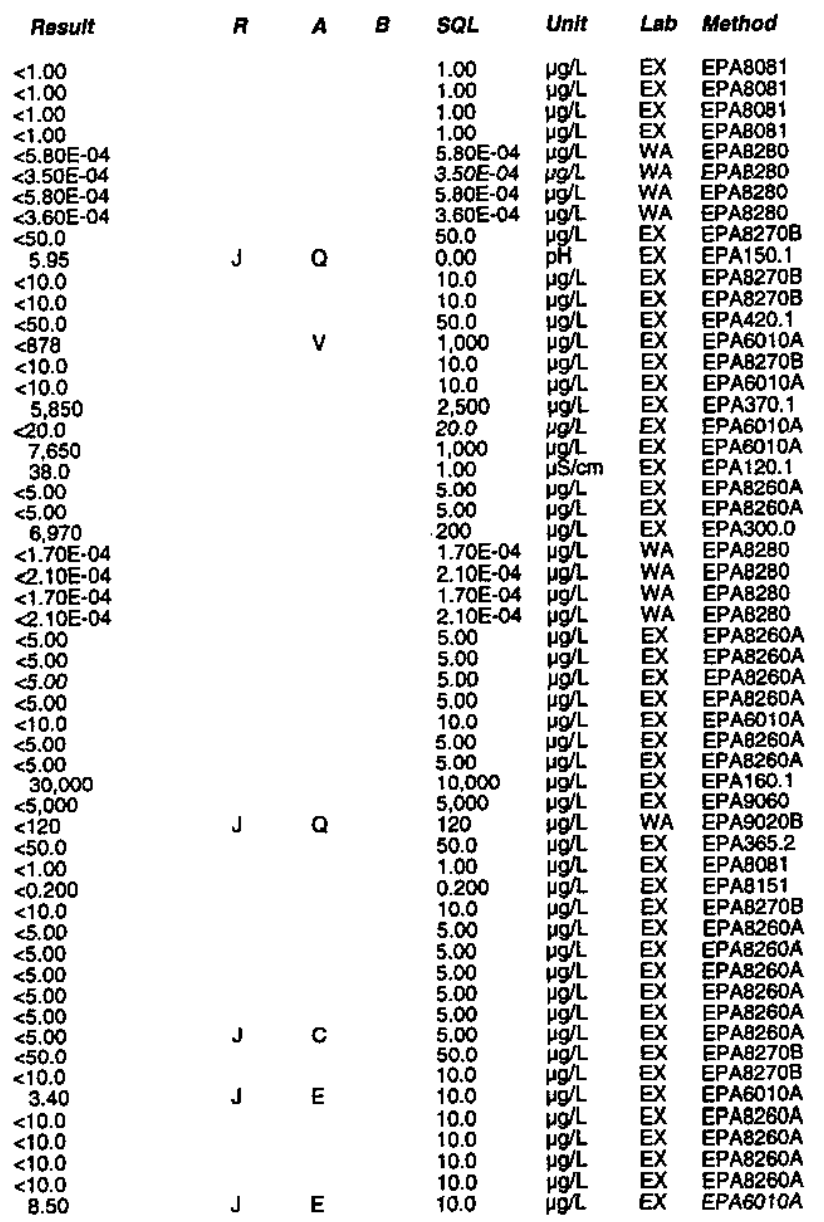

WELL CSR 10DU

MEASUREMENTS CONDUCTED IN THE FIELD

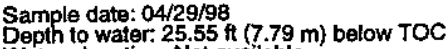

Depth 1 wh
Water e
gH: 5.5
Sp. con

5.5

Sp. conductance: $69 \mu \mathrm{S} / \mathrm{cm}$

Water evacuated from the well prior to sampling: $22 \mathrm{gal}$

ANALYSES

$F$ Aralyte

Acenaphthene
0 Acenaphthylene

O Acetone

O Anthracene

ESH-EMS-980569
Well CSR 10DU collected on 04/29/98 (cont.)

F Analyte

0 alpha-Benzene hexachloride

Resuit

deta-Benzene hexachloride

$<0.0500$
$<0.0500$

Benzidine

Benzo(b) fluoranthene

Benzoic acid

Benzo(a)pyrene

Bis (2-chloroethoxy) methane

Bis (2-chloroethyl) ether

Bis(2-ethythexyl) phinala

Bromoform

4-Bromophenyl phenyl ether

Butylbenzyl phthalate

2-sec-Butyl-4,6-dintro

Carbon terrachloside
alpha-Chlordane

gamma-Chlordan

4-Chloroaniline

4-Chloro-m-cresol

Chloroethene (Vinyl chloride)

Chloroform

2-Chomernaphthalen

4-Chlorophenyl phenyl ether

Chrysene

o-Cresol (2-Methylphenol)

: Cyanide

P,P-DDE

Dibenz(a,h)anthracene

Dibenzofuran

Dibromoctiloromethan

: 1,2-Dichlorobenzene

1.4-Dichlorobenzene

1,1-Dichloroethane

1,2-Dichloroethane

1,2-Dichloroethylene

2,4-Oichlorophenol

2,4-Dichlorophenoxyacetic acid

cis-1,3-Dichloroprop

trans-1,3-Dichloropropen

Diethyl phthalate

2,4-Dimethyl phenol

Dimethyl phthalate

2,4-Dinitrotoluen

Di-Dinctrol phthalate

Endosulfan II

Endrin

o Ethylbenzene

3-91
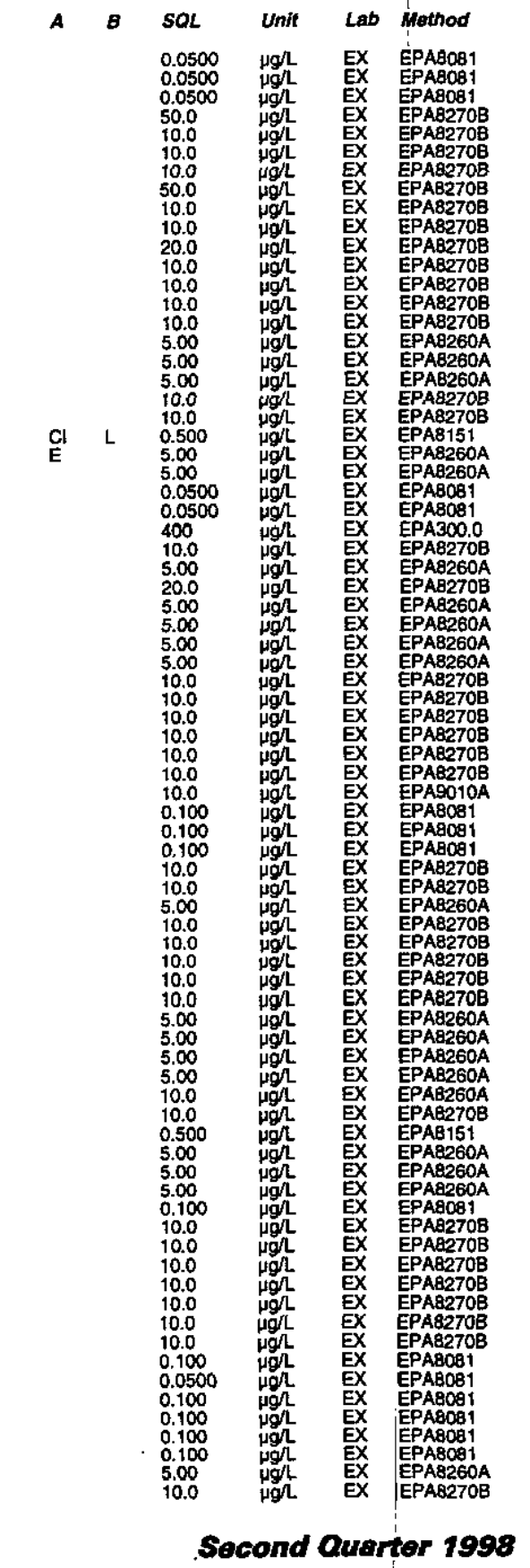
ANALYTICAL RESULTS

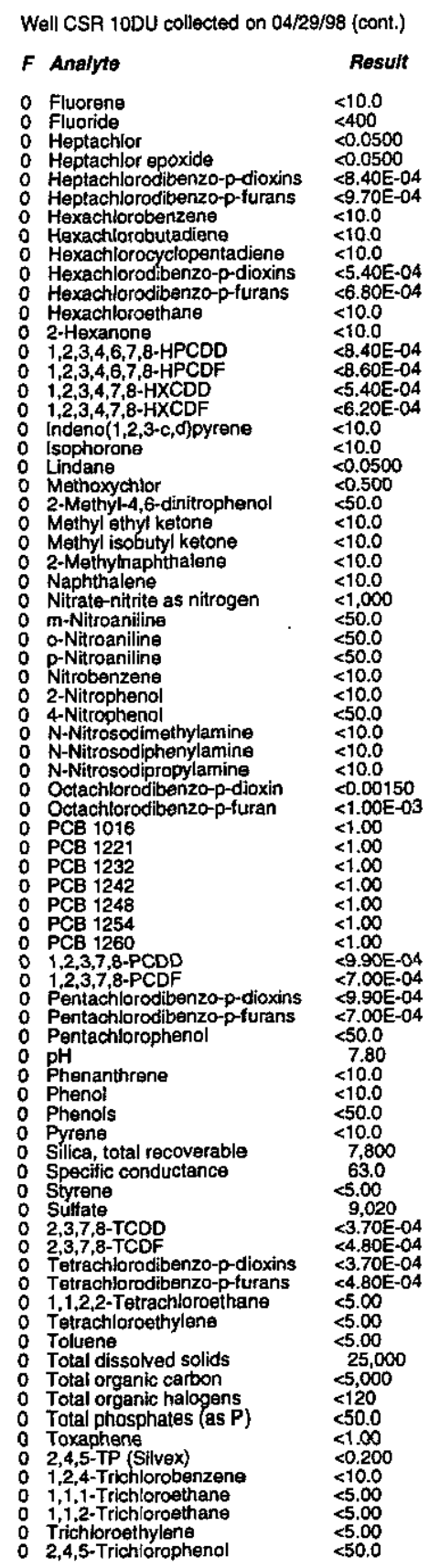

ESH-EMS-980569
Well CSR 10DU collected on 04/29/98 (cont.)

\begin{tabular}{|c|c|c|c|c|c|c|c|c|}
\hline$F$ Ansilyte & Result & $B$ & A & $B$ & SOL & Unit & Lab & Method \\
\hline $\begin{array}{ll}0 & 2,4,6-\text { Trichlorophenol } \\
0 & \text { Vinyl acetate } \\
0 & \text { Xylentes }\end{array}$ & $\begin{array}{l}<10.0 \\
<10.0 \\
<10.0\end{array}$ & & & & $\begin{array}{l}10.0 \\
10.0 \\
10.0\end{array}$ & $\begin{array}{l}\mu g / 2 \\
\mu g / 2 \\
\mu g / L\end{array}$ & $\begin{array}{l}\text { EX } \\
\text { EX } \\
\text { EX }\end{array}$ & $\begin{array}{l}\text { EPAB270B } \\
\text { EPA8260A } \\
\text { EPA8260A }\end{array}$ \\
\hline
\end{tabular}

\section{WELL CSR 10DU}

MEASUREMENTS CONDUCTED IN THE FIELD

Sample date: $06 / 1 / 98$
Depth to water: $25.25 \mathrm{ft}(7.7 \mathrm{~m})$ below TOC
Water

Water elevation: Not available

$\mathrm{gp}$. conductance: $42 \mu \mathrm{S} / \mathrm{cm}$

(a): $16^{\circ} \mathrm{C}$

Total akalinity (as CaCO3): $8 \mathrm{mgh}$
Phenolphthalein alkalinity: $0 \mathrm{mgh}$

Water evacuated from the well prior to sampling: $20 \mathrm{ga}$

ANALYSES

F Anatyte

o. Acenaphthene

Acetone

2 Aluminum, total recoverable

Anthracene
Antimony, total recoverable

Ansenic, total recoverable

Berime

alpha-Benzene hexachloride

Benziding

Benzo(a)anthracene
Benzoofbffluoranthene

Benzo (k) fluoranthene

Benzolappyrene

Beryllum, total recoverable

Bis(2-chloroethoxy) meth
Bis(2-chloroethyl) ether

0 Bis 2-chloroisopropyl) ethe

Bis(2-ethylhexply phthala

0 Bromodichioro

Bromomethane
4-Bromotheny phenyl ether

Butyibenzyl phthalate

C Cadmium, total recoverable

- Calcium, total recoverab

Carbon tetrachlorido

gamma-Chlordan

Chloride

4-Chloroaniline
Chlorobenzene
4-Chloro-m-cresol

Chloroethane

Chlorosiorm

2-Chloronnaphithalene

4-Chlorophenyl phenyl ether Chromium, total recoverable

o coball, total recoverable

m/p-Cresol

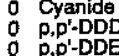

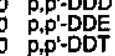
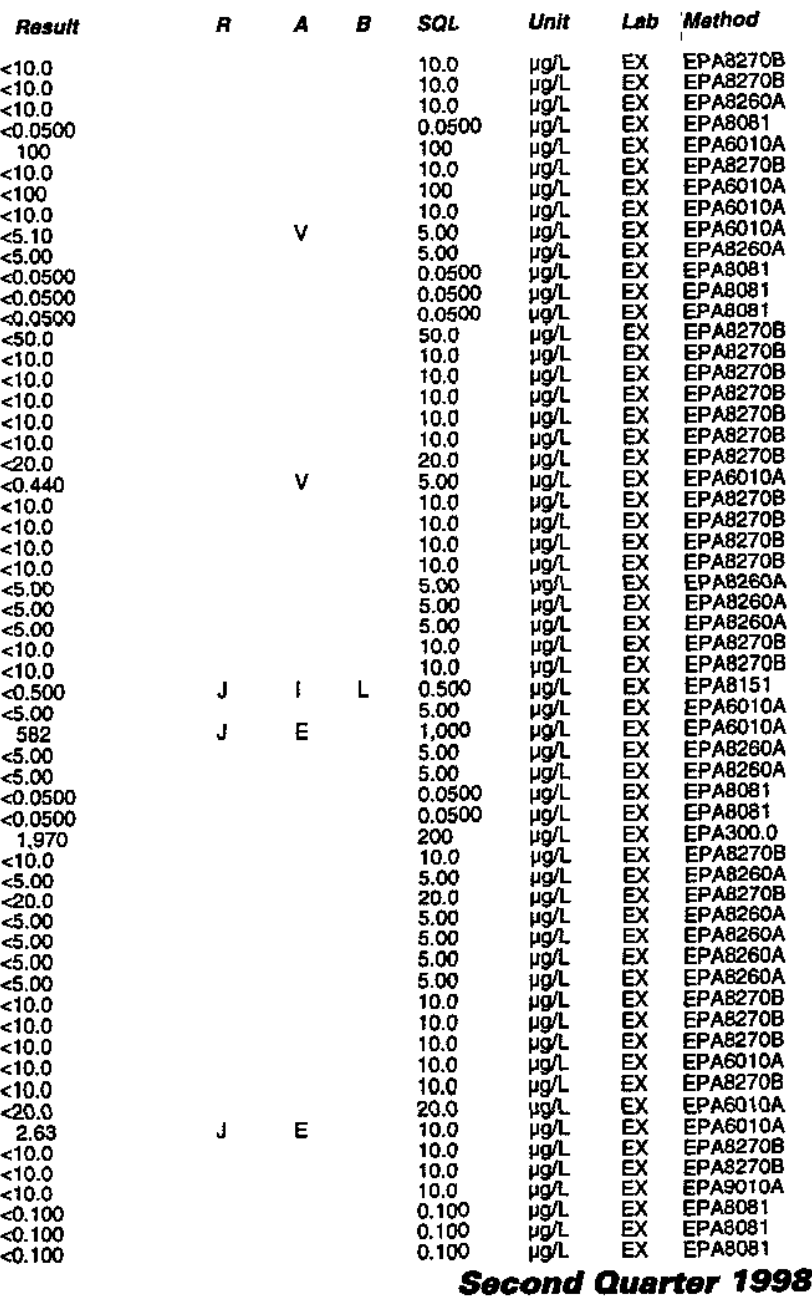
Well CSR 10DU collected on 06/01/98 (cont.)

$F$ Analyte

0 Dibenz(a,h)anthracene

Diberomochloromethane

Di-n-butyl phthalate

1,3-Dichlorobenzene

$\begin{array}{ll} & 1,4-\text { Dichlorobenzene } \\ 0 & 3,3^{\prime} \text {-Dichlorobenzidine }\end{array}$

1,1-Dichloroethane

1,1.-Dichlaroethylen

Dichloromethane

2,4-Dichlorophenof

cis-1,3-Dichloropropene

trans-1,3-Dichloropropene

Diethyl phithalate

Dimethyl phthalate

2,4-Dinitrotoluene

D.

Endosulfan sult

Endosuitan 1

Endrin aldehyde

Ethylbenzente
Fluoranthene

Fluorene

Hivoride

Heptachlor epoxide

Heptachlorodinenzo-p-dioxans

Hexachlorobenzene

Hexachlorocyclopentadiene

Hexachlorodibenzo-p-diloxins

Hexachloroethan

$2-H e x a n o n e$
$1,2,3,4,6,7,8-H P C D D$
$1,2,3,4,6,7,8-H P C D F$

$1,2,3,4,7,8, H X C D D$

Indeno $(1,2,3-c, d) p y r e n e$
iron, total recoverable

Lead, total recoverable

Lithium, total recoverable Manganese, total recoverable

y, total recoverable

2-Mextyyl-4,6-dinitrophen

Methyl isobutyl keton
$2-$ Methylnaphthalene

Naphthalene

Nickel, total recoverable

m-Nitroaniline
o-Nitroanliting

p-Nitroanilize

Nitrobenzene

N-Nitrosodimethylamine

N-Nitrosodipropylamine

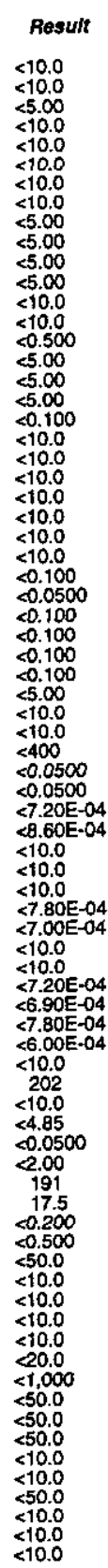

ESH-EMS-980569
Well CSR 10DU collected on 06/01/98 (cont.)

$F$ Analyte

- Octachiorodibenza-p-dioxin

PCB 1016
0
PCB 1221

O PCB 1242

0 PCB 1254

$\begin{array}{ll}0 & 1,2,3,7,8-P C D D \\ 0 & 1,2,3,7,8 C D F\end{array}$

- Pentachlorodibenzo-p-dioxin

Pentachlorodibenzo-p-furan

$\mathrm{pH}$ -

Phenol

Phenols

Pyrene Selenium, total recoverable

Sijica, total recoverable

Sodium, total recover

Styrene

$2,3,7,8-\mathrm{TCDD}$
$2,3,7, \mathrm{TCDF}$

Tetrachlorodibenzo-p-dioxins

Tetrachiorodibenzo-p-furans

Tetrachloroethylene

Toluene

Total organic carbon

Total organic halogens

0 Toxaphene

1,2,4-Trichlorobenzene

- $1,1,1,-$ Trichloroethane

2,4,5-Trichloropheno

Vanadium, total recoverable
Vand

: Vinyl acetate

- Zinc, total recoverable

WELL CSR 11DL

MEASUREMENTS CONDUCTED IN THE FIELD

Sample date: 04/29/98

Wapt to water: Not available

SH: Not available Not avaílable

$<0.00110$

$<\begin{aligned} & <.00 \mathrm{E}-04 \\ & <1.00\end{aligned}$

$<1.00$
$<1.00$
$<1.00$
$<1.00$

$<6.70 E-04$

$<6,70 \mathrm{E}-04$
$<\mathrm{B}, 70 \mathrm{E}-04$

$<50.0$
6.02
$<10.0$
$<10.0$

$<10.0$
$<50.0$
$<1,620$
$<10.0$

$<10.0$
8,200
$<20.0$
7,220

39.0
$<5.00$
4,200

$<4.40 \mathrm{E}-04$

$<5.400$

$<5.00$
$<100$
$<5.00$

30,000
5,000

$<5,000$
$<120$
$<50.0$
$<1.00$
$<0.200$
$<10.0$
$<5.00$
5.00
$<5.00$
$<50.0$
$<10.0$
$<10.0$
$<10.0$
$<10.0$
15.9

$<50.0$
$<1.00$
$<0.200$
$<10.0$
$<5.00$
$<5.00$
55.00
$<50.0$
$<10.0$
$<10.0$
$<10.0$
$<10.0$
15.9

No water was evacuated from the well prior to sampling.

ANALYSES

Rosult
$<10.0$
$<10.0$
$<10.0$
$<0.0500$
$<10.0$
55.00
$<0.0500$
50.0500
$<0.0500$
$<50.0$

: Acenaphthene

O Acettone

Anthracene

alpha.Benzene hexachlorido

deta-Benzene hexachloride

B-93

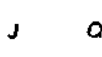

A A B SQL Unit Lab Method

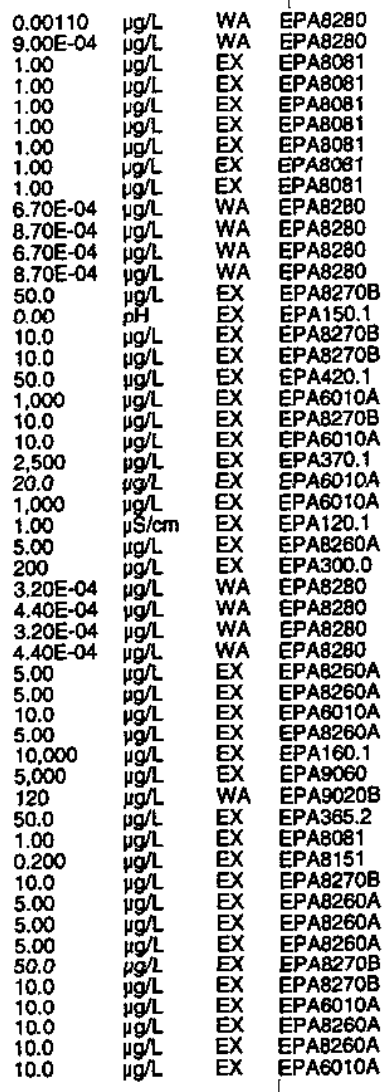

Time: Not available

Nir : Not available

Total akalinity (as CaCO3) Not available

$\therefore \quad \because \because \cdots$ 
Well CSR 1 TDL collected on 04/29/98 (cont.)

\begin{tabular}{|c|c|}
\hline Analyte & Resul \\
\hline 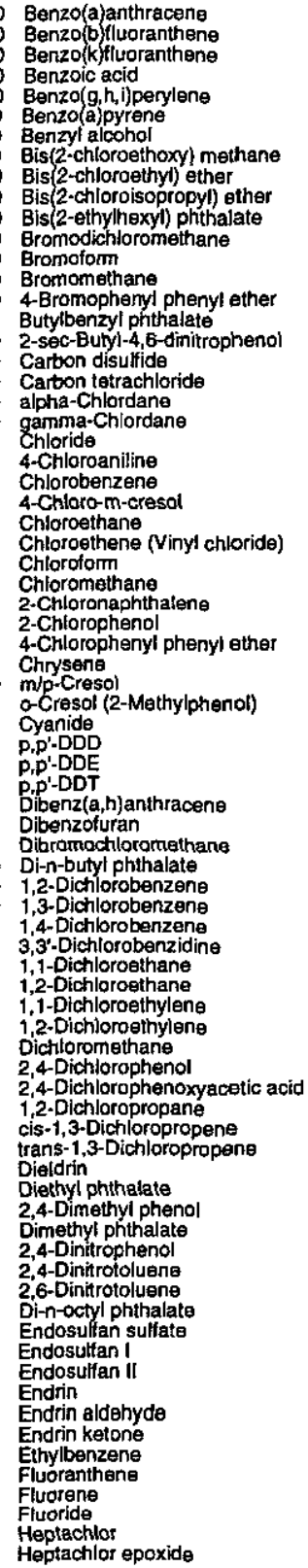 & $\begin{array}{l}<10.0 \\
<10.0 \\
<10.0 \\
<50.0 \\
<10.0 \\
<10.0 \\
20.0 \\
<10.0 \\
<10.0 \\
<10.0 \\
<10.0 \\
<5.00 \\
<5.00 \\
<5.00 \\
<10.0 \\
<10.0 \\
<0.500 \\
<5.00 \\
<5.00 \\
<0.0500 \\
<0.0500 \\
2,000 \\
<10.0 \\
<5.00 \\
20.00 \\
<5.00 \\
<5.00 \\
<5.00 \\
<1.00 \\
<10.0 \\
<10.0 \\
<10.0 \\
<10.0 \\
<10.0 \\
<10.0 \\
<10.0 \\
<0.100 \\
<0.100 \\
<0.100 \\
<10.0 \\
<10.0 \\
<5.00 \\
<10.0 \\
<10.0 \\
<10.0 \\
<10.0 \\
<10.0 \\
<5.00 \\
<5.00 \\
<5.00 \\
<5.00 \\
<10.0 \\
<10.0 \\
<0.500 \\
<5.00 \\
<5.00 \\
<5.00 \\
<0.100 \\
<10.0 \\
<10.0 \\
<10.0 \\
<10.0 \\
<10.0 \\
<10.0 \\
<10.0 \\
<0.100 \\
<0.0500 \\
<0.100 \\
<0.100 \\
<0.100 \\
<0.100 \\
<5.00 \\
<10.0 \\
<10.0 \\
<400 \\
<0.0500 \\
<0.0500\end{array}$ \\
\hline
\end{tabular}

ESH-EMS-980569
Well CSR 11DL collected on 04/29/98 (cont.)

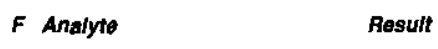

Heptachlorodibenzo-p-dioxins $<9.70 \mathrm{E}-04$

Hexachlorobenzene

$<6.60 \mathrm{E}-04$

Hexachlorocyclopentadiente $<10.0$

Hexachlorodibenzo-p-dioxins $<7.90 E-04$

$\begin{array}{ll}\text { Hexachlorodibenzo-p-furans } & <5.30 \\ \text { Hexachloroothane } & <10.0\end{array}$

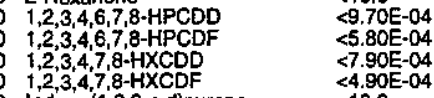

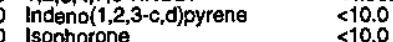

Lindane

Methoxychlor

Methyl ethy ketone

2-Methyl isobry keton

Naphthalene
Nitrate-nitrite as nitrogen

m-Nitroaniling

Nitrobenzeniline

2-Nitrophenol

$\mathrm{N}$-Nitrosodimethylamine

N-Nitrososodiphenpylamine

Octachlorodibenzo-p-dioxin

PCB 1016

PCB 1232

O PCB 1248

PCB 1260
0
$1,2,3,7,8-P C D O$

Pantachlorodibenzo-p-dioxin

Pentachlorodibenzo-p-turans

Pentachloropheno

Phenanthrene

Phenols

S Syrene

Specific conductance

: Styrene

: 2,3,7,8-TCDD

Tefrachlorodibenzo-p-dioxins
Tetrachlorodibenzo-p-furans

1,1,2,2-Tetrachloroethan

Tetrachloroethylene

Toluene

Total dissolved solids
Total organic carbon
Total organic halogen

Total phosphates (as P)

2,4,5-TP (Silvex)

1,2,4-Trichlorobenzene

1,1,2-Trichloroethan

Trichloroethylene

$2,4,6$-Trichloropheno
Vinyl acetate

O Vylenes

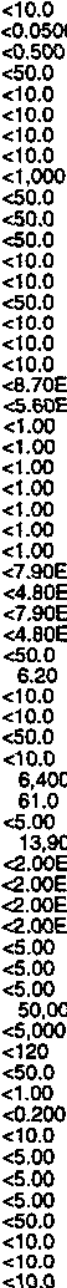

$<8.70 E-04$

$<1.00$

$<1.00$

$<1.00$

$<4.80 \mathrm{E}-04$
$<7.90 \mathrm{E}-04$
$<4.80 \mathrm{E}-04$

$<50.0$

$<10.0$
$<50.0$
$<10.0$

$<10.0$
6,400
61.0
$<.00$

$<5.000$

$<2.00 \mathrm{E}-04$

$<5.00$

$<5.00$
50.000
-5.000

$<120$

$<50.0$
$<1.00$
$<0.200$
$<10.0$
$<5.00$
$<5.00$
$<5.00$
$<50.0$
$<10.0$
$<10.0$
$<10.0$

A

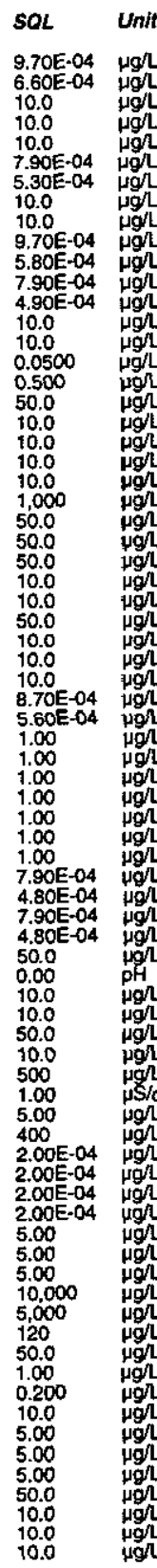

ab Mothod

WA EPAB280

$X P A 8270 B$
$X P A 270 B$

WA EPAB280

X EPAB270B

WA EPA8280

WA EPA8220

EPA8270B

EPA8081

EPAB270B
EPA8260A
EPA

EPA8270B

EPA300.0

EPA8270B

EPAB270B

EPAB2708

EPA82708

WA EPAB280

EPABOB1

EPABOB1

EPABOS

WA

WA EPA8280

EPA82708
EPAB270B

EPA82708

EPA8270B
EPA370.1
EPA120.1

EPA300.

EPA

EPAB26

EPA8260A

EPA160.1

EPA90208

EPABi51

EPAB270B

EPA8260A

EPA8270B

EPAB260A 


\section{WELL CSR 11DL}

MEASUREMENTS CONDUCTED IN THE FIELD

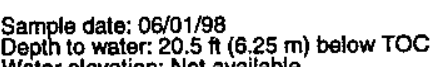
Wepth to water: $20.5 \mathrm{ft}(6,25 \mathrm{~m})$ $\mathrm{pH}$ : 5 conductance: $66 \mu \mathrm{S} / \mathrm{cm}$

Water evacuated from the well prior to sampling: $30 \mathrm{gal}$

ANALYSES

F Analyte

O. Aconaphthene

Acenaph
0 Acetone
0 Aldrin

Aluminum, total recoverable

Antimony, lotal recoverable

Arsenic, total recoverable

beta-Benzene hexachloride

delta-Benzene hexachloride

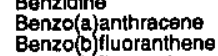

Benzo (k) ffluoranthene

Benzo(a)pyrense

Bernilium, total recoverable

Bis(2-chloroothoxy) methan
Bis 2-chloroethyl) ether

Bis (2-chloroisopropyl) ether
Bis(2-ethylhexyl) phthalate

Bromodichloromethane

Bromomethan

4-Bromophenyl phenyl ether

2-sec-Buty|-4,6-dinitrophenol

Calcium, total recoverable

Carbon disulfidi
alpha-Chtoriontloride
ane

gamma-Chlordan

4-Chloroanilin

4-Chloro-m-cresol

Chloroothethene Vinyl chloride)

Chloroform

2-Chloronaphthalen

4-Chloropphenenyl phenyl ether

Chrysene

Cobal, total recoverable
Copper, total recoverable

Copper, total recoverable
mip-Cressol
o-Cresol (2-Methylphenol)

0 Cyanide

p.,

Dibenz(a,h)anthracene

Dibromochloromethane

Di-n-butyl phthalate

1,2-Dichlorobenzen

ESH-EMS-980569
Well CSR 11DL collected on 06/01/98 (cont.)

\section{$F$ Analyte}

Time: 17:00

Ar temperature: $38.4^{\circ} \mathrm{C}$

Total apkainiy (as CaCO3): $3 \mathrm{mg} / \mathrm{L}$

o 3,3'-Dichlorobenzidine

1,2-Dichloroethane

1.2-Dichloroethylene

Dichloromethane

2,4-Dichlorophenoxyacetic acid

1,2-Dichloropropane

trans-1,3-Dichloropropene

: Diethyl phthalate

Dimethyl phthalate

2,6-Dinitrotoluene

Di-n-octyl phthalate

Endosulfan I

\section{Endrin Endrin aldehyde}

Endrin ketone

Fluoranthen

0 Fluorene

Heptachlor

Heptachlorodibenzo-p-dioxins

Heptachlorodibenzo-p-turan

Hexachlorobenzene
Hexachlorobutadiene

Hexachlorocyclopentadiens

Hexachlorodibenzo-p-p-furans

2-Hexanone

$0.2,3,4,6,7,8-\mathrm{HPCD}$
0
$1,2,3,4,6,7,8-\mathrm{HPCDF}$

1, $1,2,3,4,7,8-4 X C D D$

Indeno(1,2,3-c,d)pyren

0 isophorone

Lead, tota

Lindane

Magnesium tocoverable

- Manganesa, total recoverable

Mercury, total recoverable

2-Methyl-4,6-dinitrophenol

Methyl ethyl ketone

- Methyl isobutyl keton

- Naphthalene

No Nickel, total recoverable

o o-Nitroaniling

: Nitrobenzen

4-Nitropheno

N-Nitrosodimethylamine

N-Nitrosodiphenylamine

o Octachlorodibenzo-p-dioxin

PCB 1016

0 PCB 1232

0 PCB 1248

B-95
Result

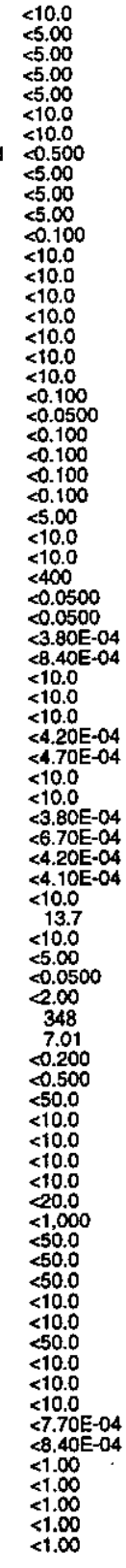

$A$

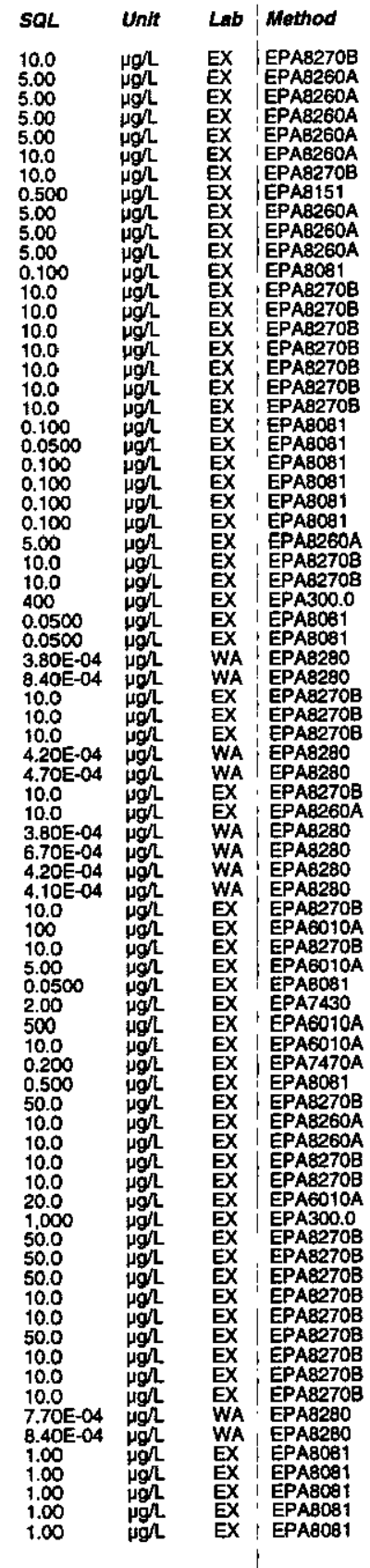

Second Quarter 1998 
Well CSR 11DL collected on 06/01/98 (cont.)

0 PCB 1254

$1,2,3,7,8-P C D D$
0

Pentachloroctibenzo-p-dioxins Pentachlorophen

Phenanthre

Phenols

Potassium, total recoverable

Selentium, total recoverable

Silica, total recoverable

Sodium, total recoverable

: Styrene

Sulfate
$2,3,7,8$-TCD

Tetrachlorodibenzo-p-dioxin

Tetrachlorodibenzo-p-turans

Thellium, total recoverable

Total dissolved solids

Total organic carbon

Total phosphatos

Tox,phen

1,2,4-Trichlorobenzen

1, 1,2 -Trichloroethan

$2,4,5$. Trichlororophen

Vanadium, total recoverable

Vinyl acetate

O Zinc, total recoverabl

\section{WELL CSR 11DU}

MEASUREMENTS CONDUCTED IN THE FIELD

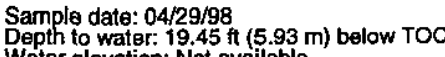

Water

p. conductance: $22 \mu \mathrm{S} / \mathrm{cm}$

urbidity: $\mathrm{N}$ TTU: $22 \mu \mathrm{S} / \mathrm{cm}$

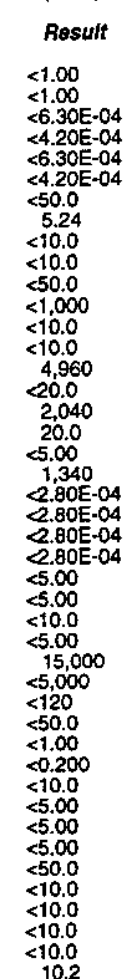

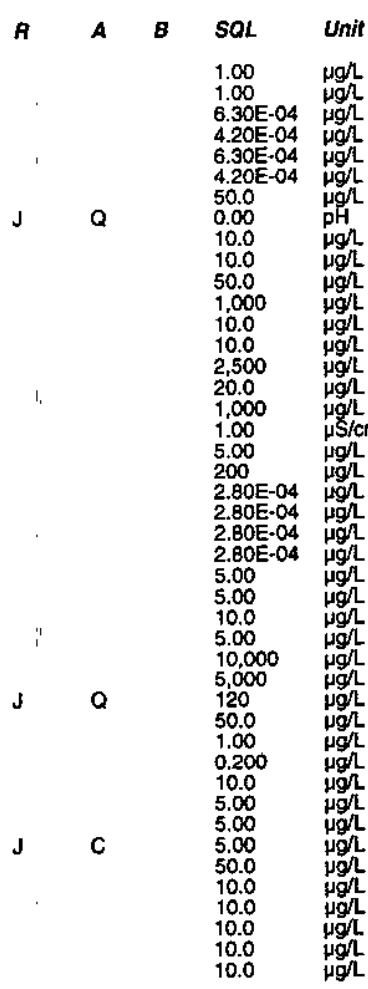

Well CSR 110 collected on 04/29/98 (cont.)

Dibromochloromethan

ANALYSES

$F$ Aralyto

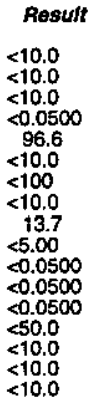

Air temperperature: $20^{\circ} \mathrm{C}$

Total alkalinity (as CaCO3); $4 \mathrm{mg} / \mathrm{L}$
Phenolphthalein alkalinity: $0 \mathrm{mg} / \mathrm{L}$

: Acenaphthene

Acetone

Aldrin

Anthracene

Arsenic, total recoverable
Barium, total recoverable

Benzene

beta-Benzene hexachloride
delta-Benzene hexachloride

Benzidine

Benzo(b) fluoranthene

ESH-EMS-980569

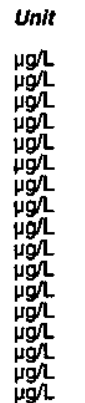

Lab Method

$\begin{array}{ll}\text { EX } & \text { EPA8270B } \\ \text { EX } & \text { EPA8270B } \\ \text { EX } & \text { EPA8260A } \\ \text { EX } & \text { EPACB1 }\end{array}$

EX EPAGO10A

EPAG010A

EPAG010A

EPABOB1
EPABOB1

EPA8081
EPA8270B
EPA82708

EX EPAB2708
F Ansiyto

O Benzoic acid

$<50.0$

- Benzola)pyren

Beryllium, total recoverable
Bis (2-chlorogthoxy) methan

Bis 2-chloroethyl) ether

Bis(2-ethylhexyl) phthalate

Boron, total recoverab

0 Bromoform

4-Bromophenyl phenyl ether

2-sec-Butyl-4,6-dinitropheno

- Cadmium, total recoverable

- Carbon disulfide

alpha-Chlordane

o ghioride

4-Chloroaniline

: Chlorobenzene

Chloroethene (Vinyl chloride) Chloroform

2-Chioronaphthalen 4-Chlorophenyl phenyl athe

Chrysene

Cobali, total recoverable

o-Cresol (2-Methytphenol)

Pyanide

p,p'-DOE

Dibenz (a,h)anthracene

Dibenzofuran

1.2-Dichlorobenzen

1,4-Dichlorobenzene

3,3'-Dichlorobenzidine

1,1-Dichloroethane

1,i-Dichloroethylene

Dichloromethane

2,4-Dichlorophenol 1,2-Dichloropropane

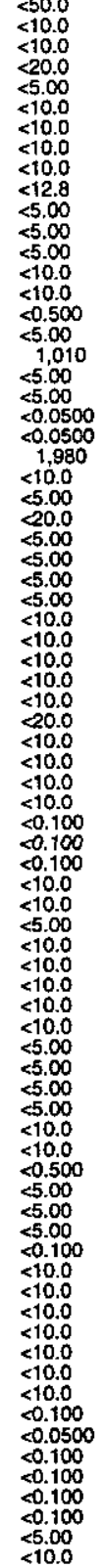

A

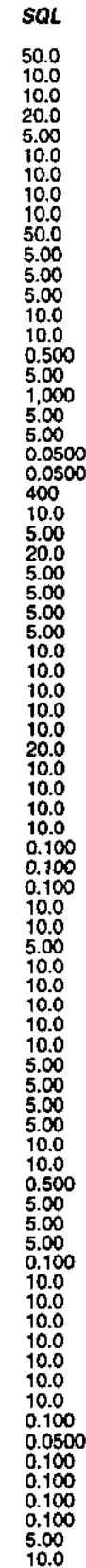

Dietthy' phthalate

2.4-Dirnethyl phen

2,4-Dinitrophenol

2,6-Dinitrotoluduene

Di-n-octyl phthatate

Endosutian I

Endrin aldehyde

E Etrylbenzene

$-96$

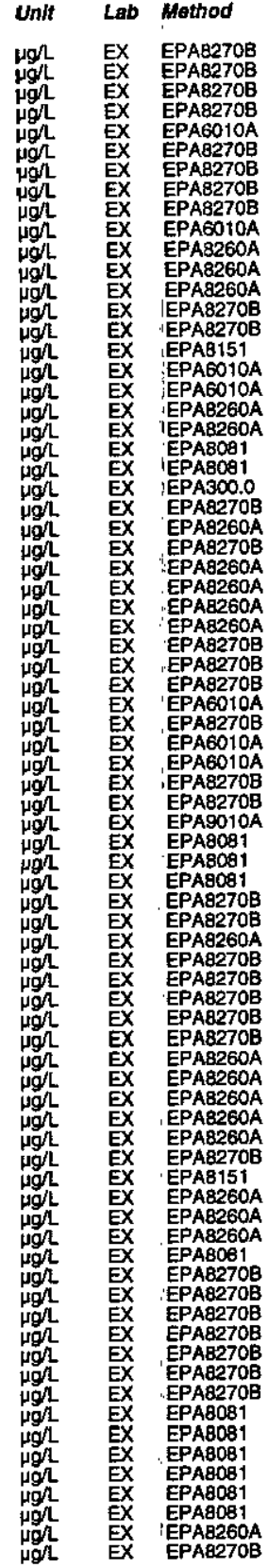

Second Quarter 1998 
Well CSR 11 DU collected on 04/29/98 (cont.)

$F$ Analyto

Fluorene

$\begin{array}{ll}\text { Heptachlór } & <10.0 \\ & <00 \\ \text { Heptachlor epoxide } & <0500\end{array}$

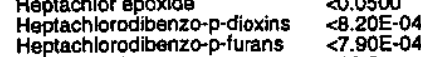

$\begin{array}{ll}0 & <10.0 \\ 0 & \text { Hexachlorobenzene }\end{array}$

Hexachforocyclopentadiene $<10.0$

Hexachiorodibenzo-p-dioxins $<9.30 \mathrm{E}-04$

Hexachloroethane

1.2,3,4,6,7,8-HPCDD

$1,2,3,4,7,8-\mathrm{HXCDD}$

indeno(1,2,3-c,d)pyrene

Isophorone

- Lithium, total recoverable

Magnesium, total recoverable

Mercury, total recoverable

Methoxychlor
2-Methyl-4,6-dinitrophenol

Methyl ethyl ketone

2-Methylnaphthalenie

Nickel, total recoverable

mintritroaniline

p-Nitroaniline

2-Nitrophenonol

N-Nitrosodimethylamine

N-Nitrosodiphenylamine

Octachlorodibenzo-p--dioxin

Octachloro

PCB 1232

0 PCB 1248

1,2,3,7,8-PCDF

Pentactilorodbenzo-p-dioxin

lorophen

Phenanthrene

Phenol

Potassium, total recoverable

Selenfium, total recoverable

Silica, total recoverable

Siver, total recoverable

Specific conductance

Sultate
$2,3,7,8 \cdot T C D D$
$2,3,8 . T C D F$

Tetrachlorodibenzo-p-dioxins

Tetrachlorodbenzo-p-furans

ESH-EMS-980569

$<10.0$

$<8.20 E-04$
$<7.10 E=04$
$<9.30 E-04$

$<4.90 \mathrm{E}-04$

$<10.0$

$<10.0$
$<5.00$
$<0.0500$

340
15.6
$<0.200$

$<0.200$
$<50.0$

$<10.0$
$<10.0$

$<10.0$
$<50.0$

$<20.0$
$<1,000$
$<50.0$

$<50.0$
$<50.0$
$<10.0$

550.0
$<10.0$
$<100$

$<10.0130$
80.0130140
0.00140

$<1.00$

\begin{tabular}{l}
$<1.000$ \\
$<1.00$ \\
$<1.00$ \\
\hline
\end{tabular}

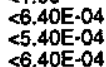

$<6.40 E-04$

$<50.0$

6.30
$<10.0$
$<10.0$
$<50.0$
$<1,900$
$<10.0$
$<10.0$
5,5000
$<20.0$
2,480
20.0
7.24
45.00
1.740
$<3.60 .-04$
$2.10 E-04$
$<3.606 .04$
$2.10 E-04$
A A B SOL Unit Lab Mothod

$10.0 \quad \mu g / L$

EX EPA8270B

EX

WA EPAB280

87.2

WA
WA
WA
WABA2B
WA EAB280
EX EPAB280
Well CSR 1 1DU collected on 04/29/98 (cont.)

F Analyte

- Tetrachloroethylene

Result

Toluene total recover

Total organic carbon

Total oposphates (as P)

- 2,4,5-TP (Sivex)

o $1,2,4$-Trichorobenzen

1,1,2-Trichlorostha

Zinc, total recoverable

WELL CSR 11DU

MEASUREMENTS CONDUCTED IN THE FIELD

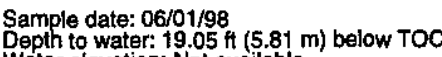

Water elevation: Not availabl
pH: 4.6
Sp. conductance: $22 \mu \mathrm{S} / \mathrm{cm}$

sp. conductance: $22 \mu \mathrm{S} / \mathrm{cm}$

WNATS

$F$ Analyte

- Acenaphthene

Acetone

2 Aldrin

0 Antimony, total recoverable

O Arsenic, total recoverable

O Benzene

beta-Benzene hexachioride
deta-Benzene hexachloride

Benzidine

Benzo(a)anthracene

Benzol fyluoranthene

Benzo(g,h,i)perylen

Benzo(a)pyrene

Berylium, total recoverable

Bis(2-chloroethoxy) methan

Bis(2-chlorosthyl) ether

Bis(2-ethylhexl') phithalat

Bromodich

4-Bromophenyl phenyl ether

2-sec-Buty-4,6-dinltiropheno

Calcium, total recoverable

Carbon disultido

- Carbon tetrachloride

gamma-Chlordan

4 Chloride
0
0

Chlorobenzene
4-Chloro-m-creso

Chloroethane

$\mathbf{B - 9 7}$

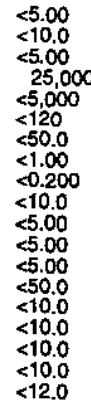

$<10.00$
$<5,0000$
25,000
$<1,000$
$<50.0$
$<1.00$
$<0.200$
$<10.0$
$<5.00$
55.00
55.00
$<50.0$
$<10.0$
$<10.0$
$<10.0$
$<10.0$
$<12.0$

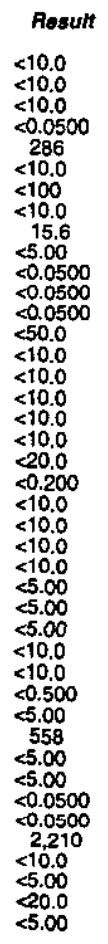

$\begin{array}{ll}0 & 2,4,5-\text { Trichloropheno } \\ 0 & 2,4,6 \text {-Trichlorophen }\end{array}$

Vanadium, total recoverable

A A B SOL Unit LAb Method

$\begin{array}{llll}5.00 & \mu g / L & \text { EX } & \text { EPA8260A } \\ 10.0 & \text { EX } & \\ 5 & \text { EPAG010A }\end{array}$

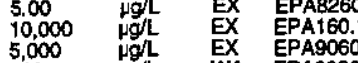

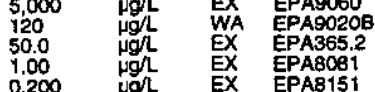

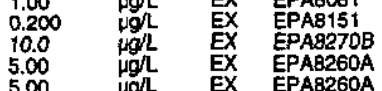

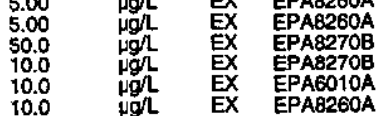

$\begin{array}{llll}10.0 & \mu g h & \text { EX } & \text { EPAG010A } \\ 10.0 & \mu g h & \text { EX } & \text { EAB260A } \\ 10.0 & \mu g h & \text { EX } & \text { EPAB260A } \\ 10.0 & \mu g h & \text { EX } & \text { EPA6010A }\end{array}$

Time: 14:56

Air temperature: $35.9^{\circ} \mathrm{C}$

Total alkalinity (as CaCO3): $0 \mathrm{mgh}$

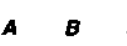

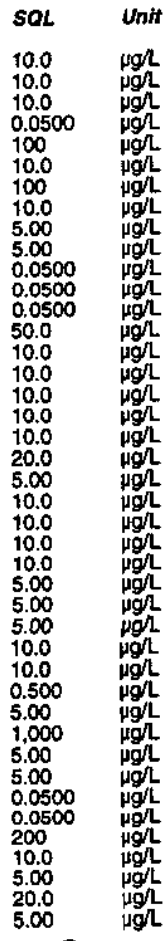

Lab Method

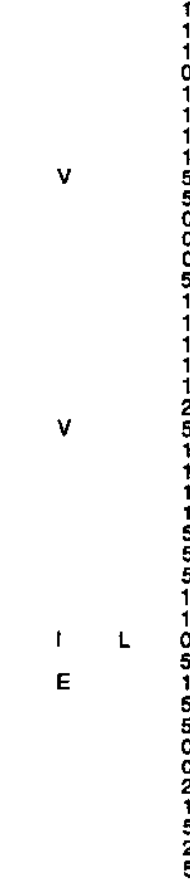

Second Quarter 1998 
Well CSR 11DU collected on 06/01/98 (cont.)

$F$ Analyte

- Chloroethene (Vinyl chloride)

Chlorometha

2-Chloronaphthalerse

4-Chlorophenol

Chromium, total recoverabt

O Cobalt, total recoverabie

m/p-Cresol
0 -Cresol (2-Methylphenol)

0 Cyanide

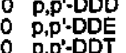

O Dibenz(a,h)anthracene

Dibromochloromethane

1,2-Dichlorobenzente

1,4-Dichlorobernzenen

o $3,3^{\prime}$-Dichlorobenenzidine

1,2-Dichloroethane

1,1-Dichloroethytene

Dichloromethane

1,4-Dichiorophenoxyace

istans-1,3-Dichloropropene

D Dieldryin phthalate

Dimethyt phenol

2,4-Dinitrophenol

2,6-Dinitrotoluene

Endosuffan sulfate

Endosulfian II

Endrin aldehyde

0 Endrin ketone

Fluoranthene

Fluoride

Heptachlor epoxide

Heptachlorodibenzo-p-dioxins

texachlordibsonzo-p-furans

Hexachlorobutadiene

Hexachlorodibenzo-p-dioxins

Hexachlorodibenzo-p-furans Hexachloroethane $2,2,3,4,6,7,8-H P C D D$
$1,2,3,4,7,8-H P C D F$ $01,2,3,4,7,8-4 \times C D D$

$\begin{array}{ll}0 & 1,2,3,4,7,8-\mathrm{HXCDF} \\ 0 & \text { Indeno }(1,2,3-\mathrm{c}, \mathrm{d}) \mathrm{Fy} \text { rene } \\ 0 & \text { Iron, total recoverable }\end{array}$

Isophorone
Lead, total recoverable

Lithium, total recoverable Magnesium, total recovererable
Manganese, total recoverable Manganese, total recoverable

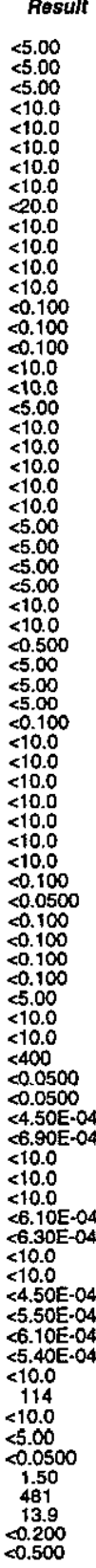

Well CSR 11DU collected on 06/01/98 (cont.)

$F$ Analyte

0 2-Methyl-4,6-dinitrophenol

Methyl isobutyl ketone

Nickel, total recoverable

Nitrate-nitrite as nitrogen

m-Nitroanitine

P-Nitroaniline

2-Nitrophenol

N-Nitrosodimethytamine

$\mathrm{N}$-Nitrosodipropylamine

Octachlorodibenzo-p-dioxin

PCB 1221

0 PCB 124

PCB 1254

$1,2,3,7,8-P C D D$

Pentachlorodibenzo-p-dioxins
Pentachlorodibenzo-p-furans

Phenanthrene

Phenol

Potassium, total recoverable

Selenium, total recoverable

Silica, total recoverable

Sodium, total recoverable

Specticic conductanco

Styrene

2 $2,3,7,8-T C D D$

Tetrachlorodibenzo-p-dioxins

Tetrachlorodibenzo-p-furan

Tetrachloroethylene
Thallium, total recoverable

Toluene

Total dissolved solids

Total organic carbon

Total organic chalogens

Total organic halogens

Total phosphates (as P)

2.4.5.TP (Silvex)

1,2,4-Trichlorobenzene

1,1,2-Trichloroethane

2,4,5-Trichloropheno

Vanadium, total recoverablo Vinyl acetato

Zinc, total recoverable

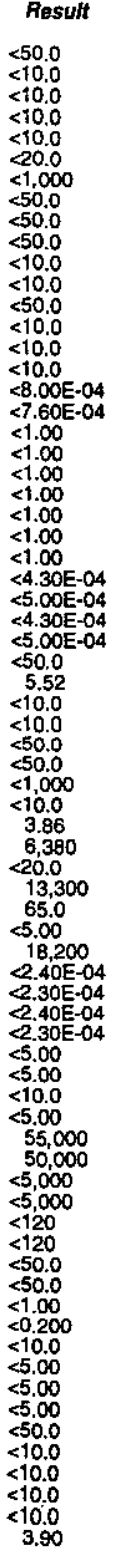

$A$

\begin{tabular}{|c|c|c|c|}
\hline & & & \\
\hline 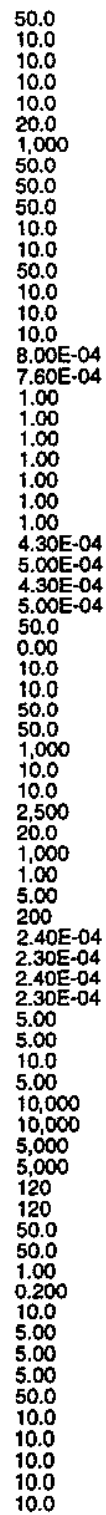 & 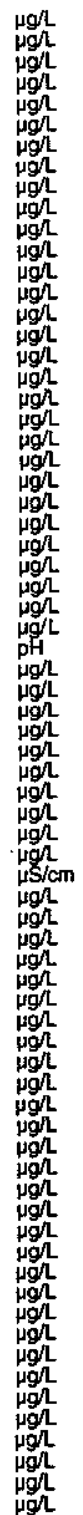 & 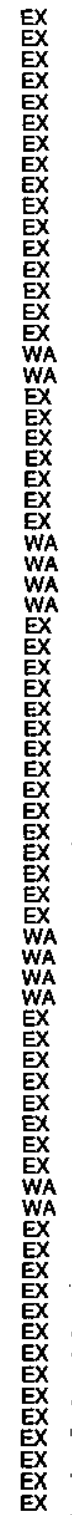 & 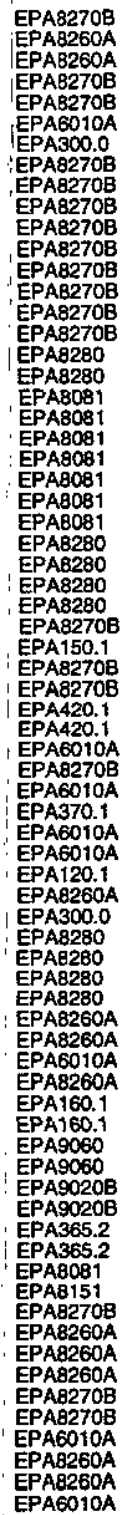 \\
\hline
\end{tabular}

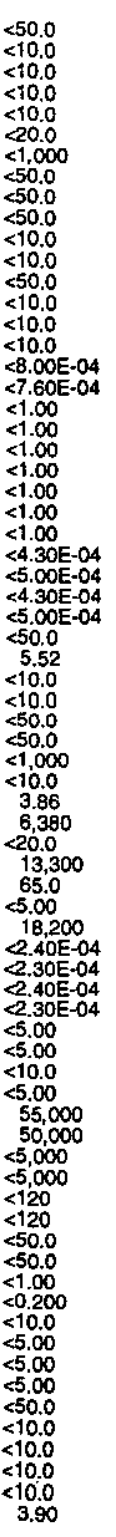


ANALYTICAL RESULTS

\section{WELL CSR 7DU}

MEASUREMENTS CONDUCTED IN THE FIELD

Sample date: $06 / 01 / 98$

Weter elevation: Not available

$\mathrm{pH}$ : Not available conductance: Not available

No water was evacuated from the well prior to sampling.

ANALYSES

$\begin{array}{lc}F \text { Analyte } & \text { Result } \\ \text { O Phenots } & <50.0 \\ \text { WELL CSR 8DU } & \end{array}$

WELL CSR 8DU

MEASUREMENTS CONDUCTED IN THE FELD

Sample date: $06 / 01 / 98$

Depth to water: Not available

git: Not available

No water was evacuated from the well prior to sampling.

ANALYSES

$F$ Analyte

Besuft

o Phenols

$<50.0$

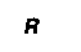

WELL CSR 9DU

MEASUREMENTS CONDUCTED IN THE FIELD

Sample date: 06/01/98

Depth to water: Not available
Water elevation: Not available

Water elevation:

Sp. conductance: Not available

urbidity: Not available

ANALYSES

$\begin{array}{lcccccccc}F \text { Analyte } & \text { Result } & \text { A } & \text { A } & \text { B } & \text { SOL } & \text { Unit } & \text { Lab Method } \\ 0 \text { Phenols } & <50.0 & & & & & 50.0 & \mu g / L & \text { EX EPA420.1 }\end{array}$

\section{WELLL DBP 1}

MEASUREMENTS CONDUCTED IN THE FIELD

Sample date: 05/04/98

Depth to water: 9.8 t $42.99 \mathrm{~m})$ below TOC

Water el

Sp. conductance: $56 \mu \mathrm{S} / \mathrm{cm}$

Wurbidity: 7 NTU

ANALYSES

\begin{tabular}{|c|c|}
\hline Analyto & Result \\
\hline 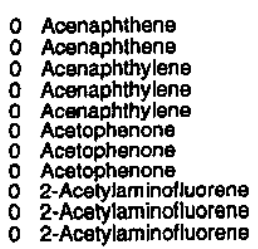 & $\begin{array}{l}<10.2 \\
<10.2 \\
<10.2 \\
<10.2 \\
<10.2 \\
<10.2 \\
<10.2 \\
<10.2 \\
<10.2 \\
<10.2 \\
<10.2\end{array}$ \\
\hline
\end{tabular}

ESH-EMS-980569
Well DBP 1 collected on 05/04/98 (cont)

\section{$F$ Analyte}

Time: Not available

Total alkalinity (as CaCO3): Not available

0 4-Aminobipheny|

4-Aminobipheny

An

Anthracen

: Anthracene

Aramite

A Asennic, total recoverable

: Arsenic, total recoverablo

0 Benzóalanthracsene

O Benzolajanthracente

Benzob) fluoranthen

o Benzob) fluoranthen

Benzo kf fluoranthene
Benzo(k)fluoranthene

Water temperature: Not availablo

Total akearinity (as CaCO3): Not available

O Benzo(k) kfluoranthen

Benzogin,

Benzolapyren

Benzo(a)pyren

Benzyy alcohol

Bis(2-chloroethoxy) methan

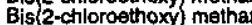

Biss2-chloroethyl) ether

Bis 2-chloroethyl) ether
Bis 2-chlorolsopropyl) ether

Bis 2-chlorolsopropyll ether

Bis (2-chloroisopropyl) ether
Bis (2-ethylhexyl) phthatate

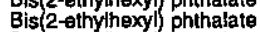

Bis(2-ethythexyl) phthalat

Bromoform

4-Bromophenyl phenyl ether

4-Bromophenyl phenyl ether

Butylbenzyl phthalate

Butylbenzyl phthalate

Butylbenzyly phthalate

4-Chloroaniline

Time: 9:25

Air temperature: $18.4^{\circ} \mathrm{C}$. 0 mol

Total alkalinity (as CaCO3): $0 \mathrm{mg} / \mathrm{L}$
Phenolphthalein alkalinity: $0 \mathrm{mg} /$

Chlorobenzene

Chlorobenzilat

Chlorobenzilat

Chlorothene (Vinyl chloride)

Chloroesthene (vinyl chloridas
2-Chloroethyl vinylether

Chloroform

Chloromethane
2-Chloronaphthalene

2-Chloronaphthalene

2.Chloronaphthalene

4-Chlorophenyl phenyly ether

4-Chloropheny phenyl athe

Chromium, total recoverable

Chrysene

0 Chrysene

B-99

Resutt
$<10.2$
$<10.2$
$<10.2$
$<10.2$
$<10.2$
$<10.2$
$<10.2$
$<10.2$
$<10.2$
$<0.4$
$<20.4$
$<20.4$
$<40.0$
$<40.0$
$<5.00$
$<10.2$
$<10.2$
$<10.2$
$<10.2$
$<10.2$
$<10.2$
$<10.2$
$<10.2$
$<10.2$
$<10.2$
$<10.2$
$<10.2$
$<10.2$
$<10.2$
$<10.2$
$<10.2$
$<10.2$
$<10.2$
$<10.2$
$<10.2$
$<10.2$
$<10.2$
$<10.2$
$<10.2$
$<10.2$
$<10.2$
$<10.2$
0.611
0.725
1.10
$<5.00$
$<5.00$
$<10.0$
$<10.2$
$<10.2$
$<10.2$
$<10.2$
$<10.2$
$<10.2$
$<5.00$
$<10.2$
$<10.2$
$<10.2$
$<5.0$
$<10.2$
$<10.2$
$<10.2$
$<10.0$
$<10.0$
$<10.0$
$<5.00$
$<10.0$
$<10.2$
$<10.2$
$<10.2$
$<10.2$
$<10.2$
$<10.2$
2.20
2.00
$<10.2$
$<10.2$
$<10.2$
$<1$
10.2

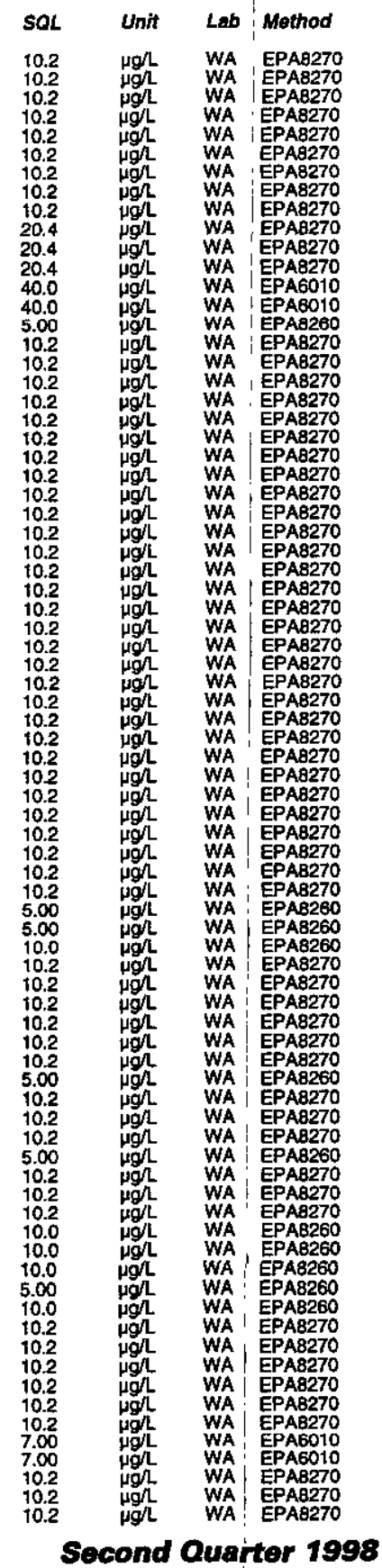


Well DBP 1 collected on 05/04/98 (cont.)

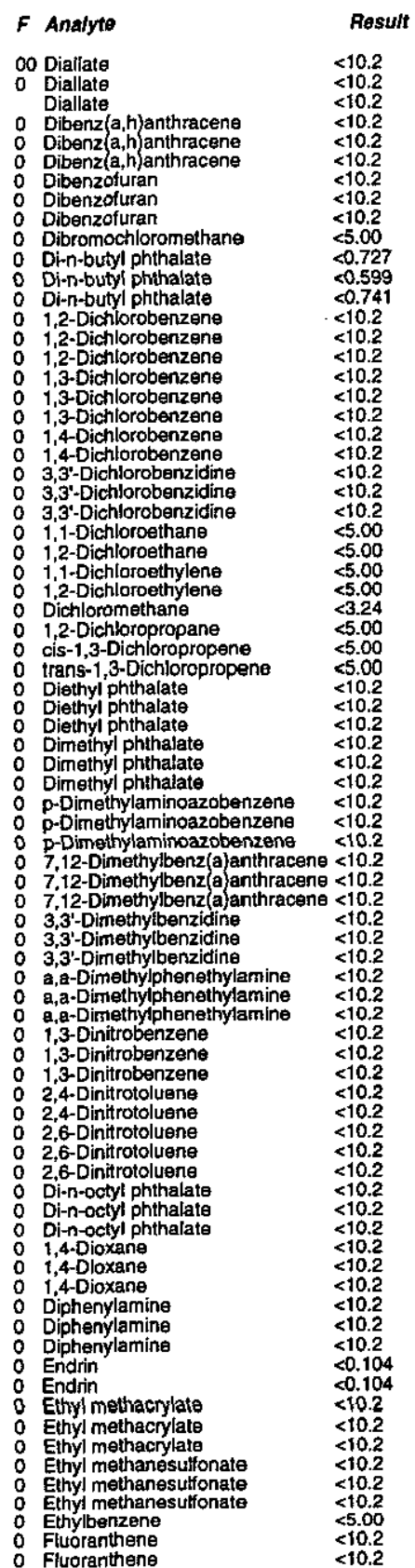

ESH-EMS-980569
Well DBP 1 collected on 05/04/98 (cont.)

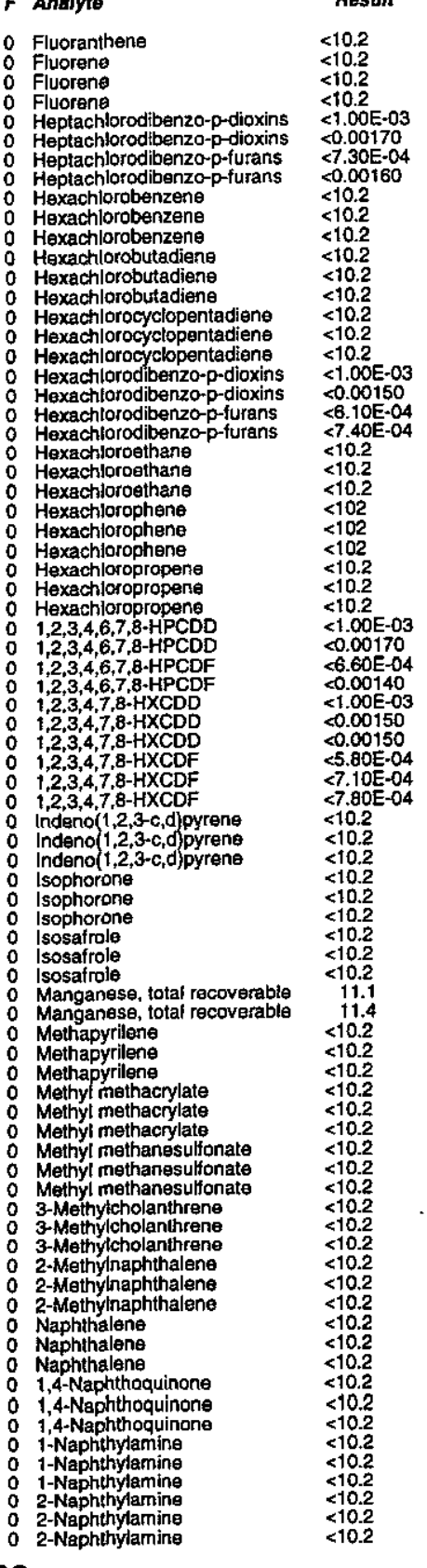

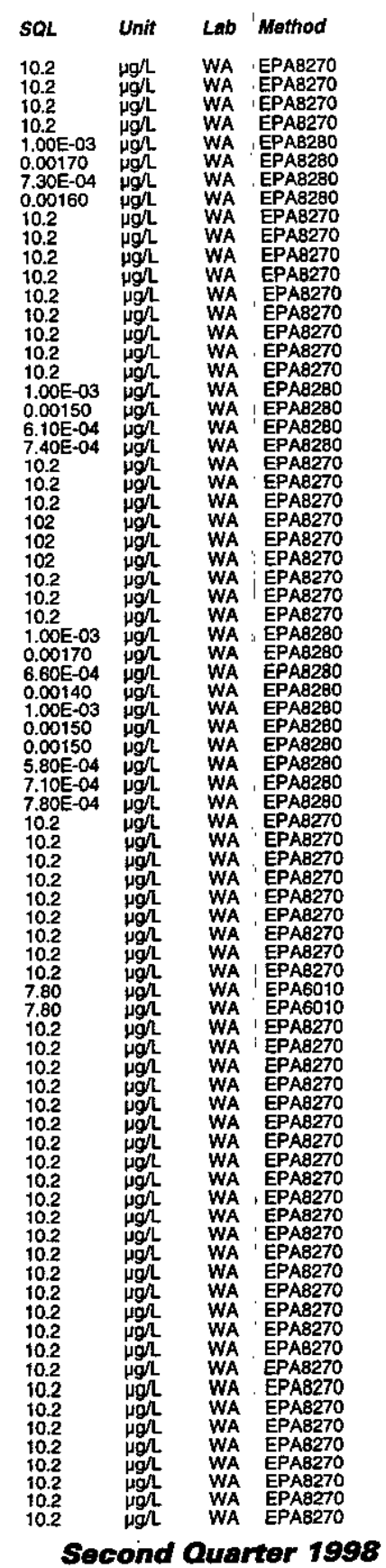


ANALYTICAL RESULTS

Well DBP 1 collected on 05/04/98 (cont.)

$F$ Analyts

m-Nitroaniline

$m$-Nitroaniline

o-Nitroarilitine

o-Nitroaniline
p-Nitroaniline

p-Nitroaniline

Nitrabenzene

Nitrobenzene
4-Nitroquinoline-1-oxide

4-Nitroquinoline-1-oxide

$\mathrm{N}$-Nitrosodil-n-butylamin

$\mathrm{N}$-Nitrosodi-n-butylamin

N-Nitrosodiathylaming

$\mathrm{N}$-Nitrosodiethylamine

N-Nitrosodimethylamine

$\mathrm{N}$-Nitrosodiphenylaming

N-Nitrosodiphenylamine
$N$-Nitrosodipropylaming

N-Nitrosodipropylamine

N-Nitrosomethylethylamine

$\mathrm{N}$-Nitrosomorpholine

N-Nitrosomorpholin

N-Nitrosopiperidine

N-Nitrosopiperidine

N-Nitrosopyrrojididine

5-Nitro-o-toluiding

Octachlorod ibenzo-p-dioxin

Octachlorodibenzo-p-dioxin

PCB 1260

PCB 1260

$1,2,3,7,8-P C D D$
0
$1,2,3,7,8-P C D D$
$0,2,3,7,-P C D F$
$1,2,3,7,8-P C D F$

$1,2,3,7,8-P C D F$
Pentachlorobenzene

Pentachlorobenzen

Pentachlorodibenzo-p-dioxin

Pentachlorodibenzo-p-furans

Pentachloroesthane

Pentachloroethane

Pentachloronitrobenzene
Pentachloronitrobenzene

Phenacetin

Phenacetin

Phenanthrese

p-Phenylenediamine
p-Phenylenediamine
p-Phenylenediamine

ESH-EMS-980569

Well DBP 1 collected on 05/04/98 (cont.)

$F$ Analyte

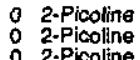

2.Picoline

o Pronamid

Pyrene

0 Pyridine

Satrole

2,3,7,8-TCDD

年,

: 2,3,7,8-TCDF $1,2,4$, Tetrachlorobenzene

1.2.4.5-Tetrachlorobenzene

Tetrachlorodibenzo-p-dioxins

Tetrachlorodibenzo-p-purans

Tetrachiorodibenzo-p-turan

o-Toludidin

1,2,4-Trichlorobenzene

o $1,1,1-$ Trichloroethane

o Trictiloroethylene

Trichlorofluoromethan

$1,3,5$-Trinitrobenzenzen

Xylenes Radium, total alpha-emitting

WELL DBP 2

MEASUREMENTS CONDUCTED IN THE FIELD

Sample date: $04 / 17 / 98 \mathrm{fop}$.

Depth to water: $6.61 \mathrm{t}(2.01 \mathrm{~m})$ below $\mathrm{m}$ )

$\mathrm{pH}: 4.5$

Sp. conductance: $270 \mu \mathrm{S} / \mathrm{cm}$

Water evacuated from the well prior to sampling: $76 \mathrm{gal}$

ANALYSES

$F$ Analyte

: Acenaphthene

Acenaphthylene

Acetophenone

: Acetophenone

2-Acetylaminofluoren

4-Aminobiphoriny

4-Aminobiphenty

: Aniline

B-101

Resutt
$<10.4$
$<10.4$
$<10.4$
$<10.4$
$<10.6$
$<10.4$
$<10.4$
$<10.6$
$<10.4$
$<10.4$
$<10.6$
$<10.4$
$<10.4$
$<10.6$
$<10.4$
$<10.4$

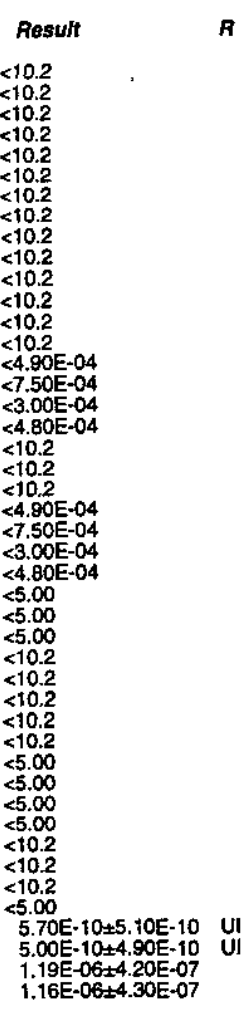

$A$

\begin{tabular}{|c|c|c|c|}
\hline SOL & Unit & Lab & Method \\
\hline $\begin{array}{l}10.2 \\
10.2 \\
10.2 \\
10.2 \\
10.2 \\
10.2 \\
10.2 \\
10.2 \\
10.2 \\
10.2 \\
10.2 \\
10.2 \\
10.2 \\
10.2 \\
4.90 E-04 \\
7.50 E-04 \\
3.00 E-04 \\
4.80 E-04 \\
10.2 \\
10.2 \\
10.2 \\
4.20 E-04 \\
7.50 E-04 \\
3.00 E-04 \\
4.80 E-04 \\
5.00 \\
5.00 \\
5.00 \\
10.2 \\
10.2 \\
10.2 \\
10.2 \\
10.2 \\
5.00 \\
5.00 \\
5.00 \\
5.00 \\
10.2 \\
10.2 \\
10.2 \\
5.00 \\
7.506-10 \\
7.50 E-10 \\
6.00 E-07 \\
6.20 E-07\end{array}$ & 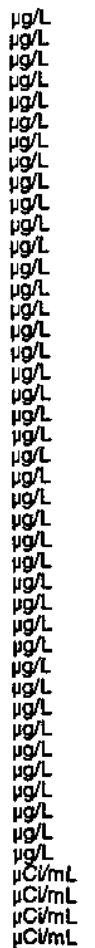 & $\begin{array}{l}\text { WA } \\
\text { WA } \\
\text { WA } \\
\text { WA } \\
\text { WA } \\
\text { WA } \\
\text { WA } \\
\text { WA } \\
\text { WA } \\
\text { WA } \\
\text { WA } \\
\text { WA } \\
\text { WA } \\
\text { WA } \\
\text { WA } \\
\text { WA } \\
\text { WA } \\
\text { WA } \\
\text { WA } \\
\text { WA } \\
\text { WA } \\
\text { WA } \\
\text { WA } \\
\text { WA } \\
\text { WA } \\
\text { WA } \\
\text { WA } \\
\text { WA } \\
\text { WA } \\
\text { WA } \\
\text { WA } \\
\text { WA } \\
\text { WA } \\
\text { WA } \\
\text { WA } \\
\text { WA } \\
\text { WA } \\
\text { WA } \\
\text { WA } \\
\text { WA } \\
\text { WA } \\
\text { TM } \\
\text { TM } \\
\text { TM } \\
\text { TM }\end{array}$ & 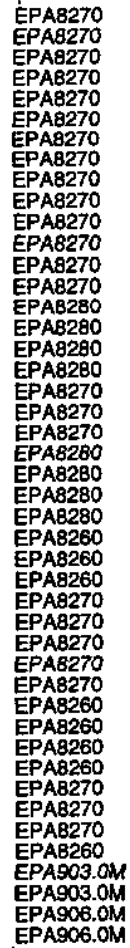 \\
\hline
\end{tabular}

Time: 13:23

Water temperature: $18.3^{\circ} \mathrm{C}$

Total alkalinity (as CaCO3): $0 \mathrm{mg} / \mathrm{L}$

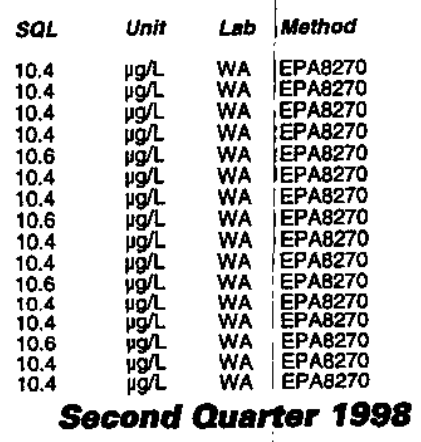


Well DBP 2 collected on 04/17/98 (cont.)

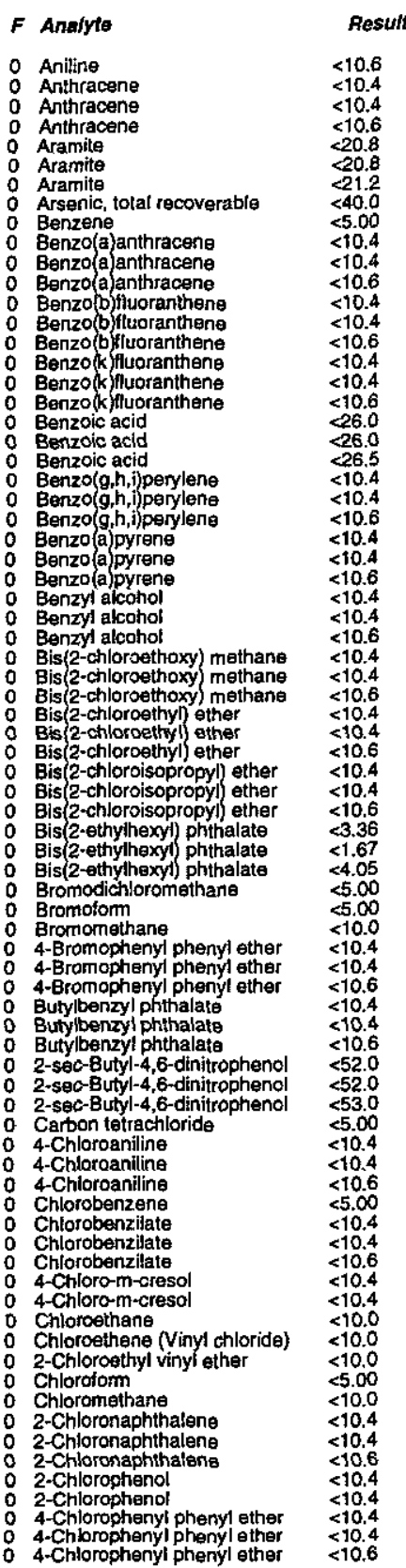

Well DBP 2 collicted on 04/17/98 (cont.)

F Analyte Result

O Chromium, total recoverable
: Chryserne
0 Chrysene

: Chrysene

: m/p-Cresol

o $\mathrm{m} / \mathrm{p}$-Cresol

o-Cresol (2-Methylphenal)

o O-Cresol (2-Methyiphenol)

$\begin{array}{ll}0 & \text { Diallate } \\ 0 & \text { Diallate } \\ 0 & \text { Diallate }\end{array}$

Dibenz(a,h)anthracene

Dibenz (a, hi) anthracene

o Dibenzofuran

o Dibenzofuran

Dibromochloromethane

Di-n-butyl phthalate

Di-n-buryly phthalate

1,2-Dichlorobenzene

1,2-Dichlorobenzene

1,3-Dichlorobenzenene

1,3-Dichlorobenzene

3,3'-Dichlororobenzenzidine

3,3
-Dichlorobenzidine

1,1-Dichloroethane

o 1,1-Dichloroethylene

2.4-Dichlorophen

2,4-Dichlorophenol

2.4-Dichlorophenol

2,6 -Dichlorophenen
2,6 -Dichlorophenol

1,2-Dichloropropane
o cis-1,3-Dichlosopropene

otrans-1,3-Dichloropropen

: Diethyl phthalate

D Diethyi phthalate

2,4-Dimethyl phenol

2,4-Dimethyy phenol

0 Dimethy phthalate

Dimethyl phthalate

p-Dimethylaminoazobenzene

p-Dimethylaminoazobenzene

7,12-Dimethylbenza(a) anthracene

7.

3.3-Dimethybenzidine

3,3 Dinedhy benzidine

a,a-Dimethyphenethylamine
0 a,a-Dimethylphenethylamine
0
a,a-Oimethylphenethylamine

1,3-Dinitrobenzene

2,4-Dinitrobenzene

2,4-Dinitrophenol

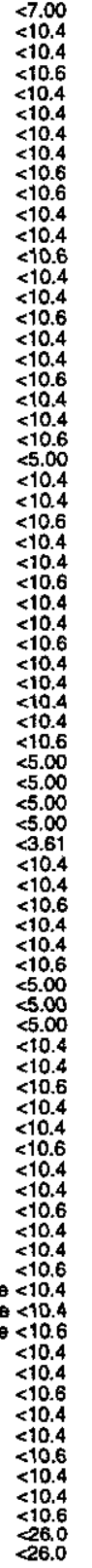

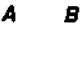

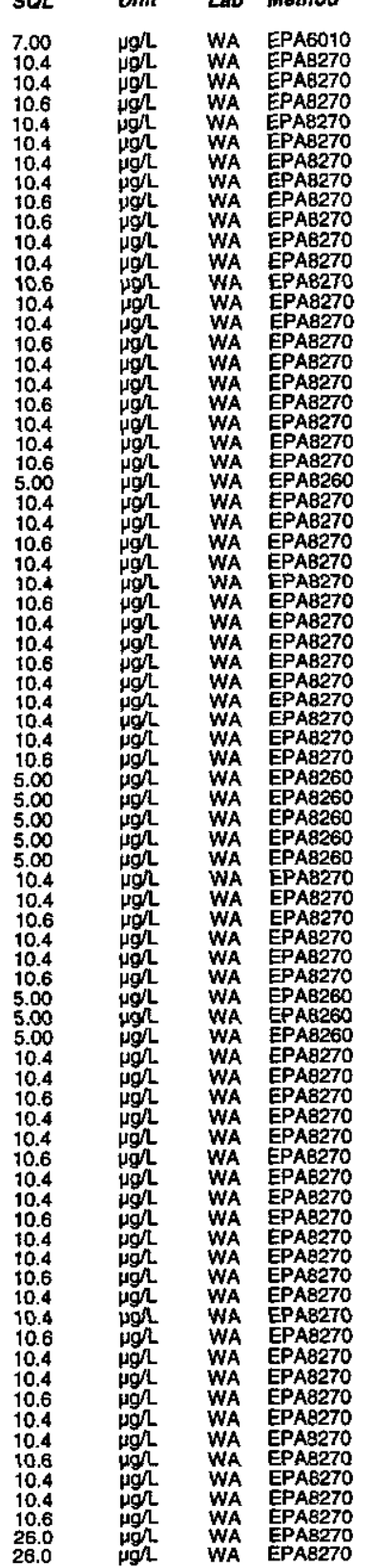

Second Quarter 1998 
Well DBP 2 collectod on 04/17/9B (cont)

$F$ Analyte

0 2,4-Dinitrophenol

2,4-Dinitrotoluen
2.4 -Dinitrotoluene
2,6 Dinitrotoluen

2,6 -Dinitrotoluene
O 2,6-Dinitrotoluene

2,6-Dinitrotoluene

Di-n-octy phthalate

1,4-Dioxane

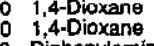

Diphenylamine

Endrin

Othy methacrylate

Ethyl methacrylate

Ethyl methanesulforate

Ethylbenzene

Fluoranthene

Fluoranthen

Fluorene

Heptachlorodibenzo-p-dioxins

Hexachlorobenzene
Hexachiorobutadien

Hexachjorobutadiene

Hexachlorocyclopentadiene

Hexachlorocyclopentadiene

Hexachlorodibenzo-p-dioxins

Hexacthlorothane

Hexachloroethane

Hexachlorophene
Hexachlorophene

Hexachilorophene

Hexachloropropene

$1,2,3,4,6,7,8-H P C D D$

$1,2,3,4,7,7,8-\mathrm{XCCDO}$
$1,2,3,4,7,8-\mathrm{HXCDF}$

Indeno( $1,2,3-c, d$ )pyrene

Indeno $(1,2,3-c, d)$ pyrene

Isophorone
isophorone

Isophorone

Isosafrole
isosafrole

Manganesa total recoverablo

Mathapyrilene

2-Methyl-4,6-dinitrophenol

2-Methyl-4,6-dinitropheno

Methyl methacrylate

Methy methacrylate

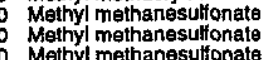

ESH-EMS-980569
Well DBP 2 collected on 04/17/98 (cont.)

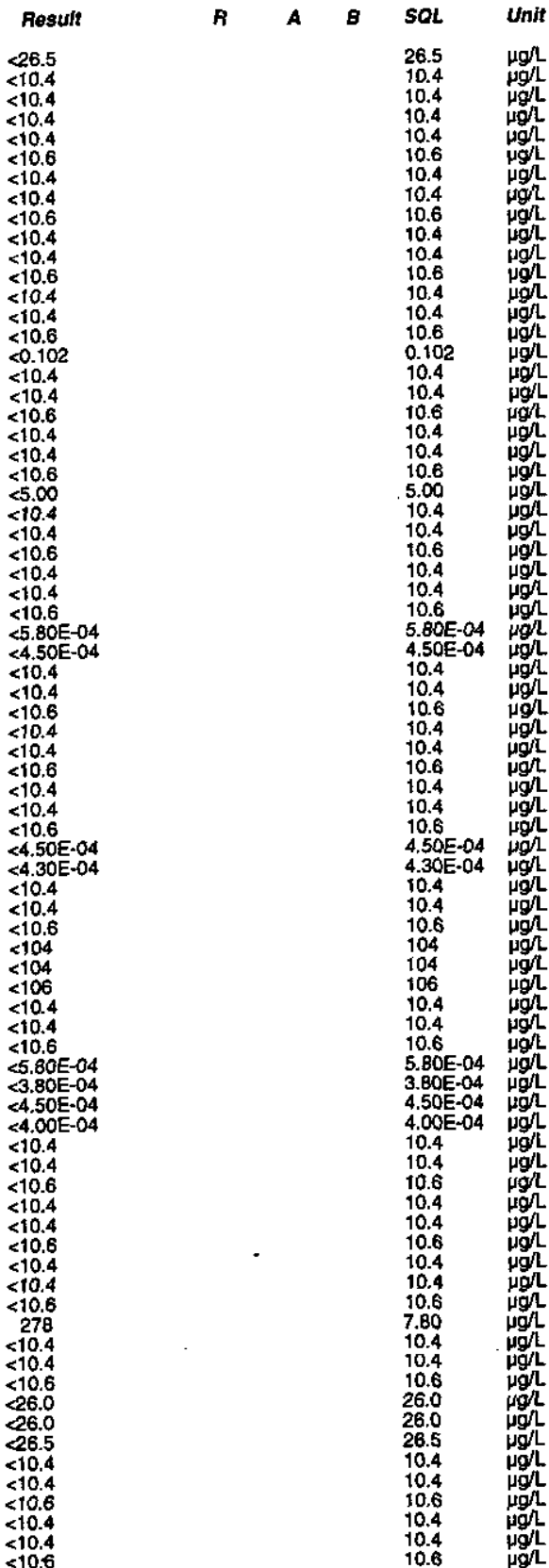

$F$ Analyte

o 3-Methylchojanthrene

2-Methylcholanthrene

2-Methylnaphthalene

Naphthalene

\section{Naphthalene}

1.4-Naphthoquinone

1-Naphthytamin

1-Naphthylamin

2-Naphthylamin

2-Naphthylamin

m-Nitroanilin

m-Nitroaniline

o-Nitroanilline

o-Nitroaniline
p-Nitroantiline

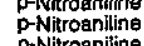

Nitrobenzene

Nitrobenzenzen:

2-Nitrophenol

\section{4-Nitropheno}

4-Nitrophenol
4-Nitroquinoling-1-oxide
4-Nitroginnoling-1-xide

4-Nitroquinoling-1-oxide

N-Nitrosodi-n-butylanine
$\mathrm{N}$-Nitrosodi-n-butylamine

N-Nitrosodi-n-butylamin
$N$-Nitrosodiethylamina

N-Nitrosodiethylamine
N-Nitrosodiethylamine

N-Nitrosodimethylamin

N-Nitrosodimethylarmin

N-Nitrosodiphenylamine

N-Nitrosodiphennylamin

N-Nitrosodipropylamine

N-Nitrosomethylathylamine

$\mathrm{N}$-Nitrosomemethylethylamilamin

N-Nititrosomomorpholin

N-Nitrosomorpholin

N-Nitrosopiperldin

N-Nitrosopopyrrolididn

N-Nitrosopyrroldidinin

5-Nitro-0-o-toluidine

Octachlorodibenzo-p-dioxin

Octachlorodibenzo-p-furan

1,2,3,7,8-PCDD

o Pentachlorobenzene

Pentachlorobenzente
0 Pentachlorodibenzo-p-dioxins
0 Pentachlorodibenzo-p-turans

Result

$<10.4$
$<10.4$

$<10.6$
$<10.4$
$<10.4$
$<10.6$

$<10.4$
$<10.4$
$<10.6$
$<10.4$

$<10.4$
$<10.6$
$<10.4$
$<10.4$

$<10.6$
$<10.4$

$<10.4$
$<10.6$
$<26.0$

$<26.5$
$<26.0$
$<26.0$

26.

26.5
$<10.4$
$<10.4$

$<10.6$

$<10.6$

260

20.8
20.8
$<21.2$
$<10.4$

$<10.4$

$<10.4$
$<10.4$
$<10.6$
$<10.4$

$<10$.

$<10.4$
$<10.4$
$<10.6$

$<10$

$<10.6$
$<10.4$
$<10.4$

$<10.6$
$<52.0$
$<52.0$

$<53.0$
$<10.4$

$<10.4$
$<10.8$
$<10.4$

$<10.4$

$<4.20 E-04$
$<4.80 E-04$

$<4.102 .04$

$<<<0.4$

$<1.6$
$<4.105-04$
$<.70 E-04$
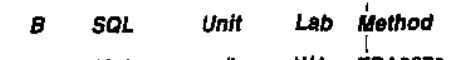

10.4 Wh E EPAB270

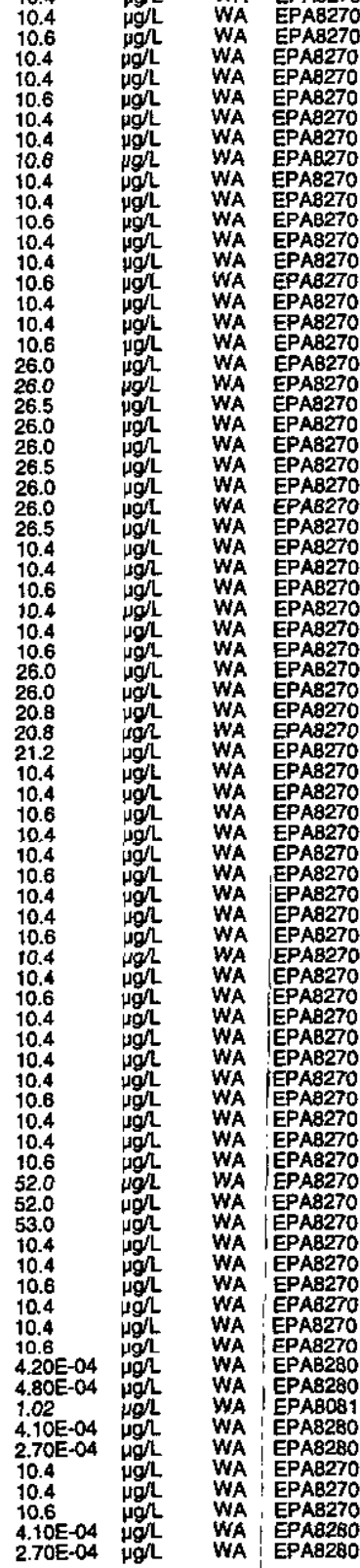

B-103

Second Quarter 1998 
Well DBP 2 collected on 04/17/98 (cont.).

$F$ Analyte

o Pentachioroethane

Pentachloronitrobenzen

Pentachboronitrobenzzene

Pentachlorophenol

Phenacetin

Phenanthrene

Phenanthrene
Phenanthrente

Phenol

p-Phenylenediamins

P.Phenylenediaminin

2.Picoline
2-Picoline

Pronamid

Pronamimid

Pyrene

Pyridine

Pyridina

2,3,7,8-TCDO

$1,2,4,5$-Tetrachlorobenzene
$1,2,5$-Tetrachlorobenzeng

1,2,4,5-Tetracthoroberzene Tetrachlorodibenzo-p-furans Tetrachloroethylene $2,3,4,6-T e$ efrachloropheno
$2,3,4,6-$ Tetrachloropheno Ooluene

o-Tolvidine

1,2,4-Trichlorobenzene

1,1,2-Trichlorosthane

Trichlorofluoromethan

2,4,5-Trichiorophenol

: 2,4,5-Trichlorophenol

2,4,6- Trichloropheno

, , 4,6-Trichlorophenel

1,3,5-Trinitrobenzene

Radium, total alpha-ernitting

0 Tritium

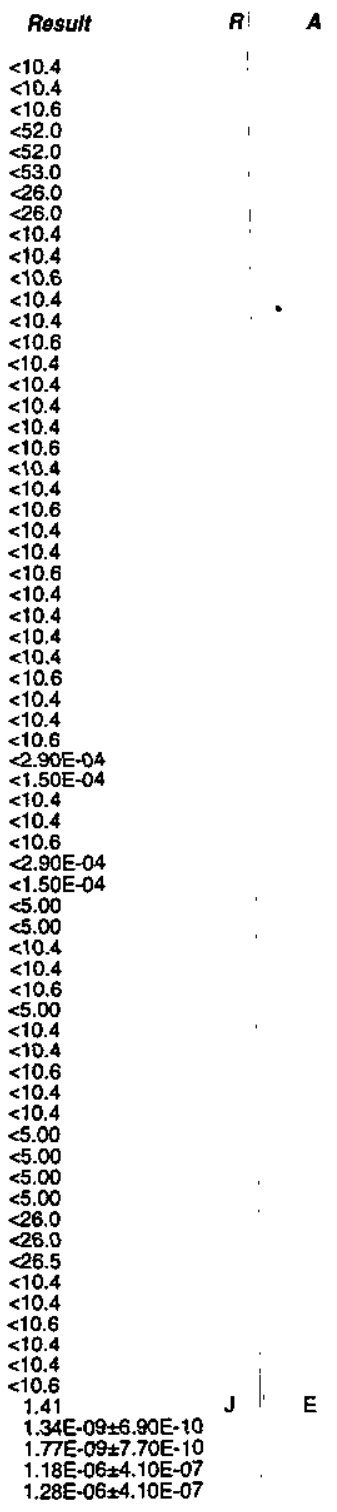

WELL DBP 3

MEASUREMENTS CONDUCTED IN THE FIELD

Sample date: $04 / 16 / 98$
Depth to water: $4.33 \mathrm{ft}(1.32 \mathrm{~m})$ below ToC
Water

Sp. conductance: $69 \mu \mathrm{S} / \mathrm{cm}$

Water evacuated from the well prior to sampling: $62 \mathrm{gal}$

ANALYSES

$F$ Analyte

Result

: Accenaphthene

Acetophenone
2-Acetylaminofluorene

Aniline

Anthracene

Arsenic, total recoverable

Benzene

Benzof byfluoranthene

Benzo(k)fluoranthen

Benzoic acid

Benzyl alcohol

Bis (2-chloroethoxy) methan

Bis(2-chloroisopropyly ether

Bromodichloromethane

Bromomethan

4-Bromophenyl phenyl ether

2-sec-Butyl-4,6-dinitropheno

Carbon tetrachloride

4.Chloroaniline

4-Chloro-m-cres

Chloroethane

Chloroethene (Vinyl chloride)

Chloroform

2-Chlorothaphthalen

4-Chiorophentyl phenyl ether

Chromium, total recoverabie

$\mathrm{m} / \mathrm{p}$-Creso

o m/p-Cresol

Diallate

Dibenzzofuran

Dibromochloromsthan

i, 3 -Dichlorobenzen

$\begin{array}{ll} & 1,4-\text { Dichlorobenzene } \\ 3,3^{-} \text {-Dichlorobenzidine }\end{array}$

o 1,i-Dichloroethane

o 1,1-Dichloroethylene

a trans-1,2-Dichloroothylen

2,4-Dichlorophenol

1,2-Dichloropropane

is-1,3-Dichloropropene
o trans-1,3-Dichloropropent
o Diethyl phthalate

$<<10.6$

$<10.6$
$<10.6$
$<10.6$
$<10.6$

$<10.6$
21.2
$<40.0$
$<5.00$

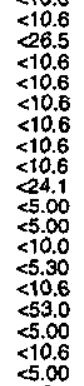

$<$

$7.20 E-10 \mu \mathrm{CVMmL}$ TM

$6.00-07$
$5.00 \mathrm{CO}-07 \mathrm{MLL}$

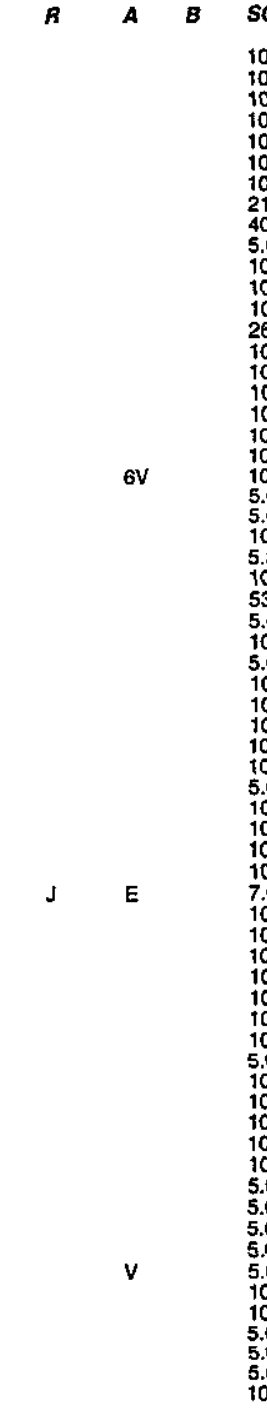

Time: 10:30

perature: $18^{\circ} \mathrm{C}$

Total alkalinity (as Caco3): $1 \mathrm{mgh}$
Phenolphthalein alkalinity: $0 \mathrm{mg}$.

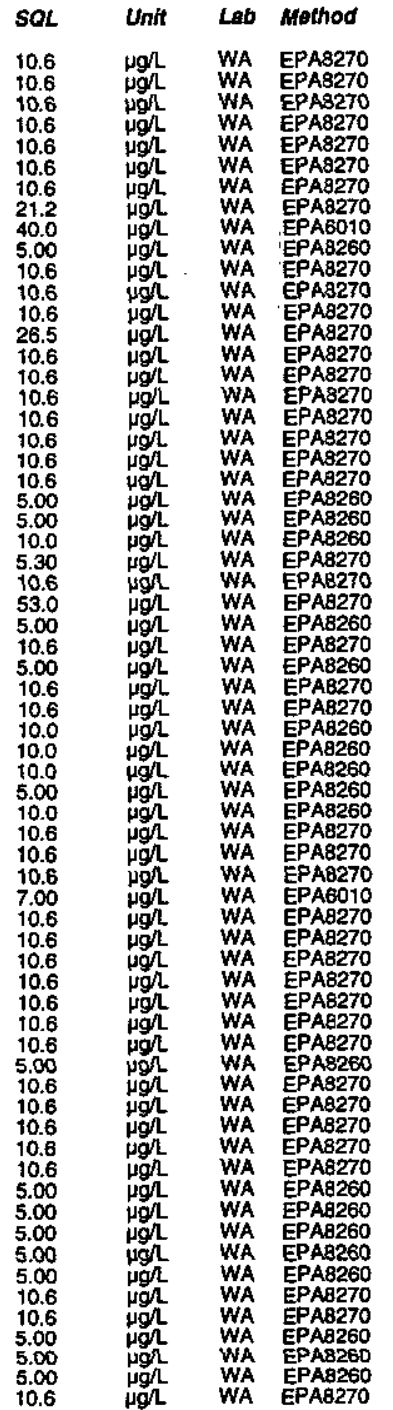

Second Quarter 1998 
Well DBP 3 collected on 04/16/98 (cont.)

$F$ Ansiyte Result

2,4-Dimethyl phenol
0 Dimethyl phthalate $<10.6$
$<10.6$

7,12-Dimethylbenz(a)anthrace a,a-Dimethylphenethylamine 1,3-Dinitrobenzene 2,4-Dinitrotoluene
2,6 -Dinitrotoluene oi-n-ootyl phthalate 1,4-Dioxane

Ethyl methacrylate

Ethytbenzene
Fluoranthene

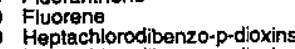
Heptachlorodibenzo-p-dioxin Heptachlorodibenzo-p-purans
Heptachlorodibenzo-p-furans Hexachlorobenzene

Hexachlorocyclopentadione
Hexachlorodibenzo-p-dioxing

rodibenzo-p-dioxins Hexachlorodibenzo-p-furans Hexachloroethan
Hexachlorophene

Hexachloropropene $1,2,3,4,6,6,6-\mathrm{HPCCD}$
$1,2,3,4,6,7,8 \mathrm{MCDDD}$ $1,2,3,4,6,7,8-\mathrm{HPCDF}$ $\begin{array}{ll}0 & 1,2,3,4,7,8-\mathrm{HXCDD} \\ 0 & 1,2,3,4,7,8-\mathrm{HXCDF}\end{array}$ indeno $(1,2,3-c, d)$ pyren isophorone

Manganese, total recoverable 2-Methyyl-4,6-dinitrophenol Methyl methacrylate 3-Methylcholanthrene
2-Methylinaphthalene Naphthalene 1-Naphthylamine
2-Naphthylamine m-Nitroaniline

p-Nitroanilíne 2-Nitrophenol 4-Nitroquinoline-1-oxide N-Nitrosodiethylamine a N-Nitrosodimethylamine o N-Nitrosodiphenylamine N-Nitrosomethylathylamine O N-Nitrosopiperidine N-Nitrosopyrrolidine octachlorodibenzo-p-dioxin Octachlorodibenzo-p-dioxín 0 PCB 1260

ESH-EMS-980569

$>106$

$\leq<0.6$

$<<10$.

$<10.7$
$<26.5$
$<10.6$

$<10.8$
$<10.8$
$<10.6$
$<10.8$

$<10.6$
$<10.6$
$<10.6$

$<10.6$

$<10.6$
26.5
26.5
26.5

$<10.6$
$<10.6$
$<26.5$
22.5

$<10.6$

$<10.6$

$<10.6$

$<10.6$
$<10.6$
$<5.0$.
$<10.6$
$<1.6$

$<10.6$
Well DBP 3 collected on 04/16/98 (cont.)

$F$ Analyte

Result

$\begin{array}{ll}0 & 1,2,3,7,8 . P C D D \\ 0 & 1,2,3,8 . P C D\end{array}$

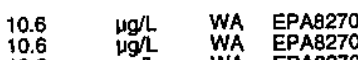

WA

WA

WA EPAB270

WA EPAB270

WA

WA

WA

WA

WE

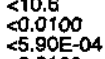

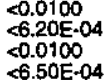

$<6.50 E-04$
$<4.000$
$<4.20=-04$

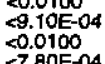

$<\rightarrow .800-04$
$<.02$

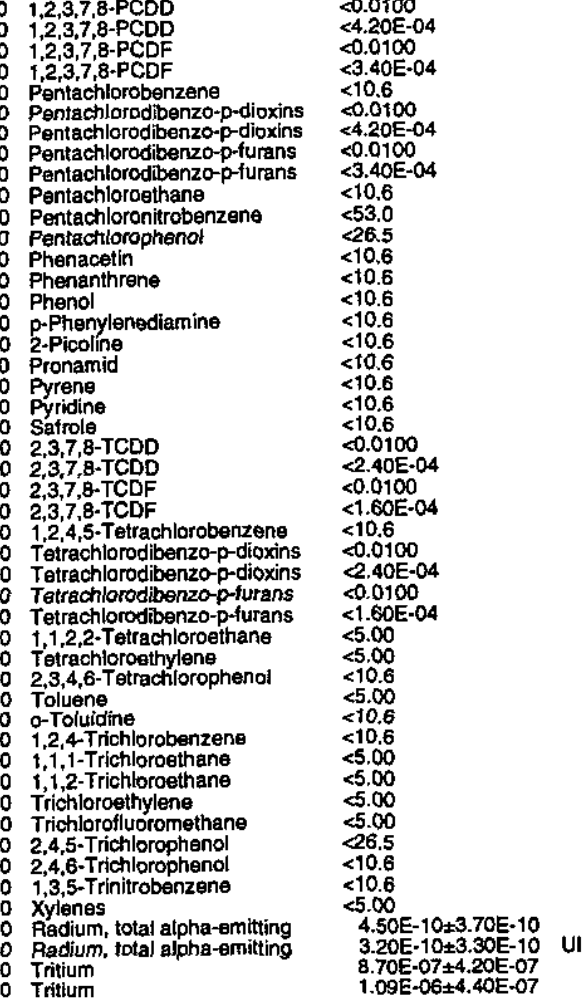

WELL DBP 3 Replicate

MEASUREMENTS CONOUCTED IN THE FIELD

Sample date: 04/16/98

Deph to water: $4.33 \mathrm{ft}(1.32 \mathrm{~m})$ below TOC

Sp. conductance: $69 \mu \mathrm{S} / \mathrm{cm}$

Weter evacuated from the well prior to sampling: 62 gal

ANALYSES

$f$ Analyte

- Acenaphthene

Acenaphthylene

2.Acetylaminoffuoren

4-Aminobipheny

: Aniline

Arsenite, total recoverable

Benzenie

Benzo(b) fluoranthene

3-105

Resuft
$<10.2$
$<10.2$
$<10.2$
$<10.2$
$<10.2$
$<10.2$
$<10.2$
20.4
$<40.0$
$<5.00$
$<10.2$
$<10.2$
$<10.2$

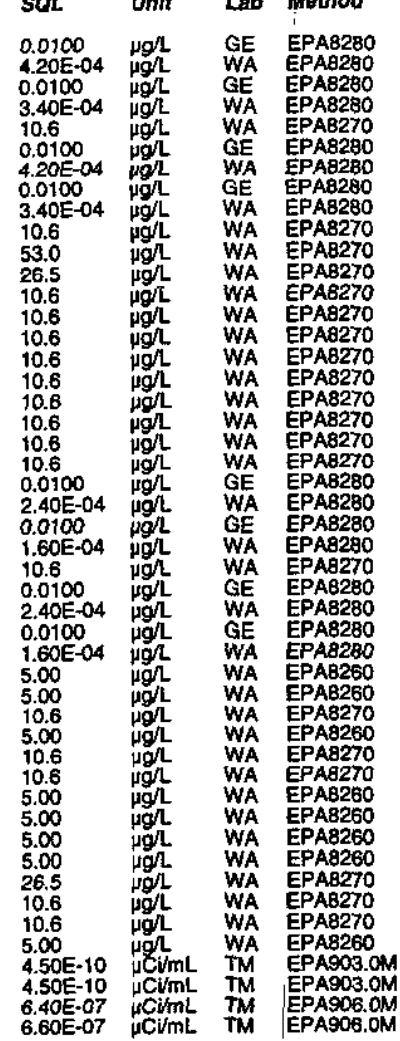

Time: 10:36

Total allalinity (as CaCO3): $1 \mathrm{mg} /$
Phenolphthalein alkalinity: $0 \mathrm{mg} L$

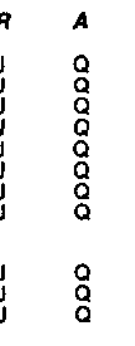

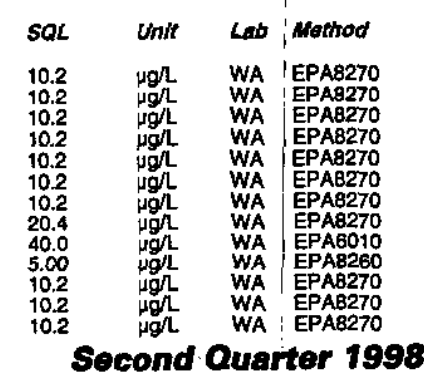


Well DBP 3 collected on 04/16/98 (cont.)

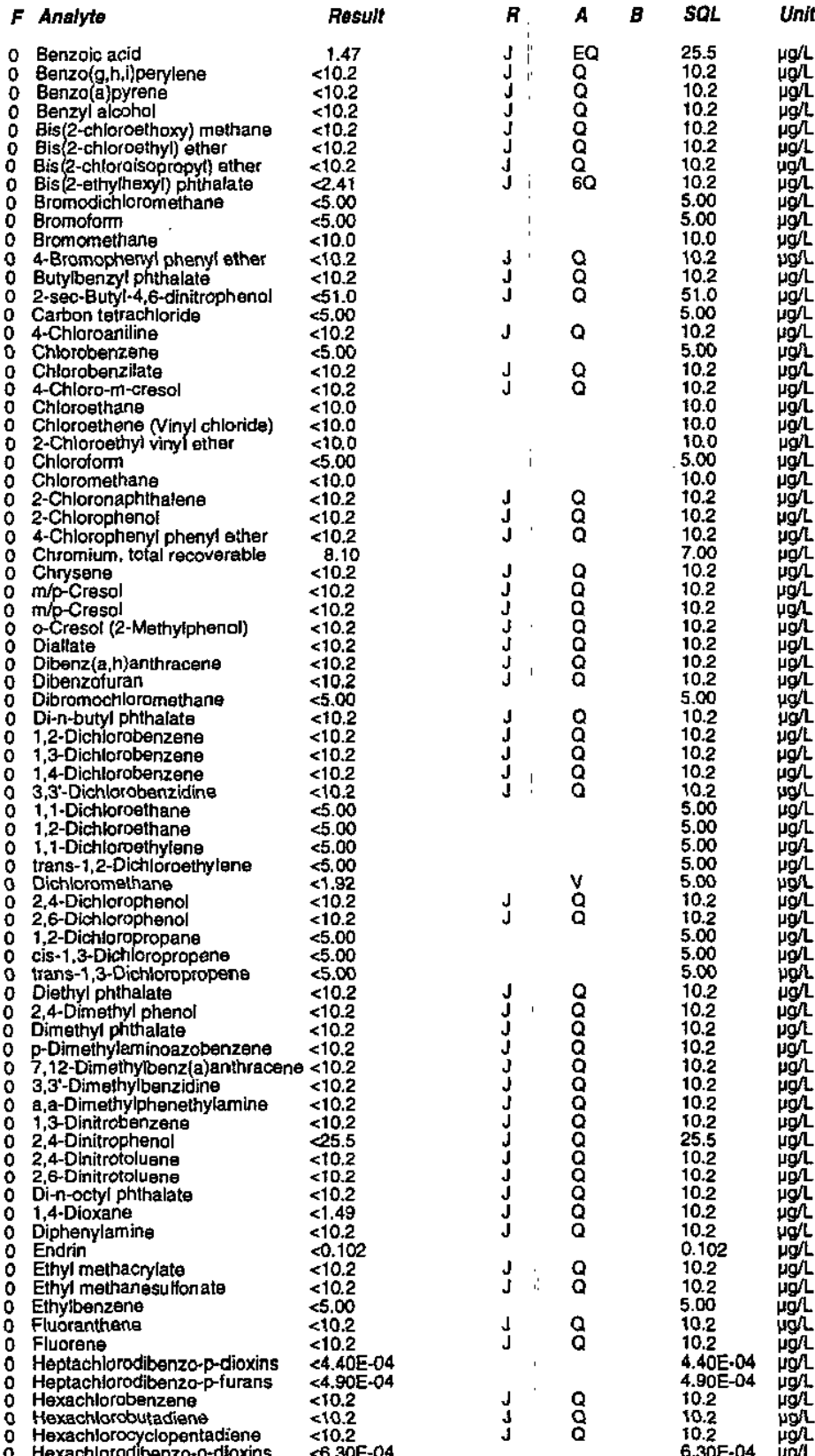

Well DBP 3 collected on 04/16/98 (cont.)

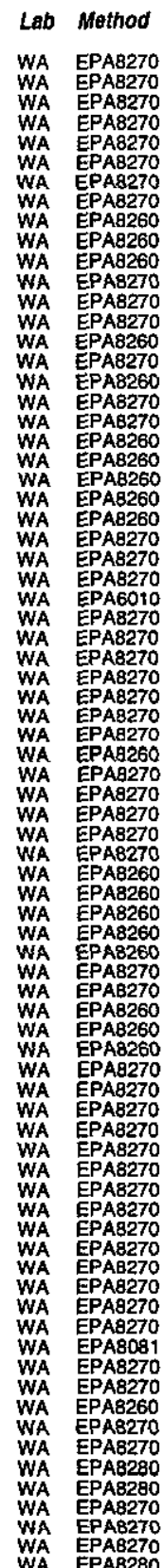

$F$ Analyto Result

: Hexachlorodibenzo-p-furans

$<3.70 \mathrm{E}-04$

o Hexachloroethan

Hexachloropropene

$\begin{array}{ll}0 & 1,2,3,4,6,7,8-H P C D F \\ 0 & , 2,3,4,7,-\mathrm{HXCOD}\end{array}$

Indeno $(1,2,3-c, d)$ pyrene

Isophorone
0 Isosafrole

Manganese, total recoverable

2-Methyl-4,6-dinitrophenol

Methyl methacrylate

3-Meithylcholanthrene

Naphthalene

1-Naphthylamine

$m$-Nitroanitine

o-Nitroaniline
p-Nitroaniline
0 -

2-Nitronzen

4-Nitrophenol

4-Nitroquinoline-1-oxide

N-Nitrosodi-n-butylamin

N-Nitrosodimethylamine

N-Nitrosomethylamine

N-Nitresomorpholine

N-Nitrosopiperidine

5-Nitro-o-toluidine

Octachlorodibenzo-p-dioxin

$1,2,3,7,8-P C D D$
$1,2,3,7,8-P C D F$

Pentachlorobenzene
0 Pentachloroditionzo-p-dioxins
0

Pentachloroethane

Pentachlorophen

Phenacelin

p-Phenylenediamine

2-Picoline

Pyrene

Safrol

Tetrachlorodibenzo-p-dioxins

1,1,2,2-Tetrachloroethane

Tetrachloroethylene
$2,3,4,6-$ Tetrachlorophen

o-Toluidin

0 1,2,4-Trichlorobenzene

1,1,2-Trichloroethane

Trichloroffluoromethane

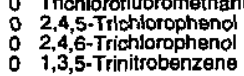

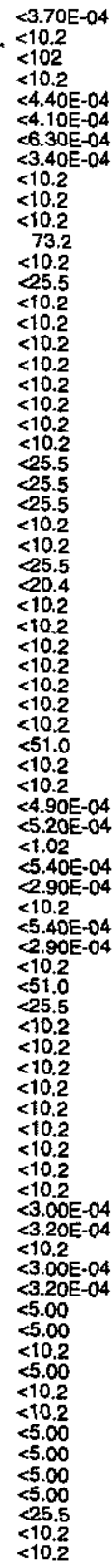

$<10.2$
$<4.40 \mathrm{E}-04$
$<4.10 \mathrm{E}-04$ $<10.2$

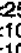

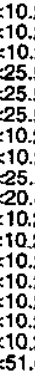

$4.90 \mathrm{E}-\mathrm{O}$

$<5.40 E-04$
$<.90 \mathrm{E}-04$

$<10.2$
$5.40 \mathrm{E}-04$
$2.90 \mathrm{E}-04$

$<51.0$
$<25.5$
$<10.2$

$<10.2$
$<10.2$
$<102$

10.2

$<3.20 \mathrm{E}-04$
$<10.2$
$<3.00 \mathrm{E}-04$
$<5.04$

.20E-04

$<10.2$

$<1.2$
$<1.2$
$<5.0$
$<.00$
5.00

$<5.00$
$<5.00$
$<25.5$
$<10.2$
$<10.2$
1,2,4,5-Tetrachlorobenzene

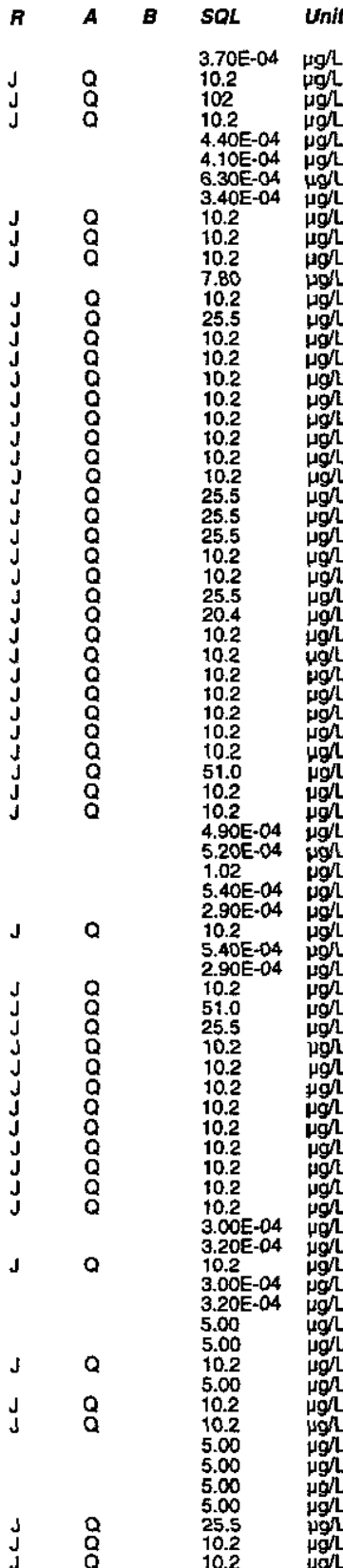

Lab Method

WA EPA8280

WA EPA8270

WA EPAB280

WA EPAB270

WA

WA EPAB270

WA

WA EPAB270

WA EPAB270

WA EPAB270

WA

WA EPA8270

WA EPA8270

WA

WA

WA EPAB270

WA WA

WA FPAB270

WA EPAB270

WA EPAB270

WA EPAB270

WA EPAE270

WA EPAB270

WA EPAB280

WA

WA EPAB280

WA

NA EPAB270

WA EPAA260

WA EPAB270

WA EPAA260

WA EPAB260

WA EPAB270

ESH-EMS-980569 
Well DBP 3 collected on 04/16/98 (cont.)

$F$ Analyte

Result

$\boldsymbol{R}$

A B SQL Unit Lab Method

$\begin{array}{lll}0 & \text { Xylenes } & <5.00 \\ 0 \text { Padium, total alpha-emitting } & 3.00 \mathrm{E}-10 \pm 2.70 \mathrm{E}-10 \text { UI } \\ 0 \text { Tritium } & 1.15 \mathrm{E}-06 \pm 4.40 \mathrm{E}-07\end{array}$

WELL DBP 3

MEASUREMENTS CONDUCTED IN THE FIELD

Sample date: $04 / 17 / 98$

Depth to water: Not available

Sh: Nof available: Not available

No water was evacuated from the well prior to sampling.

ANALYSES

\begin{tabular}{|c|c|}
\hline Analyte & Result \\
\hline 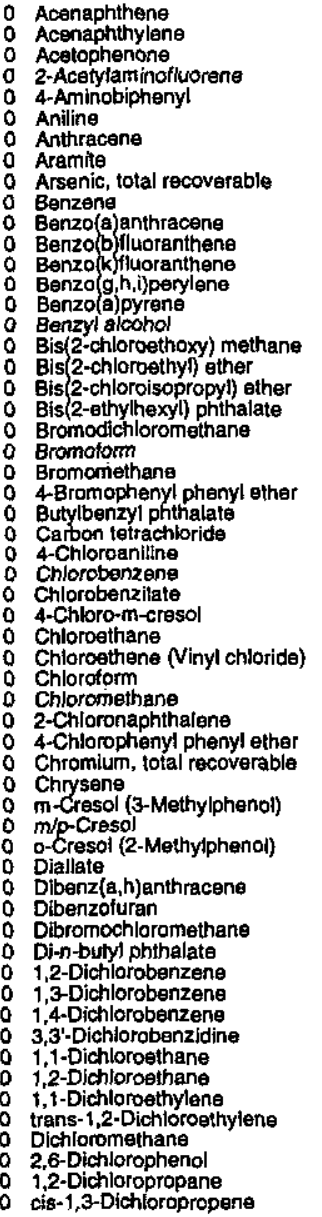 & 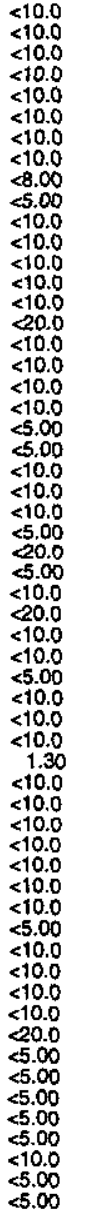 \\
\hline H-LWWS-980568 & \\
\hline
\end{tabular}

Well DBP 3 collected on 04/17/98 (cont.)

$F$ Analyte Result

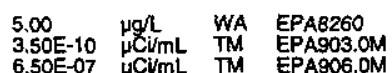

O trans-1,3-Dichloropropene Dimethoate

p-Dimethylaminoazobenzen o p-Dimb-Dimethylbenz(a)anthracene $<10.0$

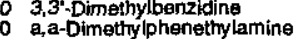
1, a, -Dimettrylphenethy $2,4-$-Dinitrotoluene
0

Time: Not available
Water temperature: Not available Air temperature: Not available Phenolphthalein alkalinity: Not availabie 2,6-Dinitrotoluene : Diphenylamin Endrin

Ethyl methanesulfionate

: Ethylbenzen

D Fluoranthen

Fluorene
Hexachlorobenzene
Hexachlorobutadien Hexachlorocyctopentadien o Hexactloroethan

: Hexachloropropene

Isophoron

$\begin{array}{ll}0 & \text { Isophorone } \\ 0 & \text { Isosatrole } \\ 0 & \text { Kosale }\end{array}$

Mapone

- Methapyrilene

0 Methyl methanesulfonate

2-Methylnaphthalene

1,4Naphthoquinone

1-Naphthylamine

m-Nitroaniline

0 o-Nitroaniline

O Nitrobenzeniline

4-Nitroquinoline-1-oxide
N-Nitrosodi-n-butylamine

N-Nitrosodiethylaming

N-Nitrosodimethylamine

N-Nitrosodipropylamine

Ninosomoriy

N-Nitrosopiperidine

N-Nitrosopyrrolidine

0 PCB 1260

: Pentachlorobenzene

Phenacetin

p-Phenylenediamine

2-Picoline

Pyrene

Safrole

1.

1, 1,2,2-Tetrachloroethane

: Tetrachloroethylene

Thionazin

o-Toluidine

1,2,4-Trichlorobenzen

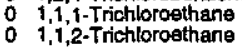

$-107$
$<5.00$

$<10.0$
$<10.0$
$<10.0$
$<10.0$
$<10.0$

$<10.0$
$<10.0$
$<10.0$
$<10.0$

$<10.0$
$<10.0$
$<10.0$
$<10.0$

$<0.0150$

$<5.00$
$<10.0$
$<10.0$
5

$<1$

$<<$

$<10.0$
$<10.0$
$<10.0$
$<10.0$

$<1.0$

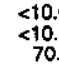

$<10.8$

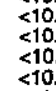

$<10.0$
$<<0.0$
$<50.0$

$<50.0$
$<50.0$
$<50.0$

$<10.0$
$<10.0$
$<10.0$

$<10.0$
$<10.0$
$<10.0$

$<10.0$
$<10.0$
$<10.0$

$<10.0$
$<10.0$
0.300

$<0.30$
$<10.0$
$<10.0$

$<10.0$
$<10.0$
$<10.0$
$<10.0$

$<10.0$
$<10.0$
$<100$

$<10.0$

$<10.0$

$<5.00$
$<10.0$

$<5.00$
$<100$

$<10.0$
$<5.00$

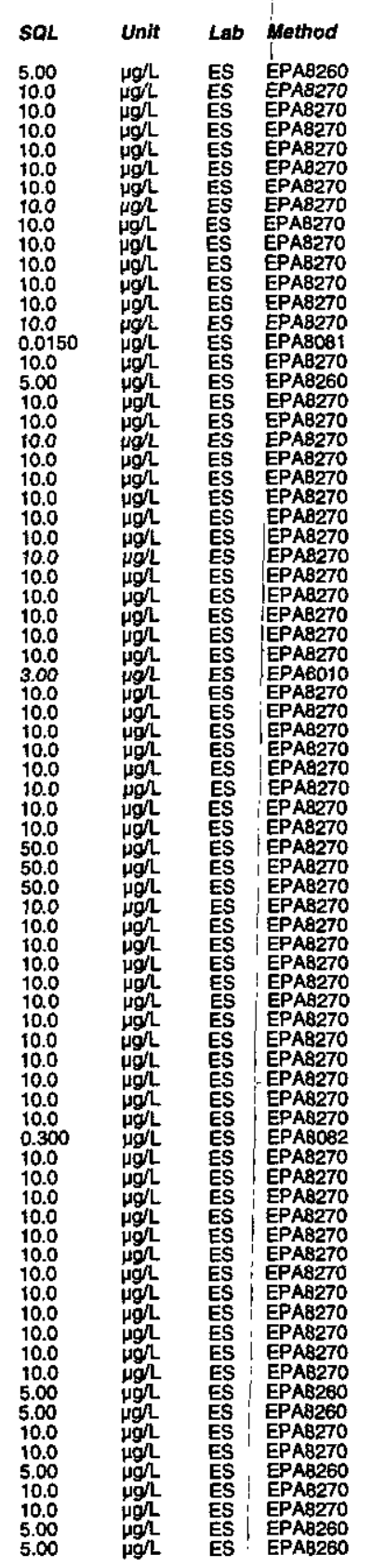

Second Quartor 1998 
Well DBP 3 collected on 04/17/98 (cont.)

$F$ Ansiyte

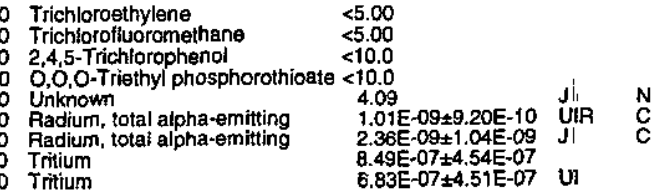

\section{WELL DBP 4}

MEASUREMENTS CONDUCTED IN THE FIELD

Sample date: $04 / 16 / 98$.

Water

Sp. conductance: $110 \mu \mathrm{S} / \mathrm{cm}$

Turbidity: 2 NTU:

ANALYSES

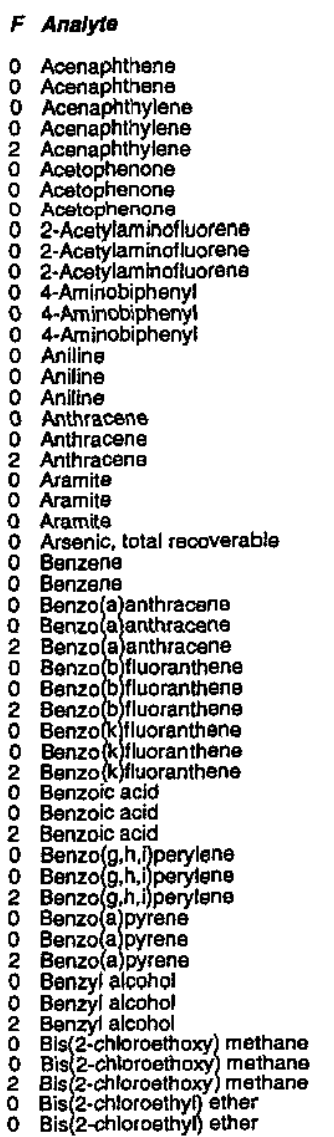

Result
$<10.6$
$<10.6$
$<10.6$
$<10.6$
10.6
$<10.6$
$<10.6$
10.6
$<10.6$
$<10.6$
10.6
$<10.6$
$<10.6$
10.6
$<10.6$
$<10.6$
10.6
$<10.6$
$<10.6$
10.6
$<1.2$
$<1.2$
21.2
$<40.0$
$<5.00$
$<5.00$
$<10.6$
$<10.6$
10.6
$<10.6$
$<10.6$
10.6
$<10.6$
$<10.6$
10.6
$<26.5$
$<26.5$
26.5
$<10.6$
$<10.6$
10.6
$<10.6$
$<10.6$
10.6
$<10.6$
$<10.6$
10.6
$<10.6$
$<10.6$
10.6
$<10.6$
$<10.6$

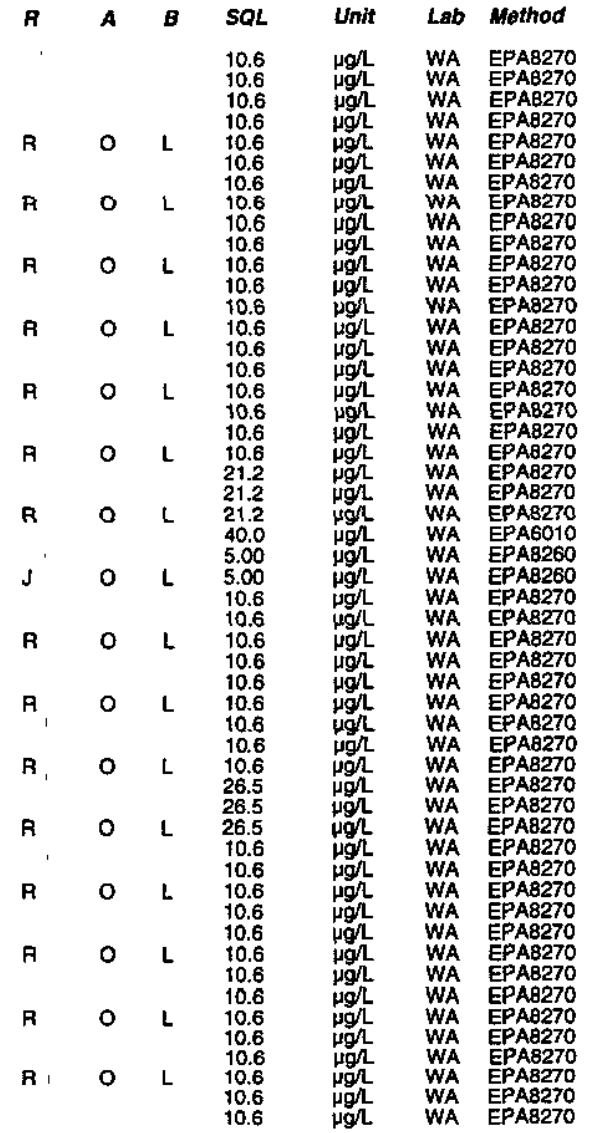

Water termperature: $17.9^{\circ} \mathrm{C}$

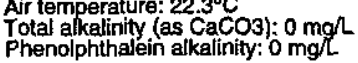

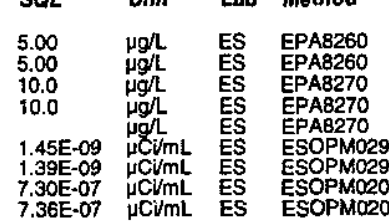

ESH-EMS-980569
Well DBP 4 collectod on 04/16/98 (cont)

2 Bis(2-chloroethyl) ether

Result

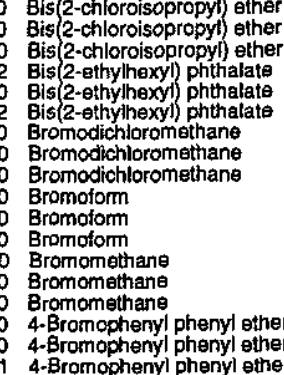

4. Bromophenyl phenyl ethe

0 Butylbenzyy phthalate

Butylbenzyl phthalate

2-5ec-Butyly-4,6-dinitrophenol

2 2-sec-Butyl-4,6-dinitroph
Carbon tetrachloride

Carbon tetrachloride

4-Chloroaniline

4-Chloroaniline

Chiorobenzene

Chlorobenzilate

Chlorobenzilate

4-Chloro-m-cresol

Chloroethare

Chloroethene Vinyl chloride Chloreethene (Vinyl chloride

Chloroethene (Vinyl chloric

2-Chloroethyl vinyl ether

2-Chlorethy

o Chooroorm

Chlorometharie

Chloramethane

2-Chloronaphthalene

2-Chloronaphthalene

2-Chloropheno

4-Chlorophenyl phenyl ether

4-Chlorophenyl phenyl ether

chromium, total recoverable

O Chrysene

Cnysene

m/p-Cresol

$\mathrm{m} / \mathrm{p}$-Cresol

$\mathrm{m} / \mathrm{p}$-Creso

a.-Cresol (2-Methylpheno)

a-Cresol (2-Methytphenol

$\begin{array}{ll}0 & \text { Dialsate } \\ 0 & \text { Diallate } \\ 0 & \text { Diallate }\end{array}$

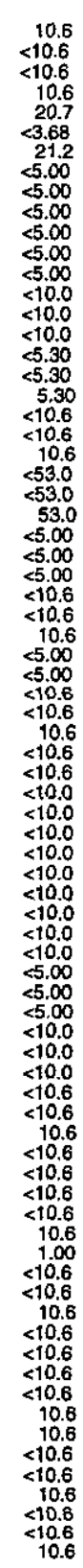

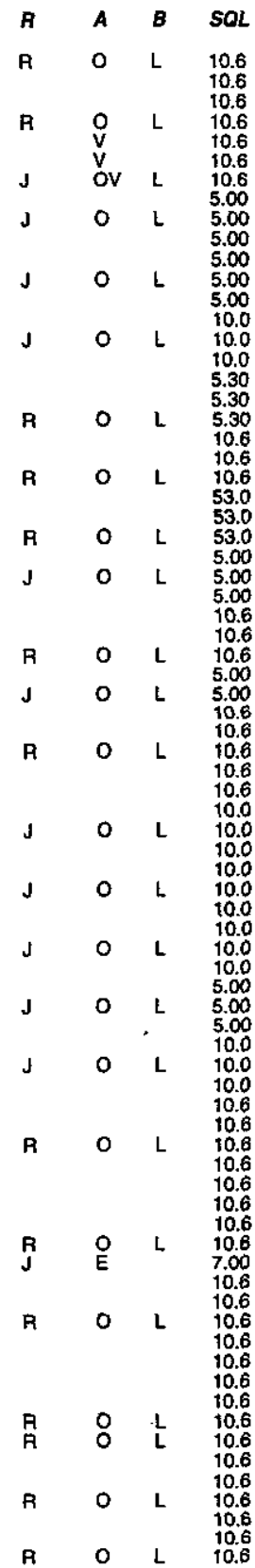

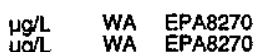

WA WA EPA8260 WA EPAB260 WA 'EPA8260 WA EPAB260 WA EPA8260 WA $:$ EPA8270

WA

WA $\quad$ EPA8270

WA EPAB270

WA

WA EPA8260

WA EPA8270

WA

WA EPAB270

WA EPA8270

WA

WA

WA EPAB260

WA ,EPAB260

WA EPAB260

WA EPAB260

WA EPAB260

WA EPA8260

WA IEPAB260

WA IEPAB270

WA EPAB270

WA IEPAB270

WA EPA6010

WA EPA8270

WA EPA8270

WA EPA8270

WA EPA8270

WA EPAA270

WA EPA8270

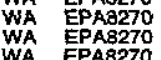

1998 
Well DBP 4 collected on 04/16/98 (cont)

F Aralyto Result

- Dibenz(a,h)anthracene Dibenzz $(a, h)$ anthracen Dibenzoturan

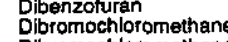
Dibromochloromethan Di-n-butyl phtthalate : Di-n-butyl phthalate 1,2-Dichlorobenzen 1,2-Dichlorobenzene 1,3-Dichborobenzen 1,4-Dichlorobenzene 3,3'-Dichlorobenzididine 1,1-Dichloroethane 1,2-Dichloroesthane 1.1-Dichloroethylen 1,2-Dichloroethylene trans-1,2-Dichloroethylen Dichloromethane 2,4-Dichlorophenen 2,4-Dichloropheno 2,6-Dlchlorophenol 2,6-Dichtoropheno 1,2-Dichioropropan cis-1 cis-1,3-Dichloropropene
cis-1,3-Dichloropropene trans-1,3-Dichloropropen trans-1,3-Dichloropropen Diethyy phshalate 2,4-Dirnethyl pheno 2,4-Dimethyl pheno Dimethyl phthalate p-Dimethylaminoazobenzen p-Dimethylaminoazobenzen 7.12-Dimethybenz (a)anthracen 7,12-Dimethylbenz (a)anthracen $\begin{array}{ll}0 & 3,3 \text {-Dimethylbenzidine } \\ 0 & 3,3-\text {-Dimethylbenzidine }\end{array}$ a,a-Dimethylphenethylamine : a,a-Dimethylphenethylamine 1,3-Dinitrobenzene 1,3-Dinitrobenzen $0,4-D i n i t r o p h e n o$
0

ESH-EMS-980569
Well DBP 4 collected on 04/16/98 (cont.)
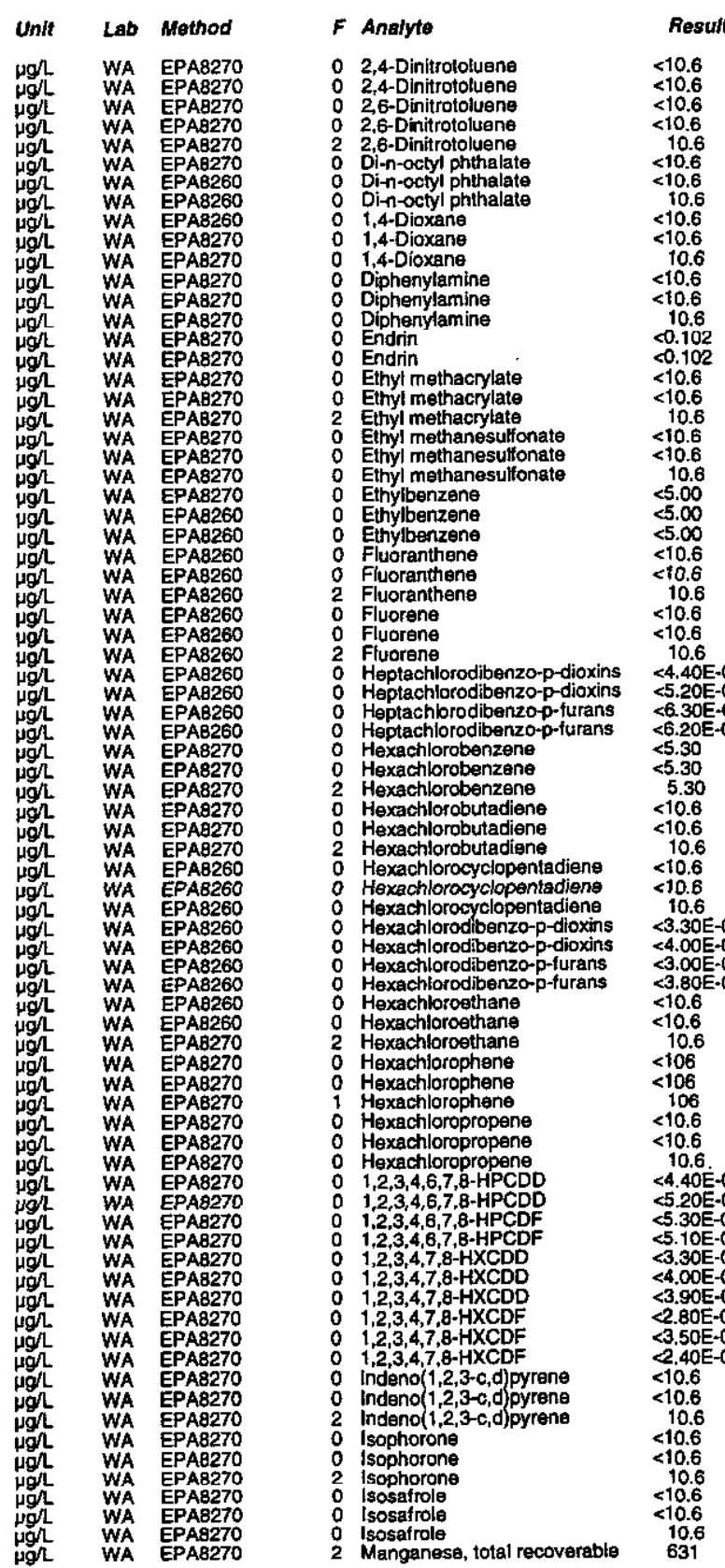

0 2,4-Dinitrotoluene

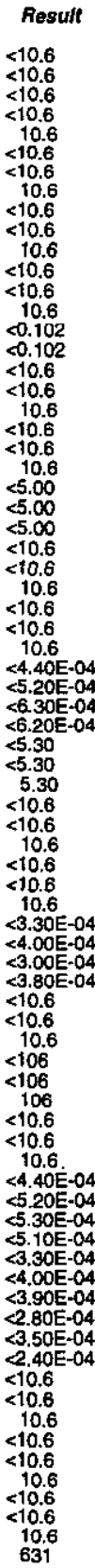
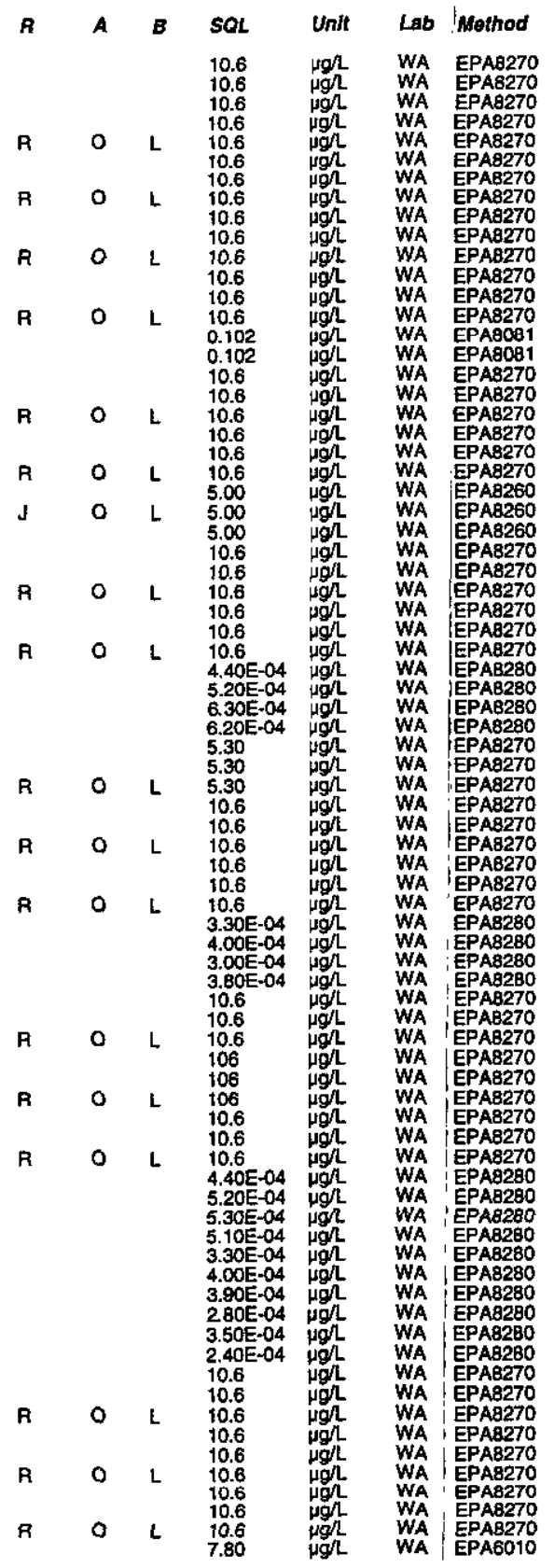
Well DBP 4 collected on 04/16/98 (cont.)

\begin{tabular}{|c|}
\hline 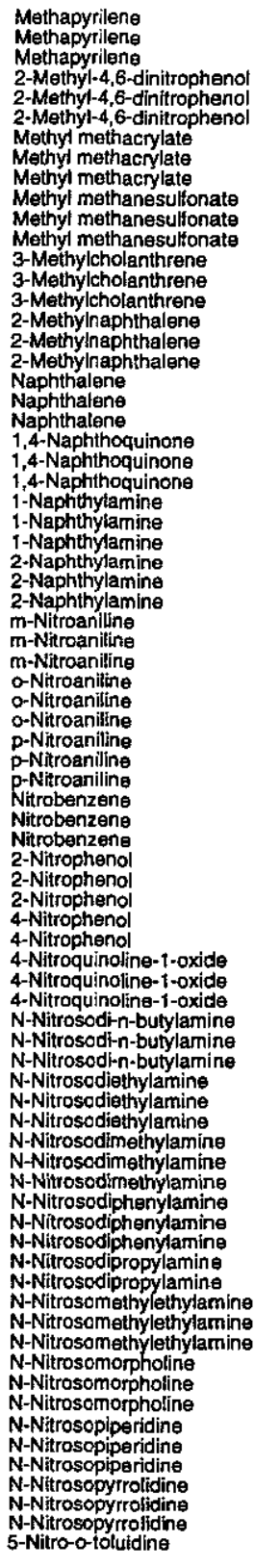 \\
\hline
\end{tabular}

ESH-EMS-980569
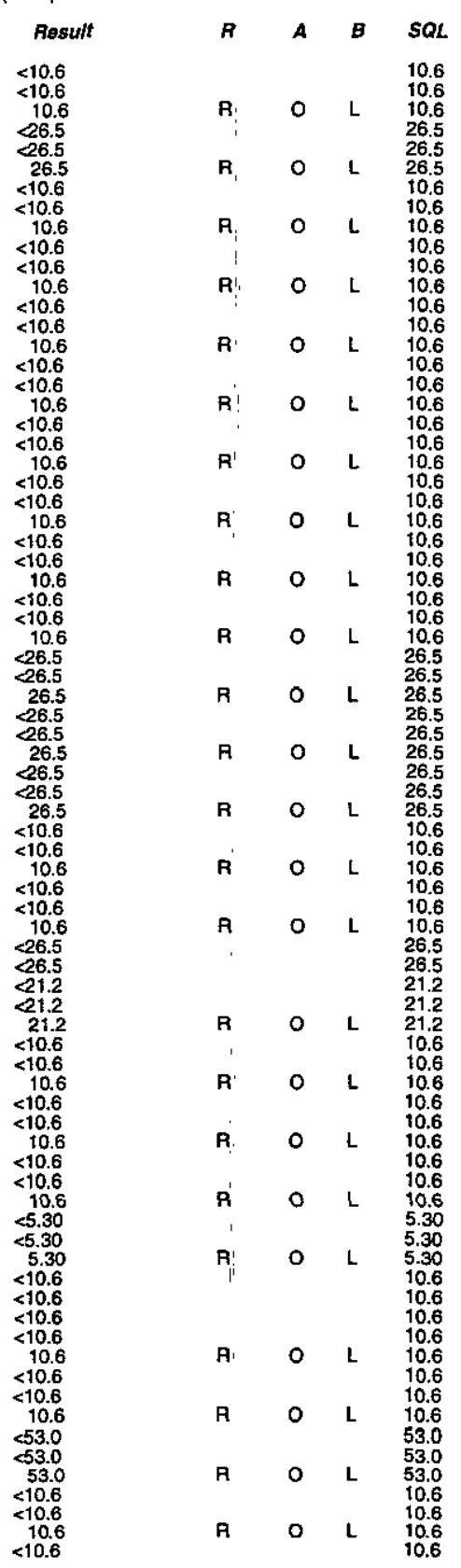

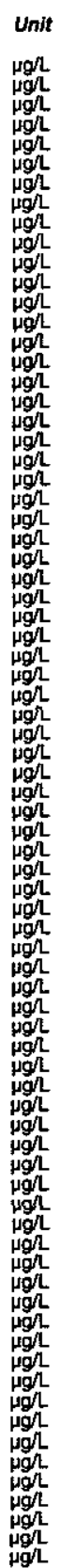

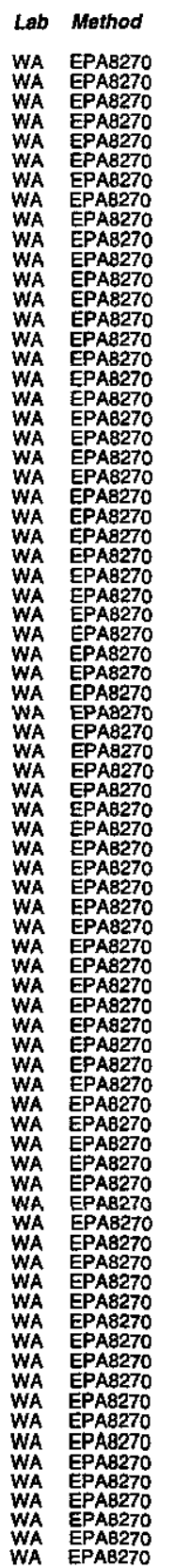

Well DBP 4 collected on 04/16/98 (cont.)

$F$ Analyte

: 5-Nitro-o-toludidine

0 Octachlorodibenzo-p-dioxin
0 Octachlorodibenzo-p-dioxin

Octachlorodibenzo-p-turan

P PCB 1260

$\begin{array}{ll}0 & 1,2,3,7,8-P C D D \\ 0 & 1,2,3,7,8-P C D D \\ 0 & 1,2,3,8-P C D F \\ 0 & 1,2,3,7,8-P C D F\end{array}$

Pentachlorobenzene

Pentachlorobenzene

rodibenzo-p-dioxins

Pentachlorodibenzo-p-purans
Pentachlorodibenzo-p-furans

Pentachloroethane
Pentachloroethane

Pentachlorcethane

Pentachloronitrobenzene

Pentachlorophenol

Pentachloroph

Phenacetin

Phenanthrene
Phenanthrent

Phenol

p-Phenylenediamine

p-phenylenediamine

2-Picoline

Pronamid

Pronamid

Pyrene

0 Pyridine

Satrole

$\begin{array}{ll}0 & \text { Satrole } \\ 0 & 2,3,7,8-T C D D \\ 0 & 2,3,7,8-T C D D\end{array}$

2,3,7,8-TCDF

$1,2,4,5$-Tetrachlorobenzene 1,2,4,5-Tetrachlorabenzene

Tetrachlorodibenzo-p-dioxins Tetrachlorodibenzo-p-furans $1,1,2,2-$ Tetractilofoeshante 1, 1,2,2-Tetrachlosoethante Tetrachloroethylene Tetrachioroethylene 2,3,4,6-Tetrachlorophenol Toluene
Toluene $\begin{array}{ll}0 \\ 0 \\ 0 & \text { Toluene } \\ 0 . \text { Toluidine } & \text { Toluidine } \\ & \end{array}$

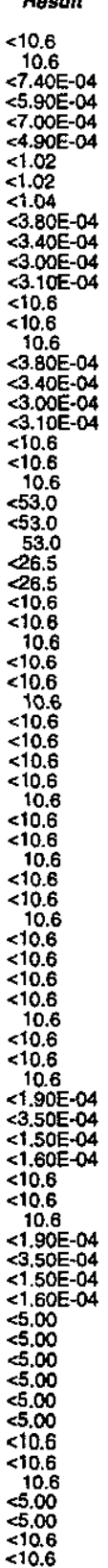

R

R

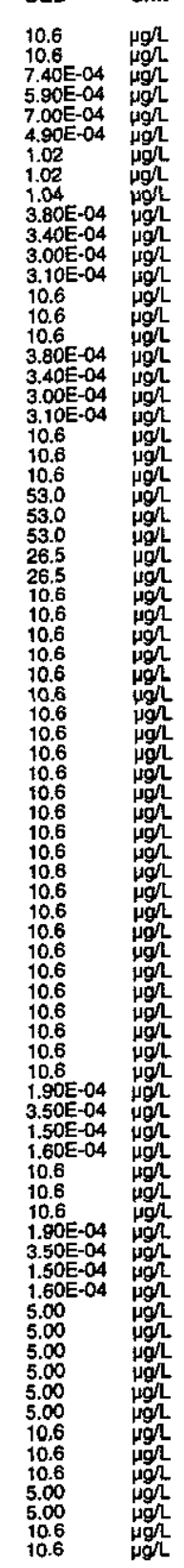

Lab Method

WA IEPAB270

WA 'EPAB270

WA

WA EPA8081

WA EPABOB1

WA EPAB280

WA EPA8280

WA EPA8270

WA ' EPAB280

WA EPA8280

WA EPA8280

WA EPAB270

WA EPA8270

WA EPAB270

WA EPA8270

WA EPA8270

WA , EPAB270

WA EPAB270

EPAB270

EPA8270

WA

EPAB270

I EPAB2

WA : EPAB270

WA WPA8270

WA EPAB28

WA EPA8280

WA EPA8270

WA, EPA8280

WA EPAB2BO

WA EPAB260

WA EPAB260

WA

WA EPA8270

WA . EPA8270

WA EPAB2260 
Well DBP 4 collected on 04/16/98 (cont.)

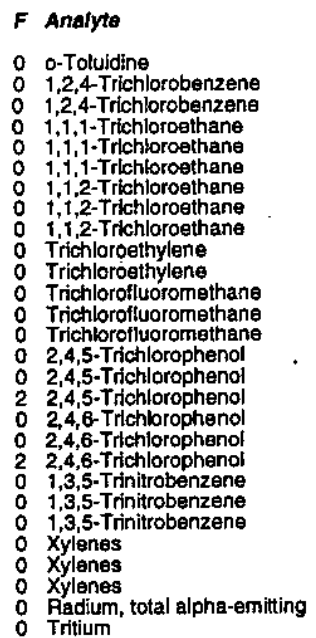

Result
10.6
$<10.6$
$<10.6$
$<5.00$
$<5.00$
$<5.00$
55.00
$<5.00$
$<5.00$
$<5.00$
$<5.00$
$<5.00$
$<5.00$
$<5.00$
$<26.5$
$<26.5$
26.5
$<10.6$
$<10.6$
10.6
$<10.6$
$<10.6$
10.6
$<5.00$
$<5.00$
$<5.00$
$6.00 \mathrm{E}-10 \pm 3.60 \mathrm{E}-10$
$8.80 \mathrm{E}-07 \pm 4.20 \mathrm{E}-07$

A B SQL

Unit Lab Mothod

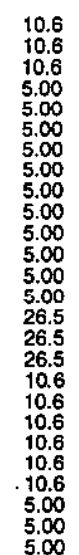

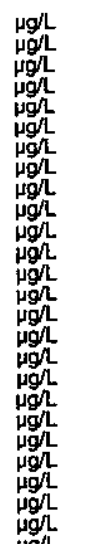

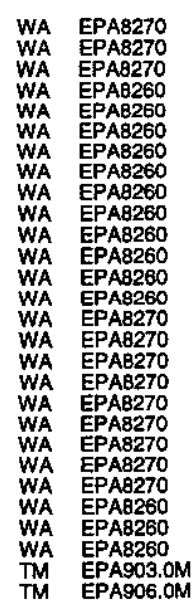

WELL DBP 5

MEASUREMENTS CONDUCTED IN THE FIELD

Sample date: $04 / 16 / 98$
Depth to water: $13.24 \mathrm{ft}(4.04 \mathrm{~m})$ below TOC
Water elevation: $121.36 \mathrm{tt}(36.99 \mathrm{~m}) \mathrm{ms}$

Depth to wat
Water ele
pH: 4.5

Sp. conductance: $47 \mu \mathrm{S} / \mathrm{cm}$

Water evacuated from the well prior to sampling: $24 \mathrm{gal}$

ANALYSES

- Acenaphthene

Acenaphthylene
2-Acetylamonino
4hiluorene

4-Amirobipheny

Anthracene

Arsenic, total recoverable

o Benzo(a)anthracene

Benzo (k)fluoranthene

Benzo( $\{$, h,, 3 perylen

Benzo(d)pyrene

Bis(2-chloroethoxy) methan
Bis(2-chloroethyn) ether

Bis (2-ecthylhexplopyl) ether

Bromodichloromethane

Bromotorm

4-Bromophenyl phenyl ether

2-sec-Butyl-4,6-dinitropheno

Carbon tetrachloride

4-Chloro-m-cres

ESH-EMS-980569

Well DBP 5 collected on 04/16/98 (cont)

$F$ Analyte

- Chloroethene (Vinyl chloride)

2-Chloroethyl vinylether

Chloroform

2-Chloronaphthalen

4.Chlorophenyl phenyl ether

Chrysene

m/p-Cresol

Dibenzofuraa

Dibromocthloromethan

1,2-Dichlorobenzen

1,4-Dichlorobenzene

1,1-Dichloroethane

1,1-Dichloroethylene

Dichloromethane
2,4-Dichloropheno

2,6-Dichlorophenol

cis-1,3-Dichioropropene

Diethyl phthalate
2.4-Dimethyl phenol

p-Dimethylaminoazobenzen

7.,12-0iny

1,3-Dinitrobenzene

2,4-Dinitrotoluene

2,6-Dinitrotoluene

1,4-Dioxare

Endrin
Ethyl methacrylate
Etyyl methanesulfonat

Ethyl methanes

Fluoranthene

Heptachlorodibenzo-p-dioxin

Hexachlorobenzene
Hexachlorobutadiene

Hexachlorocyclopentadiene

- Hexactlorodibenzo-p-dioxins

o Hexachlorodibenzo-

Hexachlorophene

Hexachloropropen:
$1,2,3,4,6,7,8-H P C D$
$1,2,3,4,6,7,8-\mathrm{HPCDF}$

$1,2,3,4,6,7,-\mathrm{HPCD}$

indeno(1,2,3-c,d)pyrene

Isophorone

Manganese, total recoverable

Mathapyrilene

Methyl methacrylate

2-Methytraphthalene

1,4-Naphthequinone

WA EPAIR

WA EPAB270

B-111
Result

$<10.0$
$<10.0$

$<5.00$
$<10.0$

$<10.6$
$<10.6$
$<10.6$

$<10.6$

$<10.6$
$<10.6$
$<10.6$

$<5.00$

$<10.6$
$<10.6$

$<5.00$

$<5.00$
$<5.00$

$<1.94$

$<.00$
$<5.00$

$<10.6$

$<10.6$
$<10.6$
$<10.6$
$<10.6$

$<10.6$
$<10.6$
$<10.6$
$<26.5$

$<10.6$
$<10.6$
$<10.6$

$<10.6$
$<10.6$
$<10.6$
$<0.102$

$<10.6$
$<10.6$
$<5.00$
$<10.6$

$<10.6$

$<5.30 \mathrm{E}-04$

$<5.20 \mathrm{E}-04$

$<4.20 \mathrm{E}-04$

$<106$

$<.60 \mathrm{E}-04$
$<4.40 \mathrm{E}-04$

$<3.60 \mathrm{E}-04$

$<10.6$

$<10.6$
3.00
$<10.6$
$<26.5$

$<10.6$
$<10.6$
$<10.6$
$<10.6$
$<10.6$

$<10.6$
$<10.6$
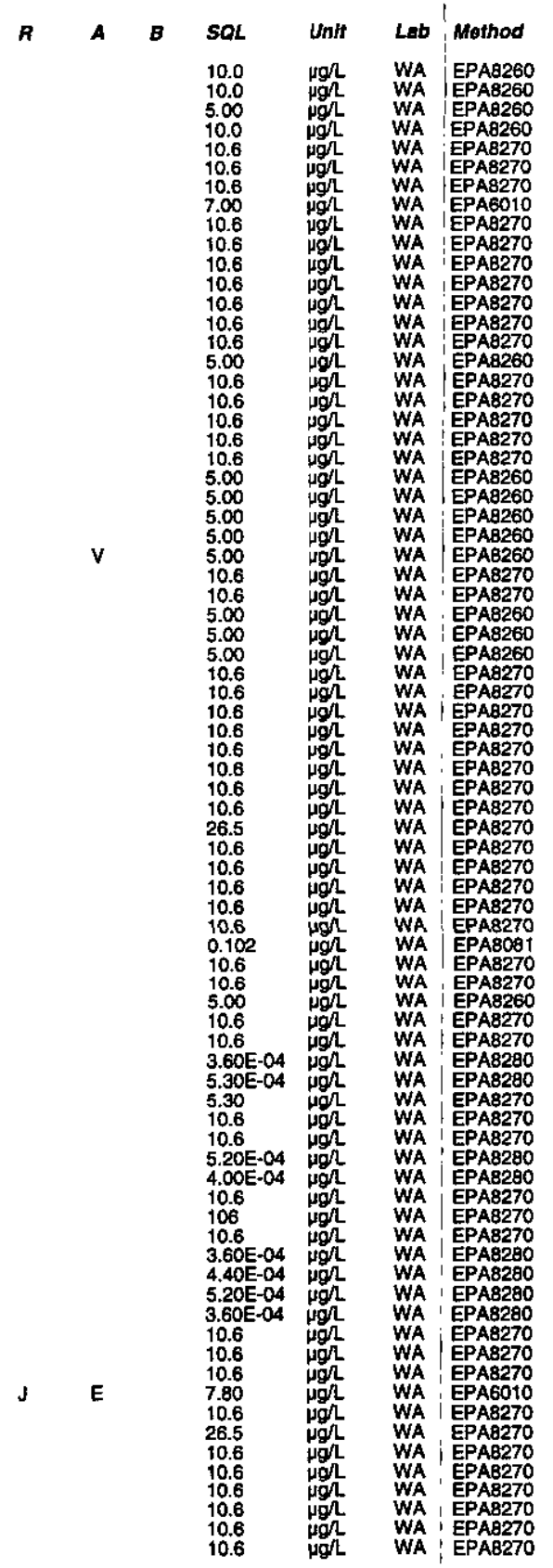

Second Quarter 1998 
Well DBP 5 collected on 04/16/98 (cont.)

$F$ Analyte

1-Naphthylamine
0

m-Natroariline

o-Nitroaniling

2-Nitrophen

4-Nitrophenol

4-Nitroquinoline-1-oxide

$\mathrm{N}$-Nitrosodiethylamine

N-Nitrosodimethylamine

N-Nitrosodipropylamine

N-Nitrosomorpholine

N-Nitrosopopyerolididine

O-Nitro-o-toluidine
Octachlorodibenzo-p-dioxin
Octachlorodibenzo-p-furan

$\mathrm{PCB} 1260$
$1,2,3,7,8-\mathrm{PCDD}$
$1,2,3,7,8-\mathrm{PCDF}$

$1,2,3,7,6-P C D F$
Pentachlorobenzene

Pentachlorodibenzo-p-dioxins

Pentactioroethane

Pentachlorophenol

Phenacetin
Phenanthren

phenenylenediamine

2-Picoline

Pyrene

Safrole

$2,3,7,8-\mathrm{TCDO}$

1,2,4,5-Totrachlorobenzene

Tetrachlorodibenzo-p-furans

Tetrachloroethlyene Tolvene

1,2,4-Trichlorobenzene

$1,1,1$-Trichlorosthan

Trichloroethylene

2,4,5-Trichlorophenol

1,3,5-Trinitrobenzene

Radium, total alpha-emitting
Tritium

\section{WELL DCB 16R}

MEASUREMENTS CONDUCTED IN THE FIELD

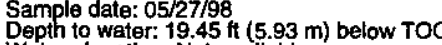

Water

Sp. conductance: $910 \mu \mathrm{S} / \mathrm{cm}$

Tubidity: 0 NTU:
Water evacuated from the well prior to sampling: $28 \mathrm{gal}$

ESH-EMS-980569

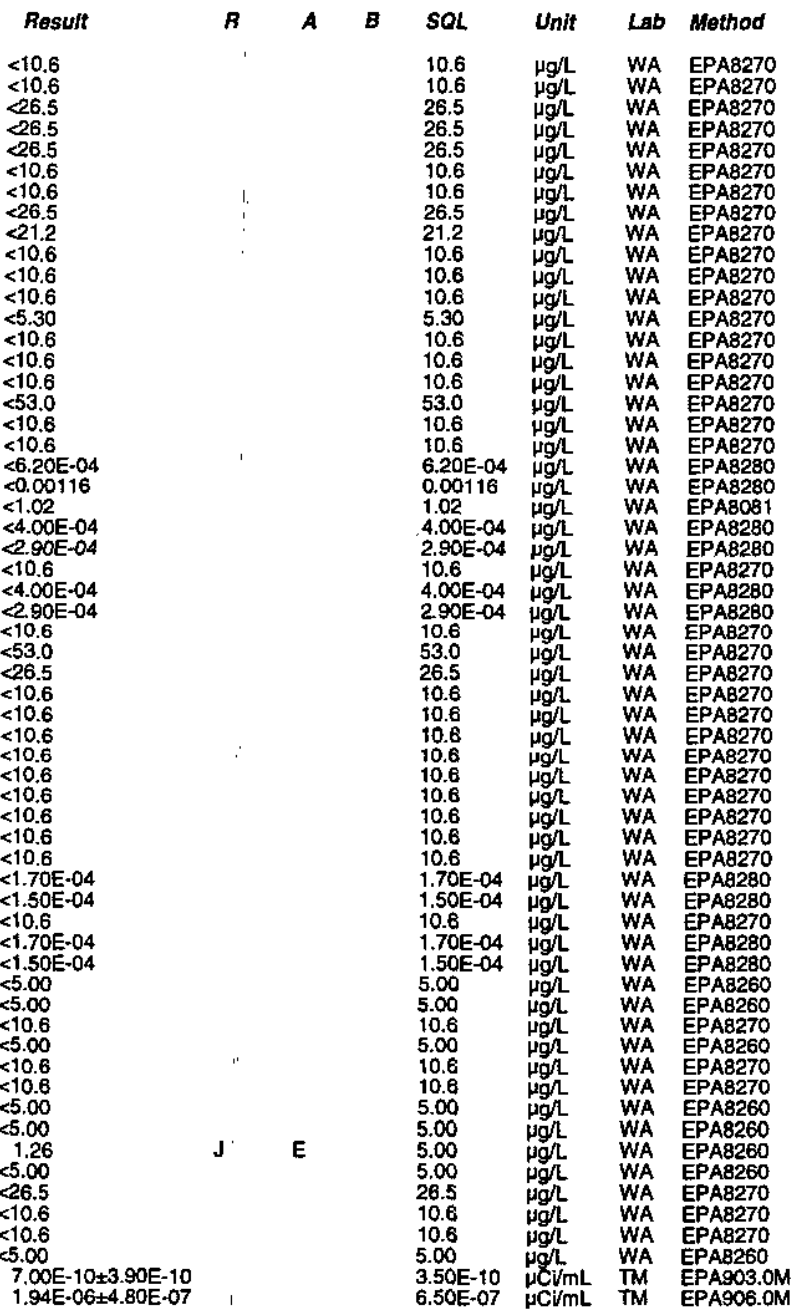

Time: $11: 40$

Water temperature: $22.8^{\circ} \mathrm{C}$

Total alkalinity (as CaCO3): $0 \mathrm{mg} /$
Well DCB 16 R collected on 05/27/98 (cont.)

ANALYSES

\begin{tabular}{|c|c|c|c|c|c|c|c|c|}
\hline Analyte & Result & B & A & $B$ & SOL & Unit & $L a b$ & Method \\
\hline 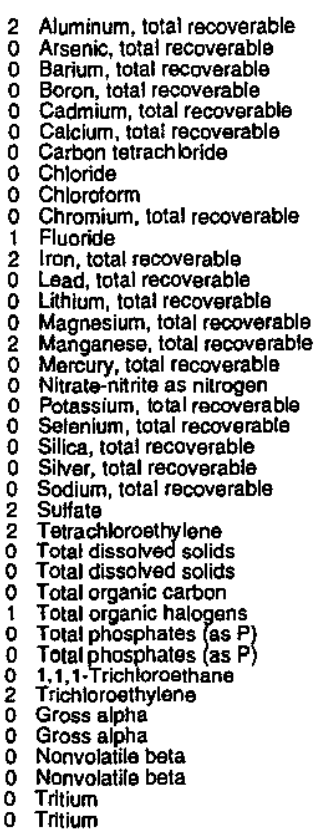 & 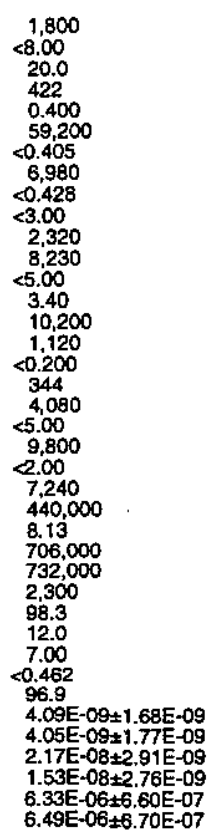 & $\begin{array}{l}J \\
J \\
J\end{array}$ & $\begin{array}{l}E Y \\
1 \\
E\end{array}$ & $\stackrel{H}{H}$ & 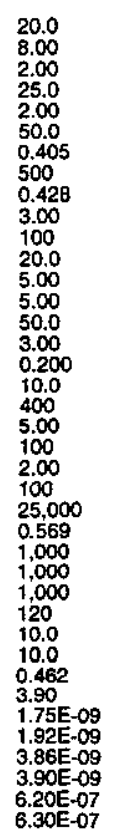 & 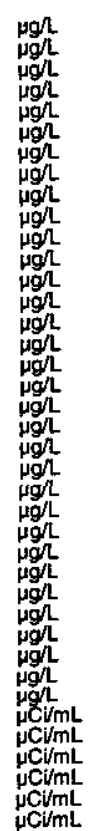 & $\begin{array}{l}\text { ES } \\
\text { ES } \\
\text { ES } \\
\text { ES } \\
\text { ES } \\
\text { ES } \\
\text { ES } \\
\text { ES } \\
\text { ES } \\
\text { ES } \\
\text { ES } \\
\text { ES } \\
\text { ES } \\
\text { ES } \\
\text { ES } \\
\text { ES } \\
\text { ES } \\
\text { ES } \\
\text { ES } \\
\text { ES } \\
W A \\
\text { ES } \\
\text { ES } \\
\text { TM } \\
T M \\
T M \\
T M \\
T M \\
T M\end{array}$ & 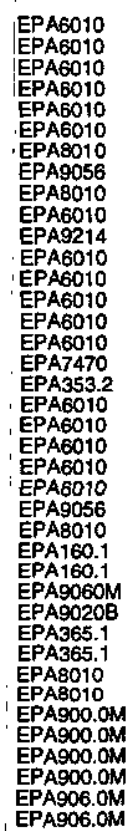 \\
\hline
\end{tabular}

\section{WELL DOB 1}

MEASUREMENTS CONDUCTED IN THE FIELD

Sample date: 06/02/98
Depth to water: $5.1 \mathrm{ft}(1.55 \mathrm{~m})$ below TOC
Water elevation: $146.6 \mathrm{ft}(44.68 \mathrm{~m}) \mathrm{ms}$

$\mathrm{pH}: 5.6$

Sp. conductance: $80 \mu \mathrm{S} / \mathrm{cm}$

Water evacuated from the well prior to sampling: 157 gal

ANALYSES

\begin{tabular}{|c|c|}
\hline Analyte & Result \\
\hline 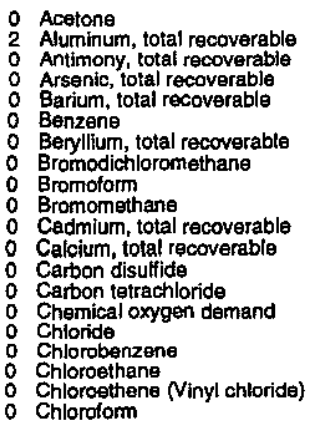 & $\begin{array}{l}<10.0 \\
67.3 \\
<100 \\
<10.0 \\
46.9 \\
<5.00 \\
<5.00 \\
<5.00 \\
<5.00 \\
<5.00 \\
<5.00 \\
5.110 \\
<5.00 \\
<5.00 \\
23,500 \\
1.690 \\
<5.00 \\
<5.00 \\
<5.00 \\
<5.00\end{array}$ \\
\hline
\end{tabular}

Time: 8:43

Total alkalinity (as Caco3): 11 mgh
Phenolphthalein alkalinity: 0 mgh

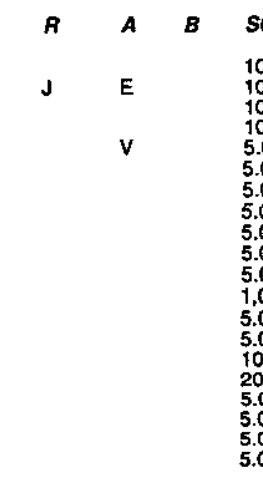

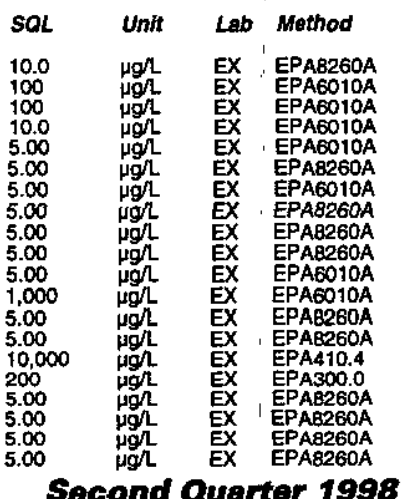


Well DOB 1 collected on 06/02/98 (cont.)

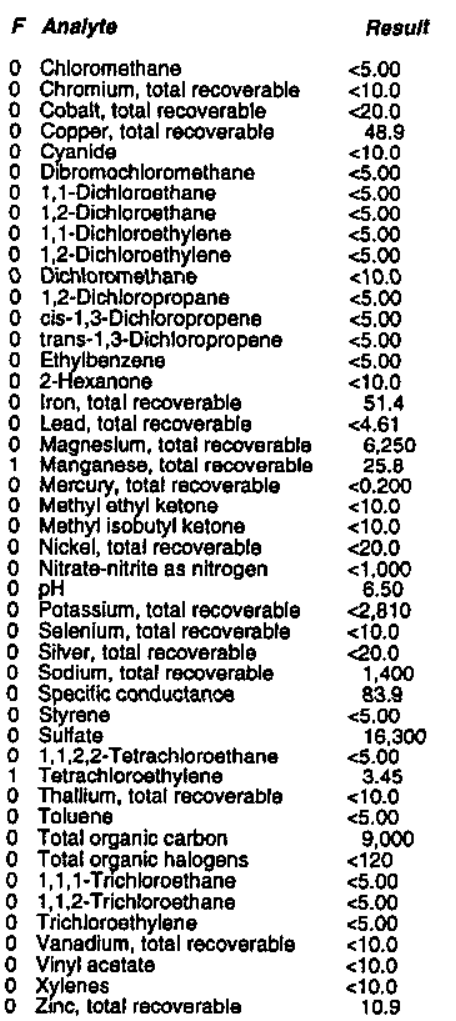

WELL DOB 2

MEASUREMENTS CONDUCTED IN THE FIELD

Sample date: $06 / 03 / 98$
Depth to water: $6.7 \mathrm{ft}(2.04 \mathrm{~m})$ below TOC
Water elevation: $145.5 \mathrm{tt}(44.35 \mathrm{~m}) \mathrm{msl}$

Water el

Sp. conductance: $72 \mu \mathrm{S} / \mathrm{cm}$

Wurbidity: 1 NTU frem the well prior to sampling: $60 \mathrm{gal}$

ANALYSES

$F$ Aneinte

0 Acetone

1 Acetone

- Antimony; total recoverable

: Antimony, total recoverable

Arsenic, total recoverable

O Barium, total recoverable

Benzene
Benzene

Beryllium, total recoverable

ESH-EMS-980569

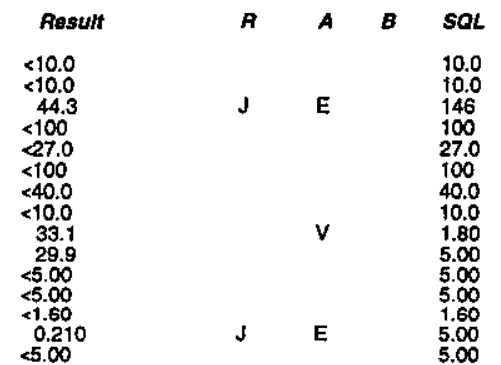

SOL
10.0
10.0
146
100
27.0
100
40.0
10.0
1.80
5.00
5.00
5.00
1.60
5.00
5.00

Well DOB 2 collected on 06/03/98 (cont.)

$F$ Analyte

Bromodichloromethane

Bromoform

Bromomethane

Carminium, total recoverable

Calcium, total recoverable

- Calcium, total reco

Carbon disulfide

Carbon tetrachloride

Chemical oxygen demand

0 Chloride

Chlorobenzene

Chloroethane

Chloroethane

Chloroettene (Vinyl chloride)

Chloroform

Chloromethane

Chromiurm, total recoverable

Cobalt, total recoverable

Cobatt, total recoverable

Copper, total recovererable

Cyanide

OD Dibromochloromethane

1,1-Dichloroethane

1,2 -Dichloroethane

1,2-Dichloroethane

1,1-Dichloroethylene

1,2-Dichloroethyle

Dichloromethane
Dichloromethane

1,2-Dichloropropane

cis-1,3-Dichloropropene

trans-1,3-3ichloropropene
trans-1,3-Dichloropropene

OEthybenzene

2-Hexanone

2-Hexanone

Iron, total recoverable
lron, total recoverable
Lead, total recoverable

Magnesium, total recoverable

Magneslum, total recoverable

Maninganese, total recoverable

o Mercury, total recoverable

Methyl ethyl ketons

o Methyl isobutyl ketone

N Methyl isobuty ketone

Nickel, total recoverable

Nitrate-nitritite as nitrogen
0 Nitrate-nitrite as nitrogen

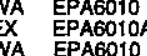

WA EPAG010

WA EPAB260

WA EPA6010

3-113

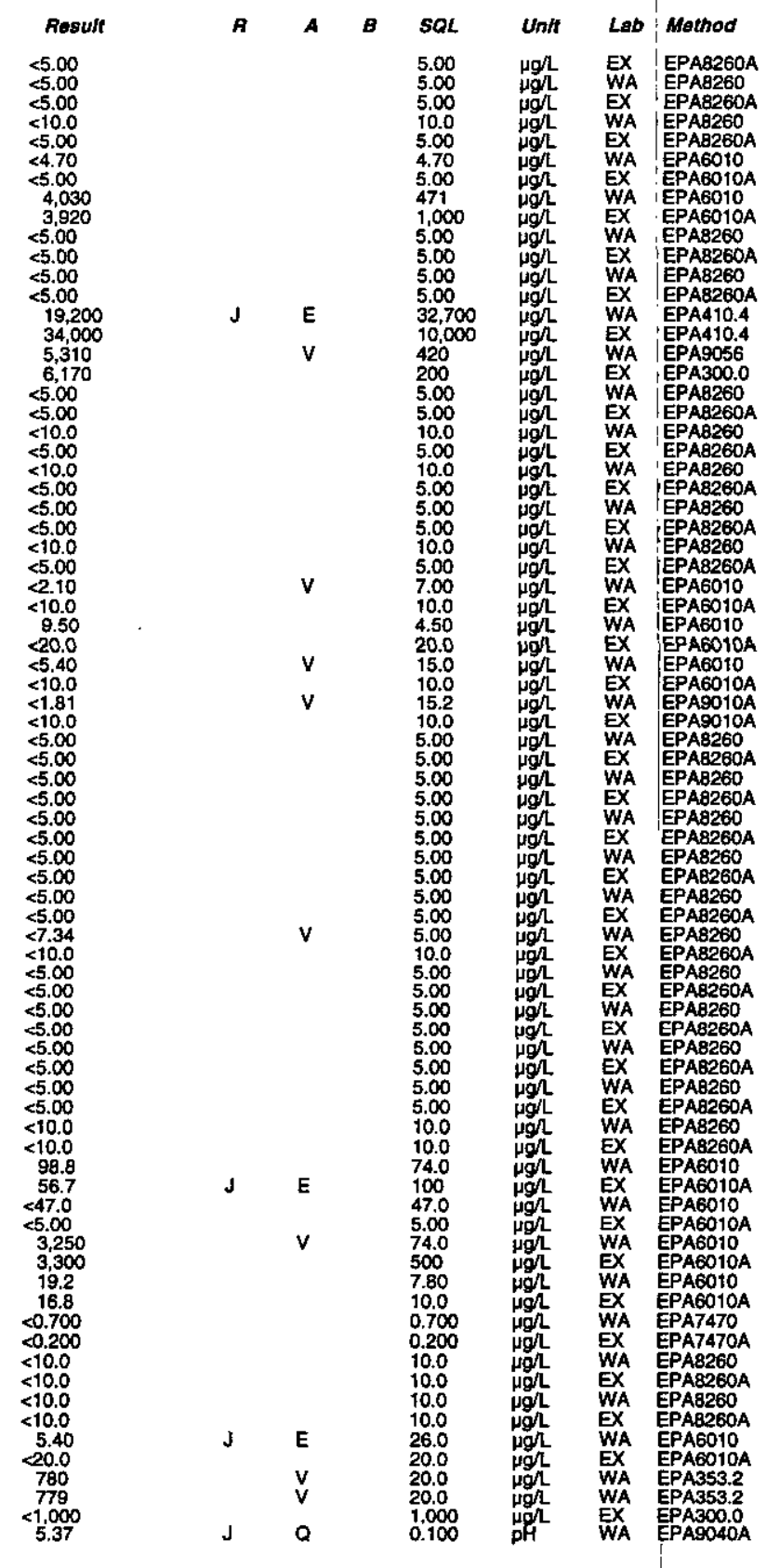

Second Quartor 1998 
Well DOB 2 collected on $06 / 03 / 98$ (cont)

\begin{tabular}{|c|c|c|c|c|c|c|c|}
\hline F Analyte & Result & $\boldsymbol{R}:$ & $A$ & SOL & Unit & Lab & Method \\
\hline 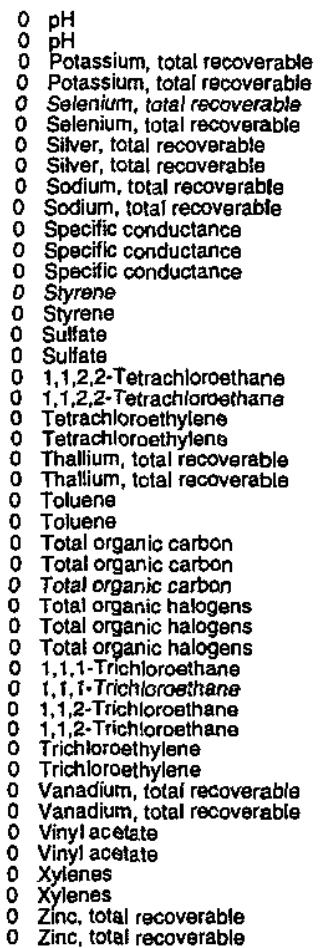 & $\begin{array}{l}5.35 \\
5.20 \\
1,380 \\
<1,640 \\
<66.0 \\
<10.0 \\
<0.830 \\
<20.0 \\
2.400 \\
2,510 \\
64.3 \\
64.6 \\
72.3 \\
<5.00 \\
<5.00 \\
13.600 \\
13,700 \\
<5.00 \\
55.00 \\
55.00 \\
55.00 \\
55.0 \\
<10.0 \\
55.00 \\
<5.00 \\
17,000 \\
13,700 \\
9,000 \\
28.6 \\
24.9 \\
25.0 \\
<5.00 \\
55.00 \\
55.00 \\
<5.00 \\
<5.00 \\
<5.00 \\
0.700 \\
<10.0 \\
<10.0 \\
<10.0 \\
5.00 \\
<10.0 \\
13.0 \\
4.67\end{array}$ & $\begin{array}{l}\mathbf{J} \\
\mathbf{j}\end{array}$ & $\begin{array}{l}a \\
o \\
v \\
v\end{array}$ & $\begin{array}{l}0.100 \\
0.00 \\
187 \\
1,000 \\
66.0 \\
10.0 \\
5.00 \\
20.0 \\
285 \\
1.000 \\
8.90 \\
8.90 \\
1.00 \\
5.00 \\
5.00 \\
680 \\
200 \\
5.00 \\
5.00 \\
5.00 \\
55.00 \\
10.0 \\
5.00 \\
5.00 \\
5.000 \\
5.000 \\
5.000 \\
120 \\
120 \\
5.00 \\
5.00 \\
5.00 \\
5.00 \\
5.00 \\
6.90 \\
10.0 \\
10.0 \\
10.0 \\
5.00 \\
10.0 \\
53.0 \\
10.0\end{array}$ & 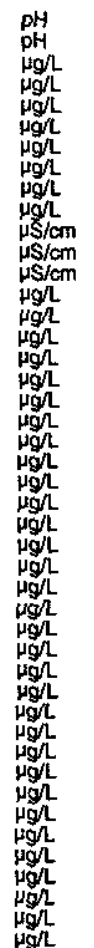 & $\begin{array}{l}\text { WA } \\
\text { EX } \\
\text { WA } \\
\text { EX } \\
\text { WA } \\
\text { EX } \\
\text { WA } \\
\text { EX } \\
\text { WA } \\
\text { EX } \\
\text { WA } \\
\text { WA } \\
\text { EX } \\
\text { WA } \\
\text { EX } \\
\text { WA } \\
\text { EX } \\
\text { WA } \\
\text { WX } \\
\text { WA } \\
\text { WA } \\
\text { EX } \\
\text { WA } \\
\text { EX } \\
\text { WA } \\
\text { WA } \\
\text { EX } \\
\text { WA } \\
\text { WA } \\
\text { WA } \\
\text { WA } \\
\text { EX } \\
\text { WA } \\
\text { WA } \\
\text { WX } \\
\text { WA } \\
\text { EX } \\
\text { WA } \\
\text { EX } \\
\text { WA } \\
\text { EX } \\
\text { WA } \\
\text { EX }\end{array}$ & 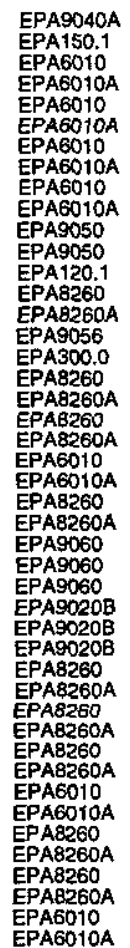 \\
\hline
\end{tabular}

WELL DOB 2 Replicate

MEASUREMENTS CONDUCTED IN THE FIELD

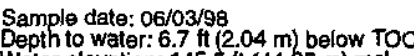
Water elevation: $145.5 \mathrm{tt}(44.35 \mathrm{~m}) \mathrm{ms}$

Sp: 4.8 conductance: $72 \mu \mathrm{S} / \mathrm{cm}$

Water evacuated from the well prior to sampling: $60 \mathrm{gal}$

ANALYSES

$F$ Analyto

Acetone Antimony, total recoverabl

Bartum, total recoverable

Beryllium, total recoverable

Bromodlehloromethane

Bromometh

Cadmium, total recoverable

Carton disufficici

Charbon tetrachlorlde
Chemical oxygen demano

ESH-EMS-980569

Result
$<10.0$
$<100$
$<100$
$<10.0$
31.7
5.00
55.00
55.00
55.00
55.00
55.00
4.070
55.00
45.00
28,800
6.000

Time: 8:52 Air temperature: $276^{\circ} \mathrm{C}$ Total alkalinity (as CaCO3): $1 \mathrm{mg} / \mathrm{L}$
Phenolphthalein alkalinity: $0 \mathrm{mg} /$
Well DOB 2 collectsd on 06/03/98 (cont)

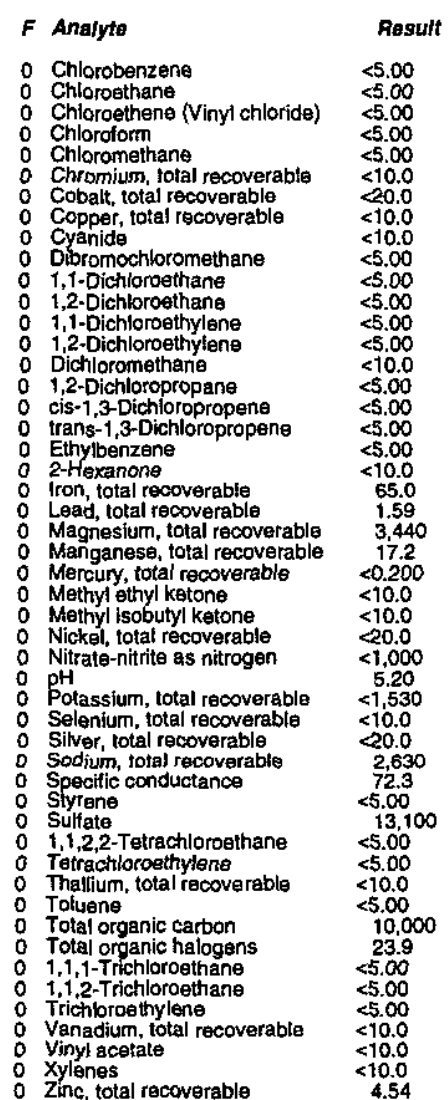

\section{WELL DOB 7}

MEASUREMENTS CONDUCTED IN THE FIELD

Sample date: 06/03/98
Depth to water $5.6 \mathrm{ft}(1.71 \mathrm{~m})$ below TOC
Water elevation: $145.3 \mathrm{ft}(44.29 \mathrm{~m}) \mathrm{msl}$

$\mathrm{pH}: 4.6$

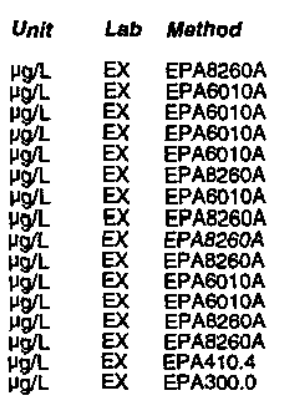

Sp. conductance: $100 \mu \mathrm{S} / \mathrm{cm}$

Water evacuated from the well prior to sampling: $14 \mathrm{gad}$

ANALYSES

$F$ Analyte

Acetone
2 Aluminum, total recoverable
0 Antimony, total recoverable

0 Antimony, total recoverable

B Barium, total recoverable

Berylllum, total recoverabt

Bromoform

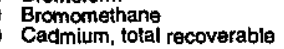

-114

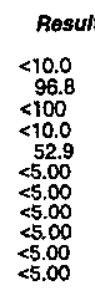

ค

Time: 8:00

Air temperature: $22.3^{\circ} \mathrm{C}$

Phenolphthalein alkalinity: $0 \mathrm{mg} \mathrm{mL}^{-}$

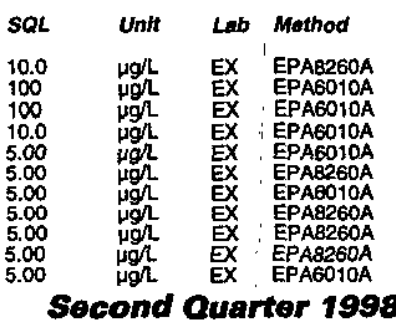

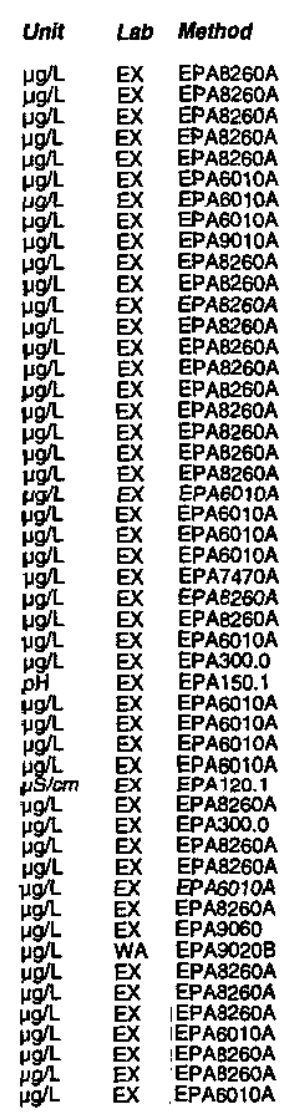


Well DOB 7 collected on 06/03/98 (cont.)

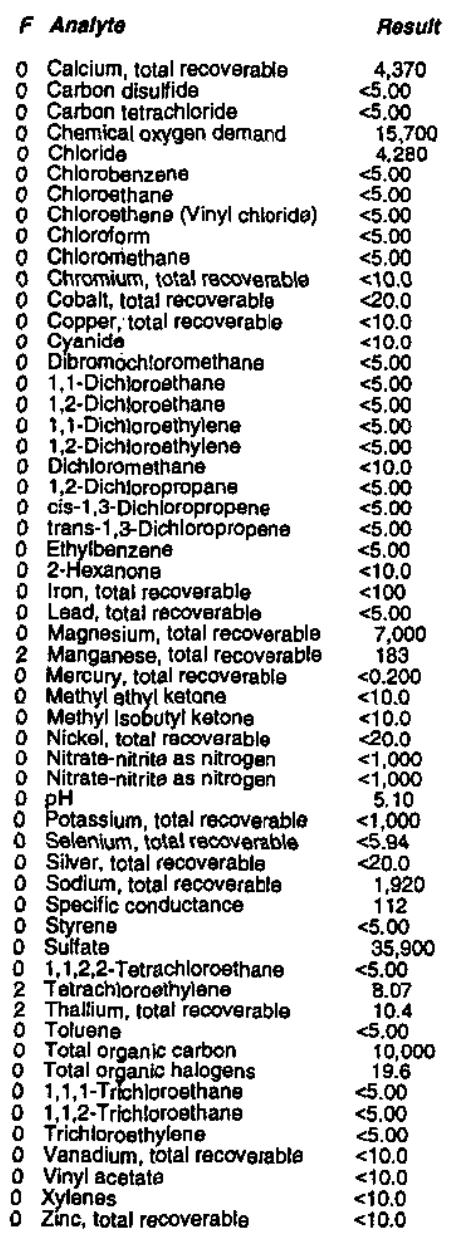

WELL DOB 8

MEASUREMENTS CONDUCTED IN THE FIELD

Sample date: $06 / 03 / 98$ Depth to water: $6.6 \mathrm{ft}$ ( $2.01 \mathrm{~m})$ below TOC

Wh: 4.8

Sp. conductance: $44 \mu \mathrm{S} / \mathrm{cm}$

Water evacuated from the well prior to sampling: 11 gal

ANALYSES

$F$ Analyte

Resuft
$<10.0$
$<100$
$<100$
$<10.0$
20.3

$<10.0$
$<100$
$<100$
$<10.0$
20.3

$\boldsymbol{R}$

$\begin{array}{lll}A \quad B & \text { SOL } & \\ & 10.0 & \\ & 100 \\ 100 & \\ 10.0 & \\ & 5.00 & \\ & & \end{array}$

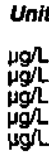

Lab Mothod

EX EPAB260A

$\begin{array}{ll}\text { EX } & \text { EPA6010A } \\ \text { EPAG010A } \\ \text { EX } \\ \text { EPAG010A } \\ \text { EPA6010A }\end{array}$

Water temperature: $17^{\circ} \mathrm{C}$

Air temperature: $31.8^{\circ} \mathrm{C}$
Total alkalinity (as CaCO3): $1 \mathrm{mgh}$
Phenolphthalein alkalinity: $0 \mathrm{mg}$ L

Aluminum, total recoverab

ESH-EMS-980569
Well DOB 8 collected on 06/03/98 (cont.)

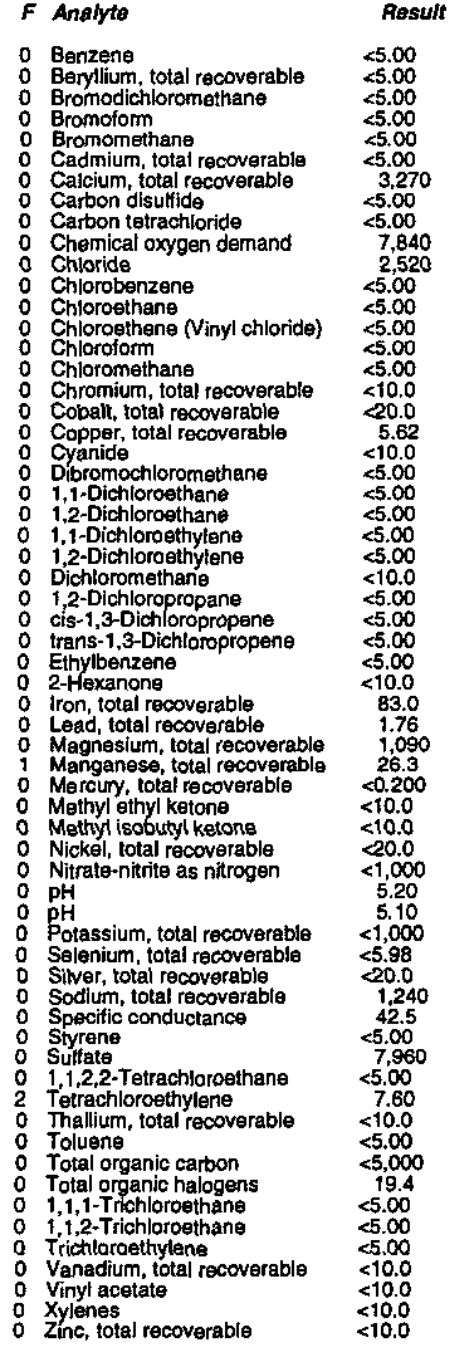

\section{WELL DOB 10}

MEASUREMENTS CONDUCTED IN THE FIELD

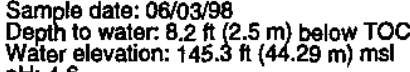

Sp: 4.6 . 6 ductance: $60 \mu \mathrm{S} / \mathrm{cm}$

Turbidity: 1 NTU
Water evacuated from the well prior to sampling: $10 \mathrm{gal}$

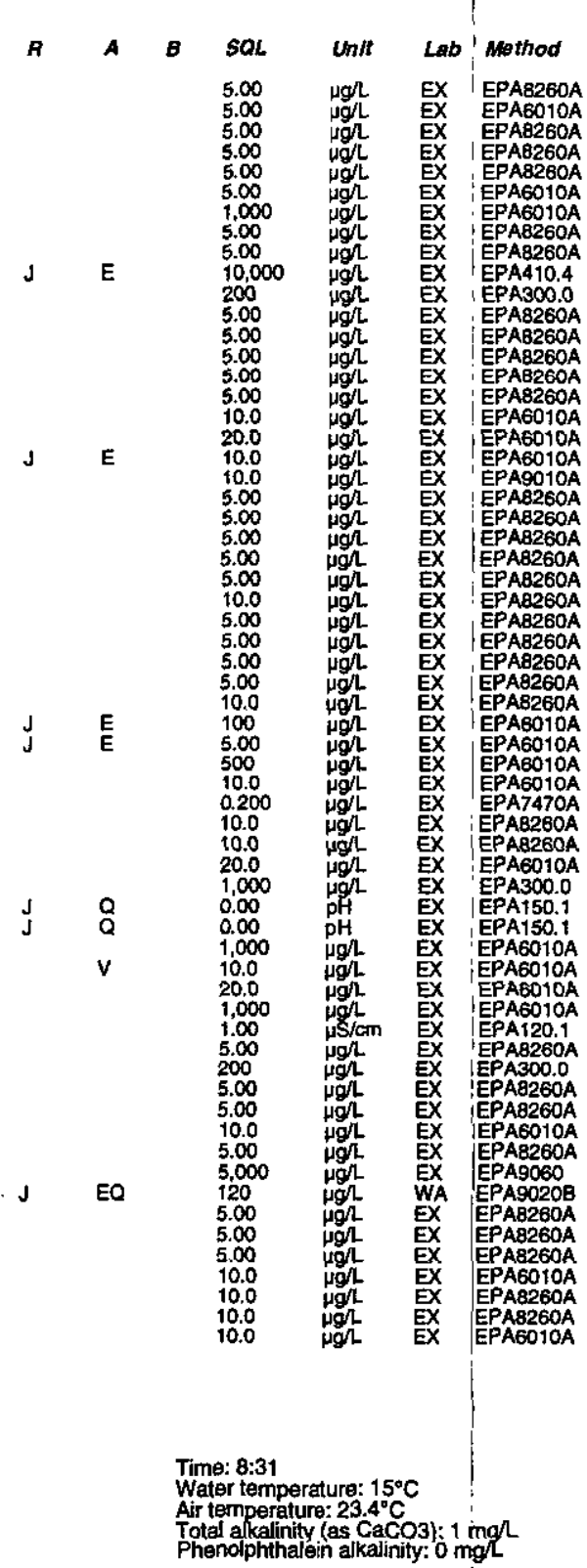

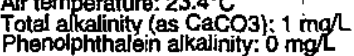

Second Quarter 1998 
Well DOB 10 collected on 06/03/98 (cont.)

ANALYSES

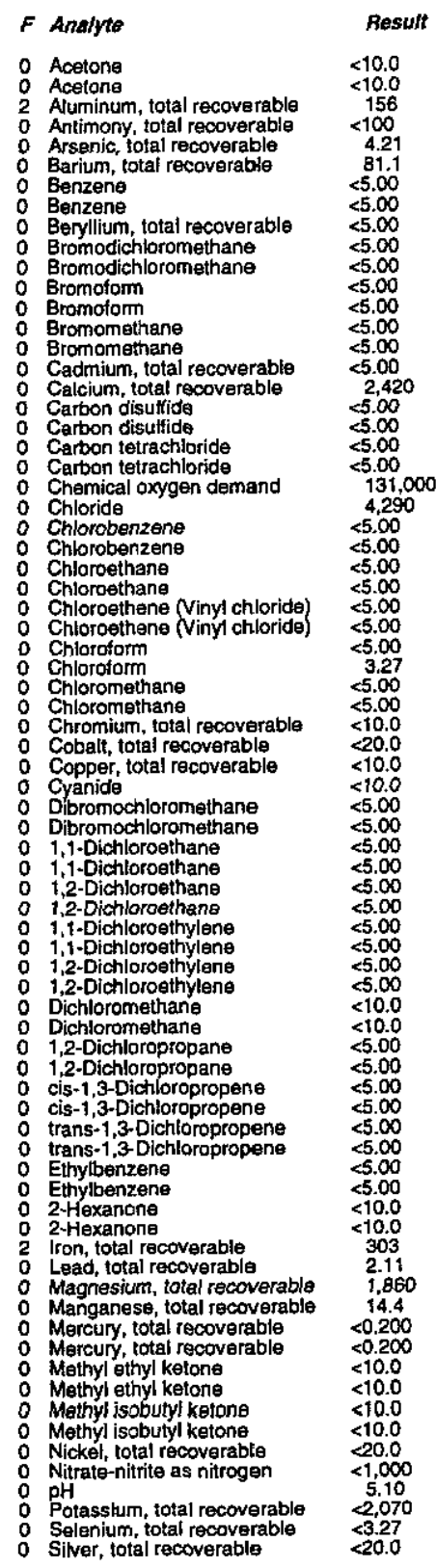

ESH-EIMS-980569
Well DOB 10 collected on 06/03/98 (cont.)

$F$ Analyte

Result
3,250
55.7
$<5.00$
$<5.00$
11,200
$<5.00$
$<5.00$
$<5.00$
$<5.00$
$<10.0$
$<5.00$
$<5.00$
6.000
43.1
$<5.00$
$<5.00$
$<5.00$
$<5.00$
$<5.00$
$<5.00$
$<10.0$
$<10.0$
$<10.0$
$<10.0$
$<10.0$
$<10.0$
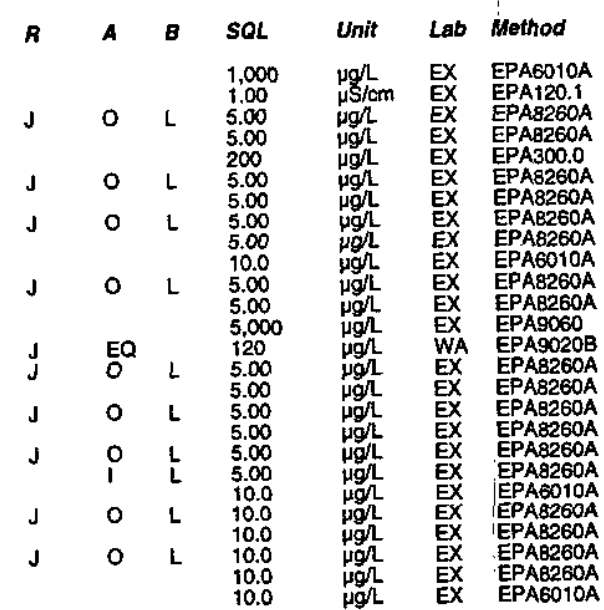

O Zinc, total recoverable

WELL DOB 12

MEASUREMENTS CONOUCTED IN THE FIELD

Sample date: $06 / 02 / 98$.

Wath

rer elevation: Not available

p. conductance: $58 \mu \mathrm{S} / \mathrm{cm}$

Water evacuated from the well prior to sampling: $17 \mathrm{gal}$ ANALYSES

$F$ Anatyte

2 Acatone

Antimony, total recoverabable

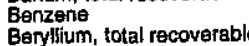

Berylsium, total recoverab

Bromotarm

Bromometha

Cadmium, total recoverable

Carbon disulfidide

Carbon tetrachloride

Chemical oxygen demand

Chloride

Chlorobenzene

Chloroethane

Chlorosorm

Chromium, total recoverable

Cobalt, total recoverable

Copper, total recoverab

Dibromochiloromethan

1, 2-Dichloroethane

1, 1.-Dichloroethylene
1,2-Dichlorothylente

1,2-Dichloropropane

B-116

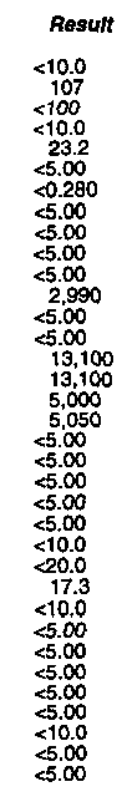

(1)

Time: 9:51

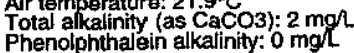


Well DOB 12 collected on 06/02/98 (cont.)

\begin{tabular}{|c|c|c|c|c|c|c|c|c|}
\hline Analyte & Resuft & H & A & 8 & SOL & Unit & Lab & Method \\
\hline 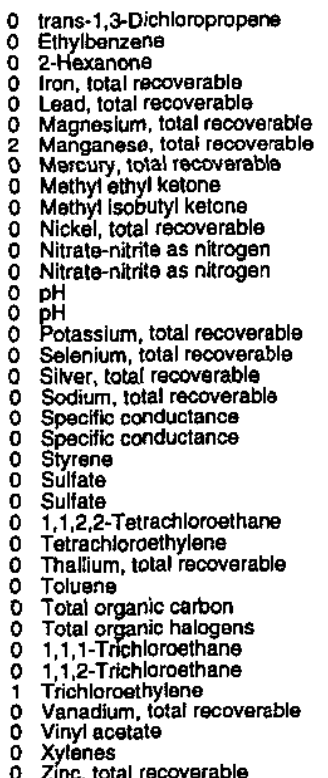 & $\begin{array}{l}<5.00 \\
<5.00 \\
<10.0 \\
55.3 \\
<2.27 \\
1,540 \\
56.5 \\
<0.200 \\
<10.0 \\
<10.0 \\
<20.0 \\
1,270 \\
1,250 \\
5.70 \\
5.60 \\
<1,000 \\
<10.0 \\
20.0 \\
4.750 \\
56.9 \\
56.9 \\
<5.00 \\
6,460 \\
6,350 \\
<5.00 \\
1.29 \\
<10.0 \\
<5.00 \\
<5,000 \\
<120 \\
<5.00 \\
<5.00 \\
2.54 \\
<10.0 \\
<10.0 \\
<10.0 \\
14.5\end{array}$ & $\mathbf{J}$ & co & H & $\begin{array}{l}5.00 \\
5.00 \\
10.0 \\
100 \\
5.00 \\
500 \\
10.0 \\
0.200 \\
10.0 \\
10.0 \\
20.0 \\
1,000 \\
1,000 \\
0.00 \\
0.00 \\
1.000 \\
10.0 \\
20.0 \\
1.000 \\
1.00 \\
1.00 \\
5.00 \\
.200 \\
200 \\
5.00 \\
5.00 \\
10.0 \\
5.00 \\
5,000 \\
120 \\
5.00 \\
5.00 \\
5.00 \\
10.0 \\
10.0 \\
10.0 \\
10.0\end{array}$ & 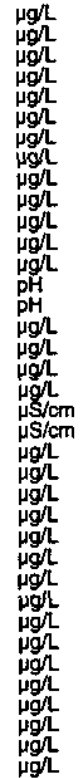 & $\begin{array}{l}\text { EX } \\
\text { EX } \\
\text { EX } \\
\text { EX } \\
\text { EX } \\
\text { EX } \\
\text { EX } \\
\text { EX } \\
\text { EX } \\
\text { EX } \\
\text { EX } \\
\text { EX } \\
\text { EX } \\
\text { EX } \\
\text { EX } \\
\text { EX } \\
\text { EX } \\
\text { EX } \\
\text { EX } \\
\text { EX } \\
\text { EX } \\
\text { EX } \\
\text { EX } \\
\text { EX } \\
\text { EX } \\
\text { WX } \\
\text { WA } \\
\text { EX } \\
\text { EX } \\
\text { EX } \\
\text { EX } \\
\text { EX } \\
\text { EX } \\
\text { EX }\end{array}$ & 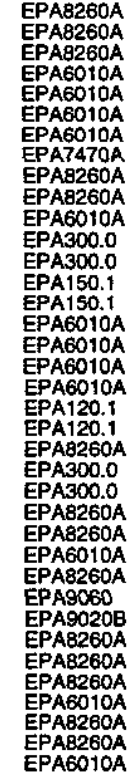 \\
\hline
\end{tabular}

\section{WELL FBP $41 C$}

MEASUREMENTS CONDUCTED IN THE FIELD

Sample date: $04 / 08 / 98$ Water elevation: Not available

p. conductance: $93 \mu \mathrm{S} / \mathrm{cm}$

Water evacuated from the well prior to sampling: $111 \mathrm{ga}$

ANALYSES

$F$ Analyto

a Alkalinity (as $\mathrm{CaCO}$ )

Bromodichloromethane

Bromoform

Calcium, total recoverable

Calcium, total recover

Cartonate

Chloroethene (Vinyl chloride)

Chloroform

Chloromathane
Dibromochloromethan

1,1-Dichloroethan

$1,1-$ Dichloroethylene
1,2 -Dichloroethylen

0 cis-1,3-Dichloropropene
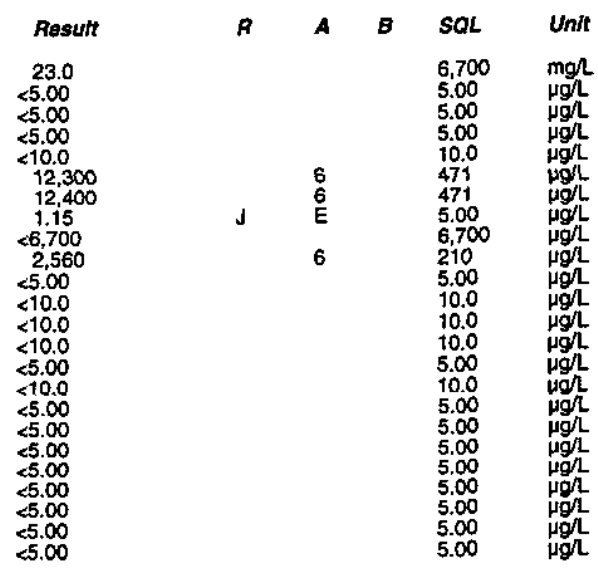

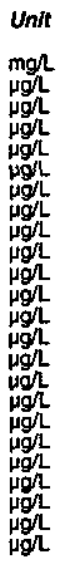

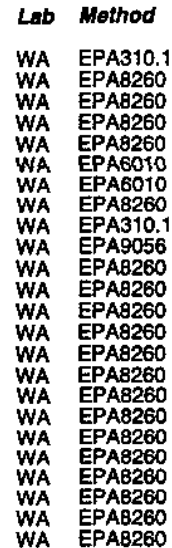

Time: $10: 48$ Water temperature: $19.6^{\circ} \mathrm{C}$ Air temperature: $23.1^{\circ} \mathrm{C}$
Total alkalinity (as CaCO3): $21 \mathrm{mg} / \mathrm{h}$
Phenolphthalein alkalinity: $0 \mathrm{mg} / \mathrm{L}$

Well FBP 41 C collected on 04/08/98 (cont.)

0 trans-1,3-Dichloropropene

o Iron, total recoverable

. Iron, total recoverable

a Nitrate as nitrogen

o Silica, total recoverable

- Sodium, total recoverable

Sulfate Ti,2,2-Trachloroethane

Tetrachloroethyleno

Total dissolved solids

Total organic halogens

Total phosphates (as ${ }^{2}$

$1,1,2-$ Trichloroethan
Trichicoroethylens

Trichloroffluoromethane

$\begin{array}{ll}0 & \text { Xylenes } \\ 0 \text { Tritium } & \\ 0 & \text { Tritium }\end{array}$

\section{WELL FBP 41C Replicate}

MEASUREMENTS CONDUCTED IN THE FIELD

Sample date: 04/08/98

Wh: 5 .

. conductance: $93 \mu \mathrm{S} / \mathrm{cm}$

Whater e. ONated from the well prior to sampling: 111 gal

ANALYSES

$F$ Analyto

A Akalinity (as $\mathrm{CaCO} 3$ )

Benzene
Bromodichlorometh
Bromoform
Bromomethene

Calcium, total secoverable

Chloride

Chloroathene (Vinyl chloride)

2.Chloroethyf vinyl ether

Chlorolom

Dibromochloromethan
1,1-Dichloroethane

1,2-Dichloroethane

1,2-Dichloroathylen

Dichloromethane

1,2-Dichloropropane
cis-1,3-Dichloropropente

trans-1,3-Dichloroprope

Etryybenzent total recoverable
Irong

Nitrate as nitrogen

Sillca, total recoverable

Sulfate

Titrachloroethyiene
Toluene

B-117

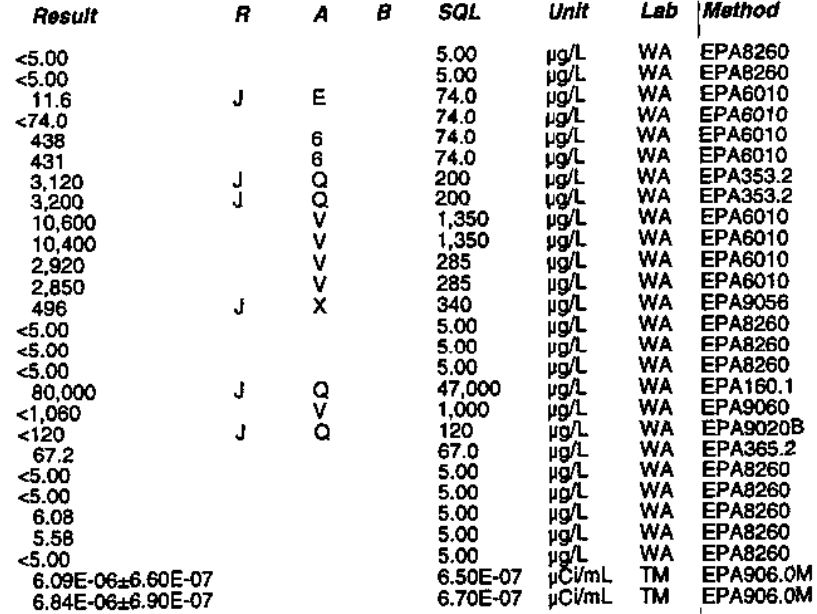

Time: 10:48

Air temperature: $2319.6^{\circ} \mathrm{C}$

Total alkalinity (as CaCO3); $21 \mathrm{mg} / \mathrm{L}$

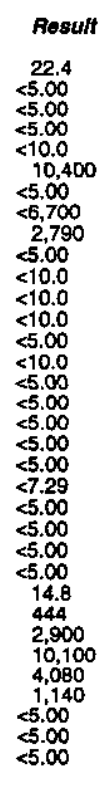

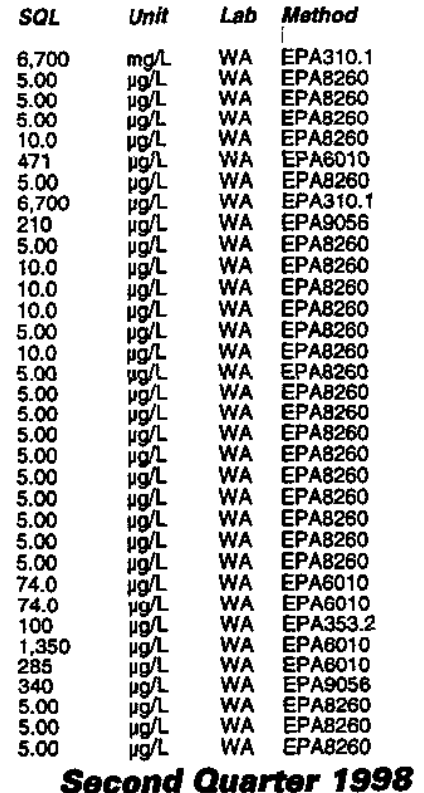


Well FBP $41 \mathrm{C}$ collected on 04/08/88 (cont.)

\begin{tabular}{|c|c|c|c|c|c|c|c|c|}
\hline F Analyte & Result & $\boldsymbol{R}$ & A & $\boldsymbol{B}$ & SQL & Unit & Lab & Method \\
\hline 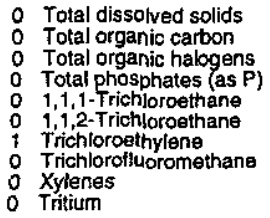 & $\begin{array}{l}70,000 \\
1,350 \\
<120 \\
85.8 \\
<5.00 \\
<5.00 \\
4.13 \\
2.98 \\
<5.00 \\
6.42 \mathrm{E}-06 \pm 6.70 \mathrm{E}-07\end{array}$ & \begin{tabular}{l|l} 
J \\
J \\
J \\
J \\
\end{tabular} & $\begin{array}{l}0 \\
\text { v } \\
0\end{array}$ & & $\begin{array}{l}47,000 \\
1,000 \\
120 \\
67.0 \\
5.00 \\
5.00 \\
5.00 \\
5.00 \\
5.00 \\
6.60 \mathrm{E}-07\end{array}$ & 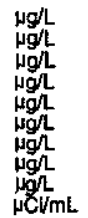 & $\begin{array}{l}\text { WA } \\
\text { WA } \\
\text { WA } \\
\text { WA } \\
\text { WA } \\
\text { WA } \\
\text { WA } \\
\text { WA } \\
\text { WA } \\
\text { TM }\end{array}$ & $\begin{array}{l}\text { EPA160.1 } \\
\text { EPA9060 } \\
\text { EPA9020B } \\
\text { EPA365.2 } \\
\text { EPA9260 } \\
\text { EPAB260 } \\
\text { EPA8260 } \\
\text { EPAE260 } \\
\text { EPAB260 } \\
\text { EPA906.0M }\end{array}$ \\
\hline
\end{tabular}

\section{WELL FBP 41C}

MEASUREMENTS CONDUCTED IN THE FIELD

Sample date: 04/23/98 Depth to
Water el
pH: 7.5 $\mathrm{HH:} 7.5$ iovation: Not avallable

p. conductance: $70 \mu \mathrm{S} / \mathrm{cm}$

Water evacuated from the well prior to sampling: 73 gal

ANALYSES

F Analyto

- Alkalinity (as $\mathrm{CaCO}$ )

Bromodichtoromethane
Bromoform

Calcium, total recoverable
Carbon tetrachloride

Caroonate

Chloride

Chloroethene (Vinyl chloride)

2-Chloroethyl vinyl ther

Chloroform

Dibromochloromethan

1,2-Dichloroethan

1, 2-Dichloroethane

Irans-1,2-Dichloroothylene

Dichloromethane
1,2 -Dichloropropan

cis-1,3-Dichloropropene Ethylbenzene

Iron, total recoverable
Magnesium, total recoverable Nitrate as nilrogen
Nitrate as nitrogen

Silica, total recoverable

$1,1,2,2$-Telrachloroethane
1

Toluene

Total dissclved solids

Total organic halogens

1,1,1-Trichloroethane

Trichloroethyouthe

Trichlorofluoromethane

Xylenes

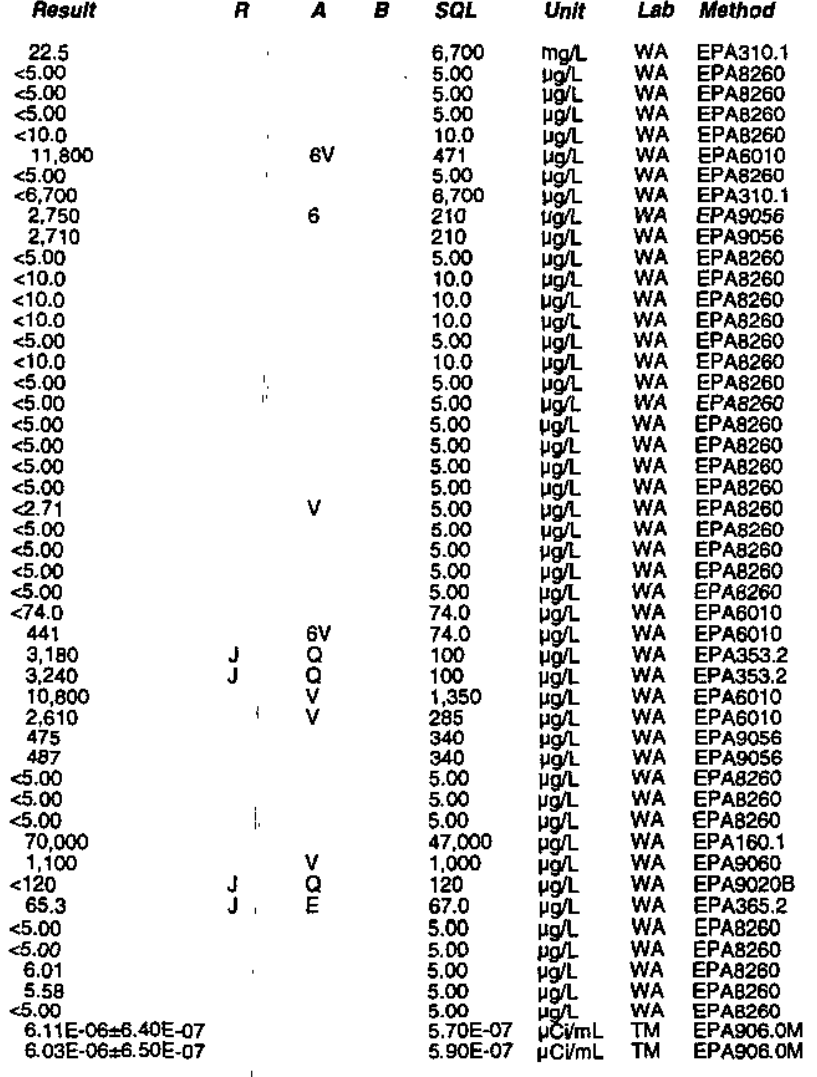

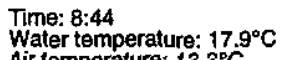

Total alkalinity (as $\mathrm{CaCO}$ ): $27 \mathrm{mgh}$

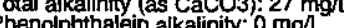

ESH-EMS-980569

\section{WELL FBP 42C}

MEASUREMENTS CONDUCTED IN THE FIELD

Sample date: 04/09/98 Water elevation: Not available

SP: 6.1 conductance: $110 \mu \mathrm{S} / \mathrm{cm}$

r temperature: $21.1^{\circ} \mathrm{C}$ Air temperature: $24.4^{\circ} \mathrm{C}$ ) $34 \mathrm{mg} /$

Water evacuated from the well prior to sampling: $\mathbf{8}$ gal

ANALYSES

$F$ Analyte

- Akalinity (as $\mathrm{CaCO}$ )

0 Benzene

Bromodichloromethane
Bromodichloromethane

Bromoform

Bromotom
Bromomethane

Calcium, total recoverable

Carton tetrachloride

Carbonate

Carbonate
Chloride
Con

Chlorobenzene

Chloroethane

Chloroethene (Vinyl chloride)

Chloroethene (Vinyl chlorida)

2-Chloroethyl vinyl ether
2-Chloroethyl vinyl ether

Chloroform

Chloromethane

Dibromochloromethane

1,1-Dichloroethane

1,1-Dichloroethane

1,2-Dichloroethane

1,1-Dichloroethylen

1,2-Dichloroethylen

D Dichloromethane

1,2-Dichloropropopane

cis-1,3-3ichloropropene
cis-1,3-Dichtioropropene

trans-1,3-Dichloropropene

Etrans-1,3-Dich

Ethylbenzene
Iron, total recoverable

Magnesium total rocor

Nitrate as nitrogen

Silica, total recoverable

Sulfiate

1,1,2,2-Tetrachloroethan

Tetractloroethylene

Toluene

Totel dissolved solidis
Total organic carton

Total organic carton
Total organic halogens
Total phosphates (as P

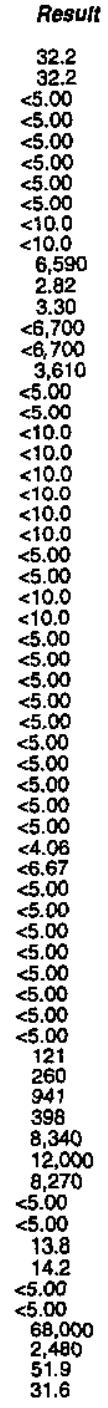

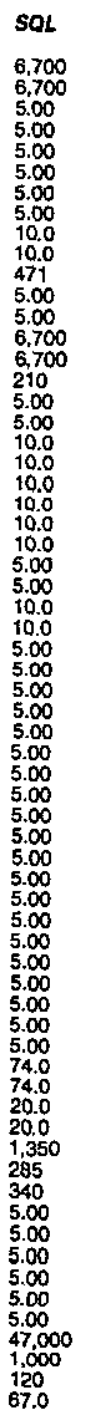

Lab Method

WA EPAB10.1

WA EPA8260

WA EPAB260

EPA260

WA EPABO1

WA EPAB260

WA EPA310.1

WA EPAO056

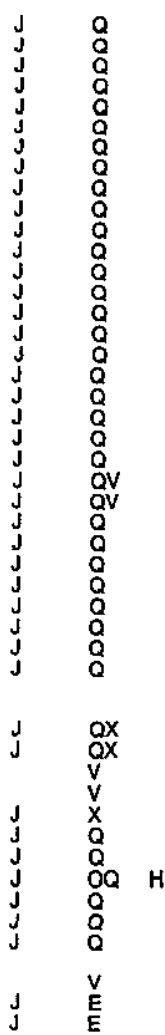

EPA8260

WA WA EPAB260

WA EPAB260

WA EPA8260

WA EPAE260

WA EPAB260

WA EPA8260

WA EPAB260

WA EPAB260

WA EPAB260

WA EPAB260

WA

WA EPA8260

WA EPA8260

WA EPA160.1

WA
WA
WA
WAAAO200B

Second Quarter 1998 
Well FBP 42C collected on 04/09/98 (cont.)

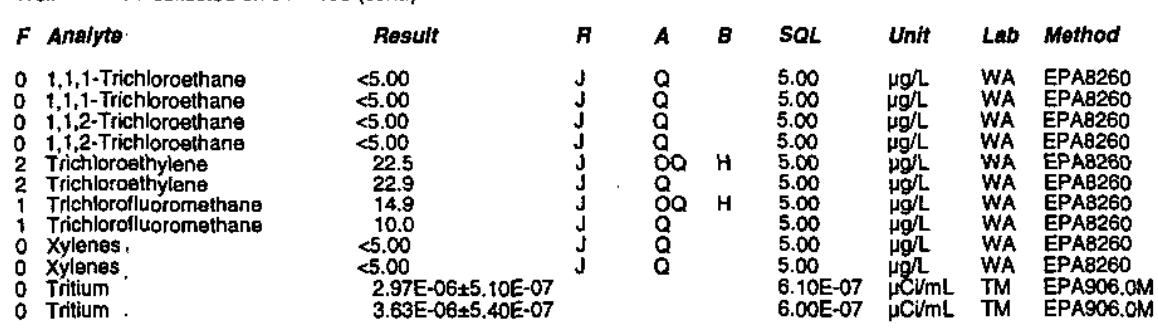

\section{WELL FBP 42C}

MEASUREMENTS CONDUCTED IN THE FIELD

Sample date: 04/23/98

Water elevation: Not available

SH: Not available conductance: Not available

Turbidity: Not available
No water was evacuated from the well prior to sampling.

ANALYSES

$F$ Analyto

: Alkalinity (as $\mathrm{CaCO}$ )

Benzene

Bromoform

Calcium! total recoverable

Carbonate

Carbonate

Chlorobenzene

Chloroethene (Vinyl chloride

2-Chloroethyl v

Dibromochloromethan

1,2-Dichloroethane

1,2-Dichloroethane

$1,1-D i c h$ loroethylene
0 trans-1,2-Dichloroethylen $\theta$

o Dichloromethane

$\begin{array}{ll}0 & \text { 1,2-Dichloropropane } \\ 0 & \text { is } 1,3 \text {-Dichloropropene }\end{array}$

Etrans-1,3-Dichloropropen

Iron, total recoverable
Magnesium, total recoverable

Nitrate as nitrogen

S Sllica, total recoverable

Suffate $i, 1,2,2$-Tetrachloroethane

Tetrachloroethylene

Toluene

Total organic carbon

Total phosphates (as P)

1,1,1-Trichlorogthan

2 Trichloroethylene

Xylenes

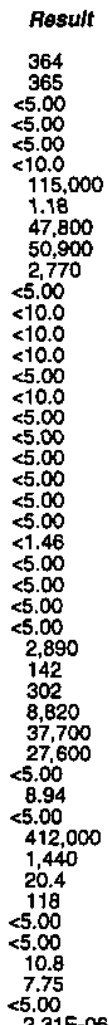

Time: Not available

Water temperature: Not available

Total alkalinity (as CacO3): Not available
Phenolphthalein alkalinity: Not available

ESH-EMS-980569

WELL FBP $43 C$

MEASUREMENTS CONDUCTED IN THE FIELD

Sample date: 04/0898
Depth to water: $41.75 \mathrm{ft}(12.73 \mathrm{~m})$ below TOC Water elevation: Not available

$\mathrm{PH}: \mathrm{B} .3$

Sp. conductance: $23 \mu \mathrm{S} / \mathrm{cm}$

Turbidity: 0 NTU Water evacuated from the well prior to sampling: 93 gal ANALYSES

\section{$F$ Analyte}

A Alkalinity (as $\mathrm{CaCO}$ )
0 Benzene
0 Bromodichloromethane

: Bromoform

Calcium, total recoverable
Carbon tetrachloride

Chisoride

Chlorobenzene

Chloroethane

o-Chooroethyl vinyl ether

Chloromethan

Dibromochloromethane

1,2-Dichloroethane

1,2-Dichloroethylene

1,2-Dichloropropan

cis-1,3-Dichloropropene
trans-1,3-Dichloropropene

Ethyybenzene
Iron, total recoverab

Magnesium, total recoverable

Silica, total recoverable

Sulfate Tetrachloroethane

Tetrachloroethylen

0 Toluene

Total dissolved sollds
Total organic carbon

Total organic halogens
Total phosphates (as P)

$1,1,1-$ Irichloroethan

Trichloroethylene

0 Xylenes

\section{WELL FBP 43C}

MEASUREMENTS CONDUCTED IN THE FIELD

Sample date: 04/22/98

Depth to water: $41.2 \mathrm{ft}(12.56 \mathrm{~m})$ below TOC

$\mathrm{pH}$. 7.8 . 8 nductance: $260 \mu \mathrm{S} / \mathrm{cm}$

Water evacuated from the weil prior to sampling: $93 \mathrm{gal}$

ANALYSES

$F$ Analyte

Alkalinity (as $\mathrm{CaCO}$ )
$:$ Alkalinity (as $\mathrm{CaCO}$ )

Alkalinity (as CaCO3)
Benzene

Res
86.9
86.3
$<5.00$
$<5.00$

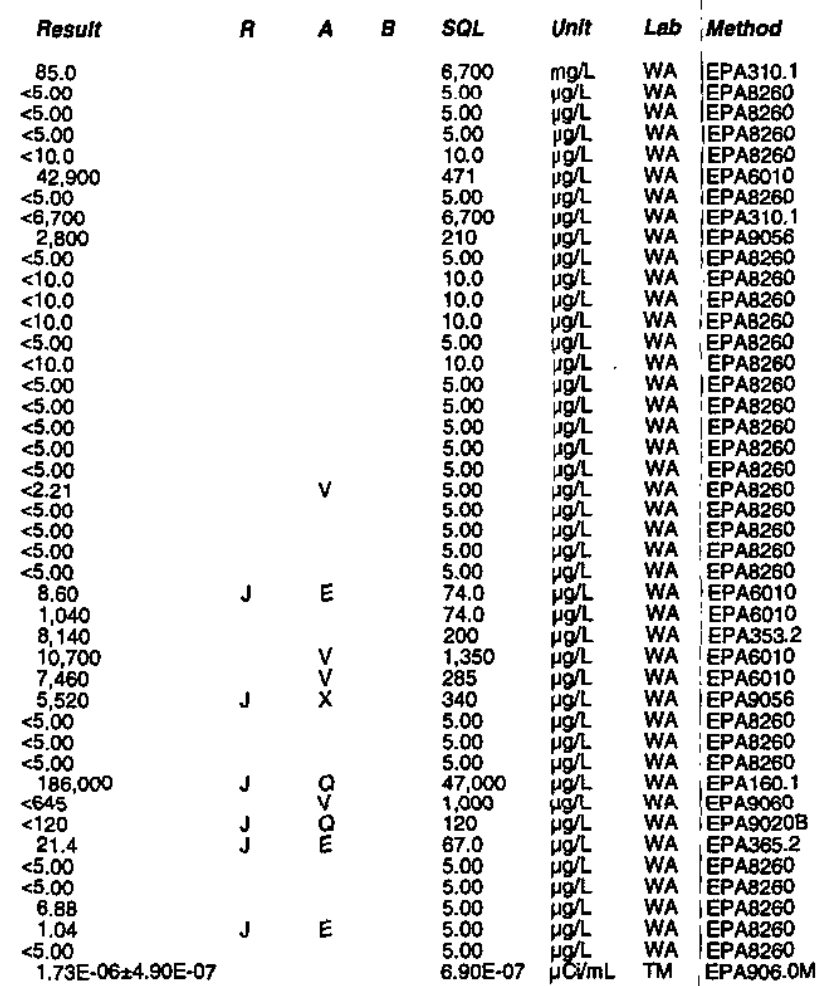

Time: 14:48

Water temperature: $212^{\circ} \mathrm{C}$

Total akalinity (as CaCO3); $75 \mathrm{mg} / \mathrm{C}$
Phenolphthalein alkalinity: $0 \mathrm{mg} / \mathrm{L}$

$3-119$

(1)

Second Quarter 1998
Time: 8:22

(As CaCO3): $80 \mathrm{mg} /$ 
Well FBP 43C collectod on 04/22/98 (cont.)

\begin{tabular}{|c|c|c|c|c|c|c|c|c|}
\hline F Analyte & Resuft & A & $\boldsymbol{A}$ & $B$ & SOL & Unt & Lab & Method \\
\hline 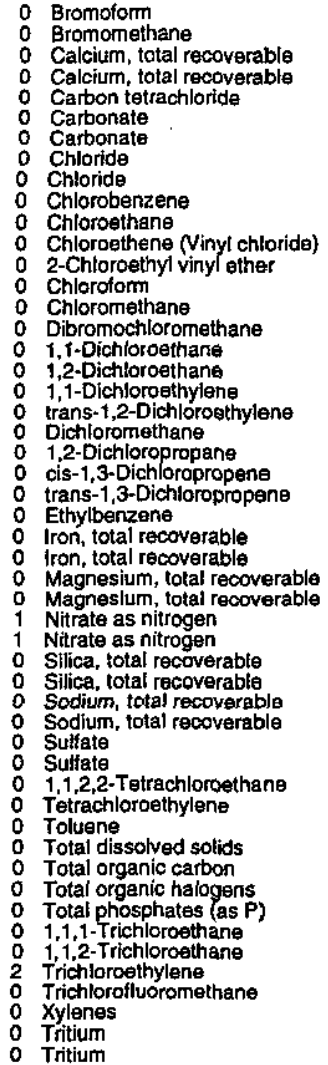 & $\begin{array}{l}<5.00 \\
<10.0 \\
41,600 \\
41,700 \\
<5.00 \\
<26,800 \\
26,800 \\
2,820 \\
2 ., 230 \\
<5.00 \\
<10.0 \\
<10.0 \\
<10.0 \\
<5.00 \\
<10.0 \\
<5.00 \\
<5.00 \\
<5.00 \\
<5.00 \\
<1.00 \\
<5.00 \\
<5.00 \\
<5.00 \\
<5.00 \\
<20.8 \\
<18.7 \\
990 \\
986 \\
7 ., 000 \\
7 ., 000 \\
.11,200 \\
11,300 \\
6,300 \\
6,280 \\
4,290 \\
4,260 \\
<5.00 \\
<5.00 \\
<5.00 \\
163,000 \\
<779 \\
<720 \\
18.6 \\
<5.00 \\
<5.00 \\
6.58 \\
<5.00 \\
<5.00 \\
1.55 E-06 \pm 4.30 E-07 \\
1.47 E-06 \pm 4.30 E-07\end{array}$ & $J$ & $\stackrel{8}{\circ}$ & & $\begin{array}{l}5.00 \\
10.0 \\
471 \\
471 \\
5.00 \\
26.800 \\
26.800 \\
210 \\
210 \\
5.00 \\
10.0 \\
10.0 \\
10.0 \\
5.00 \\
10.0 \\
5.00 \\
5.00 \\
5.00 \\
5.00 \\
5.00 \\
5.00 \\
5.00 \\
5.00 \\
5.00 \\
74.0 \\
74.0 \\
74.0 \\
74.0 \\
400 \\
400 \\
1,350 \\
1,350 \\
295 \\
285 \\
340 \\
340 \\
5.00 \\
5.00 \\
5.00 \\
47.000 \\
1.000 \\
120 \\
67.0 \\
5.00 \\
5.00 \\
5.00 \\
5.00 \\
5.90 \mathrm{E}-07 \\
6.00 \mathrm{E}-07\end{array}$ & 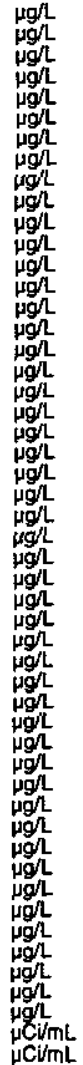 & $\begin{array}{l}\text { WA } \\
\text { WA } \\
\text { WA } \\
\text { WA } \\
\text { WA } \\
\text { WA } \\
\text { WA } \\
\text { WA } \\
\text { WA } \\
\text { WA } \\
\text { WA } \\
\text { WA } \\
\text { WA } \\
\text { WA } \\
\text { WA } \\
\text { WA } \\
\text { WA } \\
\text { WA } \\
\text { WA } \\
\text { WA } \\
\text { WA } \\
\text { WA } \\
\text { WA } \\
\text { WA } \\
\text { WA } \\
\text { WA } \\
\text { WA } \\
\text { WA } \\
\text { WA } \\
\text { WA } \\
\text { WA } \\
\text { WA } \\
\text { WA } \\
\text { WA } \\
\text { WA } \\
\text { WA } \\
\text { WA } \\
\text { WA } \\
\text { WA } \\
\text { WA } \\
\text { WA } \\
\text { WA } \\
\text { WA } \\
\text { WA } \\
\text { WA } \\
\text { WA } \\
\text { WA } \\
\text { WA } \\
\text { TM } \\
\text { TM }\end{array}$ & 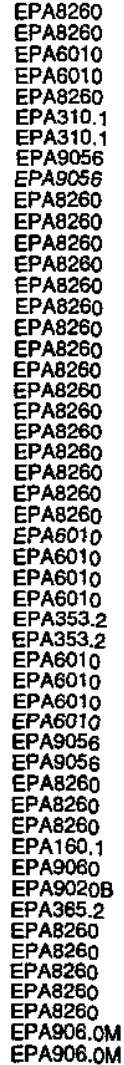 \\
\hline
\end{tabular}

\section{WELL FBP 43DL}

MEASUREMENTS CONDUCTED IN THE FIELD

Sample date: $04 / 08 / 98$
Depth to waier $41.22 \mathrm{ft}(12.56 \mathrm{~m})$ below TOC

Water o

Ho. conductance: $770 \mu \mathrm{S} / \mathrm{cm}$

Turbidity: ONTU ANALYSES

$F$ Anafyte

Alkalinity (as $\mathrm{CaCO}$ )

o Benzene

Bromolom

Calcium, total recoverable
Carbon tetrachloride

Carbonate

Chlorobenzene

ESH-EMS-980569
Well FBP 43DL collected on 04/08/98 (cont)

\section{Tritium}

MEASUREMENTS CONDUCTED IN THE FIELD

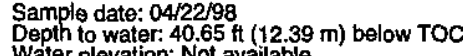

Water elevation: Not available
pH: 6.8

Sp. conductance: $780 \mu \mathrm{S} / \mathrm{cm}$

Water evacuated from the well prior to sampling: 77 gal ANALYSES

\section{$F$ Analyte}

Water temperature: $18.8^{\circ} \mathrm{C}$

Total alkalinity (as Cacos): $99 \mathrm{mgh}$

Alkalinity (as $\mathrm{CaCO}$ )

Bromodichloromethane

Bromomethane

Calcium, total recoverable
Carbon tetrachloride

Carbon tetrach

Chloride
Chlorobenzen

Chlorosthane

Chloroethene Ninyl chloride)
2-Chloroethyl vinyl ether

Chlorotom

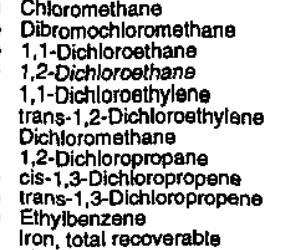

Iron, total recoverable

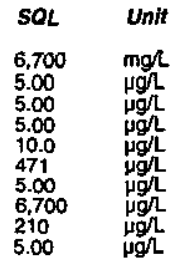

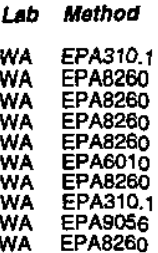

Result
$<10.0$
$<10.0$
$<10.0$
$<5.00$
$<10.0$
$<5.00$
$<5.00$
$<5.00$
$<5.00$
$<5.00$
$<.48$
$<5.00$
$<5.00$
$<5.00$
$<5.00$
7.60
9.010
66,100
9.990
22,500
13,000
$<5.00$
1.38
$<5.00$
677.000
$<944$
75.6
18.0
$<5.00$
$<5.00$
56.1
55.8
$<5.00$
$1.29 E-05 \pm 8.90 E-07$
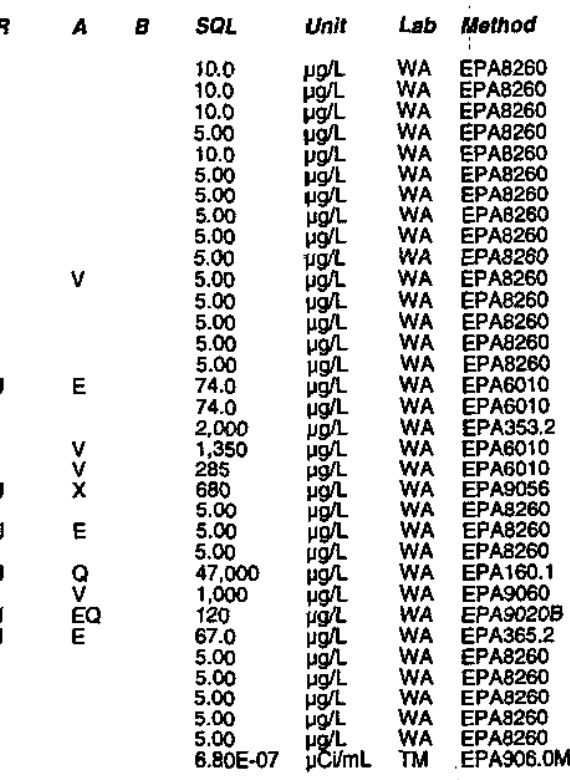

Time: 14:36

Air temperature: $25.1^{\circ} \mathrm{C}$

Total alkainity (as CaCO3): $97 \mathrm{mgh}$
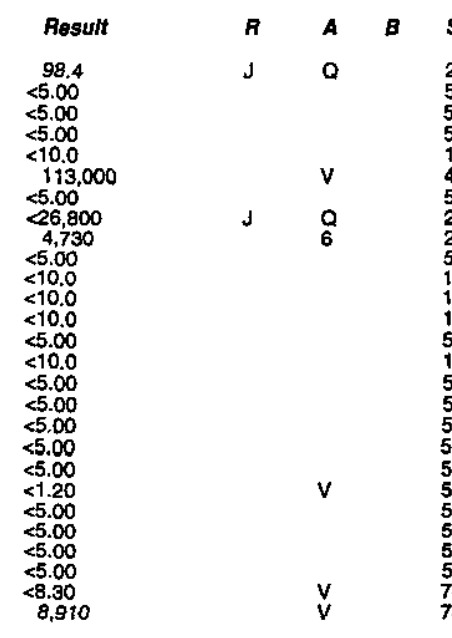

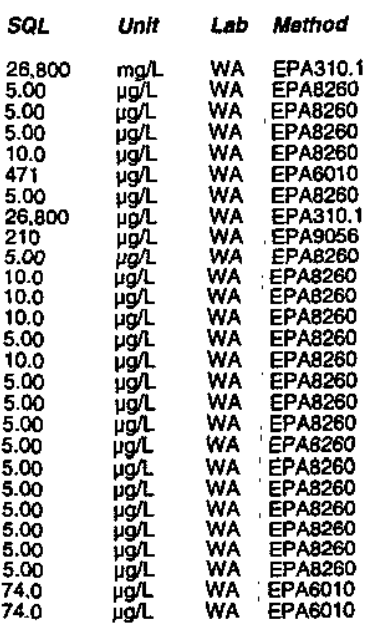

Second Quarter 1998 
Well FBP 43̧DL collected on 04/22/98 (cont.)

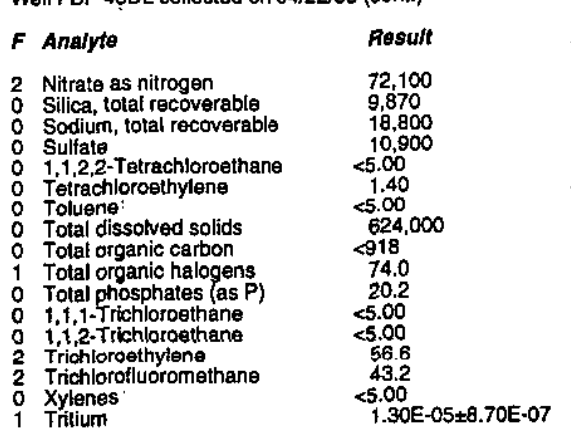

WELL FBP 43DL Replicate

MEASUREMENTS CONDUCTED IN THE FIELD

Sample date: 04/22/98
Depth to water: $40.65 \mathrm{ht}(12.39 \mathrm{~m})$ below TOC
Water elevation: Not available

Water eleval

Sp: 6.8 onductance: $780 \mu \mathrm{S} / \mathrm{cm}$

Turbidity: $1 \mathrm{NTU}$
Water evacuated from the well prior to sampling: $77 \mathrm{gal}$

ANALYSES

$F$ Analyte

Alkalinity (as $\mathrm{CaCO}$ )

O. Benzens (as Cacos)

Bromolorm

Calcium; total recoverable

Carbon tetr
Carbonate

Chloride

Chloroethene Ninyl chloride)
2-Chloroethyl vinyl ether

Chloroform

Dibromochloromethe

i, -Dichloroethene

$1,1-D$ Dichloroethylene
trans-1,2-Dichloroethylene

Dichloromethane

1,2-Dichloropropane
eis- $1,3-$ Dichloropropene

Ethylbenzene

Iron, total recoverable
Magnessium, total recoverable

Nirrate as nitrogen

Silica, total recoverable

Sullate

1,1,2,2-Tetrachloroe
TTtrachioroethylene

Toluene

Total organic carbon

Total organic halogens
Total phosphates (as P)

: Total phosphates as

o $1,1,2$-Trichloroethane

2 Trichloroethyiens

0
2 Xyitines
Tritum

ESH-EMS-980569

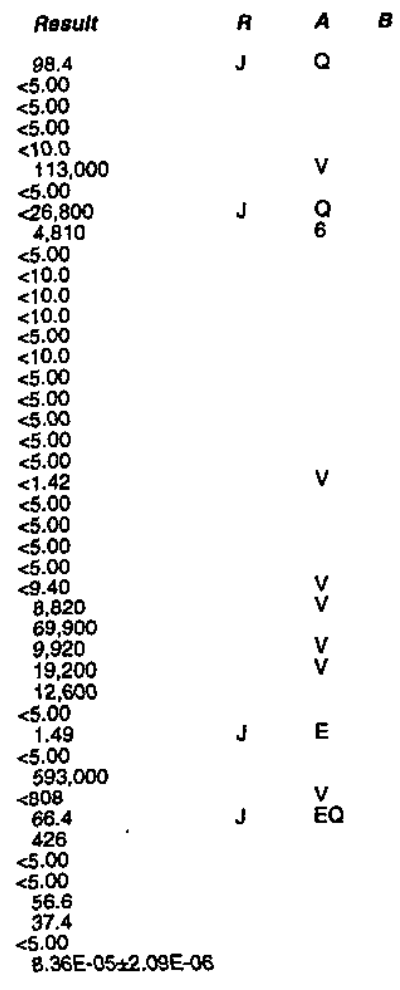

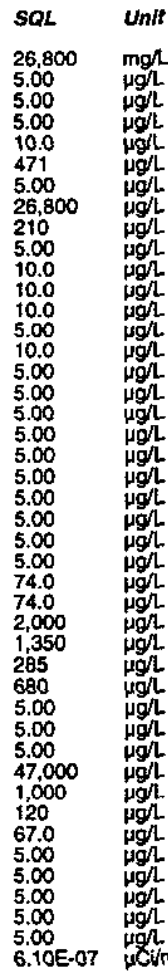

WELL FBP 44D

MEASUREMENTS CONDUCTED IN THE FIELD

Sample date: $04 / 08 / 98$
Depth to water: $17.3 \mathrm{ft}(5.27 \mathrm{~m})$ below TOC
Weter

Water elevation: Not available

$\mathrm{pH}: 4.7$. conductance: $21 \mu \mathrm{S} / \mathrm{cm}$

Turbidity: $1 \mathrm{NTU}$
Water evacuated from the well prior to sampling: $6 \mathrm{gal}$ ANALYSES

F Analyte

o Alkalinity (as $\mathrm{CaCO}$ )
a Benzene
0 Bromodichloromethane

Bromoform

Calcium, total recoverable

0 Carbonate

Chloride

Chloroethene (Vinyl chloride)

2-Chloroethyl vinyl ether

Chlorotorm

Dibromothloromethane
1,1 -Dichloroethane

1,2-Dichloroethane

1,2-Dichloroethylen

$\begin{array}{ll} & \\ 0 & \text { Dichloromethane } \\ 0 & \text { 1,-Dichloropropane } \\ 0 & \text { cis- }-1,3-\text {-Dichloropropen }\end{array}$

trans-1,3-Dichloropropene

Ethylbenzene

Magnessium total recor

Silica, total recoverable

$\begin{array}{ll}\text { Solf } & \text { Sodium, total recoverable } \\ 0 & \text { Sulfate } \\ 0 & 1,1,2,2 \text {-Tetrachloroethane }\end{array}$

Tetrachloroethylene

Toluene
Total dissolved solids
Totganic carbon

Total organic halogens

1,1,1-Trichloroethane

Trichloroethylene

0 Xylenes

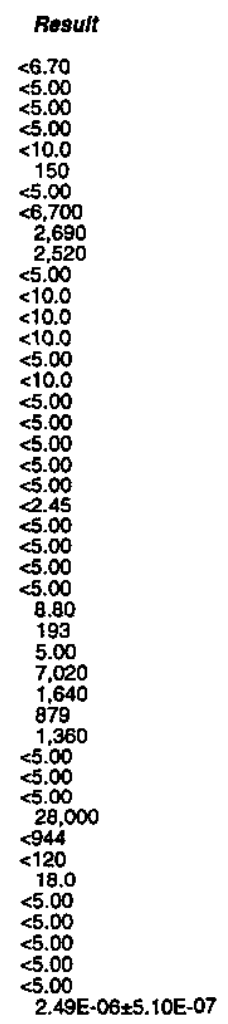

WELL FBP 44D

MEASUREMENTS CONDUCTED IN THE FIELD

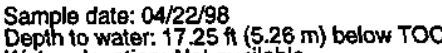

Water elevation: Not available

$\mathrm{pH}: 4.3$

conductance: $21 \mu \mathrm{S} / \mathrm{cm}$

Water evacuated from the well prior to sampling: 3 gal

ANALYSES

$F$ Analyte

Result

Alkalinity (as $\mathrm{CaCO}$ )

$<6.70$

(1)

Time: 12:30

Total akalinity (as CaCOS): $0 \mathrm{mg} / \mathrm{L}$
Phenolphthalein alkalinity: $0 \mathrm{mg} /$ 6.10E-07 WUVIML TM EPA906.OM

(n)

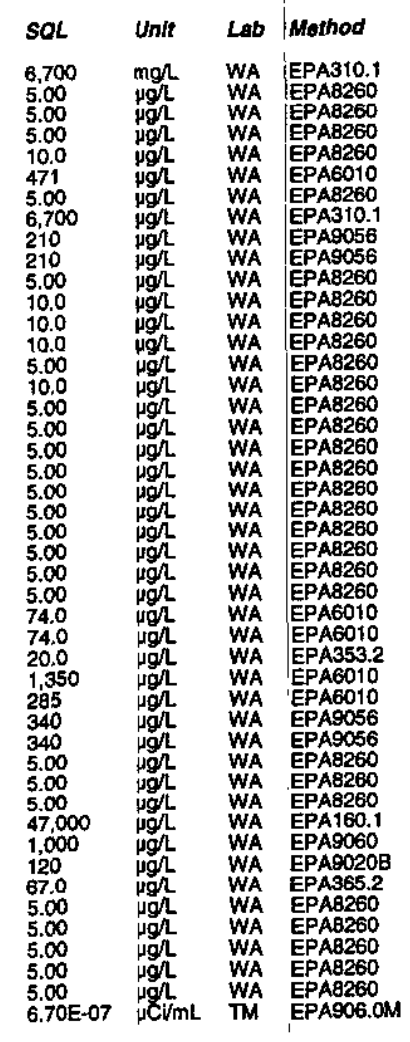

Time: 10:15

Water temperature: $17^{\circ} \mathrm{C}$

Total alkalinity. (as CaCO3): 0 ingh

Second Quarter 1998 
Well FBP 44D collected on 04/22/98 (cont.)

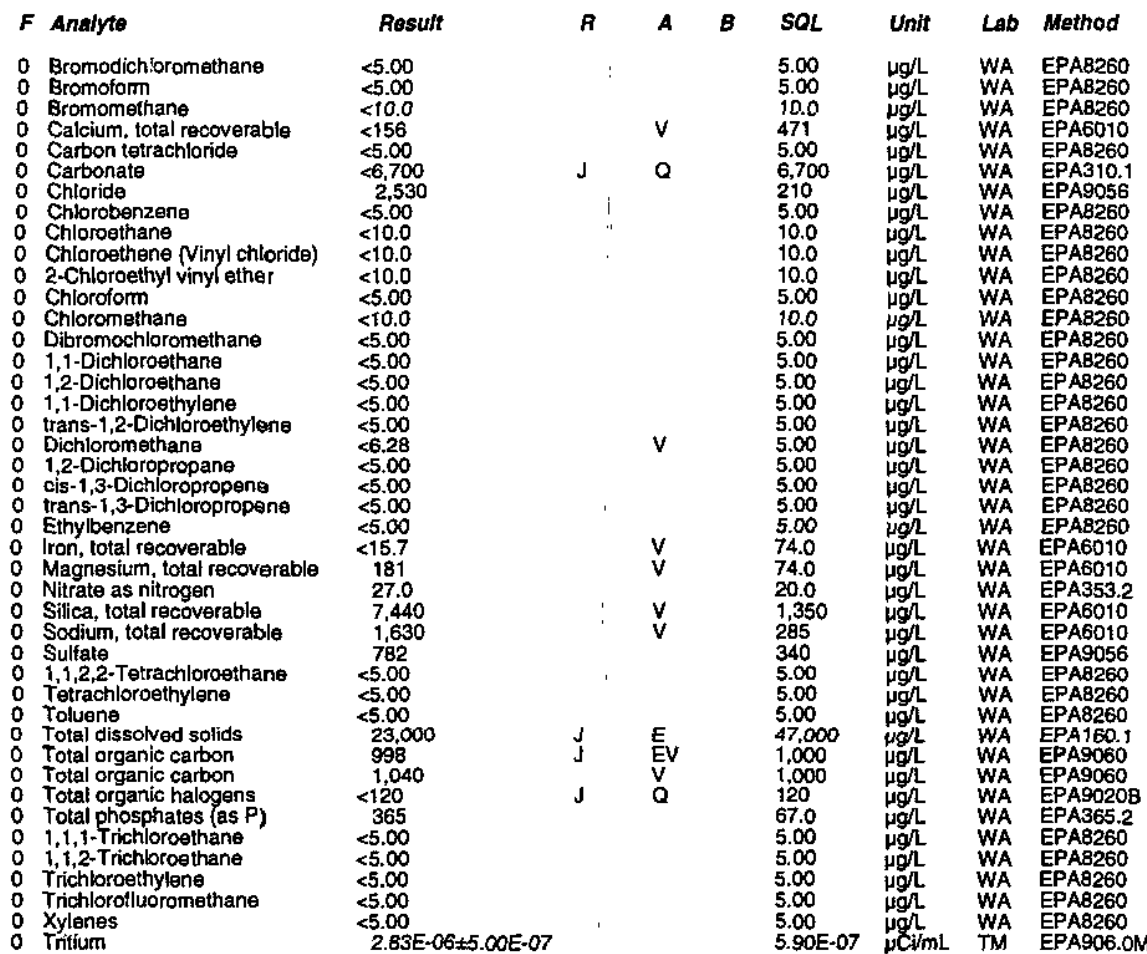

\section{WELL FBP 45D}

MEASUREMENTS CONDUCTED IN THE FIELD

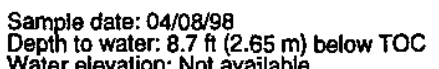

Water elevation: Not available
Hp: 5.6 .
Sp conductance: $36 \mu \mathrm{S} / \mathrm{cm}$

Water evacuated from the well prior to sampling: 2 gal

ANALYSES

$F$ Analyte

- Alkalinity (as CaCO3)

Benzene

Bromoform

O Calcium, lotal recoverable

0 Carbonate

o Chloride

Chloroethenene (Vinyi chloride)

2-Chloroethyl vinyl ether

O Chloromethane

0 Dibromochlorometh

ESH-EMS-980569
Time: $11: 12$

\section{Air temperaturere: $21^{\circ} \mathrm{C}$}

Total akelatinity (as CaCo3): $7 \mathrm{mgh}$
Phenoiphthalein alkalinity: $0 \mathrm{mg} /$
Well FBP 45D collected on 04/08/98 (cont.)

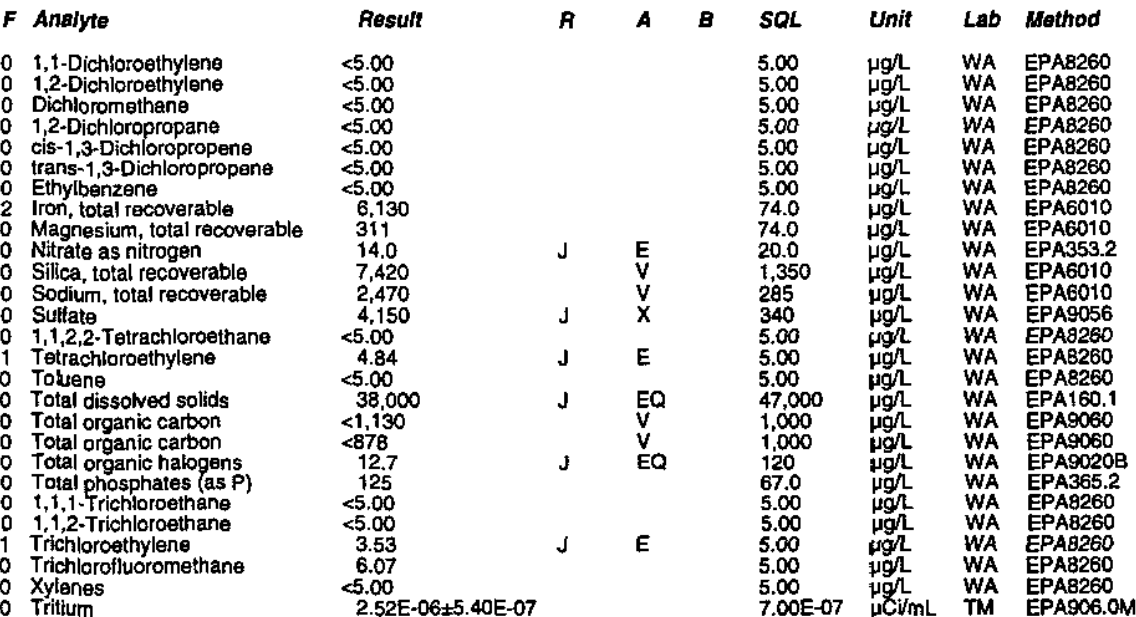

\section{WELLL FBP 45D}

MEASUREMENTS CONDUCTED IN THE FIELD

Sample date: 04/22/99
Depth to water $9.35 \mathrm{tt}(2.85 \mathrm{~m})$ below TOC

ph: 5.1 conductance: $33 \mu \mathrm{S} / \mathrm{cm}$

Water evacuated from the well prior to sampling: $2 \mathrm{gal}$

\section{ANALYSES}

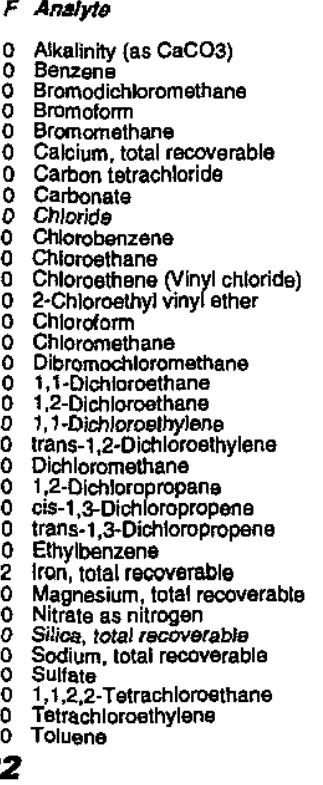

Time: 11:13

perature: $20^{\circ}$

Air temperature:
Total aksalinity (as CaCO3): $2 \mathrm{mg} /$
Phenolphthalein alkalinity: 0 mg ${ }^{2}$

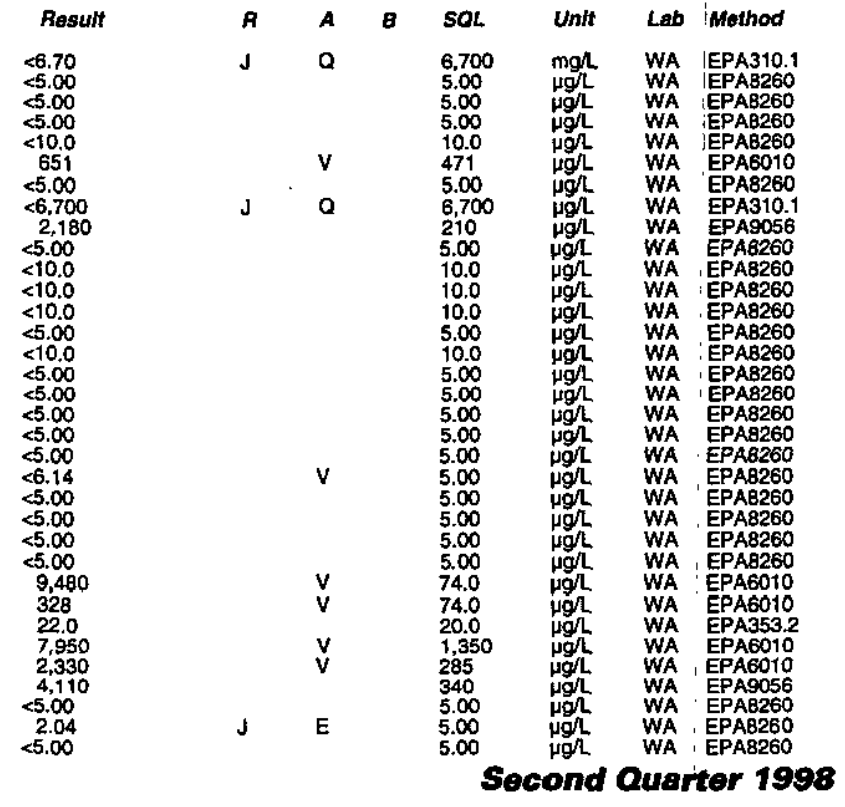

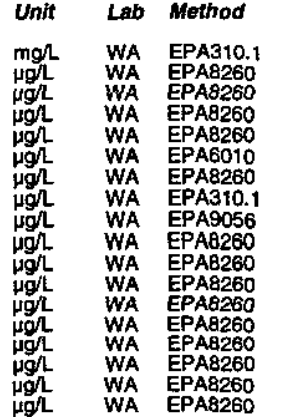

B-122 
Well FBP 45D collected on 04/22/98 (cont.)

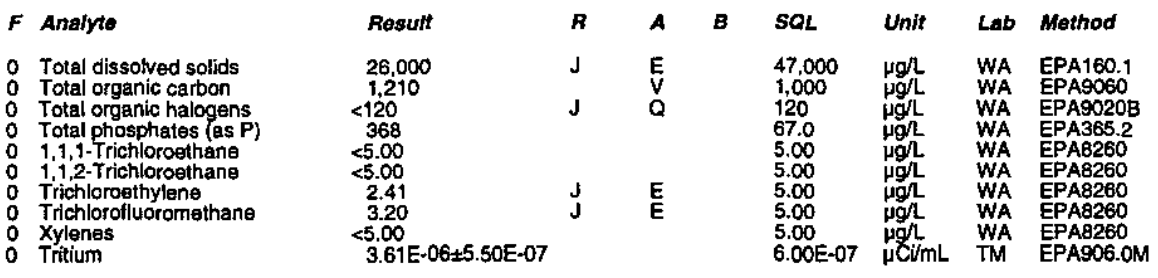

\section{WELL FBP 46D}

MEASUREMENTS CONDUCTED IN THE FIELD

Sample date: 04/08/98 Water elevation: Not available

H: 4.4

conductance: $28 \mu \mathrm{S} / \mathrm{cm}$

Water evacuated from the well prior to sampling: $4 \mathrm{gal}$

ANALYSES
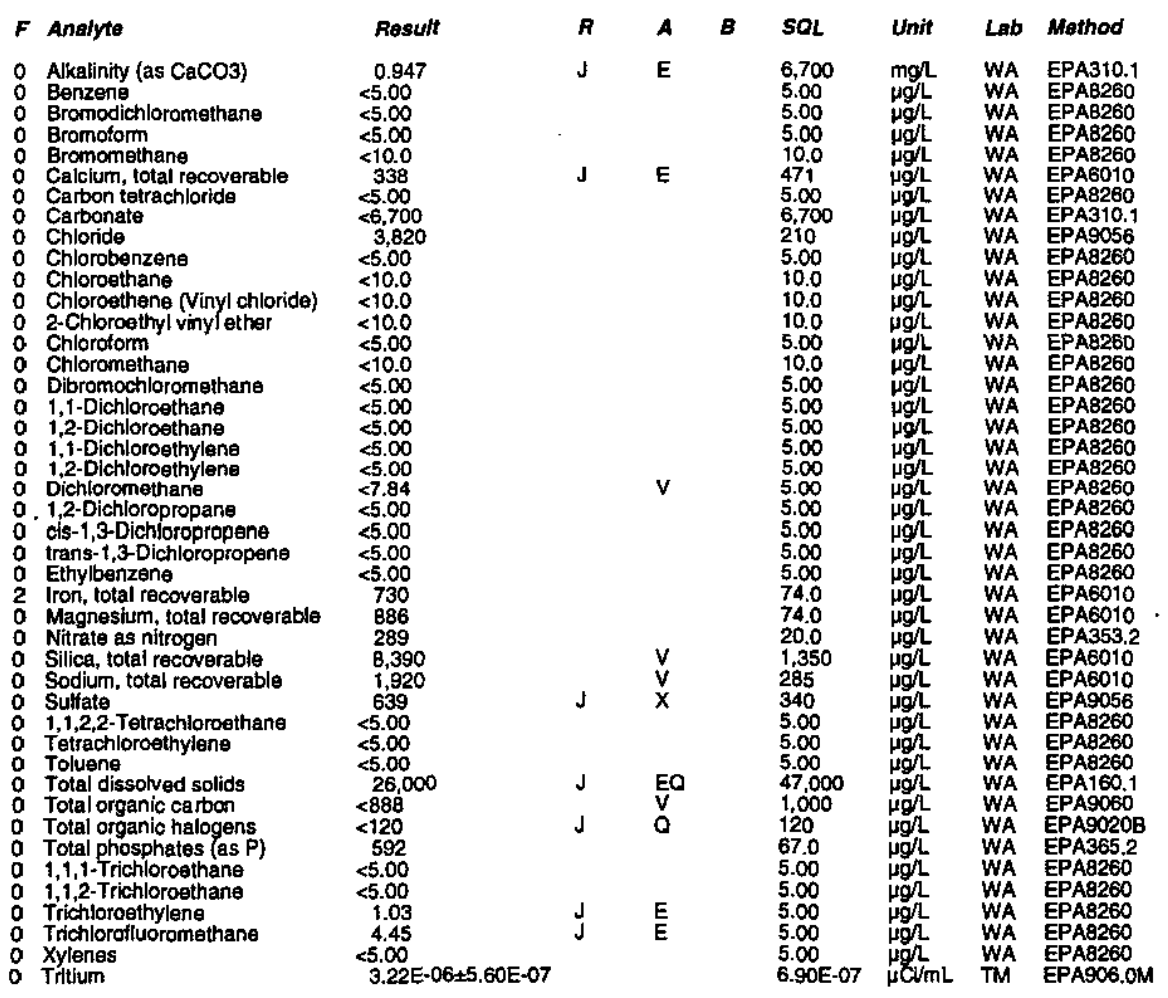

ESH-EMS-980569

Time: 8:17

erature: $171^{\circ} \mathrm{C}$

Total alkalinity (as CaCO3): $0 \mathrm{mg} /$
WELLL FBP 46D Replicate

MEASUREMENTS CONDUCTED IN THE FIELD

Sample date: $04 / 08 / 98$.

Water elevation: Not availabl

$\mathrm{Sp}$. conductance: $28 \mu \mathrm{S} / \mathrm{cm}$

Turbidity: $1 \mathrm{NTU}$
Water evacuated from the well prior to sampling: $4 \mathrm{gal}$

ANALYSES

$F$ Anatyto

Alkalinity (as $\mathrm{CaCO}$ )

o Benzene 0 (as Cacos)

: Bromoform

- Calcium, total recoverable

: Carbonate

- Chloride

0 Chloroethene (Vinyl chloride)

2 -Chloroathyl vinyl ether

Choromethan

Dibromochloromethane

1,2-Dichloroethane

o 1,2-Dichloroethylene

1,2-Dichloropropane
0 cis-1,3-Dichloroprop

trans-1,3-Dichloropropen

Ethylbenzene

o Magnesium, total recoverable

Nitrate as nitrogen

S Sodium, total recoverable

1,1,2,2-Tetrachloroethane

Tetrachloroethylen

Total dissolved solids

Total organic halogens

id 1,1,1-Trichloroethane

richloroethylene

$\begin{array}{ll}0 & \text { Xylenes } \\ 0 & \text { Tritium }\end{array}$

Result

$<6.70$
5.00

$<5.00$

1,200
$<5.00$
$<6,700$

WELL FBP 46D

MEASUREMENTS CONDUCTED IN THE FIELD

Sample date: $04 / 22 / 98$ ( $272 \mathrm{~m})$ below TOC Water elevation: Not available

$\mathrm{PH}: 4.1$

p. conductance: $26 \mu \mathrm{S} / \mathrm{cm}$

Water evacuated from the well prior to sampling: $7 \mathrm{gal}$

ANALYSES

$F$ Analyte

$\because$ Alkalinity (as $\mathrm{CaCO}$ )

Result

$\boldsymbol{R}$

(a)

$50 L$
6,700

Unit

Lab Mothod

1.04
$<5.00$

$\begin{array}{llll}0,700 & m g h & \text { WA } & \text { EPA310.1 } \\ \mathrm{ygh} & \text { WA } & \text { EPA8260 }\end{array}$

Second Quarter 1998
Time: $9: 45$

政: $16.5^{\circ} \mathrm{C}$ Total alkalinity (as CaCO3): $0 \mathrm{mg} / \mathrm{L}$ 
Well FBP 46D collected on 04/22/98 (cont.)

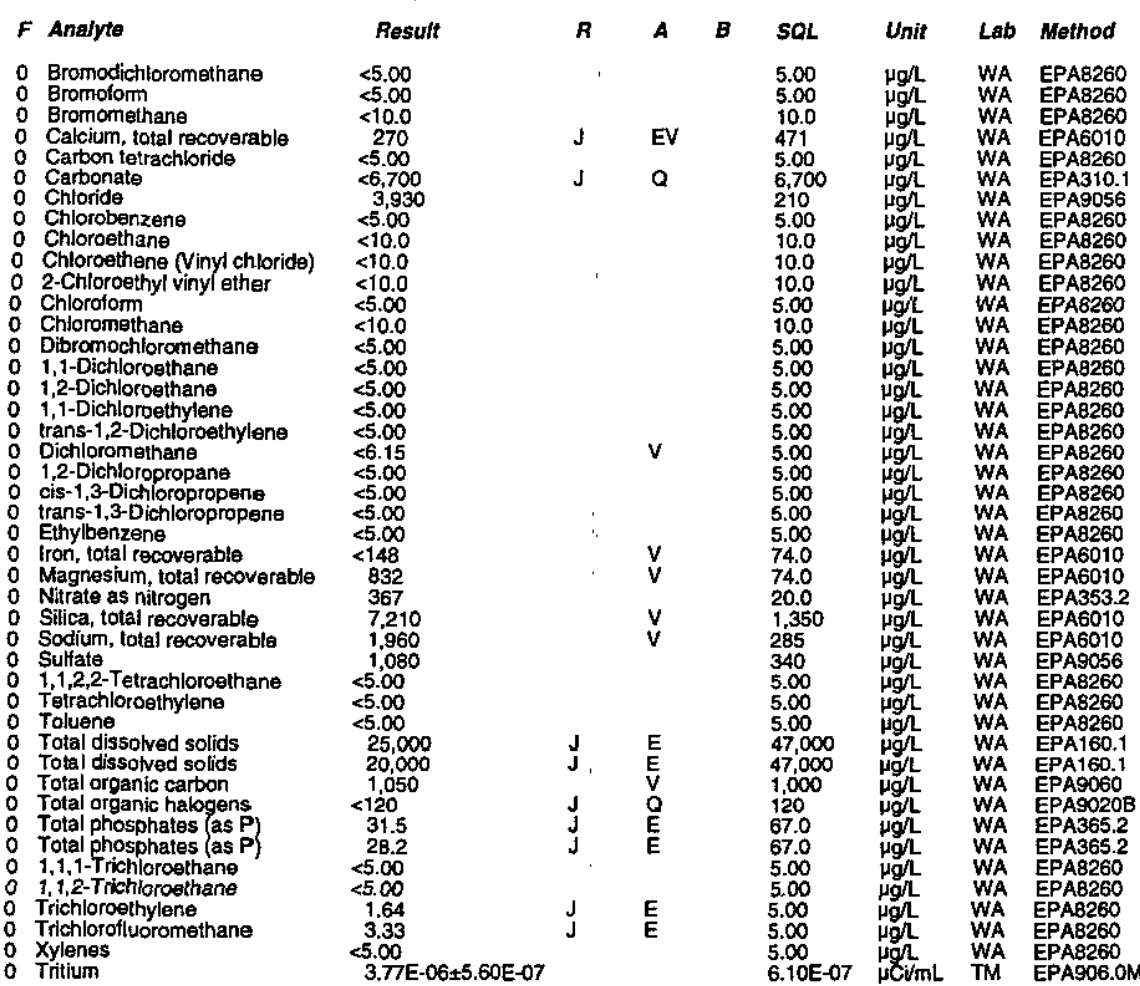

\section{WELL FBP 47D}

MEASUAEMENTS CONDUCTED IN THE FIELD

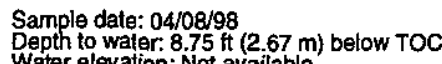
Water elevation: Not available

$\mathrm{pH}: 4.9$

Sp. conductance: $26 \mu \mathrm{S} / \mathrm{cm}$

Water evacuated from the well prior to sampling: $10 \mathrm{ga}$ ANALYSES

\begin{tabular}{|c|c|}
\hline Analyte & Result \\
\hline 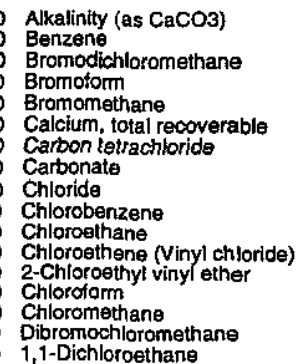 & 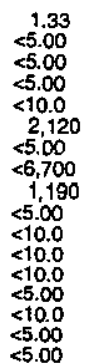 \\
\hline
\end{tabular}

Well FBP 47D collected on 04/08/98 (cont.)

$F$ Analyte
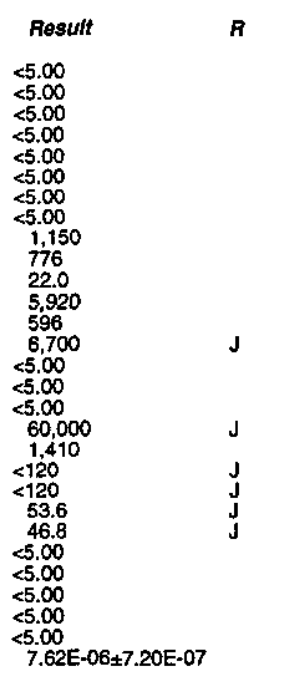

o Xylenes

1,2-Dichloroethane

1,2-Dichlorosthylen

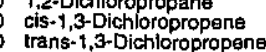

Elhylbenzene

Magnesium, total recoverable

Silica, total recoverable

1,1,2,2-Tetrachloroethane

Toluana

Total dissolved solids

Total organic habogens

Total phosphates las P

1,1,1-Trichloroethane

Trichloroffluoromethane

\section{WELL FBP 47D}

MEASUREMENTS CONDUCTED IN THE FIELD

Sample date: 04/22/98

Water elevation: Not available

$\mathrm{SH}$. Not available

was evacuated from the well prior to sampling.

ANALYSES

\section{Analyo}

Time: 12:13

Air temperature $252^{\circ} .9^{\circ} \mathrm{C}$

Total alkalinity (as CaCO3): $1 \mathrm{mg} /$
Phenolphthalein alkalinity: $0 \mathrm{mg} / \mathrm{L}$

O Alkalinity (as $\mathrm{CaCO}$ )

Bromodichloromethane

Bromolom

Calcilum, total recoverable

Carton tetrachloride

Cartonate

Chlorobenzene

Chloroethene (Vinyl criloride)

2-Chlorosthyl

Chloromethane

Dibromochloromathan

1,2-Dichloroethane

1,1-Dichloroethylene
trans-1,2-Dichloroethylen

trans-1,2-Dichloroe

cis-1,3-Dichloropropene
ttans-1,3-Dichloxopropene

Ethylbenzene

Magnesium, total recoverable

Nitrato as nitrogen

$\begin{array}{lc}\text { Magnesium, total recoverable } & 864 \\ \text { Nitrate as nitrogen } & 834 \\ \text { Silica, total recoverable } & 19.200 \\ \text { Sodium, total recoverable } & 1,010 \\ \text { Sulfate } & 5,920 \\ \text { 1,1,2,2-Totrachloroethane } & <5.00 \\ & \end{array}$

$\begin{array}{lc}\text { Magneslum, total recoverable } & 864 \\ \text { Nitrata as nitrogen } & 43.0 \\ \text { Silica, total recoverable } & 19.200 \\ \text { Sodium, total recoverable } & 1,010 \\ \text { Sulfate } & 5.920 \\ \text { 1,1,2,2-Totrachloroethane } & <5.00 \\ & \end{array}$

Result
0.994
$<5.00$
55.00
$<5.00$
$<10.0$
2.370
$<5.00$
$<6.700$
1,590
$<5.00$
$<10.0$
$<10.0$
$<10.0$
$<5.00$
$<10.0$
$<5.00$
$<5.00$
$<5.00$
$<5.00$
$<5.00$
$<5.86$
$<5.00$
$<5.00$
$<5.00$
$<5.00$
15.200
864
43.0
19.200
1,010
5.920
$<5.00$

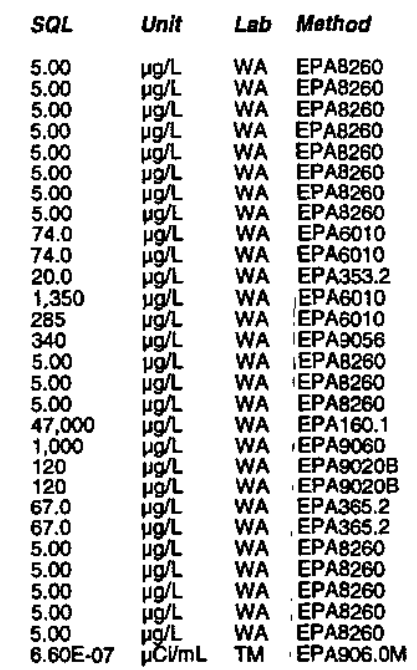

Time: Not available Arr temperature: Not available
Total alkalinity (as CacoO3): Not available
Phenolphthalein alkalinity: Not available

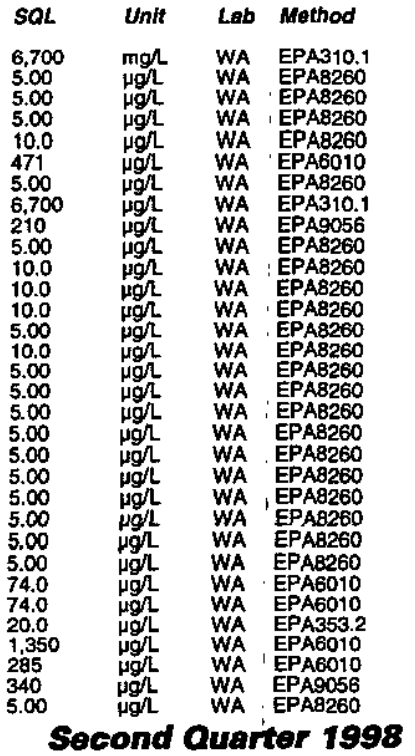


Well FBP 47D collected on 04/22/98 (cont.)

$F$ Analyte.

Result

0 Tetrachloroethylene

Toluene

Total organic halogens

1,1,1-Trichloroethane

Trichloroethylene

Trichlorofluoromethane

0 Tritium

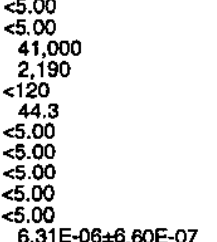

R

$\boldsymbol{B}$

WELL FBP 48D

MEASUREMENTS CONDUCTED IN THE FIELD

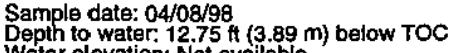

Water el

: 5.6

.

Water evacuated from the well prior to sampling: 3 gal

ANALYSES
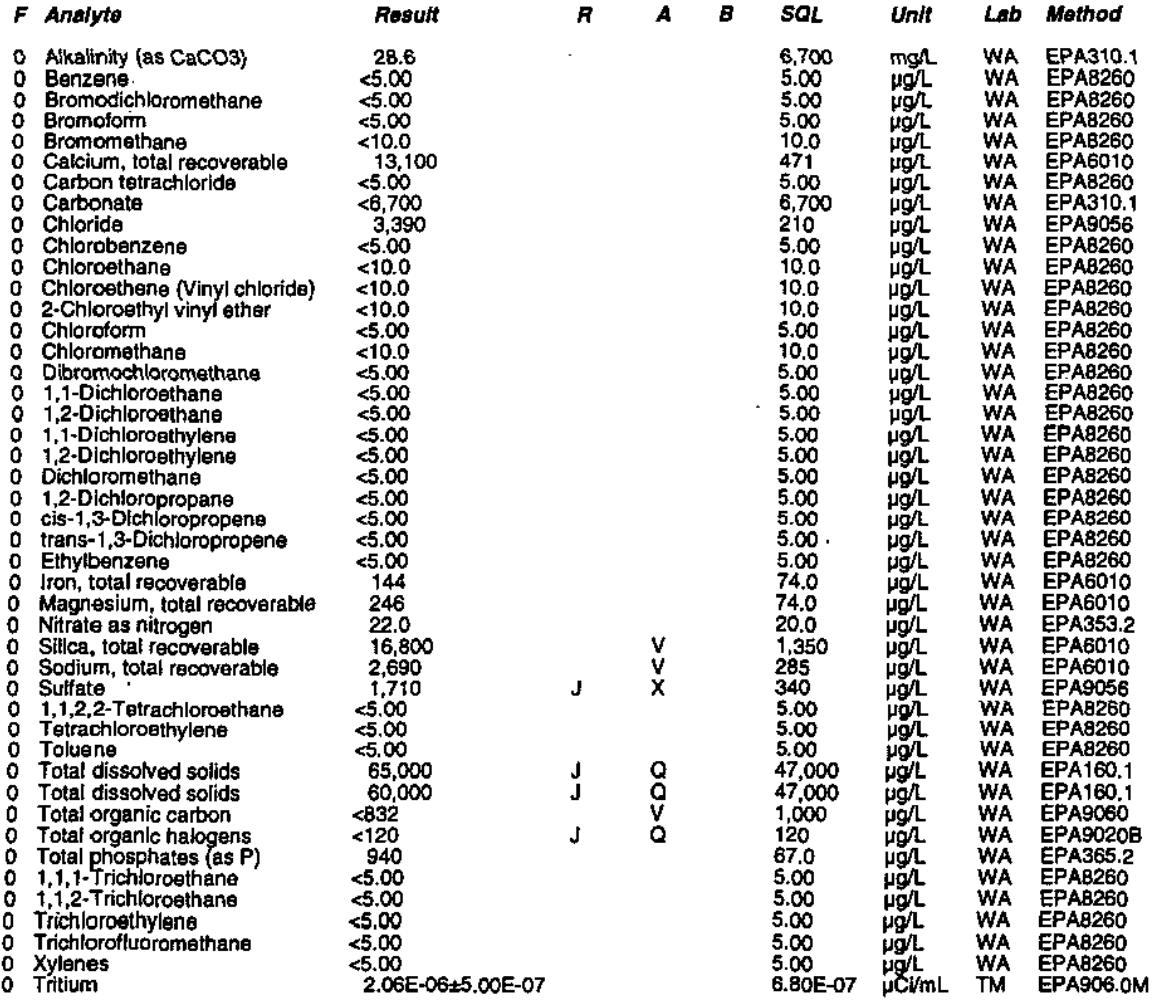

ESH-EMS-980569

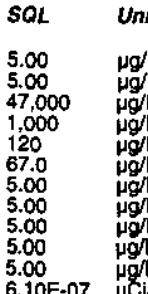

Unit Lab Method

\section{WELL FBP 48D}

MEASUREMENTS CONDUCTED IN THE FIELD

Sample date: $04 / 22 / 98$
Oepth to water: $13 \mathrm{ft}$ (3.96 m) below TOC

Water elevation: Not availabl

$\mathrm{pH}: 6.1$

Sp. conductance: $110 \mu \mathrm{S} / \mathrm{cm}$

Water evacuated from the well prior to sampling: $10 \mathrm{gat}$

ANALYSES

$F$ Analyto

Time: 12:57

Air $16.9^{\circ} \mathrm{C}$ Total alkalinity (as CaCOS): $17 \mathrm{mg} / \mathrm{L}$
Phenolphthalein alkalinity: $0 \mathrm{mg} / \mathrm{L}$

: Alkalinity (as $\mathrm{CaCO}$ )

Bromofom

Calmium, total recoverable
Carbon tetrachloride

Carbon te

Chlorobenzene

Chloroethene (Vinyl chloride)

2-Chloroethyl vinylether

Chloroform

1,t-Dichloroethane

1,2-Dlchloroethane

0 1,1 -Dichloroethylens

O Dichloromethane

o cis-1,3-Dichloropropene

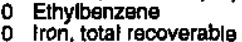

0 Magnesium total recoverable

o Silica, total recoverabie

: Sulfate

Tetrachloroethylene

Toluene

Total organic carbon

Total phosohates (as P)

1,1,1-Trichloroethane

Trichloroethylene

0 Xylenes

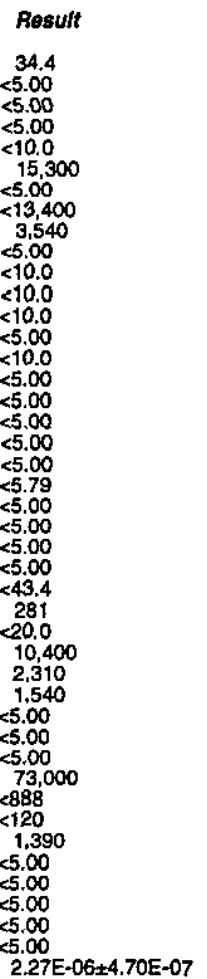

WELL FRB 1

MEASUREMENTS CONDUCTED IN THE FIELD

Sarnple date: $05 / 27 / 98$

apth to water: $51.8 \mathrm{ft}(15.79 \mathrm{~m})$ below TOC

pH: 4.4

Sp. conductance: $54 \mu \mathrm{S} / \mathrm{cm}$

Turbidity: 3 NTU: 54 HS/cm

ANALYSES

$F$ Anatroo

Aluminum, total recoverable

Arsenic, total recoverable
Barium, total recoverable

Barium, total recoverable

$-125$
Time: 11:49

Water temperature: $16.6^{\circ} \mathrm{C}$

Air temperature: 16.1 Co3): $30 \mathrm{mgh}$
Total alkalinity (as Caco3)
Phenolphthalein alkalinity: $0 \mathrm{mg} / \mathrm{L}$ 
Well FRB 1 coliected on 05/27/98 (cont.)

\begin{tabular}{|c|c|c|c|c|c|c|c|c|}
\hline Ana: & & $\boldsymbol{R}$ & & & & Init & $L a b$ & \\
\hline 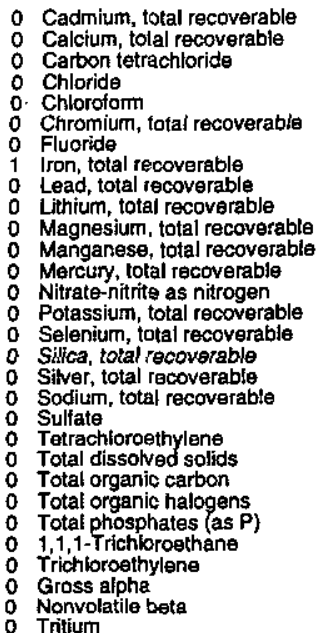 & 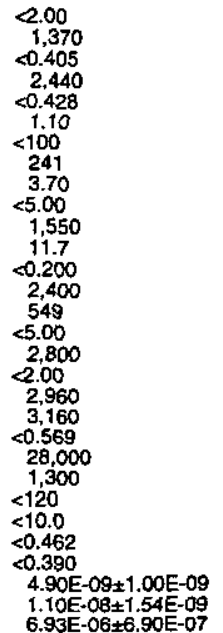 & $\begin{array}{l}J \\
J \\
J\end{array}$ & L & - & $\begin{array}{l}2.00 \\
50.0 \\
0.405 \\
500 \\
0.428 \\
3.00 \\
100 \\
20.0 \\
5.00 \\
5.00 \\
50.0 \\
3.00 \\
0.200 \\
250 \\
400 \\
5.00 \\
100 \\
2.00 \\
100 \\
5,000 \\
0.569 \\
1,000 \\
1,000 \\
120 \\
10.0 \\
0.462 \\
0.390 \\
5.40 \mathrm{E}-10\end{array}$ & 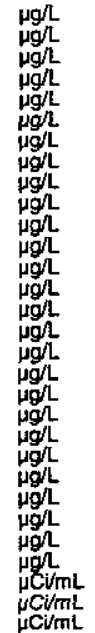 & $\begin{array}{l}\text { ES } \\
\text { ES } \\
\text { ES } \\
\text { ES } \\
\text { ES } \\
\text { ES } \\
\text { ES } \\
\text { ES } \\
\text { ES } \\
\text { ES } \\
\text { ES } \\
\text { ES } \\
\text { ES } \\
\text { ES } \\
\text { ES } \\
\text { ES } \\
\text { ES } \\
\text { ES } \\
\text { WA } \\
\text { ES } \\
\text { ES } \\
\text { ES }\end{array}$ & 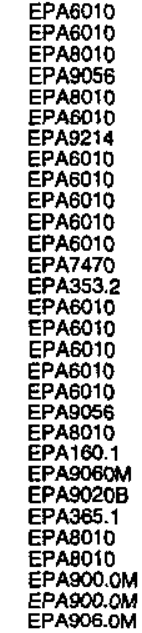 \\
\hline
\end{tabular}

WELLL FRB 3

MEASUREMENTS CONDUCTED IN THE FIELD

Sample date: $05 / 27 / 98$. Water elevation: $226.85 \mathrm{ft}(69.14 \mathrm{~m}) \mathrm{ms}$

pH: 5.2

Sp. conductance: $82 \mu \mathrm{S} / \mathrm{cm}$

Water evacuated from the well prior to sampling: 9 gal

ANALYSES

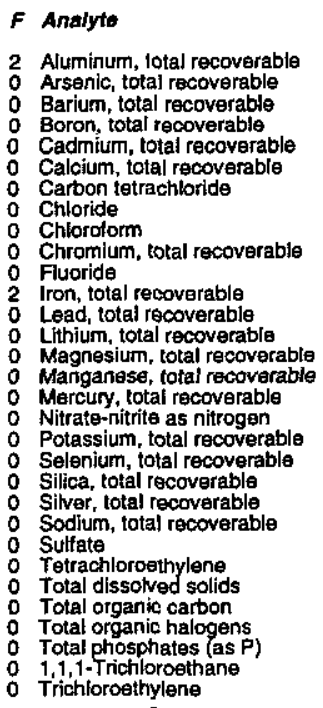

ESH-EMS-980569

Result
76.3
$<8.00$
10.0
21.2
0.300
552
$<0.405$
3.180
$<0.428$
6.80
$<100$
381
$<5.00$
$<5.00$
540
6.00
0.0500
2,310
340
$<5.00$
3.710
2.00
12,200
6,500
$<0.569$
76,900
$<1,000$
$<120$
185
$<0.462$
$<0.390$

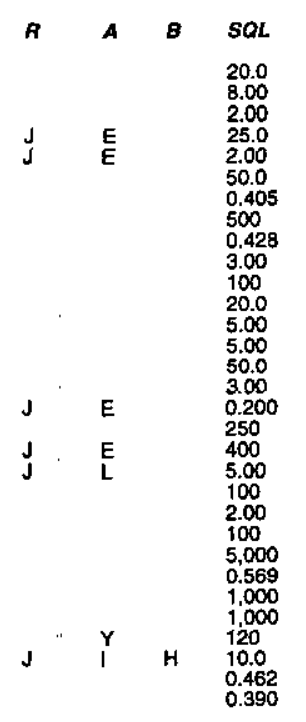

Well FRB 3 collected on 05/27/98 (cont.)

$F$ Analyte Result $\quad R \quad A \quad B \quad$ SOL Unit Lab Method

O Gross alpha $\quad 2.10 E-09 \pm 6.60 E-10 \quad 5.10 E-10 \quad \mu C V / m L$ TM EPA900.0M

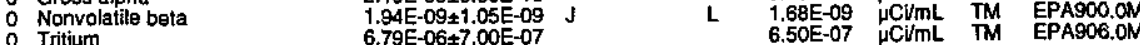

\section{WELL FRB 4}

MEASUREMENTS CONDUCTED IN THE FIELD

Sample date: $05 / 27 / 98$
Depth to water: $44 \mathrm{ft}(13.41 \mathrm{~m})$ below TOC
Water elevation: $227.1 \mathrm{ft}(69.22 \mathrm{~m})$ msl

Water elevation: $227.1 \mathrm{ft}(69.2$

Sp. conductance: $59 \mu \mathrm{S} / \mathrm{cm}$

Water temperature: $20.1^{\circ} \mathrm{C}$

Total alkalinity (as CaCO3): $0 \mathrm{mg} /$

Water evacuated from the well prior to sampling: 40 gal

ANALYSES

ANAYSES

2 Aluminum, total recoverable

: Arsenic, total recoverable

O Cadmium, total recoverable

O Calcium, total recovera

Chloride

o Chromium, total recoverable

Iron, total recoverable

Lead, total recoverable
Lthium, total recoverable

Magnesium, total recoverable

Mercury, total recoverable
Nitrate-nitrite as nitrogen

Potassium, total recoverable

Silica, total recoverable

Sodium, total recoverable

Tetrachloroethylene

Total organic carbon halogens

Total phosphates (as P)
1,1,1-Trichloroethane

Trichloroethylene

Nonvolatile beta

Tritium

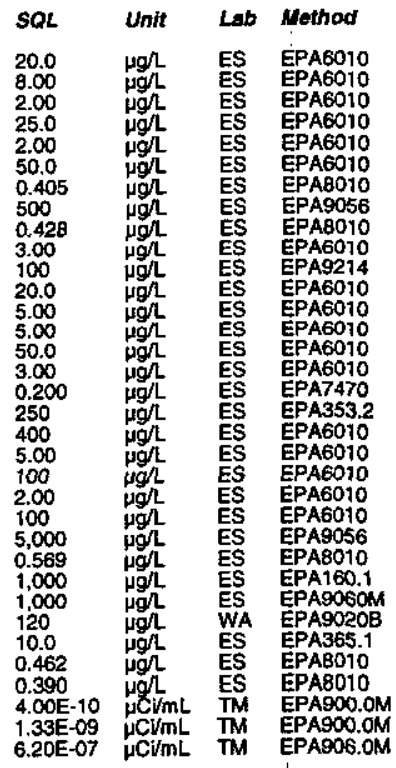

WELL FSB 76

MEASUREMENTS CONDUCTED IN THE FIELD

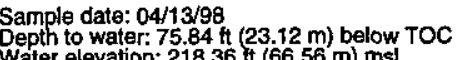

Water elevation: $218.36 \mathrm{it}(66.56 \mathrm{~m}) \mathrm{ms}$

PH: 4.2

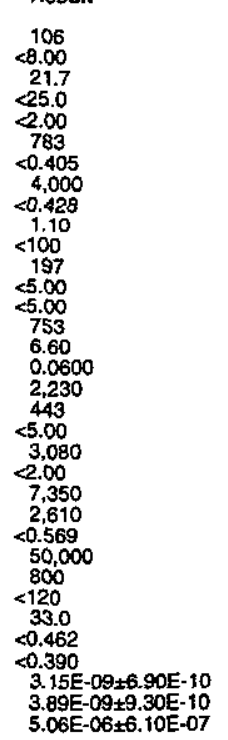

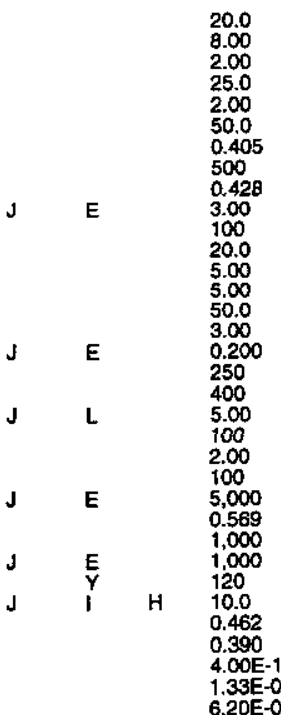

TML

-1
-1
Time: 10:42

perature: $21.1^{\circ} \mathrm{C}$

Total alkalinity (as Caco3): $0 \mathrm{mgh}$

Water evacuated from the well prior to sampling: $40 \mathrm{gal}$

ANALYSES

$F$ Ansiyte

o Cadmium, total recoverab

Nitrate-nitrite as nitrogen

$0 \mathrm{pH}$

Specific conductance

Result
$<1.00$
35.6
19.800
4.45
4.51
168

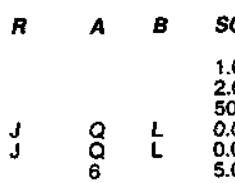

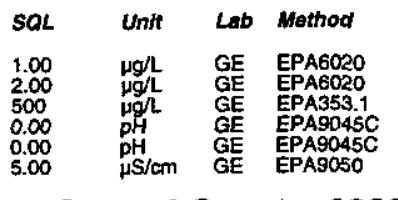


Well FSB 76 collected on 04/13/98 (cont.)

\begin{tabular}{|c|c|c|c|c|c|c|c|}
\hline F Analyto & Result & A & 8 & SQL & Unit & Lab & Method \\
\hline $\begin{array}{ll}0 & \text { Specific conductance } \\
1 & \text { Gross alpha } \\
1 & \text { Gross alpha } \\
0 & \text { Nonvolatile beta } \\
0 & \text { Nonvolatile beta } \\
2 & \text { Tritium }\end{array}$ & $\begin{array}{l}168 \\
1.31 \mathrm{E}-08+1.67 \mathrm{E}-09 \\
1.28 \mathrm{E}-08+1.59 \mathrm{E}-09 \\
1.68 \mathrm{E}-08+1.3 \mathrm{E}-09 \\
2.0 \mathrm{E}-08+1.39 \mathrm{E}-09 \\
4.39 \mathrm{E}-04 \pm \pm .62 \mathrm{E}-06\end{array}$ & $\begin{array}{l}\mathrm{C} \\
\mathrm{C}\end{array}$ & & $\begin{array}{l}5.00 \\
8.84 E-10 \\
7.00 E-10 \\
1.41 E-09 \\
1.11 E-09 \\
1.73 E-06\end{array}$ & $\begin{array}{l}\mu \mathrm{S} / \mathrm{cm} \\
\mu \mathrm{Cimm} \\
\mu \mathrm{CVimL} \\
\mu \mathrm{CV} / \mathrm{mL} \\
\mu \mathrm{CV} / \mathrm{mL} \\
\mu \mathrm{CimmL} \\
\mu\end{array}$ & $\begin{array}{l}G E \\
G P \\
G P \\
G P \\
G P \\
G P\end{array}$ & $\begin{array}{l}\text { EPA9050 } \\
\text { EPAA-001 } \\
\text { EPAA-D01 } \\
\text { EPAA-001 } \\
\text { EPIA-001 } \\
\text { EPIA-002 }\end{array}$ \\
\hline
\end{tabular}

\section{WELL FSB 76A}

MEASUREMENTS CONDUCTED IN THE FIELD

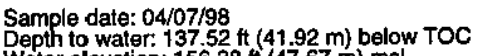

Depth to water: $137.52 \mathrm{ft}(41.92 \mathrm{~m})$ below $\mathrm{T}$
Water elevation: $156.38 \mathrm{ft}(47.67 \mathrm{~m}) \mathrm{ms}$

pH: 5.9

conductance: $110 \mu \mathrm{S} / \mathrm{cm}$

Water evacuated from the well prior to sampling: $170 \mathrm{gal}$ ANALYSES

$f$ Analyte

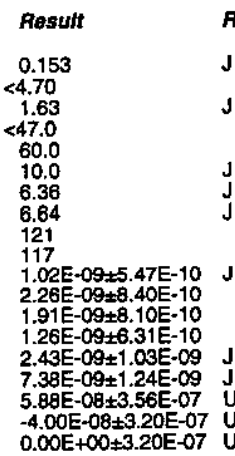

Cadmium, total recoverabl

Ladmium, rotal recovere

Lead, total recoverable

Nitrate-nitrite as nitrogen

$\mathrm{pH}_{\mathrm{pH}}$

Specitic conductance

Gross alphe

Gross alpha

Nonvolatilie beta

Tritium

Tritium

$-4.00 E-08 \pm 3.20 E-07$
$0.00 E+\infty$

\section{WELLL FSB 76A Replicate}

MEASUREMENTS CONDUCTED IN THE FIELD

Sample date: $04 / 07 / 98$
Depth to water: $137.52 \mathrm{ft}(41.92 \mathrm{~m})$ below TOC

Water elove

p. conductance: $110 \mu \mathrm{S} / \mathrm{cm}$

Tuntidity: 1 NTU 110 from

ANALYSES

$F$ Anafyte

$\begin{array}{ll}\text { Result } & \text { A } \\ <1.00 & \\ 0.805 & \mathrm{~J} \\ 610 & \mathrm{~J} \\ 6.68 & \\ 132 & 133 \\ 1.45 \mathrm{E}-09 \pm 5.68 \mathrm{E}-10 & \mathrm{~J} \\ 1.28 \mathrm{E}-09 \pm 5.98 \mathrm{E}-10 & \mathrm{U} \\ 2.13 \mathrm{E}-07 \pm 3.65 \mathrm{E}-07 & \mathrm{U}\end{array}$

Time: 14:28

ure: $21.2^{\circ} \mathrm{C}$

Total alkalinity (as CaCO3) $40 \mathrm{mgh}$

Cadmium, total recoverable Nitrate-nltrite as nitrogen

pH Specific conductan

Tritum :

J

\section{WELL FSB 76B}

MEASUREMENTS CONDUCTED IN THE FIELD Sample date: 04/09/98 Depth to water: $141.05 \mathrm{ft}(42.99 \mathrm{~m})$ below TOC Water bleation. $152.75 \mathrm{ft}(46.56 \mathrm{~m}) \mathrm{ms}$ conductance: $120 \mu \mathrm{S} / \mathrm{cm}$

Water evacuated from the well prior to sampling: $80 \mathrm{gal}$ ANALYSES

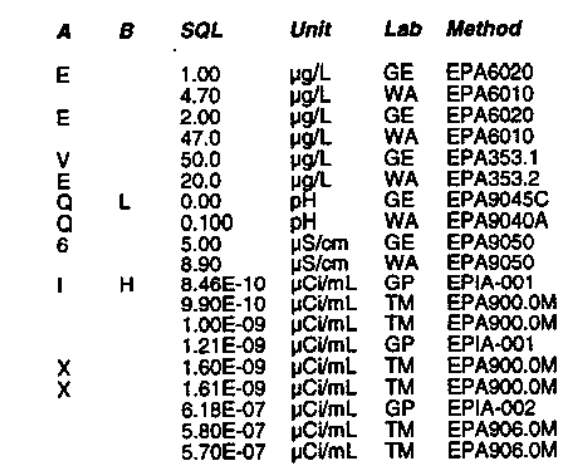

Time: 14:28

作 $21.2^{\circ} \mathrm{C}$ Total akealinity (as CaCO3): $40 \mathrm{mg} /$
$F$ Analyte

- Cadmium, total recoverable

Lead, total recoverable

Nitrate-nitrite as nitrog

Specific conductanco

Nonvolatile beta

WELL FSB 76C

MEASUREMENTS CONDUCTED IN THE FIELD

Sample date: $04 / 09 / 98$

Sp. conductance: $51 \mu \mathrm{S} / \mathrm{cm}$

Turbidity: 2 NTU

ANALYSES

$F$ Anetre

Resutt

- Cadmium, total recoverable

o Lead, total recoverable

$2 \mathrm{pH}$. nitrite as nitrog

Specific conductance

Gross alpha

Result

0.487
650

$\mathrm{E}$
$\mathrm{Q}$
$\mathrm{Q}$
$\mathrm{G}$

$1.03 E-09 \pm 5.12 E-10$
$7.78 E-10 \pm 5.96 \mathrm{E}-10$
$4.87 \mathrm{E}-07 \pm 4.46 \mathrm{E}-07$

\section{WELL FSB 77}

MEASUREMENTS CONDUCTED IN THE FIELD

Sample date: 04/06/98

Water

Sp. 3.4 con $060 \mathrm{~s} / \mathrm{cm}$

Turbidity: 2 NTU

ANALYSES

$F$ Analyte

Resuft

2 Cadmium, total recoverable

Lead, total recoverable

Nitrate-nitrite as nitrogen

$\mathrm{PH}$ Specific conductance

Gross alpha

2 Tritium

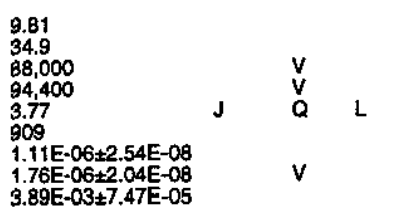

$1.76 \mathrm{E}-06 \pm 2.04 \mathrm{E}-08$
$3.89 \mathrm{E}-03 \pm 7.47 \mathrm{E}-05$
: $20.5^{\circ} \mathrm{C}$ Total alkalinity (as Caco3): $56 \mathrm{mgh}$ 
WELL FSB 78

MEASUREMENTS CONDUCTED IN THE FIELD Sample date: 04/07/98 Depth to water, $60.8 \mathrm{ft}(18.53 \mathrm{~m})$ below TOC Water elevation: $211.8 \mathrm{ft}(64.56 \mathrm{~m}) \mathrm{ms}$

Sp. conductance: $620 \mu \mathrm{S} / \mathrm{cm}$

Turbidity: 7 NTU: $620 \mu \mathrm{S} / \mathrm{cm}$

ANALYSES

\begin{tabular}{|c|c|c|c|c|c|c|c|c|}
\hline Analyte & Result & A & A & B & SQL & Unit & Lab & Method \\
\hline 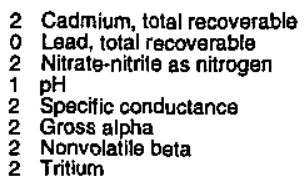 & $\begin{array}{l}19.3 \\
2.21 \\
66,800 \\
3.73 \\
734 \\
3.86 E-07 \pm 1.57 E-08 \\
1.82 E-06 \pm 2.07 E-008 \\
2.11 E-03 \pm 4.06 \mathrm{E}-05\end{array}$ & $J$ & $\begin{array}{l}V \\
Q\end{array}$ & L & $\begin{array}{l}1.00 \\
2.00 \\
2.000 \\
0.00 \\
5.00 \\
1.55 E-09 \\
2.63 E-09 \\
3.49 E-06\end{array}$ & 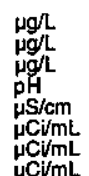 & $\begin{array}{l}G E \\
G E \\
G E \\
G E \\
G E \\
G P \\
G P \\
G P\end{array}$ & 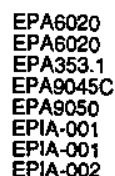 \\
\hline
\end{tabular}

\section{WELL FSB 78A}

MEASUREMENTS CONDUCTED IN THE FIELD

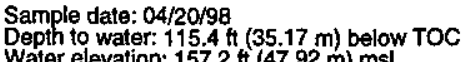

Water elevation: $157.2 \mathrm{ft}(47.92 \mathrm{~m}) \mathrm{ms}$

Sp: 6.2 conductance: $100 \mu \mathrm{S} / \mathrm{cm}$

Surbidity: $5 \mathrm{NTU}$ : $100 \mu \mathrm{S} / \mathrm{cm}$

ANALYSES

\begin{tabular}{|c|c|c|c|c|c|c|c|c|}
\hline Analyto & Result & A & A & $B$ & SOL & Unit & Lab & Method \\
\hline $\begin{array}{l}0 \text { Cadmium, total recoverable } \\
0 \text { Lead, total recoverable } \\
0 \text { Nitrate-nitrite as nitrogen } \\
0 \text { pH } \\
0 \text { Specitic conductance } \\
0 \text { Gross alpha } \\
0 \text { Norvolatile beta } \\
0 \text { Tritium }\end{array}$ & $\begin{array}{l}<1.00 \\
1.17 \\
270 \\
6.45 \\
125 \\
4.24 E-10 \pm 2.60 E-10 \\
1.84 E-09 \pm 4.98 E-10 \\
5.86 E-06 \pm 5.40 E-07\end{array}$ & J & a & L & $\begin{array}{l}1.00 \\
2.00 \\
50.0 \\
0.00 \\
5.00 \\
3.74 E-10 \\
8.24-10 \\
5.79 E-07\end{array}$ & 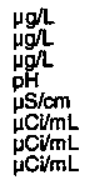 & $\begin{array}{l}\mathrm{GE} \\
\mathrm{GE} \\
\mathrm{GE} \\
\mathrm{GE} \\
\mathrm{GE} \\
\mathrm{GP} \\
\mathrm{GP} \\
\mathrm{GP}\end{array}$ & $\begin{array}{l}\text { EPAG020 } \\
\text { EPAG020 } \\
\text { EPA353.1 } \\
\text { EPAS045C } \\
\text { EPA9050 } \\
\text { EPIA-001 } \\
\text { EPIA-001 } \\
\text { EPIA-002 }\end{array}$ \\
\hline
\end{tabular}

\section{WELL FSB 78B}

MEASUREMENTS CONDUCTED IN THE FIELD

Sample date: $04 / 02198$
Depth to water $117.35 \mathrm{ft}(35.77 \mathrm{~m})$ below TOC
Water elevation: $155.45 \mathrm{ft}(47.38 \mathrm{~m}) \mathrm{msl}$

p. conductance: $210 \mu \mathrm{S} / \mathrm{cm}$

Water evacuated from the well prior to sampling: $111 \mathrm{gal}$ ANALYSES

\begin{tabular}{|c|c|c|c|c|c|c|c|c|}
\hline Analyte & Result & $\boldsymbol{A}$ & A & $B$ & SaL & Unit & $L a b$ & Method \\
\hline $\begin{array}{l}0 \text { Cadmiutm, lotal recoverable } \\
0 \text { Lead, total recoverable } \\
1 \text { Nitrate-nitrite as nitrogen } \\
0 \text { pH } \\
0 \text { Specific conductance } \\
0 \text { Gross alpha } \\
0 \text { Nonvolatile beta } \\
2 \\
2 \text { Tritium }\end{array}$ & $\begin{array}{l}<1.00 \\
2.00 \\
6.100 \\
7.16 \\
212 \\
1.68 \mathrm{E}-09+6.90 \mathrm{E}-10 \\
3.63 \mathrm{E}-09 \pm 8.79 \mathrm{E}-10 \\
1.16 \mathrm{E}-04 \pm 1.88 \mathrm{E}-06\end{array}$ & Ј :" & 0 & L & $\begin{array}{l}1.00 \\
2.00 \\
250 \\
0.00 \\
5.00 \\
5.01 \mathrm{E}-10 \\
1.38-09 \\
5.54 \mathrm{E}-07\end{array}$ & 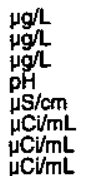 & $\begin{array}{l}G E \\
G E \\
G G E \\
G G \\
G G \\
G E \\
G P \\
G P \\
G P\end{array}$ & $\begin{array}{l}\text { EPA6020 } \\
\text { EPA6020 } \\
\text { EPA353.1 } \\
\text { EPA9045C } \\
\text { EPA9050 } \\
\text { EPIA-001 } \\
\text { EPIA-001 } \\
\text { EPIA-002 }\end{array}$ \\
\hline
\end{tabular}

Water temperature: $18^{\circ} \mathrm{C}$

Time: $12: 30$
Water temperature: $21.2^{\circ} \mathrm{C}$
Air temperature: $30.4^{\circ} \mathrm{C}$

Air temperature: $30.4^{\circ} \mathrm{C}$ ) $82 \mathrm{mg} / \mathrm{L}$

\section{WELL FSB 78C}

MEASUREMENTS CONDUCTED IN THE FIELO

Sample date: 04/07/98

Wepth to water: $63.6 \mathrm{ft}(19.39 \mathrm{~m})$ below TOC

Water elevation: $209.9 \mathrm{ft}(63.98 \mathrm{~m}) \mathrm{ms}$

Sp. conductance: $1,080 \mu \mathrm{S} / \mathrm{cm}$

Turbidity: 3 NTU

Water temperature: $17^{\circ} \mathrm{C}$

Total alkalinity (as $\mathrm{CaCO}$ ): $0 \mathrm{mgh}$

ANALYSES

$F$ Analyte

2 Cadmium, total recoverable

Nitrate-rititite as nitrogen

$\mathrm{NH}_{\mathrm{H}}$ itronitrite as nitrogen

Specific conductance
Gross alpha

Nonvolatile bet

\section{WELL FSB 78C}

MEASUREMENTS CONDUCTED IN THE FIELD

Sample date: 04/22/98

Depth to water: $63.1 \mathrm{tt}(19.23 \mathrm{~m})$ below TOC

$\mathrm{H} \mathrm{H}$. 3.8 . conductance: $1,060 \mu \mathrm{S} / \mathrm{cm}$

Water evacuated from the well prior to sampling: 1 gal

ANALYSES

F Analyte Result $R$ A $B$ SOL Unit Lab Method

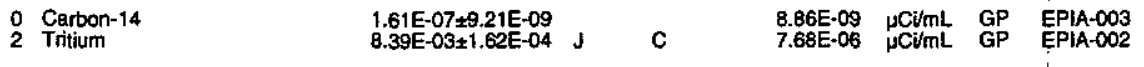

\section{WELL FSB 79}

MEASUREMENTS CONDUCTED IN THE FIELD

Sample date: $04 / 08 / 98$. $14.17 \mathrm{~m}$ ) below TOC

Water el

Time: 9:26

pH: 3.2

Sp. conductance: $1,080 \mu \mathrm{S} / \mathrm{cm}$

Water evacuated from the well prior to sampling: $43 \mathrm{gal}$

ANALYSES

$F$ Analyte

2 Cadmium, total recoverable

2 Nitrate-nitrite as nitrogen

Nitrate-nitrite as nitrogen

Specific conductance

2 Nonvolatile beta

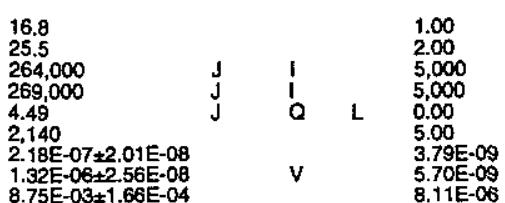

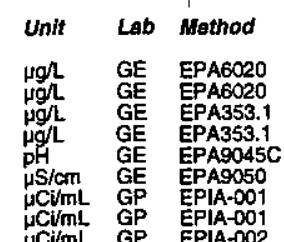

Time: 14:23

Air temperature: $27.1^{\circ} \mathrm{C}$

Total afkalinity (as CaCO3): $0 \mathrm{mgh}$

\begin{tabular}{|c|c|c|c|c|c|c|c|}
\hline Resuft & R & A & B & SQL & Unit & Lab & Method \\
\hline $\begin{array}{l}9.22 \\
1.90 \\
289,000 \\
287,000 \\
3.77 \\
2,370 \\
1.60 E-06 \pm 5.47 E-08 \\
1.62 E-06 \pm 3.41 E-08 \\
1.30 E-02+2.51 E-04\end{array}$ & $\begin{array}{l}\mathbf{J} \\
\mathbf{J} \\
\mathrm{j}\end{array}$ & $\begin{array}{l}\text { E } \\
\text { IV } \\
\text { IV } \\
Q \\
6\end{array}$ & L & $\begin{array}{l}1.00 \\
2.00 \\
5.000 \\
5.000 \\
0.00 \\
5.00 \\
3.54 E-09 \\
6.68 E-09 \\
1.08 E-05\end{array}$ & $\begin{array}{l}\mu g / \mathrm{L} \\
\mu g h \\
\mu g / \mathrm{L} \\
\mu g / \mathrm{L} \\
\mathrm{pH} \\
\mu \mathrm{S} / \mathrm{cm} \\
\mu \mathrm{CimL} \\
\mu \mathrm{CV} / \mathrm{mL} \\
\mu \mathrm{CV} / \mathrm{mL}\end{array}$ & $\begin{array}{l}\mathrm{GE} \\
\mathrm{GE} \\
\mathrm{GE} \\
\mathrm{GE} \\
\mathrm{GE} \\
\mathrm{GE} \\
\mathrm{GP} \\
\mathrm{GP} \\
\mathrm{GP}\end{array}$ & $\begin{array}{l}\text { EPA6020 } \\
\text { EPA6020 } \\
\text { EPA353.1 } \\
\text { EPA353.1 } \\
\text { EPA9045C } \\
\text { EPAO50 } \\
\text { EP|A-001 } \\
\text { EPIA-001 } \\
\text { EPIA-002 }\end{array}$ \\
\hline
\end{tabular}




\section{WELL FSB 79}

MEASUREMENTS CONDUCTED IN THE FIELD

Sample date: $04 / 22 / 98$
Depth to water: $13.66 \mathrm{ft}(4.16 \mathrm{~m})$ below TOC
Water elevation: $204.14 \mathrm{Ht}(62.22 \mathrm{~m}) \mathrm{ms}$ l

Water $\theta$

Sp: conductance: $1,060 \mu \mathrm{S} / \mathrm{cm}$

Water evacuated from the well prior to sampling: $\mathbf{4 8} \mathrm{gal}$ ANALYSES

$F$ Analyte:

2 Tritium

Result

$1.63 E-07 \pm 9.16 E-09$
$1.00 E-02 \pm 1.94 E-04$

(

\section{WELL FSB 79A}

MEASUREMENTS CONDUCTED IN THE FIELD

Sample date: 04/07/98 204 m)

Wath to water: $58.86 \mathrm{ft}(17.94 \mathrm{~m})$ below $T O C$

$\mathrm{pH}: 5.7$

Sp. conductance: $79 \mu \mathrm{S} / \mathrm{cm}$

Water evacuated from the well prior to sampling: $190 \mathrm{gal}$

ANALYSES

$F$ Analyte

$:$ Cadmium, total recoverable

Nitrate-nitrite as nitrogen

2 PH 0 secific conductance

Nonvolatile beta

1 Tritium

\section{WELL FSB 79B}

MEASUREMENTS CONDUCTED IN THE FIELD

Sample date: 04/07/98

Depth to water: $58.7 \mathrm{tt}(17.89 \mathrm{~m})$ below TOC

WH: 6.7 covation: $159.5 \mathrm{Ht}$ (48.

Water evacuated from the well prior to sampling: $127 \mathrm{gal}$

ANALYSES

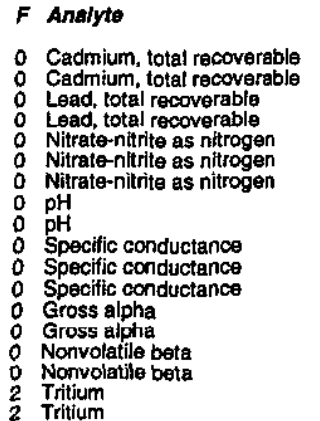

\begin{tabular}{|c|c|c|c|c|c|c|c|}
\hline Result & $\boldsymbol{A}$ & $A$ & B & $S Q L$ & Unit & Lab & Mothod \\
\hline $\begin{array}{l}<1.00 \\
<4.70 \\
0.0900 \\
<47.0 \\
2,660 \\
2,760 \\
2,780 \\
7.09 \\
7.03 \\
174 \\
174 \\
170 \\
6.45 E-10 \pm 4.70 E-10 \\
1.41 E-09 \pm 8.80 E-10 \\
3.98 E-09 \pm 7.69 E-10 \\
5.55 E-09+1.43 E-09 \\
6.93 E-0.5 \pm 1.55 E-06 \\
4.40 E-05 \pm 1.53 E-06\end{array}$ & Ut & $\begin{array}{l}0 \\
0 \\
6 \\
6\end{array}$ & L & $\begin{array}{l}1.00 \\
4.70 \\
2.00 \\
47.0 \\
50.0 \\
200 \\
20.0 \\
0.00 \\
0.100 \\
5.00 \\
5.00 \\
8.90 \\
6.85 E-10 \\
1.26 E-09 \\
1.12 E-09 \\
2.06 E-09 \\
6.18 E-07 \\
5.90 E-07\end{array}$ & 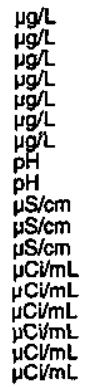 & $\begin{array}{l}G E \\
W A \\
G E \\
W A \\
G E \\
W A \\
W A \\
G E \\
W A \\
G E \\
G E \\
W A \\
G P \\
T M \\
G P \\
G M \\
G P \\
T M\end{array}$ & $\begin{array}{l}\text { EPAG020 } \\
\text { EPA6010 } \\
\text { EPAG020 } \\
\text { EPA6010 } \\
\text { EPA353.1 } \\
\text { EPA353.2 } \\
\text { EPA353.2 } \\
\text { EPA9045C } \\
\text { EPA9040A } \\
\text { EPA9050 } \\
\text { EPA9050 } \\
\text { EPA9050 } \\
\text { EPA9050 } \\
\text { EPAA-001 } \\
\text { EPA900.0M } \\
\text { EPAA.001 } \\
\text { EPA900.0M } \\
\text { EPAA-002 } \\
\text { EPA906.0M }\end{array}$ \\
\hline
\end{tabular}

Time: $13: 15$ Water temperature: $20.2^{\circ} \mathrm{C}$ Air temperature: $32.5^{\circ} \mathrm{C}$ ): $30 \mathrm{mg} /$ Total alkalinity (as CaCO3): $30 \mathrm{mg} /$
Phenolphthalein alkalinity: $0 \mathrm{mg} /$

Time: 10:31

Total alkalinity (as Caco3): $0 \mathrm{mg} /$
Phenolphthalein alkalinity: $0 \mathrm{mgL}$

B SOL Unit Lab Method

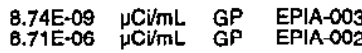

Air temperature: $13.9^{\circ} \mathrm{C}$

WELL FSB 79B Replicate

MEASUREMENTS CONDUCTED IN THE FIELD

Sample date: $04 / 07 / 98$

Sample date: 04/07/98
Depth to water: $58.7 \mathrm{ft}(17.89 \mathrm{~m})$ below TOC
Water elevation: $159.5 \mathrm{ft}(48.62 \mathrm{~m}) \mathrm{ms}$

pH: conductance: $170 \mu \mathrm{S} / \mathrm{cm}$

Turbidity: 1 NTU
Water evacuated from the well prior to sampling: $127 \mathrm{gal}$ ANALYSES

$F$ Anatro

- Cadmium, total recoverable

Lead total recoverable
0 Nitrate-nitrite as nitrogen

$\begin{array}{lll}0 & \text { Nitrat } \\ 0 & \mathrm{pH} \\ 0 & \mathrm{pH}\end{array}$

Specific conductance

Gross alpha

2 Tritium

\section{WELL FSB 79C}

MEASUREMENTS CONDUCTED IN THE FIELD

Sample date: 04/08/98

Depth to water: $20.1 \mathrm{ft}(6.13 \mathrm{~m})$ below TOC

$\mathrm{pH}: 3.6$

p. conductance: $1,040 \mu \mathrm{S} / \mathrm{cm}$

Water evacuated from the well prior to sampling: $69 \mathrm{gad}$

ANALYSES

$F$ Analyte

2 Cadmium, total recoverable

2 Nitrate-nitrite as nitrogen

20

2 Nonvolatilie beta

2 Tritium

Water temperature: $212^{\circ} \mathrm{C}$

Total alkalinity (as CaCO3): $52 \mathrm{mg} /$

\section{WELL FSB 87A}

MEASUREMENTS CONDUCTED IN THE FIELD

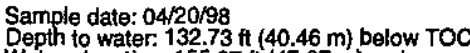
Water elevation: $155.07 \mathrm{ft}(47.27 \mathrm{~m}) \mathrm{ms}$ )

pH: 6.1

p. conductance: $100 \mu \mathrm{S} / \mathrm{cm}$

Water evacuated from the well prior to sampling: $238 \mathrm{gal}$

ANALYSES

F Analyto

0 Cadmium, total recoverable

L Lead, total recoverable

o Lead, total recoverable

Nitrate-nitrita as nitrogen

Specific conductance

Gross alpha

0 Gross alpha

$\begin{array}{ll}\text { Result } & \text { A } \\ <1.00 & \\ 4.70 & \\ 0.252 & \text { J } \\ <4.0 & \\ 90.0 & \\ 45.0 & \\ 6.29 & \mathrm{~J} \\ 6.58 & \mathrm{~J} \\ 108 & \\ 95.5 & \\ 3.12 \mathrm{E}-10 \pm 2.35 \mathrm{E}-10 & \mathrm{UI} \\ 1.10 \mathrm{E}-09 \pm 6.30 \mathrm{E}-10 & \\ 1.02 \mathrm{E}-09 \pm 6.50 \mathrm{E}-10 & \end{array}$

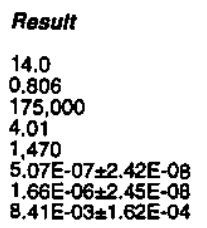

B

$\begin{array}{ll}A & B \\ E & \\ \mathrm{~V} & \\ 6 & \mathrm{~L} \\ & \end{array}$

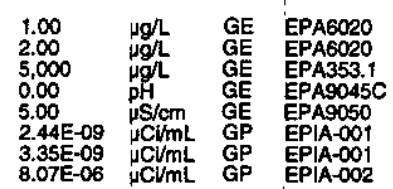

Time: 10:56

Tite: $20.2^{\circ} \mathrm{C}$

Total alkalinity (as CaCO3): $38 \mathrm{mg} /$

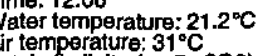

Total alkalinity (as CaCO3): $52 \mathrm{mg} / \mathrm{L}$

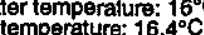

Total alkalinity (as CaCO3): $0 \mathrm{ingh}$

$\begin{array}{ll}A & B \\ E & \\ V & \\ Q & L \\ 8 & \end{array}$

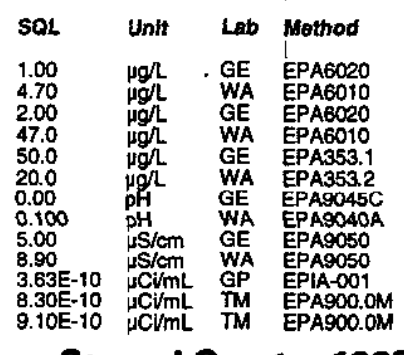

Second Quarter 1998 
Well FSB 87A collectod on 04/20/98 (cont.)

\begin{tabular}{|c|c|c|c|c|c|c|c|c|}
\hline Analyte & Result & A & $A$ & $B$ & SQL & Unit & Lab & Mathod \\
\hline $\begin{array}{ll}0 & \text { Nonvolatilie beta } \\
0 & \text { Nonvolatile beta } \\
0 & \text { Nonvolatile beta } \\
0 & \text { Tritium } \\
0 & \text { Tritium } \\
0 & \text { Tritium }\end{array}$ & $\begin{array}{l}9.16 E-10 \pm 4.30 E-10 \\
6.80 E-10 \pm 1.12 E-09 \\
6.60 E-10 \pm 1.14 E-09 \\
1.84 E-06 \pm 4.09 E-07 \\
5.30 E-07 \pm 4.10 E-07 \\
2.30 E-07 \pm 4.00 E-07\end{array}$ & $\begin{array}{l}\text { UI } \\
\text { UI } \\
\text { UI }\end{array}$ & & & $\begin{array}{l}7.76 E-10 \\
1.90 E-09 \\
1.94 \mathrm{E}-09 \\
5.79 \mathrm{E}-07 \\
6.70 \mathrm{E}-07 \\
6.80 \mathrm{E}-07\end{array}$ & $\begin{array}{l}\mu \mathrm{Ci} / \mathrm{mL} \\
\mu \mathrm{CVimL} \\
\mu \mathrm{CimL} \\
\mu \mathrm{CimL} \\
\mu \mathrm{CimL} \\
\mu \mathrm{CimL}\end{array}$ & $\begin{array}{l}G P \\
T M \\
T M \\
G P \\
T M \\
T M\end{array}$ & $\begin{array}{l}\text { EPIA-001 } \\
\text { EPA900.0M } \\
\text { EPA900.0M } \\
\text { EPIA-002 } \\
\text { EPA906.0M } \\
\text { EPA906.0M }\end{array}$ \\
\hline
\end{tabular}

\section{WELL FSB 87A Replicate}

MEASUREMENTS CONDUCTED IN THE FIELD

$$
\begin{aligned}
& \text { Sample date: 04/20/98 } \\
& \text { Depth to water } 132.73 \mathrm{ft}(40.46 \mathrm{~m}) \text { below TOC } \\
& \text { Water elevation: } 155.07 \mathrm{ft}(47.27 \mathrm{~m}) \mathrm{ms} \\
& \text { pH: } 6.1 \\
& \text { Sp. conductance: } 100 \mu \mathrm{S} / \mathrm{cm}
\end{aligned}
$$

Turbidity: ONTU:

ANALYSES

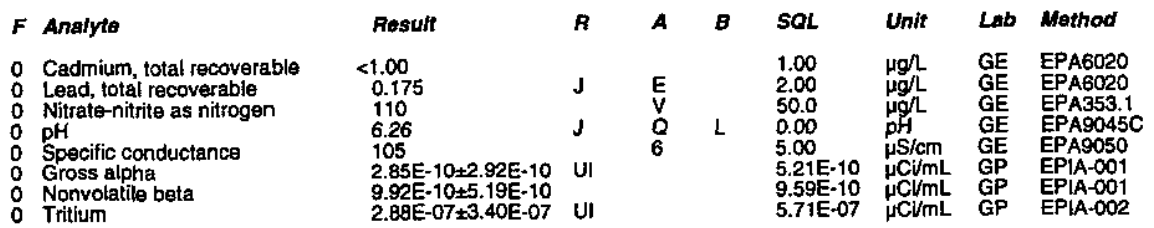

\section{WELL FSB 87B}

MEASUAEMENTS CONDUCTED IN THE FIELD

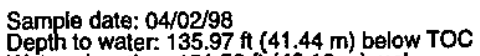

Depth to water: $135.97 \mathrm{ft}(41.44 \mathrm{~m})$ below

Water el

p. conductance: $110 \mu \mathrm{S} / \mathrm{cm}$

Water evacuated from the well prior to sampling: $100 \mathrm{gal}$

ANALYSES

$F$ Analyte

- Cadmium, fotal recoverable

Nitraterititrite as nitroge

$\mathrm{pH}$ Specific conductance

Nonvolatile beta

\begin{tabular}{|c|c|c|c|c|c|c|c|}
\hline Resuft & $\boldsymbol{B}$ & A & $B$ & SQL & Unit & $L a b$ & Mothod \\
\hline $\begin{array}{l}<1.00 \\
3.25 \\
8.550 \\
5.80 \\
103 \\
2.70 E-11 \pm 2.69 E-10 \\
3.30 E-09+8.31-10 \\
1.01 E-04 \pm 1.72 E-06\end{array}$ & UI & $\begin{array}{l}Q \\
6\end{array}$ & L & $\begin{array}{l}1.00 \\
2.00 \\
250 \\
0.00 \\
5.00 \\
6.44 E-10 \\
1.31-09 \\
5.30 E-07\end{array}$ & 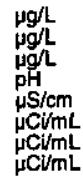 & $\begin{array}{l}\mathrm{GE} \\
\mathrm{GE} \\
\mathrm{GE} \\
\mathrm{GE} \\
\mathrm{GE} \\
\mathrm{GP} \\
\mathrm{GP} \\
\mathrm{GP}\end{array}$ & $\begin{array}{l}\text { EPA6020 } \\
\text { EPA6020 } \\
\text { EPA353. } \\
\text { EPA9045C } \\
\text { EPA9050 } \\
\text { EPIA-001 } \\
\text { EPIA-001 } \\
\text { EPIA-002 }\end{array}$ \\
\hline
\end{tabular}

2 Tritium

Time: 10:56

Total alkalinity (as CaCO3): $38 \mathrm{mg} / \mathrm{L}$
Phenolphthalein alkalinity: $0 \mathrm{mg} / \mathrm{L}$

Time: 14:05

Air temperature: $31: 8^{\circ} \mathrm{C}$

Total alkalinity (as CaCo3): $9 \mathrm{mg} / \mathrm{L}$
WELL FSB 87C

MEASUREMENTS CONDUCTED IN THE FIELD

Sample date: 0401 to

Depth to water: $77.62 \mathrm{ft}(23.66 \mathrm{~m})$ below TOC

$\mathrm{pH}: 5.8$

$209.88 \mathrm{th}(63.97 \mathrm{~m}) \mathrm{msi}$

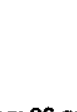

Water temperature: $20.9^{\circ} \mathrm{C}$

Total alkalinity (as CaCO3): $1 \mathrm{mgl}$

Water evacuated from the well prior to sampling: 96 gal ANALYSES

Wir $20.2^{\circ} \mathrm{C}$

\section{$F$ Analyte}

Result

- Cadmium, total recoverable

Nitrate-nitrite as nitrogen

Specific conductance

Gross alpha

2 Nonvitum

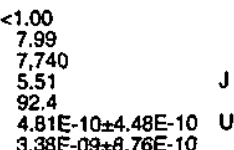

$3.38 \mathrm{E}-09+8.76 \mathrm{E}-10$
$4.41 \mathrm{E}-04+3.76 \mathrm{E}-06$

\section{WELL FSB 87D}

MEASUREMENTS CONDUCTED IN THE FIELD

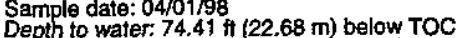

Water elevation: $212.89 \mathrm{tt}(64.89 \mathrm{~m}) \mathrm{msl}$

PH: 4.7 conductance: $53 \mu \mathrm{S} / \mathrm{cm}$

Turitidity: 2 NTU
Water evacuated from the well prior to sampling: 42 gal ANALYSES

\section{F Analyto}

Lead, total recoverable

$\mathrm{pH}$.

Gross alpha

WELL FSB $88 C$

MEASUREMENTS CONDUCTED IN THE FIELD

Sample date: $04 / 01 / 98$

Depth to water: $69.4 \mathrm{ft}(21.15 \mathrm{~m})$ below TOC

$\mathrm{H}$ : 5.1

Sp. conductance: $45 \mu \mathrm{S} / \mathrm{cm}$

Turtidity: 1 NTU 45 STh

\begin{tabular}{|c|c|c|c|c|c|c|c|c|}
\hline \multirow{3}{*}{$\begin{array}{ll}\text { F } & \text { Analyte } \\
0 & \text { Cadmium, total recoverable } \\
0 & \text { Lad, total recoverable } \\
0 & \text { Nitrate-nitrite as nitrogen } \\
0 & \text { pH } \\
0 & \text { Specific conductance } \\
0 & \text { Gross alpha } \\
0 & \text { Nonvolatile beta } \\
1 & \text { Tritium }\end{array}$} & \multirow{3}{*}{$\begin{array}{l}\text { Result } \\
<1.00 \\
0.127 \\
1,640 \\
5.36 \\
46.6 \\
1.23 E-10 \pm 2.83 E-10 \\
2.77 E-10 \pm 6.15 E-10 \\
1.47 E-05 \pm 7.57 \mathrm{E}-07\end{array}$} & \multirow[t]{3}{*}{$\boldsymbol{A}$} & \multirow[t]{2}{*}{$A$} & \multirow[b]{3}{*}{$\mathbf{L}$} & \multirow{3}{*}{$\begin{array}{l}5 O L \\
1.00 \\
2.00 \\
50.0 \\
0.00 \\
5.00 \\
6.35 E-10 \\
1.37 E-09 \\
505 E-07\end{array}$} & \multirow{3}{*}{ 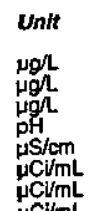 } & \multirow{3}{*}{$\begin{array}{l}L a b \\
G E \\
G E \\
G E \\
G E \\
G E \\
G P \\
G P\end{array}$} & \multirow{3}{*}{$\begin{array}{l}\text { Method } \\
\text { EPAGO20 } \\
\text { EPA6020 } \\
\text { EPA353.1 } \\
\text { EPA9045C } \\
\text { EPA9050 } \\
\text { EPAA-01 } \\
\text { EPAA-001 } \\
\text { EPIA-002 }\end{array}$} \\
\hline & & & & & & & & \\
\hline & & & $Q$ & & & & & \\
\hline
\end{tabular}
ANALYSES 


\section{WELL FSB 88D}

MEASUREMENTS CONDUCTED IN THE FIELD

Depth to water: $63.7 \mathrm{ft}(19.42 \mathrm{~m})$ below TOC

Water elevation: $218.7 \mathrm{Ht}(66.66 \mathrm{~m}) \mathrm{msl}$

pH: 3.8 conductance: $260 \mu \mathrm{s} / \mathrm{cm}$

Water evacuated from the well prior to sampling: $33 \mathrm{gal}$ ANALYSES

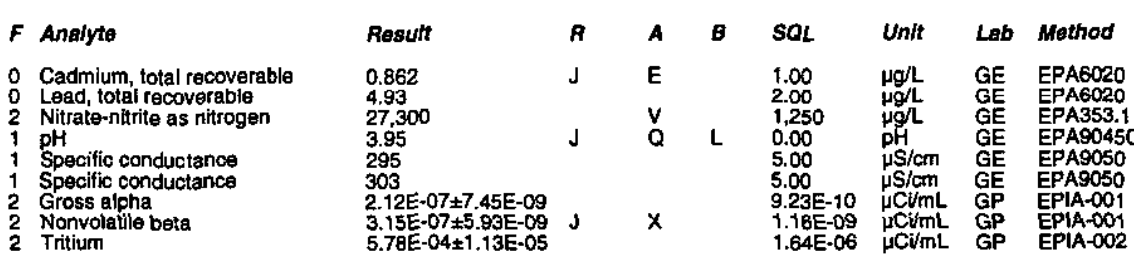

\section{WELL. FSB 89C}

MEASUREMENTS CONDUCTED IN THE FIELD

Sample date: $04 / 01 / 98$
Depth to water: $68.35 \mathrm{th}(20.83 \mathrm{~m})$ below TOC
Water elevation: $212.95 \mathrm{H}(64.91 \mathrm{~m}) \mathrm{msl}$
pH: 5.4 .
Sp. conductance: $53 \mu \mathrm{S} / \mathrm{cm}$
Turbidity: 1 NTU

pp. conductance: $53 \mu \mathrm{S} / \mathrm{cm}$

Water evacuated from the well prior to sampling: $101 \mathrm{gal}$ ANALYSES

\begin{tabular}{|c|c|c|c|c|c|c|c|c|}
\hline \multirow{3}{*}{$\begin{array}{l}\text { F Analyte } \\
0 \text { Cadmium, total recoverable } \\
0 \text { Lead, lotal recoverable } \\
0 \text { Nitrate-nitrite as nitrogen } \\
0 \text { pH } \\
0 \text { Specific conductance } \\
0 \text { Specific conductance } \\
0 \text { Gross alpha } \\
0 \text { Nonolatile beta } \\
\text { I Tritium }\end{array}$} & \multirow{3}{*}{$\begin{array}{l}\text { Resuft } \\
<1.00 \\
0.221 \\
1.760 \\
5.56 \\
54.7 \\
54.9 \\
3.07 E-10 \pm 3.61 E-10 \\
9.72 E-10 \pm 6.27 E-10 \\
179 E-05+8.20=07\end{array}$} & $\boldsymbol{R}$ & & $B$ & SOI & unt & La & \\
\hline & & $J$ & $E$ & & & & $\begin{array}{l}\text { GE } \\
\text { GE }\end{array}$ & \\
\hline & & UI & $\mathrm{Q}$ & $L$ & $\begin{array}{l}0.00 \\
5.00 \\
5.00 \\
6.76 E-10 \\
1.24 E-09 \\
5.95 E-07\end{array}$ & 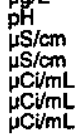 & $\begin{array}{l}\text { GE } \\
G E \\
G E \\
G P \\
G P \\
G P \\
G P\end{array}$ & $\begin{array}{l}\text { EPA9045C } \\
\text { EPA9050 } \\
\text { EPA9050 } \\
\text { EPIA-001 } \\
\text { EPIA-001 } \\
\text { EPIA-002 }\end{array}$ \\
\hline
\end{tabular}

\section{WELL FSB 89D}

MEASUREMENTS CONDUCTED IN THE FIELD

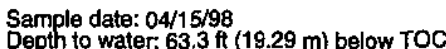

Water elevation: $217.9 \mathrm{Ht}(66.42 \mathrm{~m}) \mathrm{ms}$ (

$\mathrm{H}: 3.8$

p. conductance: $280 \mu \mathrm{S} / \mathrm{cm}$

Water evacuated from the well prior to sampling: 24 gal

ANALYSES

$F$ Analyte

- Cadmlum, total recoverable

Nitrate-nitrite as nitrogen

$\mathrm{pH}$ pecific conductance

Nonvolatille bet

Tritium
Time: $8: 38$

ir temperature: $8.9^{\circ} \mathrm{C} \mathrm{C}$

Total alkalinity (as CaCO3) $0 \mathrm{mg} / \mathrm{L}$
Phenolphthalein alkalinity: $0 \mathrm{mg}$

1.64E.06 $\mu \mathrm{CV} / \mathrm{mL}$ GP EPIA-002

Time: 8:51

Total alkailinity (as CaCO3): $11 \mathrm{mgh}$
Phenolphthalein alkalinity: $0 \mathrm{mg} / \mathrm{L}$
Water $19.7^{\circ} \mathrm{C}$

WELL FSB 90C

MEASUREMENTS CONDUCTED IN THE FIELD

Sample date: $04 / 02 / 98$
Depth to water: $66.05 \mathrm{ft}(20.13 \mathrm{~m})$ below TOC
Water elevation: $212.35 \mathrm{tt}(64.73 \mathrm{~m}) \mathrm{msl}$

$\mathrm{gH}: 6$

Turbidity: 2 NTU
Water evacuated from the well prior to sampling: $1 \mathrm{gal}$ ANALYSES

$F$ Anatyo

- Cadmium, total recoverable

Lead, total recoverablo
2 Nitrato-nitrite as nitrogen

Specitic conductance

o Gross alpha

2 Nonvolatile beta

WELL FSB 90D

MEASUREMENTS CONDUCTED IN THE FIELD

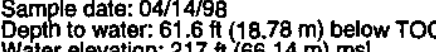

$\mathrm{pH}: 3.6$

Sp. conductance: $520 \mu \mathrm{S} / \mathrm{cm}$

Turbidity: 3 NTU

ANALYSES

$F$ Anatyto

1 Cadmium, total recoverable

2 Lead, total recoverable

2 Specific conductance

2 Gross alpha

2 Nonvolatiti

\section{WELL FSB 91C}

MEASUREMENTS CONDUCTED IN THE FIELD

Sample date: 04/27/98

Wepter olevation: $2131 \mathrm{ft}(20.21 \mathrm{~m})$ below TOC

pH: 4.9

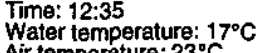

Air temperature: $23^{\circ} \mathrm{C}$

Sp. conduct

Turbicity: 3 NTU 110 ST/Cm

ANALYSSES

$F$ Anglyto

1 Cadmium, total recoverable

Lead, total recoverable

$0 \mathrm{pH}$ -

Gross alpha

2 Nonvolatile beta

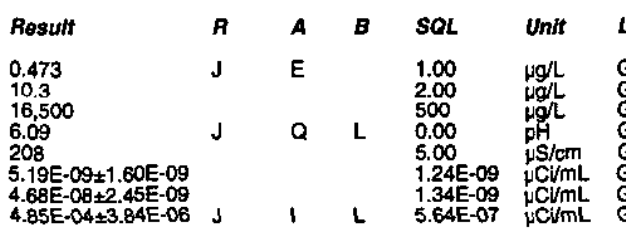

Lab Method

Wime: $8: 17$ temperature: $18.1^{\circ} \mathrm{C}$

Total alkalinity (as Caco3): $15 \mathrm{mgh}$
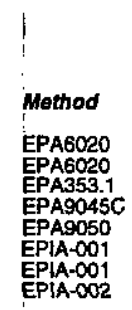

$5.64 E-07, \mathrm{C} V \mathrm{~mL}$ GP EPIAA-001

Time: 9:55

Water temperature: $15^{\circ} \mathrm{C}$ Artemperature: $14.5 \mathrm{Cl}$ ) $0 \mathrm{mgh}$ 


\section{WELL FSB 91D}

MEASUREMENTS CONDUCTED IN THE FIELD Depth to water: $63 \mathrm{Ht}(19.2 \mathrm{~m})$ below TOC
Water elevation: $216.2 \mathrm{ft}(65.9 \mathrm{~m}) \mathrm{msl}$

$\mathrm{H}: 4$

p. conductance: $140 \mu \mathrm{S} / \mathrm{cm}$

Water evacuated from the well prior to sampling: $\mathbf{3 1}$ gal ANALYSES

F Analyte

0 Cadmium, total recoverable

Lad, total recoverable
Nitrate-nitrite as nitrogen

$1 \mathrm{pH}$ Specitic conductance

Gross alpha

2 Tritium
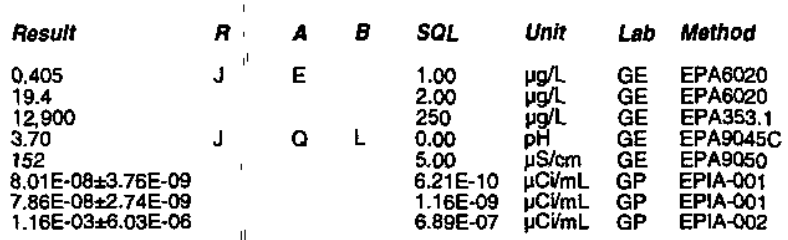

\section{WELL FSB 92C}

MEASUREMENTS CONDUCTED IN THE FIELD

Sample date: $04 / 16 / 98$
Depth to water: $64.25 \mathrm{ft}(19.58 \mathrm{~m})$ below TOC
Water elevation: $211.45 \mathrm{tt}(64.45 \mathrm{~m}) \mathrm{ms}$
pH: 8.8 .
Sp. conductance: $360 \mu \mathrm{S} / \mathrm{cm}$

pH: 8.8 conductance: $360 \mu \mathrm{S} / \mathrm{cm}$

Water evacuated from the well prior to sampling: $66 \mathrm{gal}$ ANALYSES

\begin{tabular}{|c|c|c|c|c|c|c|c|c|}
\hline Analyte & Result & A & $A$ & $B$ & SQL & Unit & Lab & Method \\
\hline $\begin{array}{l}\text { Cadmium, total recoverable } \\
\text { Lead, total recoverable }\end{array}$ & 0.546 & J & $\begin{array}{l}E \\
E\end{array}$ & & & & GE & $\begin{array}{l}\text { EPA6020 } \\
\text { EPA6020 }\end{array}$ \\
\hline $\begin{array}{l}\mathrm{pH} \\
\text { Specific conductance } \\
\text { Gross alpha } \\
\text { Nonvolatile beta } \\
\text { Totitum }\end{array}$ & $\begin{array}{l}8.77 \\
377 \\
2.67 E-08 \pm 3.19 E-09 \\
2.28 E-07 \pm 4.70 E-09 \\
8.45 E-04 \pm 5.11-06\end{array}$ & $J$ & Q & $\mathbf{L}$ & $\begin{array}{l}0.00 \\
5.00 \\
1.49 E-09 \\
1.335-09 \\
6.776-07\end{array}$ & 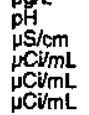 & $\begin{array}{l}G E \\
G E \\
G P \\
G P\end{array}$ & $\begin{array}{l}\text { EPA9045C } \\
\text { EPA9050 } \\
\text { EPIA-001 } \\
\text { FPIA-001 } \\
\text { EPIA-002 }\end{array}$ \\
\hline
\end{tabular}

\section{WELL FSB 92D}

MEASUREMENTS CONDUCTED IN THE FIELD

\section{Sample date: $04 / 0 \mathrm{~g} / 98$
Depth to water: $61.55 \mathrm{ft}(18.76 \mathrm{~m})$ below TOC
Water elevation: $214.35 \mathrm{ft}(65.33 \mathrm{~m}) \mathrm{msl}$}

Sp. conductance: $940 \mu \mathrm{S} / \mathrm{cm}$

Tutbidity: 2 NTU:

ANALYSES

\begin{tabular}{|c|c|c|c|c|c|c|c|}
\hline Tesult & $\boldsymbol{R}_{i}$ & A & & SOL & Unit & La & Mothod \\
\hline $\begin{array}{l}5.61 \\
11.3 \\
109.000 \\
3.93 \\
998 \\
7.73 E-07 \pm 2.70 E-08 \\
8.75 E-07 \pm 1.77 E-08 \\
3.62 E-03 \pm 6.95-05\end{array}$ & $J_{i}$ & & & $\begin{array}{l}1.00 \\
2.00 \\
5.000 \\
0.00 \\
5.00 \\
1.88 E-09 \\
3.43 E-09 \\
4.76 E-06\end{array}$ & 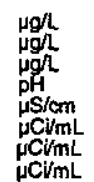 & $\begin{array}{l}\mathrm{GE} \\
\mathrm{GE} \\
\mathrm{GE} \\
\mathrm{GE} \\
\mathrm{GE} \\
\mathrm{GP} \\
\mathrm{GP}\end{array}$ & 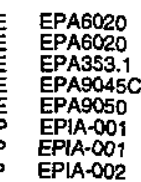 \\
\hline
\end{tabular}

Water en

$F$ Analyte

Time: 11:34

Wirer

Total alkalinity (as CaCO3): $0 \mathrm{mg} /$

Phenolphthalein alkalinity: $0 \mathrm{mgh}$

Cadmium, total recoverable

Nitrate-nitrite as nitroge

Specific conductance

Gross alpha
Nonvolatile beta $3.62 \mathrm{E}-03 \pm 6.95 \mathrm{E}-05$

Tritium

\section{WELLL FSB 93C}

MEASUREMENTS CONDUCTED IN THE FIELD

Sample date: 04/01/98

Depth to water: $65.81 \mathrm{ft}(20.06 \mathrm{~m})$ below TOC

SH: 5.1 conductance: $30 \mu \mathrm{s} / \mathrm{cm}$

Time: $12: 38$
Water temperature: $17^{\circ} \mathrm{C}$
Air temperature: $28.4^{\circ} \mathrm{C}$

Air temperature: $28.4^{\circ} \mathrm{C}$
Total akalinity (as CaCo3): $0 \mathrm{mg} /$

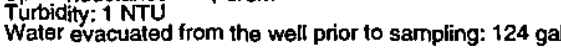
ANALYSES

\section{F Analyte}

0 Cadmium, total recoverable

- Lead, total recoverable

2 Nitrate-nitrite as nittogen

Specific conductance

1 Nonvs alatitie beta

\section{WELL FSB 93D}

MEASUREMENTS CONDUCTED IN THE FIELD

Sample date: 04/16/98

Wepth to water: $62.4 \mathrm{tt}(19.02 \mathrm{~m})$ below TOC

Water

Water temperature: $16^{\circ} \mathrm{C}$

Total alkalinity (as CaCO3) : $38 \mathrm{mg} /$
Phenolphthalein alkalinity: $0 \mathrm{mg} /$

Wrbidity: 3 NTU: $700 \mu \mathrm{S} / \mathrm{cm}$

\begin{tabular}{|c|c|c|}
\hline Result & B & A \\
\hline $\begin{array}{l}0.824 \\
0.598 \\
31,400 \\
31,200\end{array}$ & $\vec{J}$ & $\begin{array}{l}\mathrm{E} \\
\mathrm{E}\end{array}$ \\
\hline $\begin{array}{l}5.32 \\
299\end{array}$ & J & 0 \\
\hline $\begin{array}{l}3.91 E-09 \pm 1.22 E-09 \\
4.856-08+2.47 E-09 \\
9.4 E-04 \pm 5.44 E-06\end{array}$ & $\mathbf{J}$ & $c$ \\
\hline
\end{tabular}

Time: : : :59

Water temperature: $201^{\circ} \mathrm{C}$

Total aljkalinity (as CaCO3): $3 \mathrm{mgh}$
Phenolphthalein alkalinity: $0 \mathrm{mg} \mathrm{L}$
Time: 8:30

Water temperature: $16^{\circ} \mathrm{C}$

Total alkalinity (as Caco3): $0 \mathrm{mg} /$
Phenolphthaleir alkalinity: $0 \mathrm{mg} \mathrm{L}^{2}$

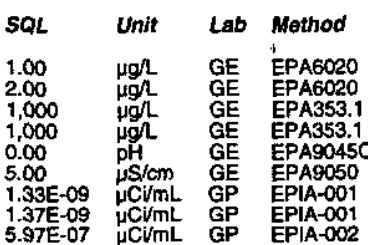

A-001
Result
2 Cadmium, total recoverable
Nitr, otal recoverable
Specific conductance
Gross alpha
2 Tritium

\begin{tabular}{|c|c|c|c|}
\hline $\begin{array}{l}1.00 \\
2.00 \\
2.500 \\
0.00 \\
5.00 \\
1.711 E-09 \\
2.38-09 \\
5.75 E-07\end{array}$ & 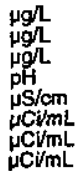 & $\begin{array}{l}\mathrm{GE} \\
\mathrm{GE} \\
\mathrm{GE} \\
\mathrm{GP} \\
\mathrm{GP}\end{array}$ & 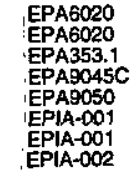 \\
\hline
\end{tabular}

WELL FSB 94C

MEASUREMENTS CONDUCTED IN THE FIELD

Sample date: 04/15/98

Water elevation: $71.2 \mathrm{ft}$ (21.7 m) below TOC

Sp: 3.8 conductance: $2,020 \mu \mathrm{S} / \mathrm{cm}$

Water evacuated from the well prior to sampling: $1 \mathrm{gal}$

ANALYSES
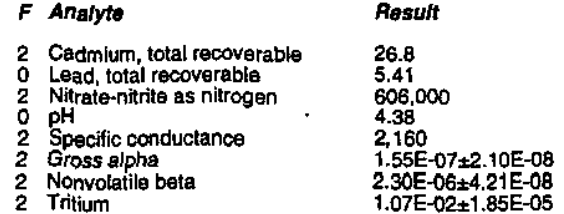

Time: 14:45

Wir temperaturature: $16^{\circ} \mathrm{C}$

Total alkalinity: (as CaCO3): $0 \mathrm{mg} / \mathrm{L}$
Phenolphthalein alkalinity: $0 \mathrm{mg} / \mathrm{L}$

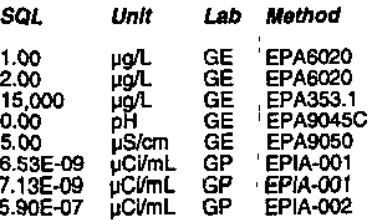




\section{WELL FSB 94C}

MEASUREMENTS CONDUCTED IN THE FIELD

Sample date: 04/23/98

Water elevation: $210.14 \mathrm{tt}(64.05 \mathrm{~m}) \mathrm{msl}$

$\mathrm{gp}$. 3.8 nductance: $2,000 \mu \mathrm{S} / \mathrm{cm}$

Water evacuated from the well prior to sampling: 1 gal

ANALYSES

$F$ Analyte.

2 Crition-14

\section{WELL FSB 94DP}

MEASUREMENTS CONDUCTED IN THE FIELD

Sample date: $04 / 13 / 98$ ( $20.71 \mathrm{~m})$ below TOC

Depth to water: $67.95 \mathrm{ft}(20.71 \mathrm{~m})$ bolow TOC
Water elevation: $212.55 \mathrm{ft}(64.79 \mathrm{~m}) \mathrm{ms}$ (

WH:3.2

conductance: $600 \mu \mathrm{S} / \mathrm{cm}$

Water evacuated from the well prior to sampling: $105 \mathrm{gal}$

Well FSB 94DR collected on 04/13/98 (cont.)

ANALYSES

$F$ Analyte

Cadmium, to:al recoverable

Lead, total recoverable

$\mathrm{pH}$ Specific conductance

Gross alpha

2 Nintum

\section{WELL FSB 94DR}

MEASUREMENTS CONDUCTED IN THE FIELD

Sample date: 04/21/98

Wepter to water: $67.8 \mathrm{tt}(20.67 \mathrm{~m})$ below TOC

$\mathrm{pH}$. 3.2 conductance: $560 \mu \mathrm{S} / \mathrm{cm}$

Water evacuated from the well prior to sampling: $100 \mathrm{gal}$

ANALYSES

F Anafyte

Result

R

0
2
2

$6.82 E-08+7.67 E-09$
$1.95 E-03 \pm 7.80 E-06$
WELL FSB 95CR

MEASUREMENTS CONDUCTED IN THE FIELD

Sample date: 04/08/98

Time: 10:58

Water temperature: $15^{\circ} \mathrm{C}$

Tir temperature: alkalinity (as Caco3): $0 \mathrm{mgh}$

Depth to water: $75 \mathrm{ft}(22.86 \mathrm{~m})$ below TOC
Water elevation: $209 \mathrm{ft}(63.7 \mathrm{~m}) \mathrm{ms}$ 1

$5 p$ conductance: $2,000 \mu \mathrm{S} / \mathrm{cm}$

NTy: $2,000 \mu \mathrm{S} / \mathrm{cm}$

Water evacuated from the well prior to sampling: $128 \mathrm{gal}$ ANALYSES

\begin{tabular}{|c|c|}
\hline F Analyte & Result \\
\hline $\begin{array}{ll}2 & \text { Cadmium, total recoverable } \\
0 & \text { Lead, total recoverable } \\
2 & \text { Nitrate-nitrite as nitrogen } \\
0 & \text { pH } \\
2 & \text { Specific conductance } \\
2 & \text { Gross alpha } \\
2 & \text { Nonvolatile beta } \\
2 & \text { Trittium } \\
2 & \text { Tritium }\end{array}$ & $\begin{array}{l}16.4 \\
0.768 \\
259,000 \\
4.20 \\
2.140 \\
1.00 E-06 \pm 4.75 E-08 \\
2.02 E-06 \pm 3.83 E-08 \\
9.35 E-03 \pm 1.71 E-04 \\
9.49 E-03 \pm 1.72 E-04\end{array}$ \\
\hline
\end{tabular}

Time: 8:56

\section{WELL FSB 95CR}

MEASUREMENTS CONDUCTED IN THE FIELD

Sample date: $04 / 21 / 98$

Depth to water: $74.7 \mathrm{ft}(22.77 \mathrm{~m})$ below TOC

$\mathrm{Sp}$. conductance: $2,000 \mu \mathrm{S} / \mathrm{cm}$

Watider evacuated from the well prior to sampling: $145 \mathrm{gal}$ ANALYSES

$F$ Analyto

Result

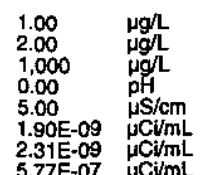

$\begin{array}{ll}\text { Lab } & \text { Mothod } \\ \text { GE } & \text { EPAG020 } \\ \text { GE } & \text { EPA020 } \\ \text { GE } & \text { EPA35.1 } \\ \text { GE } & \text { EPA9045C } \\ \text { GE } & \text { EPA9050 } \\ \text { GP } & \text { EPA-001 } \\ \text { GP } & \text { EPA-001 } \\ \text { GP } & \text { EPIA-002 }\end{array}$

0 Carbon-14

$1.41 E-07 \pm 9.12 E-09$

WELL FSB 95DR

MEASUREMENTS CONDUCTED IN THE FIELD

Sample date: $04 / 09 / 98$
Depth to water: $72.1 \mathrm{ft}(21.98 \mathrm{~m})$ below TOC
Water elevation: $212 \mathrm{ft}(64.62 \mathrm{~m}) \mathrm{ms}$ )

Time: 9:01

Total alkalinity (as CaCO3): $0 \mathrm{mg} L$

Penolphthalein alkalinity: $0 \mathrm{mgL}$

SOL Unit Lab Method

$\begin{array}{llll}9.79 E-09 & \mu C V / m L & \text { GP } & \text { EPIA-003 } \\ 5.79 E-07 & \mu \mathrm{CV} / m L & \text { GP } & \text { EPIA-002 }\end{array}$

Turbidity: 1 NTS: 998 HS/cm

Water evacuated from the well prior to sampling: 111 gal ANALYSES

- Cadmium, total recovarabio
$F$ Analyte Lead, total recoverable 1 Nitrate-nitrite as nilrog

Specific conductance

2 Gross alpha

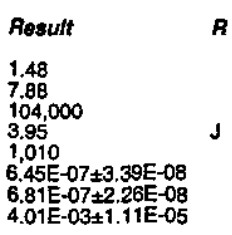

Time: 10:41 Water temperature: $16^{\circ} \mathrm{C}$ Total alkalinity (as CaCo3): $0 \mathrm{mg} /$ 


\section{WELL FSB 95DR}

MEASUREMENTS CONDUCTED IN THE FIELD

Sample date: 0412198

Depth to water: $71.65 \mathrm{ft}(21.84 \mathrm{~m})$ below TOC

Water elevation: $212.45 \mathrm{tt}(64.76 \mathrm{~m}) \mathrm{msl}$

$\mathrm{gH}: 3.2$

Sp. conductance: $920 \mu \mathrm{S} / \mathrm{cm}$

Water evacuated from the well prior to sampling: $95 \mathrm{gat}$ ANALYSES

F Analyt

${ }_{2}^{\circ}$ Carbon- 14 Resuft

$1.86 \mathrm{E}-07+1.02 \mathrm{E}-08$
$3.74 \mathrm{E}-03 \pm 1.08 \mathrm{E}-05$

\section{WELL FSB 96AR}

MEASUREMENTS CONDUCTED IN THE FIELD Sample date: 04/01/98

Depth to water $127.33 \mathrm{ft}(38.81 \mathrm{~m})$ below TOC

$\mathrm{pH}: 7$

Sp. conductance: $170 \mu \mathrm{S} / \mathrm{cm}$

Water evacuated from the well prior to sampling: $114 \mathrm{gal}$ ANALYSES

$F$ Analyte

\begin{tabular}{|c|c|c|c|c|c|c|c|}
\hline Result & $\boldsymbol{R}$ & $A$ & $\boldsymbol{B}$ & SQL & Units & Lab & Method \\
\hline $\begin{array}{l}<1.00 \\
<200 \\
1,180 \\
7.10 \\
176 \\
6.82 E-10 \pm 4.25 E-10 \\
1.18 E-09+4.49 E-10 \\
2.01 E-05 \pm 8.56 E-07\end{array}$ & اư & c & L & $\begin{array}{l}1.00 \\
200 \\
50.0 \\
0.00 \\
5.00 \\
4.73 E-10 \\
1.25 E-09 \\
5.91 E-07\end{array}$ & 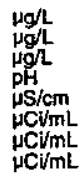 & $\begin{array}{l}\mathrm{GE} \\
\mathrm{GE} \\
\mathrm{GE} \\
\mathrm{GE} \\
\mathrm{GE} \\
\mathrm{GP} \\
\mathrm{GP} \\
\mathrm{GP}\end{array}$ & 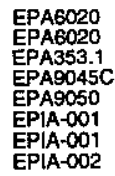 \\
\hline
\end{tabular}

: Cadmium, total recoverable

: Lead, total recoverable

Specific conductance

O Nonvolatite beta

2 Tritium $2.01 \mathrm{E}-05 \pm 8.56 \mathrm{E}-07$

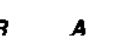

$B$ SoL

$\begin{array}{llll}9.68 \mathrm{E}-09 & \mu \mathrm{C} V \mathrm{~mL} & \mathrm{GP} & \text { EPIA-003 } \\ 5.74 \mathrm{E}-07 & \mathrm{\mu CV} / \mathrm{mL} & \mathrm{GP} & \mathrm{EPIA}-002\end{array}$

\section{WELL FSB $97 A$}

MEASUREMENTS CONDUCTED IN THE FIELD

Sample date: $04 / 01 / 98$
Depth to water: $133.1 \mathrm{ft}(40.57 \mathrm{~m})$ below TOC
Water elevation: $153 \mathrm{ft}(46.63 \mathrm{~m})$ msl

$\mathrm{pH}: 6.7$

p. conductance: $230 \mu \mathrm{S} / \mathrm{cm}$

Water evacuated from the well prior to sampling: $105 \mathrm{gal}$

Well FSB 97 A collected on 04/01/98 (cont.)

ANALYSES

$F$ Analyte

- Cadmium, total recoverable

Nitrate-nititite as nitrogen

Specific conductance

Nonvolatile beta

2 Tritium

\begin{tabular}{|c|c|c|c|c|c|c|c|}
\hline Result & $\boldsymbol{B}$ & A & B & SOL & Untt & $L a b$ & Method \\
\hline $\begin{array}{l}<1.00 \\
<2.00 \\
9.480 \\
7.04 \\
239 \\
1.61 E-09 \pm 7.02 E-10 \\
3.04 E-09+8.13 E-10 \\
2.48 E-04 \pm 2.77 E-06\end{array}$ & $\mathrm{~J}$ & C & L & $\begin{array}{l}1.00 \\
2.00 \\
300 \\
0.00 \\
5.00 \\
6.66 E-10 \\
1.27 E-09 \\
5.85 E-07\end{array}$ & 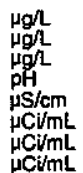 & $\begin{array}{l}G E \\
G E \\
G E \\
G E \\
G E \\
G P \\
G P \\
G P\end{array}$ & 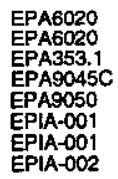 \\
\hline
\end{tabular}

\section{WELL FSB 97A}

MEASUREMENTS CONDUCTED IN THE FIELD

Sample date: 04/21/98

Water elevation: $153 \mathrm{ft}(46.63 \mathrm{~m}) \mathrm{msl}$

$\mathrm{PH}: 7$

. conductance: $220 \mu \mathrm{S} / \mathrm{cm}$

Water evacuated from the well prior to sampling: $135 \mathrm{gal}$ ANALYSES

Time: 11:46

Warter $20.2^{\circ} \mathrm{C}$

Total alkalinity (as Caco3): $8 \mathrm{mg} /$
Phenolphthalein alkalinity: $0 \mathrm{mg} \mathrm{L}^{-}$

F Analyte

Result

2 Critium

$1.14 \mathrm{E}-08^{+} \pm 5.48 \mathrm{E}-09$
$2.56 \mathrm{E}-04 \pm 2.86 \mathrm{E}-06$

R

\section{WELL FSB 97A Replicate}

MEASUREMENTS CONDUCTED IN THE FIELD

Sample date: 04/21/98

WH: 7

p. conductance: 220 S

conce: $220 \mu \mathrm{S} / \mathrm{cm}$

vacuated from the well prior to sampling: $135 \mathrm{gal}$ ANALYSES

$F$ Analyte

0 Carbon-14

\section{WELLL FSB 97C}

$1.18 \mathrm{E}-08+5.86 \mathrm{E}-09$
$2.58 \mathrm{E}-04+2.87 \mathrm{E}-06$

\section{MEASUREMENTS COND}

Sample date: $04 / 13 / 98$

Deph to water: $76.4 \mathrm{tt}(23.29$

Water el

Sp. cor

Time: 10:44

Air termperature: $222^{\circ} \mathrm{C} 4^{\circ} \mathrm{C}$

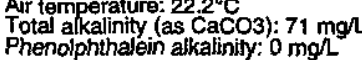

Tur. conductance: 1,000 $\mu \mathrm{S} / \mathrm{cm}$

\section{ANALYSES}

$F$ Analyto

2 Cadmium, total racoverable

2 Lead, total recoverable

$\mathrm{pH}$-ritrite as nitrog

Specitic conductance

Gross alpha

Tritium
Time: 14:25

erature: $16^{\circ}$

Total alkalinity (as Caco3): $78 \mathrm{mg} /$ 
ANALYTICAL RESULTS

\section{WELL FSB 97C}

MEASUREMENTS CONDUCTED IN THE FIELD

Sample date: 04/21/98

Sample date: $04 / 21 / 98$
Depth to water: $76.1 \mathrm{tt}(23.2 \mathrm{~m})$ below TOC
Water elevation: $210 \mathrm{ft}(64.01 \mathrm{~m}) \mathrm{ms}$

Sp. conductance: $780 \mu \mathrm{S} / \mathrm{cm}$

Turbidity: $2 \mathrm{NTU}$.
Water evacuated from the well prior to sampling: 94 gal

ANALYSES

\begin{tabular}{|c|c|c|c|c|c|c|c|}
\hline F Analyte & Resuft & $\boldsymbol{A}$ & $B$ & SOL & Unit & Lab & Method \\
\hline $\begin{array}{l}0 \text { Carbon-14 } \\
2 \text { Tritium }\end{array}$ & $\begin{array}{l}7.16 \mathrm{E}-0.9 \pm 7.67 \mathrm{E}-09 \\
3.51 \mathrm{E}-03 \pm 1.04 \mathrm{E}-05\end{array}$ & & & $\begin{array}{l}9.65 E-09 \\
5.76 E-07\end{array}$ & $\underset{\mu \mathrm{C} V / \mathrm{mL}}{\mu \mathrm{C} / \mathrm{mL}}$ & $\begin{array}{l}G P \\
G P\end{array}$ & $\begin{array}{l}\text { EPIA-003 } \\
\text { EPIA-002 }\end{array}$ \\
\hline
\end{tabular}

WELL FSB 97D

MEASUREMENTS CONDUCTED IN THE FIELD

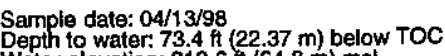

Water elevation: $212.6 \mathrm{tt}(64.8 \mathrm{~m}) \mathrm{msl}$ Sp. conductance: $400 \mu \mathrm{S} / \mathrm{cm}$

Water evacuated from the well prior to sampling: 1 gal ANALYSES

$F$ Anafyte

Resuft
3.36
64.6
42.400
4.50
383
$3.23 E-07 \pm 1.39 E-08$
$4.44-07 \pm 1.03 E-08$
$1.22 \mathrm{E}-03 \pm 6.16 \mathrm{E}-06$

Nitrate-nitrite as nitrogen

Specific conductance

Nonvolatile be

WELL FSB 97D

MEASUREMENTS CONDUCTED IN THE FIELD

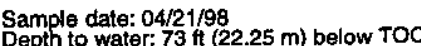

Wepth to water: $73 \mathrm{ft}(22.25 \mathrm{~m})$ below
Water elevation: $213 \mathrm{tt}(64.92 \mathrm{~m}) \mathrm{msl}$

Wh: 3.4

. conductance: $540 \mu \mathrm{S} / \mathrm{cm}$

Water evacuated from the well prior to sampling: $1 \mathrm{gal}$

ANALYSES

\begin{tabular}{|c|c|c|c|c|c|c|c|}
\hline F Anal & Result & $R$ & $B$ & SOL & Unit & Lab & Method \\
\hline $\begin{array}{l}\text { Carbon-14 } \\
\text { Carbon-14 } \\
\text { Tritium }\end{array}$ & $\begin{array}{l}8.51 \mathrm{E}-08 \pm 7.79 \mathrm{E}-09 \\
7.79 \mathrm{E}-08 \pm 7.66 \mathrm{E}-09 \\
3.52 \mathrm{E}-03 \pm 1.05 \mathrm{E}-05\end{array}$ & & & $\begin{array}{l}9.32 E-09 \\
9.39 E-09 \\
5.79 E-07\end{array}$ & $\begin{array}{l}\mu \mathrm{MCMLL} \\
\mu \mathrm{CVMmL} \\
\mu \mathrm{CV} / \mathrm{mL}\end{array}$ & $\begin{array}{l}G P \\
G P \\
G P\end{array}$ & $\begin{array}{l}\text { EPIA }-003 \\
\text { EPAAA-003 } \\
\text { EP|A-C02 }\end{array}$ \\
\hline
\end{tabular}

\section{WELL FSB 98AR}

MEASUREMENTS CONDUCTED IN THE FIELD Sample date: $04 / 20 / 98$
Depth to water: $102.52 \mathrm{ft}(31.25 \mathrm{~m})$ below TOC
Water elevation: $181.48 \mathrm{ft}(55.32 \mathrm{~m}) \mathrm{msl}$

Sp. conductance: $170 \mu \mathrm{S} / \mathrm{cm}$
$\mathrm{pH}$

Wurbidity: 1 NTU

ANALYSES

$\begin{array}{lc}\text { F Anatyte } & \text { Result } \\ 0 \text { Cadmium, total recoverable } & <1.00 \\ \text { ESH-EMUS-980569 } & \end{array}$

A

Time: 12:46

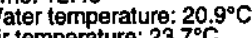

Total alkalinity (as CaCO3): $68 \mathrm{mg} /$

Time: 13:21

rature: $16^{\circ} \mathrm{C}$

Thal alkalinity (as CaCO3); $0 \mathrm{mgh}$

ESH-EMS-980569
Time: 12:55

Air temperature. $26: 0$

Phenolphthalein alkalinity: $0 \mathrm{mg}$

\begin{tabular}{|c|c|c|c|}
\hline$S O L$ & Unit & Lab & Method \\
\hline $\begin{array}{l}1.00 \\
2.00 \\
7.000 \\
0.00 \\
5.00 \\
2.23 \mathrm{E}-09 \\
2.29 \mathrm{E}-0.09 \\
5.78 \mathrm{E}-07\end{array}$ & 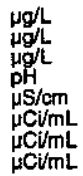 & $\begin{array}{l}\text { GE } \\
\text { GE } \\
\text { GE } \\
\text { GE } \\
G E \\
G P \\
G P \\
G P \\
\text { GP }\end{array}$ & 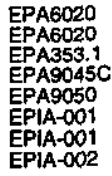 \\
\hline
\end{tabular}

Well FSB 98AR collected on 04/20/98 (cont)

$F$ Analyte

Result

- Cadmium, total recoverabie

Lead, total recoverable

Nitrate-nitrite as nitrogen

Nitrate-nitrite as nitrogen

PH

Specific conductance
Specific conductanco

Gross alpha

0 Nonvolatilila beta

Tritium

$<4.70$

$<4.70$
0.0730
$<47.0$
3,350

3,350
3,280
3,360
6.92
7.56

$13 E-09 \pm 4.52 E-10$

EE-10+6.00E-10

2.61E-09*1.30E-09

$5.52 \mathrm{E}-05 \pm 1.73 \mathrm{E}-06$

\section{WELL FSB 98AR Replicate}

MEASUREMENTS CONDUCTED IN THE FIELD

Sample date: 04/20/98

Depth to water: $102.52 \mathrm{~A}(31.25 \mathrm{~m})$ below TOC

pat: 6.6 .

ance: $170 \mu \mathrm{S} / \mathrm{cm}$

Water evacuated from the well prior to sampling: $161 \mathrm{gal}$ ANALYSES

$F$ Analyto

- Cadmium, total recoverable

Nitrate-nitrite as nitrogen

PH

Specific conductanc

Gross alpha

Nonvolatilite beta

Tritium

\section{WELL FSB 98C}

MEASUREMENTS CONDUCTED IN THE FIELD

Sample date: $04 / 13 / 98$ (22.63 $\mathrm{m})$ below TOC

Water elevation: $210.25 \mathrm{tt}(64.08 \mathrm{~m}) \mathrm{ms}$

$\mathrm{pH}: 3.2$

p. conductance: $700 \mu \mathrm{S} / \mathrm{cm}$

Water evacuated from the well prior to sampling: $90 \mathrm{gal}$ ANALYSES

$F$ Analyte

$\begin{array}{ll}2 & \text { Cadmium, total recoverable } \\ 1 & \text { Lead, total recoverable } \\ 2 & \text { Nitrate-nitrite as nitrogen } \\ 1 & \text { pH } \\ 2 & \text { Specific conductance } \\ 2 & \text { Gross alpha } \\ 2 & \text { Nonvolatile beta } \\ 2 & \text { Tritium }\end{array}$

Rosult
5.79
39.9
63,600
3.52
653
$4.21 \mathrm{E}-07 \pm 1.59 \mathrm{E}-08$
$6.28 \mathrm{E}-07 \pm 1.22 \mathrm{E}-08$
$2.80 \mathrm{E}-03 \pm 9.48 \mathrm{E}-06$

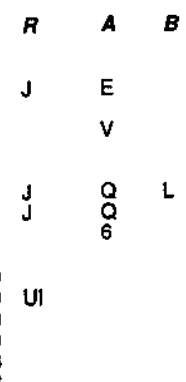

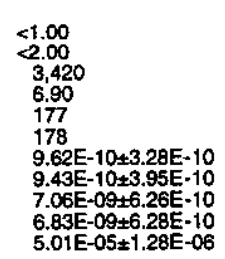

$\boldsymbol{R}$

Unit Lab Mothod

4.70 $\mu g / \mathrm{L}$ WA EPA6010

Wh WA EPAG00

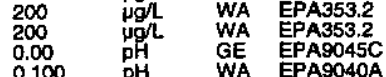

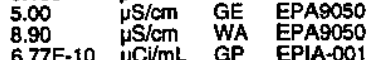

$9.00 E-10 \quad \mu \mathrm{CV} / \mathrm{mL}$ TM EPAPO0.0M

$5.78 E-07$ TCVmL TM EPA900.0M

6.80E-07 $\mu \mathrm{C} / \mathrm{mL}$ TM EPIA-002

9: 12:46

Water temperature: $20.9^{\circ} \mathrm{C}$

Total alkalinity (as CaCO3): $68 \mathrm{mg} /$

Phenolphthalein alkalinity: $0 \mathrm{mgh}$

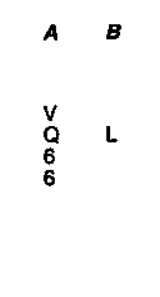

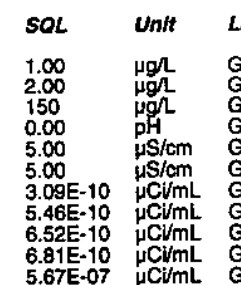

Method

EPAG020
EPA6020
EPA35.1
EPA9045C
EPA950
EPA9050
EPAA-001
EPPA-001
EPIA-001
EPAA-001
EPIA-002

Time: 12:02

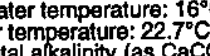

Total alkalinity (as CaCO3): $01 \mathrm{mg}$

inity: $0 \mathrm{mgh}$ 


\section{WELL FSB 98D}

MEASUREMENTS CONDUCTED IN THE FIELD

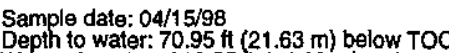
Water elevation: $213.55 \mathrm{tt}(65.09 \mathrm{~m}) \mathrm{ms}$

$\mathrm{pH}: 3.6$

p. conductance: $740 \mu \mathrm{S} / \mathrm{cm}$

Turbidity: 13 NTU
Water evacuated from the well prior to sampling: $1 \mathrm{gal}$

ANALYSES

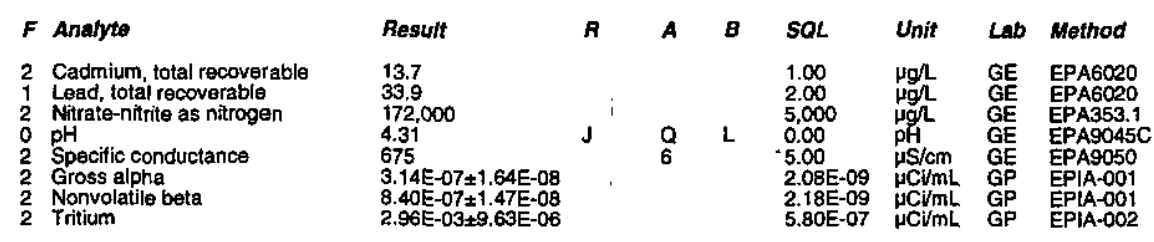

WELL FSB 99A

MEASUREMENTS CONDUCTED IN THE FIELD

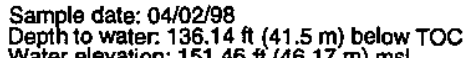

Water elevation: $151.46 \mathrm{ft}(46.17 \mathrm{~m}) \mathrm{ms}$

$\mathrm{H}: 6.7$

Sp. conductance: $170 \mu \mathrm{S} / \mathrm{cm}$

Water evacuated from the well prior to sampling: $94 \mathrm{ga}$ ANALYSES

$F$ Analyte

Result

Cadmium, total recoverable

1 Nitrate-nilrite as nitrogen

Specific conductance

Gross alpha

2 Trítium

$\begin{array}{ll}<1.00 & \\ 0.318 & J \\ 6.400 & J \\ 6.71 & J \\ 170 & 1.01 E-09 \pm 7.33 E-10 \\ 1.14 E-09 \pm 7.77 E-10 & U \\ 1.28 E-04 \pm 1.95 E-06 & \end{array}$

\section{WELL FSB 99C}

MEASUREMENTS CONDUCTED IN THE FIELD

Sample date: 04/01/98

Depth to water: $77.05 \mathrm{ft}(23.49 \mathrm{~m})$ below TOC
Water elevation: $210.65 \mathrm{tt}(64.21 \mathrm{~m}) \mathrm{msl}$

$\mathrm{pH}: 5.5$

Sp. conductance: $290 \mu \mathrm{S} / \mathrm{cm}$

Water evacuated from the well prior to sampling: $85 \mathrm{gal}$ ANALYSES

$F$ Analyto

0 Cadmium total recoverable Lead, total recoverable Nitrate-nitrite as nitrog Specific conductance Gross alpha
Nonvolatila beta

\begin{tabular}{|c|c|c|c|c|c|c|}
\hline sult & A & & SOL & Unit & Lab & Method \\
\hline & $J$ & E & & & & \\
\hline & J & & $\begin{array}{l}1,000 \\
0.00\end{array}$ & ${ }_{\mathrm{pH}}^{\mu \mathrm{g}}$ & $\begin{array}{l}\mathrm{GE} \\
\mathrm{GE}\end{array}$ & $\begin{array}{l}\text { EPA353.1 } \\
\text { EPA90450 }\end{array}$ \\
\hline $\begin{array}{l}.29 \mathrm{E}-08 \pm 2.69 \mathrm{E}-09 \\
.87 \mathrm{E}-08 \pm 3.26 \mathrm{E}-09 \\
.07 \mathrm{E}-03 \pm 5.82 \mathrm{E}-06\end{array}$ & & & $\begin{array}{l}1.11 \mathrm{E}-09 \\
1.28 \mathrm{E}-09 \\
6.02 \mathrm{E}-07\end{array}$ & $\begin{array}{l}\mu \mathrm{C} / \mathrm{mL} \\
\mu \mathrm{C} / \mathrm{mL} \\
\mu \mathrm{C} / \mathrm{mL}\end{array}$ & $\begin{array}{l}G P \\
G P \\
G P\end{array}$ & $\begin{array}{l}\text { EPIA-001 } \\
\text { EPAA-001 } \\
\text { EPIA-002 }\end{array}$ \\
\hline
\end{tabular}

Time: $13: 37$ atur $10^{\circ} \mathrm{C}$ Ar temperature: $25^{\circ} \mathrm{C}$
Total alkalinity (as $\mathrm{CaCO}$ ): $0 \mathrm{mg} /$

Time: $13: 19$ Air temperature: $30.2^{\circ} \mathrm{C}$
Total alkalinity (as CaCo3): $54 \mathrm{mg} /$

\section{WELL FSB 990}

MEASUREMENTS CONDUCTED IN THE FIELD

Sample date: 04/01/98

m) below TOC

$\mathrm{HH:} 4.9$ 4.9 vation: $213.66 \mathrm{ft}(65.12 \mathrm{~m}) \mathrm{ms}$

p. conductance: $31 \mu \mathrm{S} / \mathrm{cm}$

Water evacuated from the well prior to sampling: 41 gal ANALYSES

\section{$F$ Analyte}

Result

- Cadmium, total recoverable

Nitrate-nititite as nitrogen

Specific conductance

1 Tritium

0.424
7.31
1.530
4.63
30.7
$8.43 E-09+1.33 E-09$
$1.075-08 \pm 1.25 E-09$
$1.55 E-05 \pm 7.80 E-07$

R A (

WELL FSB100A

MEASUREMENTS CONDUCTED IN THE FIELD

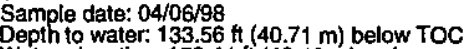
Water elevation: $152.44 \mathrm{ft}(46.46 \mathrm{~m}) \mathrm{ms}$

$\mathrm{PH}: 6.9$

p. conductance: $180 \mu \mathrm{S} / \mathrm{cm}$

Water evacuated from the well prior to sampling: $86 \mathrm{gal}$ ANALYSES

$F$ Analyte

Result

0 Cadmium, total recoverable

Nitrate-nitrite as nitrogen

0 $\mathrm{pH}$ Specific conductance

Gross alpha

Nonvolatile beta

\section{WELL FSB101A}

MEASUREMENTS CONDUCTED IN THE FIELD

Sample date: $04 / 06 / 98$

Depth to water: $131.39 \mathrm{ft}(40.05 \mathrm{~m})$ below TOC

Water ele

Sp. conductance: $170 \mu \mathrm{S} / \mathrm{cm}$

Water evacuated from the well prior to sampling: $\mathbf{4 5}$ gal

ANALYSES

\begin{tabular}{|c|}
\hline $\begin{array}{l}\text { Cadmium, total recoverable } \\
\text { Lead, total recoverabla } \\
\text { Nitrate-nitrite as nitrogen } \\
\text { pH } \\
\text { Specific conductance } \\
\text { Sppecific conductance } \\
\text { Gross alpha } \\
\text { Nonvolatile beta } \\
\text { Tritiutur }\end{array}$ \\
\hline
\end{tabular}

Result

$<1.00$
0.163
1,640
7.59
163

$8.43 E-10 \pm 4.70 E-10 \mathrm{~J}$ $2.22 \mathrm{E}-07 \pm 3.80 \mathrm{E}-07$ UI
Time: 13:48

Air temperature: $234^{\circ} \mathrm{C}$

Total alkalinity (as CaCO3): $0 \mathrm{mg} /$

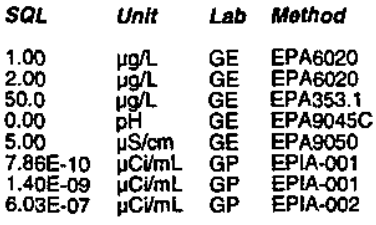

Time: 7:40

perature: $19.3^{\circ} \mathrm{C}$

Aotal alkalinity (as CaCO3): $63 \mathrm{mg} \Omega$ 


\section{WELL FSB102C}

MEASUREMENTS CONDUCTED IN THE FIELD

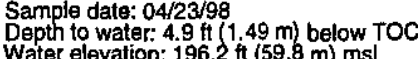 \\ Water \\ SH: 4.4 duductance: $240 \mu \mathrm{S} / \mathrm{cm}$}

Water evacuated from the well prior to sampling: $67 \mathrm{gal}$ ANALYSES

$F$ Analyo

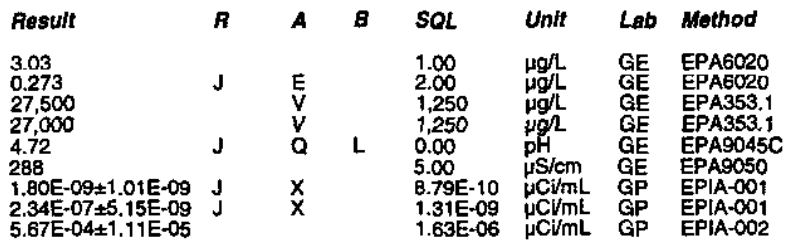

1 Cadmium, total recoverable

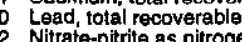

2 Nitrate-nititite as nitrogen

i specific conductance

2
2
2

\section{WELL FSB103C}

MEASUREMENTS CONDUCTED IN THE FIELD

Sample date: 04/02/98

Welow TOC

Water ele

Sp. conductance: $260 \mu \mathrm{S} / \mathrm{cm}$

Water evacuated from the well prior to sampling: $102 \mathrm{gel}$

ANALYSES

$F$ Analyte

- Cadmium, total recoverable

Lat
Nitrate-nitrite as nitrogen

$\mathrm{Sp}$ specific conductance

Nonvolatile bota

WEL FSB104C

MEASUREMENTS CONDUCTED IN THE FIELD

Sample date: $04 / 06 / 98$
Depth to water: $15.8 \mathrm{Ht}(4.82 \mathrm{~m})$ below TOC
Water elevation: $203.3 \mathrm{t}(61.9 \mathrm{~m}) \mathrm{ms}$ (

$\mathrm{PH}: 4.9$

p. conductance: $40 \mu \mathrm{S} / \mathrm{cm}$

Water evacuated from the well prior to sampling: $81 \mathrm{gal}$ ANALYSES

$F$ Analyte

- Cadmium, total recoverable

Nitrate-nitrite as nitrog

Nitrate-nitrite as nitrog

Specific conductancs

Gross alpha

$\begin{array}{ll}\text { Result } & \boldsymbol{A} \\ 0.304 & \mathrm{~J} \\ 0.578 & \mathrm{~J} \\ 25,200 & \mathrm{~J} \\ 5.73 & \\ 250 & 83 \mathrm{E}-10 \pm 7.70 \mathrm{E}-10 \\ 8.9 \mathrm{U} \\ 1.25 \mathrm{E}-08 \pm 1.64 \mathrm{E}-09 \\ 4.56 \mathrm{E}-04 \pm 3.71 \mathrm{E}-06\end{array}$

$$
\begin{aligned}
& A \\
& E \\
& \hline \\
& \hline
\end{aligned}
$$

Time: 9:37

Total alkalinity (as $\mathrm{CaCO}$ ): $0 \mathrm{mgl}$

$\begin{array}{ll}\text { Rosult } & \\ 0.997 & \\ 0.812 & J \\ 51,200 & \\ 52,000 & \\ 4.96 & J \\ 414 & 1.61 E-09 \pm 8.12 E-10 \\ 33.20 E-08 \pm 1.77 E-09 \\ 9.66 E-04 \pm 5,64 E-06\end{array}$

$\begin{array}{ll}A & B \\ E & \\ \text { Q } & \text { L } \\ 1 & H\end{array}$

Time: 12:12

Total akalinity (as Caco3): $0 \mathrm{mg} / \mathrm{h}$

Time: $13: 49$ Air temperature: $31.9^{\circ} \mathrm{C}$ Total alkalinity (as CaCO3): $3 \mathrm{mg} / \mathrm{L}$

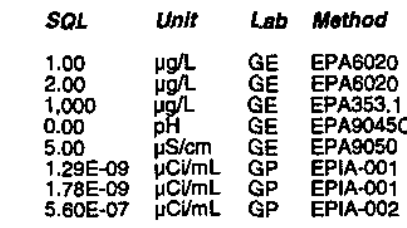

ESH-EMS-980569

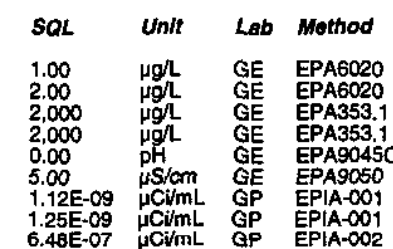

Wirer temperature: $15^{\circ} \mathrm{C}$

WELL FSB104D

MEASUREMENTS CONDUCTED IN THE FIELD

Sample date: $04 / 06 / 98$
Depth to water: $11.45 \mathrm{ft}(3.49 \mathrm{~m})$ below TOC
Water elevation: $207.75 \mathrm{ft}(63.32 \mathrm{~m}) \mathrm{msl}$

Water

Sp. conductance: $280 \mu \mathrm{S} / \mathrm{cm}$

Water evacuated from the well prior to sampling: 30 gl ANALYSES

$F$ Analyte

- Cadmium, total recoverable

2 Nitrate-nitrite as nitroge

1 Specific conductance

2 Gross alpha

2 Tritium

2.30
18.5
28.400

28,400
2.50
289

289

$1.85 E-07+8.82 E-09$
$2.24 E-07+7.20 E-09$
$1.02 E-03 \pm 1.98 E-05$

WELL FSB104D

MEASUREMENTS CONDUCTED IN THE FIELD

Sample date: $04 / 22 / 98$
Depth to water: $11.42 \mathrm{Ht}(3.48 \mathrm{~m})$ below TOC
Water elevation: $207.78 \mathrm{ft}(63.33 \mathrm{~m}) \mathrm{ms}$

$\mathrm{pH}: 3.8$

Sp. conductance: $240 \mu \mathrm{S} / \mathrm{cm}$

Water evacuated from the well prior to sampling: $28 \mathrm{gal}$

ANALYSES

$F$ Analyte

O Carbon-14

Resuit

R $A$

Time: 14:11

Wir termeterture: $16^{\circ} \mathrm{C}$

Total alkalinity (as $\mathrm{CaCO}$ ): $0 \mathrm{mgh}$

Phenolphthalein alkalinity: $0 \mathrm{mg} \mathrm{L}^{2}$

$1.35 E-0685.48 E-09$
$1.05 E-03+2.06 E-05$
$J$

Unit Lab Method

$1.00 \quad \mu g / L$ GE EPA6020

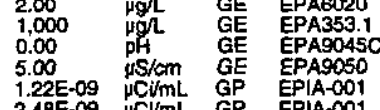

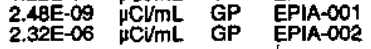

L FSB105C

MEASUREMENTS CONDUCTED IN THE FIELD

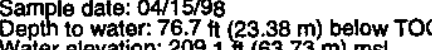

Water

Sp. conductance: $1,020 \mu \mathrm{S} / \mathrm{cm}$

Turbidity: 1 NTU $1,020 \mu \mathrm{S} / \mathrm{cm}$

ANALYSES

$F$ Analyte

2 Cadmium, total recoverable

Lead, total recoverabile

2 Nitrate-nitrite as nitrogen

nitrite as nitrogen

$1 \mathrm{pH}$

Specific conductance

Specific conductance

Gross alpha

Gross alpha

Gross alpha

Nonvolatile beta

Nonvolatitita beta

B-137
Time: 11:34

Air temperature: $216^{\circ} \mathrm{C}$

Total alkalinity (as Caco3); $0 \mathrm{mg} / \mathrm{L}$
Phenolphthalein alkalinity: $0 \mathrm{mgh}$

SOL. Unit Lab Mothod

8.69E-09 $\mu \mathrm{CVmL}$ GP EPIA-003

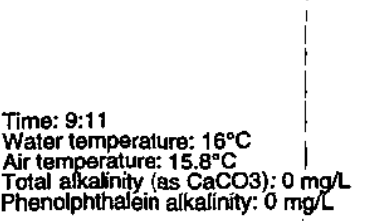


Well FSB105C collected on 04/15/98 (cont.)

\begin{tabular}{|c|c|c|c|c|c|c|c|}
\hline F Analyte & Result & $\boldsymbol{R}$ & $B$ & $S O L$ & Unit & Lab & Method \\
\hline $\begin{array}{l}2 \\
\begin{array}{l}2 \\
2 \\
2 \\
2\end{array} \text { Trititum } \\
\text { Trititum }\end{array}$ & $\begin{array}{l}6.51 \mathrm{E}-03 \pm 1.42 \mathrm{E}-05 \\
7.73 \mathrm{E}-03 \pm 1.54 \mathrm{E}-04 \\
7.51 \mathrm{E}-03 \pm 1.52 \mathrm{E}-04\end{array}$ & i & & $\begin{array}{l}5.72 \mathrm{E}-07 \\
3.57 \mathrm{E}-05 \\
3.55 \mathrm{E}-05\end{array}$ & 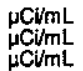 & $\begin{array}{l}\text { GP } \\
\text { TM }\end{array}$ & $\begin{array}{l}\text { EPIA-002 } \\
\text { EPA906.OM } \\
\text { EPA906.0M }\end{array}$ \\
\hline
\end{tabular}

\section{WELL FSB105C Replicate}

MEASUREMENTS CONDUCTED IN THE FIELD

Sample date: $04 / 15 / 98$

Depth to water: $76.7 \mathrm{ft}(23.38 \mathrm{~m})$ below TOC

$\mathrm{H} \cdot 3.4$

Sp. conductance: $1,020 \mu \mathrm{S} / \mathrm{cm}$

Wurbidity: 1 NTU

ANALYSES

$F$ Anaiyto

2 Cadmium, total recoverable

Lead, total recoverable

1 PH

2 Gross aloha

2 Tritium

\section{WELL FSB105DR}

MEASUREMENTS CONDUCTED IN THE FIELD

\section{Sample date: $04 / 16 / 98$
Depth to water. $73.1 \mathrm{tt}(22.28 \mathrm{~m})$ below TOC
Water elevation: $212.5 \mathrm{ft}(64.77 \mathrm{~m}) \mathrm{ms}$ \\ $\mathrm{H}: 4.2$}

Sp. conductance: $80 \mu \mathrm{S} / \mathrm{cm}$

Water evacuated from the well prior to sampling: $38 \mathrm{ga}$

ANALYSES

$F$ Analyte

Cadmium, total recoverable

Nitrate-nitrite as nitrogen

Specific conductance

2 Norvolatitio bela
Time: 9:11

Total akkalinity (as Caco3): $0 \mathrm{mg} /$

\begin{tabular}{|c|c|c|c|c|c|}
\hline$A$ & $B$ & SOL & Unit & Lab & Method \\
\hline & $L$ & $\begin{array}{l}1.00 \\
2.00 \\
.3 .750 \\
0.00 \\
5.00 \\
3.95 E-09 \\
4.24 E-09 \\
5.75 E-07\end{array}$ & 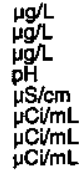 & $\begin{array}{l}G E \\
G G \\
G G \\
G E \\
G E \\
G E \\
G P \\
G P \\
G P\end{array}$ & 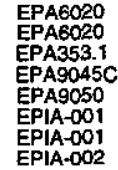 \\
\hline
\end{tabular}

Time: 9:48

Total alkalinity (as CaCO3): $0 \mathrm{mg} / \mathrm{L}$
Phenolphthalein alkalinity: $0 \mathrm{mg}$

$\begin{array}{llll}<1 . \infty & & \\ 16.3 & & 6 & \\ 7.800 & & 0 & \\ 4.23 & & 0 \\ 75.2 & & \\ 9.55 E-08 \pm 4.57 E-09 & & 6 & \\ 1.04 E-07 \pm 3.14 E-09 \\ 7.05 E-05 \pm 1.54 E-06\end{array}$

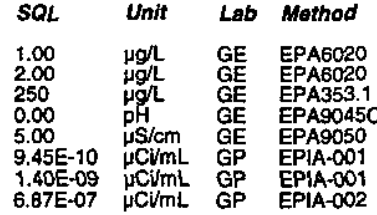

Water temperature: $16^{\circ} \mathrm{C}$

Wal temperature: $17^{\circ} \mathrm{C}$

\section{WELLL FSB106C}

MEASUREMENTS CONDUCTED IN THE FIELL

Sample date: $04 / 23 / 98$

Wepth to water: Not available

pH: 5.6 elevation: Not availab

Tup. conductance: $500 \mu \mathrm{S} / \mathrm{cm}$

Water temperature: $16^{\circ} \mathrm{C}$

Total alkalinity (as CaCO3): $30 \mathrm{mgh}$.

ANALYSES

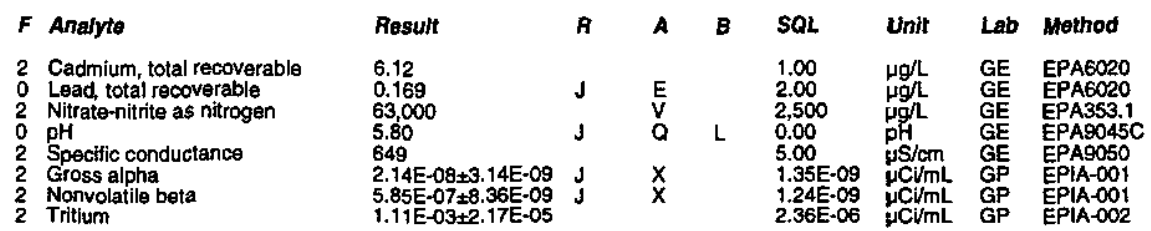

\section{WELL FSB106D}

MEASUREMENTS CONDUCTED IN THE FIELD

Sample date: 04/06/98

Depth to water: $25.8 \mathrm{t}(7.86 \mathrm{~m})$ below TOC

$\mathrm{pH}: 6.1$

Sp. conductance: $130 \mu \mathrm{S} / \mathrm{cm}$

Wutridity: $45 \mathrm{NTU}$ (Tom the well prior to sampling: $1 \mathrm{gal}$

ANALYSES

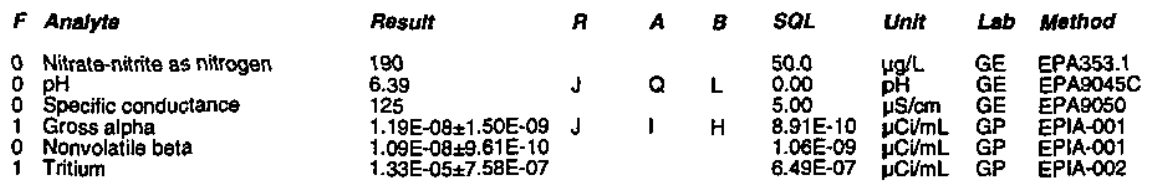

\section{WELL FSB107C}

MEASUREMENTS CONDUCTED IN THE FIELLD

Sample date: 04/06/98

Depth to water: $58.79 \mathrm{ft}(17.92 \mathrm{~m})$ below TOC

Water el wat

6.3 . $212.11 \mathrm{ft}(64.6$

Sp. conductance: $180 \mu \mathrm{S} / \mathrm{cm}$

Watter evacuated from the well prior to sampling: $117 \mathrm{gal}$ ANALYSES

F Anatyte
0 Cadmium, total recoverable
0 Cead, total recoverable
2 Nitrate-nitrite as nitrogen
0 pH
0 Specific conductance
0 Gross alpha
1 Nonnola
2 Tritium
2 Tritium

$\begin{array}{ll}\text { Aesult } & \text { R } \\ 0.870 & J \\ 0.187 & J \\ 10,100 & J \\ 6.33 & J \\ 180 & 1.55 E-09 \pm 5.93 E-10 \\ 4.18 E-08 \pm 1.92 E-09 & J \\ 1.36 E-04 \pm 2.14 E-06 & \\ 1.34 E-04 \pm 2.13 E-06 & \end{array}$

J
J
J

Time: 14:56

Water temperature: $17.1^{\circ} \mathrm{C}$ Air temperature: $28 . .^{\circ} \mathrm{C}$ ) $56^{\prime \prime} \mathrm{mg} / \mathrm{L}$ 


\section{WELLL FSB107D}

MEASUREMENTS CONDUCTED IN THE FIELD

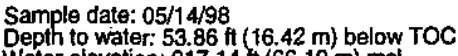

Water elova Sp. conductance: $230 \mu \mathrm{S} / \mathrm{cm}$

Wurbidity: 1 NTU: 230 from the well prior to sampling: $39 \mathrm{gal}$ ANALYSES

\begin{tabular}{|c|c|c|c|c|c|c|c|c|}
\hline Analyte & Result & $\boldsymbol{F}$ & A & $B$ & SQL & Unit & Lab & Mothod \\
\hline $\begin{array}{ll}\text { - Cadmium, total recoverable } \\
0 & \text { Ladad, total recoverable } \\
2 & \text { Nitrate-nitrite as nitrogen } \\
2 & \text { Nirrate-nitrite as nitrogen } \\
1 & \text { pH } \\
1 & \text { HH } \\
1 & \text { Specitic conductance } \\
1 & \text { Specific conductance } \\
2 & \text { Gross alpha } \\
2 & \text { Gross alpha } \\
2 & \text { Nonvolatile beta } \\
2 & \text { Nonvolatile beta } \\
2 & \text { Tritium }\end{array}$ & $\begin{array}{l}2.06 \\
<1.03 \\
32,500 \\
32,300 \\
3.72 \\
3.73 \\
384 \\
3386 \\
3.14 E-07 \pm 7.75 E-09 \\
3.51 E-07 \pm 8.39-09 \\
5.00 E-07 \pm 6.39 E-09 \\
4.77 E-07 \pm 6.36 E-09 \\
5.68 E-04 \pm 1.11 E-05\end{array}$ & $\mathbf{J}$ & $\stackrel{c}{c}$ & $\mathbf{L}$ & $\begin{array}{l}1.00 \\
2.00 \\
1,250 \\
1,250 \\
0.00 \\
0.00 \\
5.00 \\
5.00 \\
8.46 \mathrm{E}-10 \\
6.45 \mathrm{E}-10 \\
.9 .40 \mathrm{E}-10 \\
1.13 \mathrm{E}-09 \\
1.67 \mathrm{E}-06\end{array}$ & 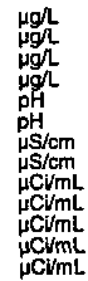 & $\begin{array}{l}G E \\
G E \\
G E \\
G E \\
G E \\
G E \\
G E \\
G E \\
G E \\
G P \\
G P \\
G P \\
G P \\
G P\end{array}$ & 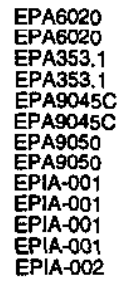 \\
\hline
\end{tabular}

\section{WELL FSB108D}

MEASUREMENTS CONDUCTED IN THE FIELD

Sample date: 04/21/98 Water evation $218.11 \mathrm{t}(66.48 \mathrm{~m}) \mathrm{ms}$ । $\mathrm{g}$ : Not available Sp. conductance: Not available

Water evacuated from the well prior to sampling: $7 \mathrm{gal}$ ANALYSES

$F$ Analyte

\begin{tabular}{|c|c|c|c|c|c|c|c|}
\hline Resuft & A & A & & SQL & Unit & Lab & Mothod \\
\hline $\begin{array}{l}<1.00 \\
7.00 \\
1.500 \\
5.84 \\
53.4 \\
7.25 E-10 \pm 3.76 E-10 \\
1.15-0955.06 E-10 \\
1.71 E-05 \pm 7.93 E-07\end{array}$ & $\mathbf{J}$ & $\begin{array}{l}v \\
\text { a }\end{array}$ & H & $\begin{array}{l}1.00 \\
2.00 \\
50.0 \\
0.00 \\
5.00 \\
4.62 E-10 \\
9.20=-10 \\
5.69 E-07\end{array}$ & 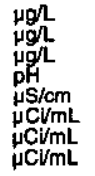 & $\begin{array}{l}\mathrm{GE} \\
\mathrm{GE} \\
\mathrm{GE} \\
\mathrm{GE} \\
\mathrm{GE} \\
\mathrm{GP} \\
\mathrm{GP} \\
\mathrm{GP}\end{array}$ & 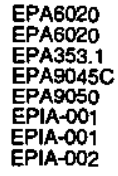 \\
\hline
\end{tabular}

- Cadmium, total recoverable Nitrate-nitrite as nitrogen Specific conductance Nonvolatile beta

\section{WELL FSB109D}

MEASUREMENTS CONDUCTED IN THE FIELD

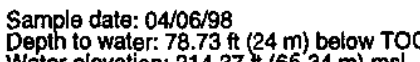

Wepter to H: 5.9 .

Water evacuated from the well prior to sampling: 1 gal ANALYSES

F Analyte

- Cadmium, total recoverable

Nitrate-nitrite as nitrogen

pH

Nonvolatile beta

ESH-EMS-980569

Time: 10:32 3 Water temperature: $22.3^{\circ} \mathrm{C}$

Total alkalinity (as CaCO3): $0 \mathrm{mg} / \mathrm{L}$
Phenolphthalein alkalinity: $0 \mathrm{mg} / \mathrm{L}$

Time: 7:22

Time: 14:08 1.08 ater temperature: $21.2^{\circ} \mathrm{C}$ Air temperature: $25.8^{\circ} \mathrm{C}$
Total alkalinity (as Caco3): $25 \mathrm{mg} / \mathrm{L}$
Phenolphthalein alkalinity: $\mathrm{mg} / \mathrm{L}$

\begin{tabular}{|c|c|c|c|c|c|c|c|}
\hline Resuft & A & A & B & $S O L$ & Unit & Lab & Method \\
\hline & J & E & & & & & EPA6020 \\
\hline $\begin{array}{l}1,380 \\
5.62\end{array}$ & $\sqrt{ }$ & 0 & 1 & $\begin{array}{l}50.0 \\
0.00\end{array}$ & & $\begin{array}{l}\mathrm{GE} \\
\mathrm{GE}\end{array}$ & $\begin{array}{l}\text { EPA } 533.1 \\
\text { EPA9045C }\end{array}$ \\
\hline $\begin{array}{l}36.5 \\
1.55 \mathrm{E}-09 \pm 5.31 \mathrm{E}-10 \\
1.92 \mathrm{E}-09 \pm 5.91 \mathrm{E}-10 \\
1.08 \mathrm{E}-05 \pm 6.96 \mathrm{E}-07\end{array}$ & J & 1 & H & $\begin{array}{l}5.55 \mathrm{E}-10 \\
9.86 \mathrm{E}-10 \\
6.22 \mathrm{E}-07\end{array}$ & 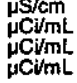 & $\begin{array}{l}\mathrm{GP} \\
\mathrm{GP} \\
\mathrm{GP}\end{array}$ & $\begin{array}{l}\text { EPA9050 } \\
\text { EPIA-001 } \\
\text { EPIA-001 } \\
\text { EPIA-002 }\end{array}$ \\
\hline
\end{tabular}

\section{WELL FSB110C}

MEASUREMENTS CONDUCTED IN THE FIELD

Sample date: 04/06/98

Water elevation: 203.15 t $(61.56 \mathrm{~m})$ below TOC

$\mathrm{pH}: 5.6$

Tp.conducta

Water evacuated from the well prior to sampling: 100 gal ANALYSES

$F$ Anaiyte

$\begin{array}{lllll}\text { Result } & \text { R } & \text { A } & \text { G } & \text { SOL } \\ 3.38 & & & & 1.00 \\ 1.14 & \text { J } & \text { E } & & 2.00 \\ 80,400 & \text { J } & \text { Q } & \text { L } & 0.000 \\ 5.70 & 0.00 \\ 5.73 & \text { J } & \text { Q } & \text { L } & 0.00 \\ 710 & & & & 5.00 \\ 711 & 5.00 \\ 7.09 E-09+1.79 E-09 & \text { J } & \text { I } & \text { H } & 1.55 E-09 \\ 1.23 E-07 \pm 3.42-09 & 1.315-09 \\ 1.93 E-03 \pm 3.78 E-05 & & & & 3.36 \mathrm{E}-06\end{array}$$$
\text { Unit }
$$

Lab Mothod

1 Cadmium, total recoverable

Nitrate-nitrite as nitrogen

$\mathrm{PH}$

Specific conductance

Nonvolatile beta

$1.23 \mathrm{E}-03 \pm 3.78 \mathrm{E}-05$

\section{WELL FSB110D}

MEASUREMENTS CONDUCTED IN THE FIELD

Sample date: $04 / 06 / 98$
Depth to water: $26 \mathrm{th}(7.92 \mathrm{~m})$ below TOC
Water elevation: $208.5 \mathrm{ft}(63.55 \mathrm{~m}) \mathrm{msl}$

Water elevation: $208.5 \mathrm{ft}(63.55$

Sp. conductance: $160 \mu \mathrm{S} / \mathrm{cm}$

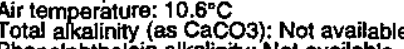

Water evacuated from the well prior to sampling: $28 \mathrm{gal}$ ANALYSES

\section{$F$ Analyte}

- Cadmium, total recoverable

0
2 Lead, total recoverable
2

Ppecific conductance

Gross alpha

\section{WELL FSB110D}

MEASUREMENTS CONDUCTED IN THE FIELD

Sample date: 04/22/98

Depth to water: $25.85 \mathrm{ft}(7.88 \mathrm{~m})$ below TOC

Whiter

.

Sp. Conductance: $140 \mu \mathrm{S} / \mathrm{cm}$

Water evacuated from the well prior to sampling: 28 gal ANALYSES

$F$ Analyte

$\begin{array}{ll}0 & \text { Carbon-14 } \\ 2 & \text { Tritium }\end{array}$

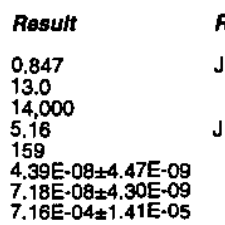

$\begin{array}{lll}A & B \\ \text { E } & \\ \mathrm{V} & \\ \mathrm{O} & L \\ \mathrm{~V} & \end{array}$

Time: 10:44

Water temperature: $16^{\circ} \mathrm{C}$

Total alkalinity (as CaCO3); $0 \mathrm{mgh}$

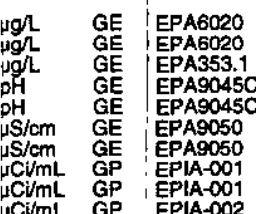

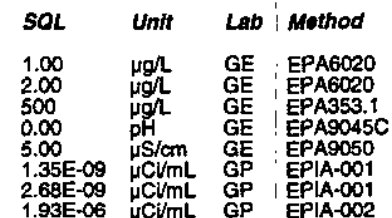

Time: 9:41 Total alkalinity (as Caco3): $0 \mathrm{mgl}$

SOL Unit Lab, Mathod $\begin{array}{lll:l}8.90 E-09 & \mu \mathrm{CV} / \mathrm{mL} & \text { GP } & \text { EPIA-003 } \\ 1.65 \mathrm{E}-06 & \mu \mathrm{Ci} / \mathrm{mL} & \text { GP } & \text { EPIA-002 }\end{array}$

Socond auartor 


\section{WELL FSB111C}

MEASUREMENTS CONDUCTED IN THE FIELD

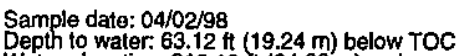
Water elevation: $213.18 \mathrm{Ht}(64.98 \mathrm{~m}) \mathrm{ms}$

$\mathrm{pH}: 4.9$

conductance: $53 \mu \mathrm{S} / \mathrm{cm}$

Water evacuated from the well prior to sampling: $91 \mathrm{gal}$ ANALYSES

$F$ Analyto

- Cadmium, total recoverable

Lead, total recoverable

Nitrate-nitrite as nitrogen

Specific conductance

Nonvolatile be

Tritium

WELL FSB111D

MEASUREMENTS CONDUCTED IN THE FIELD

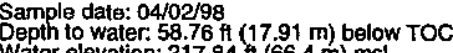

Water elevation: $217.84 \mathrm{tr}(66.4 \mathrm{~m}) \mathrm{ms}$

H: 4.9

. conductance: $32 \mu \mathrm{S} / \mathrm{cm}$

Water evacuated from the well prior to sampling: 36 gal ANALYSES

$F$ Analyte

$\begin{array}{ll}\text { Result } & \text { R } \\ 0.155 & J \\ 0.558 & J \\ 2,060 & \\ 2,060 & 5 \\ 5.34 & J \\ 54.1 & 5.62 \mathrm{E}-10 \pm 5.59 \mathrm{E}-10 \\ 3.75 \mathrm{E}-10 \pm 6.77 \mathrm{E}-10 & \mathrm{U} \\ 4.61 \mathrm{E}-06 \pm 4.88 \mathrm{E}-07 & \end{array}$

R. A

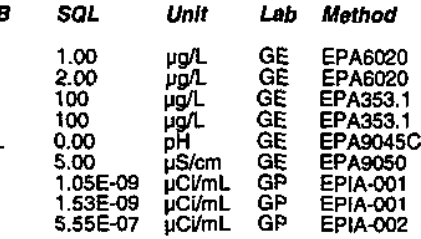

Time: 11:09

Air temperature $242^{\circ} 2^{\circ} \mathrm{C}$

Totai alkalinity (as CaCO3): $8 \mathrm{mg} /$
Phenolphthalein alkalinity: $0 \mathrm{mg} /$

Cadmium, total recoverable

Nitrato-nitrite as nitroge

$\mathrm{pH}$ Hillias astrogen

Groesicic conduct

O Nonvolatile bet

\section{WELL FSB112A}

MEASUREMENTS CONDUCTED IN THE FIELD

Sample date: 04/06/98

Depth to water: $74.91 \mathrm{ft}(22.83 \mathrm{~m})$ below TOC
Water elevation: $154.19 \mathrm{tt}(47 \mathrm{~m})$ msl

Water etert

Result

$<1.00$
4.32
1.280
4.71

1.11 $-09 \pm 6.12 \mathrm{E}-10$

2. $48 E-09+8.60 \mathrm{E}-10$

UI

Time: $11: 37$

Air temperature: $26.1^{\circ} \mathrm{C} \mathrm{C}$ Total alkalinity (as CaCOS3): $0 \mathrm{mgh}$
Phenolphthalein alkalinity: $0 \mathrm{mg} L$
Time: $11: 34$ ater temperature: $19.7^{\circ} \mathrm{C}$

Sp. conductance: $160 \mu \mathrm{S} / \mathrm{cm}$

Water evacuated from the well prior to sampling: $103 \mathrm{gal}$ ANALYSES

- Cadmium, total recoverable

- Lead, total recoverable

$\mathrm{pH}$.

Specific conductance
Specific conductance

Gross alpha

$\begin{array}{ll}0 & \text { Nonvolatile beta } \\ 2 & \text { Tritium }\end{array}$

\section{WELL FSB112C}

MEASUREMENTS CONDUCTED IN THE FIELD

Sample date: 04/06/98

Water to wavation: Not available

gp: Not available Not available

No water was evacuated from the well prior to sampling

ANALYSES

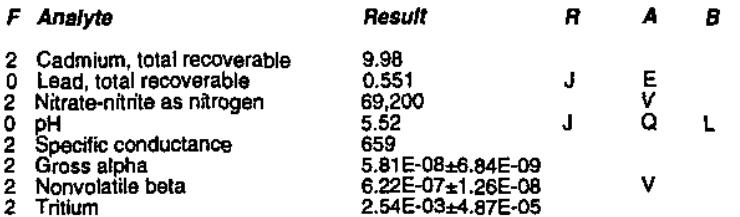

\section{WELL FSB112D}

MEASUREMENTS CONDUCTED IN THE FIELD

Sarmple date: 04/07/98

Depth to water: $20.9 \mathrm{tt}(6.37 \mathrm{~m})$ below TOC

$\mathrm{HH}: 3.6$

conductance: $260 \mu \mathrm{S} / \mathrm{cm}$

Water evacuated from the well prior to sampling: 88 gal

ANALYSES

$F$ Analyte

1 Cadmium, total recoverable

Nitrate-nitrite as nitrogen

$\mathrm{pH}$

Specific conductance

2 Notrvolatile bela

2 Tritiun

WELL FSB112D

MEASUREMENTS CONDUCTED IN THE FIELD

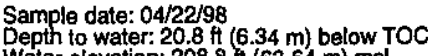

Water elevation: $208.8 \mathrm{t}(63.64 \mathrm{~m}) \mathrm{msl}$

$\mathrm{pH}: 3.6$

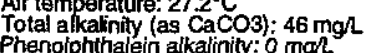

p. conductance: $300 \mu \mathrm{S} / \mathrm{cm}$

Water evacuated from the well prior to sampling: $48 \mathrm{gal}$

ANALYSES

$F$ Analyto

o. Carbon-14

2 Tritium

$3.69 \mathrm{E}-08+6.29 \mathrm{E}-09$

$3.69 E-08 \pm 6.29 E-09$
$2.76 E-08 \pm 5.98-09$
$6.73 E-04 \pm 1.32 E-05$
Time: Not available

Wot available

Total alkalinity (as CacCO3): Not available

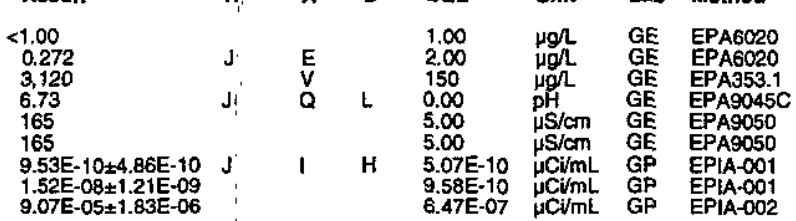

Time: $9: 38$

Wir temperature: $16^{\circ} \mathrm{C}$

Total alkalinity (as CaCO3): $0 \mathrm{mg} / \mathrm{h}$

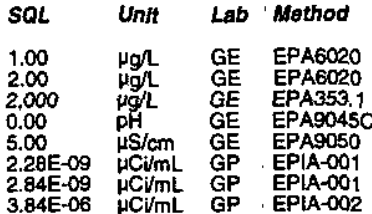

\begin{tabular}{|c|c|c|c|}
\hline$S O L$ & Unit & Lab & Method \\
\hline $\begin{array}{l}1.00 \\
2.00 \\
1,000 \\
0.00 \\
5.00 \\
1.70 E-09 \\
3.19 E-09 \\
1.92 E-06\end{array}$ & $\begin{array}{l}\mu g / \mathrm{L} \\
\mu g / \mathrm{L} \\
\mu g / \mathrm{L} \\
\mathrm{pH} \\
\mu \mathrm{S} / \mathrm{cm} \\
\mu \mathrm{C} / \mathrm{mL} \\
\mu \mathrm{C} V / \mathrm{mL} \\
\mu \mathrm{C} / \mathrm{mL}\end{array}$ & $\begin{array}{l}G E \\
G E \\
G E \\
G E \\
G E \\
G E \\
G P \\
G P \\
G P\end{array}$ & 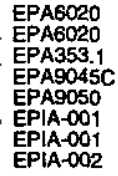 \\
\hline
\end{tabular}

Time: 12:47

Water temperature: $16^{\circ} \mathrm{C}$

Total alkalinity (as CaCO3): 0 mgh

SOL Unit Lab'Method

8.84E-09 $\mu \mathrm{CU} / \mathrm{mL}$ GP $:$ EPIA-003

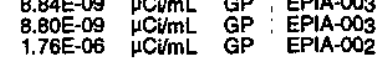




\section{WELL FSB113A}

MEASUREMENTS CONDUCTED IN THE FIELD

Sample date: $04 / 06 / 98$

Depth to water: $62.24 \mathrm{ft}(18.97 \mathrm{~m})$ below TOC

Water elor

Sp. conductance: $2,100 \mu \mathrm{S} / \mathrm{cm}$

Turtidity: 1 NTU: 100 H/cn ANALYSES

Anatyto

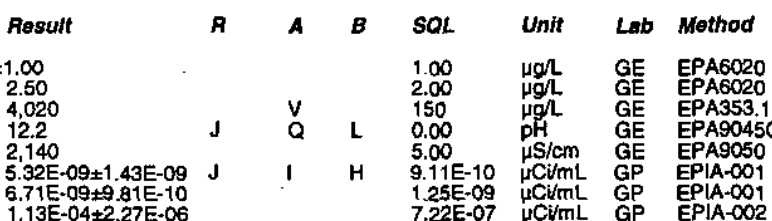

Cadmium, total recoverabla

Nitrate-nitrite as nitrogen

$\mathrm{Specitic}$ conductance

O Gonvoletile beta

\section{WELL FSB113C}

MEASUAEMENTS CONDUGTED IN THE FIELD

Sample date: $04 / 06 / 98$
Depth to water: $18.06 \mathrm{ft}(5.5 \mathrm{~m})$ below TOC
Water elevation: $204.84 \mathrm{tt}(62.44 \mathrm{~m}) \mathrm{msl}$

Water el wa

Sp. conductance: $140 \mu \mathrm{S} / \mathrm{cm}$

Turbidity: 2 NTU 140 the well prior to sampling: 1 gal ANALYSES

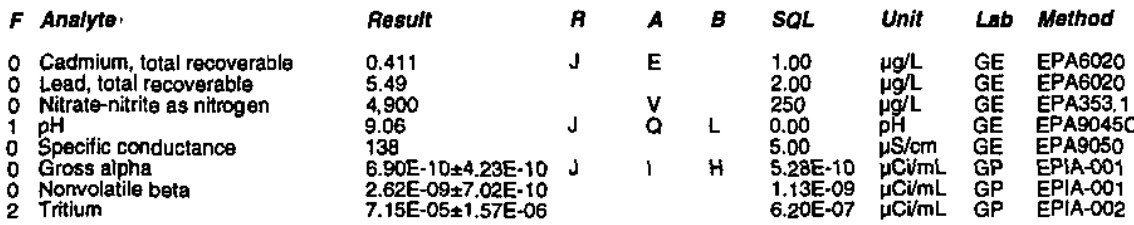

\section{WELL. FSB113D}

MEASUREMENTS CONDUCTED IN THE FIELD

\section{Sample date: $04 / 06 / 98$
Depth to water: $11.62 \mathrm{ft}(3.54 \mathrm{~m})$ below TOC
Water elevation: $210.88 \mathrm{Ht}(64.28 \mathrm{~m}) \mathrm{msl}$ \\ Water el \\ Sp. conductance: $25 \mu \mathrm{S} / \mathrm{cm}$}

Water evacuated from the well prior to sampling: $45 \mathrm{gal}$ ANALYSES

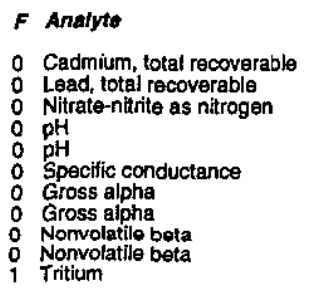

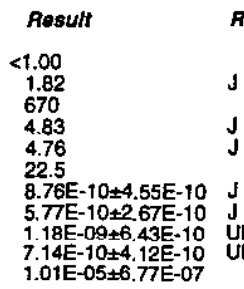

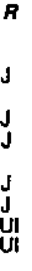

Wre: $18.8^{\circ} \mathrm{C}$

Total alkalinity (as Caco3): $450 \mathrm{mg} / \mathrm{h}$

Time: 14:21

Waler remperature: $19.1^{\circ} \mathrm{C}$
Total akalinity (as $\mathrm{CaCO}$ ): $46 \mathrm{mg}$

Water temperature: $16.9^{\circ} \mathrm{C}$

Total alkalinity (as CaCO3): $0 \mathrm{mg} / \mathrm{L}$
Phenolphthalein alkalinity: $0 \mathrm{mg} / \mathrm{L}$

\section{WELL FSB114A}

MEASUREMENTS CONDUCTED IN THE FIELD

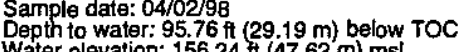$$
\text { Water }
$$

. conductance: $190 \mu \mathrm{s} / \mathrm{cm}$

Wurbidity: 2 NTU:

ANALYSES

$F$ Anatro

o Cadmium, total recoverable

- Lead, total recoverable

: $\mathrm{pH}$ Specific conductance

Gross alpha

Tritium

\section{WELL FSB114C}

MEASUREMENTS CONDUCTED IN THE FIELD

Sample date: $04 / 02 / 98$

Depth to water: $37.93 \mathrm{ft}(11.56 \mathrm{~m})$ below TOC

$\mathrm{pH}: 5.6$

Sp. conductance: $61 \mu \mathrm{S} / \mathrm{cm}$

Wuthidity: 2 NTU evacuated from the well prior to sampling: 75 gal

ANALYSES

$F$ Anolyto

Result
$<1.00$
$<2.00$
1.820
7.53
188
$6.96 \mathrm{E}-10 \pm 5.24 \mathrm{E}-10$
$1.23 \mathrm{E}-09 \pm 6.61 \mathrm{E}-10$
$1.19 \mathrm{E}-06 \pm 3.63 \mathrm{E}-07$

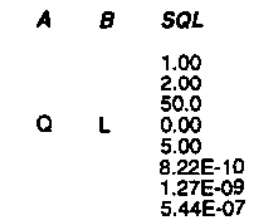

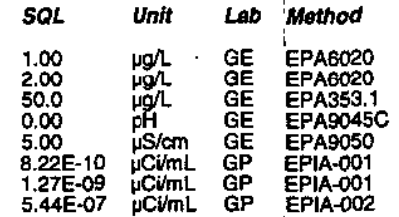

- Cadmium, total recoverable

Nitrate-nitrite as nitroge

0 Specific conductance

Gross alpha

o Tritium

\section{WELL. FSB114D}

MEASUREMENTS CONDUCTED IN THE FIELD

Sample date: $04 / 02 / 98$

Depth to water: $32.84 \mathrm{ft}(10.01 \mathrm{~m})$ below TOC

WH: 4.9

Sp. co

Turbidity: $1 \mathrm{NTU}$.

ANALYSES

$F$ Analyt

Result
0.178
1.70
2.000
5.65
62.4
$4.85 E-10 \pm 5.07 E-10$
$1.04 E-09 \pm 6.68-10$
$3.16 E-06 \pm 4.44 E-07$

Wirter

Total alkalinity (as CaCO3); $78 \mathrm{mg} /$ 


\section{WELL FSB115C}

MEASUREMENTS CONDUCTED IN THE FIELD

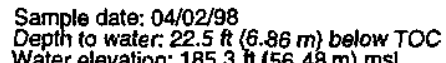
Water elevation: $185.3 \mathrm{fi}(56.48 \mathrm{~m}) \mathrm{msl}$

$\mathrm{pH}: 5.4$

p. conductance: $20 \mu \mathrm{S} / \mathrm{cm}$

Water evacuated from the well prior to sampling: $47 \mathrm{gal}$ ANALYSES

F Analyte

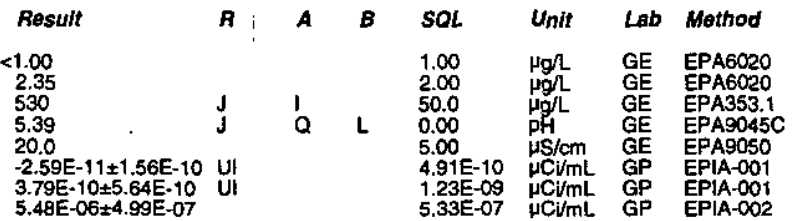

0 Cadmium, total recoverable

N Nitrate-nitrite as nitrogen

o $\mathrm{pH}$ Spcitic conductance

Gross alpha
0 Nonvolatile beta
0

\section{WELL FSB115D}

MEASUREMENTS CONDUCTED IN THE FIELD

Sample date: $04 / 02 / 98$

Depth to water $14.35 \mathrm{ft}(4.37 \mathrm{~m})$ below TOC

$\mathrm{pH}: 3.8$

p. conductance: $240 \mu \mathrm{S} / \mathrm{cm}$

Water evacuated from tha well prior to sampling: $1 \mathrm{gal}$

ANALYSES

$F$ Analyte

- Cadmium, total recoverable

Nitrate-nitrite as nitrogen

Specific conductance

Specifif conductance

1 Gross alpha

\section{WELL FSB116C}

MEASUREMENTS CONDUCTED IN THE FJELD

Sample date: $04 / 02 / 98$
Depth to water: $11.85 \mathrm{ft}(3.61 \mathrm{~m})$ below TOC
Water elevation: $190.65 \mathrm{Ht}(58.11 \mathrm{~m})$ msl
pH: 5
Sp.conductance: $22 \mu \mathrm{S} / \mathrm{cm}$
Turitidity: 2 NTU

Water evacuated from the well prior to sampling: 62 gal

ANALYSES

Analyto

Resutt
0.304
70.9
110
110
4.75
13.9
14.0
$1.18 E-08 \pm 2.06 E-09$
$7.44 E-09+1.47 E-09$
$5.63 E-06 \pm 5.00 E-07$

Cadmium, total recoverable

Nitrate-nitrito

Specific conductance

Grecific conductanca

Nonsolatile beta
Tritium

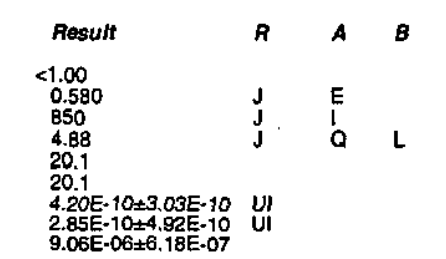

Time: 14:14

Air temperature $31^{\circ} \mathrm{C} 6^{\circ} \mathrm{C}$

Total alkalinity (as CaCO3): $0 \mathrm{mg} / \mathrm{L}$

Water temperature: $16^{\circ} \mathrm{C}$

Total alkalinity (as CaCO3): $1 \mathrm{mg} / \mathrm{L}$
Phenolphthalein alkalinity: $0 \mathrm{mg} /$

ESH-EMS-980569

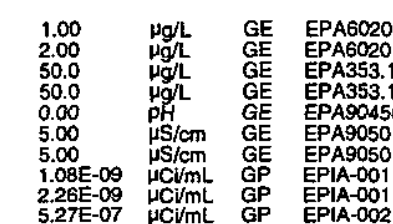

Time: 11:33 1 Water temperature: $16^{\circ} \mathrm{C}$

Ar temperature: $26.3^{\circ} \mathrm{C}$
Total alkalinity (as Caco3) $1 \mathrm{mgh}$
Phenolphthatein alkalinity: $0 \mathrm{mgh}$

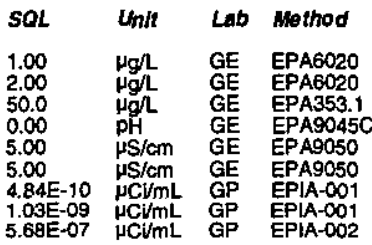

\section{WELL FSB116D}

MEASUREMENTS CONDUCTED IN THE FIELD

Sample date: 04/03/98

Wepth to water: $9.3 \mathrm{ft}(2.83 \mathrm{~m})$ below TOC

pH: 5 H: 5 conductance: $46 \mu \mathrm{S} / \mathrm{cm}$

Water evacuated from the well prior to sampling: 1 gat ANALYSES

$F$ Analyte

- Cadmium, total recoverabie

Nitrate-nitrite as nitroge

Specific conductance

Gross alpha

Tritium

WELL FSB117D

MEASUREMENTS CONDUCTED IN THE FIELD

Sample date: 04/06/98

Depth to water: $23 \mathrm{ft}(7.01 \mathrm{~m})$ below TOC
Water elevation: $207.7 \mathrm{it}(63.31 \mathrm{~m}) \mathrm{msl}$

H: 3.8

conductance: $200 \mu \mathrm{S} / \mathrm{cm}$

Water evacuated from the well prior to sampling: $85 \mathrm{gal}$

ANALYSES

F Analyte

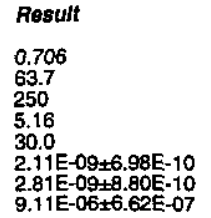

Water temperature: $14^{\circ} \mathrm{C}$

Total alkalinity (as CaCO3): $6 \mathrm{mg} /$
Phenolphthalein alkalinity: $0 \mathrm{mg} L$

- Cadmium, total recoverable

Nitrate-nitrite as nitrogen

$\mathrm{PH}$ Specific conductance

2 Nonvolatilie beta

2 Tritium

WELL FSB118D

MEASUREMENTS CONDUCTED IN THE FIELD

Sample date: $04 / 02 / 98$
Depth to water: $28.35 \mathrm{ft}(8.64 \mathrm{~m})$ below TOC
Water elevation: $214.95 \mathrm{Ht}(65.52 \mathrm{~m}) \mathrm{msl}$

$\mathrm{pH}: 5$

Water evacuated from the well prior to sampling: 62 gal

ANALYSES

F Analyte

- Cadmium, total recoverab

Lead, total recoverable

Nitrate-nitrite as nittogen

0 Specific conductance

$\begin{array}{ll}0 & \text { Gross alpha } \\ 0 & \text { Nonvolatio beta } \\ 0 & \text { Tritium }\end{array}$

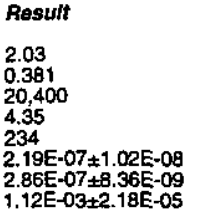

\begin{tabular}{|c|c|c|c|}
\hline 5OL & Unit & Lab & Method \\
\hline $\begin{array}{l}1.00 \\
2.00 \\
1,000 \\
0.00 \\
5.00 \\
1.74 E-09 \\
2.93 E-09 \\
2.44-06\end{array}$ & 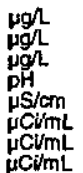 & $\begin{array}{l}\text { GE } \\
G \mathrm{GE} \\
\mathrm{GE} \\
\mathrm{GE} \\
\mathrm{GE} \\
\mathrm{GP} \\
\mathrm{GP} \\
\mathrm{GP}\end{array}$ & 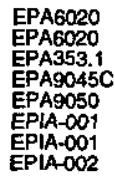 \\
\hline
\end{tabular}

Time: 11:22

Air temperarature: $16^{\circ} \mathrm{C}$

Total alkalinity (as $\mathrm{CaCO}$ ): $0 \mathrm{mg}$$$
\text { Result }
$$

$<1.00$

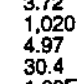

30.4
$1.00 E-09 \pm 4.51 E-10$

$1.02 E-09 \pm 5.76 E-10$ U

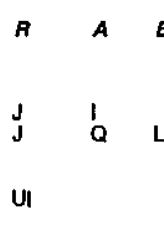

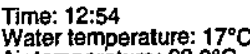

Air temperature: $29.3^{\circ} \mathrm{C}$

Total alkalinity (as CaCO3): $1 \mathrm{mg} /$
Phenolphthalein alkalinity: $0 \mathrm{mg} / \mathrm{L}$

\begin{tabular}{|c|c|c|c|}
\hline SOL & Unit & Lab & Method \\
\hline $\begin{array}{l}1.00 \\
2.00 \\
50.0 \\
0.00 \\
5.00 \\
6.52 E-10 \\
1.111-09 \\
5.47 E-07\end{array}$ & 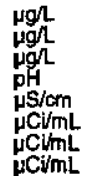 & $\begin{array}{l}G E \\
G E \\
G E \\
G E \\
G E \\
G F \\
G P \\
G P \\
G P\end{array}$ & 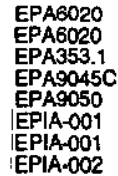 \\
\hline
\end{tabular}




\section{WELL FSB122C}

MEASUREMENTS CONDUCTED IN THE FIELD Sample date: 04/07/98 Depth to water: $15.85 \mathrm{ft}(4.83 \mathrm{~m})$ below TOC

$\mathrm{pH}: 4.4$ Sp. conductance: $680 \mu \mathrm{S} / \mathrm{cm}$

Turbidity: 1 NTU Water evacuated from the well prior to sampling: $85 \mathrm{gal}$ ANALYSES

\begin{tabular}{|c|c|c|c|c|c|c|c|c|}
\hline Analyte & Resuft & $\boldsymbol{A}$ & & & $S Q L$ & Unit & $L a b$ & Method \\
\hline $\begin{array}{l}\text { Cadmium, total recoverable } \\
\text { Lead, total recoverable } \\
\text { Nitrate-nitrite as nitrogen } \\
\text { pH } \\
\text { Specific conductance } \\
\text { Gross alpha } \\
\text { Nonvelatite beta } \\
\text { Trifium }\end{array}$ & $\begin{array}{l}1.94 \\
0.507 \\
88.400 \\
4.64 \\
778 \\
2.05 E-08 \pm 4.00 E-09 \\
9.41 E-08 \pm 5.03 E-09 \\
2.311-034.44 E-05\end{array}$ & J & & & $\begin{array}{l}1.00 \\
2.00 \\
2,000 \\
0.00 \\
5.00 \\
2.24 E-09 \\
3.06 E-09 \\
3.66-06\end{array}$ & $\begin{array}{l}\mu g / \mathrm{L} \\
\mu g / \mathrm{L} \\
\mu \mathrm{g} \\
\mathrm{pH} \\
\mu \mathrm{S} / \mathrm{cm} \\
\mu \mathrm{CmL} \\
\mu \mathrm{C} / \mathrm{mL} \\
\mu \mathrm{C} / \mathrm{mL}\end{array}$ & $\begin{array}{l}\mathrm{GE} \\
\mathrm{GE} \\
\mathrm{GE} \\
\mathrm{GE} \\
\mathrm{GE} \\
\mathrm{GP} \\
\mathrm{GP} \\
\mathrm{GP}\end{array}$ & $\begin{array}{l}\text { EPAG020 } \\
\text { EPA6020 } \\
\text { EPA353.1 } \\
\text { EPA9055C } \\
\text { EPA9050 } \\
\text { EPAA-001 } \\
\text { EPAA-001 } \\
\text { EPAA-002 }\end{array}$ \\
\hline
\end{tabular}

\section{WELL FSB122D}

MEASUREMENTS CONDUCTED IN THE FIELD

Sample date: 04/13/98

Water 1

Sp. conductance: $35 \mu \mathrm{S} / \mathrm{cm}$

Water evacuated from the well prior to sampling: 64 gal

ANALYSES

$F$ Analyte

- Cadmium, total recoverable

- Lead, total recoverable

Specific conductance

- Gross alpha

2 Tritium

WELL FSB123C

MEASUREMENTS CONDUCTED IN THE FIELD

Sample date: 04/13/98

Depth to water $26.12 \mathrm{ft}(7.96 \mathrm{~m})$ below TOC

$\mathrm{HH}: 5.5$

Sp. conductance: $70 \mu \mathrm{S} / \mathrm{cm}$

Water evacuated from the well prior to sampling: $94 \mathrm{ga}$

ANALYSES

F Analyte

\begin{tabular}{|c|c|c|c|c|c|c|c|}
\hline \multirow{3}{*}{$\begin{array}{l}\text { Resuit } \\
<1.00 \\
1.55 \\
1,830 \\
5.34 \\
36.4 \\
3.30 \mathrm{E}-10 \pm 3.66 \mathrm{E}-10 \\
1.73 \mathrm{E}-09 \pm 5.86 \mathrm{E}-10\end{array}$} & & & & $S O L$ & \multirow{3}{*}{ 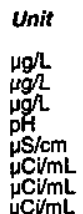 } & \multirow{3}{*}{$\begin{array}{l}L a b \\
G E \\
G E \\
G E \\
G E \\
G E \\
G E \\
G P \\
G P \\
G P\end{array}$} & \multirow{3}{*}{$\begin{array}{l}\text { Method } \\
\text { EPAG020 } \\
\text { EPAG020 } \\
\text { EPA353.1 } \\
\text { EPA9045C } \\
\text { EPA9050 } \\
\text { EPIA-001 } \\
\text { EPAA-001 } \\
\text { EPIA-002 }\end{array}$} \\
\hline & $J$ & $E$ & & & & & \\
\hline & $J$ & $\mathbf{Q}$ & & $\begin{array}{l}0.00 \\
5.00 \\
7.14 E-10 \\
1.04 E-09 \\
5.48 E-09\end{array}$ & & & \\
\hline
\end{tabular}

- Cadmium, total recoverable

Nitrate-nitrite as nitrogen

$0_{0}^{0} \mathrm{pH}$ Specific conductance

o Gross alpha

Nonvotatila be

0 Tritum
Time: 15:05

Total alkalinity (as CaCO3): $0 \mathrm{mg} L$

Time: 13:02

Wir termperature: $18.5^{\circ} \mathrm{C}$

Total alkalinity (as $\mathrm{CaCO}$ ): $3 \mathrm{mah}$
Wir tomperature: $17^{\circ} \mathrm{C}$ Penolphthalein alkalinity: $0 \mathrm{mg} h$

Time: 11:46

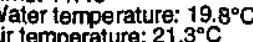
Total alkalinity (as CaCo3): $13 \mathrm{mg} /$

\section{WELL FSB123D}

MEASUREMENTS CONDUCTED IN THE FIELD

Sample date: $04 / 13 / 98$

Water elevation: 215.12 ( $\mathrm{m}$ ) below TOC

SH: 4.6 conductance: $38 \mu \mathrm{S} / \mathrm{cm}$

Water evacuated trom the well prior to sampling: $34 \mathrm{gat}$ ANALYSES

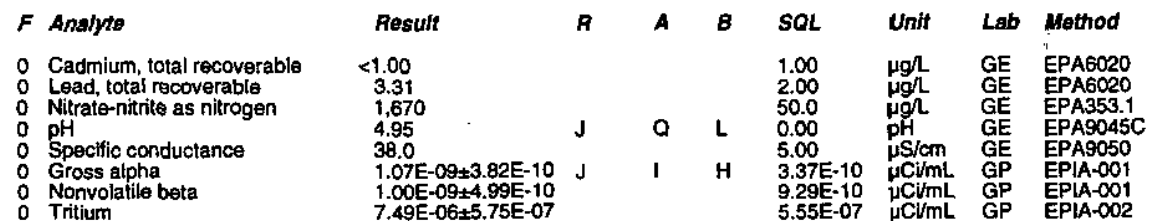

\section{WELL FSL 1D}

MEASUREMENTS CONDUCTED IN THE FIELD

Sample date: $04 / 20 / 98$
Depth to water $87.15 \mathrm{ft}(26.56 \mathrm{~m})$ below TOC

$\mathrm{pH}: 4.4$. conductance: $68 \mu \mathrm{S} / \mathrm{cm}$

Water evacuated from the well prior to sampling: 1 gal ANALYSES

\begin{tabular}{|c|c|c|c|c|c|c|c|c|}
\hline \multirow{3}{*}{$\begin{array}{ll}0 & \text { Cadmium, total recoverable } \\
0 & \text { Lead, total recoverable } \\
0 & \text { Nitrate-nitrite as nitsogen } \\
0 & \text { pH } \\
0 & \text { Specific conductance } \\
0 & \text { Gross alpha } \\
0 & \text { Nonvolatile beta } \\
2 & \text { Tritium }\end{array}$} & & \multirow[b]{2}{*}{$\mathrm{J}$} & \multirow{2}{*}{\multicolumn{2}{|c|}{ A }} & SQL & $m$ & Lab & motis \\
\hline & \multirow{2}{*}{$\begin{array}{l}0.599 \\
17.1 \\
3.810 \\
4.39 \\
49.6 \\
6.10 \mathrm{E}-09+9.67 \mathrm{E}-10 \\
6.86 \mathrm{E}-09+1.03 \mathrm{E}-09 \\
3.5 \mathrm{E}-05+10 \mathrm{E}-06\end{array}$} & & & & \multirow{2}{*}{$\begin{array}{l}1.00 \\
2.00 \\
150 \\
0.00 \\
5.00 \\
4.72 E-10 \\
1.42 E-09 \\
5.80 E-07\end{array}$} & \multirow{2}{*}{ 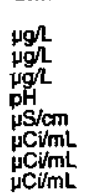 } & \multirow{2}{*}{$\begin{array}{l}G E \\
G E \\
G E \\
G E \\
G E \\
G E \\
G P \\
G P \\
G P\end{array}$} & \multirow{2}{*}{ 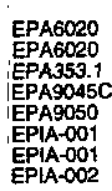 } \\
\hline & & $\mathrm{J}$ & & $\mathbf{L}$ & & & & \\
\hline
\end{tabular}

\section{WELL FSL 2D}

MEASUREMENTS CONDUCTED IN THE FIELD

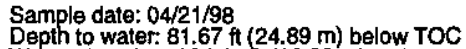
Water elevation: $224.13 \mathrm{ft}(68.32 \mathrm{~m}) \mathrm{ms}$

H: 5.2

. conductance: $71 \mu \mathrm{S} / \mathrm{cm}$

Water evacuated from the well prior to sampling: $1 \mathrm{gal}$

ANALYSES

$F$ Analyte

- Cadmium, total recoverable

Notrate-nitrita as nitrogen

o $\mathrm{pH}$ Specitic conductance

Gross alpha

o $\begin{aligned} & \text { Nonvolatilitium } \\ & 0\end{aligned}$
Time: 12:14

Warteris $191^{\circ} \mathrm{C}$

Total alkalinity (as CaCO3): $0 \mathrm{mg}$
Phenolphthalein alkalinity: $0 \mathrm{mg}$
Time: 10:21

Air temperature: $16^{\circ} \mathrm{C}$

Total alkalinity (as CaCO3): $0 \mathrm{mgh}$ 


\section{WELL FSL 3D}

MEASUREMENTS CONDUCTED IN THE FIELD

Sample date: $04 / 17 / 98$
Depth to water: $81.1 \mathrm{ft}(24.72 \mathrm{~m})$ below TOC
Water alevation: $220.9 \mathrm{tt}(67.33 \mathrm{~m}) \mathrm{ms}$

Water

Sp. conductance: $79 \mu \mathrm{s} / \mathrm{cm}$

Watbidity: $29 \mathrm{NTU}$ (rom the well prior to sampling: $1 \mathrm{gal}$ ANALYSES

$F$ Analyto

Cadmium, total rocoverablo

Lead, total recoverable

$0 \mathrm{pH}$

Specific conductance

Goss alatile be

WELLL FSL 4D

MEASUREMENTS CONDUCTED IN THE FIELD

Sample date: 04/16/98

Depth to water: $77.5 \mathrm{ft}(23.62 \mathrm{~m})$ below TOC
Water elevation: $216.6 \mathrm{tt}(66.02 \mathrm{~m}) \mathrm{ms}$

PH:5.1

Sp. conductance: $49 \mu \mathrm{S} / \mathrm{cm}$

Water evacuated from the well prior to sampling: 1 gel

ANALYSES

$F$ Analyte.

- Cadmium, total recoverable

Nitrate-nitrite as nitrogen

$\mathrm{SH}$ pecific conductance

Gross alpha

Nonvolatile beta

0 Tritium

\section{WELL. FSL 5D}

MEASUREMENTS CONDUCTED IN THE FIELD

Sample date: $04 / 15 / 98$

Depth to water: $70.25 \mathrm{At}(21.41 \mathrm{~m})$ below TOC

Water e

Sp. conductance: $180 \mu \mathrm{S} / \mathrm{cm}$

Turbidity: $2 \mathrm{NTU}$
Water evacuated from the well prior to sampling: $18 \mathrm{gal}$

ANALYSES

\section{$F$ Anatyte}

- Cadmium, total recoverable L Lead, total recoverabie

2 Nitrate-nit

$\mathrm{PH}$ Specific conductance

Gross alpha

Tritium

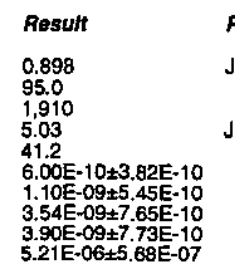

$5.21 \mathrm{E}-06 \pm 5.68 \mathrm{E}-07$

Result
0.225
1.40
17,000
4.78
180
$2.64 \mathrm{E}-0.00 \pm 2.80 \mathrm{E}-09$
$4.42 \mathrm{E}-07 \pm 6.22 \mathrm{k}-09$
$2.83 \mathrm{E}-04 \pm 3.01 \mathrm{E}-06$

Time: 8:21

Wirer $21.3^{\circ} \mathrm{C}$

Total alkalinity (as CaCO3): $31 \mathrm{mgh}$

Phenolphthalein alkalinity: $0 \mathrm{mgh}$

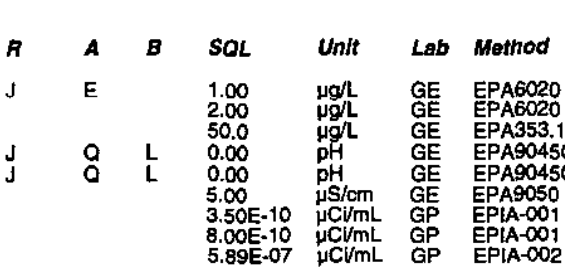

Time: $14: 28$

Air temperature: $26: 217^{\circ} \mathrm{C}$

Total alkalinity (as Caco3): $6 \mathrm{mg} / \mathrm{h}$
Phenolphthalein alkalinity: $0 \mathrm{mg}$ L

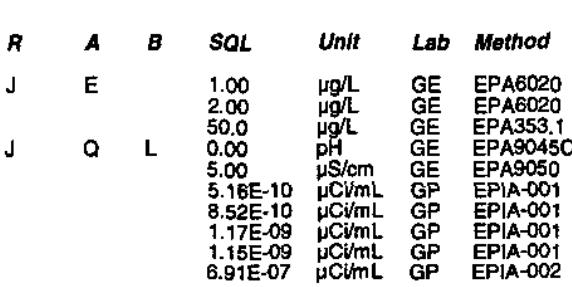

Water temperature: $24^{\circ} \mathrm{C}$

Air temperature: $23.7^{\circ} \mathrm{C}$
Total alkalinity (as CaCo3): $0 \mathrm{mg} / \mathrm{L}$
Phenolphthalein alkalinity: $0 \mathrm{mg} / \mathrm{L}$
WELL FSL 6D

MEASUREMENTS CONDUCTED IN THE FIELD

Sample date: $04 / 15 / 98$
Depth to water: $67.01 \mathrm{ft}(20.42 \mathrm{~m})$ below TOC
Water elevation: $219.19 \mathrm{tt}(66.81 \mathrm{~m}) \mathrm{ms}$

Sp: 4.8 ductance: $120 \mu \mathrm{S} / \mathrm{cm}$

Watridity: 4 NTU ANALYSES

$F$ Analro

O Cadmium, total recoverable

Lead, total recoverable

Specific conductance

Nonvolatile beta

2 Tritium

\section{WELL FSL 7D}

MEASUREMENTS CONDUCTED IN THE FIELD

Sample date: $04 / 20 / 98$

Wepth to water: $68.85 \mathrm{ft}(20.99 \mathrm{~m})$ below TOC

Pp. 4.3 onductance: $420 \mu \mathrm{S} / \mathrm{cm}$

Water evacuated from the well prior to sampling: $B$ gal ANALYSES

$F$ Analyto

1 Cadmium, total recoverable

2 Nitrate-nitrite as nitrogen

1 Specific conductance

2 Gross alpha

2 Tritium

\section{WELL FSL 8D}

MEASUREMENTS CONDUCTED IN THE FIELO

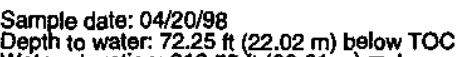

Wepth to water: $72.25 \mathrm{ft}(22.02 \mathrm{~m})$ below TOC

Sp. conductance: $96 \mu \mathrm{S} / \mathrm{cm}$

Water evacuated from the well prior to sampling: 12 ga

ANALYSES

$F$ Analyte

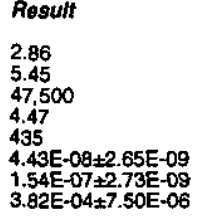

Time: 12:59

Water temperature: $22.1^{\circ} \mathrm{C}$

Total alkalinity (as Caco3): $0 \mathrm{mg} /$

O Cadmium, total recoverable

Nitrato-nitrite as nitroge

Specilic conductance

Tonvolatila beta

2 Tritium

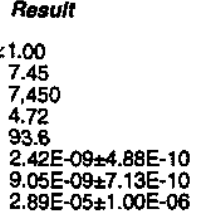

Time: 14:44

Ait temperature: $22.5^{\circ} \mathrm{C}$

Total alkalinity (as CaCO3): $0 \mathrm{mg} /$
Phenolphthalein alkalinity: $0 \mathrm{mg} / \mathrm{l}$ 


\section{WELL FSL 9D}

MEASUREMENTS CONDUCTED IN THE FIELD

Sample date: $04 / 15 / 98$.

Water el

Sp: conductance: $110 \mu \mathrm{S} / \mathrm{cm}$

Turbibidyty $2 \mathrm{NTU}$
Water evacuated from the well prior to sampling: 17 gal

ANALYSES

$F$ Analyto

O Cadmium, total recoverable

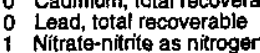

$\therefore$ pH

2
2
2
Grosss alpha

N Nonvolatitie beta

2 Tritium

\section{eta}

TK

\begin{tabular}{|c|c|c|c|c|c|c|c|}
\hline Result & $R$ & A & $B$ & SOL & Unit & Lab & Method \\
\hline $\begin{array}{l}0.267 \\
0.331 \\
9.660 \\
4.40 \\
108 \\
6.88 E-08 \pm 3.44 E-09 \\
6.26 E-08 \pm 3.28 E-09 \\
1.10 E-07 \pm 3.10 E-09 \\
1.03 E-07 \pm 3.02 E-09 \\
2.25 E-04 \pm 2.70 E-06\end{array}$ & $\begin{array}{l}\text { J } \\
\text { J } \\
\text { J } \\
\text { J }\end{array}$ & E & $\underset{H}{H}$ & $\begin{array}{l}1.00 \\
2.00 \\
300 \\
0.00 \\
5.00 \\
7.07 E-10 \\
5.05 E-10 \\
9.91 E-10 \\
1.09 E-09 \\
5.76 E-07\end{array}$ & $\begin{array}{l}\mu g / L \\
\mu g / L \\
\mu g / L \\
\mu H \\
\mu S / c m \\
\mu C / m L \\
\mu C / m L \\
\mu C / m L \\
\mu C / m L \\
\mu C / m L \\
\mu C / m L\end{array}$ & $\begin{array}{l}\mathrm{GE} \\
\mathrm{GE} \\
\mathrm{GE} \\
\mathrm{GE} \\
\mathrm{GE} \\
\mathrm{GP} \\
\mathrm{GP} \\
\mathrm{GP} \\
\mathrm{GP} \\
\mathrm{GP}\end{array}$ & $\begin{array}{l}\text { EPA6020 } \\
\text { EPA6020 } \\
\text { EPA353.1 } \\
\text { EPA9045C } \\
\text { EPA9050 } \\
\text { EPA-001 } \\
\text { EPA-001 } \\
\text { EPAA-D1 } \\
\text { EPAA-01 } \\
\text { EPAA-01 } \\
\text { EPIA-002 }\end{array}$ \\
\hline
\end{tabular}

\section{WELL HEX500TK}

MEASUREMENTS CONDUCTED IN THE FIELD

Sample date: 06/24/98

Water elevation: Not available

pH: 4

Sp. conductance: $280 \mu \mathrm{S} / \mathrm{cm}$

The well was continuously pumping

ANALYSES

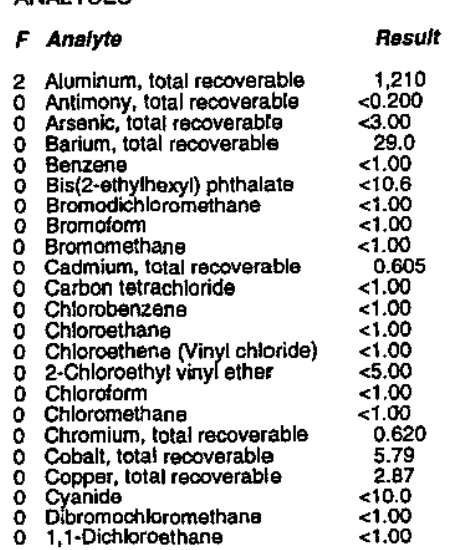

Time: 8:40

ature: $17^{\circ} \mathrm{C}$

Total alkalinity (as CaCO3): $0 \mathrm{mg} / \mathrm{L}$

Water temperature: $20.7^{\circ} \mathrm{C}$

Total alkalinity (as CaCO3): $0 \mathrm{mg} /$
Phenolphthalein alkalinity: $0 \mathrm{mg} L$

$<1.00$

Well HEX500TK collected on 06/24/98 (cont) )

\section{$F$ Anslyte}

- 1,2-Dichloroethane

trans-1,2-Dichloroethylene

1.2-Dichloropropan

cis-1,3-Dichloropropene
trans-1,3-Dichloropropene

Iron, total recoverable

Mercury, total recoverable

Mercury, otal recoverable

Selenium, total recoverabie

i, 1,2,2-Tetrachloroethe

Tin, total recoverable

T,1,1-Trichloroethane

Trichloroethylene

Trichlorofluoromethane

Vanadium, total recovera

Actinium-228

Antimicium-24

Cerium-144

Cesium-134
Cesium-137

Cositum-57

Cobalt-60

Currum-243/244

Europium-152

Europium- 15

Gross alpha
lodine-129

lodine-129

Marganese-54

Nonvolatile beta

Plutonium-239/240

Potassium-40

Promethium-144

Radium-226

Radium-226
Radium-228

Ruthenlum-106

Sodium-22
Strontium-89/90

Technetium-99

Thorium-228

Thorium-230
Result

$<1.00$

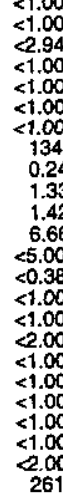

$\begin{array}{ll}7.14 E-09+1.63 E-08 & U I \\ 6.90 E-11 \pm 1.34 E-10 & U I \\ 1.66 E-09 \pm 6.37 E-09 & U I\end{array}$

$6.89 \mathrm{E}-08 \pm 7.58 \mathrm{E}-\mathrm{-}$

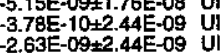

$-2.63 \mathrm{E}-09 \pm 2.44 \mathrm{E}-09$
$-4.29 \mathrm{E}-10 \pm 2.21 \mathrm{E}-09$

$1.42 \mathrm{E}-08 \pm 5.25 \mathrm{E}-09$

$6.49 E-11 \pm 3.18 E-10$ U

$2.30 \mathrm{E}-099+6.92 \mathrm{E}-09$ UI

1.90E-08+2.04E-09

$9.38 \mathrm{E}-09+2.25 \mathrm{E}-09$

$2.00 \mathrm{E}-09.5 .37 \mathrm{E}-09$ UI

$4.94 E-08 \pm 1.26 E-07$ U

$-1.73 \mathrm{E}-11 \pm 3.46 \mathrm{E}-11$ U

$2.88 \mathrm{E}-11 \pm 1.39 \mathrm{E}-10 \mathrm{U}$

$-4.48 \mathrm{E}-10+2.05 \mathrm{E}-09$ UI

$5.26 \mathrm{E}-09 \pm 1.23 \mathrm{E}-09$

$-1.72 \mathrm{E}-10 \pm 6.19 \mathrm{E}-10 \mathrm{UI}$
$-9.50 \mathrm{E}-09 \pm 2.11 \mathrm{E}-08 \mathrm{UI}$

$4.99 E-10 \pm 2.17 \mathrm{E}-09$

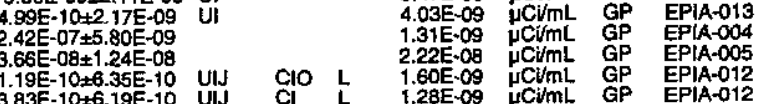

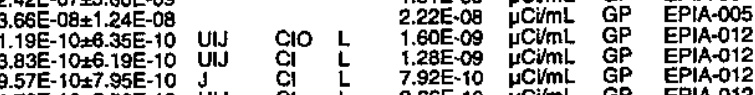

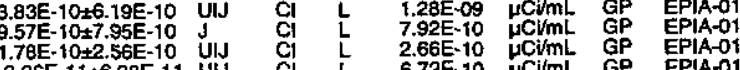


Well HEX500TK collected on 06/24/99 (cont.)

F Analyte
o Throrium-232
0 Uranium-233/234
0 Uranium-233/234
0 Uranium-235
0 Uranium-235
0 Uranium-238
0 Uranium-238
0 Ytrium-238
0 Zinc-65

\section{WELL HHP 10}

MEASUREMENTS CONDUCTED IN THE FIELD

\begin{tabular}{|c|c|}
\hline $\begin{array}{l}\text { Sample date: } 05 / 21 / 98 \\
\text { Depth to water: } 5.75 \mathrm{ft}(1.75 \mathrm{~m}) \text { below TOC } \\
\text { Water elevation: } 271.65 \mathrm{ft}(82.8 \mathrm{~m}) \mathrm{msl} \\
\text { pH: } 5.2 \text {. } \\
\text { Sp. conductance: } 84 \mu \mathrm{S} / \mathrm{cm}\end{array}$ & $\begin{array}{l}\text { Time: } 11: 19 \\
\text { Water temperature: } 16^{\circ} \mathrm{C} \\
\text { Air temperature: } 31,6^{\circ} \mathrm{C} \\
\text { Total alkalinity (as CaCo3): } 7 \mathrm{mgl} \\
\text { Phenolphthalein alkalinity: } 0 \mathrm{mg} / \mathrm{L}\end{array}$ \\
\hline
\end{tabular}

Wutididy: 1 NTU ANALYSES
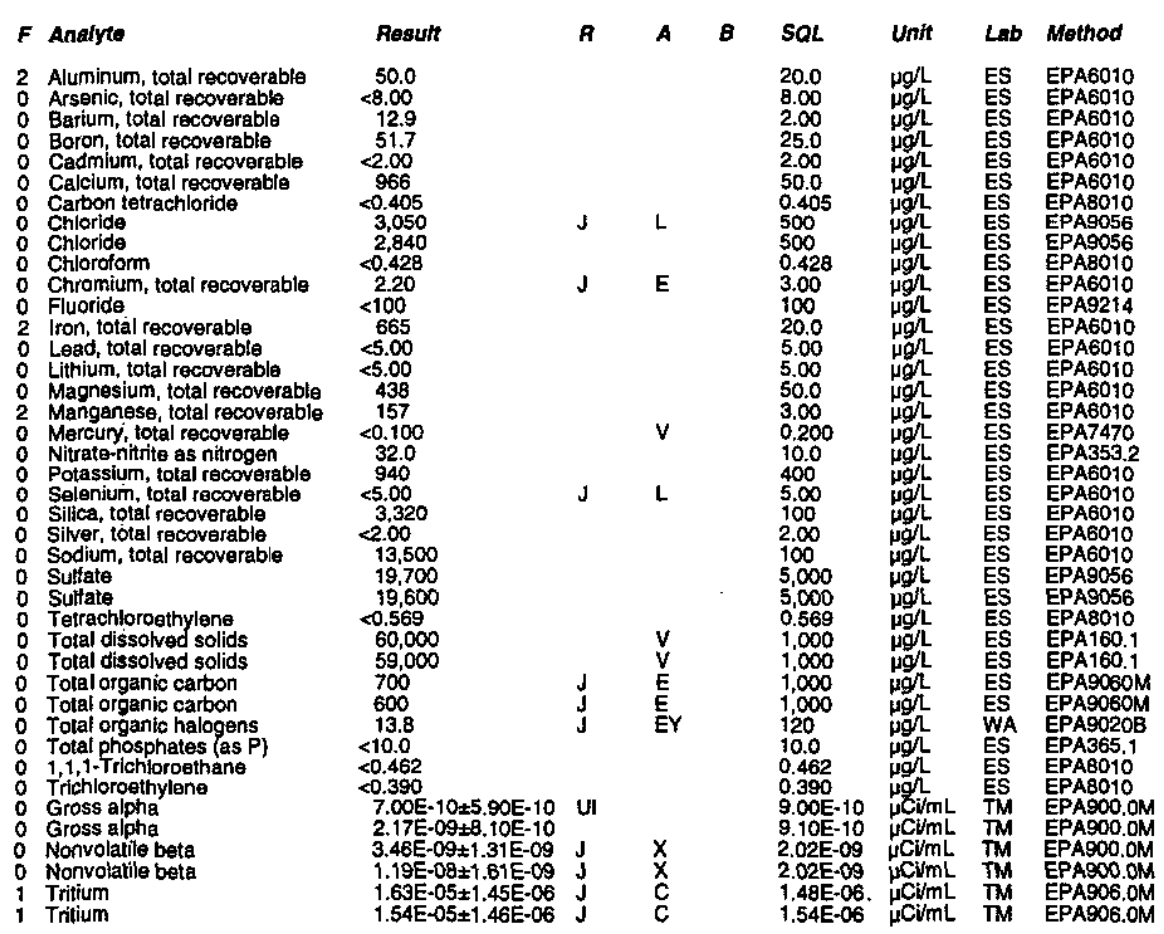

ESH-EMS-980569

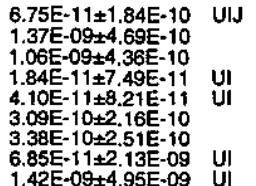

4.69E-10 $\mu \mathrm{CV} / \mathrm{mL}$ GP EP 1.23E-10 $\mu \mathrm{C} / \mathrm{mL}$ GP

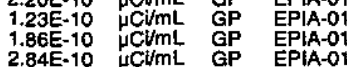

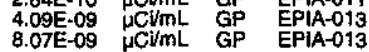

WELL HHP 2D

MEASUREMENTS CONDUCTED IN THE FIELD Sample date: 05/28/98 Depth to water $4.4 \mathrm{ft}(1.34 \mathrm{~m})$ below TOC pH: 6 Sp. conductance: $220 \mu \mathrm{S} / \mathrm{cm}$

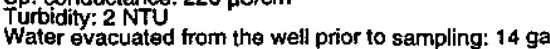
Time: 10:55 ANALYSES

$F$ Analyte

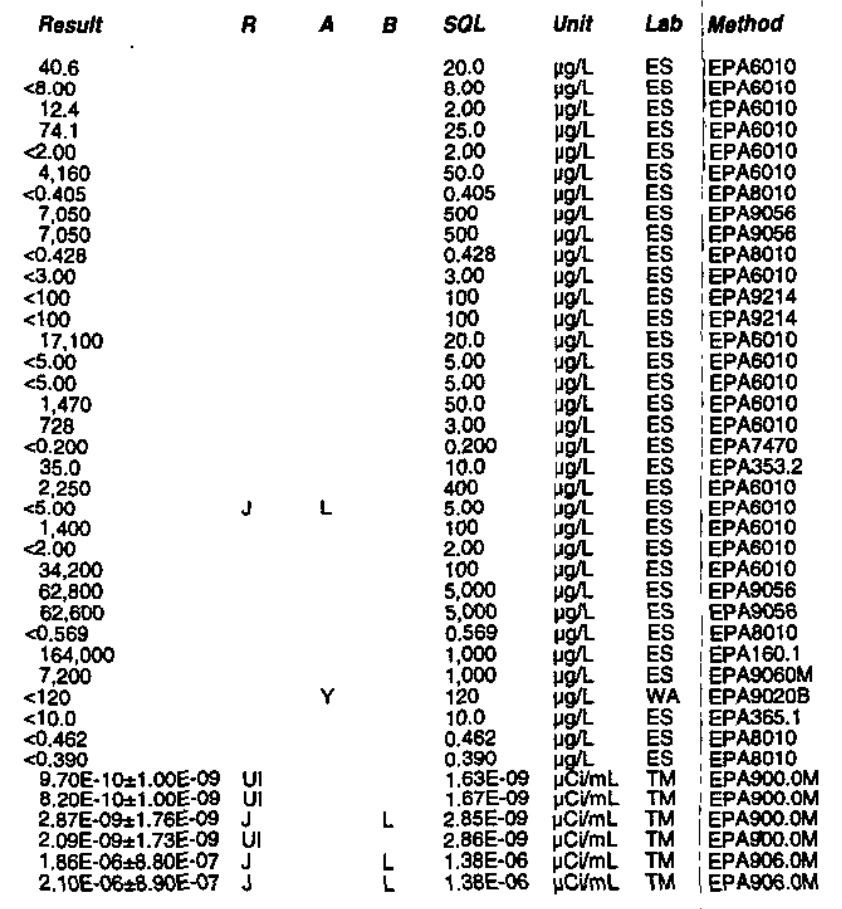

1 Aluminum, total recoverable

Arsenic, total recoverab

Boron, total recoverable

Calcium, total recoverable

Carbon tetrachloride

Chloride

Chromium, total recoverable Fluoride

Iron, total recoverable
Lead, total recoverablo

Lithium, total rocoverable

Mannganesium, total recovererable

Mercury, total recoverable

Potassium, total recoverabis

Silica, total recoverable

Sodium, total secoverab

o Sulfate

Tetrachloroethylene

Total organic halogens

Total phosphates (as P)

Trichloroethylene

Gross alpha

Nonvolatile beta

o Tritium

\section{WELL HIN600TK}

MEASUREMENTS CONDUCTED IN THE FIELD

Sample date: 04/14/98

Depth to water: Not available

$\mathrm{pH}: 3.8$

p. conductance: $340 \mu \mathrm{S} / \mathrm{cm}$

Air temperature: $26.2^{\circ} \mathrm{C}$
Total alkalinity (as CaCO3): $52 \mathrm{mg} /$
Phenolphthalein alkalinity: $\mathrm{mg} /$

The wefl was continuously pumping

ANALYSES

\begin{tabular}{|c|}
\hline Ana \\
\hline 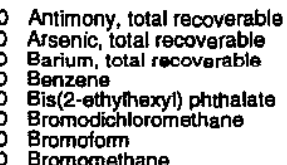 \\
\hline
\end{tabular}

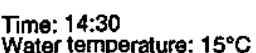

Air temperature: $13.8^{\circ} \mathrm{C}$
Total alkalinity (as Caco3): $0, \mathrm{mg} /$
Phenolphthale

(1)


Well HIN60OTK collected on 04/14/98 (cont.)

$F$ Analyte

- Cadmium, total recoverable

Chloroethene (Ninyl chloride) 2-Chloroethyl

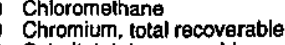
Cobalt, total recoverable

Cyanider to

Cyanide
Dibromochloromethan 1,1-Dichlorcethane

1,1 -Dichloroethylene
trans-1,2-Dichloroethylene 1,2-Dichloropropan

cis-1,3-Dichloropropene
trans-1,3-Dichloropropene

Lead, total recoverable

Mercury, total recoverable
Nickel, total recoverable

Selenium, total recoverable

Siver,
$1,1,2,2$-Tal recoverachloroethane

Tetrachloroethylene

\section{1,1-Trichloroethane}

Trichlorofluoromethane

vanadium, total recoverable

Zinc, total reco

Actinium-2:28
Americium-24

Anericium-24

Antimony-125

Carbon-14

C Crivum-144

0 Cosium-134

Cobsatt-57

Cobalt-57

Cubalt-60
Curium-242
Curium-242

Curium-242
Curium-243/244
0 Curium-243/244

0
0 Currium-24ium-245/246
0 Curium-245/246

Europium-152

Europium-154

Europium-154

Gross alpha

Gross alph

2 lodine-129

Lead-212

Manganese-54

Nicker-

volatilie bet

ESH-EMS-980569

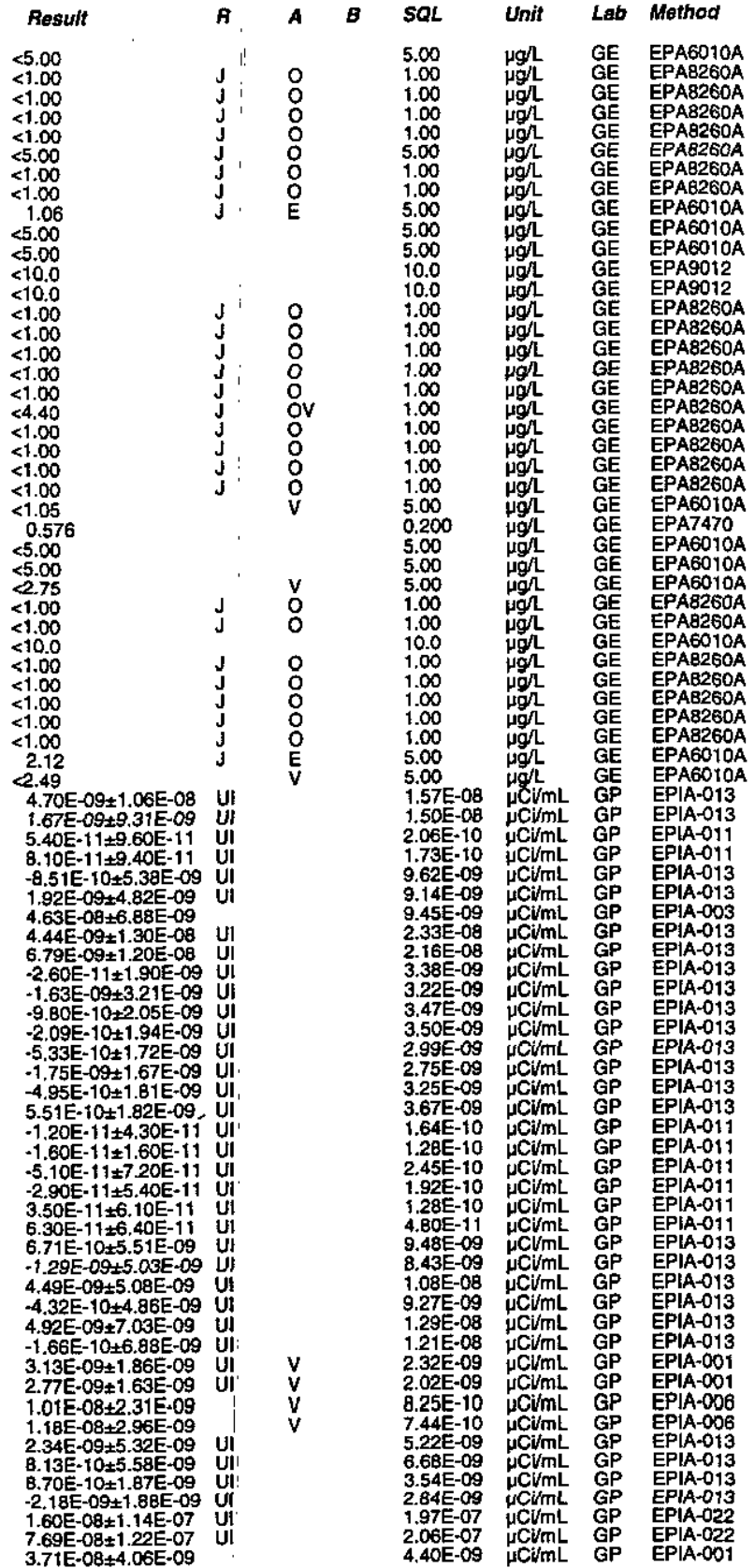

Well HINGOOTK collocted on 04/14/98 (cont)

F Analyte

1 Nonvolatily beta

Plutonium-238

Plutonium-239/240
Plutonium $239 / 240$

O Potassium-40

Promethium-144

Promethium-146

Radium-226

Radium-228

Ruthenium-106

Sodium-22

Strontium-90

0 Technetium-99

Thorium-228

Thorium-230

Thorium-23

O Tranicm-232

Uranium-235

O Uranium-235

O) Uranium-238

$0_{0}^{0}$ Yttrium-88

: Zinc-65

\section{WELL HIN600TK}

MEASUREMENTS CONDUCTED IN THE FIELD

Sample date: 06/24/98 Water elevation: Not available

$\mathrm{H}$ : 4

Sp. conductance: $500 \mu \mathrm{S} / \mathrm{cm}$

The well was continuously pumping.

ANALYSES

$F$ Analyte

2 Aluminum, total recoverable

Arsenic, total recoverable

Bis(2-ethylhexyl) phthalate

B Bromoform

Bromomethane

Carbon tetrachloride

- Chlorobenzene

Chloroethane
0 Chroethene (Vinyl chloride)
2-Chloroethyl vinyl ether

O Chloroormy

o Chromium, total recoverable

Cobalit, total recoverable

Cyanide total recoverab

B-148

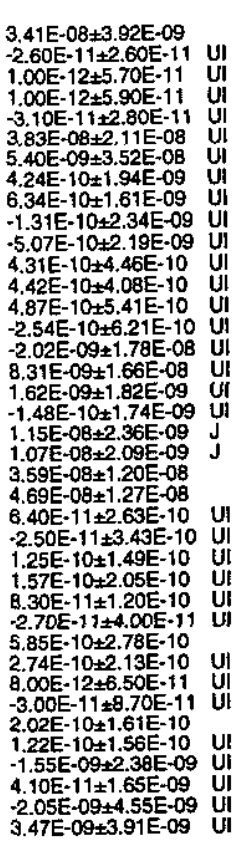

A

\begin{tabular}{|c|c|c|c|}
\hline & Unit & $L_{a b}$ & Method \\
\hline 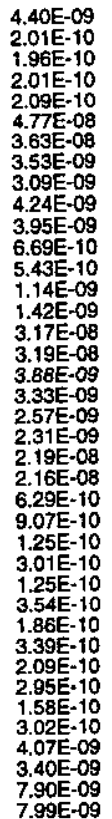 & 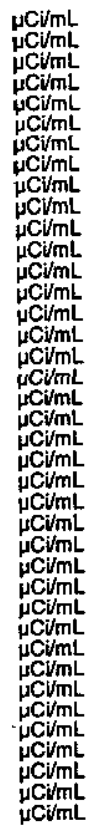 & $\begin{array}{l}G P \\
G P \\
G P \\
G P \\
G P \\
G P \\
G P \\
G P \\
G P \\
G P \\
G P \\
G P \\
G P \\
G P \\
G P \\
G P \\
G P \\
G P \\
G P \\
G P \\
G P \\
G P \\
G P \\
G P \\
G P \\
G P \\
G P \\
G P \\
G P \\
G P \\
G P \\
G P \\
G P \\
G P \\
G P \\
G P \\
G P \\
G P \\
G P\end{array}$ & 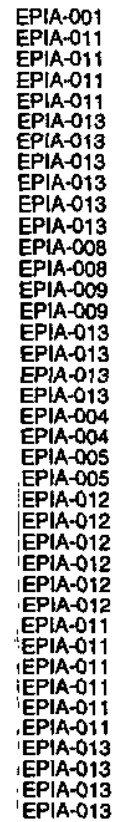 \\
\hline
\end{tabular}

Time: 8:12

rature: $16^{\circ}$

Total alkalinity (as CaCO3) $0 \mathrm{mg} /$

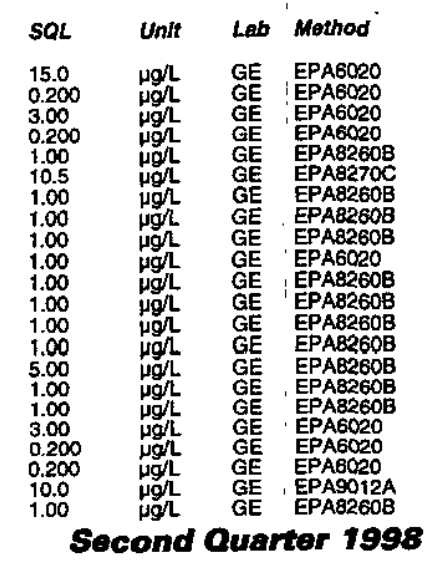




\section{Well HIN600TK collected on 06/24/88 (cont.)}

\section{$F$ Analyte}

- 1,1-Dichloroethane

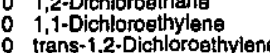

Dichloromethane

0
0
0
ctis-1,3-Dichloropropene
$1,3-D i c h l o r o p r o p e n e$

1 Ethylbenzene

1ron, total recoverable

- Mercury, total recoverable

Selenium, total recoverable

Silver, total recoverable

Tetrachloroethylene

1,1.1-Trichtoroethane

1,i,2-Trchloroethan

- Trichlorofluoromethane

O Vanaditum, total recoverable

0 Actinium-228

Americium-241

o Ambricium-24

$:$ Antimony-125

: Carbon-14

: Cestum -144

: Cesiumn-134

0 Cosium-137

Cobalt-57

O Cobalt-60

Curium-242

Curium-243/244

O Curium-245/246

Europium-152

Europium-154

Europium-154

G Gross alpha

O Gross alpha

2 lodine-1

: Lead-212

Manganese-54
Manganese-54
0 Nickel-63

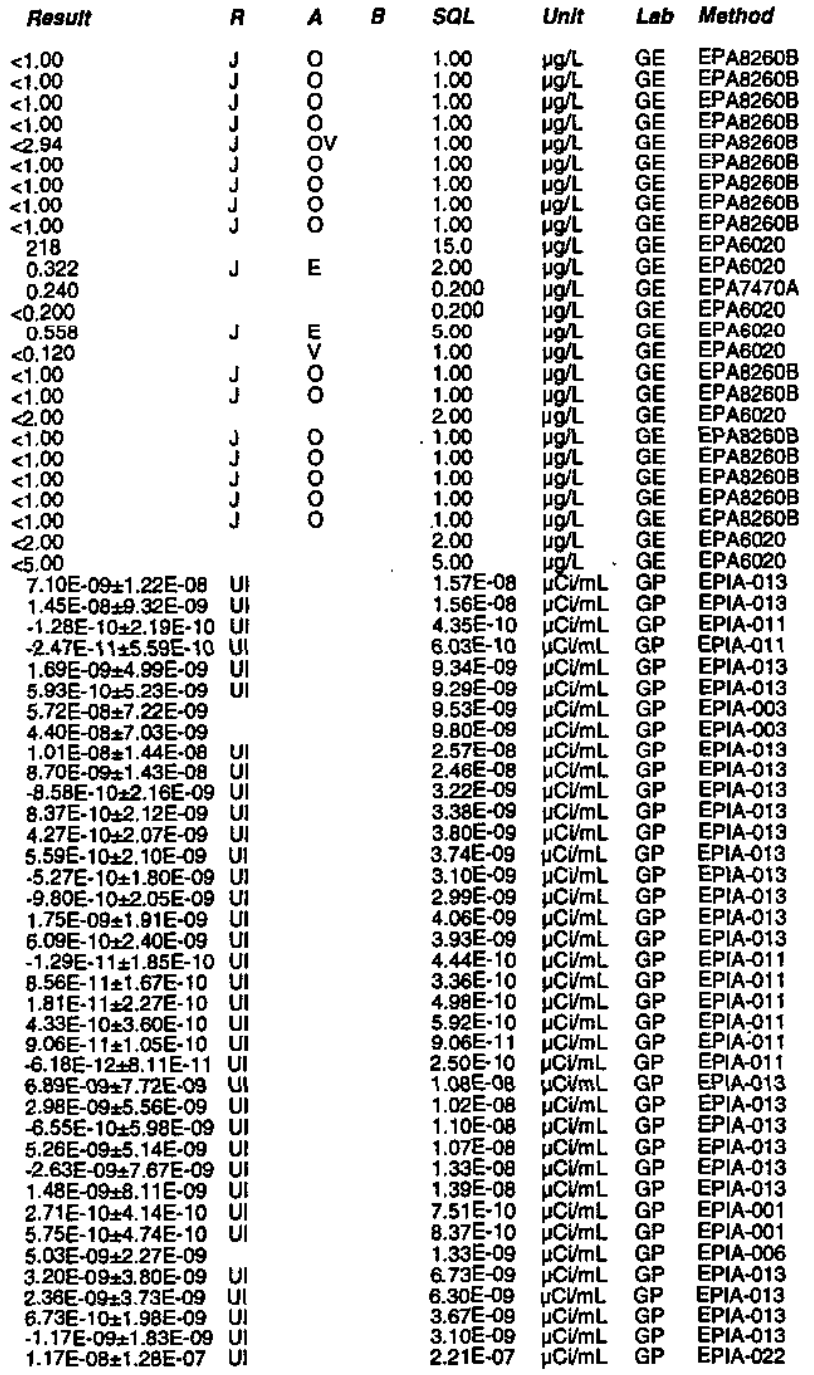

Well HIN600TK collected on 06/24/98 (cont.) $f$ Analyte

1 Nickel-63

- Nonvolatile beta

O Plutonium-238

0 Plutonium-239/240

Potassium-40

Promethium-144

Promethium -14
Promethium -14

1 Radium-222

Ruthenium-106
Ruthenium-106

Sodium-22

Sodium-22
Strontium-89/90
Strontium-89/90

Technetium-99

Thorium-228

Thorium-232

Uranium-235

: Yranlum-23

: Ytrium-8

WELL HR3 14DU

MEASUREMENTS CONDUCTED IN THE FIELD

Sample date: $05 / 21 / 98$
Depth to water: $12 \mathrm{ft}$ (3.66 m) bolow TOC
Water elevation: Not available

Water elevation: Not avallable
g 5 . conductance: $180 \mu \mathrm{S} / \mathrm{cm}$

Tutridity: $1 \mathrm{NTU}$
Water evacuated from the well prior to sampling: $10 \mathrm{gal}$

ANALYSES

F Analyte

Rosuft

2 Aluminum, total recoverable

: Arsenic, total recoverable

237
$<8.00$
20.1
$<25.0$
$3.06 E-08 \pm 1.43 E-07 \quad$ UI
$1.03 E-08 \pm 1.41 E-08$ UI

$-1.93 \mathrm{E}-10 \pm 1.88 \mathrm{E}-10 \mathrm{UI}$

$230 \mathrm{E}-10 \pm 3.22 \mathrm{E}-10$ U

$7.79 \mathrm{E}-09 \pm 3.44 \mathrm{E}-08$ U
$.68 \mathrm{E}-10+1.88 \mathrm{E}-09$

$9.56 \mathrm{E}-10+1.95 \mathrm{E}-09$

$8.50 E-10+2.52 E-09$
9.75E- $10 \pm 8.19 \mathrm{E}-10$

$2.59 \mathrm{E}-09 \pm 4.47 \mathrm{E}-10$

$8.52 E-09 \pm 3.05 E-08$ U
$5.55 E-09+1.79 E-08$ U

$2.40 \mathrm{E}-10 \pm 2.13 \mathrm{E}-09 \mathrm{U}$

$8.92 E-09+1.22 E-09$

2.12E-09.9.37E-09

$-5.34 E-09 \pm 3.28 E-09$ UI

-

$-1.23 \mathrm{E}-11 \pm 2.48 \mathrm{E}-11 \mathrm{UI}$

$1.09 E-10 \pm 1.38 E-10$

$-4.79 \mathrm{E}-10+2.37 \mathrm{E}-09 \mathrm{U}$

$1.05 E-09 \pm 4.05 E-09$ UI
$7.97 \mathrm{E}-09 \pm 9.46 \mathrm{E}-10$
$8.94 \pm 1.04 \mathrm{E}-09$

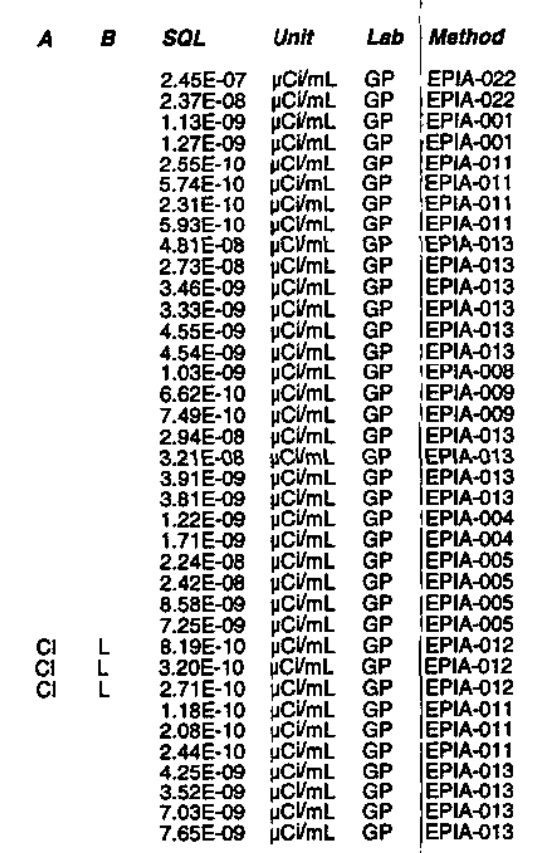

(1)

.

Time: 9:00

Airtirente $16^{\circ} \mathrm{C}$

Total alkalinity (as Cacos); $1 \mathrm{mgh}$
Phenolphthalein alkalinity: $0 \mathrm{mg} /$

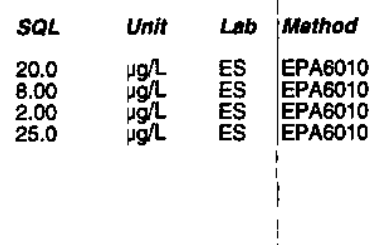


Well HR3 14DU collected on 05/21/98 (cont.)

\begin{tabular}{|c|c|c|c|c|c|c|c|c|}
\hline F Analyte & Result & $\boldsymbol{R}$ & A & $B$ & SOL & Unit & Lab & Method \\
\hline 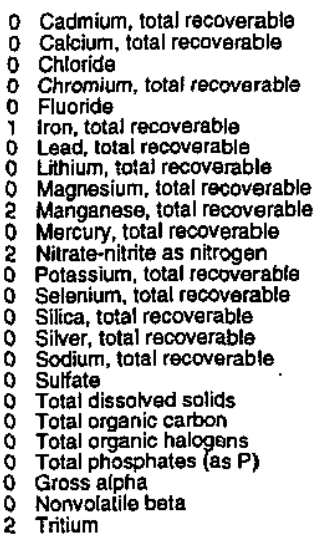 & $\begin{array}{l}<.00 \\
337 \\
4,040 \\
2.40 \\
<100 \\
281 \\
<.00 \\
<5.00 \\
250 \\
126 \\
<0.470 \\
16,600 \\
353 \\
<5.00 \\
2,890 \\
<.00 \\
36,200 \\
6.040 \\
127,000 \\
<1,000 \\
23.3 \\
<10.0 \\
1.58 E-09 \times 8.20 E-10 \\
2.46 E-08 \pm 2.16 E-09 \\
3.41 E-05 \pm 1.90 E-06\end{array}$ & $\begin{array}{l}\mathrm{J} \\
\mathrm{j}\end{array}$ & $\begin{array}{l}V \\
E \\
L\end{array}$ & $L$ & $\begin{array}{l}2.00 \\
50.0 \\
500 \\
3.00 \\
100 \\
200 \\
5.00 \\
5.00 \\
50.0 \\
3.00 \\
0.200 \\
1,000 \\
400 \\
5.00 \\
100 \\
2.00 \\
100 \\
5,000 \\
1.000 \\
1.000 \\
120 \\
10.0 \\
1.10 E-09 \\
2.42 E-09 \\
1.48 E-06\end{array}$ & 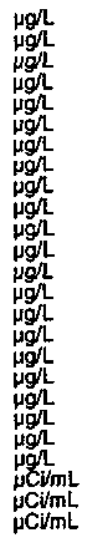 & $\begin{array}{l}\text { ES } \\
\text { ES } \\
\text { ES } \\
\text { ES } \\
\text { ES } \\
\text { ES } \\
\text { ES } \\
\text { ES } \\
\text { ES } \\
\text { ES } \\
\text { ES } \\
\text { ES } \\
\text { ES } \\
\text { ES } \\
\text { ES } \\
\text { ES } \\
\text { ES } \\
\text { WA } \\
\text { ES } \\
T M \\
T M \\
T M\end{array}$ & $\begin{array}{l}\text { EPAG010 } \\
\text { EPA6010 } \\
\text { EPA9056 } \\
\text { EPA6010 } \\
\text { EPA9214 } \\
\text { EPA6010 } \\
\text { EPAG010 } \\
\text { EPA6010 } \\
\text { EPAG010 } \\
\text { EPAG010 } \\
\text { EPA7470 } \\
\text { EPA353.2 } \\
\text { EPA6010 } \\
\text { EPA6010 } \\
\text { EPA6010 } \\
\text { EPA6010 } \\
\text { EPA6010 } \\
\text { EPA9056 } \\
\text { EPA160.1 } \\
\text { EPA9060M } \\
\text { EPA9020B } \\
\text { EPA365.1 } \\
\text { EPA900. M } \\
\text { EPA900.0M } \\
\text { EPA906.0M }\end{array}$ \\
\hline
\end{tabular}

\section{WELL HR3 15DU}

MEASUREMENTS CONDUCTED IN THE FIELD

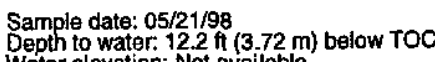

$$
\text { Water ol }
$$$$
\text { (1) } 4.8
$$$$
\text { ation: Not available }
$$$$
\text { . conductance: } 200 \mu \mathrm{S} / \mathrm{cm}
$$$$
\text { Water evacuated from the well prior to sampling: } 17 \mathrm{gal}
$$

ANALYSES

\begin{tabular}{|c|c|c|c|c|c|c|c|c|}
\hline Analyte & & $\boldsymbol{A}$ & A & 8 & SQL & Unit & Lab & Method \\
\hline 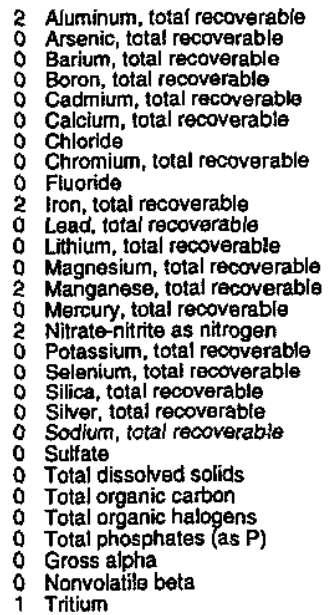 & $\begin{array}{l}534 \\
<8.00 \\
14.4 \\
<25.0 \\
1.10 \\
1, .200 \\
5,060 \\
2.80 \\
<100 \\
3,860 \\
<5.00 \\
<5.00 \\
827 \\
194 \\
<0.200 \\
22,400 \\
488 \\
<5.00 \\
3.700 \\
<2.00 \\
31,500 \\
<5,000 \\
163.000 \\
<1.000 \\
<100 \\
<10.0 \\
7.34 E-09 \pm 1.42 E-09 \\
1.11 E-09+1.53 E-09 \\
1.02 E-05 \pm 1.26 E-06\end{array}$ & $\mathrm{~s}$ & $\stackrel{L}{E}$ & & $\begin{array}{l}20.0 \\
8.00 \\
2.00 \\
25.0 \\
2.00 \\
50.0 \\
500 \\
3.00 \\
100 \\
20.0 \\
5.00 \\
5.00 \\
50.0 \\
3.00 \\
0.200 \\
2.000 \\
400 \\
5.00 \\
100 \\
2.00 \\
100 \\
5.000 \\
1.000 \\
1,000 \\
120 \\
10.0 \\
9.10 E-10 \\
1.81 E .09 \\
1.47 E .06\end{array}$ & 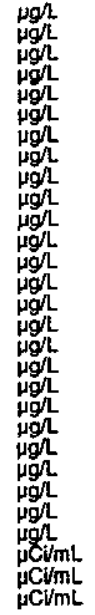 & $\begin{array}{l}\text { ES } \\
\text { ES } \\
\text { ES } \\
\text { ES } \\
\text { ES } \\
\text { ES } \\
\text { ES } \\
\text { ES } \\
\text { ES } \\
\text { ES } \\
\text { ES } \\
\text { ES } \\
\text { ES } \\
\text { ES } \\
\text { ES } \\
\text { ES } \\
\text { ES } \\
\text { ES } \\
\text { ES } \\
\text { WA } \\
\text { ES } \\
\text { TM } \\
\text { TM }\end{array}$ & $\begin{array}{l}\text { EPAG010 } \\
\text { EPAG010 } \\
\text { EPA6010 } \\
\text { EPA6010 } \\
\text { EPA6010 } \\
\text { EPA6010 } \\
\text { EPA9056 } \\
\text { EPA6010 } \\
\text { EPA9214 } \\
\text { EPA6010 } \\
\text { EPA6010 } \\
\text { EPA6010 } \\
\text { EPA6010 } \\
\text { EPA6010 } \\
\text { EPA7470 } \\
\text { EPA353.2 } \\
\text { EPA6010 } \\
\text { EPA6010 } \\
\text { EPA6010 } \\
\text { EPA6010 } \\
\text { EPA6010 } \\
\text { EPA9056 } \\
\text { EPA160.1 } \\
\text { EPA9060M } \\
\text { EPA9020B } \\
\text { EPA365.1 } \\
\text { EPA900.0M } \\
\text { EPA900.0M } \\
\text { EPA906.0M }\end{array}$ \\
\hline
\end{tabular}

Time: 8:07

Water temperature: $16^{\circ} \mathrm{C}$

Air temperature: $20.8^{\circ} \mathrm{C}$. $0 \mathrm{mg}$

\section{WELL HSB 65}

MEASUREMENTS CONDUCTED IN THE FIELD

Sarnple date: $04 / 01 / 98$ (14.99 m) below TOC (a)

$\mathrm{pH}: 4.8$. conductance: $36 \mu \mathrm{S} / \mathrm{cm}$

is temperature: $22^{\circ} \mathrm{C}$

Air temperature: $22,8 \mathrm{C}$ latinity (as $\mathrm{CaCO}$ ): $6 \mathrm{mgh}$

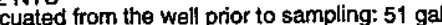

ANALYSES

\begin{tabular}{|c|c|c|c|c|c|c|c|c|}
\hline Anajyte & Rosult & A & A & B & SOL & Unit & Lab & Method \\
\hline $\begin{array}{l}\text { Mercury, total recoverable } \\
\text { Nitrate-nitrite as nitrogen } \\
\text { pH } \\
\text { Specitic conductance } \\
\text { Gross alpha } \\
\text { Nonvolatile beta } \\
\text { Tritium }\end{array}$ & $\begin{array}{l}<0.200 \\
810 \\
51.04 \\
33.0 \\
4.37 \mathrm{E}-10 \pm 4.22 \mathrm{E}-10 \\
1.17 \mathrm{E}-09 \pm 6.37 \mathrm{E}-10 \\
2.11 \mathrm{E}-05 \pm 8.77 \mathrm{E}-07\end{array}$ & J & $\begin{array}{l}0 \\
6\end{array}$ & L & $\begin{array}{l}0.200 \\
50.0 \\
0.00 \\
5.00 \\
7.94 E-10 \\
1.23 E-09 \\
5.93 E-07\end{array}$ & 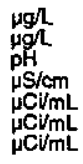 & $\begin{array}{l}G E \\
G E \\
G E \\
G E \\
G P \\
G P \\
G P\end{array}$ & $\begin{array}{l}\text { EPA7470 } \\
\text { EPA53.1 } \\
\text { EPA9045C } \\
\text { EPA9050 } \\
\text { EPIA-001 } \\
\text { EPA-01 } \\
\text { EPAA-002 }\end{array}$ \\
\hline
\end{tabular}

\section{WELL HSB 65A}

MEASUREMENTS CONDUCTED IN THE FIELD

Sample date: $04 / 13 / 98$
Depth to water: $101.05 \mathrm{ft}(30.8 \mathrm{~m})$ below TOC
Water elevation: $172.55 \mathrm{tt}(52.59 \mathrm{~m}) \mathrm{msl}$
$\mathrm{pH}: 8$

$\mathrm{SP}$ : 8 conductance: $200 \mu \mathrm{S} / \mathrm{cm}$

Water temperature: $22.5^{\circ} \mathrm{C}$

Total alkalinity (as CaCO3): $90 \mathrm{mg}$

Turbidity: O NTU

ANALYSES

\begin{tabular}{|c|c|c|c|c|c|c|c|c|}
\hline Analyte & Result & $\boldsymbol{A}$ & $A$ & B & SOL & Unte & Lab & Method \\
\hline 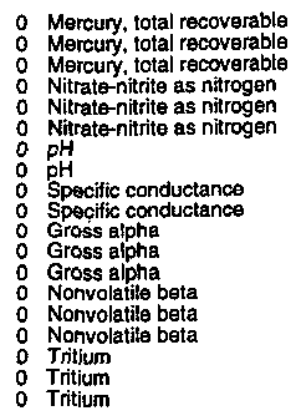 & 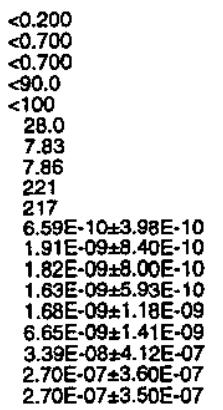 & $\begin{array}{l}\mathrm{J} \\
\mathrm{u} \\
\mathrm{u}\end{array}$ & $\begin{array}{l}Q \\
0 \\
6\end{array}$ & $\mathbf{L}$ & 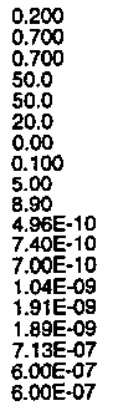 & 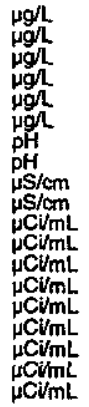 & $\begin{array}{l}G E \\
W A \\
W A \\
W E \\
G E \\
G A \\
W A \\
G E \\
W A \\
G E \\
W A \\
G P \\
T M \\
T M \\
G P \\
T M \\
T M \\
G P \\
T M \\
T M\end{array}$ & 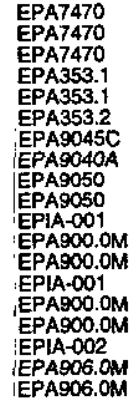 \\
\hline
\end{tabular}




\section{WELL HSB 65A'Replicate}

MEASUREMENTS CONDUCTED IN THE FIELD

Sample date: $04 / 13 / 98$
Depth to water: $101.05 \mathrm{ft}(30.8 \mathrm{~m})$ below TOC
Water alevation: $172.55 \mathrm{ft}(52.59 \mathrm{~m}) \mathrm{msl}$
o: 8

Sp. conductance: $200 \mu \mathrm{S} / \mathrm{cm}$

Water evacuated from the well prior to sampling: $147 \mathrm{gal}$

ANALYSES

\begin{tabular}{|c|c|c|c|c|c|c|c|c|}
\hline Analyte & Result & $\boldsymbol{B}$ & A & $B$ & SQL & Unit & $L a b$ & Method \\
\hline $\begin{array}{l}\text { Mercury, total recoverable } \\
\text { Nitrate-nitrite as nitrogen } \\
\text { pH } \\
\text { Specitic conductance } \\
\text { Gross alpha } \\
\text { Nonvolatite beta } \\
\text { Tritium }\end{array}$ & $\begin{array}{l}<0.200 \\
-90.0 \\
8.01 \\
220 \\
1.10 E-09 \pm 5.70 E-10 \\
1.50 E-09 \pm 6.42 E-10 \\
2.03 E-07 \pm 4.18 E-07\end{array}$ & $\mathbf{J}$ & $\begin{array}{l}V \\
Q \\
6\end{array}$ & L & $\begin{array}{l}0.200 \\
50.0 \\
0.00 \\
5.00 \\
7.35 E-10 \\
1.10 E-09 \\
7.12 E-07\end{array}$ & $\begin{array}{l}\mu g / \mathrm{L} \\
\mu \mathrm{g} / \mathrm{L} \\
\mathrm{pH} \\
\mu \mathrm{S} / \mathrm{cm} \\
\mu \mathrm{CH} / \mathrm{mL} \\
\mu \mathrm{CV} / \mathrm{mL} \\
\mu \mathrm{Cu} / \mathrm{mL}\end{array}$ & 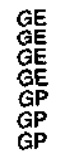 & $\begin{array}{l}\text { EPA7470 } \\
\text { EPA353.1 } \\
\text { EPA9045C } \\
\text { EPA950 } \\
\text { EPIA-001 } \\
\text { FPA.-001 } \\
\text { EPIA.002 }\end{array}$ \\
\hline
\end{tabular}

\section{WELL HSB 65B}

MEASUREMENTS CONDUCTED IN THE FIELD

Sample date: $04 / 01 / 98$
Depth to water: $4.1 \mathrm{tt}$ (14.05 m) below TOC
Water elevation: $227.6 \mathrm{ft}(69.37 \mathrm{~m}) \mathrm{ms}$

Sp. conductance: $18 \mu \mathrm{S} / \mathrm{cm}$

Water evacuated from the well prior to sampling: $205 \mathrm{gal}$

ANALYSES

f Ansivte

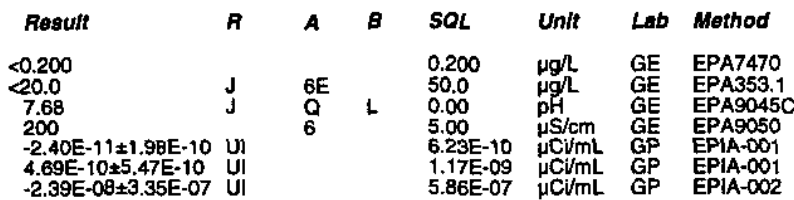

Mercury, total recoverable

$\mathrm{pH}$ Specific conductance

Gross atpha

\section{WELL HSB 65C}

MEASUREMENTS CONDUCTED IN THE FIELD

Sample date: $04 / 01 / 98$
Depth to water: $33.7 \mathrm{ft}(10.27 \mathrm{~m})$ below TOC

Water elevation: $239.9 \mathrm{Ht}(73.12 \mathrm{~m}) \mathrm{ms}$

Sp. conduclance: $60 \mu \mathrm{S} / \mathrm{cm}$

Wuter evacuated from the well prior to sampling: $56 \mathrm{gal}$

ANALYSES

\begin{tabular}{|c|c|c|c|c|c|c|c|c|}
\hline Analyte & Resuft & A & A & $B$ & SOL & Unit & Lab & Method \\
\hline $\begin{array}{l}\text { Mercury, total recoverable } \\
\text { Nitrate-nitrite as nitrogen } \\
\text { pH } \\
\text { Specitic conductance } \\
\text { Gross aloha } \\
\text { Nonvolatifle beta } \\
\text { Tritium }\end{array}$ & $\begin{array}{l}<0.200 \\
3.580 \\
4.86 \\
57.9 \\
1.70 \mathrm{E}-09 \pm 6.38 \mathrm{E}-10 \\
1.77 \mathrm{E}-09 \pm 7.07 \mathrm{E}-10 \\
1.21 \mathrm{E}-04 \pm 2.02 \mathrm{E}-06\end{array}$ & $J$ & $\begin{array}{l}6 \\
0 \\
6 \\
c\end{array}$ & L & $\begin{array}{l}0.200 \\
100 \\
0.00 \\
5.00 \\
5.89 E-10 \\
1.27 E-09 \\
6.23 E-07\end{array}$ & 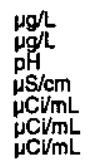 & $\begin{array}{l}G E \\
G E \\
G E \\
G E \\
G P \\
G P \\
G P\end{array}$ & $\begin{array}{l}\text { EPA7470 } \\
\text { EPA353.1 } \\
\text { EPA9045C } \\
\text { EPA9050 } \\
\text { EPAA-001 } \\
\text { EPLA-001 } \\
\text { EPIA-002 }\end{array}$ \\
\hline
\end{tabular}

Total alkalinity (as CaCO3): $90 \mathrm{mg} /$

Water temperature: $20^{\circ} \mathrm{C}$

Water temperature: $21^{\circ} \mathrm{C}$

Air temperature: $23.6^{\circ} \mathrm{C}$
Total alkalinity (as CaCO3) $2 \mathrm{mgh}$
Phenolphth $1.21 \mathrm{E}-04 \pm 2.02 \mathrm{E}-06$

\section{WELL HSB 66}

MEASUREMENTS CONDUCTED IN THE FIELD

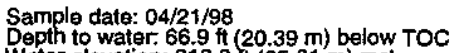

Water glevation: $213.3 \mathrm{ht}(65.01 \mathrm{~m}) \mathrm{ms}$

pH: 4.9

Water temperature: $22.5^{\circ} \mathrm{C}$

Tp. conductance: $30 \mu \mathrm{S} / \mathrm{cm}$

Water evacuated from the well prior to sampling: $39 \mathrm{ga}$ ANALYSES

$F$ Analyte

: Mercury, total recoverable

$\mathrm{pH}$ Specitic conductance

Gross alpha

1 Tritium

\section{WELLL HSB 67}

MEASUREMENTS CONDUCTED IN THE FIELD

Sample date: $04 / 06 / 98$

Sample date: $04 / 06 / 98$
Depth to water: $26.95 \mathrm{ft}(8.21 \mathrm{~m})$ below TOC
Water elevation: $210.85 \mathrm{ft}(64.27 \mathrm{~m}) \mathrm{ms}$ |
pH: 3.6

Total alkalinity (as CaCO3) $65 \mathrm{mg} /$
Phenolphthalein alkalinity: $0 \mathrm{mg} /$

Sp. conductance: $120 \mu \mathrm{S} / \mathrm{cm}$

Water evacuated from the well prior to sampling: $40 \mathrm{gal}$

ANALYSES

F Analyto

2 Mercury, total recoverable

Specific conductanco

2 Gross alpha

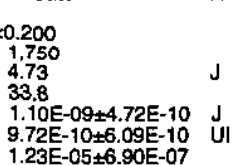

J

$$
\begin{aligned}
& \mathrm{v} \\
& \mathrm{Q} \\
& \mathrm{o}
\end{aligned}
$$

\section{Time: 14:34}

Air temperatureture: $21.3^{\circ} \mathrm{C}$

Total alkalinity (as Caco3): $1 \mathrm{mg} /$
Phenolphthalein alkalinity: $0 \mathrm{mg} / \mathrm{L}$

Result
2.40
9,600
4.11
108
$1.83 \mathrm{E}-08 \pm 1.97 \mathrm{E}-09$
$8.3 \mathrm{~B}-07 \pm 8.60 \mathrm{E}-09$
$2.53 \mathrm{E}-04 \pm 2.89 \mathrm{E}-06$
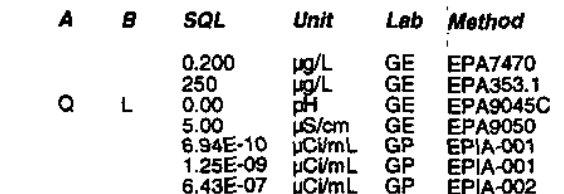

Time: 14:41

Total alkalinity (as Caco3): $0 \mathrm{mg} / \mathrm{h}$
Phenolphthalein alkalinity: $0 \mathrm{mg}$.

\section{WELL HSB 68}

MEASUREMENTS CONDUCTED IN THE FIELD

Sample date: 04/01/98

Depth to water: $26.55 \mathrm{ft}(8.09 \mathrm{~m})$ below TOC

Water

Sp.conductance: $120 \mu \mathrm{S} / \mathrm{cm}$

Turbidity: $1 \mathrm{NTU}$
Water evacuated from the well prior to sampling: $41 \mathrm{gal}$ ANALYSES

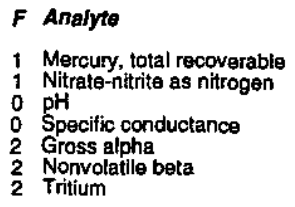




\section{WELL HSB 68A}

MEASUAEMENTS CONDUCTED IN THE FIELD

Sample date: $04 / 02 / 98$ (23.25 m) below TOC

Wepth to water: $76.29 \pi t(23.25 \mathrm{~m})$ below

$\mathrm{pH}: 7.4$

p. conductance: $110 \mu \mathrm{S} / \mathrm{cm}$

Water evacuated from the well prior to sampling: 191 gal

ANALYSES

$F$ Ansivto

Norcury, total recoverable

$\mathrm{pH}$ Specific conductance

Gross alpha
Gross alpha

Nonvolatile beta

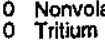

\section{WELL HSB 68B}

MEASUREMENTS CONDUCTED IN THE FIELD

Sample date: $04 / 02 / 98$
Depth to water: $31.05 \mathrm{ft}(9.46 \mathrm{~m})$ below TOC
Water elevation: $218.95 \mathrm{ft}(66.74 \mathrm{~m}) \mathrm{ms}$

$\mathrm{H}: 7.9$

. conductance: $210 \mu \mathrm{S} / \mathrm{cm}$

Water evacuated from the well prior to sampling: 138 gal

ANALYSES

$F$ Anasyte

No Mircury, total recoverable

0 Specitic conductance

Gross alpha

1 Tritium

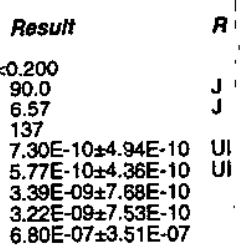

\begin{tabular}{|c|c|c|c|c|c|}
\hline $\boldsymbol{A}$ & B & SQL & Unit & Lab & Mathod \\
\hline a & L & $\begin{array}{l}0.200 \\
50.0 \\
0.00 \\
5.00 \\
8.13 E-10 \\
7.27 E-10 \\
1.23 E-09 \\
1.26 E-09 \\
5.60 E-07\end{array}$ & 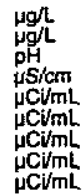 & $\begin{array}{l}G E \\
G E \\
G E \\
G E \\
G P \\
G P \\
G P \\
G P \\
G P\end{array}$ & $\begin{array}{l}\text { EPA7470 } \\
\text { EPA353.1 } \\
\text { EPA9045C } \\
\text { EPA9050 } \\
\text { EPIA-001 } \\
\text { EPIA-001 } \\
\text { EPIA-001 } \\
\text { EPIA-001 } \\
\text { EPIA-002 }\end{array}$ \\
\hline
\end{tabular}

Weter t.39 Air temperature: $30.9^{\circ} \mathrm{C}$ Total alkalinity (as $\mathrm{CaCO}$ ): $51 \mathrm{mg} /$

WELL HSB 68C

MEASUREMENTS CONDUCTED IN THE FIELD

Sample date: $04 / 28 / 98$.

Water elevation: $220 \mathrm{ft}(67.06 \mathrm{~m}) \mathrm{msl}$

$\mathrm{HH}: 5.6$
$\mathrm{Hp}$. conductance: $140 \mu \mathrm{S} / \mathrm{cm}$

Water evacuated from the well prior to sampling: $1 \mathrm{ga}$

ANALYSES

$F$ Analyte

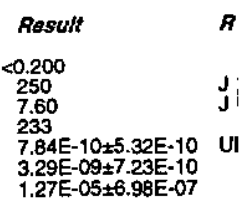

UI

Time: 11:36

Water temperature: $21.1^{\circ} \mathrm{C}$

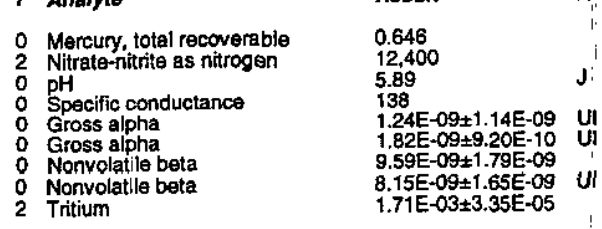
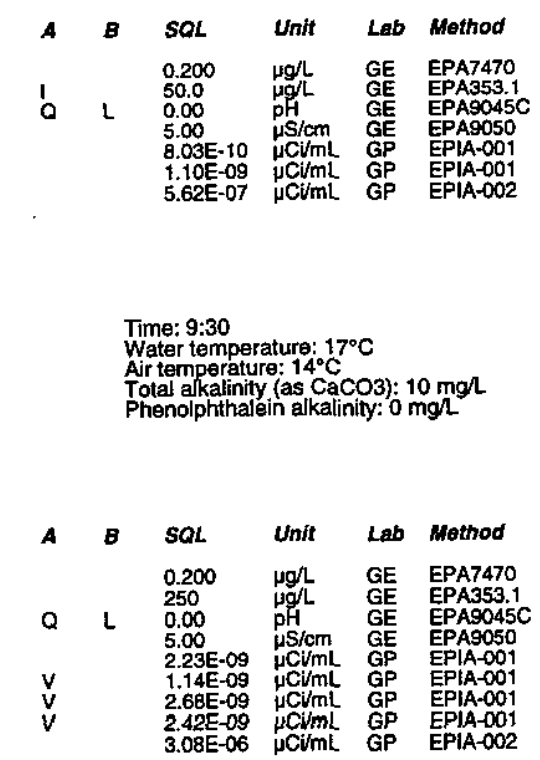

Time: 9:30

Total alkalinity (as Caco3): $10 \mathrm{mgl}$
Total alkalinity (as CaCO3): $92 \mathrm{mg} /$

\section{WELL HSB 69}

MEASUREMENTS CONDUCTED IN THE FIELD

Sample date: $04 / 01 / 98$
Depth to water: $15.5 \mathrm{ft}(4.72 \mathrm{~m})$ below TOC

Water elevation: $220.5 \mathrm{tt} / 67.21$
ph: 4.4
Sp. conductance: $52 \mu \mathrm{S} / \mathrm{cm}$

Water evacuated from the well prior to sampling: $\mathbf{4 3}$ gal

ANALYSES

$F$ Analyte

Resuth

- Mercury, total recoverable

Specific conductanco

Nonvolatile bete

2 Tritium

0.200
2,560

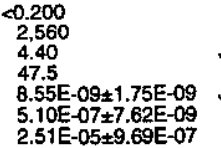

R

$L$

Time: 12:11

Total alkalinity (as CaCO3): $0 \mathrm{mg} / \mathrm{h}$

\section{WELL HSB 69A}

MEASUREMENTS CONDUCTED IN THE FIELD

$F$ Analyte

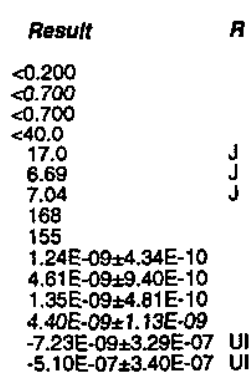

ermperature: $17^{\circ} \mathrm{C}$

WELL HSB 69A Replicate

conductance: $140 \mu \mathrm{S} / \mathrm{cm}$

$F$ Analyte
Sample date: 04/20/98

(1)

pH: 7.1

W. conductance: $140 \mu \mathrm{S} / \mathrm{cm}$

Water evacuated from the well prior to sampling: $159 \mathrm{gal}$

ANALYSES

- Mercury, total recoverable

Mercury, total recoverabie

Nitrate-rititite as nitrogen
Nitrate-nitrite as nitrogen

$0 \mathrm{pH}^{\mathrm{pH}}$

Specific conductance

Gross appha

Gross alpha

Nonvolatilita beta

O: Tritium

MEASUREMENTS CONDUCTED IN THE FIELD

Sample date: 04/20/98

er. $63.05 \mathrm{ft}(19.22 \mathrm{~m})$ below TOC

Water 7.1

Water evacuated from the well prior to sampling: $159 \mathrm{gal}$

ANALYSES

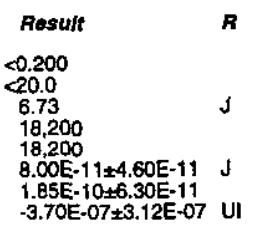

$\int_{3}$

Time: 13:12

Total alkalinity (as CaCO3): $59 \mathrm{mg} /$

Mercury, total recoverable

$\begin{array}{ll}0 & \mathrm{pH} \\ 2 & \text { Specific conductance } \\ 2 & \text { Specific conductance }\end{array}$

Gross alpha

$\begin{array}{ll}0 & \text { Nonvolatile beta } \\ 0 & \text { Trítium }\end{array}$
$1.85 E-10 \pm 6.30 E-11$
$-3.70 E-07 \pm 3.12 E-07$

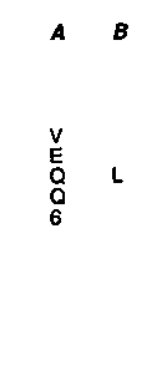

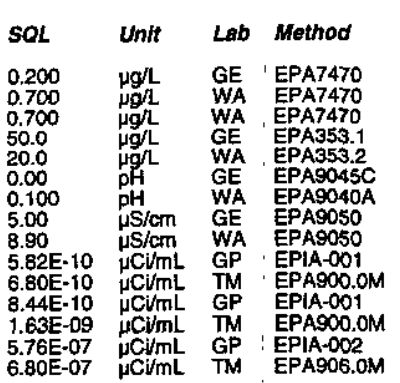

Time: 13:12

mperature: $19.8^{\circ} \mathrm{C}$

Artemperature: $26^{\circ} \mathrm{C} C \mathrm{C}$ ) $59 \mathrm{mg} \Omega$ 


\section{WELL HSB 70}

MEASUREMENTS CONDUCTED IN THE FIELD

Sample date: $04 / 07 / 98$
Depth to water: $14.86 \mathrm{ft}(4.53 \mathrm{~m})$ below TOC
Water elevation: $227.94 \mathrm{ft}(69.48 \mathrm{~m}) \mathrm{msl}$

H: 5.2

conductance: $64 \mu \mathrm{S} / \mathrm{cm}$

Water evacuated from the well prior to sampling: $48 \mathrm{gal}$ ANALYSES

\begin{tabular}{|c|c|c|c|c|c|c|c|c|}
\hline Analyte & Rosuft & $\boldsymbol{B}$ & A & B & SQL & Unit & Lab & Method \\
\hline $\begin{array}{ll}0 & \text { Mercury, total recoverable } \\
0 & \text { Nitrate-nitrite as nitrogen } \\
0 & \text { pH } \\
0 & \text { Specific conductance } \\
0 & \text { Gross aloha } \\
0 & \text { Nonvolatila beta } \\
2 & \text { Tritium }\end{array}$ & $\begin{array}{l}<0.200 \\
230 \\
4.96 \\
64.7 \\
7.38 \mathrm{E}-10 \pm 4.15 \mathrm{E}-10 \\
1.31 \mathrm{E}-08 \pm 1.13 \mathrm{E}-09 \\
2.05 \mathrm{E}-05 \pm 8.95 \mathrm{E}-07\end{array}$ & J & 1 & H & $\begin{array}{l}0.200 \\
50.0 \\
0.00 \\
5.00 \\
5.61 E-10 \\
9.87 E-10 \\
6.21 E-07\end{array}$ & $\begin{array}{l}\mu g / \mathrm{L} \\
\mu g / \\
p \mu / \\
\mu \mathrm{S} / \mathrm{mm} \\
\mu \mathrm{CimL} \\
\mu \mathrm{CimL} \\
\mu \mathrm{CimL}\end{array}$ & $\begin{array}{l}G E \\
G E \\
G G \\
G E \\
G P \\
G P \\
G P\end{array}$ & $\begin{array}{l}\text { EPA7470 } \\
\text { EPA35.1 } \\
\text { EPA9045C } \\
\text { EPA950 } \\
\text { EPIA-001 } \\
\text { EPA-001 } \\
\text { EPIA-002 }\end{array}$ \\
\hline
\end{tabular}

\section{WELL HSB 70C}

MEASUREMENTS CONDUCTED IN THE FIELD

\section{Sample date: $05 / 04 / 98$
Depth to water: $16.7 \mathrm{ft}(5.09 \mathrm{~m})$ below TOC
Water elevation: $226.4 \mathrm{ti}(69.01 \mathrm{~m}) \mathrm{ms}$ \\ $\mathrm{g} \mathrm{H}$. 6.4 conductance: $360 \mu \mathrm{S} / \mathrm{cm}$}

Wuter evacuated from the well prior to sampling: $91 \mathrm{gal}$ ANALYSES

F Analyto
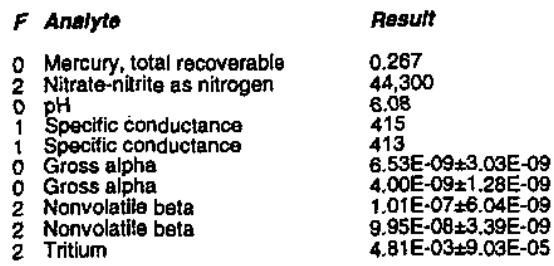

\section{WELL HSB 71}

MEASUREMENTS CONDUCTED IN THE FIELD

Sample date: $04 / 06 / 98$
Depth to watior: $14.2 \mathrm{tt}(4.33 \mathrm{~m})$ below TOC
Water elevation: $227.2 \mathrm{Ht}(69.25 \mathrm{~m}) \mathrm{msl}$

Water elevation: $227.2 \mathrm{ft}$ (69.
$\mathrm{gH}: 4.7$
$\mathrm{H}$. conductance: $24 \mu \mathrm{S} / \mathrm{cm}$

Spronductince: $24 \mu \mathrm{S} / \mathrm{cm}$

Water evacuated from the well prior to sampling: $60 \mathrm{gal}$ ANALYSES

$F$ Analyto

- Mercury, total recoverable

o $\mathrm{pH}$ Specific conductance

O Nonvolatile beta
Time: 7:37

Air temperature $9^{\circ} \mathrm{C}{ }^{14.2^{\circ} \mathrm{C}}$ Total alkalinity (as CaCO3): 1 mg/
Phenolphthalein alkalinity) $0 \mathrm{mg} /$.
Total akalinity (as CaCOS): $16 \mathrm{mg} /$
Phenolphthalein alkalinity: $\mathrm{mgh}^{2}$

Time: $11: 11$
Water temperature: $18.7^{\circ} \mathrm{C}$
Air temperature: $36.1^{\circ} \mathrm{C}$

Total alkalinity, (as CaCo3): $1 \mathrm{mg} /$

\section{WELL HSB 71C}

MEASUREMENTS CONDUCTED IN THE FIELD

Sample date: 04/21/98

Sample date: $04 / 21 / 98$
Depth to water: $15.05 \mathrm{ft}(4.59 \mathrm{~m})$ below TOC Water ele wat

Sp: conductance: $240 \mu \mathrm{S} / \mathrm{cm}$

Water evacuated from the well prior to sampling: $1 \mathrm{gal}$

ANALYSES

F Analyto

N Mercury, total recoverable

2 Nitrate-nitrite as nitrogen

1 Specific conductance

1 Nonvolatile bela

Tritium

WELLL HSB 83A

MEASUREMENTS CONDUCTED IN THE FIELD

Sample date: 04/01/98

Water elevation: 174.52 ft $(53.19 \mathrm{~m}) \mathrm{ms}$

$\mathrm{HH}: 7.4$

Water temperature: $19.3^{\circ}$

Sp. conductance: $150 \mu \mathrm{S} / \mathrm{cm}$

Water evacuated from the well prior to sampling: $150 \mathrm{gal}$

ANALYSES

$F$ Analyte

o Mercury, total recoverable

Speclic conductance

Nonvolatile beta

Trittum

$\begin{array}{ll}\text { Result } & \text { A } \\ 0.200 & \\ 29,300 & \\ 29.500 & \\ 7.44 & \mathrm{~J} \\ 346 & \mathrm{U} \\ 7.96 \mathrm{E}-0.09+1.97 \mathrm{E}-09 & \mathrm{UI} \\ 3.32 \mathrm{E}-08+2.86 \mathrm{E}-09 & \mathrm{UI} \\ 3.32 \mathrm{E}-03 \pm 6.43 \mathrm{E}-05 & \mathrm{~J}\end{array}$

\section{Time: $14: 10$}

Arrem $18.4^{\circ} \mathrm{C}$

Nrtal alkalinity (as CaCo3): 23 mgh

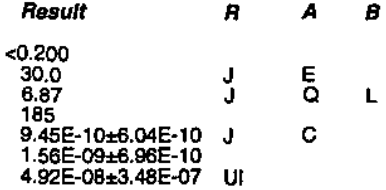

- SOL

Unit Lab Method

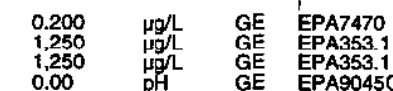

5.00 37E-09 $\mu \mathrm{HS} / \mathrm{cm}$ GE $\mathrm{GE}$ GPA9050

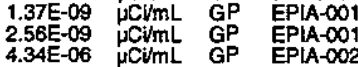

Time: 11:09 Wir temperaturture: $20.3^{\circ} \mathrm{C}$

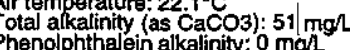

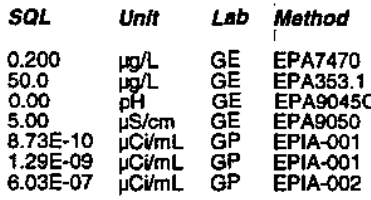

\section{WELL HSB 83B}

MEASUREMENTS CONDUCTED IN THE FIELD

Sample date: 04/01/98

Depth to water: $11.24 \mathrm{ft}(3.43 \mathrm{~m})$ below TOC

gH: 5.9 convetance: $80 \mu \mathrm{S} / \mathrm{cm}$

Water evacuated from the well prior to sampling: $160 \mathrm{gal}$ ANALYSES

\section{F Analyte}

\begin{tabular}{|c|c|c|}
\hline & $\begin{array}{l}\text { Mercury, total recoverable } \\
\text { Nitrate-nitrite as nitrogen } \\
\text { pH } \\
\text { Specific conductance } \\
\text { Gross alpha } \\
\text { Nonvolatile beta } \\
\text { Tritium }\end{array}$ & $\begin{array}{l}<0.200 \\
40.0 \\
6.64 \\
109 \\
-2.50 \mathrm{E}-11+2.38 \mathrm{E}-1 \\
1.02 \mathrm{E}-0.9 \mathrm{9}+2.20 \mathrm{E}-10 \\
1.34 \mathrm{E}-06 \pm 4.05 \mathrm{E}-07\end{array}$ \\
\hline
\end{tabular}

Time: 10:05

Wir tempermerature: $19.9^{\circ} \mathrm{C}$

Total alkalinity (as CaCOJ): $30 \mathrm{mgl}$
Phenolphthalein alkalinity: $0 \mathrm{mg} / \mathrm{L}$

$\begin{array}{ll}A & B \\ E & \\ Q & 1\end{array}$

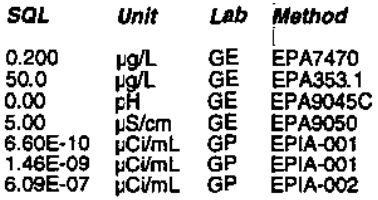


WELL HSB 85A

MEASUREMENTS CONDUCTED IN THE FIELD

Sample date: $04 / 01 / 98 \mathrm{ft}(37.95 \mathrm{~m})$ below TOC

Water 6 ole
pH: 6.7
Sp. cond

p. conductance: $130 \mu \mathrm{S} / \mathrm{cm}$

Water evacuated from the well prior to sampling: 175 gal

ANALYSES

$F$ Analyte

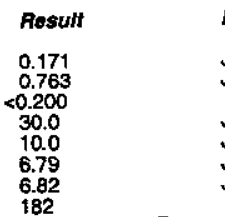

Cadmium, total recoverable Mercury, total recoverable
Nitrate-nitrite as nitrogen pH $\mathrm{PH}$ Nonvolatile bet

O Tritium

\section{$9.10 \mathrm{E}-10 \pm 6.65 \mathrm{E}-10$}

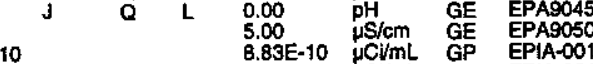
$2.20 E-09 \pm 8.45 E-10$
$2.17 \mathrm{E}-07 \pm 3.29 \mathrm{E}-07$ UIJ I L $\begin{aligned} & 1.45 \mathrm{E}-09 \\ & 5.58 \mathrm{E}-07\end{aligned}$

\section{WELL HSB 85A}

MEASUREMENTS CONDUCTED IN THE FIELD

Sample date: $04 / 20 / 98$ fit $(37.89 \mathrm{~m})$ below TOC Water $\theta$

$\mathrm{HH}: 5.9$

Sp. conductance: $160 \mu \mathrm{S} / \mathrm{cm}$

Water evacuated from the well prior to sampling: $166 \mathrm{gal}$

ANALYSES

$F$ Anatyto

: Antimony, total recoverable

Arsenic, total recoverable

Benzen

Boron, total recoverable

Bromodichloromethane

Bromoform

Bromoform

Bromomethane

Gromomethane

Cadmium, total recoverabla

Carbon tetrachloride

Chlorobenzene

Chloroesthan

Chloroethane Chloroethene (Vinyl chloride) Chloroethene Vinyl chlorid 2-Chloroethyl viny other 2-Chloroethyl vinyi ether Chloroform

Chororm
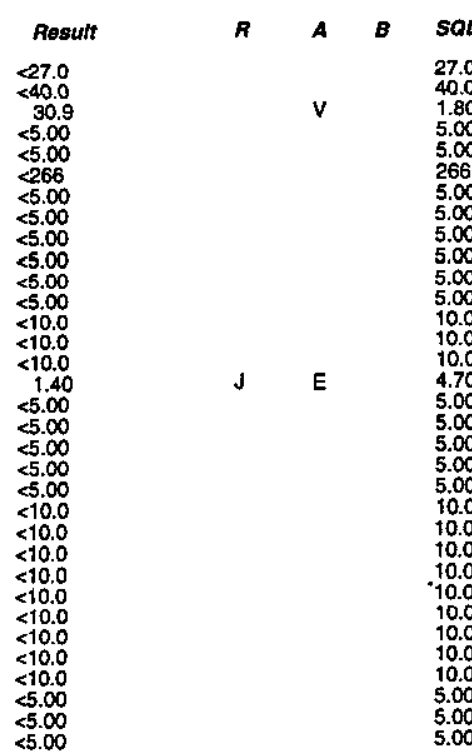

Well HSB 85A collected on 04/20/98 (cont.)

$F$ Analyte

Time: 14:14

Phenolphthalein alkalinity: $0 \mathrm{mgh}^{2}$

: Chlorometh

Chromium, total recoverable

Copper, total recoverab

Dibromochloromethane

Dibromochiloromethan

1,i-Dichloroethane

1.2-Dichloroethane

1.1-Dichlorouthana

1,2-Dichlorosthylen

1,2-Dichloroethylen

Dichloromethane

1,2-Dichloropropane

1,2-Dichloropropane

cis-1,3-Dichioropropene
cis: 1,3 -Dithloropropene

cis-1,3-Dichloropropene
trans-1,3-Dichloropropen

trans-1,3-Dichloropropene
trans-1,3-Dichloropropen

Ethylberzzene

Ethybenzene
Lead, total recoverable

Lithium, total recoverable

Nickel, total recoverable

Phenols

Selenium, total racoverable
Silver, total recoverable

Sulfate i, Tetrachloroethane

1.,

Tetrachloroethylene

Tetrachloroethylene

Tin, total recoverable

Toluene

Toluene

Total organic carbon

Total organic carbon

Total organic halogens

1,1,2-Trichloroothan

i, 2. Trichlorethan

Trichloroethylene

Trichloroethylene

Trichlorofluoromethane

xylenes

Xylenes

Zinc, total recoverable

Carbon-14
$<10.0$

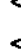

$<5.00$
$<5.00$

$<.00$
$<5.00$
$<5.00$

$<5.00$
$<5.00$
$<5.00$

$<5.00$
$<5 . \infty$

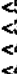

$<4.40$
$<5.00$
$<5.00$
$<5.00$
5.00
5.00
5.00
5.00
55.00
45.00
5.00

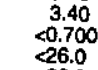

26.0
$<36.2$
$<36.2$
$<66.0$
$<5.00$

5.890
5.00
55.00

$<5.00$
$<5.00$
$<5.00$
$<5.00$

$<70.0$
$<5.00$
$<5.00$
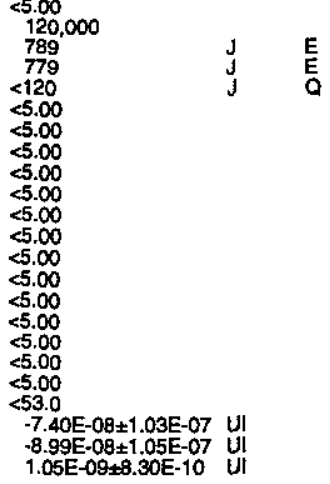

$-8.99 \mathrm{E}-08+1.05 \mathrm{E}-07$
$1.05 \mathrm{E}-09 \pm 8.30 \mathrm{E}-10$

AnaLrical

ESH-EMS-980569 
Well HSB 85A collected on 04/20/98 (cont.)

\begin{tabular}{|c|c|c|c|c|c|c|c|c|}
\hline Anajyte & Result & $\boldsymbol{A}$ & A & B & SQL & Unit & $L A b$ & Mothod \\
\hline $\begin{array}{ll}0 & \text { Gross alpha } \\
0 & \text { Nonvolatila beta } \\
0 & \text { Nonvolatile beta } \\
0 & \text { Radium, total alpha-emitting } \\
0 & \text { Radium, total alpha-emitting } \\
0 & \text { Strontium-90 } \\
0 & \text { Strontium-90 } \\
0 & \text { Trítium } \\
0 & \text { Tritium }\end{array}$ & $\begin{array}{l}1.31 E-09 \pm 9.40 E-10 \\
1.95 E-09 \pm 1.06-09 \\
6.111-09 \pm 1.311-09 \\
1.30 E-10 \pm 2.70 E-10 \\
2.30 E-10 \pm 3.00 E-10 \\
4.00 E-11 \pm 7.70-10 \\
0.00 E+00 \pm 6.90 E-10 \\
2.20 E-07 \pm 3.40 E-07 \\
2.40 E-07 \pm 3.40 E-07\end{array}$ & 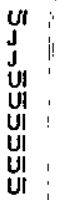 & $\begin{array}{l}x \\
x\end{array}$ & & $\begin{array}{l}1.37 E-09 \\
1.71 \mathrm{E}-09 \\
1.73 \mathrm{E}-09 \\
5.00 \mathrm{E}-10 \\
4.90 \mathrm{E}-10 \\
1.93 \mathrm{E}-09 \\
1.75 \mathrm{E}-09 \\
5.90 \mathrm{E}-07 \\
5.90 \mathrm{E}-07\end{array}$ & 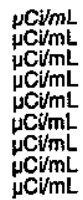 & $\begin{array}{l}\text { TM } \\
\text { TM } \\
\text { TM } \\
\text { TM } \\
T M \\
T M \\
T M \\
T M \\
T M\end{array}$ & $\begin{array}{l}\text { EPA900.OM } \\
\text { EPA900.OM } \\
\text { EPA900.0M } \\
\text { EPA903.0M } \\
\text { EPA903.0M } \\
\text { EMLSR02M } \\
\text { EMLSRO2M } \\
\text { EPA906.OM } \\
\text { EPA906.0M }\end{array}$ \\
\hline
\end{tabular}

\section{WELL HSB 85B}

MEASUREMENTS CONDUCTED IN THE FIELD

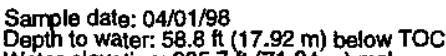
Wath to water: $58.8 \mathrm{ft}(17.92 \mathrm{~m})$ below

H: 8.1

Sp. conductance: $150 \mu \mathrm{S} / \mathrm{cm}$

Water evacuated from the well prior to sampling: $1 \mathrm{ga}$

ANALYSES

$F$ Analyte

- Mercury, total recoverable

1 Specific conductance

$\begin{array}{ll}0 & \text { Gross alpha } \\ 0 & \text { Nonvolatile bet } \\ & \end{array}$

0 Triturum

WELL HSB 85B

MEASUREMENTS CONDUCTED IN THE FIELD

Sample date: 04/20/98 $207 \mathrm{~m}$ ) below TOC

Wepth to water: $58.62 \mathrm{ft}(17.87 \mathrm{~m})$ below
Water elevation: $235.88 \mathrm{Ht}(71.9 \mathrm{~m}) \mathrm{msl}$

Sp: 9.9 . conductance: $100 \mu \mathrm{S} / \mathrm{cm}$

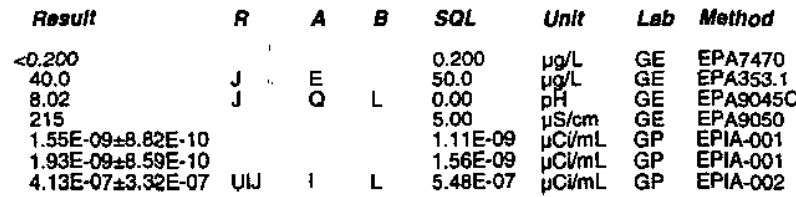

Time: 13:15

re: $21.2^{\circ}$

Total alkalinity (as CaCO3): $46 \mathrm{mg} /$

ANALYSES

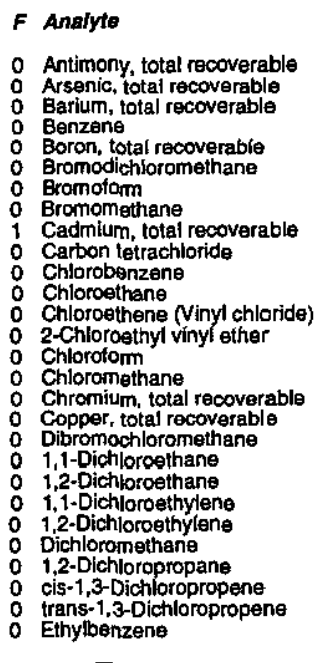

Resuft
27.0
240.0
$<4.7$
18.7
55.00
266
$<5.00$
$<5.00$
$<10.0$
4.10
$<5.00$
$<5.00$
$<10.0$
$<10.0$
$<10.0$
$<5.00$
$<10.0$
3.60
$<15.0$
$<5.00$
$<5.00$
$<5.00$
$<5.00$
$<5.00$
$<3.93$
$<5.00$
$<5.00$
$<5.00$
$<5.00$

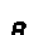

Water temperature: $20^{\circ} \mathrm{C}$

Total alkalinity (as CaCO3); $41 \mathrm{mg} / \mathrm{L}$

ESH-EMS-980569

WA WPAB260

in

Well HSB 85B collected on 04/20/98 (cont.)

\begin{tabular}{|c|c|c|c|c|c|c|c|c|}
\hline Analyto & Resuft & $\boldsymbol{R}$ & $A$ & & SQL & Unit & Lab & Method \\
\hline 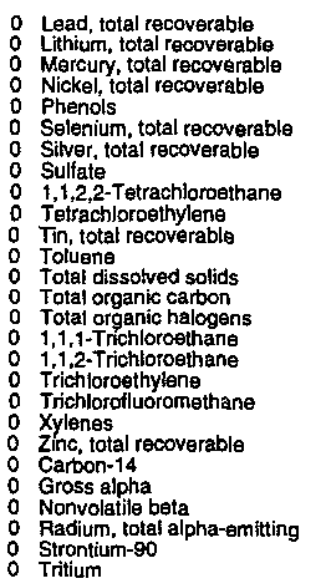 & 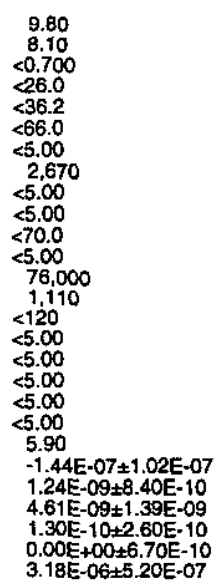 & $\mathrm{J}$ & a & & $\begin{array}{l}47.0 \\
2.70 \\
0.700 \\
26.0 \\
36.2 \\
66.0 \\
5.00 \\
340 \\
5.00 \\
5.00 \\
70.0 \\
5.00 \\
47,000 \\
1.000 \\
120 \\
5.00 \\
5.00 \\
5.00 \\
5.00 \\
5.00 \\
53.0 \\
1.84 E-07 \\
1.276-09 \\
2.08-09 \\
4.90-10 \\
1.70-10 \\
5.90-09 \\
\end{array}$ & 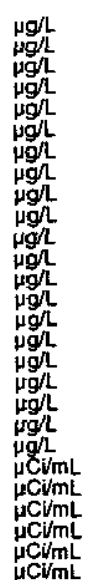 & $\begin{array}{l}\text { WA } \\
\text { WA } \\
\text { WA } \\
\text { WA } \\
\text { WA } \\
\text { WA } \\
\text { WA } \\
\text { WA } \\
\text { WA } \\
\text { WA } \\
\text { WA } \\
\text { WA } \\
\text { WA } \\
\text { WA } \\
\text { WA } \\
\text { WA } \\
\text { WA } \\
\text { WA } \\
\text { WA } \\
\text { WA } \\
\text { TM } \\
\text { TM } \\
\text { TM } \\
\text { TM } \\
\text { TM } \\
\text { TM }\end{array}$ & 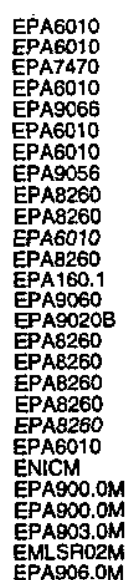 \\
\hline
\end{tabular}

\section{WELL HSB 85C}

MEASUREMENTS CONDUCTED IN THE FIELO

\section{Sample date: $04 / 01 / 98$
Depth to water: $52.4 \mathrm{ft}(15.97 \mathrm{~m})$ below TOC
Water elevation: $241.7 \mathrm{t}(73.67 \mathrm{~m}) \mathrm{ms}$
OH: 4.6 \\ .}

Water evacuated from the well prior to sampling: $69 \mathrm{gal}$

ANALYSES

$F$ Analyte

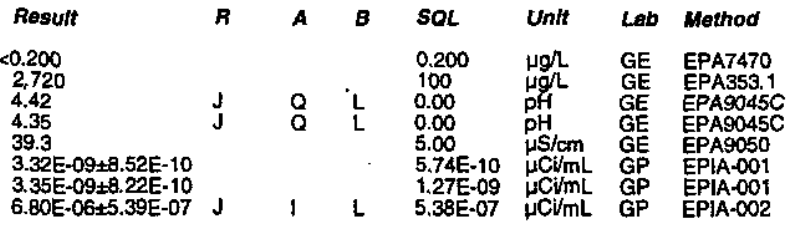

- Mercury, total recoverable

p

Specific conductance

Gross alpha

O Tritium

WELL HSB 85C

MEASUREMENTS CONDUCTED IN THE FIELD

Sample date: 04/20/98 Water elevation: $242.28 \mathrm{Ht}(73.85 \mathrm{~m}) \mathrm{ms}$

$\mathrm{pH}: 3.9$ conductance: $38 \mu \mathrm{s} / \mathrm{cm}$

Water evacuated from the well prior to sampling: $98 \mathrm{gal}$

ANALYSES

$F$ Analyte

- Antimony, total recoverable

A Arsenle, total recoverable

Benzene

Bromoform

0 Bromomethan
Time: 11:18

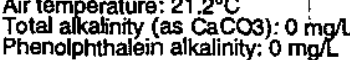

Time: 14:43

ater temperature: $21^{\circ} \mathrm{C}$

Total alkalinity (as CaCO3): $0 \mathrm{mgh}$.

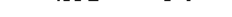


Well HSB 85C collected on 04/20/98 (cont.)

$F$ Analyte

- Cadmium, total recoverable Carbon tetrachlorid

Chloroethanena (Vinyl chloride)

2-Chloroethyl vinyl ether

Chromium, total recoverable

Copper, total recoverable

1,1-Dichloroethane

1,2-Dichloroethane

Dichloromethethren

1,2-Dichloropropane

cis-1,3-DIchoropropene

Ethylbenzene

Lead, total recoverable

Lithium, total recoverable

Nhenols

Selenium, total recoverab|

Sulfate

$1,1,2,2$-Tetrachloroethan

Tin, total recoverable

Toluen

Total dissolved solids

Total organic carbon

1,1,1-Trichlorosthane

$1,1,2 \cdot$ Trichloroathan

Trichloroestluoromethan

Xylenes

Gross alph

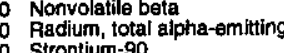

1 Tritium

\section{WELL HSB 86A}

MEASUREMENTS CONDUCTED IN THE FIELD

Sample date: $04 / 21 / 98$

Water elevation: 169.9 it $(51.79 \mathrm{~m}) \mathrm{ms}$

pH: 7.4 .

p. conductance: $110 \mu \mathrm{S} / \mathrm{cm}$

Water evacuated from the well prior to sampling: $167 \mathrm{gal}$

ANALYSES

$F$ Analyto

O Mercury, total recoverable

Mercury, otal recoverable

Nitrate-nitrite as nitrogen

Pr.

Specific conductance

Grost alpha
Gro

Gross alpha

Nonvolatile beta

ESH-EMS-980569

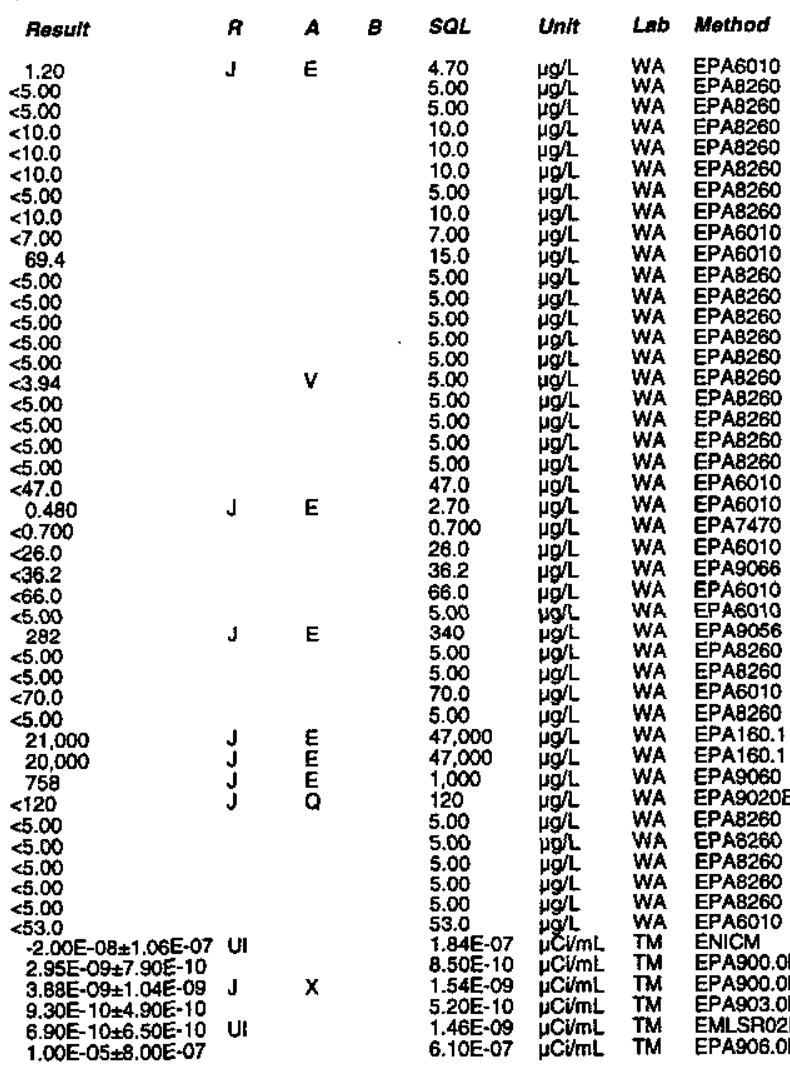

Time: 8:28

ature: $18.7^{\circ} \mathrm{C}$

Total alkalinity (as CaCo3): $47 \mathrm{mg} /$
Well HSB 86A collected on 04/21/98 (cont.)

$F$ Analyre

: Nonvolatile beta

Tritium

$-2.33 E-09+1.29 E-09$
$-1.68 E-09 \pm 1.31 E-09$

$6.68 \mathrm{E}-07 \pm 3.55 \mathrm{E}-07$

Tritium .

WELL HSB 86A Replicate

MEASUREMENTS CONDUCTED IN THE FIELD

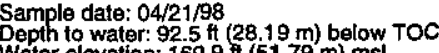
Water elevation: $169.9 \mathrm{ft}(51.79 \mathrm{~m}) \mathrm{ms}$

Sp. conductance: $110 \mu \mathrm{S} / \mathrm{cm}$

Water evacuated from the well prior to sampling: $167 \mathrm{ga}$ ANALYSES

$F$ Anafyte

Resuft

O: Mercury, total recoverable

\% $\mathrm{pH}$ Specitic conductance

Nonvolatile be

Tritium

$<0.200$

$\begin{array}{ccc}<40.0 & & V \\ 6.41 & J & Q \\ 150 & & 6\end{array}$

\section{WELL HSB 86B}

MEASUREMENTS CONDUCTED IN THE FIELD

Sample date: 04/20/98

: $37.5 \mathrm{tt}(11.43 \mathrm{~m})$ below TOC

Water elevation: 224.4 t $(68.4 \mathrm{~m}) \mathrm{ms}$

Sp. conductance: $180 \mu \mathrm{S} / \mathrm{cm}$

Water evacuated from the well prior to sampling: $158 \mathrm{gal}$

ANALYSES

$F$ Analyte

- Mercury, total recoverable

Nitrate-nitrite as nitrogen

$\mathrm{pH}$

Specific conductance

0 Tritium a SOL Unit Lab Mathod

2.37E-09 $\mu \mathrm{CV} / \mathrm{mL}$ TM IEPA900.0M $5.68 \mathrm{E}-07 \mu \mathrm{CV} / \mathrm{mL}$ GP EPAA-002

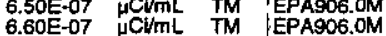

Time: 8:28

rature: $18.7^{\circ} \mathrm{C}$

otal alkalinity (as CaCO3); $47 \mathrm{mg} /$

\begin{tabular}{|c|c|c|c|c|c|c|c|}
\hline Result & $\boldsymbol{n}$ & & & SQL & & Lat & \\
\hline $\begin{array}{l}<0.200 \\
<0.700 \\
<20.0 \\
18.0 \\
6.38 \\
6.66 \\
6.60 \\
147 \\
125 \\
6.69 E-10 \pm 4.50 E-10 \\
6.80 E-10 \pm 8.80-10 \\
7.30 E-10 \pm 8.90 E-10 \\
1.23-09+0.30-10\end{array}$ & $\begin{array}{l}J \\
\mathfrak{J} \\
\mathbf{J}\end{array}$ & $\begin{array}{l}V \\
E \\
Q \\
Q \\
Q \\
Q \\
6\end{array}$ & L & $\begin{array}{l}0.200 \\
0.700 \\
50.0 \\
20.0 \\
0.00 \\
0.100 \\
0.100 \\
5.00 \\
8.90 \\
6.78 \mathrm{E}-10 \\
1.49 \mathrm{E}-09 \\
1.50 \mathrm{E}-09 \\
1.21 \mathrm{E}-09\end{array}$ & 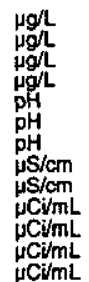 & $\begin{array}{l}G E \\
W A \\
G E \\
W A \\
G E \\
W A \\
W A \\
G E \\
W A \\
\text { GP } \\
\text { TM } \\
\text { MM } \\
\text { GP }\end{array}$ & $\begin{array}{l}\text { EPA7470 } \\
\text { EPA7470 } \\
\text { EPA353.1 } \\
\text { EPA353.2 } \\
\text { EPA9045C } \\
\text { EPA9040A } \\
\text { EPA9040A } \\
\text { EPA9050 } \\
\text { EPA9050 } \\
\text { EPA90001 } \\
\text { EPIA.001 } \\
\text { EPA900.0M } \\
\text { PFA900.0M } \\
\text { EPIA-001 }\end{array}$ \\
\hline
\end{tabular}




\section{WELL HSB101D}

MEASUREMENTS CONDUCTED IN THE FIELD Sample date: 04/07/98 Epth to water: $22.52 \mathrm{ft}(6.86 \mathrm{~m})$ below TOC Water elwa . conductance: $340 \mu \mathrm{S} / \mathrm{cm}$ Water evacuated from the well prior to sampling: 39 gal ANALYSES

\begin{tabular}{|c|c|c|c|c|c|c|c|c|}
\hline Analyte & Result & R & A & B & $S Q L$ & Unit & Lab & Method \\
\hline $\begin{array}{l}\text { Mercury, total recoverable } \\
\text { Nitrate-nitrite as nitrogen } \\
\text { pH } \\
\text { Specific conductance } \\
\text { Gross alpha } \\
\text { Nonvolatile beta } \\
\text { Tritium }\end{array}$ & $\begin{array}{l}1.57 \\
19.400 \\
7.81 \\
402 \\
6.73 \mathrm{E}-09+2.24 \mathrm{E}-09 \\
3.81 \mathrm{E}-08203.31 \mathrm{E}-09 \\
1.52 \mathrm{E}-03+2.97 \mathrm{E}-05\end{array}$ & UI & v & $L$ & $\begin{array}{l}0.200 \\
1.000 \\
0.00 \\
5.00 \\
1.78 E-09 \\
2.85 E-09 \\
2.93 E-06\end{array}$ & 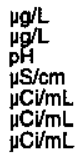 & $\begin{array}{l}G E \\
G E \\
G E \\
G E \\
G P \\
G P \\
G P\end{array}$ & $\begin{array}{l}\text { EPA7470 } \\
\text { EPA353.1 } \\
\text { EPA9045C } \\
\text { EPA9050 } \\
\text { EPIA-001 } \\
\text { EPIA-0.1 } \\
\text { EPIA-C02 }\end{array}$ \\
\hline
\end{tabular}

\section{WELL HSB102C}

MEASUREMENTS CONDUCTED IN THE FIELD

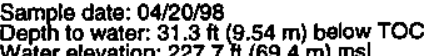

Water el

PH: 5.8 levation: $227.7 \mathrm{Ht}(69.4$,

Water ovacuated from the well prior to sampling: 89 gal ANALYSES

F Analyte

Mercury, total recoverable

$0 \mathrm{pH}$

$\mathrm{PH}$

Nonvolatle bete

WELL HSB102D

MEASUREMENTS CONDUCTED IN THE FIELD

Sample date: $04 / 03 / 98$
Depth to water: 25.79 th $(7.86 \mathrm{~m})$ below roC
Water elevation: 232.81 it $(70.96 \mathrm{~m}) \mathrm{ms}$

Water

Sp. conductance: $140 \mu \mathrm{S} / \mathrm{cm}$

Watiditity: 6 NTU

ANALYSES

F Analyte

1 Mercury, total recoverable

$\mathrm{PH}$ Specific conductance

Gross alpha

2
2 Nornovolatile beta
Tritum

$\begin{array}{ll}\text { Result } & \text { A } \\ 0.180 & J \\ 14.800 & \\ 5.93 & J \\ 5.95 & 195 \\ 2.38 E-09 \pm 5.32 E-10 \\ 5.82 E-09 \pm 6.32 E-10 \\ 1.57 E-04 \pm 3.12 E-06\end{array}$

Time: 13:14

Air termemerature: $21^{\circ} \mathrm{C}$

Total alkalinity (as CaCO3): $52 \mathrm{mgl}$
Phenolphthalein alkalinity: $0 \mathrm{mgh}$.

WELL HSB103C

MEASUREMENTS CONDUCTED IN THE FIELD Sample date: $04 / 20 / 98$

Depth to water: $20.8 \mathrm{ft}(6.34 \mathrm{~m})$ below TOC

water

Sp. conductance: $180 \mu \mathrm{S} / \mathrm{cm}$

Water evacuated from the well prior to sampling: 129 gal ANALYSES

$F$ Anatro

1 Mercury, total recoverable

$\mathrm{PH}$.

Gross alpha

Nonvolatile be

\section{WELL HSB103D}

MEASUREMENTS CONDUCTED IN THE FIELD

Sample date: 04/06198

Time: $14: 39$.

Depth to water: $18.43 \mathrm{ft}(5.62 \mathrm{~m})$ below TOC
Water elevation: $229.17 \mathrm{ft}(69.85 \mathrm{~m}) \mathrm{msl}$

Total alkalinity (as CaCO3): $19 \mathrm{mg}$

Whter

conductance: $140 \mu \mathrm{S} / \mathrm{cm}$

Water evacuated from the well prior to sampling: 50 gal ANALYSES

$f$ Anelyto

1 Mercury, total recoverable

Nitrate-nitrite as nitrogen

Specific conductance

2 Nonvolatile be
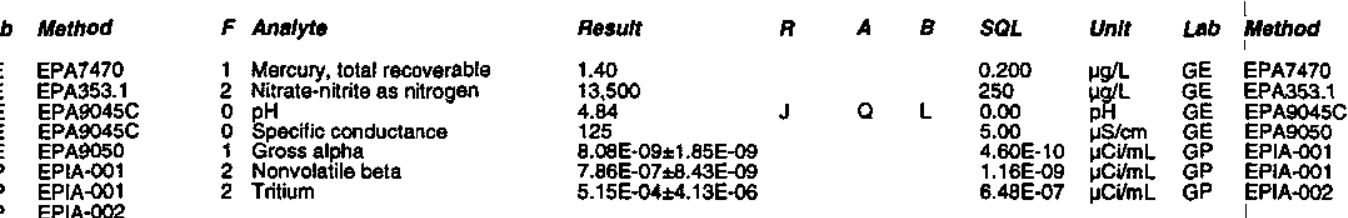

WELL HSB104C

MEASUAEMENTS CONDUCTED IN THE FIELD

Sample date: $04 / 20198$
Depth to water: $24.55 \mathrm{ft}(7.48 \mathrm{~m})$ below TOC
Water elevation: $223.35 \mathrm{tt}(68.08 \mathrm{~m}) \mathrm{msl}$

Water eve

Water temperature: $20^{\circ} \mathrm{C}$

Total alkalinity (as CaCO3): $0 \mathrm{mg} / \mathrm{h}$
Phenolphthalein alkalinity: $0 \mathrm{mgh}$

Sp. conductance: $140 \mu \mathrm{S} / \mathrm{cm}$

Water evacuated from the well prior to sampling: $101 \mathrm{gal}$ ANALYSES

\section{$F$ Analyto}

Result

1,060

4.47

4.80E-08 $\pm 5.07 E-09$ $4.26 \mathrm{E}-06 \pm 1.68 \mathrm{E}-08$
$5.96 \mathrm{E}-04 \pm 1.17 \mathrm{E}-05$

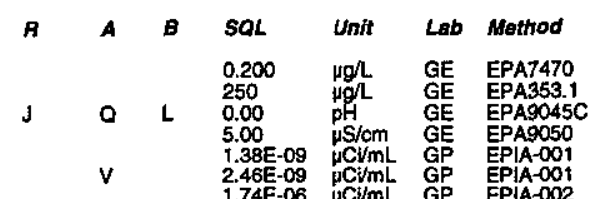

- Mercury, total recoverable Nirate-nitrite as nitrogen Specific conductance Nonvolatile bet 2 Tritium
Time: 8:26

Wret $19^{\circ} \mathrm{C}$ Total akkalinity (as CaCO3): 2 mg/ 


\section{WELL HSB104D}

MEASUREMENTS CONDUCTED IN THE FIELD Sample date: $04 / 06 / 98$
Depth to water: $19.05 \mathrm{ft}(5.81 \mathrm{~m})$ below TOC

Water Sp. conductance: $92 \mu \mathrm{S} / \mathrm{cm}$

Wubidity: ONTU ANALYSES

$F$ Analyte

2 Marcury, total recoverable

$\mathrm{pH}$ secific conductance

Grocitc conductipha
Nonvolatile beta

2 Tritium

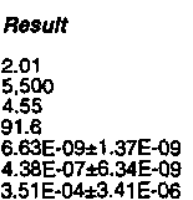

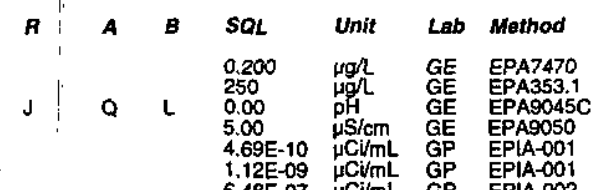

\section{WELL HSB105C}

MEASUREMENTS CONDUCTED IN THE FIELD Depth to water: $27.1 \mathrm{ft}(8.26 \mathrm{~m}$ ) below TOC
Water elevation: $222.4 \mathrm{t}(67.79 \mathrm{~m}) \mathrm{ms}$ l

$\mathrm{BH}: 5.8$

Sp. conductance: $100 \mu \mathrm{S} / \mathrm{cm}$

Water evacuated from the well pror to sampling: $100 \mathrm{gal}$ ANALYSES

$F$ Analyte

O Mercury, total recoverable

: $\mathrm{pH}$ pecific conductance

Specific conducta
Gross alpha
Nonvolatile beta

Tritium

$\begin{array}{ll}\text { Result } & \text { R } \\ 0.200 & \\ 4,850 & \\ 5.75 & \text { J } \\ 8.1 & \\ 9.60 E-11 \pm 2.44 E-10 & \text { UI } \\ 2.76 E-09 \pm 6.34 E-10 & \\ 9.45 E-05 \pm 1.76 E-06 & \end{array}$

\begin{tabular}{|c|c|c|c|c|c|}
\hline A & B & SOL & Unit & Lab & Method \\
\hline Q & L & $\begin{array}{l}0.200 \\
250 \\
0.00 \\
5.00 \\
5.63 E-10 \\
9.600-10\end{array}$ & 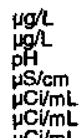 & $\begin{array}{l}G E \\
G E \\
G E \\
G E \\
G P \\
G P \\
G D\end{array}$ & 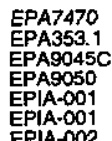 \\
\hline
\end{tabular}

Time: $10: 00$

Air termperature: $185^{\circ} \mathrm{C}$

Total akealinitity (as Cacos): $13 \mathrm{mg} /$
Phenolphthalein alkalinity: $0 \mathrm{mg} /$

WELL HSB105D

MEASUREMENTS CONDUCTED IN THE FIELD

Sample date: 04/02/98

Depth to water: $21.71 \mathrm{ft}(6.62 \mathrm{~m})$ below TOC
Water elevation: $227.79 \mathrm{ft}(69.43 \mathrm{~m}) \mathrm{msl}$

$\mathrm{pH}: 4.2$

Sp. conductance: $160 \mu \mathrm{S} / \mathrm{cm}$

Water evacuated from the well prior to sampling: 54 gal

ANALYSES

F Analyto

1 Mercury, total recoverable

$0 \mathrm{pH}$

Specific conductance

Gross alpha

2 Tritium

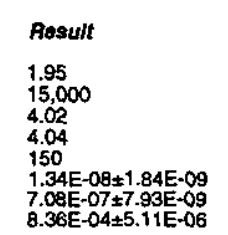

J

Wime: 8:26

Total alkalinity (as CaCO3): $0 \mathrm{mgh}$
Phenolphthalein alkalinity: $0 \mathrm{mg}$

\begin{tabular}{|c|c|c|c|}
\hline SOL & Unit & Lab & Method \\
\hline $\begin{array}{l}0.200 \\
500 \\
0.00 \\
0.00 \\
5.00 \\
4.14 E-10 \\
1.06 E-09\end{array}$ & 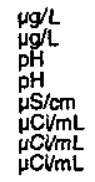 & $\begin{array}{l}G E \\
G E \\
G E \\
G E \\
G E \\
G E \\
G P \\
G P \\
G P\end{array}$ & $\begin{array}{l}\text { EPA7470 } \\
\text { EPA353.1 } \\
\text { EPA9045C } \\
\text { EPA9045C } \\
\text { EPA9050 } \\
\text { EPIA-001 } \\
\text { EPIAA-001 } \\
\text { EPAA-002 }\end{array}$ \\
\hline
\end{tabular}

\section{WELL HSB106C}

MEASUREMENTS CONDUCTED IN THE FIELD

Sample date: 04/20/98

Wepter to water $28.5 \mathrm{ft}(8.69 \mathrm{~m})$ below TOC

W. 56

Sp. conductance: $76 \mu \mathrm{s} / \mathrm{cm}$

Turbidity: 0 NTU
Water evacuated from the well prior to sampling: $154 \mathrm{gal}$ ANALYSES

\begin{tabular}{|c|c|c|c|c|c|c|c|c|}
\hline Analyto & Result & $\boldsymbol{B}$ & A & $B$ & SOL & Unit & Lab & Mothod \\
\hline $\begin{array}{l}\text { Mercury, total recoverable } \\
\text { Nitrate-nitrite as nitrogen } \\
\text { pH } \\
\text { Specific conductance } \\
\text { Gross alpha } \\
\text { Nononolatile beta } \\
\text { Tritium }\end{array}$ & $\begin{array}{l}0.270 \\
6.050 \\
5.49 \\
82.9 \\
4.89 \mathrm{E}-10 \pm 2.67 \mathrm{E}-10 \\
1.82 \mathrm{E}-09 \pm 4.80 \mathrm{E}-10 \\
1.66 \mathrm{E}-04 \pm 2.25 \mathrm{E}-06\end{array}$ & $J$ & a & L & $\begin{array}{l}0.200 \\
250 \\
0.00 \\
5.00 \\
3.83 E-10 \\
7.82 E-10 \\
5.57 E-07\end{array}$ & 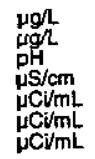 & $\begin{array}{l}G E \\
G E \\
G E \\
G E \\
G P \\
G P \\
G P\end{array}$ & $\begin{array}{l}\text { EPA7470 } \\
\text { EPAA33.1 } \\
\text { EPA9045C } \\
\text { EPA9050 } \\
\text { EPIA-001 } \\
\text { EPIA-001 } \\
\text { EPIA-0002 }\end{array}$ \\
\hline
\end{tabular}

\section{WELL HSB106D}

MEASUREMENTS CONDUCTED IN THE FIELD

\section{Sample date: $04 / 06 / 98$
Depth to water: $23.7 \mathrm{tt}(7.22 \mathrm{~m})$ below TOC
Water elevation: $229.2 \mathrm{tt}(69.86 \mathrm{~m}) \mathrm{msl}$}

$\mathrm{SH}: 4$. conductance: $64 \mu \mathrm{S} / \mathrm{cm}$

Turbidity: O NTU:
Water evacuated from the well prior to sampling: 38 gal ANALYSES

\begin{tabular}{|c|c|c|c|c|c|c|c|c|}
\hline Analyte & Result & $\boldsymbol{B}$ & A & $B$ & SQL & Unit & Lab & Method \\
\hline $\begin{array}{ll}0 & \text { Mercury, total recoverable } \\
0 & \text { Nitratentitrite as nitrogen } \\
0 & \text { pH } \\
0 & \text { Specific conductance } \\
0 & \text { Gross alpha } \\
2 & \text { Nonvolatile beta } \\
2 & \text { Tritium }\end{array}$ & $\begin{array}{l}0.684 \\
4.650 \\
4.79 \\
61.2 \\
3.83 E-09 \pm 1.02 E-09 \\
3.52 E-07 \pm 5.60 E-09 \\
1.59 E-04 \pm 2.31 E-06\end{array}$ & J & a & L & $\begin{array}{l}0.200 \\
250 \\
0.00 \\
5.00 \\
6.90 \mathrm{E}-10 \\
1.25 \mathrm{E}-09 \\
6.47 \mathrm{E}-07\end{array}$ & 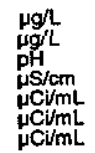 & $\begin{array}{l}G E \\
G E \\
G E \\
G E \\
G E \\
G P \\
G P \\
G P\end{array}$ & $\begin{array}{l}\text { EPA7470 } \\
\text { EPA353.1 } \\
\text { EPA9045C } \\
\text { EPA9050 } \\
\text { EPPA-0.1 } \\
\text { EPA-001 } \\
\text { EPIA-002 }\end{array}$ \\
\hline
\end{tabular}

\section{WELL HSB107C}

MEASUREMENTS CONDUCTED IN THE FIELD

Sample date: 04/21/98

(ter elevation: $221.72 \mathrm{t}(67.58 \mathrm{~m}) \mathrm{ms}$ )

pH: 5.1 conductance: $120 \mu \mathrm{S} / \mathrm{cm}$

Water evacuated from the well prior to sampling: $100 \mathrm{gal}$ ANALYSES

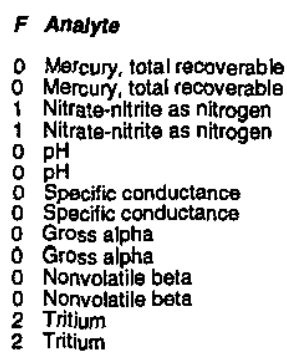

$\begin{array}{ll}\text { Resuft } & \text { A } \\ <0.200 & \\ 0.700 & \\ 7.450 & \\ 7,400 & \\ 6.40 & \mathrm{~J} \\ 6.60 & \mathrm{~J} \\ 156 & \\ 139 & \\ 1.04 \mathrm{E}-09 \pm 5.10 \mathrm{E}-10 & \mathrm{~J} \\ 3.80-10 \pm .20 \mathrm{E}-10 & \mathrm{U} \\ 7.69 \mathrm{E}-09 \pm 1.00 \mathrm{E}-09 & \\ 3.92 \mathrm{E}-09 \pm 1.10-09 \\ 3.36 \mathrm{E}-04 \pm 3.17 \mathrm{E}-06 \\ 4.00 \mathrm{E}-04 \pm 4.63 \mathrm{E}-06\end{array}$

Time: 9:42

erature: $20^{\circ}$

Total alkalinity (as CaCO3): $4 \mathrm{mgl}$
Phenolphthalein alkalinity: $0 \mathrm{mgl}$
Time: 12:11

作

Total alkalinity (as CaCO3): $0 \mathrm{mgh}$
Time: 11:12

Air temperature: $23.1^{\circ} \mathrm{C} \mathrm{C}$

Total alkalinity (as CaCO3): $21 \mathrm{mgh}$
Phenolphthalein alkalinity: 0 mgl

\begin{tabular}{|c|c|c|c|c|c|}
\hline A & $B$ & SOL & Unit & Lab & Method \\
\hline$v$ & & $\begin{array}{l}0.200 \\
0.700 \\
250\end{array}$ & $\begin{array}{l}\mu g / 2 \\
\mu g h \\
\mu g h\end{array}$ & $\begin{array}{l}\text { GE } \\
\text { WA } \\
\text { GE }\end{array}$ & $\begin{array}{l}\text { EPA7470 } \\
\text { EPA7470 } \\
\text { EPA353.1 }\end{array}$ \\
\hline $\begin{array}{l}\text { Q } \\
\text { Q }\end{array}$ & L & $\begin{array}{l}500 \\
0.00 \\
0.100 \\
5.00\end{array}$ & $\begin{array}{l}\mathrm{pg} \\
\mathrm{ph} \\
\mathrm{ph} \\
\mathrm{pHS} / \mathrm{cm}\end{array}$ & $\begin{array}{l}\text { WA } \\
\mathrm{GE} \\
\mathrm{WA} \\
\mathrm{GE}\end{array}$ & $\begin{array}{l}\text { EPA353.2 } \\
\text { EPA9045C } \\
\text { EPA9040A } \\
\text { EPA9050 }\end{array}$ \\
\hline I & H & $\begin{array}{l}8.90 \\
6.09 E-10 \\
1.07 E-09 \\
1.24 E-09 \\
1.67-09 \\
5.51 E-07 \\
6.50\end{array}$ & $\begin{array}{l}\mu \mathrm{sicm} \\
\mu \mathrm{CivmL} \\
\mu \mathrm{CV} / \mathrm{mL} \\
\mu \mathrm{C} / \mathrm{mL} \\
\mu \mathrm{CV} / \mathrm{mL} \\
\mu \mathrm{C} / \mathrm{mL}\end{array}$ & $\begin{array}{l}W A \\
G P \\
T M \\
G P \\
T M \\
G P\end{array}$ & $\begin{array}{l}\text { EPA9050 } \\
\text { EPIA.001 } \\
\text { EPA900.0M } \\
\text { EPIA-001 } \\
\text { EPA900.0M } \\
\text { EPIA-002 }\end{array}$ \\
\hline
\end{tabular}




\section{WELL HSB107C Replicate}

MEASUREMENTS CONDUCTED IN THE FIEL

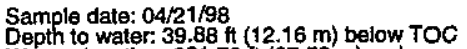

Water elevation: $221.72 \mathrm{Ht}(67.58 \mathrm{~m}) \mathrm{msl}$

SH: 5.1 conductance: $120 \mu \mathrm{S} / \mathrm{cm}$

Turbidity: 0 NTU:
Water evacuated from the well prior to sampling: $100 \mathrm{gal}$

ANALYSES

$F$ Analyte

i Mercury, total recoverable

0 Specific conductance

Gross apha

2 Tritium

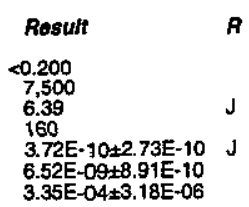

$\begin{array}{ll}\boldsymbol{B} & A \\ & \\ \mathrm{~J} & \mathrm{~V} \\ \mathrm{O} & 6 \\ \mathrm{~J} & \mathrm{i}\end{array}$

WELL HSB107D

MEASUREMENTS CONDUCTED IN THE FIELD

Sample date: 04/02/98 Water elevation: $227.15 \mathrm{ft}(69.24 \mathrm{~m}) \mathrm{msl}$

$\mathrm{H}: 4.8$

Sp. conductance: $140 \mu \mathrm{S} / \mathrm{cm}$

Water evacuated from the well prior to sampling: $50 \mathrm{gal}$ ANALYSES

$F$ Analyte

2 Mercury, total recoverable

Nitrate-nititite as nitrogen

$\mathrm{pH}$

Specific conductance

2 Gross alpha

WELL HSB108C

MEASUREMENTS CONDUCTED IN THE FIELDD

Sample date: 04/15/98

Depth to water: $45.4 \mathrm{ft}(13.84 \mathrm{~m})$ below TOC

Water olva

Sp. conductance: $140 \mu \mathrm{S} / \mathrm{cm}$

Turbidity: $1 \mathrm{NTU}$ : ANALYSES

$F$ Analyte

Mercury, total recoverable

0 Specific conductance

Gross alpha

Tritium

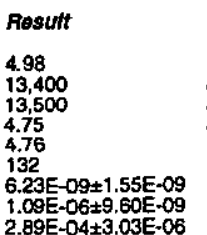

\section{Time: 11:12}

Total alkalinity (as CaCO3): $21 \mathrm{mg} \Omega$

WELL HSB108D

MEASUREMENTS CONDUCTED IN THE FIELD

Sample date: $04 / 02 / 98$
Depth to water: $40.7 \mathrm{tt}(12.41 \mathrm{~m})$ below
Water elevation: $225.6 \mathrm{ft}(68.76 \mathrm{~m}) \mathrm{ms}$

Waler elever

Sp. .8 onductance: $100 \mu \mathrm{S} / \mathrm{cm}$

Tubidity: 1 NTU

ANALYSES

$F$ Analyte

2 Mercury, total recoverable

$\because$ Specific conductance

2 Gross alpha

2 Tritium

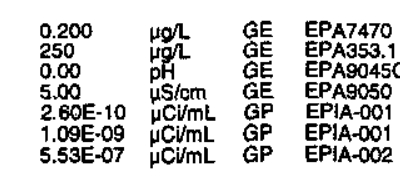

\section{WELL HSB 109C}

MEASUREMENTS CONDUCTED IN THE FIELD

Sample date: 04/09/98

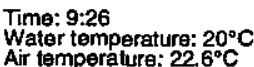

Depth to water: $40.1 \mathrm{th}(12.22 \mathrm{~m})$ below TOC
Water elevation: $221.5 \mathrm{H}(67.51 \mathrm{~m}) \mathrm{ms}$

Total alkalinity (as CaCO3): $0 \mathrm{mg} / \mathrm{L}$

Sp. conductance: $40 \mu \mathrm{S} / \mathrm{cm}$

Turbidity: 1 NTU:
Water evacuated from the well prior to sampling: $1 \mathrm{gal}$

ANALYSES

F Analyto

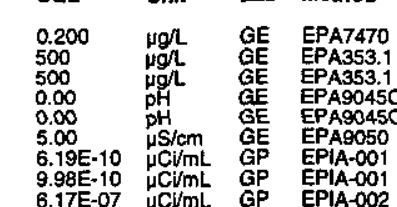

Nercury, total recoverable

$2 \mathrm{pH}$ Specific conductance

Gross alpha
0 Nonvolatile beta

2 Tritium

WELL HSB109D

MEASUREMENTS CONDUCTED IN THE FIELD

Sample date: $04 / 02 / 98$

Dopth to water $36.75 \mathrm{ft}(11.2 \mathrm{~m})$ below TOC
Water elevation: $224.45 \mathrm{Ht}(68.41 \mathrm{~m}) \mathrm{ms}$

Hi: conductance: $52 \mu \mathrm{S} / \mathrm{cm}$

Water temperature: $20^{\circ} \mathrm{C}$

Total alkalinity (as CaCOS): $61 \mathrm{mg} / \mathrm{L}$
Phenolphthalein alkalinity: $0 \mathrm{mgh}$

Turbididy: 0 NTU $52 \mu \mathrm{S} / \mathrm{cm}$

Water evacuated from the well prior to sampling: $51 \mathrm{gal}$

LISES

$F$ Analyto

- Mercury, total recoverable

Nitrate-nitrite as nitrogen

Specific conductance

2 Nonvolatile beta

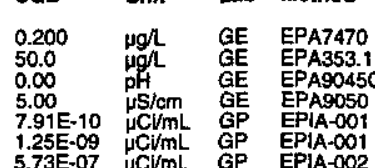

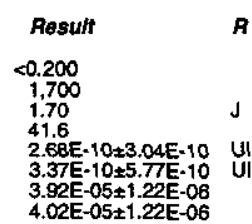

A
J
UI

$\begin{array}{ll}A & B \\ V & \\ Q & L \\ & \end{array}$

Time: 11:4

Air temperature: $29.3^{\circ} \mathrm{C}$

Total alkalinity (as CaCO3): $6 \mathrm{mg} /$

Time: 10:29

Air temperature: $23.5^{\circ} \mathrm{C}$

Phenolphthalein alkalinity: $0 \mathrm{mg} \mathrm{m}^{\mathrm{L}}$

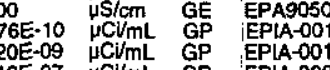

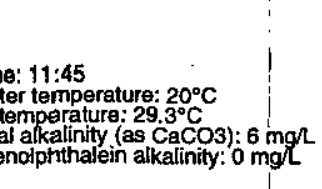

\section{$x^{2}$}

$\begin{array}{lll}\text { sQL } & \text { Untt } \\ 0.200 & \mu g / L & \mathrm{G} \\ 50.0 & \mu g / L & \mathrm{G} \\ 0.00 & \mathrm{pH} & \mathrm{G} \\ 5.00 & \mathrm{HS} / \mathrm{cm} & \mathrm{G} \\ 5.71 \mathrm{E}-10 & \mathrm{HC} / \mathrm{mL} & \mathrm{G} \\ 1.24 \mathrm{E}-09 & \mu \mathrm{CV} / \mathrm{mL} & \mathrm{G} \\ 7.41 \mathrm{E}-07 & \mathrm{HClmL} \\ 7.26 \mathrm{E}-07 & \mathrm{HCV} / \mathrm{mL} & \mathrm{G}\end{array}$
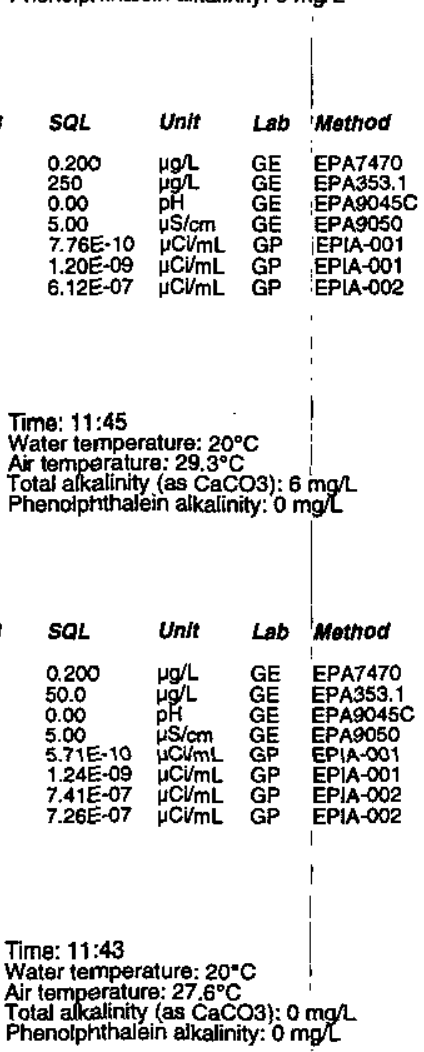

Total alkalinity (as CaCO3): $0 \mathrm{mgh}$

Resuh
0.542
3.040
4.14
45.9
$1.99 \mathrm{E}-09 \pm 6.24 \mathrm{E}-10$
$1.82 \mathrm{E}-07 \pm 3.88 \mathrm{E}-09$
$3.56 \mathrm{E}-05 \pm 1.11 \mathrm{E}-06$

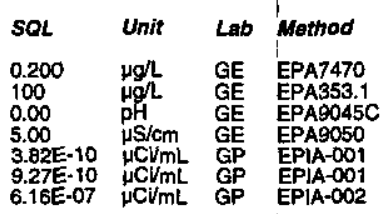




\section{WELL HSB110C}

MEASUREMENTS CONDUCTED IN THE FIELD Sample date: $04 / 09 / 98$ (10.77 m) below TOC Water Sp. conductance: $24 \mu \mathrm{S} / \mathrm{cm}$

Turbidity: 2 NTU
Water evacuated from the well prior to sampling: 73 gal ANALYSES

\begin{tabular}{|c|c|c|c|c|c|c|c|c|}
\hline F Analyto & Result & R & $A$ & $B$ & SOL & Unit & Lab & Mothod \\
\hline $\begin{array}{l}0 \text { Mercury, total recoverable } \\
0 \text { Nitratre-nitrite as nitrogenn } \\
2 \text { pH } \\
0 \text { Specific conductance } \\
0 \text { Gross alpha } \\
0 \text { Nonvolatile beta } \\
0\end{array}$ & $\begin{array}{l}<0.200 \\
440 \\
1.76 \\
23.5 \\
4.35 \mathrm{E}-10 \pm 3.23 \mathrm{E}-10 \\
8.34 \mathrm{E}-10 \pm 5.85 \mathrm{E}-10 \\
6.03 \mathrm{E}-06 \pm 6.05 \mathrm{E}-07\end{array}$ & $\begin{array}{l}J \\
U_{U} \|^{\prime \prime}\end{array}$ & $\begin{array}{l}v \\
Q\end{array}$ & $\mathrm{~L}$ & $\begin{array}{l}0.200 \\
50.0 \\
0.00 \\
5.00 \\
4.89 E-10 \\
1.17 \bar{E}-09 \\
7.27 \mathrm{E}-07\end{array}$ & 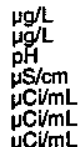 & $\begin{array}{l}G E \\
G E \\
G E \\
G E \\
G P \\
G P \\
G P\end{array}$ & $\begin{array}{l}\text { EPA7470 } \\
\text { EPA353.1 } \\
\text { EPA9045C } \\
\text { EPA9050 } \\
\text { EPIA-01 } \\
\text { EPIA-D1 } \\
\text { EPIA-002 }\end{array}$ \\
\hline
\end{tabular}

\section{WELL HSB110D}

MEASUREMENTS CONDUCTED IN THE FIELD

Sample date: 04/09/98

Water

Sp. 4.8 onductance: $40 \mu \mathrm{S} / \mathrm{cm}$

Turbidity: 1 NTU: 1 from the well prior to sampling: 30 gal

ANALYSES

\begin{tabular}{|c|c|c|c|c|c|c|c|c|}
\hline Analyte & Result & $R$ & A & $B$ & SQL & Unit & Lab & Method \\
\hline $\begin{array}{l}\text { Mercury, total recoverable } \\
\text { Nitrate-nitrite as nitrogen } \\
\text { pH } \\
\text { Specific conductance } \\
\text { Gross alpha } \\
\text { Nonvolatile beta } \\
\text { Tritium }\end{array}$ & $\begin{array}{l}<0.200 \\
1,600 \\
1.72 \\
40.2 \\
5.08 \mathrm{E}-10 \pm 4.94 \mathrm{E}-10 \\
6.08 \mathrm{E}-08 \pm 2.31 \mathrm{E}-09 \\
1.87 \mathrm{E}-05 \pm 8.64 \mathrm{E}-07\end{array}$ & $J$ & $a$ & L & $\begin{array}{l}0.200 \\
50.0 \\
0.00 \\
5.00 \\
5.79 E-10 \\
1.05 E-09 \\
7.12 E-07\end{array}$ & 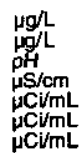 & $\begin{array}{l}G E \\
G E \\
G E \\
G E \\
G P \\
G P \\
G P\end{array}$ & 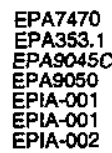 \\
\hline
\end{tabular}

\section{WELL HSB111C}

MEASUREMENTS CONDUCTED IN THE FIELD

Sample date: 04/09/98

Depth to water: $33.35 \mathrm{ft}(10.17 \mathrm{~m})$ below TOC

Water elevation: $222.65 \mathrm{ft}(67.8 \mathrm{~m}$
$\mathrm{pH}: 4.6$

Turbidity: 0 NTU
Water evacuated from the well prior to sampling: $166 \mathrm{gal}$

ANALYSES

F Analyto

2 Mercury, total recoverable

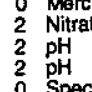

$\mathrm{pH}$ Specific conductance

$\begin{array}{ll} & \\ 0 & \text { Gross alpha } \\ 0 & \text { Nonvolatile beta }\end{array}$

2 Tritium

\begin{tabular}{|c|c|c|c|c|c|c|c|}
\hline sult & $\boldsymbol{A}$ & 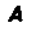 & B & $O L$ & nit & Lab & Mathod \\
\hline $\begin{array}{r}-09 \pm 6.57 E-10 \\
-08 \pm 1.48 E-09\end{array}$ & J & c & & $\begin{array}{l}0.200 \\
250 \\
0.00 \\
0.00 \\
5.00 \\
9.36 \mathrm{E}-10 \\
1.16 \mathrm{E}-09 \\
3.03 \mathrm{E}-06\end{array}$ & 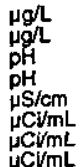 & $\begin{array}{l}G E \\
G E \\
G E \\
G E \\
G E \\
G E \\
G P \\
G P \\
G P\end{array}$ & $\begin{array}{l}\text { EPA7470 } \\
\text { EPA353.1 } \\
\text { EPA9045C } \\
\text { EPA9045C } \\
\text { EPA9050 } \\
\text { EPIA.001 } \\
\text { EPLA.001 } \\
\text { EPAA-D02 }\end{array}$ \\
\hline
\end{tabular}

\section{WELL HSB111E}

MEASUREMENTS CONDUCTED IN THE FIELD

Sample date: $04 / 02 / 98$
Depth to water: $32.58 \mathrm{ft}(9.93 \mathrm{~m})$ below TOC
Water elevation: $223.32 \mathrm{Ht}(68.07 \mathrm{~m}) \mathrm{msl}$
pH: 4 conductance: $44 \mu \mathrm{S} / \mathrm{cm}$
Sp. conductan
Turbidity: 0 NTU:

Water evacuated from the well prior to sampling: 83 gal

ANALYSES

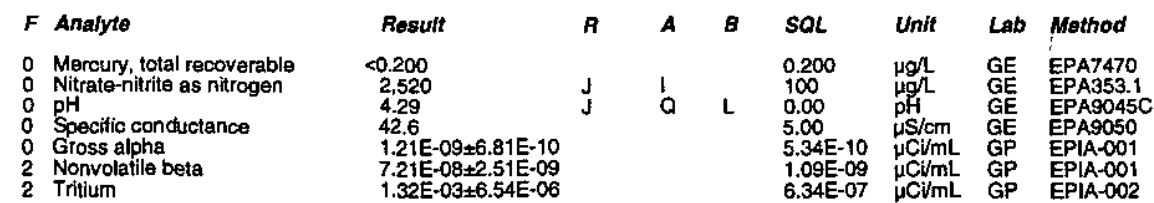

\section{WELL HSB112C}

MEASUREMENTS CONDUCTED IN THE FIELD

Sample date: $04 / 13 / 98$
Depth to water: $30.89 \mathrm{th}(9.42 \mathrm{~m})$ below TOC
Water elevation: $224.01 \mathrm{Ht}(68.28 \mathrm{~m}) \mathrm{msl}$

Water elevat

Sp. conductance: $93 \mu \mathrm{S} / \mathrm{cm}$

Turbidity: 1 NTU
Water evacuated from the well prior to sampling: $139 \mathrm{gal}$

ANALYSES

\begin{tabular}{|c|c|c|c|c|c|c|c|c|}
\hline$F$ Analyte & Result & A & $A$ & $B$ & SQL & Unit & Lab & Method \\
\hline 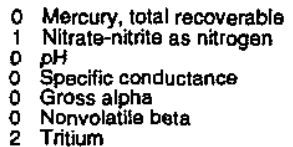 & $\begin{array}{l}<0.200 \\
5,940 \\
6.24 \\
110 \\
1.03 E-09 \pm 4.61 E-10 \\
1.10 E-08 \pm 1.09 E-09 \\
6.10 E-04 \pm 1.20 E-05\end{array}$ & 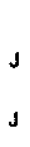 & $\begin{array}{l}v \\
\text { a }\end{array}$ & L & $\begin{array}{l}0.200 \\
150 \\
0.00 \\
5.00 \\
4.64 E-10 \\
1.08 E-09 \\
2.06 E-06\end{array}$ & 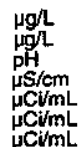 & $\begin{array}{l}G E \\
G E \\
G E \\
G E \\
G P \\
G P \\
G P\end{array}$ & $\begin{array}{l}\text { IEPA7470 } \\
\text { |EPA353.1 } \\
\text { EPA9045C } \\
\text { EPA9050 } \\
\text { EPIA-001 } \\
\text { 'EPIA-001 } \\
\text { EPIA-002 }\end{array}$ \\
\hline
\end{tabular}

\section{WELL HSB112D}

Time: 12:54

Total alkalinity (as CaCO3): $0 \mathrm{mg} /$
Phenolphthalein alkalinity: $0 \mathrm{mg} \mathrm{L}^{2}$

MEASUREMENTS CONDUT

HE FIE

Water elevation: 224.71 tt $(68.49 \mathrm{~m}) \mathrm{msl}$

\begin{tabular}{|c|c|c|c|c|c|c|c|c|}
\hline Analyte & Resuft & $\boldsymbol{R}$ & $A$ & $B$ & SaL & Unit & Lab & Method \\
\hline $\begin{array}{l}0 \text { Mercury, rotal recoverable } \\
0 \text { Nitrate-nitrite as nitrogen } \\
0 \text { pH } \\
0 \text { Specific conductance } \\
0 \text { Gross alpha } \\
0 \text { Nonvivolatile beta } \\
2 \text { Tritium }\end{array}$ & $\begin{array}{l}<0.200 \\
4.320 \\
55.50 \\
70.7 \\
4.06 \mathrm{E}-10 \pm 3.71 \mathrm{E}-10 \\
4.53 \mathrm{E}-09 \pm 7.58 \mathrm{E}-10 \\
5.88 \mathrm{E}-04 \pm 1.15 \mathrm{E}-05\end{array}$ & $\mathrm{~J}$ & c & $\mathbf{L}$ & $\begin{array}{l}0.200 \\
150 \\
0.00 \\
5.00 \\
6.63 E-10 \\
9.98 E-10 \\
2.02 E-06\end{array}$ & 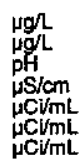 & $\begin{array}{l}\text { GE } \\
G E \\
G E \\
G E \\
G P \\
G P \\
G P\end{array}$ & $\begin{array}{l}\text { EPA7470 } \\
\text { EPA353.1 } \\
\text { EPA9045C } \\
\text { EPA9050 } \\
\text { EPIA-001 } \\
\text { EPIA-001 } \\
\text { EPIA-002 }\end{array}$ \\
\hline
\end{tabular}

Depth to water: $30.39 \mathrm{ft}(9.26 \mathrm{~m})$ below TOC

Sp. conductance: $63 \mu \mathrm{S} / \mathrm{cm}$

Turbidity: 0 NTU
Water evacuated from the well prior to sampling: $72 \mathrm{gal}$

ANALYSES

Time: 8:53

Water temperature: $18.2^{\circ} \mathrm{C}$

Arr temperature: $11.7^{\circ}$ )
Total alkalinity (as Caco3): $5 \mathrm{mg}$.
Phenolphthalein alkalinity: $0 \mathrm{mg}$.

Air temperature: $24.8^{\circ} \mathrm{C}$
Total alkalinity (as CaCO3): $0 \mathrm{mg} / \mathrm{L}$
Phenolphthatein alkalinity: $0 \mathrm{mg} /$

2 Tritium 
ANALYTICAL RESULTS

\section{WELL HSB112E}

MEASUREMENTS CONDUCTED IN THE FIELD

Sample date: $04 / 13 / 98$
Depth to water $30.48 \mathrm{ft}(9.29 \mathrm{~m})$ below TOC

Water elevation: $224.62 \mathrm{ft}(68.47 \mathrm{~m}) \mathrm{msl}$

$\mathrm{pH}: 7$ conductance: $67 \mu \mathrm{S} / \mathrm{cm}$

ANALYSES

\begin{tabular}{|c|c|c|c|c|c|c|c|c|}
\hline F Analyte & Result & R & A & B & $S Q L$ & Unit & Lab & Method \\
\hline $\begin{array}{l}\text { Mercury, total recoverable } \\
\text { Nitrate-nitrite as nitrogen } \\
\text { pH } \\
\text { Specific conductance } \\
\text { Gross alpha } \\
\text { Nonvolatile beta } \\
\text { Tritium }\end{array}$ & $\begin{array}{l}<0.200 \\
3.270 \\
4.94 \\
58.5 \\
1.80 \mathrm{~B}-09 \pm 6.40 \mathrm{E}-10 \\
8.80 \mathrm{x}-08 \pm 2.29 \mathrm{E}-09 \\
4.64 \mathrm{E}-05 \pm 1.27 \mathrm{E}-06\end{array}$ & $J$ & c & L & $\begin{array}{l}0.200 \\
150 \\
0.00 \\
5.00 \\
3.22 E-10 \\
1.03 E-09 \\
7.13 E-07\end{array}$ & $\begin{array}{l}\mu g / \mathrm{L} \\
\mu g / \mathrm{L} \\
\mathrm{pH} \\
\mu \mathrm{S} / \mathrm{cm} \\
\mu \mathrm{C} / \mathrm{mL} \\
\mu \mathrm{C} / \mathrm{mL} \\
\mu \mathrm{CimL}\end{array}$ & $\begin{array}{l}\mathrm{GE} \\
\mathrm{GE} \\
\mathrm{GE} \\
\mathrm{GE} \\
\mathrm{GP} \\
\mathrm{GP} \\
\mathrm{GP}\end{array}$ & 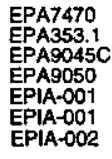 \\
\hline
\end{tabular}

\section{WELL HSB113C}

MEASUREMENTS CONDUCTED IN THE FIELD

Sample date: $04 / 21 / 98$
Depth to water $36.3 \mathrm{th}(11.06 \mathrm{~m})$ below TOC
Water elevation: $22.7 \mathrm{Ht}(68.49 \mathrm{~m}) \mathrm{msl}$

Water
oH: 5.2
op

7 th $(68.49 \mathrm{~m}) \mathrm{msl}$ m

5.2 elevation: $224.7 \mathrm{ft}(68.49$

Water evacuated from the well prior to sampling: $136 \mathrm{gal}$

ANALYSES

F Ansilyte

Mercury, total recoverable

Nitrate-nitrite as nitrogen

Nitrate-nltrite as nitrogen

$\mathrm{pH}^{\mathrm{pH}}$

Specific conductance

Gross alpha

Nonvolatile beta
Nonvolatile beta

2 Tritium

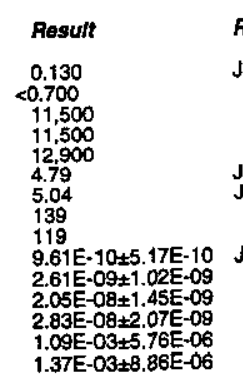

$1.09 \mathrm{E}-03 \pm 5.76 \mathrm{E}=06$

\section{WELL HSB113C Replicate}

MEASUREMENTS CONDUCTED IN THE FIELD

\section{Sample date: $04 / 21 / 98$
Depth to water: $36.3 \mathrm{At}(11.06 \mathrm{~m})$ below TOC
Water elevation: $224.7 \mathrm{ft}(68.49 \mathrm{~m})$ ms \\ $\mathrm{pH}: 5.2$ \\ p. conductance: $100 \mu \mathrm{S} / \mathrm{cm}$}

Turbidity: ONTU ANALYSES

$F$ Analyte

Mercury, total recoverable

Specific conductance

Gross alpha

2 Tritium

$\begin{array}{ll}\text { Result } & \text { A } \\ 0.127 & \text { J } \\ 11,800 & \mathrm{~J} \\ 4.83 & \\ 1.42 & 1.54 \mathrm{E}-09 \pm 5.62 \mathrm{E}-10 \\ 1.78 \mathrm{E}-08 \pm 1.34 \mathrm{E}-09 & \mathrm{~J} \\ 1.09 \mathrm{E}-03 \pm 5.74 \mathrm{E}-06 & \\ 1.11 \mathrm{E}-03 \pm 5.82 \mathrm{E}-06 & \end{array}$

J

Time: 12:49

$192^{\circ} \mathrm{C}$

Air temperature: $24.2 \mathrm{C}$

Total alkalinity (as Caco3): $0 \mathrm{mg} /$
Water temperature: $19.3^{\circ} \mathrm{C}$ Air temperature: $17.8^{\circ} \mathrm{C} C$
Total alkalinity (as CaCOS): $1 \mathrm{mgl}$
Phenolphthalein alkalinity: $\mathrm{mg}$ m

Water temperature: $19.3^{\circ} \mathrm{C}$

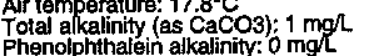

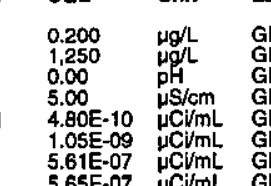

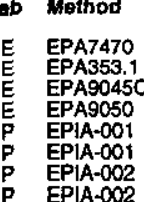

WELL HSB113D

MEASUREMENTS CONDUCTED IN THE FIELD

Sample date: $04 / 07 / 98$
Depth to water: $36.05 \mathrm{ft}(10.99 \mathrm{~m})$ below TOC
Whater elevation: $224.85 \mathrm{tt}(68.54 \mathrm{~m}) \mathrm{msl}$

Water elova

p. conductance: $320 \mu \mathrm{S} / \mathrm{cm}$

Water evacuated from the well prior to sampling: $40 \mathrm{gal}$

ANALYYSES

$F$ Analyte

2 Mercury, total recoverable

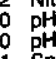

1 Specific conductance

2 Gross alpha

2 Nonvolatil

\section{WELL HSB114C}

MEASUREMENTS CONDUCTED IN THE FIELD

Sample date: $04 / 21 / 98$
Depth to water: $37.9 \mathrm{ft}(11.55 \mathrm{~m})$ below TOC
Water elevation: $225.9 \mathrm{ft}(68.86 \mathrm{~m}) \mathrm{msl}$

Water elevation: $225.9 \mathrm{ft}(68.86$
Sp: 4.4
Sp. conductance: $200 \mu \mathrm{S} / \mathrm{cm}$

Water evacuated from the well prior to sampling: $75 \mathrm{gal}$

ANALYSES

$F$ Analyte

Nercury, total recoverable

Specific conductance

1 Nonvolatile beta

Result

\section{$-09$}

Time: 8:18

rature: $19^{\circ} \mathrm{C}$

phenolohthalein alkalinity): $0 \mathrm{mgh}$

WELL HSB114D

MEASUREMENTS CONDUCTED IN THE FIELD

Sample date: 04/07/98

Sample date: $04 / 07 / 98$
Depth to water: 38.3 th $(11.67 \mathrm{~m})$ below TOC

Water elevation: $225.7 \mathrm{ft}(68.7$
gh: 4
Sp. conductance: $280 \mu \mathrm{S} / \mathrm{cm}$

Water evacuated from the well prior to sampling: 28 gal

ANALYSES

$F$ Analyte

0 Mercury, total recoverable

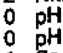

Specific conductance

2 Nonvolatila beta
0.440
29.600

4.28
4.31
332

3.27E-08 $44.47 E-09$

1.35E-06+1.77E-08

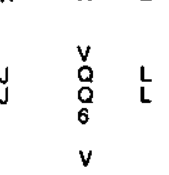

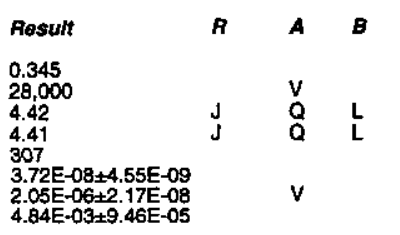

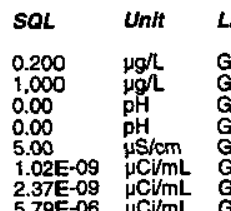

Time: $11: 36$
Water temperature: $20^{\circ} \mathrm{C}$
Air temperature: $16.8^{\circ} \mathrm{C}$

Total akalinity (as CaCO3): $0 \mathrm{mg} /$

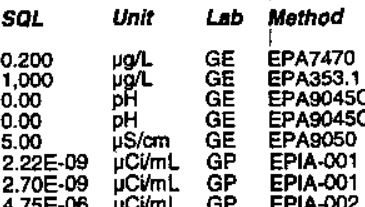

ESH-EMS-980569 


\section{WELL HSB115C}

MEASUREMENTS CONDUCTED IN THE FIELD Sample date: $04 / 27 / 98$ Weater to water: 30 ff $(9.14 \mathrm{~m})$ below TOC Water 6 p. conductance: $200 \mathrm{\mu S} / \mathrm{cm}$ Jutididity: 0 NTU: $200 \mu \mathrm{S} / \mathrm{cm}$

Water evacuated from the well prior to sampling: $119 \mathrm{gal}$ ANALYSES

\begin{tabular}{|c|c|c|c|c|c|c|c|c|}
\hline F Analyte & Result & $\boldsymbol{R}^{\prime}$ & $\boldsymbol{A}$ & B & $\mathrm{SOL}$ & Unit & Lab & Method \\
\hline $\begin{array}{ll}0 & \text { Mercury, total recoverable } \\
2 & \text { Nitrats-nitrite as nitrogen } \\
0 & \text { pH } \\
0 & \text { Specific conductance } \\
0 & \text { Gross alaha } \\
0 & \text { Nonvolatila bota } \\
2 & \text { Tritium }\end{array}$ & $\begin{array}{l}<.200 \\
19.300 \\
6.17 \\
235 \\
5.13 E-09 \pm 1.59 E-09 \\
2.23 E-08 \pm 2.43 E-09 \\
3.11 E-03 \pm 5.98 E-05\end{array}$ & $\underset{\mathrm{U}}{\mathrm{U}}$ & $\stackrel{v}{V}$ & L & $\begin{array}{l}0.200 \\
500 \\
0.00 \\
5.00 \\
1.45 E-09 \\
2.52 E-09 \\
4.27 E-06\end{array}$ & 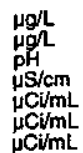 & $\begin{array}{l}G E \\
G E \\
G E \\
G E \\
G P \\
G P \\
G P\end{array}$ & $\begin{array}{l}\text { EPA7470 } \\
\text { EPA353.1 } \\
\text { EPA9045C } \\
\text { EPA9050 } \\
\text { EPIA-01 } \\
\text { EPIA-001 } \\
\text { EPIA-D02 }\end{array}$ \\
\hline
\end{tabular}

\section{WELLL HSB115D}

MEASUREMENTS CONDUCTED IN THE FIELD Sample date: $04 / 03 / 98$
Depth to water: $42.62 \mathrm{ft}(12.99 \mathrm{~m})$ below TOC
Water elevation: $226.48 \mathrm{ft}(69.03 \mathrm{~m})$ msl Water
pH: 3.8 $S p$ conductance: $160 \mu \mathrm{S} / \mathrm{cm}$

Tubiditity: 11 NTU
Water evacuated from the well prior to sampling: $1 \mathrm{gal}$ ANALYSES

\begin{tabular}{|c|c|c|c|c|c|c|c|c|}
\hline F Analyte & Aesuft & R & $A$ & $B$ & SQL & Unit & Lab & Mothod \\
\hline $\begin{array}{l}\text { Mercury, total recoverable } \\
\text { Nitrate-nitrite as nitrogen } \\
\text { pH } \\
\text { Specific conductance } \\
\text { Gross alpha } \\
\text { Gross alpha } \\
\text { Nonvolatile beta } \\
\text { Nonvolatile beta } \\
\text { Tritium }\end{array}$ & 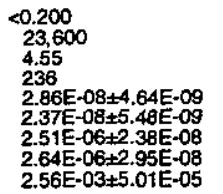 & $J$ & $\begin{array}{l}v \\
v\end{array}$ & L & $\begin{array}{l}0.200 \\
500 \\
0.00 \\
5.00 \\
1.97 \mathrm{E}-09 \\
2.12 \mathrm{E}-09 \\
2.86 \mathrm{E}-09 \\
2.87 \mathrm{E}-09 \\
3.96 \mathrm{E}-06\end{array}$ & 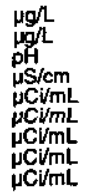 & $\begin{array}{l}G E \\
G E \\
G E \\
G E \\
G F \\
G P \\
G P \\
G P \\
G P\end{array}$ & 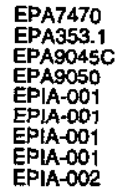 \\
\hline
\end{tabular}

\section{WELL HSB116C}

MEASUREMENTS CONDUCTED IN THE FIELD

\section{Sample date: $04 / 15 / 98$
Depth to water: $29.1 \mathrm{ft}(8.87 \mathrm{~m})$ below TOC
Water levation: $228.4 \mathrm{H}(69.62 \mathrm{~m}) \mathrm{ms}$ ) \\ Wh: 5.2 conductance: $100 \mu \mathrm{S} / \mathrm{cm}$}

Water evacuated from the well prior to sampling: 76 gal

\section{ANALYSES}

$F$ Analyte

- Mercury, total recoverable

$\mathrm{pH}$ Specific conductance

Gross elpha

2 Triftum

Air temperature: $18.3^{\circ} \mathrm{C}$

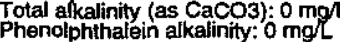

Water temperature: $19^{\circ} \mathrm{C}$

Total alkalinity.(as CaCO3): 2 mgr

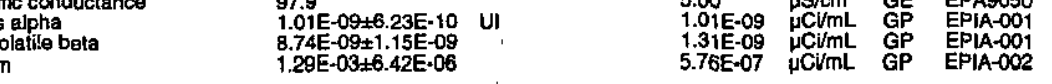

\section{WELL HSB116D}

MEASUREMENTS CONDUCTED IN THE FIELD

Sample date: $04 / 03 / 98$
Depth to water. $28.55 \mathrm{ft}(8.7 \mathrm{~m})$ below Toc
Water elevation: $228.25 \mathrm{tt}(69.57 \mathrm{~m}) \mathrm{msl}$

$\mathrm{pH}: 4.2$

Sp. conductance: $90 \mu \mathrm{S} / \mathrm{cm}$

Wutter evacuated from the well prior to sampling: 1 gal ANALYSES

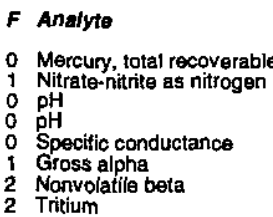

Resutt
0.357
8.000
4.52
4.53
87.2
$7.59 E-09 \pm 1.54 E-09$
$6.74 E-07 \pm 7.85-09$
$1.12 E-04 \pm 1.95 E-06$

\section{WELL HSB117A}

MEASUREMENTS CONDUCTED IN THE FIELD

Sample date: $04 / 07 / 98$

Water olevation: $167.5 \mathrm{ft}(21.25 \mathrm{~m})$ below TOC

pH: 6

che the well prior to sampling: $136 \mathrm{gal}$ ANALYSES

F Analyte
0 Mercury, total recoverable
0 Nifrate-nitite as nitrogen
0 Nitrate-nitrite as nitrogen
0 pH
0 Specitic conductance
0 Gross alpha
0 Nonvolatile beta
0 Tritum
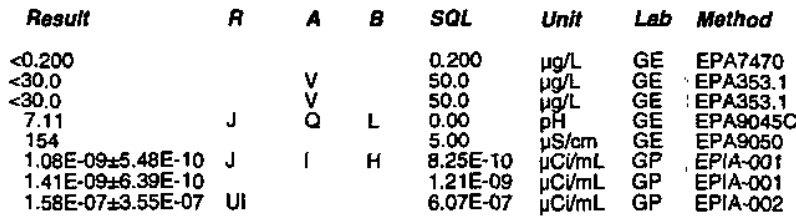

\section{WELL HSB117C}

MEASUREMENTS CONDUCTED IN THE FIELD

Sample date: 04/21/98

Depter to water: $12.45 \mathrm{ft}(3.79 \mathrm{~m})$ below TOC
Wher elevation: $224.95 \mathrm{Ht}(68.57 \mathrm{~m}) \mathrm{msl}$

Sp. conductance: $320 \mu \mathrm{S} / \mathrm{cm}$

Water evacuated from the well prior to sampling: $97 \mathrm{gal}$

Time: 8:10

Wir temperature: $20^{\circ} \mathrm{C}$

Total alkalinity (as CaCO3): $0 \mathrm{mgh}$

ANALYSES

F Analyte
0 Mercury, lotal recoverable
2 Nitrate-nitrite as nitrogen
0 pH
1 Specific conductance
1 Gross alloha
2 Nonvatatile beta
2 Tritum
2 Tritium

$\begin{array}{ll}\text { Resuth } & \text { A } \\ 0.112 & J \\ 41,300 & J \\ 4.52 & \text { J } \\ 403 & \\ 1.02 E-08 \pm 2.25 E-09 & \\ 6.24 E-08 \pm 3.69-09 & \\ 5.16 E-03 \pm 9.80-05 & J \\ 5.04 E-03 \pm 9.61 E-05 & J\end{array}$

Time: 13:01

Air temperaturature: $20^{\circ} \mathrm{C}$

Total alkalainity (as CaCO3); $0 \mathrm{mg} /$
Phenolphthalein alkalinity: $\mathrm{mg} / \mathrm{L}$
Water temperature: $17.6^{\circ} \mathrm{C}$ Total akalinity (as CaCOO3): $49 \mathrm{mg} /$
Phenolphthalein alkalinity: $0 \mathrm{mg} /$ 


\section{WELLL HSB117D}

MEASUREMENTS CONDUCTED IN THE FIELD

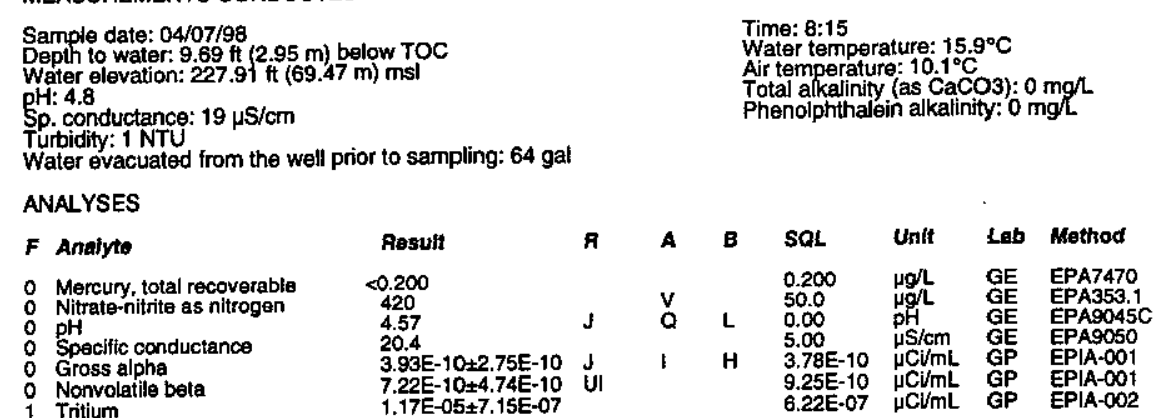

\section{WELL HSB118A}

MEASUREMENTS CONDUCTED IN THE FIELD

Sample date: $05 / 04 / 98$
Depth to water:78.2
Wt $(23.84$ m) below TOC

Water

Sp. conductance: $160 \mu \mathrm{S} / \mathrm{cm}$

Turbidity: 1 NTU

ANALYSES

\begin{tabular}{|c|c|c|c|c|c|c|c|c|}
\hline F Analyte & Resutt & R & $A$ & $B$ & $S Q L$ & Unit & Lab & Method \\
\hline $\begin{array}{l}\text { : Mercury, lotal recoverable } \\
0 \text { Nitrate-rititite as nitrogen } \\
0 \text { pHt } \\
0 \text { Specific conductance } \\
0 \text { Gross alpha } \\
0 \text { Nonvilatile beta } \\
2 \text { Tritium }\end{array}$ & $\begin{array}{l}<0.200 \\
4.440 \\
7.01 \\
199 \\
6.73 E-10 \pm 5.71 E-10 \\
5.60 E-09 \pm 9.88 E-10 \\
1.50 E-03 \pm 2.91 E-05\end{array}$ & UI & Q & L & $\begin{array}{l}0.200 \\
150 \\
0.00 \\
5.00 \\
9.81 E-10 \\
1.37 E-09 \\
2.84 E-06\end{array}$ & 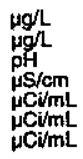 & $\begin{array}{l}G E \\
G E \\
G E \\
G E \\
G P \\
G P \\
G P\end{array}$ & $\begin{array}{l}\text { EPA7470 } \\
\text { EPA353.1 } \\
\text { EPA9050 } \\
\text { EPA9050 } \\
\text { EPAA-001 } \\
\text { EPAA-001 } \\
\text { EPIA-002 }\end{array}$ \\
\hline
\end{tabular}

\section{WELL HSB119A}

MEASUREMENTS CONDUCTED IN THE FIELD

Sample date: 04/13/98

Depth to water: $89 \mathrm{t}(27.13 \mathrm{~m})$ below TOC

Water ela

Sp. conductance: $140 \mu \mathrm{S} / \mathrm{cm}$

Turbidity: 1 NTU
Water evacuated from the well prior to sampling: $156 \mathrm{gal}$

ANALYSES

F
Analyte
0 Mercury, total recoverable
1 Nitrate-nitrite as nitrogen
0 pH
0 Specific conductance
0 Gross alpha
0 Nonvotatile beta
2 Tritium

\begin{tabular}{|c|c|c|c|c|c|c|c|}
\hline Resuft & A & $A$ & B & SQL & Unit & LAb & Method \\
\hline $\begin{array}{l}<.200 \\
5,190 \\
6.59 \\
153 \\
9.67 E-10 \pm 5.79 E-10 \\
1.32 \mathrm{E}-0.08 \pm 1.20 \mathrm{E}-09 \\
3.63 \mathrm{E}-04 \pm 7.16 \mathrm{E}-06\end{array}$ & J & $\begin{array}{l}\text { v } \\
o\end{array}$ & & $\begin{array}{l}0.200 \\
150 \\
0.00 \\
5.00 \\
9.11 E-10 \\
1.24 E-09 \\
1.57 E-06\end{array}$ & 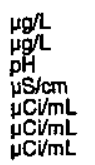 & $\begin{array}{l}\mathrm{GE} \\
\mathrm{GE} \\
\mathrm{GE} \\
\mathrm{GE} \\
\mathrm{GP} \\
\mathrm{GP} \\
\mathrm{GP}\end{array}$ & $\begin{array}{l}\text { EPA7470 } \\
\text { EPA353.1 } \\
\text { EPA9045C } \\
\text { EPA9050 } \\
\text { EPIA-001 } \\
\text { EPIA-001 } \\
\text { EPIA-002 }\end{array}$ \\
\hline
\end{tabular}

Time: 10:10

Wirter mperature: $19.8^{\circ} \mathrm{C}$

Total alkalinity (as CaCO3): $56 \mathrm{mg} /$

Water temperature: $19.9^{\circ} \mathrm{C}$

Total alkalinity (as CaCO3): $53 \mathrm{mg} / \mathrm{h}$

\section{WELL HSB120A}

MEASUREMENTS CONDUCTED IN THE FIELD

Sample date: 04/13/98 $(30.66 \mathrm{~m})$ below TOC

Water elevation: $167.6 \mathrm{ft}(51.09 \mathrm{~m}) \mathrm{msl}$

$\mathrm{pH}: 7.2$

conductance: $180 \mu \mathrm{S} / \mathrm{cm}$

Wurbidity: O NTU

ANALYSES

$F$ Analyte

Mercury, total recoverable

0 ppecific conductance

0 Nonvolatile beta

0 Tritium

Tritium HSB121A

MEASUREMENTS CONDUCTED IN THE FIELD

Sample date: $04 / 13 / 98$ f $(31.04 \mathrm{~m})$ below TOC

Water to water: $101.85 \mathrm{ft}(31.04 \mathrm{~m})$ betion: $172.75 \mathrm{tr}(52.65 \mathrm{~m}) \mathrm{ms}$

$\mathrm{H}: 7$

Pp. conductance: $200 \mu \mathrm{S} / \mathrm{cm}$

Water evacuated from the well prior to sampling: $159 \mathrm{gat}$

ANALYSES

$F$ Analyte

O Mercury, total recoverable

-nitrite as nitrogen

${ }_{0}^{0} \mathrm{PH}$ Specific conductance

$\begin{array}{ll}0 & \text { Gross alpha } \\ 0 & \text { Nonvolatile beta } \\ 0 & \text { Tritium }\end{array}$

Result
$<0.200$
$<60.0$
7.28
201
$8.02 \mathrm{E}-10 \pm 4.71 \mathrm{E}-10$
$1.74 \mathrm{E}-09 \pm 5.86-10 \mathrm{~J}$
$-4.81 \mathrm{E}-08 \pm 4.06 \mathrm{E}-07$ UI

$\begin{array}{lll}R & A & B \\ & V & \\ J & Q & L \\ & & \\ \text { J } & C & \end{array}$

Time: 10:26

Water temperature: $20^{\circ} \mathrm{C}$

Total alkalinity (as CaCO3): $54 \mathrm{mg} / \mathrm{L}$
Phenolphthalein alkalinity: $0 \mathrm{mg} / \mathrm{h}$

\section{WELL HSB122A}

MEASUREMENTS CONDUCTED IN THE FIELD

Sample date: $04 / 13 / 98$
Depth to water: $99.05 \mathrm{tt}(30.19 \mathrm{~m})$ below TOC

Water to water: $99.05 \mathrm{Ht}(30.19 \mathrm{~m})$ below

Wh: 6.8

Sp. conductance: $200 \mu \mathrm{S} / \mathrm{cm}$

Water evacuated from the well prior to sampling: $144 \mathrm{ga}$

ANALYSES

$F$ Analyte

- Mercury, total recoverable

- $\mathrm{pH}$ Specitic conductance

Gross alpha
: Nonvolatile beta
0 Tritium

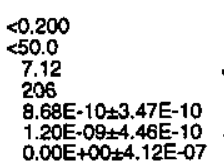

$1.00 E-09 \pm 4.4 E-10$
$0.00 E+00 \pm 4.12 E-07$

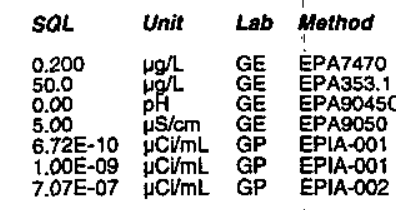

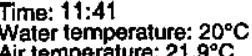

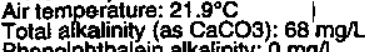

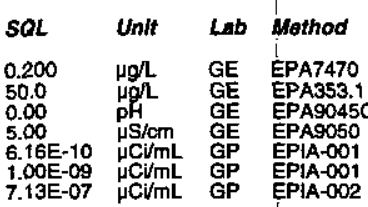

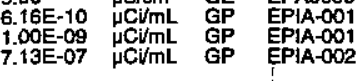

Time: 12:51

Air temporature: $24.2^{\circ} \mathrm{C}$ ) $75 \mathrm{mg} / \mathrm{L}$

\section{(1)}

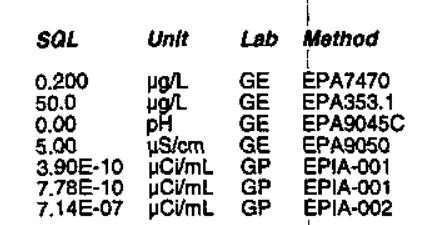




\section{WELL HSB123A}

MEASUREMENTS CONDUCTED IN THE FIELD Sample date: 04/16/98 Depth to water. $89.9 \mathrm{ft}(27.4 \mathrm{~m})$ below TOC Wh: 108 Sp. conductance: $280 \mu \mathrm{S} / \mathrm{cm}$

Turbidity: 1 NTU
Water evacuated from the well prior to sampling: 1 gal ANALYSES

\begin{tabular}{|c|c|c|c|c|c|c|c|c|}
\hline$=$ Analyte & Result & A & A & $B$ & $S Q L$ & Unit & Lab & Method \\
\hline $\begin{array}{l}\text { Mercury, total recoverable } \\
\text { Nitrate-nitrite as nitrogen } \\
\text { Nitrate-nitrite as nitrogen } \\
\text { pH } \\
\text { Specific conductance } \\
\text { Gross apha } \\
\text { Nonvolatile beta } \\
\text { Tritium }\end{array}$ & $\begin{array}{l}<0.200 \\
10.0 \\
10.0 \\
10.8 \\
320 \\
1.32 \mathrm{E}-09 \pm 6.63 \mathrm{E}-10 \\
3.46 \mathrm{E}-09 \pm 7.35 \mathrm{E}-10 \\
8.09 \mathrm{E}-08 \pm 4.01 \mathrm{E}-07\end{array}$ & $\begin{array}{l}\mathbf{J} \\
\mathbf{J}\end{array}$ & $\begin{array}{l}\mathrm{E} \\
\mathrm{E}\end{array}$ & L & $\begin{array}{l}0.200 \\
50.0 \\
50.0 \\
0.00 \\
5.00 \\
8.19 E-10 \\
1.11 E-09 \\
6.90 E-07\end{array}$ & $\begin{array}{l}\mu g / \mathrm{L} \\
\mu g / \mathrm{L} \\
\mu \mathrm{g} / \mathrm{L} \\
\mathrm{pH} \\
\mu \mathrm{S} / \mathrm{cm} \\
\mu \mathrm{C} V \mathrm{~mL} \\
\mu \mathrm{CV} / \mathrm{mL} \\
\mu \mathrm{Ci} / \mathrm{mL}\end{array}$ & $\begin{array}{l}\mathrm{GE} \\
\mathrm{GE} \\
\mathrm{GE} \\
\mathrm{GE} \\
\mathrm{GE} \\
\mathrm{GP} \\
\mathrm{GP} \\
\mathrm{GP}\end{array}$ & $\begin{array}{l}\text { EPA7470 } \\
\text { EPA353.1 } \\
\text { EPA53.1 } \\
\text { EPA9045C } \\
\text { EPA950 } \\
\text { EPIA-001 } \\
\text { EPPA.-01 } \\
\text { EPIA-002 }\end{array}$ \\
\hline
\end{tabular}

\section{WELL HSB124AR}

MEASUREMENTS CONDUCTED IN THE FIELD

Sample date: $04 / 27 / 98$
Depth to water: $93.61 \mathrm{ft}(28.53 \mathrm{~m})$ below TOC$$
\text { Water el whe }
$$

p. conductance: $200 \mu \mathrm{S} / \mathrm{cm}$

Wuter evacuated from the well prior to sampling: $136 \mathrm{gal}$

ANALYSES
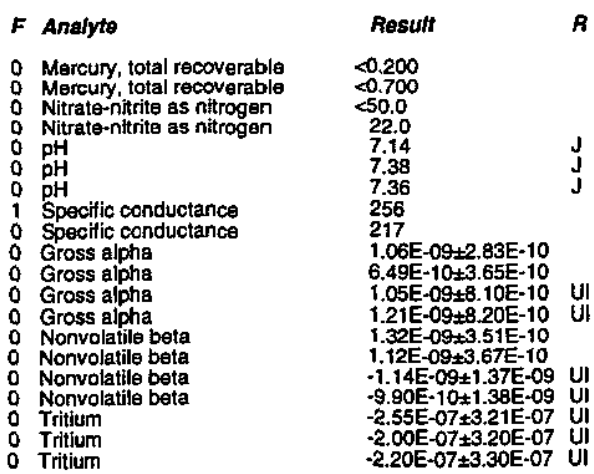

\section{WELL HSB124AR Replicate}

MEASUREMENTS CONDUCTED IN THE FIELD

Sample date: $04 / 27 / 98$
Depth to water: $93.61 \mathrm{ft}(28.53 \mathrm{~m})$ below TOC

Wepth to water: $93.61 \mathrm{ft}(28.53 \mathrm{~m})$ below

Wh: 7.4

Sp. conductance: $200 \mu \mathrm{S} / \mathrm{cm}$

Water evacuated from the well prior to sampling: $136 \mathrm{ga}$

ANALYSES

$F$ Analyte

O. Mercury, total recoverable

Nitrate-nitrite as nittrogen

ESH-EMS-980569
Time: $14: 30$

Total alkalinity (as CaCO3): $96 \mathrm{mg}$ Phenolphthalein alkalinity: $84 \mathrm{mg}$ L

Water temperature: $23^{\circ} \mathrm{C}$ Total alkalinity (as CaCO3): $71 \mathrm{mg} /$ Phenolphthalein alkalinity: $0 \mathrm{mgh}$
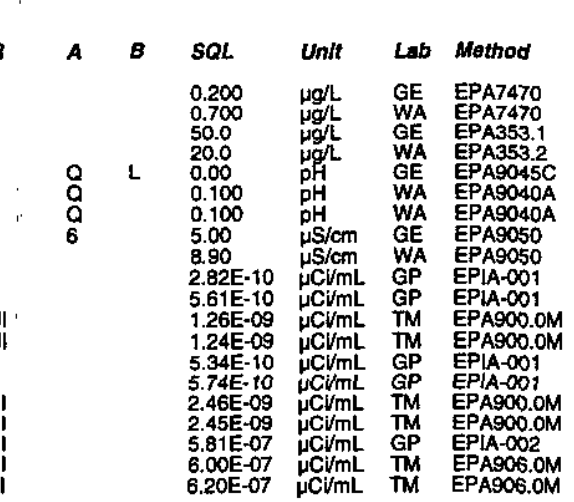

Time: 13:15

Water temperature: $23^{\circ} \mathrm{C}$

Total alkalinity (as Caco3): $71 \mathrm{mg} /$
Phenolphthalein alkalinity: $0 \mathrm{mg} / \mathrm{h}$
Water temperature: $19^{\circ} \mathrm{C}$
Well HSB124AR collected on 04/27/98 (cont.)

$F$ Analyte

0 Specific conductance

Nonvolatile beta

Tritium

Result

\section{WELL HSB125C}

MEASUREMENTS CONDUCTED IN THE FIELD

Sample date: 04/07/98

Sample date: $04 / 07 / 98$
Depth to water: $5.6 \mathrm{ft}(1.71 \mathrm{~m})$ below roC
Water glevation: $226.3 \mathrm{ft}(68.98 \mathrm{~m}) \mathrm{msl}$

H: 4.6

. conductance: $24 \mu \mathrm{S} / \mathrm{cm}$

Water evacuated from the well prior to sampling: $128 \mathrm{gal}$

ANALYSES

$F$ Analyto

- Mercury, total recoverable

Specific conductance

Gross alpha

0 Tritium

\section{WELL HSB125D}

$\begin{array}{llll}\text { Result } & \text { R } & \text { A } & \text { B } \\ <0.200 & & & \\ 140 & & \text { V } & \\ 4.96 & \text { J } & \text { Q } & \text { L } \\ 23.3 & 0 \\ 1.47 E-10 \pm 3.16 E-10 & \text { UI } & & \\ 1.13 E-09 \pm 5.31 E-10 \\ 2.69 E-06 \pm 4.62 E-07 & & & \end{array}$

Time: 14:56

in temperature: $20^{\circ} \mathrm{C}$

Total alkalinity (as CaCO3): $4 \mathrm{mg} /$

MEASUREMENTS CONDUCTED IN THE FIELD

Sample date: $04 / 21 / 98$

Depth to water: $9.49 \mathrm{ft}(289 \mathrm{~m})$ below TOC

Water et: 5.8

p. conductance: $100 \mu \mathrm{S} / \mathrm{cm}$

Water evacuated from the well prior to sampling: $49 \mathrm{gal}$

ANALYSES

$F$ Analyto

1 Mercury, total recoverable

of $\mathrm{pH}$ Secitic conductance

: Gross alpha

2 Tritium

\section{WELL HSB126C}

MEASUREMENTS CONDUCTED IN THE FIELD

Sample date: 04/02/98

Water elevation: $204 \mathrm{ft}(2.32 \mathrm{~m})$ below TOC

ph: 7.8

p. conductance: $240 \mu \mathrm{S} / \mathrm{cm}$

Water evacuated from the well prior to sampling: $65 \mathrm{gal}$

ANALYSES

$F$ Ansiyte

- Mercury, total recoverabie

$0 \mathrm{pH}$ ific conductance

O Gross alpha

2 Tritium

\section{Time: 13:23}

. $18.8^{\circ} \mathrm{C}$

Total alkalinity (as CaCO3): $1 \mathrm{mg} /$
Phenolphthalein alkalinity: 0 mg

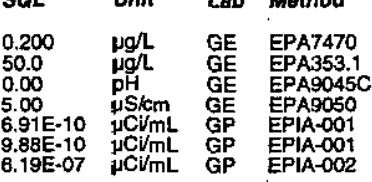

Time: 9:44

.

Air temperature: $21.4^{\circ} \mathrm{C}$
Total alkalinity (as Caco3): $53 \mathrm{mg} / \mathrm{L}$
Phenolphthalein alkalinity: $0 \mathrm{mg} /$ 


\section{WELL HSB126D}

MEASUREMENTS CONDUCTED IN THE FIELD

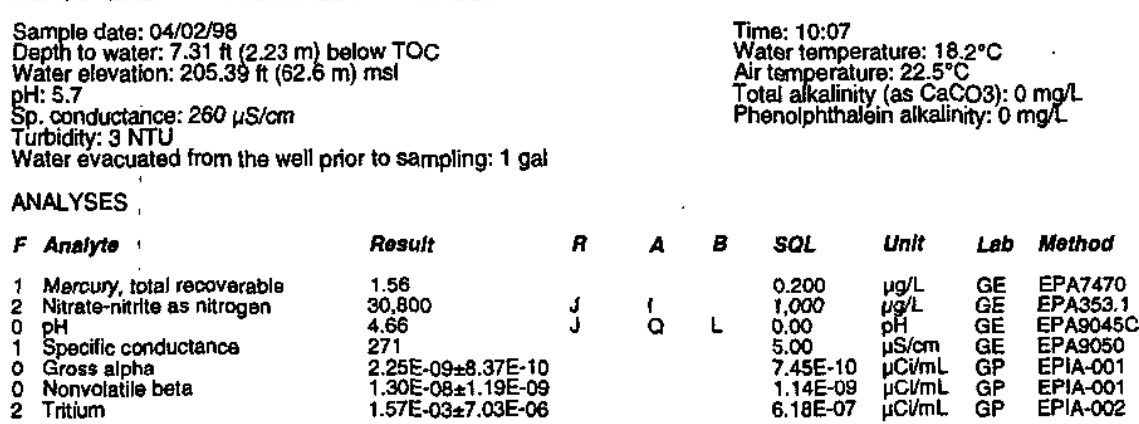

\section{WELL HSB127C}

MEASUREMENTS CONDUCTED IN THE FIELD

Sample date: 04/06/98

Depth to water: 13.85 ft (4.22 m) below TOC

Water ewe

Sp. conductance: $230 \mu \mathrm{S} / \mathrm{cm}$

Turbidity: ONTU
Water evacuated from the well prior to sampling: $96 \mathrm{gal}$ ANALYSES

\begin{tabular}{|c|c|c|c|c|c|c|c|c|}
\hline Analyte & Resuift & R & $A$ & $\boldsymbol{B}$ & SQL & Unit & $L a b$ & Method \\
\hline $\begin{array}{l}\text { Mercury, total recoverable } \\
\text { Nitrate-nitrite as nitrogen } \\
\text { pH } \\
\text { Specitic conductance } \\
\text { Gross alpha } \\
\text { Gross alpha } \\
\text { Nonvolatile beta } \\
\text { Nonvolatile beta } \\
\text { Tritium }\end{array}$ & $\begin{array}{l}<0.200 \\
10,200 \\
7.43 \\
266 \\
9.16 E-10 \pm 7.79 E-10 \\
3.69 E-11 \pm 4.47 E-10 \\
1.10 E-08 \pm 1.48 E-09 \\
8.85 E-09 \pm 1.39 E-09 \\
8.60 E-04 \pm 5.33 E-06\end{array}$ & $J$ & $Q$ & $L$ & $\begin{array}{l}0.200 \\
250 \\
0.00 \\
5.00 \\
1.25 E-09 \\
1.18 E-09 \\
1.46 E-09 \\
1.62 E-09 \\
6.48 E-07\end{array}$ & 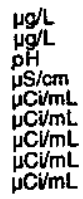 & $\begin{array}{l}G E \\
G E \\
G E \\
G E \\
G P \\
G P \\
G P \\
G P \\
G P\end{array}$ & $\begin{array}{l}\text { EPA7470 } \\
\text { EPA353.1 } \\
\text { EPA9045C } \\
\text { EPA9050 } \\
\text { EPIA-001 } \\
\text { EPIA-001 } \\
\text { EPIA-001 } \\
\text { EPIA-001 } \\
\text { EPIA-002 }\end{array}$ \\
\hline
\end{tabular}

\section{WELL HSB127D}

MEASUREMENTS CONDUCTED IN THE FIELD

Sample date: 04/06/98

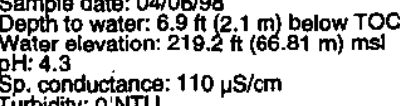

$\mathrm{pH}: 4.3$

Water evacuated from the well prior to sampling: 74 gal

ANALYSES

$F$ Analyte.

2 Mercury, total recoverable

0 pH itratertitite as numogen

Nonvolatile bete

2 Triturn

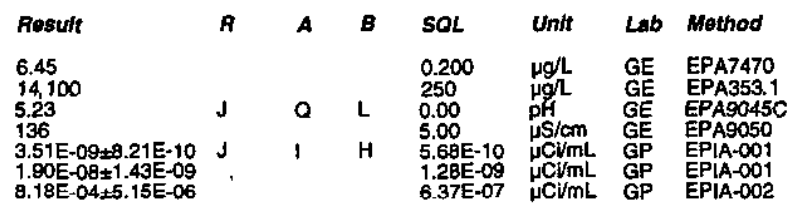

\section{WELL HSB129C}

MEASUREMENTS CONDUCTED IN THE FIELD

Sample date: $05 / 04 / 98$

Depth to water: $7.96 \mathrm{ft}(2.43 \mathrm{~m})$ below TOC
Water elevation: $207.14 \mathrm{ft}(63.14 \mathrm{~m}) \mathrm{ms} \mid$
pH: 5.2

s. conductance: $260 \mu \mathrm{S} / \mathrm{cm}$

Water evacuated from the well prior to sampling: 91 gal ANALYSES

$F$ Analyte

2 Mercury, total recoverable

o $\mathrm{pH}^{2}$

1 Specific conductance

2 Nonvolatila beta

2 Tritium

\section{WELL HSB129D}

MEASUREMENTS CONDUCTED IN THE FIELD

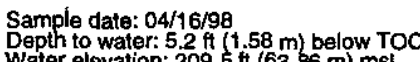

Water el

Ar temperature: $20.7^{\circ} \mathrm{C}$
Total alkalinty (as Caco3): $80 \mathrm{mg} / \mathrm{L}$
Phenolphthalein alkalinity: $0 \mathrm{mg}$

Sp. conductance: $140 \mu \mathrm{s} / \mathrm{cm}$

Water evacuated from the well prior to sampling: $84 \mathrm{gal}$

ANALYSES

$F$ Analyte

2 Mercury, total recoverable

Specific conductance

Nonvolatile bet

Tritium

\section{WELL HSB130C}

MEASUREMENTS CONDUCTED IN THE FIELD

Sample date: 04/13/98

Water elevation: $200.95 \mathrm{tt}(61.25 \mathrm{~m}) \mathrm{ms}$ !

H: 7.4

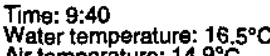

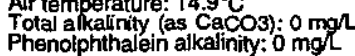

Sp. conductance: $140 \mu \mathrm{S} / \mathrm{cm}$

Water evacuated from the well prior to sampling: $81 \mathrm{gal}$

ANALYSES

$F$ Ansilyte

o Mercury, total recoverable

1 Spr

Nons alpha

: Noritium

\section{Resuit \\ 0.197
14,400
4.65

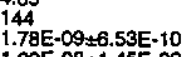 \\ $1.78 E-09 \pm 6.53 E-10$
$1.99 E-08+1.45 E-09$
$1.35 E-03 \pm 6.51 E-06$}

J

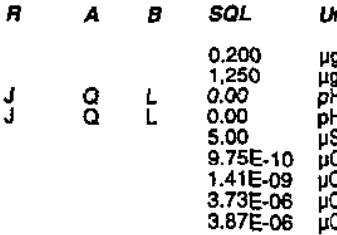

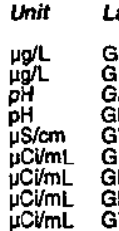

Wethod

EPA7470

EPA353.1

EPA9045C

EPIA-001

EPIA-002

Time: 12.31 Water temperature: $18^{\circ} \mathrm{C}$

Total alkaalinity (as CaCO3): $0 \mathrm{mgh}$

$$
\text { ; }
$$




\section{WELL HSB130D}

MEASUREMENTS CONDUCTED IN THE FIELD

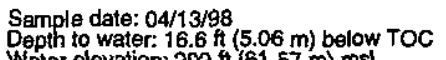

Depth to water: $16.6 \mathrm{ft}(5.06 \mathrm{~m})$ below Toc
Water elevation: $202 \mathrm{t}(61.57 \mathrm{~m}) \mathrm{ms}$ (
pH: 6

p. conductance: $78 \mu \mathrm{S} / \mathrm{cm}$

Water evacuated from the well prior to sampling: $69 \mathrm{gal}$ ANALYSES

\begin{tabular}{|c|c|c|c|c|c|c|c|c|}
\hline Ansiyte & Resuft & $\boldsymbol{A}$ & $A$ & B & SQL & Unit & Lab & Method \\
\hline $\begin{array}{l}\text { Mercury, totat recoverable } \\
\text { Nitratte-nittrite as nitrogen } \\
\text { pH } \\
\text { pH } \\
\text { Specific conductance } \\
\text { Specific conductance } \\
\text { Gross alpha } \\
\text { Nonvolatile beta } \\
\text { Tritium }\end{array}$ & $\begin{array}{l}<0.200 \\
170 \\
6.43 \\
6.44 \\
82.4 \\
82.3 \\
4.59 \mathrm{E}-10 \pm 4.09 \mathrm{E}-10 \\
1.07 \mathrm{E}-09 \pm 6.40 \mathrm{E}-10 \\
7.41 \mathrm{E}-06 \pm 6.32 \mathrm{E}-07\end{array}$ & I & $\begin{array}{l}\text { v } \\
\text { a }\end{array}$ & 1 & $\begin{array}{l}0.200 \\
50.0 \\
0.00 \\
0.00 \\
5.00 \\
5.00 \\
7.38 E-10 \\
1.26 E-09 \\
7.13 E-07\end{array}$ & $\begin{array}{l}\mu g / \mathrm{h} \\
\mu \mathrm{g} / \mathrm{L} \\
\mathrm{pH} \\
\mathrm{pH} \\
\mu \mathrm{S} / \mathrm{cm} \\
\mu \mathrm{S} / \mathrm{cm} \\
\mu \mathrm{C} / \mathrm{imL} \\
\mu \mathrm{C} / \mathrm{mL} \\
\mu \mathrm{C} / \mathrm{mL}\end{array}$ & $\begin{array}{l}\mathrm{GE} \\
\mathrm{GE} \\
\mathrm{GE} \\
\mathrm{GE} \\
\mathrm{GE} \\
\mathrm{GE} \\
\mathrm{GP} \\
\mathrm{GP} \\
\mathrm{GP}\end{array}$ & $\begin{array}{l}\text { EPA7470 } \\
\text { EPA335.1 } \\
\text { EPA9045C } \\
\text { EPA945C } \\
\text { EPA9050 } \\
\text { EPA9050 } \\
\text { EPAA-001 } \\
\text { EPAA-001 } \\
\text { EPIA-002 }\end{array}$ \\
\hline
\end{tabular}

\section{WELL HSB131C}

MEASUREMENTS CONDUCTED IN THE FIELD

Depth to water. 6.89 tt $(2.1 \mathrm{~m})$ below TOC

P.: 7.4

. conductance: $170 \mu \mathrm{S} / \mathrm{cm}$

Turbidity: 1 NTU
Water evacuated from the well prior to sampling: $119 \mathrm{gal}$ ANALYSES

$F$ Analyte

Nercury, total recoverable

pH

Specific conductance

Nonvolatito beta

WELL HSB131D

MEASUREMENTS CONDUCTED IN THE FIELD

Sample date: 04/07/98

Depth to water: $5.55 \mathrm{t}$ (1.69 m) below TOC

WH: 4.5

Sp. conductance: $28 \mu \mathrm{S} / \mathrm{cm}$

Wuater evacuated from the well prior to sampling: $29 \mathrm{gal}$

ANALYSES

$F$ Analyte

Nitrate-nitrite as nitrogen

$\mathrm{pH}$ Specific conductance

Gonvolatile bet

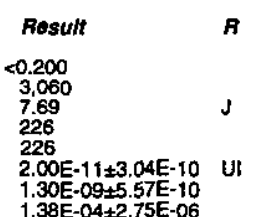

Uil

Time: 14:06

Air temperature: $259^{\circ} \mathrm{C}$

Total alkalinity (as CaCo3): $34 \mathrm{mg} / \mathrm{L}$

0 Tritium

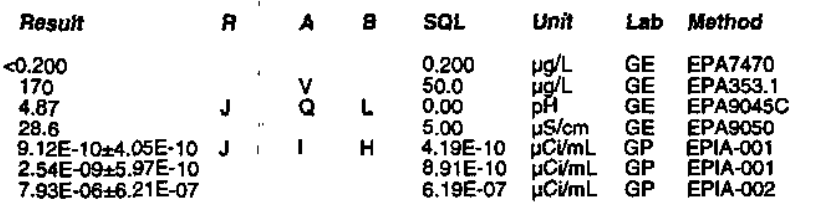

Air temperature: $21.6^{\circ} \mathrm{C}$

Total alkalinity (as CaCO3): $79 \mathrm{mg} / \mathrm{h}$
Phenolphthalein alkalinity: $0 \mathrm{mgh}$

\section{WELL HSB132C}

MEASUREMENTS CONDUCTED IN THE FIELD

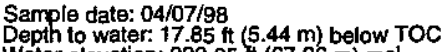
Water elevation: 222.65 t $(67.86 \mathrm{~m}) \mathrm{msl}$

pH: 5.1

p. conductance: $22 \mu \mathrm{S} / \mathrm{cm}$

Water evacuated from the well prior to sampling: $75 \mathrm{gal}$

ANALYSES

$F$ Analyte

o. Mercury, total recoverable

Spectic condustance

O Gross alpha

0 Tritium

\section{WELL HSB132D}

MEASUREMENTS CONDUCTED IN THE FIELD

Sample date: $04 / 07 / 98$
Depth to water: $18.35 \mathrm{ft}(5.59 \mathrm{~m})$ below TOC

ph: 5 eievation: $222.35 \mathrm{th} / 67 \mathrm{~m}$

Water evacuated from the well prior to sampling: $34 \mathrm{gal}$

ANALYSES

$F$ Anajyte

$\begin{array}{ll}\text { Result } & R \\ <0.200 & \\ 80.0 & \\ 5.01 & \mathrm{~J} \\ 24.1 & \\ 4.25 E-10 \pm 3.10 E-10 & \mathrm{UI} \\ 1.09 E-09 \pm 5.52 E-10 & \mathrm{UI} \\ 4.09 E-07 \pm 3.72 E-07 & \mathrm{UI}\end{array}$

Time: 14:22

$20.4^{\circ} \mathrm{C}$

Total alkalinity (as CaCO3): $3 \mathrm{mg}$

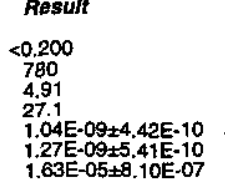

A

$B 50$

Unit

Nith

Specific conductance

Nonvolatile beta

1 Tritium

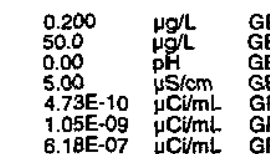

EPA7470
EPA353.1
EPA9045C
EPA950
EPIA-001
EPA.001
EPA.-002

WELL HSB133C

MEASUREMENTS CONDUCTED IN THE FIELD

Sample date: $04102 / 98$

Depth to water: $21.5 \mathrm{Ht}(6.55$ m) below TOC

Wh: 5.5

p. conductance: $35 \mu \mathrm{S} / \mathrm{cm}$

Water evacuated from the well prior to sampling: $100 \mathrm{gal}$

ANALYSES

$F$ Analyte

- Mercury, total recoverable

pH

Gross alpha

Tritium
Time: 11:47

18.3.

Total akkalinity (as CaCO3): $1 \mathrm{mg} /$
Phenolphthalein alkalinity: $\mathrm{mgh}$

SOL Unit Lab Method

0.200 $\mu g /$ GE EPA7470

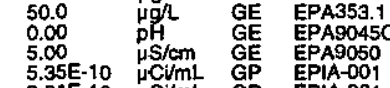

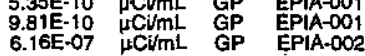

Time: 8:49

Wait ter temperature: $19^{\circ} \mathrm{C}$

Total alkalinity (as CaCo3): $8 \mathrm{mgh}$
Phenolphthalein alkalinity: $0 \mathrm{mgh}$
Total alkalinitu: (20.6.6 Caco3): $0 \mathrm{mg} / \mathrm{L}$
A B SQL Unt Lab Method

$\begin{array}{lllll}0.201 & & & & \\ 5.62 & \text { J } & 1 & \\ 380 & & 1\end{array}$

$.26 E-10 \pm 3.26 E-10$ UI
$6.52 \mathrm{E}-08 \pm 3.53 \mathrm{E}-07$ 


\section{WELL HSB133D}

MEASUREMENTS CONDUCTED IN THE FIELD

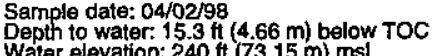
wate $\mathrm{Sp}$. conductance: $43 \mu \mathrm{S} / \mathrm{cm}$ Turbidity: 0 NTU $43 \mu / c m$ ANALYSES

$F$ Analyte

: Mercury, total recoverable

Nitrat

o $\mathrm{pH}$ Specific conductanco

: Gross alpha

2 Tritium

\section{WELL HSB134C}

MEASUREMENTS CONDUCTED IN THE FIELD

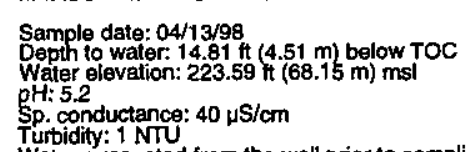

Water evacuated from the well prior to sampling: $106 \mathrm{gal}$

ANALYSES

$F$ Analyto

0 Mercury, total recoverable

Nitrate-nitrite as nitrogen

: $\mathrm{pH}$ Specific conductance

Nonvolatile beta

2 Tritium

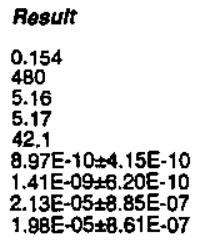

$\begin{array}{lll}\text { A } & A & B \\ J & E & \\ J & 1 & \\ J & Q & L \\ J & Q & L\end{array}$

Time: 7:53

Water temperature: $16.5^{\circ} \mathrm{C}$ Total alkalinity (as CaCO3): $5 \mathrm{mgh}$
Phenolphthalein alkalinity: $0 \mathrm{mg} /$.

\section{WELL HSB134D}

MEASUREMENTS CONDUCTED IN THE FIELD

Sample data: 04/06/98
Depph to water: $12.55 \mathrm{tt}(3.83 \mathrm{~m})$ below TOC
Water elevation: $225.55 \mathrm{th}(68.75 \mathrm{~m})$ msl

Water elevation: $225.55 \mathrm{Ht}$ (6.7
H: 3.6 .6 conductance: $86 \mu \mathrm{S} / \mathrm{cm}$

Water evacuated from the well prior to sampling: 33 gal ANALYSES

F Analyte

- Mercury, total recoverable

Nitrate-nitrite as nitrogen

Specific conductance

Nonvolatilie beta

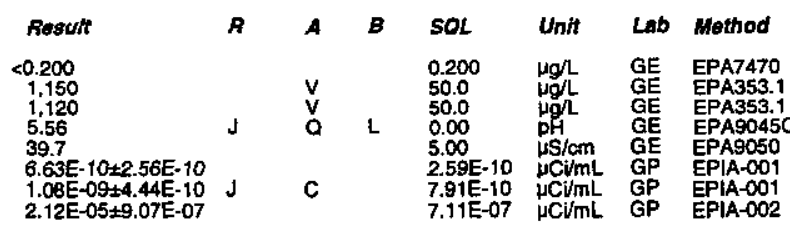

Time: $13: 50$

Water temperature: $20.5^{\circ} \mathrm{C}$

Total alkalinity. (as CaCO3): $6 \mathrm{mg} /$
Phenoiphthalein alkalinity: $0 \mathrm{mg} / \mathrm{L}$
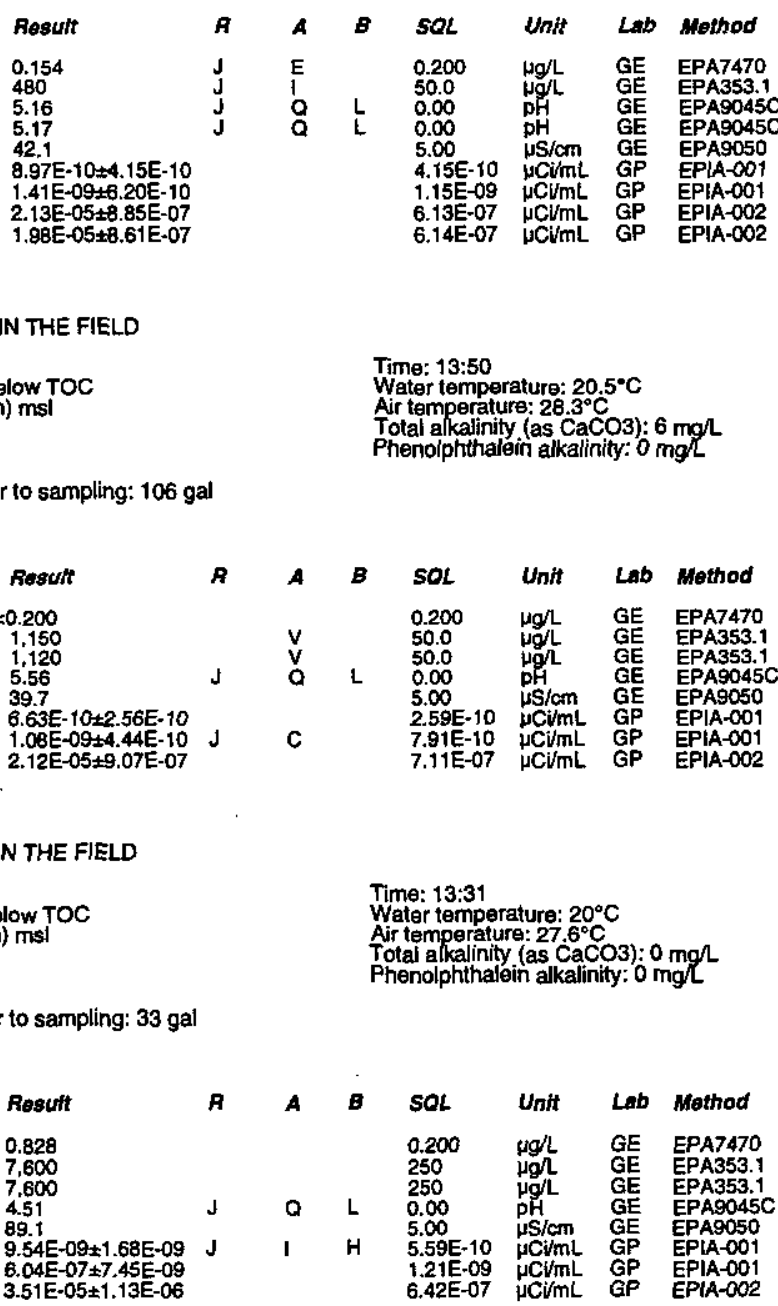
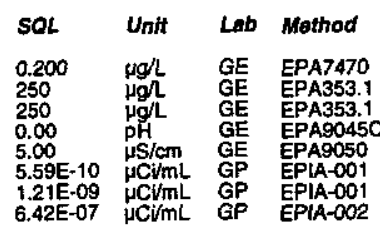

Nir temperature: $27.6^{\circ} \mathrm{C}$

Thotal alkalinity (as CaCO3): $0 \mathrm{mg} /$

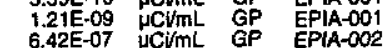

$6.04 \mathrm{E}-07 \pm 7.45 \mathrm{E}-09$
$3.51 \mathrm{E}-05 \pm 1.13 \mathrm{E}-06$
Time: 8:41

Water temperature: $17^{\circ} \mathrm{C}$ Total alkalinity (as CaCO3): $93 \mathrm{mg}$

Phenolphtharein alkalinity: $0 \mathrm{mgh}$.

\section{WELL HSB135C}

MEASUREMENTS CONDUCTED IN THE FIELD

Sample date: 04/06/98

Depter to water. $23.66 \mathrm{ft}(7.21 \mathrm{~m})$ below TOC

$\mathrm{pH}: 8.2$

S. conductance: $170 \mu \mathrm{S} / \mathrm{cm}$

Wunbidity: 6 NTU 170 ustcm

ANALYSES

$F$ Anatyto

Rosuit

: Mercury, total recoverable

0 Specitic conductance

Nonvolatile beta

WELL HSB135D

MEASUREMENTS CONDUCTED IN THE FIELD

Sample date: $04 / 06 / 98$
Depth to water: $12.59 \mathrm{H}(3.84 \mathrm{~m})$ below TOC
Water elevation: $219.71 \mathrm{tt}(66.97 \mathrm{~m}) \mathrm{msl}$

$\mathrm{pH}: 6$ lovation: $219.74 \mathrm{Ht}$

Sp. conductance: $24 \mu \mathrm{S} / \mathrm{cm}$

ANALYSES

$F$ Analyte

- Mercury, total recoverable

Specific conductance

O Gross apha

\section{WELL HSB136C}

MEASUREMENTS CONDUCTED IN THE FIELD

Sample date: $04 / 28 / 98$
Depth to water: $7.2 \mathrm{th}(2.19 \mathrm{~m})$ below TOC
Water elevation: $220.7 \mathrm{tt}(67.27 \mathrm{~m}) \mathrm{msl}$

Sp: 6 conductance: $240 \mu \mathrm{S} / \mathrm{cm}$

Turbidity: 1 NTU:
Water evacuated from the well prior to sampling: $1 \mathrm{gal}$

ANALYSES

$F$ Analyto

- Mercury, total recoverable

2 Nitrate-nitrite as nitrogen

$1 \mathrm{pH}$

1 ppecific conductance

$\begin{array}{ll}1 & \text { Gross apha } \\ 2 & \text { Nonvolatile beta } \\ 2 & \text { Tritium }\end{array}$

\section{8.42
134} $3.50 \mathrm{E}-09 \pm 7.86 \mathrm{E}-10$ 05E-05+8.98E-07

0.210

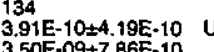

\section{A}

502
0.200
50.00
5.00
7.49

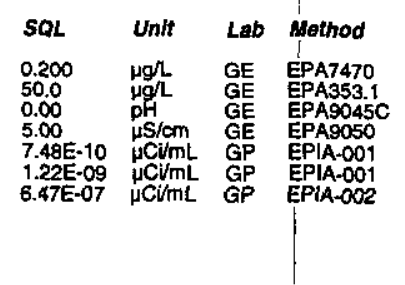

Time: 7:29

Water temperature: $13.5^{\circ} \mathrm{C}$

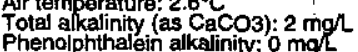

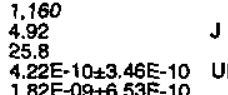

$4.22 E-10 \pm 3.46 E-10$
$1.82-09+6.53 E-10$

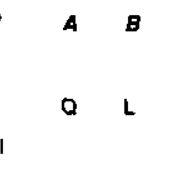

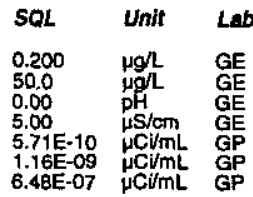

GP EPIA-001

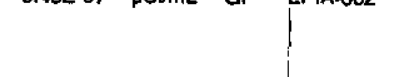

Time: 12:20

Air termperature: $17,3^{\circ} \mathrm{C}$

Phenolphthalein $\mathrm{CaCO}$ ): $21 \mathrm{mg} / \mathrm{l}$ 


\section{WELL HSB136D}

MEASUREMENTS CONDUCTED IN THE FELL Sample date: $04 / 16 / 98$ Weph to water. $5.3 \mathrm{Ht}(1.62 \mathrm{~m})$ below TOC
Water elevation: $222.7 \mathrm{tt}(67.88 \mathrm{~m}) \mathrm{msl}$ SH: 4 conductance: $300 \mu \mathrm{S} / \mathrm{cm}$ Water evacuated from the well prior to sampling: $32 \mathrm{gal}$ ANALYSES

F Analyte

0 Mercury, total recoverable

$\mathrm{PH}$ Specific conductance

Gross alpha

Nonvolatite beta
Nonvolgtile bota

2 Tritium

\section{WELL HSB137C}

MEASUREMENTS CONDUCTED IN THE FIELD

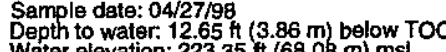

Water $\theta$

Sp. conductance: $380 \mu \mathrm{S} / \mathrm{cm}$

Water evacuated from the well prior to sampling: $84 \mathrm{gal}$

ANALYSES

\begin{tabular}{|c|c|c|c|c|c|c|c|c|}
\hline Analyte & Result & ค & A & B & SQL & Unit & Lab & Method \\
\hline $\begin{array}{ll}0 & \text { Mercury, total recoverable } \\
2 & \text { Nikrate-nititite as nitrogen } \\
0 & \text { pH } \\
1 & \text { Specific conductance } \\
0 & \text { Gross alpha } \\
2 & \text { Nonvolatile beta } \\
2 & \text { Tritium }\end{array}$ & $\begin{array}{l}0.283 \\
42,000 \\
6.01 \\
466 \\
6.61 \mathrm{E}-09 \pm 1.93 \mathrm{E}-09 \\
7.85 \mathrm{E}-08 \pm 4.00 \mathrm{E}-09 \\
0.63 \mathrm{E}-03 \pm 1.63 \mathrm{E}-04\end{array}$ & Ull & $\begin{array}{l}v \\
v\end{array}$ & $\mathbf{L}$ & $\begin{array}{l}0.200 \\
2.500 \\
0.00 \\
5.00 \\
1.65 E-09 \\
2.56 E-09 \\
7.89 E-06\end{array}$ & 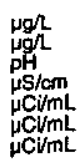 & $\begin{array}{l}G E \\
G E \\
G E \\
G E \\
G P \\
G P \\
G P\end{array}$ & 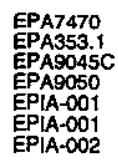 \\
\hline
\end{tabular}

\section{WELL HSB137D}

MEASUREMENTS CONDUCTED IN THE FIELD

Sample date: $04 / 27 / 98$
Depth to water: $11.85 \mathrm{ft}$ (3.61 m) below TOC

$\mathrm{H}=5$

Sp. conductance: $140 \mu \mathrm{S} / \mathrm{cm}$

Wubidity: 0 NTU

ANALYSES

$F$ Anatyte

2 Mercury, total recoverable

pH

Gross alpha
Time: 14:27

(Tm: $14: 27$ (15)

Total alkalinity (as CaCO3): $0 \mathrm{mg} / \mathrm{L}$

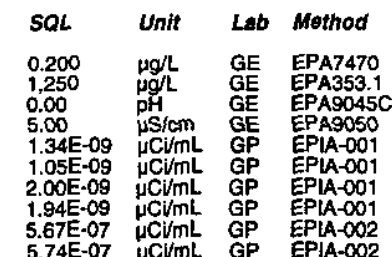

Time: 12:21

Water temperature: $20{ }^{\circ} \mathrm{C}$

Total alkalinity (as CaCO3): $9 \mathrm{mgh}$

7.89E-06 $4 \mathrm{HC} / \mathrm{mL}$ GP EPIA.002

Time: 13:21

Water temperature: $19^{\circ} \mathrm{C}$

Aotal akkalinity (as CacO3): $2 \mathrm{mgh}$
Phenolphthalein alkalinity: $0 \mathrm{mg} /$
$<0.2000$
WELL HSB138D

MEASUREMENTS CONDUCTED IN THE FIELD

Sample date: $04 / 20 / 98$

Water elevation: $228.25 \mathrm{ft}(69.57 \mathrm{~m}) \mathrm{ms}$

$\mathrm{H}: 7.6$

conductance: $64 \mu \mathrm{s} / \mathrm{cm}$

Water evacuated from the well prior to sampling: $1 \mathrm{gal}$

ANALYSES

$F$ Anajyte

Result

Mercury, total recoverable

Nitrate-nitrite as nitrogen

Specitic conductance

O Nonvolatile bete

Tritum

WELL HSB139A

MEASUREMENTS CONDUCTED IN THE FIELD

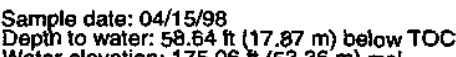

Water elevation: $175.06 \mathrm{Ht}(53.36 \mathrm{~m}) \mathrm{ms}$

H: 7.4

conductance: $190 \mu \mathrm{S} / \mathrm{cm}$

Water evacuated from the well prior to sampling: $146 \mathrm{gal}$

ANALYSES

$F$ Analyto

Resuft

Mercury, tolat recoverable

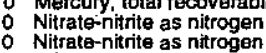

Specific conductance

Gross alpha

Nonvolatile bet

Tritium

\section{WELL HSB139C}

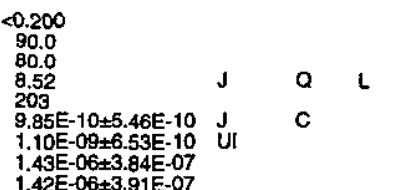

Time: 12:15

Total alkalinity (as CaCO3): $18 \mathrm{mg} / \mathrm{L}$

MEASUREME

Sarmple date: $04 / 27 / 98$
Depth to water $17.5 \mathrm{ft}(5.33 \mathrm{~m})$ below TOC
Water elevation: $216.3 \mathrm{t}(65.93 \mathrm{~m}) \mathrm{msl}$

Wate 5

sp. conductance: $320 \mu \mathrm{S} / \mathrm{cm}$

Water evacuated from the well prior to sampling: 1 gal

ANALYSES

$F$ Analyto

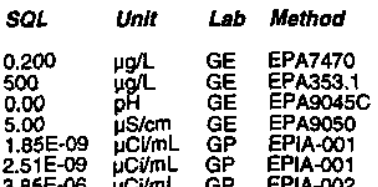

2 Mercury, total recoverablo

Mitralo nitrite as nitrogan

Specific conductance

Gross alpha
Resuit
2,10
38,000
5.53
375
$3.59 \mathrm{E}-\mathrm{O}$
$2.18 \mathrm{E}-\mathrm{O}$
$2.34 \mathrm{E}-\mathrm{O}$ U. $V$
Time: $9: 08$

Art emoerature: $191^{\circ} \mathrm{C}$

Total ajkalinity (as CaCO3): $95 \mathrm{mg} / \mathrm{L}$ 


\section{WELL HSB139D}

MEASUREMENTS CONDUCTED IN THE FIELD

Sample date: $04 / 15 / 98$
Depth to water: $8.32 \mathrm{ft}(2.54 \mathrm{~m}$ ) below TOC

Water elevation

Sp. conductance: $55 \mu \mathrm{S} / \mathrm{cm}$
Turbidity: $5 \mathrm{NTU}$.
Water evacuated from the well prior to sampling: $49 \mathrm{gal}$

ANALYSES

\begin{tabular}{|c|c|c|c|c|c|c|c|c|}
\hline Analyte & Rosuff & A & A & B & $S Q L$ & Unt & Lab & Method \\
\hline $\begin{array}{l}\text { Mercury, total recoverable } \\
\text { Nitrate-nitrite as nihrogen } \\
\text { pH } \\
\text { Specific conductance } \\
\text { Gross alpha } \\
\text { Nonvolatile beta } \\
\text { Tritium }\end{array}$ & $\begin{array}{l}<0.200 \\
1,710 \\
5.07 \\
57.4 \\
1.22 \mathrm{E}-09 \pm 5.26 \mathrm{E}-10 \\
3.36 \mathrm{E}-09 \pm 8.14 \mathrm{E}-10 \\
6.41 \mathrm{E}-05 \pm 1.47 \mathrm{E}-06\end{array}$ & $\mathrm{~J}$ & c & L & $\begin{array}{l}0.200 \\
50.0 \\
0.00 \\
5.00 \\
4.44 E-10 \\
1.22 E-09 \\
6.84 E-07\end{array}$ & $\begin{array}{l}\mu \mathrm{g} / \mathrm{L} \\
\mu \mathrm{g} \\
{ }_{\mathrm{p}} \\
\mu \mathrm{S} / \mathrm{cm} \\
\mu \mathrm{C} V \mathrm{~mL} \\
\mu \mathrm{CV} / \mathrm{mL} \\
\mu \mathrm{CimL}\end{array}$ & $\begin{array}{l}\mathrm{GE} \\
\mathrm{GE} \\
\mathrm{GE} \\
\mathrm{GE} \\
\mathrm{GP} \\
\mathrm{GP} \\
\mathrm{GP}\end{array}$ & $\begin{array}{l}\text { EPA7470 } \\
\text { EPA353.1 } \\
\text { EPA9045C } \\
\text { EPA9050 } \\
\text { EPAA-001 } \\
\text { EPAA-001 } \\
\text { EPIA-002 }\end{array}$ \\
\hline
\end{tabular}

\section{WELL HSB140A}

MEASUREMENTS CONDUCTED IN THE FIELD

Sample date: 04/06/98 .

Dappl to water. $59.09 \mathrm{ft}(18.01 \mathrm{~m})$ below TOC
Water elevation: $176.81 \mathrm{ft}(53.89 \mathrm{~m}) \mathrm{msl}$

$\mathrm{gH}: 6.5$. conductance: $120 \mu \mathrm{S} / \mathrm{cm}$

Watidity: 1 NTU ANALYSES

F Analyte

Nercury, total recoverable

: $\mathrm{pH}$ Specific conductance

Specific condu

O Nonvolatil

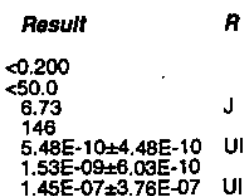

\section{WELL HSB140C}

MEASUREMENTS CONDUCTED IN THE FIELD

Sample date: 04/06/98

Wepth to water: $27.44 \mathrm{ft}(8.36 \mathrm{~m})$ below
Water elevation: $208.16 \mathrm{ft}(63.45 \mathrm{~m}) \mathrm{ms}$

PH: 6.2

Sp. conductance: $24 \mu \mathrm{S} / \mathrm{cm}$

Water evacuated from the well prior to sampling: $79 \mathrm{gal}$

ANALYSES

F Analyte

Mercury, total recoverable

$0 \mathrm{pH}$ Specific conductance

Gross alpha

Tritium
Time: 7:48

Total alkalinuty: (as CaCO3): $1 \mathrm{mg} / \mathrm{L}$
Phenolphthalein alkalinity: $0 \mathrm{mg} / \mathrm{L}$
Time: 12:19

Total afkalinity (as CaCO3): $47 \mathrm{mgh}$
Phenolphthalein alkalinity: $0 \mathrm{mgh}$
Water temperature: $20.1^{\circ} \mathrm{C}$ Air temperature: $25.2^{\circ} \mathrm{C}$ ) $4 \mathrm{mg} / \mathrm{h}$
Werat $16.9^{\circ} \mathrm{C}$

WELL HSB140D

MEASUREMENTS CONDUCTED IN THE FIELD Sample date: 04/06/98 Depth to water: $15.78 \mathrm{ft}(4.81 \mathrm{~m})$ below TOC Wh: 4 . Sp. cond . conductance: $21 \mu \mathrm{S} / \mathrm{cm}$

Water evacuated from the well prior to sampling: $47 \mathrm{gal}$ ANALYSES

F Anatro

Nercury, total recoverable

pH

Gross alpha

O Nonvolation

\section{WELL HSB141A}

MEASUREMENTS CONDUCTED IN THE FIELD

Sample date: 04/15/98

Deph to water: $75.84 \mathrm{ft}(23.12 \mathrm{~m})$ below TOC

Water elevalion. $178.76 \mathrm{ft}(54.49 \mathrm{~m}) \mathrm{ms}$

Sp. conductance: $900 \mu \mathrm{S} / \mathrm{cm}$

Wurbidity: O NTU ANALYSES

$F$ Anatyo

- Mercury total recoverable

Nitrate-ritrite as nitrogen

2 Specific conductance

Nonvolatile beta

WELL HSB141CR

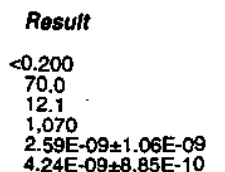
$2.59 \mathrm{E}-09 \pm 1.06 \mathrm{E}-\mathrm{Cg}$ $2.58 E-06 \pm 4.87 E-07$
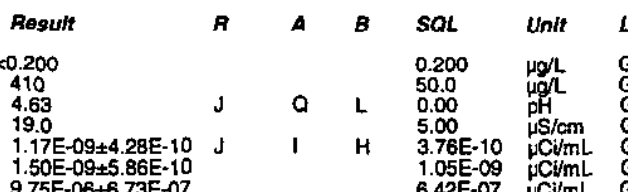

Tater temperature: $20.1^{\circ} \mathrm{C}$ Thenol alkalinity (as Caco3): $0 \mathrm{mgh}$

MEASUREMENTS CONDUCTED IN THE FIELD

Sample date: 04/15/98

Depth to water: $22.03 \mathrm{ft}(6.71 \mathrm{~m})$ below TOC
Water elevation: $232.27 \mathrm{ft}(70.8 \mathrm{~m}) \mathrm{ms}$ l

$\mathrm{H}: 6.3$

Sp. conductance: $23 \mu \mathrm{S} / \mathrm{cm}$

Water evacuated from the well prior to sampling: 125 gal ANALYSES

$F$ Analyto

- Mercury, total recoverable

Nitrate-nitrite as nitrogen

${ }_{0}^{0} \mathrm{pH}$ Specific conductanco

Nonvolatile beta

0 Nritium

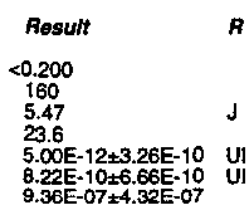

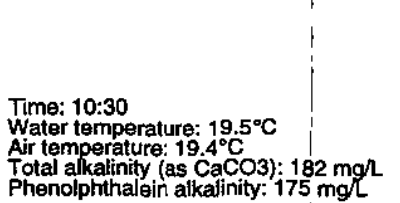

Total alkalinity (as CaCO3); $182 \mathrm{mgh}$
Phenolphthalein alkalinity: $175 \mathrm{mg} /$

Method

\begin{tabular}{|c|c|c|c|}
\hline SOL & Unit & Lab & Method \\
\hline $\begin{array}{l}0.200 \\
50.0 \\
0.00 \\
5.00 \\
1.17 E-09 \\
1.23 E-09 \\
6.87 E=07\end{array}$ & 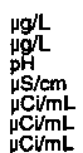 & $\begin{array}{l}\mathrm{GE} \\
\mathrm{GE} \\
\mathrm{GE} \\
\mathrm{GE} \\
\mathrm{GP} \\
\mathrm{GP} \\
\mathrm{GP}\end{array}$ & $\begin{array}{l}\text { EPA7470 } \\
\text { EPA353.1 } \\
\text { EPA99045C } \\
\text { EPA9050 } \\
\text { EPIA-001 } \\
\text { EPIA-001 } \\
\text { EPIA-002 }\end{array}$ \\
\hline
\end{tabular}

Time: 11:46

Total alkalinity (as CaCos): $8 \mathrm{mg}$

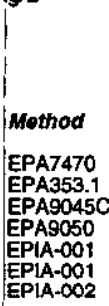

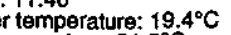




\section{WELL HSB141D}

MEASUREMENTS CONDUCTED IN THE FIELD

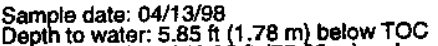
Depth to water: $5.85 \mathrm{ft}(1,78 \mathrm{~m})$ below TOC
Water elevation: $248.95 \mathrm{ft}(75.88 \mathrm{~m}) \mathrm{msl}$

WH: 4.8

p. conductance: $20 \mu \mathrm{S} / \mathrm{cm}$

Water evacuated from the well prior to sampling: $57 \mathrm{gal}$ ANALYSES

F Analyto

1. Mercury, total recoverable

: $\mathrm{pH}$ Specific conductance

Gross alpha

1 Tritium

\section{WELL HSB142C}

MEASUREMENTS CONDUCTED IN THE FIELD

\section{Sample date: $04 / 16 / 98$
Depth to water: $4.72 \mathrm{ft}(1.44 \mathrm{~m})$ below TOC
Water elevation: $199.28 \mathrm{ft}(60.74 \mathrm{~m})$ msl
pH: 4.7}

Turbidity: 2 NTU

ANALYSES

\begin{tabular}{|c|c|c|c|c|c|c|c|c|}
\hline Analyte & Result & $R$ & A & $B$ & SQL & Unit & Lab & Method \\
\hline 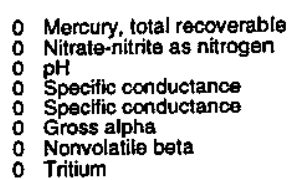 & $\begin{array}{l}<0.200 \\
330 \\
5.11 \\
21.1 \\
21.3 \\
2.67 \\
8.67-10 \pm 3.02 E-10 \\
8.8110 \pm 5.98 E-10 \\
5.85-06 \pm 5.81 E-07\end{array}$ & Uü & Q & L & $\begin{array}{l}0.200 \\
50.0 \\
0.00 \\
5.00 \\
5.00 \\
5.50 E-10 \\
1.19 E-09 \\
6.85 E-07\end{array}$ & $\begin{array}{l}\mu g / \mathrm{L} \\
\mu g / \mathrm{L} \\
\mathrm{p}_{\mathrm{H}} \\
\mu \mathrm{S} / \mathrm{cm} \\
\mu \mathrm{S} / \mathrm{cm} \\
\mu \mathrm{C} / \mathrm{mL} \\
\mu \mathrm{CV} / \mathrm{mL} \\
\mu \mathrm{Ci} / \mathrm{mL}\end{array}$ & $\begin{array}{l}\mathrm{GE} \\
\mathrm{GE} \\
\mathrm{GE} \\
\mathrm{GE} \\
\mathrm{GE} \\
\mathrm{GE} \\
\mathrm{GP} \\
\mathrm{GP}\end{array}$ & $\begin{array}{l}\text { EPA7470 } \\
\text { EPA353.1 } \\
\text { EPA9045C } \\
\text { EPA9050 } \\
\text { EPA9050 } \\
\text { EPIA-01 } \\
\text { EPIA-001 } \\
\text { EPIA-002 }\end{array}$ \\
\hline
\end{tabular}

\section{WELL HSB142D}

MEASUREMENTS CONDUCTED IN THE FIELD

Sample date: 04/16/98 Semple date: $04 / 1698$
Dath to water: 4.82 t t $(1.47 \mathrm{~m})$ below TOC
Water elevation: $199.38 \mathrm{it}(60.77 \mathrm{~m})$ msl

Water

Sp.conductance: $45 \mu \mathrm{S} / \mathrm{cm}$

ANALYSES

$F$ Analyto

0 Mercury, total recoverable

$0 \mathrm{pH}$

Specific conductance

Gross alpha

2 Tritium ime: 15:00

Ar ternperaturs: $23.7^{\circ} \mathrm{C}$

Total alkalinity (as CaCO3): $4 \mathrm{mgh}$
Art temperature: $25,1^{\circ} \mathrm{C}$. $1 \mathrm{mg}$

Air temperature: $27.3^{\circ} \mathrm{C}$
Total akalinity (as Caco3): $0 \mathrm{mgh}$
Phenolphthalein alkalinity: $0 \mathrm{mg}$.

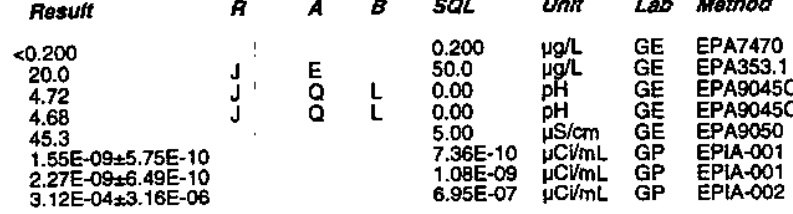

WELL HSB143C

MEASUREMENTS CONDUCTED IN THE FIELD

Sample date: $04 / 15 / 98$
Depth to water: $10.5 \mathrm{ft}(3.2 \mathrm{~m})$ below TOC
Wate

PH: 4.5 .

Turbidity: 0 NTU
Water evacuated from the well prior to sampling: 103 gal

ANALYSES

$F$ Analyto

: Mercury, total recoverable

$0 \mathrm{pH}$

Specific conductance

G Gross alpha

Tritium

\section{WELL HSB143D}

MEASUREMENTS CONDUCTED IN THE FIELD

Sample date: 04/15/98

Depth to water: $7.05 \mathrm{Ht}(2.15 \mathrm{~m})$ below TOC

$\mathrm{pH}: 4.3$

Pp: 4.3

Wp. conductance: $18 \mu \mathrm{S} / \mathrm{cm}$

Water evacuated from the well prior to sampling: $45 \mathrm{gal}$

ANALYSES

\begin{tabular}{|c|c|c|c|c|c|c|c|c|}
\hline Analyte & Result & R & $A$ & & SQL & Unit & Lab & Method \\
\hline $\begin{array}{l}\text { Mercury, total recoverable } \\
\text { Nitratt-nitrite as nitrogen } \\
\text { pH } \\
\text { pH } \\
\text { Specific conductance } \\
\text { Specific conductance } \\
\text { Gross alpha } \\
\text { Gross alpha } \\
\text { Nonvolatile beta } \\
\text { Nonvolatile beta }\end{array}$ & $\begin{array}{l}<0.200 \\
350 \\
4.70 \\
4.71 \\
19.6 \\
19.5 \\
1.42 E-09+6.01 E-10 \\
1.61 E-09 \pm 5.57 E-10 \\
9.70 E-10 \pm 6.94 E-10 \\
8.45 E-10 \pm 5.08 E-10\end{array}$ & J & $\begin{array}{l}\text { a } \\
\text { c } \\
\text { c }\end{array}$ & & $\begin{array}{l}0.200 \\
50.0 \\
0.00 \\
0.00 \\
5.00 \\
5.00 \\
6.39 E-10 \\
6.68 E-10 \\
1.40 E-09 \\
9.84 E-10 \\
6.87 E-07\end{array}$ & 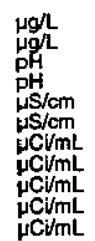 & $\begin{array}{l}\mathrm{GE} \\
\mathrm{GE} \\
\mathrm{GE} \\
\mathrm{GE} \\
\mathrm{GE} \\
\mathrm{GE} \\
\mathrm{GP} \\
\mathrm{GP} \\
\mathrm{GP} \\
\mathrm{GP} \\
\mathrm{GP}\end{array}$ & 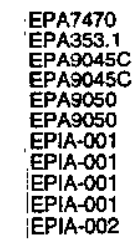 \\
\hline
\end{tabular}

\section{WELL HSB144A}

MEASUREMENTS CONDUCTED IN THE FIELD

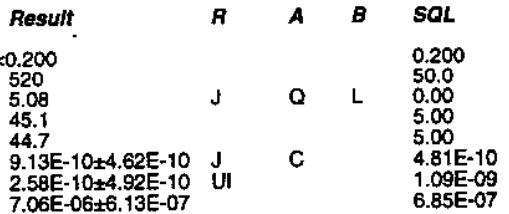

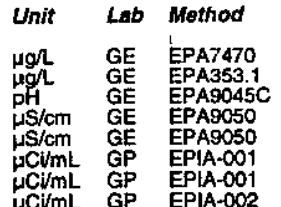

Time: 13:06

mperature: $191^{\circ} \mathrm{C}$

Total alkalinity (as CaCO3): $1 \mathrm{mg} / \mathrm{h}$
Phenolphthalein alkalinity: 0 mg/L

\begin{tabular}{|c|c|c|c|c|c|c|c|c|}
\hline Analyte & Result & $\boldsymbol{A}$ & $A$ & $B$ & $S Q L$ & Unit & Lab & Method \\
\hline $\begin{array}{ll}0 & \text { Mercury, total recoverable } \\
0 & \text { Nitrate-nitrite as nitrogen } \\
0 & \text { pH } \\
0 & \text { pH } \\
0 & \text { Specific conductance } \\
0 & \text { Gross alpha } \\
0 & \text { Nonvolatile beta } \\
2 & \text { Tritium } \\
2 & \text { Tritium }\end{array}$ & $\begin{array}{l}<0.200 \\
500 \\
6.56 \\
6.60 \\
169 \\
7.96 \mathrm{E}-10 \pm 4.72 \mathrm{E}-10 \\
3.25 \mathrm{E}-09 \pm 7.519-10 \\
1.50 \mathrm{E}-04 \pm 2.19-06 \\
1.57 \mathrm{E}-04 \pm 2.26 \mathrm{E}-06\end{array}$ & $\vec{J}$ & $\stackrel{0}{\circ}$ & $L$ & $\begin{array}{l}0.200 \\
50.0 \\
0.00 \\
0.00 \\
5.00 \\
6.70 E-10 \\
1.17 E-09 \\
6.81 E-07 \\
6.91 E-07\end{array}$ & $\begin{array}{l}\mu g / \mathrm{L} \\
\mu \mathrm{g} / \mathrm{L} \\
\mathrm{pH} \\
\mathrm{pH} \\
\mu \mathrm{S} / \mathrm{cm} \\
\mu \mathrm{C} / \mathrm{mL} \\
\mu \mathrm{Ci} / \mathrm{mL} \\
\mu \mathrm{C} / \mathrm{mL} \\
\mu \mathrm{Ci} / \mathrm{mL}\end{array}$ & $\begin{array}{l}\mathrm{GE} \\
\mathrm{GE} \\
\mathrm{GE} \\
\mathrm{GE} \\
\mathrm{GE} \\
\mathrm{GP} \\
\mathrm{GP} \\
\mathrm{GP} \\
\mathrm{GP}\end{array}$ & $\begin{array}{l}\text { EPA7470 } \\
\text { EPA353.1 } \\
\text { EPA9045C } \\
\text { EPA9045C } \\
\text { EPA9050 } \\
\text { EPIA-001 } \\
\text { EPIA-001 } \\
\text { EPIA-002 } \\
\text { EPIA-002 }\end{array}$ \\
\hline
\end{tabular}

Sample date: 04/16/98

Wepth to water: $63.7 \mathrm{tt}(19.42 \mathrm{~m})$ below TOC

$\mathrm{pH}: 6.8$

Sp. conductance: $140 \mu \mathrm{S} / \mathrm{cm}$

Water evacuated from the well prior to sampling: $302 \mathrm{gal}$

ANALYSES

Time: 11:04

Air temperarature: $21^{\circ} \mathrm{C}$

Total alkalinity (as CaCO3): $77 \mathrm{mg} /$

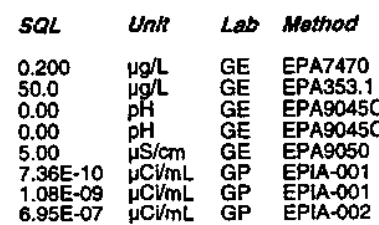




\section{WELL HSB145C}

MEASUREMENTS CONDUCTED IN THE FIELD

Sample date: $04 / 27 / 98$ (3.99 m) below TOC
Sample date: $04 / 23 / 98$
Depth to water: $20.2 \mathrm{tt}(6.16 \mathrm{~m})$ below TOC
Water elevation: $215.5 \mathrm{tt}(65.69 \mathrm{~m}) \mathrm{msl}$

H: 5.8

p. conductance: $320 \mu \mathrm{S} / \mathrm{cm}$

Water evacuated from the well pror to sampling: $98 \mathrm{gal}$

ANALYSES

$F$ Analyte

1 Mercury, total recoverable

1 Specific conductance

O Gross alpha

1 Nonvolatile bet

\section{WELL HSB145D}

MEASUREMENTS CONDUCTED IN THE FIELD Water elevation: $223.11 \mathrm{Ht}(68 \mathrm{~m}) \mathrm{ms} \mid$

PH: 4.1 .

Water evacuated from the well prior to sampling: $65 \mathrm{gal}$

ANALYSES

$F$ Analyto

2 Mercury, total recoverable

1 Specific conductance

2 Gross apha

2 Nonvola

$\begin{array}{llll}\text { Result } & \boldsymbol{A} & \boldsymbol{A} & \boldsymbol{B} \\ 1.02 & & & \\ 33.000 & & \mathrm{~V} & \\ 6.00 & \mathrm{~J} & \mathrm{Q} & 1 \\ 400 & & \\ 1.72 E-09 \pm 8.18 E-10 & \mathrm{~J} & \times & \\ 3.53 \mathrm{E}-08+2.08 E-09 & \mathrm{~J} & \times & \\ 1.50 \mathrm{E}-03 \pm 2.92 \mathrm{E}-05 & & & \end{array}$

Time: 11:16

ir temperature: $19^{\circ} \mathrm{C}$ Total alkalinity (as Caco3): $17 \mathrm{mg} /$

\section{WELL HSB146A}

MEASUREMENTS CONDUCTED IN THE FIELD

Sample date: 04/28/98

Depth to water: $74.49 \mathrm{ft}(22.7 \mathrm{~m})$ below TOC

Water 7.2

Water evacuated from the well prior to sampling: $142 \mathrm{gal}$

ANALYSES

$F$ Analyto

- Mercury, total recoverable

Nitrate-nitrite as nitrogen

${ }_{0} \mathrm{pH}$ Specific conductance

Oross alpha

: Tritium

Time: $13: 53$ Water temperature: $19.7^{\circ} \mathrm{C}$

Total alkalinity (as $\mathrm{CaCO}$ ): $77 \mathrm{mgh}$
. conductance: $160 \mu \mathrm{S} / \mathrm{cm}$

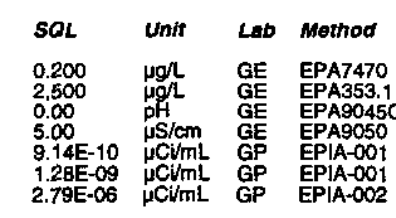

Time: 9:4

Air temperature: $20^{\circ} \mathrm{C}$
Total alkalinity (as CaCO3) $0 \mathrm{mgl}$
Phenolphthalein alkalinity: $0 \mathrm{mg} /$
WELL HSB146C

MEASUREMENTS CONDUCTED IN THE FIELD

Sample date: 04/28/98

Wepth to water: 40.9 tt $(12.47 \mathrm{~m})$ below TOC

$\mathrm{WH} 7 \mathrm{79}$

P. conductance: $56 \mathrm{\mu S} / \mathrm{cm}$

Water evacuated from the well prior to sampling: $86 \mathrm{gal}$

ANALYSES

$F$ Anelyto

Nitrate-nitrite as nitrogen

S perific conductance

Nonvolatila beta

Trítium

WELL HSB146D

MEASUREMENTS CONDUCTED IN THE FIELD

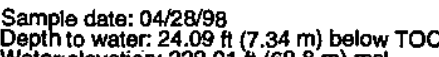

Water to waterion: $24.09 \mathrm{Ht}(7.34 \mathrm{~m})$ below

$\mathrm{H}$ : 5.4

Sp. conductance: $21 \mu \mathrm{S} / \mathrm{cm}$

Water evacuated from the well prior to sampling: 51 ga ANALYSES

F Analyte

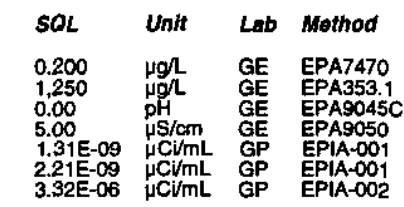

O Mercury, total recoverable

0 Specific conductance

Nonvolatile bet

Tritium

WELL HSB147D

MEASUREMENTS CONDUCTED IN THE FIELD

Sample date: 04/23/98

Depth to water. $32.85 \mathrm{ft}(10.01 \mathrm{~m})$ below TOC

$\mathrm{pH}: 5.2$

. conductance: $28 \mu \mathrm{S} / \mathrm{cm}$

Water evacuated from the well prior to sampling: $1 \mathrm{gal}$

ANALYSES

F Analyte

- Mercury, total recoverable

$0 \mathrm{pH}$

pectic conductance

Gross alpha
Nonvolatile beta
Tritium

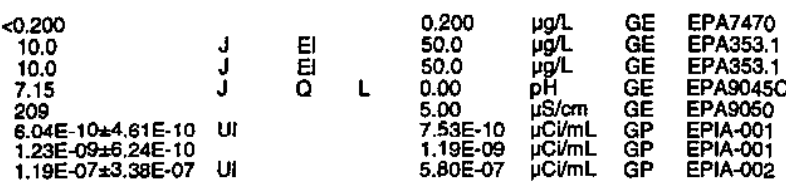

4.200
410

5.30
33.4

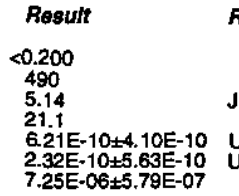

Time: 12:20 Water temperature: $19.2^{\circ} \mathrm{C}$ Total alkalinity (as CaCO3): $0 \mathrm{mg}$

Water temperature: $19^{\circ} \mathrm{C}$ otal alkalinity (as CaCo3): $18 \mathrm{mg} /$

$\llcorner\quad 5$

$5.85 E-07$ CVinL GP

5.00 HCUmL GP EPIA-O2

Time: 12:20

Air temperature $146^{\circ} \mathrm{C}$

Total alkalinity (as CaCO3): $2 \mathrm{~m}$

CaCO3); $2 \mathrm{mgl}$
$\mathrm{m}$ 


\section{WELL HSB148C}

MEASUREMENTS CONDUCTED IN THE FIELD

Sample date 04/27/98

Depth to water: $48.2 \mathrm{ft}(14.69 \mathrm{~m})$ below TOC

Sp. conductance: $160 \mu \mathrm{S} / \mathrm{cm}$

Wuater evacuated from the well prior to sampling: 4 ga ANALYSES

$F$ Analyte

: Mercury, total recoverable

2 PH

Gross alpha

0 Tritium

\section{WELL HSB148D}

MEASUREMENTS CONDUCTED IN THE FIELD

Sample date: 04/27/98 $20.29 \mathrm{~m}$ ) below TOC Wath to water: $33.76 \mathrm{ft}(10.29 \mathrm{~m})$ below

$\mathrm{pH}: 6.9$

. conductance: $120 \mu \mathrm{S} / \mathrm{cm}$

Watbidity: 11 NTU ANALYSES

F Analyto

O Mercury, total recoverable

Nitrate-nitrite as nitrogen
Nitrate-nitrite as nitrogen

$\mathrm{pH}$ Specific conductance

Gross alpha

Gross alpha
0 Nonvolatile beta
0 Tritium

\section{WELL HSB149D}

MEASUREMENTS CONDUCTED IN THE FIELD

Sample date: 04/27/98

Depth to water: $14.06 \mathrm{ft}(4.29 \mathrm{~m})$ below TOC

Water elevation: $225.94 \mathrm{kt}$
$\mathrm{HH}: 7.2$
$\mathrm{Sp} . \mathrm{conductance:} 17 \mu \mathrm{S} / \mathrm{cm}$

Turbidity: 2 NTU
Water evacuated from the well prior to sampling: $74 \mathrm{gal}$ ANALYSES

$F$ Analyte

: Mercury, total recoverable

$\mathrm{PH}_{\mathrm{Specific}}^{\mathrm{H}}$ conductance

Gross alpha

1 Tritium

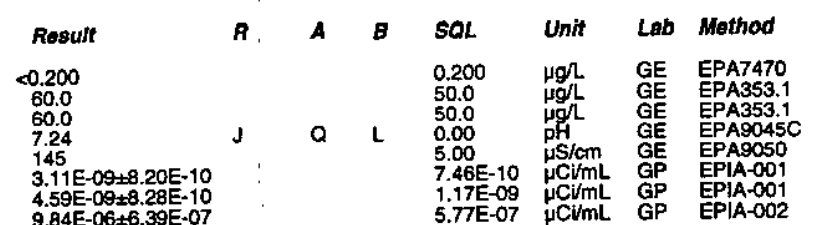

Time: 12:09

Water temperature: $18.8^{\circ} \mathrm{C}$

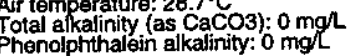

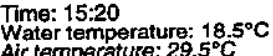
Air termperature: $29.5^{\circ} \mathrm{C}$
Total alkalinity (as CaCO3): $58 \mathrm{mg} / \mathrm{L}$
Phenolphthalein alkalinity: $0 \mathrm{mg} /$

Water temperature: $18.5^{\circ} \mathrm{C}$ Total alkalinity (as CaCOO3): $47 \mathrm{mgl}$

\begin{tabular}{|c|c|c|c|}
\hline SOL & Unit & Lab & Method \\
\hline $\begin{array}{l}0.200 \\
50.0 \\
0.00 \\
5.00 \\
6.36 E-10 \\
1.16 E-09\end{array}$ & $\begin{array}{l}\mu \mathrm{\mu} / \mathrm{L} \\
\mu \mathrm{L} / \mathrm{L} \\
\mathrm{pH} \\
\mu \mathrm{S} / \mathrm{cm} \\
\mu \mathrm{CimL} \\
\mu \mathrm{CH} / \mathrm{mL}\end{array}$ & $\begin{array}{l}\mathrm{GE} \\
\mathrm{GE} \\
\mathrm{GE} \\
\mathrm{GE} \\
\mathrm{GP} \\
\mathrm{GP} \\
\mathrm{GP}\end{array}$ & $\begin{array}{l}\text { EPA7470 } \\
\text { EPA353. } \\
\text { EPA9045 } \\
\text { EPA9050 } \\
\text { EPAA-001 } \\
\text { EPAA-001 } \\
\text { EPAA-002 }\end{array}$ \\
\hline
\end{tabular}

\begin{tabular}{|c|c|c|c|c|c|c|c|}
\hline Resulf & $\boldsymbol{A}$ & $A$ & $B$ & $S Q L$ & Unit & Lab & Method \\
\hline $\begin{array}{l}<0.200 \\
60.0 \\
4.89 \\
19.0 \\
4.68 E-10 \pm 3.07 E-10 \\
1.13 E-09+5.47 E-10 \\
1.46-05+7.49 E-10\end{array}$ & $\mathrm{~J}$ & 0 & $\mathbf{L}$ & $\begin{array}{l}0.200 \\
50.0 \\
0.00 \\
5.00 \\
4.18 E-10 \\
1.02 E-09 \\
5.85-07\end{array}$ & 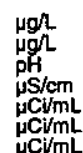 & $\begin{array}{l}G E \\
G E \\
G E \\
G E \\
G P \\
G P \\
G P\end{array}$ & $\begin{array}{l}\text { EPA7470 } \\
\text { EPA353.1 } \\
\text { EPA9045 } \\
\text { EPA9050 } \\
\text { EPIA-D01 } \\
\text { EPA-D01 } \\
\text { EPIA-002 }\end{array}$ \\
\hline
\end{tabular}

\section{WELL HSB150D}

MEASUREMENTS CONDUCTED IN THE FIELD

Sample date: $04 / 27 / 98$
Depth to water: $9.12 \mathrm{tt}(2.78 \mathrm{~m})$ below TOC

Water

Sp. conductance: $25 \mu \mathrm{S} / \mathrm{cm}$

Water evacuated from the well prior to sampling: 84 gal

ANALYSES

$F$ Analyo

Mercury, total recoverable
0 Nitrate-nitrite as nitrogen

$0 \mathrm{pH}$.

Specific conductanc
Nons alpha
Tolatile beta

Tritium

\section{WELL HSB151C}

MEASUREMENTS CONDUCTED IN THE FIELD

Sample date: 04/23/98

Depth to water: 4.29 it $(1.31 \mathrm{~m})$ below TOC
Water elevation: 209.3 f $\mathrm{f}(63.8 \mathrm{~m}) \mathrm{ms}$ )

$\mathrm{pH}: 4.8$

Sp. conductance: $86 \mu \mathrm{S} / \mathrm{cm}$

Tutridity: 1 NTU 1 from the well prior to sampling: $82 \mathrm{gal}$

ANALYSES

F Analyto

$\begin{array}{ll}\text { Result } & R \\ <0.200 & \\ <50.0 & \\ 5.18 & \mathrm{~J} \\ 29.3 & \\ 3.71 \mathrm{E}-10 \pm 3.80 \mathrm{E}-10 & \mathrm{UI} \\ 6.48 \mathrm{E}-10 \pm 5.56 \mathrm{E}-10 & \mathrm{UI} \\ 1.46 \mathrm{E}-05 \pm 7.46 \mathrm{E}-07 & \end{array}$

Total alkalinity (as CaCO3): $0 \mathrm{mgh}$

Mercury, total recoverable

PH

Gross alpha
Nonvolatile beta

2 Tritium

\section{WELL HSB151D}

MEASUREMENTS CONDUCTED IN THE FIELD

Sample date: 04/23/98

Depth to water: $4.9 \mathrm{ft}(1.49 \mathrm{~m})$ below TOC

Water el wat

p. conductance: $16 \mu \mathrm{S} / \mathrm{cm}$

Turbidity: 3 NTU

ANALYSES

F Anatyo

Mercury, total recoverable

Nitrato-nitrite as nitroge

Specitic conductance

Gross alpha
Nonvolatile beta

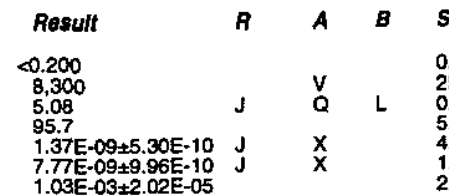

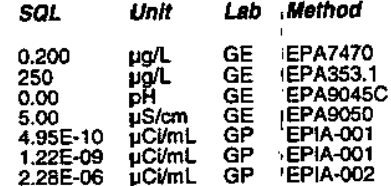

Time: 11:33

Water $11: 33$ perature: $16.8^{\circ} \mathrm{C}$

Totar alkalinity (as CaCO3): 2 


\section{WELL HSB152C}

MEASUREMENTS CONDUCTED IN THE FIELD

Sample date: 04/23/98

Sample date: $04 / 23 / 98$
Depth to water. $14.4 \mathrm{tt}(4.39 \mathrm{~m})$ below TOC
Water elevation: $199.7 \mathrm{ft}(60.87 \mathrm{~m}) \mathrm{msl}$
th: 4.6

Sp. conductance: $120 \mu \mathrm{s} / \mathrm{cm}$

Wurbidity: 1 NTU

ANALYSES

\begin{tabular}{|c|c|c|c|c|c|c|c|c|}
\hline Analyre & Result & $\boldsymbol{A}$ & A & $B$ & SaL & Unit & Lab & Mothod \\
\hline $\begin{array}{l}\text { Mercury, total recoverable } \\
\text { Nitrate-nitrite as nitrogen } \\
\text { pH } \\
\text { Specific conductance } \\
\text { Gross alpha } \\
\text { Nonvolatile beta } \\
\text { Tritium }\end{array}$ & $\begin{array}{l}<0.200 \\
11,100 \\
5.05 \\
125 \\
1.16 E-09 \pm 5.32 E-10 \\
2.19 E-08 \pm 1.50 E-09 \\
1.05 E-03+2.06 E-05\end{array}$ & J & $\begin{array}{l}\mathrm{v} \\
Q \\
x \\
x\end{array}$ & L & $\begin{array}{l}0.200 \\
250 \\
0.00 \\
5.00 \\
6.14 E-10 \\
1.16 E-09 \\
2.29 E-06\end{array}$ & 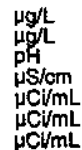 & $\begin{array}{l}G E \\
G E \\
G E \\
G E \\
G P \\
G P \\
G P\end{array}$ & $\begin{array}{l}\text { EPA7470 } \\
\text { EPA353.1 } \\
\text { EPA9045C } \\
\text { EPA9050 } \\
\text { EPAA-001 } \\
\text { EPIA-001 } \\
\text { EPAA-002 }\end{array}$ \\
\hline
\end{tabular}

\section{WELL HSB152D}

MEASUREMENTS CONDUCTED IN THE FIELD

Sample date: $04 / 23 / 98$
Depth to watior: $9.05 \mathrm{tt}(2.76 \mathrm{~m})$ below TOC
Water elevation: $205.05 \mathrm{ft}(62.5 \mathrm{~m}) \mathrm{msl}$

Water

$\mathrm{SH}$. 5 conductance: $30 \mu \mathrm{S} / \mathrm{cm}$

Turbidity: $68 \mathrm{NTU}$ N
Water evacuated from the well prior to sampling: $1 \mathrm{gal}$

ANALYSES

\begin{tabular}{|c|c|c|c|c|c|c|c|c|}
\hline Analyte & Resuft & $R$ & A & B & $S Q L$ & Unit & Lab & Method \\
\hline $\begin{array}{l}\text { Mercury, total recoverable } \\
\text { Netrate-nitrite as nitrogen } \\
\text { pH } \\
\text { pH } \\
\text { Specific conductance } \\
\text { Gross alpha } \\
\text { Nonvolatile beta } \\
\text { Tritium } \\
\text { Trititum }\end{array}$ & $\begin{array}{l}<0.200 \\
20.0 \\
5.13 \\
5.03 \\
28.6 \\
9.68 \mathrm{E}-09 \pm 1.02 E-09 \\
5.67 \mathrm{E}-09 \pm 7.22 \mathrm{E}-10 \\
1.78 \mathrm{E}-05 \pm 8.18 \mathrm{E}-07 \\
1.69 \mathrm{E}-05 \pm 8.03 E-07\end{array}$ & & $\begin{array}{l}\text { v } \\
Q \\
Q\end{array}$ & $t$ & $\begin{array}{l}0.200 \\
50.0 \\
0.00 \\
0.00 \\
5.00 \\
5.26 \mathrm{E}-10 \\
9.28 \mathrm{E}-10 \\
5.88 \mathrm{E}-07 \\
5.89 \mathrm{E}-07\end{array}$ & 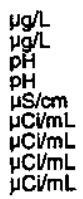 & $\begin{array}{l}G E \\
G E \\
G E \\
G E \\
G E \\
G E \\
G P \\
G P \\
G P \\
G P\end{array}$ & $\begin{array}{l}\text { EPA7470 } \\
\text { EPAA33.1 } \\
\text { EPA9045C } \\
\text { EPA9045C } \\
\text { EPA950 } \\
\text { EPIA-001 } \\
\text { EPPA-01 } \\
\text { PPIA-002 } \\
\text { EPIA-002 }\end{array}$ \\
\hline
\end{tabular}

\section{WELL HSL 1D}

MEASUREMENTS CONDUCTED IN THE FIELD

\section{Sample date: $04 / 28 / 98$
Depth to water: 23.61 ft $(7.2 \mathrm{~m})$ below TOC
Water olevation: $240.39 \mathrm{Ht}(73.27 \mathrm{~m}) \mathrm{msl}$
pH: 3.7 H. 3.7 conductance: $58 \mu \mathrm{S} / \mathrm{cm}$}

Water evacuated from the well prior to sampling: 25 gal ANALYSES

F Analyte
0 Mercury, lotal recoverable
0 Mercury, lotal recoverable
0 Nitrate-nitrite as nitrogen
0 pH
0 pH
0 Specific conductance
0 Gross apha
0 Nonvolatile beta
2 Tititum
2 Tritium

\begin{tabular}{|c|}
\hline Result \\
\hline 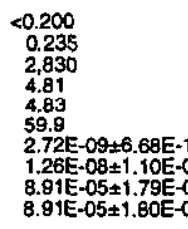 \\
\hline
\end{tabular}

Time: 9:03

Wartorimperature: $18^{\circ} \mathrm{C}$

Total alkalinity (as CaCO3): $0 \mathrm{mg} / \mathrm{L}$
Phenolphthalein alkalinity: $0 \mathrm{mg} L$ $. .91 E-05 \pm 1.79 E-06$
$.91 E-05 \pm 1.80 E-06$
WELL HSL 2D

MEASUREMENTS CONDUCTED IN THE FIELD

Sample date: 04/27/98

Depth to water: 19.02 ft $(5.8 \mathrm{~m})$ below TOC

WH: 6.7

Sp: conductance: $57 \mu \mathrm{S} / \mathrm{cm}$

Turbidity: 0 NTU

ANALYSES

$F$ Anatyto

: Mercury, total recoverabie

$0_{0} \mathrm{NH}$

Specitic conductance

Gross alpha

Tritium

WELL HSL 3D

MEASUREMENTS CONDUCTED IN THE FIELD

Sample date: $04 / 27 / 98$
Depth to water $13.78 \mathrm{ft}(4.2 \mathrm{~m})$ below roc
Water olevation: $253.82 \mathrm{Ht}(7.37 \mathrm{~m}) \mathrm{msl}$

$\mathrm{pH}: 6.9$

Time: $10: 00$ ater temperature: $19{ }^{\circ} \mathrm{C}$

Total alkalinity (as CaCO3): $1 \mathrm{mg} / \mathrm{h}$
Phenolphthalein alkalinity: $0 \mathrm{mg} /$

gh: 6.9

Turbidity: 1 NTU: $29 \mu \mathrm{S} / \mathrm{cm}$

Water evacuated from the well prior to sampling: $13 \mathrm{gal}$ ANALYSES

\begin{tabular}{|c|c|}
\hline Analyte & Result \\
\hline $\begin{array}{l}\text { Mercury, total recoverable } \\
\text { Nitrate-nitrite as nitrogen } \\
\text { pH } \\
\text { Specific conductance } \\
\text { Specific conductance } \\
\text { Gross alpha } \\
\text { Gross alpha } \\
\text { Nonvolatile beta } \\
\text { Nonvolatile beta } \\
\text { Trítium }\end{array}$ & $\begin{array}{l}0.200 \\
1.470 \\
4.86 \\
36.5 \\
35.8 \\
1.14 E-09 \pm 4.48 E-10 \\
8.79 E-10 \pm 4.69 E-10 \\
1.03 E-09 \pm 5.43 E-10 \\
1.75 E-09 \pm 7.21 E-10 \\
1.04 E-04 \pm 2.09 E-06\end{array}$ \\
\hline
\end{tabular}

\section{WELL HSL 4D}

MEASUREMENTS CONDUCTED IN THE FIELD Sample date: $04 / 27 / 98$
Depth to water: $8.35 \mathrm{ft}(2.55 \mathrm{~m})$ below TOC
Water elevation: $264.85 \mathrm{ft}(80.73 \mathrm{~m}) \mathrm{msl}$

$\mathrm{pH}: 5.9$

Water temperature: $21.4^{\circ} \mathrm{C}$

Total alkalinity (as CaCO3): $0 \mathrm{mg} /$
Phenolphthalein alkalinity: $0 \mathrm{mgh}$

Sp. conductance: $100 \mu \mathrm{S} / \mathrm{cm}$

Water evacuated from the well prior to sampling: $16 \mathrm{gal}$

ANALYSES

$F$ Analyto

- Mercury, total recoverable

o

O Grosiffic conduchact

2 Nortium

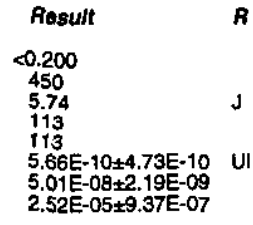

Time: 9:45

Water temperature: $19.5^{\circ} \mathrm{C}$

Artemperature: $19.4^{\circ} \mathrm{C}$ ) 1 mgl 
ANALYTICAL RESULTS

WELL HSL 5D

MEASUREMENTS CONDUCTED IN THE FIELD

Sample date: 04/24/98

Water elevation: $269.03 \mathrm{ft}(82 \mathrm{~m}) \mathrm{ms}$

Sp. conductance: $76 \mu \mathrm{S} / \mathrm{cm}$

Turbidity: 1 NTU $76 \mu \mathrm{S} / \mathrm{cm}$

Water evacuated from the well prior to sampling: $28 \mathrm{gal}$

ANALYSES

$F$ Analyto

Mencury, total recoverable

Specific conductance

Gross alpha

2 Tritium

WELL HSL 6D

MEASUREMENTS CONDUCTED IN THE FIELD

Sample date: $04 / 24 / 98$ ( 1.29 m) below TOC

Wepth to

Sp. conductance: $64 \mu \mathrm{S} / \mathrm{cm}$

Sp.conductance: $64 \mu \mathrm{S} / \mathrm{cm}$

Water evacuated from the well prior to sampling: $22 \mathrm{gal}$

ANALYSES

$F$ Anatyto

Nercury, total recoverable

Specific conductance

Nonvolatile bet:

2 Nonvolatium

\begin{tabular}{|c|c|c|c|c|c|c|c|}
\hline & A & A & $B$ & SOL & Unit & Lab & Method \\
\hline & $\mathrm{J}$ & E & & & & ie & PA7470 \\
\hline & $\mathrm{J}$ & Q & L & & 政 & $G E$ & EPA9045C \\
\hline $\begin{array}{l}E-10 \pm 3.64 E-10 \\
E-08 \pm 1.32 E-09 \\
E-05 \pm 1.17 E-06\end{array}$ & $\mathrm{~J}_{\mathrm{J}}$ & $\begin{array}{l}x \\
x\end{array}$ & & $\begin{array}{l}6.79 E-10 \\
1.16 E-09 \\
5.86 E-07\end{array}$ & 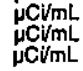 & $\begin{array}{l}G P \\
G P \\
G P\end{array}$ & $\begin{array}{l}\text { EPPA-001 } \\
\text { EPPA-001 } \\
\text { EPIA-002 }\end{array}$ \\
\hline
\end{tabular}

Time: 12:15

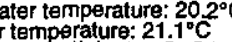
Total alkalinity (as CaCO3): $6 \mathrm{mg} / \mathrm{h}$

WELL HSL 7D

MEASUREMENTS CONDUCTED IN THE FIELD

Sample date: 04/24/98

Depth to water: $18.9 \mathrm{ft}(5.76 \mathrm{~m})$ below TOC

Water ol

H. 6.1 vation: $264.9 \mathrm{ft}$ (B)

\begin{tabular}{|c|c|c|c|c|c|c|c|}
\hline Result & R & $\boldsymbol{A}$ & $B$ & $S Q L$ & Unit & LAb & Method \\
\hline $\begin{array}{l}<0.200 \\
350 \\
4.33 \\
72.8 \\
5.23 \mathrm{E}-09 \pm 9.45 \mathrm{E}-10 \\
4.16 \mathrm{E}-09 \pm 1.92 \mathrm{E}-09 \\
4.94 \mathrm{E}-05 \pm 1.28 \mathrm{E}-06\end{array}$ & J & $\begin{array}{l}x \\
x\end{array}$ & L & $\begin{array}{l}0.200 \\
50.0 \\
0.00 \\
5.00 \\
5.89 E-10 \\
1.02 E-09 \\
5.84 E-07\end{array}$ & 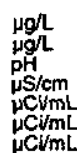 & $\begin{array}{l}G E \\
G E \\
G E \\
G E \\
G P \\
G P \\
G P\end{array}$ & $\begin{array}{l}\text { EPA7470 } \\
\text { EPA33.1 } \\
\text { EPA9045C } \\
\text { EPAO5050 } \\
\text { EPA-0.1 } \\
\text { EPAA-001 } \\
\text { EPIA-002 }\end{array}$ \\
\hline
\end{tabular}

Water evacuated from the well prior to sampling: 34 gal

ANALYSES

$F$ Analyte

$\therefore$ Mercury, total recoverable

2 Specific conductance

Gross alpha

$\begin{array}{ll}0 & \text { Nonvolabilib bata } \\ 0 & \text { Nonvolatile beta } \\ \text { Trisium }\end{array}$
Time: 11:24

Total alkalinity (as Caco3): $0 \mathrm{mg}$
Were: $18.6^{\circ} \mathrm{C}$
Time: 10:12

ure: $19.2^{\circ} \mathrm{C}$

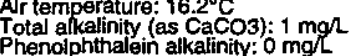

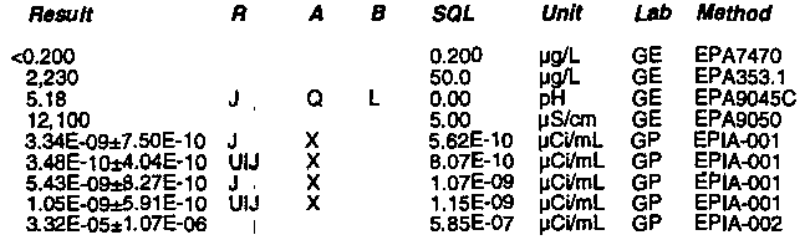

WELL HSL 8D

MEASUREMENTS CONDUCTED IN THE FIELD

Sample date: 04/24/98

Sample date: $04 / 24 / 98$
Depth to water $24.22 \mathrm{ft}(7.38 \mathrm{~m})$ below TOC
Water elevation: $264.48 \mathrm{tt}(80.61 \mathrm{~m}) \mathrm{msl}$

$\mathrm{pH}: 4.6$

g: 5

Water temperature: $22.5^{\circ} \mathrm{C}$

Total alkalinity (as CaCO3): 0 mgh

Water evacuated from the well prior to sampling: $5 \mathrm{gal}$

ANALYSES

\begin{tabular}{|c|c|c|c|c|c|c|c|c|}
\hline F Analyto & Result & $\boldsymbol{F}$ & A & 8 & SOL & Unit & Lab & Method \\
\hline $\begin{array}{ll}0 & \text { Mercury, total recoverable } \\
2 & \text { Nitrate-nitrite as nitrogen } \\
0 & \text { pH } \\
0 & \text { pH } \\
0 & \text { Specific conductance } \\
0 & \text { Gross alpha } \\
1 & \text { Nonvolatile beta } \\
2 & \text { Tritium }\end{array}$ & $\begin{array}{l}0.207 \\
15,000 \\
4.95 \\
4.96 \\
167 \\
1.47 \mathrm{E}-09 \pm 5.70 \mathrm{E}-10 \\
2.97 \mathrm{E}-08 \pm 1.64 \mathrm{E}-09 \\
1.93 \mathrm{E}-04 \pm 3.82 \mathrm{E}-06\end{array}$ & $\mathbf{J}$ & $\begin{array}{l}\mathrm{a} \\
\mathrm{a} \\
\mathrm{x} \\
\mathrm{x}\end{array}$ & $\underline{L}$ & $\begin{array}{l}0.200 \\
250 \\
0.00 \\
0.00 \\
5.00 \\
5.19 E-10 \\
1.010-09 \\
9.30 E-07\end{array}$ & 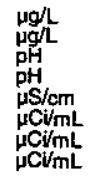 & $\begin{array}{l}G E \\
G E \\
G E \\
G E \\
G E \\
G E \\
G P \\
G P \\
G P\end{array}$ & $\begin{array}{l}\text { EPA7470 } \\
\text { EPA353.1 } \\
\text { EPA9045C } \\
\text { EPA9045C } \\
\text { EPA9050 } \\
\text { EPIA-001 } \\
\text { EPIA-001 } \\
\text { EPIA-002 }\end{array}$ \\
\hline
\end{tabular}

\section{WELL HWP 2D}

MEASUREMENTS CONDUCTED IN THE FIELD

Sample date: 05/27/98
Depth to water: $5.8 \mathrm{tt}(1.77 \mathrm{~m})$ below Toc
Water flevation: $264.2 \mathrm{ft}(80.53 \mathrm{~m}) \mathrm{ms}$.

Water ole

Sp. 5.6 conductance: $100 \mu \mathrm{S} / \mathrm{cm}$

Jurbidity: 1 NTU
Water evacuated from the well prior to sampling: $8 \mathrm{gal}$ ANALYSES
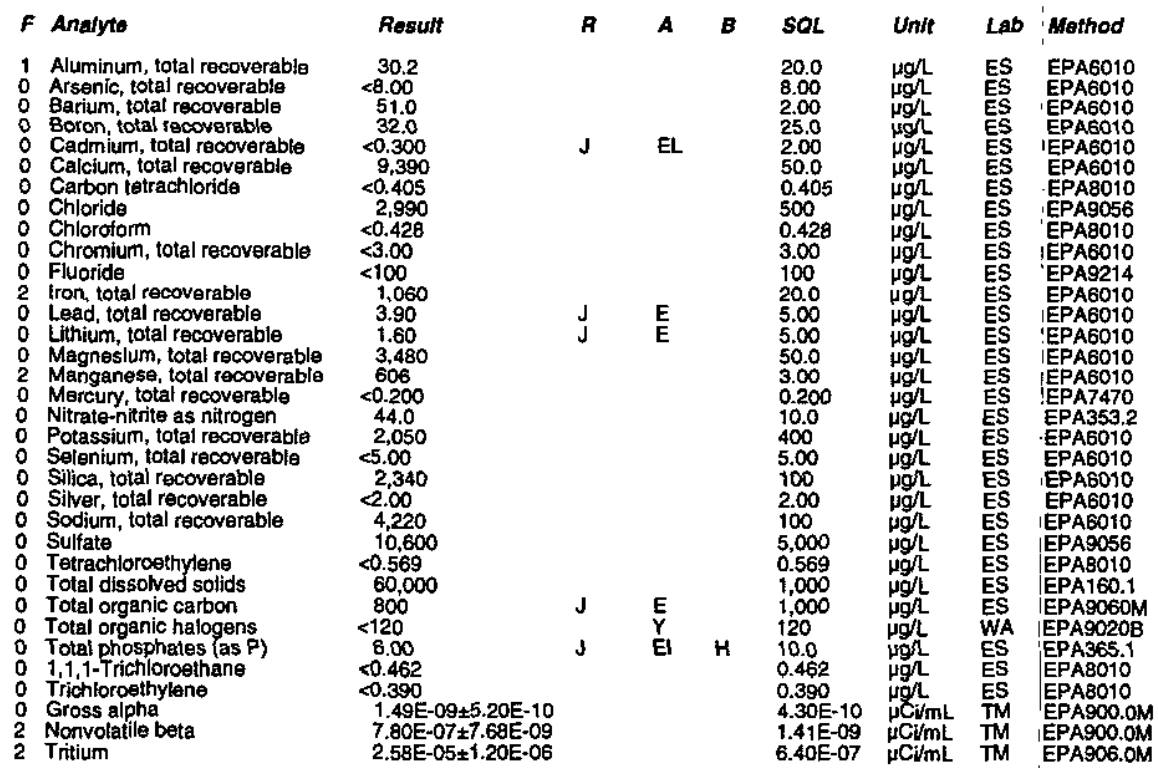

Time: 14:34

Air temperature: $36.6^{\circ} \mathrm{C}$
Total alkatinity (as CaCO3): $10 \mathrm{mg} h$ 
ANALYTICAL RESULTS

\section{WELL KBP 1D}

MEASUREMENTS CONDUCTED IN THE FIELD

Sample date: $05 / 26198$
Depht to water: $53.6 \mathrm{ft}(16.34 \mathrm{~m}$ ) below TOC
Water levation: $210.5 \mathrm{Ht}(64.16 \mathrm{~m}) \mathrm{msl}$

Water
pH: 5.4

SP. . conductance: $90 \mu \mathrm{S} / \mathrm{cm}$

TTurbidity $5 \mathrm{NTU}$
Water evacuated from the well prior to sampling: $29 \mathrm{gal}$

ANALYSES

\begin{tabular}{|c|c|c|c|c|c|c|c|c|}
\hline Ans: & & R & & & d. & nit & $L a b$ & Method \\
\hline 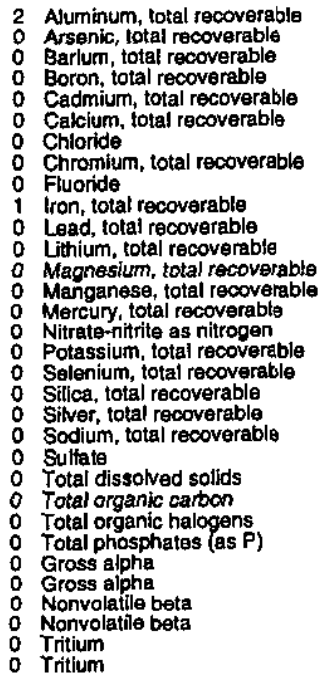 & 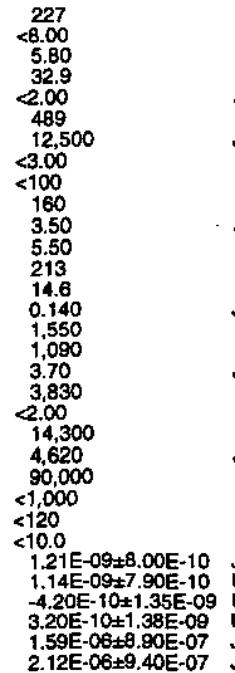 & J & $\mathbf{L}$ & L & $\begin{array}{l}20.0 \\
8.00 \\
2.00 \\
25.0 \\
2.00 \\
50.0 \\
500 \\
3.00 \\
100 \\
20.0 \\
5.00 \\
5.00 \\
50.0 \\
3.00 \\
0.200 \\
200 \\
400 \\
5.00 \\
100 \\
2.00 \\
100 \\
5.000 \\
1.000 \\
1.000 \\
120 \\
10.0 \\
1.16 E-09 \\
1.16 E-09 \\
2.39 E-09 \\
2.39 E-09 \\
1.42 E-06 \\
1.47 E-06\end{array}$ & 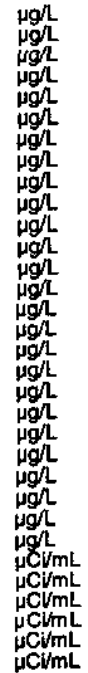 & $\begin{array}{l}\text { ES } \\
\text { ES } \\
\text { ES } \\
\text { ES } \\
\text { ES } \\
\text { ES } \\
\text { ES } \\
\text { ES } \\
\text { ES } \\
\text { ES } \\
\text { ES } \\
\text { ES } \\
\text { ES } \\
\text { ES } \\
\text { ES } \\
\text { ES } \\
\text { ES } \\
\text { ES } \\
\text { ES } \\
\text { W } \\
\text { TS } \\
\text { TM } \\
T M \\
T M \\
T M \\
T M\end{array}$ & 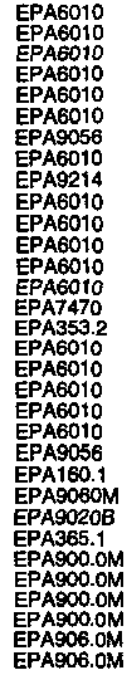 \\
\hline
\end{tabular}

\section{WELL KBP 20}

MEASUREMENTS CONDUCTED IN THE FIELD

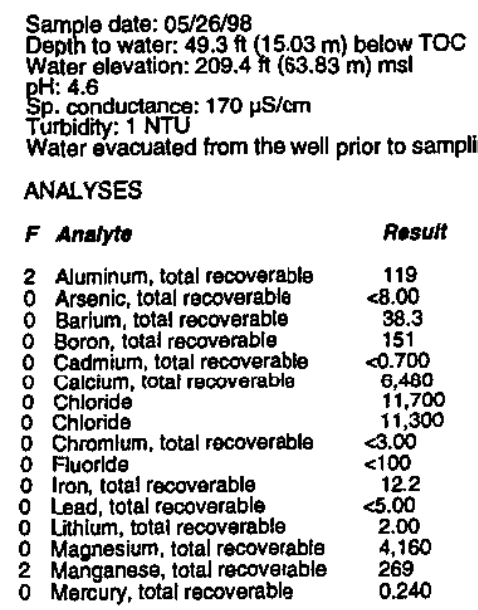

Time: $9: 53$

Wir temperature: $17^{\circ} \mathrm{C}$

Total alkalinity (as CaCo3): $0 \mathrm{mg} /$
Phenolphthalein alkalinity: $0 \mathrm{mg} \mathrm{L}^{-}$

Water temperature: $18^{\circ} \mathrm{C}$ Total alkalinity (as CaCO3): $9 \mathrm{mg} /$
Phenoiphthalein alkalinity: $0 \mathrm{mg} /$

\section{Water evacuated trom the well prior to sampling: 23 gal}
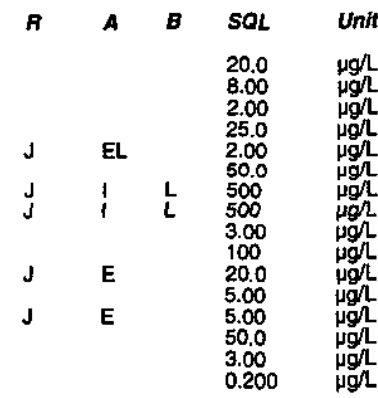

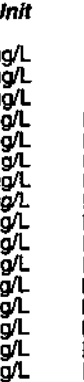

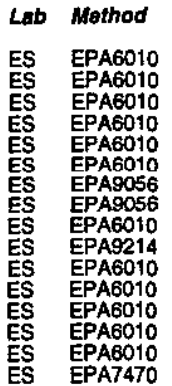

Well KBP 2D collected on 05/26/98 (cont.)

$F$ Analyte

Rosuft
921
66,030
4.20
3,910
$<2.00$
9,840
44,500
44,400
126,000
$<1,000$
$<120$
$<10.0$
$1.52 E-08+2.40 E-09$
$1.43 E-0.942 .43 E-09$
$3.61 E-06 \pm 1.00 E-06$

O Nonvolatile beta

WELL KCB 1

MEASUREMENTS CONDUCTED IN THE FIELD

Sample date: 04/30/98

Wepth to water: $54.41 \mathrm{ft}(16.58 \mathrm{~m})$ below TOC

pH: 5.2 conductance: $37 \mu \mathrm{S} / \mathrm{cm}$

Water evacuated from the well prior to sampling: $52 \mathrm{gal}$

ANALYSES

$F$ Analyto

Resuft

O Beryltium, total recoverable

Bis(2-ethylhexyly phthalat

$0 \mathrm{pH}$

Gross alpha

Gross alpha

Radium-22

Radium-228

\section{WELL KCB 3}

MEASUREMENTS CONDUCTED IN THE FIELO

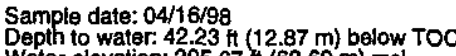

Water to watevation: $205.67 \mathrm{Ht}(62.69 \mathrm{~m}) \mathrm{ms}$

Sp: 4.1 conductance: $230 \mu \mathrm{S} / \mathrm{cm}$

Water evacuated from the well prior to sampling: 73 gal

ANALYSES

$\boldsymbol{F}$ Analyte

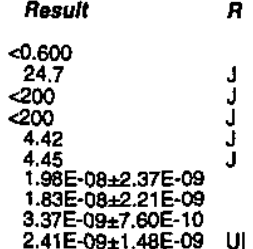

2 Beryllium, total recoverable

Chromium, hexavalent

$\mathrm{pH}$

Gross alpha

Gross alphe
Radiumm-226

2.31E-09.1.60E-10

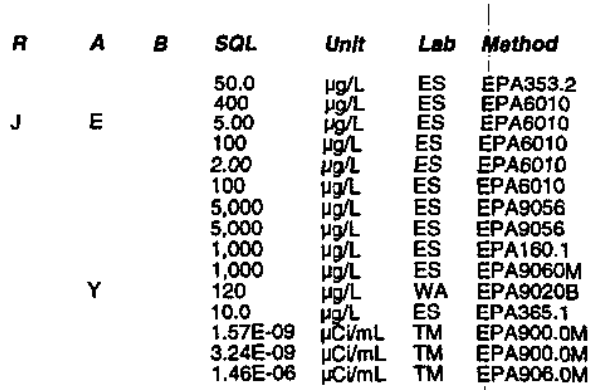

Time: 8:45

Ait $20.2^{\circ} \mathrm{C}$ Total alkalinity (as CacO3): 1 mg/

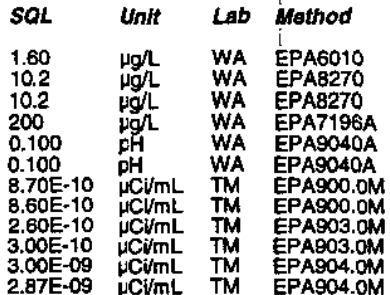

Time: 11:55

Wir 22.2

Total alkalinity (as CaCO3): $0 \mathrm{mgh}$
Phenolphthalein alkalinity: $0 \mathrm{mg} /$

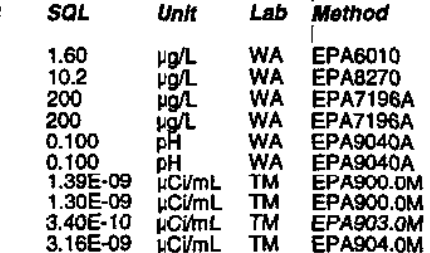

Second Quarter 1998 


\section{WELL KCB 5}

MEASUREMENTS CONDUCTED IN THE FIELD Sample date: 04/16/98 Depth to water: 45.07 tt $(13.74 \mathrm{~m})$ below TOC Wh: 4 Sp. conductance: $340 \mu \mathrm{S} / \mathrm{cm}$

Turbidity: 76 NTU
Water evacuated trom the well prior to sampling: $35 \mathrm{gal}$ ANALYSES

\begin{tabular}{|c|c|c|c|c|c|c|c|c|}
\hline Analyte & Posuft & $\boldsymbol{B}$ & $A$ & & SQL & Unit & Lab & Method \\
\hline $\begin{array}{l}\text { Bis(2-ethylhexyl) phthalate } \\
0 \text { Chromium, hexavalent } \\
0 \text { pH } \\
1 \text { Gross ajpha } \\
0 \text { Radium-226 } \\
0 \text { Radium-226 } \\
1 \text { Radium-228 } \\
1 \text { Radium-228 }\end{array}$ & 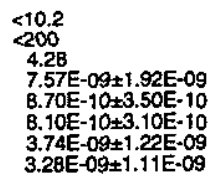 & j & $\stackrel{Q}{Q}$ & & $\begin{array}{l}10.2 \\
200 \\
0.100 \\
1.92 E-09 \\
2.100-10 \\
2.80 E-10 \\
2.23-09 \\
1.99 E-09\end{array}$ & 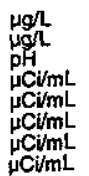 & $\begin{array}{l}\text { WA } \\
\text { WA } \\
\text { WA } \\
\text { TM } \\
\text { TM } \\
\text { TM } \\
\text { TM } \\
\text { TM }\end{array}$ & $\begin{array}{l}\text { EPAA270 } \\
\text { EPA7196A } \\
\text { PPA9040A } \\
\text { EPA900.OM } \\
\text { EPA903.M } \\
\text { EPA903.OM } \\
\text { EPA904.0M } \\
\text { EPA904.0M }\end{array}$ \\
\hline
\end{tabular}

\section{WELL KCB 6}

MEASUREMENTS CONDUCTED IN THE FIELD Sample date: $04 / 16 / 98$
Dopth to water: $44.38 \mathrm{ft}(13.53 \mathrm{~m})$ below TOC
Water

$$
\text { Water }
$$$$
\text { p. conductance: } 81 \mu \mathrm{S} / \mathrm{cm}
$$

Wuater evacuated from the well prior to sampling: 23 gal ANALYSES

$F$ Anatyto

B Beryllium, total recoverable

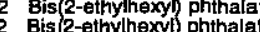
Chromium, hexavalent $:$ Gross alpha Gross alpha
0 Radium-226
0 Radium-228

\section{WELL KDB}

MEASUREMENTS CONDUCTED IN THE FIELD

Sample date: 04/17/98 Wepth to water: Not available GH: Not available
gp. conductance: Not available No water was evactuated from the well prior to sampling ANALYSES

$F$ Analyte

2 Tritium

Result $8.57 E-05+2.16 E-06$
$8.28 E-05 \pm 2.08 E-06$
Time: 10:08 Total alkalinity (as CaCO3): $0 \mathrm{mg}$ $1.99 \mathrm{E}-09 \mu \mathrm{CimL}$ TM EPA904.0ㄱ

Time: 10:42 Total alkalinity (as CaCO3): $0 \mathrm{mg} / \mathrm{L}$ Phenolphthalein alkalinity: $0 \mathrm{mg}$

Water temperature: $21.4^{\circ} \mathrm{C}$

6.50E-07 $\mu \mathrm{CV} / \mathrm{mL}$ TM EPA906.0M Water temperature: $21.9^{\circ} \mathrm{C}$

WELL KDB 1

MEASUREMENTS CONDUCTED IN THE FIELD

Sample date: 05/05/98

Depte to water: Not available

$\mathrm{pH}$ : Not available

Sp. conductance: Not available

urbidlty: Not avallable Water temperature: Not available Total alkalinity (as $\mathrm{CaCO} 3$ ): Not available

Well KDB 1 collected on 05/05/98 (cont.) ANALYSES

\begin{tabular}{|c|c|c|c|c|c|c|c|c|}
\hline Anslyte & Result & $\boldsymbol{R}$ & A & B & sal & Unit & Lab & Mothod \\
\hline $\begin{array}{ll}2 & \text { Tritium } \\
2 & \text { Tritium }\end{array}$ & $\begin{array}{l}1.11 \mathrm{E}-04 \pm 2.46 \mathrm{E}-06 \\
9.95 \mathrm{E}-05+2.24 \mathrm{E}-06\end{array}$ & & & & $\begin{array}{l}5.40 \mathrm{E}-07 \\
5.00 \mathrm{E}-07\end{array}$ & ${ }_{\mu \mathrm{CV} / \mathrm{mL}}^{\mu \mathrm{Ci}}$ & TM & $\begin{array}{l}\text { EPA906.0M } \\
\text { EPA906.0M }\end{array}$ \\
\hline
\end{tabular}

\section{WELL KDB 1}

MEASUREMENTS CONDUCTED IN THE FIELD

Sample date: 06/03/98

Depth to water: Not available

$\mathrm{H}$ : Not available

P. Conductance: Not available

No water was evacuated from the well prior to sampling.

ANALYSES

\begin{tabular}{|c|c|c|c|c|c|c|c|}
\hline F Analyte & Result & A & $B$ & SOL & Unit & Lab & Mothod \\
\hline$\frac{2}{2}$ Tritium & $\begin{array}{l}1.36 \mathrm{E}-04 \pm 3.56 \mathrm{E}-06 \\
1.42 \mathrm{E}-04 \pm 3.69 \mathrm{E}-06\end{array}$ & & & $\begin{array}{l}1.44 E-06 \\
1.47 E-06\end{array}$ & ${ }_{\mu \mathrm{CV} / \mathrm{mL}}^{\mathrm{N} V \mathrm{~mL}}$ & $T_{T M}^{T M}$ & $\begin{array}{l}\text { EPA906.0M } \\
\text { EPA906.0M }\end{array}$ \\
\hline
\end{tabular}

\section{WELL KDB 2}

MEASUREMENTS CONDUCTED IN THE FIEID

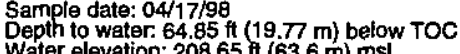

$\mathrm{pH}: 5.2$

p. conductance: $38 \mu \mathrm{S} / \mathrm{cm}$

Wuter evacuated from the well prior to sampling: 52 gal

ANALYSES

F Analyte Rosult $\quad$ A $A$ A SOL Unit Lab Mothod

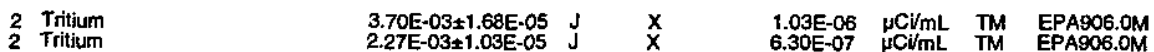

\section{WELL KDB 2}

MEASUREMENTS CONDUCTED IN THE FIELD

Sample date: $05 / 05 / 98$

Depth to water: $64.25 \mathrm{ft}(19.58 \mathrm{~m})$ below TOC

Water elov
Time: Not available

at availabłe

Air temperature: Not available
Total alkalinity (as Caco3): Not available
Phenolphthalein alkalinity: Not available
Water temperature: $17^{\circ} \mathrm{C}$

Total akalinity (as Caco3): $1 \mathrm{mg}$

Sp. conductance: $42 \mu \mathrm{S} / \mathrm{cm}$

Water evacuated from the well prior to sampling: 53 gal

ANALYSES

F Analyte

$\begin{array}{ll}2 & \text { Tritium } \\ 2 & \text { Tritium }\end{array}$

Time: 9:08

Air temperature: $158^{\circ} \mathrm{C}$

Total aikalinity (as CaCO3): $4 \mathrm{mgl}$
Phenolphthalein alkalinity: 0 mg/

- SOL Unit Lab Method

$4.02 E-05$
$4.05 E-05$${ }_{\mu C V M L}$ TM TM EPA906.0M 
WELL KDB 2

MEASUREMENTS CONDUCTED IN THE FIELD

Sample date: $06 / 03 / 98$
Depth to water: $63.4 \mathrm{ft}(19.32 \mathrm{~m})$ below TOC
Water elevation: $210.1 \mathrm{H}(64.04 \mathrm{~m}) \mathrm{ms}$
pH: 5.2
Sp. conductance: $40 \mu \mathrm{S} / \mathrm{cm}$

SH: 5.2 conductance: $40 \mu \mathrm{S} / \mathrm{cm}$

Wutbidity: 1 NTU ANALYSES

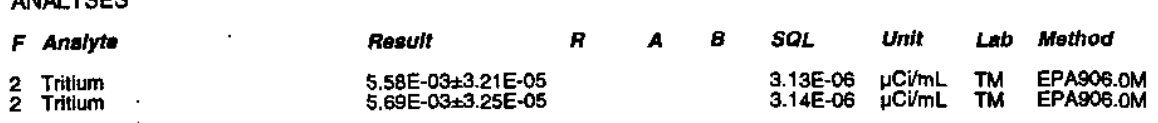

\section{WELL KDB 3}

MEASUREMENTS CONDUCTED IN THE FIELD

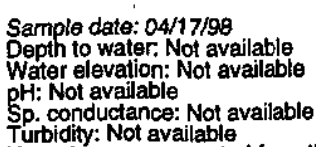

Sp. conductance: Not available

No water was evacuated from the well prior to sampling

ANALYSES

$F$ Analyte

2 Tritium

Result

$5.43 E-05 \pm 1.72 E-06$

R

WELL KDB 3

MEASUREMENTS CONDUCTED IN THE FIELD

Sample date: 05/05/98

Water elevation: Not available

Sp. Not available

Turbidity: Not available
No water was evacuated from the well prior to sampling.

ANALYSES

$F$ Analyte

2 Tritium

Rosult

R

$6.54 \mathrm{E}-05 \pm 1.86 \mathrm{E}-06$

WELL KDB 3

MEASUREMENTS CONDUCTED IN THE FIELD

Sample date: 06/03/98

Depth to water: Not available

$\mathrm{pH}$ : Not available

Sp. conductance: Not available

Turbidity: Not availation

.

ANALYYSES

$F$ Anatyite

Resutt

6.07E- $05 \pm 2.34 \mathrm{E}-06$

2 Tritium

$$
\text { , }
$$

Time: 14:00

Air termperature: $38.9^{\circ} \mathrm{C}$

Total alkalinity (as CaCO3): $1 \mathrm{mgh}$
Phenolphthalein alkalinity: $0 \mathrm{mg}$

Time: Not available

Not available

Air temperature: Not available
Total alkalinity (as Caco3): Not available
Phenolphthalein alkalinity: Not available

WELL KDB 4

MEASUREMENTS CONDUCTED IN THE FIELD

Sample date: 04/17/98

Wath to water: Not available

Wh. Nor avallable Not availablo

Turbidity: Not available
No water was evacuated from the well prior to sampling. ANALYSES

F Analyto

2 Tritium

Result

WELL KDB 4

MEASUREMENTS CONDUCTED IN THE FIELD

Sample date: 05/05/98

Depth to water: Not available

$\mathrm{pH}$ : Not available

Sp. conductance: Not availabte

No water was evaciated from the well prior to sampling.

ANALYSES

$F$ Analyte

Result

5.10E-04 $-5.36 \mathrm{E}-06$

6.40E-07 HCimL TM EPAOCG OM

2 Triturn

IN THE FIELD

MEASUREMENTS CON

Sample date: $06 / 03 / 98$

Wath to water: Not available

$\mathrm{H}$ : Not available

Sp. conductance: Not available

No water was evacuated from the well prior to sampling.

ANALYSES

$F$ Analyte

2 Tritium

Resulf

$7.21 E-04 \pm 8.71 E-06$

5.20E-07 $\mu \mathrm{CV} / \mathrm{mL}$ TM EPA906.0M

WELL KDB 5

MEASUREMENTS CONDUCTED IN THE FIELD

Sample date: 04/17/98

Depth to water: Not available

H: Not availablo avallable

p. conductance: Not available

No water was evacuated from the well prior to sampling.

Wir temperature: Not available
Total akkalinity (as CaCO3): Not available
Phenolphthalein alkalinity: Not available ANALYSES

$F$ Analyto

Result

SQL Unit Lab Method

2 Tritium

3. $.80 E-05 \pm 1.42 E-06$
Time: Not available
Water temperature: Not available
Air temperature: Not available

Total alkalinity (as CaCO3): Not available

Phenolphthalein alkalinity: Not available

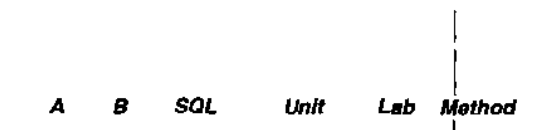

SOL Unit Lab Mothod

Time: Not available

Water temperature: Not available

Total alkalinity (as CaCO3): Not available

Phenolphthalein alkallinity: Not available

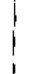

$\boldsymbol{B}$

SQL Unit Lab Method

5.60E-07 $\mathrm{NCV/mL}$ TM EPA906.0M

Time: Not available

Time: Not available Water temperature: Not available Air ternperature: Not available
Total alkalinity (as Caco 3 ) Not available

- SOL Unit Lab Method 1.69E-06 $\mu \mathrm{CV} / \mathrm{mL}$ TM EPA906.0M (1.06)

Time: Not available Water temperature: Not available Tir temperature: Not availabie Phenolphthalein alkalinity: Not available

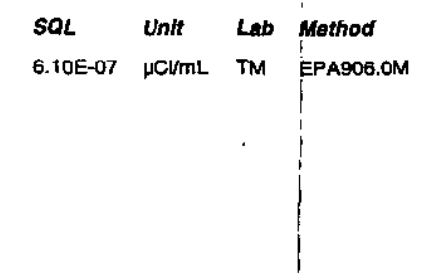


WELL KDB 5

MEASUREMENTS CONDUCTED IN THE FIELD

Sample date: $05 / 05 / 98$

Water elevation: Not available

HH: Not available

p. conduclance: Not availablo

No water was evacuated from the well prior to sampling.

ANALYSES

$F$ Analyte

Rasult

2.35E-04ะ3.49E-06

2 Tritium

WELL KDB 5

MEASUREMENTS CONDUCTED IN THE FIELD

Sample date: 06/03/98

Depth to water: Not available

$\mathrm{HH}$ : Not available

ponductance: Not available

No water was evacuated from the well prior to sampling.

ANALYSES

F Analyte

2 Tritium

Result

9. $13 \mathrm{E}-04 \pm 9.28 \mathrm{E}-06$
$1.17 \mathrm{E}-03 \pm 1.18 \mathrm{E}-05$

WELL KRP 1

MEASUREMENTS CONDUCTED IN THE FIELD

Sample date: 04/07/98

Water elevation: Not available

WH: Not available
Sp.conductance: Not available

No water was evacuated from the well prior to sampling.

ANALYSES

F Analyto

O Acenaphthene

Addrin
Aldrin

Anthracene
aloha-Benzenz hexachloride alpha-Benzene hexachloride beta-Eenzene hexachioride beta-Benzene hexachloride detia-Benzene hexachiodiride
delta-Benzene hexachloride delita-Benzens hexachlorido Benzo(a)anthracene Benzo (k)fluoranthen Benzo a pyrene Bis(2-chlorcethoxy) methan Bis (2-chloroisopropyl) ether 4-Bromophenyl phenyl ether Butyrbenzyl phthalat

o alpha-Chlordane

ESH-EMS-980569

Result
$<10.2$
$<10.2$
$<0.2$
$<0.0500$
$<100$
$<10.2$
$<0.0500$
$<0.100$
$<0.102$
$<0.0500$
$<0.100$
$<0.102$
$<0.0500$
$<0.100$
$<0.102$
$<10.2$
$<10.2$
$<10.2$
$<10.2$
$<10.2$
$<10.2$
$<10.2$
$<10.2$
$<22.8$
$<10.2$
$<1.2$
$<10.2$
$<0.0500$
$<0.100$

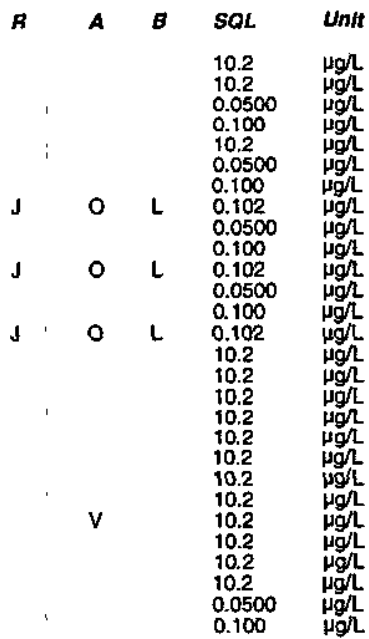

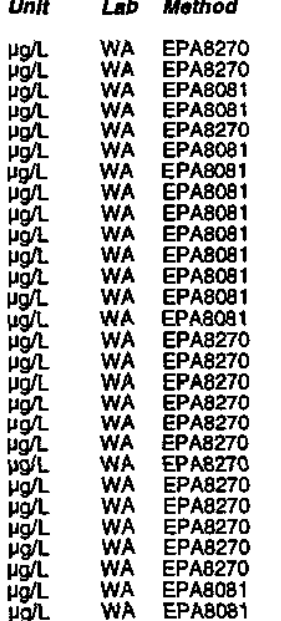

Well KRP 1 collected on 04/07/98 (cont.)

$F$ Analyte

Time: Not available Water temperature: Not available Air temperature: Not ayjilable
Total alkalinity (as Caco3): Not available

0 alpha-Chlordane

gamma-Chbordane

4-Chloroaniline

2-Chloronaphthalen

4-Chlorophenyl phenyl ether

O Chrysene

$\begin{array}{ll}0 & \mathrm{~m} / \mathrm{p} \text {-Cresol } \\ 0 & 0 \text {-Cresol (2-Methylphenol) }\end{array}$

P.P'-DDD

0 P,P

O

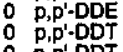

bibenz (a,h)anthracen

Dibenzofuran

Dirn-butyl phthalate

1,3-Dichlorobenzene

3,3'-Dichlorobenzidine

Dieldrin

Dietthyl phthalate

Dimethyl phithalate

2,4-Dinitrophenol

2,4-Dinitrotoluene
2,6-Dinitrotoluene

Di-n-octyl phthalate

Endosulaan sulfate

Endosulfan sulfat

Endosuttan I

Endosulfan II

Endosultan II

Endrin

Endrin keton

Endrin ketone

Fluoranthen

Fluarene

Heptachlor

Heptachlor eppoxide

Heptachlor epoxide

Hexachlorobutadiene

Hexachiorocyclopentad

Indeno( $1,2,3-c, d)$ pyren

Lindane

0 Lindane

Methoxychlor

2-Methyl-4,6-dinitropheno

Naphthalene
$m$-Nitroaniling

o-Nitroaniling

Nitrobenzene
2-Nitrophenal

2-Nitrophenal
4-Nitrophenol

$-180$ posut

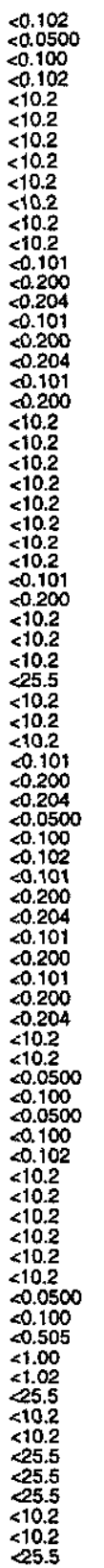

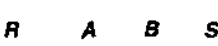

J 0

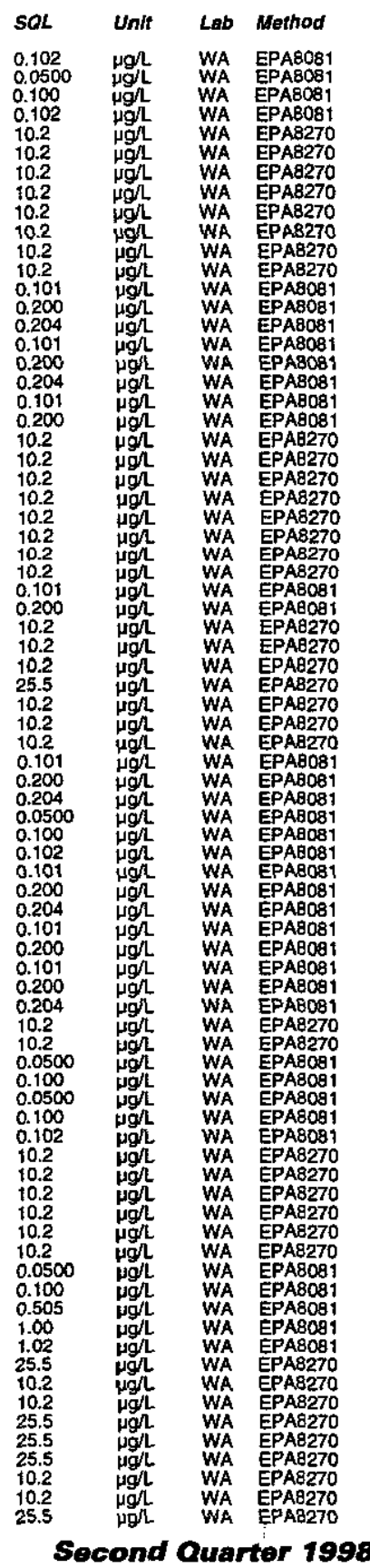


Well KRP 1 collected on 04/07/98 (cont.)

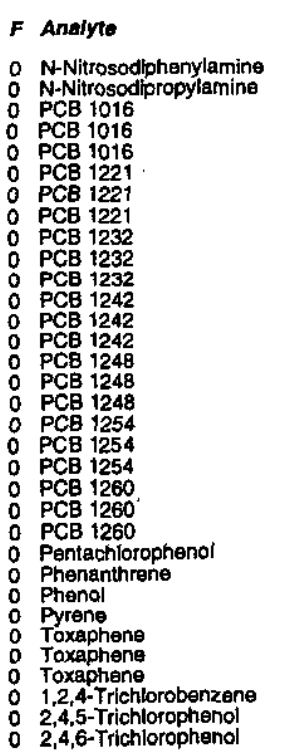

Resut

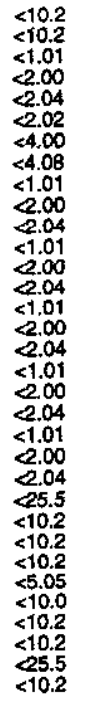

WELL KRP 2

MEASUAEMENTS CONDUCTED IN THE FIELD Sample date: $04 / 08 / 98$
Depth to wates: $33.5 \mathrm{ft}(10.21 \mathrm{~m})$ below TOC
Water 6levation: $222.6 \mathrm{ft}(67.85 \mathrm{~m}) \mathrm{ms}$ i

Water 9 levation: $222.8 \mathrm{t}$ (67.
$\mathrm{SH}: 4.7$. conductance: $28 \mu \mathrm{S} / \mathrm{cm}$

Water evacuated from the well prior to sampling: 33 gal

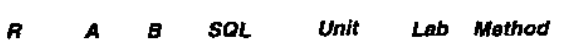

F Analyte

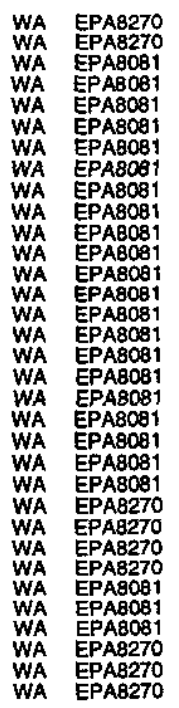

: Bis(2-chloroethoxy) methane

Bis 2-chloroethyl) ether

Bis 2-chloroethy , ether
Bis (2-chloroethyl) ether

Bis 2-chloroisopropyl) ether
Bis 2-chloroisopropyl) ether

Bis(2-chloroisopropyl) ether
Bis 2-ethylhexyl) phthalate

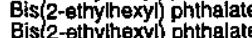

4-Bromophenyl phenyl ether
4-8romophenyl phenyl ether

Butylbenzyl phthalate

B Buylbenzyl phthalate

Carbazole

alpha-Chlordane

4amma-Chlordan

4-Chibroaniline

4-Chloro-m-eresol

2-Chloronaphthalene

2-Chlorophenol

2-Chlorophenol
4-Chlorophenyl phenyl ether

o 4-Chlorophenyy phenyl ether

OChysene

m/p-Cresol

o-Cresoi (2-Mathylphanol)

o-Cresol (2-Matryyphenol)

P,

P, $\mathrm{p}^{-}-\mathrm{DD}$

bibenz(a,h)anthracene

Dibenzza,hanthracene

Dibenzofuran

- Acenaphthene

Acenaphthylene

Acenaphthylene

Aldrin

Anthracene

alpha-Benzene hexachlorid

beta-Benzene hexachloride

delta-Benzens hexachlo

Benzo(a)anthracene

Benzodjanthracene

Benzabiffluoranthen

Benzol bifluoranthen

Benzolk fluoranthene

Benzolg,h,iperylene

Genzo $g, h, i, j$ perylerre

Benzo a pyren

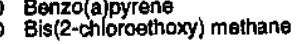

ESH-EMS-980569

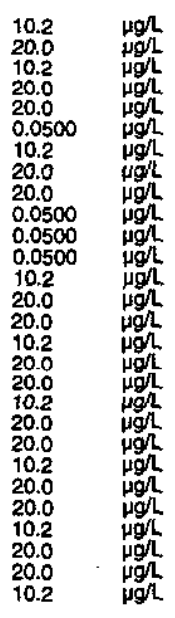

-1
-1

WA EPA8270

WA EPA8270

WA EPAB270

EPA8081

EPABD81

WA EPA8270

EPA9270

EPA8270

EPA8270

EPA8270

WA EPA8270
Dibenzofuran

Di-n-butyl phthalate

1,-n-Dutyl phathalate

1,3-Dichlorobenzen

1,3-Dichlorobenzene

1.4-Dichlorobenzene

3,3'-Dichlorobenzidine

3. Dichlorobenzidine

2,4-Dichtorophennol

Diethyl phthaiate

Diethyl phthalate

2,4-Dimethyl phen

2,4-Dimethyl phenol

B-181
Rosutt

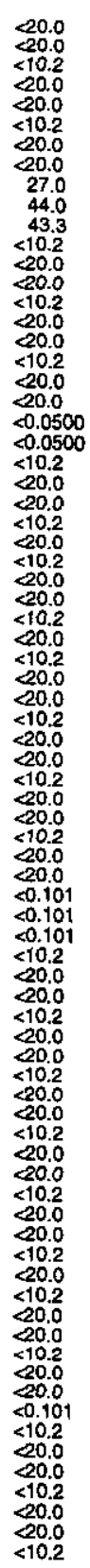

$\boldsymbol{R}$
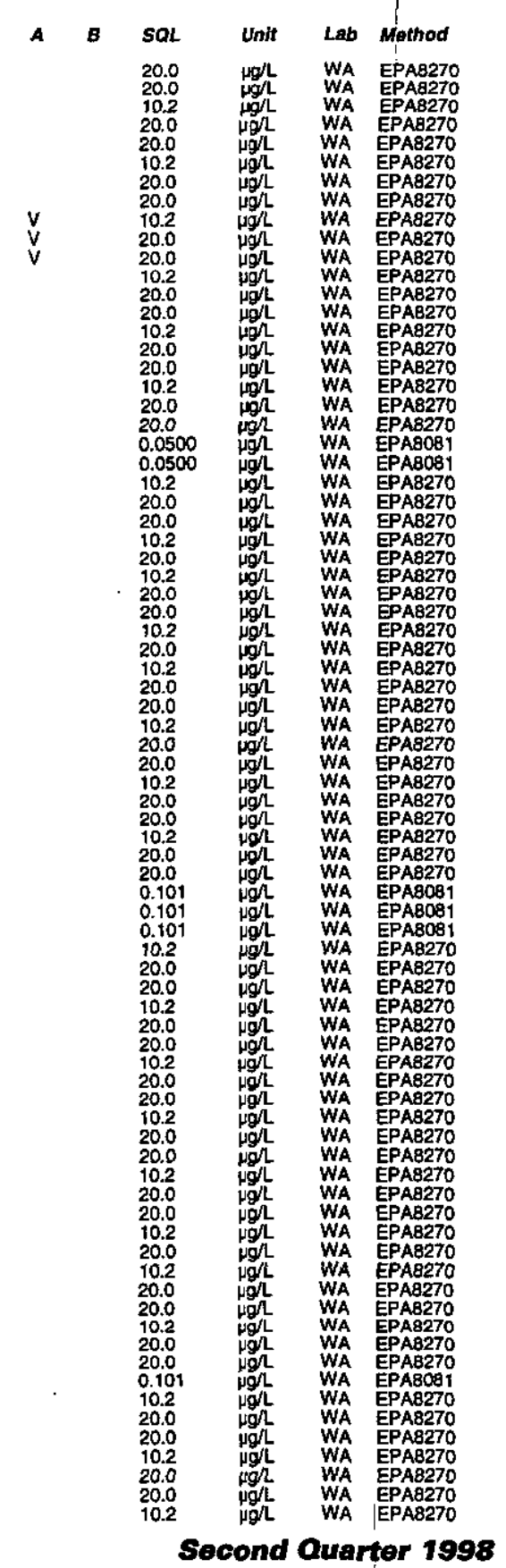
ANALYTICAL RESULTS

Well KRP 2 collected on 04/08/98 (cont.)

$F$ Analyte

0 Dimethyl phthalate

0 2.4-Dinitropheno

2,4-Dinitrophenol

2.4-Dinitrotoluene

2.6-Dinttrotoluene

2,6-Dinitrotoluene

Din-octy phthalate

Endosutian sulfate

Endosultan I

: Endrin

Fluoranthene

o Fuoranthen

Fluorene

Heptachlor

Hexachlorobenzen

Hexachlorobytadien

- Hexachlorobutadien

: Hexachlorobutadiene

Hexachlorocyyclopenentadien

Hexachloroesthane

O Hexactioroethane

0

pyrene

Isophorone
0

isophoron

Lindane

2-Methyl-4,6-dinitrophenol

2-Methy-4,6-dinitropheno

2-Methylnaphthalene

2-Methyynaphthalene

Naphthalene
Naphthalene

O Naphthalene

m-Nitroaniline

$m$-Nitroaniline
0 -Nitroaniline

o-Nitroanilin

p-Nitroaniline

$0_{0}^{0}$ Nitrobenzen

Nitrobenzen

Nitrobenzene

2-Nitrophenol

4-Nitropheno

N-Nitrosodiphenylamine

N-Nitrosodiphenylamine

N-Nitrosodiphenylamin N-Nitrosodipropylamine

0 PCB 1016

ESH-EMS-980569

Well KRP 2 collected on 04/08/98 (cont)

$F$ Analyto

: PCB 1221

0
0
0 PCB 12254

P Pentachlorophenol

o Phenanthrene

Phenanthrsne

: Phenol

0 Pyrene

1,2,4-Trichlorobenzene

1,2,4-Trichlorobenzen

2,4,5-Trichlorophen

$2,4,6$-Trichlorophenol
0

$\begin{array}{ll}0 & 2,4,6-\text { Trichlorophenol } \\ 0 & 2,4,6 \text {-Trichlorophenol }\end{array}$

WELL KRP 3

MEASUREMENTS CONDUCTED IN THE FIELD

Sample date: 04/08/98

Depth to water: $31.47 \mathrm{ft}(9.59 \mathrm{~m})$ below TOC

Wh: 4.8

p. conductance: $23 \mu \mathrm{s} / \mathrm{cm}$

Turbidity: 2 NTU

ANALYSES

$F$ Anatyo

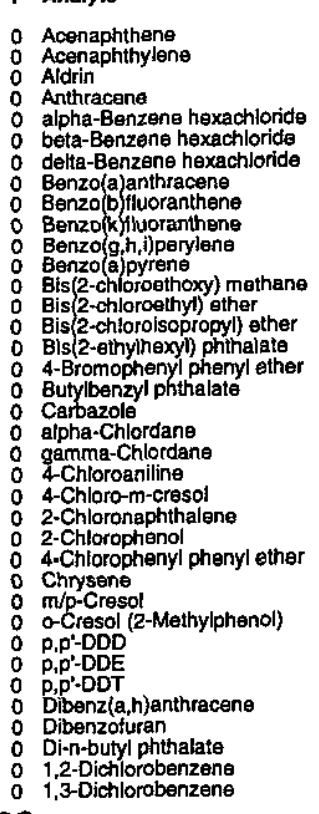

Rosult

$<10.2$
$<10.2$
$<0.0500$

$<10.2$

WA EPAB27

WA EPABOB

WA

WA

WA

WA

WA

WA

WA

WA

WA

WA

WA

WA

WA

WA

WA EPAB27

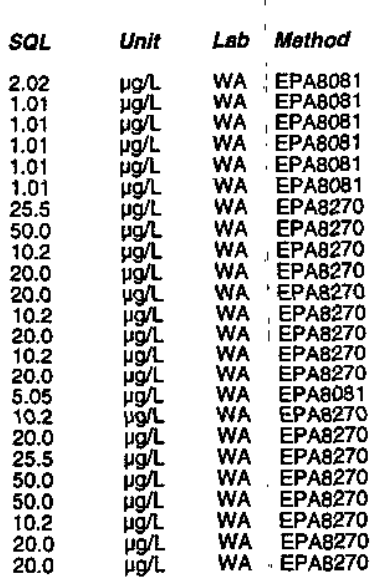

Time: 9:44

Wire: $18.4^{\circ}$

Total alkalinity (as Cacos): $1 \mathrm{mg} / \mathrm{L}$ 
Well KRP 3 collected on 04/08/98 (cont.)

$F$ Aralyte

Aosult

: 1,4-Dichlorobenzene

Dietdrin phthalate

2,4-Dimethyl phernol

2.4-Dintrophenol

2,6-Dinitrotoluenen

Eindosuffin sulfate

Endosuffan II

Endrin keton

Fluoranthene

Fluorene

Heptachlor epoxide

Hexachlorocyclopentadien

Hexachloroethane
Indeno $(1,2,3-c, d)$ pyren

Isophoron

2-Methyyt-4,6-dinitropheno

2-Methytnaphthalen

m-Nitroaniline

-Nitroaniline

Nitrobenzene

4-Nitrophenol

N-Nitrosodipropylaming

PCB 1221

: PCB 1242

PCB 1254

Pentachlorophenol

Phenol

Tyxaphen

1,2,4-Trichlorobenzene $2,4,5$-Trichlorophenal

WELL KRP 4

MEASUREMENTS CONDUCTED IN THE FIELD

Sample date: 04/08/98
Depth to water: $34.02 \mathrm{At}(10.37 \mathrm{~m})$ below TOC
Wet

Water elor

$\mathrm{SH}: 5.3$ conductance: $96 \mu \mathrm{S} / \mathrm{cm}$

Sp. conductance: $96 \mu \mathrm{S} / \mathrm{cm}$

Water evacuated from the well prior to sampling: $57 \mathrm{gal}$ ANALYSES

$F$ Analyto

Result

Acenaphthene

Aldrin

$<10.2$
$<0.0500$

alpha-Benzene hexachloride

beta-benzene hexachloride

ESH-EMS-980569

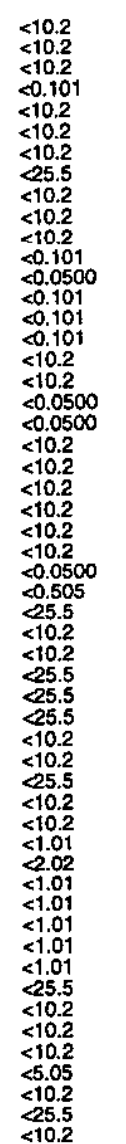

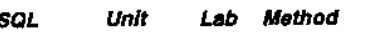

10.2 Hgh WA EPAB270

$\begin{array}{ll}10.2 & \mu g / L \\ 0.101 & \mu g / L \\ 10.2 & \mu g / L \\ 10.2 & \mu g / L\end{array}$

WA EPAB270

WA

WA EPAB270

WA

WA

WA EPAB081

WA EPABOB

WA EPAB270

WA EPABO81

WA EPAB270

WA

WA

WA EPABOB

WA

WA

WA

WA EPAB270

WA EPAB EP270

WA

WA EPAB2781

WA EPABOA

WA EPABOB

WA

WA EPAB270

WA EPAB270

WA EPAB270

WA EPA8270

Well KRP 4 collected on 04/08/98 (cont.)

- Benzo(a)anthracene.

O Benzolkffluofanthene

O Bis(2-chloroethoxy) methan

Bis (2-chloroethy) ether

0 Bis(2-ethylhexyl) phthalate

Butylbenzyl phthalate

alpha-Chordane

gamma-Chlordan

4-Chloro-m-cressol
2-Chloronaphthalene

0 4-Chlorophenyl phenyl ether

o m/p-Cresol

o o-Cresol (2-Methyiphenol)

0 P, 政-DDE

Bibenz (a,h)anthracene

Dibenzofuran

: 1,2-Dichiorobenzen

$\begin{array}{ll}0 & 1,4-\text {-Dichlorobenzene } \\ 0 & 3,3^{3} \text {-Dichlorobenzidine }\end{array}$

a Dieldrín

2iet-Dimpethyl pheno

: Dimethyl phthatate

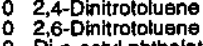

- Endosuffian sulfate

Endosultian II

O Endrin ketone

: Fluorene

Heptachlor epoxide

Hexachlorobenzene

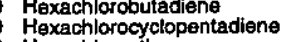

Hexachloroethane

Indeno(1,2,3-c, d)pyren

Lindane

2-Methyl-4,6-dinitropheno

Time: 8:52

Air

Total alkalinity (as CaCO3): $20 \mathrm{mg} /$
Phenolphthalein alkalinity: $0 \mathrm{mg}$ '

\section{m-Nitroaniline}

o-Nitroaniline

Nitrobenzene

2-Nitrophenol

N-Nitrosodiphonylamine

PCB 1016

O PCB 1232

0
0

PCB 1260

0 Pentachiorophe

3-183
Rosult

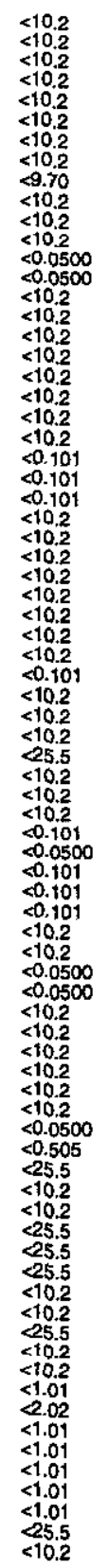

$\boldsymbol{R}$

A

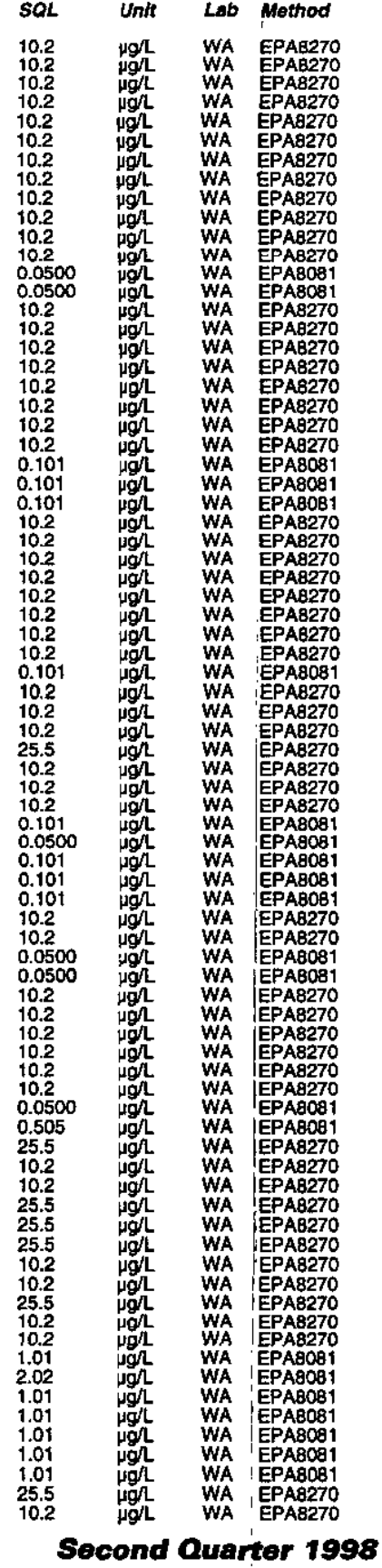


Well KRP 4 collected on 04/08/98 (cont)

$\begin{array}{llr}\text { F Analyte } & \text { Resut } \\ 0 & \text { Phenol } & <10.2 \\ 0 & \text { Pyrene } & 10.2 \\ 0 & \text { Toxaphene } & 5.05 \\ 0 & 1,2,4-\text { Trichlorobenzene } & <10.2 \\ 0 & 2,4,5-\text { Trichlorophenol } & <25.5 \\ 0 & 2,4,4 \text { - Trichlorophenol } & <10.2\end{array}$

\section{WELL KRP 4 Replicate}

MEASUREMENTS CONDUCTED IN THE FIELD

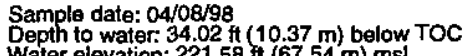
Water Sp. conductance: $96 \mu \mathrm{S} / \mathrm{cm}$ Water evacuated from the well prior to sampling: $57 \mathrm{gal}$ ANALYSES

F Analyte

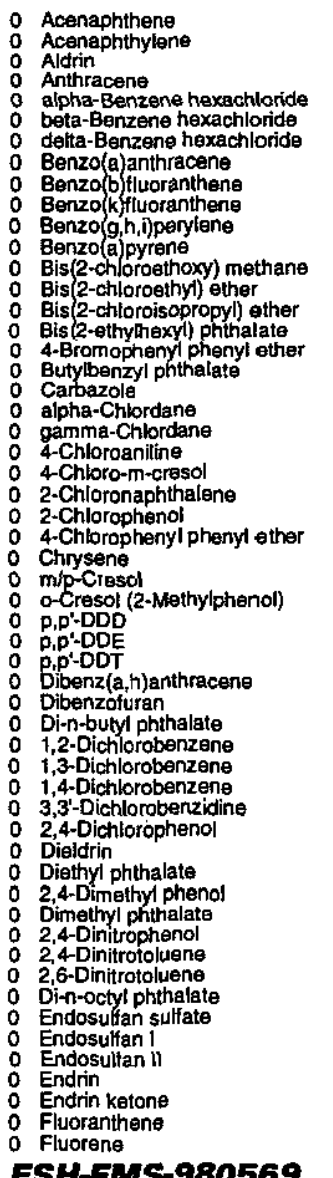

ESH-EMS-980569

\begin{tabular}{|c|c|c|c|c|c|c|}
\hline $\boldsymbol{A}_{1}$ & $A$ & $B$ & SOL & Unit & Lab & Mothod \\
\hline & & & $\begin{array}{l}10.2 \\
10.2 \\
5.05 \\
10.2 \\
25.5 \\
10.2\end{array}$ & $\begin{array}{c}\mu g h \\
g g h \\
\mu g h \\
\mu g h \\
\mu g h \\
\mu g h\end{array}$ & $\begin{array}{l}\text { WA } \\
\text { WA } \\
\text { WA } \\
\text { WA } \\
\text { WA } \\
\text { WA }\end{array}$ & $\begin{array}{l}\text { EPA8270 } \\
\text { EPAB270 } \\
\text { EPABO81 } \\
\text { EPAB270 } \\
\text { EPAB270 } \\
\text { EPAB270 }\end{array}$ \\
\hline
\end{tabular}

Time: 8:52

Waler Artal alkalinity (as CaCo3): $20 \mathrm{mgl}$
Phenolphthalein alkalinity: 0 mgh

Well KRP 4 collected on 04/08/98 (cont)

\begin{tabular}{|c|c|c|c|c|c|c|c|c|}
\hline F Analyte & Result & $\boldsymbol{F}$ & A & $B$ & SOL & Unit & Lab & Mothod \\
\hline 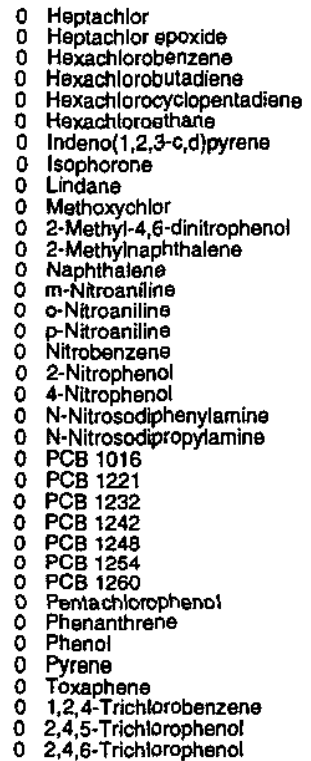 & $\begin{array}{l}<0.0500 \\
<0.0500 \\
<10.2 \\
<10.2 \\
<10.2 \\
<10.2 \\
<10.2 \\
<10.2 \\
<0.0500 \\
<0.505 \\
25.5 \\
<10.2 \\
<10.2 \\
<25.5 \\
<25.5 \\
25.5 \\
<10.2 \\
<10.2 \\
<25.5 \\
<10.2 \\
<10.2 \\
<1.01 \\
2.02 \\
<1.01 \\
<1.01 \\
<1.01 \\
<1.01 \\
<1.01 \\
<5.5 \\
<10.2 \\
<10.2 \\
<10.2 \\
<5.05 \\
<10.2 \\
25.5 \\
<10.2\end{array}$ & $\begin{array}{l}\mathbf{J} \\
\mathbf{J} \\
\mathbf{J} \\
\mathbf{J} \\
\mathbf{J}\end{array}$ & $\begin{array}{l}0 \\
0 \\
\circ \\
0 \\
0 \\
0 \\
0\end{array}$ & $\begin{array}{l}\mathrm{L} \\
\mathbf{L} \\
\mathrm{L} \\
\mathrm{L} \\
\mathrm{L}\end{array}$ & $\begin{array}{l}0.0500 \\
0.0500 \\
10.2 \\
10.2 \\
10.2 \\
10.2 \\
10.2 \\
10.2 \\
0.0500 \\
0.505 \\
25.5 \\
10.2 \\
10.2 \\
25.5 \\
25.5 \\
25.5 \\
10.2 \\
10.2 \\
25.5 \\
10.2 \\
10.2 \\
1.01 \\
2.02 \\
1.01 \\
1.01 \\
1.01 \\
1.01 \\
1.01 \\
25.5 \\
10.2 \\
10.2 \\
10.2 \\
5.05 \\
10.2 \\
25.5 \\
10.2\end{array}$ & 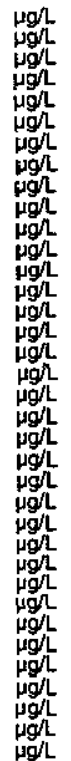 & $\begin{array}{l}\text { WA } \\
\text { WA } \\
\text { WA } \\
\text { WA } \\
\text { WA } \\
\text { WA } \\
\text { WA } \\
\text { WA } \\
\text { WA } \\
\text { WA } \\
\text { WA } \\
\text { WA } \\
\text { WA } \\
\text { WA } \\
\text { WA } \\
\text { WA } \\
\text { WA } \\
\text { WA } \\
\text { WA } \\
\text { WA } \\
\text { WA } \\
\text { WA } \\
\text { WA } \\
\text { WA } \\
\text { WA } \\
\text { WA } \\
\text { WA } \\
\text { WA } \\
\text { WA } \\
\text { WA } \\
\text { WA } \\
\text { WA } \\
\text { WA }\end{array}$ & 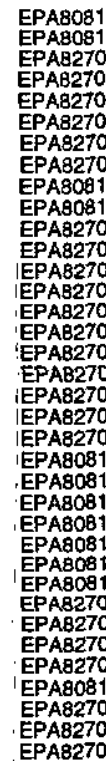 \\
\hline
\end{tabular}

\section{WELL LAW 2C}

MEASUREMENTS CONOUCTED IN THE FIELD Sample date: $04 / 17 / 98$
Depth to water: $9.55 \mathrm{tt}(2.91 \mathrm{~m})$ below TOC
Water elevation: $214.45 \mathrm{ft}(65.37 \mathrm{~m}) \mathrm{msl}$ Water el wat Sp. conductance: $46 \mu \mathrm{S} / \mathrm{cm}$

Water evacuated from the well prior to sampling: 203 gal ANALYSES

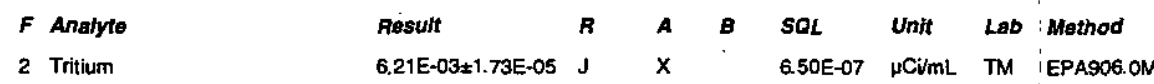

\section{WELL LAW 2C}

MEASUREMENTS CONDUCTED IN THE FIELD

\section{Sample date: 05/05/98}

Depth to water: $8.85 \mathrm{ft}(2.7 \mathrm{~m})$ below TOC

$\mathrm{pH}: 4.6$

Sp. conductance: $42 \mu \mathrm{S} / \mathrm{cm}$

Water evacuated from the well prior to sampling: 193 gal ANALYSES

$F$ Analyto

2 Tritium
Result

$6.47 E-03 \pm 1.42 E-04$ J
Time: 14:05

Air ternperature $30^{\circ}$ Total alkalinity (as CaCO3): $0 \mathrm{mgh}$
Phenolphthalein alkalinity: $0 \mathrm{mgh}$
Time: 12:24

Win

Total alkalinity (as Caco3): $0 \mathrm{mg} /$ 
ANALYTICAL RESULTS

\section{WELL LAW 2C}

MEASUREMENTS CONDUCTED IN THE FIELD

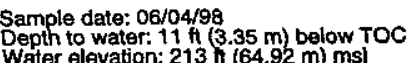

Wepter to

$\mathrm{pH}: 4.6$

Sp. conductance: $46 \mu \mathrm{S} / \mathrm{cm}$

Well LAW 2C collected on 06/04/98 (cont.)

ANALYSES

F Anstyte

Result

$1.01 E-02 \pm 4.14 E-05$

2 Tritium

WELL LBP 1D

MEASUREMENTS CONDUCTED IN THE FIELD

Sample date: 05/26/98

opth to water: $34.45 \mathrm{Ht}(10.5 \mathrm{~m})$ below TOC

Water eleat
$\mathrm{pH}: 10.6$

Sp. conductance: $260 \mu \mathrm{S} / \mathrm{cm}$

Water evacuated from the well prior to sampling: 1 gal

ANALYSES

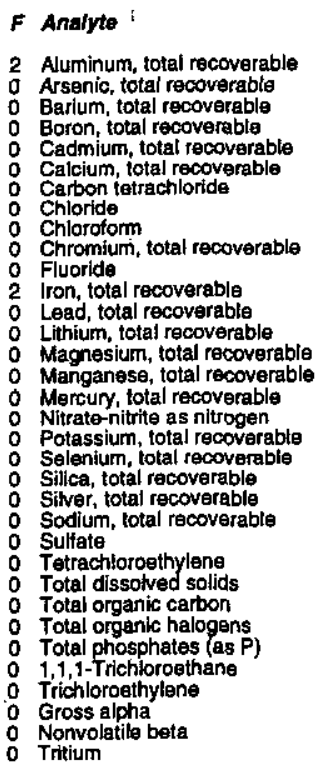

\begin{tabular}{|c|c|c|c|c|c|c|c|}
\hline Result & $R$ & $A$ & B & SQL & Unit & Lab & Mathod \\
\hline 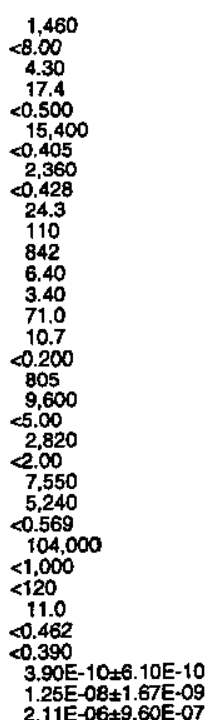 & J & $\begin{array}{l}\mathrm{E} \\
\mathrm{EL}\end{array}$ & H & $\begin{array}{l}20.0 \\
8.00 \\
2.00 \\
25.0 \\
2.00 \\
50.0 \\
0.405 \\
500 \\
0.428 \\
3.00 \\
100 \\
200 \\
5.00 \\
5.00 \\
50.0 \\
3.00 \\
0.200 \\
50.0 \\
400 \\
5.00 \\
100 \\
2.00 \\
100 \\
5.000 \\
0.569 \\
1.000 \\
1.000 \\
120 \\
10.0 \\
0.462 \\
0.390 \\
1.06 E-09 \\
2.07 E-09 \\
1.50 E-06\end{array}$ & 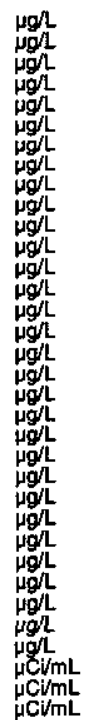 & $\begin{array}{l}\text { ES } \\
\text { ES } \\
\text { ES } \\
\text { ES } \\
\text { ES } \\
\text { ES } \\
\text { ES } \\
\text { ES } \\
\text { ES } \\
\text { ES } \\
\text { ES } \\
\text { ES } \\
\text { ES } \\
\text { ES } \\
\text { ES } \\
\text { ES } \\
\text { ES } \\
\text { ES } \\
\text { ES } \\
\text { ES } \\
\text { ES } \\
\text { ES } \\
\text { WA } \\
\text { ES } \\
\text { ES } \\
\text { TM } \\
T M \\
T M\end{array}$ & 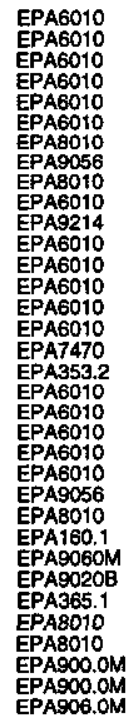 \\
\hline
\end{tabular}

ESH-EMS-980569
Time: 10:48

Air emperature: $38.1^{\circ} \mathrm{C} \mathrm{C}$

Total alkalinity (as $\mathrm{CaCO}$ ): $2 \mathrm{mg} /$
Phenolphthalein alkalinity: $0 \mathrm{mg} /$

WELL LBP 2D

MEASUREMENTS CONDUCTED IN THE FIELD

Sample date: $05 / 27 / 98$
Depth to water: $28.35 \mathrm{ft}(8.64 \mathrm{~m})$ below TOC
Water elevation: $271.05 \mathrm{ft}(82.62 \mathrm{~m}) \mathrm{ms}$

conductance: $30 \mu \mathrm{S} / \mathrm{cm}$

Wurbidity: 1 NTU ANALYSES

F Analyte

SQL Unit Lab Method

2.87E-06 $\mu \mathrm{CV} / \mathrm{mL}$ TM EPA906.0M

2 Aluminum, total recoverable

Barium, total recoverable

Cadmium, total recoverable

Carbon tetrachloride

Chioride

Chromium, total recoverable

Fluoride

Time: 8:38

Air temperature: $237^{\circ} \mathrm{C}$

Total alkalinity (as CaCO3): $58 \mathrm{mg} /$

Iron, total recoverable

Lithium, total recoverable

Manganese, total recoverable

Mercury, total recoverable

Potassium total recoverable

Silica, total recoverabrab

Silver, total recoverable
Sodium, total recoverable

Tetrachloroethylene

Total organic carbon

Total phosphates (as P

Trichbrosthylene

Nonvolatila be

$<8.00$

WELL LBP 3D

MEASUREMENTS CONDUCTED IN THE FIELD

Sample date: 05/26/98

Water

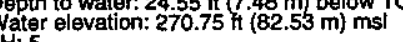

Sp. conductance: $22 \mu \mathrm{S} / \mathrm{cm}$

Water evacuated from the well prior to sampling: $27 \mathrm{gal}$

ANALYSES

$f$ Analyto

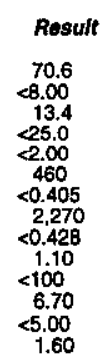

Result

Aluminum, total recoverabto

Arsenic, total recoverab

Boron, total recoverable

Calcium, total recoverable

Chloride

Chromium, total recoverable

Iron, total recoverable

Lead, lotal recoverable

$<5.00$
1.60

B-185
Air temperature: $26.5^{\circ} \mathrm{C}$

Phenolphthalein alkalinity: $0 \mathrm{mgh}$

12.9
2.00
501
$<0.405$
3.020
0.428
2.60
$<100$
13.4
5.00
5.00
871
7.40
0.0500
745
1.120
5.00

$<2,000$

$<5,000$
$<8,569$
38,000

$<.00$
$<0.462$
$<0.390$

$1.95 E-09+6.60 E-10$
$2.75 E-09+1.26 E-09$
$1.43 E-06+4.40 E-07$

A

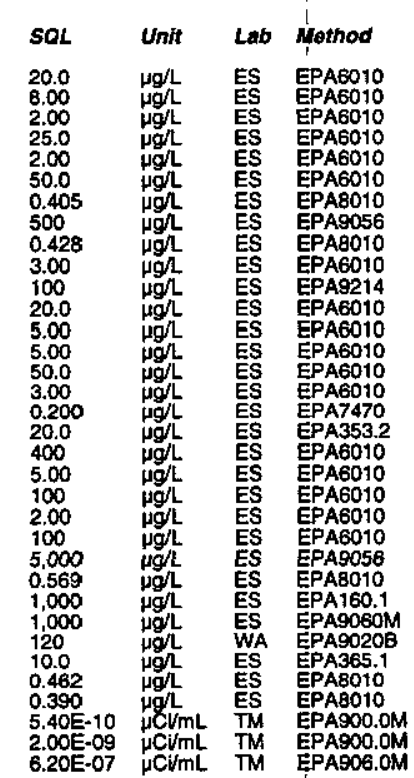

Time: 13:38

Air temperature: $34.8^{\circ} \mathrm{C}$
Total akkalinity (as Caco3) 2 mgh
Phanolphthalein alkalinity: $0 \mathrm{mg} /$ 
Well LBP 3D collected on 05/26/98 (cont.)

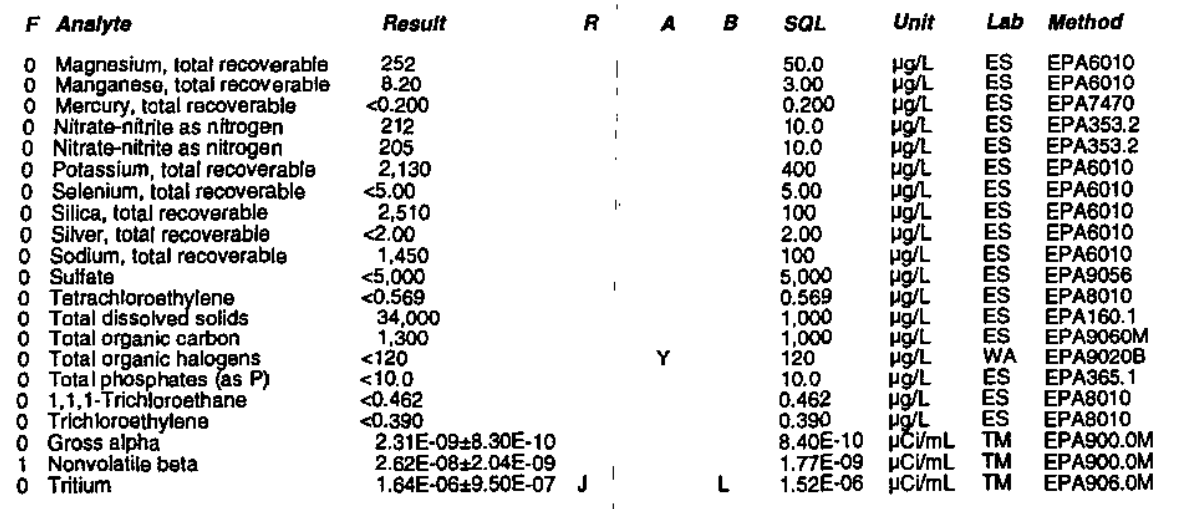

WELL LDB 1

MEASUREMENTS CONDUCTED IN THE FIELD

Sample date: 04/17/98

Water elevation: Not available

H: Not available

Not available

Turbidity: Not available

ANALYSES

$F$ Analyte

0 Tritium

Result

$3.73 E-06 \pm 5.60 E-07$

$\boldsymbol{B}$

A

Unit Lab Mathod 6.30E-07 $\mu \mathrm{CV} / \mathrm{mL}$ TM EPA906.0M

\section{WELL LDB 1}

MEASUREMENTS CONDUCTED IN THE FIELD

Sample date: $05 / 05 / 98$
Depth to water: $26.9 \mathrm{tt}(8.2 \mathrm{~m})$ below TOC

Water

Sp. conductance: $140 \mu \mathrm{S} / \mathrm{cm}$

Turbidity: $2 \mathrm{NTU}$
Water evacuated from the well prior to sampling: $41 \mathrm{gal}$

ANALYSES
$F$ Ans/yto
Result

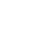
- Tritium
3.84E- $-06 \pm 5.30 \mathrm{E}-07$

WELL LDB 1

MEASUREMENTS CONDUCTED IN THE FIELD

Sample date: $06 / 04 / 98$

Depth to water: $27.25 \mathrm{ft}(8.31 \mathrm{~m}$ ) below TOC

Water elevation: $224.65 \mathrm{Ht}(68.47$
pH: 5.8
Sp. conductance: $160 \mu \mathrm{S} / \mathrm{cm}$

Water evacuated from the well prior to sampling: $90 \mathrm{gal}$

ANALYSES
$F$ Analyto
Result
R A
0 Tritium 2.50E-06.9.00E-07 UHJ $V X$
Time: 12:04
Wir
Total alkalinity (as CaCO3): $50 \mathrm{mg} /$
Phenolphthalein alkalinity: $0 \mathrm{mg} /$

Time: Not available
Water temperature: Not available Air temperature: Not available

Time: $8: 48$ Water 19 mperature: $18^{\circ} \mathrm{C}$

Air temperature: $29.6^{\circ} \mathrm{C}$ ) $51 \mathrm{mgh}$

\section{WELL LDB 2}

MEASUREMENTS CONDUCTED IN THE FIELD

Sample date: $04 / 17 / 98$

Water elevation: Not available

$\mathrm{PH}$ : Not available

Sp. conductance: Not available

No water was evacuated

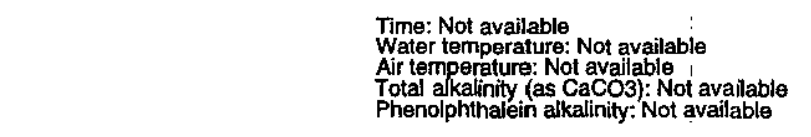

ANALYSES

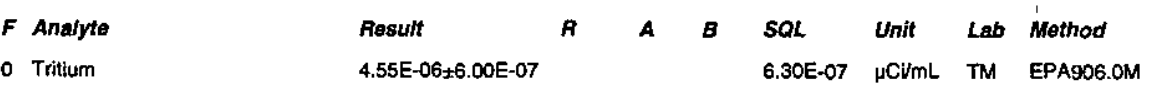

WELL LDB 2

MEASUAEMENTS CONDUCTED IN THE FIELD

Sample date: $05 / 05 / 98$

Water elevation: Not available

$\mathrm{pH}$ : Not availabie . conductance: Not availabl

Tu. conductance: Not available

No water was evacuated from the well prior to sampling.

ANALYSES

$f$ Analyte

0 Tritum

Result

$5.43 E-06 \pm 6.10 E-07$

\section{WELL LDB 2}

MEASUREMENTS CONDUCTED IN THE FIELD

Sample date: 06/04/98

Water elevation: Not available

$\mathrm{pH}$ : Not available . conductance: Not available

No water was evacuated from the well prior to sampling

ANALYSES

F Analyte Result $R$ A $B$ SOL Unit Lab Mathod

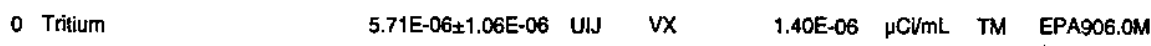

\section{WELL LDB 3}

MEASUREMENTS CONDUCTED IN THE FIELD

Sample date: $04 / 17 / 98$ (

Wepth to water: $28.7 \mathrm{ft}(8.75 \mathrm{~m})$ below

ph. 5.8 conductance: $200 \mu \mathrm{S} / \mathrm{cm}$

Water evacuated from the well prior to sampling: 74 gal

ANALYSES

$F$ Ansilyte

Besult

2 Tritium

4.54E-05 $\pm 1.57 E-06$
Time: Not available

Nir

Total alkalinity (as CaCO3): Not available
Phenolphthalein alkalinity: Not available
Time: 11:21 Total alkalinity (as $\mathrm{CaCO}$ ): $44 \mathrm{mg}$ Phenolphthalein alkalinity: $0 \mathrm{mg} /$

Time: Not available Water temperature: Not availabile Air temperature: Not available
Air temperature: $18^{\circ} \mathrm{C}$ Total alkalinity (as CaCO3) : Not available

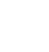

$\begin{array}{lllll}B & \text { SQL } & \text { Unit } & \text { Lab } & \text { Mothod } \\ & 6.30 E-07 & \mu \mathrm{C} / \mathrm{mL} & \text { TM } & \text { EPA906.OM }\end{array}$

ESH-EMS-980569

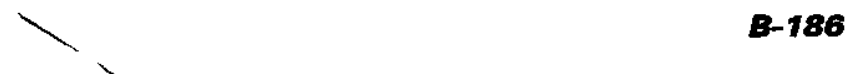




\section{WELL LDB 3}

MEASUREMENTS CONDUCTED IN THE FIELD

\section{Sarnple date: $05 / 05 / 98$
Depth to water: $28.1 \mathrm{th}(8.56 \mathrm{~m})$ below TOC
Water elevation: $225 \mathrm{tt}(68.58 \mathrm{~m}) \mathrm{ms}$ T pp. conductance: $200 \mu \mathrm{S} / \mathrm{cm}$ \\ Water evacuated from the well prior to sampling: $54 \mathrm{gal}$}

ANALYSES

$F$ Anetyco

Result

P

$2.76 E-05 \pm 1.24 E-06$

2 Tritium

WELLL LDB 3

MEASUREMENTS CONDUCTED IN THE FIELD

Sample date: 06/04/98

Water elevation: Not available

H: Not available

Sp. conductance: Not available

No water was evacuated from the well prior to sampling.

ANALYSES

$F$ Analyte

2 Tritium

Result

R A

2.03E-05 $1.56 E-06$ UIJ $V X$

B

\section{WELL LDB 4}

MEASUREMENTS CONDUCTED IN THE FIELD

Depth to water: Not available

H. Nol available

No water was evacuated from the well prior to sampling.
Time: $13: 09$ Water temperature: $16^{\circ} \mathrm{C}$

Air temperature: $29.5^{\circ} \mathrm{C}$ ) : $50 \mathrm{mg} / \mathrm{l}$

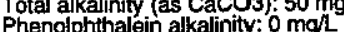

ANALYSES

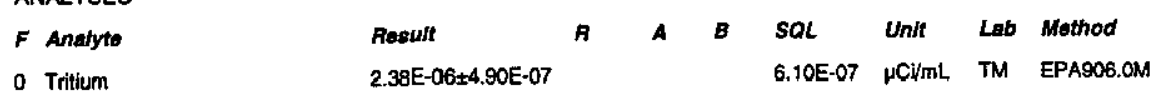

$2.38 \mathrm{E}-06 \pm 4.90 \mathrm{E}-07$

\section{WELLL LDB 4}

MEASUREMENTS CONDUCTED IN THE FIELD

Sample date: $05 / 05 / 98$
Depth to water. $26.65 \mathrm{H}(8.12 \mathrm{~m})$ below TOC
Water elevation: $222.95 \mathrm{Ht}(67.96 \mathrm{~m}) \mathrm{ms}$

Water
SH: 5

Sp. conductance: $48 \mu \mathrm{S} / \mathrm{cm}$

Water evacuated from the well prior to sampling: $1 \mathrm{gal}$

ANALYSES

$F$ Analyte

Resuth

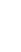

Time: Not available

Water temperature: Not availab

Total alkatinity ( (as CaCO3): Not available
Phenolphthalein alkalinity: Not available

Water temperature: Not available

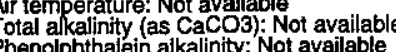

o Tritium

$3.23 E-06 \pm 4.90 E-07$

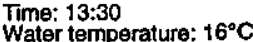

Air termperature: $29.2^{\circ} \mathrm{C}$ ) $1 \mathrm{mgh}$

5.10E-07 HCVITL TM EPAO06.0M
Sample date: 04/17/98

\section{WELL LDB 4}

MEASUREMENTS CONDUCTED IN THE FIEL.D

Sample date: 06/04/98

Water elevation: Not available

H: Not available

p. conductance: Not av

No water was evacuated from the well prior to sampling.

ANALYSES

F Analyte

Result

$\boldsymbol{R}$

2.41E-06.9.20E-07 UIJ $v X$

B SOL Unt Lab Mothod

Tritium

1.40E-06 $\mu \mathrm{C} / \mathrm{mL}$ TM EPA906.0M

\section{WELL LDS 1P}

MEASUREMENTS CONDUCTED IN THE FIELD

Sample date: $04 / 02 / 98$
Depth to water: $22.4 \mathrm{ft}(6.83 \mathrm{~m})$ below TOC

Water elevation: Not available

$\mathrm{gH}: 5$ conductance: $28 \mu \mathrm{S} / \mathrm{cm}$

Turbidity: $1 \mathrm{NTU}$ T $28 \mathrm{~S} / \mathrm{cm}$
Water evacuated from the well prior to sampling: 16 gal

ANALYSES

$F$ Analyte

Benzene
0 Ethylbenzene

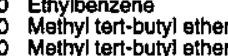

Toluene

Toluene
0 Xylenes
Xylenes

\section{WELL LFW 6R}

MEASUREMENTS CONDUCTED IN THE FIELD

Sample date: 06/12/98

Water elevation: $154.85 \mathrm{ft}(47.2 \mathrm{~m})$ below $\mathrm{ms}$ TOC

Sp: 4.6
Turbidity: 1 NTU

Water evacuated from the well prior to sampling: $12 \mathrm{gal}$ ANALYSES

\begin{tabular}{|c|c|}
\hline Analyte & \\
\hline 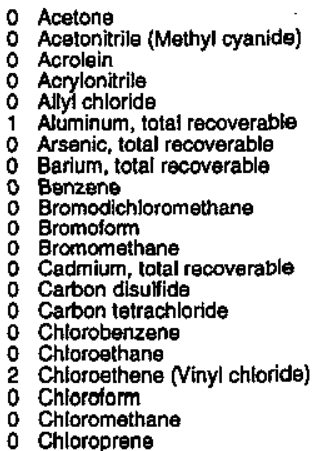 & $\begin{array}{l}<10.0 \\
<20.0 \\
<10.0 \\
<5.00 \\
<10.0 \\
35.9 \\
<8.00 \\
11.5 \\
<5.00 \\
<5.00 \\
<5.00 \\
<10.0 \\
<0.400 \\
<5.00 \\
<5.00 \\
1.50 \\
5.30 \\
4.00 \\
<5.00 \\
<10.0 \\
<5.00\end{array}$ \\
\hline
\end{tabular}
rature: Not available otal akealinity. (as CaCO3): Not available

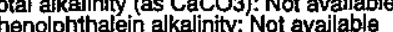

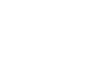

Water temperature: $17^{\circ} \mathrm{C}$

Tir tal akalinity (as CaCO3): $1 \mathrm{mg} /$
Phenolphthalein alkalinity: $0 \mathrm{mg} \mathrm{L}^{-}$

\begin{tabular}{|c|c|c|c|}
\hline SQL & $U_{n i t}$ & Lab & Method \\
\hline $\begin{array}{l}5.00 \\
5.00 \\
5.00 \\
5.00 \\
5.00 \\
5.00 \\
5.00 \\
5.00 \\
5.00\end{array}$ & 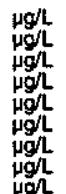 & $\begin{array}{l}\text { WA } \\
\text { WA } \\
\text { WA } \\
\text { WA } \\
\text { WA } \\
\text { WA } \\
\text { WA } \\
\text { WA } \\
\text { WA }\end{array}$ & $\begin{array}{l}\text { EPAB260 } \\
\text { EPAB2600 } \\
\text { EPAB260 } \\
\text { EPAB260 } \\
\text { EPAB260 } \\
\text { EPA } 2260 \\
\text { EPA8260 } \\
\text { EPAB260 } \\
\text { EPAB260 }\end{array}$ \\
\hline
\end{tabular}

temperature: $16^{\circ} \mathrm{C}$

Total akalinitiy (as Caco3): $0 \mathrm{mgh}$

\begin{tabular}{|c|c|c|c|c|}
\hline Result & A & $A$ & $B$ & SOL \\
\hline $\begin{array}{r}<10.0 \\
<20.0 \\
<10.0 \\
<5.00 \\
<10.0 \\
35.9 \\
<8.00 \\
11.5 \\
<5.00 \\
<5.00 \\
<5.00 \\
<10.0 \\
<0.400 \\
<5.00 \\
<5.00 \\
1.50 \\
5.30 \\
4.00 \\
<5.00 \\
<10.0 \\
<5.00\end{array}$ & $\begin{array}{l}J \\
J \\
J\end{array}$ & $\begin{array}{l}\text { E } \\
\text { E }\end{array}$ & & $\begin{array}{l}10.0 \\
20.0 \\
10.0 \\
5100 \\
10.0 \\
20.0 \\
8.00 \\
2.00 \\
5.00 \\
5.00 \\
5.00 \\
10.0 \\
5.00 \\
5.00 \\
5.00 \\
10.0 \\
100 \\
5.00 \\
10.0 \\
5.00\end{array}$ \\
\hline
\end{tabular}

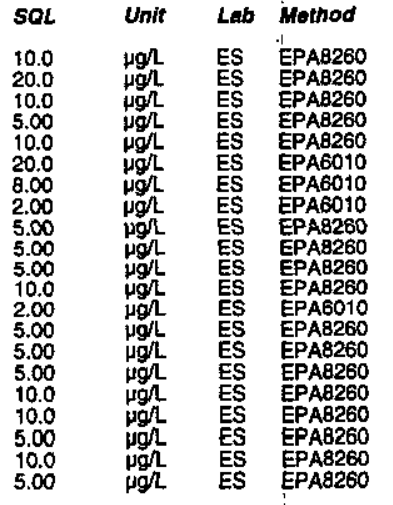

Second Quarter 1998 
ANALYTICAL RESULTS

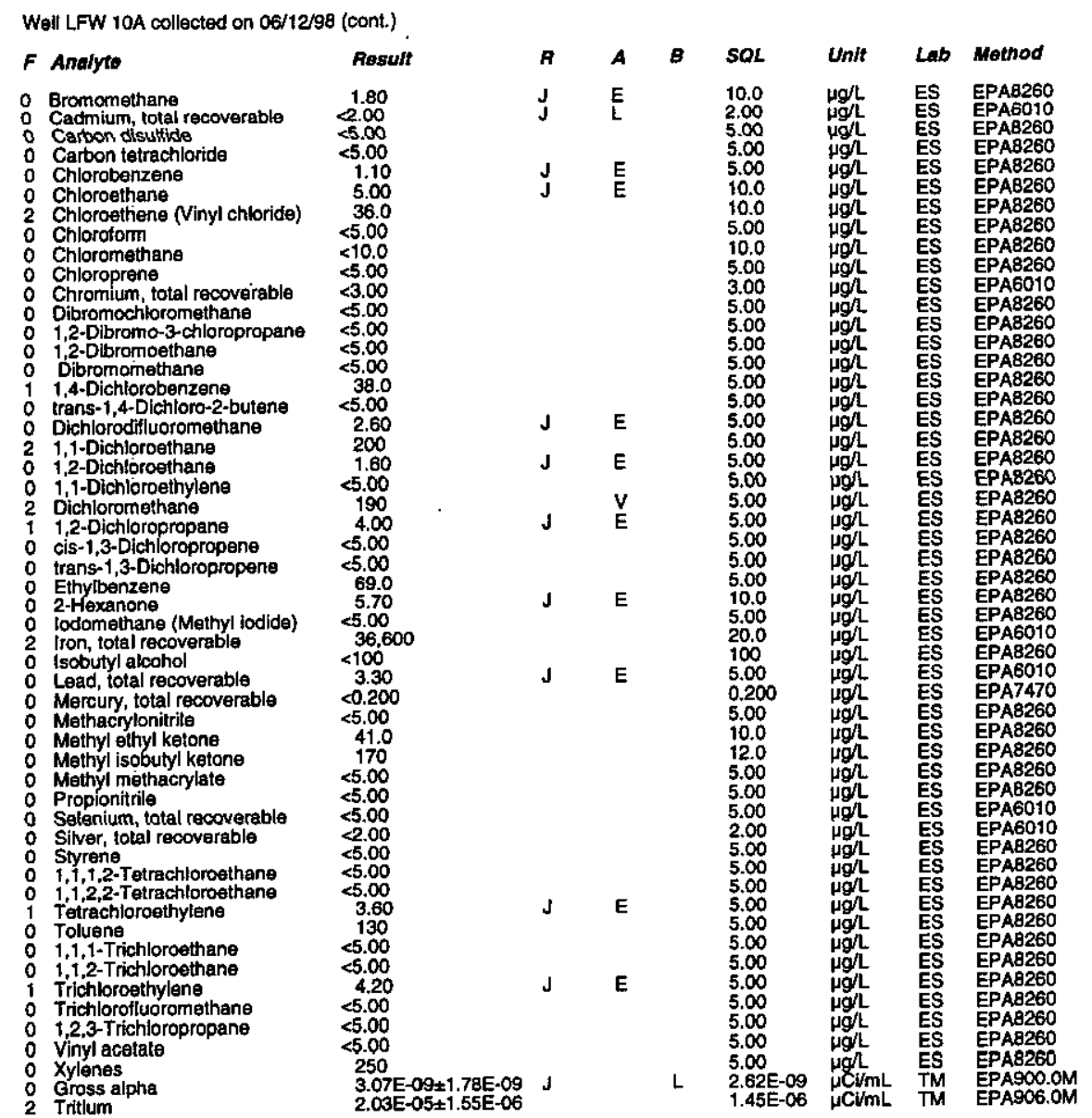

\section{WELL LFW 18}

MEASUREMENTS CONDUCTED IN THE FIELD

Sample date: $06 / 12 / 98$
Depth to water: $27.9 \mathrm{ft}(8.5 \mathrm{~m})$ below TOC

Water elevation: $147.1 \mathrm{ft}(44.84 \mathrm{~m}$
$\mathrm{gH}: 6$.
Sp. conductance: $110 \mu \mathrm{S} / \mathrm{cm}$

Turbidity: 1 NTU
Water ovacuated from the well prior to sampling: 70 gal

ANALYSES

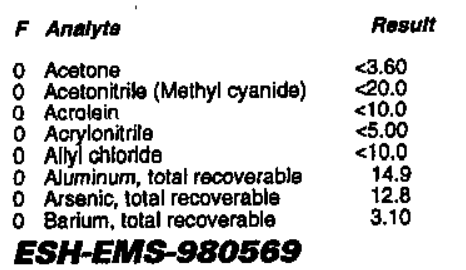

Time: 12:33 3 Water temperature: $22.6^{\circ} \mathrm{C}$

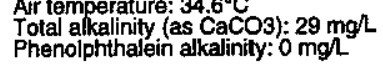

$\begin{array}{ll} & \begin{array}{r}5.0 .0 \\ J\end{array} \quad 20.0 \\ 8.00 \\ 2.00\end{array}$

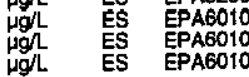

Well LFW 18 collected on 06/12/98 (cont.)
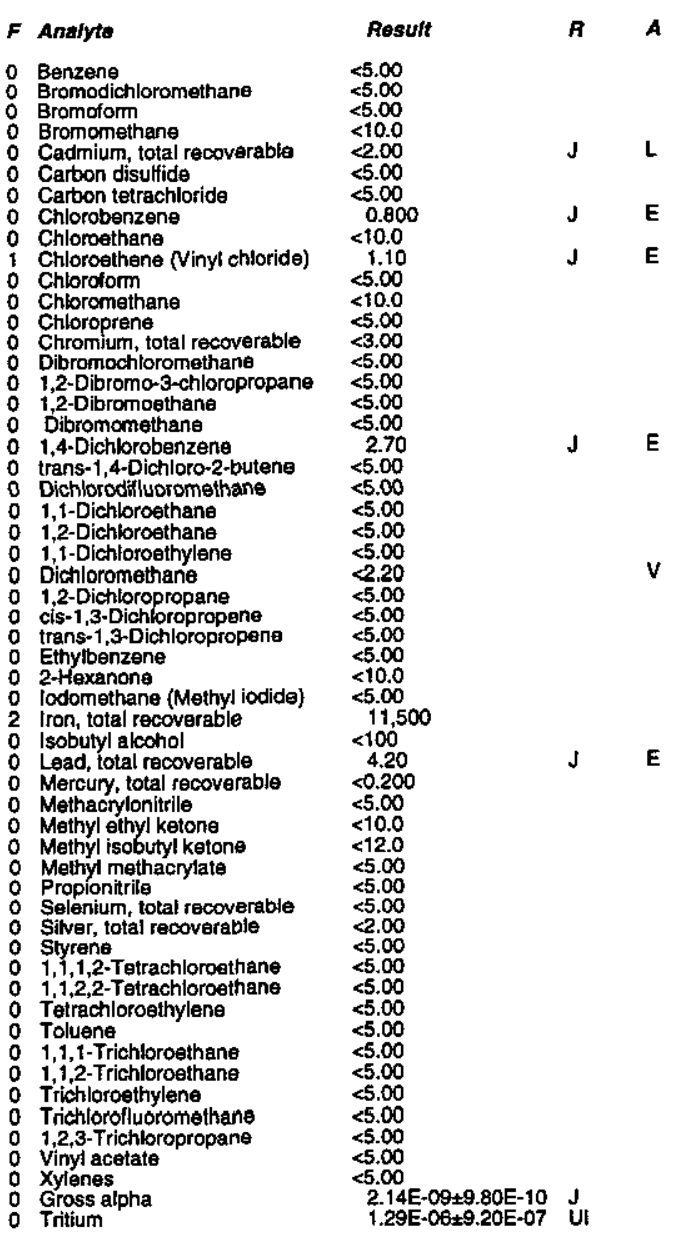

SOL Unit LAb Mothod

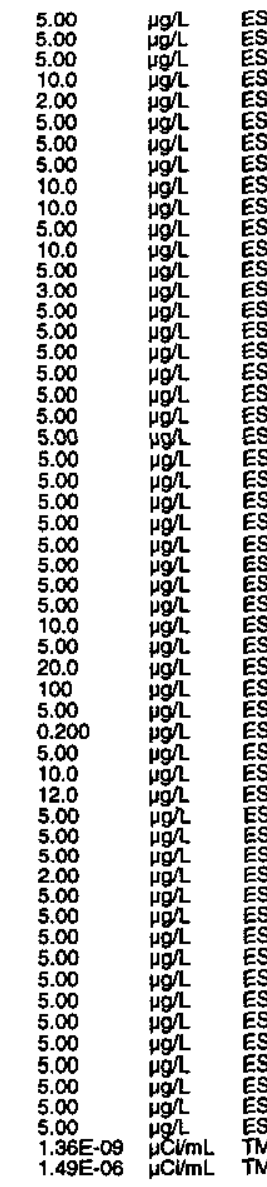

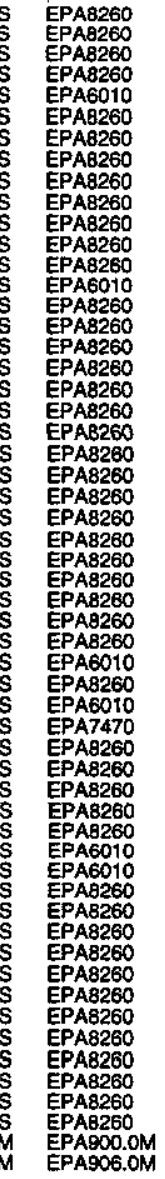

\section{WELL LFW 21}

MEASUREMENTS CONDUCTED IN THE FIELD

Sample date: $06 / 12 / 98$
Depth to water: $33.28 \mathrm{ft}(10.14 \mathrm{~m})$ below TOC
Water elevation: $142.32 \mathrm{ft}(43.38 \mathrm{~m})$ ms

Water elevation: $142.32 \mathrm{t}(43 . \mathrm{m}$
pH: 6.3
Sp. conductance: $220 \mu \mathrm{S} / \mathrm{cm}$

Water evacuated from the well prior to sampling: $70 \mathrm{gal}$

ANALYSES

$F$ Analyte

Result

o Acetone

- Acrolein

B-189
Time: 11:07

Air temperature: $343^{\circ} \mathrm{C}$

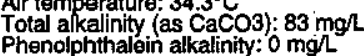

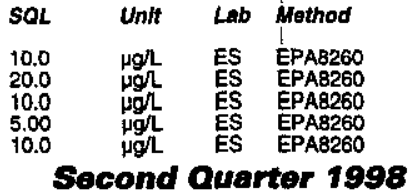


Well LFW 21 collected on 06/12/98 (cont.)

$F$ Analyte

\section{Posult}

- Aluminum, total recoverable

Barium cotal recoverable

Benzene

. Bromoform

Cadmium tone

Carbon disulfide

Chlorobenzent
Chloroethane

Chloroethane

Chloroform

Chromiun, total recoverable

1,2-Dibromoethane

1,4-Dichiorobenzen

trans-1,4-Dichloro-2-butene

1.1-Dichloroethane

1,i-Dichloroethylen
Dichloromethane

1,2-Dichloropropane
cis-1,3-Dichloropropene

trans-1,3-Dichloropropen

Ethylbenzene

2-Hexanone
lodomethane (Methyl iodide)

isobutyl alcohoi

Lead, total recoverable

Methyl tthyl keton

Methyl isobutyl ketone

Selenium, total recoverab!

Styrene -Tetrachloroethane

1,1,2,2-Totrachloroethan

Tetrachloroethylene

1,1,1-Irichloroethane

Trichloroethylene

1,2,3-Trichloropropane

$\because$ Vinyl acetate

0
0
0

\section{WELL LFW 23R}

MEASUREMENTS CONDUCTED IN THE FIELD

Sample date: $06 / 12 / 98$
Depth to water $19 \mathrm{ft}(5.79 \mathrm{~m})$ below TOC
Water levation: $151.5 \mathrm{ft}(46.18 \mathrm{~m}) \mathrm{msl}$

Water

. conductance: $24 \mu \mathrm{S} / \mathrm{cm}$

Wutbidity: O NTU

ANALYSES

$F$ Analyte

Result

A

- Acetone $\quad<10.0$

ESH-EMS-980569
Well LFW 23A collected on 06/12/98 (cont).

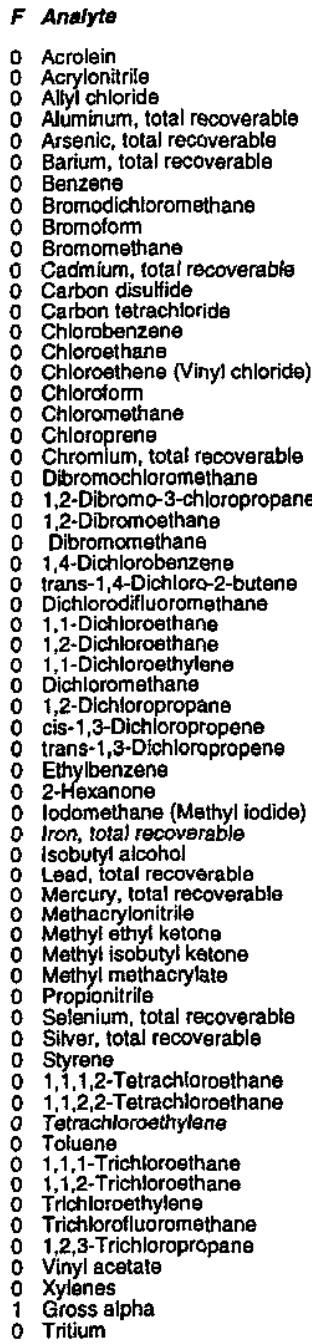

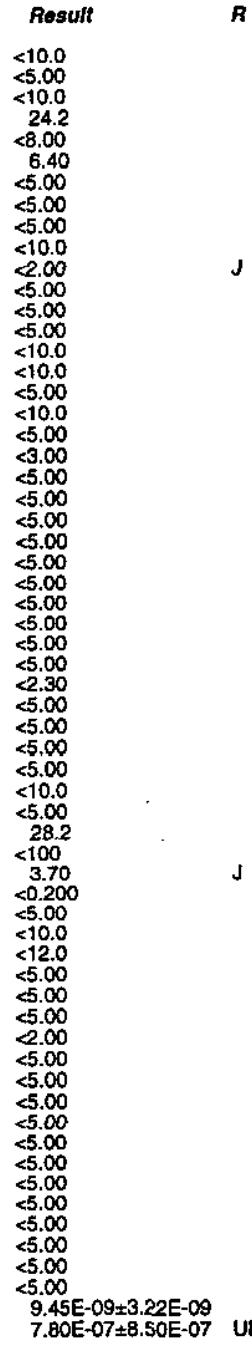

Time: 8:15

政 $16^{\circ} \mathrm{C}$

Total alkalinity (as Cacos): $0 \mathrm{mg} / \mathrm{l}$

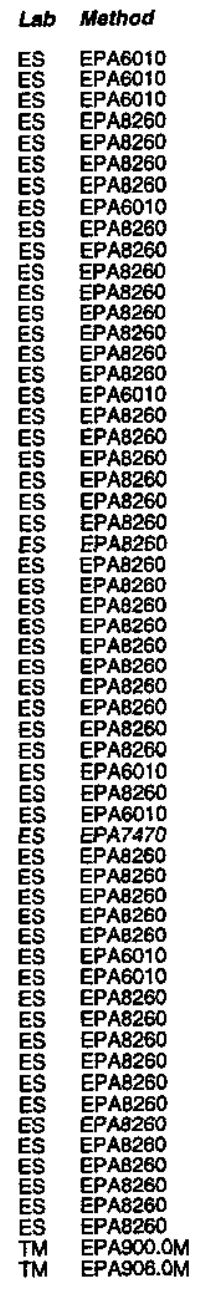

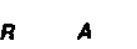

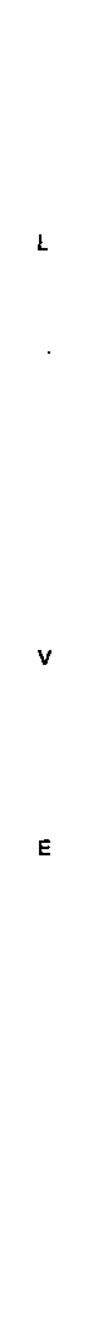

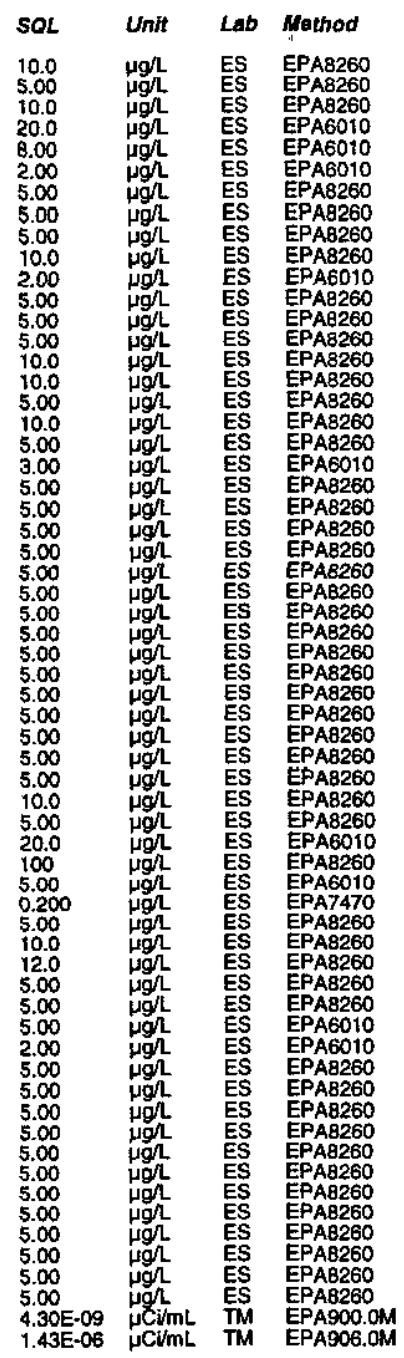

Second Quarter 1998 


\section{WELL LFW 31}

MEASUREMENTS CONDUCTED IN THE FIELD

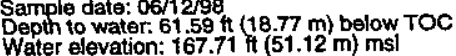
Water ela Pp. conductance: $29 \mu \mathrm{S} / \mathrm{cm}$ Watter evacuated from the well prior to sampling: 59 gal ANALYSES

$F$ Analyto

0 Acetone Acetonitirle (Methyl cyanlde) Acrolein

Acrylonitrile

Alyy chloride

Ally chloride

Arsenic, total recoverable

Benzen

Bromodichloromethane

Bromoform

Bromomathane

Cadmium, total recoverable

Carbon disulfide

Carton tetrachlorlde

Chlorobenzene

Chloroethane

Chloroethene Ninyl chloride)
Chloroethene (Vinyl chloride

Chlorotom

Chloromethane

Chloroprene

Chromium, total recoverable

Dibromochloromethane

1,2-Dibromo-3-chloropropane 1,2-Dibromoethane

Dibromomethan

1.4-Dichlorobenzene

trans-1,4-Dichloro-2-butene

Dichlorodifluoromethane

1,1-Dichloroethan

1,2-Dichloroethan

1,2-Dichloroethane

1,1-Dichloroethylene

Dichloromethane
Dichloromethane

1,2-Dlchloropropante

cis-1,3-Dichloropropen

cis-1,3-Dichloropropene

ESH-ENHS-980569
Well LFW 31 collected on 06/12/98 (cont)

$F$ Anaiyte Rosult

Time: 8:28 $20.1{ }^{\circ} \mathrm{C}$

Total alkalinity (as CaCO3): $0 \mathrm{mg} /$

trans-1,3-Dichloropropene

Etylbenzene

2-Hexanone

lodomethane (Methyl iodide)

lodomethare (Methyl iodide)

I isobutyl alcohol

Lead, total recoverable

Methacrylonitirile

: Methacrytonitrile

Methyl isobutyl ketone

Methyl isobutyl ketone

Methyl methacryiate

0 Propionitrite

: Propionitrile

Silver, to

: Styrene

etrachloroethane

Tetrachloroethylene

Toluenes

0 Toluene

o $1,1,1$-Trichloroettrame

1, 1,2 - -Trichloroesthan

Trichloroetthy'ene

Irichlorofluoromethane

1,2,3-Trichloropropane

0 Vinyl acetate

Xylenes

O Gross alpha

WELL LFW 36R

MEASUREMENTS CONOUCTED IN THE FIELD

Sample date: $06 / 10 / 98$
Depth to water: $21.75 \mathrm{ft}(6.63 \mathrm{~m})$ below TOC
Water elevation: $146.65 \mathrm{ft}(44.7 \mathrm{~m}) \mathrm{ms}$ l

$\mathrm{pH}: 6$

p. conductance: $170 \mu \mathrm{S} / \mathrm{cm}$

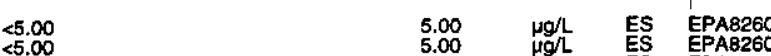

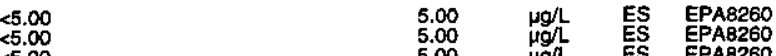

Water evacuated from the well prior to sampling: $30 \mathrm{gal}$

ANALYSES

F Analyte

Acetone

Acrolein

Alyminide

0
0 Arsenic, total recor
0

Denzen toral rocoverablo

Bromodichloromethan

191
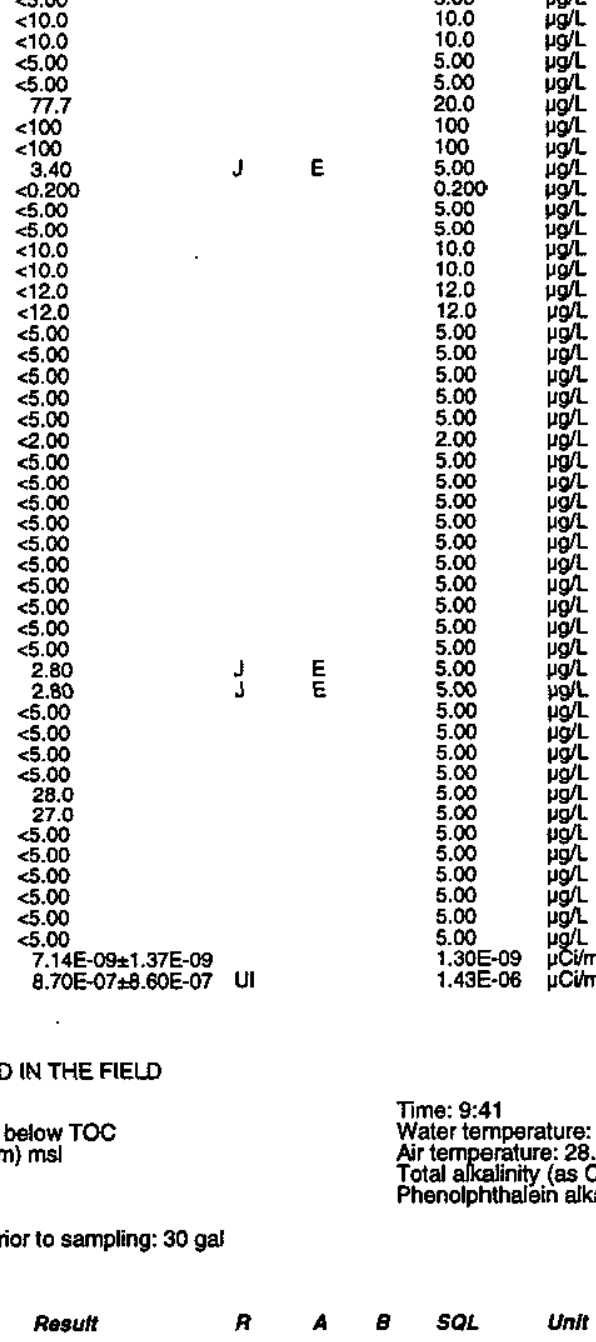

EPAB260

EPA6010

EPAB260

ES EPAB260

EPA8260

EPA8260

EPAB260

EPA8260

ES EPAG010

ESAB260

EPAB260

ES EPAB260

ES EPAB260

ES EPAB260

ES EPAB260

ES EPAB260

ES EPA8260

ES EPA8260

ES EPA8260

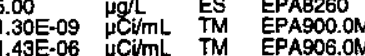
$7.14 E-09+1.37 E-09$ uI

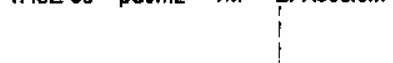

Time: $9: 41$

Water temperature: $20.8^{\circ} \mathrm{C}$

Total alkalinity, (as Cacos): $73 \mathrm{mg} \Omega$

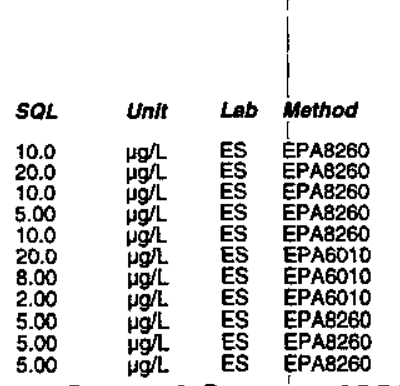

Second Quartor 1998 
Well LFW 36 R collected on 06/10/98 (cont.)

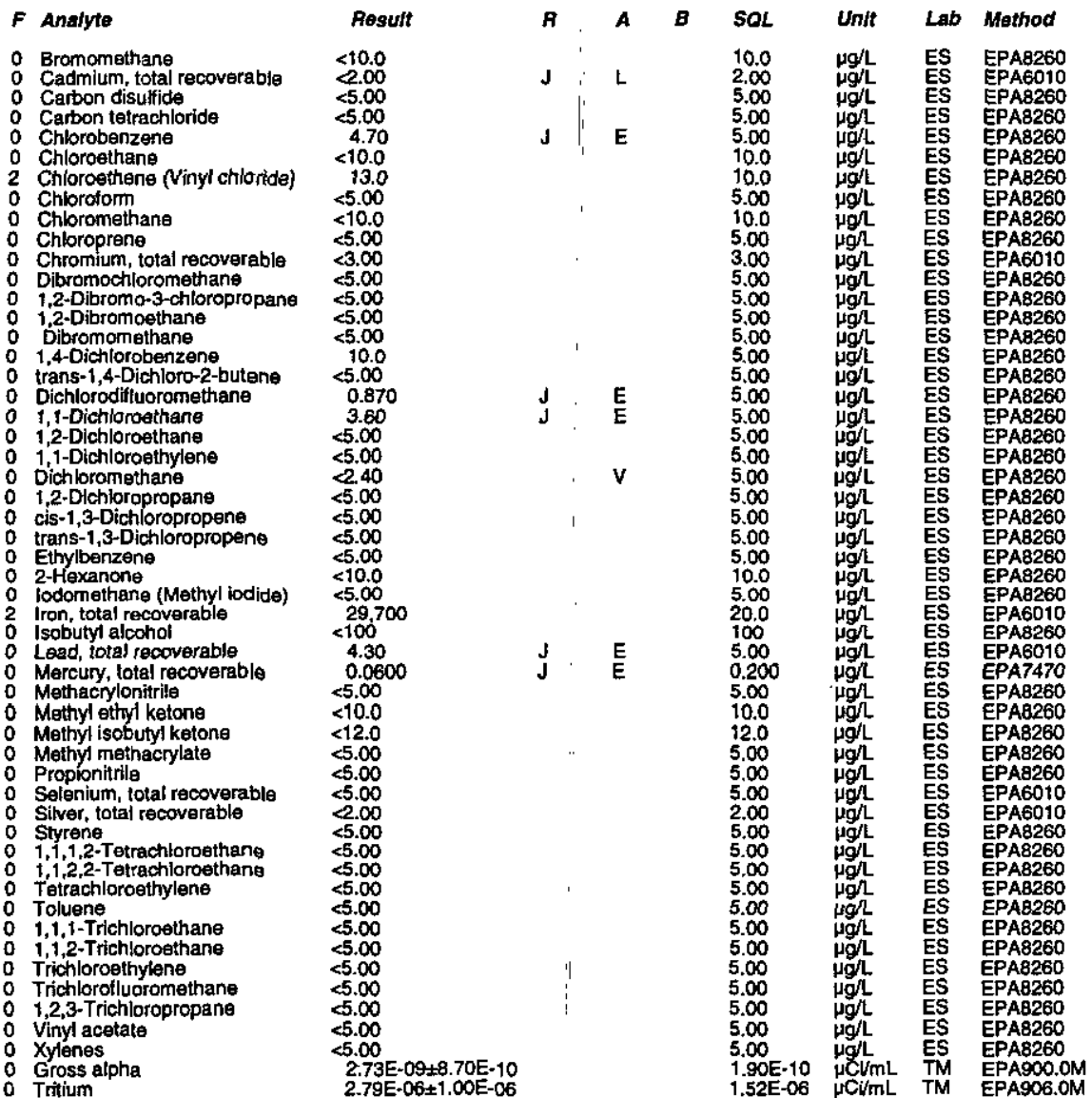

\section{WELL LFW 41R}

MEASUREMENTS CONDUCTED IN THE FIELD

Sample date: $06 / 08 / 9$

Depth to water $25.35 \mathrm{ft}(7.73 \mathrm{~m})$ below TOC

Water

P.: conductance: $20 \mu \mathrm{S} / \mathrm{cm}$
Purbidity: $0 \mathrm{NTTU}$

Water evacuated from the well prior to sampling: $12 \mathrm{gal}$

ANALYSES

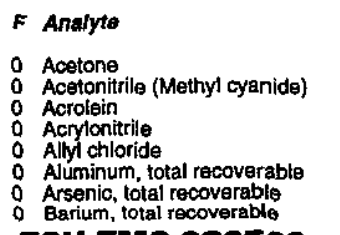

Result
$<10.0$
$<20.0$
$<10.0$
$<5.00$
$<10.0$
8.80
$<8.00$
2.70

ESH-EMS-980569

Air temperature: $13.7^{\circ} \mathrm{C}$
Total alkalinity (as Caco3): $0 \mathrm{mgh}$

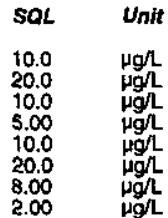

ES EPAB260
Well LFW 4tR collected on 06/08/98 (cont.)
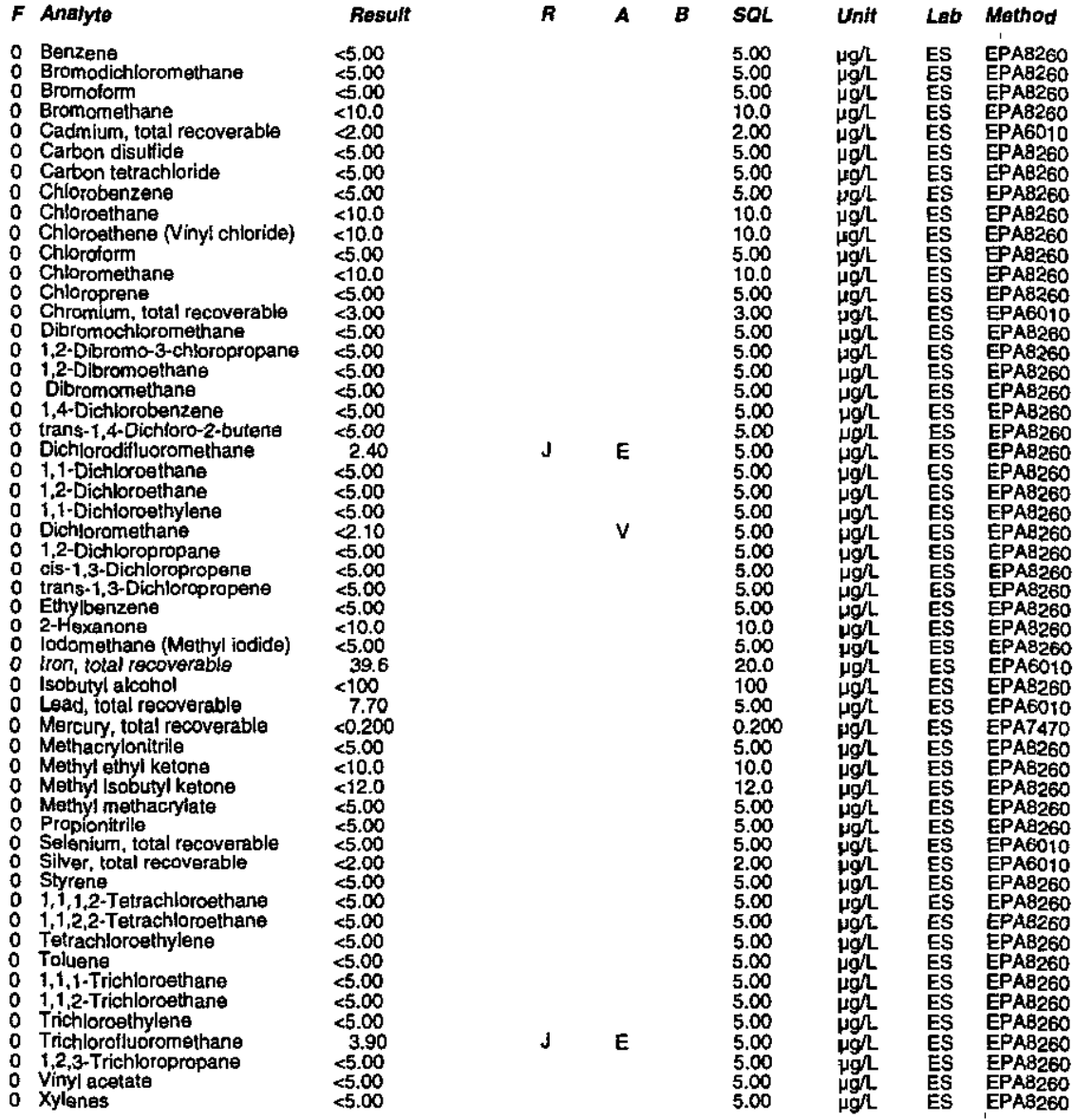

\section{WELL LFW 43B}

MEASUREMENTS CONDUCTED IN THE FIELD

Sample date: $06 / 08 / 98$
Depth to water: $35.2 \mathrm{ft}(10.73 \mathrm{~m})$ below TOC
Water elevation: $167.8 \mathrm{ft}(51.15 \mathrm{~m}) \mathrm{ms}$

$\mathrm{BH}: 5.2$

Sp. conductance: $19 \mu \mathrm{S} / \mathrm{cm}$

Water evacuated from the well prior to sampling: $203 \mathrm{ge}$

ANALYSES

0 Acetone

Acetonitilie (Methyl cyanide)

0 Acrolein

$\therefore$ Acrolein

B-192

Resuft
$<10.0$
$<10.0$
$<2.0$
$<20.0$
$<1.0$
$<10.0$
$<5.00$

Time: 9:30

Witer erature: $18.7^{\circ} \mathrm{C}$

Total alkalinity (as CaCo3): $1 \mathrm{mgh}$ 
Well LFW 43B collected on 06/08/98 (cont.)

$F$ Analyte

$\begin{array}{ll}\text { Acrylonitrile } \\ 0 & \text { Allyl chloride } \\ 0 & \text { Ally chloridos }\end{array}$

Alyuminum, total recoverable

Arsentic, total recoverable

Benzene
Benzene

Bromodichloromethane

Bromotorm

Bromomethane

Bromomethane

Carbon disulfide

Carbon tetrachloride

Chlorobenzen

Chloroethane

Chloroethane (Vinyl chloride)

Chloroetherie (Vinyl chloride)

Chlorotorm

Chloromethane

Chromiun, total recoverable

Dibromochloromethane

Dibromochloromethane

2-Dibromo-3-chloropropane

1,2-Dibromethane

Dibromomethane

1,4-Dichlorobenzene

trans-1,4-Dictiloro-2-butene

Dichlorodifluoromethan

1.1-Dichloroethane

1,2-Dichloroethane

1,2-Dichloroethane

1,1-Dichloroelthylene

Dichloromethane

1,2-Dichloropropane

cis-1,3-Dichloropropene

trans-1,3-Dichloropropen

Ethylbenzene

2-Hexanone

lodomethane (Methyl iodide)

lodomethane (Methyl iodide

Isobutyl alcohol

Lead, total recoverable

Mathacrylonitrile

Methyl ethyl ketone

Methyl isobutyl ketone

Methyl methacrylate

ESH-EMS-980569

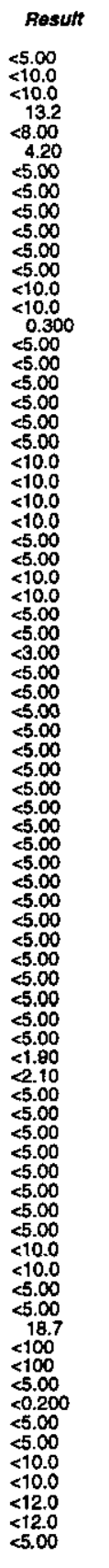

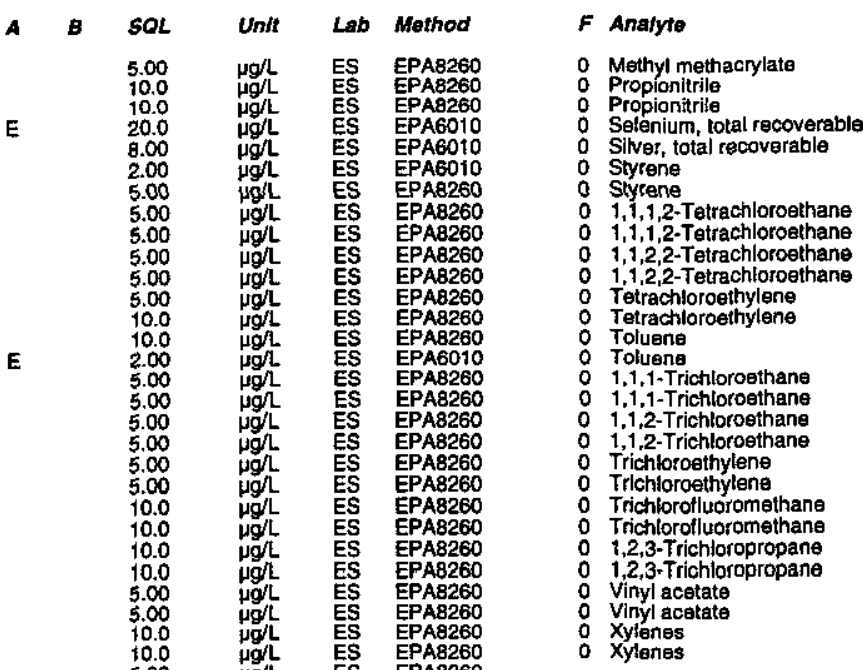

WELL LFW 43C

MEASUREMENTS CONDUCTED IN THE FIELD Sample date: 06/08/98 Depth to water: $34.45 \mathrm{ft}(10.5 \mathrm{~m})$ below TOC

pH: 5.2 .

Water evacuated from the well prior to sampling: $94 \mathrm{gal}$

ANALYSES

F Analyte

O Acetone

- Acetonitrile (Methyl cyanide)

Acrolein

Acrylonitrila

: Acrylonitrile

Aluminum, total recoverabl

A Aluminum, total recoverable

Arsenic, total recoverable

: Barium, total recoverable

Benzent

o Bromodichloromethane

Bromodichlor

: Bromoform

Bromomethane

- Cadmium, total recoverab

Carbon disulfidide

: Carbon disulfide

Carbon tetrachlorida

Chlorobenzene

B-193

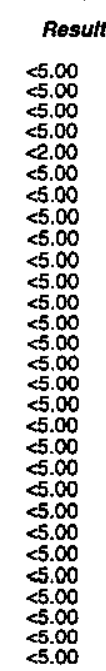

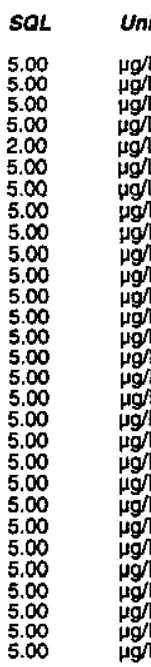

Unit Lab Mothod

ES EPAB260

EPA6010

EPA8260

ES EPA8260

ES EPAB260

ES EPA2260

ES EPA8260

ES EPA8260

ES EPA8260

ES EPA8260

EPAB260
EPAB260
EPA8260

ES EPA8260

Time: 9:43

Werature: $18.6^{\circ} \mathrm{C}$

Air temperature: $18.9^{\circ} \mathrm{C}$
Total alkalinity (as CaCO3); 0 mg/L
Phenolphthalein alkalinity: $0 \mathrm{mgh}$ 
ANALYTICAL RESULTS

Well LFW 43 C collected on 06/08/98 (cont.)

$F$ Analyt

- Ethyibenzene

lodomethane (Methyl iodide)

Isobutyl alcohol

Mercury, total recoverable

Methacrylonitrile

: Methyl ethyl ketone

Methyl methacrylate

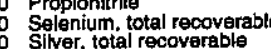

: Styrene Tetrachloroethane

Tetrachloroethylent

o Toluene

1,1,2-Trchloroethan

Trichlorofluotromethane
0
0

Xylenes

\section{WELL LFW 43D}

MEASUREMENTS CONDUCTED IN THE FIELD

Sample date: 06/09/98
Depth to water: $36.3 \mathrm{ft}(11.06 \mathrm{~m})$ below TOC
Water elevation: $166.6 \mathrm{ft}(50.78 \mathrm{~m}) \mathrm{ms}$

Whater eleve

Sp. conductance: $18 \mu \mathrm{S} / \mathrm{cm}$

Turbidity: 11 NTU
Water evacuated from the well prior to sampling: 88 gal

ANALYSES

$F$ Analyte

Acetone

: Acrolein

A Alyminum, total recoverable

Arsenic, total recoverable

Benzeni
Bromodlchloromethane

Bromoform

Cadmium, total recoverable

Carbon disulfide

Chlorobenzene

o Chloroethane

Chloroethene

Chloromethan

Chromium, total recoverable

: 1,2-Dibromoethane

1.4bromorientane

o trans-1,4-Dichloro-2-butene

o Dichlorodifluoromethan

1,2-Dichloroethane

Dichloromethane

1,2-Dichioropropane

ESH-EMS-980569

5.00
510.0
55.00
55.40
$<100$
55.00
50.200
55.00
510.0
512.0
55.00
55.00
55.00
52.00
55.00
55.00
55.00
55.00
55.00
55.00
55.00
55.00
55.00
55.00
55.00
55.00

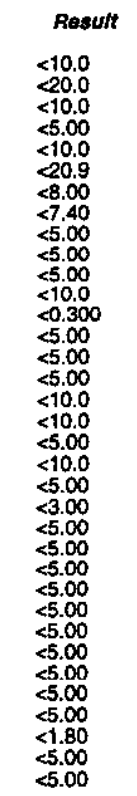
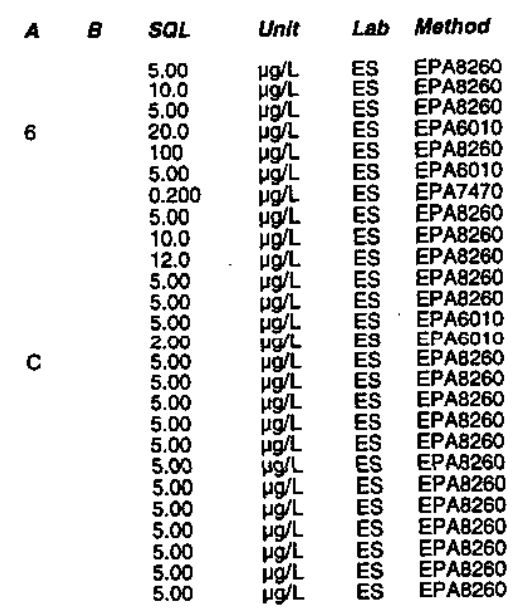

Time: 12:19

Tir temperature: $19.1^{\circ} \mathrm{C}$

Total alkalinity (as CaCO3): $0 \mathrm{mg} / \mathrm{L}$

henolphthalein alkalinity: $0 \mathrm{mgh}$

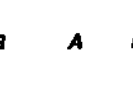

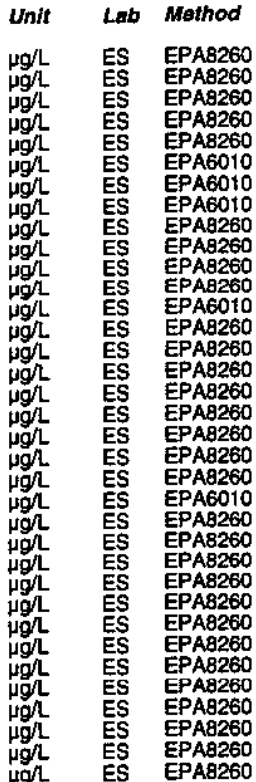

We:l LFW 43D collected on 06/09/98 (cont.)

$F$ Analyte Rosult

Itrans-1,3-Dichloropropens

2-Hexanone

tron tothane (Methyl iodide)

Isobutyl alcohol

o Mercury, total recoverable

- Methacrylonitrite

Methyl isobutyl ketone

O Methyl methacry

Selenium, total recoverable

0 Styrene

1,1,2,2-Tetrachloroethen

O Toluene

1,1,1-Trichloroethane

o Trichtoroethylene

1,2,3-Trichloropropane

Xylones

Gross alphe
Gross alpha
Tritim

0 Tritium

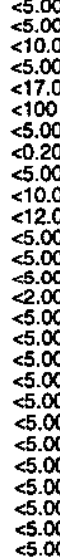

WELL LFW 45D

MEASUREMENTS CONDUCTED IN THE FIELD

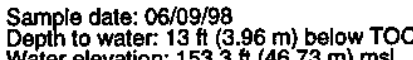

Water eleval
pH: 4.8

conductance: $42 \mu \mathrm{S} / \mathrm{cm}$

Wurbidity: 1 NTU ANALYSES

$F$ Analyte

Accatone

Acrolein

Acrylonitrile

Aluminum, total recoverable

Barim, total recoverable

Benzene
Bromodichloromethane

Bromoform

Cadmium total recoverable

Carbon disulfide

Carbon tetrachioride

Chloroethane

Chloroethene (Vinyl chloride)

Chloroform

Chroroprene

1,2-Dibromo-3-chloropropan

1,2-Dibromoethane

Dibromomethane

1,4-Dichlorobenzene

Dichlorodifluoromethan
1,1-Dichloroethane

B-195

\begin{tabular}{|c|c|c|c|}
\hline & Unit & Lab & Mothod \\
\hline $\begin{array}{l}10.0 \\
5.00 \\
20.0 \\
100 \\
5.00 \\
0.200 \\
5.00 \\
10.0 \\
12.0 \\
5.00 \\
5.00 \\
5.00 \\
2.00 \\
5.00 \\
5.00 \\
5.00 \\
5.00 \\
5.00 \\
5.00 \\
5.00 \\
5.00 \\
5.00 \\
5.00 \\
5.00 \\
5.00 \\
8.20 E-10 \\
8.000-10 \\
1.344-06 \\
1.28 E-06\end{array}$ & 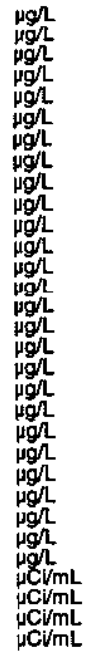 & 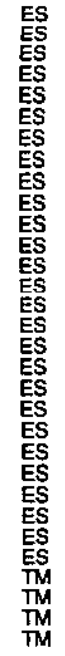 & 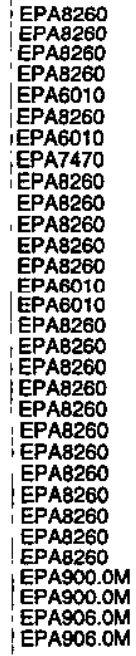 \\
\hline
\end{tabular}

Time: 11:16

Water temperature: $19.2^{\circ} \mathrm{C}$

Total alkalinity (as CaCo3): $0 \mathrm{mgh}$
Phenolphthalein alkalinity: $0 \mathrm{mgl}$

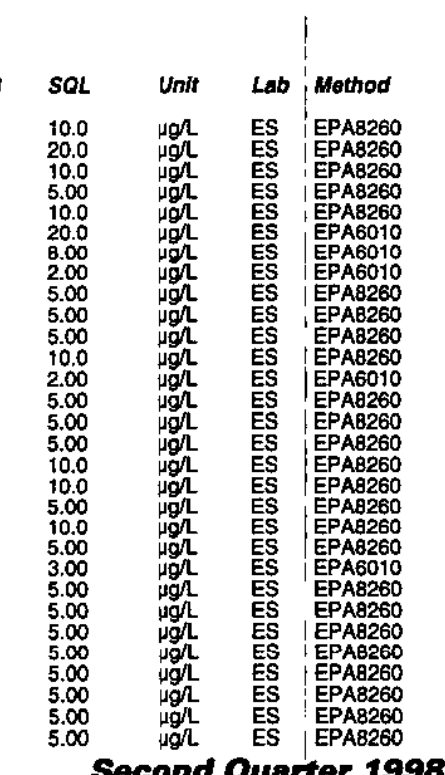


Well LFW $56 \mathrm{D}$ collected on 06/09/98 (cont.)

\begin{tabular}{|c|}
\hline 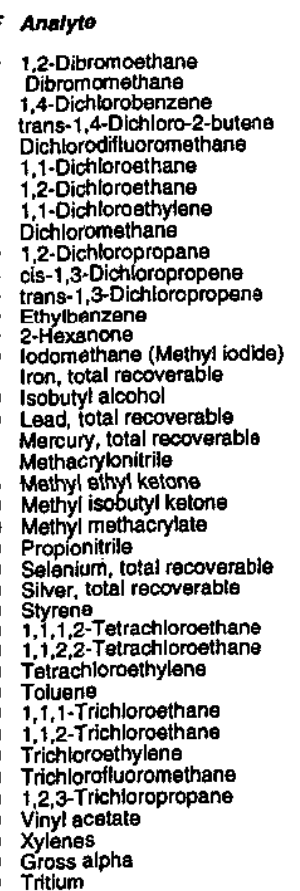 \\
\hline
\end{tabular}

WELL LFW 58D

MEASUREMENTS CONDUCTEO IN THE FIELD

Sample date: $06 / 08 / 98$ (7.78 m) below TOC

Depth 10

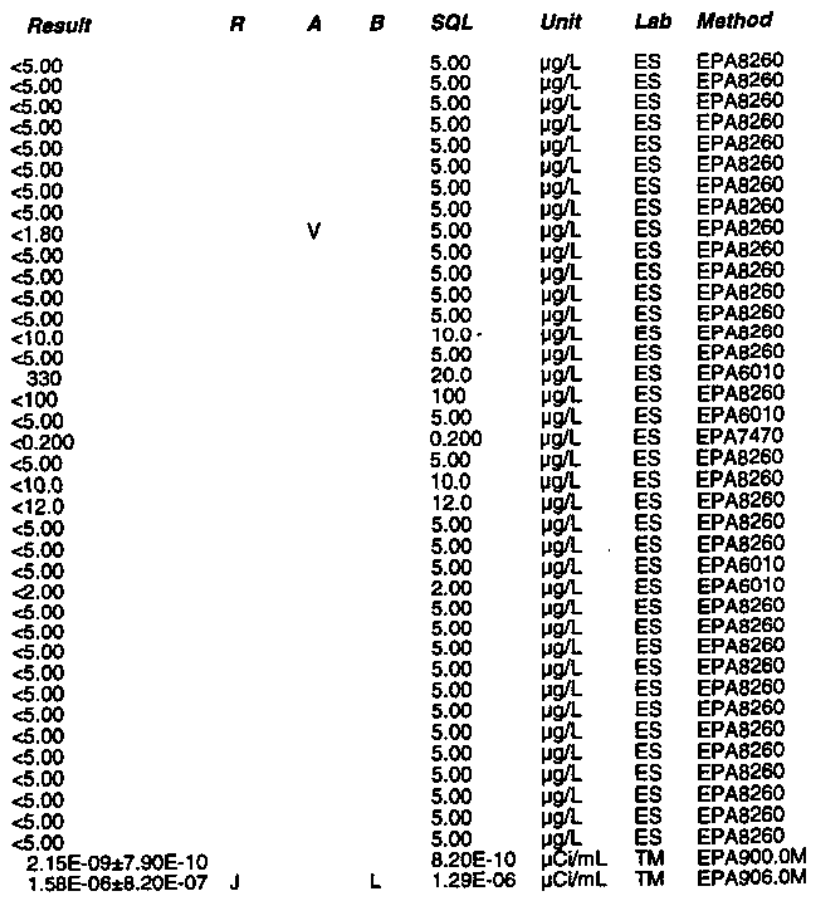

Sp. conductance: $250 \mu \mathrm{S} / \mathrm{cm}$

Water evacuated from the well prior to sampling: $35 \mathrm{gal}$

ANALYSES

$F$ Analyte

0 Acetone

Acetonitirle (Methyl cyanide)
Acotonitrlie (Methyl cyanide)

Acrolein

Acrylonitrile

Alyl chloride

Auminum, total recoverabl

Arsenic, total recoverab

Benzene
Benzene

Bromodichloromethane

Bromodich

Bromomethane

ESH-EMS-980569
Well LFW 58D collected on 06/08/98 (cont.)

$F$ Analyte Result

0 Cadmium, total recoverable Carbon disulfide

Carbon tetrachloride

Chlorobenzene
Chlorobenzene

Chloroethane

Chloroethene (Vinyl chloride)
Chloroethene (Vinyl chloride)

Chioroform

Chloromethane

Chloroprene

Chromium, total recoverable

Dibromochioromethane

1,2-Dibromo-3-chloropropan

1.2-Dibromoethane

1,2-Dibromoethane

Dibromomethana
1.4-Dichlorobenzen

1.4-Dichlorobenzene

trans-1,4-Dichloro-2-buten

Dichlorododiffluoromethan

1.1-Dichloroethane

1,2-Dichloroethane

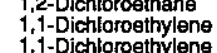

Dichloromethane

1,2.Dichloropropane

cis-1,3-Dichloropropene

trans-1,3-Dlethloropropene
trans-1,3-Dichloropropene

Ehylbenzene

2-Hexanone

2-Hexanon

lodomethane (Methy iodide)

Iron, total recoverhy iod

Isobutyl alcohol
isobutyl alcohol

Load, total recoverable
Leate Methacrylonitrile

Methyl ethyl ketone

Methyl ethyl ketone

: Methyl isobutyl ketone

Methyl methacylate

O Propionitrile

: Selenium, total recoverable

Silver, total recoverable

: Styrene

: Strene

i.1,2,2-Tetrachloroethan

Tetrachloroethylene

$\begin{array}{ll}1 & \text { Tetrachloroethylene } \\ 0 & \text { Tolueng }\end{array}$

B-197

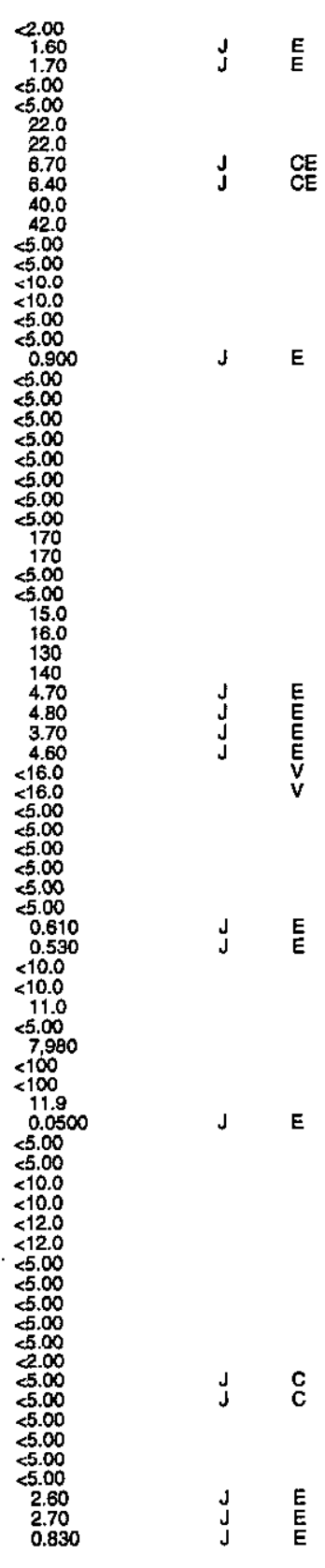


Well LFW 58 D collected on 06/08/98 (cont).

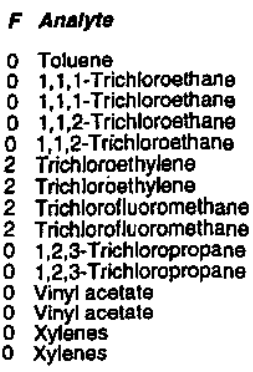

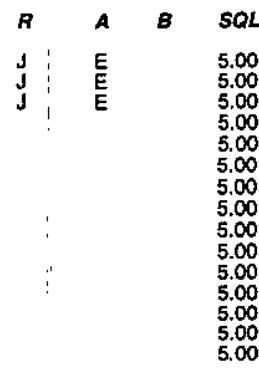

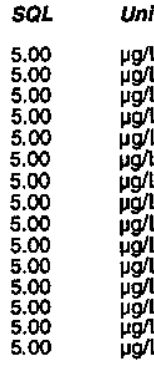

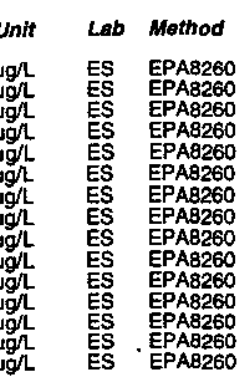

\section{WELL LFW 59D}

MEASUREMENTS CONDUCTED IN THE FIELD Sample date: $06 / 08 / 98$
Depth to water. $23.69 \mathrm{ft}(7.22 \mathrm{~m})$ below TOC
Water elevation: $143.91 \mathrm{Ht}(\mathbf{4 3 . 8 6} \mathrm{m}) \mathrm{msl}$ Water elo w: Sp: conductance: $23 \mu \mathrm{S} / \mathrm{cm}$ Water evacuated from the well prior to sampling: $103 \mathrm{gel}$ ANALYSES

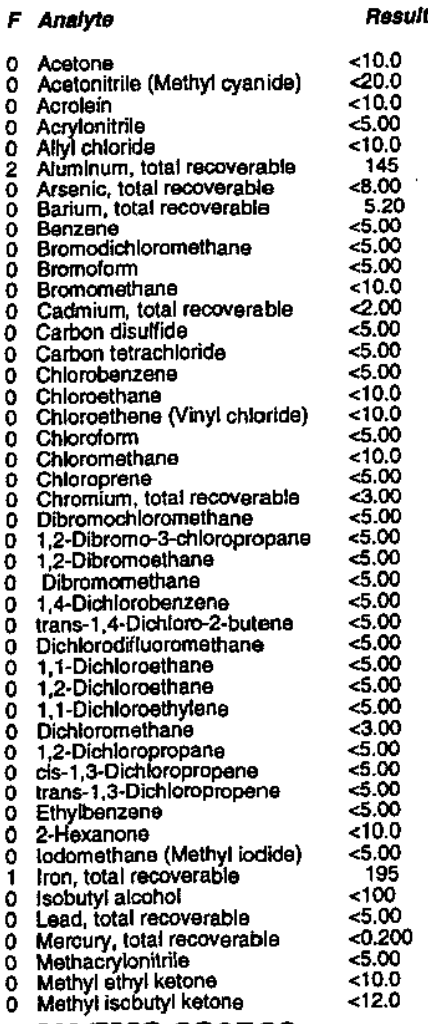

ESHEEMS-980569
Time: $11: 36$ Water temperature: $21{ }^{\circ} \mathrm{C}$ Total alkalinity (as $\mathrm{CaCO}$ ): $0 \mathrm{mg} /$
Phenolphthalein alkalinity: $0 \mathrm{mg} L$

Well LFW 59 D collected on 06/08/98 (cont)

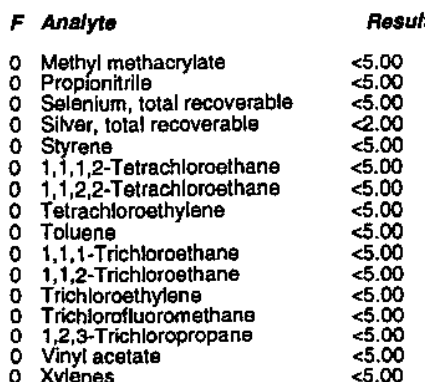

\section{WELL LFW 60C}

MEASUREMENTS CONDUCTED IN THE FIELD Sample date: $06 / 05 / 98$
Depth to water: 19.3 ft $(5.88 \mathrm{~m})$ below TOC Water elevation: $137.9 \mathrm{ft}(42.03 \mathrm{~m}) \mathrm{msl}$ $\mathrm{PH}: 5.6$

作 Water evacuated from the well prior to sampling: $68 \mathrm{gal}$ ANALYSES

$F$ Analyte

Acetone : Acroilin Aluminum, total recoverable Arsenic, total recoverabila Bromzodichloromethan Bromornethan Cadmium, total recoverable Carbon disulfide Carbon tetrachlo Chioroethane Chloroethene (Vinyt chloride) Chloromethane Chromium, total recoverable 1,2-Dibromo-3-chloropropan 1,2-Dibromoethane Dibromornethane trans-1,4-Dichloro-2-butene Dichlorodifluoromethane 1 1,1-Dichloroethane 1,1.-Dichloroethylen 1,2-Dichloropropane 1tsan-1, Ethylbenzene

2-Hexanone (Methyt iodide)
lodomethane (Mets Iron, total recovera

isobutyl alcohol Mead, total recoverable Methacylonitrile

Result
$<3.50$
20.0
$<10.0$
$<5.00$
$<10.0$
6.00
$<8.00$
5.20
0.790
$<5.00$
$<5.00$
$<10.0$
2.00
$<5.00$
$<5.00$
2.60
$<10.0$
5.70
$<500$
$<10.0$
$<5.00$
$<3.00$
$<5.00$
55.00
$<5.00$
$<5.00$
11.0
$<5.00$
1.60
13.0
$<5.00$
$<5.00$
$<2.60$
$<5.00$
$<5.00$
$<5.00$
$<1.00$
$<10.0$
$<5.00$
3.760
$<100$
6.40
$<0.200$
$<5.00$
$<10.0$

\begin{tabular}{|c|c|c|c|}
\hline SOL & Unit & Lab & Method \\
\hline $\begin{array}{l}5.00 \\
5.00 \\
5.00 \\
2.00 \\
5.00 \\
5.00 \\
5.00 \\
5.00 \\
5.00 \\
5.00 \\
5.00 \\
5.00 \\
5.00 \\
5.00 \\
5.00 \\
5.00\end{array}$ & 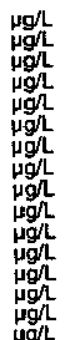 & $\begin{array}{l}\text { ES } \\
\text { ES } \\
\text { ES } \\
\text { ES } \\
\text { ES } \\
\text { ES } \\
\text { ES } \\
\text { ES } \\
\text { ES } \\
\text { ES } \\
\text { ES } \\
\text { ES } \\
\text { ES }\end{array}$ & 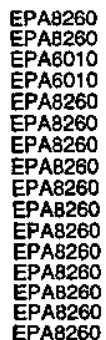 \\
\hline
\end{tabular}

Time: 11:42

Total alkalinity (as CaCO3): $20 \mathrm{mg} / \mathrm{L}$

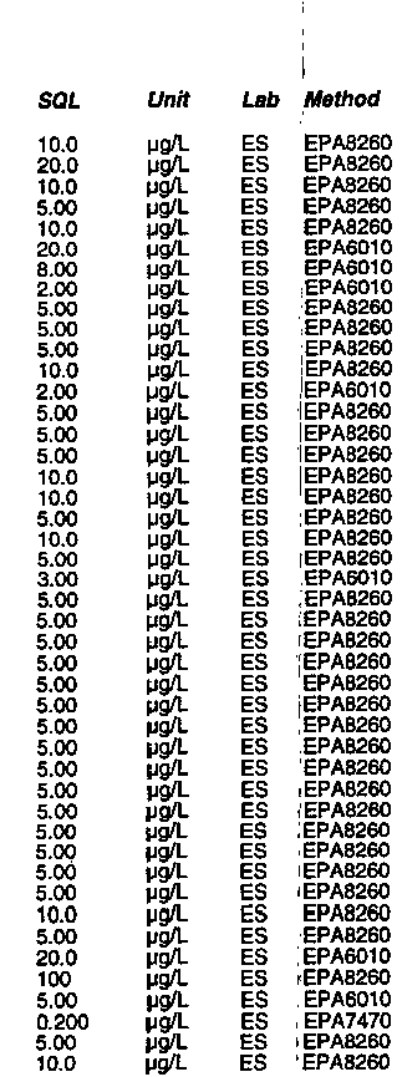

Sacond Quarter 1998 
ANALYTICAL RESULTS

Well LFW 6OC collected on 06/05/98 (cont.)

\begin{tabular}{|c|}
\hline 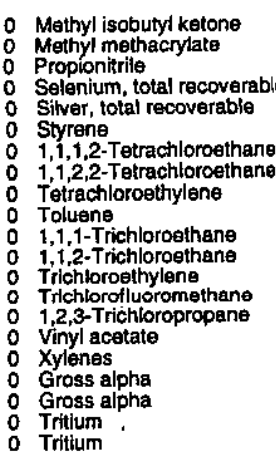 \\
\hline
\end{tabular}

\section{WELL LFW 60D}

MEASUREMENTS CONDUCTED IN THE FIELD Sample date: $04 / 03 / 98$
Oepph to water: 18.26 th $(5.57 \mathrm{~m})$ below TOC
Water elevation: $138.84 \mathrm{ti}(42.32 \mathrm{~m}) \mathrm{ms}$ Water elevation: $138.84 \mathrm{th} / \mathrm{c}$
$\mathrm{HH}$ : 7.1

Sp. conductance: $21 \mu \mathrm{S} / \mathrm{cm}$
Turbidity: 0 NTUU
Water evacuated from the well prior to sampling: 78 gal

Water evac

$F$ Analyte

: Acrtone

Acetone
Acetonitirile (Methyl cyanide)

Acrolein

Acrylonitrile

Alyy chlorida

Benzen

Bromodichloromethane

Bromodichloromethan

Bromotorm

Bromomethan

Carbon disulfida

Carbon tetrachloride

Chloroberzzens

Chlorobenzen

Chlorosethane

Chloroethene (Vinyl chloride)

Chloroform

Chloromethane

Chloroprene

Chloroprene

1,2-Dromochioromethane
1,2-Dibromo-3-chloropropane

1,2-Dibromoethane

ESH-EMS-980569

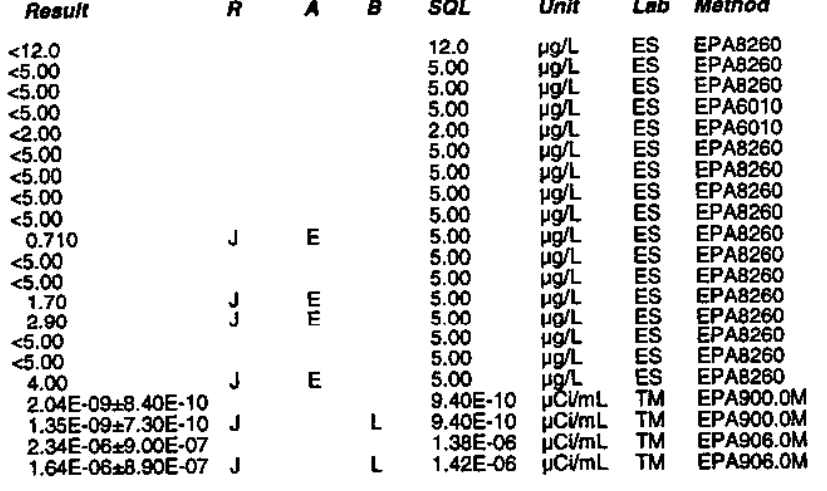

Well LFW $60 D$ collected on 04/03/98 (cont.)

F Analyto

Result

Dibromomethane

1,4-Dichlorobenzenzene

trans-1.4-Dichloro-2-butene

Dichlorodifluoromethane

1,1-Dichloroethane

1,2-Dichloroethane

1,1-Dichloroethylene

Dichloromethane

1,2-Dichloropropane

cis-1,3-Dichoropropen

trans-1.3-Dichloropropene

trans-1,3-Dichloropropen

Ehylbenzene

2-Hexanong

lodomethane (Mathyl iodide)

odomethane (Methyl iodide)

Isobutyl alcohol
Isobutyl alcohol

Methacrylonitrile

Methyl ethyl keton

Mathyl ethyl ketone

Methyl isobutyl ketone

- Methyl methacrylate

- Styrene

: Styrene-

i, i, , 2-Tetrachloroethan

1,1,2,2-Tetrachloroethane

0 Tetrachloroethylene

Toluene

1,1,1-Trichloroethane

i. 2-Trich oreethene

1, 2.2-Trichloroethan

Trichloroethylene

- Trichloroftluoromethane

1,2,3-Trichloropropane

: Vinyl acetate

0 Xylenes

xylenes

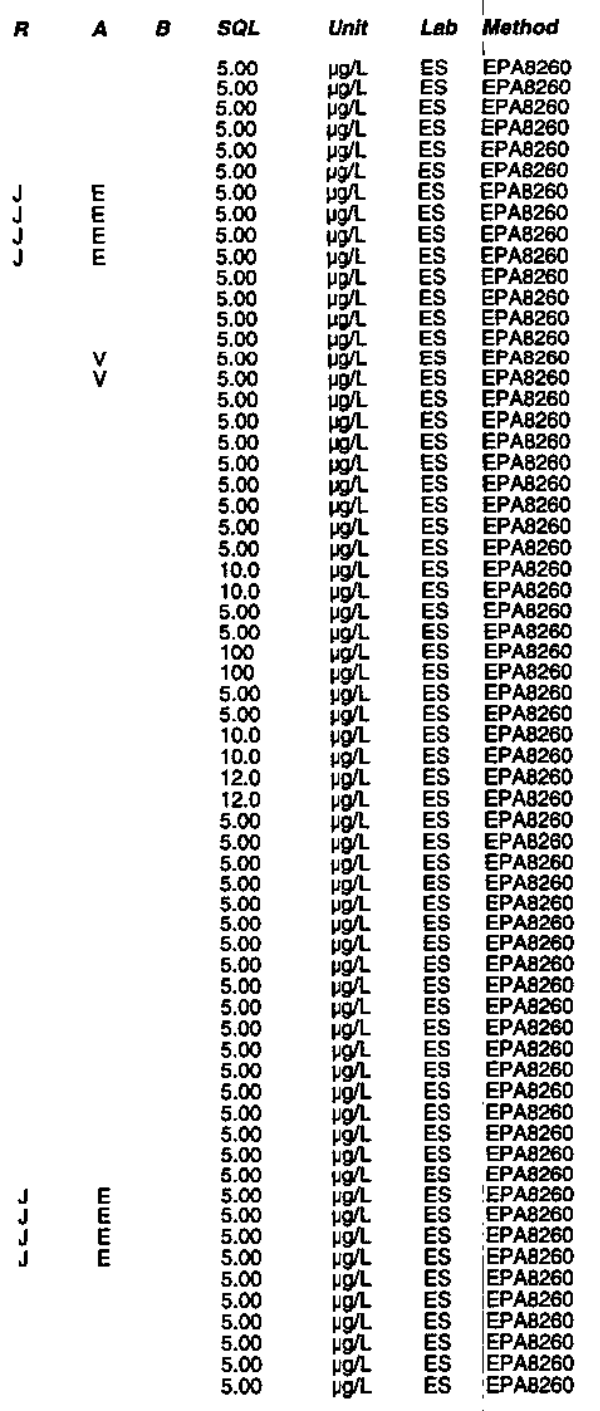

Second Quarter 1998 


\section{WELL LFW 60D}

MEASUREMENTS CONDUCTED IN THE FIELD

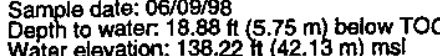

Sp. conductance: $20 \mu \mathrm{s} / \mathrm{cm}$

Turbioitity 13 NTU
Water evacuated from the well prior to sampling: 1 gal ANALYSES

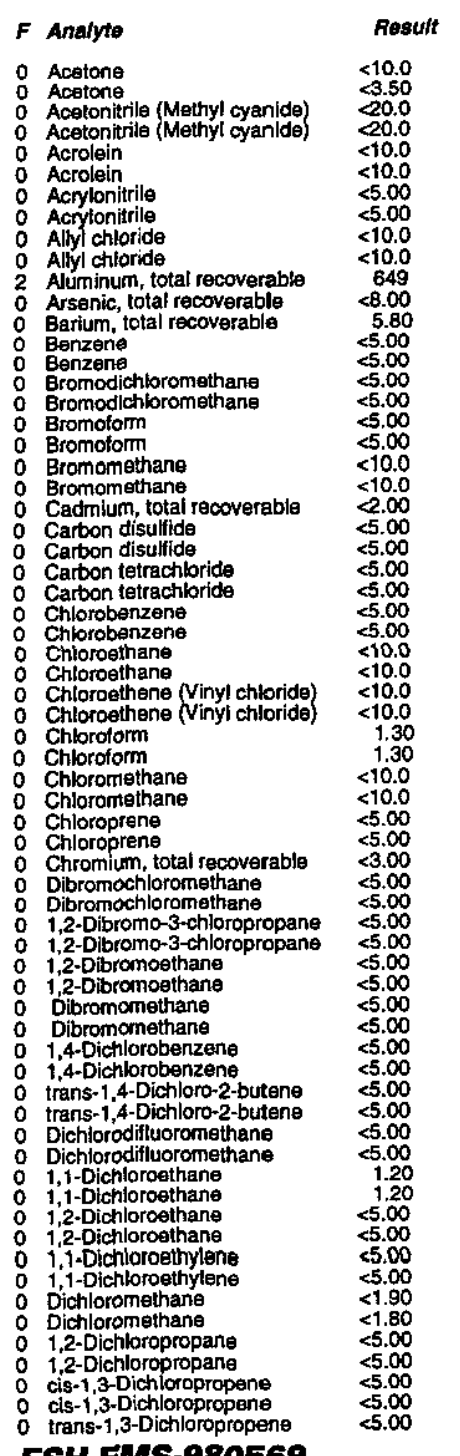

Well LFW 60D collected on 06/09/98 (cont.)

$F$ Analyto

Time: 14:00

Wat $18.5^{\circ} \mathrm{C}$

Total alkalinity (as CaCO3): $1 \mathrm{mg} / \mathrm{L}$
Phenolphthalein alkalinity: $0 \mathrm{mg} / \mathrm{L}$

0 trans-1,3-Dichtoropropene

Ethybenzenzen
$2-H e x a n o n e$

lodomethane (Mothyl iodide)

lodomethane (Methyl iodide)

2 Iron, total recovera

Isobutyl alcthol

Mercuny, total recoverable

Methacrylonitrile

Methyl ethyl ketane

Methyl isobutyl ketone

Methy! methacrylate

Proplonitrile

Selenium, total recoverable

Silver, total recoverable

Styrene

: $1.1,1,2$-Tetrachloroethane

1,1,2,2-Tetrachloroethan

Tetrachloroethylene

Toluene

1,1,1-Trichloroethane

1 $1,1,1$-Trichloroethane

Trichloroethylene

Trichloroethylene

Thichlorofluoromethane

2, 3-Trichloropropan

Vinyl acetate

0 Xylenes

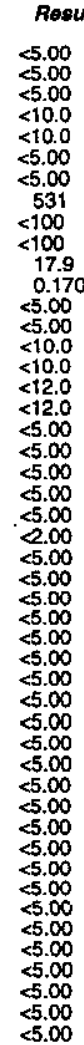

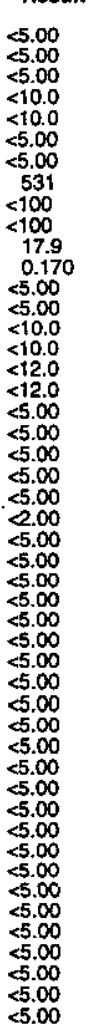

$A B$

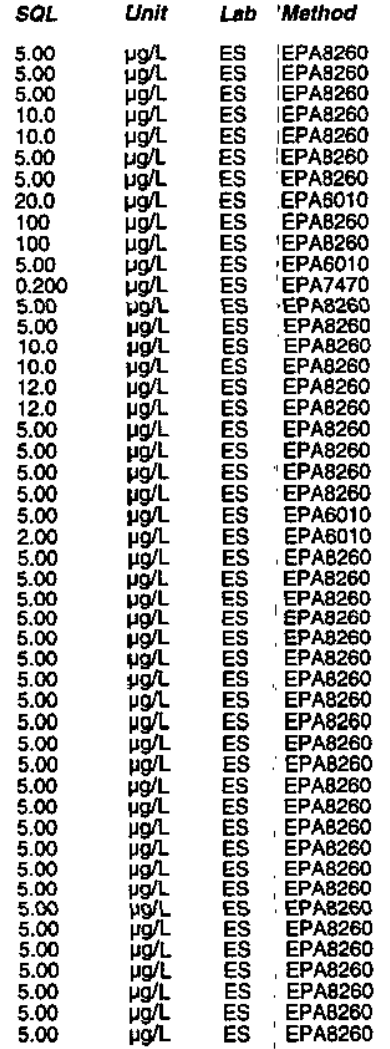

\section{WELL LFW 60D}

MEASUREMENTS CONDUCTED IN THE FIELD

Sample date: $06 / 09 / 98$

Depth to water: Not available

Water elevation: Not avaliable
$\mathrm{H}$ H. Not available
$\mathrm{S}$. conductance: Not available

No water was evacuated from the well prior to sampling. ANALYSES

$F$ Anelyto

: Gross alpha

Result

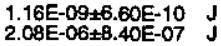

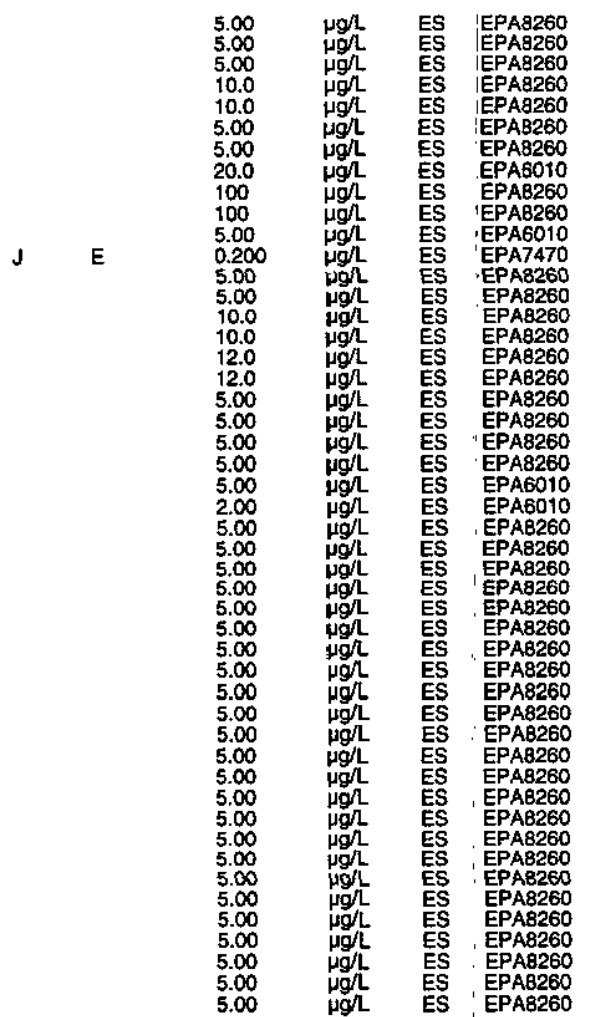

Time: Not available

Air temperature: Not availabl日
Total alkalinity (as CaCO3) Not available
Phenolphthalein alkalinity: Not available 
ANALYTICAL RESULTS

\section{WELL LFW 61D}

MEASUREMENTS CONDUCTED IN THE FIELD

Sample date: $06 / 12 / 98$
Depth to water: $23.24 \mathrm{ft}(7.08 \mathrm{~m})$ below TOC

Water elevet

Sp. conductance: $130 \mu \mathrm{S} / \mathrm{cm}$

Water evacuated from the well prior to sampling: $70 \mathrm{gal}$

ANALYSES

$F$ Aneity

0 Acetone

Acetonitrile (Methyl cyanide) Acrolein

Acrylonitrile

Allyl chloride

Aluminum, total recoverable

Aluminum, total recoverable

Arsenic, total recoverable

Barlum, total recoverable

Benzeni

Bromodichloromethane

Bromoform

Bromomethane

Bromomethane

Cadmium, total recoverable

Carton disulfide

Carbon tetrachloride

Chlorobenzene

Chlorobenzen
Chloroethane

Chloroethene (Vinyl chloride)

Chloroethene (Vinyl chlorido)

2-Chloroethyl vinyl ether

Chlorotom

O Chlosomethane

Chioroprene

Chromlum, total recoverable

Chromlum, total recover

1,2-Dibromo-3-chtoropropane

1,2 -Dibromoethane

Dibromomethane

1.2-Dichlorobenzen

1.4-Dichlorobenzene

trans-1,4-Dichlore-2-butene

Dichlorodifluoromethan

Di,hlorodifluoromethe

1,2-Dichloroethan

1 1,2-Dichbroethane

ESH-EMS-980569

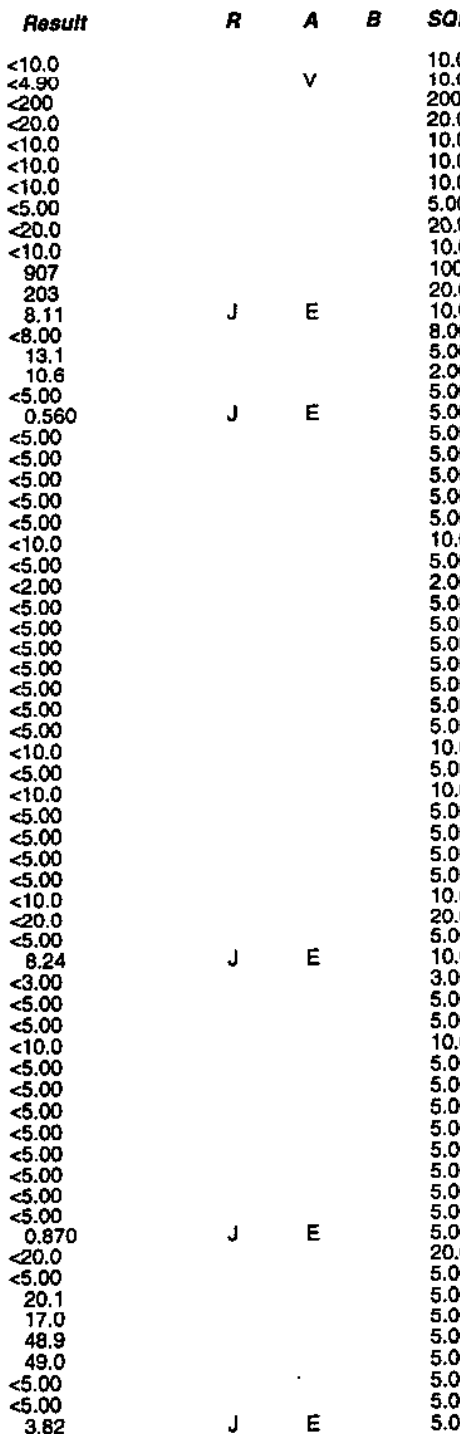

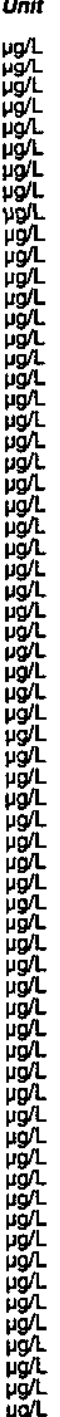

Lab Method

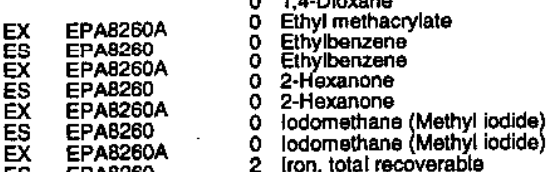

Iron, total recoverabte
tron, total recoverabt

Isobutyl alcohol

Lead, total recoverable

Mercury, total recoverable

Methacrylonitrile

Methyl ethyl ketone

o Methyl isooutyl ketone

Mithy methacrylate

Mentachenacrylate

Propionitrite

Selenium, total recoverable

Silver, total recoverable

styrene

$1,1,1,2$-Tetrachloroethane

$1,1,2,2$-Tetrachloroethane

2,2-Tetrachloroeth

1 Tetrachlorosthylene

Toluene

1,1,1-Trichloroethane

1.1, 1 -Trichloroethane

Trichloroethylene

Trichloroffluoromethene

1,2,3-Trichloropropane

Vinyl acetate

Xylenes

0 Xylenes

Gross alpha

$\begin{array}{ll}0 & \text { Tritium } \\ 0 & \text { Tritium }\end{array}$
Second Quarter 1998

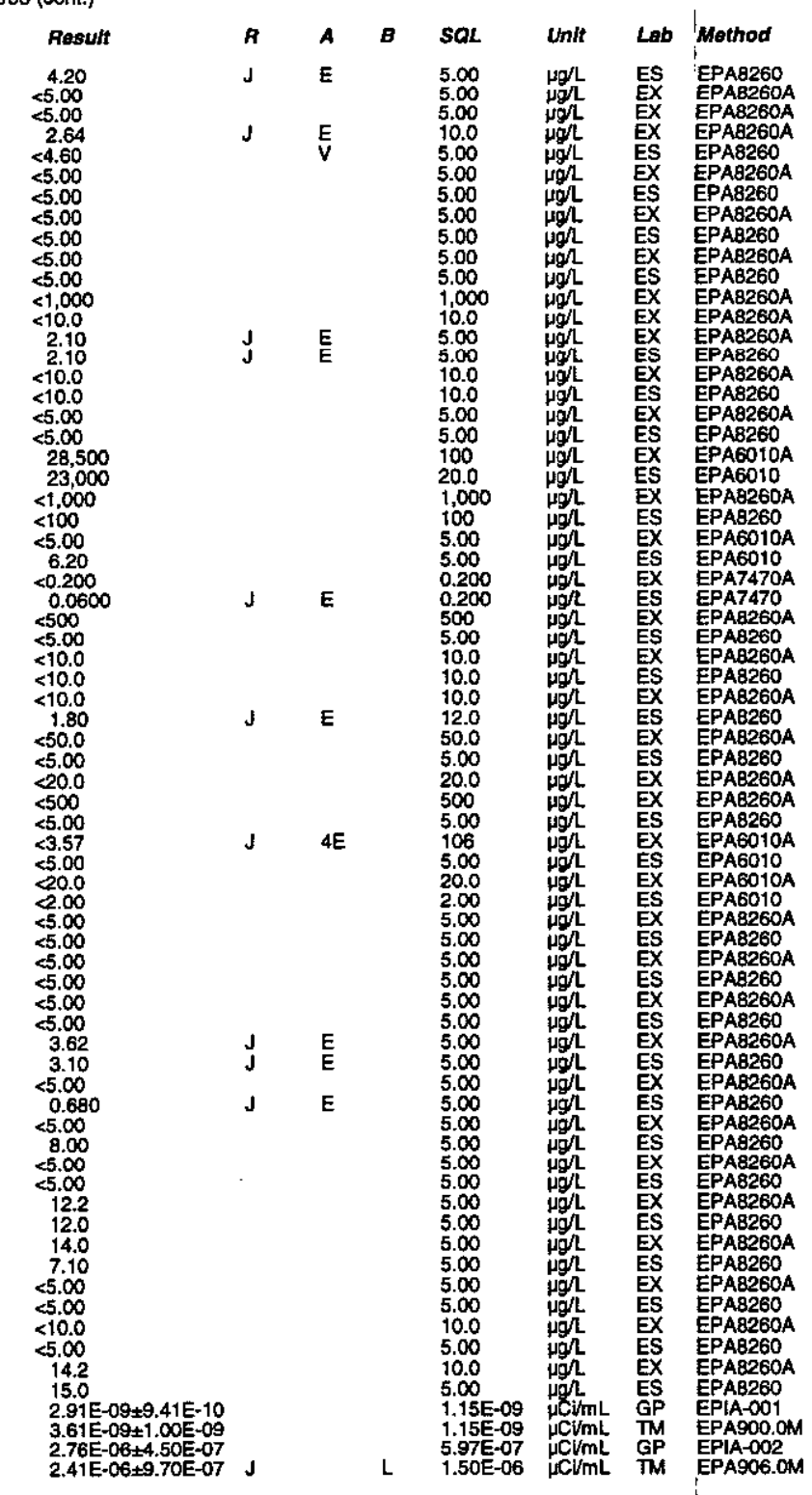




\section{WELL LFW 61D Replicate}

MEASUREMENTS CONDUCTED IN THE FIELD

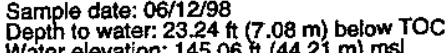

Water

Wurbidity: 3 Nite from the well prior to sampling: 70 ge

\section{ANALYSES}

F Ansiyte

: Acctone Acetonitilite (Methyl cyanide) O Acrilonitile Arsenic, total recoverable
Barium, tolal recoverable

Benzene
Bromodichloromethane

Bromomothan

Carton tetrachlorido

Chlorobenzene

Chloroethene (Vinyl chloride)

Chlorotorm

Chloromethane

Chiloroprenen, total recoverable

12.-Dibremo-3-chloronopropan

1,2 -Dibromoethane

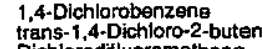

Dichlorodifluoromethan

i, 1.-Dichloroethane

i,i-Dichloroethylente
Dichloromethana

1,2-Dichloropropane

trans-1, 3-Dichloropropene

Ethylbenzene

lodomethane (Methyl iodide)

Iron, total recoverable

Lead, total recoverabable

Methacrylonitrile

o Methyl isobutyl ketone

Methyl methacrylate

Selenium, total recoverable

$1,1,1,2$, Tetrachloroethane

1.,.,2,2-Tetrachlorostha
Tetrachloroethylens

Tot

i., 1.2 -Trichlohoroethar

2
0
0
0
1

: Vyylanes

Gross alph
0 Tritum
Trite
P. conductance: $130 \mu \mathrm{S} / \mathrm{cm}$

Aluminum, total recoverable

Cadmium, total recoverable

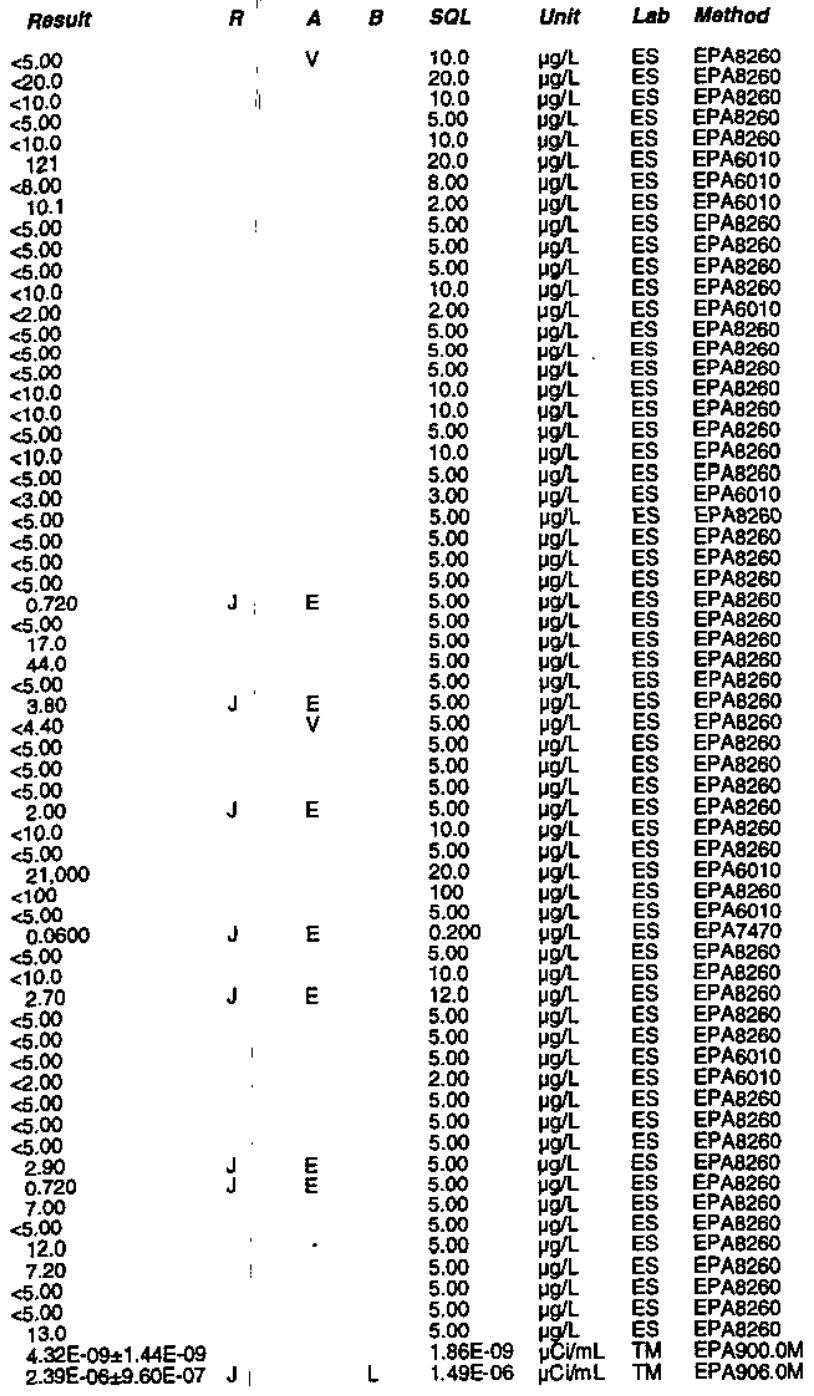

Time: 9:26

: $20.9^{\circ}$
Total alkalinity (as CaCO3): $32 \mathrm{mg} /$

ESH-EMS-980569

WELL LFW 62D

MEASUREMENTS CONDUCTED IN THE FIELD

Sample date: 04/06/98 04 m) below TOC Water elevation: $145 \mathrm{ft}(44.2 \mathrm{~m}) \mathrm{ms}$

$\mathrm{gp}$. 5.2 conductance: $140 \mu \mathrm{S} / \mathrm{cm}$

Water temperature: $19^{\circ} \mathrm{C}$

Water evacuated from the well prior to sampling: 2 gal

ANALYSES

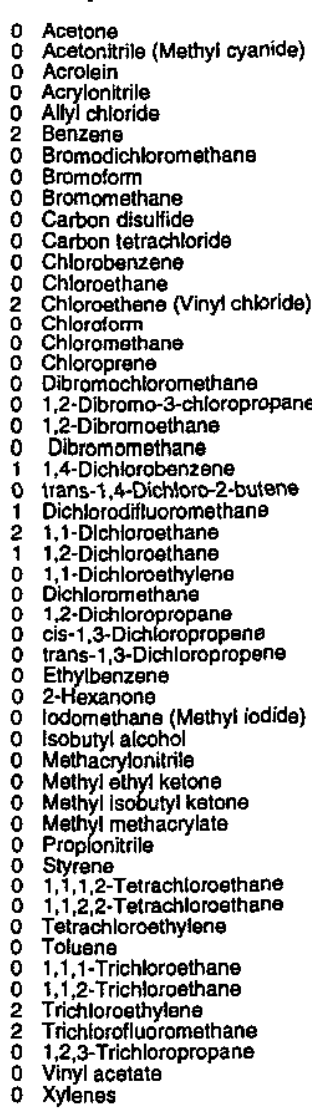

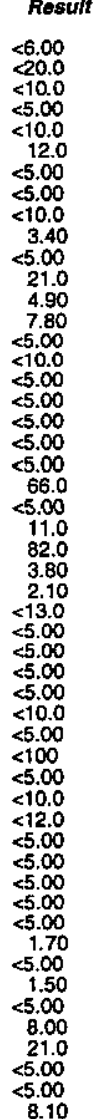

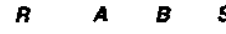

SQL
10.0
20.0
10.0
5.00
10.0
5.00
5.00
5.00
10.0
5.00
5.00
5.00
10.0
10.0
5.00
10.0
5.00
5.00
5.00
5.00
5.00
5.00
5.00
5.00
5.00
5.00
5.00
5.00
5.00
5500
5.00
10.0
5.00
100
5.00
10.0
12.0
5500
5.00
55.00
5.00
5.00
5.00
5.00
5.00
5.00
5.00
5.00
5.00
5.00

J $\quad E$

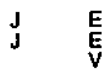

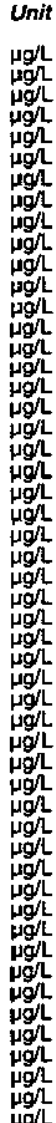

Lab Method

ES EPA8260

EPA EPA260

EPA8260

EPA8260

xylenes 
ANALYTICAL RESULTS

\section{WELL LFW 62D}

MEASUREMENTS CONDUCTED IN THE FIELD Sample date: $06 / 12 / 98$
Depth to water: $21.1 \mathrm{ft}(6.43 \mathrm{~m})$ below TOC
Water elevation: $143.7 \mathrm{tt}(43.8 \mathrm{~m})$ mst Water Sp. onductance: $130 \mu \mathrm{S} / \mathrm{cm}$ ANALYSES

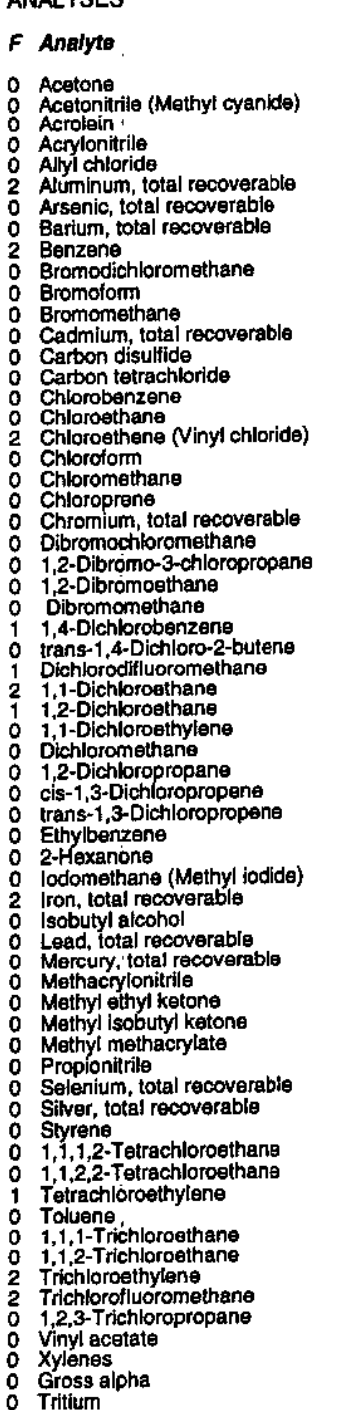

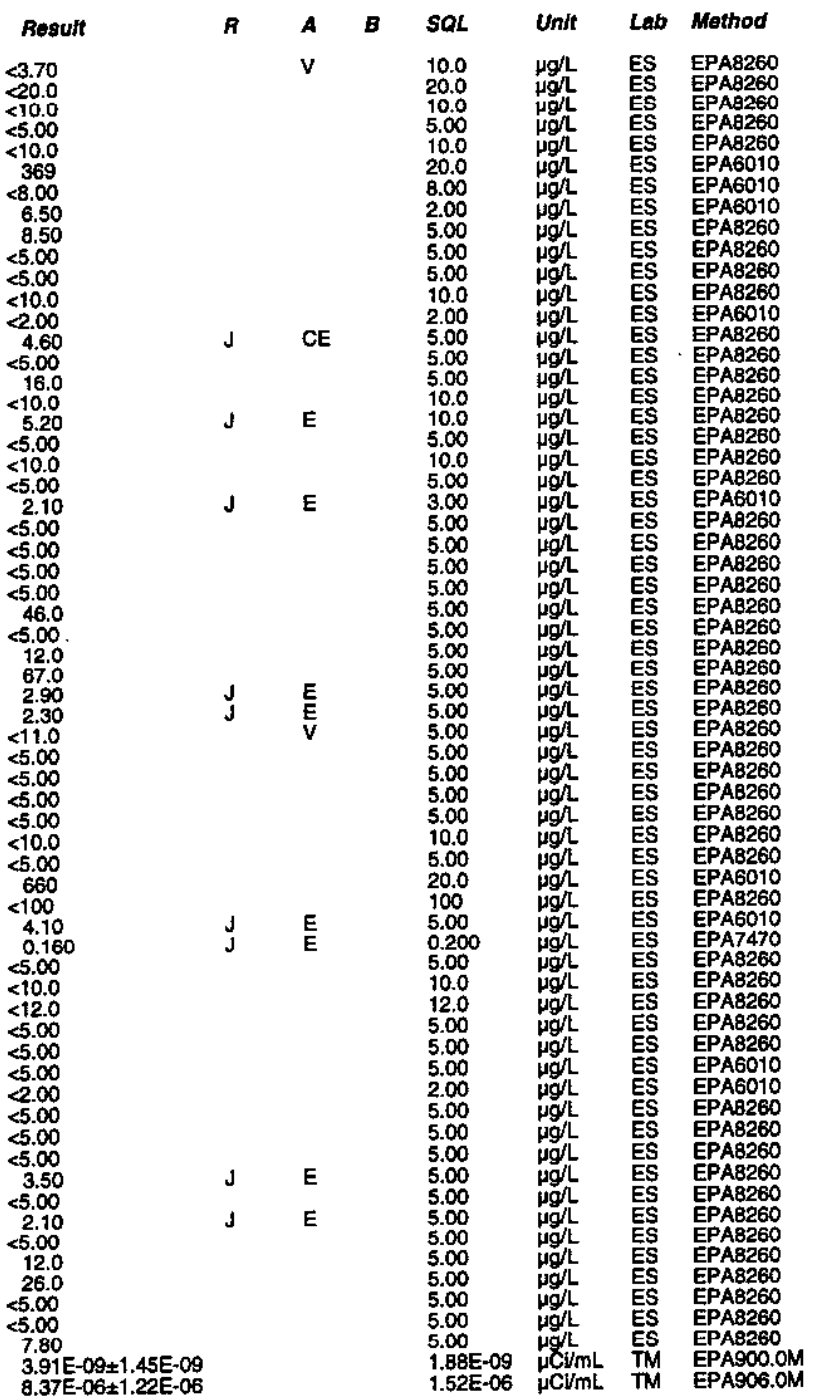

Time: 10:25 Total akgainity (as CaCO3): 1 mg/

ESH-EMS-980569
WELL LFW 63B

MEASUREMENTS CONDUCTED IN THE FIELD Sample date: $06 / 05 / 98$
Depth to water: $27.75 \mathrm{th}(8.46 \mathrm{~m})$ below TOC
Water elevation: $140.05 \mathrm{Ht}(42.69 \mathrm{~m}) \mathrm{msl}$ $\mathrm{pH}: 4$ conductance: $58 \mu \mathrm{S} / \mathrm{cm}$ Water evacuated from the well prior to sampling: 56 gal ANALYSES

$F$ Analyte

: Acetone : Acrolein Aluminum, total recoverable : Arsenic, total recoverable

Benzene

Bromotom

Cadmium, total recoverable O Carbon disultide - Carbon tetrachloride Chloroethane Chlorotorm C Chloromethan Chromium, total recoverable Dibromochloromethane Dibromomethane 1.4-Dichlorobenzene
trans-1,4-Dichloro-2-buten Dich-1,40odifluororomethane 1, 1.Dichloroethane 1,-Dichloroethylen 1,2-Dichioropropane cis-1,3-Dichloropropene

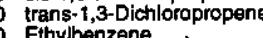
lodomethane (Methyl iodide) Iron, total recoverable - Lead, total recoverable Methacrylonitrile Methy isobutyl ketone : Mrathyl methacrylate Selenium total recoverable - Silver, total recoverable (1) 0 Toluene 0 Trichlorofluoromethane Vinyl acetate Xylenes 0 Tritium

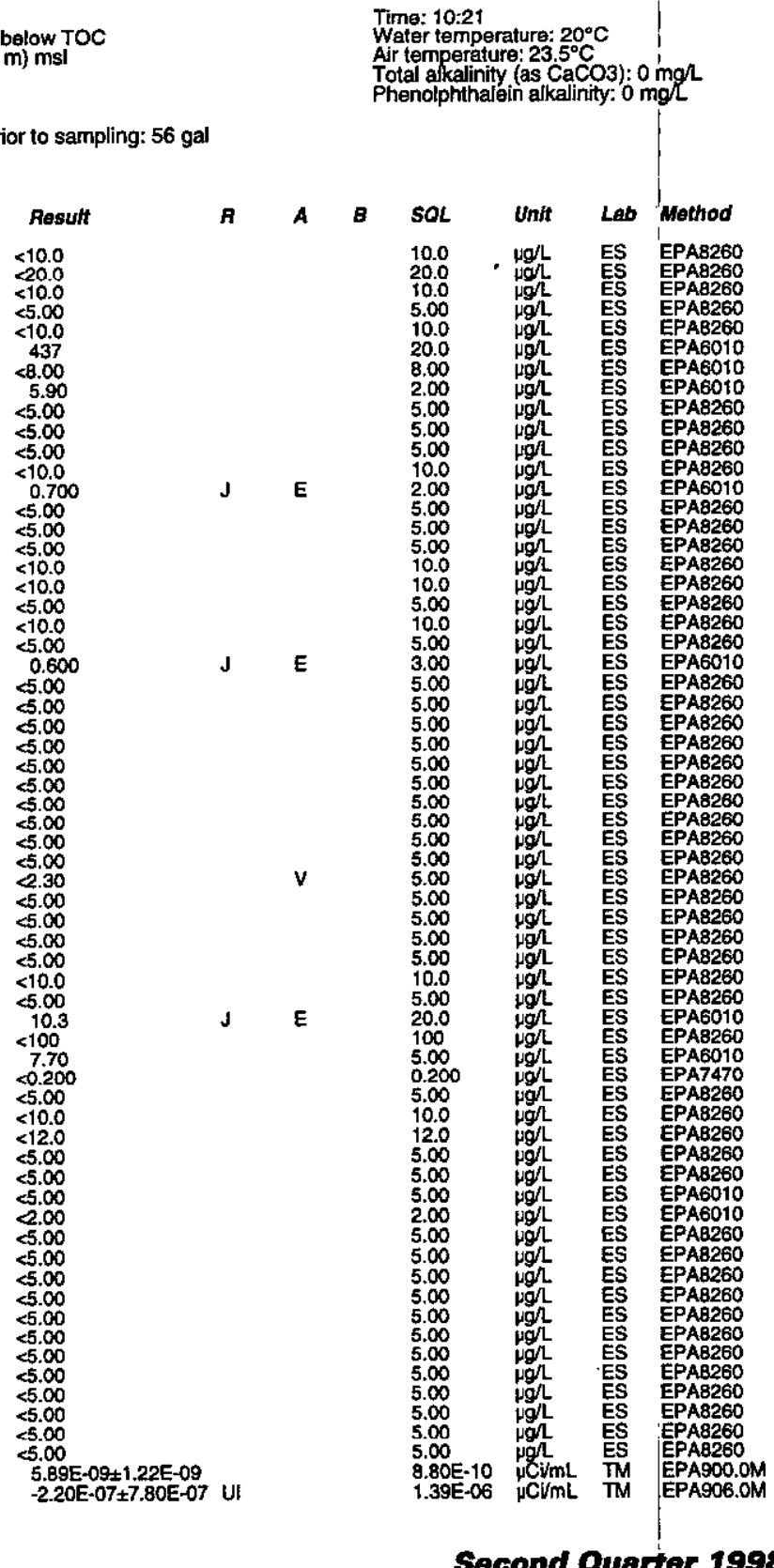

Second Quarter 1998

Time: 10:21 Total akalinity (as CaCO3): $0 \mathrm{mg} /$

$-20 \mathrm{E}-07+7.80 \mathrm{E}-07 \mathrm{U}$ 


\section{WELL LFW 63C}

MEASUREMENTS CONDUCTED IN THE FIELD Sample date: 06/05/98 Deph to water: $27.95 \mathrm{ft}(8.52 \mathrm{~m})$ below TOC $\mathrm{Sp}$. conductance: $34 \mu \mathrm{S} / \mathrm{cm}$

Turbidity: 1 NTU Water evacuated from the well prior to sampling: $77 \mathrm{gal}$ ANALYSES

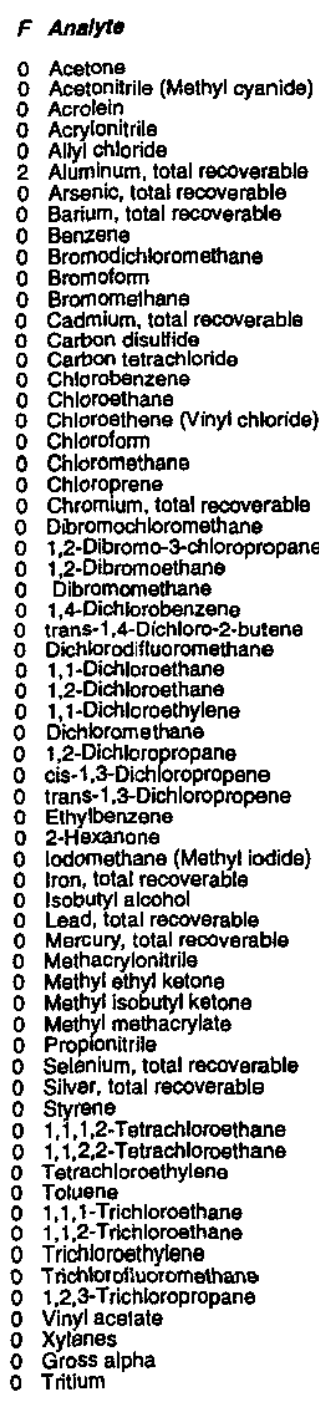

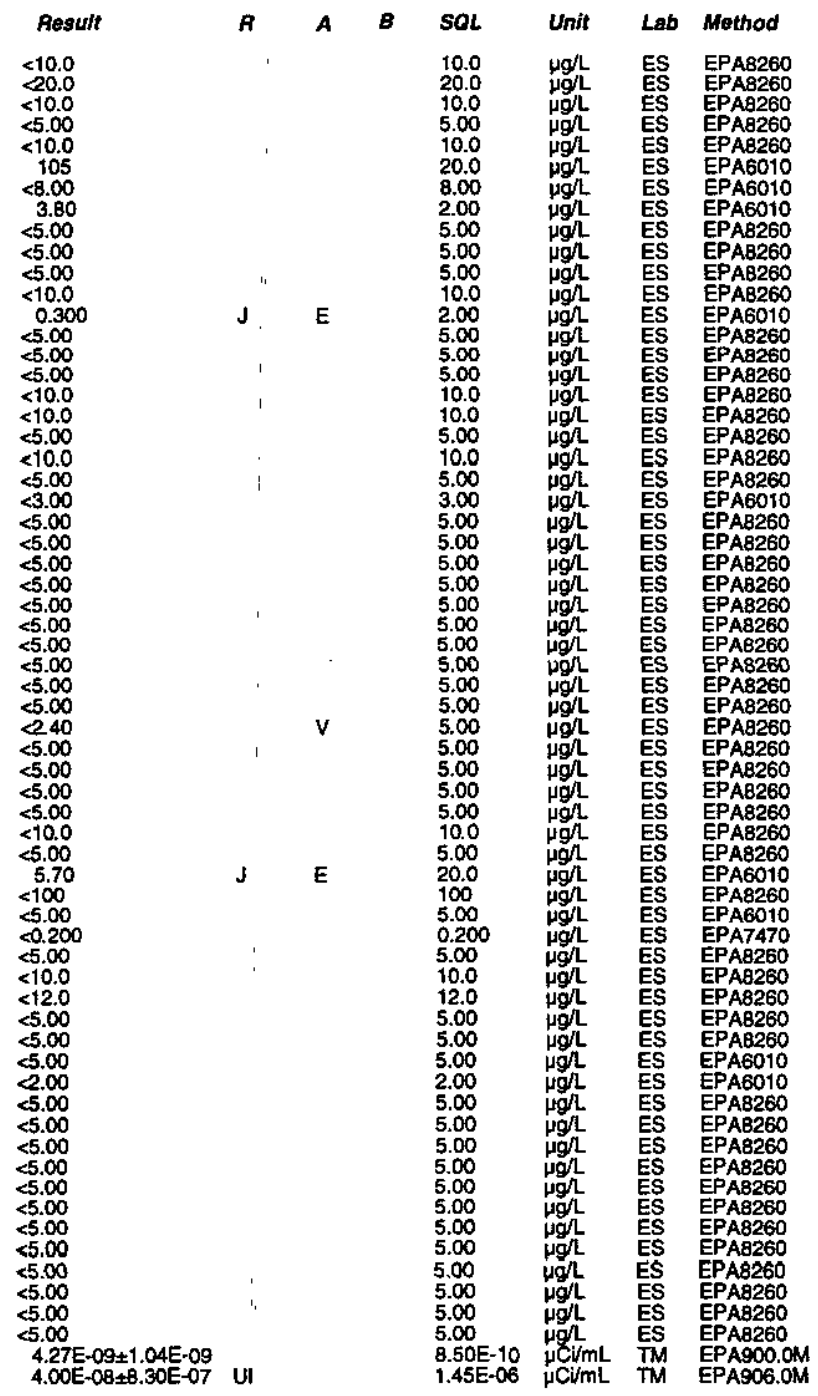
Total alkalinity (as CaCO3): $0 \mathrm{mg} / \mathrm{L}$
Phenolphthalein alkalinity: $0 \mathrm{mg} / \mathrm{L}$

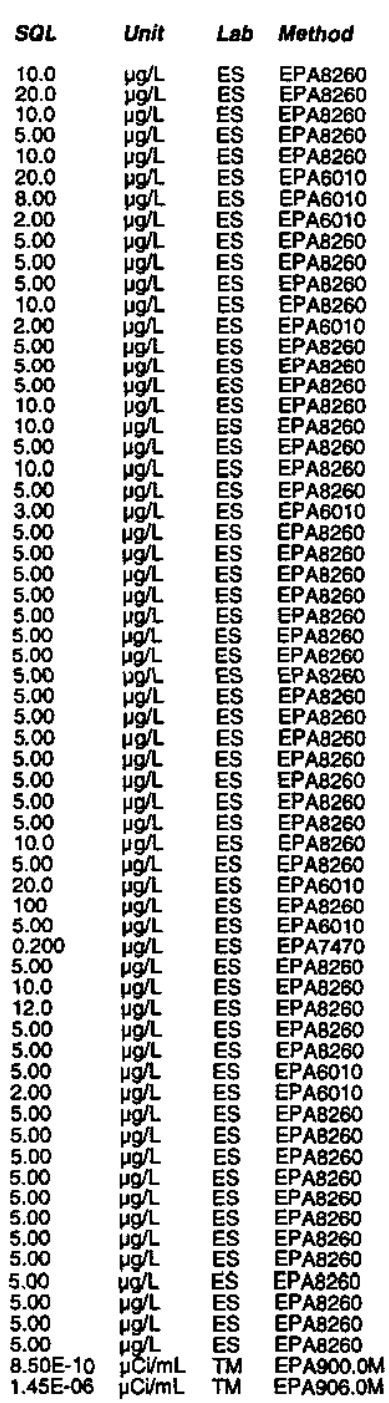

\section{WELL LFW 63D}

MEASUREMENTS CONDUCTED IN THE FIELD

Sample date: 06/08/98

Water elevation: $140.45 \mathrm{ft}(49 \mathrm{~m})$ below TOC

Hp. conductance: $32 \mu \mathrm{S} / \mathrm{cm}$

Water evacuated from the well prior to sampling: $35 \mathrm{gal}$ ANALYSES

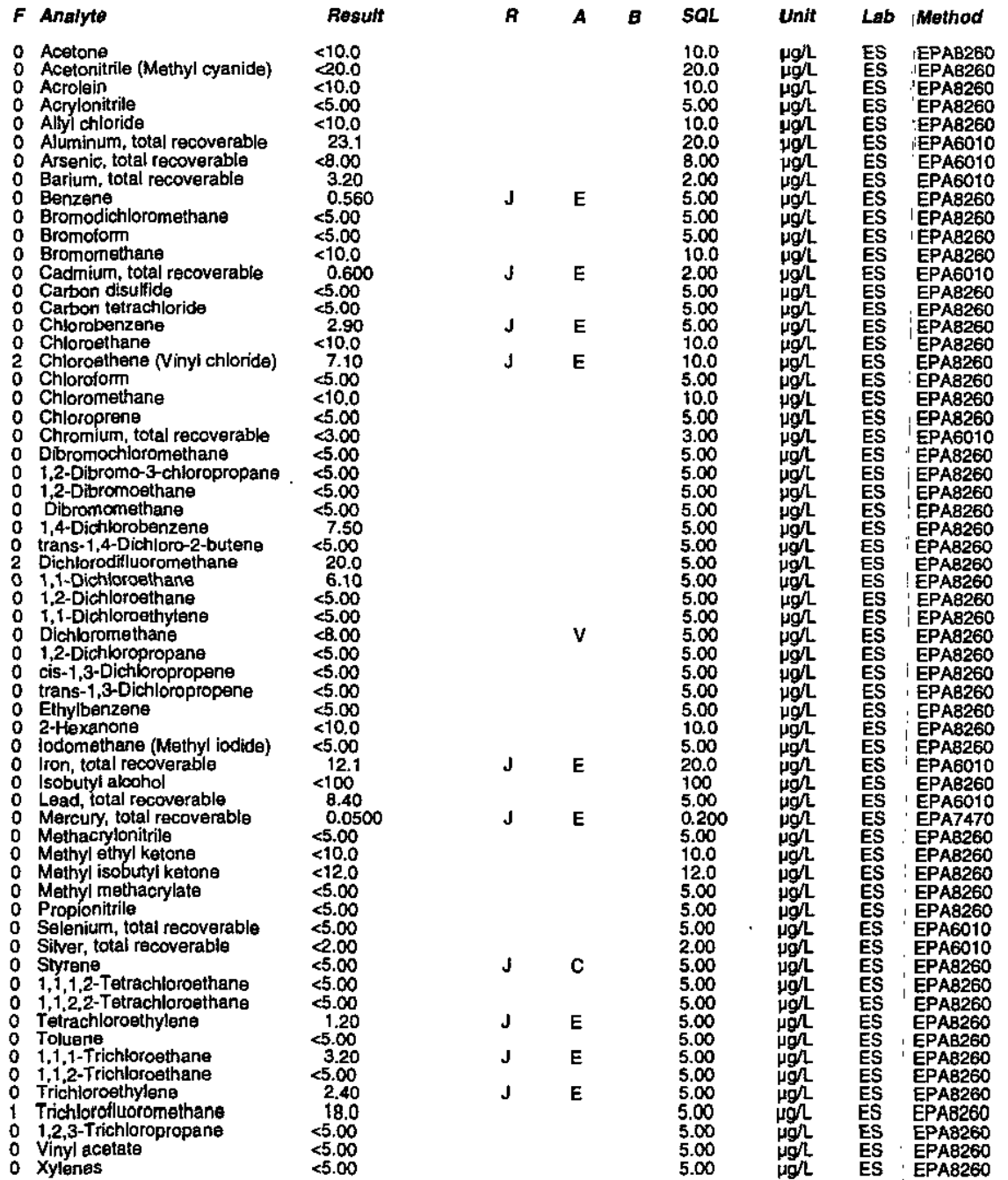

Time: 10:39

-1
0

Total alkalinity (as CaCO3): $0 \mathrm{mg} / \mathrm{L}$
Phenolphthalein alkalinity: $0 \mathrm{mg} / \mathrm{L}$ 
ANALYTICAL RESULTS

\section{WELL LFW 64C}

MEASUREMENTS CONDUCTED IN THE FIELD

\begin{tabular}{|c|c|}
\hline $\begin{array}{l}\text { Sample date: } 06 / 08 / 98 \\
\text { Deppth to water: } 12.25 \mathrm{ht}(3.73 \mathrm{~m}) \text { below TOC } \\
\text { Water elevation: } 139.95 \mathrm{Ht}(42.66 \mathrm{~m}) \mathrm{msl} \\
\text { pH: } 4.1 \\
\text { Sp. conductance: } 7 \mu \mathrm{S} / \mathrm{cm}\end{array}$ & $\begin{array}{l}\text { Time: } 8: 55 \\
\text { Water temperature: } 18.2^{\circ} \mathrm{C} \\
\text { Air temperature: } 15.3^{\circ} \mathrm{C} \\
\text { Total alkalinity (as CaCo3): } 0 \mathrm{mg} / \mathrm{h} \\
\text { Phenolphthalein alkalinity: } 0 \mathrm{mg} / \mathrm{L}\end{array}$ \\
\hline
\end{tabular}

Water evacuated from the well prior to sampling: 22 gal ANALYSES

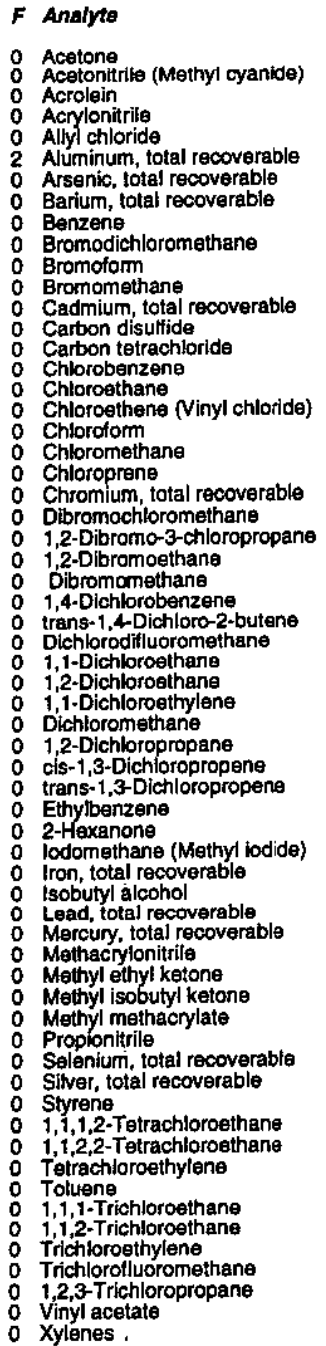

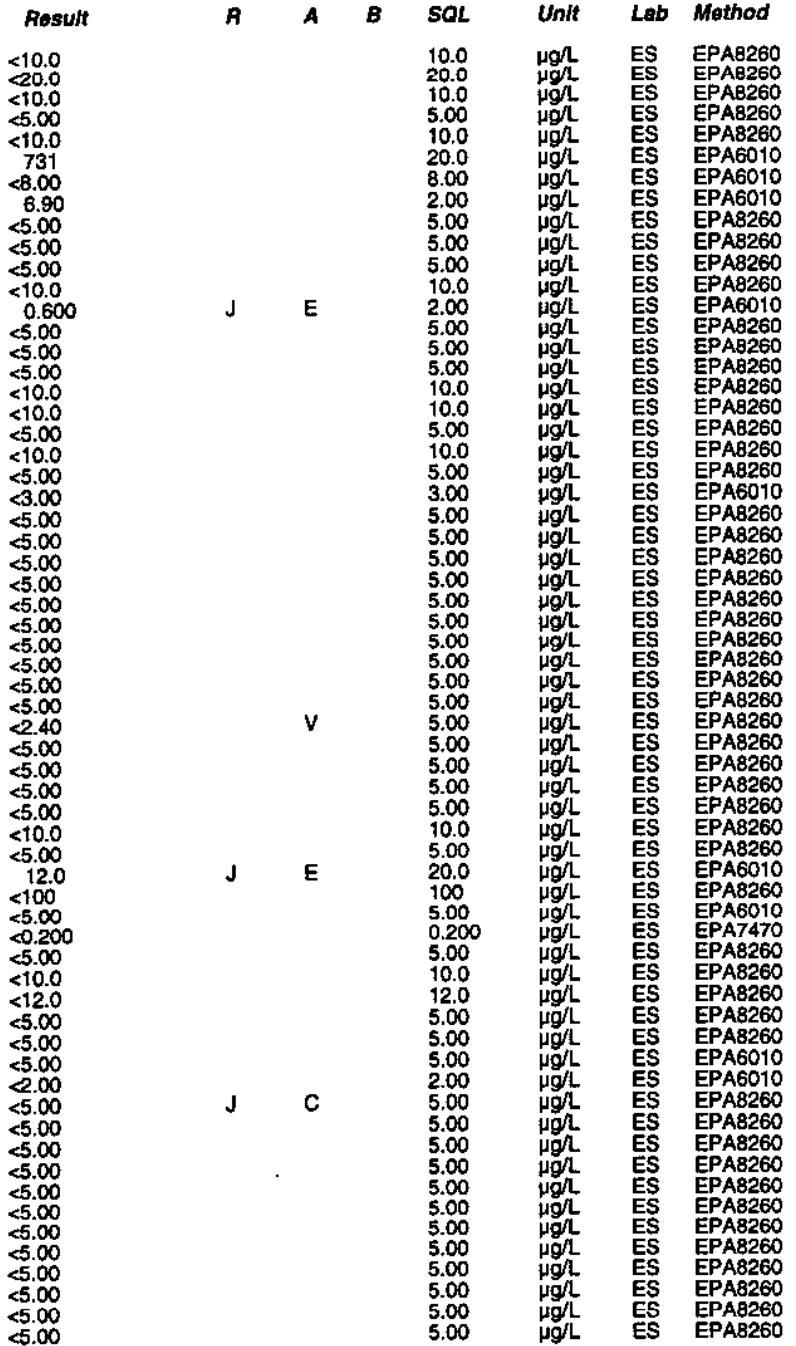

WELL LFW 64D

MEASUREMENTS CONDUCTED IN THE FIELD Sample date: $06 / 08 / 98$
Depth to water: $12.15 \mathrm{ft}$ (3.7 m) below TOC
Water elevation: $140.05 \mathrm{ft}(42.69 \mathrm{~m}) \mathrm{ms}$ l $\mathrm{pH}: 4.9$ . conductance: $48 \mu \mathrm{S} / \mathrm{cm}$ Water evacuated from the well prior to sampling: 72 gal

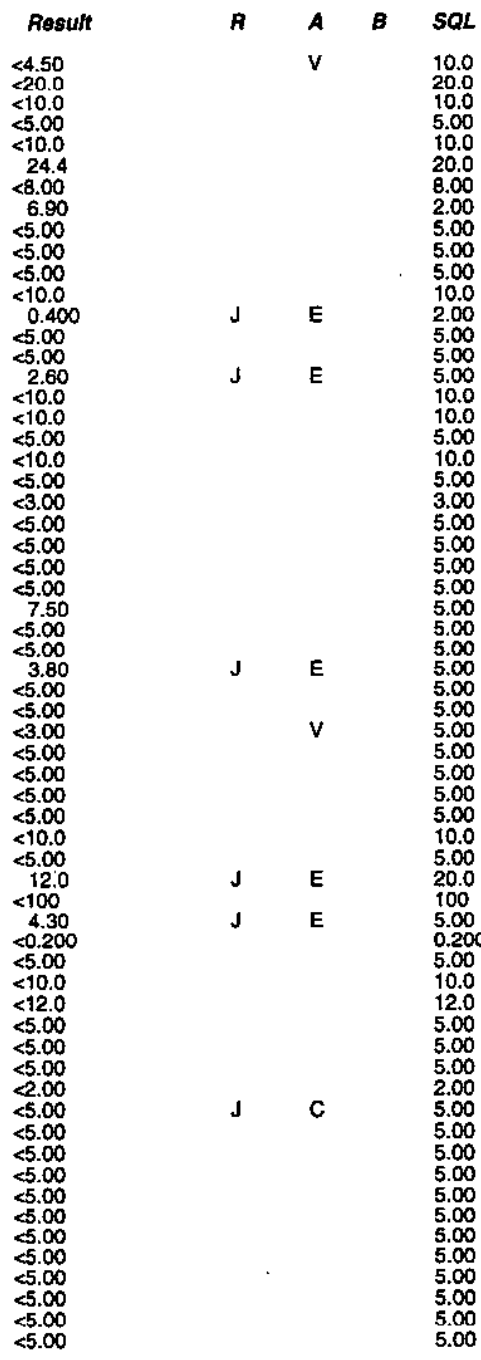

ANALYSES

\begin{tabular}{|c|}
\hline 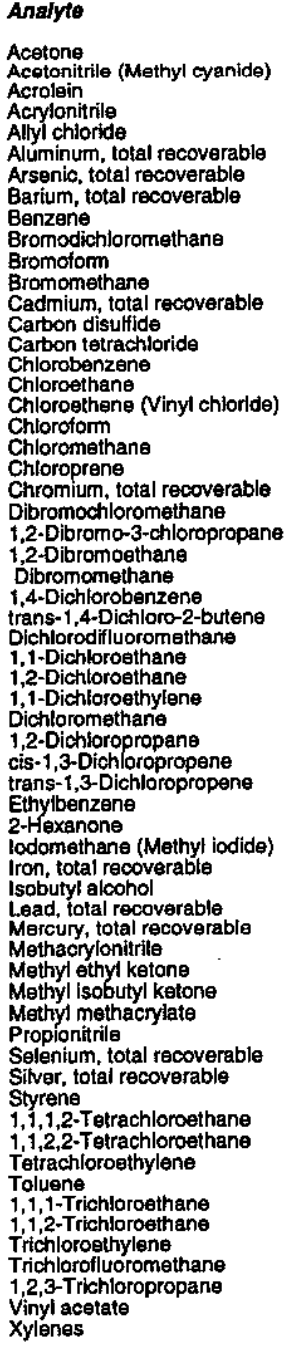 \\
\hline
\end{tabular}

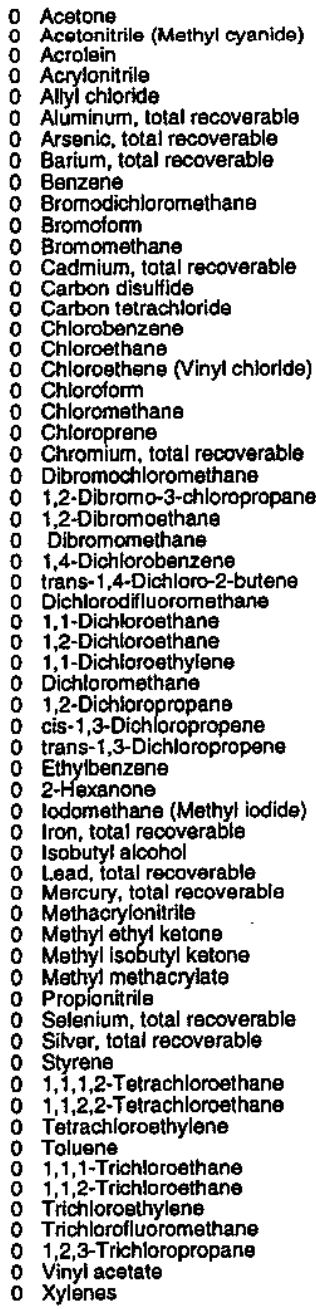

$3-205$

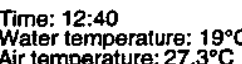
Tir tam akalinity (as CaCO3): $5 \mathrm{mgh}$
Phenolphthalein alkalinity: $0 \mathrm{mg}$ L

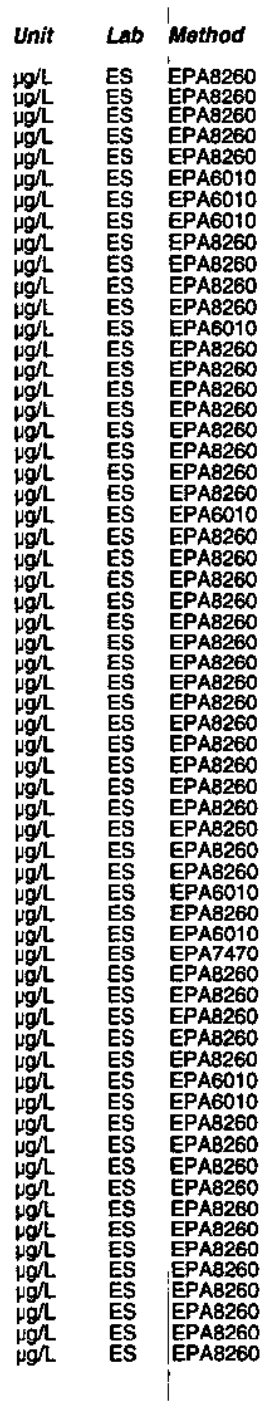

Second Quarter 1998 
ANALYTICAL RESULTS

\section{WELL LFW 65D}

MEASUREMENTS CONDUCTED IN THE FIELD

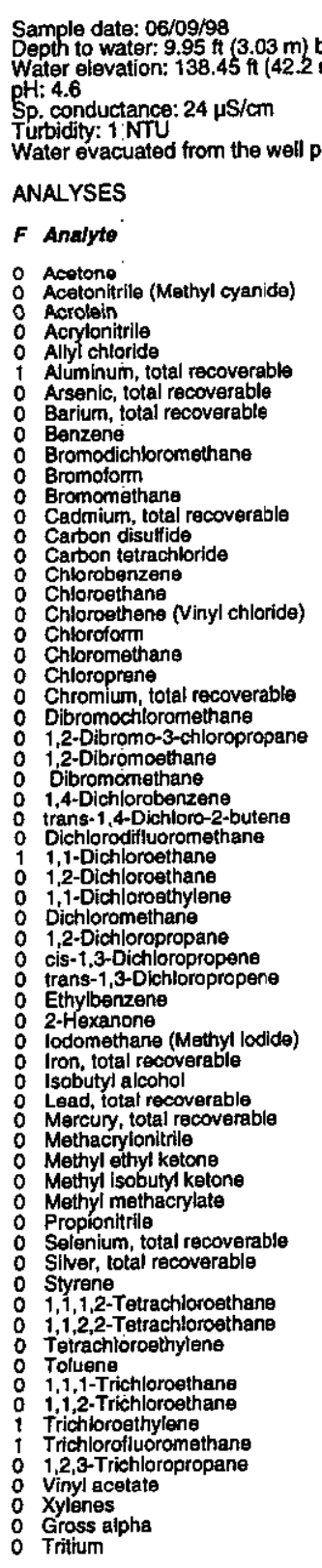

Time: 12:26 Air temperature: $28.3^{\circ} \mathrm{C}$ ) $0 \mathrm{mgh}$

\section{Turbidity: 1Ne from the well prior to sampling: $45 \mathrm{gal}$}
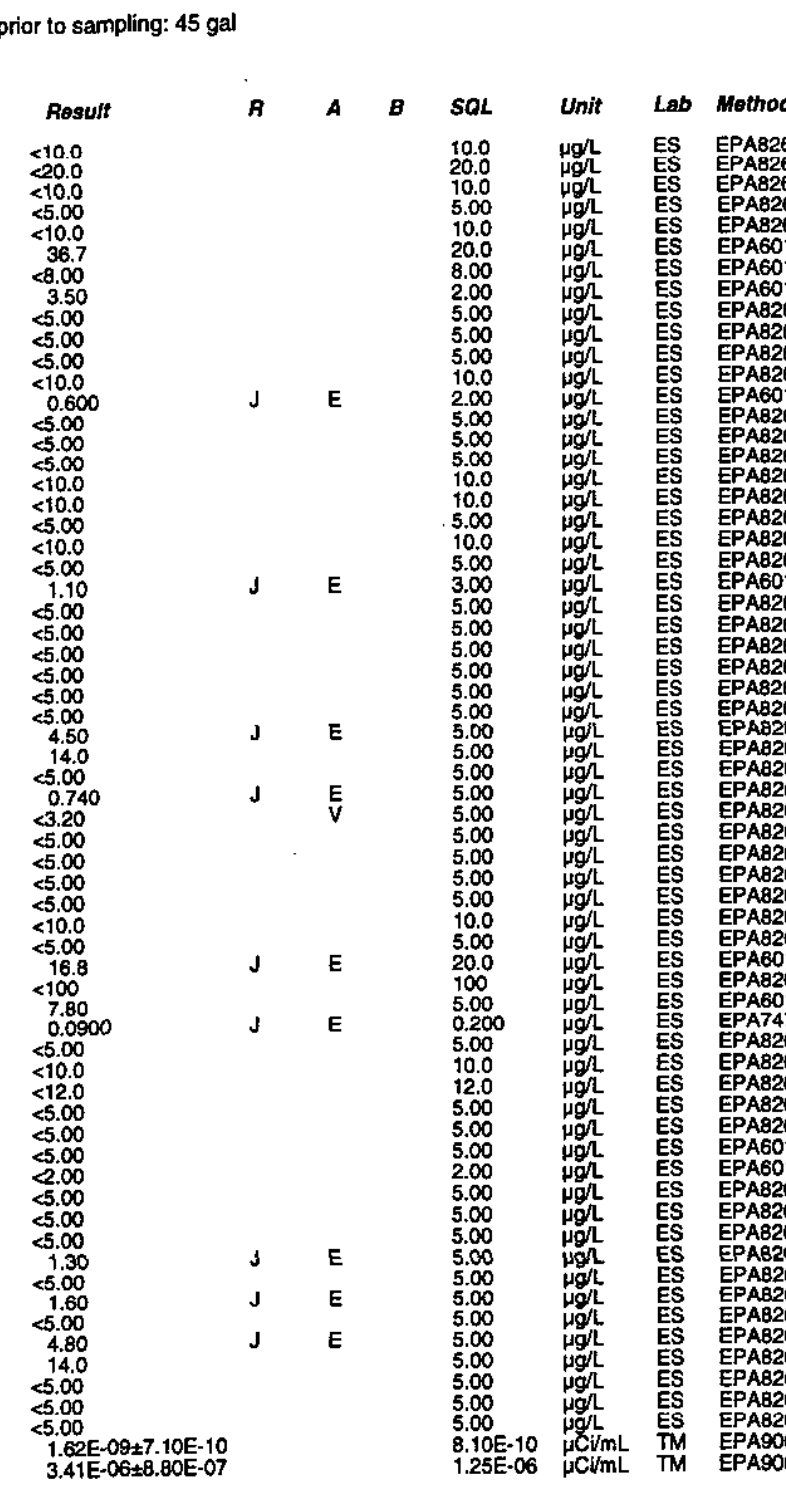

re: $18.3^{\circ} \mathrm{C}$

\section{WELL LFW 67B}

MEASUREMENTS CONDUCTED IN THE FIELD Sample date: $06 / 05 / 98$
Depth to water: $18.4 \mathrm{ft}(5.61 \mathrm{~m})$ below TOC
Water elevation: $139.3 \mathrm{ft}(42.46 \mathrm{~m}) \mathrm{msl}$ Water e $\mathrm{gH}: 4$. conductance: $59 \mu \mathrm{S} / \mathrm{cm}$

Sp. conductance: $59 \mu \mathrm{S} / \mathrm{cm}$
Turbidity: 0 NTU
Water evacuated from the well prior to sampling: 42 gal ANALYSES

F Analyte

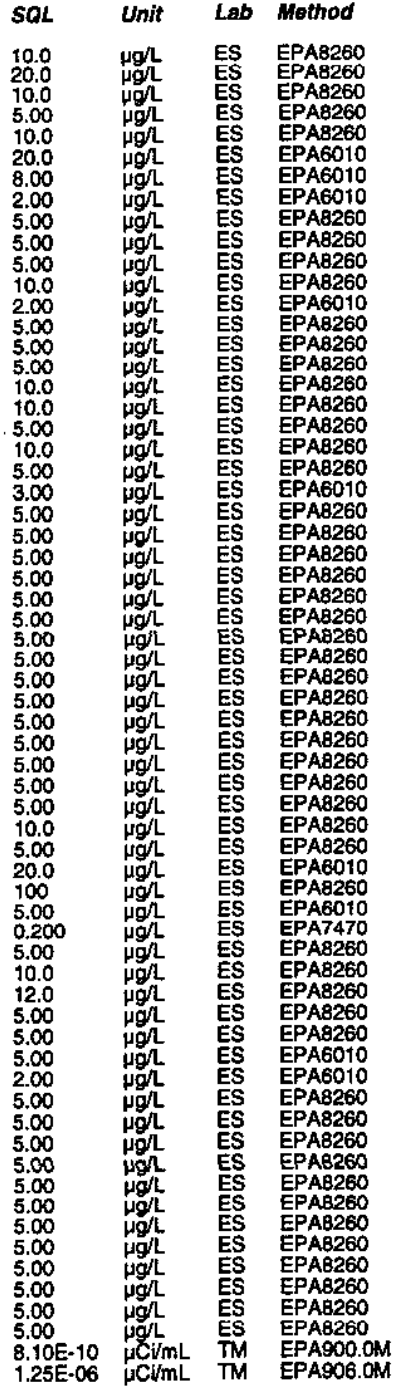

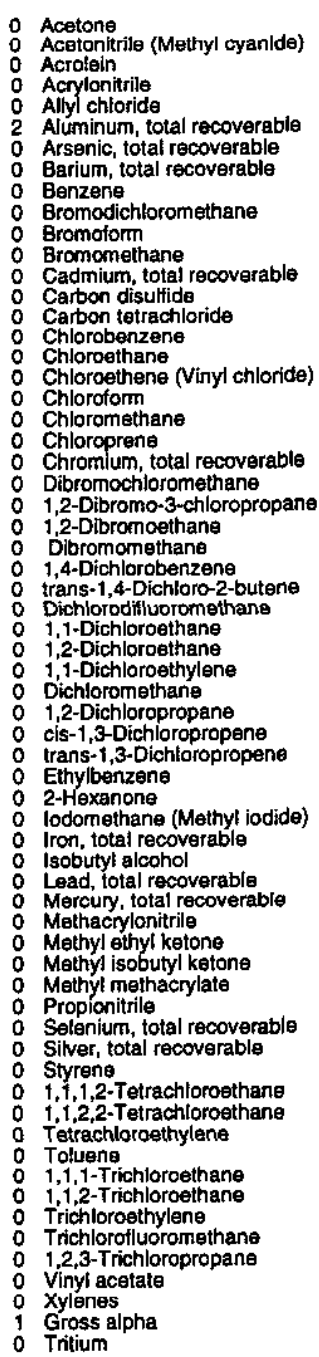

207

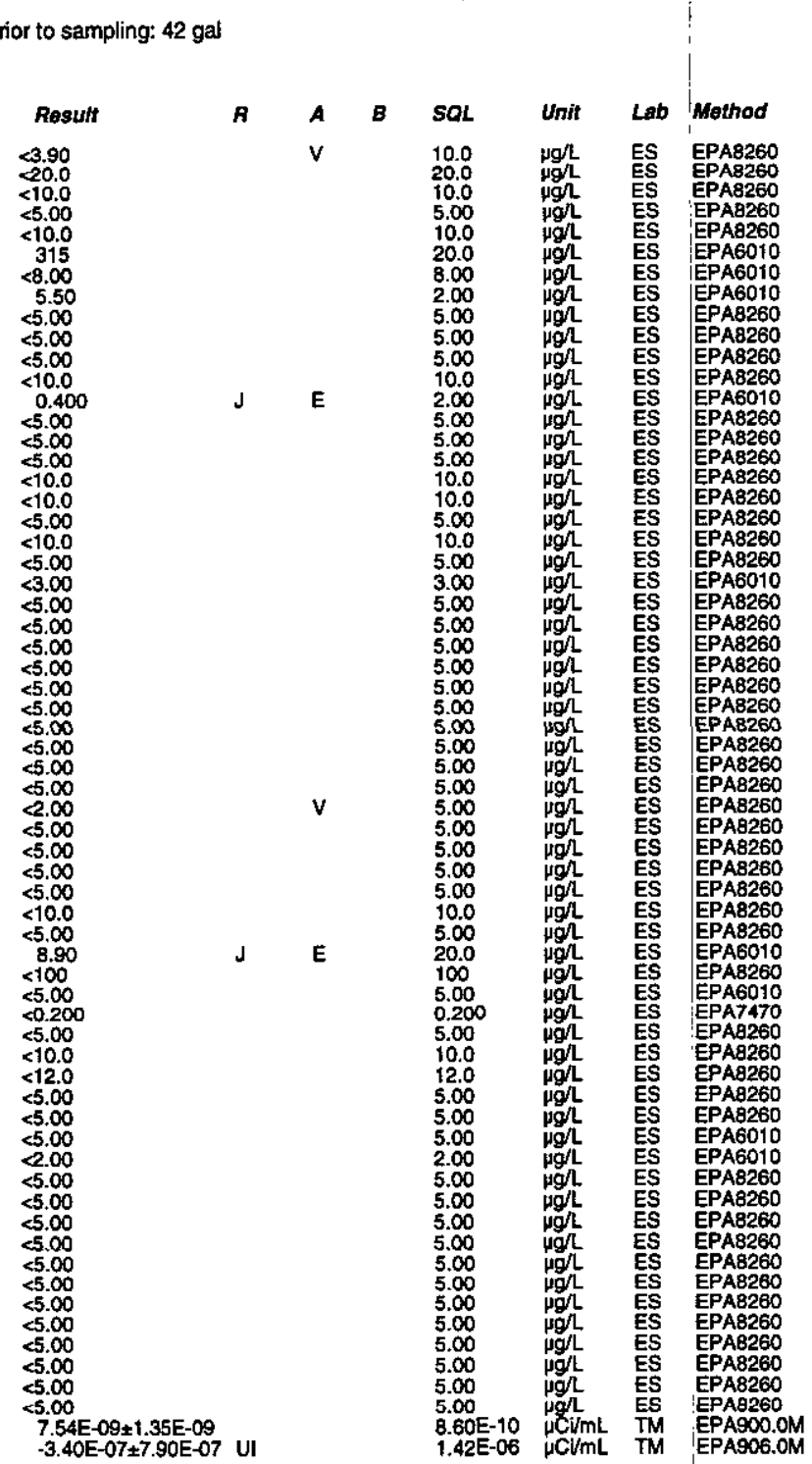

Second Quarter 1998

Time: 10:48 Air temperature: $23.6^{\circ} \mathrm{C}$ Thetal a kalling (as CaCO3): $0 \mathrm{mgh}$ 


\section{WELL LFW 67C}

MEASUREMENTS CONDUCTED IN THE FIELD Sample date: $06 / 09 / 98$
Depth to water: $18.37 \mathrm{ft}(5.6 \mathrm{~m})$ below TOC
Water elevation: $138.73 \mathrm{tt}(42.29 \mathrm{~m}) \mathrm{ms}$ Water elevation: $138.73 \mathrm{ft}(42$
pH: 6
Sp. conductance: $520 \mu \mathrm{S} / \mathrm{cm}$

Turbidity: $1 \mathrm{NTU}$ Water evacuated from the well prior to sampling: $40 \mathrm{gal}$

ANALYSES

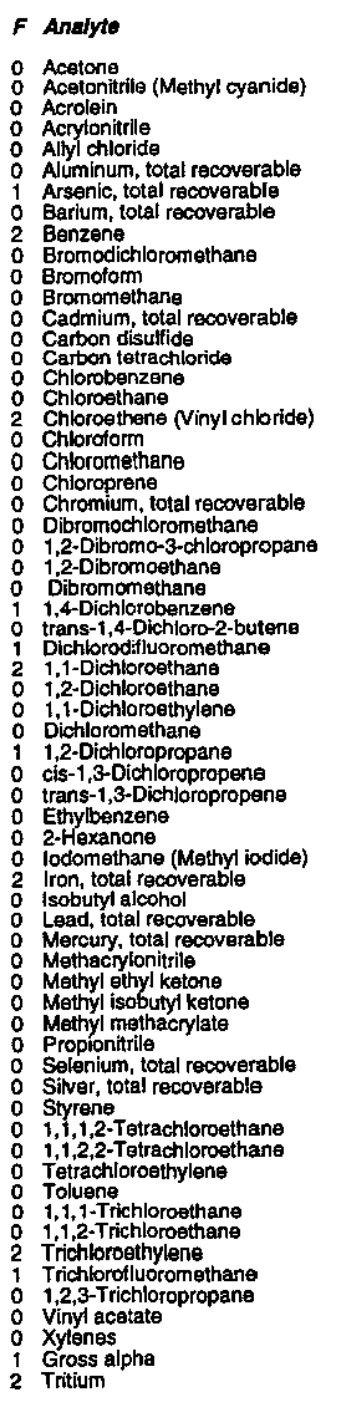

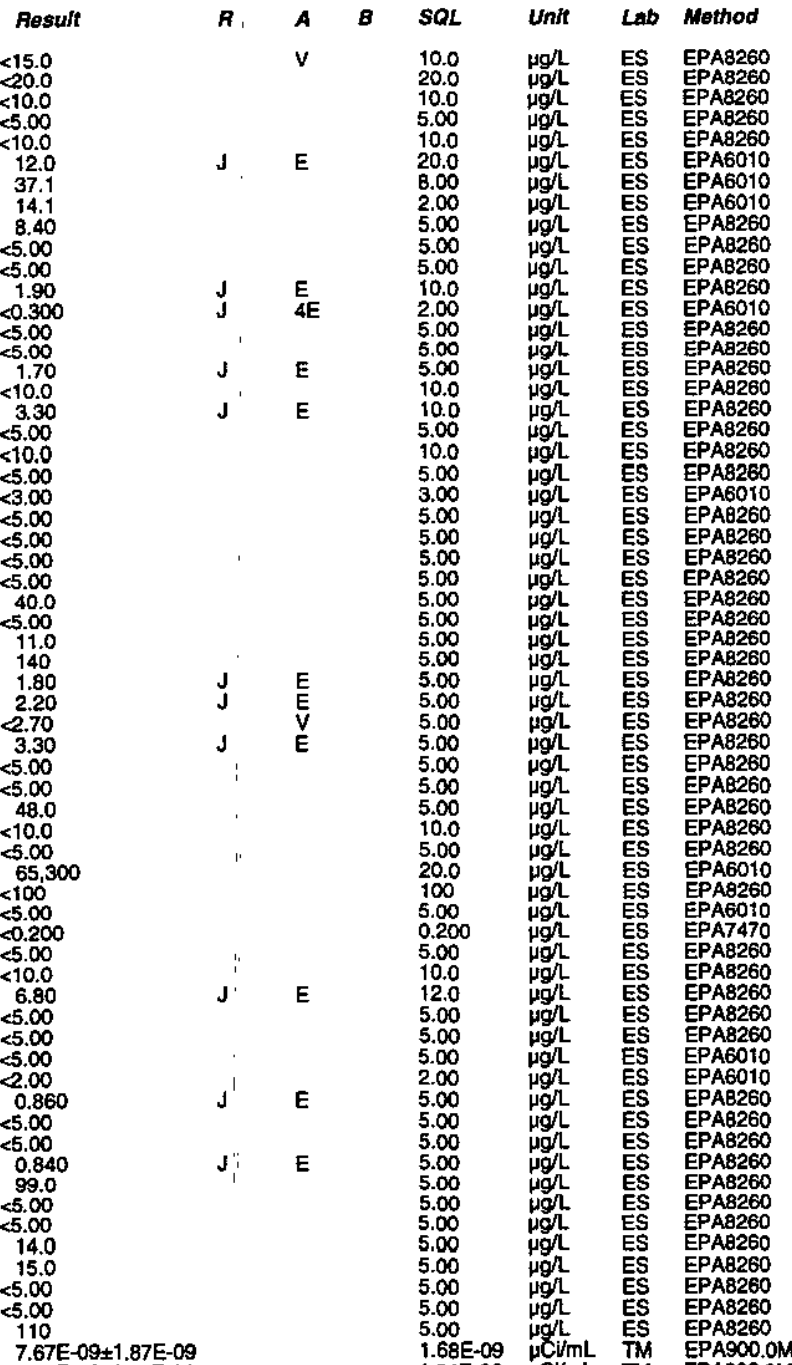

ESH-EMS-980569

\section{WELL LFW 67D}

MEASUREMENTS CONDUCTED IN THE FIELD

Time: 10:00

Air tomperenture: $20.4^{\circ} \mathrm{C}$

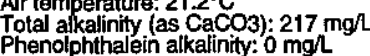

Sample date: $06 / 09 / 98$
Depth to water: $15.75 \mathrm{ft}(4.8 \mathrm{~m})$ below TOC
Water elevation: $141.95 \mathrm{ft}(43.27 \mathrm{~m}) \mathrm{msl}$
HH: 4.8 .8 .
Sp conductance: $44 \mu \mathrm{S} / \mathrm{cm}$

Water evacuated from the well prior to sampling: $90 \mathrm{gal}$

ANALYSES
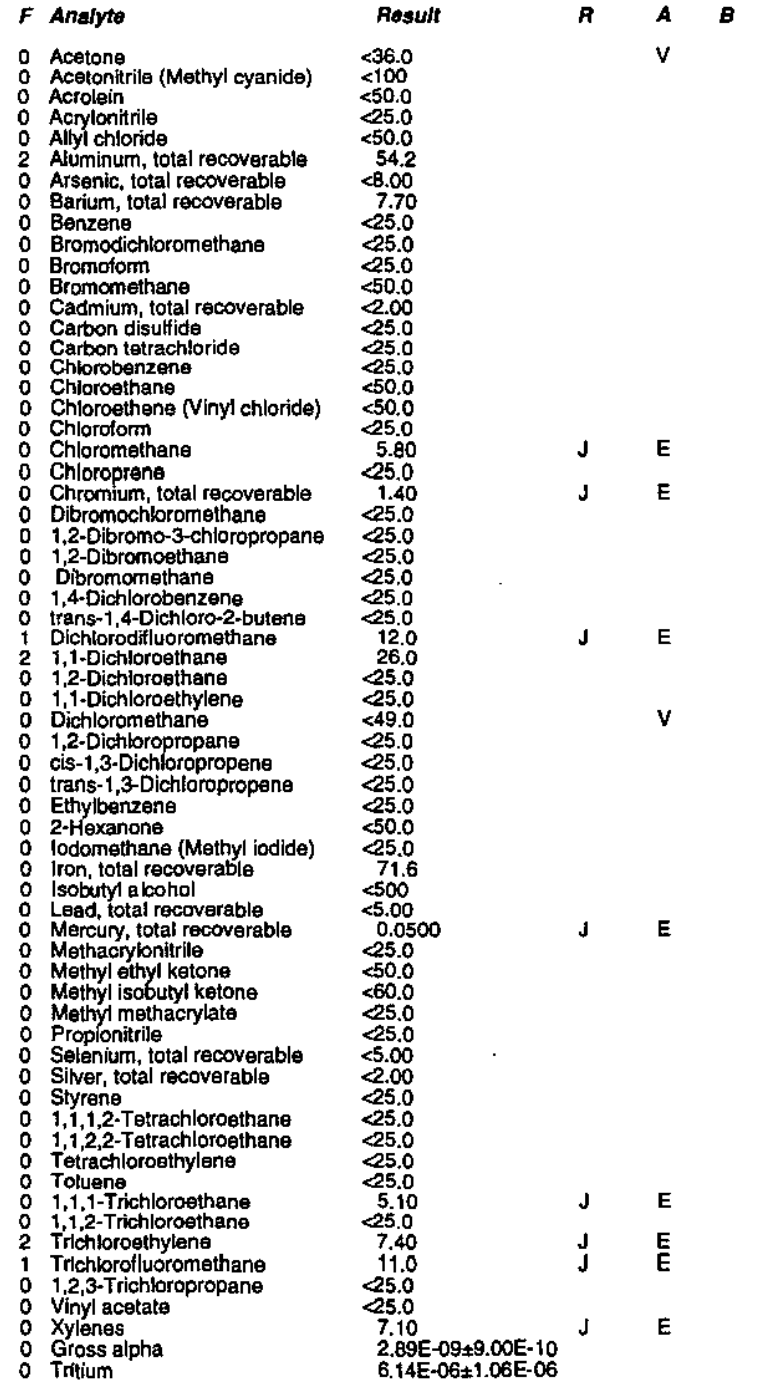

Time: 10:53

Total alkalinity (22 $\mathrm{CaCO}$ ) $0 \mathrm{~mol}$

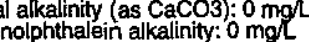

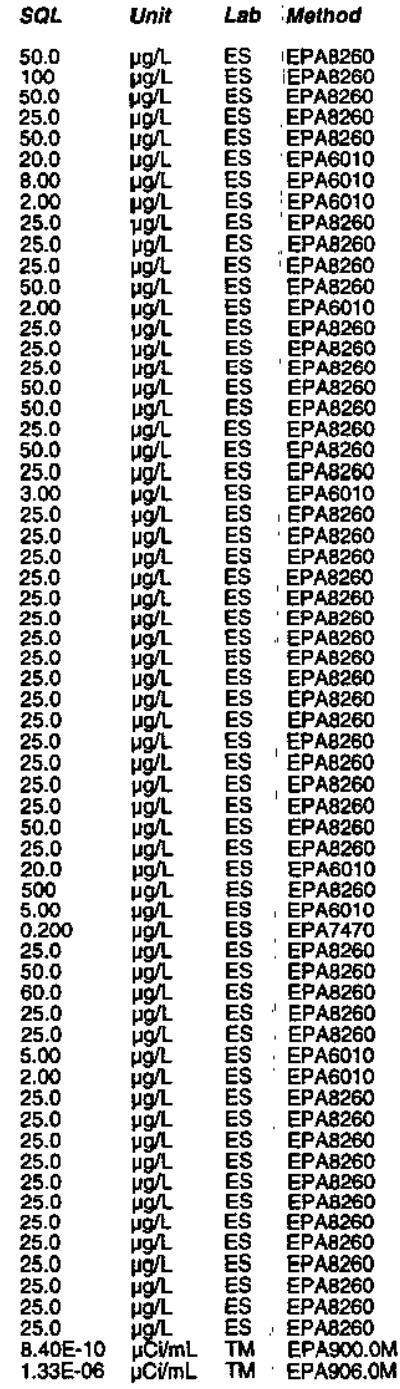

Second Quarter 1998 
ANALYTICAL RESULTS

\section{WELL. LFW 68D}

MEASUREMENTS CONDUCTED IN THE FIELD

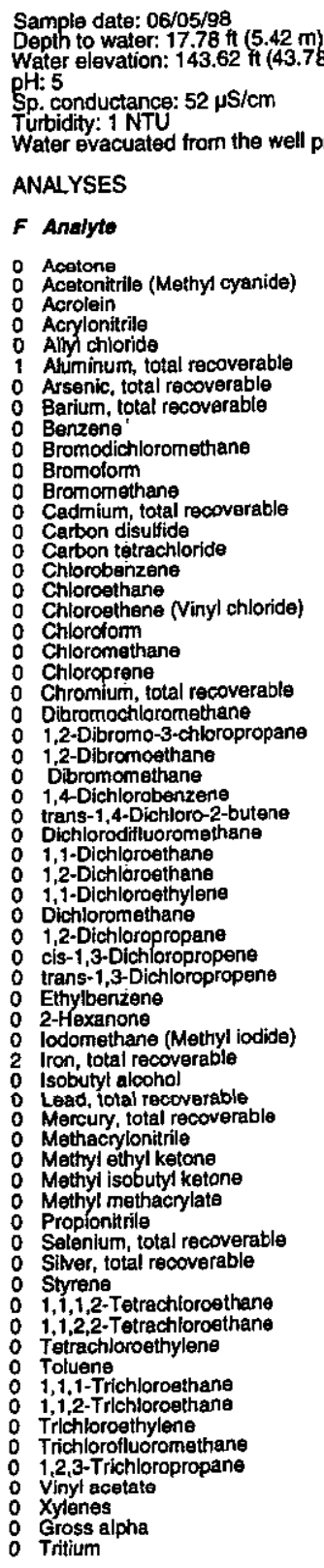

ESH-EMS-980569
Time: 9:51

Air termperature: $22.9^{\circ} \mathrm{C}$ ) $0 \mathrm{mg} /$

g: $19 \mathrm{ga}$

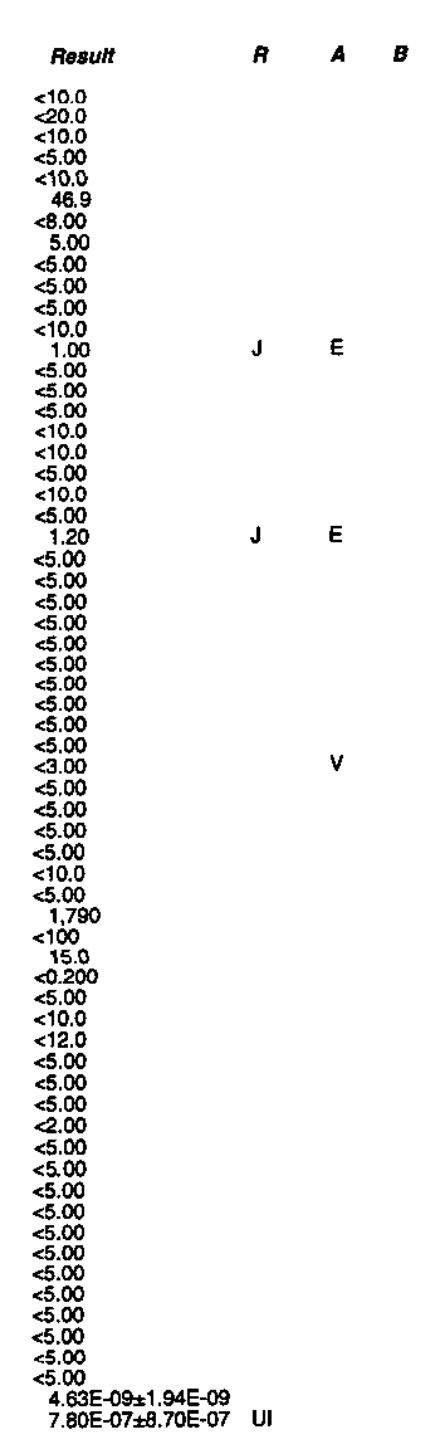

WELL LFW 69C

MEASUREMENTS CONDUCTED IN THE FIELD

Sample date: $06 / 05 / 98$ Depth to water: 8.37 tt $(2.55 \mathrm{~m})$ below TOC Depth to wate

$\mathrm{pH}: 3.9$ conductance: $50 \mu \mathrm{S} / \mathrm{cm}$

Water evacuated from the well prior to sampling: $34 \mathrm{gal}$

ANALYSES

F Analyte

: Acetone Acrolein

\section{Aluminum, total recoverable} Arsenic, total recoverable

Benzene

0 Bromoform

Cadmium, total recoverable Carbon disulfide

Carbon tetrachilo

Chloroesthene (Vinyl chloride) Chloroform

Chromiun total recoverable Dibromochlorornethane

Dibromomethane

1.4-Dichlorobenzene

Trans-1,4-Dichloro-2-buten
Dichlorodifluoromethane

1,1-Dichloroethane

t,1-Dichloroethylen 1,2-Dichtoropropane
cis-1,3-Dichloropropen : cis-1,3-Dichloropropene

lodomethane (Methyl iodide) roctial recove

: Lead, total recoverable

Methacrylonitrile Methyl isobutyl keton Methyl methacylate o Selenium, total racoverable

Styrene Totrachloroethylene

Toluene Trichloroethyleme Trichlorofluoromethane Vinyl acetate xylenes 1 Gross alpha

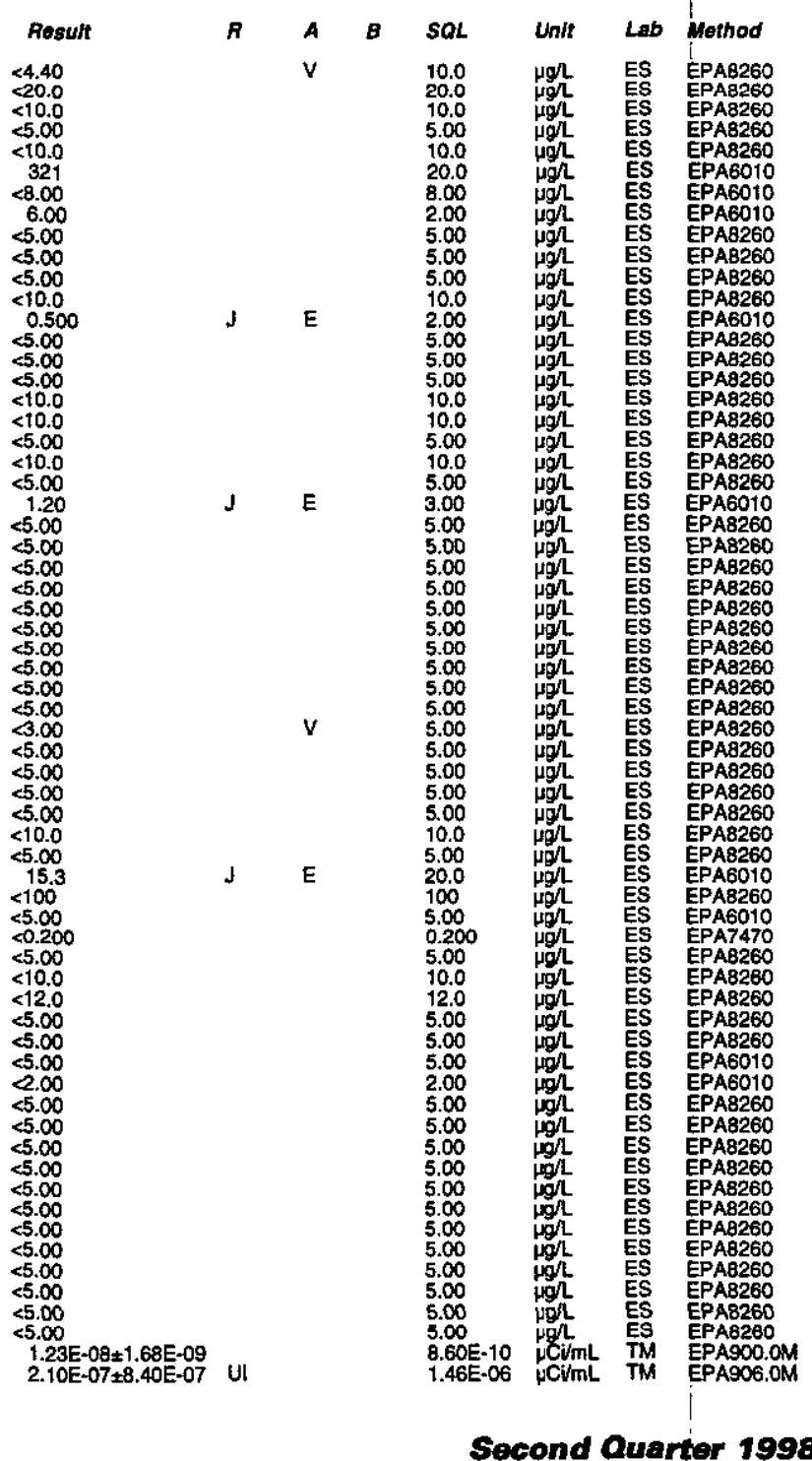

Second Quarter 1998
Time: 8:31 Air temperature: $21.1 \mathrm{C}$ (ikalinity (as $\mathrm{CaCO}$ ): $0 \mathrm{mg}$ Total alkalinity (as CaCo3):0 mg 


\section{WELL LFW 69D}

MEASUREMENTS CONDUCTED IN THE FIELD Sample date: $06 / 10 / 98$
Depth to water: 8.36 tit $(2.55 \mathrm{~m})$ below TOC
Water elevation: $137.74 \mathrm{ft}(41.38 \mathrm{~m}) \mathrm{msl}$ Water 6 Sp. conductance: $53 \mu \mathrm{S} / \mathrm{cm}$ Turbidity: 7 NTU ANALYSES

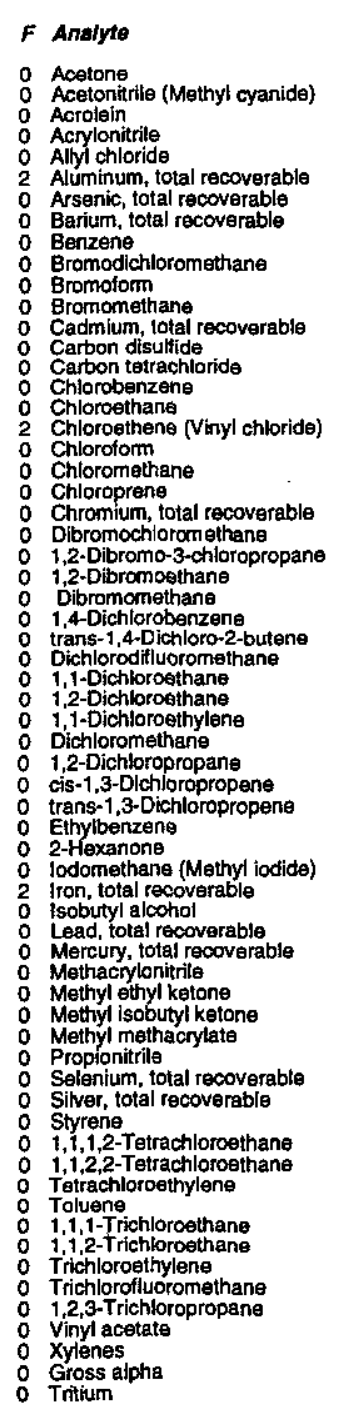

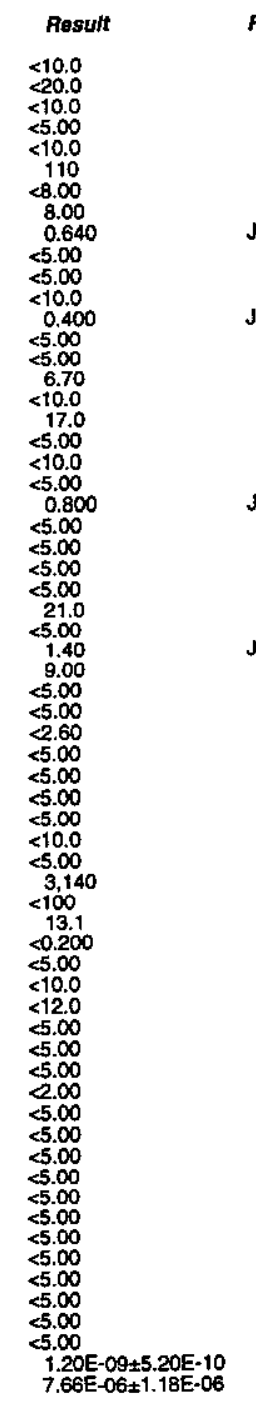

\section{WELL LFW 71B}

MEASUREMENTS CONDUCTED IN THE FIELD Sample date: $06 / 04 / 98$
Depth to water: $9.33 \mathrm{ft}(2.84 \mathrm{~m})$ below ToC
Water elevation: $137.67 \mathrm{ft}(41.96 \mathrm{~m}) \mathrm{msl}$ Water temperature: $23.4^{\circ} \mathrm{C}$ Total alkalinity (as CaCO3): $3 \mathrm{mg} /$ Phenolphthalein alkalinity: $0 \mathrm{mg}$.

Water $\mathrm{pH}: 4.2$ . conductance: $50 \mu \mathrm{S} / \mathrm{cm}$

Water evacuated from the well prior to sampling: $55 \mathrm{gal}$

Wer $20.6^{\circ} \mathrm{C}$

Air temperatura: $25.6^{\circ} \mathrm{C}$. ANALYSES
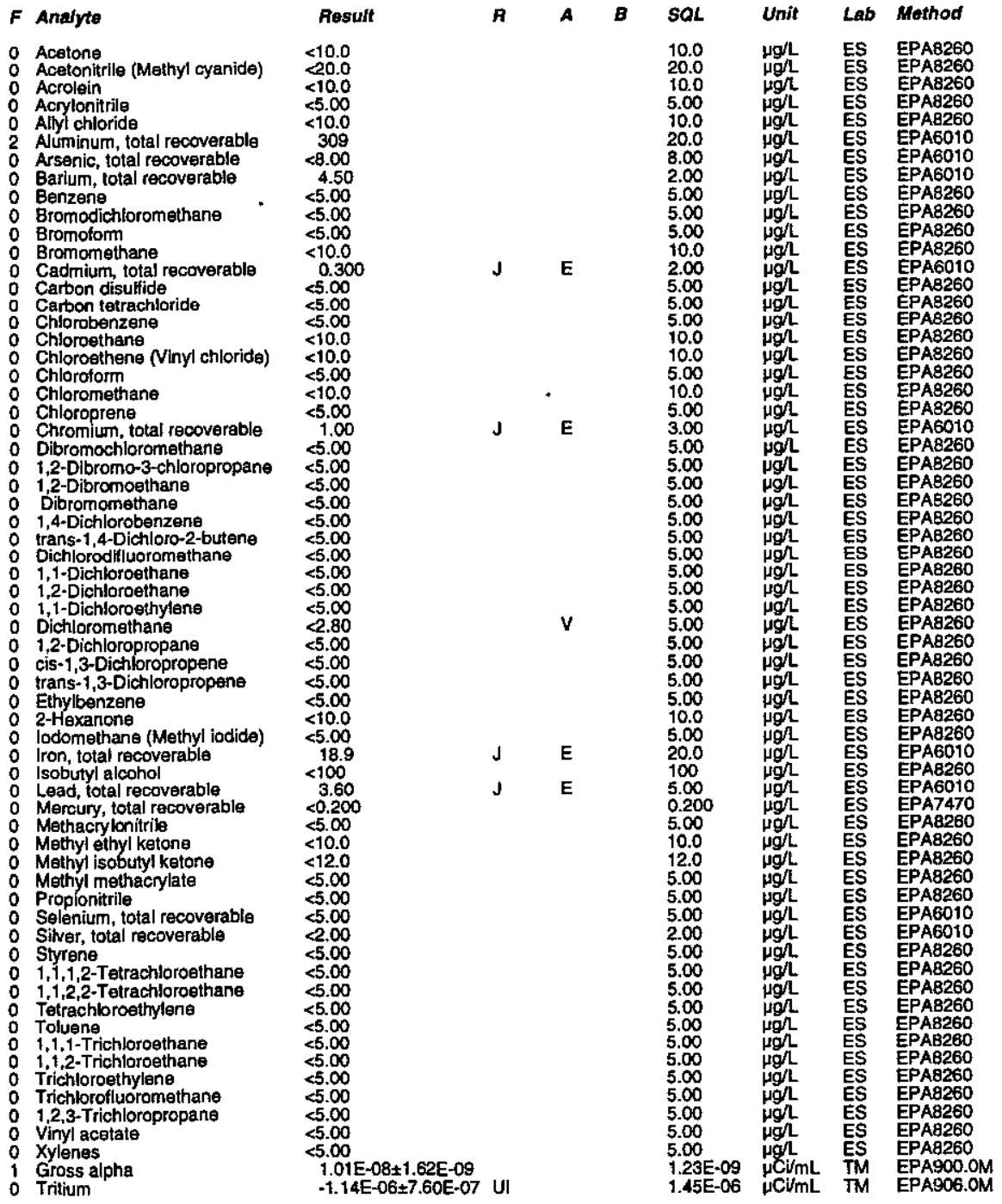


\section{WELL LFW 71C}

MEASUREMENTS CONDUCTED IN THE FIELD

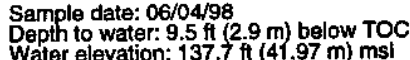

Sp: 4.5 conductance: $38 \mu \mathrm{S} / \mathrm{cm}$

Time: 9:00

Total alkabinity. (as $\mathrm{CaCO}$ ): $0 \mathrm{mgl}$

Turbidity: ONTU for the well prior to sampling: $39 \mathrm{gal}$
Water evacuated from the

ANALYSES

$F$ Analyto

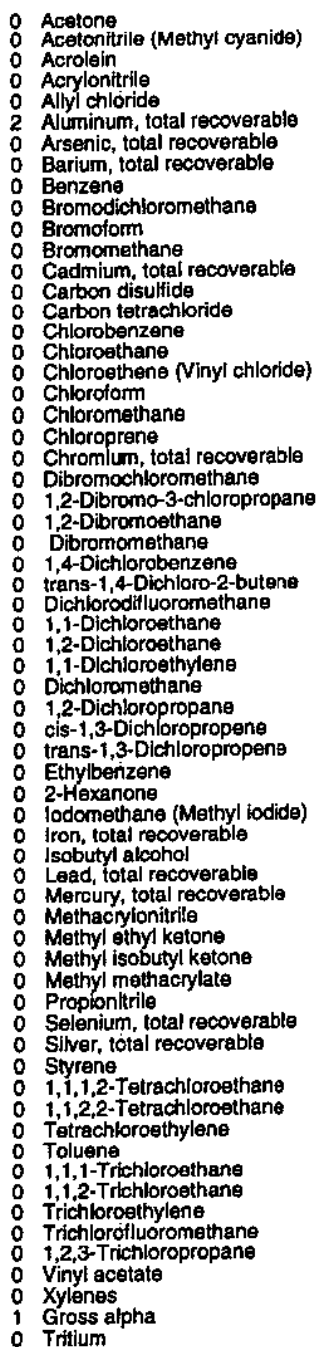

Tritium

ESH-EMS-980569
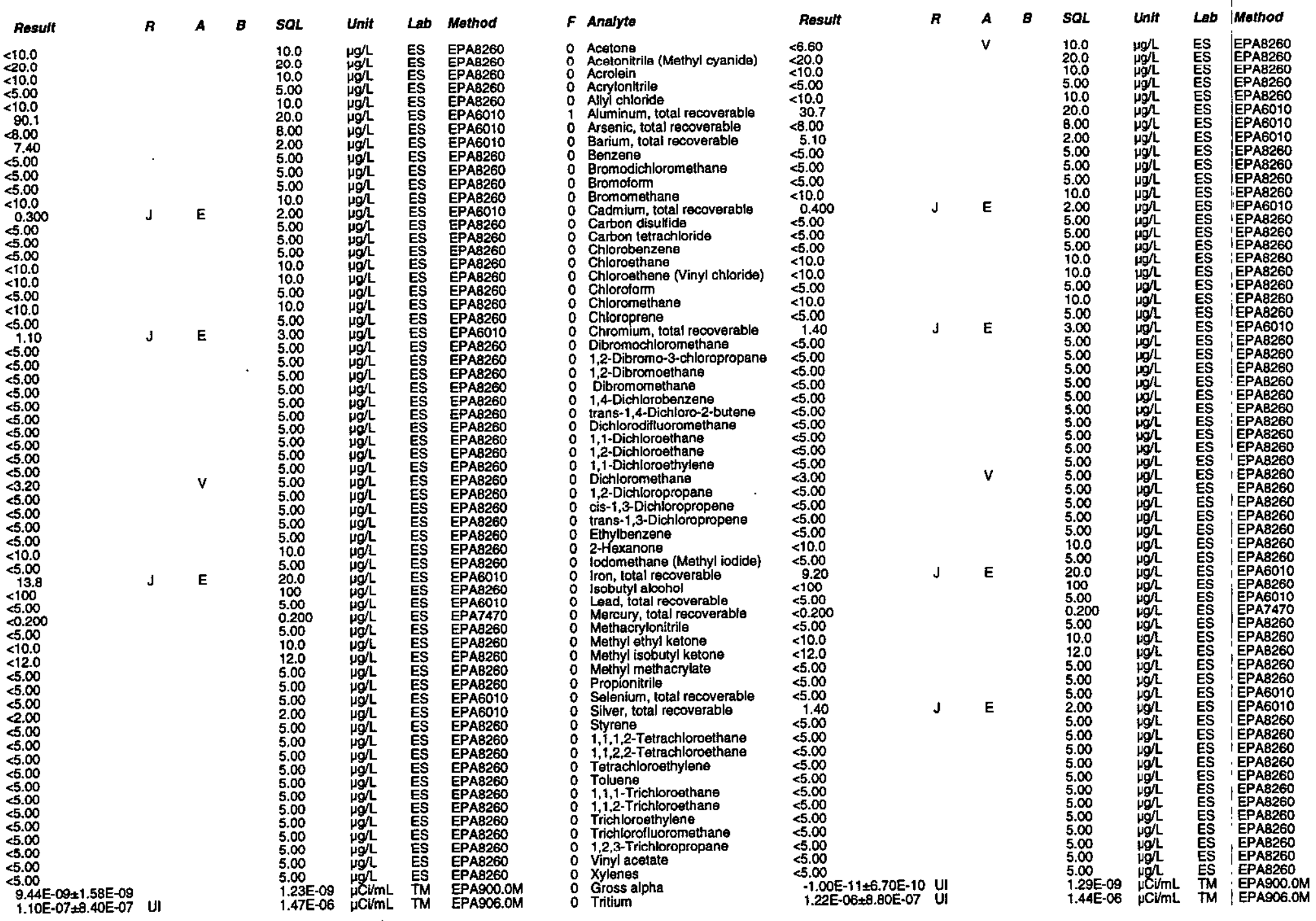

MEASUREMENTS CONDUCTED IN THE FIELD

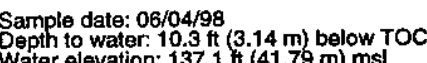

Water el

$\mathrm{sp}$. conductance: $21 \mu \mathrm{S} / \mathrm{cm}$

Water evacuated from the well prior to sampling: $60 \mathrm{gal}$ ANALYSES

Analyte

Acrolein

Barium, total recoverab

Bromodich

Cadmiurn, total recoverabio

(Ninyl chtoride)

trans-1,4-Dichloro-2-buten

1,2-Dichloroethane

Dichloromethane

Ethylbenzene

Methacrylonitrile

Selenium, total recoverab

1, 1, 1,2-Tetrachloroethan

Grones alpha
Tritium

$-1.00 E-11 \pm 6.70 E-10 U$
cis-1,3-Dichloropropen
Time: 8:14

rature: $18.3^{\circ} \mathrm{C}$

Total alkalinity (as caco3): $0 \mathrm{mg}$

hithalein alkalinity: $0 \mathrm{mg}$ 


\section{WELL MCB 15B}

MEASUREMENTS CONDUCTED IN THE FIELD

Sample date: $06 / 16 / 98$
Depth to water $162.7 \mathrm{~A}(49.59 \mathrm{~m})$ below TOC
What Water elevation: Not available

DH: 5.8

conductance: $26 \mu \mathrm{s} / \mathrm{cm}$

Water evacuated from the well prior to sampling: $60 \mathrm{gal}$

ANALYSES

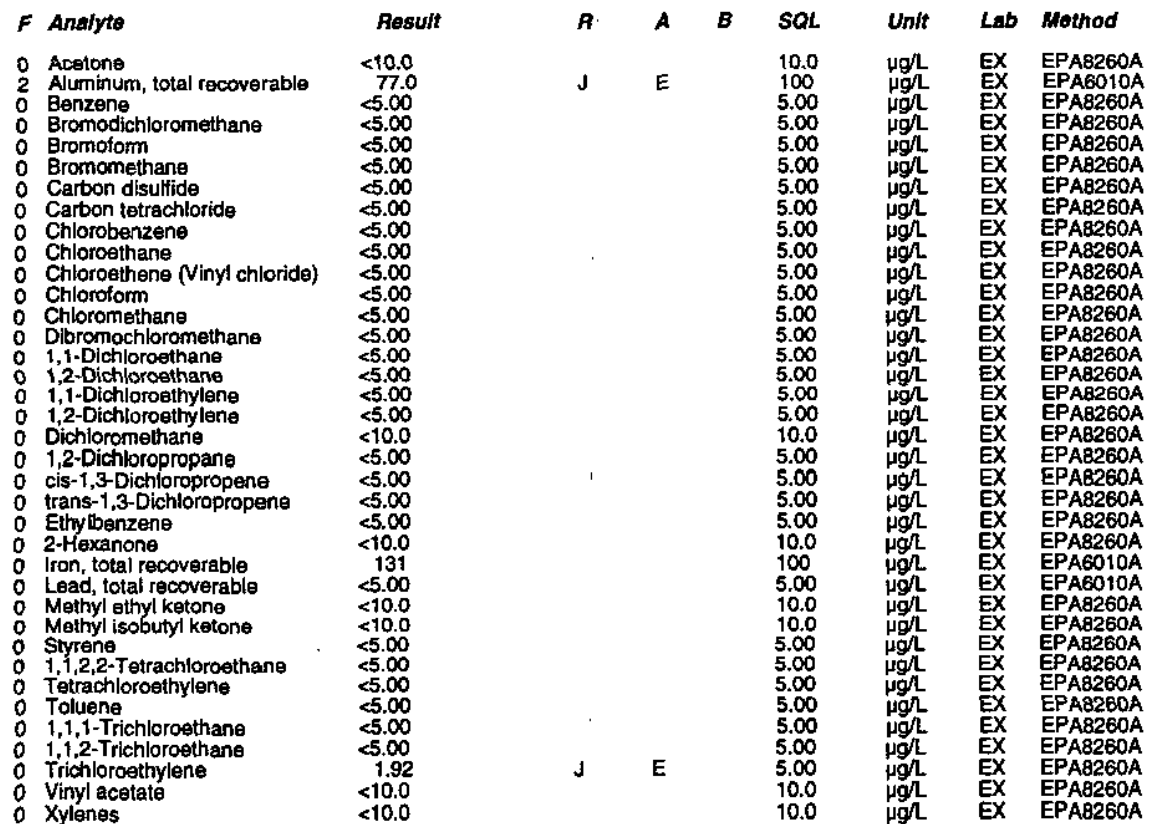

\section{WELL MCB 15C}

MEASUREMENTS CONDUCTED IN THE FIELD

Sample data: $06 / 16 / 98.7(49.34 \mathrm{~m})$ below TOC

Water

. condug $110 \mathrm{H} / \mathrm{cm}$

W. conductance: $110 \mu \mathrm{S} / \mathrm{cm}$

Water evacuated from the well prior to sampling: $17 \mathrm{gal}$

ANALYSES

\begin{tabular}{|c|c|}
\hline Analyte & Resut \\
\hline 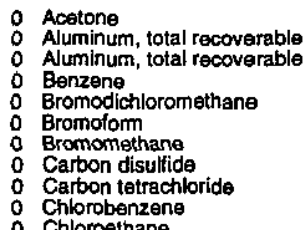 & $\begin{array}{l}250.0 \\
<100 \\
<100 \\
25.0 \\
25.0 \\
25.0 \\
25.0 \\
25.0 \\
25.0 \\
25.0 \\
25.0\end{array}$ \\
\hline
\end{tabular}

ESH-EMS-980569
Time: $12: 13$ Water temperature: $23.5^{\circ} \mathrm{C}$ Air termerature: $33.1^{\circ} \mathrm{C}$ - $70 \mathrm{mgh}$

Phelph thas alkglinty: $\mathrm{mgh}$

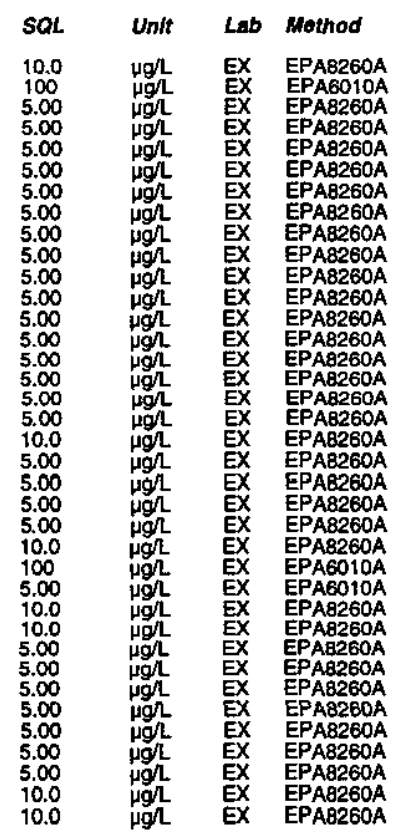

Time: 15:58

Arter temperature: $23.2^{\circ} \mathrm{C}$

Total alkalinity (as Caco3): $6 \mathrm{mg} /$
Phenolphthalein alkalinity: $0 \mathrm{mgl}$
Well MCB 15 C collected on 06/16/98 (cont)
$F$ Analyte

OO Chloroethene (Vinyl chloride)

Chloromethan

1,1-Dichloroethethane

o 1.2-Dichloroethane

o 1,1-Dichorothethylene

Dichloromethane

cis-1,3-Dichloropropene

Ethylt,enzene

2-Hexanone

Methyl isobutyl ketone

1,1,2,2-Tetrachloroethan

Totrachloroethylene

$1,1,1$-Trichloroethane
$1,1,2$-Trichloroethane

Trichloroethylene
0 Vinyl acetate

\section{WELL MCB 16B}

MEASUREMENTS CONDUCTED IN THE FIELD

Sample date: $06 / 15 / 98$ ft $(52.48 \mathrm{~m})$ below TOC

Water elevation: Not available

pH: 5.5 conductance: $24 \mu \mathrm{S} / \mathrm{cm}$

Water evacuated from the well prior to sampling: 72 gal

ANALYSES

F Analyte

Acetone
o Aluminum, total recoverable
: Arsenic, total recoverable
0 Benzene

- Bromodichloromethan

o Bromomethane

Carbon tetrachloride

Chlorosthane

Chlorosthene (Vinyl chloride) Chlorotorm

Cibromothloromethan

1.1-Dichloroethane

1,2-Dichlorosthane

o 1,2-Dichloroethylene

Dichloromethane

1,2-Dichloropropane
cis-1,3-Dichloropropene
irans-1,3-Dichloropropen

2-Hexanione

0 iron, total recoverable

- Lead, total recoverable

Methyl ethyl ketone

Selenium, total recoverable

o Styrene

B-212

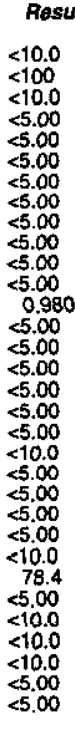

Iron, total recoverable

Lead, total recoverable

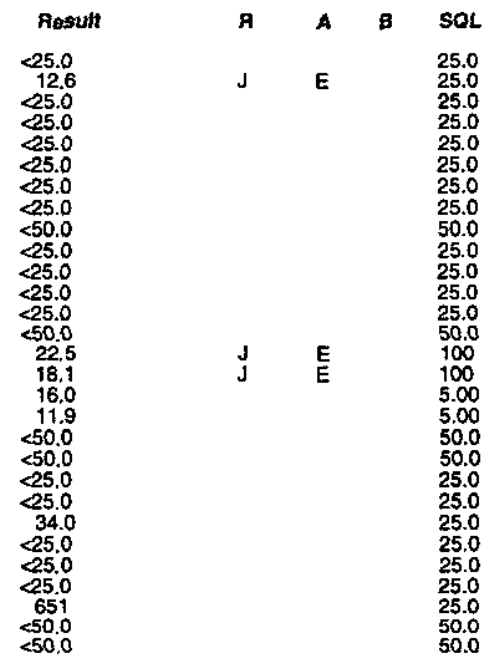

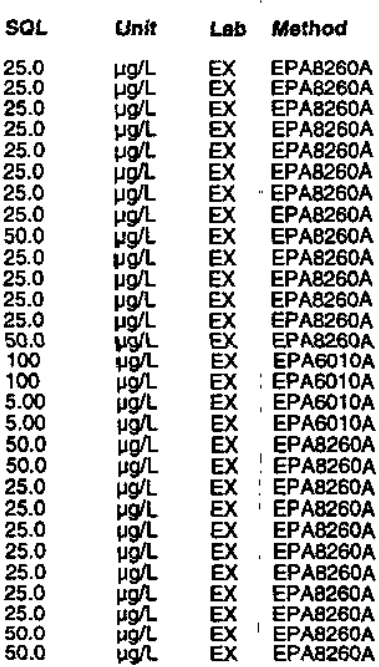

Time: 10:32

Water temperature: $21^{\circ} \mathrm{C}$

Total alkalinity (as CaCO3): $2 \mathrm{mg} /$
Phenolphthalein alkalinity: $0 \mathrm{mg} L$ $s a$
10.0
100
10.0
5.00
5.00
5.00
5.00
5.0
5.0
5.00
5.00
5.00
5.00
5.00
5.00
5.0
5.0
5.0
1.00
5.0
5.00
5.00
5.00
10.0
5.00
10.0
10.0
10.0
5.00
5.00

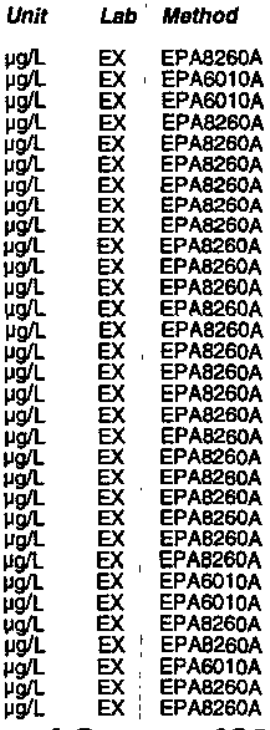

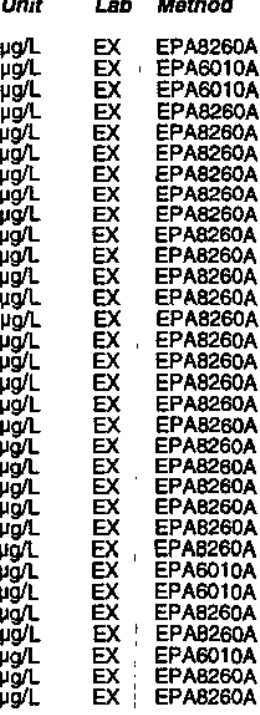


Well MCB $16 B$ collected on 06/15/98 (cont.)

o Tetrachloroethylene

$\begin{array}{ll}0 & \text { Toluene } \\ 0 & 1,1,1-\text {-Trichloroethane } \\ 0 & 1,1,2 \text {-Trichloroethane }\end{array}$

Trichloroethylene

0 Vinyl acet

\section{WELL MCB 16C}

MEASUREMENTS CONDUCTED IN THE FIELD

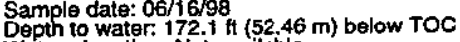

Depth to water: 172.1 It $(52.46$
Water elevation: Not available

$\mathrm{pH}: 5.8$

$<5.00$
$<5.00$
$<5.00$
$<5.00$
1.97
$<10.0$
$<10.0$

$\begin{array}{ll}\boldsymbol{A} & \boldsymbol{A} \\ \mathbf{J} & \circ \\ \mathbf{J} & \circ \\ \mathbf{J} & \circ \\ \mathbf{J} & \circ \\ \mathbf{J} & \text { EO } \\ \mathbf{J} & \circ \\ \mathbf{J} & 0\end{array}$

$\begin{array}{ccc}B & \text { soL } & \text { Unit } \\ 5.00 & \mu g h \\ 5.00 & \mu g h \\ 5.00 & \mu g h \\ 5.00 & \mu g h \\ 5.00 & \mu g h \\ 10.0 & \mu g h \\ 10.0 & \mu g \Omega\end{array}$

$\begin{array}{ll}\text { Lab } & \text { Method } \\ \text { EX EPAB260A } \\ \text { EX EPAB260A } \\ \text { EX } \\ \text { EPAB260A } \\ \text { EX EPAB260A } \\ \text { EX EPA8260A } \\ \text { EX EPA8260A } \\ \text { EX EPA8260A }\end{array}$

Time: 12:54

Witure: $23^{\circ} \mathrm{C}$

Total alkalinity (as CaCO3): $61 \mathrm{mg} /$

Water evacuated from the well prior to sampling: $\mathbf{3 7}$ gal

ANALYSES

$F$ Anelyte

Acetone

Bromodichloromethane

Bromoform

Carbon disulfide

Chibrobenzene

Chloroethane (Vinyl chloride)

Chloroform

Dibromochloromethane

1,1-Dichloroethan

1,1-Dichloroethylene

Dichloromethane

cis-1,3-Dichloropropene
0 trans-1,3-Dichloropropene

Ethylbenzene

Iron, total recoverable

Lead, total recoverablo
Methyl ethyl ketone

1,1,2,2-Tetrachloroethan

Toluene

1,1,2-Trichloroethan

: Vinyl acetate

\section{WELL MCB 17B}

MEASUREMENTS CONDUCTED IN THE FIELD

Sample date: $06 / 15 / 98$
Depth to water: $99.41 \mathrm{ft}(30.3 \mathrm{~m})$ below TOC

Water olevat

Resutt
$<10.0$
$<100$
$<5.00$
$<5.00$
$<5.00$
$<5.00$
$<5.00$
$<5.00$
$<5.00$
$<5.00$
1.12
$<5.00$
$<5.00$
$<5.00$
$<5.00$
$<5.00$
$<100$
$<5.0$
$<5.00$
$<5.00$
$<5.00$
$<10.0$
$<100$
$<5.00$
$<10.0$
$<10.0$
$<5.00$
$<5.00$
$<5.00$
$<5.00$
$<5.00$
$<5.00$
$<5.00$
$<10.0$
$<10.0$
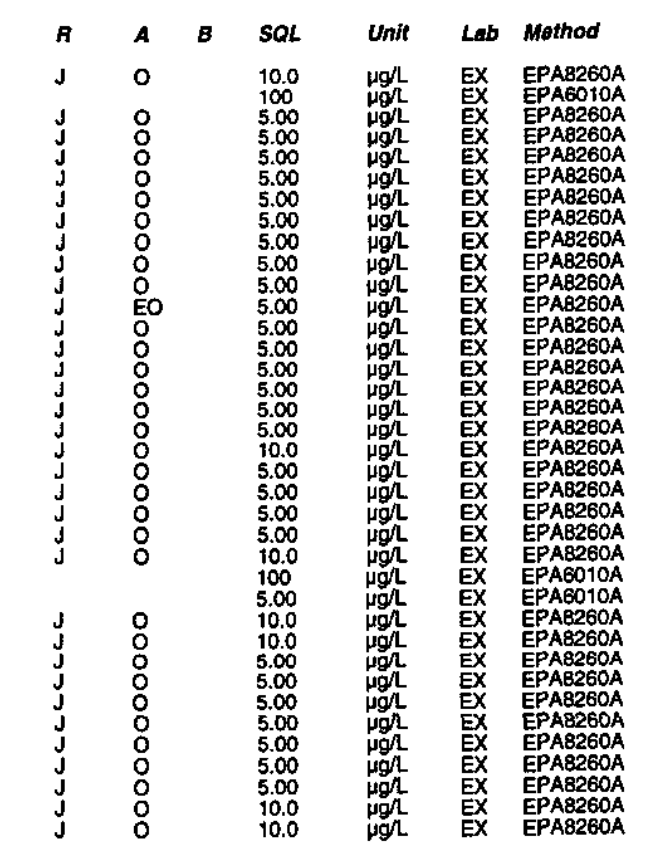

Time: 12:26

Water temperature: $20.8^{\circ} \mathrm{C}$

Total alkalinity (as CaCo3): $3 \mathrm{mgh}$

Water evacuated from the well prior to sampling: 133 gal

ESH-EMS-980569
Well MCB 17B collected on 06/15/98 (cont.)

ANALYSES

$F$ Analye

$\begin{array}{ll}0 & \text { Acetone } \\ 2 & \text { Aluminum, total recoverable } \\ 0 \text { Arsenic, total recoverable }\end{array}$

Benzene

Bromodichl

Bromoform
Bromomethan

Carbon disutfide

Carbon tetrachloride

Chlorobenzene
Chloroethane

Chloroethene (Vinyl chloride)

Chlormethan

Dibromochloromethan

1,2-Dichloroethane

1,1-Dichloroethylene

1,2-Dichloropropan

cis-1,3-Dichloropropene

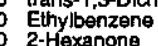

Iron, total recoverable

Methyl ethyl ketone

Solynium, total recoverable

Styrene

Tetrachloroethylene

1, Toluene

Trichloroethylene

Xylengs

WELL MCB 17B Replicate

\begin{tabular}{|c|}
\hline 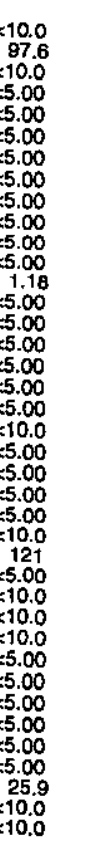 \\
\hline
\end{tabular}

$B$

SOL
10.0
100
10.0
5.00
5.00
5.00
5.00
5.00
5.00
5.00
5.00
5.00
5.00
5.00
5.00
5.00
5.00
5.00
5.00
10.0
5.00
5.00
5.00
5.00
10.0
100
5.00
10.0
10.0
10.0
5.00
5.00
5.00
5.00
5.00
5.00
5.00
10.0
10.0

MEASUREMENTS CONDUCTED IN THE FIELD

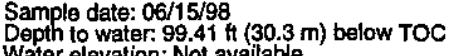

Water elo

Pp. conductance: $45 \mu \mathrm{S} / \mathrm{cm}$

Wurbidity: 2 NTU

ANALYSES

$F$ Analyte

0 Acetone
2 Aluminum, total recoverable
0 Arsenic, total recoverable

Benzene

Bromodichloro
Bromoform

Bromomethane

Carbon tetrachlorid

Chlorobenzene

Chloroethene (Vinyl chloside)

Chloroform

o Dibromochloromethane

o
0
0

1,1-Dichloroesthyne

1,2-Dichloroethylen

B-213

$\begin{array}{ll}\begin{array}{c}\text { Resuft } \\ <10.0\end{array} & \boldsymbol{A} \\ 78.5 & \mathbf{J} \\ <10.0 & \mathbf{J} \\ <5.0 & \mathbf{J} \\ <5.00 & \mathbf{J} \\ <5.00 & \mathbf{J} \\ <5.00 & \mathbf{J} \\ <5.00 & \mathbf{J} \\ <5.00 & \mathbf{J} \\ <5.00 & \mathbf{J} \\ <5.00 & \mathbf{J} \\ 1.0 & \mathbf{J} \\ <5.00 & \mathbf{J} \\ <5.00 & \mathbf{J} \\ <5.00 & \mathbf{J} \\ <5.00 & \mathbf{J} \\ <5.00 & \mathbf{J} \\ <5.00 & \mathbf{J} \\ <10.0 & \mathbf{J}\end{array}$

Time: 12:26

Wirter $20.8^{\circ} \mathrm{C}$

Total alkalinity (as CaCO3): $3 \mathrm{mgl}$

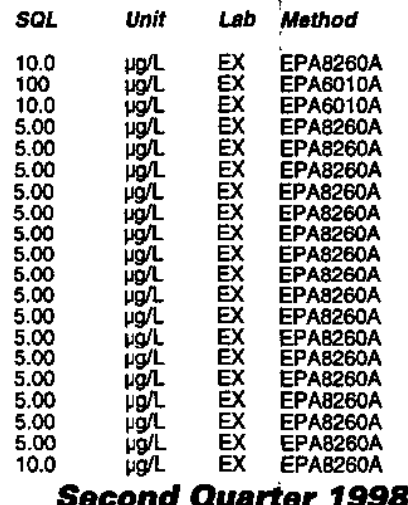

Socond Quarter 1998 
Well MCB 178 collected on 06/15/98 (cont.)

\begin{tabular}{|c|c|}
\hline & Analyte \\
\hline & 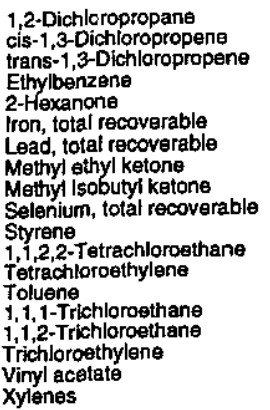 \\
\hline
\end{tabular}

Result
55.00
55.00
55.00
$<5.00$
$<10.0$
129
$<5.00$
$<10.0$
$<10.0$
$<10.0$
$<5.00$
$<5.00$
55.00
$<5.00$
$<5.00$
$<5.00$
24.6
$<10.0$
$<10.0$

\section{WELL MCB 18B}

MEASUREMENTS CONDUCTED IN THE FIELD

Sample date: 06/17/98

Water elevation: Not available
et: 5.9
Sp. conductance: $45 \mu \mathrm{S} / \mathrm{cm}$

Water evacuated from the well prior to sampling: $74 \mathrm{gal}$

ANALYSES

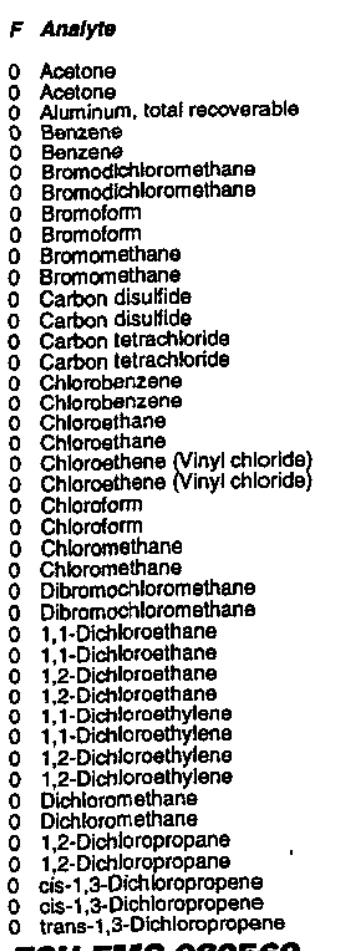

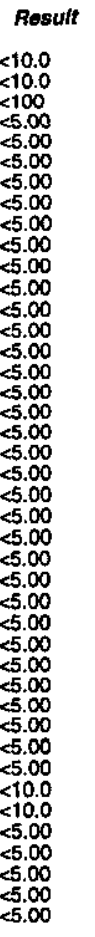

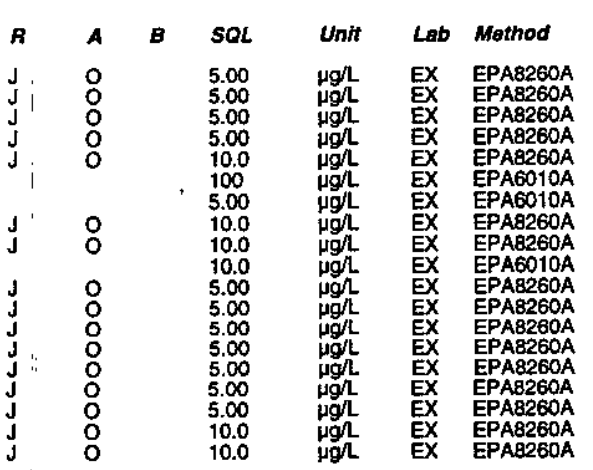

Time: 13:01

Wir temperature $333^{\circ} \mathrm{C}^{\circ} \mathrm{C}$

Arr termperature: 33 Caco3): $11 \mathrm{mg} / \mathrm{h}$

ESH-EMS-980569

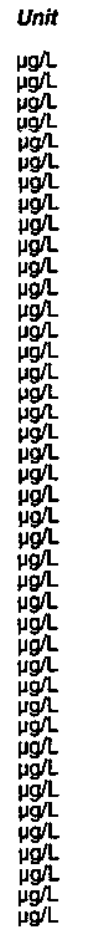

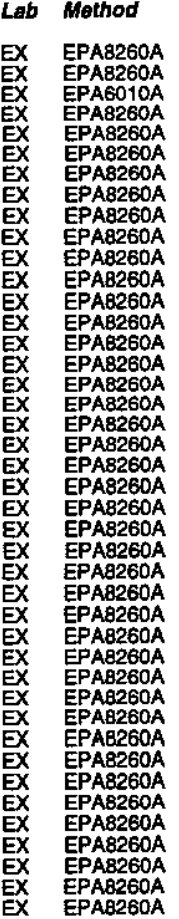

Well MCB $18 B$ collected on 06/17/98 (cont.)

$F$ Analyte

0 trans-1,3-Dichloropropene

(Ethylbenzente

2-Hexanone

o Lead, totai recoverable

Methyl ethyl ketone

Methyl isobutyl ketone

Styren

1,1,2,2-Tetrachlorosthan $\theta$
$1,1,2,2$-Tetracthoroethane

Tetrachloroethylen

Toluene

1,1,1-Trichloroethane

$1,1,2$-Trichloroethane

Trichloroethylene

Vinyl acetate

: Xylenes

\section{WELL MCB 238}

MEASUREMENTS CONDUCTED IN THE FIELD

Sample date: $05 / 06 / 98$ $\mathrm{ft}(50.98 \mathrm{~m})$ below TOC

Water

$\mathrm{Sp}$. conductance: $98 \mu \mathrm{S} / \mathrm{cm}$

Water evacuated from the well prior to sampling: 39 gal

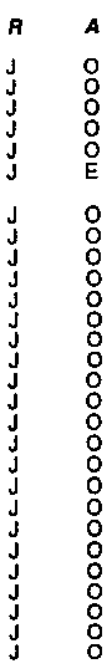

$s 0 L$
5.00
5.00
5.00
10.0
10.0
100
5.00
10.0
10.0
10.0
10.0
5.00
5.00
5.00
5.00
5.00
5.00
5.00
5.00
5.00
5.00
5.00
5.00
5.00
5.00
10.0
10.0
10.0
10.0

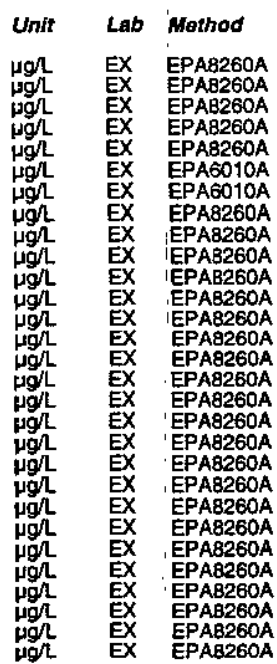

ANALYSES

$F$ Analyte

o Acetone

Bromodichloromethane

Bromomemethans

Carbon tetrachiorid

Chlorobenzen

Chloroethene (Vinyl chloride)

Chloroform

Dibromocthloromethane

1,2-Dichloroesthane

1,1-Dichloroethylene

Dichloromethane

cis-1,3-Dichloropropene
trans-1,3-Dichloropropene

Etyllbenzen

Methyl athyl ketonis

Styrene

Styrene
T, $1,2,2$-Tetrachloroethan
Totracthorethlen

Toluens

1, 1,2-Trichloroethane

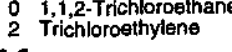

$-214$

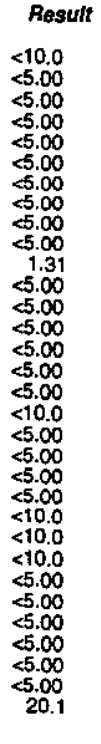

Time: 8:40

Air temperature: $16^{\circ} \mathrm{O}$

Total alkalinity (as CacO3): $31 \mathrm{mg} /$
Phenolphthalein alkalinity: 0 mgh

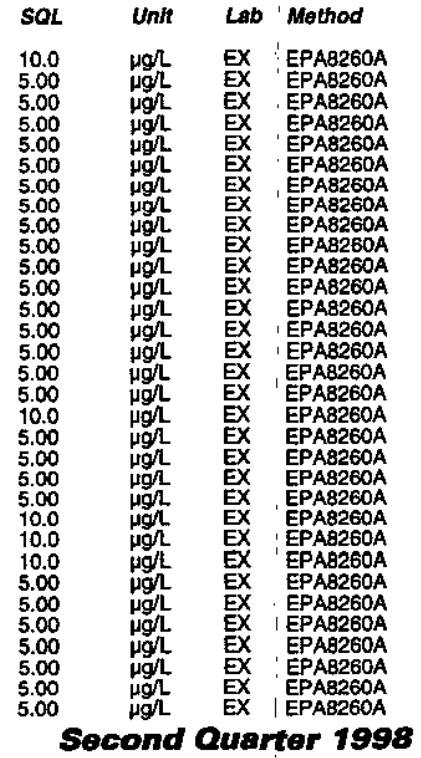


Well MCB 238 collected on 05/06/98 (cont.)

$F$ Analyte: Result

O Vinyl acétate $<10.0$

WELL MCB 23B Replicate

MEASUREMENTS CONDUCTED IN THE FIELD

Sample date: $05 / 06 / 98$ f $(50.98 \mathrm{~m})$ below TOC

Water el

:8.8

Sp. conductance: $98 \mu \mathrm{S} / \mathrm{cm}$

Turbicity: $273 \mathrm{NTU}$ Water evacuated from the well prior to sampling: $39 \mathrm{gal}$

ANALYSES

$F$ Analyte

O Acetone

Bromodichloromethane

Bromoform

Carbon disuffide

Chlorobenzen

Chloroethane (Vinyl chloride)

Chlorotorm

Dibromochloromethane

1,1-Dichloroethane

1, 1-Dichloroethylen

Dichloromethane

1,2-Dichloropropane

cis-1, - -Dichloropropene

Ethylbenzene
$2-$ Hexanone

Methyl ethyl ketone
Methyl isobutyl ketone

Styrene

Tetrachloroethylene

1,1,1-Trichloroethane

Trichlorioethylen

Xylenes

\section{WELL MCB 23B}

MEASUREMENTS CONDUCTED IN THE FIELD

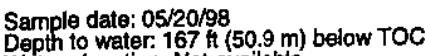

Water slevation: Not available

pH: 8.9

. conductance: $100 \mu \mathrm{S} / \mathrm{cm}$

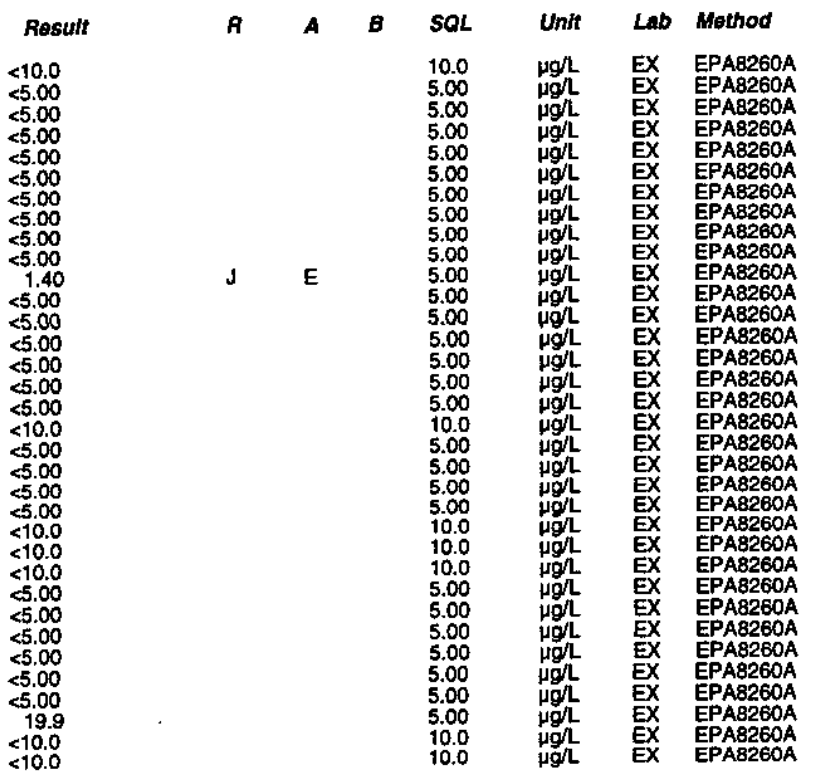

Time: 8:40

Wir temperature: $16^{\circ} \mathrm{C}$

Total alkahinity (as Cacos); $31 \mathrm{mg} \Omega$
Phenolphthalein alkalinity: $0 \mathrm{mg} /$

Water evacuated from the well prior to sampling: $44 \mathrm{gal}$

ANALYSES

Anstyte

Aluminum, total recoverable

Benzene
Bromodichioromethane

Bromomethan

ESH-EMS-980569

$\begin{array}{ll}10.0 & \mu g h \\ 100 & \mu g h \\ 100 & \mu g h \\ 5.00 & \mu g h \\ 5.00 & \mu g h \\ 5.0 & \mu g h \\ 5.00 & \mu g h\end{array}$

EX EPAB260A
Well MCB $23 B$ collected on 05/20/98 (cont.)

$F$ Analyto

$\therefore$ Carbon disultide

Chlorobenzene

O Chloroethene (Vinyl chloride)

Chloroform

Dibromochloromethane

1,1-Dichloroethane

i, -Dichloroethylene

Dichloromethan

cis-1,3-Dichloropropene
trans-1,3-Dichloropropene

2-Hexanone

2 Iron, total recoverable

Lead, total recoverabl

- Lead, total recoverabte

O Lead, tolat racoverab

Methyl isobutyl ketone

1tyrene

Toluene

1,i,2-Trichloroethan

Vinyl acetate

0 Xylenes

\section{WELL MCB 25B}

MEASUREMENTS CONDUCTED IN THE FIELD

Sample date: $05 / 07 / 98$
Depth to water: $110 \mathrm{tt}(33.53 \mathrm{~m})$ below TOC

Water elevation: Not available

p. conductance: $48 \mu \mathrm{S} / \mathrm{cm}$

Water evacuated from the well prior to sampling: $191 \mathrm{gal}$

ANALYSES

$F$ Analyto

: Acetone

Bromodichioromethane

Bromotom

Carbon tetrachlorid

Chlorobenzente

Chloroethene (Vinyl chloride)

Chlorotorm

o Chloromethane

1,1-Dichtoroesthane

1.2-Dichlorosthane

1,1-Dicichloroethylen

1,2-Dichloropropan

cis-1,3-Dichloropropene

Ethylbenzene

2-Hexanone

0 Methyl ethyl ketone
0

3-215

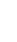

Resuft
510.0
55.00
55.00
55.00
55.00
55.00
55.00
55.00
55.00
55.00
55.00
55.00
55.00
55.00
55.00
55.00
55.00
51.0
55.00
55.00
55.00
55.00
510.0
51.0
51.00
55.00

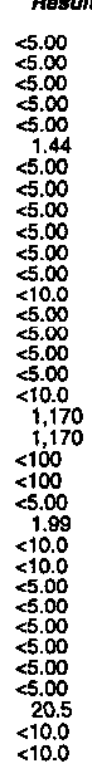

sal

Unit Lab Mothod

5.00 이 EX EPAB260A

5.00
5.00
5.00
5.00
5.00
5.00
5.00
5.00
5.00
5.00
10.0
5.00
5.00
5.00
5.00
100
100
100
100
5.00
5.00
10.0
10.0
5.00
5.00
5.00
5.00
5.00
5.00
10.0
10.0

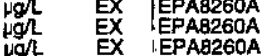

㩆

EX

EX EPAB26OA

EX EPA8260A

EX !

EX

EX EPA6010A

政

E E EAAB260A

EPA8260A
EPA260A

\section{Time: 12:37 \\ Water temperature: $16^{\circ} \mathrm{C}$ \\ Aro temperature: $19.2^{\circ} \mathrm{C}$ a $17 \mathrm{mg} / \mathrm{h}$}


ANALYTICAL RESULTS

Well MCB 25B collected on 05/07/98 (cont.)

$$
\begin{aligned}
& F \text { Analyte } \\
& \text { : 1,1,2,2-Tetractioroethane } \\
& \text { - Toluene } \\
& \text { 1,1,1-Trichloroethane } \\
& \text { 1,1,2-Trichloraeth } \\
& \text { O Vinyl acetate }
\end{aligned}
$$

\section{WELL MCB 25B}

MEASUREMENTS CONDUCTED IN THE FIELD

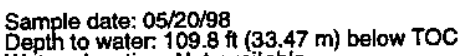
Water elevation: Not available

$\mathrm{pH}: 7.8$
$\mathrm{Sp}$. conductance: $66 \mu \mathrm{S} / \mathrm{cm}$

Water evacuated from the well prior to sampling: $140 \mathrm{gal}$

ANALYSES
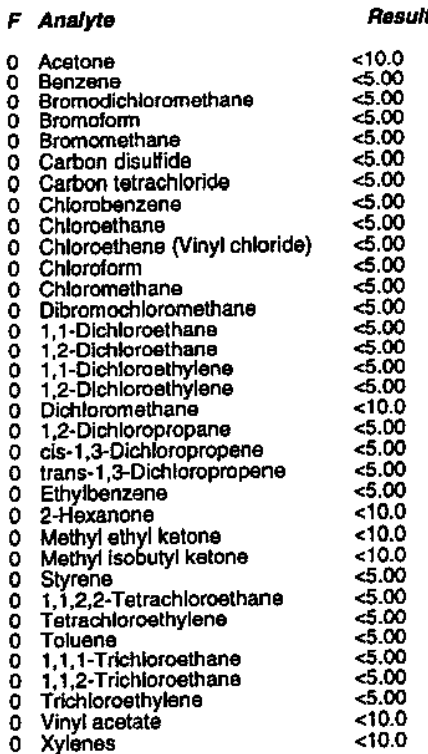

\section{WELL MCB 27B}

MEASUREMENTS CONDUCTED IN THE FIELD

Sample date: $05 / 06 / 98$
Depth to water: $69.95 \mathrm{ft}(21.32 \mathrm{~m}$ ) below TOC
Water elevation: Not available Water elevation: Not available
SH: 6.6 .
Spductance: $92 \mu \mathrm{S} / \mathrm{cm}$ Water evacuated from the well prior to sampling: 123 gal ANALYSES

$F$ Analyte Rosult $<10.0$

0 Acetono

ESH-EMS-980569
Well MCB 278 collected on 05/06/98 (cont.)

$F$ Analyte

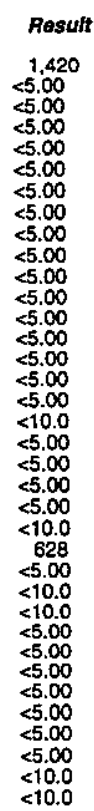

Time: $12: 39$. Air temperature: $19.5^{\circ} \mathrm{C}$
Total alkalinity (as Caco3): $30 \mathrm{mg} / \mathrm{L}$
Phenolphthalein alkalinity: $0 \mathrm{mg} / \mathrm{L}$

$\begin{array}{llll}5.00 & \mu g h & \text { EX } & \text { EPA8260A } \\ 5.00 & \mu g L & \text { EX } & \text { EPA260A } \\ 5.00 & \mu g h & \text { EX } & \text { EPA26260A } \\ 5.00 & \mu g h & \text { EX } & \text { EPA260A } \\ 5.00 & \mu g h & \text { EX } & \text { EPAB260A } \\ 5.00 & \mu g h & \text { EX } & \text { EPA26260A } \\ 10.0 & \mu g h & \text { EX } & \text { EPA8260A } \\ 10.0 & \mu g L & \text { EX } & \text { EPA8260A }\end{array}$

Aluminum, total recoverable

Bromodichloromethane

Bromomethan

0 Carbon disuffide

- Carbon tetrachloride

: Chlorobenzent

Chloroethene (Vinyi chloride)

Chorotorm

Dibromochloromethane
1,1-Dichloroethane

1,2-Dichlorosthane

1,2-Dichloroethylen

1,2-Dichloropropane

trans-1,3-Dichloropropen

Ethylbenzene
$2 . H$ exanone

2 iron, total recoverable

Methyl ethyl ketone

Styrene -Tetrachloroethan

Tetrachloroethylen

1,1,1-Trichloroethane

Trichioroethylen

0
0
0

\section{WELL MCB 27B}

MEASUREMENTS CONDUCTED IN THE FIELD

Sample date: $05 / 22 / 98$
Depth to water: $69.75 \mathrm{ft}(21.26 \mathrm{~m})$ below TOC

$\mathrm{pH}: 6$

. conductance: $78 \mu \mathrm{S} / \mathrm{cm}$

Water evacuated from the well prior to sampling: $44 \mathrm{gal}$

ANALYSES

$F$ Analyte

Acetone

Bromodichloromethan

Bromoform

Carton disutidide

Carbon tetrachiorid

Chlorobenzene

Chloroethene (Vinyl chloride)

Time: 12:52

Chloroform

Air temperature: $21,7^{\circ} \mathrm{C}$
Total alkalinity (as Cacos); $28 \mathrm{mg} / \mathrm{L}$
Phenolphthalein alkalinity: $0 \mathrm{mg} / \mathrm{L}$

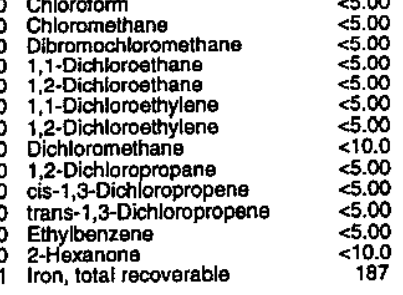

Resuft
$<10.0$
$<13$
213
$<5.00$
$<5.00$
$<5.00$
$<5.00$
$<5.00$
$<5.00$
$<5.00$
$<5.00$
$<5.00$
$<5.00$
$<5.00$
$<5.00$
$<5.00$
$<5.00$
$<5.00$
$<100$
$<5.0$
$<5.00$
$<5.00$
$<5.00$
$<100$
197

$\boldsymbol{B}$

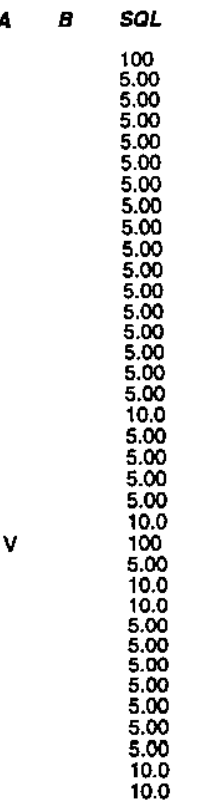

Time: 9:21

(a) $20.1^{\circ} \mathrm{C}$

Total akalilinity (as CaCO3): $23 \mathrm{mg} /$
Phenolphthalein alkalinity: $0 \mathrm{mg} /$

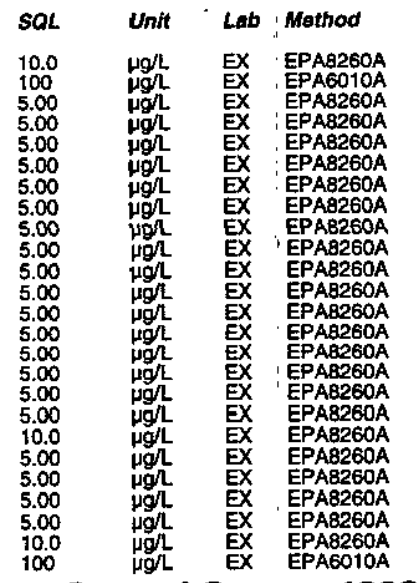

Second Quarter 1998 
ANALYTICAL RESULTS

Well MCB 278 collected on 05/22/98 (cont.)

\begin{tabular}{|c|c|c|c|c|c|c|c|c|}
\hline F Analyto & Result & $\boldsymbol{A}$ & A & $B$ & SOL & Unit & Lab & Mothod \\
\hline 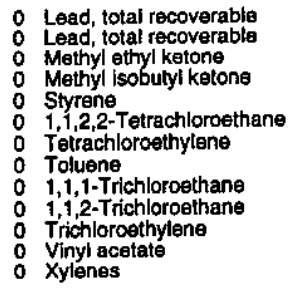 & $\begin{array}{l}2.87 \\
<100 \\
<1.0 \\
<10.0 \\
<5.00 \\
<5.00 \\
<5.00 \\
<5.00 \\
<5.00 \\
<5.00 \\
<5.00 \\
<10.0 \\
<10.0\end{array}$ & $\mathrm{~J}$ & $\mathrm{E}$ & & $\begin{array}{l}5.00 \\
100 \\
10.0 \\
10.0 \\
5.00 \\
5.00 \\
5.00 \\
5.00 \\
5.00 \\
5.00 \\
5.00 \\
10.0\end{array}$ & 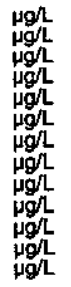 & $\begin{array}{l}\text { EX } \\
\text { EX } \\
\text { EX } \\
\text { EX } \\
\text { EX } \\
\text { EX } \\
\text { EX } \\
\text { EX } \\
\text { EX } \\
\text { EX } \\
\text { EX }\end{array}$ & $\begin{array}{l}\text { EPA6010A } \\
\text { EPAG010A } \\
\text { EPAB260A } \\
\text { EPAB260A } \\
\text { EPAB260A } \\
\text { PPAB260A } \\
\text { EPAB260A } \\
\text { EPAB260A } \\
\text { EPAB260A } \\
\text { EPAB260A } \\
\text { EPAB260A } \\
\text { EPAB260A } \\
\text { EPAB260A } \\
\text { EPAB260A }\end{array}$ \\
\hline
\end{tabular}

WELL MSB 74B

MEASUREMENTS CONDUCTED IN THE FIELD

Sample date: $06 / 16 / 98$. $31.75 \mathrm{~m}$ ) below TOC Water elevation: $210.35 \mathrm{ft}(64.12 \mathrm{~m}) \mathrm{ms}$

gH: 6

conductance: $29 \mu \mathrm{S} / \mathrm{cm}$

Water evacuated from the well prior to sampling: $132 \mathrm{gal}$

ANALYSES

\begin{tabular}{|c|c|}
\hline Analyte & Resun \\
\hline 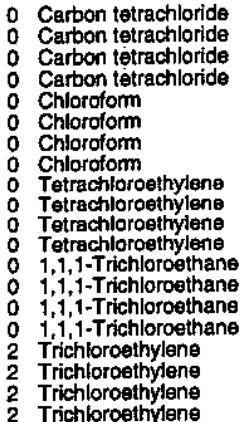 & $\begin{array}{l}<2.00 \\
<2.00 \\
<10.0 \\
<5.00 \\
<2.00 \\
<2.00 \\
<10.0 \\
<5.00 \\
2.00 \\
<.00 \\
<10.0 \\
<5.00 \\
<2.00 \\
<100 \\
<10.0 \\
<5.00 \\
67.3 \\
70.7 \\
10 . \\
97.5\end{array}$ \\
\hline
\end{tabular}

Trichloroethylene

WELL MSB 74B Replicate

MEASUREMENTS CONDUCTED IN THE FIELD

Sample date: 06/16/98 $\mathrm{fr}(31.75 \mathrm{~m})$ below TOC

Wath to water: $104.15 \mathrm{ft}(31.75 \mathrm{~m})$ below

gi: 6 . conductance: $29 \mu \mathrm{S} / \mathrm{cm}$

Turbodity 2 NTU
Water evacuated from the well prior to sampling: 132 gal

ANALYSES

$F$ Analyte

- Carbon tetrachloride

O Chloroform

Ietrachlorosthylene

: Tetrachloroethylene

o 1,1,1-Trichlorothan

2 Trichloroethylene

Resuft
$<10.0$
$<5.00$
$<10.0$
$<5.00$
$<10.0$
$<5.00$
$<10.0$
$<5.00$
799.3
99.3

ESH-EMS-980569

\section{WELL MSB 74C}

MEASUREMENTS CONDUCTED IN THE FIELD

Sample date: 06/16/98 $(31.76 \mathrm{~m})$ below TOC

Water elevation: $210.79 \mathrm{ft}(64.25 \mathrm{~m}) \mathrm{ms}$

PH: 6.7

conductance: $130 \mu \mathrm{S} / \mathrm{cm}$

Water evacuated from the well prior to sampling: $2 \mathrm{gal}$

ANALYSES

$\boldsymbol{F}$ Analyte

O Carbon tetrachloride

: Tetrachloroethylene

Time: 15:09

WELL P 26A

MEASUREMENTS CONDUCTED IN THE FIELD

Sample date: $05 / 12 / 98$
Depth to water. $32 \mathrm{tt}(9.75 \mathrm{~m})$ below TOC
Water elevation: 122 th $(37.19 \mathrm{~m}) \mathrm{msl}$

Water 6

: 5.4 conductance: $34 \mu \mathrm{S} / \mathrm{cm}$

Turbiditiy: 2 NTU
Water evacuated from the well prior to sampling: $150 \mathrm{gal}$ ANALYSES

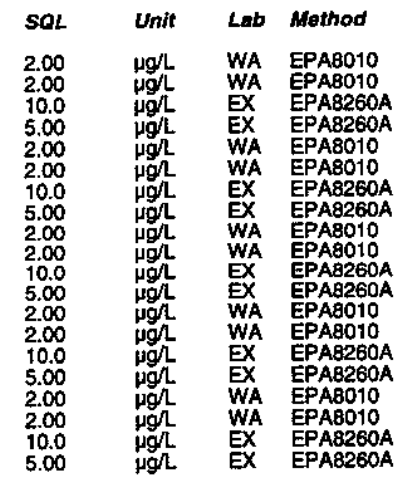

$F$ Analyte

A Aluminum, total racoverable

Carbon tetrachloride

Chlorotomm

Lead, total recoverable

Tetrachloroosthylen

1,1,1-Trichloroethane

Gross alph

WELL PBP 1D

MEASUREMENTS CONDUCTED IN THE FIELO

Sample date: 05/28/98

Depth to water: $25.95 \mathrm{ft}(7.91 \mathrm{~m})$ below TOC

$\mathrm{H}: 5.2$

Time: 15:09
Water temperature: $22.1^{\circ} \mathrm{C}$

Air temperature: $35.2{ }^{\circ} \mathrm{C}$ ) $5 \mathrm{mgh}$

Sp. conduc

urbidity: 0 NTU: $64 \mu \mathrm{S} / \mathrm{cm}$

Water evauated from the well prior to sampling: $28 \mathrm{gal}$

ANALYSES

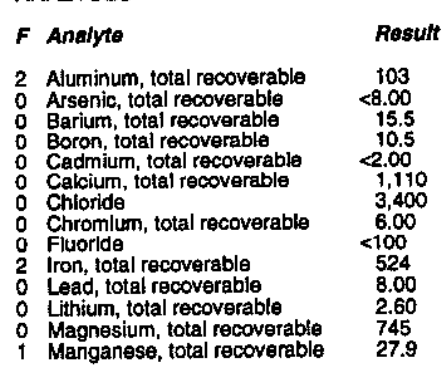

B-217

Result
$<5.00$
$<5.00$
$<5.00$
$<5.00$
76.0

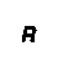

$<5.00$
$<5.00$
$<5.00$
$<5.00$
76.0

Result

$<0.005$

$<0.428$

937
55.00
$<0.200$
560.00
50.569

$2.390 \mathrm{E}-09 \pm 1.04 \mathrm{E}-09$

103
$<8.00$
15.5
10.5
$<2.00$
1.110
3.400
6.00
$<100$
524
8.00
2.60
745
27.9

Time: 14:15

Air temperature: $35.6^{\circ} \mathrm{C}$

Total allaining (as CaCO3): $32 \mathrm{mg} / \mathrm{L}$

\begin{tabular}{|c|c|c|c|}
\hline$S Q L$ & Unit & Lab & Method \\
\hline $\begin{array}{l}5.00 \\
5.00 \\
5.00 \\
5.00 \\
5.00\end{array}$ & $\begin{array}{l}\mu g / 2 \\
\mu g h \\
\mu g h \\
\mu g h\end{array}$ & $\begin{array}{l}\text { EX } \\
\text { EX } \\
\text { EX } \\
\text { EX } \\
\text { EX }\end{array}$ & $\begin{array}{l}\text { EPAB260A } \\
\text { EPA8260A } \\
\text { EPAB260A } \\
\text { EPA8260A } \\
\text { EPA8260A }\end{array}$ \\
\hline
\end{tabular}

Time: 13:07

Water temperature: $16^{\circ} \mathrm{C}$

Total akealinity (as CaCO3): $2 \mathrm{mg} / \mathrm{L}$

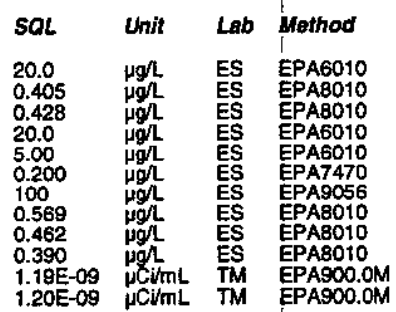

Time: 9:41

Water temperature: $21.4^{\circ} \mathrm{C}$

Total akalinity (as Caco3): $1 \mathrm{mg} /$
Phenolphthalein alkalinity: $0 \mathrm{mg} / \mathrm{L}$

Magnessium, total recoverab!
Manganese, total recoverable

30.0

Second Quarter 1998 
Well PBP 10 collected on 05/28/98 (cont.)

\begin{tabular}{|c|c|}
\hline & Anslyte \\
\hline & 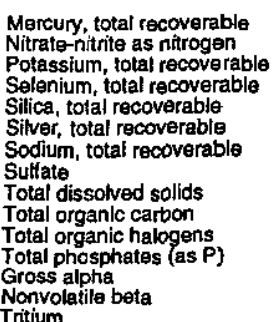 \\
\hline
\end{tabular}
Result 0.200
2,870
3,380 3,380
$<5,00$
2,690 2,690
+200
5.210 $<5,000$
58,000
7000 $<120$
$<10.0$ $2.03 E-09+7.60 \mathrm{E}-10$ $2.03 E-09 \pm 7.60 \mathrm{E}-10$
$3.21 \mathrm{E}-09 \pm 1.20 \mathrm{E}-00$
$6.94 \mathrm{E}-06 \pm 1.10 \mathrm{E}-06$

\section{WELL PBP 2D}

MEASUREMENTS CONDUCTED IN THE FIELD Sample date: 05/28/98 列 H: 4.9 Sp. conductance: $40 \mu \mathrm{S} / \mathrm{cm}$ Water evacuated from the well prior to sampling: 41 gal ANALYSES

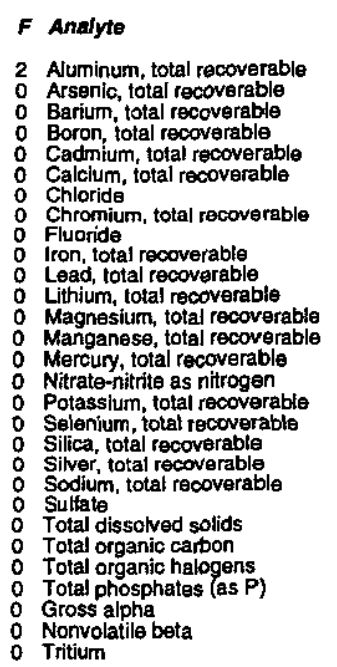

Result
67.5
$<8.00$
14.0
12.3
$<2.00$
470
3.880
$<3.00$
$<100$
7.20
$<5.00$
2.80
486
7.40
0.0500
1,190
2.390
$<5.00$
3.360
$<2.00$
3,180
55,000
50,000
500
$<120$
$<10.0$
$3.03 E-09+1.30 E-10$
$6.17-09 \pm 1.25 E-09$
$4.79 E-06 \pm 1.01 E-06$

WELL PBP 3D

MEASUREMENTS CONDUCTED IN THE FIELD

Sample date: $05 / 28 / 98$. Water elevation: $291.4 \mathrm{ft}(88.82 \mathrm{~m}) \mathrm{msl}$

$\mathrm{pH}: 4.8$

\begin{tabular}{|c|c|c|c|}
\hline & $n h t$ & Lab & Method \\
\hline $\begin{array}{l}0.200 \\
500 \\
400 \\
5.00 \\
100 \\
2.00 \\
100 \\
5,000 \\
1,000 \\
1,000 \\
120 \\
10.0 \\
9.006-10\end{array}$ & 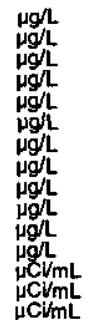 & $\begin{array}{l}\text { ES } \\
\text { ES } \\
\text { ES } \\
\text { ES } \\
\text { ES } \\
\text { ES } \\
\text { ES } \\
\text { ES } \\
\text { WS } \\
\text { WA } \\
\text { ES } \\
\text { TM }\end{array}$ & $\begin{array}{l}\text { EPA } \\
\text { EPA } \\
\text { EPAE } \\
\text { EPAE } \\
\text { EPAE } \\
\text { EPAE } \\
\text { EPAE } \\
\text { EPAS } \\
\text { EPA } \\
\text { EPAS } \\
\text { EPAS } \\
\text { EPAS } \\
\text { EPAS } \\
\text { EPAS } \\
\text { EPAS }\end{array}$ \\
\hline
\end{tabular}

Sp. conductance: $78 \mu \mathrm{s} / \mathrm{cm}$

Water evacuated from the well prior to sampling: $17 \mathrm{gal}$ ANALYSES

$F$ Analyte

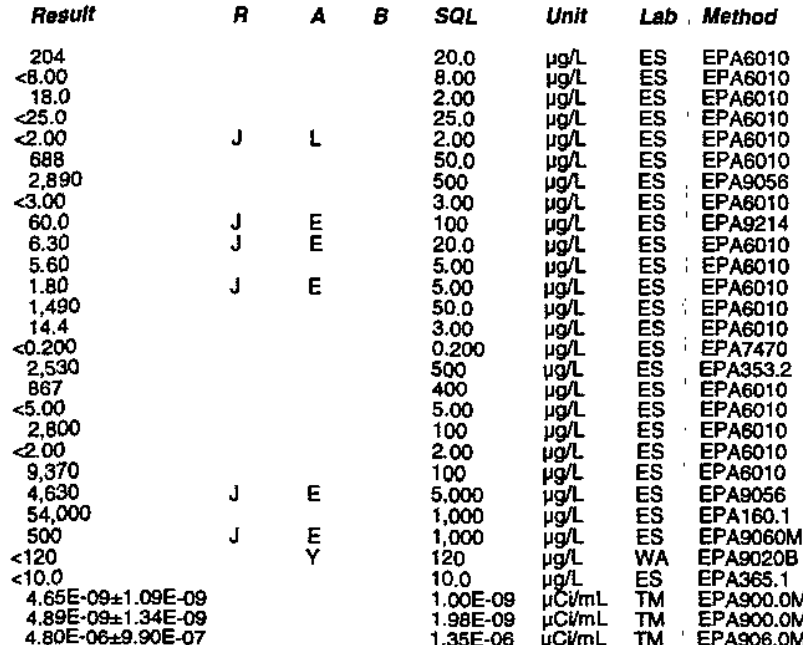

Time: 8:02

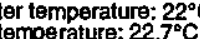

Total alkalinity (as CacO3): $0 \mathrm{mg} /$
Phenolphthalein alkalinity: $0 \mathrm{mgh}$

2 Aluminum, total recoverable

Barium, total recoverabla

Boron, total recoverable

Cadcium, total recoverable

Chloride

linon, total recoverable

Lead total recoverable

Magnesium, total recoverable

Manganese, total recoverab

Mitrate-nitrite as nitrogen

Selenium, total recoverab

Silica, total recoverable

Sodium, total recoverable

Total dissotved solids

o Total organic carbon

Total phosphates (as P)

Nonvolatile beta

\section{WELL PRP 1A}

Time: 8:30

作 $20.4^{\circ} \mathrm{C}$

Total alkalinity (as CaCO3): $0 \mathrm{mgh}$
Phenolphthalein alkalinity: $0 \mathrm{mg} \mathrm{L}$

MEASUREMENTS CONDUCTED IN THE FIELD

Sample date: 05/26/98

Wepth to water: $27.4 \mathrm{ft}(8.35 \mathrm{~m})$ below TOC

oH: 5.4

Sp. conductance: $32 \mu \mathrm{S} / \mathrm{cm}$

Wurbidity: 7 NTU 32 ,

ANALYSES

$F$ Analyto

Acenaphthene

Acenaphth
Acetone
Addrin

Aluminum, total recoverable Antimony, total recoverable Arsenic, total recoverable
Barium, total recoverable

alphia-Benzene hexacthlorido beta-Benzene hexachloride
detta-Benzzene hexachloride

Benzo(a) anthracene

Benzogb) fluoranthene

Benzoic acid

Benzo $(g, h, i)$ perylene
Time: 13:51

Water temperature: $21.1^{\circ} \mathrm{C}$

Air temperature: $36.5 \mathrm{C}$
Total alinity (as CaCo3): $3 \mathrm{mgh}$
Phenolphthaloin alkalinity: $0 \mathrm{mg}$.

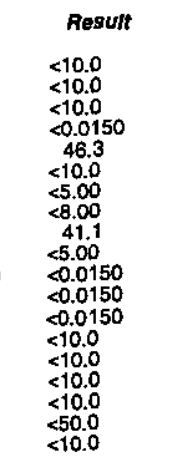
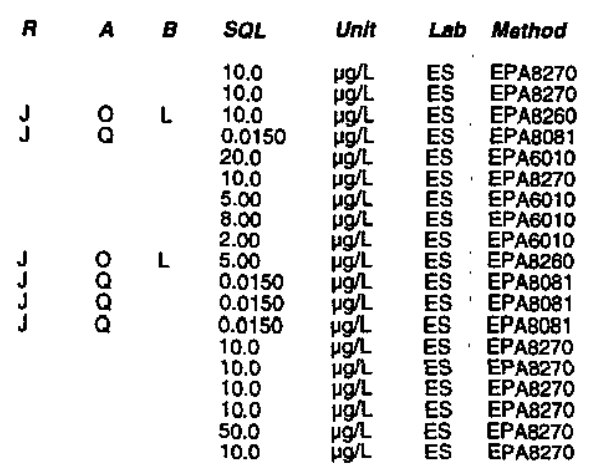

Second Quarter 1998

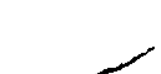


Well PRP 1 A collected on 05/26/98 (cont.)

\begin{tabular}{|c|c|c|c|c|c|c|c|}
\hline F Analyte & Resuft & A & $B$ & SOL & Unit & Lab & Mothod \\
\hline 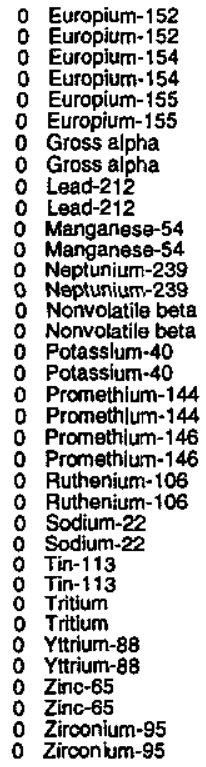 & 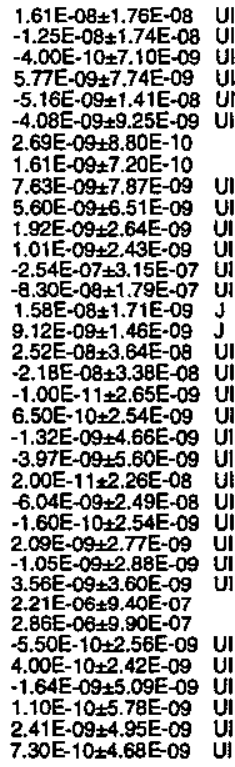 & $\begin{array}{l}x \\
x\end{array}$ & & $\begin{array}{l}3.65 E-08 \\
2.96 E-08 \\
1.33 E-08 \\
1.56 E-08 \\
2.29 E-08 \\
1.50 E-08 \\
8.50 E-10 \\
8.40 E-10 \\
6.36 E-09 \\
6.12 E-09 \\
4.90 E-09 \\
4.46 E-09 \\
5.00 E-07 \\
2.90 E-07 \\
1.79 E-09 \\
1.79 E-09 \\
4.82 E-08 \\
5.20 E-08 \\
4.46-09 \\
4.56 E-09 \\
8.12 E-09 \\
8.22 E-09 \\
4.00-08 \\
4.30 E-08 \\
4.76 E-09 \\
5.57 E-09 \\
5.00 E-09 \\
4.78 E-09 \\
1.46 E-06 \\
1.50 E-06 \\
4.75 E-09 \\
4.86 E-09 \\
8.58 E-09 \\
1.01 E-09 \\
8.34 E-09 \\
8.38 E-09\end{array}$ & 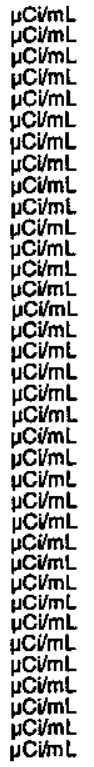 & $\begin{array}{l}T M \\
T M \\
T M \\
T M \\
T M \\
T M \\
T M \\
T M \\
T M \\
T M \\
T M \\
T M \\
T M \\
T M \\
T M \\
T M \\
T M \\
T M \\
T M \\
T M \\
T M \\
T M \\
T M \\
T M \\
T M \\
T M \\
T M \\
T M \\
T M \\
T M \\
T M \\
T M \\
T M \\
T M\end{array}$ & $\begin{array}{l}\text { EPA901.1M } \\
\text { EPA901.1M } \\
\text { EPA901.1M } \\
\text { EPA901.1M } \\
\text { EPA901.1M } \\
\text { EPA901.1M } \\
\text { EPA900.0M } \\
\text { EPA900.0M } \\
\text { EPA901.1M } \\
\text { EPA901.1M } \\
\text { EPA901.1M } \\
\text { EPA901.1M } \\
\text { EPA901.1M } \\
\text { EPA901.1M } \\
\text { EPA900.0M } \\
\text { EPA900.0M } \\
\text { EPA901.1M } \\
\text { EPA901.1M } \\
\text { EPA901.1M } \\
\text { EPA901.1M } \\
\text { EPA901.1M } \\
\text { EPA901.1M } \\
\text { EPA901.1M } \\
\text { EPA901.1M } \\
\text { EPA901.1M } \\
\text { EPA901.1M } \\
\text { EPA901.1M } \\
\text { EPA901.1M } \\
\text { EPA906. } \\
\text { EPA906. } \\
\text { EPA901.1M } \\
\text { EPA901.1M } \\
\text { EPA901.1M } \\
\text { EPA901.M } \\
\text { EPA901.1M } \\
\text { EPA901.1M }\end{array}$ \\
\hline
\end{tabular}

\section{WELL PRP 2}

MEASUREMENTS CONDUCTED IN THE FIELD

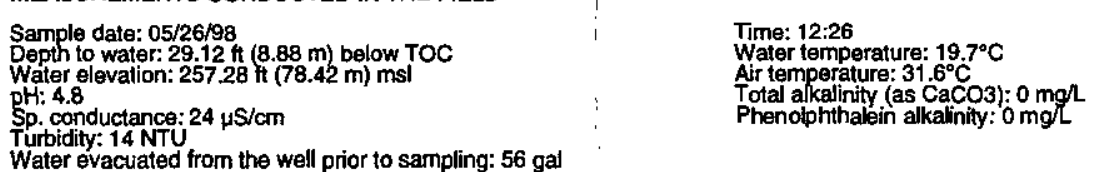

(2) well prior to sampling: 56 gat

ANALYSES

$F$ Analyto

: Acenaphthene

Acoton

2 Aluminum, total recoverable

: Anthracene

Arsenic, total recoverable
Barium, total recoverable

alpha-Berzene hexachloride beta-Benzene hexachloride defta-Benzene hexachlorid

Benzo(a) anthracene

Benzo(x) fluoranthen

Benzo(g,h,i)perylen

Bonzo(a)pyren
Benzyl alcohol

Beryllium, total recoverable

Bis(2-chloroethyl) ether

ESH-EMS-980569
Well PRP 2 collected on 05/26/98 (cont)

$F$ Analyte

Bis(2-ethylhexyl) phthalate
0 Bromodichloromethane

Bromotom

4-Bromophenyl phenyl ether Butylbenzyl phithalate

Calcium, total recoverable

Carbon disulfide

Chlordane

9amma-Chlordan

Chlorobenzene

Chloroethane

Chloroform

2-Chloronaphthalen

2-Chloropheno

4-Chlorophenyl phenyl ethe

Cobalt, total recoverable

Copper, total recoverable

o-Cresol (2-Methyyphenol)

$p, p=D D D$

P,P.DDT

Dibenz(a,h)anthracene

Dibromochloromethane

Di-n-butyl phthalate

1,2-Dichlorobenzene

3,4-Dichlorobenzene

1.2-Dlchloroethane

1,1-Dichloroesthylene

is-1,2-Dichloroethylene
trans-1,2-Dichloroethylens

Dichloromethane

1,2 -Dichloropropane

cis-1,3-Dichloropropene

Diethyl phthalate

2,4-Dimethyl pheno

2,4-Dinitrophenol

2,6-Dinitrotoluene
Di-n-octyl phthalate
Endosula

Endosulfan I

0 Endosulfan

Endrin aldehyde

Ethylbenzene

Fluorene

Heptachlor

Hexachlorobenzene
Hexachlorobutadiens

Hexachlorocyclopentadiene

Hexachloroe
2 -Hexanone

findeno( $1,2,3-c, d)$ pyrene

Result
$<1.0$
$<5.00$
$<5.00$
$<10.0$
$<10.0$
$<10.0$
$<.00$
722
$<5.00$
$<5.00$
0.0160
$<0.0150$
$<0.0150$
$<2.0$
$<5.00$
$<0.0$
$<10.0$
$<10.0$
$<5.00$
$<10.0$
$<10.0$
$<10.0$
$<10.0$
6.80
$<10.0$
$<5.00$
57.1
$<10.0$
$<10.0$
$<5.00$
$<0.0150$
$<0.0150$
$<0.0150$
$<10.0$
$<10.0$
$<5.00$
$<10.0$
$<10.0$
$<10.0$
$<10.0$
20.0
$<5.00$
$<5.00$
$<5.00$
$<5.00$
$<5.00$
$<5.00$
$<10.0$
$<5.00$
$<5.00$
$<5.00$
$<0.0150$
$<10.0$
$<10.0$
$<10.0$
$<50.0$
$<10.0$
$<10.0$
$<10.0$
$<0.0150$
$<0.0150$
$<0.0150$
$<0.0150$
$<0.0150$
$<0.0150$
$<5.00$
$<10.0$
$<10.0$
$<0.0150$
$<0.0150$
$<10.0$
$<10.0$
$<10.0$
$<10.0$
$<10.0$
$<10.0$
1.990
$<10.0$
100

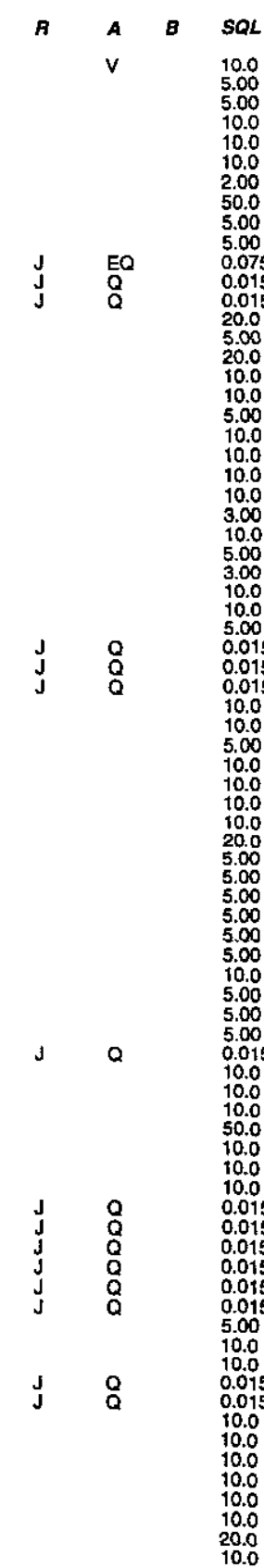

Unit Lab Mothod

10.0 Hg/ ES EPA8270

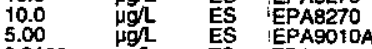


Well PRP 3 collected on 06/02/98 (cont).

\begin{tabular}{|c|c|}
\hline F Analyte & Result \\
\hline $\begin{array}{ll}0 & \text { Sodium-22 } \\
0 & \text { Soditum-22 } \\
0 & \text { Tin-113 } \\
0 & \text { Tin-113 } \\
0 & \text { Tritium } \\
0 & \text { Tritium } \\
0 & \text { Yttium } \\
0 & \text { Ytrum-88 } \\
0 & \text { Zintium-88 } \\
0 & \text { Zinc-65 } \\
0 & \text { Zinc-65 } \\
0 & \text { Zirconium-95 } \\
0 & \text { Zirconium-95 }\end{array}$ & 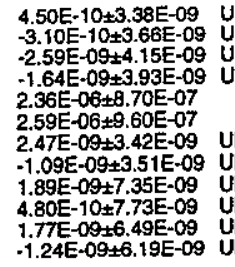 \\
\hline
\end{tabular}

WELL PRP 3

MEASUAEMENTS CONDUCTED IN THE FIELD

Sample date: $06 / 02 / 98$

Depth to water: Not available

Water elevation: Not available
pH: Not available
Sp. conductance: Not available

No water was evacuated from the well prior to sampling

ANALYSES

F Analyte

0 Acenaphthene

0 Acetone

Aldrin

Anthracena

Assenic, total recoverable

Benzzen

alpha-Benzene hexachloride deta-Benzene hexachlonide

Benzidine

Benzzolb fluoranthene

Benzoic acid

Benzo(g,h,i)peryten

Benzyl alcohol

Bis(2-chioroethoxy) methan

Bis 2-chloroethyl) ether
Bis 2-chloroisopropyl) ether

Bis(2-ethy fhexy) phthalate

Bromodichloromethane

Bromoform

Bromomethane

4-Bromophenyl phenyi ether

Cadmium total recoverab

Calcitum, total recoverablo

Carbon tetrachloride
Carbon tetractioride

Chlordane

gamma-Chlordan
4-Chloroaniline

Chlorobenzene

ESH-EMS-980569
Well PRP 3 collected on 06/02/98 (cont.)

$F$ Analyte

Result

6Ci/mL TM EPA901.1M

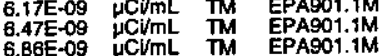

6.68E-09 $\mu \mathrm{C} / \mathrm{mL}$ TM EPA901.1M

$1.45 \mathrm{E}-06 \quad \mu \mathrm{C} / \mathrm{mL}$ TM $\mathrm{TM}$ EPA906.OM

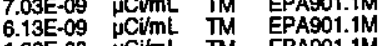

$1.33 E-08 \mu \mathrm{CimL}$ TM EPA901.1M

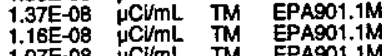

Chloroethene (Vinyl chloride)

O Chioroform

O Chloromethane

2-Chloronaphthalene

2-Chlorophenol
4-Chlorophenyl phenyl ether

Chrysente ral recoverable

Cobalt, total recoverable

$\mathrm{m} /$ p-Cresol
o-Cresol (2-Methylphenol)

P,p'-ODD

Time: Not available

Air temperature: Not available
Total akalinity (as CaCO3) Not available
Phenolphthalein alkalinity: Not available

p,p'-DDE

Dibenz(a, h)anthracene

Dibenzofuran

Dibromochloromethan

1,2-Dichlorobenzene

1.3.-Dichlicorobonzenzene
3,3'-Dlchlorobenzidine

2 3,3-Dichlorobenzidin

1,2-Dichloroethane

1,i-Dichloroethane

cis-1,2-Dichboroethylane

trans-1,2-Dichloroethylente

Dichloromethane

1,2 -Dichloropropane

1,2-1,chloropropane

trans-1,3-Dichloropropen

Dins-i, Dichloropropen

Diethyy phthalate

Dimethyl phthalate

2,4 -Dinitrotoluene
2,6 -Dinitrotoluene

Di-n-octyl phthalate

Endosulfan 1

Endosulfan

Endrin aldehyde

Endrin ketone

Ethybbenzene

. Fluorene

. Heptachlor

Hexachlorobutadiene

Hexachlorocyclopentadien

Hexachloroshan

2 - Hexanone

$\begin{array}{ll}0 & \text { Indeno(1,2,3-c,d)pyrene } \\ 2 & \text { Iron, total recoverable } \\ 0 & \text { Isophorone }\end{array}$

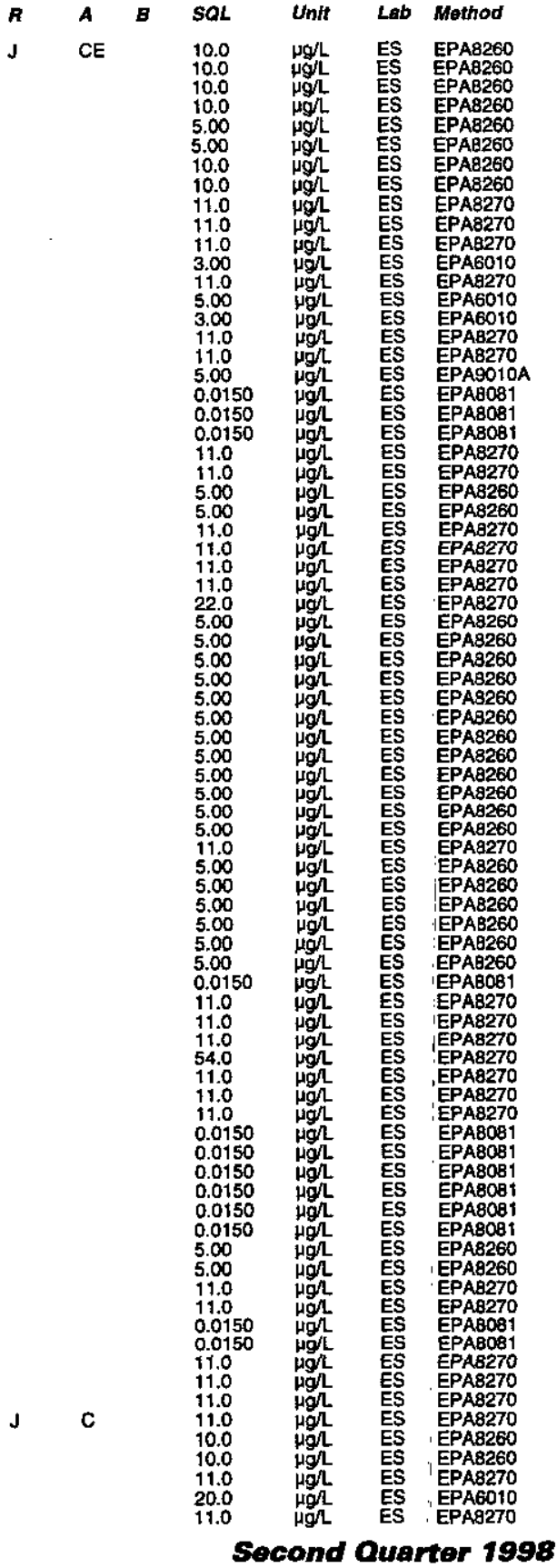


Well PRP 3 collectod on 06/02/98 (cont.)

\section{F Analyte}

Resuft

1 Lead, total recoverable Magnesium, total recoverable Manganese toral recoverab 2-Methyl-4,6-dinitrophenol

O Methy ethyl ketone

Methyl ethyl ketone

Methyl isobutyl ketone

Naphthalene
2 Nickel, tofal recoverable
m-Nitroaniline

o-Nitroanlline

2-Nitrophenenol

$\mathrm{N}$-Nitrosodiphenylamin

N-Nitrosodipropylamlne

PCB 1016
PCB 1221
PCB 1232

PCB 1242

PCB 1260

Pentachloropheno

Phenol

Potassium, total recoverabte

Syrene Silver, total recoverable

Styrene

1,1,2,2-Tetrachloroethane

Tetrachloroethylente

Thallium, total recoverable

Toluene

1,2,4-Trichlorobenzene 1,1,1-Trichloroethane

1,1,2-Trichloroethane

$1,1,2$. Trichloroethan
Trichloroethylene

Trichloroethylene

$2,4,6-$ Trichlorophenol
Vanadium, total recoverabit

Vinyl acetate

Xylenes
0 Xylenes
0 Zinc, total recoverable

\section{WELL PRP 4}

MEASUREMENTS CONDUCTED IN THE FIELD

Sample date: $05 / 29 / 98$
Depth to water. $24.76 \mathrm{ft}(7.55 \mathrm{~m})$ below TOC
Water elevation: $259.94 \mathrm{ft}(79.23 \mathrm{~m}) \mathrm{mst}$

$\mathrm{pH}$ : 4.2 conductance: $34 \mu \mathrm{S} / \mathrm{cm}$

Water evacuated from the well prior to sampling: 70 al

ANALYSES

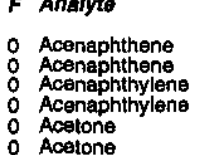

Aldrin

Aluminum, total recoverab

2 Aluminum,

Anthracene

Antimony, total recoverable

Arsenic, total recoverable

Arsenic, total recoverab

Barium, total recoverabs

Benzene
Benzene

alpha-Benzene hexachloride

beta-Benzene hexachloride

beta-Benzene hexachloride

delta-Benzene hexachlorid

Benzidine anthracene

Benzo a anthracene

Benzogbiffluoranthen

Benzo (ky)tuoranthene
. Benzo(k) fluoranthene

Benzoic acid

Benzodg, hi, perylene

Benzo(a)pyrene

Benzo(a)pyrene

Benzyl alcohol

Beryllium, total recoverable

Beryllim, total recoverable

Bis 2-chloroethoxy) methane

Biss 2-chloroethyn ether

Bis 2-chloraisopropyl) ether

Bis (2-ethylhexyl) phthalate

Bis(2-athylhexyl) phthalate

Bromodichloromethane

Bromoform

Bromomethane

4-Bromophenyl phenyl ether 4-Bromophenyy phenyl eth Butybenzyl phithalate
Butylbenzyl phthalate

coverablo Cadmium, total recoverabla Calcium, total recov

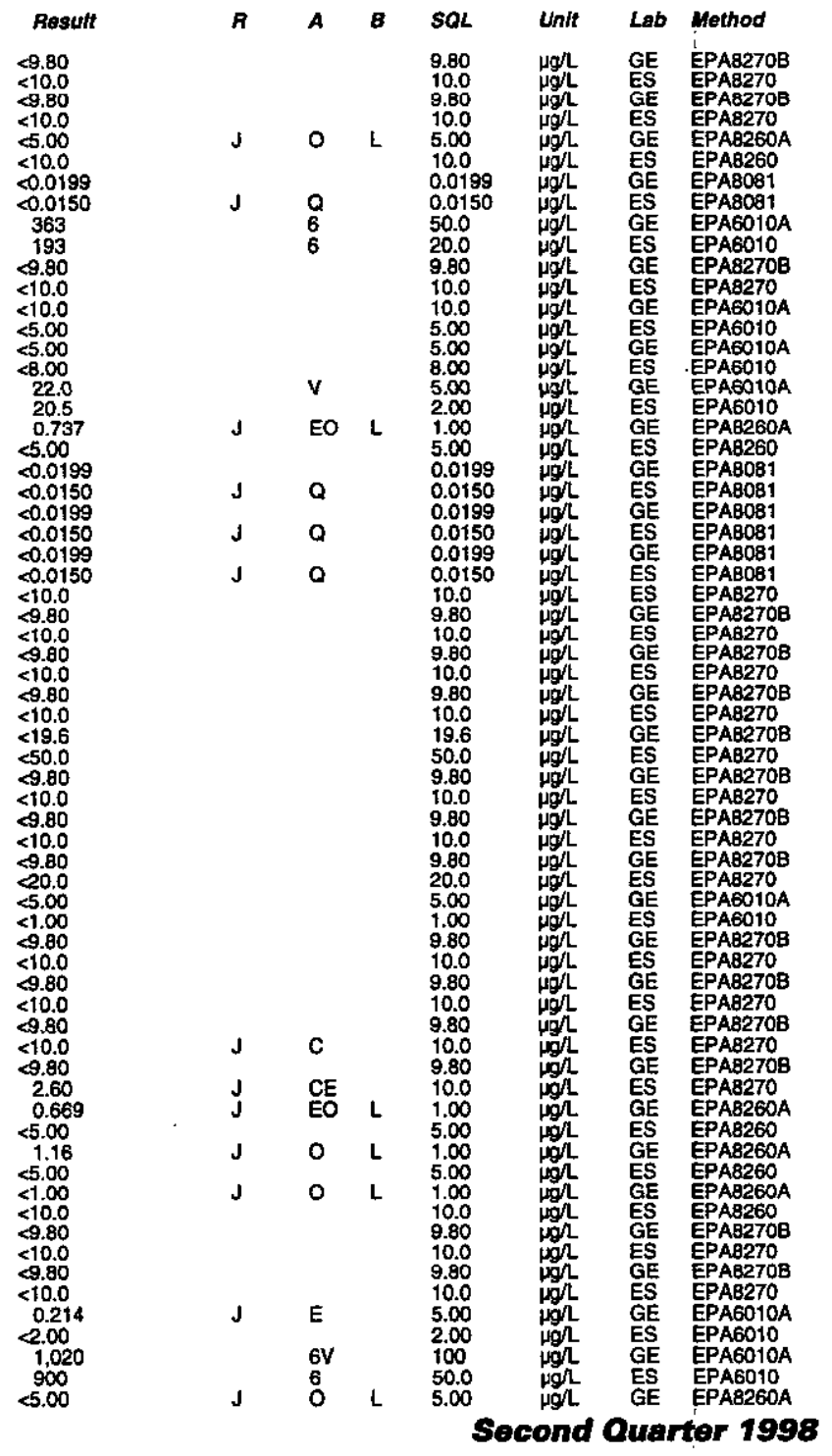

Time: 8:07

rature: $19.5^{\circ} \mathrm{C}$

Total akkalinity (as CaCO3): $0 \mathrm{mg} / \mathrm{L}$

phan 


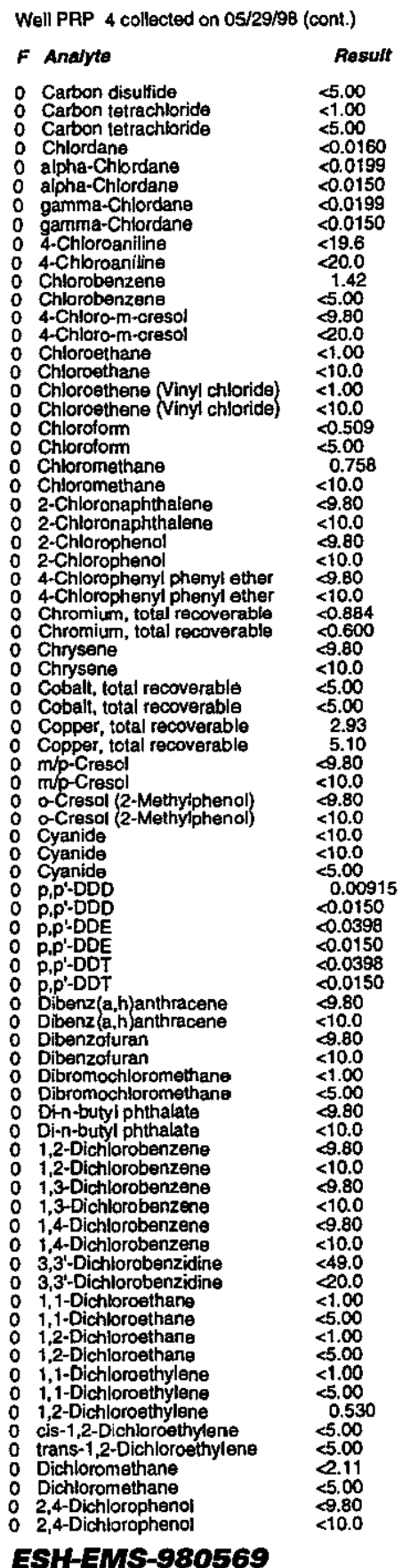

Well PRP 4 collected on 05/29/98 (cont.)

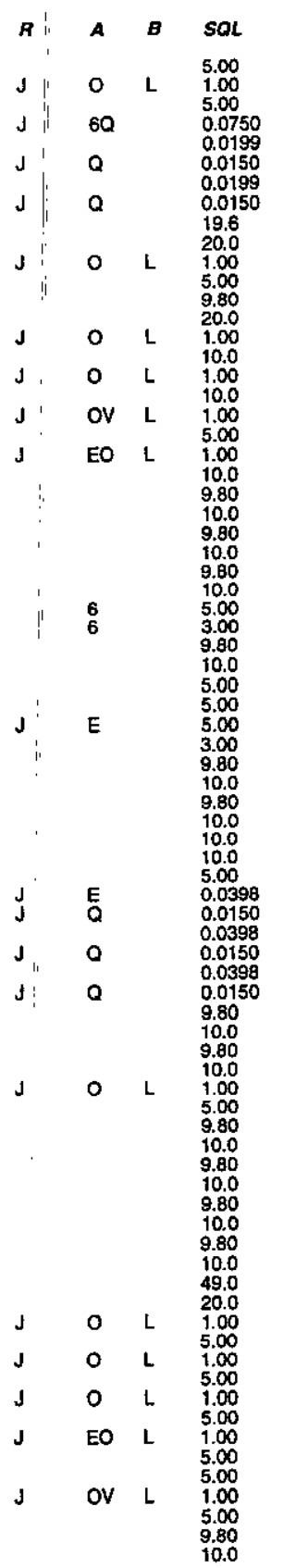

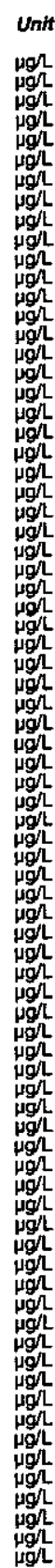

$F$ Analyte

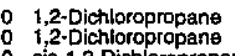

o cis-1, 3-Dichloroppopopene

trans-1,3-Dichloropropen

0 Dieldrin

Diethyl phthalate

2,4-Dimethy| phenol

Dimethyl phthalate

2,4-Dinitrophend

$2,4-D i n$
$2,4-D i n$
0

$2,4-$ Dinitrotoluene
$2,6-$ Dinitrotoluene

2,6-Dinitrotoluene

Dir-octy phthatate

Endosulian sulfate

Endosulfan

Endosulfan

Endrin

Endrin aldehyde

Endrin ketone

$\therefore$ Ethylbenzene

Fiuoranth

Fluorene

Heptactior
Heptachlor

Meptachlor epoxide

Hexachlorobenzene

Hexachborobutiadiene

Hexachlorocyclopentadiene

Hexachlorocyclopen
Hexachloroethane

Hexachibroethan

2-Hexanone

indeno( $(1,2,3-c, d)$ pyrene

isophorone

Lead, total recoverable

Lindane

Magnesium, total recoverable Magnesium, total recoverable

Manganese, total recoverab

Mercury, total recoverabi

Methoxychlor

2-Methyl-4,6-dinitrophenol
2-Methyl-4,6-dinitrophenol

Methyl ethyl ketone

Methyl ethyl ketone

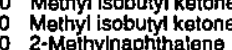

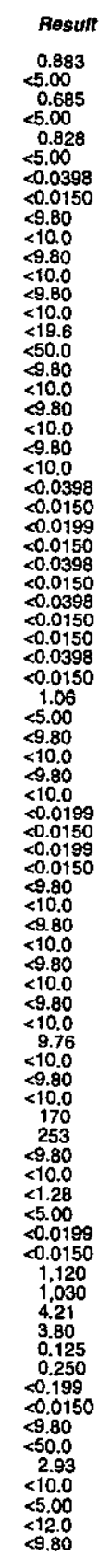

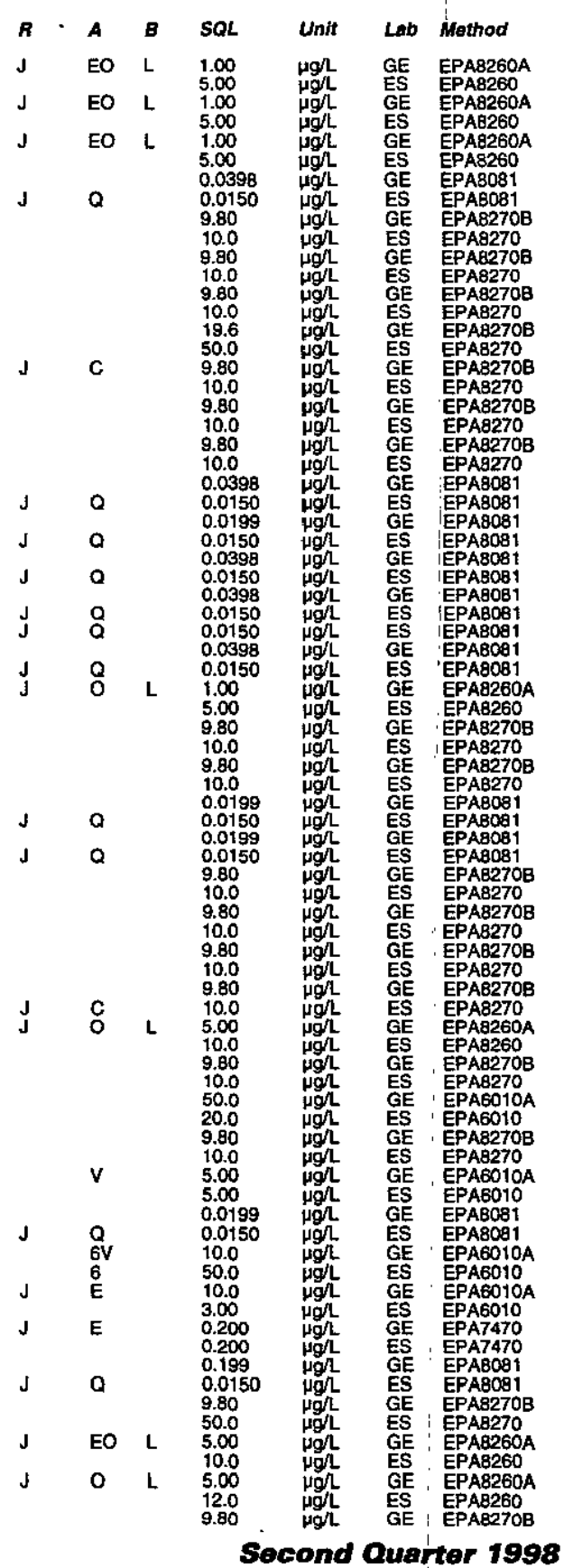


Well PRP 4 coilected on 05/29/98 (cont.)

$F$ Analyte

2-Methylnaph

Naphthalaphe $<10.0$

Nickel, total recoverable

m-Nitroaniline

o-Nitroanitin

ONAtroaniline
p-Nitroanliline

p-Nitroanilin

Nitrobenzenzene

2-Nitrophene

4 Nitrophanol

N-Nitrosodiphenylamine

N-Nitrosodiphenylamine

0
0 PCB 1016

PCB 1221

: $P C B 1221$

: PCB 1242

PCB 1248

PCB 1254
0

$P C B 1260$

Pentachlorophenol

Phenanthrene

Pheno

Potassium, total recoverabl

Syelenilum, total recoverable

Sitver, total recovarable

Silver, total recoverablo

Sodium, total recoverable

o Styrena

$1,1,2,2$-Tetrachlorosthane

Tetrachloroethylene

Tetrachloroethylene

Thallium, total recoverable

Toluene

Total organic halogens

Toxaphene

1,2,4-Trichlorobenzene

1,1,1-Trichloroethane

i., 1 - Trichloroethane

Trichloroethylene

2,4,5-Irichlorophenol
2,4,5-Jrichlorophenol

2,4,6-Trichlorophenol

Vanadium, total recoverabrable

ESH-EMS-980569
Well PRP 4 collected on 05/29/98 (cont.)

$F$ Analyto

Result

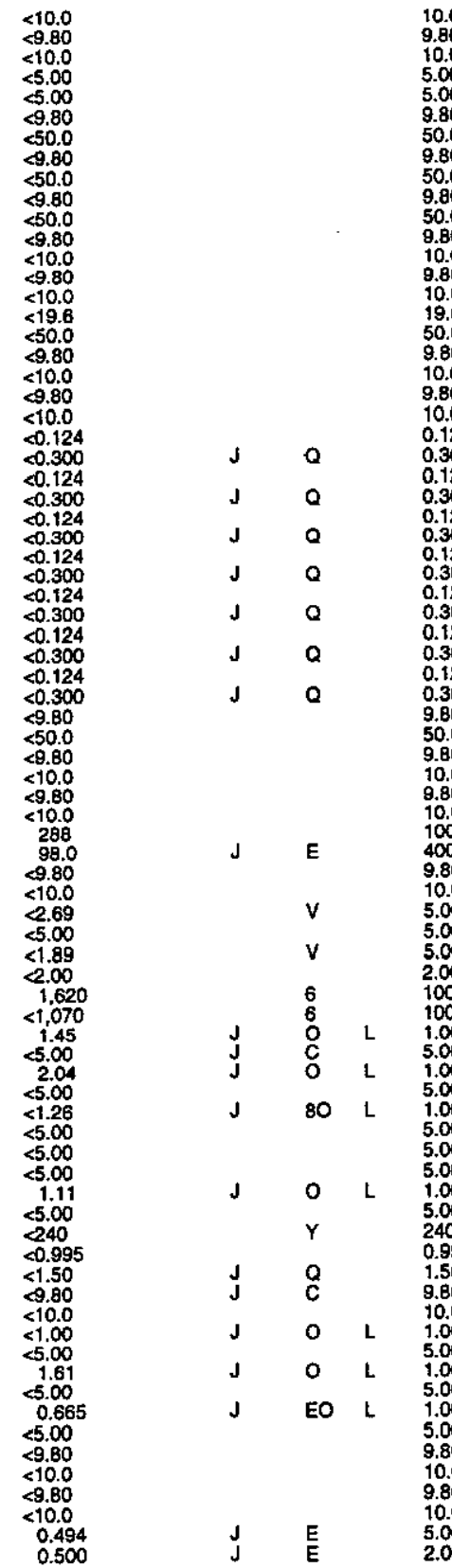

10.0
9.80
10.0
5.00
5.00
9.80
50.0
9.80
50.0
9.80
50.0
9.80
10.0
9.80
10.0
19.6
50.0
9.80
10.0
9.80
10.0
0.124
0.300
0.124
0.300
0.124
0.300
0.144
0.300
0.124
0.300
0.124
0.300
0.124
0.300
9.80
50.0
9.80
10.0
9.80
10.0
100
400
9.80
10.0
5.00
5.00
5.00
2.00
100
100
1.00
5.00
1.00
5.00
1.00
5.00
5.00
5.00
1.00
5.00
240
0.995
1.50
9.80
10.0
1.00
5.00
1.00
5.00
1.00
5.00
9.80
10.0
9.80
10.0
5.00
2.00
10

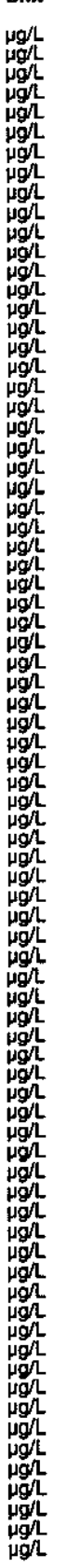

Lab Mothod

Vinyl acetate

Xylenes

Zinc, total recoverable

Actirium-228

Actinium-228

Actinium-228

Antrmony-124

Antimony-125
Antimony-125
Antimony-125

Antimony -125

Barium-133

0
0

Cerium-144

Cesium-134

Cessum-134

Cesium-137

Cesium-137

0 Cobalt-57

Cobalt-57

0 Cobalt-58

0 Cobalt-60

Cobalt-60

Europium-152
0 Europium-152
0 Europium-152
0 Europium-152
0

Europium-154

Europium-154

Europium-155

Europium-155

Gross alph

Gross alpha

Lead-212

0 Lead-212

Manganese-54

0 Manganese-54

- Manganese-54

Noptunium-239

Nonvolatilie beta

Nonvolatilie beta

Potassium-40

Potassium-40

Promethium-144

B-225

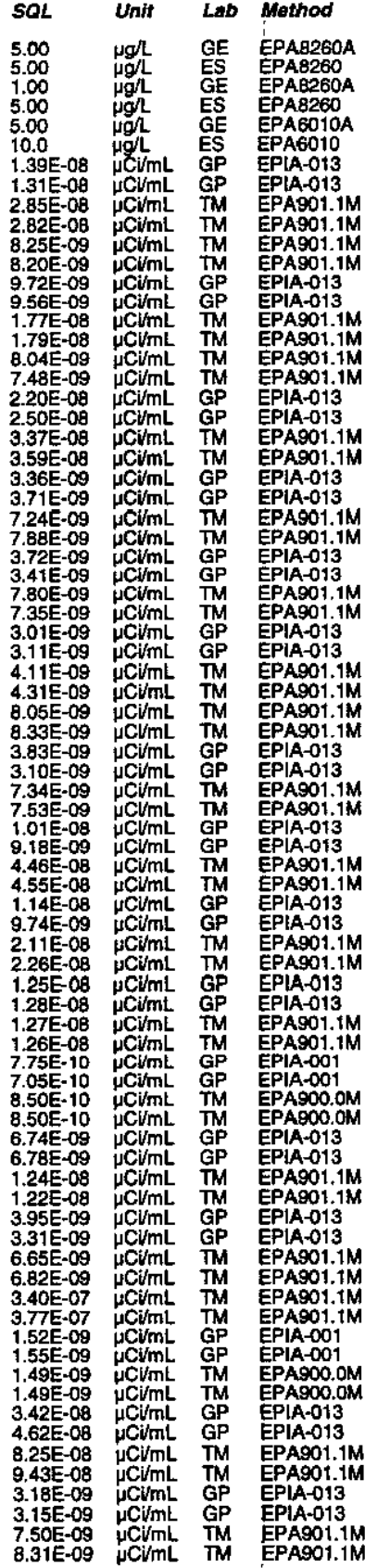

Second Quarter 1998 
ANALYTICAL RESULTS

Well PRP 4 callected on 05/29/98 (cont)

\begin{tabular}{|c|c|}
\hline F Anelyte & Result \\
\hline 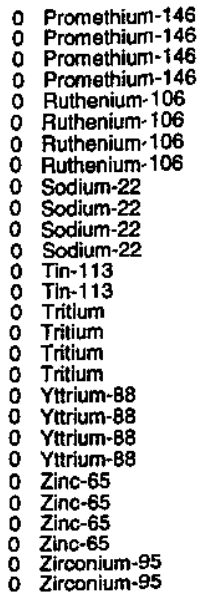 & 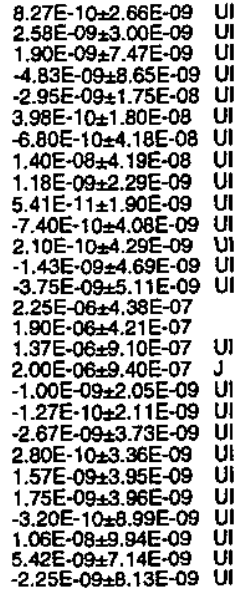 \\
\hline
\end{tabular}

\section{WELL PRP 4 Replicate}

MEASUREMENTS CONDUCTED IN THE FIELD

Sample date: $05 / 29 / 98$
Deppth to water: $24.76 \mathrm{ft}(7.55 \mathrm{~m})$ below TOC
Water elevation: $259.94 \mathrm{ft}(79.23 \mathrm{~m}) \mathrm{msl}$

g p. 4.2 conductance: $34 \mu \mathrm{S} / \mathrm{cm}$

Sp.conductance: $34 \mu \mathrm{S} / \mathrm{cm}$
Watidity: $3 \mathrm{NTU}$
Water ovacuated from the well prior to sampling: $70 \mathrm{gal}$ |:

ANALYSES

$F$ Analyte

O Acenaphthene

Acetone

2 Aluminum, total recoverable

- Atthracene

Arsenic, total recoverable

alpha-Benzene hexachloride

beta-Benzene hexachloride

Eenzidine

O Benzo(a)ganthracene

Benzo(k) fluorar

Benzofg,h,i)perylen

Benzyl alcohol

Beryllium, total recoverable

Bis 2-chlopothyl) other

Biss 2-chloroisopropyl) ether
Bis(2-ethylhexyly) phithalat

Bromoform

4 4-Bromophenyl phenyl ether

O Butylbenzy l phthalate

ESH-EMS-980569

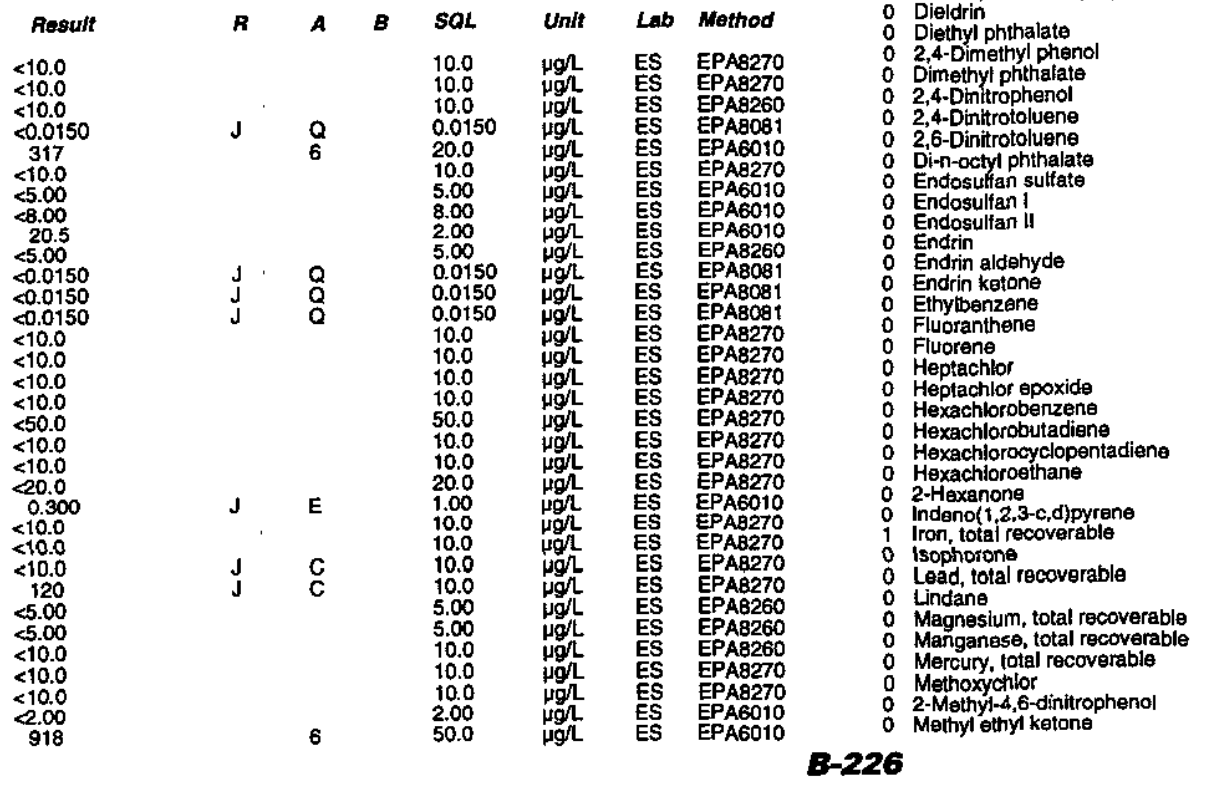

Well PRP 4 collected on 05/29/98 (cont)

$F$ Analyte

Result

\begin{tabular}{|c|c|c|c|}
\hline SOL & Unit & Lab & Method \\
\hline 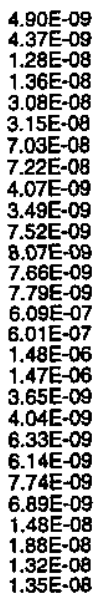 & 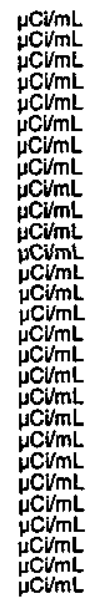 & $\begin{array}{l}G P \\
G P \\
G M \\
T M \\
G P \\
G P \\
G M \\
T M \\
T M \\
G P \\
G P \\
T M \\
T M \\
T M \\
T M \\
G P \\
G P \\
T M \\
T M \\
G P \\
G P \\
T M \\
T M \\
G P \\
G P \\
M M \\
T M \\
T M \\
T M\end{array}$ & 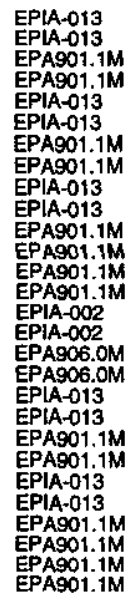 \\
\hline
\end{tabular}

Time: 8:07

Water temperature: $19.5^{\circ} \mathrm{C}$

Total alkalinity (as CaCO3): $0 \mathrm{mg}$

0 Carbon disulfide

o Chlordane

o gamma-Chiordan

0 Chlorobenzene

0 Chloroethane

Chloroethene

Chlorotorm

2-Chloronaphthalen

4-Chlorophenyl phenyl ethe

Cobalt, total recoverable

Copper, total recoverable

Cyanide

P, , '-DDD

Bpi-DDT

Dibenzofuran

Di-n-butyl phthalate

1,3-Dichlorobenzene

1,4-Dichtorobenzene

$1,1-$ Dichloroethane
t.2-Dichloroethane

trans-1,2-Dichloroettylen

2,4-Dichlorophenol

1,2-Dichloropropane

cis-1,3-Dichloropropene

Diethyl phthalate

Di-n-octyl phithalate

coverable

se, total recoverable

2-Methyl-d,6-dinitrophen

B-226

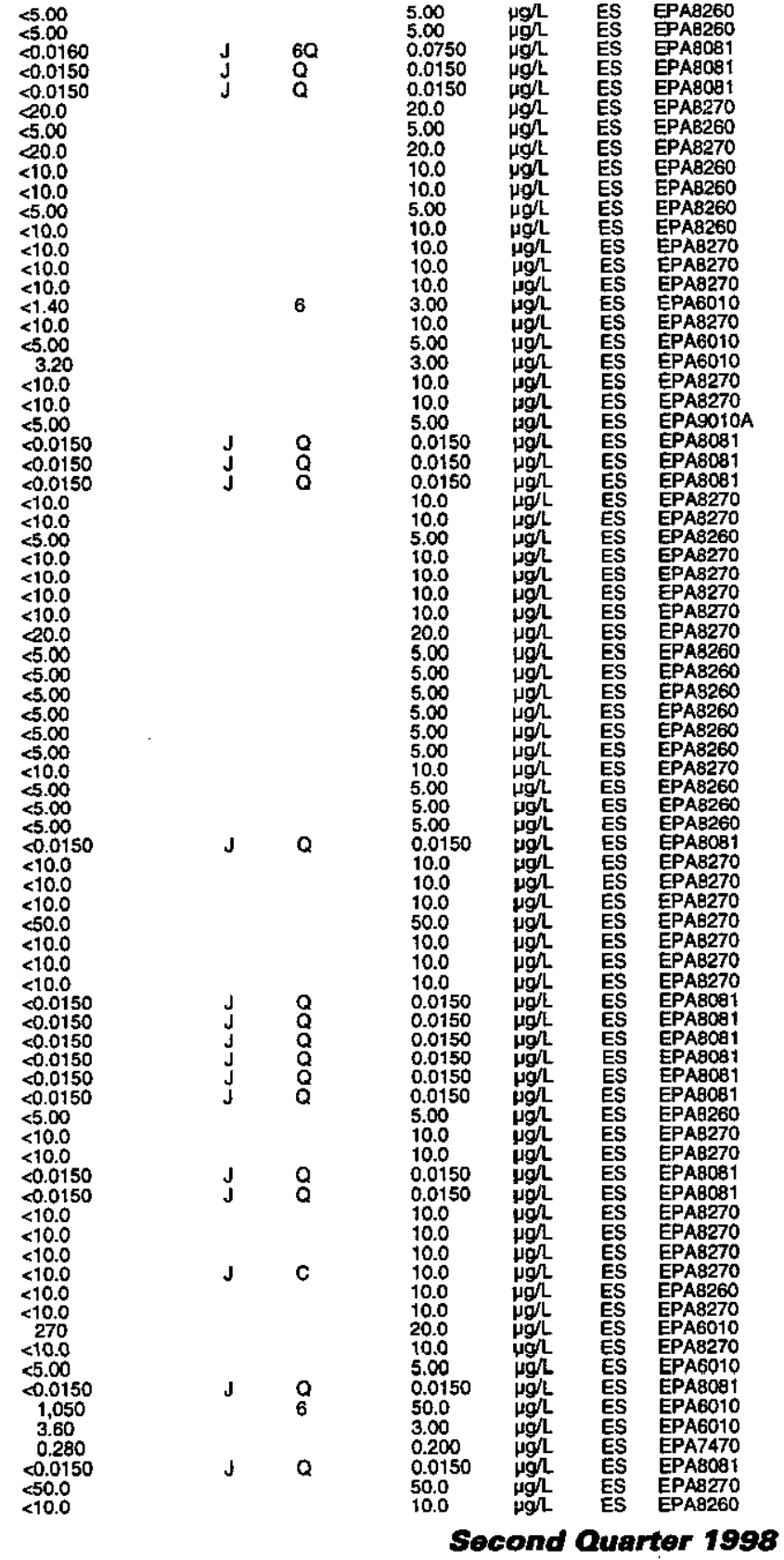


Well PRP 4 collected on 05/29/98 (cont.)

\begin{tabular}{|c|c|c|c|c|c|c|c|c|}
\hline Analyte & Result & A & $A$ & & SQL & Unit & Lab & Method \\
\hline 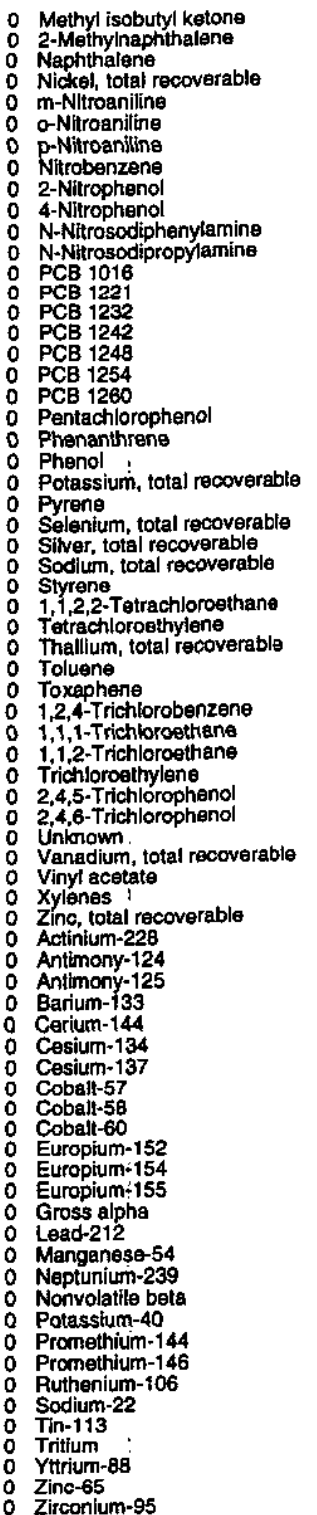 & 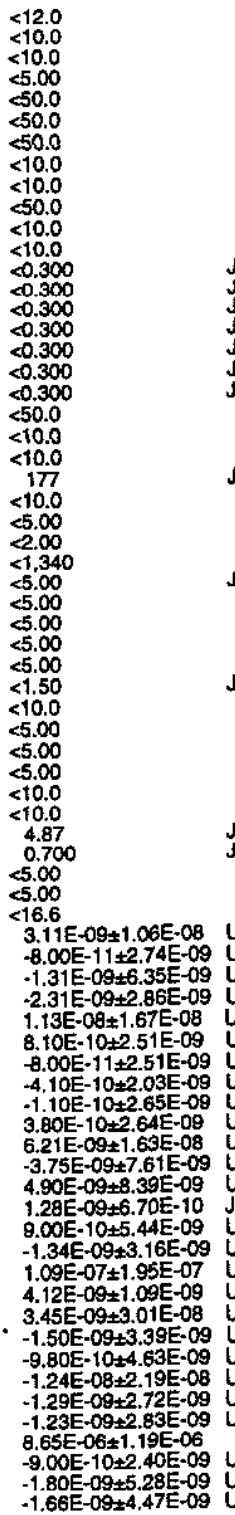 & a & $\begin{array}{l}0 \\
0 \\
Q \\
0 \\
0 \\
0 \\
0\end{array}$ & & $\begin{array}{l}2.00 \\
5.00 \\
5.00 \\
10.0 \\
1.77 \mathrm{E}-08 \\
4.11 \mathrm{E}-09 \\
1.11 \mathrm{E}-08 \\
4.76 \mathrm{E}-09 \\
2.82 \mathrm{E}-08 \\
4.50 \mathrm{E}-09 \\
4.43 \mathrm{E}-09 \\
3.32 \mathrm{E}-09 \\
4.18 \mathrm{E}-09 \\
4.73 \mathrm{E}-09 \\
3.25 \mathrm{E}-08 \\
1.35 \mathrm{E}-08 \\
1.33 \mathrm{E}-08 \\
8.60 \mathrm{E}-10 \\
6.09 \mathrm{E}-09 \\
4.64 \mathrm{E}-09 \\
3.30 \mathrm{E}-07 \\
1.49 \mathrm{E}-09 \\
5.27 \mathrm{E}-08 \\
4.50 \mathrm{E}-09 \\
8.11 \mathrm{E}-09 \\
3.68 \mathrm{E}-08 \\
4.83 \mathrm{E}-09 \\
4.89 \mathrm{E}-09 \\
1.45 \mathrm{E}-06 \\
4.17 \mathrm{E}-09 \\
8.66 \mathrm{E}-09 \\
7.61 \mathrm{E}-09\end{array}$ & 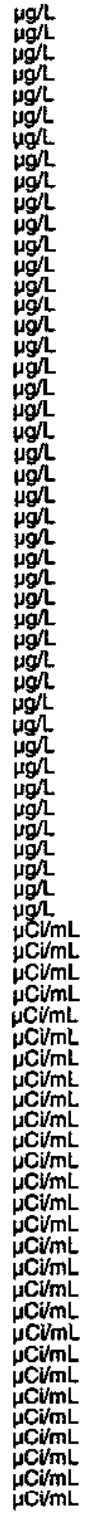 & 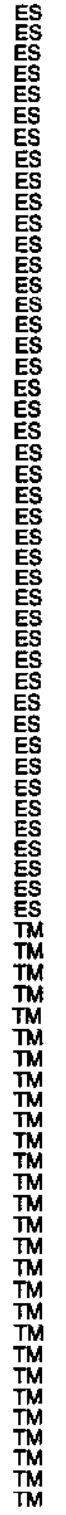 & 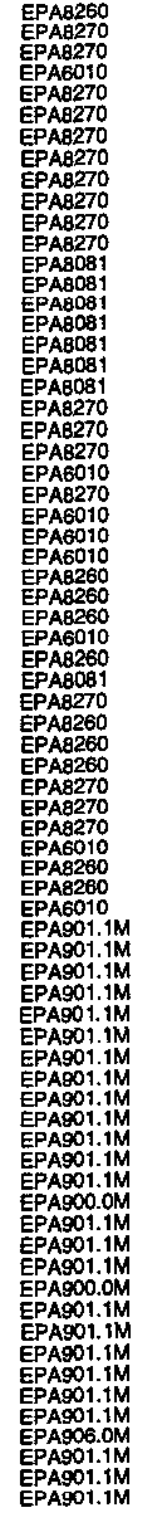 \\
\hline
\end{tabular}

WELL PRP 5

MEASUAEMENTS CONDUCTED IN THE FIELD

Sample date: $05 / 11 / 98$. Water elevation: Not availa
$\mathrm{H}: 6.1$ Sp. conductance: $57 \mu \mathrm{S} / \mathrm{cm}$

Water evacuated from the well prior to sampling: $35 \mathrm{gal}$

Time: $8: 20$ Tater temperature: $18.5^{\circ} \mathrm{C}$

ANALYSES

F Analyte

: Acenaphthene

Aluminum, total recoverabb

0 Antimony, total recoverable

Arsenic, total recoverable

Benzene

a-Benzene hexachloride beta-Benzene hexachloride
delta-Benzene hexachloride

Benzo(a)anthracene

Benzo(b) fluoranthene
Benzo(k)fluoranthene

Benzoic acid

Benzo(a)pyrene

Benzyl alicohol

Beryllium, total recoverable
Bis (2-ctloroethoxy) methan

Bis(2-chloroethyl) ether

Bis
Bis(2-ethylhexpl) phthalate

Bromodom
Bromomethane

Bromomethane
4-Bromophenyl phenyl ether

Butylbenzyl pifthalate

Calcium, total recoverable

Carbon disulfider

Chlordane

gamma-Chlordane

4-Chloroaniline

4-Chloro-m-cresol

Chloroethane (Vinyl chloride)

Chloroform

2-Chomethane

2-Chlorophenol

4-Chlorophenyl phenyl ether

Chominn,

Cobalt, total recoverable

copporisol recovrablo

o-Cresol (2-Methylphenol)

O Cyanide

p,p'-DDE

Dibenz\{a,h)anthracene

Dibromochlor

Dibromochloromethan

1,2-Dichlorobenzene

1.4-Dichlorobenzene

B-227

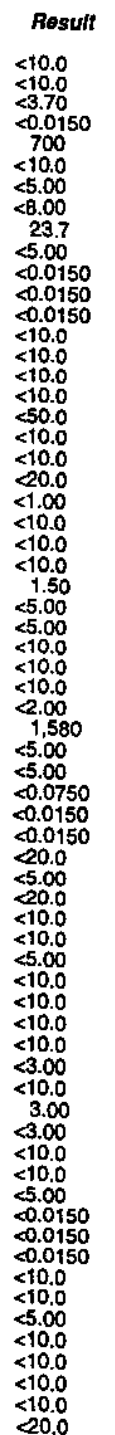

A $B$

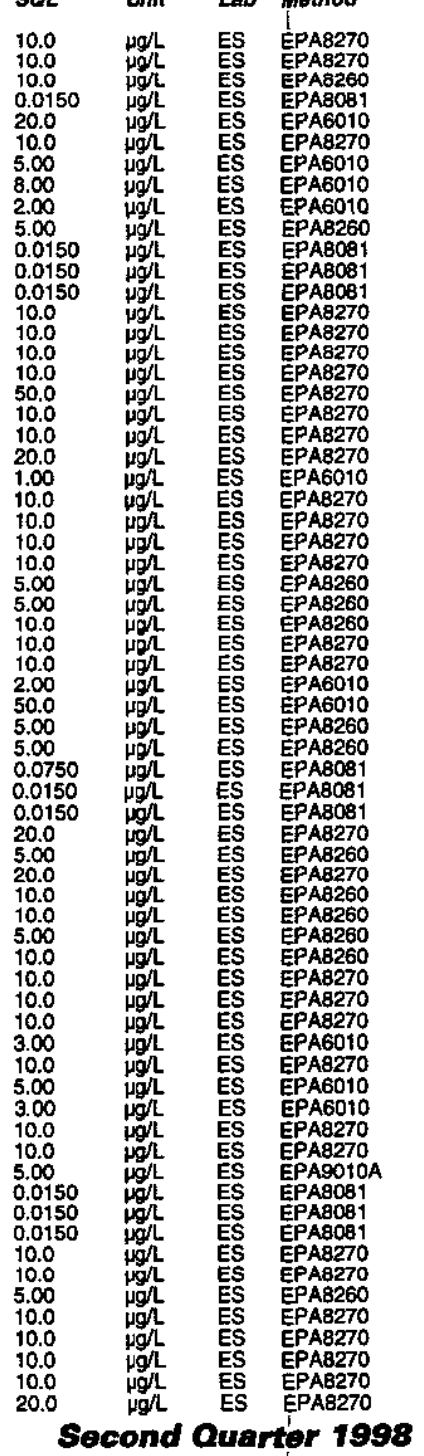


Well PRP 5 collected on 05/11/98 (cont.)

$F$ Analyte

0 1,1-Dichloroethan 1,2-Dichloroesthane cis-1,2-Dichloroethylene trans-1,2-Dichloro
Dichloromethane 2,4-Dichlorophenol 1,2-Dichloropropane trans-1,3-Dichlopropene Diethy phthalate 2,4-Dimethyl phernol 2,4-Dinitrophenol
2,4-Dinitrotoluene 2,6-Dinitrotoluene Endosuffan sulfate Endosulfan I

Endrin

Endrin aldehyde

Ethylbanzene

Fluorene

- Heptachlor epoxide

Hexachlorobutadiene

Hexachlorocyclopentadiene

2-Hexanone

Indeno(1,2,3-c,d)pyren

Isophorone

Lindane

Manganese, total recovererable

Mercury, total recoverable

2-Methyl-4,6-dinitropheno

Methyl ethyl ketone

2-Methylnaphthalen

Nickel, total recoverable

m-Nitroaniline

p-Nitroaniline

Nitrobenzene

N-Nitrosodiphenylamine

PCB 1221

PCB 1232

0 PCB 1248

Pentachlorophen

Phenanthrene

Potassium, total recoverable

Syrenium, total recoverable

Sodium, total recoverable

Styrene

Tetrachloroethylene

0 Toluene

ESH-EMS-980569

\begin{tabular}{|c|}
\hline 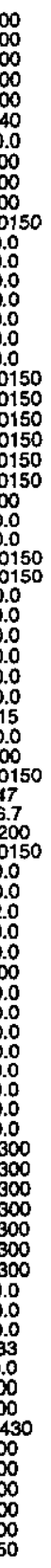 \\
\hline
\end{tabular}

$50 L$
5.00
5.00
5.00
5.00
5.00
5.00
10.0
5.0
5.00
5.00
0.0150
10.0
10.0
10.0
50.0
10.0
10.0
10.0
0.0150
0.0150
0.0150
0.0150
0.0150
0.0150
5.00
10.0
10.0
0.0150
0.0150
10.0
10.0
10.0
10.0
10.0
10.0
20.0
10.0
5.00
0.0150
50.0
3.00
0.00
0.0150
50.0
10.0
12.0
10.0
10.0
5.00
50.0
50.0
50.0
10.0
10.0
50.0
10.0
10.0
0.300
0.00
0.300
0.300
0.300
0.300
0.300
50.0
10.0
10.0
400
10.0
5.00
2.00
100
5.0
5.00
5.00
5.00
5.00
1.50
0

Well PRP 5 collected on 05/11/98 (cont.)

$F$ Analyte Result

$\begin{array}{ll}0 & 1,2,4-\text { Trichlorobenzene } \\ 0 & 1,1,1-\text { Trichloroetthane } \\ 0 & 1,1,2-T \text { richloroethane }\end{array}$

: 1,1,2-Trichloroethan

$\begin{array}{lll}0 & 2,4,5 \text {-Trichlorophenol } \\ 0 & 2,4,6-\text { Trichlorophenol }\end{array}$

: Unknowium, total secoverable

0 Vinyl acetate

Z Zinc, total recoverable

0 Actinitum-228

: Antimony-124

Antimony-125

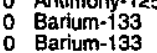

0 Barium-133

0 Cesium-144

O Cesium-134

$\begin{array}{ll}0 & \text { Cosium-137 } \\ 0 & \text { Coball-57 } \\ 0 & \text { Cobatit-57 } \\ 0 & \text { Cobalt } 58\end{array}$

$\begin{array}{ll}0 & \text { Cobalt-58 } \\ 0 & \text { Cobalt-58 } \\ 0 & \text { Cobalt }-60\end{array}$

o Cobalt-60

0 Europium-152

O Europium-154

o Europium-155

- Gross alpha

O Gross alph

Manganese-54

0 Neptunium-239

: Neptuniutri-239

: Nonvolatile be

Potassium-40

Promethium-144

0.144
0 Prombethium-146
Promnthium-146

Ruthenium-106
Ruthenium-106

Sodium-22

$\operatorname{Tin}_{\operatorname{Tin}-113}$

0 Tritium

0 Yttrium-88

0 Zinc-65

: Zirconium-95

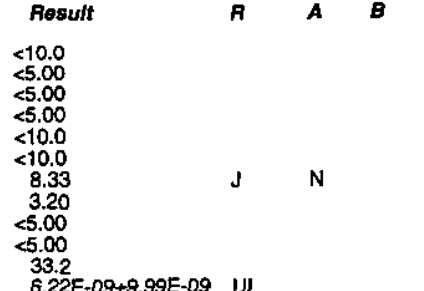

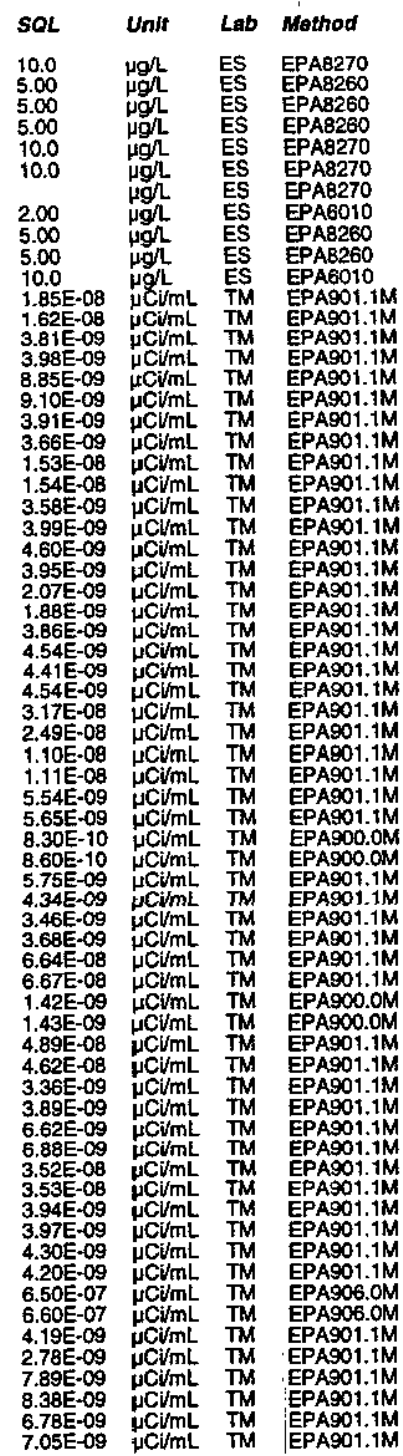


WELL PRP 5

MEASUREMENTS CONDUCTED IN THE FIELD Sample date: $05 / 26 / 98$
Depth to water: $22.24 \mathrm{ft}(6.78 \mathrm{~m})$ below TOC
W $\mathrm{pH}: 6.9$ . conductance: $46 \mu \mathrm{S} / \mathrm{cm}$ Water evacuated from the well prior to sampling: $33 \mathrm{gal}$ ANALYSES

\begin{tabular}{|c|c|}
\hline Anatyto & Resunt \\
\hline 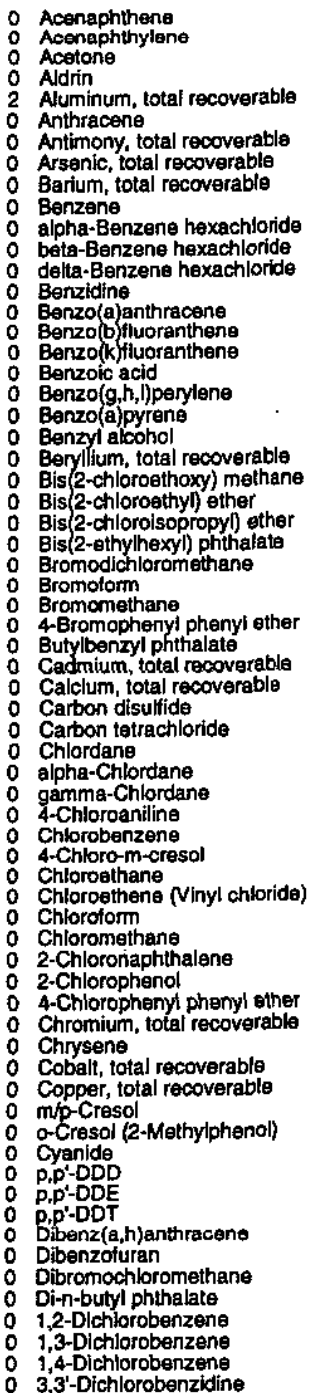 & $\begin{array}{l}<10.0 \\
<10.0 \\
<10.0 \\
<0.0150 \\
412 \\
<10.0 \\
<5.00 \\
<8.00 \\
12.0 \\
<5.00 \\
<0.0150 \\
<0.0150 \\
<0.0150 \\
<10.0 \\
<10.0 \\
<10.0 \\
<50.0 \\
<10.0 \\
<10.0 \\
<1.0 \\
<100 \\
<10.0 \\
<10.0 \\
<10.0 \\
<1.40 \\
<5.00 \\
<100 \\
<10.0 \\
<10.0 \\
<2.00 \\
08.0 \\
<5.00 \\
<5.00 \\
0.0160 \\
<0.0150 \\
<0.0150 \\
20.0 \\
<5.00 \\
20.0 \\
<10.0 \\
<10.0 \\
<5.00 \\
<10.0 \\
<10.0 \\
<10.0 \\
<10.0 \\
6.30 \\
<10.0 \\
<5.00 \\
1.80 \\
<10.0 \\
<10.0 \\
<5.00 \\
<0.0150 \\
<0.0150 \\
<0.0150 \\
<10.0 \\
<10.0 \\
<5.00 \\
0.590 \\
<10.0 \\
<10.0 \\
<10.0 \\
<20.0\end{array}$ \\
\hline
\end{tabular}

Well PRP 5 collected on 05/26/98 (cont.)

Anafyto

1,1-Dichloroethane cis-1,2-Dichloroethylene Dichloroethylene 2,4-Dichlorophenol 1,2-Dichloropropane trans-1,3-Dichloropropene Diethyl phthalate 2.4.Dimethyl phenol 2,4-Dinitrophenol
2,4-Dinitrotoluene 2,6-Dinitrotoluene Endosulfan sulfate Endosulfar

Endrin aldehyda

Endrin ketone

Fluoranthen

Fluorene

Heptachlor epoxide

\section{Hexachlorobenzene}

Hexachlorobutadiene
Hexachlorocyclopentadien

Indeno(1,2,3-c,d)pyran

Iron, total recoverable

Isophorone
Lead, total recoverable

Magnesium, total recoverable

Mangannese, total recovera

Methoxycthlor
2-Methyl-4,6-dinitrophenol

Methyl isobutyl keton

2-Methylnaphthalene

Nickel, total recoverable

m-Nitroaniline
o-Nitroaniling

P-Nitroaniline

2-Nitropheno!

$\mathrm{N}$-Nitrosodijphenylamin

PCB 1016

PCB 1232

PCB 1248

PCB 1260

Pentachlosopheno

Potassium, total recoverable

Selenlum, total recoverable

1tyrene-2, Tetrachloroethane

Tetrachloroethylene
Thallism, total recoverable

: Toluene

B-229
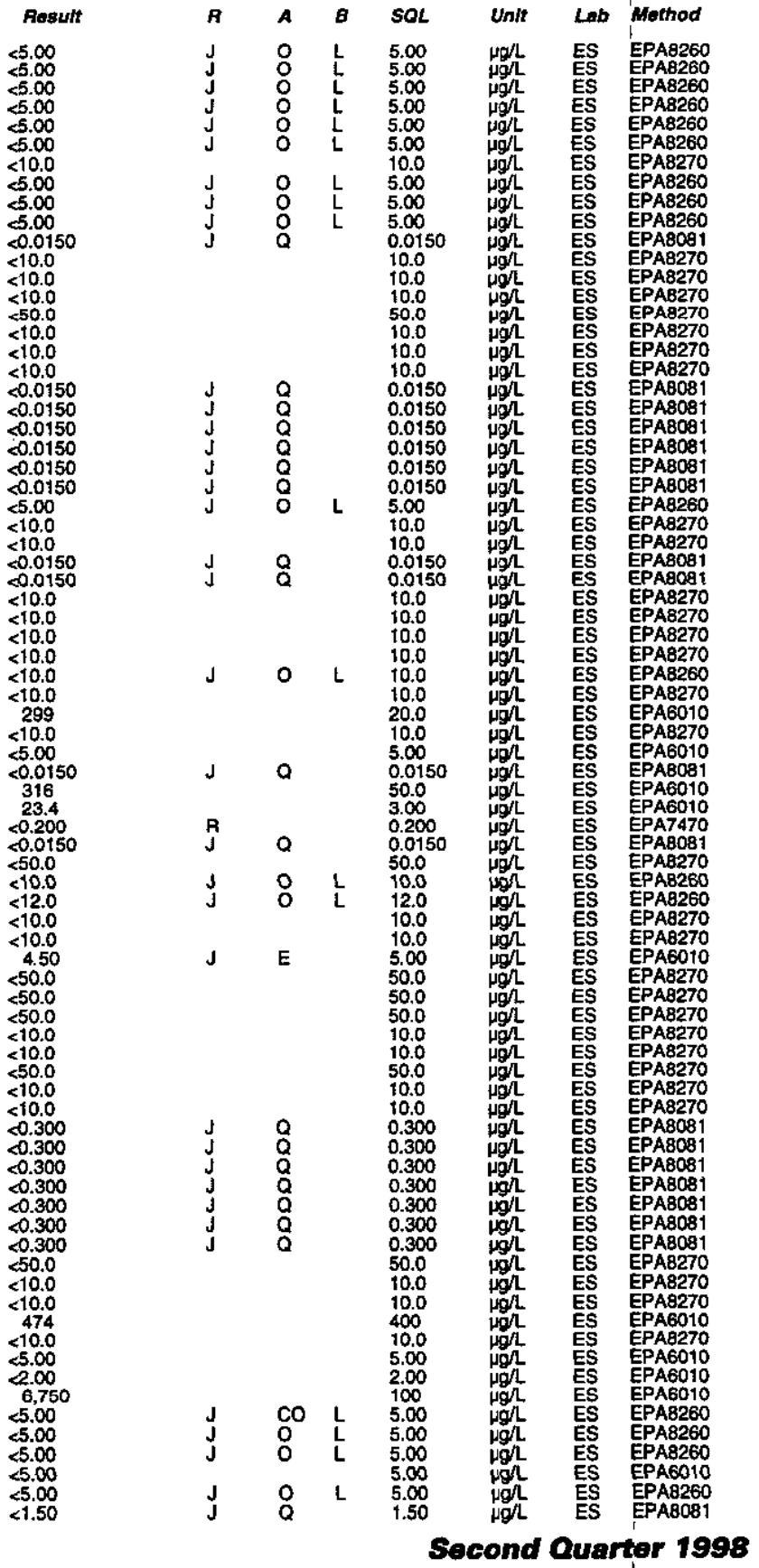
ANALYTICAL RESULTS

Well PRP 5 collected on 05/26/98 (cont.)

\begin{tabular}{|c|c|c|c|c|c|c|c|c|}
\hline Analyte & Result & $\boldsymbol{A}$ & $A$ & $B$ & SOL & Unit & Lab & Method \\
\hline 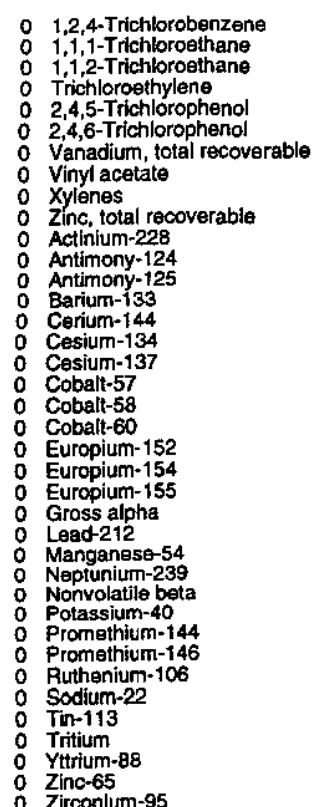 & 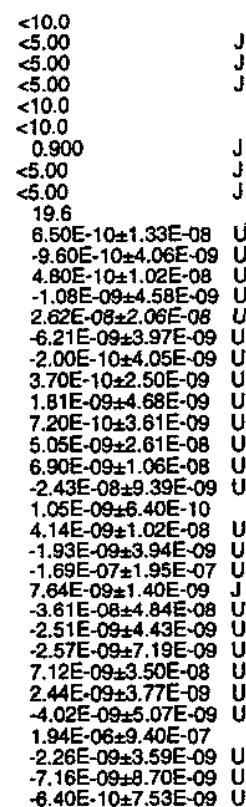 & 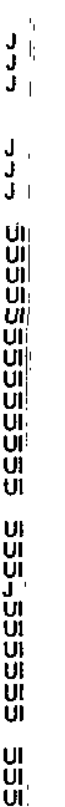 & $\begin{array}{l}E \\
0 \\
0\end{array}$ & $\begin{array}{l}\mathrm{L} \\
\mathrm{L}\end{array}$ & 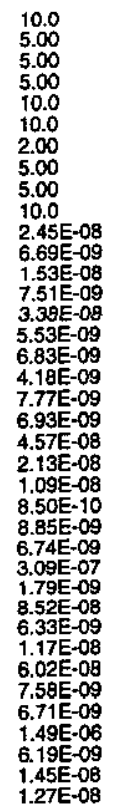 & 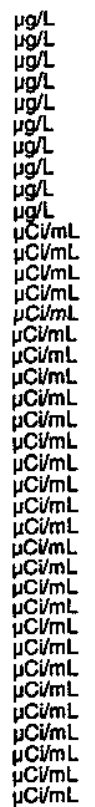 & $\begin{array}{l}\text { ES } \\
\text { ES } \\
\text { ES } \\
\text { ES } \\
\text { ES } \\
\text { ES } \\
\text { ES } \\
\text { ES } \\
\text { TM } \\
T M \\
T M \\
T M \\
T M \\
T M \\
T M \\
T M \\
T M \\
T M \\
T M \\
T M \\
T M \\
T M \\
T M \\
T M \\
T M \\
T M \\
T M \\
T M \\
T M \\
T M \\
T M \\
T M \\
T M \\
T M\end{array}$ & 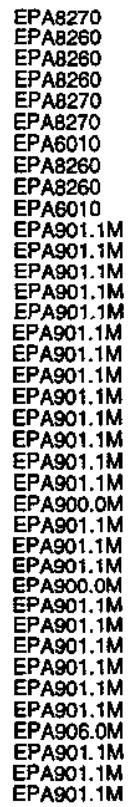 \\
\hline
\end{tabular}

WELL RAC 1

MEASUREMENTS CONDUCTED IN THE FIELD

Sample date: 06/30/9

(o water: 9.7 ft $(2.96 \mathrm{~m})$ below TOC

Wh: 5

. conductance: $56 \mu \mathrm{S} / \mathrm{cm}$

Time: 9:15

Water temperature: $24^{\circ} \mathrm{C}$

Total alkalinity (as CaCO3): $3 \mathrm{mgh}$

ANALYSES

$F$ Anatyto

: Acenaphthene

2 Aldrim

Anthracene

Arsentic, total recoverable

alpha-Benzene hexachloride

beta-Benzene hexachloride

Benzidine
Benzo(a)anthracene

Benzo(b) fluoranthene

Benzoic acid

Benzo(g,h,i)pery
Benzo(a)pyrene

Benzyl alcohol

Bis (2-chloroethoxy) methan

ESH-EMS-980569

$<.00$
$<10.0$

$<10.0$
$<10.0$
$<10.0$
Well RAC 1 collected on 06/30/98 (cont.)

$F$ Analyte

0
0 Bis(2-ethylhexyl) phthalate
0

Butylbenzyl phthatate ether

Calcium, total recoverable

alpha-Chlordane

4-Chloroaniline

2-Choro-m-cresol

4-Chlorophenenyl phenyl ethe

Chromium, total recoverable

Cobsilf, total recoverable

$\mathrm{m} / \mathrm{p}$-Cresol $\mathrm{Cres}$ (2-Methylphenol)

Cyanide

P,P-DDE

Dibenz(a,h)anthracene

Dibenzofuran

1.2-Dichlorobenzenene

3,3'-Dichlorobenziditin

2,4-Dichloropheno

0 Diethyl phthalate

2,4-Dimethyl phenol

2,4-Dinitrophenol

2,6-Dinitrotoluene

Di-D-octyl phthalate

Endosulfan I

Endrin

Endorin aldehy

O Fluorene

0 Heptachlor epoxide

Hexachlorobenzene

Hexachlorobutadiene

Hexachlorocyclopentadien

Indeno(1,2,3-c,d)pyrene
Iron, total recoverable

Isophorone

0 Lindane

Magnesium, total recoverable

Mercury, total recoverable

2-Methyl-4,6-dinitropheno

Naphthalene

1 Nickel, total recoverable

0 m-Nitroaniline

p-Nitroaniling

Nitrobenzen

2-Nitrophenol

$\mathrm{N}$-Nitrosodiphenylamine

N-Nitrosodipropylamine

$\begin{array}{lll}0 & \text { PCB } 1016 \\ 0 & \text { PCB } 1221\end{array}$

PCB 1232

: PCB 1248

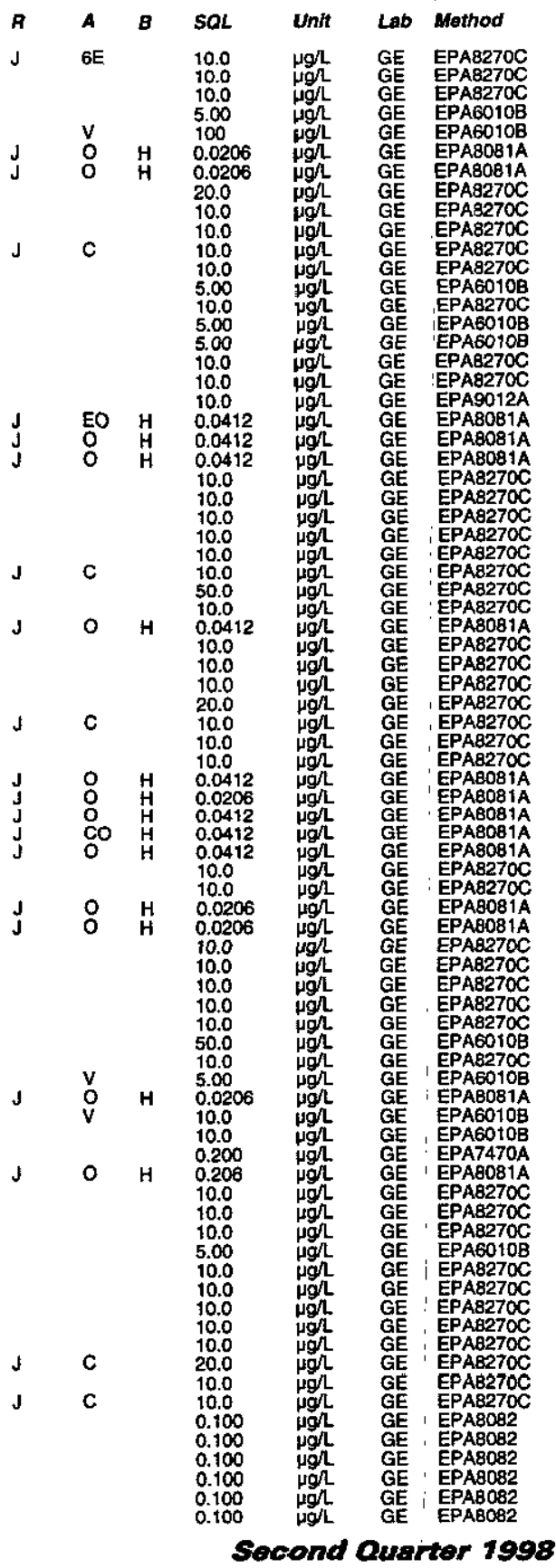


Well RAC 1 collected on 06/30/98 (cont.)

\begin{tabular}{|c|c|}
\hline Analyto & Resutt \\
\hline 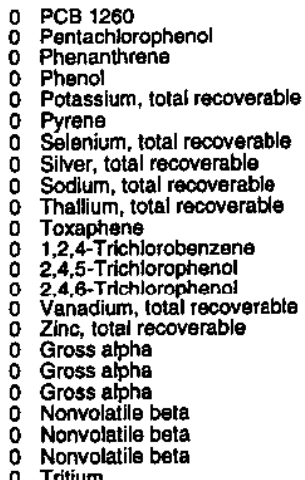 & $\begin{array}{l}<0.100 \\
<10.0 \\
<10.0 \\
<10.0 \\
517 \\
<10.0 \\
<5.00 \\
<5.00 \\
3,970 \\
<5.00 \\
<1.03 \\
<10.0 \\
<10.0 \\
<10.0 \\
1.45 \\
<6.83 \\
7.49 E-10 \pm 4.96 E-10 \\
7.70 E-10 \pm 5.40 E-10 \\
1.14 E-09 \pm 5.90 E-10 \\
1.97 E-09 \pm 8.62 E-10 \\
1.14 E-09 \pm 9.00 E-10 \\
2.03 E-09 \pm 9.40 E-10 \\
1.12 E-06 \pm 3.72 E-07\end{array}$ \\
\hline
\end{tabular}

\section{WELL RAC 1 Replicate}

MEASUREMENTS CONDUCTED IN THE FIELD

\begin{tabular}{|c|c|}
\hline 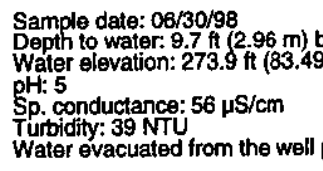 & $\begin{array}{l}\text { TOC } \\
\text { msl }\end{array}$ \\
\hline NALYSES & \\
\hline Analyte & Result \\
\hline 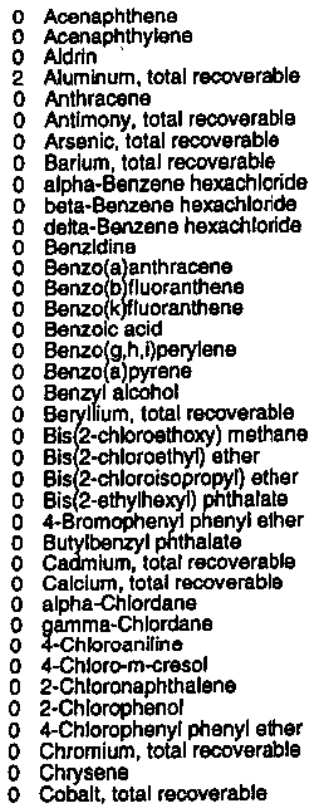 & $\begin{array}{l}<10.0 \\
<10.0 \\
<0.0198 \\
351 \\
<10.0 \\
<3.99 \\
<5.00 \\
17.4 \\
<0.0198 \\
<0.0198 \\
<0.0198 \\
<50.0 \\
<10.0 \\
<10.0 \\
<10.0 \\
<0.0 \\
<10.0 \\
<10.0 \\
<10.0 \\
<5.00 \\
<10.0 \\
<10.0 \\
<10.0 \\
<10.0 \\
<10.0 \\
<10.0 \\
<5.00 \\
3.460 \\
<0.0198 \\
<0.0198 \\
<20.0 \\
<10.0 \\
<10.0 \\
<10.0 \\
<10.0 \\
5.42 \\
<10.0 \\
<5.00\end{array}$ \\
\hline
\end{tabular}

ESH-EMS-980569

Well RAC 1 collected on 06/30/98 (cont.)

0
0
0
0
0
0
0
0
0
0
0
0
0
0
0
0
0
0
0
0
0

Analyte

P, $\mathrm{p}^{-}-\mathrm{DOD}$

P,P-DDE

Dibenz(a,h)anthracene

Dibenzofuran

1,2-Dichiorobenzene

1,4-Dichlorobenzene

2.4-Dichlorophenol
D'ieldrin

Diethyl phthalate

Dimethyl phthalate

2,4-Dinitrotoluene

Di-n-octylotuene

Endosuffan sulfa

Endosulfan I

Endrin aldehydo

Heptachlor

Heptachlor epoxide

- Hexachlorobenzenene

o Hexachlorocyclopentadiene

Hexacthloroethane
0 Indeno $(1,2,3-c, d)$ pyrene

2 Iron, total recoverable

Lead, total recoverable

Magnesium, total recoverable

- Manganese, total recoverab

: Mercury, total recoverable

2-Methyl-4,6-dinitropheno

2-Methyinaphthalers

1 Nickel, total recoverable

o m-Nitroaniline

0 o-Nitroaniline

$\because$ Nitrobenzene

2-Nitrophenol

N N-Nitrosodiphenylamine

PCB 1016
0 PCB 1221

PCB 1232

0 PCB 1248

0 PCB 1254

PCB 1260

0 Pentachloroph

Phenol
Potassium, total recoverable

o Syrenium, total recoverable

Siver, total recoverable

: Sodium, total recoverable

: 1,2,4-Trichlorobenzene

2,4,5-Trichiorophenol

$2,4,6-$ Trichlorophenol
Vanadium, total recoverable

3-231

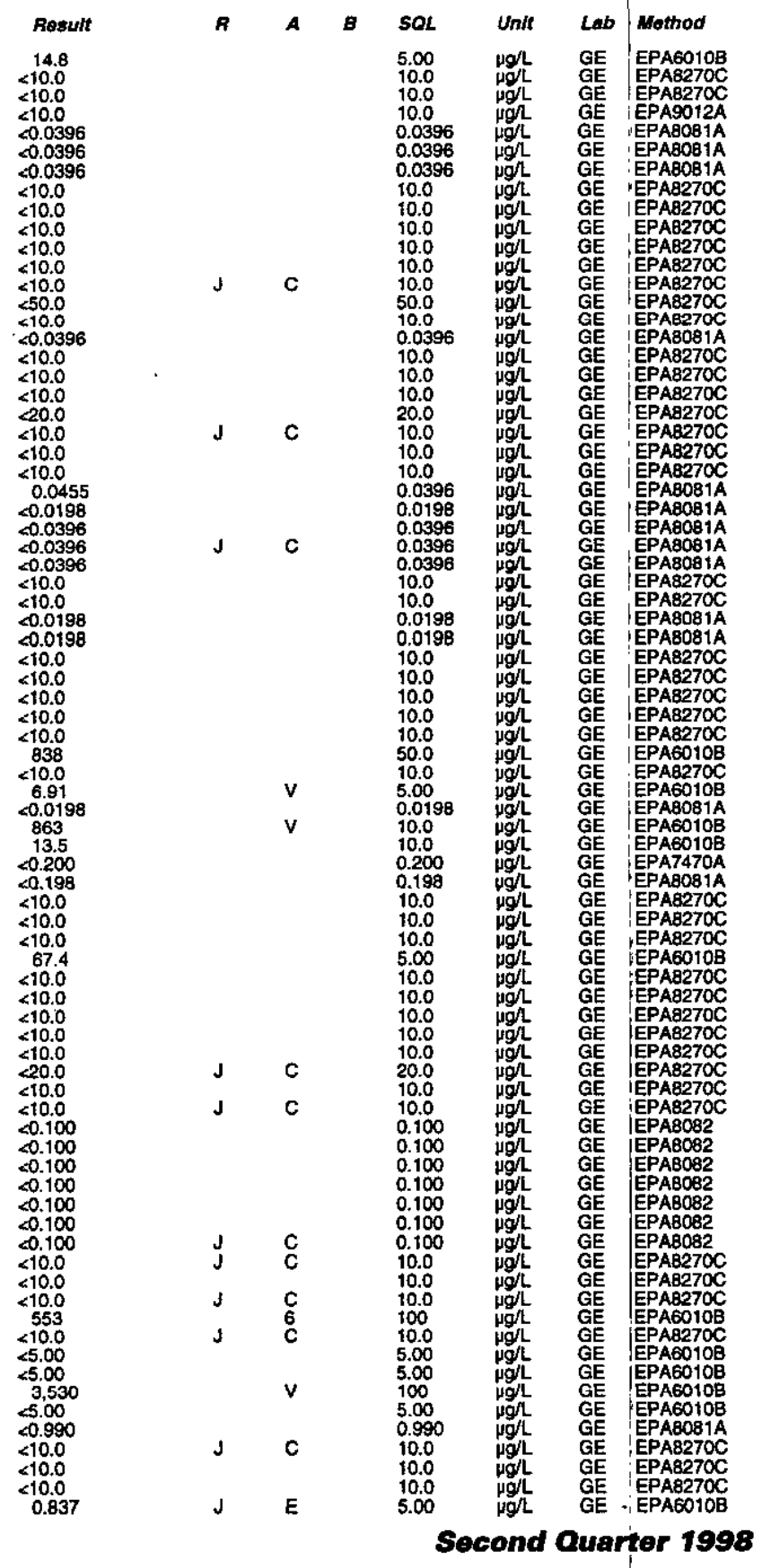


Well RAC 1 collected on 06/30/98 (cont.)

\begin{tabular}{|c|c|c|c|c|c|c|c|c|}
\hline F Analyto & Resuft & A & A & $B$ & SOL & Unth & Lab & Mothod \\
\hline $\begin{array}{l}\text { Zinc, total recoverable } \\
\text { Gross alpha } \\
\text { Nonvolatile beta } \\
\text { Trittum }\end{array}$ & $\begin{array}{r}<.28 \\
1.70 E-09 \pm 6.07 E-10 \\
2.07 E-09 \pm 9.00 E-10 \\
9.26 E-07 \pm 3.70 E-07\end{array}$ & $\mathbf{J}$ & $\begin{array}{l}v \\
c\end{array}$ & & $\begin{array}{l}5.00 \\
7.60 E-10 \\
1.62 E-09 \\
5.76 E-07\end{array}$ & 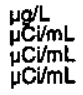 & $\begin{array}{l}\mathrm{GE} \\
\mathrm{GP} \\
\mathrm{GP} \\
\mathrm{GP}\end{array}$ & $\begin{array}{l}\text { EPAG010B } \\
\text { EPIA-001 } \\
\text { EPIA-C01 } \\
\text { EPIA-002 }\end{array}$ \\
\hline
\end{tabular}

\section{WELL RAC 2}

MEASUREMENTS CONDUCTED IN THE FIELD Sample date: $06 / 30 / 98$
Depth to water: $7.95 \mathrm{tt}(2.42 \mathrm{~m})$ below TOC
Water elevation: $272.45 \mathrm{ft}(83.04 \mathrm{~m}) \mathrm{msl}$
pH: 4.6 pH: 4.6 conductance: $140 \mu \mathrm{S} / \mathrm{cm}$

Turbidity: $1 \mathrm{NTU}$ : from the well prior to sampling: $101 \mathrm{gal}$
Water evacuated from ANALYSES

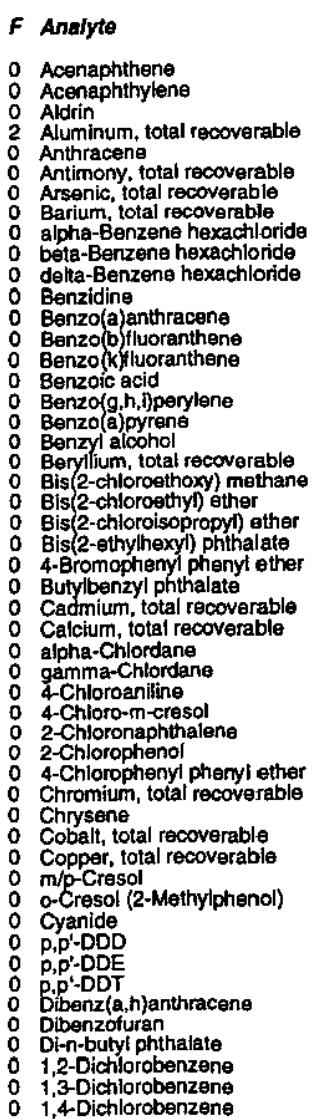

Result
$<10.0$
$<10.0$
$<0.0200$
118
$<10.0$
$<2.88$
$<500$
31.5
$<0.0200$
$<0.0200$
$<0.0200$
$<50.0$
$<10.0$
$<10.0$
$<10.0$
$<20.0$
$<10.0$
$<10.0$
$<10.0$
$<5.00$
$<10.0$
$<10.0$
$<10.0$
$<10.0$
$<10.0$
$<10.0$
$<5.00$
3.110
$<0.0200$
20.0200
20.0
$<10.0$
$<10.0$
$<10.0$
$<10.0$
1.15
$<10.0$
$<5.00$
103
$<10.0$
$<10.0$
9.08
$<0.0400$
$<0.0400$
$<0.0400$
$<10.0$
$<10.0$
$<10.0$
$<10.0$
$<10.0$
$<10.0$
110
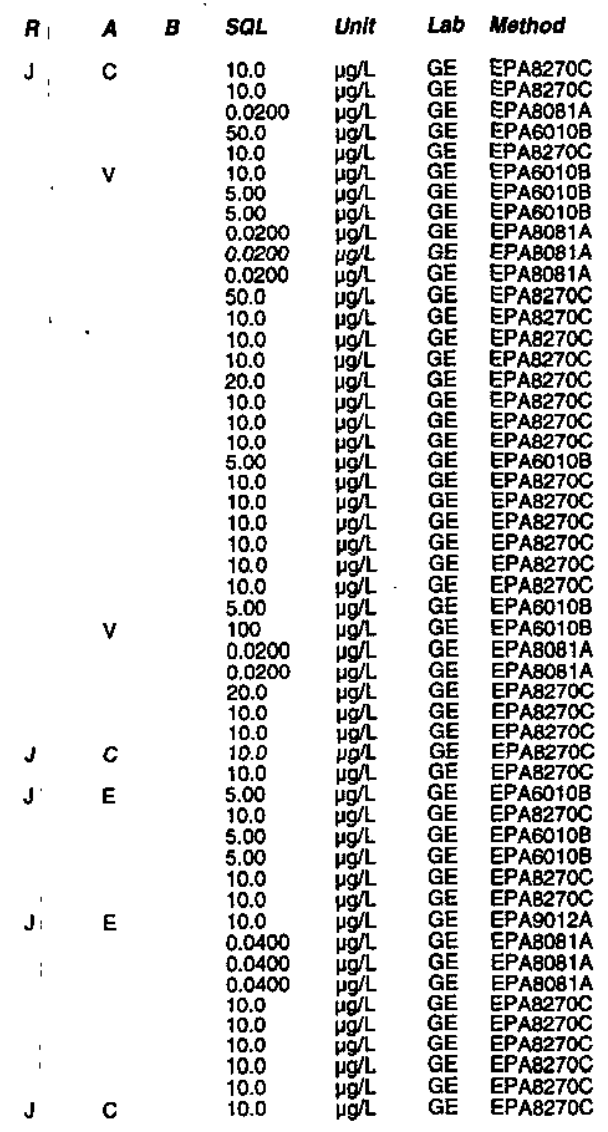

Well RAC 2 collected on 06/30/98 (cont)

$F$ Analyte

3,3'-Dichlorobenzidine
0 2,4-Dichlorophenol

$0_{0}^{0}$ Dieldrin 2,4-Dimethilat phenol
Dimethyl phthalate 2,4-Dinitrophenol 2,6-Dinitrotoluene Di-n-octyl phthalate Endosulfan ! Endrin Eldehyde Erdrin aldehyde $\therefore$ Fluorene

Heptachlor epoxide Hexachlorobontadiene Hexachlorocyciopentadien a Indeno( $(1,2,3-c, d)$ pyrene Isophorone Lindane Manganese, total recoverab 2-Methyl-4,6-dinitropheno 2-Methylinaphthalene Nickel total recoverable
m-Nitroaniline o-Nitroaniline 2-Nitropheno $\mathrm{N}$-Nitrosodiphenylamine N-Nitrosodipropylamina 0
0
0 PCB 1232 PCB 1248 PCB 1260 Phenanthrene Potassium, total recoverable Syrene Silver, total racoverabla - Sodium, total recoverable Toxaphene 2,4,5-Trichlorophenol 2,4,6-Trichlorophenol
Vanadium, total recoverablo Zinc, total recoverable Gross alpha
$:$ Nonvolatile beta
OTritium

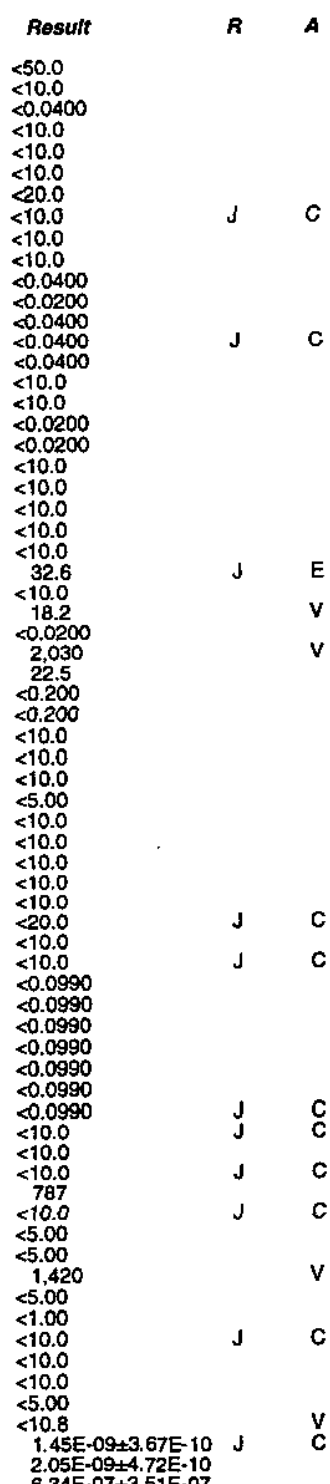


WELL RAC 3

MEASUREMENTS CONDUCTED IN THE FIELD

Sample date: $06 / 30 / 98$
Depth to water. $7.26 \mathrm{th}(2.21 \mathrm{~m})$ below TOC
Water elevation: 272.04 it $(82.92 \mathrm{~m}) \mathrm{msl}$

SH: 4.6 conductance: $42 \mu \mathrm{S} / \mathrm{cm}$

Turbidity: 2 NTU: $42 \mu \mathrm{S} / \mathrm{cm}$
Water evacuated from the well prior to sampling: $61 \mathrm{gal}$

ANALYSES
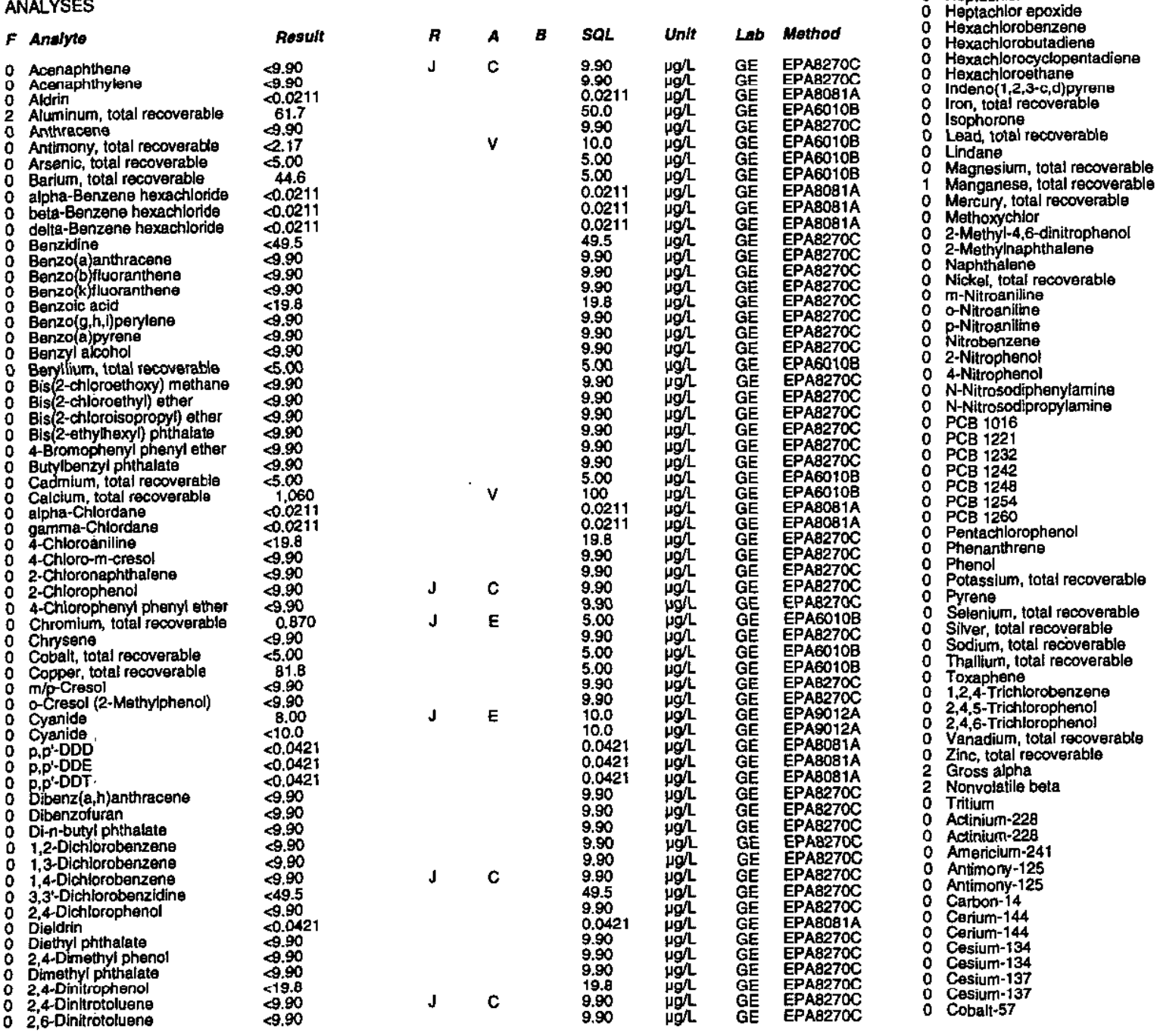

Time: 14:26 $2{ }^{\circ}$ Water temperature: $23^{\circ} \mathrm{C}$

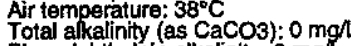

Phenolphthalein alkalinity: $0 \mathrm{mg} / \mathrm{L}$ (cont.)

$F$ Analyte

$:$ Dirn-octyl phthalate

Endosulfian !

Endrin aldehyd

Fluorene

Heptachlor epoxide

Hexachlorobutadiene
Hexachlorocyclopentadien

Indenor $1,2,3-c, d)$ pyren
Iron, total recoverable

Lead, total recoverable

Magnesium, total recoverable

Mercury, total recoverable

Methylnaphthalene
M

odtpropylamin

Potassium, total recoverable

Selenium, total recoverab

Sodjum, total recoverable

chlorobenzene

2,4,6-Trichlorophenol

Zinc, total recoverab

Antimony-125

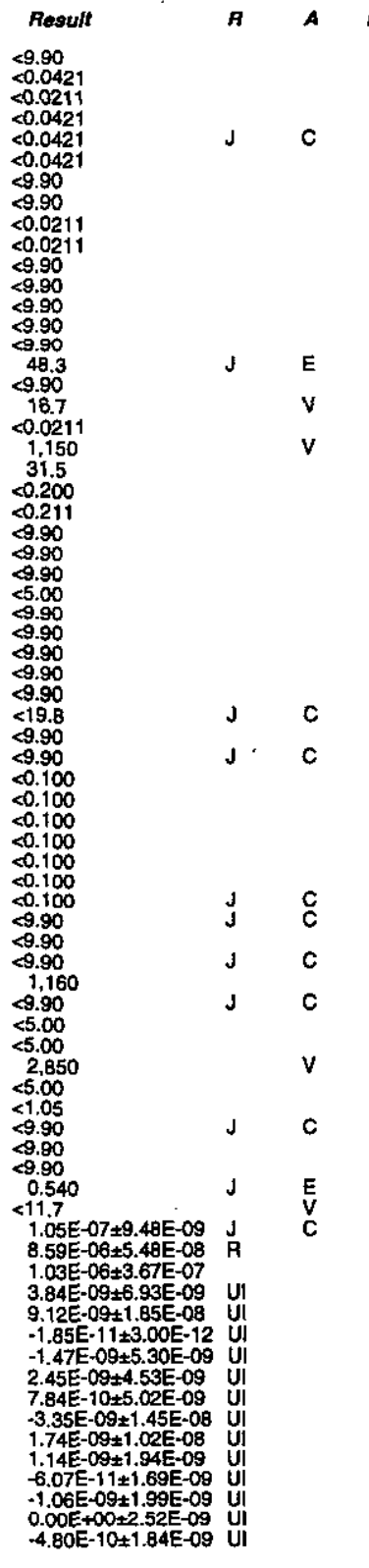

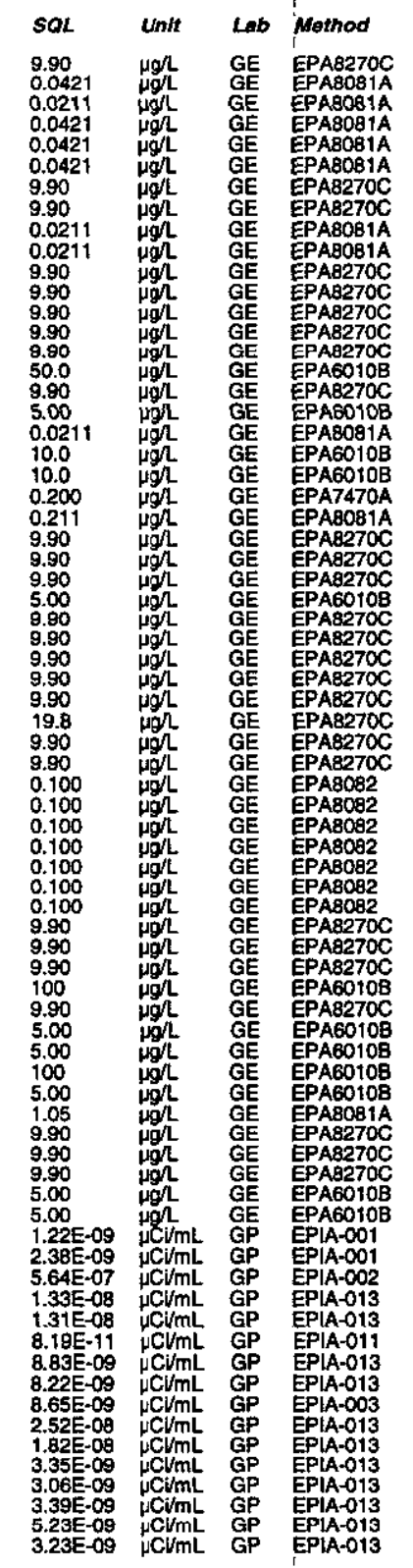


Well RAC 3 collected on 06/30/98 (cont),

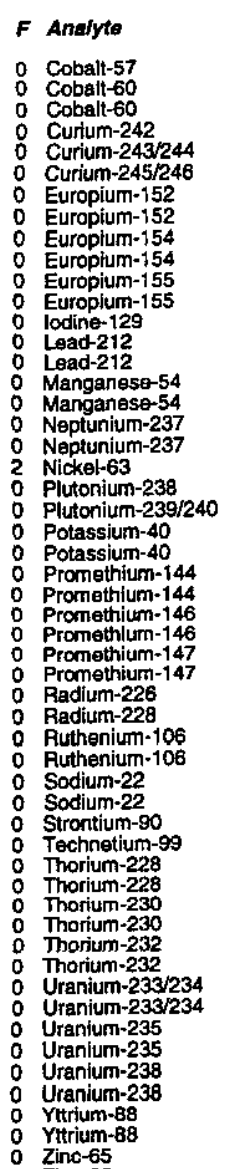

Result

3.83E-10+1.20E-09 UI $2.84 E-09+2.19 E-09$ UI । $-1.53 E-11 \pm 2.18 E-11$ UI II $1.34 E-11 \pm 5.81 E-11$ UI $3.00 \mathrm{E}-09+5.77 \mathrm{E}-09$ UI $-1.14 \mathrm{E}-09 \pm 4.72 \mathrm{E}-09 \mathrm{UI}$ 5.35E-11.5.05E-09 UI $9.4 \mathrm{E}-10+4.49 \mathrm{E}-09 \mathrm{U}$ U $.57 E-10 \pm 4.79 E-09$ UI 6.13E-11 $21.06 E-09$ UI $2.58 \mathrm{E}-10 \times 1.93 \mathrm{E}-09 \mathrm{U}$ $6.55 E-10 \pm 1.73 E-09$ UII (13E-12+35E-11 UI $5.77 E-08+1.28 \mathrm{E}-07$ UI $8.27 E-11 \pm 1.38 E-10$ U 2.79E-11+1.13E-10 U1 $4.72 \mathrm{E}-08 \pm 2.40 \mathrm{E}-08$ UI $1.18 E-09 \pm 1.90 \mathrm{c}-09$ U $3.19 E-09 \pm 3.22 E-09$ UI $1.25 E-09 \pm 6.02 E-10$ 1.70E-09+6.40E-10 $5.97 E-10 \pm 4.74 E-10$ UI 9.39E-09+1.81E-08 U 1.27E-11.1.81E-09 UI $4.82 \mathrm{E}-11 \pm 6.16 \mathrm{EE}-10 \mathrm{UI}$ $1.32 \mathrm{E}-10 \pm 9.83 E-11$
$2.11 \mathrm{E}-10 \pm 1.07 \mathrm{U}-10$
$.75 \mathrm{UIJ}$ $2.04 E-11 \pm 4.11 E-11$ UI 3.49E-114.95E-11 $-8.25 \mathrm{E}-12 \pm 1.17 \mathrm{E}-11$ U! $1.37 \mathrm{E}-100.82 \mathrm{E}-11$ $2.09 E-10+2.29 E-09$ $1.19 E-09 \pm 2.73 E-09$
$-1.94 E-09+4.20 E-09$
$\mathrm{UI}$
WELL RAC 4

MEASUREMENTS CONDUCTED IN THE FIELD Sample date: $06 / 30 / 98$ Water elevation: 271 ( $2.29 \mathrm{~m})$ below TOC

2.18E- $09 \mu C \mathrm{~V} / \mathrm{mL}$ GP EPIA-013

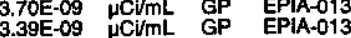

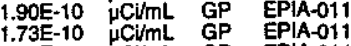
$1.03 E-08$ HCimL GP EPIA-01 8.01E-09 $\mu C U \mathrm{~mL}$ GP EPIA-013 8.53E-09 $\mu \mathrm{C} / \mathrm{mL}$ GP EPIA-013 44E-08 $\mathrm{HCVmL}$ GP EPIA-013 $1.24 E-09 \mu \mathrm{C} / \mathrm{mL}$ GP $\mathrm{GP}$ EPIA-006 $\begin{aligned} & 5.57 \mathrm{E}-09 \\ & 3.44 \mathrm{C}-09 \mathrm{~mL}\end{aligned} \mathrm{GP} / \mathrm{mL}$ GP EPIA-013 3.30E-09 $\mu \mathrm{C} / \mathrm{mL}$ GP EPIA-013 251E-10 HCCImL GP EPAA-032 $2.57 \mathrm{E}-10$ $\mu \mathrm{CVMm}$ GP EPA.-011 4.51E-08 $\mu \mathrm{C} / \mathrm{mL}$ GP EPAA-013 . 64 E-09 $4 \mathrm{C}$ /mL GP 2.93E-09 $\mu C V \mathrm{~mL}$ GP EPIA-013 $9.98 \mathrm{E}-10$ $\mu \mathrm{C} / \mathrm{mL}$ G GP $\mathrm{GP}$ EPAA-013 $\begin{aligned} & 4.32 \mathrm{E}-10 \\ & \mathrm{~N}\end{aligned} \mathrm{C} / \mathrm{mL}$ GP EPIA-00B 3.44E-0B $\mu \mathrm{C} / \mathrm{mL}$ GP EPIA-013 $3.48 \mathrm{E}-09 \mathrm{HCVmL}$ GP EPIA-013 (.06E-O9 NCUML GP EPIA-013 1.17-08 1.22E-10 $\mu \mathrm{C} / \mathrm{mL}$ GP GP EPA-012 $1.07 \mathrm{E}-10 \quad \mu \mathrm{CV} / \mathrm{mL}$ GP EPIA-012 8.68E-11 $\mu C / m L$
$5.24 E-11$ GP
CCImL GPIA-12 $5.14{ }^{2}-11 \mu \mathrm{C} / \mathrm{mL}$ GP EPIA-01 1.07E-10 $\mu \mathrm{C} i \mathrm{~mL}$ GP EPA-011 $5.24 E-11 \mu \mathrm{CimL}$ GP EPIA-01

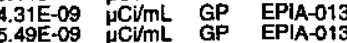
$\begin{array}{llll}5.49 E-09 & \mu \mathrm{CV} / \mathrm{mL} & \mathrm{GP} & \mathrm{EPAA}-013 \\ 7.47 \mathrm{E}-09 & \mu \mathrm{CV} / \mathrm{mL} & \mathrm{GP} & \mathrm{EPIA}-013 \\ 7.46 \mathrm{E}-09 & \mu \mathrm{CimL} & \mathrm{GP} & \mathrm{EPIA}-013\end{array}$
Water evacuated from the well prior to sampling: $70 \mathrm{gal}$ ANALYSES

$F$ Analyte

: Acenaphthene

2 Aldrin

0 Anthracene

Assenic, total recoverable

alpha-Benzene hexachloride

delta-Benzene hexachloride

Benzidine

Benzo(a) anthracenen
Benzob(b) fluoranthene

Benzolic acid

Berzo(a), hypene

Beryllium, total recoverable Bis 2-chloroethoxy) methan

Bis 2-chloroisopropyl) ether O Bis (2-ethylhexyl) phthalate 4-Bromophenyl phenyl eth Cadmium, total recoverable Calcium total recoverable alpha-Chlordane 4-Chloroaniline 2-Chloron-cresthalen 4-Chlorophenyl phenyl ether Chromium, total recoverable Chrysent

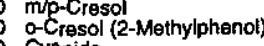
0 : P.P'-DDE

Dibenz(a,h)anthracene

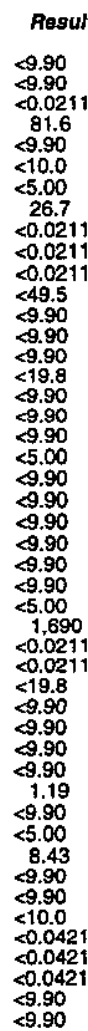

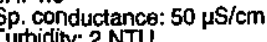
coalt, total recoverable
Water temperature: $22^{\circ} \mathrm{C}$

Total alkalinity (as CaCO3): $0 \mathrm{mg} / \mathrm{h}$

$<9.90$
$<9.90$

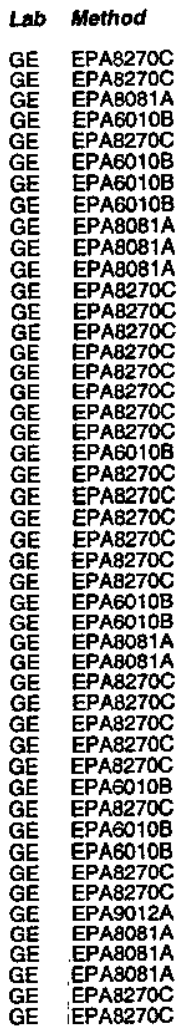




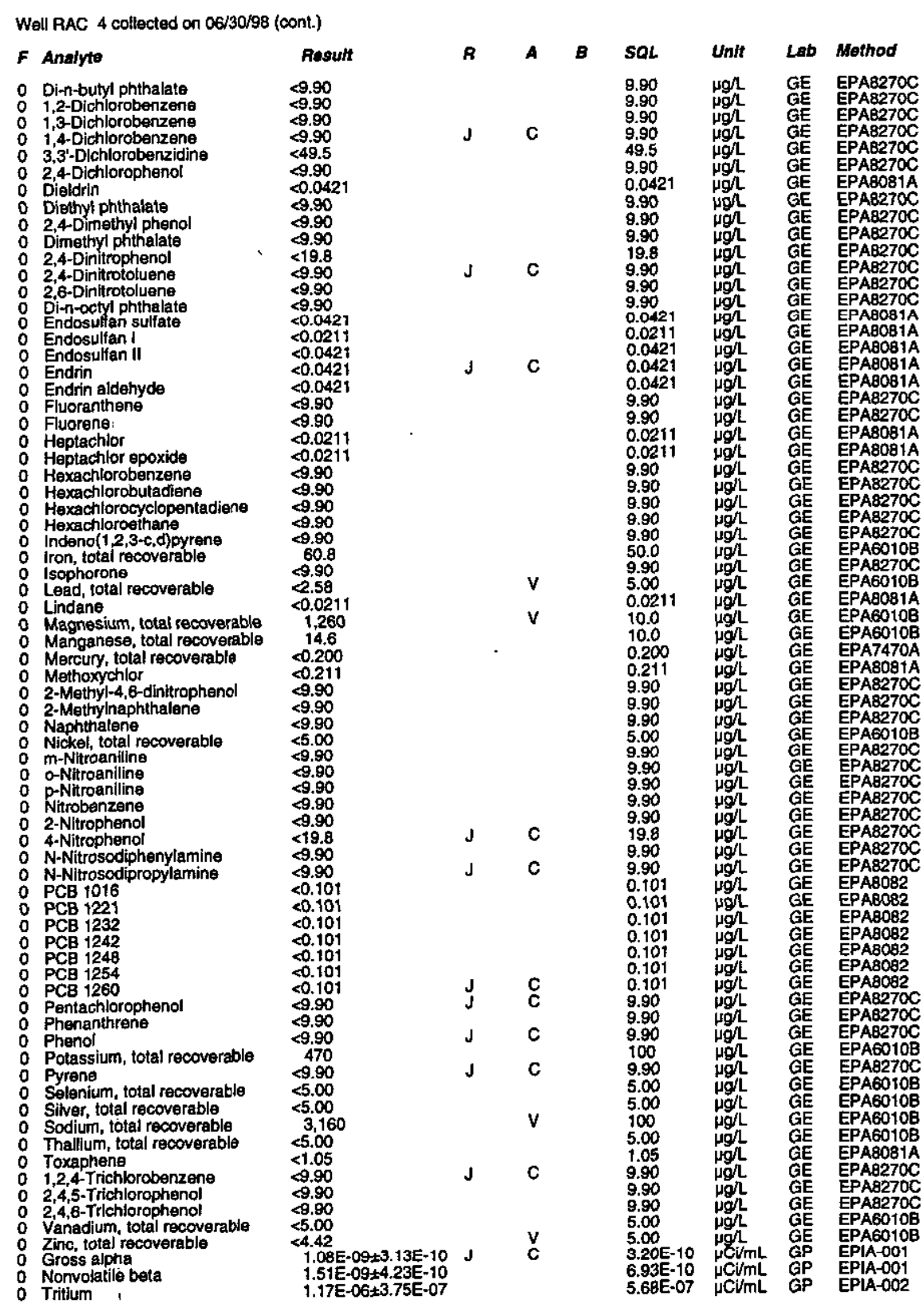

WELL RBP 1D

MEASUREMENTS CONDUCTEO IN THE FIELD Sample date: 05/28/98
Depth to water: $40 \mathrm{ft}(12.19 \mathrm{~m})$ below TOC
Water elevation: $265.7 \mathrm{ft}(80.99 \mathrm{~m}) \mathrm{ms}$ Hp. conductance: $22 \mu \mathrm{S} / \mathrm{cm}$

Warbicity: ONrer fom the well prior to sampling: $19 \mathrm{gat}$ ANALYSES

$F$ Analyte

Result

2 Aluminum, total recoverable

Cadmium, total recoverable

Chloride

Chromium, total recoverable

Iron, total recoverable

Magnesium, total recoverable

Manganese, total recovereabl

Nercury, total recoverable

Potassium, total recoverable

Silica, total recoverable

Sodium, total recoverable

Sulfate

Tetrachloroettylene

Total organic carbon

Total phosphates (as P
1,

Gross alpha

Nonvolatile beta

\section{WELL RBP 2D}

MEASUREMENTS CONDUCTED IN THE FIELD

Sample date: $05 / 28 / 98$
Oepth to water 38.1 f
Wi.

Water

H: 4.8 cotance: $32 \mu \mathrm{S} / \mathrm{cm}$

Wutbidity: I NTU:

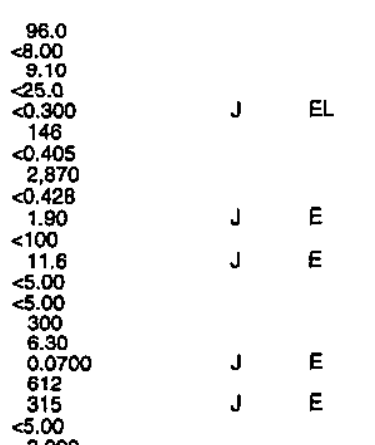

ANALYSES

2 Aluminum, total recoverable

Arsenic, total recoverable

Codm, total recoverable

Carbon totrachloride

Chromium, total recoverable

Fluonide

Lithium, total recoverable

$\begin{array}{ccc}\text { Result } & \text { A } & \text { A } \\ 109 & \text { J } & \text { L } \\ <8.00 & & \\ 10.6 & & \\ 17.9 & \text { J } & \text { E } \\ 0.300 & 899 \\ 809 & \text { J } & \text { E } \\ 3.230 & & \\ 30.230 & & \\ <3.00 & & \\ <100 & & \\ 12.8 & \text { J } & \text { E } \\ 3.20 & \text { J } & \text { E } \\ 1.60 & \text { J } & \text { E }\end{array}$

Time: 8:15

Total alkalinity (as Caco3): $0 \mathrm{mg} / \mathrm{L}$
Phenolphthalein alkalinity: $0 \mathrm{mg} /$

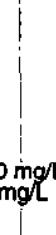

Thum

Wime: $9: 03$ ater termperature: $16^{\circ} \mathrm{C}$

Total alkalinity (as Caco3); $0 \mathrm{mgh}$
Phenolphthalein alkalinity: $0 \mathrm{mg}$. 
Well RBP 2D collected on 05/2B/98 (cont.)

\begin{tabular}{|c|c|c|c|c|c|c|c|c|}
\hline Anslyto & Resuft & $\boldsymbol{R}$ & & $B$ & SOL & Unit & Lab & Method \\
\hline 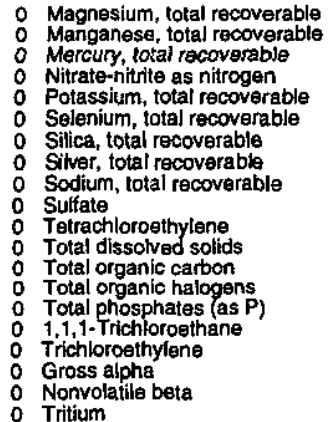 & $\begin{array}{l}701 \\
20.8 \\
0.0500 \\
1,580 \\
870 \\
<5.00 \\
3,380 \\
<200 \\
4,420 \\
<5,000 \\
1.90 \\
44,000 \\
600 \\
<120 \\
<10.0 \\
0.462 \\
<0.390 \\
4.10 E-10 \pm 4.60 E-10 \\
2.13-09 \pm 9.90 E-10 \\
6.31 E-06 \pm 1.09 E-06\end{array}$ & $J$ & $E$ & $L$ & $\begin{array}{l}50.0 \\
3.00 \\
0.200 \\
250 \\
400 \\
5.00 \\
100 \\
200 \\
100 \\
5,000 \\
0.569 \\
1.000 \\
1.000 \\
120 \\
10.0 \\
0.462 \\
0.390 \\
7.60 \mathrm{E}-10 \\
1.56 \mathrm{E}-09 \\
1.42 \mathrm{E}-06\end{array}$ & 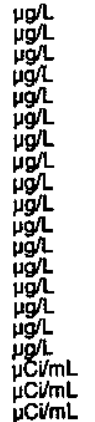 & $\begin{array}{l}\text { ES } \\
\text { ES } \\
\text { ES } \\
\text { ES } \\
\text { ES } \\
\text { ES } \\
\text { ES } \\
\text { ES } \\
\text { ES } \\
\text { ES } \\
\text { WS } \\
\text { ES } \\
\text { ES } \\
\text { TS } \\
T M \\
T M\end{array}$ & $\begin{array}{l}\text { EPA6010 } \\
\text { EPA6010 } \\
\text { EPA7470 } \\
\text { EPA353.2 } \\
\text { EPA6010 } \\
\text { EPA6010 } \\
\text { EPA6010 } \\
\text { EPA6010 } \\
\text { EPA6010 } \\
\text { EPA9056 } \\
\text { EPAB010 } \\
\text { EPA160.1 } \\
\text { EPA9060M } \\
\text { EPA9020B } \\
\text { EPA365.1 } \\
\text { EPA8010 } \\
\text { EPA8010 } \\
\text { EPA900.0M } \\
\text { EPA900.0M } \\
\text { EPA906.0M }\end{array}$ \\
\hline
\end{tabular}

\section{WELL RBP 3D}

MEASUREMENTS CONDUCTED IN THE FIELD

Sample date: 05/28/98

Wath to water: $40.2 \mathrm{ft}(12.25 \mathrm{~m})$ below TOC Sp. conductance: $34 \mu \mathrm{S} / \mathrm{cm}$

Wurbidity: O NTU

ANALYSES

$F$ Analyto

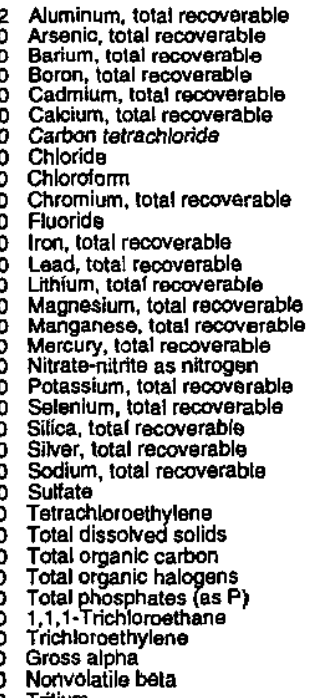

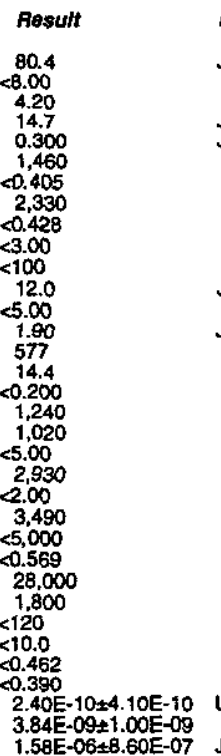

Time: 7:34

Air tememperature: $16^{\circ} \mathrm{C}$ Total ake linutity (as CaCO3): $1 \mathrm{mg} / \mathrm{L}$
Phenolphthalein alkalinity: $0 \mathrm{mgl}$
WELL RPC 1CU

MEASUREMENTS CONDUCTED IN THE FIELD

Sample date: 05/13/98

Depth to water: $38.65 \mathrm{ft}(11.78 \mathrm{~m})$ below TOC

Water elevation: $267.35 \mathrm{ft}(81.49 \mathrm{~m}) \mathrm{msl}$

Sp. conductance: $300 \mu \mathrm{S} / \mathrm{cm}$

Wurbidity: 2 NTU

ANALYSES

$f$ Analyte

: Americium-241

Gross alpha
Nonvolatile beta

\section{WELL RPC $2 \mathrm{CU}$}

$\begin{array}{lll}\text { Result } & R & A \\ 1.32 E-11 \pm 2.64 E-11 & \text { UI } & \\ 2.24 E-09 \pm 7.10 E-10 & & \\ 1.75 E-09 \pm 6.14 E-10 & & \\ 1.15 E-10 \pm 5.21 E-10 & \text { UIJ } & C\end{array}$

Time: 11:06

Waler temperature: $19^{\circ} \mathrm{C}$

Total alikalinity (as CaCO3): $139 \mathrm{mg} /$

MEASUREMENTS CONDUCTED IN THE FIELD

Sample date: 05/13/98

Water elevation: $265 \mathrm{ft}(80.77 \mathrm{~m}) \mathrm{ms}$

Sp. conductance: $16 \mu \mathrm{S} / \mathrm{cm}$

Water evacuated from the well prior to sampling: 51 ga ANALYSES

F Anaty

$\begin{array}{ll}\text { : Americium-241 } \\ 0 \\ 0 \text { Americium-241 } \\ 0 & \text { Americium-241 } \\ 0 & \text { Gross alpha } \\ 0 & \text { Gross alpha } \\ 0 & \text { Gross alpha } \\ 0 & \text { Nonvolatile beta } \\ 0 & \text { Nonvolatile beta } \\ 0 & \text { Nonvolatile beta } \\ 0 & \text { Strontium-90 } \\ 0 & \text { Strontium-90 } \\ 0 & \text { Strontium-90 }\end{array}$

Result

3.63E- $11 \pm 5.95 E-11$

$3.63 E-11 \pm 5.95 E-11$
$5.60 E-10 \pm 5.10 E-10$

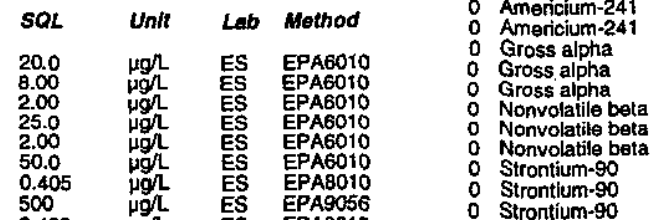

\section{WELL RPC 2CU Replicate}

$1.33 E-09+7.00 E-10$

1.22E-09.1.02E-09 $.91 \mathrm{E}-09+1.06 \mathrm{E}-09$ UI

MEASUREMENTS CONDUCTED IN THE FIELD

Sample date: $05 / 13 / 98$ Depth to water: $29.9 \mathrm{tt}(9.11 \mathrm{~m})$ below TOC

Water

Sp. conductance: $16 \mu \mathrm{S} / \mathrm{cm}$

Turbidity: O NTU

ANALYSES

$F$ Analyte

A Americium-241

O Nonvolatilie beta

7.07E-12.1.92E-11

B. $27 \mathrm{E}-10 \pm 4.14 \mathrm{E}-10$
$1.32 \mathrm{E}-09 \pm 6.21 \mathrm{E}-10$
$3.97 \mathrm{E}-10 \pm 5.63 \mathrm{E}-10$
Time: 11:13

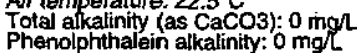

Arter temperature: $199^{\circ} \mathrm{C}$

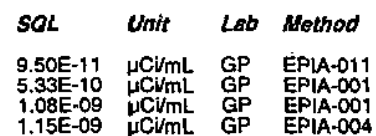

Time: 11:13

are: $19.9^{\circ} \mathrm{C}$

Total alkalinity (as Caco3): $0 \mathrm{mg} /$
Pherolphthaloen alkalinity: $0 \mathrm{mg} / \mathrm{L}$ 
WELLL RSP 2D

MEASUREMENTS CONDUCTED IN THE FIELD

Sample date: $05 / 13 / 98$
Depth to water. $11.9 \mathrm{ft}(3.63 \mathrm{~m})$ below TOC
Wer

Water to

$\mathrm{PH}$. 4.2 conductance: $62 \mu \mathrm{S} / \mathrm{cm}$

Sp.conductance: $62 \mu \mathrm{S} / \mathrm{cm}$
Tubidity: $14 \mathrm{NTU}$
Water evacuated from the well prior to sampling: $14 \mathrm{gal}$

ANALYSES

$F$ Analyto!

- Americium-241

Gross alpha

Nonvolatile beta

O Strontium-90
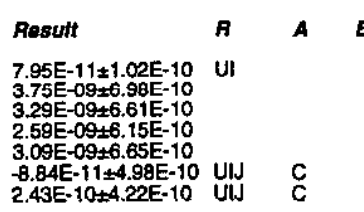

Time: $8: 51$

Air temperature: $17.1^{\circ} \mathrm{C}$

Total alkalinity (as CaCO3): $0 \mathrm{mg} /$
Phenolphthalein alkalinity: $0 \mathrm{mg}$

WELL RSP 3D

MEASUREMENTS CONDUCTED IN THE FIELD

Sample date: 05/13/98

Depth to water. $9.47 \pi(2.89 \mathrm{~m})$ below TOC

Water e

Sp. conductance: $360 \mu \mathrm{S} / \mathrm{cm}$

Turbidity: $4 \mathrm{NTU}$ :
Water evacuated from the well prior to sampling: $19 \mathrm{gal}$

ANALYSES

$F$ Analyte

0. Americium-241

Gross alpha

Nonvolatite beta

WELL RSP 70

MEASUREMENTS CONDUCTED IN THE FIELD

Sample date: $05 / 12 / 98$
Depth to water: $25.2 \mathrm{th}(7.68 \mathrm{~m})$ below TOC
Water elevation: $279.4 \mathrm{ft}(85.16 \mathrm{~m}) \mathrm{msl}$

Water el

p. conductance: $28 \mu \mathrm{S} / \mathrm{cm}$

Turbidity: 1 NTU:
Water evacuated from the well prior to sampling: $70 \mathrm{gal}$

ANALYSES

$F$ Anatyto.

0 Americium-241

Gross alpha

Nonvolatile beta

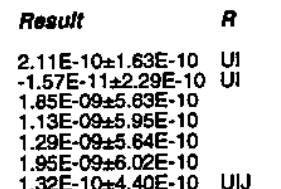

A B

\begin{tabular}{|c|c|c|c|}
\hline & Unt & Lab & Method \\
\hline $\begin{array}{l}1.87 E-10 \\
5.32 E-10 \\
4.81 E-10 \\
9.79 E-10 \\
1.04 E-09 \\
1.13 E-09\end{array}$ & 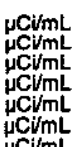 & $\begin{array}{l}G P \\
G P \\
G P \\
G P \\
G P \\
G P \\
G P\end{array}$ & 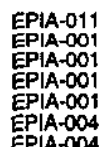 \\
\hline
\end{tabular}

$1.13 E-09 \quad \mu C V / m L$ GP

Air temperature: $17.7^{\circ} \mathrm{C}$

Total allalinity (as CaCO3): $179 \mathrm{mg} / \mathrm{L}$
Phenolphthalein alkalinity: $0 \mathrm{mg} / \mathrm{L}$

$\begin{array}{ll}\text { Resuft } & \boldsymbol{A} \\ 6.00 \mathrm{E}-12+1.50 \mathrm{E}-11 & \mathrm{UI} \\ 6.03 \mathrm{E}-10 \pm 3.28 \mathrm{E}-10 \\ 1.50 \mathrm{E}-09 \pm 5.67 \mathrm{E}-10 \\ 4.44 \mathrm{E}-10 \pm 4.94 \mathrm{E}-10 \\ 1.06 \mathrm{U}-10 \pm 5.18 \mathrm{U}-10 \\ 6.30 \mathrm{U}-10 \pm 5.64 \mathrm{E}-10 \text { UI }\end{array}$

A

Time: 11:04

Water temperature: $19^{\circ} \mathrm{C}$

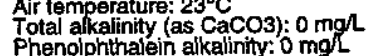
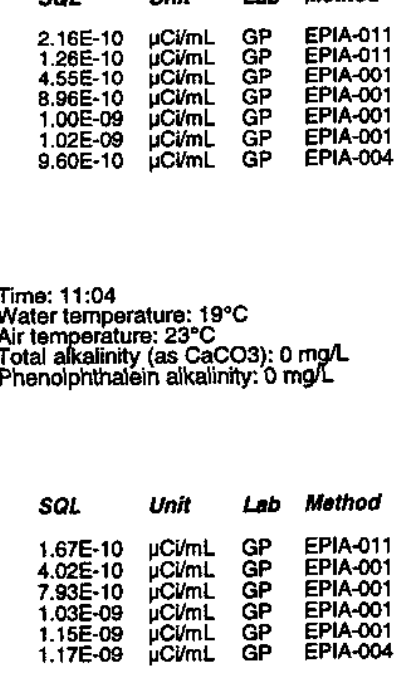

ESH-EMS-980569
WELL RWM 1

MEASUREMENTS CONDUCTED IN THE FIELD

Sample date: 04/17/98
Depth to water: Not available
Water elevation: Not available

$\mathrm{H:} 5.1$

Sp. conductance: $75 \mu \mathrm{s} / \mathrm{cm}$

The well was continuously purnping.

ANALYSES

$F$ Analyto

Result

Acetone
0 Acetone
0 Acetonitrile (Methyl cyanide)
0 Acetonitrile (Methyl cyanide)

- Acrolein

: Acrolein

- Acrylonitrile

Allyl chloride

Benzer

Bromodichloromethane
Bromodichloromethane

Bromoform
Bromomethan

Cromomethane

Carbon disulfide

Carbon tetrachlorlde

Chlorobenzen

0 Chloroethane

Chlorothane

Chloroethene (Vinyl chloric)

2-Chioroethyl vinyl ether
2-Chloroethyl vinyl ether

Chloroform

Chloromethane

Chloroprene

Dibromochloromethane

1,2-Dibromo-3-chloropropan

1,2-Dibromo-3-chloropropan

1,2-Dibromoethane

Dibromormethane

Dibromomethane

1,2-Dichlorobenzene

1,3-Dichlorobenzen

1.4-Dichlorobenzen

trans-1,4-Dichloro-2-buten

0 trans-1,4-Dichloro-2-buten

Dichlorodifluoromethans

1,1-Dichloroethane

1,2-Dichloroesthane

1,2-Dichloroethane

1,1.Dichloroethylene

trans-1,2-Dichloroethylene

Dichloromethane

1,2-Dichloropropan

-237
Time: 8:13

Airter temperature: $19.3^{\circ} \mathrm{C}$

Total akkalinity (as CaCO3): $0 \mathrm{mg} / \mathrm{h}$
Phenolphthalein alkalinity: $0 \mathrm{mg} \mathrm{L}^{-}$

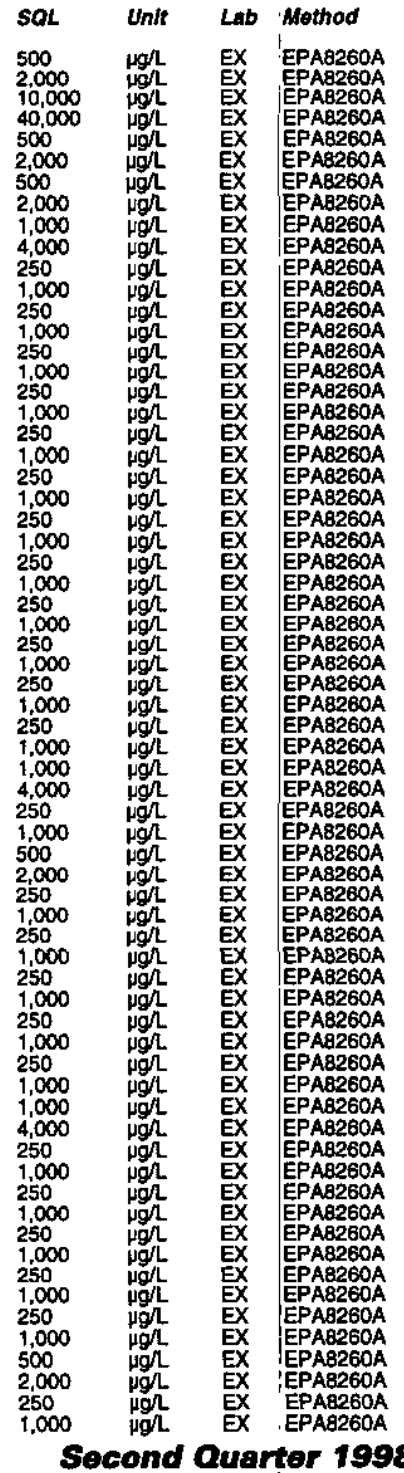


Well RWM 1 collected on 04/17/98 (cont.)

\begin{tabular}{|c|c|}
\hline Anelyte & Resulf \\
\hline 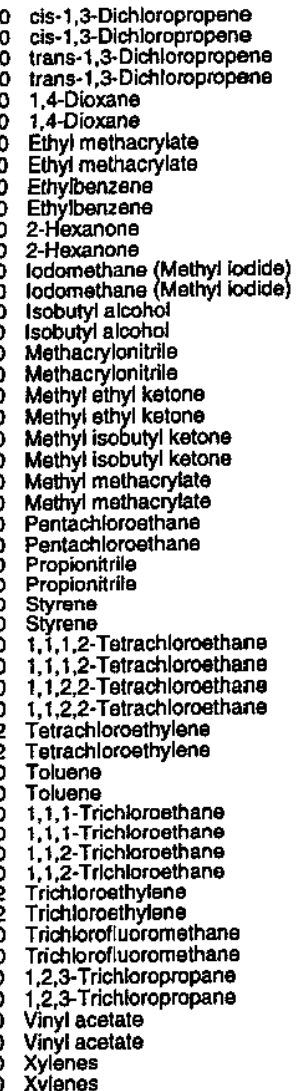 & $\begin{array}{l}250 \\
<1,000 \\
<250 \\
<1,000 \\
<50,000 \\
<200,000 \\
<500 \\
<2,000 \\
<250 \\
<1,000 \\
<500 \\
<2,000 \\
<250 \\
<1,000 \\
<50,000 \\
<200,000 \\
<25,000 \\
<100,000 \\
<500 \\
<2,000 \\
<500 \\
2,000 \\
<2,500 \\
<10,000 \\
<1,000 \\
<4,000 \\
225,000 \\
<100,000 \\
250 \\
<1,000 \\
<250 \\
<1,000 \\
250 \\
<1,000 \\
13,400 \\
13,100 \\
<250 \\
<1,000 \\
250 \\
<1,000 \\
250 \\
<1,000 \\
25,000 \\
24,100 \\
<250 \\
<1,000 \\
250 \\
<1,000 \\
<500 \\
2,000 \\
<500 \\
<2,000\end{array}$ \\
\hline
\end{tabular}

WELL RWM 1

MEASUREMENTS CONDUCTED IN THE FIELD

Sample date: $05 / 08 / 98$ (

Water el

$\mathrm{pH}: 4.2$ conductance: $68 \mu \mathrm{S} / \mathrm{cm}$

The well was continuously pumping

ANALYSES

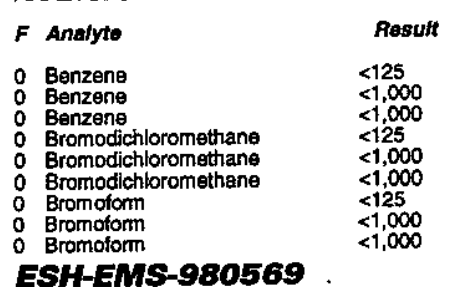

ESH-EMS-980560

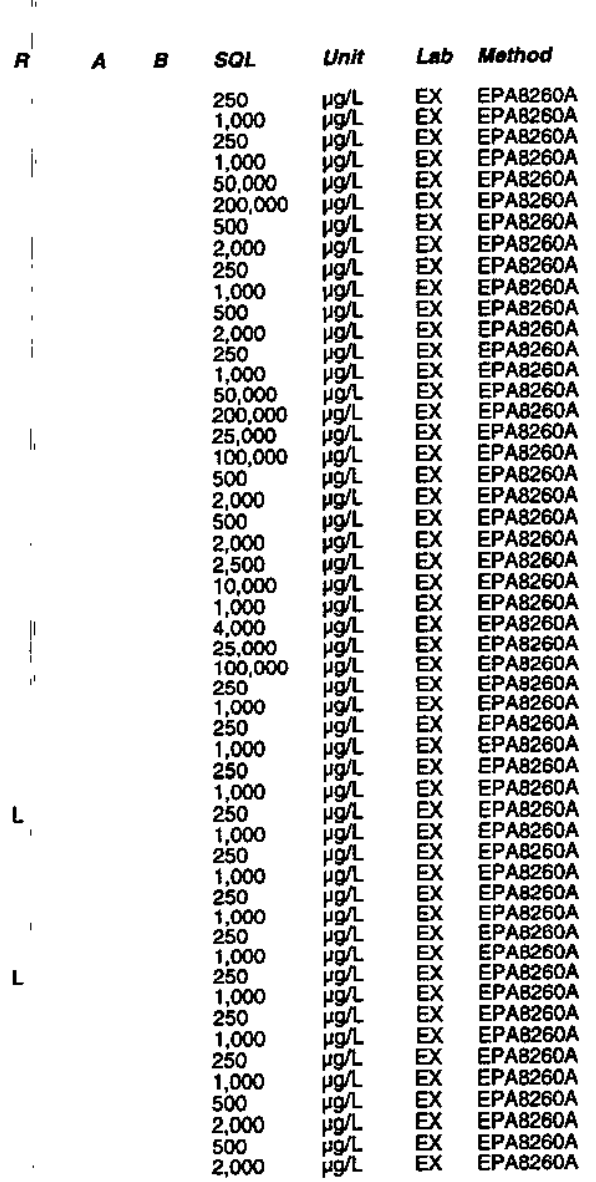

$F$ Analvio

\begin{tabular}{|c|c|}
\hline 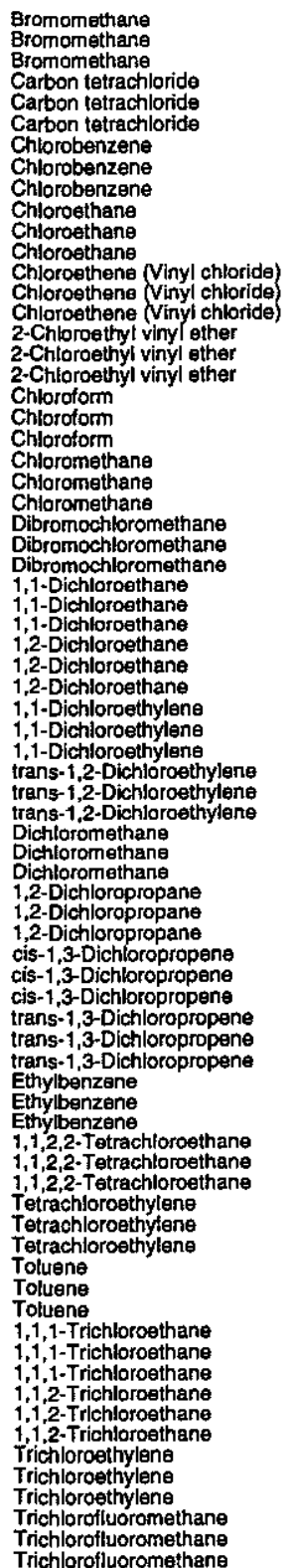 & $\begin{array}{l}<125 \\
<1,000 \\
<1,000 \\
<1,25 \\
<1,000 \\
<1,000 \\
<125 \\
<1,000 \\
<1,000 \\
<125 \\
<1,000 \\
<1,000 \\
<125 \\
<1,000 \\
<1,000 \\
<125 \\
<1,000 \\
<1,000 \\
<125 \\
<1,000 \\
<1,000 \\
<125 \\
<1,000 \\
<1,000 \\
<125 \\
<1,000 \\
<1,000 \\
<125 \\
<1,000 \\
<1,000 \\
<125 \\
<1,000 \\
<1,000 \\
<125 \\
<1,000 \\
<1,000 \\
<125 \\
<1,000 \\
<1,000 \\
2250 \\
<2,000 \\
<1,000 \\
<1,25 \\
<1,000 \\
<1,000 \\
<125 \\
<1,000 \\
<1,000 \\
<125 \\
<1,000 \\
<1,000 \\
<125 \\
<1,000 \\
<1,000 \\
<125 \\
<1,000 \\
<1,000 \\
12,200 \\
18,000 \\
14,700 \\
<125 \\
<1,000 \\
<1,000 \\
<125 \\
<1,000 \\
<1,000 \\
<125 \\
<1,000 \\
<1,000 \\
18,900 \\
26,000 \\
24,400 \\
<1,5 \\
<1,000 \\
<1,000\end{array}$ \\
\hline
\end{tabular}

Time: 8:00

perature: $18^{\circ} \mathrm{C}$ Total akkalinity (as CaCO3): $0 \mathrm{mg}$
Phenolphthalein alkalinity: $0 \mathrm{mgh}$

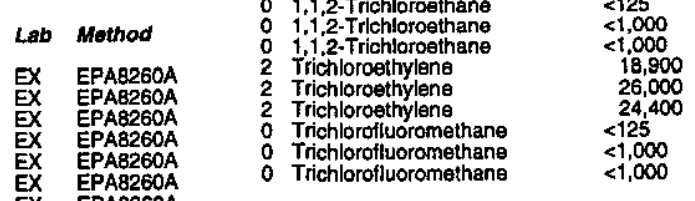

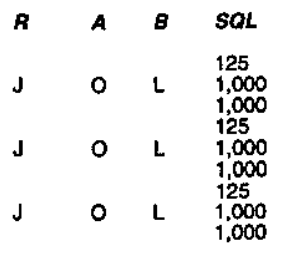

Untt
$\mu g h$
$\mu g h$
$\mu g h$
$\mu g h$
$\mu g h$
$\mu g h$
$\mu g h$
$\mu g h$
$\mu g h$
$\mu g h$

\begin{tabular}{|c|c|c|c|}
\hline $\boldsymbol{R}$ & $A$ & $B$ & SOL \\
\hline J & 0 & L & $\begin{array}{l}125 \\
1,000 \\
1,000 \\
125\end{array}$ \\
\hline $\mathbf{J}$ & 0 & L & $\begin{array}{l}1,000 \\
1,000 \\
125\end{array}$ \\
\hline J & 0 & L & $\begin{array}{l}1,000 \\
1,000 \\
125\end{array}$ \\
\hline J & 0 & L & $\begin{array}{l}1,000 \\
1,000 \\
125\end{array}$ \\
\hline $\mathbf{J}$ & 0 & L & $\begin{array}{l}1,000 \\
1,000 \\
125\end{array}$ \\
\hline J & 0 & L & $\begin{array}{l}1,000 \\
1,000 \\
125\end{array}$ \\
\hline J & 0 & L & $\begin{array}{l}1,000 \\
1,000 \\
125\end{array}$ \\
\hline J & 0 & L & $\begin{array}{l}1,000 \\
1,000 \\
125\end{array}$ \\
\hline J & 0 & $\mathbf{L}$ & $\begin{array}{l}1,000 \\
1,000 \\
125\end{array}$ \\
\hline $\mathbf{J}$ & 0 & $\mathbf{L}$ & $\begin{array}{l}1,000 \\
1,000 \\
125\end{array}$ \\
\hline J & 0 & L & $\begin{array}{l}1,000 \\
1,000 \\
125\end{array}$ \\
\hline J & 0 & L & $\begin{array}{l}1,000 \\
1,000 \\
125\end{array}$ \\
\hline J & 0 & $\mathbf{L}$ & $\begin{array}{l}1,000 \\
1,000 \\
250\end{array}$ \\
\hline J & 0 & L & $\begin{array}{l}2,000 \\
2,000 \\
125\end{array}$ \\
\hline $\mathrm{J}$ & 0 & L & $\begin{array}{l}1,000 \\
1,000 \\
125\end{array}$ \\
\hline J & 0 & L & $\begin{array}{l}1,000 \\
1,000 \\
125\end{array}$ \\
\hline J & 0 & $L$ & $\begin{array}{l}1,000 \\
1,000 \\
125\end{array}$ \\
\hline J & 0 & L & $\begin{array}{l}1,000 \\
1,000 \\
125\end{array}$ \\
\hline $\mathbf{J}$ & 0 & L & $\begin{array}{l}1,000 \\
1,000 \\
1,05\end{array}$ \\
\hline J & 0 & L & $\begin{array}{l}1,25 \\
1,000 \\
1,000 \\
125\end{array}$ \\
\hline $\mathfrak{J}$ & 0 & L & $\begin{array}{l}1,000 \\
1,000 \\
125\end{array}$ \\
\hline $\mathbf{J}$ & 0 & $\mathrm{~L}$ & $\begin{array}{l}1.000 \\
1.000 \\
125\end{array}$ \\
\hline J & 0 & $\mathbf{L}$ & $\begin{array}{l}1,000 \\
1,000\end{array}$ \\
\hline $\mathrm{j}$ & 10 & $L$ & $\begin{array}{l}1,000 \\
1,000 \\
125\end{array}$ \\
\hline$J$ & 0 & $L$ & $\begin{array}{l}1,000 \\
1,000\end{array}$ \\
\hline
\end{tabular}

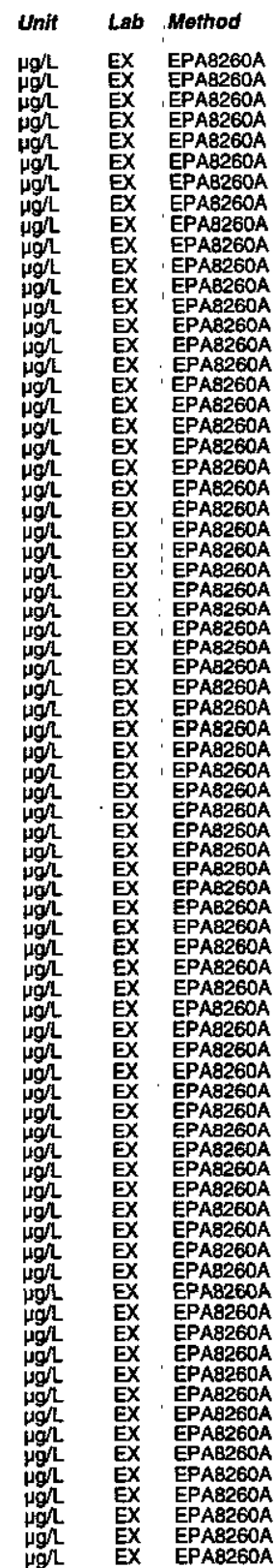




\section{WELL RWM 1}

MEASUREMENTS CONDUCTED IN THE FIELD

Sample date: 06/08/98

Water to wateration: Not available

$\mathrm{PH}: 4$.

sp. conductance: $72 \mu \mathrm{S} / \mathrm{cm}$

ANALYSES

$F$ Analyte

- Benzene

Benzeng
Bromodicthoromethane

Bromodichloromethane

Bromotom

Bromoform

Bromomethane
Bromomethane

Carbon tetrachlorid

Carbon tetrachloride

Chiorobenzzente

Chioroberzene

Chloroethane

Chioroethane Chloroethene (Vinyl chloride) Chloroesthene (Vinyl chloride
2-Chlorioethyl vinyl ether 2-Chloroethyl vinyl ether
2-Chloroettyl viny ether Chloroform

\section{Chiloromethan}

Chloromethane Dibromochloromethane 1.1-Dichloroethan 1.1. Dictloroethan 1,2-Dichloroethane 1.1-Dichloroethylen 1,1-Dichloroesthylene trans-1,2-Dichloroesthylen trans-1,2-Dichloroethylen Dichloromethane 1,2-Dichloroprop 1,2-Dichloropropane cis-1,3-Dichloropropen is-1,3-Dichloropropene trans-1,3-Diohloropropene
trans- 1,3 -Dlchloropropene Ethylbenzene Ethylbenzene $1,1,2$-Tetrachloroethane

ESHEMS-980569
Well RWM 1 collected on 06/08/98 (cont.)

$F$ Analyte

Time: 10:19

ater temperature: $21^{\circ} \mathrm{C}$

Total alkahinity (as CaCO3): $0 \mathrm{mg} /$

2 Tetrachloroethylene

Toluene

Toluene

1,1-Trichloroethan

促,

1, 2-Trichloroethane

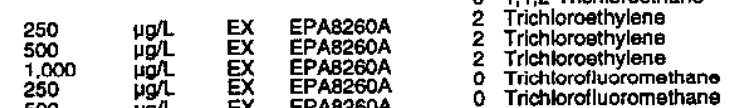

Trichlorofluoromethane

WELL RWM 2

MEASUREMENTS CONDUCTED IN THE FIELD

Sample date: 04/17/98

Water elevation: Not available

Wh: 4.3

Pp. conductance: $80 \mu \mathrm{S} / \mathrm{cm}$

The well was continuously pumping.

ANALYSES

$F$ Analyto

0 Acetone

Acetonitrile (Methyl cyanide)

: Acrolein

: Acrylonitrile

A Alyl chloride

0 Benzen

Benzene
0 Bromodichloromethane
0 Bromodichloromethane

O Bromoform

Bromomethane

Corbon disulfide

- Carbon tetrachloride

Carbon tetrachlorido

0 Chlorobenzene

Chloroethane

Chloroethene Vinyt chloride

Chloroathene (Viny chlorida

2-Chloroathyl vinyt eth

Chloroform

o Chloromethan

Chloromethan
Chloroprene

Chloropran

Dibromochloromethan

1,2-Dibromo-3-chloropropan

1,2-Dibromoethane

Dibromonethane

-239

Result
12,900
13,000
$<250$
$<500$
$<1,000$
$<50$
$<500$
$<1,000$
$<50$
$<500$
$<1,000$
19,100
22,300
21,700
$<500$
$<500$
$<1,000$

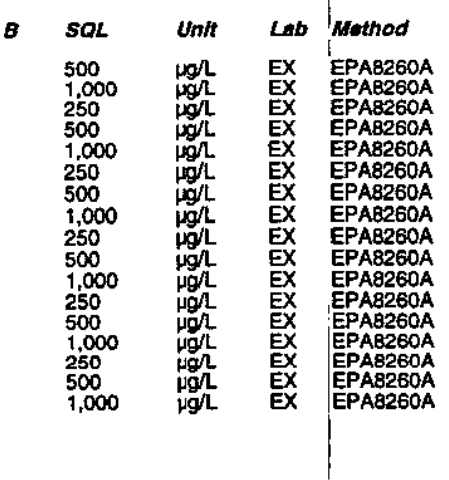

Time: 9:04

Water temperature: $20.1^{\circ} \mathrm{C}$ Air temperature: $21.3^{\circ} \mathrm{C}$ )

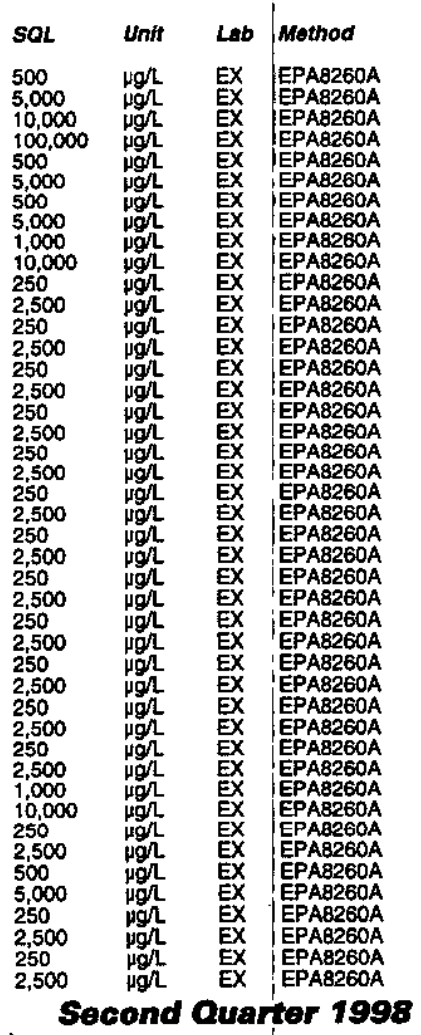


Well RWM 2 collected on 04/17/98 (cont.)

$F$ Analyto

o 1.2-Dichlorobenzens

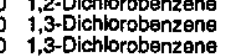

1.4-Dichlorobenzene

1,4-Dichloroberzzen
0
0

trans-1,4-Dichloro-2-buten
0 Oichlorodifluoromethane

Dichlorodifluoromethan

: 1,1-Dichloroethane

1,2-Dichlorosthane

o 1,1-Dichloroethylene

: trans-1,2-Dichloroethylene

Dichloromethane

1.2-Dichloropropane

1,2-Dichloropropane

0 cis-1,3-Dichioropropene

1.4-Dioxane

Eihyl methacrylate
Ethyl methacrylate

Ethylbenzzene

2-Hexanone

2-Hexanone

lodomethane (Methyl iodide)

isobuty alcohol

Isobutyl alcohol

Methacrylonitrile

Methyl ethyl ketone

Methyl isobuty| ketone

Mettyy methacrylate

Pentachloroethane

O Propionitrile

Styrene

1,1,1,2-Tetrachloroethane

: $1,1,1,2$-Tetrachloroethane

2 1,1,2,2-Totrachloroeth

2 Tetrachlo

0 Toluene

1,1,1-Trichloroethane

1,1,2-Trichloroethane

Trichlorosthyleng

Trichloroftuoromethane

1,2,3-Trlehloropropapan

Vinyl acetate

Vinyl acetate

0
0 Xylenes
0 Xylenes

Result

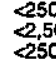

250
2,500
250
2500

$<1,000$

$<10,000$

2.500
2500
2.500
2

250
2.500
25.500
2.500

250

5500
25,000
250
2500

2,500
250
2500

250

25000
550000000
-500000

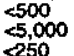

25.500
2500
2500

5

$\sum_{25000}^{2500}$

500,000
250.000
250.000
5

$\$ 500$
$<5,000$
-5500

$<500$
5,000
2,500

25000
$<1000$

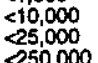

250,000
250

25000
2500
2500

2.500
250
2.500
12,200

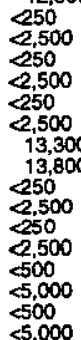

ESH-EMS-980569

WELL RWM 2

MEASUREMENTS CONDUCTED IN THE FIELD

Sample date: 05/08/98
Depth to water $210.5 \mathrm{ft}(64.16 \mathrm{~m})$ below TOC
Water elevation: $160.8 \mathrm{ft}(49.01 \mathrm{~m}) \mathrm{msl}$

$\mathrm{Sp}$. conductance: $94 \mu \mathrm{S} / \mathrm{cm}$

Turbidity: 2 NTU
The well was continuously pumping.

ANALYSES

$F$ Analyte

O Benzene

Bromodichloromethane
Bromodichloromethane

0 Bromodich

Bromornethane

Carbon tetrachloride

Chlorobenzene

Chlorosthane

Chloroetthene Vinyl chloride
Chloroethene (Vinyl chloride

2-Choroethyl vinyl ether

Chloroform

Chloromethane

Dibromocthloromethan

Dibromochllorometh

1,1 -Dichloroethane
1,2 -Dichloroethane

1,it-Dichloroethyngene

1,
0
0

Dichlioromethane
Dichloromethane

1.2-Dichloropropano

cis-1,3-Dichloropropene

trans-1,3-Dich

Ethylbenzene

1,1,2,2-Tetrachloroethane

Tetrachloroethylene

2 Tetrachilo

Toluane
$0.1,1$-Trichlorosthane

1,1,1-Trichloroethane

1,1,2-Trichloroethane

2 Trichloroesthylene

: Trichloroflluoromethane

Result

${ }_{5125}^{<125}$

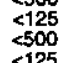

$<500$
$<15$
$<500$
$<125$

${ }_{500}^{<125}$

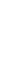

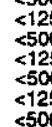

政

$<125$
$<500$
$<125$
$<500$
$<50$

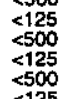

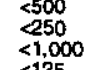

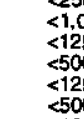

512
510
512
510
512
510
512
550
5

5500
11.600
14.100
$<125$
5

$<125$
$<500$
$<125$
$<500$
$<125$
$<500$
12,400
13,200
$<125$
$<500$
Time: 9:20

Air temperature: $21.5^{\circ} \mathrm{C}$

Tolal alkalinity (as CaCO3): $0 \mathrm{mg} / \mathrm{L}$

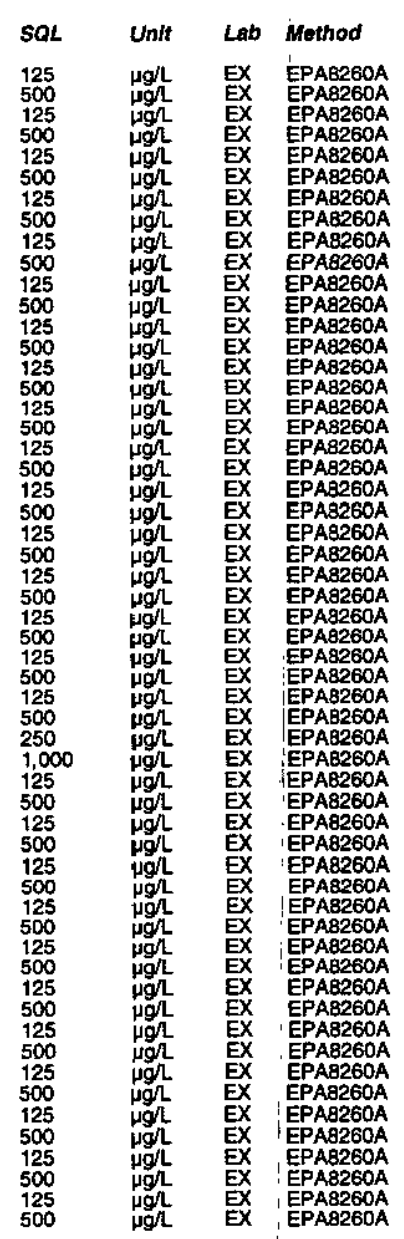


WELL RWM 2

MEASUREMENTS CONDUCTED IN THE FIELD

Sample date: 06/08/98

Water to water: Not availiable

Sp. conductance: $96 \mu \mathrm{S} / \mathrm{cm}$

ANALYSES

$F$ Analyto

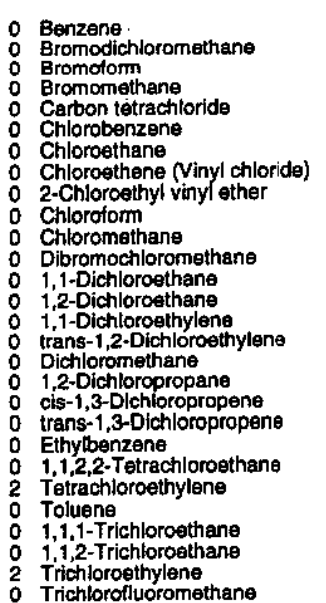

Rosult

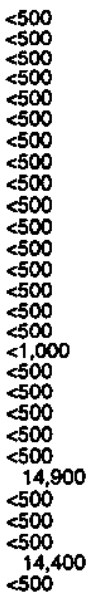

WELL RWM 3

MEASUREMENTS CONDUCTED IN THE FIELD

Sample date: 04/17/98

Depth to water: Not available
Water elevation: Not available

$\mathrm{H}: 4.7$

Sp. conductance: $49 \mu \mathrm{S} / \mathrm{cm}$

The well was continuously pumping.

ANALYSES

$F$ Anatyto

- Acetone

Acetone
0 Actonitilile (Methyl cyanide)
0 Acetonitrila (Methyl cyanide)

Acrolein

Acylonitrile

Acrylonitrile

Bromodichloromethane

Bromodichio

Bromoform

: Bromomethane

Carbon disulfide

Carbon tetrachlorido

ESH-EMS-980569
Well RWM 3 collected on 04/17/98 (cont.)

$F$ Anajyte

Time: 10:55

Air temperature: $25.5^{\circ} \mathrm{C}$
Total alkalinity (as Caco3): $0 \mathrm{mg} /$
Phenolphthalein alkalinity: $0 \mathrm{mg} /$

- Carbon tetrachloside

Chlorobenzene

Chloroethane Chloroethane
Chloroetthene Vinyl chloride) 2-Chlorosthyl vinyl ether

2-Chloroeth

Chloromethane

Chloromethan

Chloroprene
Dibromochloromethane

1,2-Dibromo-3-chloropropane

1,2-Dibromo-3-chloropropane

1,2-Dibromoethane
1,2 -Dibromoethane

Dibromomethane

1,2-Dichborobenzen

1,3-Dichiorabenzen

1.4-Dichborobenzene
1,4 -Dichlorobenzene

trans-1.4-Dichloro-2-butene

Dichlorodifluorometh

1,1-Dichloroethane

1.2-Dichloroethane

1,1-Dichloroethyline

trans-1,2-Dichloroethylene

Dichloromethane

1,2-2ichloropropane

cis-1,3-Dichloropropene

trans-1,3-Dichloropropen

1,4-Dioxane

Eithyl methacrylate
Ethyl methacylate

Ethylbenzene

Enyybenzene
E.Hexanone

Iodomethene (Methyl iodide)

lodomethane (Methyl iodide)

Isobutyl alcohol
Isobutyl alcohol

Methacrylonitrile

Methyl ethyl keton

Methyl isobutyl keton

Methyl isobutyl keton

Methyl methacylate
Methyl methacrytate

Pentachloroethane

Propionitrile

O Styrene

$1,1,0$

1.1. 2-Tetrachloroethane

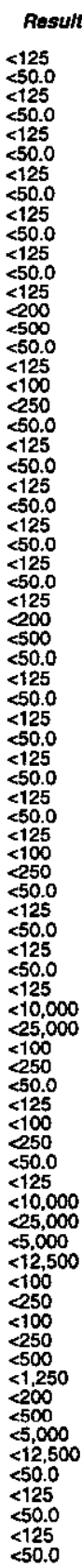

$B$

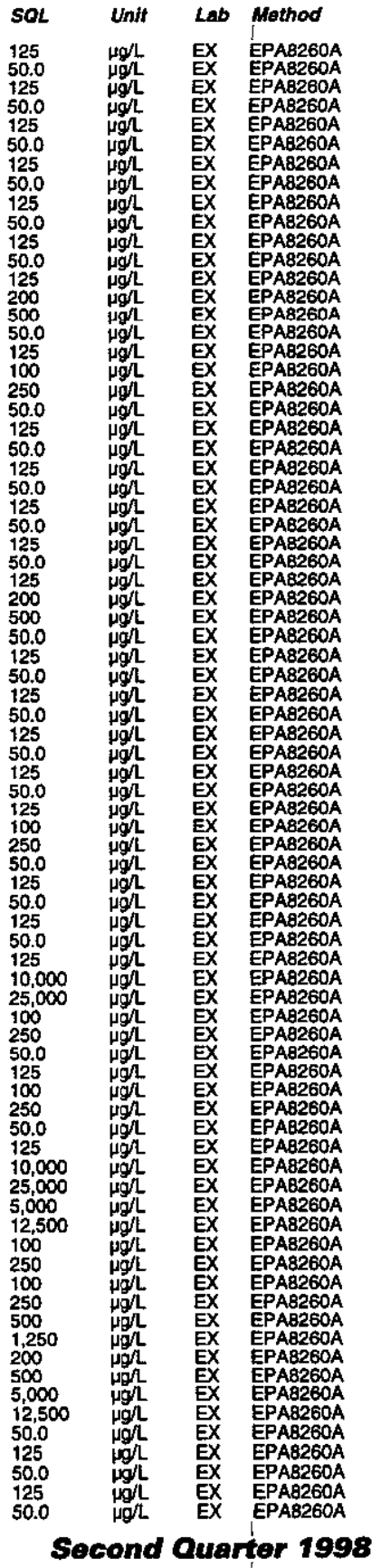


Well RWM 3 collected on 04/17/98 (cont.)

$F$ Anetyte

1, 1,2,2-Tetractioroethane

2 Tetrachloroethylene

Toluene

$\begin{array}{ll}0 & \text { Toluene } \\ 0 & 1,1,1,- \text { Trichloroethane } \\ 0 & 1,1,1-\text { Trichloroethane }\end{array}$

1,1,1-Trichloroethane

Trichloroethylest

Trichloroethylene

Tricthoroflyuoromethane

1,2,3-Trichloropropane

Vinyl acetate

O Xylanes

WELL RWM 3

MEASUREMENTS CONDUCTED IN THE FIELD Sample date: $05 / 08 / 98$
Depth to water: $168.15 \mathrm{ft}(51.25 \mathrm{~m})$ below TOC
Water elevation: $208.85 \mathrm{ft}(63.66 \mathrm{~m}) \mathrm{ms}$ $\mathrm{pH}: 4.6$. conductance: $46 \mu \mathrm{S} / \mathrm{cm}$

The well was continuousty pumping. ANALYSES

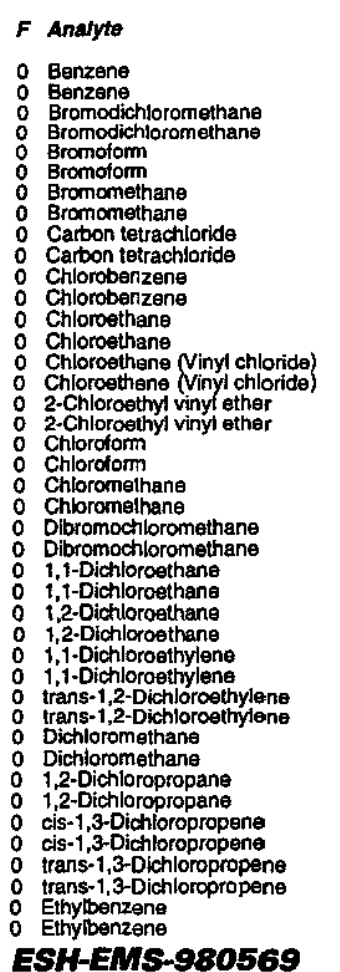

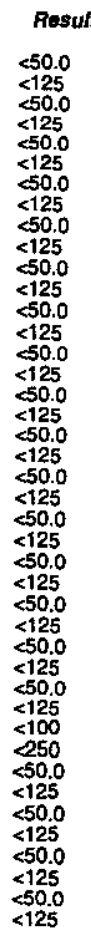

Time: 8:50

20. $20^{\circ} \mathrm{C}$

Total akerinitity: (as Caco3): $0 \mathrm{mg} / \mathrm{L}$
Phenolphthalein alkalinity: $0 \mathrm{mg} \mathrm{L}$
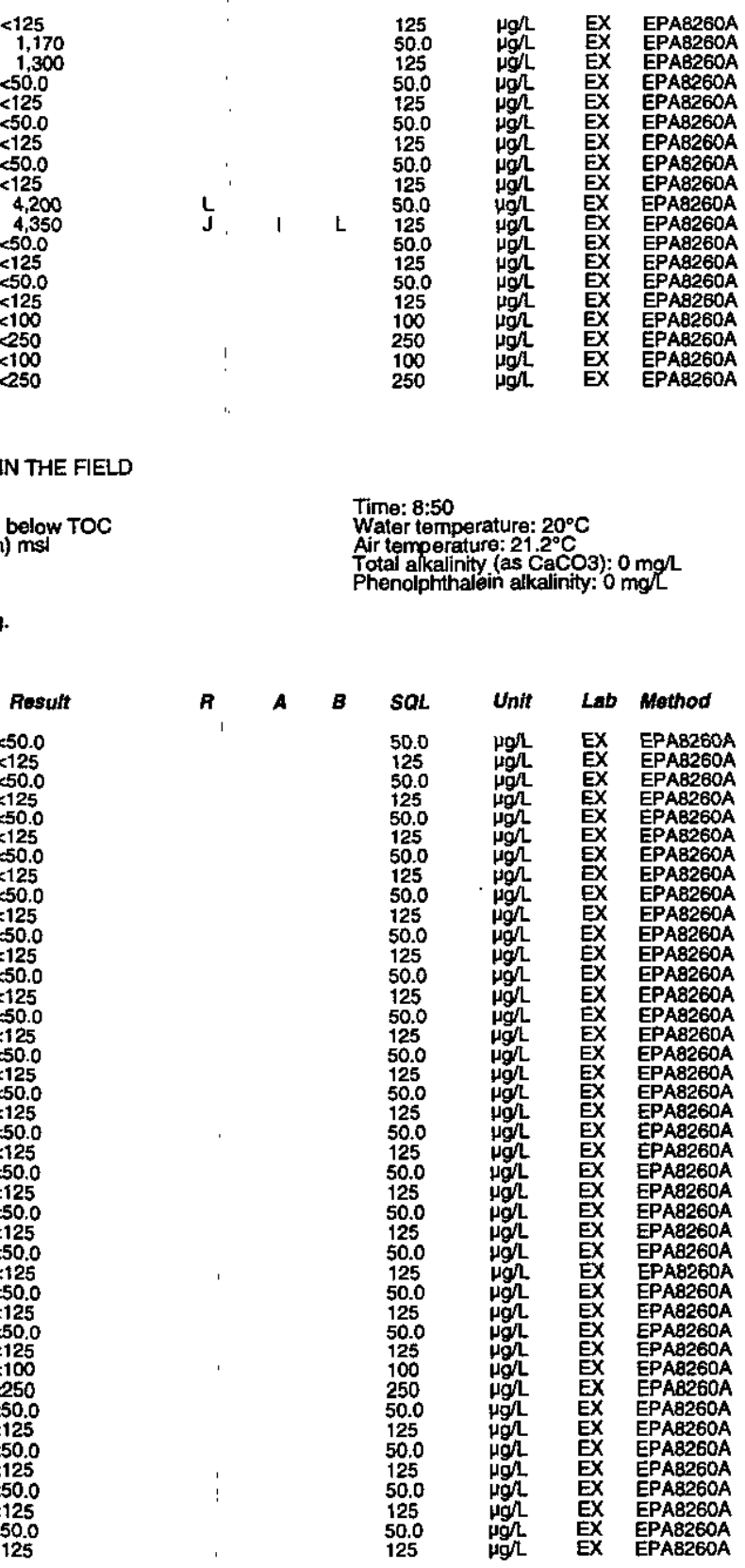

EPA8260A

Well RWM 3 collected on 05/08/98 (cont.)

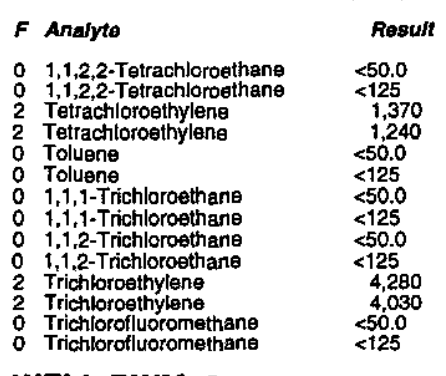

WELL RWM 3

MEASUREMENTS CONDUCTED IN THE FIELD

Sample date: 06/08/98 Water elevation: Not available $\mathrm{gH}: 4.8$ conductance: $48 \mu \mathrm{S} / \mathrm{cm}$ ANALYSES

$F$ Analyto

: Benzene
0 Benzene
O
Bromodichloromethane
O Bromodichloromethane
0 Bromoform
0 Bromoform

Bromomethens

Carbon tetrachloride

Chlorobenzente

Chlorosthane

Chloroethene Ninyl chloride)

0
0 2-Chloeroethyl vinyl cther
0 2-Chloroethyl vinyl ether

0 Chloroform

Chloromethane

Dibromochloromethane
Dibromochloromethan

1,i-Dichloroethane

1,1-Dichloroethane

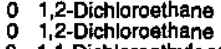

: 1,1 -Dichloroethylen

trans-1,2-Dichloroethylen
trans-1,2-Dichloroethylene

0 Dichloromethane

1,2-Dichloropropan

cis- $1,3-$ Dichloropropene

cis-1,3-Dichloropropene
trans-1,3-Dichlopropene

$\therefore$ : trans-1,3-Dichloropropene : Ethylbenzene

: 1,1,2,2-Tetrachloroethane

Titrachloroethylene Tetrachloroethylene

Toluene

EPAB260A
Time: 10:47

Total alkalinity (as CaCO3): $0 \mathrm{mg} / \mathrm{L}$
Phenolphthalein alkalinity: $0 \mathrm{mg} / \mathrm{L}$
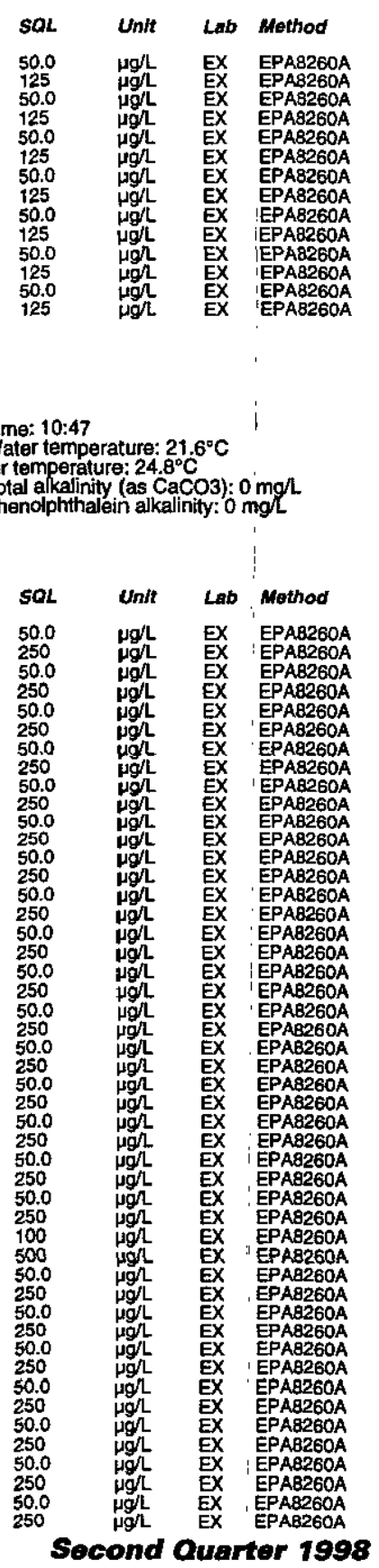
Well RWM 3 collected on 05/08/98 (cont.)

\begin{tabular}{|c|c|c|c|c|c|c|c|c|}
\hline Analyte & Result & $\boldsymbol{A}$ & $A$ & $\boldsymbol{B}$ & SOL & Untt & Lab & Method \\
\hline 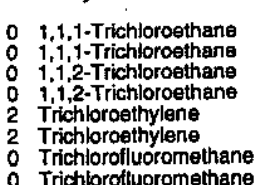 & $\begin{array}{l}<50.0 \\
250 \\
<50.0 \\
<250 \\
3,630 \\
3,710 \\
<50.0 \\
<250\end{array}$ & L & 1 & $L$ & $\begin{array}{l}50.0 \\
250 \\
50.0 \\
250 \\
50.0 \\
250 \\
50.0 \\
250\end{array}$ & 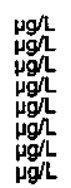 & $\begin{array}{l}\text { EX } \\
E X \\
E X \\
E X \\
E X \\
E X \\
E X \\
\text { EX } \\
\text { EX }\end{array}$ & $\begin{array}{l}\text { EPA88600A } \\
\text { EPA8260A } \\
\text { EPA8260A } \\
\text { EPAB260A } \\
\text { EPA8260A } \\
\text { EPAB260A } \\
\text { EPAB260A } \\
\text { EPA8260A }\end{array}$ \\
\hline
\end{tabular}

\section{WELL RWM 4}

MEASUREMENTS CONDUCTED IN THE FIELD

Sample date: $04 / 17 / 98$
Depth to water: $163.41 \mathrm{ft}(49.81 \mathrm{~m})$ below TOC
Water elevation: $203.09 \mathrm{Ht}(61.9 \mathrm{~m}) \mathrm{msl}$ Water 7.1 H: 7.1 conductance: $34 \mu \mathrm{S} / \mathrm{cm}$ The well was continuously pumping.

ANALYSES

F Analyto

Accetone

Acrobin

Acrylonitrile

Bromodichloromethane

Bromotom

Carbon disulfide

Chlorobenzene

Chlorosthane

Chloroethene (Vinyl chloride)

Chloromethane

Chloroprene

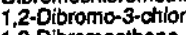

Dibromomethane

1,2-Dichlorobenzene

1,4-Dichlorobenzene
trans-1,4-Dichioro-2-buten

Dich-1orodifiluorometh

1,1-Dichloroethylene

Dichloromethane

1,2-Dichloropropane

1trans-1,3-Dichloropropor

Etyy methacryla

Ethylbenzene

lodomethane (Methyl iodide)

Methacrylonitrile

Methyl isobutyl ketone

Methyl methacrylate

Styrene

Ti, trachloroethylene

Toluene

ESH-EMS-980569
Time: 8:00

Total alkalinity (as Caco3): $0 \mathrm{mg}$

Aesuit

$<500$

$<10,000$
$<500$
$<500$
$<1,000$

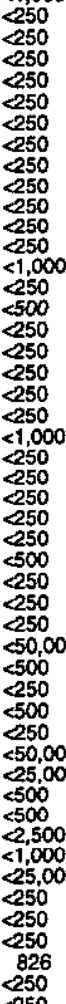

Well RWM 4 collected on 04/17/98 (cont)

$F$ Analyte

Rosult

1,1,2-Trichloroethan

1,2,3-Trichloromeropane

0 Xylenes

250
7.040
250
250
2500
2500

\section{WELL RWM 4}

MEASUREMENTS CONDUCTED IN THE FIELD Sample date: 05/07/98

Depth to water $163.3 \mathrm{ft}(49.77 \mathrm{~m})$ below TOC
Water elevation: $203.2 \mathrm{H}(61.94 \mathrm{~m})$ msl

Sp. conductance: $25 \mu \mathrm{S} / \mathrm{cm}$

Turbidity: ONTU:

ANALYSES

$F$ Analyte

Rosult

: Benzene

Bromoform

Carton tetrachloride

Chioroethane

Chloroethene (Vinyl chloride)

2-Chloroethyl vinyl ether

Chlorotorm

Dibromochloromatha

1,2-Dichloroethane

trans-1,2-Dichloroethylen

Dichloromethane

o cis-1,3-Dichloropropene

trans-1,3-Dichloropropen

1,1,2,2-Tetrachloroethe

Tetrachloroethylen

0 1,1,1-Trichloroethane

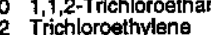

0 Trichlorofluoromethan

\section{WELL RWM 4}

MEASUREMENTS CONDUCTED IN THE FIELD

Sample date: 06/08/98

Water glevation: $203.2 \mathrm{ft}(61.94 \mathrm{~m}) \mathrm{ms}$

pH: 5.1 conductance: $26 \mu \mathrm{S} / \mathrm{cm}$

Turbidity: 1 NTU

ANALYSES

$F$ Analyte

- Benzene

Bromodichlozomethan

Bromodichloromethan

B Bromotom

Bromomethan

0
0 Cromomithane
Carbon tetrachloric

$-243$
R A $B$ SOL Unit Lab Mothod

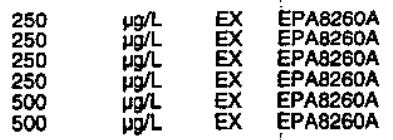

Time: $11: 10$

Wir $20.7^{\circ} \mathrm{C}$

Total alkalinity (as CaCO3): $0 \mathrm{mgh}$
Phenotphthalein alkalinity: $0 \mathrm{mgh}$ 
ANALYTICAL RESULTS

Well RWM 4 collected on 06/08/98 (cont.)

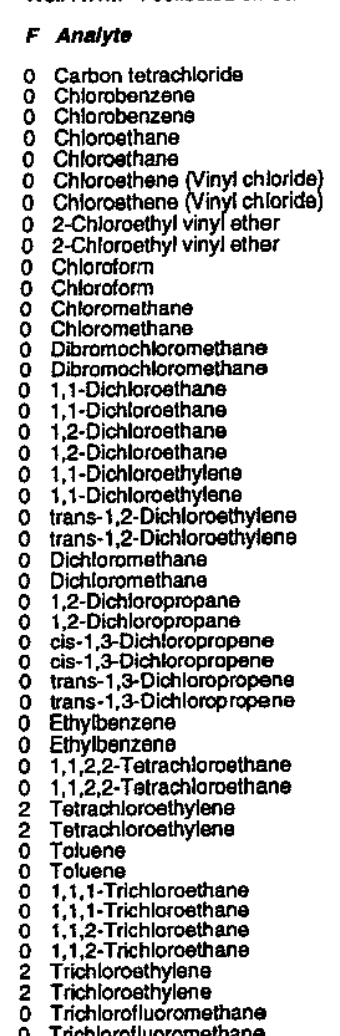

\section{WELL RWM 5}

MEASUREMENTS CONDUCTED IN THE FIELD Sample date: $04 / 17 / 98$ (t) $(48.47 \mathrm{~m})$ below TOC Warer

\begin{tabular}{|c|c|c|c|c|c|c|c|}
\hline Resulf & R & A & $B$ & $S Q L$ & Unit & Lab & Method \\
\hline $\begin{array}{l}250 \\
250 \\
250 \\
250 \\
250 \\
250 \\
250 \\
250 \\
250 \\
250 \\
250 \\
250 \\
250 \\
250 \\
250 \\
250 \\
250 \\
250 \\
250 \\
250 \\
250 \\
250 \\
250 \\
2500 \\
2500 \\
250 \\
250 \\
250 \\
250 \\
250 \\
250 \\
250 \\
250 \\
250 \\
2250 \\
857 \\
784 \\
2250 \\
250 \\
250 \\
250 \\
2250 \\
2250 \\
5,930 \\
5800 \\
250\end{array}$ & $\begin{array}{l}1 \\
\vdots \\
\vdots \\
\vdots \\
\vdots \\
1 \\
1\end{array}$ & 1 & L & $\begin{array}{l}250 \\
250 \\
250 \\
250 \\
250 \\
250 \\
250 \\
250 \\
250 \\
250 \\
250 \\
250 \\
250 \\
250 \\
250 \\
250 \\
250 \\
250 \\
250 \\
250 \\
250 \\
250 \\
250 \\
500 \\
500 \\
250 \\
250 \\
250 \\
250 \\
250 \\
250 \\
250 \\
250 \\
250 \\
250 \\
250 \\
250 \\
250 \\
250 \\
250 \\
250 \\
250 \\
250 \\
250 \\
250 \\
250 \\
250\end{array}$ & 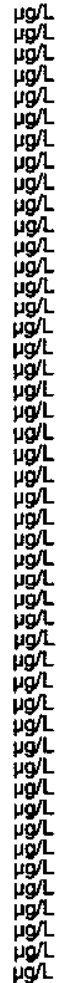 & $\begin{array}{l}\text { EX } \\
\text { EX } \\
\text { EX } \\
\text { EX } \\
\text { EX } \\
\text { EX } \\
\text { EX } \\
\text { EX } \\
\text { EX } \\
\text { EX } \\
\text { EX } \\
\text { EX } \\
\text { EX } \\
\text { EX } \\
\text { EX } \\
\text { EX } \\
\text { EX } \\
\text { EX } \\
\text { EX } \\
\text { EX } \\
\text { EX } \\
\text { EX } \\
\text { EX } \\
\text { EX } \\
\text { EX } \\
\text { EX } \\
\text { EX } \\
\text { EX } \\
\text { EX } \\
\text { EX } \\
\text { EX } \\
\text { EX } \\
\text { EX } \\
\text { EX } \\
\text { EX } \\
\text { EX } \\
\text { EX } \\
\text { EX } \\
\text { EX }\end{array}$ & 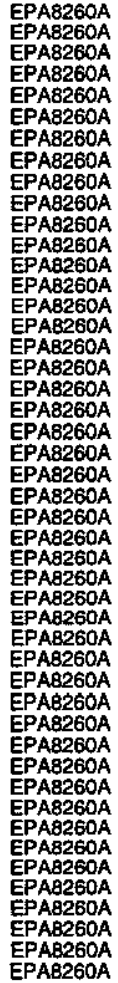 \\
\hline
\end{tabular}

Water temperature: $19.9^{\circ} \mathrm{C}$ Sp. conductance: $29 \mu \mathrm{S} / \mathrm{cm}$

Turbidity: 1 NTU
the well was continuously pumping

\section{ANALYSES}

\begin{tabular}{|c|c|}
\hline$=$ Analyte & Result \\
\hline $\begin{array}{ll}0 & \text { Acetorie } \\
0 & \text { Acetonitile (Methyl cyanide) } \\
0 & \text { Acrolein } \\
0 & \text { Acrylonitrite } \\
0 & \text { Ally chloride } \\
0 & \text { Benzenge } \\
0 & \text { Berzenene } \\
0 & \text { Bromodichloromethane } \\
0 & \text { Bromodichloromethane } \\
0 & \text { Bromoform } \\
0 & \text { Bromoform } \\
0 & \text { Bromomethane } \\
0 & \text { Bromomethane } \\
0 & \text { Carbon disulfide }\end{array}$ & $\begin{array}{l}<100 \\
<, 000 \\
<100 \\
<100 \\
<00 \\
<50.0 \\
<50.0 \\
<50.0 \\
<50.0 \\
<50.0 \\
<50.0 \\
<100 \\
<50.0 \\
<50.0\end{array}$ \\
\hline
\end{tabular}

Time: 8:46

Total alkalinity (as CaCO3): $0 \mathrm{mg} /$
Phenolphthalein alkalinity: $0 \mathrm{mgh}$

ESH-EMS-980569

Well RWM 5 collected on 04/17/98 (cont.)
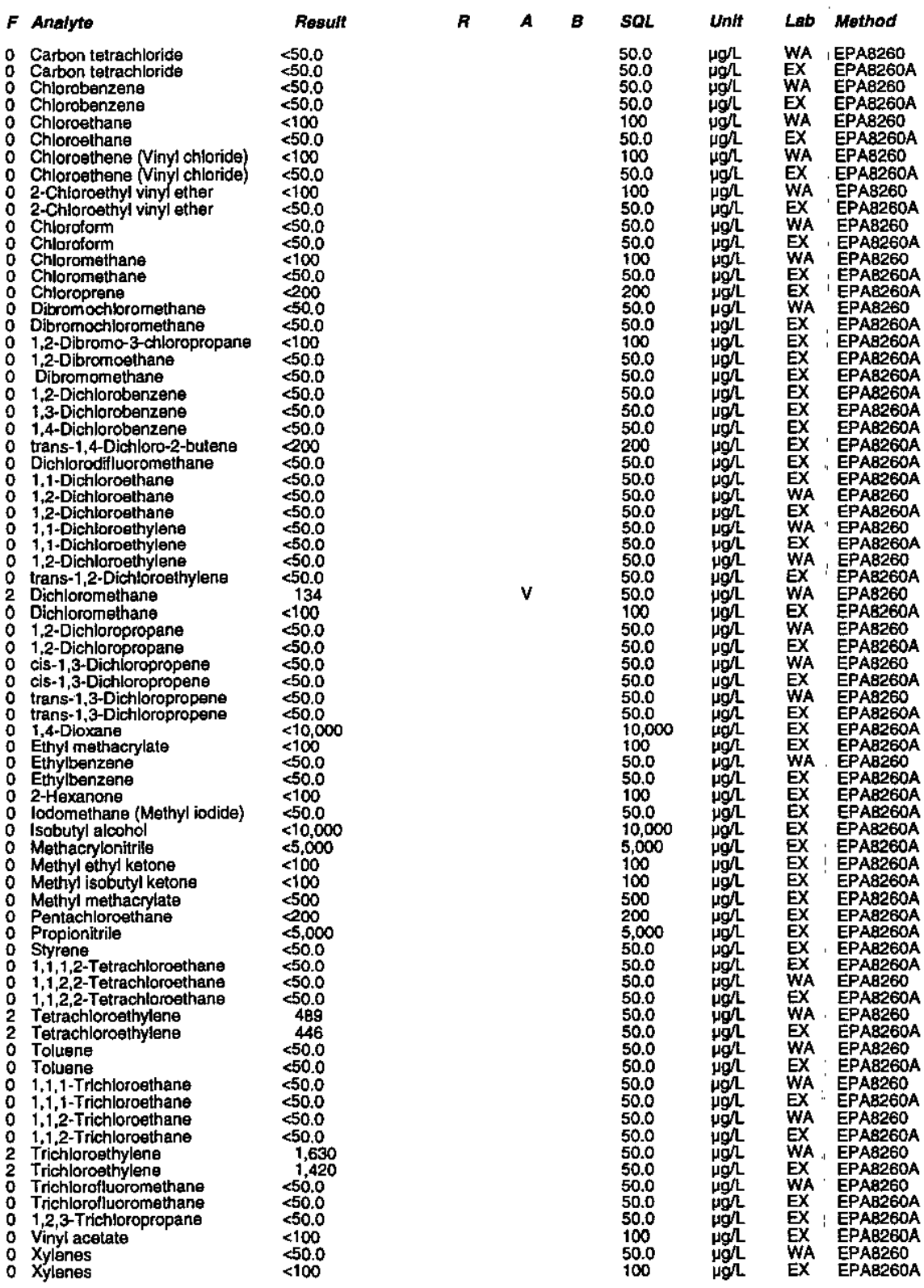
WELL RWM 5 Replicate

MEASUREMENTS CONDUCTED IN THE FIELD Sample date: $04 / 17 / 98$ ( $148.47 \mathrm{~m})$ below TOC Water Sp: 4.8 conductance: $29 \mu \mathrm{S} / \mathrm{cm}$ Tubidity: 1 NTU
The well was continuously pumping.

Well RWM 5 collected on 04/17/98 (cont.)

ANALYSES

$F$ Anatyto

Rosurt

Acetone Acrolain

Bromodichloromethane

Bromatiom

Bromomethane
Carbon disutide

Carbon tokrachlor
Chlorobenzene

Chloroethene (Vinyl chloride)
2-Chloroethyl vinyl ether
Chloroform

Chloromethane

Dibromochloromethane

1,2-Dibromo-3-chlor

1,2-Dichorbebenzen

1,3-Dichlorobenzene

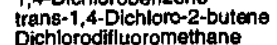

1,1-Dichloroethane

1,1-Dichloroethylene

trans-1,2-Dichiloroethylene

Dichloromethane

cis-1,3-Dichloropropene

Eithy methacrylate

2.hylbenzene

iodomethane (Mathyl iodice)

Methacrylonitrile

Methyl ethyl ketone

Methyy methacrylate

O Propiontrilile

1,1,1,2-Tetrachloroethane

i, 1,2,2-Tetrachloroethen

Tetrachloroethylene

1,1,1-Trichlordethane

Trichloroethylene

1,2,3-Trichloropropane

Vinyl acetato

$<100$

$<100$
$<100$

2

55.0
550.0
50.0
50.0
5
5

ESH-EMS-980569

\section{WELL RWM 5}

MEASUREMENTS CONDUCTED IN THE FIELD

Sample date: $05 / 08 / 98$
Depth to water: $158.25 \mathrm{ft}(48.24 \mathrm{~m})$ below TOC
Water elevation: $208.65 \mathrm{ft}(63.6 \mathrm{~m}) \mathrm{ms}$

Time: 8:46

Total alkalinity (as CaCO3): $0 \mathrm{mg} h$
Phenolphthalein alkalinity: $0 \mathrm{mg} /$

gp: 4.8 conductance: $24 \mu \mathrm{S} / \mathrm{cm}$

The well was continuously pumping.

Well RWM 5 collected on 05/08/98 (cont) ANALYSES

$F$ Analyte

o Benzene

Bromodichloromethan

Bromotorm

Bromomethane

: Carbon tetrachloride

Chlorbenzenzen

Chloroethane

Chloroethane

Chloroethene (Vinyl chlorit

2-Chloroethyl vinyl ether

2.Chloroform

Chlorotorm

Chloromethane

Dibromochloromethane

: 1,1-Dichloroethane

1,2-Dichloroethane

1,i-Dichloroethylen

trans-1,2-Dichlorosthylen

trans-1,2-Dichloroethylen

Dichloromathane

: 1,2-Dichloropropane

cis-1,3-Dichloropropen

trans-1,3-Dichlopropropene

0 trans-1,3-Dlch

Ethylbenzene

1, 1,2,2-Tetrachloroethane

1,1,2,2-Tetrachloroethan

2 Tetrachloroethylene

2 Totrachion

1.1,1-Trichloroethan

1,1,1-Trichloroesthan

1.1.2-Trichloroethan

2 Trichloroethylene

Trichloroffluoromethane

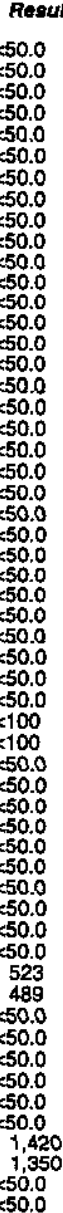

Time: 9:50

Total alkalinity (as CaCO3); $0 \mathrm{mg} /$
Phenolphthalein alkalinity: $0 \mathrm{mg}$ L

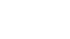

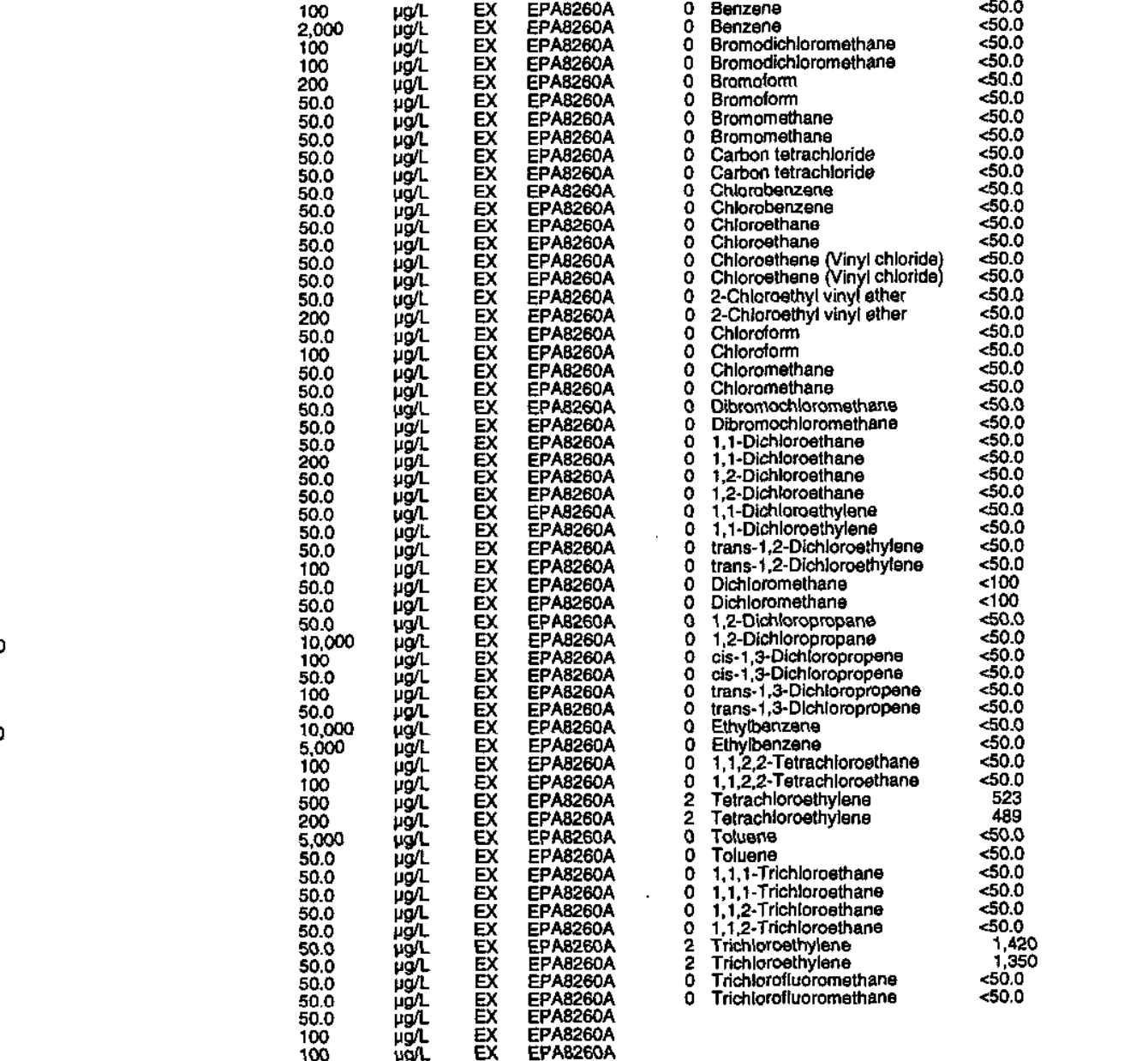
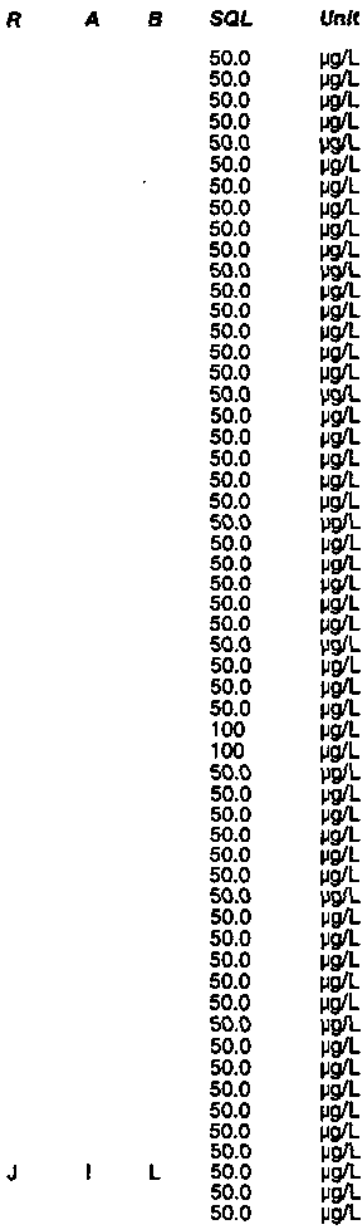

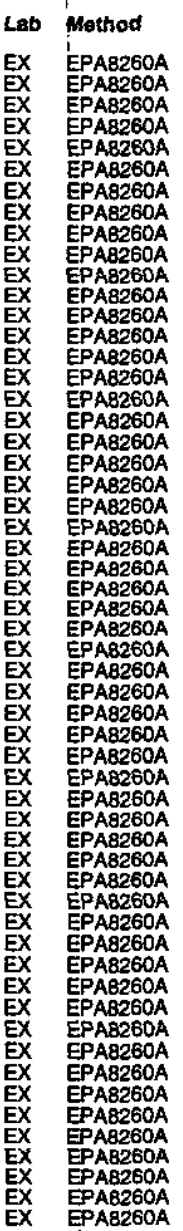

Socond Quartor 1998 
ANALYTICAL RESULTS

\section{WELL RWM 5}

MEASUREMENTS CONDUCTED IN THE FIELD Sample date: 06/08/98 $(48.57 \mathrm{~m})$ below TOC Depth to water: $159.35 \mathrm{ft}(48.57 \mathrm{~m})$ below
Water elevation: $207.55 \mathrm{ft}(63.26 \mathrm{~m}) \mathrm{ms}$
pH: 4.8

Sp. conductance: $30 \mu S / \mathrm{cm}$

The well was continuously pumping.

\section{ANALYSES}

$F$ Analyte

: Benzene

O Bromoform

Carbon tetrachlorid

Chloroethane

Chlorosthene (Vinyl chloride)

2-Chloroethyl

Chloromethane
Dibromochloromethane

1,1-Dichloroethane

1,i-Dichloroethylene
trans-1,2-Dichloroethyien

Dichloromethane

0 cis-1,3-Dichloropropene

trans-1,3-Dichloropropene

Ethylbenzene

1,1.1-Trichloroethane

2 Trichloroethylene

\section{WELLL RWM 6}

MEASUREMENTS CONDUCTED IN THE FIELD

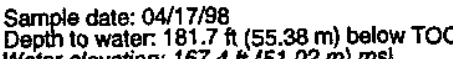
Water e

Water ele

Sp. conductance: $30 \mu \mathrm{S} / \mathrm{cm}$

The wefl was continuously pumping.

ANALYSES

F Analyto

Acetone

Acrolein

Ally chloride

Benzene
Bromodichloromethane

Bromotorm

Carton disulfide
Carbon fetrachloride

Chiorobenzen

Chlorosthene (Vinyl chloride)

2-Chloroethyl vinyl ether

CChoromethane

Dibromochloromethane

ESH-EMS-980569

Resuft
$<500$
$<10000$
$<500$
$<500$
$<1,000$
250
$<50$
250
250
250
250
$<550$
250
250
250
$<50$
$<55$
$<1,000$
$<50$
$<500$

Well RWM 6 collected on 04/17/98 (cont.)

$F$ Ansiyte

Time: 11:39

$23.8^{\circ} \mathrm{C}$ Total alkainity (as CaCO3): $0 \mathrm{mgl}$

0 1,2.Dibromoethan

1,2-Dichlorobenzene

1,4-Dichlorobennzene
trans-1,4-Dichloro-2-buten

Dichloroditiluoromethan

1,1-Dichloroethane

$1,1-$ Dichloroethylene
trans-1,2-Dichloroethylene

o Dichioromethane

1,2-Dichloropropane
cis-1,-Dichloropopopene
trans-1,3-Dichloropropene

1,4-Dioxane

Ethyl methacryla

lodomethane (Methyl iodide)

0 isobutyl aloohol

Methyl ethyl ketone

Methyl methacrylate
Pentachloroethane

Propionitrila

Styrene
$1,1,1,2$-Ttrachloroethane
$1,1,2,2$-Tetrachloroethane

Tetrachloroethylen

1,1,1-Trichloroethane

Trichloroethylene

1,2,3-Trichloropropane

0 Vinyl acetat

\section{WELL RWM 6}

MEASUREMENTS CONDUCTED IN THE FIELD

Sample date: $05 / 07 / 98$ ft $(55.61 \mathrm{~m})$ below TOC

Water elevation: $166.64 \mathrm{ft}(50.79 \mathrm{~m}) \mathrm{ms}$

$\mathrm{HH}: 4.2$

Water temperature: $20.5^{\circ} \mathrm{C}$

Aotal alkaliniry (as CaCO3) $0 \mathrm{mg}$

Sp. conductance: $31 \mu \mathrm{S} / \mathrm{cm}$

The well was continuously pumping.

ANALYSES

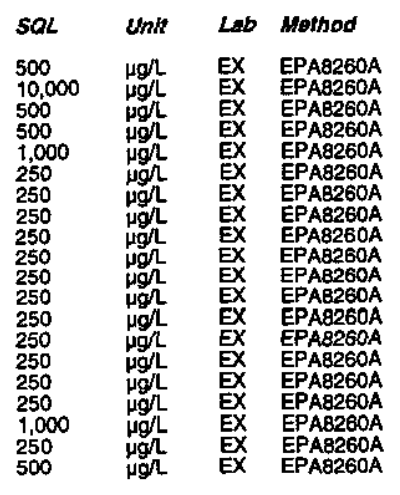

$F$ Analyte

0
0
0

Bromoform

Carton tetrachlorid

Chiorobenzene

Chloroethene (Vinyl chloride)
2-Chloroethyl vinyl ather

Chlorotom

Dibromochloromethan
1,1 -Dichloroethane

1,2-Dichloroethane

Dictloromethane

1,2-Dichloropropane
cis-1,3-Dichloropropene

trans-1,3-Dichloropropene

B-246
trans-1,2-Dichloroethylene
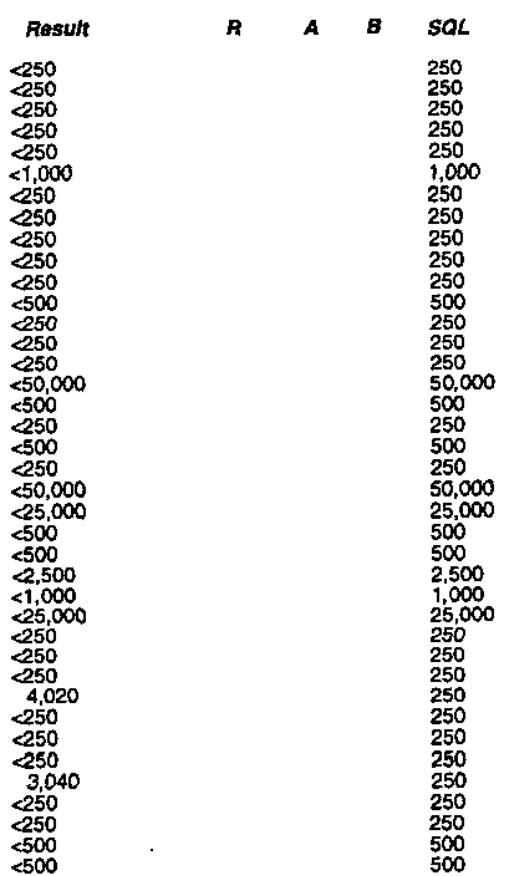

Time: 10:14

Water temperature: $21.5^{\circ} \mathrm{C}$

Total alkalinity (as CaCO3): $0 \mathrm{mgh}$
Phenolphthalein alkalinity: $0 \mathrm{mgL}$

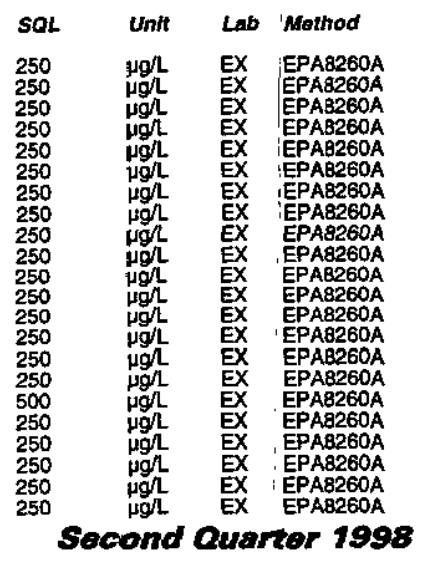


Well RWM Ǵ collected on $05017 / 98$ (cont.)

$f$ Anstyte

Resuft

2 Tetrachloroethylene

o Toluene 1,1 -Trichloroethane

o 1,1,2-Trichloroethane

Trichlorofluoromethane

4,310
250
250
250
3,140
$<250$

WELL RWM 6

MEASUREMENTS CONDUCTED IN THE FIELD

Sample date: 06/08/98

Wepth

ph: 4.9 . conductance: $30 \mu \mathrm{S} / \mathrm{cm}$

Sp. conductance: $30 \mu \mathrm{S} / \mathrm{cm}$
Tubiditit $1 \mathrm{NTU}$
The well was continuously pumping.

ANALYSES

$F$ Analyte

0 Benzene

Bromofom

Carbon tetrachlorlde

Chloroethane

Chloroethene (Vinyl chloride)

2-Chloroethyl

Chloromethane

Dibromichlorometh

i,2-Dichlorosthane

1,r-Dichloroethylene
trans-1,2-Dichloroethylene

Dichloromethane

cis-1,3-Dichloropropene
trans-1,3-Dichloropropene

Ethylbenzente

1,1,2,2-Tetrachloroethan

2 Tetrachloroethylene

o 1,1,1-Trichloroethane

Trichloroethylene

\section{WELL RWM 7}

MEASUREMENTS CONDUCTED IN THE FIELD

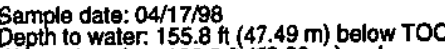

Water elevation: $193.2 \mathrm{ft}(58.89 \mathrm{~m}) \mathrm{msl}$

P. conductance: $68 \mu \mathrm{S} / \mathrm{cm}$

The well was continuously pumping.

ANALYSES

$F$ Analyte

Resuth

: Acetone

$<500$

Acrolein

Benzene.

Bromodictioromethane

B Bromoform

Aesult

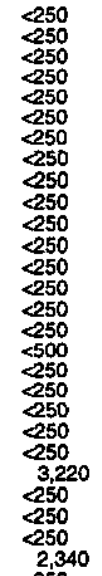

ESH-EMS-980569
$<500$
500
1,000
250
250
250
250
250
Well RWM 7 collected on 04/17/98 (cont.)

$F$ Analyte

- Carbon disulfide

Chlorobenzene

Chloroethane

C-Chorcethe Vinyl ether

Chioroforn

Chjoromethane

Chloroprente

1,2-Dibromo-3-chloropropane

1,2-Dibromoethane

1.2-Dichlorobenzene

1.3-Dlichlorobenzene

rans-1,4-Dichloro-2-buten

1.1-Dichlorosthane

1,2-Dichloroethane

trans-1,2-Dichloroethylene

Dichloromethane

cis-1,3-Dichloropropene

1,4-Dioxane

Ethylbenzens

lodomathane (Methyl iodide)

Isobutyl alcono

Methyl ethyl ketone

Methyl methacrylate

Propionitrile

Styrene-1,2-Tetrachloroethane

Toluene

Trichloroethylene

Trichlorofluoromethane

0 Vinyl aceta

\section{WELL RWM 7}

MEASUREMENTS CONDUCTED IN THE FIELD

Sample date: $05 / 07 / 98$ f $(45.97 \mathrm{~m}$ ) below TOC

Water

Time: $9: 44$

Air temperature: $21.2^{\circ} \mathrm{C}$
Total alkalinity (as Caco3): $0 \mathrm{mg} /$
Phenolphthalein alkalinity: $0 \mathrm{mg} / \mathrm{L}$

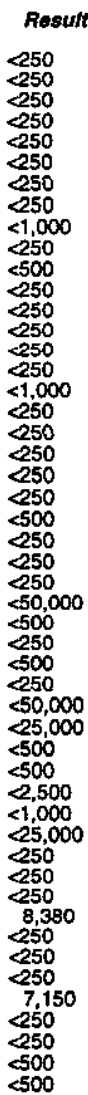

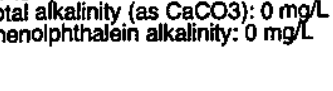

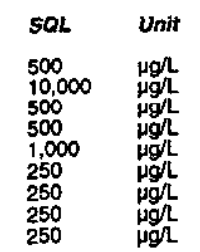

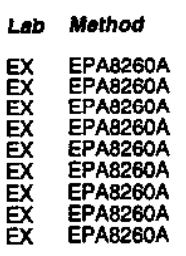

Sp. conductance: $71 \mu \mathrm{S} / \mathrm{cm}$

The well was continuously pumping.

ANALYSES

$F$ Analyte

o. Banzene

Bromodichloromethane

Bromoform

Bromomethane

Carbon tetrachloride

Carbon tetrachlorid

$B-247$

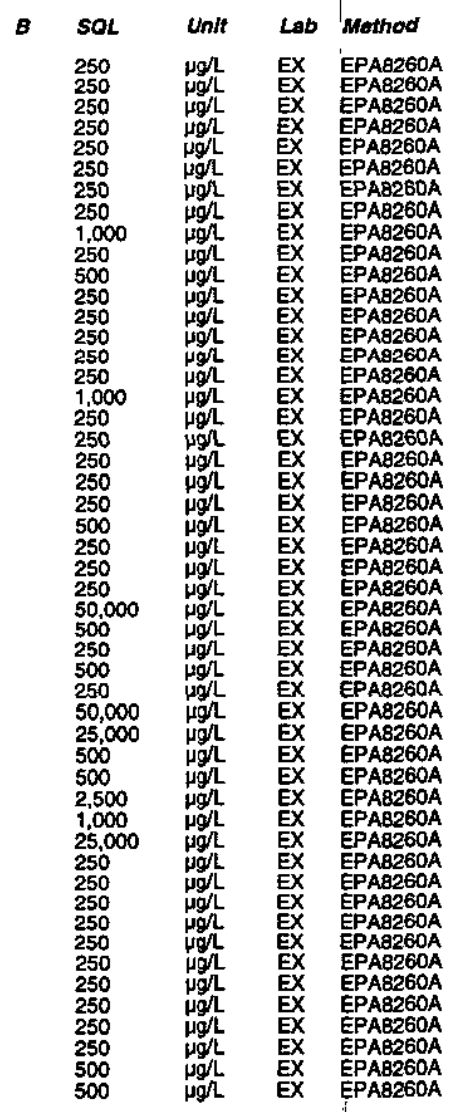

Time: 12:03

Air temperature: $24.21 .3^{\circ} \mathrm{C}$

Total alkalinity (as CaCO3): $0 \mathrm{mgh}$

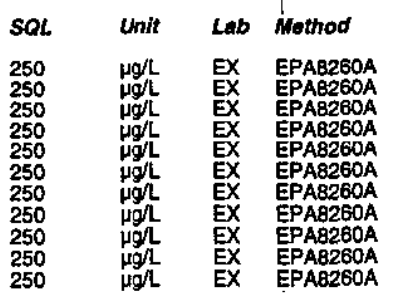

second Quarter 1998 
Well RWM 7 collected on 05/07/98 (cont)

\section{F Analyte}

: Chlorobenzene

Chloroethane
0 Chloroethene Vinyl chloride)
0 Chloroethene (Vinyl chlioride)

2-Chloroethyl vinyl ether
2-Chloroethyl vinyl ether

2.Chloroeth

Chloroform

Chioromethane

Dibromochloromethan

1.1. Dichloroesthane
1

1.2-Dlchloroethane

1,1-Dichloroethylene

trans-1,2-Dichloroethylen

Dichloromethane

1.2-Dichloropropane

cis-1,3-Dichloropropene

trans-1,3-Dichloropropen

Ettylbenzene

1,1,2,2-Tetrachloroethane

1,1,2,2-Tetrachloroetha

Tetracchloroethylene

o Toluene

1.1.1-Trichloroethane

i,i, -Trichloroethane

Trichloroethylene

2 Trichloroethylene
0 Trichlorofluoromethane
0 Trichlorofllyoromethane

WELL RWM 7

MEASUAEMENTS CONDUCTED IN THE FIELD

Sample date: 06/08/98 $\mathrm{ft}(46.68 \mathrm{~m})$ below TOC Depth to

Water el
$\mathrm{gH}: 4.8$

Sp. conductance: $70 \mu \mathrm{S} / \mathrm{cm}$

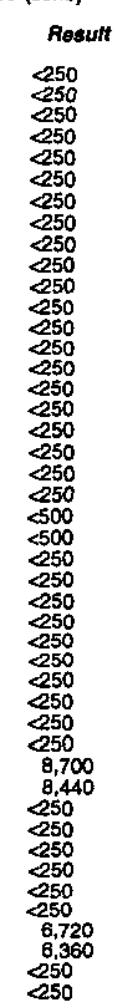

ANALYSES

$F$ Analyto

: Benzene

B Bromomethane

Camon thatrachloric

Chloroethane

0 Chloroethene (Vinyl chboride)

Chlorotom

Oo Choromethane

$\begin{array}{ll}0 & 1,1-D i c h l o r o e t h a n e \\ 0 & 1,2-D i c h l o r o e t h a n e\end{array}$

1,1-Dichloroethylene

ESH-EMS-980569

Result
250
250
250
250
250
250
250
250
250
250
250
250
250
250
250
250
250

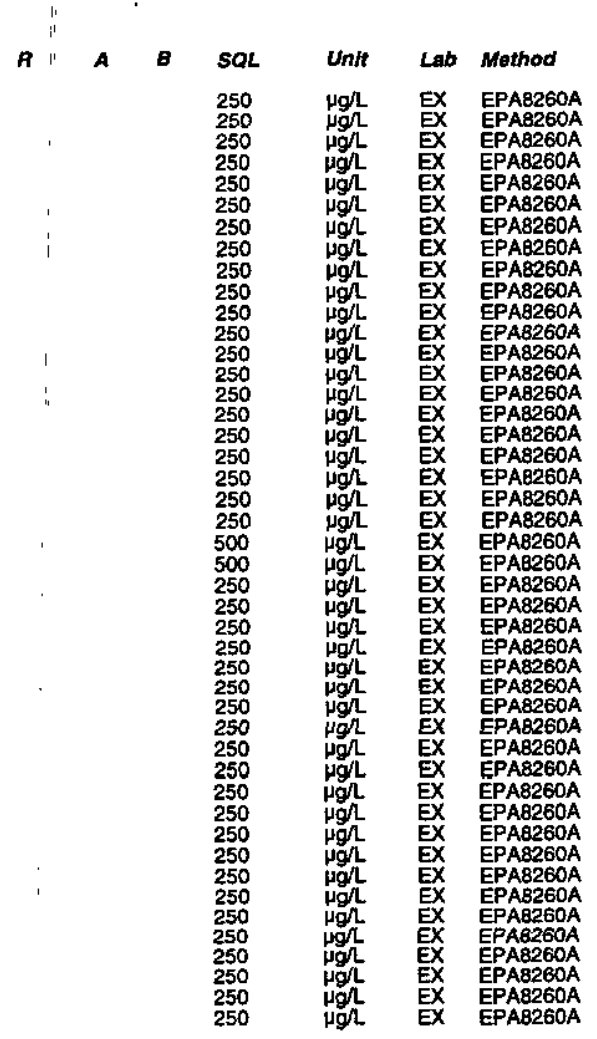

Time: 11:51

Air tempererature: $25.2^{\circ} \mathrm{C}$

Total akalinity (as Caco3): $0 \mathrm{mg} / \mathrm{L}$
Phenolphthalein alkalinity: $0 \mathrm{mg} \mathrm{L}^{2}$

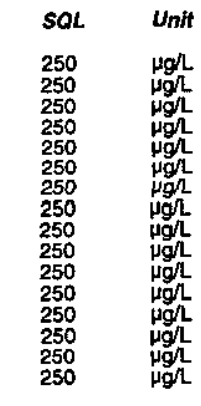

Unit
$\mu g h$
$\mu g h$
$\mu g h$
$\mu g h$
$\mu g h$
$\mu g h$
$\mu g h$
$\mu g h$
$\mu g h$
$\mu g h$
$\mu g h$
$\mu g h$
$\mu g h$
$\mu g h$
$\mu g h$
$\mu g h$

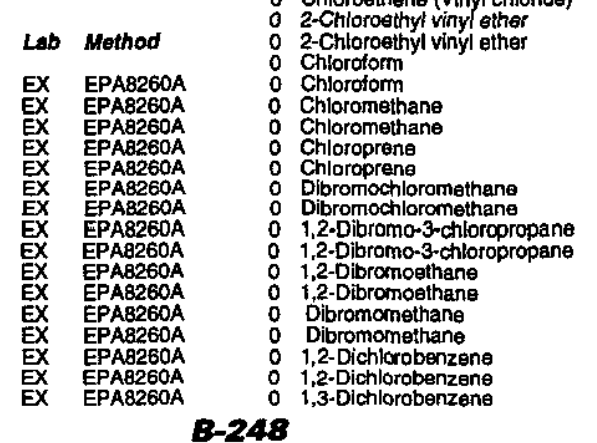

Well RWM 7 collected on 06/08/98 (cont)

\section{$F$ Analyte}

: Dichloromethane

cis-1,3-Dichlosopropene

Ethylbenzen

1,1,2,2-Tetrachloroethane
Tetrachloroethylene

o 1,1,1-Trichlorcetthane

Trichloroethylene

\section{WELL RWM 8}

MEASUREMENTS CONDUCTED IN THE FIELD

Sample date: $04 / 17 / 98$ (t $(44.53 \mathrm{~m})$ below TOC

Water elevation: $202.22 \mathrm{ft}(61.64 \mathrm{~m}) \mathrm{ms}$

$\mathrm{pH}: 4.9$

Sp. conductance: $98 \mu \mathrm{S} / \mathrm{cm}$

The well was continuously pumping.

ANALYSES

$F$ Analyte

- Acetone

Acetonititle (Methyl cyanide)
Acetonitirile (Methyl cyanide)

Acrolin

Acrylonitrile
Acylonitrile

Allyy chiloride

Eenzene

Bromodichloromethane

Bromodichloromethan

Bromoform

Bromomethane

Carbon disulfide

Carbon disutide
Carbon tetrachloride
Cetrachloride

Chlorobenzene

Chloroethane

Chloroethenene Ninyl chloride)

2-Chioroesthyl vinyl ether

Chlorotorm

-Dibromoethan

1,2-Dichlorabenzene

\begin{tabular}{|c|c|c|c|c|c|c|c|}
\hline Resuft & $\boldsymbol{F}$ & A & B & SQL & Unit & Lab & Mothod \\
\hline $\begin{array}{l}<500 \\
<250 \\
<250 \\
<250 \\
250 \\
<250 \\
5,980 \\
<250 \\
<250 \\
<250 \\
1,800\end{array}$ & $J$ & 1 & $\mathbf{L}$ & $\begin{array}{l}500 \\
250 \\
250 \\
250 \\
250 \\
250 \\
250 \\
250 \\
250 \\
250 \\
250 \\
250\end{array}$ & 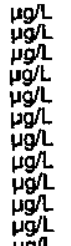 & $\begin{array}{l}\text { EX } \\
\text { EX } \\
\text { EX } \\
\text { EX } \\
\text { EX } \\
\text { EX } \\
\text { EX } \\
\text { EX } \\
\text { EX } \\
\text { EX } \\
\text { EX }\end{array}$ & $\begin{array}{l}\text { EPA8260A } \\
\text { EPAA260A } \\
\text { EPAB260A } \\
\text { EPA8260A } \\
\text { EPAB260A } \\
\text { EPA8260A } \\
\text { EPAB260A } \\
\text { EPA8260A } \\
\text { EPAE260A } \\
\text { EPA8260A } \\
\text { EPA8260A }\end{array}$ \\
\hline
\end{tabular}

Time: 8:29

Tre $19.6^{\circ} \mathrm{C}$

Total alkalinity (as CaCO3): $0 \mathrm{mg} /$
Phenolphthalein alkalinity: $0 \mathrm{mg} / \mathrm{L}$

(as

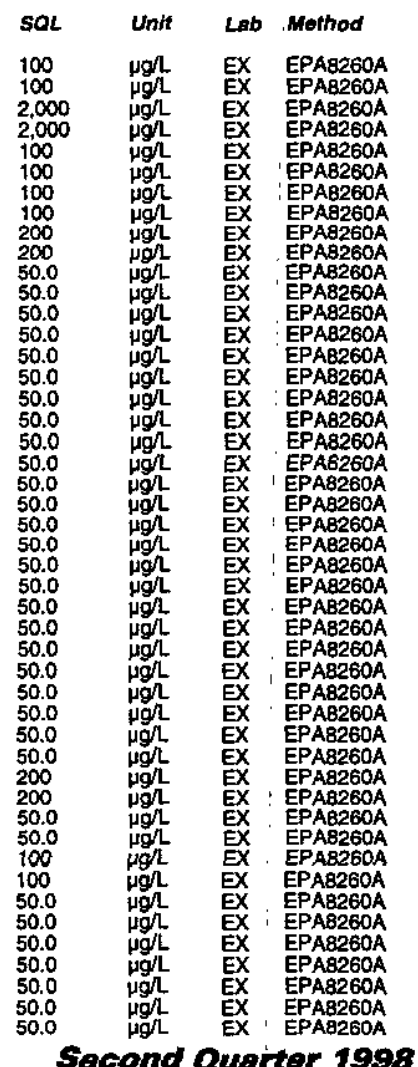


Well RWM 8 collected on 04/17/98 (cont.)

\begin{tabular}{|c|c|}
\hline \multirow[b]{2}{*}{ 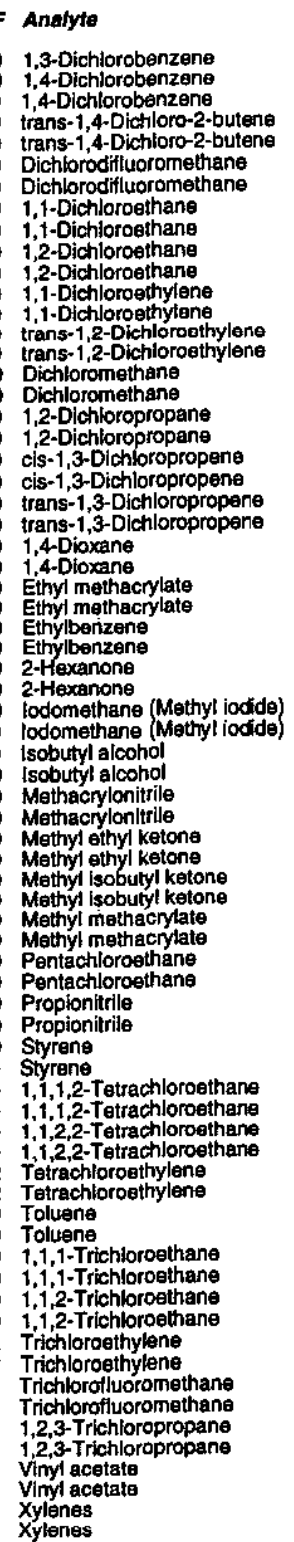 } & Rest \\
\hline & 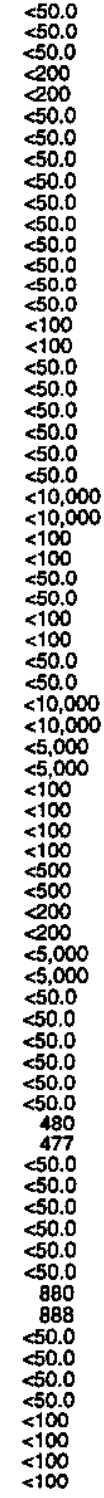 \\
\hline
\end{tabular}

WELL RWM 8

MEASUREMENTS CONDUCTED IN THE FIELD Sample date: $05 / 07 / 98$ (4t. $14.68 \mathrm{~m}$ ) below TOC pH: 4.5 Sp. conductance: $97 \mu \mathrm{S} / \mathrm{cm}$ Turbidity: ONTU: $97 /$ S/ch ANALYSES

$F$ Anatyto

$\begin{array}{ll}0 & \text { Benzene } \\ 0 & \text { Bromodichloromethane } \\ 0 & \text { Bromofomm }\end{array}$

Bromomethane

Chlorobenzene

Chloroethene (Vinyl chloride)

2-Chloroethyl vinyl ether

Chlorosom

Dibromochloromethan

1.2-Dichloroethane

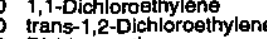

1: Dichloromethane

: cis-1,3-Dichloropropene

1. Ethylbenzene

2 Tetrachloroethylen

$\begin{array}{ll}0 & 1,1,1-T \text { Trichloroethane } \\ 0 & 1,1,2 \text {-Trichloroethan }\end{array}$

1,1,2-Trichloroethane
2 Trichloroethylene
0

WELL RWM 8

MEASUREMENTS CONDUCTED IN THE FIELD

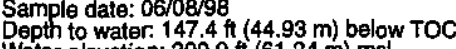

Water elevation: $200.9 \mathrm{ft}(6$
$\mathrm{pH}$ : 5 . conductance: $96 \mu \mathrm{S} / \mathrm{cm}$

The well was continuously pumping

ANALYSES

$F$ Analyte

o Benzene

O Bromodichlor

- Bromomethane

Carbon tetrachlorid

: Chlorobenzen

Chloroethere (Vinyl chloride)

2-Chloroethyl vinyl ether

Chioroform

Dibromochloromethan

1,1 -Dichloroethane
1,2-Dichloroethane

1,1-Dichloroethylens

Dichloromethane

1,2-Dichloropropane

a cis-1,3-Dichloropropene

Result

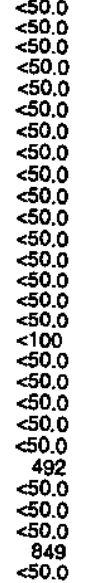

Resutt
$<50.0$
$<50.0$
$<50.0$
$<50.0$
$<50.0$
$<50.0$
$<50.0$
$<50.0$
$<50.0$
$<50.0$
550.0
$<50$.
$<50.0$
$<50.0$
$<50.0$
$<50.0$
$<100$
$<50.0$
$<50.0$
$<50.0$

Time: 8:40

Wir terature: $19.5^{\circ} \mathrm{C}$

Total akkalinity (as CaCO3): 0 mgh
Phenotphthalein alkalinity: $0 \mathrm{mg} L$

\begin{tabular}{|c|c|}
\hline$S O L$ & Un \\
\hline $\begin{array}{l}50.0 \\
50.0 \\
50.0 \\
50.0 \\
50.0 \\
50.0 \\
50.0 \\
50.0 \\
50.0 \\
50.0 \\
50.0 \\
50.0 \\
50.0 \\
50.0 \\
50.0 \\
50.0 \\
100 \\
50.0 \\
50.0 \\
50.0 \\
50.0 \\
50.0 \\
50.0 \\
50.0 \\
50.0 \\
50.0 \\
50.0 \\
50.0\end{array}$ & 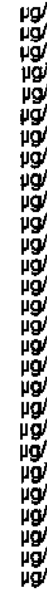 \\
\hline
\end{tabular}

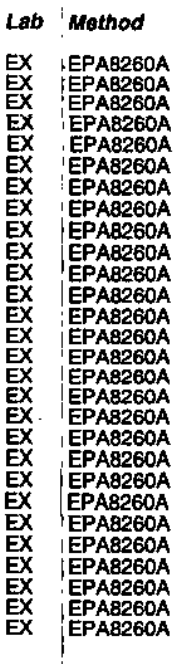

Time: 10:30 Wir tomperature: 20.2 Total alkalinity (as CaCO3): $0 \mathrm{mgh}$

\begin{tabular}{|c|c|c|c|}
\hline SOL & Unit & $L a b$ & Method \\
\hline $\begin{array}{l}50.0 \\
50.0 \\
50.0 \\
50.0 \\
50.0 \\
50.0 \\
50.0 \\
550.0 \\
50.0 \\
50.0 \\
50.0 \\
50.0 \\
550.0 \\
50.0 \\
50.0 \\
100 \\
50.0 \\
50.0 \\
50.0\end{array}$ & 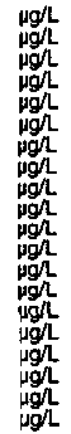 & $\begin{array}{l}\text { EX } \\
\text { EX } \\
\text { EX } \\
\text { EX } \\
\text { EX } \\
\text { EX } \\
\text { EX } \\
\text { EX } \\
\text { EX } \\
\text { EX } \\
\text { EX } \\
\text { EX } \\
\text { EX } \\
\text { EX } \\
\text { EX } \\
\text { EX } \\
\text { EX } \\
\text { EX } \\
\text { EX } \\
\text { EX }\end{array}$ & 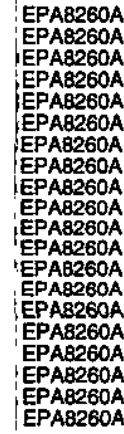 \\
\hline
\end{tabular}


Well RWM 9 collected on 06/08/98 (cont.)
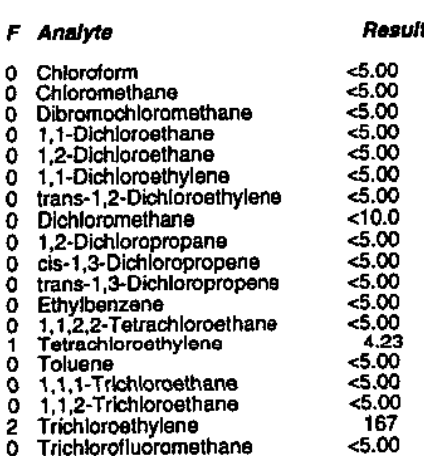

WELL RWM 10

MEASUREMENTS CONDUCTED IN THE FIELD

Sample date: 06/08/98
Depth to water $161.5 \mathrm{ft}(49.23 \mathrm{~m})$ below TOC Weter Sp. 4.9 (59.13 m) ms conductance: $120 \mu \mathrm{S} / \mathrm{cm}$ The weil was continuously pumping. ANALYSES

$F$ Analyte

0 Benzene Bromodichloromethane

Bromotam

Bromomethane
Bromomethane

Carbon tetrachloride

Chiorobenzene

Chlorobenzene

Chloroethene (Vinyl chloride)

2-Chloroethyl vinyl ether

Chlorotorm

Chloromethane

Chloromethane

Dibromochloromethane

1,1-Dichloroethane

1,1-Dichlorosthane

1,2-Dichloroethane

1.1-Dichloroethylene

trans-1,2-Dichloroethylene

Dichloromethane

1,2-Dichloropropane

cis-1,3-Dichloropropen

cis-1,3-Dichloropropene

trans-1,3-Dichloropropen

O Ethylbenzene

ESH-EIIS-980569
Well RWM 10 collected on 06/08/98 (cont.)

$F$ Analyte

: $1,1,2,2-$ Tetrachloroethane

2 Tetrachloroethylene

Toluene

$1,1,1-$ Trichloroethan

1,1,2-Trichloroethan

1,1,2-Trichloroethan

2 Trichloroethylene

Trichlorofluoromethane

WELL RWM 11

MEASUREMENTS CONDUCTED IN THE FIELD

Sample date: $04 / 17 / 98$
Depth to water: $174.55 \mathrm{ft}(53.2 \mathrm{~m})$ below TOC
Water elevation: $208.75 \mathrm{ft}(63.63 \mathrm{~m}) \mathrm{ms}$ Water elevation: $208.75 \mathrm{ft}(63.63 \mathrm{~m}) \mathrm{ms}$

$\mathrm{gH}: 4.6$. conductance: $32 \mu \mathrm{S} / \mathrm{cm}$

The well was continuously pumping

ANALYSES

$F$ Aralyto

Acetone

Acrolein

A Alyl chitroride

Bromodichloromethane

0 Bromomethane

Carbon tetrachlorida

o Chloroethane

Chloroethene (Vinyl chloride)

2-Chloroethyl vinyl ether

o Chloromethane

Chtoroprene

12-Dibromoromethane

1,2-Dibromoethane

D. Dibromomethane

1.3-Dichlorobenzen

trans-1,4-Dichloro-2-buten

1,2-Dichloroothane

trans-1,2-Dichloroethylene

1,2-Dichloropropan

: cis-1,3-Dichloropropene

Ethyl methacrylat

Ethylbenzene

lodomethane (Methyl iodide)

O Isobutyi alcohol

O Methyl ethyl ketone

Methyl methacrylate

o Pentachloroethane

$-251$

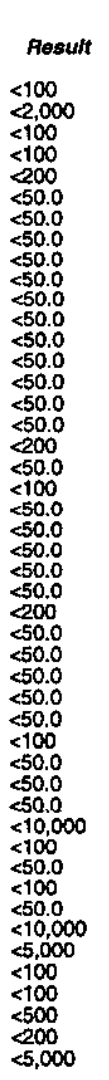

Result

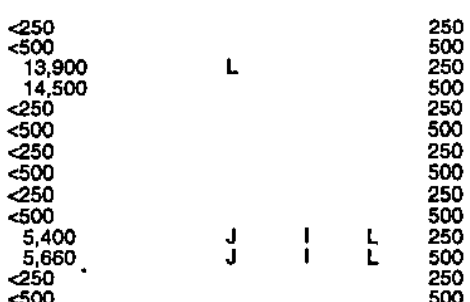

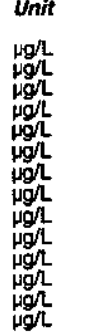

Lab Method

EPAB260A
EPAB260A

\begin{tabular}{c} 
EPAB260A \\
\hline $\mathrm{EPAB260A}$
\end{tabular}

EPAB260A

EPA8260A

\begin{tabular}{c|c}
$E P A B 260 A$ \\
\hline$E P A B 260 A$ \\
\hline
\end{tabular}

EPAB260A

Time: 10:03

Water temperature: $20.2^{\circ}$

Total alkalinity (as CaCO3): $0 \mathrm{mg} /$
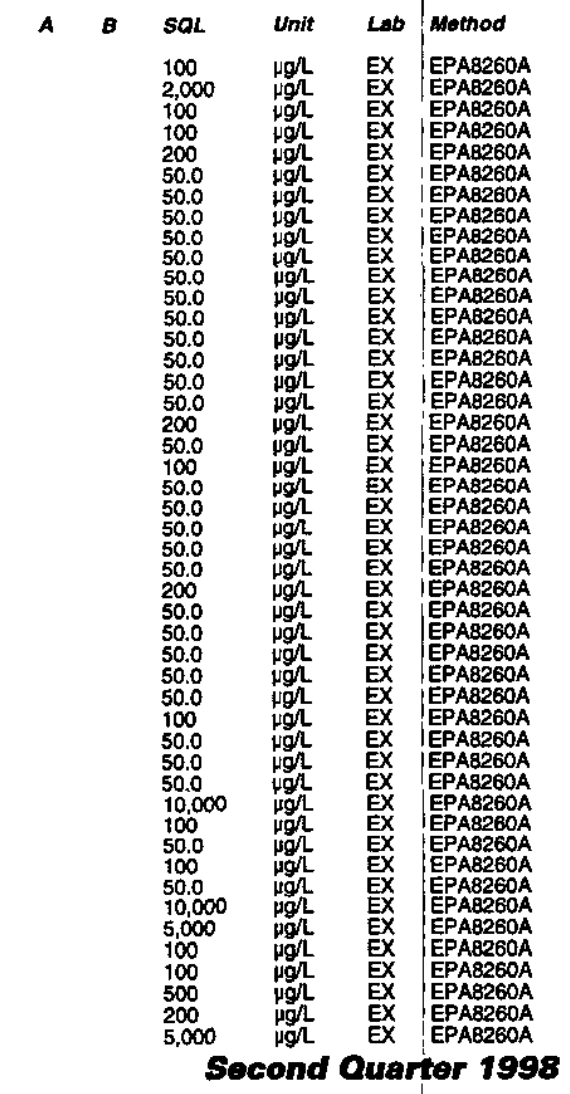
Well RWM 11 collected on 04/17/98 (cont.)

$F$ Analyte

: Styrene $1,1,2$-Tetrachloroethane

$1,1,2,2$-Tetrachloroeth
2 Tetrachloroethylene

0 Toluene $1,1,1$-Trichjoroethane

2 Trichlorosthylene

2 Trichlorosthylene

1,2,3-Trichloropropane

0 Vinyl acotato
0 Xylenes

\section{WELLL RWM 11}

MEASUREMENTS CONDUCTED IN THE FIELD

Sample date: $05 / 08 / 98$ (54.07 m) below TOC Water elevation: $205.9 \mathrm{ft}(62.76 \mathrm{~m}) \mathrm{ms}$

$\mathrm{pH}: 4.2$

Sp. conductance: $28 \mu \mathrm{S} / \mathrm{cm}$

The well was continuously pumping.

ANALYSES

$F$ Analyse

Benzen

Benzene

Bromodichlo
Bromoform

Bromoform

Bromomethane
Bromomethane

Carbon tetractiloride

Chloroberzene

Chloroethana

Chloroethane

2-Chloroethyl vinyl ethe

o Chloroform

0 Choromethane

Dibromochloromethane

1,1.-Dichloroethane

1,1-Dichloroethane

1,2-Dichloroethane

1,1-Dichloroethylene

trans-1,2-Dichloroethylen

Dichloromethane

1,2 -Dichloropropan

cis-1,3-Dichloropropene
cis-1,3-Dichloropropen

trans-1,3-Dichloropropen

Ethylbernzene

$1,1,2,2$-Tetrachloroethane

2 Tetractloroethylene

Toluene

ESH

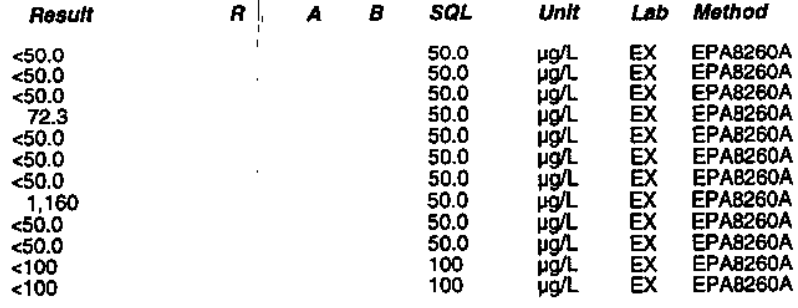

Time: 10:15

Air temperature: $26^{\circ} \mathrm{C}$
Total alkalinity (as Caco3): $0 \mathrm{mgh}$
Phenolphthalein alkalinity: $0 \mathrm{mgl}$
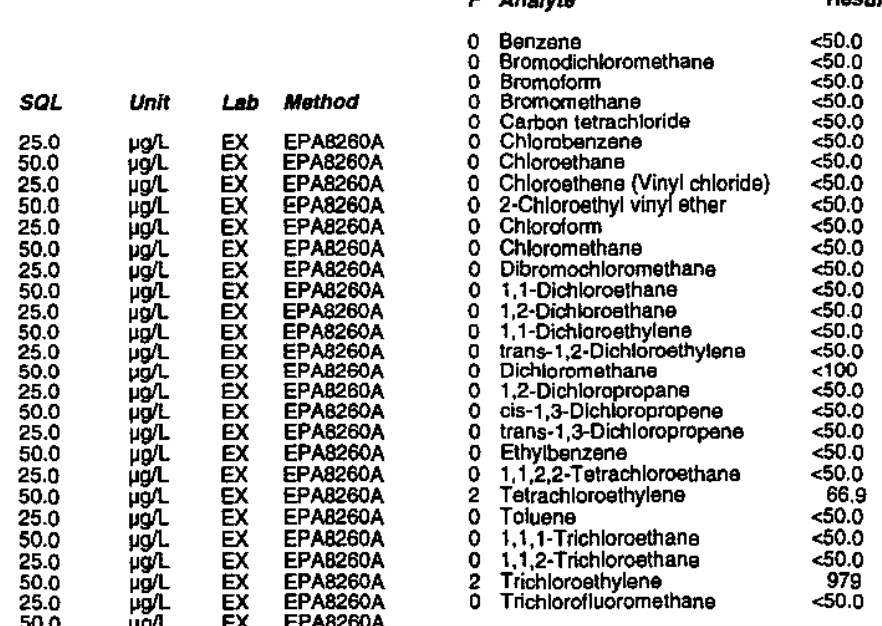

WELL RWM 12

MEASUREMENTS CONDUCTED IN THE FIELD

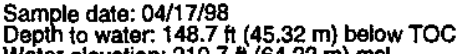

$\mathrm{g}$. $\mathrm{p}$. conductance: $42 \mu \mathrm{S} / \mathrm{cm}$

$$
\begin{aligned}
& \text { Result } \\
& <50.0 \\
& 25.0 \\
& <50.0 \\
& 1,070 \\
& 1,060 \\
& <5.0 \\
& <50.0
\end{aligned}
$$

$\begin{array}{cccc} & A & B & S Q L \\ & & & 50.0 \\ & & & 25.0 \\ & & & 50.0 \\ \text { L } & & & 50.0 \\ \text { J } & \text { L } & 25.0 \\ & & & 50.0\end{array}$

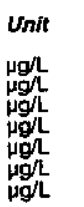

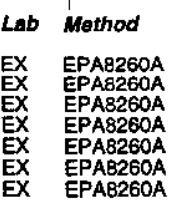

WELL RWM 11

(17.3 $(53.13 \mathrm{~m})$ below TOC Water

Sp. conductance: $29 \mu \mathrm{S} / \mathrm{cm}$

was continuously pumping.

ANALYSES

$F$ Analyte

Result

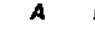

Time: 12:15

Total akalinity (as CaCO3): $0 \mathrm{mg} /$
Phenolphthalein alkalinity: $0 \mathrm{mg} /$

The well was continuously pumping.

\begin{tabular}{|c|c|}
\hline F Analyte & Result \\
\hline 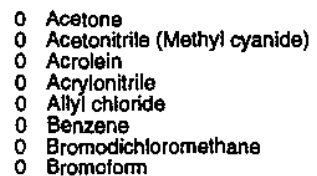 & $\begin{array}{l}<100 \\
<, 000 \\
<100 \\
<100 \\
<200 \\
<50.0 \\
50.0 \\
<50.0\end{array}$ \\
\hline
\end{tabular}

ANALYSES
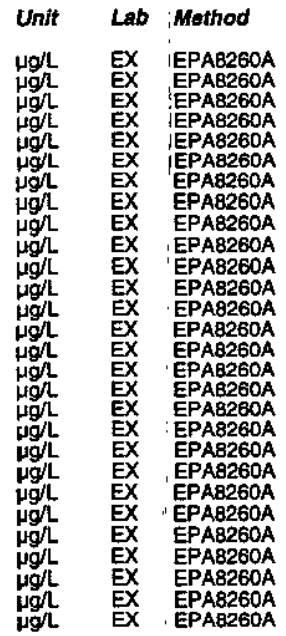

Time: 11:35

Witer $20.4^{\circ} \mathrm{C}$

Total alkalinity (as CaCO3): $0 \mathrm{mgl}$

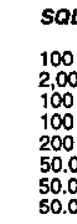

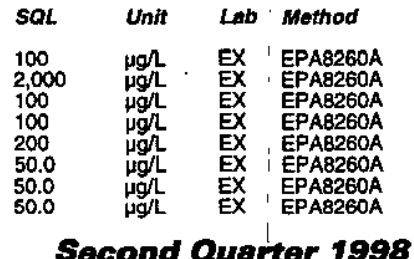


Well RWM 12 collected on 04/17/98 (cont.)

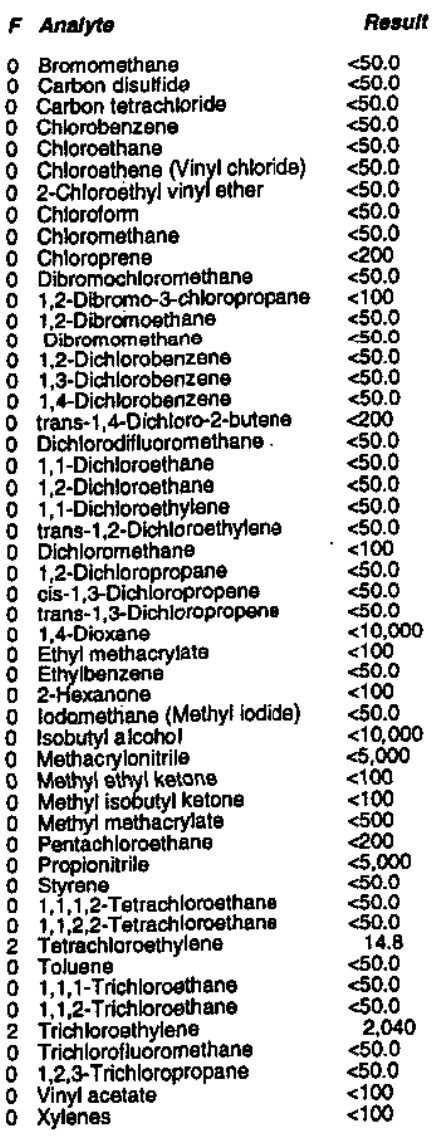

WELL RWM 12

MEASUREMENTS CONDUCTED IN THE FIELD

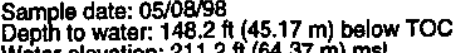
Water elevation: $211.2 \mathrm{ft}(64.37 \mathrm{~m}) \mathrm{msl}$ p. conductance: $38 \mu \mathrm{H} / \mathrm{cm}$

The wel was continuously pumping. ANALYSES

F Analyte

- Benzene

Bromodichloromethan

Bromodichloromethane
Bromodichloromethane

0
0 Bromoform
0

B Bromotom

ESH-EMS-980569

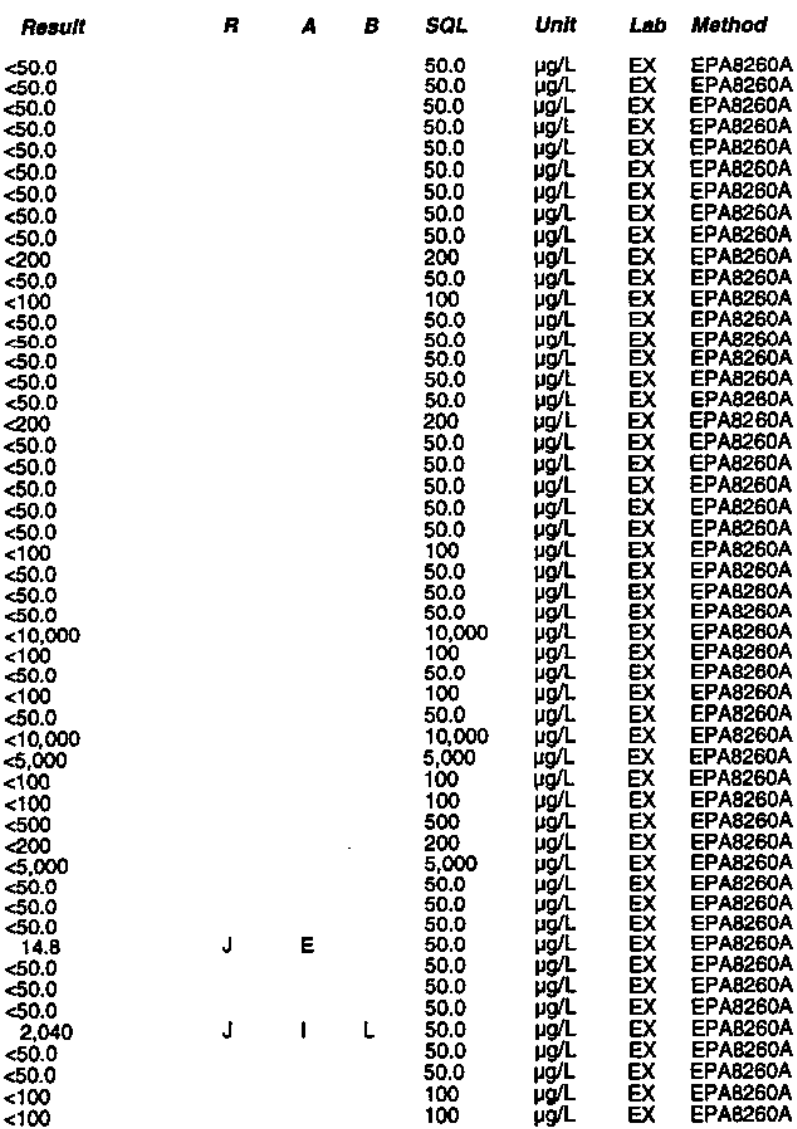

Time: 12:45

Water $21^{\circ} \mathrm{C}$

Air temperature: $28.6{ }^{\circ} \mathrm{C}$
Total alkalinity (as Caco3) $0 \mathrm{mg} / \mathrm{h}$
Phenolphthalein alkalinity: $0 \mathrm{mg} /$
Well RWM 12 collected on 05/08/98 (cont.)

- Bromornethane

Carbon tetrachloride
Carbon tetrachloride

Carbon tetrachlo

Chlorobenzen

Chlorosthane

Chloroethane

Chloroethene (Vinyl chloride)

Chloroathene (Vinyl chloride)

2-Chloroethyl vinyl ethe
2-Chloroethyl vinyl ether

Chhoroorm

Chbrotorm

Chloromethane

Dibromochloromethane

Dibromochloromethe

1.1-Dichloroetthan

1,2 -Dichloroethan

1,2-Dichloroethane

1.1-Dichloroethylen

i.i-Dichloroethylene

1,2-Dichloroethylene

trans-1,2-Dichloroethylene
trans- $1,2-$ Dichloroethylene

Dichloromethane

Dichloromethane
1,2 -Dichloropropane

1,2-Dichloropropane

cis-1,3-Dichlorpponen

cis-1,3-Dichioropropen trans-1,3-Dichloropropene

tran-1, - I chloropropene

Ethylbenzene

1,1,2,2-Tetrachloroethane 1,2,2-Tetrach Tetrachloroethylene Tetrachloroethylene : Toluene

1,1,1-Trichloroethane

$1,1,1$-Trichloroethane

1, 1,1 -Trichloroethane

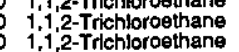

Frichloroethylene

Trichloroethylene

Trichloroflluoromethane

Trichlorofluoromethane

EPAB260A

WA EPAB260

A EPA260A

EX EPAB260A

$B-253$

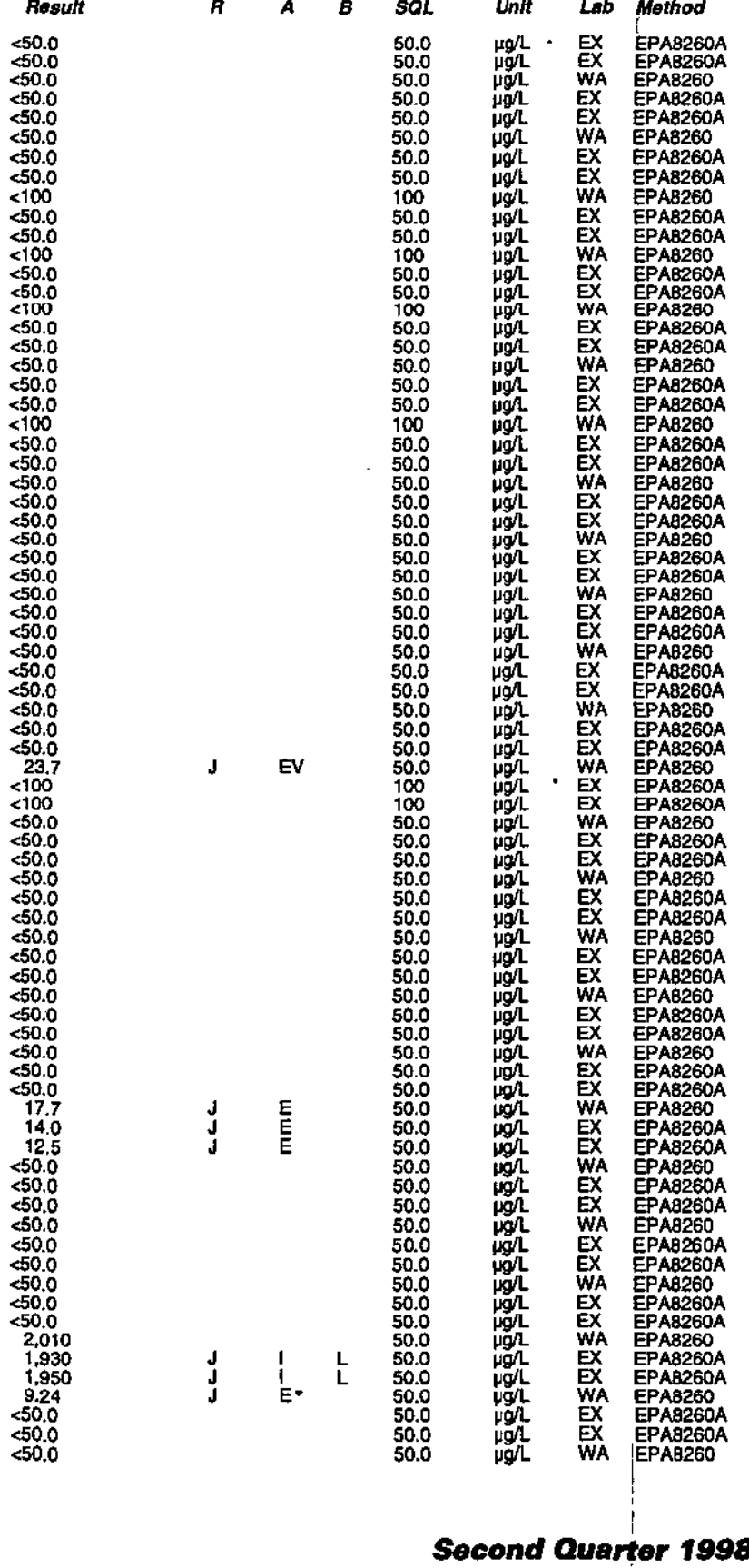




\section{WELL RWM 12 Replicate}

MEASUREMENTS CONDUCTED IN THE FIELD

Sample date: $05 / 08 / 98$.

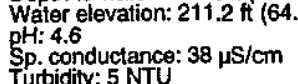

The well was continuously pumping.

\section{ANALYSES}

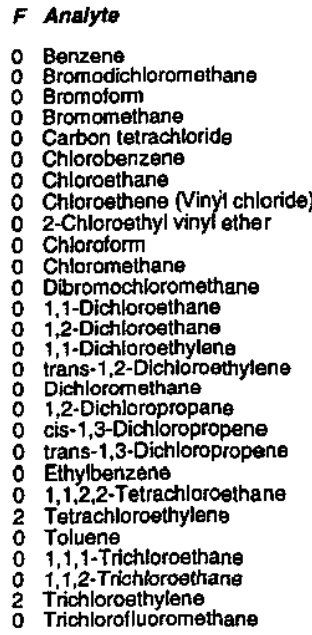

Resulf
550.0
550.0
550.0
550.0
550.0
550.0
550.0
550.0
50.0
550.0
550.0
550.0
550.0
550.0
50.0
5100
500
550.0
550.0
550.0
50.0
11.3
50.0
550.0
550.0
2.000
550.0

\section{WELL RWM 12}

MEASUREMENTS CONDUCTED IN THE FIELD

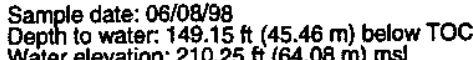
Water el $\mathrm{pH}: 4.6$

. conductance: $44 \mu \mathrm{S} / \mathrm{cm}$ The well was continuously purnping ANALYSES

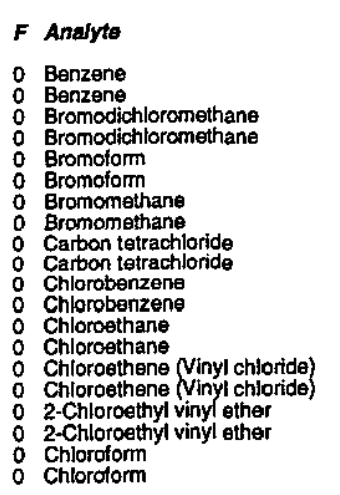

Resuft
$<50.0$
$<125$
$<50.0$
$<125$
$<50.0$
$<125$
$<50.0$
$<125$
$<50.0$
$<125$
$<50.0$
$<125$
$<50.0$
$<125$
$<50.0$
$<125$
$<50.0$
$<125$
$<50.0$
$<125$

ESH-EMS-980569
Well RWM 12 collected on 06/08/98 (cont.)

Time: 12:45

Air temperature: $28.6^{\circ} \mathrm{C}$

Total alkalinity (as CaCO3): $0 \mathrm{mg} / \mathrm{l}$

$F$ Analyte

o Chloromethane

Dibromochloromethane

1,1-Dichloroethane

: 1,2 -Dichloroethane

i,2-Dichloroethane

1,1-Dichloroethylene

Irans $1,2-$ Dichloroethylene
trans-1,2-Dichloroethylen

Dichloromethane

1,2 -Dichloropropane
i,2-Dichloropropane

cis-1,3-Dichloropropene

trans-1,3-Dichloropropen

Ethylbenzene

$1,1,2,2$ - Tetrachloroethane

Tetrachloroethylene

Toluene

1,1,1-Trichloroethane

i, 1,2 -Trichloroethane

1,1,2-Trichloroethane

Trichloroethylene

2 Irichloroethylene

Resuft
$<50.0$
$<125$
$<50.0$
$<125$
$<50.0$
$<125$
$<50.0$
$<125$
$<50.0$
$<125$
$<50.0$
$<125$
$<100$
$<50$
$<50.0$
$<125$
$<50.0$
$<125$
$<50.0$
$<125$
$<50.0$
$<125$
$<50.0$
$<125$
$<50.0$
$<125$
$<50.0$
$<125$
$<50.0$
$<125$
$<50.0$
$<125$
1.160
2,230
$<50.0$
$<125$

\section{WELL RWM 13B}

MEASUREMENTS CONDUCTED IN THE FIELD

Sample date: $04 / 17 / 98$ ( $141.9 \mathrm{~m})$ below TOC Water elevation: $198.75 \mathrm{ft}(60.58 \mathrm{~m}) \mathrm{msl}$ Sp. 5.1 conductance: $25 \mu \mathrm{S} / \mathrm{cm}$

The well was continuously pumping.

Water temperature: $22.5^{\circ} \mathrm{C}$ Air temperature: $30.5^{\circ} \mathrm{C}$.

\section{ANALYSES}

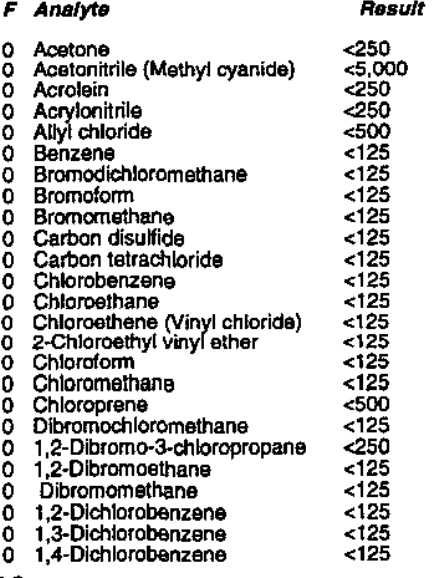

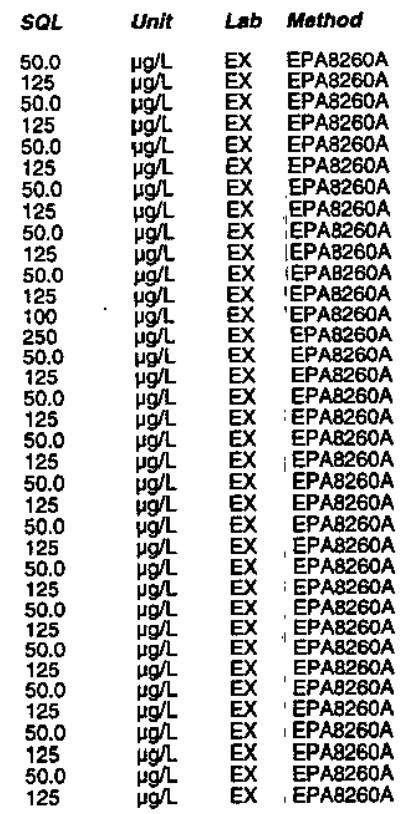

Time: 10:49

mperature: $20^{\circ} \mathrm{C}$

Air termperature: $21.9^{\circ} \mathrm{C}$
Total alkalinity (as Caco3): $0 \mathrm{mgh}$
Phenolphthalein alkalinity: $0 \mathrm{mg} /$

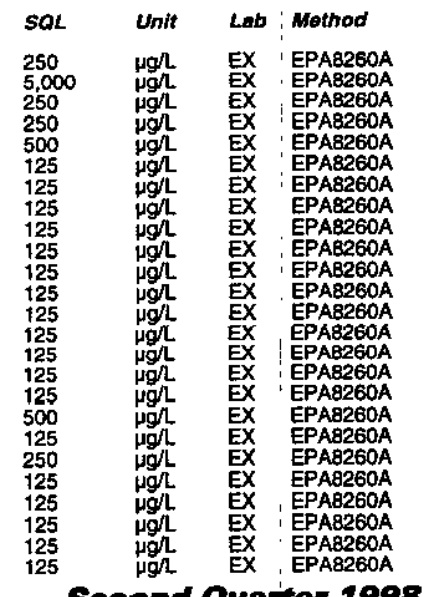

second Quarter 1998 
Well RWM 13 B collected on 04/17/98 (cont.)

$F$ Analyte

Irans-1,4-Dichloro-2-butene

1,1-Dichloroethane

1, 1-Dichloroathytene
trans-1,2-Dichloroethylene

Dichloromethane

cis-1,3-Dichtoropropene

rrans-1,3-bichloropropene

Ethyl methacrylate

2-Hexanone
lodomethene (Methyl iodide)

Isobutyl alcohol

Methyl ethyl ketone

Methyl methacrylate

Pentachloroethan

Styrene

1,1,2,2-Tetrachlorosthe

1.1,1-Trichloroethane

Trichloroethylene

1,2,3-Trichloropropane

0 Vinyl acetate
0 Xylenes

WELL RWM 13B

MEASUREMENTS CONDUCTED IN THE FIELD

Sarmple date: $05 / 07 / 98$ (t)

Water
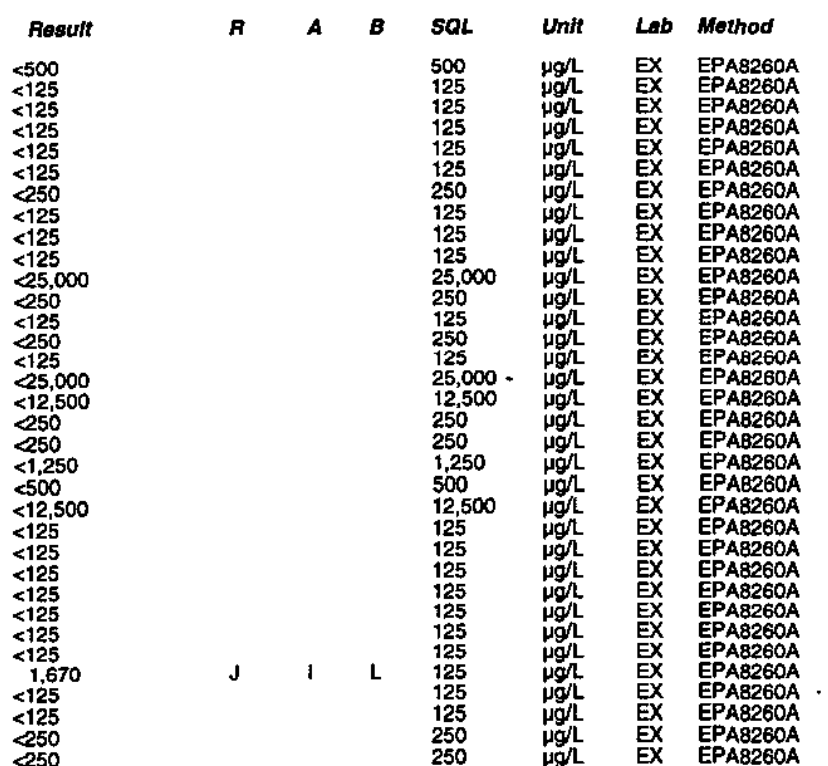

Sp. conductance: $27 \mu \mathrm{S} / \mathrm{cm}$

The well was continuously pumping. ANALYSES

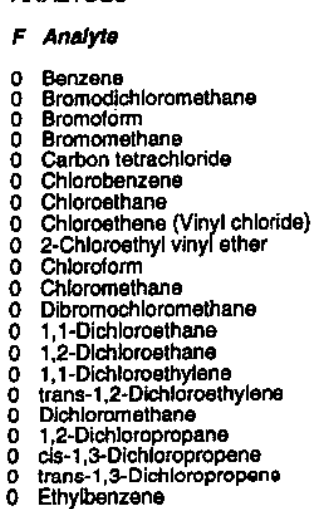

Result
$<125$
$<125$
$<125$
$<125$
$\leq 125$
$<125$
$<125$
$<125$
$<125$
$<125$
$<125$
$<125$
$<125$
$<125$
$<125$
$<125$
$<250$
$<125$
$\leq 125$
$<125$
$<125$

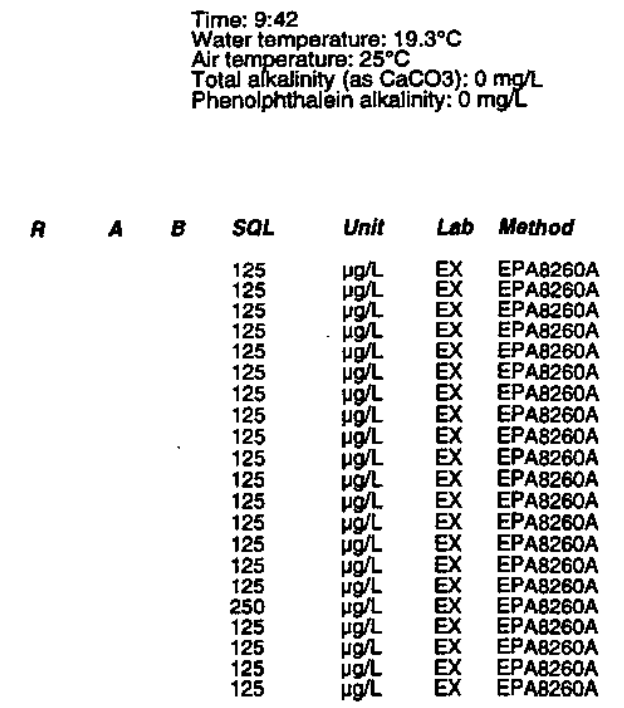

ESH-EMS-980569
Well RWM $13 B$ collected on 05/07/98 (cont.)

$F$ Analyte

$$
\begin{aligned}
& \text { Result } \\
& <125 \\
& 16.1 \\
& <125 \\
& <125 \\
& <125 \\
& 1.560 \\
& <125
\end{aligned}
$$

$1,1,2,2-T e t r a c h l o r o e t h a n$
2

: Toluene 1,1 -Trichloroethane

$\begin{array}{ll}0 & 1,1,2-\text { Trichloroethane } \\ 2 & \text { Trichioroethylene } \\ 0 & \text { Trichlorofluoremethan }\end{array}$

\section{WELL RWM 13B}

MEASUREMENTS CONDUCTED IN THE FIELD

Sample date: 06/08/98
Depth to water: $138.1 \mathrm{ft}(42.09 \mathrm{~m})$ below TOC
Water elevation: $198.1 \mathrm{ft}(60.38 \mathrm{~m}) \mathrm{msl}$
pH: 4.9

Sp. conductance: $28 \mu \mathrm{S} / \mathrm{cm}$

The well was continuously pumping.

ANALYSES

F Analyte

0 Banzene

Bromoform

Carbon tetractioride

Chlorobenzene

Chloroetthene (Vinyl chloride)
2-Crloroethyl vinyl ether

Chloroform

Chiloromethane

1,1-Dichioroethane

1,2-Dichloroethane

trans-1,2-Dichloroethylen

Dichloromethane

cis-1,3-Dichloropropene
trans-1,3-Dichloropropene

1,1,2,2-Tetrachloroeth

o Toluene

1,1,2-Trichloroethane

2 Trichloroothylene

WELL RWM 13C

MEASUREMENTS CONDUCTED IN THE FIELD

Sample date: 04/17/98

$130.1 \mathrm{ft}(39.65 \mathrm{~m})$ below TOC

Water

Sp. conductance: $35 \mu \mathrm{S} / \mathrm{cm}$

The well was continuously pumping.

ANALYSES

F Analyte

$\because$ Acetone

Acrolein

Acrlonltrile

0 Benzens

Bromodichloromethane
Bromoform

Result

$<125$
$<125$
$<125$
$<125$

$<125$
$<125$
$<125$
$<125$

$<125$
$<125$
$<125$

$<125$
$<125$
$<125$

1

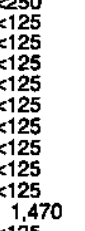

1.470

.

Result

$<250$

$<5,000$
$<250$
$<500$
$<125$
$<125$

\begin{tabular}{|c|c|c|}
\hline 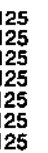 & $\begin{array}{l}\mu g / L \\
\mu g / L \\
\mu g \\
\mu g h \\
\mu g / L \\
\mu g / L \\
\mu g h\end{array}$ & $\begin{array}{l}\text { EX } \\
\text { EX } \\
\text { EX } \\
\text { EX } \\
\text { EX } \\
\text { EX } \\
\text { EX }\end{array}$ \\
\hline
\end{tabular}

A $A$ A $B$ SOL Unit Lab Method

Time: 13:09

Air temperature $23^{\circ} \mathrm{3}^{\circ} \mathrm{C}$

Total alkalinity (as CaCO3): $0, \mathrm{mg} /$
Phenolphthalein alkalinity: $0 \mathrm{mg} /$
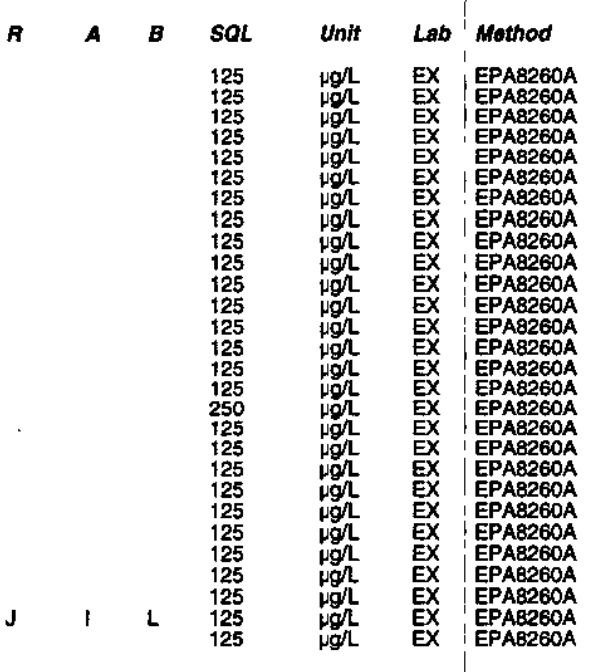

Time: 11:00

perature: $19.3^{\circ} \mathrm{C}$

Total akkalinity (as Caco3): 0 mgh

A

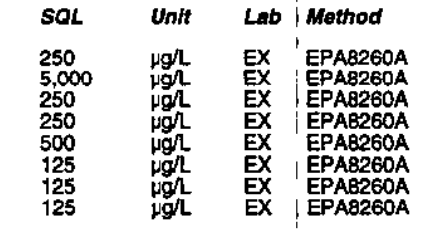

Second Quarter 1998 
ANALYTICAL RESULTS

Well RWM $13 \mathrm{C}$ collected on 04/17/98 (cont.)

$F$ Analyte

Resuft

: Bromomethane

- Carbon tetrachloride

: Chlorobenzene

0. Chloroethere (Vinyl chloride)
2-Chloroethyl vinyl ether

Chlorotorm

Chioroprene

1,2-Dibromo-3-chloropropane

1.2.Dibromoethane

1,2-Dichlorobenzene

trans-1,4-Dichloro-2-butene

Dichlorodifluoromethane

: 1,1-Dichlorosthane

$\begin{array}{ll}0 & 1,1-D i c h l o r o e t h y l e n \\ 0 & \text { trans-1,2-Dichloroethylene }\end{array}$

Dichloromethane

$\begin{array}{ll}0 & 1 \text { 2-Dichloropropane } \\ 0 & \text { cis-1,3-Dichloropopropene } \\ 0 & \text { irans-1,3-Dichloropropene }\end{array}$

$1,4-D i o x a n s$
0
0

E Ethylbenzene

2-Hexanone (Methyl lodide)

Isobutyl alcoho

Methacrylonitrile
Methyl ethyl ketone
Methyl isobutyl ketone

Methyl isobutyl ketone

Pentachloroethane

Propionititio

1,1,1,2-Tetrachlorosthane

2 Tetrachloroethylente

0 1,1,1-Trichloroethane

Trichloroethylene

Trichlorofluoromethane

o Vinyl acetate

WELL RWM 13C

MEASUREMENTS CONDUCTED IN THE FIELD

Sample daie: 05/07/98

Sample date: $05 / 07 / 98$
Depth to water $130 \mathrm{tt}(39.62 \mathrm{~m})$ below TOC
Water elevation: $206.4 \mathrm{ft}(62.91 \mathrm{~m}) \mathrm{msl}$

$\mathrm{PH}: 4.5$

p. conductance: $33 \mu \mathrm{S} / \mathrm{cm}$

The well was continuously pumping.

ANALYSES

$F$ Analyto Rosut

0 Benzene

Bromodichlor
Bromoform

Bromomethane

Chlorobenzene

Chioroesthane

2-Chloroethyl (Vinyl chloride)

ESH-EMS-980569

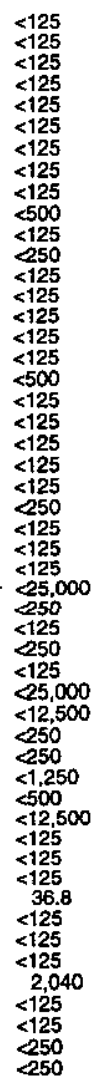

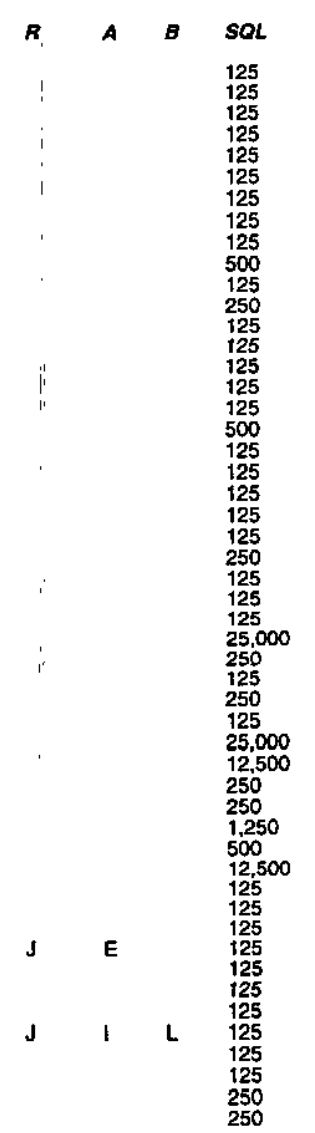

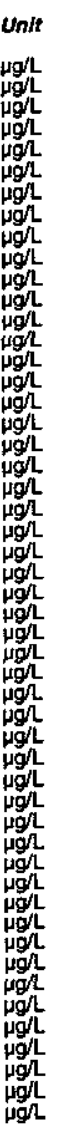

Lab Method

EPAB260A

EPAB260A

EPAB260A

EPAB260A

EPA8260A

EPAB260A

EPAB260A

EPA8260A

EPA8260A

EPAB260A

EPAB200A

EPAB260A
EPAB260A
EPAB260A

\begin{tabular}{l} 
EPA8260A \\
EPAB260A \\
\hline EPA260A \\
\hline
\end{tabular}

EPA8260A

EPAB260A

EPAB260A

EPAB260A

EPA8260A

EPAB260A
EPAB260A
EPA8260A

EPA8260A

EPA9260A

EPAB260A

EPAB260A

EPA8260A
Well RWM 13C collected on 05/07/98 (cont.)

$F$ Analyte

: Chloromethane

1.1-Dichloroethan

i, -Dichloroethylene
trans-1,2-Dichloroethylen

Dichiloromethane

cis-1,3-Dichloropropene

o Ethylbenzene

Tetrachloroethylene

2 Trichloroethylene

WELL RWM 13C

MEASUREMENTS CONDUCTED IN THE FIELD

Sample date: $06 / 08 / 98$ f $(39.69 \mathrm{~m})$ below TOC Water el

$\mathrm{H}: 4.9$
$\mathrm{p}$. conductance: $32 \mu \mathrm{S} / \mathrm{cm}$

The wefl was continuously pumpin

ANALYSES
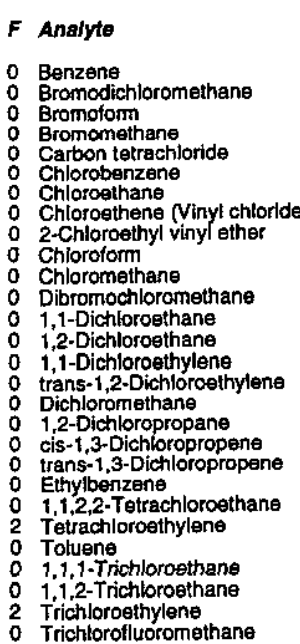

Result
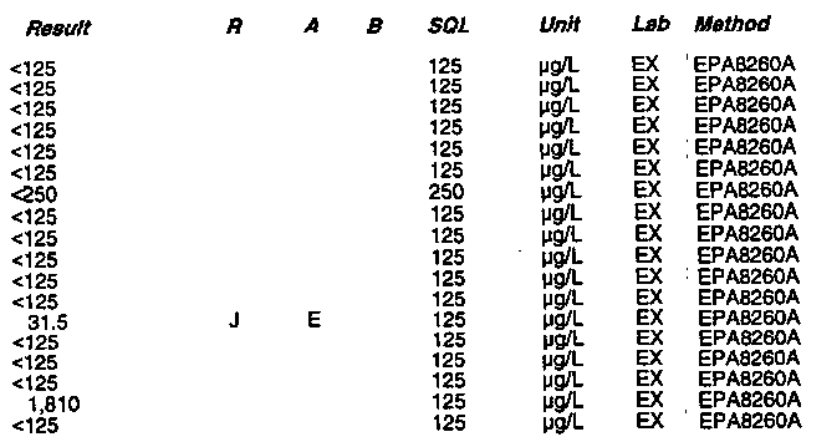

: $21.4^{\circ} \mathrm{C}$

Total alkalinity (as Caco3): $0 \mathrm{mgh}$

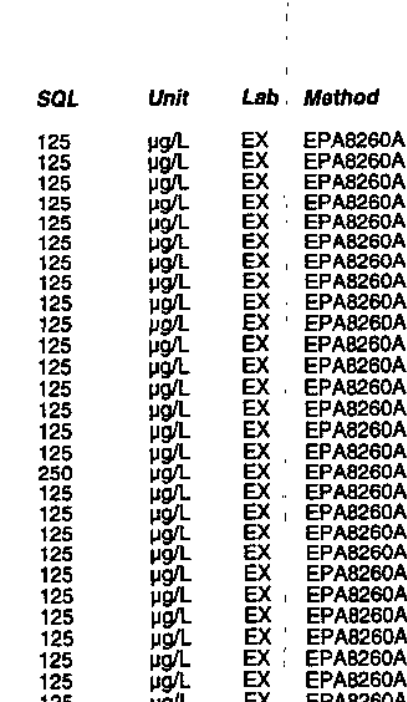

Trichloroethylene
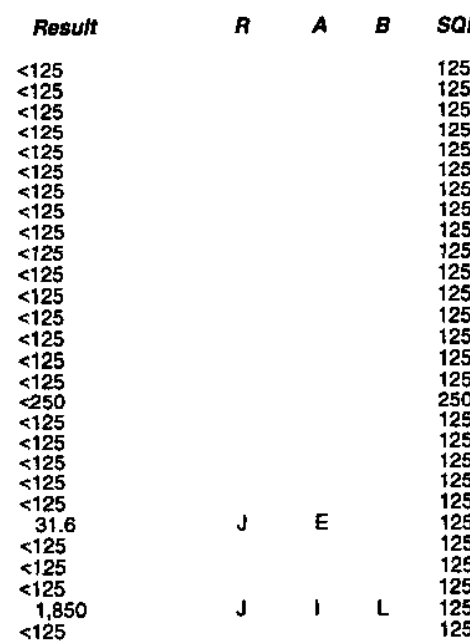

1,1,1-Trichloroethane
Time: 9:45

Air temperature: $25.6^{\circ} \mathrm{C}$ ) $0 \mathrm{mg}$. $\begin{array}{ll}\text { saL } & \text { Unit } \\ 125 & \mu g / L \\ 125 & \mu g / L \\ 125 & \mu g / L \\ 125 & \mu g / L \\ 125 & \mu g h \text { L } \\ 125 & \mu g / \text { L } \\ 125 & \mu g / L \\ 125 & \mu g / \text { L } \\ 125 & \mu g h \text { } \\ 125 & \mu g L\end{array}$

Lab Mothod

EX EPA8260A

EX EPAB260A

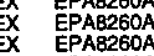

EPA8260A 
WELL RWM 14B

MEASUREMENTS CONDUCTED IN THE FIELD

Sample date: 04/17/98 Water elevation: $208.7 \mathrm{ft}(63.61 \mathrm{~m}) \mathrm{ms}$ $\mathrm{Sp}$. 4.7 onductance: $27 \mu \mathrm{S} / \mathrm{cm}$ Sp.conductance: $27 \mu \mathrm{S} / \mathrm{cm}$
Thibidity: 1 NTU
The wal was continuously pumping. ANALYSES
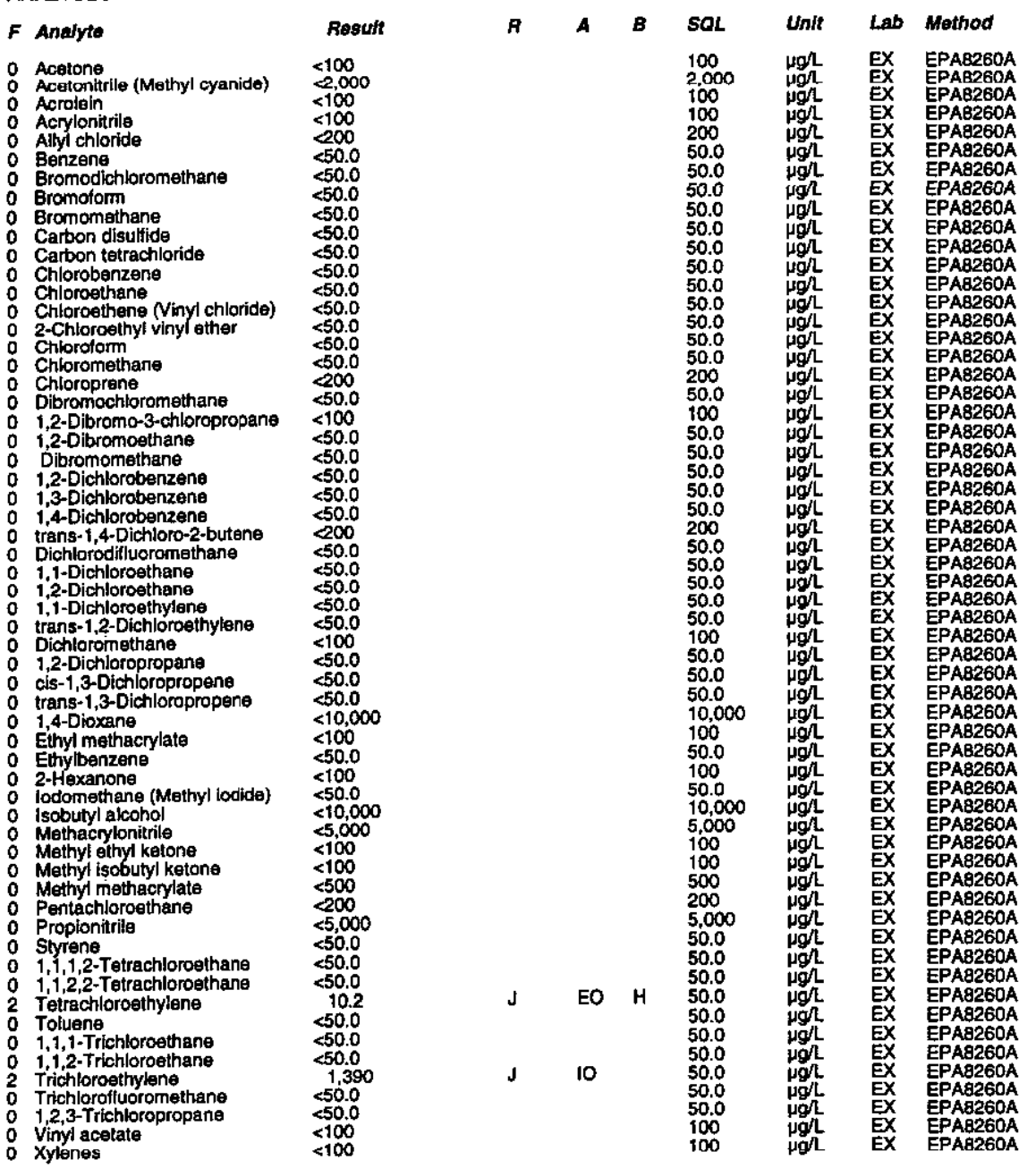

\section{WELL RWM 14B}

MEASUREMENTS CONDUCTED IN THE FIELD Sample date: $05 / 08 / 98$
Depth to water: $143.45 \mathrm{ht}(43.72 \mathrm{~m})$ below TOC WH: 4.4
$\mathrm{gp}$. conductances: $24 \mu \mathrm{S} / \mathrm{cm}$ Turbidity: 3 NTU 24 pen ANALYSES

\begin{tabular}{|c|c|}
\hline & Result \\
\hline 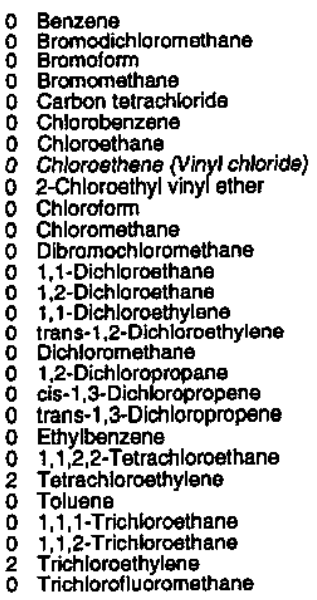 & $\begin{array}{l}<50.0 \\
<50.0 \\
<50.0 \\
<50.0 \\
<50.0 \\
<50.0 \\
50.0 \\
<50.0 \\
<50.0 \\
<50.0 \\
<50.0 \\
<50.0 \\
<50.0 \\
<50.0 \\
<50.0 \\
<50.0 \\
<50.0 \\
<50.0 \\
<50.0 \\
<50.0 \\
<50.0 \\
5.56 \\
<50.0 \\
<50.0 \\
<50.0 \\
1,230 \\
<50.0\end{array}$ \\
\hline
\end{tabular}

\section{WELL RWM 14B}

MEASUREMENTS CONDUCTED IN THE FIELD Sample date: $06 / 08 / 98$ (4).56 m) below TOC Water elevation: $208.3 \mathrm{ft}(63.49 \mathrm{~m}) \mathrm{ms}$ pH: 4.6 conductance: $31 \mu \mathrm{S} / \mathrm{cm}$ The well was continuously pumping. ANALYSES

$F$ Analyto

Result
$<50.0$
$<50.0$
$<50.0$
$<50.0$
550.0
$<50.0$
550.0
550.0
550.0
$<50.0$
$<50.0$
$<50.0$

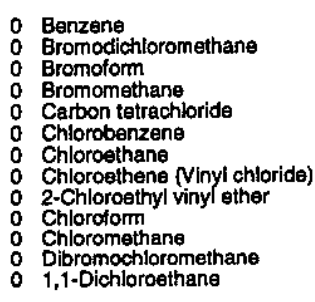

Time: $11: 30$ Air temperature: $262^{\circ} \mathrm{C}$ Total alkalinity (as CaCO3): $0 \mathrm{mg} /$
B B

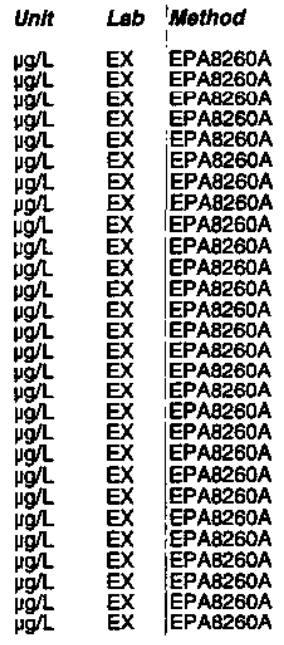
Time: $12: 36$ Water $127^{\circ} \mathrm{C}$ Air temperature: $30.3^{\circ} \mathrm{C}$ Total alkalinity (as CaCO3): $0 \mathrm{mg} / \mathrm{L}$

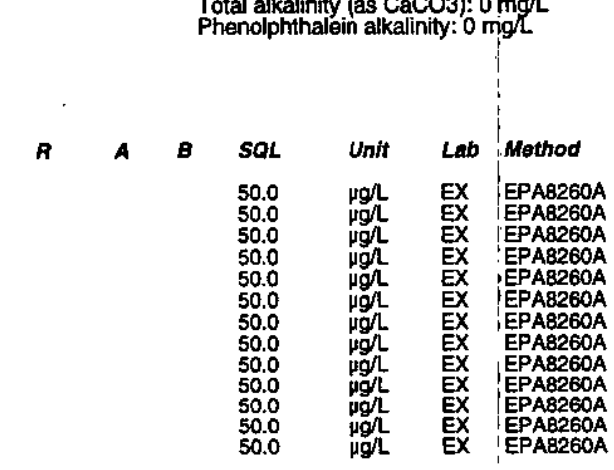


Well RWM 14B collected on 06/08/98 (cont.)

$f$ Analyte

Result
$<50.0$
$<50.0$
$<50.0$
$<100$
$<50.0$
$<50.0$
$<50.0$
$<50.0$
$<50.0$
8.70
$<50.0$
$<50.0$
$<50.0$
1.240
$<50.0$

2 Trichloroethylene

\section{WELL RWM 14C}

MEASUREMENTS CONDUCTED IN THE FIELD

Sample date: 04/17/98

Wepth to water: Not available

$\mathrm{pH}: 4.7$

p. conductance: $39 \mu \mathrm{S} / \mathrm{cm}$

the weit was continuously pumping.

ANALYSES

$F$ Analyte

O Acetone

Acrolein

Allyi chloride

Bromodichtoromethane

Bromotomm

Carbon disulfide

Chlorobenzene

Chloroethene (Vinyl chlorlde)
2-Chloroethyl vinyl ether

2-Chloroethyl vinyl ether

Chloromethane

Dibromochloromethane

1,2-Dibromoethane

1,2-Dichloroberenzen

1,4-Dichlorobenzen

trans-1,4-Dichloro-2-butene
Dichlorodifiluoromethane

1.1-Olchiloroethane

1.2-Dichloroethane

trans-1,2-Dichloroethylen

1,2-Dichloropropan

cis-1,3-Dichloropropene

Ethylbenzene

Ethylbenzene

ESH-EMS-980569
Time: 12:20

temperature: $19.9^{\circ} \mathrm{C}$

Total akalinity (as CaCO3): $0 \mathrm{mg} /$
Phenolphthalein alkalinity: $0 \mathrm{mg} /$

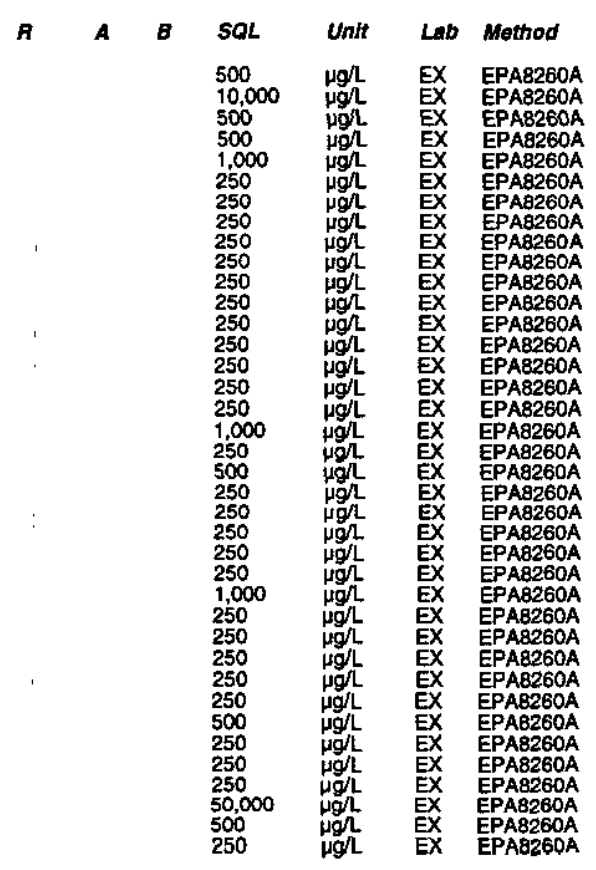

Well RWM 14C collected on 04/17/98 (cont.)

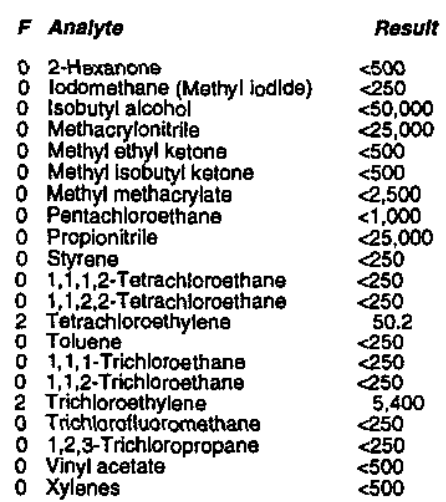

R

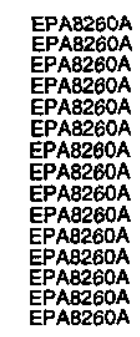

\section{WELL RWM 14C}

MEASUREMENTS CONDUCTED IN THE FIELD

Sample date: $05 / 08 / 98$
Depth to water: $149.6 \mathrm{ft}(45.5 \mathrm{~m})$ below TOC
What

Water elevation: $201.8 \mathrm{ft}$ (

Tumidit:11 NTU: 36 HS/cm

The well was continuously pumping.

ANALYSES

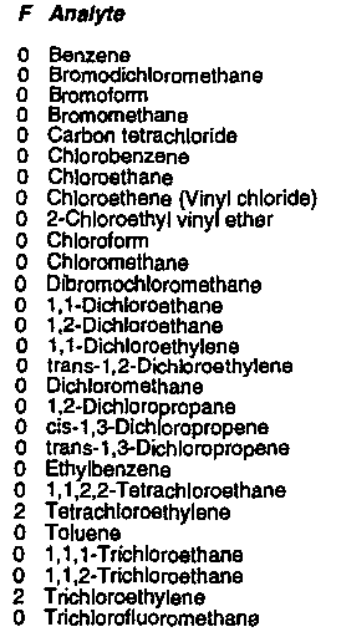

Resutt
250
250
250
250
250
250
250
250
250
250
250
250
250
250
250
250
250
$<500$
4250
250
250
250
450
48.1
$<250$
2550
4250
5560
$<250$

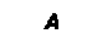

SQL
250
250
250
250
250
250
250
250
250
250
250
250
250
250
250
250
500
250
250
250
250
250
250
250
250
250
250
250

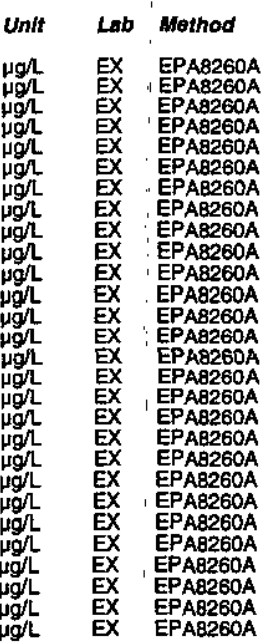

Time: $12: 00$

Total alkalinity (as Caco3): $0 \mathrm{mg} /$
Phenolphthalein alkalinity: $\mathrm{mg} \mathrm{L}^{2}$

\begin{tabular}{|c|c|c|c|}
\hline & & Lab & Method \\
\hline $\begin{array}{l}500 \\
250 \\
50,000 \\
25,000 \\
500 \\
500 \\
2,500 \\
1,000 \\
25,000 \\
250 \\
250 \\
250 \\
250 \\
250 \\
250 \\
250 \\
250 \\
250 \\
250 \\
500\end{array}$ & 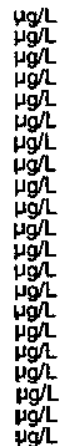 & $\begin{array}{l}\text { EX } \\
\text { EX } \\
\text { EX } \\
\text { EX } \\
\text { EX } \\
\text { EX } \\
\text { EX } \\
\text { EX } \\
\text { EX } \\
\text { EX } \\
\text { EX } \\
\text { EX } \\
\text { EX } \\
\text { EX } \\
\text { EX } \\
\text { EX } \\
\text { EX } \\
\text { EX } \\
\text { EX } \\
\text { EX }\end{array}$ & 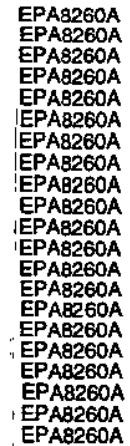 \\
\hline
\end{tabular}




\section{WELL RWM 14C}

MEASUREMENTS CONDUCTED IN THE FIELD Sample date: 06/08/98 $\mathrm{ft}(45.71 \mathrm{~m})$ below TOC ater elevation: $201.45 \mathrm{ft}(61.4 \mathrm{~m}) \mathrm{ms}$ p. conductance: $38 \mu \mathrm{S} / \mathrm{cm}$ The well was continuously purmping ANALYSES

$F$ Analyto Result

: Benzens

Bromodichloromethane

Bromoform

Bromomethane

Carbon tetrachiloride

Carbon tetrachloride

Chlorobenzene

Chlorcethane

Chloroethane

2-Chloroethyl vinyl ether

Chloroform

Chloromethane

Chlorornethane

Dibromochloromethan

1,1-Dichloroethan

1,2-Dichloroethane

1,1-Dichloroethylene

trans-1,2-Dichloroethylens

Dichloromethane

Dichloromethane

cis-1,3-Dichloropropen

cis-1,3-Dichloropropene

trans-1,3-Dichloropropene

Ehyybenzene

$1,1,2,2$-Tetrachloroethane

2 Tetrachloroothylene

Toluene

1.1,1-Trichloroethane

1.1,1-Trichloroethane

1,1,2-Trichloroethan

Trichloroethylene

Trichloroethylene

Trichlorofluoromethane

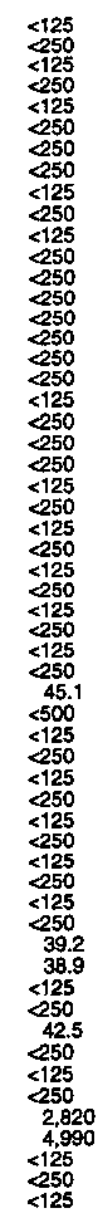

EV

Time: 12:43

Air temperature: Not available
Total alkatinity (as CacCo3): $0 \mathrm{mg} /$
Phenolphthalein alkalinity: $0 \mathrm{mg} /$

\section{WELL RWM 14C Replicate}

MEASUREMENTS CONDUCTED IN THE FIELD Sample date: $06 / 08 / 98$
Depth to water: $149.95 \mathrm{tt}(45.71 \mathrm{~m})$ below TOC
Water elevation: $201.45 \mathrm{ft}(61.4 \mathrm{~m})$ msl Sp. conductance: $38 \mathrm{\mu S} / \mathrm{cm}$

Turbidity: 26 NTU

\section{ANALYSES}

\section{F Analyto}
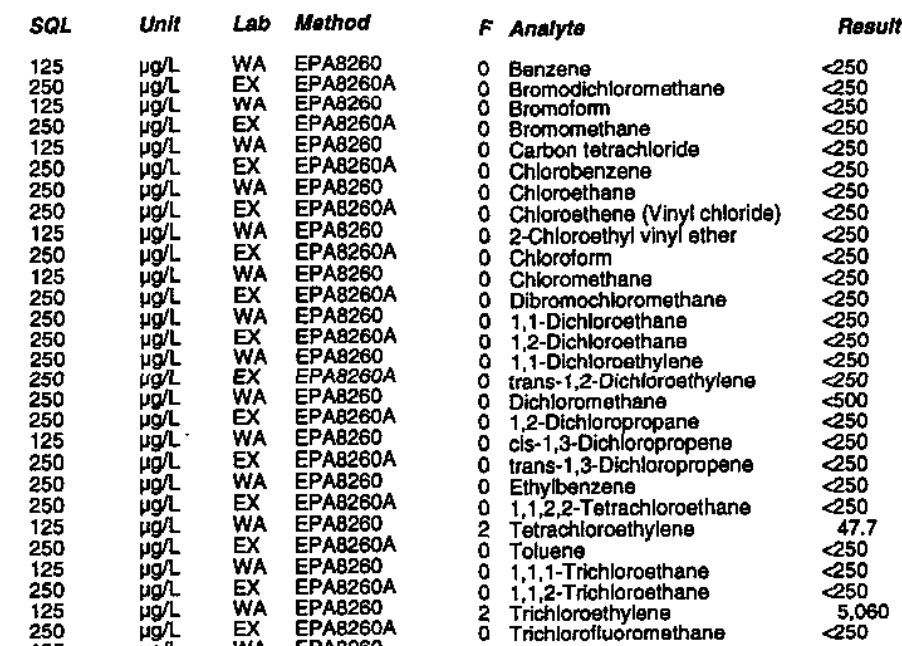

WA EPAB260A

2 Trichloroesthylens
Time: 12:43

ir temerare: $21.2^{\circ} \mathrm{C}$

Totel akalinity. (as CaCO3): $0 \mathrm{mgh}$
Phenolphthalein alkalinity: $0 \mathrm{mgh}$

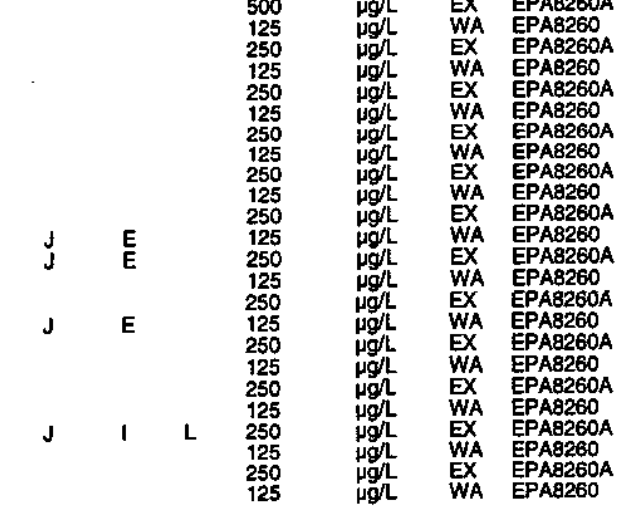




\section{WELL RWM 15B}

MEASUREMENTS GONDUGTED IN THE FIELD Sample date: 04/17/98 Water elevation: $207.28 \mathrm{ft}(63.18 \mathrm{~m}) \mathrm{msl}$ $\mathrm{H}: 4.9$ Sp. conductance: $24 \mu \mathrm{S} / \mathrm{cm}$

The well was continuously pumping.

ANALYSES

F Analyte

: Acetone Acetonitrile (Methyl cyanide)

Acrolein

Ally chloride

Bromodichloromethane

Bromoform

Carbon disulfide

Carbon tetrachloride

Chloroethene (Vinyl chloride)
2-Chloroethyl vinyl ether

Chloromethane

Chibromochectloromethane

1,2-Dibromo-3-chloropropans

Dibromomethane

1,2-Dichlorobenzene

1,4-Dichlorobenzene
trans-1,4-Dichloro-2-bu

Dichiorodifluoromethane

1.1-Dichloroethane

1,1-Dichloroethylene
trans-1,2-Dichloroethylene

1.2-Dichloropropan

cis-1,3-Dichloropropene
trans-1,3-Dichloropropene

Ethyl methacrylate

Ethylbenzene

2-Hexanone

Isobuty' alcohol

Methyl ethyl ketone

Methyl methacrylate

Pentachloroethan

1,1,1,2-Tetrachloroethane $1,1,2,2$-Tetrachloroethan

Tolueno

1,1,2-Trichloroethane Trichloroethylene 1,2,3-Trichloropropane Xylenes

\begin{tabular}{|c|}
\hline 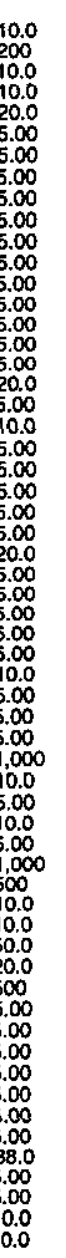 \\
\hline
\end{tabular}

(1)

WELL RWM 15B

MEASUREMENTS CONDUCTED IN THE FIELD Sample date: $05 / 07 / 98$

Time: $11: 12$ Depth to water: $162.32 \mathrm{ft}(49.48 \mathrm{~m})$ below TOC Total alkalinity (as CaCO3): $0 \mathrm{mgh}$ Sp. conductance: $25 \mu \mathrm{S} / \mathrm{cm}$ The well was continuously pumping ANALYSES

\begin{tabular}{|c|c|}
\hline \multirow[b]{2}{*}{ 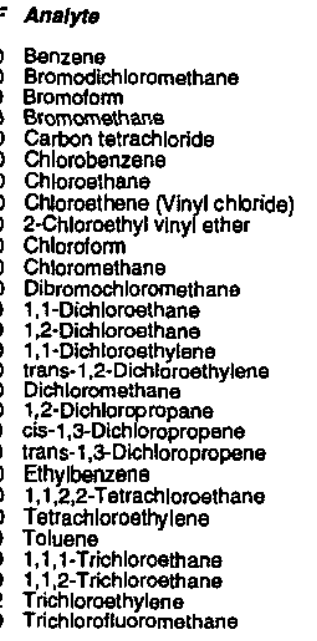 } & Resuth \\
\hline & 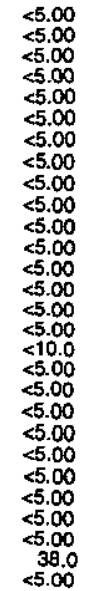 \\
\hline
\end{tabular}

\section{WELL RWM 15B}

MEASUREMENTS CONDUCTED IN THE FIELD Sample date: $06 / 08 / 98$
Depth to water: $162.5 \mathrm{ft}(49.53 \mathrm{~m})$ below TOC Water Sp. conductance: $22 \mu \mathrm{S} / \mathrm{cm}$ The well was continuously pumping. ANALYSES

\begin{tabular}{|c|c|}
\hline Analyte & Rest \\
\hline 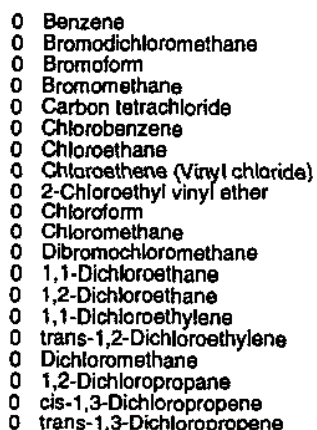 & $\begin{array}{l}<5.00 \\
<5.00 \\
<5.00 \\
<5.00 \\
<5.00 \\
<5.00 \\
<5.00 \\
<5.00 \\
<5.00 \\
<5.00 \\
<5.00 \\
<5.00 \\
<5.00 \\
<5.00 \\
<5.00 \\
<10.0 \\
<5.00 \\
<5.00 \\
<5.00\end{array}$ \\
\hline
\end{tabular}

Time: : :17

ure: 19.1

Total alikalinity (as Caco3): $0 \mathrm{mgh}$

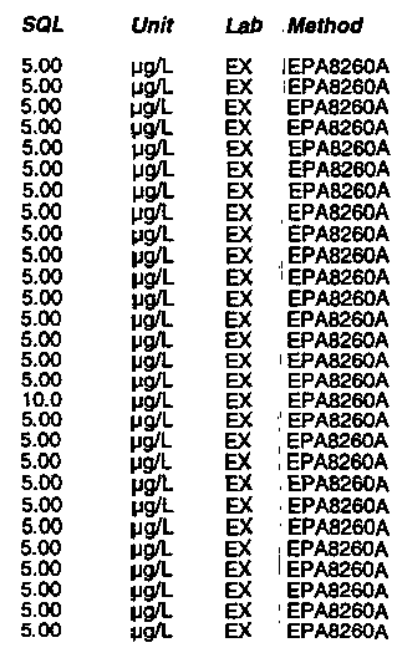

Time: $13: 25$

Water temperature: $20.6^{\circ} \mathrm{C}$

Total alkalinity (as $\mathrm{CaCO}$ ): 0 imgh

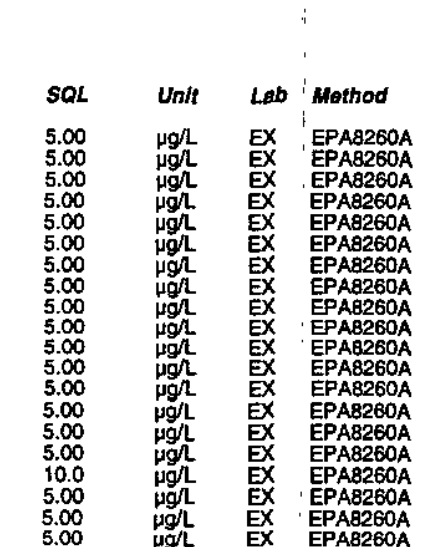

Second Quarter 1998

$+2$


ANALYTICAL RESULTS

\section{Well RWM 15B collected on 06/08/98 (cont.)}

$F$ Analyte Resuft O Ethylbenzane
$01,1,2$-Tetrachloroethane
0 Tetrachloroethylene 1,1,1-Trichloroethane Trichloroe

WELI TBG

MEASUREMENTS CONDUCTED IN THE FIELD

Sample date: $05 / 13 / 98$
Depth to water: 49 ft $(14.94 \mathrm{~m})$ below TOC
Water elevation: $102.2 \mathrm{ft}(31.15 \mathrm{~m}) \mathrm{msl}$

PH: 42

$<5.00$

$<5.00$

$<5.00$

$<5.00$
A B SOL

$\begin{array}{ll} & \\ 5.00 & \text { Unft } \\ 5.00 & \mu g h \\ 5.00 & \mu g h \\ 5.00 & \mu g h \\ 5.00 & \mu g h \\ 5.00 & \mu g h \\ 5.00 & \mu g h \\ 5.00 & \mu g h \\ 5.00 & \mu g h\end{array}$

unft
$\mu g h$
$\mu g h$
$\mu g h$
$\mu g h$
$\mu g h$
$\mu g h$
$\mu g h$

Lab Mothod

EX EPAB260A

EX EPAB260A

EPAB260A

EPAB260A
Wubidity: 1 NTU

ANALYSES

$\boldsymbol{F}$ Analyto

2 Aluminum, total recoverable

Caroon ferrachionide
Chloroform

Iron, total recoverable

Mercury, total recovera

Nitrate as nitrogen

Tetractiloroethylene

Trichloroethylene

Gross alpha

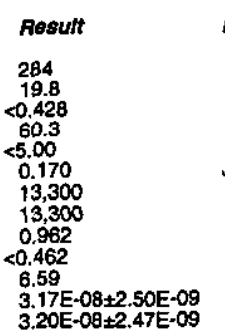

ค

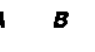

\section{WELL TBG 3}

MEASUREMENTS CONDUCTED IN THE FIELD

Sample date: $05 / 11 / 98$
Depth to water: 44.7 (13.62 m) below TOC
Wet

Water el

p. conductance: $140 \mu \mathrm{S} / \mathrm{cm}$

Turbidity: 2 NTU ANALYSES

\begin{tabular}{|c|c|c|c|c|c|c|c|c|}
\hline Analyto & Result & $\boldsymbol{A}$ & A & $B$ & SOL & Unit & Lab & Method \\
\hline 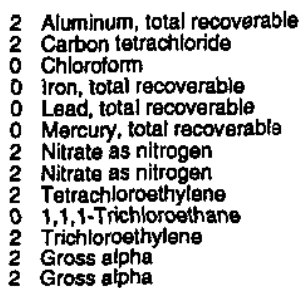 & $\begin{array}{l}211 \\
336 \\
20.5 \\
36.9 \\
<5.00 \\
0.340 \\
14,200 \\
14.100 \\
8.05 \\
<0.462 \\
1.040 \\
3.59 E-08 \pm 3.23 E-09 \\
3.20 E-08 \pm 2.98 E-09\end{array}$ & $\mathbf{J}$ & $\begin{array}{l}Q V \\
Q V\end{array}$ & & $\begin{array}{l}20.0 \\
4.05 \\
0.42 B \\
20.0 \\
5.00 \\
0.200 \\
100 \\
100 \\
0.569 \\
0.462 \\
39.0 \\
9.40 \mathrm{E}-10 \\
8.90 \mathrm{E}-10\end{array}$ & 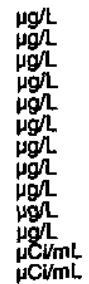 & $\begin{array}{l}\text { ES } \\
\text { ES } \\
\text { ES } \\
\text { ES } \\
\text { ES } \\
\text { ES } \\
\text { ES } \\
\text { ES } \\
\text { ES } \\
\text { ES } \\
\text { TM }\end{array}$ & $\begin{array}{l}\text { EPA6010 } \\
\text { EPAB010 } \\
\text { EPAB010 } \\
\text { EPA6010 } \\
\text { EPA6010 } \\
\text { EPA7470 } \\
\text { EPA9056 } \\
\text { EPA9566 } \\
\text { EPAB010 } \\
\text { EPAB010 } \\
\text { EPABO10 } \\
\text { EPA900.0M } \\
\text { EPA900.0M }\end{array}$ \\
\hline
\end{tabular}

Time: 12:25

Total alkalinity (as Caco3); $0 \mathrm{mg} /$

\section{WELL TBG 4}

MEASUREMENTS CONDUCTED IN THE FIELD

Sample date: 05/11/98

Depth to water. $44.4 \mathrm{tt}(13.53 \mathrm{~m})$ bolow TOC
Water elevation: $106.9 \mathrm{Ht}(32.58 \mathrm{~m}) \mathrm{ms}$

D: 42

$\mathrm{Sp}$. conductance: $220 \mu \mathrm{S} / \mathrm{cm}$

Water ovacuated from the well prior to sampling: 28 gal

ANALYSES

F Analyte

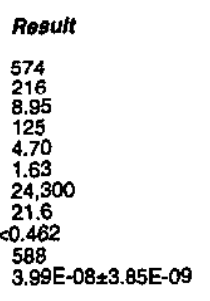

Aluminum, total recoverable

Chloroform

Lead, total recoverable

Nitrate as nitrogen

Terrachiorcesthylene
$1,1,1-T$ richloroethane

2 Trichlorosthylene

3.99E-08×3.85E- 09

\section{WELL TBG 5}

MEASUREMENTS CONDUCTED IN THE FIELD

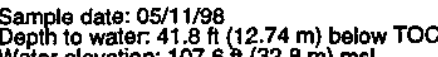

Water elevation: $107.6 \mathrm{ft}(32.8 \mathrm{~m}) \mathrm{msl}$

WH: 5

Sp. conductance: $60 \mu \mathrm{S} / \mathrm{cm}$

Water evacuated from the well prior to sampling: $27 \mathrm{gal}$
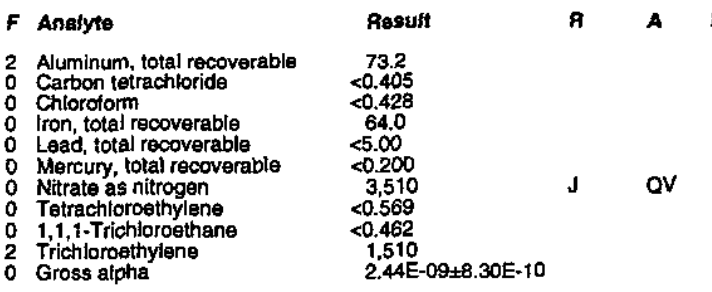

2 Trichloroethyl
0.390
$1.00 E-09$
$\mu$

Time: 11:49

Total alkalinity (as CaCO3): $0 \mathrm{mg} /$

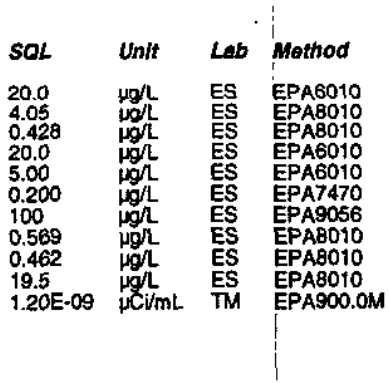

Time: 10:43
Water temperature: $17^{\circ} \mathrm{C}$
Air temperature: $25.7^{\circ} \mathrm{C}$ Total alkalinitity (as CaCO3) $1 \mathrm{mgh}$

Time: 13:05

Water temperature: $17^{\circ} \mathrm{C}$

Total alkalinity (as CaCOS): $0 \mathrm{mg} /$
Phenolphthalein alkalinity: $0 \mathrm{mgh}$

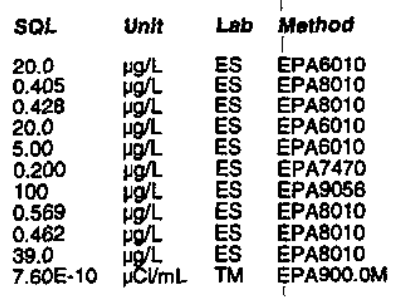




\section{WELL TBG 5A}

MEASUREMENTS CONDUCTED IN THE FIEL Sample date: 05/13/98 Depth to water: 43.454 (13.24 m) below TOC Water elevalion Sp. conductance: $28 \mu \mathrm{S} / \mathrm{cm}$ Turbidity: 3 NTU
Water evacuated from the well prior to sampling: $97 \mathrm{gal}$ ANALYSES

$F$ Analyte

A Aluminum, total recoverable
0 Carbon tetrachloride Chiorotom Lead, total recoverabable Nirrate as nittrogen 1,1,1-Trlchioroethen 0
0
0

WELL TBG 5B

MEASUREMENTS CONDUCTED IN THE FIELD Sample date: $05 / 15 / 98$
Depth to water. $32.5 \mathrm{ft}(9.91 \mathrm{~m})$ below Toc
Water elevation: $116.9 \mathrm{~m}(35.63 \mathrm{~m}) \mathrm{ms}$ Water elevation: $116.9 \mathrm{ht}$ (35. Sp. conductance: $35 \mu \mathrm{S} / \mathrm{cm}$

\begin{tabular}{|c|c|c|c|c|c|c|c|}
\hline Result & A & A & B & SOL & Unit & Lab & Method \\
\hline $\begin{array}{l}7.50 \\
<0.405 \\
<0.428 \\
43.2 \\
5.00 \\
50.200 \\
750 \\
<0.569 \\
0.462 \\
0.390 \\
1.22 E-09 \pm 5.60 E-10\end{array}$ & $\mathbf{J}^{\prime \prime}$ & E & & $\begin{array}{l}20.0 \\
0.405 \\
0.428 \\
20.0 \\
5.00 \\
0.200 \\
100 \\
0.569 \\
0.462 \\
0.390 \\
7.40 E-10\end{array}$ & 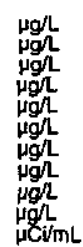 & $\begin{array}{l}\text { ES } \\
\text { ES } \\
\text { ES } \\
\text { ES } \\
\text { ES } \\
\text { ES } \\
\text { ES } \\
\text { ES } \\
\text { ES } \\
\text { TM }\end{array}$ & $\begin{array}{l}\text { EPA6010 } \\
\text { EPAB010 } \\
\text { EPA8010 } \\
\text { EPA6010 } \\
\text { EPA6010 } \\
\text { EPA7470 } \\
\text { EPA9056 } \\
\text { EPAB010 } \\
\text { EPA8010 } \\
\text { EPA8010 } \\
\text { EPA900.0M }\end{array}$ \\
\hline
\end{tabular}
ANALYSES

\begin{tabular}{|c|}
\hline Analyte \\
\hline 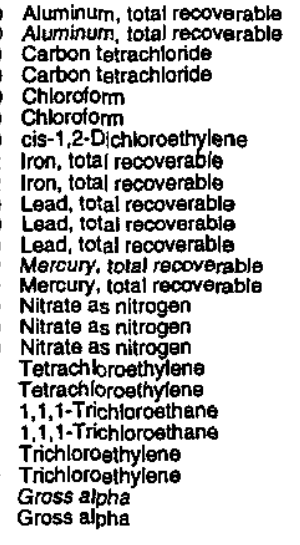 \\
\hline
\end{tabular}

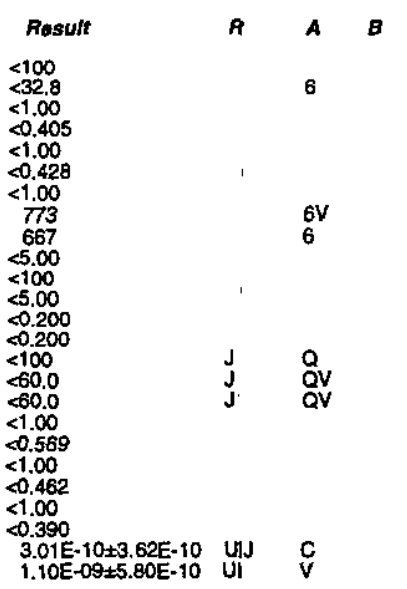

Time: 8:34

Time: 11:49 Air memperature: $17^{\circ} \mathrm{C}$ Total alkalinity (as CaCO3): $3 \mathrm{mgh}$

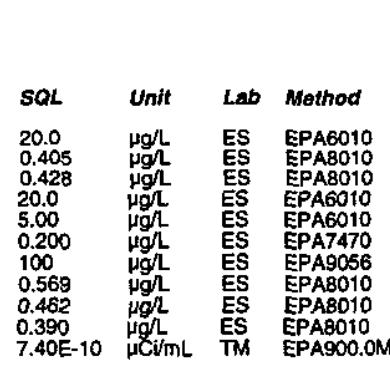

ir temperature: $18.9^{\circ} \mathrm{C}$ Totai alkainity (as CaCO3): $0 \mathrm{mgh}$

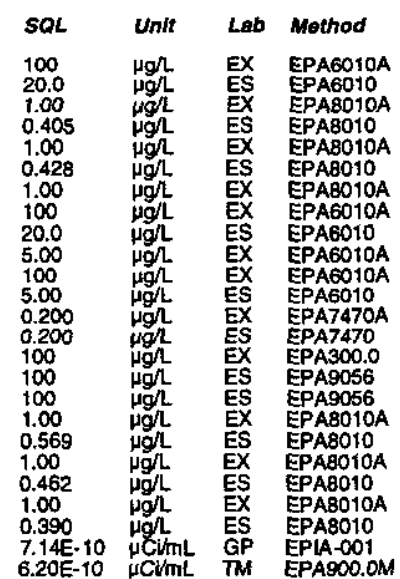

WELL TBG 5B Replicate

MEASUREMENTS CONDUCTED IN THE FIELD Depth to water. $32.5 \mathrm{ft}(9.91 \mathrm{~m})$ below TOC

$\mathrm{PH}: 49$

4.9

Sp.conductance: $35 \mu \mathrm{S} / \mathrm{cm}$

Water evacuated from the well prior to sampling: $128 \mathrm{gal}$ ANALYSES

$F$ Analyte

A Auminum, total recoverab!e

Chloroform

Mead, total recoverable

Nitrate as nilrogen

1,1,1-Trichloroethan

Trichloroethylene

Gross alpha

\section{WELL TBG 6}

MEASUREMENTS CONDUCTED IN THE FIELD

Sample date: $05 / 11 / 98$
Depth to water: $42 \mathrm{ft}(12.8 \mathrm{~m})$ below TOC
Water elevation: $106.1 \mathrm{ft}(32.34 \mathrm{~m}) \mathrm{ms} !$

$4: 4$

. conductance: $120 \mu \mathrm{S} / \mathrm{cm}$

Wuatidity: 4 NTU evacuated from the well prior to sampling: $35 \mathrm{gal}$

ANALYSES

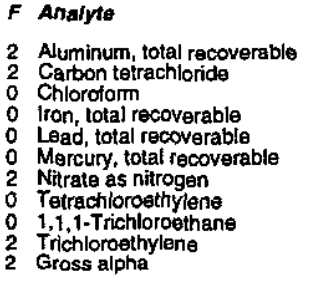

Result

175
7.07

0.899
110
$<.00$
0.560

0.560
11,600

8.462

$2.05 E-08 \pm 2.32 E-09$
Time: 8:34

ir temperature: $22.3^{\circ} \mathrm{C}$

Thal alkalinity (as Caco3): $0 \mathrm{mgh}$
Time: 9:47

Water temperature: $17^{\circ} \mathrm{C}$

Total akealinity (as CaCO3): $0 \mathrm{mg}^{2}$

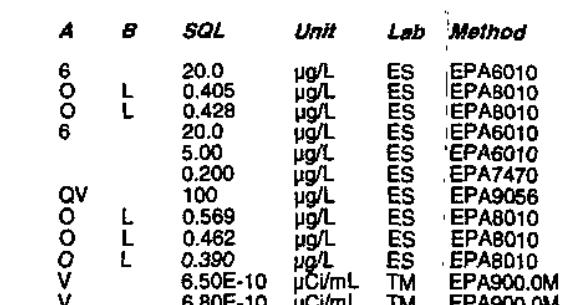




\section{WELL TCM 2}

MEASUREMENTS CONDUCTED IN THE FIELD

Sample date: 04/20/98 epth to water: $3 \mathrm{ff}(0.91 \mathrm{~m})$ below TOC
(at H: 5.2 5.2 conductance: $100 \mu \mathrm{S} / \mathrm{cm}$ Water evacuated from the well prior to sampling: $40 \mathrm{gal}$ ANALYSES

$F$ Analyto

2 Carbon tetrachloride

Carbon tetrachloride

Chloroform

cis-1,2-Dichloroethylene

cis-1,2-Dichloroethylene
cis- 1,2 -Dichloroethylene

Tetrachloroethylene

Tetrachloroethylene

$1,1,1$-Trichlorotethane
$1,1,1-$ Trichloroethane

Trichtoroethylene

2 Trichloroethylen

\section{WELL TCM 2 Replicate}

MEASUREMENTS CONDUCTED IN THE FIELD

Sample date: 04/20/98
Depth to water: 3 tt $(0.91 \mathrm{~m})$ below TOC
Wet

Water

Pp. conductance: $100 \mu \mathrm{S} / \mathrm{cm}$

Water evacuated from the well prior to sampling: 40 gal

ANALYSES

$F$ Anatyto

Resuth
12.7
2.46
23.0
1.25
$<0.462$
128

Carbon tetrachloride

cis-1,2-Dlchloroethylen

Tetrachloroethylen

WELL TIR 3B

MEASUREMENTS CONDUCTED IN THE FIELD

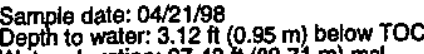

Water elevat

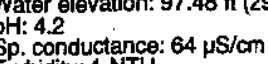

Water evacuated from the well prior to sampling: 5 ga

ANALYSES

$F$ Analyte

Aesutt
25.7
2.02
49.0
1.10
$<0.462$
179

2 Carbon tetrachloride

1 cis-1,2-Dichloroethylen

Tetrachloroethylene

2 Trictioroethylens

179

ESH-EMS-980569
Time: $14: 48$

An temperature: $21.6^{\circ} \mathrm{C}$

Total alkalinity (as CaCos); $4 \mathrm{mgh}$
Phenolohthalein alkalinity: $0 \mathrm{mg}$ L

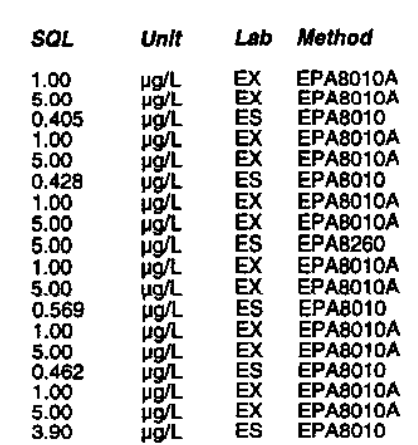

Wirer $15^{\circ} \mathrm{C}$

Total alkalinity (as CaCO3): $4 \mathrm{mgl}$
Phenolphthalein alkalinity: $\mathrm{mg} \mathrm{mL}^{2}$
WELL TNX 1D

MEASUREMENTS CONDUCTED IN THE FIELD

Sample date: 05/13/98

Depth to water: $55.99 \mathrm{ft}(17.07 \mathrm{~m})$ bedow TOC

Water eve

Sp. conductance: $41 \mu \mathrm{S} / \mathrm{cm}$

Turbidity: 1 NTU $41 \mu \mathrm{S} / \mathrm{cm}$

ANALYSES

$F$ Analyta

- Aluminum, total recoverable

Chloroform

Lead, total recovarable
Mete

Nitrate as nitrogen

1,1,1-Trichlorosthane

Trichloroethylen
0 Gross alpha

WELL TNX 2D

MEASUREMENTS CONDUCTED IN THE FIELD

Sample date: $05 / 13 / 98$.

Water el

5.7 .

Sp. conductance: $41 \mu \mathrm{S} / \mathrm{cm}$

Water evacuated from the well prior to sampling: $50 \mathrm{gal}$

ANALYSES

$F$ Analyte

Result

- Aluminum, total recoverable

Aluminum, toat
$:$ Carbon tetrach
0 Chiorotorm

Iron, total recoverable

Mercury, total recover

Nitrate as nitrogen

1, 1,1-Trichloryethane

Trichloroethylen
0 Gross alpha

Resuft

$<20.0$

720
3.40
0.260
90.0
$<0.569$
$<0.462$

$<0.462$

$27.09+6.20 \mathrm{E}-10$

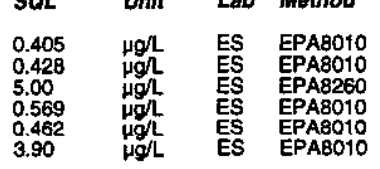

24.8
$<0.405$

0.642
38.3
$<5.00$

$<.00$
0.310
1.030
$<0.5699$

3. $3.14 \mathrm{E}-09 \times 8.40 \mathrm{E}-10$
Time: 13:57

Water temperature: $22.1{ }^{\circ} \mathrm{C}$

Total allalinity (as CaCo3): $5 \mathrm{mgl}$
Time: 9:53

Water temperature: $18^{\circ} \mathrm{C}$
Air temperature: $12.8^{\circ} \mathrm{C}$

Air temperature: $12.8^{\circ} \mathrm{C}$
Total alkalinity (as Caco3); $0 \mathrm{mgh}$
Phenolphthalein alkalinity: $0 \mathrm{mg} / \mathrm{L}$

EMTS 
WELL TNX 3D

MEASUREMENTS CONDUCTED IN THE FELD Sample date: 05/13/98 Depth to water: $53.19 \mathrm{H}(16.21 \mathrm{~m})$ below TOC Water evalon. $101.11 \mathrm{ft}(30.82 \mathrm{~m}) \mathrm{msl}$

Sp. conductance: $380 \mu \mathrm{S} / \mathrm{cm}$

Wurbidity: 6 NTU ANALYSES

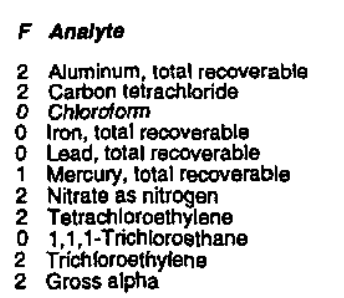

Result
755
31.8
2.24
120
3.60
1.23
19,800
12.8
$<0.462$
230
$1.93 \mathrm{E}-08 \pm 2.07 \mathrm{E}-09$

\section{WELL TNX 4D}

MEASUREMENTS CONDUCTED IN THE FIELD

Sample date: 05/14/98

Wepth to water: $42.9 \mathrm{ft}(13.08 \mathrm{~m})$ below TOC

Hp. conductance: $64 \mu \mathrm{S} / \mathrm{cm}$

Water evacuated from the well prior to sampling: $1 \mathrm{gal}$

ANALYSES

$F$ Analyte

: Gross alpha

Resuft

$4.55 E-09 * 1.09 E-09$
$5.21 E-09 * 1.17 E-09$

\section{WELL TNX 4D}

MEASUREMENTS CONDUCTED IN THE FIELD

Sample date: 05/21/98

Depth to water. $42.89 \mathrm{ft}(13.07 \mathrm{~m})$ below TOC

Water el 4.8

p. conductance: $50 \mu \mathrm{S} / \mathrm{cm}$

Water evacuated from the well prior to sampling: 29 gal

ANALYSES

$F$ Analyte

2 Aluminum, total recoverable

Chloroform

Iron, total recoverable

Mercury, total recoverablo

Tetrachloroethylene

Trichiloroethysent

Result
137
1.50
$<0.428$
115
$<.00$
$<0.200$
2.070
0.858
0.462
2.27

Time: 8:57

Total alkalinity (as CaCO3): $0 \mathrm{mgh}$
Phenolphthalein alkalinity: $0 \mathrm{mg}$ L
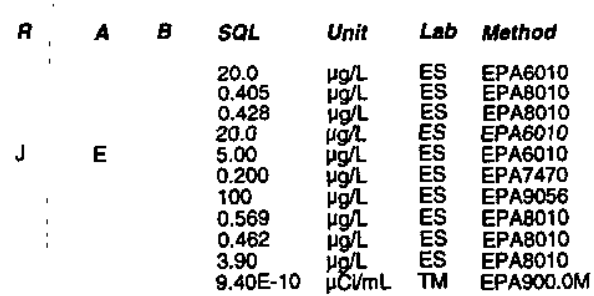

Time: $9: 18$
Water temperature: $15^{\circ} \mathrm{C}$
Air temperature: $22.9^{\circ} \mathrm{C}$

Total alkalinity (as CaCO3): $2 \mathrm{mgh}$
Air temperature: $23.4^{\circ} \mathrm{C}$

WELL TNX 7D

MEASUAEMENTS CONDUCTED IN THE FIELD

Sample date: $05 / 14 / 98$
Depth to water: $48.5 \mathrm{tt}(14.78 \mathrm{~m})$ below TOC
Water elevation: $102.4 \mathrm{th}(31.21 \mathrm{~m}) \mathrm{msl}$

Water

Sp. conductance: $200 \mu \mathrm{S} / \mathrm{cm}$

Watbidity: 2 NTU Wacuated from the well prior to sampling: $1 \mathrm{gal}$ ANALYSES

$\begin{array}{lllllllll}F \text { Analyte } & \text { Result } & \text { A } & A & B & \text { SOL } & \text { Unit Lab Mathod } \\ 0 & \text { Gross alpha } & 2.47 E-09 \pm 8.60 \mathrm{E}-10 & & & & 9.00 \mathrm{E}-10 & \text { LCVImL } & \text { TM EPA900.0M }\end{array}$

\section{WELL TNX 7D}

MEASUREMENTS CONDUCTED IN THE FIELD

Sample date: 05/21/98

Depth to water: $48.81 \mathrm{ft}(14.88 \mathrm{~m})$ below TOC
Water elevation: $102.09 \mathrm{tt}(31.12 \mathrm{~m}) \mathrm{ms}$
pH: 5

Sp. conductance: $28 \mu \mathrm{S} / \mathrm{cm}$

Water evacuated from the well prior to sampling: $1 \mathrm{gal}$ ANALYSES

\begin{tabular}{|c|c|}
\hline & ESU \\
\hline 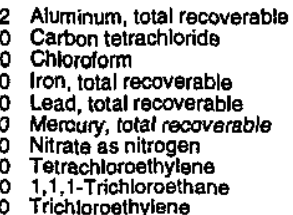 & $\begin{array}{l}64.8 \\
<0.405 \\
<0.428 \\
136 \\
4.10 \\
<0.200 \\
<100 \\
<0.569 \\
<0.462 \\
<0.390\end{array}$ \\
\hline
\end{tabular}

Time: 7:54

Air temperature: $18: 5^{\circ} \mathrm{C}$

Total alkalinity (as CaCO3): $0 \mathrm{mg} /$

\section{WELL TNX 8D}

MEASUREMENTS CONDUCTED IN THE FIELD

Sample date: $05 / 12 / 98$
Depth to water: $5.66 \mathrm{tt}(1.73 \mathrm{~m})$ below TOC
Water elevation: $94.64 \mathrm{tt}(28.85 \mathrm{~m}) \mathrm{msl}$

Water

Time: $11: 33$ Water temperature: $21.9^{\circ} \mathrm{C}$

Air temperature: $26.5^{\circ} \mathrm{C}$
Total alkalinity (as CaCO3): $2 \mathrm{mg} /$
Phervolphthalein alkalinity: $0 \mathrm{mgl}$

Sp. con

. conductance: $100 \mu \mathrm{S} / \mathrm{cm}$

Water evacuated from the well prior to sampling: 43 gal ANALYSES
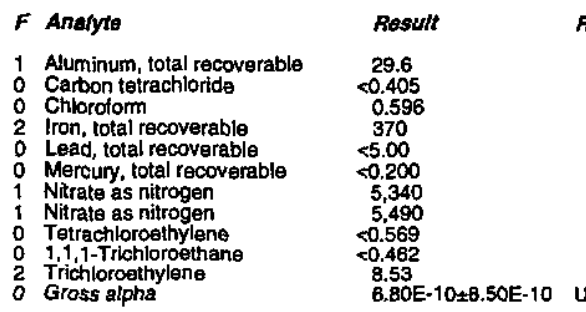

a

\section{Time: 12:30

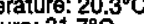 \\ Total akalinity (as Caco3): $3 \mathrm{mgh}$}


ANALYTICAL RESULTS

\section{WELL TNX 9D}

MEASUREMENTS CONDUCTED IN THE FIELD

Sample date: 05/12/98
Depth to water: $6.25 \mathrm{tt}(1.91 \mathrm{~m})$ below TOC
Water elevation: $95.45 \mathrm{t}(29.09 \mathrm{~m}) \mathrm{msl}$

Water el

pp. conductance: $96 \mu \mathrm{S} / \mathrm{cm}$

Turbidity: $1 \mathrm{NTU}$ : $96 \mathrm{~S} / \mathrm{cm}$
Water evacuated from the well prior to sampling: 93 gal

ANALYSES

$F$ Analyte

2 Aluminum, total recoverable

Chibroform

Iron, total recoverable
Lead total recoverable

Mercury, total recoverablo

Nitrate as nitrogen

1,1,1-Trichloroethane

Trictloroethylene
0 Gross alpha

\section{WELL TNX 10D}

MEASUREMENTS CONDUCTED IN THE FIELD

Sample date: 05/18/98
Depth to water: 6.75 $\mathrm{ft}(2.06 \mathrm{~m})$ below TOC
Water elevation: $95.55 \mathrm{tt}(29.12 \mathrm{~m}) \mathrm{msl}$

H: 5

p. conductance: $120 \mu \mathrm{S} / \mathrm{cm}$

Water evacuated from the well prior to sampling: $40 \mathrm{gal}$

ANALYSES

F Analyte

2 Aluminum, total recoverable

Chlorotorm
Iron, total recout

Iron, total recoverable

Mercuny total recoverablo

Nitrate as nitrogen
Nitrate as nitrogen

Tatrachloroethylene

Trichloroethylene

0 Gross alpha

Resut
79.6
$<0.405$
00.428
3.400
$<5.00$
0.200
240
0.569
$<0.462$
0.399
$1.18 \mathrm{E}-09 \pm 6.90 \mathrm{E}-10$

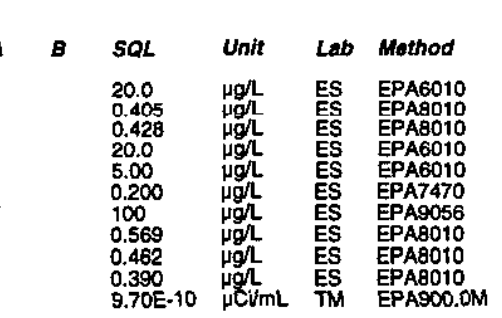

\section{WELL. TNX 11D}

\section{MEASUREMENTS CONDUCTED IN THE FIELD}

Sample date: 05/12/98

Depth to water: $5.5 \mathrm{ft}(1.68 \mathrm{~m})$ below TOC

Water

Sp. conductance: $56 \mu \mathrm{S} / \mathrm{cm}$

Sp. conductance: $56 \mu \mathrm{S} / \mathrm{cm}$

Water evacuated from the well prior to sampling: $45 \mathrm{gal}$

ANALYSES

$F$ Analyte

Aluminum, total recoverable

Chloroform

2 Iron, total recoverable

2 Nercury, total recovera

ESH-EMS-980569
Time: 14:33

Total allalinity (as CaCOC3): $11 \mathrm{mg} /$

Time: 9:09

Total alkalinity (as CaCO3): $30 \mathrm{mgh}$

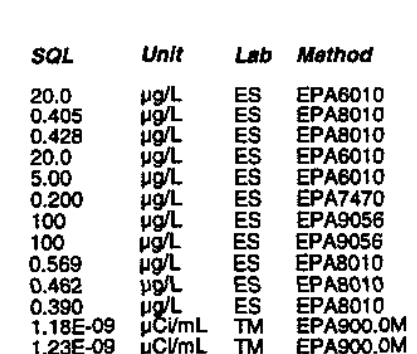

Time: 13:39
Water temperature: $2{ }^{\circ} \mathrm{C}$
Air temperature: $27.4^{\circ} \mathrm{C}$

Aotal alkalinity (as Caco3): $2 \mathrm{mg} / \mathrm{L}$
Air temperature: $26.8^{\circ} \mathrm{C}$

Air temperature: $20.4^{\circ} \mathrm{C}$
Well TNX 11D collected on 05/12/98 (cont.)

F Analyte

: Tetrachloroethylene $\quad<0.569$ : Trichloroethylene

$<0.462$

\section{WELL TNX 12D}

MEASUREMENTS CONDUCTED IN THE FIELD

Sample date: 05/12/98

Water to wateration: $3.93 \mathrm{ft}(1.2 \mathrm{~m})$ below TOC

$\mathrm{pH}: 6.3$. conductance: $55 \mu \mathrm{S} / \mathrm{cm}$

Water evacuated from the well prior to sampling: $44 \mathrm{gal}$

ANALYSES

F Analyto

Resut

Aluminum, total racoverable

Carbon tetrachioride

o Iron, total recoverable

Mercury, total recoverable

Tetrachloroethylene

1,1,1-Trichloroethan

0 Gross alpha

\section{WELL TNX 16D}

MEASUREMENTS CONDUCTED IN THE FIELD

Sample date: 04/21/98

Depth to water. $2.05 \mathrm{tt}(0.62 \mathrm{~m})$ below TOC

Water

Sp. conductance: $140 \mu \mathrm{S} / \mathrm{cm}$

Turbidity: O NTU:

ANALYSES

$F$ Analyte

1 Carbon tetrachlorido cis-1,2-Dichloroethylene Tetrachloroethylene

i,1,1-Trichloroethan
2 Trichloroethylene

Resutt
3.76
0.978
3.60
0.693
$<0.462$
45.1

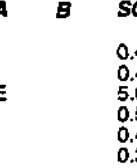

Method

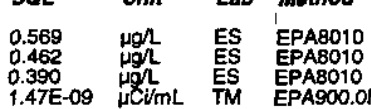

Time: 13:23

Ware $19.6^{\circ} \mathrm{C}$

Total akalinity (as CaCO3): $16 \mathrm{mg} / \mathrm{h}$ 
ANALYTICAL RESULTS

\section{WELL TNX 27D}

MEASUREMENTS CONDUCTED IN THE FIELD

Sample date: $06 / 03 / 98$
Depth to water. $13.51 \mathrm{tt}(4.12 \mathrm{~m})$ below TOC
Water elevation: $97.09 \mathrm{ft}(29.59 \mathrm{~m}) \mathrm{msl}$

Water elevation: $97.09 \mathrm{ft}(29.5)$
PH: 5.9 .
Tpunductance: $91 \mu \mathrm{S} / \mathrm{cm}$

Water evacuated from the well prior to sampling: 8 gal

ANALYSES

$F$ Analyto

- Total organic halogens

Nonvolatile beta

Tritium

WELL TNX 27D

MEASUREMENTS CONDUCTED IN THE FIELD

Sample date: 06/04/98

Depth to water: Not available

WH: Not available
$\mathrm{H}$. conductance: Not available

No water was evacuated from the well prior to sampling

ANALYSES

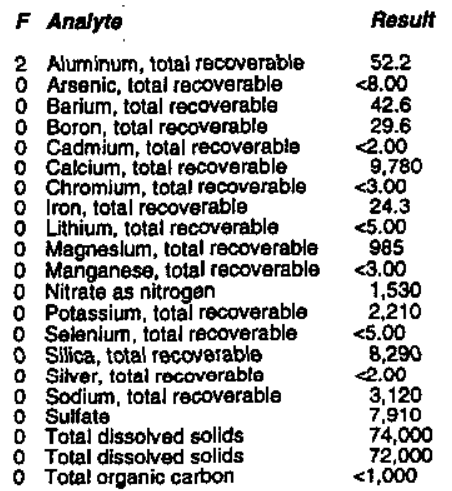

Result
52.2
58.20
42.6
29.6
2.00
9.00
$<3.780$
24.3
$<5.00$
9.05
$<3.00$
1,530
2,210
$<5.00$
8.290
-2.00
3,120
7,910
74,000
72,000
$<1,000$

WELL TRW 1

MEASUREMENTS CONDUCTED IN THE FIELD

Sample date: $05 / 14 / 98$.

Water e water: $62.9 \mathrm{tt}(19.17 \mathrm{~m})$ below

Whater 4.4

Sp. conductance: $220 \mu \mathrm{S} / \mathrm{cm}$

The well was continuously pumping.

ANALYSES

$F$ Analyte

0 Gross aipha

Result

3.54E-09:1.02E-09
Time: 12:02

Water temperature: $20.4^{\circ} \mathrm{C}$

Total akalinity (as CaCO3): $19 \mathrm{mg} / \mathrm{h}$

SOL Unit Lab Method

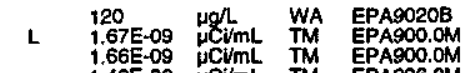

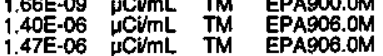
Water temperature: Not available Total alkalinity (as Caco3): Not available
Phenolphthalein alkalinity: Not available

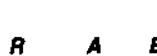

\begin{tabular}{|c|c|c|c|}
\hline $5 O L$ & Unit & Lab & Mothod \\
\hline $\begin{array}{l}20.0 \\
8.00 \\
2.00 \\
25.0 \\
2.00 \\
50.0 \\
3.00 \\
20.0 \\
5.00 \\
50.0 \\
3.00 \\
100 \\
400 \\
5.00 \\
100 \\
2.00 \\
100 \\
5.000 \\
1,000 \\
1.000 \\
1.000\end{array}$ & 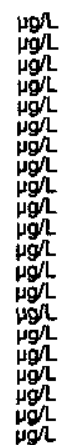 & $\begin{array}{l}\text { ES } \\
\text { ES } \\
\text { ES } \\
\text { ES } \\
\text { ES } \\
\text { ES } \\
\text { ES } \\
\text { ES } \\
\text { ES } \\
\text { ES } \\
\text { ES } \\
\text { ES } \\
\text { ES } \\
\text { ES } \\
\text { ES } \\
\text { ES } \\
\text { ES }\end{array}$ & 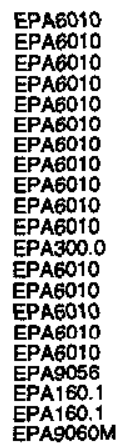 \\
\hline
\end{tabular}

WELL TRW 1

MEASUREMENTS CONDUCTED IN THE FIELD

Sample date: 05/21/98

Depth to water. $62.9 \mathrm{ft}(19.17 \mathrm{~m})$ below TOC

$4 \mathrm{ft}(28.47 \mathrm{~m}) \mathrm{msl}$

Sp. conductance: $120 \mu \mathrm{S} / \mathrm{cm}$

The well was continuously purnping. ANALYSES

F Analyte

2 Aluminum, total recoverable

Iron, total recoverable

Mercury, total recoverabl

Totrachloroethylen

O
2 Trichloroethylene

WELL TRW 1

MEASUREMENTS CONDUCTED IN THE FIELLD

Sample date: 06/03/98

Depth to water. Not available

Sp. 5 conductance: $160 \mu \mathrm{S} / \mathrm{cm}$

The well was continuously pumping.

ANALYSES

$F$ Analyte

2 Aluminum, total recoverable

Chloroform

- Iron, total recoverabla

1 Mercury, total recoverab

2 Nitrate as nitrogen

Trichloraethylene

G Gross alpha

Resust
119
14.0
0.971
9.10
$<5.00$
0.840
10.900
1.39
$<0.462$
170

Resut
119
14.0
0.971
9.10
5.00
0.840
10.900
1.39
0.462
170

THE FIEL Result

187
8.11
0.847

47.6
5.40
1.05

1.05
12,600
12,700

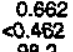

5..2 $25 \mathrm{E}-09+1.37 \mathrm{E}-09$
Tetrachloroethylene

Time: 13:00

Air temperperature: $23.1^{\circ} \mathrm{C}$

Total alkalinity (as CaCO3): 4 mg/l

SQL Unit Lab Mothod

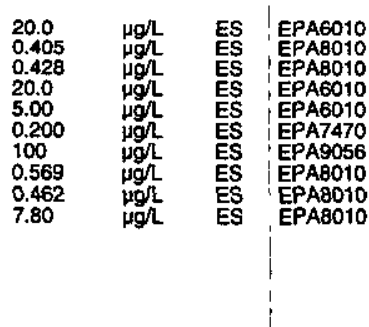

Time: 10:15

ir temperature: $36^{\circ} \mathrm{C}$

Total alkaininty (as $\mathrm{CaCO}$ ): $0 \mathrm{mg}$

Water temperature: $16^{\circ} \mathrm{C}$

Total alkalinity (as Cacos): $0 \mathrm{mg} / \mathrm{L}$

Sal Unt Lab Method

8.30E-10 $\mu \mathrm{CV} / \mathrm{mL}$ TM EPA900.0M 
WELL TRW 2

MEASUREMENTS CONDUCTED IN THE FIELD Sample date: $04 / 20 / 98$ ft $(17.55 \mathrm{~m})$ below TOC Water elevation: $96.73 \mathrm{ft}(29.48 \mathrm{~m}) \mathrm{ms}$ Sp. conductance: $80 \mu \mathrm{S} / \mathrm{cm}$ The well was continuously pumping. ANALYSES

\begin{tabular}{|c|c|}
\hline Analyte & Resuft \\
\hline 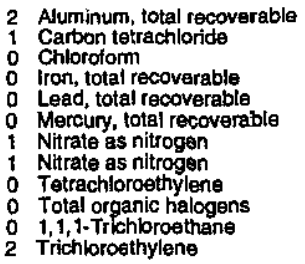 & $\begin{array}{l}362 \\
3.62 \\
0.519 \\
20.8 \\
<.00 \\
0.430 \\
5.070 \\
5.060 \\
0.782 \\
<120 \\
<0.462 \\
35.8\end{array}$ \\
\hline
\end{tabular}

\section{WELL TRW 2}

MEASUREMENTS CONDUCTED IN THE FIELD Sample date: 05/14/98

Wapth to wali: $6.52 \mathrm{ft}(18.45 \mathrm{~m})$ below TOC

$\mathrm{H}: 3.4$

Sp. conductance: $200 \mu \mathrm{S} / \mathrm{cm}$

The well was continuously pumping.

\section{ANALYSES}

$F$ Anatyte

Rosuft

- Gross alpha

$5.82 E-09+1.24 E-09$

WELL TRW 2

MEASUREMENTS CONDUCTED IN THE FIELD

Sample date: 05/21/98

Water elovater: $60.4 \mathrm{ft}(18.41 \mathrm{~m})$ below TOC

$\mathrm{pH}: 4.8$

. conductance: $92 \mu \mathrm{S} / \mathrm{cm}$

The well was continuously pumping.

\section{ANALYSES}

$F$ Anatyte
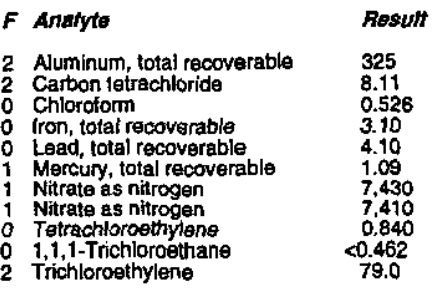

Time: $8: 36$

Ar temperature: $12.8^{\circ} \mathrm{C} 4^{\circ} \mathrm{C}$

Total alkalinity (as CaCo3); $1 \mathrm{mg} /$
Phenolphthalein alkalinity: $0 \mathrm{mg} /$

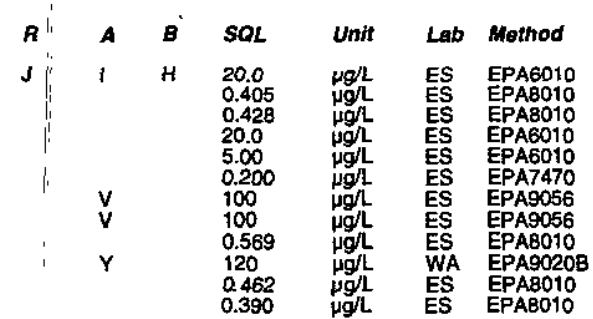

Water temperature: $16^{\circ} \mathrm{C}$

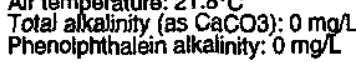

SaL Unit Lab Method 7.80E-10 $\mu \mathrm{CV} / \mathrm{mL}$ TM EPA900.0M

Time: 12:45

Air temperature: $345^{\circ} \mathrm{C}$

Air temperature: $34 . \mathrm{C}$
Total alkalinity (as Caco3): $3 \mathrm{mgh}$
Phenolphthalein alkalinity: $0 \mathrm{mg} \mathcal{L}^{\circ}$

\begin{tabular}{|c|c|c|c|c|c|c|}
\hline A & A & B & $S Q L$ & Unit & Lab & Mothod \\
\hline I & E & & $\begin{array}{l}20.0 \\
0.405 \\
0.428 \\
20.0 \\
5.00 \\
0.200 \\
100 \\
100 \\
0.569 \\
0.462 \\
3.90\end{array}$ & 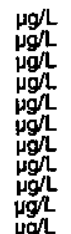 & $\begin{array}{l}\text { ES } \\
\text { ES } \\
\text { ES } \\
\text { ES } \\
\text { ES } \\
\text { ES } \\
\text { ES } \\
\text { ES } \\
\text { ES } \\
\text { ES } \\
\text { ES }\end{array}$ & $\begin{array}{l}\text { EPA6010 } \\
\text { EPAB010 } \\
\text { EPAB010 } \\
\text { EPA6010 } \\
\text { EPAG010 } \\
\text { EPA7470 } \\
\text { EPA9056 } \\
\text { EPA95056 } \\
\text { EPAB010 } \\
\text { EPA8010 } \\
\text { EPAB010 }\end{array}$ \\
\hline
\end{tabular}

WELL TRW 2

MEASUREMENTS CONDUCTED IN THE FIELD

Sample date: $06 / 03 / 98$

Depth to water: Not available
Water elevation: Not available

$\mathrm{H}: 4.8$

s. conductance: $110 \mu \mathrm{S} / \mathrm{cm}$

Tutidity: ONTU:

$110 \mu \mathrm{S} / \mathrm{cm}$

Water temperature: $23.4^{\circ} \mathrm{C}$

Total alkalinity (as CaCO3): $0 \mathrm{mg} /$

ANALYSES

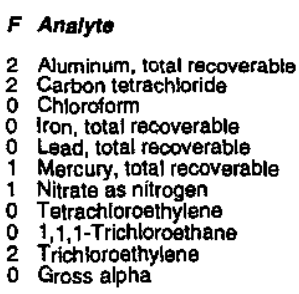

Rosut
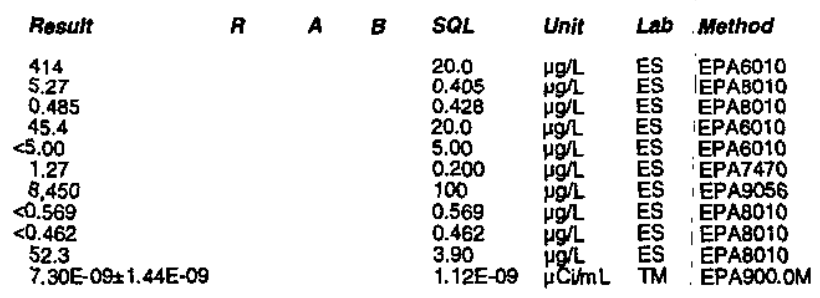

WELL TRW 3

MEASUREMENTS CONDUCTED IN THE FIELD

Sample date: 05/29/98

Depht to water: Not available

W: 5.6 levation: Not avallab

urbidity: 11 NTU $72 \mu \mathrm{S} / \mathrm{cm}$

Water temperature: $17^{\circ} \mathrm{C}$

Total aikalinity (as CaCO3): $13 \mathrm{mg} \Omega$

ANALYSES

$F$ Anabyto

$\begin{array}{llll}\text { Resutt } & \text { A } & \text { A } & \text { B } \\ 12.3 & \text { J } & \text { E } & \\ 3.66 & & \\ <0.428 & & & \\ 229 & 3.50 & & \\ 0.0500 & \text { J } & \text { E } & \\ 1.750 & \text { J } & 0 & \\ <0.569 & & & \\ <0.462 & & & \\ 93.4 & & \\ 4.97 \mathrm{E}-09 \pm 1.16 \mathrm{E}-09 & & & \\ 3.88 \mathrm{E}-09 \pm 1.05 \mathrm{E}-09 & & & \end{array}$

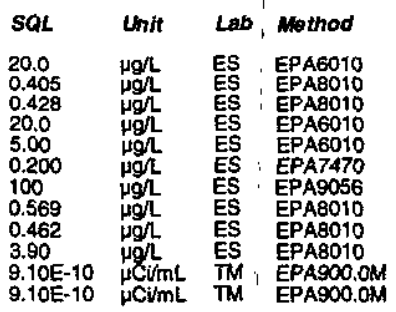

Aluminum, total recoverable

Chlorotorm

Lead, total recoverable

Mercury, total recove
Nitrate as nitrogen
Ten

$1,1,1$-Trichloroethane

Trichloroethylet
0 Gross alpha
0 Gross alpha 


\section{WELL TRW 3}

MEASUREMENTS CONDUCTED IN THE FIELO

Sample date: 06/03/98

Wepth to water. Not available

$\mathrm{pH}: 5.4$ uctance: $65 \mu \mathrm{S} / \mathrm{cm}$

Sp. conductance: $65 \mu \mathrm{S} / \mathrm{cm}$

ANALYSES

\begin{tabular}{|c|c|c|c|c|c|c|c|c|}
\hline Analyte & Result & A & A & B & SOL & Unit & Lab & Method \\
\hline $\begin{array}{ll}0 & \text { Aluminum, total recoverable } \\
2 & \text { Carton tetrachloride } \\
0 & \text { Chloroform } \\
0 & \text { Iron, total recoverable } \\
0 & \text { Lead, total recoverable } \\
0 & \text { Mercury, total recoverable } \\
0 & \text { Nitrate as nitrogen } \\
0 & \text { Tetracthloroethylene } \\
0 & 1,1,1-\text { Trichloroethane } \\
2 & \text { Trichloroethylene } \\
0 & \text { Gross alpha }\end{array}$ & $\begin{array}{l}15.8 \\
5.12 \\
0.428 \\
16.5 \\
5.00 \\
<0.200 \\
1.780 \\
<0.569 \\
<0.462 \\
108 \\
1.88 E-09 \pm 8.40 E-10\end{array}$ & $\mathbf{J}$ & $\mathbf{E}$ & L & $\begin{array}{l}20.0 \\
0.405 \\
0.428 \\
20.0 \\
5.00 \\
0.200 \\
100 \\
0.569 \\
0.462 \\
3.90 \\
1.05 \mathrm{E}-09\end{array}$ & 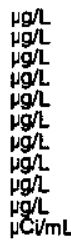 & $\begin{array}{l}\text { ES } \\
\text { ES } \\
\text { ES } \\
\text { ES } \\
\text { ES } \\
\text { ES } \\
\text { ES } \\
\text { ES } \\
\text { TM }\end{array}$ & $\begin{array}{l}\text { EPA6010 } \\
\text { EPA8010 } \\
\text { EPABO10 } \\
\text { EPA6010 } \\
\text { EPA6010 } \\
\text { EPA7470 } \\
\text { EPA9056 } \\
\text { EPA8010 } \\
\text { EPA8010 } \\
\text { EPA8010 } \\
\text { EPA900.0N }\end{array}$ \\
\hline
\end{tabular}

\section{WELL TRW 4}

MEASUREMENTS CONDUCTED IN THE FELLO

Sample date: 05/29/98

Sample date: 05/29/98
Oepth to water:53.7t $(16.37 \mathrm{~m})$ below TOC
Water elevation: $97.2 \mathrm{ft}(29.63 \mathrm{~m}) \mathrm{msl}$
oH: 4.2

Sp. conductance: $200 \mu \mathrm{S} / \mathrm{cm}$

The wefl was continuously pumping

ANALYSES

Anelyto

Aluminum, total recoverable

Carbon tetrachlorid

Iron, total recoverable

Mercury, total recoverab

Nitrate as nitrogen

Tetrachloroethylene

Trichloroethylene

G Gross alpha

\section{WELL TRW 4}

MEASUREMENTS CONDUCTED IN THE FIELD

Sample date: 06/03/98

Depth to water: Not available
Water elevation: Not available

gh: 5

Sp. conductance: $66 \mu \mathrm{S} / \mathrm{cm}$

The well was continuously pumping.

ANALYSES

$F$ Anelyto

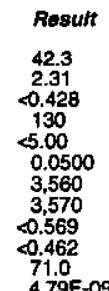

42.3
2.31
0.428
130
5.00
0.0500
3.560
3.570
60.569
0.462
71.0
$4.79 E-09+1.15 E-09$

- Aluminum, total recoverable

1 Aluminum, total recove

1 Carbon tetrachloride

o Chloroform

Chloroform

ESH-EMS-980569
Time: 10:50

Total alkalinity (as CaCO3): $7 \mathrm{mgh}$
Phenolphthalein alkalinity: $0 \mathrm{mgh}$

$1.05 \mathrm{E}-09 \mathrm{NC \textrm {V } m L}$ TM EPA900.0
Water temperature: $23.3^{\circ} \mathrm{C}$

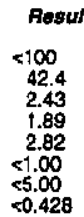
5.428
$=0.00$

Well TRW 4 collected on 06/03/98 (cont.)
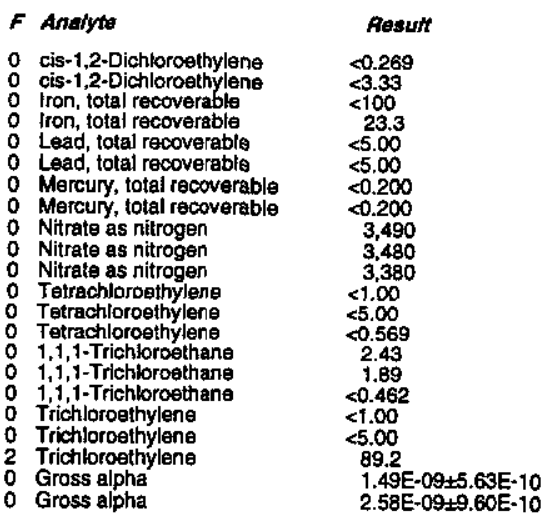

\subsection{E-09.5.63E-10}

\section{Replicate}

MEASUREMENTS CONDUCTED IN THE FIELD

Sample date: 06/03/98

Water elevation: Not available

H: 5

Water temperature: $17^{\circ} \mathrm{C}$

Total alkalinity (as CaCO3): $0 \mathrm{mg} /$
Phenolphthalein alkalinity: $0 \mathrm{mg}$.

Sp. conductance: $66 \mu \mathrm{S} / \mathrm{cm}$

The well was continuously pumping. ANALYSES

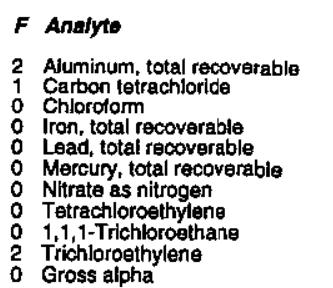

Result
53.0
2.88
0.428
39.2
55.00
$<0.200$
3.360
$<0.569$
$<0.462$
84.9

WELL XSB 1A

MEASUREMENTS CONDUCTED IN THE FIELD

Sample date: 05/15/98

Wepth to water: $56.75 \mathrm{ft}(17.3 \mathrm{~m})$ below TOC

$\mathrm{pH}: 5.2$

Total alkalinity (as CaCo3): $0 \mathrm{mgh}$
Phenolphthalein alkalinity: $0 \mathrm{mg} /$

Sp. conductance: $70 \mu \mathrm{S} / \mathrm{cm}$

Water evacuated from the well prior to sampling: $105 \mathrm{ga}$ ANALYSES

\begin{tabular}{|c|c|}
\hline F Anatyte & Resuth \\
\hline 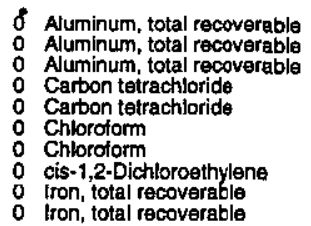 & $\begin{array}{l}<100 \\
<100 \\
<1.8 \\
<1.00 \\
<0.405 \\
<1.00 \\
<0.428 \\
<1.00 \\
<100 \\
<100\end{array}$ \\
\hline
\end{tabular}

\begin{tabular}{|c|c|c|c|}
\hline$S O L$ & Unit & Lat & b Method \\
\hline $\begin{array}{l}100 \\
20.0 \\
1.00 \\
5.00 \\
0.405 \\
1.00 \\
5.00 \\
.00\end{array}$ & 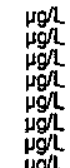 & $\begin{array}{l}\text { EX } \\
\text { ES } \\
\text { EX } \\
\text { EX } \\
\text { ES } \\
\text { EX } \\
\text { EX }\end{array}$ & 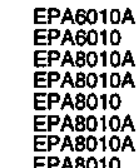 \\
\hline
\end{tabular}

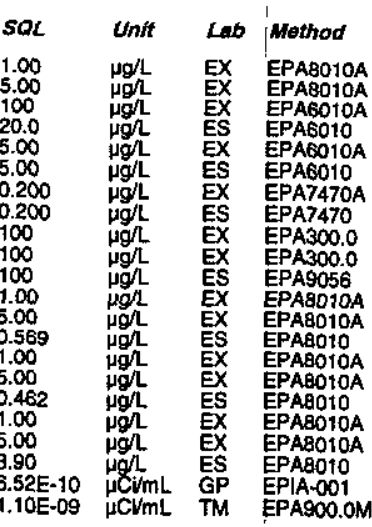

Time: 10:25

rature: $23.3^{\circ} \mathrm{C}$

Total alkalinity (as CaCO3): 0 mgl

5

R


Well XSB 1 A collected on 05/15/98 (cont.)

\begin{tabular}{|c|c|c|c|c|c|c|c|c|}
\hline Analyte & Result & $\boldsymbol{R}$ & $\boldsymbol{A}$ & 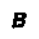 & SOL & Unit & $L a b$ & Method \\
\hline 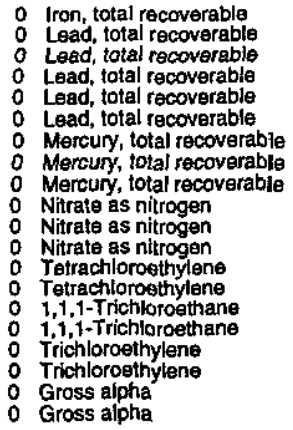 & $\begin{array}{l}<61.3 \\
5.00 \\
55.00 \\
<100 \\
<100 \\
5.90 \\
50.200 \\
00.200 \\
0.0500 \\
1.810 \\
1,820 \\
1.740 \\
<1.00 \\
<0.569 \\
<1.00 \\
<0.462 \\
<1.00 \\
<0.390 \\
8.21 E-10 \pm 4.26 E-10 \\
2.73 E-09 \pm 9.50 \mathrm{E}-10\end{array}$ & $\begin{array}{l}\mathbf{J} \\
\mathbf{J} \\
\mathbf{J} \\
\mathbf{J}\end{array}$ & $\begin{array}{l}\text { E } \\
Q \\
Q \\
Q \\
Q V\end{array}$ & & $\begin{array}{l}20.0 \\
5.00 \\
5.00 \\
100 \\
100 \\
5.00 \\
0.200 \\
0.200 \\
0.200 \\
100 \\
100 \\
100 \\
1.00 \\
0.569 \\
1.00 \\
0.462 \\
1.00 \\
0.390 \\
5.79 E-10 \\
9.10 E-10\end{array}$ & 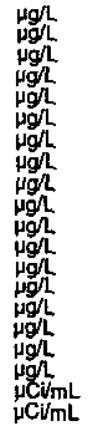 & $\begin{array}{l}\text { ES } \\
\text { EX } \\
\text { EX } \\
\text { EX } \\
\text { EX } \\
\text { ES } \\
\text { EX } \\
\text { EX } \\
\text { ES } \\
\text { EX } \\
\text { ES } \\
\text { EX } \\
\text { ES } \\
\text { EX } \\
\text { ES } \\
\text { ES } \\
\text { GP } \\
\text { TM }\end{array}$ & $\begin{array}{l}\text { EPAG010 } \\
\text { EPA6010A } \\
\text { EPAG010A } \\
\text { EPA6010A } \\
\text { EPA6010A } \\
\text { EPA6010 } \\
\text { EPA7470A } \\
\text { EPA7470A } \\
\text { EPA7470 } \\
\text { EPA300.0 } \\
\text { EPA300.0 } \\
\text { EPA9056 } \\
\text { EPA8010A } \\
\text { EPA8010 } \\
\text { EPAB010A } \\
\text { EPAB010 } \\
\text { EPAB010A } \\
\text { EPA8010 } \\
\text { EPIA.001 } \\
\text { EPA900.0M }\end{array}$ \\
\hline
\end{tabular}

\section{WELL XSB 1A Replicate}

MEASUREMENTS CONDUCTED IN THE FIELD

\section{Sample date: $05 / 15 / 98$
Depth to water: $56.75 \mathrm{th}(17.3 \mathrm{~m})$ below TOC
Water elevation: $99.25 \mathrm{ft}(30.25 \mathrm{~m}) \mathrm{msl}$ \\ Water conductance: $70 \mu \mathrm{S} / \mathrm{cm}$}

Water evacuated from the well prior to sampling: $105 \mathrm{gal}$

ANALYSES

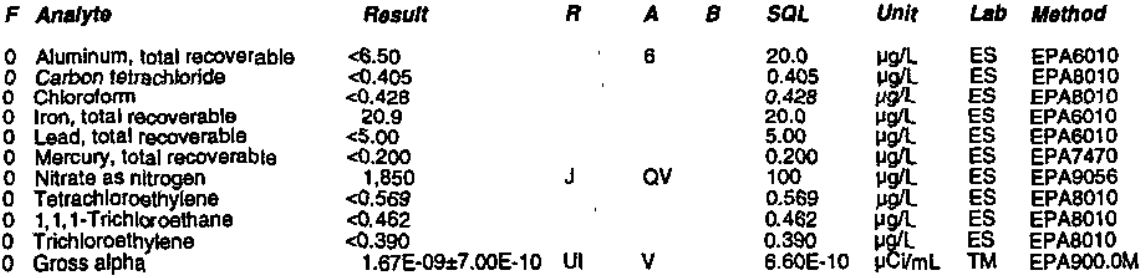

\section{WELL XSB 1B}

MEASUREMENTS CONDUCTED IN THE FIELD

\section{Sample date: $05 / 13 / 98$
Depth to water: $50.4 \mathrm{ft}(15.36 \mathrm{~m})$ below TOC
Water elevation: $105.5 \mathrm{ft}(32.16 \mathrm{~m}) \mathrm{ms}$ \\ Water e} p. conductance: $34 \mu \mathrm{S} / \mathrm{cm}$

Water evacuated from the well prior to sampling: $216 \mathrm{gal}$

ANALYSES

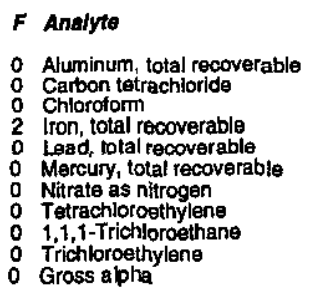

$\begin{array}{ll}\text { Rosult } & 15.5 \\ <0.405 & \\ <0.428 & \\ 788 & 5.00 \\ 0.200 & 130 \\ <0.569 & \\ <0.462 & \\ <0.390 & J \\ 1.29 E-09 \pm 6.50 E-10\end{array}$

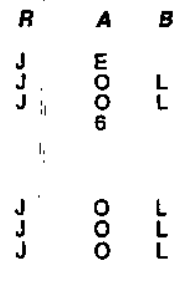

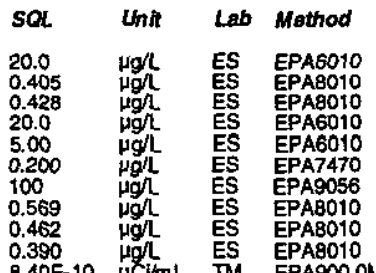

\section{WELL XSB 1D}

MEASUREMENTS CONOUCTED IN THE FIELD

Sample date: 05/13/98

Depth to water: $56.45 \mathrm{ft}(17.21 \mathrm{~m})$ below TOC

$\mathrm{pH}: 42$

Sp. conductance: $660 \mu \mathrm{S} / \mathrm{cm}$

Water evacuated from the well prior to sampling: $144 \mathrm{gal}$ ANALYSES
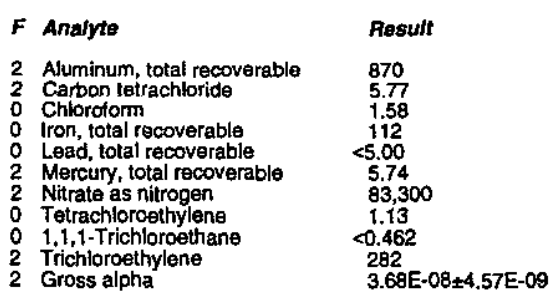

\section{WELL XSB 20}

MEASUREMENTS CONDUCTED IN THE FIELD

Sample date: 05/11/98

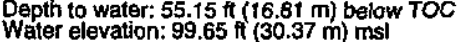

$\mathrm{HH}: 6$. conductance: $145 \mu \mathrm{S} / \mathrm{cm}$

Water evacuated from the well prior to sampling: $46 \mathrm{ga}$ ANALYSES

\section{$F$ Analyto}

$\therefore$ Aluminum, total recoverable

Chlorotorm

Lead, total recoverabrable

Mercury, total recovera
Nitrate as nitrogen

Tetrachloroethylene

1,1,1-Trichloroethan

2 Trichloroethylen

Result
13.0
1.37
0.768
14.3
$<5.00$
$<0.200$
6.110
0.159
$<0.462$
31.4
$3.97 E-09 \pm 1.19 E-09$

Time: 10:34

Water temperature: $16^{\circ} \mathrm{C}$

Total alkalinity (as CaCO3): $4 \mathrm{mg} / \mathrm{L}$
Phenolphthalein alkalinity: $0 \mathrm{mg} / \mathrm{L}$
Time: 9:28

rature: $16^{\circ} \mathrm{C}$

Total alkalinity (as CaCO3): $0 \mathrm{mg} / \mathrm{L}$
Time: 14:06

Air temperature: $31^{\circ} \mathrm{C} \mathrm{C}$

Total alkalinity (as CaCO3): $23 \mathrm{mg} /$
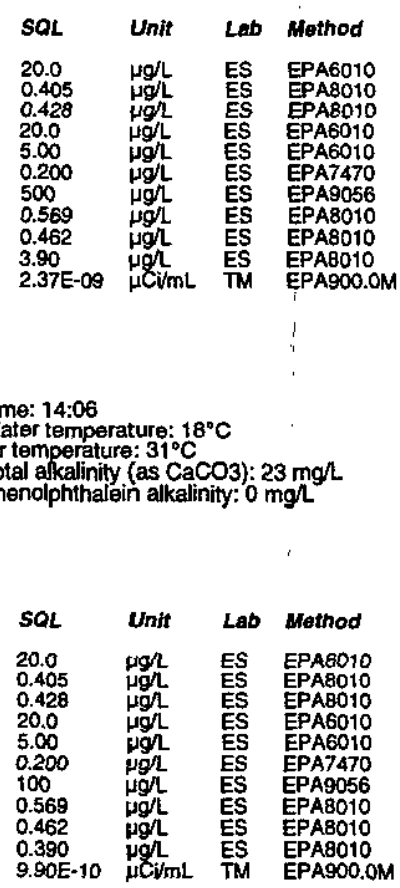


\section{WELL XSB 3A}

MEASUREMENTS CONDUCTED IN THE FIELD

Sample date: $05 / 13 / 98$
Depth to water $55.9 \mathrm{ft}$ (17.04 m) below TOC
Water elevation: $101.1 \mathrm{ft}(30.82 \mathrm{~m}) \mathrm{msl}$

(a)

Sp. conductance: $120 \mu \mathrm{S} / \mathrm{cm}$

Water evacuated from the well prior to sampling: $68 \mathrm{~g}$

ANALYSES

F Anajyto

Result

2 Aluminum, total recoverable

Chloroform

Lead, total recoverababie

Mercury, total recoverab

Tetrachloroethylene

1,1,1-Trichloroethan

Grichloroethylen

WELL XSB 4D

MEASUREMENTS CONDUCTED IN THE FIELD

Sample date: 05/12/98

Depth to water: $55 \mathrm{ft}(16.76 \mathrm{~m})$ below TOC

$\mathrm{pH}: 5.4$

conductance: $220 \mu \mathrm{S} / \mathrm{cm}$

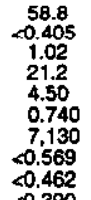

58.8
$<0.405$
1.02
21.2
4.50
0.740
7.130
$<0.569$
0.462

$<.390$

Water evacuated from the well prior to sampling: $64 \mathrm{gal}$

ANALYSES
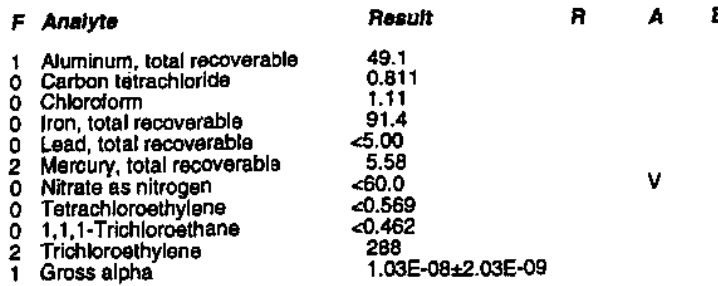

Time: 11:05

Art temperaturity: (as CaCO3): $1 \mathrm{mg} /$
Phenolphthalein alkalinity: $0 \mathrm{mg} L$

Gross alpha

Time: 13:46

Water temperature: $18^{\circ} \mathrm{C}$

Total alkalinity (as CaCO3); $4 \mathrm{mgh}$

\section{WELL XSB 5A}

MEASUREMENTS CONDUCTED IN THE FIELD

Sample date: $05 / 15 / 98$

Depth to water: $13.24 \mathrm{ft}(4.04 \mathrm{~m})$ below TOC

Water elevation: $98.76 \mathrm{ft}(30.1 \mathrm{~m}) \mathrm{msl}$

Sp. conductance: $190 \mu \mathrm{S} / \mathrm{cm}$

Water evacuated from the well prior to sampling: $40 \mathrm{gal}$

ANALYSES

$F$ Analyto

Result

1 Aluminum, total recoverable

Chlorotorm

1 Lead, total recorarb

Mercury, total recoverable

2 Nitrate as nitrogen

1,1,1-Trichloroethane

2 Trichloroethylen

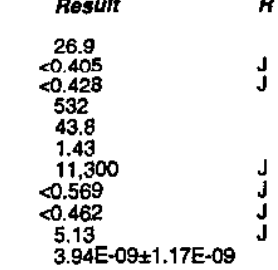

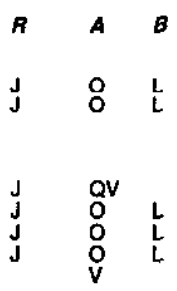
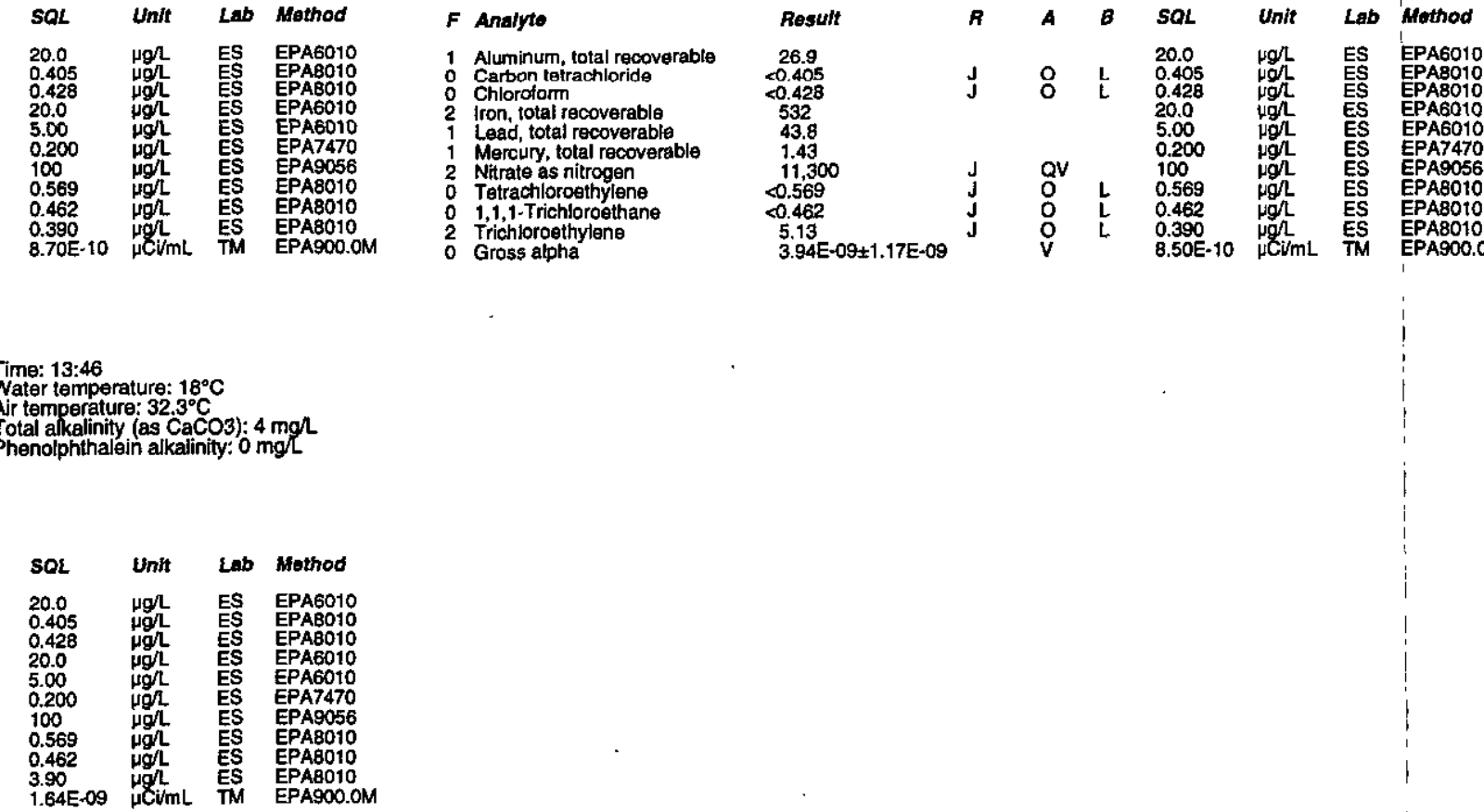

Time: 8:52

Water temperature: $17.8^{\circ} \mathrm{C}$

Total alkalinity (as CaCO3): $4 \mathrm{mgh}$

\section{.}
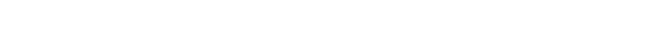

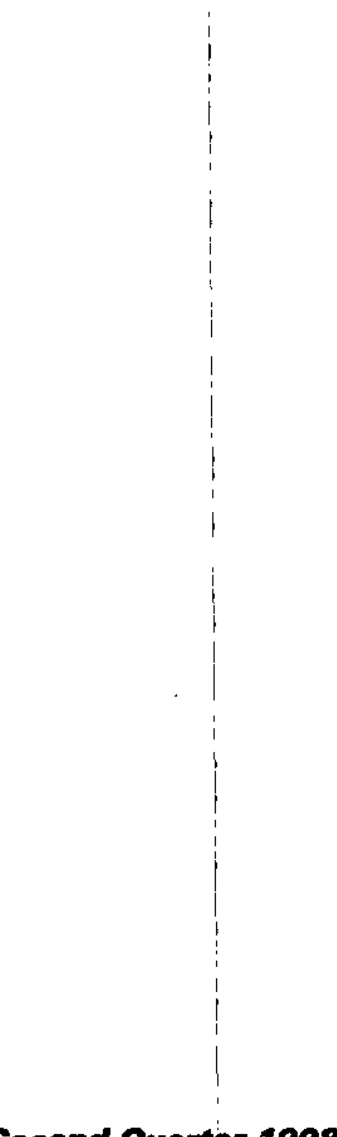




\section{Appendix C. Sampling Blanks Results}

This section presents the analytical results for sampling blanks analyzed during second quarter 1998. 
NOTES 


\section{WELL QA 2B}

MEASUREMENTS CONDUCTED IN THE FIELD

Sample date: 05/04/98 Air temperature: Not avaitable

$\mathrm{pH}: 4.8$

Sp. conductance: $10 \mu \mathrm{S} / \mathrm{cm}$

ANALYSES

F Analyto

- Alkalinity (as $\mathrm{CaCO}$ )

o Arsenic, total recoverable

Basium, total recoverable

Cadmium, total recoverable

Copper, total recoverable

Lithium, total recoverable

Mercury, total recoverable
Nickel, total recoverable

Selenium, total recoverable

Sulfate

Tin, total recoverable

Total organic carbon

Total organic halogens

Zinc, total roco

Gross alph

Gross alpha
Nonvolatile

Nonvolatile beta

Radium, total alpha-emitting

Strontium-90

0 Tritium

\section{WELL QA 4B}

MEASUREMENTS CONDUCTED IN THE FIELD

Sample date: $05 / 11 / 98$

Water temperature: $28^{\circ} \mathrm{C}$

$\mathrm{H}: \mathrm{B}$.

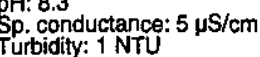

ANALYSES

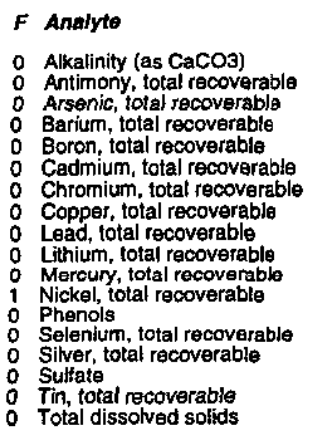

ESH- FMS-980569

Result
$<6.70$
$<67.0$
270.0
$<40.0$
20.850
266
$<4.70$
$<7.00$
$<13.8$
$<47.0$
2.70
$<0.700$
91.4
$<36.2$
$<66.0$
$<5.00$
$<340$
$<70.0$
6,000

Time: $9 \cdot 24$

Total alkalinity (as CaCO3): $0 \mathrm{mg} / \mathrm{L}$

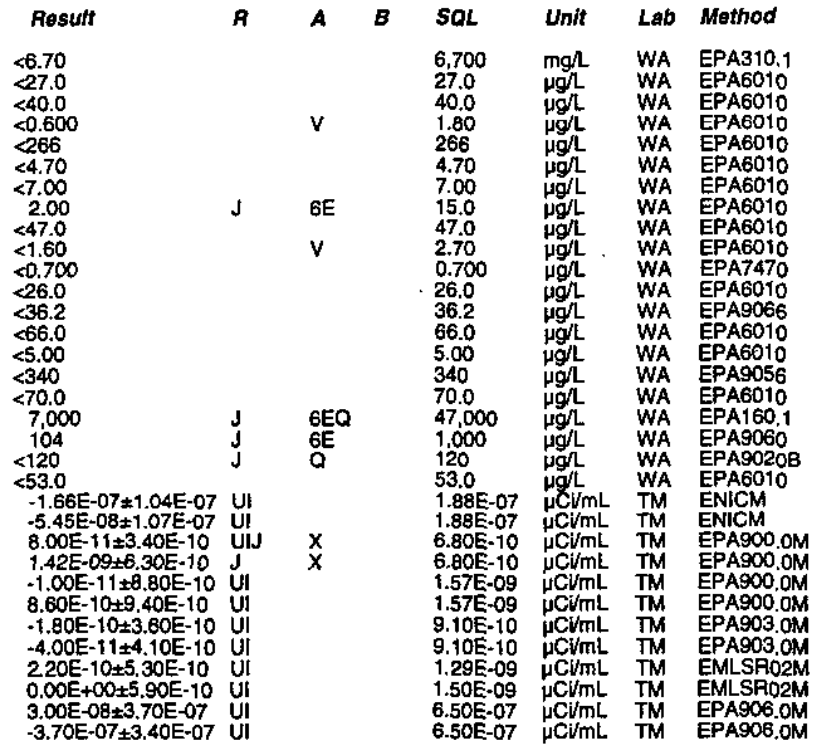

Time: 13:18

Total alkalinity (as CaCO3): $0 \mathrm{mgl}$
Well OA $4 B$ collected on 05/11/98 (cont.)

$F$ Anaiyte

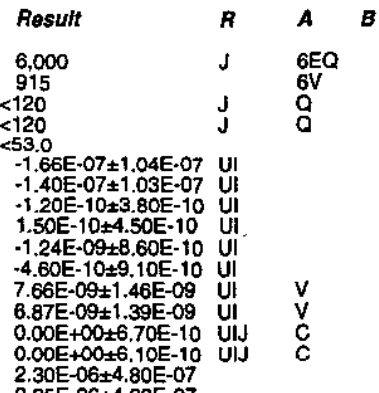

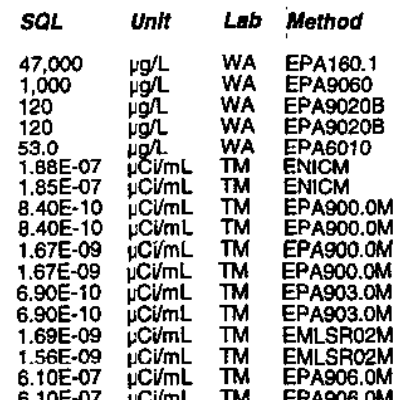

: Strontium-so

$2.25 \mathrm{E}-06 \pm 4.80 \mathrm{E}-07$

$6.10 \mathrm{E}-07 \mathrm{\mu CV} / \mathrm{mL}$ TM EPA906.0M

\section{WELL QA 6B}

MEASUREMENTS CONDUCTED IN THE FIELD

Sample date: 04/07/98

Water temperature: Not available

Air temperature: Not available

Sp. conductance: Not available

No water was evacuated from the well prior to sampling. ANALYSES

$F$ Analyte

- Cadmium, total recoverab

Lead, total recoverable

Nitrate-nitrite as nitrogen

Specific conductance

0 Gross alpha

- Tritium

\section{WELL QA 8B}

MEASUREMENTS CONDUCTED IN THE FIELD

Sampie date: 04/07/98

Water temperature: Not available

$\mathrm{OH}$ : Not available

Sp. conductance: Not available

No water was evacuated from the well prior to sampling.

ANALYSES

$F$ Anatyto

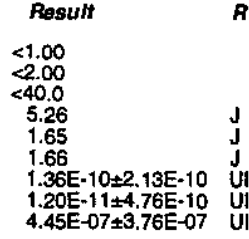

Time: .

Total alkalinity (as $\mathrm{CaCO}$ ): Not available enolphthalein alkalinity: Not available

- Cadmium, total recoverable

Nitrato-nitrite as nutrog

$\mathrm{O}^{\mathrm{pH}}$

Specific conductance

Gross alpha

Nonvolatile beta

: Nonvolatile beta
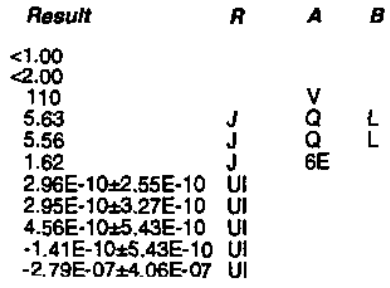

Time:

Total alkalinity (as CaCO3): Not available
Phenolphthalein alkalinity: Not available

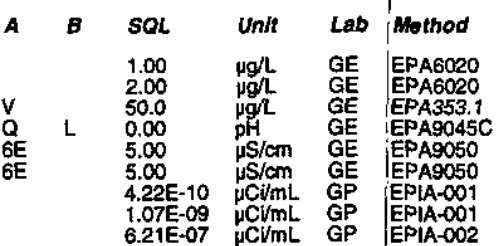

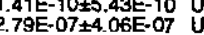

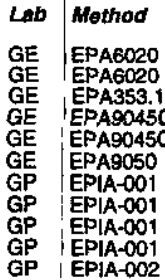




\section{WELL QA 10B}

MEASUREMENTS CONDUCTED IN THE FIELD

Sample date: 04/20/98

Water temperature: $26.6^{\circ} \mathrm{C}$

$\mathrm{gH}: 4.5$

Sp. conductance: $1 \mu \mathrm{S} / \mathrm{cm}$

ANALYSES

\begin{tabular}{|c|c|c|c|c|c|c|c|c|}
\hline Analyte & Result & $\boldsymbol{A}$ & $A$ & $B$ & $S Q L$ & Unit & Lab & Method \\
\hline $\begin{array}{l}\text { Cadmium, total recoverable } \\
\text { Lead, total recoverable } \\
\text { Nitrate-nitrite as nitrogen } \\
\text { pH } \\
\text { Specific conductance } \\
\text { Specific conductance } \\
\text { Gross alpha } \\
\text { Nonvolatile beta } \\
\text { Tritium }\end{array}$ & $\begin{array}{l}<1.00 \\
2.00 \\
20.0 \\
5.13 \\
2.93 \\
2.90 \\
3.59 E-10 \pm 2.28 E-10 \\
3.80 E-11 \pm 4.74 E-10 \\
-1.02 E-07 \pm 3.17 E-07\end{array}$ & \begin{tabular}{l|l}
$J$ & 1 \\
$J$ & \\
$J$ & \\
$J$ & \\
$U$ & 1
\end{tabular} & $\begin{array}{l}v \\
Q \\
6 E \\
6 E \\
i\end{array}$ & H & $\begin{array}{l}1.00 \\
2.00 \\
50.0 \\
0.00 \\
5.00 \\
5.00 \\
.08 E-10 \\
1.06 E-09 \\
5.62 E-07\end{array}$ & 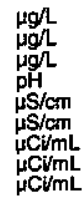 & $\begin{array}{l}G E \\
G E \\
G E \\
G E \\
G E \\
G E \\
G E \\
G P \\
G P \\
G P\end{array}$ & $\begin{array}{l}\text { EPA6020 } \\
\text { EPA6020 } \\
\text { EPA3531 } \\
\text { EPA90450 } \\
\text { EPA9050 } \\
\text { EPA9050 } \\
\text { EPIA-001 } \\
\text { EPIA-001 } \\
\text { EPIA-002 }\end{array}$ \\
\hline
\end{tabular}

\section{WELL QA 12B}

MEASUREMENTS CONDUCTED IN THE FIELD

Sample date: 04/20/98

Water temperature: $26.6^{\circ} \mathrm{C}$
Ar temperature: $23.7^{\circ} \mathrm{C}$
pH: $4.6^{\circ}$

Sp. conductance: $1 \mu \mathrm{S} / \mathrm{cm}$
Turbidity: 0 NTU

ANALYSES

\section{$F$ Analyto}

Result

0 Cadmium, total recoverable

Nitrate-nitrite as nitroge

N ${ }_{0} \mathrm{Nit}$

Specific conductance

Norvsolatile bete

$<1.00$
2.00
$<10.0$
$<20.0$
4.81
3.89
1.98
2.67

\section{WELL QA 14B}

MEASUREMENTS CONDUCTED IN THE FIELD

Sample date: 04/15/98

Ait termperature Not Not available

Ait tomperature: Not available

Sp. conductance: Not available

No water was evacuated from the well prior to sampling.

ANALYSES

F Analyte
0 Cadmium, total recoverable
0 Lead, total recoverable
0 Nitrate-nitrite as nitrogen
0 pH
0 Specific conductance
0 Specific conductance
0 Gross alpha
0 Nonvolatila beta
0 Tritium

$\begin{array}{ll}\text { Resuft } & \boldsymbol{R} \\ <1.00 & \\ <2.00 & \\ 20.0 & \mathrm{~J} \\ 5.60 & \mathrm{~J} \\ 1.66 & \mathrm{~J} \\ 1.68 & \mathrm{~J} \\ 1.59 \mathrm{E}-10 \pm 2.83 \mathrm{E}-10 & \mathrm{UI} \\ 1.09 \mathrm{E}-10 \pm 5.16 \mathrm{E}-10 & \mathrm{UI} \\ -7.25 \mathrm{E}-09 \pm 3.30 \mathrm{E}-07 & \mathrm{UI}\end{array}$

Time: 10:56

Total alkalinity (as CaCO3) $1 \mathrm{mgh}$
Phenolphthatein alkalinity: $0 \mathrm{mg} / \mathrm{L}$

Total alkalinity (as CaCO3): $1 \mathrm{mgl}$
Phenolphthalein alkalinity: $0 \mathrm{mg}$

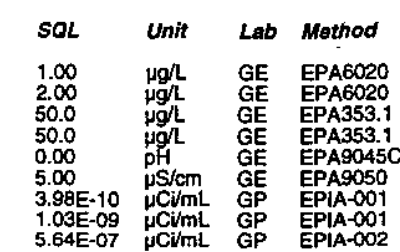
Total alkalinity (as CaCO3): Not available
Phenolphthalein alkalinity: Not available
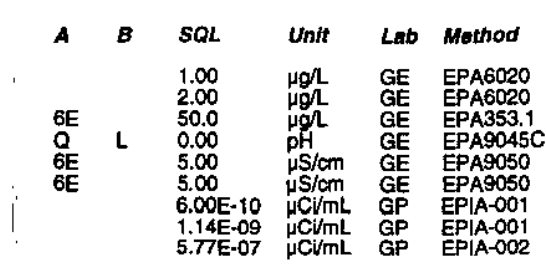

WELL QA 16B

MEASUREMENTS CONDUCTED IN THE FIELD

Sample date: 04/13/98

Water temperature: Not available

Air temperature: Not available

Sp: Not available Not available

No water was evacuated from the well prior to sampling.

ANALYSES

F Analyte

- Mercury, total recoverable

Nitrate-nitrite as nitrogen
0

$00 \mathrm{pH}$

Specific conductance

Gross alpha

: Nonvola

\section{WELL QA 18B}

MEASUREMENTS CONDUCTED IN THE FIELD

Sample date: $04 / 20 / 98$
Water temperature: $20.2^{\circ} \mathrm{C}$

Air temperature: $26^{\circ} \mathrm{C}$

Sp. conductance: $4 \mu \mathrm{S} / \mathrm{cm}$

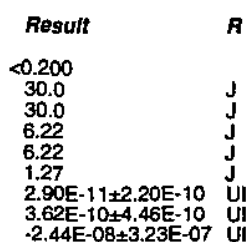

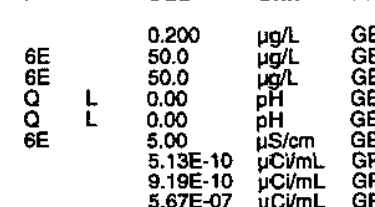

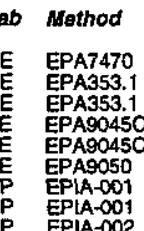

Total alkalinity (as $\mathrm{CaCO}$ ): Not available

ANALYSES

$F$ Analyte

$\because$ Mercury, total recoverable

$\mathrm{pH}$

Specific conductance

Gross alpha

N Nonvolatila beta

\section{WELLL QA 20B}

MEASUREMENTS CONDUCTED IN THE FIELD

Sample date: $04 / 21 / 98$

Water temperature: $19.9^{\circ} \mathrm{C}$

Air tempera

Sp. conductance: $3 \mu \mathrm{S} / \mathrm{cm}$

Turbidity: 1 NTU

$F$ Analyte

Nitrate-nitrite as nitrogen

pH

Specificic conductance

Gross alpha
Nonvolatile beta
Time: $13: 12$

Total alkalinity (as CaCO3): $0 \mathrm{mg} /$
Phenolphthalein alkalinity: $0 \mathrm{mg} / \mathrm{L}$

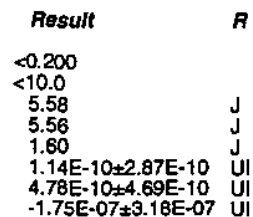

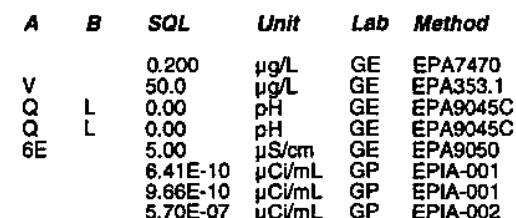

Time: 8:28

Total alkalinity (as CaCO3): $0 \mathrm{mg}$

\begin{tabular}{|c|c|c|c|}
\hline & Unit & Lab & Wethod \\
\hline $\begin{array}{l}0.200 \\
50.0 \\
0.00 \\
5.00 \\
5.00 \\
5.52 E-10 \\
1.08 E-09 \\
5.79 E-07\end{array}$ & $\begin{array}{l}\mu g / \mathrm{L} \\
\mu g / \mathrm{L} \\
\mathrm{pH}^{2} \\
\mu \mathrm{S} / \mathrm{cm} \\
\mu \mathrm{S} / \mathrm{mm} \\
\mu \mathrm{C} / \mathrm{mL} \\
\mu \mathrm{C} / \mathrm{mL} \\
\mu \mathrm{C} / \mathrm{mL}\end{array}$ & $\begin{array}{l}G E \\
G E \\
G E \\
G E \\
G E \\
G E \\
G P \\
G P \\
G P\end{array}$ & $\begin{array}{l}\text { EPA7470 } \\
\text { EPA353.1 } \\
\text { EPA9045C } \\
\text { EPA9050 } \\
\text { EPA9050 } \\
\text { EPIA-001 } \\
\text { EPIA-001 } \\
\text { EPIA-002 }\end{array}$ \\
\hline
\end{tabular}




\section{WELL QA 22B}

MEASUREMENTS CONDUCTED IN THE FIELD

Sample date: $04 / 20 / 98$
Water temperature: $20.2^{\circ} \mathrm{C}$
Air temperature: $27^{\circ} \mathrm{C}$

Air temperature: $27^{\circ} \mathrm{C}$

Sp. conductadity: 0 .

ANALYSES

F Analyte.

Mercury, total recoverable

$\begin{array}{lll}0 & \text { Nitra } \\ 0 & \mathrm{pH} \\ 0 & \mathrm{pH} \\ 0 & \mathrm{Spoc}\end{array}$

Specific conductance

Gross apha

WELLL QA 24B

MEASUREMENTS CONDUCTED IN THE FIELD

Sample date: 04/21/98

Air termperature: $23.1^{\circ} \mathrm{C}$

Sp: conductance: $3 \mu \mathrm{S} / \mathrm{cm}$
Turbidity: $1 \mathrm{NTU}$

ANALYSES

F Analyto

Mercury, total recoverable

${ }_{0}^{0} \mathrm{pH}$

Specific conductance

Gross alpha

Nonvolatila beta

\section{WELL QA 26B}

MEASUREMENTS CONDUCTED IN THE FIELD

Sample date: $04 / 21 / 98$

Water temperature: $19.9^{\circ} \mathrm{C}$

Air temp 4.2

Sp.conductance: $3 \mu \mathrm{S} / \mathrm{cm}$

ANALYSES

F Analyto

Mercury, total recoverable
Nitrate-nitrite as nitrogen

$\mathrm{pH}$

$\mathrm{SH}$ pecific conductance

Gross alpha

Gross alpha

Nonvolatile beta

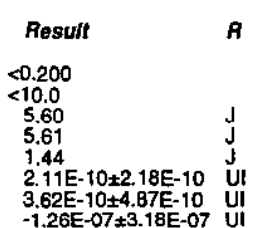

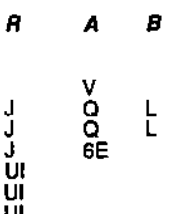

Time: 8:46

Total alkalinity (as CaCO3): $0 \mathrm{mg} / \mathrm{L}$
Phenolphthalein alkalinity: $0 \mathrm{mg} \mathrm{m}^{2}$

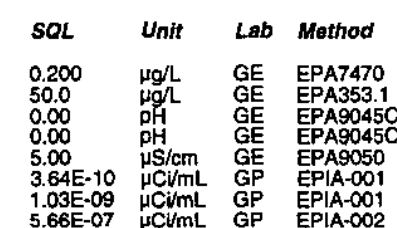

$1.03 E-09 \mu \mathrm{H} / \mathrm{mL}$ GP $\mathrm{GP}$ EP EPAA-001

Time: 11:12

Total alkalinity (as CaCO3): $0 \mathrm{mgh}$
Phenolphthalein alkalinity: $0 \mathrm{mgh}$
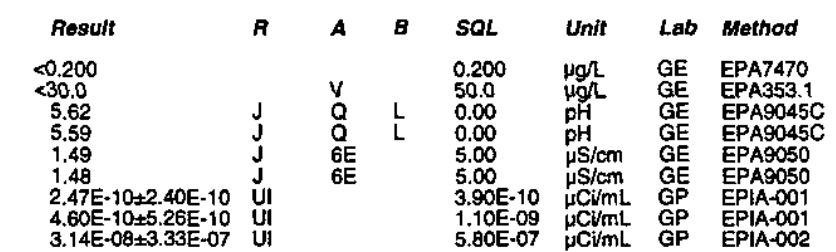

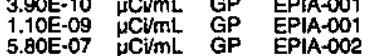

Time: 9:36

Total alkalinity (as CaCO3): $0 \mathrm{mgl}$
Phenolphthalein alkalinity: $0 \mathrm{mg} L$
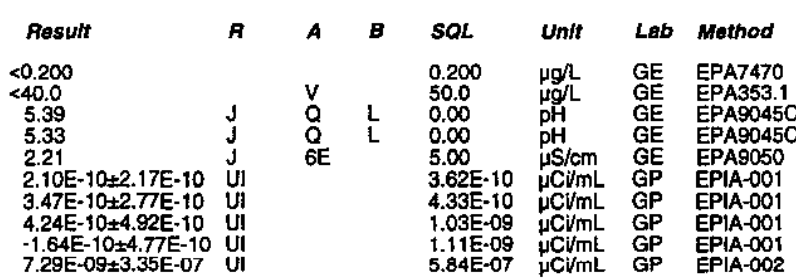

\section{WELL QA 288}

MEASUREMENTS CONDUCTED IN THE FIELD

Sample date: $04 / 27 / 98$

Air temperature: $32.7^{\circ} \mathrm{C}$

Turbidity: 1 NTU: $2 \mu \mathrm{S} / \mathrm{cm}$

ANALYSES

$F$ Analyte

Mercury, total recoverable

0 Specific conductance

0 Gross alpha

Tritium

WELL QA 30B

MEASUREMENTS CONDUCTED IN THE FIELD

Sample date: $06 / 08 / 98$

Air temperature: $23.3^{\circ} \mathrm{C}$

$\mathrm{gH}: 4.2$ conductance: $6 \mu \mathrm{S} / \mathrm{cm}$

ANALYSES

$F$ Analyte

Result
8.40
$<8.00$
2.20
0.400
1.60
11.3
3.30
$<0.200$
$<5.00$
1.70

- Aluminum, total recoverable

Barium, total recoverable

Chromium, total recoverablo

Lead, total recoverable

Selenify, total tolac recoverababla

WELL QA 32B

MEASUREMENTS CONDUCTED IN THE FIELD

Sample date: $06 / 12 / 98.0$

Air temperature: $30.2^{\circ} \mathrm{C}$

Sp. conductance: $4 \mu \mathrm{S} / \mathrm{cm}$
Turbidity: 1 NTU

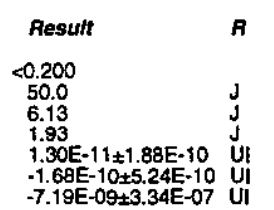

ANALYSES

$F$ Analyte

- Aluminum, total recoverable

Arsenic, total

- Barium, total recoverable

Chromium, total recoverable

Iron, total recoverable

Mercury, total recoverablo

- Silver, total recoverable

: Gross alpha

: Tritium
Time: $9: 43$

Total alkalinity (as Caco3): $0 \mathrm{mg} /$

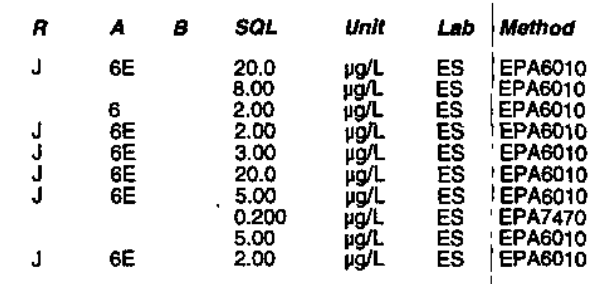

Time: 9:26

Total alkalinity (as $\mathrm{CaCO}$ ): $1 \mathrm{mg} /$

Result
20.0
88.00
2.00
2.00
$<3.00$
$<20.0$
55.00
50.200
25.00
2.00
$5.00 E-10 \pm 4.10 E-10$
$2.90 E-10 \pm 3.50 E-10$
$-2.50 E-07 \pm 7.90 E-07$
$-3.90 E-07 \pm 7.50 E-07$




\section{WELL QA 34B}

MEASUREMENTS CONDUCTED IN THE FIELD

Sample date: $05 / 15 / 98$

Air temperature: $22.3^{\circ} \mathrm{C}$

Sp: 7.7

ANALYSES

$F$ Analyte

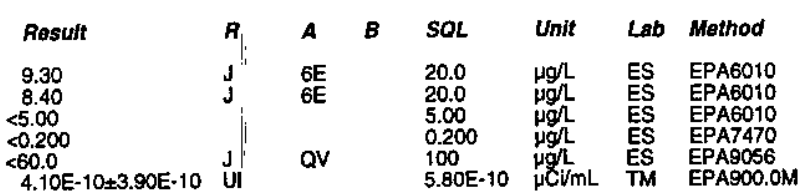

Iron, total recoverable

Mercury, total recoverablo

0 Gross alpha

WELL QA 36B

MEASUREMENTS CONDUCTED IN THE FIELD

Sample date: $04 / 15 / 98$

Air term

p. conductance: $1 \mu \mathrm{s} / \mathrm{cm}$

Turbidity: 0 N

ANALYSES

F Ansilyte

0 Acenaphthene

Aldrin

Ammonia nitrogen

Anthracene

Arsenic, total recoverable

alpha-Benzene hexachiloride

delta-Benzene hexachloride

Benzo(a) anthracene

Benzo(k) fluoranthene

Benzoic acid

Benzo(a) pyrene

Beryllium, total recoverable

Bis (2-chloroethoxy) meth
Bis 2 -chloroethyl) ether

Bis(2-chloroisopropy') ether

Boron, total recoverable
$4-$ Bromophenyl phenyl ether

Caksium, lotal recoverable

alpha-Chlordane

Chloride

4-Chibroaniline
4-Chlorom-cresol
2.Chloronaphthalen

2-Chloronaphthale

4 - Chlorophennyl phenyl ethe
Chromium, total recoverable

Cobalt, total recoverable

Copper, total recoverable
$0 \mathrm{~m} / \mathrm{p}$-Cressol

ESH-EMS-980569

Well QA $36 B$ collected on 04/15/98 (cont.)

$F$ Analyte

Time: $8: 34$

Total alkalinity (as CaCO3): $1 \mathrm{mg} /$
Phenolphthalein alkalinity: $0 \mathrm{mg} L$

o-Cresol (2-Methylphenol)

Cyanida

Dibenz(a,h)anthracene

Dibenzofuran

1,2-Dichlorobenzens

1,4-Dichlorobenzene

3,3'-Dichlorobenziditin
2,4-Dichlorophenol

Diedrin phthatate

2,4 -Dimethyl phenol
Dimethyl phthalate

2.4-Dinitrophenol

2,4-Dinitrotoluene

Di-n-octyl phthalate

Endosulfan I

Endrin

Endrin aldehyde
Endrin ketone

Total alkalinity (as CaCO3): $1 \mathrm{mg} /$

Fluoranth

Heptachlor
Heptachlor epoxide

Hexachlorobenzene

Hexachlorocyclopentedien

Hexachloroesthane

Indeno(1,2,3-c,d)pyren
Iron, totai recoverable

Isophorone
Lead, total recoverable

o Lindane

Mercury, total recoverable

Methoxychlor

2-Methyinaphthalens

Niphthalene

Nitrate as nitrogen

O m-Nitroaniline

o-Nitroaniline

0 ${ }_{0}$ Nitrobenzenne

2-Nitropheno

4-Nitrophenol
N-Nitrosodjphenylamine

O PCB 1016

0
0

Pentachloropheno

Phenanthrene

Potassium, total recoverable

Pyrene total recoverable

Silver, total recoverable

o Sulfate Thallium, total recoverable

Tolal organic carbon
Total phosphates (as P)

Toxaphene

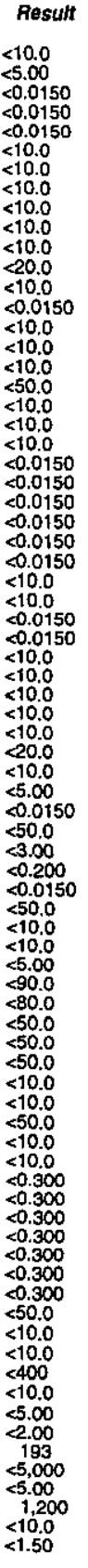

R

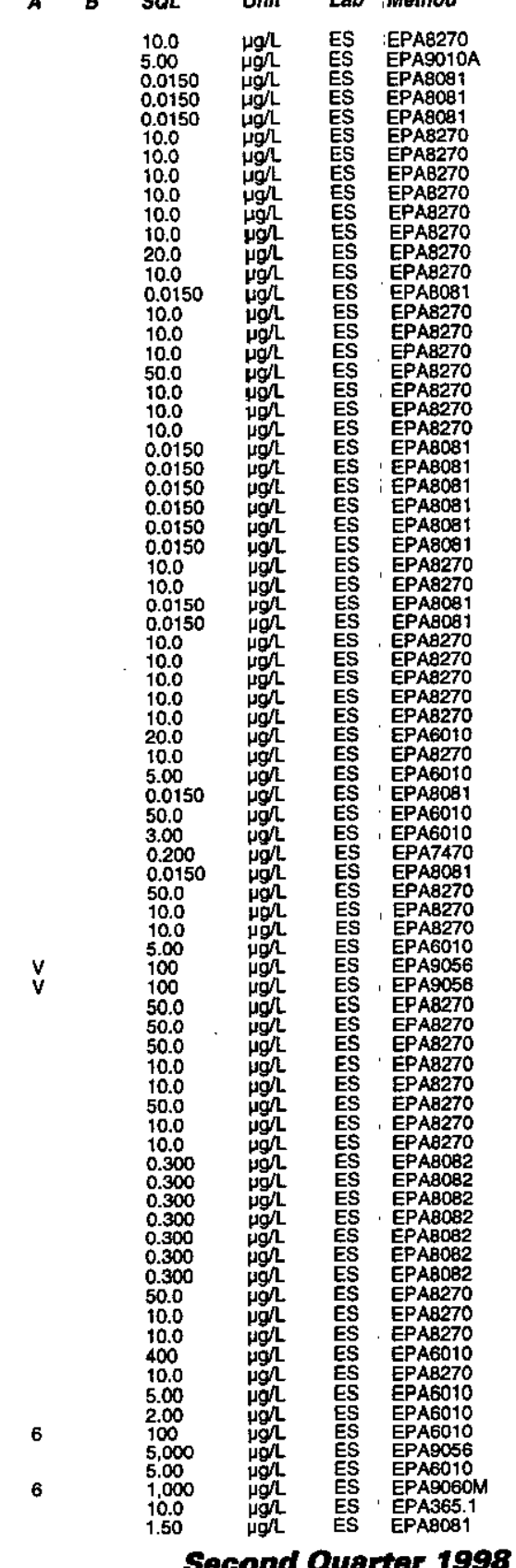


Well QA 36B collected on 04/15/98 (cont.)

$F$ Analyte

o $1,2,4$-Trichlorobenzene

2,4,6-Trichlorophenel

Z Vanadium, total recoverable

O Americium-24

A Americium-241

Antimony-125

$\begin{array}{ll}0 & \text { Cosium-134 } \\ 0 & \text { Cesium-137 } \\ 0 & \text { Cositis }\end{array}$

0 Cobalt-57

: Curium-242

Curium-243/244

Curium-2 245/246
Curiumm-245/246

Europium-152

Europium-155

Gross alpha
lodine-129

Lead-212

Manganese-54

Nickel-63

Nonvolatile beta
Plutonium-238

Piutonium-239/240

Promethium-144
Promethium-147

Promethium-146

Radium-22

Radiumm-228
Authenium-106

Sodium-22

Technettum-99

Thorium-228

Thorium-232

Tritium 234

Uranium-235

Uranium-235

0 Zinc-65

\section{WELL QA 38B}

MEASUREMENTS CONDUCTED IN THE FIELD

Sarnple date: $06 / 03 / 98$
Water temperature: $28.8^{\circ} \mathrm{C}$
Arr temperature: $36.7^{\circ} \mathrm{C} \mathrm{C}$

Air temp

Sp. conductance: $3 \mu \mathrm{S} / \mathrm{cm}$

Turbidity: 0 NTH

$F$ Analyte

- Aluminum, total recoverable

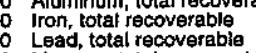

- Mercury, total recovoverab

Gross alpha

Resuft

$\boldsymbol{A}$

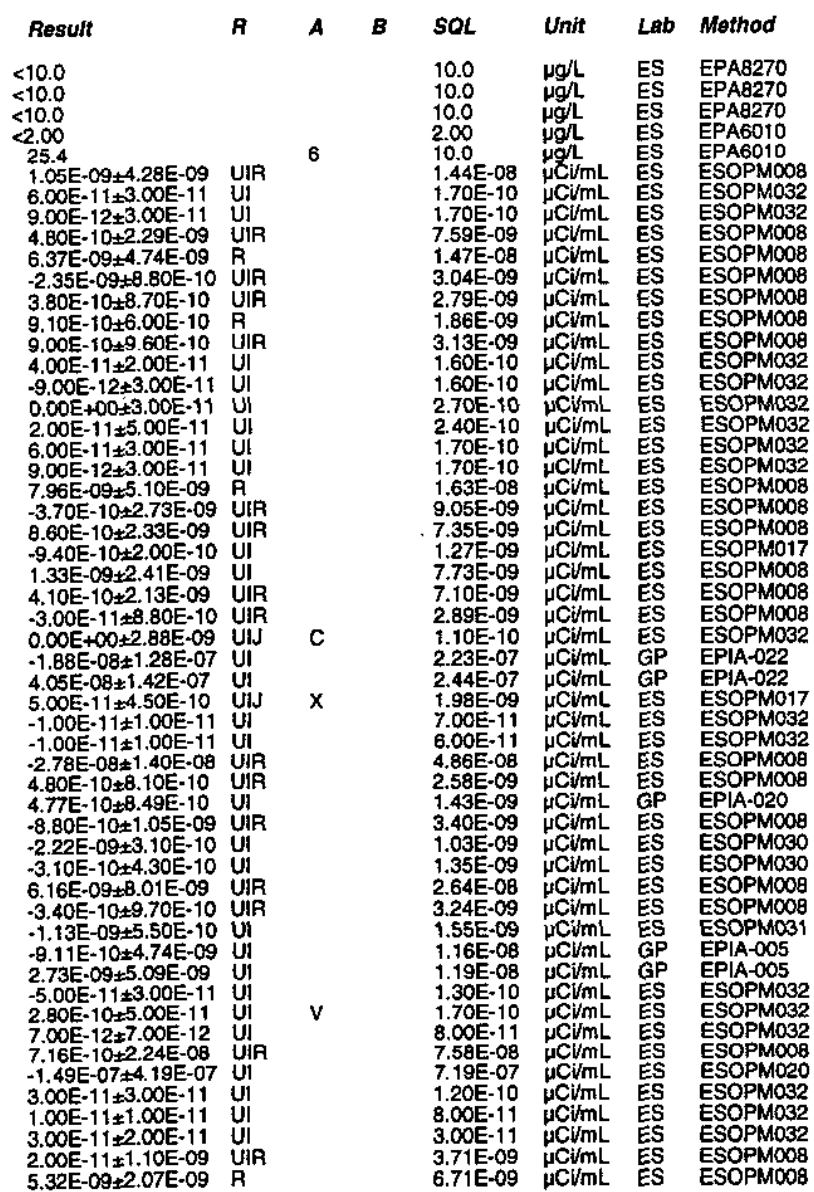

$5.32 \mathrm{E}-09+2.07 \mathrm{E}-09$ R

ESH-EMS-980569

\section{WELL QA 40B}

MEASUREMENTS CONDUCTED IN THE FIELD

Sample date: $05 / 15 / 98$

Air ter temperature: $24.3^{\circ} \mathrm{C}$

Sp.conductance: $2 \mu \mathrm{S} / \mathrm{cm}$

ANALYSES

$F$ Analyto

1 Aluminum, total recoverable

- Lead, total recoverable

- Mercury, total recoverabla

0 Nitrate as nitrogen

\section{WELL OA 48B}

MEASUREMENTS CONDUCTED IN THE FIELD

Sample date: 06/03/98

Air termperature: $22.8^{\circ} \mathrm{C}$

$\mathrm{pH}: 5$

Sp. conductance: $2 \mu \mathrm{S} / \mathrm{cm}$

ANALYSES

$F$ Analyte

- Aluminum, total recoverable

Antimony, total recoverable

Antimony, totail recoverable

Arsenic, total recoverable

Barium, total recoverable

Barium, total recoverable

Cadmium, total recoverable

Cadmium, total recoverab

Caccium, total recoverable

Chioride

Chromilum, total recoverable

Cobalt, total recoverable

Copper, total recoverable

Cyanide

Iron, total recoverable

Lead, total recoverable

Magnesium, total recoverabl

Manganese, lotal recoverable

Manganese, total recoverab
Mercury, total recoverable

Nickel, total recoverable

Nitrate-nitrite as nitrogen

Potassium, total recoverable

Selenium, total recoverable
Selenlum, total recoverable

Silenlum, total recerereab

Sodium, total recoverab

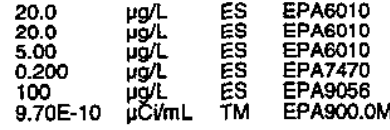

c-7
Result

32.6
18.8
4.30
$<0.200$
$<60.0$
$1.80 \mathrm{E}-1$

Time: 9:03

Total alkalinity (as CaCO3): $1 \mathrm{mg} /$

B A $B$ SOL Unit Lab /Mathod

$\begin{array}{lllll} & 6 & 20.0 & \mu g / \mathrm{L} & \mathrm{ES} \\ J & 6 \mathrm{EE} & 20.0 & \mu g / \mathrm{L} & \mathrm{ES} \\ \mathrm{J} & 6 \mathrm{E} & 5.00 & \mu g, & \mathrm{ES} \\ \mathrm{J} & \mathrm{OV} & 0.200 & \mu g / \mathrm{LS} & \mathrm{ES} \\ \mathrm{J} & \mathrm{ov} & 100 & \mu g / \mathrm{L} & \mathrm{ES}\end{array}$

$1000.10 \%$

PA900.0M

S IN THE FIELD

Time: 9:52

Total alkalinity (as CaCO3): $1 \mathrm{mgh}$

$<100$
$<100$

$<100$
$<100$
$<10.0$

$<10.0$
$<10.0$
$<5.00$

$<5$

$<5.00$
$<5.00$
$<1,000$
$<1,000$

$<10,000$
$<200$
$<10.0$

$<10.0$
$<10.0$
$<20.0$
$<20.0$

$<10.0$
$<10.0$
$<10.0$

$<13.8$
13.8
$<100$
$<5.00$
$<5.00$
$<500$
$<500$
$<10.0$
$<10.0$
$<0.200$
$<200$
$<20.0$
$<1.000$
6.10
$<1,660$
$<1,000$
$<10.0$
$<10.0$
$<20.0$
$<20.0$
$<1,000$
$<1,000$

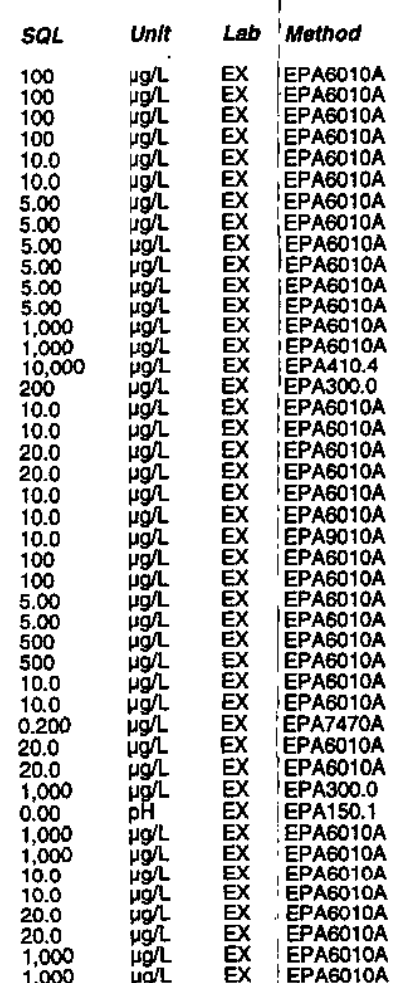

Second Quarter 1998 
SAMPLING BLANKS RESULTS

Well QA 48B collected on 06/03/98 (cont.)

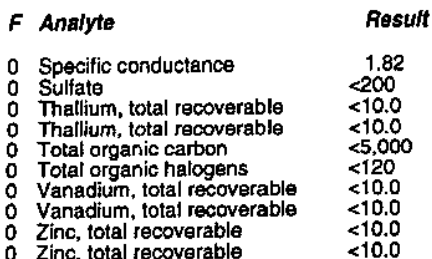

MEASUREMENTS CONDUCTED IN THE FIELD

Sample date: $04 / 16 / 98$
Water temperature $2.4^{\circ} \mathrm{C}$
Air temperature: $14.8^{\circ} \mathrm{C}$

Sp: conductance: $0 \mu \mathrm{S} / \mathrm{cm}$

ANALYSES

$\boldsymbol{F}$ Ansiyts

- Acenaphthene

Acetophenone
2-Acetylarninofluoren

Aniline

Arsenic, total recoverable

Benzo(a)anthracene

nzo(k) fluoranthen

Benzo(g,h,i)perylen

Benzo(a)pyrene

Bis(2-chloroethoxy) methane

Bis 2-chloroothyl) ether

Bis (2-ethylhexyl) phithalate

Butylbenzyl phthalate 4-Chloroaniline

S-Chloro-m-crese

-Chloronaphthalen

4-Chlorophenyl phenyl ether

Chrysene

m/p-Cresol

Diallate

Dibonzofuran nalate

1,2-Dichlorobenzene

1,4-Dichlorobanzene

2,4-Dichlorophenol

Diethyl phthalate
2.4-Dimethyl pheno

Dimethyl phthalate

7.12-Dimethylbenz(a)anthrac

a,a-Dimethylphenethylamine
1,3-Dinitrobenzene

ESH-EMS-980569

Well QA $50 B$ collected on 04/16/98 (cont.)

Manganese, total recoverable

6V

WA

WA EPAB270

WA

WA

WA EPA8270

WA EPA8270

WA EPAB270

WA EPAB270

WA EPA8270

WA EPA8270

WA EPAB270

WA EPAB270

WA EPAB270

WA EPAB270

WA EPAB270

WA EPAB270

WA EPA8270
$F$ Analyte

2,4-Dinitrophenol

2,6-Dinitrototuene

0 Di-n-octyl phthala

O Diphenylam

E Ethyl methacrylate

Fluoranthene

Fiuorene

prodibenzo-p-dioxins

Heptachlorodibenzo-p-furans

Hexachlorobenzene
Hexachlorobutadien

Hexachlorocyclopentadiene

Hexachlorodibenzo-p-dioxins
Hexachlorodibenzo-p-furans

Hexachloroethane

Hexachloropropene

$1,2,3,4,6,7,8-\mathrm{HPCD}$

$1,2,3,4,7,8-H X C D F$
Indeno $(1,2,3-c, d) p y r e n e$

Isophorone

Methapyrilene

Methyl methacrylate

Methyl methanesulfion

3-Methylcholanthrene
2-Methyinaphthalene

Naphthalene

1-Naphthylamine

m-Nitroaniline

o-Nitroaniline

p-Nitroanilin

2-Nitrophennol

4-Nitrophenol

Result

$\frac{\pi 25.5}{<10.6}$

$<10.6$

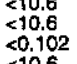

$<10.6$

$<4.080 .04$
$<7005-04$
5

$<5.30$
$<10.6$

$<3.70 \mathrm{E}-04$

5106
$<106$
5

$<10.6$
$<4.80 E-04$
$<5.80 E-04$

$<5.80 \mathrm{E}-04$
$<3.70 \mathrm{E}-04$
$<3.90 \mathrm{E}-04$

$<10.6$

$<1.6$
$<10.6$
$<700$

$<6.5$
$<10.6$
$<10.6$
$<10.6$

N-Nitrosodimethylamin

$\mathrm{N}$-Nitrosodipropylamine

$\mathrm{N}$-Nitrosomorpholine

N-Nitrosopipenidine

5-Nitro-0-toluidine

Octachlorodibenzo-p-dioxin
Octachlorodibenzo-p-furan

1,2,3,7,8-PCDD

Pentachlorobenzene
Pentachlorodibenzo-p-dioxins
Pentachlorodibenzo-p-furans

Pentachloroethane

Phenanthren

phenol

p-Phenylen

Pyrens

2,3.7,8-TCDO

C-8

$<3.00 \mathrm{E}-04$

$<10.6$
$<53.0$

$<1.6$
$<10.6$

$<10.6$
$<10.6$

$<10.6$
$<10.6$
$<10.6$

$<10.6$
$<2.00 \mathrm{E}-04$
$<2.00 \mathrm{E}-04$
saL

26.5 Hg/ WA EPAE270

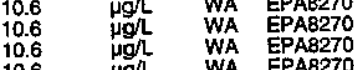

$\begin{array}{llll}10.6 & \mu g / L & \text { WA } & \text { EPAB270 } \\ 10.6 & \mu g L & \text { WA } & \text { EPAB270 } \\ 0.102 & \mu g / L & \text { WA } & \text { EPABOB1 }\end{array}$

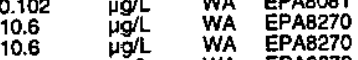

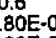

5.30

10.6

3.70E-04

10.6

10.6
$4.80 \mathrm{E}-04$
$5.80 \mathrm{E}-04$

$3.70 E-04$

$10.6 \quad \mu g / 2$

10.6
7.80
10.6
26.5

26.5
10.6
10.6

$\begin{array}{ll}10.6 & \\ 10.6 & \mu 9\end{array}$

10.6
10.6

$\begin{array}{ll}10.6 & \mu g / 2 \\ 26.5 & \mathrm{pg} / \mathrm{L} \\ 26.5 & \mathrm{~L}\end{array}$

26.5
10.6
10.6

$\begin{array}{ll}21.2 & \\ 10.6 & \mu g \\ 1 & \end{array}$

10.6
5.30

10.6
10.6
10.6

53.0
10.6
10.6

$7.00 \mathrm{E}-04$

$5.00 E-04$

3.50E-04 
Well OA $50 B$ collected on 04/16/98 (cont)

\section{$F$ Analyto} Result

1,2,4,5-Tetrachlorobenzene

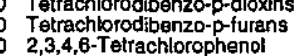
: 0 -Tofuidine $\begin{array}{ll}0 & \\ 0 & 2,4,5-\text { Trlchlorophentol } \\ 0 & 2,4,6-\text { Trlchlorophenol }\end{array}$ $\begin{array}{ll}0 & 1,3,5-\text { Trinilrobenzene } \\ 0 & <10.6 \\ 0 \text { Padium, total alpha-emitting } & 1.00 \mathrm{E}-10 \pm 1.90 \mathrm{E}-10 \mathrm{UI} \\ 0 & -2.00 \mathrm{E}-07 \pm 3.50 \mathrm{E}-07 \text { UI }\end{array}$ $<10.6$ $<2.60 E-04$
$<10.6$ $<10.6$
$<10.6$
$<10.6$

\section{WELL QA 52B}

MEASUREMENTS CONDUCTED IN THE FIELD Sample date: $04 / 22 / 98$
Water temperature: $18.7^{\circ} \mathrm{C}$
Air temperature: $25.1^{\circ} \mathrm{C}$
pH: 4.1 .19 .
Sp.conductance: $4 \mu \mathrm{S} / \mathrm{cm}$
Turbidity: 0 NTUU ANALYSES

$F$ Analyte

$\therefore$ Alkalinity (as CaCO3) Carbonato Iron, total recoverable
Magnesium, total recoverable Silica, total recoverablo Sodium, total recoverable Sullate Total organic carbon Total organic halogenens - Tritium

\section{WELL QA 54B}

MEASUREMENTS CONDUCTED IN THE FIELD

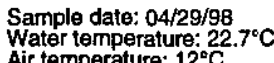
Air temperature: $12^{\circ} \mathrm{C}$ pH: 8.5 Turbidity: 0 NTE

\section{$F$ Analyte}

: Acenaphthene

Aldrin Anthruacene
Antimony, fotal recoverable Antimony, total recoverable Barium, total recoverable detth-Benzene hexachloride Benzo(a)anthracene Benzo(k) filuoranthene Benzog(a,hi)perytene
Benzo(a)pyrene

ESH-EMS-980569

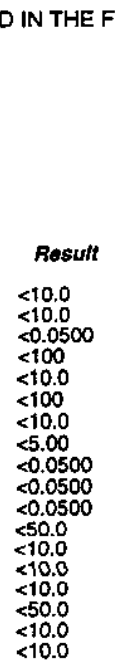

A A $B$ SQL Unit Lab Method

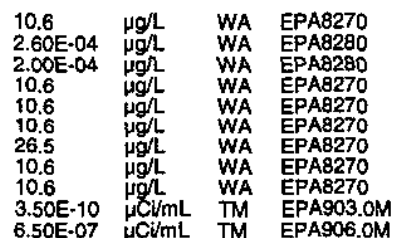

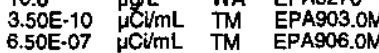

Time: 14:36

Total alkalinity (as CaCO3): $1 \mathrm{mg}$ L
Phenolphthalein alkalinity: $0 \mathrm{mgh}$

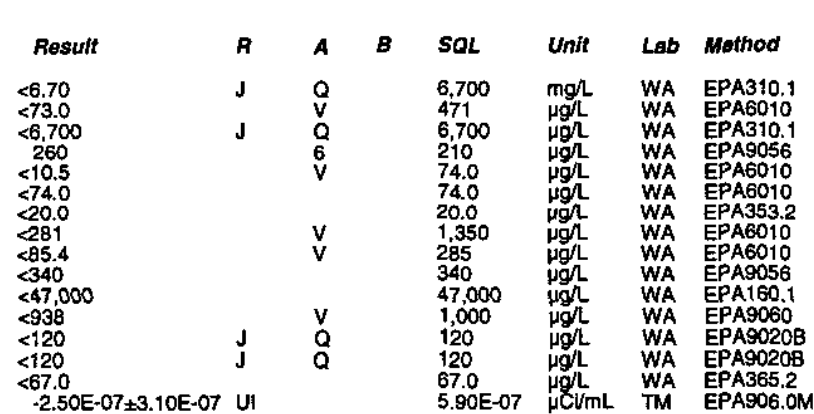

Time: 9:03

Total alkalinity (as CaCO3): $1 \mathrm{mg} /$
Phenolphthalein alkalinity: $0 \mathrm{mg} /$

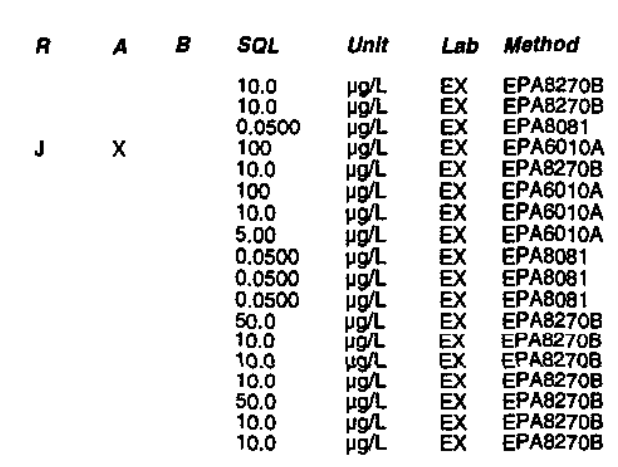

Well QA 54B collected on 04/29/98 (cont)

f Analyte

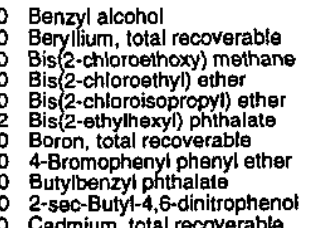
Calcium, total recoverable alpha-Chlordane

4-Chloroanitine

4-Chloro-m-cresol 2-Chlorophenol C-Chiorophenyl phenyl ether Cobalis total recoverabo m/p-Cresol recoverable

o-Cresol (2-Methylphenol)

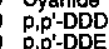

\section{$\mathrm{P}, \mathrm{p}-\mathrm{DDE}$
$\mathrm{P}, \mathrm{P} \cdot \mathrm{DDT}$}

Dibenz(a,h)anthracene

Dibenzofuran

1,3-Dichlorobenzenene

3.'.

2,4-Dichlorophenol

2,4-Dichlosophenoxyacetic acid

Diethy phthalate

Dimethy' phthalate

2.4-Dinitrophenol

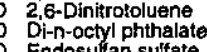

Endosulfan sultat

O Endosuttan

Endrin ajdehyde

Fiuorene

Fluoride

Heptachlor epoxida

Heplachlorodibenzo-p-dioxins

Hexachlorobenzenen

Hexachlorocyclopentadiens
Hexachlorodibenzo-p-dioxins

Hexachlorodibenzo-p-furans Hexachloroethane
$1,2,3,4,6,7,8-\mathrm{HPCDO}$

\section{$1,2,3,4,7,8 . \mathrm{HXCDO}$}

Indeno(1,2,3-c,d)pyrene

Iron, tota recoverable
Isophorone

Lead, total recoverable

Lithium, total recoverable

Magnesium, total recoverable
Manganese, total recoverable

C-9

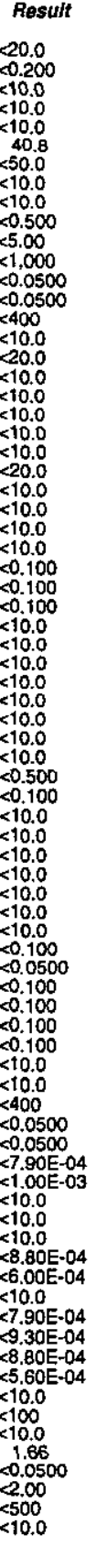
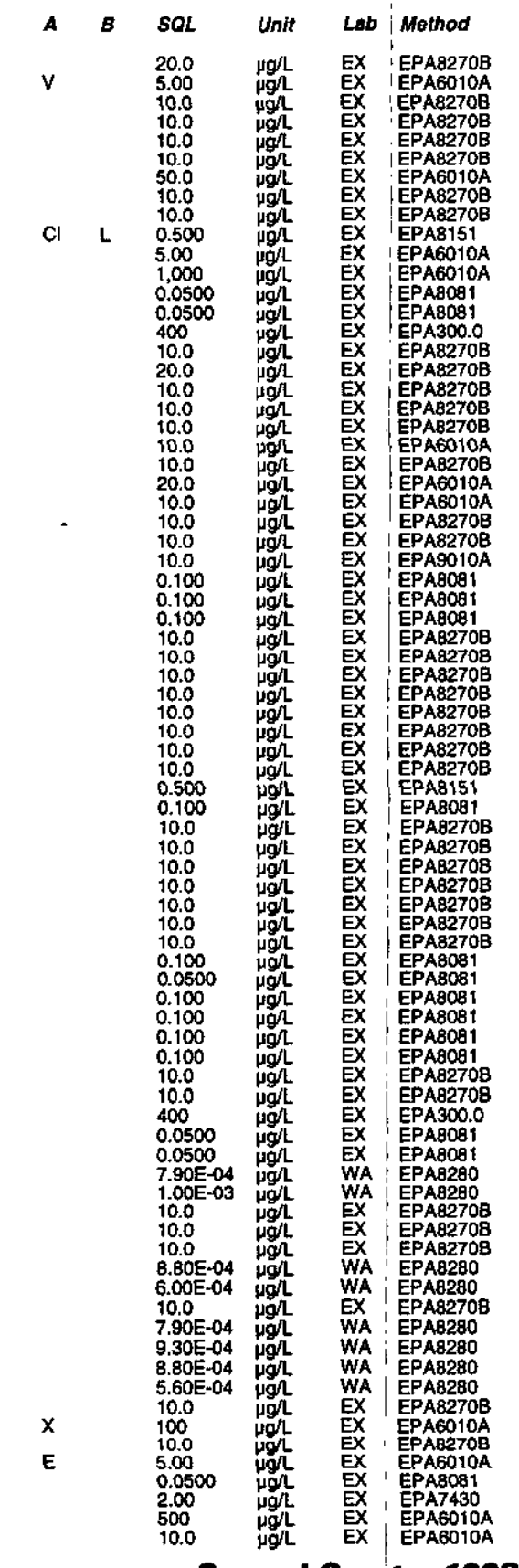
Well QA 54B collected on 04/29/98 (cont.)

\begin{tabular}{|c|c|c|c|c|c|c|c|c|}
\hline Analyte & Result & $\boldsymbol{R}_{\text {, }}$ & A & $B$ & SQL & Unit & Lab & Method \\
\hline 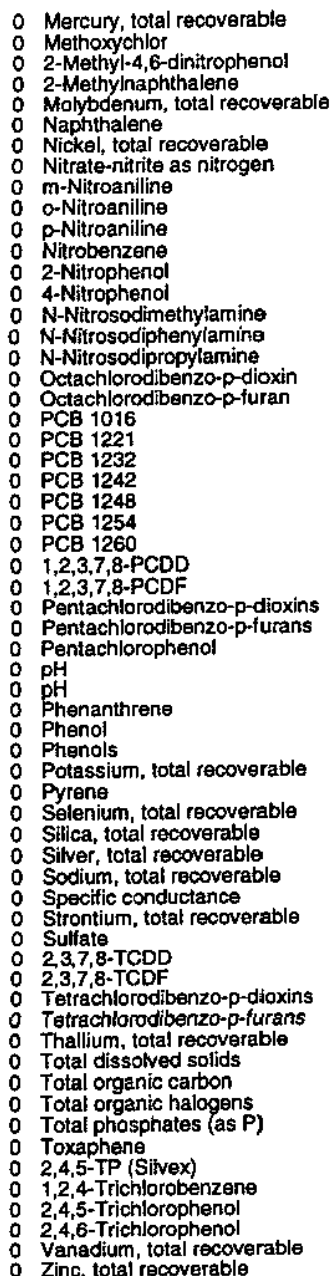 & $\begin{array}{l}<0.200 \\
00.500 \\
<50.0 \\
<10.0 \\
<11.8 \\
<10.0 \\
20.0 \\
<1.000 \\
<50.0 \\
<50.0 \\
<50.0 \\
<10.0 \\
<10.0 \\
<50.0 \\
<10.0 \\
<10.0 \\
<10.0 \\
<0.00140 \\
<8.40 E-04 \\
<1.00 \\
<1.00 \\
<1.00 \\
<1.00 \\
<1.00 \\
<1.00 \\
<1.00 \\
<7.20 E-04 \\
<6.70 E-04 \\
<7.20 E-04 \\
<6.70 E-04 \\
<50.0 \\
6.10 \\
6.00 \\
610.0 \\
<10.0 \\
<50.0 \\
<1,000 \\
<10.0 \\
<10.0 \\
<100 \\
20.0 \\
<1,000 \\
0.940 \\
<10.0 \\
<400 \\
<4.00 E-04 \\
22.60 E-04 \\
<4.00 E-04 \\
22.60 E-04 \\
<10.0 \\
<10,000 \\
<5,000 \\
<120 \\
<50.0 \\
<1.00 \\
<0.200 \\
<10.0 \\
<50.0 \\
<10.0 \\
4.16 \\
<10.0\end{array}$ & ${ }_{\mathbf{J}}$ & $\underset{E}{X}$ & & $\begin{array}{l}0.200 \\
0.500 \\
50.0 \\
10.0 \\
50.0 \\
10.0 \\
20.0 \\
1.000 \\
50.0 \\
50.0 \\
50.0 \\
10.0 \\
10.0 \\
50.0 \\
10.0 \\
10.0 \\
10.0 \\
0.00140 \\
8.40 E-04 \\
1.00 \\
1.00 \\
1.00 \\
1.00 \\
1.00 \\
1.00 \\
7.20 E-04 \\
6.70 E-04 \\
7.20 E-04 \\
6.70 E-04 \\
50.0 \\
0.00 \\
0.00 \\
10.0 \\
10.0 \\
50.0 \\
1,000 \\
10.0 \\
10.0 \\
100 \\
200 \\
1.000 \\
1.00 \\
10.0 \\
400 \\
4.00 E-04 \\
2.60 E-04 \\
4.00 E \\
2.60-04 \\
10.0-04 \\
10.000 \\
5,000 \\
120 \\
50.0 \\
1.00 \\
0.200 \\
100 \\
50.0 \\
10.0 \\
10.0 \\
10.0\end{array}$ & 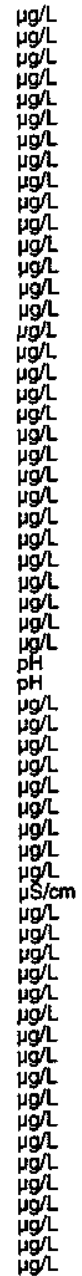 & $\begin{array}{l}\text { EX } \\
\text { EX } \\
\text { EX } \\
\text { EX } \\
\text { EX } \\
\text { EX } \\
\text { EX } \\
\text { EX } \\
\text { EX } \\
\text { EX } \\
\text { EX } \\
\text { EX } \\
\text { EX } \\
\text { EX } \\
\text { EX } \\
\text { WA } \\
\text { WA } \\
\text { EX } \\
\text { EX } \\
\text { EX } \\
\text { EX } \\
\text { EX } \\
\text { WA } \\
\text { WA } \\
\text { WA } \\
\text { WA } \\
\text { EX } \\
\text { EX } \\
\text { EX } \\
\text { EX } \\
\text { EX } \\
\text { EX } \\
\text { EX } \\
\text { EX } \\
E X \\
\text { EX } \\
\text { EX } \\
\text { EX } \\
\text { EX } \\
\text { WA } \\
\text { WA } \\
\text { WA } \\
\text { EA } \\
\text { EX } \\
\text { EX } \\
\text { WA } \\
\text { EX } \\
\text { EX } \\
\text { EX } \\
\text { EX } \\
\text { EX } \\
\text { EX } \\
\text { EX }\end{array}$ & 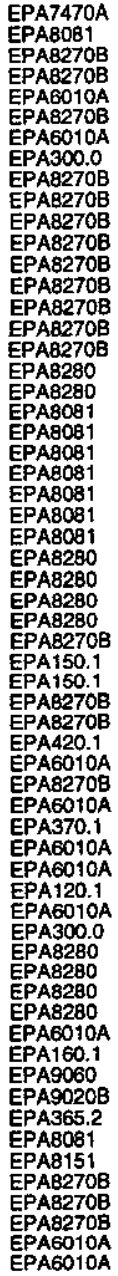 \\
\hline
\end{tabular}

\section{WELL QA 56B}

MEASUREMENTS CONDUCTED IN THE FIELD Sample date: $06 / 01 / 98 \mathrm{O}$ Air temperature: $36.6^{\circ} \mathrm{C}$ Sp. conductance: $19 \mu \mathrm{S} / \mathrm{cm}$ ANALYSES

\section{F Analyte}

- Acenaphthene

Aluminum, total recoverable

Antimony, total recoverable Arsenic, total recoverable
Barium, total recoverabie

beta-Benzene hexachloride delta-Benzene hexachloride
Benzidine

Benzo(a)anthracene

Benzo (k)fluoranthene

Benzolagyrene

Benzyl alcohol

Beryllium, total recoverable
Bis 2 -chloroethoxy) methan

Bis 2-chioroethoxy) meth

Biss 2-chloroisopropyl) ether

2. Bis(2-ethythexyl) phithalate

2-sec-Butyl-4,6-dinitrophen

Cadmium, tolas recoverable

alpha-Chlordane

Chloride

4-Chloroaniline
4-Chloro-m-cresol

2-Chloronaphthalens

4-Chlorophenenyl phenyl ether Chromlum, total recoverab

Copper, total recoverable

o-Cresol (2-Methylphenol)

Cyanide

P.
0

Dibenz(a,h)anthracen

Dibenzofuran

1,2-Dichlorobenzene

\section{4-Oichlorobenzense} 2,4-Dichtorophenol
2,4-Dichlorophenoxyacetic acid

\begin{tabular}{|c|}
\hline 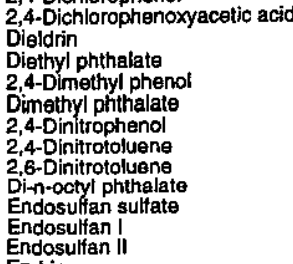 \\
\hline
\end{tabular}

Endosulfan I

$\$ 0.100$

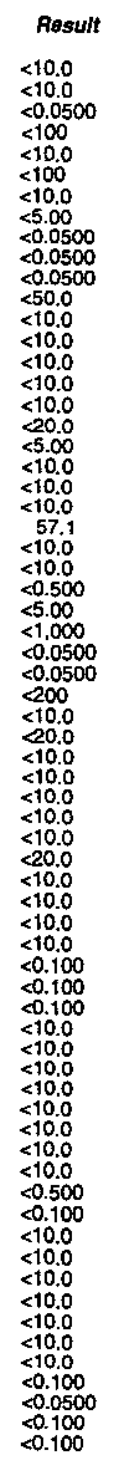

R A

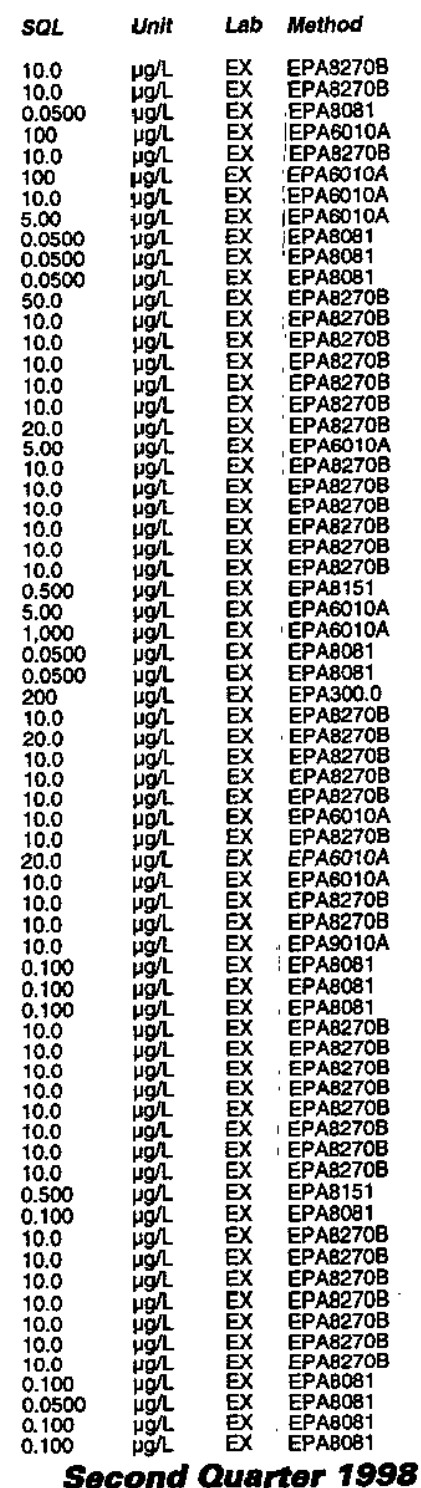


SAMPLING BLANKS RESULTS

\section{Well QA $56 B$ collected on 06/01/98 (cont)}

$F$ Analyte

- Endrin aldehyde

Fndrin kertone

o Fluorene

Heptachlor epoxide

Heptachlorodibenzo-p-dioxins

Hexachlorobenzene

Hexachlorocyclopentadiene

Hexachlorodibenzo-p-dioxins
Hexachlorodibenzo-p-furans

o Hexachloroethane

$\begin{array}{lll}0 & 1,2,3,4,6,7,8-4 P C D P \\ 0 & 1,2,3,4,8, H C D D\end{array}$

$1,2,3,4,7,8-H \times C D F$

Iron, total recoverable

Lead, total recoverable

Lindane thium, total recoverable

Magnesium, total recoverable

- Manganese, total recoverabla

Melhoxychior

2-Methylinaphthalene

Nickel, total recoverable

Nitrate-nitrite as nitrogen

m-Nitroaniline
o-Nitroaniline

P-Nitroaniline

2-Nitrophenol

o N-Nitrosodimethylamine

N-Nitrosodipropylamine

Octachlorodibenzo-p-dioxin

O PCB 1016

0 PCB 1242

: $\mathrm{PCB} 1248$

$\begin{array}{ll}0 & P C B \\ 0 & 1,260 \\ 0 & 1,3,7,8-P C D D\end{array}$

Pentachlorodibenzo-p-dioxin

Pentachlorodibenzo-p-turan

Phenanthrene

Phenols

Potassium, total recoverable

Syrene

Silica, total recoverable

Siver, total recoverable

Specitic conductanco

Sulialo $2,3,7,-T C D$

Tetrachlorodibenzo-p-dioxins

Tetractiorodibenzo-p-furans

Thallum, total recover

Total organic carbon

ESH-EMS-980569

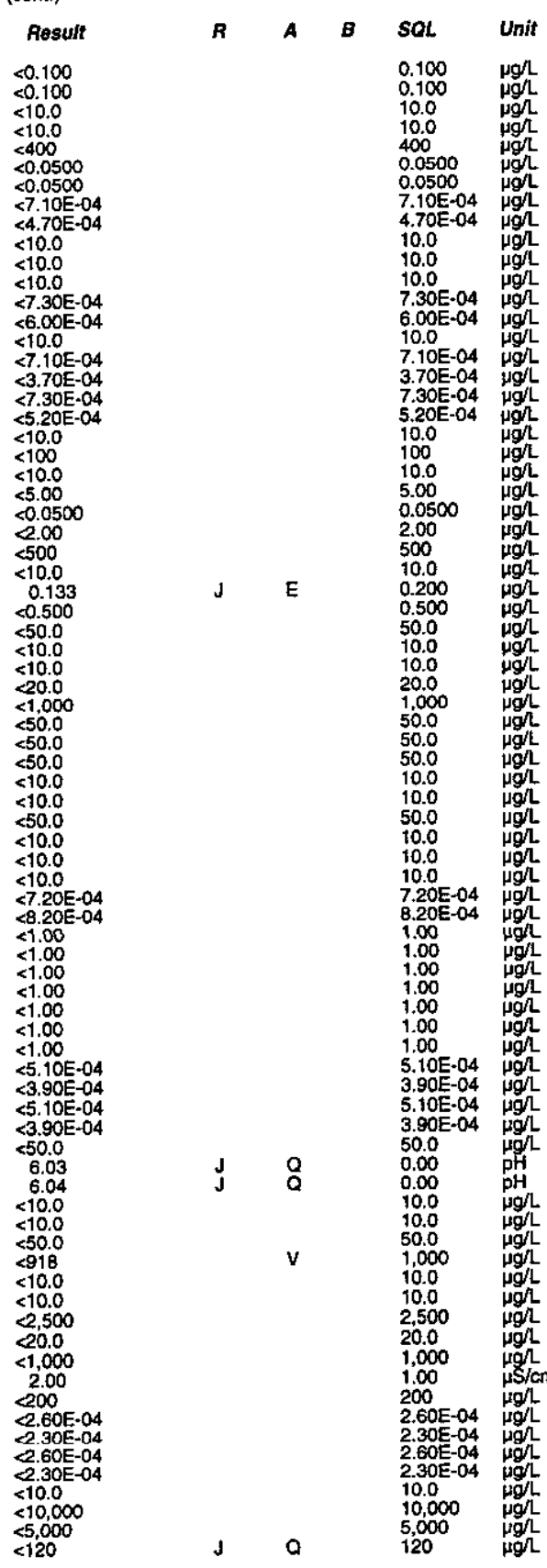

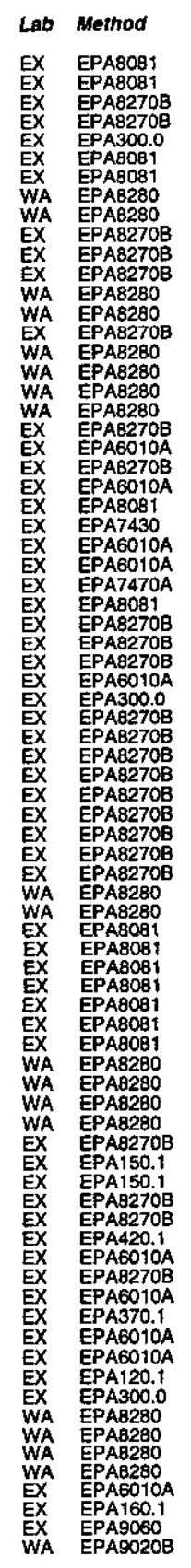

$F$ Analyte

0 Total phosphates (as P)

Toxaphene

1,2,4-Trichlorobenzene

o Vanadium, total recoverable

WELL QA 68B

MEASUREMENTS CONDUCTED IN THE FIELD

Sample date: 04/21/98
Water temperature: Not available
Air temperature: Not available

Air temperature: Not available
pH: Not available

Sp. conductance: Not available

No water was evacuated from the well prior to sampling

ANALYSES

$F$ Analyte

$\begin{array}{ll}0 & \text { Carbon-14 } \\ 0 & \text { Carbon-14 } \\ 0 & \text { Tritium }\end{array}$

Result

WELL QA 70B

MEASUREMENTS CONDUCTED IN THE FIELD

Sample date: $05 / 13 / 98$

Air temperature: $22.5^{\circ} \mathrm{C}$

gH: 3.6 conductance: $4 \mu \mathrm{S} / \mathrm{cm}$

ANALYSES

$F$ Analyte

- Americium-241

o Nonvolatila beta

$-3.89 \mathrm{E}-09 \pm 5.04 \mathrm{E}-09 \mathrm{UI}$
$-3.66 \mathrm{E}-10 \pm 5.12 \mathrm{E}-09$
$-1.54 \mathrm{E}-07 \pm 3.83 \mathrm{E}-07$

WELL QA 74B

MEASUREMENTS CONDUCTED IN THE FIELD

Sample date: 05/29/98

Air temperature: $25.2^{\circ} \mathrm{C}$

$\mathrm{PH}: 6$ conductance: $3 \mu \mathrm{S} / \mathrm{cm}$

ANALYSES

$F$ Analyte

Acenaphthene

Acatoni

Aluminum, total recoverabte

Antitimaceny, total recoverable

Arsenic, total recoverabie

Benzene

beta-Benzene hexachloride
delta-Benzene hexachloride

C-11

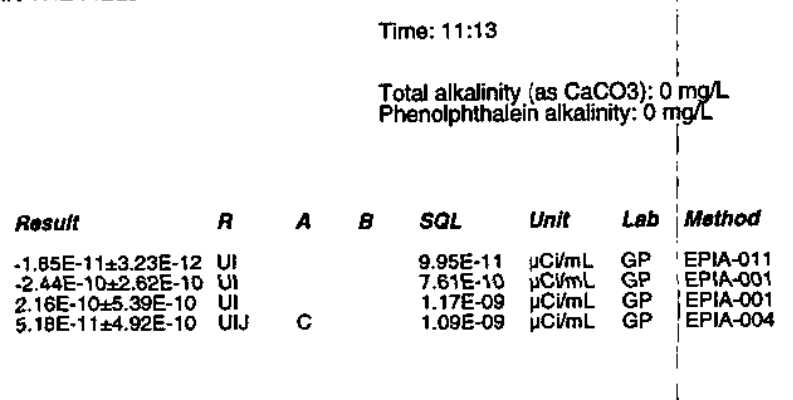

Time: 8:07

Total alkalinity (as Caco3): $1 \mathrm{mg} /$

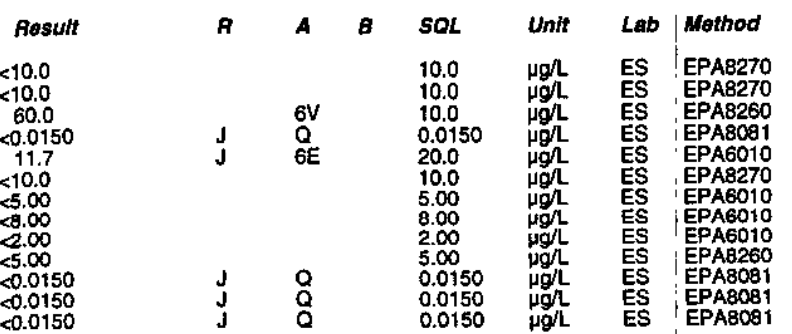

Second Quarter 1998
Total alkalinity (as $\mathrm{CaCO}$ ): Not available Phenolphthalein alkalinity: Not available $8.97 E-09 \mu \mathrm{CV} / \mathrm{mL}$ GP |EPIA-003 8.89E-09 $\mu \mathrm{CV} V \mathrm{~mL}$ GP

Time: 11: 
SAMPLING BLANKS RESULTS

Well QA 74B collected on 05/29/98 (cont)

$F$ Analyte

- Benzidine

Benzo (b) fluoranthene
Benzo (k) fluoranthens

Benzoic acid

Benzo(a)pyrene

Berylium, total recoverable

Bis (2-chloroethyl) ether

Bis (2-chloroisopropyl) ethe
Bis(2-ethylhexyl) phthalate

Bromodichloromethene

Bromotorm

Bromomethane
4-Bromophenyl phenyl ether

Cadmium, total recoverable

Carbon disulfide

Chlordane

gamma-Chlordan

4-Chlorobenzene

Chloreethene (Vinyl chloride)

Chloroform

2-Chloronappthalen

4-Chlorophenyl phenyl ather

Cobalt total recoverable

Copper, tolal recoverable

o-Cresol (2-Methylphenal)

P,p'-DDD

Pibenz(a,h)anthracene

Dibenzofuran

Di-n-butyl phthalate

1,2-Dichlorobenzen

1,4-Dichlorobenzene

1,1-Dichloroethane

1.1.-Dichloroethane

cis-1,2-Dichloroethylene

2,4-Dichlorophenol

cis-1,3-Dichloropropen

trans-1,3-Dichloropropene

2iethyl phthalate

Dimethyi phthalate

2.4-Dinitrotoluen

Di-n-octyl phthalate

Endosulfan I

Endrin

o Endrin ketone

ESH-EMS-980569

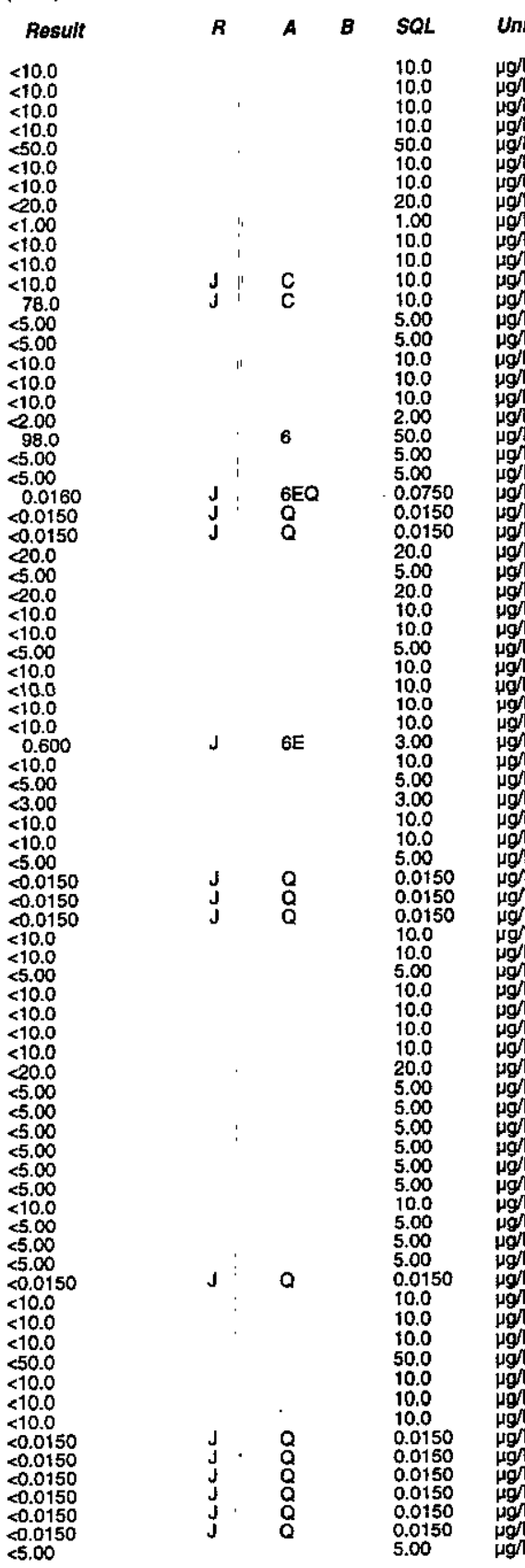

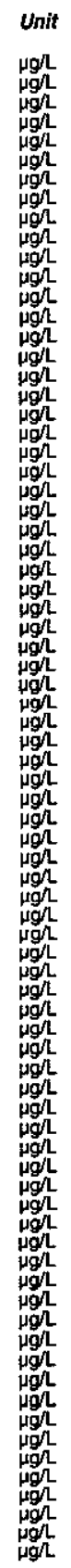

Lab Method

ES EPA8270

EPA8270

EPA8270

EPAB270

EPA0270

EPA2270

EPAB270
EPAB260

EPA8260

EPA8270

EPA6010

EPA8260

EPAB081

EPAB260

EPA8260

EPA8260

EPAB2600

EPA8270

EPA8270

EPA6010

EPA9270

EPAB081

EPABO81

EPAB260
EPAB270
EPAB270

EPAB270

EPA8270

EPAB260

EPA8260

EPAB260

EPA8260

EPA8081

EPAB270

EPA8270

EPAB270

EPABOB

EPABOB1
EPABOS1
EPABOB 1

EPAB081

EPAB081
Well QA 748 collected on 05/29/98 (cont.)

$F$ Analyte Result

- Fluoranthene

0 Fluorene

H Heptachlor epoxide

0 Hexachlorobutadiene
o Hexachlorocyclopentadien

: Hexachlorocyclopen

$\begin{array}{ll}2 \text { 2-Hexantone } \\ 0 & \text { Indeno }(1,2,3-c, d) \text { pyren }\end{array}$

0 . Iron, totai recoverable

Lead, tolal recoverable

o Magnesium, total recoverabte

Manganes, total recoverab

o Methoxychlor

: 2-Methyl-4,6-dinitrophe

. Methyl isobutyl ketone

$\begin{array}{ll} & \text { 2-Methyinaphthalene } \\ 0 & \text { Naphthalene } \\ 0 & \text { Nickel, total recoverable } \\ 0 & \text { m-Nitroaniline }\end{array}$

$\begin{array}{ll}0 & \text { o-Nitroanilife } \\ 0 & \text { p-Nitroaniline }\end{array}$

Nitrobenzene

4-Nitropheno:

N-Nitrosodiphenylamine

PCB 1016
0

0
0

D $P C B 1254$

Pentachtoroptenol

Phiananthrone

Phenol
Potassium, total recoverable

Pyyrene
Selenium, total recoverab

Siver, total reccoverable

1tyrene, Tetrachloroethane

Tetrachloroethylene

0 Toluens,

o 1,2,4-Trichlorcbenzene

1,1, - Trichloroethane

Trichloroethylene
$2,4,5$-Trichlorophenol

Vanadium, total recoverable

Vinyl acetate

Zinc, total recoverable

Antimony-124

Antimony-125

Bartum- 133

O. Cesium-134

0 Cobalt-57

Cobalt-60

Europium-154

C-12

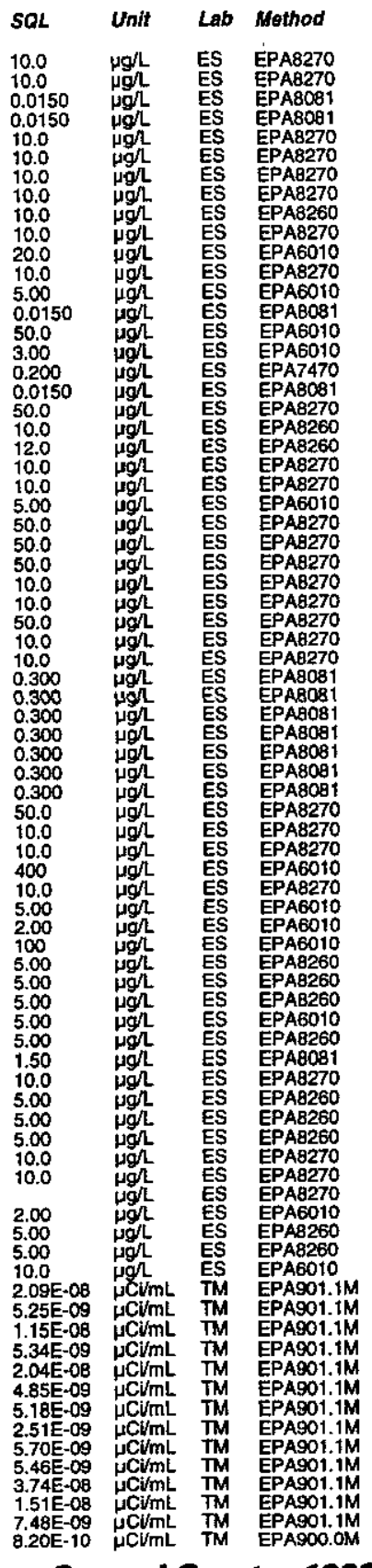

Second Quarter 1998 
Well QA 74B collected on 05/29/98 (cont.)

\begin{tabular}{|c|c|}
\hline Analyte & Result \\
\hline 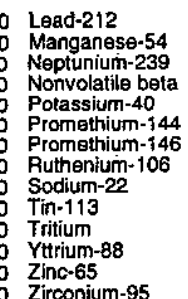 & 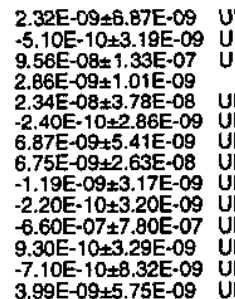 \\
\hline
\end{tabular}

\section{WELL QA 76B}

MEASUREMENTS CONDUCTED IN THE FIELD

Sample date: $06 / 15 / 98$
Water temperature: $29.6^{\circ} \mathrm{C}$
Air temperature: $31.7^{\circ} \mathrm{C}$

$\mathrm{HH}: 4.3$ rare: $31.7 \mathrm{C}$

Sp. conductance: $5 \mu \mathrm{S} / \mathrm{cm}$

ANALYSES

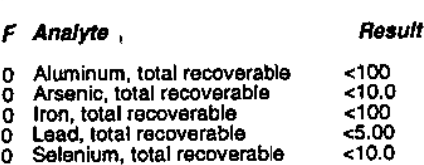

\section{WELL QA 80B}

MEASUREMENTS CONDUCTED IN THE FIELD

\section{Sample date: 06/30/98 \\ Air temperature: Not availabla \\ Sp. conductance: Not available}

No water was evacuated from the well prior to sampling.

ANALYSES

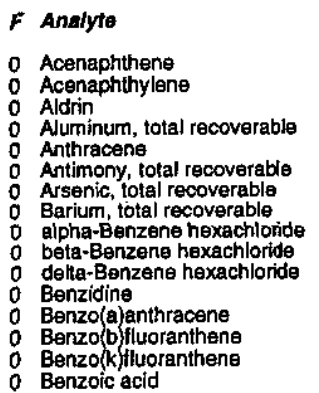

Result
$<10.0$
$<10.0$
$<0.0196$
$<50.0$
$<10.0$
$<2.06$
$<5.00$
$<500$
$<0.0196$
$<0.0196$
$<0.0196$
$<50.0$
$<10.0$
$<10.0$
$<10.0$
$<20.0$

Time:

Total alkalinity (as CaCO3): Not available
Phenolphthalein alkalinity: Not available

Total alkalinity (as CaCO3) $1 \mathrm{mg} / \mathrm{L}$
Phenolphthalein alkalinity: $0 \mathrm{mg} L$

$\begin{array}{llll}100 & \mu g h & \text { EX } & \text { EPAGO10A } \\ 10.0 & \mu g h & \text { EX } & \text { EPAG010A } \\ 100 & \mu g h & \text { EX } & \text { EPAGO1OA } \\ 5.00 & \mu g h & \text { EX } & \text { EPAGO1OA } \\ 10.0 & \mu g / L & \text { EX } & \text { EPAGO10A }\end{array}$

\begin{tabular}{|c|c|c|c|}
\hline & Unit & Lab & Method \\
\hline $\begin{array}{l}5.76 \mathrm{E}-09 \\
5.62 \mathrm{E}-09 \\
2.39 \mathrm{E}-07 \\
1.48 \mathrm{E}-09 \\
4.54 \mathrm{E}-08 \\
5.11 \mathrm{E}-09 \\
9.39 \mathrm{E}-09 \\
4.82 \mathrm{E}-08 \\
5.39 \mathrm{E}-09 \\
5.30 \mathrm{E}-09 \\
1.43 \mathrm{E}-06\end{array}$ & 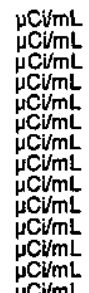 & $\begin{array}{l}M M \\
T M \\
T M \\
T M \\
T M \\
T M \\
T M \\
T M \\
T M \\
T M \\
T M \\
T M \\
T M\end{array}$ & 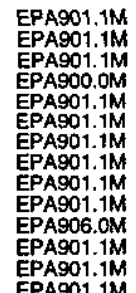 \\
\hline
\end{tabular}

Well QA 80B collected on 06/30/98 (cont.)

$F$ Analyte

Benzo(g,h,i)perylene

Benzyl alcohol

Bis (2-chloroethoxy) methan
Bis (2-chloroethyl) ether

Bis (2-choroisopropyt) ether
Bis(2-othylhexyi) phthalato

4-Bromophenyl phenyl ether

Cadmium, total recoverab!

alpha-Chbordane

4-Chloroaniline

4-Chloro-m-cressel

2-Chlorophenol

4.Chlorophenyl phenyl ather
Chromium, total recoverabte

Chrysene

Cobalt, total recoverable
0 Copper, total recoverable

m/c-Cresol Methytphenol)

0 Cyanide

P, p $^{\circ}$-DDE

Dibenz(a,h)anthracene

Dibenzoturan

1,2-Dictilorobenzene

1.4-Dichlorobenzene

2,4-Dichlorophenol

Dieldrin

2,4-Dimethyl phenol

2.4-Dinitrophenol

2,4-Dinitrotoluene
2,6-Dinitrotoluene

Di-n-octyl phthalate

Endosultan I

Endrin Eldin adehydo

Fluoranthe

Heptachlor

Heptachlor epoxide

Hexachlorobenzene
Hexachlorobutadiene

Hexachlorocyclopentadien

Hexachloroethane
Indenoo $1,2,3-c, d)$ pyrene

Lead, total recoverable

Magnesium total recoverabl

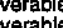

Mercury, total recoverable

2-Methyl-4,6-dinitrophenol

2-Methyinaphthalene

Nickel, total recoverable

m-Nitroanilline

P-Nitroaniline

2--Nitionhenenol
4-Nitrophenol

c-13
Result

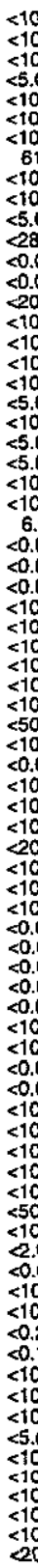

$<10.0$
$<10.0$
$<10.0$
$<5.00$
$<10.0$
$<10.0$
$<10.0$
61.4
$<10.0$
$<10.0$
$<1.0$
$<5.00$
$<28.0$
$<0.0196$
$<0.0196$
$<20.0$
$<10.0$
$<10.0$
$<10.0$
$<10.0$
$<5.00$
$<10.0$
$<5.00$
$<5.00$
$<10.0$
$<10.0$
6.95
$<0.0392$
$<0.0392$
$<0.0392$
$<10.0$
$<10.0$
$<10.0$
$<10.0$
$<10.0$
$<10.0$
$<50.0$
$<10.0$
$<0.0392$
$<10.0$
$<10.0$
$<10.0$
$<20.0$
$<10.0$
$<10.0$
$<10.0$
$<0.0392$
$<0.0196$
$<0.0392$
$<0.0392$
$<0.0392$
$<10.0$
$<10.0$
$<0.0196$
$<0.0196$
$<10.0$
$<10.0$
$<10.0$
$<10.0$
$<10.0$
$<50.0$
$<10.0$
$<2.01$
$<0.0196$
$<10.0$
$<10.0$
$<0.200$
$<0.196$
$<10.0$
$<10.0$
$<10.0$
$<5.00$
$<10.0$
$<10.0$
$<10.0$
$<10.0$
$<10.0$
$<20.0$
20.0

$\boldsymbol{R}$

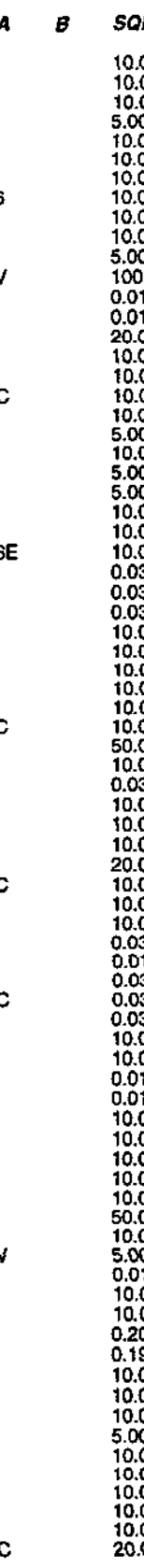

SQL Unit LOD Uothod

10.0 ugh GE EPAB270C

10.0 HgL GE EPAB270C

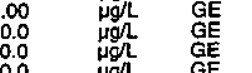

10.0
10.0
10.0

100196
0.0196

1.0 .0
20.0
10.0
10.0
10.0
10.0
50.0
10.0
5.00
5.00
10.0
10.0
10.0
0.039
0.039
0.039
10.039
10.0
10.0
10.0
10.0
10.0
50.0
10.0
0.039
10.0
10.0
10.0
20.0
10.0
10.0
10.0
0.039
0.039
00.039
0.039
0.039
10.0
10.0
0.019
0.019
0.019
10.0
10.0
10.0
10.0
10.0
50.0
10.0
5.00
0.019
10.0
10.0
0.200
0.196
10.0
10.0
10.0
5.00
10.0
10.0
10.0
10.0
10.0
20.0
2.0

E EPA

GE

EPAO0108

EAPBOB1A

政A EPA8270

EPAB270

Second Quarter 1998 
Well QA 80B collected on 06/30/98 (cont.)

\begin{tabular}{|c|c|c|c|c|c|c|c|c|}
\hline Analyto & Result & $\boldsymbol{A}$ & A & $B$ & SQL & Unit & Lab & Method \\
\hline 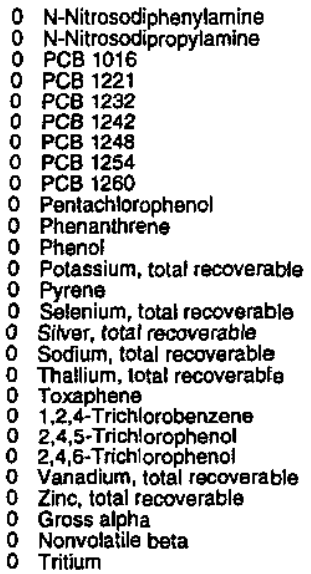 & $\begin{array}{l}<10.0 \\
<10.0 \\
<0.102 \\
<0.102 \\
<0.102 \\
<0.102 \\
<0.102 \\
<0.102 \\
<0.102 \\
<10.0 \\
<10.0 \\
<10.0 \\
17.3 \\
<10.0 \\
<5.00 \\
<5.00 \\
<4.2 \\
<5.00 \\
<0.980 \\
<1.0 \\
<10.0 \\
<10.0 \\
<5.00 \\
<1.37 \\
1.65 E-10 \pm 2.53 E-10 \\
1.27 E-08 \pm 8.30-10 \\
-7.63 E-08 \pm 3.24 E-07\end{array}$ & $\begin{array}{l:l}\mathbf{J} & 1 \\
\mathbf{J} & 1 \\
\mathbf{J} & \\
\mathbf{J} & \\
\mathbf{J} & \end{array}$ & $\begin{array}{l}c \\
C \\
c \\
\text { GE } \\
C\end{array}$ & & $\begin{array}{l}10.0 \\
10.0 \\
0.102 \\
0.102 \\
0.102 \\
0.102 \\
0.102 \\
0.102 \\
0.102 \\
10.0 \\
10.0 \\
10.0 \\
100 \\
10.0 \\
5.00 \\
5.00 \\
100 \\
5.00 \\
0.980 \\
10.0 \\
10.0 \\
10.0 \\
5.00 \\
5.00 \\
4.64 \mathrm{E}-10 \\
7.81 \mathrm{E}-10 \\
5.71 \mathrm{E}-07\end{array}$ & 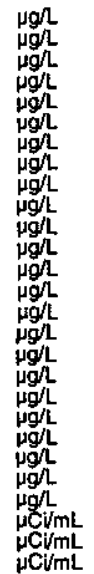 & $\begin{array}{l}G E \\
G E \\
G E \\
G E \\
G E \\
G E \\
G E \\
G E \\
G E \\
G E \\
G E \\
G E \\
G E \\
G E \\
G E \\
G E \\
G E \\
G E \\
G E \\
G E \\
G E \\
G E \\
G E \\
G E \\
G P \\
G P \\
G P\end{array}$ & 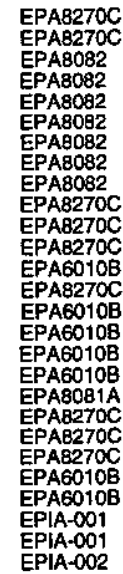 \\
\hline
\end{tabular}

\section{WELL QA 94A}

MEASUREMENTS CONDUCTED IN THE FIELD

Sample date: 06/15/98

Water temperature: $28.2^{\circ} \mathrm{C}$

Air temperature: Not avallab
gi: 7.3
Sp.conductance: $1 \mu \mathrm{S} / \mathrm{cm}$

ANALYSES
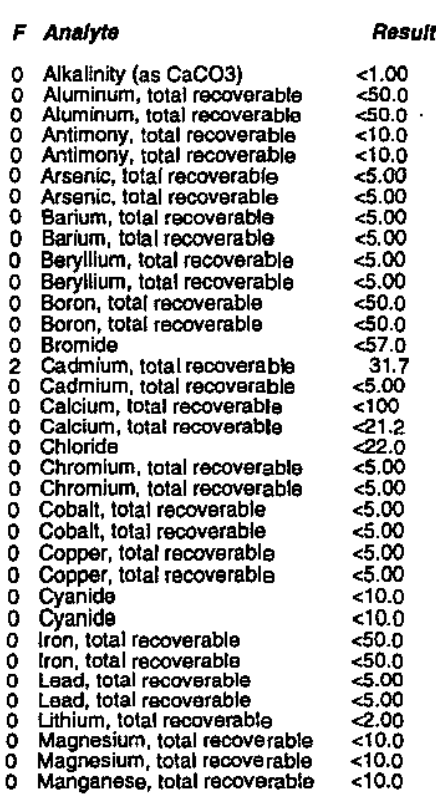

ESH-EMS-980569

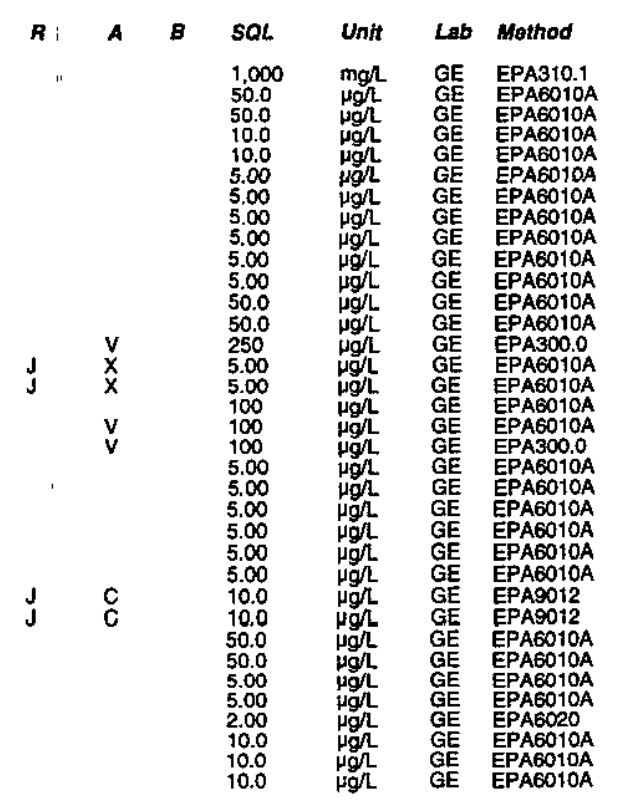

Well QA 94A collected on 06/15/98 (cont.)

$F$ Analyte

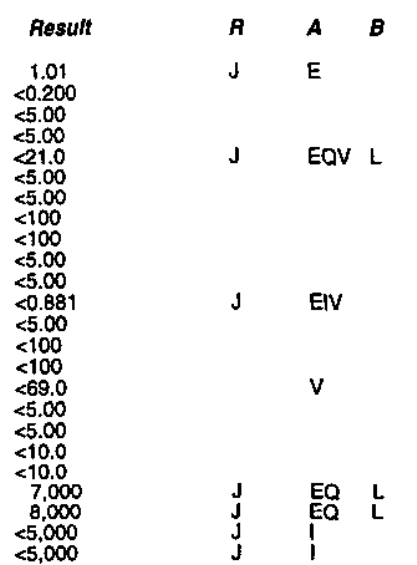

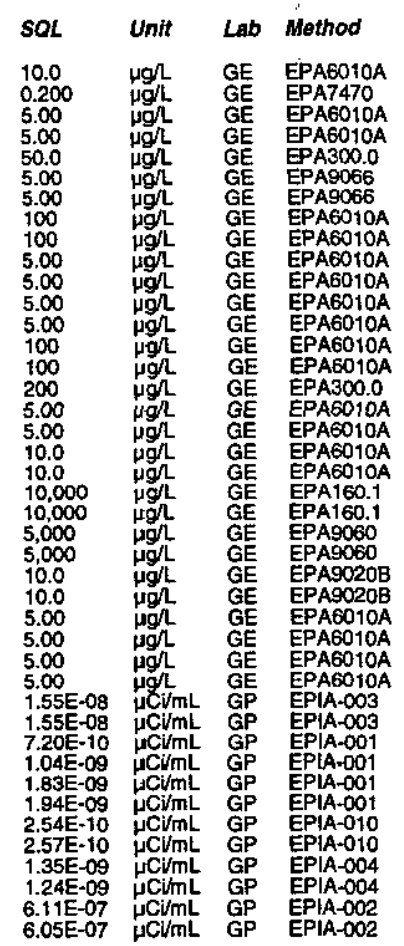

Total alkalinity (as Caco3); $1 \mathrm{mg} / \mathrm{L}$
Phenolphthalein alkalinity: $0 \mathrm{mg} L$

- Manganese, total recoverable

Nickel, total recoverabte

N Nickel, total recoverab

0 Phenols

Potassium, total recoverable

Potassium, total recoverable

Selenium, total recoverabable

Siver, total recoverable

: Sodium, total recoverable

Sultate

: Thallium, total recoverable

Tin, total recoverable

Total dissolved solids

O Total organic carbon

Total organic halogens

Vanadium, total recoverabie

Zinc, total recoverable

Carbon-14

Gross alpha

Nonvolatilie beta

Radjum, total alpha-emitting
Radium, total alpha-emitting

Strontium-90

0 Tritium

\section{WELL QA 96A}

MEASUREMENTS CONDUCTED IN THE FIELD

Sarmple date: $04 / 08 / 98.0$

Air temperature: $23.1^{\circ} \mathrm{C}$

Sp: conductance: $3 \mu \mathrm{S} / \mathrm{cm}$

ANALYSES

$F$ Analyte

: Alkalinity (as $\mathrm{CaCO} 3$ )

Cartonate

Chloride

Magnesium, total recoverable

Nitrate as nitrogen

S Silica, total recoverable

0 Sulfate

Total dissolved solids
0 Total organic carton
0 Total organic hatogens

Total organic halogens
Total phosphates (as P)
Tritium

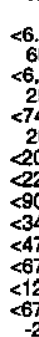

$\begin{array}{lr}\text { Result } & \text { A } \\ <6.70 & \\ 68.6 & \mathrm{~J} \\ <6.700 & \\ 298 & \\ <74.0 & \\ 26.0 & \mathrm{~J} \\ <20.0 & \\ <220 & \\ <90.2 & \mathrm{~J} \\ <340 & \mathrm{~J} \\ <47.000 & \mathrm{~J} \\ <673 & <120 \\ <67.0 & \mathrm{~J} \\ -2.90 \mathrm{E}-07 \pm 3.60 \mathrm{E}-07 & \mathrm{UH}\end{array}$

Total alkalinity (as CaCO3): $0 \mathrm{mg} / \mathrm{L}$

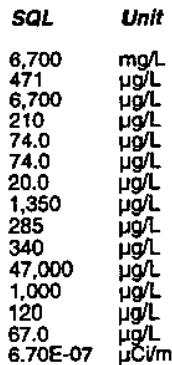

Lab Method

WA EPA310.1

WA EPAGO10

WA

WA EPAG010

WA EPA6010

WA EPA9056

WA EPA9060

WA EPA3620.2 


\section{WELL TRP100B}

MEASUREMENTS CONDUCTED IN THE FIELD

Sample date: 04/21/98

Air temporature Not at available

PH: Not available Not available

No water wos evaculted from the well prior to sampling. ANALYSES

$F$ Ansilyte

0 Acetone

Bromodichloromethane

Bromotom

Carbon disulfide

Chlorobenzene

Chloroethane

Chloroform

Dibromochloromethane

1, 1-Dichloroethane

1,1-Dichloroethylene

Dichloromethane

cis-1,3-Dichhoropropene

Ethylbenzene

Methyj ethyl ketone
Methyl isobutyl ketone

Styrene

Tetrachloroethylene

Toluene

1,1,2-Trichloroethane

Vinyl acetate

\section{WELL TRP101B}

MEASUREMENTS CONDUCTED IN THE FIELD

Sample date: 05/05/98

Water temperature: Not available

Air temperature: Not available

Sp. conductance: Not available

Turbicity: Not available
No water was evacuated from the well prior to sampling. ANALYSES

F Anglyto

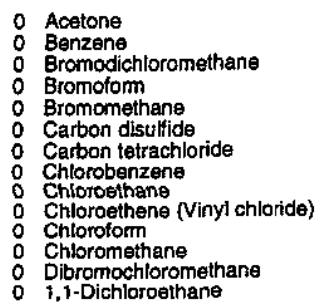

Dibromochlorometha
1,i-Dichloroethane

ESH-EMS-980569

$<5$

$<1 . \infty$
$<1.00$
$<1.00$
$<1.00$

0.947
$<1.00$
$<1.00$

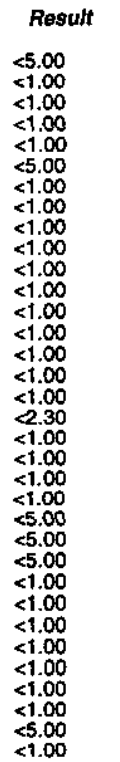

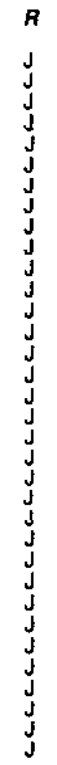

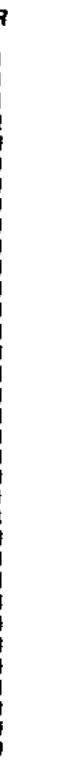

Well TRP101B collected on 05/05/98 (cont)
$F$ Analyte

1,2-Dichloroethane

1,2-Dichloroethylen

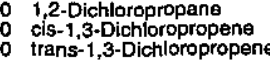

Ethylbenzene

0 Methynene lhy ketone
0 Methyl isobutyl keton

: Styrene

Totrachloroethylene

o 1,1,1-Trichloroethane

Trichloroethylane

0 Vinyl acetate

MEASUREMENTS CONDUCTED IN THE FIELD

Water temperature: Not available

Air temperature: Not available

Sp. conductance: Not available

No water was evacuated from the well prior to sampling.

ANALYSES

F Analyto

0 Acetone

Bromodichloromethan

- Bromoform

Carton disulfide

Carbon tetrachloride

Chloroethane
Chloroethene (VInyl chloride)

Chloroform

Dibromochloromethane

1,1-Dichloroethane

1,2-Dichloroethane

1,2-Dichloroethylen

1,2-Dichloropropan

cis-1,3-Dichloropropene

Enthytibenzene
2-Hexanone

$\begin{array}{ll}\text { : } & \text {-Hexanone } \\ 0 & \text { Methyl ethyl ketone } \\ 0 & \text { Methyl isobuty' ketone }\end{array}$

: Styrene

T,1,2, 2-Tetrachioroetrach

1,1,1-Trichloroethane

T,1,2-Trichloroethan

o Vinyl acetale

X Xylenes

Result

$<1.00$
$<1.00$
$<1.00$
$<6.53$
$<1.00$
$<1.00$
$<1.00$
$<1.00$
$<5.00$
$<5.00$
$<5.00$
$<1.00$
$<1.00$
$<1.00$
$<1.00$
$<1.00$
$<1.00$
$<1.00$
$<5.00$
$<1.00$

IN THE FIELD

Result

$<5.00$

$<1.00$

$<1.00$
$<1.00$
55.00

$<1.00$
$<1.00$
$<1.00$

$<1.00$
$<1.00$
$<1.00$
$<1.00$

$<1.00$
$<1.00$
$<1.00$

$<><1.00$

$<1.40$

$<1.00$

$<1.00$

5.00
5.00
$<1.00$

$<1.00$
$<1.00$
$<1.00$

$<1.00$
$<1.00$
5100

$<1.00$
$<1.00$
$<5.00$
Dichloromethane

\section{WELL TRP102B}

Sample date: 05/12/98

$\mathrm{GE}$

EPAB2OA

GE EPAB260A

EPAB260A

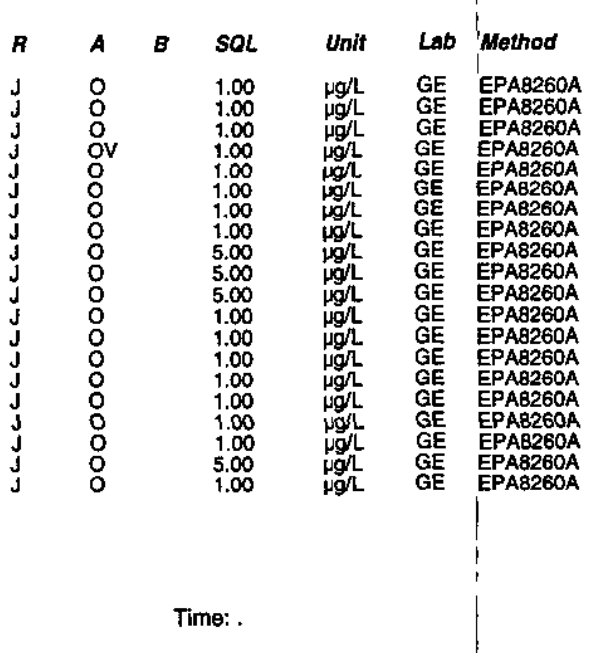

Total alkalinity (as $\mathrm{CaCO}$ ): Not avaitable inity (as CacO3): Not available

\begin{tabular}{|c|c|c|c|}
\hline SQL & Unit & Lab & Mothad \\
\hline $\begin{array}{l}5.00 \\
1.00 \\
1.00 \\
1.00 \\
1.00 \\
5.00 \\
1.00 \\
1.00 \\
1.00 \\
1.00 \\
1.00 \\
1.00 \\
1.00 \\
1.00 \\
1.00 \\
1.00 \\
1.00 \\
1.00 \\
1.00 \\
1.00 \\
1.00 \\
5.00 \\
5.00 \\
5.00 \\
1.00 \\
1.00 \\
1.00 \\
1.00 \\
1.00 \\
5.00 \\
1.00\end{array}$ & 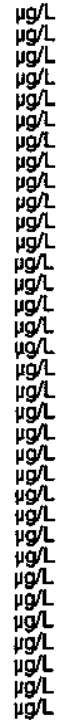 & $\begin{array}{l}G E \\
G E \\
G E \\
G E \\
G E \\
G E \\
G E \\
G E \\
G E \\
G E \\
G E \\
G E \\
G E \\
G E \\
G E \\
G E \\
G E \\
G E \\
G E \\
G E \\
G E \\
G E \\
G E \\
G E \\
G E \\
G E \\
G E \\
G E \\
G E \\
G E \\
G E \\
G E \\
G E \\
G E \\
G E\end{array}$ & $\begin{array}{l}\text { EPAB260A } \\
\text { EPAB260A } \\
\text { EPAB260A } \\
\text { EPAB260A } \\
\text { EPAB260A } \\
\text { EPAB260A } \\
\text { EPAB260A } \\
\text { EPAB260A } \\
\text { EPAB260A } \\
\text { EPA8260A } \\
\text { EPAB260A } \\
\text { EPAB260A } \\
\text { EPAB260A } \\
\text { EPAB260A } \\
\text { EPAB260A } \\
\text { EPAB260A } \\
\text { EPAB260A } \\
\text { EPAB260A } \\
\text { EPAB260A } \\
\text { EPA8260A } \\
\text { EPAB260A } \\
\text { EPA8260A } \\
\text { EPAB260A } \\
\text { EPA8260A } \\
\text { EPAB260A } \\
\text { EPA8260A } \\
\text { EPAB260A } \\
\text { EPAB260A } \\
\text { EPAB260A } \\
\text { EPAB260A } \\
\text { EPAB260A } \\
\text { EPAB260A } \\
\text { EPAB260A } \\
\text { EPAB260A }\end{array}$ \\
\hline
\end{tabular}

Second Quarter 1998 
SAMPLING BLANKS RESULTS

\section{WELL TRP120B}

MEASUREMENTS CONDUCTED IN THE FIELD

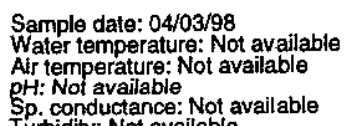

H. Nonductance: Not available

No water was evacuated from the well prior to sampling.

ANALYSES

\begin{tabular}{|c|c|}
\hline Analyte & Result \\
\hline 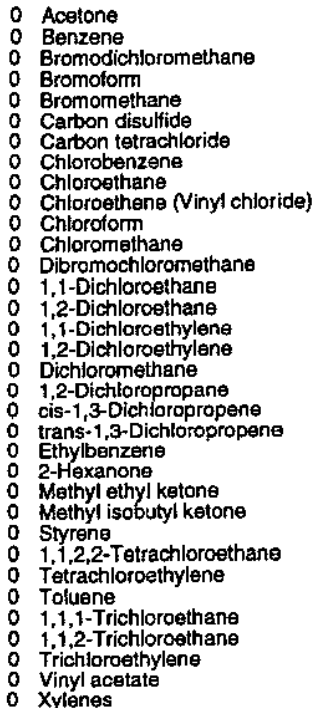 & $\begin{array}{l}<10.0 \\
<5.00 \\
<5.00 \\
<5.00 \\
<10.0 \\
<5.00 \\
<5.00 \\
<5.00 \\
<10.0 \\
<10.0 \\
<5.00 \\
<5.0 \\
<5.00 \\
<5.00 \\
<5.00 \\
<5.00 \\
1.76 \\
<5.00 \\
<5.00 \\
<5.00 \\
<100 \\
<10.0 \\
<10.0 \\
<5.00 \\
<5.00 \\
<5.00 \\
<5.00 \\
<5.00 \\
<5.00 \\
<1.00 \\
<10.0 \\
<5.00\end{array}$ \\
\hline
\end{tabular}

\section{WELL TRP121B}

MEASUREMENTS CONDUCTED IN THE FIELD

Sample date: 04/21/98

Water temperature: Not available

Arr temperature: Not available

Sp. conductance: Not available

No water was evacuated from the well prior to sampling

\section{ANALYSES}

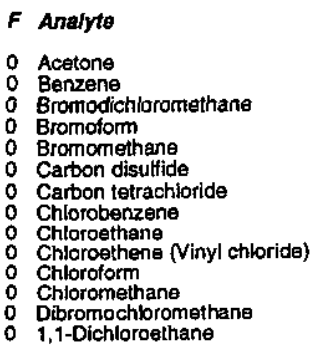

Result
$<10.0$
$<5.00$
55.00
$<5.00$
510.0
45.00
55.00
55.00
$<10.0$
510.0
$<5.00$
510.0
55.00
45.00

Total alkalinity (as CaCO3): Not available
Phenolphthalein alkalinity: Not available

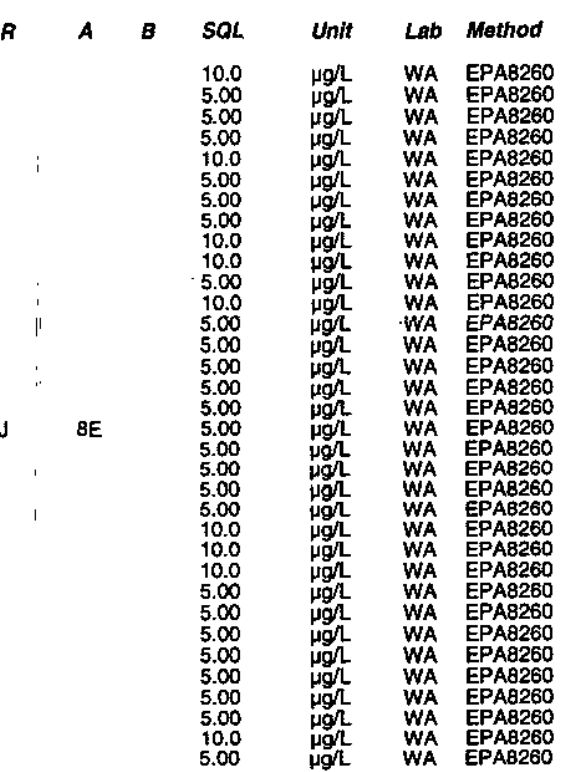

Time: .

Total alkalinity (as CaCO3): Not available
Phenolphthalein alkalinity: Not available

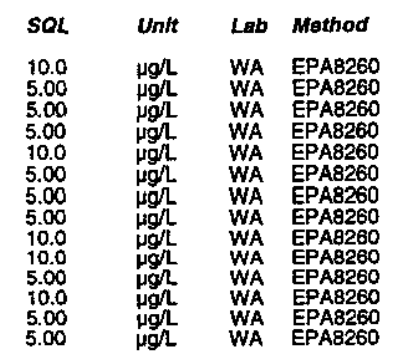

Well TRP 121 B collected on 04/21/98 (cont.)

$F$ Analyte

Resuft

1,2-Dichloroethane

1,2-Dichloroethylen

Dichloromethane

cis-1,3-Dichiloropropene

trans-1,3.Dichlor

Methyl ethyl ketone

Methyl isobutyl ketone

$1,1,2,2$-Tetrachlorosthane

Tolvene

Trichloroethylene

Vinyl acetate

\section{WELL TRP122B}

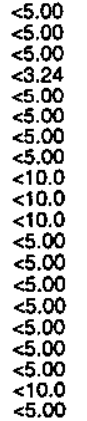

MEASUREMENTS CONDUCTED IN THE FIELD

Sample date: 05/01/98

Water temperature: Not available

Air temperature: Not available

$\mathrm{pp}$. conductance: Not available

No water was evacuated from the well prior to sampling.

ANALYSES

$F$ Analyte

Resu

O Acetone

Bromodichloromethane

Bromoform

Cromomsthane

Chloroethane

Chlorotorm

Chloromethane

1,1-Dichloroethane

1,1 -Dichloroethylene
1.2-Dichloroothylene

cis-1,3-Dichloropropene
trans-1,3-Dichloropropene

2hylbenzene

Methyy ettryl ketone

1,1,2,2-Tetrachloroethane

Tetrachloroethylene

1, 1,1-Trichloroethane

Trichloroethyleth

Vinyl acetate
Xylenes

Resuft
$<10.0$
$<5.00$
$<5.00$
$<5.00$
$<10.0$
$<5.00$
$<5.00$
$<5.00$
$<10.0$
$<10.0$
$<5.00$
$<10.0$
$<5.00$
55.00
$<5.00$
55.00
$<5.00$
1.92
$<5.00$
55.00
$<5.00$
25.00
$<10.0$
$<10.0$
$<10.0$
$<5.00$
25.00
$<5.00$
$<5.00$
$<5.00$
$<5.00$
$<5.00$
$<10.0$
$<5.00$

R A

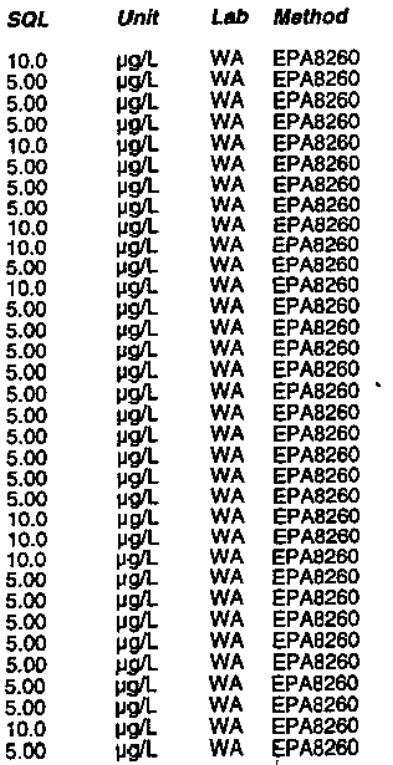

Time:

Total alkalinity (as CaCO3): Not available
Phenolphthalein alkalinity: Not available

\begin{tabular}{|c|c|c|c|}
\hline SOL & Unit & $L a b$ & Method \\
\hline $\begin{array}{l}5.00 \\
5.00 \\
5.00 \\
5.00 \\
5.00 \\
5.00 \\
5.00 \\
5.00 \\
10.0 \\
10.0 \\
10.0 \\
5.00 \\
5.00 \\
5.00 \\
5.00 \\
5.00 \\
5.00 \\
5.00 \\
10.0 \\
5.00\end{array}$ & $\begin{array}{l}\mu g h \\
\mu g h \\
\mu g h \\
\mu g h \\
\mu g h \\
\mu g h \\
\mu g h \\
\mu g h \\
\mu g h \\
\mu g h \\
\mu g / 2 \\
\mu g h \\
\mu g h \\
\mu g h \\
\mu g h \\
\mu g h \\
\mu g h \\
\mu g h \\
\mu g h \\
\mu g h \\
\mu g h \\
\mu g h \\
\mu g h\end{array}$ & $\begin{array}{l}\text { WA } \\
\text { WA } \\
\text { WA } \\
\text { WA } \\
\text { WA } \\
\text { WA } \\
\text { WA } \\
\text { WA } \\
\text { WA } \\
\text { WA } \\
\text { WA } \\
\text { WA } \\
\text { WA } \\
\text { WA } \\
\text { WA } \\
\text { WA } \\
\text { WA } \\
\text { WA } \\
\text { WA } \\
\text { WA }\end{array}$ & $\begin{array}{l}\text { EPAB260 } \\
\text { EPAB260 } \\
\text { EPA8260 } \\
\text { EPAB260 } \\
\text { EPA8260 } \\
\text { EPAB260 } \\
\text { EPA8260 } \\
\text { EPA8260 } \\
\text { EPAB260 } \\
\text { EPAB260 } \\
\text { EPAB260 } \\
\text { EPAB260 } \\
\text { EPA8260 } \\
\text { EPA8260 } \\
\text { EPAB260 } \\
\text { EPA8260 } \\
\text { EPA8260 } \\
\text { EPA8260 } \\
\text { EPAB250 } \\
E P A B 260\end{array}$ \\
\hline
\end{tabular}

ESH-EMS-980569 


\section{WELL TRP123B}

MEASUAEMENTS CONDUCTED IN THE FIELD

Sample date: $05 / 04 / 98$
Water temperature: Not availabl
Air temperatura: Not available

SH: Not available Sponductance: Not available

ANALYSES

$F$ Analyte

o Acotone.

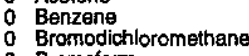

Bromoform

Carbon disulfide

Carbon tetrachlo

Chloroethane

Chloromethan

Dibromochloromethane

1.1.Dichloroethylene

Dichloromethane

cis-1,3-Dichloropropene

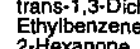

Methyl ethyl katone

Styrene

Tetrachloroethylene

: Toluene

$1,1,2$-Trichioroethan

V Vinyl acetate

WELL TRP124B

MEASUREMENTS CONDUCTED IN THE FIELD

Sample date: $05 / 05 / 98$

Water temperature: Not available

Air temperature:

conductance $\mathrm{Nat}$ evailablo

No water was evacuated from the well prior to sampling.

ANALYSES

$F$ Analyto

O Acetone

Bromodichloromethane

Bromoform

Carbon disulfide

Carbon tetrachibrid

Chlorobenzene

Chlorosthene Ninyl chloride)

Chlormethan

$\begin{array}{ll}0 & \text { Dibromochloromethan } \\ 0 & 1,1-\text { Dichloroethane }\end{array}$

ESH-EMS-980569

Result
$<4.29$
$<5.00$
$<5.00$
$<5.00$
$<10.0$
55.00
$<5.00$
5.00
$<10.0$
$<10.0$
$<5.00$
$<10.0$
$<5.00$
$<5.00$

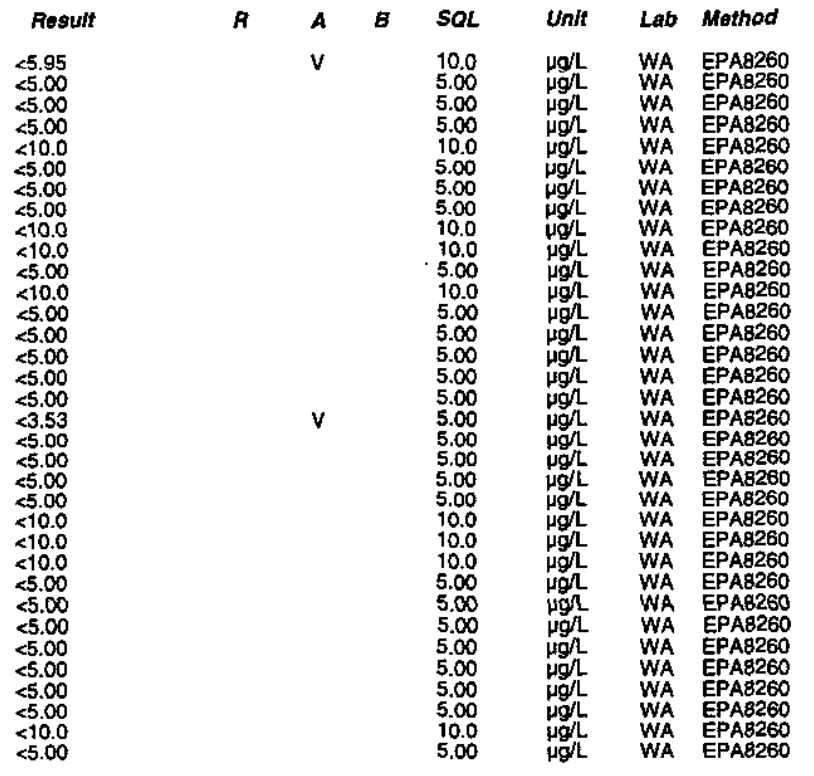

Time: .

Total alkalinity (as Caco3): Not available
Phenolphthalein alkalinity: Not available

$\boldsymbol{R}$

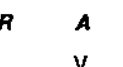

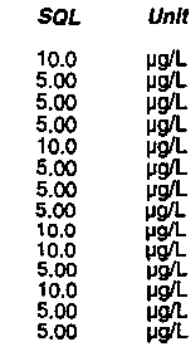

$\begin{array}{ll}\text { Lab } & \text { Mothod } \\ \text { WA } & \text { EPA8260 } \\ \text { WA } & \text { EPA8260 } \\ \text { WA } & \text { EPAB260 } \\ \text { WA } & \text { EPA8260 } \\ \text { WA } & \text { EPAB260 } \\ \text { WA } & \text { EPA8260 } \\ \text { WA } & \text { EPA8260 } \\ \text { WA } & \text { EPA8260 } \\ \text { WA } & \text { EPAB260 } \\ \text { WA } & \text { EPAB260 } \\ \text { WA } & \text { EPAB260 } \\ \text { WA } & \text { EPAB260 } \\ \text { WA } & \text { EPAB260 } \\ \text { WA } & \text { EPA8260 }\end{array}$

Well TRP124B collected on 05/05/98 (cont)

$F$ Analyte

0 1,2-Dichloroethane

$\begin{array}{ll}1,1-D i c h l o r o e t h y l e n \\ 0 & 1,2-D i c h l o r o e t h y l e n e \\ 0 & \text { Dichloromethane }\end{array}$

1,2-Dichloropropane

trans-1,3-Dichloropropen

Enyylbenzente

0. Methyl ethyl ketone
0 Methyl isobutyl ketone

: Styrene

$1,1,1$-Trichloroethane

Tr, 2 -Trichloroethan

Vinyl acetate
Xylenes

\section{WELL TRP125B}

MEASUREMENTS CONDUCTED IN THE FIELD

Sample date: 05/06/98

ature: Not available

Air emperature: Not available

Sp. conductance: Not available

No water was evacuated from the well prior to sampling.

ANALYSES

F Analyto

0 Acetone

Bromodichloromethane

Bromotorm

Carbon distitide

Carbon tetrachiloride

Chloroethane

Dibromochloromethane

1,1-Dichloroethane

1,2-Dichloroethane

o 1,1-Dichloroesthylene

1.2-Dichioropropan

cis-1,3-Dichloropropene

Ethylbenzen

M. Hexanone

Styrene

Toluene

1,1,2-Trichlorcethane

Trichloroethylene

Xylenes

Result

$<6.72$

$<5.00$

$<10.0$
$<5.00$
$<5.00$

$<5.00$
$<10.0$
$<10.0$
$<5.00$

$<10.0$

$<5.00$
$<5.00$
$<5.00$

$<5.00$
$<.12$
$<5.00$
$<.00$

$\$ 5.00$
$<5.00$
$<10.0$

$<10.0$
$<5.00$
55.00

$<5.00$

55.00
55.00
$<10.0$
55.00

-17
$\boldsymbol{A}$

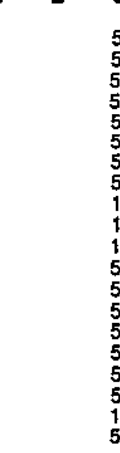

5.00
5.00
5.00
5.00
5.00
5.00
5.00
5.00
10.0
10.0
10.0
5.00
5.00
5.00
5.00
5.00
5.00
5.00
5.00
5.00

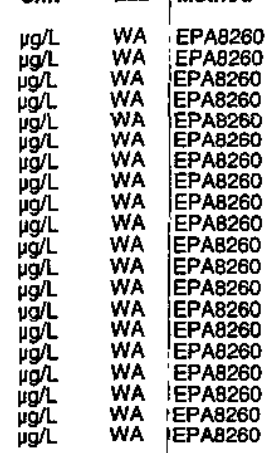

Time: .

Total alkalinity (as $\mathrm{CaCO}$ ): Not available

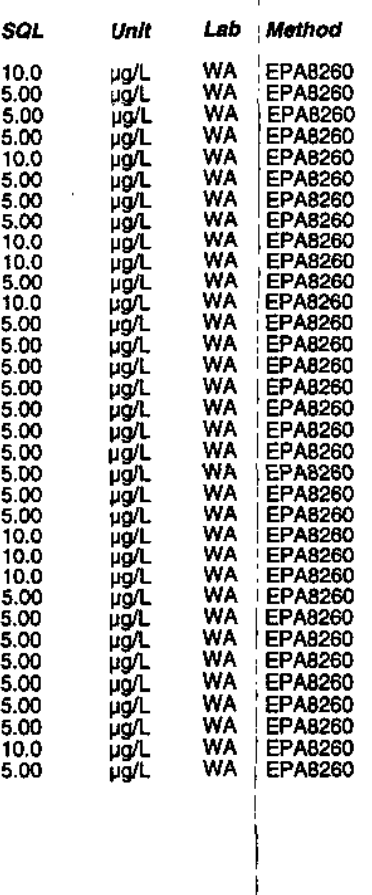

Second Quarter 1998 


\section{WELL TRP126B}

MEASUREMENTS CONDUCTED IN THE FIELD

Sample date: 05/07/98

Water temperature: Not available

Air temperature: Not available
DH: Not availabie

Sp. conductance: Not available

No water was evacuated from the well prior to sampling

ANALYSES

$F$ Analyto

0 Acetone

0 Bromodichloromethane

Bromomethan

Carbon disulfide

Chibrobenzene

Chloroethene (Vinyl chloride)

Chlorotorm

Dibromochloromethan

1,2-Dichloroethane

1,1-Dichloroethylene
1,2 -Dichloroethylen

Dichloromethane

1,2-Dichtoropropane
cis-1,3-Dichloropropene

trans-1,3-Dichloropropen

2-Hexanone

Methyl ethyl katone

Styrene -1,2,2-Tetrachloroethan

Totrachloroethylene

1,1.1.-Trichloroethane

Trichloroethylene

\section{WELL TRP127B}

MEASUREM MENTS CONDUCTED IN THE FIELD

Sample date: 05/08/98

Water temperature: Not availablo

Air temperature: Not available
pH: Not available

Sp. conductance: Not available

ANALYSES

\begin{tabular}{|c|c|}
\hline Analyte & Resuft \\
\hline $\begin{array}{ll}0 & \text { Acetone } \\
0 & \text { Benzenne } \\
0 & \text { Bromodichloromethane } \\
0 & \text { Bromotorm } \\
0 & \text { Bromomethane } \\
0 & \text { Carbon disulfide } \\
0 & \text { Carbon tetrachloride } \\
0 & \text { Chlorobenzene } \\
0 & \text { Chloroethane } \\
0 & \text { Chloroethene (Vinyl chloride) } \\
0 & \text { Chlorotomn } \\
0 & \text { Chloromethane } \\
0 & \text { Dibromochloromethane } \\
0 & 1,1-\text { Dichloroethane }\end{array}$ & $\begin{array}{l}<10.0 \\
<5.00 \\
<5.00 \\
<5.00 \\
<10.0 \\
<5.00 \\
<5.00 \\
<5.00 \\
<10.0 \\
<10.0 \\
<5.00 \\
<10.0 \\
<5.00 \\
<5 . \infty\end{array}$ \\
\hline
\end{tabular}

ESH-EMS-980569
Well TRP127B collected on 05/08/98 (cont.)

$F$ Analyte

Time: .

Total alkalinity (as CaCO3): Not available

$\begin{array}{ll}0 & 1,2-\text { Dichloroethane } \\ \text { 1,1-Dichloroethylene }\end{array}$

1,2-Dichloroethylen

Dichloromethane
$1,2-$ Dichloropropane
cis-1,3-Dichlioropropen

cis-1,3-Dichloropropene
trans-1,3-Dichloropropene

trans-1,3-Dich

Methyl ethyl ketone

Methyl isobutyl ketone

1,1,2,2-Tetrachloroethan

Tolueno

1,1,1-Trichloroethane

Trichloroethylene
Vinyl acetate

WELL TRP128B

MEASUREMENTS CONDUCTED IN THE FIELD

Sample date: 05/08/98

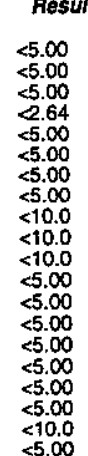

5.00
5.00
5.00
5.00
5.00
5.00
5.00
5.00
5.00
10.0
10.0
10.0
5.00
5.00
5.00
5.00
5.00
5.00
100
5.00

Unit Lab Method

Warer emperature: Not available

Air temperature: Not available

Sp. conductance: Not available

No water was evacuated from the well prior to sampling.

ANALYSES

F Analyto

0 Acetone

Bromodichloromethane

Bromomethe

Carbon disulfide

CChiorobenzene

Chloroethane

Chloroform

Dibromochloromethane

1,1-Dichloroethane

1,1-1-Dichloroethylene

1,2 -Dichloroethylen
Dichloromethane

1,2-Dichloropropane

cis-1,3-Dichoropropene
trans-1,3-Dichloropropene

Ethy!benzen

$\begin{array}{ll}0 & \text { Methyl ethyl ketone } \\ 0 & \text { Methyl isobutyl ketone }\end{array}$

o Methyl isobutyl ketone

Tetrachloroothylene

Toluene

Trichloroethylene

O Vinyl acetate

Rosult

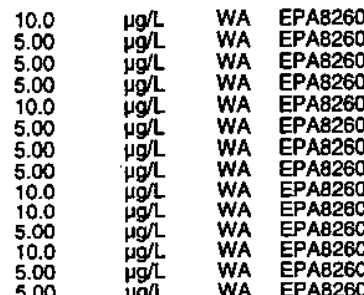

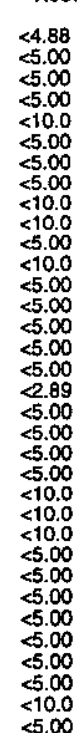

Time: .

Total alkalinity (as CaCO3): Not available
Phenolphthalein alkalinity: Not available

\begin{tabular}{|c|c|c|}
\hline Unit & LAb & Method \\
\hline 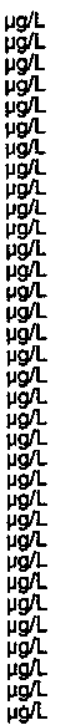 & $\begin{array}{l}\text { WA } \\
\text { WA } \\
\text { WA } \\
\text { WA } \\
\text { WA } \\
\text { WA } \\
\text { WA } \\
\text { WA } \\
\text { WA } \\
\text { WA } \\
\text { WA } \\
\text { WA } \\
\text { WA } \\
\text { WA } \\
\text { WA } \\
\text { WA } \\
\text { WA } \\
\text { WA } \\
\text { WA } \\
\text { WA } \\
\text { WA } \\
\text { WA } \\
\text { WA } \\
\text { WA } \\
\text { WA } \\
\text { WA } \\
\text { WA } \\
\text { WA } \\
\text { WA } \\
\text { WA } \\
\text { WA } \\
\text { WA } \\
\text { WA } \\
\text { WA }\end{array}$ & 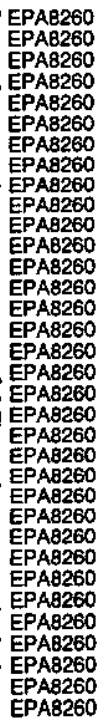 \\
\hline
\end{tabular}

Second Quarter 1998

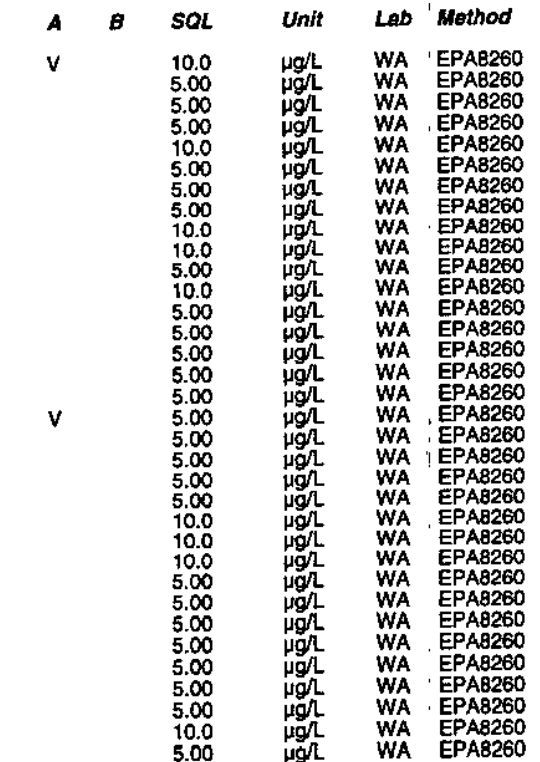




\section{WELL TRP129B}

MEASUREMENTS CONDUCTED IN THE FIELD Sample date: 05/11/98 Water temperature: Not available pH: Not available Turbidity: Not available ANALYSES

$F$ Analyte

0 Acetone

B Bromodichloromethane

Bromotom

Carbon disulfide

Carbon tatrachlo

Chloroethenene (Vinyl chloride)

Chloromethan

Dibromochloromethan

1,1-Dichloroethane

1,1 -Dichloroethylene

Dichloromethane

1,2-Dichloropropents

trans-1,3-Dich

2-Hexanone

1,1,2,2-Tetrachloroethan

Totrachloroethylene

1,1,1-Trichloroethane

Ti, 2-Trichloroethan

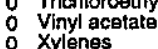

WELL TRP130B

MEASUREMENTS CONDUCTED IN THE FIELD

Sample date: 04/08/98

Water temperature: Not available

Air temperature: Not avaliable

pp. Not availabie

No water was evacuated from the well prior to sampling.

ANALYSES

F Analyto

0 Acetone

Bromodichloromethane

Bromolomm

: Bromomethane

Carbon tetrachlorid

Chlorobenzene

Chloroethene (Vinyl chloride)

Chloromernano

$\begin{array}{ll}0 & \text { Dibromochloromethan } \\ \text { 1,1.Dichloroethane } & \end{array}$

ESH-EMS-980569
Well TRP130B collected on 04/08/98 (cont.)

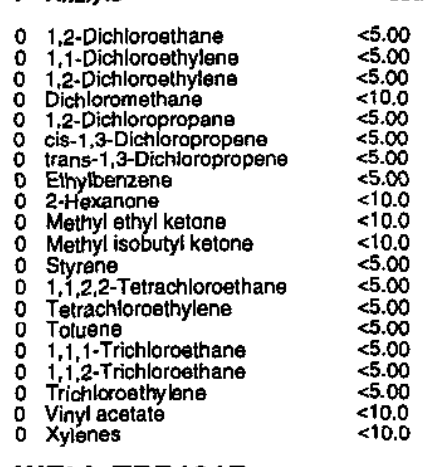

$<5.00$
$<5.00$
$<5.00$
$<10.0$
$<5.00$
$<5.00$
$<5.00$
$<5.00$
$<10.0$
$<10.0$
$<10.0$
$<5.00$
$<5.00$
$<5.00$
$<5.00$
$<5.00$
$<5.00$
$<5.00$
$<10.0$
$<10.0$

$\boldsymbol{R}$

\begin{tabular}{|c|c|c|c|}
\hline SOL & Unit & Lab & Method \\
\hline $\begin{array}{l}5.00 \\
5.00 \\
5.00 \\
10.0 \\
5.00 \\
5.00 \\
5.00 \\
500 \\
10.0 \\
10.0 \\
5.0 \\
5.00 \\
5.00 \\
5.00 \\
5.00 \\
5.00 \\
5.00 \\
100 \\
10.0\end{array}$ & 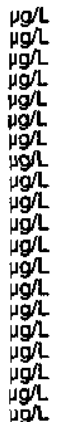 & $\begin{array}{l}\text { EX } \\
\text { EX } \\
\text { EX } \\
\text { EX } \\
\text { EX } \\
\text { EX } \\
\text { EX } \\
\text { EX } \\
\text { EX } \\
\text { EX } \\
\text { EX } \\
\text { EX } \\
\text { EX } \\
\text { EX } \\
\text { EX } \\
\text { EX } \\
\text { EX } \\
\text { EX } \\
\text { EX } \\
\text { EX }\end{array}$ & 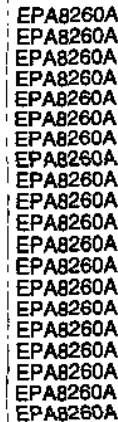 \\
\hline
\end{tabular}

WELL TRP131B

MEASUREMENTS CONDUCTED IN THE FIELD

Sample date: 04/16/98

ater temperature: Not available

H: Nol available

p. con

No water was evacuated from the well prior to sampling.

ANALYSES

$F$ Analyte

0 Aceton

Bromodichloromethane

Bromotorm

Carbon tetrachlorid

Chlorobenzene

Chloroethene (Vinyl chloride)

Chlorotorm

Dibromochloromethane

1,2-Dichloroethan

1,2-Dichloroethylen

D Dichlorornethang

1,2-Dichloropropane
cis-1,3-Dichloropropene

Total alkalinity (as $\mathrm{CaCO}$ ): Not available

trans-1,3-Dichloropropen

Ethylbenzen

Methyl ethyl ketone
Methyl isobutyl ketone

Styrene

Tetrachloroethylen

1,1,1-Trichloroethane

1,1,2-Trichloroethan

Trichloroethylen
Unknown

$:$ Vinyl acetat

Resuft

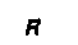

$<10.0$

$<5.00$
$<5.0$
$<5.00$
$<5.00$

$<5.00$
$<5.00$
$<5.00$
$<5.00$

10.0
5.00
5.00
5.00
5.00
5.00
5.00
5.00
5.00
5.00
5.00
5.00
5.00
5.00

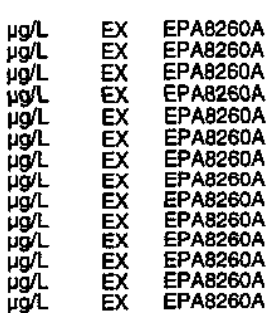

C-19
Time: .

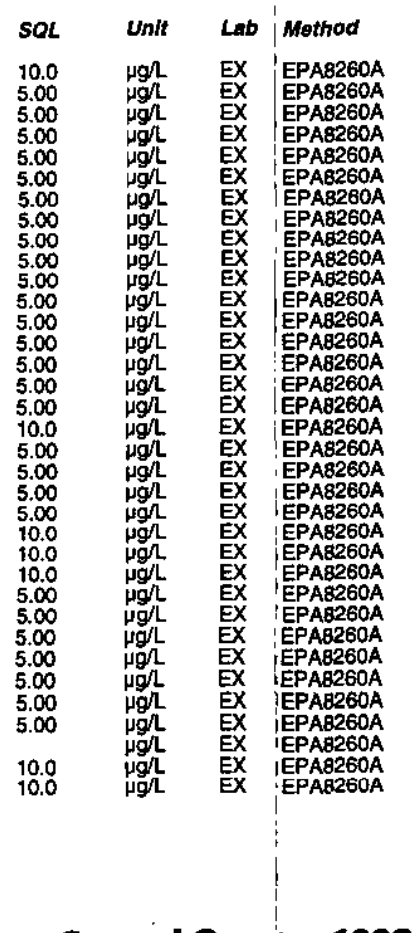

Second Quarter 1998
Total alkalinity (as $\mathrm{CaCO}$ ): Not available 


\section{WELL TRP132B}

MEASUREMENTS CONDUCTED IN THE FIELD

Sample date: 04/20/98

Water temperature: Not available

Air temperature: Not available

Sp. conductance: Not available

No water was evacuated from the well pror to sampling.

ANALYSES

$F$ Analyto

- Acotone

Benzene
Benzene

Bromodichloromethane

Bromotom

Bromornethan

Carbon disulfide

Carbon disultide
Carbon tetrachloride

Chlorobenzene

Chlorobenzene

Chloroethene Vinyl chloride)

O Chloroetten

Chloroform

Dibromochloromethane

Dibromochloromethan

1,1-Dichloroethane

1,2-Dichloroethane

1.1.-Dichloroethylene

1,2-Dichloroethylene

Dichloromethane

1,2-Dichloropropane

1,2-Dichloropropane
cis-1,3-Dichforopropene

trans-1,3-Dichloropropen

trans-1,3-Dichloropropene

Ethylbenzene

2-Hexanone

Mathyl ethyl ketone

Methyl isobutyl keton

styren

1, ,2,2-Tetrachloroethane

Tetrachloroethylene

0 Toluene

Resuft
$<10.0$
$<10.0$
$<5.00$
$<5.00$
$<5.00$
$<5.00$
$<5.00$
$<5.00$
$<5.00$
$<5.00$
$<5.00$
$<5.00$
$<5.00$
$<5.00$
$<5.00$
$<5.00$
$<5.00$
$<5.00$
$<5.00$
$<5.00$
$<5.00$
$<5.00$
$<5.00$
$<5.00$
$<5.00$
$<5.00$
$<5.00$
$<5.00$
$<5.00$
$<5.00$
$<5.00$
$<5.00$
$<10.0$
$<10.0$
$<5.00$
$<5.00$
$<5.00$
$<5.00$
$<5.00$
$<5.00$
$<5.00$
$<5.00$
$<10.0$
$<10.0$
$<10.0$
$<10.0$
$<10.0$
$<10.0$
$<5.00$
$<5.00$
$<5.00$
$<5.00$
$<5.00$
$<5.00$
$<5.00$
$<5.00$

Total alkalinity (as CaCO3): Not available

\begin{tabular}{|c|c|c|c|}
\hline SOL & Unit & Lab & Mathod \\
\hline $\begin{array}{l}10.0 \\
10.0 \\
5.00 \\
5.00 \\
5.00 \\
5.00 \\
5.00 \\
5.00 \\
5.00 \\
5.00 \\
5.00 \\
5.00 \\
5.00 \\
5.00 \\
5.00 \\
5.00 \\
5.00 \\
5.00 \\
5.00 \\
5.00 \\
5.00 \\
5.00 \\
5.00 \\
5.00 \\
5.00 \\
5.00 \\
5.00 \\
5.00 \\
5.00 \\
5.00 \\
5.00 \\
10.0 \\
5.00 \\
5.00 \\
5.00 \\
5.00 \\
5.00 \\
5.00 \\
5.00 \\
5.00 \\
10.0 \\
10.0 \\
10.0 \\
10.0 \\
10.0 \\
10.0 \\
5.00 \\
5.00 \\
5.00 \\
5.00 \\
5.00 \\
5.00\end{array}$ & 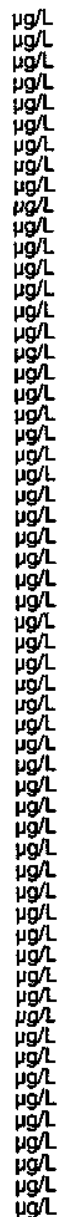 & $\begin{array}{l}\text { EX } \\
\text { EX } \\
\text { EX } \\
\text { EX } \\
\text { EX } \\
\text { EX } \\
\text { EX } \\
\text { EX } \\
\text { EX } \\
\text { EX } \\
\text { EX } \\
\text { EX } \\
\text { EX } \\
\text { EX } \\
\text { EX } \\
\text { EX } \\
\text { EX } \\
\text { EX } \\
\text { EX } \\
\text { EX } \\
\text { EX } \\
\text { EX } \\
\text { EX } \\
\text { EX } \\
\text { EX } \\
\text { EX } \\
\text { EX } \\
\text { EX } \\
\text { EX } \\
\text { EX } \\
\text { EX } \\
\text { EX } \\
\text { EX } \\
\text { EX } \\
\text { EX } \\
\text { EX } \\
\text { EX } \\
\text { EX } \\
\text { EX } \\
\text { EX } \\
\text { EX } \\
\text { EX } \\
\text { EX } \\
\text { EX } \\
\text { EX } \\
\text { EX } \\
E X\end{array}$ & 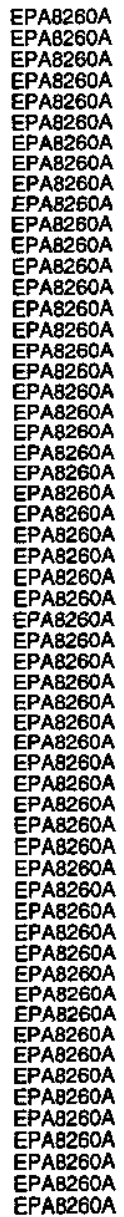 \\
\hline
\end{tabular}

Well TRP132B collected on 04/20/98 (cont.)

$F$ Analyte

Resuit

1,1,1-Trichloroethane

: 1,1,1-Trichloroethane

1,1,2-Trichlorcethane

o Trichlorosthylene

V Vinyl actate

0 xylenes

WELL TRP133B

MEASUREMENTS CONDUCTED IN THE FIELD

Sample date: 04/23/98

Water temperature: Not available

Air termperature: Not available
pH: Not availabie

Nroidity: Not available

ANALYSES

$F$ Analyte

- Acetone

Bromodictloromethan

Bromonethan

Carbon disulfide

Chlorobenzene

Choroethane Vinyl chloride)

Chlorotom

Dibromochloromethan

t.1-Dichloroethane

1,1-Dichloroethylane

1,2-Dichloroethylene

cis-1,3-Dichloropane -1,3-Dichloropropen

2-Hexanone

Methyl ethyl ketone

$1,1,2,2$-Tetrachloroethane

Toluene

1,1,1-Trichloroethane

Trichloroethylene

Viknown
Xylenes actate

\begin{tabular}{|c|c|c|c|}
\hline SOL & Unit & Lab & Method \\
\hline $\begin{array}{l}5.00 \\
5.0 \\
5.00 \\
5.00 \\
5.00 \\
5.00\end{array}$ & 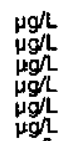 & $\begin{array}{l}\text { EX } \\
\text { EX } \\
\text { EX } \\
\text { EX } \\
\text { EX } \\
\text { EX }\end{array}$ & $\begin{array}{l}\text { EPA8260A } \\
\text { EPA8260A } \\
\text { EPA8260A } \\
\text { EPA8260A } \\
\text { EPA8260A } \\
\text { EPAB260A }\end{array}$ \\
\hline 10.0 & 政 & 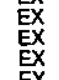 & $\begin{array}{l}\text { EPAB260A } \\
\text { EPAB260A } \\
\text { EPA3260A }\end{array}$ \\
\hline
\end{tabular}

Time: .

Total alkalinity (as CaCO3): Not available
Phenolphthalein alkalinity: Not available

\begin{tabular}{|c|c|c|c|}
\hline$S Q L$ & Unit & Lab & Method \\
\hline $\begin{array}{l}10.0 \\
5.00 \\
5.00 \\
5.00 \\
5.00 \\
5.00 \\
5.00 \\
5.00 \\
5.00 \\
5.00 \\
5.00 \\
5.00 \\
5.00 \\
5.00 \\
5.00 \\
100 \\
5.00 \\
5.00 \\
5.00 \\
5.00 \\
10.0 \\
100 \\
100 \\
5.00 \\
5.00 \\
5.00 \\
5.00 \\
5.00 \\
5.00 \\
5.00\end{array}$ & 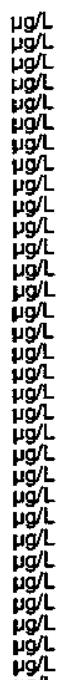 & $\begin{array}{l}\text { EX } \\
\text { EX } \\
\text { EX } \\
\text { EX } \\
\text { EX } \\
\text { EX } \\
\text { EX } \\
\text { EX } \\
\text { EX } \\
\text { EX } \\
\text { EX } \\
\text { EX } \\
\text { EX } \\
\text { EX } \\
\text { EX } \\
\text { EX } \\
\text { EX } \\
\text { EX } \\
\text { EX } \\
\text { EX } \\
\text { EX } \\
\text { EX } \\
\text { EX } \\
\text { EX } \\
\text { EX } \\
\text { EX } \\
\text { EX } \\
\text { EX } \\
\text { EX } \\
\text { EX } \\
E X\end{array}$ & 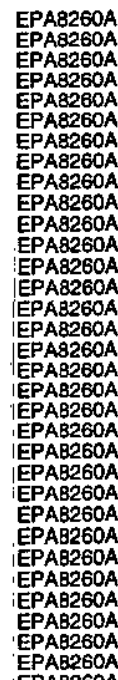 \\
\hline 10.0 & & $\begin{array}{l}\text { EX } \\
\text { EX } \\
\text { EX }\end{array}$ & EPAB260A \\
\hline
\end{tabular}




\section{WELL TRP134B}

MEASUREMENTS CONDUCTED IN THE FIELD

Sample date: $05 / 08 / 98$
Water temperature: Not avaitable

Air temperature: Not availablo

Sp. conductance: Not available

ANALYSES

$F$ Analyte

O Acetone

Bromodichlorcmethane

Bromotorm

Carton disulfide

Carbon totrachlo
Chlorobenzene

Chloroethene (Vinyi chloride)

Chloromethane

Dibromochioromethan

1,1-Dichloroethane

1.1.-Dichloroethylene

Dichloromethane

cis-1,3-Dichloropropen

trans-1,3-Dichloropropen

E-texanene

Methyl ethyl ketone

1,2,2-Tetrachorother

Tetrachloroethylene

0 Toluene

1,1,2-Trichloroethan

Urichloroethyle

O Unknown

Vinyl acetato
Xylenes

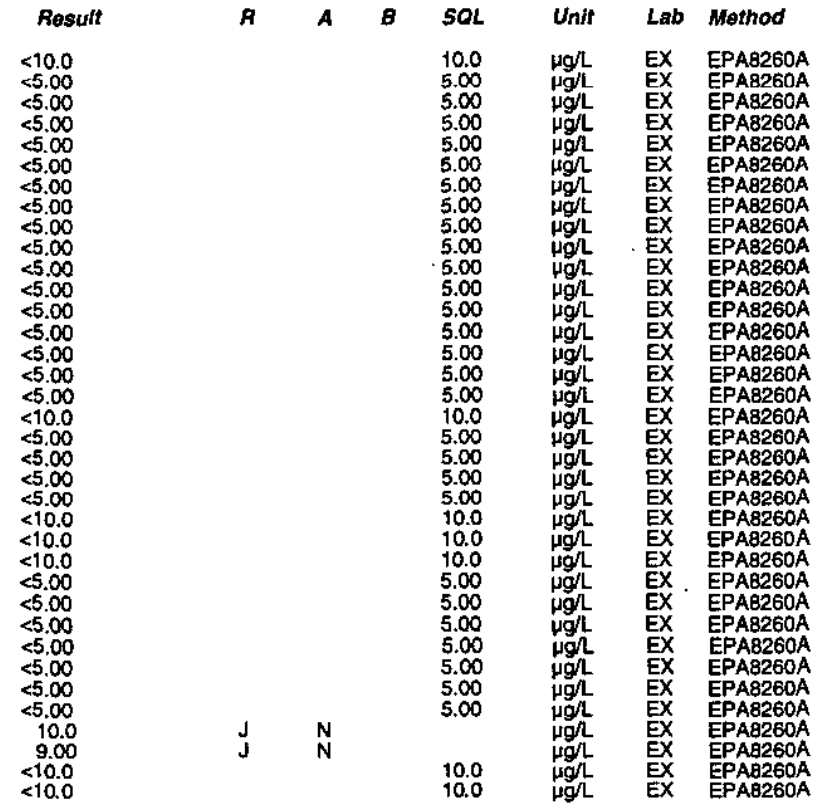

\section{WELLL TRP135B}

MEASUREMENTS CONDUCTED IN THE FIELD

Sample date: 05/11/98

Air

$\mathrm{SP}$ : Nol available

No water was evacuated from the well prior to sampling. ANALYSES

$F$ Analyte

o Acetone

O Bromenedichloromethane

Bromomethan

Carbon disulfide.

Chiorobenzene

Chloroethene (Vinyl chloride)

Chlorotorm

Dibromochloromethane

1,2-Dichloroethane

1,1-Dichloroethylene

Dichloromethane

cis-1,3-Dichloropropene

Ethytbenzene

Mettyl ethyl ketone

$1,1,2,2$-Tetrachloroethane

Tetrachloroethylene

Toluene

o 1,1,1-Trichloroethane

Trichloroethylene

Unknown 1

o Vinyl acetate

\section{WELL TRP136B}

MEASUREMENTS CONDUCTED IN THE FIELD

Sample date: 05/14/98

\begin{tabular}{|c|}
\hline $\begin{array}{l}10.0 \\
5.00 \\
5.00 \\
5.00 \\
5.00 \\
5.00 \\
5.00 \\
5.00 \\
5.00 \\
5.00 \\
5.00 \\
5.00 \\
5.00 \\
5.00 \\
5.00 \\
5.00 \\
10.0 \\
5.00 \\
5.00 \\
5.00 \\
10.0 \\
10.0 \\
10.0 \\
5.00 \\
5.00 \\
5.00 \\
5.00 \\
5.00 \\
5.00 \\
5.00 \\
9.00 \\
6.00 \\
10.0\end{array}$ \\
\hline
\end{tabular}

A $B$

H: Not availabil

p. conductance: Not available

No water was evacuated from the well prior to sampling.

ANALYSES

$F$ Anstyto

Rosult
$<10.0$
5.00
55.00
55.00
$<5.00$

- Acetone

Bromomethan

5.00
$<5.00$

sol

Unit Lab Method

Time:

Total alkalinity (as CaCO3) Not available
Phenolphthalein alkalinity: Not available

Total alkalinity (as CaCO3): Not available
Phenolphthalein alkalinity: Not available

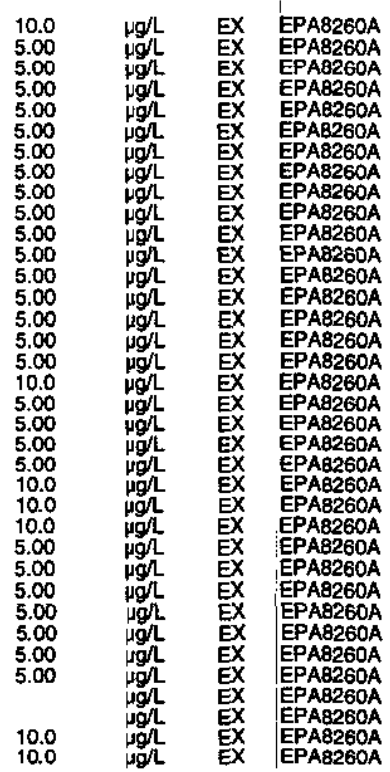

$\begin{array}{lll:l}\text { saL } & \text { Unit } & \text { Lab } & \text { Method } \\ 10.0 & \mu g h & \text { EX } & \text { EPA8260A } \\ 5.00 & \mu g h & \text { EX } & \text { EPA826AA } \\ 5.00 & \mu g h & E X & \text { EPAB260A } \\ 5.00 & \mu g L & E X & \text { EPA8260A } \\ 5.00 & \mu g L & E X & \text { EPAB260A }\end{array}$


Well TRP136B collected on 05/14/98 (cont.)

$\boldsymbol{F}$ Analyte

- Carbon disulfide Carbon tetrachlorid

Chloroethan

Chioroform

Dibromochloromethane

1.1-Dichloroethane

1,1-Dichloroesthylen

1,2-Dichloroethylen

1,2-Dichloropropane

cis-1,3-Dichloropropene
trans-1,3-Dichloropropen

2-Hexanone

Methyl ethyl ketone
Methyl isobutyl ketone

Styrene $1,1,2$-Tetrachloroethan

Tetrachloroethylene

1,1,1-Trichloroethane

Trichloroethylens

Unknown 12

Vinyi acetale
0 Xylenes

\section{WELL TRP137B}

MEASUREMENTS CONDUCTED IN THE FIELD

Sample date: 05/21/98

Water temperature: Not available

Air temperature: Not available

p. conductance: Not available

No water was evacuated from the well prior to sampling. ANALYSES

$F$ Analyte

0 Acetone

Bromodichloromethane

Bromornathan

Carbon disulfide

Carbon tetrachloride

Chlorosthane

Chloroethene (Vinyl chloride)

Chlorotorm

Dibromochloromethane

1,i-Dichloroethane

1,1-Dichloroethylene

Dichloromethane

1,2-Dichloropropane

trans-1,3-Dichloropropen

Ethylbenzene
2 -Hexanone

Mexanone
Methyl ethyl ketone
isobutyl ketone

Styrene

Tetrachloroethylene

1,1,1-Trichloroethane

ESH-EMS-980569

\begin{tabular}{|c|c|c|c|c|c|c|c|}
\hline Result & $\boldsymbol{A}$ & $A$ & $B$ & $S Q L$ & Unit & Lab & Method \\
\hline $\begin{array}{r}<5.00 \\
<5.00 \\
<5.00 \\
<5.00 \\
5.00 \\
55.00 \\
5.00 \\
55.00 \\
<5.00 \\
<5.00 \\
5.00 \\
<5.00 \\
<10.0 \\
<5.00 \\
55.00 \\
<5.00 \\
<5.00 \\
<10.0 \\
<10.0 \\
<10.0 \\
55.00 \\
<5.00 \\
<5.00 \\
<5.00 \\
<5.00 \\
5.00 \\
5.00 \\
11.0 \\
15.0 \\
<10.0 \\
<10.0\end{array}$ & $\underset{\mathbf{J}}{\mathbf{J}}$ & $\stackrel{N}{N}$ & & $\begin{array}{l}5.00 \\
5.00 \\
5.00 \\
5.00 \\
5.00 \\
5.00 \\
5.00 \\
5.00 \\
5.00 \\
5.00 \\
5.00 \\
10.0 \\
5.00 \\
5.00 \\
5.00 \\
5.00 \\
10.0 \\
10.0 \\
10.0 \\
5.00 \\
5.00 \\
5.00 \\
5.00 \\
5.00 \\
5.00\end{array}$ & 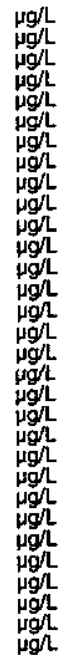 & $\begin{array}{l}\text { EX } \\
\text { EX } \\
\text { EX } \\
\text { EX } \\
\text { EX } \\
\text { EX } \\
\text { EX } \\
\text { EX } \\
\text { EX } \\
\text { EX } \\
\text { EX } \\
\text { EX } \\
\text { EX } \\
\text { EX } \\
\text { EX } \\
\text { EX } \\
\text { EX } \\
\text { EX } \\
\text { EX } \\
\text { EX } \\
\text { EX } \\
\text { EX } \\
\text { EX } \\
\text { EX } \\
\text { EX } \\
\text { EX } \\
\text { EX }\end{array}$ & 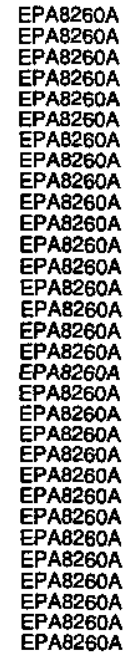 \\
\hline
\end{tabular}

Time: . Total alkalinity (as $\mathrm{CaCO}$ ): Not available
Phenolphthalein alkalinity: Not available

sQL
10.0
5.00
5.00
5.00
5.00
5.00
5.00
5.00
5.00
5.00
5.00
5.00
5.00
5.00
5.00
5.00
5.00
10.0
5.00
5.00
5.00
5.00
10.0
10.0
10.0
5.00
5.00
5.00
5.00
5.00

Well TRP $137 B$ collected on 05/21/98 (cont.)

$F$ Antlyte

$\begin{array}{ll}0 & 1,1,2-T r i c h l o r o e t h a n \theta \\ 0 & \text { Trichloroethylene }\end{array}$

: Uniknown

: Xylenes

$<5.00$
$<5.00$
5.00
$<10.0$
$<10.0$

R

B SOL

SOL Unit

Lab Method

WELL TRP138B

MEASUREMENTS CONDUCTED IN THE FIELD

Sample date: 05/28/98

Water temperature: Not available

Air temperature: Not available
pH: Nol available
Sp. conductance: Not available

Sp. conductance: Not available

No water was evacuated from the well prior to sampling.

ANALYSES

$F$ Analyte

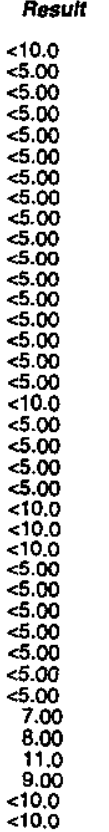

R

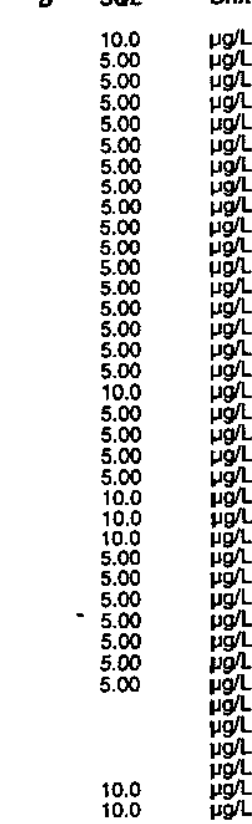

- Acetone

Bromotichlor

Bromomethane

- Carbon disultidide

Chloroethane

Chloroethente

Dibromochloromethan

1,2 -Dichloroethane

1,2-Dichloroeshylen

Dichloromethane

cis- 1,3 -Dichloropropene
0 trans-1,3-Dichioropropene

Ethylbenzen

Methyl ethyl ketone

1, 1,2,2-Tetrachloroethan

Tetractloroethylen

1,1,1-Trichloroethane

Trichioroethylen

Unknown

Vinyl acetate

\section{WELL TRP139B}

MEASUREMENTS CONDUCTED IN THE FIELD

Sample date: 06/03/98

Water temperature: Not available

pH: Not availabie

p. Conductance: Not available

No water was evacuated from the well prior to sampling.

Time: .

Total alkalinity (as CacO3): Not available Penolphthalein alkalinity: Not available

Second Quarter 1998
Unit Lab Method

Total alkalinity (as CaCO3): Not available

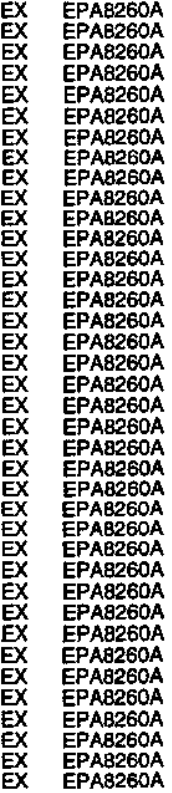


Well TRP139B collected on 06/03/98 (cont.)

ANALYSES

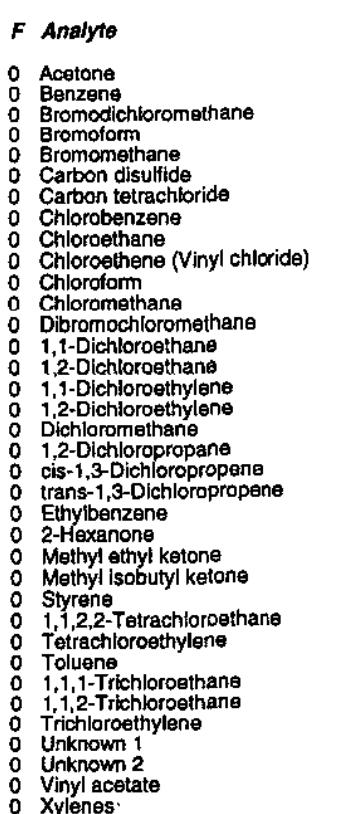

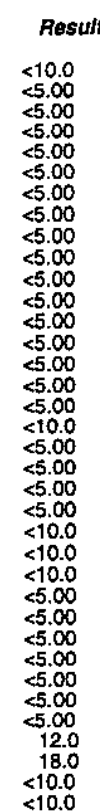

\section{WELL TRP140B}

MEASUREMENTS CONDUCTED IN THE FIELD

Sample date: 06/04/98

Water temperature: Not availabt

gH: Not availabie

No water was evacuated from the well prior to sampling. ANALYSES

F Arsilyte

0 Acetone

Bromodichloromethane

Bromotomethan

Carbon disultide

Carbon tetrachlo

Chloroethane

Chloroethene (Vinyl chloride)

Chlorotorm

Dibromochloromethane

1,1-Dichloroethane

1,2-Dichloroethane

1,2-Dichloroethylen

1,2-Dichloropongene

trans-1,3-Dichloropropene

o 2-Hexanone

ESH-ENS-980569

Result
$<10.0$
$<5.00$
$<5.00$
$<5.00$
$<5.00$
55.00
$<5.00$
55.00
$<5.00$
55.00
$<5.00$
$<5.00$
$<5.00$
55.00
55.00
55.00
$<500$
$<10.0$
$<5.00$
5500
$<5.00$
$<5.00$
$<10.0$

Time: .

Total alkalinity (as CaCO3): Not available
Phenolphthalein alkalinity: Not available
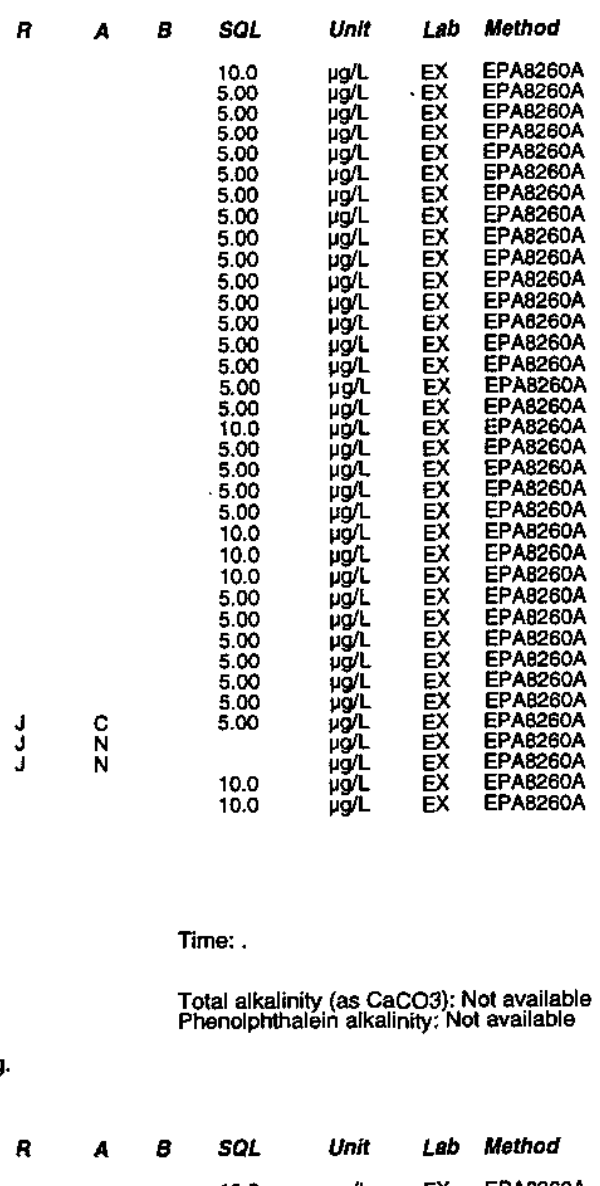

$s Q L$
10.0
5.00
5.00
5.00
5.00
5.00
5.00
5.00
5.00
5.00
5.00
5.00
5.00
5.00
5.00
5.00
5.00
10.0
5.00
5.00
5.00
500
10.0

Well TRP 140B collected on 06/04/98 (cont.)

$F$ Analyte

O Methyl ethyl ketone

O Styrene

- Tolvene

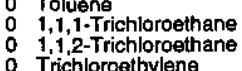

O Trichloroethylen

0 Vylenes

\section{WELL TRP141B}

MEASUREMENTS CONDUCTED IN THE FIELD

Sample date: 06/09/98

Wirter temperature: Not available

Air temperature: Not availabie

Sp. conductance: Not available

No water was evacuated from the well prior to sampling

ANALYSES

$F$ Analyte

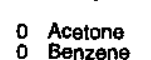

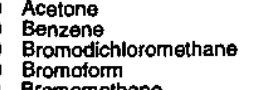

Cromomethane

Carbon tetrachlorid

: Chlorobenzene

Chloroethene (Vinyl chloride)

Chloroform

0 Dibromochloromethane

o 1,2 -Dichloroethane

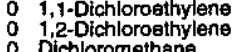

1,2-Dichloropropane

: cis-1,3-Dichloropropene

: Ethylbenzene

Methyl ethyl ketone

Styrene

: $1,1,2,2-$ Tetrachloroeth

1.1,1-Trichlorosthane

: 1,1,2-Trichloroethane

: Unknown

O Xylenes

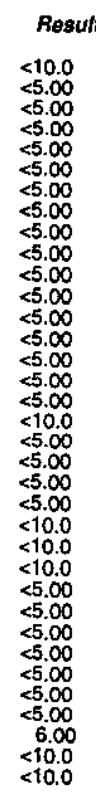

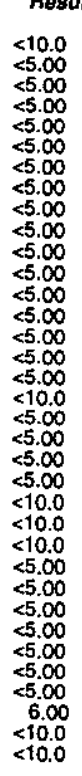
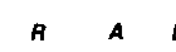

$5 Q L$
10.0
5.00
5.00
5.00
5.00
5.00
5.00
5.00
5.00
5.00
5.00
5.00
5.00
5.00
5.00
5.00
10.0
5.00
5.00
5.00
5.00
10.0
10.0
10.0
5.00
5.00
5.00
5.00
5.00
5.00
10.0
10.0

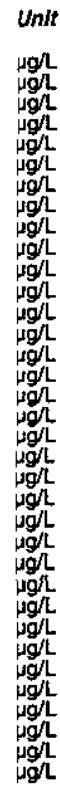

Lab Mothod

EX IEPA8260A

EX EPAB260A

Ex

EX

EX

EX

Ex

EX

\begin{tabular}{c}
$E_{X}$ \\
EPAB260A \\
\hline
\end{tabular}

EX EPAB260A

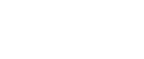

EPAB260A 


\section{WELL TRP142B}

MEASUREMENTS CONDUCTED IN THE FIELD

Sample date: 06/11/98

Water temperature: Not available

$\mathrm{pH}$ : Not available

No water was evacuateded from the well prior to sampling.

ANALYSES

$F$ Analyte

0 Acetone

Bromodichloromethane

Bromomethan

Carbon disuffide

Chlorobenzen

Chloroethene (Vinyl chloride)

Chloroform

Dibromochloromethane

1,1-Dichloroethane

1,-Dichloroethane

Dichloromethane

1,2-Dichloropropane
cis-1,3-Dichloropropene

Ethylbenzene

2-Hexanone

Styrene

1,1,2,2-Tettachloroethan

0 Toluene

$1,1,1-$ Trichloroethane
$1,1,2-$ Trichloroethane

Trichloroethylens

Unknown
0 Vinyl acetate
Xytenes

\section{WELL TRP143B}

MEASUREMENTS CONDUCTED IN THE FIELD

Sample date: 06/15/98

Water temperature: Not available
Air temperature: Not available
to Not available

Sp. conductance: Not available

No water was evacuated from the well prior to sampling.

ANALYSES

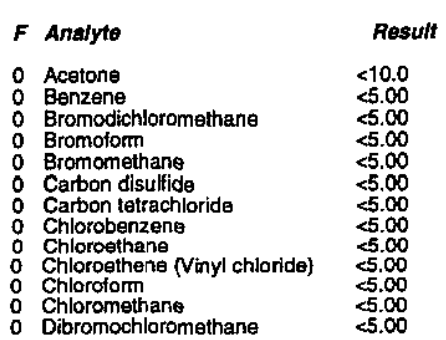

ESH-EMS-980569

Well TRP 143B collected on 06/15/98 (cont.)

$F$ Analyte

Time:

Total alkalinity (as $\mathrm{CaCO}$ ): Not available

1,1-Dichloroethane

1, 1, -Dichloroethane

Dichloromethane

1,2-Dichlozopropane
cis- $-1,3-0$-Dichloropopropene

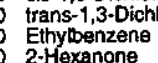

o Methyl ethyl ketone

Styrene
$1,1,2,2$-Tetrachloroethane

0 1,1,1-Trichloroethane

: Trichloroethylens

Unknown 1 1

0 Vinyl acotate

\section{WELL TRP144B}

MEASUREMENTS CONDUCTED IN THE FIELD

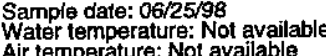

Air temperature: Not available
pH: Not available
Sp. conductance: Not available

Sp. conductance: Not available
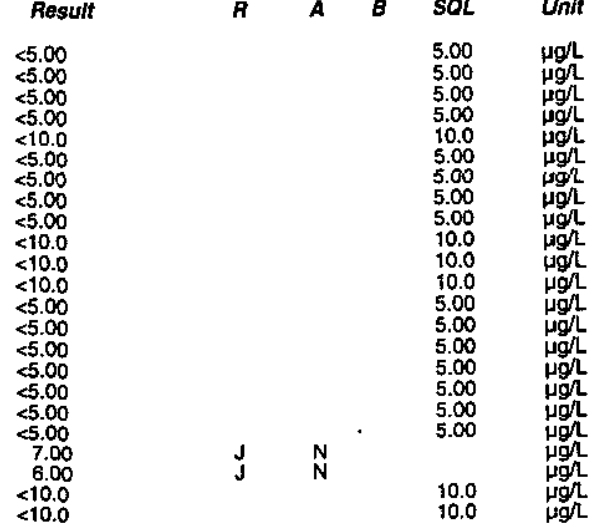

Lab Method

.

ANALYSES

$F$ Analyte

Result
$<10.0$
55.00
55.00
55.00
5.00
55.00
5.00
5.00
55.00
5.00
55.00
55.00
55.00
55.00
55.00
55.00
55.00
510.0
55.0
55.00
55.00
55.00
510.0
10.0
510.0
55.0
55.00
55.0
55.00
55.00
55.00
55.00
5.00
510.0
$<10.0$

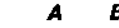

Acatone

o Bromodichloromethane

Bromomethane

: Carbon disutifide

Chlorobenzent

Chloroethene (Vinyl chloride)

Chlorotorm

Dibromochloromethan

1, 1-Dichloroethane

1,i-Dichtoroethylene

Dichloromethane

cis-1,3-Dichloropropen

trans-1,3-Dichloropropen

2-Hexanone

Methyl isobutyl ketone

Styrene

Totrachloroethylene

1,1,1-Trichloroethane

Trichioroethylene

O Unkyl acetate
Time:

Total alkalinity (as CaCO3): Not available

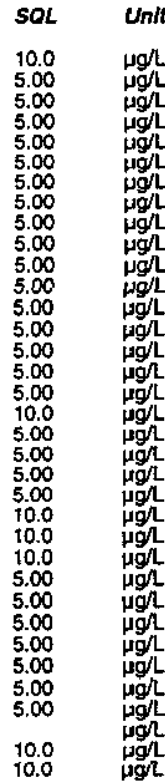

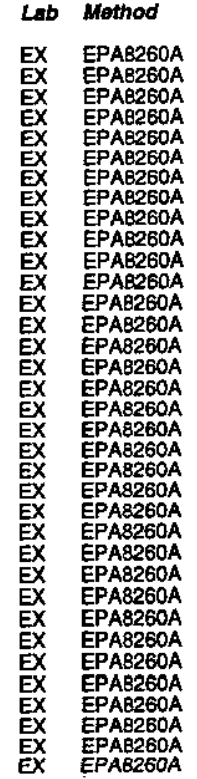


SAMPLING BLANKS RESULTS

\section{WELL TRP156B}

MEASUREMENTS CONDUCTED IN THE FIELD Sample date: 06/05/98

Water temperature: Not available

Air : Not availabie

p. conductance: Not avalable

No water was evacuated from the well prior to sampling ANALYSES

$F$ Analyte

0 Acetone

Bromodichloromethane

Bromomathan

Carbon disutfide

Carbon tetrachlorido

Chloroethane

Chlorothene (Vinyl chloride)

Chloromethan

1,1-Dichloroethylene

tis-1,2-Dichloroethylene

Dichloromethane

cis-1,3-Dichloropropene

Ethylbenzene

Methyl ethyl ketone

1, 1,2,2-Tetrachtoroethane

$1,1,1-$ Trichloroethane

Trichlorioethylene

0 Vinyl acetat
0 Xylenes.

\section{WELL TRP157B}

MEASUREMENTS CONDUCTED IN THE FIELD

Sample date: 06/08/98

Water temperature: Not available

Air temperature: Not available

Sp. conductance: Not available

Turbidity: Not available
No water was evacuated trom the well prior to sampling.

ANALYSES

$F$ Analyte

O Acetone

Bromodichloromethane

Bromoform

Carbon disulfide

: Carbon letrachlo

Chlorethane

Chlorotorm

Dibromochloromethane

ESH-EMS-980569

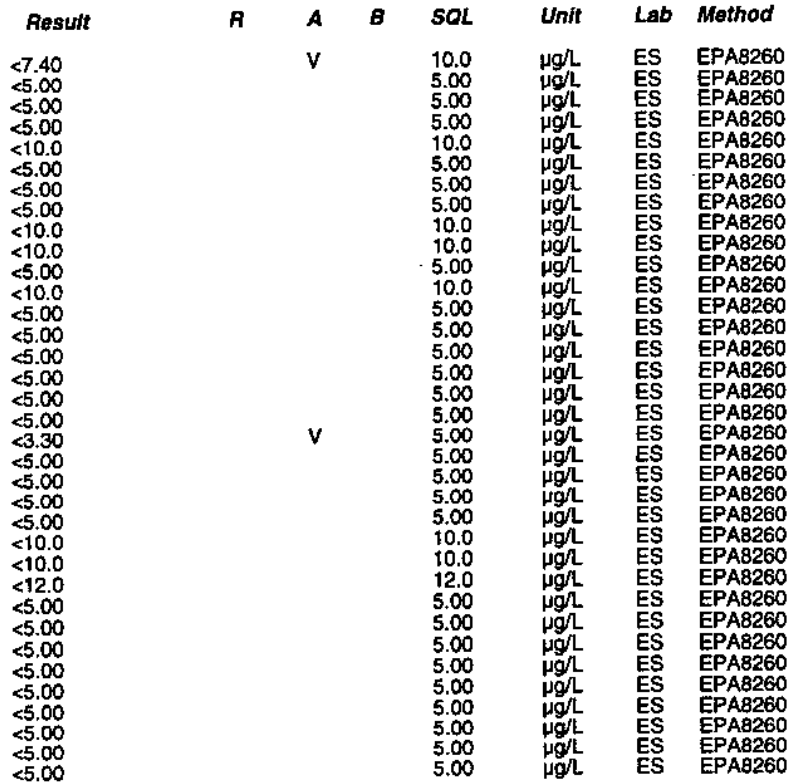

Time:

Total alkalinity (as CaCO3): Not available

Total alkalinity (as $\mathrm{CaCO}$ ): Not available Phenolphthalein alkalinity: Not available

$F$ Analyte Result

0 1,1-Dichloroethane

o 1,1-Dichloroethylyna

of

Dichloromethane

cis-1,3-Dichloropropene

0 Ethylbenzene

Methyl ethyl ketone

Styrene

1,1,2,2-Tetrachloroeth

Tetrachloroethylene

1,1,1-Trichloroethane Trichloroethylen
Vinyl acetate

0 Xylenes

$<5.00$
5.00
5.00
5.00
5.00
5.80
$<5.00$
55.00
55.00
55.00
$<1.0$
$<10$.
$<1.0$
$<5.00$
$<5.00$
$<5.00$
$<5.00$
$<5.00$
$<5.00$
$<5.00$
$<5.00$
$<5.00$

\section{WELL TRP158B}

MEASUREMENTS CONDUCTED IN THE FIELD

Sample date: 06/09/98

Water temperature: Not available

$\mathrm{H}$ : Not availabis

Sp. conductance: Not available

No water was evacuated from the well prior to sampling.

ANALYSES

$F$ Analyte

0 Acetone

O Bromodichloromethane

Bromolorm

Carton disulfide

- Chlorobenzene

Chloroethane

C. Chloroform

Dibromochloromethan

1,1-Dichboroethane

1,1-Dichloroethylene

trans-1,2-Dichloroethy
Dichloromethane

1,2-Dichloropropane

trans-1,3-Dichloropropen

2-Hyxanone

Methyl isobutyl ketone

Styrens

Tetrachloroethylene

$1,1,1-$ Trichloroethane
$1,1,2$-Trichloreothane

Trichloroethylene

0 Vinyl aceta

$R .60$
$<5.60$
55.00
55.00
$<5.00$
$<10.0$
55.00
55.00
55.00
$<10.0$
$<10.0$
5.00
510.0
5.00
55.00
55.00
55.00
5.00
55.00
$<.70$
$<5.00$
5.00
55.00
5.00
$<10.0$
$<10.0$
$<12.0$
5.00
55.00
5.00
55.00
55.00
55.00
55.00
55.00
$<5.00$

Time:

Total alkalinity (as CaCO3): Not available
Phenolphthale in alkalinity: Not available

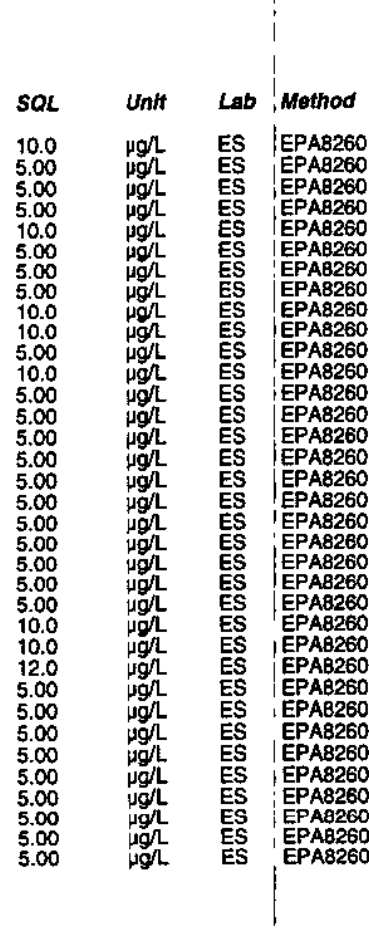

C-25

Second Quarter 1998 
SAMPLING BLANKS RESULTS

\section{WELL TRP160B}

MEASUREMENTS CONDUCTED IN THE FIELD

Sample date: 06/11/98

Air temperature: Not available

$\mathrm{gH}$ : Not available

No water was evacuated from the well prior to sampling. ANALYSES

ANALYSE

- Acetone

Bromodichloromethan

Bromotom

Carbon tetrachlorid

Chlorobenzene

Chloroethene (Vinyl chloride)

Chlorotorm

Dibromochioromethane

$1,1 \cdot$ Dichloroethane
1,2 - Dichloroethane

1,1.Dichlorosthylene

trans-1,2-Dichloroethylen

cis-1,3-Dichloropropene
trans-1,3-Dichloropropene

Ethyibenzent

Methyl ethyl ketone

1,1,2,2-Tetrachloroethan

Tetrachloroethylene

1,1,1-Trichloroethane

Trichloroethylens

: Vinyl aceta

\section{WELL TRP161B}

MEASUREMENTS CONDUCTED IN THE FIELD

Sample date: 06/15/98

Water temperature: Not available

$\mathrm{pH}$ : Not availabie

p. conductance: Not anc

No water was evacuated from the well prior to sampling.

ANALYSES

$F$ Analyte

0 Acetone

Bromodichloromethane

Bromotorm

Carbon disultide

Carbon tetrachio

Chloroethane

Chloroethene (Vinyl chloride)

Dibromochloromethan

ESH-EMS-980569

0.0
Well TRP161B collected on 06/15/98 (cont.)

$F$ Analyte

1,1-Dichloroethane

Time: .

Total alkalinity (as CaCO3): Not available

1,1-Dichloroethylene

Irans-1,2-Dichloroethylene

1,2-Dichloropropane

cis-1,3-Dichoropropene
trans- -1, 3-Dichloropropene

Ethylbenzene

Methyl isobutyl keton

1,1,2,2-Tetrachloroethane

1,1.1-Trichloroethane

Trichloroethytane

Vinyl acetat

\section{WELL TRP166B}

MEASUREMENTS CONDUCTED IN THE FIELD

Sample date: 04/21/98

Water temperature: Not available

Air temperature: Not available

Sp. conductance: Not available

No water was evacuated from the well prior to sampling. ANALYSES

$F$ Analyte Result

$\begin{array}{lll}0 & \text { Acetone } \\ 0 & \text { Benzenene } \\ 0 & \text { Bromodichloromethane } \\ \text { Bromotom } & \end{array}$

Bromoiom

Carbon disulfide

Carbon tetrachibido

Chloroethane

Chloroethene

Ditoromethane

1,1-Dichloroethane

1,2-Dichloroethane

cis-1,2-Dichloroethylene
irans-1,2-Dichloroethylen

Dichloromethane

ciss-1,3-Dichloropropene
irens-1,3-Dichloropropen

Ethybenzene

Methyl athyl ketone

$1,1,2,2$-Tetrachlorosthan

Tatrachloroethylene

Toluene

1,i,2-Trichloroethane

Trichloroethylene
Vinyl acetate

Xylenes

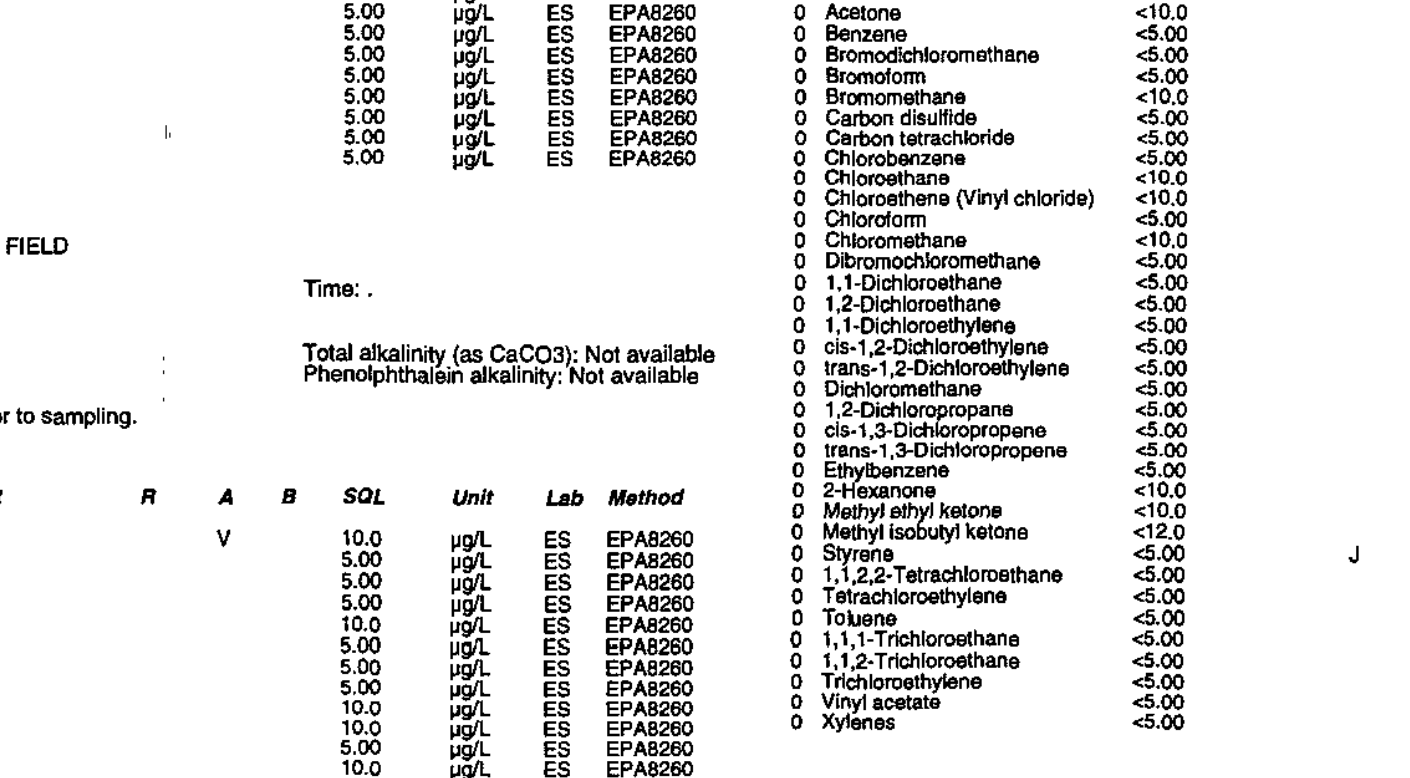

R
Time: .

Total alkalinity (as CaCO3): Not available

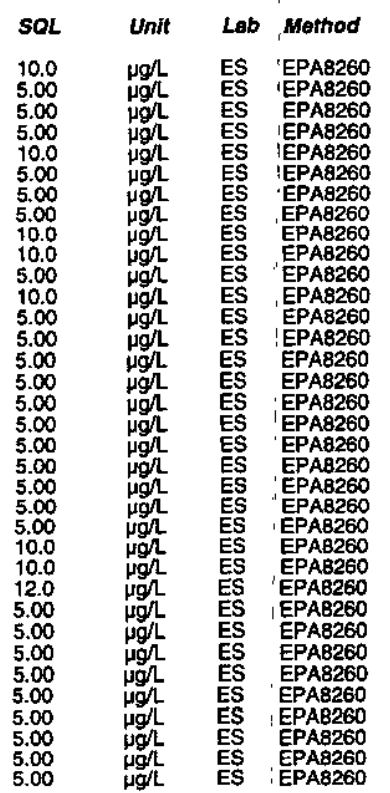

Second Quarter 1998 


\section{WELL TRP170B}

MEASUREMENTS CONDUCTED IN THE FIELD

Sample date: 05/14/98

Water temperature: Not available

Air temperature: Not available

p. conductance: Not available

Turbidty: Not available ANALYSES

F Analyte

O Acetone

Bromodichloromethane

Bromoform

Carbon disulfide

Carbon tetrachiloride

Chlorobenzente

Chloroethene (Vinyl chloride)

Chlorotion

Dibromochloromethane

1,2-Dichloroethane

1,1-Dichloroethylenie

trans-1,2-Dichloroethylene

1,2-Dichloropropan

cis-1,3-Dichloropropene
trans-1,3-Dichloropropene

Elhylbenzene

Methyl ethyl ketone
Methyl isobutyl ketone

Styrene

Tetrachlorcethylene

Toluene

1,1,2-Trichloroethane

V Vinyl acetate

WELL TRP172B

MEASUREMENTS CONDUCTED IN THE FIELD

Sample date: 05/18/98

Water temperature: Not available

Air temperature: Not

Not available

No water was evacuated from the well prior to sampling

ANALYSES

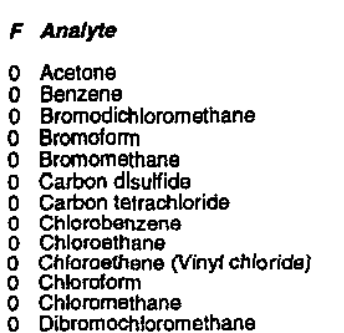

Result
$<10.0$
5.00
55.00
5.00
510.0
5.00
55.00
5.00
510.0
$<10.0$
5.00
510.0
$<5.00$

ESH-EMS-980569

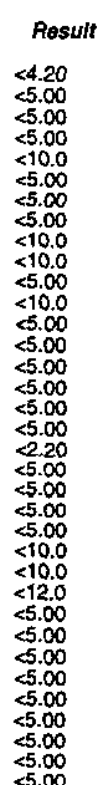

Well TRP172B collected on 05/18/98 (cont.)

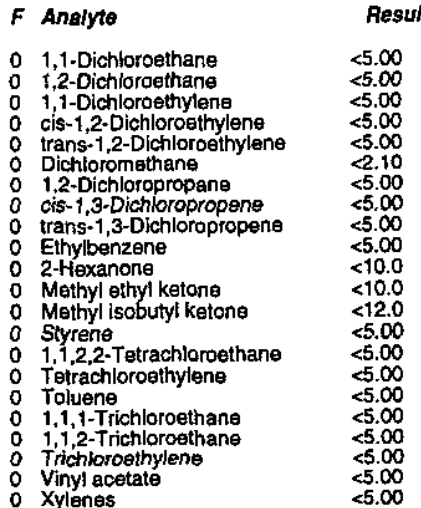

Time:

Total alkalinity (as CaCO3): Not available

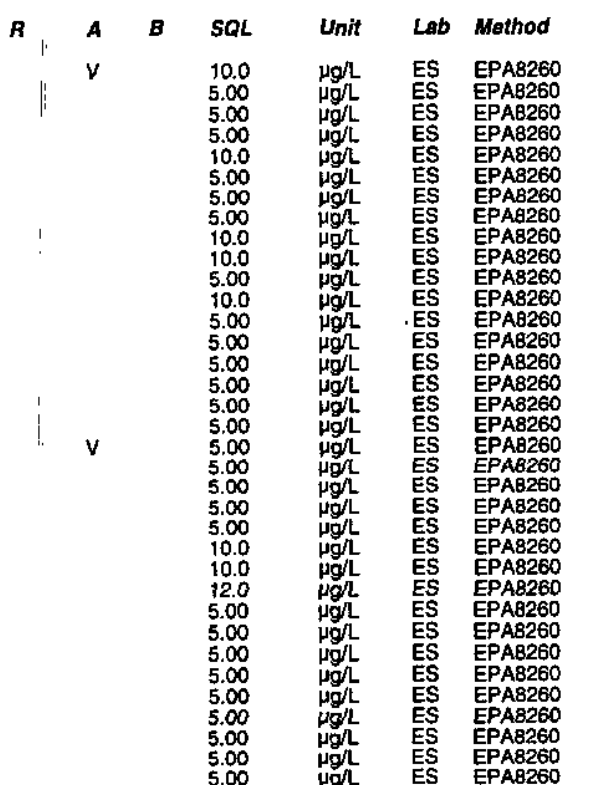

\section{WELL TRP173B}

MEASUREMENTS CONDUCTED IN THE FIELD

Sample date: 05/19/98

Water temperature: Not available

Air temperature: Not available

Sp. Conductance: Not available

Turbicity: Not available
No water was evacuated from the well prior to sampling

ANALYSES

$F$ Analyte

o Acetone

Bromodichloromethane

o Bromomethan

Carbon distrfide

Chibon tetrachlo

CCloroethene (Vinyl chloride)

Chloroform

Dibromochloromethane

1.1-Dichloroethane

1,1-Dichloroethylen

cis-1,2-Dichlorosthylene

trans-1,2-Dichloroethy

cis-1,3-Dichlioropropene

Irans-1,3-Dich

Methyl ethyl ketone

Methyl isobutyl ketone

$1,1,2,2-$ Tetrachloroethan

- Tetrachloroethylene

1,1,1-Trichloroethan

1,1,2.Trichioroethan
Trichloroethylens

0 Vinyl aceta
0 Xylenes

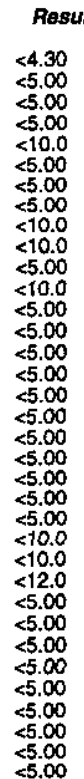

Time: .

Total alkalinity (as CaCO3): Not available
Phenolphthalein alkalinity: Not available

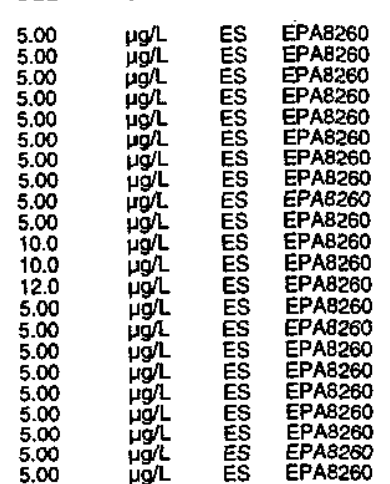

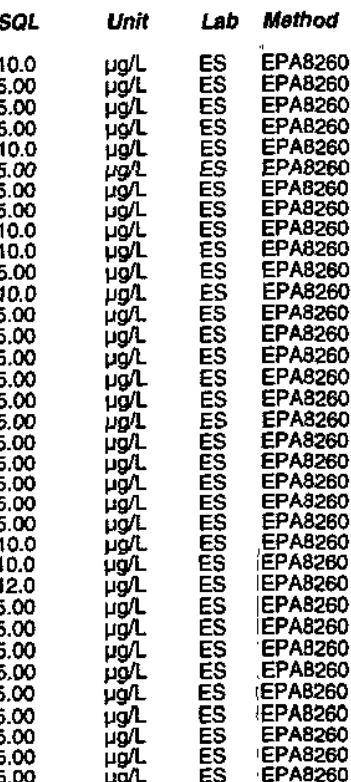




\section{WELL TRP176B}

MEASUREMENTS CONDUCTED IN THE FIELD

Sample date: 04/21/98

Water temperature: Not available

$\mathrm{pH}$ : Nol available

Turbidity: Not available

ANALYSES

$F$ Analyte

0 Acetone

Bromodichloromethane

o Bromotom

Carbon disulfide

Chrorobenzene

Chloroethane
0 Chloroethene (Vinyl chloride)

Chlorotorm

D Dibromochloromethane

1,1-Dichloroethane

$\begin{array}{ll}1,2-\text {-Dichloroethane } \\ 0 & 1,1 \text {.Dichloroethylene }\end{array}$

1,2-Dichloroethylene

1,2-Dichloropropane

trans-1,3-Dichloropropen

Ethytbenzene

Methyl tonthyl ketone
Methyl isobutyl keton

Syrrene

Tetrachloroethylene

1,1,1-Trichloroethan

Trichloroethylethe

Vinnl acetate

\section{WELL TRP177B}

MEASUREMENTS CONDUCTED IN THE FIELD

Sample date: 05/18/98

Water temperature: Not available

Air temperature: Not available
gH: Not available
Sp. conductance: Not available

No water was evacuated from the well prior to sampling. ANALYSES

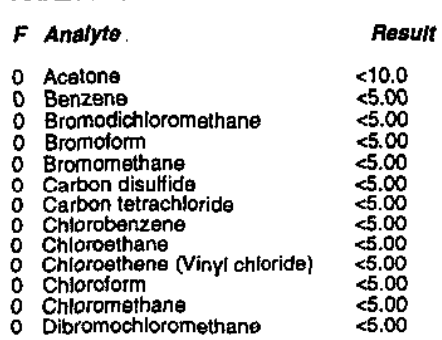

ESH-EMS-980569

Resutt
$<10.0$
55.00
55.00
55.00
5.00
55.00
55.00
55.00
55.00
55.00
55.00
5.00
55.00
55.00
55.00
55.00
55.00
510.0
55.00
55.00
55.00
55.00
10.0
510.0
10.0
55.00
55.00
55.00
55.00
55.00
55.00
55.00
16.0
10.0
510.

Result
10.0
5.00
5.00
5.00
5.00
5.00
5.00
5.00
5.00
5.00
5.00
5.00

Well TRP1778 collected on 05/18/98 (cont.)

$F$ Analyte

Time: .

Total alkalinity (as CaCO3): Not available
Phenolphthalein alkalinity: Not available
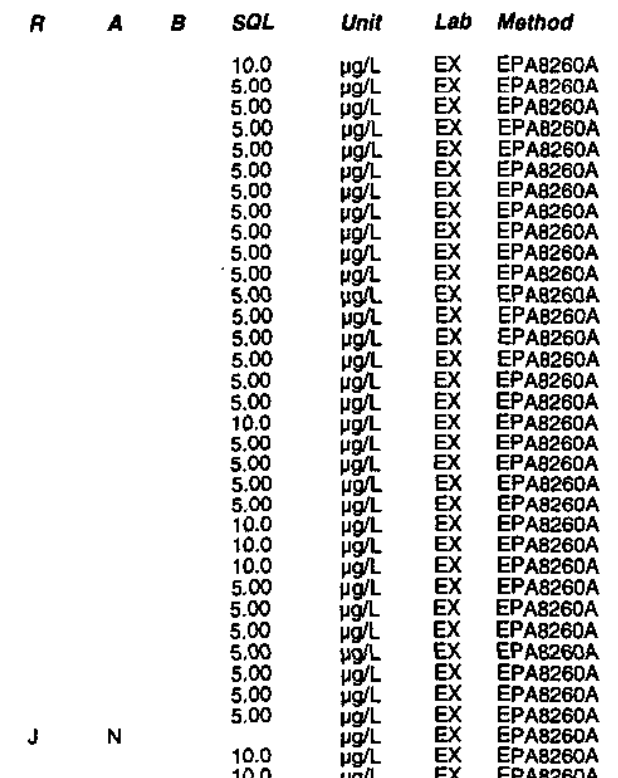

Time:

Total alkalinity (as $\mathrm{CaCO}$ ): Not available

Phenolphthalein alkalinity: Not available

$\begin{array}{cc}A \quad B \quad & 50 L \\ & 10.0 \\ & 5.00 \\ 5 & 5.00 \\ & 5.00 \\ & 5.00 \\ 5.00 \\ 5.00 \\ 5.00 \\ 5.00 \\ 5.00 \\ 5.00 \\ \\ 5.00\end{array}$

Tetrachloroethylene

Resuh
$<10.0$
$<5.00$
$<5.00$
55.00
$<10.0$
$<5.00$
$<5.00$
$<5.00$
$<10.0$
$<10.0$
55.00
$<10.0$
55.00
$<5.00$
55.00
$<5.00$
55.00
$<5.00$
$<5.00$
$<5.00$
$<5.00$
$<5.00$
$<5.00$
$<10.0$
$<10.0$
$<12.0$
$<5.00$
$<5.00$
$<5.00$
$<5.00$
$<5.00$
55.00
$<5.00$
$<5.00$
$<5.00$ $\begin{array}{ll}0 & 1,1-D i c h l o r o e t h a n e \\ 0 & 1,2-D i c h l o r o e t h a n e\end{array}$

1,1-Dichloroethylene

o Dichioromethane

o cis-1,3-Dichloropropene

Ethylbenzene

. Methyl ethyl ketone

Styrene

1,1, -Trichloroethane

Trichloroethylene

Unknown 2

$:$ Xylenes

\section{WELL TRP186B}

MEASUREMENTS CONDUCTED IN THE FIELD

Sample date: 05/27/98

Airter temperature: Not available

Arr temperature: Not available
$\mathrm{pH}$ : Not availabie
$\mathrm{Sp}$ conductance: Not available

No water was evacuated from the well prior to sampling.

ANALYSES

$F$ Analyte

: Acetane

Bromodichtoromethane

Bromoform

Carbon disulfide

Chlorobenzene

Chloroathene (Vinyl chloride)

Chloroform

Dibromochloromethane

1,1-Dichloroethane

$\begin{array}{ll}0 & 1,1-D i c h l o r o e t h y l e n e \\ \text { cis-1,2-Dichloroethylene }\end{array}$

: trans-1,2-Dichloroethy

1,2-Dichloropropane
cis-1,3-Dichloropropen

trans-1,3-Dichloropropen

Ethylbenzene

Methyl ethyl ketone

Styrene

$1,1,2,2$-Tetrachloroethan

0 Tetrachloroethylene

o $1,1,1-$ Trichloroethane

: Trichloroethylen

0 Vinyl acetate

$B$

Total alkalinity (as CaCO3) Not available
Phenolphthalein alkalinity: Not available

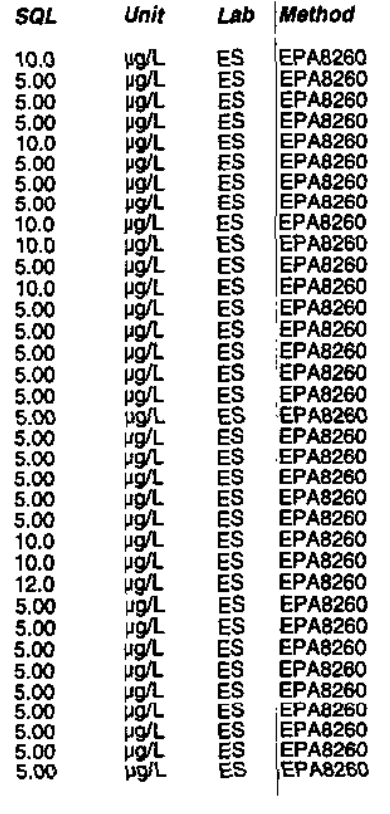

Second Quarter 1998 


\section{WELL TRP187B}

MEASUREMENTS CONDUCTED IN THE FIELD

Sample date: 05/28/98

Water temperature: Not available

Air temperature: Not available
H: Not available

conductance: Not available

No water was evacuated from the well prior to sampling. ANALYSES

\begin{tabular}{|c|c|}
\hline Analyte & Rosut \\
\hline 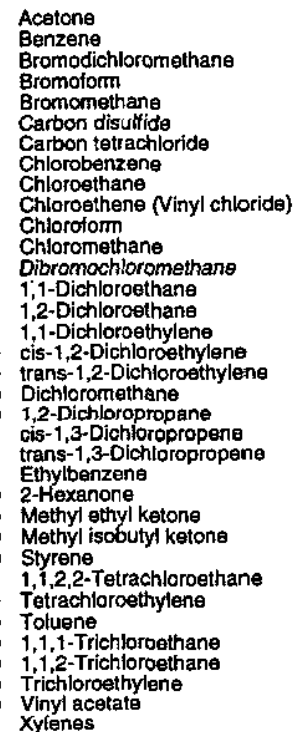 & $\begin{array}{l}<10.0 \\
<5.00 \\
<5.00 \\
<5.00 \\
<10.0 \\
<5.00 \\
<5.00 \\
<5.00 \\
<10.0 \\
<10.0 \\
<5.00 \\
<10.0 \\
<5.00 \\
<5.00 \\
<5.00 \\
<5.00 \\
<5.00 \\
<5.00 \\
<5.00 \\
<5.00 \\
<5.00 \\
<5.00 \\
<10.0 \\
<1.0 \\
<12.0 \\
<5.00 \\
<5.00 \\
<5.00 \\
<5.00 \\
<5.00 \\
<5.00 \\
<5.00 \\
<5.00 \\
<5.00\end{array}$ \\
\hline
\end{tabular}

\section{WELL TRP188B}

MEASUREMENTS CONDUCTED IN THE FIELO

Sample date: $05 / 29 / 98$

Water temperature: Not availabie

Air temperature: Not available

Sp. Nonductance: Not available

No water was evacuated from the well prior to sampling

ANALYSES

F Anaiyte

: Acetone

Bromodichloromethane

Bromoform

Carbon disulfide

Carbon tetrachloride

Chloroethane
Chloroethene (Vinyl chtoride)

Chlorotorm

Dibromocthoromethane

ESH-EMS-980569

Well TRP $188 B$ collected on 05/29/98 (cont.)

$F$ Analyte

Time:

Total alkalinity (as CaCO3): Not available

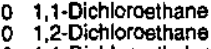

cis-1,2-Dichloroethylene
trans-1,2-Dichioroethylen

Dichloromethane

cis-1,3-Dichloropropene

0 trans-1,3-Dichlor

2-Hexanone

Methyl isobutyl ketone

$1,1,2,2$-Tetrachloroethane

Toluene

1,1,1-Trichloroethane

Trichloroethylene
Vinyl acetate

WELL TRP189B

MEASUREMENTS CONDUCTED IN THE FIELD

Sample date: 06/03/98

$<5.00$
5.00
5.00
55.00
5.00
5.00
5500
55.00
55.00
55.00
$<100$
$<10.0$
$<1.0$
$<5.00$
$<5.00$
$<500$
$<5.00$
$<5.00$
$<5.00$
55.00
$<5.00$
5500

B SQ

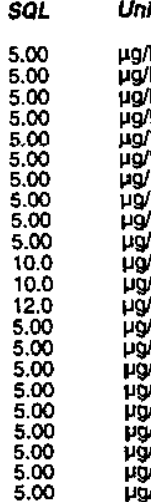

Unit Lab Method

Water temperature: Not available
Not available

Air temperature: Not availabio

Sp.conductance: Not available

No water was evacuated trom the well prior to sampling. ANALYSES

F Anatyto

$\begin{array}{ll}\text { D } & \text { Acetone } \\ 0 & \text { Benzene } \\ 0 & \text { Bromodichloromethane }\end{array}$

Bromomethan

Carbon disulfide

Charon terrach

Chloroethane Vinyt chloride)

Chloroethene
Chloroform

Dibromochtoromethan

1.1-Dichloroethan

1,1-Dichloroethylene

o cis-1,2-Dichloroethylene

Dichloromethane

colis-1,3-Dichloropropene

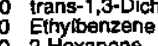

Methyl ethyl ketone

Methyl isobutyl ketone

$1,1,2,2$-Tetrachloroethane

Tetrachiorosthylene

Toluente

1,1,2-Trichloroethan
Trichloroethylene

Vinyl acetate
Xytenes

Rosult

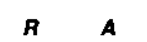

Time:

Total alkalinity (as CaCO3): Not available

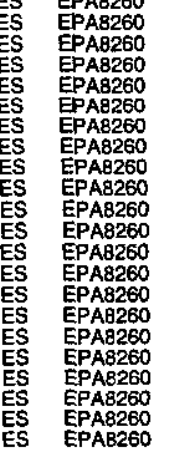

AB260

Total alkalinity (as CaCO3): Not available

502
10.0
5.00
5.00
5.00
10.0
5.00
5.00
5.00
10.0
10.0
5100
5.00

\begin{tabular}{|c|c|}
\hline $\begin{array}{l}\text { ES } \\
\text { ES } \\
\text { ES } \\
\text { ES } \\
\text { ES } \\
\text { ES } \\
\text { ES } \\
\text { ES } \\
\text { ES } \\
\text { ES } \\
\text { ES }\end{array}$ & 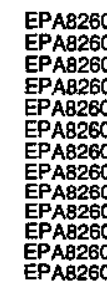 \\
\hline
\end{tabular}

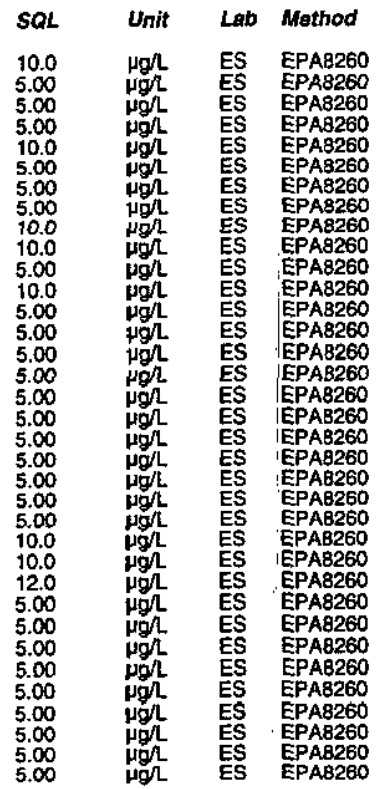

Second Quarter 1998 


\section{WELL TRP190B}

MEASUAEMENTS CONDUCTED IN THE FIELD Sample date: 06/04/98

Water temperature: Not available

Air temperature: Not available

$\mathrm{SH}$ : Nol avaliable Not available

Turbidity: Not available ANALYSES

F* Anatro

: Acetone

Bromodichloromethan

Bromorometh

Carbon disulfide

Carbon tetrachi
Chiorobebzenta

Chlosoethane

Chloromethan

Dibromochloromethan

1,1-Dichloroethan

i1-Dichloroethyleng

cis-1,2-Dichloroethylene
trans-1,2-Dichloroethylen

1,2-Dichloropropan

cis-1,3-Dichloropropene
irans-1,3-Dichloropropene

Ethylbenzent

Methyl ethyl ketone

STyjuculy keton

Styrene

1,1,1-Trichloroethane

Trichloroethylene
Vinyl acetate

\section{WELL TRP206A}

MEASUREMENTS CONDUCTED IN THE FIELD

Sample date: 04/06/98

Water temperature: Not available

Air temperature: Not available

Sp. conductance: Not availabl

No water was evacuated from the well prior to sampling.

ANALYSES

$F$ Analyto

0 Acetone

Bromodichloromethane

O Bromoform

Cromomethane

Carbon tetrachlorid

Chloroethene (Vinyl chloride)

ESH-EMS-980569
Well TRP206A collected on 04/06/98 (cont.)

F Analyte

Time:

Total alkalinity (as CaCO3): Not available

1,9-Dichloroethane

cis-1,2-Dichloroethylene

o trans-1,2-Dichloroethyle

1,2-Dichtoropropane

cis-1,3-Dichloropropene
trans-1,3-Dichloropropene

Ethylbenzene

Methyl ethyl ketone

Styrene-Tetrachloroethane

Toluene

1,1,1-Trichloroethane

Trichloroethylene

: Viknown acetate

\section{WELL TRP206A}

MEASUREMENTS CONDUCTED IN THE FIELD

Sample date: 04/15/98

Water temperature: Not available

Air temperature: Not available

Sp. conductance: Not available

Turbidity: Not avalable

ANALYSES

$F$ Analyte

: Acetone

Bromodichloromethan

Cromomethane

Carbon disulfidie

O Chlorobenzenen

Chloroethan

Chloroethene (Vinyl chloride)

Chloromethane

1,1-Dichloroethane

1,1-Dichloroethylen

: cis-1,2-Dichloroethylene

Dichloromethane

cis-1,3-Dichloropropene

Ethylbenzene

Methyl ethyl ketone

Styrene

$1,1,2,2$-Tetrachloroethan

0 Tetrachloroethylene

1,1.1-Trichloroethane

Trichloroethylent

0 Vynyl aceta

Resul
$<4.20$
$<5.00$
$<5.00$
$<5.00$
$<10.0$
$<5.00$
$<5.00$
$<5.00$
$<10.0$
$<10.0$
1.80
$<10.0$
$<5.00$
$<5.00$
$<5.00$
$<5.00$
$<5.00$
$<5.00$
$<2.50$
$<5.00$
$<5.00$
$<5.00$
$<500$
$<10.0$
$<10.0$
$<12.0$
$<5.00$
$<5.00$
$<5.00$
$<5.00$
$<5.00$
$<5.00$
$<5.00$
$<5.00$
55.00

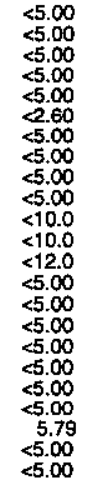

A

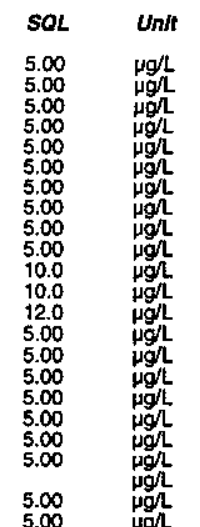

Lab Method

\begin{tabular}{l|l} 
ES & EPAB260 \\
ES & EPAB260
\end{tabular}

ES

। EPAA260

S EPA8260

S

EPA8260

: EPA8260

ES।

: EPAB260

EPAB260
C-31

$<10.0$

5.00
10.0
5.00 
WELL TRP207A

MEASUREMENTS CONDUCTED IN THE FIELD Sample date: 04/16/98 No: Not available
: available Air temperature: Not available Sp. conductance: Not available No water was evacuated from the well prior to sampling. ANALYSES

$F$ Analyte

- Acetone

Bromodichlosomethane

Bromoform

Carton disulfide

Carbon tetrachlorido

Chloroethane vinyl chloride)

Chlorotorm

Dibromochloromethan

1,2-Dichloroethane

$\begin{array}{ll}0 & 1,1-\text { Dichloroethylene } \\ 0 & \text { cis-1,2-Dichloroothylene }\end{array}$

trans-1,2-Dichloroethylen

Dichloromethane

cis-1,3-Dichloropropene

Ethylbenzene

2-hexanone

Styrene

1,1,2,2-Tetrachloroeth

Toluene

$1,1,2$-Trichloroethan

0 Vinyl acatate

WELL TRP208B

MEASUREMENTS CONDUCTED IN THE FIELD

Sample date: $04 / 16 / 98$

Air temperature: Not available

pit: Not available . conductance: Not available

Turbidity: Not available
No water was evacuated from the well prior to sampling.

ANALYYSES

$F$-Analyte

- Acetone

Bromodichloromethane

Bromoform

Carbon disultide

Carbon tetrachlorida

Chloroethane

Chloroform

Dibromochloromethane

\begin{tabular}{|c|c|c|c|c|c|c|c|}
\hline Result & $\boldsymbol{A}^{\prime \prime}$ & A & $B$ & SQL & Unit & Lab & Method \\
\hline $\begin{array}{l}<10.0 \\
<5.00 \\
<5.00 \\
<5.00 \\
<10.0 \\
<5.00 \\
<5.00 \\
<5.00 \\
<10.0 \\
<10.0 \\
<5.00 \\
<10.0 \\
<5.00 \\
<5.00 \\
<5.00 \\
<5.00 \\
<5.00 \\
<5.00 \\
<5.00 \\
5.00 \\
55.00 \\
<5.00 \\
<5.00 \\
<10.0 \\
<10.0 \\
<12.0 \\
<5.00 \\
<5.00 \\
<5.00 \\
<5.00 \\
<5.00 \\
<5.00 \\
55.00 \\
<5.00\end{array}$ & $\begin{array}{l} \\
1 \\
\vdots \\
\vdots \\
\vdots \\
\vdots\end{array}$ & c & & $\begin{array}{l}10.0 \\
5.00 \\
5.00 \\
5.00 \\
10.0 \\
5.00 \\
5.00 \\
5.00 \\
10.0 \\
10.0 \\
5.00 \\
10.0 \\
5.00 \\
5.00 \\
5.00 \\
5.00 \\
5.00 \\
5.00 \\
5.00 \\
5.00 \\
5.00 \\
5.00 \\
10.0 \\
10.0 \\
12.0 \\
5.00 \\
5.00 \\
5.00 \\
5.00 \\
5.00 \\
5.00 \\
5.00 \\
5.00 \\
5.00\end{array}$ & 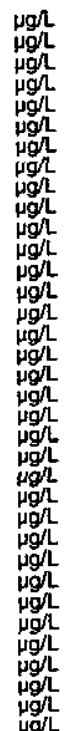 & 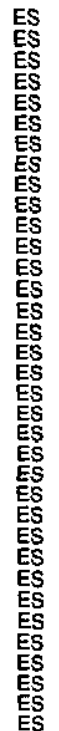 & 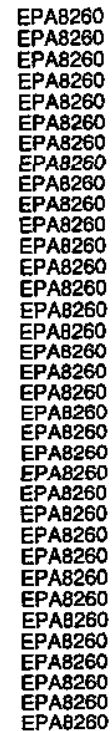 \\
\hline
\end{tabular}

ESH-EMS-980569

Time: .

Total alkalinity (as CaCO3): Not available
Well TRP208B collected on 04/16/98 (cont.)

$F$ Analyte

Resuft

: 1,1-Dichloroethane

$\begin{array}{ll}0 & 1,1-D i c h l o r o e t h y l e n \\ 0 & 1,2 \text {-Dichloroethyien }\end{array}$

Dichloromethane

cis-1,3-Dichloropropene

Ethylbenzene

2-Hexanone
0
0

Styrene
$1,1,2,2$-Tetrachioroethane

Tetrachloroen

1,1,1-Trichloroethane

Trichloroethylene

Xylenes

\section{WELL TRP209B}

MEASUREMENTS CONDUCTED IN THE FIELD

Sample date: 04/17/98

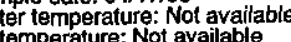

H: No available

conductance: Not available

$<5.00$
55.00
5.00
55.00
$<6.62$
$<5.00$
55.00
5.00
5.00
$<10.0$
$<1.0$
$<10.0$
$<5.00$
$<5.00$
$<5.00$
$<5.00$
$<5.00$
$<5.00$
$<5.00$
$<10.0$
$<5.00$

sel Unit

Lab Nothod

No water was evacuated from the well prior to sampling.

ANALYSES

$F$ Analyte

O Acetone

Benzene

Bromborm

Carbon disulfide

Carbon tetrachioride

Chloroethane

Chloroethenene

Chlorotorm

Dibromocthoromethane

i, - -Dichloroethane

1,1-Dichloroetthylen

Dichloromethane

cis-1.3-Dichloropropropene

2-Hibenzenen

Methanone

Styrene 2 -Tetrachtoroethane

Trachno

1,1,1-Trichloroethane

1,1,2-Trichloroethan

Vinyl acetate

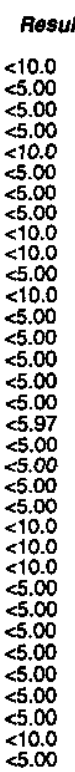

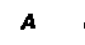

501
10.0
5.00
5.00
5.00
10.0
5.00
5.00
5.00
10.0
10.0
5.00
10.0
5.00
5.00
5.00
5.00
5.00
5.00
5.0
5.00
5.00
5.00
10.0
10.0
10.0
5.00
5.00
5.00
5.00
5.00
5.00
10.0
5.00

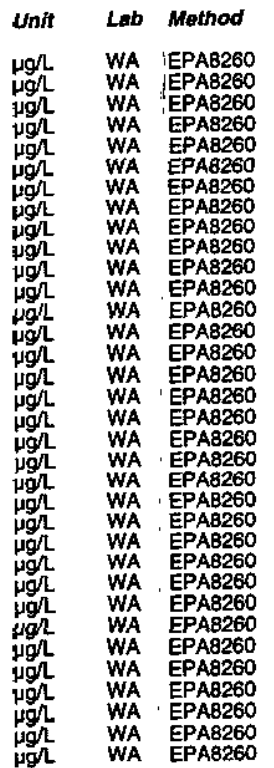

Second Quarter 1998

Time:

Total alkalinity (as CacO3): Not availabte

\begin{tabular}{|c|c|c|c|}
\hline SOL & Unit & Lab & Method \\
\hline $\begin{array}{l}10.0 \\
5.00 \\
5.00 \\
5.00 \\
10.0 \\
5.00 \\
5.00 \\
500 \\
10.0 \\
10.0 \\
5.00 \\
10.0 \\
5.00 \\
5.00 \\
5.00 \\
5.00 \\
5.00 \\
5.00 \\
5.00 \\
5.00 \\
5.00 \\
1.00 \\
10.0 \\
10.0 \\
5.00 \\
5.00 \\
5.00 \\
5.00 \\
5.00 \\
5.00 \\
5.00 \\
10.0 \\
5.0\end{array}$ & $\begin{array}{l}\mu g h \\
\mu g h \\
\mu g h \\
\mu g h \\
\mu g h \\
\mu g h \\
\mu g h \\
\mu g h \\
\mu g h \\
\mu g h \\
\mu g h \\
\mu g h \\
\mu g h \\
\mu g h \\
\mu g h \\
\mu g h \\
\mu g h \\
\mu g h \\
\mu g h \\
\mu g h \\
\mu g h \\
\mu g h \\
\mu g h \\
\mu g h \\
\mu g h \\
\mu g h \\
\mu g h \\
\mu g h \\
\mu g h \\
\mu g h \\
\mu g h \\
\mu g h \\
\mu g h \\
\mu g h \\
\mu g h \\
\mu g h\end{array}$ & $\begin{array}{l}\text { WA } \\
\text { WA } \\
\text { WA } \\
\text { WA } \\
\text { WA } \\
\text { WA } \\
\text { WA } \\
\text { WA } \\
\text { WA } \\
\text { WA } \\
\text { WA } \\
\text { WA } \\
\text { WA } \\
\text { WA } \\
\text { WA } \\
\text { WA } \\
\text { WA } \\
\text { WA } \\
\text { WA } \\
\text { WA } \\
\text { WA } \\
\text { WA } \\
\text { WA } \\
\text { WA } \\
\text { WA } \\
\text { WA } \\
\text { WA } \\
\text { WA } \\
\text { WA } \\
\text { WA } \\
\text { WA } \\
\text { WA } \\
\text { WA } \\
\text { WA }\end{array}$ & 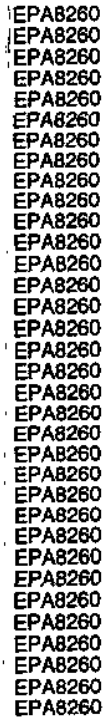 \\
\hline
\end{tabular}


SAMPLING BLANKS RESULTS

\section{WELL TRP210B}

MEASUREMENTS CONDUCTED IN THE FIELD

Sample date: 04/20/98

Water temperature: Not available

$\mathrm{ph}$ : Not available

Sp. conductance: Not available

Turbidity: Nol available

ANALYSES

\begin{tabular}{|c|c|c|c|c|c|c|c|c|}
\hline Analyte & Result & R & A & $B$ & SOL & Unit & Lab & Method \\
\hline 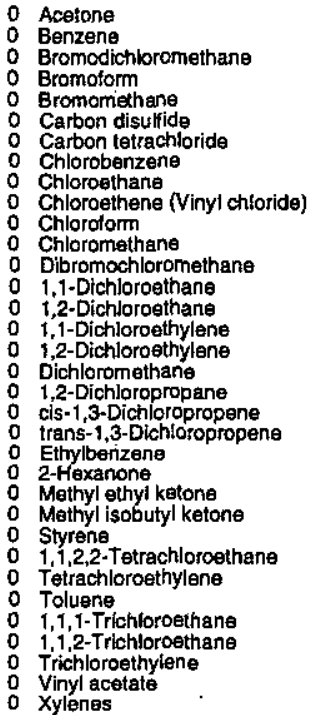 & 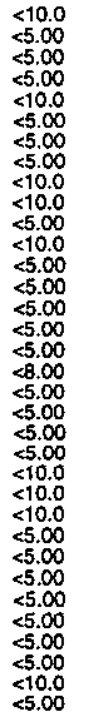 & & $v$ & & $\begin{array}{l}10.0 \\
5.00 \\
5.00 \\
5.00 \\
10.0 \\
5.00 \\
5.00 \\
5.00 \\
100 \\
10.0 \\
5.00 \\
10.0 \\
5.00 \\
5.00 \\
5.00 \\
5.00 \\
5.00 \\
5.00 \\
5.00 \\
5.00 \\
5.00 \\
100 \\
10.0 \\
10.0 \\
5.00 \\
5.00 \\
5.00 \\
5.00 \\
5.00 \\
100 \\
5.00\end{array}$ & 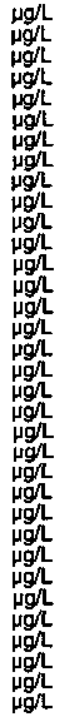 & $\begin{array}{l}\text { WA } \\
\text { WA } \\
\text { WA } \\
\text { WA } \\
\text { WA } \\
\text { WA } \\
\text { WA } \\
\text { WA } \\
\text { WA } \\
\text { WA } \\
\text { WA } \\
\text { WA } \\
\text { WA } \\
\text { WA } \\
\text { WA } \\
\text { WA } \\
\text { WA } \\
\text { WA } \\
\text { WA } \\
\text { WA } \\
\text { WA } \\
\text { WA } \\
\text { WA } \\
\text { WA } \\
\text { WA } \\
\text { WA } \\
\text { WA } \\
\text { WA } \\
\text { WA } \\
\text { WA } \\
\text { WA } \\
\text { WA } \\
\text { WA }\end{array}$ & $\begin{array}{l}\text { EPAB260 } \\
\text { EPAB260 } \\
\text { EPAB260 } \\
\text { EPAB260 } \\
\text { EPA8260 } \\
\text { EPAB260 } \\
\text { EPAB2600 } \\
\text { EPA8260 } \\
\text { EPA8260 } \\
\text { EPA8260 } \\
\text { EPA8260 } \\
\text { EPA8260 } \\
\text { EPA8260 } \\
\text { EPAB260 } \\
\text { EPA8260 } \\
\text { EPAB260 } \\
\text { EPAB260 } \\
\text { EPAB260 } \\
\text { EPAB260 } \\
\text { EPAB260 } \\
\text { EPAB260 } \\
\text { EPAB260 } \\
\text { EPAB260 } \\
\text { EPAB260 } \\
\text { EPAB260 } \\
\text { EPAB260 } \\
\text { EPAB260 } \\
\text { EPAB260 } \\
\text { EPAB260 } \\
\text { EPAB260 } \\
\text { EPA8260 } \\
\text { EPAB260 } \\
\text { EPAB260 } \\
\text { EPAB260 }\end{array}$ \\
\hline
\end{tabular}

\section{WELL TRP212B}

MEASUREMENTS CONDUCTED IN THE FIELD

Sample date: 04/17/98

Water temperature: Not available

Air temperature: Not available

Sp. conductance: Not available

No water was evacuated from the well prior to sampling.

ANALYSES

\begin{tabular}{|c|}
\hline Analyte \\
\hline $\begin{array}{ll}0 & \text { Acetone } \\
0 & \text { Acetonitrile (Methyl cyanide) } \\
0 & \text { Acrolein } \\
0 & \text { Acrylonitrile } \\
0 & \text { Allyl chloride } \\
0 & \text { Benzeng } \\
0 & \text { Bromodichloromethane } \\
0 & \text { Bromofomm } \\
0 & \text { Bromomethane } \\
0 & \text { Carbon disulfide } \\
0 & \text { Carbon tetrachloride } \\
0 & \text { Chlorobenzene } \\
0 & \text { Chloroethane } \\
0 & \text { Chloroethene (Vinyl chloride) }\end{array}$ \\
\hline
\end{tabular}

ESH-EMS-980569
Time:

Total alkatinity (as CacO3): Not available

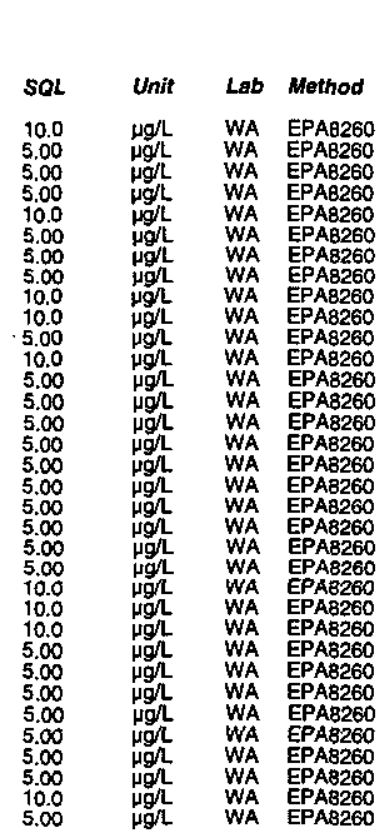

Time:

Total alkalinity (as CaCO3): Not available
Phenolphthalein alkalinity: Not available

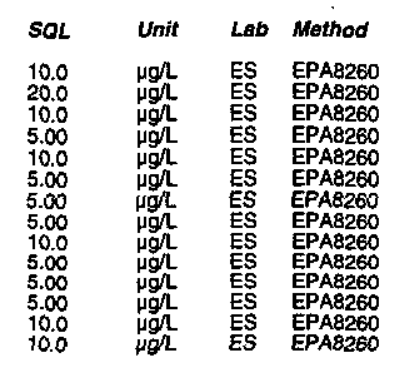

Well TRP212B collected on 04/17/98 (cont.)

$F$ Analyto

0 Chlorotorm

Chloromethane

1,2-Dibromo-3-chlorop

1,2-Dibromoethan

trans-1,4-Dichloro-2.-buten
Dichlorodifluoromethane

1,1-Dichloroethane

cis-1,2-Dichloroethyle

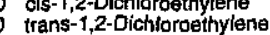

Dichloromethane
1,2-Dichloropropane

cis-1,3-Dichloropropene

E Ethylbenzene

2 -Hexanone

(Methyl iodide)

Methacrylonitrile

Methyl isobutyl ketone

Methyl methacryla

Styrene

1, 2,2-Tetrachloroethane

Tetrachloroethylene
Toluene

$1,1,1-$ Trichloroethane

Trichiorosthylens

Trichlorofluoromethane

Vinyl acetato

o Xylenes

\section{WELL TRP213B}

MEASUREMENTS CONDUCTED IN THE FIELD

Sample date: 04/23/98

Air temperature: Not available

SH: Not available . conductance: Not available

No water was evacuated from the well prior to sampling. ANALYSES

\section{Analyte}

0 Acetone

Bromodichloromethane

Bromoform

Carbon tetrachloride

Chlorobenzene

Chloroethene (Vinyl chloride)

Chloroform

o Chloromethane

1,Dichlorosthan

1,1-Dichloroethylene

Dichloromethane

cis-1,3-Dichloropropene

trans-1,3-Dich

c-33

Result
$<.38$
$<5.00$
$<5.00$
$<5.00$
$<10.0$
$<5.00$
$<5.00$
$<5.00$
$<10.0$
$<10.0$
$<5.00$
$<10.0$
$<5.00$
$<5.00$
$<5.00$
$<5.00$
$<5.00$
$<5.22$
$<5.00$
$<5.00$
$<5.00$
$<5.00$

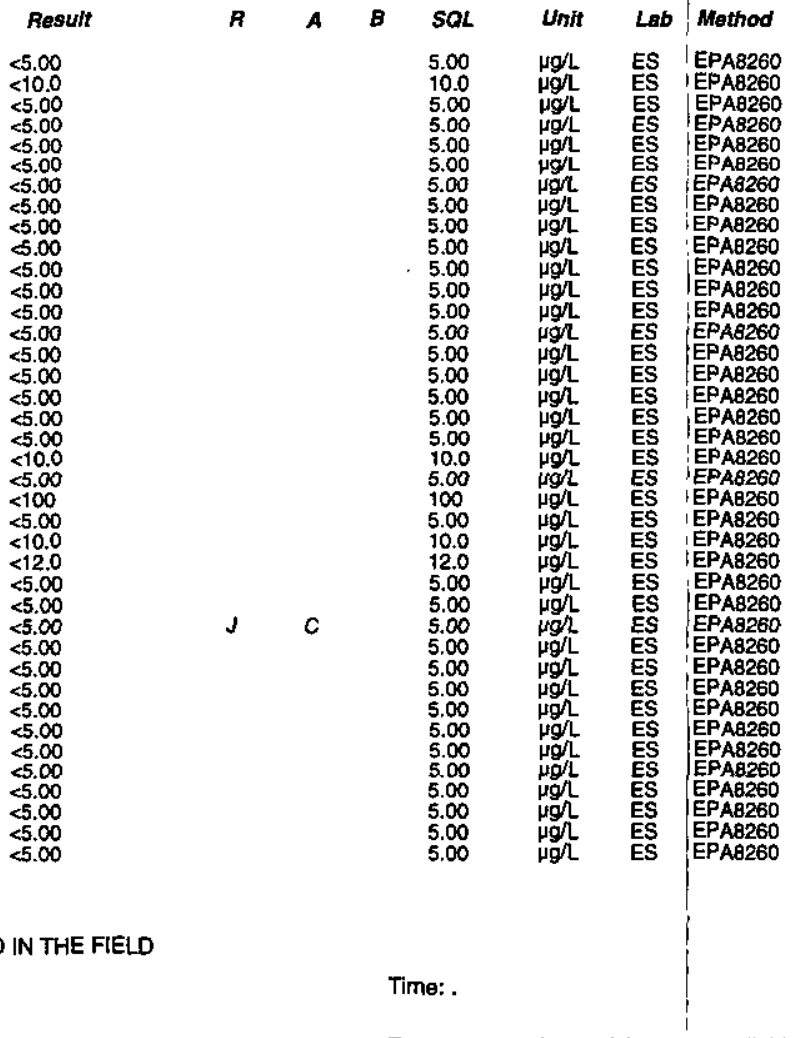

Total alkalinity (as CaCO3): Not available
Phenolphthalein alkalinity: Not available
A

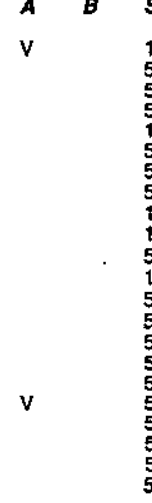

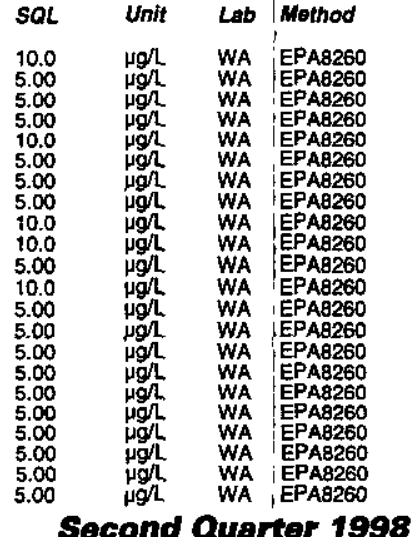


Well TRP2138 collected on 04/23/98 (cont,)

\begin{tabular}{|c|c|}
\hline Analyte & Result \\
\hline $\begin{array}{l}\text { 2-Hexanone } \\
\text { Methyl ethyl ketone } \\
\text { Methyl isoobutyl ketone } \\
\text { Styrene } \\
1,1,2,2 \text {-Tetrachloroethane } \\
\text { Tetrachloroethylene } \\
\text { Toluene } \\
1,1,1 \text {-Trichloroethane } \\
1,1,2 \text {-Trichloroethane } \\
\text { Trichlorothylene } \\
\text { Vinyl acetate } \\
\text { Xylenes }\end{array}$ & $\begin{array}{l}<10.0 \\
<10.0 \\
<10.0 \\
<5.00 \\
<5.00 \\
<5.00 \\
<5.00 \\
<5.00 \\
<5.00 \\
<5.00 \\
<10.0 \\
<5.00\end{array}$ \\
\hline
\end{tabular}

\section{WELL TRP214B}

MEASUREMENTS CONDUCTED IN THE FIELD

Sample date: 04/24/98

Water temperature: Not available

$\mathrm{pH}$ : Not available

Sp. conductance: Not available

No water was evacuated from the well prior to sampling.

ANALYSES

F Analyte

0 Acetone

Bromodichloromethan

Bromomethan

Carbon disultide

Chlorabenzene

Chloroethane

Chloroform

Dibromochloromethane

1,1-Dichloroethane

1,1-Dichloroethylen

Dichloromethane

cis-1,3-Dichloroppropene

Ethylbenzene

Methyl ethyl ketone

Ityrene

- Tetrachloroethylene

1,1,1-Trichloroethane

Trichloroethylene

0. Vinyl aceta
0 Xylenes

\section{WELL TRP216B}

MEASUREMENTS CONDUCTED IN THE FIELD

Sample date: 04/03/98

Resutt
$<10.0$
55.00
55.00
5.00
510.0
55.00
55.00
55.00
510.0
410.0
55.00
510.0
55.00
55.00
55.00
5.00
55.00
5.08
55.00
5.00
55.00
5.00
510.0
10.0
510.0
55.00
55.00
55.00
55.00
55.00
55.00
55.00
510.0
55.00

Water temperature: Not

Air temperature: Not avaliable

gH: Not availabie

No water was evacuated from the well prior to sampling.

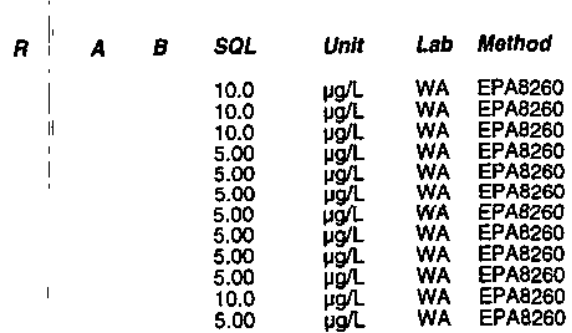

Time: .

Total alkalinity (as CaCO3): Not available
Phenolphthalein alkalinity: Not available

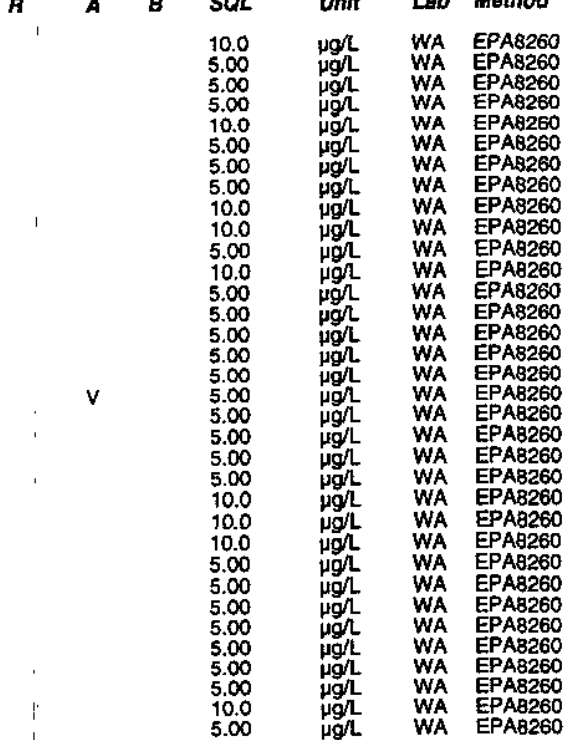

Time: .

Total alkalinity (as CaCO3): Not available
Well TRP2168 collected on 04/03/98 (cont.)

ANALYSES

\begin{tabular}{|c|c|}
\hline Analyte & Result \\
\hline $\begin{array}{ll}0 & \text { Acetone } \\
0 & \text { Bromomethane } \\
0 & \text { Carbon disulfide } \\
0 & \text { Chloroethane } \\
0 & \text { Chloroethene Vinyl chloride } \\
0 & \text { Chloromethane }\end{array}$ & $\begin{array}{l}<10.0 \\
<10.0 \\
<5.00 \\
<10.0 \\
<10.0 \\
<10.0\end{array}$ \\
\hline
\end{tabular}

Chloromethane $<5.00$

\section{WELL TRP217B}

MEASUREMENTS CONDUCTED IN THE FIELD

Sample date: 04/06/98

Wer temperature: Not available

Air temperature: Not

available

No water was evacuated from the well prior to sampling.

ANALYSES

F Analyte

o Acetone

Bromodichloromethane

Bromotorm

Carton tetrachloric

Chlorobenzene

Chloroethene (Vinyl chloride)

Chloroform

Dibromochloromethante

1,1-Dichloroethane

1,i-Dichioroethylen

Dichloromethane
1 2-Dichloropropane

cis-1,3-Dichloropropene

Ethylbenzene

Methyl ethyl ketone

Styrens

Totrachloro

1,1,1-Trichloroethane

$1,1,2-$ Trichloroethane
Trichloroethylene

Vinyl acstate

WELL TRP218B

MEASUREMENTS CONDUCTED IN THE FIELD

Sample date: 05/01/98

mperature: Not availabl

H: Not available

Not available

No water was evacuated from the well prior to sampling.
R A

$\begin{array}{ll}\text { SOL } & \text { Unit } \\ 10.0 & \mu g \Omega \\ 10.0 & \mu g / L \\ 5.00 & \mu g / L \\ 10.0 & \mu g / L \\ 10.0 & \mu g / L \\ 10.0 & \mu g / L \\ 5.00 & \mu g / L\end{array}$

Lab Method

WA EPA8260

WA EPA8260

WA EPAB260

Time: .

Total alkalinity (as $\mathrm{CaCO}$ ): Not available

ESH-EMS-980569 Total alkalinity (as CaCO3) Not available 
Well TRP218B collected on 05/01/98 (cont.)

ANALYSES

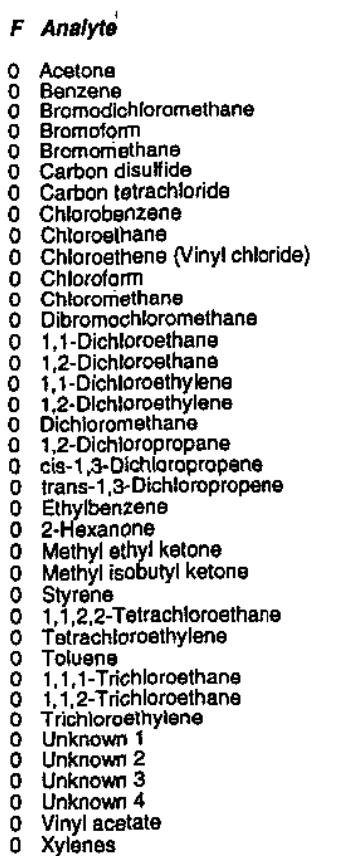

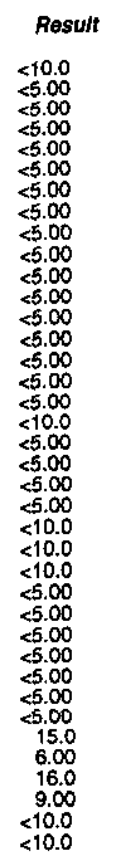

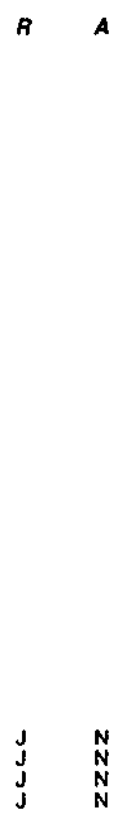

\section{WELL TRP219B}

MEASUREMENTS CONDUCTED IN THE FIELD

Sample date: 05/01/98

Water temperature: Not available

HH: No availabie
$\mathrm{gp}$. conductance: Not available

No water was evacuated from the well prior to sampling.

ANALYSES

\begin{tabular}{|c|}
\hline 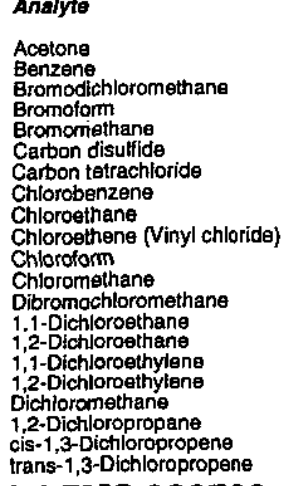 \\
\hline
\end{tabular}

ESH-EMS-980569
Well TRP219B collected on 05/01/98 (cont.)

Result

- Ethylbenzene

Methyl ethyl ketone

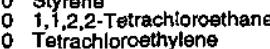

o Toluene

o $1,1,2$-Trichloresthane

- Trichloroethylene

Unknown 2

$\therefore$ Vinyl acetal

$<5.00$
$<10.0$
$<10.0$
$<10.0$
$<5.00$
$<5.00$
$<5.00$
$<5.00$
$<5.00$
$<5.00$
$<5.00$
27.0
11.0
$<10.0$
$<10.0$

WELL TRP224B

MEASUREMENTS CONDUCTED IN THE FIELD

Sample date: 04/30/98

Ar temperature: Not available

$\mathrm{pH}$ : Not available

p. conductance: Not available

No water was evacuated from the well prior to sampling.

ANALYSES

$F$ Analyto

0 Acetone

Benzene

Bromodichloromethane

Bromoform

Bromoform

Bromomethane

Carbon disulfide

Carbon tetrachloride

- Chlorobenzene

Chloroethane

Chloroethene Vinyl chloride

Chloroethene (Vinyi chloride

Chloroform

Chloromethan

Dhloromethane

Dibromochloromethane

1.1-Dichloroethane

: 1,1 -Dichloroethan

1,1-Dichloroethylen

: 1,1-Dichloroethylen

oroethylen

Dichloromethan

1,2-Dichloropropane

cis-1,3-Dichloropropene

trans-1,3-Dichloropropen

Ethylbenzene

2-Hexanone
0 2-Hexanone

C-35

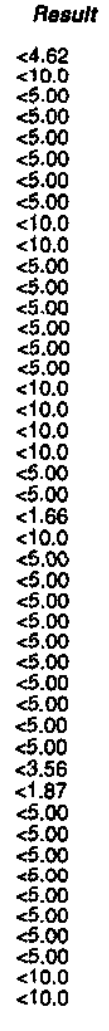

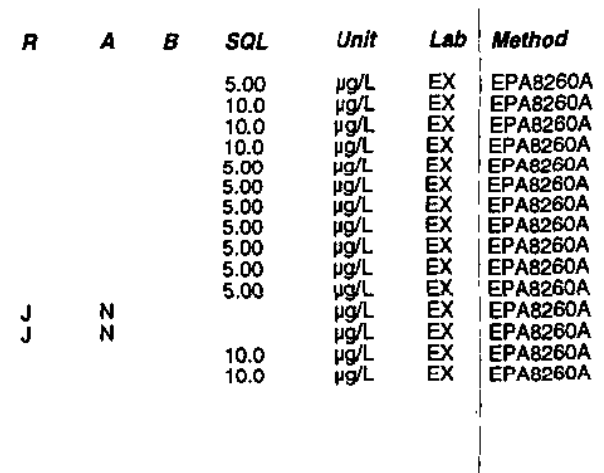

Time: .

Total alkalinity (as $\mathrm{CaCO}$ ) : Not available 
SAMPLING BLANKS RESULTS

Well TRP228B collected on 05/26/98 (cont.)

$F$ Analyte

- Chioromethane

1,1-Dichloroethane
1,2-Dichloroethane

1,1-Dichloroethylene

Dichloromathane
1.2-Dichiaropropane

cis-1,3-Dichloropropene

Ethylbenzene

Methyl ethyl ketone

Styrene

Tetrachloroethylene

$1,1,1-$ Trichloroethane
$1,1,2-$ Triahloroethane

Trichloroethylen

Vinyl acetate

WELLL TRP230B

MEASUREMENTS CONDUCTED IN THE FIELD

Water temperature: Not available

$\mathrm{HH}$ : Not available

No water was evacuated from the well prior to sampling. ANALYSES

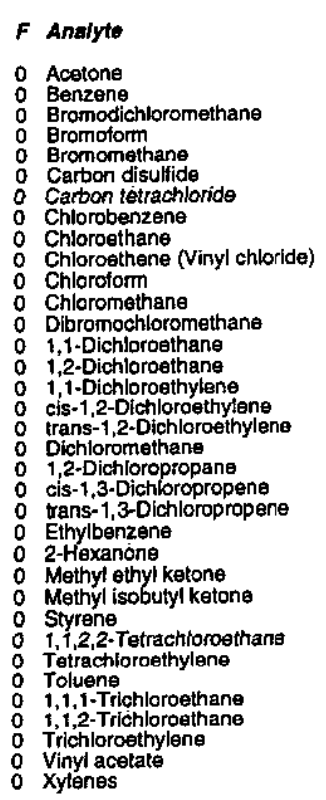

Resuh
$<10.0$
$<5.00$
$<5.00$
$<5.00$
$<10.0$
$<5.00$
$<5.00$
$<5.00$
$<10.0$
$<10.0$
$<5.00$
$<10.0$
$<5.00$
$<5.00$
$<5.00$
$<5.00$
$<5.00$
$<5.00$
$<.10$
$<5.00$
$<5.00$
$<5.00$
$<100$
$<1.0$
$<12.0$
$<5.0$
$<5.00$
$<5.00$
$<5.00$
$<5.00$
$<5.00$
$<5.00$
$<5.00$
$<5.00$

ESH-EMS-980569

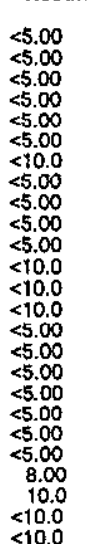

R

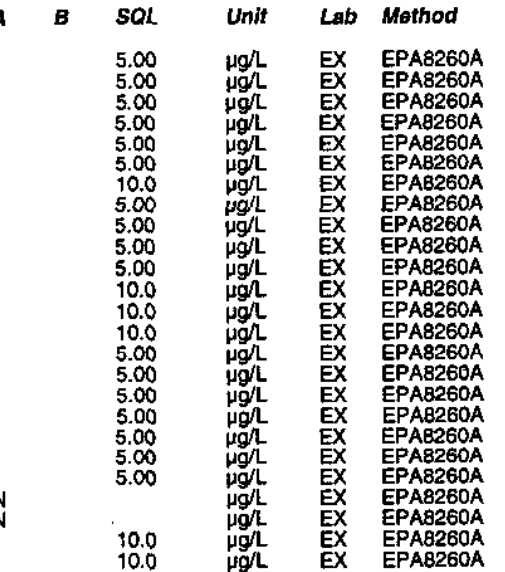

Time:

Total alkalinity (as CaCO3): Not available
Phenolphthalein alkalinity: Not available
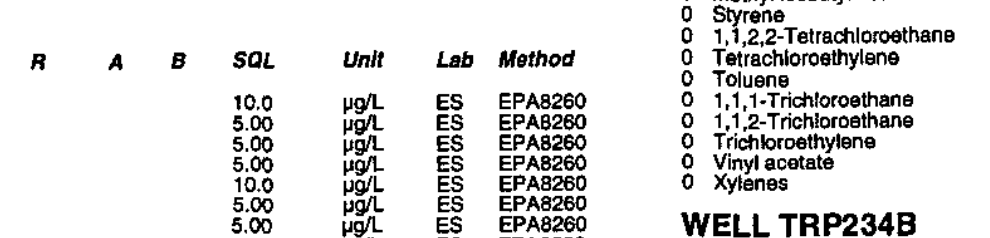

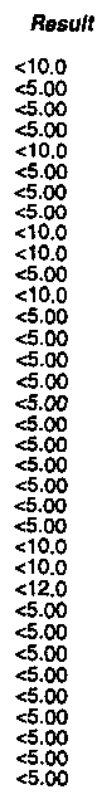

\section{WELL TRP234B}

MEASUREMENTS CONDUCTED IN THE FIELD

Sample date: 06/01/98

Wer temperature: Not available

Arr temperature:

Sp. conductance: Not available

No water was evacuated from the well prior to sampling.

ANALYSES

F Analyte

0 Acetone

Bromodichloromethane

0 Bromotorm:

O Caromonethantisutide

Carbon tetrachloride

O Chlorobenzene

o Chloroethene (Vinyl chloride)

Chloroform

: Chloromethane

C.37

$\begin{array}{ll}\text { Result } & \boldsymbol{R} \\ <5.00 & \mathbf{J} \\ <1.00 & \mathbf{J} \\ <1.00 & \mathbf{J} \\ <1.00 & \mathbf{J} \\ <1.00 & \mathbf{J} \\ <5.00 & \mathbf{J} \\ <1.00 & \mathbf{J} \\ <1.00 & \mathbf{J} \\ <1.00 & \mathbf{J} \\ <1.00 & \mathbf{J} \\ <1.00 & \mathbf{J} \\ <1.00 & \end{array}$

Time: .

Total alkalinity (as $\mathrm{CaCO}$ ): Not available
Time:

Total alkalinity (as $\mathrm{CaCO}$ ): Not available

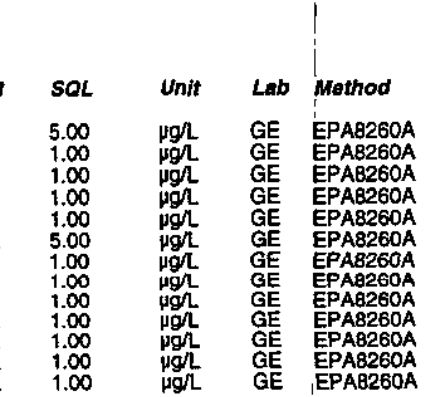

Second Quarter 1998 
SAMPLING BLANKS RESULTS

Well TRP2348 collected on 06/01/98 (cont.)

$F$ Analyte

1,1-Dichloroethane

o 1,i-Dichlorosthylene

1,2-Dichloroethylen

1,2-Dichloropropane

trans-1,3-Dichtoropropen

2-Hexanone

Methyl ethyl ketone

Styrene Thach Tetrachloroethan

Tetrachloroethylene

1.4.1-Trichloroethane

Trichloroethylene
0 Vinyl acetate

\section{WELL TRP235B}

MEASUREMENTS CONDUCTED IN THE FIELD

Sample date: 05/12/98
Water temperature: Not available

$\mathrm{OH}$ : Not available

p. conductance: Not available

No water was evacuated from the well prior to sampling.

ANALYSES

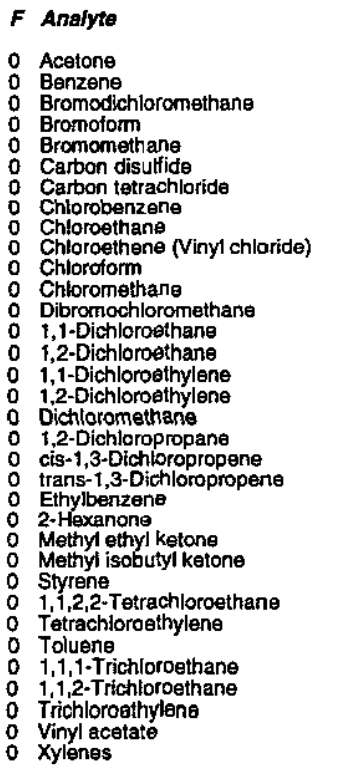

\begin{tabular}{|c|}
\hline $\begin{array}{l}<4.36 \\
<5.00 \\
<5.00 \\
<5.00 \\
<10.0 \\
<5.00 \\
<5.00 \\
<5.00 \\
<10.0 \\
<1.0 \\
<5.00 \\
<10.0 \\
<5.00 \\
<5.00 \\
<5.00 \\
<5.00 \\
<5.00 \\
<1.17 \\
<5.00 \\
<5.00 \\
<5.00 \\
<5.00 \\
<10.0 \\
<10.0 \\
<10.0 \\
<5.00 \\
<5.00 \\
<5.00 \\
<5.00 \\
<5.00 \\
<5.00 \\
<5.00 \\
<50.0 \\
<5.00\end{array}$ \\
\hline
\end{tabular}

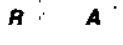

Time:

Total alkalinity (as CaCO3): Not available
Phenolphthalein alkalinity: Not available

\begin{tabular}{|c|c|c|c|c|c|}
\hline & B & SOL & Unit & Lab & Method \\
\hline $\begin{array}{l}0 \\
0 \\
0 \\
0 \\
0 \\
0 \\
0 \\
0 \\
0 \\
0 \\
0 \\
0 \\
0 \\
0 \\
0 \\
8 \text { EE } \\
0 \\
0 \\
0 \\
0 \\
0\end{array}$ & $\begin{array}{l}\mathrm{L} \\
\mathbf{L} \\
\mathbf{L} \\
\mathbf{L} \\
\mathbf{L} \\
\mathbf{L} \\
\mathbf{L} \\
\mathbf{L} \\
\mathbf{L} \\
\mathbf{L} \\
\mathbf{L} \\
\mathbf{L}\end{array}$ & $\begin{array}{l}1.00 \\
1.00 \\
1.00 \\
1.00 \\
1.00 \\
1.00 \\
1.00 \\
1.00 \\
5.00 \\
5.00 \\
5.00 \\
1.00 \\
1.00 \\
1.00 \\
1.00 \\
1.00 \\
1.00 \\
5.00 \\
1.00\end{array}$ & 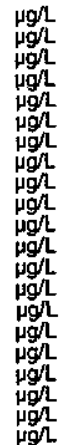 & $\begin{array}{l}G E \\
G E \\
G E \\
G E \\
G E \\
G E \\
G E \\
G E \\
G E \\
G E \\
G E \\
G E \\
G E \\
G E \\
G E \\
G E \\
G E \\
G E \\
G E \\
G E \\
G E \\
G E\end{array}$ & 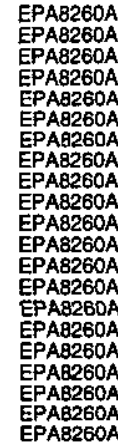 \\
\hline
\end{tabular}

WELLL TRP236B

MEASUREMENTS CONDUCTED IN THE FIELD

Sample date: 06/04/98

Water temperature: Not available

Air temperature: Not available

ctance: Not available

No water was evacuated from the well prior to sampling.

ANALYSES

$F$ Analyte

0 Acetone

Bromodichloromethane

Bromoform

Carton disulfide

- Chlorobenzente

Chloroethene (Vinyl chloride)

Chloroform

o Chloromothane

1,1-Dichloroethane

1,1-Dichloroesthylen

Dichloromethane

: 1,2 -Dichloropropane

0 trans-1,3-Dichloropropene

2-Hexanone

Methyl ethyl ketone

1tyrene

Toluene

1,1,1-Trichloroethane

Vinchloroethylen

Xylenes

WELL TRP237B

MEASUREMENTS CONDUCTED IN THE FIELD

Sample date: 06/09/98

Air temperature: Not available

$\mathrm{H} \mathrm{H}$ : Not availabie avallable

Sp.conductance: Not available

No water was evacuated from the well prior to sampling.

ANALYSES

F Analyte

$\begin{array}{ll}0 & \text { Acetone } \\ 0 & \text { Benzent }\end{array}$

0 Bromodichloromethan

Bromotorm

o Cartoon disulfide

0 Carton tetrachloride

O Chlorobenzens

Chloroethene (Vinyl chloride)

Chloroform

Dibromechloromethan
0 1,

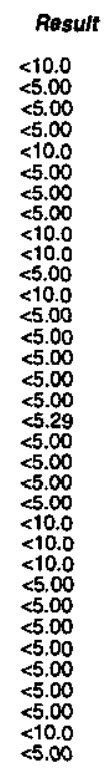

Time:

Total alkalinity (as $\mathrm{CaCO}$ ): Not available
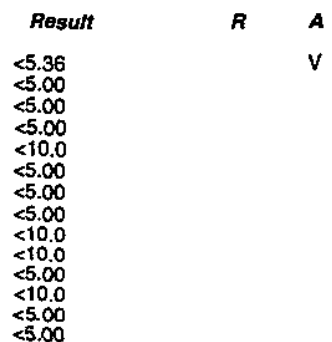

50
10.0
5.00
5.00
5.00
10.0
5.00
5.00
5.00
10.0
5.00
10.0
5.00
$\mathbf{5} .0$

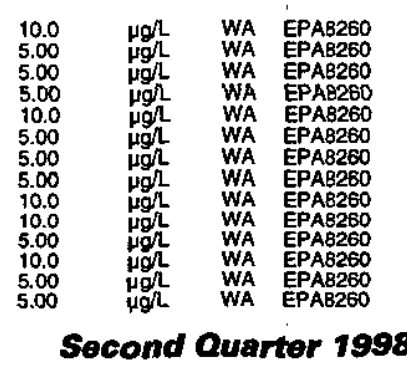

Time: .

Total alkalinity (as $\mathrm{CaCO}$ ): Not available 
Well TRP237B collected on 06/09/98 (cont.)

$F$ Analyte

0 1,2-Dichloroethane

1,2-Dichloroesthylene

1,2-Dlchloropropane

trans-1,3-Dichloropropen

Ethylbenzen

o Mexyl ethyl ketone

Styrene

1, 2,2-Tetrachloroeth

1.1,1-Trichloroethane

Trichlorosthylenthan

0
0
0

WELL TRP238B

MEASUREMENTS CONDUCTED IN THE FIELD

Sample date: 06/11/98

Water temperature: Not available

Air temperature

Sp. conductance: Not available

No water was evacuated from the well prior to sampling.

ANALYSES

$F$ Analyte

0 Acetone

Bromodichloromethan

Bromoform

Carbon dísulficide

Carton tetrachlorido

Chloroethane

Chloroform

Dibromochbromethan

1.i-Dichloroethane

1,1-Dichloroethylene

Dichloromethane

1,2-Dichloropropane

cis-1,3-Dichloropropene

Ethylbenzene

2-Hexanong

Styrene $1,2,2$-Tetrachloroethane

Tetracthloroethylene

1.1,1-Trichloroethane
$1,12-$ Trichloroethan

Triachloriosthylene

xylenes:

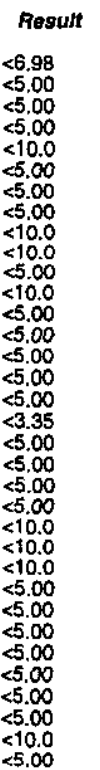

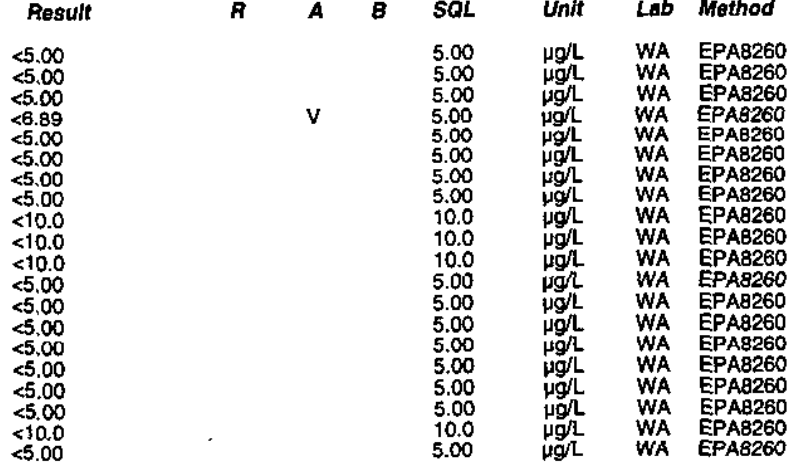

Time: .

Total alkalinity (as $\mathrm{CaCO}$ ): Not available

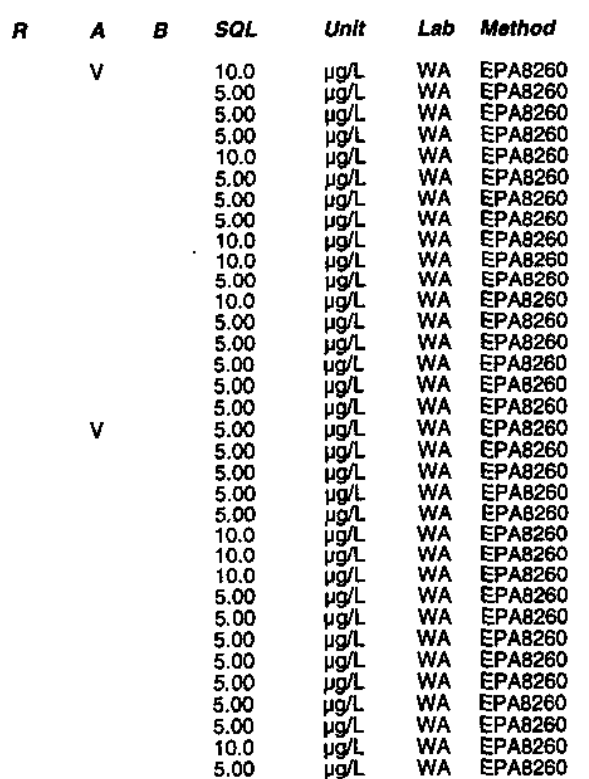

WELL TRP239B

MEASUREMENTS CONDUCTED IN THE FIELD

Sample date: 06/17/98

Prature: Not available

Air temperature: Not availabi

Sp. conductance: Not available

No water was evacuated from the well prior to sampling.

ANALYSES

$F$ Analyte

- Acetone

Bromodictloramethan

Bromoform

Carbon disulfide

Chiorobenzene

Chloroethene (Vinyl chloride)

Chloroform

Dibromochloromethane

1.2-Dichloroethane

$\begin{array}{ll}0 & 1,1-D i c h l o r o e t h y l e n \theta \\ 0 & 1,2-D i c h l o r o e t h y l e n \theta\end{array}$

Dichloromethane

cis-1,3-Dichloropropene
trans-1,3-Dichloropropene

Etrylbenzene

2-Hexanone
0
Methyl ethyl ketons

Styrens

$1,1,2,2$-Tetrachloroethan
Tetrachloroethylene

1.1uene

i.1.2-Trichloroethane
Trichioroethylene

Vinyl acetate
Xylenes

\section{WELL TRP240B}

MEASUREMENTS CONDUCTED IN THE FIELD

Sample date: 06/29/98

Wistar

Arr temperature:

p. conductance: Not available

No water was evacuated from the well prior to sampling.

ANALYSES

$F$ Analyte

O Acetone

Bromodichloromethane

Bromomethan

Carbon disultide

Chlorobenzene

Chloroethane

Chlorotorne

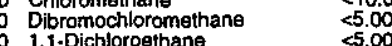

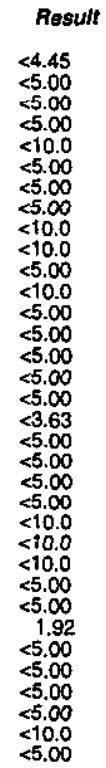

R

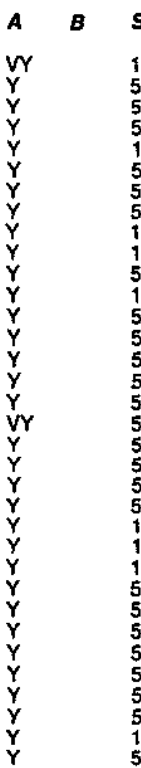

$S Q L$
10.0
5.00
5.00
5.00
10.0
5.00
5.00
5.00
10.0
10.0
5.00
10.0
5.00
5.00
5.00
5.00
5.00
5.00
5500
5.00
5.00
10.0
10.0
10.0
5.00
5.00
5.00
5.00
5.00
5.00
5100
5.00

Unit Lab Method

Hgl WA EPAB260

WA EPAB260

WA

WA

WA

WA EPAA260

WA EPA8260

WA EPAB26

WA EPA8260

WA EPAB260

WA EPA8260

WA EPA8260

WA EPA8260

WA EPA8260

WA EPA8260

WA EPAB260

WA EPAB260

Time: .

Total alkalinity (as CaCO3) Not available
Phenolphthalein alkalinity: Not available

C-39

Result
54.84
55.00
55.00
55.00
$<100$
45.00
55.00
55.00
510.0
510.0
5100
510.0
55.00
-5.00

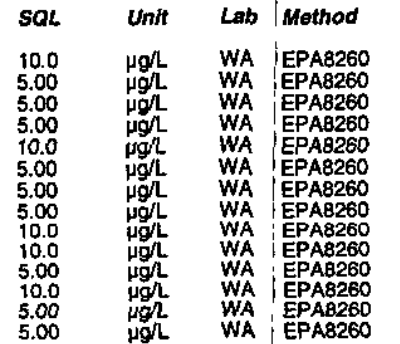

Second Quarter 1998 
SAMPLING BLANKS RESULTS

Well TRP240B collected on 06/29/98 (cont.)

\begin{tabular}{|c|c|}
\hline Analyte & Resu \\
\hline 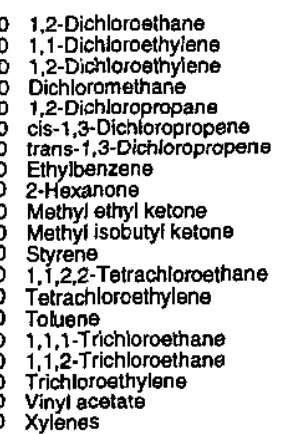 & $\begin{array}{l}<5.00 \\
<5.00 \\
<5.00 \\
<4.72 \\
<5.00 \\
<5.00 \\
<5.00 \\
<5.00 \\
<10.0 \\
<10.0 \\
<10.0 \\
<5.00 \\
<5.00 \\
<5.00 \\
<5.00 \\
<5.00 \\
<5.00 \\
<5.00 \\
<10.0 \\
<5.00\end{array}$ \\
\hline
\end{tabular}

\section{WELL TRP241B}

MEASUYAEMENTS CONDUCTED IN THE FIELD

Sample date: 06/16/98

Water temperature: Not available

AH: Not available

p. conductance: Not available

No water was evacuated from the well prior to sampling

ANALYSES

$F$ Analyte

O Acetone

Bromodichloromethane

Bromotom

Carbon disulfide

Chiorobenzene

Chloroetherie (Vinyl chloride)

Chloroform

Dibromochloromethane

1,2-Dichloroethane

1.1-Dichlorcethylen

Dichioromethane

cis-1,3-Dichloropropene

Ethylbenzene

2-Hexanone
Methyl ethyl ketone
Methyl isobutyl ketoto

Styrene

Ti, 2,2-Tetrachloroeth

$1,1,1$-Trichloroethane

$1,1,2$-Trichioroethan

Unknown 1

0.0 Vinyl acota
0 Xylenos

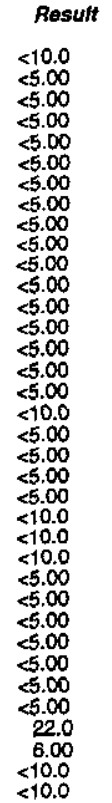

ESH-EMS-980569

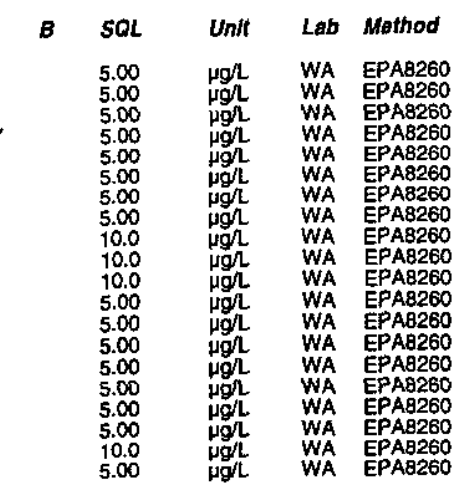

Time:

Total alkalinity (as CaCO3): Not available

\begin{tabular}{|c|c|c|c|}
\hline SOL & Unit & Lab & Method \\
\hline $\begin{array}{l}10.0 \\
5.00 \\
5.00 \\
5.00 \\
5.00 \\
5.00 \\
5.00 \\
5.00 \\
5.00 \\
5.00 \\
5.00 \\
5.00 \\
5.00 \\
5.00 \\
5.00 \\
5.00 \\
10.0 \\
5.00 \\
5.00 \\
5.00 \\
10.0 \\
10.0 \\
10.0 \\
5.00 \\
5.00 \\
5.00 \\
5.00 \\
5.00 \\
5.00 \\
5.00\end{array}$ & $\begin{array}{l}\mu g h \\
\mu g h \\
\mu g h \\
\mu g h \\
\mu g h \\
\mu g h \\
\mu g h \\
\mu g h \\
\mu g h \\
\mu g h \\
\mu g h \\
\mu g h \\
\mu g h \\
\mu g h \\
\mu g h \\
\mu g h \\
\mu g h \\
\mu g h \\
\mu g h \\
\mu g h \\
\mu g h \\
\mu g h \\
\mu g h \\
\mu g h \\
\mu g h \\
\mu g h \\
\mu g h \\
\mu g h \\
\mu g h \\
\mu g h \\
\mu g h \\
\mu g h \\
\mu g h \\
\mu g\end{array}$ & 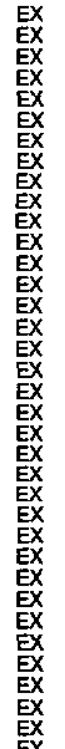 & 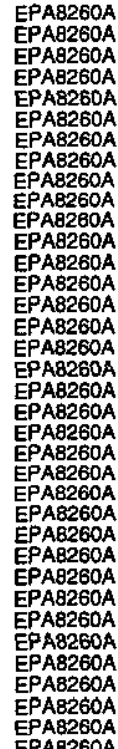 \\
\hline
\end{tabular}

WELL TRP242B

MEASUREMENTS CONDUCTED IN THE FIELD

Sample date: 06/18/98

Air tempererature: Not available

Ar temperature: Not available
$\mathrm{pH}:$ Not available

Sp. conductance: Not available

No water was evacuated from the well prior to sampling.

ANALYSES

$F$ Analyte

0 Acetone

Bromodichloromethane

Bromotorn

Carbon disultidide

Chlorobenzene

Chloroethene (Vinyl chloride)

Chloroform

Dibromochloromethane

1,2-Dichloroethane

1,1-Dichloroethylene

Dichloromethane

c. cis-1,3-Dichloropropene

2-Hexanone

Methyl ethyl ketone

S1,1,2,2-Tetrachloroethan

Tetrachloroethylen

$1,1,1-$ Trichloroethans
$1,1,2-$ Trichloroethane

Trichloroethylen

Unknown 2
Vinyl acetato

Vinyl acata
Xylenes

\section{WELL TRP243B}

MEASUREMENTS CONDUCTED IN THE FIELD

Sample date: $06 / 17 / 98$

Water temperature: Not available

Air temperature: Not available

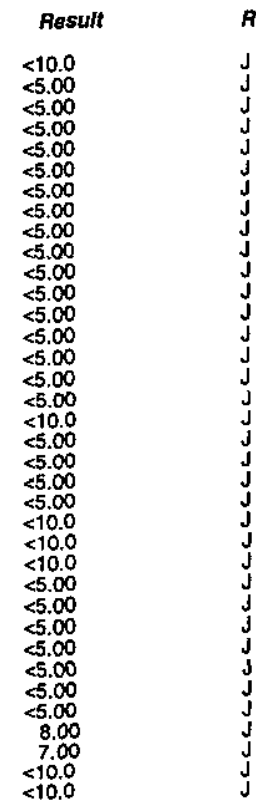

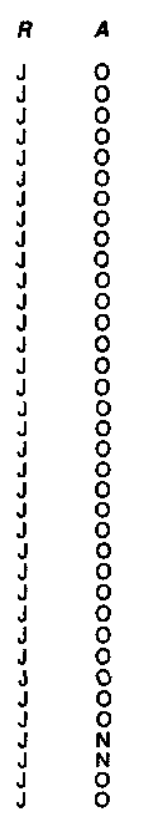

Time:

Total alkalinity (as CaCO3): Not available

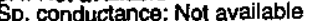

No water was evacuated from the well prior to sampling.

ANALYSES

$F$ Anatyte

0 Acetone

0 Bromodichloromethan

Bromoform

Carbon disulfide

Carbon tetrachlbrida

Chloroesthane
Chloroesthene (Vinyl chloride)

Chborotorm

c-40

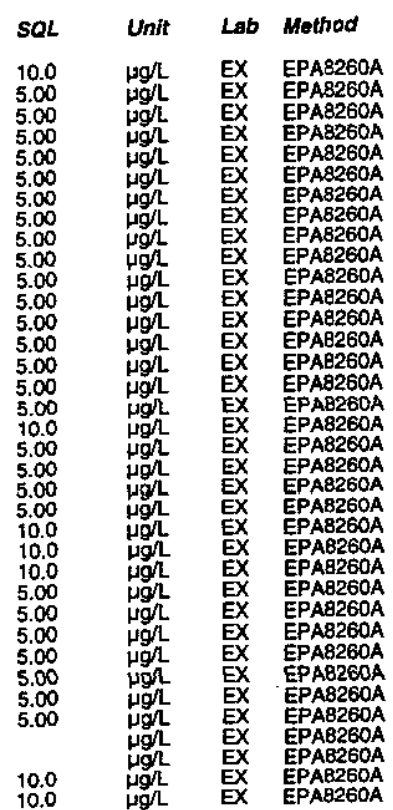

Time:

Total alkalinity (as $\mathrm{CaCO}$ ): Not available

sQL
10.0
5.00
5.00
5.00
5.00
5.00
5.00
5.00
5.00
5.00
5.00

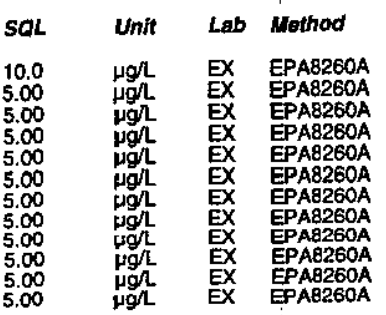

Second Quarter 1998 
Well TRP243B collected on 06/17/98 (cont.)

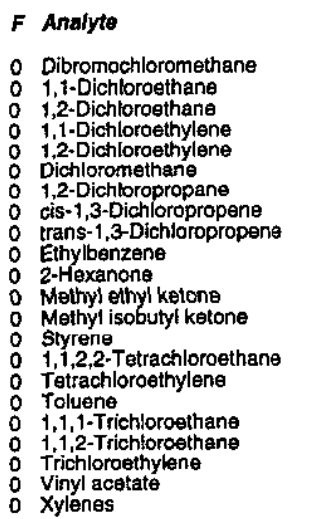

Result
$<5.00$
$<5.00$
$<5.00$
$<5.00$
$<5.00$
$<10.0$
$<5.00$
$<5.00$
$<5.00$
$<5.00$
$<10.0$
$<10.0$
$<10.0$
$<5.00$
$<5.00$
$<5.00$
$<5.00$
$<5.00$
$<5.00$
$<5.00$
$<10.0$
$<10.0$

WELL TRP289A

MEASUREMENTS CONDUCTED IN THE FIELD

Water temperature: Not available

Air temperature: Not available

P. conductance: Not available

No water was evacuated from the well prior to sampling. ANALYSES

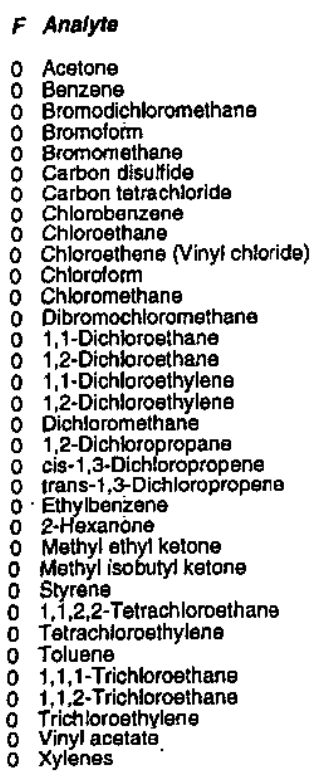

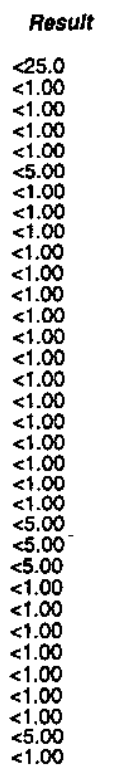

\section{WELL TRP292A}

MEASUREMENTS CONDUCTED IN THE FIELD

Sample date: 06/16/98

Water temperature: Not available

Air temperature: Not available
$\mathrm{pH}$ : Nol available

Sp. conductance: Not available

No water was evacuated from the well prior to sampling.

ANALYSES

F Analyte

- Acetone

Bromodichloromethane

Bromoform
Bromomethan
Cantong

Carbon disulfide

Chlorobenzene

Chloroethane

Chloroform

Dibromochloromethane

1,1-Dichloroethane

1.1-Dichloroethylene

Dichloromethane

1,2-Dis-Dichioropropen

trans-1,3-Dictiloropropen

Ethylbenzen

Methyl ethyl ketone
Methyl isobutyl ketone

1.1,2,2-Tetrachlorosthane

Tetrachloroethylene

${ }_{0}^{0}$ Toluene $1,1,1-$ Trichloroethane

o 1, , . Trichloroethane

o vinyl acetate

\section{WELL. TRP294A}

Resuft
$<6.08$
$<5.00$
$<5.00$
$<5.00$
$<10.0$
$<5.00$
$<5.00$
$<5.00$
$<10.0$
$<10.0$
$<5.00$
$<10.0$
$<5.00$
$<5.00$
$<5.00$
$<5.00$
$<5.00$
$<6.17$
$<5.00$
$<5.00$
$<5.00$
$<5.00$
$<10.0$
$<10$.
$<10.0$
$<5.00$
$<5.00$
$<5.00$
$<5.00$
$<5.00$
$<5.00$
$<5.00$
$<10.0$
$<5.00$

MEASUREMENTS CONDUCTED IN THE FIELD

Sample date: 04/09/98

Water temperature: Not available
Air temperature: Not available

Air temperature: Not available

Sp. conductance: Not available

Turbidity: Not available

ANALYSES

$F$ Analyte

: Acetone

Bromodichloromethan

Bromotom

Carbon disulfide

Chibon tetrachloride

Chloroethene (Vinyl chloride)

Chloroethene

Chloromethane

1,1-Dichloroethane

$0-41$

Result
$<10.0$
$<5.00$
$<5.00$
$<5.00$
$<10.0$
$<5.00$
$<5.00$
$<5.00$
$<10.0$
$<1.0$
55.00
$<1.0$
55.00
$<5.00$

Time:

Total alkalinity (as CaCO3): Not available
Phenolphthalein alkalinity: Not availabie

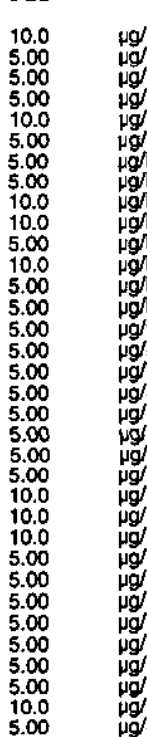

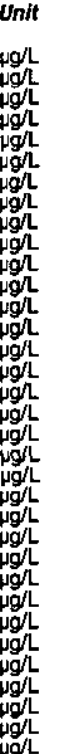

Lab Method

WA EPAB260

WA EPAB260

WA

WA EPA8260

A EPA8260

NA EPAB260

WA EPAB260

WA EPAB260

WA EPA8260

WA EPA260

WA EPAB260

WA EPA8260

WA EPA8260

WA EPAB260

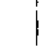

Time: .

Total alkadinity (as CaCO3): Not available Penolphthalein alkalinity: Not available

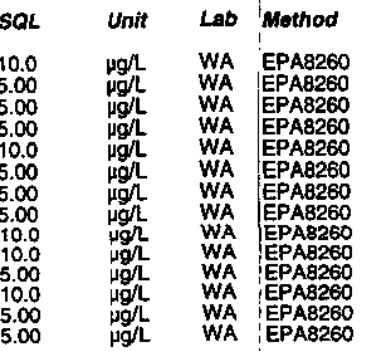

Second Quarter 1998 
SAMPLING BLANKS RESULTS

Well TAP294A collected on 04/09/98 (cont.)

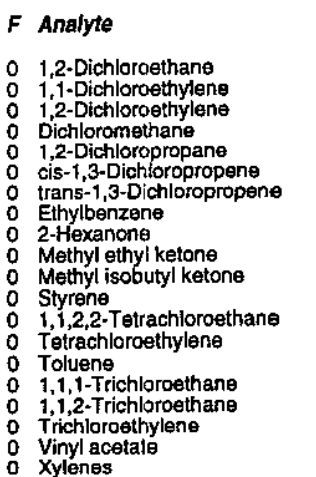

Result
$<5.00$
$<5.00$
$<5.00$
$<5.00$
$<5.00$
$<5.00$
$<5.00$
$<5.00$
$<10.0$
$<10.0$
$<1.0$
$<5.00$
$<5.00$
$<5.00$
$<5.00$
$<5.00$
$<5.00$
$<500$
$<10.0$
$<5.00$

\section{WELL TRP295A}

MEASUREMENTS CONDUCTED IN THE FIELD

Sample date: 04/01/98

Water temperature: Not available

$\mathrm{pH}$ : Not availabio

p. conductance: Not available

No water was evacuated from the well prior to sampling

ANALYSES

$F$ Analyte

Fesult
$<10.0$
5.00
5.00
5.00
510.0
5.00
55.00
5.00
$<10.0$
$<10.0$
$<5.00$
$<10.0$
$<5.00$
55.00
$<5.00$
$<5.00$
$<5.00$
$<10.1$
$<5.00$
$<5.00$
$<5.00$
$<5.00$
$<10$.
$<10$.
$<10$.
$<5.00$
$<5.00$
$<5.00$
$<5.00$
$<5.00$
$<5.00$
$<5.00$
$<10.0$
$<5.00$

0 Acetone

Bromomethan

Carbon disulfide

Chlorobenzene

(Vinyl chloride)

Chlorotorm

Dibromochioromethane

1,1-Dichloroethane

1,1-Dichloroethylene

Dichloromethane

1,2-Dichloropropane
cis-1,3-Dichloropropen

2-Hexanone

Methyl thy ketone

Styrene

Tetrachloroethylene

1,1,1-Trichloroethane

Trichloroethyleng

$:$ vinyl ace
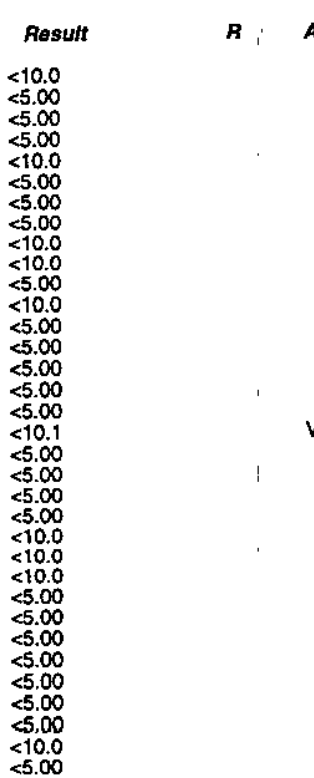

Time:

Total alkalinity (as CaCO3) Not available

\begin{tabular}{|c|c|c|c|}
\hline $\mathrm{OQL}$ & Unit & Lab & Method \\
\hline $\begin{array}{l}5.00 \\
5.00 \\
5.00 \\
5.00 \\
5.00 \\
5.00 \\
5.00 \\
5.00 \\
10.0 \\
10.0 \\
10.0 \\
5.00 \\
5.00 \\
5.00 \\
5.00 \\
5.00 \\
5.00 \\
5.00 \\
10.0 \\
5.00\end{array}$ & 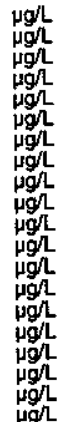 & $\begin{array}{l}\text { WA } \\
\text { WA } \\
\text { WA } \\
\text { WA } \\
\text { WA } \\
\text { WA } \\
\text { WA } \\
\text { WA } \\
\text { WA } \\
\text { WA } \\
\text { WA } \\
\text { WA } \\
\text { WA } \\
\text { WA } \\
\text { WA } \\
\text { WA } \\
\text { WA } \\
\text { WA } \\
\text { WA } \\
\text { WA }\end{array}$ & 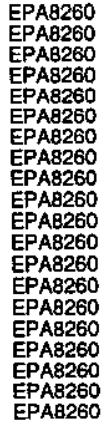 \\
\hline
\end{tabular}

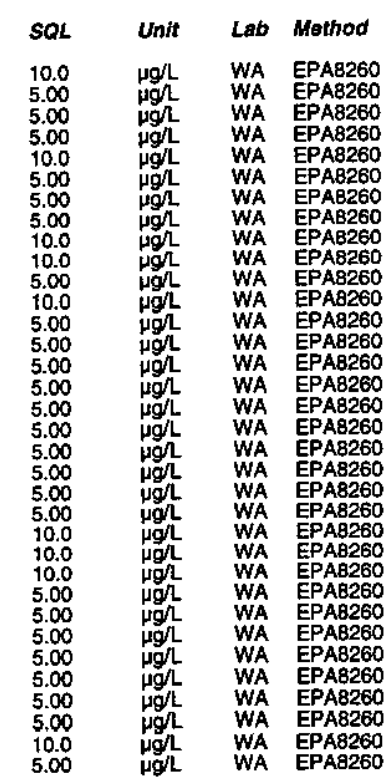

\section{WELL TRP296A}

MEASUREMENTS CONDUCTED IN THE FIELD

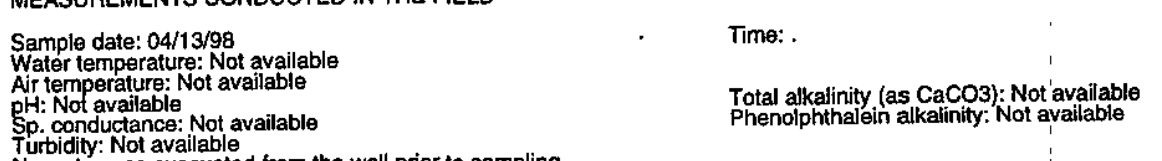

No water was evacuated from the well prior to sampling.

ANALYSES

F Analyte

Result
$<10.0$
$<5.00$
55.00
55.00
$<10.0$
1.13
55.00
5.00
510.0
$<10.0$
55.00
1.80
55.00
5.00
55.00
5.00
55.00
6.60
55.00
5.00
550
5.00
510.0
$<10.0$
$<1.0$
55.00
55.00
5.00
55.00
55.00
55.00
55.00
510.
$<5.00$

B

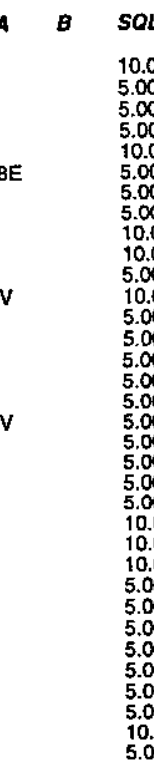

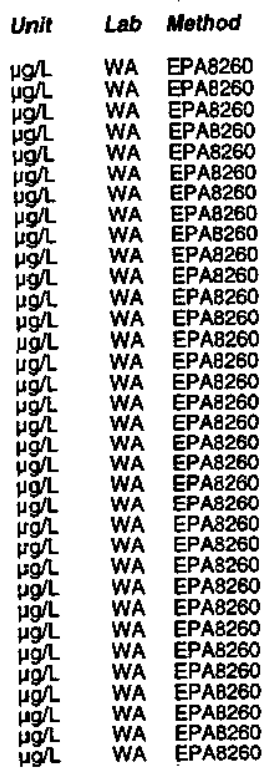

0 Acetone

Bromodichloromethane

Bromotorm

Carbon tetractilorido

Chlorobenzene

thene (Vinyl chloride)

Chloromethan

1,2-Dichloroethane

1,1-Dichloroethylene

trans-1,3-Dichioropropen

Methyl isobutyl ketone

1,1,2,2-Totrachloroethane

Toluene

o $1,1,1$-Trichloroethan

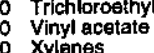

$<5.00$

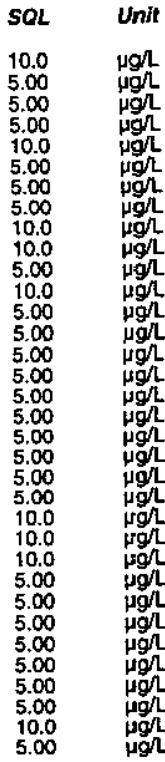

WA EPAB260 